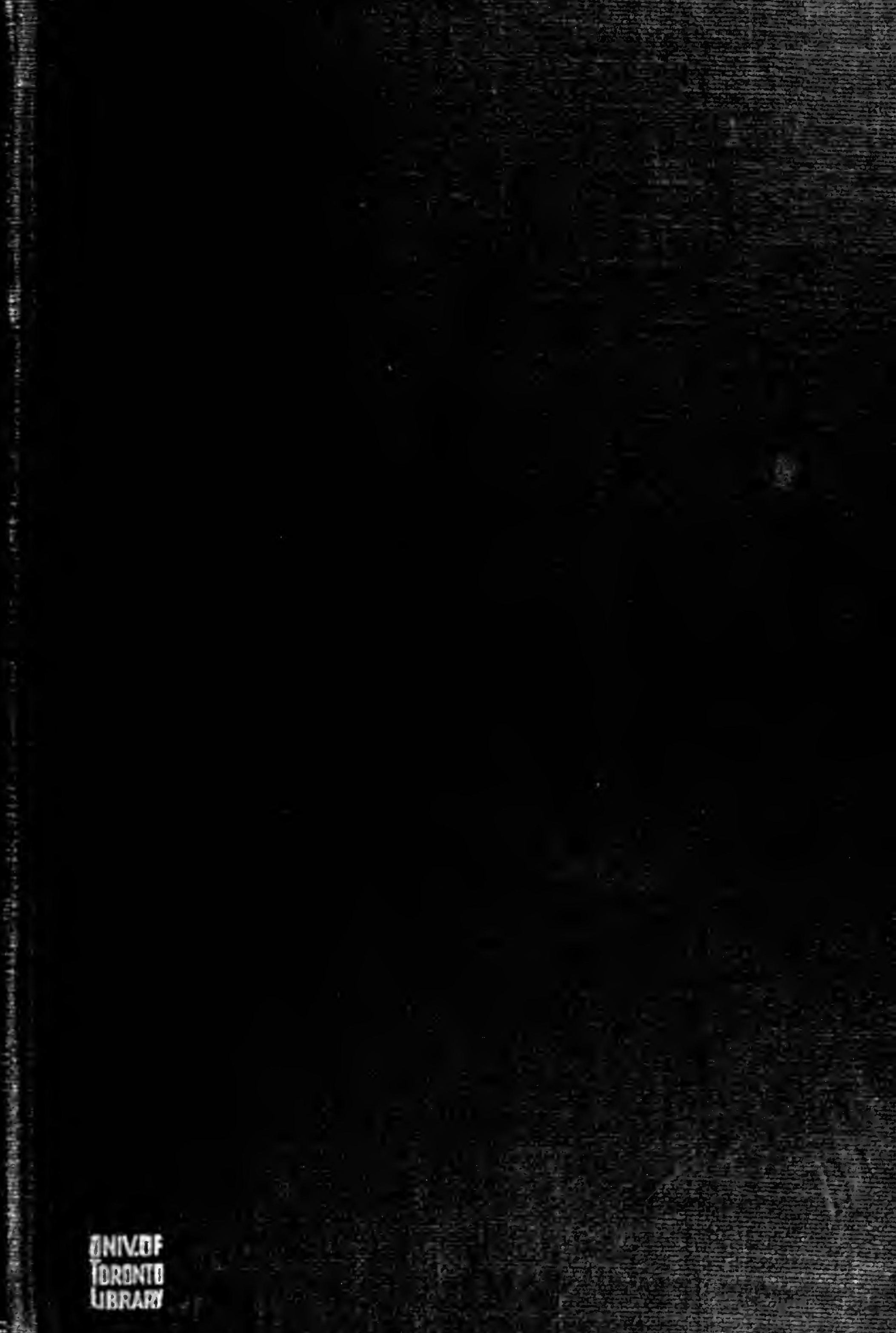





. 



\section{CATALOGUE}

DES

\section{MANUSCRITS ARABES}





\section{Paris. BIBLIOThèque NATIONALE}

DÉPARTEMENT DES MANUSGRITS

\section{CATALOGUE}

DES

MANUSCRITS ARABES

PAR

M. LE BARON DE SLANE

YEMBRE DE L'INSTITUT

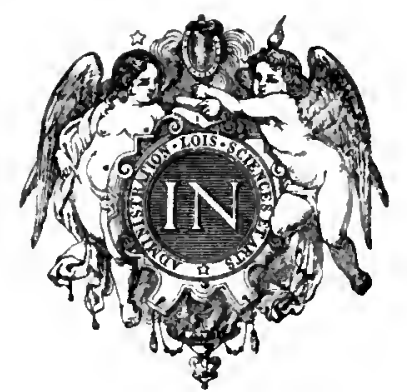

$\frac{580.505}{17.7 .53}$

PARIS

IMPRIMERIE NATIONALE

$1883-1895$ 
$z 621$
$P 22 A 6$ 


\section{AVERTISSEMENT.}

L'origine du fonds des manuscrits arabes de la Bibliothèque nationale remonte aux commencements mêmes de l'ancienne bibliothèque des rois de France. Dans la Bibliothèque de Blois, il y avait 6 manuscrits arabes. La Bibliothèque de Fontainebleau, paraît-il, renfermait 40 volumes orientaux (1). La bibliothèque de la reine Catherine de Médicis, d'après l'inventaire dressé en ${ }^{1589}$, possédait 5 manuscrits arabes. Ce petit nombre de volumes, non seulement ne reçut aucun accroissement pendant toute la première moitié $d u x v_{1}{ }^{\mathfrak{e}}$ siècle, mais plusieurs de ces manuscrits s'étaient perdus ou avaient été égarés; car dans le catalogue de la Bibliothèque du Roi, dressé en 1622 et en 1645 , on ne trouve mentionnés que 9 manuscrits arabes.

Ginq manuscrits furent acquis en $\mathbf{1 6 6 7}$, lors de la vente des livres de l'intendant Foucquet.

C'est à partir de 1668 que l'on enregistre les premiers accroissements considérables. En cette année, l'échange qui eut lieu entre la Bibliothèque Mazarine et la Bibliothèque du Roi amena dans cette dernière 194 manuscrits arabes, et l'acquisition de la bibliothèque du président Gilbert Gaulmin, ${ }_{2} 47$ manuscrits. Vers cette époque aussi, on commença à recevoir les manuscrits achetés en Orient par divers agents, chargés par Colbert de rechercher des manuscrits pour la Bibliothèque du Roi. Neuf manuscrits arabes, achetés à Constantinople, arrivèrent en 1669;3 autres, un peu plus tard. Une mission qui eut le plus grand succès, aussi bien pour la Bibliothèque du Roi que pour celle de Colbert, fut celle dont avait été chargé J.-B. Wansleben ou Vansleb, qui parcourut les principałes villes du Levant entre les années $167_{1}^{1}$ et $167^{5}$ et envoya à la Bibliothèque du Roi 63 o manuscrits orientaux, parmi lesquels les ouvrages arabes étaient au nombre de 430 . Petis de la Croix rapporta de ses voyages en Asie 12 manuscrits arabes. Le catalogue dressé en ${ }_{1} 677$ par Pierre Dipy et l'inventaire de ${ }_{168} 8_{2}$ énumèrent 897 manuscrits arabes ${ }^{(2)}$.

Aucune acquisition importante de manuscrits arabes ne signale la fin du xvile siecle, soit que les occasions aient manqué, soit que le garde général de la Bibliothèque du Roi, Le Tellier, archevêque de Reims, ne portât pas aux littératures orientales le même intérêt que son prédécesseur ${ }^{(3)}$. Cependant la collection de ses propres manuscrits, donnée par lui à la Bibliothèque du Roi en 1700 , contenait 5 manuscrits arabes. La même année, 3 manuscrits druzes furent présentés à Louis XIV par un médecin de Damas.

(1) Six de ces volumes actuellement cotés $395,408,414$, 419,1053 el 1077 reçurent a teur passage dans la bibliothèque de Fontainebleau la reliure au cbiffre de Henri II qu'ils ont encore.

(2) Ces manuscrits sont cotés 368 à 1228 . Mais il y a plusieurs sous-chiffres.

(3) On lit dans une lettre de Galland à Huet, datée de Caen,

21 mars 1701 : «Si dans le tems que j'estois à Constantinople emploié à acheter des manuscrits et des médailles antiques pour le Roy, je n'awois pas reçu un ordre suggéré par Ml. l'archevesque de Rheims de ne pas acheter des manuscrits orientaux, pour lesquels il a une grande aversion, j'estois résolu d'en acheter un, le plus beau que l'on puisse imaginer. * (Ms. franç. 6138, p. 151.) 
La collection formée par Melchisedech Thévenot et achetée en $17^{12}$ comprenait $9^{6}$ manuscrits arabes. En 1715 , la Bibliothèque reçut 15 manuscrits arabes provenant de la succession de Galland; en 1719,8 manuscrits qui faisaient partie de la bibliothèque de Philibert de La Mare, et, vers le même temps, 23 manuscrits que Paul Lucas avait rapportés de ses voyages. En $17^{2} 9$ et 1730 , l'abbé Sevin, envoyé au Levant, en même temps que l'abbé Fourmont, afin de rechercher des manuscrits et des antiquités, acquit à Constantinople plus de 200 manuscrits arabes, et, après son retour en France, grâce aux rełations qu'il avait nouées pendant son séjour en Turquie, on reçut encore d'autres envois de manuscrits orientaux.

En ${ }_{17} 3_{2}$, l'acquisition de la bibliothèque de Colbert fit entrer dans la Bibliothèque du Roi 188 manuscrits arabes. Vers 1738 , on acheta 44 manuscrits rapportés d'Orient par Benoît de Maillet, ancien consul général et inspecteur des établissements français du Levant.

Ces diverses acquisitions portèrent le nombre des manuscrits arabes de la Bibliothèque du Roi à 1,626 numéros en 1,683 volumes, dont le catalogue a été imprimé en $17^{3} 9$.

Les manuscrits entrés depuis cette époque forment le supplément de l'ancien fonds arabe. Ce nouveau fonds, qui d'abord se composait d'un petit nombre de volumes acquis durant la seconde moitié du xvıı siècle, a été surtout augmenté, pendant la Révolution, par l'incorporation des bibliothèques des couvents, qui apportèrent au grand dépôt national environ 350 manuscrits arabes (dont plus de 300 proviennent de l'abbaye de Saint-Germain-des-Prés), et par la campagne d'Égypte, qui y amena 320 manuscrits, tant arabes que turcs et persans. Mais les accroissements ont été plus importants dans le cours du xix ${ }^{\text {e }}$ siècle. A part les achats plus ou moins fréquents, selon les occasions qui se présentaient, et qui n'ont jamais cessé; à part aussi quelques dons qui sont venus enrichir le fonds arabe ( 18 manuscrits provenant d'un collège d'Alger, déposés à la Bibliothèque par le Ministre de la guerre en 1832, 18 manuscrits donnés par le $D^{r}$ Clot Bey en 1866, 17 manuscrits druzes donnés par M. Eugène Poujadc en 1867 ), il convient de mentionner particulièrement l'acquisition, faite en 1833 , de la collection de 1,500 manuscrits, en majeure partie arabes, qui avait été formée par Asselin de Cherville, agent consulaire de France en Égypte.

Le nombre total des manuscrits du supplément arabe, au moment où fut arrêtée la rédaction du présent catalogue, était de 2,507 numéros en 3,004 volumes. 479 manuscrits ont été acquis dans ces dernières années.

Le premier catalogue des manuscrits arabes de l'ancienne Bibliothèque du Roi date de 1677 (voir ci-après no 4484). Il est de la main de Pierre Diyâb, d'Alep, connu sous le nom de Pierre Dipy, qui avait décrit aussi les manuscrits orientaux de la bibliothèque de Colbert. Cependant il n'est pas certain que ce Syrien en soit le seul auteur. Quoi qu'il en soit, ce travail ayant paru insuffisant, deux savants illustres, d'Herbelot et l'abbé Renaudot, se chargèrent de rédiger de nouvelles notices qui, réunies et coordonnées, formèrent le premier volume du catalogue général des manuscrits de la Bibliothèque du Roi, achevé vers $1690^{(1)}$. Vingt-cinq ans plus tard, en 1715 , le Syrien Barout, interprète de la Bibliothèque du Roi, entreprit de dresser un nouveau répertoire des ma-

(1) Ce catalogue est conservé sous le $n^{\circ} 5408$ des nouvelles acquisitions françaises. 
nuscrits arabes, turcs et persans ${ }^{(1)}$. Enfin, en 1735 , au moment où l'on songea à imprimer les catalogues, on jugea nécessaire de charger le Maronite Ascary de faire la description, non seulement des manuscrits nouvellement acquis, mais de tous les manuscrits syriaques et arabes. Les bulletins d'Ascary ont été joints aux volumes auxquels ils se rapportent; mais on a eu le bon esprit de faire imprimer, sauf quelques légères modifications, les anciennes notices de d'Herbelot et de Renaudot. Le catalogue des manuscrits orientaux fut publié en 1739 .

Les collections acquises postérieurement à cette date avaient été l'objet de divers travaux avant de prendre place sur les rayons de la Bibliothèque nationale. Dès l'année 1657, Elzéar de Sanxay, missionnaire de l'ordre des capucins, avait dressé le catalogue des manuscrits du chancelier Séguier (voir ci-après $n^{\circ}$ 4483). Ces mêmes manuscrits et ceux de Renaudot, qui, réunis, formaient la partie principale du fonds arabe de l'abbaye de Saint-Germain-des-Prés, étaient pourvus de notices très exactes de Renaudot. Après lincendie de la Bibliothèque de Saint-Germain, en 1794, Silvestre de Sacy avait rédigé un inventaire complet des manuscrits orientaux de cet établissement ${ }^{(2)}$. Un inventaire de la collection d'Asselin avait été dressé, en ${ }_{1825}$, au Caire (voir ci-après no 4481 ), et M. de Slane avait été chargé d'en faire un autre après qu'elle eut été acquise par la Bibliothèque royale. Mais, afin de faciliter l'usage de tant de manuscrits de diverses provenances, on crut nécessaire de dresser un catalogue général de tous les manuscrits orientaux. Voici, à ce sujet, les renseignements communiqués au Journal asiatique par M. J. Reinaud, alors conservateur adjoint de la section orientale du département des manuscrits, et insérés dans le numéro de janvier 1846 de ce recueil : "Le travail a naturellement commencé par les manuscrits qui sont entrés à la Bibliothèque royale postérieurement à l'an 1739 , année où fut rédigé le catalogue imprimé. Les catalogues des suppléments persan et turk, ainsi que celui des traductions manuscrites de livres orientaux, sont terminés depuis longtemps; les bulletins rédigés par M. Reinaud furent recopiés, il y a quelques années, par l'honorable feu Loiseleur-Deslongchamps, et reliés en volume, de manière à pouvoir être mis dans les mains du public. M. Reinaud achève en ce moment la catalogue du supplément arabe, et déjà la plus grande partie des bulletins ont été recopiés par M. Defrémery. Un certain nombre de bulletins avaient été rédigés par $M$. le baron de Slane; ils ont été revus et complétés sur les volumes mêmes... Il reste à revoir un à un les manuscrits arabes, persans et turks de l'ancien fonds et à soumettre les divers fonds à une classification générale. "

Mais les administrateurs de la Bibliothèque se préoccupèrent surtout de mettre entre les mains des savants un nouveau catalogue imprimé. Un éminent savant italien, feu Michel Amari, fut occupé pendant plusieurs années à soumettre à une revision minutieuse le fonds arabe et il rédigea un grand nombre de notices (voir ci-après $n^{\text {os }} 4494$ à 4501 ). Le travail, interrompu en 1859 par le départ de M. Amari, fut repris en 1867 par M. H. Derenbourg (voir ci-après nos 4502 à 4505 ). Ge savant ayant, à son tour, quitté la Bibliothèque en $187^{\circ}$, l'administration, pour mener à bonne fin un travail depuis si longtemps commencé, s'adressa, en $187^{2}$, à M. le baron Mac Guckin de Slane, membre de l'Institut et l'un des arabisants les plus justement renommés de l'Europe. M. de Slane, malgré son Age avancé, se consacra à cette tâche avec un grand dévouement jusqu'aux derniers jours de sa vie, rédigeant les notices sous une forme définitive et absolument prêtes pour l’impression. Il

(1) Ce catalogue, qui n'est pas achevé, est conservé sous le $n^{\circ} 5407$ des nouvelles acquisitions françaises.
(9) Ce répertoire est conservé sous le $n^{\circ} 5439$ des nowvelles acquisitions françaises. 
laissa le présent catalogue presque entièrement achevé au moment de sa mort. Quelques erreurs de détail que l'on y rencontrera ne sont pas de nature à diminuer le mérite du grand arabisant. Celles qui n'ont pas été relevées dans les additions et eorrections et dans les notes ajoutées au bas des pages des premières feuilles pourront être corrigées dans un supplément des nouvelles acquisitions qu'il y aura lieu de publier dans quelques années. Mais, dès à présent, le travail de M. de Slane ne laissera pas de servir utilement les recherches. La description plus exacte des ouvrages et la fusion en une seule série des manuscrits de l'ancien fonds et du supplément disposés dans un ordre méthodique seront appréciées par tous les orientalistes. Au moyen de la concordance des anciens et des nouveaux numéros imprimée à la fin du volume, chacun retrouvera facilement les ouvrages cités auparavant avec les anciennes cotes. 


\section{CATALOGUE \\ DES \\ MANUSCRITS ARABES \\ DE LA BIBLIOTHÈQUE NATIONALE, \\ PAR \\ M. LE BARON DE SLANE, \\ MEMBRE DE L'ISTITUT.}

Premier fascicule. 
IMPRIMERIE NATIONALE. - 1883. 


\title{
CATALOGUE DES MANUSCRITS ORIENTAUX.
}

\section{MANUSCRITS}

\author{
DU \\ F O NDS ARABE. \\ ANCIEN FONDS,
}

SLPPLÉMENT ET FONDS DIVERS.

\section{A. - OUVRAGES CHRÉTIENS.}

1.

BIBLE.

\section{1.}

L'Ancien Testament, précédé d'une Introduction.

L'auteur de l'Introduction dit que la version du Pentateuque reproduite par lui est celle que Said, rabbin de Fayyoum, traducteur très-habile et très-considéré, avait faite sur le texte hébreu. Le copiste avait écrit $S a^{a} i d$, moine, ألهوبان, de Fayyoum, leçon changée, plus tard, en ألربان Cotte correction a été faite postérieurement ì l'an 1734, car Joseph Ascari, en écrivant sur un des feuillets de garde la notice de ce volume, y avait lu نhe puisqu'il dit que te traducteur se nommait Saidus Phaioumensis monachus Cophtus. Quoi qu'il en soil, le personnage ainsi désigné nंest autre que le célèbre rabbin Saadias Gaon de Fayyoûm. Cette Introduction, remplissant trois pages et demie, offre une critique très-juste du travail de Saadias. Elle se trouve reproduite, avec une traduction latine, dans te volume que C. F. Schnurrer a fait paraitre à Gotha, l'an $\mathbf{1 7 9 0}$, sous le titre de - Dissertationes philologico-criticæn, p. 197 et suiv.

S. de Sacy a donné une nolice de cette version de
l'Ancien Testament et un extrait de l'Introduction dans son " Hémoire sur la version arabe des tivres de Noïse". (Voyez les e Mónoires de l'Académie des inscriptions", t. XLIX, p. 78 et suiv.)

La version de Saadias contenue dans ce volume a été corrigée à l'encre rouge par l'auteur de l'Introduction. Ce dernier ne se nomme pas, mais une note du copiste, qui était musulman (royez fol. 404), nous apprend qu'il appartenait ì une lamille du Vieux-Caire, et qu'il s'appelait Fadht-Allah, fils de Théodore (تصادرس), fils de Yoûsouf, fils de Fadhl-Hllal.

D'après une autre note (fol. $387 \mathrm{v}^{\circ}$ ), le (raducteur des petits Prophètes était un savant prêtre d'Alexandrie, qui avait pris pour base de son travail un vieux livre, écrit sur parchemin, en caractères latins : من نسخة عتيقة

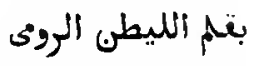

Ce ms. est un de ceux qui ont servi pour l'édition de la version arabe insérée dans la Polyglolte de Paris.

Preniers versets de la Genèse : أول ما خلق الله السماء

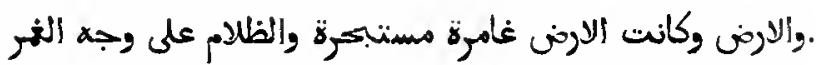

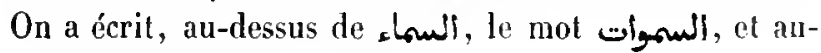

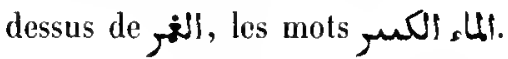

Papier. 459 feuiltets. Hauteur du volume, 34 centimètres et demi ; largeur, 23 centimètres et demi. 29 lignes par page. Ms. daté des années $99^{2-99^{3}}$ de l'hégire. - (Ancien fonds 1, Colberl 900.) 


\section{2 .}

L'Ancien Testament. Manuscrit moderne el très-bien écrit. Les deux volumes dont se compose cet exemplaire sont retiés coscmble, mais le second a été placé avant le premier (royez fol. 256). Le premier rolume finit par les deux livres des Paraliponènes; le second commence par Esdras et finit par les deux livres des Maccabées.

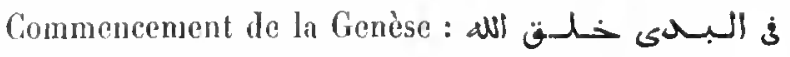
السماء والاون وكانت الارن خاوية خالية وكانت الظمله عـلى iो

Papier. 479 fenillets. Hauteur, 25 centimètres; largeur, 18 centimètres. 23 lignes par page. - (Supplément 1, fonds Ducaurroy.)

3.

Le Pentatenque. Ce volnme, écrit à Paris, en 1685 , prar Jean de Danns, a été copié sur le ms. $n^{\circ} \mathbf{1}$.

Papier. 477 feuillets. Hauteur, 20 centimètres; largeur, 15 centimìtres. 3 lignes par page. - (Supptément 4 bis, S. Geneviève.)

\section{4.}

Le Pentateuque. Cette ancienne version parait avoir été faite sur te texte samaritain. Elle est précédée d'unc prélace de deux pages, dans laquelle l'auteur indique la filière imaginaire par laquelle le texte de la Loj a passé de Noïse à ses deruiers successeurs. Il ressort d'une table des matières, inscrite sur le verso dı second feuillet, que nous n'arons ici qu'un premier rolume de l'Ancien Testament. On remarque, en tête du ms., treize lignes en langue syriaque, dans lesquelles il est question des douze pierres frécieuses du pectorat. Les goses syriaques assez nomhreuses qui se trourent sur les marges sont lirées, pour la plupart, du commentaire sur l'Ancien Testament, composé par Mar-Denys Bar-Salibi. On remarque sur le recto du dernier levillet du volume une courte dissertation, en syrialque, sur la chronologie biblique.

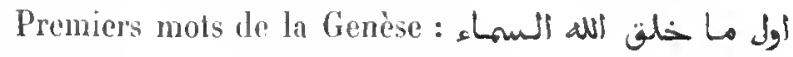

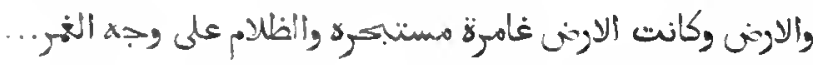

Papier. 113 feuillots. llauteur, 25 centinèlres; targeur, 25 centimètres. 23 lignes par page. Plusieurs feuillets du commencoment et de la fin sont mutilés. xm1 siècle. - (Ancien fonds 3.)

\section{5 .}

Le Pentateuque. Cette version est précédée d'une courte préface, dans laquelle un nommé Abou 'l-Barakàt Ibı Sa id al-Bosrì le Syrien dit qu'ayant entrepris de faire une traduction du Pentaleuque à l'aide du texte samaritain et du texte syriaque, il avait recomnu que celle dont ses coreligionnaires se servaient était remplie de fautes et de contre-sens, bien qu'elle eủt pour auteur «le savant juif al-Fayyoûmì, c'est-ì-dire Saadias. Cette préface, étrangrement défigurée par des fautes et des omissions, se retrouve au complet dans le ms. $n^{\circ} 6$; mais là on lit, au lieu d'Abou '1-Barakàt Iton Sacid, le nom d'Abou Sacid Ibn abì 'l-Hosain lbn abì Sacid. (Voyez à ce sujet le Ménoire de S. de Sacy dans le t. XLIX des "Mémoires de l'Académic des inscriptions $n, p, 51$ et suiv. Ce savant n'luésite pas à regarder cette version comme l'ouvrage d'Abou Sacid). En tête de chaque chapitie se voient quelques mots du texte samarilain, et aux marges plusieurs scholies critiques et philologiques. En reliant ce volume, on a placé douze feuillets, depuis te huitième jusqu'au dix-neuvième, la tête en bas.

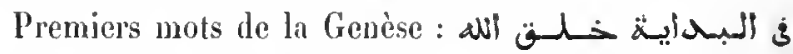

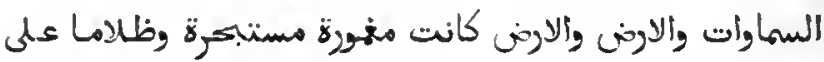
إلج

Papier. 232 f fuillets. Ilanteur, 27 centimètres; largeur, 18 centimètres. $x r^{\circ}$ siècle. $-($ Ancien fonds $\%)$

6.

Le Pentateuque. Cette version est faite sur le texte samaritain et a pour auteur Abou Sa id llbn abî 'l-Ḥosiinl Ibn abi Saeid. S. de Sacy a donné une notice de ce ms, dans les alémoires de l'Académic des inscriptions, , t. XLIX, p. 10 et suiv. (Voyez le numéro précédent.)

Le texte est accompagné d'un assez grand nombre de notes marginales. Le premier feuillet et les deux derniers portent encore quelques notes ajoutées après coup et n'ayant aucun rapport au texte.

Premiers mots de la Genèse : للبحدائة خلف ألم ألسماوأت

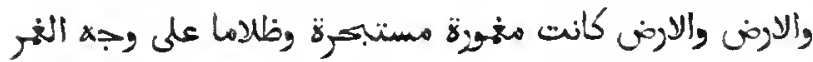

Papier. 337 feuillets. Hauteur, 27 centimètres; largeur, 17 centinètres. 14 à 15 tignes par page. Its. daté de l'an 836 de l'hégire (1432-1433 de J. C.). Les trois derniers fenillets sont d'une écriture plus récente et ditent de l'an 971 de l'liégire. - (Ancien fonds 4.) 


\section{7.}

Le Pentateuque. Ce ms. est une copie fiite à Paris sur le ms. $\mathbf{n}^{\circ} 6$. Le copiste, Jean de Damas Ibn Qatà, يوحنا الثايى بر تطا L. de Longuerue. (Voyez en Mémoires de l'Académie des inseriptions , t. XLIX, p. 19 et 20.) A voir l'écriture peu gracieuse de ce volume, on serait porté à croire qu'Ibn Qạ̣a était né et avait été élevé en Europe.

Papier. 341 fenillets. Hauteur, 29 centimètres; largeur, 22 centimètres. 16 lignes par page. - (Supplément 2.)

\section{8.}

Le Pentaleuque. Ce volume renferme une rersion du texte samaritain, précédée d'une introduction et d'une table des chapitres de la Genèse. Selon S. de Sacy, qui en a donné une notice étendue dans les - Mémoires de l'Académic des inseriptions $\pi$, 1. XLIX, p. 105 et suiv., cette rersion est, au fond, la même que celle dont les mss. 5 et 6 nous fournissent un texte plus ancien.

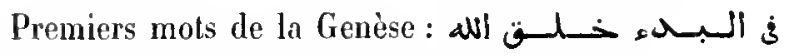

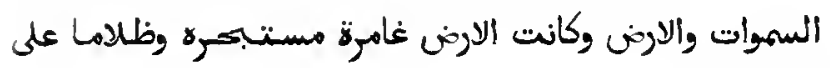
وجه النمجروات

Papier. 282 feuillets. Hauteur, 21 centimètres; largeur, 15 centimètres. 17 lignes par page. $x \mathbf{r i}^{e}$ siècle. - (Aneien fonds 12.)

\section{9.}

Le Pentateuque, Iraduit sur la version des Septante. Le volume, dont l'écriture est assez belle, porte la date du mois de rebî́a second, 683 de l'hégire (1283 de J. C.).

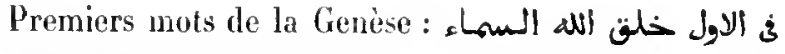

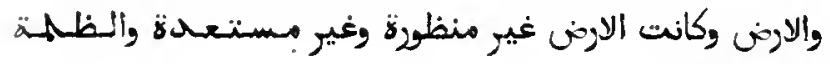

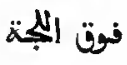

Papier. 329 feuillets. Hauteur, 24 centimètres; largeur, 16 centimètres et demi. 13 lignes par page. - (Supplément 3, Oratoire.)

\section{0.}

Le Pentateuque, traduit sur la version des Septante. Le texte est divisé en leçons et accompagné de gloses. Le copiste achera d'écrire le livre des Nombres (fol. 153) l'an 730 de l'hégire ( 1330 de J. C.).

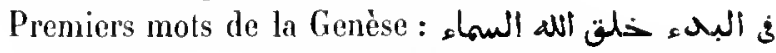
والارتن وكانت اللارن غير مستعدّه وكانت ظلمة الهم على الغنق :

Papier. ${ }_{1} 78$ feuillets. Hauteur, 26 entimètres; largeur, 17 centimètres. 20 à 22 lignes par page. - (Supplément 5, $\mathrm{S}^{\mathrm{t}}$-Germain 220.)

\section{1.}

Le Pentateuque, traluit sur la version des Septante. Le texte est divisé en lecons, selon l'usage de l'Église copte. Des gloses, pen étendues, sont insérées dans le texte, à la suite de plusieurs lecons. Un assez grand nombre de feuillets, tant au commencement qu'au milieu et ì la fin du volume, ayant disparu, ont été remplacés par d'autres, l'an 1600 de J. C. Une note à la fin de l'Exode nous apprend que le copiste avait terminé la transcription de cette partie du Pentateuque l'an 1047 de l'ère des martyr's ( 133 I de J. C. ).

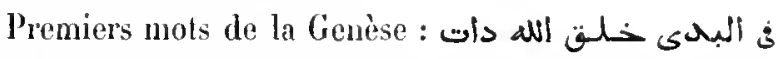

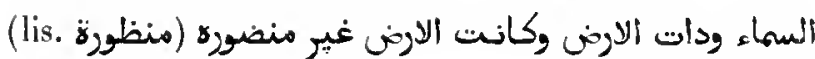

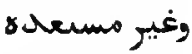

Papier. a 44 feuiltets. Hauteur, 26 centimètres; largeur, 15 centimètres et demi. 21 lignes par page. - (Supplément 4, $S^{2}$-Germain 8.)

\section{2.}

Le Pentateuque, traduit sur la rersion des Septante. Le copiste de ce beau ms., Djordjos (1) prểre Abou 'l.Mofaddhel et petit-fils d'Amin al-Molk, a acheve son trarail l'an des martyrs 1067 , on de l'hégire 754 , dates qui correspondent à l'an 1353 de J. C. Au-dlessus des noms propres qui se présentent daus lo texte de ce volume, on trouve leur transcription en caraclères coptes. Les marges nous offrent un assez grand nombre de notes en écriture $t a^{\complement} / h k$, indiquant les variantes du texte hébreu et la signification de certains mots. Une de ces notes, inserite sur le fol. 224 , porte nn long passage qui ne se trouvait pas dans le volume dont celui-ci est la copie, et que le copiste avait rencontré dans le texte des Septante et dans l'hébreu. Une autre note, inserite sur le dernier feuillet, nous apprend que le texte de ce ms. a été collationné avec les textes grec, hébreu et copte. Les deux premiers feuillets sont couverts d'arabesques très-bien exécutées en or et en couleurs, selon le goût arabe. Les cncadrements des deux 
premières pages de chaque livre du texte sont richement ornés et portent deux lignes d'écriture en caractères coufiques, que nous lisons ainsi :

Fol. $2 v^{\circ}$ et 3 :

$$
\begin{aligned}
& \text { بحو تورأة موسى النبى الني } \\
& \text { عليه السلام السفر الاول }
\end{aligned}
$$

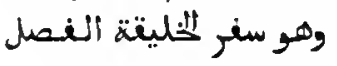

$$
\begin{aligned}
& \text { الاول مه السفو الاول }
\end{aligned}
$$

Fol. 71 r et $^{\circ}$ :

$$
\begin{aligned}
& \text { السفر الثنان وهو سنر }
\end{aligned}
$$

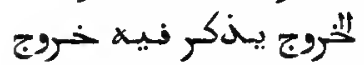

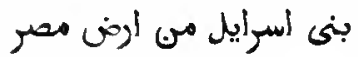

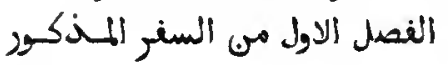

Fol. $132 v^{\circ}$ et 133 :

$$
\begin{aligned}
& \text { السفر الثالث وهو سنى اللاوييى يخكر }
\end{aligned}
$$

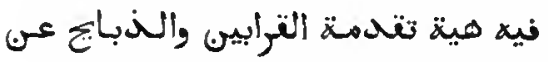

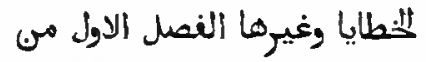

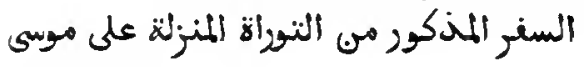

Fol. $176 v^{\circ}$ et 177 :

$$
\begin{aligned}
& \text { السفر الرابع وهوسفر العهدد } \\
& \text { يذكر فيه أسماء بنى أسرايل }
\end{aligned}
$$

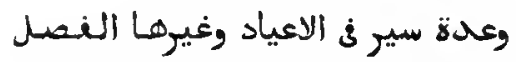

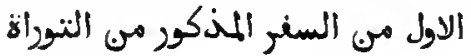

Fol. $2371^{\circ}$ et 238 :

$$
\begin{aligned}
& \text { السفر لثامس وهو سفر المثناة يكحدر (sic) }
\end{aligned}
$$

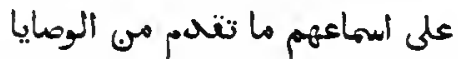

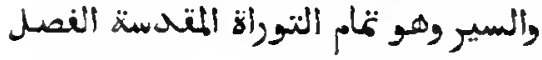

$$
\begin{aligned}
& \text { الاول مى السفر المذكور مى النوراتة }
\end{aligned}
$$

On lit à la fin du volume les inseriptions suivantes:

Fol. 289 et 290 :

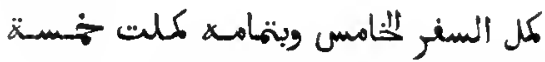

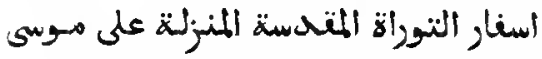

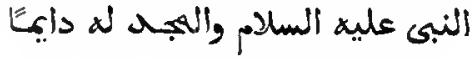

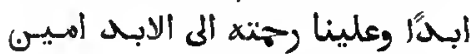

Papier. 290 feuillets. Hauteur, 38 centimètres et demi; largeur, 37 centimètres. 13 lignes par page. - (Supplément 3 bis.)

\section{3.}

Le Pentateuque, traduit sur la version des Septante par al-Hiàrith ben Sinân ben Senbât (ســاطL). (Voyez fol. 200.) Le prenier feuillet du ms. manque; les quatre dernjers sont d'une écriture moderne.

Papier. 245 feuillets. Hauteur, 25 centimèłres; largeur, 18 centimètres. 16 à 17 lignes par page. $x v^{\circ}$ siècle. - (Ancien fonds 10 , Colbert 4980 .)

\section{4.}

Le Pentateuque, traduit sụr la version des Septante par al-ḷânith ben Sinân (voyez le feuillet $85 \mathrm{v}^{\circ}$ ), traducteur qui vivait vers la fin du $x^{e}{ }^{e}$ siècle.

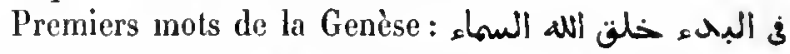

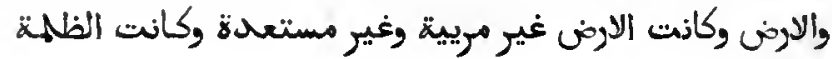
على الغتق والغ ونات

Papier. 307 feuillets. Hanteur, 25 centimètres; largeur, 17 centimètres. s 4 à \& 5 lignes par page. - ( 1 acien fonds 5.$)$

\section{5.}

Le Pentateuque, traduit sur la rersion des Septante. Les sept premiers feuillets et les deux derniers sont d'une écriture moderne. Une note en arabe, inserite sur le dernier feuillet, nous apprend que ce ms. arait été relié l'an du monde 7087 ( 1569 de J. C.). Les feuillets de garde, tant du commencement que de la fin, ont appartenu à un volume imprimé qui renfermait un eucologe en langue grecque.

Premiers mots de la Genèse : خَ البدء خلفن الله السماء

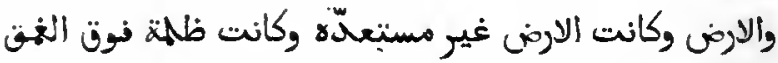

Papier. 3 so feuillels. Hauteur, 20 centimètres; largeur, 14 centimètres. 14 lignes par page. Les feuillets ajoutés après coup portent 16 ou 17 lignes. - (Ancien fonds 11.)

\section{6.}

Le Pentateuque. Les ringt premiers feuillets de ce ms. sont d'une ćcriture plus réeente que les autres. Les six dernières pages contiennent des règles pour calculer les fêtes de l'année. Ce fut l'an 954 de l'ère des martyrs ( $1238-1239$ de J. C.) que le copiste termina son travail. 
On remarque sur les pages de ce volume un grand nombre de notes marginales, ajoutées après coup.

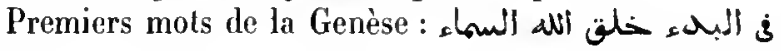

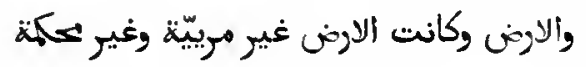

Papier. 239 feuillets. Jlanteur, 25 centimetres; largeur, 17 centimètres. 19 liģnes par paye. - (Ancien fonds $5 \mathrm{~A}$.)

\section{7.}

Le Pentateuque, traduit sur la pechito, écrit sur deux colonnes. Le copiste a inséré dans le texte un grand nombre de gloses et de commentaires, empruntés aux ouvrages d'Éplrem le Syrien, de S. Jean Chrysostome, de S. Basile, de S. Hippolyte, de Jacques d'Édesse, de Jacques de Seroudj et de Denys Barsalibi. A la suite du Deutéronome se trouve encore un long commentaire sur le Lévitique. Deux feuillets, qui paraissent appartenir à ce commentaire, sont collés sur l'intérien de la couverture. Le copiste de ce beau ms. a achevé son travail l'an ${ }^{3} 377$ de l'ère des martyrs ( 1661 de J. C. .).

Premiers mots de la Genèse :

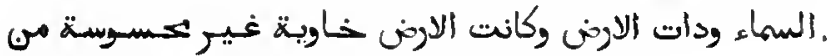

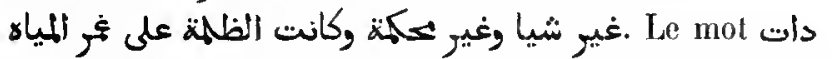
ou is est employé pour représenter le préfixe hélureu - $n$ s et le syriaque $\mathbf{s}$, qui servent à marquer l'accusatif des noms déterminés.

Papier. 398 feuillets. JJauteur, 30 centimètres; largeur, so centimètres. 15 lignes par page. - (Ancien fonds 6.)

\section{8.}

La Genèse, accompagnée d'un commentaire. Celte version, dans laquelle est intercalé un commentaire assez étendu, est faite sur la version pechito. Elle est divisée en leçons et paraît avoir été destinée à l'usage de l'Éğlise copte. Nous ne connaissons pas le nom de l'autenr, cai nous croyons ne devoir tenir aucun compte du renseignement fourni par le titre inserit sur le recto du premier feuillet et qui porte ces mots : كتناب المغ ألاول مبر المتسورة لإن بـركات اللمعتبــ. Il s'agit ici, sans doute, d'un médecin de Baggdad, appelé Abou 'L-Barakàt Hibat-Allah, qui vivait vers la fin du $\mathrm{vl}^{e}$ siècle de l'hégire, et qui abandonna la religion clırétienne pour embrasser l'islamisme. Il a composé plusicurs ouvrages, dont un porte le

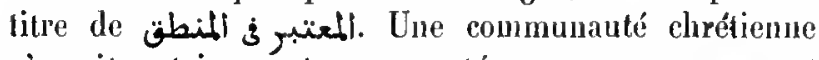
n'aurait certainement pas accepté un ourrage provenant d'un apostat. Cette traduction n'est pas non plus celle d'Abou-Sa id, à qui le copiste du ms. $\mathrm{n}^{\circ} 5$ donne à tort le prénom d'Abou'l-Barakât. Les premiers feuillets de ce volume et les derniers, au nombre de plus de trente, sont d'une écriture plus moderne que le corps de l'ouvrage.

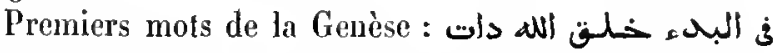
السماء وداتت ألاون وكانت الاورن غير منظوره وغير مسسعده

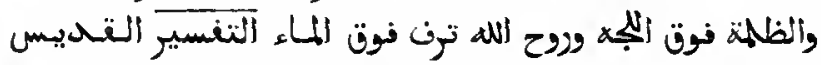

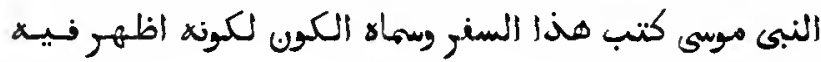
كون

Papier. 352 feuillets. Hauteur, a 4 centimètres; largeur, 15 centimètres et demi. 15 à , 6 lignes par page. xiv siècle. - (Ancien fonds 7.)

\section{9 .}

La Genèse avec un commentiure. Le texte el le commentaire sont les mémes que ceux du numéro précédent. L'écriture paraît être du $x^{\circ} i^{\circ}$ siècle.

Papier. 454 feuillets. Hauteur, so centimètres; largeur, 15 centimètres et demi. 13 lignes par page. - (Ancien fonds 31.)

\section{0.}

La Genèse, accompagnée d'un commentaire. Celte version et les gloses qui y sont intercalées sont les mènes que celles des deux numéros précédents. Le ms. est dafé de l'an 1306 de l'ère des martyrs ( 1590 de J. C. ).

Papier. 156 feuillets. Hauteur, 30 centimètres; largeur, 17 centimètres et demi. 25 lignes par page. - (Ancien fonds 8. )

\section{1.}

La Genèse, divisée en lecons et accompagnée de gloses. Cette version parait avoir été faite sur la pechito et collationnée avec la version des Septante. La copie est de l'an 1313 de l'ère copte ( 1597 de J. C.).

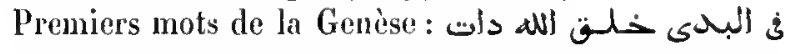

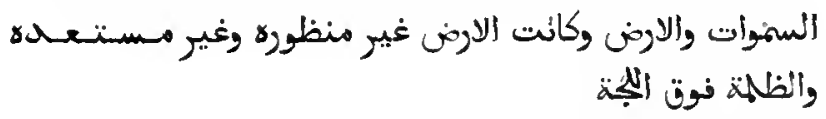

Papier. 177 feuillets. Hauteur, 28 centimètres et demi; largeur, 19 centimètres et demi. 2 , lignes par page. - (Supptément 6.) 
22.

Les Lirres de Josué, des Juges et des Rois. Beau nus., écrit l'an 1060 des martyrs (1344 de J. C.). (Voyez fol. 27.) Plusieurs fenillets du volume qui s'étaient perdus ont été remplacés par d'autres, l'an 1288 des martyrs ( 157 1 de J. C. .).

Premiers mols du Livre de Josué : مى بعد وفاة مسوسى

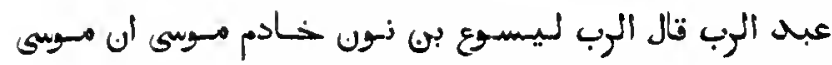

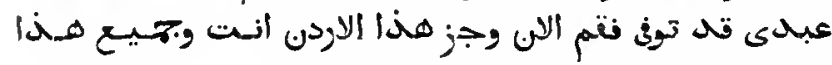

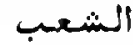

Papier. 194 feuillets. Hauteur, 35 centimètres; largenr, 17 centimètres. 20 à 22 lignes par page. - (Supplément 8, $\mathrm{S}^{\mathrm{t}}$-Germain 10.)

\section{3.}

Le Livre de Josué et les autres livres historiques de l'Ancien Teslament, à l'exception du Lirre d'Esdras. Beau ms. du $x r^{\circ}$ sièele, mais incomplet à la fin, à partir du

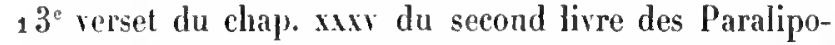
mènes. Un feuillet, ajouté plus tard pour dissimuler celte lacune, renferme quelques lignes d'un commentaire sur Je Lirre de Job.

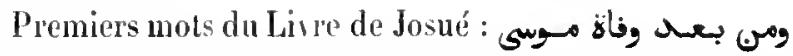

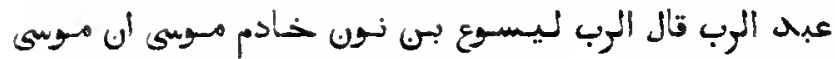

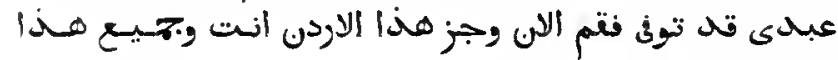

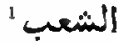

Papier. 188 fenillets. Hanteur, 33 centimètres et demi; largeur, 25 centimètres. 23 à 26 lignes par page. - (Supplément 7 , St-Germain 9 .)

\section{4.}

Les deux Lirres des Paralipomènes. On remarque, entre les feuillets 38 et 39 , une lacune qui s'étend depuis le chapitre xxıx, 3 , du premier live, jusqu'au chapitre xin, 3, du deuxième livre.

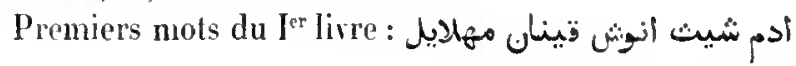

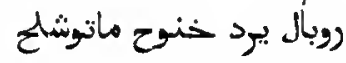

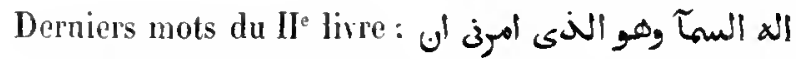

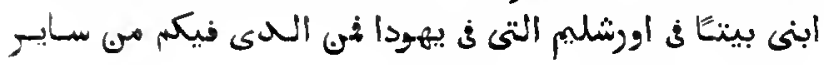

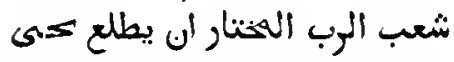

Papier. 68 feuillets. Hauteur, 25 centimètres; largeur, 17 centimètres. 17 lignes par page. — (Supplément $9, S^{\prime}$-Germain 11.)

\section{5.}

Les Livres prophétiques. Ce ms., écrit l'an $99^{4}$ de l'hégire ( 1585 de J. G.), renferme les Livres disaïe, de Jérémie, d'Ézéchiel, de Daniel, et des douze petits prophètes.

Papier. 256 feuillets. Hauteur, 30 centimètres et demi; largeur, 21 centimètres. 19 lignes par page. - (Supplément 22, S'-Germain 12.)

\section{6.}

$1^{\circ}$ Psautier melkite.

2 ' (Fol. 118.) Les Cantiques de la Bible.

Papier. 129 feuillets. Hauteur, 18 centimètres et demi; Jargeur, 3 centimètres et demi. 12 lignes par page. Manuscrit mutilé au commencement et à la fin. 11 est daté de l'an 6900 de l'ère d'Adam ( 1400 de J. C.). - (Supplément 1965 bis.)

\section{7.}

Psautier, à l'usage de l'Église melkite. Ce volume renferme les cent einquante et un psaumes, divisés en sept parties, pour les ollices du matin ( thisma. Viennent ensuite les dix Canliques et l'office de la sainte Vierge.

Quelques feuillets de ce ms. sont très-endommagés par l'usirge; ceux du commencement et de la fin ont été remplacés par d'autres d'une écriture plus inoderne.

1'apier. 86 feuillets. Hauteur, 17 centimètres et demi; largeur, 12 centimètres et demi. 12 lignes par page. $x v^{\mathrm{E}}$ siècle. - (Supplément 12.)

\section{8.}

$1^{\circ}$ Les Psaumes de Darid, au nombre de cent cillquante et un. Ils sont divisés, selon l'usage de l'Église

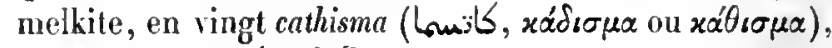
et les doxa (دكا, $\delta 6 \xi_{\alpha}$ ) y sont indiqués. Par le doxa, on entend la récitation du Gloria patri.

$2^{\circ}$ (Fol. $107 \mathrm{Y}^{\circ}$ ) Les cantiques de l'Ancien Testament.

$3^{\circ}$ (Fol. 119.) Prières pour chaque jour de la semaine.

$41^{\circ}$ (Fol. 130.) Prières du soir.

$5 \circ$ (Fol. 137.) Derniers conseils (وصيتة) adressés par Sałomon à son fils.

' Le texte tout entier est conforme à celui du ms. précédent. H. Z. 
$6^{\circ}$ (Fol. $1391^{\circ}$.) Prières pour chaque jour de la semaine.

$7^{\circ}$ (Fol. 14 v $^{\circ}$.) Prière de S. Jean Chrysostome.

$8^{\circ}$ (Fol. $142 \mathrm{r}^{\circ}$.) Prières de S. Jean Damasène.

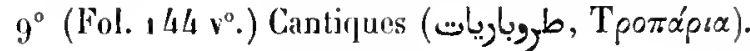

$10^{\circ}$ (Fol. 147.) Poëme qui rime en ب, et qui a pour sujet le renoncement aux biens de ce monde.

$11^{\circ}$ (Fol. $\left.148 r^{\circ}.\right)$ Derniers couseils adressés par Loymân le sagè à son fils.

$12^{\circ}$ (Fol. 153.) Vepres.

$13^{\circ}$ (Fol. 161.) Calendrier des fütes de l'annóe.

Les feuillets de garde, à la fiu du volume, sont converts de notes nécrologiques, de recettes médicales, eic., écrites de direrses mains et n'ayant aucme importance.

Papier. 171 feuillets. Hauteur, 21 centimètres; largeur, 15 contimètres. 15 à 21 lignes par pagre. Ms. écrit à Tripoli de Syrie et daté de l'an 945 de l'hépire $(1538-1539)$. - (Ancien fonds 15.)

\section{9 .}

Psautier melkite. Une main curopéenne y a riouté un essai de traduction interlinéaire en latin. Les rent cinquante et un psaumes sont divisés en sept sections ef en vingt cathisma, avec l'indication des doxa. A la suite des Psaumes, viennent les dix Cantiques, accompagnés d'une traduction latine.

Ce ms. a élé exécuté en 982 de l'hégire ( 157 h de J. C.), par Naçr-Mlah lbn-Yọınna, de T'ripoli.

Papier. 141 feuillets. IIauteur, 18 centimètres; largeur, 13 rentimètres. - (Ancien fonds 19 , Colbert 6186.$)$

\section{0 .}

Psautier melkite. Ce petil volume, très-bien écril et portant la date de 7083 de l'ère du monde ( 1575 de J. C. ), renferme les Psaumes et tes dix Canliques. Les P'saumes sont divisés en sept matimées ( jours de la semaine, et en vingt cathisma. Le cent cingunte ot unième psamme porte le titre suivant:

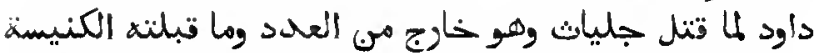
( Ce psaume, qui a élé récilé par David lors- qu'il eut tué Goliath, est exclu du nombre (des psaumes qui sont recus). L'Église ne l'a pas accepté, parce qu'il sent la vaine gloire. $n$

Papier. 171 feuillets. Ilauteur, 13 centimètres; largeur, 9 rentimètres. 13 lignes par page. - (Ancien fonds 17.)

\section{1.}

Psautier melkite, très-bien écrit; chaque page du texte est entourée d'un encadrement en or. Le ms. est daté de l'an du monde 7083 ( 1575 de J. C. ). Les eing premiers feuillets sont d'une écriture plus moderne; les derniers feuillets ont disparu. II renferme les cent cinquante psaumes, les dix Cantiques, un cantique composé par Mar-Élie, métropolitain de Nisibe, et une prière ou litanie qui comيا مب خلق السماوات والاون بكشينه : mence par ces mots

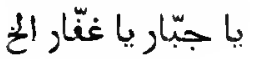

Les psaumes sont divisés en cathisma avec doxa.

Commencennent du liuitiome psaume : إبها ألرب ربـنـا

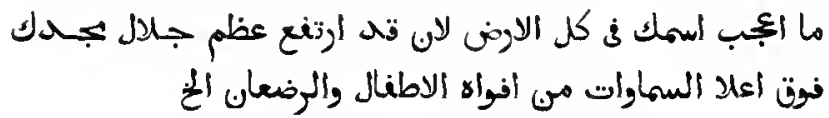

Papier. 140 feuillets. Ilauteur, 17 centimètres et demi; largeur, 10 centinètres et demi. 13 lignes par page. - (Supplément 17.)

\section{2 .}

Psautier, à l'nsage de l'Église melkite. Ce ms., daté de l'an 7101 de l'ère du monde ( 1593 de J. C.), renlérme d'abord les cent cinquante et un psaumes, divisés en sept 5 pour les offices du matiu, et en vingt cathisma; puis les dix Cintiques.

Papier. 175 feuillets. Hauteur, 21 centimètres; largeur, $1 j$ centimètres. 13 lignes par page. - (Suppléinent 13.)

\section{3.}

Psautier melkite, apporté de likile de Chypre. Il est assez mal écrit et incomplet, tant au commencement qu'à la fin. Les psaumes sont divisés en cathisma.

Papier. 109 feuillets. Hauteur, 20 centimètres; largeur, 14 centimètres. 12 à 15 tignes par page. - (Ancien fonds 16 , Colbert 6011.) 


\section{4.}

Psautier, à l'usage de l'Église melkite. Ce volume, très-bien écrit et dalé de l'an $7^{162}$ de l'ère mondaine (1654 de J. C.), renferme les psaumes, dirisés en matinées (سكر), et en cathisma avec doxa; puis viennent lès dix Cantiques.

Papier. 208 feuillets. Hauteur, 15 centimètres el demi; largeur, 10 centimètres et demi. 11 lignes par page. - (Supplément $15, \mathrm{~S}^{\mathrm{t}}$ Germain 515.)

\section{5.}

Psautier melkite, renfermanl les cent cinquante psaumes et les dix Cantiques. 11 est bien écrit et porle la date de l'an 7177 de l'ère mondaine ( 1669 de J. C.). Les psaumes sont divisés en sept parties pour les offices du matiu; les doxa y sont marqués.

Papier. 154 feuillets. llauteur, 15 centimètres; largeur, 10 centinètres et demi. 13 lignes par page. - (Supptément 16.)

\section{6.}

Psautier melkite, renfermant les Psaumes, divisés en seph $\mathbf{~ ( m a t i n e ́ e s ~ o u ~ o f f i c e s ~ p o u r ~ l e s ~ j o u r s ~ d e ~ l a ~ s e m a i n e ) , ~}$ et en vingl cathisma. Le nombre des psaumes est de cent cinquante, mais à ta suite du dernier se troure un acte de contrition, suivi d'une prière adressée à Dieu et d'une in ocation à la sainte Vierge. Les treize dernières pages renferment les dix Cantiques de l'Ancien et du Nouveau Testament.

Papier. 8 a feuillets. Hauteur, 22 centimètres; largeur, 16 centinuètres. 7 lignes par page. xr11 siècle. - (Ancien fonds $16 \mathrm{~A}$.)

\section{7.}

Psautier melkite, renfermant les Psaumes, au nombre de cent cinquante et un, divisés en sept parties, pour les offices des jours de la semaine, et les dix Cantiques.

Volume de 188 feuillets. Hanteur, 15 centimètres; largeur, 10 centimètres. 3 tignes par page. xrı' siècle. - (Ancien fonds so, Colbert 6513.$)$

\section{8.}

Psaulier melkite, renfermant les Psaumes, au nombre de cent cinquante et un, divisés en cathisma, accompagnés de doxa. Ensuite viennent les dix Cantiques.

Papier. 77 feuillets. Hauteur, 23 centimètres; largeur, 17 centimètres. 17 lignes par page. xril' siècle. - (Supplément 10.)

\section{9.}

Psautier melkite, renfermant :

$1^{\circ}$ Les cent cinquante et un Psaumes, divisés en sejt matinées.

$2^{\circ}$ Les dix Cantiques de l'Ancieu et du Noureau Testamient.

$3^{\circ}$ Prières et litanies de la sainte Vierge.

Papier. 216 feuillets. Hauteur,, 5 centimètres; largenr, 11 centimetres. 11 lignes par page. $x^{2}$ min $^{\circ}$ siècle. - (Ancien fonds 18.)

\section{0.}

Le Psautier, à l'usage de l'Église copte. Ce ms., écrit l'an 1009 de l'ère des martyrs (1294 de J. C.), offre un grand nombre de lacunes, qu'une main peu habile a essayé de combler. Il renferme :

$1^{\circ}$ Un traité sur les prédictions que renferment les psaumes, au sujet de Notre-Seigneur, et sur la classification des psaumes. L'auteur de cet écrit a pris pour base de son travail le traité composé par le schaikh AlMakìn (النشيخ المكيی), qui, après avoir embrassé la vie monastique, reçut le titre de Révérend Père Siméon le Reclus (الاب التحيس سمعان للمبيس).

$2^{\circ}$ Un passage où S. Jean Chrysostome parle de la tecture des saintes écriturés, et un autre contenant des réflexions morales.

$3^{\circ}$ Sur ta division des psaumes en cinq classes.

$4^{\circ}$ Dates et indications historiques se rapportant à t'histoire du monde et aux patriarches, par S. Épiphane, érêque de Chypre.

$5^{\circ}$ Exhortation, par S. Grégoire.

$6^{\circ}$ (Fol. $24 v^{\circ}$.) Les Psaumes de David, y compris le cent cinquante et unième, accompagnés de quelques notes marginales.

$7^{\circ}$ Les sept prières que le chrétien est tenu de réciter chaque jour. 
$8^{\circ}$ Les Cantiques de l'Ancien et du Nouveau Testament.

$9^{\circ}$ Le symbole de Nicée.

Premier verset du premier psaume : طوبا للوجل الني

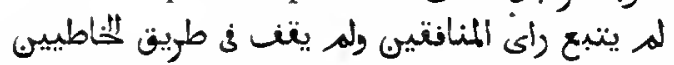

Papier. 240 feuillets. Hauteur, 17 centimètres; largeur, 11 centimètres et demi. 1 lignes par page. - (Ancien fonds 14.)

\section{1.}

Ge volume commence par une introduction, attribuée au prêtre Abou '1-Faradj 'Abd Allah Jhu al-Ṭyyib, et remplissant quatorze pages. L'auteur de cet écrit traite du caractère des Psaumes, de leur classification, des diverses voies d'inspiration par lesquelles David les avait reçus, etc. Le texte de ce traité offre des lacunes, surtout vers la fin. Il est suivi d'un second traité de fuarante pages consacré au même sujet, qui présente un abrégé des doctrines énoncées sur ces malières par $\mathrm{S}$. Athanase, patriarche de la chaire apostolique d'Alexandrie, et par d'autres docteurs de l'Église. Ce traité a pour auteur Semcàu ben Kalil. Ensuite vient la version des Psaumes, accompagnée d'un grand nombre de notes marginales, dont plusieurs donnent les variantes obtenues jar la collation de la version grecque avec la version copte. Le psaume cu se trouve dans ce ms. Les douze demiers feuillets renferment les Cantiques de l'Ancien et du Nourean Testament. Ce ms. paraît être du commencenient du $x^{\circ}{ }^{\circ}$ siècle. Un certain nombre de feuillets ont été remplacés par d'autres d'une écriture assez moderne.

طوبا للوجل النذى : Commencenent du premier psaume

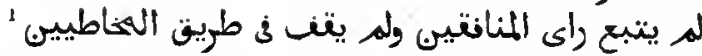

Papier. 139 feuiltets. Hauteur, 20 centimètres; Jargeur, 14 centimètres. 15 lignes par poge. — (Ancien fonds 13.)

\section{2.}

Ce volume, écrit l'an 1149 des martyrs (1433 deJ. C.), renfermic :

$1^{\circ}$ L'exhortation de S. Grégoire.

$2^{\circ}$ Les Psaumes, au nombre de cent cinquante et un.

$3^{\circ}$ Les dix Cantiques et quelques prières.
On lit à la fin du ms. une note singulière dont voici le texte el la traduction:

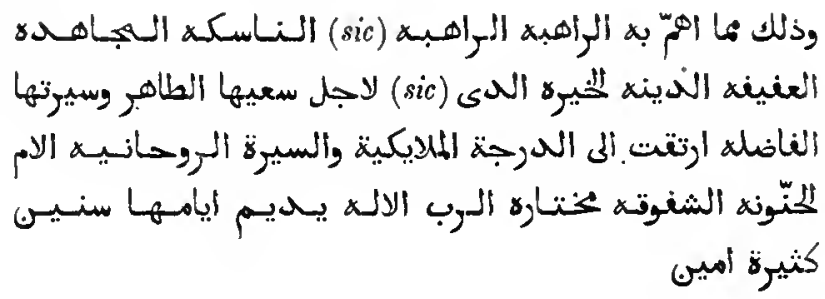

(Écrit) selon le désir de la religicuse, dévote et vaillante dans la lutte spirituelle, de la femme chaste, pieuse et vertucuse qui, à cause de sa conduite pure et excellente, se trouve élevée au degré angélique et aux bauteurs de la vie spirituelle; de la mère pleine de compassion et d'indulgence, l'élue du Seigneur. Que Dieu prolonge ses jours pendant beaucoup d'années!r

Papier. $33_{1}$ feuittets. Hauleur, 17 centimètres et demi; targeur, 13 centimèlres. 1 lignes par page. - (Supplément 14.)

\section{3.}

Ce volume commence par une introduction, dans laquelle l'auteur énmmère les passages des Paumes qui prédisent la naissance, la mort et la résurrection de JésusChrist. Il indique ensuite par leurs numéros les psaumes composés par David, et ceux dont les anteurs sont Assaf, Zacharie, Haggée, Nathan et les fils de Coré. Il marque aussi la division du psautier en cinq sections (نصـول).

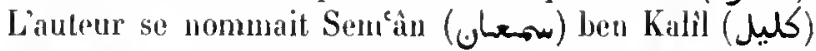
ben Mlaqàra (s, olo), et portait le surnom de Moine rechs

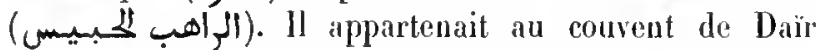
Yohannès, dans lo désert de Scété, où il avait lait pro-

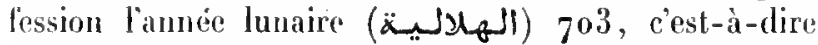
l'an 703 de l'légire, année qui corresprondait à l'an 1303 de l'ère clirétienne. Ce religieux avait composé deux كناب روضة : autres ourrages, dont l'un portait le titre de كناب ووضن Jardin du solitaire et la consolation de l'anachorèter; l'autre était un commentaire sur l'Évangile de S. Matthieu. (Voyez fol. $20 v^{\circ}$ de ce ms.)

A la suite de l'Introduclion se trouve une exhortation, composée par S. Grégoire le Théologien, évêque de Nazianze. Les psaumes, au nombre de cent cinquante et un, riennent ensuite; puis les Cantiques, la Prière dominicale et le Symbole de Nicée.

\footnotetext{
${ }^{1}$ Ce verset est à peu près le mème que le premier verset du psautier contenu dans le ms. 40; mais it y a d'assez nombreuses différences entre tes deux textes. H. Z.
}

Max. oriextalX. - Il. 
Ce manuscrit parait êre du $\mathrm{uv}^{\mathrm{e}}$ siècle. Les premiers lenillets et les derniers sont d'me main plus moderne.

Papier. 234 feuillets. ffanteur, 18 centimètres; largeur, 12 centimètres. 11 lignes par page. - (Supplément 11, St-Germain 23\%.)

\section{4.}

Les Psammes. Ce ins., paginé avec des chiffies coptes, porte la date de l'an 1352 des martyrs (1634-1635 de J. C.). Chaque psaume est précédé d'une note indiquant les vertus miraculeuses qu'il feit paraître lorsqu'on le lit arec une certaine intention ou quon le porte sur soi romme un talisman. Parmi les notes et chiffres ajoutés après coup sur les feuillets de garde, il y a une note cécite certainement par un musulman, et indiquant la manière de composer et d'employer un talisman très-utile. Ce volume renferme cent cinquante psanmes. Le premier psimme commence ainsi :

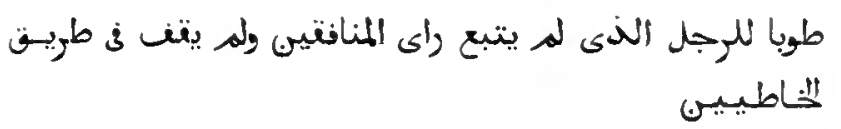

Papier. 182 feuiltets. Hauleur, 15 centimètres el demi; largeur, 11 centimètres. 14 lignes par page. - (Ancien fonds 19 A.)

\section{5.}

Les Psanmes, suivis des Cantiques de l'Ancien Testament, le tout écrit par un Européen.

طوبق للوجل النَى : Premier verset du premier psaume

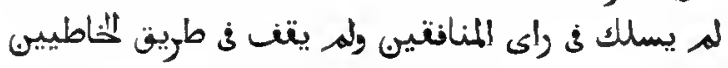

Ce texte est celni de l'Église copte.

Papier. 91 fenillets. Hanteur, 30 centimètres; largeur, 20 centi. mètres. 23 lighnes par page. $\times \mathbf{v} 11^{\circ}$ siècle. - (Ancien fonds 9.)

\section{6.}

Psantier.

Papier. 70 feuillets. Hauteur, 18 centimètres; largeur, 14 centimétres. 18 liggnes par page. xvil siècle. - (Supplément 2370. )

\section{7.}

Psaulier écrit l'an $\mathbf{1 6 9 0}$ de J. C. pour les jésuites do la mission du Gaire. C'est une copie du texte publié par la Congrégalion de la Propagande.

Papier. 151 fenillets. Ilauteur, 15 centimètres; largeur, 10 centimètres. 15 lignes par page. - (Ancien fonds $20 \mathrm{~A}$.)

\section{8.}

Psautier écrit l'an 1784 de J. C., divisé en sept parties; les versets sont séparés et numérotés. Les cent cinquante et un psaumes sont suivis des dix Cantiques.

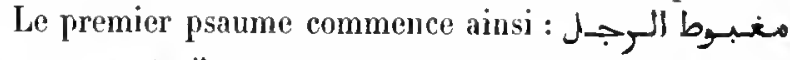

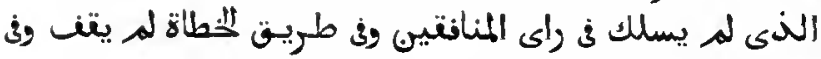

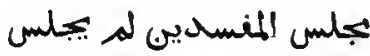

On roit que cette version differe de la version recue dans l'Église melkite et dans l'Église copte. Le copiste, Djordjis Mikhaïl, était maître d'école (مودب) au Caaire.

Papier. 187 feuillets. flauteur, 16 centimètres; largeur, 11 centimèlres. 15 lignes par page. - (Supplément 19.)

\section{9.}

$1^{\circ}$ Les Proverbes de Salomon.

$2^{\circ}$ (Fol. 57.) L'Ecclésiaste.

$3^{\circ}\left(\right.$ Fol. $80 \mathrm{v}^{\circ}$.) Conseils que Loqmân le Sage, étant sur son lit de mort, adressa à son fils.

$4^{\circ}$ (Fol. 83.) Extraits des conseils que Salomon, fils do Donid, adressa ì son fils.

$5^{\circ}$ (Fol. $\left.88 r^{\circ}.\right)$ Un court extrait du discours dans lequel Jésus, fils de Sirach, donna des conseils à son fils.

$6^{\circ}\left(\right.$ Fol. $\left.90 v^{\circ}.\right)$ Discours adressé par le sage Socrate à son fils.

$7^{\circ}$ (Fol. 93.) Recueil de sentences prononcées par les sages et traduites du copte en arabe.

$8^{\circ}$ (Fol. 119.$)$ Récit du voyage de Zosime au séjour des bienheureux.

$9^{\circ}$ (Fol. $142 v^{\circ}$.) Épitre dans laquelle Hermès le Sage adresse des réprimandes à l'àme et l'invite à renoncer aux occupations mondaines.

$10^{\circ}$ (Fol. 204.) Avertissements adressés aux prêtres par Sévère, éếque d'Achmounainn, le même qui, avant d'entrer dans la vie monastique, était connu sous Je nom d'Mou Bischir Ibn al-Moqaffac, le secrétaire égyptien.

$11^{\circ}\left(F_{01} 217 v^{\circ}\right.$.) Histoire de Secundus le philosophe. 
Le ms. parait ètre du $\mathbf{x v}^{\mathbf{e}}$ siècle. Quelques feuillets, au commencement et à la fin, sont d'une écriture moderne.

Papier. 284 feuillets. Hauteur, 18 centimètres; largenr, 13 centimètres. Environ 13 lignes par page. - (Supplément 93, Saint-Germain 231 .)

\section{0.}

Ce manuscrit renferme :

\section{L'Ecclésiastique.}

$2^{\circ}$ (Fol. $41 v^{\circ}$.) La Sagesse de Salomon.

$3^{\circ}$ (Fol. 59.) Une introduction à la Sagesse de Salomon.

$4^{\circ}\left(\right.$ Fol. $\left.60 \mathrm{r}^{\circ}.\right)$ Les Proverbes.

$5^{\circ}$ (Fol. 91.) L'Ecclésiaste.

$6^{\circ}$ (Fol. $100 v^{\circ}$.) Le Cantique des Cantiques.

$7^{\circ}$ (Fol. $105 v^{\circ}$.) L'histoire du roi Salomon et de lia femme de Jésus, fils de Sirach.

Le premier ouvrage, intitulé : «Le livre de Ischou'a ben Schìrâkh, secrétaire de Solaïmân Ibn Dîwoud, roi d'Israël; à Jérusalem $n$, commence par ces mots :

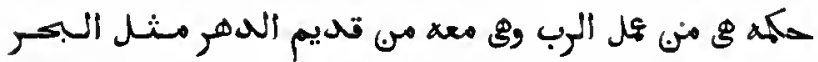

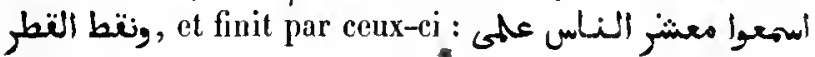

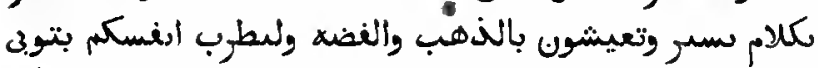

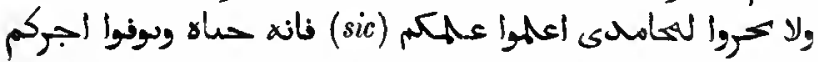

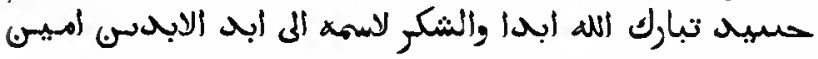

La version de la Sagesse, qui a pour auteur al-Illàritl ben Sinân Ibn Senbât (wiسب), conıne nous l'apjurend le

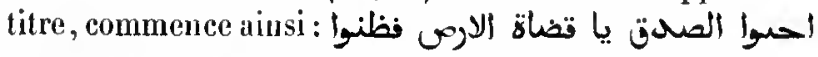
et finit par ces inols :

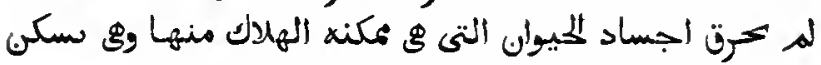

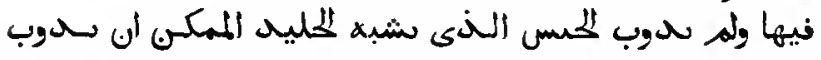

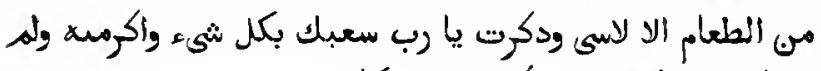

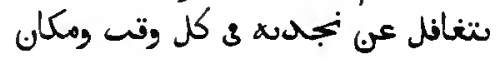

L'iutroduction à la Sagesse de Salomon a probablement été composée par luảritı ben Sinâu. L'auteur y expose les motifs qui portèrent Salomon à donmer un certain parallélisme aux maximes qu'il énonce, et à faire figurer dans ses apologues des animaux et des êtres inanimés, en leur attribuant la faculté de la parole.

Le Livre des Proverbes commence par ces mots : هذه
امثنال سلهان به داود ملك أسرائيل ك-تبهها لمسعـم بها الادب

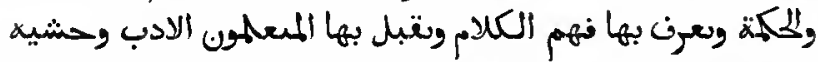

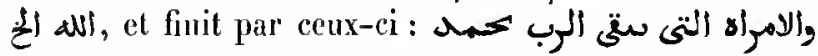

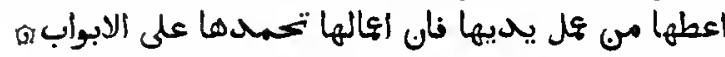

خطب جامع لاككيم ابر : L'Ecclésiaste commence ainsi

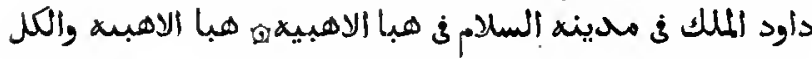

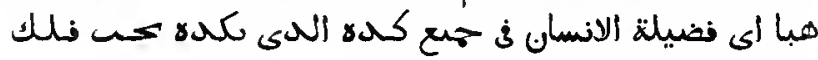

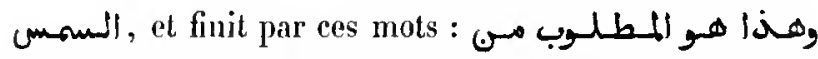

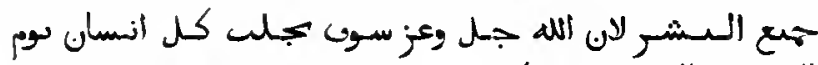

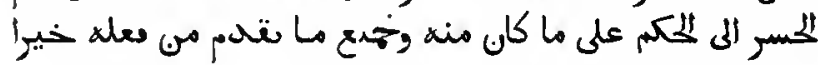

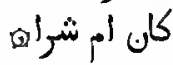

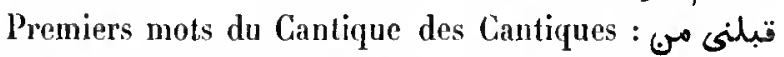

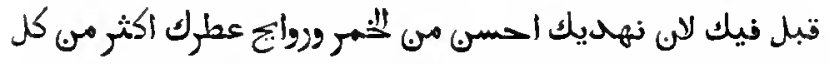

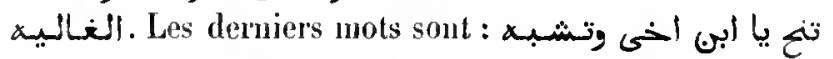

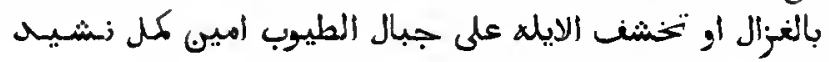

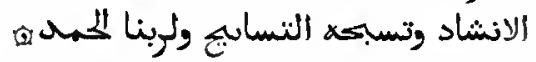

La dernière pièce contenue dans ce volume est intitulée : تصه أمراك يسوع سم شيراخ مع سليمان بر دأود الغكيم. C'est une espèce de ronan, dont le commencement rappelle l'histoire de David et Betlısabée, et qui se ternine par la justification de la femme.

Ce ms. a dủ être écrit vers le commencement du $\mathrm{svl}^{\mathrm{e}}$ siècle; il est tout de la même main, à l'exception des cint derniers feuillets. Lancienne pagination est en chiffres coples.

Papier. 108 feuillets. Hauteur, 20 centimètres; largenr, 13 centimètrez el demi. ${ }_{7} 7$ lignes par page. - (Supplément 2o, SaintGermain 232.)

\section{1.}

Les Évangiles, divisés en leçons, selon l'usage de l'Église copte. Les trois premières pages du ms. sont courertes de notes indiquant des naissances et des décès; ces notes sont du $\mathrm{xvi}^{\circ}$ siècle. Sur le verso du second feuiltet, on roit cind portraits, grossièrement exécutés, et représentant Jésus-Christ et les quatre évangélistes. Ces figures sont entourées d'arabesques dans le goût byzantin. Le troisième feuillet commence par l'évangile de S. Matthieu. Le premier verset du second chapitre (selon la division de la Vulgate) se lit ainsi dius ce ms. : وميلاد

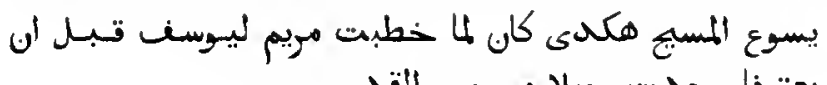

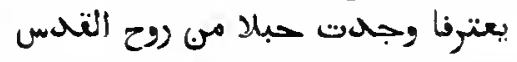

La copie de l'évangile de S. Natthieu a été achevép l'an 1129 de l'ère des martyrs (1413 de J. G.). 
L'évangile de $\mathrm{S}$. Marc est précédé d'une prière se terminant par une note sur $\mathrm{S}$. Narc et une liste de chapitres. A la fin de cet évangile se tronve encore la date de 1129 des martyrs.

L'érangile de S. Luc est précédé d'une courte notice hiographique et d'une liste de chapitres. A la fin de celle liste et sur une parlie de la page laissće en blanc, on a écrit une notice sur le martyre de $\mathrm{S}$. Luc.

L'évangile de $\mathrm{S}$. Jean a aussi son introduction et sa liste de chipitres. Les derniers feuillets sont d'une écriInre plus récente que les autres. Suit un feuillet (f. 226 ) qui contient encore les derniers versets de cet érangile, avec la date de 1037 des mirtyrs, et qui parait aroir appartenu au ms. dont celui-ci est la copie. Sur le verso de ce feuillet, une autre main a inscrit un soi-disant symbole de Nicée, pièce qu'une note de Renandol a eu raison dequalifier d“insielsa et a Nicana longe dissimilis. Sur le verso ¿lu feuillet suivant se trouve one autre pièce, intitulée: Extrait du live d'Esdras, traitant de la sortie de l'ìme du corps\%.

Le feuillel 229 commence par la fin dune phrase; aussi a-t-il dû être précédé d'un autre qui ne s'y trouve plus. Il renferme l'indication du nombre des chapitres contenus dans chaque évangile. Les feuillets suivants contienment une concordance semblable au canou eusébien et l'indication des lecons pour les principales fütes de l'année.

Papier. 243 feuillets. llautcur, 26 centimètres; largeur, 18 centimètres. 14 lignes par page. Ms. du $x^{\circ}$ sièrte. La reliure est de la mème époque; elle est dans le goût arabe et a dñ ètre fort belle. (Supplément 25.)

\section{2.}

Les Érangiles, divisés en lecons pour tous les jours de l'année, et survis de commentaires qui paraissent être de $\mathrm{S}$. Jean Chrysostome. Le premier feuillet et les six derniers sont d'une écriture beaucoup plus moderne que le corps de l'ouvrage. Il en est de même des feuillets numérotés 22, 33 et 24 . Une note en arabe, écrite sur le verso du feuillet 4 , nous apprend que cet exemplaire des Évangiles fut donné à l'église de Saint-Hanania (حنانيا) , a Damas, l'an du monde 7043 (1535 de J. C.).

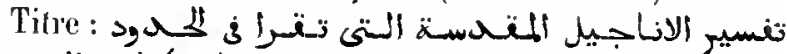
ت Explication des saints Evangiles qu'on lit les jours l'ériés, les sabbats, les fêtes et toute lannéc\%. Le volume commence par les lecons des fêtes mobiles.

Papier. 148 feuillets numérotés en chiffres coptes. Écriture à deux colonnes. Hauteur, 31 centimètres et demi; largeur, 22 centimètres.
28 lignes par page, excepté dans les feuillets qui ont remplacé ceux qui manquaient. - (Supplément a3.)

\section{3.}

Les quatre Évangiles, divisés en lecons et précédés d'un tableau en caractìres syriaques indiquant les leçons de chaque fête de l'année. Les deux feuillets de garde sont en parchemin et ont appartenu à un ms. arménien.

Papier. 220 feuillets. Hauteur, 22 centimètres; largeur, 16 centimètres et demi. 17 liģnes par page. Ce manuscrit a élé rapporté de l'Inde et prarait èrre de la fin du xvi' siècle. - (Supplément 24.)

\section{4.}

Les quatre Évangiles, précédés chacun dune courte notice sur l'auteur et d'une liste des chapilres. En tête du volume se trouve d'abord le Canon harmonique, puis la notice sur S. Matllieu et l'indication des passages de l'Ancien Testament cités dans les Évangiles. Un avertissement, dont l'écriture est la même que celle du corps de l'ourrage, nous apprend que le texte de cet exemplaire a été corrigé au moyen de plusieurs antres mss., les uns syriaques, les autres grees et coptes.

Papier. 222 fenillets. llanteur, 15 centimètres; largeur, 11 centimètres. 13 lignes par page. Ms, datẻ de l'an 1028 de l'hégrire (i619 de J. C.). - (Ancien fonds 27 , Colbert 6528.)

\section{5.}

Les quatre Évangiles, ạvec des commentaires abrégés, ('mpruntés à S. Jean Chrysostone, S. Cyrille, Sérère d'Antioche, Grégoire de Nazianze, Épiphane, Titos et autres docteurs de l'Église. Ms. copié l'an 1336 de l'ère des martyrs ( 1619 de J. C.), sur un autre ms. portant la date de 1005 des inartyrs ( 1288 de J. C ).

Papier. 208 fenillets. llauteur, 20 centimètres; largeur, 15 centimètres. Le nombre des lignes par page varie de ís à 18 . - (Supptément 29, Saiul-Germain $2 / 7$.)

\section{6.}

Les 'quatre Évangiles, précédés d'une notice préliminaire qui renferme l'indication du nombre des chapitres 
contenus dans chaque évangile, une concordauce dans le genre du Canon eusébien, l'indication des passages de l'Ancien Testament qui se trouvent cités dans claque évangile, et une introduction générale à l'évangile de S. Matthieu. Les trois autres évangiles ont clacun une notice du même genre. Une note, de la même écriture que le reste du volume, nous apprend que le texte de ce ms. a été revu et corrigé par l'ćditeur, à l'aide de plusieurs mss., les uns en langue syriaque, les autres en langue grecque (roumiya), et d'autres encore en copte et en arabe. Viennent ensuite quelques exemples de ces corrections.

Papier. 248 fenillets. Hauteur, 19 centimètres et demi; largeur, 14 centimètres et demi. 13 lignes par page. Manuscrit du xvu' siècle. Les o7 ‘̛o sont marqués en chiffres coptes. - (Supplément 27 , SaintGermain $23 \mathrm{~g}$.)

\section{7.}

Les quatre Évangiles. Ce ms., écrit l'an 1362 de l'ère des martyrs ( 1646 de J. C.), commence par une introduction renfermant une concordance semblable au canon d'Eusèbe. Chaque évangile est précérlé d'uu index des chapitres. Les chiffres de la concordance et ceux des marges sont en caractères coptes.

Commencement du second chapitre de S. Matthieu :

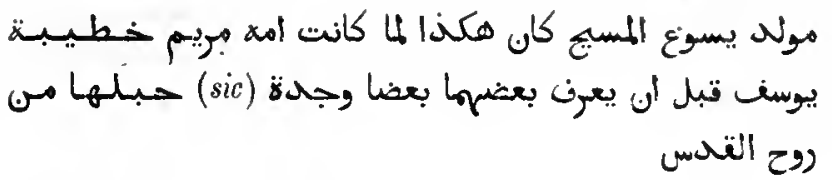

L'évangile de $\mathrm{S}$. Marc commence ainsi :

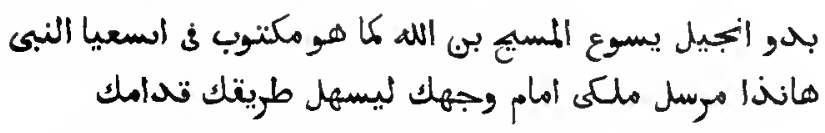

Commencement de S. Luc :

لاجل أن كثيبيث راموأ ترتيب تصص الامسور النى (sic)

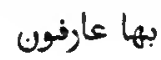

Commencement de l'évangile de S. Jean :

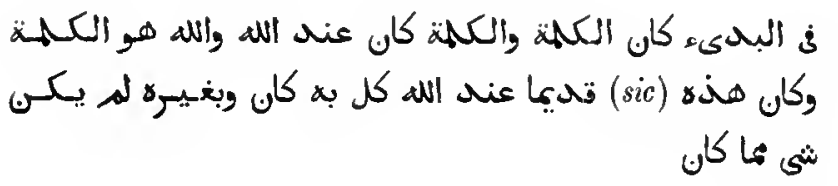

Papier. 250 feuillels. Hauteur, 21 centimètres; largeur, 15 centimètres. 13 lignes par page. - (Ancien fonds 24 A.)

\section{8.}

Les Évangiles. Version dans laquelle l'auteur, Abou 'lMawâhib Yáqoủb Ibn Nacma ( $\ddot{x}_{x \rightarrow}$ ) lbn Petrus alDibsi, grammairien, philologue et professeur, Maronite de nation et natif'd'Alep, essaye de remettre en bean style arabe la traduction vulgaire de cette partie du Nonvean Testament. Il dit, dans la préface, qu'il a adopté pour base de son travail une rersion en prose rimće et cadencée, qu'arait çomposée un métropolitain de Nisibe, appelé 'Abd-Ischoua'. Il nous apprend aussi qu'il a supprimé les rimes et les remplissages dont son devancier s'était servi, et qu'il a terminé sa tâche l'an $\mathbf{1}_{91} 1 \mathrm{deJ}$. C. Chaque évangile est précédé d'une courte introduction, renfermant des réflexions morales. La préface ainsi que les introductions. sont écrites dans un style très-recherché. Les soixante derniers feuillets renferment un glossaire des mots peu usités qui se rencontrent dans la préface et dans la version elle-même. Ce rocabulaire nous offre les mots dans l'ordịe où ils se présentent au lecteur qui parcourt le volume. Nous lisons dans la notice d'Ascari qui se tromve en tête du volume, qu'il n'existe que deux exemplaires de cette version, l'un à la Bibliothéque du Roi et l'autre à Alep.

Voici le commencement du second chapitre de l'érangile de S. Matthieu :

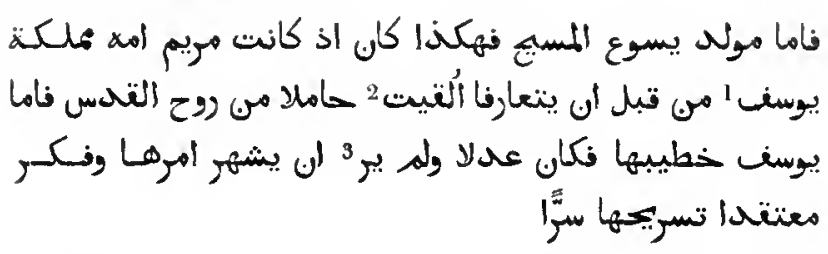

Commencement du premier chapitre de l'évangile de S. Mar'c :

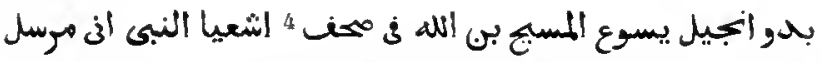

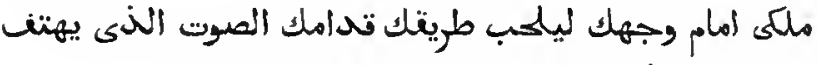

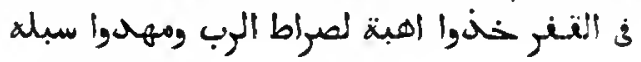

Commencement de l'évangile de S. Luc :

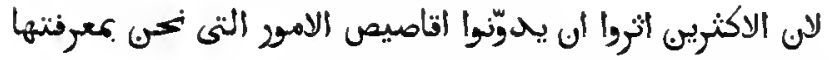

$$
\begin{aligned}
& \text { أولى حسبها اداه الينا الذين. كانوا شاهلمير. }
\end{aligned}
$$

Commencement de l'évangile de S. Jean :

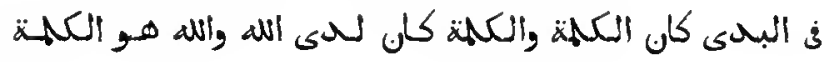

\footnotetext{
1 Le ms. porte بيوسن. H. Z.

'Lisez أنفيت, ainsi que porte le ms. H. Z.
}

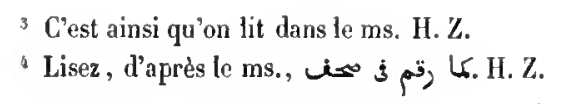




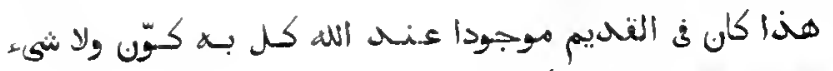
موجود مى دونغ مثا كان.

Papier. 243 feuillets. Hauteur, 20 centimètres el demi; largeur, 14 centimètres et demi. 15 lignes par page. - (Ancien fonds 24 B.)

\section{9 .}

L'évangile de S. Malthieu, rapproché des autres évangiles, et commenté par S. Jean Chrysostome et d'autres Pères de l'Église.

Le premier feuillet de l'ourrage commence par ces mots :

$$
\begin{aligned}
& \text { مر تغسير معانى انجبيل متنى }
\end{aligned}
$$

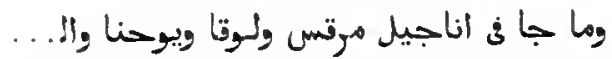

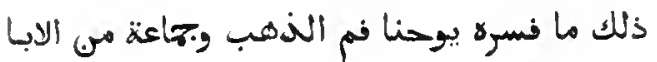

$$
\begin{aligned}
& \text { التحديسين. } \\
& \text { قال أن ألانبيل لفظه يونانية وتفسيرها البشنارة والمعرفها }
\end{aligned}
$$

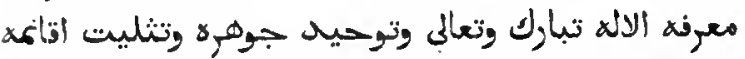

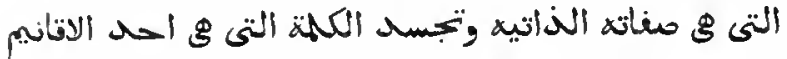

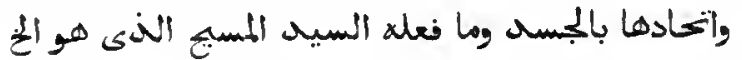

Derrier's mots de l'ourrage :

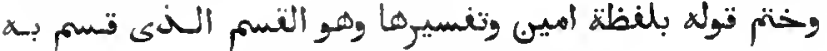

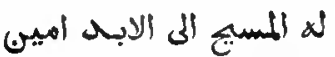

Le ms., très-bien écrit, paraìt être du $x v^{0}$ siècle. Les traits de l'écriture du prenier leuillet, étant devenus trèspailes, ont été rétablis par un scribe ignorant et naladroit.

Papier. 78 feniltets. Hauleur, 24 centimètres et demi; largeur, 16 centimètres et demi. 19 ligues par page. - (Ancien fonds 28.)

\section{0.}

Copie de l'érangile de S. Jean, faite à Paris, l'an 1599 , pall un malif de Harseille, appelé سَوفَيْيُ (Soufin?). Henri IV arait, dil-on, à son serrice, un ralet de pied nommé Honoré Sofeyn.

Papier. gif Fenittets. Hauteur, 17 centimètres; targeur, 11 centimétres. 10 lignes par page. - (Supplément 26 , Jacobins S. Honoré.)

\section{1.}

L'évangile de S. Jean, précédé d une courte biographie de cet évangéliste, et de l'indication des passages de l'Ancien Testament qui se trouvent mentionnés dans son évangile.

Papier. 165 feuillets. Hauteur, 10 centimèlres; largeur, 6 centimètres et demi. 9 lignes par page. Ms. daté de l’an 1665 de J. C. (Ancien fonds $27 \mathrm{~A}$.)

\section{2.}

L'évangile de S. Jean.

Le premier chapitre commence ainsi :

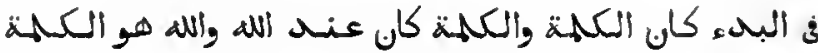

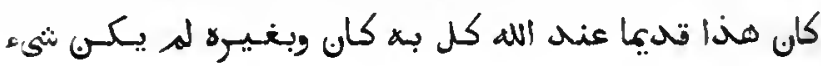
US

Papier. 84 feuillets. Hauteur, 21 centimètres; largeur, 15 centimètres. 10 lignes par page. Ns. du xvi" siècle. - (Ancien fonds 24.)

\section{3.}

Les Ĺpitres et les Actes des Apôtres. Ce ms., très-bien écrit, est une copie faite l'aı 1056 des martyrs (1340 de J. C.), sur un volume écrit l'an 1016 de la même ère ( 1300 de J. C.), et renfermant la traduction d'une version syriaque des Épitres el des Actes. En tête se troure une préface de quatre pages, traitant de la conversion et de la mission de $\mathrm{S}$. Paut. Une seconde préface, traduite apparemment du syriaque, traite de la vie et des épitres de S. Paul, et se termine par une table des passages empruntés par cet apôtre à l'Ancien Teslanent. Suivent les épiltres de S.Paul, de S. Pierre, de S. Jean et de S. Jacques, et les Actes des Apôtres. On trouve, aux folios 1, $100,114,186$ et 187 , quelques passages en copte.

Papier. 188 feuiltets. Hauteur, 25 centimètres et demi; largeur, 16 centimètres el demi. 17 lignes par parge. - (Ancien fonds 21.)

\section{4.}

Les Épitres et les Actes. Ce ms., d'une belle écriture, paraît ètre du $\mathrm{xv}^{\mathrm{e}}$ siècle. Il renferme:

$1^{\circ}$ Une courte notice sur la vie et les écrits de S. Paul.

$2^{\circ}$ Les quatorze Épitres de S. Paul.

$3^{\circ}$ Les Épitres catholiques.

$4^{\circ}$ Les Actes des Apútres. 
On lit au commencement de la quatorzième épitre, celle qui est adressée aux Hébreux, que ce texte, conforıne à la version syriaque, est la quatrième épitre dins la rersion copte saîdique, et la dixième dans la version copte bohaïrite. Les divisions du texte sont marquées, en chilfres coptes, sur les marges de la plupart des leuillets.

Papier, 157 feuillets. Hauteur, 26 centimètres; largeur, 16 centimètres el demi. 19 lignes par page. - (Ancien fonds 22.)

\section{5.}

Les Épîtres de S. Paul, les Épîtres catholiques et les Actes des Apôtres, traduits, comme on l'apprend par une note inscrite au fol. $4 \mathrm{v}^{\circ}$, du syriaque, et précédés d'une courte introduction.

Papier. 247 feuillets. Hauteur, 21 centimètres; largeur, 15 centimètres et denii. 13 lignes par page. Mts. daté de l'an 1330 des martyrs (161/4 de J. C.). - (Supplément 31, Saint-Germain s44.)

\section{6.}

Les Épitres de S. Paul, les Épîtres catholiques el les Actes des Apôtres.

Papier. 297 feuillets. Hauteur, 2 เ cenlimètres et demi; largeur, 15 centimètres. 13 lignes par page. Ms. daté de l'an 1367 de l'ère copte (1641 de J. C.). - (Ancien fonds 25.$)$

\section{7.}

L'Apocalypse, avec un commentaire qui s'étend jusqu'au verset 6 du chapitre $x x$. Rien dans le texte n'indique le nom de l'auteur; nous royons seulement qu'il était partisan des doctrines professées par les Millénaires, et qu'il cite (fol. $19^{6} \mathrm{v}^{\circ}$ ) les opinions de S. Ankolitos (أنقوليطس، أيغوليطسن Hippolytus), pape de Rome (بابا وروية), et de Paul Boûschì, évêque égyptien (بولص (سقف مصر المعرون بالبُوشنى), au sujet du nombre de la Bète. On sait que S. Hippolyte, évêque et martyr, vivait dans le $11^{\mathrm{e}}$ siècle. On a de lui un ourrage intitulé «De Antechristo liber $\%$. On lit sur le premier leuillet que l'auteur de ce commenlaire était S. Jean Chrysostome, indication changée en أنتوليد par celui qui a inscrit sur le recto du même feuillet le titre de l'ouvrage, en l'attribuant, et bien à tort, à Ankolithos. pape de Rome, et à Paul Boûschì, évêque d'Aclımounaïn. Il faut observer que ce feuillet et le suivant sont d'me écrilure beaucoup plus moderne que le corps de l'ouvrage. Il n'y a ni préface, ni introduction. Voici le troisième verset du premier clıapitre (voyez fol. $4 \mathrm{r}^{\circ}$ ), avec le commencement du commentaire :

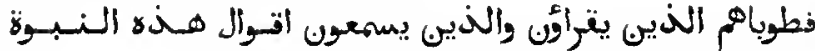

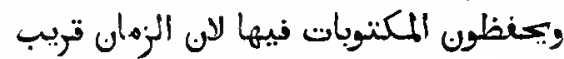

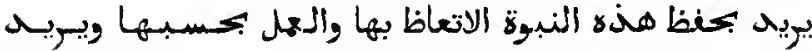

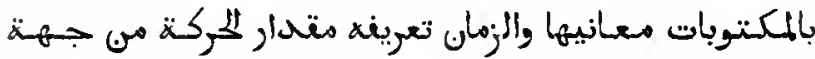

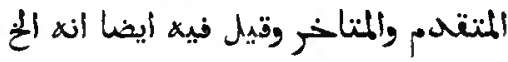

Papier. 312 feuillets. Hauteur, a 3 centimètres el demi; largeur. 18 centimètres. 15 lignes par page. Mts. de la fin da $x v^{e}$ siècle. (Ancien fonds 23 .)

II.

\section{LIVRES APOCRYPIES ET PSEUDÉPIGRAPIIES.}

\section{8.}

$1^{\circ}$ Testament que notre père Adam adressa à son fits Seth.

$2^{0}$ (Fol. 11.) Paraboles tirées d'animaux, d'oiseaux, de plantes, etc, et appliquées à Jésus le Messic et à ses doctrines 1 .

$3^{\circ}$ (Fol. 22.) Extrait d'un discours de S. Jean Chrysostome sur la patience.

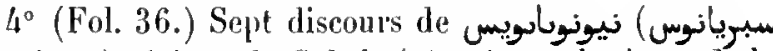
Severiamus), évêque de Gabala (جبلة), sur les jours de la création. (Voyez la "Bibliotheca græeca de Fabricius, éd. de Harless, t. X, p. 508. )

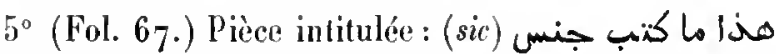

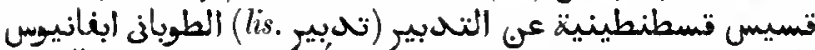
Ecrit de Jean, prêtre de Constantinople, louchant l'éducation du bienheureux Épiplane, évêque de l'ile de Chypre." (Voyez la r Biblioth. græcan, t. VHI, p. 256 , et t. X, p. 223.)

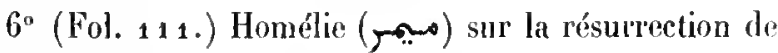
Jésus-Christ.

$7^{\circ}$ (Fol. $3_{1}$.) Réponse à certaines gens qui, dans leur ignorance, avaient demandé quel besoin il y avait de l'In-

\footnotetext{
- Cet ouvrage est une rédaction arabe assez ancienne du Physiologus. H. Z.
} 
carnation, de la Passion el de la Résurrection de JésusChrist.

$8^{\circ}$ (Fol. 133.$)$ Homélie sur la glorieuse Ascension.

$9^{\circ}$ (Fol. 142.) Homélie sur le Paraclète consolateur.

$10^{\circ}$ (Fol. 165.) Homélie sur l'assomption de la sainte Vierge (متختيم: marat Mlaryam).

$11^{\circ}$ (Fol. 182.) Homélie sur le crucifiement.

$12^{\circ}$ (Fol. 205.) Homélie prononcée par S. Théophile (ثاوفيشيس), patriarche d'Alexandrie, sur les saints mystères de la Cène, le jeudi saint.

$13^{\circ}$ (Fol. 212.) Table des matières contenues dans chaque chapitre des quatre érangiles.

$14^{\circ}$ (Fol. 247.) Notice sur la vie de S. Paul. A la fin de ce traité, qui parait aroir été rédigé pour servir d'introduction aux épitres, l'auteur dit que les épitres araient été traduites du syriaque en arabe, et vérifiées sur la rersion copte et sur le texte gree.

$15^{\circ}$ (Fol. 250.) Le dix-huitiène sermon de S. Cyrille (غر) de Jérusitem.

$16^{\circ}$ (Fol. $2 \gamma^{3}$.) Le treizième discours du même docterli.

$17^{\circ}$ (Fol. 296.) Discours intitulé :

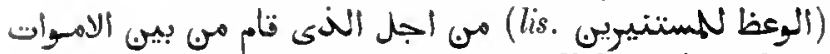
Exhortation adressée à ceux qui recherehent des éclaircissements au sujet de celui qui se leva d'entre les morts et monta au ciel, où il s'assit ì la droite du Père.

$18^{\circ}$ (Fol. 312.) Quinzième discours de S. Cyrille de Jérusalem.

$19^{\circ}$ (Fol. 323.) Seizième discour's dı même.

$20^{\circ}$ (Fol. 340.) Dix-septiène discoms du mène. La fin manque.

Les cinq derniers discours font partie des Catéchèses de S. Cyrille de Jérusalem. (Voyez la Bibliotheca græca de Fabricius, éd. Harless, t. VII, p. 438, 440.)

Ce rolume est écrit en entier de la mème main. Une note inscrite an folio 110 nous apprend que ce ms. a été exécuté l'an 1651 de l'ère d'Alexandre $(1339$ de J. C.).

Papier. 352 fenillets. Itauteur, 25 centimétres; largeur, 17 centimètres. 13 à 17 tignes par page. - (Ancien fonds 52.)

\section{9.}

$1^{\circ}$ Histoire de Joseph, fils de Jacob.

$2^{\circ}$ (Fol. $79 r^{\circ}$.) Discours de S. Jean Chrysostome sur l'Annonciation.

$3^{\circ}$ (Fol. $86 r^{\circ}$.) Histoire de Job.

$4^{\circ}$ (Fol. $9^{8} \mathbf{v}^{\circ}$.) Quelques miracles de la sainte Vierge.

$5^{\circ}$ (Fol. 163.) Récit de ce qui arriva à notre seigneur Aluraham et à sa femme Sarah, lorsqu'ils quittèrent la terre de Canaan pour se rendre en Égypte.

$6^{\circ}$ (Fol. 179.) Miracles opérés par l'archange Michel.

$7^{\circ}$ (Fol. 183.) Prière de Zacharie le prêtre, lors de la naissance de son fils Jean-Baptiste.

$8^{\circ}$ (Fol. 184.) Prière de S. Éphrem le Syrien.

$9^{\circ}$ (Fol. 187.) Prière de Har-Isaac le Syrien.

$10^{\circ}$ (Fol. 191.) Sermon de Paul Boûschì (بولص البوثىى) sur l'Annonciation.

$11^{\circ}$ (Fol. 224.) Sermon sur la mort de Joseph le charpentier, surnommé l'époux de Notre-Dame Marie.

Papier. 243 feuiltets. Hauteur, 17 centimètres; largeur, 13 centimètres. 10 lignes par page. Ns. daté de t'an 1050 des martyrs (1334 de J.C.). - (Supplément $9^{4}$, Saint-Germain 341.)

\section{0 .}

$1^{\circ}$ Histoire des Pères bienheureux, descendants de Youànâdâb (يواناداب), qui s'étaient établis dans la contrée

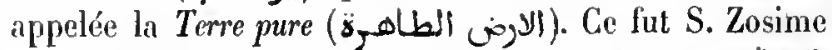
qui, monté sur une autruche, traversa le désert, arriva à un flewre qu'il passa miraculeusement, et trouva une population juive, dont laieul s'était échappé de la captivité de Babylone. Gette légende commence à la dernière page du ms.; la suite se trouve au fol. $1 \mathrm{r}^{\circ}$, et s'arrête au fol. $49 \mathrm{r}^{\circ}$. Il $\mathrm{y}$ a plusieurs lacunes et quelques feuillets ont été interrertis.

$2^{\circ}$ (Fol. 5o.) Histoire du moine Boheïra. Les trois premiers feuillets manquent, et il y a quelques lacunes au milieu du texte.

$3^{\circ}$ (Fol. $126 r^{\circ}$.) Interprétation d'un songe par Sibylle (سبــ), fille d'Héraclius, chef des païens (حنفاء) d'Éphèse. Cent philosophes de la ville de Rome eurent tous ce songe dans la même nuit.

$4^{\circ}\left(\right.$ Fol. ${ }_{14} \mathrm{v}^{\circ}$.) Controrerse qui eut lieu er la pré- 


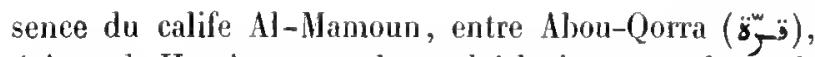
érêque de Harrân, et quelques théologiens musulmans ?.

Papier. 215 feuillets. Hauteur, 16 centimètres; largeur, 11 centimètres. g lignes par page. Ms. du $\times v^{\circ}$ siècle. - (Ancien fonds 1 70.)

\section{1.}

Ce volume renferme les mêmes opuscules que le ins. précédent, sur lequel il a été copié. Il offre les mêmes lacunes et plusieurs passages sont intervertis.

$1^{\circ}$ (Fol. $1 v^{\circ}$.) Sibylle d'Éphèse.

$2^{\circ}$ (Fol. 11.) Controverse soutenue par Abon-Qorra.

$3^{\circ}$ Légende de Bohaïra.

$4^{\circ}$ Voyage de Zosime chez les Pères bienheureux.

Papier. $9^{8}$ feuillets. Hauteur, 16 centimètres et demi; largeur, 10 centimètres el demi. $\mathrm{H}$ s. du $\mathrm{x}_{\mathrm{v}} \mathrm{e}^{\mathrm{e}}$ siècle. -14 lignes par page. - (Ancien fonds 171.)

\section{2.}

1 ${ }^{\circ}$ Voyage de S. Zosime au séjour des bienheureux.

$2^{\circ}$ (Fol. 22.) Sur l'utilité des messes que l'on dit pour les fidèles qui sont morts en Jésus-Christ.

$3^{\circ}$ (Fol. 24.) Profession de foi orthodoxe.

40 Réponse du prêtre Alou Bàscher (باثشى) à la yuestion de savoir s'il faut accepter les prescriptions de la loi comme étant du ressort de la foi ou comme ćtant du ressort de la raison, ou bien comme étant du ressort de la foi et de la raison simultanćment (fol. $25 v^{\circ}$ ). D'après une note qu'on lit au folio $27 \mathrm{~V}^{\circ}$, Abou Bàscher mourut à Torâ (بط, (ب) l'an 920 de l'ère de Dioclétien (1204 de J. C.) (fol. $27 \mathrm{v}^{\circ}$ ). Selon te Dictionmaire géographique de Yâqoût, le village de Torà était silué sur le Nil, près de Fostat, dans la direction de la haute Egypte.

$5^{\circ}$ (Fol. 28.) Sermon de S. Éphrena sur la pémitence.

$6^{\circ}$ Vie du saint homme Anba Barsoûmà (بوسوما), le Nu,

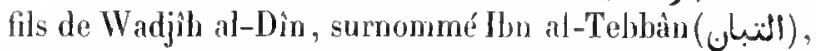
et secrétaire de Schadjar al-Dorr (fol. $\left.31 v^{\circ}\right)$. Il mourut l'an 1033 des martyrs ( 1317 de J. (.). Au feuillet 42 commence l'histoire des quarante-trois miracles opérés par ce saint. On sail qu'après l'assassinat de Tourân Schàl, dernier sultan ayyoubide de l'Égypte, sa femme, Schadjar al-Dorr ebouche de perles», fut nommée régente de ce pays.

Papier. 83 fenillets. Hauteur, 19 centimètres; largenr, 14 centimètres. 17 lignes par page. Ms. daté de l'an 1074 des martyrs (135R de J. C..). - (Supplément 91.)

\section{3.}

$1^{\circ}$ Vie el miracles de la sainte vierge et marlyre Mehräi (s)_o_o); légende racontée par Anba Fîlenîfos

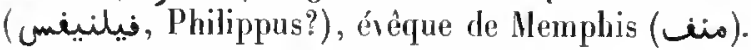

$2^{\circ}$ (Fol. $\left.39 r^{\circ}.\right)$ Miracles de l'ange saint Michel.

Papier. 51 feuillets. Hauteur, 17 centimètres; largeur, 12 centimètres et demi. Nanoscrit du xvi' siècle -- (Supplément ${ }_{19} 6$ 亿 bis.)

\section{4.}

$1^{\circ}$ Histoire de S. Pierre et de sa prédicalion à Rome.

$2^{\circ}$ (Fol. 14.) Martyre de S. Pierre.

$3^{\circ}$ (Fol. 20.) Martyre de S. Paul, à Rome.

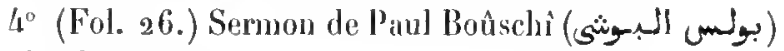
sur la Nativité.

$5^{\circ}$ (Fol. $39 r^{\circ}$.) Sermon de Paul Boûschî sur le baptême de Notre-Seigneur.

$6^{\circ}$ (Fol. 51.) Sermon composé par Jacques, érêque de Saroudj, sur le prophète Jonas (يونان) et sur la pénitence des habitants de Ninive.

$7^{\circ}$ (Fol. 79.) Sermon de Paul Boûschì sur l'Amoncjation.

$8^{\circ}$ (Fol. 93.) Discours composé par Épiphane, archeı̀que de Chypre, pour être lu le dimanche des Raneaux.

$9^{\circ}$ (Fol. $\left.102 v^{\circ}.\right)$ Sermons de S. Jean Chrysostome su les six jours de la création.

$10^{\circ}$ (Fol. $112 \vee^{\circ}$. ) Panégyrique de Job, par S. Jean Chrysostome.

$11^{\circ}$ (Fol. $120 v^{\circ}$. ) Semon de S. Jean Chrysostome sur la pécheresse qui a oint le Seigneur.

\footnotetext{
ISur Théodore Aboucarra et ses ourrages, voyez Fabricius, Biblioth. groca, éd. de Harless, t. X, p. 36 f et suir. - Migne, Patrol.graca, t. XCVII, col. I 461 et suiv. - Comparez Catal. des mss. syriaques et Hax, ondersalx. -11 .
}

saléens, p. 155 . - Dans le ms. syriaque-carschouni de la Bibliohieque nationale, $\mathrm{n}_{2}^{\circ} 38$, fol. 167 , Aboncarra ou Aboncorra est appelé MlarSiméon. H. Z. 
$12^{\circ}$ (Fol. 133.) Sermon de S. Jean Chrysostome sur le jeudi saint et le lavement des pieds.

$13^{\circ}$ (Fol. $139 \vee^{\circ}$.) Sermon de S. Éphrem sur la pission de Notre-Seigneur.

${ }_{1} 4^{\circ}$ (Fol. $144 \mathrm{~V}^{\circ}$.) Histoire de S. Denys l'Aréopagrite, composée pour être lue le rendredi saint.

${ }_{15}^{\circ}$ (Fol. 155.) Sermon de Jacques, évêque de Saroudj, sur le bon larron.

${ }_{1} 6^{\circ}$ (Fol. $163 \vee^{\circ}$.) Sermon de Grégoire, évèque de Nysse, sur la résurrection de Notre-Seigneur.

Papier. 179 Seuiltets. Hauteur, 25 centimètres; largeur, 16 centimèIres. 17 lignes par page. Éeriture qui paratt être de la fin du $x m^{\circ}$ siècle. - (Ancien fonds 151.)

\section{5.}

$1^{\circ}$ (Fol. $2 v^{\circ}$.) Actes de S. Picrue dans la ville de liome.

$\left.2^{\circ}\left(F_{0}\right]_{.} 181^{\circ}.\right)$ Martyre de S. Pierre.

$3^{\circ}$ (Fol. 25.) Aetes de S. Paul dans la ville de Rome.

$4^{\circ}$ (Fol. 31.) Légende des Jeux disciples, André et Barthélemy, et leur's actes dans la ville de Beïront (Berlons بوتوس).

$5^{\circ}$ (Fol. 55.) Vie et prédication de S. Thomas (وماسون dans l'Inde.

$6^{\circ}$ (Fol. 72.) Martyre de S. Thomas.

$7^{\circ}$ (Fol. $83 v^{\circ}$.) Traduction des passages tirés des liv'es prophétiques, des épitres de S. Paul, des évangiles et des prières quon lit pendant la génuflexion le jour de la Pentecôte.

. $8^{\circ}$ (Fol. 108.) Traduction des prophéties qu'ou lit au ealéchumène, lors du baptème.

$9^{\circ}$ (Fol. 112.) Canon composé par Anha Pierre, évèque de Behnesa, et destiné à ètre lu à l'office du matin, le cinquième jour du mois d'abilb, fète de S. Pierre et de S. Paul.

$10^{\circ}$ (Fol. 1 23.) Quelques prières pour la fète de Pícques. Sur le verso du feuillet 120 , on voit six lignes en langue grecque écrites en caractères coptes. C'est une invocation adressée par le scribe à Jésus-Christ. Sur le verso du feuillet 122 et le recto et le rerso du feuillet 125 se trouvent quelques lignes en copte.

Papier. 125 feuillets. Hauteur, 22 centimètres; largeur, 15 centi- mètres. 15 lignes par page. Lc ms. parait être du $x v^{\mathrm{e}}$ siècle. 一 (Ancien fonds 152.)

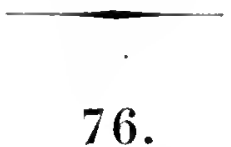

Le live appelé ordinairement s'Apocalypse de S. P'ierre el faussement aftribué à S. Clément (uạil)). Il traite de la eréation du monde, du testament adressé par Adam à son fils Seth, de Moïse, d'Aaron, de JésusChrist, des apôtres, de l'antéchrist, de la fin du monde, etc. Dans les autres exemplaires appartenant à la $\mathrm{Bi}-$ bliothèque, ce recueil est divisć en quatre-vingt-dixneuf chapitres. Voici la traduction de la note écrite à l'encre rouge et placée à la tête de l'ouvrage en guise de titre : - En invoquant l'aide el la faveur de Dieu, nous com-

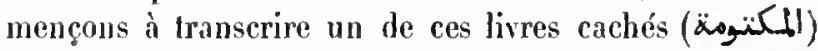
qui ont pour auteur S. Clément, disciple de Simễn alSafa (S. Pierre), et qu'il ordonna de tenir loin des regards du vulgaire. Ce livre se distingue des autres par le titre de Jefeuillets pleins de mystères». Il contient l'exposition (Jittéralement : l'état) des généalogies, plusieurs mystères que notre Sauveur, Jésus te Hessie, communiqua à ses disciples Simên (S. Pierre) et Yáqoûb (S. Jacques), l'indication de ce qui aura lieu à la fin des temps, la manière dont notre seigneur le Nessie quittera le ciel pour reparaitre dans le monde, la mention des erreurs qui s'y répandront, ete. Ce lirre est un des six appartenant à Clément qui ont été cachés et gardés soigneusement daus la ville de Rome, depuis le temps des premiers disciples. $n$

Dans cet ouvrage apocryphe, on fait raconter par S. Clément ses entretiens avec S. Pierre.

Dans le Catalogue de la Bibliothèque Bodléienne, t. 1, $2^{\mathrm{e}}$ partie, page 49 , on trouve une notice sur un ms. du mème ouvrage et les titres des quatre-vingt-lıuit premiers chapitres.

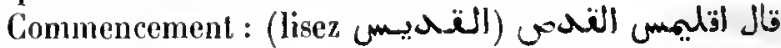

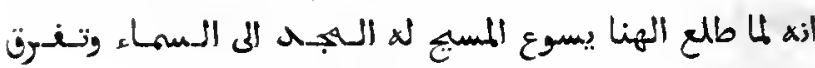

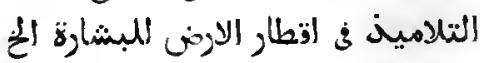

Volume écrit au vieux Caire, l'an 1053 des martyrs ( $1336-1337$ de J. C.), et reproduisant le texte d'un ms. copié, l'an 1004 des martyrs (1288 de J. C.), sur un autre ms. qui portait la date de 944 de la méme ère (1 228 de J. C.). Celui-ci eut pour prototype un ms. de l'an 572 de l'hégire ( $1177^{6-1} 17_{7}$ de J. C.). Notre exemplaire est très-bien écrit et porte toutes les motions.

Papier. 133 fenillets. Hauteur, 26 centimètres; targeur, 16 cenlimètres et demi. 21 lignes par page. - (Aneien fonds 54.) 


\section{7.}

Apoealypse de S. Pierre. Voici la traduction de la préface qui, dans cet exemplaire, est un peu différente :

"Ceci est un des livres de S. Clément (لاقليمس السليج), disciple de Simon Pierre, chef des apôtres, ete. C'est un des livres mis à part (المبتوتة), que S. Clément ordonna de cacher au vulgaire. Il est appelé "Kitâb al-Madjâll»

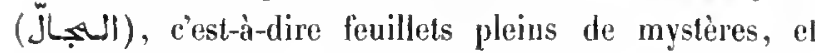
renlerme beaucoup d'idées, les unes profondes, les autres claires, touchant les mystères que notre seigneur et Dieu et sauveur, Jésus le Messie, avait fait connaîtue à Simóoûn al-Şafa Petros et à son disciple Yácqoûb (S. Jacques). Ceux-ci traitèrent des choses qui eurent lieu depuis le commencement de la création et de ce qui arrivera jusqu’à la fin des temps; ils parlèrent de la seconde venue de notre Dieu et seigneur Jésus-Christ, et de ce que feront les hommes rertueux et les méchants. C'est le livre qui, depuis le temps des saints apôtres, resta caché à Nicosie (الاصفتية). ville de l'ile de Chypre.n

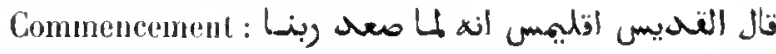

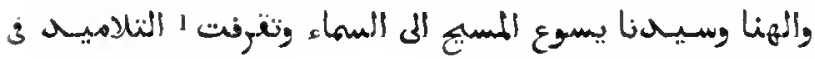

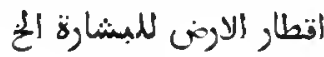

Papier. 71 feuillets. Hauteur, 32 centimètres; largeur, 21 centinètres. 26 lignes par page. Ns. daté de l'an 1076 de l'hégire ( 1665 de J. C.). - (Ancien fonds 53.)

\section{8.}

- Apocalypse de S. Pierre. La prélitce de cet exemplaire est à peu près la même que celle du $1^{\circ}$ précédent, seulement le nom de la ville de Nicosie est écrit ألافتسية.

Papier. 185 feuillets. Iautenr, 24 centimètres et demi; largeur, 18 centimètres. 16 lignes par page. Ms. du xur siècle, sauf les lunit derniers feuillets. - (Ancien fonds $53 \mathrm{~A}$.)

\section{9.}

L'A pocalypse de S. Pierre.

Papier. 305 feuillets. Hauteur, 18 centinètres; largeur, 14 centimètres. 13 lignes par page. Ms. du $x v^{\circ}$ siècle. - (Ancien fonds 70. )

\section{0 .}

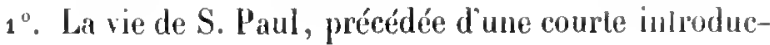
lion.

$2^{\circ}$. (Fol. $10 v^{\circ}$.) L'épître adressée par S. Paul à l'Église de Laodicée. Le copiste dit avoir copié ce lexte sur un ms. écrit en caractères maghrébins, l'an 1151 de J. C. Ce ms. Jenlermait les épîtres traduiles du lalin en arahe par ي-رونم, nom qui, probablement, est une transeription de Hieronymus ( $\mathrm{S}$. Jérôme).

3\%. (Fol. 17 $^{\circ}$.) L'A pocalypse de S. Jean.

Papier. 83 feuillets. Hauteur, 26 centimètres et demi; largeur, 19 centimètres. 10 lignes par page. Ms. du xvri siècle. - (Ancien fonds 142.)

\section{1.}

$1^{\circ}$ Fin de la légende de S. André l'apơtre.

$2^{\circ}$ (Fol. $\left.4 r^{\circ}.\right)$ ithes actes de S. Audré el de S. Barthéleny, disciples de notre seigneur Jésus-Christ. Ce ful dans la ville de Barnous (برنسوس), après leur retour des oasis, qu'ils opérèrent ces choses.'n

$3^{\circ}$ (Fol. $26 r^{\circ}$.) Martyre de S. André (أis), disciple du Seigneur.

$4^{\circ}$ (Fol. 31.) Histoire de S. Jacques, fils de Zébédée et lirère de S. Jean l'évangéliste. Récit de sa prédicalion dans la ville de Debrià (دبي) et de son martyre.

$5^{\circ}$ (Fol. $39 \%^{\circ}$.) Martyre de S. Jean l'évangéliste, fils de

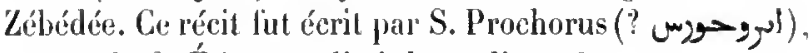
parent de S. Étienne, diseiple et diacre ${ }^{2}$.

$6^{\circ}$ (Fol. $68 r^{\circ}$.) Histoire de S. Pierre, chef des disciples, et de S. Philippe l'apotre.

$7^{\circ}$ (Fol. $7^{4} v^{\circ}$.) Martyre de S. Philippe le diseiple.

$8^{\circ}$ (Fol. $78 v^{\circ}$.) Prédication de S. Barthélemy, et sus fréquentes missions dans la capitale des oasis.

9. (Fol. 9o.) Apostolat de S. Thomas dans la capilalt: de l'Inde.

$10^{\circ}$ (Fol. $114 v^{\circ}$ et lol. 119, l. 1.) Actes de S. Malthieu l'érangéliste dans la ville des prètres (d'Apollon).

$11^{\circ}$ (Fol. 131.) Martyre de S. Jaeques, lils de Cléephas (خلف) et disciple du Seigneur.

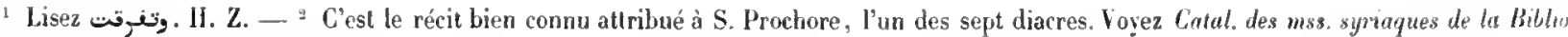
theque nationale, p. 189. H. \%.
} 
$12^{\circ}$ (Fol. $132 r^{\circ}$.) Martyre de Simon ou Jude, fils de

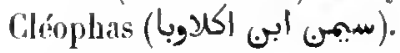

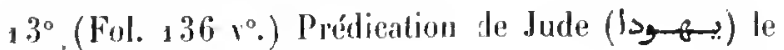
Bienheurenx, lière du Seigneur, nommé aussi Thaddée (b) (b)

$14^{\circ}$ (Fol. 144.) Apostolat du bienheureux Matthieu " (oنs), diseiple du Seigneur, daus la ville dont les liahilants mangraient les hommes.

$15^{\circ}$ (Fol. $157 \mathrm{r}^{\circ}$. ) Martyre du même.

${ }_{16}^{\circ}$ (Fol. 161.) Apostolat de S. Jacjues le disciple, appelé le lirère du Seigneur.

$17^{\circ}$ (Fol. $\left.163 v^{\circ}.\right)$ Son inartyre.

$18^{\circ}$ (Fol. 169.) Panégyrique do S. Mare l'évangéliste, par l'évêque Sćrère?

$19^{\circ}$ (Fol. 1 95.) Hartyre ale S. Lue, disciple, apootre et ‘nangéliste. La fin manque.

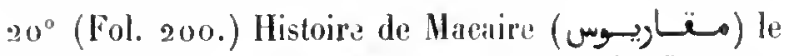
Firand, et de son frère, Macaire d'Alexandrie. L'auteur de ce récit s'appelait Julien (يوليانس), et était natil' d'Aqlìs, dans la haute Egypte ${ }^{3}$.

$21^{\circ}$ (Fol. 236.) Réeit de la vie de S. Philippe et de ce qui lui arriva à Carthage pendaut son apostolat dans cette ville.

Papier. 24 J feuillets. Hauteur, 22 centimètres; largenr, 15 centimètres. I 2 à । 3 lignes par page. Ms. du xvi siècle. - (Supplément 88, Saint-Germain 242.)

III.

\section{COMIENTIIRES DE LAI BIBLE.}

\section{2.}

$1^{\circ}$ Commeutaire sul quelques passages de l'Ancien Testament. Le commencenent manque, le premier feuillet n'étant qu'une fabrication assez moderne d'un libraire peu scrupuleux et peu instruit.

$2^{\prime}$ (Fol. 52.) Obserrations sur le Noureau Testament.

$3^{*}$ (Fol. 68 r.) Traité sur la nature de Dieu, par un monophỵsite. $4^{\circ}$ (Fol. $7^{3}$.) Notice abrégée des questions que Timothée (طبموتاوس) diseuta à diverses reprises, en la présence (du calife abbaside) al-Mehdi, commandant des croyants.

Cette pièce diffère de celle qui porte à peu près le même titre et qui se trouve dans le ms. du Supplément $n^{\circ} 107$.

$5^{\circ}$ (Fol. 95.) Discussion qui eut lieu en la présence d'un certain vizir, et dans laquelle trois docteurs chrétiens, 'Abd-Iclıôa , métropolitain nestorien, Abou-Qorra, évêque melkite, et Abou-Râita (يطة)), le jacobite, expliquèrent leurs eroyances respectives.

Cet opuscule n'est pas le même que celui qui est contenu dans le ns. $n^{\circ} 114$ de l'Ancien fonds.

$6^{\circ}($ Fol, 98.) Réfutation des astrologues par le sehaikl Abou 'l-Fath 'Abd-Allah Ibn al-Fadhl.

$7^{\circ}$ (Fol. 1 00.) "Que chaque chose procède de Dieu, soit par un effet de son bon plaisir, soit par suite d'unc disposition formelle, soit encore par suite de son indifférence." كلم ت > >

$8^{\circ}$ (Fol, $101 \mathbf{r}^{\circ}$.) Commentaire sur eette parole de l'Évangile: "Mon père, qui est aussi le vôtre, etc.

$9^{\circ}$ (Fol, 102.) Traité de morale el de théologie, composé par Ibn Atredì (آن), le nestorien, et intitulé - le Guiden (كتاب الههد). L'auteur, qui était disciple d'Ihn al-Tayyib, a laissé un traité de médecine, intitulé r lo

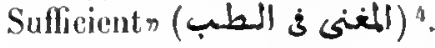

$10^{\circ}$ (Fol. 138.) Épître de Mar-Élie (يليا), métropolitain de Nisibe.

Dans ce traité, l'auteur fournit au vizir Abou 'I-Qàsim Hosaīn Ibn Ali al-Maghrebi des éclaircissements sur les doctrines de la religion ehrétienne, Ce ministre lui arait demandé des renseiģnements à ee sujet, l'an 417 de l'hégire, pendant qu'il était à Nisibe. L'épitre commence par une préface de six pages. Les demiers feuillets du traité ayant disparu, on les a remplacés par quatre autres, d'une écriture très-serrée et renfermant le commencement d'un sermon prononé à l'oecasion de la fète de Barklıaumà (بوخ) Le vizir Hosaïn Hon 'Ali al-Maghrebi mourut l'an 418 de l'hégire. Sil vic se trouve dans le Dictiomaire biographique d'Ibn Khallicàn ${ }^{5}$.

$11^{\circ}$ (Fol. 159.$)$ Traité de politique, par Aristote (كناب
Lisez Mathias. H. Z

Sévère, évèrque d'Aschmounain. H. Z.

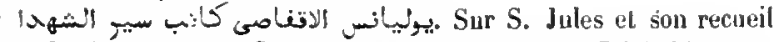
de vies des Saints, voyez Catul. dcs mss. éthiopiens de la Bibliothèque naunnale, p. 156 et passim. - Georgi, De miraculis S. Coluthi, Prief., p. ruv et suiv. - Dans le synaxare arabe des Jacobiles, an vingt- deuxième jour du mois de lòt, le nom du saint el celui de la ville sont écrits plus correctement, يو'يساس الاقنوصى H. Z.

4 Ibn-Atredi est probablement le surnom d'un auteur connu sous le nom de Abou 'L-Hasan Sa'jd-ben-Hibatallah. II. Z.

${ }^{5}$ Comparez Assemani, Biblintheca oriuntalis, tome III, pars I, p. 270. H. Z. 
ألسياسة لاسطاطاليسس), adressé à son disciple, Alexandre, fils de Philippe, surnommé Dsou 'I-Qarnaïr.

Cel ouvrage, faussement attribué au grand philosophe grec, renferme dix discours ou chapitres, dont te dernier, ayant pour sujet les talismans, est rempli de caractères cabalistiques. Suivent quatre pages, que le copiste avail laissées en blanc, et qu'une mán peu exercée a couvertes de prescriptions médicales et de signes cabalistiques. Le copiste reprend ensuite le traité de politique, et donne le commencement d'un chapitre qui traite des plantes. Puis viennent d'autres prescriptions médicales.

Papier. 200 feuillets. Hauteur, 18 centimètres; largeur, 14 centimètres. 11 lignnes par page. Le ms. paraît ètre du viv siècte. — (Ancien fonds 1 19.)

\section{3.}

Copie d'une partie des notes qui se trourent inserites sur les marges du ms. $n^{\circ} 6$. Le copiste, Solaïmân Ibn Yacqoub, a terminé le quarante-troisième feuillet de ce volume l'an 1685 de J. C. Les quatre derniers feuillets paraissent étre d'une autre main et renferment de courtes notices obituaires, dont la plupart se trouvent également sur les marges du ins. cité.

48 feuillets. Hanteur, 15 centimètres; largeur, 11 centimètres. 14 li gnes par page. - (Ancien fouds 35.)

\section{4.}

Les Homélies de S. Jean Chrysostone sur la Genèse. Le texte, écrit à deux colonnes, est incomplet, plusieurs feuillets ayant disparu, à la fin du volume. Une partie du soixante-cinquième discours et les deux derniers, le soixante-sixième et le soixante-septième, manquent.

Papier. 328 feuillets. Hauteur, 33 centimètres ot demi; largeur, 34 centimetres. 24 lignes par page. Ms. de la fin lu viv siècle. (Ancien fonds 60 , Colbert 947.)

\section{5.}

Seconde partie du commentaire d'Abou 'l-Faradj 'IbdAllah Ibn al-Ṭayih sur les quatre Évangiles. C'est un volume dépareillé du ms. original de J'ouvrage qui renlerme l'explication de deux évangiles seulement, celui de Luc et celui de Jan. Selon une indication fournie par Bar-Hebræus, Ibn at-Tayyib mourut l'an 1355 d'Alexandre ( 1043 de J. C.). Ce commentaire, rédigé d'abord en syriaque, fut traduit en arabe par l'anteur luimême.

II manque un feuillet entre ceux qui sont numérotés 79 et 80 .

Papier. 164 feuillets. Hauteur, 26 centimètres; Largeur, 17 centimètres. Les premières pages portent 18 lignes, les pages suivantes 19. Ms. du $\mathrm{xl}^{\mathrm{e}}$ siècle. - (Supplément 28 his, Saint-Germain 217.)

\section{6 .}

Commentaire d'Abou '1-Faradj Ibn al-Tayyib sur les quatre Évangiles. Ce volume renferme J'explication des évangiles de S. Marc, de S. Luc et de S. Jean; il a été copié sur l'exemplaire précédent, en l'an 964 des martyrs (1248 de J. C.).

Papier. 303 feuillels. Hauteur, 25 centimètres; largeur, 17 centimètres el demi. 18 lignes par page. - (Supptément 28 , Saint-Gremain 29.)

\section{7.}

Commentaire sur les évangiles que l'on récite chaqut" dimanche de l'année, tant de jour que de nuit, ainsi que su" Jes évangiles des lêtes du Seigneur (ألاعياد السيحية). C'est un abrégé des commentaires de $\mathrm{S}$. Jean Chrysostome et d'autres docteurs. Le dernier feuillet, qui remplace un leuillet perilu, porte la date de l'an 1310 des martyrs $\left(15 g^{3}\right.$ do. J. C. .).

Papier. 166 feuiltets. Hauteur, 26 centimètres; fargyeur, 17 centimètres et demi. I 1 à 15 lignes par page. Ms. de la fin du w vièrle ou du commencement du $\mathbf{s v i}$. - (Ancien fonds 61.)

\section{8.}

$1^{\circ}$ Explication des évangiles des dimanches et des lêtes de l'année copte.

$2^{\circ}$ (Fol. 212.) Abrégé d'un discours sur la nalisilé du Sauveur, par Jacques, évèque de Saroudj.

$3^{\circ}$ (Fol. 217 .) Discours de S. Grégoire de Vazianze sur le mème sujet.

Les demiers feuillets de cette priece manquent. 
$4^{\circ}$ (Fol. $234 v^{\circ}$.) Discours sur la diversité des doctrines professées par les sectes clirétiennes.

Celte pièce est d'une main moderne.

Papier. 240 fenillets. Ilauteur, 14 centimètres; largeur, 11 cenlimètres. 1 à 13 lignes par pagge. Ms. qui paraît être de la fin du xı1 $v^{\circ}$ siècle. - (Supplément 75 , Saint-Germain 528.)

\section{9 .}

Explication des épitres et des évangiles que l'on récite daus l'Église copte pendant la semaine sainte. Parmi les Pìres ol doctenrs de l'Église dont les ourrages ont été unis à contribution par le compilateur, on remarque S. Jean Chrysostome, S. Cyrille, S. Athauase et S. Basile.

Le volume porte li date de 1311 de l'ère des martyrs $(1595$ de J. C.).

Papier. 304 leuillets. Hauteur, a 1 centimètres el demi; largeur, 16 centimètres. 14 et 15 lignes par page. - (Ancien fonds 3.)

\section{0.}

Première partie d'un commentaire sur les évangiles et les épitres que l'on récite, les dimanches et les fêtes, dans l'Église copte. En tête se trouve une introduction qui remplit plus de cinquante pages.

Papier. 395 feuillets. Hauteur, 21 centimètres; largeur, 15 centimètres. 13 lignes par page. Ms. du xure siècle. - (Ancien fonds 33, Colhert 453g.)

\section{1.}

Ge volume renferme la suite de l'ourage contenu daus le uns. jrécédent el en forme le second volume. Une nole inscrite sur te dernier feuillet nous apprend que ce ms. arait été collationné l'an 1314 des martyrs ( 1598 de J. C.).

Papier. 288 feuillets. Hautenr, 21 centimètres; largeur, 15 centimètres. 13 lignes par page. - (Ancien fonds 34.)

\section{2.}

Sixième volune d'une version arabe des Homélies de
S. Jean Chrysostome sur l'Érangile de S. Matthieu. Après la liste des cluapitres, dont il ne reste que la dernière page, viennent la soixante-seizième hométie et les suirantes, jusqu'à la quatre-vingt-dixième, qui est incomplète.

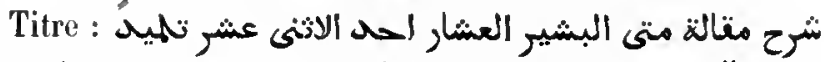

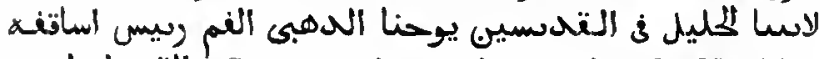
"Commentaire sur les paroles de Matthieu l'érangéliste et publicain, l'un des douze disciples; ourrage de notre père, qui tient un rang éminent parmi les saints, Jean Bouche-d'Or, chef des érêques de Constantinople. $n$

Papier. 169 feuillets. Hauteur, 24 centimèlres; largeur, 16 centimètres et demi. 16 lignes par page. Is. du xvi' siècle. - (Ancien fonds 29 , Colbert 4826.)

\section{3.}

Commentaire sur l'Évangile de S. Jean. C'est une compilation dont les écrits de S. Jean Chrysostome, de S. Cyrille, de $\mathrm{S}$. Sévère ${ }^{1}$, de $\mathrm{S}$. Athanase, de $\mathrm{S}$. Grégoire et d'autres Pères de l'Eglise ont fourni des matériaux. Ce volume parait être de la fin du xiv siècte. Il a beaucoup souffert de l'humidité. On voit sur le recto du premier feuillet une prière en carschouni.

Papier. 108 feuillets. Hauteur, 26 centimètres; largeur, 18 centimètres. 14 à 16 lignes par page. - (Ancien fonds 30.)

\section{4.}

Commentaire de S. Jean Clırysostome, patriarche de Constantinople, sur une partie de la première épìtre de S. Paul aux Corinthiens. L'ourrage est divisé en dix-sept discours, dont chacun est suivi d'une exhortation.

Papier. $12 b$ feuillets. Hauteur, 24 centimètres et demi; largenr, 16 centimètres. 18 lignes par page. Ms. très-bien écrit et daté de l'an 95 2 des martyrs ( 1236 de J. C.). - (Supplément 32 , Saint-Germain 33.)

\section{5.}

Commentaire de S. Jean Chrysostome sur l'Épître de S. Paul aux Hébreux, traduit du gree en arabe par Constantin le prêlre (uـاهI), natif d'Antioche. Le texte de cette traduction est identiquement le même que celui de

LSérère, patriarche d'Antioche. H. Z. 
la traduction attribuée à 'Abd-Allah Ibn al-Fadhl (royez le numéro suivant). Ce volume est daté de l'an dı monde 6726 ( 1218 de J. C.).

Papier. 301 fenillets. Hauteur, a 1 centimètres; largeur, 15 centimètres el demi. 17 lignes par page. - (Supplément 71, SaintGermain 30.)

\section{6.}

Trente-quatre homélies de S. Jeau Chrysostome, dans lesquelles il explique l'Épitre de S. Paul aux Hélıreux. Ges discours furent traduits du grec en arube par le métropolitain 'Abd-Allah Jbn a]-Fadhl. Une autre main a écrit sur le dernier feuillet que ce ms. fut copié par les soins de Sophrone, évêque melkite du Sacid (la haute Égyple), l'an $67{ }^{3} 7$ de l'ère du monde, date qui correspond à l'an $6{ }_{2} 6$ de l'hégire (1229 de J. C.). Rien n'empêche d'accepter celte indication; l'aspect du volume, la qualité du papier et la forme massive de l'écriture se rapportent au $\times 1 \mathbf{I}^{\circ}$ siècle de notre ère. Le premier feuillet est d'une autre main.

Papier. 217 feuillets. Hauteur, 27 centimètres et demi; largeur, 20 centimètres. 21 lignes par page. - (Ancien fonds 63 , Colbert 248\%.)

\section{IV.}

\section{LITURGIES ET RITUELS.}

\section{7.}

Liordre de la messe, suivant l'usage de l'Église de Rome. Volume écrit l'in i 744 de J. C.

Papier. $2 / 4$ feuillets. Hauteur, 15 centimètres; largeur, 10 centimètres. 16 lignes par page. - (Supplément 40.)

\section{8.}

Rituel de l'Église copte, composé l'an 1127 des martyrs (14:1 de J. C.), sur l'ordre d'Anba Gabriel (انسبـا (غبسيال , quatre-vingl-luuitième patriarche de l'Église d'Alexandrie. Cet ouvrage, rédigé en arabe et en copte, renferme les rubriques et les indications des prières que l'on récite aux cérémonies du baptême, de l'absolution, du mariage, des ordinations, de J'extrême-anclion el de la prise de l'habit monastique. On y trouve aussi quel- ques autres prières et trois tabıles, dont l'une sert ì déterminer les épactes; la seconde (fol. $17^{\circ}$ et suiv.) est une table de multiplication, et la troisième (fol. $17^{4} \mathrm{et}$ suiv.) présente les formes des chiffres arabes, diwani, coptes el indiens.

Papier. 175 feuillets, dont plusieurs sont restés en blanc. Hauteur, 21 centimètres; largeur, 15 rentimètres. 14 lignes par page. - - (Ancien fonds 42.$)$

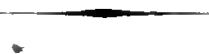

\section{9.}

Rites du baptême et du mariage dans l'Église copte.

Papier. 284 fenillets, paginés de gauclıe à droite, et, de plus, 15 feuillets paginés de droite à gauche. Hauteur, 23 centimètres; largeur, 17 cenlimètres. 15 lignes par page. Us. du xviı" sièrle. - (Supplément 1961 bis. Renandot.)

\section{0.}

Différents traités ayant pour sujet la préparation du saint chrême, selon le rite de l'Église copte.

Le premier ouvrage, composé par un prélat copte, sur la demande du suffragant d'Anba-Yiégoûl, nuphrien (مغويان) de l'église orthodoxe jacobite de Mossoul, reuferme la description du saint chrême, et traite eusuile de la manière dont on le remouvelle, des ingrédients dont il doit se composer el des procédés employés diuns sil préparation; en un mot. de tous les usages de l'igglise copte à cet égard. Suivent six autres traités, renfermant la description des rites que les patriarches d'Alexandrie avaient suivis dans la préparation et dans la bénédiction du saint chrème, aux années $1015,1021,1036,1046$, 1056 et 1062 de l'ère des martyrs $(1299,1305.1320$. 1330,1340 et 1346 de J. C.).

La seconde partie du volume contient un ourage écrit en cople et en arabe, qui traite du mếme sujet.

Papier. 181 feuillets. Ilauteur, 26 centimètres; Jargeur. 17 centimètres et demi. 17 lignes par page pour les traités arabes, 21 à 26 pour les traités coptes. Ms. du xiv siècle. - (Ancien fonds 37.)

\section{1.}

Prière qu'on récite sur le métropolitain, lors de son intronisation. Cette prière remplit quatorze feuillets, mais elle n'occupe que la moitié de chaque page; l'autre moitié devait probabjement recevoir la traduction copte. Le 
cahier suivant se compose de six feuillets, et contient la formule d'exhortation (وصيّة) adressée aux métropolitains et aux érêques, lors de leur intronisation (تنتسير). Dans le premier cahier, les pages se suivent de gauche à droite.

Papier. 20 feuillets. Hauteur, 27 centimètres; largeur, 19 centimètres. 22 lignes par page. Ms. du xvit siècle. - (Supplément 1959 bis.)

\section{V.}

\section{OFFICES ET PRIERES.}

\section{$-102$.}

Prières usitées dans l'Église melkite. Cette collection est distribuéc en dix-huit sections, dont la cinquième (fol. $641^{\circ}$ ) est un octoêchos qui paraît être celui de Jean de Damas.

Papier. 299 feuillets. Hauteur, 9 centimètres; largeur, 7 centimètres. 12 lignes par page. Ms. daté de l'an 1596 de J. C. - (Ancien fonds 46.$)$

\section{3.}

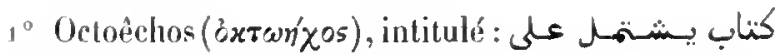

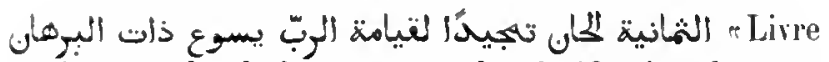
venfermant les luit tons pour la glorification de cette preure irréfragable, la résurrection du Seigneur Jésus. It est dit encore dans le titre que cet ourrage eut pour auteur's le saint père Jean, prêtre de Danas ( $\mathrm{S}$. Jean Damascène), et d'autres maitres éminents, compositeurs de rhythmes. Titre du premier ton : Premier ton pour la résurrection, le dimanche soir, sur (le

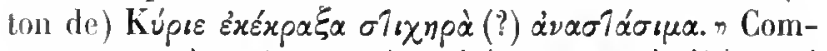

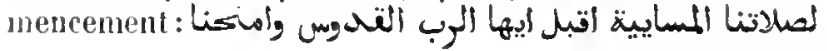

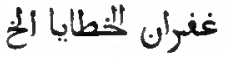

En lète du volume on lit que S. Jean Damascène poriait le surnom de Medjra al-Dsahab eruisseau d'or, Chrysarmhos \%. Voyez la « Bibliotheca graca m de Fábricius, éd. Harless, t. V11, p. 701 , et t. IX, p. 738.

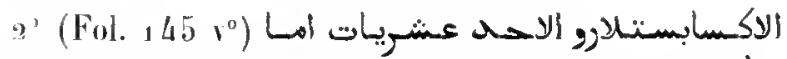

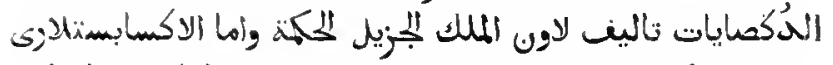

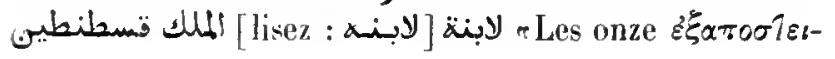

$\lambda \alpha$ pra . Les Doxa sont l'ouvrage de Léon, roi de haute sagesse (l'empereur Léon, le sage ou le philosophe), mais les Exaposteilaria ont pour auteur son fils, le roi Constantin. $\rightarrow$ Le premier exaposteilarion commence ainsi : لتجبتم

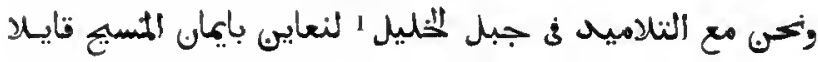
قد اخخت سلطار في السماء فوق وعلى الاون السفل

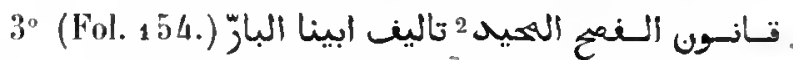
م Canon (hỹmne) de la Pàque glorieuse, œuvre de notre saint père Jean, prêtre de Damas. n

Papier. ${ }_{16}{ }_{1}$ feuillets. Hauleur, 21 centimètres; largeur, 15 centimètres, 17 lignes par page. Ns. daté de l'an 7166 du monde. (Aucien fonds 44, Colbert 45,5.)

\section{4.}

Recueil d'hymnes à l'usage de l'Église melkite. On y trouve tous les troparia (اطبوباويات) et les contakia (قنادق) que l'on récite dans le cours de l'année. Ouvrage traduit du grec (وهو منتول من الروىى).

Papier. 105 feuillets. Hauteur, 16 centimètres; largeur, 10 .centimètres. 12 lignes par page. Ms. du $x^{2}{ }^{e}$ siècte. - (Ancien fonds 51 , Colbert 6502.)

\section{5.}

Leçons et prières usitées dans les offrces de l'Église melkite pendant le carême et les fêtes de l'année. Ce ms. fut écrit l'an 7084 du monde $(1576$ de J. C.), par un moine de Daïr-Kanisa (دير كنيسa), couvent situé dans le village d'Ablal! (_أ), arrondissement de Karak-Nouh. Cet endroit est situé dans la Coelésyrie, au sud-ouest de Baalbec et à une demi-lieue de Zehlé.

Papier. 107 feuillets. Hauteur, 28 centimètres et demi; largeur, so centimètres. 18 et 19 lignes par page. - (Ancien fonds 36.)

\section{6.}

Leçons tirées des Actes des apòtres et des Épîtres de S. Paul, et destinées à être récitées aux jours de fète, selon l'usage de l'Église melkite. Chacune de ces leçons est suivie d'un commentaire qui paraît être de $\mathrm{S}$. Jean Chrysostome. Vient ensuite un calendrier indiquant les fètes de l'année syriaque et renfermant des passages ex-

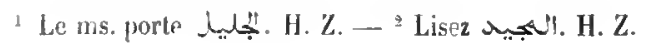


'traits des Épîtres de S. Paul, accompagnés aussi de commentaires. Au commencement du volume se trouvent trois feuillets d'une autre main renfermant des prières à l'usage des personnes qui assistent à la messe. Ce ms. paraît être du $x$ viı siècle.

Papier. 168 fcuillets. Hauteur, 21 centimètres el demi; largeur, 16 centimètres. 13 à 15 lignes par page. - (Ancien fonds 26.)

\section{7.}

$1^{\circ}$ Prières du jour et de la nuit, à l'usage de l'Église melkite.

$2^{\circ}$ Pelite collection de prières diverses.

$3^{\circ}$ Histoire apocryphe du patriarche Job) (fol. 162),

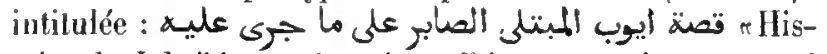
toire de Job l'éprouvé, qui souffrit aree patience ce qui lui était arrivé.n Le dernier feuillet de cette légende manque.

Papier. 188 feuillets. Hauteur, 15 centimètres; largeur, 9 centimètres. 9 à 13 lignes par page. Ms. daté de l'an 1385 de J. C. (Ancien fonds 50 , Colbert 6567.)

\section{8.}

$1^{\circ}$ Livre d'Heures à l'usage de l'Église melkile.

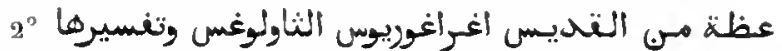
- Les conseils moraux de S. Grégoire le théologien, avec commentaire. $n$

$3^{\circ}$ Les Psaumes, jusqu'au commencement du cenl vingt-neuviène. Cette version se rapproche du texte de la Propagande.

Au verso du dernier feuillet du us., on lit ingl el une lignes en grec. Cetle note nous apprend yu'un diacre, natif de Thessalonique, arait relié le volume l'an $69^{2} 9$ de f'ère du monde (1421 de J. C.). La reliure actuelle est beaucoup plus moderne et a élé faite à Paris.

Papier. 265 feuillets. Hauteur, 16 centimètres; largeur, 11 centimètres el demi. 10 à 12 lignes par page. - (Ancien fonds 48.)

\section{9 .}

Livre d'Heures de l'Église melkite. Les cinq derniers MAX. ORIETtALX. - II. feuillets, d'une écriture plus moderne, renferment des prières spéciales.

Papier. 149 fcuillcts. Hauteur, 10 centimètres; largeur, 7 centimètres. 10 à 13 lignes par page. Ms. du xvı" siècle. - (Ancien fonds 40.)

\section{0.}

Passages de la Bible, dont chacun est suivi de son anlienne (تمزيهمة) el de son verset des Psaumes, prokeimenon (بركيمنــ), tels qu'on les lil dans 1'Église melkite.

Papier. 189 fcuillets. Hauteur, 22 centimètres; largeur, 15 centimètres et demi. 16 lignes par page. - (Ancien fonds 40.)

\section{1.}

Recueil de prières et de lilanies à l'usage de l'Église melkite. Au feuillet $184 v^{\circ}$ commence une série de prières en syriaque. Les feuillets 187 et suivants sont écrits d'une main peu exercée, et renferment encore quelques prières en arabe.

Il manque quelques feuillets au commencement ot it la fin.

Papier. 199 feuillets. Hauteur, 21 centimètres; largeur, 16 centimètros. 16 lighnes par page. Ms. du xvi siècle. - (Ancien fonds 43. Cotbert 4648.)

\section{2.}

Ordre des leçons que l'on récite chaque jour dans l'Église copte. Les legons sont indiquées par les premiers el les derniers mots.

Papier. $a 63$ feuillets. Hauteur, 16 centimètres; largeur, 10 centimètres. 9 à 12 lignes par page. Ms. du xvissiècle. - (Ancien fonds 45.)

\section{3.}

Leçons et antiennes pour le servire de la semaine sainte, selor l'usage de l'Église copte. Ce ms. al pour litre :

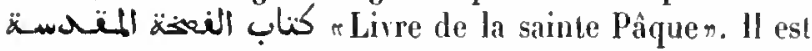
très-bien écrit et porte la date de l'an 1029 des martyrs (1314 de J. G.). Les folios $152,153,178,179$ sont d'une écriture moins élégante et plus moderne que les autres. Les trois derniers feuillets, apparemment de la 
mème main que le corps de l'ourrage, renferment des réflexions pieuses et l'indication de certaines classes de personnes sur lesquelles on doit appeler les bénédictions de Dieu.

Papier. 185 feuillets. Hanteur, 24 centimètres; largeur, 16 cenlimètres. 13 lignes par page. - (Ancien fonds 41.)

\section{4.}

$I^{\circ}$ Sept supplications (طاب) ou prières. La première est attrilunée à $\mathrm{S}$. Athanase et la seconde à S. Ephrem; les aulres sont tirées de diverses sources. Ce ms. est lien écrit et parait être du $x^{e}{ }^{e}$ siècle; il est mutilé au commencement et à la fin, mais les feuillets qui y manquaient ont été remplacés par l'autres d'une écriture grossière el mal formée. Le copiste qui les a tracés nous informe qu'il avait en sons les yeux un exemplaire écrit l'an 1346 des marlyrs ( 1630 de J. C.), et reproduisant le texte d'un autre ms. qui, disait-on, avait appartenu à

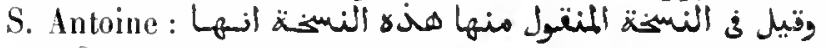

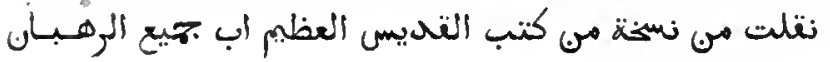

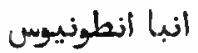

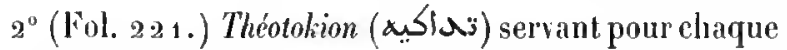
jour de la semaine. Ces cantiques, composés en l'honneur de la vierge Marie, sont traduits du copte. En tête de chaque cantique se trouvent les premiers mots du texte copte ${ }^{\circ}$ ni y correspond. $\Lambda$ la fin (fol. $2851^{\circ}$ ), on lit une doxologie (دكصابية) en l'honneur de la Vierge, des anges et des saints.

Papier. 310 feuillets. Ilauteur, 16 centimètres; largeur, 11 centimètres et demi. 12 lignes par page. - (Ancien fonds 47.)

\section{5.}

$1^{\circ}$ Prières formant douze sections (فنشيب), en syriaque phescholi'o edivision $n)$.

$2^{\circ}$ Prières que l'on récite an sortir du lit.

$3^{\circ}$ Prières diverses.

$4^{\circ}$ Prières que l'on récite lors de la messe.

$5^{\circ}$ Prières de plusieurs Pères de l'Éğlise.

$6^{\circ}$ Prières diverses.

$7^{\circ}$ Prière attribuéc à l'abbé Bimîn (انبا بيهير), surnommé le Reclus (al-IIabis).

$8^{\circ}$ Prières diverses.
Les derniers lenillets, au nombre de vingt-deux, renferment encore des prières écrites à la hâte et sans soin par une autre main.

Papier. 126 feuillets. Hauteur, 10 centimélres el demi; largeur, 7 centimèlres. 18 lignes par page. Ms. du xvì siècle. - (Supplément 36.)

\section{6.}

Livre d'Heures, renfermant les prières des sept parties de la journée. Éeril à Paris, l'an 1677 de J. C., par Yohannà ben Djordjos toen Qaṭâ (تطا) , natif de Damas.

Papier. 150 feuillets. Ilauteur, 16 centimètres; largeur, 10 centimètres. 15 liggnes par page. - (Supplément 34.)

\section{7.}

Les Heures.

On a relié en tête du volume un exemplaire du psautier, en hébreu, imprimé à Paris, l'an 1545, par Rohert Estienne.

Papier. Hauteur, 10 centimètres; largeur, 7 centimètres. - (Supplément 35.)

\section{8.}

Les Heures, pour l'usage des Maronites de la Syrie, et des litanies d'après le rite de l'Église romaine. Les dix premiers feuillets paraissent avoir appartenu à un psautier arabe.

Papier. 119 feuillets. Hauteur, 10 centimètres; largeur, 7 centimètres et demi. 1, lignes par page. Ms. du commencement du xvule siècle. — (Supplément 39.)

\section{9.}

Prières et litanies. Le ms. parait ètre du commencement du xvır siècle.

Papier. 22 fenillets. Hauteur, 16 centimètres el demi; largeur, 11 centimètres. 1 o lignes par page. - (Supplément 43.)

\section{0.}

Prières, psaumes et litanies, à l'usage des Maronites. 
Oil trouve à la fin du volume un tableau qui indique les lêtes mobiles, à partir de l'an ${ }^{693}$ de J. C. jusqu'à l'an 1800 .

Papier. 126 feuillets. Hauteur, 17 centimètres; largeur, 11 centimètres. 15 lignes par page. Ms. du xwı" siècle. - (Supplément 44.)

\section{1.}

Prières ef litanies à l'usage des communiants.

Papier. 17 feuillets. Hauteur, 10 centimètres; largeur, 7 centimètres. 10 lignes par page. Ms. du xvu1 siècle. - (Supplément 38.)

\section{2.}

Recueil naronile contenant le psaume 1o3, les sept psaumes pénitentiaux, des prières et des maximes des Pères de l'Église.

Papier. 16 feuillets. Hauleur, 15 centimètres; largeur, 10 centimètres. 13 lignes par page. Ms. du xvi siède. - (Supplément 45.)

\section{3.}

Prières el litanies à l'usage de l'Église maronite. Petit volume écrit en France, l'an 18 5 , par Michel d'Alep (ي) (يخائيل

Papier. 80 feuillets. Hauteur, 10 centimètres et demi; largeur, 7 centimètres et demi. 13 lignes par page. — (Supplément 37.)

\section{4.}

Petit volume écrit paf un Emopéen el renfermant la Symbole de Nicée, le Décalogue, plusienrs prières et quelques extraits in Coran.

Papier. 49 feuillets. Hauteur, 12 centimètres; Jargeur, 8 centimètres. 7 lignes jar page. Ns. du xvi' sièrle. - (Supplément 49.)

\section{5.}

Olfice de la sainte Vierge et prières qu'on doit lni adresser. Ourrage dont les matériaux ont été tirés des écrits des saints Pères et mis en ordre par le R. P. Joseph, jésuite.

Papier. 138 feuillels. Hauteur, 11 centimètres; largeur, 7 centimètres. 13 lignes par page. Ms. du xvu' siècle. - (Supplément 46.)

\section{6.}

Médilations pieuses pour chaque jour du mois. Liateur dit, dans sa préface, qu’il a évilé les réflexions prolondes, dans le genre de celles d'Hypocrate et de Sénèque, pour ne donner que des pensées simples el dignes d'un chrétien. Volume écrit l'an 1685 de J. C., par un natif de Damas, nommé Solaïmân ben Yacqoûb.

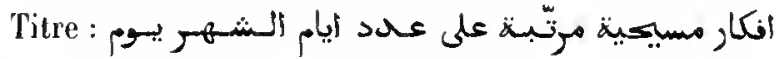
Méditations chréliennes pour chaque joull du mois. $\pi$

Papier. 60 feuillets. Hauteur, is centimètres et demi; largeur, 8 centimèètres el demi. 13 lignes par page. - (Supplément 33.)

\section{7.}

$1^{\circ}$ Méditations pour les trenle jours du mois et pou! la messe, etc., par Petros Ibn Petros Ibn Ishâq, prêlre maronite et économe du comsnt, à Alep.

$2^{\circ}$ (Fol. 120.) Prières composées par S. François de Sales, évếque de Genère, à l'usage dés prèlres qui iont cétébrer lat mresse et des fidèles qui doivent y assister. En carschouni.

Japier. 163 feuillets. Hauleur, I/ centimètres; largeur, 9 centimètres. 2 I lignes par page dans l'article $1^{\circ}, 18$ ligues par page dans l'article $2^{\circ}$. - (Supplément ig65.)

\section{8.}

Io Traité dont le premier feuillet et le litre mancuent, et qui consiste en instructions, prières et méditalions.

$2^{\circ}$ Ourrage traduil de litalien, et inlitulé : $\operatorname{Ln}$ mois de médilations, à l'usage des jeunes calholiques qui

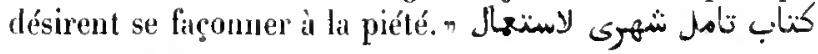

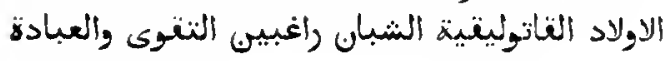

tapier. 48 feuillels. Hauteur, 13 centimètres el demi; largeur, y centimètres. Volume écrit l'an 173.2, an Collège de la Propagande. (Supplément 6..) 


\section{9.}

Exercices spiriluels pour les dix jours de la Retraite. Ourrage composé d'abord en italien par le P. Onufre Pic-

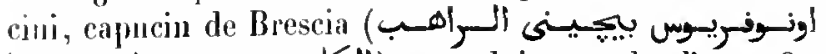

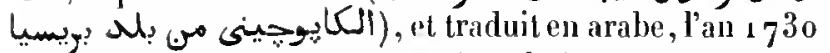
de J. C. , jur le prêtre Josaphat (بوإيسئ), moine de S. Antoine. L'exemplaire de la Bibliothèque fut copié sur le ms. original, l'an 1731 de J. C., par Khidr, fils de Maqdisí Hormoz, prêtre chaldéen de Ninive.

Papier. 334 feuiltets. Ilanteur, 15 centimètres; largeur, 10 centimètres et demi. 15 lignes par page. - (Supplément 41.)

\section{0 .}

Prières et litanies à l'usage des prètres arméniens. Volume écrit l'an 1 -43 de J. C., par Yoḷannâ (Liح), fils du Khodja Yáqoûh, administrateur de l'église de. SaintGeorges (om $>$ (o), à Mardin.

Panier. 53 feuillets. Hauteur, 16 centimètres; targeur, 11 centiin èlres. 1:t ligones par page. - (Supplément 4a.)

VI.

\section{HOMÉLIES.}

\section{1.}

$1^{\circ}$ Discours dans lequel Démélrius, archevèque d'Anlioche (دمينتريوس رييس أساقغة أنطاكية), célèbre les mériles du saint martyı Victor (بنطي) , fils de Romanus.

$2^{\circ}$ (Fol. 72.) Prophétie dans laquelle S. Samuel (صموبل, supérieur du monastère de Calamoûn, dans la province d'al-Fayyoûn, prédit les érénements qui auront lieu lors de la lin du monde.

$3^{\circ}$ Chapitre tiré du eDiscours concernant le Hessien

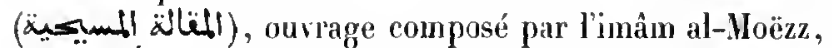
calife d'Égypte. Il fut copié de la main de l'érêque Paulus, surnomné natif de Damiette, sur un exemplaire dont la souscription portail : "Fin du livre. Louange à Dieu, seigneur des mondes! Ceci a été cécit de la main de Djacfar ibn 'Âmir (عـامب), au mois de djomada second de l'an 3o8. n L'ouvrage ne peut pas être d'ał-Moëzz, qui uaquit l'an 319 de l'hégire. Dans le court extrait que nous avons ici, l'auteur veut prouver que Dieu ne se laisse voir aux hommes que sous une figure humaine (ce qui, en effet, est un des principes de la religion chiitefatimite), el cela lui donne l'occasion de citer l'apparition de Dieu sous la forme de Jésus-Christ. Comme tous les écrits qui se rapportent aux doctrines secrètes des sectes chiites, celui-ci n'est pas facile à comprendre.

$4^{\circ}$ (Fol. $\left.9^{\circ} \mathrm{v}^{\circ}.\right)$ Quelques miracles de l'ange Michel, chef des puissances célestes.

Papier. 109 feuittets. Hauteur, 15 centimètres; largeur, 11 centimètres el demi. 10 lignes par page, excepté plusieurs feuiltets du traité $\mathrm{n}^{\circ} 2$, où te nombre des lignes varie de 11 à 13 . Ms. écrit l'an 1156 des martyrs (1440 de J. C.). - (Supplément 27, Saint-Germain 527.)

\section{2.}

1 Panégyriques d'Abrahain, d'Isaac et de Jacob, prononcés par $\mathrm{S}$. Nhanase, patriarche d'Alexandie.

$2^{\circ}$ (Fol. $24 r^{\circ}$.) Homélie de S. Éphrem, ayant pour sujet Ja Iransfiguration du Messie sur le nont Thabor (نور) (ت)

3० (Fol. 32.) Homélie sur le trépas (انتشنقال) d'Anbâ Matthieu, patriarche (jacobite) d'Alexandrie, et récit du martyre de plusieurs de ses ouailles $(x>y, \mid l)$. Nous y lisons (fol. 40 et 55) que Matthieu fut nommé patriarche l'an 1094 des martyrs $(1378$ de J. C. $)$, et qu'il mourut l'an 1125 de la même ère ( 1409 de J. C.). L'auteur parle des rapports qui eurent lieu entre ce patriarche et les Francs. Parni les quarante-neuf martyrs dont il fait mention, il y avait quelques Franes (fol. $50 \mathrm{v}^{\circ}, 51$ ).

$4^{\circ}$ (Fol. 59.) Histoire de la fondation de deux églises au vieux Caire, l'une sous l'invocation de $S^{\text {te }}$ Barbe $(8 ; 0)$ (ب) et l'autre sous celle de S. Serge $(س,-m)$. Dans cette légende, l'auteur parle du siège de Damiette par les Croisés, l'an 465 de l'hégire (1 1072 de J. C.).

$5^{\circ}$ (Fol. $\left.75 v^{\circ}.\right)$ Voyage du patriarche Abraham et de sa femme Sarah, et leur arrivée en Égypte, par S. Éphrem.

$6^{\circ}$ (Fol. $84{ }^{\circ}$.) Homélie sur le bon larron, par Jacques, évêque de Saroûdj.

$7^{\circ}$ (Fol. $92 \vee^{\circ}$.) Homélie de S. Éphrem sur la charité, le repentir et le jugement demier (الدينونة).

$8^{\circ}\left(\right.$ Fol. $102 \vee^{\circ}$.) Histoire de l'émir Màroùn, de ses. enliants el de sa femme Marie. Ce titre est placé à la lin de lhomélie, tandis qu'en tète on lit : "Récit de quelques-uns des nombreux miracles opérés par la croix, ete. $\gg$

$9^{\circ}$ (Fol. 116.) Fragment d'une homélie qui, d'après une note ajoutée après coup, avait pour sujet Mar Mina

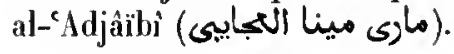


$10^{\circ}\left(\right.$ Fol. $116 v^{\circ}$.) Homélie composée par S. Cyrille, patriarche d'Alexandrie, pour la fête de la Sainte Croix.

$11^{\circ}$ (Fol. 124.) Histoire de la sainte femme Fikyà (فيتيا), épouse de Jésus, fils de Sirach, vizir de Salomon, fils de David.

$12^{\circ}$ (Fol. 127 V$^{\circ}$.) Vie de S. Argénius (لارجانيوس) et de Marie, sa fille.

$13^{\circ}$ (Fol. $139 v^{\circ}$.) Panégyrique de la sainte Vierge Marie, composé par Anbà Cyriaque (انبا هوياقوس), érêque de Behnesà.

$14^{\circ}$ (Fol. $147 \mathrm{~V}^{\circ}$.) Histoire d'Hélène (هيلانه ), mère de l'empereur Constantin.

${ }_{15}^{\circ}$ (Fol. 156.) Questions proposées par 'Isà lbn Ishâaq Ibn Zor'a à Yoúsouf Ibn abì 'l-Ḥakìm al-Bohaïrî, originaire de Meyâfàreqìn, l'an 377 de l'héģire $\left(9^{8} 7\right.$ $988 \mathrm{de} \mathrm{J.} \mathrm{C.).} \mathrm{Ce} \mathrm{sont} \mathrm{des} \mathrm{questions} \mathrm{théologiques,} \mathrm{au}$ nombre de dix-sept.

${ }_{1} \dot{6}^{\circ}$ (Fol. $166 v^{\circ}$.) Traité dans lequel on cherche à démontrer que les hommes qui cultivent la logique et la philosophie ne méritent pas le reproche d'irréligion. Cet écrit est attribué par le copiste à 'Isâ, fils de Zorea, mais il ne renferme aucun passage qui puisse autoriser cette supposition. D'ailleurs il porte en tête la fornule par laquelle les musulmans commencent tous leurs ourrages. D'après l'auteur du "Tarikh al-Ḥlokamàn, le chrétien 'Isâ Ibn Zor'a naquit à Baghdâd, l'an 331 de l'hégire $(942-943$ de J. C.) , et mourut l'an 398 (1007-1008 de J. C.).

$17^{\circ}$ (Fol. ${ }_{17}$ o.) Discours d'Arislote sur le gouvernement de soi-même (التندبي). Ce traité porte aussi la formule musulmane.

$18^{\circ}$ (Fol. $171 v^{\circ}$.) Exposilion de l'opinion des jacobites all sujet de l'incarnalion de J. C.

$19^{\circ}$ (Fol. 172.) Réponse d'Aubà David (دويح) à une question qui circulail dans la ville d'Alexandrie, au sujet de l'incarnation du Messie.

Papier. 176 feuillets. Hauteur, 20 centimètres et demi; largeur, 15 centimètres. 18 lignes par page. Manuscrit daté de l'an 1345 des martyrs ( 1629 de J. C.). - (Ancien fonds 71.$)$

\section{3.}

Vingt-six homélies de S. Basile le Grand, traduites du grec. La première homélie est incomplète, les huit premiers feuillets ayant disparu. Il en est de même de la vingt sixième, dont la fin manque. Quelques-uns de ces discours n'existent plus en grec 1 .

Papier. 287 feuillets. Hauteur, 27 centimètres; largeur, 18 centimètres. 17 à 19 ligues par page. $\mathrm{xv}^{\mathrm{e}}$ siècle. -- (Ancien fonds 58.)

\section{4.}

$1^{\circ}$ L'Hexaméron (الاكسبمـارس), ou discours sur les six jours de la création. Les cinq premiers discours sont de S. Basile, et le sixième de S. Grégoire de Nysse.

$2^{\circ}$ (Fol. 171.) L'A pologie de S. Grégoire. Les feuillets 204 et 205 paraissent appartenir à un autre exemplaire de l'Hexaméron.

Papier. 206 feuillets. Hauteur, 26 centimètres et demi; largeur, 18 centimetres et demi. 19 lignes par page. xvi siecle. -- (Ancien fonds 59. )

\section{5.}

Les sermons de S. Éphrem suivis de l'éloge de S. Eيlirem par S. Grégoire, érèque de Nysse. Titre : ميام Homélies, épitres et discours de notre saint père $S$. Éphrem le Syriell."

Ces sermons sont au nombre de cinquante-deux. Les litres, sauf quelques légères variantes, cocrespondent à ceux stes cinquanle-deux premières homélies qu’Assemani a indiquées dans sa $\approx$ Bibliotheca orientalis n, I. I, P. 150 , d'après III ms. de Rome.

L'éloge composé par l'éréque de Nysse remplit trentecinq feuillets, à partir du deux cent soixante dix-huitième. Il a pour titre : مدحة قالها الاب القديس اغريغويوس اسقت eÉloge de S. Éphrem, prononcé par S. Grégoire, éréque de Nysse." A lia fin ( Tol. $2931^{\circ}$ ),

\footnotetext{
'Le ms. contient : La fin de l'humelie sur le psaume $1^{\text {er }}$; thomélie sur le psaume vin; les deux homélies sur le psaume xIv; les homélies sur les psaumes xxI1, xxvI11, xxix, xxxu, xxxIII, xxxvII, xLIv, xLv, xLvıI, LIx, LxI, cxıv et cxv; les deux hométies sur le Jeûne; l'homéłie

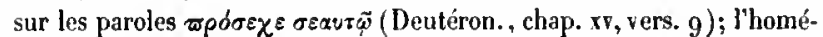
lie sur le passage de l'évangile de S. Luc, chap. xı, vers. 18; l'homélie
}

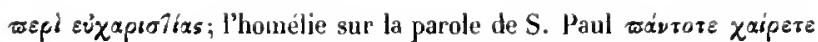
$x \tau \lambda .\left(1^{\text {re }}\right.$ ép. aux Thessaloniciens, chap. $v$, vers 16$)$ et sur $S^{\text {te Juliette; }}$ l'homélie Quod Deus non est auctor malorum; l'homélie In ebriosis. Toutes ces pièces se trouvent, en grec, dans les mss. et dans les éditions des œuvres de S. Basile. H. Z. 
on lit une note qui commence par ces mols : نسفل هذا

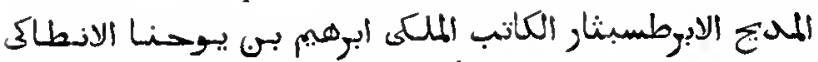

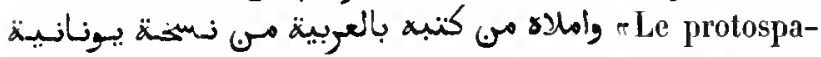
llaire el secrétaire, Abraham, fils de Jean le Melkite, natif d'Antioche, dicta en arabe cet éloge, au fur et à mesure qu'il le lisail daus le texte grec.

Les deux dernier's feuillets du volume contiennent des règles au moyen desquelles on peut trouver les épactes, la Pâque, la correspondance de l'ère des martyrs avec celles d'Alexandre, de J. C. et de l'hégire.

Papier. 295 leuillets. Hauleur, 23 centimètres el demi; largeur, 18 centimètres. 19 lignes par page. $x_{11} 1^{2}$ siècle. - (Ancien fonds 57.)

\section{6.}

Homélies, épitres el discours de S. Éphrem, au nombre de cinquanle-rleux, suivis du Panégyrique de S. Éplırem, par S. Grégoire de Nysse. Eu têle du solume se trouve la lisle des litres.

Papier. 35 - feuillets. Hauteur, 23 centimètres; largeur, 16 centimè tres. 19 lignes par page. Ms. du xu" siecle. (Plusieurs feuillets ont élé ajoulés après coup.) - (Supplément 69 , Saint-Germain 35.)

\section{7.}

Les sermons de S. Éplirem et l'éloge de ce docteur par S. Grégoire, évêque de Nysse. Les qualre premières homé. lies et le commencement de la cinquième manquent. Le feuillet $s^{8}$ nappartient pas au volume; il faisait partie d'un livere d'Heures en langue copte.

Papier. 300 fenillels. Hauteur, a6 centimètres el demi; largeur, is centimètres. Les pages de la première partie du ms. portent cliaenne 31 lignes, les autres n'en portent ordinairement que $17 . x_{1}{ }^{e}$ siècle. - (Aneien fonds 55.)

\section{8.}

Les homélies, épilres et discours de S. Éplrem le Syrien, au nombre de cinquante, suivis de son éloge (lol. $3501^{\circ}$ ), composé par S. Gr'égoire, évêque de Nysse. La liste des titres se troun en tểe du volume et s'accorde exactement alsec celle qu'Assemani a donnée dans fa "Bihliotheca orientalis, I. I, p. 150 et suir.

Papier. 371 feuillets. Hanteur, 24 centimètres et demi; largeur, 16 centimètres el demi. 17 lignes par page. xar sièele. - (Supplèment 67, Saint-Germain 34.)

\section{9.}

Ce volune est de deux écritures, dont la plus ancieune commence au folio $7^{3}$ et finit au folio 326 .

$1^{\circ}$ Les honélies de S. Éphrem, à l'exception des cinq prenières, du commencement de la sixième et de la plus grande parlie de la cinquante-deuxième. Une main plus moderue a écrit la plupart des feuillets qui manquaient. Le ms. commence par la liste des homélies, suivie d'une vie de $\mathrm{S}$. Éphrem, qui remplit vingt feuillets. Celle notice biographique a beaucoup d'analogie avec le texte syriaque publié par Assemani dans sa nibliotheca orieutalis $n$, t. I, p. 26 . Suirent les homélies, dont la quarante-newiène se termine au rerso du folio $3_{2} 6$. Ce même feuillet nous donne le titre et les deux preniières lignes de la cinquantième homélie, qui est restée iıcomplèle.

مع قول أبينا : Fol. 327.$)$ Discours portant ce titre

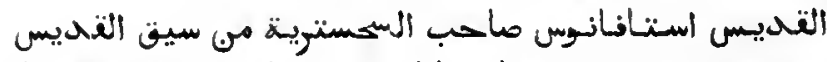
Extrait du discours de notre père Étienne, chef (surveillant?) des cellules

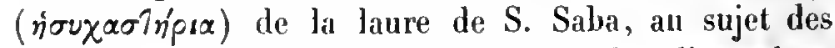
vigiles (áyputvías) pour les matinées des dimanches, etc. $\pi$

$3^{\circ}$ (Fol. $329 v^{\circ}$.) Exhortation adressée par S. Jean Chrysostome aux frères qui se disposent à prendre l'habit monastique.

$4^{\circ}$ (Fol. 335.) Légende sans titre, qui a pour sujet les risions d'une sainte femme.

$5^{\circ}$ (Fol. 339 1 $^{\circ}$.) Histoire d'un moine de la haute Egypte, qui arait eu une vision de l'autre monde. La fin de cette pièce nanque.

$6^{\circ}$ (Fol. $\left.343 \vee^{\circ}.\right)$ Notice d'une comète qui avait paru (eu Syrie?) au commencement du mois de teschrin u de l'an du monde 7086 ( 1578 de J. C.).

Le dernier feulllet reproduit le conmencement de la ie de S. Ephrem, telle qu'elle se troure an folio $8 \%$ La suile se trouve au folio 2 , puis an folio 1. Lá copie n'esl pas acherée.

Papier. 344 feuillets. Hauteur, 25 centimètres; largeur, 17 centimètres et demi. 17 lignes par page. Ms. du $x^{e}$ sièele. La plus grande partie des feuillets, ajoutés après coup, onl été écrits en l'an $7^{062}$ du monde. - (Aneien fonds 56, Colbert 2866.)

\section{0.}

Les lomélies, épitres et discours de S. Éphrem. 
Cet exemplaire, daté de l'an 1405 des martyrs ( 1689 de J. C.), paraît être une copie du ms. $\mathrm{n}^{\circ} \mathbf{1} 38$, mais il ne renferme pas l'éloge de $\mathrm{S}$. Ephrem par $\mathrm{S}$. Grégoire de Nysse.

Papier. ${ }_{262}$ feuillets. Hauteur, $3_{2}$ centimètres; largeur, a 1 centimètres el demi. 18 à so lignes par page. - (Supplément 68.)

\section{1.}

$1^{\circ}$ Panégyrique de la sainte Vierge par S. Cyritle, évêque de Jérusalem.

$2^{\circ}$ (Fol. 12.) Légende de l'apôtre S. Matıhieu et des miracles opérés par la vierge Marie ${ }^{\perp}$.

$3^{\circ}$ (Fol. 31.) Homélie composée par S. Cyrille, patriarche d'Alexandrie, et renfermant le panégyrique de la sainte Vierge.

$4^{\circ}$ (Fol. 63.) Homélie sur la Nativité, par Paul Boûschì.

$5^{\circ}\left(F_{0} .77 v^{\circ}.\right)$ Homélie sur le baptême de Nolre-Seigneur, par le même auteur.

$6^{\circ}$ (Fol. $89 \vee^{\circ}$. ) Homélie dı même, pour la fète de l'Annonciation.

Papier. 104 feuillels. Hauteur, 21 .centimètres el demi; largeur, 15 centimètres. 13 à 17 lignes par page. $x \nabla^{\circ}$ sièrle. - (Supplément 73 , Saint-Germain 248.)

\section{2.}

Version alsrégée des sermons de S. Jean Chrysostome, au nombre de quatre-ringl-sept. Après la préface, dans laquelle il expose les motifs qui le portèrent à entreprendre son travail, le rédacteur indique le sujet de chaque sermon ef en donne une courte analyse. Le titre du

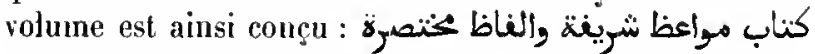

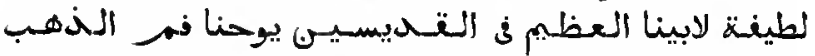
|live d'avertissements précieux et abrégé de beaux passages (offerts par les discours) de notre père, qui est si grand parmi les saints, Jean Bouche d'Or, archevêque de Constantinople. "

Papier. 149 feuillets. Hauteur, 31 centimètres; largeur, a 1 centimètres. 21 lignes par page. Ms. daté de l'an 7169 de l'ère du monde ( 1661 de J. C.). - (Supplément 7o.)

\section{3.}

$1^{\circ}$ Douze homélies de S. Jean Chrysostom :

1. Homélie pour le dimanche, le mercredi et le vendredi.

2. (Fol. 4.) Sur la résurrection de Lazare.

3. (Fol. 21.) Pour le dimanche des Rameaux.

4. $\left(F_{0 l}{ }_{2} 6 v^{\circ}\right.$.) Sur le figuier stérile.

5. (Fol. 35.) Sur les dix vierges.

6. (Fol. 43.) Sur la pécheresse qui oignit les pieds de Jésus-Christ.

7. (Fol. 69.) Sur la passion du Messic.

8. (Fol. $9^{6}$ $^{\circ}$.) Sur la Pâque.

9. (Fol. 1 03.) Pour le dimanche in albis.

10. (Fol. 112.) Suc l'Ascension.

11. (Fol. 122 .) Sur la naissance de S. Jean-Baptiste.

12. (Fol. 128 .) Sur la décollation de S. Jean-Baptiste.

$2^{\circ}$ (Fol. 133.) Récit de la translation de la lète de S. Jean-Baptiste à Émèse.

Au milien des homélies de S. Jean Chrysostome se trousent intercalées les pièces suivantes:

$3^{\circ}$ (Fol. 1o.) Deux homélies de S. Épiphane, archevèque de Chypre, dont l'une pour le dimanche des Ramıaux et l'autre pour le samedi sainl.

$4^{\circ}$ (Fol. 58.) Homélie de Théophile, patriarche d'Alexandrie, sur les mystères de la cène dı Seigneur.

$5^{\circ}\left(\right.$ Fol. $116 v^{\circ}$.) Homélie de S. Athanase, patriarche d'Alexandrie, sur le dimanche de la Pentecôte.

6 (Fol. $138 v^{\circ}$.) Deux homélies de S. Éphrem, dont l'une sur le prophète Élie et l'autre sur la Transfiguration.

$7^{\circ}$ (Fol. 157.) Trois courtes légendes, donl une a pour sujel un moine de Scété, et l'autre un saint nonuné Arsène.

$8^{\circ}$ (Fol. 159.) Recueil des passages du Pentateuque et des livres prophétiques que l'on récite dans l'Église (melkite) pendant le carême el anx lêtes de la sainte

\footnotetext{
${ }^{1}$ C'est l'histoire de la délivrance de l'apòtre S. Mathias, à Béryte, par la S'e Vierge. Voyez Catalogue des mss. éthiopiens, p. 60. H. Z.
} 
Vierge et des saints. Ces passages sont accompagnés chacus de leur antienne et de leur prokeimenon.

Papier. 246 feuillets, qui ne sont pas tous de la mềme époque ni du même format. La partie la plus ancienne existait déjà l'an $6818 \mathrm{du}$ monde ( 1310 de J. C.), car une note écrite sur la marge du folio 151 porte cette date. Hauteur, 25 centimètres; largeur, 17 centimètres. Dans la partie la plus ancienne, le nombre des ligones varie de 14 à 16 . (Ancien fonds 63, Colberl 4214.)

\section{4.}

$1^{\circ}$ Homélie de S. Jean Chrysostome sur le renoncement aux choses de ce monde, sur le jeûne et sur la prière.

$2^{\circ}$ (Fol. 9.) Homélie dans laquelle le grand S. Abou-

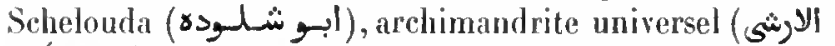

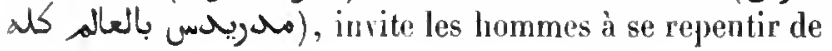
lenrs péchés ${ }^{1 .}$

$3^{\circ}$ (Fol. 23.) Les quatre Évangiles, précédés de tables de concoldance, de préfuces et de notices sur les évangrélistes. Cette partie du uns. est datée de l'an 1026 de l'hégire ( 1617 de J. C.).

Le copiste assure pue celte version a été corrigée avec le secours de plusieurs anciens manuscrits en syriaque, (n) lalin (ärog) et en copte (voyez fol. 189). Les homélies sont d'une autre écriture que les évangiles.

Papier. 190 feuillets. Hanteur, 19 centimètres; largeur, 14 centimètres et demi. Dans la première partie, il y a 14 lignes par page, dans la dernière, 16 lignes. - (Ancien fonds 74 .)

\section{5.}

1. Homélie de S. Jean Chrysostome sur l'Annoneiation et sur la naissance de S. Jean-Baptiste.

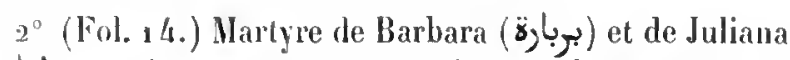
(بيوليازة), qui moururent pour la foi dans la ville d'Hélio-

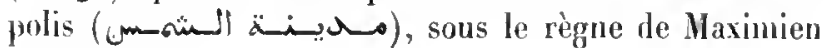
(متسمبانوسي).

$3^{\circ}$ (Fol. $261^{\circ}$.) Homélie de S. Jean Chrysostome sur. l'Annoncialion.

$4^{\circ}$ (Fol. 3..) Autre homélie du même sur le même sujet.

$5^{\circ}$ (Fol. $\left.5 \mathrm{v}^{\circ}.\right)$ Autre homélie du mème sur le même sirjet.
Une note marginale nous apprend que cette version a été faite sur un exemplaire copte appartenant à la bibliothèque du monastère de Saint-Macaire.

$6^{\circ}$ (Fol. 77.) Homélie sur le trépas du patriarehe Anbâ Matthieu, et récit du martyre de plusieurs de ses ouailles.

La même pièce se trouve dans le ms. $n^{\circ}{ }_{1} 32$.

$7^{\circ}$ (Fol, 155.) «Discours de S. Cyrille de Jérusalem à la louange des vingt-quatre prêtres que S. Jean l'apôtre vit assis autoùr du trône de Dieu (Apocalypse, iv, 4). Leur fête était céléhrée le 24 du mois d'athîr (هنت2).

Suit un cantique en copte, arec la traduction en arabe, destiné à être récité en ce jour.

$8^{\circ}\left(\right.$ Fol. $161 v^{\circ}$.) Panégyrique des quatre animaux spilituels et incorporels dont le même apôtre fait mention dans l'Apocalypse. Ce discours est de S. Jean Chrysostome.

$9^{\circ}$ (Fol. ${ }^{1} 79$ r $^{\circ}$.) Homélie de Théodose, patriarehe d'Alexandrie, sur l'archange Michel.

10 $0^{\circ}$ (Fol. 2 19.) Homélie d'Anastase, érêque de l'ile de Samothrace (? أتراك (ا) ), sur le même sujet.

$11^{\circ}$ (Fol. $263 v^{\circ}$.) Miracles de l'archange Michel.

$12^{\circ}$ (Fol. $280 v^{\circ}$.) Homélie d'Arclsélaüs, érêque de la ville d'Irâ (?, إيبر), sur l'archange Gabriel.

Papier. 310 feuillets. Hauteur, 22 centimètres; largeur, 16 rentimètres. Environ 14 lignes par page. Volume écrit t'an 1357 des martyrs (1641 de J. C.). - (Supplément 65, Saint-Germain 250.)

\section{6.}

Homélies de S. Jean Chrysostome. Le rédacteur anonyme de ce recueil, qui était probablement jacohite, nous apprend dans sa préface (fol. 1 à 4), qu'après aroir abrégé les homélies, il les a classées de manière à servil pour l'office de tous les dimanches de l'amnée et pour les jours de la semaine sainte 2 .

Papier. 208 feuitlets. Hauteur, 22 centimètres; largeur, 15 centimètres. Environ 17 lignes par page. Hs. dı xvil ${ }^{e}$ siècle. - (Ancien Conds 6.)

\section{7.}

$1^{\circ}$ Homélie de S. Épiphane, archerèque de l’ile de

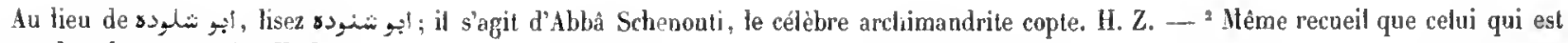
contenu dans te ms. ${ }^{\circ} 142$. H. Z. 
Chypre, sur l'enterrement du corps de Notre-Seigneur Jésus-Christ.

$2^{\circ}$ (Fol. 15.) Homélie de l'érêque S. Grégoire ${ }^{1}$ sur la résurrection de Notre-Seigneur.

$3^{\circ}\left(\right.$ Fol. $27 \mathrm{v}^{\circ}$.) Maxinues morales de S. Grégoire le Théologien, évêque de Nazianze (نازبنزوا).

$4^{\circ}$ (Fol. 31.) Homélie de S. Grégoire le Théologien sur la fête de Pâque.

$5^{\circ}$ (Fol. 34.) Homélie du même sur le même sujet.

$6^{\circ}$ (Fol. 58.) Homélie du même sur le dimanehe nou-

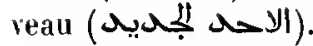

$7^{\circ}$ (Fol. 67.) Homélie sur l'aseension de Notre-Seigneur.

$8^{\circ}$ (Fol. 75.) Honiélie de S. Grégoire le Thúologien sur la Pentecôte (iألتنتستى).

$9^{\circ}$ (Fol. 89.) Apologie de S. Gr'égoire le Théologien, dans laquelle il s'excuse d'aroir hésilé à accepter le sacerdoce.

$10^{\circ}$ (Fol. 122.) Martyre de l'apòtre S. Philippe.

$11^{\circ}$ (Fol. 146.$)$ Histoire de S. Denys l'A réopagite.

$12^{\circ}$ (Fol. 162.) Vie du saint père Anbà Théodore (تادوس) qui, par sa dérotion el par sa mortification, pendant qu'il était moine dans la laure de Saint-Saba, mérita d'être élevé au siége épiscopal d'Édesse. Cet écrit a pour auteur Basile, diseiple de Théodore el évéque de Manbadj (Bambyce, Hiéropolis).

On troure dans celte notice (folios $19^{6} v^{\circ}$ ol suir.) une longue et singulière histoire de la eonversion du calile at-Màmoûn au christianisme, par Théodore, el du martyre de ce prince.

${ }_{1} 3^{\circ}$ (Fol. $221 \mathrm{r}^{\circ}$.) Histoire de la fondation de l'église de Saint-Élie al-Astabi, ايليا الاستبى 22, sur la montagne appelée Djebet-Aouf el située en face de Jérusalem, du côté de la mer Morte.

$14^{\circ}$ (Fol. 232 .) Histoire de la nativité de Notre Dame Marie (مكتميه et de Notre-Seigneur Jésus -Christ, hisloire attribuée à l'apôtre S. Jacques, dit le frèce de. Notre-Seiyneur.

Les derniers feuillels de cet opnscule manquent.

${ }_{1}^{\circ}$ (Fol. 306 à $3211^{\circ}$, puis lol. 261 el suiv.) Hisloire du S. P. Sylvestre, pape de Rome et premier des patriarches, composée par l'évêque Eusèbe Pamphile (أوسابيوس المبنغيلى).
Le fol. 305 doit se placer après le fol. 326 .

Papier. 326 feuillets. Hauteur, 25 centimètres; largcur, 16 centimètres. 15 à 17 lignes par page. Ms. du xv siècle. Le fol. 203 a ćté ajouté en l'an 1522. - (Ancien fonds 73 , Colbert 3797.)

\section{8.}

1 - Panégyrique de l'archange Michel, par Sévère, patriarclse d'Antioche.

$2^{\circ}$ (Fol. 2o.) Quelques mirtacles de l'archange Michel.

$3^{\circ}$ (Fol. 34.) Discours sur les mérites de l'archange, ministre de l'Annonciation, par Anbâ Archélaüs, érêque de la ville d'îrâ.

$4^{\circ}$ (Fol. 57.) Panégyrique de l'archange Gabriel, par Anbâ Aour (ggl), évêque de Fayyoûm.

$5^{\circ}$ (Fol. 81.) Description des quatre animaux incorporels dont parle l'archevêque de Constantinople, S. Jean Chrrysostome, d'après la version d'Aboù Ghâlamschisch (غالمشنيi).

Le copiste ou le rédacleur a confondu S. Jean Chrysostome avec S. Jean, l'auteur de l'Apocalypse; quant ì Abou Ghâlamschisch, cंest une altération du mot apocalypse.

$6^{\circ}$ (Fol. $119 v^{\circ}$.) Panégyrique de S. Georges, par Anbì Théodose, évêque de Gangres (bșiغ).

$7^{\circ}$ (Fol. 201.) Récit des douze miracles opérés par $\mathrm{S}$. Gieorges.

$8^{\circ}$ (Fol. $215 r^{\circ}$.) Discours en l'honneur de S. Théodore, protecteur de la ville d'Antioche et vainqueur des Persars, par Théodore (تـادوس), patriarche d'Antioche.

C'est une sorte de roman, dans lequel on raconte des fables au sujet d'une guerre entreprise par un emperemr clurétien contre le roi sassanide.

$9^{\circ}$ (Fol. 271.) Martyre de S. Gyriaqute (قوياتوس) el de sa mère Juliette (يوليطة).

$10^{\circ}$ (Fol. 295.) Vie d'Anbâ Harmonia (هرمسنسيـة) racontée par Abbâ Hoûr.

Papier. 331 feuillets. Hauteur, 21 centimètres; largeur, 15 centimètres. 12 et 13 lignes par page. Ms. daté de l'an 1371 des martỵrs (1655 de J. C.). - (Ancien fonds 108.)

\section{9.}

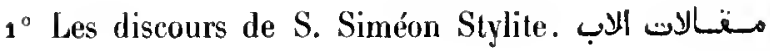

I S. Grégoire de Nysse (دوسس). II. Z. - ${ }^{2}$ Le ms. poite إيليا الاستب الغيور; ce sont les attributs du prophète Élie. II. Z.

Mas. orientaux. - II. 
.القحيس مار سمعان اللغـودى L'auteur de ces discours est Siméon Stylite le jeune, surnommé Thaumastorite.

$2^{\circ}$ (Fol. $164 v^{\circ}$.) Paroles et questions, au nombre de dix, par le même.

$3^{\circ}$ (Fol. $\left.184 v^{\circ}.\right)$ Questions traitées par le mème. Elles sont au nombre de quarante et une.

$4^{\circ}$ (Fol. 212.) La cinquième homélie d'Isaac, évêque de Ninive.

$5^{\circ}$ ( $\left.F_{01}{ }_{2} 16.\right)$ Extraits d'autres écrits du même évèque.

Papier. $2 / 9$ feuillets. Hlauteur, 26 centimètres; largeur, 17 centimètres. Le nombre des lignes par page varie de 19 à 31. - (Supplément 7 4, Saint-Germain 36.)

\section{0 .}

$1^{\circ}$ Exhortation qu'Anbâ Vicentius ${ }^{1}$ (بسنتيوس), érêque de Qefṭ (قنط), en Égle, adressa par écrit aux habitants de son diocèse, étant alors sur son lit de mort. Dans cette pièce, il prédic la conquête de l'Égypte par les Arabes musulmans et les violences qu'ils exerceraient sur les chrétiens.

$2^{\circ}$ (Fol. 14.) Explication de la vision que le prophète Daniel raconta à son disciple lisdras, et indication de ce qui doit arriver aux enfants d'Ismaël et d'Agar la Copte.

$3^{\circ}$ (Fol. 20.) Prophétie sous forme de sermon, altribnée à Aubâ Samuel, supérieur du monastère de Cal• mồlı.

$4^{\circ}$ (Fol. 31.) Martyre da grand saint persan S. Jacyues l'Intercis.

A la fin de cette pièce (fol. 48), se trouve une invocation en copte.

$5^{\circ}$ (Fol. 49.) Actes et miracles de S. Victor; discour's composé par Anbà Dénıétrius, archerêque d'Antioche, te même qui conféra l'ordre de la prêtrise à $\mathrm{S}$. Jeau Chrysostome. Il le prononça lors de la consécration de la grande église qui fut placée sous l'invocation du saint martyr, Victor, fils du vizir Romanus.

$6^{\circ}$ (Fol. 93.) Récit d'un grand miracle qui eut lieu le jour de la consécration de l'église de $\mathrm{S}$. Victor.

$7^{\circ}$ (Fol. 101.$)$ Récit de sept miracles que Dieu opéra par la main du saint martyr Ptolémée (إبطاوساس), le jour de la consécration de l'église dédiée à ce saint.

$8^{\circ}\left(\right.$ Fol. $1111^{\circ}$.) Sermon d'Anbâ Cyriaque (هوياقوس), évêque de Belnesâ, dans lequel il fait le panégyrique de la sainte Vierge et parle des larmes qu'elle répandit sul' le tombeau de son Fils.

$9^{\circ}$ (Fol. 141.) Homélie à la louange de la sainte Vierge, prononcée par Anbâ Basile, archevêque de Césarée de Cappadoce, dans la grande église consacrée à la sainte Vierge, et bâtie à l'or'ient de la ville par le général (متحم) Romanus.

$10^{\circ}$ (Fol. 157.) Sur la mort de la sainte Vierge, et description de son passage de ce monde transitoire à la vie éternelle.

$11^{\circ}$ (Fol. 171.) Panégyrique de la sainte Vierge, par Cyrille, archevêque de Jérusalem.

$12^{\circ}$ (Fol. 193 .) Discours sur la présentation de la sainte Vierge au temple, coinposé par André de Jérusalen

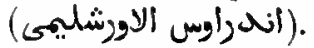

$13^{\circ}$ (Fol. 202.) Épitre adressée par Sévère, patriarche d'Antioche, à la sainte vierge Anastasie.

$14^{\circ}$ (Fol. $212 v^{\circ}$.) Panégyrique du général (أسبهسلحار) Basilidès, martyr de Jésus-Clirist; discours composé par Célestin (كلستتينوس), archerèque de Rome, sur le désir de trois autres généraux, compatriotes du défunt et officiers au service de Théodose.

$15^{\circ}$ (Fol. 280.) Fragment d'un. recueil de canons : *Vingt-quatrième chapitre. Sur le mariage. Extrait du titre (تطان), qui défend le divorce absolument."

$16^{\circ}$ (Fol. 290.) Extrait des canons écrits par Pierre, disciple de Jésus-Clırist et chef des apôtres, el adressés par luj à S. Clément.

$17^{\circ}$ (Fol. 30o.) Histoire de Secundus le philosophe, et ses réponses à plusieurs questions.

Papier. 333 feuillets. Hautcur, 21 centimètres; largeur, 15 centimètres. Ces pièces sont de diverses maius, et le nonbre des lignes par page varic pour chaque pièce. Aux folios 201 el $279 \mathrm{v}^{\circ}$, on trouve la date de 1322 des martyrs (1606 de J. C. ). — (Ancien fonds 107.)

\section{1}

$1^{\circ}$ Homélie de S. Jean Damascène sur l'Annonciation.

$2^{\circ}$ (Fol. $7 \mathrm{v}^{\circ}$.) Homélie de S. Grégoire le Théologien sur la Nalivité.

\footnotetext{
1 Pisenti ou Pisentios. H. Z.
} 
$3^{\circ}$ (Fol. 25.) Homélie de S. Jean Chrysostome sur la Nativité.

$4^{\circ}$ (Fol. $38 \vee^{\circ}$.) Panégyrique de la sainte Vierge par S. Épiphane.

$5^{\circ}$ (Fol. 58.) Homélie de S. Jean Chrysostome sur le massacre des innocents.

$6^{\circ}$ (Fol. $67 v^{\circ}$.) Discours de S. Cyrille d'Alexandrie sur la Circoncision.

$7^{\circ}$ (Fol. $76 \vee^{\circ}$.) Homélie de S. Jean Chrysostome sur le baptême de J. C.

$8^{\circ}$ (Fol. $87 \mathrm{v}^{\circ}$.) Homélie du même sur le mème sujet.

9" (Fol. 95.) Fragment d'une homélie sans titre.

$10^{\circ}$ (Fol. $1171^{\circ}$.) Homélie de S. Éphrem sur la foi et la charité.

$11^{\circ}$ (Fol. 124. ) Homélie du mène sur la fin du monde et la venue de l'Autéchrist.

$12^{\circ}$ (Fol. $142 v^{\circ}$.) Homélie de S. Jean Chrysostome sur les afflictions, les maladies et la misère auxquelles l'homme est exposé.

$13^{\circ}$ (Fol. 14g.) Homélie de S. Éphrem sur la charité et lè jeûne.

$14^{\circ}$ (Fol. 154.) Homélie du mème sur la pénitence.

$15^{\circ}$ (Fol. $168 r^{\circ}$.) Homélie de S. Jean Chrysostome sur la parabole du Phariséen (الفويسى) el du Publicain (j) العiار).

$16^{\circ}$ (Fol. $\left.173 \checkmark^{\circ}.\right)$ Homélie du même sur l'Eufant pi'odigue (الابسن النياطر النهم).

$17^{\circ}$ (Fol. 194.) Homélie du néme sur la résurrection de Lazare.

$18^{\circ}$ (Fol. $199 v^{\circ}$.) Homélie du même sur le dimanche des Rameaux.

$19^{\circ}$ (Fol. 206.) Homélie du mêne sur le figuier stérile:

$20^{\circ}$ (Fol. 215.) Homélie du mème sur les dix vierges.

$21^{\circ}$ (Fol. 224.) Homélie de S. Épliren sur la pécheresse qui oignil les pieds du Seignent.

$22^{\circ}$ (Fol. $2331^{\circ}$.) Homélie de S. Jein Chrysostome sur l'Eucharistie.

„23 (Fol. 248.) Homélie du mème sur le vendredi saint, sur le reniement de Pierre et sur la conversion du bon larron. $24^{\circ}$ (Fol. $258 \vee^{\circ}$.) Histoire de S. Jean l'aumônier', patriarche d'Alexandrie, écrite par Léonce, évêque de Néapolis (نالس (ن) dans l'ile de Chypre.

La fin de ce récit manque.

Papier. 274 feuiltets. Hauteur, 24 centimètres; largeur, 15 centimètres et demi. 13 lignes par page. Ms. du su $7^{\circ}$ siècle. - (Ancien fonds $7^{6}$, Cotbert 4994.)

\section{2.}

$1^{\circ}$ L'ouvrage appelé ordinairement le Martyre de Pilate. Discours de notre révérend Père Cyriaque (هياقوس), évêque de Behnesâ, sur la résurrection de Notre-Seigneur Jésus le Messie, et sur les souffrances que Pilate le Nabatéen éprouva à Jérusalem, lors du clucifiement. L'auteur fait aussi mention de Joseph d'Arimathie النذى مـ. ألt de Nicodème, les deux respectables chefs. Il fait connaitre les tourments que Pilate eut à subir de la part des juifs, à cause du Seigneur le Nessie, et le maurais traitement qu'Hérode lui infligea avant de l'envoyer à Rome, capitale de l'empire, où il eut la tête tranchée, ce qui compléta son martyre. Il y est aussi question de ce qu'on trone dans un écrit ayant pour auteurs Amaliel ${ }^{1}$ (عالـيال) et Ananias (أنايوس), qui assistèrent avec Joseph et Nicodème à la Passion, etc. "

$2^{\circ}$ ( liol. $47 \mathrm{v}^{\circ}$.) Lutte spiriluelle que le révérend Anbâ Boûlà $($ بولا), le Syrien, eut à soutenir contre Satan.

$3^{\circ}$ (Fol. $70 v^{\circ}$.) Sermon de S. Jean Chrysostome sur les six jours de la création.

4" (Fol. 8o.) Sermon de Jacques, évêque de Saroùd, sur le sacrifice d'lsaac, type de la Passion de Notre-Seigneur.

$5^{\circ}$ (Fol. $90{ }^{\circ}$.) le martyre de Şalib (صـليسب), natil d'Aschmounaïn.

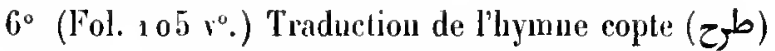
qu'on chante à l'oflice de S. Șalib, suivi du texte original.

$7^{\circ}$ (Fol. $108 \vee^{\circ}$.) Histoire de Joseph et de ses frères.

La fin de cette pièce manque.

Papier. 143 fenitlets. Hauteur, so eentimètres et demi; largeur, 15 centimètres. 15 tignes par page, à l'exception du dernier opuscule, qui est d'une autre écriture, et dans lequet le nombre des liznes paŕ page varie de 13 à $20 . x$ si $^{\circ}$ sièrle. - (Ancien fonds 1 fo.)

"Lisez Ginaitiel. II. Z. 


\section{3.}

Ce volume a souffert de l'humidité de telle sorte que la plus grande partie du texte est devenue illisible. Il se tromvait dans cet état lorsqu'il entra dans la bibliothèque de Colbert. Voici les titres des opuscules qu'il renferme, antant qu'on pent les déchiffrer.

I Homélie de S. Cyriaque (هرياتوس), évêque de Behnesi, sur la luite de la Sainte Famille en Egypte.

$2^{\circ}\left(\right.$ Fol. $8 v^{\circ}$.) Discours sur la vie méritoire d'Anbà 'Hanı (ś), qui mourut l'an 1059 des martyrs ( 1343 (te .t. C.).

$3^{\circ}$ (Fol. 22.)'Première partie de l'r Histoire des paIriarches d'Alexandrie\%.

$4^{\circ}$ (Fol. $92 v^{\circ}$.) Comnémoration de la mort de Salomon, lils de Divid et roi disraël.

$5^{\circ}$ (Fol. $9^{6} r^{\circ}$.) Discours sur le martyre dı saint père Aubâ Grégorios (S. Grégoire l'Hlluminateur), patriarche des Arméniens.

$6^{\circ}$ (Fol. 102.) Discours sur la mort d'Aboû Timsàl! (z'مَ), qui souffrit le martyre sous Dioclétien.

$7^{\circ}$ (Fol. 112.) Vie du bienheureux père Aubâ Élie (ايلياس), l'anachorète, qui avait fixé sa demeure sur la montagne de Bouâ (بوا)

$8^{\circ}$ (Fol. $114^{\circ}$.) Disconrs composé par le saint père Isaac (الساك), érêque de la ville d'Enșenâ (انصiاك), dans la Thébaide, sur la découverte du corps de S. Coluthus (sic $($ S)

$9^{\circ}$ (Fol. 124.) Discours sur le martyre d'Anbà Anrmonios (امونيوس), emprisonné sous Dioclétien et mis ensuite à mort.

$10^{\circ}$ (Fol. 135.) Récit de ce que souffrit pour la loi Dioscore (ديستوروس), patriarche d'Alexandrie, qui fut condammé par le concile de Clialcédoine.

$11^{\circ}$ (Fol. $139 \%^{\circ}$.) Miracles de S. Basile, érêque de Ciésarée de Cappadoce, racontés par son disciple Hilarion (ي) (ي) (يون).

$12^{\circ}$ (Fol. 164.) Martyre d'Anbà Nifà (نسيـiا), natif de la ville de Saft (سفb), dans la haute Égypte, et qui lécut sous Dioclétien.

${ }_{1} 3^{\circ}$ (Fol. 170.) Histoire des saintes vierges et martyres Pistis, Elpis el Agapé (Foi, Espérance et Charité), qui ont souffert sous le règne d'Hadrien. $14^{\circ}$ (Fol. $1741^{\circ}$.) Histoire de S. Longin (Jينجوس), confesseur et hégumène, qui, aidé par son père spirituel, Lucius, maintint l'observance des préceptes de l'Évangile.

$15^{\circ}$ (Fol. $1861^{\circ}$. ) Vie de Mar Abschâi (ابنئى), saint religieux.

$16^{\circ}$ (Fol. 203.) Histoire de Mar Théodore (تصادوس), fils de Basilidès (واستبليشل), le vizir. Il vivail sous le règne de Dioclétien.

$17^{\circ}$ (Fol. 216.) Vie du saint homme Aboû Fâna (ابسبو) فانة).

$18^{\circ}$ (Fol. 226.) Vie de S. Macrobe (مفووفيوس); natil de Tkòou, dans la Thébaide.

$19^{\circ}$ (Fol. 234.$)$ Martyre d'Aboù Qalta (أبو قلتة), natil" d'Eirsenenà, qui souffrit sous Diociétien.

$20^{\circ}$ (Fol. $235 r^{\circ}$.) Miracles des deux martyrs Serge et Bacchus (um).

$21^{\circ}$ (Fol. $240 v^{\circ}$.) Miracles de Théodore le martyr ( église.

$22^{\circ}$ (Fol. $2431^{\circ}$.) Discours composé par Sévère, patriarche d'Antioche, à l'occasion de la découverte du corps de S. Philothée (فيلوناوس) et de la dédicace de son église.

$23^{\circ}$ (Fol. 250.) Discours composé par Anbà Matthieu (متح), septième du nom, sur les miracles de Behnân ) et de sa sour Sarah, et sur la dédicace de leur église.

$24^{\circ}$ (Fol. 254.) Martyre de S. Démétrius, sous le règne de Maximien.

$25^{\circ}$ (Fol. 255.) Martyre de S. Bitlàn (بيطلن (ب) I.

$26^{\circ}$ (Fol. 257 .) Histoire de Jean l'aumònier, patriarche d'Alexandrie, par Léonce, érêque de Néapolis, dans l'île de Chypre.

$27^{\circ}$ (Fol. 285.) Vie de S. Épiphane.

$28^{\circ}$ (1'ol. 314.) Le livre d'Esther l'Israélite.

$29^{\circ}$ (Fol. $318 v^{\circ}$.) Le Livre de Judith (يوديد) l'Israélite.

$30^{\circ}$ (Fol. 334.) Le Lirre de Tobie.

$31^{\circ}$ (Fol. $341 v^{\circ}$.) Le Livre de Job.

$32^{\circ}$ (Fol. 363.) L'Ecclésiastique.

$33^{\circ}$ (Fol. $386 v^{\circ}$.) La Sagesse.

$34^{\circ}$ (Fol. 400.) Avertissenent préliminaire aux P'roverbes de Salomon.

\footnotetext{
1 بنطان بطان est une transcription fautive pour-à-dire Pantaléémon (te médecin). H. Z.
} 
$35^{\circ}$ (Fol. $401 v^{\circ}$.) Les Proverbes de Salomon.

$36^{\circ}$ (Fol. 432.) L'Ecclésiaste.

$37^{\circ}$ (Fol. 438.) Panégyrique de $\mathrm{S}^{\text {to }}$ Diladjì (ذيلى), par Yoûnos, évêque d'Esnâ. Cette sainte subit le martyre sous Maximien.

$38^{\circ}$ (Fol. $445 v^{\circ}$.) Histoire de Jean al-Nemrosì (النمسىى), qui subit le martyre l'an1 1298 (1582).

$39^{\circ}$ (Fol. $452 v^{\circ}$.) Sermon sur les dix vierges, par Anbẩ Zoïle? (سيوس), patriarche d'Alexandrie.

$40^{\circ}$ (Fol. $461 v^{\circ}$.) Sermon d'Anbâ Cyrus ${ }^{1}$ sur ce que le prophète Daniel lui révéla en songe.

41 (Fol. 470.) Sermon composé par Jacques, évèque de Saroûdj, sur la mort d'Aaron le grand prêtre.

Papier. 477 feuillets. Hauteur, a 1 centimètres; largeur, 15 centimètres. 21 on 2 a lignes par page, excepté tes feuiltets 438 et suivants, qui portent 18 lignes par page. $x$ vir siècle. - (Ancien fonds 149 , Colbert 4442.)

\section{4.}

1. Homélie dans laquelle Élie (أيليا), évèque d'Alısaii (إبصا), célèbre les mérites du saint mártyr Anbâ Ahsoûdi (أبصودى), évêgue de la même ville.

$2^{\circ}$ (Fol. 29.) Ilistoire du vaillant soldat et martyr,

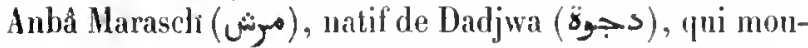
rut pour la foi, sous le r’ègne de Dioclétien.

3* (Fol. 38.) Courte relation des miracles opérés par les SS. Côme, Damien, Anthyne, Léonce, Eutrope, et

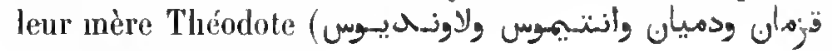

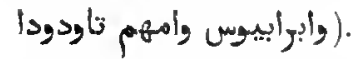

$4^{\circ}$ (Fol. 53.) Ilistoire du saint prètre (ك) et martỷr Abbâ Noûb (ابازوب), l'éln du Seignenr.

$5^{\circ}$ (Fol. 64 $v^{\circ}$.) Histoire véritable du saint père Moïse surnommé l'Homme de Dieu. Il naquit ì Ronle; son père se nommait Luphémius et sa mère Galéna (غي)

$6^{\circ}$ (Fol. 79.) Histoire du saint martyr Moïse le Noir. $7^{\circ}$ (Fol. $93 v^{\circ}$.) Panégyrique du saint contesseur Anbè Benfà (بنغا), par Victor (بنطا), évềue d'Enṣenâ (انصنا).

$8^{\circ}$ (Fol. 106.) Sermon prononcé par S. Basile le Grand, évếue de Cappadoce, lors de la consécration de l'éğlis" de la Sainte-Vierge.

$9^{\circ}$ (Fol. 145.) Disconrs de S. Cyrille, érêque de Jérusalem, sur la vie de S. Matthien ${ }^{2}$ et sur les miracles de la sainte Vierge.

$10^{\circ}$ (Fol. 167.) Miracles opérés par la sainte Vierge daus Atrib (أتبيب, ville de la haute Égypte), sous le règne d'al-llàmoûn, fils de Haroûn al-Raschìd.

$11^{\circ}$ Disconrs prononcé par Jean, moine du monaslère

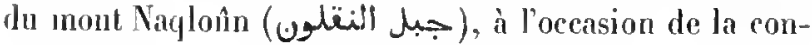
sécration de l'église de l'Archange-Gabriel.

Papier. 201 feuillets. Ilanteur, 21 centimètres; fargeur, 15 centimètres. 14 à 16 lignes par page. Hs. daté des années $1320-1323$ des martyrs (1604-1607 de J. C.). - (Supplément 76 , Saint-Germain 249 .)

\section{5.}

$1^{\circ}$ Sernon au sujet d'un miracte opéré par la sainle lemme Marinà (Liئo), supérienre du couvent de reli-

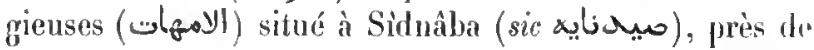
Danas. On lit en marge et à côté du titre deux notes yui signifient: "Qu'il soit excommunić, celui qui lil rolles histoire mensongère ${ }^{3}$."

$2^{\circ}$ (Page 12.) Somnon de S. Éphrem sur la nativilé de la sainte Vierges.

30 (Page a'..) Sirmon de S. Cyrille, patriarche de Jérusilem, sur la prósentation de la sainte Vicrge au temple.

40 (Page 46.) Discours de S. Cyrille, patriarche d'Ilexandrie, sur la mort do la sainte Vierge.

$5^{\circ}$ (1’age 77.) Discours prononcé par S. Basile le Grand, éveque de Cappadoce, en commémoration de la sainte Vielge.

$6^{\circ}$ (Page 109. .) Discours de S. Basile, évèque de Jérusalem, sur l'apôtre S. Matthieu et sur mn miracle opérí par la sainte Vierge 4 .

$7^{\circ}$ (Page 127.) Discoms de S. Cyrille d'Hexandrie sur l'Assomption.

$8^{\circ}$ (Pagre 145.) Diseours de S. Jean Chrysostonne sul la fuite en Égypte.

\footnotetext{
1 Au lieu de Cyrus et, à l'article précédent, Zoile, lisez Athanase. Le ms. porte, dans les deux endpoils, l. H. Z.

${ }^{ \pm}$Lisez Mathias, et comparez ci-dessus $n^{\circ} 141,2^{\circ}$. H. Z.

${ }^{3}$ An lieu de Sidnâba, lisez Saidnàya. C'est l'histoire bien connue
}

de l'image miraculense de la sainte Vierge, conservée dans celt vitle. 11. Z.

4. An lieu de S. Basile, lisez S. Cyrille, et au tieu de S. Matthieu, lisez S. Mathias, Comparez ci-dessus n ${ }^{04} 141,3^{\circ}$ et 154,9 . H. Z. 
$9^{\circ}$ (Page 160. Discours de Cyriaque, érêque de Behnesà, sur la fuite en Égypte et sur le séjour de la Vierge et de l'enfant Jésus dans Bisoûs (بيسوس), à l'est de Behnesà.

$10^{\circ}$ (Page 178.) Discours de Cyriaque sur la fuite en Égypte cl sur le séjour de la Vierge et de l'enfant Jésus dans la localité appelée plus tard Daïr al-Moḥarraq.

$11^{\circ}$ (Page 188.) Discours de Théophite, patriarche d'Hlexandrie, sur la fuite en Égypte et sur le séjour de la Viergo et de l'enfant Jésus dans la montagne de Qaṣqâm (تصنام), appelée maintenant Daïr al-Moharraq.

$12^{\circ}$ (Page 217 .) Récit des miracles de la Vierge.

$13^{\circ}$ (Page 263.) Discours sur un miracle opéré par la sainte Vierge dans la ville d'Atrib (أتريب), près du vieux Caire, sous le califat d'al-Màmon̂u, fils de Haroûn alliaschid.

Le ms. a élé copié dans l'ile de Rlıodes, l'an 1202 de f"ere des martyrs (1486 de J. C.).

Papier. $27^{4}$ pages. Hauteur, 26 centimètres; largeur, 19 centimètres. 18 a 21 tignes par page. - (Ancien fonds 143.)

\section{6.}

Vingt-deux homélies on discours (khotba) pour les diverses fètes de l'amnée. Ces pièces sont écrites en belle prose rimée, dans le genre de celle des Maqámát d'al-Hal'ìri. La vingt-Iroisieme section renferme l'explication de artains termes employés dans la khotba de la Nativité. Cette hotba devait se trouver 'n tête du volume, mais les leuillęts qui la contenaient manquent. Les derniers lenillets du volume devaient contenir la suite des gloses et l'explication de toutes les expressions difficiles qui se rencontrent dans chacun de ces discours, inais its manquent également. Le nou de l'auteur et le titre de l'ourage sont incomnus. Un titre qui a élé écrit sur le verso du premier leuillet et quelques lignes collées sur le reclo du second feuillet sont l'ourrage d'un faussaire.

Papier. 79 feuillets. Hauteur, 24 cenlimètres; largeur, 16 centiuètres et demi. 1 I lignes par page. xiv siècle. - (Ancien fonds 89. )
VII.

\section{TRAITÉS DE THÉOLOGIE.}

\section{7.}

$1^{\circ}$ "Épittre du saint père Lucius au saint père Évagrius " إئ . Commenأنت إيها الاب ساكى ف البرية كمى هور

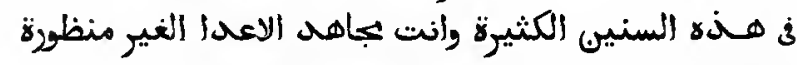

L'auteur de cette lettre prie Évagrius de composer pour lui un traité dans lequel seraient indiquées les ruses employées par les démons pour nuire à la vie monastique.

$2^{\circ}$ (Fol. 3.) Réponse d'Évagrius à Lucius.

$3^{\circ}$ (Fol. $3 v^{\circ}$.) Traité de l'excellence de la vie solitaire, composé par Évagrius, sur la demande de Lucius l'Arien, patriarche d'Alexandrie. Évagrius 'fut ordonné diacre à Constantinople, l'an 381 . Il passa les dernières annces de sa vie au couvent de Nitrie, et composa plusieurs ouvrages, dont les titres se trouvent dans la r Bibliotheca rraci de Fabricius, éd. de Harles, t. IX, p. 284.

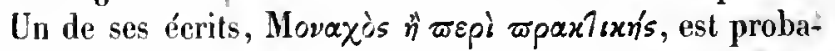
blement celui dont nous avons ici la traduction. Dans cette version, il forme trente-cing chapitres, et se termine an feuillet 153. Ensuite viennent plusieurs discours et sermons dı même auteur ${ }^{1}$.

$4^{\circ}$ (Fol. 175. .) Nolice sur la vie d'Évagrius, par un de ses disciples.

$5^{\circ}$ (Fol. $178 v^{\circ}$.) Sommaire d'un sermon. Incomplet.

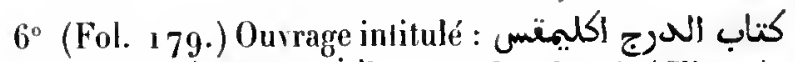

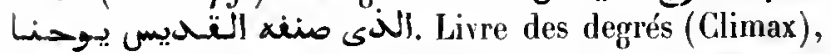
composé par Jean le Scholastique, surnommé Climacus. Lun des cahiers (fol. 285 à 294 ) se trouve renversé dans le volume. Le cahier qui devait précéder celui-ci manque, comme lindique l'ancienne pagination copte.

$7^{\circ}$ (Fol. 298.) -Discours composés par le saint père Jean Carpathius (كرياتيوس sic), moine célèbre, et adressés
- Celte première partie du ms. lenferme un grand nombre de traités d'Évagrius. On y trouve d'atrord les deux traités sur les Vertus et les Vices adressés à Euloge (l'a ticle $2^{\circ}$ ci-dessus en est le premier chapitre) at publiés sous le non de S. Nit (voyez Migne, Patrol. graca, 1. LXXIX, col. 1093 et suiv.): puis (fol. $35 v^{\circ}$ ) le traité sur la Prière, mais sans la préface ( Migne, l. c., col. 1168 el suiv.); ensuite (fol. 53) les ring premières sentences des Capita practica ad Anatolium ( Migne,

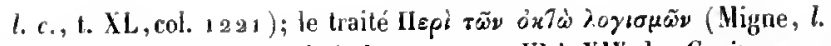
c., t. Xl., col. 1972 ct suiv.); les sentences VI à XIX des Capita praclica; diverses sentences du rógas कpax7ixós (Migne, l. $c$., col. 1244 et suiv.) mêtées à d'autres sentences; des extraits des Dicta sanctorum, elc. Plusieurs de ces compilations ne se trouvent ni dans les cuvres publiées d'Évagrius, ni parmi celles de S. Nil. H. Z. 
par lui aux moines de l'Inde, en réponse à des questions qu'ils lui avaient soumises. " Ce traité est la traduction du

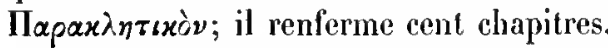

$8^{\circ}$ (Fol. 312.) Légende de l'abbé de Qalaf, le Qalaf de S. Antoine, derrière Qolzoum, et testament qu'il adressa à son fils.

$9^{\circ}$ (Fol. $316 \mathrm{r}^{\circ}$.) Deux discours de Mar Isaac, dont le dernier est incomplet.

$10^{\circ}$ (Fol. $322 v^{\circ}$.) Ouvrage sur la vie dévote, renfermant des homélies, des petits traités et des discours, dont l'auteur est nommé le Vieillard spirituel (المنيخ الروحان). II s'agit de S. Saba. Assemani a donné les titres de ces pièces dans la $*$ Bibliotheca orientalis $»$, t. I, p. 433 ef suiv. Les deux derniers discours manquent.

Papier. ${ }_{777}$ feuillets. Hauteur, 26 centimètres; largeur, 17 centịmètres. 15 à 17 lignes par page. La partie du volume qui contient les numéros 6 et suivants est probablement du xıv siècle. Les autres parties sont plus modernes. - (Ancien fonds 64.)

\section{8.}

$1^{\circ}$ Ourrage en vingt-quatre chapitres, dans lesquels In auteur inconnu traite de plusieurs questions morales et religieuses. Le volume se termine par ces mots : "Fin du discours profitable», ce qui, trèsprobablement, est le vrai titte de l'ouvrage. On lit sur

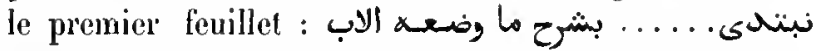

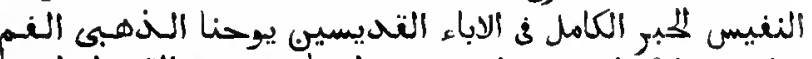

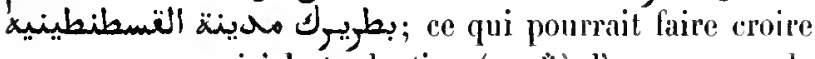
que nous avous ici la traduction ( 2 ) d'un ourrage de S. Jean Chrysostome. Mais ce feuillet est d'une écriture beaucoup plus moderne que le reste de l'onvage et ne peut faire autorité. Voici le titre du prenier chapitre:

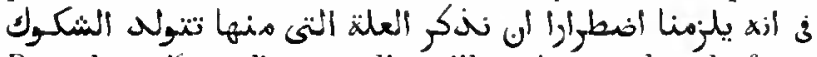
Dans la préface, l'auteur dit qu'il arait pour but de fournir des remèdes à ceux qui souffraient de maladies spirituelles.

$2^{\circ}$ (Fol. 98.) Discours dans lequel S. Jean Chrysostome réfute les opinions des idolàtres (أوتسانـيـيـن, pour (أit) au sujet du Messie.

La fin de ce traité manque.

$3^{\circ}$ (Fot. 147.) Un feuillet qui parait avoir appartenu ì une histoire des juifs.

$4^{\circ}$ (Fol. 148.) Un feuillet qui a dù appartenir à un Iraité sur les talismans.

Papier. 148 feuillets. Hauteur, 18 centimètres; largeur, 14 centimètres et demi. 13 lignes par page. Ms. du xı1 ${ }^{\circ}$ siècle. - (Supplément 72 , Sainl-Germain 25\%.)

\section{9.}

Les ouvres de S. Saba. L'auteur y est désigné par les mots ille saint spirituel et parfait, généralement connu sous lo titre d'alSchaikh (le vieillard)r.

Papier. 170 feuillets. Hauteur, 25 centimètres et deni ; targeur, 17 centimètres. 15 lignes par page. Ms. daté de l'an 1030 des martyrs ( 1314 de J. C.). - (Aneien fonds 86.)

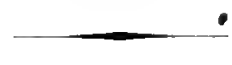

\section{0.}

Sermons et épitres du Vieillard spirituel (S. Saba).

Papier. 187 feuillels. Hauteur, 26 centimètres; largeur, 17 centimètres et demi. 15 lignes par page. Hs. du $x v^{*}$ siècle. - (Ancien fonds 65 .)

\section{1.}

Ourrage intitulé: "Livre des Degrés, c'est-ì-dire l'Échelle des vertus, composé par S. Jean, supérieur du monastère du Mont-Sinaï, et adressé à Jean, supérieur du

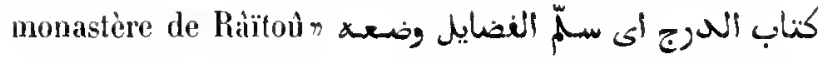

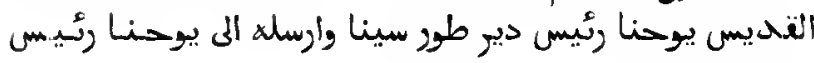

$$
\text { دير رايتوا }
$$

C'est la version arabe du cClimax», célèbre traité sur la rie monastique, qui a pour auleur Jean le Scolastique, surnommé Climacus. Le monastère de Ràitoù était silué auprès des soixante-dix sources d'Elim, sur le territoire du Mont-Sinai. L'omrage commence par une épitre adressée à Jean, supérieur de Râitoû; ensuite vient la liste des chapitres ou homélies, au nombre de trente et un, et l'indication de leurs sujets. La fin de la trente et unième homélie (مهمبار) manque.

Papier. 2o4 feuillets. Hauleur, 26 centimétres et demi; largeur, 17 centimètres. 17 lignes par page. Ms. du xıv siècle. - (Ancien fonds 67.)

\section{2.}

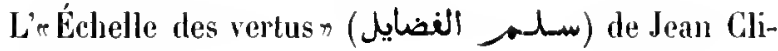
macus.

Papier. 165 fenillets. Hauteur, 21 centimètres; largeun, 15 centimètres. 21 lignes par page. Ms. écrit à Rome, au collége de Ponte Sisto, en l'an ${ }_{798} 8$ de J. C. - (Supplément 68.) 


\section{3.}

1. Traité adressé par S. Haxime à Elpidius. Cet écrit a pour sujet la charité ot l'ubservance des préceptes de fWrangile. Il est disisé an quatre sections, dont chacune contient. cent paragraphtres (راس ), tirés des écrits des anriens Pieres. Cisst probablement la traduction du $K \varepsilon \varphi \alpha^{\prime}-$

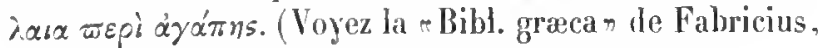
f́d. de Harles, 1. IX. p. 640.)

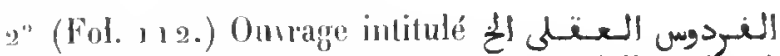
.. 1+ Paradis intellectuel, avec l'explication (allégorique) des plantes et des arbres que Dieu y a placés

On tronve dans le Catalogue des inss. arabes de la Bihliothèque bodlérenne, t. 11, par's II, page 44, un long "strat de cet ouvrage, dont lauteur est inconuu.

$3^{\circ}$ (Fol. 291.) Traité de morale chrétiemne, sans

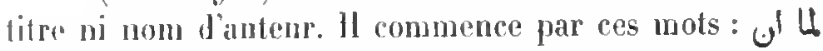

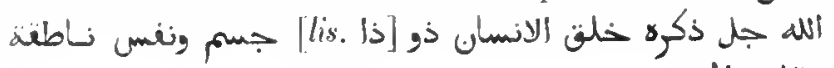

$$
\text { عنلية المُ }
$$

Paprice. 305 fenillets. Hauteur, 17 centimètres; largeur, 1 a centimètres el demi. 11 à 12 lignes par page. La première partie du ms. est probablement du xiv siècle, la seconde, à partir du fol. 112 , du xuा - (Aneien fonds 75 , Colbert 6513.)

\section{4.}

Traité théologrique, intitulé e Les cent discours ins-

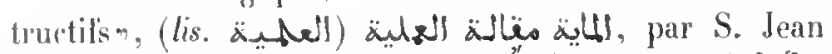

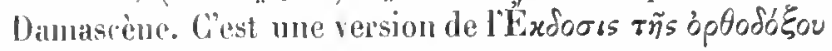
aifisws de cet auteur. Les tilres des chapitres corresfondent à peu près à reux qui se trouvent dans l'édition Jo Le Quien (Paris, 1712).

Papier. . 32 feuillets, dont les derniers sont mutilés. It manque à cet exeuplaire te frontispice, une partie de la table des chapitres et phusieurs feuillets à la fin. Hauteur, 2 a rentireètres; largeur, 15 centinietres et demi. 13 ligrnes par page. Ms. du xu1" siècle. -- (Ancien londs 96 .

\section{5.}

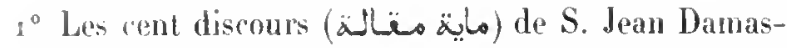
cène. En tite de l'murage se trouve la liste des chapitres.

$2^{\circ}$ (1)age 22y.) Traité de philosophie, de logique el de métaphysique, en cinquante-trois chapitres, par $\mathrm{S}$. Jean Damascène. Cet ourrage est précédé d'une lettre adresscé

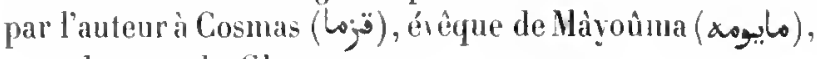
port de mer de Ghazzil. $3^{\circ}$ (Page 305.) Cinq discours sur 1a foi, renfermant une réfutation des hérétiques : nestoriens, jacobites et iconoclastes.

$4^{\circ}$ (Page 39o.) Traité dans lequel Paul d'Antioche, évêque de Sidon, expose la croyance chrétienne relative à l'unité de Dieu, et démontre que les chrétiens ne sont pas des polythéistes. Cet ouvrage renferme vingt-deux chapitres.

$5^{\circ}$ (Page 410.$)$ Courte exposition de la doctrine chrétienne au sujet de l'unité et de la trinité de Dieu. L'auteur de ce traité est Paul d'Antioche.

Papier. 417 pages. Hauteur, 29 centimètres; targeur, 19 centimètres. 25 lignes par page. Ms. daté de l'an 7144 du monde. - (Supplément 77.)

\section{6.}

- La Solution des doutes et la Réfutation des objections

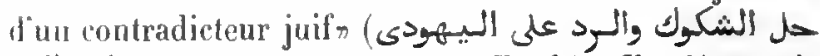
ill'), ourrage composé par Ibrahîm Jlon 'Aoun, te Nestoricn. Les premiers feuillets de ce volume ayant disparu, on les a remplacés par le commencement d'un trailé intitulé : «Cinq difficultés offertes par l'Évangile et

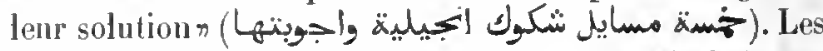
questions proposées sont d'Abou 'l-Hasan al-Mokhtâr Jbn al-llasan Jun 'Abdoûn, médecin de Baghdâd; les réponses sont d'Élie (الميسا), évêque nestorien de Nisibe. Assemani parle de cet omrage et de l'auteur, dans la "Bihl. or. s, t. III, $1^{\text {re }}$ partie, p. 509 . Voyez aussi Aboû 'lBarakât, daus le ms. de l'ancien fonds, $n^{\circ} 84$, fol. 112.

Papier. 210 feuillets. Hauteur, 21 centimètres; largeur, 14 centimètres. 17 lignes par parge. 11 s. daté de l'an 938 de l'ère des martyrs (1.2. de J. C.). - (Supplément 108 , Saint-Germain 275.)

\section{7.}

"Questions proposées par Aboû-'İsà al-IVarrâq et les

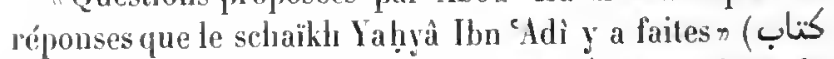

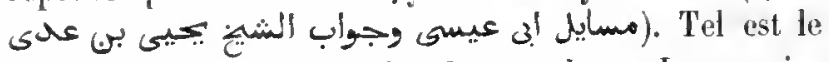
titre inscrit sur la tranche de ce volume. Le premier feuillet manque. Dans un autre exemplaire de cet ourage (royez le $11^{\circ}$ suivant), le titre se lit ainsi : كناب ألرد على كناب إبى عيبسى المواقة

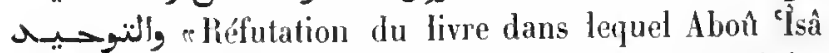
al-Warrây traile des dogmes de la religion, de la trinité et de limitén. L'ourrago d'Aboû 'Îsâ, dont les rrais noms étaient Moḷanmed Ibn Haroun, était dirigé contre les. 
croyances des jacobites, des nestoriens et des melkites. Dans l'ourrage de Yahyâ Ibn 'Adi, chaque objection d'Ibn 'Îsâ est rapportée textuellenent et suivie de la réponse de Yahyâ. Ce ms. a élé copié sur l'exemplaire de l'auteur, l'an 944 des martyrs (1 228 de J. C.) , au monastèred'Aboủ Yohannès, près du Caire, par Yoùsof, fils de Koủil

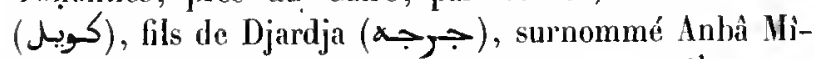

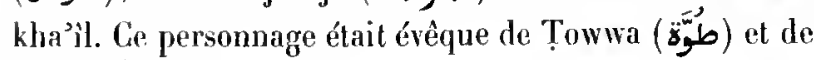
ṬanIâ (طنت).

Papier. 248 feuillets. Hauteur, 25 centimètres; largeur, 18 centimètres. 17 lignes par page. - (Ancien fonds 100.)

\section{8.}

Ouvrage dans lequel le philosophe Yabyà Ibn 'Adì Ibn Homaïd lbn Zakaryâ réfute les attayues que Moḅammed İhn Haroûn, généralement connu sous le nom d'Aboû 'Îsâ al-Warrâr, arait dirigées contre les trois sectes chrélieunes, à savoir : les jacobites, les nestoriens et les melkites. (Voyez le $n^{\circ}$ précédent.)

Papier. 285 feuillets. Hauteur, 25 centimètres; largeur, 16 centimètres et demi. 17 lignes par page. Ms. daté de l'an 1302 des martyrs ( 1586 de J. C.). - (Supplément 106.)

\section{9.}

Les opuscules théologiques de Yạ̣yâ lbn 'Adì, natif de Basra, et d'Aboû Râita (وايطة) Habìh Ibn Khadma, le jacolite :

$1^{\circ}$ Discours sur l'unité de Dieu, telle que: l'entendent les chrétiens.

$0^{\circ}$ (Fol. 21.) Discours sur la vérité du dogme chrétien touchant le Créateur, qui est une seule substance, donée de trois qualités.

$3^{\circ}$ (Fol. 23.) Discours sur l'assimilation que font les chrétiens entre le Fils ef I'Intelligent (عاقل), et entre 1'Esprit et l'objet de lintelligence (Jeم), tout an niant que te Fils soit l'objet de l'intelligence et que l'Esprit soit lintelligent ${ }^{1}$.

$4^{\circ}$ (Fol. $231^{\circ}$.) Réponse de Yalıyà à cerlaines questions quion lui arait adressées au sujet des trois personnes formant un seul Dieu.

$5^{\circ}\left(\right.$ Fol. $26 \vee^{\circ}$.) Discours dans lequel sont indiquées les preuves qui démontrent la vérité de la doctrine chrétieune au sujet du Créateur, à savoir qu'il est ume substance unique, douée de trois qualités spéciales, qu'on appells personnes (اقتبوم)

$6^{\circ}\left(\right.$ Fol. $30 v^{\circ}$.) Réponse à une question qui fat débattue en la présence d'Alì Ibn 'Îsâ Ibn al-Djarràh, vizir du calife abbaside al-Moqtadir, au sujet de la trinité et de l'unité.

$7^{\circ}\left(\right.$ Fol. $31 \mathrm{v}^{\circ}$.) Discours sur la nécessité de l'incarnation (تأسّس

$8^{\circ}$ (Fol. $34 \mathrm{v}^{\circ}$.) Réponse à un argument par lequel on avait coulu démontrer que l'union du Verbe aver. l'homme, considérée au moment de la mort (du Clurist), élait impossible.

$9^{\circ}$ (Fol. 37.) Réponse à une question proposée prall les adversaires des chrétiens, qui prétendaient que cenxci abaissaient les qualités du Messie en professant le? dogme de l'incarnation.

$10^{\circ}$ (Fol. 41.) Traité sur l'erreur de ceux qui enseignent que le Hessie est unique, non par subslance, mais par accident.

$11^{\circ}$ (Fol. $42 v^{\circ}$.) Réponse de Yaḷyâ lbu 'Adì à trois questions qui lui furent adressées par son ami Ahoû 'Alì

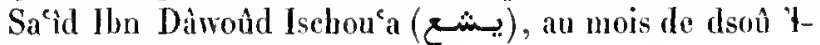
qa da 358 ( 960 de J. C. $)$.

Yalıà Ibn 'Adì mourut à Baghlıdàd, l'an 364 de l'bégire $\left(97^{4-975}\right.$ de J. C. $)$.

$12^{\circ}$ (Fol. 47.) Réfutation des objections laites par le philosophe Yáqoûb lbu Ishậy al-Kindì à la doctrine de la Trinité.

$13^{\circ}$ (Fol. $51 v^{\circ}$.) Épitre sur la Trimité, par Aboù Ràịa I!ahib Ibn Khadma (aodخ), jacobile de Takrît.

$14^{\circ}$ (Fol. 63 \} ^ { \circ } \text { .) Épitre du mème sur lincarmation. }

$15^{\circ}$ (Fol. 81.) Réfutation des melkites, an sujet d" l'unité de la nature de J. C., par le même anteur.

$16^{\circ}$ (Fol. $84 v^{\circ}$.) Épître dans laquelte le mème dorteur justifie l'usage d'adresser trois taqdis à Celuj qui liut crucifié pour nous. Voici la formule du taqdis (تقفحليسب) : " $\hat{O}$ toi, le saint, le Dieu tout puissant qui ne meurt pas, crucifié pour notre salut, montre-nous la miséricorde! -

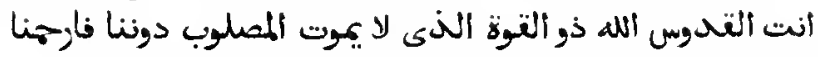

$17^{\circ}$ (Fol. 91.) Discours du même auteur sur te mènt sujet. On y remarque un passage en copte arec nne expli-

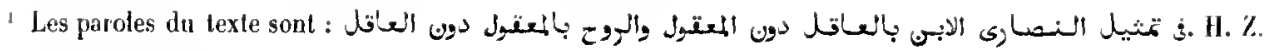


cation (تغسير), suivi de quelques lémoignages tirés des Prophètes et des Pères de l'Église.

Papier. 98 feuillets. En têle se trouve une croix dorée, accompagnée des initiales des mots İnooũs Xpratòs viòs $\Theta \varepsilon o \tilde{u}$; an pied de la croix est inscrit le mot $\vartheta \varepsilon \omega \lambda$ oryos (sic). Hauteur, 20 centimètres et demi ; largeur, 14 centimètres et demi. 18 à 21 lignes par page. Is. daté de l'an 1064 de l'hégire ( 1654 de J. C.). - - (Ancien fonds 101.)

\section{0.}

"Solution des questious proposées par Aubå Sévère (ساويسرس), évêque d'Aschmounaïn; connu sous le nom

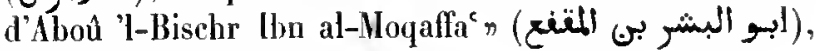
écrivain du $x^{e}$ siècle.

1 Sur le mystere de la Trinité.

$2^{\circ}$ (Fol. 21.) Sur l'incarnation et le crucifiement du fils de Dieu.

$3^{\circ}$ (Fol. $52 v^{\circ}$.) Explicalion des passages du Penlateuque et du live de Josné qui servent à démontrer la vérité de la doctrine chrétienne.

$4^{\circ}$ (Fol. 68.) De l'agneau pascal el de la conversion du pain et du vin en la chair et le sang du Messie.

. $5^{\circ}$ (Fol. 8o.) Du combat spirituel et de la manière dont les fidèles peuvent vaincre les démons.

$6^{\circ}\left(\right.$ Fol. $\left.101 \mathrm{~V}^{\circ}.\right)$ L'excellence du dimanche démontrée.

$7^{\circ}$ (Fol. 1 14.) Pourquoi on jeûne les mercredis et les vendredis.

$8^{\circ}$ (Fol. 125.) Comment le jeùne doit être praliqué.

$9^{\circ}$ (Fol. $1351^{\circ}$.) Dissertation sur la mort que le Seigneur, étant sur la croix, a vaincue.

$10^{\circ}$ (Fol. 147.) Preuves de l'orhhodoxie de la docIrine jacobite.

$11^{\circ}$ (Fol. 160. ) Explication du cantique de Moïse, dı cantique de sa sour Marie, el des psaumes 35 el 150.

$12^{\circ}$ (Fol. 171.) Explicalion de la quatrième vision de Daniel.

$13^{\circ}$ (Fol. 1 $7^{5}$.) Le canlique des trois Enfants, précédé et suivi d'observalions.

$14^{\circ}$ (Fol. $180 v^{\circ}$.) Traité pour consoler les fidèles el pour les encourager à supporter arec patience les chagrins qu'ils éprowent.

Papier. 188 feuillets. Les 50 derniers feuillets sont plus ou moins rongés dans la marge supérieure. Hauteur, 26 centimètres; largeur, 17 centimètres. 17 lignes par page. Ms. de la fin du xıu' siècle. (Ancien fonds 83.)

\section{1.}

1 "Explication du syıbole de la foi et appréciation des termes dans tesquels il est conçın, ouvrage composé par Sévère Ibı al-Moqaffac, évêque d'Aschmounaïn. C'est un précis de l'histoire des conciles et une démonstration de la vérité des doctrines professées par les jacobites. Le traité se compose de dix chapitres, dont le dernier, qui est te plus long et le plus important (voyez fol. $37 \mathrm{v}^{\circ}$ ), a domné son litre à louvrage. Aboú 'l-Barakât l'indique sous ce titre ( oyez ms. $n^{\circ} 203$, fol. 1 13 ), ainsi qu'un des auteurs de l'Histoire des patriarches d'Alexandrie (voyez a. f., $n^{\circ} 140, p .93$, et $11^{\circ} 161$, fol. 212 ).

$2^{\circ}$ (Fol. 85.) Ouvrage intitulé paroles utiles ^, daus lequel Sévère, évêque d’Áschmounaïn, adresse à un ami une défense des doctrines de sa religion, et cite à l'appui les paroles des prophètes et des évangélistes. En tête de l'ouvrage on lit: «Sentences des docteurs de l'Église, touchant la foi ortlodoxe, » mais le vrai titre se trouve à la fin du traité.

Papier. 21 2 feuillets. Ilauteur, 15 centimètres; largeur, 10 centimètres et demi. Environ 15 lignes par page. Ms. daté de l'an $133 / 4$ des inariyrs ( 1618 de J. C.). - (Ancien fonds 162.)

\section{2.}

$1^{\circ}$ Ouvrage dans lequel Sévère Ibn al-Moqafla‘, évèque d'Aschnounaïn, signale les erreurs commises par Sa'id lbn Baṭîq(Eutychius), dans son Histoire des palriarches, el relève les allaques dirigées par lui contre les jacohites. C'est par erreur que le copiste a intitılé ce traité

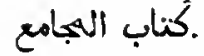

$2^{\circ}$ (Fol. $7^{4 .}$ ) Traité sur le jeùne, par Sévère, évêque d'Asclimounaïn.

$3^{\circ}$ (Fol. $90 \mathrm{v}^{\circ}$.) Lettre dans laquelle uu juif, nommé

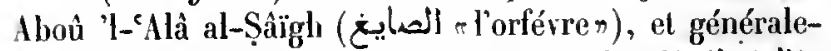
ment counu sous le nom d'Aklıoû Dàwoûd al-Balàt (b) (الب)), soumet à un docteur chıétien, nommé Aboû 'l-Fakhr alMasilụi, plusieurs difficultés qu'il avait rencontrées dans tes Évangiles.

$4^{\circ}$ (Fol. $9^{6} \mathrm{\vee}^{\circ}$.) Réponse à la lettre précédente, par Aboù 'l-Fakhr' al-Masihìi.

$5^{\circ}\left(\right.$ Fol. $116 \mathrm{v}^{\circ}$.) Lettre dans laquelle un juil adresse à un chrétien des objections contre la divinité de J. C. et contre d'autres doctrines de la religion chrétienne. 
$6^{\circ}$ (Fol. $123 v^{\circ}$.) Réponse du chrétien à la lettre précédente.

$7^{\circ}$ (Fol. $164 v^{\circ}$.) Troisième lettre du juif Aboû 'l-'Alâ Ibnn Mocallà al-Ṣaîgh au docteur chrétien Aboû 'l-Fakhr.

$8^{\circ}$ (Fol. 166.) Réponse à la troisième lettre du juil. Le copiste n'a reproduit que le commencement de cette réponse et s'est arrêté au milieu d'une phrase.

Papier. 166 feuiltets, dont plusieurs ont été rétablis par une main assez moderne. Hauteur, 17 ceutimètres; largeur, 1 a centimètres. 11 lignes par page. La partie ancienne du ms. est datée de l'an 690 de J'hégire (1 ag1 de J. C.). — (Supplément 79.)

\section{3.}

$1^{\circ}$ Réfutation de Sa id Ibn Baṭig (Eutychius), l'auteur des c Annales r. Le commencement manque. C'est à tort que, dans cetle copie, une main moderne a attribué ce traité à Aboû 'Ali 'Îsà Ibn Zor'a (z̈sj), le jacobite; le véritable auteur est Sévère d'Asclmmounain.

$2^{\circ}$ (Fol. $39 v^{\circ}$.) Traité dans lequel 'İsá Ibn Zor'a, élève du docte philosophe Yahyâ Ibn 'Adì, prouve qu'on a attribué injustement aux chrétiens jacobites l'opinion حue le Fils Éternel soulfrit corporellement (بلمول الالم (بالابى الازذ). Ibn Zor'a naquit l'an 331 de l'tégire (942943 de J. C.), et mourut en 398 ( $1007-1008$ de J. C.).

$3^{\circ}$ (Fol. 46.) Traité dans lequed S. Jean Chrysostome fournit les preuves de la venue du Fils bien-aimé de Dieu.

$4^{\circ}$ (Fol. 75.) Traité composé par 'Îsâ Ibu Zor'a, et adressé par lui, lan 387 (997 de J. C.), à Bischr Lbn Fenhàs (فناس) Ibn Schóaib, comptable juil'.

Cet écrit contient les réponses à certaines questions controversées et se termine par une note dans laquelle le même écrivain explique la signification de quelques termes employés dans la métaphysique.

$5^{\circ}$ (Fol. 77.) Traité sur le jeùnæ, l'ammônce el la prière.

$6^{\circ}$ (Fol. 79.) Série de questions que Yoùsol llon alHakim al-Boḅaïri envoya de Meyalì̀reqìn, l'an $387(997$ Je J. C.), à l'adresse d'îsà Ibn Zor'a, a lec les réponses de celui-ei.

$7^{\circ}$ (Fol. $\left.861^{\circ}.\right)$ Autres questions, adressées par Ibn at-Hakînı à lbı Zor'a, l'à 386 (996 de J. C.).

$8^{\circ}$ (Fol. $91 \vee^{\circ}$. ) Opinion d'un philosophe d'Orient an sujet de la Trinilé. $9^{\circ}$ (Fol. 92.) Opuscule attribué à Ibn Zor a, et composé à la suite d'une conférence dans laquelle on s'était occupé des dogmes professés par les Grecs, les jacobites et les nestoriens, au sujet de la Trinité et de l'incarnation.

$10^{\circ}$ (Fol. 99.) Traité sur l'origine des êtres et sur les qualités qu'on attribue à l'essence primordiale; l'auteur y indique sous quel rapport les chrétiens considèrent cette essence comme unique et multiple, comme substantielle et personnelle. Cet opuscule est attribué à un nonmé Aboù Solä̈màn Ṭàhir.

$11^{\circ}$ (Fol. $101 v^{\circ}$.) Traité sur les quatre points (de controierse) auxquels a donné naissance la doctrine de l'unité de Dieu, telle que l'entendent les chrétiens. L'auIenr' est 'Îsâ Ibn Zor'á.

$12^{\circ}$ (Fol. 109. ) Note ajoutée par 'îsâ Ibn Zor a à la fin de son traité sur l'unité et la Trinité.

${ }_{13} 3^{\circ}$ (Fol. 113.) Extrait d'un traité sur la divinité de J. C., composé par l'émiuent philosophe Yalyyâ lbı 'Adi, préceptenr d'Ibn Zor'a.

$14^{\circ}$ (Fol. 117.$)$ Discours du saint solitaire Mar Isaac le Syrien, sur la prière et le jeûne. Isaac, disciple de S. Éphren, composa un grand nombre d'homélies.

$15^{\circ}$ (Fol. 125.) Sermon de Jean le Syrien, connu sous le nom d'al-Selıaikh. C'est le mênıe que S. Saba. Cre sermon est le vingt-cinquième de la liste donnée par Assemani, "Bibl. or.", t. 1, p. 440.

$16^{\circ}$ (Fol. 127.) Abrégé de plusieurs traités de Mar Isaac le Syrien. L'auleur de cet abrégé se nommait Honoûn (حنو) ), fils d'omar, fils de Yohanuà, fils d'alŞalt. Il s'adresse, dans sa préface, à un grand personnage qui désirait prendre connaissance des écrits de Mar lsare, el qui, ne sachant pas la langue syrienne, l'avait invié à faine une analyse cn arabe ou une version abrégér de ces ourrages instructifs ${ }^{1}$.

$17^{\circ}$ (Fol. 147.) Traité sur la pénitence, par le prètre et philosophe Abou 'I-Faradj "Abd Allah Hbu al-Ṭyyil (الطيبب).

$18^{\circ}$ (Fol. 156.) Trailé sur l'incarnation.

$19^{\circ}$ (Fol. $1671^{\circ}$.) Recueil de modèles du slyle épistolaire. L'anteur, qui était musulman, dit avoir trousé ces pièces dans un ms. très-ancien et très-incorrect.

Les trois derniers fenillets de uotie nıs. sont liors de leur place. Ils lont partie d'une instruction religieuse, 
pent-ètre d'une des pièces qui se trourent dans co volirme.

Papier. ${ }_{170}$ feuillets. Hlauteur, 25 centimètres et demi; largeur, 15 centimètres ret demi. 17 lignes par page. Ms. du xuv" sièrle. (Ancien fonds go.)

\section{4.}

Les opuscutes d'lbn Zor'a. Ce célèbre docleur jacobite portail le surnom d'Aboû-'Ali, el était fits d'ìsâ Ibn Ishàq Hon Zorea :

$1^{\circ}$ Épître écrite au mois de dsoû 'l-ḥiddja $378 / 9^{8} 9$ de J. C.), el adressée à un de ses confrères. Dans cet écrit, il donne la solution de quelques difficultés que son correspondant lui arail signalées.

$2^{\circ}$ (Fol. $10 \mathrm{r}^{\circ}$.) Exposition de la croyance des chróliens jacobiles, el justificalion de cette secte d'une accusation dirigée conlre elle.

$3^{\circ}$ (Fol. $\left.38 \vee^{\circ}.\right)$ Discours adressé, l'an 387 (997 de J. C. ), à un juif nommé Bischr Ibn Fenhạs Ibn Schóaib, valculateur.

$4^{\circ}$ (Fol. 44.) Discours sur les quatre questions qu'on a soulevées au sujet de l'union (des deux nalures de J. C.).

$5^{\circ}$ (Fol. $53 r^{\circ}$.) Réfutation d'un traité composé contre les chréliens par Aboû 'l-Qàsim 'Abd Allah Ibn Ahmad, nalif de Balkh, et intitulé $*$ Preures de première force"

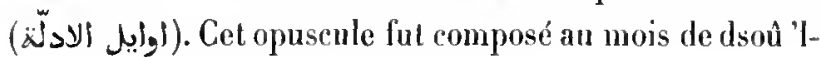
ḷiddja 387 (997 de J. C.).

$6^{\circ}$ (Fol. $6_{7}$.) Traité sur la nature des trois persommes de la Trinité. L'auteur a composé cette dissertalion l'après le conseil de Yạyà, fils de țamìd Ibn Zakaryâ, son ancien professeur, qui lni apparut en songe, l'an $129^{\circ}$ (lisez 1299 ) de l'ère d'Alexandre, date qui correspond à l'an 378 de l'hégire $\left({ }_{9}^{88-98} 9\right.$ de J. C. $)$.

$7^{\circ}$ (Ibid.) Queslions se rattachant aux préceptes du jeûne, de la prière el des roux.

$8^{\circ}$ (Fol. $7^{6 .)}$ Réponses à plusieurs questions que Yoûsol al-Boḷaïri, surnommé Aboù-ḷakim, lui avait adressées de la ville de Meyâfàreqìn, l'an 387 (997 de J. C.).

$9^{\circ}$ (Fol. 87.) Questions adressées à Ibn Zor`a, l'an 386 ( $99^{6}$ de J. C.), par Inn Hakìm, natif de Meyàfàreqìn. Cet opuscule est incomplet; on n'y trouve que deux queslions et la réponse à la première.

Papier. 88 feuillets. llauteur, 16 centimètres et demi; largeur, 12 centimètres el demi. 11 lignes par page. Ms. du xıv' siècle. - (Ancirn fonds $g^{8}$.)

\section{5.}

Traité de morale, divisé en douze chapitres, el inti-

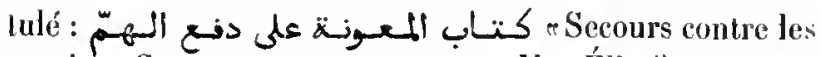

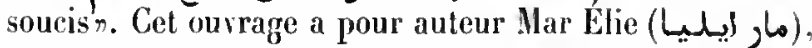
métropolitain de Nisibe el chef des nestoriens. Il vivai dans la première moilié du $x^{\circ}{ }^{\circ}$ siècle. Voyez le "Calalogue de la Bibliothèque bodléiennen, t. II, p. 43 et 4 4, où se trouvent les tilres des chapitres. Dans notre $\mathrm{ms}$, la liste des chapitres occupe le recto du septième l'euillet. A la suile de ce traité se trouve le recueil appelé erables de Loqmàn $\%$. Le copiste termina son travail l'an 1016 des martyrs ( 1300 de J. C.). On voit que ce recueil, dont le style est si barbare, élait connu au $\mathrm{xm}^{\mathrm{e}}$ siècle.

Papier. 144 feuillets. Hauteur, 17 centimètres; largeur, 12 centimètres et demi. 14 lignes par page. - (Supplément 58, Saint-Grermain 540.)

\section{6.}

$1^{\circ}$ Exemplaire incomplet de l'ourrage ascélique intitulé مهod Secours contre les soucis $\pi$. La fin inanque.

$2^{\circ}$ (Fol. 83.) Fragment acéphale d'un exemplaire du "Livre du gouremement", attribué à Arislote. Voyez cidessus, $n^{\circ} 82$.

$3^{\circ}$ (Fol. 133.) Fragnent acéphale d'un recueil de pré. ceptes politiques, altribués, les uns à un roi du Yemen, d'autres à un Arabe bédouin, à Cosroès Anouschirwàn et à son vizil Bouzourdjmihr. Le commencement et la fit manquent.

Papier. 136 feuillets. Hauteur, \& centimètres; largeur, 15 cenlimètres. 15 lignes par page. Ns. dn xvu" siècle. Il porte un grand nombre de notes de la main du $\mathrm{D}^{\mathrm{r}}$ Picques. - (Supplément 63.)

\section{7.}

1 Histaire de la conlërence qui ent lien dans la capitale de la Mauritanic occidentale, entre un moine, grand métaphysicien, el te vizir Sâḥ̣ib al-Sa âda. C'est un dialogue inaginaire, dans lequel un moine défend, contre un musulman, les dogmes de sa religion. Le premier feuillel, qui est d'une écriture bien plus moderne que le réste du ins., donne te tilre du traité, puis une introduclion qui commence au milieu d'une phrase. On roit par là que le copiste avait sous les yeux un ms. 
dont le premier feuillet s'était perdu. La prélace nous apprend que le dialogue a été composé par un sarant lhéologien, Aboû 'l-Faradj 'Abd Allah Ibn al-Ṭabib (ailleurs al-Ṭayib); secrétaire de Timothée, patriarche nestorien d'Orient.

$2^{2}$ Extrait d'un ouvrage anonyme, dans lequel on traite de plusieurs événements de la vie de J. C. Cet extrait se compose de la dernière partie du chapitre $m$ et des chapitres suivants, jusqu'au douzième inclusivement. Le feuillet 28 devait renfermer le commencement du chapitre 111, mais il nous offre un récil qui ne se rattache pas à celui qui se lit sur la page suivante. Ce feuillet est moderne et de la même main que le premier feuillet du volume.

Voici les titres des chapitres quatrième, cinquième et sixiène :

$$
\begin{aligned}
& \text { المتناب الوابع لاجل متهودية الرب مب يوحنا ابب زكريا }
\end{aligned}
$$

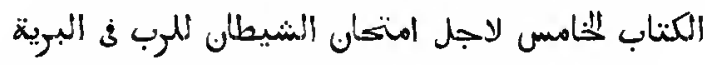

$$
\begin{aligned}
& \text { المتناب السادس لاجل إعال ألرب المحيبذ ف الانجيل مهن } \\
& \text { حير. الصبغة. . . . }
\end{aligned}
$$

$3^{\circ}$ (Fol. $115 v^{\circ}$.) Quelques miracles opérés par la sainte Vierge dans le monastère situé à Banhà al-'Asal (بنها (ب) Le commencenent de cet opuscule est l'ouvre du copiste qui a écrit les feuillets a et 28 . tier.

$4^{\circ}$ (Fol. $133 v^{\circ}$.) Histoire de S. Joseph le charpen-

$5^{\circ}$ (Fol. $1459^{\circ}$.) Formules de prieres ou supplications (ط), enpruntées aux écrits des saints Pères el aux ابصات (psautiers?) coptes.

Papier. 189 feuillets. Ilauteur, ga centimètres; largeur, 16 centimètres. 17 मे 3 s lignes par page. Hs. de deux écritures, dont la moins ancienne est datée de l'an 1005 des martyrs ( 1289 de J. C.). Quelques feuiltets onl été ajoutés à une époque assez moderne pour remplacer et même pour déguiser cerlaines lacunes. - (Ancien fonds 104 .)

\section{8.}

$1^{\circ}$ Ouvrage théologique, inlitulé "Thériaque des intelligences $n$, traité qui, d'après l’inseription sur le frontispice, eut pour auteur le prètre thoû 'l-Khaïr, dit lbn al-Ghaib. Une note dı copiste, inserite sur le feuillet 170 , nous apprend que lo livre tint achevé à Émèse, l'an 1364 des Séleucides (1052 de J. C.). Il s'agit nécessairement de la composition de l'ourrage, car le ms. que nous avons ici est du xime siècle. L'ourrage est désigné aussi par le litre de "Décourerte des mystères cachés dans les prin-

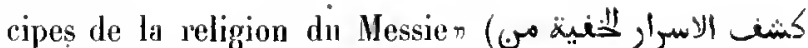

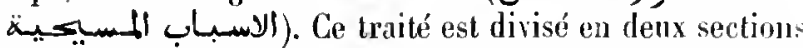
(äz), dont la première renferme vingt-quatre chapuitre. (فصول), et la seconde cinq. A la fin, le copiste a repuroduit quelques notes qui se trouvaient dans le ms. original. Parmi ces notes, on remarque un court extrail th "Guide des égarés n de Maïmovide, et un autre, liré de l'ouvrage intitulé re Signes directeurs, traitant des principe:

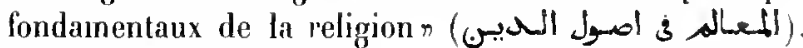
par Fakh" at-Din al-kàzí.

$2^{\circ}$ (Fol. 171.) Anecdote conceruant le grand S. Macaire, et rapportée par $\mathrm{S}$. Hacaire d'Alexandrie.

3० (Fol. ${ }^{7}$ 5.) « Comment Sibylle (سبر) , fille de Héraclius $(ه, 0)$, chef des philosophes, explipua le songe que cent hommes eurent, la même nuit, dans la ville de Rome, sous le règne d'Auguste César. .

$4^{\circ}$ (Fol. 181.) Prescriptions tirées des livres des médecins.

Papier. $18 \mathrm{~g}$ feuillets. Ilauteur, 19 centimètres; targeur, 13 centimètres. 1 a lignnes par page. Ms. du xuı" siècte. La pagination en chiffres coptes fait reconnaître la pert de plusieurs fevillets. - (Ancien fonds 102 .)

\section{9}

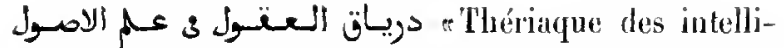
genees, traitant dés prineipes de la toi ». (Vovez le $1^{\circ}$ précédent dont celui-ci parait ètre la copje.)

Papier. 82 feuiltets. Hauteur, a1 centimètres; largeur, 1 s centimètres. a 3 lignes par page. Hs. daté de l'an 1054 de l'hégire (164h de J. C. ). - (Ancien fonds 97.)

\section{0.}

Autre exemplaire de l'ouvrage intitulé « Thériaque des intelligences $n$.

Papier. 102 feuillets. Hauteur, 20 centimètres; largeur, 15 centimètres. 13 lignes par page. Ms. date de l'an 1035 de l'ẗre khararjienne $\left(z_{2}(خ)\right.$, c'est-à-dire de l'ère de Yezdeguird ( 1615 de J. C. $)$ - (Ancien fonds $103 \mathrm{~A}$.)

\section{1.}

Ce volume renterme l'ouvrage intitulé "le Grand recueil", compilation théologique, divisée en 
soixante-trois chapitres, et traitant des dogmes, de la morale et de la discipline monastique. L'auteur, dans la préface (fol. $1 v^{\circ}$ ), se donne la qualité de moine du MontToir ( الاسود), près d'Antioche. Il dil avoil composé ret ouvrage à l'exemple d'An tiochus, moine de Saint-Saba, près Jérusalem, qui écrivit son recueil ou pandecte (لماوى

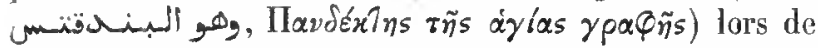
linvasion de la Syrie par les Perses (au vi siècie de J. C.). De même, dit l'auteur, royant les Turcs (Seldjoukides) emvahir le mème pays, sous le règne de Constantin Dn-

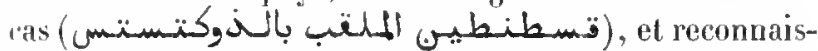
sant que les chrétiens pourraient désormais difficilement se procurer des livres, jai eu l'idée de réunir dans mu seul ouvage toutes les doctrines de la religion aver les commentaires yui se trouvent éparpillés dans une multitude de volumes. $n$ Le compilateur a puisé ses mafŕpiaux daus la Bible, dans les ćcrits des saints P'ères, daus les décrets des conciles et dans les tois impériales. Selon une note écrite de la main de Renaudot et insérée dans le volune, l'auteur n'a fait que travestir et interpoler l'ouvrage d'Antiochus, dans le but de soutenir les doctrines de la secte jacobite?

An verso du feuillet 334 commence un traité, accompagné de deux tableaux qui servent à déterminer la Pâque et les jours de fète de chaque année. Au feuillet 336 se trowve un traité, composé par S. Basile, évêque

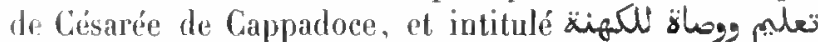
- Instruction et conseils aux prêtres \%. Au verso du feuillet 336 on lit une note du mène auteur, intitulée 3 gان

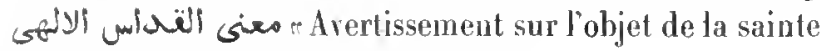
messe", et trois formules de prières.

Papier. 337 leuiltets, dont tous, à l'exception des trois derniers, sont écrits à double colonne. Hauteur, 34 centimètres; largeur, a 6 centimètres. 31 lignes par page. Mls. daté de l'an 6744 de t'ère du monde, correspondant à l'an 633 de l'hégire (1 a36 de J. C.). - (Ancien londs 6 s.)

\section{2.}

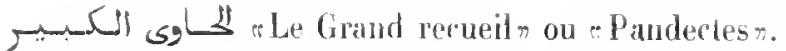
Autre axenuplaire de l'our rage jrécédent.

Papier. 759 feuillets. Hauteur, 3 i centimètres; largeur, a 1 centimètres. 22 lignes par page. Ns. daté cte l'an 7155 de l'ère du monde ( 1647 de J. C.). Le copiste étail un prêtre, natif de Tripoli, en Syrie, et desservant de l'éģise de la Résurrection, à Jérusalem. -- (Ancien fonds 78 , Colbert $98_{2}$.)

\section{3.}

Exposition des doetrines des Pères de l'Église, au sujet des dogmes de la foi. Pour former cette compilation, l'auteur a mis à contribution les écrits de plus de soixante docteurs et Pères de l'Église. En tête du volume se trouve une liste de chapitres; à la fir, on rencontre quelques passages tirés de diverses homélies sur l'incarnation².

Papier. 405 feuillets. Hauteur, 25 centimètres et demi ; largeur, 18 centimètres. 17 tignes par page. La première partie du ms., jusqu'au folio 239 , à l'exception des neuf premiers feuittets, est du xi1" siècle. -- (Supplément 51, Saint-Germain 31.)

\section{$+$ \\ 184.}

Traité de théologie, sans titre, divisé en trente-trois chapitres ( $(y)$, clont les premiers traitent de la Trinité, de l'incarnation et des commandements de Dieu; presque tous les autres traitent de la confession, de la communion et des devoirs de la vie nomastique. I'après quelques-unes des rubriques, ee seraient des réponses à diverses questious qu'on arait sounises à Anbâ Michel, patriarche d'Antioche, ì S. Cyrille, à S. Basile, à Anbâ Semeân, patriarche d'Alexandrie, el à d'antres docteurs. Ce ms. fut copié au monastère de Saint-Macaire, dans Je désert de Scété, l'an 980 (ou 930?) des martyrs ( 1264 ou 1214 de J. G.).

Papier. 175 feuiltels, dont quetrues-uns sont des restaurations faites par une main assez moderne. Hauteur, 25 centimètres et demi; targeur, 16 centimètres. 18 a 19 lignes par page. - (Ancien fonds 79.)

\section{5.}

Hême ourrage. Les deux premiers leuillets, contenant une grande partie de l'istroduction, inanquent, et le recto du lénillet actuellement coté I est devenu presque illisible. On ne trouve dans ce volume que vingt chapitres (wil) et le commencement du vingt et unième. En conparant le texte des chapitres $1, n$, vı, $\mathbf{x}$ de ce ms. avec celui des mêmes chapitres du $m s . n^{\circ} 184$, on remarque des différences assez considérables. Il semble qu'il y ait

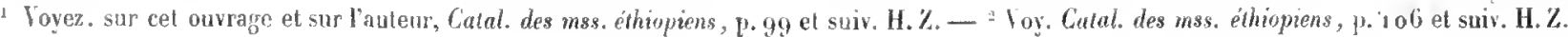


lieu d'admettre deux versions d'un même texte grec, ou bien deux rédactions différentes d'un même traité.

Papier. 130 feuillets. Hautenr, 25 centimètres et demi; largear, 17 èentimètres. 17 à 18 lignes par parye. Le ins. parait être de la fin du xıı" siècle. - (Ancien fonds 85 .)

\section{6.}

Relation d'une controverse qui eut lieu à Alep, entre Georges $(3,-)$, moine du monastère de Saint-Siméon, et trois docteurs musulmans, l'an 6615 du monde ( 1123 de J. C.), en présence de l'émir al-Mélik al-Moschanmer (fils de Saladin), et sous le règne d'al-Mélik al-Zàhlir Ghâzî, fils de Saladin et souverain d'Autioche et d'Alep. Cette défense de la religion clırétienne a été traduite par Le Grand, et publiée à Paris, en 1767, in-12, sous le titre de eControverse sur la religion chrétienne

Papier. 49 feuillets. Hauteur, 23 centimètres; largeur, 15 centimètres. 15 liggnes par page. Ms. daté de l'an 1897 de l'ère d'Alexandre ( 1585 de J. C.). Il a été copié au monastère de Baï-Marqos, à Jérusalem, par l'ordre de Mar-Dàwoûd, appelé anssi Dâwoñd-Schah, métropolitain de eette ville. - (Aneien fonds 106.)

\section{7.}

Controverse qui eut lien à Alep, entre Georges le moine et trois docteurs musulmans. C'est le même ouvrage que le précédent.

Papier. 98 feuillets. Itauteur, 1 j cenlimètres; largenr, 10 centiniètres. 13 lignes par page. Ms. daté de l'an du monde 7168. - (Supplénent 103.)

\section{8.}

Relation d'une controverse qui eut lien à Alep, entro Georges, moine du monastère de Saint-Siméon a]-Baḅrì ( $(s)$ ), et Irois docteurs musulmans. Dans ce ms., le copiste a mis par erreur le nom do Baibars à la place de celui de Ghảzi. C'est le mème ourrage que les deux précédents.

Papier. 53 feuillets. Hanleur, 16 centimètrès et demi; targeur, 10 centimètres el demi. 17 lignes par page. Ms. du rvin' siècle. — (Supplément 101.)

\section{9.}

Controverse qui eut lieu à Alep, entre Georges le moine et trois docteurs musulmans. Ce ms. paraìt ètre une copie du $n^{\circ} 186$. Il est daté de l’an 16 go de J. C.

Papier. 45 fenillets. Hautenr, 30 centimètres; largeur, a centimètres. 14 lignes par page. - (Supplément 101.)

\section{0.}

كتاب الإبهل "La Tour . On trouve en tête du volmme me note qui dit que l'auteur de cet ourrage se nommait 'Amr, fils de Matthieu, fils de Behnàm al-Ṭarrhài, mais cette indication, écrite à une époque assez récente et par mo main peu lıabile, est fausse. Le véritalıle auteur est Màrì

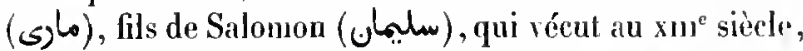
ainsi qu'on le voit dans ce ms., p. 909, 1. 1. Assemani, après avoir partagé l'erreur de ceux qui attribuaient cel ouvrage à 'Amr, auteur du xiv e siecle, s'est corrigé, dans le troisième volume de sa $*$ Bibliotheca orientalis $\pi, p .554$,

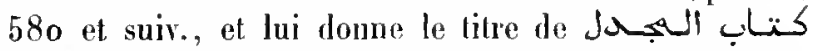
J Ia Tonr, servant de lien d'observalion et de défense». Il a domné aussi un tablean des sections et chapitres dont l'ourrage se compose. Son tableau correspond exactement à celui qui se trouve aux pages 19 el suiv. de notre ms.

Dans la cinquieme section, chapitre v, pages 708 à 911 , se trouse l'histoire des primats d'(Mrient, depuis les temps apostoliques, et des catholicos ou patriarches nestoriens. A mesure que la chronique approche du temps de l'autenr, elle devient plus rétaillée. Dans cotte parlie, ell" offre cles faits importants pour l'histoire des caliles de Baghdâd, et contient le texte de quelques rescrits que ces princes avient adressés aux primats nestoriens (royez p. 879). Cette cluronique finit par la biographie d'Ebedjésu, mort l'an 1147 de notre ère; mais un appendice, ajouté après coup, d'une main assez moderne (p. 911 ì 921 ), contient les biographies de quelques autres primats, jusqu'à l'an 1317; un tableau des diocises nestoriens et la profession de foi d'un des métropolitains de Nisibe. Sur deux feuillets de l'ancien ms. restés en blanc (p. 679,680$)$, on a écrit une notice chronologiejue at historique de Jésus-Clirist.

Papier. ${ }_{10} 5$ pages. Hauteur, 26 centimètres; largeur, 19 centimètres. 17 lignes par page. Ms. du xm ${ }^{e}$ sièele. - (Aneien fonds 82 , Colbert 5246.)

\section{1.}

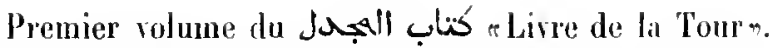
Une note en tìte du volume et me autre à la fin atlri- 
buent cet ourrage à 'Omar' (ou 'Amr), fils de Matthieu (م), a)-Ṭärhânì le Nestorien.

Papier. 213 fevillets. Hanteur, \& 5 centimètres et demi; larģeur, 18 rentinètres. 17 lignes par page. Ms. dı xıv siècle. Un possesseur a insmit sur le frontispice une note qui est datée de l'an 1157 des martyrs (1 औ,1 de d. C.). - (Supplément 53, Saint-Germain 58.)

\section{2.}

Seconde partie du thivre de la Tourn. Plinsicurs feuillets du commencement et les cinquante derniers sont d'une écriture plus moderne que le corps dir lonvrage, qui paraît être du xu1 e siècle. Les feuillets qui servent à remplir les lacuues du volume furent écrits f'an 1283 des marlyrs ( 1567 de J. C.) (royez fol. $251 v^{\circ}$ ). $l_{13}$ scribe qui a complélé le ms., s'étant aperçu d'une lacune dans le volume qu'il transcrivait, a laissé en blanc fo folio $273 r^{\circ}$ el les qualre feuillets suivants. Sur quelyurs-uns de's derniers feuillets, on remarque des notes marginales et mème des interpolalions dans lesquelles le copiste de cette porlion de l'ourrage et un lecteur appartenant à la secle jacobile s'élèvent avec indignation contre les opinions nestoriennes de l'auteur.

Papier. a 95 feuillets. Hautenr, 22 centimètres; largeur, 15 centimètres at demi. 1 - lignes par page. - (Supplément 53 bis, Saint(Sermain 58 bis.)

\section{3.}

Tوضة الفويد وسلوة اللوحـيــ -Prairie du solitaire et consolation pour l'anachorète" liauteur, Siméon (سمعن), fils de Kalil lbu Maqâra (ö), ́ntait du monaslère d'Aboû Yohannès (Saint-Jean-le-Nain), dans le désert de Scété.

Lourrage, écrit en très-heau style et en prose rimée, se compose d'une introduclion el de douze chapilies, ayaul chacun un sujet qui lui est propre. Ces sujets sont : la création de l'homme, la foi, la piété, la prière, le jeûne el les actes de dévotion, la patience, la charité, la chasleté, l'humilité, le pardon des injures, le mépris dı monde et les exercices spirituels.

Papier. 209 feuillets. Hanteur, 26 centimètres et demi; largeur, 18 centimètres. i 8 lignes par page. Ms. copié à Alep, l'an 1896 de l'ère des Grees ( 1584 de J. C.). - (Ancien fonds 87.)

\section{4.}

Traité de morale, intilulé - Prière du solitaire et con- solation pour l'anachorète , composé par le R. P. Siméon te jeune, fils de Kalìl Ibn Maqâra, moine du monastère de Saint-Jean-le-Nain (لألصيـ), situé dans le désert de Scété (الاستبط).

Entre chaque feuillet du texte arabe se troure une traduction latine, écrite avec soin, dont l'auleur est le R. P. F. Colestino de S. Liduina, carme déchaussé.

Papier. 361 feuillets. Hauteur, 31 centimetres; largeur, 21 contimètres. 19 lignes par page du texte arabe. xvir siècle. - (Supplément 56.)

\section{5.}

كتاب ألاعتراف والمهل النذى يخلص النغس Traité intitulé م. مe la confession et des pratiques qui délivient l’âme du péclién. Au commencement el. à la fin du vo-

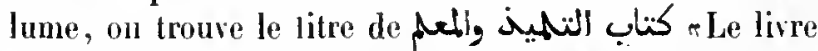
du disciple et du maitre $\%$. Fn effet, l'ourrage se compose de vingt-trois entretiens, dans lesquels un maitre répond aux questions d'un disciple. Ces entretiens roulent principalement sur la nécessité de la confession et de la pénitence. L'auteur a intercalé, entre le dixième et le onzième dialogue, un chapitre dans lequel il démontre que l'Église du Messie ne doit pas être scindée ni divisée. S'il faut en croire un renseignement donné dans la préface, les matériaux qui ont servi à la composition de cet ouvrage furent tirés de la Bible et des écrits des saints Pères, puis traduits en arabe par le patriarche d'Alexandrie, Cyrille

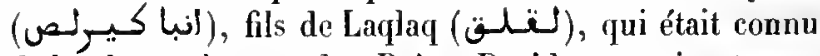
d'abord sous le nom de r Prêtre Davidn, et qui eut pour collaboraleur le prêtre Paul Boûschî (بسولص المبوتى). Ce Gyrille fut élevé au patriarcat l’an 1235 de J. C.

Papier. 184 feuillets. Hautenr, 21 centimètres; largeur, 35 centimètres. 14 lignes par page. Ms. daté de l'an $\$ 387$ des martyrs ( 1671 de J. C.). - (Supplément 48.)

\section{6.}

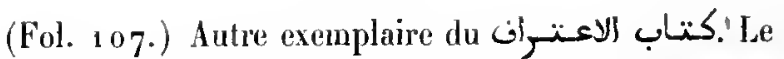
fruillel 259 a été placé par inégarde à la fin de l'ourrage. Le dernier feuillet contient le commencement d'un traité reufermant quelques exlraits des constitutions de Basile, de Léon et de Constantin (Porphyrogéuète), sur les cas de dissolution du mariage.

Papier. 269 feuiltets. Hauteur, 18 centimètres; largeur, 13 centimètres. 33 lignes par page. Ms. daté de l'an 7007 du monde, $90 / \mathrm{h}$ de l'hégire (1 499 de J. C.). - (Ancien fonds 1 15.) 


\section{7.}

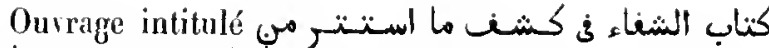

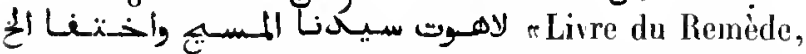
composé pour mettre au jour ce qui était caché conrernant la divinité de Notre-Seigneur le Messie, ainsi que la réalité de sa divinité et de son humanité, etc.». L'anteur de ce traité nous informe dans la préface qu'il se nommait Aboû Schâkir, fils dı moine Aboû 'l-Karm Pétros, qu'il était diacre de l'église de Notre-Dame, au vieux Caire, église des Coples jacobites (النختصة بالتبط) (البعاقبة), et qu'il s'occupait de ce travail l'an 984 des marlyrs ( 1268 de J. C.). Dans le ms. $\mathrm{n}^{\circ} 203$ (royez ciaprès), fol. $116 r^{\circ}$, Aboû '-Barakât fait mention de cet aurrage, ainsi que d'autres du même auteur, à qui il donne le nom d'A boù Schàkir al-Sinì al-Râhib Ibn alRischa.

Papier. ${ }_{2} 69$ feuillets. Hauteur, 26 centimètres el demi; largeur, 18 centimètres. 21 lignes par page. Ms. autograple du xı1 ${ }^{*}$ siècle, trèsbien écrit et portant en marge les corrections de t'auteur. - (Supplément 52, Saint-Germain 56.)

\section{8.}

$1^{\circ}$ Commentaire sur le Symbole de Nicée (الامانة المتحسحسة 'Assâl.

$2^{\circ}\left(F_{0 l} .201^{\circ}\right.$.) Tableau symoptique des noms des mois syriaques et coptes.

$3^{\circ}$. (Fol. 21.) Exposé de la conférence qui eut licu entre Aboû Qorra ( $\left(\boldsymbol{s}_{\text {, }}\right)$ et le calife abbaside al-llìmoùn, in la présence de quelques docleurs musulnans. Com-

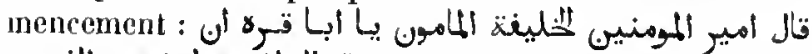

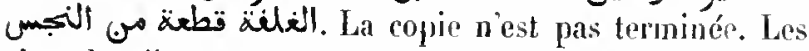
cini dernières payres du volume sont couvertes de notes et de figures cabalistiques.

Papier. 84 fenillets. Hauteur, 14 centimètres; largeur, 10 centimètres. 10 à 13 lignes par page. Ms. du av siècle. - (Ancien fonds 116 .)

\section{9.}

$1^{\circ}$ Abrégé d'un Irailé sur la trinité et l'unilé, composé au Caire vers la fin de l'an 673 de l'hégire ( 1274 de J. C. ), par l'éminent métaphysicien et docteur chréticn Aboù 'lFadhàil Ibn al-'Assàl (Juméll).

Max. onientacx. - 11 . $2^{\circ}$ (Fol. 12.) Le troisième chapitre de la seconde seclion du Kitâb al-MIadjdal, chapitre intitulé le Renforcement (التنشيديد).

$3^{\circ}$ (Fol. 19.) Témoignages des philosophes païens (ألثالوث), au sujet de la Trinitét).

40 (Fol. 22.) - Manifestation du saint Érangilen (تصريح (ألانجيل الطاهى . Cet article, ainsi que le précédent, est emprunté au troisième chapitre de la seconde section du Madjdal ou "Lirre de la Tour .

$5^{\circ}$ (Fol. 27.) Chapitre sur l'union (des deux natures de J. C.). Cet article ne se trouve pas dans le Madjdal.

$6^{\circ}$ (Fol. 35.) Lettre renfermant une exposition de la doctrine concernant la Trinité el l'incarnation. Elle est attribuée à un homme qui fut ordonné prêtre, afin d'être altaché au monastère du patriarche (jacobile), à Antioche. Ce patriarche, dont l'auteur fait un grand éloge, se nommait Ignace (اغناطيوس).

Papier. 44 feuillets. Hautcur, 17 centimètres; largenr, 13 centimètres. 13 lignes par page. Ms. daté de l'an 673 de l'hégire ( $127^{4}$ de J. C.). On voit par l'ancienne pagination en chiffres coptes et par ta table des maticres écrite au $\mathrm{xm}^{\circ}$ siecle, que ce ms. est incomplet. It manque 117 fenitlets au commencement et plusicurs autres dans le corps du ms. - (Ancien fonds 103. .)

\section{0.}

Traité de théologie dogmatique, dans lequel l'auteur, Aboû Isḷàq Ibn al-Fadhl Ibn al-`Assâl, expose d'un manière très-systématique les doctrines de l'Église chréliemne jacobile. Cet ourrage a pour titre : بهوع أصول iالديب r Recueil des dogmes fondamentaux de la religion et indication de ce qu'on peut enseigner en fait des résultats certains (lournis par le raisonnement) n. Cet ourrage est divisé en cind sections et en soixante-dix chapitres, dont on trouve la liste au fol. $61^{\circ}$ et aux trois feuillets suivants. Dans cet exposé, l'auteur réfule les oljjections des philosophes, des juils, des musulmans, des nestoriens et des melkites. Dans le premier chapilre, se trouvent quelques renseignements sur les ourrages théologiques des Coples, des Syriens, des Arméniens et des Nestoriens. Dans les chapitres xwm, xvm, xIx, qui traitent de Dien et de la Trinité, l'auteur a inséré plusieurs extraits d'ourrages araljes peu commus, composés par des chrétiens ou par des musulmans. Les derniers feuillets de ce volume nous offrent mne liste chronologique des sultans otlomans jusqu'à l'an 1013 de l'hégire, et une liste des gourerneurs de l'Égypte, depnis l'an 922 jusqu'à l'an 1040. Ces pièces sont d'une écriture plus moderne que le reste du ms. Au verso du der- 
nier feuillet, on lit les dates de tous les grands événements qui curent lieu dans le monde depuis la création jusqu’à Jésus-Christ.

Papier. $33_{7}$ fenillets. Hauteur, 30 centimetres; largeur, a cenlimètres et demi. Ig lignes par page. $x \mathbf{x}^{\circ}$ siècle. La seconde partie du volume, à partir du fol. 168 , porte ta date de 1022 de l'hégire ( 1613 de J. C.). - (Ancien fonds 80.)

\section{1.}

Les deux premières sections de l'ouvrage théologique

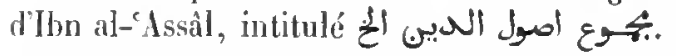

Papicr. 503 feuitlets. Hanteur, 25 centimètres; largeur, 17 centimẻtres et demi. 13 lignes par page. Its. de deux mains, dont la plus ancienne paraît être de la fin du xin' siècle. - (Ancien fonds 81.)

\section{2.}

Volume renfermant des fragments considérables de deux grands ouvrages de théologie chrétienne, un opuscule complet de plilosophie et quelques débris d'un ouwage d'Aboú-Hầnid al-Ghazzàli, intitulé unléli, ou, selon Haddji-Khalifa, des philosophes r, aux feuillets actuellement cotés 13,14 , $15,39,40,41,42$. Les folios 1 à 12 contiennent un traité de théologie dogrnatique, composé par un chrétien pour la défense de sa foi. Le commencement et la fin manquent. L'ouvrage est rédigé sous forme d'objections et de réponses (تولهم فاتول). Au folio 16 commence un opuscule dans lequel un anteur anonyme a rassemblé les maximes des quatre philosophes ( thagore, Socrate, Platon et Aristote. On trouve ensuite (fol. $171^{\circ}$ ) un morceau intitudé "les Conseils d'or'r; ce sont probablement les Vers dorés. Au fol. $36 v^{\circ}$ commence un traité de Mohì at-Dìn at'Adjami, natif d'Ispahân, sur l'intelligence, l'intelligent et l'intelligilble; la fin manque. Au fol. 43 , on rencontre le second chapitre préliminaire d'un ouvage de pliilosophie. Dans ce chapitre, on cherche à démontrer que les corps, au commencement, n'étaient pas en mowement. Suit la trente-neuvième des questions traitées dans l'ouvrage, question se rapportant à l'unité de Dieu. Ensuite vient la quarantième, où l'on traite de l'essence et des attributs; puis la quarante el unième, sur la divinité du Messie, où quelques textes du Noureau Testament sont cités, les uns en grec (caractères coptes), et les autres en copte. Vient ensuite la vingt-troisième question, qui se rapporte à cetle parole de Notre-Seigneur $*$ Dieu seul est saint. n Suivent les autres questions dans leur ordre, jusqu'ì la trente-huitième (qui est incomplète) de la sixiène section. Au fol. 123 se trouve la dernière partir du troisieme discours (ällie) d'un autre ouvrage, dans lequel on disente quelques dogmes de la religion. Suirent le qualrième discours (fol. 127), le dix-neuvième (fol. 132), le vingtième (fol. 135), le vingt et unième (fol. 138 ), le vingt-deuxiène (fol. 140 ), le vingt-huitième (lol. $144 v^{\circ}$ ), le vingt-troisieme (fol. 145 bis), le vingtquatrième ( fol. ${ }_{147} \mathrm{r}^{\circ}$ ), le vingt-cinquième (fol. 152), le vingt-sixième (fol. $154 \mathrm{v}^{\circ}$ ), le vingt-septième ( lol. $159 \mathrm{v}^{\circ}$ ). Au fol. 165 se trouve une liste de chapitres contenus dans le premier volume d'un ourrage de controverse chrétienne. Cette liste se composait de trente-six cliapitres $(b a b)$, mais le premier feuillet, renfermant l'indication des einq premicrs chapitres, manque. L'ourrage se composait de réponses faites par un chrétien à un juif qui avait présenté des objections contre certains passages dı Nouveau Testament. De lous ces chapitres, on ne trouve que le premier, le second, le quatricme et le cinquième; ensuite viennent plusieurs chapitres du second volune, depuis le dix-septième jusquau quarantedeuxième, et depuis le quarante-troisième jusqu'an nilieu du cinquante-cinquième. La fin de ce dernier manque.

Papier. 216 feuittets. Hauteur, 25 centimètres; largeur, 17 centimètres. 17 à 22 lignes par page. Ms. du xv siècle. le fragment du $\mathrm{Ma}_{\mathrm{a}}$ quacid est daté de l'an 709 ( 1310 de J. C.). - (Ancien fonds 88.2.)

\section{3.}

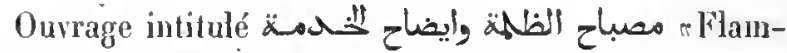
beau des ténèbres et explication du service divin ». C'eśt une sorte d'encyclopédie ecclésiastique, à l'usage des jacobites d'Égypte. Le compilateur, Aboù 'l-Barakât Ibn Kabar $(ك)$, vivait à la fin du xur ${ }^{\mathrm{e}}$ et au commencement du xıv siècle. Voici la liste des chapitres dont se compose cet ouvrage :

1. (Fol. 5.) Sur les dognnes fondamentaux de la religion.

2. (Fol. $21 r^{\circ}$.) Sur la foi orthodoxe.

3. (Fol. 32.) Sur l'incarnation.

4. (Fol. 36.) Sur l'histoire des apôtres.

5. (Fol. $43 r^{\circ}$.) Sur les conciles et sur les canons recus par l'Eglise.

6. (Fol. 83.) Sur les livres de la Bible qui sont reçus par l'Église.

7. (Fol. 109.) Sur les écrits des Pères de l'Égglise. 
8. (Fol. 1 1 8.) Sur la construction des églises, sur leur consécration et sur la consécration des autels.

9. (Fol. 127.) Sur la préparation et la consécration du saint chrême.

10. (Fol. 140.) Sur la présentation et le choix du patriarche, et sur sa consécration.

11. (Fol. $154 v^{\circ}$.) Sur le choix et la consécralion des érêques.

12. (Fol. 172.) Sur l'ordination des prêtres.

13. (Fol. 177.) Sur les diacres.

14. (Fol. 186.) Sur les moines et la vie monastique.

15. (Fol. $189 v^{\circ}$.) Sur le baptême.

16. (Fol. 195.) Sur les prières du jour et de la nuit.

17. (Fol. $203 v^{\circ}$.) Sur la messe el te saint sacrifice.

18. (Fol. 210 .) Sur te jeûne du carême.

19. (Fol. 21 4.) Sur les saints jour's de la cinquantaine (الذهسيو), ou du temps' pascal, depuis Pâques jusqu’à la Pentecôte.

20. (Fol. $217 \mathrm{r}^{\circ}$.) Sur les fiançailles (Slol), les couronnes et te mariage.

21. (Fol. 227.) Sur les funérailles et sur les prières pour les malades.

22. (Fol. $239 \mathrm{v}^{\circ}$.) Indication des leçons pour chaque jour de l'année.

23. (Fol. 26o.) Tables pour calculer l'épacte.

24. (Fol. 266.) Sur l'usage des images et des cloches, sur la communion, l'encens, le port de ceintures, les lumières, le signe de la croix, l'obligation d'ètre déchaussé dans l'église, etc.

Suit un chapitre renfermant des tables chronologiques, des listes des patriarches de l'Ancien Testament, des souverains, des patriarches d'Alexandric, et des prières en copte et en arabe que l'on récite dans certaines occasions. A la fin, il manque un ou deux feuillets.

Papier. 296 feuillets. Hauteur, 27 centimètres; targeur, 18 centimètres. 19 lignes par page. MIs. du xiv siècle. - (Ancien fonds 8\%.)

\section{4.}

$1^{\circ}$ Récit d'une controverse qui eut lien à Merw entre un moine nommé Schoûhâ (pour Schoubhâa) la-Ischoñca

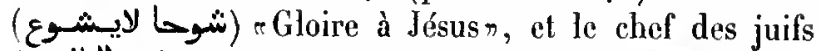
(وأس بالواتوع), au sujet de Notre-Seigneur le Messie. $2^{\circ}$ (Fol. 38.) Prolégomènes des saints évangiles, composés l'an 713 de l'hégire $(13,3$ de J. C.), par 'Abd Ischoù a (Ebed-Jésu), métropolitain de Nisibe, et placés par lui en tête de sa version arabe des évangiles, version dans laquetle if avait employé le parallélisme des phrases et les expressions les plus recherchées de la langue.

$3^{\circ}$ (Fol. 44.) Discours dans lequel 'Abd Ischoû'a, métropolitain de Nisibe, expose ses croyances sur la Trinité et l'unité, l'incarnation, etc.

$4^{\circ}$ (Fol. $49 \mathbf{v}^{\circ}$.) Épître dans laquelle un musulman - raconte que, dans un entrelien avec un chrétien, celuici lui avait cité, à l'appui de ses croyances, un grand nombre de passages du Coran, passages que l'écrivain a soin d'indiquer.

Papier. 68 fenillets. Hauteur, 22 centimètres; largeur, 12 centimètres. Dans le premier opuscule, le nombre des lignes par page est de 22 , dans le second de 16 , et dans les deux autres de 20 . Ms. de deux écritures, dont la première est de l'an 1620 de l'ère des Grecs ( 1308 de J. C.), et la seconde, à partir da fol. 49 , de l'an 1647 de la même ère. - (Ancien fonds 105.)

\section{5.}

$1^{\circ}$ Traité sur la foi, la prière, etc., divisé ell dix chapitres, dont les cinq premiers et une grande partie du sixième manquent.

$2^{\circ}$ (Fol. 14.) Le symbole du concile de Nicée, suivi de quelques prières, d'une invocation et d'un charme pour guérir les épileptiques.

$3^{\circ}$ (Fol. 16.) Discussion qui cut lieu, l'an 347 des martyrs (631 de J. C.), entre un juif helléniste, nomné 'Amrần, et deux moines d'un monastère situé dans le diocèse de TTarâbiya (طية), dans la basse Egypte, au sujel de la religion chrétienne.

$4^{\circ}$ (Fol. 62 $r^{\circ}$.) Explication des dix commandements, par S. Jean Chrysostome.

$5^{\circ}$ (Fol. $79 v^{\circ} \cdot$ ) Explication du symbole de Nicée, composée par le prêtre Aboû 'l-Madjd Ibn-Loûs (لوس), natif de Monya Benî Khasiib, sur la demande de Gabriel, érêque de Qồ. La copie n'est pas terminéc.

$6^{\circ}$ (Fol. 85.) Fragments d'un commentaire sur l'Ancien et le Noureau Testament. Plusieurs feuillets sont transposés.

$7^{\circ}$ (Fol. 107.) Fragments d'un commentaire sur les épitres de S. Paul.

$8^{\circ}$ (Fol. 1 1 0.) Explication de la liturgie copte. Le vo- 
lume ne contient que les deux premières parties de ce traité.

$9^{\circ}$ (Fol. 1 3.) Phusieurs chapitres des sections II et III du "Guide des égrarés $\pi$, de Maïmonide.

$10^{\circ}$ (Fol. 136.) Dernière page de l'Hexaméron (اكسبم) de S. Basile.

$11^{\circ}$ (Fol. $136 \mathrm{v}^{\circ}$.) Prophétic, sous forme d'un sermon, allribuéc à Anbà Samuel (صم-ريـل), supérieur du monastìne de Calmoûn. Lauteur de cette pièce prédit le triomphe des clirétions sur les musulmans.

$12^{\circ}$ (Fol. $150 v^{\circ}$.) Septième miracle de S. Basile, ávèque de Césarée de Cappadoce, qui converlit an ehrislianisme le médecin et philosophe juil nommé Yousof.

$13^{\circ}$ (Fol 153.) Relation de ce qui s'est passé au monastère de Notre-Dame, à Namyì (نميا), touchant le sarerdoce héréditaire de Notre-Scigneur Jésus et son entrée an Trmple. Un chrétien de la Syric, appelé Philippe, est indiqué comme l'auteur de ce récit. Il raconte que, sous te rèrne de Julien, it entendit de la honche de son ami 'Théolose, médecin juil, les traditions du peuple juil, an sujet de la mission de Jésus-Christ, el que ce doctenr linit par embrasser te chrislianisme.

$14^{\circ}$ (Fol. 161.) Fragnent, sans commencement ni fin, d'une prophétie qui ammonce le triomphe délinitil des chréticns sur les musulnans. Dans cette piece, c'est Jésus-Christ qui est censé parler.

Popier. 166 fenitlets. Hautcur, 25 centimetres; targeur, 17 centimètres. Ms. de diverses écritures. La pièce qui se trouve en tète du volume, la plus ancienne, porte la date $\left(\right.$ fot. $\left.33 v^{\circ}\right)$ de 1060 des martyrs (1344 de J. C. .) . - (Ancien fonds 95.$)$

\section{6.}

1 "Le soulagement des chagrinsn, traité composé par Élie (الياليال évêque de Jérusalem, et

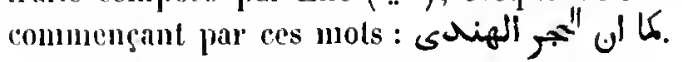

فرايح الغوأيد في المول : Fol. 12 vº.) Traité intitule elhenseignements précienx sur les bases le la religion el des dogmes». Ciest un résumé de théslogie jacobite.

$3^{\circ}$ (Fol. $623^{\circ}$.) Sermon ou exhortation commencant

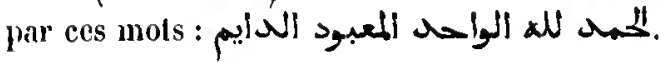

$4^{\circ}$ (Fol. $65 v^{\circ}$.) Récil allégorique, intitulé : تصـد

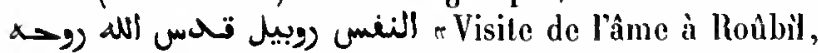

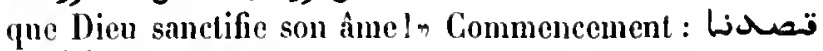

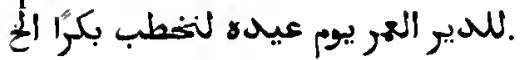

$5^{\circ}$ - Exposition de la sainte foin, commençant par les

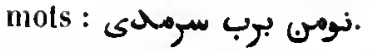

$6^{\circ} \quad\left(\right.$ Fol. $67 v^{\circ}$.) Entrelien de Șâlih Ibn 'Abd al-Qadoùs avec un moine de la Chine.

$7^{\circ}$ (Fol. $85 v^{\circ}$.) Anecdotes d'un moine de la ville de Nedjrin.

$8^{\circ}$ (Fol. 88.) Sentences attribuées à S. Grégoire et à quelques philosophes.

$9^{\circ}$ (Fol. 92.) Épitre dans laquelle Mar Élic, métropolitain de Nisibe, raconte à un ami ce qui s'est passé aux conférences qu’il eut, l'an 417 de l'hégire, avec le vizir About 1-Qàsim al-Hosaïn Ibn 'Alì al-Maghlurebi. Dans la première conférence, il s'agit de la Trinité, et dans la seconde, de l'Incarnation. La sixième conférence (fol. 1 a 7) a pour sujet les sciences possédées par les chrétiens, telles que la grammaire, la philosophie, l'écriture et la logique.

$10^{\circ}$ (Fol. $164 v^{\circ}$. ) Traité des poids et des mesures que l'on emploic dans le commerce, en scize chapitres, par Mar F́lie, métropolitain de Nisibe.

$\because$ (Fol. $184{ }^{\circ}$.) Prière qui ne manque jamais d'être exaucée, composéc par Abou Makhlad Ilyâ (اليّ), le secrétaire, natif de Mossoul.

$12^{\circ}$ (Fol. 194.) Pièce de vers, renfermant des exhortations religieuses.

Papier. 204 feuiltets. Haulcur, 18 centimètres; targeur, 12 centimétres. 11 tignes par page. Mls. daté de l'an $77^{3}$ de l'hégire ( $1371-$ 137 a de J. C.). - (Ancien fonds 114.)

\section{7.}

rLe Bijou, traitant des sciences ecclésiastiques $n$.

Cet ourrage traite de la théologie dogmatique, de la morale, de la liturgie et de la discipline ecclésiastique; en somme, des doclrines et nsages de l'Église cople.

lin 枪te se trouve la liste des chapitres, qui sont au nombre de cent onze. Liautenr, Jean, fils d'Abou Zakaryà, était connu sous le surnom d'Ibn Sabà' (ابر سباع).

Papicr. 209 feuiltets. Hauteur, 17 centimètres; largeur, 12 centimètres. 13 lignes par page. Ms. de ta fin du xuv siècle. - (Ancien fonds 113.)

\section{8.}

Autre exemplaire de l'ouvrage intitulé e Le Bijon, trailant des sciences ecclésiastiques», par Ibu Sabấ.

Papier. 133 feuillets. Hauteur, 21 centimètres; largeur, 15 centi- 
mètres. 15 lignes par page. $\mathrm{Ns}$. copié l'an 1354 des martyrs ( 1638 de J. C.). - (Ancien fonds 99.)

\section{9.}

كناب المر الثميى في ايضاح الاعتقاد ف : Ouvrage intitulé

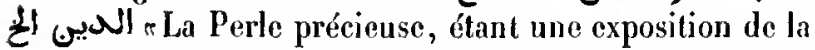
loi, ouvrage tiré des paroles que les prophèles, les apôtres, les doctcura de l'Église et les patriarches ont énoncées au sujet de l'incarnation du Seigneur, de son ascension et de l'envoi du Paraclet».

L'auteur de ce traité est inconnu, mais il appartenait certainement à la secte jacobite. En tèle du volumo, on lit quelques règles pour calculer la Pàque et le carême, d'après la contume de l'Église copte.

Papier. 260 fenillets. Hanteur, 16 centimètres; largeur, 10 centimètres. 11 lignes par page. Ms. daté de l'an 1268 des martyrs $(1552$ de J. C.). - (Supplément 54, Saint-Germain 3a9.)

\section{0.}

"La Perle précieuse». Mème ouvrage que le précédent.

Papier. 166 feuillets. Hauteur, 2 I centimètres et demi; largeur, 15 centimètres. 16 lignes par page. Ns. daté de l'an 1350 des martyrs (1634 de J. C.). - - (Ancien fonds 102 bis.)

\section{1.}

1 Traité sur la prière.

$2^{\circ}$ (Fol. 55.) le premier cantique de Moïse.

$3^{\circ}$ Le premier chapitre d'un ouvrage inlitılé « Les flambeaux" (ابلمابي).

$4^{\circ}$ Autre chapilre du même ourrage, sur la pencté (8) (الطها:

1'apier. 11/4 fenillets. Hautenr, 12 centimètres; largeur, 9 centimètres et demi. 9 lignes par page. Ms. daté de l'an 1581 de J. C. (Supplément 57, Saint-Germain 5.9 bis.)

\section{2.}

$1^{\circ}$ "Commentaire sur la lormule $"$ Au nom du Pére, dı
Fils et du Saint-Esprit», suivi de l'exposition de l'unité du Créatcur, quant à son essence divine, et de la trinité de ses altributs, quant à ses trois personnes. Traité acconpagné d'une réfutation à l'adresse des hérétiques ignorants et des juifs, gens qui professent l'unité de Dien el qui nient la trinité."

$2^{\circ}$ (Fol. 9.) Homélie prononcéc par le prêtre Panl Boûschi, à la fète de l'Amonciation.

$3^{\circ}$ (Fol. $22 \mathrm{v}^{\circ}$.) Homélie de S. Cyrille, patriarche d'Alexandrie, sur la fète de la Circoncision et de l'entrée du Scignenr au Temple.

$4^{\circ}$ (Fol. $28 v^{\circ}$.) Honélic de Jacques, évêque de Saroùdj, sur l'entréc du Messic au Temple.

$5^{\circ}$ (Fol. $\left.45 v^{\circ}.\right)$ Homélie du prètre Paul Boûschî sur la Nativilé.

$6^{\circ}$ (Fol. 58.) Honélic dı mème sur la Théophanie (sic أناوانيه), c'est-di-dire le saint baptème, appelé aussi la Fête de la Manifestation.

$7^{\circ}$ (Fol. 6g.) Traité dans lequel Sévère d'Aschmonnaïn relève les erreurs et fausses représentations de Sa id beu Batriy (Eutychius), auteur des "Annales $\%$.

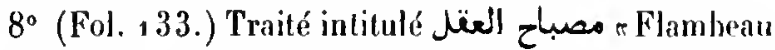
de lintelligence $n$, et renfermant une exposition sommaire de la doctrine chrétienne, par Sévère d'Aschmounaïn.

$9^{\circ}$ (Fol.122.) Vic de S. Denys l'Aréopagite (تيوناسيوس)

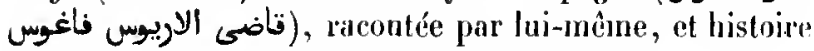
de la vision quil eut dans la ville de Baatbec.

$10^{\circ}$ (Fol. 135.) Légende de Mároûn (ملون) el de sa femme.

$11^{\circ}$ (Hol. 149.) Panégyrique de S. Victor, fils du vi-

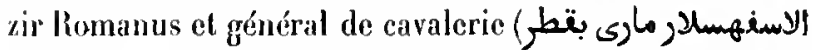

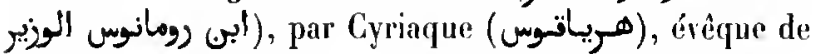
Behmesà (en Égypte).

$12^{\circ}$ (Fol. 214 .) Histoire de Joseph, fils de Jacols et roi d'Égypte.

$13^{\circ}$ (Fol. 261.) Martyre d'Abà Hoûr (اباهور), de Siryàkoûs (en Égyple).

$14^{\circ}$ (Fol. 276.) Autres légendes sur le mène snjet.

${ }_{15}^{\circ}$ (Fol. $283 r^{\circ}$.) Vie d'Alexandre le Grand. La lin de cette histoire romanesque manque.

Papier. 32a feuillets. Hauteur, a 1 centimètres; largenr, 15 centimètres et demi. 17 lignes par page dans la première parlie. La première partie dn ms., qui en est aussi la plus ancienne, est datée de l'an 1317 des martyrs (1601 de J.C.). - (Supplément 55, Saint-Germain 272.) 


\section{3.}

$1^{\circ}$ "Questions ayant pour but de raffermir la foi et de faire sentir l'excellence de la religion chrétienne».

$2^{\circ}$ (Fol. $191^{\circ}$.) "Questions (au nombre de cent cinquante-cin( ) augitées par $S$. Basile et $S$. Grégoirer.

$3^{\circ}$ (Fol. 73.) Qnestions, au nombre de trente-sept, qui furent trowées dans une pièce écrite de la main de Michel (مبيل), évêque de Malidj (ليج), en Égypte.

$4^{\circ}$ (Fol. 78 .) Notice sur l'onguent que la pécheresse répandit sur le corps du Seigneur.

$5^{\circ}$ (Fol. 8o.) Questions et notices concernant les prêtres et les moines.

$6^{\circ}$ (Fol. 96.) Questions et réponses, recueilties dans les Canons apostoliques, par Athanase, évèque de Cos, en Egypte.

$7^{\circ}$ (Fol. 103.) Abrégéé des canons décrétés par les apôtres et les conciles.

$8^{\circ}$ (Fol. 107.) Traité sur le baptềne.

$9^{\circ}$ (Fol. 111 .) Traité sur la dìme.

$10^{\circ}$ (Fol. $112 \mathrm{v}^{\circ}$.) Traité sur la signification de cette parole des philosophes: "l'homme est un microcosmen.

$11^{\circ}$ (1'ol. $1221^{\circ}$.) Traité sur l'unité de Dieu.

$12^{\circ}$ (Fol. 126.) «Livre de la Pâque glorieuse \%. C'est une dissertation sur linstitution de cette fète et sur son importance. Elle est attribuée à Démétrius (sنتويوس), patriarche d'Alexandrie, d'Alyssinie, de Nubic, des cinq villes occidentales (la P'entapole) el de l'Ifrikiya (la Mauritanie). Mais d'après une note marginale, cet écril serait de Sévère, évêque d'Aschmounaïn.

${ }_{1} 3^{\circ}$ (Fol. 128 .) Entretiens de Moïse avec le Seigneur sur le mont Sinaï.

$14^{\circ}$ (Fol. 137. ) Comseils sur les devoirs d'un chrétien, par S. Étienne, protomartyro.

$15^{\circ}$ (Fol. $1441^{\circ}$.) Lettre d'exhortations, envoyée du ciel par S. Athanase, l'an 1750 de l'ère d'Alexandre ( 1438 de J. C.), et qui tomba dans l'église des SS. Pierreet-l'aul, à Rome.

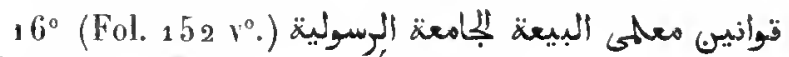
"Canons des docteurs de l'Église catliolique et apostolique $\%$

$17^{\circ}$ (Fol. $166 \vee^{\circ}$.) Éclaircissements sur le jeûne.

$18^{\circ}$ (Fol. 180.) Sur la cause des tribulations qui afligent les fideles. $19^{\circ}\left(\right.$ Fol. $190 \mathrm{r}^{\circ}$.) Sur la confession et son utilité.

$20^{\circ}$ (Fol. 201.) Histoire de la persécution que S. Macaire lancien et S. Macaire d'Alexandrie eurent à subir de la part de Lucius, usurpateur de la chaire patriarcale d'Alexandrie. II est dit que celte pièce a ćté composée par Socrate, auteur des Vies des saints el esclare de Jules d'Aqfilias, ville de la laute Egypte.

Papier. 246 feuiltels. Ilauteur, 2 i centimètres; targeur, 15 centimètres. 15 lignes par page. Als. écrit vers la fin du xví siècte. Le folio 2 , ajouté après coup, porte la date de l'an ${ }_{1} 3_{1} 8$ des martyrs (1602 de J. C.). - (Ancien fonds 72.)

\section{4.}

$1^{\circ}$ "Traité dans lequel un de nos saints hommes réfute l'opinion de ceux qui enseignent que Marie ne doit pas être appelée la Mère de Dien».

$2^{\circ}$ (Fol. 26.) Discussion entre le moine Anbâ Abrahan (ابراهام), natif de Tibériade, et le musulman 'Abd al-Ralınıân, au sujet de la vérité de la religion chrétienne. On y a joint une légende qui renferme le récit des miracles opérés par ce moine, et du martyre de quelques musulmans quil avait convertis. Ce récit est attribué au susdit 'Abd al-Raḥmân, que bon désigne par le titre d'émir et par' le surnom d'Ibn 'Abd al-Mâlik Ibn al-Sâlị̣ le Haschémide (inembre de la famille de Mahomet).

$3^{\circ}$ (Fol. 48.) Épitre envoyée de l'ile de Chypre au schaikh Taqi al-Dìn Ibn al-Taïmiya (curil), à Damas. C'est un exposé peu fidèle de la doclrine chrétienne. Ilon al-Taïmiya, docteur hanéfite, mourut à Damas, l'an 728 de l'héggire ( $3_{2} 7_{-1} 3_{2} 8$ de J. C.).

$4^{\circ}$ (Fol. $65 \mathrm{v}^{\circ}$.) Controverse dans laquelle deux moines d'Égyple parriennent, avec le concours de leur évêque, à convertir un juif nommé 'Amrân le lévite. Cet érénement est placé dans l'année 347 des martyrs $(631$ de J. C.).

$5^{\circ}\left(\right.$ Fol. $114 v^{\circ}$.) rVersion du Livre de la Sagesse el des Proverbes de Salomon, fils de David\%. Dans une introduction dont le commencement a été supprimé, le traducteur fait remarquer la différence qui existe entre la prosodie et la versification des Arabes et celles des Grees, des Syriens et des Hébreux. 11 nous apprend aussi que la plupart des écrits de Salomon furent perdus pendant la Captivité. A la suite de l'introduction vient une version de l'Ecclésiaste, du Cantique des cantiques, de la Sagesse et des Proverbes. Cette traduction differe tout à lait de celles de Saadias et de la Propagande.

$6^{\circ}$ (Fol. 186.) Les jugements du roi Salomon, fils de 
David. Le premier de ces récits est tiré du $11 l^{\circ}$ livre des Rois, chapitre In; pour le second, on a emprunté au Nouvean Testament les noms de Marthe et de Marie pour en faire les filles de Joachin et les conlemporaines de Salomon. Les autres récits sont tout aussi fabuleux.

$7^{\circ}$ (Fol. $203 r^{\circ}$.) Relation d'une controverse qui cut licu entre un chrétien el un juif.

$8^{\circ}$ (Fol. 220.) Explication de la prière dominicale, par Anbâ André (انحرباوس).

$9^{\circ}$ (Fol. $221 v^{\circ}$.) Explication du Crédo, tiréc de l'ouvrage d'lbn al-`Assâl, intitulé : كتـاب الاصول (1).

$10^{n}$ (Fol. $227 \mathrm{v}^{\circ}$.) Réponses d'Athanase, patriarche d'Alexandric, à certaines questions qu'on lui avait adressées.

$11^{\circ}$ (Fol. 232.) Version d'un dialogue qui eut lieu entre S. Grégoire et son élève, S. Éphrem, au sujet de vingt-trois questions théologiques. En tête se trouve une notice sur S. Éphrem.

$12^{\circ}$ (Fol. 245.) Copie de la charte accordée par Mahomet, fils d'Abd Allah et petit-fits d'Abd al-Mot!ladib, à tous les chréticns, avec les signatures d'environ une trentaine des Compagnons.

C'est une des nombreuses rédactions de ce document apocryplie.

Papier. 262 feniltets. Hauteur, 29 centimètres; largeur, 20 centimètres et demi. 17 lignes par page. Ms. daté de l'an 1254 des martyrs ( 1538 de J. C.). Deux souscriptions, l'une au fol. $11^{1}$ ' et l'autre au fol. 125 , nous apprennent que te copiste de ce nıs. se nommait Georges, qu'il était de la religion jacobite et d'origine curopéenne; mais rien dans son écriture n'indique l'écrivain franc. - (Ancien fonds 88.)

\section{5.}

$1^{\circ}$ Réponses aux objections faites par certains musulmans aux doctrines de la religion chrétienne. Ce traité تح وافا كتابك وانت تلذكر فيبه مـا جرى : commence ainsi

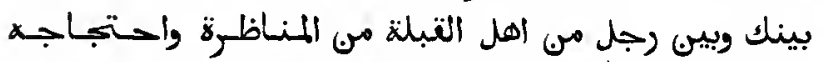

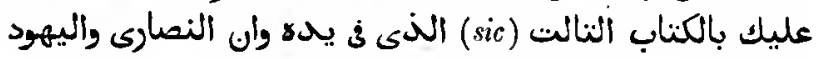

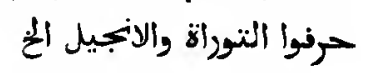

$2^{\circ}$ (Fol. 5o.) Défense de la religion chrétienne par Abraham, moine du monastère d'Édesse et natif de Tibériade, en Syrie, dans une séance présidéc par l'émir 'Abd a]-Raḥmân, fils d'eAbd al-Màlik le Hacléénide et gouverneur de Jérusalem.

$3^{\circ}$ (Fol. $83 v^{\circ}$.) Preures de l'abolition de la loi mosaïque et de la vérité de la religion chrétienne.

$4^{\circ}$ (Fol. 121.) Relation d'une conférence dans la- quelle Aboù Qorra (قo trente-quatre questions que le calife al-Ilâmoủn lui avait adressées.

Cette pièce est probablement apocryphe.

$5^{\circ}$ (Fol. $154 \mathrm{r}^{\circ}$.) Vision du moine Bohaïra et ses entrevues arec Mahomet; récit fait par lui-même an moine Morheb (مرهب).

خبر بكيوة الواهب : Cette pièce apocryphe est intituléc 3. Histoire de Boḥaïra le moine avec l'Árabe bédouin $\pi$.

$6^{\circ}\left(F_{01}{ }_{17} 6 \mathrm{v}^{\circ}\right.$.) "Treize questions adressées par le calife al-Malıdì à l'excellent Père Catlıolicos, primat des nestoriens $:$ :

$7^{\circ}$ (Fol. 186.) Controverse soutenue par Anbà Yoûnos, patriarche d'Alexandrie, contre un juif et un melkite. Celte discussion eut lieu du temps d'Abd al-' $\Delta$ zìn, gouverneur de l'Égypte, le mène qui restaura $\left({ }^{\xi}\right)$ le nilomètre de Holwàn. La discusșion prit son origine dans la découverte d'un morceau de la vraie croix qui s'était trouvé parmi d'autres objets composant la succession d'un juif.

$8^{\circ}$ (Fol. 203.) Épitre dans laquelle un ami de l'imàm Taqi al-Din Ibn Taïmiya, de Damas, lui expose les résultats des recherches qu'il avait faites dans l'ile de Chypre pour constater les vraies croyances des chrétiens.

Cette lettre, écrite l'an 716 de l'hégire $(1316$ de J. C.), par un inusulman, est remplie de faits controuvés et d'appréciations erronćes.

$9^{\circ}$ (Fol. $228 v^{\circ}$.) Controverse qui eut lieu en la présence (du calife) 'Abd Allah al-llàmoûn, entre Aboù Qorra, évêque de Harràn, el plusieurs théologiens musulmans.

$10^{\circ}$ (Fol. 261. ) Questions adressées par Zaïn al-Dìn al-liamli, Schaikh al-lslàm (chef des docteurs musulmans), au patriarche du Caire et à la communauté chrétienne de celle ville.

Ces questions forment une pièce de vers de sept lignes. La réponse des chrétiens est en vingt-quatre vers, dont la mesure et la rime s'accordent avec celles de la pièce qu'ils araient recue. Ces questions ont rapport aux principales doctrines de l'Église chrétienne.

Papier. ${ }_{3} 62$ fenitlets. Hauteur, 18 centimètres; largeur, 13 centimètres. ${ }_{7}$ tignes par page. Ms. daté de t'an 1306 des martyrs $\left(159^{\circ}\right.$ de J. C.). - (Supplément 107 , Saint-Germain 276.)

\section{6.}

Défonse de l'authenticité de l'Ancien el du Nouveau 
Testament contre les allaques des musulmans. Owrage sans tille ni nom d'auleur. Ce ms. avait fail partie du ms. turc $n^{\circ} 121$ de l'ancien fonds.

Papier. 30 feuillets. Haulenr, 21 centimètres; largeur, 14 centimèIres. 21 lignes par page. Ms. du xriı siècle. — (Supplément 47.)

\section{7.}

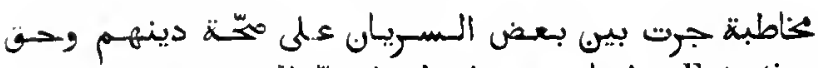
Entretien qui ent lieu entre quelques Syriens, au sujet de la pureté de leur religion et de l'orthodoxie de leurs aïenx...

Papier. 39 feuillets. Ilauteur, 18 centimètres; largeur, 12 centimètres el deni. 14 lignes par page. Ms. de la fin dı $x^{\prime} i^{c}$ siècle. (Supplément 106 bis, Arsenal.)

\section{8.}

Qurrage intitulé Entreliens spirituels n. Cé sont trois dialogues sur la religion chrétienue, daus lesquels l'aulenr lait parler deux sarants musulmans qui revenaient du pèlerinage de la Mecque. Ces docteurs, dont l'un se nomme Sinàn et l'autre Ahmad, finissent par reconnaitre l'excellence du christianisme. On voit, en parcourant l'ourrage, qu'il a élé composé par un chrélien commaissant très-imparfaitement les musulmans et peu au courant de la frammaire arabe. Le style de cet écrit est vulgaire et incorrecl. Ce volume est une copie du texte imprimé à Rome, dans un caractère mal formé et Irèsdifficile à lire. Une traduction anglaise de cet ourrage " paru ì Londres, en 1615 , sous le litre de Mohammed, his imposlure, etc. $n$, in-8 $8^{\circ}$, par W. Bedwell.

le ms. est de la main d'un nommé (Honoré Sol'cine), domeslique (تابع) ru grand roi français (Henri IV), qui l'écrivil à Marseille (all ;o)". Les premières pages portent une traduction interlinéaire qui parail être de la main du $D^{r}$ Picques.

Papier. 99 feuillets. Hauteur, 16 cenlimètres; largeur, s o centimètres. 10 lignes par page. - (Supplément 1 04, Jacobins Saint-Ilonoré.)

\section{9.}

Autre copie du مصاحبـات ووحسانسيـ. Elle est d'une main européenne el porte la dale de 1599 de J. C.

Papier. 264 pages. Hauteur, 16 centimètres el demi; largeur,
10 centimètres et demi. 9 lignes par page. - (Supplément 105 bis, Arsenal.)

\section{0.}

Profession de foi (اعتقاد الامانة), copiée sur le texte imprimé à Rome, l'an 1566 . On y a joint une version interlinéaire en latin.

Papier. 2 \& feuillets d'une écriture européenne. Hauteur, i 7 centimètres; largeur, 10 centimètres et demi. 10 lignes par page. - (Ancien fonds 117 ,)

\section{1.}

$1^{\circ}$ - Réponse au traité composé par Anastase, en vue de jeter la discorde (لومى الانشقات) entre les Grees et les Latins orlhodoxes. Cela ent lieu à l'époque où le P. KîrJoachim (كير يوأكيم) élail patriarche d'Antioche. D Dans cette répronse, l'iluteur, qui était évidemment catholique romain, déclare d'abord qu'Anastase n'élait pas te irai nom de la personne qui composa ce traité, et nie que le pape Grégoire XIII eût envoyé des légats en Orient pour effectuer la réunion des deux Églises. Il s'agissait, en réalité, d'un écrit dans lequel ce pape exposa au patriarche de Constantinople l'avantage qui résulterait de la réforme du calendrier. Toute la réponse roule sur celte question et sur la procession du Sainl-Esprit.

$2^{\circ}\left(\right.$ Fol. $30 v^{\circ}$.) Exhlortations à la piété.

$3^{\circ}$ (Fol. 35.) Récit d’une controverse qui eut lieu entre les chrétiens de la Syrie, au sujet de la purelé de leur religion et de l'orthodoxie de leurs aïenx. (Voyez cidessus $n^{\circ} 217$.)

Papier. 76 feuillets. Hauleur, 17 centimètres; largeur, 10 centimètres et demi. 12 à 14 lignes par page. Ms. du xvı๋ siècle. - (Supplément 99.)

\section{2}

Volume intitulé : "Doctrina christiana idiomate italico, latino, graco, arabico el gallico, Marco Antonio Gaïolio, divinarum literarum professore, Gallo-Annonæensi, Concinnatore."

Une note de la main d'Ascari, à la fin du volume, nous apprend que cet ourrage est une reproduction de la version arabe et du texte italien, imprimés à Romé par la 
Propagande, et que 13 P. Gaiot n'y a ajouté que les repsions grecque et française.

Papier. 98 feuillets. Hautenr, a 2 centimètres; largeur, 15 centimètres. 17 lignes par page. IIs. du xvi1" siècle. - (Ancien fonds 111.)

\section{3 .}

La première partie de l'onrage inlitulé : خلان "Le Salut des pécheurs , en trente-Init chapitres (m)). L'anteur se nommait Agapius (أغابيوس); il élait natif de. Crète, moine du mont Atlıs, el vivait an $\mathrm{xvu}^{\mathrm{e}}$ siecle. Le texte original de l'ourrage, composé en grec moderne

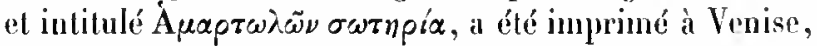
lan 1641 de J. C. Voyez la eBibliotheca graeca" de Fabricius, éd. de Hartes, t. XI, p. $3 g^{6}$.

Papier. 201 feuiltels. Hauteur, 17 centimètres; largeur, 15 centimètres. 7 lignes par page. Ms. daté de l'an 7199 dı monde ( 1691 de J. C.). - (Supplénent 59 , Saint-Germain $25 \%$.)

\section{4.}

$1^{\circ}$ Réfutation de treize points de doctrine professés par les hérétiques qui ont paru récemment en Flance (الافركجي_ة el dans d'autres pays de l'Europe, el quion nomme Qoloûniyin (تلفونسيسيـ) i, par Kir Macilrius, patriarche d'Antioche. Traité composé à Dannas, l'an $167_{71}$ de J. G.

$2^{\circ}\left(\right.$ Fol. $16 v^{\circ}$.) Réfutalion de huit autres points de doctrine professés par les mêmes héréliques.

Les deux pièces sont signées de la main du parriarche, scellées de son sceau, et portent les signatures de plusieurs curés, ainsi que celle du métropolitain de Boṣra et du llauràı.

Papier. a a feuillets. IJauteur, 16 centimètres; largeur, a 1 centimctres. 15 lignes par page. - (Supplément 1962 bis.)

\section{5.}

Rouleau de papier contenant la profession de loi de la secte copte jacobite, rédigée le 18 athìr 1388 (167 I de J. C.), par Matthieu, patriarche copte d'Alexandric. Cette pièce, portant la signature du patriarche, celle du consul français à Alexandrie et celles des négociants français éta- blis dans celte ville, fut écrite sur la demande d'Olier de Nointel, ambassadeur français au Levant. La note: officielle qui constate ce dernier fait et qui est inscritr au verso du rouleau, porte la date de 1672 .

(Ancien fonds 92.)

\section{6.}

Rouleau de papier portaut une seconde épitre de llatthien, patriarche d'Alexandrie, dans laquelle ce prélal expliyue la croyance des coples jacobites a sujet de la présence réelle. Cetle pièce, légalisée de la mème nuanière que la précédente, est également datée de l'an 1388 des martyrs.

(Ancien fonds 93. )

\section{7.}

Deux rouleaux de papier, daus un étui, contenant la profession de foi des chréliens coptes an Caire, en arabe, et des chrétiens arméniens de la même ville, en arnéuien. Ces pièces, légalisées par le consul de Franco an Caire, portent la date de 1672 .

(Supplément 89 bis.)

\section{8 .}

Version française de l'e Imilation de Jésus-Clırist ", accompagnée d'une traduction arabe. La version est celle du sicur de Beüil, prieur de Saint-Val. Elle est imprinée? et lonme un volume in-18, de 466 pages, qui parut à l'aris, l'an 1691 . La traduction arabe, faite à Nlep par le P. Ignace d'Orléans, avee le concours d'un homme de lettres du pays, est de l'écriture de Pétis de la Croix.

(Supplément 64.)

\section{9 .}

Courte introduction à la logique et à la théologie clnétiennes. Ce volume, intilulé Isagoge (ايساغوت3), est d'une?

' C'est-à-dire les Calvinistes. H. Z.

Mas. oriestaux. - 11 . 
main enropéenne. La copie n’est pas terminée. En regard dis texte arabe se trome me Iraduction laline.

Papier. 3/4 feuillcts. Hauteur, 15 centinètres; largeur, 10 centimèłres. 1 liz̧nes par paģe. Ms. dur xvu' siècle. - (Supplément 5o.)

\section{0 .}

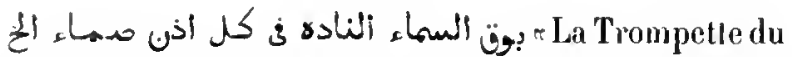
riel retenlissanl aux oreilles sourdes, pour la conversion des péchemrs. L'ourrage se compose de trois sections, dont rhacme est précédée d'une lisle des chapitres. C'est la traduction d'un livre français ou italien, composé, l'an 1717 de J. G., par le R. P. Joseph, capncin et missionnaire lrangais au Caire. Celte version arabe porte la neme dile.

Papier. 256 feuillets. Hauteur, a centimètres; largeur, 15 centimidres. 18 liģnes par page. - (Supplément 64 bis, Arsenal.)

\section{1.}

Ouvage composé par un Druse converli au christia-

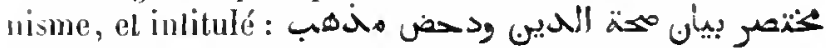
Exposition abrégée de la rraic foi et de la faihlesse du systeme religienx que professent les injliés d'entre les nuitaires (Druses) n. Ce traité parait avoir clé rédigé sous la direction d’un Europécu.

Papie:. 39 feuillets. Hauteur, 31 centimètres; largeur, 14 cenlimètres el demi. 16 lignes par page. Ms. du xvure siècle. - (Supptément 109.)

\section{2.}

Exposition de la doctrine clurélienne catholique. Ourage divisé en plusicurs chapitres, dont chacun renferme un dialogue entre un préceptenr et son disciple.

Papier. $1 \unlhd 3$ feuillets. Hautcur, 15 centimètres et demi; largeur, 11 centimètres. 15 lignes par page. Ms. daté de l'an 1745 de J. C. (Sinplément 60.)

\section{3.}

Petit traité de la doctrine chrétienne, suivi du Credo et de la litanie de la Vierge. Écrit à Paris, vers l'an 1830 , par Brahimschah, maronite, qui, ensuite, fut interprète de l'amée d'Mfrique.

Papier. 43 feuillets. Hauteur, 10 centimètres; largenr, 7 centimètres. 9 lignes par page. - (Supplément 60 bis.)

VIII.

\section{GONCIIES ET CANONS.}

\section{4.}

(c) Live des synodes et des canons », recueil des conciles de l'Église melkite.

$1^{\circ}$ Table des matières. Les premiers feuillets manquent.

$2^{0}$ (Fol. 13.) Liste des conciles.

$3^{\circ}\left(\right.$ Fol. $\left.16,{ }^{\circ}.\right)$ - Histoire des actes des saints apôtres, à partil de l'ascension de Notre-Seigneur, et indication des camons et des règlements qu'ils ont établis; le tout extrait des lives de Clément.

$4^{\circ}$ (Fol. 23.) r Les quatre-ringl et un canons ou titres ) des disciples, pièces publiées par Clément.

$5^{\circ}$ (Fol. $\left.34 r^{\circ}.\right)$ rCanons promulgués par les apôtres pour l'organisation dn sacerdoce, et provenant de Siméon le Cananéen'.

$6^{\circ}$ (Fol. 45.) Les vingt-quatre canons du concile d'Aucyre.

$7^{\circ}$ (Fol. $501^{\circ}$.) Les quatorze canons de Néocésarée (ناوكسيا), dits de Carthage.

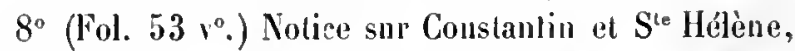
et sur la comocation du concile de Nicée, suivic d'une note sur les luérésies.

$9^{\circ}$ (Fol. 62.) Nolice sur le concile de Nicée, appelé de Synode des trois cent dix-huit évéques.

$10^{\circ}$ (Fol. 64.) Les vingt canons du concile de Nicée.

$11^{\circ}$ (Fol. 7o.) Quatre-vingl-quatre canons du mème concile.

$12^{\circ}$ (Fol. $89 v^{\circ}$.) Statuts du mème concile, concernant les luabitants des monastères et les moines².

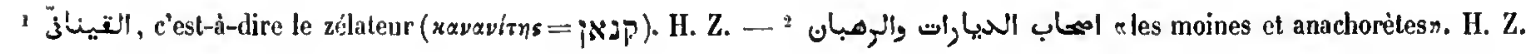


${ }_{13}^{\circ}\left(F_{0} 01.95 \vee^{\circ}.\right)$ Règlements adoptés par le même concile, au sujet des monastieres.

$14^{\circ}$ (Fol. $1011^{\circ}$.) Les vingt canons du concile de Gangres (غنقاسu), prérédés de la lettre aux évếques d'Arménie.

$15^{\circ}$ (Fol. $105 \vee^{\circ}$.) Les vingt-cing canons du concile d'Antioche, précédés des lettres synodales.

$16^{\circ}$ (Fol. 112 .) Les cinquante-neuf canons du concile de Laodicée, en Phrygic.

$17^{\circ}$ (Fol. 121.) Les vingt el un canons du concile de Sardique.

${ }_{1}^{\circ}$ (Fol. 128.) Le deuxième concile général de Constantinople. Notice préliminaire el quatre canons.

$19^{\circ}$ (Fol. 132.) Le concile d'Éphèse. Notice préliminaire el décrel mique.

$20^{\circ}$ (Fol. 135.) Les vingt-sept canons du concile de Chalcédoine.

$21^{\circ}$ (Fol. 146.) Courte notice sur le cinquième concile général de Constantinople.

$22^{\circ}$ (Fol. 147.) Le sixième concile général de Conslantinople. Notice; lettres de Jean VI, de Constant et de Martin. Récit de la persécution de Martin.

. $23^{\circ}$ (Fol. $\left.160 r^{\circ}.\right)$ Les canons et statuts dressés par S. Épiplıane, patriarche de Constantinople, d'après l'ordre de Justinien (السطنيكن), roi fortuné el vrai eroyant.

$24^{\circ}$ (Fol. $1801^{\circ}$.) Liste de dix-neuf hérésiarques.

${ }_{2} 5^{\circ}$ (Fol. 183.) r Reeueil des canons spirituels, e'est-ìdire des obligations envers Dieu qui doivent être strictement obser ées. Ces canons ont été extraits des quatre livres des Rois, volumes écrits sous les yeux des trois cent dix-huit évêques du grand concile de Niéée, et en la présence du roi Conslantin.» Suivent les canons dont folseserition est seulement recommandée.

$\Xi 6^{\circ}$ (Fol. 211.) Les statuts de l'ancienne loi, au nombre de cinquante-deux.

$27^{\circ}$ (Fol. 229.) Canous écrits par Clément, pape de

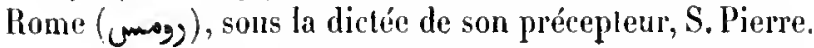

${ }_{2} 8^{\circ}$ (Fol. 233.) Déeisions des rois orthodoxes Constantin, 'lléodose et Léon.

$29^{\circ}$ (Fol. $2541^{\circ}$.) Les quatorze canons de S. Basile.

$30^{\circ}$ (Fol. $2561^{\circ}$.) Les premières lignes de la profession de foi d'Hiérothée, précepteur de Denys l'Aréopagite.

Le ms. est incomplet au commencement el à la fin.

Papier. 256 feuillets. Hauteur, 25 centimètres; largeur, 16 centimètres. 20 lignes par page. Ms. du xilı siècle. -- (Ancien fonds 1 27.)

\section{5.}

Recueil de canons.

$1^{\circ}$ Observations préliminaires et lable des matières.

$2^{\circ}$ (Fol. 20.) Liste des conciles.

$3^{\circ}$ (Fol. 27.) Actes des saints apôtres, à partir de l'Ascension; canons et règlenents qu'ils ont établis.

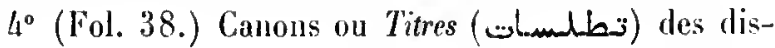
ciples.

$5^{\circ}$ (Fol. $\left.52 v^{\circ}.\right)$ Canons élablis par les saints apôtres pour le règlement dı sacerdoce.

$6^{\circ}$ (Fol. 66.) Les canons d'Ancyre.

$7^{\circ}$ (Fol. $731^{\circ}$.) Les canons de Néocésarée, dits de Carthage.

$8^{\circ}$ (Fol. $7^{8 .}$ ) Notice sur Constantiu et sur sa mère Hélène.

$9^{\circ}$ (Fol. $\left.89 r^{\circ}.\right)$ Notice sur le concile de Nicée.

$10^{\circ}$ (Fol. $91 \mathrm{~V}^{\circ}$.) Les vingt canons du concile de Nieée.

$11^{\circ}$ (Fol. 101.$)$ Quatre-vingt-quatre canons du mème concile.

$12^{\circ}$ (Fol. $124 r^{\circ}$.) Statuts du même concile, au sujel des noines, etc.

$13^{\circ}$ (Fol. $1311^{\circ}$. ) Staluts relatifs aux monasteres.

$14^{\circ}$ (Fol. 139.) Liste des liérésiarques. Le premier leuillet manque.

${ }_{15^{\circ}}$ (Ibid.) Explication du symbole de foi qu'on récitr le Jeudi saint en préparant le saint chrême (الميرون).

${ }_{16} 6^{\circ}\left(\right.$ Fol. 1 h $11^{\circ}$.) Noms des soixante-douze disciples de J. C.

$17^{\circ}$ (Fol. 142.) Les canons spirituels, extraits des quatre livres des Rois, ete.

$18^{\circ}$ (Fol. 175.) Les statuts de l'ancienne loi.

$19^{\circ}$ (Fol. 197.) Les slatuts de Clément, pape de Ronn? $($ (umg)

$20^{\circ}$ (Fol. $2021^{\circ}$.) Canons tirés des décisions des rois orthodoxes Constantin, Théodose et Léon.

$21^{\circ}$ (Fol. 229.) Les yuarante-sept canons d'Épiphane, patriarche de Constantinople.

$22^{\circ}$ (Fol. $232 \vee^{\circ}$.) Les canous de S. Basile.

$23^{\circ}$ (Fol. $235 v^{\circ}$.) La profession de foi, servant à délinir (تحیی) la nature de la substance divine, par Hiérothée. 
240 (Fol. 2.37.) Notice sur les sept conciles généI'mx.

On lit an verso de ce feuillet une note greeque, constalaut que ce ms. appartenait à Arsène, archerèue de Maximianopolis, et à son cousin P'ierre, prêtre, et invoquant la malédiction des trois cent dix-huit (évêques du concile do Nicée) sur la persomme qui déroberait le volume.

$25^{\circ}$ (Fol. 238.) Les canous du concile de Gangres ( غنان).

2.6. (Fol. 243.) Les canons du concile d'Autioche.

$27^{\circ}$ (Fol. 251.) Les ranons du concile de Laodicée, an mombre de cinguante-neul.

$38^{\circ}$ (Fol. 262.) Les canons du concile de Sardique.

$29^{\circ}\left(F_{0} 01.27^{\circ} \vee^{\circ}\right.$ ) Le deuxiène concile général de Constantinople.

$30^{*}$ (Fol. 275.) Le concile d'Éphise.

$31^{\circ}$ (Fol. 280.) Le concile do Chalcédoine.

$32^{\circ}$ (Fol. 293.) Le cinquième concilé général de Conslantinople.

$33^{\circ}$ (Fol. $29^{4} \vee^{\circ}$.) Le septième concile gúnéral de Constantinople.

$34^{\circ}$ (Fol. 312.) Les canons d'Épiphane.

$35^{\circ}$ (Fol. 338.) Sur les mariages qui sont permis par l'Église universelle.

$36^{\circ}$ (Fol. 340.) Les quarante chapitres ou titres promulgués par les rois fortunés et augustes (الاوغسطيين) Basile, Constantin et Jéon.

C'est une version libre du Прóxępos Nópos.

t’apier. 104 reuiltets. Ilauteur, 23 centimètres; largeur, 15 centimètres et demi. 17 lignes par page. Ms. du xin" siècle. - (Ancien fonds 128 , Colbert $/ 477$.)

\section{6 .}

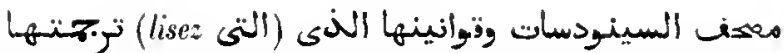
rLes synodes el leurs canons, c'est-àdire les obligations envers Dieu qui doivent ètre strictement observées n. Ce recueil, à l'usage des melkites de la Syrie, renferme les pièces suivantes:

$1^{\circ}$ Préface.

$2^{\circ}\left(F_{0}{ }_{0} .2 v^{\circ}.\right)$ Manière de préparer le saint clırême. $3^{\circ}$ (Fol. 4.) Sommaires de quatre conciles provinciaux (le premier, le deuxième, le cinquième el le sixième), et de quatre conciles généraux (le troisième, le quatrième, le cinquième el le septième), en grec et en arabe.

On y trouve aussi les sommaires du troisieme et du quatrième concile provincial en arabe, écrit arec des caractires syriaques.

$4^{\circ}$ Indication des diverses hérésies, depuis celle d'Arius jusqu’ì celle des monothélites Sergins et Pyrrhus (وكرجه)

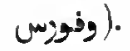

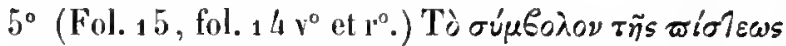

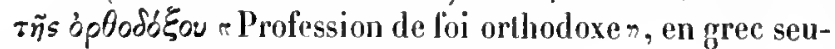
lement.

La traduction arabe se troure an fol. $27^{\circ} \mathrm{r}^{\circ}$.

$6^{\circ}$ (Fol. $15 v^{\circ}$.) Les canons des saints apôtres, tirés des écrits de Clément.

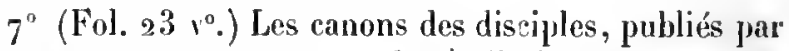

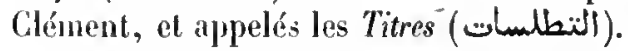

$8^{\circ}$ (Fol. $35 \mathrm{v}^{\circ}$.) Canons des saints apôtres sur l'organisation du sacerdoce (نظام المكهـنستوت), par Siméon le Canancén (القينان).

$9^{\circ}$ (Fol. $461^{\circ}$.) Canons du concile d'Ancyre, précédés d'un sommaire en grec el en arabe.

$10^{\circ}$ (Fol. 53.) Cianons dn concile de Néocésarée, dit de Cartlugge. lin tête se trouve un sommaire en grec et en arabe.

$11^{\circ}$ (Fol. 56.) Notice sur Constantin et sur sa mère Hélène, avec une revue des sectes et des hérésies qui succéderent aux persécutions.

$12^{\circ}$ (Fol. $65 \mathrm{v}^{\circ}$. ) Synode tenu par trois cent dix-liuit évèques dans la ville de Nicée.

Il y a une courte introduction en grec et en arabe.

${ }_{1} 3^{\circ}\left(\right.$ Fol. $67 v^{\circ}$.) Les vingl canons du concile de Nicée.

$14^{\circ}$ (Fol. $\left.791^{\circ}.\right)$ Autres canons du concile de Nicée.

$15^{\circ}\left(\right.$ Fol. $\left.99 v^{\circ}{ }^{\circ}\right)$ Autres prescriptions du même concile touchant les reclus et les noines.

${ }_{16}^{\circ}$ (Fol. $105 v^{\circ}$.) Autres statuts concernant les monastères et la consécration des églises.

$17^{\circ}$ (Fol. $111 \mathrm{v}^{\circ}$. ) Canons du concile de Gangres (غنغراس).

En tête se trouve une courte introduction en grec et en arabe.

$18^{\circ}$ (Fol. $116 v^{\circ}$.) Canons du concile d'Antioche, avec une introduction en grec et en arabe. 
$19^{\circ}\left(\mathrm{F}_{0} \mathrm{l}_{12} 3 \mathrm{\vee}^{\circ}\right.$.) Les cinquante-neuf canons du concile de Laodicée.

$20^{\circ}$ (Fol. $133 v^{\circ}$.) Les canons du concile de Sardique.

$21^{\circ}$ (Fol. $140 r^{\circ}$.) Concile de Constantinople (deuxième concile général). Il y a une notice préliminaire, dont le rommencement est en grec et en arabe; puis viennent "quatre canons.

$22^{\circ}$ (Fol. 145.) Concile d'Éphèse, avec une introduction dont le commencement est en grec et en arabe.

$23^{\circ}$ (Fol. $149 v^{\circ}$.) Le quatrième concile de Chalcédoine, arec une note préliminaire en grec et en arabe.

$24^{\circ}\left(\right.$ Fol. $155 v^{\circ}$.) Les vingt-sept canons dı concile de Chalcédoine.

$25^{\circ}$ (Fol. $163 \vee^{\circ}$.) Le sixième concile général de Constantinople.

Dans la notice prélininaire se trouvent deux lettres apostoliques du pape de Rome et quelquos autres pièces.

${ }_{2} 6^{\circ}$ (Fol. 181.) Canons présentés par le synode dụ sixième concile au roi Justinien.

$27^{\circ}$ (Fol. 2 1 4.) Le septième concile géuéral (deuxième concile) tenu à Nicée.

Notice et canons au nombre de vingt-deus.

${ }_{2} 8^{\circ}$ (Fol. 224.) «Règlement du septième concile général, concermant l'élection des évêrfues, les voux qu'ils doivent prononcer, ainsi que les prètres, les diacres et les autres menlores du clergé (بقية الاكليووس). On y traite aussi des religieux, hommes et femmes.»

$29^{\circ}$ (Fol. $248 r^{\circ}$.) Canons et règlements composés par Epiphane, patriarche de Constantinople, sur la demande de l'empereur Justinien.

$30^{\circ}$ (Fol. 270.) Liste des lérétiques.

$31^{\circ}$ (Fol. $2701^{\circ}$.) Version arabe de la profession de loi dont le texte grec se trome aux fol. 14 et $15 \mathrm{du}$ présent ms.

$32^{\circ}$ (Fol. 273.) rLes canons spirituels, c'est-à-dire les obligations envers Dieu qui dojvent être strictement observées. Ils se trouvent dans les quatre livres impériaux qui furent écrits sous les yeux des trois cent dix-huit évêques du grand concile, et en la présence de l'empereur Constantin. $\gg$

33 (Fol. 30o.) Les statuts de l'ancienne loi (احكبم)

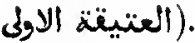

Nous n'avous jei que le commencement de ce recueil.

Papier. 300 feuiltets. Hanteur, 25 centimètres; largeur, 16 centimètres. 19 à 21 lignes par page. Ms. du $x^{e} v^{e}$ siècle. - (Ancien fonds 118.)

\section{7.}

$1^{\circ}$ Concile d'Éphèse; fragment du discours de Cyrille contre Nestorius, et défunition de la foi.

$2^{\circ}\left(F_{0}\right.$. $2 \iota^{\circ}$.) Vingt-neuf canons du concile de Chalcédoine.

$3^{\circ}$ (Fol. 7.) Courte notice du cinquième concile de Constantinople.

$4^{\circ}$ (Fol. $7 \mathrm{v}^{\circ}$.) Notice du sixième concile de Constantinople, et copies de quelques lettres qui s'y rapportent, professions de foi ct canons.

$5^{\circ}$ (Fol. $24 \vee^{\circ}$.) Canous du septième concile cemutenique.

$6^{\circ}$ (Fol. 37.) Canons du concile (dit) de Carthage.

Papier. ${ }_{7} 7$ fenillets écrits sur deux colonnes. Ilauteur, 3 o centinètres; largeur, 20 centimètres. 26 lignes par page. Its. du $x^{2} 1^{\bullet}$ siècle. - ( Ancien fonds 1.4.)

\section{8.}

Recueil de canons, savoir :

1 Canons du concile d'Antioche.

$2^{\circ}$ (Fol. 10.) Notice sur Constantin le Grand.

$3^{\circ}$ (Fol. $27 \vee^{\circ}$.) Notice sur le concile de Nicée.

$4^{\circ}$ (Fol. 33.) Les vingt canons de Nicée.

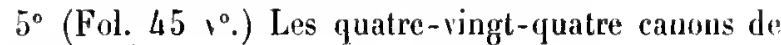
Nicée.

$6^{\circ}$ (Fol. 84.) Les canons de Nicée qui concernent les moines et les monastères.

$7^{\circ}$ (Fol. $\left.112 \vee^{\circ}.\right)$ Les vingt canons de Nicée, traduits sur une rersion copte.

$8^{\circ}$ (Fol. 132.) Canons du concile de Constantinople.

$9^{\circ}$ (Fol. 138.) Canon unique du concile d'Éphèse.

$10^{\circ}$ (Fol. 139.) Concile d'Ancyre.

$11^{\circ}$ (Fol. 149.) Concile de Laodicée.

$12^{\circ}$ (Fol. $164 v^{\circ}$.) Concile de Sardique.

$13^{\circ}$ (Fol. $175 v^{\circ}$.) Concile de Néocésarée, dit de Carthage.

$14^{\circ}$ (Fol. $180 v^{\circ}$.) Concile de Carthage.

$15^{\circ}$ (Fol. $214 v^{\circ}$.) Conçile de Gangres.

${ }_{16}^{\circ}$ (Fol. 218.) Tables des canons d'dutioche et the Laodicée. 
$17^{\circ}$ (Fol. 231 1․) Canons de S. Hippolyte (ابوليدس)), archerêque de lione.

${ }_{1}^{\circ}\left(\right.$ Fol. $259 \wedge^{\circ}$.) Canons de S. Basile.

$19^{\circ}\left(\right.$ Fol. $\left.29^{4} 1^{\circ}.\right)$ Canons de S. Athanase.

20" (Fol. 325.) Abrégé des canons, par Michel, métropolitain de Daniette.

$21^{\circ}$ (Fol.329.) Canons de Gyrille, patriarche d'Alexandrie.

$22^{\circ}$ (Fol. 336.) Charte établissant une convention pntre Cyrille el ses évêques.

$23^{\circ}$ (Fol. 339.$)$ Autre charte de Gyrille.

$24^{\circ}$ (Fol. $\left.346 r^{\circ}.\right)$ Autre du mème.

$25^{\circ}$ (Fol. $349 v^{\circ}$.) Autre du même.

${ }_{2} 6^{\circ}$ (Fo1. 351.) Questions relatives à la discipline ecclésiastique, adressées par Christodule (احمسطادلو), métropolitain de Damiette, au patriarche Cyrille, arec les r'íponses de celui-ci.

$27^{\circ}$ (Fol. 353.) Cauons de S. Jean Chrysostome.

$28^{\circ}$ (Fol. 354 , . .) Canons transiloires (äojll).

$29^{\circ}$ (Fol. 361.) Autre copie des canons transitoires.

$30^{\circ}$ (Fol. 37o.) Fragment acéphale des canons des docteur's de l'Église.

$31^{\circ}$ (Fol. 378.) Règlements institués par les Pères de l'Erglise, au sujet des prètres, des moines el des fidèles ("u général.

$32^{\circ}$ (Fol. $3841^{\circ}$.) Clef d'un chiffre dont se serraient les éerivains coptes.

Papier. 385 feuillets. Hanteur, 21 centimètres; largeur, 14 centimètres. Us. composé de cahiers rícrils à différentes époques. - (Supplẻment 86, Saint-Germain 34.)

\section{9.}

Recneil de canons, rédigé probablement à l'usage de l'Église copte jacobite.

$1^{\circ}$ Préface aux canons du premier coneile général de Nicée.

$2^{\circ}$ (Fol. 12.) Titres des vingt canons du même concile et texte des canons.

$3^{\circ}$ (Fol. 18.) Version du symbole de Nicée, précédée d'une courte notice el suivie d'un commentaire. $4^{\circ}$ (Fol. $201^{\circ}$.) Trente canons concernant les prêtres, les moines et les églises.

5 (Fol. 31.) Notice sur le concile de Nicée.

$6^{\circ}$ (Fol. 45.) Les quatre-ringts canons dits arabiques.

$7^{\circ}$ (Fol. 75.) Trente-trois canons du concile de Nicée, relatifs aux reclus (إمحاب الديارات-) ef aux moines.

$8^{\circ}$ (Fol. 92.) Symbole de foi adopté par le même concile.

$9^{\circ}\left(F_{0} .9^{8} 1^{\circ}.\right)$ Notice sur le deuxiène concile cecuménique (premier de Constantinople), suivic de sept canons.

$10^{\circ}$ (Fol. 103.) eVingt-trois canons, par lesquels cent cinquante évêques, qui se réumirent (dans le sccond concile acuménique) à Constantinoplo, excommunièrent tous cux qui professaient des opinions hétérodoxes au sujet de la Sainte Trinité.

$11^{\circ}$ (Fol. 1 o6.) Concile d'Éplièse.

- $12^{\circ}$ (Fol. 109.) Concile d'Ancyre; lable et canons, au nombre de vingt-quatre.

$13^{\circ}$ (Fol. 1 18 .) Concile de Néocésarée, dit concile de Carthage; table et lexte de quatorze canons. Quelques mols étrangers à l'arabe sont accompagnés de leur transcription en caraclères coptes.

$14^{\circ}$ (Fol. 122.) Concile de Gangres (غنغراس); noms des vingt-cing énêques; texte de leur lettre synodale; lable et texte des ringt canons.

$15^{\circ}$ (Fol. 128.) Les ingt et un canons du concile de Sardique.

${ }_{16}^{\circ}$ (Fol. $138 v^{\circ}$.) Concile d'Autioche; courte notice, table, vingt-cinq canons et noms des érêques.

$17^{\circ}$ (Fol. $\left.148 v^{\circ}.\right)$ Concile de Laodicée; lable, cinquante-neuf canons el noms des éréques.

$18^{\circ}$ (Fol. 164.) Les quatre-ringt-trois canons du concile d'Anlioche; lettre synodale, noms des évêques et texte des canons. Le tout est traduit du copte.

$19^{\circ}$ (Fol. $\left.17^{6} \mathrm{v}^{\circ}.\right)$ Les quatre-ringt-dix-huil canons du concile de Carthage et notice sur ce concile, dont la réunion eut lieu l'an $59_{2} 5$ de l'ere du monde, date qui correspondait à l'an 150 de l'ère des martyrs (433-434 de J. C.). A celte époque, dil le rédacteur du recueil, Honorius régnait à Rome, et Théodose le jeune élait dans la troisième année de son règne.

Papier. ${ }_{197}$ feuiltets. Hauteur, 23 centimètres et demi; largeur, 16 centimèlres. 17 lignes par page. Ms. du $x v^{e}$ siècle. - (Ancien fonds 119. ) 


\section{0.}

$1^{\circ}$ Les dix derniers canons du concile de Véocésarée.

$2^{\circ}$ (Fol. $5 r^{\circ}$.) Les canons du concile de Gangres.

Il mancue un feuillet ou deux entre les folios actuellement cotés 6 et 7 .

$3^{\circ}$ (Fol. $9 v^{\circ}$.) Les vingt et $u n$ canons du concile de Sardique.

$4^{\circ}$ (Fol. 18.) Les canous du concile d'Autioche.

$5^{\circ}$ (Fol. $27 \mathrm{v}^{\circ}$.) Les canons du concile de Liıdicée.

$6^{\circ}$ (Fol. 41.) Notice sur Constantin, fils d'Hélène, et énumération de plusiemrs sectes loérétiques.

$7^{\circ}$ (Fol. 54.) Vingt canons du concile de Nicée.

$8^{\circ}\left(F_{0 l} .70 v^{\circ}\right.$.) Autres canons, au nombro de quatrevingt-quatre, émanés du mồme concile. Nicée.

$9^{\circ}$ (Fol. 105.) Trente-trois ranons du concile de

$10^{\circ}$ (Fol. 127 v.) Symbole orthodoxe da Nicée.

$11^{\circ}$ (Fol. 129.) Canons du concile de Constantinople (deuxième concile génésal).

$12^{\circ}$ (Fol. $1321^{\circ}$.) Vingt-trois canons du mène concile.

$13^{\circ}$ (Fol. 137.) Décret du concile d'Éphèse (ummil).

$14^{\circ}$ Plusieurs canons dont les titres, écrits à l'encre rouge, sont eflacés par la rétusté. Ce sont le; trinte cainons transitoires qu'on trome dans le $11^{\circ} 238$.

Papier. 150 feuiltets. Hanteur, 36 centimètres et demi; largeur, 17 centimètres. 17 lignes par page. Ms. du siv siècte. - (SuppléInent 8o.)

\section{1.}

$1^{\circ}$ Canons, au nombre de soixante et onze, que les apòtres publièrent par l'entremise de Clément.

$2^{\circ}$ (Fol. 40.) Canons, au nombre de cinpuante-six, provenant de la mème source.

$3^{\circ}$ (Fol. 51.) Le deuxième live du commentaire dı schaikh al-Ṣafi (الصن) Ibn al-`Assàl.

Ce sont les quatre-vingt-trois canons, dits arabiques, qu'on attribue faussement au concile de Nicée.

$4^{\circ}$ (Fol. 82.) Les canons du concile d'Ancyre.

$5^{\circ}$ (Fol. 88.) Les canons du concile de Néocésarée, dit de Carthage.
Ils sont an nombre de quinze, et se rapportent aux marjages et aux prétres.

$6^{\circ}\left(\right.$ Fol. $\left.9^{\circ} v^{\circ}.\right)$ Les vingt canons du concile de Gangres.

$7^{\circ}$ ( $\mathrm{F}_{0} \mathrm{I} .9^{5}$.) Les quairi-vingt-trois canons du concile d'Antioche.

$8^{\circ}$ (Fol. $110 v^{\circ}$.) Notice sur Constantin.

$9^{\circ}$ (Fol. ${ }_{2} 3 v^{\circ}$.) Canons du concile de Nicée, au nombre de vingt.

$10^{\circ}$ (Fol. $1301^{\circ}$.) Notice sur le concile de Nicée.

$11^{\circ}$ (Fol. 142.) Cinquante-neuf canons du concile de Laodicée.

$12^{\circ}$ (Fol. $155 \vee^{\circ}$.) lingt et un canous du concile de Sardique.

Papier. 164 feuiltets. Hauteur, 25 centimètres; lirrreur, 17 centimètres et demi. 18 liggnes par page. Us. du xiv siècle. - (Supplément 81 , Saint-Germain 40.)

\section{2.}

$1^{\circ}$ Nolice sur les conciles ceuméniques de Nicée, der Constantinople, d'Éphèse, de Chalcédoine et de Constantinople; sur les conciles provincianx d'Ancyre, de Néocésa rée, d'Ancyre, de Sardique, d'Antioche, de Laodicée, atc.

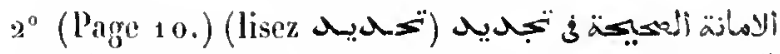

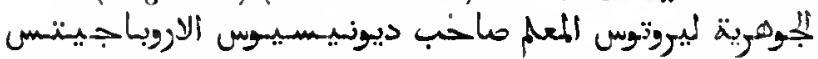
"Profession de loi pour définir la nature de la substance" divine, par le maitre Hiérotlcée, précepteur de Denys l'Aréopagite."

$3^{\circ}$ (Page 13.) Prolession de foi, rédigée par Denys l'Aréopagrite.

$4^{\circ}$ (Page 16.) Opuscule dont on a laissé le litre eal

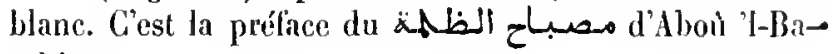
rakit.

50 (Page 23.) Notice sur les apôtres (الابسعليبي), sur ce ruils firent après l'ascension du Seigneur et sur les prescriptions, camons et règlements qu'ils établirent. Document tiré des écrits de Clément.

$6^{\circ}$ (Page 43.) Les quatre-vingt et un canons, appelés Titres, que les disciples adoptèrent unanimement, et qui nous furent transmis par Clément, sur l'autorilé de son précepteur, S. Pierre.

$7^{\circ}$ (Page 68.) Canons des saints apôtres, sur l'organisation du sacerdoce, transmis par Simceon le Cananćen.

$8^{\circ}$ (Page 98.) Canons écrits par Clément, jape de Rome (رومس), sous la dictée de son précepteur, S. Pirrer. 
$9^{\circ}$ (Page 114. Canons du concile d'Ancyre, au nombre de vingt-quatre.

$10^{\circ}$ (Page 122.) Les quatorze canons du concile de Néocésarée, dit de Carthage.

11 (Page 143.) Nolice sur Constantin et sur sa mère Hélène, et sur la convocation du concile de Nicée.

$12^{\circ}$ (l'age 169.$)$ Notice sur le synode des trois cent dixhuit évêrues tenu à Nicée, lequel fut le premier concile général.

$13^{\circ}$ (Page $17^{5}$.) Les vingl canons du concile de Nicée.

$14^{\circ}$ (Page 196.) Autres canous du même concile, au nombre de quatre-vingt-quatre.

150" (Page 263.) Autres canons du même concile, pour régles l'état des haluitants des monastères et des moines.

${ }_{16}^{\circ}$ (Page 281.) Canons relatifs aux monastères et à la consécration des églises.

$17^{\circ}$ (Page 303.) Les vingt canons dı concile de Gangl'es, arec l'épitre aux évèques d'A rménie.

$18^{\circ}$ (l'age 320. ) Les vingt et $m$ canons du concile de Sardique.

$19^{\circ}$ (Page 345.) Les vingt-cinq canons du concile d'Antioclie.

$20^{\circ}$ (Page 374.) Les cinquante-neuf canons du concile de Laodicée, en P'hrygie.

$21^{\circ}$ (Page 408.) Concile de Constantinople (deuxième concile général); quatre canons, arec nne notice prélininaire.

$22^{\circ}$ (Page 422.) Concile d'Éphèse. Notice prélimiaire et décret.

$23^{\circ}$ (Page 432.) "Recueil des canons spirituels, c'est-rire des obligations envers Dien tui doirent être stricement observées, tirées des quatre volumes des lives les Rois qui furent écrits sous les yeux des trois cent dix-huit évèques dı grand concile de Nicée, et en la présence du roi Constantin. s Suivent les canons dont l'observation est seulement recommandée.

$24^{\circ}$ (Page 511. ) Décisions (تضايب) des rois orthodoxes Constantin, Théodose et Léon. C'est une collection de cent trente lois de droit civil. Les quarante-trois premières lois sont attribuées à Constantin, et les autres à Théodose.

250 (Page 528.) Les statuts de l'ancienne loi (حكام) (العتيقيتة).
26 (Page 619.) rTexte de la noble loin (ناموس),

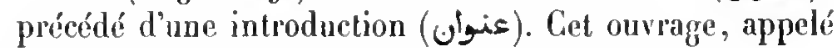
aussi les n Quarante titresn (النتطلسات الاوبعون) (كنور), est un re-

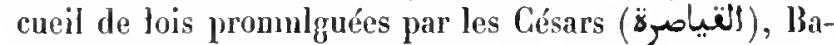
sile, Constantin et Léon. L'original grec est hien connu sous le titre de II póxespos Nópros.

Papier. $79^{8}$ pages. Hauleur, 20 centimètres; largeur, 15 centimètres. 17 lignes par page. Ms. du xvi" siècte. - (Ancien fonds 125. )

\section{3.}

liecueil de canons.

1 Table des matières.

$2^{\circ}$ (Fol. $2 v^{\circ}$.) Les trente canons des saints apôtres (الابسطلييي). Une notice historique est placée en tête de la collection, et une autre à la fin.

$3^{\circ}\left(\mathrm{F}_{0} \mathrm{l} .17 \mathrm{v}^{\circ}\right.$.) Les quatre-vingt et un canons des disciples.

$4^{\circ}$ (Fol. 41.) Les soixante et onze canons des apôtres, transmis par Clément, sur l'autorité de son précepteur, S. Pierre.

On lit dans lintroduction: " Les melkites, les jacobites sylions et les nestoriens se servent d'une même version arabe, renfermant quatre-vingt-trois canons. Selon Ibn al-Tayyib, docteur nestorien, dans son livre intitulé r la Jurisprudence des clirétiens» (نقه الهنصارى), la version possédée par ses corełigionnaires renferme quatre-vingtdeux canons. Les Coptes en possèdent deux versions, dont l'une renferme soixante el onze canons et l'au tre cinquantesix. Les trois versions s'accordent, yuant au texte, et ne different que par la division et le nombre des sections.

$5^{\circ}$ (Fol. $82 v^{\circ}$.) La seconde version copte, renfermant cinquante-six canons.

$6^{\circ}\left(\right.$ Fol. $\left.9^{4} \mathrm{v}^{\circ}.\right)$ res Didascalia, c'est-à-dire renseignement $n$, renfermant trente-neuf chapitres, et composés par Paul, l’apôtre, par Jacques, frère du Seigneur et évêque de Jérusalem, èt par les autres apôtres. n

$7^{\circ}$ (Fol. $205 v^{\circ}$.) Canons des apôtres transmis par Siméon le Cananéen, sur l'organisation du sacerdoce.

$8^{\circ}$ (Fol. $220 \mathrm{v}^{\circ}$.) Canons écrits par S. Pierre, sous la dictée de N. S. Jésus-Christ, et communiqués par lui à son disciple Clément, pape de Rome.

Papier. 298 feniltcts. Hanteur, 20 centimètres et demi; Jargeur, 15 centimètres. 13 lignes par page. Ns. daté de t'an 1357 des martyrs ( 1641 de J. C. ). - (Ancien londs 196.$)$ 


\section{4.}

Recueil de canons :

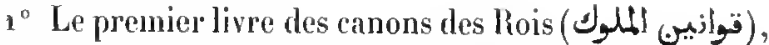

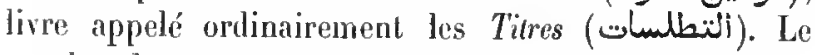
nombre de res canons est de quarante.

$2^{\circ}$ (Fol. 61.) Le deuxième livre des canons des Rois, au nombre de cent trente.

$3^{\circ}$ (Fol. 106.) Les canons du concile de Carthage, au nombre de cent vingt-trois. Les derniers feuillets manquent.

Papier. 123 feuiltets. Hauteur, 25 centimètres; largeur, 16 centimètres et demi. 19 à 21 liggnes par page. Ms. du $x_{10}{ }^{\circ}$ siècle. (Supplément 82, Saint-Germain 31.)

\section{5.}

Recueil de canous par al-Safi lbn al-'Assâl. Cette compilation, où les canons sont classés dans un ordre méthodique, forme le code religieux, civil et pénal des Coples jacobites. L'ouvrage se compose d'une introduction en deux parties, et de cinquante et un livres (باب), divisés en deux sections. La première partie de l'introduction indigue les bases fondamentales du droit canon, à savoir, l'Écriture sainte, les canons de l'Égglise et l'analogie (تياس), c'est-à-dire les principes déduits des indications lournies par l'Écriture et les canons. La seconde partie renl'erme la liste des documents dont l'auteur s'est servi, et l'explication des monogranmes par lesquels il désigne les sources où il a puisé. Voici la liste de ces documents : l'Ancien et le Nouveau Testament; les trente canous attribués à un concile tenu par les apôtres, à Jérusalem; les canons des apootres, publiés par $\mathrm{S}$. Clóment; le recueil

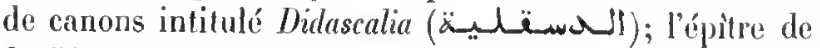
S. Pierre à S. Clément; les canons d'Ancre; les canons de Néocésarée, dits canons de Carthage; les canons de Gangres, d'Antioche, de Nicée, de Laodicée et de Sardique; les douze canons du pape Hippolyte (بولمدس), de Porto; les treize canons de S. Basile, et enfin les canons des hois (توانيی( Geux-ci forment quatre collections, au sujet desquelles Ibn al- Assâl donne des renseignements intéressants (fol. 6). La prenière scction de l'ouvrage renferne vingt-deux livres, dont tous ont pour sujel le culte et le clergé. La deuxième section est consacrée aux affaires séculières, et renferme les lois relatives à l'individu, à la lamille et à la cité (艹ِ

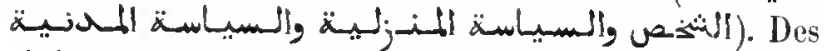
règlements et aussi des conseils ecclésiastiques sur la May. orientaix, - II. nourriture, 1'habillement, etc., se trouvent mêlés aux fois positives du code civil et du code pénal. On y cite tantôt la Bible, tantòt les conciles et tantôt les Tïres (تطاس (تط) , on compilation des lois romaines, et quelquefors même des lois spéciales à la société copte, sous li domination musuhnanc. Tels sont les rigglements de quelques patriarches, au sujet des successions. A la fin du volume se trouve un appendice intitulé a Cllapilre des successionss (اب) ألمئر).

Papier. 216 feuillets. Hauteur, 26 centimètres et demi; largeur, 18 centimètres. 19 lignes par page. Ms. de la fin dn xu siècte - (Ancien fonds 123.)

\section{6.}

Recucil de canons, par lbn al-`Assill, beau ms., dont les derniers feuillets ont été rétablis par une main moderne. A la lin de l'ouvrage se trouve la date de 1256 des martyrs et celle de l'in 947 de l'hégire, qui correspondent toutes les deux à l'an 1540 de J. C. C'est là, sans doutc, l'année où le volume a été restauré, car la partif ancienne du ms. parait être du xıv siècle.

Papier. 242 fenillets. Hauteur, 25 centimètres et demi; largeur 18 centimètres. 16 lignes par page. - (Supplément 85, Saint-Germain 42 bis.)

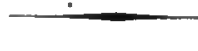

\section{7.}

Recueil de canons, par Ibn al-'Assill. Les preniers feuillets de cet exemplaire el le dernier sont d'une écriture plus moderne que le reste du volume.

Papier. ${ }_{2} 57$ feuillets. Ilauteur, 26 centimètres; largeur, 17 centimêtres. 18 ligunes par page. Le ms. paraît ètre du $x v^{8}$ siècle. - (Aneien londs 1.1.)

\section{8.}

Recueil de canons, par lbn al-cAssâl.

Papier. 231 feuillets. Hauteur, 26 centimètres; largeur, 18 centimètres. 17 lignes par page. Ns. daté de l'an 1193 des martyrs ( $1477 \mathrm{de}$ J. C.). - (Ancien fonds 122.)

\section{9.}

Recueil de canons, par Ibn al-'Assàl, suivi de l'ap)- 
pendice sur les successions, contenant les règles sanetionnées par Cyritle, patriarche d`Alexandrie. Cet exemplaire parait ètre du $x v^{e}$ siécle; les premiers et les derniers feuillets sont d'une écriture plus moderne; le folio 321 , qui reproduit la date du ms. original, est écrit sur papicr européen du xvie sjecle. Le colume dont nous avous ici une copie fut écrit l'an 978 des martyrs ( 1262 de J. C.), dans la maison d'lbu al-Assål, par le

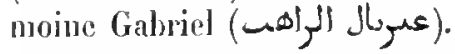

Papier. 327 feuitlels. Hauteur, 25 centimètres; largeur, 17 centimètres. 15 lignes par page. - (Supptément 84, Saint-Germain 42.)

\section{0 .}

$1^{\circ}$ م Recueil de canons n, par Faradj-Allah, natil' d'Ekhmìm, en Égyte. Gette compilation, faite pour l'usage des jacobites, est un résumé, par ordre des matières, de diverses collections de canons. Elle est divisée en deux parties, dont la prenière, relative au culte, renferme vingt-six chapitres, et la deuxième, ayant pour sujet la morale, en ronferme cinquante. Cette partie contient aussi une esquisse de l'organisation judiciaire choz les Coptes, ainsi que de leurs lois riviles, dont la plupart sont tirées de la jurisprudence romaine. On y cite quelques titres (تطاسu) du code impérial. Parini les lois sur les successions, l'auteur rapporte (fol. $180 v^{\circ}$ ) la loi Falcidia (Muيll). Le chapitre suivant est copié d'un ourrage composé par Aboù 'J-Faradj 'Ald-Allah Ibn abi al-Tayyib, et intitulé «Paradis de l'orthodoxie pour les chrétiens" (فردوس الارتمكسية للطايفة النصوانية) La partie la plus intéressante de l'ourrage, an point de ve de la jurisprudence, commence au chapitre xxxun de la seconde partie (fol. 159).

$2^{\circ}$ (Fol. 238.) Vers techniques, renlermant l'indication des canons qui ròglent les devoirs des prêtres dans l'Église copte.

Une note, écrite au verso du folio 238 , nous apprend

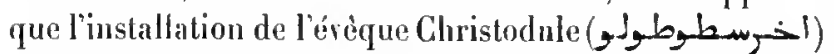
eut lieu l'an 1372 de l'ère des martyrs (1656 de J. C.), et que celle du patriarche Marc (موقن) eut lieu la mème année.

$3^{\circ}$ (Fol. 240.) Conseils adressés aux prètres, par Sćvère d'Antioche.

$4^{\circ}$ (Fol. $244 r^{\circ}$.) Notes et tables direrses pour le calendrier copte, suivies d'une table synoptique, donnant les épactes et les fêtes pour les années coptes 1336 à 1420 ( 1620 à 1704 de J. C. ) .

Papier. 253 feuiltets. Llauleur, 37 centimètres et demi; largeur,
19 centimètres et demi. 17 tignes par page. Les derniers feuiltets, à partir du $338^{\circ}$, sont du xrı" siècle. Le reste du volume date de l'an 1073 des martyrs ( 1357 de J. C.). - (Ancien fonds 1 20.)

\section{1 .}

"Recueil de canons, ouvrage du aux soins du maitre Maqàra (ö), prêtre attaché au monastère de SaintJean-le-Nain, établissement situé dans le désert de Scété (تشيهاتش). Il tira ces documents d'un grand nombre de livres trourés par lui soit dans les monastères du désert, soit au Caire. Après un travail laborieux de plusieurs années, il compléta la collection dont ce ms. offre la copie exacte. $n$ L'ouvrage renferme les pièces suivantes :

1 Table générale.

$2^{\circ}\left(\right.$ Fol. $\left.3 v^{\circ}.\right)$ Notice sur les travaux des apòtres, après l'ascension de J. C., et sur l'authenticité de leurs canons.

3० (Fol. 11.) Les canons apostoliques (ابسطلوسيات) des disciples.

$4^{\circ}$ (Fol. 18.) Canons touchant le règlemeut du sacerdoce.

$5^{\circ}\left(F_{0}\right.$ ol. $37 v^{\circ}$.) Canons des saints a pòtres, ayant pour but l'institution de l'Église, édités par S. Clément. Ces règlements sont au nomhre de soixante et onze. On lit à la fin du chapitre que, dans le texte gree, le nombre de ces canons est de quatre-ringt et un.

$6^{\circ}$ (Fol. 38.) Canons de la sainte Église, arrêtés par les apôtres et édités par S. Clément. Ces canons sont au nombre de cinquante-six.

$7^{\circ}$ (Fol. 42.) Les Didascalia (Ji) lormant trente-neuf chapitres.

$8^{\circ}\left(\right.$ Fol. $\left.90{ }^{\circ}.\right)$ Les camons de S. Clément, désignés aussi par le titre de eEpitre de S. Pierren.

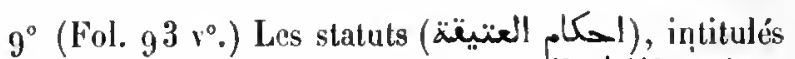

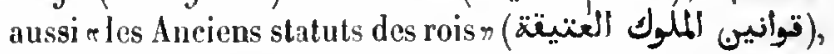
tirés de la loi ancienne par les apôtres, sous l'iuspiration du Saint-Esprit. On y trouve (fol. $103 \mathrm{v}^{0}$ ) une prétendue déclaration des apótres, au sujet des parties de la loi judaïque qu'il fant conserver dans la société chrétienne.

$10^{\circ}$ (Fol. $1041^{\circ}$. ) Concile d'Ancyre.

$11^{\circ}$ (Fol. 108.) Concile de Néocésarée, dit de Carthage.

$12^{\circ}$ (Fol. $\left.1091^{\circ}.\right)$ Concile de Gangres.

$13^{\circ}$ (Fol. 1 12.) Concile d'Antioche; vingt-cing canons. 
$14^{\circ}$ (Fol. 121.) Notice sur Constantin le Grand et sur les motifs qui le porlèrent à conroquer le concile de Nicée.

$15^{\circ}$ (Ibid.) Notice sur le concile de Nicée, suivie des vingl canous communs.

$16^{\circ}$ (Fol. 127.) Les quatre-ıingt-quatre canons du même concile.

$17^{\circ}$ (Fol. $138 \vee^{\circ}$.) Canons du wême concile, pour le règlement des monastères, suivis du symbole de la foi orthodoxe.

$18^{\circ}$ (Fol. 148.) Vingt canons traduits du copte; ils s'accordent, dit le copiste du ms., avec les canons de $\mathrm{Ni}$ cée traduits du grec. Gette. version correspond en partie seulement aux vingt canons du lexte gree. A la suite se trouve une notice listorique.

$19^{\circ}$ (Fol. 152.) Deuxiène concile général de Constantinople; vingt-sept canons.

$20^{\circ}$ (Fol. 154.) Concile d'Éphèse. On n'y troure que le simple décret.

$21^{\circ}$ (Ibid.) Concile de Laodicée.

$22^{\circ}$ (Fol. 159. ) Concile de Sardique.

$3^{\circ}$ (Fol, $1621^{\circ}$.) Trente-liuit canons, transmis par Hippolyte (ابوليحس), archerêque de Rome (S. Hippolyte, unartyr, dit de Porto). Il est dit que ces canons ont èté promulgués par les apôtres, sous l'inspiration du SaintEsprit.

$24^{\circ}$ (Fol. $1711^{\circ}$.) Canons de S. Basile; deux séries, dont la première est de treize canons et la seconde de cent six.

${ }_{2} 5^{\circ}$ (Fol. $188 v^{\circ}$.) e Les quatre livres de canons, inti-

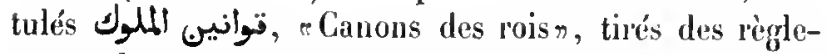
ments des empereurs, et mis par écrit en présence des évèques du concile général de Nicée.

Le premier livre, appelé eles Titresn, se compose de quarante chapitres.

$26^{\circ}$ (Fol. 222.) Deuxième livre des canons impériaux renfermant cent trente canons.

$27^{\circ}$ (Fol. $233 r^{\circ}$.) Le troisiène livre des canons impériaux.

${ }_{2} 8^{\circ}\left(\mathrm{F}_{0} \mathrm{l} .{ }_{2} / 47 v^{\circ}\right.$.) e Canons de quelques pieux rois, adoptés par un décret des Pères du concile de Nicée. On suppose quil s'agit de Léon el de Justin. Ce recueil est traduit de l'hébreu en arabe. $\mathrm{Ce}$ recueil est intitulé aussi, dans notre ms., canons impériaux $\%$.

$29^{\circ}$ (Fol. $260 r^{\circ}$. ) r Testament de Notre-Seigneur et
Dieu, Jésus le Messie, fait après sa résurrection, el alloculion qu'il adressa aux apôtres. C'est la prenière pièce de la main de S. Clément. $n$ Cette pièce apocryphe est intitulée العزهد السيدى : Testament du Seigneur».

$30^{\circ}$ (Fol. 278.) "Canons des saints apootres, denxiène pièce de la main de Clément."

Suivent les pièces 3, 4, 5, 6, attribuées à S. Clément.

$31^{\circ}$ (Fol. 296.) Canons du concile de Carthage, au nombre de cent vingt-trois.

Ce concile, dil l'auteur, fut lenu l'an $59_{2} 5 \mathrm{du}$ monde, date qui correspondait à l'an 150 des martyrs (l'an 434 de J. C.), alors que Théodore le Jeune, fils de Théodore le Grand, régnait à Constantinople, et Honorius (انوريوس) à Rome, Cliristodule (كرسدلد) étant pape de cetle ville.

$32^{\circ}$ (Fol. 306.) r Cimons du grand concile réun à Antioche el à Laodicée. "C'est une copie, arec quelques variantes, des canons de ces deux conciles, que le rédacteur a réunis en un seul recueil.

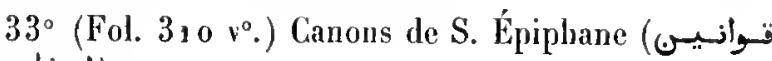
(ابيغانيوس).

$34^{\circ}$ (Fol, 312. ) Canons de S. Jean Clirysostonıe, an nombre de douze.

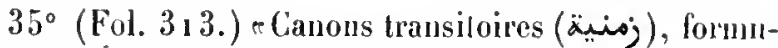
lés par les saints Peres qui nous ont précédés. On les promulgua à cause de la dureté du temps et d'après le désir de cenx qui se repentaient avec componction.

$36^{\circ}$ (Fol. 316.) Préceptes altriluués à S. Grégoire, évêque de Nysse.

$37^{\circ}\left(\right.$ Fol. $3161^{\circ}$.) Liste des sept siéges patriarcaux.

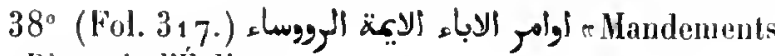
des Pères de l'Églisen.

$39^{\circ}$ (Fol. 319. (9) Canons des docteurs de l'Egliser, traduits du copte. Il y en a quatreingt-deux.

$40^{\circ}$ (Fol. 323.) Canons de l'Église, mis en ordre par S. Alhanase, patriarche d'Alexandrie, au nombre d" cent sept. A la fin du livre, le rédacteur, Michel, évêqui de Tennis (تنيس), nous apprend qu'il avait classé ces canons dans un ordre plus commode. Vient ensuite un appendice, intitulé ePassage qui se trouve dans le liv" des prêtres francs $\%$. C'est une paraphrase de la profession de foi orthodoxe, suivie de deux commentaires jacobites.

$41^{\circ}$ (Fol. $\left.339 \vee^{\circ}.\right)$ Abrégé de la doctrine du saint P'èce Micliel, métropolitain de Damiette, touchant les instilutions (lilléralenent: les règles déduiles de la loi, جزابيات (النّتريعة) de l'Église copte. 
$42^{\circ}\left(\right.$ Fol. $3411^{\circ}$.) "Copie d'un canon écrit par Christodule (اخخيسطادل), patriajehe d'Alexandrie.n

$43^{\circ}$ (Fol. 343. ) Cinnons de Cyrille, soixante-septième patriarche d'Alexandric.

$44^{\circ}$ (Fol. 347.) Canons de Gabriel, surnommé IbnTarik, palriarche d'Alexandrie.

$45^{\circ}$ (Fol. 351.) * Copie des canons qui concement les prètres et les églises d'Alexandrie, et qui furent écrits par Gabriel lbu Tarik, au mois de payni (بوون) de l'an 870 des martyrs ( 1154 de J. C.)."

$46^{\circ}$ (Fol. 352.) Mlrégé des règlements concernant les successions, d'après les autorités anciennes et modernes, par Gabricl Iton Tarik.

$47^{\circ}$ (Fol. $353 v^{\circ}$. ) Copie d'mu acte renfermant certaines stipulations entre Cyrille, patriarche d'Alexandrie, ot ses érêques.

$48^{\circ}$ (Fol. 355.) Dispositions arrètées par le patriarche Cyrille, aver le concours des évêques et des notables (إخنَ) coples, el ratifiées ensuite par le noureau patriarehe, Anhà Yoûnos. Ces dispositions concernent les haptèmes, les mariages et les successions. L'acte fut signé I. 20 du mois de thoth de l'an 955 des martyrs (1 239 de J. C.).

$49^{\circ}$ (Fol. $36 \mathrm{v}^{\circ}$.) Convention arrètée entre le mème patriarehe et ses érèques, au mois de thoth de l'an $9^{5} 7$ des martyrs (1241 de J. C.). La réunion eut lieu au Chàteau (la citadelle dn Caire, siége du gouvernement égyptien), en la présence du vizir Mo in al-Din et de plusieurs notables clirétiens et musulmans.

$50^{\circ}$ (Fol. 363.) Hegglement concernant les legs pieux et les aumônes, publié par le patriarche Cyrille, au mois de pharamouti 956 ( 1240 de J. C.).

$51^{\circ}$ (Fol. $364 v^{\circ}$.) Autre règlement du mème patriarche, publié le 24 du mois de plaramouti $9^{56}$ (1240 de J. C.). Il se rajporte aux füles de l'Église ropte.

$52^{\circ}$ (Ibid.) Dix thèses sur la discipline ecclésiastique, proposćes par Clıristodule, métropolitain de Damiette, et résolues par Cyrille, an mois de payni g56 ( 1240 de J. C.).

Papier. 366 feuillets. Hateur, $3 / 4$ centimetres et demi; largeur, 25 centimètres. 24 lignes par page. Ms. daté de l'an 1069 de l'ère des martyrs ( 1353 de J. t..). - (Supptément 83, Saint-Germain 41.)

\section{2.}

$1^{\circ}$ Recueil de canons, en deux parties. Le texte est à peu près le même que celui du $n^{\circ}$ précédent. Il fut copié au Caire, l'an 1664 , par les soins de Vansleb. Quelques articles du recueil ont été supprimés propter certas causas, comme Vansled, lui-même l'a écrit en marge de la table des matières.

$2^{\circ}$ (Page 69t.) Introduction à l'étude des canous, par Aboû Șalạ̣ Yoùnos Ibn 'Abd Allah, surnommé Ibn Bânà (بان).

3० (Page 707.) Abrégé des lois établies par les Pères de l'Église pour le règlement des successions.

$4^{\circ}$ (Page 711.) Chapitre sur la solution, par analogie, des questions relatives aux successions. Ce chapitre est un extrait du r Paradis de la chrétientén (فودوس النصرانية) ouvrage composé par Aboû "1-Faradj 'Abd Allah Ibn alṬabib (ou al-Ṭayyib), prêtre nestorien.

$5^{\circ}$ Tables des épactes et des fêtes mobiles du calendrier copte, depuis l'an 1092 des marlyrs ( 1376 de J. C.) jusqu'à l'an 1131 ( 14.5 de J. C. $)$, aree la correspondance de l'ère du monde, de l'ère de l'incarnation et de l'ère des martyrs.

Papier. 724 pages. Ilauteur, 30 centimètres; largeur, a 1 centimètres. 38 à 30 lignes par page. L'écrilure change, à partir de la page 455 . (Supplément 78.)

IX.

\section{VIES DES SAINTS.}

\section{3.}

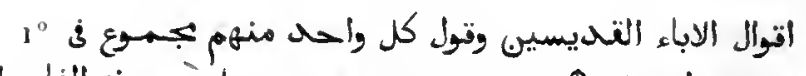

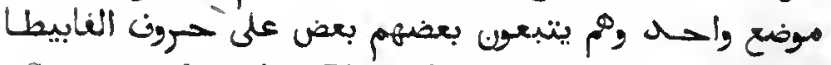
iSentences des saints Pères. Chaque sentence est inscrite sous le nom de celui qui l'a prononcée. On a rangé ces noms selon l'ordre des lettres de l'alphabet grecn. Ce recueil, qui renferme des notices sur plusieurs anachorètes, des anecdotes qui les concernent et des paroles qu'on leur attribue, est sans doute traduit du grec. Il a beaucoup d'analogie arec les $\pi$ Apophthegmata Patrumn, pulliés par Cotelier dans les - Monumenta Ecelesia græcæn, t. I, p. 338 et suir.; et quelques paragraphes sont une version libre de certains passages des $n$ Apophtheg-

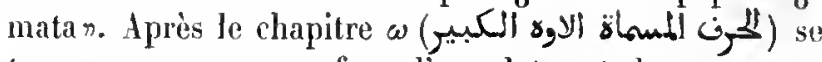
trouve une masse confuse d'anecdotes et de sentences, remplissant plusieurs feuillets, à partir du fol. 142.

$2^{\circ}$ (Fol. 219.$)$ rQuestions que S. Siméon le Stylite, re-

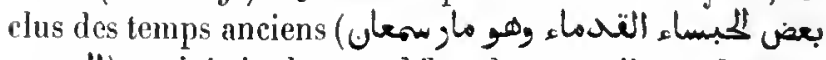
(العهودى ), qui était alors au début de sa carrière, adressa à 
l'estimable précepteur (مeo) Mar Isaac, avec les réponses de celui-ci.n

$3^{\circ}$ (Fol. 233.) Discours de S. Macaire sur la prière.

$4^{\circ}$ (Fol. 235.) Epitre de S. Macaire à ses chers enfanls.

$5^{\circ}\left(\right.$ Fol. $\left.242 v^{\circ}.\right)$ Quelques sentences de morale, par S. Hacaire.

$6^{\circ}$ (Fol. $244 v^{\circ}$.) Extrait d'une homélie de S. Jean Chrysostome sur l'envie.

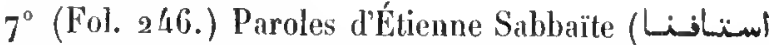
sic الساذأييتنى), moine de S. Saba, sur la vie monastique.

Cet opuscule n'est pas complet, les derniers feuillets du ms. manquent.

Papier. 250 feuillets. Hauteur, 28 centimètres; largeur, a 1 centimètres. 22 lignes par page. Hs. du xiv siècle. - (Ancien fonds 144.)

\section{4.}

Le Synaxare des Helkites de la Syrie, renfermant les vies des saints et des martyrs pour chaque jour de l'année, à partir du commencement du mois de septembre. Les derniers feuillets, contenant la fin di mois d'aoùt, manquent.

Papier. 297 feuillets. Ilauteur, 18 centimètres; largeur, 1/1 centimètres. 18 lignes par page. Ms. du $x^{e}$ siècte. - (Ancien fonds 150 , Colbert 59go.)

\section{5.}

Synaxare à l'usage des Melkites de la Syrie.

Papier. 39 z feuillets (les feuillets 34 ì 82 sont restés en blanc. II n'y a cependant pas de lacune dans le texte). Les deux derniers feuillets manquent. Hanteur, 25 centimètres; largeur, 17 centimètres. Dans la première partie dn ms., datée de l'an 170 / de J. C., le nombre de lignes par page varie de 18 à 24 ; dans la seconde, qui est du xví siècle, il y en a 17 partout. - (Ancien fonds $1 / 1$.

\section{6.}

Synaxare de l'Église copte.

Cet exemplaire se compose de deux parties, reliées en un seul volume.

Papier. 289 feuillets. Hauteur, 30 centimètres et demi; largrour, 20 centimètres et demi. 21 lignes par page. Le manuscrit parait ètre du xvII" siècle. - (Supplément go, Saint-Germain 121.)

\section{7.}

$1^{\circ}$ Vie de S. Antoine, par Athanase, patriarche d'Alexindrie.

$2^{\circ}$ (Fol. 38.) Vie et miracles de S. Éphrem le Syrien.

$3^{\circ}$ (Fol. 57.) Vie de S. Hacaire (wكاربوس) l'Égyptien, par Sérapion, disciple de S. Antoine.

$4^{\circ}$ (Fol. 68.) Vie de S. Euthymius (أفنيميوس) le Grand, institutenr des Laures (معام الاسيات).

$5^{\circ}$ (Fol. 87.) Vie de S. Théodose, chef et instituteur de tous les monastères du désert de Jérusalem.

$6^{\circ}$ (Fol. 92.) Vie de S. Palladius, ermite d'Amhàl

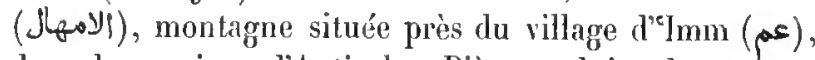
dans la province d'Antioche. Pièce traduite du grec en arabe, par le médecin 'Îsà, fils de Constantin.

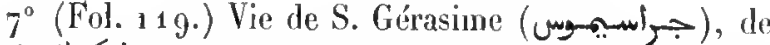
Lycie (يكيا), par Cyrille, prêtre du inonastère de SaintSaba.

$8^{\circ}$ (Fol. $122 \mathrm{v}^{\circ}$.) Homélie dIsaac, évèque de Ninive, sur la pénitence et le renoncement au monde.

$9^{\circ}$ (Fol. 130. ) Homélie de S. Éphrem le Syrien sur la pénilence et sur le salut de l'àme.

$10^{\circ}$ (Fol. 133.) Exhortation adressée par S. Éphrem à ceux qui s'adoment au vin et aux lemmes.

$11^{\circ}$ (Fol. 139.) Autre homélie de S. Éphrem sur la pénitence et sur le salut de lâme.

$12^{\circ}$ (Fol. 147.$)$ Vie de S. Paul de la Thébaïde (الثنيني), le premier ermite.

$13^{\circ}$ (Fol. 149.) Vie du pèlerin Marc al-Timaqânì

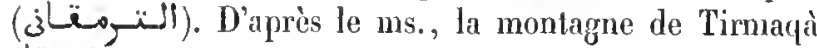
(تقبم: est située au delà de l'Abyssinie, sur le bord de la mer', à vingt-cinq journées d'Alexandrie.

$14^{\circ}$ (Fol. 153.) Enseignement (تعلم) de S. Macaire, et récit de ce qui lui apparut en fait d'œurres des démons.

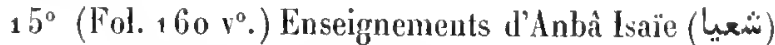
pour la conduile de celui qui reut offrir son âme à Dieu.

$16^{\circ}$ (Fol. 170. ) Sentences de S. Denys l'Aréopagite et de S. Maxime. Extraits du livre intitulé e al-Hâwìn (roy. ci-dessus, $\mathbf{1}^{0} 181$ ).

$17^{\circ}$ (Fol. $\left.172 V^{\circ}.\right)$ Récit d'Anbâ Cassianus (قسيانوس) le Romain, au sujet de quelques moines de Scélé.

$18^{\circ}$ (Fol. 179.) Vie de S. Arsène (ugivinl). 
$19^{\circ}$ (Fol. $\left.1941^{\circ}.\right)$ Vie de S. Saba (oا سابا).

Papiel. 224 fenillets. Hauteur, 29 centimètres et demi; largeur, 20 centimètres et demi. 23 lignes par page. Ms. daté de l'an 7181 du monde ( 1673 de J. C. ). - (Ancien fonds 145 , Colbert 2768 .)

\section{8.}

$1^{\circ}$ Miracles de S. Basile le Grand, racontés par son disciple, Mar Hilarion (أيلوريون).

$2^{\circ}$ (Fol. 48.) Histoire du moine Boḷaïra, racontée par le moine Serge (wm). Légende composée vers le $x 11^{\circ}$ siecle.

$3^{\circ}$ (Fol. 64.) Vies des SS. Galactius (غالكتتسيـوس) et Epistimé (بيستيمى))

$4^{\circ}$ (Fol. 73.) Fragment du livre intitulé: ilinstruclion suflisinte, au sujet de la réalité salulairen. Cet ourrage, composé par Gérasime (جنجأسيمسن) supérieur du monastère de S. Siméon (wes), renferme des lémoignages empruntés à l'Ancien el au Nouveau Testament, anx ourrages philosophiques des Grecs et au Coran (كناب المسلمب).

$5^{\circ}$ (Fol. $78 v^{\circ}$.) Abrégé de théologie dogmatique, com: posé par le moine Paul d'Antioche, érêque de Sidon.

$6^{\circ}$ (Fol. 97.) Opuscule dans lequel Paul d'Antioche parle des direrses sectes chrétiennes qui existaient de son temps.

$7^{\circ}$ (Fol. 104.$)$ Abrégé de la doctrine clirétienne, composé par Paul d'Anlioche, sur la demande du schaikh Aboû 'l-Seroûr', de Tinnis.

$8^{\circ}$ (Fol. $105 v^{\circ}$.) Professiou de foi, rédigée par Paul d'Antioche, afin d'etre opposée à toutes les professions de foi hérétiques.

$9^{\circ}$ (Fol. $1111 \mathrm{v}^{\circ}$.) Chapitre sur la réalité du royage des mages à Belhléem.

$10^{\circ}$ (Fol. $114 v^{\circ}$.) Traité de Paul d'Anlioche sur la ligne de conduite (المسيLاسLات) que les hommes crojent être agréable à Dieu el qui, en réalité, provoque sa colìre.

$11^{\circ}$ (Fol. 120.) Panégyrique des quarante marlyrs, par S. Basile le Grand. Les noms de ces inartyrs se trouvent à la fin de la pièce.

$12^{\circ}$ (Fol. 128.) Fragment d'une légende dans laquelle se trouve la mention d'un miracle opéré par SS. Cosme et Damien.

$13^{\circ}$ (Fol..1 29.) Légende du grand saint Mar Dsoûınat

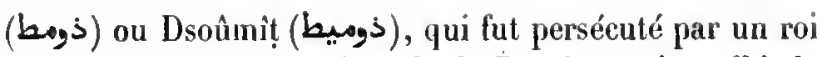
infidèle. Il s'agit peut-être de S. Domèce qui souffrit le martyre sous Julien.

$14^{\circ}$ (Fol. 13 2.) Explication de la Pâque, de l'agneau et du changement du pain et du vin en la chair et le sang du Messie.

$15^{\circ}$ (Fol. $139 \vee^{\circ}$.) Traité sur̃ la manière de combattro les démons tentaleurs.

$16^{\circ}$ (Fol. 152.) Histoire des SS. Maxime (s) et Domèce (ذومLاتيـوس), enfants de Léon, l'emipereur grec. D'après cette légende, les princes allèrent trouver S. Macaire, dans le désert de Scété.

$17^{\circ}$ (Fol. $\left.177 v^{\circ}.\right)$ Anecdotes sur S. Antoine.

$18^{\circ}$ (Fol. 181.) Histoire de S. Macaire, père des moines du désert de Scélé, par Sérapion, disciple de S. Antoine le Grand.

$19^{\circ}$ (Fol. $19^{8} v^{\circ}$.) Histoire de Ste Thaïs (bهus).

$20^{\circ}$ (Fol. 201.) Histoire de Se Cyriaque (قرياقة).

$21^{\circ}$ (Fol. $202 v^{\circ}$.) Histoire d'un ermite qui demeura cinquante ans dans un désert.

$22^{\circ}$ (Fol. 207.) Actes de S. Thomas, apôtre de l'Inde.

${ }_{2} 3^{\circ}$ (Fol. $2{ }_{1} 5 v^{\circ}$.) Martyre de S. Thomas.

$24^{\circ}$ (Fol. 218 .) Histoire d'llérode et de S. Jean-Baptiste. Le commencement manque.

${ }_{2} 5^{\circ}\left(F_{0} l_{2} 23 v^{\circ}.\right)$ Martyre des saints apôtres Pierre et Paul.

$26^{\circ}$ (Fol. $247^{\circ} 1^{\circ}$ ) Controverse religieuse qui eut lieu entre le moine Ibrahim de Tibériade d'un côté, et de l'autre 'Abd al-Rạ̣mân le Hachénile, secondé par Manșoûr al-'Absî.

$27^{\circ}$ (Fol. 275.) Quelques passages des homélies proمست تهول (noncées par Grégoire, le théologien scolastique

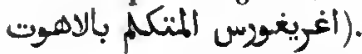

Papier. 280 feuillets. Hauteur, 21 centimètres et demi ; targeur, 15 centimètres et demi. 19 à 23 lignes par page. Le ms. parait ètre du commencement du $8 v^{\circ}$ siècle. - (Ancien fonds , 56, Colbert 4600.)

\section{9 .}

$1^{\circ}$ Histoire de S. Macaire, père des noines du désert de Scété, par Sérapion, disciple du grand S. Antoine.

$2^{\circ}$ (Fol. 57.) Vie et mérites d'Ababius (ابابيوس), habitant du désert de Scété. 
$3^{\circ}\left(\right.$ Fol. $\left.104 v^{\circ}.\right)$ Vie du vertucux anachorète Timothée (تجماثيوس), contemporain du calife Haroûn al-Raschid. Ce saint mourut l'an 257 de l'hégire.

$4^{\circ}$ (Fol. 151.) Vic de S. Jean l'Aumônier, patriarche d'Alexandrie, traduite de l'ourrage grec composé par Léonce, évéque de Néapolis, en Chypre.

$5^{\circ}$ (Fol. 220.) Histoire de la femme à la main brûléc.

$6^{\circ}$ (Fol. 232.) Histoire de l'homme qui passa en jugement devant Dieu, trois jours avant sa mort.

$7^{\circ}$ (Fol. 237.) Histoire d'un négociant charitable.

$8^{\circ}$ (Fol. $242 v^{\circ}$.) Histoires de quelques saints.

$9^{\circ}$ (Fol. 246.) Réponse d'un maitre à son disciple, qui demanda pourquoi le bon larron fut admis dans le paradis.

Papier. 2 íf feuillets. Hanteur, 18 centimètres; largeur, 13 centimètres. Ms. de plusieurs écritures dont la plus ancienne parail étre du xıv' siècle. -- (Ancien fonds 167 , Colbert 6034.)

\section{0 .}

$1^{\circ}$ Vie du saint pèlerin Marc de Tirmaqà. Les premiers feuillets de cet opuscule, qui manquaient, ont été remplacés par deux autres, renfermant le commencencnt de la vie du saint auachorète Anbà Sérapion.

$2^{\circ}\left(F_{0} l .20 v^{\circ}\right.$.) Histoire de $S^{t o}$ Théodora d'Alexandrie, qui fut expulsée du couvent, avec un enfant qu'elle avait auprès d'elle.

$3^{\circ}$ (Fol. $51 v^{\circ}$.) Les douze miracles de S. Basile.

$4^{\circ}$ (Fol. $115 v^{\circ}$.) Homélie de S. Éphrem sur la résurrection et sur la fin du monde.

$5^{\circ}$ (Fol. $126 \vee^{\circ}$.) Homélie de Jacques, évèque de Saroùdj, sur le bon larron.

$6^{\circ}$ (Fol. 1 44.) Homélie de S. Jean Chrysostome sur la trahison des juifs, qui livrèrent N. S. Jésus, le Messie.

$7^{\circ}$ (Fol. 151.) Histoire de S. Onuphre (انغويوس) et de ses compagnons, Paphnuce (بفنـوتـيـوس) Zosime (روسيما).

$8^{\circ}$ (Fol. $186 \mathrm{r}^{\circ}$. ) Discours dans lequel Isaac, évêque de Ninive, traite des quatre sources d'où dérivent tous les péchés. La fin manque.

Papier. 212 feuiltéts et, de plus, un feuiltet de parchemin, fragment d'un antiphonaire grec du $x^{e}$ siècle. Hauteur, 17 centimètres; largeur, 13 centimètres. 9 lignes par page. La partie la plus ancienne du ms. est du xiv siècle. - (Ancien fonds 168 , Colbert $617^{4}$.)

\section{1 .}

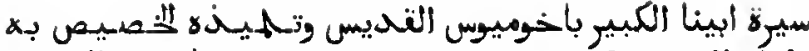
"Histoire de S. Pacôme et de son disciple favori, Théodore".

Cette biographie est la traduction d'un texte grec, conposé par un témoin des actes de S. Pacôme.

Papier. 273 feuillets. Hauteur, 17 centimètres; largeur, 12 centimètres. 14 lignes par page. Le manuscrit parait ètre de la fin dı xiv' siècle. - (Ancien fonds 165, Colbert 6027.)

\section{2.}

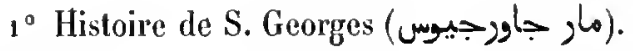

$2^{\circ}$ (Fol. $29 v^{\circ}$. ) Histoire de $\mathrm{S}$. Jacques l'Intercis (chill).

$3^{\circ}\left(F_{0 l} .44 v^{\circ}.\right)$ Histoire d'un négociant chrétien d'Édesse et de sa femme, et d'un Arménien, leur associé.

$4^{\circ}$ (Fol. 5o.) Histoire d'un homme d'Ascalon.

$5^{\circ}$ (Fol. $52 r^{\circ}$.) Homélic de S. Éphrem le Syrien sur les vertus de la sainte Croix.

$6^{\circ}\left(F_{0} l .58 \vee^{\circ}.\right)$ Miracles opérés par $S^{t e}$ Marina d̀ Saijdnâyà (صيحنابا).

$7^{\circ}$ (Fol. $65 r^{\circ}$.) Discours de S. Jacques, frère de NotreSeigneur, sur la nativité de la sainte Vierge.

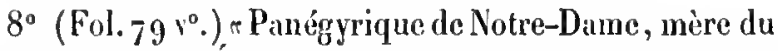
Seigneur, par S. Ejphrem le Syrien, traduit par le P. Yòhamani, auteur du présent livre, qui y a fait les additions nécessaires. $n$

$9^{\circ}\left(F^{F}\right.$ ol. $9^{8} v^{\circ}$.) Homélic de S. Jean Chrysostome sur

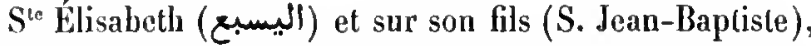
et sur le rocher qui s'ourrit pour les cacher.

$10^{\circ}$ (Fol. 101.) Histoire de ce qui arriva au saint prètre Boûlà (بول), pendant qu'il était au bain, dans la ville des Samaritains, et comment Satan lui apparut et lui raconta tout ce quil avait fait.

$11^{\circ}$ (Fol. $118 v^{\circ}$. ) Histoires de quelques saints personnages.

$12^{\circ}$ (Fol. 122.) Histoire de S. Démétrius.

$13^{\circ}$ (Fol. 13 o.) Homélie surl'Annonciation, par S. Jean Clirysostome.

14\% (Fol. 140.) Récit d'un moine du couvent de Saint-Saba, ì Jérusalem, sur la prise de cette ville par les Perses. 
$15^{\circ}$ (Fol. $153 v^{\circ}$.) Homélie de S. Basile le Grand sur la mort el sur le jugement demier.

${ }_{16}^{\circ}$ (Fol. 159.$)$ Hisloire de Joseph, rendu par ses frères.

$17^{\circ}$ (Fol. 189 ト $^{\circ}$.) Homélic de S. Jean Clırysostome, qu'on lil le jour de Pấques.

$18^{\circ}$ (Fol. 192.) Vie de S. Arsène.

$19^{\circ}$ (Fol. $212 V^{\circ}$.) Histoire de S. Marcel (مكسكس). Il esl dit que cette histoire, écrite avec une certaine encre, le vendredi ou le dimanche, guérit les femmes possédées, et est d'une grande utilité aux femmes dont les enfanls meurent en bas àge.

$20^{\circ}$ (Fol. $228 r^{\circ}$.) Homélie de S. Basile, destinée à etre lue les dimanclies et les vendredis, et auprès des agonisants.

$21^{\circ}$ (Fol. $232 \mathrm{v}^{\circ}$.) Homélie de S. Jean Chrysostome sur la pénitence.

$22^{\circ}$ (Fol. 239.$)$ Histoire d'Isaac, fils d'Abraham (ابراهميم).

${ }_{2} 3^{\circ}\left(\right.$ Fol. $243 r^{\circ}$.) Histoire de la tentation d'un homme sage et riche.

La fin manque.

$24^{\circ}$ (Fol. 245.) Prières pour la fête de l'Épiphanie.

Papier. 250 fenillets. Hanteur, 21 centimètres; largenr, 15 centimè̀res. 10 à 13 lignes par page. Mss. du xve siècte. -- (Ancien fonds 154 , Colbert 4441.)

\section{3.}

1 Martyre de S. Georges.

$2^{\circ}$ (Fol. $331^{\circ}$.) Histoire de la vie et du martyre de S. Mercure (موقوريوس).

$3^{\circ}$ (Fol. 53.) Panégrrique composé par Théodore (تادوس), archerêque d'Antioche, en l'honneur des saints martyrs Théodore l'oriental ef Théodore général de cavalerie (الاسفهسان).

$4^{\circ}$ (Fol. 7o.) Panégyrique de la sainte Vierge, par $\mathrm{Cy}$ rille, archerêque d'Al xandrie.

$5^{\circ}$ (Fol. 91.) Disconrs sur la sainte Vierge el sur l'Assomption, par Cyrille, patriarche d'Alexandrie.

$6^{\circ}$ (Fol. 103.) Sermon prononcé en commémoration de la sainte Vierge et de la fondation de son église, par S. Basile, érêque de Césarée. $7^{\circ}$ (Fol. 111.) Fragments d'un discours sur là vie d'Anbâ Tomâs (تخاس), un des Pères du désert.

$8^{\circ}$ (Fol. 116.$)$ Martyre d'Abbà Hoûr (أبا هون).

$9^{\circ}$ (Fol. $1211^{\circ}$ ) Vie d'un saint homne de Dieu, appelé Moïse.

$10^{\circ}$ (Fol. 128 .) Vie d'Abânoûb (S. Anoubi?).

Le commencement et la fin manquent.

$11^{\circ}$ (Fol, 139.) Discours sur l'arrivéc de Notre-Seigneur à la sainte montagne de Qasqâm (قستام), près de Behnesâ. Élie.

$12^{\circ}$ (Fol. 166.) Homélie sur le monastère du prophète

Le commencement manque.

$13^{\circ}$ (Fol. $169 \mathrm{r}^{\circ}$.) Homélie de S. Jean Chrysostome pour le dimanche des Rameaux.

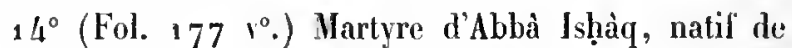
Difra (دفرة), dans le diocèse de Banà (بنا).

$15^{\circ}$ (Fol. $188 \vee^{\circ}$.) Vie du prophète Habacuc.

$16^{\circ}$ (Fol. 196.) Martyre de Ste Marina (ماربي).

Papier. 206 feuillets. flantenr, 21 centimètres et demi; largeur, 16 centimètres. Le nombre des lignes par page varie beaucoup. Ms. d'écrilures diverses du xv' siècle. - (Ancien fonds 153.)

\section{4.}

$1^{\circ}$ Vie de $\mathrm{S}$. Jean Calybite, auteur du livre intitulé "l'Evangile d'or ${ }^{1} n$.

$2^{\circ}$ (Fol. 19.) Martỵre d'Abbâ Ishââ, de Difrà (دفى ).

30 (Fol. 33.) Homélie de Jacques (مارى يعتسوب), érêque de Saroûdj, dans laquelle il explique la signification mystique du sacrifice d'Abraham.

$4^{\circ}$ (Fol. 45.) Explication du verset : $x$ Notre père qui es dans les cieux $n$, par S. Jean Chrysostome.

$5^{\circ}$ (Fol. 55.) Panégyrique de S. Jean-Baptiste, 'par S. Jean Chrysostome.

$6^{\circ}\left(\right.$ Fol. $64 v^{\circ}$.) Exposition de l'histoire de S. JeanBaptiste, par $\mathrm{S}$. Jean Chrysostome.

- $7^{\circ}$ (Fol. $7^{\circ} v^{\circ}$.) rexposé de la cause qui enleva la royauté de David à la descendance du roi Salomon pour la transmettre (aux princes) du pays des Nedjâschî, qui est l'Abyssinie."

\footnotetext{
1 rpossesseur de l'Évangile d'orn. H. Z.
} 
$8^{\circ}$ (Fol. 82.) "Histoire de l'apôtre et érangéliste S. Marc, premier patriarche et archevèque d'Alexandrie, qui prècha au nom du Messie, en Égypte, dans la Pentapole, en Mauritanie, en Abyssinie, en Nubie, r etc.

Nous n'aions ici qu'un fragment de l'ouvrage.

$9^{\circ}\left(F_{0} .84 v^{\circ}\right.$.) «Questions ayant pour but de raffermir la foi et de laire sentir l'excellence de la religion chrétienne."

$10^{\circ}$ (Fol. 107.) Épitre (الابسmb) envoyée du ciel à S. Athanase, pour recommander l'obseriance du dimanche. Ce saint était alors, l'an 1750 de l'ère d'Alexandre ( 1438 de J. C.), patriarche de la ville de Rome.

Le commencement de cette pièce a ćté modifié et ne s'accorde pas avec les autres exemplaires de cet ouvrage.

$11^{\circ}$ (Fol. $1141^{\circ}$.) Lilnistoire des bienbeureux cnfants de Yoûnảdâb (يوناداب).

C'est le récit du royage de Zosime à l'ile des Bienheureux.

Papier. 129 feuillets. Hauteur, 21 centimètres et deni; largenr, 15 centimètres. Le nombre des lignes par pagre, dans la partie la plus ancienne du ms., est de 12; dans l'antre partie, it varie beaucoup. Ms. de deux écrilures, dont la moins ancienne est datée (fol. $54 v^{\circ}$ ) de l'an 1310 des martyrs $\left(159^{4}\right.$ de J. C.). - (Supplément $9^{2}$, Saint-Germain 350.)

\section{5.}

$1^{\circ}$ Histoire de S. Zosime (jزيما)

$2^{\circ}$ (Fol. $24 r^{\circ}$.) Homélie de S. Éphrem le Syrien sur la différence qui existe entre le vice et la vertu.

$3^{\circ}$ (Fol. $39 v^{\circ}$.) Histoire de la mort d'Aaron (Hoïse dépouille Aaron du vêtement de grand-prêtre).

$4^{\circ}$ (Fol. $491^{\circ}$.) Homélie de S. Jean Ghrysostome sur cette parole de S. Paul : éésus le Messic a sauvé, au moyen du sang de la croix, ce qui est dans le ciel et ce qui est sur la terre. $\pi$

$5^{\circ}$ (Fol. $55 \mathrm{r}^{\circ}$.) Homélie de Jacques, élêque de Saroûdj, sur la naissance de S. Jean-Baptiste.

$6^{\circ}$ (Fol. $66 r^{\circ}$.) m Histoine de la mort de Notre-Dame, mère de Dieu."

$7^{\circ}$ (Fol. 77.) « Miracle de Notre-Dame, mèré de la lumière.n

$8^{\circ}$ (Fol. $79 \vee^{\circ}$.) Histoire de S. Jacques l'Intercis (c)ill).

$9^{\circ}$ (Fol. 92.) Homélie de Mar Isṭâq, évêque de Ninive, sur la pénitence et sur le renoncement au monde.

Nax. onestaux. - $\mathrm{tl}$. $10^{\circ}$ (Fol. 107.$)$ Homélie de S. Théodule (ثاؤألأسن) sur le mauvais riche, sur Lazare et sur la pénitence.

$11^{\circ}$ (Fol. 120.) Homélie de S. Éplırem sur la fin du monde et sur l'Antéchrist.

$12^{\circ}$ (Fol. $1321^{\circ}$.) Homélie de S. Éphrem sur la s ${ }^{2}-$ conde renue du Messic, sur la charité et sur la foi, traduite par Nicon (نيتوب) le noine, métropolitain de Manbedj (Bambyce, Hiéropolis).

$13^{\circ}$ (Fol. 151.) Histoire édifiante, racontée par un des saints l'ères, au sujet d'un anachor'cte qui avait demeuré pendant cinquante ans dans le désert.

$14^{\circ}$ (Fol. 154.) Homélie de S. Jean Chrysostome sur le dimanche, te mercredi et le vendredi.

$15^{\circ}$ (Fol. 159.) Homélie de S. Jean Chrysostome? contre ceux qui s'absentent de la messe et de la sainte. table.

${ }_{16}^{\circ}$ (Fol. $\left.164 v^{\circ}.\right)$ Récit du ravissement du saint Pìre Grégoire, qui fut enlevé au ciel, où il vit des choses merreilleuses.

Les derniers feuillets manquent.

Papier. 174 feuillets. Hanteur, 15 centimètres; largenr, 10 centimètres. 13 à 14 lignes par page. Is. du xwil siècle. - (Ancien fonds 166. .)

\section{6.}

$1^{\circ}$ (Fol. 9.) Vie de S. Jean Chrysostome par Georges, archeréque d'Alexandrie, traduite du grec.

La fin manque.

$2^{\circ}$ (Fol. $162 \vee^{\circ}$.) Martyre des SS. Serge et Bacchns (ب) (ب) (ب)

Cette traduction s'accorde en général avec le texte gree.

$3^{\circ}$ (Fol. $185 \mathrm{v}^{\circ}$.) Histoire du saint disciple, Jean le? Théologien (الثناولرغسu).

$4^{\circ}$ (Fol. 192.) Relation de la vie el du martyre d" Febronia (فبورونيا), femme dérote et pieuse, qui fut mise à mort dans la ville de Nisibe, sous le règne de Dioclétien.

La fin de cette relation manque. Les Bollandistes en ont donné le texte grec, Oct. t. III, p. 871 .

Les premiers feuillets de ce volume et le feuillet 161 renferment des prières et des notes écrites de diverses mains.

Papier. 209 feuillets. Hauteur, 19 centimètres et demi; largeur, 13 centimètres et demi. Le premier opuscule a 15 lignes par page. Dans les autres, le nombre des lignes varie considérablement. Ms. de 
diverses écritures du xın siécle. D’après une note qu'on lit au folio 4 , un chrétien de Syrie a vu ce ms. à Venise, l'an 1003, sans doute de l'ère des martyrs (1287 de J. C.). - (Ancien fonds 16'.)

\section{7.}

$1^{\circ}$ Vie de S. Jean Chrysostome, patriarche de Conslantinople, par Georges, archevèque d'Alexandrie. Le traduçtent dil, dans une courte introduction, que te fond de l'onrrage est emprunté à un dialogue cutre Théodore (isg), diacre de Rome, et l'érêque Palladius.

$2^{\circ}$ (Fol. $143 v^{\circ}$.) Histoire de Théodore (تادوس), négo("iant de Constantinople, et dn juif Abraham.

$3^{\circ}$ (Fol. $153 \mathrm{v}^{\circ}$.) Histoire d'un païen de Nisibe, dont la fomme étail clırélienne.

$4^{\circ}$ (Fol. 157.) Hisloire d'un jeune homme pécheur el libertin racontée par $S$. Alhanase.

$5^{\circ}$ (Fol. $160 \vee^{\circ}$.) Sermon dans lequel Anastase, supérieur du courent du mont Sinaï, explique le sens du sixième psaume, à propos du commencement du carème.

Papier. 171 feuillets. Ilauteur, 26 centinètres; largeur, 16 centimètres et demi. 16 lignes par page au commencement du volume, 1'is 17. - (Supplément 96, Saint-Germain 127.)

\section{8.}

Histoire de Barlaam et Josaphat. Voici la traduction du litre : Récil profitable à l'àme, tiré de l'intérieur de l'Abyssinir, c'esl-à-dire de l'Inde, el apporté à Jérusalom, par les soins de Yoûlıannâ, moine très-dislingué de la laure (سيـق de Saint-Saba, elc."S'il faul en croire une nole marginale (fol. $21^{\circ}$ ), ce moine élait te célèbre S. Jean Damascène. Les cinq dernières pages du volume renferment une courte légende, te commencemenl de l'érangite de $S$. Jean et le commencenenl d'ume lable contenant le comput de la Pique copte pour quelques années.

Papier. 231 feuillets. Hauteur, 18 centimètres; largenr, 3 centimètres. 15 lignes par page. Is. Jaté de l'an 6873 du monde (1365 de J. C.). - (Supplément 11, Saint-Germain 343.)

\section{9.}

Histoire de Barlaam et Josaphat. Le commencement manque.
Papier. 323 feuillets. Hauteur, 17 centimètres; largeur, 11 centimètres. 13 à $1 /$ lignes par page, excepté aux derniers feuillets à partir du fol. :17, qui, plus modernes que le rezte du ms., ne contiennent que 11 lignes par page. Manuserit daté de lan du monde 6729 (1231 de J. C.): mais le scribe a sans doute reproduit ici la date du ms. dont il faisait la copie; le présent ms. est probablement du $x_{1}{ }^{e}$ siècle. -.. (Ancien fonds 169 , Colbert 6143 .)

\section{0.}

Histoire de Barlaam et Josaphlial. La fin manque.

Papier. 108 feuillets. Hanteur, 37 centimètres; largeur, 18 centimètres. 19 lignes par page. IIs. du xiv siècle. - (Ancien fonds 146 , Colbert 4080.)

\section{1.}

Hisloire de Barlaam et Josaphat. Le commencement de cel exemplaire est le mème que celui du ms. $1^{\circ} 268$, saul' qu’à la place des mots r laure de Saint-Saban (سيست

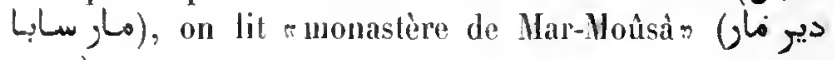
$(\mathbf{s}, 0)$.

Papier. 202 fenillets. Hauteur, 25 centimètres; largeur, 17 centjmètres. 17 lignes par page. Les sept premiers feuillets el les luvit derniers sont d'une écriture plus moderne que le reste du ms., qui paraît étre du uv ${ }^{\bullet}$ siècle. Les espaces laissés en blanc par le copiste devaient recevoir des dessins. - (Supplénent 112 , Saiut-Germain 124.)

\section{2 .}

Histoire de Barlaam et Josaphat. En tête du volume se troure une page d'écriture, qui parait aroir apyartenu à un ouvage de controverse dont on n'aurait pas achevé la transcription.

Papier. 242 feullets. Ilauteur, 21 centimètres; largeur, ${ }_{1} 5$ centimètres. 13 lignes par page. Ms. daté de l'an 1358 des martyrs (1643 de J. C. . . - (Ancien fonds $160 \mathrm{~A}$.)

\section{3.}

Histoire de Baplaam et Josaphat. Voici la traduction du litre qu'on lit dans cet exemplaire : "Vie du bienhemreux et saint personnage Yowàsaf (يـواصغ), fils d'Antîr (انتير), roi de la ville d'al-Hind (l'Inde), et histoire de ce qui lui arriva de la part du grand et bienheu- 
reux saint, le P. Anbà Barlàm (برلام); réril de sa sorie de ce monde transitoire, ayant abandonné le royaume de l'Inde pour obtenir le royaume céleste. On y raconte des choses mer eilleuses, an point d'étonner lintelligence. C'est l'un des ourrages composés par un saint moine, demenrant dans la montagne de Getsémané (ä-مانس Lauteur y parle dignement des vertus de ce saint (Yowàsaf), de la conversion de son père Antìr, qui cessa d'adorer les idoles vers la fin de sa vie et recomnut le Hessie. Si con ereion eut lieu par les efforts de son fils, S. Yowàsal, "t par la bonté de Dicu très-lraut, qui accomplit les promesses faites à cenx qui limoquent, car il ne désire pas la mort du pécheur."

Papier. $17^{4}$ feuillets. Hauteur, 39 centimètres; largeur, \&1 centimètres et demi. 21 lignes par page. Ms. daté de l'an $1 / 49$ des martyrs ( 1763 de J. C. ). Dessins à la płume coloriés. - (Supplément i 10. .)

\section{4.}

Histoire de Barbaam et Josaphat. Le premier paragraphe de cet exemplaire est à preu près le mème que celui da $n^{\circ}$ précédent.

Papier. 18 亿 feuillets. Hauteur, $3 \mathrm{a}$ centimètres; largeur, a 1 centimètres. 17 lignes par page. Us. daté de l'an $149^{4}$ des martyrs $\left(177^{8}\right.$ de J. C.). Dessins coloriés. - (Supplément 113.)

\section{5.}

$1 \circ$ Histoire de Secundus (سكندس). le philosophe.

$2^{\circ}$ (Fol. 35.) Histoire de la mort et panégyrique

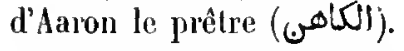

$3^{\circ}$ (Fol. 44.) Conférences (مناجات) de Moïse avec le Seigneur, au sujet des dix conmandements.

$4^{\circ}$ (Fol. 51.) Sermon prononcé par S. Basile, archevèque de Césarée de Cappadoce, à l'occasion de la consécration de réglise de Notre-Dame-llarie (م-تميرم).

$5^{\circ}$ (Fol. 71.) Histoire de la naissance de Moïse, de ses conlérences arec le Seigneur et de sa mort.

$6^{\circ}$ (Fol. $7^{4 .)}$ Sur la mort du patriarche Joseph.

$7^{\circ}$ (Fol. $7^{4} \mathrm{v}^{\circ}$.) Histoire de la mort de Salomon.

$8^{\circ}$ (Fol. 83.) Histoire de la mort de S. Joseph.

$9^{\circ}$ (Fol. 92.) Histoire du voyage d'Abraham el de Sarah en Égyple, par S. Éphrem.

$10^{\circ}$ (Fol. 98.) Histoire extraordinaire de Théodose
(ياضوسيوس sic), juif de Jérusalem, qui s'était fait chrótiell.

$11^{\circ}$ (Fol. 1 12.) Histoire de deux frères qui, élant dpvenus moines, vivaient et priaient ensemble, jusqu'à ce que l'ennemi (le démon) parvint à les séparer.

$12^{\circ}$ (Fol. 144.) Miracles opérés par S. Basile.

$13^{\circ}$ (Fol. $123 v^{\circ}$.) Histoire d'un jeune homme et d'un' princesse.

$14^{\circ}\left(\right.$ Fol. $130 v^{\circ}$.) Conseils el enseignements attribués anx sages des temps anciens.

La fin de cette pièce manque.

$15^{\circ}$ (Fol. 133.) Histoire de la mort de Notre-Dane Marie $(0$ (متميم), trailé attribué à S. Jean, fils de Zébédće.

${ }_{1} 6^{\circ}$ (Fol. $142 r^{\circ}$. ) Nartyre de S. Georges.

$17^{\circ}\left(F_{01 .} 17^{\circ} r^{\circ}\right.$.) Miracles de S. Georges.

$18^{\circ}$ (Fol. 207.) Surmon prónoncé par S. Théodore l'évèque, an jour de la fête de l'archange Nichel.

$19^{\circ}$ (Fol. $2441^{\circ}$.) Sermon de S. Grégoire l'érêque, à l'occasion de la lête de l'archange Gabriel.

$20^{\circ}$ (Fol. 256.) Histoire de la deseente du Saint-Esprit sur les disciples de J. C.

$21^{\circ}$ (Fol. $2571^{\circ}$.) Énumération des qualités dn tion appliquées à J. C.

$22^{\circ}$ (Fol. 258.) Sur la sainte Trinité.

Papier. 959 feuilicts. Hauteur, 21 centimètres et demi; largeur, 15 centimètres. 14 à 20 lignes par page. Nis. daté de l'an 1401 des martyrs ( 1685 de J. C.). - (Ancien fonds 69 A.)

\section{6 .}

Volume renfermant un grrand nombre d'écrits édifiants, tratuits du gree par les soins de l'abbé Antoine, moin' et préceptenr dans le monastère de S. Siméon le Thanmahrirge (مارى سمعان النجاييى) :

$1^{\circ}$ Dialogues de S. Grégoire le Grand, précédés d'une introduction, dont te commencement manque. La fin du traité manque égalemınt.

$2^{\circ}$ (Fol. 145.) Récil de l'apparition de Jésus-Christ, sous la figure d'un mendiant, dans un monastère dirigé par un abbé peu charitable. Le commencement manque.

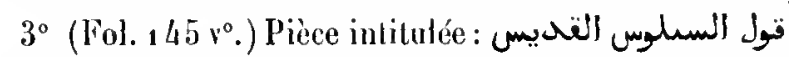
. Discours de S. Alsilloûs (?) sur l'humilité C'est min recueil d'anecdotes tirées de diverses sources.

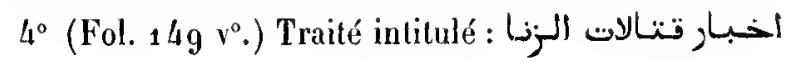


* Luttes coutre la concupiscencen. Dans une de ces anecdotes, il est lait mention du monastiere de Scéfé (الاستيط).

50 (Fol. 151.) Recueil d'anecdotes, ayant pour titre: أخبلر ف اجتناب الدينونه laut ériter les jugements téméraires».

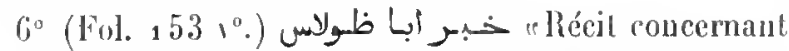
abbâ Zuoullis", suivi de quelques anecdoles. L'auteur dp

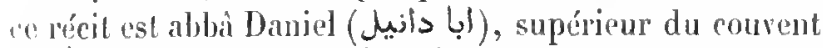
de cîll ill-Ladshab (عام المذهب), puis de celui de Scété, qui virait probablement vers la fin du v viècle. (Voy. - Acta sauctorum", octols., t. IV, [. $99^{8 .}$ )

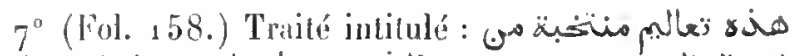

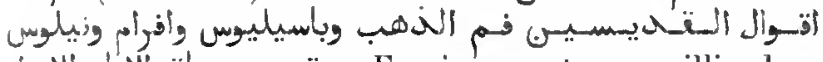
enseignements recueillis dans les discours de Chingsostome, de Basile, d'Éphrem, de Vilus, de Carpus (Polycarpe), et d'autres saints J'eres". Los feuillets 167 et 168 sont d'une écriture moderne.

8. Histoire du marchand d'argenterie (Athamase) et de sa femme (Andromaque)", racontée par abjjà Daniel, supérieur dı monastère de Seété. Les Bollandistes ont donné, dans les r Acta sanctorumn, octob., t. IV, 1. $99^{8}$, le texte grrec et la iraduction latine de cette légende. La version arahe parait être une paraphrase du gree.

$9^{\circ}$ (Fol. 173 .) Récit attribué à abbâ Daniel, et intitulé : : Sur l'affectation de la taciturnitér.

$10^{\circ}\left(\right.$ Fol. ${ }_{17} 5$.) Autre récit, altribué au mème, et portant le titre de sistoire du tailleur de pierress.

$11^{\circ}$ (Fol. 179.) Histoire de quatre vieillards qui s'étaient engagés à virre ensemble dans ce inonde et à se loir diuns l'autre.

$12^{\circ}$ (Fol. $180{ }^{\circ}$.) Histoire d'un moine dout le corps, après sa mort, devenu très-noir, arait repris son aspect normal.

$13^{\circ}$ (Fol. $1811^{\circ}$.) Légende du mèmr genre que la précédente.

$14^{\circ}$ (Fol. $182 \vdash^{\circ}$.) Quelques maximes d'Allanase, érềue d'Alexandrie.

$15^{\circ}$ (Fol. 183.) Maximes de l'ablué Macaire, sui ies de plusieurs anecdotes et légendes.

16 عظات واخبار نافعة : $16^{\circ}$ (Fol. $204 v^{\circ}$.) Pièce intitulée "Conseils et récits d'un grand profit pour l'àme, par le bienheureux Zosimen. C'est une

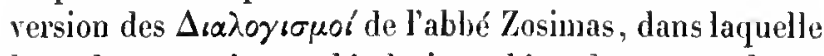
le traducteur a interpolé plusieurs légendes et anecdotes.
Dans cette partie du volume, plusieurs feuillets sont intervertis.

$17^{\circ}$ (Fol. $209 v^{0}$.) Histoire d'un bijoutier (جوهـ, جوى).

${ }_{1}^{\circ}$ (Fol. 216.) Histoire de cerlains moines qui, tentés. par le diable, demandèrent des conseils à l'abbé Zénon (زينو). Cette légende est incomplète.

$19^{\circ}\left(F^{\circ} 01.217 \mathrm{~V}^{\circ}\right.$ ) Histoire d'un moine qui, tourmenté par la chair, se réfugia dans la tanière d'une hyène.

$20^{\circ}$ (Fol. 219.) Histoire d'un évêque malade qui commit un péclné avec une religieuse qui le soignait.

$21^{\circ}$ (Fol. 221.) Histoire de la tentation et de la pénitence d'un nommé Pant, habitant du Sacid, en Égypte.

اخبيل, نافعة حكاها : $22^{\circ}$ (Fol. 223.) Recueil inlitulé

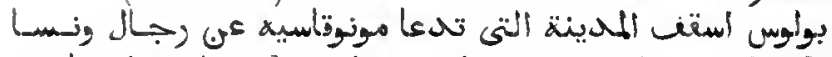
(بـ - Anecdotes instructives, racontées par Paul, érêque de Moûnoûyâsiya (Honembasie ou Malvasie, ville (lu Péloponnèse), au sujet de certains liommes et femmes qui s’élaient distingués par leur mérite».

a. Histoire de trois femmes qui récurent sous le règne de Constantio (Porphyrogénète), fils de Léon le Philosophe. Paul, l'auteur du recueil, dit quili tenait d'un témoin oculaire le fait dont il rend compte.

b. (Fol. 226.) Histoire d'un homme qui passa en jugement devant Dieu, trois jours avant sa mort.

c. (Fol. 228 .) Histoire d'un homme qui se confessa à un vieillard, sur le mont Olympe.

d. (Fol. $228 r^{\circ}$.) Histoire de la femme qui alla chez l'abbé Néopliyte pour se conlesser.

${ }_{2} 3^{\circ}$ (Fol. $2301^{\circ}$.) Histoire d'un paurre qui priait dans l'église de la Nère de Dieu, à Chalcédoine (لموتوانية).

$24^{\circ}$ (Fol. 232.) Histoire d'un prêtre qui fut interdit par son érèque.

${ }_{2} 5^{\circ}$ (Fol. 233 .) Histoire d'un prêtre qui tomba dans - l'abime de la fornication

${ }_{2} 6^{\circ}\left(\right.$ Fol. $234 \mathrm{v}^{\circ}$.) Hisloire de trois moines qui furent enlerés des côtes de la Calabre par des Musulmans et emmenés captils en Alrique.

$27^{\circ}\left(F_{01.2} 37 Y^{\circ}\right.$.) Histoire d'mn jeune garçon qui cut une vision mervelleuse, en recevant le saint baptême. Le fait se passa dans le Péloponıèse, du temps des empereurs Léonl el Alexandre.

$28^{\circ}$ (Fol. 233.) Histoire d'un moine qui habitait une carerne. 
$29^{\circ}$ (Fol. $242 r^{\circ}$.) Histoire diune femme ressuscitée après sa mort.

$30^{\circ}$ (Fol. $244 \mathrm{v}^{\circ}$.) Histoire de la bienheureuse Harthe, supérieure du convent de la Mìre de Dien.

$31^{\circ}$ (liol. 246.) Histoire de la découverte miraculcuse

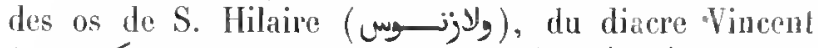
(فيكنتنيبوس) et de la vierge Eulalie (هولاليx المبـتول). Ces l'eliques, demeurées cachées dans l'ile de Crète, pendant l'occupation musulmano, furent retrourées plus lard; puis, sous les règnes de Léon et d'Alexandre, elles furent transportćes à l'égglise métropolitaine par Nicétas (نيقيطان), évêque de Monembasie.

$32^{\circ}$ (Fol.247.) llisloire d'un miracle opéré par l'image

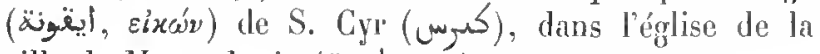
ville de Monembasie (مونوناسية).

$33^{\circ}$ (Fol. $248 \vee^{\circ}$.) Histoire de Théophile l'éconone (ألاتنو qui dut son patdon à l'intercession de la Nère de Dieu.

$34^{\circ}$ (1501. 258.) Aele original (sur papier), par lequel

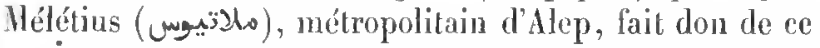
ms. à l'église de Notre-Dane, dans cette ville, afin qüil soit à l'usage des orthodoxes du rite romain (Jy) (الإ;تلكيسيu). Cette pièce est datée de l'an du monde 7151 (1643 de J. C.).

Vélin. 258 feuillets. Hauteur, 24 centimètres el demi; Jargeur, 17 centimètres. 18 à 20 lignes par page. L'écriture du ms. est ancienne et rappelte par sa forme la roideur de l'écriture coufiçue et les traits angulaires de l'écriture syriaque. En plusieurs pages des mols et des lignes entières, presque effacés par la vétusté, ont été retouchés et restanrés, mais pas toujours d'une manière heureuse. Cela est surtout évident an folio 297 , lignes 13 et 14 , où se trouve la dale du ms.; le scribe en a surchargé les traits effacés, de sorte qu'on y lit maintenant l'an 1091 d'Alexandre, ce qui répond à l'an 779 de J. C. Hais on trowve au fol. «3 7 la mention d'événements rui se passèrent sous les règnes de Léon le Philosople et de son successeur Alexandre, c'est-à-dire dans la première moitié du xie siècle. Il est assez probable que le ms. fut écrit vers le commencement du xu ${ }^{e}$ siccle. Plusienis feuillets du volume sont hors de leur place. Les huit premiers fenillets et le dernier sont modernes. - (Ancien fonds 66, Colbert 4219.)

\section{7.}

Martyrologe égyptien, renfermant les pièces suirantes:

$1^{\circ}$ Première partic da marlyre de S. Pirơou (أبيرو) et de son frère, S. Athom (أتوم)), natifs de Senbàt (سنبطوط) , dans le diocèse de Bousir-Banâ.

$2^{\circ}$ (Fol. 19.) Deuxième partie dn martyre des SS. Pirôou et Athom; récit de la belle conlession qu'ils firent, en présence de Pompée (كمبيدوس), gouverneur de Farma, et des miracles et prodiges que Dieu opera en rette ville par leur moyen.

$3^{\circ}\left(\right.$ Fol. 30 v $^{0}$.) Troisiène partie du martyre des SS. Piroon ef Athom, qui furent mis à murt par Publius (بيليوس), gouvermeur de Ṣaminoun (iأحُون).

$4^{\circ}$ (Fol. 41.) Martyre d'Agathon (أغساتسو) et de se: frères, Pjerre et Jean, ainsi que de leur's sœurs, Amoùn (أهو) et Amoûnà (أهونا), et de leur belle-mère, Refoa (aij), natifs de Kous, qui furent mis à nort sous te règne de Dioclétien et de Haximien.

$5^{\circ}$ (Fol. $74 \mathrm{r}^{\circ}$.) Marlyre de Jean et de son cousin Sinéon, natif's de umlog ou umbü, lieu situé dans la province d'at-Gharbiya, en Egyte.

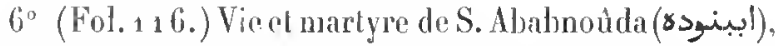
du pays de Bandarà (buijl), dans le diocèse de Banà (ب). Ce saint soutfit sous Dioclétien.

Papier. 170) feuillets. Hanteur, 21 centimètres et demi; largeu;, 14 centimètres. 13 à 15 lignes par page. Ms. daté de l'an 1946 des martyrs ( 1530 de J. C.). - (Supplément 89 , Saint-(Yermain 351.)

\section{8.}

$1^{\circ}$ Qualante histoines édifinutes, racontées par les moines de Waidi-Habib (هبي) et autres lieux. C'est te recueil inlilulé e l'uradis des délices\%. (Voy. le $\mu^{\circ}$ suivant.)

$2^{\circ}$ (Fol. $1551^{\circ}$.) Histoire de S. Xénaphore (? أكسنافر), de ses deux fils et de sa femme. L'un des fils s'appelail dreatius et l'autre Jean; la femme se nommait Harthe (م-). Le père était patrice romain; ses fils, qu'il envoya à Beirout pour fanre leurs études, embrassèrent la lie nonastique; le père el la mère suivirent leur exemple.

$3^{\circ}$ (Fol. 164.) Histoire de S. Hacaire le Grand et de S. Macaire d'Alexandrie.

$4^{\circ}$ ( $1^{7} 01.189 v^{\circ}$.) Histoire de Moïse, fils d'Luphémieı (أوفيميانوس), de Rone, sullnommé l'Homme de Dieu.

Papier. 199 feuillets. Hauteur, 36 centimètres; largeur, 17 centimètres et demi. 17 lignes par page. Ifs. daté de l'an 1010 des martyrs ( 1294 de J. C.). Une note, inscrite sur le dernier feuillet du ms. par un des anciens possesseurs, porte la date de 1108 des martyrs. (Supplément 97, Saint-Germain 126.)

\section{9.}

Recueil de quarante légendes, intitulé "Paradis des délices $\%$. On lit en tête de l'ourrage le titoe suirant: "Ce 
livre, intitulé eParadis des délices (فردوس النغيnم), est clésigné dans la plupart des exemplaires par le titre de r Jardins des Peres moinesn (بساتين الابا الرهبان). Il est profitable au lectenr el à celui qui l'entend expliquer, et qui désire marcher dans les voies de la priété et se délirere des tribulations du monde."

Ces légrendes sont de divers auteurs. On y troure quelques détails sur la vie intérieure des monastères de l'Égypte, à une éporgue antérieure à la conqnête musulmane.

Papier. 401 feuillets. Hauteur, 17 centimètres; largeur, 13 contimetres. 10 tignes par page. Ms. du xwv siecte. - (Ancien fonds 163.)

\section{0.}

1 م "Quarante histoires". C'est le même ouvrage que le précédent.

$2^{\circ}$ (Fol. 244.) Récit et discours édifiants, par Yoûsâb (يوسواب), moine de Scété.

3० (Fol. 253.) Extrait de l'ourrage intitulé : كتناب

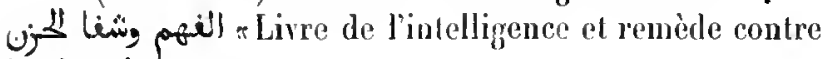
le clagrinn.

$4^{\circ}$ (Fol. 26o.) Préceptes utiles pour les moines.

$5^{\circ}$ (Fol. 3o 4.) Histoire qui a été racontée par un saint homme qui avait demeuré pendant cinquante ans dans le désert.

$6^{\circ}$ (Fol. $308 v^{\circ}$.) Exhortation à la lecture des livres saints, par S. Jean Chrysostone.

$7^{\circ}$ (Fol. $31_{15}$.) Liste chronologique des grands événements du monde, jussu'il l'hégire; suivie de tableaux indiquant le commencement des quatre saisons de l'année, les noms des grands et des petits prophètes, et les noms des mois coptes et syriajues.

Papier. 318 feuillets. Hatteur, a 1 centimètres et demi; largeur, 15 centimètres et deni. 14 lignes par parge. Ms. daté de t'an 1321 des martyrs (1605 de J. C.). -. (Ancien fonds 155.)

\section{1 .}

$1^{\circ}$ Histoire de S. Jean le Deïlémite, origginaire de Mossoul, qui souffrit le martyre dans les premiers temps de la domination musulmane.

$2^{\circ}$ (Fol. 88.) Homélie de S. Jean Chrysostome sur la décollation de S. Jean-Baptiste. $3^{\circ}$ (Fol. $9^{6 .)}$ Homélie du même smi le baptême de Jésus-Christ.

4 (Fol. 103.) Testament d'Adam, adressé à Setl.

$5^{\circ}$ (Fol. 109. ) Prophétie de Sibylle, fille du roi philosoplıe Héraclius.

$6^{\circ}$ (Fol. $117 \mathrm{v}^{\circ}$.) Histoire de Ḥasana $\left(\ddot{\alpha}\right.$ Hima $\left._{-}\right)$, fille d'Israël.

$7^{\circ}$ (Fol. $1449^{\circ}$.) Récit d'un miracle qui eut lieu dans l'église de Mar Élie (الياسu), au Mont 'Auf (جبل عون).

$8^{\circ}$ (Fol. 153.) Histoire du prophète Élie, toujours vi-

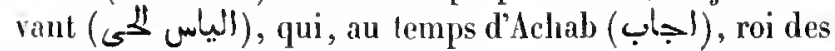
Israélites, lia le ciel et la terre, et empêcha la pluie de tomber.

$9^{\circ}$ (Fol. 188.) Homélie de S. Jean Chrysostome sur la pénitence.

$10^{\circ}$ (Fol. 207.) Épître de Jésus-Christ à Abgar (أبجى), roi d'Édesse.

$11^{\circ}$ (Fol. $207 v^{\circ}$.) Histoire de ce qui arriva au saint moine Jérémie (إيباميا)), à Damas et en Égypte.

$12^{\circ}$ (Fol. 229.) Histoire du saint Pèlerin Marc, qui sćjourna sur le Tiruaqâ (التوم), montagne située au delà de l'Abyssinie, sur le bord de l'Océan.

$13^{\circ}$ (Fol. $2421^{\circ}$.) Histoire du marchand et des merveilles de la puissance de Notre-Seigneur dont il fut témoin.

${ }_{14} 4^{\circ}\left(F_{0 l}{ }_{2} 47 v^{\circ}\right.$.) Dissertation sur la charité, tirée du livre intitulé al'lelaircissement" (الايضطاح).

$15^{\circ}\left(\mathrm{F}_{0} \mathrm{~L}_{2} 49 \mathrm{r}^{\circ}.\right)$ Extrait d'un discours prononcé par un religieux. On croit que cette pièce est la traduction

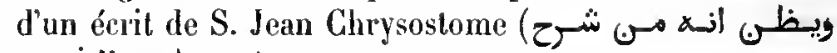
(يوحنا فم الذهب (1).

${ }_{16^{\circ}}$ (Fol., 264.) Homélie sur le sixième psaume par le R. P. Anastase, supérieur du monastère de Sinaï.

$17^{\circ}$ (Fol. $282 v^{\circ}$.) Histoire de la femme à la main brûlée.

$18^{\circ}$ (Fol. $287 v^{\circ}$.) Histoire du guerrier (جنــ) de Carthage qui mourul sous le patriciat de Nicétas (نيقيط), visita le purgatoire et l'enfer, puis, rendu à la vie, raconta au grand philosophe Thalassius (ثلاسـيـوس) ce qu'il avait vu.

$19^{\circ}\left(\right.$ Fol. $29^{2} \mathrm{v}^{\circ}$.) Histoire racontée par le bienheureux Zosime (زوسم) qui dit l'avoir-apprise de notre Père Théophane el de Théodore (ثناوذورس) le médecin.

$20^{\circ}$ (Fol. $295 v^{\circ}$.) Discours sur le jugement dernier (الدينونة), par Jean, surnommé le Merveilleux (Thaumaturge?), de Guérisseur (النجيب المناف). 
$21^{\circ}$ (Fol. 297.) Homélie de S. Basile sur le dimanche et le vendredi, et sur la séparation de l'àme et du corps.

$22^{\circ}$ (Fol. 303.) Autre homélie, sur les mêmes sujets, altribuée à $\mathrm{S}$. Basile. Moise.

$23^{\circ}$ (Fol. 3 1 $\left.3 v^{\circ}.\right)$ Hisloire de la mort du prophète

$24^{\circ}$ (Fol. 314.) Histoire d'Abraham et de son fils Isaac.

$25^{\circ}$ (Fol. 3 28 .) Histoire de Joseph, fils d'un rerrier juil. S'étant converti au christianisme, il fut jeté dans une lournaise (انوب) par son père", et en sortit le lendemain sain et sauf.

26 $6^{\circ}$ (Fol. 322.) Histoire du saint martyr Théodore (u), qui souffrit sous Julien l'A postal.

$27^{\circ}$ (Fol. 342.) Histoire de l'invention de la rraie croix, par Hélène.

$28^{\circ}$ (Fol. 35o.) Extrail d'une Lomélie sur la séparation de l'àme el du corps.

$29^{\circ}$ (Fol. 351 r. $^{\circ}$ ) Homélie de S. Jean Clirysostome sur le jugement dernier.

$30^{\circ}$ (Fol. $3531^{\circ}$.) Homélie du mème str ta foi ct sur la fréquentation de l'église.

$31^{\circ}$ (Fol. $355 \gamma^{\circ}$.) Trente avertissements, lirés de l'enseigrement des saints Pìres.

$32^{\circ}$ (Fol. $356 \%^{\circ}$ ) Homélie sur lincarnation.

$33^{\circ}$ (Fol. $359 \vee^{\circ}$.) Enseignements et arentissentents pour ceux qui cherchent le salut.

Papier. 361 feuillets. Hanteur, 18 centimitses el demi; largenr, 13 centimètres. 19 à 13 lignes par page. Its. daté des années 70.54 el 7055 de l"ère du monde ( 154 (j-15/47 de J. C.)... (Aneien fonds 158 , Colbert 6141.)

\section{2 .}

1 o Mistoire d'Anbà Barșaumà le Nu ('أعويان), fils d'alWadjỉh, surnommé Ibn-al-Tabbàn êfils du narchand de paille\%, et secrétaire de Schadjar al-Dorr (e bouche de perles $\%$ ), princesse souveraine de l'Égypte, l'an 1250 de J. C. On y trouve le récit de ses miractes el de ses sonfliances pour la cause de Dieu.

$2^{\circ}$ (Fol. $18 v^{\circ}$. ) Quelques-uns des miracles opérés par Barsaumà.

$3^{\circ}$ (Fol. $7^{2} \mathrm{r}^{\circ}$.) Discours lu dans le monastère de

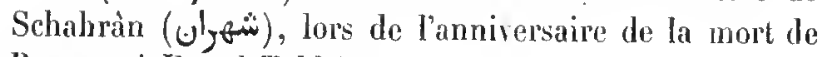
Barşaumà Ibn al-Tabbàn

$4^{\circ}$ (Fol. $82 v^{\circ}$. ) Vie et miracles du saint P. Fiuridj

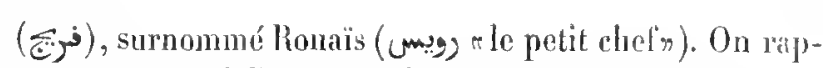
porte sa mort à l'an 1121 des martyrs ( 1405 de J. C.).

$5^{\circ}$ (Fol. $140{ }^{\circ}$.) Panégyrique du saint P. Ronais.

$6^{\circ}$ (Fol. 144.) Prières en langue copte, composées par le saint P. Rouaïs.

$7^{\circ}$ (Fol. $152 v^{\circ}$. ) Notice sur Anbà Abrabam (أبرأهام)

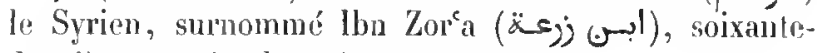
denxième patriarche d'Alexandrie.

Cette pièce renferme, de plus, quelques anecdotes au sujel d'un palriarche nommé Sévère, et de ses rapports arre le calife latémide al-No Joizz.

Papier. 186 feuillets. IIauteur, a 1 centimètres; largeur, 15 centimètres. 1.3 à 14 lignes pa. page. Is. daté de l'an $1377^{5}$ des mariyıs (1659 de J. C. . . - (Ancien fonds 157.)

\section{3.}

Recueil d'anecdotes et de discour's édifiants, attribués ì des moines distingués par la sainleté de leur vie. Le compilatenr dit aroir pris ses malériaux dans le livre intituḱ "le Paradisn (فرد), el dans d'autres onldges. Lianteur du "Paradis se nommail Aboù 'I-Fadhàï al-Ṣalì, fils d'Aboù ']-Moladdlial. Au lolio 68, on trouve quelipues extrats, empruntés à l'ourage intitulé elos Jardins des

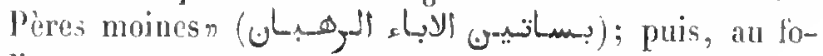
lio 92 , commence une suite d'extraits du r Climax"

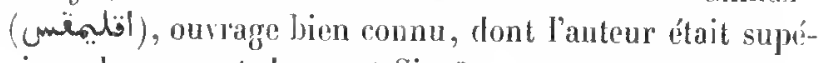
licul du couvent du mont Sinaĩ.

La fin du volume inanque; rar le dernier feuillet a été composé exprès et à une époque assez récente, afin de remplir la lacune. On voit par la paginalion copte que trois feuillets mancjuent au commencement, et plusieurs lemillets an milien du volume.

Papier. 133 fenillets. Hauteur, 26 centimcldres et demi; largeur, 17 centimètres el demi. 17 lignes par page. Le ms. parait ètre du vun siècle. - (Supptément 98 , Saint-Germain 123.)

\section{4.}

"Vie du bienheurenx père, du grand saint, du prè̀tre,

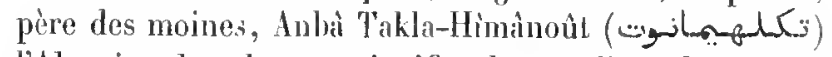
l'Abyssin, dont le nom signifie ex le paradis de la trinité. (فودوس اللثنلمون Cet ourage fut envoyé d'Abyssinie à Anbâ Gabricl, quatre-ingt-quinziène patriarche (d'Alexandrie), par Claudius (أقلوديوس), roi d'Aloyssinic.n

Papier. 140 feuillets. IIauteur, o.s centimètres; largeu?, 1 is centimètres. 1 a à 13 liggnes par page. Nls. daté de l'an 13 u des marty: ( 1591 de J. C.). - (Ancien fonds 159.) 


\section{5.}

Quelques légendes touchant la chasteté, recueil composé par un chrétien copte. Le premier de ces récils, qui sert de carlre aux autres, a pour sujet l'action d'un certain Mboû 'I-Sảbì (أبو الصفا), qui se fit eunuque. On discute à ce propos les opinions de quelques écrivains grecs et

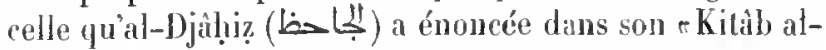
Haïwân \%. L'ourrage commence par ces mots : avi

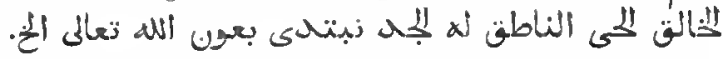

Papier. 39 fenillets. Hanteur, 21 ecntimètres; largeur, 15 centimitres. 13 lignes par page. Us. lalé de l'an 1372 des martyrs ( 1650 de J. C.). - (Ancien fouds 857.)

\section{6.}

Ilistoires édifiantes, dont plusieurs sont tirées de li Bible, mais plus ou moins modifuées. On y trouve aussi des homélies et des anecdotes mupruntées à l'hagiographic orientale.

Papier. 214 feniltets. Hanteur, 23 eentimètres; largeur, 16 centimètres et demi. 18 à 25 lignes par page. Ils. écrit à Jérusalem en 1785 de J. C. - (Supplément 31. )

X.

\section{HISTOIRE.}

\section{7.}

Fragment d'une histoire ecclésiastique par un auteu' copte. Flle contenait au moins vingt et un chapitres. Ce lragment se compose de vingt-quatre feuillets, dont plusieur's sont hors de leur place, ainsi qu'on peut le rrconnaitre par l'ancienne pagination en chiffres coptes. Voici les titres de quelques chapitres:

Estras le prètre est tué; histoire des sept l'rères mis it nort par Anliochus; Hérode; Dara, roi de Médie, et Cyrus, roi de Perse, marchent contue les Kitzdaniles; Belchazzar, roi de Babylone, est tuŕ; explication des mots inscrits sur la muraille de la salle du festin; Isaïe, le prophète; histoire de Mardochée el de sa nièce Esther; questions proposées aux philosophes par Alexandre; histoire des Juil's après la mort d'Alexandre. - Livre XX. Administration du sacrement de l'extrême-onction '.

Papier. Hauteur, 17 centinètres et demi; targeur, 13 centimètres et demi. 1 lignes par page. xne siècle. - (Supptément 2067.)

\section{8.}

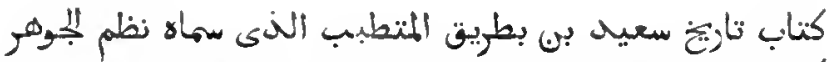

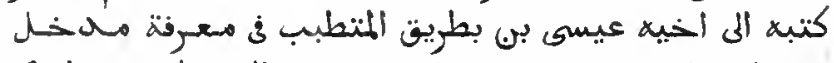

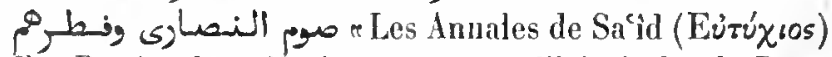
Ibn Batrìy, le médecin, ourrage qu'il intitula e le Rang de perles\%, et qu'il adressa à sou frère, 'İsà lbn Baț’íq, le médecin, pour lui faire connaitue ì quelles époqu s de l'année commence et finil la Pàqué des chréliens $\pi$.

Ce titre n'indique nullement le contenu de l'ourrage. Il en est de même de la liste des chapitres qui se troure dins la préface, et qui appartient plutôt à un traité de chronologrie qu'à un résumé de l'histoire du monde. Liillustre Pocock, dans sou édition de ce lirre, rejette arec raison cette liste comme une interpolation (royez $\sim$ Eutychii Annales », Oxoniæe, 1659 , fin de la préface). La suscription mise en tête de l'ourrage aurait dû se terminer

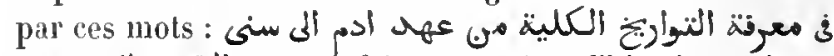
الهيجرة الاسلامينة selle, depuis le temps d'Adam jusqu'aux années de l'hégiren. Cette leçon est celle que Pocock a ildoptée et qui se trouve aussi dans le ms. $n^{\circ} 292$ (royez ci-après).

A la suile des Annales $n$, qui se terminent à l'an 326 de l'hégire, se trouve, dans le présent mis., une continuation, qui commence à l'an 349 de l'hégire et s'arrêtè à l'an 400 . D’après une note inscrite au bas du folio 212 , celte continuation aurait pour auteur te célèbre Jean d'Antioche.

Papier. 218 feuillets. Hauteur, 26 centimètres; largeur, 16 cenlimètres et demi. 17 lignes par page. Ms. du xiv' siècle. - (Ancien fonds 831 .)

\section{9.}

Les Annales d'Eutychius. Le texte et le titre de cet
1 Ce sont des extraits de quelque version de l'histoire des Juifs par Joseph-ben-Gorion. Le chapitre sur l'extrème-onetion, d'une autre écrilure que les fenillets précédents, n'avait pas appartenu au ms. pri- mitif. Mais le folio $147 \mathrm{dn}$ ms. 158 (voyez ci-dessus, $n^{\circ} 158,3^{\circ}$ ) en est un autre fragment. H. $Z$. 
exemplaire sont les mêmes que ceux du ms. précédent. La fin de l'ourrage nanque.

Papier. 323 feuillets. Hauteur, 25 centimètres; largeur, 16 centimètres et demi. 14 lignes par page. Ms. du xiv e siècle; it parait avoir été éerit par un musulman. - (Ancien fonds 134.)

\section{0.}

Les Annales d'Eutychius. Le titre et le texte sont les mêmes que dans les deux mss. précédents.

Papier. 201 feuillets. Hauteur, 3o centimètres et demi; largeur, so centimètres. 13 lignes par page dans la première partie, 19 dans la seconde. Ms. de deux éeritures différentes. La plus ancienne, celle du commencement, est probablement du xv siècle; l'autre est du commencement du xvir". Le dernier feuillet du ms. porte la date de l'an $7^{109}$ du monde ( $160 \mathrm{t}$ de J. C.). - (Ancien fonds 133 .)

\section{1.}

Les Annales d'Eutychius. Titre et texle comme dans les mss. précédents. Au folio $8_{2} v^{\circ}$ commence la continuation de l'ouvrage par Jean d'Anlioche (Yahyà Ibn Sa îd al-Antâkî). Cet auteur nous apprend dans sa préface qu'après avoir remanié son ouvrage deux fois, il se rendit à Antioche, l'ąn 403 de I'lıégice (1 $1012-1013$ de J. C.), où il trouva plusieurs documents listoriques, à l'aide desquels il put achever la rédaction définilive de son travail. Cette continuation, rédigée sous forme d'annales, offre des renseignements importants pour l'histoire de l'empire byzantin et des denx ealifals, celui des Abbasides et celui des Fatémides. On y lrouve aussi les noms des patriarches d'Alexandrie, de Jérusalem, d'Antioche el de Constantinople. La copie n'est pas lerminée. Le récil s'arrête au milieu de l'an 417 de l'hégire (1026 de J. C. .).

Papier. 137 fenillets. Hauteur, 30 centimètres ; largeur, 19 centimètres et demi. $\$ 5$ lignes par page. Le ms. paraît être de la fin du xru" siècle. - (Ancien fonds $131 \AA$.)

\section{2.}

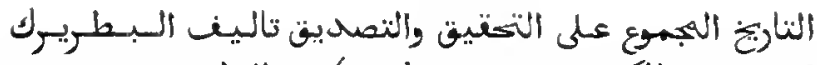

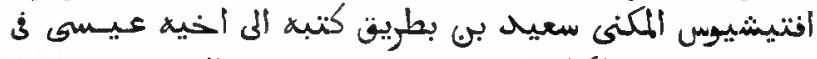

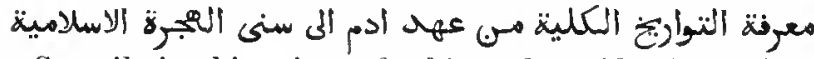
"Compilation historique, fondée sur la vérification et l'authenticité (des faits), ouvrage du patriarche Eutychius, appelé Sacid Ibn Batriq, qui l'adressa à son frère 'Isà, pour lui faire connaitre l'histoire universelle, depuis le

Itan. orientaux. - H. lemps d'Adam jusqu'aux années de l'hégire islamique.

On roit que le titre de cet exemplaire est plus conforme au contenu de l'ouvrage que celui des mss, précédents. La lisie des chapitres ne se trouve pas dans la préface de ce ms. Le texte s'accorde avec celui de l'édition de Pocock.

Papier. 315 feuillets. Hauteur, 32 centimètres et demi; largeur, 21 centimètres. 19 lignes par page. Ms. daté de l'an 7132 du monde (1624 de J. C.). - (Ancien fonds 13 .)

\section{3.}

Les Annales d'Eutychius, texte conforme à celui qui est contenu dans le numéro précédent.

Au conmencement et à la fin se trourent quelques feuillets très-mal écrits d'un livre de liturgie.

Papier. 277 feuillets. Hauteur, 31 centimètres; largeur, 21 centimètres. 17 lignes par pagge. Hs. copié l'an du monde 7155 (1647 de J. C.). - (Ancien fonds s 35 , Colbert a 186 .)

\section{4.}

Histoire universelle d'lhn al-Amid " تاريخ أبر العيد surnommé al-llakìn (Elmacin). Ce volume renferme l'histoire du monde, depuis la création jusquà la treizième année du rògne d'Héraclius, date qui correspond à la première année de l'hégire.

Papier. 258 feuillets. Hauteur, 25 centinètres; largeur, 17 centimètres. Ms. de plusieurs ćcritures; la partie la plus aneienne et la plus considérable est du xıv siècle. - (Supplément 751 , Saint-Germain 102.)

\section{5.}

Seconde partie de l'Histoire universelle d'al-Makin. Elle commence à l'hégire et va jusqu'à l'an 414 (10231024 de J. C.). Cette copie peut servir à corriger une partie des nombreuses fautes qu'on rencontre dans I'édition d'Erpenius, laquelle, toutefois, s'étend jusqu'ì l'an 512 ( 11118 de J. C.).

Papier. 65 feuillets. Hauteur, 33 centimètres; largeur, a a centimètres. 33 liggnes par page. Ns. copié à 'l'unis, vers l'an 1854. (Supplément 751 bis.)

\section{6.}

L'Histoire des dynasties d'Aboû '1-Faradj. Titre: 


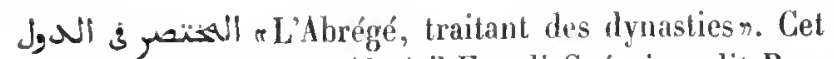
ouvrage, composé par' Aboû 'l-Faradj Grégoire, dil BarHebraus, a été publié par Pocock (Oxford, 1663). La lacune qui se trouve à la page 562 de l'édition peut se combler à l'aide de ce ms.

Papier. ${ }_{152}$ feuiflets. Llauteur, 25 centimètres; largeur, 15 centimètres. 24 lignes par page. Ms. du $x^{*}$ siècle. Les sept derniers feuillets sont d'une main plus moderne. Au bas du dernier feuillet se trouve la note que Pocock a reproduite dans la préface de son édition, et qui nous apprend qu'Aboû 'I-Faradj mourut dans la religion musulmane. D'après une autre note, inscrite sur la même page; l'auteur de la première note serait Ibn Khallikân; mais cela ne saurait être vrai, ce biographe étant mort quelques années avant Aboú 't-Faradj. (Ancien fonds 137 , Cotbert 4178 .)

\section{7.}

L'Histoire des dynasties d'Aboú '1-Faradj. Le texte de re ms. est très-correct. II s'arrêtait d'abord à l'an 676 de l'hégire; mais le copiste l'a complété plus tard. On y trouve un grand nombre de notes marginales, et, sur les leuillets de garde, plusieurs extraits de divers on rages, quelques vers et beancoup de notes chronologiques, historiques et géographiques. La plupart des notes historiques concernent la ville d'Amid et la Mésopotamie; les aulres se rapportent ì la Syrie, à la Palestine et aux conquêtes de Djenguì-Khàn. On y trowe aussi une liste des soixante-lıuit grands prètres juifs, à partir d'Aaron, une liste des patriarches d'Antioche, une liste des primats jacobites d'Orient, jusqu'à l'an 1805 de l'ère des Séleurides (1493 de J. C.), et une liste des cathohicos nestoriens. Le feuillet 180 porte deux notes en syriaque, dont l'une est la notice biographique d'un métropolitain nommé Jean. L'autre nous apprend qu'en l'an 1873 ( 1561 de J. C. ), ce ms. appartenait au courent syrien de Saint-Moise, l'un des monastères de Scété. L'autenr de cos notes, qui est le copiste nême du ms., était évèque, et se nommait Timothée; it termina son travail l"an 1866 de l’ère des Sélencides ( 1554 de J. C.). Il est possible que ce prétat fint to Timothée, érêque d'Amid, qui virait encore l'an 1583 de J. C., et dont il est fait nention dans "Oriens christianus $"$, t. II, p. 1418.

Papier. 184 feuitlets. Hauteur, si rentimètres et demi; largeur, 14 centimètres. 19 lignes par page. - (Ancien fonds 1 ' 7 .)

\section{8.}

L'Histoire des dynasties d'Aboû 'l-Faradj.

Papier. 163. fenitlets. Hauteur, 25 centimètres; largeur, 17 centi- mètres et demi. 19 lignes par page. Mts. écrit en l'an 1006 de l'hépire ( 1598 de J. C.) par un scribe musulman, comme parait l'indiquer le Bismillah qui se lit en tête de la première page. - (Ancien fonds 136. .)

\section{9.}

L'Histoire des dynasties d'Abou '1-Faradj. Cet exemplaire, écrit par un elırétien, bien qu'il porte en tête Ja formule musulmane du Bismillah, commence ainsi : هذا

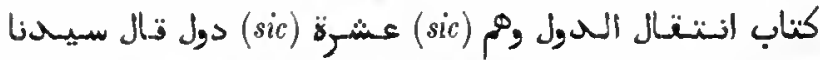

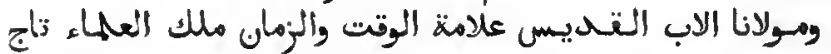

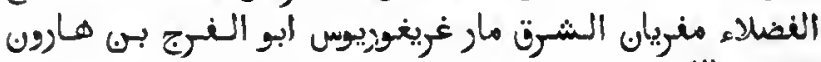
"Ceci est le livre de la "'Transmission des empires $n$, qui sont au nombre de dix. Voici ce qu'a dit notre seigneur et maitre, le r'évérend père, le savant de l'époque et du temps, te roi des docteur's, la couronne des hommes de mérite, le maphrien (métropolitaia) de l'Orient, Mar Grégoire Aboù 'l-Faradj Ibn Hàroùn, médecin philosophe; que Dieu sanctifie la Jumière de son tombeau. Amen!n

Papier. 211 fenillets. Hauteur, 3o centimètres; largeur, 20 centimètres. a l lignes par page. Ns. copié l'an $1 / 409$ des martyrs ( 1693 de J. C. ). - (Ancien fonds 136 A.)

\section{0 .}

Histoire du monde, depuis la création jusqu'au temps de Jésus-Christ, ouvrage composé par un chrétien, et renfermant le développement des faits indiqués dans Ja première partie des Annales d'Eutychius. Outre f'histoire d'Adam, des patriarches, des Israélites, des Plıaraons et des l'tolémées, on y trouve une cosmologie (fol. 106), une description de la terre, des sept climats et des planetes, avec l'indication des villes, des pays et des climats sur lesquels chacune de ces planètes préside. Ce chapitre se trouve placé entre celui de Nemrod et celui des rois coples de f'Egpte. Louvrage se termine par une notice sur les lieux saints ( fol. $489 \mathrm{v}^{\circ}$ ), précédée de ła mention des miracles opérés par J. C. et confirmant les prédictions des prophètes.

Papier. 5o feuillets. Hanteur, 26 rentimètres; largeur, 17 centimètres. Ns. dı $\mathbf{1} 11^{\circ}$ siècle. Des lacunes très-nombreuses ont été comblées par divers copistes et à diverses époques; l'ordre des cahiers est entièrenent bouleversé. - (Supptément $75_{2}$, Saint-Germain 96.)

\section{1 et 302 .}

Histoire des patriarches . . . . سي الاباء البطارتة 
d'Alexandrie», recueil de notices et de mémoires, rédigés à diverses époques et par divers auteurs, divisé en trois sections, formant deux volumes. $A$ la suite du titre et de quelques chapitres qui servent de préface et d'inIroduction, se trouvent vingt-neuf chapitres, appelés سيرة , et dont chacun renferme plusieurs notices biographiques; ensuite viennent quelques suppléments, dont le dernier et le plus important contient les anmales de l'Église d'Alexandrie. La préface, composée par le premier rédacteur de l'ourrage, nous apprend que Sévère Ibn al-

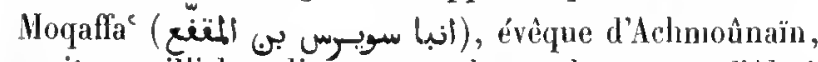
avait recueilli dans divers monastères, tels que ceux d'Aboù Maqâr (أبو مëار, S. Macaire) et de Nahyâ (نهيا), el dans les collections des particuliers, un grand nombre de notices sur les patriarches d'Alexandrie. Mauhoûb Ibn Manşoûr, qu'on a reconnu être l'auteur de la préface, ajoute, en parlant de lui-même, qu'après de longues et pénibles recherches, il étail parvenu à rassembler les cahiers épars qui renfermaient ces documents, et qu'il y a ajouté une sîra de sa composition (la neuvième). Sévère d'Achmoûnaïn, dans une autre préface, déclare aroir eu recours à quelques-uns de ses coreligionnaires pour obtenir la traduction en arabe de certaines notices biographiques, ćcrites originairement en grec ou en copte, langues ignorées alors ( $\mathrm{x}^{\mathrm{e}}$ siècle) par la grande majorité des chréliens de l'Égypte. Il fit aussi transcrire quelques documents des temps anciens, c'est-à-dire les canons des conciles, et composa pour son ouvrage un supplément renfermant l'histoire des patriarches, ses contenporains. Maulıoub coordonna ces pièces et y en ajouta d'autres. C'est cette rédaction, retouchée par Marc lbn Zor'a et d'autres contimuateurs, que contient le présent ms. Mauhoûb, diacre d'Alexandrie, écrivait dans la seconde moitié du $\mathrm{xl}^{\mathrm{e}}$ siècle.

Deux votumes. Papier, 266 et 44 i pages. Ilauteur du premier volume, 34 centimètres; largeur, 25 centimetres el demi. llauteur du second volume, 35 centimètres: largeur, 27 centimètres. 25 tignes par page. Le ms. parail être du milieu du $x v^{*}$ siècle. - (Ancien fonds 139 et 140.$)$

\section{3.}

Histoire des patriarches d'Alexandrie; volume dépareillé, commençant par la notice biographique du quarante-neuvième patriarche, et finissant par celle du soixante-cinquième. Les premiers feuillets manquent, ainsi que les deniers. Quelques feuillets, au commencement du volume, sont rongés. Au fol. 159 , on trouve une addition importante écrite par le diacre Aboû Djaïl Michel, fils de Bodaïr, de Demenhour.

Papier. 278 feuillets. Hauteur, 18 centimètres; largeur, 14 centi- mètres. 13 à 16 lignes par page. Le nis. parait ètre du xıv' siècle. (Ancien fonds 161.)

\section{4.}

Histoire des patriarches d'Alexandrie.

Papier. 204 feuillels. Hauteur, 22 centimètres; largeur, 15 centimèlres el demi. 19 lignes par page. Us. copié à Alep, t'an 7105 de l'ère du monde ( 1597 de J. C.). - (Ancien fonds 148.)

\section{5.}

$1^{\circ}$ Diver's extraits de l'Histoire des patriarches d'Alexandrie, copiés, probahlement sur les mss. 301 et 302 .

$2^{\circ}$ (Fol. 31 1.) La cent dounième lomélie de S. Atlianase, patriarche d'Alexandrie, quill prononca à l'occasion de la visite que lui fit S. Antoine.

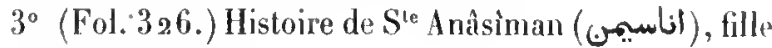
du roi des Romains.

$4^{\circ}$ (Fol. 33^.) Histoire d'une sainte lemme, racontée par Aubà Maqàra (S. Macaire).

$5^{\circ}$ (Fol. 332.) Première des histoires racontées par un sint personnage.

$6^{\circ}$ (Fol. 341.) Panégyrique des martyrs Anbà Abschài (انبا أبنشاى) et Anbâ Pierre.

$7^{\circ}$ (Fol. 342.) Histoire de quelques saints, tirée des ćcrits du R. P. Victor (بتطب), le secrélaire, chef du

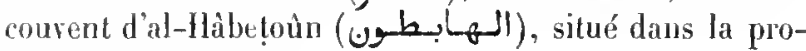
vince d'Alexandrie.

$8^{\circ}$ (Fol. 353.) Comment le corps du grand martyr

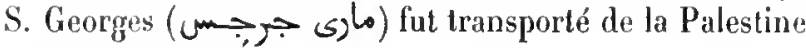
jusqu'à la haute Egypte.

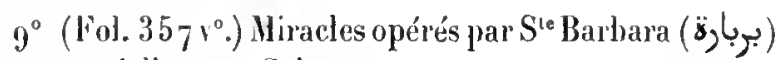
dans son église, au Caire.

$10^{\circ}$ (Fol. 361.) Homélie de S. Jacques de Saroûdj, sur l'incrédulițé de Thomas l'apôtre.

$11^{\circ}$ Les quatre dernier's feuillets du nns. renlement un exirait du Menæon copte. (Le 16 décembre, service de commémoration des trois enlants, Ananias, Azarias et Misaël.)

Papier. 370 feuiltets. Hauteur, 21 centimètres; largeur, 15 centimètres. Le nombre des lignes par page varje beaucoup; au conınencement on en compte 17 , el vers ta fin 23 . 11 s. transcrit l'an ${ }_{13} 35$ des martyrs (1609 de J. C.). - (Supplément 656, Saint-Germain 352:) 


\section{6.}

Notices sur un certain nombre de patriarches d'Alexandrie, à commencer par Anbâ Cyrille, fils de Logloq (لقلق) , soixante-quinzième patriarche. Cet article remplit vingtsept feuillets. Les quatre fenillets suivants ont été laissés en blanc. Viemment ensuite des rotices sur Anbâ Athanase ben Kalîl (كايل), soixante-seizième patriarche, et sur ses successeurs, jusqu’à Anbâ Yoûnos, quatre-vingt-dix-neuvieme patriarche. En tôte du volume se trouve celte note de Renaudot : Supplementum historiæ patriarcharum Alexandrinorum.

Papier. 62 feuillets. Hanteur, \& 3 centimètres; largeur, 17 centimètres. 15 lignes par page. Ms. du xvı" siècle. - (Supplément 1960 bis.)

\section{7.}

Histoire des monastères d'Égypte. Cet ouvrage n'a ni préface, ni titre; car le tilre qu'on lit en tête du volume

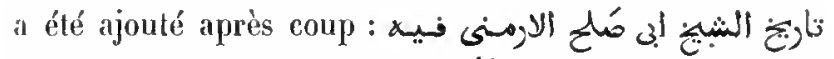
Mllistoire du schaikh Aboû Salah l'Arménien, dans laquelle on trouve des renseignements sur les localités du Caire et sur les terrains qu'on y a concédés." II semblerait que le libraire a voulu faire passer ce volume pour un exemplaire du "Khitat" d'at-llaqrizi. L'auteur commença son travail l'an 564 de l'hégire (1168-1169 de J. C.), mais il ne paraît pas l'avoir terminé (roy. fol. $1 \mathrm{v}^{\circ}$ et $112 \mathrm{v}^{\circ}$ ). Cet ouvrage traite principalement de l'histoire des monastères de l'Égypte, sur lesquels il fournit des renseignements très-précieux. Parmi les nombreuses indications topographiques et historiques dont il est rempli, on rencontre quelques renseignements sur les Ayyoubides, sur les établissements nestoriens en Asie, sur le Yemen, l'Inde, la Malaisie, ete.

- Papier. 113 feuillets. Hauteur, 26 rentimètres; largeur, 17 centimètres. 17 ligues par page. Ms. copié au Caire, l'an 1054 des martyr's, date qui correspond à l'an 738 de l'hégire ( 1338 de J. C.). - (Ancien londs 138.)

\section{8.}

Histoire des Maronites : leur origine et preuves de leur orthodoxie, par Étienne Pierre, patriarche d'Antioclie. Cet ouvrage renferme dix-liuit eliapitres, dont le contem est indiqué dans une liste très-développée qui se trouve en tête du volume.
Papier. 178 feuillets. Hautenr, 21 centimètres; largeur, 14 centimètres. 21 lignes par page. Ms. daté de l'an 1799. - (Supplément 782.)

XI.

\section{OUVRAGES DIVERS.}

\section{9 .}

$1^{\circ}$ Notice sur Aristote (أرسطاطالسu), ses doctrines et sa vie.

$2^{\circ}\left(\mathrm{Fol} .3 v^{\circ}.\right)$ Louanges et remerciements adressés au Créateur par Aristote.

$3^{\circ}$ (Fol. 9.) Extrait du discours prononcé par Aristote quand le roi linvita à parler en public.

$4^{\circ}\left(\right.$ Fol. $13 v^{\circ}$.) Enseignements pour ceux qui savent les entendre.

$5^{\circ}$ (Ibid.) Histoire d'Alexandre, surnommé Dsoû 'lQarnain.

$6^{\circ}$ (Fol. 32.) Lettre qu'Alexandre, avant de mourir, adressa à sa mère.

$7^{\circ}$ (Fol. 35.) Vie, préceptes et enseignements de Loqmàn le sage.

$8^{\circ}$ (Fol. $44 \Upsilon^{\circ}$.) Réponse de Loqmân à cette question : "Quel est l'homme te plus savant?"

$9^{\circ}$ (Fol. 47.) Derniers conseits que Loqmàn adressa à son fils.

$10^{\circ}$ (Fol. $48 v^{\circ}$.) Testaments de Loqmân et de Jésus, fils de Siracl.

$11^{\circ}$ (Fol. $\left.50 \mathrm{v}^{\circ}.\right)$ Vie et enseignements du sage Galien (جالينوس).

$12^{\circ}$ (Fol. $\left.52 v^{\circ}.\right)$ Autres enseignements du sage Galien.

${ }_{1} 3^{\circ}\left(\right.$ Fol. $\left.54 v^{\circ}.\right)$ Histoire de Secundus le philosophe.

$14^{\circ}$ (Fol. $104 v^{\circ}$ ) r Prière de S. Cyprien (تبريانوس), qui, d'abord magicien, se convertit à la religion de Jésus le Messie, devint évêque de Carthage ( $(\ddot{x})$, et subit. la mort du martyre par le glaive. Cette piece, traduite du gree en arabe, est une bonne anulette pour chasser les démons et neutraliser le mauvais ail."

$15^{\circ}$ (Fol. 112.) Notice sur les sept conciles et sur les cátuses de leur convocation.

Il s'agit du concile de Nicée, des deux conciles d'Éphèse et des quatre conciles de Constantinople. L'auteur du traité était jacobite. 
$16^{\circ}$ (Fol. 127.) Exposition de la foi orthodoxe, telle que les apôtres du Nessie la communiquèrent aux Coptes.

$17^{\circ}$ (Fol. 129.) Traité en quatre sections, dans lequel un évêque de Kaskar (كسكى) démontre l'orthodoxie de la croyance jacobite et indique les causes du schisme.

Papier. 156 feuillets. Hauteur, 26 centimètres; largeur, 17 centimètres et demi. 15 lignes par page. Mts. du $x v^{*}$ siècle. - (Supplément 95 , Saint-Germain 139 .)

\section{0.}

$1^{\circ}$. Histoire des philosophes », ourage appelé aussi الههوجل r. Le Bon guide». Le premier feuillet manque. On y trouve d'abord l'histoire apocryphe d'Aristote et d'Alexandre.

$3^{\circ}$ (Fol. 38.) Maxinés d'Athanase (أتناسيوس).

$3^{\circ}$ (Fol. $38 v^{\circ}$.) Histoire de Loqmàn le sage.

$4^{\circ}$ (Fol. $49 v^{\circ}$.) Testament de Loqunàn, adressé à son fils.

$5^{\circ}$ (Fol. $52 v^{\circ}$.) Testaments de Salomon, fils de David, et de Jésus, fils de Sirach.

$6^{\circ}$ (Fol. $53 \mathrm{v}^{\circ}$.) Les Paroles de مهادرخشيش

$7^{\circ}$ (Fol. $56 v^{\circ}$.) Les Maximes de Grégoire et de Galien le médecin.

$8^{\circ}$ (Fol. 61.) Histoire de Sceundus. Pourquoi il garda le silence jusqu’à sa mort. Ses conférences avec l'empereur Hadrien et ses réponses aux questions qu'on lui adressa.

$9^{\circ}$ YFol. 108.$)$ Testament de Jàrith Ibn Káab.

Les feuillets 20 ì 34 sont intervertis; il faut les lire dans cet ordre : $30,22,21,24$ et 23 .

Papier. 116 feuillets. Hauteur, 21 centimètres; largeur, 15 centimètres. 15 lignes par page. Ms. du xvı' siècle. - (Ancien fonds 943.)

\section{1 .}

$1^{-}$Lettre écrite par S. Athanase et descendue du ciel, à Rome, l'an 1438. Cette épître recommande l'observation du dinianche.

$2^{\circ}$ (Fol. 16.) Maximes de sagesse.

$3^{\circ}$ (Fol. 19.) Prières à la sainte Vierge, aux archanges, etc.

$4^{\circ}$ (Fol. 8ュ.) Office de la sainte Vierge. $5^{\circ}$ (Fol. 122.) Cantique de la sainte Vierge.

$6^{\circ}$ (Fol. 124.) Abrégé de la prière d'Athanase l'apostolique (الرسورى).

Papier. 138 feuillets. Hauteur, 16 centimètres; targeur, 10 centimètres et demi. 9 à 11 lignes par page. Is. du xv" siècle. Chaque pièce est d'une main différente. - (Ancien fonds 77 . $^{\circ}$

\section{2.}

1. Description de Jérusalem, de l'église de la Résurrection, de Bethléem, de Nazareth et des autres lieux saints, par un chrétien de Syrie.

$2^{\circ}$ (Fol. 19.) Note sur l'arrivée du sultan Amurat] IV à dlep, en l'an du monde $7140(1632$ de' J. C. $)$, sur son expédition contre Baghdâd, sur la prise de celte ville et l'avènement du sultan Ibrahim en 1640 de J. C.

$3^{\circ}$ (Fol. $19 r^{\circ}$.) Poème dans lequel le métropolitain 'Îsà (عيسى), disciple dı patriarche Kyr Joachim, décrit les églises, couvents et autres monuments qu'il avait vus pendant un voyage en Russie, en Valachie el en d'autres pays.

$4^{\circ}$ (Fol. 22.) Description du couvent et des églises du mont Sinaï, avec les itinéraires partant du Caire, de Gaza et de Jérusalem.

$5^{\circ}$ (Fol. $33 v^{\circ}$.) Notes sur un prétendu ins. en parchemin renfermant l'histoire du monde depuis la création, et Ia description de tous les animaux el de toutes les plantes. Suivent quelques notes sur la longueur du jour, pendant l'été, en Bourgogne, en Flandres et en Angleterre.

$6^{\circ}$ (Fol. $34 \vee^{\circ}$.) Description fabuleuse de la ville de lome, empruntée en grande partie aux écrivains musulmans.

$7^{\circ}$ (Fol. $38 \mathrm{v}^{\circ}$.) Description de Constantinople, de Rome et d'Alexandrie.

$8^{\circ}$ (Fol. $42 \vee^{\circ}$.) Histoire et description de la ville d'Alltioche, depuis sa fondation.

$9^{\circ}$ (Fol. 53.) Histoire et description du temple de Salomon.

$10^{\circ}\left(\right.$ Fol. $\left.54 \mathrm{v}^{\circ}.\right)$ llistoire d'Alexandre Dsoù '1-Qarnaīn.

$11^{\circ}$ (Fol. 59.) Sur les trente merveilles dı monde; sur la citadelle d'Alep; sur la grande mosquée de cette ville, et sur quelques événements qui s'y sont passés.

$12^{\circ}$ (Fol. $7^{3}$.) Testament de Loqumân adressé à son fils. 
$13^{\circ}$ (Fol. 74.) Testament d'al-Hàrith tbn Kấab (كاعب) adressé à son fils.

Papier. 75 fenillets. Hauteur, 21 centimetres; largeur, 15 centimètres et demi. 15 lignes par page. Ms. du xrin' siècte - (Supplément 949.)

\section{3.}

Relation d'un pèlerinage fait au couvent de SainteCatherine, au mont Sinai, l'an 1753 de J. C., par le schaïkh Khalì Sahbâgh (صباغ) al-Sehâmi. Il y a une bonne description du couvent et des églises du mont Sinai, aree les dimensions de ces édifices. L'auteur dit aussi qnelques mots de la bibliothèque du couvent. A la fin de la relation vient une litanie (bulb) que l'on doit réciter après la conmunion.

Papier. 14 feuillets. Itanteur, \& 1 centimètres et demi ; targeur, 14 centimètres et demi. Environ so lignes par page. - (Supplément 948.)

\section{4.}

Guide des embarrassés, leur enseignant à trouver le jour de la fête des chrétiens\%. Ce traité se compose de quelques tableanx indiquant l'époque de la Påque chez les Coptes et les juifs, pour toute la période qui s'étend depuis . l'an 1312 des martyrs ( 1596 de J. C.) jusqu'en 143 । de cetle ère (1715 de J. C.), arec les jours correspondants de l'année arabe. Ces tables comparatives sont prérédées d'une introduction, dans laquelle l'auteur musulman, Khidhr (خضر) ben 'Abd al-Qàdir al-Borlosì al-

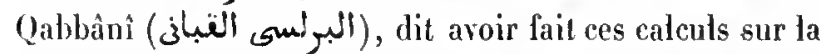
demande de quelques jacobites qui ne se trouvaient pas d'accord avec les autres chrétiens sur la fixation de la fête de pàques.

Papier. 6 feuillets. Hauteur, 31 centimètres; largeur, s o centimètres. Ms. de la fin du xri siecle, probablement autograplie. - (Ancien fonds 91, Colbert 1161.)

\section{5.}

Ce volume renferme deux opuscules, dont le premier, composé à Damas par le R. P. Britius (برسيوس), capucin français, traite de la nécessité de remplacer le vieux style par le style grégorien dans le calcul du carème, de la Pàque et des autres fêtes mobiles. Le second opuscule est du même auteur; il traite de l'utilité de l'oraison mentale.

Papier. 42 feuillets. Hauteur, 21 centimètres; largeur, 15 centimètres. 19 lignes par page. Ms. écrit l'an 1055 de l'hégire (1645 de J. C. ). - (Ancien fonds 110.$)$

\section{6.}

Diplòmè par lequel Gabriel, quatre-vingt-quinziène patriarche jacobite d'Alexandrie, constate que, le $13 \mathrm{du}$ mois d'abîb 1266 de l'ère des martyrs ( 1550 de J. C.), il avait conféré le diaconat à Jean et à Georges, fils de Gabriel, inteudant du pajais (القلاية, littéralement : cellule) palriarcal.

Rouleau en papier. Écriture à l'encre noire et à l'encre rouge. (Ancien fonds $9^{4}$.)

\section{7.}

Rouleau, long d'environ douze mètres, renfermant loriginal d'un acte par lequel Gabriel, quatre-vingt: quinzième patriarche d'Alexandrie, confie à Jean, fils de Georges, surnommé Ibn al-Sinàni (المنسان), l'administration de l'église de Saint.Mer'curius (موقوريوس), située au

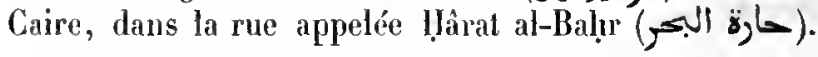

Rouleau en papier. Écriture en caractère neskhi, en 'noir, rouge et blen. Au commencement plusieurs vignettes ornées et dorées. Ms. daté de l'an 1276 des martyrs (1559 de J. C.). - (Anrien fonds 39.)

\section{8.}

Rouleau, long de plus de vingt-cinq mètres, large de trente et un centimetres, renfermant un acte par lequel Anbà Gabriel, quatre-vingt-quinzième patriarche d'Alexandrie, nomme une commission de trois diacres pour l'administration de son Église. On voit en tête de la pièce, sur une longueur de plus de quatre mètres, une série de vignetles de diverses formes en or et en couleur. Les plus grandes contienuent des inscriptions.

Rouleau en papier. Écriture du xrı siècle. - (Supplément 2344.)

\section{9.}

Rouleau, long. d'euviron douze mètres et demi (les 
lignes ont une longueur de vingt centimètres), renfermant des lettres de provision, datées de l'an 1354 de l'ère des martyrs (1638 de J. C.), accordées par Matthieu III, patriarche d'Alexandrie, au mocallim Salib, fils d'Aboû '1-Faradj, l'autorisant ì exercer les fonctions d'intendant ou d'économe dans le monastère de NotreDame d"Adoûya (آلعهلويس), et aussi dans le monastère

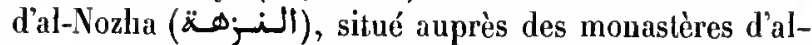
Tin (الـطبيسن) et al-Atfihiya, aux environs du Caire. Un aulre document du même genre, du même âge et émanant de la mème source, se trouve dans la Bibliothèque Bodléienne. Voyez, pour la description détaillée, le catalogue de Nicoll, t. II, p. $47_{5} 5$ et suivantes.

Rouleau en papier. Écriture neskhi à t'encre noire et à l'encre rouge. Au commencement plusieurs vignettes. - (Ancien fonds 38.)

\section{0.}

Lettres de provisions du supérieur du couvent des Sy. riens, daus la vallée de Natron, données par le synode patriarcal d'Égypte, en faveur d'Aboû 'l-Faradj al-Barmawi, l'an 1352 des martyrs (1636 de J. C.). En tête se trouve la formule de la Trinité en copte.

Roulean en papier. - (Supplément 90 bis.)

\section{1.}

Lettre d'Adyâm Sagad, roi d'Abyssinie, au pape Clément Xl.

Rouleau. - (Supplément 9413.)

\section{2.}

Recueil de plusieurs pièces de vers sur l'histoire et les doctrines de la religion clrétienne, depuis la Conception jusqu'à l'an 1700 de J. C. L'auteur, Gabriel Ibn Farhât, évêque maronite, en avait composé la première édition en 1697 .

$7^{3}$ feuillets. Ilauleur, 21 centimètres; largeur, 16 centimètres. 11 lignes par page. Ms. du xvit siècle. - (Ancien fonds $1482 \mathrm{~A}$.)

\section{3.}

Le "Divan » de Djarmânôs Ibn Farhât, évêque d'Alep, avec le commentaire du prêtre maronite Arsène al-Fâklıourì.

Papier. 505 feuillets. Hauteur, 21 centimètres et demi; largenr, 16 centimètres. 21 à 23 ligues par page. Ms. daté de I'an ${ }_{1} 837$ de J. C. - (Supplément 2177 .)

\section{B. - OUVRages musulmans.}

I.

\section{CORAN.}

\section{4.}

Ce volume et les cinquante-sept qui suivent renferment des feuillets de parchemin, de diverses dimensions, au nombre d'environ quatre mille luuit cents, provenant de deux cent vingt-sept exemplaires du Coran. Asselin de Cherville, agent du consulat de France en Égypte, avait recueilli ces fragments au Caire, et la Bibliothèque en a fait l'acquisition en 1830. Les feuillels ont été classés par M. Anari.

Fragments du Coran.

Très-grosse écriture carrée, d’ùn style raide, tel que devaient l'offrir les premiers essais d'écriture coufique; douze lignes par page; sans points-royelles; quelques rares points diacritiques, ajoutés après coup. Les versets sont séparés par un groupe de six ou sept traits parallèles de diverses couleurs; une rosace grossièrement peinte sert à iudiquer les groupes de cinq versets; de grands dẹssins d'une forme carrée marquent les groupes de dix versets; de larges bandes assez grossièrement exécutées servent à séparer les sourates. (Ms. du commencement

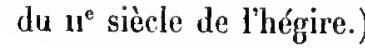

Contenu: sourates 111, versets 100 à 108,116 à 126 , 133 à 140,175 à $184 ; 1 v, 3$ à 10,12 à 16,28 à 33,40 à 46,91 à 94,121 à $127 ; v, 1$ à 26,45 à $49 ; \times x \times 1 v$, 11 et suiv.; Xxxv, 1 à $39 ; L v, 1$ à 27 ; Lxvıı, 51 et suiv.; LXIX; LXX; LXX1, 1 à 20,40 et suiv.; LXx11, 1 à $16 ;$ LXXv; Lxxvı, 1 à 22 ; Lxxvıl, 11 à 41 ; Lxxx, 10 et suiv.; LXxxı. 1 et 2 ; xcv, 5 et suiv.; xevı, 1 à $19 ; \mathrm{c}, 3$ et suiv.; $\mathrm{c}$; cll; cv, 1 et suiv.; cvı; evı, 1 à 7 .

Vélin. 46 feuittets. Hauteur, 55 centimètres et demi; largeur, 63 centimètres. - (Supplément 150 lii.) 


\section{MANUSGRITS ORIENTAUX.}

\section{5 .}

Fragments de onze exemplaires du Coran.

$1^{\circ}$ (Fol. 1 à 12.) Petite écriture coufique, se rapprochant dı neshli; dix-luuit lignes par page; toutes les lettres sont pourvues de traits diacritiques, qui ne se dis. tinguent pas beaucoup de simples points; points-royelles; les versets sont séparés par un groupe de trois points . ; un alif, grossièrement marqué à l'encre rouge, indique les groupes de cinc versets, un rond en noir et en rouge les groupes de dix versets; les sourates se terminent par un lhâtima, écrit à l'encre rouge, contemporain du texte. (Ms. du n $n^{e}$ siècle de l'hégire.)

Contenu: sourates $\mathrm{x} I 1 \mathrm{I}, 8$ et suix.; $\mathrm{xIv} ; \mathrm{xv} ; \mathrm{xvI}, 1$ à 75 ; xxvı, 133 à 199 ; xxvır, 51 et suiv.; xxvır, 1 à 18,71 et suiv.; xxix, 1 à 6 .

$2^{\circ}$ (Fol. 13 ì 19.) Grande et belle écriture coufique; sejt lignes par page; quelques traits diacritiques, dont quelques-uns en jaune et en rouge; points-royelles en rouge, avec variantes en vert; les versets sont séparés par quatre ou six petits traits; le hâ confique doré indique les groupes de cinq versets, une bande circulaire en ol et en couleur, renlemant le nom d'une dizaine en toutes lettres, les groupes de dix rersets. (Ms. du $v^{e}$ siècle de l'hégire.)

Contenu: sourate xn, 24 à 33,38 à 40,46 à 51.

$3^{\circ}$ (1Fol. 20 et 21.) Écriture coufique, moins ancienne que la précédente et moins élégante; onze lignes par page; des points diacritiques ont été ajoutés après coup dans quelques endroits; quelques points-voyelles en ronge; les rersets ne sont pas séparés. (Ms. de la fin du Iv siècle de l'hégire.)

Contemin: sourate $\mathrm{xx}, 67$ à 85 .

$4^{\circ}$ (Fol. 22.) Belle écriture coufique; dix ligues par page; traits diacritiques, ajoutés après coup; pointsvoyelles en rouge avec variantes en vert; les versets ne sont pas séparés; une lettre numérale en or, sur un fond rouge, entourée d'une bande historiée, désigne la fin d'un groupe de dix versets. (Us. du rve siècle de l'hégire.)

Contenu : sourate xxv, 22 à 26 .

$5^{\circ}$ (Fol. 23.) Belle écriture coufique; cinq lignes par page; sans traits diacritiques; points-voyelles en rouge arec variantes en bleu et en vert; chaque verset se termine par un oruentent en forme de pendeloque renferuant le عس en lettres dorées; à la marge on voit le mot ell or sur un fond rouge, entouré d'une bande historiée; cette marque indique la fin dn premier groupe de dix versets. (Ms. de la fin du $\mathbf{w}^{\mathrm{e}}$ siècle de l'hégire.)

Contenu: sourate xcı, 6 à 13 . $6^{\circ}$ (Fol. 24 à 29.) Belle écriture coufique; dix lignes par page; points-royelles; nombreux traits diacritiques, ajoutés après coup; les versets ne sont pas séparés; un $h d$ coufique doré indique les groupes de cinq rersets, et une lettre numérale en or, sur un fond rouge grossièrement encadré, les groupes de dix versets. (Ms. du $1 v^{\bullet}$ siècle de l'hégire.)

Contenu: sourates $\mathrm{L}, 16$ à $26 ; \mathrm{s}, 1 \mathrm{r}, 1$ à 46 .

$7^{\circ}$ (Fol. 30 à 32.) Belle et grosse écriture coufique; sept lignes par page; points-royelles; quelques traits diacritiques, ajoutés après coup; variantes des voyelles en jaune; les hamza sont indiqués par des points verts; les versets ne sont pas séparés; à la fin de chaque groupe de cinq versets se trouve un ornement en forme de pendeloque historiée, renfermant le mot um écrit en lettres d'or sur un fond blanc. (Is. du rve siècle de l'hégire.)

Contemu: sourates II, 192 à $194 ; 1 x, 70 ; x x x ı 1,49$ et 50 .

$8^{\circ}$ (Fol. 33 à 43.) Grosse écriture coufique, à traits fort raccoureis; le fâ et le qâf ont la forme d'un cercle plein, rattaché à la ligne par une courte tige; l'ain ressemble à un fi dont on aurait détaché Ja moitié supérieure; les traits diacritiques, ajoutés après coup, ressemblent à des points un peu allongés; points-voyelles en rouge; les versets sont séparés par un groupe de cinq ou six traits; lo ha doré marque les groupes de cinq versets; les noms des dizaines sont écrits en toules lettres, or sur rouge, arec bandeau historié. (Ms. de la fin du Iv siècle de l'hégire.)

Contenu: sourates xvi, 53 à $106 ; \mathbf{x x x u v , ~} 3$ I à $38 ; \mathrm{xxxv}$, 2 à 15.

$9^{\circ}$ (Fol. 44.) Belle et grosse écriture coufique; cinq lignes par page; sans traits diacritiques; voyelles en rouge, arec variantes en bleu; un point vert indique le hamza; les versets ne sont pas séparés. (Ms. de la fin du $\mathbf{1 I}^{\circ}$ siècle de l'hégire.)

Contenu: sourate viı, 49 à 51 .

$10^{\circ}$ (Fol. 45 à 59,59 bis, 59 ter. à 101.) Belle et grosse écriture coufique; sept lignes par page; quelques signes diacritiques, ajoutés après coup; points-voyelles en rouge, avec variantes en jaune et els rert; le hamza est indiqué quelquefois par un point vert; les versets sont séparés par de petites l'osaces dorées; plusieurs grandes rosaces, dessinées, les unes en marge, les autres dans le texte, indiquent les groupes de dix et de cinq versets; ces derniers se terminent par le hâ doré. Deux titres de sourates, écrits en lettres d'or et contemporains du

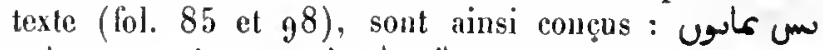

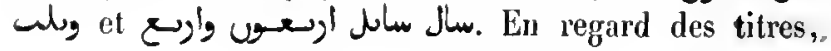


sur la marge, se trouvent de grands fleurons, bien exécutés en or et en couleurs. (Ms. du $1 v^{\circ}$ siècle.)

Contenu: sourates 11,63 à $81 ; \mathbf{w}, 28$ à 29,36 à 39 , $87,9^{5}$ à $97 ; \mathrm{xvI}, 15$ à 26,38 et 39,93 et $94 ; \mathrm{xx}, 5$ à 17,82 à 86,106 à 109,113 à 119,125 à 128 ; xíniı, 54 à 81 ; xxIv, 28 à 43 ; xxxv, 44 et suir.; xxxvı, 1 à 5 ; xxxvı, 8 à 13 ; xııx, 1 à 7,12 à $15 ; \mathrm{L}, 21$ à 31 ; Lxux, 21 et suir.; Lxx, 1 à $24 ; \mathrm{Lxxv}, 23$ à 28 .

$11^{\circ}$ (Fol. 102 à 145.) Belle écriture coufique; sept lignes par page; quelques points-royelles et de rares traits diacritiques; les versets sont séparés par trois petits traits ||| ; le hâ coufique marque les groupes de cinq versets, un médaillon portant le nom de la dizaine, les groupes de dix versets. He ms. dont proviennent ces feuillets était divisé en sections (جز se termine au fol. 105. Le verso de ce fenillel est occupé par un dessin assez bien exécuté, en or et en couleur, et représentant un parallélogramme en blauc, ayant pour encadrement un pasé en mosaïque, entouré de baguettes historićes et coupé, au milieu de chaque côté, par une arabesque circulaire; à la marge se trouve un grand fleuron en or. Ce dessin, qui rappelle l'art byzantin de la fin du $\times 1^{\oplus}$ siècle, représente la saddjada ou tapis de prière, et la qibla. (Mls. du Iv siècle de l'hégire.)

Contenu: sourates 11, 144 à $146 ; x+1,33$ à 38,51 , 52,86 à $93 ;$ xvr, 119 à $123 ; x$ vin, 21 à 59,83 à 91 ; xvm, 18 et 19,40 à $55 ; x x m, 31$ à 34,36 à 44,46 à $65 ; x \times 111,14$ à 37 .

Vélin. 147 feuillets. Hauteur, 25 centimètres; Jargeur, 32 centimètres. - (Supplément 150 C c..)

\section{6.}

Fragments de trois exemplaires du Coran.

$1^{\circ}$ (Fol. 1 à 6.) Écriture du Hidjâz; 11 et 12 lignes par page; quelques traits diacritiques, contemporains du texte; sans points-voyelles; le qâf est marqué d'un seul trait au-dessous de la ligne; le $y d$ final est très allongé vers la droite; les versets sont séparés par des groupes de trois ou de quatre traits. La sourate xin se termine par les mots

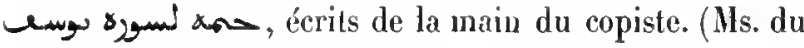
$11^{\mathrm{e}}$ siècle de l'hégire.)

Conteru : sourates $\mathbf{x} 1,96$ et suiv.; xıv, 19 et suiv.; $x$, 1 à 99 .

$2^{\circ}$ (Fol. 7 et 8.) Écriture du Ḷidjàz; 11 lignes par page; quelques traits diacritiques très-fins, contemporains du texte; sans points-voyelles; les versets sont séparés par des groupes de plusieurs traits; un rond rouge, un carré rouge et un alif de la même couleur indiquent

Mav. orievtalx. - II. les groupes de cinq et de dix versets. (Ms. du r $^{\mathrm{e}}$ siècle de l'hégire.)

Contenu: sourate viı, 38 à 55 .

$3^{\circ}$ (Fol. 9 à 16 .) Écriture coufique, sans traits diacritiques, mais avec des points-royelles; quinze lignes par page; les versets sont séparés par trois traits"l; chaque groupe de dix versets est suivi d'une étoile ou rosace bistoriée; des ligues laissées en blane pour receroir les titres des sourates ont été remplies plus tard; ces titres sont à l'encre rouge et d'une écriture qui peut s'appeler coufique brisée, et qui représente la transition du coufique au neskhi. (Ms. dı II $^{\circ}$ siècle de l'hégire.)

Contenu : sourates LIX, 16 et suiv.; Lx; LX1; LXII; LXIII; LXIv; LXv, 1 à 6 .

Vélin. 16 feuillets. Hauteur, 19 centimètres et demi; largeur, 28 centimètres. - (Supplément 150 E.)

\section{7}

Fragments d'un exemplaire du Coran.

Écriture coulique; dix-lruit lignes par page; sans traits diacritiques; quelques points-voyelles; les rersets sont séparés par trois traits obliques superposés; chaque groupe de dix iersets se termine par un petit carré en jaune, arec des traces de dorure; les sourates (fol. 6 et 12) sont séparées par une torsade dorée, occupant une ligne entière; on $y$ a inserit, après coup, les titres en petits caractères rouges; au folio 1, ligne 6, le mot

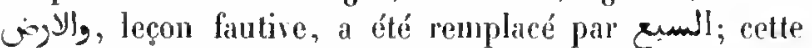
correction est écrite en neskhi ancien. (Hs. du $1^{\circ}$ siècle de l'hégire.)

Contenu: sourates xxu11, 82 et suiv.; xxiv, 1 à 56 ; xxxiv, 44 et suiv.; xxxv, 1 à 22 ; xxxvin, 22 à $48 ; \mathrm{xL}, 36$ à 72 ; XLI, 23 et suiv.; XLI1, 1 à 4 ; XL111, 35 à 68 ; XLVI, 10 à 25 .

Vélin. 14 feuillets. Hauteur, 28 centimètres el demi; largeur, 30 centimètres. - (Supplément $150 \mathrm{~K}$.)

\section{8.}

Fragments de cinq exemplaires du Coran.

$1^{\circ}$ (Fol. 1 à 70.$)$ Écriture du Hidjàz, se rapprochant du neskhi; le nombre des lignes par page varie de vingt et une à vingt-cing; sans points-royelles; quelques rares points diacritiques qui semblent être contemporains du texte; les alif de prolongation sont omis (le mot قال écrit ainsi : $(\omega)$; une main plus moderne a indiqué les groupes 
de cinq versets par une lettre de l'alphabet arabe, entourée de points noirs; une autre lettre, ayant la valeur d'une dizaine, et entonrée d'un cercle de points noirs, marque les grompes de dix rersets; une ligue laissée en blanc servait à marquer la fin de chaque sourate; plus tard, on y avait inscrit le titre de la sourate suivante à l'encre rouge (fol. $491^{\circ}, 51,62$ ), mais ces titres se sont effacés presque parlout. Aux lolios 1 à 28 , la fin de chaque verset est indiquée par ce signe 二二二; les folios $281^{\circ}$ à 30 sont d'une autre main, et la séparation des versets est indiquée par le signe 三三; au verso du folio 30 , le premier copiste a repris son travail, puis, au verso du folio 32 , il a cédé le calan à soll conlirère qui a continué l'ouvrage -jusqu'à la fin du folio 38. Les folios $38 \mathrm{v}^{\circ}$ à 56 sont de l'écriture du premier copiste; les feuillets suivants jusqu'au dernier du fragment sont de la main d'un troisième scribe qui s'est servi du siģne :: pour séparer les versets. L'écriture de lous ces feuillets est celle du llidjâz et se reconnait facilement à l'aspect des traits montants qui ont tons une inclinaison très-prononcée vers la droite. "Le plus antien caractère arabe, dit l'auteur du Filhrist, est celui de la Mecque; ensuite vient celui de Médine, puis celui de Baṣra, puis celui de Koûfa. Dans le caractère de la Mecque et dans celui de Médine, les alif sont lorteInent inclinés vers le côté droit de la main, et la figure des lettres est un peu couchée. "Une ligne en blanc à la fin de chaque sourate prouve qu'on avait alors l'habitude d'y inscrire les titres des chapitres, usage qui s'établit vers la fin du $\mathbf{u}^{\mathrm{e}}$ siècle de l'hégire. (Ms. du $\mathrm{nI}^{\mathrm{e}}$ siècle de l'hégire.)

Contenu : sourates $11,27^{6}$ et suiv.; III, 1 à 38 , puis 78 et suiv.; iv; v, 1 à $37 ;$ v, 20 et suiv.; vı; vıı, 1 à $25 ; \mathrm{Ix}, 67$ et suiv.; $\mathrm{x}, 1$ à $79 ; \mathrm{x} 11,85$ el suiv.; xı1 ;

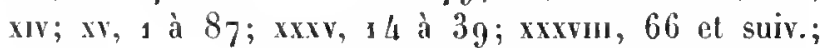

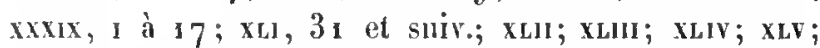
XLVI, 1 à $7 ; \mathrm{LX}, 7$ el suiv.; $\mathbf{L x I} ; \mathbf{L X I I}$; LXIII, 1 à $9 ; \mathrm{LxV}$, 2 et suiv.; Lxvi; Lxvı, 1 à 27 ; Lxıx, 2 et suiv.; Lxx; LXX1; LXXII, 1 et 2.

$2^{\circ}$ (Fol. 71 à 86.) Écriture du Hidjàz, se rapprochant du neskhi; le nombre des lignes par page varie de vingttrois à vingt-cinq; sans points-royelles; quelques traits diacritiques ajoutés par le copiste lui-même; ces traits sont si pen allongés qu'on pourrait les prendre pour des points; des groupes de cinq ou six traits disposés

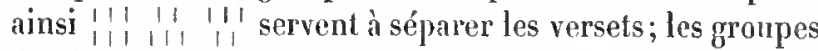
de cinq el de dix versets ne sont pas marqués; des lignes brisées et quelquefois entre-croisées indiquent la fin de chaque sourate; chacune de ces chaînes (سلسف) occupe une ligne en longueur et en largeur; l'emploi de bandes ou cliaìnes pour séparer les sourates précédait l'usage

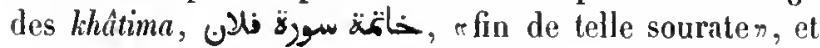

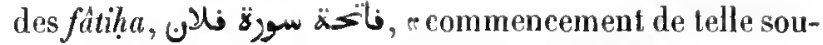
rater. (Ms. de la fin du $11^{\circ}$ siècle de l'hégire.)

Contenu : sourates $\mathrm{x}, \mathbf{3 6}$ et suiv.; xı, I à $112 ; \mathrm{xx}, 99$ à $128, \sqrt{3} \mathbf{s}_{1}$ et suiv.; $\mathbf{x x ı} ; \mathbf{x x ı}$ (lacune de gnelques versets); xxil1, 1 à 27 .

$3^{\circ}$ (Fol. 87 à 89. ) Écriture du Hidjàz, mais moins penchée et plus grosse que l'écriture ordinaire; le nombre des lignes par page varie de vingt-trois à vingt-cinq; sans points-voyelles; assez nombreux traits diacritiques, contemporains du texie; les versets sont séparés par un groupe de cinq traits ou gros points disposés en forme de cercle; les groupes de cinq et de dix rersets ne sont pas indiqués; une ligne laissée en blanc pour recevoir In titre de sourate a été remplie après coup par ces

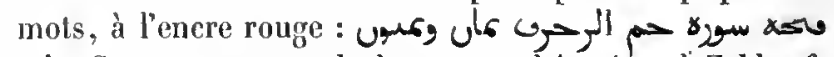
ul "Commencement de la sourate ḥâ-mim al-Zakhraf, 88 versets». (Ms. de la fin du $11^{\circ}$ siècle de l'hégire.)

Contenu : sourates xulu, 4 et suiv.; xul1, 1 à 16 .

$4^{\circ}$ (Fol. go et 95.) Écriture du même genre que la précédente, mais encore plus grosse; vingt-quatre et vingt-cinq lignes jar page; le yâ final se prolonge beaucoup vers la droite; sans points-royelles; nombrenx points diacriliques contemporains du texte; les versets sont séparés par un cercle de points; des ronds, composés d'un cercle rouge entouré de points noirs et renfermant des points noirs et rouges disposés aussi en cercle, indiquent les groupes de dix versets et semblent etre une addition postérieure. Ce l'ragment est probablement un peu plus moderne que le précédent.

Contenu : sourates v, 10 à 70 ; vi, 39 à 113 .

$5^{\circ}$ (Fol. 96 et 97.) Écriture du Hidjâz; vingt lignes par page; sans points-royelles; nombreux traits diacritiques, qui ne sont pas tous contemporains du texte; les versets sont súparés par un groupe de six traits disposés ainsi 三三; un cercle noir, très-grossièrement tracé par une main plus récente, indique la fin du premier groupe de dix versets d'une sourate; une bande assez bien historiée en dicerses couleurs remplit une ligne laissée en blanc entre deux sourates. (Ms. du $\|^{\circ}$ siècle de l'hégire.)

Contenu : sourates $\mathrm{xxv}$, dernier verset; $\mathbf{x x v 1 , 1}$ à 51 ; xxvill, 9 à 32 .

Vélin. 97 fevitlets. Hauteur; 34 centimètres; largeur, 26 centimètres. - (Supplément $150 \mathrm{~A}$.)

\section{9 .}

Fragments de six exemplaires du Coran.

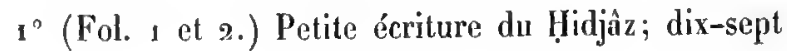


ligues par page; sans points diacritiques, ni pointsvoyelles; les versets sont séparés par des points à peine visibles; les groupes de dix versets sont indiqués par un petit cercle rouge; les titres des sourates, écrits à l'encre rouge, et contemporains du texte, commencent

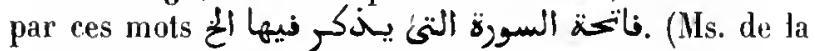
fin du ${ }^{\mathrm{e}}{ }^{\mathrm{e}}$ siècle de l'hégire.)

Contenu: sourates Lxvı, 8 et suiv.; Lxvıl, 1 à $19 ;$ Lxix, 31 et suiv.; $\mathbf{L x x}, 1$ à 39 .

$2^{\circ}$ (Fol. 3 à 14.) Petite écriture coufique; dix-sept lignes par page; sans traits diacritiques; quelques pointsvoyelles; aucune marque pour distinguer les versets; un cercle tracé à l'encre ronge marque les groupes de dix versets; l'écriture de quelques feuillets a été repassée à l'encre noire. Les titres des sonrates sont écrits à l'encre rouge et contemporains du texte. (Ms. de la fin du $u^{e}$ siecle de l'hégire.)

Contenu : sourates 11,219 à 247,272 et suiv.; 111, 1 à 24 ; Lıx, 8 et suiv.; LX; LXı; LXı, 1 à 11 .

$3^{\circ}$ (Fol. 15 à 20.) Petite écriture counfique; seize lignes par page; sans points diacritiques; points-royelles. Les titres des sourates, écrits à l'encre d'or', sont contemporains du texle. Les versets ne sont pas séparés. Les groupes de cinq versets sont marqués par un hó doré, les groupes de dix rersets par une rosace historiée. (Ms. du commencement du $11^{\mathrm{e}}$ siècle de l'hégire.)

Contenu: sourates Xliv, 29 et suiv.; XLv; XLvı, 1 à 25 ; xuvil, 18 à 33 .

$4^{\circ}$ (Fol. 21 à 26 .) Petite écriture coufique; dix-sept lignes par page; quelques points diacritiques ajoutés après coup; points-royelles; un point jaune désigne le hamza; des rosaces historićes indiquent les groupes de dix versets. Au folio $25 \mathrm{v}^{\circ}$ on lit ce titre de sourate, écrit en or et contemporain du texte : هود مانx وعسرون Hoûd,

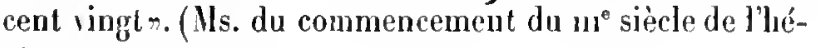
gire.)

Contenu : sourates $\mathrm{x}, 35$ et suir.; $\mathbf{x 1}, 1$ à 20.

$5^{\circ}$ (Fol. 27 à 36.) Petite et grosse écriture coufique; l'alif isolé est représenté par un simple trait vertical; quinze lignes par page; nombreux traits diacritiques contemporains du texte; points-voyelles; les versets ne sont pas séparés; les groupes de dix versets sont indiqués par des ronds en noir et. en rouge. (Ms. du $11^{\mathrm{e}}$ siècle de l'hégire.)

Contenu: sourate ıv, 28 à 122 .

$6^{\circ}$ (Fol. 37 à 39.) Petite et grosse écriture confique; dix lignes par page; quelques traits diacritiques, contemporains du texte; points-voyelles, arec variantes à l'encre verte; les versets sont séparés par trois points en or, formant triangle; les groupes de cinq versets sont indiqués par un ha doré, et les groupes de dix versets par un petit cercle en or et en couleur, renfermant le nom de la dizaine écrit en toutes lettres avec de l'encre d'or. (Ms. du $\|^{\mathrm{e}}$ siècle de l'hégire.)

Contenu : sourate xxw, 6 à 23 .

Vélin. 39 feuillets. Hauteur, 14 centimètres et demi ; largeur, 19 centimètres et demi. -- (Supplément $150 \mathrm{MI}$.)

\section{0 .}

Fragments de six exemplaires du Coran.

$1^{\circ}$ (Fol. 1 à 2.) Grosse écriture du Ḩidjâz, se rapprochant du neskhi; ringt-cing et vingt-six lignes par page; nombreux traits diacritiques contemporains du texte; sans points-voyelles; les versets sont séparés par un groupe de six traits disposés ainsi I//; ; les groupes de cinq et de dix rersets sonl indiqués par des ronds grossièrement tracés en noir et ell rouge; une sourate se termine (fol. $1 \mathrm{v}^{0}, 1.20$ ) par ces mots, écrits de la main

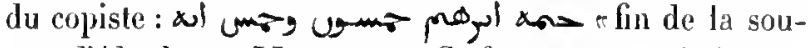
rate d'Abraham, 55 versets $\%$. Ce fragnent parait ètre de la fin du $\mathbf{1}^{\circ}$ siècle de l'hégire.

Contenu : sourates xır, 28 et suiv.; xr, 1 à 79 .

$2^{\circ}$ (Fol. 3 à 1 o.) Grosse écriture du Hidjàz, se rapproclınt de l'écriture coufique; quinzo et seize lignes par page; points-voyelles et nombreux traits diacritiques contemporains du texte; les rersets sont séparés par. le signe $\therefore$; le qâf est marqué d'un trait au-dessous de la ligne; les groupes de cinq rersets sont parfois indiqués, d'une main plus moderne, par un gros alif confique évidé; un cercle noir entouré d'un trait rouge marque les groupes de dix versets; ce signe parait être contemporain du texte. Une grosse étoile en rouge et en noir (fol. $4 \mathrm{v}^{\circ}$, dernière ligne), tracée par le copiste lui-même, est placée à la fin d'une première centaine de versets. Ce fragment parait être du $11^{e}$ siècle de l'hégire.

Contenu : sourates ıv, 83 à $150 ; x v u, 70$ à 88 ; xvıu, 9 à 20.

$3^{\circ}$ (Fol. 11 à 1 9.) Écriture du Hidjàz, se rapprochant de l'écriture coufique; vingt-cinq lignes par page; pointsvoyelles; nombreux traits diacritiques contemporains du texte; une ligne horizontale rouge indique le wasla; le quff est marqué d'un trait au-dessous de la ligne; le signe $\equiv$ indique la fin d'un verset; une lettre coufique, évidée et dorée, ayant une valeur numérale, sert à marquer les gronpes de dix versets; une bande à dessins assez bien exécutés en or et en couleur (fol. 12 et fol. 18 ) sépare les sourates. Les titres des sourates ont été ajoutés a]jrès 


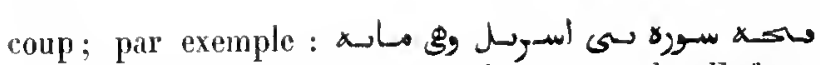
وعسى te Commencement de la sourate des Enfants d'lsräl, elle se compose de cent vingt versetsm. ( $\mathrm{H}_{\mathrm{s}}$. du

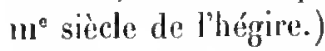

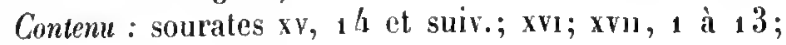
38 à 61 .

$4^{\circ}$ (Fol. 20 à 3o.) Écriture de transition entre celle du Hidjâz et celle de l'Jràq; seize et dix-sept lignes par page; quelques points-voyelles; nombreux traits diacritiques contemporains du texte; le qif est marqué d'un point au-dessous de la ligne; le signe /// sert à séparer les versets; quelques groupes de cinq et de dix versets sont indiqués par des carrés en noir et par des ronds. Au fol. $30 \mathrm{v}^{\circ}$ on lil un titre de sourate écrit à l'encre rouge, d'une main plus

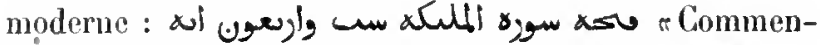
rement de la sourite de's Anges, 46 versets». (Ms. du $\mathrm{ur}^{\mathrm{e}}$ siccle de l'hégire.)

Contenu : sourates 1 , 89 à 100,145 à $159 ; x, 14$ à ı 00 ; xxxı11, 37 à 49 ; xxxiv, 42 el suiv.; xxxv, 1 à 3 .

$5^{\circ}$ (Fol. 3 I à 49.) Écriture de transition analogue à l'écriture du fragment précédent; dix-huit lignes par page; points-royelles assez nombreux; le fatha est parfois représenté par un alif à l'encre rouge, le dhamma par un wâw; beaucoup de traits diacritiques ont été ajontés après coup; le qâf est marqué de denx traits au-dessus de la ligne, et le fa d'un trait au-dessous, le sin de trois traits placés au-dessous et lirigés obliquement vers la gauche; un groupe de quatre ou cinq traits sépare les rersets; quelques groupes de cinq et de dix rersets sont indiqués par des losanges ou par des ronds tracés à l'encre noire; un titre de sourate à l'encre ronge (fol. 38), ajouté apris coup, commence par les mots - Sourate rle la Table». (Ms. dn m $^{\mathrm{e}}$ siècle de l'hégire.)

Contenu: sourates Iv, 80 à 109,130 à $158 ; \mathrm{v}, 1$ à 6 ; Ix, 54 à $120 ; x 11,87$ à 110 ; xxxul, 33 à $51 ; x x x ı v, 18$ ลे 30 .

$6^{\circ}$ (Fol. 50 ì 69.) Écriture du Hijijàz se rapprochant beanconp du neskli; le nomlse des lignes par page varie de dix-neuf à vingt-deux; le trait inlérieur dn yâ funal est très-allongé vers la droite, quelquelois jusqu'à l'extrémitć de la ligne; les points-voyelles manquent tont à fait; les traits diacriliques sont rares; un groupe de traits disposés ausi 三E sert à séparer les versets; les lignes destinées à receroir les titres des sourates sont restées en blanc. Ce fragment est probablement de la fiu du $u^{e}$ siècle de l'hégrire.

Contenu : sourates III, 182 et suiv.; Iv, 1 à 52,97 à 170 ; VII, 124 et suiv.; virt; $1 \mathrm{x} ; \mathrm{x}, 1$ à 32 .

Vélin. 69 fenillets. Hauteur, 38 centimètres; largeur, 31 centimètres. - (Supplément 150 B.)

\section{1 .}

Fragments d'un exemplaire du Coran.

Belle écriture du ḷidjałz; dix-neuf lignes par page; sans points-voyelles; quelques traits diacritiqnes contemporains du texte; le qâf est marqué d'un trait audessous de la ligne; les versets sont séparés par un groupe de cinq points disposés en triangle $\therefore$; les groupes de dix versets sont indiqués par des lettres numérales inscrites dans des ronds; les lignes qui avaient été laissées en blanc pour les titres des sourates n'ont pas ćté remplies; une main plus récente a inséré à la fin de chaque sourate l'ancienne formule, par exemple : حمه سورك بيى اسرىل. Des lettres numérales accompagnent ces inscriplions et indiquent le nombre de versets dont se composent les sourates. Sur quelques fenillets on trouve inscrits en anciens caractères neskhi les mots - Consacré à Dieu, qu'il soit exalté et glorifiér. Ces fragments sont probablement de la fin du $\mathrm{r}^{\circ}$ siècle de l'hégire.

Contenu : sourates 11, 119 à $260 ;$ v11, 162 et suiv.; vilı; $1 \mathrm{x}, 1$ à 34 ; xıv, 1 1 et suiv.; xv; xvı; xvı; xvmr, 1 à $6 ; \mathrm{xxv} ; \mathrm{xxvı}, 1$ à $18 ; \mathrm{xLI11}, 81$ et suiv.; xuıv, 1 ì 47 xur, 8 et suiv.; xlvı, 1 à 7,20 el suiv.; xLvn, 1 à 18 , 38 et suir.; xLVII ; XLIX ; L ; LI ; LII ; LIII LVII; LVIII; LIX, 1 à 11 .

Vélin. 56 feuiltels. Hauteur, 43 centimètres; largeur, 35 centimètres et demi. - (Supplément 150 C.)

\section{2.}

Fragments d'un exemplaire du Coran.

Belle écriture coufque; vingt et une lignes par page; sans points-royelles; quelques traits diacritiques contemporaius du texte; les versets sont séparés par le signe "/; chaque groupe de dix versets est indiqué par un rond rouge; des lignes laissées en blanc pour les titres des sourates ont été remplies en écriture neskhi du $\mathbf{v l}^{\mathrm{e}}$ ou du vñ siècle de l'hégire. Le mot wy, inscrit sur les marges de quelques feuillets, indique que cet exemplaire $\mathrm{du}$ Coran avait appartenu à une mosquée. Ce fragment parait être de la fin du $u^{\mathbb{e}}$ siècle de l'hégire.

Contenu : sourates III, 59 à $172 ;$ vir, 1 à 156,169 et suiv.; vm, 1 à 7,29 et suiv.; $1 x, 1$ à 26 , 40 à 74 ; xıाı, 4 et suiv.; xıv; xv; xvı, 1 à 38 ; $\mathbf{x x}, 65$ et suiv.; xx, 1 ; xxxı, 24 et suiv.; xxxul ; xxxı ; xxxv, 1 à 12 ; xxxvı, 6 et suiv.; xxxvı; xxxvır; xxxıx, 1 à 8 ; LIv, 24 et suiv.; LV, 1 à 22.

Vélin. 49 feuillets. Hauteur, 46 centimètres; largeur, 37 centimètres. - (Supplément 150 D.) 


\section{3.}

Fragments de quatre exemplaires du Coran.

$1^{\circ}$ (Fol. 1 à 2o.) Écriture du Hidjàz se distinguant par la longueur des traits qui unissent les lettres; quinze lignes par page; traits diacritiques contemporains du texte; sans points-royelles; les rersets sont séparés par un groupe de traits disposés ainsi /ili//; les divisions par groupes de dix versets sont marquées par une rosace dessinée à l'encre noire. Les titres des sourates (fol. $g \mathrm{v}^{0}$ et fol. $17 \mathrm{r}^{\circ}$ ) ajoutés après coup en caractères neskhi, à l'enere jaune, sont à peu près effacés. (Ms. du commencement du $\|^{e}$ siècle de l'hégire.)

Contenu: sourates xu, 13 à 39 , puis 77 et suiv.; xılı; $\mathbf{x u v}, 1$ à 28 .

$2^{\circ}$ (Fol. 21 à 32.) Écriture coufique aux traits plus minces qu'à l'ordinaire; seize lignes par page; pointsvoyelles; trails diacriliques contemporains du texte, réduits à peu près à la dimension de points; la marque distinctive du qấf est placée au-dessous de la lettre; les groupes de dix versets sont indiqués par urr gros point noir entouré d'un cercle de même couleur; les lignes laissées en blanc pour marquer la séparation des sourates (fol. $26 \checkmark^{\circ}$ et fol. 30 ) out été remplies plus tard par

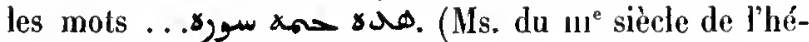
gire.)

Contenu : sourates xxı, 57 à $87 ;$ xxil, 22 à $41 ;$ xxvı, 26 et suiv.; xxvı1 ; xxvı11, 1 à 53 .

$3^{\circ}$ (Fol. 33 à 6o.) Écriture coufique dont les traits montants sont peu allongés; quinze lignes par page; points-voyelles; sans points diacritiques; des bandes dessinées à la plume par un artiste plus ou moins habile, maintenant presque effacées (fol. $38 \mathrm{r}^{\circ}, 44,50$ et 57 ), remplissent les blanes que le copiste avait laissés à la fin de chaque sourate; de petites rosaces exécutées par le mềne artiste indiquent les groupes de dix versets. (Ms. du ul $^{e}$ siècle de l'hégire.)

Contenu : sourates xil, 43 à 68 ; xulı, 5 et suiv.; xıv; $\mathrm{xv}, 1$ à 25,85 el suiv.; $\mathrm{xv}_{1}, 1$ à 10,70 à $80 ; \mathrm{xx}, 132$ et suiv.; xxı, 1 à 13,33 et suiv.; xxıl, 1 à 31 ; xxvı, 81 et suiv.; xxv11, 1 à 60 .

$4^{\circ}$ (Fol. 61 à $7^{8 .}$.) Ecriture coufique semblable à celle du fragment précédent; dix-sept lignes par page; pointsvoyelles; sans points diacritiques; les hamza et les djazm sont indiqués par des points verts; chaque groupe de dix versets se termine par un rond historié peu élégant; sur les lignes qui avaient été laissées en blane pour séparer les sourates on a inscrit plus tard les titres des sou- rates : ... C. Commencement de la sourate... r (Mls. du $\mu^{\mathrm{e}}$ siècle de l'hégire.)

Contenu : sourates $\operatorname{xxxv}, 37$ et suiv.; xxxvı, 1 à 50 ; xxxvıl, 2 à 115 ; xuIII, 31 et suiv.; xLIv; xLv; xLvı; XLVII, 1 à 23 ; LIII, 23 et suiv.; LIV; LV; LVI; LVII, 1 à 16 .

Vélin. 78 feuiltets. Hauteur, 21 centimètres et demi; largeur, 28 centimètres. - (Supplément 150 F.)

\section{4.}

Fragments de douze exemplaires du Coran.

$1^{\circ}$ (Fol. 1 à 12.) Écriture du Hiidjâz; dix-sept liggnes par page; quelques traits diacritiques, contemporains du texte, et des points diacritiques, ajoutés après coup; voyelles marquées par des points rouges en forme de losanges; les versets sont séparés par un groupe de quatre traits ainsi disposés $/ / /$; un cercle rouge sert à indiquer les groupes de cinq versets; une ligne a été laissée en blanc pour séparer deux sourates $\left(\right.$ fol. $\left.6 \mathrm{v}^{\circ}\right)$. (Ms. du $11^{\mathrm{e}}$ siècle de l'hégire.)

Contenu: sourates ıv, 86 à $96 ; \mathrm{v}, 2$ à $22 ;$ xxxiv, 7 et suiv,; xxxy ; xxxvı; xxxvı, 1 à 29 .

$2^{\circ}$ (Fol. 13 à 24.) Éeriture du Ḥidjàz, moins grosse que celle du fragment précédent; seize lignes par page; points-royelles et quelques traits diacritiques; les groupes de dix versets sont indiqués par un grand rond en rouge; les groupes de cinq versets par un alif évidé; les sourates sout séparées par des bandes ou par des torsades, grossièrement exécutées en couleur; une main plus moderne a inscrit à la fin de chaque sourate le titre et le nombre des rersets de la sourate. (Mls. du commencement du III' siècle de l'hégire.)

Contenu, sourates xxxıv, 10 à $42 ; \mathrm{xuI}, 53$ et suiv.; xLII; xLIII; xLIV; $x L v ;$ xLVI, 1 à 3 .

$3^{\circ}$ (Fol. 25 à 49. .) Écriture du Ḥidjâz; vingt el une lignes par page; nombreux traits diacritiques contemporains du texte; les groupes de dix versets sont indiqués par un cercle rouge entouré de points noirs; quatre cereles entourés de points noirs et disposés en carré indiquent le centième rerset d'une sourate; trois traits superposés et placés obliquement marquent la fin de chaque verset; des bandes assez bien dessinées à la plume et coloriées séparent les sourates; une main plus moderne a écrit en caractères coufiques, à la fin de chaque sourate, le titre et le nombre des versets. (Ms. du $11^{\circ}$ siècle.)

Contenu : sourates x1, 101 et suiv.; xII et les sourates suivantes jusqu'à $x$ vIII, 48, à l'exception des versets 9 à 18 de la sourate $x 11$. 
$4^{\circ}$ (Fol. 50 à 62.) Écriture de Baṣra (?); lettres allongées horizontalement; les traits verticaux sont raccourcis de manière à former des losanges dont l'angle supéricur est penché vers la droite; plusieurs lettres sont piriformes, et leurs traits inférjeurs dirjgés vers la gauche; les $f a$ ot les qiff, an milieu d'un mot, sont représentés par des disques circulaires, rattachés par un pédoncule très-court à la ligne luorizontale de l'écriture; le ghain médial ressemble à un ghain coufique dont les deux têtes auraient été relranchées obliquement de droite à gauche. Quinze lignes par page; points-royelles en rouge aver variantes en différentes couleurs; sans points diacritiques; un trait horizontal jaune indique le wassla; les versets ne sont pas séparés; un cercle évidé, contemporain dir lexte, indique les gronpes de cinq versets; un blanc de trois lignes (fol. $561^{\circ}$ ) sépare les sourates xxxvm et xxxrm; à la fin de lat sonrate xxxun, on lit une note خاتمة سوزة اللصس : [ألصافات [lisez fo la sourate alSifat, cent quatre-ringt-deux rersets $\%$.

Cette écriture, malgré son aspect lizarre, est iraiment belle, mais difficile à lire. Elle est évidemment celle d'une grande école de calligraphie, prohablement l'école de Baṣra. (Ms, du $1 u^{\text {e }}$ siècle de l'hégire.)

Conteme : sourates $\mathrm{xxv11}, 24$ à 57 ; xxxir, $17^{1}$ et suiv.; xxxงll, 1 à 25 ; xxxix, 9 à 24 .

$5^{\circ}$ (Jol. 63.) Écriture de Médine (?); la queue de l'alif, an lien de se prolonger vers la droite en devenant graduellement plus mince, comme dans l'écriture coufique, se termine brusquement en pointe tournée à droite; te $f a$ et le $q d f$, an milicu d'un mot, ont la forme d'une poire dont la queue s'attache à la ligne d'écriture; le 'aïn est représenté par une figure semblable, mais tronquée par le haut et légèrement évidée; la queue du mîm final est très-courte et se dirige horizontalement vers la gauche; les dents des lettres et les hastes sont droites, épaisses et carrées; seize lignes par page; sans points-royelles; quelques traits diacritiques contemporains du texte; un alif coufique, évidé et doré, marque la fin d'un groupe de cinq versets; une rosace historiée, la fin d'un groupe de dix versets. (Ms. de la fin du $\mathrm{I}^{\circ}$ siècle de l'hégire.)

Contemu : sourate $x 11,52$ à 65 .

$6^{\circ}$ (Fol. 64 à 66.) Belle écriture coufique; treize lignes par page; points-royelles; quelques traits diacritiques contemporains du texte; les versets sont séparés par trois ou quatre traits disposés ainsi ///, et remplacés plus tard par trois cercles en or formant triangle; un cercle en $\mathrm{or}^{\mathrm{s}}$ et en couleur (fol. $64 \mathrm{v}^{\circ}$ ), renfermant la lettre numérique sad, se trome à la fin du verset 60 de la $1 v^{e}$ sourate; une marque semblable se trouve au verso dir folio 66 ; un aulre signe de forme carée, renfermant la lettre 'ain = $7^{\circ}$, a élé inséré à la suite du verset qui, dans l'édition de Flügel, porte le $n^{\circ} 73$. (Manuscr. de la fin du $\mathrm{mi}^{\mathrm{e}}$ siècle.)

Contenu : sourate Iv, 61 à $7^{4}, 9^{1}$ à $9^{4}$.

$7^{\circ}$ (Fol. 67.) Belle écriture coufique; quatorze lignes par page; points-ıyelles arec variantes; quelques traits diacritiques contemporains du texte; les versets sont séparés par de petites rosaces en or, hien exécutées; un carré historié et renfermant un noûn marque la fin du cinquantiène verset de la sourate. (Ms. de la fin du me siècle de l'hégire.)

Contenu : sourate $\mathrm{xxx}, 45$ à 53 .

$8^{\circ}$ (Fol. 68 à 87.) Belle écrilure coufique; quinze lignes par page; points-voyelles; queleues traits diacritiques contemporains du texte; un signe de cette forme sert à séparer les versets; des rosaces liistoriées, assez bien exécutées et renfermant des lettres numérales, indiquent les groupes de dix versets; en quelques endroits, un hâ doré masque les groupes de cinq versets. (Ms. du u $\mathrm{u}^{\mathrm{e}}$ siècle.)

Contenu: sourate $\mathrm{w}, 23$ à 160 .

$9^{\circ}$ (Fol. 88.) Écriture du Hidjâz; seize lignes par page; points-royelles; traits diacritiques ajoutés après coup; les versets ne sont pas séparés; des cercles grossjèrement dessinés à l'enere rouge marquent les groupes de dix versets. (Ms, du $u^{\mathrm{e}}$ siècle.)

Contenu : sourate $\mathrm{m}, 51$ iो 67 .

$10^{\circ}$ (lol. 89 à 141.) Belle écriture de l'école de Damas (?); hastes très-allongées; les queues de quelques lettres finales, telles que le sîn, le noûn et le $y \hat{a}$, forment de grands demi-cercles tournés vers la gauche; la haste du nimn final est pendante el se recourbe vers la gauche; les autres lettres n'on! pas la forme anguleuse qui distingue les produits plus récents de cette école calligraphique. Cinq lignes par page; traits diacritiques ajoutés au texte un peu plus tard; points-royelles avec variantes; un point vert indique le hamza; quelques alif de prolongation ont été insérés après coup, les uns à l'encre rouge, les autres à l'encre jaune; les versets se terminent par de petites rosaces bien exécutées en or et en couleur; le hî doré marque les groupes de cinq versets; de grandes rosaces historiées, à dessins différents et très-bien exécutés, renfermant des noms de dizajnes, indiquent les groupes de dix versets. ( $\mathrm{H}_{\mathrm{s}}$ du $\mathrm{v}^{\mathrm{e}}$ siècle de l'hégire.)

Contenu : sourates 11,41 à 48,55 à 58,76 à 79 , 235 à 248,256 à $260 ; 11,43$ à 51,57 à 73,84 à $90 ; \mathrm{N}, 4$ à $9 ; \mathrm{v}, 84$ à $92 ; \mathrm{vi}, 39$ à 44,75 à $121 ; \mathrm{vII}$, 17 à $23 ; \mathbf{x x I}, 22$ à 45,66 à 74,81 à $89 ; x x I I, 13$ à $19 ;$ xxill, 73 à $81 ;$ xxiv, 51 à $55 ;$ xxvı, 83 à 116 ; xxvu, 1 à 10,16 à 23,33 à $40 ; \operatorname{xxxv}, 39$ à $47 ;$ xuri, 
14 à $17 ; \operatorname{xLIH}, 37$ à $61 ; x L \varphi v, 1$ à $16 ; x L V I, 1$ à 7 ; xuviII, 21 à 25 (déchiré); LviII, 13 à 19 ; LXIII, 6 à 10 (déchiré); cxvın, 4 à 39 ; Lxxum, 18 à 34 .

$11^{\circ}$ (Fol. 142 à 148.) Belle écriture coufrque; treize lignes par page; traits diacritiques probablement contemporains du texte; points-voyelles; les versets sont séparés par de petites rosaces historiées; un hâ doré marque les groupes de cinq rersets; les groupes de dix versets sont indiqués par une grande rosace en or, insérée dans le texte, et une autre encore plus grande en or et en couleurs, dessinée sur la marge et renfermant le nom de la dizaine écrit en toutes lettres. Deux titres de sourate (fol. $147 \mathrm{r}^{\circ}$ et $156 \mathrm{r}^{\circ}$ ) sont écrits en lettres d'or trèsbien exécutées; à la marge, à côté des titres, on voit des arabesques à fleurons; une note marginale en caractères coufiques dorés, indiquant l'une des grandes divisions du Coran (par moitiés, quarts, sixièmes, elc.), se trouve au verso du folio 144 . (Ms. du rve siècle.)

Contenu : sourates xvin, 42 et suiv.; xix, 1 à 29 ; xxvm, 12 à $43 ; x x x, 30$ aे 41 ; xxxıv, 12 et suiv.; xxxv, 1 à 19 .

$12^{\circ}$ (Fol. 159 à 2 15.$)$ Grande et magnifique écriture coufrque; cinq lignes par page; des ronds dorés avec un point rouge an centre servent de points-royelles; sans traits diacritiques; des points bleus indiquent les hamza; la plupart des versets se terminent par une pendeloque historiée, renfermant le mot $x$; les folios 194 et 199

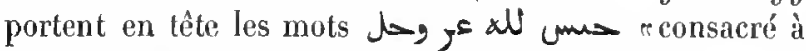
Dieu tout-puissant». Ces mots sont écrits en catractères neskhi. (Ms. du iv ${ }^{e}$ siècle de l'hégire.)

Contenu : sourates 11, 56 et 57,64 ì 66,74 et 75 ; 111,80 à $84 ; 11,96$ à 101,120 d̀ 122,127 et 128 , 130 à $132,27^{3}$ et $274,27^{6}, 278,279,282,283$; III, 8 à 12 (feuillets mutilés), 20, 21,68 à $75 ; 1 \mathrm{v}, 40$, 42 à 45,46 à 50,85 à 94,97 à 99,117 à 128,130 à 132 .

Vélin. 915 feuillets. Hauleur, 31 centimètres; largeur, 10 centimètres et demi. - (Supplérnent 150 G.)

\section{5.}

Fragments d'un exemplaire du Coran. Écriture de transition, se rapprochant de celle de l'Iràq, mais conservant encore le caractère de l'écriture du Ịidjàz; vingt lignes par page; tous les traits diacritiques sont marqués et paraissent être contemporains du texte; quelques pointsvoyelles en rouge; les sourates sont séparées par de larges bandes, dont une (fol. 8) se compose de dix carrés, portant chacun une croix de Saint-André, ondée et contournée de triangles, lesquels forment une croix pattée. La première croix est de couleur violette, la seconde est verte, et la troisiène jaune, et ainsi de smite. Une autre bande, composée de dix triangles verts, sur des fonds violets et jaunes, se trouve au verso du folio 5. Ces ornements sont exécutés très-grossièrement. Les titres des sourates, qui ont été ajoutés après coup, d'une écriture qui se rapproche beaucoup du neskhi, commencẻnt par les mots $\boldsymbol{\gamma}_{j}$ w alif, évidé et colorié moitié rouge, moitié vert, indique les groupes de cinq versets; un petit losange, de couleur jaune, marque la fin de chaque verset; un carré mal formé et colorié en rouge et en jaune termine chaque groupe de dix versets. (Ms. du commencement du II $^{e}$ siècle de l'hégire.)

Contenu: sourates xvın, 19 à $36 ; \mathbf{x L}, 8$ et suiv.; xu; $\mathrm{XLI1}, 1$ à 14 .

Vélin. 10 feuiltets. Hauleur, 52 centimètres; largeur, 35 centimètres. - (Supplément $150 \mathrm{~L}$. )

\section{6.}

Fragments d'un exemplaire du Coran, écrits en beaux caractères coufiques; vingt lignes par page. Le texte est presque entièrement dépourvu de traits diacritiques; les points-voyelles, à l'encre rouge, sont assez nombreux; le hamza est quelquefois marqué par un point jaune, surmonté d'un trait rouge; les lignes qui devaient contenir lus titres des sourates sont restées en blanc; les groupes de cinq et de dix versets se terminent par un gros alif élidé ou par un cercle. Sirr la marge du folio 7 est inscrite une note, tracée à la hâte en gros caractères neskhi (deux mots sont presque effacés), qui est d'une grande importance pour fixer l'àge de ce ms. : هل

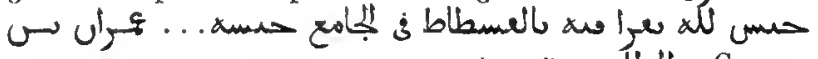

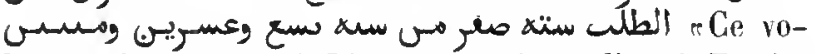
lume a été consacré à Dieu pour qu'on y lise, à Fostạt, dans la mosquée; il fut donné par (le nom a disparu arec un morceau du bord du feuillet) 'Amrân ben al-Ṭalab (ou al-Tayyib), le six șafir de l'an vingt-neuf et deux cent. Cette date correspond au mois de novembre 843 de J. C. II. Amari a lu etrois cents $\%$, à la place de vus deux cents"; mais il nous semble que, dans ce groupe de lettres, la partie supérieure de l'initiale mîm est encore visible, ainsi que la queue du noûn final. Au reste, on retrouve dans ce fragment tous les caractères d'un ms. du In siècle.

Contenu : sourates III, 55 à 108,153 à $166 ; 1 \mathrm{v}, 28$ à $38 ;$ xxxvı, t à 76,169 et suiv.; xxxvıI, 1 à 29,86

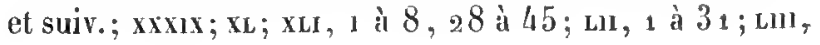


12 et suiv.; LIv, 1 à 8,36 et suir.; Lv, 1 à $19 ;$ Lxm, 10 et suiv.; LXIv; Lxv; LXvı; Lxvır ; LXvIII, 1 à 33 .

Vélin. 34 fenillets. Hauteur, 40 centimètres; largeur, 34 centimètres. - (Supplément $150 \mathrm{H}$.)

\section{7.}

Fragments de cinq exemplaires du Coran.

$1^{\circ}$ (Fol. 1 à 6.) Écriture de transition entre celle du Hidjâz et celle de l'Trâq; seize ligues par page; traits diacritiques, ajoulés après coup; points-voyelles en rouge et variantes en vert; m groupe de quatre ou de cinq traits, I/I/, sépare les versets; les groupes de dix versets sont marqués par un alif à l'encre rouge; titres des sourates, contemporains du texte, écrits par le copiste Juimême en caractères coufiques et à l'encre rouge. (Ms. du III ${ }^{\mathrm{e}}$ siècle de l'hégire.)

Contenu: sourates Iv, 136 et suiv.; v, 1 ì 22.

$2^{\circ}$ (Fol. 7 à 9. ) Écriture du Hidjàz; seize lignes par page; quelques traits diacritiques; nombreux pointsroyelles; les versets ne sont pas séparés. Au fol. $7 v^{\circ}$ se trouve ce titre, à l'encre rouge, de la mềne écriture que le texte : x.s أ. cents versets $\%$. (Ms. de la fin du $\mathrm{u}^{\mathrm{e}}$ siècle.)

Contenu : sourates 11,282 et sujv.; 111,1 à 4 , et 28 à 51 .

$3^{\circ}$ (Fol. 10 à 48.) Belle écriture coufique, quinze ligues par page; assez nombreux traits diacritiques contemporains du texte; points-royelles en rouge; les versets sout séparés par trois traits //; claque groupe de cing versets est suivi d'un alif à l'encre rouge; les groupes de dix versets se terminent par une figure carrée ou ovale, dont l'intérieur porte un dessin en couleur et en 01 ; les titres des sourates et le nombre des rersets (par

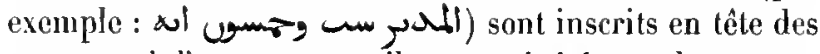
sourates, à l'encre rougge; ils sont répétés sur la marge, très-bien dessinés en lettres d'or. (Ms. du $11^{e}$ siècle de l'hégire.)

Contenu: sourates 11,66 à $145 ; \mathrm{v}, 96$ à $109 ; \mathrm{vI}, 87$ à 99,116 à 138,148 à $162 ; \mathrm{x}, 49$ et suiv.; $x_{11}, 1$ à $19 ; x^{2} 1,2$ à $78 ; x x v ı, 12$ à $63 ; x x x ı, 9$ à $19 ;$ Lvı, 21 et suiv.; Lvil, 16 et suiv.; LIx, 1 et 2 ; Lxxın, 20 et suiv.; LxxIv; Lxxv, 1 à 9 ; Lxxvı, 6 et suir.; Lxxvı; Lxxvılı, 1 à 37 .

40 (Fol. 49 à 87.) Belle écriture coufique; quinze lignes par page; sans traits diacritiques; points-royelles en rouge; les versets ne sont pas séparés; les groupes de cinq versets sont indiqués par un hâ doré, et les groupes de dix iersets par une rosace historiée, renfermant le nombre des versets écrit en toutes lettres et en or; les titres des sourates sont écrits en lettres d'or et paraissent contemporains du texte; en marge des titres se trouvent des fleurons en or. (Ms. du commencement du mie siècle de l'hégire.)

Contenu: sourates $\mathrm{I}, 152$ à 168,181 à $192 ; \mathrm{IX}, 82$ à $130 ; x, 81$ à $92 ; x I, 25$ à 34,46 à 57,67 et suiv.; $\mathrm{xII}_{1} 1$ à 14,33 à 55,79 à 103 ; xvi, 37 à 99,110 et suiv.; xvı, 1 à $72 ; x \times 11,37$ à 53 .

$5^{\circ}$ (Fol. 88 à 94.) Écriture coufique; quinze lignes par page; points-voyelles en rouge; points diacritiques ajoutés après coup; un hâ doré termine chaque groupe de cinq versets; chaque groupe de dix rersets est suivi d'un carré renfermant une lettre en or ayant une valeur numérale; le nombre est écrit en toutes lettres dans an cercle tracé sur la marge du même leuillet. (Ms. du $11^{\mathrm{e}}$ siècle de l'hégire.)

Contenu: sourates $x, 17$ à 31,53 à $81 ; x_{1}, 22$ à 43 .

Vélin. 34 feuillets. Hauteur, 27 centimètres; largeur, 34 centimètres et demi. - (Supplément 150 1.)

\section{8.}

Fragments de trois exemplaires du Coran.

$1^{\circ}$ (Fol. 1 à 1 2.) Petite écriture coufique; seize lignes par page; sans traits diacritiques; points-royelles; les versets ne sont pas séparés; les groupes de cinq versets sont indiqués par un $h a ̂$ doré, les groupes de dix versets par des cercles en or et en couleur; les titres des sourates (fol. $6 \mathrm{v}^{\circ}$ et $10 \mathrm{\vee}^{\circ}$ ), écrits en or, sont contemporains du texte;

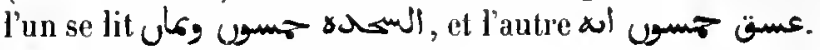
(Ms. du ${ }^{\mathrm{e}}{ }^{\mathrm{e}}$ siècle de l'hégire.)

Contenu : sourates $\mathbf{x L}, 2$ et suir.; XLI; XLII, 1 à 3,14 à $26 ; \mathrm{xuv}, 7$ à 40 .

$2^{\circ}$ (Fol. 13 à 35.) Grosse écriture coufique, de grandeur moyenne; dix lignes par page; sans traits diacritiques; points-royelles; les versets ne sont pas séparés; les titres, écrits en or, sont contemporains du texte. (Ms. de la fin du II $^{\mathrm{e}}$ siècle de l'bégire.)

Contenu: sourates Iv, 140 et suiv.; v, 1 à 46 ; xxvı, 36 à 180 .

$3^{\circ}$ (Fol. 35 à 37. .) Petite écriture coufique, assez belle; neuf lignes par page; le noûn final est pourvu d'un trait diacritique; points-voyelles; les versets ne sont pas séparés. (Ms. du III $^{\mathrm{e}}$ siècle de l'hégire.)

Contenu : sourate sv, 97 à 106.

Vétin. 37 fevittets. Hanteur, I 1 centimètres; targeur, 17 centimètres. - (Supplément $150 \mathrm{~N}$.) 


\section{9.}

Fragments d'un exemplaire du Coran.

ferilure coufique, plus fine que l'éeriture ordinaine; vingt-deux lignes par page; traits diaeritiques, probablement moins anciens que le texte; points-royelles; te hamza est marqué par un point vert; les rersets ne sont pas séparés; un hâ doré indique les groupes de cinq versets; un eercle en couleur, arec une lettre numérale en or, termine chaque groupe de dix rersets; les titres des sourates, éerits en leitres d'or et contemporains du texte, sont encadrés dans une moulure d'or, simple, mais bien exécutée; les marges et une partie du texte de ces feuillets ont été rongées. (Ms. du milieu du nI $^{\mathrm{e}}$ siècle de l'hégire.)

Contenu: sourates 11,96 à 106,187 et suiv.; 111 iv; v; v1; v11, 1 à 7 .

Vélin. 75 feuillets. Hauteur, 25 centimètres; targeur, 15 centimètres et demi. - (Supplément 1 5o Q.)

\section{0 .}

Fragments de dix exemplaires du Coran.

$2^{\circ}$ (Fol. 1 à 12.) Petite écriture coufique, se rapprochant du neskhi; quinze lignes par page; quelques traits diaeritiques, eontemporains du texte, et quelques petits points rouges pour marquer les voyelles; les versets ne sont pas séparés; chaque groupe de dix versets est suivi d'un cercle rouge, entouré de points noirs. (Ms. de la fin du $11^{\mathrm{e}}$ siècle de l'hégire.)

Contenu: sourates $1 \mathrm{v}, 29$ à 117,143 à $169 ; \mathrm{v}, 31$ à 52 .

$2^{\circ}$ (Fol. 13 à 3o.) Écriture du Hidjâz, tirant légèrement sur le neskhi; seize lignes par page; quelques points diacritiques, ajoutés après coup; sans points-royelles; les litres des sourates, à l'encre rouge, d'une écriture plus réeente que le texte, commencent par les mols was un cercle rouge el noil a ćté tracé à la fin de quelques groupes de dix versets. (Ms. de la fin dn $11^{\mathrm{e}}$ siècle de l'hégịie.)

Contenu : sourates xxx, 22 et suiv.; xxxi à xxxy; xxxvi, 1 à 51 .

$3^{\circ}$ (Fol. 31 à 46.) Petite écriture confique, à gros Iraits; seize lignes par page; sans marques diacritiques; points-royelles; les rersets ne sont pas séparés; in $h a$ doré marque les groupes de cinq versets, el un rond en or et en conleur les groupes de dix versets; les titres des sourates, écrits en letures d'or, sont contemporains du texte. (Ms. du $111^{\circ}$ siècle de l'hégire.)

$$
\text { Max. oriextaux. - } 11 \text {. }
$$

Contenu : sonrates xın, 15 et suir.; xıv; xv, 1 à 88 ; $\mathrm{xxı}, 67$ et suir.; xxı1, 1 à 67 .

$4^{\circ}$ (Fol. 47 à 66.) Petite écriture eoufique; quinze lignes par page; sans marques diacritiques; pointsvoyelles; litres des sourates en leltres d'or, contemporaius du texte; les versets ne sont pas séparés; un $h \hat{a}$ doré indique les groupes de cinq versets, un cercle en or et en conleur les groupes de dix versets. (Ms. du miè siècle de l'hégire.)

Contemu: sourates $1 \mathrm{x}, 119$ et suiv.; $\mathrm{x} ; \mathrm{x}, \mathrm{x}$ à 86 .

$5^{\circ}$ (Fol. 67 à 76.$)$ Belle écriture confique; quinze lignes par page; les traits diacritiques, mis presque partout, ont été ajontés après coup; points-voyelles assez nombreux; les versets ne sont pas séparés; un $h a ̂$ doré indique les groupes de einq versets, et un cercle en or et en couleur les groupes de dix versets. (Ms. de la fin dn $111^{\circ}$ siècle de l'hégire.)

Contenu : sourate $\mathrm{xi}, 3$ à $\mathbf{1 1 6}$.

$6^{\circ}$ (Fol. 77 à 105.$)$ Belle écriture confique; seiz lignes par page; points-voyelles; quelques points diaeritiques ajoulés après eoup; un gros point en or termine chaque verset, un hâ doré sépare les groupes de einq versets, el une rosace en or et en couleur les groupes de dix versets; les litres des sourates sont en or; le ya final s'allonge quelquefois vers la droite et même jusqu'à la fin de la ligne. (Ms. du n $^{\mathrm{e}}$ siècle de l'légire.)

Conteme: sourates 111, 99 à 110,153 à $117 ;$ v11, 26 à $150 ; \operatorname{xxxux}, 10 \mathrm{et}$ suiv.; xL, 1 à $69 ; \mathrm{xLv}, 27$ et suiv.; Xutr, 1 à 4; Llll, 30 el suiv.; LIV, 1 à 27 ; LXVI, 12 ; LXVIl; Lxvill, 1 ì 7 .

$7^{\circ}$ (Fol. 106 à 110.) Écriture coufique, inclinée vers la gauche; quatorze lignes par pagre; sans marques diacritiques; points-royelles; division en groupes de einq el de dix versets; un titre de sourate contemporain du texte, écrit en or, se tronve au folio 108 . (Ms. du $1 m^{e}$ sièrle de l'hégire.)

Contenu: sourates xv, 27 el suiv.; xvı, 1 à 28 .

$8^{\circ}$ (Fol. 111 à 1 19.) Grosse écriture eonfique, légèrement inclinée vers la gauche; douze ligues par page; sans maryues diacritiques; points-royelles; les versets ne sont pas séparés; un hâ doré marque les groupes de cint versets, et un rond doré les groupes de dix versels; titre de sourate (fot. 114) en leftres d'or contemporain du texte. (Ms. de la fin du $111^{\mathrm{e}}$ siète.)

Contenu: sourates xxıv, 35 et suir.; $x_{x v}, 1$ à 71 .

$9^{\circ}$ (Fol. 120.) Belle éeriture coufique; seize lignes [par page; quelques points diacritiques, ajoutés après coup; points-royelles; un hâ doré marque les groupes de cinq 
versets, et un cercle doró les groupes de dix versets. (Ms. du $11^{\mathrm{e}}$ siècle de l'hégire.)

Contenu: sourate xuvm, 4 ì 15.

$10^{\circ}$ (Fol. 121.) Ecriture minre et angulaire, plulôt neskhi que coufique; quatorze lignes par page; sans signes diacritiques; quelques traces de points-royelles. (Ms. de la fin du v $^{e}$ siécle de l'hégire.)

Contenu: sourate vil, 34 à 49 .

Vélin. 121 feuilfets. Hauteur, 17 centimètres; largeur, 23 centimèlres. - (Supplément $150 \mathrm{P}$.

\section{1.}

Fragments de deux exemplaires du Coran.

$1^{\circ}$ (Fol. 1 à 1 2. $)$ Grande et belle écriture confique; sept lignes par jage; points-royelles en rouge, arec variantes en d'autres couleurs; des traits diacritiques assez nombreux, ainsi que plusieurs signes orthographiques, ont été ajoutés après coup aux folios 22 et suivants; les versets sonl séparés par un rond en or, dont le centre est rouge et la circonférence bleue; une sorte de pendeloque historiée, renfermant le mot $\mathbf{m}$, marque les groupes de cinq versets; un nom de dizaine, écrit en toutes lettres, or sur blanc ou sur couleur, et entouré d'une bande listoriée, indique les groupes de dix versets. Au folio 32 on trouve un titre de sourate écrit en lettres d'or, et, à la marge, une arabesque circulaire en or et en couleur, l'eprésentant des palmes posées sur une mosaïque. Au folio 102 se trouve un dessin en or et en couleur, servant à remplir la page laissée en blanc à la fin d'une des seclions $(s-\rightarrow)$; cel ornement représente un tapis de prière, saddjáda, à fond blane, sur lequel s'étend un filet de rubans eutrelacés; une large bordure, formée de bagnettes brisées et entre-croisées, entoure le tout: $\Lambda$ l'une des extrénités du tapis on voit une arabesque piriforme, en or et en couleurs, représentant la qibla. (Ms. du commencement du $\mathrm{I}^{\mathrm{e}}$ siecle de l'hégire.)

Contenu: sourates 11,46 à 63,79 et 80,99 à 102 , 136 à 138,141 à $143,192,200$ à 203,228 à 234, ${ }_{2} 65,266,276$ à $279 ; 11,74$ à $76 ; 1 \mathrm{v}, 130$ à 135,139 à $142 ; \mathrm{v1}, 161$ et suir.; vil, 1 à 24,45 à 47,55 et 56 ; vill, 43 à 46,50 et $51 ; 1 \mathrm{x}, 75$ à 77,87 à 89,97 à 99 ; xil, 6 à 16,23 à 30,33 à 38,44 à $47 ; x v, 7$ à 17 ; xvil, 77 à $87,9^{\circ}$ à $9^{6}, 99$ à $106 ; x v m, 101$ à $107 ; x 1 x$, 13 à $25 ; \mathrm{xx}, 13$ à 19,44 à 49,86 à 89,113 à 115 , 131 à $134 ; x x 1,21$ à $24 ; x x v 11,51$ à $63 ; x x v 11,15$ à 31 , 34 à 36,69 à 72,80 à $82 ; x x ı x, 63$ à $66 ; x x x, 35$ à 37 , 53 à $56 ; \operatorname{xxxl}_{1} 18$ à $20 ; \operatorname{xxx}_{111}, 9$ à 14,52 à $58 ; \operatorname{xxxvı,}$ 27 à 60,74 à $82 ; x x x v 11,18$ à 23,118 à 129,144 à $152 ;$ xxxvIl, 2 à 9,50 à $55 ; x_{L 1}, 39$ à 44,47 à $50 ;$ XlıI, 10 à 14,18 à 23,31 à 35 ; XLvi, 9 à $14 ;$ LIII, 53 à 60 .

$2^{\circ}$ (Fol. 130 à 201.) Belle écriture coufique, à gros traits; cinq lignes par page; points-royelles en rouge, avec variantes en jaune et en bleu; traits diacritiques, ajoutés après coup à l'encre verte; les versets sont séparés par trois cereles dorés, disposés en forme de trèfle; des alf de prolongation en vert, en jaune et en bleu; les groupes de cinq versets se terminent par une rosace historiée renfermant le mol ums; une rosace plus grande et plus belle, renfermant le nom d'une dizaine en toutes letires, indique la fin de chaque groupe de dix versets.

Un autre feuillet de cet exemplaire du Coran se trouve à la Bibliothèque royale de Copenhague; il a dû précéder immédiatement le folio 130 de notre ms. (Voyez la planche VII de la brochure intitulée r. Lettre à M. Bröndstedn, par M. Lindberg. Copenhague, 183o.)

(Is. du même âge que le précédent.)

Contenu: sourates 11,18 à 21,25 à 34,41 à 45,48 à $50,7^{3}$ et $74,9^{4}$ à $9^{6}, 100$ à 104,106 el 107,111 et 112,114 et 115,141 à 143,172 à 180,216 et 217 ; III, 31,40 à $42,43,53$ et 54,86 à $97 ;$ vi, 131 à 133 , 14 et 142,147 à $149 ; 1 x, 72$ et 73,97 à $102 ;$ xIII, 35

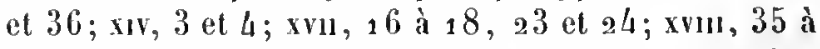
37,48 et $49 ; x \times 11,72$ à $74 ;$ xxvı, 61 à 71,79 à 83 ; xxxu, 14 el $15 ; x x x i v, 22$ el 23 ; xxxy, 32 à 34 ; Lxiv, 3 et 4,6 ว่ 9,16 à 18 .

Vélin. 201 femillets. Hautenr, 95 centimètres; largeur, 31 centimùtres et demi. - (Supptément 150 D d.)

\section{2.}

Fragments de trois exemplaires du Coran.

$1^{\circ}$ (Fol. 1 à 29.) Belle écriture coufique légèrement arrondie; les groupes de lettres sont soigneusement séparés; onze lignes par page; quelques traits diacritiques, contemporains du texte; points-royelles; variantes de points-voyelles en vert; un 'aïn tronqué, à l'encre verte, indique le hamsa; les versets sout séparéz par des cercles en rouge el en or; le mol um-, écrit à la marge, en caractères blancs sur un fond circulaire rouge et or, indique les groupes de cinq versets; ce rond est entouré d'un cercle blanc, puis d'un autre cercle en or el en rouge; un ornement semblable porte en toutes lettres l'indication des groupes de dix versets; un titre de sourate (fol. $8 v^{\circ}$ ), contemporain du texte, est écrit en blanc, sur une large bande rouge et or, arec un fleuron sem- 
blable en marge, le tout passablement bien exécuté. (Ms. du commencement du $v^{e}$ sièele de l'hégire.)

Contenu: sourates v, 105 et $106 ; \mathrm{v} 1,6$ à $17 ; 1 x, 9^{1}$

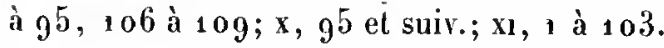

$2^{\circ}$ (Fol. 30 à 38.) Très-belle écriture de Damas, aux hastes élané́es et aux traits anguleux, se rapprochant beaucoup du neskhi; neuf lignes par page; traits diacritiques contemporains du texte; points-voyelles; un point bleu indique le hamza; des rosaces dorées séparent les versets; d'autres rosaces, à la marge, exécutées en or et en couleurs, indiquent, par les inscriptions qu'elles portent, le nombre des groupes de cinq et de dix versets. (Ms. de la fin du $v^{*}$ siècle de l'hégire.)

Contenu: sourates II, 15 G à $181 ; \mathrm{Ix}, 44$ à 48 .

$3^{\circ}$ (Fol. 39 à 47.) Écriture coufique; quinze lignes par page; traits et points diacritiques; points-royelles; les versets, les groupes de cinq et de dix rersets se terminent, comme à l'ordinaire, par des rosaces en or et en couleur. (Ms. de la fin du $\mathrm{Iv}^{\mathrm{\theta}}$ siècle de l'hégire.)

Contenu : sourates Iv, 47 à $58 ;$ vi, 60 à 65,103 à $109 ;$ vill, 69 à $73 ; 1 \mathrm{x}, 16$ à $20 ; \mathrm{xv}, 31$ à $45 ; \mathrm{xx} 111,64$ ì 84 .

Vélin. 47 feuillets. Hauteur, 29 centimètres et demi ; largeur, 20 centimètres. - (Supplément $150 \mathrm{~V}$.)

\section{3.}

Volume renfermant la plus grande partie du texte du Coran. Petite écriture coufique inclinée à gauche; seize lignes par page; points diacritiques très-rares; pointsvoyelles; des cereles en or et des fleurons coloriés indiquent les groupes de dix versets; les titres des sourates, contemporains du texte, sont écrits en jaune; ces titres commencent par le mot سورو Aux folios $119 \mathrm{r}^{\circ}$ et $161 \mathrm{r}^{\circ}$, se trouve une note en neskhi, qui nous apprend que ce volume avait appartenu à un nommé Ạmmad Aboû'l

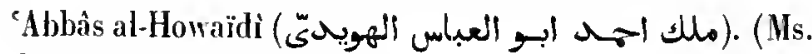
du $\mathbf{r v}^{\mathbf{e}}$ siècle de l'lıégire.)

Contenu: sourates 11,23 à cvir.. (Il y a quelques lacunes au milieu du texte, et le dernier feuillet est hors de sa place.)

Vélin. ${ }_{2} 6$ feuillets. Hauteur, 14 centimètres et demi; targeur, s1 centimètres. - (Supplément 150 R.)

\section{4.}

Fragments de lrois exemplaires du Coran.

$1^{\circ}$ (Fol. 1 à 5.) Grosse écriture coufique, de gran- deur moyenne; l'alif est représenté par un simple trait vertical, sans queue; la queue du mîm est dirigée en bas; dix lignes par page; quelques traits diacritiques; points-yoyelles; les versets ne sont pas séparés; un $h a$ à l'encre noire indique les groupes de cinq, une rosace en couleur, les groupes de dix versets. (Ms. du Iv siècle de l'hégire.)

Contenu: sourate vil, 131 à 156 .

$2^{\circ}$ (Fol. 6 à 14.) Belle écriture coufique; sept lignes par page; nombreux traits diacritiques, mais plus modernes que le texte; points-royelles; un point vert indique le hamza; les versets se terminent par des rosaces dorées, les groupes de cinq versets par des hâ dorés, et les groupes de dix versets par des cercles entourés de petits fleurons d'or', renfermant le nombre des dizaines écrit en toutes lettres, en or sur un fond de couleur. (Ms. du "I" siècle de l'hégire.)

Contenu: sourate 1v, 123 à 152 .

$3^{\circ}$ (Fol. 15 à 39.) Belle écriture coufique; six lignes par page; quelques traits diacritiques, ajoutés après coup; points-royelles; les versets ne sont pas séparés; le hì doré marque les groupes de cinq versets, et une rosace en or el en couleur les groupes de dix versets. (Ms. du $111^{\mathrm{e}}$ siècle de l'hégire.)

Contenu : sourate Iv, 85 à 135 .

Vétin. 39 feuillets. Hauteur, 1 a centimètres; largeur, 17 centimètres et demi. - (Supplément $150 \mathrm{~S}$.)

\section{5.}

Fragments de trois exemplaires du Coran.

$1^{\circ}$ (Fol. 1 à 9.) Grosse écriture coufique; l'alif est représenté par un simple trait rertical; la queue du mim est dirigée en bas; quinze lignes par page; sans marques diacritiques; points-royelles assez nombreux; les versets ne sont pas séparés; des cercles rouges grossièrement exécutés marquent les groupes de dix versets; les titres des sourates, contemporains du texte, sont écrits à l'encre jaune. (Ms. du $\mathrm{v}^{\mathrm{e}}$ siècle de l'hégire.)

Contenu: sourates v, 49 à 58,94 à $110 ; x$ vil1, 45 à 71 ; $\mathrm{xx1x}, 16$ à $29 ; x \times x, 53$ et suiv.; xxxı, 1 à $10 ; x \times x v 11$, 132 et suiv.; $x x x v 11,1$ à 19 .

$2^{\circ}$ (Fol. 10 à 39.$)$ Belle écriture coufique; seize lignes par page; sans marques diacritiques; points-yoyelles assez. nombreux; les versets se terminent par trois traits $\equiv$, les groupes de einq versets par un $h \hat{a}$ à t'encre noire, ef les groupes de dix versets par un rond jaune; la queue du ya final est allongée vers la droite; les titres des cha- 
pitres (fol. $20 \mathrm{v}^{\circ}$ et 36 ) sont à l'enere rouge. (Hs. du $111^{\mathrm{e}}$ siècle de l'hégire.)

Contenu: sourates 11, 180 à $260 ;$ III, 192 et suir.; Iv, 1 à $91 ; \mathrm{v}, 36$ à 71 ; v1, 145 et suiv.; v11, 1 à 51 .

$3^{\circ}$ (Fol. 40 ì 46.) Grosse écriture coufique dont les hastes sont raccourcies et les traits horizontaux allongés; le fâ et le qâf, au milien des mots, ont la forme circulaine et s'élèvent au-dessus de la ligne; seize lignes par page; sans traits diacritiques; les points-voyelles ont la forme d'un losange; les versets sont séparés par trois trails 三; un rond, grossièrement tracé à la plume et rolorié, marque chaque groupe de dix versets; les lignes qui araient été laissées en blanc pour les titres de chapitre ont été remplies plus tard à l'encre rongre. (Ms. dı $111^{\mathrm{e}}$ siècle de l'hégire.)

Contenu : sourates xuv1, 20 et suiv.; xuvin; xuIx, I ì 15.

Vélin. 46 feuillets. Hauteur, 19 centimètres et demi; largeur, $\$ 5$ centimètres. - (Supplément 150 T.)

\section{6.}

Fragments de trois ou quatre exemplaires du Coran.

$1^{\circ}$ (Fol. 1 à 18.) Grande et belle écriture coufique; sept lignes par page; traits diacritiques fort rares; pointsvoyelles en or avec variantes en bleu ou en ronge; le hamza est indiqué par ın point vert; une jetite rosace en or sépare les versets; un ha doré marque les groupes de cin(1, et une rosace en or, bien dessinée et reofermant une let!re numérale, les groupes de dix versets; le titre d'une sourate (fol. $13 \mathrm{v}^{\circ}$ ) en or, contemporain du lexte, est placé entre deux baguettes, d'un dessin simple, en or; à la marge on voit un fleuron très-bien exécuté en or et en conleur. Quelques feuillets sont très-endommagés par l'humidité; sur d'autres, une main peu habile a repassé à l'encre plusieurs lignes dont les caractères commencaient à s'elfacer. Au fol. $13 v^{\circ}$ on trouve, en nesklri ancien, une note qui constate que le Coran dont ces feuillets faisaient partie avait été donné en waqf à la chapelle (مشن) située en dehors de la ville de Tyr, par un personnage nommé al-Ḥasan al-Tonoukkhi, fils d'Alì, fils d'Ahmad, fils de Djáfar, fils d'abî llarâm; la date du dépòt n'est pas mentionnée. (Hs. du $1 \mathrm{v}^{0}$ siècle de l'hégire.)

Contenu : sourates xLIx, 1 à 17; Llı, 23 et suiv.; LII, 1 à 34 .

$2^{\circ}$ (Fol. 19 à 41 .) Grande et belle écriture coufique; six lignes par page; sans marques diacritiqnes; pointsvoyelles en rouge; les rersets sont séparés par de petites rosaces en or; un hà doré marque les groupes de cinq versets, et une rosace bien exécutée, en or et en couleur, renfermant le nombre écrit en toutes lettres, les groupes de dix versets. (Ms. du $1 v^{\ominus}$ siècle de l'hégire.)

Contenu : sourates III, 129 à $133 ; \mathrm{xr}, 27$ à 54 ; xvin, 37 à $38 ; \mathrm{xu}, 37$ à 45 .

$3^{\circ}$ (Fol. 42 à 48.) Grande et belle écriture coufique ayant le même caractère que celle des feuillets précédents. Les deux fragments ont probablement fait partie du même rolume. (Ms. du ive siècle de l'hégire.)

Contenu: sourate $\mathrm{xxxm}, 44$ à 53 .

$4^{\circ}$ (Fol. 49 à 137.$)$ Grande et belle écriture coufique; cinq lignes par page; traits diacritiques coutemporains du texte; points-royelles à l'encre rouge; des rosaces assez bien dessinées, en or et en coulenr, sur les marges du texte, indiquent les groupes de cinq et de dix versets; une petite rosace en or sépare les versets; les titres des sourales sont contemporains du texte et en lettres dorées (royez fol. $73,101,127$ ); à côté de chaque titre se trouve un fleuron ou arabesque d'une forme triangulaire, bien exécuté, en or et en couleur. Parmi ces fragments, on trouve la première sourate suivie immédiatement de la onzième, el plus loin la même sourate est suivie de la vingt-deuxième. II. Amari croit que ces feuillets appartenaient à des sections (جز $)$ ) différentes, et que la première soura te était reproduite en tête de cliaque section. (Ms. de la fin du $1 v^{e}$ siècle de l'hégire.)

Contenu : sourates 11,63 à $66 ; 1 \mathrm{v}, 118,136$ à 139 , 143 à $145 ;$ vi, 118,$119 ;$ vil, $51,57,58,72,73,84$, $85 ; 1 x, 47$ à $61 ; 1,7 ; x ı, 1$ à $3 ; x 11,42$ à 45,67 à 72 ; $\mathrm{xm}, 18,19 ; \mathrm{x} \mathbf{}, 3$ à $6,11,12,46,47 ; \mathrm{xv}, 2$ à 6,28 d $31,126,127 ; x ı x, 22$ à $32,34,36 ; x x, 4,5 ; 1,2$ et suiv.; xxı, 1 à 5,85 à $87 ; x_{x 11} 71,72 ; \mathbf{x x} 1,25$ à 28 , 48 à $51 ; \operatorname{xux}, 9,16$ à $18 ; \mathbf{L}, 21$ à $30 ; \mathbf{u x}, 17$ à 19 ; Lx, 6 à 8 ; Lxvı11, 7 et suiv.; Lxıx, 1 à 44 ; Lxxıx, 5 à 11 .

Vélin. 137 feuiltets. Hauteur, 21 centimètres; largeur, a 7 centimètres et demi. - (Supplément ${ }_{150} \mathrm{X}$.)

\section{7.}

Fragments de deux exemplaires du Coran.

$1^{\circ}$ (Fol. 1 à 5.) Très-belle écriture coufique de moyenne grandeur; cinq lignes par page; sans traits diacritiques; points-royelles à l'encre rouge, arec variantes en couleur; le hamza est marqué par un point vert; quelques teschdid de forme moderne sont indiqués à l'encre bleue; les versets sont séparés par de petites rosaces dorées, les groupes de cinq versets par une rosace en or et en couleur, renfermant le mot $\mathrm{m}_{\boldsymbol{r}}$, el les groupes 
de dix rersets par une rosace semblable, renfermant un nom de dizaine en toutes lettres; un ornement en forme d'étoile, très-bien dessiné sur la marge dı fol. $22 \mathrm{r}^{\circ}$, renferme le mot $\ddot{8}$. Le feuillet qui contenait les versets 24 et 26 de la sourate xxxıx ayant disparu à une époque déjà ancienne, une main plus moderne les a reproduits en neskli sur la marge supérieure du feuillet suivant. (Ms. du $\mathrm{Iv}^{\mathrm{e}}$ siècle de l'hégire.)

Contenu : sourates $\mathrm{x} 1 \mathrm{x}, 52$ à 55,77 à $80 ; \mathrm{xx}, 108$ à $120 ; x x 1 v, 14$ à 21,28 à $46 ; x x x v 11,23$ à $85 ;$ xxxix, l à $28 ;$ xull, 59 à 62 .

$2^{\circ}$ (Fol. 52, 52 bis, 52 ter, 53 à 97.) Belle écriture coufique; cinq lignes par page; points diacritiques, ajoutés par une autre main; points-voyelles en rouge avec variantes en vert; les versets sont séparés par un triangle en trèlle, composé de trois petits ronds dorés; les groupes de cinq versets se terminent par le hâ doré, et les groupes de dix versels par une rosace renfermant l'indication du nombre en toutes lettres; les titres des sourates, écrits en lettres d'or, se terminent par un fleuron qui se déreloppe sur la marge (roy. fol. 65 et 93 ); le fleuron du feuillet 65 ressemble à une fleur de lys. En tête de ce mème feuillet se trouvent quelques mots écrits en neskhi ancien, mais en grande partie effacés; on ne distingue avec certitude que ces mots : هـ (Ms. de la fin du $1 v^{\bullet}$ siècle de l'hégire.)

Contenu : sourates II, 180 à $183 ;$ III, 166 et suiv.; Iv, 1 à $27 ; \mathrm{x} 1,44$ à $49 ;$ xxxvı1, 10 à 25,36 et suiv.; $\operatorname{xxx}_{1 x}$, 1 à $3 ; \mathbf{L v}, 58$ à 78 .

Vétin. 99 ferillets. Hauteur, 15 centimètres el demi; targeur, 21 centimètres. - (Supptément $150 \mathrm{Y}$.)

\section{8.}

Fragments de dix exemplaires du Corau.

$1^{\circ}$ (Fol. 1 à 8 .) Belle écriture coufique; six lignes par page; quelques traits diacritiques, contemporains du texte; points-royelles; un point jaune indique le hamza; les versets sont séparés par une petite rosace dorée; les groupes de cinq versets se terminent par le hâ doré; les groupes de dix versets ne sont pas indiqués. (Ms. du iv siècle de l'hégire.)

Contenu: sourate $x, 22$ à 31 .

$2^{\circ}$ (Fol. 9 à 36.) Belle écriture coufique; sept lignes par page; quelques traits diacritiques, ajoutés par une autre main; le qif est marqué d'un trait au-dessous de la ligne; points-royelles en rouge; les versets ne sont pas séparés; le ha doré marque les groupes de cinq versets, une rosace, renfemant un nom de dizaine en toutes lettres, les groupes de dix versets; le titre d'une sourate, (fol. 16) en lettres d'or, contemporain du texte, est placé entre deux baguettes historiées, avec un fleuron hor's du cadre. (Ms. du iv siècle de l'lıégire.)

Contenn : sourates vı, 186 et suiv.; vul, 1 à $26 ; \mathrm{xv}$, 117 à $120 ; x v 11,7$ à 12,46 à $66,7^{0}$ à $72 ; x 1 x, 40$ à $81 ; \operatorname{xxx} 1 x, 8$ à 28 .

$3^{\circ}$ (Fol. 37 à 64.) Belle écriture confique; six lignes par page; traits diacritiques ajoutés après coup; pointsvoyelles; les versets sont marqués par un fleuron en or, ayant la forme d'une pendeloque, les groupes de cinq versets par un $h a \hat{~ d o r e ́, ~ e t ~ l e s ~ g r o u p e s ~ d e ~ d i x ~ v e r s e t s ~ p a r ~}$ un cercle historié, renfermant le numéro du groupe en toutes lettres. (Ms. du $1 v^{e}$ siècle de l'hégire.)

Contenu: sourate $\mathbf{1 x}, 42$ à 61 .

$4^{\circ}$ (Fol. 65 à 76 .) Belle écriture coufique; sept lignes par page; traits diacritiques ajoutés après coup; pointsroyelles; de petits ronds jaunes séparent les versets; le $h \hat{a}$ doré indique les groupes de cinq, et une rosace en or et en couleur, dans laquelle le nom de la dizaine est écrit en tontes lettres, les groupes de dix versets. (Ms. du $1 v^{e}$ siècle de l'hégire.)

Contenu : sourates vilı, 26 à $28 ; \mathrm{x}, 67$ à $69 ; \mathrm{xr}, 15$ à 44 .

$5^{\circ}$ (Fol. 77 à 126.$)$ Belle écriture coufique; sept lignes par page; quelques rares traits diacritiques; pointsvoyelles; le fatha esi en or; le lesra est indiqué par un point vert, le dhamma par un point rouge, et le hamza par un point bleu; les versets sont marqués par un rond en or, les groupes de cinq versets par un hd en or et en couleur, de la forme d'une pendeloque, et les groupes de dix versets par une rosace cloisonnée en or et cn conleur, portant le numéro du groupe en toutes lettres. (Ms. du Iv siècle de l'hégire.)

Contenu : sourates 11,66 à 106,128 à $130 ;$ vu, 140 à 156 ; xxıv, 29 à 31 ; xxvı, 9 à 22,28 à 107 ; xxvılı, 1 à 21 .

$6^{\circ}$ (Fol. 126 à 142.) Belle écriture coufique; cinq ligues par page; l'encre, d'un noir très-foncé, a parfaitement résisté à l'humidité; sans. signes diacritiqnes; points-royelles en rouge arec variantes en jaune; le soukoun en rert; chaque verset se termine par une petite rosace en or et en couleur; un cercle en or et en couleur, renfermant le mot ur, placé à la marge, indique les groupes de cinq versets; une grande étoile en or et en couleur, renfermant le nom d'ume dizaine en toutes lettres, marque les groupes de dix rersets. (Ms. dı $1 \mathbf{V}^{\theta}$ siècle de l'hégir'e.)

Contenu : sourate 11,160 à 167,169 à 180 .

$7^{\circ}$ (Fol. 143 à 152.) Belle écriture coufique; neuf 
lignes par page; sans marques diacritiques; points-voyelles en rouge; un point vert indique le hamza; un titre de sourate, écrit en or, est contemporain du texte; en marge du titre, se trouve un fleuron en or; les versets ne sont pas séparés; le hi doré marque les groupes de cinq rersets, et une rosace en or et en couleur, portant le numéro écrit en toutes lettres, les groupes de dix versets. (Ms. du iv siècle de l'hégire.)

Contenu: sourates $11,9^{5}$ et suiv.; $x 111,1$ à 17 .

$8^{\circ}$ (Fol. 153 à 157. ) Belle écriture coufique; luuit lignes par page; sans traits diacritiques; points-voyelles an rouge; les versets sont séparés par un petit fleuron en or; les groupes de cing et de dix rersets sont marqués de la même manière que dans le fragment précédent. (Hs. du $1 \mathrm{v}^{\mathrm{e}}$ siècle de l'hégire.)

Contenn: sourate $\mathrm{xxx}, 4$ is 37 .

$9^{\circ}$ (Fol. 158 à 16o.) Ecriture coufique; cinq lignes par page; sans points-rovelles; quelques rares points diacritiques; les versets ne sont pas séparés. (Ms. du $1 v^{\mathrm{e}}$ siècle de l'hégire.)

Contenu: sourate xx11, 5 à 7,18 à 20 .

$10^{\circ}$ (Fol. 161.) Belle écriture coufique; sept lignes par page; sans points diacritiques; points-royelles en rouge avec variantes en jaune; un point vert désigne le hamza; en marge, une étoile bien exécntée, en or et en couleur, renfermant le nom d'une dizaine en toutes lettres, níarque la fin d'un groupe de dix rersets; un rond en or sépare les versets. (Ms. du $w^{\mathbf{e}}$ siècle de l'hégire.)

Contenu: sourate $x_{1}, 3$, à 33 .

Vélin. 161 feuillets. Hauteur, 19 centimèlres et derni; largeur, 25 centimètres et demi. - (Supplément $150 \mathrm{Z}$.)

\section{9.}

Fragments de six exemplaires du Coran.

$1{ }^{\circ}$ (Fol. 1 à 26.) Belle écriture coufique; dix lignes par page; les points diacritiques ont été ajoutés à une époque relativement récente; points-royelles en rouge; les points verts représentent les hamza; les versets ne sont pas séparés; un ha doré indique les groupes de cinq versets, et une grosse étoile, en or et en couleur, renfermant un numéro de dizaine, les groupes de dix versets; ces étoiles se trourent tantôt dans le texte, tantôt à la marge; titre de sourate en or, avec fleuron triaugulaire en marge. (Ms. du $1 \mathrm{r}^{\mathrm{c}}$ siècle de l'hégire.)

Contenu: sourates vıı, 19 à 26,32 à 38,59 à $65,7_{1}^{1}$ à $74 ; 1 x, 3$ à 38,42 à 48,81 à $9^{1 ;} \times x_{x 1}, 57$ à 73,109 et suiv.; xxı, 1 à 20,25 à 35,39 à 53 .

$2^{\circ}$ (Fol. 27 à 66.) Écriture coufique; scize lignes pas page; quelques traits diacritiques et un grand nombre de points diacritiques ajoutés après coup; les versets sont séparés par un signe de cette forme $₹$; les groupes de cinq et de dix rersets sont indiqués par une lettre numérale, inséréc dans un carré; les titres de chapitres, en lettres d'or, sont contemporains du texte. (Ms. du Iv $v^{\mathrm{e}}$ siècle de l'hégire.)

Contenu: sourates vı, 16 à $28 ;$ vı, 143 à $154 ; \mathrm{xLv}$, 3 à 16 ; LxIv, 14 et suiv,; Lxv à cxı.

$3^{\circ}$ (Fol. 67 à 71.) Grosse et belle écriture coufique; sept lignes par page; quelques traits diacritiques; pointsroyelles à l'encre rouge; une rosace en or termine chaque rerset; des étoiles en or et en couleur, renfermant, les unes le mot $\mathrm{um}$, les autres le mot عسم, se trouvent sur les marges, et indiquent les groupes de einq et de dix rersets. (Ms. du $1 \mathrm{v}^{\mathrm{B}}$ siècle de l'hégire.)

Contenu: sourate 11,139 à 141,159 à 160,165 à $16_{9}, 7^{2}$ à $17^{4}$.

$4^{\circ}$ (Fol. 72 à $7^{3}, 7^{3}$ bis à 85,85 bis à 102 .) Grande et belle écrilure coufique; cinq lignes par page; quelques traits diacritiques; points-royelles; des rosaces historiées indiquent les divisions du texte; les versets sont séparés par des rosaces dorées; de grands ronds historiés, renfermant, les uns le mot $\mathrm{mr}$, les autres le nom de la dizaine, indiquent les groupes de cinq et de dix versets. (Ms. de la fin du $1^{\circ}$ siècle de l'hégire.)

Contenu : sourates 11,250 ì $252 ; 111,86$ à 90,94 à $9^{6}, 9^{8}$ et $99 ; 1 \mathrm{r}, 21$ et $22 ; \mathrm{v}, 45 ; 1 \mathrm{x}, 102$ à $106 ; \mathrm{x} 11$, 110 et $111 ; x+11,7$ et 8 ; xxwy, 22 à $28 ; x x v, 37$ à 39 , 55 et $56 ;$ xxxrv, 22 à $28 ; x x x v, 6$ et 7,34 à $37 ;$ xxxvı, 2 à $6 ; x \mathrm{LJx}, 1$ à $10 ; \mathrm{L}, 13$ à 15.

$5^{\circ}$ (Fol. 103 à 118 .) Grosse écriture coufique; six lignes par page; quelques traits diacritiques; pointsvoyelles; les hamza sont indiqués par des points jaunes ou par de petits traits horizontaux rouges, accompagnés d'un point bleu; les versets sont séparés par une petite rosace en or'; quelques teschlid en rouge; des étoiles placées sur la marge indiquent les groupes de cinq et de dix versets. (Ms. du $1 \mathrm{v}^{\mathrm{e}}$ siècle de l'hégire.)

Contemu: sourates xxi, 19 à 22,43 à $60 ; x L I, 24$ à 42 .

$6^{\circ}$ (Fol. 119 à 136.) Petite écriture coufique; quinze lignes par page; les lignes sont très-rapprochées, tandis que les groupes de lettres ainsi que les lettres isolées sont bien séparés; points-royelles; un trait rouge indique le hamza; chaque versel est suivi d'une petite rosace dorée; des rosaces dorées indiquent également les groupes de cinq et de dix versets; les sections du Coran sont 
indiquées sur les marges en lettres d'or'; litre en lettres d'or contemporain du texte. (Ms. du w siècle de l'hégire.)

Contenu: sourates $\mathrm{Ix}, 75$ à $104 ; \mathrm{x}, 19$ à 62 ; xxı1 , 28 et suiv.; xxıv, 1 à 3 . .

Vélin. 138 fenillets. Hauteur, 22 centimètres; Jargeur, 28 centiinètres. - (Supplément s so B b.)

\section{0 .}

Fragments de deux exemplaires du Coran.

$1^{\circ}$ (Fol. 1 à 42, 42 bis, 42 ter, 43 à 58,58 bis à 14.) Belle et grande écriture coufique; cing ligues par page; traits diacritiques contemporains du rexte; pointsvoyelles en rouge, avec variantes en or, en jaune et en vert; un petit rond historié en or maryue la fin de chaque verset; un hidoré indique les groupes de cinq versets, une belle et grande rosace historiée, renfermant le nom d'une dizaine en toules lettres, les groupes de dix versets; les titres de sourates, écrits en lettres d'or, sont contemporains du texte; le premier (fol. $61 r^{\circ}$ ) a en marge une grande arabesque en or et en couleur; le second (fol. $129 \mathrm{v}^{\circ}$ ) est en lettres d'or, sur un beau fond historié, rouge et blanc, avec encadrement très-bien exécuté en or, et une grande arabesque dorée en marge; le troisième (fol. $141 \mathbf{v}^{\circ}$ ) est sur fond blanc, avec une grande arabesque en marge; la moitiú de la dernière ligne de la sourate précédente est remplie par' une bande, exécutée en or et en couleur, d'un très-beau dessin. (Ms. du IV siècle de l'hégire.)

Contenu : sourates II, 21 à 28,80 à 85,87 à 89,261 à $271 ; 111,87$ à 96,153 à $158 ; \mathbf{v}, 86$ à $92 ;$ vi, 9 เ à $9^{3}, 139$ à $148 ; 1 \mathrm{x}, 88$ à $9^{0} ; \mathrm{x}, 48$ à $82 ; \mathrm{x}$ II, 43 à 50 ; $\mathrm{xv}, 1$ à 27,80 et suiv.; xvi, İ $10 ; \mathrm{xv11}, 3$ ।

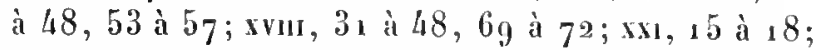
xxı11, 7 à 15,33 à $40 ; \mathrm{xxuv}, 53$ à 56,59 ef $60 ; \mathrm{xxv}, 1$ à 3,65 à $75 ; \mathrm{xxv1}, 1$ à 4,13 ì 18,71 à 77,104 à $109 ;$ Xxxv111, 2 à 7 ; xxxix, 22 à $29 ; x_{111}, 29$ à $47 ;$ LII, 11 à 47 ; L11, 2 I et suiv.; Luv, 1 à $45 ;$ xcı, 14 el suiv.

$2^{\circ}$ (Fol. 142 à 237.) Grande et très-belle écriture coufique; ciny lignes par page; quelques traits diacritiques; quelques alif de prolongation en rouge; pointsvoyelles en ronge, avec rariantes en reit et en jaune; les versets sont séparés par des ronds dorés et bistoriés, les groupes de cinq versets par des pendeloques, et les groupes de dix et les centaines par de belles rosaces historiées; une sourate se termine (fol. $191 v^{\circ}$ ) par une ligne de feuillage doré. (Ms. dı $1 v^{e}$ siècle de l'hégire.)

Contemi : sourates III, 151 à $160 ; 1 \mathrm{v}, 8$ à $10,12 \mathrm{et} 13$, 38 et 39,41 à $45,65,124$ à $130 ;$ vill, 7 h̀ $76 ; 1 \mathrm{x}, 3$ à 5,96 à 98,100 et $101 ; x H, 26$ et $27 ;$ xvıI1, 81 à 83 ; xxı, 16 à 18 ; xxvı, 65 à 78,83 à 89,94 à $95 ;$ xxxı, 1 et 2 ; XxxiII, 19 à 21,35 et 36 ; xxxiv, 11 et 12,27 à 32,38 à $42 ;$ xxxvu, 142 à $145 ; \mathrm{xL}, 22$ et 23,29 et 30 ; $\mathrm{xLV}, 20$ à 22 ; xLvi, 8 à 10,14 à 16,25 à 33 ; xLVI, 19 à 21,29 et $30 ; \mathrm{xlvIII}, 16$ à $23 ; \mathrm{L}, 9$ à 13,16 à 18 ; LVI1, 1 à 10 .

Vélin. 2 h 1 feuillets. Ilauteur, 2 centimètres et demi; largenr, 3a centimètres. - (Supplément $150 \mathrm{E}$ e.)

\section{1 .}

Fragments d'un exemplaire dı Coran,

Belle et grande écriture coufique; cing lignes par page; quelques traits diacritiques, ajoutés après coup; pointsroyelles en rouge, avec variantes en bleu; chaque verset. se termine par le mot أية, inscrit dans une pendeloque historice; les groupes de cinq et de dix versets sont indiqués par des rosaces en or et en couleurs; les titres (fol. 200 et 249 ), écrits en lettres d'or, sont contemporains du texte; en marge de chaque titre se trouve une grande rosace en or et en couleurs; le verso du fol. 105 , qui contient la fin d'une section (جز $)$, est occupé par un beau dessin en or et en couleurs, représentant un tapis de prière, arec un gros rond historié en marge; on lit au mềne folio et aux folios 230 et 27 , une note en neshihi, constatant que cet exemplaire du Coran avait été donné en waqf à la mosquée appelée al-Djâmi $l$ 'Atiq (la mosquée d'Amr, au vieux Caire). Voici le texte de celte note, à laquelle nous ajoutons les points dia-

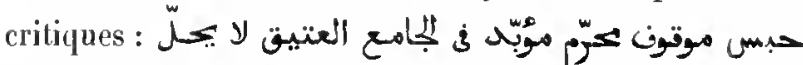

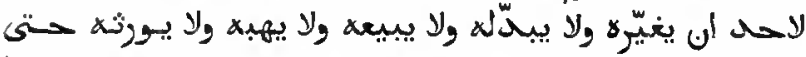

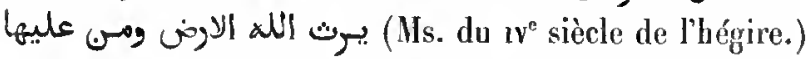

Contenu: sourates Iv, 123 à $134 ; 11,168$ à 170,175 et $17^{6,183}$ à 193,199 à $2.03,211$ à 214,219 à 226,231 et $232,234,242$ à 244,264 à 266,282 et $283 ; 111,6$ à 9,51 à 53,66 à $72 ; \mathrm{Iv}, 78$ et $79,9^{6}$, 104 et $105 ; \mathrm{v}, 1$ et 2,51 et $52 ; \mathrm{vI}, 34$ à 38,44 ì 48,51 el 52,54 à 56,57 à 59,76 à 78,124 à 131 ; v11, 21 à 25,30 et 31,36 et 37,66 à 68,71 ì 77 , 83 et 84,108 et 109,112 à 114,119 iो 125,127 à $130,133,139$ à 143,160 et 161,164 à 166,167 et 168 ; vitr, 16 à 19,39 à 49,47 et 48,51 et 52,54 à 63,67 à $73 ; \mathrm{xx}, 24$ à 26,34 à 36,60 et 61,80 à 89,118 et $119 ; \mathbf{x}, 13,3$ เ ̀̀ 47,61 et 62,81 à 83 ; $\mathrm{x} 1,60$ à 62,69 à 73,78 à $81,9^{3}$ à $9^{5}, 101$ iो 103 ; xiI, 104 et $108 ; x+1,33$ et $34 ; x ı, 11$ à 13,21 et 22 ; xv, 39 à 42,57 à $61 ;$ xvı, 73 et 74,92 et $93 ;$ xviı, , à 14,16 à 19,25 à 30,32 à 34,47 el 48,104 à 106 : 
xvilı, 28 à 30,89 à $93 ; x 1 x, 1$ à 5,20 à $23 ; x x 11,69$ à 73 ; xxiv, 3 à $5,11,23$ à 29,31 ì 33,37 à 40,47 à 50,60 et suiv.; xxv, 1 et $2 ; x x v 1,68$ à $72 ; x x v 11,40$ à 44 ; xxvı11, 38 et $39 ; \mathbf{x x u x}, 33$ à $35 ; \mathbf{x x x}, 19$ à 29 ; xxxill, 4 à 10,44 à 48,53 à $60 ; \operatorname{xxxuv,~21~à~} 23,51$ ì 54 ; xxxv, 43 et 44 ; xxxy, 16 à 18 ; xxxv11, 27 à 30 , 45 à 54,59 à $74 ;$ xxxvill, 59 à 69,65 à $69,7^{3}$ à 76 ; xLII, 21 à 22,25 à $28 ; x \mathrm{LV}, 9$ et 10,12 à $14 ; \mathrm{xLV}, 10$ et 11,17 à 19,34 et suiv.; xuvll, 1 à 33 ; xulx, 1 et 2 , 6 à $9 ; \mathrm{L}, 22$ à 26 ; Lxv, 5 et 6 ; Lxvi, 6 à $12 ; \mathrm{Lxxv}$, 4 à 10.

Vétin. 279 feuillets. Hauteur, 25 centimètres; largeur, 33 centimètres. - (Supplément $150 \mathrm{Ff}$.)

\section{2.}

Fragments de huit exemplaires du Coran.

$1^{\circ}$ (Fol. 1.) Belle écriture coufique, de moyenne grandeur; seize et dix-sept lignes par page; points rouges pour les voyelles; points verts pour les hamza; sans traits diacritiques; les rersets ne sont pas séparés; une ligne a été laissée en blanc pour recevoir le titre d'une sourate. (Ms. du s $^{\mathrm{e}}$ siècle de l'hégire.)

Contenn : sourates xulx, 17 et suiv.; L, 1 à 15.

$2^{\circ}$ (Fol. 2.) Belle et grosse écriture coufique; six lignes par page; paints rouges pour les royelles; points jaunes pour les hamza; sans traits diacritiques; les versets sont séparés par un petit fleuron doré, les groupes de cinq versets par un ha doré. (Ms. du $\mathbf{r}^{\mathrm{c}}$ siècle de l'luégire.)

Contenu: sourate $\mathrm{xxxv}, 41$ à 45 .

$3^{\circ}$ (Fol. 3 à 5.) Belle et grosse écriture coufique; six lignes par page; sans traits diacritiques; points rouges pour les royelles; un groupe de quatre traits /// sépare les rersets; un hâ doré indique les groupes de cinq, une petite rosace historiée, renfermant un chiffre de dizaine en or sur un fond blanc, les groupes de dix versets. (Ms. du $1 v^{e}$ siècle de l'hégire.)

Contenu: sourate Lxim, 10 à 37 .

$4^{\circ}$ (Fol. 6.) Belle et grosse écriture coufique; six lignes par page; points rouges pour les voyelles; quelques traits diacritiques, dont un seul est contemporain du texte; un rond en or et en couleur sépare les versets. (Ms. du $1 v^{\mathrm{e}}$ siècle de l'hégire.)

Contenu : sourate iv, 23 et 24.

$5^{\circ}$ (Fol. 7 à 27.) Belle écriture coufique, de moyenne grandeur; onze lignes par page; points diacritiques, plus modernes que le texte; points-royelles en rouge, arec va- riantes en vert; 'les titres de sourates (fol. 16 et 25 ) en or, sur un fond blanc, paraissent être contemporains du texte; les versets ne sont pas séparés; un $h \hat{A}$ doré indique les groupes de cinq versets, une petite rosace historiée, renfermant un chiffre de dizaine, les groupes de dix versets; au fol. 14 , en marge, on lit ces mots en lettres d'or: r moitié du troisième septièmen; au

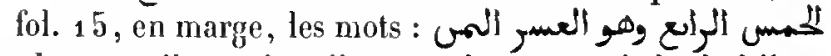
- le quatrième cinquième, qui est aussi le huitième dixième", en lettres d'or. (Ms. de la fin du $\mathbf{v}^{\mathrm{e}}$ siècle de l'hégire.)

Contenu : sourates $1 \mathrm{x}, 59$ à 70,79 à $84 ; \mathrm{x}, 31$ à 67 ; $\mathrm{xL1}, 45$ et suiv.; xL11; xL11, 1 à 28 .

$6^{\circ}$ (Fol. 28 à 31.) Belle et grosse écriture coufique de grandeur moyenne; sept lignes par page; quelques traits diacritiques, moins anciens que le texte; pointsroyelles en rouge; un point vert pour le hamza; le mot $x$, inscrit dans une pendeloque historiée, marque la fin de chaque verset; le mot um, écrit en marge et entouré d'un bandeau historié, indique les groupes de cinq versets, un nom de dizaine, dans un encadrement circulaire, or, rouge et vert, les groupes de dix versets. (Ms. du $1 v^{\mathrm{e}}$ siècle de l'hégire.)

Contenu: sourate v, 16 à 18,22 à 24,37 à 44 .

$7^{\circ}$ (Fol. 3ュ à 76 .) Belle écriture coufique; six lignes par page; traits diacritiques, ajoutés après coup; pointsvoyelles en rouge; un point vert pour le hamza; une pendeloque historiée sépare les rersets; un hâ doré indique les groupes de cinq rersets, et un nom de dizaine en lettres d'or, entouré d'une bande cloisonnée, or et couleurs, les groupes de dix rersets. (Ms. du $\mathbf{v}^{\mathbf{e}}$ siècle de l'hégire.)

Contenu: sourates 11,19 à $36 ;$ vill, 29 et $30 ; x 11,80$

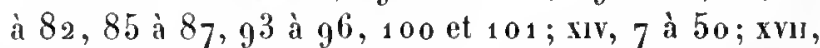

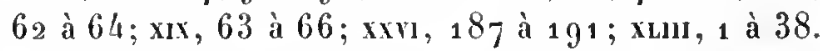

$8^{\circ}$ (Fol. 77 à 161.$)$ Belle écriture coufique; cinq lignes par page; quelques traits diacritiques; points-royelles en louge, arec variantes en jaune; quelques alif de prolongation, ajoutés après coup à l'encre rouge ou à l'encre jaune; un petit fleuron doré sépare les rersets; des rosaces en or et en couleurs, portant le mot ur ou le nom d'une dizaine, indiquent les groupes de cinq et de dix versets; sur la marge du folio 142 , on trouve un titre de sourate en lettres blanches, sur un fond rouge, avec arabesques d'or, accompagné d'un grand fleuron or et couleurs; ce titre est bien exécuté et contemporain du texte. (Ms. du r $^{\circ}$ siècle de l'hégire.)

Contenu: sourates 111,77 à $79 ; \mathbf{v 1}, 12,23$ à 25,27 à 34 ; v11, 61 et 62,68 et 69,71 à 84 ; v11, 4 à 6,9 à 21 ; $\mathrm{x}, 61$ à $69,7^{4}$ à $81,9^{4}$ et $9^{5} ; \mathrm{x} 11,65$ et $66,7^{4}$ à $7^{6}$, 
77 à $87 ; x x, 101$ à $106 ; x \times 111,37$ à 39,56 à $62 ;$ xxvı, 201 et suir.; xxvı, 1 à 3 ; xxxıv, 3 à 6 ; xxxvı, 27 à $32 ;$ XLII, 40 à $43 ;$ XLIII, 7 à 9,24 à $46 ;$ LVIII, $9 ; \mathrm{LX}$, $10 ; \mathrm{LX1}, 6$ et 7 .

Vélin. 161 feuillets. Hauteur, 21 centimètres; largeur, 38 centimètres. - (Supplément $150 \mathrm{G}$ g.)

\section{$+$ \\ 353.}

Fragments de quatre exemplaires du Coran.

$1^{\circ}$ (Fol. 1 à 11.) Betle écriture coufique, de moyenne grandeur; sept lignes par page; points diacriliques ajoutés après coup; points-royelles en rouge, avec quetrues variantes; les versets sont séparés par une petite rosace historiée; les groupes de ciuq et do dix versets sont indiqués, à la marge, par des rosaces portant le not ur ou le nom d'une dizaine; les litres des sourates sont contemporains du texte. An recto du premier feuillet, on voit les dessins d'une saddjada et d'une qibla, en or et en couleurs. Ces dessins indiguent le commeucement et la lin d'une section (s; ). (Ms. du $\mathbf{v}^{\mathrm{e}}$ siècte de l'hégire.)

Contenu: sourates $1 ; 11,1$ à 19,211 à 225.

$2^{\circ}$ (Fol. 12 à 23. ) Écriture coufique; dix lignes par page; points-royelles et traits diacritiques plus nodernes que le texle; les versets ne sont pas séparés; le ha doré - indique les groupes de cinq rersets, el des rosaces, or et couleurs, insérées dans le texte, les groupes de dix versets. (Ms. du $\mathrm{v}^{\mathrm{e}}$ siècle de l'hórgire.)

Contenu : somrate 11, 154. à 187,194 à 199,207 à 238 .

$3^{\circ}$ (Fol. 24 à 45.) Écriture coufique; dix lignes par page; points-royelles avec variantes; sans traits diarritiques; une petite rosace historiée sépare les versets; le hi doré marque les groupes de einq versets, une rosace, or et couleurs, dessinéc tantôt en marge, tinntôt dans le texte, et renfermant le nom d'une dizaine, les groupes de dix rersets; les titres de sourates (fol. 26 et 44), en or sur blanc, somt contemporains du lexte. (Ms. du av sièrle de l'hégire.)

Contenu: sourales 11, 206 à 209,215 a $220 ; \times x 1,112$; $\mathrm{xx} 1 \mathrm{I}, 1$ aे 47 ; xxv, 26 aे 47 ; xxy1, 146 el suiv.; xxv11, 1 à 10 .

$4^{\circ}$ (Fol. 46 à 56.) Belle écriture coufique; huit lignes par page; sans traits diacritiques; points-voyelles en rouge, avec variantes; un point vert désigne le hamza; quelques alif de prolongation ont été ajoutés après coup à l'encre verte; les rersets ne sont pas séparés; le hà doré indique les groupes de einq versets, une rosace

$$
\text { Mav, onimacix. - H. }
$$

insérée dans le texte, les groupes de dix versets. (Ms. du IV $^{\mathrm{e}}$ siècle de l'hégire.)

Contenu: sourate 111,20 à 41,183 à 186 .

Vélin. 56 feuillets. Hauteur, 17 centimètres el demi; largeur, 23 centimètres et demi. - (Supplément 150 li.)

\section{4.}

Fragments de cinq exemplaires du Coran.

$1^{\circ}$ (Fol. 1 à 1 o.) Belle écriture coufique, de moyenne grandeur; onze lignes par page; points-royelles en rouge; Laits diacritiques ajoutés après coup, ainsi que les groupes de trois traits $\%$, qui séparent les versets; un há doré indique les groupes de cinq versets, des rosaces ornées, les groupes de dix versets. (Ms. du $1 v^{e}$ siècle de l'hégire.)

Contemu: sourate 111,122 à 174 .

$2^{\circ}$ (Fol. 1 1 à ı 3.) Belle écriture coufique, de moyenme grandeur; huit lignes par page; points-royelles en rouge, avec variantes; sans traits diacritiques; les versets ne sont pas séparés; les groupes de cinq rersets sont indiqués par un ha doró, et les groupes de dix versels par une rosace ornée. ( $1 \mathrm{~s}$. du $1 v^{\mathrm{e}}$ siècle de l'hégire.)

Contenu: sourates xxix, 57 à $62 ; \mathrm{xxx}_{2} 21$ à 25,28 à 32 .

$3^{\circ}$ (Fol. 14 à 3 1.) Belle écriture coufique, de moyenne grandeur; six lignes par page; points-ıoyelles en rouge, irec variantes; sans traits diacritiques; quelques points diacritiques, ajoutés après coup); un titre de sourate. écril en or, est contemporain du texte (fol. 22); le ha doré indique les groupes de cinq versets, et la rosace historiéc les groupes de dix versets. (Ms. du $1 v^{e}$ siècte de l'hégire.)

Contenu: sourates $\mathrm{x} ı 1,18$ et suiv.; xır, 1 à $6 ; \mathrm{xu}$, 5 à 36 .

$4^{\circ}$ (Fol. 32 à $7^{5}$.) Belle écriture coufique, de moyenne grandeur; sept lignes par page; points-voyelles en rouge, avec variantes à l'encre verte; sans distiuction de versets; le hi doré indique les groupes de cinq rersets, la rosace historiée, renfermant le nom d'une dizaine, les groupes de dix versets; le folio 35, qui remplace un feuillel perdu. est d'une autre main; le contenu du l'euillet précédent, qui arail disparu aussi, a été rétabli sur la nlarge inférieure du fol. $34 \mathrm{v}^{\circ}$ et sur la marge supéricure du lol. 35 , en écriture nesklii, dépournue de points diacriliques; cette écriture paraìt être du $v^{e}$ sićcle. (Ms. du $1 v^{e}$ sièrle de l'lóggire.)

Contenu: sourates v, 98 à $114 ; v, 1$ à $5 ;$ vill, 29 à 34 , 50 à $55 ; 1 x, 30$ à $9^{4} ; x x, 68$ à 73,89 à $9^{5} ; \mathrm{L}, 2$ à 7 . 
$5^{\circ}$ (Fol. $7^{6}$ à 83.) Belle écriture coufique, de moyenne l'andeur; six lignes par page; points-royelles en rouge; quelques points diacritiques ajoutés après coup; les versets sont séparés par un groupe de trois traits; le hâ doré indique les groupes de cinq versets, et la rosace ornép les groupes de dix versets.

Contenu : sourale $x x i v, 27$ à 35 .

Vélin. 83 feuillets. Hauteur, 17 centinètres; largeur, 22 centimètres. - (Supplément $150 \mathrm{Kk}$.)

\section{5.}

Fragments de deux exemplaires du Coran.

$1^{\circ}$ (Fol. 1 à 44.) Belle écritur's confique; sept lignes par page; points-royelles en rouge; points diacritiques, ajoutés après coup; les versets sont séparés par nue petite rosace; les groupes de cinq et de dix versets sont indiqués par des rosaces historiées, la plupart à la marge; titres de sourate (lol. $\left.91^{\circ}, 18 r^{\circ}\right)$ en lettres d'or, conlemporains du texte. (Ms. du $\mathrm{v}^{\mathrm{n}}$ siècle de l'hégire.)

Contenu: sourates 11,19 à 21,220 à $222 ; 111,96$ à 110,173 à 176 ; xxxı, 32 et suiv.; xxx11; xxs111, 1 à 30 , 35 à 42,60 à $63 ;$ xxxvir, 78 à 179 .

$2^{\circ}$ (Fol. 45 à 73. ) Belle écriture confique; huit lipnes par page; points-royelles en ronge; points diacriliques, ajoutés après coup; un tilre de sonrate (fol. $57 \vee^{\circ}$ ), en lettres d'or, est contemporain du texte; un hà doré marque les groupes de cinq, une rosace historiée, les groupes de dix versets; une arabesque se trouve à la marge du fol. 60 . (Ms. de la fin du me siècle de l'bégire.)

Contenu : sourates vı, 22 à $44 ;$ vi, 131 à 133,146 à $149 ; \mathrm{xl}_{1}, 18$ ì 20,45 et 46,85 à $89 ; \mathrm{xxxlv}, 51$ el suiv.; xxxv, 1 à 5,29 à $33 ; \mathrm{xL}, 46$ à $74 ; x_{L v 111,1} 1$ à 25 ; LIX, 2 at 3 .

Vétin. $7^{3}$ feuillets. Hauteur, 17 centimètres et demi; largeur, 9' centimètres. -- (Supptément 150 LI.)

\section{6.}

Fragments de lıuit exemplaires du Coran.

$1^{\circ}$ (Fol. 1 à 46.) Belle écriture coufique, à gros traits et de moyenne grandeur; cinq lignes par page; pointsroyelles en rouge; des points verts pour les hamza; quelques traits diacritiques ajoutés après coup; les versets sont séparés par une petite rosace en or; les groupes de cinq versets sont indiqués par un $h a ̂$ doré et, à la marge, par une rosace renfermant le mot $\mathbf{\text { Tw; }}$ des rosaces plus grandes, en or et en couleurs, renfermant les noms des dizaines, sont dessinées à la marge pour marquer les groupes de dix versets. An folio $17^{\circ} \mathrm{r}^{\circ}$ se trouve un titre de sourate, eu lettres d'or, contemporain du texte, et à la marge, un beau tleuron ayant la, forme d'un vase. (Ms. du w siècle de l'hégire.)

Contenu : solrates xi, 105 aे $107,110,111,116$ à $118 ; x^{2} 1,92$ à $96 ; x v 11,15$ à $31 ; x+11,109$ et suiv.; xix, 1 à 21 ; xxvi11, 43 à 45,51 à 54,57 à 74 ; xxxilı, 52 à $57 ; \operatorname{xxxy}, 13$ à $14 ; \operatorname{xxxIx}, 9$ à $14 ; \mathrm{LI}, 4$ à 11.

$2^{\circ}$ (Fol. 47.) Belle écriture coufique, de moyenne grandeur; cinq lignes par page; points-voyelles en rouge; points verts pour les hamza; les versets sont séparés par une petite rosace dorée et listoriée. (Ms. du $1 v^{\circledR}$ siècle de l'hégire.)

Contenu: sourate $x \times 11,21$ à 23.

$3^{\circ}$ (Fol. 48.) Belle écriture coufique; cinq lignes par page; sans points-voyelles; les versets ne sont pas séparés; Io noûn final est marqué d'un trait diacritique, qui a été ajouté après comp. (Ms. du wo siècle de l'hégire.)

Contenu: sourate xxvill, 49 à 51 .

$4^{\circ}$ (Fol. 49 à 52.) Belle écriture confique; cinq lignes par page; points-royelles en rouge; les versets sont séparés par six points dorés, groupés en triangle. (Is. du commencement du $1 v^{\bullet}$ siècle de l'hégire.)

Contenu: sourate 11, 189 ot $19^{0}, 238$ à 241.

$5^{\circ}$ (Fol. 53 à 57. ) Belle écriture coufique; cinq lignes par page; points-voyelles en rouge; traits diacritiques, ajoutés après coup; les versets sont séparés par six points dorés formant un triangle; un hà doré indique les groupes de cinq, la rosace dorée, portant un noin de dizaine, les groupes de dix versets. (Ms. du commencement du $\mathrm{vv}^{\bullet}$ siècle de l'hégire.)

Contenu: sourate 11, 119 à 122,125 à 127,129 ì 131 .

$6^{\circ}$ (Fol. 58.) Belle écriture coufique; cinq lignes par page; points-voyelles en rouge; quelques traits diacritiques, ajoutés après coup; les versets ne sont pas séparés; nne petite rosace historiée marque les groupes de dix versets. (Ms. du $\mathrm{Iv}^{\mathrm{e}}$ siècle de l'hégire.)

Contemu : sourate $\mathrm{Ix}, 20$ à 23.

$7^{\circ}$ (Fol. 59.) Belle écriture coufique; cinq lignes par page; points-royelles en rouge; points verts pour les hamza; les versets sont séparés par un triangle composé de six points dorés; le hâ doré indique les groupes de cinq versets. (Ms. de la fin du $m^{\mathrm{e}}$ siècle de l'hégire.)

Contenu : sourate $\mathrm{xxı}, 55$ à 57 .

$8^{\circ}$ (Fol. 6o.) Grosse écriture coufique, de moyenne 
grandeur; cinq lignes par page; points-voyclles en rouge; points jaunes pour les hamza; les alif de prolongation sont à l'encre rouge; le wașla est indiqué par un trait horizontal vert; une rosace hisloriée sépare les versets. (Ms. du $\mathbf{v}^{\mathbf{e}}$ siècle de l'hégire.)

Contemi : sourate xxxix, 22.

Vélin. 60 feuillets. Hauteur, 18 centimètres; targeur, 24 centi mètres. - (Supplément 1 วัo Nn.)

\section{7.}

Fragments d'un exemplaire du Coran.

Belle et grosse éeriture coulique, de moyenne grandeur; cing lignes par page; points-royelles en rouge, avec variantes en conleurs; quelques traits diacritiques en vert; les alif de prolongation, les teschdid, les djazm et autres signes orthographiques également en vert; les versets sont séparés par une feuille de trèlle, composée de trois points dorés; le hi doré indique les groupes de cing versets, la rosace historiée, renfermant un nom de dizaine, et dessinée tantòt dans le texte, tantòt à la marge, les groupes de dix versets; les titres de sourates (fol: $63 \mathrm{v}^{\circ}$, $88 \mathrm{r}^{\circ}$ ), en lettres d'or, sont contemporains du texte; en marge de chaque titre on voit un fleuron assez bien exécuté. (Ms. du wo siècle de l'hégire.)

Contenu: sourates 11, 204 et $205,214,270$ à $274 ; 1 \mathrm{v}$, 36 à 42,65 et 66,120 à 122,130 et $131 ;$ v1, $1 / 4$ et 145,152 à $160 ;$ v11, 12 à 16,27 et 28,114 à 119 ; $\mathrm{xi}, 14$ et $25,24 \dot{\mathrm{a}} 28,77,79,85$ et $86 ; \mathrm{x}, 41$ aे 46 , $9^{4}$ à 97,112 à $115 ;$ xxı $, 5,76$ et $77 ;$ xxı11, $9^{3}$ à 97 ; xxıv, 28 et 19 , 42 à 50 ; xxxıv, 31 à 43 ; xxxı, 5 द à 61 , 77 et suiv.; xxxyll, 1 à 12,71 ì 105 ; xxxyıl , 34 ì 36 , 62 ì 65,69 à $72 ; x L, 15$ et 16 ; xLII, 1 ì 3,47 ì 52 ; xul1, 4 à 14 ; xLy, 3 h et suiv.; xLvı, 1 ì 3 ; เxxvı, 36 i) 47 ; Lxxy, 3 à 7 .

Vétin. $9^{2}$ feuillets. Hauteur; 19 centimètres; largeur, 27 centimètres. - (Supplément i 5o 0o.)

\section{8.}

Fragments de six exemplaires du Coran.

$1^{\circ}$ (Fol. 1 à 1 o.) Betle écriture coufique, de moyenne grandeur; six lignes par page; points-royelles en rouge; trails diacritiques, ajoutés apr'ès coup; les versets sont séparés par un trèfle doré; les groupes de dix versets sont indiqués par des rosaces historiées, renfermant les noms des dizaines, tantòt à la marge, tantôt dans le texte; une rosace, à la marge, renfermant le mot wr, et le hi doré indiquent les groupes de cinq versets. (Ms. du Iv $v^{\mathrm{e}}$ siècle de l'hégire.)

Contenu: sourate $x$ vilı, 74 à 106 .

$2^{\circ}$ (Fol. 11 à 2o.) Belle écriture coufique, à gros traits et de grandeur moyenne; six lignes par page; pointsroyelles en rouge, avec variantes; traits diacritiques, ajoutés après coup; une rosace listoriée, renfermant un nom de dizane, indique les groupes de dix rersets, et le hi doré les groupes de cinq versets. Au folio $14 v^{\circ}$ on tronve un titre de sourate en or, eontemporain du texte; m fleuron en marge dı titre. Aı verso du folio 11 comInence une seetion $(\underset{\sim}{\circ})$. Le reeto, qui avait été laissé en blanc, contient la note suivante, en caractères coufiques, se rapprothant beaucoup du neskhi, et accompagnés de traits diacritiques peu allongés : وقنغ هـذ

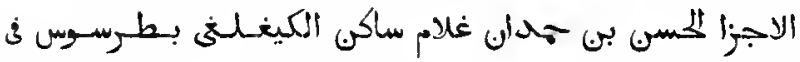

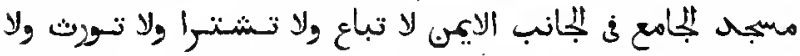

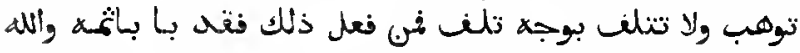
توهب , Al-Hasan ben Haindâı, serviteur de Sàkin al-Kighlighi, a déposé ces sections, comme donation perpétuelle, dans la grande mosquée de Tarse, còté droit. On ne doit pas les vendre, ni les acheter, ni les receroir comme héritage, ni les donner, ni les gâter en aucune maniere. Quiconque fera cela, se chargera d'un crime dont Dien lui fera rendre compte : Dieu suffit pour faire rendre compte. (Coran, xxxm, $3_{9}$.)

Au-dessous de ectle inscription se trourent deux lignes décriture neshli, dont roici le texie et la traduction :

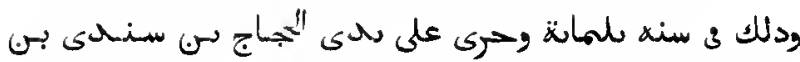

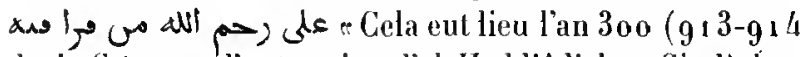
de J. C.), par l'entremise d'al-Haddjâdj ben Sindì ben 'Ali. Que Dieu montre sa miséricorde à quiconque y lii."

Au-dessus de la même inscription, on lit les mots suirants, écrits en neskhi cursif : ('Ali ben al-Hosaïn l'a fait sortir de Balad al-Roûm (l'Asie Mineure), l'an 730 (1329-1330 de J. C.). (Ms. de la fin du $11^{e}$ siècle dı l'hégire.)

Contenu: sourates xLI, 46 et suiı.; xuII, 1 à 15.

$3^{\circ}$ (Fol. 21 à 28.) Belle écriture coufique, à gros traits et de grandeur moyenne; huit lignes par page; points-royelles en rouge, avec variantes; une rosace historiée indique les groupes de dix versets, le hâ doré les groupes de einq versets. Én tête de la cinquième section (fol.21) se trouve une note d'une bonne écriture coufique, ajoutée après coup, qui constate que le nommé Yaḷyà ben Sa id, surnommé lbn H hì (هاه), avait donné 
cette section et treize autres à un établissement religieux. (Ms. du $\mathrm{v}^{\mathrm{e}}$ siècle de lhégire.)

Contenu : sourates vir, 170 à $183 ; x_{x v ı}, 9$ à 17,62 à $69 ;$ xxy111, 18 à 20 .

$4^{\circ}$ (Fol. 29 à 35.) Belle écriture coufique, de moyenne grandeur; cinq lignes par page; points-royelles en rouge, avec variantes; sans traits diacritiques; les versets sont séparés par nne petite rasace; une grande rosace historiée marque les groupes de dix versets. (Ms. du $\mathbf{w}^{\mathrm{e}}$ siècle de l'hégire.)

Contenu: sourates $11,19^{2}$ à $19^{4} ; \mathrm{xiv}, 40$ à $42 ; x \mathrm{x}$, 19 à $22 ; x \times 1,44$ à 46.

$5^{\circ}$ (Fol. 36 à 41.) Belle écriture coufique, de moyenne grandeur; neuf lignes par page; points-royelles en ronge; les versets sont séparés par un trèlle doré; un hâ doré indique les groupes de cinq, et une rosace, tantôt à la marge, tantôt dans le texte, les groupes de dix versets. (Ms. du $v^{\mathrm{e}}$ siècle de l'llégire.)

Contemu : sourate xvr, 28 à 38,44 à 50,72 à 75,79 iे 82 .

$6^{\circ}$ (Fol. 42.) Jolie écriture coufique, de moyeune grandeur; sept lignes par page; points-royelles en rouge; traits diacritiques ajoutés après coup; les versets ne sont pas séparés. (Ms. du $1 v^{e}$ siècle de l'hégire.)

Contenu: sourate 11,270 à 273 .

Vélin. 4 a feuillets. Hauteur, a 1 centimètres el demi; largeur, 15 centimètres. - (Supplément 150 Qq.)

\section{9.}

Fragments de trois exemplaires du Coran.

$1^{\circ}$ (Fol. 1 à 75.$)$ Belle écritıre coufique, de moyenne grandeur; huil lignes par page; les lolios 24 et 43 ne portent que six lignes, le folio $75 \mathrm{v}^{\circ}$, quatre lignes; pointsroyelles en rouge, arec rariantes; quelques traits diacriliques, ajoutés aprés coup; les versets sont séparés par un rond doré; le hâ doré indique les groupes de cinq, des rosaces historiées, renfermant un nom de dizaine, les groupes de dix versets; les titres de sourates, écrits en or, sont contemporains du texte. (Ms. du $1 v^{\mathrm{e}}$ siècle de l'hégire.)

Contenu: sourates $x x m, 47$ et suiv.; $x x 1 x$ et suivantes, jusqu'à xxxiv, 18.

$2^{\circ}$ (Fol. 76 et 77.) Belle écriture coufique, de moyenne grandeur; luuit lignes par page; points-royelles en rouge, avec variantes; des ronds dorés indiquent les groupes de dix versets. (Ms. du $1 v^{e}$ siècle de l'légire.)

Contenu : sourate 1 v, 156 à 165 . $3^{\circ}$ (Fol. 78 à 84.) Belle écriture coufique, de moyenne grandeur; sept lignes par page; points-royelles en ronge; le $h a$ doré indique les groupes de cinq, et la rosace les groupes de dix versets. (Ms. du iv siècle de l'hégrire.)

Contemu : sourate xir, 5 à 29 .

Vélin. 84 feuillets. Hauteur, a 1 centimètres ; largeur, 15 centimètres. - (Supplément 150 Rr.)

\section{0.}

Fragments de deux exemplaires du Coran.

$1^{\circ}$ (Fol. 1 à .3.) Belle écriture coufique, de moyenne grandeur; six lignes par page; points-voyelles en rouge; poinls rerts pour les hamza; les versets sout séparés par une pendeloque historiée, portant le not ג̄يt. (Ms. dn i $v^{\mathrm{c}}$ siècle de l'hégire.)

Contenu: sourates xıx, 17 à 21,34 à 37 xLvıı, 17 et 18 .

$2^{\circ}$ (Fol. 4 à i 7.) Belle écriture coufique, de moyenne grandeur; sept lignes par page; points-voyelles en rouge; points verts pour les hamza et pour les variantes; une rosace portant le mot um indique les groupes de cinq rersets, une autre rosace, portant un nom de dizaine, les groupes de dix versets. Aux folios 16 verso et 17 recto, on lit les mots suivants, écrits à la hâte,

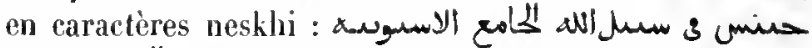
-Donation piense, faite à la mosquée de..., côté droit», c'est-à-dire rà déposer dans l'armoire, du còté droit". (Ms. du iv siècle de l’hégire.)

Contenu: sourates xxvi1, 48 à $64 ; x x 1 x, 12$ à 33 .

Vétin. 17 feuillets. Hauteur, 15 centimètres; fargeur, 21 centimètres. - (Supplément 150 Ss.)

\section{1 .}

Fragments de six exemplaires du Coran.

$1^{\circ}$ (Fol. 1 à 3.) Belle écrilure coufique, de moyenne grandeur; sept lignes par page; points-voyelles en ronge; les versets sont séparés par un trèfle d'or. Au verso du folio a commence la vingt-septième section du Coran; au recto, une note de huit lignes, en écriture neskhi, constate que la nommée Kolthoum, fille de Yahyâ, avait donné cette section en wayf à la grande mosquée dn

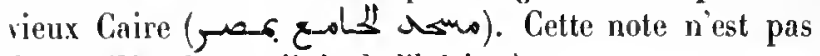
datée. (Ms. du $1 v^{\mathrm{e}}$ siècle de l'hégire.)

Contenu: sourates $\mathrm{xLI}, 46$ et $47 ; \mathrm{XLII}_{1}, 12$ à 15 .

$2^{\circ}$ (Fol. 4.) Belle écriture coufique; quatre ligues par 
page; points-voyelles en rouge; un rond doré sépare les versets; une rosace historiée indique les groupes de dix versets. Au verso du feuillet on voit un assez joli dessin d'une saddjâda et d'une qibla. Ce feuillet est le dernier d'une section. (Ms. du $\mathbf{v}^{\mathrm{e}}$ siècle de l'hégire.)

Contenu : sourate xxriv, 19 et 20.

$3^{\circ}$ (Fol. 5 et 6. ) Belle écriture coufique; huit lignes par page; points-royelles en rouge, avec variantes; les versets se terminent par un rond doré. (Ms. du $\mathbf{v}^{\mathrm{e}}$ siècle de l'hégire.)

Contenu : sourate $x 1 v, 21$ à 27.

$4^{\circ}$ (Fol. 7.) Belle écriture coufique; huit lignes par page; points-royelles en rouge; le hâ doré indique les groupes de cinq rersets. (Ms. du $\mathbf{l v}^{\mathrm{e}}$ siècle de l'hégire.)

Contenu: sourate vilı, 4 à 8 .

$5^{\circ}$ (Fol. 8 el 9.) Belle écriture coufique; huit lignes par page; points-royelles en rouge, avec variantes; un rond doré marque un groupe de dix rersets. (Ms. du Iv siècle de l'luégire.)

Contenu: sourate Iv, $7^{4}$ à 77,81 el 85 .

$6^{\circ}$ (Fol. 10 à $3{ }_{1}$.) Belle écriture coufique; sept lignes par page; points-royelles en rouge; traits diacritiques ajoutés après coup; une rosace hisloriée marque les groupes de dix iersets. (Hs. de la fin du $\mathbf{v}^{\mathrm{e}}$ siècle de l'hégire.)

Contenu: sourates $1 \mathrm{x}, 99$ à $120 ; \mathrm{xv} 1,29$ à $33 ; \mathrm{xx}_{1}$, 25 à 96 ; xLv1ı, 13 à $17 ;$ xLvill, 11 à 25 .

Vétin. 3 I feuillets. Hauteur, 15 centimètres; largeur, 21 centimètres. - (Supptément $150 \mathrm{Tl}$.)

\section{2 .}

Fragments de deux exemplaires du Coran.

$1^{\circ}$ (Fol. 1 à 89.) Assez belle écriture coufique; sept lignes par page; points-royelles en rouge, avec variantes en couleur; sans traits diacritiques; quelques alif de prolongation ajoutés après coup à l'encre jaune; de petits ronds historiés séparent les versets; de petites rosaces historiées, renfermant le mot um, indiquent les groupes de cinq versets, une grande rosace du même genre, renfermant le non d'une dizaine, les groupes de dix versets; titres de sourates (fol. $41 y^{\circ}$ et 75 ) contemporains du texte. (Ms. du $1 v^{e}$ siècle de l'hégire.)

Contenu: sourates II, 8 ì̀ 101,103 à 105,108 à 113 , 265 à $277 ; 111,175$ à $198 ; 1 v, 95$ et $96 ;$ vi, 4 à 10 , 70 à $75,9^{4}$ à $108 ; x 11,111 ; x 111,1$ à $16 ; x v 1,46$ à 72 , 78 à 93,98 à $119 ; x x v ı 11,64$ à $69 ; \times x \times 1,3$ à 6,25 et suiv.; xxxı, 1 à $20 ; x x x 111,20$ à $27 ; x x x ı x, 34$ à 43 , 46 à $48 ; x_{L v}, 22$ à 27.

$2^{\circ}$ (Fol. $9^{0}$ ì 131. ) Belle écriture coufique; sept lignes par page; sans traits diacritiques; points-royelles en rouge, avec variantes; un point vert pour le hamza; les versets se terminent par le not آيّا, enlermé dans une pendeloque; une petite rosace historiée, renfermant le mot $\mathrm{m} \rightarrow$, indique les groupes de cinq rersets, un nom de dizaine, inscrit dans une rosace historiée, les groupes de dix versets. (Ms. du v $^{\mathrm{e}}$ siècle de l'hégire.)

Contenu : sourates 11,181 à $183 ; 1 \mathrm{v}, 161$ et $162 ; \mathrm{v}$, $2,3,22$ à $35,48,56$ à $63 ; x, 81$ à $107 ; x \mathbf{x}, 91$ à $116 ;$ xıv, 32 à $41 ; x v, 53$ à $59 ; x v ı, 21$ à $47 ; x v ı, 25$ à 30 .

Vèlin. 131 feuiltets. Hauteur, 17 centimètres; largeur, 33 centimètres et demi. - (Supplément 150 Uu.)

\section{3.}

Fragments de trois exemplaires du Coran.

$1^{\circ}$ (Fol. 1 à 46.) Écriture coufique, de moyenne grandeur; sept lignes par page; points-royelles en rouge; quelques traits diacritiques ajoulés après coup, et un assez grand nombre de points diacritiques encore plus modernes; les rersets ne sont pas séparés; le hả doré indique les groupes de cinq versets, la rosace, les groupes de dix versets; un titre de sourate (fol. $35 \mathbf{v}^{\circ}$ ), en leltres d'or, est contemporain du texte. (Ms. du $\mathbf{v}^{\circledR}$ siècle de l'hégire.)

Contenu: sourates vıl, 27 à 46 ; xvı, 38 et suiv.; xvı, $1 \dot{2} 46$.

$2^{\circ}$ (Fol. 47 à 53.) Belle écriture coufique; sept lignes par page; points-voyelles en rouge; quelques trails diacritiques ajoutés après coup; les versets ne sont pas séparés. (Ms. du $\mathrm{v}^{\mathrm{e}}$ siècle de l'lrégire.)

Contenu : sourate vi, 80 à 98 .

$3^{\circ}$ (Fol. 54.) Écriture coufique ordinaire; huit lignes par page; les alif sont indiqués par un trait droit; pointsroyelles arec variantes; les versets ne sont pas séparés; titre de sonrate en lettres d'or. (Ms. du iv siècle de l'luégire.)

Contem : sourates $\mathrm{xx}, 13 \mathbf{1}$ et suiv.; $\mathbf{x x}, 2$.

Vélin. 54 feuillets. Hauteur, 13 centimètres et demi ; largeur, 19 centimètres. - (Supplément $150 \mathrm{Vv}$.)

\section{4.}

Fragments de deux exemplaires du Coran.

$1^{\circ}$ (Fol. 1 à 3.) Écriture coufique ordinaire; cinq lignes 
par page; points-royelles en rouge; les versets sont séparés par de pelits fleurons en or. (Ms. du $1 v^{\mathrm{e}}$ siècle de l'hégire.)

Contenu: sourates $11,19^{4} \dot{a} 19^{6} ; \mathrm{vu}, 154$ et 155 , 160 à 168 .

$2^{\circ}$ (Fol. 4 a 42.) Grande et assez belle écriture coulique; cinq lignes par page; points-royelles en rouge; les variantes et autres signes orthographiques en couleur; quelques trails diacritiques ajoutés après coup; les rersets ne sont pas séparés; le ha doré indiyue les groupes de cinq versets, une rosace, les groupes de dix versets. (Ms. du $\mathrm{v}^{\mathrm{e}}$ siècle de l'hégire.)

Comenu: sonrates $11,254,260 ; 1 \mathrm{v}, 28$ à $34,38,46$ ef $47 ; \mathrm{rll}, 102$ à 120,148 et $149 ; 1 \mathrm{x}, 101$ à $109 ; \times x_{1}$, 99 ì 102,105 à $108 ; x x x v, 35$ à $45 ; x$ xul, 24 à 28 .

Vélin. 42 feuiltets. Ifauteur, 14 centimèlres et demi; largeur, zo centimètres. - (Suppiément $150 \mathrm{~W} \mathrm{w.)}$

\section{5.}

l'ragments de deux exemplaires du Coran.

$1^{\circ}$ (Fol. 1 à 73.) Grande et assez belle écriture conlique; quatre lignes par page; points-royelles en rouge, ivec variantes en couleur; traits diacritiques, ajoutés après coup; les versets sont séparés par un trèfle d'or; te hâ doré indique les groupes de cinq versets, uue grosse rosace historiéc, renfermant un nom de dizaine, les groupes de dix versets. (Ms. du $1 v^{\circ}$ siècle de l'hégire.)

Contenu : sourates 11,98 à $102,256,260$ et $261 ; \mathrm{v}$, 20 à $37 ;$ v11, 19 à 21,52 à $56 ; x, 50$ à $61 ; x 1,45$ à 56 ; xxilı, 77 à $93 ; \mathrm{xxuv}, 33$ à $40 ; \mathbf{x x I x}, 39$ et 40,49 à 52 ; xxxı, 62 à 67,71 à $73 ; x_{4}, 16,24$ et 25 .

$2^{\circ}$ (Fol. $7^{4}$ à 136.) Assez belle écriture coufique de moyenne grandeur; cinq lignes par page; points-voyelles "n ronge, alec variantes; quelques traits diacritiques ajoutés après coup; le hà doré indique les groupes de cing rersits, une rosace historiée, les groupes de dix versets; litres dr sourates (fol. 99 et $129 r^{\circ}$ ) en lettres d'or, contemporains du lexte. (Us. du $\mathrm{r}^{\mathrm{e}}$ siècle de l'hégire.)

Contenu: sourates $\times x v, 23$ à 45,70 à $72 ; x \times r, 22$ à 73 ; xxxıv, 45 el suiv.; xxxv, 1 à 8,11 à $21 ; x u l 11,8$ a 32,65 et suiv.; xusv, 14 à 21,27 à 44 .

Vétin. 136 feuillets. Hauteur, 12 centinètres et demi; largeur, 17 centimètres. - (Supplément $150 \mathrm{X}$ x.)

\section{6.}

Fragments de six exemplaires du Coran.

$I^{\circ}$ (Fol. 1 à 6 .) Écriture coufique de moyenne grandeur; six lignes par page; points-royelles en rouge; gros points diacritiques de couleur grise, ajoutés après coup; les versets sont séparés par un petit fleuron; le hâ doré indique les groupes de cinq versets, une rosace historiée, renfermant le nom d'une dizaine, les groupes de dix versets. (Ms. du r $v^{\mathrm{e}}$ siècle de l'hégire.)

Contenu : sourate 111,6 à 18 .

$2^{\circ}$ (Fol. 7 à 10.) Eeriture coufique de moyenne grandeur; six lignes par page; points-royetles en rouge, avec variantes; traits diacritiques d'une grande finesse, ajoutés apr'ès coup; les versets sont séparés par un petit fleuron d'or; le $h \hat{a}$ doré indique les groupes de cinq versets, la rosace listoriée, renferınant le nom d'une dizaine, les groupes de dix versets. (Ms. du $\mathbf{v}^{e}$ siècle de l'hégire.)

Contenu: sourate $\mathrm{xx}, 119$ à 131 .

$3^{\circ}$ (Fol. 11 à 24.$)$ Belle écriture coufique de moyenne graudeur; cinq lignes par page; points-royelles en ronge; les variantes et autres signes orthographiques en couleur; les versets sont séparés par des ronds dorés. (Ms. du iv siècle de l'hégire.)

Contenu: sourates $x, 72$ à $74 ;$ xil1, 25 à $33 ;$ Lxvi , 8 à $12 ;$ LXxill, 20,33 à 35 .

$4^{\circ}$ (Fol. 25 à 62.) Écriture coufique ordinaire; huit lignes par page; points-royelles en rouge, avec variantes en conteur; quelques traits et points diacritiques ajoutés après coup; les versets ne sont pas sćparés; le hâ doré indique les groupes de cinq versets, la rosace historiée, renfermant te nom de la dizaine, les groupes de dix versets. (Ms. de la fin du iv siècle de l'hégire.)

Contenu : sourates 11, 153 à $233 ; \mathrm{xxv}, 206$ à 228 ; xxvII, 28 à $39 ; x x x, 27$ à 41 .

$5^{\circ}$ (lol. 63 à 72. ) Écriture coufique de moyenne grandeur; six lignes par page; points-royelles en rouge, arec variantes; sans marques diacritiques; les versets ne sont pas séparés; le $h d$ indique les groupes de cinq versets, et la rosace listoriée les groupes de dix versets. (Ms. du $w^{\mathrm{e}}$ siècle de l'hégire.)

Conteme: sourate v, 4 ì 18 .

$6^{\circ}$ (Fol. 73 à 85.) Écriture coufique un peu grosse; sept lignes par page; points-royelles en rouge; un point vert pour le hamza; traits diacritiques ajoutés après coup; le $h a \hat{~ i n d i q u e ~ l e s ~ g r o u p e s ~ d e ~ c i n q ~ v e r s e t s, ~ e t ~ l a ~ r o s a c e ~}$ listoriée les groupes de dix versets; titres de sourates -( fol. $7^{3}$ et 82 ) en lettres d'or, contemporains du texte. (Ms. du $v^{\mathrm{e}}$ siècle de l'hégire.)

Contenu : sourates LIx, 22 et suiv.; LX, 1 à $12 ; L x 1,9$ et suir.; LXIı, 1 à 11 .

Vélin. 85 feuillets. Hauteur, 13 centimètres: targeur, 18 centimètres. - (Supptément $150 \mathrm{Y}$.) 


\section{7.}

Fragments de neuf exemplaires du Coran.

$1^{\circ}$ (Fol. 1 à 8.) Éeriture coufique ordinaire; huit lignes par page; points-royelles en rouge; quelques traits diacritiques sur le noûn final; les versets ne sont pas séparés; le hâ doré indique les groupes de cinq rersets, la rosace historiée tes groupes de dix versets. (Ms. du $\mathbf{w}^{\circledR}$ siècle de l'hégire.)

Contenu : sourates 111,31 à $33 ; x ı x, 7$ à 13,36 à 41 , 52 à $57 ; x x, 8$ à $16 ; x x x ı v, 23$ à 32,38 à 4 ..

$2^{\circ}$ (Fol. 9 ì 16.) Écriture confique, dont les traits horizontaux sont très-allongés; dix lignes par page; pointsvoyelles en rouge; points verts pour les hamza; quelques alif de prolongation à l'encre verte; les versets ne sout pas séparés; un $h a$, écrit à l'encre jaune, indique les groupes de cinq versets, la rosace historiće les groupes de dix versets. (Hs. du $1 v^{\mathrm{e}}$ siècle de l'hégire.)

Contenu : sourate 1,76 à 111,125 à 130 .

$3^{\circ}$ (Fol. 17 à 2o.) Belle écriture confique; lunit lignes par page; sans points-royelles, ni signes diacritiques; les versels ne sont pas séparés. (Ms. du iv siècle de l'hégire.)

Contenu : sourate iv, 156 à 168 .

$4^{\circ}$ (Fol. 21 à 36.) Écriture coufique, à gros traits et de grandeur moyeme; huit lignes par page; pointsroyelles en rouge; traits diacritiques très-raccourcis, ajoutés après coup; le ha doré indique les groupes de cinq versets, la rosace historice les groupes de dix versets; titre de sourate (fol. $31 v^{\circ}$ ) en lettres d'or, contemporain du texte. (Ms. de la fin du $1 v^{\mathrm{e}}$ siècle de l'hégire.)

Contenu: sourates xwm, 24 à 59,107 et suir.; $x 1 x, 1$ iो $5 \mathrm{I} ; \mathrm{xulx}, 5$ ì 10 .

$5^{\circ}$ (Fol. 37 à 4o.) Petile écriture confique; dix lignes par page; points-royetles en rouge; les rersets ne sont jas séparés; le hâ doré indique les groupes de cinq versets, la rosace historiée les groupes de dix versets; titre de sourate en lettres d'or, contemporain du texte. (Ms. du (commencement du $\mathrm{v}^{\mathrm{0}}$ siècle.)

Contenu: sourates $\mathrm{xxxı}, 3$ et suiv.; xxxn, 1 ì 30.

$6^{\circ}$ (Fol. 41 à 5o.) Belle écriture coufirue; cinq lignes par page; points-royelles en ronge; points diacriliques ajoutés après coup; quelques versets se terminent par un Heuron en or; le ha doré indique les groupes de cing versets, la rosace historiée, renfermant le nom de la dizaine, les groupes de dix rersets. (Ms. du $\mathbf{~ v v}^{\mathrm{e}}$ siècle de l'hégire.)

Contenu: sourate xxvı, 7 à 40 . $7^{\circ}$ (Fol. 51 à 58.) Petite écriture coufique; neuf lignes par page; points-royelles en rouge; quelques traits diacritiques sur le nốn final; les versets ne sont pas séparés; le hâ doré indique les grompes de cinq versets, une petite rosace listoriée les groupes de dix versels. (Ms. du viècle de l'hégire.)

Contenu: sourate xu, 56 à 101.

$8^{\circ}$ (Fol. 59 à 61.) Fragment semblable au précédent. (Ms. du $\mathbf{v}^{\mathrm{e}}$ siècle de l'hégire.)

Contenu : sourate 1 , 58 à 70 .

$9^{\circ}$ (Fol. 60 à 63.) Écriture coufique; quinze lignes par page; points-voyelles en rouge; sans marques diacritiques, ni signes pour distinguer les versets; titre de sourate (fol. 63) à l'encre rouge. (Ms. du v viècle de l'légire.)

Contenu: sourates $\times x v, 31$ à $51 ; x x v 1,216$ et suiv.; xxviı, 1 à 16.

Vélin. 63 feuillets. Hauteur, 1 a centinètres et demi; largeur. 17 centimètres. - (Supplémenl $150 \mathrm{Z}$ z.)

\section{8.}

Fragments d'im exemplaire du Coran.

Belle écriture coufique; six lignes par page; pointsvoyelles en rouge, arec variantes; quelques traits diacritiques; les versets sont séparés par une petite rosace historiée; une rosace historiće, renlermant le mot حسu, indique les groupes de cinq versets, une rosace historiée, de grande dimension, renfermant le nom de la dizaine, les gronpes de dix versets. (Ms. du $\mathbf{~ v v}^{\mathrm{C}}$ siècle de l'hégire.)

Contenu: sourates 11,276 à $282 ; 1 v, 154$ à $166 ; 1 \mathrm{x}$, 5 à $30 ; x x v, 51$ à $54 ; x \times x 1 x, 14$ à 24.

Vélin. 13 feuillets. Ifauteur. zo centłmètres et demi; largeur, 14 centimètres et clemi. - (Supplément $150 \mathrm{~B} \mathrm{~b} \mathrm{b.)}$

\section{9.}

Fragments de quatre exemplaires dı Coran.

$1^{\circ}$ (Fol. 1 à 5.) Belle écriture coufique, dont les hastes inclinent légèrement vers la gauche; quatorze et quinze lignes par page; nombreux traits diacritiques; pointsvoyelles; plusieurs versets se terminent par un rond jąune; titres des sourates à l'encre jaunc; le texte a été gratté et corrigé en plusieurs endroits. (Ms. de la fin du Iv $\mathrm{v}^{\mathrm{O}}$ siècle de l'hégire.)

Contenu : sourates Ix, 88 à $9^{8 ;}$ xxxvı, 53 à ı 133 ; xxxvilt, 21 et suiv.; xxxIx, 1 à 5 . 
$2^{\circ}$ (Fol. 6 à 1 2.) Belle écriture coufique, à gros traits; quinze lignes par page; le lexle porte presque tous les traits diacritiques; points-voyelles; les versets ue sont pas séparés; un hâd de couleur jaune indique les groupes de cinq rersets, et un rond de la même couleur les groupes de dix versets. (Ms. du iv siècle de l'hégire.)

Contenu : sourate v, 2 à 69 .

$3^{\circ}$ (Fol. 13 à 22.) Belle écriture coufique, à gros Iraits; quinze liynes par page; traits diacritiques assez nombreux; points-voyelles en rouge; les versets ne sont pas séparés; un hâ doré indique les groupes de cinq versets, une rosace en or et en couleur les groupes de dix versets. (Iss. du commencenient du $v^{\mathrm{e}}$ siècle.)

Contenu: sourates 11, 248 à $276 ;$ III, 122 à 171 .

$4^{\circ}$ (Fol. 23.) Éeriture coufique, inclinée vers la ganche; quatorze lignes par page; sans traits diacritiques; points-voyelles en rouge; les versets ne sont pas séparés.

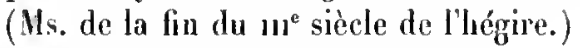

Contenu : sourate $\mathrm{x}, 30$ à 46 .

Vélin. ${ }_{2} 3$ feuillets. Hauteur, ${ }_{15} 5$ centimètres el demi; largeur, 3 a centimètres. - (Supplément 150 U.)

\section{0 .}

Fragments de trois exemplaires du Coran.

$1^{\circ}$ (Fol. 1 à 11.) Écriture coufiquè, tirant sur le neskhi; treize lignes par page; quelques points diacritiques, ajoutés après coup; points-voyelles; des points verts indiquent les hamza; quelques passages ont été corrigés par une main plus moderne; la mềme main a repassé plusieurs mots à l'eucre noire; titres des sourates a l'encre noire, contemporains du texte, en petite écri-

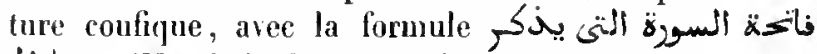
لميه. (Ms. de la fin du $1 v^{\mathrm{e}}$ siècle de l'hégire.)

Contenu : sourates $x 11,56$ à $6_{9} ; x 1 v, 29$ et suiv.; xv; xvı, 1 à $10 ; x$ vıı, 15 à 37,104 et suiv.; xıx, 1 à 38 .

$2^{\circ}$ (Fol. 12 et 13.) Écriture coufique; scize lignes par page; quelques traits diacritiques, contemporains du texte; points-royelles; le hamza est indiqué par un point vert; les versets se terminent par quatre petils traits "//; un gros alif colorié marque les groupes de cinq versets, et une petite rosace coloriée les groupes de dix versets. (Ms. du $11^{e}$ siècle de l'hégire.)

Contenu: sourate $\mathrm{x} 1,60$ à 90 .

$3^{\circ}$ (Fol. 14 à 68.) Jolie écriture coufique, peuchant légèrement vers la gauche; quinze lignes par page; quelques traits diacritiques, dont la majeure partie a été ajoutée après coup; points-voyelles; les versets sont séparés par deux on trois petits traits; un hì à l'encre rouge marque les groupes de eing versets, et une petite rosace en rouge et en vert les groupes de dix versets; titres des sourates contemporains du texte, écrits alternativement en rouge et en vert. (Ms. du $m^{\circ}$ siècle de l'hégire.)

Contenu: sourates xvı, 82 à $106 ; \mathrm{xvm}, 110$ et suiv.; xvıı, 1 à 14; xL, 16 et suiv.; xLı à LvHı, 4; LXXII, 20 et suiv.; Lxxıv; Lxxv, 1 à 16 .

Vélin. 68 feuillets. Hanteur, 16 centimètres et demi; largeur, 22 centimètres et demi. - (Supplément 1500. )

\subsection{1 .}

Fraginent d'un exemplaire du Coran.

Grosse écriture coufique, tirant sur le neskhi; treize et quatorze lignes par page; sans marques diacritiques; points-royelles en rouge; les versets sont séparés par plusieurs traits ainsi disposés $/ / /$; un cercle écartelé de rouge et de vert indique les groupes de dix versets; titre de sourate à l'encre rouge, contemporain du texte. (Ms. de la fin du $\mathbf{~ v}^{\mathrm{e}}$ siècle de l'hégire.)

Contenul: sourates 11,163 à 172,185 à 203,221 à $229 ; 111,115$ à $136 ; \mathrm{v}, 163$ et suiv.; v, 1 à 35 .

Vélin. 1 a feuillets. Hauteur, 35 centimètres; largeur, 40 centimètres. - (Supplément 150 A a.)

\section{2 .}

Fragments d'un exemplaire du Coran.

Belle écriture coufique, de moyenne grandeur; six lignes par page; points-voyelles en rouge; traits diacritiques ajoutés après coup; le hâ doré indique les groupes de cinq rersets, des rosaces historiées, dont quelquesunes à la marge, les groupes de dix versets; le recto du folio 9 est encadré dans une arabesque historiée avec fleurou, formant le commencement d'une section ( $\Sigma_{j} \rightarrow$ ); titres de sourates ( fol. $26,43 v^{0}$ et $55 v^{\circ}$ ) en lettres d'or, contemporains $d u$ texte. (Ms. de la fin du $v^{\circ}$ siecle de l'hégire.)

Contenu : sourates II, 32 à 60,231 et ${ }_{2} 32 ; 1 \mathrm{v}, 38$ à 49,55 à $61 ;$ vıı, 2 à 5,19 à $22 ; x 1 v, 32$ à $52 ; x v$, 1 à 6,27 à 34,86 à $9^{5} ; \mathrm{xix}, 19$ et suiv.; $\mathbf{x x}, \mathbf{1}$ à 30 ; xxw, 49 à 52,58 à $60 ; x x v, 5$ à 9,17 à 21,58 à $61 ;$ Lxiu, 16 et suiv.; Lxvir, 1 .

Vélin. 55 feuillets. Hauteur, 17 centimètres; largeur, 20 centimèlres el demi. - (Supplément 150 M m.) 


\section{3.}

Fragments de quatre exemplaires du Coran.

$1^{\circ}$ (Fol. 1 à 1o.) Belle écriture coufique, mince et élancée; sept lignes par page; points diacritiques en rouge; points rerts pour les hamza; traits diacritiques, raccourcis presque à la dimension de simples points, qui paraissent être contemporaius du texte; les rersets se terminent par une petite rosace listoriée; le hâ dor:́ indique les groupes de cinq versets, la rosace listoriée, les groupes de dix versels. (Ms. de la fin du $\mathrm{IV}^{\mathrm{e}}$ siècle de l'hégire.)

Contenu: sourate Iv, 118 à 139 .

$2^{\circ}$ (Fol. 11 à 16 .) Grosse écriture coufique, de moyenne grandeur; neuf lignes par page; points-royelles en rouge; traits diacritiques, ajoutés après coup; le $h d$ doré indique les groupes de cinq versets, et la rosace historiée, dessinée en marge, renfermant le nom de la dizaine, les groupes de dix rersets. (Ms. de la fin du $v^{\mathfrak{e}}$ siècle de l'hégire.)

Contenu: sourates xvu, $7^{2}$ à $93 ; x L v 11,17$ à 20.

$3^{\circ}$ (Fol. 17 à 26.) Écriture coufique, semblable à celle du fragment précédent; neuf lignes par page; pointsroyelles en louge; quelques traits diacritiques contemporains du texte, et un assez grand nombre de points diacritiques ajoutés plus tard; le hâ doré indique les groupes de cinq versets, la rosace historiće, portant le nom de la dizaine, les groupes de dix rersets; titre de sourate ( ol. $25 v^{\circ}$ ) en lettres d'or, avec fleuron en marge, contemporain du texte. (Ms. de la fin du $\mathbf{I v}^{\mathrm{e}}$ siècle de l'hégire.)

Contenu: sourates $\mathrm{v}, 145$ à $163 ; \mathrm{xL}, 52$ et suiv.; sulı, 1 à 3,15 à 19 .

$4^{\circ}$ (Fol. 27 à 32.) Éeriture coufique, mince et élancé; six lignes par page; points-royelles en rouge, avec variantes eu couleurs; petits traits diacritiques, ajoutés après coup; les versets sont séparés par une petite rosace historiée; le hâ doré indique les groupes de cinq versets, la rosace listoriée, portant le uom de la dizaine, les groupes de dix rersets. (Ms. du $1 v^{\mathbf{e}}$ siècle de l'hégire.)

Contenu : sourates xxv, 68 à $7^{5} ; \mathrm{xxv}, 4$ à 16 .

Vélin. $3_{2}$ fenillets. Hlauteur, 20 centimètres; targeur, 14 cențimètres. - (Supptément 150 C c c.)

\section{4.}

Fragments de quatre exemplaires du Coran.

$.1^{\circ}$ (Fol. 1 à 12.) Petite écriture coufique, se rapproMan. orientalx. - II. chant beaucoup de l'écriture maghrebine ou ancien neskhi; neul lignes par page; points-voyeltes en rouge, avec variautes el autres signes orthographiques en couleur; saus marques diacritiques; les versets ne sont pas séparés; le hi doré indique les groupes de cinq versets, et la rosace. historiée les groupes de dix versets; titre de sourale (fol. $2 v^{\circ}$ ) en lettres d'or, contemporain du texte. (Ms. de la fin du $\mathbf{v}^{\mathrm{e}}$ siècle de l'hégire.)

Contenu: sourates xvı, 102 et suir.; xvıı, 1 i 27 ; xxxil, 36 à 69 .

$2^{\circ}$ (Fol. 13 à 22.) Écrilure du mẹne genre que la précédente, mais un peu plus grosse; einq lignes par page; points-voyelles en rouge; points verts pour les hamza; sans points ni traits diacritiques; les versets me sont pas séparés; le hâ doré indique les groupes de cinq versets, des rosaces mal exécutées, les groupes de dix versets; titre de sourate (fol. $21 \mathrm{~V}^{\circ}$ ) en lettres d'or, a vec flenIon en marge, le tout contemporain du texte. (Ms. du $\mathbf{v}^{\mathrm{e}}$ siècle de l'hégire.)

Contenu : sourates Xxı, 77 et suiv.; xxı, 1 à 4 .

$3^{\circ}$ (Fol, 23 à $6_{2}$.) Écriture du mème genre que la précédente, mais peu soiguée; sept lignes par page; points-royelles en rouge; traits diacritiques ajoutés après coup; les versets ne sont pas séparés; le $h \hat{a}$ doré indique les groupes de cinq versets, la rosace, mal exécutée, les groupes de dix versets; titres de sourates (fol. 28 el $61 v^{\circ}$ ) en letures d'or, contemporains du texte. (Hs. du $\mathrm{v}^{\mathrm{e}}$ siècle de l'hégire.)

Contenu: sourates Iv, 134 à 147,168 et suiv.; r, 1 à 13,24 et suiv.; $\mathrm{r}, 1$ à 6 .

$4^{\circ}$ (Fol. 63 et 64.) Écriture du même genre que les précédentes, nais plus maigre; neul lignes par page; points-voyelles en rouge; sans points diacritiques; signes orthographiques de diverses couleurs; on y remarque des teschdid ayant la lorme actuclle, à l'enere bleue; les versets ne sont pas séparés; petite rosace historiée pour les groupes de dix rersets. (Ms. du commencement dı $v^{\mathrm{c}}$ siècle.)

Contenu : sourate v, 24 à 31,69 à 73 .

Vétin. 64 feuillets. Hauteur, 12 cenlimètres et demi; largeur, 17 centimètres. - (Supplément $150 \mathrm{~F} f \mathrm{f}$.)

\section{5 .}

Fragments de quatre exemplaires du Coran.

$1^{\circ}$ (Fol. a à 30.$)$ Écriture coufique, à gros traits et de grandeur inoyenne; six ligues par page; points-royelles en rouge; points diacritiques ajoutés aptès coup; les ril'- 
sets ne sont pas séparés; le ha doré iudique les groupes de cinq versets, un rond doré, entouré de quatre points en couleur, les groupes de dix versets; titre de sourate (fol. 19) en lettres d'or, contemporain du texte. (Ms. de la fiı du sve siècle de l'bégire.)

Contemu: sourates 11,159 et suiv.; $1 v, 1$ à 19 .

$2^{\circ}$ (Fol. 31 à 49.) Belle écriture coufique ordinaire; rinq lignes par page; points-royelles en rouge; quelques Iraits diacritiques, contemporains du texte; les versets ne sont pas séparés; le hâ doré iudique les groupes de cinq versets, un rond doré, entre quatre points en couleur, les groupes de dix rersets. (Ms. de la fin du $1 v^{\circ}$ siècle de l'hégire.)

Contenu: sourate xvil, 61 à 104 .

$3^{\circ}$ (Fol. 50 ì 58.) Belle écriture coufique; cinq lignes par page; points-royelles en rouge, avee variantes en couleurs; traits diacritiques ajoutés après coup; les versets sont séparés par un rond doré; le hâ doré indique les groupes de cinq versets, un rond doré et entouré de huit autres plus petits, les groupes de dix versets. (Ms. du Iv siecle de l'hégire.)

Contenu: somrate xxvı, 16 à 32 .

$4^{\circ}$ (Fol. 59 à 64.) Belle écriture coufique; cing lignes par page; points-royelles en rouge; quelques traits diacritiques qui paraissent être coutemporains du texte; versets séparés par un rond en or et en couleurs; le hâ indique les groupes de cinq versets, une grande rosace historiće, portant le mot عشترون, les groupes de dix versets. (Ns. du iv siècle de l'bégire.)

Contemu: sourate xLvıl, 1 à 11 .

Vélin. 64 feuillets. Hauteur, 11 centimètres; largeur, 16 centimètres. - (Supplément $150 \mathrm{H}$ h h.)

\section{6.}

Fragments de deux exemplaires du Coran.

$1^{\circ}$ (Fol. I à 75. ) Écriture coufinue, de moyenne grandeur; neuf lignes par page; points diacritiques, ajoutés après coup; points-royelles en rouge; les versets ne sont pas séparés; un hi doré indique les groupes de cinq rersets, une petite rosace, or el couleur, les groupes de dix versets; titres de sourates (fol. $59 v^{\circ}$ et $70 \mathrm{v}^{\circ}$ ) en lettres d'or, contemporains du texte. (Ms. du commencement du $v^{\mathrm{c}}$ sicele de l'hégire.)

Contem : sourates v, 21 à 25,37 à $59 ; \mathrm{v}, 11$ à 82 ; viı, $17^{6}$ à $203 ; 1 \mathrm{x}, 20$ à $90 ; \mathrm{xxı}, 28$ à $9^{0} ; \mathrm{xxxvII}, 102$ et suiv.; xxxvılı; Xxxıx, 1 à 26 .

$2^{\circ}$ (Fol. $7^{6}$ à 103.) Écriture coufique, de moyenne grandeur; six lignes par page; points-royelles en rouge, avec variantes en jaune; les hamza en vert; les alif de prolongation ont été ajoutés après coup à l'encre rouge, ainsi que les points diacritiques; les versets ne sont pas séparés. Le fol. $82 \mathrm{r}^{\circ}$, ayant été laissé en blane, porte maintenant une note en écriture courante, dépourvue de points diacritiques, que nous lisons ainsi : هذا لبز

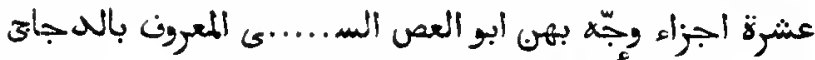

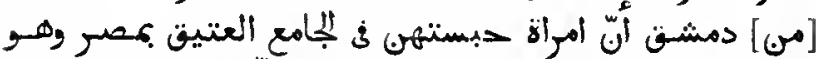

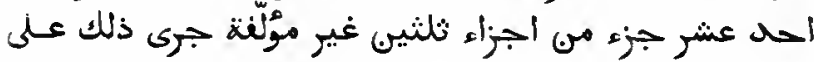

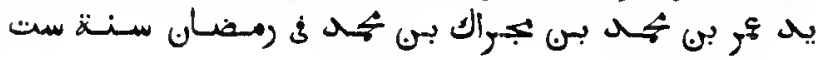

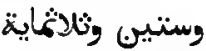

Cette section, avec dix autres, fut envoyée de Damas, par $\Lambda$ boû 'I-`Aṣ al-Sa . . î, généralement appelé al-Dadjàdji, (qui disait) qu'une femme les avait données comme waqf à la mosquée du Caire, nomméc al-Djânic 'l-'Atiq. Ce sont onze sections sur trente, formant chacune uu calier séparé. (Ce don) se fit par l'entremise d'Omar, fils de Mohammad, fils de Madjrâk, fils de Moḷammad, au mois de ramadhân de l'an 366 (977 de J. C.).» Ciette note ne paraît pas être de la même main que celles qui se trouvent dans le $\mathrm{ms} . \mathrm{n}^{\circ} 35 \mathrm{l}$ (royez ci-dessus). (Ms. du $1 v^{\mathrm{c}}$ siècle de l'hégire.)

Contenu: sourates vı, 29 à $38 ;$ vır, 42 à $47 ; x, 98$ et suiv.; xı, 1 et $2 ; x ı 11,7$ à 15,25 à $34 ; x I v, 39$ et 40 , 49 à 51 .

Vélin. 103 feuillets. Hauteur, 19 centimètres; largeur, 24 centimè̀tres. - (Supptément $150 \mathrm{H}$ h.)

\section{7.}

Fragments de deux exemplaires du Coran.

$1^{\circ}$ (Fol. 1 à 23.) Belle écriture de Damas, aux formes angulaires, aux queues arrondies et aux hastes élancées; cinq lignes par page; points-royelles en rouge, avec variantes en couleur; triits diacritiques contemporains du texte; une petite rosace dorée sépare les versets; une rosace historiée, portant le mot $\mathbf{\sim}$, indique les groupes de cinq rersets, d'autres rosaces, d'une dimension bien plus grande, portant le nom de la dizaine, les groupes de dix versets. (Ms. du commencement $d u v^{e}$ siècle de l'hégire.)

Contenu: sourates 11,131 à $135 ; 111,163$ à $183 ; \mathrm{iv,}$ 54 à 70,80 à $82 ; x$ ü, 21 à $41 ; x$ III, 40 à 43,55 à 57 .

$2^{\circ}$ (Fol. 24 à 64.) Écriture du même genre que la précédente; cinq lignes par page; points-voyelles en 
rouge, avec variantes en couleur; traits diacritiques contemporains du texte; de petites rosaces historiées, renfermant le mot $x$, , et assez mal exécutées, séparent les versets; des rosaces contenant le mot um indiquent les groupes de cinq versets, d'antres rosaces. plus grandes, les groupes de dix versets. (Ms. du ve siècle de l'hégire.)

Contenu: sourates II, 193 à 205,210 à 214,220 à $223 ; \mathrm{v}, 69$ à $80 ; \mathrm{v} 11,122$ à $124 ; \mathrm{x}, 33$ à 34,$40 ; \mathrm{xv}$, 2 à 28,97 à $116 ;$ xvıl, 109 à $111 ;$ xvıl, $16 ;$ LxH, 9 et suiv.; Lxiv, 14 à 16.

Vélin. 64 feuillets. Hauteur, 22 centimètres; targeur, 17 cenlimètres. - (Supplément 150 E e e.)

\section{8.}

Fragment d'un exemplaire du Coran.

Écriture coufique; six lignes par page; points-royelles en rouge; les hamza sont indiqués par des points jaunes; un trait vert horizontal désigne le waşla; les versets sont séparés par une petite rosace dorée; un hả doré indique les groupes de cinq versets; titres de sourates (fol. $61^{\circ}$, 4 \& et $77 \mathrm{v}^{\circ}$ ) en caractères coufiques, tracés avec de l'encre d'or et contemporains du texte; en regard de chaque titre se trouve un fleuron bien exécuté, en or et en coulenrs.

Contenu : sourates xxxv, à partir du verset 45 ; xxxuı; xxxvin et les vingt-deux premiers versets de la sourate xxxix. Il y a une lacune entre les folios 1 et 2 . (Ms. du commencement dı $\mathrm{v}^{\circ}$ siècle de l'hégire.)

Vétin. 9o feuitlels. Hauteur, 15 centimètres et demi; largeur, 23 centimètres. - (Supplément 158, Saint-Germain 286 bis.)

\section{9 .}

Fragments de six exemplaires du Coran.

$1^{\circ}$ (Fol. 1 à 5.) Grande écriture coulique; sept lignes par page; traits diacritiques contemporains du texte; points-royelles; un rond en or sépare les versets; un hd doré indicpue les groupes de cinq versets, une rosace en or et en conleurs, dessinée sur la marge, et portant le nombre de la dizaine en toutes lettres, les groupes de dix versets; titre de sourate (lol. $3 v^{\circ}$ ) en lettres d'or, contemporain du texte; en marge, à côté du titre, une rosace piriforme, en or et en couleurs, dans laquelle est inscrit en toutes lettres le nombre des versets. (Ms. du $\mathbf{v}^{\mathrm{e}}$ siecle de l'hégire.)

Contenu : sourates LII, 38 à 48 ; LIII, 33 et suiv.; LIv, 1 à 4; Lxil1, 17 à 33 .

$2^{\circ}$ (Fol. 6 ì 10 , et 10 bis à 30 .) Écriture semblable à celle du fragment précédent, mais moins soiggnéé; il u'y a que six lignes par page, et la rosace indiquant les groupes de dix rersets est placée dans le texte. (Hs. de la fin du $v^{\mathrm{e}}$ siècle de l'hégire.)

Contemu: sourates vı, 11 a ̀े $138 ; 1 \mathrm{x}, 60$ à 76,80 à 82 , 110 à 112,116 et suiv.; $x x x 1 x, 48$ à 68 .

$3^{\circ}$ (Fol. 31 à 39.$)$ Ecriture coufique, dont les traits verticaux sont légèrement inclinés vers la gauche; l'alif est représenté par un trait droit; huit lignes par page; points-voyelles; un trait horizontal en rouge représente le waṣla; les versets ne sont pas séparés; un ha doré indique les groupes de cing versets, une rosace en or et en couleur, les groupes de dix versets; un des titres des sourates (fol, 33) est en blane, sur un fond d'or et de couleurs; les deux autres (fol. $35 v^{\circ}$ et 39 ) sont en lettres d'or, et occupent le milieu d'un encadrement, assez grossièrement dessiné, en or et en couleurs; ces titres sont plus modernes que le texte. (Ms. du viècle de l'hégire.)

Contenu: sourates Ir, 274 à $282 ; \mathrm{r}, 119$ et suiv.; vı, 1 à $12 ;$ xulu, 80 et suiv.; xhw, I à $17 ; \mathrm{xL}, 92$ et suiv.; XLVı, 1 à 6 .

$4^{\circ}$ (Fol. 40 à 45.) Écriture coufique, se rapprochant beaucoup du neskhi ancien; six lignes par page; traits diacritiques; la lettre qôf est marquée d'un trait au-dessous de la ligne; points-ıoyelles; les versets ne sont pas séparés; le hâ doré indique les groupes de cinq versets, une rosace en or et en couleurs, les groupes de dix versets. (Ms. de la fin du v siècle de l'hégire.)

Contenu; sourates $\times 1,36$ à 39 ; xxxiv, 6 à 19 .

$5^{\circ}$ (Fol. 46 à 76 .) Écriture configue, se rapproehant du neskhi; points diacritiques et points-voyelles; le qâf est marqué d'un point au-dessous ; titre de sourate (fol. 46) à l'encre jaune. (Ms. de la fin du $1 v^{\mathbf{e}}$ siècle de l'hégire.)

Contenu; sourates 111, 200; 1v, 1 à 199.

$6^{\circ}$ (Fol, 77 et 78 .) Écriture de Damas, dont les traits verlicaux affectent qnelquefois une légère courbure; les lettres isolées et les groupes de lettres sont bien détachés les uns des antres; sans marques diacritiques; pointsvoyelles en rouge; les versets sont séparés par trois points dorés, disposés en forme de triangle; une rosace d'or', assez bien dessinée, indique les groupes de cinq versets. (Ms. du v siècle de l'hégir'e.)

Contenu: sourate $\times x_{1}, 7$ à 13,40 à 46 .

Vétin. 79 feuittets. Hauteur, 18 centimètres; largenr, 32 centimètres el demi. - (Supplément 150 W.)

\section{0.}

Fragments de einy exemplaires du Coran. 
$1^{\circ}$ (Fol. i à 7.) Grosse écriture coufique, peu élégante; six lignes par page; points-voyclles en ronge, avec variantes; trails diacriliques ajoulés après coup; les versets sont séparés par une petite rosace historiée; au fol. 2, le texte est placé entre deux bandes historiées, arec trois fleurous historiés en marge. C'est le commencement d'une seclion. (Ms. du vo siecle de l'hégire.)

Contemu: sourates xxrin, 12 à $14 ;$ XLIX, 2 à 15 .

$3^{\circ}$ (Fol. 7 bis à 3o.) ficrilure coufique, peu ćlégante; ring lignes par page; points-royelles en rouge, avec variantes; traits diacritiques plus modernes que le texte; le ho doré indigue les groupes de cinq versets, et la rosace historiée les grompes de dix versels. (Ms. du vº siècle de l'hégile.)

Contenu: sourales v, 156 à 159 ; vil, 10 à 13 ; $1 \mathrm{x}$, 34 à $36,7^{6}$ à 79,93 à 95,107 à $110 ; x, 26$ à 29,39 à $44 ; \mathrm{xr}, 32$ à $38 ; \mathrm{xxv11}, 48$ à 71 .

$3^{\circ}$ (Fol. 3 i à 51.$)$ Grosse ćcriture coufique, de moyenne grandeur; cinq lignes par prage; points-voyelles en rouge, avec variantes; des rosaces dorées séparent les versets; des pendeloques historiées indiquent les groujes de cinq versets, des rosaces ornées, les groupes de dix versets. (Ms. du $1 v^{0}$ siècle de l'hégrire.)

Contenu: sourates Ix, 3 à $13 ; x i r, 15$ à 17,30 à 31 ; $x \times x, 14$ et 15,35 à 37,43 à 45 ; xxxurl, 39 à 54,60 à 81 .

$4^{\circ}$ (Fol.52 à 64.) Belle écriture coufique, de moyenne grandeur; six lignes par page; points-voyelles en rouge, avec variantes; le hi doré indique les groupes de cinq versets, la rosace historiée, les groupes de dix versets. Une saddjada et une qibla, très-bien dessinées en or et en couleurs, marquent le commencement diune section. (Ms. du $1 \mathrm{w}^{\mathrm{e}}$ siècle de l'hégrire.)

Contenu: sourates HI, 122 ì $128 ; \mathrm{xI}, 49$ ì 63 ; xxr, 56 el $57 ; \mathrm{xx}^{2}, 18$ à 22 .

$5^{\circ}$ (Fol. 65 i 67. ) Belle écrilure coufique moyenne; six lignes par page; points-rojelles en rouge; traits diacritiques ajoutés après coup; le ha doré indique les groupes de cing versets; une rosace, à la marge du fol. $65 \mathrm{v}^{\circ}$, indique la fin d'inn groupe de dix versets. (Hs. de ta fin du Iv $^{\mathrm{e}}$ siècle de lhégire.)

Contenu: sourate xuII, 20 à 27.

Vélin. 70 feuillets. Hauteur, 15 centimètres et demi ̨ largeur, 32 centimètres. - (Supplément 150 P p.)

\section{1 .}

Fragments de sept exemplaires du Cornn. $1^{\circ}$ (Fol. 1 à 54.$)$ Écriture coufique ordinaire; six lignes par page; points-royelles en rouge; points rerts pour le hamza; sans marques diacritiques; les versels ne sont pas séparés; le hâ doré indique les groupes de cinq versets, et la rosace historiée les groupes de dix versets; titres de sourates (fol. $91^{\circ}, 44 r^{\circ}, 51$ ) en lattres d'or, contemporains du texte. (Ms. du ${ }^{\circ}$ siècle de l'hégire.)

Contenu : sourates $1 x, 113$ et suiv.; $x, 1$ à 62,88 et suir.; XI, 1 à $9 ;$ LXIv, 7 et suiv.; LXv, 1 ì 6 .

$2^{\circ}$ (Fol. 55 à 63.$)$ Écriture coufique moyenne; eind lignes par page; quelques traits diacritiques; pointsroyelles en rouge; point vert pour le hanza; une petite rosace sépare les versets; le hd indique les groupes de cinq versets, une rosace historiée les groupes de dix versets; litre de sourate (fol. 6o) en or, contemporain du texte. (Is. du $v^{e}$ siècle de l'hégrire.)

Contenu: sourates XuII, 45 et suiv.; XLIII, 1 à $9 ;$ LVII, 1 I.

$3^{\circ}$ (Fol. 64 et 66.) Écriture coufique ordinaire; huit lignes par page; l'alif est représenté par un trait droit; la queue du mîm est dirigće en has; points-royelles en rouge; point vert pour le hamsa. (IIs. du v viècle de l'hégire.)

Contenu: sourate xv1, 63 à 66,95 à 99 .

$4^{\circ}$ (Fol. 66 à 69.) Écriture coufinue ordinaire; cinq et six lignes par page; semblable pour le reste au fragment précédent. (Ms. dı $v^{\circ}$ siècle de l'liégire.)

Contenu : sourate $\mathrm{xx}, 41$ ì $49,7^{6}$ à 83 .

$5^{\circ}$ (Fol. 70 à 80. ) Ériture coufique ordinaire; cind lignes jar page; points-royelles en rouge; points diacritiques ajoutés après coup; les versets sont sćparés par une petite rosace historiée. (Ms. de la fin du $\mathbf{I V}^{\mathrm{e}}$ siècle de l'hégire.)

Contenu: sourates III, $161-175 ;$ xxru, 65 à 68 .

$6^{\circ}$ (Fol. 81 et 82.) Écriture coufique ordinaire; l'alij est représenté par un trait vertical; la queue du mitm est dirigée en bas; six lignes par page; points-voyelles en rouge; litre de sourate en lettres d'or et encadré, avec fleuron en marge, contemporain du texte. (Ms. du v siècle de J'hégire.)

Contenu: sourates I, 2 et suiv.; 11, 1, 9 à 13 .

$7^{\circ}$ (Fol. 83.) Écriture coufique ordinaire; six lignes par page; points-royelles en rouge; trait diacritique sur le noûn final; rosace liistoriée. (Ns. du $v^{\mathrm{e}}$ siècle de l'hégire.)

Contenu: sourate II, 166 à 168 .

Vélin. 83 feuiltets. Hauteur, 11 centimètres; largeur, 16 centimètres. - (Supplément $150 \mathrm{~A}$ a a.) 


\section{2.}

Fragments de einq exemplaires du Coran.

$1^{\circ}$ (Fol. 1 à 17.) Écriture coufique, brisée et angulaire, se rapprochant beaucoup de l'ancienne écriture neskhi; six lignes par page; points-royelles en rouge; sans traits ni points diacritiques; les versets ne sont pas séparés; le hâ doré indique les groupes de cinq versets, et une rosace grossièrement exéculée les groujes de dix versets; litre de sourate (fol. $16 v^{\circ}$ ) en lettres d'or, contemporain du texte. (Ms. du $v^{\mathrm{e}}$ siècle de l'hégrire.)

Contenu: sourates Iv, 115 à $136 ;$ vill, 4 à $10 ; \mathrm{x}, 96$ à $101 ; \mathrm{x}, 1$ à 12 ; xrm, 32 à $59 ; \mathrm{Lx}, 3$ à $10 ; \mathrm{Lx}, 6$ et suiv.; Lxu, 1 à 7 .

$2^{\circ}$ (Fol. 18 ̀̀ 35.) Écriture du même genre que la précédente, mais plus rapprochée du neskhi; sept ligues par page; points-royelles en rouge, arec variantes en couleurs; points diacritiques ajoulés après coup; les versets sont séparés par une petite rosace historiée; łe hâ doré indique les groupes de cinq versets, une grosse rosace en ol et en couleur, tantôt insérée dans le texte, tantôt en marge, les groupes de dix versets; titre de sourate (fol. 32) en lettres d'or, contemporain du texte, avee fleuron à la marge. (Ms. du v viècle de lhégire.)

Conternu: sourates 11,79 à $99 ; \mathbf{x x v ı , ~} 45$ à 88 ; xuır, 61 à 67,77 et suiv.; xLIv, 1 à 4 4.

$3^{\circ}$ (Fol. 36 à 58.) Ancienne éeriture neskhi; six lignes par page; points-royelles en rouge; points rerts pont les hamza; des pendeloques historiées, reutermant lu: mot xl, séparent les versets; le hâ doré indique les gronpes de cing versels, la rosace historiée les groupes de dix rersets; titre de sourate (fol. 46) en lettres d'or, contemporain dn texte, avec un fleuron à la marge. (Ms. de la fin du $v^{\text {e }}$ siòcle de l'hégire.)

Contenu : sourates 11, 138 à 160,200 à $209 ;$ vin, $7^{3}$ et suiv.; $1 \mathrm{x}, 1$ \& 37 .

$4^{\circ}$ (Fol. 59 à 6.) Écriture du même genre que la précédente; points-voyelles en rouge; traits diacritiques ajoutés après coup; le hâ doré indique les groupes de cinq versets, une rosace grossièrement historiée, les gronpes de dix rersets. (Ns. de la fin du $v^{0}$ siècle de l'hégire.)

Contemu: sourates v11, 99 मे $115 ; \mathrm{xxx}, 17$ ì 22.

$5^{\circ}$ (Fol. 62 et 63.) Éeriture ueskhi; neuf lignes par page; points-royeltes en rouge; sans marques diacritiques; les rersets ne sont pas séparés; des rosaces hisforiées indiquent les groupes de dix versets. (Hs. de la fin du v siècle de l'hégrire.)

Conteme: sourate $1 \mathrm{x}, 13$ à 21,36 à 42 .

Vélin. 63 feuillets. Hautenr, a 1 centimètres; largeur, 15 centimètres et demi. - (Supptément, $50 \mathrm{D} \mathrm{d} d$.)

\section{3.}

Fragnents de quatre exemplaires du Coran.

$1^{\circ}$ (Fol. 1 à 8.) Belle écriture de Damas; sept lignes par page; points-royelles en rouge; points verts pour les hamza; teschdid de la forme actuelle, à l'encre bleue; nombreux traits diacritipues, contemporains du texte; le qâf esl surmonté de deux traits; les rersets sont séparés par une petite rosace en or el en couleur; le hầ doré indique les groupes de cinq versets, la rosace historiée, les groupes de dix versets. (Ms. du v siècle de l'hégire.)

Contenu: sourate v1, 62 ì 84.

$2^{\circ}$ (Fol. 9 à 19.$)$ Écriture coufique, de moyenne grandeur; sept lignes par page; points-royelles en rouge, arec variantes en couleurs; lraits diacritiques ajontés après coup; les versets sont séparés par une petite rosace dorée; des rosaces, portant le mot $\mathbf{r}$, indiquent les groupes de cinq versets, d'autres rosaces, porlant chaeun un nom de dizaine, les groupes de dix versets. (Ms. de la fin du $1 v^{*}$ sièele de l'hégire.)

Contenu: sourates vi, 7 à $12 ; \mathrm{v11}, 131$ à 134,145 et $146 ; \mathrm{x}, 64$ à $73 ; \mathrm{xx}, 48$ à 51,78 à 80 .

$3^{\circ}$ (Fol. 20 et 21.) Jolie écriture de Damas, angulaire el brisée; dix lignes par page; quelques traits diaeritiques, contemporains elu texte; te qúf est surmonté de deux traits; points-royelles et autres signes orthograpliques de forme moderne, à l'encre rouge; les versets et groupes de versets ne sont pas séparés. (Ms. du v siècle de l'hégrire.)

Contemu: sourate 11,276 à 282 .

$4^{\circ}$ (Fol. 22 et 23 .) Écriture neskli; neul' lignes par page; points diacritiques; sans points-royelles, deux points sur le qaj; les rersets ne sont pas séparés; des rosaces tracées à l'encre indiquent les groupes de dix versets. (Ns. de la fin du $v^{\mathrm{e}}$ siècle de l'hégire.)

Contenu: sourate xxvıı, 19 à 30 .

Vẻlin. 23 feuillets. Hauteur, 17 centimètres; largeur, 12 centimètres. - (Supplément $150 \mathrm{G} \mathrm{g} g$.)

\section{4.}

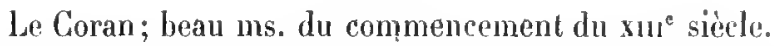
Les derniers feuillets, renfermant la sourate ${ }^{j} j$ jز les quatorze sourates suivantes, manquent. Le texte n'est pas ponctué, ni divisé en versets, mais les groupes do: dix versets sont marqués. Une main italienne, de la lin du xı" siècle, a éerit plusieurs rennarques en latin su" les prenières pages du volume, et un grand nombre 
de gloses et de tradurtions sur les marges de presque toutes les pages. On reconnait, à la lecture de ces notes, que l'écrivain était un peclésiastique catholique romain, et qu'il possédait une parfaite connaissance du Coran et de la langue arabe. Sur le leuillet de garde, à la fin du rolune, on lit la note suivante : r Fx Bibliotheca Jo. Hurati Boistallerii. Emi 10 coro (coronis?) a quodam Constantinopolitano.

Papier. 348 feuillets. Hauteur, 23 centimètres; targeur, 17 centimètres et demi. 17 lignes par page. - (Ancien fonds 209. )

\section{5.}

Le Colan; exemplaire daté de l'an 703 de l'hégire (1304 de J. C.). Ce volume, de provenance espagnole, probablement de Grenade, est écrit dans un caractère qui se rapproche beaucoup de l'écriture coufique et qui se distingue par l'élógance des traits et par leur netteté. les deux premières pages portent chacune une arabesque rarrée, en or et en couleurs. Les titres des sourates sont en lettres d'or'; les divisions du texte sont indiquées par des rosaces, tracées sur les marges, et offrant presque partout un dessin différent. Des cartouches ogivales marquent

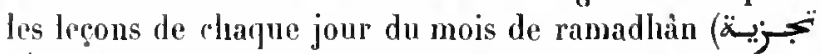
(رسضـ (رous ces ornements sont d'une exécution parlaile. Deux arabesques, en forme d'óchiquier, et ne renlermant aucune inscription, se trouvent à la fin du texte all verso du folio 129 et au recto du folio suivant. Viennent ensuite deux feuillets portant une très-belle arabesque, servant d'encadrement à une inscription en confique, en lettres d'or, dont roici la traduction : $r$ Ce colume a élé lerminé avec le bon secours de Dieu; grâces lui soient rendues! Que la bénédiction et la meilleure des salutations de la part de Dien reposent sur notre seigrneur et prophète et patron, Moḷammad, et sur sa famille pure el vertueuse! louange à Dieu, Seigneur de loutes les créatures! Ce rolume fut achevé al mois de djoumàdà second de l'an 703.

Lorthographe est relle des anciens exemplaires; les signes phonétiques et autres sont ceux des neilleurs mss, occidentaux. Notre exemplaire a conservé intacte son ancienne reliure, dont l'ornementation atteste le bon goùt des artistes maures-espagnols.

Vélin. $-13_{2}$ feuiltets. Hauteur, 18 centimètres; largeur, 17 centimètres et demi. 25 lignes par page. - (Ancien fonds 143.)

\section{6.}

Le Coran; exemplaire écrit en caractères oceidentaux.
L'écriture, petite et nince, offre un beau modèle de calligraphie; c'est l'écriture maure-espagnole dans toute son élégance. L'orthographe est celle des anciens mss. du Coran; les motions sont à l'encre rouge, les djazm et les teschdid à l'encre bleue; les alif de prolongation, supprimés dans le texte, y ont été ajoutés à l'encre rouge. Les titres des sourites sont écrits en lettres d'or. Le premier feuillet, renfermant la première sonrate et une partie de la seconde, manque, ainsi que les derniers feuillets, qui devaient contenir les sourales Lxxxul et suivantes. Il y a aussi quelques lacunes dans le corps de l'ouvrage.

Vélin. 78 feuillets. (Le folio 33 n'sppartient pas à ce ms.) Hauteur, 17 centimètres et demi; largeur, 16 centimètres. 29 lignes par page. Ifs. du xive siècle. - (Supplément 135. .)

\section{7.}

Lę Coran; exemplaire très-bien écrit, en gros caractères, et portant, outre les signes de ponctuation, un grand nombre de gloses marginales, indiquant les direrses leçons du texte. Les feuillets du commencement et ceux de la fin, ainsi que plusieurs dans le corps du volume, sont d'une écriture moderne, d'une nain peu exercée. Le nombre de ces feuillets restaurés est environ d'une centaine.

Papier. 484 feuillets. Hauteur, 33 centimètres et demi; targeur, 25 centimètres. 11 lignes par page. Ms. dı xıv siècle. - (Supptéinent 139 .)

\section{8 .}

Les sourates 111 et iv du Coran, écrites en caractères maghrebins. Les points-royelles et les alif de prolongation sont ì l'encre rouge, les teschdid et les djazm à l'encre bleue; un point jaune indique le hamza, et un point vert le waşla; un trèfle d'or sépare les versets; mn hì coufique doré marque la fin de cliaque groupe de cinq versets; des rosaces historiées, ì la marge, indiquent les groupes de. dix rersets; un titre de sourate (fol. 42) est en caractères confirues et en lettres d'or, aree une grande rosace à la marge. Au premier feuillet on voit un ornement, représentant un tapis carré, assez bien exécuté en or et en couleurs; les deux dernières pages sont entourées d'un cadre exécuté en or et en argent. Ce ms. provient de la mosquée d'al-Zaïtoûna, à Tunis, mais il parait aroir été écrit en Espagne.

Vélin. $8_{7}$ feuillets. Hanteur, 19 centimètres et demi; largeur, 17 centimètres et demi. 9 lignes par page. Ms. du xiv siècte. (Supplément ${ }_{157}$, Saint-Germain 289.) 


\section{9 : 392 .}

Les rolumes 1, 2, 3 et 5 d'un exemplaire du Coran, éerit en lettres d'argent sur papier pourpré. Il manque los sections 19 à 24 ; il y a en outre quelques lacumes de moindre étendue, et quelıues feuillets sont déplacés. Bonne écriture neskhi occidentale; les points diacritiques, les sigues des royelles, les teschdid et les autres marques orthographigues out la forme moderne. Les versets se terminent par une pendeloque renfermant un trifle doré; les groupes de cinq versets sont indiqués par un $h d$ coufique doré, et les groupes de dix versets par une rosace en or, entonrée d'un cercle. Les sourates ne portent pas de titres, mais elles se terminent par un Lhatima; voici celui de la cinquième sourate :

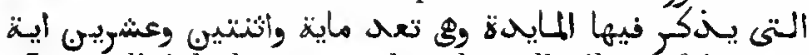
:La totalité de la sourate dans laquelle il est fait mention de la Table; elle compte cent vingt-deux versets.n En tête du premier volume se trouve un arertissement remplissant deux pages, et faisant connaitre les signes par lesquels le copiste a indiqué les variantes des sept leçons et celles qui se présentent dans la division des versets. Le ms. a été probablement éerit à Grenade.

4 volumes. Papier. Le premier volume renferme $9^{\circ}$ feuillels, te deuxième $8_{2}$, le troisième 68 , et le cinquième 77 . Hauteur, a 1 centimètres et demi ; largeur, 16 centimètres. 13 lignes par page. Ms. du xı* siècle. - (Supplément 152, Saint-Germain $68,69,70,71$.

\section{3.}

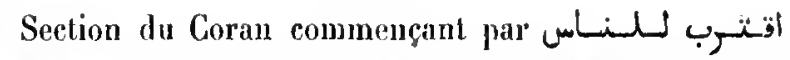

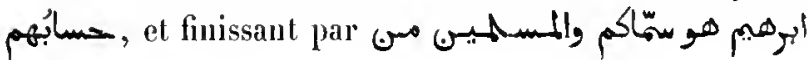
قبهل

Papier. 38 feuillets. Hauteur, $2 / 4$ centimètres; largeur, 16 cenlimètres. 6 lignes par page; les deux premières pages ne portent que 4 lignes, tracées sur un fond orné et entourées d'un eneadrement doré; frontispice carré avec inscription en lettres d'or, Mts. du sıve siècle. - (Supplément 1974.)

\section{4.}

Le Coran, très-bien écrit, et portant les signes des sections, des groupes do dix versets et de la ponctuation. Un des derniers cahiers a été remplacé par une main plus moderne. Ce ms. est daté de l'an $77^{\circ}$ de l'héggire (1369 de J. G.). Il a appartenu à Galland. On lit sur le feuillet de garde de la fin un passage du Coran qui sert d'amulette pour faciliter les accoucbements difficiles.

Papier. 290 feuillets. Hanteur, 15 centimèlres; largeur, 10 centimètres. 17 lignes par page. - (Ancien funds 210.)

\section{5 .}

Le second volume d'un exemplaire du Coran qui devait se composer de quatre volumes. Il renferme les sonrates vil à xvin; mais il $y$ a une lacune à la fin de la sourate xin et au commencement de la sourate xıv. Ce texte, écrit probablement vers la fin du $x^{\mathrm{e}}$ siècle, en beaux caractères neskli occidentaux ou espagnols, est accompagné des royelles à l'encre rouge: les soukoûn el les teschdid sont à l'encre bleue, les alif de prolongation, a l'enere rouge. Une note, en écriture courante el assez difficile à lire, en tête du ms., nous apprend que ce rolume, avec ses trois frères, c'est-à-dire les trois volumes faisant partie du mêne exenplaire, était contenu dans

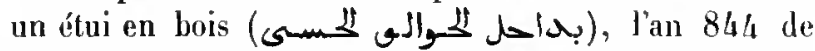
l'hégire (1440 de J. C.), époque où le possesseur le donna en wagf (حس ) à la grande mosquée (المسكمد) de Malaga.

Vélin. 89 feuiltets. Hauteur, 14 centimètres el demi ; largeur, 19 cenlimètres. 16 lignes par page. Volume relié à l'orientale. 11 porte les armes de Henri $1 \mathrm{II}$, quoiqu'il vienne de la bibliothèque de Colbert. (Ancien fonds 219 , Colbert 6481.)

\section{6.}

Feuillet détaché d'un exemplaire du Coran.

Papier. Ifauteur, 41 centimètres; largeur, 29 centimètres. 17 lignes par page. Grande et belle écriture espagnole du xiv siècle, les contours des lettres sont tracés en noir et l'intérieur avait été doré. - (Supplément 3250.)

\section{7.}

Second volume d'un exemplaire du Coran. II commence par le troisième verset de la dix-neuvième sourate. et finit au unilieu du vingtième verset de la quatre-vingtneuvième sourate. Les derniers feuillets manquent. Ce volume parait être de la fin du $x_{1} v^{\mathrm{e}}$ siècle; il est écrit en grands et beaux caractères; des ćloiles marquent les groupes de dix versets. Le texte n'est pas ponctué. Andessus de chaque mot arabe se trouve l'équivalent persan. Sur la marge du premier feuillet et sur le leuillet de 
garde de la fin on lit les mots suivants, tracés évidem-

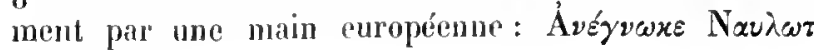
$\tau \delta \delta \delta, 1573$.

Papier. 374 feuillels. IJauleur, 39 centimètres; largeur, 19 centimètres et demi. 8 lignes par page. - (Ancien fonds 177 , Colbert 1032.)

\section{8.}

Le Coran; exemplaire daté de l'an 831 de l'hégire ( 1437 de J. C.). Le texte, très-bien écrit, porte les signes ordinajres de division et de ponctuation. Les pages sont ricadrées d'un filet rouge; les deux premières sont ornées d'une arabesque. Ce volume fut trouvé à la prise de Bude, en 1686.

Papier. 3.8 feuillets. Itauteur, 14 centimètres; largeur, 11 centimètres. 13 tignes par page. - (Supplément 141 bis.)

\section{9 .}

Le Coran en écriture coulique.

A la suite de la denière sourate se trouve une note, tracée en caractères coufiques, et d'une écriture plus moكتب بوسم : derne que le corps de l'ouvrage, ainsi conçue

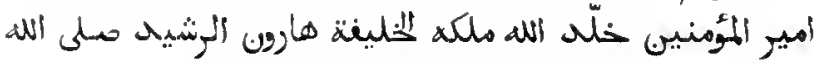

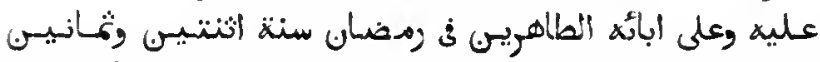

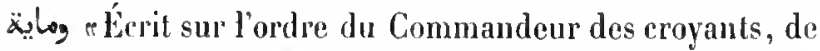
ұıi Dieu perpétue te règue, le calile Haroûn al-Raschid, ì lui Dieu soit propice, ainsi qu'ì ses ancêtres, les purs; an mois de ramadhân de l'an $182\left(798\right.$ de $\left.\mathrm{J}, \mathrm{C}_{4}\right)$. n Cette inscription a domné lieu de croire que notre ms. faisait partie d'un présent que le calife Haroûn al-Raschìd avait anvoyé à Charlemagne. Un examen attentif du ms., de son écriture, de sa reliure et de l'étui qui le renferme, nous autorise à repousser cette légende:

$1^{\circ}$ Lécriture du ms. ressemble à celle des monnaies coufiques du $x^{e}$ siècle, et sa fraịcheur ainsi que la blancheur des feuillets ne permettent pas de le regarder comme plus ancien que cetle époque.

$2^{\circ}$ Les feuillets sont numérotés en chiffres indiens, de la forme de ceux qu'on remarque dans les mss. du $x v 1^{\circ}$ et du xrir ${ }^{\mathrm{i}}$ siècle.

$3^{\circ}$ Le ms. a été réparé en Orient, sans doute au $\mathrm{XV}^{\mathfrak{c}}$ siècle.

$4^{\circ}$ La reliure du ms. est évidenment orientale, et du $\mathrm{Xri}^{\mathrm{e}}$ siècle. $5^{\circ}$ L'étui en peau, fait exprès pour ce ms., porte sur le rebord l'inscription ordinaire en neskhi moderne.: ل الا يمسه الا المطهرون.

$6^{\circ}$ En dedans de l'étui on lit: "Ex munificentia magristri Cochu, $1787 \cdot \pi$

$7^{\circ}$ La note arabe dont nous avons donné le texte a été ajoulée à une époque assez l'écente, comme il est facile de le reconmaitre à la couleur de lencre et aux formes peu archaïques de plusieurs lettres.

$8^{\circ}$ La formule employée, en parlant du calife: «à qui Dieu soit propice, ainsi qu'z̀ ses ancêtres, les purs, $r$ appartient an lite schiite et ne pourait être appliquée à un ralile abbaside.

11 résulte de ces indications, que le volume est $\mathrm{du} \mathrm{Ix}^{\mathrm{c}}$ on $d u x^{\circ}$ siècle; qu'il fut raccommodé et relié en Orient au $\mathrm{Xr}^{\mathrm{e}}$ siècle; quil recut sa pagination au wrre siecte; qu'en l'an 1787 il se trouvait entre les mains d'un Européen, et que la Bibliothèque du roi n'a pu lacquéria que postéricurement à cette date.

Le texte de ce ms. n'offre d'autres divisions que celle en groupes de dix versets; il est dépourvu de points diacritiques. Les points rouges, placés tantôt au milieu des lignes, tantôt au-dessus et au-dessous des mots, marquent les ham:a et même quelques motions. Its paraissent' avoir été ajoutés après coup.

Vélin. 369 feuillets. Hauteur, 4 cenlimètres; largeur, 7 centimètres el demi. 11 lignes par page. - (Supplément 114. .)

\section{0.}

Le Coran. Le texte est accompagué des signes de division et des signes indiquant la ponctuation. Les deux premières pages sont encadrées d'une belle arabesque en or et en azur, mais un peu fanée. La reliure originale, bien que trés-latiguée, oflre un bel échantitlon de l'art arabe; le dessin représente un parallélogramme d'environ 18 centimètres sur 12 , dans lequel se déploient sur un fond d'or les rolutes, les spirales et les fleurons d'une arabesque très-légère et très-élégante.

Papier. 324 feuillets. Hauteur, 33 centimètres; targeur, 17 centimètres. 12 lignes par page. Ms. du xıv siècle. - (Ancien fonds 192 , Colbert 3633.)

\section{1.}

Le Coran; beau ms. dont l'écriture, la reliure et l'ornementation sont du même genre et de la même époque 
que celles du ms. décrit sous le $\mathrm{n}^{\circ}$ précédent. On y remarque de plus, sur le verso du premier fenillet, une bolle arabesque en forme d'étoile renfermant, en guise d'épigraphe, une partie du verset go de la dix-septiène sonrale; une éloile semblable, dessinée sur le recto du second fenillet, contient la fin du verset: rQuand les hommes et les génies se réuniraient pour produire quelque chose de semblable à ce Coran, ils ne produiraient rien de pareil, lors mème qüils s'aideraient mutuellement !n A la fin du volume se troure la prière que le musulman doit réciler après avoir lu le texte en entier, puis vient le Fal-namé en persan et en écriture ta lì.

Papier. 463 fenillels. Itantenr, 32 centinètres el demi; largenr, 20 centimèlres et demi. 9 lignes par page. - (Ancien fonds 176 , Col. bert 3097.)

\section{2.}

Volume composé de cahiers appartenant à divers exemplaires dı Coran, presque tous très-mal écrits, en caractères occidentaux. Les six premiers feuillets sont de l'écriture de Constanlinople; le feuillet 7 est africain; les feuillets suivants jusqu'au folio 163 ont appartenu ì un exemplaire écrit en Espagne au $x v^{\circ}$ siècle; on $y$ a joint quelques feuillets en écriture orientale du xvi siècle, pour remplir les lacunes. Les feuillets 167 à 201 ont appartenu à un autre exemplaire espagnol du mêne àcre que le précédent. Les feuillets 202 à 227 sont d'une autre écriture el probablement du même siècle. Les cahiers suivants jusqu’à l'avant-demier sont aussi d'une écriture occidenlale, et paraissent avoil élé écrits en Afrique. Ils offrent cette particularité que le texle arabe porte entre les lignes de courtes gloses et explications, les unes en arabe et les autres en une langue qui semble ètre un dialecte berber. Le demier fenillet, écril en Afrique, renferme la fin du Coran.

Tous ces cahiers, à l'exception des derniers, n'offrent aucun intérêt. Le volume entier porle les marques d'un long usage chez une population grossière.

Papier. ${ }_{54} 5$ feuillets. Hauleur, 20 centimètres; largeır, is centimètres el demi. - (Supplément 124.)

\section{3.}

Le Coran; exenuplaire en caractères neskhi oceidentaux, de diverses mains. Les signes orthographiques sont

Mas. orientaux. - II. ceux de tous les exemplaires africains. Les prentiers et les derniers feuillets manquent.

Papier. 283 feuillels. Hauleur, 21 centimètres; largeur, I// centimètres et demi. 16 lignes par page. Ns. qui paralt étre du $x 7^{\circ}$ siècle. - (Supplément 137.)

\section{4.}

Le Coran ; exemplaire d'une bonne écriture du xv siècle. Les signes de division et de ponctuation y sont marqués. Des notes, renfermant des Iraditions (حلبن) servant à éclaircir le sens du texte, sont inscrites sur les marges de quelqnes feuillets. La dernière sourale manque.

Papier. ${ }_{162}$ feuillets. Hlauteur, 26 centimètres; largeur, 17 cenlinètres et demi, 19 lignes par paģe. - (Supplément 1/18 vi.)

\section{5.}

Le Coran; exemplaire du $\mathbf{x v}^{e}$ siècle. Il y manque deux cahiers, contenant la fin de la sourate xvi et le comnencement de la sourate xvir.

Papier. 367 feuillets. Hlauleur, 18 centimèlres; largeur; 1 is centimètres et demi. 12 lignes par page. Relié aux armes el au chiffre de Henri IV, -- (Ancien fonds 195 .)

\section{6.}

Le Coran; exemplaire du $x v^{e}$ siècle, hien écrit et portant les signes de division et de poncluation. Il parait avoir beaucoup servi. Le dernier fenillet est d'une écriture plus moderne.

Papier. 249 feuillets. Hauleur, 25 centimèlres; largenr, 16 cenlimètres eț demi. 15 tignes par page. - (Ancien fonds 194 .)

\section{7.}

Le Coran, d'une belle écriture orientale, divisé en trente sections ( $>$ ) et pourvu des signes de ponctuation.

Papier. 388 feuilfets. Hanteur, 32 centimètres; largeur, s3 centimètres. 10 lignes par page. Ms. du $x v^{e}$ siècle relié aux armes et au chiffre de Fouquet. - (Ancien fonds 172.) 


\section{8 .}

Lo Coran; belle écriture orientale, qui parait ètre du $\mathrm{xv}^{\mathrm{e}}$ siècle. La division par sections $\mathrm{y}$ est indiquée ainsi que la poncluation. Sur le verso du premier feuillet est iuscril un acle de constitution de maqf. Cette note, rédigée en mavais arabe, nous apprend que cel exemplaire fut donné à la mosquée de la ciladelle d'Otrante ( أترند) dans la Ponille (يولي), l'an 886 de l'hégire (1481 de J. G.).

Papier. 392 fenillets. Ilauteur, 26 centimètres; largeur, 17 centimètres et demi. 13 lignes par page. Relié anx arnıes de France et an chiffre de Henri II. - (Ancien fonds 173.)

\section{9 .}

Fenillet portant sur un seul côté six lignes du Coran.

Papier. Hauleur, 32 centimètres et demi; Jargeur, 23 centimètres. Grosse écriture maghrebine du $\mathbf{x v}^{e}$ siècle. - (Supplément 2a 51.)

\section{0 .}

Fragnent d'un exemplaire du Coran, commençant par le sixième rerset de la seconde sourate et finissant arec la dix-huitième sourate. Les motions ou royelles y sont marquées à l'encre rouge. L'écriture est très-mauvaise, comme celle de la plupart des mss. arabes écrits

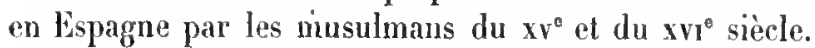
A la suite de ce fragment, an folio 126 , se trouvent onze lignes écrites en caractères arabes et paraissant renfermer un charme contre la fièrre. Cette pièce est rédigée en espagnol mếlé d'arabe. Le leuillet 132 est un fragment d'un traité de jurisprudence. Le feuillet suivant est une ammlette. Ce volume provient de la succession du due de Bomrnomille, qui ful vice-roi el capitaine général de Barcelone, in 1680 .

Papier. 133 feuillets. Hauteur, 29 centimètres; largeur, 20 centimétres. 17 lignes par page. - (Ancien fonds 18.)

\section{1.}

Le Coran; exemplaire en caractères orientaux, d'ume écriture Irès-serrée el très-fine, qui parait être de la fin du $x v^{e}$ siècle.

Papier. 160 feuillets. Hauteur, 11 centimètres et demi; largeur, 10 centimètres. 15 lignes par page. - (Supplément 144.)

\section{2.}

Les sourates xv et xv du Coran; grande écrilure neskhi occidentale; cind lignes par page; les points-voyelles et les alif de prolongation en rouge; les djazm et les teschdid en vert; litres de sourates en caraclères coufiques trèsmal dessinés à l'enere d'or; les rersets sont séparés par un trèfle d'or, les groupes de cinq versets par des penIleloques d'or, el les gruupes de dix versets, par de grands ronds hisloriés.

Au commencement du volume se trouve un calier de - lingt pages, d'une écriture $\mathbf{d u} \times \mathrm{xn}^{\mathrm{e}}$ siécle, ayant appartenu à un ouvrage en langue lurque, qui traite du sens de certains passages du Coran, quand on consulte le sort au moyen de ce livre. Trùs-belle écriture neskhi.

Papier. 68 feuillets. Hauteur, 33 centimètres; largeur, 23 centimètres. Ns. de la fin du $x^{e}$ siècle. - (Supplément 16j.)

\section{3.}

Le Coran; ms. d'une assez bonne écriture daté de l'an 923 de l'hégire ( 1517 de J. C.). La division par parlies et par huiliènıes de section $(\underset{*}{*})$ est indiquée, mais les signes de poncluation manquent. Les alif de prolongation sont en rouge.

Papier. 515 pages. Ilauteur, 17 centimètres; largeur, 12 centimétres el demi. 15 lignes par page. - (Supplément. 120 , Saint-Germain $27^{8}$.)

\section{4.}

Le Coran; bonne écriture orientale. La division du texte en sections et en groupes de dix versets est indiquée, ainsi que la ponctuation. D'après un acte de donation inscrit sur le recto du premier feuillet, ce volume fut donné à la mosquée de Qal'at Nowâ نُوَ (Castel-Novo, en Dalmalie?) l'an 943 de l'hégire ( 1536 de J. G.).

Papier. ${ }_{29} 6$ feuiltets. Hauteur, 31 centimètres; largeur, 20 centimètres et demi. 15 lignes par page. $\mathrm{N}_{\mathrm{s}}$. du $\mathrm{xv}^{\circ}{ }^{\circ}$ siècle, relié aux armes et au chiffre de Henri 1I. - (Ancien fonds 174.)

\section{5.}

Le Coran, d'une belle écriture persane, daté du mois 
de safar 945 (juillet 1538 de J. C.). Le texte est ponctué et divisé en sections et en groupes de dix versets. Les pages sont encadrées d'un filet d'or. Les titres des sonrates sont en or. Une arabesque assez simple, qui ornait les deux premières pages, a été effacée par une main européenne. A la fin da volune on trouve un traité de divination, en persan, remplissant cinq pages.

Papier. 352 feuillets. Hauteur, 12 cenlimètres; largeur, 8 centimètres et demi. 14 lignes par page. - (Supplément 127.)

\section{6.}

Le Coran; ms. daté de l'an 956 de l'hégire ( 549 de J. C.). Le texte est accompagné des signes de division et de ponctuation.

Papier. 297 feuillets. Hauteur, 13 centimètres; largeur, 6 centimètres. 15 lignes par page. — (Supplément 1 18, Saint-Germain 531.)

\section{7.}

Le Coran; beau ms. qui paraîtêttre de la fin du xv siècle. Le texte est divisé en parties el porte les signes de ponctuation. Les deux premières pages sont encadrées d'une arabesque assez bien exécutée. Un possesseur du ms. a inscrit son nom sur le recto du premier fenillet avec la date de $9^{5} 7$ ( 1550 de J, C.). Sur la même page on roit la signature de Du Ryer, traducteur du Coran.

Papjer. 191 feuillets. Hanteur, 18 centimètres; largeur, 13 centimètres. 15 lignes par page. - (Supplément 122, Saint-Germain $28 \%$, )

\section{8.}

Le Coran, d'une très-belle écriture neshhi. Le texte porte les signes de ponctuation. Les groupes do cinq versets sont indiqués, à la nuarge, par des étoiles qui sont alternativement à fond d'azur et à fond d'or. Les quatre premières pages du texte, les deux pages qui se trousnt au milien dı volume el les deux dernières pages du tește sont encalrées d'arabesques, exéculées en or et en couleurs, d'un très-bean dessin. La quatriène et la cinquième page sont écriles sur un fond d'or. Les titres des somrates sont entonrés de belles arabespnes. La reliure orientale, qui est à repli et qui se ferme au moyen de deux agrales en argent, est ornée, tant en dedans quiau dehors, d'arabesques et d'inseriptions en caractère neskhi, renfernant des versets du Coran. Ces ormenents sont en or el en couleurs.

A la fin dn volume se troure un pelit traité en vers per-

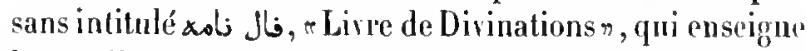
la manière de consulter le sort an moyen du Coran. Cetle piéce, écrite en tálìq, est de la main dı copiste qui a transcrit le reste du volume.

Un acte de donation, rédigé en ture et inscrit sur lo recto du premier fenillet, nous apprend que ce magnifique volume fut donné par le grand vizir Sinân Pacha à l'église de Yâniq (يانق) qui venait d'être convertie en mosquée. Cette pièce est datée de l'an 1003 de l'hégire ( 1594 de J. C.). Meninski nous apprend que Yâniq, en latin Iaurinum et en italien Giavarino, est une ville de Hongrie.

Papier. 450 feuillets. Hauteur, 39 centimètres; largeur, 25 centimètres et demi. 10 lignes par page. - (Ancien fonds 175 , Colbert 1391$.

\section{9.}

Le Coran. Les titres des sourales sont en lettres d'or. 11 en est de même des mots inscrils sur les marges el qui indiquent la division du texte en soixante parties (حزب) et en quarts de partie. Les signes de ponctuation ny sont pas marqués. Le ms., qui parait ètre du $x_{v 1}^{\circ}$ siècle, est relić aux armes et au chiffre de Henri II. Le commencement, jusquau verset 81 ile la sourate 1, manque.

Papier. 218 feuillets. Hauteur, 28 centimètres; largeur, 20 centimètres. 13 lignes par page. - (Ancien fonds 1 80.)

\section{0 .}

Le Coran, écrit en caractères neskhi occidentaux et probablement par un Maure espagnol qui élait émigré au Maroc. Le style de l'écriture est tout à fait celui de la bonne école espagnole. Les points-royelles et les alif de prolongation sont en rouge. La division par parties y est indiquée. Les titres des sourates sont en lettres coufiques, lavées d'or.

Au folio 343 se trouvent quelques lignes en rers radjaz. paraissant renfermer une opération d'arithmétique; mais la manvaise écriture ot les fantes d'orthographe empếchent d'en recomnaitre la nature. Sur le cerso du même lenillet on lit une recette,pour la préparation de la pierre

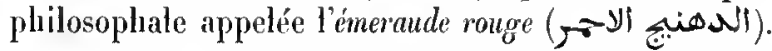

Papier. 34 / feuillets. Hauteur, 20 centimètres et demi; largeur, 
15 centimètres. 15 lignes par page. Ms. du xvi siècle. - (Ancien ronds 188 .)

\section{1.}

Le Coran. Tous les signes de division et de ponctualion sont indiqués. Les l'euillets 1 et 2 sont d'une écriture plus moderne que le reste du ms. Le deruier feuillet manque. Le feuillet 60 et les neut feuillets suivants ont áté renversés à la reliure.

Papier. 300 pages. Hauteur, 23 centimètres; largeur, 15 centimètres. 13 lignes par page. Ms. du $x \mathrm{vi}^{\mathrm{e}}$ siècle. - (Ancien fouds $\mathbf{1} 9^{\circ}$, Colbert 4993.)

\section{2.}

Le Coran. Les signes de division et de ponctuation sont indiqués. La fin de la sourate intitulée li - La Nouvellen el les sourates suivantes manquent.

Papier. 274 feuillets. Hauteur, 18 centimètres; largenr, 13 centimètres et deni. 5 lignes par page. $\mathrm{M} s$. du $\mathbf{x v i}^{\circ}$ siècle. - (Ancien fonds 191 , Colbert 6144.)

\section{3.}

Le septième volume d'un exemplaire du Coran, écrit en caractères neskhi occidentaux, contenant les sourates xxxvıו et suivantes jusquà da fin de la sourate un. L'écriture est grande et d'un très-beau style; l'encre est d'une couleur brune et loncée; les points-royelles sont en rouge, les soukoun et les teschdid en vert; les hamza sont représentés par des points rouges et les tamxin sont figurés de la manière ordinaire. Les alif de prolongation sont marqués à l'encre rouge. Les groupes de cinq et de dix versets sont indiqués par des disques inscrits dans le texte ou sur les marges, et ricliement dorés; les disques des groupes de dix versets sont des cercles, ceux des groupes de cinq versets ont la forme d'un angle aigu fermé par un demi-cercle. Les titres des sourates sont écrits en caractères coufiques à l'encre d'or. Sur le verso du premier fenillet se trouve une belle arabesque représentant un cercle inscrit dans un carré et renfermant un treillage de raies blanches forntant étoile, et dont le fond est une croix grecque à queue d'ąronde. Le même ornement est reproduit sur le recto du second feuillet. A la fin du volume on voit deux ornements du même genre, seulement le treillage est remplacé par une note en caractères neskthi, qui contient l'explicit de la septième partie et une invocation pour Hahomet et sa famille.

Vélin. 114 feuillets. Hauteur, 20 centimètres; largeur, 18 centimètres. 9 lignes par page. Ms. du xvi' siècle. - (Ancien fonds 202.)

\section{4.}

Les dernières sourates du Coran, à partir de la sourate orfl.

Papier. 58 fenillets. Hauteur, 20 centimètres; largeur, 14 centimètres. 12 ou 13 tignes par page. Ns. dn $\times x^{e}{ }^{e}$ sièsle. - (Aucien fonds so6.)

\section{5 .}

Extraits du Coran accompagnés d'une traduction espagrnole, écrite en caractères arabes. M. de Sacy a donné la notice de ce volume daus le tome IV des r Notices et extraitsn, page $6{ }_{2} 6$ et suivantes. Ce uns. offre un exemple de cette mauvaise écriture maure-espagnole dont on se servait à Grenade au $x v^{\mathbf{e}}$ siècle.

Papier. 119 fenillets. Hauteur, 20 centimètres; largeur, 13 centimètres et demi. 19 lignes par page. - (Ancien fonds 108, Colbert 3652.)

\section{6.}

Le Coran, lexte pourvu des signes de division et de ponctuation. Au commencement se trouve une belle arabesque renfermant la première sourate, écrite sur un fond d'or et en caractères microscopiques. Le texte est encadré de filets très-fins, rehaussés d'un trait d'or. La reliure sort probablement d'un atelier persan; elle est encore trèsbelle, bien que très-fatiguée.

Papier. 434 feuillets. Hauteur du volume, 11 centimètres et demi; largeur, 7 centimètres et demi. Hauteur des pages écrites, 6 centimètres; lorgeur, 3 centimètres et demi. 12 lignes par page. Ms. du xvi siècle. - (Ancien fonds 211, Colbert 6627.)

\section{7.}

Le Coran, texte pourvu des signes de division et de poncluation. Le texte des quatre premières pages est en- 
touré de belles arabesques; le copiste y a mis pour épigraphe les versets $7^{6}$ à 79 de la sourate cv. Aux autres pages, le texte est encadré de filets noirs et bleus, rehanssés d'or. Les derniers feuillets manquent.

Papier. $43_{9}$ feuillets. Ilauteur, 19 centimètres; largenr, 9 centimètres. 11 lignes par page. Us, du xv" siècle. - (Ancien fonds a 1 a.)

\section{8.}

Le Coran. Le texte, pourvu des signes de division et de ponctuation, est encadré d'un filet rouge. La première sourate el le commencement de la seconde sont entourés d'une arabesque à fond d'azur.

Papier. 268 feuillets. Hauteur, 15 centimètres; largeur, 10 centimètres. 15 lignes par page. Ms. du xṿ siècle. - (Ancien fonds a $\mathbf{5} 5$, Colbert 6418.)

\section{9 .}

Le Coran, texte pourvu des signes de division et de ponctuation. La première sourate et le commencement de la seconde sont entourés d'une arabesque en azur et en or. Les autres pages sont encadrées de trois filets noirs rehaussés d'or. $\Lambda$ la fin du volume se trouvent des instructions en langue turque sur la manière dont il faut consulter le sort au moyen du Coraı, avant d'entreprendre un royage. Au verso du folio 327 se trouve une priere en arabe, suivie d'une pièce de vers en turc remplissant douze pages et faisant connaitre les indications que chaque lettre de l'alphabet fournit à celui qui consulte le sort. Reliure orientale.

Papier. 334 feuillets. Hauteur, 13 centimètres et demi; largenr, 9 centimètres. 15 lignes par page. MIs. du xvi siècle. - (Incieu fonds 16, Colbert 6636.)

\section{0 .}

Le Coran, texte pourvu des signes de division et de ponctuation. Ia première sourate occupe deux pages dont chacune est couverte d'une arabesque en azur et en or. Les autres pages sont encadrées de quatre filets de couleur et d'un filet d'or.

Papier. 466 feuillets. Hauteur, 13 centimètres; largeur, 8 centimètres. 12 lignes par page. Ms. du $x^{\circ}{ }^{\circ}$ siècle. - (Ancien fonds 217.$)$

\section{1.}

Le Coran; ms. de deux écritures différentes. Le premier feuillet, ayant disparu, a été remplacé par une main européenne. Le folio 301 , qui devait contenir la sourate Lxxxiv en entier et les seize premiers versets de li sourate suivante, est resté en blanc. Le texte est accompagné des signes de division et de ponctuation.

Papier. 310 feuillets. Hauteur, 15 centimètres; largenr, 10 centimètres et demi. Dans la première moitié du volume, les pages contiennent 17 lignes; dans la seconde moitié, le nombre des lignes est de 15 . Ms. du xpre siècle. - (Ancien fonds 218.)

\section{2.}

Volume renfermant des extraits du Coran de diverses écritures.

Papier. 65 feuillets. Hauteur, 15 centimètres; largeur, 10 centimètres. 9 lignes par page. Ms. du $\mathbf{~ v i}^{\circ}$ siècle. - (Ancien fonds 230. .)

\section{3.}

Quelques sourates du Coran. Écriture de Constantinople. Les deux premières pages sont ornées d'une arabesque, toutes les autres sont encadrées d'un filet doré.

Papier. 60 feuillets. Hauteur, 16 centimètres; largenr, 11 centinièlres. 7 lignes par page. Ms. du $x^{*}{ }^{*}$ siècle. - (Ancien fonds 331. )

\section{4.}

Le Coran, texte pourvu des signes de division et de ponctuation. Les pages sont encadrées d'un filet rouge. Les titres des sourales sont écrits à l'encre rouge, et les deux premiers sont entourés d'une arabesque.

Papier. 300 feuillets. Hanteur, 18 centimètres et demi; largeur, 11 centimètres et demi. 15 lignes par page. Mts. du xvie siècle. (Supplément 138.)

\section{5.}

Le Coran. Les motions sont marquées très-irrégulièrement. Les titres des sourates sont en lettres d'or. Le verso du premier feuillet et le recto du second portent 
chacun une arabesque circulaire, assez hien exécutée. Au verso du second fenillet se trouse une jolie arabesque carl'éc, arec une fleur an milien. Le recto du lroisième feuillet contient une autre arabesque carrée, au inilieu de laquelle le mot wis, tracéen caractères coufiques, est reproduit deux fois. Le folio 3 rerso et le folio 4 recto contiennent le lexte de la première somrate el du commencement de la seconde, encadré dans une jolie arabesque. Les pages suirantes sont entonrées de filets noirs et d'un filet d'or. Le dernier (ahier est d'une autre main et remplace sept leuillets perdus.

Papier. 187 feuillets. Hauteur, g centimètres; largeur, 8 centimètres. 11 lignes prar page. Ms. duxvi siècle. - (Supplément 49 ter.)

\section{6.}

La tingt-troisieme section ( $>$ ) du Coran. Les signes de division ont la forme d'assez grands disques exécutés en or ef en conleurs. Les titres des sourates et les derniers versets sont entomés de belles arabesques. Il y a quelques lacunes.

Papier. 16 feuillets. Hauteur, 38 centimètres; largeur, 26 centimètres. 5 tignes par page. IIs. du xvi siècle. - (Supplément 150 , Saint-Germain 59 .)

\section{7.}

Tress-grand exemplaire dı Goran en caractères neskli orientaux, ayant appartenu à la mosquée d'al-Azhar, au Caire, et rapporté en France l'an 1800 par J. J. Marcel. Les titres des sourates sont en lettres d'or, les versets séparés par des rosetles dorées. Le texte des deux premières pagges et des deux dernières est encadré d'une arabesque dessinée avec soin, mais d'un gont fort médiocre. L'écrilure est grande, régulière et assez belle, sans toutefois égaler en beauté celle du ms. $n^{\circ} 418$.

Hauteur, 7 I centimètres; largeur, 21 centimètres el demi. 13 lignes par page. MIs. du xvi siècle. - (Supplément 152 bis.)

\section{8 à 440.}

Trois volumes d'un exemplaire du Coran. Très-grosse écriture neskhi-africaine. Les traits qui marquent les royetles sont en rouge; les waṣla sont indiqués par un gros rond de couleur rerte, et les hamza par un rond jaune. Les versets sont séparés par un trèfle d'or. Le ha coufique doré indique les groupes de cinq versets, un très-gros rond en or et en couleur, les groupes de dix versets. Les tilres des sourates sont écrits en caractères coufiques, évidés et dorés; les uns sont encadrés avec une certaine élégance, les autres accompagnés d'un fleuron assez bien dessiné en or et en couleur, sur la marge du leuillet.

Le premier volume contient les sourates 1, II et 11, le second volume, les sourates iv à vi, et le troisième, les sourates xxvı à xxxvı. En tête du second volume, on lit ces mots : "C'est Lalchoran que Charles te Quint, empereur des homains et roy des Espagnes, aporla de ses expéditions de Tunis et Alger et que le cardinal de Granvelle avoit tiré de l'Escurial pour le mettré en sa bibliothèque."

Papier. 114,118 el 121 feuillets. Hauteur, 38 centimètres el demi; largeur, 27 centimètres. 9 lignes par page. - (Supplément 170.)

\section{1.}

Volume de diverses écritures, renfermant plusieurs sourales du Coran, suivies de prières et de litanies en langue turque. A la fin se tronve la Borda de Boûsîni, trèsbien écrite en caractère taliq et accompagnée de toutes les motions. Le texte du poème est entouré d'un filet d'or.

Papier. 206 feuillets. Hauteur, 15 centimètres; targeur, 9 centimètres et demi. - (Ancien fonds 197.)

\section{2.}

Les sourates xuvı à u du Coran. Trìs-belle écriture. Le texte est encådré d'un filet rouge. A la fin du volmme se trouve un feuillet qui contient la copie d'un passeport daté de l'an 1008 de l'hégire ( 1599 de J. C.) et adressé par la cour du Maroc à un de ses kaïds, le nommé IbnBaddja, lui ordonnant de laisser partir pour son pays le médecin franc Étienne Hubert (السطفى هوبرت) qui s'était rendu à ladite cour. Suivent te signalement du médecin et celui de son domestique, Lubin Ponce. Cette copie, faite par un Européen peu habitué à la lecture de prèces arabes, renferme plusieurs limtes.

On a collé sur le plat intérieur une helle pièce de calligraphie arabe, renfermant quelques versets du Coran.

Papier. 25 feuillets. Hauteur, 24 centimètres; largeur, 16 centimètres. 9 lignes par page. - (Ancien fonds 199 , Colbert 38.2.) 


\section{3.}

Les sourates vi, xxxvı, xur, xuvı, Lv, cxyı et Lxxviı du Coran. Une prière en arabe a été écrite sur la margre du folio 2 ; une autre prière est insérée dans le texte au folio 28. En tèle du folio 55 verso se trouve une dissertation en turc sur les vertus d'une cerlaine prière, celle probablement qui a été transcrite au folio 65. Les feuillets qui suivent contienment des prières et des jassages du Coran.

Papier. 82 fenillets. Hauteur, 16 centimètres; largeur, 10 centimètres. 9 lignes par page. Ms. du $\mathbf{~ v v l}^{\circ}$ siècle. - (Ancien fonds 220.)

\section{4.}

Les sourates vi, xxxvi, Lxvir et Lxxrui du Coran. Silr les marges de quelques feuillets et à la fin du volume se trouvent des prières en arabe avec des litres en turc.

Papier. 38 feuillets. Hauteur, 15 centinètres el demi; largeur, 10 centimètres et demi. 9 lignes par page. Ms. du xv1" siècle. - (Ancien fonds as 3 , Colbert $641 \%$.)

\section{5.}

Les sourates vi, xxxy, xuvili et Lxvil du Coran. Volume de diverses écritures. A la fin se trouve une prière en ture.

Papier. 35 feuillets. Hauteur, 16 centimètres; largeur, 10 centimètres et demi. 9 tignes par page. Ms. du xvi siècle. - (Ancien fonds 224, Colbert 6412.)

\section{6.}

Les sourates vı, xxxı, xxxvı, xuy, xuvm, Lv, LVı, Lxvı el uxxin du Coran. An folio 42 commence une instruction, en langue turque, indiquant ce que le croyant doil faire afin que ses prières soient exaucées.

Papier. 85 feuiltets. Hauteur, 9 centimètres; largeur, 5 centimètres et demi. 9 lignes par page. Ms. du xvi siècle. - (Ancien fonds 23 h, Colbert 6619 .)

\section{7.}

Extraits de plusieurs sourates du Coran, avec une ver- sion interlinéaire en espagnol. Certains termes religieux comme paradis, ange, ete., ne sont pas traduits, mais transcrits en caractères européens, et le mot Dieu est toujours écrit en arabe (Wil). Ce volume a été écrit en entier, texte et traduclion, à Salonique, par un musulman es]agnol nommé Ibrahìn Isquierdo, en l'an 976 de l'hégire ( $1568 \mathrm{de}$ J. C.). L'écriture arabe est une mauvaise inilation de l'écriture occidentale, ou maghrebine, celle dn texte espagnol est au contraire très-régulière et très-belle.

Papier. 107 feuillets. Hauteur, 21 centimètres; largeur, 14 centimètres et demi. 5 lignes par page. - (Ancien fonds 201.)

\section{8.}

Le Coran, texte de la rédaction d'O(limân, avec les voyelles et les signes orthographiques que Doûrì et Soûsì avaient transmis à leurs disciples sur l'autorité du célèbre lecteur Aboû 'Amr Ibn al-'Alà. En marge se trouvent les variantes provenant des maitres lecteurs des diverses écoles. Ces variantes sont écriles à l'encre rouge. Le texte porte les signes de ponctuation. Aı folio ${ }_{2} 6_{7}$, à la suite du texte, se trouve une note du rédacteur dans laquelle il explique les chiffres dont il s'est servi pour indiquer les sources des variantes, etc. M. de Sacy a inséré la traduction de cette pièce dans la notice très-étendue quil a donnée de notre ms. (Voyez $r$ Notices el extraits $\pi$, etc., tome IX, page 76 .) Sur le verso du leuillet 270 on lit une note attribuée au calife 'Alì relative à la manière de consulter le sort au moyen du Coran. Aı verso du feuillet suivant se trouve une prière composée pour servir à des opérations magiques et qu'on attribue à Aboù ḷàmid alGhazzâli. Le feuillet suivant contient ur chame pour faire dormir les enfants. Ms. daté de l'an 979 de l'hégire $(1571$ de J. C.).

Papier. 275 feuitlets. Hauteur, 20 centimètres et demi; largeur, 15 centimètres. 15 lignes par page. - (Ancien fonds 189 , Colluert 3641 .)

\section{9.}

Le Coran. Is. de forme octogone, daté de l'an $99^{\circ}$ de l'hégire ( 1582 de J. C.). L'écriture, line, mais pen élégante, parait être d'ume plume persane. Le dernier feuillet porte le nom de l'un des anciens possesseurs : Molianmad, fils de Timur-Khan.

Papier. 338 feuillets. 10 centimètres de diamètre. - (Supplément 123 , Supplément de Saint-Germain 27.) 


\section{0 .}

Le Coran, exemplaire daté de l'an 996 (1588 de J. c.), éeril par un copiste turc. Les signes de division et de ponctuation manjuent.

Papier. 321 feuillets. Hanteur, 19 centimètres; largeur, 14 centimètres. 15 lignes par page. - (Ancien fonds 186.)

\section{1.}

Le Coran, texte pourru des signes de ponctuation. Les parlies et les groupes de dix versels sont marqués à l'enere rouge sur les marges. Celle eopie a élé exéculée par un scribe ture en l'an 999 de l'hégire ( 1590 de J. C.).

Papier. 304 feuillets. Hauteur, 21 centimètres; largeur, 15 centimètres. 13 lignes par page. - (Ancien fonds 185.)

\section{2.}

La section XIX du Coran, renfermant la fin de la sonrate $x x y$, la somrale $x x v ı$ en enlier el la première parlie de la sourate xxvir. Ce volume lut donné, en 1648, à Charles de Montehal, arehevéque de Toulonse, par Anntoine Gaiot, protesseur de littérature sacrée.

Papier. 3 f feuillets. Hauteur, 18 centimètres; largeur, 13 centimètres; 9 lignes par page. Ms. du xvie siècle. - (Ancien fonds 200.)

\section{3.}

Le Coran; exemplaire daté de l'an 1001 de l'hégire ( $59^{3}$ de J. C.). Dans la première partie du volume, les litres des sourates sont restés en blane. Les points qui séparent les versels el les signes de ponctuation sont souvent omis. A la fin du volume se trouve la prière que l'on réeite après asoir terminé la lecture du Coran en enlier.

Papier. 303 feuillets. Hauteur, 30 centimètres; largeur, 19 centimètres el demi. 13 lignes par page. - (Supplément 130.)

\section{4.}

Le Coran, texte pourvu des signes de division, mais non ponctué.

Papier. 402 feuillets. Hauteur, 17 centimètres; largeur, 11 centi- mètres. 13 lignes par page. Ms. de la fin du $x v^{e}$ siècle. - (Supplément 121, Saint-Germain 280.)

\section{5.}

Le Coran, copie exécutée à Constantinople. Les titres des sourates sont écrils à l'encre rouge. Les signes de division et de ponctuation sont omis. Le premier et le dernier feuillet manquent. A la fin se trouve une pièce arabe que l'on réeite après avoir terminé la lecture du Coran. Cette prière remplit à peu près trois pages. Suit une prière en ture, dans laquelle il est fait mention du sultan Sélim (سُمِئ), fils de Solaïmân.

Papier. 203 feuillets. Hauteur, a 7 centimètres; Jargeur, 20 centimètres. 15 lignes par page. Ms. de la fin du xrı siècte. - (Supplément 128.)

\section{6.}

Le Corau. Une belle arabesque orne les deux premières pages; les autres pages sont entourées de filets noirs, relraussés de filets d'or. Texte pourvu des signes de division et de poneluation.

Papier. 305 feuillets. Hauteur, 15 centimètres; largeur, 10 centimètres. 15 lignes par page. Ms. de la fin du $x^{\prime} 1^{\circ}$ siècle. - (Supplément $148 \mathrm{v}$ )

\section{7.}

Les sourates vi, xxxvi, xulv, xuril, Lv, Lvi, LXvil et Lxxvıı du Coran; bonne écriture neskhi. Les versets sont séparés par un rond en or; titres des sourates en or; texle encadré; les deux premières pages portent des arabesques en or et en couleurs, formant un encadremeut dont chaque moitié renferme cinq lignes de texte.

Papier. 81 feuillets. Hauteur, 19 centimètres et demi; Iargeur, 8 centimètres et demi. g lignes par page. Ms. de la fin du xri siècle. - (Supplément 169.)

\section{8.}

Le Coran; exemplaire de diverses écritures, dout celle qui remplil le milien du volume, depuis le folio 49 jusqu'au folio 278 , paraît être de la fin du $x^{2} \mathbf{l}^{e}$ siècle. 
Le texte de cette partie est écrit sur papier européen, de même que les premiers feuillets, qui ont été ajoutés pour remplir une lacune. Les derniers feuillets sont écrits sur papier de riz. Le texte porte partout les signes de division et de ponctuation. A la suite du Coran, vient une prière à l'usage de ceux qui achèvent la lecture de ce livre; puis (fol. $282 \mathrm{v}^{\circ}$ ) un traité sur la manière de lire le Coran à haute voix, avec les contractions phonéliques et les intonations convenables. Cette pièce, dont la fin manque, devait recevoir des gloses intertinćaires en langue malaie; elle en porte quelques-unes, mais le tra. vail n'a pas élé terniné. Au reste, on remarque dans plusieurs parties du volume de courtes notes en malai.

Papier. $29^{\circ}$ feuillets. Hauteur, 30 centimètres; largeur, 19 centimètres et demi. 15 lignes par page dans la partie prineipale du volune; les premiers fevillets en portenl. 17 . Ms. du commeneement du xvi ${ }^{\circ}$ siècle. - (Supplément 129.)

\section{9 .}

Le Coran; exemplaire daté de l'an 1011 de l'hégire ( 1062 de J. C.). Le texte porte les signes de division el de ponctuation. Une arabesque assez simple orne les deux premières pages. Les autres pages sont encadrées de deux traits rouges.

Papier. $7^{30}$ pages. Hauteur, ${ }_{2} 5$ eentimètres; largeur, 18 cenlinètres. 13 lignes par page. - (Supptément 148.)

\section{0.}

Extraits du Coran, accompagnés des signes de ponetuation. Les trois premières sourates et les liuit dernières sout reproduites en entier; quant aux autres, le copiste n'en a donné que les premières lignes. On lit sur le dernier feuillet la note suivante : a Quelques chapitres de l'Aleoran, eserits par François de Boulogrne, Ture que mon frère avoit retiré des gardes du roy, en vi ${ }^{\mathrm{c}}$ xll. $\rightarrow$ Ce Ins. fut donc écrit en 1612 , probablement à Paris.

Papier. 54 fenillets. Hauteur, 27 rentimètres; largeur, 19 centimètres et demi. 15 lignes par page. - (Ancien fonds 184.)

\section{1.}

Le Coran, ms. daté de l'all 1026 de l'hégire (1617 Mas. onextaix. - it. de J. C.). On y remarque plnsieurs lacunes, dont la plupart ont été remplies par d'autres copistes.

Papier. 457 feuillets. Hantenr, 22 centimètres; largeur, 14 centimètres et demi. 13 lignes par page. - (Supplément 153, Saint-Germain 277.)

462.

Le Coran; exemplaire de diverses écritures; celle qui remplit la plus grande partie du volume est d'une main turque et porte la date de l'an 1036 de l'hégire $\left(16_{2} 6\right.$ de J. G.).

Papier. 348 feuiltets. Hauteur, 15 centimètres; largenr, 10 centimèıres. 13 tignes par page. - (Supplément 145.)

\section{3.}

Le Coran, texte pourvu des signes de division et de ponctuation. Les deux premières pages sont entourées d'une arabesque. Le ms. est daté de l'an 1049 de l'hégirét ( 1639 de J, C.). A la fin se trouve une prière, dans laquelle celui qui vient de faire la lecture à laute voix d'me partie de ce livre demande à Dieu le pardon des fautes de lecture qu'il aurait pu commettre. Les divers grenres de ces fautes y sont énumérés.

Papier. 464 feuillets. Hauteur, 15 centimètres; largeur, io centimètres. 12 lignes par page. - (Supplément 116 , Saint-Germain 532.)

\section{4.}

Le Coran, texte dépourvu de points-voyelles, daté de l'an 1059 de l'hégire ( 1649 de J. C.).

Papier. 344 feuitlets. Hanteur, 11 eentimètres; largenr, 8 eentimètres. 18 ligues par page. - (Aneien fonds 214, Colbert 6611.)

\section{5.}

Le Coran; exemplaire daté de l'an 1059 ( 1649 de J. C.). Les signes de division par groupes de dix versets sont marqués, ainsi que les signes de ponctuation.

Papier. $33_{2}$ feuillets. Hautenr, 19 centimètres et demi; largeur, 13 centimètres. 15 lignes par page. - (Supplément 121 B.) 


\section{6.}

Le Coran, en mauvaise écriture mághrebine, daté de l'an 1069 de l'hégire ( 1659 de J. C.). Les premiers lemillets manguent. Le texle est accompagné de fous les signes orthographiques. Les six dernières pages sont couvertes de morceaux san in térêt, en prose cl en vers.

Papier. 175 feuillets. Hauteur, 18 centimètres; largeur, 15 centimètres. 17 lignes par page. - (Supplément 154, Saint-Germain 283.)

\section{7.}

Le Coran; lexte exéculé en Perse, pourvu des signes de division et de poncluation.

Papier. 449 feuillets. Hauteur, 26 centimètres et demi ; largeur, 1 1 centimètres el demi. 15 lignnes par page. Ms. du xvir siècle. (Ancien fonds 179.)

\section{8.}

Le Coran; exemplaire écrit en grande partie pà un Européen. Le texte, à partir du folio 20 , est accompagné d'une traduction française interlinéaire, dont on ne connait pas l'auteur. Les folios 297 à 304 renferment la lable des chapitres et des matières.

Papier. 306 feuillets. Hauleur, 28 centimètres; largeur, 19 centimètres. Le nombre des lignes par page n'est pas constant. Ms. du ıvı siècle. - (Ancien fonds 183.)

\section{9.}

Le Coran ; cxemplaire pen soigné et d'une écriture médiocre.

Papier. $2 / 9$ feuillets. Hanteur, 21 centimètres ; largeur, 15 centimètres. 15 lignes par page. Ms. du xwr siècle, - (Ancien fonds 193.)

\section{0.}

Les dernières sourates du Coran, à partir de la sourate sxvı. La première sourate a été ajouléc à la fin.

Papier. 38 feuillets. Hautenr, 20 centimèrres et demi; largeur, 14 centimètres. 11 lignes par page. Ms. du xv11 siècle. - (Ancien fonds ${ }_{19}^{6}$, 'Colbert 4977.)

\section{1.}

Les sourates V1, xxxv1, xLvı1, Lxvi, Lxxvi1 et suivantes du Coran. La première sourate est placée à la fin. Ms. pourvu des signes de division et de ponctuation.

Papier. 74 feuillets. Hauteur, ao centimètres; largeur, 13 centimètres et demi. 9 lignes par page. Ms. du xvir siècle. - (Ancien fonds 203.)

\section{2.}

Quelques sourates du Coran. Texte très-incorrect. A la fin se trouvent quelques prières.

Papier. 12 a feuillets. Hauteur, a centimètres et demi; largeur, 13 centimètres. 9 lignes par page. Ms. du xri siècle. - (Ancien fonds 205.)

\section{3.}

La treizième section du Coran, contenant la fin de la sourate $x{ }^{\prime}$, la sourate $x u 1$ en cntier et le conmencement de la sourate xiv.

Papier. 23 feuillets. Hauteur, 20 centimètres; largeur, 14 centimètres. 9 lignes par page. Ms. du xvi" siècle. - (Ancien fonds 207.)

\section{4.}

Le Coran, texte pourvu des signes de division et de ponctuation. Les pages sont encadrées d'un filet rouge.

Papier. 337 feuillets. Hauteur, 17 centimètres; largeur, 12 centimètres. 15 lignes par page. Ms. du $\mathbf{x v i}^{\circ}$ siècle. - (Ancien fonds 213.)

\section{5.}

Les sourates xxxvı, xLvu, Lv, cxvi, cxxvuı du Coran, suivies de la litanie de Nahomet, de quelques invocations et quelques autres extraits du Coran.

Papier. 4h feuillets. Hauteur, 16 centimètres; Jargeur, 10 centimètres. Première partie, 9 lignes par page; seconde partie, 7 lignes.

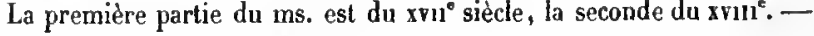
(Ancien fonds 221, Colbert 6409.) 


\section{6.}

Les somrates 1, vı, xxxvı, xuvin el cxxvin du Coran. Les deux premières pages sont ornées d'une belle arahesque en or et en couleurs; les antres pages sont encadrées de deux filets d'or.

Papier. 61 feuillets. Hauteur, 10 centimètres; largeur, 16 centimètres et demi. 9 lignes par page. Ms. du xvı ${ }^{e}$ siècle. - (Ancien fonds 222.)

\section{7.}

Les sourates vi, xxxv, Lxvi et cxxvin du Coran. Suivent quelques traditions du Prophète, des litanies et des prières, le tout en langue turque.

Papier. $9^{6}$ feuillets. Hauteur, 10 centimètres et demi; largeur, 7 centimètres et demi. 7 lignes par page, Ms, du xvı e siècle. - (Ancien fonds 225 , Colbert 6615 .

\section{8.}

\section{Plusieurs sourates du Coran.}

Papier. 38 feuillets. Hauteur, 15 centimètres; largeur, 10 centimètres et demi. 9 lignes par page. Ms, du xvin' siècle. - (Ancien fonds 236.)

479 ,

Les premières sourates du Coran, jusqu'au cinquantesixième verset de la neuvième sourate. Les deux premières pages contiennent une arabesque assez grossièrement exécutée.

Papier. 130 fenillets. Hauteur, 14 centimètres et demi; largeur, 9 centimètres et demi. 13 lignes par page. - (Ancien fonds 237 .)

\section{0 .}

Les sourates vi, xviI, xxxvi, xuIv, xuvil, LV, LVı, LVII, Lix, Lxvi, Lxxvı et Lxxvin du Coran. Le texte est pourvu des signes de division el de ponctuation. Le folio 15 porte en marge une prière, le folio 21 , une litanie. A la fun de la dernière sourate, on trouve la prière quon récite après la lecture du Coran. Au folio 63 , on lit une courte ins-
Iruction en ture sur la manière de faire son salut, suivie de prières et d'une litanie en arabe. Tous ces textes sonnt encadrés d'or.

Papier. 67 feuillets. Hauteur, 18 centimètres et deuni; largeur, 1 s centimètres. 11 lignes par page. Ms. du xvil siècte. - (Ancien fonds 238 .)

\section{1.}

Le Coran, texte pourvu des signes de ponctuation. Les sections et les quarts de section sont indiqués à la narge.

Papier. 269 feuillets. Hanteur, 30 centimètres; largeur, so centimètres et demi. 15 lignes par page. MIs. du xvi" siècle. - (Supplément 115 , Saint-Germain 63.)

\section{2.}

Le Coran, texte non ponclué, mais divisé en sections et en groupes de dix versets. Une arabesque d'une bonne exécution entoure les deux premières pages du texle. Très-belle reliure.

Papier. 324 feuillets. Hauteur, 26 centimètres; largeur, 17 centimètres. 13 lignes par page. Ms. du xvı" siècle. - (Supplément 117 , Saint-Germain 65.)

\section{3.}

Le Coran. Les premiers feuillets, contenant la sourate 1 et les cent dix-sept premiers versets de la sollrate 1 , manquent. Le copiste a négligé d'écrire les litres des sourates, ainsi que les signes de division et de ponctuation.

Papier. $29^{4}$ feuillets. Hauteur, so centimètres et demi; largenr, $1 /$ centimètres et demi. 13 lignes par page. Ms. du xvi1' siècle. (Supplément 119, Saint-Germain 278.)

\section{4.}

Le Coran, texte divisé en groupes de dix versets et ponclué. Les titres des sourates sont écrits ì l'encre bleue; les pages encadrées d'un filet d'or. A la fin se Irouve un tableau, au moyen duquel on consulte le sort.

Papier. 367 fenillets. Hauteur, 18 centimètres; largeur, 12 centi- 
mètres. 15 lignes par page. Ms. du xvu' siècle. - (Supplément 126 ; provient de la maison professe des Jésuites, à Paris.)

\section{5.}

Le Coran, ms. qui parait avoir été exéculé dans l'Inde. Texle ponclué. Les pages sont grossièrement encadrées de deux filets rouges.

Papier. 347 feuillets. Hauteur, 22 centimètres; largeur, 15 centimètres. 3 lignes par page. Ms. du xvir siècle. - (Supplément 132.)

\section{6.}

Le Coran; exemplaire pourvu des signes de division, mais non ponctué.

Papier. 311 feuillets. Hauteur, 21 centimètres et demi; largeur, 15 centimètres. 15 lignes par page. Ms. du xvı" siècle. - (Supplément 141.)

\section{7.}

Le Corall.

Papier. 38, feuillets. Hauteur, 21 centimètres; largeur, I 5 centimètres. 3 lignes par page. Ms. du xviı sièele. - (Supplément 146.)

\section{8.}

Le Coran, texte pourvu des signes de division et de poncluation.

Papier. 244 feuillets. Hauteur, 30 centimètres; largeur, 20 centimèlres. 5 lignés par page. Mls. du xviı" siècle. - (Supplément 147.)

\section{9.}

Le Coran; exemplaire écrit sur papier de riz, probablement en Malaisie. L'écriture est régulière, mais peu gracieuse. Les signes de ponclualion sont narqués. Les deux premières pages portent lıuil lignes de texte, entourées d'une arabesque assez bien dessinée, mais coloriéc de la façon la plus barbare.

Papier. 334 feuillets. Hauteur, 24 centimètres; largeur, 16 centimètres. 13 liggnes par page. Ms. du xvi1 siècle.—(Supplément 148, vu ; vient de la Bibliothèque Mazarine.)

\section{0 .}

Les dernières sourates du Coran, à parlir de la fin de la dix-lunilième. Belle écriture africaine. Les motions, les teschdid et les alif rétablis sont en rouge; les waṣla sont marqués par un point vert, et les hamza par un point jaune.

Papier. 195 feuillels. Hauteur, 20 centimètres; largeur, 15 centimètres. Le nombre des lignes par page varie de 15 à 17. Ms. du $\mathbf{v r}^{\circ}$ siècle. - (Supplément 149 ; provient de la maison professe des Jésuites, à Paris.)

\section{1.}

Les dix-sept premières sourates du Coran, et soixantetreize versets de la sourate xvm. Écriture africaine.

Papier. $9^{2}$ feuillets. Hauteur, 18 centimètres; largenr, 13 centimètres et demi. 19 lignes par page. Ns. du хvi' siècle. - (Supplément 149 bis; provient de la maison professe des Jésuites, à Paris.)

\section{2.}

Les sourates xvı et xvi du Coran, qui forment la quatorzième section d'un exemplaire divisé en trente seclions. Un nommé Sâtim ben 'Abd al-Karim l'avail donné en waqf, avec les autres sections, à la grande inosquée de مســــ Une note en français nous apprend que ce rolume fut pris, en l'ile Damjouan, l'an 1700 , dans un temple des Mahométans où il y en avait beaucoup d'autres semblables. L'ile d'Anjouana est l'une des Comores.

Papier. 15 feuillets. Hauteur, 15 centimètres; largeur, 11 centimètres. 13 lignes par page. Ms. du xvı siècle. - (Supplément 151 , Saint-Germain 533.)

\section{3.}

Les sourates xix à Lxxvı du Coran, d'une mauvaise écriture européenne; en unarge, un assez grand nombre de notes et d'essais de traduction, tant en frauçais qu'en latin.

Papier. 428 pages. Hauteur, 13 centimètres; largeur, 15 centimètres et demi. Le nombre des lignes par page varie de 10 à $15 . \mathrm{Ms}$. du xv11" siècle. - (Supplément 155, Saint-Germain 285.) 


\section{4.}

Les sourates vı, xxxvı, xuI, xLVII, LXvil, Lxxvilı el ex du Coran.

Papier. 62 feuillets. Hauteur, 16 centimètres; largeur, 10 centimètres et demi. 7 lignes par page. Ms. du xni" siècle. - (Supplément 155 his, Arsenal.)

\section{5.}

Les sourates Lxvı et suivantes du Coran; mauvaise écriture maghrebine.

Papier. 58 fenillets. Hantenr, 20 centimètres et demi ; largenr, 15 centimètres et demi. 11 lignes par page. Ms. du xvin' siècle. - (Supplément 156 .)

\section{6.}

Les sourates Lxvı à Lxxvıl du Colan. Les titres sonl omis.

Papier. 16 fenillets. Ifauteur, a centimètres; largeur, 15 centimètres. 11 lignes par page. Mls. du xvi" siècle. - (Supplément 166.)

\section{7.}

Les sourates exxvil et suivantes du Coran; écrilure neskhi turque. Les titres sont omis.

Papier. as feuillets. Hauteur, 19 centimètres et demi; largeur, 14 centimètres. 9 lignes par page. Ms. du xvu siècle. - (Supplément 168.)

\section{8.}

Les sourates Lxxvm el suivanles du Coran; écriture neskhi lurque. Les tilres sonl omis.

Papier. 18 fenillets. Hauteur, 21 centimètres; largeur, 15 centimètres. 11 lignes par page. Ms. du xvi" siècle. - (Supplément 168 bis . Sainte-Geneviève.)

\section{9 .}

Le Coran; exemplaire daté de l'an 1090 de l'hégire
( 1679 de J. C. ); les signes de division par groupes de dix versets et les signes de ponctuation sont marqués. Les pages sont encadrées de deux filels rouges. A la fin du rolume se trouve la prière que l'on récile après avoir achevé la lecture du Coran. Au folio 36 a, commence un traité en turc sur les medda, les ikhfa, les idgham et autres signes de prononciation.

Papier. 368 feuillets. Hauteur, $\mathbf{2} 5$ centimètres; largeur, 18 centimètres. 13 lignes par page. - (Supplément 136.)

\section{0.}

Le Coran; ms. daté de l'an 1096 de l'légire ( 1685 de J. C.); les divisions usuelles sont marquées, ainsi que les signes de ponctuation; les pages sont encadrées de filets rouges et bleus.

Papier. 402 feuillets. Hauteur, 19 centimètres et demi ; largeur, 13 centimètres. 11 lignes par page. - (Aucien fonds 187.)

\section{1 .}

Le Coran, texte pourvu des signes de division el de ponctuation. Les pages sont encadrées d'un filel d'or: Jes tilres des chapilres dessinés en blanc sur un fond d'or; les deux premières pages sont entourées d'une assez betle arabesque. D'après un acte de waqf inscrit sur le recto du premier feuillet, ce ms. ful donné à un élablissement religieux, qui n'est pas nommé, par Aboû 'lHosaïn 'Ali, dey d'Alger, en 1124 de l'hégire ( 712 de J. C.). Deux notes en latin, qu'on lit en tête du volume, témoignent que ce volume fut porté à Paris près d'un siècle avant la conquête française de l'Agóérie.

Papier. 335 feuillets. Hautenr, 20 centimètres; Jargeur, 12 centimètres et demi. 17 lignes par page. Its. de la fin du xrı" siècle. (Supplément 140.)

\section{2.}

Le Coran, texte pourvu des signes de division el de ponctuation. Une belle arabesque entoure te texte des deux premières pages. Les autres pages sont encadrées de filels noirs et rouges. La reliure, richement doréc, est en maroquin rouge et d'un travail l'rançais; elle esl de la fin du $\times$ vir $^{e}$ siècle.

Papier. 255 feuillets. Hautenr, 25 centimètres et demi; largeur, 18 centimètres et demi. 15 lignes par page. Ms. do xvo" siècle. (Supplément 148 ter, Arsenal.) 


\section{3.}

Seconde moilié d'un Coran.

Papier. 143 feuillets. Hauteur, 21 centimètres; largeur, 16 centimètres. 11 à 17 lignes par page. Ms. du xrı๋ siècle. - (Supplément 1969$.

\section{4.}

Quelques sourates du Coran.

Papier. 69 feuillets. Hanteur, 36 centimètres; largeur, 11 centimètres. 1 lignes par page. Ms. du xviı siècle. - (Supplément i970.)

\section{5.}

Uهم لا Une section du Coran, commençant par les nots

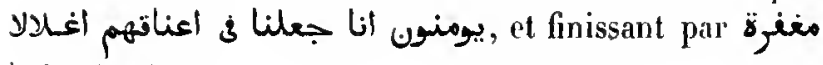

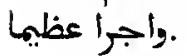

Papier. 31 feuillets. Hanteur, 16 centimètres; largeur, 10 centimètres. 11 lignes par page. Ms. du zvı" siècle. -- (Supplément 1971.)

\section{6.}

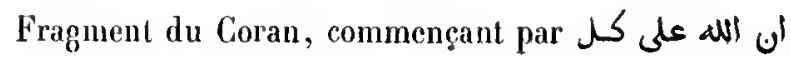

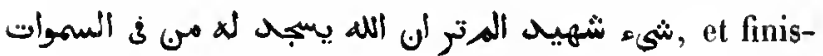

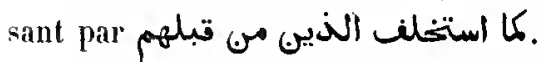

Papier. 26 fenillets. Ifauteur, 20 centimètres et demi ; largeur, 15 centimètres. 13 lignes par page. Ms, du xwr1 ${ }^{e}$ siècle. - (Supplément 1975 .)

\section{7.}

Quelques extraits du Coran. Cahier d'écriture d'un Européen qui apprenait l'arabe d'un maitre indigène.

Papier. 33 feuillets. Hauteur, 91 centimètres; largeur, 16 centimètres et demi. Ms. du xvit siècle. - (Supplément i 976.)

\section{8.}

Extrait du Coran, commençant par la sourate الانعام, et finissant au inilieu d'un verset de la sourate يس. Textc encadré.

Papier. 52 feuillets. Hauteur, 10 centimètres; largeur, 7 centimètres. 7 lignes par page. Ms. du xvı! siècle. — (Supplément 1977.)

\section{9.}

Lc Coran; exemplaire en caraclères africains, écril probablcment par un nègre. Les deux premières sourates manquent. Les voyelles et autres signes sont marqués à l'encre rouge.

Papier. 307 feuillets. Hauteur, 19 centimètres; largeur. 15 centimètres. Le nombre des lignes par page varie de 13 à i 5 . Ms. de la fin dn xwi' siècle. - (Supplément 161.$)$

\section{0 .}

Les sourates Lxxvu et suivantes du Coran; écriture neskhi orientale; le texte n'est pas divisé en versets.

Papier. 55 feuillets. Hauteur, 14 centimètres et demi; largeur, 11 centimètres. 7 lignes par page. Its. de la fin du xvm siècle. - (Supplément 163.)

\section{1.}

Les sourates Lxxvıı et suivantes du Coran; mauraise écriture neskhi, caractère de Constantinople. Les titres des sourates sont omis.

Papier. 19 feuillets. Hauleur, 21 centimètres; largenr, 15 centimètres. 1 lignes par page. Ms. de la fin du xvil siècle. - (Supplément 167. )

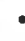

\section{2.}

Le Coran, exemplaire daté de l'an $1129(1717$ de J. C.), pourvu des signes de division et de ponctuation.

Papier. 274 feuillets. Hauteur, 25 centimètces; largeur, 19 centimètres. 15 lignes par page. - (Supplément 148 bis, Arsenal.)

\section{3.}

Petit volume, composé de deux parties, dont la première, écrite en neskhi oricntal, renferme les sourates xxxv, xuvı, Lxvı, Lxxvın et $\mathrm{Lv}$ du Coran. La seconde parlie, écrite en neskhi occidental, renferme des prières, des amulettes, des conseils adressés par un vizir 
à son fils au sujet des vertus d'une amulette; un petit traité indiquant toutes les conditions à remplir pour que la prière soit valable, etc. Ms. écrit l'an 1130 de l'hégire ( 1718 de J. C.), probablement à Constantinople.

Papier. 202 feuillets. Hauteur, 9 centimètres et demi; largeur, 6 centimètres et demi. - (Supplément 159 bis.)

\section{4 à 541.}

Le Coran, divisé en trente sections. Vingt-huit volumes de seize à vingt feuillets de différents formats. Il manque les sections $11,17,18,19,20,21$ et 26 . Les sections $1,2,12,15$ et 25 sont en double. Écriture nesklıi dı xvu ${ }^{e}$ siècle. Cet exemplaire avait été donné en waqf à un étal)lissement religieux, peut-être à l'une des mosquées du Caire, par l'émir Hasan, serviteur du colonel (المير اللوى) lsmaël Beg, l'an 1205 de l'hégire (1 791 de J. C.).

(Supplément t63.)

\section{2 à 570.}

Le Coran, divisé en trente sections. Vingt-neuf volımes de trente à quarante feuillets de différents formats. Les sectious $8,19,22,23,30$ manquent. Les sections 9, 14,16 et 24 sont en double. Écriture neskhi du xvin ${ }^{\circ}$ sièele. En tête de la cinquième section se trouve un certificat de waqf, daté du mois de moharram de l'an 1140 de l'hégire ( $177^{2} 7$ de J. C.).

(Supplément 164.)

\section{1.}

Rouleau de papier, long de 3 mètres 80 centimètres', et large de 6 centimètres et demi, devant servir d'amulette et contenant le texte entier du Coran, en caractères presque microscopiques sans motions, ni points diacriiqques. Quelques passages du texte sont disposés de mauière à représenter les mots qui forment le verset du Trône (sourate 11, 256). Le scribe a employé de l'encre rouge et de l'encre noire.

(Supplément $\$ 18$ viı.)

\section{2.}

Le Coran, texte portant les signes de ponctuation.
Les deux premières pages sont encadrées d'une arabesque; les autres pages sont entourées de deux filets, l'un rouge et l'autre bleu. Ce ins. parait provenir de l'Inde; il a été écrit au $x^{\prime}{ }^{\circ}{ }^{\circ}$ siècle, antérieurement à l'an 1158 de l'hégire ( 145 de J. C.).

Papier. 416 feuillets. Hauteur, 21 centimètres et demi; largeur, 15 centimètres el demi. 10 lị̈nes par page. - (Supptément 148 w. Arsenal.)

\section{3.}

Le Coran; exemplaire écrit dans l'Inde, l'an 1185 de l'hégire ( $77^{1}$ de J. C.) ; texte pourvu des signes de division et de poncluation. En tête du volume se trouve une série de notes en français, indiquant, d'une manière très-sommaire, le contenu de quelques sourates. Cette pièce a pour auteur Ouessant, rinterprète juré du roy, du persan, maure et bengal.» A la fin du volume on lit une note en persan, domant le nombre des lettres contenues dans ehaque sourate.

Papier. ${ }_{1087}$ pages. Hanteur, 25 centimètres; largeur, 17 centimètres et demi. 11 lignes par page. - (Supplément 133.)

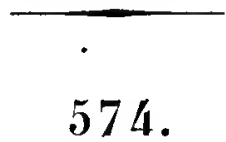

Le Coran; exemplaire éerit dans l'Inde, l'an 1191 de l'hégire ( 1777 de J. C.); texte pourvu des signes de division et de ponetuation.

Papier. 456 feuillets. Hauteur, 23 centimètres et demi; largeur, 17 centimètres. 13 lignes par page. - (Supplément 13/.)

\section{5.}

le Coran; exemplaire daté de l'an 1194 de l'hégire ( 1780 de J. C.). Écriture maghlıhehine.

Papier. 203 feuillets. Hauteur, 25 centimètres et demi; largeur, 18 centimètres. 20 lignes par page. - (Supplément 1967.)

\section{6.}

Le Coran; exemplaire daté de l'an $119^{5}$ de l'hégire ( ${ }_{7} 78$ de J. C.). Écriture maghrehine.

Papier. 180 feuillets. Hauteur, 25 centimètres; largeur, 18 centimètres. 19 à 21 lignes par page. - (Supplément 1968 


\section{7.}

Les sections 1, 2, 3, 4, 5, 10, 15,20,25 et 30 du Coran. Ces sections forment antant de eahiers, dont chaque feuillet porte sur le reclo une partie du texte, pourvu des signes phonétiques et des signes de ponctuation. Fn tête du volume se trouve une liste des sourates avec Indicalion du nombre des lettres contenues dans chaque sourate, ainsi que du nombre lolal, qui est de 357,786 , et du nombre de versets de chaque sourate; suivent quelques prières à liusage des musulmans, accompagnées d'une traduction en persan. Ces cahiers ont été rerits au Bengale, sous la direction de Ouessant, et porlent la date de 1784 de J. C.

Papier. 478 feuillets, dont 96 sont restés en blanc. Hauteur, a 9 centimètres et demi; largeur, 19 centimètres et demi. 11 ligrnes par page. - (Supplément 131.$)$

\section{8.}

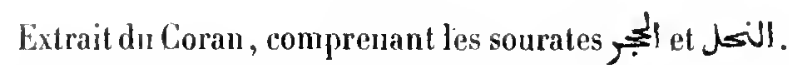
l'apier. 21 feuillets. Hauleur, 21 centimètres; largeur, 15 centimètres. 9 ligues par page Ms. du xvil" siècle. - (Supplément 1973.)

\section{9.}

تلك الرسل فضّدلنا Section du Coran, commençant par

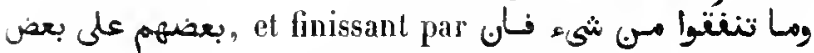
مls all.

Papier. 30 feuiltets. Hauteur, 21 cenlimètres; largeur, 15 centimètres. 7 lignes par page. Ms. du xvı" siècle. - (Supplément 1979.)

\section{0.}

Extraits du Coran, en caractères coufiques. C'est un essai assez bien réussi d'un musulman du xvm ${ }^{\mathbf{e}}$ siècle.

Papier. 4 feuillets. Hauteur, 25 centimètres; largeur, 26 centimètres et demi. - (Supplément 2949.)

\section{1.}

Quelques sourates et passages du Coran.

Papier. 12 feuiltets. Hauteur, 18 centimètres; targeur, 11 centi- mètres. 13 à 18 lignes par page. Ms. du xvir siècle. - (Supplément 2225.)

\section{2.}

Fragment d'un exemplaire du Coran, écrit sur papier de riz, dans l'île de Java.

Papier. $7_{2}$ feuillets. Hauteur, 21 centimètres; largeur, 14 centimètres et demi. 11 lignes par page. MIs. du xvin' siècle. - (Supplément 2171.)

\section{3.}

l'remiers feuillets d'un exemplaire du Coran, écrits sur papier de riz, et provenant de l'ile de Java.

Papier. 26 feuillets. Hauteur, 24 centimètres; largeur, 17 centimètres et demi. 25 lignes par page. Ms. du xvi11' siècle. - (Supplément 2:72).

\section{4.}

Plusieurs extraits du Coran, Ce volume, qui commence par la Fatiha, et se termine par la sourate al-Nas, est écrit sur papier de riz; il vient de l'ile de Java.

Papier. 43 feuillets. Ilauteur, 24 centimètres et demi ; largeur, 16 cen-

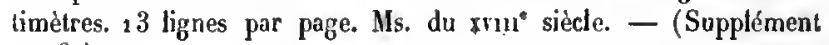
2173.)

\section{5.}

Les trente-sept dernières sourates du Coran, précédées d'un syllabaire arabe.

Papier. 42 fenillets. Hauteur, 18 centimètres et demi; largeur, 12 centimètres. 7 ligues par page dans la première partie, et 10 dans la seconde. - (Supptément $248 \mathrm{ix}$.)

\section{6.}

Les sourates ıv à xvu du Coran; écriture africaine. Les motions, les signes orthographiques et les signez phonétiques sont en rouge, en bleu, en vert et en jaune, selon l'usage de l'Afrique et de l'Espagne.

Papier. 131 feuillets. Hauteur, 25 centimètres; largeur, 19 centimètres. 12 lignes par page. Ms. du xviu siècle. - (Supplément 149 1v, Arsenal.) 


\section{7.}

Le Coran; exemplaire daté de l'an 1200 de l'hégire ( 786 de J. C.), et apporté de l'Égypte an commencement de ce siècle. Texte pourvu des signes de division et de ponctuation. Une arabesque, grossièrement exécutée, orne les denx premières pages. Les autres pages sont entourées d'un filet d'or.

Papier. $29^{3}$ fenillets. Hauleur, 3 a centimètres et demi; targeur, 91 centimètres. 15 lignes par page. - (Supplément 142.)

\section{8 .}

Le Coran, à partir de la sourate dix-neuvième; mauvaise écriture maghrebine. Les motions et autres signes orthographiques sont en rouge. Ce ms. a été probablement écrit au Sénégal, vers la fin du xvme siècle.

Papier, 127 feuillets. Hauteur, 21 centimètres; largeur, 15 centimètres et demi. 15 Jignes par page. - (Supplément 160.)

\section{9.}

Le Coran; belle écriture africaine. Ce volume, qui avait appartenu à un établissement religieux de la ville de Constantine, a été écrit l'an 1242 de l'hégire (1826 de J. C.). C'est le texte dans sa forme occidentale, avec les motions en rouge, les djesma et les teschdid en vert, les hamza marqués par un point rouge, et les alif de prolongation également en rouge. Le mot aVl est toujours écrit avec de l'encre de couleur. Les pages sont encadrées d'un filet vert et de deux filets rouges. Deux arabesques, au commencement du volume, sont d'un beau dessin, mais mal exécutées.

Papier, 166 feuillels. Ilauteur, 37 centimètres et demi; largeur, 26 centimètres et demi. 17 lignes par page. - (Supplément 125.)

II.

\section{COMMENTAIRES DU CORAN.}

\section{0.}

rexplication des mots et des noms peu connus qui se rencontrent dans le Corann, par Aboù Bakr Mohammad ibn 'Azìz al-Sidjistânî (mort en 330 de l'hégire). L'auteur suit l'ordre alphabélique, puis l'ordre des royelles, fatha, dhamma, kesra. L'ouvrage commence par

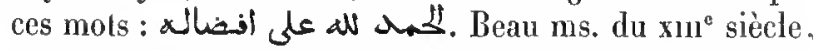
mais défiguré par des chiffres et des notes latines marginales et interlinéaires qu'un étudiant européen du xvII $^{\circ}$ siècle y a ajoutés. Les trois derniers feuiltets du volume sont d'une écriture moderne qui paraît être du commencement du xv1 ${ }^{\mathrm{e}}$ siècle.

Papier. 60 feuillets. Hauteur, 24 centimètres et demi; largeur, 17 centimètres. 19 lignes par page. - (Ancien fonds 258.)

\section{1.}

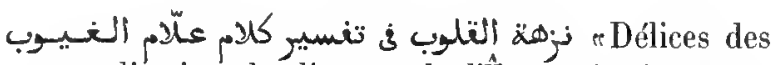
cœurs, explication du discours de l'Être qui sait tout ce

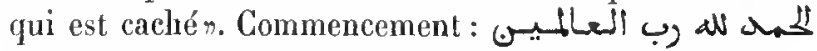

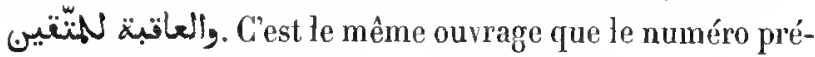
cédent.

Papier. $7^{9}$ fenillets. Hauteur, 22 centimètres; largeur, 17 centimètres. 21 à 29 lignes par page. Ms. de la fin du xvin' siècle. (Supplément 1982.)

\section{2.}

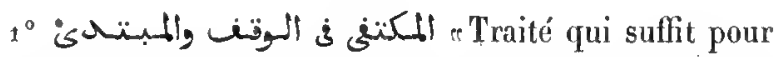
faire connaitre les pauses et les commencements des phrases (dans la lecture du Coran)", par Aboû 'Amr 'Othmân ibn Saî̀ al-Dànî. (Voyez sur cet auteur le numéro suivant.)

$2^{\circ}\left(F_{0} 1.200 v^{\circ}\right.$. tion de la science de bien lire le Coran à haute voix"; ouvrage composé vers la fin de l'an 769 de l'hégire ( 1368 de J. C.), par Sclıams al-Din Aboú '1-Khaïr ibn al-

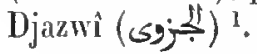

$3^{\circ}$ (Fol. 149.) (4brégé et exposition", traité dans lequel Aboû 'Aunr al-Dànî expose les bases du. système de lecture du Coran adopté par Nâfic (نافع). Nons n'avons ici que quelques chapitres de ce traité.

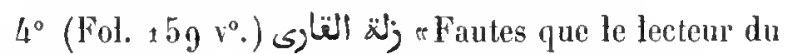
Coran est exposé à commettren, par Nadjm al-Dìn Aboû Hafs ${ }^{e}$ Omar ibu Mohammad al-Nasafi.

50 (Fol. $164 v^{\circ}$. (Exposé des convenances que doivent observer ceux qui savent

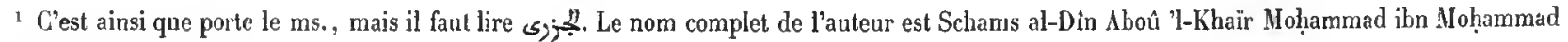
ibn al-Djazarî. H. Z.

Mas, oriextaux. - II. 
le Coran par cœurn, par Aboû Zakarìyâ Yaḷyà ibu Schal'al' al-Nawàwì.

$6^{\circ}$ (Fol. 215.) Commencement d'un traité en vers sur les héritages.

Ms. dalé de l'an 1123 de l'liégire (1 711 de J. C.).

Papier. 215 feuillets. Hauteur, 18 centimètres et demi; largeur, $1 / 4$ centimètres. 18 lignes par page. - (Supplèment 194.)

\section{3.}

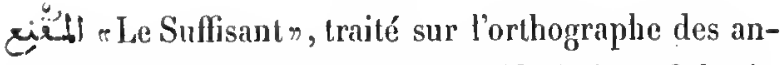
ciens exemplaires du Coran. L'autcur, Aboú 'Amr ${ }^{\complement} O$ thımân ibn Sa'id ibn 'Othmân, client de la famille des Omayyades (ألآموى), surnommé AI-Dâni, parce qu’il habitait Denia, en Espagne, mourul dans cetle ville en 417 de l'hégire, selon Al-Dsahabi, ou en 444, selon Hadji Khalla et AlHaqqarî. Dans cet exemplaire, la préface commence ainsi :

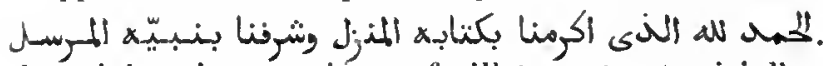
Cie traité, qui se termine au feuillet $72 \mathrm{r}^{\circ}$, est suivi d'un opuscule du même auteur, intitulé كتاب النقاب , qui traite de l'origine des points-royelles. Hadji Klıalfa dit que le

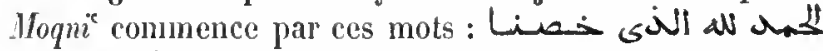

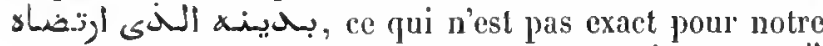

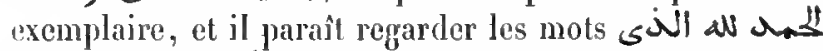
fi traité sur l'origine des points-royelles. Au reste, son aulicle bibliographique est mal rédigé et pen clair. "Ce ms. est d'une bonne main, et écrit arec soin; mais il y est survenu quelques lacunes, qui ont été réparées par une mauraise main, et il y manque encore plusieurs pages, surtout ì la fin de l'ouvrage. Les parties restituées sont les quatre premiers feuillets et les feuillets $27,28,29$, $30,3_{1}$ et $32, \pi$ M. de Sacy, dont nous venons de citer les paroles, a donné une notice très-détaillée de ce ms., avec la traduction dı trailé sur les points-royelles, dans le tome VIIl des "Notices et Extraits des manuscrits\%. Les lacunes signalées par M. de Sacy ont été remplies, au $x \mathbf{x l}^{\circ}$ siècle, par un copiste aussi peu habile que peu instruit. On y remarque plusicurs fautes de grammaire et d'orthographe. Le titre de l'ouvrage, inscrit par le même copiste sur le recto du premier feuillet, est ainsi rédigé:

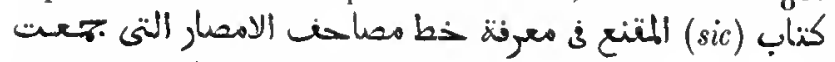

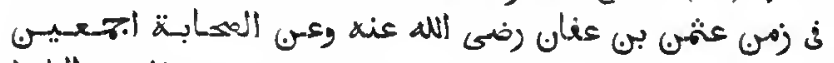

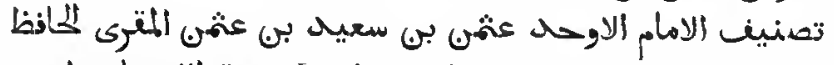
). Le titre primitif paraìt être celui que lon trouve daus le dictionnaire de Hadji Khalfa, et qui

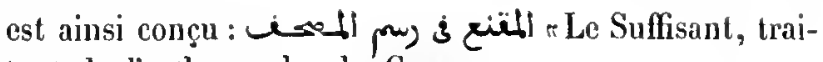
tant de l'orthographe du Coran \%.

Papier. 84 feuillets. Hauteur, 26 centimètres; largenr, 16 centimètres. 15 lignes par page. Ms. du xiv siècle. - (Ancien fonds 239 .)

\section{4.}

Commentaire du Coran, attribué à l'imâm Al-Mahdawì. D'après une note inscrite sur un des plats de la leliure, le titre de ce commentaire serait التنغصيل; mais, comme les premiers feuillefs du volume manquent, ainsi que les derniers, on ne saurait dire si cette indication est exacte. Toutefois, la rédaction de cet ouvrage a une grande analogie avec celle de l'exemplaise du Tasşil que Hadji Khalfa a eu entre les mains (voyez le Dictionnaire bibljographique, t. 1I, p. 384). Ce ins. commence par le trentequatrième versel de la sourate 1 et s'arrête au trente el unième verset de la sourate $\mathbf{i x}$.

Papier. 320 feuillets. Hanteur, 77 centimètres; largeur, 18 centimètres. 25 lignes par page. Ns. du $x v^{\circ}$ siècle. - (Sưpptément 181.)

\section{5.}

Commentaire du Coran, sans titre ni nom d'auteur. Les premiers feuillets et les derniers manquent. Le ms. commence par une introduction et finit au deux cent soixantequinzième verset de la sourate 1. Dans cet ourrage, l'auteur traite des leçons du Coran, de l'exégèse, de l'analyse grammaticale et des versets abrogeants et abrogés. Il cite comme ses antorités les commentateurs et traditionnistes les plus célèbres des quatre premiers siècles de l'hégire, et s'appuie très-souvent sur les indications que son professeur, Aboû 'l-Qâsim al-Naïsaboûrì (al-Hasan ibn Mohammad), lui avait fournies de vive voix (لُظظ). Or', nous savons par Hadji Khalfa, t. 1l, p. 382, que ce personnage moul'ut en 406 de l'bégire (1015 de J. C.). Un des chapitres

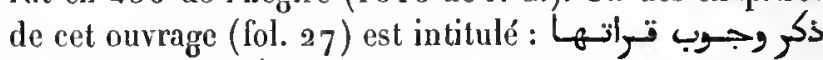
وت : Le commentaire sur la sourate 11 ( fol. $\left.29 \mathrm{v}^{\circ}\right)$ commence ainsi : و

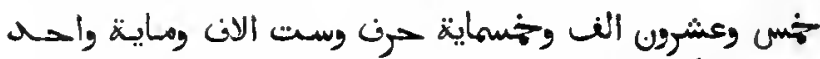

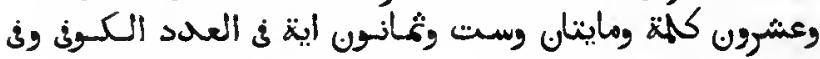

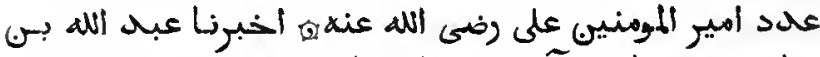

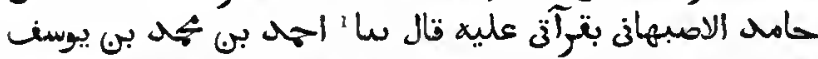

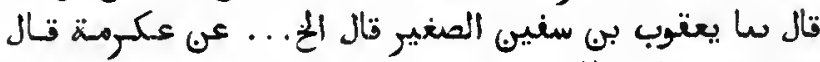

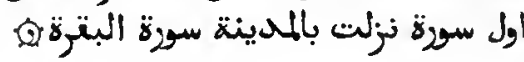


Papier. 328 feuillets. Hauteur, 22 centimètres; largeur, 15 centimètres. 20 lignes par page. Ms. du xure siècle. Quelques feuillets sont intervertis. - (Supplément 180, Sorbonne 290.)

\section{6.}

Le second volume du is أن Résumé de l'anatyse grammaticale du Coran». C'est non-senlement une analyse du lexte du Coran, mais aussi un commentaire. L'auteur, Aboû Zakarìyà Yahyâ ibn 'Alî al-

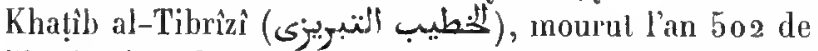
l'hégire ( $1108-1109$ de J. C.). Celle parlie de l'ourrage commence par la sourale vi et finit par la sourate xxm. Le volume a été copié sur un exemplaire écrit de la main de Schihâb al-Dìn Aḥmad ibn 'Alì al-Djacbarî, surnommé al-Samin (المهيn), l'un des disciples de f'auteur. Au rerso du dernier feuillet se trouve la copie de deux certificats d'audition (سماع) qui étaient inscrits sur l'exemplaire d'lbn al-Samin (صورة سماع 3 الأصل), dalés, l'un de 546 de l'hégire, l'autre de 542 (1 147-1 148 de J. C.).

Papier. ${ }_{159}$ fenillets. Hauteur, 25 centimètres; largeur, 17 centimètres. a9 à 34 lignes par page. - - (Supplément 186 bis.)

\section{7 à 599.}

Trois volumes dépareillés du commentaire du Coran

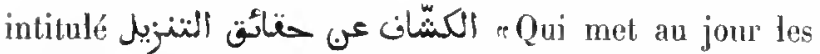
vérités de la révélation", par Al-Zamakhscharì (Aboû 'lQâsim Mohammad ilon 'Omar), surnommé Djâr Allah.

a. Le premier volume, daté de l'an 856 de l'hégire (1452 de J. C.), renferme tes six premières sourates. Lo texte du Coran, écrit à l'encre rouge, est intercalé dans te commentaire. Notes marginales.

Papier. 284 feuillets. Hanteur, 27 centimètres; largeur, 18 centimètres. 23 lignes par page. - (Supplément 171 A, Ducaurroy 9.)

b. Le second volume, donl les premiers feuillets manquent, renferme les sourates nn et sujvantes, jusqu'au commencement de la sourate $\mathrm{x} x$. Le texte entier du Coran n'y est pas donné. Écriture du $x u^{c}$ siècle. Notes marginales.

Papier. 230 feuillets. Hauteur, 3 a centimètres; largeur, 21 centimètres. s3 lignes par page. - (Supplément $171 \mathrm{~B}$, Ducaurroy 9.) c. Le troisième volune, copié à Baghlıâd, en $7^{32}$ de t'hégire (1331-1332 de J. C.), sur le ms. de l'auteur, renlerme la fin de l'ouvrage, à partir de la sourale xix. Le lexte entier du Coran est écrit par morceaux sur les marges.

Le dernier feuillet du ms. conlient un extrait de l'ou-

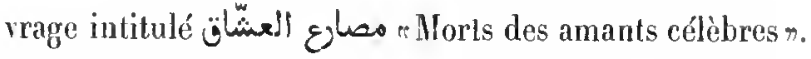

Papier. 405 feuillets. Hauteur, 23 centimètres; largeur, 16 centimètres. - (Supplément ${ }_{171} \mathrm{C}$, Ducaurroy 2.)

\section{0 а̀ 603.}

Quatre volumes dépareillés du Kaschschâf de Zamakhscharì.

a. Le premier volume est composé de cahiers ayant appartenu à divers exemplail'es de l'ouvrage. Le texte s'arrête au commencement de la sourate vi. La reliure est de. la fin du $x v]^{e}$ siècle.

Papier. a 43 fenillets. Hauteur, 36 centimètres; largeur, 17 cenlimètres et demi. - (Supplément $17^{2}$ A.)

b. Le second volume commence par la sourate vi el finit par la sourate xvin. Ms. toul entier de la mème main et daté de l'an 875 de l'hégire $(1470-1471$ de J. C.). Le texte du Coran esl intercalé daus le lexte, à t'encre rouge.

Papier. 310 feuillets. Hauteur, 36 centimètres; largeur, 18 centimètres. 25 lignes par page. - (Supplément 172 B.)

c. Le troisième volume commence par la sourale xix et finit par la sourate xxxv. Ce ms. paraît être du $\mathbf{x v ^ { \mathrm { e } }}$ siècle.

Papier. 380 feuiltets. Hauteur, 26 centimètres et demi; largeur, 18 centimètres. 33 lignes par page. - (Supplément $172 \mathrm{G}$ C.)

d. Le quatrième volume commence par fa sourate xxxv1. Exemplaire écrit à la Mecque, l'an 5 a 8 de l'hégire ( 1114

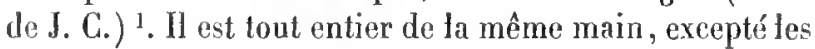
trois premiers feuillets, qui sont une restauration.

Papier. 191 feuillets. Hauteur, 26 centimètres; largeur, 18 centimètres. 25 lignes par page. - (Supplément $17^{2} \mathrm{D}$.)

\section{4.}

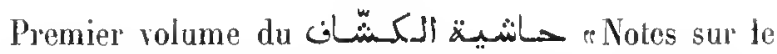
Kaschschaff», explication des passages obscurs qui se trou-
1 C'est la date du ms. autographe. La note qui renferme cette date se trouve également à la fin du $n^{\circ} 599$. Elle a été reproduile d'après le ms. aulographe, par différents copistes. Le présent ms. a été écrit à Hamât, en 6 go de l'hégire. H. Z. 
vent dans le Kaschschdf de Zamakhschari, par Qoṭb at-

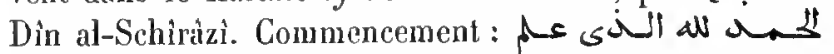

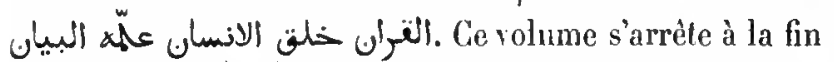
de la sourate ll النساء Une quatriène main a inscrit sur les marges un assez grand nombre de notes.

Papier. 149 feuitlets. Hauteur, 28 centimètres; largeur, 19 centimètres et demi. 31 et 32 lignes par page. Ms. du $\times v^{e}$ siècte. - (Ancion fonds 249. )

\section{5.}

rGloses sur le Kaschschâf» de Zamakłıscharì, par un auteur inconnu. Ce volume, qui est le dernier de l'ouvrage, commence par la sourate Lxxr. Le ms., autographe et d'une mauvaise écriture, sans points diacritiques, est du $x^{e}$ siècle.

Papier. 301 feuiltets. Hauteur, a 3 centimètres et demi; largeur, 15 centimètres. 27 à 29 lignes par page. - (Aneien fonds 266 .)

\section{6.}

1 Fragment d'un commentaire (حانتئن) sur le Kaschschâf de Zamakhschari. Commencement :

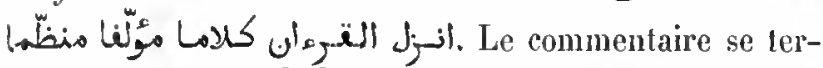
mine au verset $9_{1}$ de la sourate 1 . Le texte est accompaguné de nombreuses notes interlinéaires et marginales.

$2^{\circ}$ (Fol. 40.) Fragments d'un commentaire du Coran, qui parait être celui de Zamakhschari, suivis d'une note de Sinàn-Efendi sur un passage d'Al-Baïdhâwì.

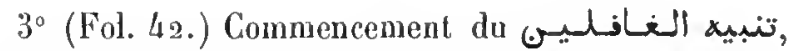
exlortations morales, par Aboú 'l-Laïth Nașr ibn Mohammad ibn lbràhìn al-Samarqandi, mort en 375 de l'hégire.

4 (Fol. 62.) Fragment d'un recueil de traditions authentiques (محاح), qui commence par celles qui se rapportent à l'ablution $\left(و\right.$ g $_{2}$, et se termine par les premières traditions se rapportant à la manière d'assister

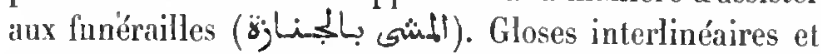
marginales. L'écriture est la même que celle de l'article $1^{\circ}$.

$5^{\circ}$ (Fol. 92.) Première partie de l'ouvrage intitulé

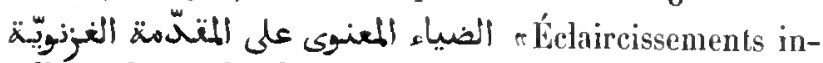
tellectuels sur les Prolégomènes du Glaznéviten. Com-

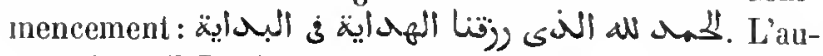
teur, Aboû 'l-Baqâ Moḷammad ibn al-Dhị̂a, membre de la tribu de Qoraisch et docleur hanéfite, explique dans cet ouvrage les passages obscurs qui se reneontrent dans

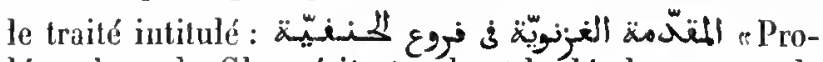
légomènes du Gliaznévite touchant le déreloppement de l'étude des points secondaires du droit hanéfiter. Aḷmad iln Molammad, de Ghazna, mourut en 593 de l'hégire ( $119^{6}$ de J. C.), Ibn al-Dhiyâ en 854 ( 1450 de J. C.).

Papier. 199 feuillets. Hauteur, 3o centimètres; largeur, 20 centimètres. 20 à 30 lignes par page. Écritures diverses du $x v^{\circ}$ siècle. (Ancien fonds 257 .)

\section{7.}

Le treizième volume d'un ouvrage dans lequel le vizir 'Aun al-Dîn Aloû 'l-Moẓaffar Yaḷyâ ibn Hobaïra indique les mots du Coran sur la lecture desquels les grands maîtres de lecture du Coran n'étaient pas d'accord. Il suit l'ordre des sourates, signale successirement les mots qu'un ou plusieurs des lecteurs prononçaient de différentes manières, et explique la signification de ces variantes. Chacun des mots dont il parle forme le sujet d'un paragraphe, en général assez court. L'ouvrage a pour titre

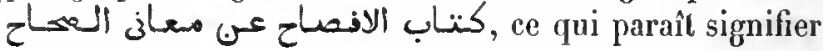
Explication du sens de chaque (variante) autoriséen. Hadji Khalfa, dans son Dictionnaire bibliographique (t. I, p. 371 ), regarde le mot $\tau^{2}$ ll comme l'équivalent de les traditions authentiquesn, mais il n'est pas question de traditions dans ce livre. Au reste, Hadji Khalfa ne paraît pas avoir vu cet ouvrage. Ce ms., qui commence par la sourate النساء, et se termine par la sourate ألم, a été collationné avec un exemplaire appartenant à un ćtablissement religieux fondé à Damas par Noûr al-Dîn. Ge travail de révision fut terminé au mois de dsoû 'l-ḥiddja de l'an 582 de l'hégire (férrier 1187 de J. C.). D'un autre côté, on lit sur le recto du premier feuillet une note d'après laquelle ce volume fut écrit du vivant de l'auteur. Le vizir Ibn Hobaïra mourut en 560 de l'hégire ( 1 i 65 de J. C.).

Papier. 188 feuiltets. Hanteur, 26 centimètres; largeur, 17 centimètres. 17 lignes par page. - (Ancien fonds 347. )

\section{8.}

Le second rolume d'un commentaire du Coran qui devait remplir huit volumes et auquel l'auteur, Hoddja at-Dìn Moḷammad ibı Zafar, le même qui cómposa le

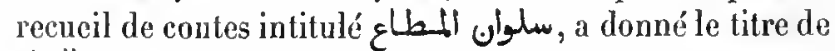
La source de la vien. Ce volume commenee 
au verset 86 de la sourate m et se termine par la sourate vi. Il est daté de l'an 858 de l'hégire (1454 de J. C.).

Papier. 187 feuillets. Hauteur, 28 centimètres; largeur, 18 cenlimitres et demi. 37 lignes par page. - (Ancien fonds 348. )

\section{9 .}

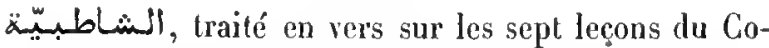
ran, par Ibn Ferro (فيّ) al-Schâtibì (natif de Xativa, en Espagne). L'auteur avait donné à son ourrage le titre de Amulette (ohjet) de tous les souhaits et aspect des féticilations n; mais le titre de Schátibiyya a préralu. C'est un poënne didactique, renfermant $117^{3}$ vers, qui se terminent tous par la même syllabe lâm-alif. Dans les premier's chapitres, Ibn Ferro expose les règles de l'orthographe canonique; puis il indique, sourate par sourate, les variantes que présentent les systèmes de chacun des sept grands lecteurs. Quelques mss. de la Schâtibiyya donnent à lbn Ferro le surnom d'Aboû' $l$ Qásin, mais il est certain qu'il se nommait $\mathrm{Al-Qàsim} \mathrm{Aboù}$ Mohaminad. La copie est datée de l'an 1123 de l'hégire ( 1711 de J. C.).

Le dernier feuillet de ce volume a appartenu à un autre commentaire du Coran; il renferme la fin de la sourate $\mathrm{xIV}$ et le commencement de la sourate $\mathrm{xv}$.

Papier. 94 feuillets. Hauteur, 28 centimètres; largeur, 21 centimètres. 7 lignes par page. - (Supplément 196 .)

\section{0.}

$1^{\circ}$ مة Hoyen de parvenir à comprendre l'Aqílan. Ce commentaire sur l'Aqíla ou Rayyiyya, d'Al-Schâtibi, a été composé par 'Alam al-Dìn

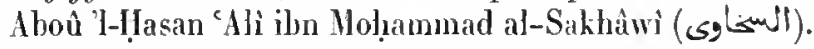
Exemplaire écrit à Damas, en 632 (1234-1 235 de J. C.), du vivant même de l'auteur. M. de Sacy a publié un arlicle sur ce ms. et sur l'ourrage dans les "Notices et Extraits", t. VIII, p. 333 et suiv.

$2^{\circ}$ (Fol. $149 \mathrm{v}^{\circ}$.) Neuf vers mnémoniques, servant à faire connaitre les sigles employés pour désigner les principaux lecteurs. Cetle petite pièce est intitulée : الــ Taqì al-Din al-Djarâidi (?) sur les sigles $n$.

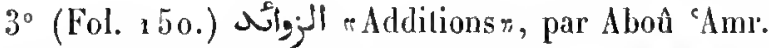
C'est une pièce de vingt-six vers, rimant en rá moqayyad et traitant de l'orthographe du Coran. $4^{\circ}$ (Fol. 151.) Traité en vers sur la prononciation des lettres, par Aboû 'Amr, de Cordoue. Publié par S. de Sacy dans les $\pi$ Notices et Extraits $\pi$, t. VHI, p. 352.

$5^{\circ}$ (Fol. 152.) Quelques vers extraits d'un ouvrage in-

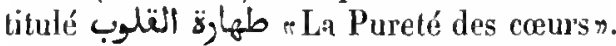

Papier. 152 feuiltets. Hauteur, 18 centimètres; largeur, 13 centimètres. 15 lignes par page. - (Supplément 193 , Saint-Germain 282.)

\section{1.}

La première moitié de l'ouvrage intitulé : نتح الوصيد

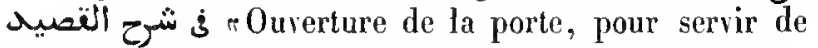
commentaire au poëmer. L'auteur, 'Alam al-Din al-Sakhâwi, y développe d'une manière très-détaillée la construction grammaticale ef la signification de chacun des vers dont se compose la Schatibiyya d'lbn Ferro.

Papier. 155 feuillets. Hauleur, 26 centimètres हैt demi; largeur, 18 centimètres. 17 lignes par page. Ms. du xri' siècle. - (Supplément 197.)

\section{2.}

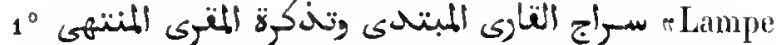
pour le lecteur qui commence, et aide-mémoire pour le maître de lecture accomplin. C'est un commentaire sur la Schatiliyya, par 'Alì ibn 'Othmån, surnommé lbn al-pásich (ابك المقامع). L'autenr de la Schatibiyya est désigné par le surnom d'Aboû Mollammad et par le nom de Qásim. Copie datée de l'an 1212 de l'hégire (1797-1798 de J. C.).

$2^{\circ}$ (Fol. $211 \mathrm{v}^{\circ}$.) Liste des dicerses lecons du Coran, sourate par sourate; les sigles qui désignent les noms des lecteurs sont écrits dans les interlignes à l'encre rouge.

$3^{\circ}$ (Fol. 225.) Commentaire grammatical sur le bis-

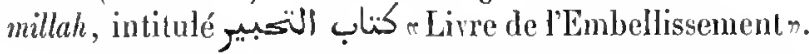

$4^{\circ}$ (Fol. $229 r^{\circ}$ (. Registre de toutes les leçons du Coran adoptées par Nâfi $n$, l'un des sept grands lecteurs. L'auteur de cet ourrage se nonmait Moḥammad ibn 'Abd al-Raḥmân, et appartenail à l'aït

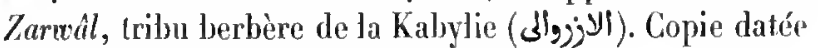
de l'an 1184 de l'hégire (1 770 de J. C.).

Papier. 290 fenillets. Hauteur, 19 centimètres et demi; largeur, 15 centimètres. 24 lignes par page. - (Supplément 198.)

\section{3.}

: i Le Grand commentaire". Cet ouvrage, 
appelé aussi مغاتيح الغيب :Les Clefs du mystèren, a pour auteur l'imâm Faklır al-Din Mohammad ibı 'Omar alRàzi, qui arail entrepris de mettre au jour tous les mystères que renferme le texte du Coran. Il déclare que la première sourate scule pourrait donner lieu à dix mille questions. En effet, il consacre à l'explication des sept versets de la Fatha un chapitre de cent vingt-quatre pages de nolre ms. L'auteur ćtant morl en 606 de l'légire (1 209 1210 de J. C.), son ourrage fut terminé par le grand cadi Schilıtib al-Dín Aḷmad ibn Khalì al-Khowayyì, de Damas. Notre ms., daté de l'an 188 (1 $77^{4-1} 77^{5}$ de J. C.), renferme le commentaire des quatre premières sourates.

Papier. 563 feuillets. Hauteur, 33 centimètres; largeur, 23 centimètres et demi. 49 lignes par page. - (Supplément 177.)

\section{4.}

Le qualrième volume du كناب النتنوبر في التنغسير كختصر r.'Éclaircissement au sujet de l'exégèse pour servir d'abrégé du Tafsîr al-Kabîrn de Fakhr al-Dìn al-Ràzì. Le Tanwîr a élé composé par Schams al-Dìn Aboû 'Alıd Allah Mohanmmad ibn ahî 'l-Qâsim ibn 'Abd al-Sa-

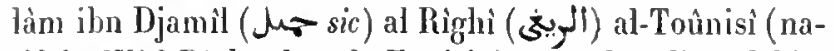
tif de Wâd Righ, dans la Tunisie), grand cadi malékite d'Alexandrie, qui a achevé son travail en 707 de l'lıégire (1307-1308 de J. C.). Ce volume renferme la sourate v et la sourate vi, jusqu'au verset 94 . 11 est tout entier de la même main, et l'écriture est presque entierement dépourve de points diacritiques.

Papier. 1279 feuillets. Hauteur, 25 centimètres et demi; fargeur, ${ }^{1} 7$ centmètres. 21 lignes par page. IIs. du $x^{0}$ siècte. - (Supplément $178 \mathrm{~A}$, Saint-Germain $7^{4}$.)

\section{5.}

Le Iroisiène volume d'un exemplaire du التنغسيـ. Comme il commence précisément au passage où sarrête le numéro précédent, qui est le quatrième voJume diul autre exemplaire, un libraire a changé le mot

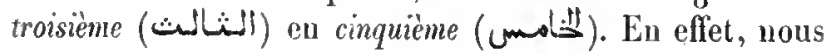
pourons le regarder comme le cinquième volume de l'exemplaire qui apparlient à la Bibliothèque. Nous apprenons par la souscription, que Faklır al-Din al-Ràzì avait achevé celte partic de son ourrage en $60 \mathrm{l}$ de l'hégire, et que son abréviateur avait fini en 708 de l'hégire (13081309 de J. C.). Notre ms. est daté de l'an 724 de l'hégire (1324 de J. C.). Il renferme la sourate vi, à partir du verset $9^{4}$, et les sourates suivantes jusqu'ì la xvir ${ }^{\circ}$ inclusivement.

Papier. 224 feuillets. Ilauteur, 26 centimètres; largeur, 17 centi- mètres et demi. Les 37 premiers feuillets sont d'une écriture plus moderne et d'environ 40 lignes par page; les autres feuillets ont 26 lignes par page. - ( Supplément 178 B, Saint-Germain 75.)

\section{6.}

Sixième volume d'un exemplaire du Tanwir fì 'l-Tafsî, commencant par la sourate xix et finissant au verset 44 de la sourate xxw. L'écriture des deux derniers feuillels est la même que celle du numéro précédent.

Papier. 181 feuillets. Hauteur, 26 centimètres; Jargeur, 18 centimètres. 29 el 30 lignes par page. Ms. du s $\mathbf{r}^{*}$ siècle. - (Supplément $178 \mathrm{C}$, Saint-Germain 76 .)

\section{7.}

Huitième volume d'un exemplaire du Tanwîr fi ' $l$ Tafsîr, renfermant les sourates xxix, versets 45 à $\mathbf{L}$.

Papier. 197 feuillets. Hauteur, 25 centimetres et demi; largeur, 17 centimètres. 23 lignes par page. Mls. du xiv ${ }^{e}$ siècle. - (Supplément ${ }_{178} \mathrm{D}$, Saint-Germain $77^{\circ}$ )

\section{8 et 619.}

Huitième volume, relié en deux tomes, d'un exemplaire du Tanwir fi 'l-Tafsir, commençant par la sourate ur el finissant au milieu du commentaire de la sourate cxir.

Papier. 139 feuillets. Hauteur, 25 centimètres et demi; largeur, 16 centimètres. 21 lignes par page. - (Supplément $178 \mathrm{E}$, F, SaintGermain 78 el 215 bis.)

\section{0 .}

Exposition de l'analyse grammaticale du texte du Coran », par Aboû '1-Baqâ cAbd Allah ibn al-Hosaïn al-'Okbarì (العبكى, natif d'Okbara, ville située dans l'arrondissement de Dodjail, à dix parasanges de Baghdàd), al-Faradhî (أن_ان ele calculateur' $n$, mort en 616 de l'hégire ( $\begin{array}{lll}1 & 2 & 1\end{array}$ de J. C.) Le titı'e de l'ouvrage n'est pas mentionné dans le ms., mais il se trouve dans le Dictionuare bibliographique de Hadji Khalfa, et à la fin du $n^{\circ} 621$. Le premier feuillet manque.

Papier. 198 feuillets. Hauteur, 28 centimètres; largeur, 20 centimètres et demi. 29 lignes par page. Ms. du xü siècle. - (Supplément 179 , Ducaurroy 3.) 


\section{1.}

Le Tỉbyân d'Aboû 'l-Baqâ al-'Okbari. La présente copie, écrite en beau caractère maghrebin espagnol, par un Berbère appelé 'Abd Allah ibn 'Aliq al-Lowatì, porte ta date de 801 de l'hégire ( 1398 de J. C.).

Papier. 144 feuillels. Hanteur, 29 centimètres; largenr, 19 centimètres. 35 lignes par pagec. - (Ancien fonds 251.)

\section{2.}

Second volume de l'ouvrage intitulé "Indications de trésors", commentaire du Coran, composé par 'Izz al-Dìn 'Abd al-Razzâq ibn Rizq-Allah ibn abî 'l-Haïdjâ, natif de Râs-'Aün (الوسعنى).'La partie du Coran dont on $\mathrm{y}$ trouve l'explication conmence au milieu du verset 1 i de la sourate 11 et finit avec la sourate Iv. Dans ce commentaire, qui est très-étendu; on Irouve plusieurs dissertations, dont une (fol. $52 \mathrm{v}^{\circ}$ ) sur les expéditions auxquelles assista Mahomet; une autre (fol. $54 \mathrm{v}^{\circ}$ ) sur la présence des anges au combat de Bedr; une autre (fol. $64 v^{\circ}$ ) sur le combal d'Ohod; une antre $\left(\right.$ fol. $\left.112 \mathrm{v}^{\circ}\right)$, en cinq sections, sur la signification du terme 200 ; une autre (fol. 1 i $6 \mathrm{v}^{\circ}$ ) sur la peine réservée aux fornicateurs, etc. Ms. daté de l'an 634 de l'bé-

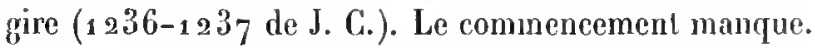
Au verso du fol. 199 se trouve un certificat de leclure, daté de l'an 730 de l'hégire. Le même feuillet et le suivant contiennent deux extraits d'un autre commentaire du Coran.

Papier. 200 feuillets. Hauteur, 25 centimètres; largeur, 17 centimètres et demi. 15 lignes par page. - (Supplément 185.)

\section{3.}

Questions et réponses touchant les difficultés que présente le texte du Coran, en ce qui coneerne la grammaire

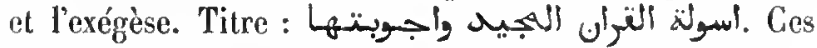
questions et réponses sont disposées dans l'ordre des sourates. L'auteur, Molıammad ibn ahì Bahr ibn 'Mbd al-Qâdir al-Râzì, mourut en 660 de l'hégire (1261-1262 de J. C.). Ms. daté de l'an 723 de l'hégire ( 1323 de J. C.). Quelques feuillets perdus ont été remplacés par une main plus moderne.

Papier. 1 ig fenillets. Hauteur, 18 centimètres et demi; largeur, 12 centimètres. 25 lignes par page. - (Ancien fonds 272.)
624.

$1^{\circ}$ Les Questions et réponses de Moḷammad ibn abì Bakr al-Ràzi. Copie datée de l'an 832 de l'hégire (1432I 433 de J. C.).

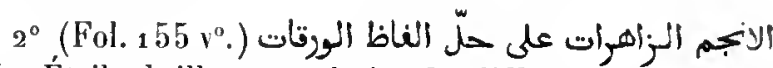
" Les Etoiles brillantes; solution des difficultés que présentent les termes employés dans le Waraqâtr. L'ouvrage intitulé Waraqât e leuillets n, qui traite des principes du droit schaféite, a pour auteur Aboù 'l-Ma âtì al-Djowaïni, généralement connu sous le tilre d'Imâm al-Haramaïn, mort en 478 de l'hégire ( $1085-1086$ de J. C.). L'anteur dı commentaire des "Étoiles brillantes ", Kamâl al-Din $\mathrm{Ho}_{0}$ ḥammad, mourut en 874 de l'hégrire $(1469-1470$ de I. C. $)$, seton Hadji-Khalfa.

$3^{\circ}$ (Fol. 209 1 $^{\circ}$ ) Recueil de notes sur le partage des successions. La copie est de la même main que l'alticle $1^{\circ}$

$4^{\circ}\left(I^{*} 01.214 \mathrm{~V}^{\circ}.\right)$ Deux pièces de vers en langue lurque.

Papier. 217 feuillets. Ilauleur, 18 centimètres; largenr, $1 / 4$ centimètres. 13 à 19 liggnes par page. Ms. du $x^{\circ}$ siècle. - (Ancien fonds 270.)

\section{5 .}

Les Questions ef réponses, de Mohammad ibu abì Bakr al-1iázì. Les feuillets de garde sont couverts de notes en prose et en vers, ćtrangères ì l'ouvrage.

Papier. 171 feuillets. Ilauteur, 25 centinè̀tres et demi; largeur, 16 centimètres. 23 à 26 lignes par page. Ms. du xv siècle. - (Supplément 189 .)

\section{6.}

Dissertation de Djalâl al-Dìn Mohammad al-Razzàq sur

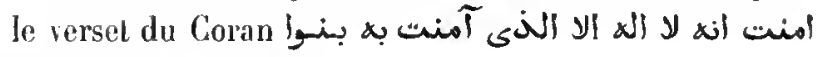

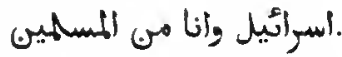

Papier. 2 feuillets. Hauteur, 19 centimètres; largeur, 10 centimètres et demi. 27 lignes par page. - (Supplément 2253.)

\section{7.}

Commentaire du Coran d'Al-Baïdlàivi, intiluté 
rLumières de la révélation et secrets de l'exégèsen.

Papier. 498 feuillets. Hauteur, a 6 centimètres; largeur, go centimètres. 22 à 24 lignes par page. xvi' siècle. - (Supplément 173 , Anquetil 35.)

\section{8.}

Commentaire du Coran d'Al-Baïdbâtvì. Cet exemplaire renferme un texte très-correct, ainsi que le constate une note en arabe, écrite sur le recto du premier feuillet. Le ms. est daté de l'an $9^{69}$ de l'hégire (1562 de J. C.). La préface commence par ces mots :

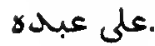

Papicr. 335 feuillets. Hauteur, 31 centimètres; largeur, 21 centimètres. 38 à 41 lignes par page. - (Ancien fonds a 52.)

\section{9 et 630.}

Gommentaire du Coran d'AI-Baïdhâwî. Exemplaire daté de l'an 1067 de l'hégire ( 1657 de J. C.).

2 volumes. Papier. 369 et 249 feuillets. Hauteur, a 1 centinètres; largeur, 15 centimètres. 25 lignes par page. - (Ancien fonds a 65 et 963.$)$

\section{1.}

Commentaire du Coran d'Al-Baïdhâwî. Première moitié de l'ouvrage, rẹnfermant les sourates 1 à xvill.

Papier. 4 1 3 feuillets. Hauteur, 25 centimètres; largeur, 18 centimètres. 21 lignes par page. Mls. du $x v^{a}$ ou du $x^{2} 1^{e}$ siècle. - (Supplément ${ }_{17} 7^{5}$ )

\section{2 et 633.}

Commentaire du Coran d'Al-Baïdhâwî. Exemplaire daté de l'an 1210 de l'hégire (1795-1796 de J. G.).

2 volumes. Papier. 398 et 38 a feuillets. Hauteur, 22 centimètres; largeur, 26 centimètres. 25 lignes par page. - (Supplément 176.)

\section{4.}

Volume dépareillé d'un exemplaire du commentaire du
Coran d'Al-Baïdhâwì, commencant par la sourate xvıl (الdككهi), et finissant au verset 140 de la sourate xxvi (النشعراء). Notes marginales. Le premier feuillet est d'une main plus moderne; la fin manque.

Papier. 88 feuillets. Hauteur, 28 centimètres; largeur, 18 centimètres et demi. 31 liggnes par page. Ms. du xvi siècle. - (Ancien fonds 253. )

\section{5.}

Le second et dernier volume du commentaire du Coran d'Al-Baïdhâwi. Quelques feuillets manquent au commencement; il ne reste du commentaire de la sourate xvil que les dernières lignes. Quelques notes marginales.

Papier. 316 fenillets. Hauteur, a 8 centimètres; largeur, 16 centimètres. 27 à 28 lignes par page. Ms. du xvil siècle. - (Supplément 174. )

\section{6.}

Notes sur la partie du commentaire du Coran d'Al-Baidhâwì qui se compose de la préface et de l'explication de la première sourate. L'auteur, Aḥmad ibn 'Alî ibn 'Othmân, avait dédié cet ouvrage au sultan Mourad Khân (Amurat III).

Papier. 117 feuillets. Hauteur, 21 centimètres el demi; largeur, 13 centimètres. 13 lignes par page. Ms. dn $\times \mathbf{x v}^{\mathrm{e}}$ siècle. - (Ancien fonds 264 .)

\section{7.}

Volume dépareillé d'un grand commentaire du Coran. Les feuillets du commencement et de la fin ayant disparu, une main plus moderne les a remplacés par d'autres qui ne paraissent pas apparlenir à l'ouvrage. Le titre même, inscrit au recto du premier feuillet, est inexact, car il attribue ce commentaire à un docteur nommé Al-Qortobî (sans doute Mohammad ibn Ahmad, natif de Cordoue, et auteur d'un commentaire du Coran. Voyez Hadji Khalfa, t. II, p. 499); mais dans divers endroits de l'ouvrage, le schaikh Al-Qorțobì est cité et son nom est accompagné des mots all composition de cet ourrage. Ge volume ne contient que l'explication des versels 100 à $\mathbf{1 8 3}$ de la sourate $\mathbf{n}$.

Papier. 138 feuilfets. Hanteur, 26 centimètres; largeur, 16 centimètres. 23 à 26 lignes par page. Ms. du xil' siècle. - (Supplément 288.) 


\section{8.}

( L'L'toile du bien dirigé, lancée contre le (démon) transgresseur", par l’imâm Mlohammad ibn Moḷannad, surnommé Ibn al-Ho allim. Cet ouvrage est une diatribe dirigée contre un docteur hanbalite qui avait donné à certains passages du Coran une interprélalion différente de celles des docteurs aschearites. Pour appuyer ses propres opinions, l'auteur cite l'autorité de plusieurs docteurs orthotoxes, dont il donne les biographies, el dont il mentionne les om rages. Ciefte liste commence au califal d'Aboû Bakr, el s'arrète à l'an zo 6 de J'hégire. Les Asch'arites y tiennent une place très-distinguée. L'ourrage, divisé en seize chapitres (roy. fol. $261^{\circ}$ ), a été composé à l'époque où le sultan mamlonc Al-Nașr, fils d'Al-Mâlik a\}-Manşoùr Kalavoun, remporta sa prande vicloire sur les Mongols (en 1303 de J. C.). Ce volume est autographe; il porte les additions de lautenr, dont quelques-unes sont écrites sur des onglets.

Papier. 327 feuiltets. Hautcur, a 7 centimètres; largenr, 18 centimètres. 23 lignes par page. -- (Supplément 200 , Saint-Germain 85.)

\section{9 .}

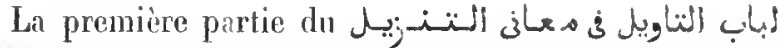
"Moelle de l'exégèse, touchant tes idées exprintées taus le livre révélém. C'est une grande compilation, dans laquelle l'auleur, 'Alì ibn Moł̣anmad ibn Iloràhîm ibn Khalil al-Baghdidi al-Schilai, smrnonné Al-Khizm, reproduil de nombreux passages tirés de diver's commen-

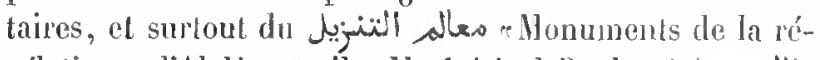

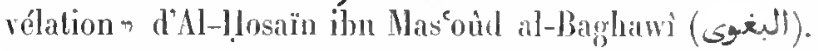
A]-Khàzin avait recu le surnom de Schitio, pare que sa

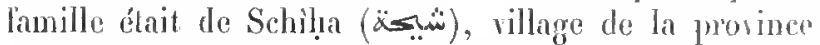
d'Alep; mais it était né à Baghduad, en 673 de licégire (1274-1275 de J. C.). Le nonn d'Al-Khazin "le trésorict's lui lut donné parce quil élait bibliolhécaire du collége

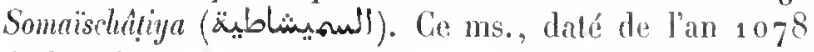
de l'hégire (1667-1668 de J. C.), conlient le commentaire des somrales I à vi.

Papier. 589 feuiltets. Ilanteur, 21 centimitres ct deni; largeur, 17 centinètres. 25 lignes par page. - (Supptément 1861.)

\section{0.}

Premier rolume du commentaire d'Al-Khàzin. Le texte Max. onextacx. - $\mathrm{H}$. s'arrète aur verset 238 de la sourate 11 . Ms. daté de l'an 865 de l'bégire (1460-1461 de J. C.).

Papier. 470 feuitlets. Hauteur, 26 ecnlimètres; largeur, 17 centjmètres et demi. 11 tignes par page. - (Supplément 187.)

\section{1.}

Seconde partie du commentaire d'Al-Khàzin. Ce volume contient les sourates vil à xvıl.

Papier. 716 feuillets. Hanteur, a a centimètres et demi; largeur, 17 centimètres. al lignes par page. Ms. de diverses écritures du xrrt siècle. - (Supplément 186 III.)

\section{2}

Dernière partie du commentaire d'Al-Khàzin. Ce volume contient les sourates xvm à cxr. Ms. daté de l'an 1167 de l'hégire (1753-175/ de 3. C. ).

Papier. 602 feuillets. Hauteur, 23 centimètres; largeur, 16 centimèrres. Les premiers feuillets ont 27 lignes, les antres 25. - (Supplément 186 IV.)

\section{3.}

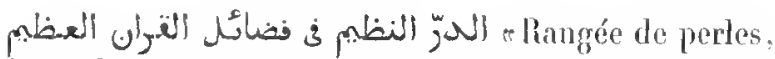
traitant des vertus atmirables du saint Coran", par Ibn

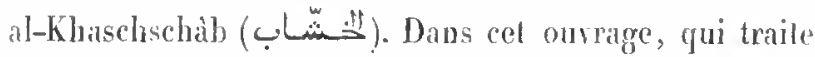
des vertus mystiques des versels du Cornen, l'auteur a

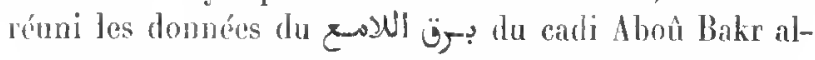
Ghassåni, et dı d'Ahoù Hàmid al-Ghazali, en y insérant qualques can'és magiques. empruntés an trailé d'Al-Boủui. Le demier leuillet contient un certificat de lecture. daté de l'iul 1008 de l'hógrire (1509) de J. C..).

Papier. 180 feuillets. IIanteur, 21 rentimètres; largeur, 15 centimètres. 13 liggnes par pagàe. Ms. du xv1 siècle. - (Stipplément 1! 1.)

\section{4.}

10 Cadenu pour l'homme insliuit, trailant des mots peu nsités qui se trou-

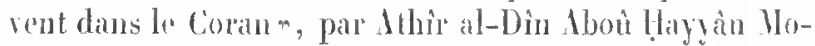
hammad ibn Youtsolibn Ilayyin al-Andalosi, nort en $7 / 5$ de l'hégire ( $344-1345$ de J. C.). Les mols explicpués sont rangés dans l'ordre de l'alplabel. 


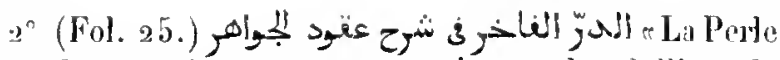
magnifique, qui est un commentaire sur les Collicrs de piencries", par Djamâl al-Dìn Aboû Yacyoûb Yoûsof ibm

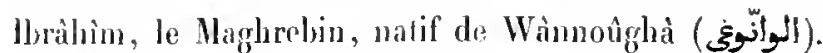
(Le Wàmoûghà, grand territoire de l'Algérie, s'élend au sud du 1)jurdjura, depuis Ṣoûr al-Ghozlàn ou Aumale, jusqu'aux Bibàn ou les Portes de Fer.) L'auteur de l'ourrage commentó, dont le litre entier est

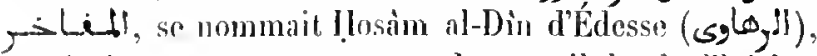
at vivait an commencement du $x^{e}$ siècle de l'hégire. 1)an ce commentaire, le compilatenl a emprunté des malériaux à plusieurs autres écrivains. Il a divisé son travail on quatre seclions, précédées d'une introduction

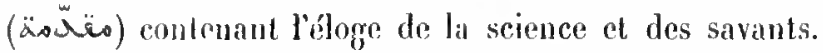
1):11s la première seclion, il traitr de la conduite (si) du próneleur, dans sa vie et dans ses enseignements; la seronde scetion laile de la conduite des disciples; la frosième, des liwres, et la quatrième, de la vie des collíperes. Caest un recueil do tradilions ot d'anecdotes.

$:$ (Fol. $157 r^{\circ}$.) Liste de proverbes, rangés dans l'ordro A* l'alphabet.

Papier. 162 fenillets. Hauteur, 19 centimitres; largeur, 14 canlimètres. 16 ì 19 lignos par page. Ns. du $x^{\circ}{ }^{\circ}$ siècle. - (Ancien fonds 367. )

\section{5.}

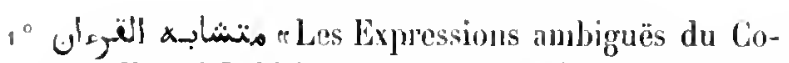
lan", par Ilsn al-Labbàn, mort en 740 (1348-1349 de J. (.). Ces expressions, d'iprès l'uuteur, ne doivent pas Ahro entendues dans lour sens littéral, qui conduirail à l'iulluroponorphisme. Coumencement : . I I fin manyue.

פ' (Fol.30.) Fragment du conmentaire de Dàoùd ibn

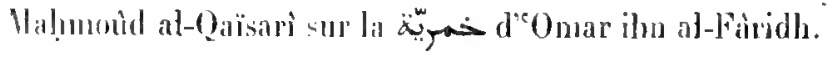

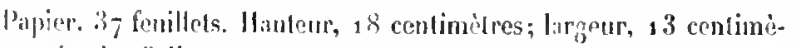
tres et demi. 13 ligfnes par page. Ms. du xut siècle. - (Supplément 31.5.)

\section{6.}

Commentaire du Coran, prer 'Abd al-Rahmàn ibn Mo-

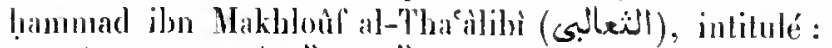

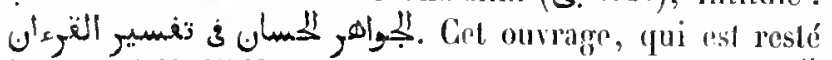
inconum à Hadji Khallir, commence par ces mols : und

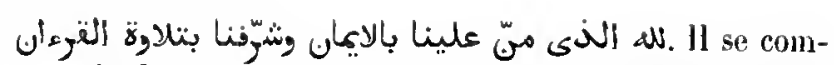
pose de deux parties, dont la première occupe 355 feuillets. A la fin de l'ourrage, l'auteur nous apprend qu'il arait terminé son travail le 25 rabica premier de l'an 833 de l'hégire (1429 de J. C.). Le présent exemplaire a été copié, sur l'aulogrnphe, au mois de ramadhân de l'an 877 (janvier 1473 de J. C.). Ecriture maghrebine de dirorse: mains.

Papier. 586 feuillets, dont trois, entre la première partie et la seconde, sont restés en blanc. Hauleur, 31 centimètres; largeur, ga centimètres. 35 dे 27 lignes par page. - (Ancien fonds $25 \%$.)

\section{7 el 648.}

(es Belles pierreries, commentaire du Corann, par 'Abd al-Raḥmân ibn Mobammad ilm Maklilouf al-Tha ilibì. Ms. dalé de J'an 1064 de l'hégrive (1654 de J. C.).

2. vahumes. Papier. 220 et a 57 feuillets. Ilauteur, 29 centimètres; lurzeur, go centimètres. 33 lignes par page. $\longrightarrow$ (Supplément 1978 ct 1979.$)$

\section{9.}

Ourrage auquel l'auteur, Schans al-Din Moḷammad ibn Almnad ibn al-'Inad (sl-dل), a donné deux litres, à

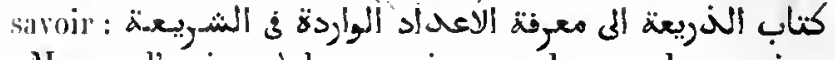
"Moyen d'arriver ì la connaissance des nombres qui se

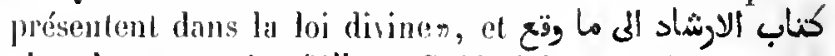
كaide à la comnaissance des nombres qui se présentent dans la jurisprudence el ailleurs\%. C'est nne compilation de tous les passages du Corall, des commentaires de ce livre, el des traditions, dans lesfuels il est fail menlion des nombres. Les traditions sont clissées dans l'ordre adopté pour les lirres de droit. L'auteur a acheré son travail en 836 de J'hégire (1432-1433 de J. C.).

Papier. 384 feuillets. Hauteur, a 8 centimètres; largeur, 18 centimètres el demi. 23 lignes par page. — (Supplément 201.)

\section{0 .}

1. Traité du repos de la voix (waqf) dans la lecture
I Voyez cependant Hadji-Khalfa, édition de Flügel, t. II, p. 642. L'ouvrage commence, dans notre ms. comme dans Harlji-Khalfa, par

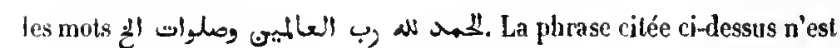
que la seconte. H. Z. 
du Coran, par Sacd Allah ibn Hosaïn d'Adscrhädjàn, généralement connu sous le nom de Salmàsì (w) (royez fol. 7). L'ouvrage commence par ces mots : دمان يحأ. D'après une rubrique inscrite au lol. 108; le titre serait : بح-

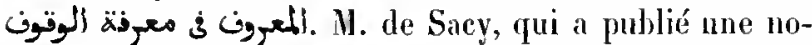
tice sur cet opuscule et sur le suirant dans les e Nolices et Extraits" (t. VIII, p. 360), croit que nolre exemplaire est de la main de l'auteur. Ms. dalé de l'an 847 de l'hégire (1/143-1444 de J. C. $)$.

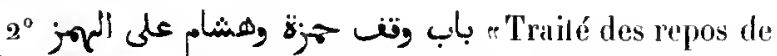
voix sur le hamza, praliqués par liamza et Hischàm ", par Al-Schàtibi.

Papier. 129 feuiltets. Hauteur, 18 centimètres et demi; largeur, 13 centimètres et demi. Le premier traité a 11 lignes par pare, lo second 17 ligoes. - (Ancien fonds 262.)

\section{1.}

$1^{\circ}$-Traité sur les pauses dans la lecture du Coran \%. Cut ourrage, attribué à Sa ${ }^{e} \mathrm{~d}$ al-Din Aboủ Sa'id Moḷammad ihn Mobammad ibn Khalifa, se compose d'une courte introduction, divisée en cing sections, et de la lisle des mots iqui, dans chaque sourate, doivent être suivis d'une pause. Ces mots sont rangés dans l'ordre où le texte de la sourate nous les présente, et sont accompagnés de letlres narquées à l'encre rouge qui indiquent la malure de la pause. La copje est datce de l'an 882 de l'hégire (1/77 de J. C.).

- $2^{\circ}$ (Fol. 67.) Ohservations d'Aboû Bahr Mohammad ibn al-Qàsim al-Aubàri, mort en 328 do l'brigine, sur les passages du Coran où, au lieu de ä, on trome écrit $\underset{.}{ }$

$3^{\circ}$ (Fol. Gg.) Note sur le tamrin, le teschdid, lr medd,

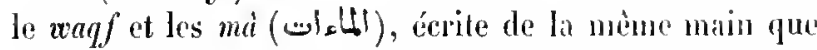
larticle $2^{\circ}$.

$4^{\circ}$ (Fol. $731^{\circ}$.) Poüme didactique sur ta manière de lire le Coran, par' 'Alam al-Din 'Ali ibu Moḷammad at-

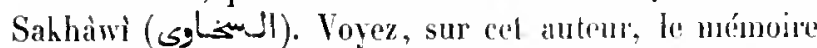
de S. de Sacy, Notices et Extraits m, t. 1111, 1. 336. La rime du poëme est en $\mathcal{H}$.

$5^{\circ}$ (Fol. $7^{6} \vee^{\circ}$. ) Vers techniques, dont la rime est en, et qui indiquent les divers cas dans lesquels te yt finail, dans le texte du Coran, est pourvu ou non pournu d'une royelle.

6) (Fol. $77 \%$.) Riggle pour connaitre le jour de la se- mane par lequel commence chaque mois de l'amée nusulmane.

$7^{\circ}$ (Fol. $81 \vee^{\circ}$.) Recetle prour liare de l'encre arec la noix de galle.

Papier. 81 feuillets. Hanteur, 18 centimètres; largeur, 13 centiinètres. 13 el 14 lignes par page. - (Ancien fonds 259. .)

\section{2.}

eCommenlaire des deax Djalàl alDin». La première partie de l'ourrage, qui s'élend jusqu'à la fin de la sourate xvil, a été composée en 850 de l'hégire (1446-1447 de J. C.), par Djalail al-Din Mohammad ibn Aḅmad al-Mahallì (Ji), la seconde parlie par Djalâl al-Din 'Abd al-Ralımàn ibn abì liakr alSoyoùti (الميوطى), qui a aclievé son travail en 870. (Voyez la préface et une note copiée sur l'cxemplaire autographe de Soyouti et insérée entre les deux parties de l'ourayos (fol. $84 \mathrm{r}^{\circ}$ et $\left.85 \mathrm{r}^{\circ}\right)$.

Papier. 18:3 feuillets. Hauteur, 27 centimitres et demi; largeur, 17 centimètres et demi. Les pages de la première partic portent $33.3 \mathrm{li}$ gnes, celles de la seconde partie 31 lignes. Ms. du $x^{\circ}$ siecle. - (Supflément 182 , Saint-Germain 79.)

\section{3.}

Le Tafsir al-Djalâlain, exemplaire daté de l'an 1141 do l'hégire (1 728 de J. C.). Au fol. 2 commence une copie du commentaire du Coran d'Alıô Zakariyà al-Anşàri,

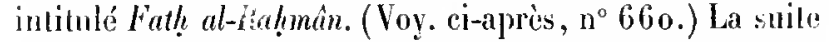
de ce commentaire est inscrite sur les marges des feuillats suivants. En tiete du volume on lit nn passage enprunté à un autre commentaire du Coran.

Papier. 190 fenillets. Ilauteur, 30 centimètres; largeur, 22 centimètres. 27 lignes par page. - (Supplément 183.)

\section{4.}

La première partie du Tafsir al-Djalaklaîn. 11 y a quelquess gloses interlinéaires en langure jasanaise.

Les feuillets de garde sont en papier végétal, apparemment de bambou.

Papier. 165 fenitlets. Hauleur, 30 centimètres et demi; larseurer, 18 centimètres el demi. 21 lignes par page. - (Suplúment 18\%.) 


\section{5.}

Premiers cahiers du Tafsir al-Djalalain. Cet exemplaire s'arrête à l'explication des mots وترغبون أب تنكميوهن.

Papier. 128 feuillets. llauteur, 23 cenlimètres; largeur, 15 centimétres el demi. 19 liggnes par page. Mls. do vvü siècle. - (Suppléinent 3980.$)$

\section{6.}

Traité des seiences qui ont pour objet le texte du Coran n, par Djaläl al-Din 'Alud al-Rahmàn al-Soyoûti. C'est la première partie de l'ouvrage. Copie très-négligée et très-incorrecle. II y a un grand nombre de lacumes.

Papier. 100 feuillels. Hanteur, 31 centimètres; largeur, 21 centimètres el demi. 3 o à 33 lignes par page. Its. In xvic siècle. — (Supplénent 193.)

\section{7.}

Première partic de l'Itqân de Soyoûtị.

Papier. 181 feuillels. llauteur, 22 cenlimèlres; largeur, 16 renlimètres. 2 s lignes par page. Ms. du xvme siècle. - (Supplément $7_{7}$ A.)

\section{8.}

La seconde moitié de l'Itquin de Soyoûtì. Ms. daté de l'in $1: 212$ de l'hégire (1797 de J. C.).

Papier. 179 feuillets. llauleur, 23 centimètres; largeur, 15 centimètues et demi. 2/3 et 95 lignes par page. - (Supplément 17 1 B.)

\section{9.}

Plusicurs opuscules de Djalìl al-Din al-Soyoụti :

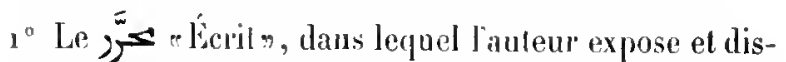
cule les opinions des docteurs au sujel dr la significalion du verset 2 de la sourate surm dil lionan, rerset qui

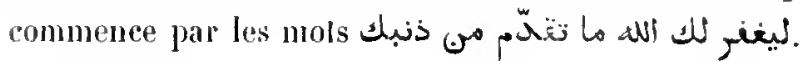

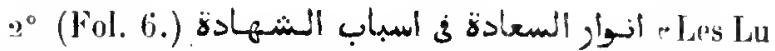
mières de la lélicité, traitant des circonstances qui constiluent le martyre\%. Disserlation fondée sur lus lradilions de Halsomel.

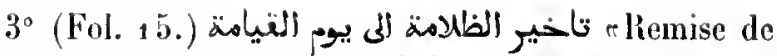
la transgression jusqu'au jour de la résurrection $\%$. Ce sont des récils relatil's ì des personnes qui, ayant reçu des offenses, araient refusé toute satisfaction pour s'en remetlre au jugement de Dieu, lors de la résurrection.

$4^{\circ}$ (Fol. 21. ( Parfum ajouté au plaisirn, abrégé de l'ourrage d'lbn abì 'l-Dounyà intitulé

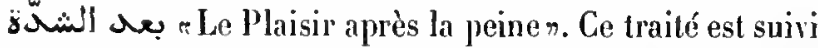
d'une anthologie poétique, formée de passages composés par divers poëtes.

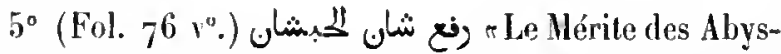
sins exaltén, traité qui se compose d'une introduction, de sept chapitres et d'une conclusion. C'est un recueil de tradilions, de récits et d'anecdoles qui montrent les Abyssins sous le jour le plus farorable.

60. Fol. Guide à la comnaissance des origines". On y trouve l'énumération des usages et imrenlions et de leurs auteurs, des époques où certaines maladies parurenl daus le monde pour la première fois, itc.

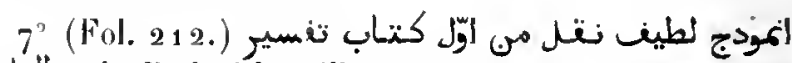
أبر elit échanlillon, liré du commencement du commentaire qu'Thn al-Khàin rédigea pour éclaircir le texte du Coran r. (Voyez ci-dessus, n $^{\text {os }} 639$ et suiv.) Cet abrégé se compose de plusieurs chapitres, dont le premier' a pour sujet l'excellence du Coran; le second traite des peines auxquelles s'expose celui qui parle du Coran sans le connaitre; le troisième traite de la manière dont lurent réunis les divers passages de ce livre, et de l'opinion de ceux qui affmment qu'il a été rérélé en sept dialectes $(\mathbf{C}, \mathbf{- 1})$; ce chapitre renlerme l'explication de certains termes employés par les traditionnistes, et l'indicalion de l'ordre dans lequel les passages qui composènt. le Coran furent révélés à Mahomet. Le quatrième chapitre a pour sujet les sept dialectes du Corau.

Papier. 239 feuillels. Hanleur, 21 cenlimètres; largeur, 18 centimẻtres. Quelques pièces ont 15 lignes par page, d'aulres ${ }_{17}^{7}$. Ms. de diverses écrilures du $x^{\prime} u^{e}$ siècle. - (Ancien fonds 441.) 1

\section{0.}

Explication, par la grâce de Dieu miséricordieux, de ce qui est obseur dans le Corann, par Aboû Yaḥyà Zakarîyâ al-Anșârì, mort en 926 de l'hégire ( 1520 de J. C.). Ms. daté de l'an $107^{3}$ de l'lıégire (1662-1663 de J. C.).

Papier. 171 fenillets. Hauleur, 21 centimètres; largeur, 15 centimèlres el demi. 19 lignes par page. - (Ancien fonds 269 .) 


\section{1.}

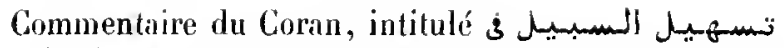
a r Aplanissement de la voie qui mìne ì l'intelligence du live révétćn, par le docteur sclaféite Alooù 'l-Hasan al-Bakri. Commencement :

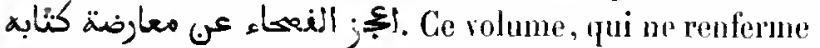
que la première moilié de l'ouvrage, c'est-ì-dire l's dixhuit premières sourates, fut écrit en 945 de l'hégire ( 1538 1539 de J. C. ), du vivant de l'auteur, et probablement au Caire. En tìte du volume se trouve un lrontispice orné, portant le titre de l'ourage et le nom de l'auteur.

Papier. 250 feuillets. Hauleur, 26 centimèlres ; largeur, 17 centimètres et demi. 29 lignes par page. - (Incien fonds a 41.)

\section{2 .}

Seconde moitié àu commentaire dn Coran Il'Aboù 'lHasan al-Bakri, commençant par la sourate xıs. Deux notes, l'une au commencement du volume, l'autre à la fin, nous apprennent que l'auteur avait commencé son travail en $9^{2} 3$ de l'hégire $(1517$ de J. C. ), et qu'il l'avait terminé en 926 de l'hégire $(1520$ de J. C.). Us. daté de l'an 1001 de l'hégire ( 1591 de J. C.).

Papier. 455 feuillets. Ilauteur, 31 centimetres; largeur, 15 centimètres. 23 lignes par page. - (Ancien fonds $26 \%$ )

\section{3.}

Collection d'opuscules se rapportant an texte ef ì li lecture du Coran. M. de Sacy a consácré à ce ms. III article dams les $n$ Notices et Extraitsn, I. VIII, 1. 355.

1 Liste des mots dont l'orthographe donne lieu ì des observations.

$2^{\circ}$ (Fol. 45.) Sur le salaire que l'on doit payer pour la récitation du Coran.

$3^{\circ}$ (Fol. $45 v^{\circ}$.) Que la pureté du loxle du Coran sc conserve mieux par la traditión orale gure par la tradition écrite.

$4^{\circ}$ (Fol. $46 \iota^{\circ}$.) Notice sur la formalion der recuril du Coran.

$5^{\circ}$ (Fol. 50 v. $^{\circ}$ ) Riggles orlhographiques que l'on doil suivre pour le hamza.

$6^{\circ}$ (Fol. 53.) Sur les irrégularités de l'orthograple du Coran. Traité analogrue à linticle $1^{\circ}$. $7^{\circ}$ (Fol. 120 ฯ $^{\circ}$.) Prière composée de paroles du Coran et relative ì la lecture de ce livre.

$8^{\circ}$ (Fol. $122{ }^{\circ}$.) Un troisième traité de l'orthographe du Coran. Incomplet.

$9^{\circ}$ (Fol. 157.) Copie d'un chapitre du مü (royez cidessus, $n^{\circ} 593$ ), dans lequel l'auteur indique les variantes des exemplaires du Hidjàz, de la Syrie et de I'Iràq.

$10^{\circ}$ (Fol. $161 r^{\circ}$.) Prière pour le jour du pè̀lerinage consacré à la station sur le mont 'Aralàt. Cette prière est attribuce à 'Mli Zaïn al-cìlsidìn.

$11^{\circ}$ (Fol. $164 r^{\circ}$.) Liste de tous les mots du Coran dans lesquels il y a un hamza qui pent àtre articulé de diverses manières.

$12^{\circ}$ (Fol. $166 r^{\circ}$.) Sigyes de convenlion pour indiquer les différentes leçous du Coran.

$13^{\circ}\left(\right.$ Fol. $17^{\circ} 1^{\circ}$.) Trailé sur l'alphalset arabe. Texte et traduction publies par M. de Sacy dans les r Notices at Extraits", t. IX, p. 1 et suiv.

$14^{\circ}$ (Fol. 186 เ. $^{\circ}$ ) Sur les divisions du Coran.

$15^{\circ}$ (Fol. $193 \checkmark^{\circ}$.) Sur les rites que l'on doil observer lorsqu'on récile le Coran.

Papier. $19^{5}$ feuillets. Hauteur, 23 centimètres et demi; targenr, 15 centimétres, 15 à 20 lifgnes par page. Is. du xvó siècle. - ( Inrien fonds 260.$)$

\section{4.}

Thaité sur les différentes legons du Coran. On y Irouse d'aloord quelepues notions générales sur l'orthomaphe du Coman, puis les variantes de chaque sourate, il enlin te nombre de mots et de lettres qui entrent dans le: fexte sacré. Le titre de l'oun rage et le nom de l'auteur sont inconnus. C'est une compilation moderne, car AlSoyounṭi y ust cité. Ms. daté de l'an 1068 de l'hógire ( 1658 de J. C.).

Papier. 59 linillels. Hauteur, as centimètres; largeur, 15 centimètres of demi. 9 ì â lignes par page. - (Supplément 190.)

\section{5.}

1" Commentaire sur la preniere sourales du Coran.

كناب النامح وحزب الفلاح Trailé des préceples de la refigion, par' li" 
sclaïkh Aboù 'J-'Abbàs Schiluâb al-Dîn Aḷnad, fils de Mol!ammad ill-Zaihid.'

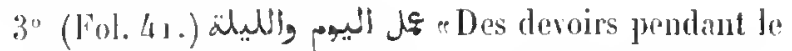
jour al la muil m, par Soyoutti.

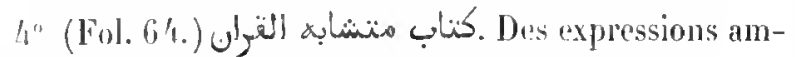

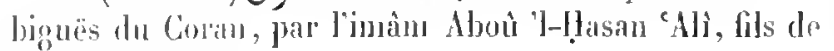
Ilamkal al-Kixì.

5o (Fol. 79.) Prieres, extraits divers, ele.

6) (Fol. $156{ }^{\circ}$.) Conseils en vers, par Molyyi al-Dì al-Gililain.

Papier. 165 feuillets, flauteur, so centimètres; largeur, 15 centi-

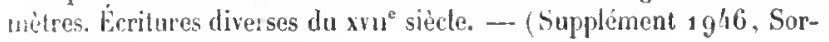
honne $38 \%$.)

\section{6.}

1 Traité d'un prédicateur du temps du sultan Mourad Kluan, dans lequel l'anteur explique quelques passagyes da Corian.

$a^{\circ}\left(F^{\circ} 01.91^{\circ}.\right)$ Observations sur un traité de la jurispridence du mariage.

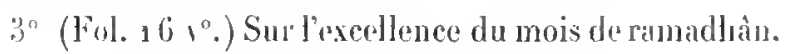

4" (Fol. $\left.261^{\circ}.\right)$ Autre trailé semblable.

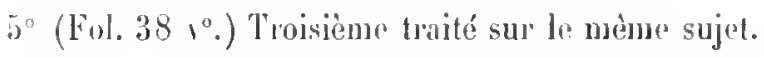

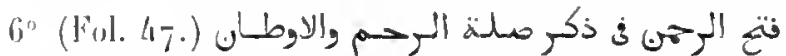
"Sur les linens du sang et l'amour de la patrien, par Aloud Rakr iln Ilolammad ibn Ibribin at-lialabi.

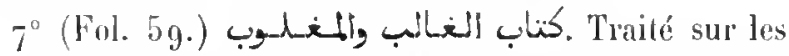
jours nélastes, par Aristote. (Voyez Vlenrich, De aucIortum gracorum", p. 162 , el le Calalogue des mss. arabes, fersans et lupes do la Bibliohréque de Leipzig, 1. 337.$)$

80 (Fol. $691^{\circ}$.) Traité de la capitation et du hbaradj.

$9^{\circ}$ (Fol. $751^{\circ}$.) Autre traité sur le même sujet, an turc.

$10^{\circ}$ (Fol. $811^{\circ}$ ) Traité de l'admiuistration politique, à l'usage des gourerucurs et des cadis.

$11^{\circ}$ (Fol. 99.) Dix décisions, fn lure, jał llasan Tschelabi Qaníli-Zàdè.

$12^{\circ}$ (Fol. $\left.1041^{\circ}.\right)$ Conseils à la jeunesse.

$13^{\circ}$ (Fol. $1091^{\circ}$.) Cinq lraditions sur la bienveil-

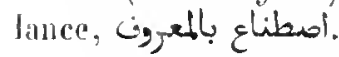

Papier. 112 feuillets. Hauteur, 21 centimètres; hargeur, 15 centimètres et demi. 9 à 21 lignes jar paģr. Écritures diverses du zru1" et du xıx siècle. -- (Supplément 1945, Ducaurroy 40.)

\section{7.}

1 م Essai d'obréger le contrnu du Morschid", par Ajoû Yạ̣yà al-Anşầ. Le Morschid on "guide" est un traité sur les pauses (لوقلف) slülg) que doivent observer ceux qui récitent le Coran. Lautcul se nommait Al-1̣asan ibn abì 'l-No'mânì. Ciet abrégé indique la ponctuation du Coran, sourate par sourate.

$2^{\circ}$ (1 ol. 162.) Profession de toi ("aquida) attribuéc à 'Ali, fils d'Aboû Ṭadib.

Ms. daté de l'an 1157 de l'hégire (1 744 de J. C.).

Papier. 163 feuillets. Hanteur, 16 centimètres; largenr, 11 centimètres. 15 lignes par pağe. - (Supplément 195.)

\section{8.}

$1^{\circ}$ Traité (ôlug anonyme sur le sens des quatre premier's versets de la sourate xurn du Coran.

$2^{\circ}$ (Fol. 10.) Abrégé de la foi musulmane, en persan.

$3 \circ$ (Fol. $26 v^{\circ}$.) Explication, en persin, des mots par lesquels on désigne les quatre-vingt-dix-neul attributs de Dieu.

$4^{\circ}$ (Fol. $20 \quad 1^{\circ}$.) Indication des vertus attribuées à chaque somate du Coran. Ein persan.

Papier. 26 feuillets. Ifauteur, 16 centimètres et demi; largeur, 10 centimètres. Les pages du premier traité contiennent 17 lignes, celles des trois autres n'en portent que $\mathbf{1} 3$. Ms. du xvit" siècle. - (Ancien fonds $27^{\text {t.) }}$ )

\section{9 .}

$1^{\circ}$ Épîtle dans laquello le schaikh Yaḷyâ ibn Mlọam-

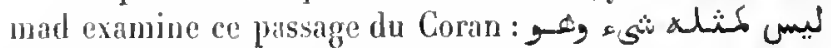

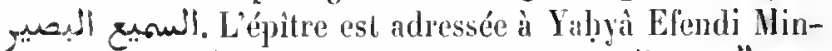
حàuadè (s s

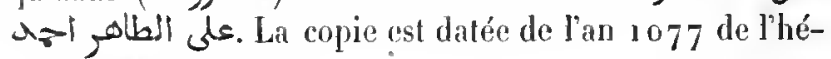
gire $(1607$ de J. C.).

$2^{\circ}$ (Fol. 29.) Notice biographique du schaikh Khaïr al-Dìn al-Ranuli. Celle piéce est datée de l'au 1081 de l'hégirie $\left({ }_{1} 6_{7}\right.$ a de J. C. $)$.

$3^{\circ}$ (Fol. 38.) Épitre du schaỉkh al-1slàm Yaḷyâ Efendi Hinqàrzàdè, multi de Rommélie, dans laquelle il consulte Khaïr al-Dìn al-Randi sur une question relative à l'expiation du prarjure, asce la réponse de celui-ci. 
$4^{\circ}$ (Fol. 5 1 $1^{\circ}$.) Trailé sur le qîra!, le dámiq, le habba, 10 dirlem et le dinir. Écriture du $\mathrm{xrmo}^{\mathrm{e}}$ siècle.

Papier. 58 fenillets. Hanteur, 15 conlimetres; largeur, 10 contimètres et demi. 15 à 21 lignes par page. - (Supplément $186 \mathrm{r}$.)

\section{0.}

Analyse grammaticale du texte du Corain. On lit sur

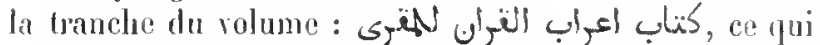
peut faire croire que l'auteur était comm sous le nom d'Al-Maqqari. La perte des premiers feuillets empéclse de reconnaître si celle indication est exacte. Le ms. commence par le deux cent cinquante-quatrième res'set de la sourate us. Ms. daté de Tuuss, de l'an 1071 de l'hérgire (1660-166i"de J. C.).

Papier. 2 s9 feuillets. Hauteur, so cenlimètres et demi; largenenr, 13 centimètres el demi. 19 lignes jar page. - (Supplément 190.)

\section{1}

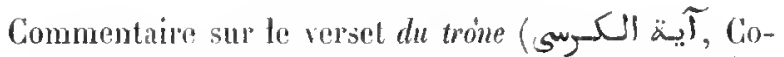

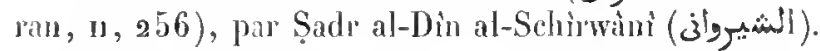

Papier. 6 feuillets. Hauteur, 15 centimètres; largeur, 10 centimètres. Environ 30 lignes par page. Us. du xvi siecle. -. (Ancien fonds $\Omega 7^{\prime}$ A.)

\section{2}

$1^{-}$Tuaité sur les pauses à olsicher dans la lecture du

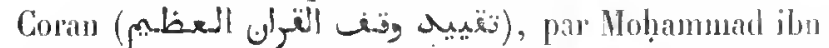

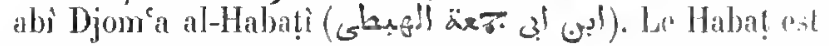
une province de l'empire marocain. La ponctualions da lexte du Coran est indiquéc somate par sumate.

$2^{\circ}$ (Fol. $49 \mathrm{r}^{\circ}$.) La Schatibiyga d'lbn Ferro.

$3^{\circ}$ (Fol. $91 v^{\circ}$.) liAlfyya, traité de grammaire d'llon Mâlik.

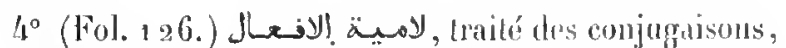
d'llun Malik. Tous les vers de co poëne didactique se terminent on lam-alif.

50 (Fol. $1311^{\circ}$.) Courl exposé de la théorie do lir jurisprudence (المول des gandes divisions de ceth science, et définitions des principaux termes techniques.

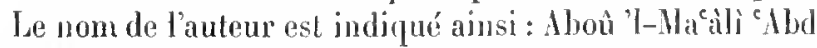
al-Màlik, auteur, dil-on, de plusiours ouvrages instructifs. Il s'agit évidemment du célibre docteur schaléite,

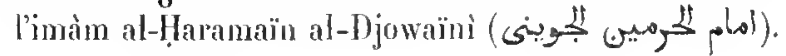

Ms. daté de l'an 1183 de l'hégire $(1769$ de J. C..).

Papier. 139 fenillets. Itautenr, is contimètres et demi; largeur, 1 亿 centimètres. 10 liģnes par page. - (Supplément 195 bis.)

\section{3.}

1" Traité de Molıammad ibn Yahyà al-Schirwàui sur l'importance de certains passages du Coran. Commence-

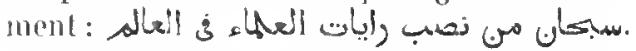

$2^{\circ}$ (Fol. y $1^{\circ}$.) Observations critiques sur quelques

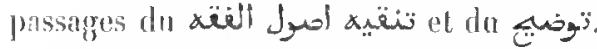

$3^{\circ}$ (Fol. $121^{\circ}$.) Observations sur quelpues questions relatives à la purilicalion.

$4^{\circ}$ (Fol. $8 v^{3}$.) Observations sur quelques passares dn traité de philosophice scolastique intilulé فight.

$\left.50\left(F_{0}\right] .2 \% v^{\circ}.\right)$ Obervations sme queldues passages

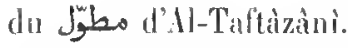

Papier. 26 fenillets. Ilanteur, 20 centimètres; langeur, 13 centimètres. 15 ligines par page. Iss. du xvm siècle. - (Supptément 1865.)

\section{4.}

$1^{\circ}$ (Fol. $1 v^{\circ}$.) Analyse grammaticalo de la prennière soltrite du Coran.

$3^{\circ}$ (Fol. $5 v^{\circ}$. ) Observations sur les notions grammaficales, suives d'un commentaire grammatical sur un lraité scientifique commencant par ces mots : avi . La fin manque.

En tète du volume se trouve mote note sur la prière da inctiedi.

Pajic:, 8 lenillets. Hanten', 17 centimètres et demi ; largenr, 13 cenlimètıe. 11 lignes par pagre. Ms. du xwn siècle. - (Supplément 2.5\%.)

111.

\section{TRAIITIONS.}

\section{5.}

طٌط "Voje aplanie", recueil de unditions classées par ordre de matières, publió d'après Mallik ibu dnas

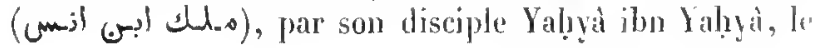


mème qui fit prélaloir le syslème de droit malékite en Espagne. Les chapilles sonl rangés à peu près dans l'ordre adoplé pour la pluparl des trailés de jurisprudence. Cel exemplaire, composé de deux parties reliées ensenble, est écril sur parchemin et dalé de l'an 726 de l'hégire (13) 6 de J. C.). L'écriture, maghreline-espagnole, est d'une grande élégance. Les litres des chapitres el des paragraphes sont tractís en or ou cu dilférentes couleurs. Sur le reclo du prenier feuillet on vit une vignette donl les couleurs el la dorure ont presque enticrement disparu. linfre la premiere partie el la seconde (fol. $75 v^{\circ}, 76$ ), on remarque deux encadrements, dessinés et ornés arec arl; le premier renferme deux vers el les denières lignes du texle; le second porte aussi denx lignes, entre lesquelles se hrome une note qui nous applend que le ms. fut copié sur l'ordu’e d'um persomnage appelé Aboû lshàq Ibrâhim ibn abi 'Othmàn al-Ragràgui (كائك)', de la Iribu marocaine appelée Ragraga. A la suile du lolio 76 on a intercalé deux feuillets de parchemin qui vavaient appartenu à un autre recueil de traditions, et dont l'écrilure maghrebine espagnole, extrènement petite, est d'une élégance loule particulière. Ces teuillets contiennent la fin du chapitre de la fornication et le commencenent de celui du marage. La seconde partic du Moxa!ni, commencaut par le chapitre du divorce, est de la même main fue la premiere, et se termine, comme celle-ci, par deux pages cucadrées, où se retrouvent la date et le nom du personmage qui arail lait copier l'ourage.

Yélin. 154 feuillets. Hauleur, 24 centimètres; largeur, 20 centimètres. 25 lignes jiar page. - (Supplément 388.)

\section{6.}

Recuril de Iraditions, probablement le Mowa!nâ de Màlik. Le commencement el la fin manquent '.

Vélin. 26 feuillets. Hauteur, a centimètres; largenr, 16 cenlimètres. so lignes par page. Hs. du xur siècle. - (Supplément 2354.)

\section{7.}

Le Mora!nâ de Mâlik. Ce ms., daté de l'an 1 i 86 de l'hégire ( $177^{2}$ de J. C.), avail été dommé en waqf jar Sậlị bey à la mosquée quil avait londée dans le Soư al-
Djoma', à Constantine. Lacle de donation (fol. $2 \mathbf{r}^{\circ}$ ) est laté de l'an 1198 de l'héggire (1 784 de J. C.).

Papier. 171 feuillets. Hauteur, 26 centimètres: largeur, 18 centimètres. 26 lignes par page. — (Supplément 389 .)

\section{8.}

Le Mowat! de Mâlik. Exemplaire daté de l'an 1191 de l'hégire (1777 de J. C.).

Papier. 195 feuiltets. Hauteur, 30 centimètres; largeur, so centimètres el demi. 21 lignes par page. - (Supplément 387.)

\section{9.}

Le Salıî̀ d'Al-Bokhâri. Cet exemplaire, qui est complet en un volume, commence par le chapilre intitulé : . En tête du volume se trouve unc note relalive à quelques termes techniques employés par les Iraditionnistes.

Papier. 457 feuillets. Hanteur, a 7 centimètres; largeur, 17 centimètres el demi. Au commencement 31 lignes, ensuite 29 lignes par page. Ms. dı xv siècle. - (Supplément 299.)

\section{0 х 683.}

Le Salîh d'Al-Bokhậi, en quatre volumes. Le premier cahier du premier volume manque. Les chapitres sont soigneusement marqués, au moyen d'encres de diverses couleurs. Exemplare daté de l'an 1139 de l'bégire $(1727$ de J. G.).

4 volumes. Papicr. 203, 218,235 et a 36 feuillets. Hauteur, 30 centimètres; largeur, a 1 centimètres et deui. 2 lignes par page. - (Supplèment 300.)

\section{4 et 685 .}

Le Saltịl d'Al-Bokhâri, en deux volumes. Exemplaire daté de l'an 146 de l'hégire ( 1734 de J. C.).

2 volumes. Papier. 310 el 47 , feuillets. Hauteur, 30 centimètres; largeur, 19 centimètres. 31 lignes par page. - (Supplémenl 295.)

\footnotetext{
1 Ce recueil n'est pas le Mowrat!â, mais un fragment de la grande collection de Bokhàrî. On y tronve plnşicurs chapitres du lirre du. Pè.
}

leinagge et du livre du Jeûne. Les feuillets du ms. soul transposés, et il y a quelques lacunes. H. $Z$. 


\section{6.}

Le Salẩh d'Al-Bokhârî. Ms. daté de l'an 1168 de l'hégire ( 1755 de J. C.).

Papier. $47_{1}$ fevillels. Hauteur, 32 centimètres et demi; largeur, so centimètres. 33 liģnes par page. - (Supplément 301.)

\section{7.}

Le Sahîh d'Al-Bokhầri; premier volume, commençant

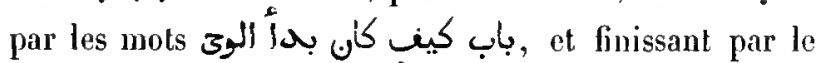

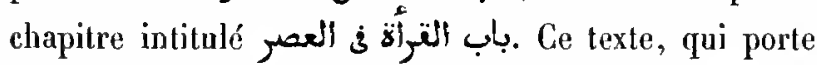
les points-royelles, a été collationné arec soin.

Papier. 141 feuillets. Hauteur, 27 centimètres; largeur, 18 centimètres. 17 lignes par page. Mls. du xum siècle. - (Ancien fonds 355 .)

\section{8.}

Le Sahîh d'Al-Bokhàrî̀; premier volume, comnençant

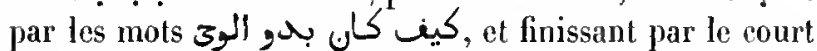

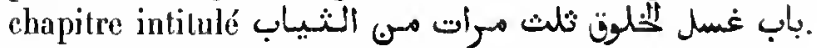
Texte pourvu des points-royelles. Il y a des notes marginales en assez grand nombre, dont la plupart renferment des indieations phitologiques. Les têtes de chapjilre sont écrites à l'encre rouge. Ce volume a été éerit an mois de djomâdâ second de l'an 833 de lhégire (mars 1430 de J. G.).

Papier. 200 fevillets. Hauteur, 37 centimètres et demi; largeur, 18 centimètres et demi. 19 lignes par page. - (Ancien fonds 24.)

\section{9.}

La première partie du Sahîh d'Al-Bokhàrì, commen-

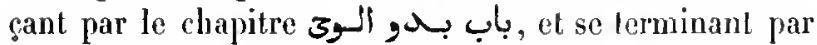

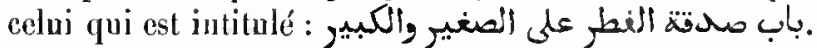
On lit au verso du premier feuillet un acle de vvaqf, daté de l'an 1208 de l'hégire (1793-1794 de J. C.), el constatant la donation de ce volume à la mosquée fondée par Sâliḥ Bey, près de Constantine.

Papier. 216 feuillets. Hauteur, 29 centimètres el demi; largeur, 21 centimètres. so lignes par page. Ms. du xvi siècle. - (Supplément 296.)

Mar. orientalx. - H.

\section{0.}

Le Salîh d'Al-Bokhâri; seconde partie, commençant

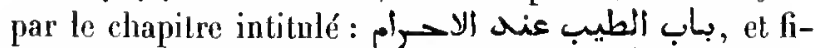
nissant par le chapitre intitulé : باب فكاك اللاسير . Texte pourvu des points-royelles. Notes marginales. Ce volume, qui fait suite au $\mathrm{n}^{\circ} 688$, a été éerit le dernies mois de l'an 833 de l'hégire (octobre 1430 de J. C.), et a reçu les dernières corrections dix ans plus tard.

Papier. 216 feuillets. Hauteur, 27 centimètres et demi ; largeur, 18 centimètres el demi. 19 lignes par page; le cahier composé des feuillets 199 à 208 a été renversé par le relieur. - (Ancien fonds 343.)

\section{1.}

Troisième volume d'un exemplaire du Salîh d'Al-Bo-

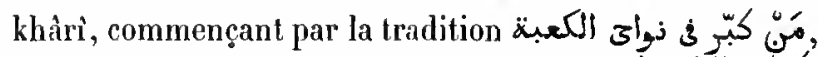

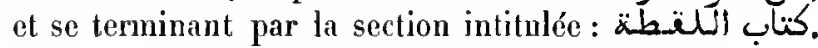
Texte portant les points-voyelles. Notes marginales.

Papier. 210 feuillets. Hauteur, 26 centimetres et demi; largeur, 18 centimètres. 15 lignes par page. $\mathrm{Hs}$. du $\mathrm{xvi}^{\circ}$ siècle. - (Ancien fonds 244.)

\section{2 .}

Treizième volume d'un exemplaire du Sahih d'Al-Bo-

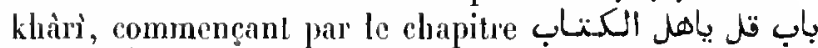

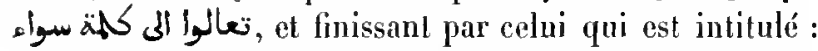

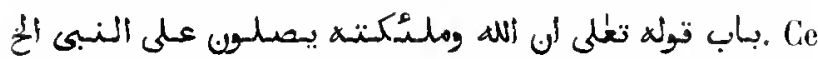
iolume fut enlevé à la grande mosquée de Bóne, lors de l'expédition de Charles-Quint contre Tunis.

Papier. 154 feuillets. Hauteur, 25 centimetres; Jargeur, 19 centimètres. 13 lignes pal page. Ns. du $x^{*}{ }^{*}$ siècle. - (Supplément 298.)

\section{3.}

Le Salînh d'Al-Bokhàrì, dixième et dermière partie, commençant par le chapitre intitulé : باب الرجم بالمكلى Cet exemplaire, exécnté par un scribe nalif du Ḥaurìn. et daté de l'an 894 de l'hégire $(1489$ de J. C.), porte quelques corrections et un certain nombre de notes margrinales. Fronlispice orné.

Papier. 185 fenillets. Ifauteur, 2 centimètres et demi; largeur, 16 centimètres. 17 lignes par page. - (Ancien fonds 392 , Colhert 5057.) 


\section{4.}

La dernière parlie du Saḩị d'Al-Bokhàrì, commençanl

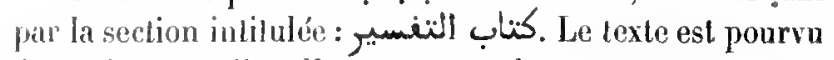
des points-voyelles. En marge, quelques notes et correcLions. Lá copie de ce ms. fut achevée au mois de moḷarram de l'an 8,5 (avril-mai 1 h1 2 de J. C.).

Papier. 292 feuillets. Hanteur, a 7 centimètres: targeur, 18 centimètres. ig lignes par page. - (Ancien fonds 245.)

\section{5 .}

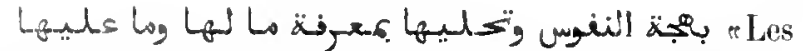
ànes embellies et parées an moyen de la conuaissance de leurs droits el de len's devoirsn, par Aboû Molıammad 'Alud Allah ibn Sacid ibn abì Djamra al-Azdì, natif d'Espagne, pour servir de commenlaire à son abrégé du

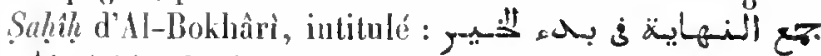
(sic) "Conjonction des limites qui marquent te premier et le dernier degré du bonheur' nis.) Ce n'est que le second volume de l'ouvrage, écril à llostaganem, en 1106 de l'hégire ( 1695 de J. C.), par Aḷmad ibn 'Alì, de Grenade. La fin manque.

Papier. 226 fouillels. Hauteur, 30 centimètres; largcur, 20 centimètres. 30 à 3 a lignes par page. - (Supptément aoog.)

\section{6.}

Ouvrage daus lequel Badr al-Dìn Moḥammad al-Zarkaschì (जübj!! ), docteur schaféite, mort en $79^{4}$ de l'héyire (1391-1392 de J. C. ), ćclaircit par de courtes notes les difficultés philologiques, grammaticales, orthographinges el historiques du Salthh d'Al-Bokhàri. Cet exemplaire, d'une bonne écriture cursive, parait aroir été transcil par un savant pour son propre usage. Les marges porlent un assez grand nombre de notes de la mème main. Les once premiers lieuillets ont été ajoulés après coup pour remplacer un cahier qui s'élait perdu. Les mots a les passages expliqués sont écrits à l'encre rouge.

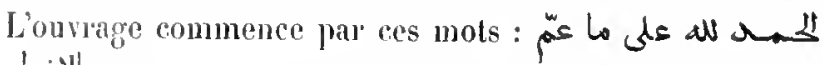
oleily.

Papier. 1 he feuiltets. Ilauteur, 27 centimètres et demi; largenr, 18 centimètres et demi. 3 , lignes par page. - - (Ancien fonds 246. )

\section{7.}

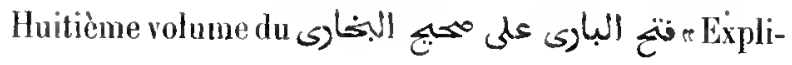

cation du Salîh d'M-Bokhâri, laite avec l'aide de Dieu par Schihâb al-Dìn M ̣̣mad ibn 'Alì ilon Hadjr al-'Asqalânì, docteur schaleủite, nort en 852 de l'hégire (14481449 de J. C.). Voyez, sur ce commentaire, le Dictionnaire bihliographique de Hadji Khalfa, t. Il, p. 525 et suiv. Les chapitres du Salı̂̉ commentés dans ce vo-

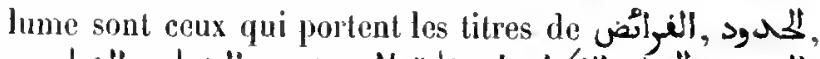

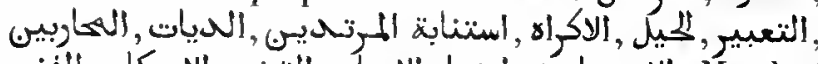

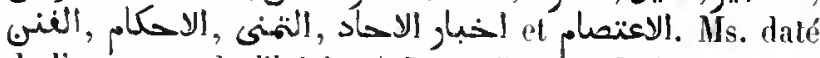
de l'an 1001 de l'hégire $(1592-1593$ de J. C. ).

Papier. 355 feuillets. Ilanteur, 31 centimètres; largeur, 21 centimètres. 35 lignes par page. - (Ancien fonds 351.)

\section{8.}

Qnatrième volume du commentaire de Badr al-Dìn al-'Aïnì sur le Sahî̉ d'Al-Bokhårì, commençant par le

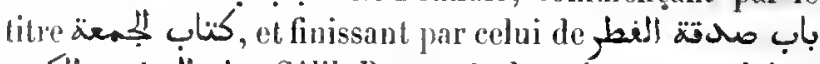
ئ. Sảlil Bey avait donné cel exemplaire, qui élail alor's complet, en $1 \mathbf{1} \mathbf{g}^{6}$ de l'hégire (1 782 de J. C. ), ì la mosquée qu'il avail lail construire et qui porte son $110 m$ dans le roisinage de Constantine.

Papier. 633 feuillets. Hanteur, 3o centimètres; largeur, 30 centimètres. 33 lignes par page. Ms. du xvir siècle. - (Supplément 297.)

\section{9 .}

Seplième volume du commentaire d'Al-'Aïnî sur le Sahîh d'Al-Bokhàri. Ce volume a fait parlic du même excmplaire que le ms. précédent. Il commence par le

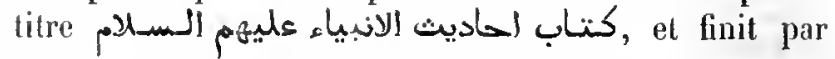

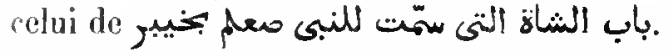

Papier. 423 feuillets. Hauteur, 39 centimètres; largeur, 20 centimétres et demi. 23 lignes par page. $\rightarrow$ (Supplément 297 bis.)

\section{0 .}

Neuvième volume du commentaire d'Al-Aïnì sur le Salihh d'Al-Bokhàri. Il commence par le chapitre intitulé : باب ما كنا لنهتحلى لـولا

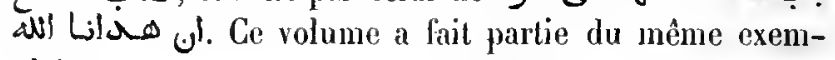
plaire que les deux numéros précédents.

Papier. 622 feuillets. Hauteur, a 8 centimètres; largeur, so centimètres. 35 lignes par page. - (Supplément 297 ter.) 


\section{1.}

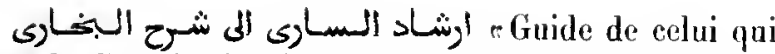
cherche l'explication (du Salhîh) d'Al-Bokhârì̀. L'auteur,

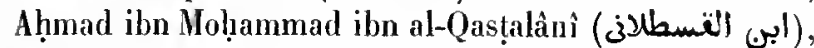
docteur schaféite, naquit au Gaire, en 851 de l'hégire (1447-1448 de J. C.), et mourut en $9^{2} 3$ de l'hégire ( $15{ }_{1} 7$ de J. G.). Nous avons ici le premier des dix rolumes dont se compose l'ourage. Le commentateur, dans sa préface, traite des grands mérites des traditionnistes el doune ensuite l'explication des nombreux termes techniques de la science des traditions. Dans le einquième chapitre $\left(\right.$ fol. $\left.361^{\circ}\right)$, il donne une biographie assez étendue d'Al-Bokhârì. Le commentaire propremcut dit commence au fol. 55. Les marges du volume portent un certain nombre de notes. Le second volume de cet exemplaire devait commencer par le chapitre intitulé : باب المواقيت

Papier. 635 feuillets. Hauteur, 23 centimètres; largenr, 16 centimètres. 25 lignes par page. IIs. du xvu ${ }^{\mathrm{e}}$ siècle. - (Supplément 301 bis.)

\section{2 et 703.}

Deux volumes sans commencement ni fin, el composés de cahiers renfermant une portion d'un grand commentaire sur le Sahîh d'Al-Bohhârì, probablement du

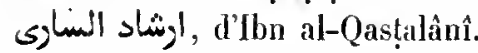

2 volumes. Papier. 610 el 610 feuillets. Hauteur, 22 centimètres; largeur, 16 centimètres. 2 lignes par page. Ms. du xix ${ }^{e}$ siècle.-(Supplément :007 et 2008 .)

\section{4.}

Second volume du recucil de traditions comnu sons le

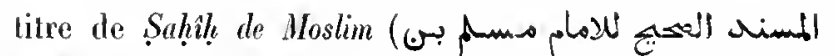
ألمَّاج البيوع), et finissant par celui de linlerprétation dn Coran (كـ). Le titre et le nom de l'anteul' sont inserits sur le lrontispice en or et en coulear's. Ms. daté de l'an 760 de l'hégire ( 1359 de J. C..).

Papier. 291 feuillets. Ilauteur, 31 centimètres et demi; largeur, 21 centimètres et demi. 27 lignes par page. - (Ancien fonds 489.)

\section{5.}

Première partie de l'abrégé (مختِ) du Sahîh de Mos- lim, par Zakî al-Dìn 'Abd al-'Azìm al-Mondsirî, célèbre docteur schatéite, natif d'Égypte, mort en 656 de l'hégire (1 258 de J. C.). Voyez le Dictionnaire biographique d'lbu Khallikân, vol. 1, p. 89 de la traduction de M. de Slane.

Papier. 205 feuitlets. Hauleur, 26 centimèlres; largeur, 17 centimèlres. 19 lignes par page. Ms. du xiv siècle. - (Ancien fonds $47^{8}$.)

\section{6.}

كتاب السنه. recueil de traditions publić par línn Mâdja

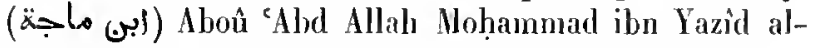
Qazwìni, mort en $27^{3}$ de lhégire $(887$ do d. C.). A la fin du volume se trouvent un assez grand nombre de ces'tificats d'audition dont quelques-uns sont reproduits d'après l'exemplaire dont celui-ci est la copie. Hs. daté do" lan 730 de l'hégire ( 1330 de J. C.).

Papier. 303 feuiltets. Ifauteur, 26 centimètres; largeur, 18 centimètres et demi. 23 lignes par page. -- (Supplément 306, SaintGermain 84.)

\section{7.}

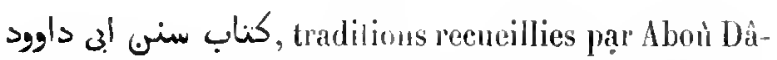
woñd Solaïmân ibı al-A seléath, de Sidjistàn. Ce volunıe commence par les traditions relatives à l'ablution (الموضوء), et finit par celles qui sc rajp porten! aux in ocations (_sovi). On lit au verso du demier l'enillet un certifical d'études, dans Iequel le schaïh al-Islàm 'Abd al-Wahhâb 'Alì ibı 'Alì déclare que les frères Madjd al-Dìn Mboụ 'l-Sacâdàt al-Moubârık ibı Molıammad ibur al-Athìr et le savant

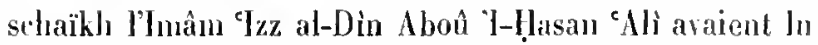
ce volune tour à tour en sa présence, ainsi que le fils de leur sour, appelé Safí al-Din Aboû 'l-Hasan 'Mlì ibu Sa îd ibn Wahbàn. La demière Ircon quils reçrent eul licu au commencement de dsou 'l-qa'da 585 (décembre 1189 de J. C.). 'Tzz al-Din ibu al-Athì' dont il est lail mention dans celle pièce est l'anteur de la grande chronique intitulce le Kamil.

Papier. 2 (5a feuillets. Ilanteur, a 4 centimètres; largeur, 17 centimètres. 19 tiznns par page. Us. du xil" siècte. - (Ancien fonds 518 .)

\section{8.}

Le recueil de traditions (كتاب المسنى) d'Aboû Dìwoùd al-Sidjistâni. Ce rolume, daté de l'an 6ot de l'hégire 
(1207 de J. C.), commence par la seconde section et finit par la douzième : on sait qu'un exemplaire complet contient trente-deux sections. Le ms. est Lrès-ljien ćcrit et porte en marge de nombreuses corrections. Les blancs laissés au commencement et à la fin de chaque section sont remplis de certificats qui nous font connaître les diverses époques où ce volume a été collationné, et les noms des docteurs qui ont pris part à ce travail. Plusieurs de ces documents sont datés des années 654 el 655 , et portent la signature antographe d'eAbd al- Azîm al-Mondsiri.

Papier. 172 feuillets. Hanteur, 24 centimètres; largeur, 17 centimètres et demi. 25 lignes par page. - (Ancien fonds 354.)

\section{9}

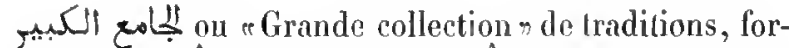
mée pal Ảboû 'îsâ Hohammad ibn cîsì al-Tirmidsî, mort ell 279 de l'hégire $\left(89_{2}-89^{3}\right.$ de J. C. $)$. Ce volume, daté de l'an 547 de l'hégire (1 $152-1153$ de J. C.), est d'une écrilure cursive qu'on parient difficilemenl à lire. Ens lêle se trouve un isnâd ratlachant l'édileur, 'Alıd al-Ilélik ibn abì 'l-Qâsim, à l'anteur de l'ouvrage, et indiquant par quelle filiere le texte lui élait parvenu oralement. Les deux premiers feuillets et les trois deruiers contiennent. environ une quarantaine d'attestations de diverses mains. Les auteurs de ces notes déclarent quils ont lu on entendu lire ce volume en tont on en partie. Presque tontes ces pic̀ces, émanant de docteurs égypliens, espagnols, africains, syriens, etc., sont datées du vic siècle de l'hégire.

Papier. 272 feuillets. Hauteur, 26 centimètres; largeur, 17 centimètres et demi. 32 lignes par page. - (Supplément 302.)

\section{0 et 711 .}

Abrégé du grand recueil de traditions d'Aboû 'Îsà Moḷammad al-Tirmidsi, par Nadjm al-Din Molıammod ibn 'Aqil (عتيل) al-Bàlesì, mort en 729 de l'hégire (1 328 1329 de J. C. .). Cette copie porle la dale de 747 de l'hégire (1346-1347 de J. C.).

2 volumes. Papier. 164 et 183 feuillets. Hauteur, 28 centimètres et demi; largeur, 20 centimètres. 21 lignes par page. -- (Ancien fonds 471 et 472.$)$

\section{2.}

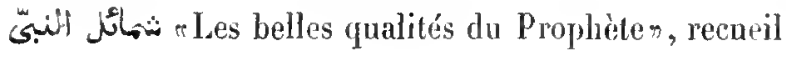

de traditions rédigé par Aboû 'Îsâ Mohammad ibn 'Îsâ ibn Saura al-Tirmidsî. Dans ce recueil, l'anteur s'est occupé plutôt des pratiques personnelles de Mahomet que de ses qualités morales et intellectuelles. Cet exemplaire, qui est du xiv siècle, a été écrit d'après les lecons données à Alep, en 723 de l'hégire (1323 de J. C.), par le schaikh 'Lzz al-Dìn 'Abd al-Moûmin ibn al-'Adjamì (ى. أ Le texte est surchargé de notes marginales, interlinéaires et inscrites sur des onglets.

Papier. 79 feuillels. Hauteur, 27 centimètres; largeur, 19 centimètres. 15 lignes par page. - (Supplément 507.)

\section{3.}

\section{Le نُمائل d'Al-Tirmidsi.}

Papier. 129 fenillets (y compris deux feuillets blancs, fol. 48 et 55 , qui remplacent deux feuillets qui manquent). Hauteur, 17 centimètres et demi; largeur, 11 centimètres et demi. 1 I lignes par page. Is. du $x^{\circ} 1^{\circ}$ siècle. - (Supplément 5o6.)

\section{4}

re meilleur seconrs pour lintelligence du texte du Schamâil s, ou commentaire phi-

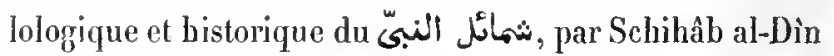
Ahmad ibn Hadjr al-Mlakkî, mort en $97^{3}$ de l'hégire (1565-1566 de J. C.). Ce commentaire a été composé ev أما بعا laiels.

Papier. 278 feuillets. Hauteur, 21 centimètres; largeur, 15 centimètres et demi. 19 lignes par page. $\mathrm{Ms} . \mathrm{du} \mathrm{xvl}^{\mathrm{e}}$ siècle. - (Ancien fonds 423. )

\section{5.}

r.Le meilleur secours pour lintelligence du Schamaïlr, par Schihâb al-Dìn Aḥmad ibn liadjr. La copie est datée de l'an 1092 de l'hégire ( 1681 de J. C.).

Papier. 210 feuillets. Hauteur, 21 centimètres; largeur, 15 centimètres. 23 lignes par page. - (Supplément 2020.)

\section{6.}

Manteaux de choix sur 
les qualités de l'Élu ", par Ismài il ibn Ghonaïn (غنم) al-

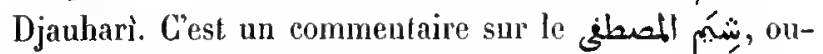
vrage du même auteur, et qui n'est qu'un abrégé du نثمائل d'Al-Tirmidsì. Le texte du pü, écrit à l'encre rouge, est intercalé dans le commentaire. Ms. dalé de l'an 1205 de l'hégire ( 1700 de J. C.).

Papier. $7^{\circ}$ feuillels. Hauteur, 33 centimètres et demi; largeur, 16 centimètres el demi. 21 lignes par page. - (Supplément 508.)

\section{7.}

Volume dépareillé, probablement le second, d'un re-

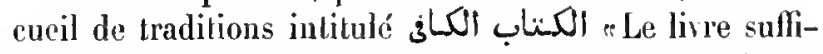
sant\%. Ces traditions proviennent presque toutes d'Alì ou de quelques-uns de ses descendants, tels qu'Al-Ḥasan, fils d'celì, Aboû Dja far Moḥammad, petil-fils d'Al-Ḥosaïn, Aboû 'Abd Allah, surnommó Al-Nafs al-Zakiyya, et 'Alì ibu Moủsâ, surnommé Al-Ridhâ. Elles sont classées par matières, comme dans toules les collections semblables, et forment une série de chapitres, dont ce

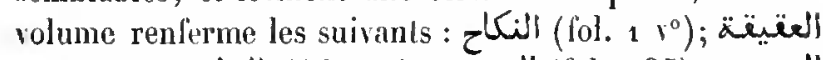

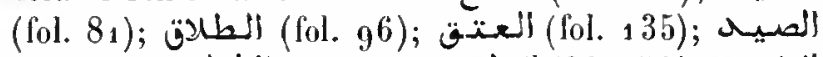

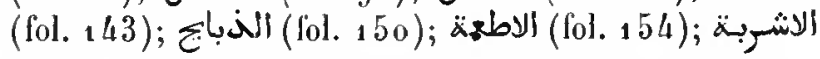

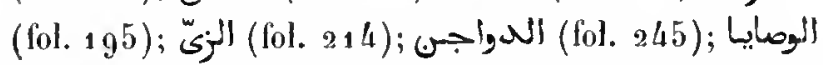

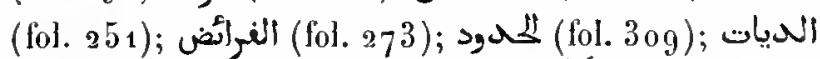
(fol. 341); الاحكام (fol. 388); (fol. 398$)$.

Ce ms., daté de l'an 1062 de l'hégire (1652 de J. C.), a élé enlevé ì une mosquée dans le pays des Motoalis ( $($ ( $)$ ), en ${ }_{7} 750$, par l'émir des Druzes.

Papier. 107 feuillets. Hauteur, 31 centimètres; largeur, so centimètres. 23 lignes par page. - (Supptément a 76 .)

\section{8.}

res Abrogeants ot le: abrogés en fail de tradilions», par Aboû Ḥậ̂ ibn Schàhìn (ناهيی), mort en 385 de l'héggire $(995$ de J. C.). Les premiers leuillets manquent. Ms. écril an Caire, en $57^{\mathrm{h}}$ de l'hégire ( 117 7-1 179 de J. C.).

Papier. 67 fenillets. Hauteur, 19 centimètres; largeur, 14 centimètres. 28 lignes par page. - (Ancien fonds 383.)

\section{9.}

-Les Lampes da corps des traditions",

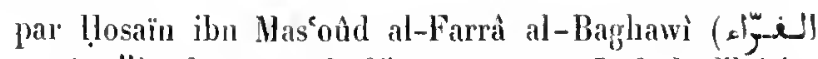

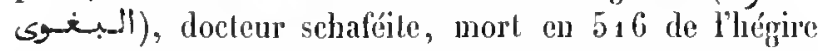
(1122-1123 de J. C.). C'est un recueil coordonné de toutes les traditions certaines et probables qui se trourent dans les grandes collections d'Al-Bokhàri, de Moslim et d'autres traditionnistes. Texte pourvu des points-ı oyelles. A u recto du second feuillet se trouve une longue note, dans larpelle sont expliqués les principaux termes lechniques de la science des traditions. Beaucoup de notes marginales el interlinéaires. Ms. daté de l'an 799 de l'hégire ( 1396 61397 de J. C.).

Papier. 334 feuillets. Hanteur, 28 centimètres; largeur, 18 centinuètres el demi. 17 lignes par page. -- (Supptément 303 , Ducaurroy 5.)

\section{0 .}

Co Niche pour le Mașibîh (les lampes)n. C'est une nourelle édition, annotée el augnentée, dn

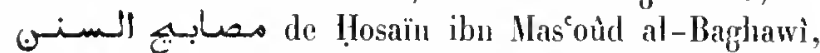
par Walì al-Dìn $A$ boû 'Abd Allah Mohammad ibu eAbd Allah al-Khatih, qui a acleevé son travail en 7 ta de l'hégire (1341-1342 de J. C.). Cet ourrage a été traduil ea anglais par Malthews (Calcutta, 1809,2 vol. in- $4^{\circ}$ ). Notre exemplaire renlerme environ la première moilié de l'ourrage el s'arrète au livre $X$, chap. v, $\$ 2$ ( 1.1, p. $5_{7} 2$ de la traduction). Les rubriques, à partir du feuillet 130 , sont restées en blanc.

Papier. ${ }_{152}$ feuillets. Hauteur, 30 centimètres; largeur, 19 centimètres. 25 lignes par page. Is. du $\mathrm{xvi}^{\bullet}$ siècle. - (Incien fonds 35.3.)

\section{1}

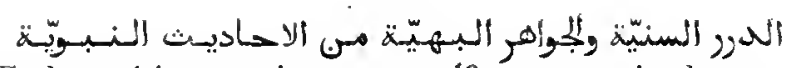
Perles précieuses el joyaux magnifiques, extraits des traditions du Prophc̀ten, ourrage renlermant les traditions relatives aux curres de piété et de bienfaisance, et dédié à Son Excellence (المتّ) Aboù 'l-Ulahàsin Yoùsof, surintendant du domaine privé du calife fitémide $\mathrm{H}$ - ${ }^{\mathrm{A}}$ Adhod li-

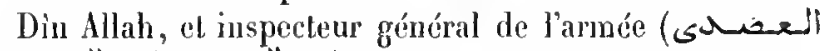

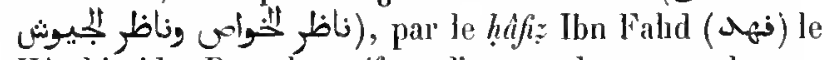
Hàschimide. Dans la próface, l'auteur donne une longrue liste des mosquées, colléges, hópitaux, puits, fonlaines, que ce persomnage arait fail construire au Caire, ì ta Mecque, à Yanboua et antres lieux. A la lin se trourent quelques prières qui sont réputées être d'une verlu mer- 
veilleuse. Ms. écrit ì la llecque, en 855 de l'hégire (1451 the J. C. .).

Papier. 97 feuillets. Hauteur, 16 centimètres; largeur, 11 centimètres. 1 lignes par page. - (Ancien fonds 4.56.)

\section{2.}

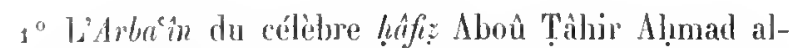
Silati. (Voyez to Dictionnaire Jiographique d'Ibn Khallikân, t. 1, p. 86 de la traduction.) Chacune des tıaditions de ce récueil ayant été recueillie dans une ville dillérente, l'ourrage est habituellement désigné par le

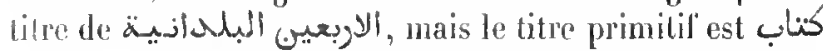

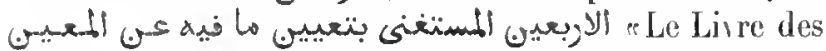
quarante, pourant se passer d'éclaircissement (litléralenent: de secours) par la précision de son contenur. La prélace fournit quelques judications au sujet des royages de l'anteur. l es dejniers leuillets de ce traité sont trausposés; ils sont actuellement cotés 44,33 et 32 .

$2^{\circ}$ (Fol. 11.) Un Arba in composé de tradilions dont chacune a été recueillie dans un livie différent. L'auteur,

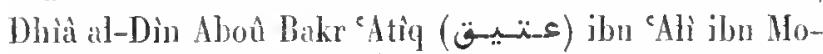
lıammad ibn' 'Omar' ssiobll, natil' de Héral, a dicté son our rage à un de ses disciples, en 637 de l'liégire (12391240 de J. C.).

$3^{\circ}$ (Fol. 34.) L'Arba'in des Mohammad, ainsi nonmé parce que ces traditions furent transmises successivement d'un traditionniste appelé Molommad à un autre du mêne nom. Le compilateur, Aboû Bakr Moḷammad ihn

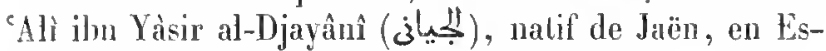
pagrne, a rédiggé son ourrage en 557 de l'hégire (1 162 de l. G.).

$4^{\circ}$ (Fol. 45.) L'Arbein d'Aboû 'Abd Allah Moḷammad

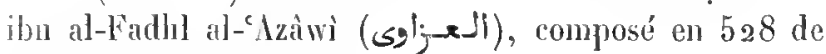
l'hégine (1133-11 34 de J. C.).

50 (Fol. 55.) L'Arbaến septénaire (الاوبعيب المسباعيات). Traditions qui remontent à Al-Bokhârì et à Moslim, et qui ont été recueillies par sept de leurs disciples. Le compilateur, Aboû 'l-Maćlì 'Abd al-Mon'im (مeidl), était né en 497 de l'hégire (1 $103-1104$ de J. C.).

$6^{\circ}$ (Fol. 67.) L'Arba'in d'Aboû 'Abd Allah al-Qàsim ibn al-Falhl al-Thaqafi, transmis par lui an hafi: Silalï. Liauteur mourut en 489 ( 1096 de J. C.). Ce sont quarante chapitres assez courts et ayant pour sujel la morale et la retigion.

$7^{\circ}$ (Fol. 1 0o.) L'Árbacin d'Aboû Nașr Mohamamad ibn 'Alì, généralement désigné par le surnom d'Ibn Wad'ân.

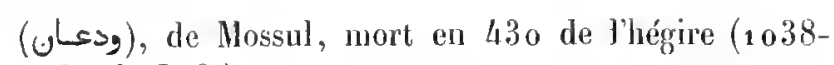
1039 de J. C.).

$8^{\circ}\left(\right.$ Fol. $116 \mathrm{v}^{\circ}$.) Une quaranlaine de chapitres trèscourts, dans lesquels se trousent rapportées les tradilions sur la religion et sur la morale. J. (i.).

Ms. écrit à Alep, en 881 de l'hégire $(1476-1477$ de

Papier. 123 feuiltets. Hautcur, 18 centimètres; largeur, 13 centimètres. 19 liggnes par page. - (Ancicn fonds 389.)

\section{3.}

Recueil de traditions, formé, comme l'indique une note du copiste, par Qoṭ al-Dìn Aboû 'I-Barakât Mansoûr ibn Hibat Allah, matif de Kharizme. D'après cette inême note, ces sentences, au nombre de cing mille deux cent soixante-six, ont été tirées des recucils d'Al-Bokhârì, de Meslim, d'Aboû Dàwoûd, de Tirmidsî, d'AlNasâi, d'llın Mâdja, d'Al-Dàrinî, de Mâlik, de Dâraqotnì et d'Al-Baïhaqì. Le copiste ajoute qu'il manque à son exemplaire les deux premiers leuillets, renfermant une préface dans laquelle l'auteur parle des ouvrages composés sur le nême sujet. Ca volume commence par le chapitre sur la loi (باب الايمان), et finit an milieu de la troisième section du chapitre intitulé الصير ح والمساء والمنام . Les derniers feuillets mantjuent.

Papier. 227 feuillets. Hauteur, a centimètres et demi; largeur 15 centimètres. 18 à 20 lignes par page. Its. du $x v 1^{e}$ siècle. — (Ancien fonds 391 .)

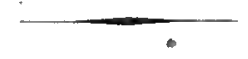

\section{4.}

Fécondation des esprits pour ceux qui recherchent les sources de l'histoire et de la bjographien, par Djanâl al-Dìn Aboù 'lFaradj 'Abd al-Raḥmàn ibn 'Alì ibn al-Djauzî, moraliste et prédicateur célèbre, mort en 597 de l'hégre (1201 de J. C.). lbun Khallikân a donné la liog̣raphie de cet auteur dans son Dictionnaire biographique (t. II, p. 98 de la traduction anglaise). Cet ouvrage est un manuel à l'usage des traditionnistes. Il commence à la création d'Adaun, présente ensuite des notices jlus ou moins détaillées sur les prophètes, sur Mahomet, sur les membres de sa famille el sur les premiers califes, el des listes pas ordse alphabétique des compagnons, de ceux qui ont I'ansmis des traditions, de ceux qui assistèrent au serment de l'Aqaba, de ceux qui émigrèrent en Abyssinie ou à Médine, de ceux qui assistèrent aux combats de Badr et 
d'Ohod, de ceux qui se fixèrent à la Mecque, à Médine, à Koufa, à Baṣra, à Al-Madàïn ou dans le Yemàma et te Balpraïn, etc. En tète du volume se troure une liste très-détaillée des clıapitres. Ms. daté de l'an 791 de l'hégire ( 1389 de J. C.).

Papier. $27^{2}$ feuiliets. Hauteur, 26 centimètres el demi; largeur. 19 centimètres. 25 lignes par page. --. (Ancien fonds 631.)

\section{5.}

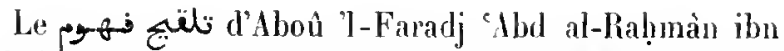
'Alì ibn al-Djauzi; première noitié de l'ouvrage, se terminant par le chapitre qui contient les noms des premiers musulmans qui naquirent en Abyssinie.

Papier. a 84 feuillets. IIautenr, 22 centimètres; largeur, 16 centimètres. 5 lignes par page. Ms. dn xvı" siècle. - (Supplíment 668.)

\section{6 .}

مe Les paroles du l'rophète qui servent de base aux maximes du droit musulman \%. Ces traditions sont classées dans l'ordre adopté pour les traités de jurisprudence. L'auteur, 'Alud al-Ghan' ibn 'Abd al-Wâhid ibn 'Alì ibn abì Soroûr, natif de Jérusalem, mourut en 600 de l'hégire (1 203-1 204 de J. C.). Le ms. est daté de l'an 742 de l'hégire $(1311-1342$ de J. G.). A la fin du volume se trouvent trois iljaza, on certificats d'étude.

Papier. $9^{8}$ feuiltets. Hauteur, 17 centimètres; larỵeur, 13 centimètres. 10 lignes par page. - (Supplémenl 29o.)

\section{7.}

$1^{\circ}$ Le مكسام Wạhịd.

$2^{\circ}$ (Fol. $53 v^{\circ}$ (. (لاصـول - Voir qui mène à la conmaissance des principes de la jurisprudencer, par le cadi Nàsir al-Dìn CAbd Allah al-Bä̈lhàìi.

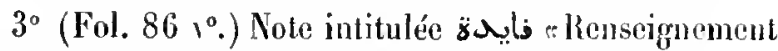
utilen, et renfermant des observations grammaticales sur les mots ifiet qu'on lit dans le Coran.

Papier. 87 fenillets. Hauteur, 25 centimètres el demi; largeur, 17 centimètres et demi. 21 lignes par page. Ms. du xvi siècle. - (Supplément $\mathrm{a} 8 \mathrm{~g}$.)

\section{8.}

Volume détaché, probablenent le sixième, d'un exem-

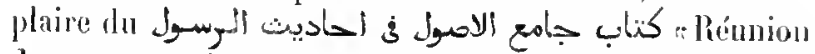
des sources, cost-it-dire des traditions du Prophèter. Cief ourrage renferme toutes les traditions, distribuées, suirant leur contenu, en plusiemrs chapitres qui sont classés dans l'ordre de l'alphalset. A la fin de chaque chapitre. se troure l'explication des termes olsscurs on peu connus

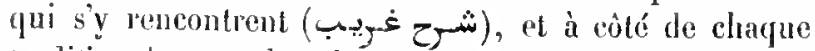
tradition le nom de celui à qui on la laisait remonter', ainsi que des sigles, à l'encre ronge, indiquant l'une ou l'autre des six grandes collections de tradilions authentiques d'où le compilateur l'arait tirée. Ce raste recueil a ćté composé par Madjd al-Dì Aboù '1-Sa àchàt Moubârilk ibn Moḥammad al-Djazari, frère de l'listorien Ibn al-Athìr. (Voyez les Extraits des historiens arabes relatils aux Croisadess, 1. I, p. 752, et le second volume de la traduction d'lbn Khallikin, p. 551.) Le prenier feuillet manque, ainsi que le dernier. Le volmme commence par le chapitre de la lettre ghän qui estintitulé: Les expéditions

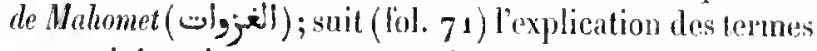
peu usités qui se rencontrent dans ce chapitre; ensuite, au fol. 87 , commence la lettre fa, dont le juremire chapitre, intitulé les Mérites (فضائل), remplit le reste du volume. An fol. 216 nous trourous la neuvième section du chapitre.des Mérites, et an fol. $27^{4} \mathrm{r}^{\circ}$, la quinzième section (نوع) du treizième chapitre des Mérites. Le chapitre des Mérites est cousacró ì la loi, à la prière, aux vertus et aux mérites des comprgnous de Mahomet, etc.

Papier. $27^{4}$ feuillets. Hauteur, 27 centimètres et demi; largeur, 19 centimètres el demi. 19 lignes par page. Ils. du vve siècle. - (Supplément 5̇go.)

\section{9 .}

Le septieme volume d'un exemplaire du جأمع الاصول de Madjul al-Din Moubàrak ilon al-Athìr, contenant les ar-

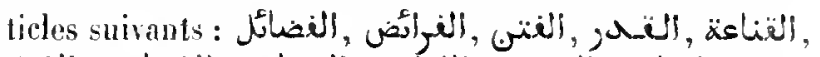

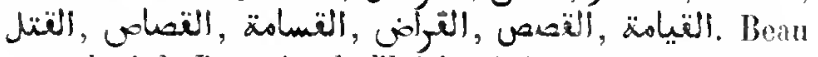
ms., daté de I'an 742 de l'hégire (1341-1342 de J. C. .). et écrit pour être placé dans la bibliothèque de l'émir. Bélıâdur al-Badri, licutenant dı gourerieur de la citadelle du Caire (نايب والى تقعة لمبل

Papier. 23a feuillets. Hanteur, 36 centimètres et demi; largeur, 17 centimètres et domi. 19 lignes par page. - (Supplément 313. ) 


\section{0.}

Traité qui facitite la connaissance des matières contenues dans le جـ جـ جـ ألاصول, par' Wahịid al-Dìn 'Alod al-Raḷmuân ibn 'Atì al-

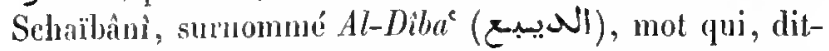
on, signifie r blanen dans la langue des Nubiens. Cet auteur, de l'école schaféite, mourut au commencement de l'an 866 de l'hégire ( $1461-1462$ de J. C. $)^{1}$. Dans cel ourange, les traditions sont distribuées en seetions qui correspondent à celles des traités de droit, et qui, contrajrement ì l'usage, sont raugées dans l'ordre de l'alphabet. Un index général, placé en tête du volume, indique le sujet de chacun des trois cent cinquante chapitres dont se comprose l'ouvrage. Ce ms. a été exéculé en 988 de Fhérgire ( 1580 de J. C.), à la Mecque, dans le collége hanéfite appelé Solnimaniyya, d'après son fondateur, le sultan ottoman Soliman.

Papier. 373 feuillets. Hauteur, 33 centimètres; largeur, 18 centimètres et demi. 35 tignes par page. - (Ancien fonds 349.)

\section{1.}

La seconde moitié d'un commentaire sur le Mosnad, ou corps de traditions authentiques, qui ont été transmises par l'imâm Al-Schafi î (Noḷammad ibn Idrìs alMottadibi). C'est probablement l'ourrage de Madjd al-Dìn Aboû 't-Sa âdât Moubârak at-Djazari, surnommé lbn atAhir. Hadji Khalfa désigne ce comnenfaire par le titre

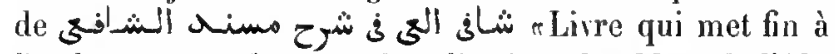
l'embarras, renfernant l'explication du Mosnad d'AlSchafi'ir. Le titre, tel qu'ił est écrit en tète du ms., est d'une main plus moderne et renferme des erreurs.

Papier. 295 feuillets. Hauteur, 27 centimètres et demi; largeur, 19 centimètres. 25 à 30 lignes par page. Ms. du $x_{10}{ }^{\circ}$ siècle. - (Supplément 430, Saint-Germain 87.)

\section{2.}

Compagnon pour ceux qui ont renoncé au monde, afin de se déroner au service du Seigneur de toutes les eréaturesn, recueil de trois cents traditions, suivies d'histoires édifiantes et de courtes pièces de vers. L'auteur, Al-Mo âfà (alefli) ibn abì Ismấit ibn abì 'l-Sinân, natif de Mossul, nnourut en 630 de l'hégire (1232-1233 de J. C.). A u premier leuittel se trouve un frontispice orné, et à la fin du ms. une viguette portant le nom d'un général égyptien nommée Abd al-1kazzàq ihn abì 'l-Faradj.

Papier. 188 feuillets. Hauteur, 37 centimètres; largeur, 18 centimètres. ${ }^{7} 7$ lignes par page. Ms. du xiv ou du $\mathbf{x v}^{\circ}$ siècte. - (Supplément 5o3.)

\section{3 .}

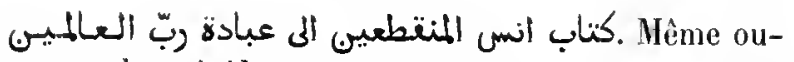
vrage que le précédent.

Papier. 138 feuillets. Hauleur, 21 centimètres; largeur, 15 centimètres. 19 lignes par page. Ms. du xvi sièele. - (Supplément. 502.)

\section{4.}

Compagnon pour les gens qui ont renoncé au monde, et démonstration à l'usage des gens dévotsn. Mème ourrage que les deux précédents. $A$ la fin se trouve un appendice contenant la généalogie de Mahomet. Hs. daté de l'an 955 de l'hégire (1548 de J. C.).

Papier. 291 feuillets. Hauteur, 20 centimètres; largeur, 15 centimètres. 15 tignes par page. - (Supplément 5o 1.)

\section{5.}

ה Compagnon pour les gens qui ont renoncé au monden. Même ourrage que les précédents. Cet exemplaire, daté de l'an 976 de l'hégire (1568. 1569 de J. C.), contient le mêne appendice que le nis. 734 .

Papier. 159 feuillets. Hauteur, 30 centimètres et demi; largeur, 21 centimètres. 13 tignes par page. - (Supplément 500 .)

\section{6.}

rindication des (sources d'où dérivent

\footnotetext{
${ }^{1}$ Dans la notice biographique qui se trouve en tête du volume, it est dit que l'auteur était né en 866 de l'hégire, et qu'il était mort en 9 4h; D'après une note finate, l'ouvrage a été achevé en 916 . H. Z.
} 
les) maximes de droit „, traité méthodique de jurisprudence, avec l'indication des traditions sur lesquelles chaque article du code est fondé, par le grand cadi Bahâ al-Dîn Aboû 'l-Mahâsin Yoûsof ibn Râfí ibn Tamìm ibn Schaddâd. Le présent exemplaire a été copié sur le propre manuscrit de l'auteur, qui se fit lire la copie à deux reprises. La Vie de Saladin, publiée par A. Schultens, est du même auteur. Ms. daté de l'an 631 de l'hégire (1 233 1234 de J. C.).

Papier. 173 feuillets. Hauteur, 28 centimètres; largeur, so centimètres. 31 lignes par page. - (Supplément 31 2.)

\section{7.}

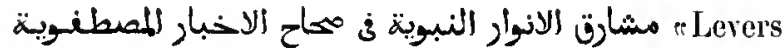
des lumières prophétiques, traitant des récits authentiques faits par l'Elu (Mahomet) $\pi$, recueil de traditions authentiques, classées dans un ordre qui permet de les trouver plus facilement, par Radhì al-Dìn Hasan ibn Mo-

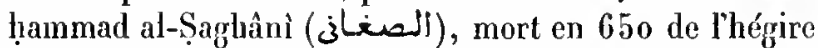
(1252-1253 de J. C.). Le copiste de ce ms. a omis la préface, dans laquelle l'auteur avait sans doute exposé son système de classification, dont Hadji Khalfa parle brièvement (t. V, p. 547). Nombreuses notes marginales. Ms. daté de l'an 979 de l'hégire $\left(157^{1-15} 7^{2}\right.$ de J. C.).

Papier. 154 feuillets. Hauteur, 22 centimètres; largeur, 16 centimètres. 15 lignes par page, à l'exception des premiers feuillets qui sont d'une autre main et portent 25 ligues par page. - (Ancien fonds 387.)

\section{8.}

Parterres des fleurs éclatantes, pour servir de commentaire an Mascháriq alAnwarn, traité composé en 611 de l'hégire, par 'Abd al-Latif ibn 'Abd al-'Azìz, surnommé Ibn al-Mâlik. Com-

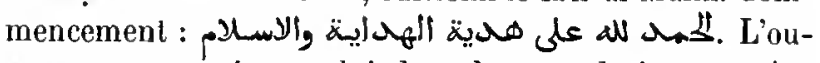
vage commenté est celui dont le second titre est على مكاح الاخبلار, et qui donne l'explication des telmes pen connus qui se rencontrent dans les trois principaux recueils de tradilions, celui de Mâlik, celui d'Al-Bokbârì et celui de Moslim, et a pour auteur le célèbre cadi Tyâdł (عيان) ibn Moûsâ al-Yạısobì, mort en 544 de l'hégire
(1149 de J. C.) '. Ms. daté de l'an 1038 de l'hégire ( 1628 de J. C.).

Papier. 299 feuillets. Hauteur, 27 centimètres et dem; largeur, 18 centimètres et demi. 23 lignes par page. - (Supplément 2010.)

\section{9.}

, Éclats des fleurs, pour servir de commentaire au Maschâriq al-Anwârn d'AlSaghânî, par 'Abd al-Lațîf ibn 'Abd al-'Azîz, surnommé lbn al-Mâlik. Ce volume avait été donné en waqf à la mosquée et au collége fondés près de Constantine par Sâlih Bey. L'acte de donation (fol. $1 \mathrm{r}^{0}$ ) porte la date de 1201 de l'hégire (1 $786-1787$ de J. C.).

Papier. 264 feuillets. Hauteur, 3o centimètres et demi; largeur, ${ }_{19}$ centimètres. 3o lignes par page. Ms. du xvmi siècle. - (Supplément 306 bis.)

\section{0.}

Encouragement et avertissement 7 , recueil de Iraditions formé par Zakî al-Dìn 'Abd al-'Azìn al-Mondsiri, mort en 656 de l'hégire (1259 de J. C.). Nous n'avons ici que le premier volume de l'ouvrage. Il y a plusieurs lacunes dans le corps dn volume.

Papier. 226 feuillets. Hauteur, 18 centimètres et demi; largeur, 14 centimètres. 17 lignes par page. Ms. du $x^{\circ}$ siècle. - (Ancien fonds $43_{2}$.)

\section{1.}

Le premier volume du الترغيب وألترهيسب d"Abd al'Azîim al-Mondsirì. Ms. daté de l'an 829 de l'hégire (1426 de J. C.).

Papier. 219 feuillets. Hauteur, 25 centimètres; largeur, 15 centimètres. 25 lignes par page. - (Supplement 307, Saint-Germain 86.)

\section{2.}

كت التب التيسير : La seconde partie d'un ouvrage intitulé Livre qui rend facile et qui aplanit n, et qui est

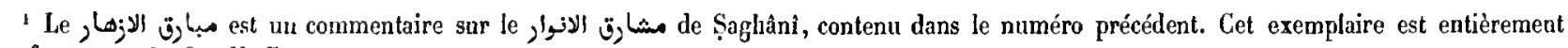
conforme au $\mathrm{n}^{\circ} 739$. H. Z. 
un abrégé du التترغيب والتتـوهـيـبـ d"Abd al-'Azîm alNondsirì. L'auteur se nommait Hoḥammad ibn 'Ammâr al-Mâlikì. Ce volume, qui est autographe, commence par te chapitre du jeûne et finit par celui des louanges et de linvocation, الذكر,

Papier. 133 feuillets. Hauteur, 16 centimètres; largeur, 12 centimètres. 17 lignes par page. Ms. du XIV ou du xv siècle. - (Supplément 308 , Saint-Germain 392.)

\section{3.}

$1^{\circ}$ Extrait du thes Jardins des hommes vertueux", recueil de traditions formé par Aboû Zakarìyâ Yalıyâ ibu Scharaf al-Nawawì, docteur schaféite, de Damas.

$2^{\circ}\left(\right.$ Fol. $174 r^{\circ}$ ) $)$ Histoire extraordinaire, tirée du

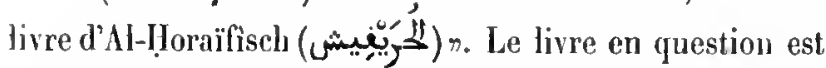
un recueil de discours et d'listoires édifiantes, intitulé الموض النائق

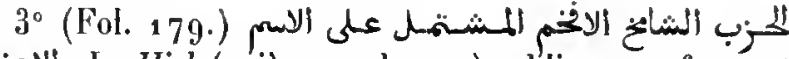

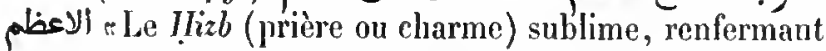
le grand nom de Dieun, par Karim al-Dín Aboû '1-Ba-

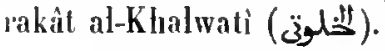

$4^{\circ}$ (Fol. $188 v^{\circ}$.) Le Hirb de Sidi Noḷammad alHlanafi.

$5^{\circ}$ (Kol. ${ }_{9}^{5} v^{\circ}$.) Le ḷizb de l’imåm Al-Schafiei.

$6^{\circ}\left(\right.$ Fol. $19^{8}$ v $^{\circ}$.) Prière d'Aboû ']- $-^{\circ}$ Abbâs al-Boủni, servant de préservatif contre les gónies et les démons.

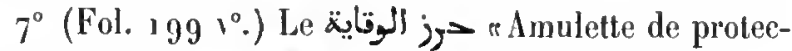
tion n, composé par Moḷyî al-Dîn ibu al-'Arahî al-Ḥâtimi.

$8^{\circ}$ (Fol. 204.) sluclavocation par laquelle on fait périr ses enmemisn.

$9^{\circ}\left(\right.$ Fol. 204 $v^{\circ}$ ) ( Charme pour vaincren,

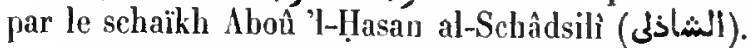

$10^{\circ}\left(F_{0} .207 v^{\circ}.\right)$ Prière à réciter le matin (ئد (يقرا عند ألصباح (10).

$11^{\circ}$ (Fol. $209 v^{\circ}$.) Autres prières et renseignements utiles (نوأئا).

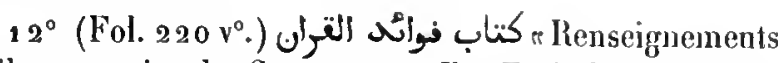
utiles au sujet du Coran", par Ihn Farischta. Dans ce petit traité on donne le nombre des mots et des lettres de chaque sourate du Coran, ainsi que les traditions où sont indiquées les vertus de chaque sourate.
${ }_{1}^{\circ}$ (Fol. 271.) Autres prières et invocations.

$14^{\circ}$ (Fol. $\left.286 r^{\circ}.\right)$ Qaṣida mystique, intitulée "Qui délirre des soucis", poëme dans lequel se trouve, dit-on, le grand nom de Dieu. (Voyez le Dictiounaire bibliographique de Hadji Khalfa, t. IV, p. 551.)

$15^{\circ}$ (Fol. 289.) La Qașida du faquir Aḷmad al-Khâmì (ى).

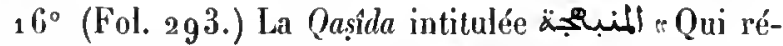
jouit n, poëne mystique de Sidì Moṣtafâ al-Bakrì.

$17^{\circ}\left(\right.$ Fol. $297 \mathbf{v}^{\circ}$.) Charmes et recettes talismaniques.

Papier. 301 feuillets. Hauteur, 22 centimètres; largeur, 15 centimètres et demi. 10 et 11 lignes par page. Ms. du xvin' siècle. (Supplément 233.)

\section{4.}

$1^{\circ}$ Arba în (Quarante traditions), rédigé par Yalıyâ ibn Scharaf al-Nawawî. L'auteur dit quili a achevé cet ourrage en 668 de l'bégire (1269-i $27^{\circ}$ de J. C.).

$2^{\circ}$ (Fol. 17. 7. Prières à réciter dans les malheurs et les afllictionss, par le même auteur.

$3^{\circ}$ (Fol. 28.) Arba in, au sujet des vertus de la sourate du Coran, inlitulée الاخخلام, par Yoùsof ilon "Abd Allâh al-Ḥosaïn al-Ormiyoûnî (الإميونغ), docteur schaféite.

$4^{\circ}$ (Fol. $37 v^{\circ}{ }^{\circ}$ ) Arbain au sujet du verset du trône, par le même auteur. Les traditions, au nombre de quarante et une, sont suivies d'un commentaire sur ce verset et de quelques paroles des docteurs sur le même sujet. L'auteur expose ensuite les vertus mystérieuses de ce verset (fol. 49 ), et termine sa notice par un extrait du لنمس المعارن d'Aboû 'l-'Abbàs Aḷmad al-Boûní.

$5^{\circ}$ (Fol. $51^{\circ}$.) Arba in sur les mérites de Mahomet, l'enroyé de Dieu, par le mênie auteur.

$6^{\circ}$ (Fol. 6o.) Arba in sur les mérites du pèlerinage et de l'omra, ou visite de la Ville Sainte, par Wali al-Din al-Bașîr bi 'Aini Qalbihi (l'ami de la religion, qui voit avec l'œil de son cœur). Un court chapitre, sous forme de khatima (conclusion), termine le recueil.

$7^{\circ}$ (Fol. $70 v^{\circ}$.) Commentaire de Khâlid ibn 'Abd Allah al-Azharì sur le Borda d'Al-Boûsînì. C'est un travail bien fait; le texte dı poëme est reproduit à l'encre rouge.

$8^{\circ}$ (Fol. 120.) Traité attribué à Aboû 'l-Fadhl ibn Ḥadjr al-`Asqaânîi, dans lequel ce docteur répond à vingt- 
neuf questions touchant l'état de l'àme après la mort du corps.

$9^{\circ}$ (Fol. $132 v^{\circ}$.) Traité anonyme sur les devoirs el les cérémonies du pèlerinage de la Mecque.

$10^{\circ}$ (Fol. 138.) Chronologie de la vie de Mahomet, tirée du تهذيب الاسمكاء d'Al-Nawawi, dont le texte a été publié par M. Wüstenfeld.

Papier. 139 feuillets. Hauteur, 20 centimètres; largeur, 15 centimètres. 15 à 2 I lignes par page. Mls. de diverses écritures du xvil' siècle. - (Ancien fonds 385. )

\section{5.}

r Commentaire sur les quarante traditions" d'Al-Nawawi. Le commeneement manque. Ms. daté de l'an 1054 de l'hégire (1644-1645 de J. C.).

Papier. 87 feuillets. Hauteur, 21 centimètres; largeur, 15 centimètres. 21 lignes par page. - (Supplément 2014.)

\section{6.}

$1^{\circ}$ L'Arba în d'Al-Nawawî, commenté par Mohammad ibn Ahmad at-Hauafi. Ce commentaire, composé en 812 de l'hégire (1409-1410 de J. C.), est, en général, philologique, mais il renferme aussi de courtes notices biographiques sur quelques savants. Commencement : :

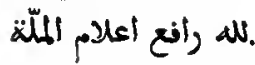

$2^{\circ}$ خ Cessation de l'inquiétude, commentaire sur la Manzoûma d'Ibn Farah". La Manzoûma, qui se compose de trente rers et contient une énumération des termes techniques employés dans la science des traditions, a pour auteur Schilıảb al-Dìn Ihn Farah, de Séville. L'auteur du commentaire, 'I $z z$ al-Dìn Moḷammad ibn Alumad ibn Djamấa, nourut en 817 de l'hégire (1414-1415 de J. C.). Ms. daté de l'an 1022 de l'hégire (1613 de J. C.).

Papier. 206 feuillets. Hauteur, 22 centimètres; largeur, 15 centimètres. 15 lignes par page. - (Ancien fonds $39^{3}$.)

\section{7.}

Commentaire sur l'Arba în d'Al-Nawawì, par Aboû 'l'Abbàs Aḷmad al-Lakhmì, fils du vizir Aboû Soroûr
Faradj ibn Aḥmad. Ms. daté de l'an 1068 de l'hégire (1657-1658 de J. C.).

Papier. 116 feuillets. Hauteur, so centimètres et demi; largeur, 15 centimètres. 25 lignes par page. - (Supplément 294.)

\section{8.}

$1^{\circ}$. Acquisition manifeste, commentaire sur l'Arbacinn d'Al-Nawawì, par Schihâb al-Dìn Aḷmad ibn Hadju al-Haïthamî. Cet ouvrage a été composé en 951 de l'hégire (1544-1545 de J. C.).

$2^{\circ}$ (Fol. $170 \mathrm{v}^{\circ}$.) Discours d'Aboû Ịâmid al-Ghazâlì, sur la uécessité de dompter ses passions.

$3^{\circ}$ (Fol. 171.) Fin d'un traité de morale, intitulé : Acquisilion facile des moyens d'existence n, par Djalàl al-Dìn al-Soyoûti.

La partie principale du ms. a été écrite en 1064 de l'hégire $(1673-1674$ de J. C. $)$.

Papier. 172 feuillets. Hauteur, 21 centimètres; largeur, 15 centimètres. 33 lignes par page. - (Supptément 293. )

\section{9.}

- Explications concédées(?)n, par

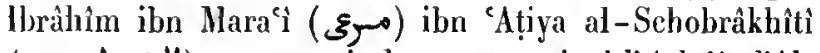
(النثبراخيتن), pour servir de commentaire à l'Arba'în d'AlNawawi. Au commencement de l'ouvrage se trouve une notice biographique de Yaḷyâ ilon Morî $(s, 0$ ) al-Nawawî, d'après laquelle il était né en 631 de l'hégire (1 233 1234 de J. C.), et mort en 676 de l'hégire (1 $277^{-12} 7^{8}$ de J. C.). Ms. daté de l'an 1161 de l'hégire (1 738 de J. C.).

Papier. a 58 feuillets. Hauteur, 22 centimètres el demi; largeur, 17 centimèlres. 25 lignes par page. - (Supplément 292.)

\section{0.}

" Les professeurs de Fakhr al-Dìn n, par Aboû 'l-Hasan 'Alì ibn Aḷmad, surnommé Fakhr alDìn, et généralement appelé Ibn al-Bokhârî. Cet auteur, natil de Jérusalem, appartenait à la secte hanbalite. D'après Hadji Khalfa (t. I, p. $29^{\circ}$, et t. V, p. 561), il mourut en 6 go de l'hégire (1291 de J. C.). Cet ourrage, que Hadji Khalfa mentionne sous le titre de أسنى اللـتاصد 
, أعذب ألموارد, est un recueil de traditions, classées sous les noms des professeurs qui les avaient transmises de vive yoix à l'auleur; il contient aussi de courtes notices biographiques sur la plupart de ces docteurs. 11 est divisé en vingl-trois sections; le nombre des docteurs cités est de soixante-deux, sans compter six femmes professeurs

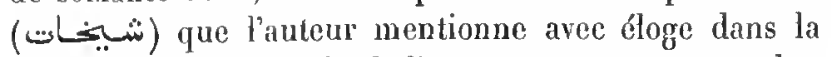
dernière section. A la fin de l'ouvrage se trouvent un chapitre supplémentaire, qui a été ajouté par l'éditeur, Djamât ał-Dîn Aḷmad ibn Moḥammad al-Ẓâhirì, et un second chapitre supplémentaire, par Aboû 'l-Ḥaddjâdj Yoûsol ibn al-Mozakiì ( المز). Le ms. a été écrit au couvent des derviches, ì Syriảqoûs, près du Caire, en 837 de l'hégire (1433-1434 de J. C.).

Papier. 163 feuillets. Hauteur, 24 centimètres; largeur, 16 centimètres. 25 lignes par page. - (Ancien fonds $37^{6 .}$ )

\section{1.}

res rérités de la Sonna mises au jour $»$, ou commentaire critique du recueil de lradilions intitulé scos, par Al-Hosaïn ibn 'Abd Allah

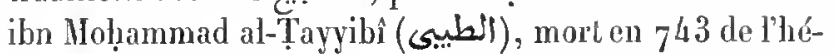
gire (1342-1343 de J. C.). Un faussaire a ćcrit, en tête

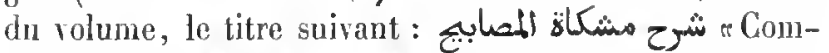
mentaire du Mischkat al-Masabihhn; il a aussi attéré le texte de la préface dans deux endroits, en y ajoutant te mot مسئنكاك. Cependant il n'y a rien dans la préface qui puisse faire supposer que l'ouvrage ait été composé en vue d'élucider le texte du Mischkât. Ce nom n'y est pas باب mentionné. Le dernier chapitre est intitulé مرينة

Papier. 322 feuillets. Hauteur, 27 centimètres; largeur, 18 centimètres. 31 lignes par .page. Hs. de diverses écritures du $x v 1^{\circ}$ siècle. - (Supplément 304.)

\section{2.}

La seconde moitié de l'ouvrage intitulé حتائنت اللمصابسيج, commençant par la section intitulée باب نتواب ك, كتـاب المبـيـوع هذه الإنهاب.

Papier. 530 feuillets. Hauteur, 22 centimètres; largeur, 16 centimètres. Les premières pages portent 31 lignes, les autres 25 . Ms. de diverses écritures do xvı" siècle. - (Supplément 305.)

\section{3.}

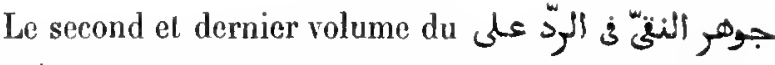
"La perle fine, pour servir de réfutation d'AlBaibaqìn, ou critique des deux recueils de traditions, le grand et le petit (المنى الكبيى والصغير), formés par AlBaihaqì (Aboù Bakr Aḥmad al-Khosroûdjerdì), mort en 458 de l'hégire (1 o66 de J: C.), par 'Alì ibn 'Othmân ibn al-Turkomânî, qui mit au net sa réfutation. en 747 de l'bégire (1346-1347 de J. C.). Au folio 2 on lit une notice biographique sur Loqmân, tirée du تهذيب الاسماء d'Al-Nawawì. Le folio 239 a dú faire partie d'un traité de droit; il y est question des conditions sous lesquelles les chrétiens peuvent conserver leurs églises. Ms. daté de l'an 801 de l'hégire (1398-1399 de J. C.).

Papier. ${ }_{2} 39$ feuillets. Hauteur, 26 rentinètres et demi; largeur, 16 centimètres et demi. 23 lignes par page. - (Ancien fonds 477.)

\section{4.}

S Traité en vers sur la science des traditions", par 'Abd al-Rahîm ibn al-Hosain alAthị̂̀ al-'Irâqì, accompagné d'un commentaire du même auteur. Hadji Khalfa en a parlé sous le titre de المغبّة

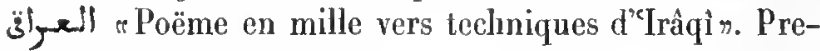
mier vers du poëme :

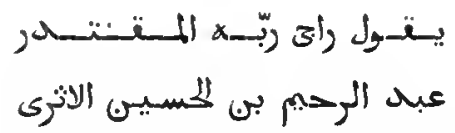

Premiers mots de la préface du commentaire : גم

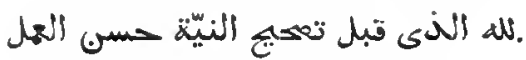

L'auteur dit avoir compose ce commentaire ell $77^{1}$ de l'hégire ( 1370 de J. C.).

Papier. 284 feuillets. Hauteur, 25 centimètres; largeur, 14 centimètres et demi. 19 lignes par page. Ms. du xvm" siècle. - (Supplément 2018.)

\section{5.}

Instruction pour l'élève et aide-mémoire pour le maitre \%. Traité sur la science 
des traditions, rédjgé en vers, par le docteur Zaïn alDìn 'Abd al-Rahị̂m al-'Irâqî '.

Papier. 38 feuitlets. Hauteur, 20 centimètres; largeur, 15 centimètres. 15 lignes par page. Ms. du xvm siècle. — (Supplément ø88.)

\section{6.}

Exposé de ce qui reste à faire pour l'ellucidation de l'Alfyya d'Al-'Sràqîn. Commentaire de Zakarìyâ ibn Moḷammad ibn Ạ̣mad al-Anṣârì, mort en 928 de l'hégire (1521-1522 de J. C.), sur l'Alfyya de Zaïn al-Dìn 'Abd al-Raḷim ibn al-Ḥosaïn al-`râqî. Ms. daté de l'an 1108 de l'hégire ( $1696-1697$ de J. C.).

Papier. 203 feuiltets. Hauteur, a 1 centimètres et demi; largeur, 15 centimètres. 19 lignes par page. - (Supplément 316 bis.)

\section{7.}

Un $A r b a^{e} i n$, ou recueil de.quarante traditions. La première commence par ces mots : cuvres se jugent d'après l'intention . Les trois dernières pages, qu'on avait laissées en blanc, portent maintenant des notes de diverses mains et de peu d'importance. $\Lambda$ la fin du volume on lit la note suivante, écrite en lettres كتبه المملوك تصروك مه خانسم مر : d'or sur un fond bleu طبتة الروى الكبوى

Papier. 38 feuillets. Hauteur, 27 centimètres; targeur, 18 centimètres. 7 lignes par page. Ms. du xiv siècte. - (Ancien fonds 350.)

\section{8.}

1. Le تنيبيد d'Ml-Sarrâdj al-Nafzi, recueil de traditions et de notices biographiques, par Yạ̣yì ibn Aḷmad ibn Mohammad al-Nafzì al-Ḥimyar'i al-Sarridj

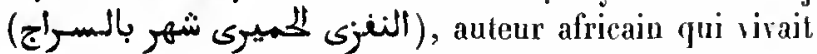
à la fin du vı" siècle de l'hégire. D’après la préface, cet ouvrage devait contenir cinq chapitres, savoir : 1. Sur limportance des traditions et des traditionnistes. 2. Sur les idjaza (أجاز) ou licences d'enseigner les traditions. 3. Sur les docteurs africains et espagnols desquels l'auteur avait appris des traditions et reçu des enseignements dans cette branche des connaissances. 4. Énumération des ouvrages que l'auteur avait étudiés sous ses professeurs. 5. Plusicurs séries d'autorités (isnad) servant à terminer l'ourrage. Les deux derniers chapitres manquent.

$2^{0}{ }^{2}$ rL'haleine des jardins et le repos de l'esprit», traité sur les mérites de la prière qu'on adresse à Dieu en faveur du prophète Mahomet, par Ibn al-Marì Moḷammad ibu Ibrảhìm al-Ma àfirì. L'auteur y a intercalé beaucoup de vers.

Ms. daté de l'an $9^{55}$ de l'hégire (1546-1547 de J. C.).

Papier. 170 feuillets. Ifauteur, 20 centimètres; largeur, 15 centimètres. 25 lignes par page dans le premier ouvrage, 23 lignes dans le second. - (Ancien fonds 38..)

\section{9.}

مur extrait de la l'éflexion, pour servir de commentaire ì l'ourrage intitulé : Résumé de la partie technique de la science des traditions», par 'Abd Allah ibn Moḷammad al-Schanschoùrì. Ce docteur avait composé le Résumé, en $79^{6}$ ( 1394 de J. C. ), pour l'usage de son fils, et l'a pubtié plus tard avec un commentaire perpétuel. Notre volume renferme le texte et le commentaire.

Papier. 82 feuillets. Hauteur, 21 centimètres; targeur, 15 centimètres. Le nombre de lignes par page va en diminuant, de 92 à 14 . Ms. du $x v^{\circ}$ siècte. - (Supplément 287 .)

\section{0.}

$1^{\circ}$ Le premier feuillet et les trois derniers d'un ouvrage intitulé : Choix de réllexions, traitant des locutions conventionnelles employées par les docteurs de la science des traditions $\pi$, par Schiluáb al-Din Aḷmad ibn 'Alî ibn Hadjr al- Asqalànì, mort en 852 de l'hégire (1448-1449 de J. C.). Copie datée de l'an 821 de l'hégire (1418 de J. C.).

$2^{\circ}$ (Fol. 5.) Dernière page d'une lettre contenant des conseils adressés à un jeune professeur, par Ahmad ibn Moḥammad ibn Yahyà ał-Bokhı̂̉rì.

كناب d'Aboû 'l-Qàsim al-Samarqandi. Ces extraits formaient plusieurs chapitres, dont chacun arait pour sujet une question de droit ou de morale. Nous n'en

${ }^{1}$ C'est te mème ourrage que le précédent, sans te commentaire. Le titre est de la main du copiste. H. Z. - ${ }^{2}$ Le ms. porte te sab. II. Z. 
arons ici que le premier, traitant de l'excellence de l'éludition et du mérite des savants, et le commencement du sccond.

$4^{\circ}$ (Fol. 23.) Fin d'un canlique attribué à un soufi appeté Moḷanmad ibn abì Bakr ibn al-Moftì al-Bokhârî;

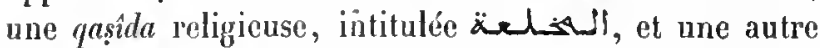
qaṣîla du unême genre, attribuée au schaïh Bahâ al-Dìn ibn Behâdur.

$5^{\circ}$ (Fol. $24 r^{\circ}$.) Traité de Hibat Allah ibn Salâma sur les versets du Coran qui abrogent ou qui sont abrogés

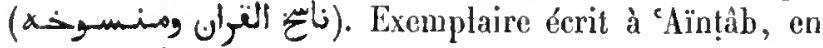
Syrie, en 853 de l'hégire (1449 de J. C.).

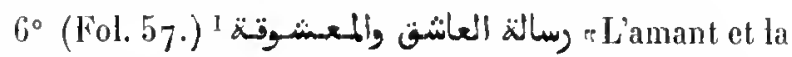
bien-aiméen, épitre dans laquelle un schaikh, nommé 'Alıd Altah ilon Mohammad Schâhaiwer (ثاهاور) al-Asadi, explique la parole d'un docteur nommé Aboû 'I-Hasan

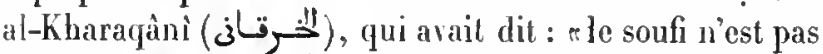

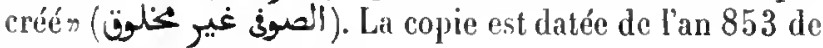
l'hégire ( 1449 de J. C.).

$7^{\circ}\left(\mathrm{Fol}_{\mathrm{o}} \mathrm{G}_{2}{ }^{\circ}\right.$.) Prière, suivie d'un wird (office à réciter), composé par un grand docteur soufi, nommé Zaïn al-Milla al-Khawafì (3ولخ

$8^{\circ}$ (Fol. 65.) Prière appelée d'une sorte de litanie.

$9^{\circ}$ (Fol. 67.) Réflexions morales et religieuses, divisées en trente-quatre cliapilres très-courts, appelés sourates, suivies de quelques traditions.

\section{$10^{\circ}$ (Fol. $\left.7^{3} \mathrm{r}^{\circ}.\right)$ Abrégé de jurisprudence.}

Papier. 82 feuillets. Hauteur, 18 centimètres; targeur, 13 centimètres et demi. 20 à 30 lignes par pagre. Ms. de diverses mains. (Ancien fonds 380.)

\section{1.}

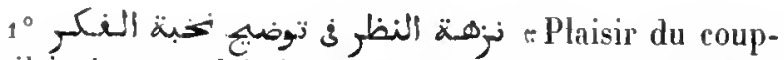
d'oeil jeté pour éclaircir le Nolhbat al-Figr s, par l'auteur même du traité original, Aḷmad ibn Hadjr al-'Asqalâni. (Voyez l'article $1^{\circ}$ du numéro précédent.) Commence-

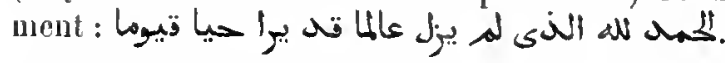

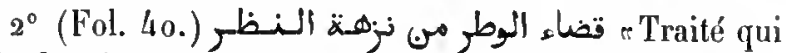
fait obtenir du Nozhat al-Nazr lout ce qui est nécessairen, commentaire très-étendu sur l'ouvrage précédent, par

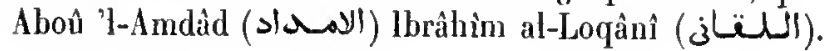

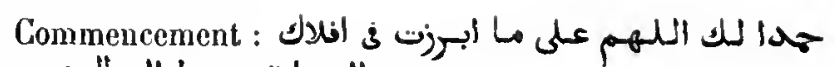

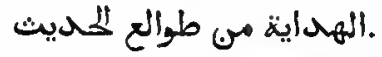

Papier. $3{ }_{9} 6$ fenillets. Hauteur, 20 centimètres et demi; largeur, 14 centimètres et demi. 20 à 23 lignes par page dans le premier traité, 21 lignes par page dans le second. Ms. du xvit" siècle. - (Supplément 2019 .)

\section{2 .}

$1^{\circ}$ Arbaîn, par Mohammad ibn Mohammad ibn Mol!ammad al-Djazarì (s)زب

$2^{\circ}$ (Fol. $3 r^{\circ}$.) Derniers conseits (وصيّة) adressés par l'imâm Aboû Hanîfa à ses disciples. Commencement :

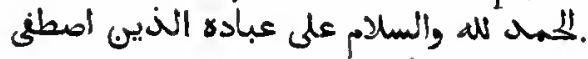

$3^{\circ}\left(\right.$ Fol. $6 v^{\circ}$.) Conseils spirituels adressés par un soufi aux jeunes gens qui reulent s'adonner à la vie dévote. Ce discours commence par les mots at. Hadji Khalfa mentionne cet opuscule sous le titre Conseils donnés à Jérusatem n, et nomme comme auteur Zaïn al-Din Abou Bakr Mohammad alKhawâfi, mort en 838 de l'hégire (1434-1435 de J. C.).

Ms. daté de l'an 882 de l'luégire (1477-1478 de J. C.).

Papier. 38 feuillets. Hauteur, 17 centimètres et demi; largeur, 13 centimètres. 15 lignes par page: - (Ancien fonds 386.)

\section{3.}

Recueil de traditions, sans titre, distribuées on cinq sections, dont la première, intitulée Introduction, traite de la croyance orthodoxe; la seconde, désignée comme le premier chapitre, a pour sujet l'excellence des tradilions sac̉rées; la troisième fait valoir le haut mérite des Iraditionnistes; la quatrième indique la nécessité de suive la sonna du Prophète, et la cinquième, intitulée Conclusion, renferme quelques traditions qui recommandent aux souverains musulmans la pratique de la justice. Ce traité a été rédigé à l'intention du sultan mamlouc Al-Mâlik al-Zâhir Djaqmaq, par un de ses serviteurs, nommé Hosaïn al-Fathị (1) al-Schîràzì.

A la fin du volume se troure, écrit d'une autre main, un sermon sur les mérites des trois premiers califes, qui avait été prononcé devant le calife 'Omar ibn 'Abd al'Aziz, par 'Abd Allah ibn Ahtam (ت̈هl).

Papier. 52 feuillets. Hauteur, 18 centimètres; largeur, 13 centimètres et demi. 7 lignes par page. Ms. du $\mathbf{x v}^{\mathrm{e}}$ siècle. - (Supplément 310 .)

\footnotetext{
1 Le ms. porte سالة المانثق اله المعشوق. H. Z.
} 


\section{4.}

Second volume d'un recueil de traditions. Chaque Iradition (le volume en renferme quatre-vingt-dix-neuf, à partir de la cent et unième) est suivie de réflexions morales et d'autres observations. Les feuillets du ms. ne se suivent pas dans leur ordre, et les derniers feuillets manquent. Les numéros des traditions sont écrits en loutes lettres, mais en plusieurs endroits ils sont allérés, pour faire croire qu'ils se suivaient régulièrement et que l'ouvrage était complet. L'auteur de celle fraude est probablement le même personnage qui a inscrit sur le recto dn premier feuillet, d'uue écriture très-mal formée, le titre

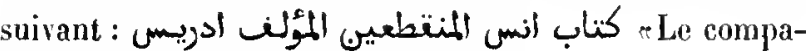
gnon des solitaires; l'auteur est Idrìs ».

Papier. 156 feuillets. Hauteur, 25 centimetres; largeur, 16 centimètres et demi. 11 lignes par page. Ns. du $x^{*}$ siècle. - (Supplément 309.)

\section{5 .}

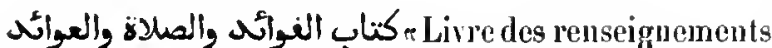
ulites, de la prière et des pratiquesn. C'est un mélange de traditions, de prières et d'indications talismaniques, divisées en cent clıapitres, par, Aboû 'l-llasan 'Alì al'Alawì. Selon Hadji Khalfa, cet ouvrage aurait pour' auteur Schihàb al-Dìn Aḷmad ibn Ahmad ibn'Abd al-Latị' al-Schardji (3ث) al-Zobaidi, mort en 898 de l'lógion (1492-1493 de J. G.). La fin manque.

Papier. ${ }_{157}$ feuillets. Hauteur, 21 centimètres; largeur, 15 cuntimètres. 15 lignes par page. Ns. du xwı siècle. - (Supplément 311.)

\section{6.}

Dernière parie du recueil de traditions intitulé : a Lí petile collection n, par Djalâl al-Din 'Abd al-Raḥmân al-Soyoûți. Les traditions sont énumérées dans l'ordre de l'alphabet, d'après le premier mot de chaque tradition. Ge volume commence

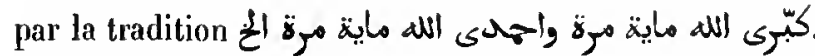
Nombreuses notes marginales. Ms. daté de l'an 1169 de l'hégire ( 1756 de J. C.).

Papier. 209 feuillets. Hauteur, 22 centimètres et demi; largeur, 16 centimètres. ${ }_{7} 7$ lignes par page. - (Supplément 2011.)

\section{7.}

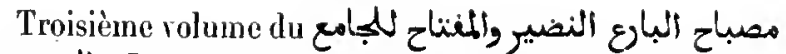
"Lampe Irauscendante et brillante, et clef du Djami al-Saghîr $\leadsto$, par Aḷmad ibn Mohammnad ibn Aḷmad al-Anșârì al-Matboûlì (المتبول). C'est un commentaire sur la Petite colleclion de traditions d'AI-Soyoúlí. Cel ouvrage a dô être très-volumineux, car le présent ms. ne renferme qu'une partic de la première lettre de l'alphabel. Hadji Khalla le mentionue sous le litre de sf الاستخد

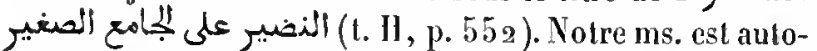

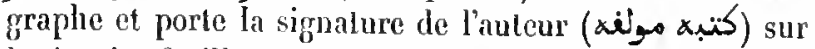
le dernier feuillet et ì la suite des nombreuses notes de collalion qui se trourent inscrites sur les marges du volume. Ms. dalé de l'an 1000 de l'hégire $\left({ }_{1} 5_{91}\right.$ de J. C. $)$.

Papier. 418 feuillets. Hauteur, 2a centimètres; largeur, 16 centimètres. 25 lignes par paģe. - (Supplément 315 bis.)

\section{8 et 769 .}

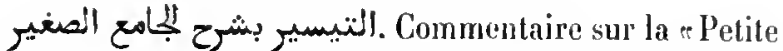
collection: d'Al-Soyoûti. C"est l'abrégé d'un commentaire beaucoup plus étendu, que l'auteur, 'Abd al-Raonf al-

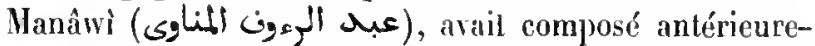
ment, et dont la longueur avait donné lieu à des plaintes. Il a suivi loordre alphabélique du Djamie al-Saghîr. Dans cot exemplaire, divisé en deux volumes, le texle est écrit à l'encre rougge. Le ms. est daté de l'an 1183 de l'hégire ( ${ }^{7} 69$ de J. C.).

2 volumes. Papier. 385 et 34 a feuillets. Hauteur, 26 centimètres et demi; largeur, 19 centimètres. 25 lignes par page. Ms. du xvm1 siècle. - (Supplément 315 ter.)

\section{$770 \div 772$.}

Le second, le troisième et le quatrième volume du commentaire de Scluams al-Din Mohammad al-'Alqami sur la "Petite collectionn de Soyouti. Les premiers feuillets du tome II et du tome IV manquent. Ms. daté de l'an 1020 de l'hégire (1611-1612 de J. C.).

3 volumes. Papier. $3_{2} 8,298$ et 287 feuillets. Hauteur, 30 centimètres et demi; largeur, 18 centimètres et demi. 32 a 35 lignes par page. Ms. du xrue siècle. - (Supplément 315.)

\section{3.}

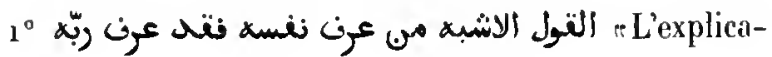


tion la plus prohable du sens de la tradition ainsi conçe : celui qui se connaît lui-même connaît Dieu n, par Djalâl al-Dìn 'Abd al-Raḷ̣mân al-Soyoụ̂ị.

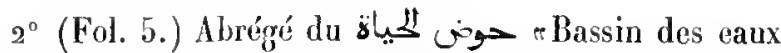
de la vie $»$, par Rokn al-Din Mlolammad al-Samarqandi. Ciest un traité en partie philosophique, en partie talismanique.

Papier. 26 feuillets. Hauteur, 15 centimètres et demi; largeur, 20 centimètres et demi. 17 lignes par page. Ms. du xvi siècle. (Ancien fonds 463.)

\section{4.}

En tête du volume se trouve une note, de la main de M. de Sacy, ainsi concue : "Ce uns. contient un grand nombre de morceaux de l'Alcorun, en arabe, ot beaucoup de prières et autres pièces écrites en espagnol mêlé de mots arabes, et en caraclère arabe africain. Quelquesunes de ces prières s'y trouvent dans les deux langues. Aux fol. 400 et suivants se trouvent diverses prophéties sur les malheurs et scandales qui doivent arriver en Espagne, dont quelques-unes, sont attribuées à S. Isidore. Ce ms. est imparfait au commencement; il commence au feuillet $114 . n$ (Il s'agit d'une ancienne cote au crayon.)

$1^{\circ}$ Traité sur les traditions de Mahomet, en espagnol mêlé de termes de la religion musulmane en arahe, le tout écrit en caractères arabes. Le commencement manque.

$2^{\circ}$ (Fol. $3_{7}$.) Prières musulmanes, partie en espagnol écrit en caractères arabes, partie en arabe.

- $3^{\circ}$ (Fol. 41.) Dialogue de quelques juifs avec Mahomet, en espaguol écrit en caractères arabes.

$4^{\circ}$ (Fol. 54.) Extrait d'un livre intitulé Libro Abisador llamado de los negligentes. En espagnol écril en caractères arahes. C'est le تنبيx الغانليه d'Aboù 'l-Lailh (أبو الليث) Naṣr ibu Mohammad, de Samarcande.

$5^{\circ}$ (Fol. 77.) Récit édifiant, en espagnol écrit en caractères alabes, suivi de quelques prières en arabe, attribuées à Aboû Moslim.

$6^{\circ}$ (Fol. 80.) Prières pour ểre récitées anx fètes indiquées par le calendrier musulman. En espagnol écrit en caractères arabes.

$7^{\circ}$ (Fol. 87.) Instructions aux musulmans, relalivement à la mort. En espagnol écrit en caractères arabes.

$8^{\circ}$ (Fol. 89.$)$ Extraits du Coran, en arabe. Les sourates les plus comrles sont données en entier. Quelquefois elles sont survies de gloses et de prières en espagnol. $9^{\circ}$ (Fol. 189.) Diverses traditions touchant Mahomet, la pricre et le jour du jugement dernier. Le cadre est un récit altribué à 'Omar. La fin manque.

$10^{\circ}$ (Fol. 255.) Prières diverses, en arabe, accompagnées d'une version espagnole écrite en caractères arabes.

$11^{\circ}$ (Fol. 264.) Histoire de Moise, en espagnol écrit en caractìres arabes.

$12^{\circ}$ (Fol. $288 \vee^{\circ}$.) Prophétie dans laquelle 'Alî ibn Djàbir al-Fàrâsî (على بى جابر الفنارإى) annonce ce qui doil arriver en Espagne et ailleurs. En espagnol écrit en caractères arabes.

$13^{\circ}$ (Fol. $293 v^{\circ}$.) Prophéties attribuées à S. Isidore $(?)$ ), شاك'اتُ (?irées de son livre intitulé Secreto de los secretos

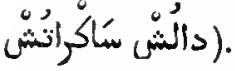

$14^{\circ}\left(\right.$ Fol. $308 v^{\circ}$.) Conférences de Moìse avec Dieu. Cet opuscule est divisé en plusieurs sections. A la fin on lit:

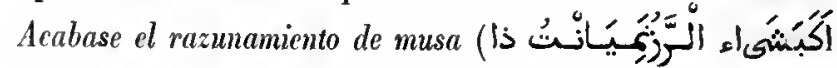
(مُ). En espagnol écrit en caractères arabes.

$15^{\circ}$ (Fol. $343 v^{\circ}$.) Prières pour diverses occasions. En espagnol écrit en caractères arabes.

Papier. 473 feuillets, en y comptaut huit feuitlets restés en blane. Hauteur, 19 centimètres; largeur, 14 centimètres. 9 à 13 lignes par page. Ms. du xvi siècle. — (Supplément 159 , Saint-Germain 208.)

\section{5.}

$1^{\circ}$ Quelques traditions de Mahomet, avec un commentaire en deux sections.

$2^{\circ}$ (Fol. 25.) Les quarante traditions de Jérusalem, التحديّة, recueillies par Moḷammad ibn Djamâl al-Dîn Aqsarâi.

$3^{\circ}$ (Fol. 34.) Petit recueil de traditions.

$4^{\circ}$ (Fol. 37.) Pièce de vers, en arabe, à la louange de la science.

$5^{\circ}$ (Fol. 42.) Petit recueil de traditions.

$6^{\circ}$ (Fol. 45.) Courte prière pour le sultan Murâd-Khân, fils d'Aḷmad-Khân.

$7^{\circ}$ (Fol. 46.) Fragments de diverses mains, les uns en prose, les autres en vers; quelques-uns sont en langue turque.

Papier. 56 fenillets. Hauteur, 21 centimètres; targeur, 14 centimètres. 5 à 23 lignes par page. Ms. de diverses écritures. - (Ancien fonds 285 .) 


\section{6.}

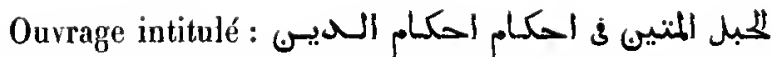
* La corde solide pour consolider les maximes de la religion». C'est un trailé dans lequel l'auteur, Bahà al-Dìn al-'Âmilì (lll), passe en revue les traditions qui servent d'appui aux maximes de la loi religieuse. Il a été composé dans la mosquée de Meschhed-'Alì, dans le Khorâsân, en 1007 de l'hégire ( ${ }_{1} 5_{9} 8-1599$ de J. C.). Ce volume n'est que le premier de l'ouvrage, et a pour sujet la prière et les purifications. Il a été copié sur l'autographe, en 1029 de l'hégìne (1620 de J. C.). Aux fol. 100 et suiv., l'auteur, en parlant des eaux dormantes dont on peut faire usage pour les purifications, donne un traité sur la mesure du volume des eaux, et l'accompagne de plusieurs figures géométriques. Commencement : لـ .

Papier. 226 feuillels. Hauteur, 26 centimètres; largeur, 13 centimètres. $z_{1}^{\prime}$ liggnes par page. Ms. du xv $u^{e}$ siècle. — (Ancien londs a 77.)

\section{7.}

Le بمن Thésor des vérités, renfermant les paroles de la meilleure des créatures》. L'auleur, 'Abd al-Raoûf al-Manâwî (عبد الزءون المناوى), y a rassemblé toutes les paroles de Mahomet qui se trouvent rapportées dans les divers recueils de traditions, et les a classées dans l'ordre de l'alphabet, en tenant seulement compte du premier mot de chaque parole ou maxime. Des sigles à l'encre rouge indiquent les sources d'où proviennent ces paroles. Un acte authentique, daté de l'an 1208 de l'hégire $\left(179^{3-1} 79^{4}\right.$ de J. C.), qu'on lit au fol. 2 , constate que ce volume avait été consacré comme waqf par Mohammad ibn Koudjek 'Ali, qui, nous te savons, était natif de la ville de Constantine.

Papier. 105 feuillets. Hauteur, 31 centimètres; largeur, 19 centimètres et demi. 25 lignes par page. Écriture à deux colonnes du xvil siècle. - (Supplément 303 bis.)

\section{8.}

$1^{\circ}$ Les vingl et une deruières tradilions d'un $A r b a^{c} \hat{i} n$.
$2^{\circ}\left(F_{0} 0.3 v^{\circ}.\right)$ Paroles et maximes attribuées à Mahomel.

Papier. 7 feuillets. Jlauteur, 14 centimètres et demi; largenr, 1 o centimètres ot demi. , 3 lignes par page. Ms. du xvı siècle. (Supplément 20013.)

\section{9.}

Recueil de traditions, commençant par un $A r b a^{e} i n$. Les premiers et les derniers feuillets manquent.

Papier. 65 feuillets. Hauteur, ao centimètres; largeur, 13 centimètres et demi. Ms. du $x v^{\circ}$ siècle. - (Supplément 2353.)

\section{0 .}

$1^{\circ}$ Les فرأئ ou Devoirs d'un musulman, traditions recueillies par le célébre ascète Al-Hasan al-Basrì, et classées, suivant les matières, en cinquante-quatre chapitres ${ }^{1}$.

$2^{\circ}\left(F_{0} .1 .15 \vee^{\circ}\right.$.) Cent paroles ou sentences, prononcées par Mahomet, et expliquées chacune par deux vers e॥ langue turque.

$3^{\circ}$ (Fol. $24 \mathrm{v}^{\circ}$.) Discours d'Anbâ-Yoûnos, évêque de Asyoût, sur le martyre de plusieurs chrétiens dans la ville d'Esné (أسنا) Il y est fait mention de la mort de S ${ }^{\text {te }}$ Dilàdjì et de ses qualre enfants. Copie datée de l'an 1236 des inartyrs ( 1520 de J. C. $)$.

Papier. 115 feuillets. Ifauteur, 21 centimètres; largeur, 14 centimètres. 12 et a 4 lignes par page. - (Ancien fonds 390 .)

\section{1.}

Traité sur l'excellence du mois de ramadhân. Cet ourrage, qui se compose d'un avant-propos et de quaranle et une tradilions, a pour auteur Moḥammad ibn abì Soroûr al-Șiddiquì, le même qui a composé un abrégé du Khitat d'Al-Haqrìzì. Commencement : تضغل الشرف عبادs.

Papier. 26 feuillets. Hauteur, ao centimètres et demi; largeur 15 centimètres. 13 lignes par page. Ms. du $8 v u^{\circ}$ siècle. - (Ancien fonds 44a.)

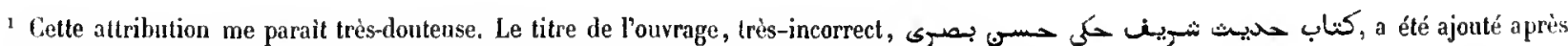
coup; il ne faut en tenir aucun compte. Hasan de Bașra est seulement cité dans la préface. H. Z.

Mas, onievtaux. -11 . 


\section{2.}

$1^{\circ}$ Lidrba in do llohammad ibn abì Bakr.

$2^{\circ}$ (Fol. 64.) Extrait du رون d'Al-Horaifisch, dans lequel est racontée la conversion de plusieurs moines espagnols à l'islamisme, par Boû-Medin (ابو أمدين), célèbre docteur musulman, natif de Tlemcen.

$3^{\circ}$ (Fol. 66.) Quelques observations sur la manière de faire la prière.

1" (Fol. 68.) l'oëme composé par Mohaunnad ibu So-

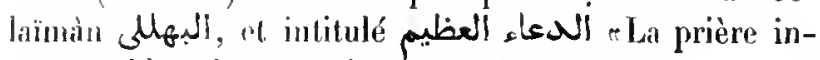
comparablen. Les preniers vers manquent.

Pa|jier. 69 fenillets. Hauteur, 19 centimètres; largeur, 13 centimètres et demi. 15 lignes par page. Ms. du svic siècle. - (Supptément 291.)

\section{3.}

La tradition intitulée "La Miséricordey, arec les isnâd qui la font remonter jusqu'anx premiers rapporteurs, par Aḷmad al-Djauharì. Voici le texte de

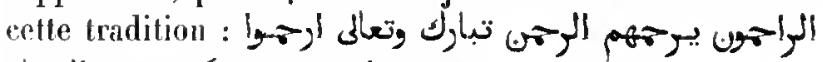

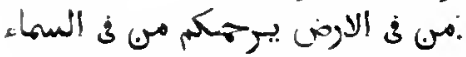

Papier. 8 feuillets. Hauteur, 16 centimètres; largeur, 11 centimètres. 9 lignes par page. Ms. du xvun" siècle. - (Supptément 314.)

IV.

\section{DROIT.}

\section{A. - PRINCIPES DU DROIT.}

\section{4.}

$1^{\circ}$ Ourrage, sans préface ni nom d'auteur, dans lequel sont exposés les principes d'après lesquels le légiste doit se guider diuns ses déductions. Le premier chapitre traite du terme rol ordre, commindement ; le dernier indique la significalion précise des particules de la limgue arabe (حرون المعان) . Le texte est accompigné d'un grand nombre de notes, les unes marginales on interlinéaires, les autres écrites sur des onglets. Ce traité sur la théorie de la jurisprudence est peut-être edui qui est altribué ì Mohammad ibn al-Ḥasan (al-Schaïbainì), el dont nous possédons un commentaire écrit par Aboù Bakr Moḷammadl al-Saraklsis. (Voyez le numéro suivant.)

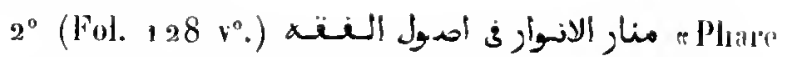
des lumières, traité sur les principes de la science du droil", par Aloou '1-Barakàt 'Abd Allàlı ibn Alumad alNasali, surnommé Hâfiz al-Dìn, mort en 710 de l'hégir' ( $1310-1311$ de J. C. ). Copie datée de l'an 754 de l'hégire (เ353-1354 de J. C.). Le folio 177 appartient is l'ourrage, bien qu'il soit séparé par un cahier d'une écriture plus inoderne.

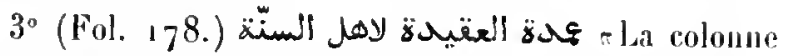
du dogme souniter, par Hạfiẓ al-Dìn 'Abd Allâh ihu Aḷmad at-Nasafí.

Papier. 191 feuitlets. Hauteur, 25 centimètres; largeur, 17 centimètres. 13 el 17 lignes par page. - (Ancien fonds 486 .)

\section{5 .}

Commentaire sur un ouvrage composé par Hoḷammad ibn al-ḷasan (al-Schaïbànî?), et qui traite de la théorie de la jurisprudeuce. (Voyez le numéro précédent.) Ce commentinire a pour auteur Aboû Bakr Mohanmad ibn ibì Sahl al-Saraklısí, qui dit l'avoir composé cu 499 de l'hégire ( $1105-11060$ de J. C.), dans la Transoxiane. Louباب (الاب

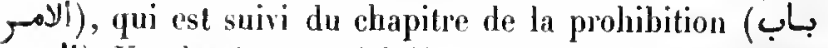
(النهنى (1). Un chapitre spécial (fol. $7^{0}$ ) traite des particules (i) ileo).

Papier, 179 feuillets. Hanteur, \& 7 centimètres; largeur, 16 centimètres et demi. 25 tignes par page. Ms. dn xv ${ }^{e}$ siècle. - (Ancien fonds 5०9.)

\section{6.}

Second volume d'un ouvrage de théologie scolastique, intitulé : كتاب الوصول اله مسائل ألاصول : Inlroduction à la connaissance des questions qui se rattachent aux principes (de la foi)n, par Aboù Ishâa Ibrähìm ibn 'Ali ibu Yoûsof al-Schîrâzi. Les derniers feuillets manquent. Le uns. conmence par le chapitre بيان لخبر وأثبات صيغته.

Papier. 169 feuillets. Hauteur, 25 centimètres et demi; largeur, 17 centimètres el demi. 21 lignes par page. Ms. du $x 1^{\circ}$ siècle. - ( $\mathrm{An}-$ cien fonds 359 .)

\section{7.}

Ourrage sans titre ni nom d'auteur, renfermant des notes sur des conférences tenues à Baghdâd, an Caire et ailleurs, el dins lesquelles plusieurs docleurs, les uns 
hanéfites, les autres sehaféites, malékites ou hanbalites, araient fait connaitre lenrs opinions sur différerts points de droit. L'auteur avait assisté à plusicurs de ces réunions. Il a inséré dans son ouvrage d'autres notes du mème genre, qu'il avait reeueillies dans ses lecture's, mais il n'a observé aucun ordre dans le elassement de ces pièces. Il se tronvait à Baghdàd, sous le règne du calife abbaside Al-Nostazhir Billah, entre les années 487 ot 511 de l'hégire ( 1094 à 1117 de J. C. ), et y rencontra le célìbre docteur schaféite Al-Kiyà al-Haràsì, qui y élait venu comme ambassadeur du sultan seldjouqide Barkyaroq. (Voyez les lol. 99, 159 et 206 .) Vls. daté de l'an 534 de l'hégire (1140 de J. C.). C'est done bien à tort qu'une main plus moderne a inscrit sur كناب كنش : le recto du premier leuillet le titre suivant ä-لji, qui est le titre d'nn onrrage sur les différences des quatre écoles de droil, par Al-Scha' ràni, auteur dn $\mathrm{xv} \mathbf{r}^{\circ}$ siecle.

Papier. 267 feuillets. Hauteur, a 6 centimètres; largenr, 17 centimètres. 20 lignes par page. - (Supplément 452.)

\section{8.}

Tableau synoplique des questions controversées\%, ouvrage composé en 563 de l'hégire (1167-1168 de J.C.), par Aboû Schodjấ Mohanmmad ibn 'Alì ibn Scho'aỉb, surnommé Ibn al-Dahlhân (ابر) C'est une série de tableaux, dans lesquel. sont exposés el discutés les points de jurisprudence sn lesquels les docteurs de l'école sehaféite sont cI désaecord avee ceux des trois autres. L'antenr élait lui-mème schaféite. Ces tableaux sont divisés en plusieurs colonnes. où se trouvent: $1^{\circ} \mathrm{la}$ question ; $2^{\circ} \mathrm{l}^{\prime}$ opinion schaféite; $3^{\circ} \mathrm{l}^{1} \mathrm{O}-$ pinion hanéfite; $4^{\circ}$ à $7^{\circ}$ les bases de ces opinions, sous le double rapport de l'autorité et de la raison; $8^{\circ} \mathrm{et} 9^{\circ}$ les opinions malékite et hanbalite; $10^{\circ}$ oloservations générales. Les questions sont classées en quatre sechions : celles qui concernent les devoirs religieux (ilsherell), celles des transactions eiviles (äloles), celles du mariag" (نكاح), et celles des crimes (جنايات). L'auteur y a joint nue introduction, dans laquelle il classe les letres de l'alphabet selon leurs sons et expose les éléments les plus simples de la grammaire et do la logique. A lia suite des tableaux, il a placé une liste des principaux Iraditionnistes et juriseonsulıes de lislanisme, au nombre d'environ huit cents. Ms, copié en 802 de l'hégire (1399-
1400 de J. C.), pour un haut personnage manlone.

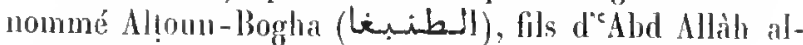
Asehyja (الانتشقى).

Papier. 89 feuillots. Hauteur, 42 centimètres; largeur, 30 centimètres et demi. - (Supplément 449 , Dueaurroy 13.)

\section{9.}

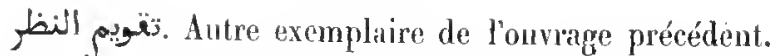
II est mienx éeril et porte la date de 1,65 de l'hégire (1654-1655 de J. C.). A la fin de l'ouvrage se trouvent quelques nołes sur le partage des suceessions ol un tableau général pour faciliter rette opéralion.

Papier. 1 1 3 feuillets. Hauteur, 43 centimètres el demi; largeur. 28 centimètres el demi. - (Supplément 45o.)

\section{0 .}

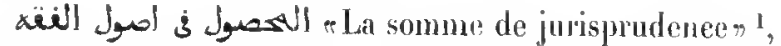
par Fakhr al-Din al-Rảzi (Molıammad ibn 'Omar). Cont-

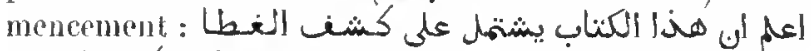
. Ms. daté de l'an 620 de l’hégive (1 29:3 de J. C.).

Papier. 153 feuillels. Hauleur, 1 ; centimètres; largeur, 12 centimètres el demi. 15 lignes par page. - (Ancien fonds 408.)

\section{1.}

r Rallermissement des bases des jugements r, par Sail al-1)in 'Ali ibn abì 'Ali al-ìmidi (الإم), mort en 631 de l'héginte (1 $233-1234$ de J. C.). Cet ouvrage, qui traile des principes de la jurisprudence schaféite, est détlí ì MI-Malik al-Mo a acam, sultan de Damas, qui réśnail de 615 à 694 de l'hŕgires (1218 ì 1227 de J. C.).

Papier. 28 g leuillets. Hanteur, 27 centimètres; largeur, 18 centimètres el demi. 29 lignes par page. Us. du $\mathrm{xp}^{\mathrm{e}}$ siècle. - (Ancien fords hat.)

\section{2.}

$1^{\circ}$ Traité anonyme sul les principes de la jurisporu-

'Le titre, lel qu'il se trouve dans le ms., est كتاب المعصول 3 عم الاصول. II. Z. 


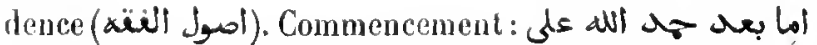
نواله. Beaucoup de notes marginales et interlinéaires. Le ms. est incomplet à la fin, ce qu'une note, ajoutée après coup (royez fol. $421^{\circ}$ ), était destinée à dissimuler.

$2^{\circ}$ (Fol. 43.) şoûran d'Ibn Doraïd, par Ibn Hischâm al-Lakhmî. Le commencement, l'explicalion des quatorze premiers vers, manque. Une note marginate (fol. $132 \mathrm{v}^{\circ}$ ) nous apprend que cet exemplaire a été collationné à Damas, en 685 de l'bégire (1 286 de J. C.).

$3^{\circ}$ (Fol. $133 v^{\circ}$.) Treize vers, dans lesquels Ibn Doraid indique les noms des parties du corps humain dont le genre est masculin et ceux dout le genre est féminin.

$4^{\circ}$ (Fol. $134 v^{\circ}$.) Pièce de cinquante vers, dans chacun desquels Ibn Doraid introduit un nom se terminant par un alif bref, et le même nonn se terminant par un alif long. Lauteur indique anssi le sens de chacun de ces mols.

Pupier. 137 feuillets. Hauteur, 25 centimètres; largeur, 17 centimètres et demi. 15 à 17 lignes par page. - (Ancien fonds 49o.)

\section{3.}

Le cinquiène volume du traité de jurisprudence intiluté r c'Extrême limite de la certitude, traitant des lraditions el des maximes de droit», par Mohibb ad-Dìn Aḷmad ibı 'Abd Allâh ibn Nohammad al-Ṭabarì, natif de la Hecque et mufti de celle ville. Le volume commence par la section de composition à l'amiable (flli), et finit par celle du droit de la

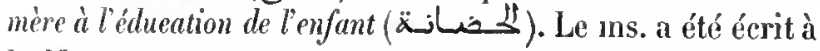
la Mecque, en 707 de l'hégire (1307-1308 de J. C.), du vivant de l'auteur. Écriture dépourve de points diacritiques.

Papier. 169 feuiltets. Hauteur, 26 centimètres; largeur, 19 centimètres. 33 lignes par page. - (Ancien fonds 485.)

\section{4.}

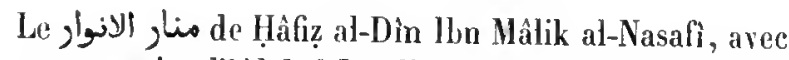
le commentaire d"Abd at-Latîf Farischta. Le commentaire

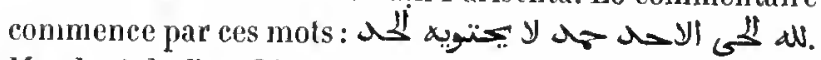
Ms. daté de l'an 846 de l'hégire (1442-1443 de J. C.).

Papier. 125 fenillels. Hauteur, 28 centimètres; largeur, 18 centimétres. 31 lignes par page. - (Ancien fonds 507.$)$

\section{5.}

Le commentaire d'Abd al-Lațif Farisclita sur le $M a-$ nâr al-Anwâr de ḷâfiz̨ a]-Dìn al-Nasafi. Le texte du Manâr est écrit à l'encre rouge. Le premier feuillet manque.

Papier. 217 feuillets. Hautenr, 22 centimètres el demi; largeur, 16 centimètres. 23 lignes par page. Ms. du xvm sièele. - (Supplément 375 .)

\section{- 796.}

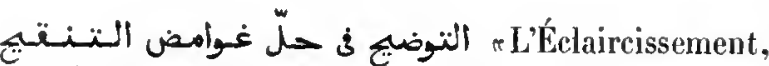
servant à résoudre les difficultés du Tanqîhn, commenlaire composé par Sadr al-Schari'a 'Obaïd Allah ibn Mascoûd ibn Tâdj al-Scharía (تاج النشريعة), pour élucider son propre ourrage. Bel exemplaire de l'an 1029 de l'lıégire ( $161_{9}$ de J. C.).

Papier. 200 feuillets. Hauteur, 21 centimètres; largeur, 13 centimètres. 21 lignes par page. - (Supplément 348, Saint-Germain 30n.)

\section{7.}

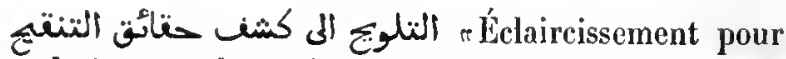
jeter du jour sur les vérités renfermées dans le Tanqih n, par Sa'd al-Dìn Mašoûd ibn 'Omar al-Taftâzânî. Cet ouvrage, qui est un commentaire complet du تنتيج الاصول de Şadr' al-Schari'a 'Obaïd Allah ibn Mas'oûd al-M̆all-

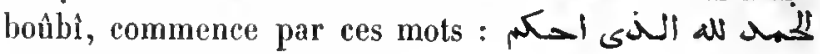
. . . . بكتابه اصول الشنوبعة الغّراء.

Papier. 338 feuillets. Hauteur, 23 centimètres el demi; largeur, is centimètres. 25 lignes par page. Ms. du xvire siècle. - (Supplément 349.)

\section{8.}

r Remaniement du texte du Tanqihn n, par lbn Kemâl-Pacha. Bel exemplaire de l'an 964 de l'hégire (1556-1557 de J. G.).

Papier. 205 feuillets. Hauteur, 29 centimètres; largeur, 16 centimètres. 19 lignes par page. - (Supplément 347 , Ducaurroy 16.)

\section{9.}

Commentaire de Sclıams al-Dln al-Iṣfahảni (Aboû 'lThanâ Mạ̣moûd ibn 'Abd al-Raḥmân) sur le traité de 


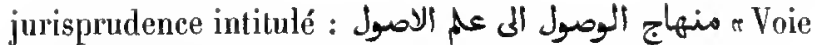
pour arriver à la connaissance des principes», par le cadi Nảsir al-Dîn 'Abd Allàh ilon 'Omar al-Baïdhâwi. Schams al-Dìn, mort en 749 de l'hégire, avait composé ce commentaire au Caire, en 734 de l'hégire (1333-1 334 de J. C.). Copie datée de l'an $77^{4}(1372-1373$ de J. C.).

Papier. 77 feuillets. Hauteur, 22 centimètres et demi; largeur, 16 centimètres. 29 lignes par page. - (Ancien fonds 528.)

\section{0.}

Commentaire de Schihàb al-Dîn Aḷmad ibn Hosaïn

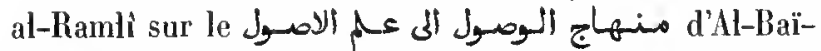
dhâwî. Il y a des lacunes considérables au commencement, au milieu et à la fin.

Papier. 114 feuillets. Hauteur, 3o centimètres et demi; largeur, 21 centimètres. 33 lignes par page. Ms. du xvir siècle. - (Supplément 2230.)

\section{1.}

Commentaire d'Adhod al-Dìn 'Abd at-Raḥınân al-Îdjî (الايجيسى), mort en $7^{56}$ de l'hégire (1355 de J. C.), sur le reتُ d'Aboû 'Amr 'Othmân ibn 'Omar, mort en 646 de l'hégire (1248-1249 de J. C.). Le Molhtaṣar est un abrégé, fait par l'auteur lui-même, du grand ouvrage de jurisprudence malékite, intitulé منتهى ألسؤال والامل, qui traite des principes et des topiques. L'ouvrage commence

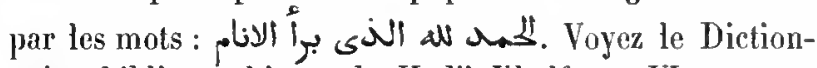
naire bibliographique de Hadji Khalfa, t. VI, p. 171. Ms. daté de l'an 1013 de l'hégire (1605 de J. C.). L'écriture des deux premières pages el des deux dernières est devenue presque illisible. Notes marginales.

Papier. 311 feuillets. Hanteur, 24 centimètres; largeur, 12 centimètres. so lignes par page. - (Supplément 406.)

\section{2 .}

éclaircissement», commentaire d'Amîr Kâtib ibn Amîr 'Onıar at-Itqânî (الاتنتانَ), mort en 758 de l'hégire ( 1357 de J. C.), sur le Hosâm at-Dîn Moḷammad al-Akhsîkatî (الاخسيكتن)), mort en 644 de l'hégire (1246-1247 de J. C.). Le Montakhab est un résumé des doctrines fondamentales de l'écołe hanéfite. Ms. daté de l'an $7^{6} 7$ de l'hégire (1365-1366 de J. C.).

Papier. 168 feuillets. Hauteur, 27 centimètres; largeur, 19 centimètres. 25 lignes par page. — (Supplément 324, Saint-Germain 80.)

\section{3.}

Le traité de jurisprudence schaféite intitulé "Collection de recueils n, parTâdj al-Dìn 'Abd al-Wahhâb

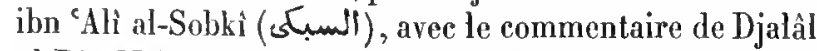
al-Dìn Moḥanmad ibn Aḷmad al-Mạ̣allî (ألى ). Beaucoup de notes marginales.

Papier. 224 feuillets. Hauteur, 22 centimètres; largeur, 15 centimètres. \&3 lignes par page. Ms. du xvü siècle.-(Supplément 436.)

\section{4.}

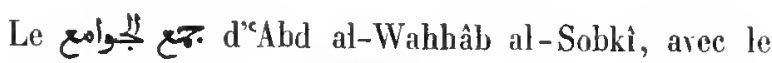
commentaire d'At-Mạ̣alli. Ms. daté de l'an 1129 de l'hégire ( $17^{17} 7$ de J. C.).

Papier. 302 feuillets. Hauteur, 21 centimètres; largeur, 15 centimètres. 19 liğnes par page. - (Supplément 435.)

\section{5 .}

Premier volume du الآيات البينات Signes manifestes \%, ou Explication du commentaire de Djalâl al-Dîn al-Mahallì sur le rocto par le schaikh al-Istàm Schiháb al-Dìn Aḷmad ibn Qâsim al-Ṣabbàgh al-'Ibâdi.

Papier. 637 feuillets. Hauteur, 22 centimètres; largeur, 16 centimètres. 21 lignnes par page. Ms. duxvm'siècle. - (Supplément 436 bis.)

\section{6.}

Premier volume des Gloses, حاشية, au par le schaikh 'Îsâ ibn Moḥammad al-Barâwì (البّأوى).

Papier. 380 feuillets. Hauteur, 22 centimètres; largeur, 16 centimètres. 19 lignes par page. Ms. du xvmiècle. —(Supplément 438 bis.)

\section{7.}

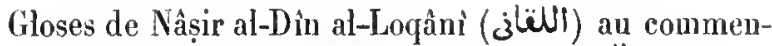
taire de Djatà al-Dîn al-Mạallì sur le co to

Papier. 145 feuillets. Hauteur, 24 centimètres; laryeur, 16 centimètres et demi. 21 lignes par page. Ms. du xwú siècle. - (Supplément 438.) 


\section{8.}

Hême ourrage que le unméro précédent.

Papier. 167 fenillets. Hauteur, 29 centimètres et demi ; Laryeur, 16 centimètres et demi. a ligues par page. Mts. du xrou" siècle. (Supplément 430 .)

\section{9 .}

$1^{\circ}$ Commentaine sur le le Moelle des principes $\%$, ou abrégé du wolume que deux leuillets dn prenier calier et le troisieme cahier en entier.

$2^{\circ}$ (Fol. 1 1.) Un fenillel contenant la fin du treizième chapitre el le commencement du quatorziene (نباب النكاح)

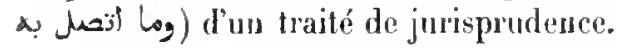

$3^{\circ}$ (Fol. 12.) Quelques feuillets d'un traité d'onirocrilie.

$4^{\circ}$ (Fol. 21.) Un feuiltet d'un traité cabalistique.

$5^{\circ}$ (Fol. 23.) lragments, de diverses mains, d'un Iraité sur les vertus secrètes des lettres de l'alphabet el sur les talismans.

$6^{\circ}$ (Fol. 3h.) Cahier détaché d'un commentaire sur uu traité de logique.

$7^{\circ}$ (Fol. 44.) Feuillets détachés diune collection de traditions. On y trouve des paroles de Mahomet sur les fonctions de cadi, sur le talion, sur le selment de discutpation (قسامة) ; sur les enfauts an berceau qui parlaient, sur les sept dormants, etc. Ios noms des Iraditionnistes sont inserits en marge.

8 (Fol. 5o.) Deux fenillels du d'Aboû 'l-Faradj Grégoire (Bar Hebræus), copjés par' un homme venu de l'Orient, pour (ugogourmont), professeur d'hébreu à Paris.

$9^{\circ}$ (Fol. $51 v^{\circ}$ ) Copie d'un acte authentique (ونيـنة $\ddot{0}$ : par lequel lo sultan othoman Aḷmad Khàn, fils du sultan Mohammad Khan al-Ghàzi, constitue en waqf pour des ceuvres pies un assez grand nombre d'inneubles situés en Egypte.

$10^{\circ}\left(F_{0} .60 v^{\circ}\right.$.) Commentaire perpétuel de Moḷammad al-Hanafi al-Tibrizî, mort vers l'an goo de l'hégire

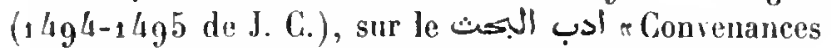
à observer dans les discussions\%, petil traité d'une dizaine de lignes, du célebre Adhod al-Dì al-Îdji. (Voyez la Bibliographie de Hadji Khalfa. I. J, p. q 10 ,
211.) La copie est datée de l'an 1108 de l'hégire $(1696$ de J. C.).

$11^{\circ}$ (Fol. 80.) Prenier fenillet d'un recueil de fahles, écrit de la main d'Asselin.

Papier. 8o feuillets. Ilauteur, a 3 cenlimètres et demi; largeur, 16 centimètres. Ms. de diverses écritures et de diverses époques. (Supplément во26.)

\section{0.}

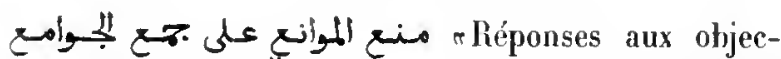
tions faites au rolo. de trente-deux, sont placées en lête de l'ouvrage. Suivent les réponses faites par le schaỉkh al-Islâm Aboû 'I-Naṣr 'Abd al-Wahbâb ibn 'Ali ibu 'Abd al-Kâfí al-Sobki, auteur du . Ms. daté de l'an 1179 de l'hégire (1 766 de J. C.).

Papier. 72 feuillets. Ilauteur, 23 centimètres; largeur, 16 centimètres. 23 lignes par page. - (Supplément 437.)

\section{1 .}

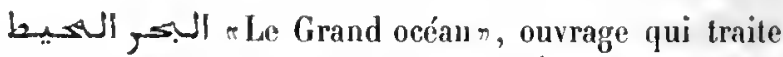

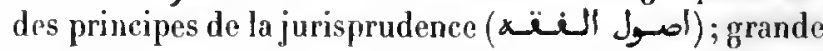
compilation, rédigée au Caire, en 777 de l'hégire (1375-1376 de J.C.), d'après les écrits, non-seulement des unusulmans orthodoxes, à commencer par ceux d'AlSchafi í, fondateur de la science, mais aussi d'après les livres des Zahirites (ألظاهـريس), des Motazélites et des Schiites. L'auteur est sans doute le célèbre docteur schaféite Badr al-Din Moḷammad ilon 'Abd Allah al-Zar-

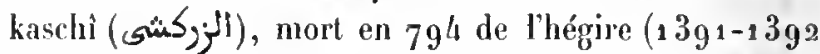
de J. C.). On remarque sur le frontispice un rond trèséléfyamment dessiné en or et en couleurs, renfermant une inscription persane en or, sur un fond azuré. Nous y li-

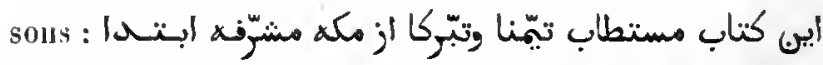

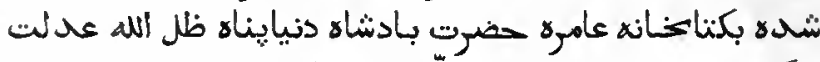

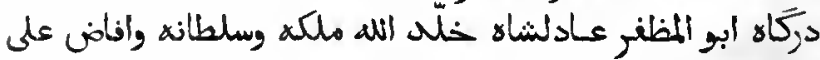

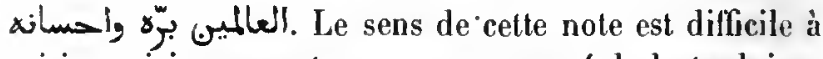
saisir; voici comment nous avons essayé de la traduire: -Ce livre précieux (envoyé) de la sainte ville de la Mecque, afin de porter bonlieur el bénédictions, ful commencé pour (êre mis dans) la riche bibliothèque de Sa Majesté, asile du nıonde, ombre de Dieu, siége de la justice, Aboû '1-Mozaffar Ẩdil-Schảh (roi juste); que Dieu éternise son règne et sa puissance, qu'il lui accorde de verser des faveurs et des 
bienfaits sur toutes les créatures. n Ces litres et attribuls sont ceux d'un souverain indien, et, en effet, à l'époque où la trauscription de cet exempłaire fut achevée (l’an 882 de J'héggire), un prince appeté Al-Moẓaffar régnait sur te pays de Guzerate. An-dessus de cette note, une main plus moderne a tracé asse\% grossièrement un certificat, daté de l'an 906 de l'hégice (1500 de J. C.), déclarant que Son Excellence le grand énir Ezbek ou Uzbek (أزبك) al-Hâlikì al-Makhdoủmì al-Saifi arait fait don (waqf) de ce volume à la mosquée (djamé) qu'il avait J'ondée dans le

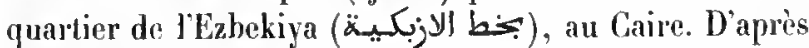
ces indications, on peut supjoser que notre ms., envoyé de la Necque à un prince indien, tomba plus tard entre les mains d'un émir égyptien, qui te doma à une mosquée dı Caire.

Papier. 37 o feuillets. Hauteur', 87 centimètres et demi; largeur, 18 centimètres. 35 lignes par page. - (Supplément 431.)

\section{2.}

$1^{\circ}$ Questions sur quelques points obscurs de la jurisprudence. Nous lisons dans la préface que l'auteur avait donné à son opuscule le titre peu intelligible de المسائل الغـزيسة ف الاحكام العزية Peut-être cette phrase a-t-elle été défigurée par un scribe, car Hadji Khalfa indique ce

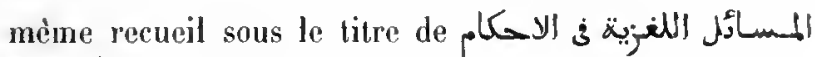
Q Quastiones anigmatica de statulis legalilus r.

$2^{\circ}$ (Fol. 12.) Commencement d'un sermon.

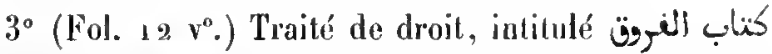
"Points sur lesquels les docteurs ne sont pas d'aceord $\eta$.

$4^{\circ}$ (Fol. $32{ }^{\circ}$.) Deux questions de jurisprudence avec. leur solution.

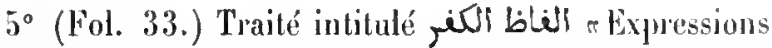
hérétiques $\%$. Il s'igit de certaines expressions dont se servent très-innocemment les gens peu instruits, et qui, étant prises ì la lettre, seraient contraires aux dogmes de la loi.

$6^{\circ}$ (Fol. 42 $\mathrm{v}^{\circ}$.) Abrégé de jurisprudence intitulé ä كوك Cadeau pour les princes", par Zaün al-Dìn Moḷammad ibn abì Bakr al-Râzì.

$7^{\circ}$ (Fol. 6g.) Fragment d'un connnentaire sur un traité de grammaire.

Ce nus. a élé exécuté entre les anuées 802 at 804 de l'hégire.

Papier. 69 feuillets. Hauteur, 20 centimètres; largeur, 13 centimètres. 21 lignes par page. - (Ancien fonds 57 '.)

\section{3.}

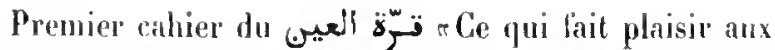
yeux", commenlaire de Mohanmad ibn Mobammad ihn 'Abd al-Rahmàu al-Khattảb, docteur sclaféite, sur les alenilles $\rightarrow$, trailé daus lequel l'Imàm al-llaranaïn al-Djowainj expose les principes du droit schaléite.

Papier. g fenillets. Hanteur, a centimètres et demi; largeur, ij centimètres et demi. 23 lignes par page. Ms. du xvin siècte. - (Supplément $2927 \cdot$ )

\section{4.}

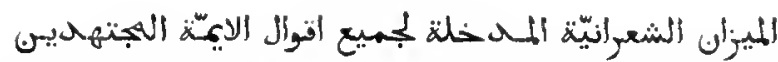
o La Balance de Schacràini, servant d'introduction ì la comnaissance des rloctrines énoncées par les imàm modjtahil et par leurs disciples, relativenient (aux questions qui se rattachent) ì la loi nualıométanen, par 'Abd al-Wahhàb al-Schacriui, lils d'Alımad ibn 'Ali, etc. Ce docteur mourut dans la dernièr' moitié du $x^{\mathrm{e}}$ sićcle de l'hégoire (entre 1543 et $15 g^{1}$ de J. C.). Le Mizan est consacré principalement à indiquer les points sur lesquels les légyistes des quatre écoles orthodoxes sont en désaccord. Dans ce traité, le not هيز est toujours considéré comme étant du gentro léminim. Ms. daté de l'an $99^{6}$ de l'bégire (1 588 de J. C.).

Papier. $25 \mathrm{j}$ feuiltets. Hauteur, 29 centimètres ct demi; largeur, 19 centimètres et deıni. 31 lignes par page. - (Ancien fonds 369 .)

\section{5.}

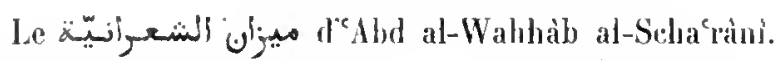
Exxmplaire daté de l'an $107^{5}$ de l'hégire (1664-1665 de J. C.).

Papier. 262 feuillets. Hauteur, ag centimètres; largeur, so centimètres. 31 lignes par page. - (Supplément 15.1.)

\section{6.}

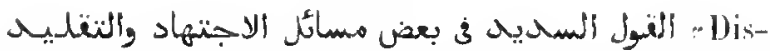
cours bien intentionné sur quelques questions se ratlachant au procédé des doctenrs qui jugent pour emx-mèmes et de ceux fui suivent lautorité d'un maitres, par le schaikh al-Islàm Mol!ammad (ibn) 'Abd al-Açim ibn 
Farrouklı, docteur hanéfite de la Mecque. Ourrage composé vers le inilieu du $x \mathbf{x i}^{\mathrm{e}}$ siecle. (Voyez fol. 7.)

Papier. 21 feuillets. Hauteur, a 1 centimètres et demi; largeur, 15 centimètres. 21 lignes par page. Ms. du xvil siècle. - (Supplément 265.$)$

\section{7}

Dissertation du schaikh Moḥammadal-Hafnâwi (كنإن) sur l'obligation de s'en tenir à la parole de l'imâm quand

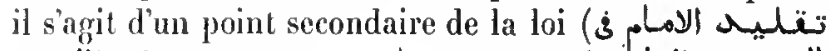

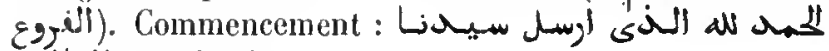
.

Papier. 3 feuillets. Hauteur, so centimètres; largeur, 15 centimè̀tres. Ms. du xvıı siècle. — (Supplément 2228.)

\section{8.}

La perle précieuse et l'abreuvoir d'eau puren, commentaire de Mayyâra (zَّئ) Moḷammad ibı abì '1-'Abbàs Aḷnad, sur le poëme d'Abd al-IVâhid ibn 'Ảschir, natif d'Espagne, intitulé ${ }^{-1}$

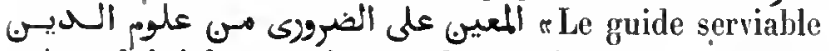
qui conduit à la connaissance de ce qui est essentiel dans les sciences religieuses $\pi$. Nous avons ici le texte du Morschid arec le commentaire. Premiers mots de la préface

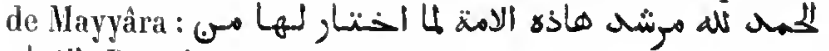
الإيملن. Premier's vers du poëne :

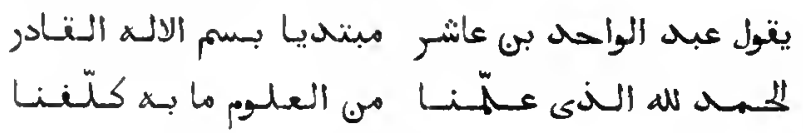

Ms. daté de l'an 1175 de l'hégire ( 1762 de J. C.).

Papier. 104 feuillets. Hauteur, 21 centimètres; largeur, 15 centimètres. 17 lignes par page. - (Supplément 2022.)

\section{9.}

Commentaire sur un pelit ouvrage qui traite des prinripes de la jurisprudence (أصول الغتعه), et spécialement de la doctrine de l'istişhâb et de l'idjtihâd. Le commencement manque. Ms. daté de l'an 1210 de l'hégire (1 796 de J. C.).

Papier, 53 feuillets. Hauteur, 23 centimètres; largeur, 15 centimètres et demi. 21 lignes par page. - (Supplément 2015.)

\section{B. - D ROIT SPÉCIAL.}

1. DROIT HANÉFITE.

\section{0.}

Rédaction poétique et commentaire en prose du grand traité de droit lıanéfite, intitulé recueil $r$, de Moḥammad ibn Ḥasan al-Schaibânì. L'auteur des vers et du commentaire est Aboû Nașr Aḷmad

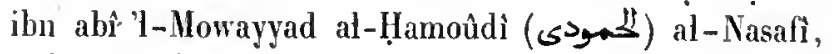
qui a terminé la rédaction de cet ouvrage en 515 de l'hégire (1121-1 122 de J. C.). Les vers de chaque chapilre ont tous la même rime, mais la rime varie d'un chapitre à un autre. Ms. daté de l'an 618 de l'hégire (1221 de J. G.).

Papier. 283 feuillets. Hauteur, 25 centimètres; largeur, 17 centimètres. 21 lignes par page. - (Ancien fonds 503.)

\section{1.}

بLe Petit recueils, abrégé de jurisprudence lıanéfite, par Mohammad ibn al-Hasan al-Scliaibânî, dans la rédaction de Ḥosâm al-Din 'Omar ibn 'Abd al-'Azîz al-Bokhârì, mort en 586 de l'bégire (1 $19^{\circ}$ de J. C.). Ms. daté de l'an 740 de l'hégire $(1339-1340$ de J. C.). Nombreuses notes marginales; les fevillets de garde sont chargés de notes relatives à différents points de droit, etc.

Papier. 194 feuillets. Hauteur, 24 centimètres; largeur, 15 centimètres. 15 lignes par page dans la première moitié du volume, 17 lignes daus la seconde. - (Aucien fonds 521.)

\section{2.}

Le جامع الصغير de Moḥammad al-Schaïbânî, dans la rédaction d"Omar ibn 'Abd al-'Aziz al-Bokhârì. Cet exemplaire paraît moins complet que le ${ }^{\circ}$ précédent. Ms. daté de l'an 1140 de l'hégire (1727-1723 de J. C.). Notes marginales.

Papier. 208 feuillets. Hauteur, 34 centimètres; largeur, 23 centimètres. 13 lignes par page. - (Supplément 378 .)

\section{3.}

juبl Rayonnement de la lune (ou de Badr)n, 
rédaction en vers du جامع الصغير, par Badr al-Dìn Aboû Naṣr Maḥmoûd ibn abì Bakr al-Farâhì (\$)_الع), qui a composé cet opuscule en 617 de l'hégire (1220-12.21 de J. C.). Les derniers feuillets manquent.

Papier. 44 feuillets. Hauteur, a2 centimètres; largeur, 15 centimètres et demi. 15 lignes par page. IIs. du xiv ${ }^{\circ}$ siècle. - (Supplément 379.)

\section{4.}

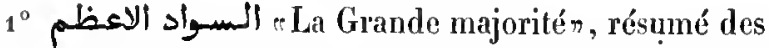
croyances des musulmans orthodoxes. Le ms. nomme comme auteur Aboû Hafs al-Kabìr, docteur du rile hanéfite; mais Hadji Khalfa nous appreud que ce traité n'est qu'un abrégé de l'ouvrage dans lequel le cadi hanéfite Aboû '1-Qâsim Ibrâhîm ibn Nohammad, surnommé Al-Hakim al-Samarqandi "le sage de Samareanden, mort en 342 de l'hégire (953-954 de J. C.), discute soixantedeux questions de droil.

$2^{\circ}$ (Fol. $51 v^{\circ}$.) Traité dans lequel l'imâm Aboû '1-

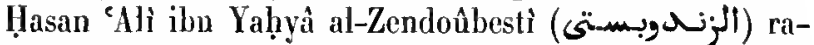
conte, sur l'autorilé d'un personnage qu'il désigne par le titre de jurisconsulte (ألفتيه), de quelle manière la sagesse divine s'est manifestée dans certains faits de l'Ancien Testament, de la vie de Mahomel et de l'histoire naturelle. La fin manque.

$3^{\circ}$ (Fol. 61.) Troisième, qualrième et cinquième cahiers d'un commentaire sur un traité de jurisprudence, par un docteur désigné dans la suseription par les noms et titres de schaikh, imam, Kamâl al-Din (JكالJ) IIandân (U大). Le Moltaqd'l-Bahrain est cité dans ce commentaire. Ms. daté de l'an 1009 de l'hégire (1600-1601 de J. G.).

Papier. 84 feuillets. Hauteur, 23 centimètres; largenr, 15 centimètres et demi. 19 lignes par page. - (Supplément 38ョ.)

\section{5 .}

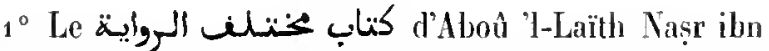
Mohammad al-Samarqandì. Dans cet ouvrage, l'auteur rapporte, classés dans l'ordre des matières, les divers points de doctrine sur lesquuels les jurisconsultes de l'école hanéfite ne s'accordaient pas avec leur maittre. On lit à la fin que la copie a été acherée en 591 de l'hógire $\left(\begin{array}{l}1 \\ 195\end{array}\right.$ de J. C.), dans le collége que le prince seldjouqide Mirânschâh, fils de Qàwerd (قاو)

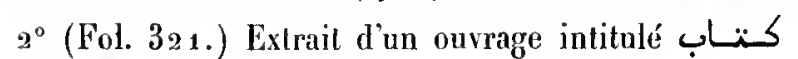
Max. orientalx. -1$\}$. dolic (sic). On y trouve quelques questions de droil aver leur solulion.

3 (Fol. 322.) ألاعتقاد الكاسان. Profession de foi musulmane, par Aboû Bakr ibn Maśoud ihn Aḷmad al-Kâsânî.

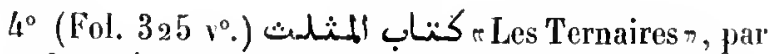
Qoṭrob (تطبرب) ibn Aḷmad le grammairien. C'est un Iraité sur les mots de la langue arabe dont le sens change selon les voyelles qu'on ajoute à la première lettre radicale. Nous n'avons ici qu'une parlie du traité.

$5^{\circ}$ (Fol. 327.) Trois queslions de droit avec leur solution. La première est en langue persane.

$6^{\circ}$ (Fol. $3{ }_{3} 8$.) Questions relatives au partage des successions, avec leur.solution au moyen de l'algère.

Les articles $2^{\circ}$ à $6^{\circ}$ sont de la même main que l'article $1^{\circ}$.

Papier. 339 feuillets. Hauteur, 25 centimètres et demi; largeur, 17 centimètres. 23 lignes par page. - (Supplément 340, Saint-Germain 8o.)

\section{6.}

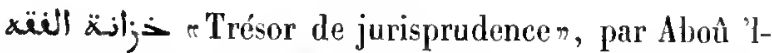
Laïth al-Samarqandi. Ms. daté de l’an 1152 de l'hégiro ( 1740 de J. C.).

Papier. $9_{1}$ feuillets. Hauteur, 22 centimètres et demi; largeur, 16 centimètres. 19 lignes par page. - (Supplément 381.)

\section{7.}

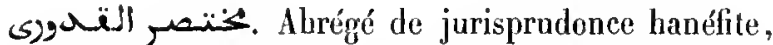
par Al-Qodoû́rì. Cet exemplaire commence, ainsi que lons les aulres manuscrits du Molihtasar appartenant ì la $\mathrm{Bi}-$ bliothèque, par le titre de la première section, tandis que l'exemplaire cité par Hadji Khalfa portait une préface.

Papier. 165 feuillets. Hauteur, 26 centimètres et demi; largeur, 18 centimètres. 13 lignes par page. Ms. du $x^{\circ}$ siècle. - (Supplóment 336 .

\section{8.}

$1^{\circ}$ Le Mokhtașar d'Al-Qodoûrì. Copie datée de lan $89^{2}$ de l'hégire ( 1487 de J. C.).

$2^{\circ}$ (Fol. $16_{7} v^{\circ}$. Chapitre sur les 
conditions à remplir pour la validité de la prièren. Copie datée de l'an 980 de l'hégrire ( 1572 de J. C.).

En tête du volume se trouvent, outre une note sur l'ourrage d'Al-Qodoûrì, đuelques prières, dont une est suivie d'un commenlaire d'une écriture différente, puis neuf pages de commenlaires sur la prière appelée sc التنتوت- Trois feuillels, insérés avec quelques onglets entre le Mohhtasar et le Bâb al-Schoroût, contiennent des gloses et des notes peu importantes, les unes en arabe, les autres enl lure.

Papier. ${ }_{1} 6$ feuillets. thauteur, 21 centimètres; largeur, 1/1 centimèlres el demi. Dans la première partie, 11 lignes, dans la seconde, 9 lignes par page. - (Ancien fonds 530.)

\section{9 .}

Le. Mokhtașar d'Al-Qodoüri. Exemplaire daté de l'an 932 de l'hégire (1525-1526 de J. C.).

Papier. 93 feuillets. Hautenr, 21 centimètres; largeur, I 4 centimètres. 15 lignes par page. - (Supplément 337.)

\section{0.}

$1^{\circ}$ Le Mokhtașar d'At-Qodoùrì. Copie datée de l'an 994 de l'hégire (1586 de J. C.). Le premier feuillet manque.

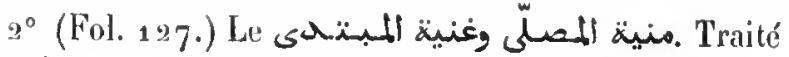
complet sur la prière, par Sadid al-Dìn al-Kâschghari.

Papier. 193 lenillets. Hauteul, 3 I centimètres et demi; largeur, 15 centimètres et demi. Dans la première partie, 1 a lignes par page, dans la seconde, 13 lignes par page. - (Supplément 1873.)

\section{1.}

Le Mokhtasar d'Al-Qodoûri. Exemplaire daté de l'an 1036 de l'hégire (1626-1627 de J. C.).

Papier. 153 feuillets. Hauteur, 13 centimètres; largeur, 7 centimètres et demi. 17 lignes par page. —- (Supplément 338.)

\section{2.}

Le Mokhtuşar d'A1-Qodoûrî. Notes marginales et interlinéaires.

Papier. 1 a 7 feuillets. Hauteur, 21 centimètres; largeur, 14 centimètres el demi. 13 lignes par page. Ms. du xr1 siècle. - (Supplément 333 , Saint-Germain 331.)

\section{3.}

1. Le Mokhtaşar d'Al-Qodoûri. Exemplaire daté de l'an 1090 de l'hégire (1679 de J. C.).

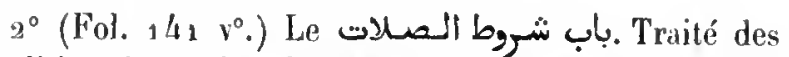
conditions à remplir afin d'assurer la validité de la prière. Dans cette copie, le titre est écrit šlll (sic) نتهوت.

Papier. 143 feuillets. Ilauteur, 21 centimètres; largeur, 14 centrimètres. 15 lignes par page. - (Supplément 334, Saint-Germain 304.)

\section{4.}

Troisième et dernier volume du commentaire sur le Mokhtaşar d'Al-Qodoûri, par Aḷmad ilon Hohammad ibu Djafar al-Baghdadi, surnommé الاتطع a le manchot». Le

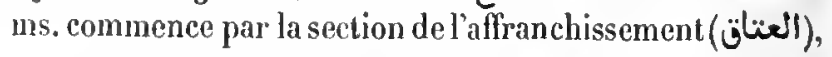
et finit par celle des successions (ألفِرأض). La copie est datée de l'an 611 de l'hégire (1214-1215 de J. C.).

Papier. 265 feuillets. Hauteur, 22 centimètres; largeur, 14 centimètres. 19 lignes par page. - (Supptément 339.)

\section{5.}

"Le Joyau brillant n, commentaire du Mokhtaşar d'Al-Qodoùri, par le schaikh et imâm Aboù 'lHosaïn. Selon Hadji Khalfa, l'auteur de cet ouvrage se nommait Aboû Bakr ibn 'Ali al-lladdàdi (s)lall'). C'om-

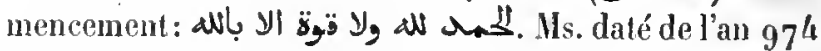
de l'hégire (1566-1567 de J. C.). Quelques notes marginales. En tête du volume se trouvent plusieurs questions de droit avec leurs solutions.

Papier. 300 feuillets. Hauteur, 28 centimètres el demi; largeur, so centimètres. 33 lignes par page. - (Ancien fonds 502.)

\section{6.}

Les اصول المزدوى. Ouvrage qui traite des principes de la jurisprudence hanéfite, par l'imâm 'Alì ibn Mohammad al-Pezdewi, mort en 482 de l'hégire $(1089-1090$ de 
J. G.). Ms. daté de l'an 651 de l'hégire (1253-1254 de J. C.).

Papier. 200 feuillets. Hauteur, 18 centimètres et demi; Jargeur, 14 centimètres ot demi. 19 lignes par page. - (Ancien fonds 527.)

\section{7 et 838 .}

r Grand traité des lois de la guerren, par Al-Sarakhsî (المسرخسى). C'est un commentaire sur l'ouvrage composé sur le même sujet par Moḥammad ibn alHasan al-Schaïbânî. Al-Sarakhisì (Aboû Bakr Moḥammad ibn abî Sahl) termina la rédaction de son ouvrage en 480 de l'hégire (1087-1088 de J. C.). Dans la préface, il raconte pour quel motif Al-Schaibånì, disciple d'Aboû Hanifa, s'était abstenu de citer l'autorité de son condisciple, le célèbre jurisconsulte Aboû Yoûsof. En tête du volume se trouvent une liste des chapitres et quelques notes, parmi lesquelles on remarque trois courtes notices biographiques sur A1-Sarakhsî. Cet exemplaire, daté de l'an 864 de l'hégire (1459-1460 de J. C.), a été écrit pour la bibliothèque du sultan Mohammad ibn 'Othmân, con. quérant de Coustantinople. 11 est de diverses mains. Chaque volume a un frontispice, orné d'arabesques, portant le titre en lettres blanches, sur un fond d'or et de couleurs.

2 volumes. Papier. 248 et ${ }_{7} 73$ feuillets. Hauteur, ${ }_{2} 6$ centimètres et demi ; largeur, 17 centimètres et demi. 25 lignes par page. - (Supplément 380.)

\section{9.}

e Supplément aux collections des décisions juridiques $\%$. Une note, inscrite sur le dernier feuillet, donnie à l'ouvrage le titre de r. Petite collection de décisions n, el nomme comme auteur 110sâm (حسام), c'est-à-dire Hlosâm al-Dìn. Lourrage n'a pas de préface et commence immédiatement par le chipitre des purifications (كتاب الططهارات).

Papier. ${ }_{232}$ feuillets. Hauteur, 28 centimètres; largeur, 18 centimètres. 33 lignes par page. Ms. du xıve siècle. - (Ancien fonds 492.)

\section{0.}

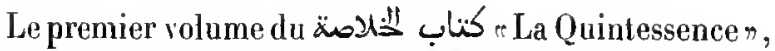
renfermant une coliection de décisions juridiques, disposées dans l'ordre des matières. Co volume devait se ter- miner par le chapitre du change des monnaies (الصرن), mais les derniers feuillets manquent. L'auteur, Ṭ̂luir iłn Aḅmad ibn 'Abd al-Raschîd' al-Bokhârî, mourut en 542 de l'hégire (1147-1148 de J. C.). Louvrage, au dire de Hadji Khalfa, porte aussi le titre de خلاصسة اللغـتساوى, et forme un seul volume; unais, sur ce dernier point, Hadji-Khalfa s'est évidemment trompé, car le présent exemplaire ne renferme, comme l'indique la table des matières, que le quart de l'ourrage.

Papier. 329 feuillets. Hanteur, 26 centimètres; largeur, 18 centimètres et demi. 23 lignes par page. Ns. du $x v^{e}$ sièele. - (Supplément 37 4.)

\section{1.}

مDécisions tirées des principes (de la science) et classées par chapitres". Commencement : وباسمه بينئك كل كن كناب. Le nom de l'auteur est inconnu. Ce volume renferme vingt-huit cliapitres sur quarante, et le commencement du vingt-neuvième. Les derniers feuillets manquent.

Papier. 181 feuillets. Hauteur, 30 centimètres; largeur, 19 centimètres. 33 lignes par page. Ms. du xr1 siècle. - (Ancien fonds 493.)

\section{2.}

Premier volume de la

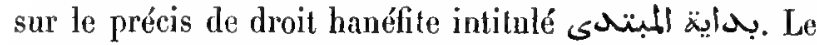
texte et le commentaire ont pour auteur Borhân al-Din Aboû 'l-Hasan 'Alî ibn abî Bakr ibn 'Alod at-Djalîl iłon alKhalì al-Marghînànî (المرغينان). Ce volume finit par te chapitre du marché à terme avec avance du prix (ألسمينام). Nombreuses gloses marginales et interlinéaires.

Papier. 225 feuillets. Hauteur, s 6 centimètres; largeur, 17 centimètres et demi. 23 lignes par page. Mr. du xvi siècle. - (Supplément 440, Sorbonne 265.)

\section{3.}

La seconde moitié de la Hidaya, par Borhân al-Dìn 'Alì ibn alıì Bakr al-Marghìnâuî. Ms. daté de l'an $77^{1}$ de l'hégire ( 1369 de J. C.). Notes marginales. A la fin du volume se trouvent de nombreux extraits et notes se rapportant à des questions de jurisprudence.

Papier. a 76 feuillets. Hauteur, 27 centimètres; largeur, 18 centimètres et demi. 33 lignes par page. - (Ancien fonds 495 .) 


\section{4.}

Le dernier volume de la Hidâya, commençant par le

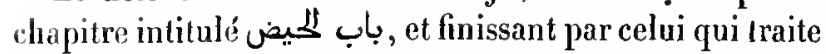
des questions diverses. Les premiers feuillets manquent.

Papier. 218 feuiltets. Hauteur, 22 centimètres; largeur, 15 centimètres et demi. 23 lignes par page. Nls. du xvi" siècle. - (Ancien fonds 517 .)

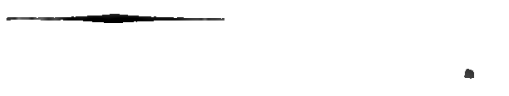

\section{5.}

Le troisième volume d'un exemplaire du معراج المراية

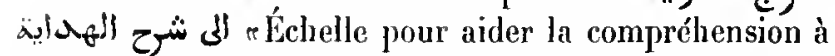
monter jusqu’à lintelligence de la Hidâyan, par Qiwàm al-Dìn Moḥammad ibn Moḥammad al-Bokhârì al-Kâkî

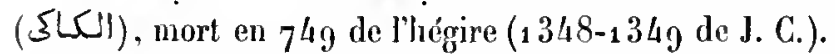
On ne trouve dans ce volume que les trois chapitres du mariage, de lallaitement et du divorce.

Papier. 292 feuillets. Ilauteur, 25 centiuètres; largeur, 17 centimètres. 25 lignes par page. Ms. du $\mathrm{xv}^{0}$ siècle. - (Supplément 443.)

\section{6.}

العناية, commentaire sur la Hidaya, par Akmal (أمكل)

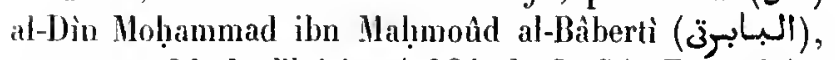
morl en 786 de l'hégire ( 1384 de J. C.). Exemplaire composé de deux parties, et daté de l'an $9^{5} 7$ de l'hégire ( 1550 de J. C.).

Papier. 62o feuillets. Hauteur, 29 centinètres; largeur, 19 centimètres. 33 lignes par page. - (Ancien fonds 494.)

\section{7.}

Lá seconde moitié de l'huiya, par Akmal al-Dìn. Ms. daté de l'an 1035 de l'hégire (1625-1626 de J. C.).

Papier. 408 feuillets. Hauteur, s6 centimètres; largeur, 19 centimètres. -- (Supplément 1443.)

\section{8.}

Volume dépareillé, d'un grand commentaire sur un Iraité de droit hanéfite, consacré en entier aux questions qui se rattachent à la purification (الطهاgli). Le commencement manque. Line main moderne a écril sur le

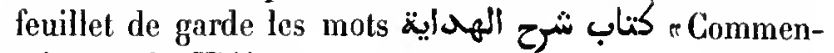
taire sur la Hidâyan.

Papier. 188 feuittets. Hauleur, 26 centimètres; largeur, 18 centimètres et demi. 23 lignes par page. Ms. du xiv ${ }^{\mathrm{c}}$ siècle. - (Ancien fonds 5o6.)

\section{9.}

Sixième volume d'un commentaire sur un traité de droit, probablement la Hidáya, renfermant les chapitres de la mise en culture des terrains incultes, des boissons défendues, de la chasse, des gages (hypothèques), des crimes, du prix du sang. L'auteur anonyme, mort en $7^{58}$ de l'hégire ( 1357 de J. C.), cite d'autres commentaires sur le mème ourrage, tels que le Kifàya, l'Inàya et le Ghìyat al-Bayân. Ms. daté (au fol. 102) de l'an $9^{8} 7$ de l'hégire $\left({ }_{1} 5_{79}\right.$ de J. C.).

Papier. 147 feuillets. Hauteur, 22 centimètres; largeur, 15 centimètres. 21 liģnes par page. - (Supplément 385.)

\section{0.}

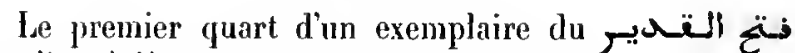
R Révélation du Tout-Puissant à son faible et paurre serviteurn, ou commentaire de la Hidaya, par Kamâl al-Din Moḥammad ihn 'Alud al-Wâhịid, de Sivâs, surnommé Ibn al-Hammânı (أبر ألهمّام), qui avait commencé la composition de cet ourrage en 899 de l'hégire ( 1426 de J. C.). Ms. daté de l'an 1076 de l'hégire (16651666 de J. C.).

Papier. 328 feuiltets. Hauteur, 3 I centimètres; largeur, 21 centimètres. 35 lignes par page. - (Supplément 441.)

\section{1 .}

rextraits de la Hidinan, par le mufti 'Mlà al-Dìn 'Alì ibn Aḷmad al-Djamâli, docteur hanéfite, mort en 932 de l'hégire (1525-1526 de J. C.). Ms. daté de l'an 1055 de l'hégire (1645 de J. C.).

Papier. 136 feuiltets. Hauteur, 20 centimètres et demi; largeur, 13 centimètres et demi. 19 lignes par page. - (Supptément 383 bis, Arsenal.) 
852.

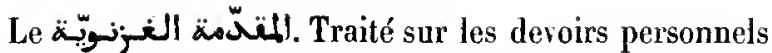
du musulman, tels que les purifications, ta prière et le jeùne, par Aḷmad ibn Mohammad al-Ghaznawi, mort en 593 de l'hégire ( $11196-1197$ de J. C.).

Papier. 152 fenillets. Hauteur, 21 centimètres et demi; largeur, 15 centimètres. 11 lignes par page. Ms. du xvin siècle. - (Supplément $3{ }_{2} 5$, Saint-Germain 303 .)

\section{3.}

(الاخوزى vie futuren, abrégé de l'ouvrage intitulé "La lumière tirée de la signification du texte $\approx$, lequel esl un commentaire sur la Moqaddama d'Al-Ghaznawî, par Ibn Diyà al-Dìn (Mohammad ibn Aḷmad al-Qoraschî). Le Mașabihl a pour auteur Moṣlị̣ al-Dìn Hamza ibn Ibràhîm ibn Wali al-Dìn al-Roûmì. Le texte de la Moqaddama est inséré dans le commentaire, à l'encre rouge. Exemplaire de la main de l'auleur, daté de l'an 1007 de l'hégire $(1598-$ 1599 de J. C.).

Papier. 292 feuillets. Hauteur, 21 centimètres; largeur, 15 centimètres. 19 lignes, puis 15 lignes par page. - (Supplément 326.)

\section{4.}

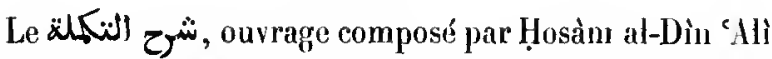
ibn Aḥmad ibn Makki al-Ràzì, pour expliquer le lexte du Takmila, traité qu’il avait rédigé pour servir de supplément au Mokhtașar, ou Abrégé de droit haméfile, d’HQodoûrì.

Papier. ${ }_{2} 3_{2}$ feuillets. Hauteur, 26 centimètres et demi; largeur,

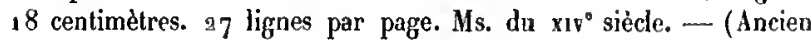
fonds 5oo.)

\section{5.}

Volume dépareillé d'un grand ouvrage de jurisprudence hanéfite. La partie principale du texle consiste en questions de droit arec leurs solutions. Le premier chapilre

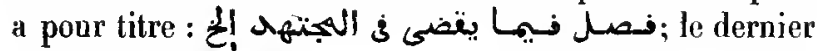

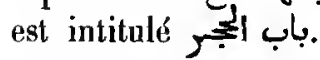

Papier. 225 feuillets. Hauteur, 27 centimètres; largenr, 18 centimètres et demi. 33 lignes par page. Ns. du $\mathbf{x v i}^{\circ}$ siècle. - (Ancien fonds 487. )

\section{6 et 857.}

النتناوى الظهويّة. Deux volumes (le deuxième et le troisième) des décisions légales, du docleur hanéfite Zahì al-Dìn Aboù Bakr Moḥammad ibn Aḥmad al-Bokhàrì, mort en 619 de l'hégire $(1222$ de J. C.). Ms. dalé de l'an 1111 de l'hégire (1699-1700 de J. C.).

2 vol. Papier. 256 et 269 feuillets. Hanteur, 28 centimètres et demi; largeur, 20 centimètres. 19 lignes par page. - - (Supplément 354.)

\section{8.}

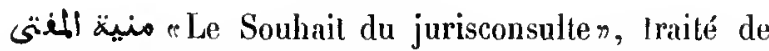
dıoit hanéfile, par Yoûsof ibn abi Sad ibn Ahmad al-Sidjistàni. L'auteur a inséré dans son ouvrage les décisions légales de Nadjom al-Dìn al-Khâsì et de Sirâdj al-Dîn al-Auschì (الاونىى).

Papier. 431 feuillets. Hauteur, 21 centimètres; largeur, 15 centimètres. 15 liggnes par page. Ms. dı xv11 siècle. - (Ancien fonds 541.$)$

\section{9.}

traité de droit touchant le partage des successions, par Mohamnad ibn Mohammad ibn 'Abd al-liaschìd al-Sedjâwendì, surnommé Sirîdj al-Dîn. Cet exemplaire est accompagné de notes en turce el en arabe. Un onglel, posé entre les feuillets 3 el 4, renlerme le commencement de ce trailé, mis en vers tures. La suite de celte traduction est inscrite sur les marges du volume. Ms. daté de l'an 973 de l'hégire (1565-1566 de .J. C.).

Papier. 56 feuillets. Hauteur, 18 centimètres; targeur, 11 centimètres et demi. 7 lignes par page. - (Ancien fonds 576.$)$

\section{0.}

La Siradjiyya de Sedjàwendì.

Papier. 77 feuillets. Hauteur, 17 centimètres et demi; largeur, 1 centimètres. 5 lignes par page. Ms. du xvu' siècle. -- (Ancien fonds 55o.)

\section{1.}

La Siradjiyya de Sedjâwendì. Exemplaire copié dans 
l'ile, de Chypre, en 1o4o de l'hégire (1630-1631 de J. C.).

$2^{\circ}\left(F_{0} . v_{2} v^{\circ}\right)$ Commentaire anonyme sur la Sir $h-$ dj̈yya. Exemplaire copié au même endroit que l'ouvrage précédent et par le même scribe, et daté de l'an 1040 de l'hégire.

$3^{\circ}$ (Fol. $9^{3} v^{\circ}$ ) ) الم-1, autre commentaire sur le même trailé. Exemplaire de la même main que les artictes précédents, et dalé de l'an 1050 de l'hégire (1640-1641 de J. C.).

$4^{\circ}$ (Fol. $136 \vee^{\circ}$.) Traité du partage des successions, par 'Alî ibn Khidr, de Belgrade. Copie autographe, datée de l'an 1078 de l'hégire (1667-1668 de J. C.). Cómmen-

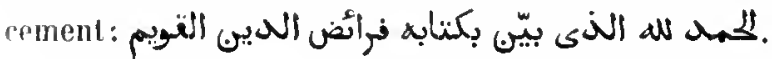

$5^{\circ}$ (1'ol. $142 v^{\circ}$.) Autre traité sur le même sujet, inlitulé جوأهر النوائض, par llon Kamâl Paschazàdè. Com-

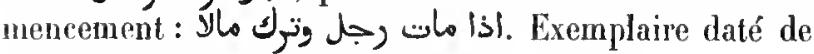
l'an 1080 de t'hégire (1669-1670 de J. C.).

$6^{\circ}\left(\right.$ Fol. $\left.147 \vee^{\circ}.\right)$ La Sirádjiyya, traduite en vers tures, alec un commentaire dans la même langue, par Toûr-

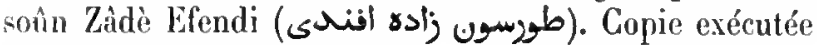
par le mème scribe que les trois premiers articles, el datée de l'an 1050 de l'hégire.

Papier. 201 feuillets. Hauleur, 21 centinètres et demi; largeur, 13 centimètres. 11 à 27 lignes par page. - (Ancien fonds $52 \%$.)

\section{2.}

La Sirâdjiyya de Sedjâwendi. Exemplaire daté de l'an 1050 de l'hégrire ( 1641 de J. C.).

Papier. 40 feuillets. Hanteur, 8 centimètres; largeur, 5 centimètres et demi. 12 liģnes par page. - (Supplément 469 , Oratoire.)

\section{3.}

La Sicadjiyya de Sedjàwendi. Notes marginales.

Papier. 27 feuillets. Hauteur, 19 centimètres; largeur, 11 centimètres. 11 lignes par page. Ms. du xv11 siècle. - (Ancien fonds 575.)

\section{4.}

Commentaire sur la Siradjiyya, par Schams al-Dîn Mo- ḩammad ibn Hamza al-Fanârì. Exemplaire daté de l'an 871 de l'hégire (1466-1467 de J. C.).

Papier. $9^{6}$ feuillets. Hauteur, a centimètres; largeur, 29 centimètres et demi. 17 liggnes par page. - (Ancien fonds 551.)

\section{5.}

$1^{\circ}$ Commentaire sur la Siradjüya, par un auteur in-

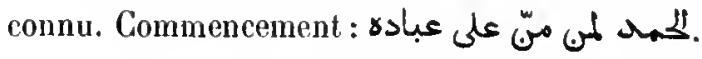

$2^{\circ}$ (Fol. $43 v^{\circ}$.) Le ضوء السئج, commentaire sur la SirAdjiyya, par Maḥmoûd ibn abì Bakr al-Kilâbâdì (s)بsicil)

Ces deux ouvrages sont écrits de la même main; la copie porte la date de 831 de l'hégire (1427-1428 de J. C.). Les feuillets de garde, au commencement et à la fin du volume, sont couverts de notes de diverses mains, se rapportant pour la plupart à des questions relatives au partage des successions.

Papier. 180 feuillets. Hauteur, 17 centimètres et demi; largeur 15 centimètres. 17 lignes par page. - (Ancien fonds 554.)

\section{6.}

Commentaire anonyme sur la Sirâdjuyya. Même ouvrage que le $\mathrm{n}^{\circ} 861,2^{\circ}$. Copie datée de l'an 908 de l'hégire (1502-1503 de J. C.).

Papier. 63 fevillets. Hauteur, 18 centimètres et demi ; largeur, 13 centimètres. 21 lignes par page. - (Supplément 467 , Saint-Germain 33.)

\section{7.}

$1^{\circ}$ Comnentaire sur la Siradjiyya. Même ouvrage que le précédent. Exemplaire daté de l'an 950 de l'hégire (1543-1544 de J. C.).

$2^{\circ}$ (Fol. 6g.) Fragment d'une dissertation sur les espérances de J'homme.

$3^{\circ}\left(\right.$ Fol. $69 v^{\circ}$.) Notes sur des questions touchant le partage des successions.

$4^{\circ}$ (Fol. $71 v^{\circ}$.) Traité en vers sur le partage des successions, avec un commentaire. L'auteur du poëme et du commentaire se nommait Mohsin al-Qaisarì (c التيصرى), mort en 755 de l'hégire (1354 de J. C.). Exemplaire daté de l'an 982 de l'hégire $(1574-1575$ de J. C.). 
$5^{\circ}$ (Fol. $133 v^{\circ}$.) Texle du même poëme. Exemplaire daté de l'an 1023 de l'hégire (1614 de J. C.).

Papier. 138 feuillets. Hauteur, 2 1 centimètres et demi; largeur, 15 centimètres. 19 à 21 lignes par page. - (Ancien fonds 552.)

\section{8.}

Commentaire sur la Sirddjuya. Même ouvrage que l'article $1^{\circ} \mathrm{du}$ numéro précédent. Nom]ıreuses notes marginales en langue turque. Exemplaire daté de l'an 953 de l'hégire (1545-1546 de J. C.).

Papier. 95 feuillets. Hauteur, 23 centimètres et demi; targeur, 16 centimètres el demi. 17 lignes par page. - (Supplément 468, Sorbonne 268 .)

\section{9.}

$1^{\circ}$ Commentaire sur la Siridjiyya. Même ouvrage que les numéros précédents. Exemplaire daté de l'an 997 do l'hégire ( 1589 de J. C.). Nombreuses notes marginales.

$2^{\circ}$ (Fol. $111 v^{\circ}$.) Exemples, en langue lurque, de la manière dont ou applique les règles de calcul indiquées dans la Siradjiyya.

Papier. 114 feuillets. Hauteur, 19 centimètres el demi; largeur. i3 centimètres el demi. 17 lignes par page - (Ancien fonds 553.)

\section{0.}

$1^{\circ}$ Commentaire sur la Siradjiyya. Mème ouvrage que les uumérọs précédents. Ms. daté de l'an 1173 de l'luégire $(1759-1760$ de J. C. $)$.

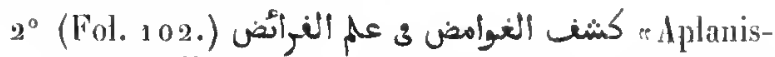
sement des difficultés qui se reneontrent dans lart de partager les successioms al-Dìn Aboû 1-Djoud Mohammad, fils de Mohammad Sibt al-Mâridìnì (سبط المباردينى). Exemplaire dalé de l'an 1085 de l'hégire $(1674$ de J. C. $)$.

$3^{\circ}$ (Fol. $\left.140 v^{\circ}.\right)$ Copie d'une note eque l'on avait trouvée dans l'écriture d'Al-Malik al-Kàmil. " C'est un tableau de douze cases, paraissant indiquer un jour de jeûne pour chaque mois de l'année.

$4^{\circ}$ (Fol. 141.) Note sur la concordance de J'année musulmane avee l'année solaire.

Papier. 141 feuillets. Hauteur, 21 centimètres; largeur, 16 centimètres. 21 lignes par page. - (Supplémeni 461.)

\section{1.}

Premiers eahiers d'une copie du mème commentaire anonyme sur la Siradjiyya qui se trouve dans les numéros précédents.

Papier. 28 feuillets. Hauteur, 20 centimètres el demi; largeur, 14 centimètres et demi. 31 lignes par page. Ms. dn xvı1 siècle. (Supplément 2033.)

\section{2.}

جأifl. Commentaire sur la Sirtidjyya. Commence-

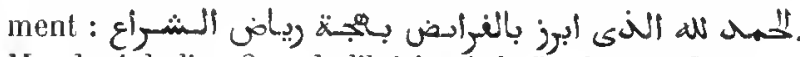
Ms. daté de l'an 870 de l'hégire $(1475-1476$ de J. C.).

Papier. 6a fenillets. Hauteur, i 8 centinètres; largeur, 13 centimètres el demi. 19 lignes par page. - (Ancien fonds 56. .)

\section{3.}

"Cadeau pour les princes", traité de droit lanéfite, divisé en dix chapitres (la purification, la prière, la dìme, le jeûne, le pèlerinage, la guerre sainle, la chasse, les actes répréliensibles, le partage des successions, le gain licile ou illicite.), par Zaïn al-Dìn Moḷammad ibn abî Bakr al-Râzî. Ms. daté de l'an 1001 de l'hégire $\left(159^{2-1} 5 g^{3}\right.$ de J. C. $)$.

Papier. 6o feuillets. IIauteur, 21 centimètres; largeur, 14 centimètres el demi. 13 lignes par page. - (Supplément 383.)

\section{4.}

The Tohfat al-Molouk, de Zaïn al-Dìn al-Rázi, avee le commentaire de Hohammad iłn 'Abd al-Latif. Notes marginales.

Papier. 349 feuillets. Hauteur, 23 centimètres; largeur, 13 centimètres et demi. 19 lignes par page. Ms. du $x_{n}{ }^{e}$ siècle. - (Supplément 384.)

\section{5.}

Traité de droit hanéfite, intitulé الهختار للفنتوى. Dans le titre de ce commentaire, on a donné à l'auteur le tilre honorifique de Djamál al-Din et le patronymique d'Al-Bel- 
dedjî (sulall)'. Ms. daté de t'an 838 de l'hégire (14341435 de J. C.).

Papier. 101 feuillets. Hauteur, 18 centimètres; largeur, 13 centimètres et demi. 15 lignes par page. - (Ancien fonds 543.)

\section{6.}

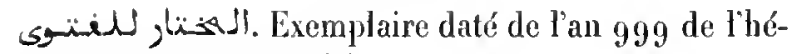
gire $\left(15 g_{0-1} 59^{1}\right.$ de J. C. $)$.

Papier. 103 feuillets. Hauteur, 14 centimètres et demi; largeur, 20 centimetres et deni. 1.5 lignes par page. - (Ancien fonds 5/4.)

\section{7.}

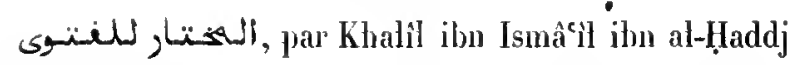
Haïder 2.

Papier. 111 feuillets. Hauteur, 21 centimètres; largeur, 15 centimètres. 15 tignes par page. Ms. du xvm ${ }^{e}$ siècle. - (Supptément 372 . Saint-Gernain 3 14.)

\section{8.}

 servil de commentaire au Mokhtârn de Khalíl jbn Ismaeil ibn al-Haddj. Le commentaire est du même docteur ${ }^{3}$. Cet exemplaire se compose de deux volumes reliés en un seul. Le second volume commence au fol. $159 \mathrm{v}^{\circ}$. La partie la plus ancienne du ms. a été écrite en 891 de l'hégire (1486 de J. C.). A peu près la moitié du volume consiste en feuillets écrits beaucoup plus tard pour combler un grand nombie de lacunes.

Papier. 344 feuillets. Hauteur, 27 centimètres; largeur, 18 centimètres. 23 ì 99 lignes par page. - (Supplément 377.)

\section{9 .}

Le second rolume du, الاختيار لنثرح النجنيار Le Choix, traité composé pour servir de commentaire au Mokhtîrn. Le texte et le commentaire sont du même auteur, Aboû ']Fadhl 'Abd Allah ibn Mahmoûd ibn Maudoûd, de Mosul, mort en 683 de l'hégire (1284-1 285 de J. C.). Ms. daté de l'an 843 de l'hégire (1439-1440 de J. C.).

Papier. 184 feuillets. Hauteur, 27 centimètres et demi; largeur, 18 centimètres. 25 lignes par page. - (Ancien fonds 508.)

\section{0 .}

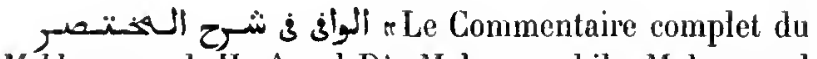
Molhtaṣar n, de Hosâm al-Dìn Mohammad ibn Mohammad al-Akhsîkatî (الاخخسيكتى), par Ḥ́osaïn ihn 'Alì ibn Ḥad-

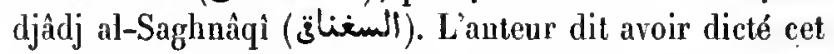
ouvrage à ses élèves en $69_{2}$ de l'hégire (1 293 de J. C.). Ce ins. porte des corrections qui paraissent être de la main de l'auteur.

Papier. 255 feuillets. Hauteur, 24 centimètres; largeur, 16 centimètres. 2, lignes par page. - (Ancien fonds 561.)

\section{1.}

(ب) Confluent des deux mers et conjonction des deux lmminaires n, traité de jurisprudence, dans lequel l'auteur, Borhân al-Dìn al-Sấâtì (الساءاتة), a combiné les doctrines d'Al-Qodoûri et d'Aboû Hafṣ al-Nasafì. C'est un abrégé très-estimé de droit hanéfile.

- Papier. 86 feuillets. Hauteur, 29 centimètres; largeur, 17 centimètres. 23 tignes par page. Ms. de diverses écritures du xiv siècle. (Ancien fonds 48.)

\section{2.}

Le Madjmac al-Bahraïn d'Ilbn al-Sâcâti. Nombreuses notes. marginales et interlinéaires.

Papicr. 231 feuillets. Hauteur, 29 centimètres et demi; largeur, 14 centimètres et demi. 13 lignes par page. Ns. du $x r^{e}$ siècle. - (Supplément 329.)
"Voici le nom complet de l'auteur, d'après le présent ms. :

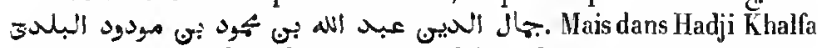
(t. V, p. 436) et dans d'autres exemplaires, l'auteur est appelé $\underset{ }{\mathrm{C}}$ الديس.... Les numéros suivants, qui contiennent le mème ourrage, ne donuent pas le nom de l'auteur. H. Z.

\footnotetext{
* L'ourrage est le même que celui qui est contenu dans les deux numéros précédents. Khalîl ibn Ismâil est le nom du copiste du présent exemplaire. H. Z.

${ }^{3}$ Pour le vrai nom de l'auteur, voyez le numéro suivant. H. $Z$.
} 


\section{3.}

Le Madjma al-Bahrain d'Ibn al-Sâêttì. Ms. daté de l'an goo de l'hégire ( 1494 de J. C.). Nombreuses notes marginales et interlinéaires.

Papier. $17^{4}$ feuillets. Hauteur, 27 centimètres et demi; Jargeur, 18 centimètres. 13 lignes par page. - (Supplément 328, Saint-Germain 183.)

\section{4.}

$1^{\circ}$ Le Madjmac al-Balıraïn d'Ibn al-Sấâtì. Dans la dernière moitié du volume, les feuillets sont, les uns de couleur blanche, les autres de couleur jaune. Le texte est accompagné de notes marginales et interlinéaires.

$2^{\circ}$ (Fol. 125.) Prière intitulée : Prière de l'ensevelissement n. Le ms. porte plusieurs questions légales sur le recto du premier feuillet.

Papicr. 127 feuillets. Hauteur, 27 centimètres et demi; largeur, 18 centimètres. 13 et 15 lignes par page. Ms. du xv' siècle. - (Ancien fonds 483. )

\section{5.}

(Gloses 》, composées par Al-Aqserâi (الاقسرأىى) (Moḷammad ibn Moḥammad ibn Moḷanmad), pour éclaircir le commentaire dans lequel l'auteur du Madjmac al-Bahrain explique les difficultés de son propre ouvrage. Ms. daté de l'an 761 de l'hégire (1360 de J. C.). Écriture cursive, de la main de l'auteur. A partir du fol. $20 v^{\circ}$, on a cessé d'inscrire les rubriques.

Papier. 101 feuillets. Hauteur, 25 centimètres et demi; largeur, 17 centimètres et demi. 23 et 24 lignes par page. - (Supplément 33o.)

\section{6.}

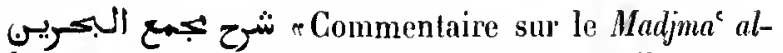
Bahraïn, pal "Abd al-Latif ibn 'Abd al-'Aziz ibn Amìn at-Din. Le volume ne renferme que le premier quart de l'ouvrage.

Papier. 121 feuillets. Hautcur, 26 centimètres et demi; largeur, 18 centimètres. 27 lignes par page. Ms. du $x^{e}{ }^{e}$ siècle. - (Supplément 33a.)

Mas. orientaUX. - Il.

\section{7.}

Commentaire d'A Abd al-Lațif ibn 'Abd al-'Azîz sur le Madjma al-Bahraïn. Les premiers feuillets et plusieurs feuillets au milieu manquent. Ms. daté de l'an 896 de l'hégire (1490-1491 de J. C.).

Papier. 302 feuillets. Hauteur, 27 contimètres; largeur, 18 centimètres. 27 à 33 lignes par page. - (Supplément 2030.)

\section{8 .}

Premier volume $d u$ commentaire d"Abd al-Latif ibn 'Abd al-'Aziz ibn Amîn al-Din sur le Madjmac al-Bahraïn. Ms. daté de l'an 897 de l'hégire (1492 de J. C.). Notes marginales.

Papier. 429 feuillets. Hauteur, 27 centimètres et demi; largeur, 18 centimètres. 25 à 27 lignes par page. - (Supplément 331.)

\section{9.}

Premier volume du commentaire $d^{\prime c} A b d$ al-Latif ibn 'Abd al-'Azìz sur le Madjma al-Bặraïn. Notes marginales et interlinéaires.

Papier. ${ }_{19} 6$ feuillets. Hauteur, 25 centimc̀tres; largeur, 17 centimètres el demi. 25 lignes par page. Ms. du $x^{2} \mathfrak{1}^{e}$ siècle. - (Ancien fonds 484 .)

\section{0 .}

i Le Suffisant ", ouvrage composé par Aboû 'l-Barakât "Abd Allâh ibn Aḷmad al-Nasafi, pour développer" les doctrines exposées dans son abrégé de jurisprudence intitulé الوأوا.

Papier. 604 feuillets. Hauteur, 28 centimètres; largeur, 16 centimètres et demi. 23 lignes par page. Ms. du xvi siècle. - (Supplément 352 , Anquetil 36.)

\section{1.}

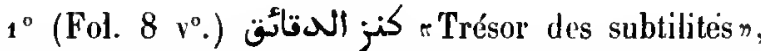
traité de jurisprudence hanéfite, par Aboû 'l-Barakât `Abd Allàb ibn Ahmad al-Nasafi. Cet exemplaire est chargé de notes marginales et interlinéaires, à l'exception du der- 
nier tiers de l'ouvrage qui ne porle ni notes, ni titres de chapitres. La copie est datée de l'an 822 de l'hégire (1419 de J. C.).

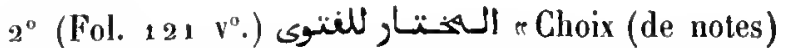
pour servir à la décision des questions juridiques $\%$. (Voyez ei-dessus, $\mathrm{n}^{\text {os }} 8{ }_{7} 5$ et suiv.)

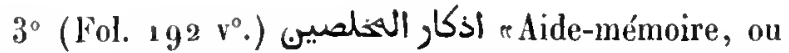
Manuel des croyants sincères $n$, par un auteur anonyme du $v^{\circ}{ }^{\circ}$ siècle de l'hégire. C'est un traité en cinq chapitres, sur la prière, d'après le Coran, les traditions et les opi-

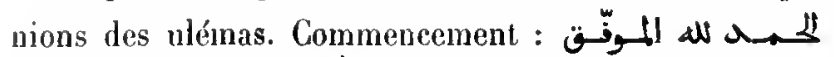
لكيرات النجيب للمعوات. Les feuillets sont alternativement blanes et jaunes.

Les fol. 2 à $8 v^{\circ}$ et le fol. $117 v^{\circ}$ sont remplis de notes relatives à des questions de jurisprudence et aux tradilions.

Papier. 209 feuiliets. Hauteur, 27 centimètres et demi; largeur, 18 centimètres et demi. 13 à 17 lignes par page. Ms. du xv siècle. (Ancien fonds 473 .)

\section{2.}

Lن كنز الدقائق d'Aboû '1-Barakât al-Nasafi. Exemplaire daté de l'an 838 de l'hégọire (1434 de J. C.), convert de notes marginales et interlinéaires. Les trois derniers feuillets contiennent des notes sur différents points de droit.

Papier. 1 /9 feuillets. Hauteur, 28 centimètres et demi; largeur, 18 centimètres. 11 lignes par page. -- (Ancien fonds 474.)

\section{3.}

Le كنز الدقائق d'Aboû 'l-Barakàt al-Nasafi. Ms. daté de l'an 862 de l'hégirire ( 1457 de J. C.).

Papier. 187 feuillets. Hlauteur, 21 centimètres et demi; largeur, 15 centimètres et demi. 13 lignes par page. - (Supplément 361. )

\section{4.}

Le كنز المدقتابيُقن d'Aboù 'l-Barakât al-Nasafi. Ns. daté de l'an $107^{4}$ de l'hégire (1663-1664 de J. C.).

Papier. 188 feuillets. Hauteur, 21 centimètres; largeur, 15 centimètres. 15 lignes par page. - (Ancien fonds 536.)

\section{5.}

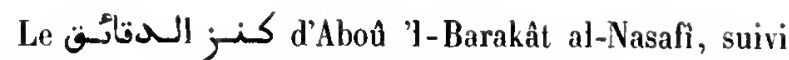
$\left(\right.$ fol. $170 \mathrm{v}^{\circ}$ ) d'une notice sur la vie et sur les éerits de l'auteur. Ms. daté de l'an 1085 de l'bégire $(1675$ de J. C.).

Papier. ${ }_{1} 7^{5}$ feuillets. Hautenr, 15 centimètres; largeur, 10 centimètres. 15 liggnes par page. - (Supplément 362.)

\section{6 .}

Le كنز الدنائق , avec un commentaire perpétnel, dont l'auteur nous est inconnu.

Papier. 433 feuillets. Hanteur, as centimètres; largeur, 15 centimètres et demi. 21 à 27 lignes par page. Ms. de diverses écritures du xvin' siècle. - (Supplément 358.)

\section{7 et 898 .}

Commentaire du Kanz al-Daqä̈q, par 'Othmån ibn 'Ali al-Zailaci (الزيلs), mort en 743 de l'hégire (13421343 de J. C.).

3 vol. Papier. 431 et 464 feuillets. Hauteur, 31 centimètres; largeur, 20 centimètres et demi. 31 lignes par page. - (Supplément 355 et 356.$)$

\section{9 .}

rourités subtiles, pour servir de comnentaire au Kanz al-Daqáiq n, par Mohammad ibn Aḷmad al-'Aïnî, mort en 818 de l'hégire ( 1415 1416 de J. C.). Le commencement et la fin manquent.

Papier. 450 feuillets. Hauteur, 20 centimètres; largenr, 15 centimètres et demi. Ms. du xvm" siècle. - (Supplément 2028.)

\section{0 .}

Le second volume du ومز تلنائق Ms. daté de l'an 1129 de l'hégire ( $7^{1} 7$ de J. C.).

Papier. 430 feuillets. Hauteur, 33 centimètres; largenr, 22 centimètres. 31 lignes par page. - (Supplément 360.) 


\section{1.}

res vérités pures, traité servant de commentaire au Kanz al-Daqäiq", par Ibrâhîm ibn Moḥammad, lecteur du Coran, mort en 907 de l'hégire (1502 de J. C.). Ms. daté de l'an 1140 de l'hégrire $\left(17^{2} 7^{-1} 7^{2} 8\right.$ de J. C.). Nombreuses notes marginales de l'écriture du copiste.

Papier. 251 feuillets. Hauteur, 56 centimètres et demi; largeur, 23 centimètres. 21 lignes, puis 33 lignes par page. - (Supplément 359.)

\section{2.}

$1^{\circ}$ Le second volume du الإيـضـاح "Éclaircissement ,

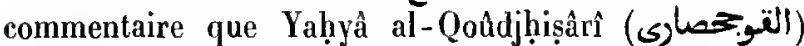
avait composé pour éclaircir les obscurités du Kanz alDaqäiq. L'ouvrage commence par le chapitre des ventes.

$2^{\circ}$ (Fol. $202 v^{\circ}$.) Extrait du commentaire d'Al-Zailaei (الزيلع) sur le Kanz al-Daqaïq.

En tête du volume se trouvent quelques décisions légales sur la responsabilité de ceux qui, en allumant du feu à la campagne, causent, par leur imprudence, des incendies dans les propriétés voisines.

Papier. 208 feuillets. Hanteur, 26 centimètres et demi; largeur, 18 centimètres et demi. 27 lignes par page. Ms. du xvi' siècle. - (Supplément 363.)

\section{3.}

"La mer attrayanten, commentaire sur le Kanz al-Daqâiq, par Zaïn al-'Ábidin ibn Nadjìm (يجم) al-Miṣrì. L'ouvrage s'arrête à la fin du chapitre du pèlerinage. Notes marginales.

Papier. 459 fenillets. Hauteur, 30 centimètres; largeur, 23 centimètres. 29 à 32 lignes par page. Ms. du xvi siècle. - (Supplément 364, )

\section{4.}

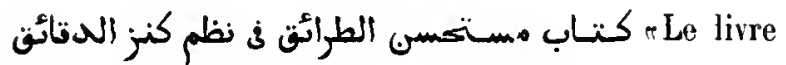

aux méthodes approuvées, reproduisant en vers le contenu du Kanz al-Daqâ̈q", par Ahmad ibn 'Alì al-Ham-

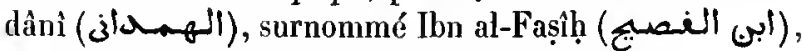
mort en 755 de l'hégire (1354 de J. C.).

Papier. 186 feuillets. Hauteur, 21 centimètres ct demi; largeur, 15 centimètres. 13 lignes par page. Ms. du xvil' siècle. - (Supplément 357.)

\section{5.}

Préservatif du texte des questions disculćes dans la Hidaya \%, par l'imâm Borhân

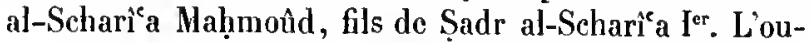
vrage commenté est l'exposition de la jurisprudence hanbalite d'Ibn al-Kbattâb Maḥfoûz al-Ṭoûbâdì (الطوبادى)1. Ms. daté de l'an 879 de l'hégire (1474-1475 de J. C.). Dans la première moitié du volume, il y a beaucoup de notes marginales et interinéaires. Quelques feuillets perdus ont été remplacés plus tard.

Papier. 148 fewillets. Hauteur, 28 centimètres; largeur, 18 centimètres. 11 à 17 lignes par page. - (Ancien fonds $47^{\circ}$.)

\section{6.}

La Wiqáya. Ms. daté de l'an $97^{1}$ de l'hégire (15631564 de J. C. ).

Papier. 209 feuillets. Hauteur, 21 centimètres; largeur, 15 centimètres. 9 lignes par page. - (Supplément 343. )

\section{7.}

Abrégé de la Wiqaya dẹe Maḥmoûd ibn Ṣadr al-Scharîa, par' Obaïd Allâh ibn Mascoûd ibn Tâdj al-Scharía. Com-

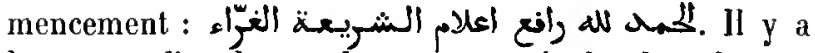
beaucoup d'onglets et de notes marginales dans la première moitié du volume. Les derniers feuillets manquent.

Papier. 130 feuillets. Hauteur, 16 centimètres et demi; largeur, 10 centimètres et demi. 11 et 13 lignes par page. $\mathrm{Is}_{s}$ du xvı" siècle. - (Supplément 2038.)

${ }^{1}$ La Wiqáya a pour base le traité de droit hanéfite appelé Hidaya, dont l'auteur est Borhàn al-Dín al-Marghinåní. (Voyez ci-dessus, nos 843 et suiv.) H. Z. 


\section{8.}

كتناب صد, المنتربعة , commentaire de Tâdj al-Sclıaría 'Obaïd Allâhı ibn Mascoûd sur les passages difficiles de la Maḥmoûd. Exemplaire éerit à Constantinople et daté de l'an 911 de l'hégire (1505-1506 de J. C.). Notes marginales.

Papier. 190 feuillets. Hauteur, 26 centimètres et demi; largeur, 17 centimètres et demi. 21 lignes par page. - (Ancien fonds 501.)

\section{9 .}

Le Sadr al-Scharî́a d'Obaïd Altâh ibn Mascoûd. Ms. daté de l'an 958 de l'hégire ( 1551 de J. C.). Les feuillets de garde sont couverts de notes relatives à divers points de droit et d'extraits d'autres ouvrages. Notes marginales et interlinéaires.

Papier. 187 feuillets. Ilauteur, 27 centimètres et demi; largeur, 18 centimètres et demi. 23 et 24 lignes par page. - (Ancien fonds 488.)

\section{0.}

Le Sadr al-Scharî‘ $a$ d’Obaïd Allâh ibn Mas'oủd. Ms. daté de l'an 1056 de l'hégire ( 1646 de J. C.). Notes marginales de la main du copiste.

Papier. 253 feuillets. Hanteur, 25 centimètres; largeur, 14 centimètres. 19 lignes par page. - (Supplément 341, Sorbonne 293.)

\section{1 et 912 .}

Le Sadr al-Schari`a. Exemplaire daté de l'an 1099 de l'hégire (1687-1688 de J. C.).

A la fin du premier volume se trouve une décision légale au sujet des waqf conditionnels.

a volumes. Papier. 220 et 214 feuillets. Hauteur, 21 centimètres; largeur, 14 centimètres et demi. 17 lignes par page. - (Supplément 342.)

\section{3.}

Le Sadr al-Schari $a$. Ms. daté de l'an 1125 de l'hégire ( 1713 de J. G.).

Papier. ${ }_{2} 52$ feuillets. Hauteur, 27 centimètres; largeur, 16 centi- mètres ct demi. a lignes pas page dans la première moitié du volume, 19 dans la seconde. - (Ancien fonds 510.$)$

\section{4.}

Gloses de Ya qoûb Pacha sur le Sadr al-Scharîa. Ms. daté de l'an 908 de l'hégire (1502-1503 de J. C.). L'un des plats du volume porte la signature d'Abraham Ecchellensis.

Papier. 219 feuillets. Hauteur, 18 centimètres et demi; largeur, 13 centimètres et demi. 21 lignes par page. - (Supplément 344.)

\section{5.}

Gloses de Yáqoûb Pacha sur le Sadr al-Scharî́a. Ms. daté de l'an 962 de l'hégire (1554-1555 de J. C.).

Papier. ${ }_{17} 5$ feuillets. Hauteur, 21 centimètres et demi; largeur, 15 centimètres. 25 lignes par page. - (Supplément 350.)

\section{6.}

Gloses de Ya qoûlb Pacha sur le Șadr al-Scharî $a$.

Papier. 209 feuillets. Hauteur, 22 centimètres; largeur, 16 centimètres. 17 lignes par page. Ms. du xvı siècle. - (Ancien fonds 537.)

\section{7.}

المالح Rectification de la Wiqdya», par le molla Ibn Kemàl Paclıa (Schams al-Dìn Aḷmad ibn Solaïmân), mort en 940 de l'hégire (1533-1534 de J. C.). Ce traité renferme non-seulement des corrections à la Wiqâya, mais aussi au Sadr al-Scharic $a$. Commencement : is $\mathrm{su} \rightarrow \mathbf{f}$ الببدا أيسة والنهاية على المهدأية واللوقاية. Ms. daté de l'an 980 de l'hégire (1572-1573 de J. C.). Texte encadré en or et en couleurs; notes marginales de la main du copiste.

Papier. 309 fenillets. Hauteur, 26 centimètres; largeur, 16 centimètres et demi. 21 lignes par page. - (Supplénent 345.)

\section{8.}

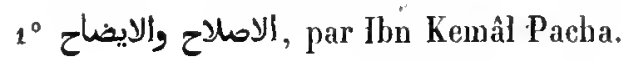


$2^{\circ}$ (Fol. $200 \vee^{\circ}$.) Commentaire sur les douze premiers chapitres de la Wiqáya.

Ms. daté de l'an $99^{1}$ de l'hégire (1583 de J. C.).

Papier. 238 feuillets. Hauteur, 28 centimètres; largeur, 17 centimètres. 27 lignes par page. - (Ancien fonds 377 .)

\section{9.}

الاصلح , الايضاح, par Ibn Kemâl Pacha. Ms. dalé de l'an 1036 de l'hégire (1626-1627 de J. C.). Nombreuses notes marginales de la main du copiste.

Papier. 265 feuillets. Hauteur, 25 centimètres et demi; largeur, 15 centimètres et demi. 23 lignes par page. - (Supplément 3/46.)

\section{0.}

الاصلح , الايضضا, par Ibn Kemâl Pacha.

Papier. a 38 feuillets. Hauteur, 20 centimètres; largeur, 13 centimètres et demi. s I lignes par page. Ms. du xvi siècle. - (Ancien fonds 538.)

\section{1.}

$1^{\circ}$ Explication d'un passage du اصلح quel l'auteur de cet ouvrage fait une exception en ce qui concerne la prière faite dans la ka ba. Commencement:

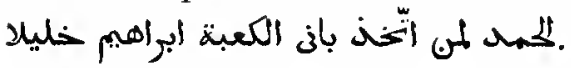

$2^{\circ}$ (Fol. 5.) Fragment d'un recueil de paroles de Mahomet, accompagnées d'observations phitologiques:

Papier. 8 feuillets. Hauteur, 19 centimètres et demi; largeur, 6 centimètres et demi. 15 lignes par page. Ms. du xvun' siècle. - (Supplément 2034.)

\section{2 .}

ئ aloses de Dedeb Efendin sur le Sadr al-Scharî́a. Ms. daté de l'an 1073 de l'hégire (16621663 de J. C.).

Papier. 69 feuillets. Hauteur, 21 centimètres ; largeur, 15 centimètres. „3 lignes par page. — (Supplément 350 bis.)

\section{3.}

r Fécondation des esprits», recueil de questions légales avec leurs réponses, par Aḥmad ibn 'Obaïd Allâlı (le ms. porte 'Abd Allâh) al-Mạ̣boûbî, connu sous le nom de Sadr al-Scharík $I^{e r}$.

Papier. 176 feuillets. Hauteur, 20 centimètres et demi; largeur, 15 centimètres. 17 liggnes par page. Ms. du xv1 siècle. - (Supplément 351 .)

\section{4.}

r L'Indicaleur des Iradilions citées dans la Hidéya et la Kholâsan, par 'Alà al-Dîn 'Alì ibn 'Othmân al-Turkomànî, de Màridìn, mort en 750 de l'hégire (1349-1350 de J. C.).

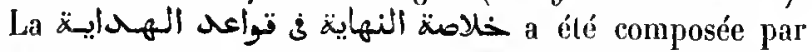
Maḥmoûd ibn Aḥmad al-Qoûnî (d'Icone). L'ouvrage $d^{\prime c}$ Alâ al-Dìn se compose principalement d'annotations se rapportant aux traditions citées dans la Hidáya el la Kholâşa. Ms. daté de l'an 755 de l'hégire (1354 de J. C.).

Papier. 1 a feuillets. Hauteur, a 1 centimètres; largeur, 14 centimètres. 21 lignes par page. - (Ancien fonds 394 .)

\section{5.}

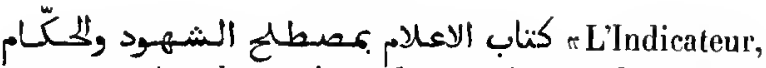
faisant connaitre la pratique des notaires et des magistrats n. Formulaire d'actes notariés, par Aboù Isḥâq 'Alì ibn Ạ̣mad al-Ṭarsoûsi, mort en 758 de l'hégire ( 1357 de J. C.). Le dernier chapitre de l'ourrage est consacré à l'explicalion des surnoms, sobriquets et titres. Le dernier feuillet manque et a élé remplacé par un autre, contenant un extrait du Coran, puis dix lignes, d'une écriture de convention, qui paraissent renfermer une formule magique.

Papier. 137 feuillets. Hauteur, 18 centimètres et demi; largeur, 14 centimètres. 15 lignes par page. Ms. du xıv siècle. - (Supplément 453.)

\section{6.}

$1^{\circ}$ م Formulaire d'actes notariés n, par Ibrâhîm ibn 'Alì al-Ṭarsoûsì ' . Copie datée de l'an 861 de l'bégine (1456 de J. C.).

\footnotetext{
'Le copiste de cet exemplaire, dans un titre placé en tẻte du ms., indique comme auteur Nàșir at-Dìn ibn al-Siràdj al-Ḥanafi al-Dimaschqî.
} Deux possesseurs orientaux ont corrigé le titre, en y insérant le nom de Ṭarsoúsí. H. Z. 
$2^{\circ}$ Fol. 94.) (كسون ألنتعويـi. Modèles de lettres, en cinq chapitres, dont le premier indique la manière d'écrire aux rois; le second contient des lettres adressées à des vizirs; le troisième, des lettres aux cadis; le quatrième, des lettres adressées à des hommes pieux; le cinquième traite des surnoms. Commencement : أl . Même écriture que celle de l'article $1^{\circ}$.

$3^{\circ}$ (Fol. $1141^{\circ}$.) Document, en langue turque, par lequel Moḷammad ibn 'Alì al-Fenârì, grand-juge de Rumélie, porte à la connaissance du public une note écrite par Al-Taftazânì sur la marge de son exemplaire du Kaschschâf. Ce document est intitulé :

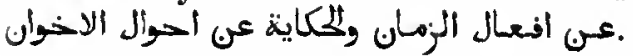

$4^{\circ}$ (Fol. 116.) Copie d'un acte notarié et d'un acte relatif au partage d'une succession. En ture.

$5^{\circ}$ (Fol. $124 r^{\circ}$.) Traité des actes notariés, en vingtquatre chapitres.

$6^{\circ}$ (Fol. 138.) Liste des mots arabes qui désignent les personnes qui exercent des métiers, suivie d'une liste d'adjectils qui s'emploient dans les signalements, soit des hommes, soit des chevaux. Chaque terme est accompagné de son équivalent ture.

$7^{\circ}\left(F_{0} l_{1} 3_{9} v^{\circ}.\right)$ Pièce notariée, en persan, suivic d'autres pièces et notes en persan.

$8^{\circ}$ (Fol. $143 v^{\circ}$.) Formulaire d'actes notariés, par le derviche Mohamnad ibn Eflàtoûn ibn Kemâl al-Dìn.

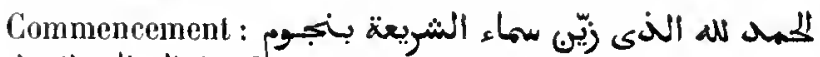

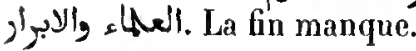

Papier. 166 feuillets. Hauteur, 18 centimètres; largeur, 13 centimètres et demi. Ns. du xvi' siècle (à l'exception des deux premières pièces). - (Supplément 1877 .)

\section{7.}

r Perles pour celui qui est parvenu au but, et trésor pour celui qui suit la bonne direction », par Sirâdj al-Dîn Aboû Bakr ibn 'Alì ibn Moûsâ al-Hàmilì ( (الكهاi). C'est une rédaction en vers du

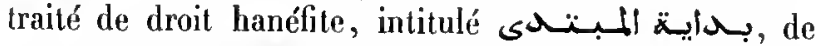
Borhàn al-Dìn al-Marghìnânî. Cet ouvrage est suivi d'une autre pièce de vers, moins étendue, touchant je partage des successions (الـفـأبضض). Ms. daté de l'an 990 de l'hégire (1582 de J. C.).

Papier. 199 feuillets. Hauteur, 21 centimètres; largeur, 15 centimètres. 13 lignes par page. - (Supplément 444.)

\section{8.}

Perles ramassées dans les océans", résumé de droit hanéfite, en vers techniques se terminant en لע, par Al-Hasan ibn Scharaf (شــ) al-Tibrìzi, mort en $77^{\circ}$ de l'hégire (1368-1369 de J. C. $)^{1}$. Ces vers sont au nombre de 4,250.

Papier. ${ }_{152}$ feuillets. Hauteur, 21 centimètres; largeur, 15 centimètres et demi. 15 lignes par page. Ms. du xwn sièele. - (Supplément 353.)

\section{9 .}

r.Livre des pierres précieusesn, traité

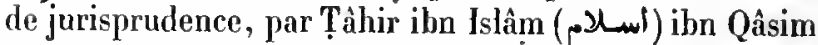
al-Anșâri, al-Khowârezmì. Le premier chapitre renferme les preuves de l'existence el de l'unité du Créateur; le second a pour sujet les purifications; le troisième indique ce qui invalide l'ablution; le quatrième traite de l'ablution complète; le cinquième, de la prière; le sixième, de la récitation du Coran; le septième, de la prière du vendredi et des prières des deux fêtes; le huitième, des purifications des royageurs; le neuvième est consacré à des renseignements utiles, et le dixième indique les convenances que les personnes engagées dans la pratique de la vie dévote sont tenues à observer. L'auteur nous apprend qu'il avait royagé en Asie Mineure, et qu'il a terminé la composition de son ourrage en $77^{1}$ de l'hégire $(1369-1370$ de J. C.). Dans la préface, il donne une liste des nombreux ouvrages dont il s'est servi. L'ourrage commence par ces mots : Hadji Khalfa le mentionne dans sa Bibliographie, sous le titre de . جراهر الفix. Notes marginales, surtount au commencement.

Papier. 159 feuillels. Hauteur, 20 centimètres et demi; largeur, 13 centimètres. 19 liznes par page. Ms. du xvi siècle. - (Ancien fonds 417. )

\footnotetext{
${ }^{1}$ Dans ce ms., l'auteur est seulement désigné par le titre de Mohyi at-Dìn. H. Z. .
} 


\section{0.}

\section{Le Kitâb al-Djawadhir de Ṭâhir ibn Islân.}

Papier. 108 feuillets. Hauleur, 21 centimètres; largeur, 15 centimètres. 19 liğnes par page. Ms. du xvil siècle. - (Supplément 316 , Sorbonne 274.)

\section{1.}

Le Kitab al-Djawahir de Tâhir ibn Islâm. En tête du volume se trouve une notice, ajoutée après coup, sur les prophètes, depuis Adam. A la fin se trouve un extrait du traité de morale intitulé تنبيه الغافليه.

Papier. 157 feuillets. Hauteur, 21 centimètres; largeur, 15 centimètres. $a 1$ lignes par page. Ns. du xvi1 siècle. - (Supplémeni 317.$)$

\section{2.}

Le Kitab al-Djawahir de Tâhir ibn Islàn. Eù tête dı $\mathrm{ms}$. se trouve un index assez bien fait. Sur le recto du premier feuillet on a inserit quelques vers, composés en langue turque par Kemâl Pacha Zàdè. Ms. daté de l'an 1335 de l'hégire (1 723 de J. C.).

Papier. 185 feuillets. Hantelir, 22 centimètres et demi; largeur, 15 centimètres et demi. 17 lignes par page. - (Supplément 57 ×.)

\section{3.}

rTraité étendu sur les contrats n, par

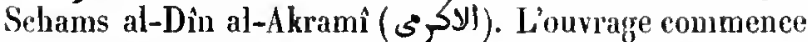

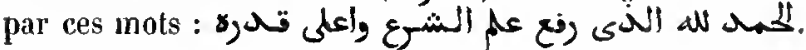
(Voyez Hadji Khalfa, t. IV, p. 47.) Les premiers et les derniers feuillets sont couverts de notes relatives à différents points de jurisprudence. Le fitre inscrit sur le premier feuillef et sur la tranche du volume n'est pas exact. Ms. daté de l'an 8,8 de l'hégire (1415 de J. C.).

Papier. 185 feuillets. Hauteur, 18 centimitres et demi; largeur, 14 centimètres. 14 et 15 lignes par page. - (Supplément 455.)

\section{4.}

r Poëme composé de mille distiques et renfermant les règles du partage des suecessions n. C'est probablement l'ouvrage que Hadji Khalfa attribue an

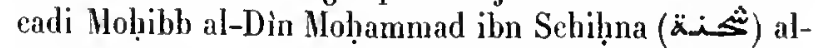
Halabì, mort en 815 de l'hégire (1412-1413 de J. C.). Le premier feuillet manque. En têle du second feuillet se trouve le distique suivant, qui terminait sans doute la lihotba ou préface :

$$
\text { وأسال الله الهكيم العونا على كال نظمها واللصسونا }
$$

Ms. daté de l'an 982 de l'hégire (1575 de J. C.).

Papier. 42 fenillets. Hautcur, 21 centimètres; largeur, 15 centimètres et demi. 13 ligrnes par page. - (Supplément 462.)

\section{5.}

Paroles des juges, faisant savoir comment former des jugementsn, par le grand eadi d'Alep, Abou '1-Walìd Aḅmad ibn Schiluna '. Ce Iraité, composé de trente clapitres, traite des devoirs du cadi et des jugements à prononcer dans les cas ordinaires. A la fin du volume se trouve une prière ayant une grande veriu, qui est précédée d'une introduction en langue turque. Cette pièce est intitulée شـ دعاء فرس ألهـ. Ms. daté de l'an 1080 de l'hégire (1669-1670 de J. G.).

Papier. 192 feuillets. Hauteur, 21 centimètres; largeur, 15 rentimètres. 17 lignes par page. - (Ancieu fonds 540.)

\section{6.}

r Les Perles des juges, pour servir de commentaire au Ghorar al-Ahkamn, par le molla Khosroù al-lioûmi. L'ouvrage commenté est du inêne auteur et est reproduit en entier, à l'encre rouge. Exemplaire daté de l'an $9^{64}$ de l'hégire (1556-1557 de J. C.). En tête du volume se trouvent une notice biographique de

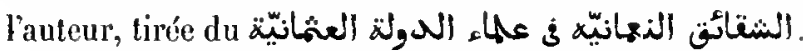
et un grand nombre de notes détachées, relatives à des questions de jurisprudence et à divers autres sujets.

Papier. ${ }_{2} 3_{2}$ feuillets. Hauteur, 28 centimètres et demi; largeur, so centimètres. 33 lignes par page. - (Supplément 318 , Sorbonne 263 .) 


\section{7.}

Le Dorar al-Hokkîm de Khosroû a1-Roûmi. Ms. daté de l'an 1008 de l'hégire ( $1599-1600$ de J. C.).

papier. 479 feuillets. Hauteur, 25 centimètres; largeur, 15 centimètres. 23 lignes par page. - (Ancien fonds 479.)

\section{8.}

Le Dorar al-Ḥokkâm de Khosroû al-Roûmî. Exemplaire daté de l'an 1013 de l'hégire ( 1604 de J. C.).

Papier. $47^{5}$ feuillets. Hauteur, 23 centimètres et demi; largeur, 15 centimètres. 23 lignes par page. - (Supplément 321. )

\section{9.}

Le Dorar al-Ḥokkam de Klosroû al-Roûmi. Exemplaire dalé de l'an 1029 de l'hégire (1620 de J. C.).

Papier. 413 feuillets. Hautcur, 28 centimèlres; Jargeur, 16 centimètres et derni. 23 lignes par page. - (Ancien fonds 504, Colbert 5055$.

\section{0.}

Le Dorar al-Ịokkâm de Khosroû al-Roûmî. Les premiers feuillets manquent.

Papier. 353 feuillets. Hauteur, 26 centimètres el demi; largeur, 15 centimètres. 29 lignes par page. Mfs. du xvı siècle. - (Supplément 32a.)

\section{1 et 942.}

Le Dorar al-I!okkîn de Khosroû al-Roûmì. La copie n'a pas été achevée. I] manque la dernière section et la moitié de l'avant-dernière.

2 vul. Papier. 303 et 295 feuillets. Hauteur, 31 centimètres; largeur, 15 centimètres et demi. 25 lignes par page. 11 s. du xvine siècle. -(Supplément 3i9.)

\section{3.}

Gloses sur quelques passages du Dorar al-Hokkâm de Khosroû al-Roûmî. Ce traité anonyme commence par les

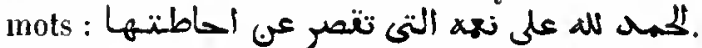

Papier. 19 feuillets. Hauteur, 21 centimètres et demi; largeur, 14 centimètres et demi. 25 lignes par page. Ms. du xvu siècle. - (Supplément 320. .)

\section{4.}

Le premier volume d'un commentaire sur le Zad alFaqîr "Provisions de voyage de l'homme pauvren, traité de jurisprudence hanéfite, composé par Kamâl al-Dîn ibn Hammâm (ابر) همام) , mort, d'après Hadji Klıalfa, en 861 de l'hégire (1456-1457 de J. C.). Le commentaire, inti-

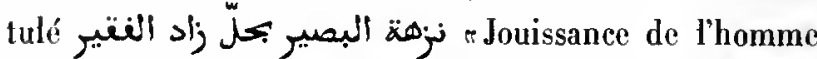
clairroyant, qui Jit l'explication du Zad al-Faqîr», a pour anteur "Abd al-Raḷîm al-Maschnâwî (المنشناوى) ${ }^{1}$. Dans cet exemplaire, il y a une lacune dau moins un feuillet, entre les folios actuetlement cotés 2 et 3 . A la fin du volume il manque un ou plusieurs feuillets. F́criture cursive et difficile à lire.

Papier. 131 fenillets. Hauteur, 21 centimètres et demi; largeur ${ }_{15}$ centimètres. 25 lignes par page. Its. de la fin du $x v^{\circ}$ siècle. (Ancien fonds 566.)

\section{5.}

1 o rivre pour le redressement de l'esprit de l'homme intelligent $n$, recueil de questions de droit avec leur solution, d'après la jurisprudence de l'école hanéfite. Le nom de l'auteur ne se trouve pas mentionné dans le dictionnaire de Hadji Khalfa. En tête de notre ms., où le titre est indiqué d'une manière inexacte, l'auteur est nommé Aboû 'l-Mahâsin

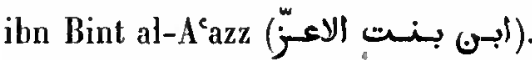

$2^{\circ}$ (Fol. $107 \mathbf{v}^{\circ}$.) Vision d'Aboû Ḥâzion al-Madanî et sa conférence avec lange Gahriel.

$3^{\circ}$ (Fol. 111 v $^{\circ}$. Fautes que le lecteur du Coran est exposé à commettre $n$, et qui, en certains cas, peuvent invalider la prière.

\footnotetext{
1 C'est ainsi que le nom est orthographié dans le titre, qui paraît écrit de la main du copiste. H. Z.
} 
$4^{\circ}$ (Fol. 127.) Notes biographiques sur les quatre grands jurisconsultes.

$5^{\circ}$ (Fol. $127 \mathrm{v}^{\circ}$.) Questions el réponses au sujet de la prière.

$6^{\circ}$ (Fol. 1 29.) Énumération des patriarches qui sont les auteurs des différentes parties de la prière.

Manuscrit tout entier de la mềne main, daté (royez fol. $\left.126 v^{\circ}\right)$ de l'an 872 de l'hégice (1467-1468 de J. C.).

Papier. 129 fenillets. Hauleur, 18 centimètres et demi; largeur, 14 centimètres. 15 lignes par page. - (Ancien fonds 56o.)

\section{6.}

Traité de jurisprudence haméfite. Le commencement manque. Le uns. commence au milieu du chapitre du divoree, et finit par celui des fondations pieuses, dont voici les premiers mots : تال أبو حنيفة رهم الله لا بـزول

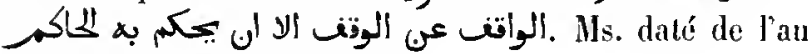
892 de l'hégire (1487 de J. C.).

Papier. 166 feuillets. Hauleur, 18 centimètres; largeur, I' centimètres. 19 lignes par page. - (Ancien fonds 558.)

\section{7.}

Dernières pages d'un formulaire de requètes adressćes au tribunal. Ms. daté de l'an 9o4 de l'hégire $(1498$ de J. C.).

Papier. 5 feuiltels. IIauteur, 18 centimètres; largeur, 13 centimètres. 21 tignes par page. - (Supplément 2256.)

\section{8.}

هollection de" Mowayyad-Zadle.. Recucil d'extraits d'un grand nombre d'ourages de droit hanéfite, par 'Abd al-Raḷmân ibu al-Mlowaygad alAmâsì, mort en 922 de l'hégire (1516 de J. C.). Ms. daté de lan 1039 de l'hégire (1629-1630 de l. C. .). Les premiers feuillets renferment deux lables des matières et plusieurs notes de diverses mains.

Papier 142 feuillets. Hauteur, 26 centimètres; targenr, 15 centimètres el derni. 3 , lignes par page. - (Supplément 373 , Ducaurroy.)

Mas, oriextaUX. - 11.

\section{9.}

Traité anouyme de jurisprudence hanéfite, se composant d'extraits d'un grand nombre d'ouvrages, dont quelques-uus sont du $x^{e}$ siècle de notre ère. Ces extrails sont classés daus l'ordre adopté pour les traités de jurisprudence. Au recto du fol. 4 se trouve un acte authentique, daté de l'an 1180 de l'hégire (1766 de J. C.), qui constate que ce volume avait été donné à la grande

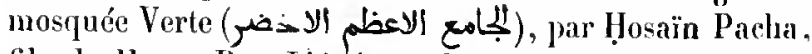
fils de Hasan Bey. L'écriture de cette pièce est maghrebine.

Papier. 442 feniltets. Hanteur, 29 centimètres et demi; largeur, 15 centimètres et demi. $3 \mathrm{t}$ lignes par page. Hs. du xw11' siècle. (Supplément 37ı.)

\section{0 .}

Décisions légales du cadi Zakariyàr. Le cadi Aboû Yalyà Zakariyà ibn Mohammad ibn Aḷmad ibn Zakariyà al-Anșàrì, dloc-

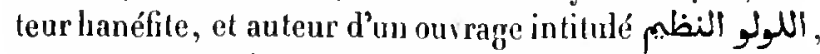
mourut en $9_{2} 6$ de l'hégire ( 520 de J. C.). Liauteur anoاعلام الإتمام بr. Indices du zèle que l'on a nis à rassembler les décisions du schatiklı al-lslàm\%. Le ms. porte päهام: il manque peut-être un mot.

Papier. 156 fenillets. Hauteur, 2 a centimètres et remi; largeur, 15 centimètres et deni. 17 lignes par page. Us. dn xvi ${ }^{\circ}$ siècle. (Ancien fonds 5/2.)

\section{1.}

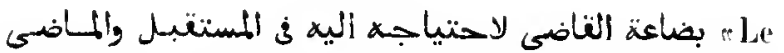
Capital du cadi, ce donI il arait besoin dans le passé el qui lui sera utile dans l'avenir", formulaire d'acles notariés, par Pìr Moḷammad ibn Moûsì al-Broúsi.

Papier. 60 fenitlets. Hauteur, 19 centimètres; largeur, is centimètre's. 13 et 14 lignes par page. Ms. du xwme siècle. - - (Ancien fonds 547$.

\section{2.}

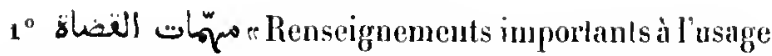
des cadis $n$, formulaire d'actes judiciaires el notariés, ré-

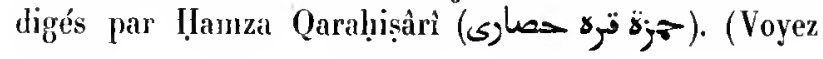


Hadji Khalfa, t. V1, p. 280.) La transcriplion n’a pas élé acherée.

$z^{\circ}\left(F_{0}\right.$ l. $58 v^{\circ}$.) Acte par lequel un père excommunie el dóshérile son fils, Derwich, qui huvail du vin publisuemenl, mangeait du bachich et commetlail d'aulres péchés.

$3^{\circ}$ (Fol. $\left.7^{1} \mathrm{r}^{\circ}.\right)$ Pormulaire d'actes judiciaires, par Molarmmad, de la ville de Brousse, fils d'Iflâtoun allioumi, généralemenl commu sous le nom d'Iflàtoûn Zàdè (fils de Plalon), mort en $9^{3} 7$ de l'hégire (1530-1531 de. J. C.). (Voyez Iladji Khalfi, t. IV, p. 46.)

$4^{\circ}$ (Fol. $101 \vee^{\circ}$.) Formulaire d'actes judiciajres, en langue lurque. La préface commence par ces mols : $\lambda_{-}$

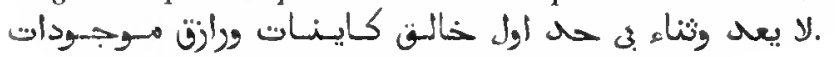
Copie datée de l'an 998 de l'hégire ( 590 de J. C.).

$5^{\circ}$ (Fol. $121 \mathrm{r}^{\circ}$ ) Modèles d'acles judiciaires ol de waqf, en ture, précédés d'une longne préface.

$6^{\circ}\left(\right.$ Fol. $187 v^{\circ}$.) Acte en arabe, par lequel cerlaines propriélús, dont le détail est très-longog, sont cousacrées à des ouv'es pies.

Papier. 210 feuillets. Ilauteur, 21 centimètres; largenr, 13 centimètres. 35 lignes par page. Ms. du xv" siècle. - (Supplément 456. Sorbonne.)

\section{3.}

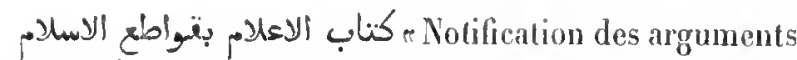
péremptoires de lislamismen, traité dans lequel un julisconsulte, nommé Schihâb al-Dìn A ̣̣mad ibn Ịodjr alHaülıamì, justife certaines décisions légales qu'il avait dounées à la Mecque, en 942 de l'hégire (1535-1536 de J. C.), el qui lui avaient alliré les altaques des ignorants. Cel exemplaire parait avoir été écril du vilant de l'auteur.

Papier. 82 fenillets. Lfauteur, 31 centimètres; largeur, 15 centimètres. 19 lignes par page. - (Supplément 459.)

\section{4.}

Abrégé de droil. Ouvrage sans préface, commencant

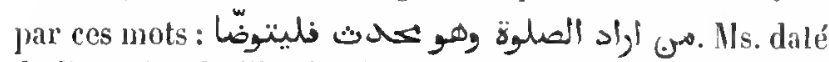
de t'an $9^{5} 9$ de Jliegrire (155a de J. C.). On y remarque ‘uelques lacunes.

Papier. 158 fenillets. Ilauteur, a centimètres; largeur, 16 centimètres. 11 lignes par page. - (Ancien londs 532.)

\section{5.}

Trésor des serviteurs de Dieu, dans lequel sont indiqués les mérites de la guerre sainle et des incursions sur le territoire des infidèles n, par Ramadhàn ibn Mosțafà ilon al-WValí ibn alHổddj Yoûsof, docteur hanéfite. L'ouvrage est dédié an sultan Soliman II, fils de Sélim, fils de Bayazid, et renferme dix-neul' chapitres, arec une introduction. Copie datée de l'an 954 de l'hégire (1547-1548 de J. C.).

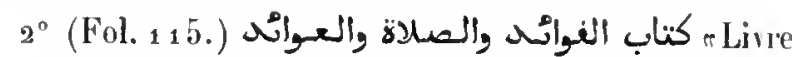
des conmaissances utiles, des prières et des praliques religieuses n, par Aboù 'l-Hasan 'Alì al-'Alawì al-Yamanì. Le commencement manque. La copie est de la méme main que l'article $1^{\circ}$ et porle la date de $9^{5} 7$ de l'bégire (1550 de J. C.).

$3^{\circ}$ (Fol. $256 v^{\circ}$.) Diagramme composé de trois disques concentriques, dont le premier, qui est le plus grand, est immobile; le second, portant un indicateur marqué uri "soleil », est divisé, sur la marge, en trente parties; le troisiène, qui est le plus petit, porte un indicateur marqué r runen. La marge du disque immobile est divisée en douze parties, dont chacune est subdivisée en trente et un degrés; un cercle renferme ảes signes du zodiaque, puis ¿ l'intérieur de ce cercle on troure les noms des mansions de la lune. Ensujite vient un 'autre cercle, divisé en vingl-huil parties inégales, dans lesquelles sonl inscrites les lettres de l'alphabet arabe, dans l'ordre de leur valeur numéripue.

Le premier feuillet contient une prière.

Papier. 256 fenillets. Ilauteur, 21 centimètres; largeur, 15 centimètres. 8 à 15 lignes par page. - (Supplément 476 .)

\section{6.}

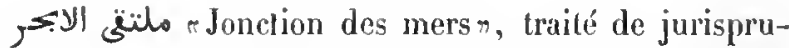
dence hanéfite, par Ibrảlsìm al-1̣alabì, mort en 956 de Thégire (1549 de J. C.). Exemplaire daté de l'an 923 de l'bégire (1517 de J. C.).

Papier. $1 / 49$ feuillets. Itauteır, 18 centimètres; largeır, 10 centimètres. 21 lignes par page. - (Ancien fonds 573.)

\section{7.}

Le Moltaqa 'l-Abhor d'lbrâlìm al-Halabì. Les premiers feuillets portent des notes toucluant divers points de juris- 
prudence et de discipline. Ms. daté de l'an 1058 de l'hégire ( 1648 de J. C.).

Papier. $3{ }_{2} 3$ feuillets. Hauteur, 17 centimètres; largeur, 10 centimètres. 15 lignes par page. — (Supplément 365.)

\section{8.}

Le Mollaqâ 'l-Abḥor d'Ibrâhìm al-Ḥalabî. Exemplaire de diverses écritures, daté de l'an 1065 de l'bégire (1654$1655 \mathrm{de} \mathrm{J.} \mathrm{C.).} \mathrm{Nombrenses} \mathrm{notes} \mathrm{marginales.}$

Papier. 233 feuillets. Hauteur, 19 centimètres; largeur, 11 centimètres. 18 à 23 lignes par jage. - (Ancien fonds 572.)

\section{9 .}

Le Moltaqa 'l-Abhor d'lbrâhîm al-Halabì. Exemplaire daté de l'an 1069 de l'hégire (1658-1659 de J. C.). Nombreuses notes marginales.

Papier. 33, feuillets. Hauteur, 20 centimètres; largeur, 13 centimètres et demi. 13 lignes par page. - (Supplément 367. )

\section{0 .}

Le Moltaqd 'l-Abhor d'Ibràhîm al-Halabì. Exemplaire incomplet vers la fin. Le premier leuillet et les Irois derniers contiennent des pièces de rers et des sentences pieuses; on y trouve aussi les noms des sept dormants.

Papier. 122 feuillets. Hauteur, 18 centimètres et demi; largeur, 13 centimètres et demi. 15 lignes par page. Ms. du xvi siècle. (Supplément 370 .)

\section{1 .}

Le Moltaqú 'l-Abhor d'Ibrâhim al-ḷalalji. Les derniers feuillets manquent.

Papier. 159 feuillets. Hauteur, 20 centimètres; largeur, 12 centimètres et demi. 19 lignes par page. Ms. du xviı siècle. - (Supplément 366.)

\section{2 et 963.}

\section{Le Moltaqâ' 'l-Abhor'.}

2 vol. Papier. 566 et 618 feuillets. Hauteur, a 1 centimètres; largeur, 17 centimètres. 25 ligues par page. - (Supplément 36.9 )

\section{4.}

Le Molaqu'l-Abhor. Le commencement et la fin manquent.

Papier. 168 leuillets. Hauteur. 18 centimètres et demi; largeur, 13 centimètres. 15 lignes par page. Ms. du xviı siècle. - (Supplément 2052.)

\section{5 et 966.}

Confluent des rivières, pour servir de commentaire au Moltaqa 'l-Abhorn, par' 'Abd al-Rạ̣mân ibn Mọ̣ammad ibn Solaïmân SchaïklîZàdè.

2 vol. Papier. 33 o et 331 feuillets. Hautenr, 33 centimètres; largeur, 2a centimètres. 35 lignes par page. Ms. du xvin' siècle. - (Supplément 368.)

\section{7.}

rLes ressemblances et les conforunités ", traité des principes de la jurisprndence hanéfite, par Zaïn al-Č̉bidìn ibn lbrâhìm al-Miṣri, surnommé le Sclıaiklı Zaïn ibn-Nadjìn, mort en 970 de l'hégire (15621563 de J. C.).

Papier. 252 feuillets. Hlauteur, 19 centimètres et demi; largeur, 12 centimètres et demi. 21 lignes par page. Ms. du vvir siècle. - (Ancien fonds 529 .)

\section{8.}

Le Kitîb al-Aschbahl de Zaïn ibn-Nadjim.

Papier. 201 feuillets. Ilauteur, 22 centimètres; largeur, 15 centimètres. 23 liggnes par pagre. - (Supplément 2 \$36.)

\footnotetext{
1 Ces deux volumes renferment l'ouvrage intitulé $n^{\circ 8} 9^{65}$ et 966 ). La prèsente copie est datée de l'an 1116 de l'hégire (1 jo4 de J. C.). Le premier feuillet de la préface manque. H. $Z$.
} 


\section{9 .}

Commentaire snr un opuscule qui traite de la purification. Le chapilre inlitulé (fol. 40),

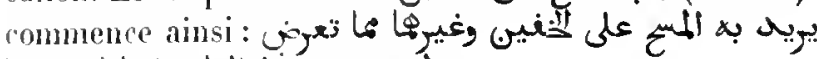

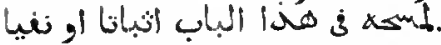

Papier. 59 feuillets. Hauteur, a 3 centimètres; largeur, 13 centimètres. 21 lignes par page. Ms. du xvi siècle. - (Supplément 475.)

\section{0 .}

$1^{19}$ Commentaire sur un traité de droil, sans tilre, ni nom d'auteur, commençant par ces mols : نلالإل

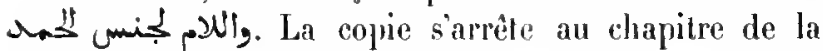

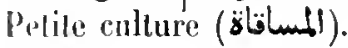

" (Fol. 37.) Commentaire sur le (ل) d'lbn at-Sic'àtí, par 'Abd al-Latif' ibn 'Abrl al-'Azìz ibn Amìn il-Din. C'est le commencoment de l'ouvrage; la eopie sarrête vers la fin dn live premier.

3० (Fol. 47.) Traité de jurisprudence hanéfite. Le conmencement mantue. L'exemplaire commence vers le milien du livre de l'Associalion commerciale ( $\ddot{\alpha} S_{5}$-lll). Écriture dépoursue de points diacritiques.

Papier. 118 fenillets. Hauteur, 27 centimètres et demi ; largenr, 17 cenlimètres. ${ }_{2} 5$ à 37 lignes par page. Us. de diverses écritnres du $x v^{e}$ et du wire siecle. - (Ancien fonds 512.)

\section{1.}

Abrégé de jurisprudence, commençant par ees mots :

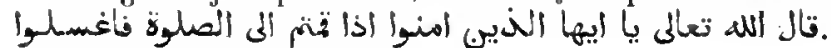
Nombreuses noles marginales.

Papier. 177 feuillets. Hauteur, 17 centimèlres; largeur, 11 cenlimètres. 12 liggnes par parge. Ms. du vv. siècle. - (Ancieu fontls $57_{1 .}$ )

\section{2.}

Fragment d'un lraité de droit hanćfite. C'esl une parlie du chapitre de la purification.

Papier. 80 feuillets. Ilauteur, 2 a centimètres et demi; $\operatorname{targeur}$, 16 centimètres. 15 lignes par page. Ms. du xvi siècle. - (Ancien fonds 5 s 2.)

\section{3.}

Examen critique, paf Qalànisit. Cel ouvrage est mentionné par Hadji Khalfa sous le titre de rExamen eritique des cas". Daus ce traité de droit, l'auteur signale les divergences d'opinion qui exislaient entre les docteurs de l'école de jurisprudence hanéfite, et subsidiairement les opinions d'AlSchâfí et de Mâlik.

Papier. 182 feuillets. Hauteur, 21 centimètres; largeur, 15 centimètres et demi. 25 lignes par page. Ms. du xvü siècle. -- (Supplément 386.)

\section{4.}

"Déeisions des muflis", par "Abd alQàdir ibn Yoûsof. L'auteur a liré ees décisions d'un grand nombre de reencils de jurisprudence hanéfite el les a elassées dans l'ordre généralement adopté pour. les Iraités de jurisprudence.

Papier. 253 fenillets. Hauteur, 21 centimètres; largeur, 15 centimètres, 23 lignes par page. Ms. du xvin' siècle. - (Supplément 323.)

\section{5.}

Les déeisions juridiques du eadi hanéfite Mobyì al-Din Mboù "1-CAbbâs Aḥmad, fils de Ṣadr al-Dìn Aboủ Isḥâq Ibrihim.

Papier. 76 feuillets. Hauteur, at centimètres et demi; largeur, 15 centimètres. 27 lignes par page. Ms. du xvu' siècle. - (Ancien fonds 499.)

\section{6.}

$1^{\circ}$ م Joyaux de prix, pour servir de commentaire an traité de droit hanéfite intitulé la Perle magnifique». Les deux ourrages sont du même auteur, 'Omar ibn 'Omar al-Zohrî (الزهوى). Le commentaire a été eomposé en 1046 de l'hégire (16361637 de J. C. ), el notre exemplaire est dalé de l'an 1102 de l'héggire $\left(1690-169^{1}\right.$ de J. C.):

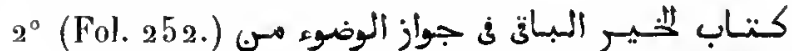
النساق : Le bien durable, preuve qu'il est permis de faire 
l'ablution dans les Lassins à jet d'eau ". L'auteur, Zaïn al'Ábidìn ibn Nadjìm, avait composé ce Iraité en 951 de thégire (1544-1545 de J. C.).

Papier. 26/4 feuillets. Hauteur, a 1 centimètres; largeur, 1) centimètres. a lignes par page dans le premier traité, 19 lignes dans le sccond. - (Supplément 376 .)

\section{7.}

Manuel de jurisprudence hanéfite, sans titre, ni prélace, ni nom d'anteur. Nombrenses notes marginales. Les derniers feuillets du volume sont couverts de notes relatives à différentes questions de droit, les unes en arabe, les autres en turc.

Papier. 105 feuillets. Hanteur, 21 centimètres; largeur, 15 centimètres. 13 ligues par page. Ms. du vv" ${ }^{*}$ siècle. - (4 ncien fonds 5 ao.)

\section{8.}

1 Question el réponse touchant un point de droit.

2" (Fol. 2.) Conseils de Mahomet à sa fille Fìtima.

$3^{\circ}$ (Fol. 9.) Deruières instructions d'Aboul llanifa à ses disciples.

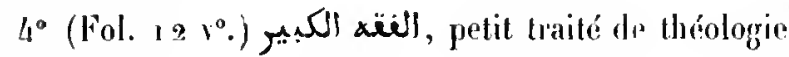
d'Abou Hamifa.

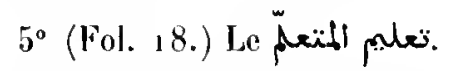

$6^{\circ}$ (Fol. 196.) Le Sict Cot onviage traite des sept règles quil faut observer dans charue acte de la vie musulmane. Le premier chapitre commence par la science et par l'énumération des sept classes do sarants. L'autem se nommait Aboû 'l-Ṭayyib Handàı ilın Ịamdonya.

$7^{\circ}$ (Fol. $9^{6 .}$ ) Notes direrses, les unes en arabe, les autres en turc.

Papier. 99 feuillets. Hauteur, 21 centimètres; largeur, 14 centimètres et demi. 16 à go lignes par page. Ils. Un xvı siècle. - (Supplément 1884.)

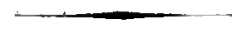

\section{9 .}

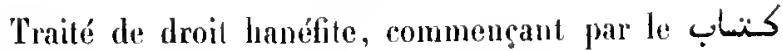
s.)

Papier. 187 feuillets. Ifauteur, 20 centimètres; largeur, 13 cenli- mètres. 13 lignes par page. Ms. du xvi1 siècle. - (Supplément 2029 , Saint Germain 295.)

\section{0 .}

Cahier détaché d'un commentaire sur un traité de droit hanéfite. Ce fragment renferme la fin de la section des lois qui règlent la position de l'élranger', puis le chapitre sur le kharâdj et la djizya, yui commence par ces mols : تال

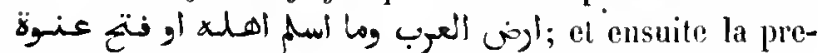
mière partie du chapitre sur l'apostasie, dont roici le

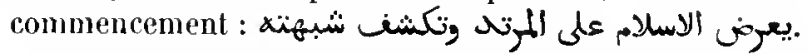

Papier. 12 feuillets. llauteur, 30 centimètres et demi; largeur, 20 centimètres et demi. 31 lignes par payre. Ns. du xvin' siècle. (Supplément 2231.)

\section{1.}

Fragment d'un trailé de jurisprudence hanéfite, commengant au milien du chapitre de l'alfranchissement. Lat marge supérieure du volume, ayant été endommagée pas. l'humidité, a été coupée par le relieur. Les chapitres du traité sont désignés par le mot كتاب

Papier. 195 feuiltets. Hauteur, 13 centimètres; largeur, 11 centimètres. 6 à 11 lignes par page. Ms. dı xvm" siècle, -(Supplément 2414 , Arsenal.)

\section{2.}

Consultation donnée par le schaïh al-Islàm llasan al-

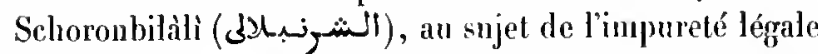
qui peut résulter de l'emploi des pois à cautère. Cette pièce, rúdigée en 1166 de l'lıégire ( 7 752-1 753 de J. C.), porte le tille de الاحككام الملكّة "Sommaire des opinions touchant le liquide du pois".

Papier. 6 funillets. Hauteur, 15 centimètres ct denui ; largeur, a a centimètres. 5 lignes par page. Ms. duxrı" siècle. - (Supplément / /ł.)

\section{DROIT SCHÄHÉITE.}

\section{3.}

Eécisions légales du cadi Hosaïn\%. L'auteur schaféite Aboù 'Alì al-ḷosaïn ibn Iloḥm- 
mad al-Marwaroûdi mourut en 462 de l'hégire (10691070 de J. C.).

P'apier. 85 feuill ts. Hauteur, a 6 centimètres; largeur, 17 centimetres. 6 lignes par page Us. du $x v^{e}$ siécle. - (Ancien fonds 497.)

\section{4.}

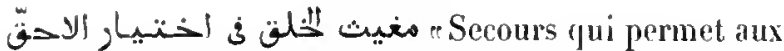
hommes de faire le meilleur eloix n, par l'Lmàm al-I!aramain Aboû '1-Macâlì al-Djowaïni. L'auteur cherche à prouver la supériorité de la jurisprudence schâféite sur rolles des autres écoles.

Papier. 77 feuillels. Hauteur, 30 centimetres; largeur, 14 centimèlres. 25 lignes par page. Ms. du xvi1 siècle.- (Supplément 410 lis.)

\section{5 .}

"Sommaire" de jurisprudence schâléite, par" Aboù llàmid al-Gliazàli. Le ins., de deux mails différentes, est daté de l'an $5 g^{4}$ de l'hégire $\left(1197^{-1} 19^{8} \mathrm{de}\right.$ J. C.). Le prenier feuillet manque.

Papicr. 291 feuillets. Hautcur, 20 centimètres; largeur, 14 centjmètres. 15 lignes par page dans les promiers cabiers, 25 lignes dans les raliers snirants. - (Supplément 409 , Saint-Germain 329.)

\section{6.}

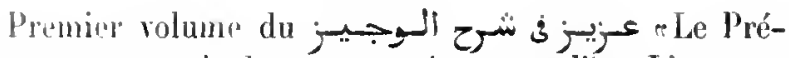
ricux, pour servir de commentaire au wadjizn. Lourrage commenté est l'épitomé de droit schàféite d'Aboû Hàmid al-Glazali. Le commentaire est d'Aboù 'l-Qásim 'Abd alharim ibn Moḷammad al-Qazwìni al-Râfici, auteur du xu ${ }^{e}$ siecle. (Voyez Hadji Khalfa, t. II, p. 272 , et t. VI, p. 428.) Ms. autograjhe; écriture cursive ot difficile à lire. Lis derniers lienillets manquent.

Papies. 275 feuillets. Hanleur, an centimètres; largeur, 13 centimetres. 20 à 25 lignes par page. -- (Ancien fonds 562.)

\section{7 : 989.}

Trois volumes, le premier, le second of le quatrieme, du commentaire sur le $\rightarrow$, Le Sommairen, d'Aloù Hânid al-Ghazàli, par hboù 'l-Qàsim 'Abd al-Karìn ibn
Moḷammad al-Ráfí i. Ms. daté de l'an $738-739$ de l'hégire (1338-1339 de J. C.).

3 vol. Papier. $230,{ }_{2} 47$ et 261 feuillets. Hanteur, 29 centimètres; largeur, 15 centimètres. 19 lignes par page. - (Supplément 408.)

\section{0 .}

:Le Jardin », par Mohyî̀ al-Dìn Aboû Zakariyâ Yaḷyâ ibn Scharaf a]-Nawawî. C'est un abrégé du commentaire d'Aboû 'l-Qàsim 'Abd al-Karìm al-Râfi'ì sur le Wadjiz d'Aboû Hầmid al-Ghazâli. Ms. daté de l'an $79^{6}$ de l'hégire $(1393-1394$ de J. C. $)$.

Papier. 649 feuillets. Hautcur, 24 centimètres el demi; largeur, 17 contimètres. 35 lignes par page. - (Ancien fonds 523.)

\section{1.}

Second volume de l'ourrage intitulé

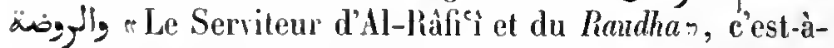
dire qui sert à expliquer les difficultés du Raudha ou Jardin, de Molyyì al-Din al-Nawawì. (Voyez le numéro précédent.) Le présent volume ne contient qu'une partie de lourrage, à savoir le chapitre de la purification arec du sable (تيمّم ), et une partie du chapitre de la prière. L'auteur est Badr al-Din Molımmad ibn Behådur ibn 'Abd Allah al-Zarkaschi.

Papier. 291 feuillets. Hanteur, 27 centimètres el demi; largeur, 18 centimètres. 3 lignnes par page. Us. du $\mathbf{x}^{\mathrm{t}}$ siècle. - (Supplément 43.)

\section{2 .}

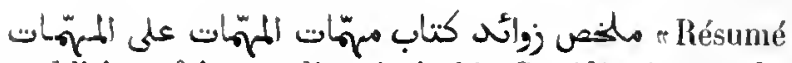
des additions faites au livre intitulé: Considerations sur les Considerations auxquelles domérent lieu les Considérations». Ce denier ourrage avait pour sujet le texte du äg, d'AlNawawi. Les Considérations sur le Raudha ont élé composées par Djamâl al-Din al-Asnawi (الاسنوى), mort en $77^{2}$ de l'hégire (1370-1371 de J. C.), et les Considérations sur les Considérations, par Zaïn al-Din al-Tràqi, mort en 806 de l'hégire (1403-1404 de J. C.). Les Nouvelles considérations auxquelles ce dernier traité donna lieu sont d'un autem que mous ne connaissons pas. Le Riésumé des additions faites à celui-ci est attribué à un docteur nommé Alouk Yazid al-Dowài (ilgull). Les additions ellesmêmes provenaient d'Al-Bolqini et d'autres docteurs. Le 
Résumé commence par le clapitre sur les rentes ef finit par celui de l'affranchissement.

Papier. $9^{8}$ feuitlels. Hauteur, 22 centimètres el demi; largeur, is centimètres et demi. 25 lignes par page. Ms. du xvil siècle. (Ancien fonds 535.)

\section{3.}

Les deux premiers volumes, reliés en un seul, de l'ou-

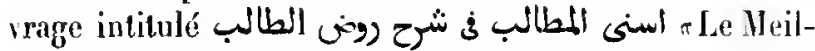
leur des trésors à rechercher, commentaire sur le Raudl al-Talib». Lourrage commenté est un abrégé de jurisprudence schâféite ${ }^{1}$, par Scharaf al-Dìn Ibrâhìm ibn al-

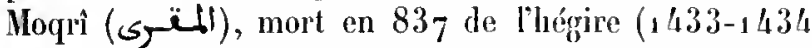
de J. C.). Le commentaire est du schaikh al-Istam Aboù Yahyả Zakariyà al-Anşàlì. Les demiers l'euillets du second volume manquent, car celui qui porte la cole 649 est l'œurre d'un faussaire. On voit par la liste des chapitres ( $60.414 v^{\circ}$ ) que le dernier quart du volume a disparu. Le texte de l'ouvrage commenté est écrit à l'encre rouge.

Papier. 6'19 feuillets. Hauteur, a centimètres; largeur, 15 centimètres. 19 ligues jar page. Ms. du xvi" siècle. - (Supplément 431 I.)

\section{4.}

Le quatrième et le cinquiène volume du commentaire de Zakarigà al-Anṣirì sur le Raudh al-Tálib.

Papier. 506 feuiltets. Mtèmes dimensions que le numéro précédent. 19 lignes par page. Mss. du xvi" siècle. - (Supptément 434 11.)

\section{5.}

Le cinquième et le sixième volume du commentaire de Zakariyà al-Aişàri sur le Raudh al-Ṭalib. Le cinquiene volume est daté de l'an 801 de l'hérgire (1379 de J. C. ), (1t le sixième de l'an 944 de l'hégire ( 1537 de J. C.).

Papier. 505 feuillels. Nlèmes dimensions que tes deux muméros précédents. 19 lignes par parce. - (Supplément 43 ' 1tt.)

\section{6.}

r Connaissances nécessaires pour celui qui veut exercer les fonctions de cadin. Lourrage, di-

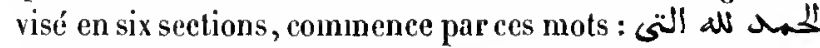

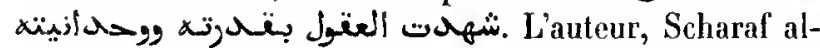
Din Ibrâhim ibn 'Abd Allah, natif de la ville de Hamàt, surnommé lbn abì al-Damm, docteur de droit schàléite, mourut, d'après Hadji Khalfa (t. I, p.222), en 642 de l'hégire (1244-1245 de J. C.). Ms. daté de l'an 852 de l'hégire (1438-1439 de J. C.).

Papier. 157 fenillets. Ilauteur, 31 rentimètres et demi; largeur, 21 centimètres. 19 lignes par page. - (Supplément 457 , Saint-Germain 135.)

\section{7.}

(L) Petit contenant $\pi$, précis de jurisprudence schàléite, composé par Nadjn al-Dìn 'Abd alGhaffàr al-Qazwini, mort en 665 de l'hógire (1 $266-1267$ de J. C.). Le frontispice de ce volume est orné d'arabesques, et porte l'inscription suivante en caractères cou-

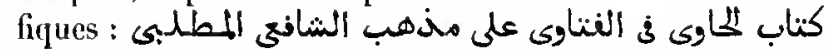
"Le Contenant, renfermant la jurisprudence de l'école d'Al-Schàfici al-Mottalibì (descendant d'Al-Moțalib, fils de 'Abd Manàf) r. Chaque feuillet du texte a été cncadré, plus tard, dans un feuillet plus grand, afin que les marges fussent assez larges pour recevoir des annolations. Cette opération a été faite arec une grande habileté.

Papier. 153 feuillets. Hauleu;, 16 centimètres; largeur, 11 centimèlres. 13 lignes par page. Ns. du $x v^{\circ}$ siècle. -. (Supplément $h 16$, Saint-Germain 54a.)

\section{8.}

Commentaire sur "Le Petit contenant " d'Al-Qazwìnì. Le titre et le nom de l'auteur ne sont pas connus, mais c'est le plus ancien commentaire de l'ourage de Qazwìni, car le présent ms. est daté de l’an 710 de l'lıégire (1310 de J. G.). Il commence par ces mots : al J

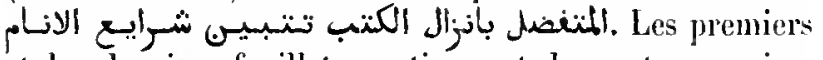
et les derniers feuillets contiennent des notes peu importantes, dont quelques-unes en persan, le commencement d'un autre commentaire sur le llâai, et quelques contes.

Papier. 319 feuillets. Ilauteur, 25 centimètres; largeur, 11 centimètres. 30 lignes par page. - (Supplément 4 17.)

\footnotetext{
1 C'est un extrait du Ratudha. 11. \%.
} 


\section{9.}

rL'Élégance approwréc, commentaire sur le Bahdjat al-Wardiyyan, par

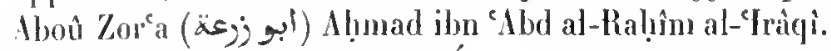
I. Irailú appelé le Bahdja "L'Élégants, de Zaïn at-Din 'Omar ibn al-Hozaffar' al-Wardì, est une rédaction en r's du résumé de jurisprudence schaféite composé par Dadjun al-1) in cAbd al-Ghaffì ibn 'Abd al-Karinı al-Qazwini, et inlituté lient que la seconde moitié de lourage, est daté de l'an 859 de l'hégire (1455 de J. C.). Au commencement se trourenl phusieurs satires, en vers, contre les Tures, cl une ancedole relative ì $\mathrm{Al}-\mathrm{Schaffi} i$ i $_{\text {il }}$ la fu les dernitr's vers du Wardiyga. Nous y lisons que ee poème fut achevé peu de temps après l’an 730 de l’hégrire (1330 de J. C.). Suit l'indication de quelques terres situces daus diverses provinces de frégyple, et payant des rederances en nature à la grande mosquée d'H-Ghomrì $(s, i t)$.

Papier. 245 fenillets. Ilauteur, 28 centimètres; largeur, 18 centimètres. 31 lignes par page. — (Supplément 415 bis.)

\section{0 .}

La seconde moilié de l'ourrage incilulé

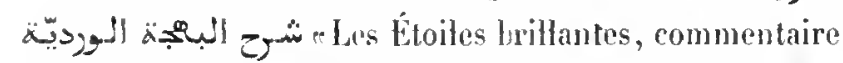
sur le Bahdjat al-Il ardiyya", par lo cadi Zakarjyâ ibn Molımmad al-Auscàr'. Ms. dalé de l’an 1084 de thégire ( $16-3-1674$ de J. C. .)

Papier. 328 feuillets. Hauteur, a2 centimètres; largeur, 15 centimitres el demi. 21 ligaes par page. - (Supplément 415.)

\section{1.}

Suroud wolune diun traité de droil. Le commencentent manque, mais on lit à la fin le litre suivant: تسمسيك

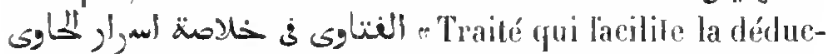
fion dopinions juridiques, quand elte est appliquéc anx secerels du Hiwio. Le premier chapile complet dans ce

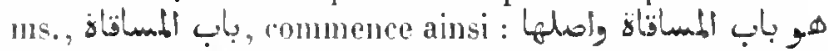

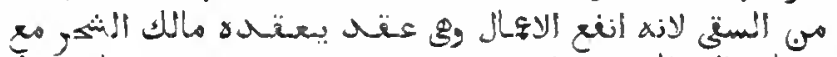

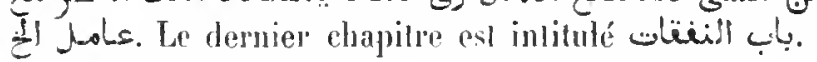

Papier. 198 tcuillets. Hauteur, 27 centimètres; largeur, 18 centimétres. 27 lignes par page. Ms. du xvi siècle. - (Supplénent 247. )

\section{2 .}

Le منهاج الطالبيه, abrégé de droit schåféite, par Nol!yì al-Din al-Nawawi. C'est un résumé, et un commentaire en même temps, du traité d'Al-Râfí ì (أكى), intilulé ¿ النحّ. Ms. daté de l'an 860 de l'hégire (1456 de J. C.). Il y a une lacune entre les fenillets 172 et 173 .

やapier. 174 fenillets. Hauteur, 17 centimètres; largeur, 13 centinutres. 9 lignes par page. - (Ancien fonds 531.)

\section{3.}

Le Minhâdj al-Talibin d'Al-Nawawì. Ms. daté de l'an 997 de l'hégire (1588-1589 de J. C.).

Papier. 207 feuillets. Hlauteur, 20 centimètres et demi; largeur, 15 centimètres. 17 lignes par page. - (Supplément 428.)

\section{4.}

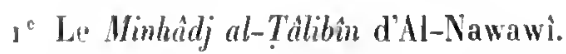

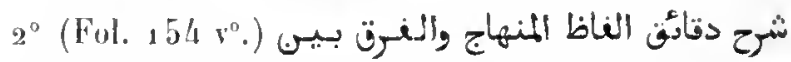

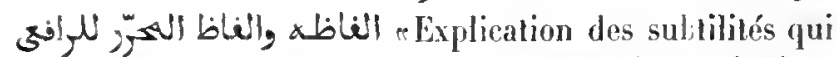
se trouvent dans la terminologie du Minhadj, et indication des différences qui existent entre cette terninologie et celle du Molearrar d'Al-Làfièr.

$3^{\circ}$ (Fol. 168 r $^{\circ}$.) La sonrate du Coran intilutée Yâ-sîn.

Papier. 17 o feuillets. Ifauteur, 21 centimètres; largeur, 16 centimètres. 20 lignes par page. - (Supplément 418.)

\section{5 .}

Commentaire de Schihâb at-Din Aḷmad ibn Handàn Al-Adsra'i (الاذز), morl en 783 de l'hégire (1381-1382 de J. C.), sur te Minhâdj al-Talibin. Ce ms. est l'arantdernier volume d'un exemplaire composé primitivement de neuf tomes. En eflet, il commence par un des derniers paragraphes du chapitre de la capitation (äet fint vers le milieu llu chapitre des lómoignages

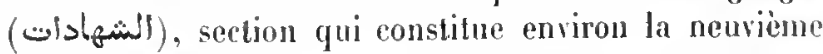
parlic du Winhudj.

Papier. 328 fenillets. flauteur, 27 centimètres; largeur, 18 centimètres. 31 lignes par page. Ms. du $\mathbf{s v}^{\circ}$ siècle. - (Supplément 429.) 


\section{6.}

(l La voic à suivre par les personnes qui désirent posséder un alorégé du Minhadj al-Ṭalibînn, par Schams al-Din Mohanmad ibn Yoûsof al-Qoûnawî (الفونوى), mort en 788 de l'hégire (1 386 de I. C.). Ms. daté de l'an 753 de l'hégire (1352 de J. C.). Écriture dépourve de points diacritiques; notes marginales '.

Papier. 218 feuillets. Hauteur, 27 centimètres; largeur, 19 centimètres. Le nombre de lignes par page varie de 25 a $37 .-$ (Ancien fonds 5.4 .)

\section{7.}

Le iroisième volume du Conmentaire du Minhidj alTalibin, par Badr al-Din Moḷammad ibn 'Ahd Allah alZarkaschì, mort en $79^{4}$ de l'hégire $(13)_{1-1} 39_{2}$ du J. C.).

Papier. 299 feuillets. Hanteur, 28 centimètres; largenr, is centimètres et demi. 25 lignes par pagre. Ms. du $x^{\circ}$ siècle. - (Aucien fonds 505 , Colbert 2485 .)

\section{8.}

Volume dépareillé d'un exemplaire du commentaire d'Al-Zarkaschî̀ sur Je Minhâdj al-Ṭalibîn, commencant par le chapitre de la petite culture (مساقات), et finissant par te clapitre de la distribution de la dime d'aumóne (تسم الصدقات). Le volume sujant derait commencer par le chapitre du mariage (نكاح).

Papier. 255 fenillets. Hauteur, 27 centimètres; largeur, 18 centiuıères et demi. 24 à 26 lignes par page. Ms. du xvi sièele. - (Supplément 420.)

\section{9 .}

Septième ef avant-dernier volume de louvrage inti-

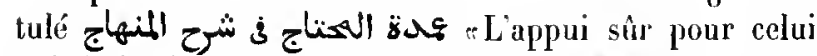
qui désire bien comprendre le texte du Minhadj\%. Selon Hadji Khalfa, l'auteur du conmentaire se nommait Siradj al-Din 'Omar ibn' 'Alì ibn al-Molaqqin (velfl), docteur schâféite, mort en 804 de l'hégire (1401-1402 de I. C.). Ms. daté de l'an 855 de l'hégire $(1451$ de J. C.).

Papier. 216 feuillets. Hauteur, 27 centimètres et demi; largeur, 18 centimètres et demi. 25 lignes par page. - (Supplement 4a 4 .)

\section{0.}

La seconde moitié d'un conmentaire-anonyme sur le Minhadj al-Talibin. Ce commentaire differe de tous les autres commentaires du Minhadj que possède la Bibliothèque nationale. Le volume commence par le clapitra des waqf. Ms. daté de l'an 822 de l'hégire ( 1419 de J. C.).

Papier. 291 feuillets. IFauteur, 25 centimètres; largeur, 16 centimètres. Le nombre de lignes par page varie de 23 ì 99 . - (Supplément 447 .)

\section{1.}

Commentaire de Djalàl al-Din al-Mahallì sur le Minhadj al-Talibin. Le texte entier dı Minhâdj s'y trouve écrit à l'encre rouge. L'auteur arait terminé son travail en 860 de l'hégire (1456 de J. C.). Nombreuses notes marginales.

Papier. 462 feuillets. Hauteur, 30 centimètres; largeur, 21 centimètres. Au commencement 33 lignes, puis a lignes par page. Ms. du xvit siècle. - (Supplément 4a 7.)

\section{2.}

Guide pour condnire liillrestigateur curieux à la connaissance dı contenu du Mohaqqiq", traité dans lequel le schaikh Aboû 'l-Ḥasan al-Bakrì al-Ṣiddiqî (descendant du calife Aboù Bakr alSiddiq) explique les difficultés du Mohaqqiq on vérificateur, ouvrage composé par Djahâl al-Dìn al-Mahallì pour développer le sens du Minhadj. Ms. daté de laan 1033 de l'hégire (1623-1624 de J. C.).

Papier. 250 feuillets. Ilauteur, a 1 centimètres; largenr, 15 centimètres et demi. 23 lignes par page. - (Supplément 419.)

\section{3.}

$1^{\circ}$ Fragment (le premier cahier) du commentaire du

\footnotetext{
Ces notes marginales, qui sont des additions et des corrections, paraissent être de la main de l'auteur. H. Z. MaY. onextalx. - 11 .
} 
Vinhâdj al-Tálibin, par le docteur schàféite Schanı alDîn ibun al-Qáyàtì (التقاياتة).

$2^{\circ}$ (Fol. 12.) Copie des gloses écrites par le schaïkh Badr al-Din al-Zarkaschì sur les marges de son exemplaire du trailé de jurisprudence inlitulé datée de l’an 878 de l'hégire (1473-1474 de J. C.).

$3^{\circ}\left(l^{*}\right.$ ol. $\left.22 v^{\circ}.\right)$ 'Traité de jurisprudence schâféite, avec un conmentaire, dont une partie considérable est attribuée au schaikh Al-Bolqînî (البلفينى). Cet opuscule commence par le chapitre relatif aux fonctions de cadi (كتنب التضاء), et finit par le chapitre qui traite des es-

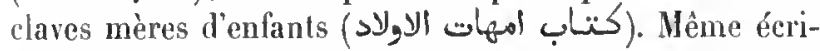
ture que le traité précédent. Copie datée de l'an 887 de l'hégire ( 1482 de J. C.). Le recto du folio 22 est un fragment d'un traité d'astrologie.

$4^{\circ}$ (Fol. $\left.100 v^{\circ}.\right)$ Trailé des topiques, intitulé الاغوراب (cLa nouveauté, traitant de la manière de raisonner des Arabes du déserl n, par Kamål al-Dìn Aboù 'lBarakât 'Alyd al-Raḷmån ibn Moḥammad al-Anbâlı̀, mort en 577 de l'hégire (1181-1182 de J. C.).

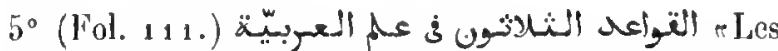
trente principes fondamentaux de l'analyse grammaticale de la langue araben, par Schihâb al-Dín A ḥnad ibn

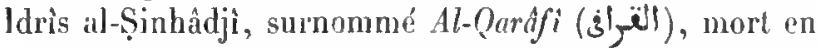
684 de lhégire $(1285-1286$ de J. C. $)$. Le vérilable titre de cet ouvrage est très-probablement : البواعد المسنيّة في rLes principes d'une valeur approuvée, faisant connaitre les secrets de l'analyse grammaticalen. Copie datće de l'an 878 de l'hégire (1473-1474 de J. C.).

$6^{\circ}\left(\right.$ fiol. $123 \gamma^{\circ}$. النتهذيب ف المنططن. Traité de logique de Sa d al-Din al-Taftàzânì. Quelques notes marginales. Copie datée de l'an 878 de l'hégire $(1473-1474$ de J. C.).

$7^{\circ}$ (Fol. $133 \vee^{\circ}$.) Traité de logique, par Mohammad ibn Scharif al-Hosaïni, commençant par ces mots : المنطق

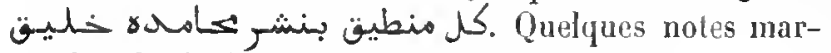
ginales. Copie datée de l'an 878 de l'hégire.

$8^{\circ}$ (Fol. $147 \mathrm{v}^{\circ}$.) Traité de logique, composé en langue persane, par le Sayyid Scharif al-Hosaïni, et traduit en arabe par son fils, Moḅammad. La préface du traducteur

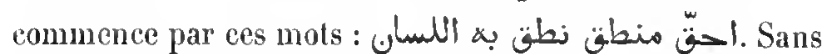
points diacritiques. Noles maroginales. Copie datée de l'an 878 de l'léegire.

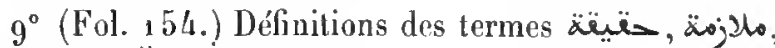
to La note sur la signification de ce dernier mot est assez étendue.

$10^{\circ}$ (Fol. $\left.154 v^{\circ}.\right)$ Commentaire de Khaïr al-Din al-

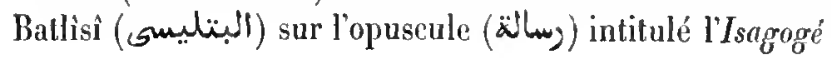

dAlkîr al-Din al-Abharî. Notes marginales. Copie datée de l'an 887 de l'hégire (1482 de J. C.).

Papier. 203 fenillets. Hauteur, 18 centimètres et demi; largeur, $1 /$ centimètres. 10 à 21 tignes par page. - (Ancien fonds 564.)

\section{4}

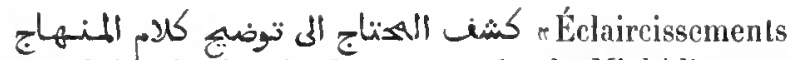
pour celui qui a besoin de comprendre le Minhâdjn, ourrage anonyme, dont nous n'avons ici que le premier volume, commençant par le chapitre de la purification et finissant par le chapitre du pèlerinage.

Papier. 315 feuillets. Hauteur, 25 centimètres; largeur, 17 centimètres et demi. 25 lignes par page. Ms. du xvi siècle. - (Ancien fonds 35 r.)

\section{5 .}

Commentaire dı schäklı Noûr al-Din 'Alì al-Halabì sur l'ouvrage dans lequel le schaikh al-Islàm Zakariyà al-Anșàrì explique les difficultés du Minhâdj al-Ṭalibîn.

Le premier feuillet manque.

Papier. 145 / feuillets. Hauteur, 31 centimètres; Jargeur, so centimètres et deni. 33 lignes par page. Us. du xvı' siècle. — (Supplément 425.)

\section{6.}

Dernière partie du commentaire du schaiklı al-Islàm 'Ali al-I!alabì sur l'explication du Minhadjal-Talibin, par le schaỉkh al-Islâm Zakariyâ al-Anșàrì. Le rolume commence par le chapitre sur le partage des successions (الفرائض).

Papier. 36.3 feuillets. Flauteur, 21 centimètres; largeur, 15 centimètres et demi. 21 lignes par page. Ms. du xvu siẻcle. — (Supplément 125 bis.)

\section{7 à 1020 .}

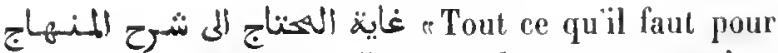
lintelligence du Minhâdj». L'auteur de ce commentaire, Zaïn al-Dìn Mohammad ibn Ạmad ibn Ilamza al-Ramli (Gogli) al-Anșầì, était schaikh al-Islàm el docteur eu jurisprudence scliâféite. L'ourrage, qui est très-élendu,

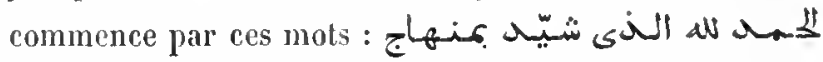
دينه الركان. النثريعة الغّّاء. Liauteur l'a termince en $97^{3}$ de l'hégire ( 1565 de J. C.). 
Au commencement du volume, l'auteur est appelé Schams al-Dìn Moḥammad a]-Ramli. Ms. daté de l'an 1191 de l'hégire (1777 de J. C.).

4 volumes. Papier. $62_{9}, 554,447$ et 426 feuiltets. Hauteur, 23 centimètres; largeur, 16 centimètres. 25 lignes par page. - (Supplément 421.)

\section{1 .}

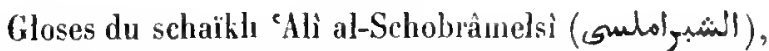
pour faciliter l'intelligence du commentaire d'Aí-liamlì sur le Minhâdj. Ce volune devait se terminer par le cha-

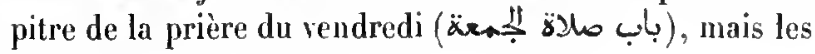
derniers feuillets manquent.

Papier. 29o feuillets. Hauteur, 30 centimètres; largeur, 21 centimètres. 33 lignes par page. Ms. du xvı' siècle. - (Supplément 42.)

\section{2 .}

Second volume et première moilié du quatrième et dernier rolume des gloses d'Al-Sclıobràmelsì sur le commentaire d'Al-Ramlì.

Papier. $57^{-1}$ feuillets. Hauteur, 23 centimètres; largenr, 17 centimètres. 23 à 26 lignes par page. Ms. du xun siècle. - (Supplément 423 bis.)

\section{3.}

Second et dernier volume d'un commentaire sur un traité de droit. 11 y a lieu de croire que c'est le commentaire de Madjd al-Din Aboû Bakr ibn Isma îl al-Senkeloûmî (ألسنكلونى) ou al-Senkeloùnì (السنكلون), sur le Tanbîh d'Áboû 1slıâq al-Schìrâzì. (Voyez Hadji Khalfa, t. II, p. 430, 434.) Un libraire a inscrit sur le premier

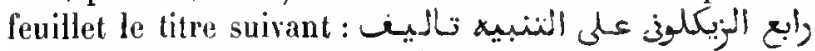

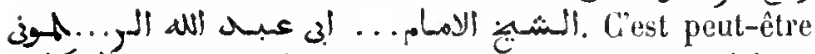
ic qu'il faut lire. Au reste, nous n'avons pas ici un quatrième volume, mais bien un second, ainsi que l'atteste la souscription ein du tome Il r. Le ms. commence par le chapitre des prêts et se termine par le chapitre des dispositions lestamentaires. Voici les premiers

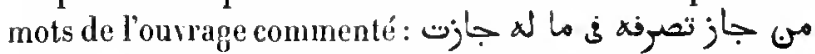
أعارته. Ms. daté de l'an 76 he l'hégire (1363 de J. C.).

Papier. 197 feuillets. Hauteur, 19 centimètres; largeur, 14 centimètres et demi. 18 lignes par page. - (Supplément 411.$)$

\section{4.}

Commentaire sur le traité de jurisprudence schâféite intitulé Naṣr al.Din 'Abd Allàh ibn 'Omar al-Baïdhâwî, mort en 685 de l'hégire (1 286 de J. C.). Le premier feuillet du rolume ayant disparu, nous ne pouvons indiquer avec certitude le nom de l'auteur. Nous inclinons à croire que ce conımentaire a été composé par 'Abd Allàh ibu Moḷammad al-Farghàn. Hs. daté de l'an 806 de l'hégire (1403-1404 de J. C.).

Papier. 436 feuillets. Hauteur, 25 centimètres: largeur, 14 centimètres et demi. a 3 lignes par page. - (Ancien fonds 511. )

\section{5 .}

$1^{\circ}$ r. Recueil de traités sur le partage des successions et sur le calcul des parts", par le docteur schâféite Mohammad ibn Scharaf al-Kalài (ى) (Si), mort en 777 de l'hégire $\left(137^{5-1} 376\right.$ de J. C.). Hadji Khalfa, t. V, p. 471, a donné la liste de ces traités, empruntée à la préface de cette compilation. Copie datée de l'an 909 de l'hégire ( 1504 de J. C.).

$2^{\circ}$ (Fol, 49.) Problèmes, en rers, relatifs au calcul des parts; notes sur les degrés de parenté indiqués par le mol عصبات; autres problèmes en prose.

3० (Fol. 51 r. . Chapitre sur les dispositions testamentaires ${ }^{\circ}$. Série de questions relatives au calcul des parts.

$4^{\circ}\left(\right.$ Fol. $\left.80 v^{\circ}.\right)$ Notes délachées, les unes sur des questions de droit, les autres sur le partage des successions.

Papier. 82 feuillets. Hauteur, 18 centimètres et demi; largeur, 13 centimèlres el demi. 1 ; et 18 lignes par page. - (Supplément 164.)

\section{6 .}

Quatrième volume du du grand Océan $n$, commentaire du schaïh Nadjin al-Din Aḷmad ibn Moḷammad ibn Makkî al-Qanoùlì (لغإ), docteur sclıâféite, sur le texte du وسبط "Trailé ıoyenr, ouvragre de jurisprudence, composé par Aboù Hànid alGhazàli. Le uss., dont les premiers feuillets manquent, commence par le chapitre des crimes (مبايات), et se termine par le chapitre relatif aux esclaves mères (مـان) 
الإولاد). Ms. daté de l'an 863 de l'hégire (1458-1459 de J. C.).

l'apier. 347 feuillets. Hauteur, 27 centimètres; largeur, 18 centinritres. 29 lignes par page. - (Supplément 408 bis.)

\section{7.}

Volume dépareillé et incomplet au commencement, formant le second quart d'un traité de droit, qui porte le lilre de de docteurs schâféiles nous porlent à croire que c'est le traité de jurisprudence schâféite composé par Yoûsof ibn

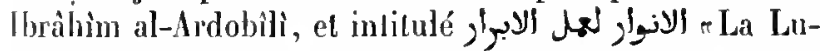
mière pour diriger les justes dans teurs actionsn. Le volume contient la fin du chapitre du mariage, qui est suivi du chapilıe du serment, et se lermine par le chapitre de l’alfranchissement des esclares mères, عتنق أمهات الاولاد.

P'apicr. 253 feuillets. Hanteur, a 7 centimètres; largeur, 17 centimètres et demi. 23 lignes par page. 11s. du xvi siècle. - (Supplément (112.)

\section{8.}

Commentaire sus un traité de droit. Le commencement el la fin manquent. Ce rolume devait commencer par le chapitre de la société en participation $(0-10)$, et finir par le chapilre des objets trouvés (لقط). L'auteur du commentaire cile un assez grand nombre de traités schâféiles et quelques Irailés hauéfites, tous antérieurs au $\mathrm{xy}^{\mathrm{c}}$ siècle de notre ère. C'est par imposture qu'une nain متناب : plus modeme a écrit en lête du premier feuillet rLe Tabșira d'Ibn Farhorin; un feuillel manque . La mème main a effacé la ríclame du dernier feuillet et l'a remplacée par les mots

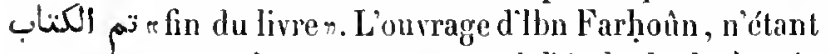
pas un comnenlaire et appartenant à l'école de droit mâlékite, u’a rien de commun avee celui-ci.

Papier. 324 feuillets. Hauteur, 27 centimètres et demi; largeur, 18 centimètres et demi. 3 , lignes par page. Ms. du $x^{e}$ siècle. - (Suppiément lao.)

\section{9 .}

ألاقتُصاد في كفاية العُبّاد Le juste inilieu, manuel suffisant pour des parties contraclantes n, traité en vers, renfermant les lois du mariage. L'auleur élait un schajkh nl-Istàn nommé Aboû '1-'Abhâs Schihâb al-Dìn Nḷmad
Ihn al-'Imàd (العاد). Nous arons ici le lexte du poème, accompagné d'un commentaire écrit par Schams at-Dìn Mohammad, fils de l'auteur.

Papicr. 62 feuillets. Hauteur, 31 centimètres; largeur, 15 centimètres. $2 \overline{5}$ lignes par page. Ms. du xvi1' siècle. - (Supplément 460.)

\section{0.}

Second volume d'un commentaire sur un lraité de droit schâféile, commençant par le chapitre des ventes et finissant par le chapitre du partage du butin. Le volume snivant devail commencer par le chapitre du mariage. Ms. daté de l'an 859 de l'hégire (1455 de J. C.).

Papier. ${ }_{2} 60$ feuiltets. Hauteur, 28 centimètres; largeur, 18 centimètres et demi. 31 lignes par page. - (Supplément 426 .)

\section{1.}

Exposé des finesses cachées et acquisition de l'art de calculer les partsn, ouvrage dans lequel le docteur schâféite Schihâb al-Dín Aboû '1-Abbâs Ạ̣mad ibn al-Madjdì reproduit, avec des modifications et des additions, bien que sous une forme abrégée, le contenu de son traité sur le partage des suecessions, intitulé julif. Un natif du Maghrel, a écrit sur les derniers feuillets du rolume une longue instruclion sur la manière de consulter le sort, au moyen du tableau cabalistique appelé la noble zä̈rdja. Voyez sur ce tableau, nommé aussi adirdja d'Al-Sibti, la traduction des Prolégomènes d'Ibn Khaldoîn, tome I, page 245.

Papier. 131 feuillets. Hauteur, a1 centimètres; largeur, 15 centimètres. 13 lignes par page. Mls. du xvi ${ }^{\circ}$ sièclc. - (Ancien fonds 556.)

\section{2.}

م Extraits choisis dans les grands recueits, par Al-Nisaiin. Cet auteur, dont le nom complet est Aboù Bakr ibn Bahrain (بــ) al-Ansàrì al-Zaïni, vivait encore à l'époque où ce volume fut écrit, c'est-àdire en 889 de thégire ( 1484 de J. C.), puisque le dessinateur du frontispice l'ait suire son nom de ta lor-

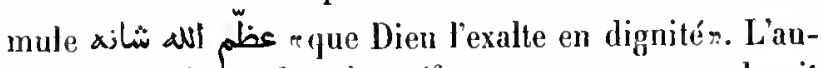
teur nous informe dans ta préface que son ouvrage devait être un abrégé du commentaire d'Aboû 1-Qàsim 'Abd alKarim ibn Mohammad al-Ráfíi (ألرى) sur le Wadjiz. 
d'Aboù llàmid al-Ghazài, et quil y a ajouté des extraits d'autres ourrages, dont il donne les litres. Le frontispice, por'lant le titre de l'ourrage el les noms de l'auteur, est dessiné avec beancoup de gont el exécuté en or et eu conleurs. Les deux premières pages sont encadrécs (n or, ainsi que la dernière qui porte, de plus, divers dessins dorés et coloriés.

Papier. 3,3 feuillets. Hauleur, 27 centimètres; largeur, 18 centimètres, 41 tignes par page. - (Supplément 410.)

\section{3.}

Questions de droit musulman avec leur solulion. Le commencentent et la fin manquent. Le litre de l'ourrage et le nom de lauteur nous sont inconnus. Le premier feuillet porte, il est rrai, nne prélace, mais les drrniers mots de la page ne se rattachent pas aux mots par lesquels commence la page suivante; d'ailleurs l'écriture est dillérente de celle du corps du ms. Ce feuillet appartienl à un autre ourrage.

Papier. 221 feuillels. Llauteur, 18 centimètres; largenr, 14 centimètres. 19 lignes par page. Ifs. dı xv' siècle, - (Ancien fonds 4a 8 .)

\section{4.}

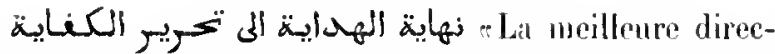
tion pour bien saisir le sens de la Kifayam. La Kifaya est un traité en vers sur les lois qui, d'après la jurisjorudence

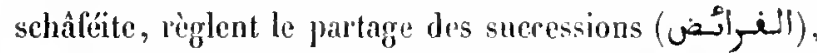
et a pour anteur Aboù '1-'Abbàs Aḷmad ibn Moluammad al-Hâim (الههايم), mort en 887 de l'héggire (1 482 , le J. C.). Le commentaire a été composé par le: schaikl al-lskim Aboù Yaḷyà Zakariyà al-Anșiri, mort en 910 de Phégire (1504-1505 de J. C.). Le texte du poèmest érit ì l'encre rouge ot interealé daus le commentaire. Ns. dalé de l'an 1190 de l'hégiro (1708-1709 de J. C.).

papier. 155 feniltets. Hanteur, 21 rentimetres et demi; largeur, 15 centimètres. 23 lignes par prage. - (Supplément 433.)

\section{5.}

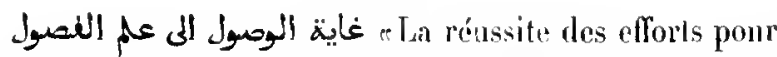
bien comprendre le Fosoûl", , ou communtaire du schaïk al-Islàm Aboû Yalyai Zahariyà al-Arṣàri sur le traité inlitule porlanls, servant à faire comnaitre les lois dhérilage che\% le penple (musulman)", jar Schihâb al-Din Aḷmad ibu Nolyammad, surnommé Ibn al-Hä̈m (ابع) الهايم). Le text: de cet ourrage, écrit ì l'encre rouge, est intercalé dans le commentaire.

Papier. 118 feuillets. Ilautenr, 21 centimètres; largeur, 15 centimètres. 23 lignes par pagre. Mls. du xvir siècle. - (Supplément 463.)

\section{6.}

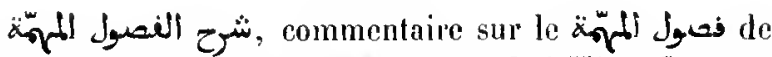
Schihàl al-Din Al!mad ibn Mlọammad al-Häm. Le texte du Fosoûl, écrit à l'encre rouge, est intercalé dans le commentaire, qui a pour auteur Schans al-Din Moḷammad Siltt al-Mlàridini. Ms. daté de l'an 918 de l'hégire (1512 de J. C.).

Papier. 158 feuillets. Iauteur, 18 centimètres; largeur, 13 centimètres et demi. Le nombre de lignes par page est d'abord de 17 , mais il augmente graduellement jusqu'à a $4 .-$ (Ancien fonds 557. .)

\section{7.}

- Les lumières éclatantes, commentaire sur le traité du partage des successions d'Al-Oschnohis, par Molyammad iln Mohammad al-Schaibi (Geثبال Le nom de l'auteur de l'ourrage rommenté est Aboì 'I-Fadhl 'Abd al-'Aziz ibn 'Alì, natif d'Oschnoh. Le village ainsi nommé était sitné à denx jounnées d'Ormiya et à cinq journées d'Arbelles. Al-Oschnohì mourut en 450 de l'hégiro (1058 de J. C.). Ms. daté de J'an 862 de l'hégire (1457-1458 de J. (i.).

Papier. 130 feuillets. Itauteur, 18 centinè̀tres et demi; largeur, 1 ' centimètres. 15 à 19 lignes par page. - (Ancien fonds 549.)

\section{8.}

" Cialeall joull' ceux qui cherchent l'explication du Talvir Tanqih al-Jo$b a b$, trailé de droit schâléile, pas le cadi Mbon Ialı̣a Zakariyà al-Ansàrì. Le Talırîr "Constatation" a été conposé jar le mème anteur pour fixer le sens du Tampill al-Lobâb, ourrage dans lejuel Aboù Zor'a al-Jingi corrigea le texle dn Lobâb al-Fiqh e Moelle de la jurisprudencen, composé par le docteur schàféite N!̣mad ibn Mohammad al-Malıànili. Aboù Yalỵà al-Anșàri mourul 
en $9^{26}$ de l'hérgire ( 1520 de J. C. ), Al-Irâqì en 826 de Thégire (1423 de J. C.), et Al-Mạ̣àmili (النهاملى) en 415 de l'héggire (1024-1025 de J. C.). Ms. daté de l'an 1001 de l'hégire $\left(159_{2-1}^{2-1} 9_{9}^{3}\right.$ de J. C.).

P'apier. 179 fenillets. Hautenr, 24 centimètres; largeur, 17 centimètres. 21 lignes par page. - (Supplément 4 14.)

\section{9 .}

Lr Tolgat al-Tollâb du cadi Aboû Yaḷyà al-Anșàcì. Ms. daté de l'an $117^{5}$ de l'luégire $\left(17^{61-1762}\right.$ de J. C.).

Papier. 366 feuillets. Hauteur, 23 centimètres; largeur, 16 centimétres et demi. 15 liggnes par parge. - (Supplément 413.)

\section{0.}

Premier volume du commentaire du schaïkh Hasan alMardabaghi (ابـان sur le texte el le commentaire du Tahrîr, c'est-ì-dire sur lo Tolgfat al-Tollâb d'Aboû Yahyâ al l-Arṣììi.

Papier. 549 feuillets. llauteur, 23 centimètres; largour, 16 centimitres. 2.3 lignes par page. Ns. du xvu siècle. - (Supplément 414 bis.)

\section{1.}

- Guide approuvé du notariat, traitant des contrats et des minutes d'actes authentiques», ourrage composé en Égypte vers le commencement du $x^{e}$ siecle, par Naș al-Din Moḷammad al-Dja far'i, docteur schàféite. Ms. daté de l'an 1139 de l'hégire (1 726 de J. C.).

Papier. 77 feuillets. Hauteur, 21 centimètres; largeur, 15 centimètres. 21 lignes par page. - (Supplément 454.)

\section{2.}

1 'Traité des successions (فرانض), en rers, intitulé

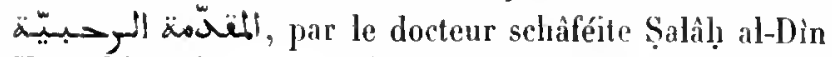
Yoùsof ibn 'Abd al-Latîi al-Hamawi, accompagné d'un commentaire composé par Badr al-Din Mohanmad, surnonmé Sibt al-Mâridîn.

$2^{\circ}$ (Fol. 29.) Deux feuillets, de la même écriture que les précédents, contenant un chapitre intitulé الاصسل
هLe septième principe, savoir l'amour du monde. Extrait du Kitab alArba inn. La fin manque.

$3^{\circ}\left(\right.$ Fol. $31 v^{\circ}$.) Les premiers feuillets d'un traité de كتاب الطهارة قال ألw : droit qui commence par ces mots تعالى بيا إيّها النذبي أمنوا

$4^{\circ}$ (Fol. 35.) Fragment d'un traité de droit. C'est une partie du chapitre relatif à la manière d'égorger les animaux.

$5^{\circ}$ (Fol. 39.) Fragment d'un traité de droit. C'est le chapitre de la prière et des purifications.

$6^{\circ}$ (Fol. $47 v^{\circ}$.) Le premier cahier de l'abrégé du

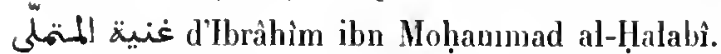

$7^{\circ}$ (Fol. $\left.57 r^{\circ}.\right)$ Premier eahier d'un chapilre tiré d'un traité de droit intitulé كناب 3 ادب اللغاضى. Ce traité est ull commentaire d'un autre ouvrage, et expose alternativement, par les formules قول قول rje disn, les opinions de l'auteur du traité et cetles du commentateur.

$8^{\circ}$ (Fol. $641^{\circ}$.) Fragment diun commentaire sur le chapitre des locations (باب الاجبـا; droit.

$9^{\circ}$ (Fol. 72.) l'ragment d'un traité de jurisprudence, renfermant la deruière portion du chapitre de la prière el les chapitres suivants, jusqu'an chapitre de l'allaitement. 11 commence par la section intitulée باب صلموة الم-مسافول -De la prièce du voyageurn.

$10^{\circ}$ (Fol. 132.) Fragment d'un traité de droil. Ciest le commencement du chapitre de la procuration.

$11^{\circ}$ (Fol. 133.) Fragment d'un commentaire sur un traité de droit. C'est une partie du chapitre relatif aux ablutions.

$12^{\circ}$ (Fol. 134.) Fragment d'un commentaire sur un traité de droit, chapitre des purifications. Quelques notes marginales.

$13^{\circ}$ (Fol. 138.) Fragment d'un traité de droit, chapitre des ventes.

${ }_{14} 4^{\circ}$ (Fol. 139.$)$ Fragment d'un traité de droit, chapitre des purifications.

$15^{\circ}$ (Fol. 147. ) Fragment d'un traité de droit, chapitre des ventes.

${ }_{16^{\circ}}$ (Fol. 148.) Fragment d'un traité de droit, chapitre du témoignage.

$17^{\circ}$ (Fol. 149.) Fragment d'un traité de droit, chapitre de la cantion (älill). Notes marginales. 
$18^{\circ}$ (Fol. 150.$)$ Fragment d'un trailé de droit, chapitre du témoignage.

$19^{\circ}$ (Fol. 151.) Cahicr d'un commentaire sur un traité de droit, chapitres de li location, de laffranchissenent conditionnel el de la caution.

$20^{\circ}$ (Fol. 169.) Autre fragment du mème ourrage, mais sans les rubriques.

21 ${ }^{\circ}$ (Fol. 187.) Fragment dı méme commentaire, chapitres du décès, de la compulsion, de l'émancipation et de l'usurpation.

$22^{\circ}$ (Fol. 214 .) Fragment d'un commentairc sur un traité des principes de la jurisprudence. Beaucoup de notes marginales et interlinéaires.

s $3^{\circ}$ (Fol. 2 19 .) Fraginent d'un commentaire sur un traité de théologie scolastique. Beaucoup de notes nalginales.

$24^{\circ}$ (Fol. 226.) Le premier cahier d'un commentaire sur un traité de théologie scolastique.

25 (Fol. 234.) Fragment d'un commentaire sur un traité de théologie scolastique.

${ }_{26}^{\circ}$ (Fol. 236.) Fragment d'un commentaire sul traité de logique.

$27^{\circ}$ (Ful. 246.) Fragment d'un traité de métaphysique.

${ }_{2} 8^{\circ}$ (Fol. 256.) Fragment d'un traité de logiciue.

$29^{\circ}$ (Fol. 257.) Fragment d'un commenulaire sul' un traité de logique.

$30^{\circ}$ (Fol. 261.) Trois autres fragments du mème genre.

$31^{\circ}$ (Fol. $267 v^{\circ}$.) Premicr calier l'un commentaire sur un traité de métaphysique.

$32^{\circ}$ (Fol. 277.) Plusieurs feuillets ayant appartenu à des traités de logique, de théologic scolastique, etc.

$33^{\circ}$ (Fol. 299.) Premier cahier d'un traité dans lequel l'auteur anonyme se propose d'éclaircir los obscurilés da الغوائح الغنارية

$34^{\circ}$ (Fol. 307.) Note sur la significalion des nots

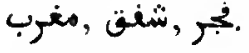

Papier. 307 feuillets. Hauteur, a centimètres; largeur, 15 centimètres et demi. 11 à 23 lignes par page. Écritures diverses du xrà siècle. - (Ancien fonds $\mathbf{5 5 5}$.)

\section{3.}

Seconde partic d'un recucil de décisions juridiques inlilulé مecueil contenant les décisions qui étaient restées éparses $\pi$, ouvrage sans nom d'anteur. Celte partie est composée de denx sections, dont la première commence par le chapilre de la procuration (كناب الوكالة), el finit par le chapitre du parlage des successions (اللنسرأض); la seconde section (fol. 120 ) commence par le chapitre des dispositions testamentaires (كتاب الوصايا), el finit par le chapitre du di-

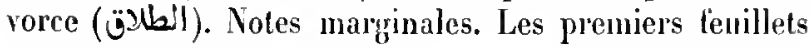
manquent.

Papier. 228 fenillets. Hauteur, a 4 centimetres et demi; largeur, 16 centinuètres et demi. 27 lignes par page. Ms. du $x v^{\circ}$ siècle. - (Ancien fonds 498 .)

\section{4.}

Consultation, datée de l'an 976 de l'hégire (1568 de J. C.), de Nadjm al-Din Nol!ammad ibn Mlımad al-Ghaï! i (الغيطى), doctcur scháféitc, au sujel de la tradilion qui assure que le Proplièle avait donné certaines terres en tonte propriété à Tamim al-Dàri. Le tilre de cette concession étail, disait-on, de la main d"Ali, ct portait les signatures d'Aboù Bakr et d"e Omar. Is. daté de l'an 1116 de lhégire (1704-1705 de J. C.).

Papier. 9 feuillets. Hauteur, 20 centimètres et demi ; largeur, 15 centimètres. 2 I lignes par page. - (Supplément 472.)

\section{5}

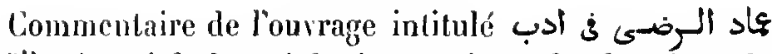
التضا Appui de la satisfaction, traitant des fonctions de cadin de Zakariyà al-Anșàrì al-Sanikî (السنيكى), par 'Abd al-Raouf al-Manâwî (عبلد الرؤن (كناوى), docteur schàféitc. Le texte, écril à l'encre rouge, est intercalé dans le commentaire. 'Abd al-Raoul' a achevé son travail en 991 de l'hégrire ( 1583 de J. C.). Notre excmplaire a été copié denx annécs plus lard. An fol. 11, l'anteur du commentaire donne la notice biographique d'un grand cadi, nommé Scharaf al-Dìn Aboù 'l-Faradj 'Âsâ ibu 'Othnìn al-Ghazzi ( الغز), anten" d'un traité qui avait serii de prototype à l'e Imâd.

Papier, 191 fenillets. Hauteur, 21 centimètres; largeur, 15 centimètres. 21 lignes par page. - (Ancien fonds 565.)

\section{6}

$1^{\circ}$ Premier feuillet du commentaire d'Abd al-Rinoul 
al-Manàwi sur to traité de jurisprudence d'Al-Mahâmili, intitulé بل ela moellen.

$2^{\circ}$ (Fol. 2.) Cahier d'un commentaire perpétuel snr un traité de droit. Il s'agil des dispositions testamentaires.

$3^{\circ}$ (Fol. 12.) Autre cahier d'un commentaire perpétuel sur un traité de droit. Il s'agit de la chasse et des virtimes pour le sacrifice.

$4^{\circ}$ (Fol. 20.) Six feuillets d'un recueil de légendes musulmanes.

$\tilde{b}^{\circ}$ (Fol. 26 . Dernier calıier du dialogue entre Mahomet et Abon Horaïra sur la religion.

$6^{\circ}$ (Fol. 37. ) Joles diverses, suivies des premiers feuillets diun traité suc la connaissance de Dieu au sens subjectil', composé par 'Abd al-llakim ibn Schams al-Din, auteur indien du xrue siècle, pour le sultan Aboù 1-Moz̧aflar Schams al-Dìn Moḥammad Schâh Djiłıân Ṣâhib al-Kînân.

Pajper. 42 feuillets. Hauteur, 24 centimctres; largeur, 16 centimetres, 19 à 23 lignes par page. Écritures diverses du xvi siècle. (supplement 2027. )

\section{7.}

rlétoile qui se leve. ourrage qui traile de ce quin notaire a besoin de ronnaitre", instructions sur la manière de rédiger des acles judiciaires, par Molıammad ibn 'Abd Allàh al-Djor'-

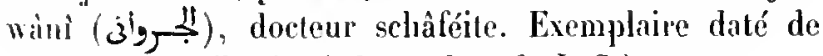
l'an 1010 de l'hégrire $(1601 \cdot 1602$ de J. C. $)$.

Papir. 84 feuiltets. Hauteur, 19 centimètres et demi; largeur, 15 centimetres. I 1 lignes par page. - (Ancien fonds 545.)

\section{8.}

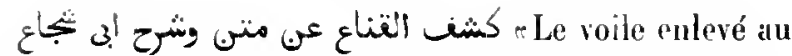
textr at au commentaire d'Aboù Schodjâcn. L'omrage comnenté par Abou Schodjà est le traité de jurisprudence schàféite de Schams al-Dìn ỉn Qầim (تشاسم) al-Ghozzî ou al-Ghazzi (الغزى). L'ourage el le commentaire ne sont pas mentionnés, non plus que les deux auteurs, dans Hadji Khalfa. Le Kaschf al-Qiná renferme les observations que le schaïhhı al-Islàm Aboû '1-Dhiyâ (أبو الضياء) Noûr al-Dìn 'Alì al-Schobràmelsî avait faites pendant les leçons où il expliquait le Irailé d'lbn Qàsim el celui du commentateur. Ces observations ont été recueillies et publiées par 'Abd al-Raḅmân al-Mạ̣allî, docteur' schâféite atlaché à la mosquée d'Al-Azhar, au Caire. Ms. daté de l'an 1163 de l'hégire ( 1750 de J. C.).

Papier. 73 feuillets. Ilauteur, a3 centimètres; targeur, 16 centimètres et demi. 29 lignes par page. - (Supplément $4_{2} 3$.)

\section{9.}

ذب Présent pour l'amateur», commentaire de Nohammad al-Djauharî al-Khâlidì sur le نبو المطائب نو Chemin de celui qui poursuit le plus noble des buts n, ourrage qui est le résumé et le commentaire philologique d'un traité de droit schâféite composé par Badr al-Dìn Zakariyâ al-Anșàrì, et intitulé min des étudiants". L'Ithâf a été composé en 1198 de l'hégire (1 784 de J. C.). Commencement : (5) all

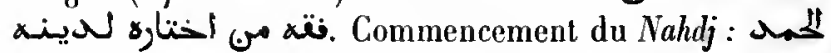
sul. Deux parties reliées en un seul volume, datées de l'an 1199 de l'hégire (1 785 de J. C.).

Papier. 432 feuillets. Hauteur, 23 centimètres et demi; largeur, 16 centimètres et demi. 19 lignes par page. - (Supplément 2032.)

\section{DROIT MÁLÉKITE.}

\section{0.}

$1^{\circ}$ Traité de droit mâlékite attribué à 'Abd al-Ralımân ibn al-Qàsim, l'un des priucipaux disciples de Mảlik. Une liste des chapitres, en tête du ms., qui ne correspond pas exactement à la série des chapitres qui se trourent dans le volume, est suivie d'une tradition rapportée par Soḥnoûn (سكنوب), un autre disciple de Mâlik, sur l'autorité d'Abd al-Raḥmân ibn al-Qấsim ibn Moḥammad (au lieu d'ibu Khâlid), et le témoignage d'une série de onze traditionnistes. Ce passage parait être une fabrication maladroite. Au reste, la plupart des renseignements contenus dans le traité sont donnés directement sur l'autorité d'Ibn al-Qâsim, qui les anrail reçus de la bouche de Mâlik.

$2^{\circ}$ (Fol. 95.) Traité sans titre ni nom d'auteur, en prose mêlée de vers, contenant des récits fabuleux au sujet de Mahomet.

$3^{\circ}$ (Fol. 109.) Histoire fabmleuse du juif 'Abd Allah ibn Salàm et de son entretien arec Mahomet.

$4^{\circ}$ (Fol. 133.) Traité sur la peine du talion (3 القصام). On y cite l'autorité du célèbre docteur mâlékite Yaḥyâ ibn Yaḷyâ. 
$5^{\circ}$ (Fol. 138.) Note sur les vertus d'un certain vers qui, étant récité trois mille fois chaque jour, pendant quarante et un jours, produil des effets merveilleux. L'auleur de cette pièce, dout la fin manque, est désigné par le

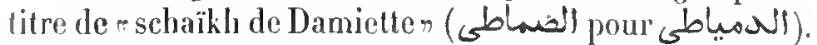

Cé ms., daté de l'an 1143 de l'hégire $(1-31$ de J. C.) (voyez fol. $9^{2} 1^{\circ}$ ), avait appartenu à Salliṭ bey, qui le donna en wayf, l'an 1190 de l'hégire (1776 de J. C.), à la grande mosquée qu'il avail fondée dans le Soúq alDjom $a$, à Constantine.

Papier. 139 fenillets. Hanteur, 20 cenlimètres; largeur, 1/4 centimètres. 18 à 20 lignes par page. - (Supplément 390.)

\section{1 .}

Exanen critique des questions traitées dans la Modaweana dans la Molhtalatar, par Aboû Sạid Klıalaf ibn abî 'L-Qùsim al-Barcidsici, our rage composé en 372 de l'Féggrice (982 de J. C.). Exemplaire dalé de l'an 850 de Thégire (1446-1447 de J. C.).

Papier. 857 feuillets. Ilinuteur, 25 centimetres; largeur, 18 centimètres et demi. 26 lignes par pare. -- (Supplément 34.5.$)$

\section{2 .}

Autre exenplaire du même ouvrague. Les derniers feuillets manquent. Les quatre premiers fenillets sont une restauration faite au $\mathrm{xvu}^{\mathrm{e}}$ siecle.

Papier. 230 fenillets. Hanteur, 26 centimitres; largeur, 19 centimétres et demi. 31 lignes par page. Ms. du $x v^{e}$ siècle. - (Supplément 396 .)

\section{3.}

Autre exemplaire du même ourrage.

Papier. ${ }^{2} 52$ fenillets. Hauteur, 28 rentimẻtres; laryeur, 20 centimètres et demi. 23 lignes par page dans les premiers fertillets, 31 dans les derniers. Ms. du $\mathbf{x v}^{\mathrm{e}}$ siècte. - (Ancien fonds 481.)

\section{4.}

1 Second volume d'un traité de droit målékite, inlitulé

Mas, oniextatx. - II. énoncées dans lin Modawwana». L'auteur du Taqyid a commenté très-longuement le texte d'Ibn al-Qḋim. L'exem-. plaire dont nous avons ici le second volume a dit se composer de trois ou quatre volumes.

$2^{\circ}$ (Fol. 1. 1. Examen crilique des questions traitées dans la Modawwana el la Molihtalatan. Le commencement et la fin manyuent. Les lolios cotés 2 I 7 el suivants doivent c̀tre placés a rant le lolio 131 . Il y a, de plus, quelques lacunes dans le corps du volume.

Papier. 223 feuillets. Hauteur, a 8 centimètres et deni; largenr, 20 centimè̀res et demi. 37 lignes par page dans le premier traité, 37 dans le second. Écriture maure-espagnole du $x m^{\circ}$ siède. - (Ancien fonds 469 .)

\section{5.}

Traité de jurisprudence màlékite. Le commencemsenl et la fin manquent, et plusieurs feuillets sont intervertis. Au fol. a commence le chapitre de la chasse (وناب الصيد يائily), au dernier fenillet le chapitre de l'affranchisscment. Nombreuses notes margiuales, dont une partie considérable est écrite à l'encre ronge. Nous lisons dans l'opuscule de II. Vincent, intitulé Éudes sur la loi musulmane, page 41, que ce volume est probabtenınt une copie de l'Otbiyya, traité de droit musulman, composé par 11-'Otbi (Moḷammad ibn Alımad ibu 'Abd al-'Aziz), qui arait écudié sous Yalıyâ iln Yaḷyà et qui momrut un 254 de l'hégire ( 868 de J. G.).

Papier. 115 feuillets. Hauleur, 25 centimètres; largeur, 17 centimètres et demi. 29 lignes par page. Écriture maure-espagnole du $\mathrm{x}_{1}^{\mathrm{e}}$ siècle. - (Ancien fonds 5.5.$)$

\section{6.}

Recueil de questions de droit avec leurs solutions, d'après la jurisprudence mâlékite. C'est une compilation de renseignements empruntés aux éerits d'Ibn al-Mawàz (j) d'lbn Habîb, d'lbn 'Abdoûs, d'Abd al-'Aziz al'Otbi, d'Hbn Solnnoûn et d'autres grands docteurs de. l'école de Malik. L'autorité de Soḥnoùn et d'lbn al-Qà$\operatorname{sim} y$ est soment invoquée. La majeure partie de ce rolume est consacréc à des questions d'affranchissement. Les premiers et les derniers feuillets manquent.

Papier. 189 feuillets. Ilauteur, 27 centimètres; Jargeur, 20 centimètres. 25 tignes par page. Ms. du xvil" siècle. - (Supplément 392 bis.) 


\section{7.}

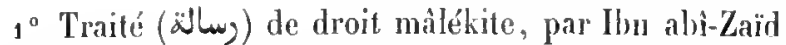
al-Qaïrawànî, mort en 389 de l'hégire ( 999 de J. C.). Lo texle porte tontes les voyelles. Copie du $\mathrm{xv}^{\mathrm{e}}$ siecle.

$2^{\circ}$ (Fol. 68.) L’Adjorroûmiyya, traité de grammaire arabe, composé par Moḥammad ibn Dawoùd al-Ṣinhàdji,

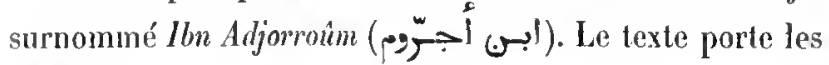
voyelles.

$3^{\circ}$ (Fol. 74.) Traité sur la théorie du droit, commen-

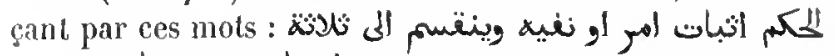

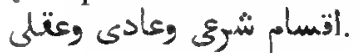

$4^{\circ}$ (Fol. 78 ` $^{\circ}$.) Traité smr les viandes prohibées, pal' Aboû 'I-Walid inn Roschd, cadi de Coudoue, grand-père d'Arerroès. Très-mauraise écriture.

$5^{\circ}$ (Fol. $82 v^{\circ}$.) Traité des vontes, en vers techniqunes, distribué en quinze sections et une conclusion. Les opinions d'Ibn Djamâca el d'Ibn al-Qìsim y sont citées.

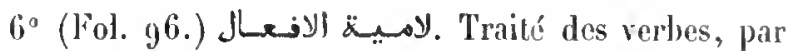
Ibn Målik, avec un commentaire par un anonyme. Ce traité est en vers, dont chacun se termine par la syllabe la (ע). Le texte porte les royelles.

$7^{\circ}$ (Fol. $1131^{\circ}$.) Pjèce de dix-sept vers, renfermant les reggles de permutation pour l'alif, par' 'Alsd al-Dàim, natif de Téza, au Maroc.

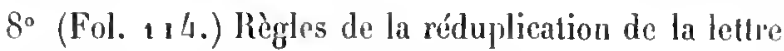
$y \hat{i}$, snivies de quelques pièces de vers.

$9^{\circ}\left(F_{0} .115 \gamma^{\circ}.\right)$ Formulaire d'actes, à l'usage des notaires, intitulé r Contrats de Fezn. Copic datée de l'an 1049 de l'hégire $(1639-1640$ de J. C.).

$10^{\circ}$ (Fol. 142 ${ }^{\circ}$. ) Prière suivie de quelques vers.

$11^{\circ}$ (Fol. 143.) Fragment d'un traité sur les vertus particulières de chaque sourate du Coran.

$12^{\circ}$ (Fol. 144.) Trois fragments d'un traité sur les ventes, en vers.

$13^{\circ}$ (Fol. $144 v^{\circ}$.) Traité en vers sur l'alif brel, l'alif long, l'insertion (ilgham), les yâ, etc., par Mohammad ibn Aḷmad al-Xliknâsì, surnommé Ibn Ghảzî (ابر غازى) al-'Othmànî.

$14^{\circ}$ (Fol. $148 r^{\circ}$.) Traité sur le partage des successions, par Abon̂ Naṣr. Copié en 1053 de l'hégire (16431644 de J. G.).

$15^{\circ}$ (Fol. 165.) Trajté en vers sur les dogmes de la foi musulmane, sur la purification, la prière, etc. Poème à l'usage des enfants (الرجبوزة الولمان). $16^{\circ}$ (Fol. $169 \vee^{\circ}$. ) P'oème sur les deroirs dn musulman, pa!' 'Abd al-Ralımàn.

$17^{\circ}$ (Fol. $189 \mathrm{v}^{\circ}$.) Traité sur les dognies de la foi

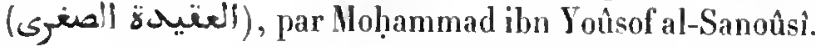

$18^{\circ}$ (Fol. $195 v^{\circ}$.) Poème indiquant les lecons du Coran adoptées à la Mecque. L'auteur, Mohamnad ibn

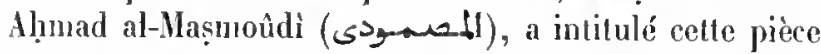
Récit offert en cadeau à celui qui commence l'étude des leçons mecquoises \%. Co Iraité est suivi d'un appendice en vers sur le même sujet.

$19^{\circ}$ (Fol. $208 v^{\circ}$.) Neuf vers techniques, qui présentent une explication des leltres on sigles par lesquels on a l'habitude de désigner les principaux lecteurs du Coran.

$20^{\circ}$ (Fol. 209.) Diverses règles d'orthographe et de grammaire, en vers.

$21^{\circ}$ (Fol. 2, 4.) Série de poc̀mes à la louange de Mahomet. La première de ces pièces rime en $d$, la seconde en $b a ́$, la troisième en $t a ́$, jusqu'ì la fin de l'alphabet. L'auleur, Moḷammad ibn Roschd al-Baghdâdi, a intitulé son

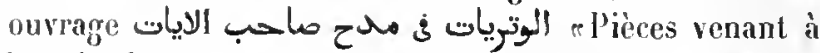
la suite les unes des autres et renfermant les louanges du Vaître des signes", c'est-à-dire de Mahomet.

$22^{\circ}$ (Fol. $237 \mathrm{v}^{\circ}$.) Poème dont la rime alternante est le nom de Maliomet.

$23^{\circ}$ (Fol. 240.) Les noms des vingt-luuit mansions du zodiaque; puis quatre vers relatifs à la manière de trouver la qibla, ou la direction de la Mecque, ì l'aide des étoiles de la grande Ourse.

$24^{\circ}$ (Fol. 245 .) Sermon ou prière pour demander la pluie (خطبة الاستستاء).

${ }_{2} 5^{\circ}$ (liol. 249.) Sermon pour les deux grandes fêtes

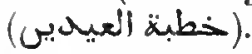

${ }_{2} 6^{\circ}$ (Fol. 251 .) Traité de grammaire, par Moḥamuad jlon 'Omar ibn 'Othmân.

$27^{\circ}$ (Fol. 256.) Termes grammalicaux avec leurs définitions (ححر) , par le schaikh Schihâb al-Din.

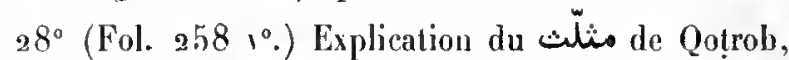
par ${ }^{\mathrm{C}} \mathrm{Ab} \mathrm{b}$ al- $\mathrm{C}$ Aziz al-Miknàsî.

Papier, 259 feuillets. Hauteur, 19 centinètres; largeur; 124 centimètres. Écritures diverses des $\mathrm{xv}^{\circ}$, $\mathrm{xvI}^{\circ}$ el $\mathrm{xvIr}^{\circ}$ siècles. - (Ancien fonds 526. .)

\section{8.}

La dسالة d'Ibn abì Zaijd al-Qairrawànî. Ms. daté de l'an 
1059 de l'hégire ( 1649 de J. C.). Les premiers fenillets manquent.

Papier. 140 feuillets. Hauleur, 23 centimètres et demi; largeur, 16 centimètres et demi. 13 lignes par page. - (Supplément 391.)

\section{9 .}

La gسـالـ d'lbn abì Zaïd al-Qaïrawànì. Ms. daté de l'an 1083 de l'hégire $\left(167^{2-1} 6_{7} 3\right.$ de J. C. $)$. Quelques notes marginales.

Papier. 128 feuillets. Hauteur, 21 centimètres; largeur, 15 centimètres. 11 lignes par page. - (Ancien fonds 430.)

\section{0.}

1 La La d'lbn abì Zaïd al-Qaïrawànì.

$2^{\circ}$ (Fol. 69.) Trailé en vers (râiya) sur la prononciation des lellres du Coran, par Yạyà ibn Moùsì al-Djazon̂lî. Prenier vers :

$$
\text { بحات لبـسم الم الركتى مسولانـا }
$$

$3^{\circ}$ (Fol. $821^{\circ}$.) L L Aqîda d'Al-Sanoùsì (Moḷammad

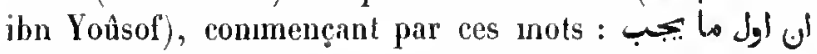

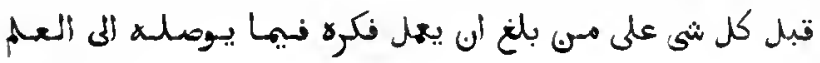
$8>$ ster.

40 (Fol. 96.) L"Aqida d'Al-Sanoîsì, commencaut par

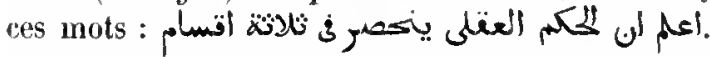

$5^{\circ}$ (Fol. 101.) Aulre ouvrage de Sanoúsî. (Voyez cidessus, $n^{\circ} 1057,3^{\circ}$.)

$6^{\circ}$ (Fol. 105 .) Traité sur l'existence de Dieu. Commen-

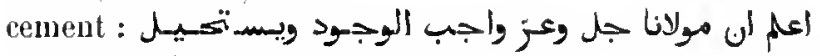

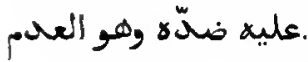

$7^{\circ}$ (Fol. 1 06.) (حرز الامان. Traité en vers sur la lecture du Coran, par lbu Fierro al-Schàtibì.

8. (Fol. $144 r^{\circ}$.) L'Alfiyya d'lbn Màlik.

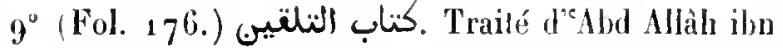
Moûsâ al-Saràqi sur les devoirs religieux du musulman.

$10^{\circ}$ (Fol. I 89.) Traité inlitulé كلكاب المكل, renliermant des traditions au sujet de la prière, du jeùne, de l'ablution, etc.

11 (Fol. 212.) Série de questions touchant dirers points de la doctrine musulnane, arec les réponses. $12^{\circ}$ Fol. $\left.2211^{\circ}.\right)$ Prière en vers, composée par H!asan ibn Mašoud al-Yoûsî (اليوسى). Premier vers :

يا وب يا رجم يا مه لا طلب الا الله وعنـلها يسرجبا الاوب

Papier. a a' 1 feuillets. Hauleur, a centimètres; largeur, g 4 centimètres. Ms. du xu $1^{\circ}$ siècle. - (Supplément $187^{6}$.)

\section{1 .}

$1^{\circ}$ La yالغ d'lbn abî Zaïd al-Qairawàni.

$2^{\circ}$ (Fol. 77.) Traité des venles d'lbn Djamấa, mis en vers par Aboû Zaïd 'Alod al-Raḥmàn al-Tilimsâni.

$3^{\circ}$ (Fol. 87 $^{\circ}$.) Traité des devoirs du musulman, en vers, par 'Abd al-Raḅmàn al-Raq'ì (

$4^{\circ}$, Fol. 106.) Trailé en ver's sur l'année et ses divisions.

$5^{\circ}\left(\right.$ Fol. $112 \%^{\circ}$.) Traité en vers sur l'orthographe du Coran, par Hoḷammad ibn Ibrâhìn al-Omawi (الإ) al-Scharischî. Premier rers :

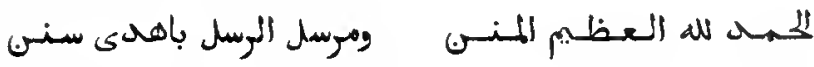

$6^{\circ}$ (Fol. $127 v^{\circ}$.) Aulre poème sur le même sujet, par Ibn Barri. Premier vers :

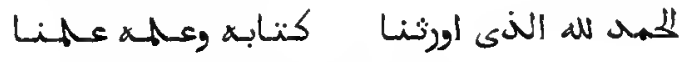

$7^{\circ}$ (Fol. $134 v^{\circ}$.) L'Adjorroûmiyya.

$8^{\circ}$ (Fol. 140.) Indicalion des sections du Coran, pal moilié, par quarl, par huilième, par ḥizb, etc. Le conımencement manque.

$9^{\circ}\left(\right.$ Kol. $\left.167 \%^{\circ}.\right)$ L'Alfyya d'Ibn Màlik.

$10^{\circ}$ (Fol. 204.) L'Aqida d'Al-Sanoûsì. (Voyez le numéro précédent, article $4^{\circ}$.)

$11^{\circ}$ (Fol. 208.) Traité d'Al-Sanoûsi sur les devoirs de lout homme responsable de ses actes.

$12^{\circ}$ (Fol. $209 v^{\circ}$.) Autre traité d'Al-Sanoûsi. (Voyez cidessus, $\mathrm{n}^{\circ} 1057,3^{\circ}$.)

Papier. 211 feuillets. Hauteur, 19 centimètres et demi; largeur, 13 centimètres et demi. Écritures diverses da xvil" et du xwn" siècle. - (Supplément 1875.)

\section{2.}

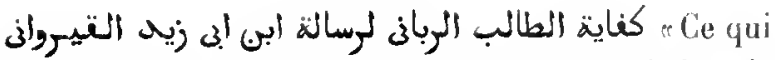
suffit pour faire comprendre à celui qui poursuit la voie spirituelle la Risâla d'Ibn abí Zaïd al-Qaïrawânì ». L'auteur 
de ce commenlaire est Mloû 'l-Hasan al-Màlikì. Notes marginales. La fin mangue.

Papier. 104 feuillets. Hanteur, a i centimètres et demi; largeur, 16 centimètres. 23 lignes par page. Is. du xru siècle. - - Supplément 2021 .)

\section{3 а 1069.}

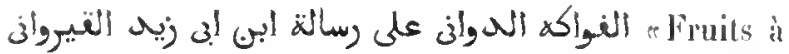
la portée de lout le monde, (commentaire) sur la Risála

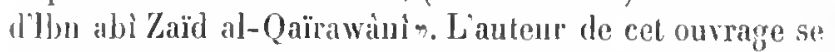
nommait Schihàb al-Dìn Aḷmad ibn Ghonaïm (غنم) ibn Sillim, malif de Baghdàd, doctenr mâlékite attaché à la mosquéc d'Al-Azhar, au Caire. Ns. daté de l'an 1170 de l'hérire $\left(17^{5} 7\right.$ de J. C.). Cet exemplaire formait deux volımes, qui ont été reliés en sept tumes.

Sept volumes. Papier. 220,177, 228, 287. 278, 307, 251 fenillets. Hauteur, 22 centimètres; largeur, 15 centimìtres. 19 ligqnes par parge. - (Supplément 392.)

\section{0 .}

Second et dernier volume d'un commentaire sur la Risalla d'Ibn abì Zaïd al-Qairrawànì. Les premiers leuillets manquent. Ms. daté de l'an 1165 de l'hégire (1752 de J. C.).

Papier. 450 feuiltets. Ilauteur, 21 centimètres; largenr, 15 centimòtres. 21 lignes par page. - (Supplément 407.)

\section{1.}

Les deux dernières panties d'un trailć de droit mảlékite consacré aux matières litigieuses. Daprès une note finale el d'après le titre écrit sur la tranche, cet ourage porte le titre de النبعرة, et a pour auteur un doctenr nommé Aboû 'l-ḷisan al-Lakhmi. Ia première parlie du ms, est datée de l'au 1247 de l'hégire (1831-1832 de J. C.), et la seconde, d'une autre main, porte la date de 1242 de l'hégire $(1826-1827$ de J. C. ).

Papier. 396 feuiflets. Ifauteur, 31 centimètres; largreur, 31 rentitnètres. 31 lignes par pağe. - (Supplément 3.̣g.)

\section{2.}

Les décisions juridiques d'Aboû 'I-Walid Moḷammad ibn Ahmad ibn Rosclıd (وشـد), imàm de la grande mosquée de Cordoue, el grand-père du célèirre Averroès (Ibun Roschd). La plupart des questions auxquelles répond l'auleur lui avaient élé adressées de différentes villes musulmanes de l'Espagne, ainsi que de Ceuta, de Tanger et de la ville de Maroc. D'autres lui avaient été proposées par les princes almoravides ( $\mathrm{fol} .83,107 \mathrm{r}^{\circ}, 116 \mathrm{v}^{\circ}, 1201^{\circ}$, $\left.123,142 v^{\circ}\right)$. Ces questions ne sont pas classćes par mattières. Le compilateur, Ibn al-Warrên (أبسن المولن), y al intercalé quelques dissertations ou lecons laites par lbı Rosehd à ses élèves. On y trouve des renseignements sur quelques faits de l'histoire d'Espagne, sur certains usages (fol. $106 \mathrm{v}^{\circ}$ ), et mème sur l'administration militaire (fot. $\left.170 v^{\circ}\right)$. A la fin du volune, l'éditeur donne une liste des écrits d'llon Rosclıd, et mentionne quelques événements de la vie politique de ce cadi qui, selon lui, naquit en 450 de l'hégire (1058 de J. C.), et mourut en 520 ( 1126 de J. C.). Ms. daté de l'an 722 de l'hégire ( 1322 de J. C.).

Papier. 177 feuillets. Hauteur, 28 centimètres; largenr, 22 centinètres. 27 lignes par page. -- (Supplément 398.)

\section{3.}

Huitiome el dernier volume d'un conmentaire sur le أحكام, traité de droit mâlékite. Le compilateur mentionne quelquefois les opinions d'Aboû llanifa, d'AlSchâfí ì et d'autres docteurs, el indique par des sigles les sources où il a puisé.

Un certifical de vente, inserit sur le verso du dernier feuillet, nous apprend que le nommé Alumad ihn أنسفغد, se trourant à Tombouktou (تنبكنت), en $9^{83}$ de l'hégire $\left(157^{5-1576}\right.$ de J. C.), a acheté ce rolume d'un étudiant qui venait de passer cinq ans à Fez et au Maroc, et qu'il l'a payé quatre mithqal d'or et un sixième de mithqual.

Papier. 189 feuillets. IJauteur, 2 b centimètres; largeur, 20 centimètros. 27 lignes par page dans la première partie el 31 ligrnes dans la seconde. Is. de deux mains diflérentes. Écriture maure-espagnole dux $x^{\circ}$ on du $\mathrm{xu}^{\mathrm{e}}$ siècle. - (Aneien fonds 480.)

\section{4.}

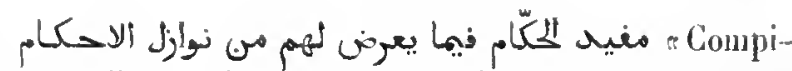
lation utile aux jugres pour ce qui se rapporte aux cas imprévus qui peuvent se présenter devant eux \%. Traité de droil mâléhite sur les questions litigieuses, divisé en dix sections, par Aboù 'I-Walid Hischàm ibn 'Abd Allàh. 


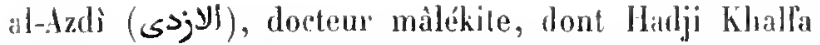
place la mort en 606 de l'hégrire $(1209-1210$ de J. C. $)$. Ms. dalé de l’an 1186 de thégire (1772 de J. C.).

Papier. 138 fenillets. Hauleur, 25 centimètres; largeur, 17 centimètres el drmi. 29 lignes par page. - (Supplément 400 bis.)

\section{5.}

Commentaire de Molıammal ibn abi Bakr ibn Yoù-

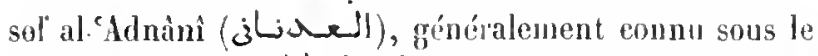
nom d'Ibn Adjàna (أبر أجانان), sur le Traité das successions d'Aboù 'l-Qàsim Alumad ibn Klualal' al-Kalái (g)كli), surnommé Al-llaufi ( 588 de l'heirire ( $119^{2}$ de J. C.). du fol. $3 v^{\circ}$ se trouve une notice biographipue de cel auteur. La plus grande partie du commentaire roule sur le calcul des parts. I la fin du volume se trowe un chapitre d'emiron ynatre pages, sur un problème de partage.

Papier. 158 feuillets. Ilauteur, 26 eentimètres; largeur, 18 centi-

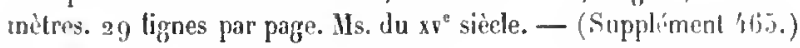

\section{6.}

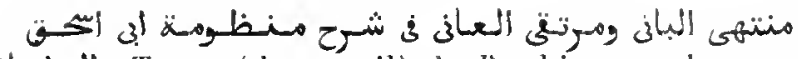

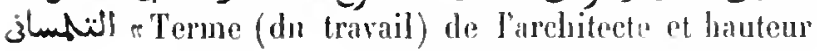
¿ laquelle parient celui qui s'efforce, pour servir de commentaire à la Mañouma d'Aboủ Ishạiy, de Tlemeenn. La Mansouma est un Irailé an vers sur le partage des successions. composé par Mrou Isluà Itraihim ilon abi Bakr, né à Tlemeen, en Gog de l'hégrire (1212-1213 de J. C.), et mort à Ceuta, rers l'an ligo de I'hécyire (1292 de J. C.). Pour sa biographie, logez fol. 2 du jpésent ms. Lauteur du commenlaire se nommait Yác foùb

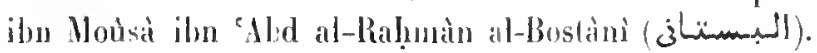
Un certifical inscrit sur le secto du premien feuillel, daté de l'an 1903 de llógine, nous apprend yue ce ons. lut donné en waqf par Săliḷ Bey au collère qu’il avait fonclé auprès de la mosquée de Sidi '1-Kitlini (jLiكCi), a

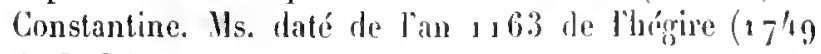
de J. C.).

Papier. 301 feuillets. Ifauleur, 22 ecnfimètres; largeut, 15 centimèrres et demi. 25 lignes par page. - (Supplément 160. )

\section{7.}

1 . L’alsrégé de jurisprudence mâlékite de Khalil ibn
Islàqq ilon Yacqoûb, traité qu’on désigne ordinairement parl le titre de كنتص سيخى خيليل "Abrégé de Sidi Khalil». Exemplaire éerit à Grenade, en 877 de I'bégire $\left(1472-147^{3}\right.$ de J. C. $)$. Au fol. $1 v^{\circ}$ se trourent quinze ver's, dans lesquels le eadi el prolesseur Aboû 'Amr iłn Manzour (منظور), qui étail contemporain du copiste, fait l'élogge de Sidi Khalil el de son ourrage.

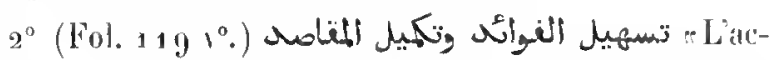
quisition des comnaissances utiles renduc lacile, et l'aecomplissement des objets qu'ors avail en rue complètement ellectuén. Traité de grammaire en prose, composé par Djamâl al-Din Molaammad ibn Milik, J'auteur de l'Alfyya. Plusieurs notes marginales sont empruntées à un commentaire du nème auleur. Exemplaire ćcrit à Grenade, en 860 de J'héguire ( 1456 de J. C.), par le même copiste que l'articte précédent.

$3^{\circ}$ (Fol. $132 v^{\circ}$.) L'Alfyya d'Ibn Mâlik, traité de gurauımaire en vers, avee des gloses marginales. Exemplaire écrit à Grenade, en 860 de l'hégine, de la mème main que les précédenls.

4 (Fol. $199 \mathrm{v}^{\circ}$.) La Schạibiyya d'Aboù 'J-Qásim ibn Fierro al-Schàtilsi. Ecrit à Grenade, en 860 de l'hégọir. par le nême copiste.

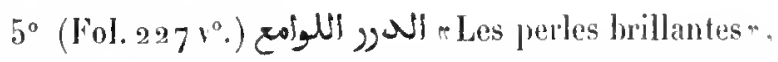

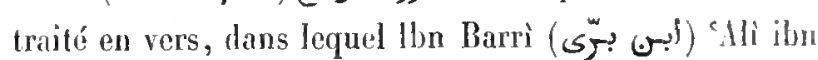
Noḷammad al-Ribâtị (الكباطى) expose le systìne de lecture du Cosan suivi par Nâfe (نــ). Toiei le premier vers de cette pièce :

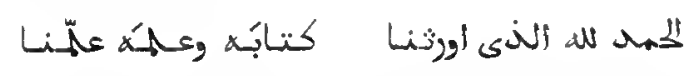

Lin marge se troment guelques gloses tirées d'un commenlaire, dont l'auteur est désigné par le titre de MlIIanloûrì (5)وتنilli).

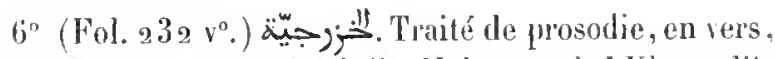
par Dhiya al-Din 'Abd Hlah ibn Mohammad al-Khazradji , natil d'Espagne. Copie dake de l'an 862 de J'hégire.

$7^{\circ}$ (Fol. a35. Abrégé de prosodie, en prose. Cet opus-

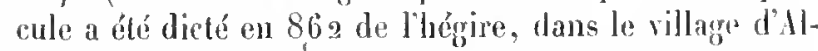
Fakhar (Ia tuilerie), près de Grenade.

$8^{\circ}$ (Fol. ə36.) Réponse à Iboù 'I-I!lasau al-Aschín', qui arait refusé à la grammaire te titre de scienca.

Papier. 236 feuillets. lfauteur, 20 eentimètres; laryené, 1 ' centimètres. 23 lignes par page. - (Mneien fonds 53 .).

\section{8.}

Le Mohhtasar on alorégéé de droit musulman de Khalil 
ihn Islyày. Exemplaire daté de l'an 1034 de l'hégire (16241625 de J. C.). Nombreuses notes marginales.

Papier. 148 feuillets. Ilauteur, 3 a centinèères et demi; targeur, 17 centimètres. 17 lignes par page. - (Supplément 400 ter.)

\section{9 .}

Premier volume du commentaire d'Ahmad al-Zarqànì (الزخان) sur l'Abrégé de Sidi Khalil. Ce gossateur, quil ne faut pas confondre avec son homonyure, "Mbd al-Bàyi al-Zaryàni, autre commentateur du même ouuage, se nommait Aḥmad iln Molıammad. Il était mort

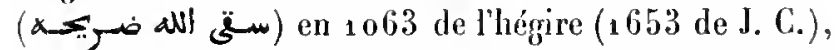
époque à laquelle fut écrit le présent exemplaire de son ourage; tandis que ' $\mathrm{b}$ bd al-Bàqi ne mourut qu'en lo9g de l'hégrire (1687-1688 de J. C.). Au reste, les deux commentaires different beauconp l'un de l'autre. Ce rolume renferme à peu pris le tiers de l'ouvrage; il finit par le chapitre de la pension alimentaire (نغتة). Le premier leuillet contient une pièce ajoutée après coup, à savoir, l'explication des formules par lesquelles Ilon 'Arala, rélèbre docteur mâlékite, désignail les auteurs dont il citait les opinions.

Papier. 155 feuillets. Ilauteur, 21 centimètres; largeur, 15 centimètres et demi. 31 lignes par page. - (Supplément 402.)

\section{0 et 1081.}

Deux volumes dépareillés du commentaire d'Aboû 'llrschâd 'Alì al-Adjhoûri (الاججهو) sur l'Abrégé de Sidi Khalil. Le premier volume commence au milieu dn clarpitre du pèlerinage et finit par le chapitre de la guerre sainte. Le second volume conmence par le chapitre de lapowasic. Ms. daté de l'an 1076-1078 de l'hégire (1 666-1668 de J. C.).

2 volumes. Papicr. 426 et 355 feuillets. Hauteur, 20 centimètres; largeur, 15 centimètres. 25 lignes par page. — (Supplément 397.)

\section{2 à 1087.}

Commentaire d" 1 bd al-Bàq í ibn Yoùsol' al-Zarqùn, mort en 1099 de l'hégire $\left(1687^{-1} 688\right.$ de J. C. $)$, snl l'Abrégé de Sidì Kbalil.

6 volumes. Papier. $712,652,643,416,623,714$ feuillets. Hauteur, 21 centimèt'es; largeur, 15 centimètres. 19 lignes par page. (Suppléinent 2394 à 2399 .)

\section{8 à 1090.}

Trois rolumes, le premier, le second et le dernier, du commentaire d"Abd al-Bàqì al-Zarqânì sur l'Abrégé de Sìdì Khalil. Cet exemplaire était composé d'au moins quatre volumes. Comme les douze premiers feuillets du premier volume avaient disparu, on les a remplacés, pour dissimuler la lacune, par le unême nombre de feuillets empruntés à un autre volume de l'exemplaire.

3 volumes. Papier. $617,47^{2}$ et 497 feuillets. Hauteur, 22 centimètres et demi; largeur, 16 centimètres. 21 lignes par page. Ms. du xviri siècle. - (Supplément 401.)

\section{1 .}

Quatriène et dernier volume du commentaire d'Abr al-Bàłjì al-Zarqânî sur l'Abrégé de Sidi Khalì, com-

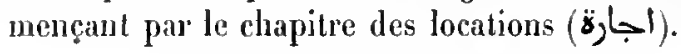

Papier. ${ }_{2} 3$ g feuillets. Hauteur, 30 centimètres; largenr, 20 centimètres el demi. 31 lignes par page. Ms. du xrü siècle. - (Supplémert toa bis.)

\section{2 .}

Commentaire sur l'Abrégé de Sidi Khalil. Volune mulilé au commencenent et à lá fin.

Papier. 81 feuillets. Hauteur, 28 centimètres; largenr, 19 centimètres et deni. 46 et 47 lignes par page. - (Supplément 2351 .)

\section{3.}

Premier volume du commentaire de Molammad al-

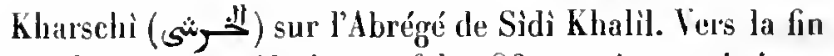
du chapitre du pèlerinage, fol. 183 , parait une écrilure plus régulière, qui continue jusquà la fin du volnme; mais ces nouveaux feuillets ont dù appartenir à un autre volume du même ouvrage et ne sont pas à leur place.

Papicr. 212 feuillets. Hauleur, 33 centimètres; largeur, 23 centimètres. 34 à 42 lignes par pagre. MS. du xvi̊ siècle. - (Supplément 403.)

\section{4.}

Le premier quart du commentaire d'Al-Kharschì sur 
l'Abrégé de Sìdi Khali, se terminant par le chapitre du pèlerinage. Ms. dalé de l'an 199 de l'hégire ( 7 8 de J. C.). En lête du volume se Irouvent quelques traditions de Mahomet ot quelques notes peu importanles; d̀ la fin plusienrs note; écrites de diverses mains, sur des morceanx de papier détachés, parmi lesquels se trouve mol leuillet qui paraît avoir appartenu ì un antre volume du commentaire d'A1-Kharschì. Le reste se compose de vers, de notes peu intéressanles, de talismans, otc.

Papier. 219 feuillets. Hanteur, 35 centimètres et demi; largeur, 18 centimètres. 31 lignes par page an comnencement, puis 27 . (Supplénent 405.)

\section{5.}

Second volume d'un exemplaire du commentaire de Mohammad al-Kharschì, sur l'Hrégé de Sidi Khatil, commençant par le chapitre de la dime. Ms. dalé de l'an 1106 de lhégire ( $169^{5}$ de J. C.).

Papier. 301 feniltets. Hautenr, 21 centimetres; largeul, t.j rentiınètres. 9 १ lignes par pagge. - (Supplément sn:3.)

\section{6.}

Second volume du commentaire d'Al-Kharschì sur l'Abrégé de Sidi Klıalil, commençant par le chapitıe des ventes et se lerminant par celui do la petite culture (مساقانت). Us. daté de l'an 1189 de l'hégira (1775-1776 de J. C.).

Papier. 291 fenillels. Hantru:, 26 centimètres; largeur, 18 centimètres. 27 et a 8 lignes par page. - (Supplénent 10\%.)

\section{7.}

Commentaire lress-étendu sur un traité de jurisprudence. Le volume commence saus prélace ni bismillàh, par le titre du chapitre qui ourre la section de la priere. Au lol. 235 se trouve le chapitre de la dine. Premières lignes

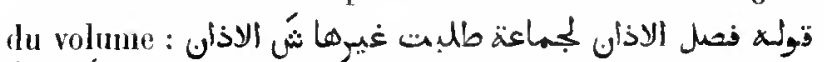

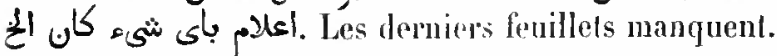

Papier. 356 feuitlets. Ilauteur, s'́ centineties; largeur, 17 centimètres el demi. 25 liģnes par paçr. Ms. du xrü siecle. - (Supplement $302 / 6$.)

\section{8.}

Commentairesur un traité de droit mâlékite ${ }^{\text {. Le com- }}$ mencement et la fin manquent, ainsi que plusieurs leuillets dans le corps du volume, qui commence par le chapitre de la purification avec du sable. L'auleur dit : باب فيمى لم يبه الملاء وصفة التنهم وهلأ ترتيب حسسى 4

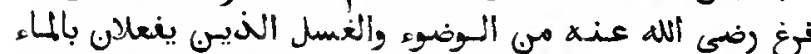

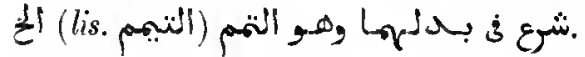

Papier. 126 fenittets. Ilauleur, 30 centimètres; targeur, a centimètres. 27 à ag liggnes par pagre. Ms. du พw1 siède. - (Supptément 2356.)

\section{9 .}

Volume dépareillé d'un commentaire sur un traité de jurisprudence. D’après le titre écrit sur la tranche du livre, ce serail le quatrieme volume d'un commentaire su' l'Omda, Parmi les nombreux ouvrages qui portent ce titre, il serait difficile d'indiquer avec cerlitude celui dont il s'agit ici. C'est peut-être l" Omda dı célèbre Aboû Bakr Mohammad al-Schâschì, docteur scháféite; mais le commentatenr appartenait certainement à l'école de Mâlik (voyez fol. $27^{6} \mathrm{v}^{\circ}$ ). Le volume كتاب الزكاة قال النثيخ رهـ

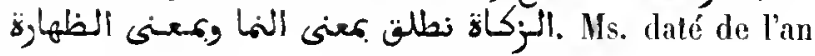
806 de l'hégire ( $1403-1404$ de J. C.).

Papier. 276 feuillets. Hauteur, 26 centimètres; largeur, 16 centimètres et demi. 26 lignes par parge. - (Supplément 39\%, Saint-Germain 83.)

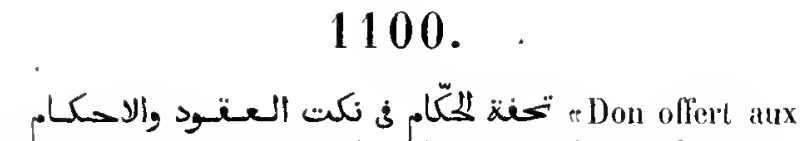
juges, traitant des minulies (ì observer) dans les actes aulientiques et les sentences n. Ce manuel de jurisprudence en ver's a úté composé en 835 de l'hégire $(1432$ do J. C.), par Hoḷanmad ibn Moḷammad ibn ¿̣̇sim (عاصم) al-Qaïsì, grand cadi de Grenade. Ms. daté de l'an 1241 de l'hégire ( 1826 de J. C.).

Papier, 113 pages. Hauteur, 19 centimètres; largeur, 12 centimètres el demi. 16 tignes par page. — (Supplément 393.)

\footnotetext{
'C'est un commentaire sur l'Abrégé de Sidi Khatil, de mème que le numéro précédent. II. Z.
} 


\section{1 .}

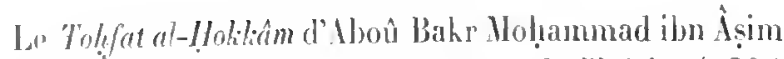
al-0aisi. Exemplibro dalé de l'an 1252 de l'luégire (1836 do l. (..). En lèle se trome une lisle des chapilres. Nombruses notes maryinates.

Papier. 68 feuilhets. Hauteur, aj centimètres el demi; largeur, 19 centindies. 15 liggnes par pagre. - (Supplément 2337.)

\section{2.}

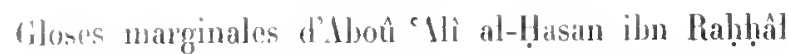

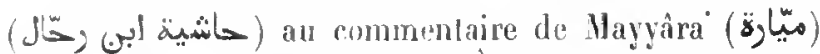

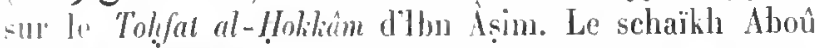
CHrl Mlàh Molıanmad ibm Aḷmad, surnommé Mayyâra, matil de Fez, vivait vers la fin du $\mathrm{sI}^{\circ}$ siecle de l'hégire (xrun" siècle de lèce chrélienne). Hs. daté de l'an 1248 do thégire (1832 de J. C.).

Papjer. 205 feuiltets. Hautenr, 21 centinètres; largeur. 15 centimètrea. s2 lignes par page. - (Supplément 394.)

\section{3.}

Cimmmentaire sur un traité de droit. Le commencemenl manque. Le chajuitre de la prière (fol. 2 ) commence par

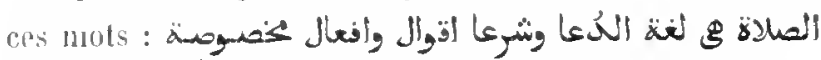
. Le lexte commenté, écrit à l'encre

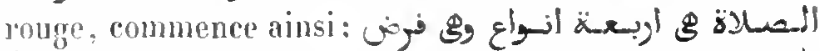

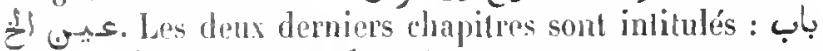
باب حكم الاولاد el qui montre que nous nianous pas ici la lin de f'ourrage. Ms. daté de l'an 1180 d" l'heggire (1 767 de J. C.).

Pinjer. 26 g feuillets. Hauteur, 23 centimètres; largeur, 10 centimètres ef demi. 25 lignes par paze. - (Supplément 2232.)

\section{B)ROIT II.TBALITE.}

\section{4.}

Second volume d'un traité de droil qui parail être to ib suffisant", du docteur hanbalite Nowafliq al-Dï ibu Qodàma ("Mbd Allâh ibu Aḷmad), natif de Jérusatem, mott en 620 de l'hégire (1 223 de J. C.). Le commenerment, jusqu à la fin du cluapitre de lu composition à l'amiable (ألصا), manque. Le dernier chapitre a pour sujet le sement de ne pas cohabiter (الايل2ء).

Papier. 289 feuillets. Hauteur, 23 centimètres; largeur, 16 centimètres. 19 à 21 lignes par page. Ms. du xuv" sièce.e. - (Ancien fonds 533.)

\section{5 .}

rivre de la direction ver's la roie droiten, traité de droit hanbalite, par le chérif Ilın abì Hoûsâ al-Hâschimi. Premiers mots : W W

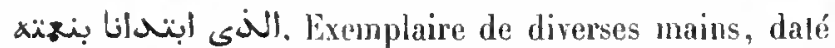
de l'an 892 de l'hégire ( 1487 de J. C.). On lit au premier feuillet un fragment d'un traité de métaphysique.

Papier. 164 feuillets. Hauteur, 27 centimètres; largeur, 18 centimètres. 25 lignes par page dans la partie la plus ancienne, et 27 partout aillenrs. - (Ancien fonds $4-5.5$ )

\section{6.}

Exposé sỵstématique du droit hanbalile(?). Le titre paraît ètre indiqué dans la préface par les mots :

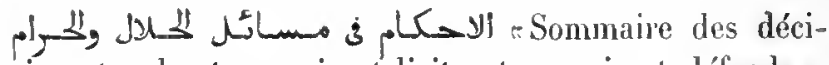
sions touchant ce qui est licite et ce qui est défendu L'auteur se nommait te schaikh Nadjm al-Dìn Aboû '1Qàsin al-Mahalli (لvali), sill faut s'en rapporter à une note inscrite sur le recto du premier feuillet. La prélace

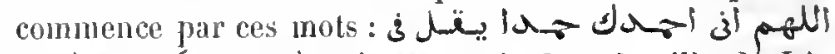

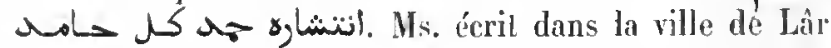

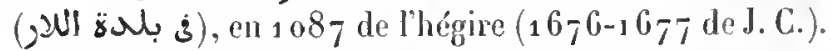

Papier. 464 feuillets. Hauteur, 25 centimètres; largeur, 17 cenlimetres. 14 lifines par pagye. - (Supplément 446.)

\section{7.}

La riche prairie, renfermant l'explication de l'Abrégé du Moqu'r $r$, ourrage composé en 1043 de l'hégire (1633-1634 de J. C.), par le schaikh Mansoutr ibn Yoûnos al-Bahoûtì (البهـوت). Le Moqme, traité de droit hanbalite, a pour auteur Mowalliq al-Din 'Abd Allah ibn Qodàma, et l'Abrégé, Scharal' al-Dìn Hoô 'I-Nadjâ (ابسو, Moûsâ ibn Alumad al-Maqdisi.

Papier. 259 feuillets. Hauteır, 21 centimètres et demi; largeur, 16 centimètres. 33 à 27 lirgnes par page. Ms. du xvist siècle. - (Supplément 445.) 


\section{DROIT SCHITE}

\section{8.}

1 م ك- Livre à l'usage de celui qui ne trouve pas de jurisconsulten, traité de droit schîite, par Ibn Bâboûyeh (Aboû Dja'far Molıammad ibn 'Alì). Ce traité a élé composé sur la demande d'un descendant $d^{\text {'s }} \mathrm{Alì,}$ qui a désigné, comme modèle à suivre, l'ouvrage du médecin Moł̣ammad ibn Zakariyâ al-Pâzì,

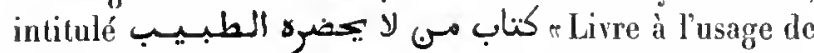
celui qui n'a pas de médecin auprés de luin. De la troisième section de l'ouvrage il ne reste qu'un cahier. A la fin se trouve un chapitre dans lequel l'auteur explique les sigles dont il s'est servi pour désigner les lraditionnistes. Copie datée des années 1033 et 1035 de l'hégire (1625-1627 de J. C.).

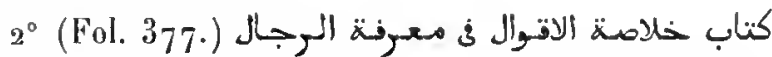
:La quintessence de ce qu'on a dit pour faire connaitre les hommes (qui ont transmis des tralilions) n, dictionnaire biographique des traditionnistes, compilé par Djamàl al-Dìn al-Ḥasan ibn Yoûsof ibn al-Moțahhir. Copie datée de l'an 103 a de l'hégire.

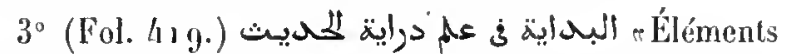
de la critique des traditions $\%$, dissertation attribuée à un

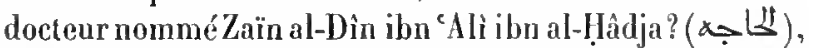
et désigné par le titre de النشهيد النثان - le second ma1tyrn. Copie de la même date et de la même écriture que l’article précédent.

Papier. 4a4 feuillets. Ianteur, a centimètres et demi; largeur, 15 centimètres. 27 à 38 lignes par page. - (Ancien fonds 406.)

\section{6. ÉCOLES NOY DÉTERMINÉES.}

\section{9.}

Traité de droil. Le commencement, jusqu'au milieu du livre des successions, manque. On lit en tête du premier feuillet les mots . . كناب التهذخيسب لو (Aboû 'Ali al-Zaddjìdjî?). Ms. daté de l'an $77^{4}$ de l'hégire (1372 de J. C.).

Papier. 149 feuillets. Hauteur, 87 centinètres et demi; largeur, 18 centimètres et demi. 33 lignes par page. - (Ancien fonds 496.)

\section{0 .}

Dernière partie d'un traité de jurisprudence. Le ms. Mav. orientalx. - II. commence par le livre des successions (ميـراث), dont les premiers feuillets manquent. On a cherché à dissimule' cette lacune, en collant un feuillet de papier blanc sur le recto du feuillet 1 , et en y inscrivant le titre de ald Premier volume du commentaire sur le $M a^{e} \hat{A} n \hat{\imath}$ ' $l$-Athâr dı savant imâm Al-Tahâiwìn. On sait que louvragoc de Taḷâwi a pour sujet les traditions de Mahomet, tandis que le présent ms. traite de la jurisprudence. L'ouvrage se termine par le chapitre intitulé de la mère à l'éducation de son enfant n. Presque tous les chapilres commencent par les mots all

Papier. 240 feuillets. Hauteur, s6 centimètres; largenr, 19 centimètres. 31 lignes par page. Ms. du xıv siècle. - (Ancien fonds 5 1.3.)

\section{1}

Premier volume d'un commentaire sur un traité de jurisprudence. Le commencement et la fin manquent. Après la section de la prière vient celle des funérailles (fol. 68). La section de la dime commence au fol. $9^{8} \mathrm{v}^{\circ}$; le cha-

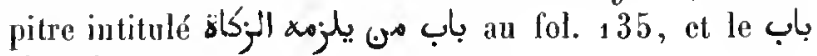
الاحكرام au fol. $2011^{\circ}$.

Papier. 957 feuillets. Hauteur, a 8 centimètres; largeur, 18 centimètres. 95 à 28 lignes par page. Ms. du $x^{e}$ siècle. - (Supplément 3025 .)

\section{2.}

Volume dépareillé d'un commentaire sur un traité de jurisprudence commençant par le chapitre de l'anatbème

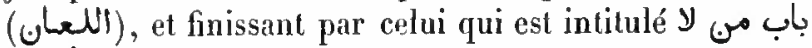
r Clbapitre du délinquant pour qui le payement du prix du sang n'est pas obligatoiren. On roit, à la fin du volume, que l'auteur du traité conmenté se nommait Aboû lsḥàq (Aboû Ishâq al-Schîràzî?).

Papier. s95 feuillets. Hauteur, s 6 centimètres; largeur, 17 centimètres el demi. 23 lignes par page. Ms. du $x v^{\circ}$ siècle. - (Ancien fonds 467. )

\section{3.}

Texte et commentaire d'un traité sur la purificalion

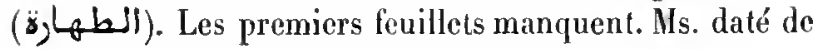
l'an 968 de l'hégire $(1560-1561$ de J. C. $)$.

Papier. 161 feuillets. Hauteur, 22 centimètres; largeur, 16 centimètres. 19 lignes par page. - (Ancien fonds 286.) 


\section{4.}

Traité de droit musulman. Le commencement manque. Le premier chapitre qui se présente a pour titre باب الجميب. أن lis فأن ; le demier chapitre traite du partage des sue-

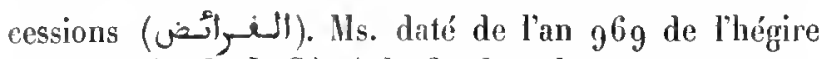
(1561-1562 de J. C.). A la fin du volume se trouve un court traité sul la prière, attribué à Aboù 'l-Laïth alSamarqandi.

Papier. 68 feuillets. Ilauteur, 20 centimètres el demi; largeur, 15 centimètres. 19 lignes par page. - (Ancien fonds 534.)

\section{5 .}

Frayment d'un commentaire sur un Iraité de jurisprudence. Les premiers feuillets contiennent la fin du ehapitre sur l'ablution générale (غسل). Au fol. 11 eommence le chapitre sur l'ablution partielle (وضموء), el au fol. $60 \mathrm{v}^{\circ}$, le chapitre sur la purification avec du sable.

Papier. 60 feuillets. Hanteur, 25 centimètres et demi: largenr, 17 centimètres et denii. ${ }_{2} 5$ lignes par page. Ms. du $x^{8}$ siècle. - (Ancien fonds 27 .)

\section{6.}

Dernier volnme d'un traité de jurisprudence, commencant par le ehapitre des ventes et finissant par le chapitre des questions diverses. Voici les premiers mots du chapitre des ventes : قال البيع ينعنح بالايجأب والقبيول.

Papier. 32a feuillets. Ilauteur, a 1 centimètres et demi; largenr, 16 centimètres. a1 lignes par page. Ms. du xri siècle. - (Ancien fonds 548.)

\section{7.}

Formulaire d'actes notariés et autres, sans préface, ni titre, ni nom d'auteur.

Papier. ${ }_{17} 8$ feuillets. Hauteur, 21 centimètres et demi; largeur, 16 centimètres. 19 lignes par page. Ms. du 1 vri $^{\mathrm{e}}$ siècle. - (Supplément 458.)

\section{8.}

Ciopie de deux actes authentiques par lesquels Aboû
Naṣr Qàitluey (قايتنباى), sultan mamlouc qui régna en Égypte de 879 à go 1 de l'hégire (1468-1496 de J. C.), constitua plusieurs de ses propriétés en waqf, afin que les revenus en fussent aflectés à des ceuvres pies. On y remarque la fondalion d'un waqf pour l'achat du blé qui devait étre distribué sous forme de petits pains et de bouillie (دسيـة ) aux pauvres de la Mecque et de Médine, ainsi qu'aux vovageurs nécessiteux qui passeraient par ces villes. La première de ces pièces est datée de l'an 888 , la seconde de 889 . Suivent d'autres pièces, en assez grand nombre, dont la dernière porte la date de $9^{88}$ de l'hégire ( 1580 de J. C. ); elles se rapportent à l'administration desdites propriétés. La descriplion et la délimitation des immeubles constitués en waqf remplissent un grand nombre de pages. Ce volume parait être de la fin du $x^{2} t^{\circledR}$ siècle; les actes ont été copiés sur les originaux.

Papier. 335 feuillets. Hauteur, 37 centimètres; largeur, 18 centimètres. 18 lignes par page. - (Supplément 471.)

\section{9 .}

Copie d'un acte de waqf daté de l'an 964 de l'hégire (1566-1567 de J. C.), déclaraut que Aḷmad Pacha, gouverneur de la Syrie, avait consacré à des ouvres pies les revenus de certains immeubles, sis à Damas et ailleurs. On lit dans eette pièce la deseription de ces propriétés, et l'emploi de leurs revenus est indiqué avec détails. Ms. daté de l'an 983 de l'hégire $\left(1575-157^{6}\right.$ de J. C.).

Papier. 14 feuillets. Hauteur, 31 centimètres; targeur, 14 centimètres et demi. ${ }_{7} 7$ liggnes par page. - (Supplément 473. )

\section{0 .}

Origival d'un acte de waqf dressé au tribunal de la mosquée d'Al-Șâlị, au Caire (مصر), en 1130 de l'hégire ( 17,8 de J. C.), portant que l'émir 'Alì Kelkhodà

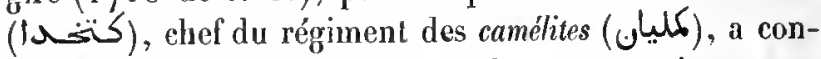
sacré une partie de ses biens à des œuvres pies et une partie aux deux villes saintes (la Meeque et Médine), après extinetion de ses descendants directs. Ce document est muni des signatures et cachets des juges et des témoins. Il renferme l'énumération et la description des nombreuses propriélés qui devaient constituer le waqf.

Papier. $3_{9}$ feuillets. Hauteur, a centimètres; largeur, 15 centimètres. 9 ligues par page. -- (Supplément 470. ) 
V.

\section{THÉOLOGIE.}

\section{1. - Traités SUR la PRtère.}

\section{1.}

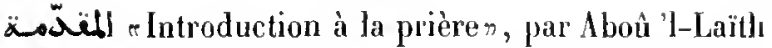
Naṣr ibn Moḷammad al-Samargandi, mort en 375 de lhégire ( $985 \mathrm{de}$ J. C.). Les derniers leuillets manquent.

Papier. 5o feuillets. Hauteur, 17 centimétres; largeur, 11 centjmètres. 9 tirnes par page. Ms. du xur siècle. - (Ancien fonds 309.)

\section{2.}

1० La Moqaddama d'Aboù 'l-Laïh al-Sanminyandi.

$2^{\circ}$ (Fol. 26.) Quelques traditions.

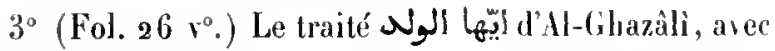
la préface.

$4^{\circ}$ (Fol. $39 r^{\circ}$.) Tableau du nombre de sourates, versets, mots et lettres que renferme le Coran, arec l'indication des pauses.

$5^{\circ}$ (Fol. $46 v^{\circ}$.) Traité en ture sur l'art de lire le Coran.

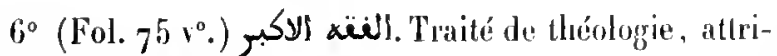
bué à Aboû Hanilia.

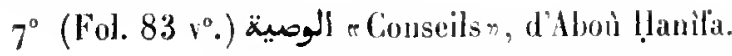

$8^{\circ}$ (Fol. 99.) Histoire d'Aboù ḷanifa et d'un matérialiste (sه).

Papier. 100 fenillets. Hauteur, 20 centimètres; largeur, 1't centimètres. 15 liggnes par page. Ms. de diverses éeritures dn rvı" siècle. - (Supplément 1867.$)$

\section{3 .}

La Moqaddama d'Aboù l-Laïlh al-Sanarqandi. Ms. daté de l'an 1186 de l'hégire $\left(177^{2-1} 77^{3}\right.$ de J. C. $)$.

Papier. $5_{2}$ feuillets. Hauteur, 22 centimètres; largeur, 16 centimètres. 9 lignes par page. - (Supplément 2 21.)

\section{4.}

Élucidation», commentaire de Mostafà ibu

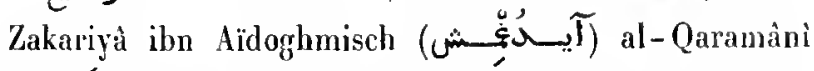

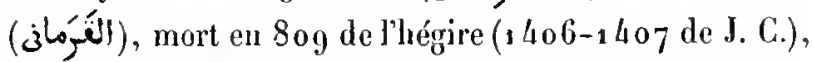
sur la Moqaddama d'Aboù 'l-Laith al-Samarqandi. L'auteur a terminé son travail, au Caire, en 762 de l'bégire (1360-1361 de J. C.).

Papier. 86 feuillets. Hauteur, 27 centimètres; largeur, 18 centimètres et demi. 17 et 19 lignes par page. Ms. du xvi siècle. - (Ancien fonds 275 .)

\section{5 .}

Le commentaire d'lbn Aïdoghmisch al-Qaramànì sul la Moqaddama d'Aboû 'l-Laïth al-Samarqandi.

Papier. 103 feuillets. Hauteur, 21 centimètres; largeur, 16 centiunètres. 19 lignes par page. Ms. du xvi siècle. - (Ancieu fonds 291.)

\section{6.}

$1^{\circ}$ Le commentaire d'lbn Aïdoghmisch al-Qaramànì sur la Moqaddama d'Aboû 'l-Laïth al-Sanarqandi. Copie datée de l'an 991 de l'hégire (1583 de J. C.).

$2^{\circ}$ (Fol. 118 r.o. La wie la plus facile pour accomplir Jes cérémonies du pè̀eriuage $n$, daprès les prescriptions dn rite hanéfite. Ouvrage composé par 'Ali ibn Ibràhnim al-Ghamrì (الغيخى). A parlir du fol. 122 , le copiste a écrit sur les marges, et en suivant les pages dans l'ordre inverse, la suite et la fin de ce traité.

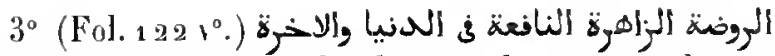
* Le jardin fleuri et profitable, lant dans ce monde que dans l'autre\%. C'est un recueil de ce que les grands docten's de lislamisme ont dit au sujet de l'excellence de la prière du rendredi. L'auteur se nonmait Mohyì ad-Dìn Moḷammad ibn Solaimàı al-Roùmì, génératement comu sous le nom de Al-Kanyadji (3انكان).

Papier. 132 feuillets. Hauteur, 24 centimètres et demi; largeur, 14 centinètres. 33 lignes par page. - (Supplément 220.)

\section{7.}

Le commentaire d'lbu Aidoghmisch al-Qaramânì sưr 28. 
la Moqaddama d'Aboû 'l-Laïth al-Samarqandi. Ms. daté de l'an 1005 de l'bégire (1596-1597 de J. C.).

Papier. 183 feuillets. Ilauleur, 21 centimètres; largeur, 12 centimètres et demi. 17 lignes par page. - (Ancien fonds 308.)

\section{8.}

$1^{\circ}$ Commentaire sur la Moqaddama d'Aboù 'I-Laïth alSamarqandi.

$2^{\circ}$ (Fol. $29 v^{\circ}$.) Paroles de Mahomet touchant les devoirs du musulman.

$3^{\circ}$ (Fol. $37 v^{\circ}$.) . Traité sur les dogmes de la religion, par Sacid ibn Moûsâ al-ḷalabi.

$4^{\circ}$ (Fol. $44 v^{\circ}$. ) La Borda d'Al-Boûșirì.

$5^{\circ}$ (Fol. $48 \mathbf{v}^{\circ}$.) Traité cabalistique sur le grand nom de Dieu. La fin manque.

$6^{\circ}$ (Fol. 5o.) Quelques traditions.

$7^{\circ}$ (Fol. 51.$)$ Le même traité que l'article 5 ci-dessus, mais commençant par une phrase en langage cabalistique.

$$
8^{\circ} \text { (Fol. 53.) Prières. }
$$

Papier. 55 feuillets. Hauteur, 18 centimètres; largeur, 12 centimètres et demi. 18 à 21 lignes par page. Ms. du xrm1 siècle. - (Supplément 1866.)

\section{9.}

Les pierres fines, explication des termes employés dans l'Asmáwiyya , commentaire d'Aḷmad ibn Torkî ibn Ahmmad, sur un traité dans lequel Sìdi Molyanmad ibn Moḷammad ibn A ḥmad explique les obscurités de la Mogaddama ou introduction à la prière d"Abd al-Bâlrì al- Asmâwì. Commencement : كes marges et les feuillets de garde sont couverts de notes.

Papier. 154 feuillets. Hauteur, 22 centimètres; largeur, 16 centimètres. 11 lignes par page. Iss. du xvu" sièclc. - (Supplément 2037.)

\section{0.}

"Livre de prières», par Aboû Zakariyà Yaḥyà al-Nawawì, mort en 676 de l'hégire (12771278 de J. C.). C'est un manuel de dérotion et de poli- tesse, indiquant les prières qu'on peut réciter dans chaque circonstance de la vie et les règles de la bienséance. Ms. dalé de l'an $7^{3} 7$ de l'hégire ( 1337 de J. C.).

Papier. 214 feuillets. Hauteur, 26 centimètres; largeur, 18 centimètres. 23 lignes par page. - (Supplément 493.)

\section{1.}

Premier eahier du commentaire d'Al-Malwi (أللوى) sur le dsikr employé par Yalyyà al-Nawawì. Commencement:

Papier. 10 feuillcts. Llauteur, 17 centimètres; largeur, 11 centimètres et demi. 17 lignes par page. Ms. du xvm" siède. - (Supplément $19^{8} 7$.)

\section{2.}

م Souhait de celui qui veut faire la prière et (guide) suffisant pour le novicen, ourage sans nom d'auteur, mais attribué à Sadid al-Dìn, de Kàschghar. Les mots sont espacés, à la manière européenne; le texte est encadré; le frontispice porte le titre

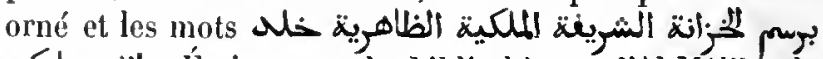
aClo all "Écrit pour la bibliothèque d'AI-Málik alZâhir, que Dieu éternise son règne!r

Papier. 117 feuillets. Hauteur, 26 centimètres et demi; largeur, 18 centimètres. 11 lignes par page. Ms. du xiv ${ }^{\circ}$ siècle. - (Ancien fonds 292.)

\section{3.}

Le Monyat al-Mosalli. Ms. daté de l'an 1022 de l'hégire ( 16,3 de J. C.).

Papier. 41 feuillels. Ilauteur, 20 centimètres; largeur, 15 centinuètres. 23 lignes par page. - (Ancien fonds 294.)

\section{4.}

$1^{\circ}$ Le Monyat al-Moṣalli. Ms. daté de l'an 1023 de J'hégire (16,4-16,5 de J. C.). Nombreuses notes marginales et interlinéaires.

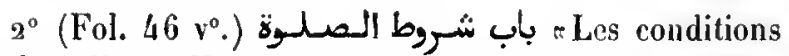
de la prièren. Nombreuses notes marginales et interdinéaires.

$3^{\circ}$ (Fol. 49.) Notes, les unes en arabe, les autres en ture, sur diverses questions qui se rattachent à la prière. 
$4^{\circ}$ (Fol. 5 \& $v^{\circ}$.) Commentaire d'llymad TasehkeupriZàdé (mort en $9^{68}$ de l'hégire) sur la Moqaddama (z̈od (الصلوة de Schams al-Dìn Molıammad al-Fanàrì (النغاري). Le commentaire commence par ces mots : لم جعل الصلوة تالية للايمان.

$5^{\circ}$ Notes en arabe et en turc sur diverses questions de droit.

Papier. 89 feuillets. Hauteur, 21 centimètres; largeur, 15 centimétres. 17 et 19 lignes par page. Nls. de diverses écritures do $\mathrm{x}_{1}^{\circ}$ et du xm siècle. - (Ancien fonds 293 .)

\section{5.}

Le Monyal al-Mosalli. Ms. daté de l'an 1045 de l'hégire (1635-1636 de J. C.).

Papier. 69 feuillets. Hauteur, 20 centimètres; largeur, 15 centimẻtres. 15 lignes par page. - (Ancien fonds 283.)

\section{6.}

- Le Monyat al-Moṣalli.

$2^{\circ}$ (Fol. $83 v^{\circ}$ ) ( Cliapitre des conditions de la prière r. Dissertation sur les huit conditions à remplir pour que la prière soil valide.

$3^{\circ}$ (Fol. $9^{4} v^{\circ}$.) Djanâl al-Dìn ibu al-ḷadjib.

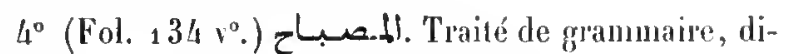
visé en cinq sections, par Al-Hoțarrizi.

Papier. 161 feuillets. Hanteur 21 cenlimètrcs; largeur, 15 centimètres. 8 à 15 lignes par page. Ns. de diverses érritures du xvin siècle. -( Ancien fonds 287.)

\section{7.}

Le Monyat al-Mosalli. Nombreuses notes marginales. -

Papier. 86 feuillets. Hauteur, 11 centimètres et demi ; Iargeur, 20 centimètres et demi. 15 lignes par page. Ms. du xw1 ${ }^{\circ}$ siècle. (Ancien Conds 3o6.)

\section{8.}

Le Monyat al-Mosalli. A la fin du volume se trouve une prière ou invocation (Li les) en ture.

Papier. 61 feuillets. Hauteur, a 1 centimètres; largeur, 14 centi- mètres et demi. a lignes par page. Ms. du $x^{\prime} u^{\circ}$ siècle. - (Supplément 228.)

\section{9.}

S'aunonce de l'explication des mystères renfermés dans (la formule de) la profession de loi et dans l'appel à la prièren, ouvrage at-

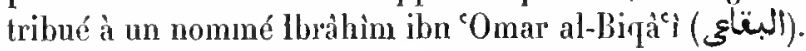
L'auteur dit (fol. 81) qu'il a composé cet ourrage en 873 , au Caire, place de la Porte de la fète (وحبة باب العيد), daus l'espace de trois jours. Ms. daté de l'an 875 de l'hégire (1470-1471 de J. C.).

Papier. 8a feuillets. Hauteur, 14 centimètres; largenr, 9 centimètres. 7 lignes par page. - (Ancien fonds 3 11.)

\section{0.}

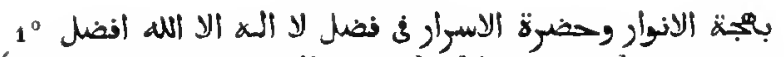
"Léclat des lumières et la découverte des secrets, traitant de l'excellence de la formule: Il n'y a pas de dieu excepté Dieu, comme acte de commémoration", ouvrage composé par le scliaikh Ridhà al-Dìn Șiddìq ibn Macroûf. Commencement:

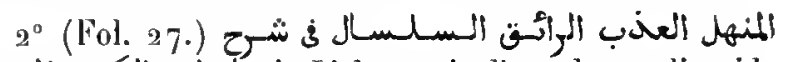
L'Clabreuvoir d'eau douce, limpide et agréable, contenant l'explication des noms de Dieu, le grand, qu'il soit exalté!n, ouvrage du mènı auteur,

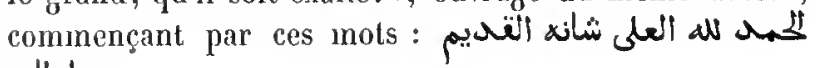
xiblu.

$3^{\circ}$ (Fol. 117 .) Charmes et amulettes.

Ms. daté de l'an 1037 de l'hégire (1627-1628 de J. C.).

Papier. 118 fenitlets. Haateur, so rentimètres el demi; largeur, 15 centimètres. 17 lignes par page. - (Supplément 222.)

\section{1.}

$1^{\circ}$ Conditions à remplir pour que la prière soit validen. Cet exemplaire commence par les

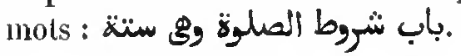

$2^{\circ}$ (Fol. $16 \mathbf{v}^{\circ}$.) La Moqaddama d'Aboû 'l-Laïtl atSamarqandi.

$3^{\circ}$ (Fol. 81.) La 'Aqîda d'Al-Sanoûsi.

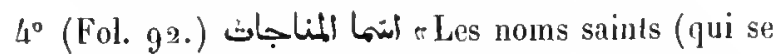
présentent) dans les oraisons $"$, titre d'une prière qu'on 
prélend être inn pisaume de David, traduit de l'hébreu, par 'Abd Allâh ibn 'Abị̣às, cousin de Nahomet.

$5^{\circ}$ (Fol. 99.) Récit fait par un saint personnage, nommé Ibrâlùm al-Taminì, qui, se trouvant dans la haclba, eut une entrevue arec le prophète Élie (Al-Khiḍr), et fut ensuite porté au ciel, où il vit le prophète Miahomet.

Papier. 1 of feuilfets. Hanteur, 16 centimètres et demi; largenr, 11 centimètres et demi. 10 à 13 lignes par page. Ns. de diverses écritures du xvi siècle. - (Ancien fonds 307.)

\section{2.}

$1^{\circ}$ Le Bâb Schoroû! al-Salit.

$2^{\circ}$ (Fol. $14 v^{\circ}$.) La Moqaddama d'Aboù '1-Laïth alSamarqandì.

$3^{\circ}$ (Fol. 67.) Questions relatives à cerlaines pratiques religieuses, notanment celles des derviches. En turc.

Ms. daté de l'an $99^{5}$ de l'hégire (1587 de J. C.).

Papier. 89 fenillets. Hauteur, 15 centimètres el demi; largeur, 11 rentimètres. 11 lignes par page. - (Ancien fonds 455.)

\section{3.}

$1^{\circ}$ Le Báb Schoroût al-Salât.

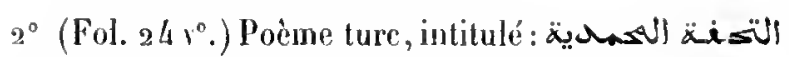
re cadeau mihométans, ayant pour sujet les conditions de la prière.

$3^{\circ}$ (Fol. 33.) Alhum renfermant des notes de divers genres et de plusieurs mains; le tout en langue turque.

En lête du volume se trouvent des noles diverses en langue turque.

Papier. 53 feuillets. Hanteur, 15 centimitres; la!geur, 10 centimètres. a lignes par page. Us. du $x+1^{\circ}$ siècle. -. (Ancien fonds 310 , ('ollhert 64:3.)

\section{4.}

\section{Le Bùb Schoronit al-Salât.}

Papicr. 7 fenillets. Hauteur, 21 centimètres; largeur, 15 centimètres. 11 lignes par page. - (Supplément 23\%)

\section{5 .}

Pages détachées d'un traité sur les conditions de la prière.

Papier. 8 feuillets. Hauteur, 20 centimètres; largeur, 15 centimètres. 7 lignes par page. Ms. du xwu" siècle. - (Supptément 2255.)

\section{6.}

مألم Indications lirées des bonnes sources \%, commentaire sur un chapitre détaché qui traite des conditions à remplir pour que la prière soit valide (بـاب

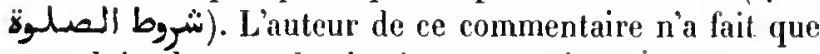
reproduire le texte du chapitre, en y ajoutant des explications. Dans la préface, il donne la généalogie de Mahomet, sur l'autorité d'un ourrage intitulé $ح^{2 L}$ ela Rectification", servant de commentaire à la préface

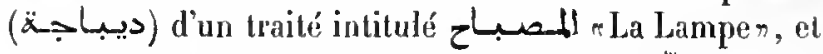
aux deux commentaires d'un traité intitulé troductionr. Ms. daté de l'an 1052 de l'bégire (16421643 de J. C.).

Papier. $7^{2}$ feuillets. Hauteur, 20 centimétres; largeur, 18 centimètres et demi. 11 lignes par page. - (Ancien fonds 284.)

\section{7 et 1148 .}

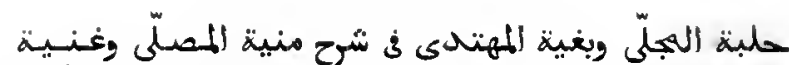
s' L'Hippodrome du vainqueur et le souhait du bien dirigé, commentaire sur le Monyat al-Mosallìn, par Ibn Amî Ḥaddj (بك) امير حاج) Schams al-Dìn Mohammad ibı Moḷammad al-Halahi, auteur hanéfite, mort en 879 de lhégire (1474-1475 de J. C.). Exemplaire daté des années 1179 et 1181 de l'léegire $(1-65-1767$. de J. C.). Hadji Khalfa mentionne cel ourrage sous le titre de حليّة النيّلى.

9 volumes. Papier. 503 et 616 feuiliets. Hauteur, a 2 centimètres; targeur, 16 centimètres. a 1 lignes par page. - (Supplément 220.)

\section{9.}

"Abrégé du Ghonyat al-Motamalli", par Ibrâhìm ibn Mohamınad at-Hałabî, mort en $9^{56}$ de l'hégire ( 1549 de J. C.). Le texte est accompagné d'un assez grand nombre de gloses. En tête du volume se 
trouse une liste des chapitres. Exemplaire daté de l'an 1136 de l'hégire (1 723-1724 de J. C.).

Papier. 199 feuillets. Hanteur, 2a rentimètres; largeur, 15 centimètres. 21 lignes par page. - (Supplément 23o bis, Sorbonne.)

\section{0 .}

Abrégé du Ghonyat al-Motamalli, par lbràhim ibn Molammad al-Halabi. Nombreuses gloses marginales. $A$ la fin du volume se trouve une liste des chapitres. Ms. de deux mains différentes, daté de l'an 1156 (1743 de J. G.).

Papier. 23o feuillets. Hauteur, 22 centimètres; largeur, 15 rentimètres et demi. 17 liggnes par page. -- (Supplément a30.)

\section{1 .}

Hbrégé dn Ghonyat al-Motamalli, par Ibràhim ibn Moḷammad ibn Hbrâhìm al-llalabî. Ms. daté de l'an 1179 de l'hégire (1 765-1 766 de J. C.).

Papier. 369 feuillets. Hauteur, 18 centimètres; largeur, 1 c centimètres. 15 liggnes par page. - (Supptémenl 227.)

\section{2.}

eEncouragement de celui qui patienten, commentaire d'Ibrâhìm ibn Moḷammad al-Ịalabì sur le Monyat al-Mosalli. Le commentaire commence par les

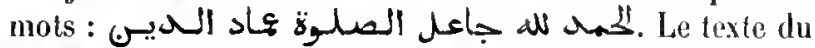
Monyat est reprodnit en entier. Ms. daté de l'an 1047 de thégire (1 637 de J. G.).

Papier. 203 feuillets. Hauteur, a9 centimitres; largeur, 20 centimètres el demi. 29 à 31 lignes par page. - (Ancien londs 276.)

\section{3.}

كتناب المرّ المنضصود في الصلوة والسبلام على صاحهب اللـنام r Les Perles montées, traité de la prière par laquelle on appelle les bénédictions célestes sur celui qui occupe la station la plus belle n, c'est-à-dire sur Mahomet. Onvrage composé par le schaikh al-łslàm Schilaab al-Dìn Ahmad ilon Hadjr ( la Mecque, mort en 973 (1565-1566 de J. C.).

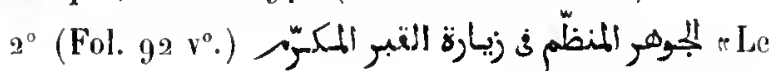

Bijou bien monté, traité sur le pèlerinage au tombean très-honorén, celui de Mahomet. Dans ce livre, l'auteur, Schihåb al-Din ibn Ịadjr, donme des renseignements sur l'origine de ce pèlerinage el sur les préparatifs qu'on faisait de son temps avant de s'y engager.

Papier. 179 feuillets. Hauteur, a 1 centimètres; largeur, 13 centimèlres. Les feuillets du premier taité portent 21 lignes par page, et ceux du second 17 lignes. Ms. de deux mains différentes du vvi sièrte. - (Supplémenl 218.)

\section{4.}

$1^{\circ}$ Le Dorr al-Mandhoûd de Schihâb al-Din ibn lịadjr, exemplaire daté de l'an 1167 de l'hégire $(1753-1754$ de J. C.).

$2^{\circ}$ (Fol. 80.) Passages relatifs à la prière, extraits de

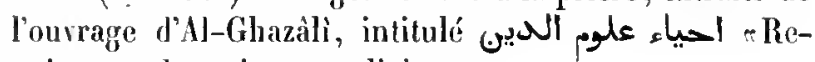
maissance des sciences religieuses $n$.

3 (Fol. 85.) Passages, lirés du حلية الاببرأ de Nawawi, relatifs aux prières appelées, أذ, c'est-ì-dire commémorations de la bonté de Dieu.

Papier. 88 fenillets. Hauteur, 23 centimètres el demi; largeur, 16 eentimètres. 23 lignes par page. Ms. du xviu siècle. - (Supplément 219.)

\section{5 .}

1 posé en 975 de l'hégire (1567-1568 de J. C.), par Moḷammad Pìr 'Alì al-Birgheli. Copie datée de l'an 1028 le l'hégire ( 1619 de J. C.).

$2^{\circ}$ (Fol. 18.) Pièces diverses en langue turque.

Papier. 83 fenillets. Hautour, 21 centimètres; largeur, 15 centimètres. - (Ancien fonds ago.)

\section{6.}

$1^{\circ}$ Dernières pages d'un traité dans lequel !losàm alDin, natif d'Alep et mufti d'Amasie, examine s'il est permis d'élever la voix en récitant des prières et des lilanies.

$2^{\circ}$ (Fol. $2 v^{\circ}$.) Traité dans lequel un auteur anonynuc réfute les opinions de quelques légistes qui prétendent que la danse des Soufis (وقص المتتصوّفة) esl contraire ì la loi divine. 
$3^{\circ}$ (Fol. $131^{\circ}$.) Épitre formant le treizième chapitre de l'ouvrage intilulé diques en ce qui regarde les Soufis», ouvrage composé par Fadıl Allah ibn Nolıammad ibn Ayyoûb. On trouve dans le Dictionnaire de Hadji Khalfa un extrait de la préfice de cet ouvrage.

$4^{\circ}$ (Fol. $38 r^{\circ}$.) Traité dans lequel le schaikh al-Islàn Djamâl al-Dìn al-Qacanànì (

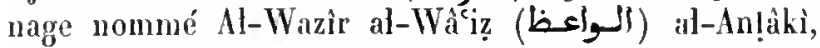
qui avait condamné certaines pratiques des Soufis, telles que les danses, les sants et les invocalions accompagnés de cris. L'auleur de cet opuscule mourut en 934 de l'hégire $\left(1527^{-1} 528\right.$ de J. C.).

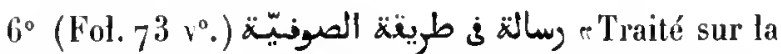
r'egle des Soufis», par Molıammad ibn Hamza, arrièrepetit-fils de Schilıàb al-Dìn al-Sohrawardi.

Papier, 100 feuiltets. Ifauteur, a a centimètres; largeur, 14 centimitres. 19 lignes par page. Ms. du xrü siecle. - (Ancien fonds 444.)

\section{7.}

r Les Jovaux de la prière et les rubis de la vie, ourrage composé postérieurement à la prise de Samarcande par Tamerlan, et desliné à ramener les fidìles à J'olsservance exacte de toutes les cérénonies de la prière. On désigne l'auteur par les titres de Schaikh des schailihs de lislamisme, l'imâm Al-Noṣ̣ıî al Nisiluì (النهصى النامى ). Ms. daté de l'an 1065 de l'hégire (1654-1655 de J. C.).

Papier. 106 feuillets. Hauteur, 21 centimètres; largeur, 14 centimètres el demi. 17 lignes par page. - (Supplément 2 26.)

\section{8.}

r éclaircissements pour le salut des âmes $\%$, ouvrage dans lequel Aboû l-1khlàs Hasan

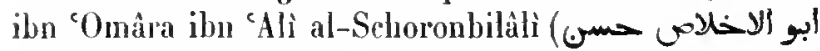

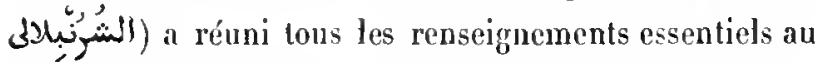
musulman qui reut s'acquilter rigourensement de ses devoirs religieux el surtont de celni de la prière.

Papier. 77 fenillets. Hauteur, 22 centimetres; largeur, 16 rentimètres. 15 lignes par page. Ms. du xru⿰ siècle. - (Supplément 224.)

\section{9.}

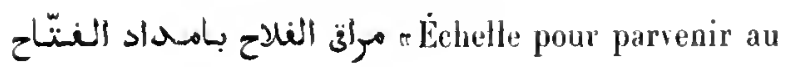

bonheur avee le secours de Dieun, commentaire sur le Noûr al-Idhăh de Hasan al-Schoronbilàlì.

Papier. 212 feuillets. Hauteur, 21 centimètres; largeur, 14 centimètres et demi. 19 à a 3 lignes par page. Ms. de diverses écritures du $\mathrm{xw}^{\circ}$ siècle. - (Supplément a 25.$)$

\section{0.}

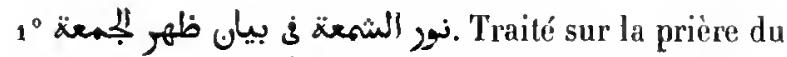
vendredi. Quelques prières sont intercalées dans ce traité.

$2^{\circ}$ (Fol. 26 vo.) Traité sur la prière, intilulé : لُعروس

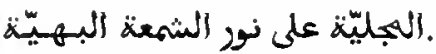

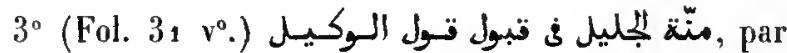
Aboû 'l-Jkhlâs Illasan al Wafầi al-Schoronbilâli. Traité sur la question de savoir si le témoignage d'un fondé de pouvoirs ou intendant est recerable en certains cas.

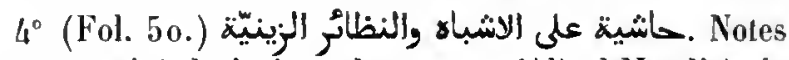
sur un traité de jurisprudence, par 'Alì al-Maqdisì alHanali.

50 Fol. 79. Recueil d'extraits en vers, renfermant des renseignements utiles et instructifs, par Soyoûtị.

6 Fol. 92. (2. Badí en l'honneur de Nahomet, par Soyoûtî́.

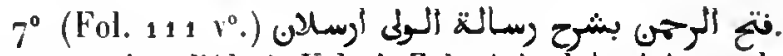
Commentaire d'Aboû Yahyâ Zakarìyâ al-Anșârì sur le traité de l'unité de Dieu, composé par Al-Walì Arslàn, de Damas.

$8^{\circ}$ (Fol. $121 \mathrm{v}^{\circ}$.) Dissertation sur une question de droit, par Schoronbilàli.

$9^{\circ}$ (Fol. $129 \mathrm{v}^{\circ}$.) Commentaire sur le poème de Tantarẩni, par Moḥammad al-Bihischıtî.

$11^{\circ}$ (Fol. $138 \mathrm{v}^{\circ}$.) Texte du même poème, avec une traduction persane.

$12^{\circ}$ (Fol. 141.) Dissertation sur une question de jurisprudence, par Schoronbilâli.

$13^{\circ}$ (Fol. $159 \mathrm{r}^{\circ}$.) Traité sur certaines erreurs populaires.

$14^{\circ}$ (Fol. $170 \mathrm{v}^{\circ}$.) Traité d'Al-Aqhisârì sur l'organisation de la société dans les pays musulmans.

$15^{\circ}$ (Fol. $178 \vee^{\circ}$.) Dissertation sur l'art de réciter lo Coran.

Papier. 182 fevillets. Hlauteur, 20 centimètres; largeur, 13 centimètres. 19 à 25 lignes par page. Érritures diverses du xwı' siècle. (Supplément 1947, Ducauroy 42.) 


\section{1.}

Commentaire très-détaillé sur un ouragge qui fraite de كتاب مــواقتيــت : sull "Traité des temps de la prière". Les mots isolís et les passages du texte qui sont l'objet de gloses et d'explications sout écrits à l'encre rouge. Le nom du commentateur et celui de l'auteur du livre commenté ne sont pas connus. Les derniers feuillets manquent.

Papier. 610 feuillets. IJauteur, a 3 centimélres; Jarrgeur, 16 centimètres el demi. 21 lignes par page. Ms. dn svin siècle. - (Supp) ment 213.)

\section{2.}

Fragment d'un commenfaire d'un traité sur la prière suivi de diverses dissertations.

Papier. 8 feuillets. Hantenr, a centimètres; largeur, 14 centimètres. 19 lignes par page. Ifs. du xvm" siècle. - (Supplément 2041.)

\section{PRIËRES ET INVOGATJONS}

\section{3.}

Plusiems cahiers de diverses mains, renlermant des passages du Coran, des prières et cles sermons pour les jours de liête, etc. Quelques-mues de cess priè'es sont en espagnol écrit en caractères arabes, d'atpro's le syslíme décrit par 11. de Sacy (voyez les Notices ot Extraits, t. IV, p. 6.6, et $1 . X 11$, p. 311). Ces pièces sont, les unes du $\mathbf{x v}^{e}$ siècle, les antres du xvre. Dans les pières les plus anciennes, l'écriture a encore conservé le type du bon maghrebin, mais dans les autres elle est roide, anguleuse "t mal formée, comme en général dans les manuscrits espagnols écrits en carnctères arabes.

Papier. 188 feniltels. Ifauteur, 21 centiniètes et demi; largeur, 1's centimètres et demi. - (Supplémenl 263.)

\section{4.}

1 La sourate vi du Coran.

$2^{\circ}$ (Fol. 1 7.) Qnelques prières, dont une en turc.

$3^{\circ}$ (Fol. $25 v^{\circ}$.) Indication des heures les plus fortunées (أشَرث الساعات) de la journée.

Papier. 26 fenillets. Ilauteur, 12 centimètres; largeur, 8 centimètres. 1 lignes par paye. Ils, du $\mathrm{rvi}^{\circ}$ siècle. - (Supplément 212.)

\section{5 .}

$1^{\circ}$ Les somates ve xxxi, Lxvi et Lxxrut du Coran.

$2^{\circ}$ (Fol. 5o.) Prières diverses, en arabe et en ture.

$3^{\circ}$ (Fol. 108.) Petit traité en turc sur les principes de

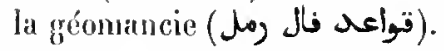

Papier. 110 feuillets. Ilauteur, 11 centimètres; largeur, 7 centimètres el demi. Écritures diverses du $\mathrm{wm}^{\mathrm{e}}$ siècle - (Supplément 211.)

\section{6.}

Les sourates 1, vi, xxxvi, xurui, Lxin et cxxvin dı Coran, suivies (au fol. 64) d'une série de prières pu arabe et en turc, enIremêlées d'extrails du Corau. Au

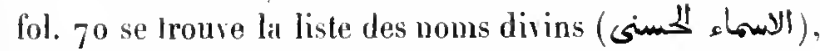
et au lol. $721^{\circ}$ la liste des noms par lesquels on désigne? Mahomet (السماء النبى).

Papier. 106 feuillets. Hautenr, 15 centimètres et demi; largreur, 10 centimètres. 9 lignes par page. Ms. du xwn' siècle. - (Supplément 209.)

\section{7.}

$1^{\circ}$ Une prière contre la peste.

$2^{\circ}$ (Fol. $2 v^{\circ}$.) Les sourates $v 1, x v m$, xxxu, גxxvı. L, uvı et wri du Coran, accompagnées de queleques prières.

$3^{\circ}$ (Fol. 57 et suiv.) Prières, les unes en alabe, l's autres en turc.

$4^{\circ}$ (Fol. $72 v^{\circ}$.) La Borda d'Al-Boûsìri, avec les molions.

$5^{\circ}$ (Fol. 85.) Quelques notes en turc, suivies d'une prière en arabe que l'on récite après la lecture dn Coran.

Les feuiltets 88 à 117 , sont restés en blanc.

$6^{\circ}$ (Fol. 117. ) Prière en lure, suivie d'un passage dı Cornal.

Les feuillets 119 à 123 sont restés en blanc.

$7^{\circ}$ (Fol. ${ }_{2} 3 \mathrm{v}^{\circ}$.) Pricres el invocations en arabe.

$8^{\circ}$ (Fol. 132.) Prières et lyymnes en langue turque.

$7^{\circ}$ (Fol. $141 v^{\circ}$.) Prière en arabe, composée par le schaïh Ibràhìm Efendi.

$10^{\circ}$ (Fol. 143 et suiv.) Plusieurs morceaux de poésie en langue turque.

$12^{\circ}$ (Fol. 169.$)$ Invocalions en ture et en arabe.

Paperer. 171 feuiliets. Hauleur, 19 centimètres el demi; largeur, 
$1 /$ centimètres et demi. Hs. de diverses écrilures du $\mathrm{xvil}^{e}$ sièrle. (Ancien fonds 198 , Colberl 4966 .)

\section{8.}

Liire de dérolion, renfermant les prières canoniqnes, plusieurs sourates el fragments du Coran, un oflice (ag) pour les sept jours de la semine, parlie en arabe, partie en lure (fol. $\left.605^{\circ}\right)$; la liste des noms excellents (fol. $200 \mathrm{v}^{\circ}$ (at 243 ); quelques talismans (fol. 203 et suiv.); quelques prieres et une litanie en langue turque (fol. 206 ).

Papier. 245 feuiltets. llanteur, 15 centimètres; largenr, 10 rentimètres. 9 à 11 lignes par page. Hs. du xvi siècle. - (Ancien fonds 3/8.)

\section{9.}

$1^{\circ}$ lopt, composé des paroles dn prince des apôtres n, ouvrage dans lequel Moḷammad ibn Moḷammad ibn Mohammad al-Djazarì ( $\left(5 ;-\frac{1}{3}\right)$, doctenr schâféilu, mort en 833 de l'hégire (1429-1430 de J. C.), a réuni un certain nombre de lraditions puisées anx somres les plus authenliques, el d'un inlérêt tont particulier pour les vais croyanls. Cet ourage a me grande réputation chez les musulmans. Le litre est en or et en couleurs, mais la dernière partie ayanl disparu par suite de la délérioration du feuillet, a élé remplacée par une arabesque, empruntée à un aulre ms. Copie datée de l'an 854 de l'hégrire ( 1450 de J. C.).

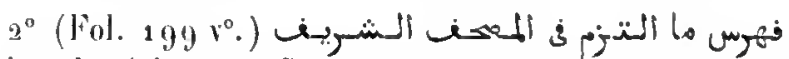
"Liste des (vingl-neuf) règles qui ont élé observées dans la composilion du livre sacrér. Il sagit de certaines expressions du Coran. Eu tète du volume on trouve une liste dis chapilres dont se comprose le IIisn, el quelques notes et prières, les mues en arabe, les autres en lurc.

Papier. 209 feuillets. Hauteur, Ig centimètres; largeur, 13 centimètres. g lig̨nes par page daus le premier traité, 20 dans le second. - (Supplément 48\%.)

\section{0.}

$1^{\circ}$ r Le Châleau bien fortifié, composé de tradilions du prince des apôtres», par Molıammad al-Djazari.

$2^{\circ}$ (Fol. 111 .) La Borda, de Al-Boûșìnì. Points-voyelles. Papier. 1 /49 feuillets. Hauteur, 1 n centimètres; largeur, 7 centi- mètres et demi. 6 à 13 lignes par page. le premier tra té est du

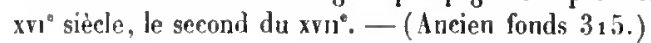

\section{1.}

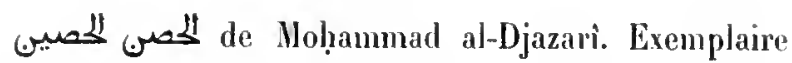
dalé de l'an 1015 de l'hégire (1606-1607 de J. G.). Les premiers feuillets manquent.

Papier. I 25 feuillets. Hauteur, 9 centimètres et demi ; largeur, 6 cenlimètres el demi. 9 à 11 lignes par page. - (Ancien fonds 343.)

\section{2.}

Petit lirre destiné à servir d'amulette, renlemuant :

$1^{\circ}$ Un recueil de prières, intitulé (sic).

$2^{\circ}$ (Fol. $151^{\circ}$.) Une amulette pour se dérober à ses ennenis, intitulée r Le Rideau admirablen. Celle pièce est attribuée à 'Ali ibn abi Țàlib. Suivent d'autres pièces du même genre el quelques tableaux talismaniques.

Papier. 64 feuillets. llauteur, 6 centimètres et demi ; largeur, 6 centimètres et demi. 9 lignes par page. Ms. du xvı" sièele. - (Supplément 203.)

\section{3.}

مـ Invocations efficaces (litLér. vivautes) et roie à suivre pour arriver à ses fins \%. C'est un recueil de prières, d'invocations, d'amulettes préservatives, elc. Quelques-unes de ces pièces sont attribuées à Mahomet, à 'Alí, aux douze imams el à d'autres saints personnages. L'auteur, Aboû 'l-Qàsim 'Ali ibn Dja'far ibn Molammad al-Tàwous, élait un descendant d"Alì et vivait dans la première moitié du vue siècle de l'hégire (royez fol. 192).

Papier. 258 feuillets. Hauteur, 25 centimètres; largeur, 16 centimètres. 17 lignes par page. Ms. du xvi' siècle. - (Ancien fonds 281 .)

\section{4.}

i ca Feuille complèten, reeueil de prières altribncées à 'Ali et conservées par tradition orole dans la famille de ce calife. On lit dans la préface que ces prières, adaplées aux diverses circonstances de la 
vic, ont été mises au jour par 'Omaïr (عيى), fils d'AlMotawakkil ibn Håroûn Thaqafi. Le rouleau sur lequel clles se trouvaient inscrites avait été confé à celui-ci par Yahyâ ilon Zaïd, descendant d`Ali. 11 manque un feuillel au commencement et plusieurs à la fin.

Papier. 173 feuiltets. Hauteur, 15 centimètres; largeur, 8 centimètres et demi. 11 lignes par page. Ms. du xvi siècle. - (Supplément 214.)

\section{5.}

La Salîfat al-Kamila, texte arabe, avec une traduction persane interlinéare. Le texte est écrit en neskhi, la traduction en ta liq et à l'encre rouge.

Papier. 174 feuiltets. Hauteur, 25 centimètres; largeur, 12 centimètres et demi. 11 tignes par page. Vts. du xvi siècle. - (Supplément 217 bis.)

\section{6.}

Recueil de matières diverses, composé au Xvi siècle, probablenent au Caire. Le titre de l'uuvrage nous est inconnu, mais le contenu du volume est assez bien indiqué par la liste des chapitres qui en occupe les premières pages et qui porte cette rubrique: نبخن لوزاد وإدية Chloix d'Heures, de prières et de connaissances utiles \%. Le mot rendu ici par heures indique certains passages du Coran, que les dévots récitent chaque jour en ve d'obtenir la faveur de Dicu.

$1^{0}$ Heures tirées de la collection intitulée الاوراد الزينيّيّة - Les Heures de Zaïn al-Dìn , titre honorifique d'un personnage qui se nommait Molıammad ibn Moḷammad al-Hâlì - le déchaussén, mort en 838 de l'hégire (14341435 de J. C.).

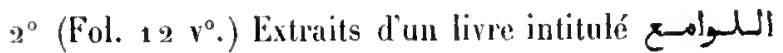

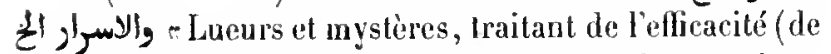
certains passages) du Curan, et contenant des anecdotes authentiques à ce sujet».

$3^{\circ}$ (Fol. $13 \vee^{\circ}$.) Heures pour les sept jours de la semaine.

$4^{\circ}$ (Fol. 16.) Prières composées de versets du Coran et servant de préservatifs contre les accidents, etc.

$5^{\circ}$ (Fol. $24 r^{\circ}$.) Prières pour l'anniversaire de la naissance du Prophète, par le schaikh 'Alà al-Din 'Ali, suivies d'un grand nombre de qașila el d'autres pièces de vers, les unes en l'hommeur de Mahonet, les autres relatives à diveri sujets religieux. $6^{\circ}$ (Fol. 42.) Chapitre sur les vertus des médicaments simples, par ordre alplıabétique, tiré d'un livre intitulé id Directions poll le bien de l'àme et du corpsn.

$7^{\circ}$ (Fol. Go vo.) Traitement du prurit et de la gale. liecettes diverses, tirées du même ouvrage.

$8^{\circ}\left(F_{0} ._{6} v^{\circ}\right.$.) Plusieurs recettes superstitienses (tilismans, pratiques astrologiques, etc.).

$9^{\circ}$ (Fol. 76 .) Noms et explication des figures que l'on obtient par la géomancie; puis quelques notes chronulogiques de peu dimportance, se terminant pir la mention de Qâï Bey, sultan d'Égypte.

$10^{\circ}$ (Fol. $781^{\circ}$.) Noms des stations, ou maisons, du soleil el de la lune.

$11^{\circ}$ (Fol. 79.) Remèdes el diverses sortes de thériaques.

$12^{\circ}$ (Fol. 8o.) Abrégé du traité de médecine en vers teclıniques (ordjoûza) qui porte le nom d'Avicenne.

$13^{\circ}$ (Fol. $80 v^{\circ}$.) Sur les vertus cabalistiques de cortains mots renfermant la lettre $b$.

$14^{\circ}$ (Fol. $\left.81 v^{\circ}.\right)$ Des chiffres au moyen desquels on peut écrire en abrégé les noms de nombre.

$15^{\circ}$ (Fol. 82.) Alphabets secrets; recette pour détruire les effets de la magie; remaryues sur les mois coptes et syriaques.

$16^{\circ}\left(\right.$ Fol. $83 v^{\circ}$.) Extrait du traité des minéraux inli-

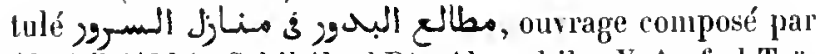
Aboû 'I-'Abbàs Schilıảb al-Dỉn Aḷmad ibn Yoûsof al-Taïfàschì (التينانثي). Un livre portant ce titre est mentionné dans le Dictionnaire bibliographique de Hadji Khalfa, mais attribué à 'Alà al-Dìn 'Alì ibn 'Abd Allàh al-Belıâi (3)

17\%. (Fol. $88,{ }^{\circ}$.) Recettes, amulettes, talismans et figures cabalistiques.

$18^{\circ}$ (Fol. $93 \checkmark^{\circ}$.) Énuméralion des vertus de certaines amulettes, conıposées de versets du Coran.

$19^{\circ}$ (Fol. $951^{\circ}$.) Carrés magiques.

$20^{\circ}$ (Fol. 96.) Noms des mois chez les Berbers, les Grees, les Coptes, ete., suivis de notions astrologiques se rattachant aux jours de chaque mois.

$21^{\circ}$ (Fol. 98.) Les vingt-huit mansions (Jio) de la lune. Autres talismans et amulettes.

$22^{\circ}$ (Fol. 102.) Prescriptions médicales, tirées d'un ouvrage d'Aboû Bakı' Mọ̣ammad al-Rảzì.

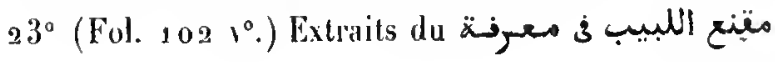


Trailé satisfaisant pour l'homme intelligent rai ient śceuper de la composition des remedesn, par Seharaf al-Dìn Moùsâ al-Boldàni. C'est un recueil de recelles.

$24^{\circ}$ (Fol. 144.) Vingul-neul questions adressées an schaïhb al-lslàm Aboù 'l-Abbîs Aḥmad ibn lladjı al'Aspalàn', au sujet des morts, de l'interrogatoile du tombean, etc.; chaque question est suivie du fatwa lendu par ("s) docleus.

$25^{\circ}$ (Fol. $\left.1455^{\circ}.\right)$ Exlraits d'un ourrage composé par l“imàm A]-Solamì sur les devorrs sociaux imposés à chaque

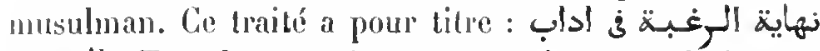
"Tous les renseignemonts qu'on jeut désires" au sujert des convenances sociales\%.

$20^{\circ}$ (Fol. 15..) Dissertation sur le múme sujel, par Al-fibatilì.

$27^{\circ}$ (Fol. 154.) Sur les comenauces que l'ou doil gardir' yitand on vil au bails.

$28^{\circ}$ (Fol. $154 r^{\circ}$.) Instructions et formulaire il l'usage des notaires.

$29^{\circ}$ (Fol. 173.) Tradilions au sujel des versels du Coran et de leur nombre.

$30^{\circ}$ (Fol. 179.) Opinion du docleur "Hbd Allà ibn Ạ̣mad al-Tasafí, au sujel de l'emploi du بِ c'esl-à-diro chu hachich.

$31^{\circ}$ (Fol. $179 \vee^{\circ}$.) Épitre dans laquelle uu docleur nommé Schans (?) al-Dìn Moḷammad ibn al-Àmidì condamne ceux qui se livrenl au péché de sodomie.

$33^{\circ}$ (Fol. 181.) Sur la divinalion an moyen du Coran.

يسواقفيـت $33^{\circ}$ (Fol. 182.) Extrait d'un lirre intitulé

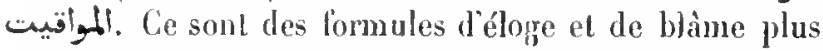
ou moins élé:antes, qui onl étú employées par des prosatenrs, des poites ot des persomages marquants. Ces formules se rapportenl aux sujels les plus divers : le monde, les femmes, la poésie, la morl, ete.

34 (Fol. 201.) Traité sur le gourernement de soimème (المسياسة الانسسانبيسة), dans lequel on indique les devoirs de l’homme envers lui-même et sa famille, et envers l'État. Cette derniere partie renferme un chapitre sur lart mililaire, فصل في سياسة أور جيون (fol. $2: 11 v^{0}$ ).

$35^{\circ}$ (Fol. 215.) Extrails du ore d'Aboù 'I-Mansoù' Tha àlabí. C'est une collection d'anecdoles curieuses, de maximes, de moralités, de phrases sur divers sujels, et de beaux passages en prose rimée.

Ce recueil est divisé en qualre cent quarante chapilres, dont la liste oreupe les onze premier's feuillets.

Papier. 222 feuiltets. Hauleur, 27 centimètres; largeur, 18 centi-

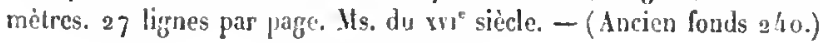

\section{7.}

1 م - La Parure des hommes vertueux el le signe distinctif (on la livée) des hommes de bien», ouvrage dans lequel Moḷyì al-Dìn Yahyà ibn Scharaf al-Nawawi indique les prières les plus propres à être exaucées, ainsi que les éjaculations quil convient de proférer dans les diverses circonstances de la vie. Ces invocations, en général très-courtes, proviennent des premier's temps de l'islamisme, et le compilateur, pour constater leur authenlicité, cite l'aulorilé des meilleurs tradilionnistes. Copie datée de l'an 868 de l'hégire (1465 de J. C.).

$2^{\circ}$ (lool. 197.) Un Arba în de quarante-deux traditions, dans lesquelles sont énoncés les prineipes de l'islamisme. le feuillet renfermant les trois premieres tradilions manque. A la suite de ce petil recueil se trouvent le premier el le dernier feuillet d'uu traité sur l'orthographe des mots peu commus que renferment ces traditions.

Papier. 303 feuillets. IIauteur, 27 centimètres; largeur, 18 centimètres; 21 lignes par page. -- (Supplémenl 217.)

\section{8.}

$1^{\circ}$ prières qui sont agréées (de Dieu) la nuil el le journ, ourrage dans lequel Djalàl al-Din 'Abd al-Raḥmàn alSoyoùti a rassemblé en un seul corps les prières et invocalions qui se trouraient dans l'ourage composé par Molıyi al-Dìn Aboû Zakariyà Yahyà al-Nawawi (المنسووى),

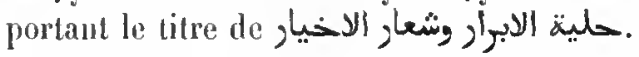

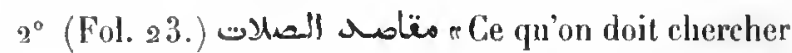
dans la prières, par 'Abd al-'Aziz ibn 'Abd al-Salàn alSolanini (aلmil).

$3^{\circ}$ (Fol. 29.) Une longue qasida, commençant par ces

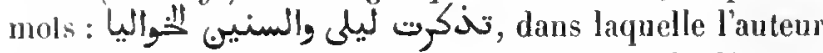
exprime, sous l'emblème de son amour pour Lailâ, tout l'amour qu'un dérot doit porter à Dieu. Suivent quelques notes en prose, puis, fol. 34, trois canliques (موثنّ) religieux. Vient ensuite une qasîda d'Al-Nawawi, commen-

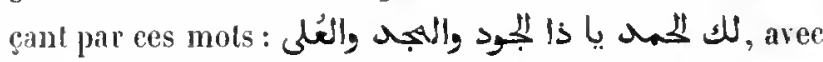
une traduclion interlinéaire en langue turque.

$4^{\circ}$ (Fol. 37.) Poìmes, notes diverses et fragments littéraires de diverses écrilures.

Papier. 6' feuiltets. Hauleur, 30 centinètres et demi; largeur, 15 centimètres. Mls. du xun siècle. - (Ancien fonds 3o a.) 


\section{9.}

1. Prières musulmanes.

$2^{\circ}$ (Fol. 12.) Divers fragments d'un ou de deux commentaires sur l'Abrégé de droil de Sidi Khalil.

Papicr. 15a feuillels. Hautenr, 25 centimètres: largenr, 18 centimètres. 15 à 34 lignes par page. Écritures diverses dı xvmº siècle. (Supplément s44.)

\section{0 .}

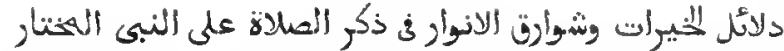
". Indications de bonnes ourres et brillantes lumières, traitant de la prière en l'honneur du prophèle choisin. L'auteur se nommail Aboû "Abd Hlàh Mohammad ibn Solaimàn al-Djozoúlì, membre de la tribu berberre de $\mathrm{Dji}$ roùla, mort en 870 de l'hégire (1465-1466 de J. C.). Ce sont des litanies et des prieres en l'honnent de Mahomet. Quelques rigneltes nal exécutées; on tìte, le plan de la mosquée de Médine. Nombrensis notes marginales.

Papier. 56 fenillets. Hautcur, 2o centimètres et demi; largenr,

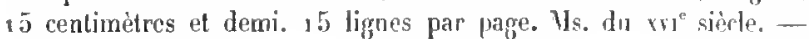
(Supplément 1985. )

\section{1.}

Le Daldïl al-Khairât. Exemplaire daté de l'an 1007 de I'hégire (1598-1599 de J. C.).

l'apier. 1 o 1 feuillets. Hauteur, so centimètres; largeur', 15 centimètres. 9 lignes par page. - (Ancien fonds 300.)

\section{2 .}

\section{Le Dalail al-Khaïht.}

Papier. 83 feuillets. Hanteur, s a centimètres et demi; largeur, 1 h centimètres. 13 lignes par page. Ms. du vvn siècle. $\longrightarrow$ (Supplément 497, Saint-Germain 317.)

\section{3.}

\section{Le Dalâil al-Khairat.}

Papier. 105 fenillets. Hautenr, 17 cenlimètres: larpeur, 17 centi- mètres et demi. 11 lignes par pagge. Ms. du xvı ${ }^{\mathbb{E}}$ siècle. - (Supplément 498, Saint-Germain 318.)

\section{4}

Le Dalail al-Khairat. Au fol. $11 \mathrm{v}^{\circ}$ et au lol. 12 se trouvenl deux dessins assez bien faits, représentant le lombeau de Mabomet et de ses deux successeurs, Aboù Bakr et 'Omar.

Papier. $7^{2}$ feuillets. Hauteur, 21 centimètres; largeur, 15 centimètres. 14 lignes par page. Ms. du Xvu siècle. — (Ancien fonds 288.)

\section{5 .}

$1^{\circ}$ Le Dalail al-Khä̈rât. Exemplaite dalé de l'an 1035 de l'hégire (1625-1626 de J. C.).

$2^{\circ}$ (Fol. $9^{1} \mathrm{v}^{\circ}$.) Un Arba in, ou collection de quarante tradilions altribuées à Mahomet.

Papier. 97 fcuillets. Hautenr, 15 centimètres; largenr, 10 centimèlres et denii. 11 lignes par page. - (Ancien fonds 31 2.)

\section{6.}

1" Le Daläl al-Khairât. Copie datée de l’an 1049 de l'hégire (1639-1640 de J. C.).

$2^{\circ}$ (Fol. 47.) Poème, divisé en plusieurs chapitres, sur les devoirs et les pratiques religieuses des musulmans. Copie datée de l'an 1049 de l’hégire. L'autcur se désigne par le titre de ألفتيه عابِ الركار.

Papier. 65 feniltels. Ilauleur, 21 centinètres ct demi; largeur, 15 centimètres. 17 à 18 lignes par page. - (Ancien fonds 297.)

\section{7.}

$1^{\circ}$ Le Dalail al-Khairat. Aux fol. $17 v^{\circ}$ et 18 se trouvent le plan de lintérieur de la mosquée de Médine el la réprésentation du minbar, ou pupitre.

$2^{\circ}$ (Fol. 1 1 g.) Fếltre dans laquelle le schaikh 'Abd al-Raḥmân al-Thálabì (الثع) fait le récit de ses visions. 11 recommande cet éçit comme un excellent talisman pour écarter les danger's.

Papier. 124 feuillets. Hantcur, 22 centimètres; largeur, 16 centimètres. 11 lignes par page. Ms. du xvu"siècle. - (Incien fonds 296. ) 


\section{8.}

\section{Le Dalail al-Khairât.}

Papier. 150 feuillels. Hauteur, 23 centimètres; largeur, 17 centimètres. g lignes par page. Ms. du xrs ${ }^{e}$ siècle. - (Ancien fonds 301.)

\section{9 .}

\section{Le Dalail al-Khaïnât.}

Papier. 112 feuillets. Hauteur, 14 centimètres; largeur, 10 centimètres. 11 lignes par page. Ms. du wrn siècłe. $-\left(\right.$ Ancien fonds $3{ }_{13} 3$.)

\section{0.}

\section{Le Dalâil al-Khaïrât.}

Papier. 107 feuillets. Hauteur, 20 centimètres; largeur, 15 centimètres. 1 a lignes par page. Ms. du xvı" sièele. - (Supplément 495 , Saint-Gernain 315.)

\section{1.}

\section{Le Dalâil al-Khaïrât.}

Papier. 9 a feuillets. Hauteur, 20 centimètres; largeur, 15 centiinètres. 1 a lignes par page. Ms. du xru siècle. - (Supplément 496 , Saint-Germain 316.)

\section{2.}

Le Dalâil al-Khaìnát. Exemplaire daté de l'an 1132 de l'hégire (1790 de J. C.).

Papier. 116 fenillets, dont lez deux derniers portent la représentation de la chaussure de Mahomet. Hauteur, 28 centimètres et demi; largeur, 19 centimètres. 9 lignes par page, dont la premiëre, la cinquième et la dernière sont plus longues que les autres. - (Suppléinent 494 .)

\section{3.}

$1^{\circ}$ Le Dalail al-Khairât. Copie datée de lan 1165 de l'bégire $(1752$ de J. C. $)$.

$2^{\circ}$ (Fol. 56.) Lil prière intilulée l'imàm Aboû 'l-Hasan al-Schàdsili (المشناذلى).

$3^{\circ}$ (Fol. $\left.60 \%^{\circ}.\right)$ Les quatre-vingt-dix-neuf fondements de la foi. $4^{\circ}$ (Fol. 61.) Prières pour chaque jour de la semaine.

$5^{\circ}$ (Fol. 64 $\vee^{\circ}$.) Conmenlaire d'Aḥmad ibn Molımmad al-Bornoûși (ألبرنوصىى) sur cerlains vers mystiques composés par le schaikh Noùr al-Din, de Damiette.

$6^{\circ}$ (Fol. 77.) Les divers noms par lesquels on désigne Maliomet.

$7^{\circ}$ (Fol. 89.) Copie d'une lettre dans laquelle un cerlain schaikh Aḷmad, gardien du tombeau du Prophète, raconte une vision dont il avait été favorisé.

A la fin du volume se trouvent quelques lettres d'affaires, des notes de direrses mains, des prières, etc.

Papier. $9^{8}$ feuillets. Hauteur, 18 centimètres; largeur, 13 centimètres. 14 à 18 lignes par page. Ms. de diverses érritures. - (Supplément 499 bis.)

\section{4.}

Le Dalâil al-Khaîrât. Exemplaire daté de l'an 1187 de l'hégire (1 $77^{4}$ de J. C.).

Papier. 101 fenillets. Hauteur, 15 centimètres; largeur, 10 centimètres. 1 a lignes par page. - (Supplément a \$46.)

\section{5.}

\section{Le Dalail al-Khairât.}

Papier. 142 feuillets. Hauteur, 10 centimètres et demi; largeur, 7 centimètres et demi. 9 lignes par page. Ms. du xvur siècte. - (Supplément 499.)

\section{6.}

Le Dalâil al-Khaïat. Aux fol. $131^{\circ}$ et $14 \mathrm{r}^{\circ}$, se trouvent deux dessins coloriés, représeutant les mosquées de la Mecque et de Médine. Ms. daté de l'an ${ }_{12} 6_{1}$ de l'hégire (1 845-1846 de J. C.).

Papier. 82 feuillets. Hanteur, 15 centimètres el demi; largeur, 10 centimètres. 11 lignes par page. - (Supplément 206 bis.)

\section{7.}

$1^{\circ}$ un i Les Cinq joyaux $\pi$, recueil de prières et de litanies, distribuées en cinq chapitres, par Mohammad ibn Khatîir (خطي) al-Din ibn Bâyazid ibn Khodja Farid al-A!̣̂aı' (خواجه فريد اللعير), ouvrage composé en 956 
de l'hégire ( 1549 de J. C.). La dernière parlie du recueil renferme un grand nombre d'amulettes et de figures cabalistiques.

$2^{\circ}$ (Fol. $168 \mathrm{v}^{\circ}$.) Traité anonyme sur l'usage el les vertus cabalisliques d'un cercle (s, أيسر), ou plutôt d'un groupe de cercles concentriques, donl on attribue l'insenlion à $\mathrm{Al}-\mathrm{Sch}$ âdsilì, fondateur de l'ordre de derviches qui porte son nom.

$3^{\circ}$ (Fol. $173 \vee^{\circ}$.) Trailé anonyme sur les principaux altributs de Dieu et sur le caractère prophélique de Malomet.

$4^{\circ}$ (Fol. $176 v^{\circ}$.) Carré magique, pour faciliter les accouchements difficiles.

Is. daté de l'an $107^{6}$ de l'hégire (1 665-1666 de J. C.).

Papier. ${ }_{7} 6$ fcuillets. Hauteur, s1 centimètres; largeur, 15 centimètres et demi. 95 lignes par page. - (Ancien fonds 305.$)$

\section{8.}

$1^{0}$ م- Prières que les musulmans chantent et par lesquelles ils s'excitenl à la piété. L'auleur est le schaïklı Sadr al-Dìn Aboù 'l-Macáli Mozaffar, lils de Noḥammad, de Schî̀ràz.

$2^{\circ}$ (Fol. $46 \mathrm{r}^{\circ}$.) Choix de lettres de Qotb al-Din Kòsclikenâri, les unes en persan, les aulres en arabe, suivi d'autres extraits, en vers et en prose.

Papier. 406 feuillets. Haufeur, 19 centimètres; largenr, 19 centimètres et denii. 15 à 25 lignes par page. Ns. du xv11" siècle. - (Supplément 1952 , Oratoire.)

\section{9.}

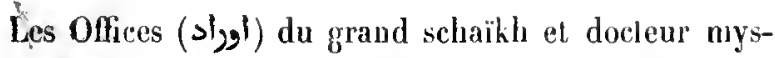
tique Mobyî̀ al-Dìn ibn al-çrabì. Ce sont des prières pour chaque jour de la semaine, dont la récilation est recommandée aux hommes dérots.

'Papier. 29 feuillets. Hauteur, 21 centimètres et demi; largeur, 14 centimètres. 1 lignes par page. Ms. du xvı e siècle. - (Supplément 315.$)$

\section{0.}

$1^{\circ}$ rOffice (ou rituel) des scigneurs (derviches)". Collection de prières, d'invocations et de cantiques, formée par le schaïkh Aboù 'l-Walä Moḷam$\operatorname{llad}(0,0)$.

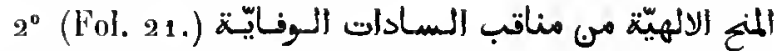
- Les Dons spirituels provenant des mérites des seigneurs (derviches) de l'ordre d'Aboù 'l-WVafầ, par Aboû '1-Latâiif, généralement connu sous le nom d'Ibn Faris (فارس). C'est un recueil de tradilions pieuses, dont la plupart proviennent des dévols qui se tenaient dans le célèbre sancluaire de Meclıhed-'Ali.

Papier. $7^{0}$ feuillets. Hauteur, 21 centimètres et demi; largeur, 16 centimètres. 1 i d̀ 13 lignes par page. Ms. du xvı" siècle. - (Ancion fonds ag8.)

\section{1.}

$1^{\circ}$ Recueil de prières du genre appelé حزب, formanl un oflice, dont on récite une partie le matin, l'autre le soir. L'auteur dit avoir appris ces prières de son précepteur, qui arait mis à profit le grand hizb des derviches schàdsilites el qui avait étudié sous Aboù Mohammad 'Abd Allàh al-Ghazwàni et Sidi Mohammad ibn Solaïmâu al-Djozoûlì. Le premier feuillet manque.

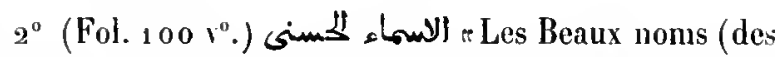
altributs de Dieu) $\pi$, arec les prières qui doirent accompagner chacun de ces noms, par Sỉd 'Abd Allàh ibn Mlohammad ibn 'Abbâd (عباد). Copié à Fez, en 1011 de l'hégire (1602-1603 de J. C.).

Papier. 131 fenillets. Hauteur, 17 centimètres; largeur, 11 centimètres et demi. 9 lignes par page. - (Ancien fonds a.9.)

\section{2.}

Prière attribuée au schaïkh 'Abd Allâh ibn Yâsìn (يس). Ms. daté de l'an 1251 de l'hégire (1835 de J. C.).

Papier. 28 feuillets. Hauteur, 1 centimètres; largeur, 8 centimètres. o à 12 lignes par page. - (Supplément 1986.)

\section{3.}

$1^{\circ}$ (Fol. $\left.3 \mathrm{v}^{\circ}.\right)$ Prière qui parait être le commencement de la préface de quelque ouvrage. Commencement : .

$2^{\circ}\left(\right.$ Fol. $9 \mathbf{v}^{\circ}$.) Itinéraire du Caire à Médine, en pas- 
sant par la Mecque. Ce n'est qu'une liste des stations et des distances.

$3^{\circ}$ (Fol. 12.) Commentaire d'Aboû Zaïd 'Abd al-Ral!mâu ibn. Mohammad al-Fâsì (culell), natil de Fez, sur le IIizb (حزب), ou recueil de prières d'Aboû 'l-Hasan alSchaddsili.

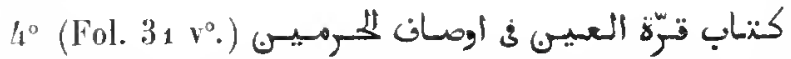
"Réjouissance des yeux, ou description des deux villes saiutes". Description topographique et histoire de la Mecque et de Médine, depuis les temps anciens jusqu'au $1 \mathrm{~s}^{\mathrm{e}}$ siècle de l'hégire ( $\mathrm{xy}^{\mathrm{e}}$ siècle de l'ère chrétienne), par

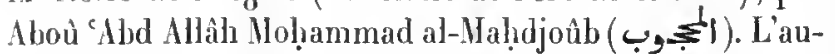
teur donne (lol. 32 ) la liste des auteurs et des ouvrages qui lui ont lourni ses renseignements. Au fol. $41 v^{\circ}$ se trouve un plan de la $K a b a$, et au fol. 72 un plan de la nosquée de Médine.

$5^{\circ}$ (Fol. $158 v^{\circ}$.) Poìne rimant ell râ, sur les cérémonies à observer pendant le pèlerinage de la Mecque, par le légiste et gr'anmairien Mḷmad ibn Molıammad ibn كـتـاب (المناسك 3 عم اللمناسك Livre du dévot, sur les cérémonies du pèlerinager, d'lbn al-Móallâ (Gedi).

$6^{\circ}$ (Fol. 160.) Éloge de Zaïn al-Ẩbidìn, poème célebre de Farazdak. En voici le premier vers :

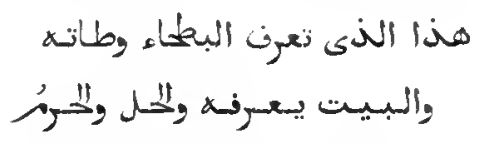

$7^{\circ}$ (Fol. 161.) Élogọ d'Aboû '1-'Abbàs.

$s^{\circ}\left(\right.$ Fol. $161 \mathrm{r}^{\circ}$.) Inauguration d'Aboû Bakr.

$9^{\circ}$ (Fol. 162.) Mort d'tboû Bakl.

$10^{\circ}$ (Fol. 165.) Inauguration d`Otlımàn.

lls. lout entier de la mème main.

Papier. 166 fenillets. Hanteur, so centimètres; largeur, 14 centimétres. 23 à s 4 lignes par page. Ms. đu wi siècle. - (Supplément 216 bis.)

\section{4.}

Prière du pécheur pour obtenir la miséricorde de Dieu, par les mérites des premier's musulmans, à conmencer par les dix évangélisés. Les nous de ces unusulmans sont classés, dans l'ordre alphabétique, en trois listes; la première renferme ceux des mohâdjir ou émigrés, el des anșâr; la seconde, les noms de ceux qui furent tués au combat d'Ohod, et la troisième, les noms

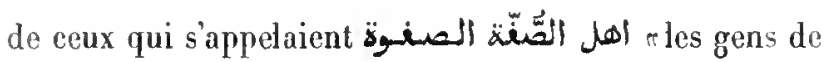

l'Estrade ou du Banen. (Voyez Caussin de Perceval, Essai sur l'histoire des Arabes, t. III, p. 334.)

Papier. 103 fenillets. Hauteur, 14 centimètres et demi; largeur, 1 a centimètres. 7 lignes par page. Ms. du xvi1' siècle. - (Supplément 213 bis.)

\section{5.}

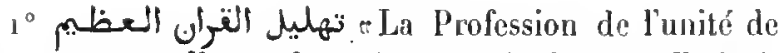
Dieu, comme elle est formulée dans le Coran». Il s'agit

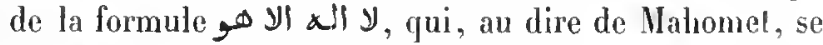
présente dans le Coran trente-sept fois.

$2^{\circ}\left(\right.$ Fol. $3 v^{\circ}$.) Invocation dans laquelle le tahlil est employé plusieurs jois.

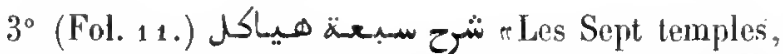
avec leur explication». Le hailal était une prière mystique écrite sur les pieds du trône de Dieu (sur le huitième pied se trouvail le tahlil). Adam en avait reçu une copie, qui passa à Noé, puis à Abraham, à Moïse, à Jésus et à Malıomet. Cette prière élait toujours sous les yeux de celui qui la possédait, et lui procurait un bonheur parfait. Ce sont sept entretiens de Mahomet avec les anges et les patriarches.

$4^{\circ}$ (Fol. 71.) Prière.

$5^{\circ}$ (Fol. 78.) Prière intitulée du unarin $\%$.

$6^{\circ}$ (Fol. 84.) « Le Talisman des talismans, el le Trésor des trésors $\%$ Prière, légende et litanie.

$\tau^{\circ}\left(\right.$ Fol. $101 \mathrm{v}^{\circ}$.) Autres prières ct invocations.

Ce ms., écrit en 1117 de l'hégire (1706 de J. C.), par un nommé Al-1̣addji Hausili Ogglou, est très-incorrect.

Papier. 210 fenillets. Hanteur, 14 centimètres et demi; largeur, 8 centimètres et demi. 8 lignes par page. - (Supplément 216.)

\section{6.}

$1^{\circ}$ (Fol. 3.) Prière.

$2^{\circ}$ (Fol. 7.) Autre prière, suivie de quelques notes et de pièces de vers.

$3^{\circ}$ (Fol. 1 o.) Sur les devoirs du musulinan en voyage.

$4^{\circ}$ (Fol. 11.) Conseil religieux.

$5^{\circ}$ (Fol. 11 r. $^{\circ}$ ) Commentaire d'Al-Sanoûsi (Moḷmmad ibn Youssof) sur' son ouvrage intitulé 'Aqîda.

$6^{\circ}$ (Fol. 88.) Le Le Qotrob, mis en vers, avec les additions de Tammâm ibn 'Abd al-Salàm. 
$7^{\circ}$ (Fol. 91.) L'Aqîda d'Al-Sanoûsî.

$8^{\circ}$ (Fol. 107.) Prières, notes el exlraits.

$9^{\circ}$ (Fol. $111 v^{\circ}$.) Poème sur les devoirs du eroyant, d'après la loi musulmane, par le Faqûlı 'Abd al-Ralịnàn. Premier vers :

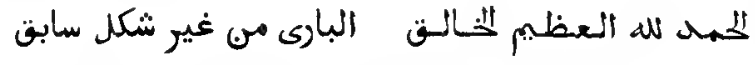

$10^{\circ}$ (Fol. $1511^{\circ}$.) La Borda d'Al-Boủṣini. هان

$11^{\circ}$ (Fol. 169. ) La Qasîda lâmiya d'Omm Hàni (

$12^{\circ}$ (Fol. $\left.171 v^{\circ}.\right)$ L'Adjorroûmiyya.

$13^{\circ}$ (Fol. 183 v.) Poème d'Aboú Moqrae (أبو مـترع) sur le calcul des nativités.

$14^{\circ}$ (Fol. $199 \mathrm{v}^{\circ}$.) Noles et exlrails.

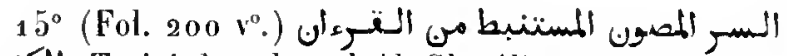

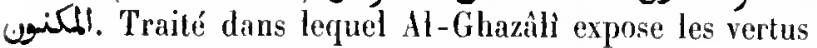
secrèles de cerlains passages du Coran.

$16^{\circ}$ (Fol. $204 v^{\circ}$.) Notes et extrails divers.

Nombreuses noles marrinales.

Papier. 208 feuillets. Hauteur, 19 centimètres et demi; largeur, 15 centimètres. F́critures diverses du $x_{n}{ }^{e}$ siècle. - (Supplément 1 870.)

\section{7.}

$1^{\circ}$ Prières et invocalions.

$2^{\circ}$ Sur certains versets du Coran ayant de grandes vertus magiques. En ture.

Papier. 6 feuillets. Ilauteur, 17 centimètres et demi ; largeur, 10 centimètres et demi. Ils. du wn" siècle. - (Supplément $19^{83 .)}$

\section{8.}

Pricres.

Papier. 96 feuillets. Hauteur, 13 centimètres; largeur, 9 centimètres. 9 lignes par page. Ms. du xvi" siècle. - (Supplément 1984.)

\section{9.}

Prières, dont une, en vers, renferme les sainls noms de Dieu.

Papier. 109 feuillets. Hauteur, 11 centimètres; largeur, 8 centimètres. 9 lignes par page. IIs. do $\mathbf{~ v u}^{\circ}{ }^{\circ}$ siècle. - (Supplément 1988.) Mas. onjextiux. - II.

\section{0.}

$1^{\circ}$ Prièe en vingl-trois strophes de einq vers. Première slrophe:

$$
\begin{aligned}
& \text { يا سامع المعهاء ويا فاطر النسماء } \\
& \text { ويا دايم المبتـاء ويا واسبع العطلاء } \\
& \text { بلذي الناقة العديم }
\end{aligned}
$$

Tous les cinquièmes vers ont la mème rime.

$2^{\circ}$ (Fol. $9 v^{\circ}$. ) Longue prière en prose.

Papier. 14 feuillets. Hauteur, 18 centimètres et demi; largeur, 10 centimètres. 1 a lignes par page. Us. du ximi siècle. - (Supplément 1989 .)

\section{1.}

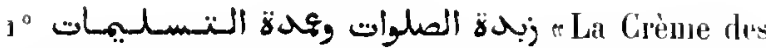
prières el le pilier des salulations $\pi$, recucil de prières en l'honneur de Mahomet, par un derviche nommé 'Mlì ibn Solaïmân al-Silikfoûi (المبرِكفى).

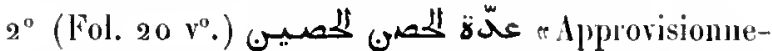
ment du Château fortn. C'est un abrégé du Hisn al-Hasîn, fait par l'auleur tui-même, Schams al-Dìn Moḷammad ibn Mlọammad ibn Moḷammad al-Djazari.

Papier. 64 feuillets. Hauteur, 21 centimètres; largeur, 15 centimètres el demi. 17 lignes par page. Ms. du xwo siècle. - (Supplíment 205.)

\section{2}

Les Dons de Médine, bitanie en l'homneur du meilleur des êtres créés ", e'est-à-dire de Mahomel. Pièce composée par un nalif de Damas, appelé Moṣtafâ ibn 'Abd al-Qâdir al-Dihnì

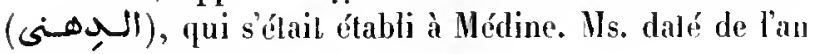
1217 de l'hégire ( 1802 de J. C.).

Papier. 4 feuillets. Hauteur, 16 centimètres el demi ; largeur, 11 centimètres. 18 à 25 lignes par page. - (Supplément 206.)

\section{3.}

$1^{\circ}$ Prière à réeiler après la lecture du Dalail al-Youbowwa: La fin manque. 
$2^{\circ}$ (Fol. 4.) Extraits dune colleclion de cantiques chréliens.

Papier. 5 feuillets. Hlauteur, 16 centimètres et demi; largeur, 11 centimetres. 17 lignes par page dans le premier fragment, 12 et 13 lignes dans le second. Ms. dı xwiı sièele. - (Supplément a2s4.)

\section{4.}

Recucil de fragments de diverses mains. On y trouve des prières, des extraits du Coran, des receltes médicinales, des figures talismaniques, des indications astrologicques et d'autres compositions superstilieuses.

Papier. 114 fenillets. Ilanteur, 17 centimètres; largeur, 11, centimètres. Ns. de diverses éerikures du wie siècle. - (Supplément $21 /$ bis.)

\section{5.}

Recueil de prières intitulé de "L'Amulette d'lbn Hischàm», de "La Prière du vizil' $n$, etc.

Papier. 40 feuillets. Hauteur, 14 centimètres; largenr, 9 centi-

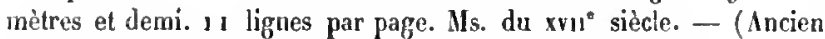
fonds 346. .

\section{6.}

Invocations, prières et listes de noms, pour servir d'amulettes :

$1^{\circ}$ باء

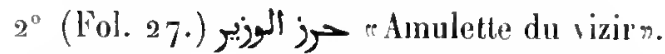

$3^{\circ}$ (Fol. $36 \mathrm{v}^{\circ}$.) L'amulette de Yoûsol al-Ṣinlıàdj (إ)

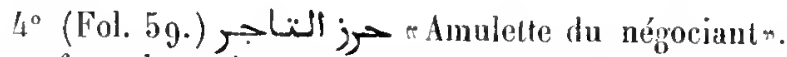
Cette formule, qui est censée ètre utile daus les opéralions commerciales, provient d'Anas ibn Millik, l'un des compagnons du Prophète.

$5^{\circ}$ (Fol. 62.) L'Amulette d"Alì ibn abì Ṭảlib.

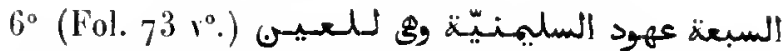
Les Sepl reconmandalions de Salomon, préscrvatilis contre le manvais oil, les regards du démon et contre les larves $\%$. Cette pièce esl accompagnée de chiffres et de figures talismaniques.

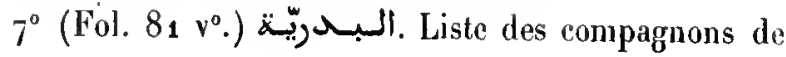

Nahomet qui prirent part au combat de Badr. L'auteui, Dja far ibu Ḥasan al-Barzandjì (البوزنجي), parle d'abord de ceux qui sont les mieux connus, puis il donne la liste alphabétique de ceux qui n'étaient connus que par des surnoms. Dans la préface, il s'étend longuement sur les vertus de cette liste qui, dit-i\}, est une amulette approuvée contre les brigands et les bêtes léroces.

Papier. 136 feuillets. Ilauteur, 10 centimètres; largeur, 7 centimètres et demi, 10 lignes par page. Ms. du xrü siècle. - (Supplément 207.$)$

\section{7.}

Petil live formé de dix feuillets de carton, se repliant les uns sur les autres, et renfermant $r$ les grands noms de Dieun, quelques courtes sourates du Coran, le verset du trồe, des prières, les portraits détaillés de Mahomet et des quatre premiers califes.

Carton. 10 fenillets. Hanteur, 14 centimètres; largeur, 10 centimètres. 10 à 14 lignes par page. - (Supplément 204 .)

\section{8.}

Recueil de formules, d'invocations et d'amulettes pour toutes sortes de circonstances. Les derniers feuillets manquenl.

Papier. ${ }_{1} 6$ pages. Hauteur, 10 centimètres et demi; largeur, 7 centimètres et demi. 10 à i a lignes par page. Ms. du xvil' siècle. (Supplément 210.)

\section{9 .}

Recueil d'extrails du Coran, destinés à scrvir de talismans (דائل).

Papier. $5_{2}$ feuillets. Hauteur, 15 centimètres; largeur, 10 centimètres. Les premières pages contiennent 9 lignes, les autres 7 lignes.

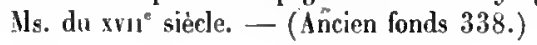

\section{0 .}

Recueil de talismans, les uns écrits avec des lettres isolées et des chiffres, les autres en caractères ordinaires. Les lignes de plusieurs de ces textes sont écrites alternativement à l'encre rouge el à l'encre noire.

Papier. 75 feuillets. Hauteur, 13 centimètres; largeur, 9 centimètres. 6 à $ı$ a lignes par page. Ils. du xvie siècle. - (Ancjen fonds $33 \%$ ) 


\section{1 .}

Recueil d'extraits du Coran, destinés à servir de talismans.

Papier. 25 feuillets. Hauteur, 15 centimètres et demi; largeur, 10 centimètres. 9 lignes par page. Ms. du xvı" siècle. - (Ancien fonds 33. .)

\section{2 .}

Hecueil de prières, d'inrocations superstitieuses, de mots et de passages écrits en chiffres, et de figures talismaniques.

Papier. 66 feuillets. Ilauteur, 18 centimètres et deni; largeur, 11 centimètres et demi. 11 à 16 lirnes par page. Ms. de diverses mains du xviri siècle. - (Supplément 208.)

\section{3.}

Recueil de pric̀res, de lilanies et d'anulettes.

Papier. 202 fenillets. Hauteur, 11 centimètres el demi; largeur, 7 centimètres et demi. 8 à 11 lignes par page. Ms. du svi" siècle. - (Ancien fonds 345.)

\section{4.}

1. Prières et invocations, précédées d'une méthode de divination au moyen des lettres du Coran, attribuée à Djacfar al-Şàdiq.

$2^{\circ}$ (Fol. 16.) Énumération, sous torme de dialogue, des infractions qui inıalident le pèlerinage.

$3^{\circ}$ (Fol. 28.) Récit attribué à lbn 'Abbàs, rappor'tant une conversation de Malıomet avec des patriarclies el des anges, au sujet de la vertu de certaines prières et formules cabalistiques.

$4^{\circ}$ (Fol. $791^{\circ}$.) T'raité attribué à Dja far al-Sàdiq sur le clioix des jours propices (اختيhرات).

$5^{\circ}$ (Fol. 88.) Invocations et pratiques cabalistiques, que l'on désigne par le nom de l'astre percant $\pi$. Au fol. $99 v^{\circ}$ se trouve la figure d'un talisman.

$6^{\circ}$ (Fol. 1 oo.) Pièce de vers, accompagnée de chiffres rabalistiques.

$7^{\circ}$ (Fol. $107 v^{\circ}$.) Prières et invocations, accompagnées de signes cabalistiques.

8* (Fol. 1 48.) Le poème de Borda. $9^{\circ}$ (Fol. 169.$)$ Charmes et invocations.

Papier. a/43 feuillets. Hauleur, 15 centimètres et demi; largeur, 11 centimètres. 10 lignes par page. Ms. du xvı siècle. - (Ancien fonds 340.)

\section{5 .}

Alliveurs de la lumière divinen, par

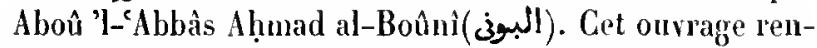
ferme des prières et des litanies pour chaque lieure des sept jours de' la semaine, et une suite de chapitres sur l'inlluence des quatre-vingt-dix-neuf noms de Dieu. La

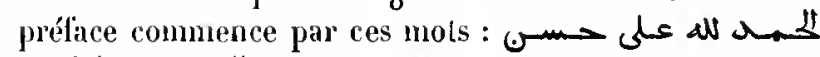
توفيته وأسالم هم أية لطريته gire (1441-1442 de J. C.).

Papier. 41 feuillets. Hauteur, 23 centimètres; largeur, 15 centimètres. 17 lignes par page. - (Ancien londs 303.)

\section{6 .}

Le Loma't al-Noûrdinyya d'Aboû 'L-'Abbàs al-Boûnî. Lal distribution des matières dans cet exemplaire n'est pas tout à fait la mème que dans le numéro précédent. Les derniers feuillets manquent.

Papier. 61 feuillels. Hauteur, 14 centimètres; largeur, 9 centiıètres. 15 lignes par page. Ms. du $\times x^{e}{ }^{e}$ siècle. - (Ancien fonds 460 .)

\section{7.}

Prières et litanies cabalistiques. Au fol. 24 , on trouve la liste des noms ou attributs de Dieu (الاسهـاء لمسنى); au fol. $441^{\circ}$, la tiste de tous les prophètes et envoyés de Dieu, d'après le d'lbrâhîm ibn Hosaïn al-Fàradhì (ألفارضس), mort vers l'an 880 de l'hégire ( $1475-147^{6}$ de J. C.), el, au fol. $51 v^{\circ}$, une décision juridique motivée, par laquelle un schaïhh al-lslàm, appelé 'Abd al-Haqu, condanne l'usage du café.

Papier. 63 feuillets. Hauleur, so centimètres et demi; largenr. 1.5 centimètres. I lignes par page. - (Supplément 202.)

\section{8 .}

Prières et lormules cabalistiques.

Papier. 119 feuillets. Ifautcur, 6 centimetres; laryeul, 8 centinètres. 5 à 7 lignes par page. Ms. du xwn siècle. - (Ancien fonds 459 .) 
3 THEOLOGHE DOS VITIOUE ET SCOLASTIOUE.

\section{9 .}

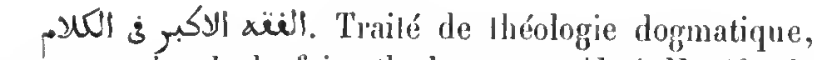
on sommaire de la foi orthodoxe, par Abou Hlanifa alNoemàn, surnommé l'Imâm al-ễzim, fondateur du système de droit hanéfite. Le lexte de ce petil traité, écrit à l'oncre rouge, est intercalé dans un commentaire dont

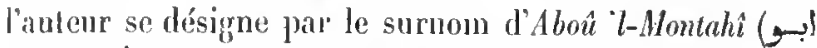
(I), mais, en réalité, portait les noms de Mollà Alumad ilon Motrammad al-Maghhnîsâwî (s, splon lladji Khalfa, a Ierminé son Iravail en 939 de l'hégive (1 $532-1533$ de J. C.).

Papier. 46 fenillets. Hanteur, 20 centimètres et demi; largeur, 13 centimètres et demi. 15 tignes par page. Ms. du xvri siècle. (Supplément 357. )

\section{0 .}

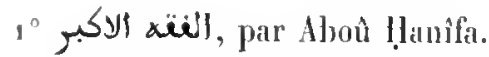

?" (Fol. 6.) Les conseils (وصيّة) d'Abon llanili.

$3 \circ$ (Fol. 9.) Traité de religion et de morale, par 'Omar Elendi.

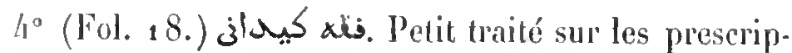
lions de ta loi.

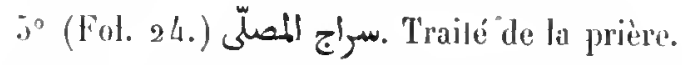

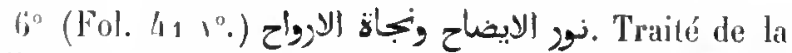
priàre el do jeûne, par Aboú 'l-Ikhtâs Hasan al-IVafäi Scluoronbilàli on Schoroubilä (النئنبانى), docleur hanéfite, mort, sełon Hidji-Khalfa (t. H1, 1. 189), en 1 o69 de lhégire (1658-1659 de J. C.).

$7^{\circ}$ (Fol. $7^{1}{ }^{\circ}$.) Traité de droit lanéfile, composé par le schaikh llasan, el mis en vers par Ahmad al-Bahloukl.

$8^{\circ}$ (Fol. 97.) Sur diverses prières : celles des deux grandes fèles, celle des éclipses, celle des enterrements if celle des rogations.

$9^{\circ}$ (Fol. $99 \mathrm{v}^{\circ}$.) Un Arbain de quarante-deux tradilions, dont chacnne renferme une des bases essentielles de l'islianisme.

$10^{\circ}$ (Fol. 106.) Poésies religieuses de Mohammad ibn Mazroûq al-Tilinsaini, de Boù Medìn (Aboû Madyan Schoraib) el de Mohamnad al-Touàli.

$11^{\circ}$ (Fol. $110 v^{\circ}$.) Prières et litanies. $12^{\circ}\left(1001.117 \mathrm{v}^{\circ}\right.$.) Recettes pour teindre les chereux.

$13^{\circ}$ (Fol. 1 18.) Analyse grammaticale du Bismillah et du Tá awwouds.

14\% (Fol. 123.) Traditions sur la création d'Adam et sur l'ange de la mort, etc.

${ }_{15}^{\circ}$ (Fol. $127 \mathrm{v}^{\circ}$.) Traité sur les obligations de tout homme qui est responsable de ses actes (مكلغ), arec un commentaire.

$16^{\circ}$ (Fol. $\left.154 v^{\circ}.\right)$ Commentaire de Khàlid al-Azharì sur l'Adjorroûmiyya.

Papier. 179 feuillets. Hauteur, 2 a centimètres; largeur, 16 centimitres. 16 à v/ lignes par page. Ms. du xvm" siècle. - (Supplément $18-4$.)

\section{1 .}

Exposé de la doctrine des Schîites, au snjet de l'Imâm. Cet ourage, écril par Ibı Bâboûyeh (بابوي) al-Kommi, partisan de la doctrine des duodécimains, a pour litre :

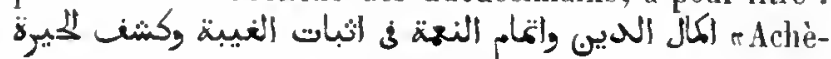
rement de la religion et accomplissement de la grâce divine, servant à jorouver la réalité de l'absence (ou dispalition du douzième imàm) et à dissiper les incerlitudes\%. lon Bàboûyeh (Aboû Djafar Moḷammad ibn 'Alì ibn al-Hosaïn ibn Hoùsâ), auteur du $\mathbf{v}^{\mathrm{e}}$ siècle de l'hégire (voyez Tousy's List of schy'ah Books, Calcutta, 1 853-1855, p. 304), traite surlout du douzième imâm, Mohammad al-Mahdi, appelé Al-Qâin (لتابيم). Il fait mention de quelques fractions de la secte schiite, et il cite à l'appui de ses opinions le Coran, les tradilions de Mahomet el les livres de I'Ancien et du Noureau Testament. Il donme l'histoire des imåms, soit visibles, soit cachés, qui se sont succédé depuis le commencement du monde. rLa succession des prophètes, dit-il, peut être interrompue, mais it doit y avoil toujonrs un imàm. "L'ouvrage est divisé en deux parties (royez lol. 9o). La copie porte la date de 1066 de l'hégire (1655-1656 de J. C.).

Papier. 198 Peuillets. Hauteur, 24 centimètres et demi; largeur, 16 centimètres. 25 lignes par page. - (Ancien fonds 400.)

\section{2.}

"Océan de théologien, traité de théologie scolastique par Abou '1-Mo'in (1) al-Nasafi.

Papier. 164 feuiltets. Hauteur, 11 centimètres; largeur, 14 centjmètres et demi. 1 lignes par page. Ms. du xviı siècle. - (Supplément ${ }_{2} 66$. .) 


\section{3.}

Le مكي d'Al-Nasafi. Exemplaire daté de l'an $117^{2}$ de l'hégire ( $1758-1759$ de J. G.).

Papier. 80 feuillets. IIauteur, a centimètres; Jargeur, 15 centimètres et demi. 13 lignes par page. - (Supplérnent 367.$)$

\section{4.}

Commentaire de Sa'd al-Dìn Mas oủd a1-Taftàzànì sur I'Aqdid d'Al-Nasafi. Commencement : a . Exemplaire daté de l'an 864 de" l'hégire (1459-146o de J. C.).

Papier. 115 feuillets. Hauteur, 22 centimètres et demi; largeur, 13 centimètres. 3 lignes par page. -- (Supplément 30 to.)

\section{5 .}

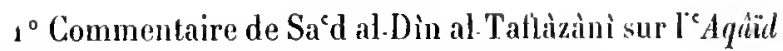
d'Al-Nasafi. Notes marginales et interlinéaires.

$2^{\circ}$ (Fol. 64. Wotice incomplite des soixante-donze hérésies qui naquirent an se'in do lislamisme.

Me. daté de l'an 877 de l'hígire $(1472-1473$ de J. C. $)$.

Papier. 65 feuillets. Hauteur, 21 centimètres et demi; largeur, 13 centimètres et demi. 18 à 21 liggnes par page. - (Supplément ${ }_{2} 51$. .)

\section{6.}

$1{ }^{\circ}$ Commentaire d'Al-Taflàzànì sur l'Aquäl d'Al-Nasafí. Copie datée de l'an 915 de l'hégire ( $1509-1510$ de J. C.). Nombreuses gloses marginales et interlinéaires.

$2^{\circ}$ (Fol. $130 v^{\circ}$.) Gloses se rapportanl au texte d'un traitẻ de théologie musulmane. Rien n'indique le nom de l'auleur. Copie dalée de: l'an 860 de l'hégire (1456 de J. C.).

$3^{\circ}$ (Fol. $1391^{\circ}$.) Commencement du commentaire d'Al-Khiyâli sur 1'c 1 quäd d'Al-Nasafì. C'e fragment renferme la dédicace à Kemàl Pacha.

$4^{\circ}$ (Fol. $1 / 40 v^{\circ}$.) Exemplaire complet du commentaire d’Hl-Khiyâlì sur $\mathrm{l}^{`} A$ quäld. Ainsi que le fragment précé-

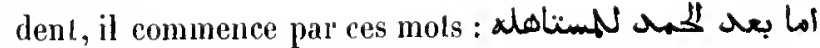
ألصاوة Gloses marginales. Copie datée de l'an 915 de l'hégire (1509-1510 de J. C.).

$5^{\circ}$ (Fol. $182 v^{\circ}$.) Quelques observations sur la théorie de la grammaire, par le molli Saed al-Dìn.

Papier. 184 feuillels. IIauteur, 18 centimètres; largeur, 13 centimètres. 11 iे 15 lignes par pare. - - (Ancien fonds 407.)

\section{7.}

$1^{\circ}$ Commentaire d'Al-Taflàzàuì sur l'Aquäl d'Al-Nasafí. Copie datée de l'an $9^{6} 9$ de l'hégire ( 1562 de J. C.).

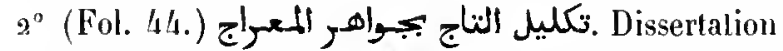
sur le voyage nocturne de Mahomet an ciel, composée en 1015 de l'hégire ( 1606 de J. C.), par Aboû 'l-Taulic

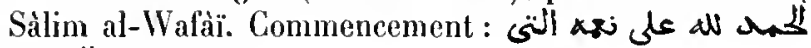

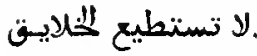

Papier. 75 feuillets. Hauteur, 21 centimètres; largeur, 15 centimètres el demi. 21 lignes par page. - (Supplément 1872.)

\section{8 .}

Commentaire d'Al-Taftàzàni sur l'A Aü̈d d'Al-Nasalì. Gloses et noles marginales. Ms. daté de l'an 1012 de l'hérgire (1603-1604 de J. C.). Les deux derniers lenillels sont couverts de notes détachées, en langue turque.

Papier. 106 feuillets. Hauteur, a centimètres; largeur, 12 centimètres. 11 lignes par pare. - (Ancien fonds 454.)

\section{9 .}

Commentaire d'Al-Taftàzànì sur l'Aquieid d'Al-Nasalit. Notes marginales.

Papier. 102 feuillets. Hauleur, a centimètres; largeur, 17 centi-

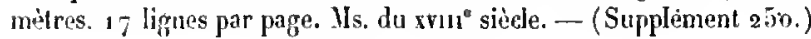

\section{0.}

Explication du commentaire d'Al-Taftàini sur $\mathrm{I}^{\text {'CA }}$ quïel d'Al-Nasafi. L'auteur ne se nomme pas, mais on lit en tète du ms. qu'il sappelait Moḥammad ibn Al-Schiḷna 


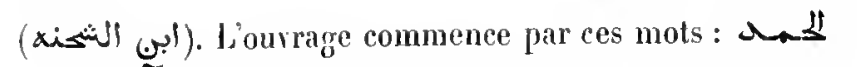

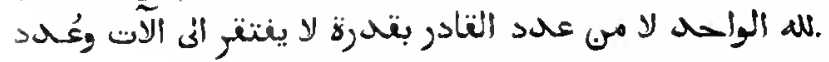

Papier. 327 fenillets. Hauteur, 22 centimètres; largeur, 16 centimètres et demi. 27 it 31 lignes par page. Its. du xvin" siècle. - (Supplément 8.i...)

\section{1.}

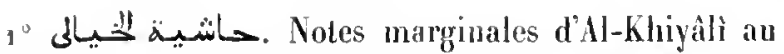
commenlaire de Taflàzàni sur l'c Aquill de Nasafi. Ms. d'une f́crilure peu élégante. Les nombreuses notes el additions qui se tronvent sur les marges sont de la main du copiste, qui, sil faut en croire une note inscrite sur le froulispice, ful l'anteur lui-même. Voyez cependant l'article suivanl.

. حانثية كستل (. Noles marginates de Kastal,

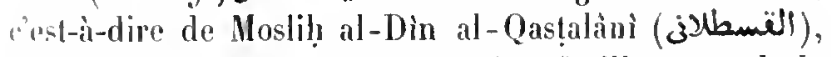
an mème commentaire. Les premier's feuillets sont de la mèm. main que les précédents; les autres sont d'un copiste y)ui a lerminé son travail en 135 de l'hégire (1 722-1 723 de J. C.). Al-Qastalànî mourul en 901 de l'hégire, et il li ist guère probable que son onvage ait été copié par AlKhivàli, mort en 860 de l'hégire.

Papier. 121 feuillets. Hauteur, 21 centimètres; largeur, 15 centimüpes. 95 liggnes par page. - (Supplément 253.)

\section{2.}

Comuentaire de 'Abd al-l lakim sur les Notes marginalos d'M-Khiyâli.

Pajier. z 4 h feuillets. Hauteur, s3 centimètres; largeur, 16 centimètres. ‥3 liognes par page. Ms. du xvm siècle. - (Supplénent 254.)

\section{3.}

$1^{\circ}$ Explication du commenlaire de hira homàl sur les Notes marginales d'Al-Khigalì.

$2^{\circ}$ (Fol. $891^{\circ}$.) Explication du commentaire de l.ossåm al-Din Hasan al-Kàni (l) sur l'Isagogé de Porphyre, par Moḷyî al-Dìn Tàlidjì.

Ms. daté de l'in 971 de l'hégire (1563-1564 de J. C.).

Papier. 139 feuillets. Hauteur, 2 2 centimètres et demi; largenr, 1 la centimètres. 24 on 25 lignes par page dans le premicr traité, 21 ligues dans le second. - (Ancien fonds 396 .)

\section{4.}

(Élucidation des questions soulerées dans le commentaire de l" Aqâid $\pitchfork$, par Niẓàm al-Dì Aḷmad ibn Schaikh 'Alì al-Qàdhì, natif de Badakhschàn

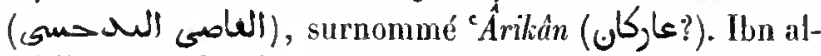
Qàdhî approfondit quelques questions très-obseures de théologie dogmatique, qu'un commentateur de l'Aqaiid, peut-être Al-Taftâzânî, arait soulevées dans son ourrage. Ms. daté de l'an 992 de l'hégire (1584 de J. C.). L'écrilure est dépourvue de points diacritiques.

Papier. 230 feuiltets. Hauteur, 25 centimètres et demi; largeur, 14 rentimètres et demi. 19 lignes par page. - (Ancien fonds 357.)

\section{5.}

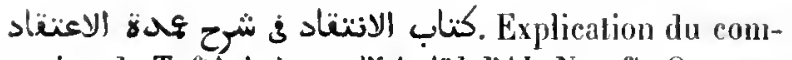
mentaire de Taftâzàn sur l`Aqâỉ d'AI-Nasafi. Ouvrage

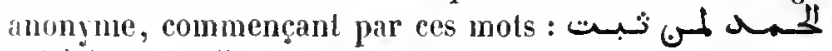
. Ms. daté de l'an 858 de l'hégire (1454 de J. C.).

Papier. 99 feuillets. Hauteur, 37 centimètres et demi; largeur, 17 centimètres. 29 lignes par page. - (Ancien fonds 361.)

\section{6.}

(La théologie scolislique portée jusqu'à ses dernières limites ", par Aboù 'l-Fat!̣ Mohammad iłn 'Abd al-Karîm al-Schahrastànî, l'auteur du Trailé sur les religions et les seetes, لsill, Mll, mort en 548 de l'hégire (1153-1154 de J. C.). Le Niháya se compose de vingt chapitres (تواعد), dont chacun établit un prineipe de la théologie acharite, à savoir :

1. Que le monde est noureau, c'est-ádire, a eu un commencement dans le temps.

2. Que tous les ètres onl élé crés.

3. Que Dieu est unique.

4. Réfulation de l'assimilation, c'est-à-dire, de l'anthropomorphisme.

5. Réfutation de la doctrine qui refuse à Dieu lout attribut (تعطيل).

6. Sur les états $\left(ل^{\prime}\right)$, c'est-à-dire, les jugements qui concluent de l'existence d'attributs à l'existence d'un sujet qui les porte.

7. Le néant (مولمull) est-il un être? 
La fin de ce chapitre manque dans le ms., ainsi que les quatre chapitres suivants. Le donzième cllapitre, dont it ne reste que la fin, piraì être une rélitation de la doctrine motazélite relative aux attribuls de Dieu el à sa parole (le Coran). En effet, les Motazélites niaient l'étrornité des atlributs et affirmaient que la parole était rréée.

13. Que la parole du Créateur est unique.

14. Que la parole de l'homme est réellement un être.

15. Ce qu'on entend par les attributs de l'andilion el de la vue.

16. Qu'au moyen de lintellect (لتّs) on peut roir Dien et l'entendre.

17. Sur la distinction du bien et du mal (والتقبئ

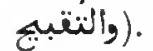

18. Réfutation de la doctrine qui affirme que toutes les actions de Dieu ont leur but el leur motif.

19. De la qualité prophétique, de la réalité des miracles el de l'impeccabilité des prophètes.

20. Preuse de la qualité prophétique de Mahomet et de la réalité de ses miracles.

Ms. daté de l'an 580 de l'hégire (1184-1 185 de J. C.). Une lacune qui existait entre les feuillets 7 el 58 a été en partie comblée par un copiste dn xvı ${ }^{e}$ siècle.

A la fin du volume se trouve l'histoire, en persan, de la sainte Vierge et de l'enfint Jésus en Égypte.

Papier. 211 feuillets. Hauteur, a 4 centimètres; largeur, 16 centimètres. 13 lignes par page, dans la partic ancienne du ms., 17 lignes dans la partie moderne. - (Supplément 239.)

\section{7.}

1" Pages de mélaphysique" ou r Pages de théologie scolastiquen, sans nom d'auteur. Commencement : الوجيود والوحهرة Les deniers fenillels manquent.

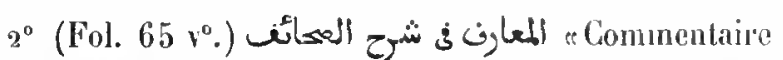
sur le Sahaif», ouvrage que Hadji Khalfa parait attrilouer ì Áboû 'l-Laïth al-Samarqandi. Les premiers caliers manquent.

$3^{\circ}$ (Fol. 144.) Trailé sur les croyances des philosophes (أعنقاد ) par Schihâb al-Dìn al-Sohrawardi.

Ms. dalé de l'an $77^{5}$ de l'hégrire $(1373-1374$ de J. C.).

Papier. 145 feuillets. Hanteur, 22 centimètres et demi; largeur, 15 centimètres. Les feniltets du premier traité portent 23 lignes par page, ceux du second et du troisième 3 , ligrnes. - (Ancien fonds 398 .)

\section{8.}

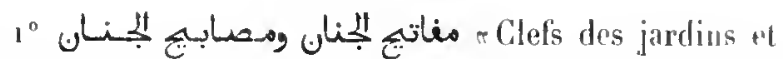

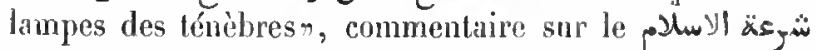
de Rokn al-Islàm Inàm-Zàdé, par Yáqoûb Sayyid 'Ali, Commencement: وجبا.

$2^{\circ}$ (Fol. $219 \mathrm{v}^{\circ}$.) Dissertation d'Al-Ghazâlì (Djamál al-Islâm Mḷmad ibn Molıummad) sur les mérites de la

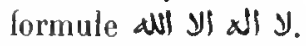

$3^{\circ}$ (Fol. $2291^{\circ}$.) Le Minhadj al-ḉbidin d'Al-Ghazâlì (Hodjdat al-Islầm Aboû !̣àmid Moḷanmad).

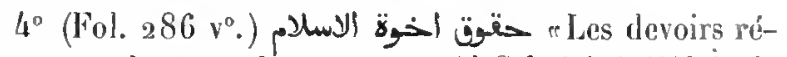
ciproques des musulinansn, par Al-Schaeràni ("Abd alWahhâb ibn Aḷmad). Commencement : a d all ونستنعينه

$5^{\circ}$ (Fol. 330. ) Vocabulaire arabe, persan el ture, par ordie de matières.

Les quatre premiers traités sont datés de l'an 922 de l'hégire $(1516$ de J. C. ), le cinquième de l'an 869 de l'hégire (146/-1465 de J. C.).

Papier. 368 feuillets. Hauteur, a centimètres et demi; largeur, 14 centimètres et demi. 25 lignes par page. - (Supplément 1869.)

\section{9.}

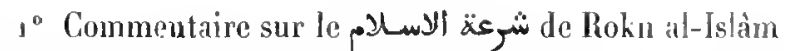
Imåm-Zàdé, par Yacqoûb ilın Sayyid 'Ali.

$2^{\circ}$ (Fol. $257 v^{\circ}$.) Chapitre sur l'ablution (لوقوء), ex-

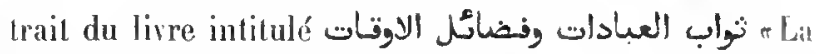
Récompense des actes de dérolion et les mérites des Heures (prières)r, par un personnage surnommé الايمّّة (1150-1151 de J. C.).

Papier. 257 feuillets. Ilauteur, ag centimètres; largeur, a t centimètres. פj lignes par page. Mts. du ww siècle. - (Ancien fonds 1660.)

\section{0 .}

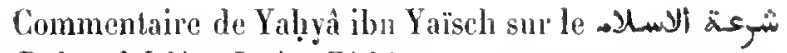
de Rokn al-Islàm Imâm-Zàdé.

Papier. 200 feuillets. Hauteur, 18 centinètres; Jargeur, 13 cenilmètres. 19 à 2 ' lignes par page. $V_{s}$. du xvi" siècle, probabtrment autographe. - (Ancien fonds 563.) 


\section{1}

$1^{\circ}$ خوء Commentaire d"Alì ibn Soltàn Moḥammad al-Kàrì, mort en 1014 de l'hégire (1605-1606 de I. C.), sur le يتول العبح ou بحء ألاهان ou traité de théologie scolastique, en vers, par le schaïhlı Sirâdj al-Din 'Alì ibn 'Othmấn al-Ausì (الاوسى). Le commentaire com-

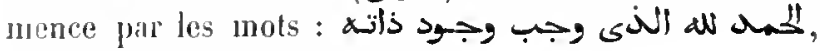
et le poème par ce vers :

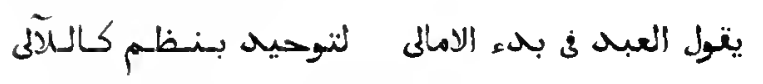

Nombreuses notes nuarginales.

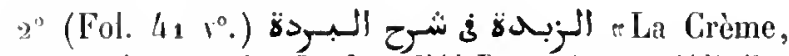
commentaire sur la Borden d'Al-Boûșirì, par 'Alì ibn

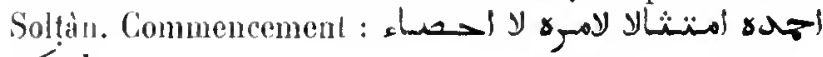

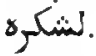

$3^{\circ}$ (Fol. 14 1 $1^{\circ}$.) Le takhmis de la Borda qui commence par les mots : ما بال قلبك لا ينفك ذا اله

$4^{\circ}$ (Fol. 158.) Autre taklmîs du même poème, com-

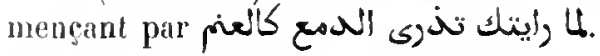

Ms. daté de l'an $117_{4}^{4}$ de l'hégire $\left(\begin{array}{l}1 \\ 7\end{array} 6_{1}\right.$ de J. C. $)$. Texte entouré d'un double encadrement en or et en encre noire; dans la prenière pièce, l'espace compris entre les deux encadrements est couvert de notes; il y a deux vigoneltes, assez bien exécutées; les ver's sont écrits à l'encre rouge.

1'apier. $17^{4}$ fevillets. llauteur, 21 centinètres et demi; Jargeur, 16 centimètres. 19 lignes par page dans la première pièce, 15 dans les trois autres. - (Supplément 1471.)

\section{2.}

Traité de lleéologie scolastique, et réfutation des dualistes (fol. 26). des mages (fol. 27), des chrétiens $\left(\right.$ fol. $\left.271^{\circ}\right)$, et des sectes juires $\left(\right.$ fol. $\left.74 r^{\circ}\right)$, par un schiite de la secte des duodécimains (royez fol. 80 et suirants). Les sept premiers et les deux derniers feuillets manquent. II manque en oulre un feuillet entre les folios actuellement cotés 73 et 74 , et un feuillet entre les folios $8_{1}$ et $8_{2}$.

Papier. $9^{8}$ feuillels. Hauteur, 18 centimètres et demi; larerenr, 12 contimètres et deni. 15 lignes par page. Ms. dn xul siècle. (Supplément 25n.)

\section{3.}

(rive de cinquante questions touchant les dogmes de la religion", ouvrage d'un musulman orthodoxe, qui vivait sous le règne du calife abbaside Al-Naṣr li-Din Illah, entre les années 575 et 622 de l'hégire ( $1179-1225$ de J. C.). Une main assez moderne a inscrit sur le revers du plat de la couverture les mots Al-Ràzî. Cette indication est peut-être exacte, car nous savons que Fakhr al-Din Mohammad ibn ' Omar al-Ràzì mourut en 606 de l'hégire. L'ourrage commence par les

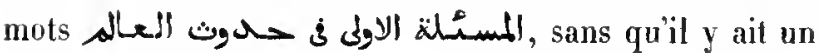
mot de préface.

Papier. 18 fenillets. Hauteur, 17 centimètres; largeur, 10 centimètres. 11 lignes par page. Ms. du $x v^{\circ}$ siècle. - (Ancien fonds 452.)

\section{4.}

Exposition distincte, commentaire du Mohassalm. Ce dernier ourrage est un traité de métaphysique et de théologie, composé par Fakhr al-Din al-Ràzì (Moḷammad ibn 'Omar). Le nom du commentateur ne parait nulle part ${ }^{1}$. L'ourrage commence par ces

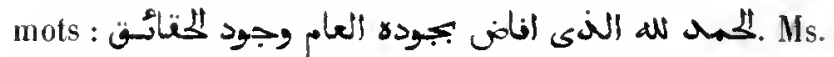
daté de l'an 709 de l'hégire (1309-1310 de J. C.).

Papier. 248 feuillets. Hauteur, 22 centimètres el demi; largeur, 12 centimètres. 27 lignes par page. - (Ancien fonds 404.)

\section{5.}

(Les Levers des lumières de l'horizon de la spéculationn, traité de métaphysique et de théologie dogmatique, par le cadi 'Abd Allâh ibn 'Omar al-Baïdhâwì, auteur du commentaire du Coran. Nous arons ici le texte de l'onrage, accompagné d'un commentaire perpétuel. L'ourrage commence par ces mots : Le commentaire com-

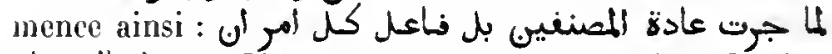

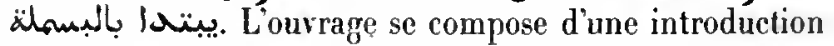
et de trois chapitres, dont le premier a pour sujet les

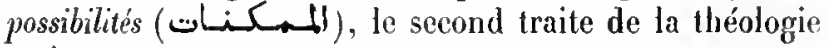
(ألالهيات), et le troisième des qualités qui constituent la

D’après Hadji Khalfa (t. V, p. 4a2), ce commentaire a été composé par 'Alì ilon 'Omar al-Kâtibì at-Qazwîni. H. Z. 
ficulté prophétique (النبوات). L'auteur du commentaire est incomnu. Ms. daté de l'an $89^{6}$ de l'hégire (1 $49^{0-1} 49^{1}$ de J. C.).

Papier. 223 feuiltets. Hauteur, 18 centimètres el demi; targenr, 10 centimètres. 15 à 25 tignes par page. - (Ancien fonds 273.)

\section{6.}

\section{Le طوالع الانوإ d'Al-Baïdlıâwî.}

Papier. 84 feuillets. llanteur, 23 centimètres et demi; targeur 13 centimètres et demi. 1 a liggnes par page. Ms. du xvi siècle. - (Ancien fonds 403.)

\section{7.}

(Les Levers (des lumières) des spéculations», commentaire sur le طوالع الانوار d'Al-Baidllàwi, par Aboû 'l-Thanâ Schams al-Dìn Malımoûd ibn 'Abd alRạ̣mân al-Iṣfahảini, mort en 745 de l'hégrire (13441345 de J. C. ). Dans cet exemplaire, l'ourrage commence par les premiers mots de la préface du طوالع. Ws. daté de l'an 843 de Thégire (1439-1440 de J. C.). Nombreuses gloses marginales.

Papier. 139 feuiltets. Hanteur, 37 centimètres et demi; largeur, 17 centimètres et demi. 27 lignes par page. - (Ancien fonds 360.)

\section{8.}

Le مطالع الانظار d'Aboù 'I-Thanâ Schams al-Dìu al-Iṣfahânì. Cet exemplaire commence par les mots : all in

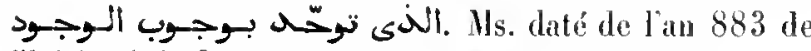
l'hégire (1478-1479 de .l. C.). Noles marginales.

Papier. 197 feuillets. Hauteur, 19 centimetres; largeur, 13 centimètres. 17 lignes par page. - (Ancien fonds 410. )

\section{9 .}

Traité de théologie scolastique (1) Le commencement et la fin manquent. Plusieurs feuillets sont lor's de leur place, d'antres sont rencersés. L'ounrage est divisé en livres (كتاب), en seclions (فمسل) et en

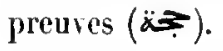

Papier. 177 feuillets. Hauleur, 25 centimètres et demi; targeur, 16 centimètres et demi. 23 lignes par page. Ms. du xmi ou dn xıv siècle. - (Supplément 242.)

$$
\text { Mar. orgentaux. }-11 \text {. }
$$

\section{0.}

Première partie du commentaire d'Al-Siràdj al-llindi sur le بحيع التنظام, célèbre traité de théologie dogmatique de Hozalfar' al-Dì Aḥnad ibn 'Ali, surnommé lbı al-Sì àli, mort en 694 de thégire. Le commentaire, qui se compose de quatre parties, porte le titre de

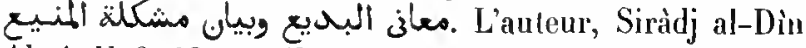
Aboni llafs. 'Omar ibn Isḷiq, de Ghazna, dit l'Indien

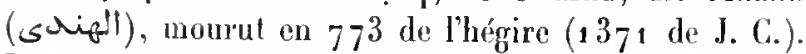
Les premiers el les deruiers feuillets manquent.

Papier. ${ }_{2} 59$ feuillets. Hauteur, 28 centimètres; largeur, 18 centimètres et demi. 25 lignes par page. Ms. du xvi siècle. - (Ancien fonds 255.)

\section{1 .}

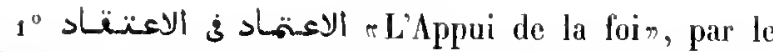
háfi: Aboû 'l-Barakàt 'Abd Allàlı ibu Aḷmad al-Nasali. mort en 710 de l'hégire $(1310-1311$ de J. C.). C'est mu

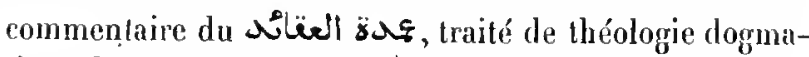
tique du inème auteur. Le أعتماد commence par ces mots :

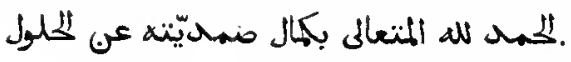

$2^{\circ}$ (Fol. 114. . Exposition de la foi musulmaue, par Nadjm al-Dìn Aboû Hafṣ `Omar ibn Molyammad al-Nasafi. Cet exemplaire commence par les

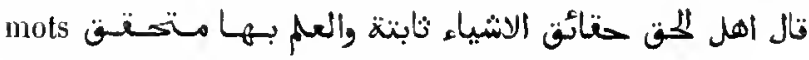
خالافا للسوفسطائية. Quelques notes marginales.

Papier. 117 fenillets. Hanteur, 19 centimètres et demi; largeur, 14 centimètres. 18 lignes par paye. Ifs. du xuv siècle. - (Ancien fonds 419.)

\section{2.}

$1^{\circ}$ Commentaire sur le مواقغ oélèbre traité de métaphysique et de théologie scolastique d'Al-Îdjì ("Adhod al-Dìn 'Abd al-Raḥmân). Ce commentaire, dont nous u'aıons ici que les quinze prenières pages, est attribué à 'Alà al-Dìn 'Alì al-Toùsi, mort en 940 de l'hégire (1533-1534 de J. G.).

$2^{\circ}$ (Fol. 9.) Commentaire anonyme (jeut-être celui de Kanaâl al-Dîn Mas'oùd al-Schirwàni) sur l'ourrage de Schanıs al-Din Mohammad ad-Samarqandi, iutitulé Règłes à observer dans les discussions scientifiques $\pi$. 
$3^{\circ}$ (Fol. $43 r^{\circ}$.) Commentaire de Sacd al-Din ad-Taltàzâni sur l"Aqäil d'Al-Nasafí. Exemplaire écrit à Angora el daté de l'an 974 de l'hégire (1566-1567 de J. C.).

$4^{\circ}$ (Fol. 133.) Commentaire abrégé sur la préface du Mişuâh, célébre traité de grammaire, composé par AlMotarrizi.

Papier. 133 feuillets. Hauteur, a 1 centimètres; largeur, 15 centimẻtres. Ms. de diverses écritures da xvi" siècle. - (Ancien fonds 4,8.)

\section{3.}

Gloses d'un anonyme sur te traité de théologie d'Adhod al-Din al-îdji, intitulé

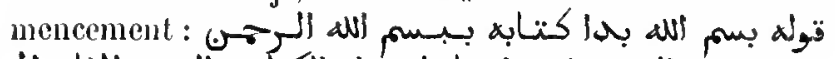

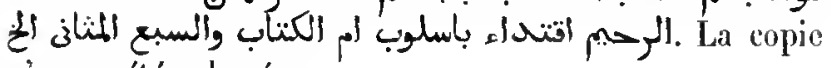
n’a pas été achevée.

Papier. 39 fenillets. Hautenr, 15 centimètres et demi; largeur, 10 centimètres. 15 lignes par page. Ms. du xvine siècle. - (Supplémeat 2039.)

\section{4.}

$1^{\circ}$ Commentaire de Mìr Aboû 'ł-Fatḥ al-Ardebilì sur l'ouvrage d'Adhod al-Dìn 'Abd al-Raḥmân al-Î̀dji, traitant des règles à observer dans la discussion des ques-

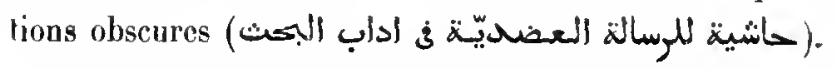

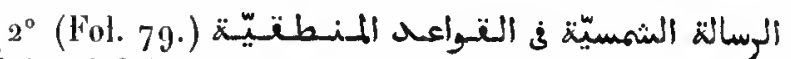
( Épititre à Schams al-Din sur les principes fondamentaux de la logiquen. Notes marginales.

Papier. 132 feuillels. Itauteur, 2 a centimètres; largeur, y a centimètres. 13 lignes par page. Ms. du xvn" siècle. — (Ancien fonds 465.)

\section{5.}

Commentaire sur les chapitres cinquième et sixième du مـاصـ, traité de lhéologie scolaslique et de métaphysique (الههيات), d'Al-Taftàzâni. Les premiers feuillets contiennent de nombreuses noles marginales.

Papier. 77 feuillets. Hauteur, 27 centimètres; largeur, 18 centimètres. a 9 lignes par page. Ms. du xv1 siècle. - (Ancien fonds 366.$)$

\section{6.}

1요 .Preuves tranchantes à l'appui des principes des croyances", traité anonyme de théologie scolastique, commençant par ces mots : גa (لف بارى النسم وكعيى الرمم pice du manuscrit est faux. Le véritable titre se trouve à la fin de l'ourrage. Hadji Khalfa donne le mème titre,

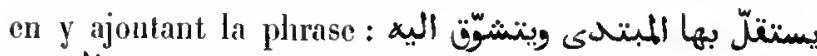
المنتنهى ; or, cette plurase se retronve, à une variante près, dans notre manuscrit, à la suite du tilre (fol. $112 \mathrm{v}^{\circ}$ ). Copie datée de l'an 847 de l'hégire (1 443-1444 de J. C.).

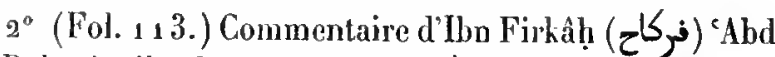
al-Rilumân ibn lbràhim sur le ورقات "Fevilles", traité dans lequel te célèbre Imâm al-ḷaramaïn Aboù 'I-Ma'âlî al-Djowainini expose les principes (اصول) du droit schâféite. Copie datéc de l'an 877 de l'hégire (1472-1473 de J. C.).

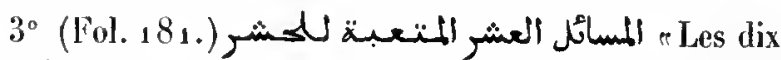
questions dont la solution défie les efforts des gens Ibn Barri (أبى برى), surnommér le roi des grammairiens", nous domne ici les réponses à ces questions, qui se rapportent toutes à des difficultés grammaticales. Écriture du $x v^{e}$ siecle.

$4^{\circ}$ (Fol. $218 r^{\circ}$.) Traité sur le partage des successions, ourrage inonyme, commençant par ces mots : All زبّ العالميب. Copie datée de l'an 785 de l'hégire (1383-1384 de J. C.).

$5^{\circ}$ (Fol. $250 v^{\circ}$.) Traité des successions, en vers, par Yalıyà ibn abì Bakr al-IIlanafi. En voici le premier hé-

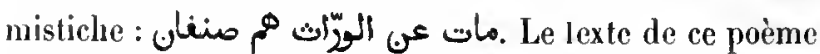
est accompagné de notes marginales et suivi de plusieurs tableaux.

$6^{\circ}$ (Fol. 270.) Dissertation en prose sur le partage des successions.

$7^{\circ}$ (Fol. $271 v^{\circ}$.) Traité sur le partage des successions, rédigé en vers, par Moḥsin al-Qaïṣarì. Voici le

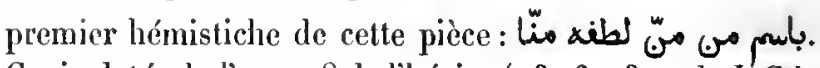
Copie datée de l'an $77^{8}$ de l'hégire ( $1376-1377$ de J.C.).

Papier. 280 fenillets. Hauteur, 17 centimètres; largeur, 12 centimètres el demi. - (Ancien fonds 405.$)$

\section{7.}

$1^{\circ}$ Résumé des discussions au sujet de la manière dont les événements dépendent de la puissance divinen. Traité anonyme. Copie du $x v^{0}$ siècle.

$2^{\circ}$ (Fol. 3.) Gloses au commentaire de Ḥossâm al-Dìn Ịasan al-Kànì (الكان) sur le traité de logique d'Athîr al- 
Dîn Mofaddhal ibn 'Omar al-Abharì (الإبهوى), intitulé

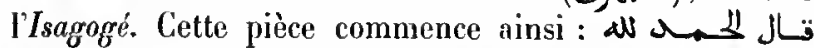

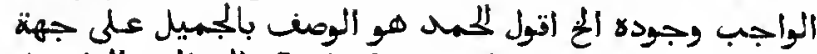

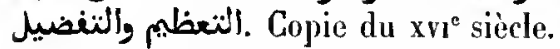

Papier. 8 feuillets. Hauteur, 21 centimètres; Jargeur, 15 centimètres. 22 à 38 lignes par page. - (Supplément 527 .)

\section{8.}

年 Le Poème algérienn, composé d'un assez grand nombre de vers rimant en lam. Chaque paragraphe de ce poème, qui. traite de l'unité de Dien, est accompagné d'un commentaire, souvent très-développé. La Manzốma a pour auteur Aboû 'l-'Abbâs Aḷmad ibn 'Abd Altăh â-Djazâiri, natif d'Alger. Le commentaire que nous avons ici a été composé par le célèbre docteur maghrebin Aboû 'Abd Allâh Moḷammad ibn Yuùsof al-Sanoûsi (المنتوسى).

Papier. 376 feuillets. Hauteur, 22 centimètres; largetır, 15 centimètres. 29 lignes par page. - (Supplément 240.$)$

\section{9.}

م Les Coruscations brillantes se rapportant à la Manzoûma algérienne". Commentaire sur la Manzoûma, par le schaïkh al-Jslàm Mohammad at-Djaulıarì al-Khâlidì. Exemplaire écrit en 1196 de l'hégire (1 782 de J. C.), probablement pour l'auteur.

Papier. 72 fenillets. Hauleur, 22 centimètres; largeur, 26 centimètres. so et 21 lignes par page. - (Supplément 241.$)$

\section{0 .}

$1^{\circ}$ ألعيد, ou Exposition de la foi musulmane, par Aboù 'Abd Allàh Mohammad ibn Yoûsol' al-Sanoûsì. Com-

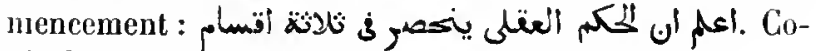
pie datée de l'an 1029 de l'hégire (1620 de J. G.).

$2^{\circ}$ (Fol. $8 v^{\circ}$.) Le Dalail al-Khaïrât. Au fol. $18 \vee^{\circ}$ se trouve Je plan du tombeau de Nahomet.

$3^{\circ}$ (Fol. $82 \vee^{\circ}$.) Traité de théologie scolastique, com-

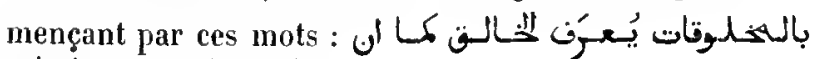
بالمصنوءات بعرن الصانع.

$4^{\circ}$ (Fol. 86.) Prière commençant par les mots : بلت جلت all to is is

Papier. 86 feuillets. Hauteur, 18 centimètres; largeur, 14 centi- mètres. 13 tignes par page. Ms. du xiv siècte. - (Ancien fonds 302 , Colbert 3915 .)

\section{1.}

عحلة أهل النتوفيق والتنسديد في تُح عتيده أهل التنوحيد "Le Soutien de ceux qui jouissent de la grâce de Dieu et de sa boune direction, traité servant à expliquer le texte de I" Aqîla (ou profession de loi) des unitaires $\%$. Les deux ouvrages ont pour auteur l'imàm Moḥammad ibn Yoûsof al-Sanoûsî, qui a composé deux 'Aqida, une grande et une petite. Nous avons iei le commentaire de la grande 'Aqîda (ألعتيده الكبرى). Ms. daté de l'an 1114 (17021703 de J. C.).

Papier. ${ }_{1} 78$ feuillets. Hauteur, 21 centimètres; largeur, 15 centimètres. 23 lignnes par page. - (Supplément 247 .)

\section{2.}

Autre exemplaire de l'Omda d'Al-Sanoûsî. Ms. daté de l'an 1154 de l'bégire (1741-1742 de J. G.).

Papier. 132 feuillets. Hauteur, a 1 centimètres et demi; largeur, ${ }_{15}$ centimètres et demi. 23 à 25 lignes par page. - (Supplément 246.)

\section{3.}

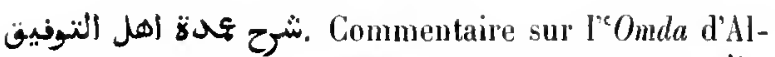

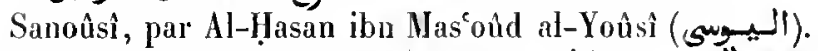

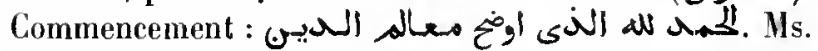
daté de l'an 1119 de l'hégire (1 707-1708 de J. C.).

Papier. ${ }_{2} 69$ fenillets. Hauteur, 29 centimètres et demi; largeur, 18 centimètres et demi. 29 lignes par page. - (Supplément 248.)

\section{4.}

Commentaire sur l'c Omda d'Al-Sanoủsì, par un auteur quoon désigne par te titre d'Al-'Akkànì (s) sك́li). Voyez les notes marginales, fol. 1 el fol. 11 du volume. Conn-

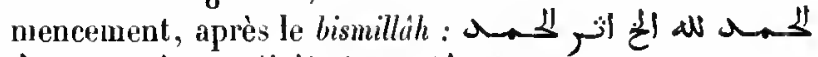

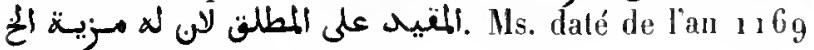
de l'hégire ( 1756 de J. G.).

Papier. 259 feuillets. Hauteur, 22 centimètres; largeur, 16 centimètres et demi. 23 et 2 ' lignes par page. - (Supplément 3247 .) 


\section{5 .}

L_‘ Omda d'Al-Sanoûsì, abrégé par l'auteur lui-même.

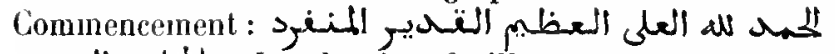

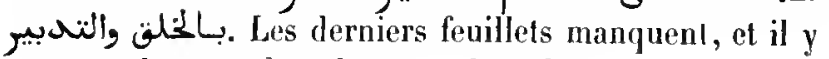
i quatre lacunes dans le corps du volume.

Papicr. 117 feuillets. Ilauteur, 21 centimètres et demi; largeur. 15 centimètres et demi. 3 lignes par page. Mls. du $x^{2} r^{e}$ siècle.— (Supplément 2248.)

\section{6 .}

$1^{\circ}$ Commentaire sur la Petite "Aqîla d'All-Sanoủsì", par Moḷammad al-Màmoùn ibn Mohammad al-Ifafṣi (c)ill). Copie datée de l'an 1104 de l'hégire $(1595-1596$ de J. C.). Commencement :

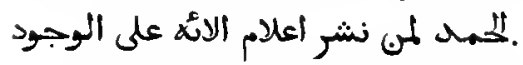

$2^{0}$ (Fol. 29.) Gloses de Ilamíd al-Sac dì, fils d'e Abd

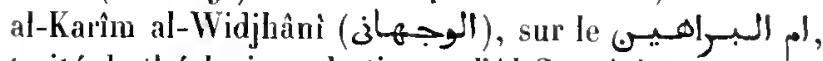
traité de théologie scolastique, d'Al-Sanoùsì.

Papier. 52 feuillets. Hanteur, 21 centimètres et demi; largeur, 15 centimètres et demi. 23 lignes par page. - (Supplément $2 / 9$. .)

\section{7.}

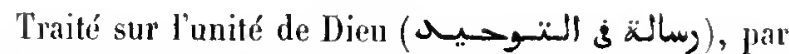
Loṭ Mllâh ibn Aḥmad al-Ịosaïnî, exemplaire présenté par l'auteur à Solaïmân Pacha, lors de l'arrivée de celui-ci en Égypte, en 943 de l'hégire (1536-1537 de J. C.).

Papier. $5 \imath$ feuillets. Hauteur, 16 centimètres et demi; largeur, 1 a centimètres, 11 tignes par page. - (Supplément 264.)

\section{8.}

10 Dissertation sur la preuve inlellectuelle el la preuve traditionnelle.

$2^{\circ} \quad$ Fol. $\left.2 v^{\circ}.\right)$ Commentaire du traité précédent, accompagné de notes marginales el interlinéaires, intitulé شَح الاداب العضديّة لمولانا حنّى

$3^{\circ}$ (Fol. 16.) Instructions morales et religieuses, adressées par Mahomet à Aboû Horaïra.

$4^{\circ}$ (Fol. $\left.30 v^{\circ}.\right)$ Traité de logique, commencanl par

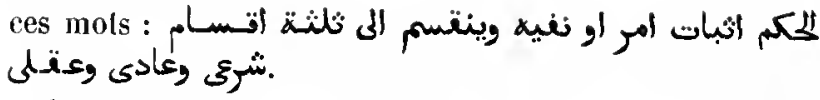

$5^{\circ}$ (Fol. $35 \mathrm{v}^{\circ}$.) Traité de dialectique, altribué à Tachkeupri Zàdé, et accompagné d'un commentaire. Com-

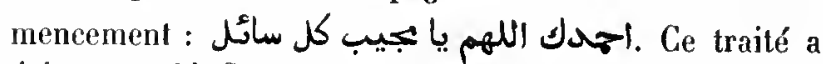
été composé à Constantinople, en 964 de l'hégire (15561557 de J. C.).

$6^{\circ}\left(\right.$ Fol. $49 \mathrm{v}^{\circ}$.) Sur quelques questions obscures de droit musulman. En ture.

Papier. 66 fenillets. Hauteur, 15 centimètres et demi; largeur, 11 centimètres. 11 lignes par page, à l'exception du troisième traité qui en a 17. Ms. de diverses écritures du $x 1^{\circ}$ siècle. - (Ancien fonds 336.)

\section{9.}

: Réponses claires à des questions sur des matières obscures, , traité dans lequel un docteur nommé 'Alì ibn Moḥammad al-Miṣrî répond ¿ différentes questions touchant la théologie, les tradilions, la philologie et l'exégèse du Coran. L'auteur vivait postérieurement à Djalàl al-Dìn al-Soyoûtị, dont il cite l'aulorité (fol. $9^{8} \mathrm{v}^{\circ}$ ). Ms. daté de l'an 1109 de l'hégire ( $697^{-1698}$ de J. C.).

Papier. 502 feuillets. Hauteur, 21 centimètres et demi; largeur, 16 centimètres. 23 lignes par page. - - (Supplément 448.)

\section{0.}

Commentaire sur un traité de théologie scolastique. Commencement : Lol. Nombreuses notes marginales.

Papier. 81 feuillets. Hauteur, 27 centimètres; largeur, 17 centimètres. 23 à 26 lignes par page. Ms. du $x^{2} \mathfrak{u}^{e}$ siècle. - (Ancien fonds 365 .)

\section{1.}

a Le Djauharat al-Tauhîd (expliqué et) offert en cadeau à l'étudiantn, commentaire d'Abd al-Salàm ibn Jbrâhìm al-Loqânî (cقإلli),

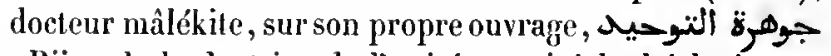
- Bijou de la doctrine de l'unitén, traité de théologie scolastique en vers. Selon Hadji Khalfa, cet auteur mourut en 1041 de l'hégire (1631-1632 de J. C.).

Papier. 110 feuillets. Hanteur, 22 centimètres; largeur, 15 centimètres et demi. 19 lignes par page. Ms. du xvic siècle. -- (Supplément 244.) 


\section{2 .}

Autre exemplaire du أنحاف المريد. Mls. daté de l'an 1093 de l'bégire ( 1682 de J. C.).

Papier. 89 feuillets. Hauteur, 20 centimètres et demi ; largeur, 14 centimètres et demi. 23 lignes par page. - (Supplément 245.)

\section{3.}

(-La Manzoùma du (schaikh mâlékite Noùr al-Dìn 'Ali) al-Adjhoûrì sur les dogmes de la foin, en vers du mètre radjaz, accompagné d'un commentaire du même auteur. Le texte du joème est écrit à l'encre rouge.

Papier. 69 feuillets. Hauteur, 21 centimètres et demi ; largeur, 15 centimètres et demi. 23 lignes par page. Ms. du xvi ${ }^{e}$ siècle. - (Supplément 334 .)

\section{4.}

La Manzoûma de Noûr al-Dìn 'Alì al-Adjloùrì, arec le commentaire de l'auteur.

Papier. 93 feuillets. Hauteur, 20 centimètres el demi; largeur, 5 centimètres. 23 lignes par page. Mls. du xvm siècle. - (Supplément ${ }_{2} 35$.)

\section{5.}

1 - Traité des principes de l'islamisme et des clevoir's des musulmans, formant soixante el une seclions (مسئلة).

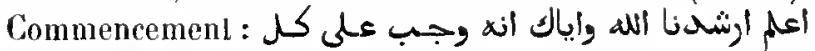

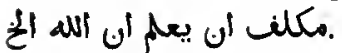

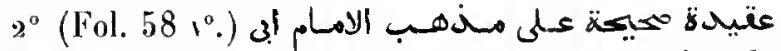
حنيغة La croyance orlhodoxe, d'après la dochine de l'imâm Aboǹ llanifas. Pièce de vers (limiya), connue sous le tilre de بـاء الامـالى, par Siridj al-1)in 'Ali ibn Moḥmmad al-Oûschî (الأوثنى). l'remier vers :

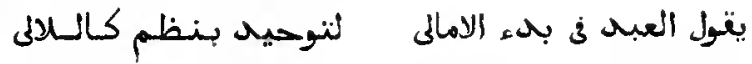

$3^{\circ}$ (Fol. $61 v^{\circ}$.) Commenlaire sur te poème précédent, par Ibu Djamâca ('Izz al-Dìn Moḷammad).

4 (Fol. 75.) L'"Aqidat All al-Somna d'Al-Nasafi ("Omar ibn Mol!ammad).

$5^{\circ}$ (Fol. $821^{\circ}$.) L'Aqîla d'Al-Sanoùsì (Moḷanmad ibn
Yoûsof). Démonstralion logique de deux articles de foi musulmane.

Ms. daté de l'au 1052 de l'hégire (1643 de J. C.).

Papier. 86 feuillets. Hauteur, 21 centimètres et demi; largeur, 14 centumètres et demi. 13 lignes par page. - (Supplément 1868.)

\section{6.}

$1^{\circ}$ اصول الشنى. Trailé de la religion musulnane.

$2^{\circ}$ (Fol. $34 v^{\circ}$.) L'Aqaid, d'Al-Nasafi.

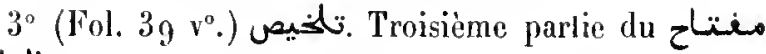
العلوم.

$4^{\circ}$ (Fol. $78 \checkmark^{\circ}$.) Traité de prosodie, par Aboû 'Abrt Allàh Voḷammad Aboù 'l-Djaïsch al-Andaloûsî.

$5^{\circ}\left(\mathrm{F}_{0} \mathrm{l} .87 \mathrm{v}^{\circ}\right.$.) Traité du parlage des successions.

$6^{\circ}$ (Fol. $101 v^{0}$.) Divers extraits en lurc.

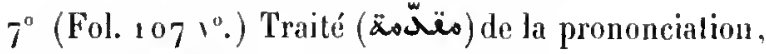
en vers, par Moḥammad ibn al-Djazarì.

$8^{\circ}$ (Fol. $110 \%^{\circ}$. ) Traité des devoirs du musulman.

$9^{\circ}$ (Fol. $114 v^{\circ}$.) Commencement du traité de logique d'Al-Abhari.

$10^{\circ}$ (Fol. $117 \mathrm{v}^{\circ}$.) Traité de lecture et de prononciation.

$11^{\circ}$ (Fol. 158.) La Kafiya, accompagnée de nombreuses gloses.

$19^{\circ}$ (Fol. $203 \vee^{\circ}$.) Grammaire persane, en arabe.

$13^{\circ}$ (Fol. 217.) Traité de cabale, en turc.

Nombreuses notes marginales et interlinéaires.

Papier. 227, feuillets. Hauteur, 21 entimètres; largeur, 11 centimètres. Écritures diverses du xvir siècle; plusieurs pièces sont datées des années 1078 ou 1079 de l'hégire (1668-1669 de J. C.). - (Supplément 1948 , Oratoire.)

\section{7.}

1 Traité de théologie, par Yạyd ibu abì Bakr al-lyanafi, traduit du persan par l'auteur lni-même.

$2^{\circ}$ (Fol. 14.) Liste chronologique des soufis qui se sont lransmis la tariqa, ou système de pratiques religieuses enseigné par le calife Aboû Bakr.

$3^{\circ}$ (Fol. 16.) Notes et extraits divers.

$4^{\circ}$ (Fol. $19 r^{\circ}$.) Traité, en persan, sut les devoirs du musulman. 


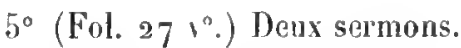

$6^{\circ}\left(\mathrm{Fol}_{2} 8 \mathrm{v}^{\circ}\right.$.) Alrrégé du Qawấ id al-I rẩb, traité de grammatre d'Ibn Hischàm.

$7^{\circ}$ (Fol. $30 v^{\circ}$.) Commentaire sur le Qawấid d'lbn Hischıân.

$8^{\circ}$ (Fol. 43.) Une pièce de vers en persan, et deux autres en turc.

$9^{\circ}$ (Fol. $44 v^{\circ}$.) Fatwa du mufti 'Hî Tchelébi, au sujel des exercices des soufis.

$10^{\circ}\left(\right.$ Fol. $\left.461^{\circ}.\right)$ Fragments divers.

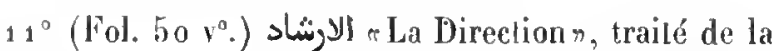
religion musulmane, selon la doctrine d'Aboû Hanifa.

Papicr. 89 feuillets. Hlauteur, 20 centimètres; largeur, 13 centimètres et demi. F́critures diverses du xrm ${ }^{e}$ siècle. - (Supplénent 1871$.

\section{8 .}

Gloses de Schibàb al-Din Aḥmad al-Malawì (الملوى), sul un traité de théologie qui paraît aroir élé l'édigé en vers $\left(z_{2}-;\right)$ i). Le comnencement manque.

Papier. 75 feuillets. Hauteur, 22 centimètres et demi ; largeur, 16 centimètres. 23 lignes par page. Ms. du xis siècte. - (Supplément 2023. .

\section{THÉOLOGIE MORALE.}

\section{9 .}

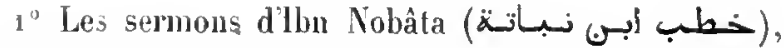
célèbre prédicateur de la cour des llamdånides, mort en $37^{4}$ de l'bégire (984-985 de J. C.), sur la religion, la morale, les fêtes musulmanes, la guerre contre les infideles (sL_ I $)$, etc., suivis de courtes allocutions, prononcées devant plusieurs princes hamdanides, à l'occasion des vicloires qu'ils avaient remportées sur les armées lyyzantines. Le nom complet de l'auteur était Aboû Yahyà 'Abd al-Rahim ibn Mohammad ibn Ismacull ibn Nobâta al-Fàraqi, natif de Mayyâfàraqìn. M. de Slane a publié un de ces sermons dans le Journal asiatique, numiéro de janvier 1840, p. 66 et suiv.

$2^{\circ}$ (Fol. $2021^{\circ}$.) Douze sermons d'Aboû Țâhir Moliammad, fils de lbun Nobàta.

Ms. écrit à Damas, en 690 de l'hégire (1 291 de J. C.). Les folios 1 à 9 sont d'une main plus récente. Au com- mencement et à la fin du volume se trouvent des fragments d'invocations et de sermons, des certificats d'origine du ms., de collation et de lecture.

Papier. 225 feuillets. Hauteur, 19 centimètres; largeur, 12 centimètres et deni. ı 3 lignes par page. - (Ancien fonds 451.)

\section{0 .}

م Commentaire sur les sermons des Ibn Nobâta», par un auteur anonyme. Cet ourrage coumence par les mots : نـائك وبحيـل : Entre le quatre-vingt-uenvièmo et le quatre-vingt-dixième sermon, l'auteur a inséré une

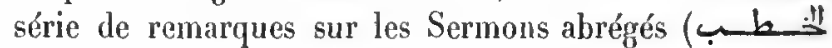
ألنختصرة), qui sont au nombre de neuf. Il présente ensuite des observations sur certaines allocutions (فصل) du même auteur, sur les douze discours d'Aboû Tâhir Moḷammad, fils d'Abd al-Raḥmân ibn Nolıàta, sur un sermon de mariage et sur un discours d'Aboû 'l-Qâsim, arrière-petit-fils du grand prédicateur. Ms. daté de l'an 777 de l'hégire $(1375-1376$ de J. C.).

Hapier. 123 feuillets. Hauteur, 17 centimètres ct demi; largeur, 12 centinètres et demi. 15 lignes par page. -- (Ancien fonds 450 , Colbert 6059 .)

\section{1.}

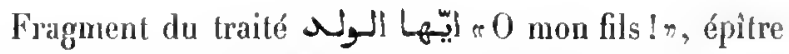
daus laquelle Abou Hàmid al-Ghazàli enseigne à un de ses disciples les comnaissances qui, seules, peurent servir pour la vie future.

Papier. 2 feuillets. Hânteur, 21 centimètres; largeur, 15 centimètres. 33 à 35 lignes par page. M/s. du $x^{2} 1^{e}$ ou du xru' siècle. (Supplément 521.)

\section{2.}

(La Voie à suire par les serviteurs de Dieu», traité de théologie morale, composé par Aboû Ịâmid al-Ghazâlì. (Voyez Hadji Khalfa t. VI, p. 21 10.) Les feuillels de garde portent quelques prières et des notes insignifiantes; la date du colume, exprimée par une série de fractions, qu'on lil au folio 110 , est évidemment une mystification.

Papier. 110 feuillets. Hauteur, 18 centimètres; largeur, 13 centimètres. 17 lignes par page. Ms. du xvi siècle. - (Supplément 529, Oraloire.) 


\section{3.}

مائه Commencement de la bonne direclions, traité de morale religgieuse, par hhoû ḷànid al-

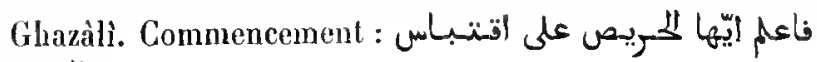
Nell.

$2^{\circ}$ (Fol. $44 \mathrm{v}^{\circ}$. ) Qasida d'Aboù 'I-Fatl! al-Bostì. Premier vers :

$$
\begin{aligned}
& \text { زيـادة الملرء } 3 \text { دنسيـاه نستصـان }
\end{aligned}
$$

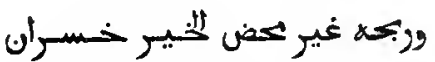

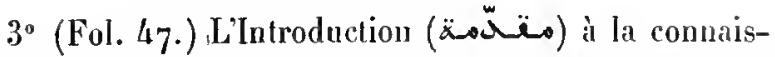
sance de l'islamisme, par Schans al-Dìn Mohammad alSchernoûbì (النشرنو.3).

Papier. 58 feuillets. Hauteur, 20 centimètres et demi; largeur, 15 centimètres. 23 lignes par page dans le premier traité, 19 dans les deux autres. Ms. du xvı" siècle. - (Supplément 1883.)

\section{4.}

- Cadeau pour l'ami, traitant des règles à observer relativement aux enfants $n$, par Moḷammad ibn abì Bakr ilon Ayyoûb, surnommé Ibn Qayyim al-Djoûziya (fils du recleur du collège londé à Baghdâd par Ilon at-Djoûzî?). C'est un lıaité sur l'éducation physique, morale et religieuse des enfants, divisé en dix-sept chapitres (بـاب), dont chacun est subdivisé en plusicurs sections (فصل). L'auteur mourut en 571 de

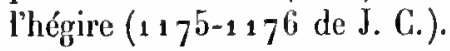

Papier. $7^{3}$ feuillets. Hauteur, 21 centimètres; largeur, 15 centimètres et demi. 25 à 28 lignes par page. Ms. dn xuıe siècle. - (Supplément 514.)

\section{5 .}

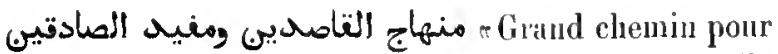
ceux qui se dirigent (vers le bien) et (avertissement) utile pour les (cœurs) sincères $»$, discours sur plusieurs sujets de morale, de religion et sur les convenances sociales, par Aboû 'l-Faradj 'Abd al-Ralụnàn ibn 'Mlì ibn Moḷammad ibn al-Djauzî. Ms. dalé de l'an 1109 de l'hégire ( $1697^{-1} 698$ de J. C.).

Papier. 87 feuillets. Hauteur, 21 centimètres; largeur, 15 centimètres et demi. 33 lignes par page. - (Supplément 512.$)$

\section{6 .}

r Censure de la concupiscence». Traité sur les moyens de dompter les passions, en cinquante discours, par Aboǹ '1-Faradj 'Abd al-Raḷmàn ibn 'Alì ibn Noḷammad ibn al-Djauzi. Ms. daté de l'an 746 de l'hégire (1345 de J. C.). Le volume porte la signalure du voyageur Soetzen.

Papier. 301 feuillets. Hauteur, 21 centimètres; largeur, 15 centimètres. 1 liggnes par page. - (Supplément 513.)

\section{7.}

"Océan de larmes", recueil de trentedeux discours ou sermons, en prose et en prose rimée, entremêlée de vers, par Aboû Moḷammad (Aboù 'L-Faradj) 'Mbd al-Rahmàn ibu 'Ali al-Djauzì.

Papier. 77 ferillets. Hauteur, 20 centimètres; largeur, 19 centimètres et demi. 19 lignes par page. Ms. du xvi1' siccle. - (Supplément 511.)

\section{8.}

"Couronne de la fiancéen, traité de théologie morale, par Ibn 'Alâ Allàh al-Iskandari, mort en $7^{\circ} 9$ de l'hégrire $(1309-1310$ de J. C.).

Papier. 21 feuillets. Hauteur, 23 centimètres; largeur, 16 centimètres et demi. 27 lignes par page. Ms. du xvi' ${ }^{6}$ siècle. - (Supplément 515 .

\section{9 .}

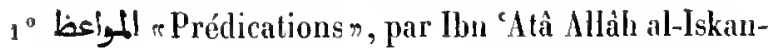
dario.

$2^{\circ}\left(\right.$ Fol. $\left.36 v^{\circ}.\right)$ Collection de recettes médicales, eu douze chapitres.

Papier. 68 feuillets. Hauteur, 21 centimètres; largeur, 14 centimètres et demi. 91 lignes par page. Ms. du xvı é siècle. - (Supplément 1883 .)

\section{0.}

Marques éclatantes pour (distinguer) les qualités louables et les ordures avilissantes qui se rattachent aux vices », par Djamâl al-Dìn Mohammad ibn Ibrâhìm al-Kotbì, mort en 718 de l'hégire (1318-1319 de J. C.). Recueil de paroles remarquables au sujet des vertus et des vices. L'auteur a encadré ces passages dans une prose très-recherchée. Ce Iraité renferme seize chapitres (باب), dont chacun est 
divisé en trois sections ( sections est donnée dans l'iutroduction. L'ourrage com-

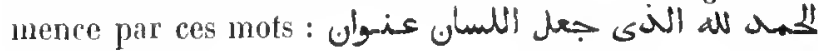

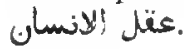

Papier. 208 feuillets. Haulenr, 26 centimètres; largenr, 17 centimètres. 35 lignes par page. Ms. du xive siècle, écrit probablement du vivant de l'auteur. - (Ancien fonds 886.)

\section{1.}

Le Ghorar al-Khasâis de Moḷammad ibn lbràluîm alKotbì.

Papier. 219 feuillets. Hauteur, 26 centimètres et demi; largeur, 18 centimètres et demi. 21 lignes par page. Ms. dı xır siècle. (Supplément 516.)

\section{2.}

Le Ghorar al-Khasâis d'A1-Kotbì. Les Lrois ou quatre derniers feuillets manquent. Le fol. 126 n'appartient pas à l'our rage.

Papier. 126 feuillets. Ilauteur, 21 centimètres; largeur, 15 centimètres. 21 lignes par page. Ms. du $\mathrm{xvi}^{\mathrm{e}}$ siècte. - (Supplément 517.)

\section{3.}

$1^{\circ}$ Le Ghorar al-Khaṣaiş de Mohammad ibn Ibrâhû́m al-Kotbì.

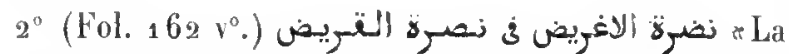
H'teur de patmier loule fraiche, étant une défense de la poésiè, par Abou 'Alì al-Hozaffar ibn al-Fadhl ihn Yalıyâ al- 'Alawi al-Hosaïni. Ce trailé de l'art poétique, composé pour te vizir Moḷammad al-'Alkamî ( izir d'Ml-Mostacen Billah), est divisé en ring seclions of renferme de nounbreuses pièces de ver's.

$3^{\circ}$ (Fol. 247.) Quelques Qusî̉a el firagmeuts poéliques, lirés de la Kharida d'Tınâd al-Dín al-lṣfahànì.

$4^{\circ}$ (Fol. 250.) Récil d'une vision, tiré de $1^{\prime \prime}$ Adjäib alMakhloûqát d'A1-Qazwini. J. C.).

Ws. dalé de 1039-1040 de l'hégire (1629-163o de

Papier. 250 feuillets. Hauteur, 20 centimètres et demi; largeur, 15 centimètres et demi. 22 à 23 tignacs par page. - (Ancien fonds 434.)

\section{4.}

\section{Le Ghorar al-Khasaitis d'Al-Kotbî.}

Papier. 189 feuillets. Hauteur, 21 centimètres; largeur, 15 centimẻtres. 25 lignes par page. Ms. du $x{ }^{\circ}{ }^{\circ}$ siècte. - (Supplément 518. )

\section{5.}

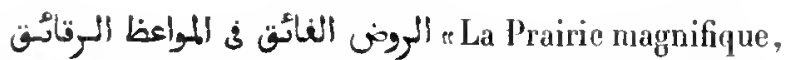
contenant des exhortations touchantesn, par le schaikh

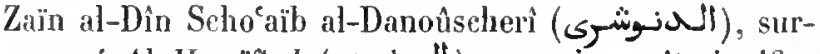
nommé Al-Horaifisch (بيشيش), ce qui paraît signifier "l'humble personnage . Hadji Khalfa (t. HI, p. 42) place la mort d'Al-Horaifíseh en 801 de l'hégire, mais il se trompe sur les noms de l'auteur. Le Raudh al-Faíq est un recueil d'anecdoles édifiantes, de traditions, de pièces de vers sur des sujets de morale, ete., divisé en cinquantedeux discours ou sermons. Chaque discours est consacré à un scul sujet. Cet exemplaire, daté de l'an 1024 de l'hégire ( 1615 de J. C.), présente de nombreuses lacunes.

Papier. 264 feuiltets. Hauteur, 21 centimètres et demi; largeur, 15 centimètres et demi. 18 à 20 lignes par page. - (Ancien fonds 447).

\section{6.}

\section{Le Raudh al-Faïq d'Al-Horaifisch.}

Papier. 347 feuillets. Hauteur, 20 centimètres; largeur, 14 et 15 centimètres. 2 lignes par page. Ms. du xrı' siècle. Les premiers et tes derniers feuillets ont été ajoutés après coup. - (Supplément 1774.)

\section{7.}

\section{Le Raudh al-Fain d'Al-Horaifiseh.}

Papier. 364 feuillets. Hauteur, 21 centimètres; largeur, 15 et 16 centimètres. 23 lignes par page dans les premiers feuillets, a lignes dans les autres. Ms. du xwn' siècle. Les cinquante premiers feuillets ont f́tẻ ajoutés après coup. - (Supplément 1775 .)

\section{8.}

Le Raudh al-l'äiq d'A1-Horaifîsch. Exemplaire daté de l'an 1061 de l'hégire $(\mathbf{1} 651$ de J. C.)

Papier. 208 feuillets. Hauteur, 30 centimètres et deni; largeur, 21 centimètres. 25 lignes par page. - (Supplément 1773.) 


\section{9.}

Le Raudh al-Faiqq d'AI-Horaifîsch. Ms. daté de l'an 1145 de l'hégire (1 732-1 733 de J. C.).

Papier. 180 feuillets. Hauteur, 27 centimètres et demi; largeur, 17 centimètres. 29 lignes par page. - (Supplément 637.)

\section{0.}

Jouissance pour les lecteurs, pour servir de consolalion aux hommes palients». Cet ouvage se compose de quatre-vingl-six versets du Coran, qui recommandent la patience et la conslance dans l'adversité. Chacm de ces versets est suivi d'une explication empruntée au Lobâb al-Tâuil, commenlaire d'Al-Klâzin sur le Coran. Une main plus moderne a inscrit sur les deux dernières pages, qui étaient reslées en błanc, une histoire fabuleuse attribuée à Mâfik ilon Inas.

Papier. 116 feuillets. Hauteur, 21 centimètres; largeur, 15 centimètres et demi. 11 lignes par page. Ms. du xviı siècle. - (Supplément 510. .)

\section{1.}

La première moitié de l'ouvrage intitulé بـس بـ

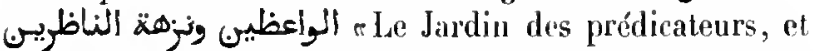
spectacle attrayant pour les observatenrs\%. C'est un recueil de discours moraux et religieux, à l'adresse des lons musulmans. L'onvrage se compose de cent trente sermons (uls). Le présent ms. conlient les soixanteIrois premiers. Le nom de l'auteur est inconnu, mais on voit par la liste des ourrages qu'ił dit aroir mis à conlribution, et parmi lesquels se troure un traité de l'imàm 'Abd Allah ibn As'ad (السعد) al-Yäfi'i (اليانى), morl en 768 de l'hégire (1366-1367 de J. C.), qu’il n'a pu écrire qu'après le second tiers du vm siècle de l'hégrire.

Papier. 604 fenillets. Ilauteur, 21 centimètres; largeur, 15 centimètres. 21 liggnes par page. Ms. du xvı siècle. - (Supplément 256.)

\section{2.}

مبرد الاكباد عنح مسوت الاولاد Consolalious (à un ami) sur la mort de ses enfants n, par Schams al-Din Moḷammad al-Dimaschqì, docteur schaféile, mort en 842 de

$$
\text { Nax, omentaux. - II. }
$$

Thégire (1438-1439 de J. C.). Ge sont différents passages du Coran, des Iraditions et des anecdotes concernant les hommes dévols.

Papier. 4 s feuillets. Hauteur, 17 centimètres; largeur, 12 centimètres et demi. 15 lignes par page. Ms. du $\mathbf{x v}^{\circ}$ siècle. - (Ancien fonds 464.)

\section{3.}

Pureté des caur's et luumble soumission à celui qui comnait tout ce qui est caclén, par 'Alud al-`Aziz (ibn Ahmad ilın Sacid) al-Dìrini

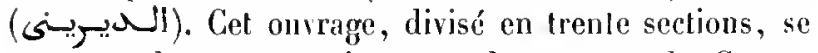
rompose de commentaires sur des versels du Coran, d'anecdotes édifiantes, de conseils, de prières, de beaux morceaux de vers et de prose, etc. Le premier feuillel manque. Vers la fin de la troisième section se trouve une grande lacune, qui s'étend jusqu'à la dix-neuvième section, dont il ne reste que la fin. Ms. dalé de l'an 1159 de l'hégire ( 1746 de J. C.).

Papier. 102 feuillets. Hanteur, 21 centimètres; largeur, 15 centimètres et demi. 19 lignes par page. - (Supplément 2017.)

\section{4.}

r Les Seplénaires, pour servir d'averlissement aux créatures . Ce sont sept discours ou sermons pour les sept jours de la semaine. L'auteur, Aboû 'l-Naṣr Moḷammad ibn 'Abd al-Raḷmân

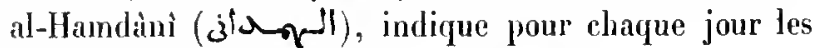
grands événements de l'histoire de Mahomet.

Papier. 6o feuillets. Hautenr, a centimètres; largeur, 15 centimètres. 20 à 29 lignes par page. Ms. de différentes mains du xvı" siècle. - (Supplément 528.)

\section{5.}

Premier cahier des Septénaires d'Aboû 'l-Naṣr Moḥammad ibn 'Abd al-Ralı̀màn al-Handànî.

Papier. 20 feuillets. Hauteur, 28 centimètres; largeur, 19 centimètres et demi. 33 ì 47 lignes par page. Ms. du xvi" siècle. - (Supplément 2035 .)

\section{6.}

1 'Trailé de morale, sans titre ni nom d'autem', qui 
se compose d'extraits du Coran, de traditions plus ou moins authentiques et d'bistoires édifiantes. L'ourrage est divisé en sections, appelées tantôt بـ tantồt Après une longue introduction, la première section traite de la peine qu'encourt celui qui néglige la prière; la seconde indique li peine due à celui qui boil du in; trois autres cliapitres ont pour sujet la punition des fornicateur's, de ceux qui relusent de payer la dime, et des meurtriers; un aulre chapitre traite de la défense de s'adonner à la musique. La copie n'est pas terminée. Le commencement manque.

$2^{\circ}$ (Fol. 91.) Une prière.

30 (Fol. 92.) Traité ascétique, divisé en sections (باب et (كب) . Cé traité anonyme commence par ces mots: أن المه والملايكة يصلون على المنبى الايسة en latin, écrites par un savant européen du xvir siècle, peut-être le président Gillıert Gaulmin.

Papier. 376 pagres. Hauleur, 20 centimètres; largeur, 14 centimètres el demi. 14 à 15 lignes par page. Its. du xvín siècle. - (Ancien fonds 388.)

\section{7.}

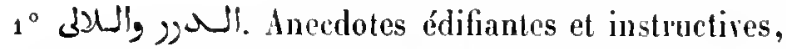
qu'un savant doctcur, peut-être Al-Sakhàwi, arait recueillics dans ses lectures.

$2^{\circ}\left(\mathrm{F}_{0} \mathrm{l} .131 \vee^{\circ}\right.$.) Qasida limiyya (sur les saints noms de Dieu), par Noûr al-Dìn al-Dimyâtị, arec le commentaire de Zarroùq (زورق) Aḅmad ibn Moḥammad al-Bornosi.

Papier. 136 feuillets. Itauleur, 22 centimètres; largeur, 16 centimètres. 23 lignnes par pagoe. Ms. du xvı11' siècle. - (Supplément 1885.)

\section{8.}

Exhortations dans lesquelles on recommande de songer à la mort et aux choses de l'autre vien, ouvrage divisé en six chapitres, précédés d'une introduction et suivis d'une conclusion. L'auteur, dont le nom est resté inconnu, l'a composé pour consoler un de ses amis dont le fils venait de mourir. Il mentionne dans l'introduction les noms des docteurs qui avaient déjà traité ce sujet, et en premicr licu celui de son professeur Djalàl al-Din al-Soyoûti. Le traité com-

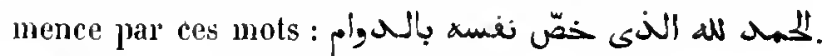
Ms. daté de l’an 1194 de l'hégire ( 1780 de J. C.).

Papier. 197 feuitlets. Ilauteur, 22 centimètres; largeur, 15 centimètres et demi. ${ }_{9} 9$ lignes par page. - (Supplément 523.)

\section{9.}

وصية الادب ou "Glosesn sur le traité intitulé "Conseils sur les bienséances", par "Alì ibn Mohammad, généralement appelé Al-Miṣri (النشهير بالمصرى). Le v'ai

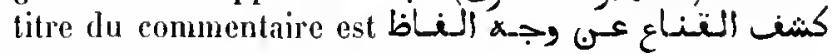
(lisez Le Secret dévoilé de paroles douces à entendren. L'ouvrage commenté se compose d'un grand nombre de paragraplies très-courts, dans lesquels l'auteur indique aux derviches les fautes qu'ils sont exposés à commeltre. Au l'ol. 39 se trouve une liste d'ouvrages dont ils doivent éviter la lecture, entre autres les écrits de Mohyi al-Din ibn al-'Arabì, ceux de 'Abd al-ḷayq ibn Sab'în, ceux d'lbn Hazm al-Zahiri, plusieurs passages de l'Ihya 'Oloúm al-Din d'Al-Ghazâlì, certaines parties du Kaschschâf d'Al-Zamakhschari et du وصيّـة و الادب , ni le commentaire d'Al-Miṣri. Ms. daté de l'an 1191 de l'hégire (1 777 de J. C.).

Papier. 80 feuillets. Ilauteur, a 1 centimètres; largeur, 15 centimètres et demi. 21 lignes par page. - (Supplément 525.)

\section{0.}

rLes Statuts, commentaire sur le Supplément des statuts (fol. $\left.21^{\circ}\right)$. Commentaire anonyme sur un traité de inorale intitulé r Suplément des Statuts (ou de Maximes de morale), et purification (du cœur, en le délivrant) des vices\%. Nous lisons dans la préface que te Takmila a pour auteur un imàm nommé Schams al-Dìn Aḷmad ibn Yahyà ibn A ḥmad, surnommé $A l$ Mahdi. Hadji Khalla ne mentionne ni l'ouvrage, ni le commentaire. Ms. daté de l'an 1069 de l'hégire (1658 de J. C.).

Papier. 248 feuillets. Hauteur, 20 centimètres et demi; largeur, 15 centimètres. ${ }_{9}$ lignes par page. - (Supplément 524.)

\section{1 .}

La Voie de Molıammad et les coutumes d'Ahnrad $\leadsto$, c'est-à-dire de Mahomet. Traité de morale ef de dognatique, composé par le molla Moḷanmad ibn Pir 'Ali al-Birgueli, mort en 981 de l'hégire (1573-1574 de J. C.). Commencement : w d di

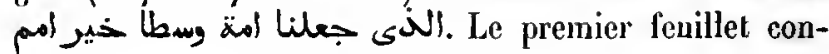


lient l'explication des sigles par lesquels I'anteur désigne les traditionnistes dont il cite l'autorité. Ms. daté de l'an 1033 de l'héggire (1623-1624 de J. C.). Notes marginales cl interlinéaires.

Papier. 162 feuillets. Hauteur, ao centimèlres et demi ; largeur, 14 centimètres et demi. 15 lignes par page. - (Ancien fonds 433.)

\section{2 .}

Le mème ouvrage. Exemplaire daté de l'an 1118 de I'hégrire (1706-1 707 de J. C.). Les huil premier's feuillets sont d'une main plus moderne.

Papier. 194 feuillets. Hauteur, 20 centimètres ef demi; largeur, 13 cenlimètres. 17 lignes par page. - (Supplément 534 bis.)

\section{3.}

ecouférences n de Roùnı̀ Elendi. Aḷmad ibn 'Abd al-Qàdir Rounnî Efendi, né dans l'ile de Chypre, passa une grande partie de sa vie à Aq-llișàr cle chàleau blanc», l'ancienne Thyatira, ville de l'Asic Mineure. Il dit, dans la préface, que son intention étant de rélormer les mœurs par des arertissements lirés des sources sacrées et des écrits des docteurs orthodoxes, il a composé cent discours, remplis de bons conseils. Dans notro ms., les deux derniers discours et une partie du quatrevingt-huitième manquent.

Papier. 445 feuillets. Hauteur, 22 centimètres; largeur, 1/4 centimètres et demi. 19 lignes par page. Ms. du xvit siècle. - (Ancien fonds 516.)

\section{4.}

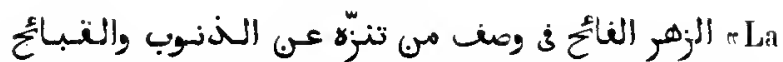
Fleur odorante, description de ceux qui se tiennent loin des péchés et des actions viles». Tel est le tilre inscrit sur le recto du premier feuillet du ms. C'est un traité des devoirs du musulnan. On y trouve beancoup d'anecdotes édifiantes et des morceaux de poésie. Commence-

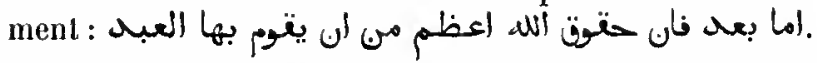

Papier. 40 fevillets. Ilauteur, 16 centimètres; largeur, 22 centimètres. 25 lignes par page. Mls. du xu1 ${ }^{\mathrm{e}}$ siècle. - (Supplément 2036.)

\section{5.}

10 Discours en prose rimée entremélée de rers, dins lequel un auteur anonyme rapporte d'abord un dialogue entre lui et sa propre àme; il raconte ensuite qu'il fut transporté dans un jardin mystique, où il rencontra tous les grands écrivains qui avaient fait l'ornement de l'islamisme daus les temps passés, et dont J'un l'ait un éloge long et pompeux d'un docteur dont il ne mentionne pas le nom, et que le copiste du ms. (fol. $16 \mathrm{v}^{\circ}$ ) dit être Al-Baïdhàivi. Une antre main a inscrit sur le recto du

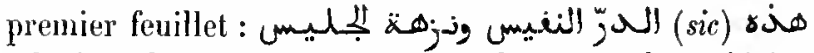
-Ceci est la perle précieuse et le charme de la sociétén, mais ce tilre ne paraît pas authentique.

$2^{\circ}$ (Fol. $29 v^{\circ}$.) Requête d'un étudiant arrivant au Caire, qui se recommande à la bienveillance d'un vizir de l'empire ottoman.

Papier. 32 feuillets. Hauteur, 19 centimètres el demi; largeur, 1 a centimètres el demi. 13 à 15 liznes par page. Ms. du xwi siècle. -(Supplément 526.)

\section{6.}

Ms. renfermant des maximes de morale, des anecdotes édifiantes, des récits apocryplies de l'Ancien Testament, etc. Le commencement manque. Les derniers leuillets contiennent des prieres.

Papier. 88 feuillets. Hauteur, 21 centimètres; largeur, 15 centimètres. 15 lignes par page. Ms. du xvı' siècle. - (Ancien fonds 395 .)

\section{7.}

Recueil de traditions saintes $n$. Ce recueil se compose de quatre-vingt et un discours, dont chacun traite d'un point de morale ou de religion, et dans lesquels on trouve des extraits du Coran, des traditions et des prières. Commencement :

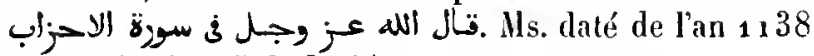
de l'hégire (1 725 de J. C.).

Papier. 210 feuillets. Hauteur, 16 centimètres; largeur, 10 cenlimètres. 11 lignes par page. - (Supplément 333. )

\section{8.}

$1^{\circ}$ كتاب التتبككايّات. Recueil d'histoires pieuses, de traditions, de demandes el de réponses sur diverses matières de religion, etc., traduit du persan en arabe, par Yoûnis ibn Aidoghnisch ibn Hasan, originaire de Malatia. 
$2^{\circ}\left(\right.$ Fol. $40 \vee^{\circ}$.) Dissertation sur la création, sur Mahomet, sur les hommes et les anges, sur la mort et le jugement dernier.

$3^{\circ}$ (Fol. 67.) Commentaire sur le فرأئ de Moḷammad ibn 'Abd al-Raschìd Sedjàwendì.

$14^{\circ}$ (Fol. $\left.147 \%^{\circ}.\right)$ Autre traité du partage des successions.

Papier. 158 feuillets. Hauteur, 19 centimètres; largeur, if centimètres. Écritures diverses du xw1 $1^{\circ}$ siècle. - (Supplément 1937 , Saint-Germain 449.)

\section{9 .}

Cahier détaché d'un recueil de sermons. Ce fragment commence par la fin du douzième et finit au commencement du vingt-neuvième sermon. Le texte est accompazoné de toutes les motions et de quelques gloses marginales.

Papier. 12 feuillets. IIauteur, $1 / 4$ centimètres et demi; largeur, 11 centimètres. "I lignes par page. Ms. du rrı siècle. - (Supptéinent 2254.)

\section{THÉOLOGHE HYTIQUE.}

\section{0.}

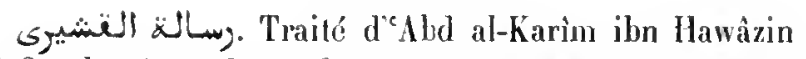
al-Qoschaïri sur le soufisme, composé en 437 de l'hégire (1 045-1 o 46 de J. C.). Ce volume renferme les vingt premier's chapitres de l'ouvrage, savoir :

1. (Fol. $3 v^{\circ}$.) Les croyances de cet ordre (طايغة).

3. (Fol. 11.) Les grands docteurs du soufisme.

3. (Fol. 43.) Explication des termes mystiques qui ont cours chez les sonfis.

4. (Fol. 67 ${ }^{\circ}$.) Du repentir (توبة).

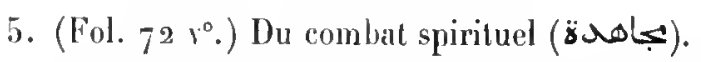

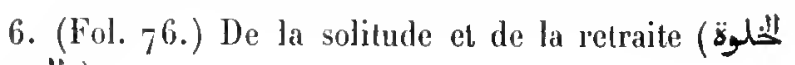
$\ddot{d}_{j-x l y)}$

7. (Fol. $76 \mathrm{v}^{0}$.) De la crainte de Dien (تنوى).

8. (Fol. 81.) De la dévotion (ع39).

9. (Fol. 85.) Du renoncement ( $\left.\nu^{-j}\right)$.

10. (Fol. 88.) Du silence (صمت).

11. (Fol. $9^{1} \mathrm{v}^{\circ}$.) De la crainte (خون)

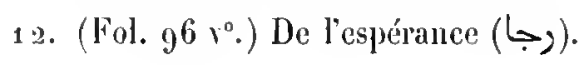

13. (Fol. 103.) De la faim et de la suppression des

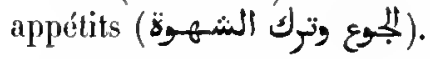

14. (Fol. 106.) De l'humilité et de la condescen-

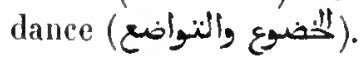

15. (Fol. $110 V^{\circ}$.) De la l'ésistance aux passions ( (uill).

16. (Fol. $113 v^{\circ}$.) De l'envie (حسد)).

17. (Fol. $116 v^{\circ}$.) Du contentement (ق̈)

18. (Fol. 126 ,\%) De la reconnaissance (نك).

19. (Fol. $129 v^{\circ}$.) De la certitude (يقي)).

20. (Fol. 133.) De la patience (صبر).

Ms. daté de l'an 839 de l'hégóire (1435 de J. C.).

Papier. 136 feuillets. Hauteur, 26 centimètres; largeur, 17 centimètres. 15 lignes par page. - (Supptément 561.)

\section{1.}

Opuscules d'Aboú Ḥamid Moḥmmad ibn Moḷammad ibn Mohimmad al-Ghazîlì :

1 1 r Connaissances intellectuetles n, dissertation mystique, en cinq chapitres, dans laquelle l'au-

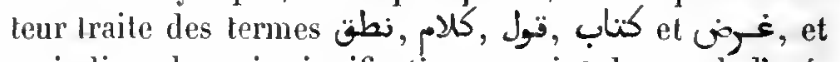
en indique la vraic signification au point de vue de l'exégèse. Le dernier chapitre, intitulé الغرو out qu’on se proposen, est consacré exclusivement aux lettres dont se composent les mots.

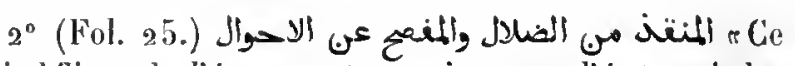
qui délive de l'égarement et qui expose l'état rai des choses . liésumé des doctrines des diverses sectes philosophiques. L'auteur raconte l'histoire de ses propres éludes et de ses efforts pour arriver à la connaissance de la vérilé. Le texte de ce traité a été publié, avec une traduction française, par M. Schmölders, Paris, 1842, in- $8^{\circ}$.

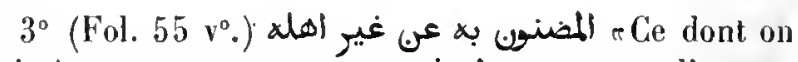
doit être avare envers ceux qui n'en sont pas dignes», réponses de l'auteur à des questions qu'on lui avait adressées. Dans ce traité, Ghazâli soutient l'éternité du monde et écarte de Dieu tous les altributs (royez Munk, Mílanges de philosophie juive et arabe, ]. 382).

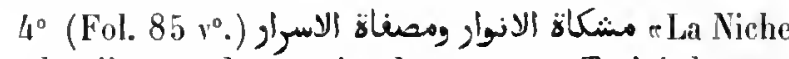
aux lumières et la passoire des secrels $»$. Traité de soufisme et réfutation des doctrines philosophiques, com-

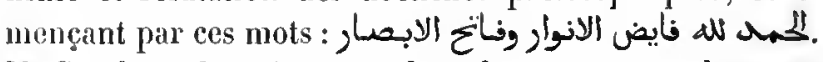
M. Gosche a donné une analyse de cel ouvrage dans son 
mémoire inlitulé Ueber Ghazzâlis Leben und Werke (royez Abhandlungen der $K$. Akademie der Wissenschaften zu Berlin, 1858 , p. 263 ).

$5^{\circ}\left(\right.$ Fol. $1141^{\circ}$.) Table astrologique, suivie de quelques notes (sur les coups de trompette dont il est question dans le Coran) et de quelque's traditions.

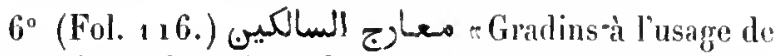
ceux qui marehent (dans la voie spirituelle) n, I raité mystique, composé de sejt "gradinsn (mi râdj), reufermant des instructions et des exhortations.

$7^{\circ}$ (Fol. $177 v^{\circ}$.) Note sur la qualité appelée

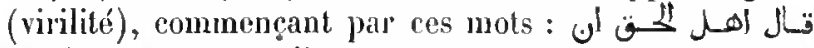
النتوة شعبة مه. النبورة Suivent plusieurs notes el traditions de diverses mains.

Les deux premiers feuillets sont couverts de notes de diverses natures, parmi lesquell's on remarque une notice biographique sur Ghazàli.

Papier. 181 feuillets. Ilauteur, 25 centimètres et demi; largeur, 15 centimètres et demi. 17 lignes par page. Ms. du xiv siècle; un certain nombre de feuiltets sont d'une écriture plus moderne. - (Ancien fonds 88\%.)

\section{2.}

Connaissances accordées (par la grice de Dieu)n, traité de soufisme, par Abon llafș al-Solrawardi. Plusieurs feuillets, à la fin de l'ourage, d'une écriture moins ancienne que les autres, sont datés de l'an 783 de l'lıégire $(1381-1382$ de J. C. $)$. Les marges de presque tous les leuillets portent des notes et des variantes en grand nombre. A la suite de l'ouvrage (lol. $1941^{\circ}$ ) se trouvent quelques règles de conduite pour les aspirants à la vie céleste; au fol. $196 \mathrm{v}^{\circ}$, un extrait du commentairo du Coran, d'Al-Qortobi, et au fol. $19^{5}$ le dessin d'une échelle, représentant les divers degrós par lesquels le soufi doit passer pour arriver à la perliaction. Pour la vie d'Al-Sohrawardi, voyez Ibu Khallikin, t. II, page 382 de la traduction anglaise.

Papier. 197 feuillets. Hauteur, 25 centimetres; largeur, 16 centimètres et demi. a lignes par page. Ms. du xmin siècle. - (Ancien fonds 375 .)

\section{3 : 1335.}

Les Révélations mecquoises, faisant romaitre les mystères de Dieu et des anges», par Hoḷyî al-Din Aboû 'Abd
Halı Holıammad ibn 'Alì Jbn al-'Arabi. Recuril mysstique, divisé en dix-sept lives et en cinq cent soixante chapitres. (Voyez, sur cet ouvage, lo Catalogue des manuscrits de la Bibliothèque de Leipzig, p. 4go et suiv.)

3 volumes. Papier. $43_{2}, 496$ et 551 feuillets. Hauteur, 32 cenlimètres; largem, 2o centimètres. 29 lignes par page. Écritures diverses du $\times \mathbf{v i}^{\circ}$ sièrle. - (Supplément 237 .)

\section{6.}

الغتوحات المكسيـة de Mlolyi al-Din Ibu al-'Arabì. Aux fol. 418 et suivants, se trouvent les plans des cieux, du paradis, de l'enler, etc. Ms. dalé de 1026-1027 de l'bégrire $\left(1617^{-1} 618\right.$ de J. C. $)$.

Papier. 567 feuillets. Jlauteur, 30 centimètres; largeur, a 1 centimètres. 41 tignes par pagre. - (Ancien fonds 362.)

\section{7.}

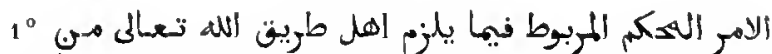
ClOrdre positif et formel, touchant les olstigations que les gens de la voie de bieu doivent remplic $\%$. Sur les devoirs du soufi, par Moḷyi al-Din lbn al-`Arabî.

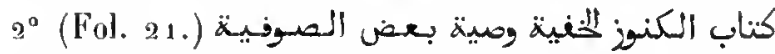
"Livre des trésors cachés, renfermant des conseils adressés à un certain soufin, par le selaäkh Moḷammad alŞiddìq.

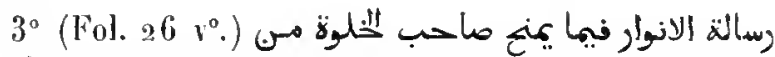
CLes Lumières, traité indiquant les mystères dont la connaissance est donnée au solitaire (qui s'est détaché du monde)", par llon al- Arabi.

$4^{\circ}$ (Fol. $34 v^{\circ}$.) Traité dans lequel un auteur anonyme, peut-ètre Mohyi al-Din Ibn al- Alabi, démontre que

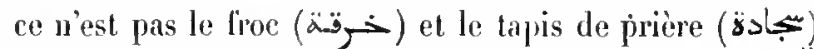

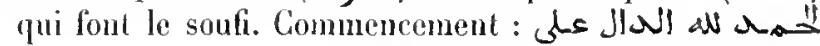

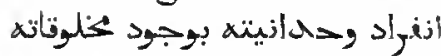

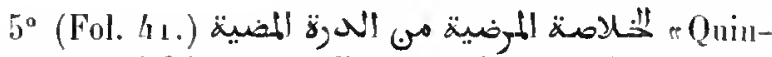
tessence satisfaisante de l'ouvrage intitulé Al-Dorra alModhîan. C'est un guide des aspirants à la dignité de soufi, par le célèbre docteur maghrebin Boù Medin (Moḷammad ibn Aḷmad). Le Dorra ou Perle brillante est du mêne auteur.

$6^{\circ}$ (Fol. 92. (instiuctions pour les aspirantsn, traité dans lequel le célibre docteur Al-Solnrawardi (Aboû 'L-Nadjib Dhiyà al-Dìn 'Abd al-Qidir) explique la doctrine des soufis. 


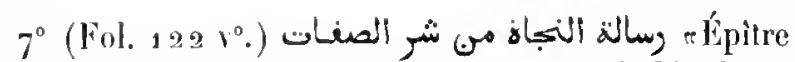
sur les noyens d'échapper aux mauraises habitudes", exposé des devoins du soufi, par un anonyme.

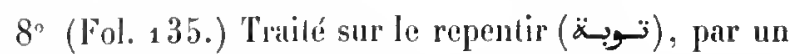

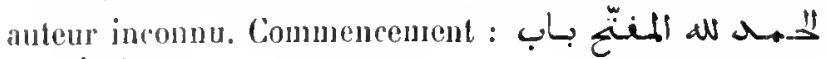

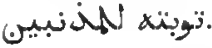

$9^{\circ}$ (Fol. $1391^{\circ}$.) Commencement d'un discours myslique, adressé par un anonyme à Qoṭ al-Dì Efendi, aluterr de l'Lrschâd (ألأنشا).

$10^{\circ}$ (Fol. $1401^{\circ}$.) Traité sur les devoirs des derviches de Fordre de Naqschbandi, par Alıou Sa ìd al-Khâdimi.

$11^{\circ}$ (Fol. $145 v^{\circ}$.) Traité sur le même sujet, par Houfti

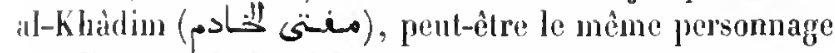
que l'anteur de l'article précédent.

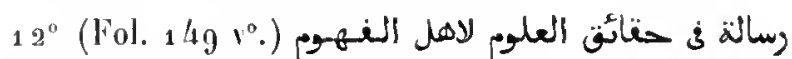
- Sur les rais caracteres des conmaissances (acquises, soit par inspiration, sol par l'étude), traité adressé aux genens intelligents n, par Aboû Ịânid Moḥammad ibn Mlọmmad ibn Moḷammad al-Ghazàli. Un autre traité du mème genre se trouve sur les marges des fol. $153 v^{0}$ à $158 v^{\circ}$.

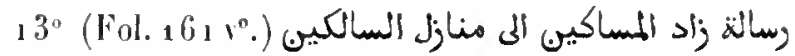
-Provisions de ronte pour les paurres qui venlent se randre aux demeures de ceux qui ont marché dans la bonne voicn, instructions spirituelles, par Abou 'l-lia-

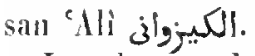

La plupart des pieces sont datées de l'an 1056 de l'hégire (1646-1647 de J. C.).

Papier. 164 feuillets. Hauteur, 31 centindres; largeur, 14 centimìtres. 25 lignes par page, excepté dans le dernier article, où l'écrilure est très-serrée.- (Supplément 559 .)

\section{8.}

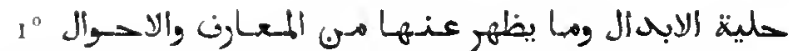
- Parure des hommes dévols et ce qu'elle laisse paraitre en fait de comaissances el d'états $n$, trailé mystique, composé à Triü, près de la Mlecque, en 599 de l'hégoire (1203 de J. C.), par Moḷyi al-Din lon al-Arabi. Com-

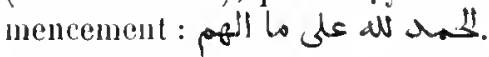

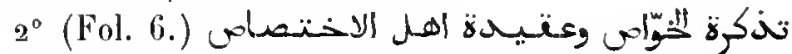
* Aide-mémoire des intimes et croyances religieuses des gens de distinctionn, traité dogmatique et mystique de Mohyi al-Dìn Ibn al-Arabi, commencant par les mèmes mots que le traité précédent.

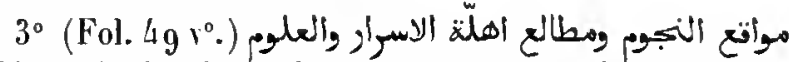
"Lieux de la chute des astres, et nourelles lunes des mystères et des conuaissancesn, traité mystique, par Mohyî al-Dìn lbn al-"Arabî̀. Commencement : بـ

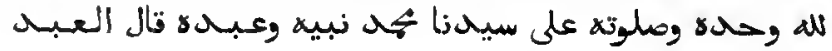
ألنقيي

$4^{\circ}$ (Fol. $\left.1177^{\circ}.\right)$ Notice biographique de Nohỵi al Din Ibn al-"Arabì.

$5^{\circ}$ (Fol. 127.) Traité de théologie myslique, de psychologie et d'astrologie, apparemment du même auteur. Le commencement, paraìt-il, manque; la première page

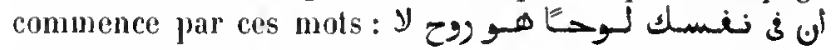

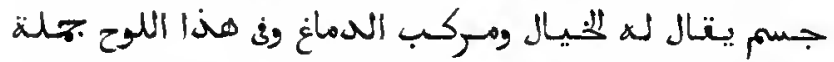

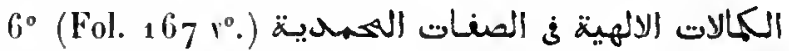
- Les Perfections divines, démontrées par les qualités de Mahomet», ourrage en sept chapitres, composé par l'auteur du الانسار المكامل ف معرفة الاواخر والاوايـ, c'estil-dire par le souf 'Ahd al-Karim ilon lbrâhìm al-Djili,

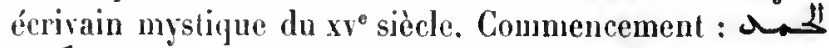

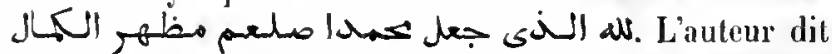
avoir composé cet ouvrage à Gluaza, en 803 de l'hégire (1400-1401 de J. C.). Le second chapitue est consacré à une explication mystique des quatre-ringt-dix-neuf noms de Dieu.

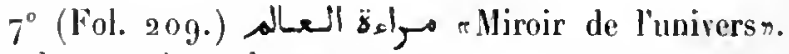
Sur les mystères du macrocosme, par un auteur anonyule.

$8^{\circ}\left(\right.$ Fol. $\left.2211^{\circ}.\right)$ Traité des définitions, par Avicenne.

La première pièce est datée de l'an 1113 de l'hégire (1701-1702 de J. C.). Les autres, loutes de la même main, sont datées des années 1084 et 1088 de l'hégire (1673-1678 de J. C.).

Papier. 22 3 feuillets. Hauteur, 26 cenlimètres el demi; largeur, 15 centimètres. 31 lignes par page, puis 28. - (Supplément 2045.)

\section{9 .}

$1^{\circ}$ Extrait du Mohyì al-Din lbn al-'Arabì éllumère les points de jessemblance entre l'homme et l'univers, entre le macrocosme et le microcosme. L'ourrage commence par ces mots : الـ

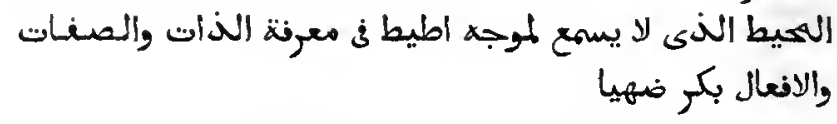

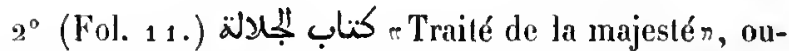
vrage cabalistique, dans lequel thn al-'Arabî traite des

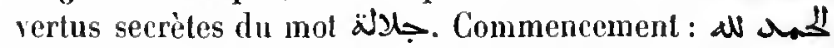

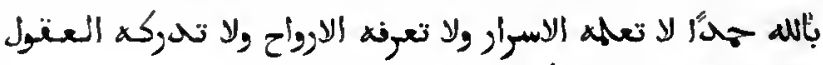

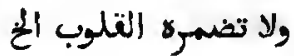


$3^{\circ}$ (Fol. 1 h vo.) (لإب Traité de l'éternilén, par Ibo al-'Arabi. L'auteur y expose les signifieations mysliques et secrètes du mot $j$ l. Commencement : d.

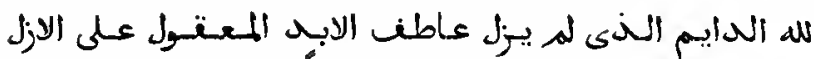

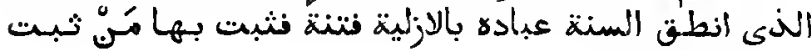

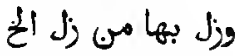

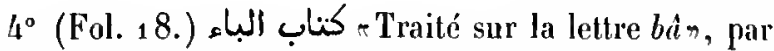

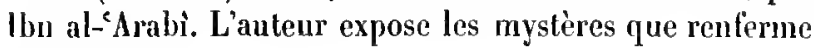
celte lettre.

$5^{\circ}$ (Fol. $22 \mathrm{v}^{\circ}$.) Poésies nıystiques, accompagnées d'un commentaire. Les vers, ainsi que le commentaire, sont de Ibn al-'Arabi. C'est l'ouvrage dont Hadji Khalfa fait menlion, sous le titre de تربحان الاتشواق rLInterprète des désirs $n$.

Is. daté de l'an 97^ de l'hégire ( $1563-1564$ de J. C.).

Papier. 80 feuillets. Hanteur, 26 eentimètres et demi; largeur, 19 centimètres et demi. 29 à 33 lignes par page. - (Supplément 3046 .)

\section{0.}

Cliatons (ou pierres précieuses) de la sagessen, recueil, divisé en vingt-sept chapilres (فص), de maximes de sagesse attribuées aux patriarches et aux prophètes, par Mohyì al-Dìn Ibn al-Arabi. Chaque chapitre contient les maxines d'un seul personnage. Voyez la Bibliographie de Hadji Khalfa, 1. IV, p. 434. L'ouvrage

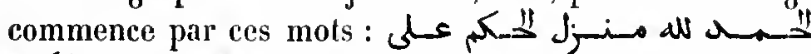
. Ms. daté de l'an 726 de l'hégire (1 326 de J. C.).

Papier. 127 feuillets. Hauteur, 19 centimètres; largeur, 11 centimètres et demi. 17 lignes par page. - (Ancien fonds 457 .)

\section{1.}

Le même ouvrage.

Papier. 99 feuillets. Hauleur, 2o centimètres; largeur. 15 centimètres. 19 lignes par page. $11 s$. du $\times{ }^{e}{ }^{e}$ siècle. - (Ancien fonds 414 , Colbert 498.)

\section{2.}

Commentaire sur le Fosous al-Hikam, par 'Abd al-Razzâq ibn abì '1-Ghanâïm al-Kàschì al-Qáschànì. L'ouvrage

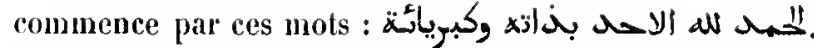
Ms. daté de l'an 1008 de l'hégire ( $1599^{-1600}$ de J. C.).

Papier. 23/ feuillets. Hauteur, a centimètres; largeur, 15 centimètres et demi. 31 lignes par page. - (Ancien fonds 415 , Colbert 5002.)

\section{3.}

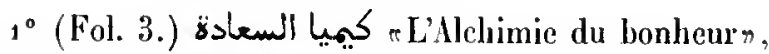
traité mystique, par Molyyì al-Dìn Ibn al-`Arabì.

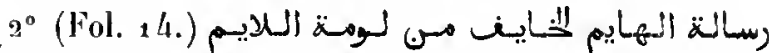
"Épiltre adressée à celui qui resle flottant et indécis par

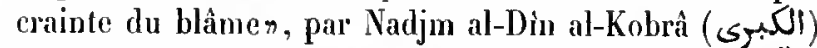

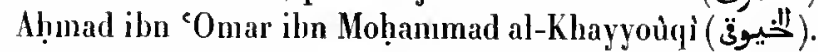
L'auteur indique les dix moyens par lesquels on obtient la pureté de l'àme et du corps.

30 (Fol. 35.) Texte et commentaire de la يَّئية, poème d"Omar ibn al-Fàridh (الكفارن). Quelques notes marginales.

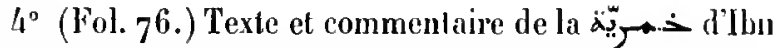
al-Fàridh. Cette copie est datée de l'an 998 de l'hégire (15 go de J. C.).

$5^{\circ}$ (Fol. 102.) Commentaire du mème poème, par'Alà al-Dill ibn Șadaqa.

$6^{\circ}$ (Fol. 120.) Récit d'Aboú 'Abd Allah ibn llandoưn, au sujet d'une pièce de vers que le calife Al-Motawakkil avait découverte dans un monastère, près d'Al-Roṣàfa.

Les articles $3^{\circ}$ à $6^{\circ}$ paraissent être de la même main.

En tête du volume se trouvent quelques vers, attribués à l'imàn Al-Sehâfíi, et une note sur 'Alì Efendi Qanâlì Zàdè, puis un talisman pour dissiper les chagrins.

Papier. 120 feuillets. Hauteur, 19 centimètres; largeur, 11 centimètres. 13 à 15 lignes par page. Ms. du wri siècle. -(Ancien fonds 461 .)

\section{4.}

1 o rdmonition pour toucher les cœurs et trésor d'acquisitions spirituelles", ouvrage nystique, renfermant des exhortations, des prières, des anecdotes édifiantes, des pièces de vers et des réflexions morales. Nous lisons uans la préface que c'est un abrégé du T'atimma ou Supplément, résumé d'un trailé

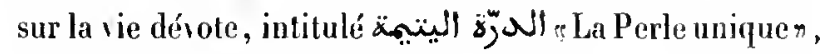
onvrage que Hadji Khatla (t. HI, p. 212) altribue au grand littérateur Abd Allah ibn al-Moqaffic. Dans le titre écrit en têté du volume l'auteur est nommé Moḷyì al-Din, 
natif de Grenade (sic المترناطى), cn Espagne, personnage qui ne peut êlre que le célèbre mystique Ibn al-`drabî. Il y a une lacune de trois cahiers entre les folios actuellement cotés 1 et 2.

$2^{\circ}$ (Fol. $7^{8 .)}$ Plusieurs morceaux édifiants en prose ol ell rers.

$3^{\circ}$ (Fol. $82 v^{\circ}$.) Commentaire mystique sur le Bismillâh, par Molanmand ibu Mobârak al-Tonoûkhì, générale-

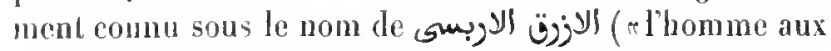
yeux bleus", natif de Laribus, dans la Tunisie?). 11 renlerme trois chapitres, précédés d'une introduction et suivis de quelques passages sur le même sujet.

$4^{\circ}$ (Fol. 102.) Nanuel, en prose et en vers, pour l'homme dévot qui désire atteindre à ce degré d'illuminisme que les soufis désignent par le terme -conuaissancer. Le commencement manque.

Volume écrit ì la Necque, en 888 de l'hégire (14801481 de J. C.).

Papier. 137 feuillets. Hauleur, 26 centimètres; largeur, 18 centimètres. 25 lignes, puis 23 tignes par page. - (Supplément 565.)

\section{5.}

Trésor désiré par ceux qui marchent dans la roie spirituelle, renfermant l'explication des stations auxquelles les voyageurs peuvent atteindren, trailé de morale religiense et nystique, en cent discour's, par Ibn al-'Ațtàr (Khalîl ibn Solaïmàn al-Ịanbalì). Ms. daté de l'an 688 de l'héçirc ( 289 de J. C.).

Papier. 347 feuitlets. Ilauteur, 26 centimètres; largeur, an centimètres. 17 lignes par page. - (Supplément 557.)

\section{6.}

Commentaire sur Je Mandãil al-Säirin, par Kamâl alDìn 'Abd al-Razzày al-Kàschi, mort en 702 de l'hégire (1302-1303 de J. C.). Le (لمسايسيس. Stations des voyageurs n est un traité de la vie spirituelle, très-estimé des musulmans, dont l'auteur, 'Mbd Allah ibn Mohammad al-Harawi (الههوى), mourut en 481 de l'hégire (1088-1089 de J. C.). La date de 4 dernier feuillet du volunıe, est fausse.

Papier. 189 fenillets. Hauteur, 27 centimètres et demi; largenr, 18 centimètres. Environ 17 lignes par page. Ms. du xve siècle. - (Anrien fonds 37 .)

\section{7.}

$1^{\circ}$-Traité de la terminologie des soufis ", par Kamâl al-Dìn Aboû 'I-Ghanåīm 'Abd al-Razzâq al-Kûschî̀. Nous n'arons ici que la première des deux parties dont se compose l'ouvrage. Les mots de ce dictionnaire sont disposés dans l'ancien ordre (abdjad) de l'alplabet arabe.

$2^{\circ}$ (Fol. 32.) Vocabulaire des termes employés par les soufis, par Mohyì al-Dîn lbn al-'Arabî, commençaut

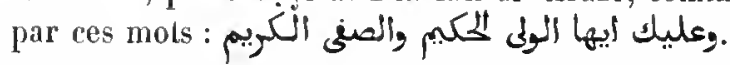

Papier. 35 fenillets. Hauteur, 21 centimètres; largeur, 14 centimètres. a lignes par page. Ms. du $x \mathbf{v i}^{e}$ siècte. - (Ancien fonds 4a 5.)

\section{8.}

áclaircissement sur la nécessité de suppliner la juécaution $\%$, traité de soufisme, dans lequel Tảdj al-Dìn ibn 'Aṭa Allah (Ạ̣mad ibn Mohammad ibu 'Abrd al-Karı̀n), mort en 709 de l'hégire ( 1309 -1 310 de J. C.), enseigne que les précautions sont inutiles contre le destin. Le premier l'euillet, qui était resté en blane, porte maintenant quelques notes insignifiantes. Le second feuillet contient le titre de l'ourrage; les noms de l'auteur et les titres de plusienrs antres ouvrages qu'il a composés. Ms. daté de l'an 914 de l'hégire (1508 de J. C.).

Papier. 84 feuillets. flauteur, 30 centimètres el demi ; largeur, 15 centimètres. 21 lignes par page. - (Supplément 520.)

\section{9.}

eles Apophthegmes d'c Aṭà Allah \%, traité de morale et de mysticisme, par 'Ațâ Allah Tàdj al-Dìn Alımad al-Iskandarànì al-Schàdsili. Nous avons ici le texte complet de l'ouvrage, avec un commentaire dont l'auteur est resté inconnu. Ms. daté de Constanlinople, de l'an 1023 de l'bégire ( 1614 de J. C.). Le commentaire

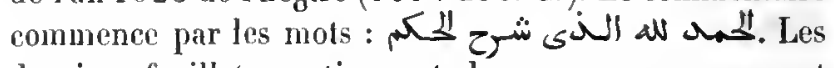
derniers feuillets contiennent des passages en prose et en vers, se rapportant à la vie dévole; on y trouve aussi le fragment d'un commentaire sur un auire ouvrage du même genre.

Papier. go fenillets. Hauteur, 30 centimètres et demi; largeur, 21 centimètres. Environ 30 lignes par page. - (Ancien fonds 373 .) 


\section{0.}

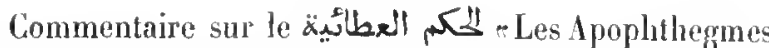
d"Aṭi Allah", par le docteur soufi Ibn 'Abbâd (she) Moḥanmad ibn lbràhim al-Nafzì al-Ṣardanì (s;idill) jدs, natif de Nafza, ville situće dans la Sardaniya, province de la Tunisie).

Papier. 134 feuillets. Hauteur, 28 centimètres; largeur, 18 centimètres. 27 lignes par page. Ms. du xv siècle. - (Supplément 258.)

\section{1.}

Commentaice sur les Apophthegmes d'c Atà Mllah, par Inn schaïkh soufi, nommé Sicli Mohanmad ibn Dikrà

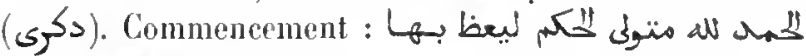
ه. Ms. daté de l'an 1142 de l'hógire (1633 de J. C.).

Papier. 305 feuillets. Hauteur, 23 centimètres; largeur, 16 centimèlres. 25 lignes par page. - (Supplément :567.)

\section{2.}

Gloses d'un auteur anonyme sur les Apophthegmes d"Atà Allalı. A la fin se trouve une qașida myslique de soixante-deux vers qui riment en $b$.

Papier. 26 feuillets. Hauteur, 21 centinètres; largeur, 15 centi-

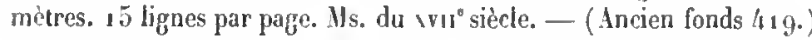

\section{3.}

"Collection de maximes morales et pliilosophiques", par ${ }^{~ C A l i ~ i b n ~ H o s s a ̀ m ~ a l-D i ̀ n, ~}$ surnommé Al-Mottaqi ('المتلى). Cies sentences, qui se rapportent principalement à la discipline religieuse des mut sulnans, et surtout à celle des soulis, sont au nombre d'environ trois mille, dont cinq cents ont été empruntées par l'auteur à différentes sources (قتتباسات) ; cinq cents lui avaient été communiquées (تضمينات); deux cents tra-

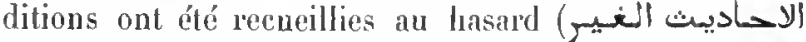

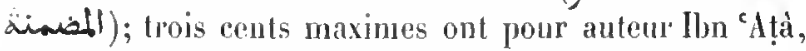
deux cents provienuent des ćlèves de celuj-ci, et le reste est emprunté aux discours des premiers musulmans. Ces passages sont classés dans l'ordre de matières.

Papier. 273 feuillels. Hauteur, 21 centimètres; largeur, 1 l' centimètres el demi. 17 lignes par page. Ms. du xvin $^{\circ}$ siècle. - (Ancien fonds 14 / 8.)

$$
\text { Man. oriestaux. }-1 \text {. }
$$

\section{4.}

r. Les Inspirations divines n, ouvrage divisé en plusieurs clapitres (ناب كات lesquels sont exposées quelques-unes des doctrines transcendantes qui araient cours chez les soufis. Commence-

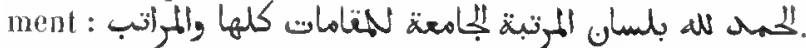
Cet ouvrage, que l'auteur, Șadr al-Dìn Mlolımmad ibn Isḷåq ibn Moḷammad al-Qoûnawi (القونوى), inort en 673 de l'hégire (1 2 74-12 $7^{5}$ de J. C.), n’avait pas achevé, : été terminé en $7^{3} 9$ de l'hégire ( $1338-1339$ de J. C. ), pal' Moḷammad ibn Aḷmad ibn Moḷammad al-Qoûnawi, qui élait peut-être le petit-fils de l'auteur. Ce traité est précédé d'une note de quatre pages, intitulée بيان سلك الهر بxposition de lil suite des chefs de l'ordre de Mohammad et de la voie suivie par nos seigneurs les soufis n. Nous y lisons que Mlohammad ibn Isḷâq ibn Moḥammad, l'auteur du نحكات, avait recu la khirqa, ou froc de grand-maitre de l'ordre des soufis, de la main de Mohammad ibn 'Ali lbn al-c Arabì al-Hâtimî, à qui ce vêtement avait été transmis par un schaikh appelé Al-Qassâr, qui l'arait reçu d'un autre schaikh, et ainsi de suite, énumération qui remonte jusqu’à 'Ali, fils d'Aboû Ṭalib. Vient ensuite une seconde série du même genre, commençant aussi par le nom de Moḥanmad ibn Ishâaq. Une troisième liste indique comment la khirka passa de Mahomet à 'Alì, de 'Alì à AIỊasan al-Baṣrì, etc., jusqu'au sclıaikh Sadr al-Dìn alQoủnawi. Iladji Khalfa a décril cet ouvrage sous le titre de reuflles divins \%. Hs. daté de l'an 998 de l'hégire (1589-159o de J. C.). Les derniers feuillets sont datés de l'an 1072 de l'hégire $(1161-1162$ de J. C.).

Papier. 138 feuillets. Hauteur, 30 cenlimètres; largeur, 14 centimètres. 19 lignes par page. - (Ancien fonds 426. )

\section{5 .}

La Démonstration, traitant des secrets de la science de la balancen, c'est-àdire de l'équilibre que Dieu a établi entre toutes les parlies de la nature, par Al-Djildakì (Sol! 5 ) Aïdemur ibı 'Alì, écrivain mystique qui, selon Iladji Khalfa (t. II, p. 38), florissait vers le milieu du vin ${ }^{\circ}$ siècle de l'hégire. Nous avons ici le prenier livre du troisième discours du quatrième volume de l'ouvrage. L'auteur traite d'abord de l'ìme et de ses facultós, puis des facultés de l'homme. Deux tables, dont l'une est incomplète, ont été ajoutées en tête du volume. Les pagres du premier cahier sont plus 
grandes que celles des cahiers suirants. A la fin du volume se trouvent des notes diverses en assez grand nombre, notamment des recettes dalchimie, en langue Inivue.

Papier. 168 fenillets. Hanteur, 20 centimètres el demi; largeur, 15 centimedres. Au commencement, 19 lignes par page, puis $17 . \mathrm{Mts}$. du wir siècle. - (Supptément 582.)

\section{6.}

elHomme parfait, traité faisant connaitre les origines et les finsn. Lauteur, 'Abd al-Karìn ibı Ibràhim ibn 'Abd al-Karlìm ibn Khalifa, natif du Guilàn (Al-Djilì), qui vivait dans la seconde moitié du $\mathrm{x}_{\mathrm{v}}^{\mathrm{e}}$ siècle, cherclıe à démontrer que l'homme ne parvient à la perfection que par la conmaissance parfaite de Dieu et de ses attributs. La préface

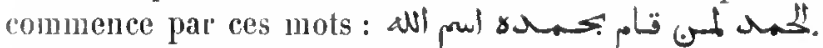
Suivent soixante-trois chapitres, dont voici les titres :

;

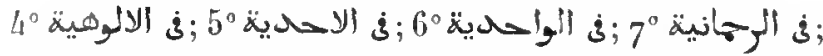
; التنشبيـه

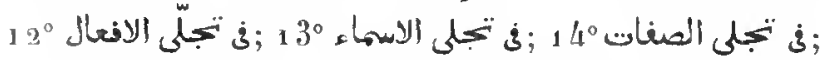
$15^{\circ}$ ف في الارادة $19^{\circ}$ ة $23^{\circ}$ J 3 ;

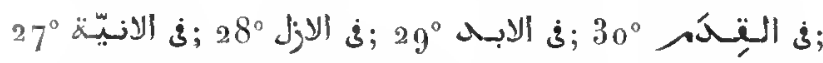

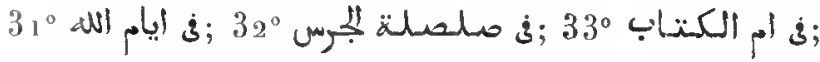

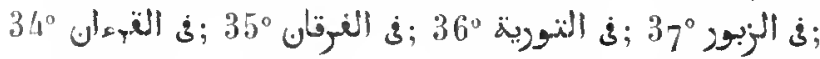
في فاكة $38^{\circ}$

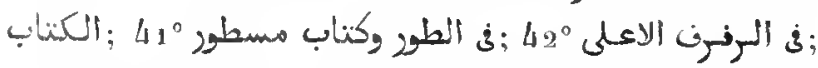

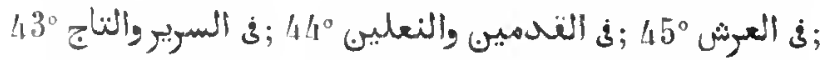

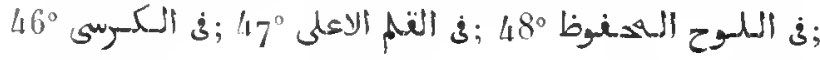

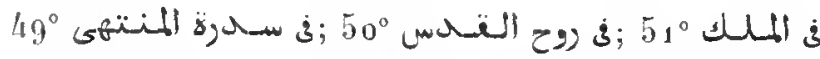

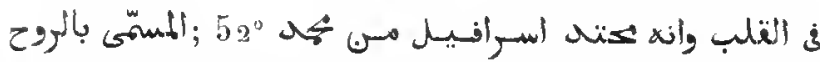

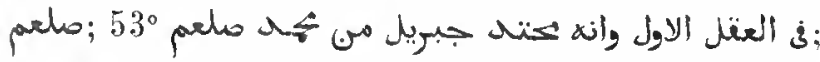

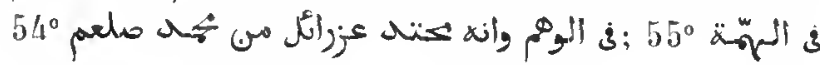

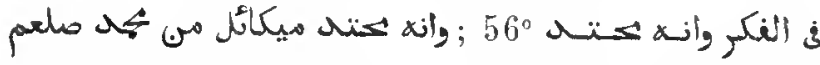

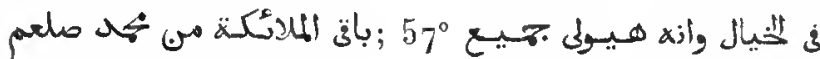

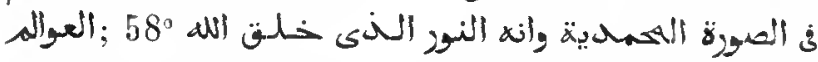

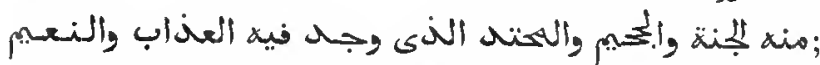

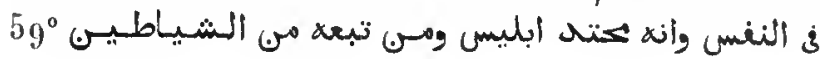

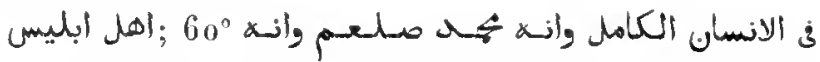

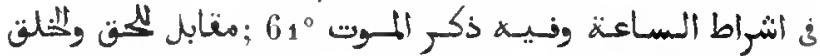

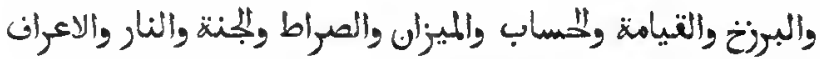

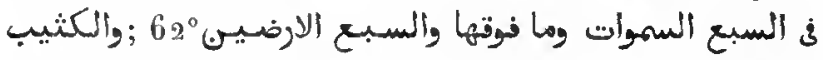

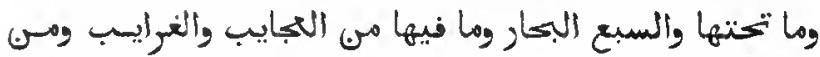

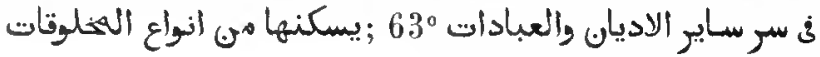

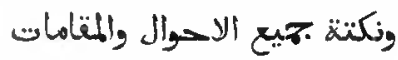

On roit par cette liste que l'Insán al-Kámil est un des recueils les plus complets des doctrines des soufis. L'auteur a inséré dans son ouvrage un grand nombre de vers mysliques.

Papier. 119 feuitlets. Hautenr, 20 centimètres; largeur, 13 centimètres et demi. 23 lignes par page. Ns. du xvi siecle. - (Supplément 57 个.)

\section{7.}

L'Insân al-Kâmil d'Abd al-Karìn ilon Ibrâhìm al-Djîlì. Ms. daté de l'an 971 de l'hégire (1564 de J. C.).

Papier. 185 feuitlets. Hauteur, 22 centimètres; targeur, 12 centimètres. 21 lignes par page. - (Supplément 575.)

\section{8.}

L'Insin al-Kámil d'Abd al-Karim al-Djîli. Ms. daté de l'an 1015 de l'hégire (1606-1607 de J. C.).

Papier. 146 feuittets. Hauteur, 21 centimètres; largeur, 15 centimètres ct demi. 25 lignes par page. - (Ancien fonds 437.)

\section{9 .}

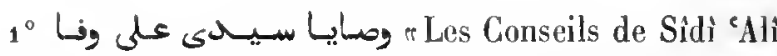
Wafà n. Ce sont des conseils et des instructions religieuses qu'un derviche exalté avait reçus du chef de son ordre,

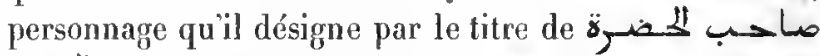
Le Seigneur de la présence wafaïennen. Cies conseils, dit-il, émanés de Dieu, lui furent transmis par l'entremise de son chef. Au fol. $10 v^{\circ}$, il raconte qu'en 800 de l'hégire ( $3_{97-1} 3_{9} 8$ de J. C. ), il mourut lui-même et revint ensuite à la vie. Au lol. $11 \mathrm{v}^{\circ}$, il écrit que Dieu,

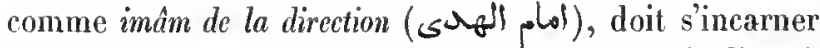
et prendre la figure d'un lomme, doctrine particulière à cette branche de la secte schiite qu'on appelle les extra- 
vagants. Copie datée de l'an 971 de l'hégire (1563-1564 (le J. C.).

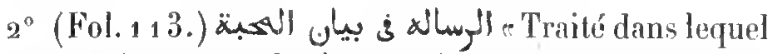
on expose la nature de l'amour (de Dieu)r, par Khalil Nllah ibn Noûr Allah ibn Mo în at-Din Yazdi. Commence-

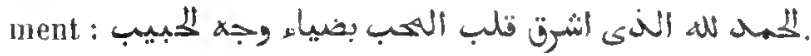

Papier. 122 feuillets. Hanteur, 21 centimètres et demi; largeur, 15 centimètres et demi. 19 lignes par page dans le premier ouvrage, 13 lignes dans te second. - (Ancien fonds 424.)

\section{0 .}

1 م Diminution des difficultés pour l'obtention de la prééninenrer. Exposé des pratiques an moyen desquelles l'àme parvient à exprcel des influences surnaturelles sur les êtres créés. L'auteur, 'Ibd al-Khâliq ibn abì 'L-Qàsim al-Miṣrì al-Khazradjì, a divisé son livre en quatre sertions: la première est consacrée aux exercices ou pratiques qui lapplochent l'àme dn (iréateur (وباضـات ربّانـيـة); la seconde indiefue les praliques qui disposent l'ante à recevoir les conmaissances qui émanent du monde de l'entendement et de l'àme universelle; la troisiène décrit les pratiques qui mettent l'àme en rapport avec les anges qui président atx sept corps célestes (وياضL ); la quatrine expose les pratiqnes qui assurent à l'àme le concour's des diverses classes de génies (الرباضات الطبيعية).

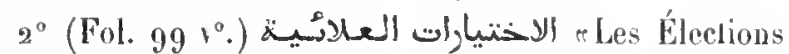
d"Alà al-Dinn, trailé sur le choix (élection) des heures propices quand il s'agit de s'engager dans nne entreprise, par Aboú 'Abd Allah Hohammad ilon 'Omar al-Rázi. Cet ouvrage astrologique a été composés sur la demande d'un sultan de Kharizm, appelé $A$ boû 'I-Mozaffar 'Mlài al-Dìn, Borhân amîr al-Moûminin (epreune démonstrative de la puissance du commandeur des croyants $"$ ).

$3^{\circ}$ (Fol. $138 \mathrm{v}^{\circ}$.) Recette pour teindre les rheveux.

Papier. 139 fenillets. Hauteur, 21 centimètres et demi; largeur, 15 centimètres el demi. 15 lignes par page. Uls. do $x v^{\circ}$ siècle. - ( ( $n$ cien fonds 427 .)

\section{1.}

ب Les Cliasses d'A1-Scharnoùbìn. Cet ourage, qui a été dicté par AI-Scharnoûbì à son élève, Al-

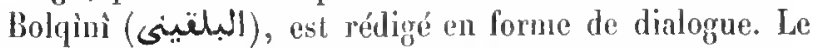
grand qotb et ghath de l'ordre mystérieux d'hommes spirituels, directeurs des événenents du monde, Aḷmad ibn
'Othmân al-Scharnoủbi, raconte à son élève, l'aspirant Moḷammad al-Bolyinì, les miracles opérés par lui-mênıe, ainsi que par ses prédécesseurs, Ibròhìn al-Dessoûyi (î), "Abd at-Qiddir, le sayyid Aḷmad al-Rifäi et pal" plnsieurs autres saints thanmaturges. M. de Sacy, dans le Journal des Savants, aoùt 1831 , page 158 , parle de celte corporation, ainsi que des qotb "pỏles $n$, des grauth "secoursn, des autad "pieux ou piquets", et des abdâl "remplaçants", etc., dont elle est composée. Voyez aussi 1e Dictionnaire biographique d'Ibn Khallikản, t. III, p. $9^{8}$, de la traduction anglaise. Une autre main a écrit sur le verso dı dernier leuillet la première partie d'une qaşîda mystique.

Papier. 42 feuillets. Hauteur, 21 centimètres; Jargeur, 15 centimètres. 21 lignes par page. Ms. du xvi siècle. - (Supptément 648.)

\section{2.}

re Mystérieux dévoilé, par le qo!̣b Al-Scharnoûbì. Même ouvrage que lo précédent. Exemplaire daté de l'an 1106 de l'hégire $(1695$ de J. C.).

Papier, 27 feuilfets. Hauteur, 21 centimètres; largeur, 15 rentjmètres et demi. 23 lignes par page. - (Supplément 639.)

\section{3.}

$1^{\circ}$ 3ystérieux dévoilér. Mêne onvrage que les deux précédents. A la fin se trowrent quelques traditions fabuleuses sur Mahomet.

$2^{\circ}$ (Fol. $53 v^{\circ}$.) Histoire de Tamìn ibn Habìb al-Dảrî.

$3^{\circ}$ (Fol. $78 r^{\circ}$.) Sur les premières prédications de Mahonnet, ses controverses avec les Qoraïschites, ses miracles, etc., par Aboû 'l-1lasan al-Bakri.

$4^{\circ}$ (Fol. $122 \mathrm{~V}^{\circ}$.) Historiettes édifiantes, dont la première a pour sujet le devoir de laire l'aumône à cenx qui cherchent la science.

$5^{\circ}$ (Fol. $124 v^{\circ}$.) Prétendu récit fait par Al-Schafiei, an sujel du fils d'un évèque, avec lequel il s'était entrotenu à la Hecque.

$6^{\circ}\left(\right.$ Fol. $126 v^{\circ}$.) Histoire de Taraddoud la belle esclave.

$7^{\circ}$ (Fol. $354 v^{\circ}$.) Dialogue de Jésus-Christ avec le crâne d'un ancien émir des croyants, en Syrie.

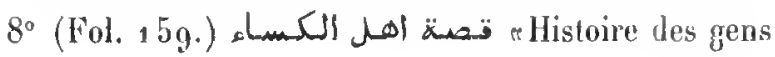
33. 
du manteau \%. Récit de la fareur spéciale que Mahomet avail accordée à 'Mli, à Fätima et à leurs enfants.

$9^{\circ}$ (Fol. 163.) Derniers conseils adressés par Mahomet à 'Alì ibn abì Tạlib.

$10^{\circ}$ (Fol. $\left.17^{4} 1^{\circ}.\right)$ Hisloire d'Hl-Kabbâs ilon l.lanzala

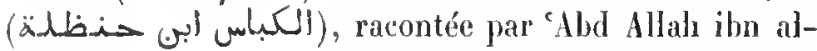
Zolain'.

$11^{\circ}$ (Fol. $1831^{\circ}$.) Aventures d"Ali ibu abi Talib, que J. Proplièle avait enroyé pour combaltre un dragon.

$12^{\circ}$ (Fol. $1941^{\circ}$.) Pièces de vers attribuées à l’imàm ll-Schâfị

$13^{\circ}$ (Fol. $19^{6} \mathrm{v}^{\circ}$.) Histoire de I'entretien d'Al-Haddjadj avec un jeune homme.

$14^{\circ}$ (Fol. $\left.205 \mathrm{v}^{0}.\right)$ Récit de l'entretien de Moïse avec Dieu.

$15^{\circ}$ (Fol. $2071^{\circ}$.) Enlpetien d'Olhmàn avec Mahomol sur divers sujets. Dialogue qui eut lieu enlre Malomet et Iblis.

$16^{\circ}$ Fol. 217. (F) مenlicrs pour arriver aux jouissances dn laisser-aller $\%$, traité de philosophie mystique, par le derviche 'Abd al-Ralımàn ibn Molnammad al-Bistáni, mort en 858 de l'hégire ( 1454 de J. C.). Ce recueil de belles phrases, de maximes de sagesse, de récits et d'anecdotes historiques, emprunlés à différenls ouvrages, est divisé en quarante-six chapilres, intitulés är "élégrances\%. Ces clıpitres commencent ordinairenrent par une invocation en forme de lellre, suivic d'un trait d'esprit ou de sagesse, soit en prose, soit en ver's, el d'une anecdote historique. Le style de ces arlicles est très-élégant et très-recherché.

Ms. Lout entier de la même main, daté de l'an 1204 de l'hégire $(1789-1790$ de J. C. $)$.

Pippier. 272 feuillets. Hauteur, 23 centimètres; largeur, 16 centimìtres. 19 liģnes par page. - (Supplément 519.)

\section{4.}

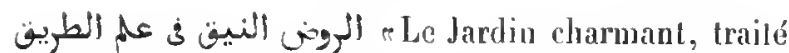
de la conmaissance de la voien, par le schaikh Hohammad ibn Yoûsof al-'Addjàn (U) Poème sur le soufisme, en trente-six paragraphes, appetés $y^{3}$ ecircuit, loulnéen, et composés chacun de cinq rers, suivi d'un commentaire, par le schä̈h Mol!ammad ibn al-Hanafi.

Papier. 124 fenillets. Hauteur, 21 centimètres; largenr, 14 centimètres et demi. Au commencement 23 lignes par page, puis 19. Is. du xvis siècle. - (Supplément 560.)

\section{5.}

Traité de la vie dévote et de la connaissance de Dieu, par un auteur soufi. Line note en langue turque, en tête du volume, nous apprend que cet ouvrage a pour titre

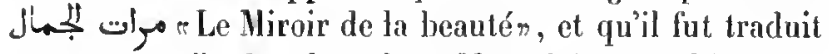
en ture sur l'ordre du sultan Mourad (Amurath). Com-

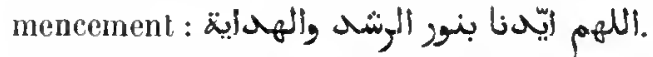

Papier. 38 feuillets. Hauleur, 3 centimètres; largeur, 13 centimètres et demi. 15 lignes par parge. Ms. du xvü siècle. - (Ancien fonds $43 \mathrm{~s}$, Colbert 5959.$)$

\section{6.}

Mysteres des signes (ou rersets du Coran) et lumières des (grâces) données comme provisions", traité de théologie, partie scolastique, partie mystique, dont l'auteur, Sadr al-Din Moḅammad, paraît avoir appartenu à une confrérie de derviches. Commen-

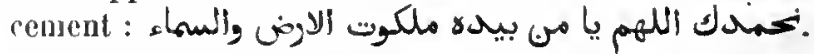

Papier. 158 feuillets. Hauteur. 20 centimètres; largeur, 12 centimètres. 17 lignes par page. Ms. du xvme siècle. - (Supplément ${ }_{262 .}$ )

\section{7.}

Principes des préliminaires de l'arrivéen, c'est-à-dire principes des opérations et pratiques spirituelles à laide desquelles on entre dans la vie dévote, et qui lont parvenir l'àme jusqu'à la véritable connaissance de Dieu. Traité de soufisme, par le célèbre derviche et ascète Ibrâhìm ibn Maḷmoûd al-Schâdsilì. Le texle, écrit à l'encre rouge, est accompagné d'un commentaire du même auteur, commentaire intitulé Haleines de la sincépité, en réponse à une demande, pour servir d'explication an traité intitulé Oșoûl Moqaddamât al-Woşoûl». Le premier feuillet de ce volume manque. Sur le verso du feuillet 117 l'auteur a inscrit, de sa propre main,

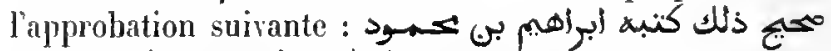

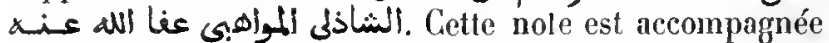
d'un certifreat de lecture, daté du mois de rebîa second 906 (novembre 1500 ). Au fol. 118 commence une prière

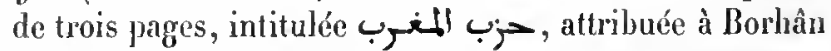
al-Dîn Ibrâhìm al-Schâdsilì. An fol. $1191^{\circ}$ se trouve un court poène mystique du même auteur.

Papier. 199 feuillets. Hanteur, 19 centimètres; largeur, 14 centimètres. 13 lignes par page. Ms. de la fin du $\mathbf{x v}^{e}$ siècle. - (Supplément 566.) 


\section{8.}

أم Fleur éclatante dans le ciel (?) des pratiques des derviches schàdsilites $\%$. Traité des doctrines et des pratiques particulières à l'orclre des Schàdsilites, par Áboù Ibráhim 'Ali al-Azhari. C'est, pour ainsi dire, un manuel d'aspiraut. Commen-

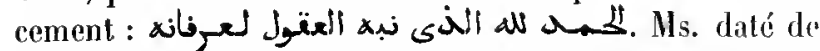
l'an 907 de l'hégire (1501 de J. C.). On voil, smr le fronlispice et sur le verso du dernier feuillet, deux médaillons en or et en couleurs, grossièrement exécutés; chaque page porte en marge deux fleurons dorés et un rond entourant un trèle ou un bouton de fleur. Quelqnes notes marginales.

Papier. 119 feuillets. Hauleur, 18 centimètres; largeur, 14 centimètres. 15 lignes par page. - (Supplément 570 , Saint-Germain 388.)

\section{9 .}

Jardin jour les aspirantsn, manuel à l'usage de ceux qui veulent s'adonner à la vic contemplative et aux pratiques du soufisme, par le schaikh lbn Yazdân Yâr (ami de Dieu) Aboû Djaefar Moḥamnad ihn

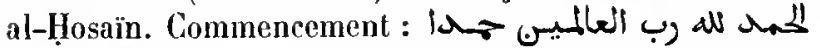
بك. Ms. daté de l'an $9^{80}$ de l'hégire $\left(157^{2}\right.$ de J. C.).

Papier. 2 a 1 fenillets. Hauteur, 16 centimètres; largeur, 10 centimètres et demi. 7 lignes par page. - (Ancien fonds 458.)

\section{0.}

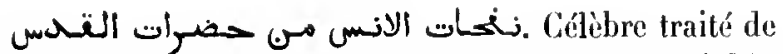
soufisme, composé en persan par Al-Djàmi (Noûr al-Dìn 'Abd al-Raḥmân) et traduit en arabe par Tàdj al-Dìn al'Othmân, derviche de l'ordre des Naqschibandìs. Ms. dalé de l'an 1104 de l'hégire ( $6_{9} 3$ de J. C. .).

Papier. 245 feuillets. Hauteur, a centimètres el demi; largeur, 5 centimètres el demi. 25 lignes par page. - (Supplément ao4u.)

\section{1.}

Soutien de la vérité sublime et raffermissement de la voie de Schâdsilìn, par 'Abd al-Rạ̣mân ali-Soyoûṭ̂. C'esl une apologie de l'ordre de derviches fondé par Al-Schảdsili.
أن علم النصون ف نفسه عم تُبن رفيع : Commencement

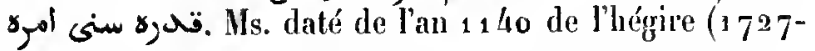
1728 de J. C.).

Papier. 61 feuillets. Hauteur, a 1 centimètres; largeur, 15 centimètres et demi. a 1 ligrues par page. - (Supplément 555.)

\section{2.}

位itre à nos frères les légistes et les maitres dans la connaissance du texte dn Coran n. Traite sur le sens mystique de quelqnes passages du Coran, composé à Sâliḥiyya, près de Damas, en $9^{35}$ de l'hégire ( $1509^{-15} 10$ de J. C.), par un Maghrebin nommé 'Ali ibn Maïmoûn. L'auteur, de race berbère, fail remonter sa généalogie jusqu'à Al-Ilasan, fils d'Ali ibn abì Tàlib. Dans la préface, i] parle de quelques-uns de ses compatriotes et de ses professeurs. Ms. daté de l'an $99^{\circ}$ de l'hégire (1582 de J. C.).

Papier. 85 feuillets. Hauteur, 24 centimètres; largeur, 15 centimètres. 19 lignes par page. $-($ Ancien fonds 436 . $)$

\section{3.}

La Perle unique et le collier avantageux, trailé faisant connaitre les gens de la doctrine de lunitén, par Moḷammad iln Schocailb al-Hidjàzì. Ce traité de soufisme, composć probablement au $\mathrm{xvu}^{\circ}$ siècle, commence par une inlroduction ( mystérieux qui occupent les rangs et les grades les plus d́levés dans l'ordre (أمحاب المراتب والموظايف); suivent denx chapilres (باب), dont le premier renferme des détails sur

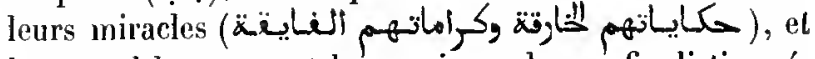
le second les noms et les maximes des soufis distingués par leur savoir (أقوال عائهم وأسمائهم). Un long exposé, lenfermant des renseignements utiles, des principes et des maximes (فوايح وقوأعل , احككام), termine le volume.

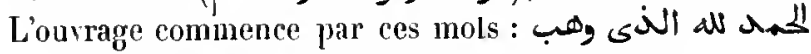

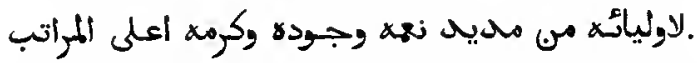

Papier. 78 feuillets. Hauteur, a centimètres; largeur, 15 centimètres. 25 lignes par page. - (Supplément 563.)

\section{4.}

1" Termes techniques ", employés par 
les soufis et rangús dans l'ordre de l'abdjad. Le prenier feuillet manque.

$2^{\circ}$ (Fol. 25. (5) :Livre de l'approbation", divisé en six chapitres, savoir : $1^{\circ}$ sur les diverses aclions donl l'homme est responsable; $2^{\circ}$ règles pour la récilalion des litanies (dsikr) et pour la lecture du Coran; $3^{\circ}$ courenauces quil faul observer en mangeant et en burant; $4^{\circ}$ comenances qu'il fant observer it l'égard des femmes, et $5^{\circ}$ allx funérailles; $6^{\circ}$ solution de diverses queslions.

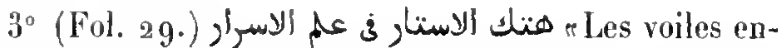
levés devant les mysteres", Iraité en dix sections, sur la doctrine des soufis. L'auteur, qui ne se nomme pas, dit aroir emprunté ses matériaux aux ourrages de Moḷyì alDîn ibu al- Arabì.

$4^{\circ}$ Fol. 33. Recueil de liadilions provenaut du P'rophète\%. Ces traditions sont classées dans l'ordre des matières et forment cent chapilres. En tête se lrouve une notice sur les diverses colteclions de traditions.

$5^{\circ}$ (Fol. 6o.) Examen de cette maxime des unitaires, c'est-à-dire des soufis panthéistes, que rien n’existe, ex-

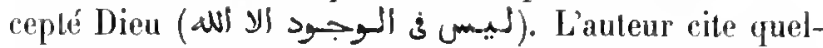
ques passages d'un ourrage persan d'Aḥmad al-Ghazâlì.

$6^{\circ}$ (Fol. $63 \vee^{\circ}$.) Première pagre d'une série de queslions adressées aux ulémas, touchant linterrogatoire du tombeau, elc. La fin des questions et les réponses manquent.

$7^{\circ}$ (Fol. 64.) Liste des choses défendues par les médecins.

Les derniers feuillets contiennent quelques extraits et fragments en prose et en vers.

Papier. 66 feuillets. Hauteur, so centimètres et demi; largeur, 17 centimètres et demi. 23 ligues par page. Ms. du svi siècle. - (Supptément 564.)

\section{5 .}

Sur (la congrégation religieuse appelée) la Fotourwa (ou ordre de la noblesse)r. Cet écrit est attribué à Moḷammad ibn 'Ả hà al-Dìn ibn al-Ridlıâ. L'anteur fait remonter l'iustitution de la Fotouwwa jusqu'ì Adam; il retrace l'histoire de l'ordre, donne des conseits au lecteur, l'exhorle à embrasser la vie dévote et à entrer dans la voic (طريتة). C'est une produclion assez moderne qui parait avoir été composée par un derviche.

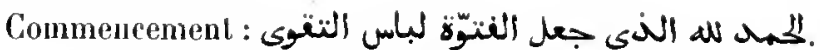
Le ms. porte la signature de $\mathrm{P}$. Lucas, an. 1718 \%.

Раріег. 39 feuillets. IIauteur, 17 centimètres; largeur, 10 centimètres et demi. 15 lignes par page. Ms. duxvu' siéele. - (Ancien fonds 453.)

\section{6.}

La première moitié du كتاب الغتوّة Le texte ne s'accorde pas toujours avec celui des autres exemplaires.

Papier. 37 feuillets. Ilauleur, 15 centimètres et demi ; largeur, 10 centimètres. 9 lignes par page. Ms. du xrı̀ siècle. - (Supplément 569.)

\section{7.}

Le كتناب الغنّوة A la fin du ms. se trouve un fragment d'un recueil de maximes, classées dans l'ordre de l'alphabel, par Mosțafì ibn Kamâl al-Dìn al-Kbalwatì. Ms. daté de l'an 1145 de l'hégire (1 733 de J. C.).

Papier. 38 feuillets. Ilauteur, I 7 centimètres; largeur, I I centimètres. 14 lignes par page. - (Supplément 568.)

\section{8.}

قرّة العيى الباصرة فيما يزهل في اللهنيا وبـرغـب في الآخــة "Rafraichissement de l'œil elairroyant, traité qui enscigne à unt́priser les choses de ce monde el à désirer celles de l'autren. Traité de morale ascélique qui renferme des traditions, des réeils édifiants et des morceaux de poésie. Le nom de l'auteur est inconnu. Ms. daté de l'an 1084 de l'hégire $(1673-1674$ de J. C. $)$.

Papier. 126 feuillets. Hauteur, 2.0 centimètres et demi; largeur, 15 centimètres. 33 lignes par page. - (Supplément 522.)

\section{9 .}

$1^{\circ}$ Sur les sept stations par lesquelles l'âme doit passer avant d'arriver à l'union avec la divinité. Com-

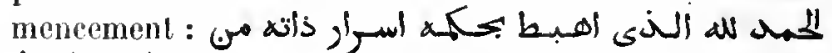
لأ le litre suivant : كتاب المسبر والسلوك اله طريق مالك لملكوك.

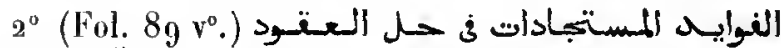
. Traité dans lequel le schaïk 'Alì al-Khațib explique les obscurités de son 'Oqoûd al-Djauhariyyât, ou- 
vrage dans lequel il démontrait la réalité des attributs

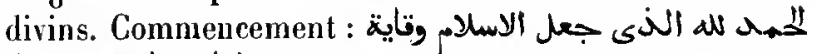
. نلا وجاية مب النار.

Papier, 103 feuillets. Hauteur, 21 centimètres; largeur, 15 centimètres et demi. 19 lignes par page dans la première pièce, el 23 lignes dans la seconde. Ms. du xvm1 siècle. - (Supplément 1879.)

\section{0 .}

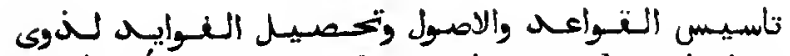
rÉtablissement des maximes et des principes faisant acquérir des connaissances utiles aux aspirants qui parviennent $\pi$, traité dans lequel A ḥmad ibn Aḷmad البرنيسى أبرى développe un grand nombre de mavimes de la métaphysique professée par les soufis.

Papier. 59 feuittets. Hauteur, so centimètres; largeur, 15 centimètres. 2 I lignes par page. Ms. du xvi" siècle. - (Supplément 558.)

\section{MATIÈRES DIVERSES DE THÉOLOGIE.}

\section{1}

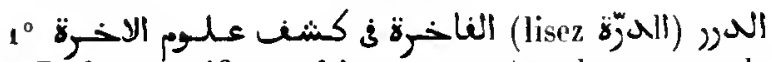
"La Perle magnifique, faisant connaitre les secrets de l'autre vie $\pi$, par Abou Hàmid al-Ghazâlì. L'auteur parle de l'état des àmes après la mort et du jugement deruier. $O n$ voit que ce traité n'est pas authenlique.

$2^{\circ}$ (Fol. 20. (م) Nouvelles des habitants du Paradis ». Description assez détaillée du paradis.

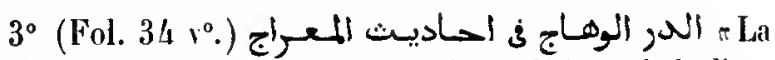
Perle ardente, renfermant le récit traditionnel de l'ascension de Mahomet au ciel $r$.

$4^{\circ}$ (Fol. $\left.43 v^{\circ}.\right)$ Figure talismanique.

$5^{\circ}$ (Fol. 44.) Forme el contenu de liuscription qui se trouve sur la planche ou tablette de Vénus, لوح الزهرئ

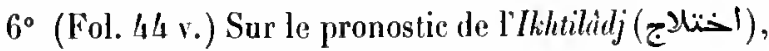
ou frisson involontaire d'un menbre quelconque du corps humain.

Papier. 46 feuillets. Hauteur, 18 centimètres et demi ; largeur, 13 centimètres. 19 lignes par page. Ms. du xv' siècle. - (Supplément 961.)

\section{2.}

$1^{\circ}$ Le partie, differe de l'exemplaire précédent.

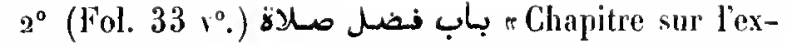
cellence d'une certaine prièren. Il est dit que cette prière assure à celui qui la récite le paradis et toutes ses jouissances.

Ms. daté de l’an 1153 de l'hégire $(1740-1741$ de J. G.).

Papier. 35 feuillets. Ifauteur, 21 centimètres; largeur, 15 centimètres et demi. 33 lignes par page. - (Supplément 260.)

\section{3.}

e lixtrait du Takhyirn. Tel est le litre inscrit deux fois sur le premier feuillet de ce manuscrit et une fois sur le dernier feuillet. L'ourrage a pour auteur Fakhr Al-Dìn Aboû Bakr Mohammad al-Râzì, el renferme un commentaire sur les quatre-vingl-dix-nent noms

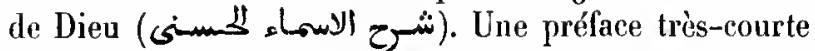
nous apprend que le Takhyîr avait été composé par Aboû 'I. Qàsin 'Albd al-Karìm al-Qoschaïri, mais aucun traité portant ce titre ne se trouve mentionné dans le Dictionnaire bibliographique de Hadji Khalfa. Il y a cependant un ouvrage d'Al-Qoschaïrì, intitulé Takhbir (تخبـيــ fi ilm al-Tadskir « Renseignements sur les litanies $n$, renfermant quatre-ringt-dix-neuf chapitres, consacrés chacun à un nom de Diei. C'est probablement de cet ourrage que Faklır al-Dìn s'est servi, et le véritable titre de notre $\mathrm{ms}$. serail Mohiluar al-Talihbir. Ms. daté de l'an 1106 de l'hégire $\left(1597^{-1} 598\right.$ de J. C. $)$. Les premiers et les derniers fruillets sont couverts de notes et d'extraits divers, le tout de la même main.

Papier. 38 fevillets. Hauteur, $2 \mathbf{t}$ centimètres et demi; largeur 15 centimètres. 25 tignes par page. - (Supplément 562.)

\section{4.}

ristoire des pécheur's qui se sont convertis à Dieun, par Mowaffiq al-Din 'Alıd Allah ibu Aḥmad al-Maqdisî, surnommé lbn Qodàma, mort en 620 de l'hégire (1223 de J. C.). L'ouvrage commence

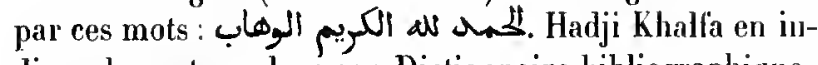
dique le contenu dans son Dictionnaire bibliographique, t. V, p. 65. Ms. daté de l'an $7_{2} 2$ de l'hégure $(1331-1332$ de J. G.). Quelques leuillets sont d'une écriture plus moderne.

Papier. 146 feuillets. Hauteur, 17 centimètres; largeur, 12 rentimètres et demi. 15 lignes par page. - (Ancien fonds 445.) 


\section{5 .}

Le Kitab al-Tawwabin, de Mowalliq al-Dìn 'Abd Allah ibn Qodàma. A la fin de l'ourrage se trouvent plusieurs pièces de vers, dont la première, rimant en $a$, renferme l'éloge de Habomet.

papier. 105 feuillets. Hlanteur, 18 centimètres; largenr, 13 centimètres et demi. 17 à, 8 lignes par page. Ms. du xv $v^{*}$ siècle. - (Supplément 5og.)

\section{6.}

1 Sur la création du monde, des anges et de l'homme, par Ibn al-`Arabì. La préface conmence par ces mots :

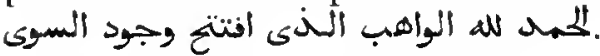

$2^{\circ}$ (Fol. 25 v.) (Indicalion des voies par lesquelles les bonnes cuvres montent

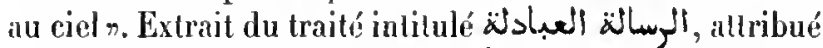

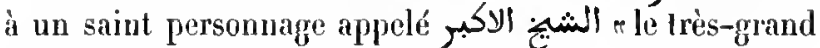
schaiklın. C'est probablement Ibn al-'Arabî qui est ainsi désigné.

$3^{\circ}$ (Fol. 29 v ve.) Le زبحة التهتين ونزهة التنوفيق. Commentaire de Pìr Moḷammad ibn Qoth al-Dìn al-Khoûyi (خوبي) sur l'ourrage mystique de Ṣadr al-Din Mohammad ibn Ishâaq al-Qoûnì (d'Icone), intitulé is نصويق r Sentences pour faire connaitre la iraie nature de l'être qui est distinct de lous les autres» (?). Selon Hadji Khalfa, Moḷammad al-Qoûnî mourut en 673 de l'hégire (1 $27^{4-1} 27^{5}$ de J. C.), et Pìr Họ̣ammad al-Khoûyî termina son commentaire en 856 de l'légire ( 1452 de J. C.).

Papier. 237 feuillets. Ifauteur, 21 centimètres; largeur, 14 centimètres. 19 à 23 lignes par parge. Diverses écritures du xri sièele. (Aucien fonds 409. )

\section{7.}

ح' Conducteur des âmes vers le pays des joies\%. Sur les merveilles de la vie future, par Schams al-Dîn Moṭammad ibn Qayyim al-Djauziya, docteur hanbalite, mort en 751 de l'hégire (13501351 de J. G.). L'ouvrage est divisé en soixante-dix chapitres. Ms. daté de l'an 1153 de l'hégire (1 740-1 741 de J. C.).

Papier. 394 feuillets. Hauleur, 21 centinètres et demi; largeur, 14 centimètres et demi. 14 à 17 lignes par page. - (Supplément 578.)

\section{8.}

(كام المرجان ف الحكام البان. Amas de corail, traité relatif à tout ce qui concerne les génies $»$, par Schams alDìn al-Ischbilì (الاتنبلى sic), docteur hanéfite, natif de Séville ( royez le titre du ms.). L'auteur de eette compilation, divisée en cent quarante chapitres, a puisé ses reuseignements dans soixante-dix ouvrages, dont la liste se trouve au fol. $4 v^{\circ}$, à la suite de la liste des chapitres. Selon Hadji Khalfa, t. I, p. 386, le eadi Badr al-Din Mohammad ibn 'Abd Allah al-Schiblì (الستسبـلى) mourut en 769 de l'hégire ( $1367-1368$ de J. C.). Commencement

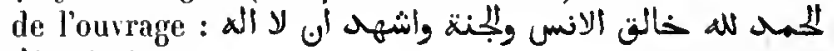

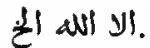

Papier. 146 feuiltets. Hauteur, 26 centimètres et demi; largeur, 18 eentimètres. 21 lignes par page. Ms. dn $\mathbf{x v 1}^{\circ}$ siècle. - (Supplément 581.)

\section{9.}

كبائك ف اخبار الملائك. Traditions sur les anges, par Soyoûtị.

Papier. 46 feuillets. Hauleur, 21 centimètres; largeur, 15 centimètres. 21 lignes par page. Ms. du xvm1 siècle. - (Supplément 2443.)

\section{0.}

$1^{\circ}$ كناب بشنى الكثيب بلقاء للمبيب, par Soyoûtị. C'est un abrégé du grand ouvrage du même auteur sur l'état des àmes après la mort.

$2^{\circ}$ (Fol. 26.) كتناب فنتوح الغنـيـب, par Molyyì al-Dìn Aboû Moḷammad 'Abd al-Qâdir ilun abì Șâlị̣ al-Ḥanbali.

Papier. 83 feuillets. Hauteur, 20 centimètres; largeur, 14 centimètres. 15 à 17 lignes par page. Ms. du xvı" siècle. - (Supplément 2442 .)

\section{1.}

$1^{-}$Examen des traditions qui se rapportent à la reconnaissance enver Dieu et à la mort, par un auteur in-

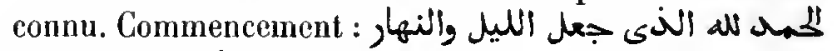

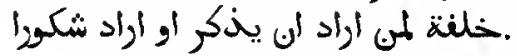

$2^{\circ}$ (Fol. 34.) Sur les peines de l'enfer, extrait d'un الكوكب commentaire sur un recueil de traditions intitulé ألمنير. 
$3^{\circ}$ (Fol. $35 \mathrm{r}^{\circ}$.) Sur certaines traditions provenant de Mahomet. Saus introduction.

$4^{\circ}$ (Fol. $47 r^{\circ}$.) Recueil de traditions se rapportant à plusieurs points du dogme musulman.

$5^{\circ}$ (Fol. $57 v^{\circ}$.) Dissertation sur les devoirs du musulman.

$6^{\circ}\left(\right.$ Fol. $60 \mathrm{v}^{\circ}$.) r Sacliez, musulinans, que ce monde n'est pas un lieu de demeure fixe... $\rightarrow$ En turc.

$7^{\circ}$ (Fol. 63.) Traité de théologie. Le commencenent manque.

$8^{\circ}$ (Fol. 76.) Notes diverses, dont une, en langue turque, donne le portrait de Mahomet.

$9^{\circ}$ (Fol. $80 \vee^{\circ}$.) Sur le partage des successions, sans prélace ni nom d'auteur.

$10^{\circ}$ (Fol. $102 \vee^{\circ}$.) Le Táalloum al-Mota allam.

$11^{\circ}$ (Fol. $114 v^{\circ}$.) Conseils d'Aboù Hanifa.

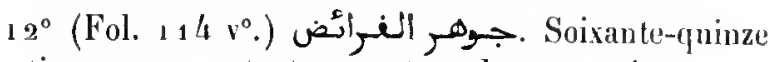
questions se rapportant au partage des sucessions.

$13^{\circ}$ (Fol. $123 \mathbf{v}^{\circ}$.) Notes et traditions diverses.

$14^{\circ}\left(F_{0}\right.$. $126 r^{\circ}$ ) Sur diverses questions touclant la foi, par Yahyâ jbn abì Bakr al-Hanafí. Commencement :

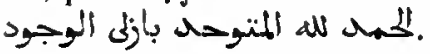

$15^{\circ}$ (Fol. $145 \mathrm{v}^{\circ}$.) Traditions pour l'instruction des musulmans. $A$ la fin se trowvent quelques instructions en turc.

$16^{\circ}$ (Fol. 156.) Noles diverses.

$17^{\circ}$ (Fol. 157.) Conseils moraux. Le commencemenl manque.

Papier, 161 feuillets. Hlauteur, 21 centimètres; targeur, 15 centimètres. 13 à 19 lignes par page. Écritures diverses $d u x^{\circ} t^{\circ}$ et du xwin siècle. - (Supplément 1856.)

\section{2 .}

Fragment d'un ourrage de théologie, dans lequel se

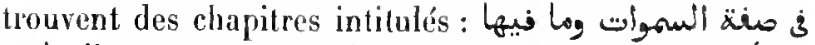

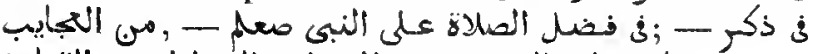

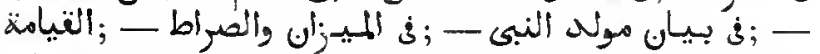

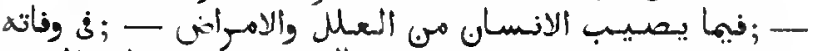

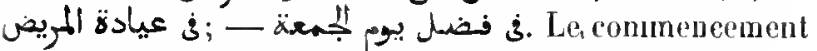
et la fin manqment, ainsi que plusieurs feuillets dans le corps de l'omrage.

Papier. 35 feuillets. Hauteur, so centimètres; largeur, it centimètres et demi. 2 I lignes par page. Ms. du xrane siècle. - (Supptément 2167 .)

$$
\text { MAs. ontextalX. - II. }
$$

\section{3.}

Dissertations sur le prophétisme et les prophèles, sur Mabomet et ses grands mérites, sur certains miractes, tels que la séparation de la lune en deux, sur les anges, leur nature et leur impeccabilité. L'auteur cile de nombreuses traditions, dont il diseute ordinairement l'authenticité. Le commencement et la fin manquent, et il y a des lacunes dans le corps du volume.

Papier. 178 feuillets. Hanteur, 23 centimètres et demi; targeur, 17 centimètres. 21 à 23 lignes par page. Ms. de la fin du xville siècle. - (Supplément so16.)

\section{4}

r Cadeau de prix, renfermant des réponses à des questions bien accueillies $n$, par A ḥmad ibn 'Abd al-Laṭif al-Bischbìschî (ألبشبيشئ). L'auteur répond à une série de questions que le vizir ottoman 'Abd al-Raḥmân Pacha lui avait adressées au sujet de la faculté prophétique, de la prière, de la mort, des

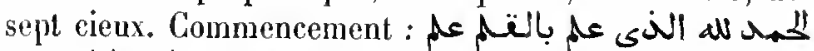
الانسان ol. Ms. daté de l'an 1146 de l'hégire (1 733 1734 de J. (i.).

Papier. 24 feuillets. Hauteur, 22 centimètres; largeur, 16 centimètres et demi. 21 lignes par page. - (Supplément 556.)

\section{5 .}

$1^{\circ}$ Sur les soixante-dix péehés graves (كباير) et sur les chàtiments qui leur sont réservés.

$2^{\circ}$ (Fol. $13{ }^{\circ}$.) La Borda d'Al-Boûsìnì. Les deux premiers vers sont accompagnés d'une traduction interlibéaire en tıre.

$3^{\circ}$ (Fol. 17.) Opinion d'Aboû Bakr al-Ràzì sur l'état des âmes après leur sortie du corps.

$4^{\circ}$ (Fol. $17 \mathrm{~V}^{\circ}$.) Traité sur la prière, avec des réponses à certaines questions, extrait de l'introduction du

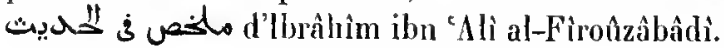

$5^{\circ}$ (Fol. 21.) Quelques traditions.

$6^{\circ}$ (Fol. 22.) Traité sur les prières d'obligation.

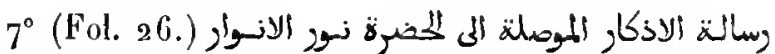
"Traité des prières de commémoration qui rapprochent l'homme de celui qui est la lumière des lumières $n$, par le soufi Al-Scharaf al-Balììi. 
$8^{\circ}\left(F_{0} .39 v^{\circ}.\right)$ Traité sur les prières que le novice eu sonfisme doit réciter. Commencement : كمبد (1)

$9^{\circ}$ (Fol. $411^{\circ}$.) Traité mystique sur Dieu et sur la création des immes.

$10^{\circ}$ (Fol. 47.) Traité en ture sur les quatre espèces

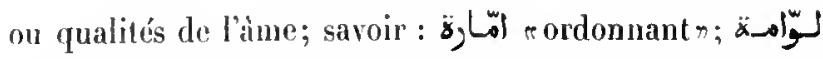

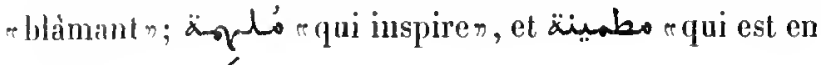
reposn.

Papier. 49 feuillets. Hauteur, 21 centimètres et demi; largeur, 15 centimètres. 11 ì 2.2 liggnes par page. Éeritures diverses du xvie et du xrü siècle. - (Sujplément 1840.)

\section{6.}

$1^{\circ}$ Traité sur le Bismillah, par Zaïn al-Dìn Aboû Zakariyà al-Anșàrì. La fin manque.

$2^{\circ}$ (Fol. $81^{\circ}$ ) La Schansiyya, traité de logique, par Nadjm at-Din 'Omar al-Qazwini al-Kâtibî. Commence-

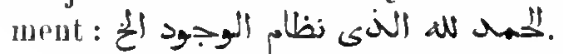

$3^{\circ}$ (Fol. $23 v^{\circ}$. (Froyances des anciens musulmans ", traité dognatique, par Aboù Jsḥây al-Schì-

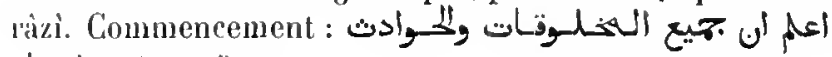

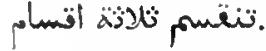

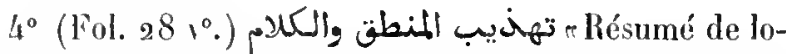
grique et de scolastiquen, par Sa d al-Dìn al-Taftàzâni.

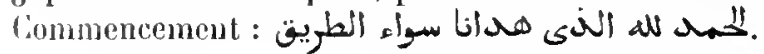

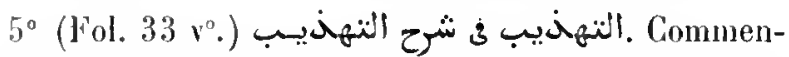
laire sur le Tahdsib d'Al-Taftàzini, par 'Obaïd Allad ibn

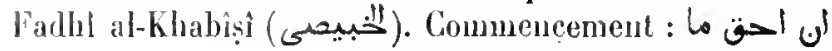

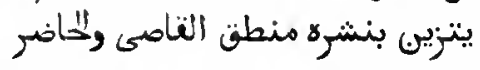

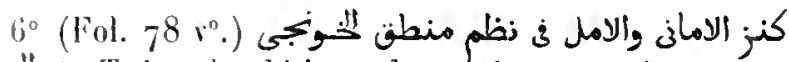

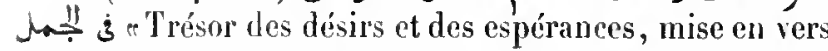
du Iraité de logique d'Al-Khoùndji, intitulé les Propositions", par Hn Marzoûq, de Tlemcen.

$7^{\circ}$ (Fol. $851^{\circ}$.) Commentaire d'Al-Fanàri sur l'Isagrogé d'Athir al-Din al-Abharî.

$8^{\circ}$ (Fol. $97 r^{\circ}$.) Commentaire de Djalàl al-Dìn al-Mahallì sur le Waraquat de l'Imàm al-liaramaïn.

$9^{\circ}$ (Fol. 105.) Dernières pages d'un traité d'arithmélique en vers, suivi d'un commentaire en prose.

$10^{\circ}$ (Fol. $1061^{\circ}$ ) Questions touchant le partage des successions.

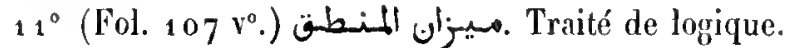

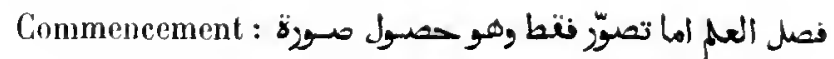

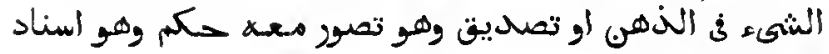

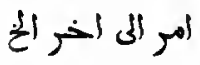

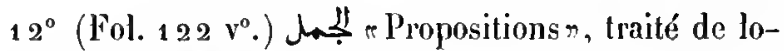
gique, par Ibu Nìmàwar al-Khoûndji. Nombreuses gloses inarginales et interlinéaires.

$13^{\circ}\left(F_{0} .1 .130 \mathrm{v}^{\circ}\right.$.) Traité de logique, sans titre, ni nom d'auteur. Conmencement : فصل اللنظ أمها دال بـاللمطابقة

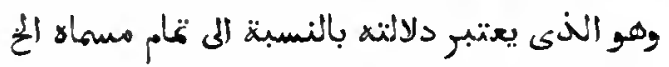

$14^{\circ}$ (Fol. $1431^{\circ}$.) Réfutation d'une docirine anthropomorphique qu'on arait tirée de certaius noms de Dieu, cités dans le Coran. Commencement : بيذاته وصفاته Sans Iitre ni nom d'auteur.

Papier. 170 feuillets. Hauteur, 19 centimètres; largeur, 14 centimètres. 9 à 25 lignes par page. Écritures diverses du $\mathbf{x i v}^{\circ}$, du $\mathbf{x r}^{\circ}$ et du xvi siècle. -- (Ancien fonds 440.$)$

\section{7.}

Ouvrage composé de cent sections ou paragraphes, appelés sourates, et précédés du Bismillah, comme les sourattes du Coran. Dans plusieurs de ces pièces, Dieu adresse la jarole à David, et dans quelques-unes il annonce la venue du prophète Hahomet. Cette prétendue traduction des psaumes de David est une curre entièrement apocryphe. Les premiers feuillets, renfermant les huit premières sourates et le commencement de la neuvième, manquent. Le $\mathrm{D}^{\mathrm{r}}$ Pieques avait voulu combler cette lacune, en copiant, sur un manuserit que nous ne connaissons pas, les sourates qui manquaient; mais, s'étant probablement aperçu que l'ourrage où il croyait les avoir trouvées était en réalité une traduction des psaumes, il n'a pas achevé la copie. (Voyez fol. 2.)

Papier. 40 feuillets. Hauteur, 21 centimètres et demi; largeur, 13 centimètres et demi. 13 lignes par page. Ms. du xvi๋ siècle. (Supplément 236.)

\section{8.}

Opuscules (وسائل) du schaïklı Fakhr al-Din 'Aldd Allah 'Mlì ibn Aḷınad al-Ḥirâlì (d', لم) :

$1^{\circ}$ Instructions religieuses pour les fidèles, touchant l'accomplissement de la prière et la conduite qu'ils doirent tenir en vue de la mort.

$2^{\circ}$ (Fol. 12.) (C) Coup d'œiln sur les significations mystiques des lettres de l'alphabet et sur leur 
emploi dans le but de connaitre l'avenir. Commencement:

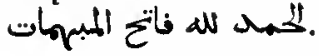

30 (Fol. 112.) Traité cabalistique, intitulé Explication de la signification des lettres qui sont les éléments dont se composent les mots dans les langues de tous les peuples $\%$.

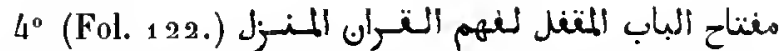
- La Clef qui ouvre la porte fermée et qui permet de comprendre le Coran révétén. Traité sur l'interprétation mystique du Coran.

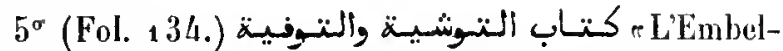
lissement et l'accomplissement t, traité mystique sur le caractère el sur l'objet du Coran.

6ºl. 146.) (Foldtache de la clef n, etc., supplément au traité intitulé le Miftâl.

$7^{\circ}$ (Fol. 176.) Recueil de maximes el de réflexions d'Al-1̣tirâli, publié probablement par un de ses diseiples.

$8^{\circ}$ (Fol. 188.) Sur le sens du mol tel qu'il est employé dans le Coran. Ms. daté de l'an $7^{21}$ de l'hégire (1321 de J. C.).

Papier. 197 feuillets. Hauteur, 17 centimètres et demi; largeur, 13 centimètres. 20 à 23 lignes par page. - (Ancien fonds 435.)

\section{9 .}

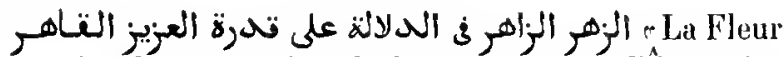
épanouie, démonstration de la puissance de l'Être trèsgrand qui domine tout", par Mlọammad ibn Molıanmad al-Dabsiyâinî (اللهبسيسياوى). Vingyt-qualre sections, suivies d'un épilogue. L'auteur parłe des mérites du Prophète, de la eréation des cieux el de la terre, des mois et des jours, de la prière, des vertus morales, des maladies, de la mort, de la naissance, elc. C'est un reeueil de traditions, de réeits édifiants el d'extraits en prose et

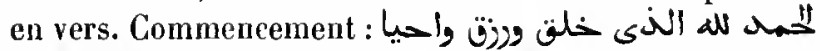
وأمات. Ms. daté de l'an 1109 de l'hégire (1697-1698 de J. C.).

Papier. 156 feuillets. Hauteur, 21 centimètres; largeur, 15 centimètres et demi. 23 lignes par page. - (Supplément $57^{2}$.)

\section{0 .}

rTrésor de mystères et pensées fécondantes", par Abou "Abd Allah Mohammad ibn Sacid

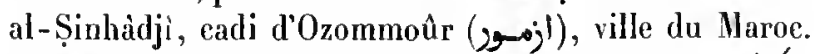
Lourrage est divisé en quatre sections, appelées اردكان "piliers", subdivisées en chapilres, فـصسول, et en para-

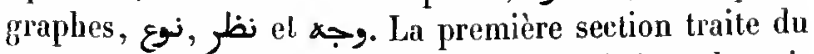
monde supérieur, la seconde du monde inférieur, la troisième de l'àge de l'homme, des ordonnances d'obligation (ألاحكام النكلينية), de la mort, de la sortie de làme du corps et de l'endroit qu'elle doit oceuper dans le Barzakh; la qualrième section est consacrée à la résurrection des morts, aux réeompenses et aux peines, elc.

Papier. 273 feuillets. Hauteur, 21 centimètres; largeur, 16 centimètres. 2 i ligues par page. Ms. du xv11 siècle. - (Supplément $5_{7} 6$. )

\section{1.}

Le Kanz al-Asrâr d'Al-Șinhàdji.

Papier. ${ }_{2} 37$ feuillets. Hauteur, 2 1 centimètres et demi; largeur, 15 centimètres et demi. 23 puis 21 lignes par page. Écritures diverses du xvi et du xvı" siècle. - (Supplément 577 .)

\section{2.}

Reeueil de traditions touchant la création d'Adam et d'Ève, leur expulsion du Paradis, l'histoire de Caïn et d'Abel, et autres matières de la mythologie musulmane.

Papier. 109 feuillets. Hauteur, 33 centimètres; largeur, a 1 centimètres. 17 à 21 lignes par page. Ms. d'écriture européenne du xvı1 siècle. - (Ancien fonds 371 .)

\section{3.}

Merveilles éclatautes, trailé sur les événements des siècles», ouvrage attribué au schaikh 'Abd Allah al-Başrì, commenģant par ces

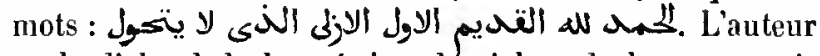
parle d'abord de la création du ciel et de la terre, puis il traite des fleuves, du Nil, du phare d'Alexandrie, de la colonne de Sévère, ete. Il passe eusuite à l'histoire d'Adam, des patriarches, de Salomon, de Dsoû 1-Qarnaïn, de Jonas, de Jean, fils de Zacharie, de la vierge Marie, de Jésus, de l'Antéchrist, de Mahomet, des merreilles de I'Égypte, ete.

Ms. daté de l'an 1154 de l'hégire (1 74 1 de J. C.).

Papier. 200 feuillets. Hauteur, a centimètres; largeur, 15 centimètres. 21 lignes par page. - (Supplément 573.) 


\section{4.}

Histoire du monde, depuis la création jusqu'à la mort d'Adam. Recueil de légendes attribuées à Wahb ibn Monabbih, Ka`b al-Aḷbâr, et autres traditionnistes de la même école.

Papier. 2a feuillets. Ilauteur, 21 centimètres; largeur, 13 centimètres et demi. 15 lignes par page. Ms. du xwy siècle. - (Supplément 2053.)

\section{5.}

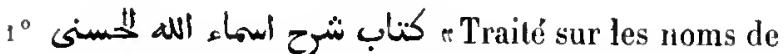
Dieu", par A ḥmad al-... Dans la préface, l'ouvrage est

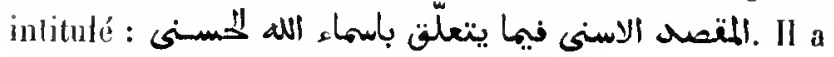
été composé en 1170 de thégire.

$2^{\circ}$ (Fol. 61.) Traité sur les noms de Dieu, par Ghazàli.

Is. dalé de l'an 1180 de l'hégire $\left(17^{6} 7\right.$ de J. C. $)$.

Papier. 136 feuillets. Hauteur, 22 centimètres; largeur, 16 centimètres. 21 lignes par page. - (Supplément 2438.)

\section{CROYAYCES IIÉTÉRODOXES.}

\section{6.}

rLes Religions et les sectesn, par Schahrastânî. Cet ouvrage a élé publié par Cureton, et Iraduit en allemand par Haarbrücker. Ms. daté de l'an $9^{6} 7$ de l'hégire (1 560 de J. C.).

Papjer. 182 feuillels. Hauteur, 25 centimètres et demi; largeur, 18 centimètres el demi. 21 lignes par page. - (Supplément 277.0)

\section{7.}

\section{Ie لsill, Mo de Schahrastâni.}

Papier. 242 feuillets. Hauteur, 23 centimètres et demi; largeur, 16 centimètres. as lignes par page. IIs. du xvir' siècle. - (Suppléinent 278.)

\section{8.}

Écrits sacrés des Druzes. Prenier volume, contenant les Iraités suivants :

$$
\begin{aligned}
& \text { ميلاد مولانا لماكم جلّ ذكره (.Fol. 2. }
\end{aligned}
$$

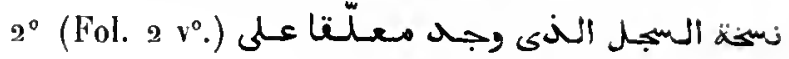

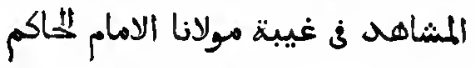

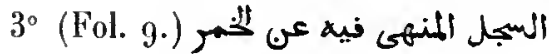

خبر اليهود والنصارى (Fol 10.00

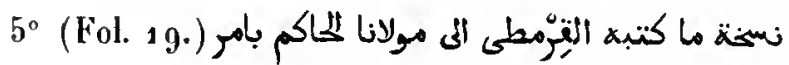

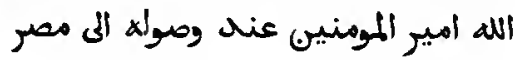

6اجابه سلأفه علينl (Fol. Ibid.)

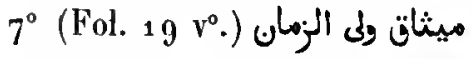

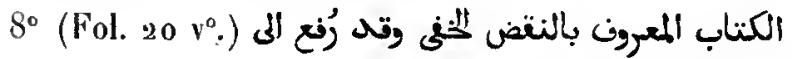

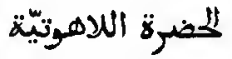

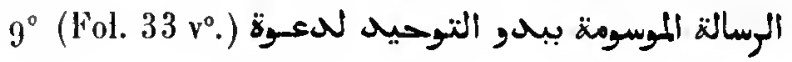
랄

$10^{\circ}$ ميثاتً النساء (Fol. 38.

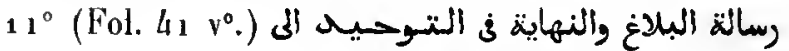

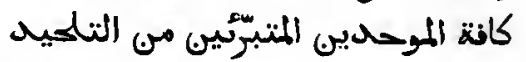

$12^{\circ}$ (Fol. 50. الغاية والنصبكة

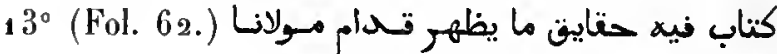

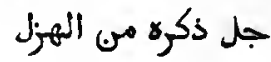

$14^{\circ}$ (Fol. 74.) السيرة المستبعهمة

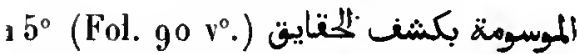

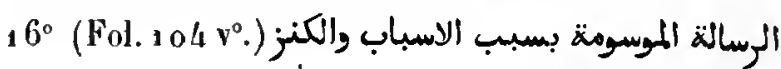
لمث أيقن واستخجاب الموسوة

Points-voyelles; les têtes des paragraphes sont à l'encre rouge, et les titres en lettres d'or; les textes des fol. $2 \mathrm{j}^{\circ}$ et $3 \mathrm{r}^{\circ}$ sont encadrés dans un filet d'or.

Papier. 119 feuillets. Hauteur, 21 centimètres; largeur, 15 centimètres. 15 lignes par page. Ms. du xvi siècle. - (Ancien fonds 1580.)

\section{9.}

Les quatorze premiers traités des écrits sacrés des Druzes.

Ms. daté de l'an 1084 de l'hégire $(1673$ de J. C.).

Papier. 121 feuillets. Hauteur, 22 centimètres; largeur, 15 centimètres. 13 lignes par page. - (Supplément 1993.) 


\section{0.}

Premier volume des écrits sacrés des Druzes.

Papier. 106 feuillets. Hauteur, 21 centimètres; largeur, 15 centimètres. 15 lignes par page. Ms. du xvı" siècle. - (Supplément 2421 .)

\section{1.}

Les quatorze premiers traités des écrits sacrés des Druzes.

Papier. 129 feuillets, en y comprenant un feuillet de garde. Hauteur, 22 centimètres; largeur, 16 centimètres. 15 lignes par page, et 13 lignes à partir du fol. 40. Ms. du xvill siècle. - (Supplément 200o.)

\section{2.}

Écrits sacrés des Druzes. Ce volume renferme les traités suivants :

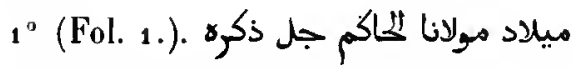

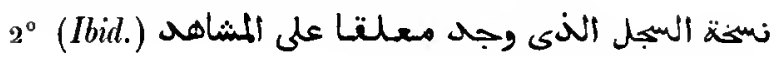

$$
\begin{aligned}
& \text { ف غيبة مولانا اللامام كلاكم }
\end{aligned}
$$

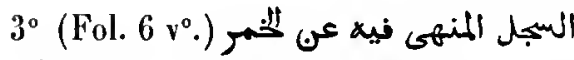

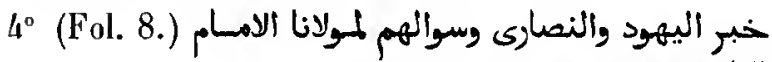

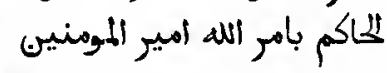

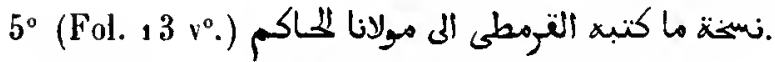

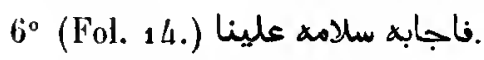

$7^{\circ}$ (Ibid.) ميثات ولى الزمان

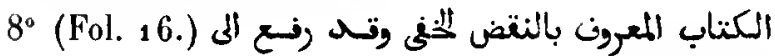
للاضرة الالهوية

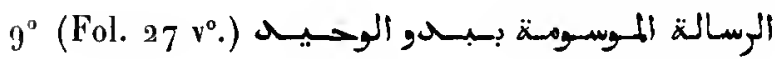

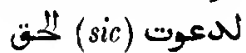

$10^{\circ}$ (Fol. 32.) ميثات الننساء

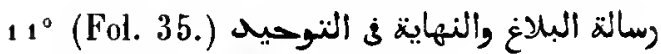

$12^{\circ}$ Fol. 43. الغاية والنصبه

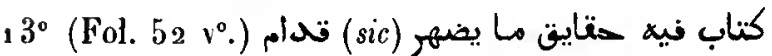

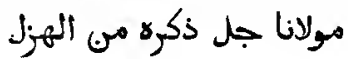

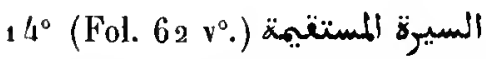

$15^{\circ}$ (Fol. 77 v . الموسومة بكنف لإنقايقن

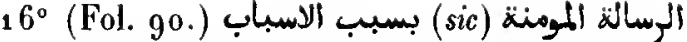

Papier. 1 oo feuillets. Hauteur, a3 centimètres et demi; largeur, 16 centimètres et demi. 16 lignes par page. Ms. du xix siècle. - (Supplément 27 ter.)

\section{3.}

Les traités $5,7,8$ et 13 des écrits sacrés des Druzes.

Papier. 26 feuillets. Hauteur, 21 centimètres; largeur, 15 centimètres. 13 à 14 lignes jar page. Ms. dı xvı" siède. - (Supplément 1999.)

\section{4.}

Écrits sacrés des Druzes. Ce volume renferme les traités suivants :

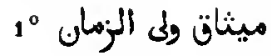

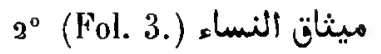

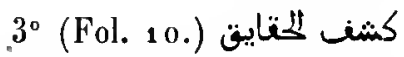

Papier. 37 feuillets. Ilantenr, 15 centimèlres; largeur, 11 centimètres. 11 lignes par page. Ms. du xv11" siècle. - (Supplément 271 bis.)

\section{5.}

Second rolume des écrits sacrés des Druzes :

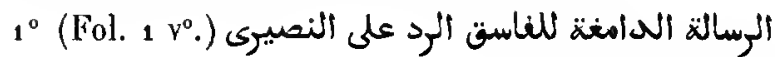
لعنx اللولى

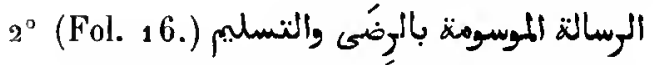

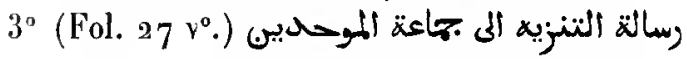

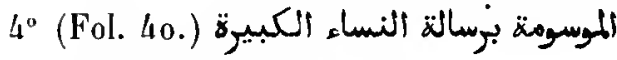

50 الصُبكتة الكاينة (Fol. 49.

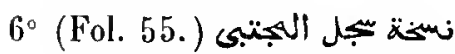

تقنليد الرضَى سفير اللُّدرة (56. Fol.

تنقليد المتتننى (Fol. 61.

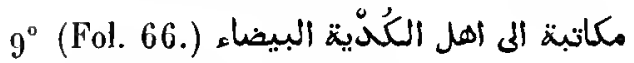

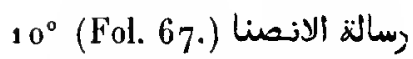

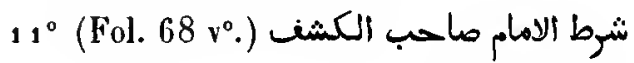

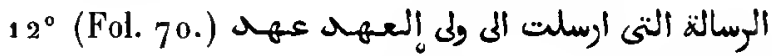

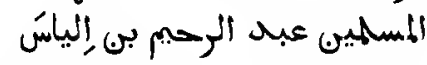

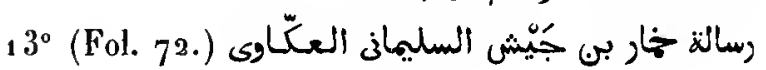


المسالة المنفخد الم القاضى (Fol. 74.

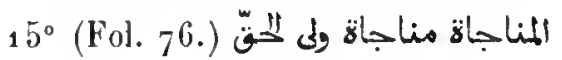

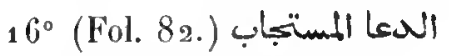

التتنديس دعا السادقين (Fol. 86.

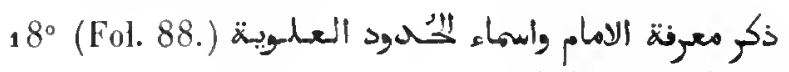
روحانيّا وجسمانيّا

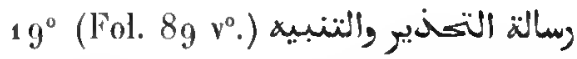

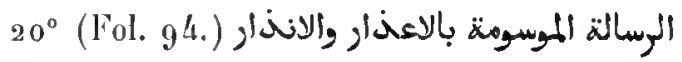

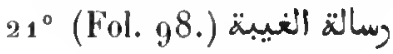

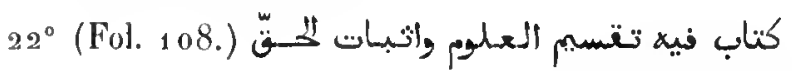

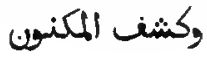

الموسومة برسالة الزناد (Fol. 123.

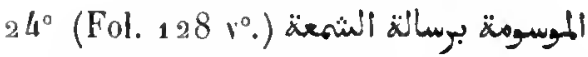

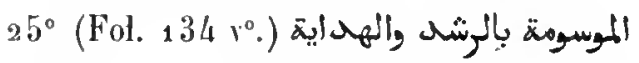

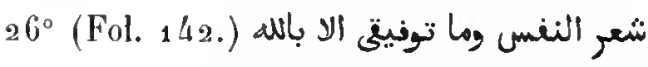

Titres ornés; gloses marginales et interlinéaires à l'encre rouge.

Papier. 143 feuillets. Hauteur, 20 centimètres et demi; largeur, 15 centimètres et demi. 11 lignes par page. Ms. du $x \mathbf{v}^{\circ}$ siècle. (Ancien fonds 1581.)

\section{6.}

Second rolume des écrits sacrés des Druzes. Mls. renfermant les mêmes pièces que le précédent.

Papier. 136 feuillets. Hauteur, 16 centimètres; largeur, 10 centimètres et demi. 13 à 15 lignes par page. Ms. de plusieurs écrilures, dont la plus ancienne paraît être du $x v^{\circ}$ siècle. - (Supplément 271.)

\section{7.}

Second volume des écrits sacrés des Druzes. Ms. renfermant les mêmes pièces que les deux précédents.

Texte arec les voyelles, accompagné de notes, points et sigles à l'encre rouge.

Papier. 105 feuillets. Hauteur, 21 centimètres et demi; largeur, 15 centimètres. 3 lignes par page. Ms. du xvi siècle. - (Supplément 273. )

\section{8.}

Second volume des écrits sacrés des Druzes, et les sept

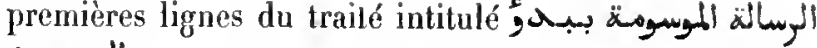

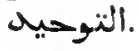

Papier. 123 feuillets. Hauteur, 16 centimètres et demi; largeur, 13 centimètres. 13 lignes par page. Ms. du $x_{n} 1^{\circ}$ siècle; un certain nombre de feuillets sont plus modernes. - (Supplément 1997.)

\section{9.}

Second volume des écrits sacrés des Druzes :

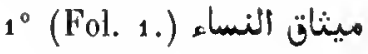

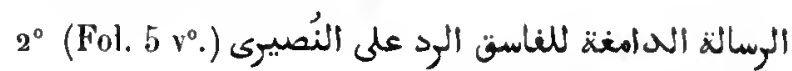

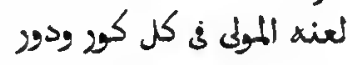

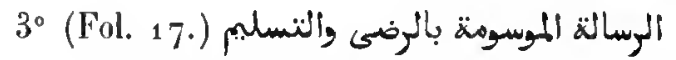

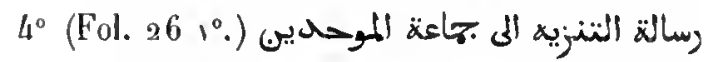

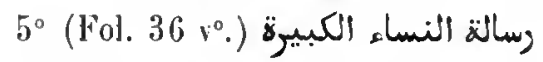

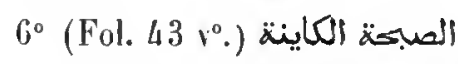

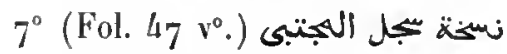

نسية تقليد المتتنى (Fol. 53.

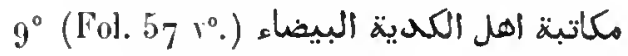

وسالة الانصنا (Fol. 58.

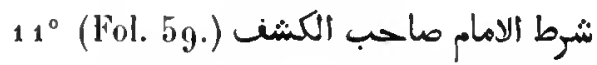

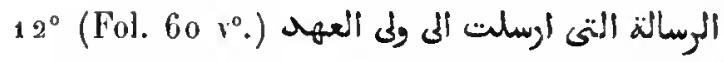

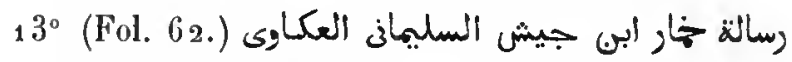

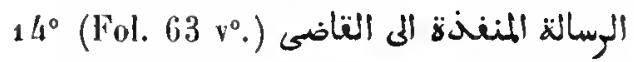

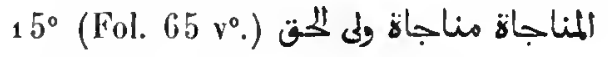

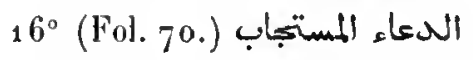

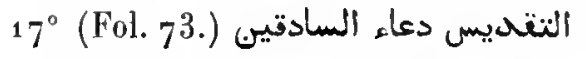

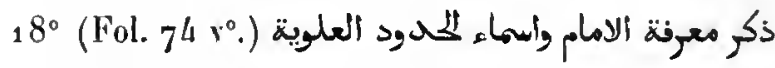

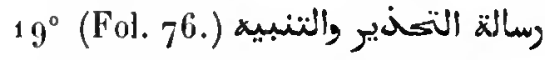

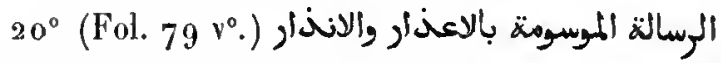

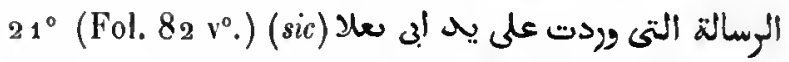

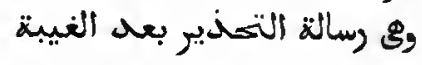

$22^{\circ}$ (Fol. 90 ن

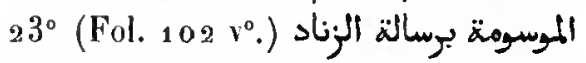

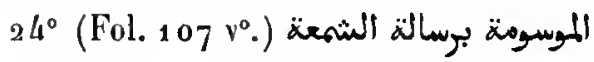

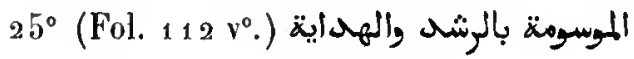

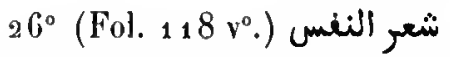

Papier. 120 feuillets. Hauteur, 21 centimètres; largeur, 16 centimètres. 13 lignes par page. Ms. du xrr1" siècle. - (Supplément ${ }_{7} 5$ ter.) 


\section{0.}

Second volume des écrits sacrés des Druzes, renfermant les mêmes traités que le $n^{\circ} 1415$.

Texte pourvu des points-voyelles.

Papier. 1 og feuillets. Hautenr, 20 centimètres et demi; largeur, 15 centimètres. 13 lignes par page. Ms. du xvi̊ siècle. - (Supplément 370. .)

\section{1.}

Second volume des écrits sacrés des Druzes, renfermant les mêmes pièces que le numéro précédent.

Au fol. $103 \gamma^{\circ}$ commence une pièce d'une autre ćcriture que celle de l'ouvrage, portant le titre de réfutation des partisans de la doclrine allégoriquen.

Papier. 106 feuillets. Hauteur, 21 centimètres; largeur, 15 centimètres. 15 lignes par page. Ms. du xvie siècle. - (Supplément 270 bis.)

\section{2.}

Second volume des écrits sacrés des Druzes. Exemplaire daté de l'an 1238 de l'hégire (1822-1823 de J. C.). Texte entouré de trois trajts, rouge, vert et rouge; frontispice orné de figures circulaires en or el en couleurs. Au recto du premier feuillet se lrouve la liste des traités; cette page est très-ornée; le verso du dernjer leuillet porte la date, entourée d'une figure géométrique en or et en couleurs. Au fol. $111 \mathrm{r}^{\circ}$ on remarque un titre très-orné.

Papier. 113 feuillets. Hauteur, 21 centimètres; largeur, 16 centimètres. 3 lignes par page. - (Supplément 1998.)

\section{3.}

Second volume des écrits sacrés des Druzes. Cet exemplaire renferme les traités qui, dans l'Exposé de la religion des Druzes de M. de Sacy (1. II, préface, p. ccccoxvi et sujv.), sont énumérés sous les numéros XV à XXXVIII.

Papier. 99 feuillets. Hauteur, 22 centimètres; largeur, 15 centimètres et demi. 13 lignes par page. Ms. du xvir siècle. - (Supplément 1995.)

\section{4.}

Traités rassemblés pour l'instruction des Druzes, for- mant le premier des sept volumes que l'auteur, obéissant aux ordres de Qaïm al-Zamân (Hamza), avait entrepris de composer. Après la préface, qui se termine par une longue exhortation aux fidiles, on trouve les pièces suirantes :

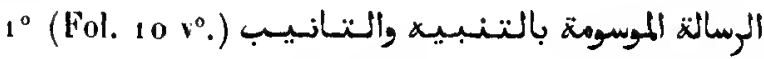
والتبوبيز

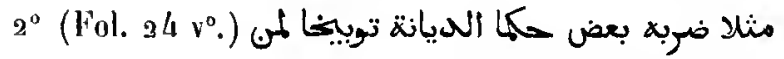

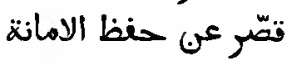

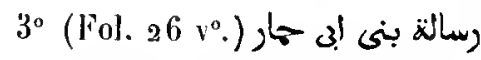

تقليد لاحق التقليد الاول (Fol. 30 (

تقليد سُكُيه (Fol. 33.

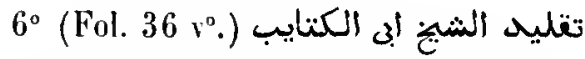

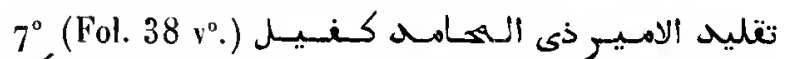

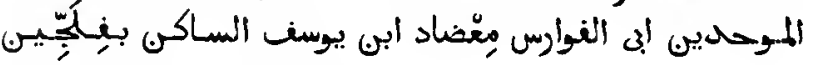

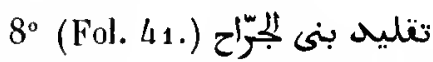

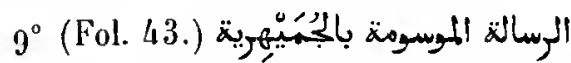

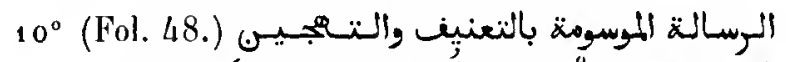

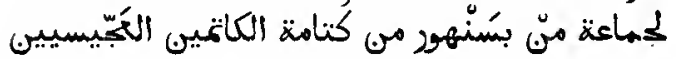

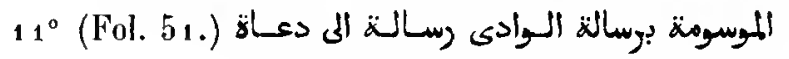

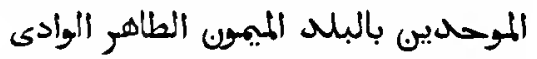

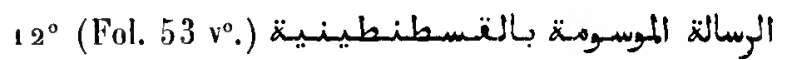

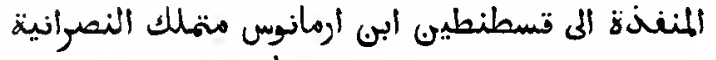

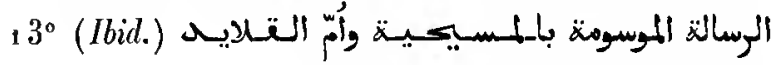
المنسكية وقامعة العقايد النثركية الموسية

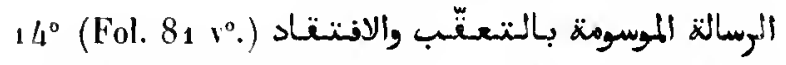

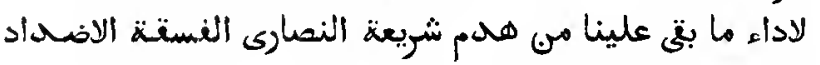

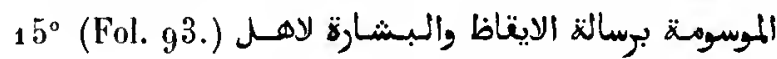

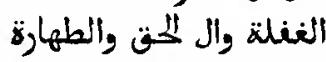

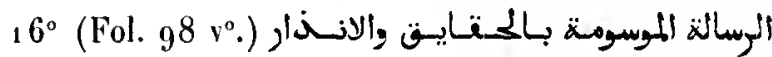

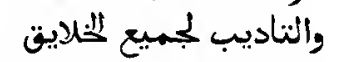

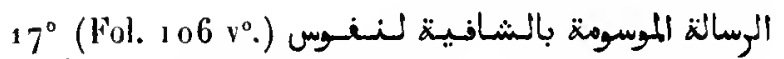

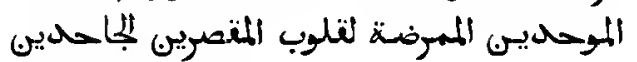

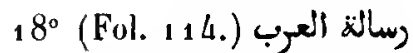

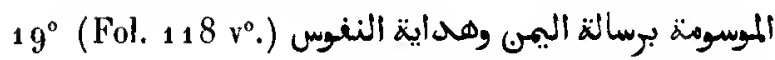

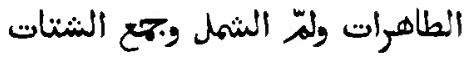

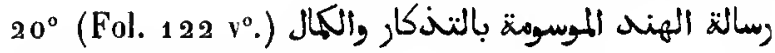

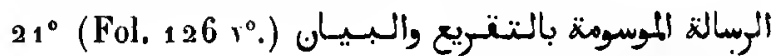
وأقامة المجة لولى الزمأن لموسن 


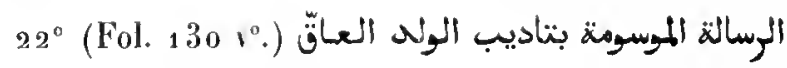
من. اللاولاد

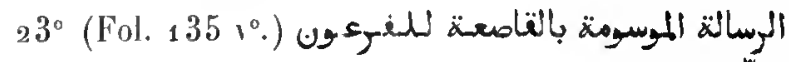
टी हुँ

$24^{\circ}$ (Fol. 140 v $^{\circ}$ )

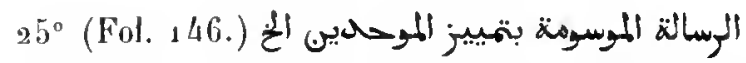

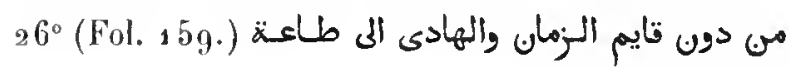
الرجمن

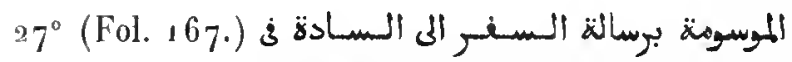

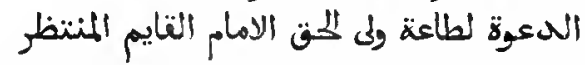

Les titres des épîtres sonl écrits en or et en couleurs, les têtes des paragraphes à l'encre rouge; les passages en prose riméc sont divisés par des fleurons en or et en couleurs, ou par des ronds de couteur bieue.

Papier. 177 feuillets. Hauteur, 21 centimètres; largeur, $1 /$ centimètres et demi. 15 lignes par page. Ms. du xvie siècle. - (Supplément 274 bis.)

\section{5 .}

Les écrits sacrés des Druzes. Volume renfermant les mèmes trailés que le numéro précédent.

Papier. 396 Ceuillets. Hauteur, a) centimètres; largeur, 16 centimètres. 25 lignes par page. Ms. du xvi1 siècle. - (Supplément 275.)

\section{6.}

Les écrits sacrés des Druzes. Cie sont les traités qui, dans l'Exposé de la religion des Druzes, sont énumérés sous les numéros XLI à LXVIII. Les premiers feuillets manquent.

Papier. 138 fenillets. Hauteur, zo centimètres et demi; largeur, 15 centimètres. 15 lignes par page. Ms. de diverses mains du xvu siècle. - (Supplément 1996.)

\section{7.}

Eerits sacrés des Druzes:

$1^{\circ}$ (Fol. a.) Traité, sans titre, commençant par ces

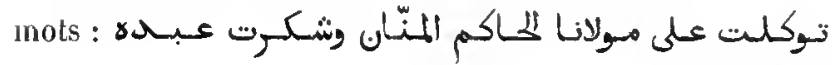
قايم الزمان.

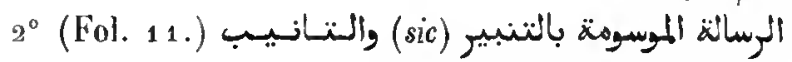
والنتوبيخ والنتوقيف (sie)
30

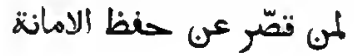

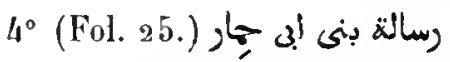

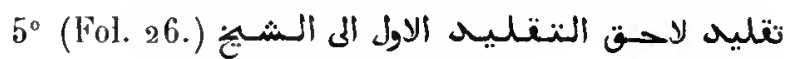

تقليح سكين (Fol. 31.

اللهنتار

$7^{\circ}$ (Fol. 34 vo.) تقليد النشيخ إق الكثنايب.

تنليد الامير ذى النحامد كفيل الموحلين (Fol. 36.

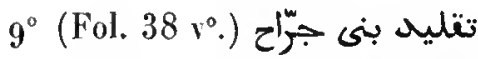

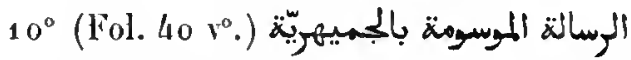

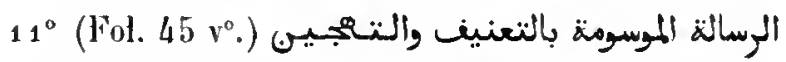

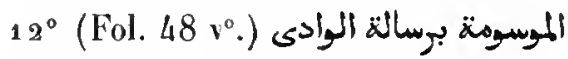

الرسالة الموسومة بالقسطنطينية (Fol. 52 v

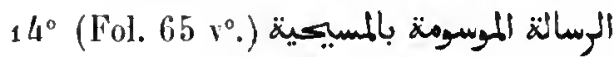

الكسالة ألموسوهة بالتعتب والافتنتاد (Fol. 77

Les deux derniers feuillets conljennent une note sur les trente limites (sic) ذكر الثناثيى. Le traité nº 1 est de la main de Pétis de la Croix; quelques feuillets perdus ont été rélablis par le même orieutaliste.

Papier. 89 feuiflets. Hauteur, 21 centimètres et demi; largeur, 15 centimètres et demi. 15 lignes par page. La parlie ancienne du ms. est du $\mathbf{x v}^{*}$ siècle. - (Ancien fonds 1583.)

\section{8 .}

Les écrits sacrés des Druzes. Ce sont les traités XLI à $\mathrm{LV}$.

Papier. 109 feuillets. Hauteur, 22 centimètres; largeur, 16 centimètres et demi. 13 lignes par page. Hs. du xvin siècle. - (Supplément $199^{4}$.)

\section{9 .}

Écrits sacrés des Druzes:

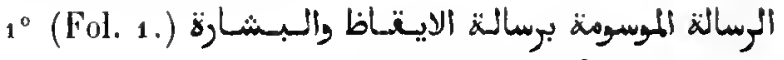

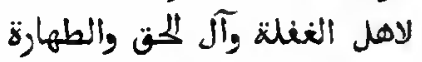

المرسالة الموسووة بالكتايق والانفار والتناديسب (601.6.

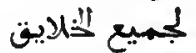

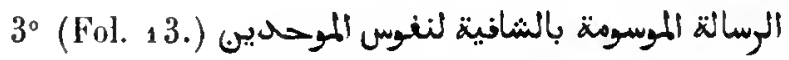

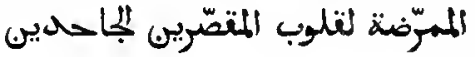




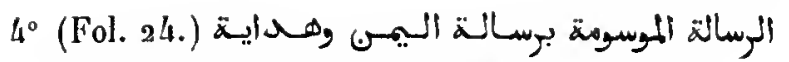

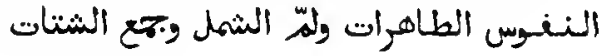

50. 28. (Fol. 28)

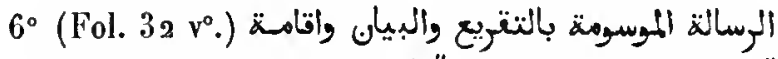

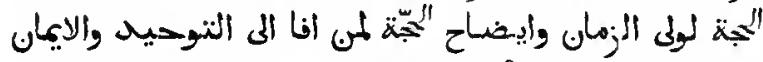

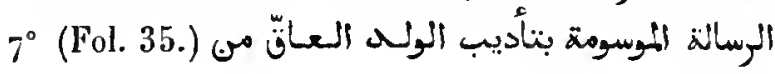
الاولاد

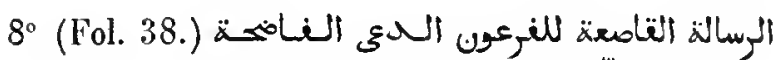

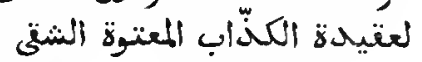

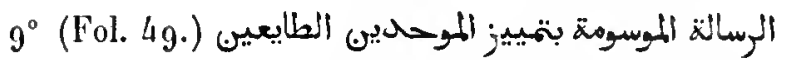
من حزب العصاه الفستة الناكثين

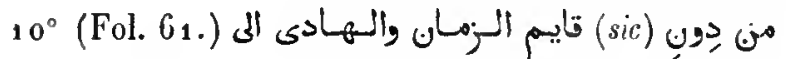
طاعة التوكى دون

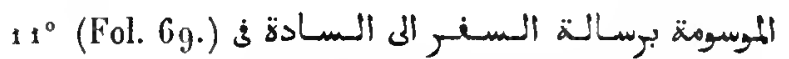

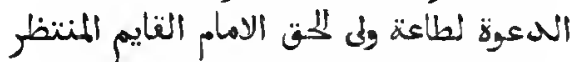

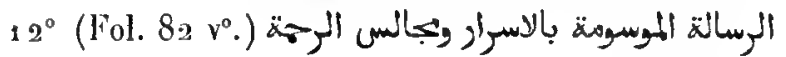

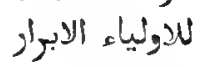

${ }_{13}^{\circ}$ (Fol. $88 v^{\circ}$.) Les trois premières liggues du traité

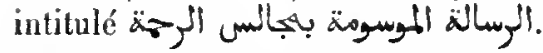

On a inséré, à la suite du fol. 79 , une gravure représentant I'rémir Fechrredin, prince des Druses ${ }^{2}$.

Papier. 88 feuillets, dont les 78 premiers sont de la main de Pétis de la Croix, copiés sur un ms. «donné aux RR. PP. dominicains par le $\mathrm{D}^{\mathrm{r}} \mathrm{Pic}(\mathrm{sic})$ r. Les folios 82 et siiv. sont d'une main orientale du sv siècle. Hauteur, 31 centimètres; largeur, 15 centimètres. 15 lignes par page. - (Ancien fonds 1583.)

\section{0.}

Écrits sacrés des Druzes :

الموسومة دسالة الايتاظ والبيان (sic) لالهل (Fol. 2 vo

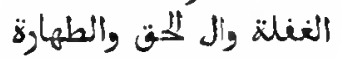

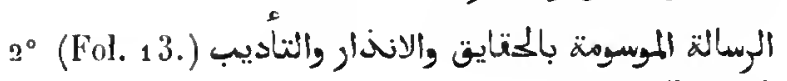

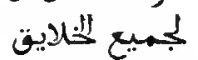

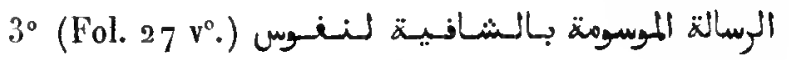

40 (Fol. 41.) وسالة العرب

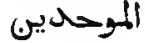

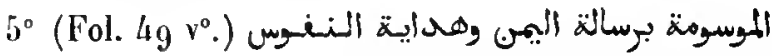

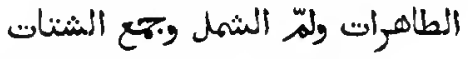

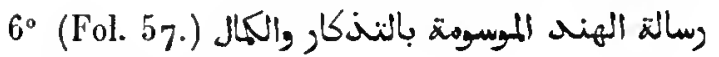

MAv. ORIERTaLT. - HI.
7 الرسالة الموسومة بالتتريع والبيان، واتـامـة (Fol. 64 vo

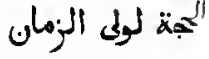

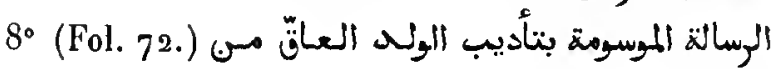
الاولاد المساد

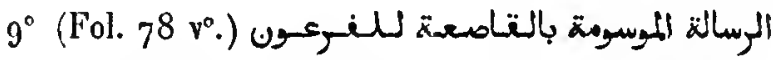

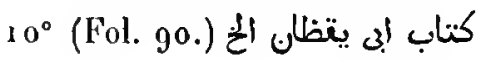
है।

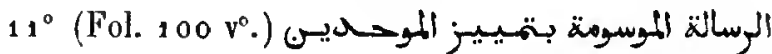

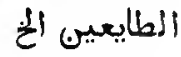

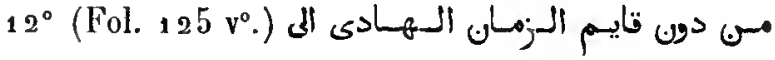
طاعة الرمت دايتم

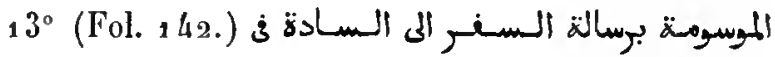
لُ

Le texte est accompagné des voyelles. Notes à l'encre rouge.

Papier. ${ }_{162}$ feujllets. Hauteur, 15 centimètres et demi; largeur, 11 centimètres. 11 lignes par page. Ms. du xv siècle. - (Supplément $27^{4}$.)

\section{1.}

Écrils sacrés des Druzes. Ce sont les traités LVH à LXVIII. Quelques gloses marginales.

Papier. 79 feuillets. lJauteur, 20 centimètres et demi ; largenr, 15 centimètres. 13 lignes par page, et 14 lignes à partir du fol. 38 . Hs. du $\mathrm{xrr}^{\circ}$ siècle. - (Supplément 1993.)

\section{2.}

Écrits sacrés des Druzes :

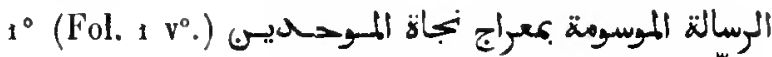
وسمي حياز الموتنيق

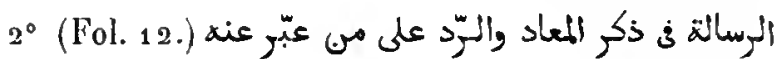
بالغلط والالحاد

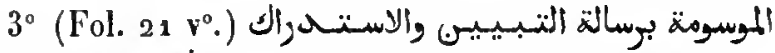

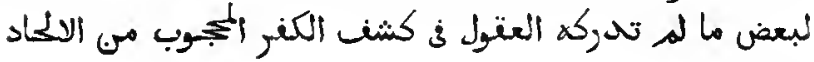
والانشراك

المسالة المموسومة بالاسرايلية الصأمغة لاهلـ (Fol. 32.

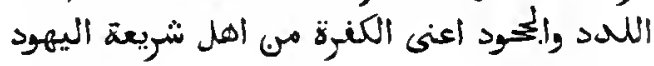

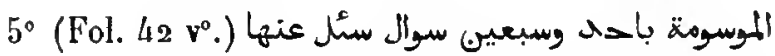

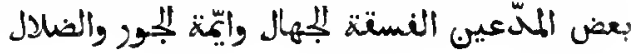




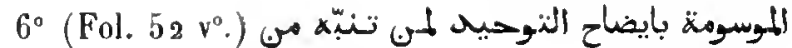

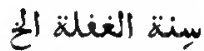

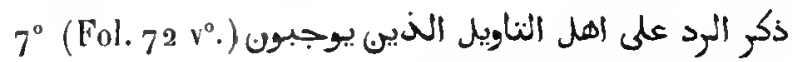

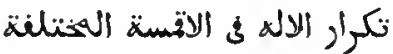

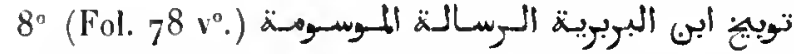

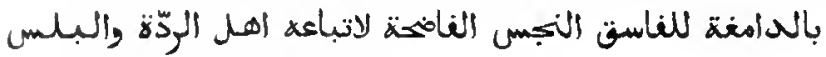
$9^{\circ}$ توبيز لاحتن (Fol. 88.

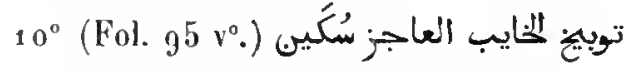

11 توبيز أبر لبه حصيّة (Fol. 110.

$12^{\circ}$ توبيج سهل (Fol. 118.

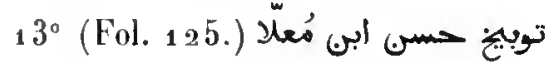

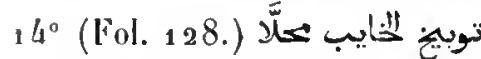

15 وسالة البنات المكبيرة (33. 1301 (Fol

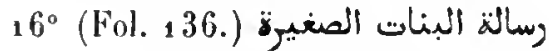

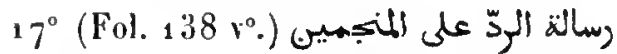

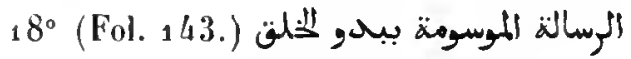

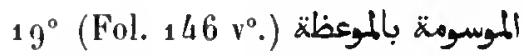

$20^{\circ}$ (Fol. $148 v^{\circ}$ )

$21^{\circ}$ (Fol. 149 vo.) كاتبة المسنسية أب الكتنايب

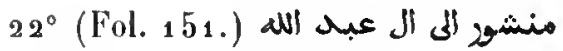

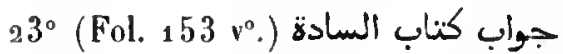

إكتاب المنفخ على يح سرأيا (Fol. 155.

$25^{\circ}$ (Fol. 157 vo.)

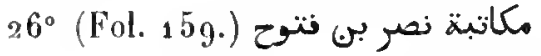

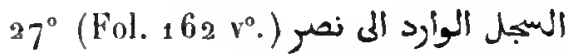

$28^{\circ}$ (Fol. $163 v^{\circ}$.

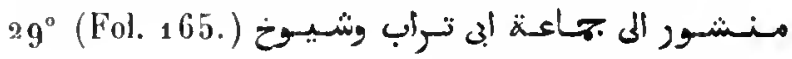
المراضع مهر ألاهل والامهاب

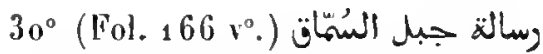

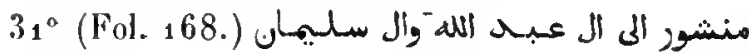

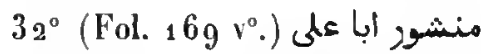

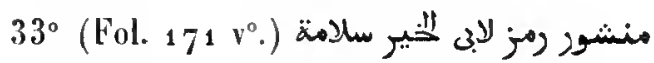

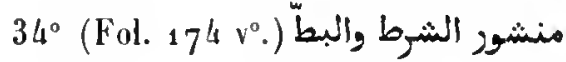

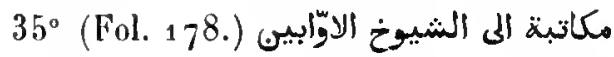

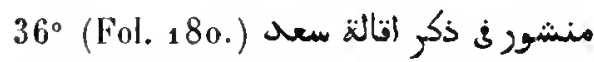

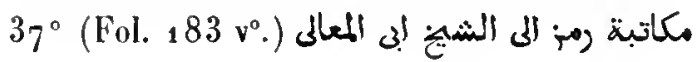

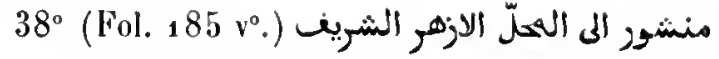

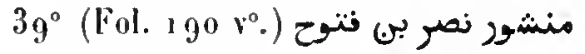

$40^{\circ}$ (Fol. 19 4.

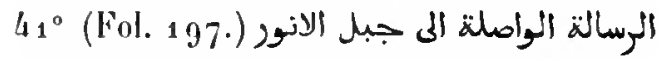

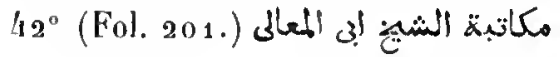

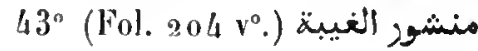

C'est le même recueil que celui dont $S$. de Sacy a donné la liste des chapitres dans son Exposé de l'histoire des Druzes, p. ccccxcvil el suiv. Quelques notes marginales et interlinéaires ì l'encre rouge.

Papier. 206 fenillets. Hauteur, 22 centimètres; largeur, 15 centimètres. 15 lignes par page dans la première partie, 13 lignes dans la seconde. Ms. du xvi" siècle. - (Supplément 272.)

\section{3.}

Écrits sacrés des Druzes. Ce volume renfirme les pièces 78 à 123 de la liste de M. de Sacy.

Papier. 13, fenillets. Hauteur, 18 centimètres; largeur, 14 centimètres. 13 lignes par page. Ms. du xrü siècle. - (Supplément 1990.)

\section{4.}

Écrits sacrés des Druzes. Ce volume renferme les mènes pièces que le précédent.

Papier. 109 feuillets. Ilauteur, 22 centimètres; largeur, 15 centimètres et demi. 15 lignes par page. Ms. du rvı siècle. - (Supplément 1991.)

\section{5.}

Écrits sacrés des Druzes :

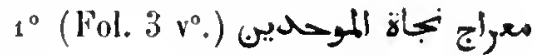

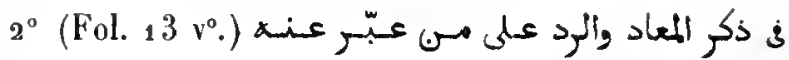
بالغلظ والالحاد

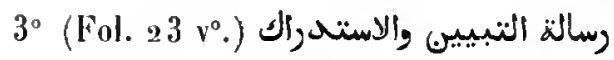

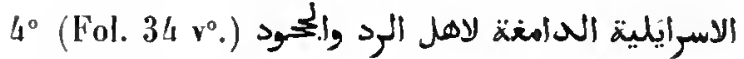

50 Fol. 45. (5موسومة باحه وسبعيى سوال

60 (Fol. 54 vo..) ايضاح التوحيد

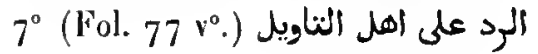


Les deux premiers feuillets contiennent une pièce intitulée les Facultés de l'intellect»; les deux derniers une prière ou invocation, suivie d'une litanie.

Texte accompagné de toutes les voyelles. Nombreuses notes inarginales à l'encre rouge.

Papier. 83 feuillets. Hanteur, a t centimètres ef demi; largeur, 15 centimètres et demi. 15 . lignes par page. Ms. du $\mathrm{xri}^{*}$ siècle. (Supplément 272 bis.)

\section{6.}

Commentaire sur le cinquième traité des écrits sacrés des Druzes, intitulé ميثاق وله ألزمان el'ormule d'engagement envers le lieutenant de ce sièclen.

Papier. $7^{8}$ feuillets. Hauteur, 15 centimètres; largeur, 10 centimètres el demi. 13 tignes par page. Mts. du xvur siècle. - (Supplément 2002.)

\section{7.}

$1^{\circ}$ Commentaire sur le cinquième traité des écrits sacrés des Druzes. Même ouvrage que le précédent. Les premiers feuillets manquent.

$2^{\circ}$ (Fol. $55 v^{\circ}$.) Le soixante-sixième traité des écrits sacrés des Druzes.

Papier. 56 feuiflets. Hauteur, 17 centimétres et demi; largeur, 13 centimètres. 13 lignes par page. Ms. du xvil' siècle. - (Supplément 2002.)

\section{8.}

Commentaire ou discours moral qui parait se rapporter au premier paragraphe du cinquième traité des écrits sacrés des Druzes. Commencement : $\ddot{a} \rightarrow$

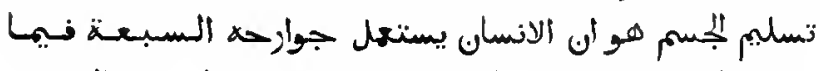

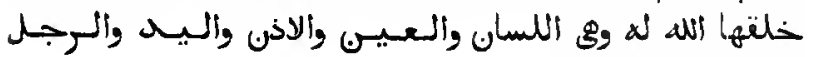

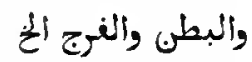

Papier. 133 feuilfets. Hauteur, 15 centimètres; fargeur, 10 centimètres el demi. 1 lignes par page. Ms. du xru' siècle. - (Supplément 2003.)

\section{9 .}

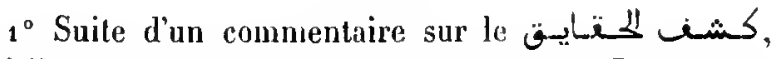
treizième traité des écrits sacrés des Druzes. Le premier passage commenté est le suivant : ثم نرجيع للمرون ومانبها

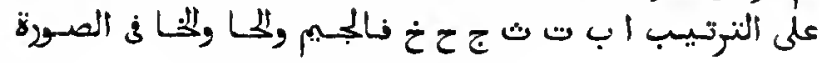

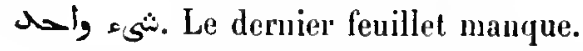

$2^{\circ}$ (Fol. 6g.) Commentaire sur une pièce dont les premiers mats paraissent être : . . . .

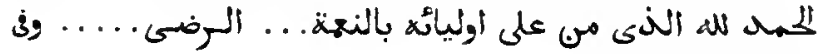
حتائن ألهزل

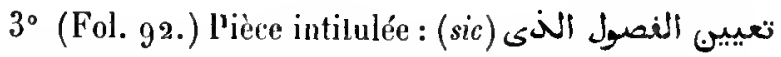

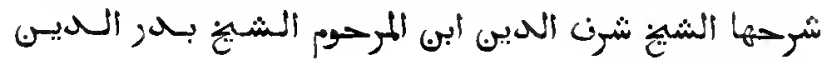
وهو دون المبلوغ

$4^{\circ}$ (Fol, 1 oo.) Prière attribuée au schaikh al-Faddlil.

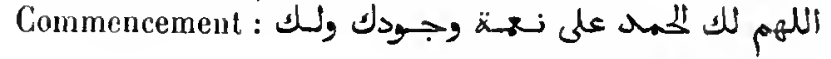

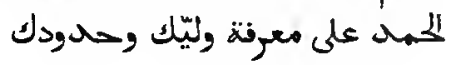

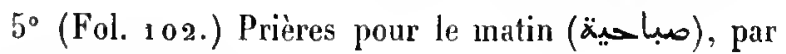
le mème docteur.

$6^{\circ}\left(F_{01} .105 v^{\circ}.\right)$ Prière à l'éciter sur un néopliyte, afin de le garantir contre linfluence du mauvais œil.

$7^{\circ}\left(\right.$ Fol. $106 \mathrm{v}^{\circ}$.) Gloses sur quelques passages des écrits sacrés des Druzes.

$8^{\circ}$ (Fol. 109.) Énumération des cinquante-quatre choses qu'on est obligé de connaitre.

$9^{\circ}$ (Fol. 114 .) Poème et morceiux divers.

$10^{\circ}$ (Fol. 121.) Notice incomplète sur les principaux ministres $(>, ح)$ ) de la secte druze.

$11^{\circ}$ (Fol. 127.$)$ Mérites du Sayyid al-Amír.

$12^{\circ}$ (Fol. 131.) Anecdotes touchant le schaïkh Aboû Hilâl, mort en 1050 de l'hégirc (1 640 de J. C.).

Papier. 132 feuillets. Hauteur, 15 centimètres ef demi; largeur,

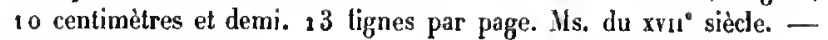
(Supplénent 2004.)

\section{0.}

Exposé de la religion des Druzes, commençant (fol. 3) par une liste de passages lirés du Pentateuque, des Psaumes, des Évangiles et du Coran, et devant servir à établir la vérité des doctrines druzes. Ces passages sout suivis d'un commentaire très-délaillé d'un paragraplıc du 吾 depuis le fol. $9^{\circ} \mathrm{v}^{\circ}$, ligne 13 , jusquau fol. $9^{1}$, ligne 7 ). L'auteur donne ensuite (fol. 19) l'interprétation allégorique du premies passage du Pentateuque et l'explique, ainsi que tous les autres, comme étant la parole mème 
de la Divinité qui, płns tard, s'est incarnéc dans Al-Hâkim. Cet ouvrage a été composé en 408 de l'hégire ( 1011 7-1018 de J. C.). Sur les trois premières pages laissées en blanc, le copiste du ms. a écrif quelques renseignements à l'usage des illeltrés d'entre les Druzes.

Papier. $9^{6}$ feuillets. Hauteur, 18 centimètres et demi; largeur, 13 centimètres et demi. 13 lignes par page. $\mathrm{Hs}$. du xwi siède. - (Supplément 268 bis.)

\section{1.}

Exposé de ła religion des Druzes, intilulé ( Exposilion abrégée du cours du temps \#. C'est un traité de théologic scolaslique de la secte des Druzes, commençant par ces mols : على عa substifution du sin au sad dans le mol متسفر indique que l'anteur lui-mêne appartenait à cette secte. Trois pages qui étaient restées en blanc au commencement du volume, porlent maintenant un traité

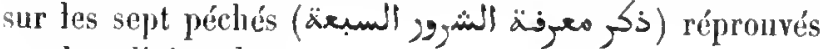
par la religion druze.

Papier. 79 feuillets. Hauteur, 18 centimèlres; largeur, 14 centjmètres. 13 lignes par page. Ms. du xri siécle. - (Supplément 272 ter.)

\section{2.}

Hème ouvrage. Le premier feuillel de cet exemplaire manque. A la fu du volume, on a inséré deux pièces,

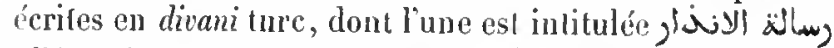

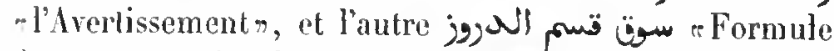
du scrment usité chez les Druzes ᄁ. Hs. daté de l'an 1053 de t'hégrine (1 644 de J. C.).

Papier. 139 feuillets. İlauteur, 15 centimètres et demi; largeur, 10 centimèlres et demi. 13 lignes par page. - (Supjuément 275 bis.)

\section{3.}

Abrégé du كنتصدر المبأن. L'auteur, qui s’intitule le prétre IIanna (التس (أنس ), médecin, a achevé son Iravail en 1807 de J. C. Cet exempłaire est de la main de Jean Varsy, savant orientaliste de Marseille, qui a terminé cette copie en 1852 , étant ałors àgé de soixante-dix-sept ans. Le texte de ce traité, accompagné d'une traduction francaise, a été publié à Paris, en 1863 , sous le titre de Théogonie des Druzes.

Papier. 45 feuillets. Hauteur, 21 centimetres; largeur, 13 centimètres. 3 lignes par page. - (Supplément 269 bis.)

\section{4.}

Catéchisme des Druzes, intitulé

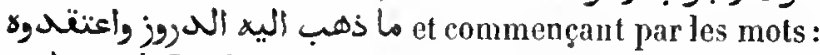
أدروزى أنت La dernière des réponses porte le.nº 104 , et finit ainsi : وباشاواتت (sic) أعحاب مناصب عاليه

Papier. 15 feuillets. Hauteur, 16 centimètres; Jargeur, 10 centimètres. 15 lignes par page. Ms. du xvi" siècle. - (Supplémenl 269. )

\section{5.}

Catéchisme des Druzes, copié sur le uns. précédent, à Paris (بان), par Denys Chaouch, prêtre maronite de Saint-Jean-d'Acre, professeur d'arabe ct interprète à ła Bibliothèque du roi.

Papier. 15 feuillets. Hauteur, 40 centimètres; largeur, 25 centimètres. 36 liggnes par page. Is. du xrm1 siècle. - (Supplément 268.)

\section{6.}

Catéchisme des Druzes.

Papier. 15 feuiltets. Hauleur, 20 centimètres; lorgeur, 13 cenlimètres. 13 lignes par page. Ms. du xux" siẻcle. - (Supplément 2005.)

\section{7.}

Catécliisme des Druzes.

Rouleaur de papier vert. Longueur, 6 mètres; fargeur, $1 / 4$ centimétres et demi. - (Supplément 2346.)

\section{8.}

Poème composé de plus de trois cents slances de ciny hémistiches. L’auteur, qui élait Druze, y parłe de la création dı monde et raconte l'histoire des patriarches et des prophètes, jusquà Mahomet, puis celte des Omayyades, des Abbasides el des Fatémites, jusqu'à Al-Hàkim.

IIs. daté de l'an 1168 de l'hégire (1 755 de J. C.).

Papier. 159 fenillets. Hauleur, 16 centimètres el demi; largeur, 11 centimètres. 11 lignes par page. - (Supplément 2006.) 


\section{9.}

Écrits sacrés de la secte des Nosaïriens.

1 م Ouvrage intitulé d'après l'auteur, ele livre du fondements, parce que, ditil, c'est la base de toules les comnaissances el l'exposé de la sagesse de Salomon, fils de David. Ce prophète, ayan reçu de Dieu l'ordre de composer le présent ourage, avait réuni les savants des quatre parties du nonde, et avait, d'après leurs conseils, lait composer d'abord un traité sur

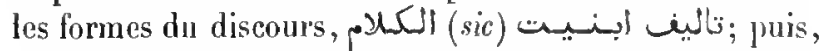
pour rédiger l'Asoûs, il arait choisi entre ces docteurs un seuł qui, en présence des autres, répondail à différentes questions relatives à la nature de Dien, à la malière inlorme, ì la création, aux anges, à lout ce qui est daus le ciel et sur la terre. Suit ce long dialogue, dans lequel le wis ou equestionneury formule les demandes, et le ste ou rsavant n donme les l'éponses. Le présent exemplaire a été copié à lias Baghlia? (xules), dépendance d'A-'Olaïna, chatcau forl silué sur le territoire de Safitai (صLn), qui fait partie dur liwa ou gouvernement de Tripoli (sأسلسu), en 1206 d'une hógire que le copiste appelte hétaïenme et molnammédane

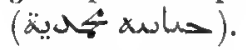

$2^{\circ}$ (Fol. 8o.) Deux pièces de ver's ì la louange d’hli, la première par le copiste de ce iolume, Yoúsol, fils du

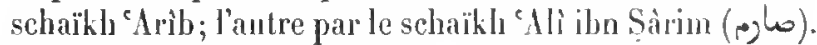

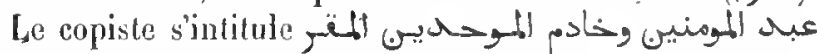

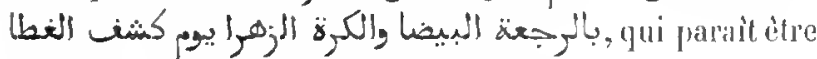
une formule particulière aux Nosainlieus.

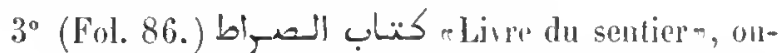
vragre composé par Al-Noliddlual iton 'Onar, rot transmis oralement (slg,) par le schaikh Aboù 'I-Jasan Mul!am-

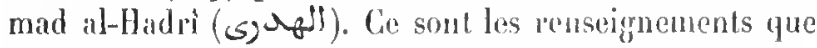
Al-Moladdhal avait recueillis de li houche de son maitre

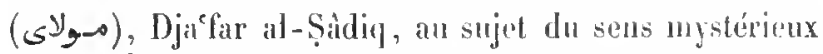
du mot w esentiers, et de quelques autros frrmes,

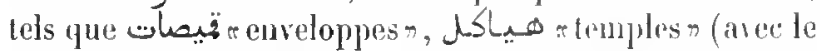
sens de corps ou figures), etc. Ce traité, de mêtme que le précédent, est très-olsscur et intelliqgible aux seuls initiés. Le copiste a daté son tratrail de la manière sni-

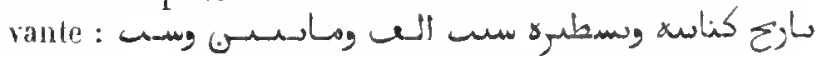

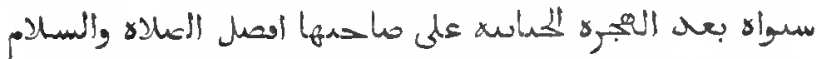
"Date de la transcription de ce volume: mille deux cent six ans après l'hégrire látiöenue (?), sur l'anteur de laquelle soit la bénédiction at le salut». La mème ère est employée dans le volume suivant. Nombreuses fautes d'orthographe et do grammaire.

Papier. 182 feuiflets. Hauteur, 21 centimètros et demi; largeur,
16 centimètres. 13 à 16 liggnes par page. Ms. du xvu* siècle. - (Supplément $275 \mathrm{D}$.)

\section{0.}

Écrits sacrés des Nosaïriens.

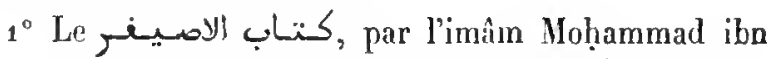

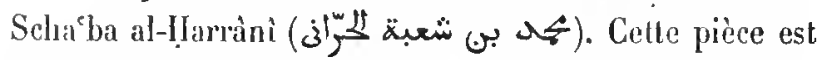
datée de l'an 1208 de l'hégire prophétique luétaienne (x)

$2^{\circ}$ (Fol. 42.) Traité sur la doctrine de l'unité de Dieu

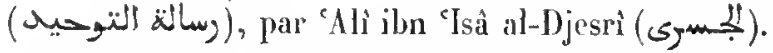

$3^{\circ}$ (Fol. 48 \%.) Questions adressées par Aboû 'Albd Allah ilon Iİ̀oùn al-Sảigh (الصفئ) à Al-Hosaïn ibn Ham-

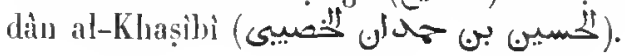

$4^{\circ}$ (Fol. 54.) Traité qui commence par ces mots :

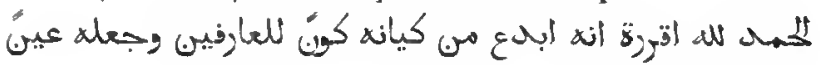
culled

$5^{\circ}$ (Fol. 65.) Dessin circulaire, renfermant les noms de Mohammad et de Salmàn (سلمان) quatre lois l'épétés, accompagné d'une figure ovale qui renferme le nom du

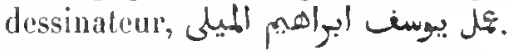

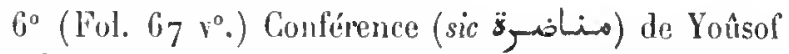
ibn al-'Adjoûz al-Ilalabi, généralement connu sous le nom

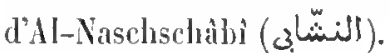

$7^{\circ}$ (Fol. $1301^{\circ}$.) Traité d'Al-Mofaddlıal sur les douze

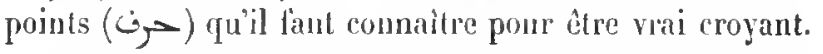

$8^{\circ}$ (Fol. 155.) Trailé sur les devoir's de l'inàn et sur l'affiliation à la secte. Pièce datée de l'an 1211 d'une ère justu’ ì présent incomnue.

$9^{\circ}$ (Fol. ${ }_{16} 6_{7}{ }^{\circ}$.) Élégric composée par le schaïh 'Alì jlu Manșoùr, développée dans un talhmis par le schaikh Moùsà al-Rabt (الكبط). Piece datée de l'an 1211.

$10^{\circ}$ (Fol. $17^{4} r^{\circ}$.) Poc̀me de Moḷammad al-Kalåzî $(s ; 3<11)$

$11^{\circ}$ (Fol. $1-51^{\circ}$.) Puème du schaïkh Ịasan al-Adjroûd

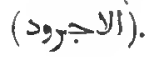

$12^{\circ}$ (Fol. $17^{6},^{\circ}$.) Relation écrite par Al-llosaïn ibn Hàroûn al-Ṣaigh de la conférence qui avait en lien en 340 chez son maitre, 'Ali ibn 'Isà al-Djesri, au sujet de cette doctine que Dieu n'acepte les actions d'aucune personne

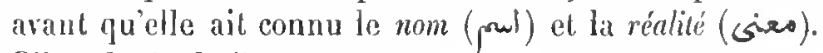
Pièce datée de l'an 1212.

Papier. 179 feuiltets. Hauteur, a 3 centimètres; largeur, 16 centimètres. 13 à 16 lignes par page. Ms. du xvi" siecle. - (Supplément $275 \mathrm{E}$.) 


\section{1.}

Les neurres romplètes du Mahdi des Almohades, volume d'une très-belle écriture maure-espagnole, datée de la dernière décade dı mois de schachàn de l'an 579 ( 25 novembre au 5 décembre 1183 de J. C.). Titre du recueil :

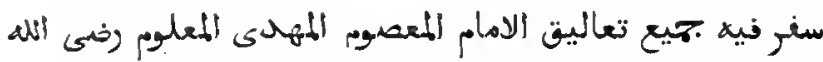

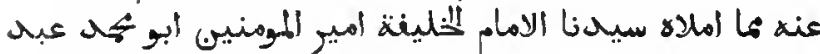
Nolume renfermant la totalité des écrits de l'imàm impeccable, du Mahdi connu, sur qui soil la gràce de Dien! Pièces diclées par notre seigneur l’imâm, calife el commandant des Croyants, Aboû Moḥanmad "Abd al-Moûmin ibn cAlì".

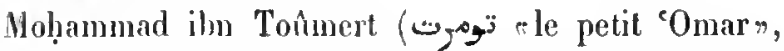
en laugue berljère), s'étant lait accepter par les tribus berbères de l'Atlas comme l'imàm attendu, personnage uystérieux qui, lors de la consommation des siècles, doit se montrel sous le nom d'Al-Mahdi et renouveler le monde, et ayant renversé la dyuastie des Almoravides et fondé celle des Almohades (Al-Mowahhidin eunitairesr), avait eu pour successeur son élère farori, "Abd al-Moûnin ibn 'Alì, qui, sous les titres de calife et de Commandeur des Croyants, régna sur le Maroc et une grande partie de l'Espagne, et mourut en 558 de l'hégire ( 1163 de J. C.). Le Malıdi Ibn Toûmert, en sa qualité d'envoyé céleste, a ait pris le litre de ma şoûm rimpeccable", et, pour se distinguer du Malddi des schiites, qu'on désignait sous le titre de l'attendu, de l'imám qui doit venir, il s'étrit appelé le commu, c'est-à-dire le visible. Pour l'histoire du Mahdi des Almohades, on peut consulter l'Histoire des Berbers, d'Ibn Khaldoun, t. II, p. 161 de la traduction, et le Dictionnaire biographique d'Ibn Khallikîn, traduction anglaise, t. II, p. 182 .

Ce volume renferme les traités suivants, qui, tous, sont divisés en sections, cliapitres et paragraphes.

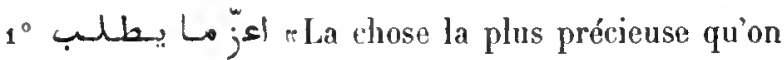
puisse rechercher\%, traité des principes de la loi mu-

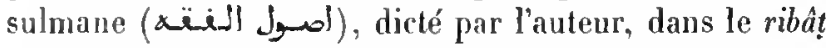
ou couvent des llergha, tribu qui habitait la montagne portant leur nom, au Maroc, en 515 de l'hégire (1 121 1122 de J. C.).

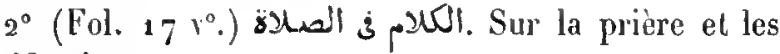
purifications.

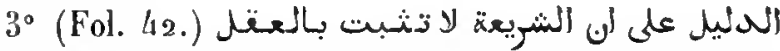
oreuve que la simple raison ne peut, en aucune façon, établir les principes de la loi révélée\%.

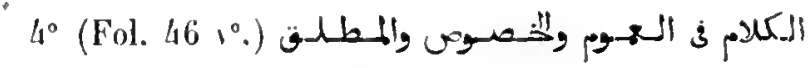

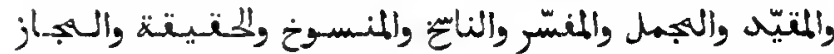

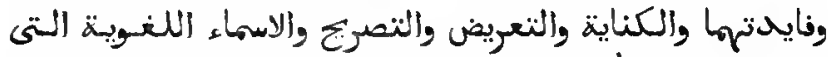

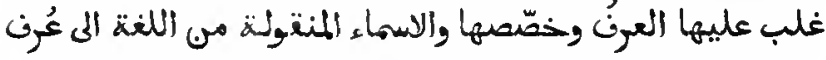
r Trailé sur le général et le particulier, sur l'absolu et le relatif (liltéralement : le restreint), sur le sommaire et le développé, sur l'abrogeant et l'abrogé, sur le (sens) vrai et le (sens) figuré, et sur l'ulilité de ces deux choses, sur la métonymie, l'allusion, et sur le sens propre, sur les mots anxquels l'usage a donné une signification nouvelle et spécifique, ef sur les mots empruntés au langage pour être employés comme termes techniques de la loir.

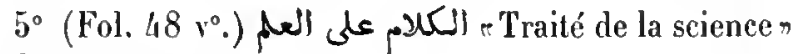
et de ses divisions.

$6^{\circ}$ (Fol. 5o.) (- Les connaissances". Cellesci forment deux classes, ولـ re non-existantr, et r l'existant $"$, dont chacun peut être absolu ou restreint.

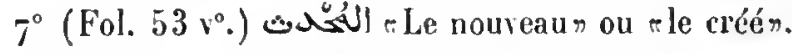

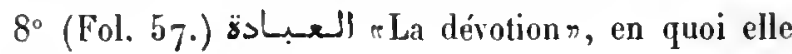
consiste.

$9^{\circ}$ (Fol. 59. ) Sur l'excellence de la doctrine de l'unité

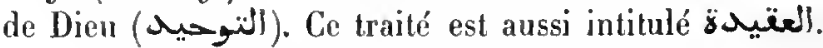

$10^{\circ}$ (Fol. $611^{\circ}$.) Sur l'unité du Créateur et sur l'imâmat.

$11^{\circ}$ (Fol. 65.) Sur les principes des sciences religieuses.

$12^{\circ}$ (Fol. 66.) Diatribe très-virulente contre les AImoravides (بولثم).

$13^{\circ}$ (Fol. 68.) Sur l'islamisme et sur les devoirs des musulmans.

$14^{\circ}\left(\right.$ Fol. $69 v^{\circ}$.) Sur la profession de l'unité de Dieu.

$15^{\circ}$ (Fol. $7^{4 .}$ ) Traditions se rapportant aux doctrines musulmanes.

${ }_{16}^{\circ}$ (Fol. 79.) Traditions relatives à Mahomet.

$17^{\circ}$ (Fol. $86 \mathrm{v}^{\circ}$.) Contre le détournement du butin (غل)

${ }_{1}^{\circ}$ (Fol. 90.) Contre l'usage du vin.

$19^{\circ}$ (Fol. 93.) Sur la guerre sainte (stoll).

Papier. $9^{8}$ feuiltets. Hauteur, 21 centimètres et demi; targeur, 16 cenlimètres. 27 tignes par page. - (Supplément 238.) 


\section{CONTROVERSE.}

\section{2.}

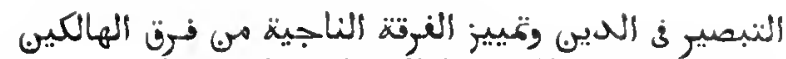
"Démonstration de la vraie religion et distinction établie entre la secte qui sera sauvée el celles qui seront perduesn, par Aboû '1-Hozaffar Tâluir ibn Mohammad alIsfarâinìi, mort en 471 de l'hégire. Ce traité est divisé en quinze chapitres, dont voici les litres, énumérés dans la prélace :

1. المباب الاول في بيان أول خلاف ظاهر ف الاسملم

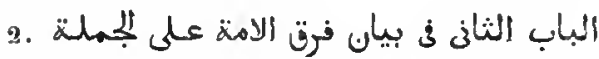

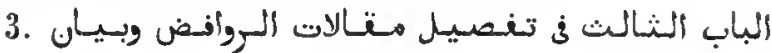
فضابكهor (لباب

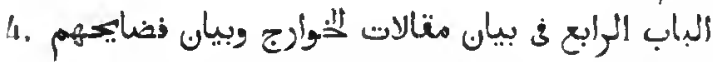

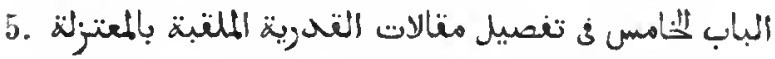
وبيان فضابيكهم

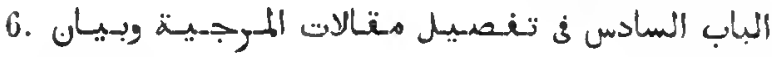
فن

7. البهاب السابع ف تغصيل منالات النجارية ويبان فضايكهم

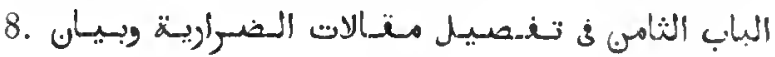
نضايجه

9. الباب التناسع ف تنصيل منالات المبكربة وبيان فضايكهم

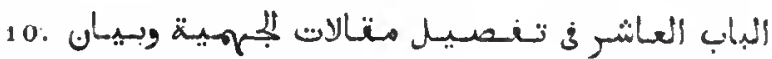
نضايكاب

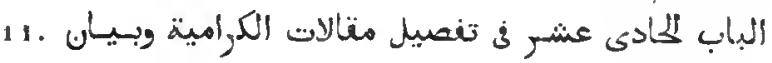
نفابكهo

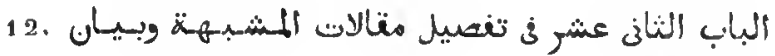
نضابكي

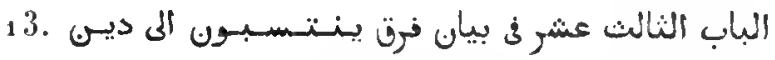

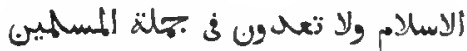

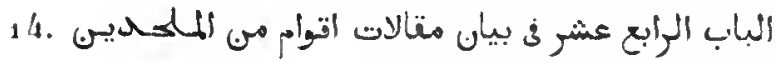
كانوا قبل ظهور دولة الاسلام

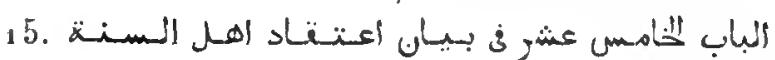

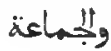

Ms. daté de l'an 1229 de l'héggire (1814 de J. C.).

Papier. 130 feuillels. Hauleur, a 3 centimètres et demi; largeur, 16 centimètres. Environ 20 lignes par page. - (Supplément 279.)

\section{3.}

Exposé des eroyances des diverses sectes hérétiques, nées au sein de lislamisme. Le volume, dont les premiers feuillels manquent, commence par les dernières lignes d'une notice sur la troisième l'action des Ráfédhiles. L'auteur parle ensuite des autres branches de cette secte el passe aux Zaidites et aux Bahrites; puis il éllumère $\left(f_{0}, 231^{\circ}\right)$ lous les descendants $d^{\prime c} A l i$, qui s'étaient révaltés contre les Omayyades ct les Abbasides. A cette occasion, il reproduit une pièce de vers composée sur la mort tragique d'Al-IIosiïn. Il s'occupe ensuite des Khàrédjites et temine par les Motazélites. Le nom de l'auteur", qui vivait probablement au $v^{e}$ siècle de l'hégire, n'est pas mentionné. Ce volunie, daté de l'an 586 de l'hégire ( 11 go de J. C.), est la copie d'un exemplaire plus ancien.

Papier. 200 fenillets. Hauteur, 18 centimètres; largeur, 13 centimètres. 21 lignes par paùe. - (Supplément 280.)

\section{4.}

ens d'ceil jetés sur les voies (doctrines) suivies par les lommes $₫$, ouvrage anonyme, qui est une défense de l'islanisme et la rélutation des doctrines des juifs, des chrétiens el des philosophes. L'auteur est désigné, en tête du volume, par le litre d'imám İloddjat al-Islam, par lequel on désigne ordinairement le célèbre philosophe Aboû llànid al-Gihazilli; mais ce docteur est cité lui-même dans la préface (fol. 5), ainsi que l'ouvrage sur les religions et les seetes de Schahrestànì. Cet ouvrage, très-bien fait au point de vue musulıan, se compose de quatre chapitres préliminaires et de six sections. Dans le premier chapitre, l'auteur avertit ses lecteurs de ne pas confondre ce traité avec un autre quil avait composé sur le même sujet. Le sccond chapitre préliminaire fail connaitre les notifs qui portaient l'auteur à composer cet ouvrage. Dans le troisième chapitre, il indique comment on pent rédnire ì huit points toutes les doctrines redigieuses et toutes les opinions philosophiques. Le quatrieme chapitre explique en quoi consiste la qualité de propliète et la différenen qui existe entre un simple prophète et un prophète chargé d'une mission. La prenière section traite de Mahomet el de sa qualité de prophèle; la seconde, des diverses seetes cliréliennes; la troisième, de la religion juive; la quatrième, de la religion des mages; la cinquiène, des doctrines des différentes nations et des opinions des 
philosophes. Dans la sixième et dernière section, l'auteur résume toutes ses disserlations et distingue entre les iraies doctrines et les f'ausses.

Papier. 97 feuillets. Ilautenr, a 6 centimètres et demi; largeur, 17 centimẻlres et demi. 15 lig̣nes par page. Ms. du $x v^{*}$ siècle. (Ancien fonds 368.)

\section{5.}

Copie du ms. précédent, exécutée à Paris, en 1692 , par Solaümàn ibn Yáqoủb, de Damas.

Papier. $9^{4}$ feuillets. Ilauteur, 29 centimètres targeur, 20 centimètres. 15 liggnes par page. - (Supplément a86.)

\section{6.}

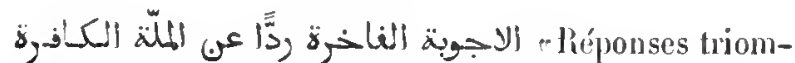
phantes pour scrvir de réfutation aux asserlions de la secte des mécréants\%. C'est un ourrage de controverse, dans lequel l'autenr, peut-êl'e le renégat juif Samuel ibn Yalıyâ ( voyez l'article suiıant), z'épond très-longuement à cent six objeclions faites à l'islamisme, les unes par les juils, les aulres par les chrétiens. Cette partic de l'ouvrage forme trois sections, باب. La quatriène section renferme cinquante et un passages du Pentateuque et de l'Évangile, dans lesquels, suivant l'auteur, la venue de Mahomet est prédite. Chacun de ces passages est suivi

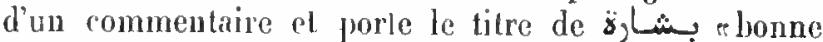
nouvellen. Le premier feuillet manque.

$2^{\circ}$ (Fol. 59.) Derniers feuillets d'une réfutation de la religion juive, par Samuel ibn Yahyâ le Maghrebin, juil converti à l'islamisme. (Voyez, sur ce persomnage, Casiri, Bibl. ar. hisp., 1. 1, p. 440 , et une note de M. Munk, dans le Joumal asialique, calier de juillet 1842.) Dans ce trailé, l'auterr cite des passages du Pentateuque, transcrits en caraclères arabes, à l'encre rouge.

$3^{\circ}$ (Fol. $64 v^{\circ}$.) Relation de la conversion de Samuel ibn Yaḷyâ à l'islamisme, et du songe dans lequel il vit Mahomet, ce qui cut lieu vers la fin de l'an 558 de l'hégire (1 163 de J. G.).

Co ms. porte, à la fiu, la date de 735 de l'hégire (1334-1335 deJ. C.), et au fol. 58 la date de 737 .

Papier. 68 feuillets. Hanteur, 28 centimètres; largeur, ao centimètres. 25 lignes par page. - (Supplément 284.)

\section{7.}

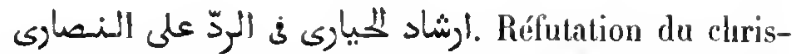
tianisme, par 'Tzz al-Dì 'Abd al-'Aziz Moḷammad alDamìrî al-Daïrìì al-Schâfíi. La copie n'est pas achevée.

Papier. 3o feuillets. Hauteur, 14 centimètres; largeur, 9 centimètres. 15 lignes par page. Ms. du $\times 1 x^{\circ}$ siècle. - (Supptément 2441.)

\section{8.}

"Décisions religieuses n, diatribe contre la secte schiite et contre Isma il Schâh, roi de Perse. L'auteur, Hosaīn ibn 'Abd Allah al-Schirwâni, adressa cet ouvrage, qui a été terminé en $9^{4} 7$ de l'hégire (15401541 de J. C.), au sultan ottoman Solaïmân Khàn, pour l'engager à faire la guerre aux Persans. Il commence par les

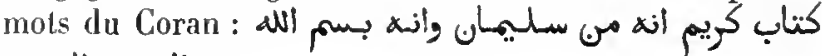

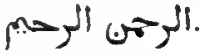

Papier. 42 feuillets. Jlauteur, 21 centimètres; largeur, 15 centimètres. 11 lignes par page. Ms. du $x_{n 1}{ }^{\circ}$ siècte. - (Ancien fonds 429. )

\section{9.}

eoups portés aux hérétiques et aux agitateurs", par le chérif Mluammad ibn Rasoûl al-Barzandjì (للبوزنجي). Ce traité de polémique orthodoxe, dans lequel l'auteur discute les vingt erreurs, هig, des Râfédhites, a pour base un ouvrage beaucoup plus étendu, que le chéril Mìrzâ Makhdoûm, nort vers l'an $99^{5}$ de l'hégire $(1587$ de J. C.), arait fait paraître sous le même titre. L'abrériateur dil avoir entrepris sa tâche en 1097 de l'hégire. Selon Hadji Khalfa, il mourut en 1103 de l'hégire $(1691-1692$ de J. C.). Ms. daté de l'an 1126 de l'hégire (1714 de J. C.).

Papier. 144 feuillets. Hauteur, 22 centimètres et demi; largeur, 16 centimètres. 21 lignes par pare. - (Supplément 283.)

\section{0.}

La première partie d'un ouvrage de controverse, inti-

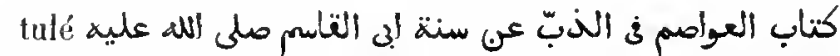
"Les asiles (ou forteresses) pour la protection de la sonna d'Aboú '1-Qàsim (Mahomet)», par Aboû 'Abd Allah 
Moḥammad ibn Ibrà̀hı̀m al-Ḥasanì al-Qàsimì al-Hidavì (الذهادوى), chef d'une communauté de derviches et un des théologiens les plus savants de son temps. L'auteur, mort antérieurement à l'an 1030 de l'hégire $(1620$ de J. C.), probablement vers la fin du $\mathrm{x}^{\mathrm{e}}$ siècte de l'hégire, défend, dans cet ouvrage prolixe et verbeux, l'autorité des anciens imams et des livres des traditions contre les objections d'un soufi, nommé cAli ibn Nohammad ibn abi 'I-Qàsim, dont il était le père spirituel. Ces objections, rédigées sous forme de dissertation, occupent les vingt premiers feuillets du volume.

Papier. 239 feuillels. Hauteur, 30 centimètres el demi; largeur, 21 centimètres. 25 lignes par page. -- (Ancien fonds 370. )

\section{1.}

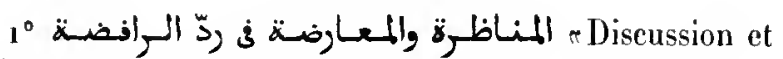
réfutation des opinions des hérétiques $\%$, par 'Abd Allah ibn Fâris al-Tàzi (التازى) (né à Téza, dans le Haroc). Ce traité a été composé en 1009 de l'hégire $(1600-1601$ de J. C.).

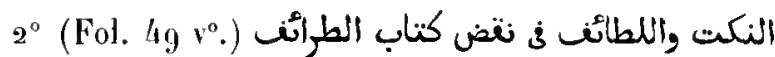
rTrails d'esprit et de finesse, pour servir de réfutation au livre intitulé Kitâb al-Taräfr. Ce dernier ouvrage avait été composé par uı membre de la secte appclée L'auteur de la réfutation appartenait an rite orthodoxe.

Ms. daté de l'an 1127 de l'hégire (1715-1716 de J. C.).

Papier. 97 feuillets. Hautenr, 21 centimètres et demi; largeur, 15 centimètres el demi. 21 lignes par page. - (Supplèment 28\%.)

\section{2.}

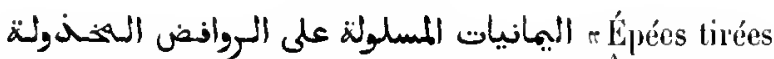
pour confondre les hérétiques », par Zaïn al- Ábidin Yoùsof ihn Mohammad al-Koùràni (3/). Ce traité de polémique, qui est me réponse à un toaité schiite qui avait été répantu dans le public, en 1066 de l'hégire (1655-1656 de J. C.), est dédié au sultan ottoman, Mohammad IV, fils d'Ibrihìn. Ns. daté de l'an 1070 ; liontispice doré, avec arabesques; texte encadré en or et en couleurs.

Papier. 99 feuillets. Hauteur, 21 centimètres; largenr, 12 centimètres el demi. 13 lignes par page. - (Supplément 281.)

\section{3.}

Ms. sans titre ni nom d'auteur. C'est une défense de Mav. ORIERTaCX. - 11 . l'islamisme contre les objections des juifs el des ehrétiens, dédiée au sultan ottoman, Mohammad 111, fils d'Amurath (مُاد)'

Papier. 63 feuillets. Hauteur, 18 centimètres et demi; Jargeur, 13 centimètres. 7 lignes par page. Ms. du xvi siècle. - (Ancien fonds 399 .)

\section{4.}

م Cadeau pour lhomme intelligent, contenant la réfutation des (doctrines professées par les) sectateurs du Crucifién. Ouvrage dirigé contre la religion chrélienne, par un renégat de Mlayorque qui avait pris le nom d' $\mathrm{d}^{2}$ bd Allah Tardjomân. Un nommé Aboù 'l-Ghaitlı Hohammad al-Qasschâsch (الغشانث) a ajouté une prélace à cet ouvrage, et l'a dédié au sultan otloman, Aḷmad, fils de Mollammad et petit-fils d'Amurath III. Dans les premiers clapitres, l'auteur, qui élait devenu drogman à la cour de Tunis, raconte l'histoire de sa jeunesse et de sa conversion. Il avait fail ses premières études à Lériela, et arait ensuite étudié la tlıéologie à Bologne, en ltalie. Il parle ensuite de quelques événements qui eurent lieu en Tunisie, vers la fin rlı Xıv siècle, el de Foceupation d'A1-Mahdiya par les Génois et les Français, en 1389 de J. C. (Voyez, sur ce personnage, la Revue africaine, numéro de juillet $186 \%$.) Ms. daté de l'an 1212 de l'bégire (1797-1 $79^{8}$ de J. C.).

Papier. 64 feuillets. Hauteur, a centimètres; largeur, 15 centimètres. 15 lignes par page. - (Supplément 285.)

VI.

\section{HIST OIRE.}

\section{IISTOIRE UNIVERSELLE.}

\section{5.}

- Recueil des connaissances utiles r, par "Abd Allah ibn Moslim Ibn Qotaiba. L'édition lichographiée de M. Wüsteuledd renferme le texte des fol. 1 à 11 I

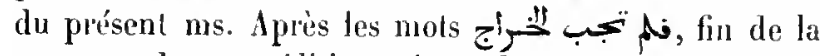
pagge $\mathbf{m r 4}$ de cette édition, vient, dans notre exemplaire, un chajultre qui traite des rois du Yémen, depuis 'Abd ibn Abraham; un autre sur les rois d'Abyssinie qui régnèrent dans le Yémen, pnis une notice sur les rois arabes de la Syrie, et une notice biographique de Mahomel, qui parait être tirée de la Clıronique d'Aboù 'l-Faradj ibn 
al-Djauzì enfin la mention de quelques événements curieux; l'un de ces derniers est accompagné d'une date : l'an 1006 de l'hégire ( 1597 de J. C.). Notes marginales.

Papier. 182 feuillets. Ilauteur, 30 centimètres et demi; largeur, 20 centimètres et demi. 28 à 31 lignes par page. Ms. dı xvı" siècle. - (Supplément 2059.)

\section{6.}

Premier volume de la Chronique d'Abou Dja'far Hoḷammad ilun Djarìr Al-Ṭabari, nort en 310 de l'lıégire (923 de J. C.). Le récit s'arrête au milieu de l'histoire de Joseph et de Pharaon. Premiers mots de la prélace :

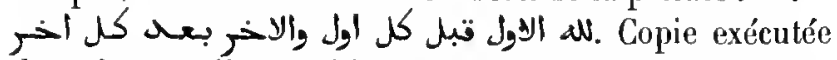
daus la première moitié de ce siècle, probablement à Constantinople. Au commencement, quelques passages sont laissés en blanc.

Papier. 138 feuillets. Ilauteur, 29. centimètres et demi; largeur, ${ }_{9} 9$ centimètres. 25 lignes par page. - (Supplément 2338.)

\section{7.}

r. Chronique d'Al-Ṭabarì. Ce volume, le troisième d'un très-bel exemplaire de l'ouvrage, commence par la naissance de Mahomet et se termine par le combat de Badr. Il a été collationné une première fois par un inconuu, et la seconde lois par un écrivain que l'on croit ètre Schanns al-Dì, l'anteur des Annales de l'islamisme.

Papier. 208 feuillets. Hanteur, 24 centimètres; largeur, 16 centinètres et demi. 17 lignes par page. Ils. du vor" siècle. - (Ancien fonds 627.)

\section{8.}

$1^{\circ}$ Volume délaché de la Chronique d'Al-Tabar'i. Ce ms., dont les preniers et les derviers feuillets manquent, commence au milieu d'un chapitre se rapportant ì l'an 82 de l'hégire ( 701 de J. C.), et se termine au milieu de l'an 101 de l'hégire $\left(71^{1}\right.$-7 720 de J. C. $)$. Plusieurs feuillets sont intervertis; ainsi les années $9^{2}$ et $9^{3}$ de l'hégire suivent l'au $9^{6}$, et un feuillet de cette dernière année est placé entre les années 97 et 99 . L'année $9^{8}$ n'est pas indiquée.

$2^{\circ}$ (Page 340.) Quatre fenillets d'un exenplaire du Kámil d'Ibn al-Athir, contenant la fin de l'an $29^{6}$ de l'hégire el le premier chapitre de l'an 297 . Le feuillet actuellement coté $342-343$ doit être placé à la suite du feuillet coté $344-345$.

Papier. 347 pages. Hauteur, 24 centimètres; largeur, 16 centimètres et demi. 5 lignes par page. Ms. du xm! siècte. - (Supplément 74 4.)

\section{9.}

r Supplément à la Chronique d'AlTabarì, par Aboû ']-Hasan Moḷamınad, fils d'c Abd al-

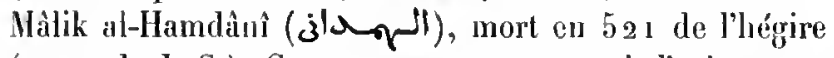
(1 1227 de J. C.). Get ouvrage commence à l'avèmement de Moqtadir, et finit à l'an $48_{7}^{\circ}$, à l'arènement d'Al-Mostazhlir. Le présent ms., qui est le premier du volume, se termine par l'an $36_{7}$ de l'hégire. La préface commence

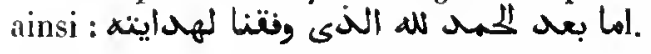

Papier. 154 feuillets. Hauteur, 2 a centimèires et demi; largeur, 16 centimètres el demi. 19 lignes par page. Is. du xvu siècle. (Supplément 744 bis.)

\section{0.}

مثتص الثبائب Abrégé de (l'ouvrage intitulé) les Merveilles (du monde) $\gg$, at(ril)ué à Al-Maseoủdi. C'est le traité généralement conuu sous le titre d'Alhbâr al-Zamân. Après une courte mention des préadamites et des génies, d'Adam et de Noé, l'auteur parte des mers, des îles de l'océan Indien et de la Méditerranée; il raconte l'histoire d'Adam, de Noé et de Japbet, ainsi que l'histoire des Grees, des Chinois et des Franes. Il décrit ensuite les merveilles de l'Égypte et donue de courtes notices sur les rois et les Plıaraons qui ont régné sur ce pays, avant et après le déluge. C'est un recueil de fables. Le frontispice, en or et en couleurs, est une pièce rapportée, et semble être du $x^{\circ} \imath^{\circ}$ siècle.

Papier. 168 feuillets. Hanteur, 26 centimètres; largeur, 18 centimètres. 5 liğnes par page. MIs. du xiv" siècle. - (Ancien fonds go1.)

\section{1.}

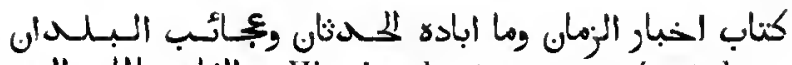
(listoire des temps passés et de ce que les jours et les nuits ont détruit, ainsi que des merveilles des pays, de ce qui est couvert par l'eau et de ce qui est luabité \%. C'est le même ouvrage que le précédent. 
Le présent exemplaire porte le nom de l'anteur supposé, Aboû '1-Hasan 'Alì ibn al-Hosaïn ibı 'Alî ibn 'Abd Allalı

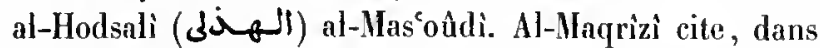
le Khitat (édition de Boulàq, t. I, p. rv, 1. 10), un court passage de l'Akhbâr al-Zamân d'Aboû 'l-Ḥasan al-Mas'on̂di. On trouve ce passage au fol. $57 v^{\circ}$ de ce ms. Ms. daté de l'an 882 de l'hégire ( 1477 de J. C.).

Papier. 132 feuillets. Hauteur, 18 centimètres; largeur, 13 centimètres et demi. 15 lignes par page. - (Supplément 719.)

\section{2 .}

Le Mokhtaşar al-'Adjäib ou Akhbâr al-Zamân, attribué à Al-Mas'oûdì. Ms. daté de l'an 953 de l'hégire (1546 de J. C.).

Papier. 443 pages. Hauteur, so centimètres et demi; largeur, 15 centimètres. 3 lignes par page. - (Ancien fonds $9^{55 .}$ )

\section{3.}

Même ouvrage. C'est une copie faite par Pétis de la Croix sur un ms. daté de l'an 1038 de l'hégire (1629 de J. C.). En regard des dix-sept premiers feuillets se trouve une traduction française de la main du même orientaliste.

Papier. $9^{5}$ feuillets. Hauteur, 31 centimètres; largeur, 20 centimètres et demi. 20 à 29 lignes par page. - (Supplément 717.)

\section{4.}

Le même ouvrage, copié par un Européen, probablement par Asselin de Cherville.

Papier. 127 feuillets. Hauteur, 22 centimètres et demi; largeur 15 centimètres. 25 à a6 lignes par page. Hs. du xix' siècle. - (Supplément 7 18.)

\section{5.}

Première moitié du même ourrage (كتـاب اخدبس (الزمان وغرائب البكر والموان. Le premier feuillet manque.

Papier. 77 feuillets. Ilauteur, $2 / 4$ centimètres; largeur, 16 centimètres et demi. 17 lignes par page. Ms. de la fin du xim ${ }^{e}$ siècle. (Supplément 717 bis.)

\section{6 et 1477.}

بes Prairies d'or », par Al-Mascoûdì. La première partie du premier volume a été copiée en 922 le l'hégire ( 1516 de J. C.); cette date est inscrite sur le frontispice. Le reste du ms. est de l'an 1120 de l'hégire (1708-1709 de J. C.). Cet exemplaire du Moroutdj est ordinairement appelé Manuscrit de Constantinople.

a volumes. Papier. 471 et 358 feuillets. Hauteur, 17 centimètres et demi ; largeur, 9 centimètres. 7 liggnes par page. - (Supplénıent 714. )

\section{8.}

Même ouvrage. La première partie du ms., jusqu'au milieu du fol. $71 \mathrm{v}^{0}$, n'appartient pas à l'ourrage. Ces premiers feuillets contiennent des extraits de l'Akhbär al-Zamân. Ms. daté de l'an 1119 de l'hégire (17071708 de J. C.).

Papier. $4_{9} 3$ feuillets. Hauteur, 30 centimètres; largeur, so centimètres. 27 lignes par page. - (Ancien fonds $599 \mathrm{A.}$ )

\section{9 .}

Mème ouvrage. Ms. daté de l'an 1131 de l'hégire ( 1719 de J. C.).

Papier. 465 feuillets. Hauteur, a 3 centimètres; largeur, 13 centimètres. 27 lignes par page. - (Supplément 715.)

\section{0 : 1483.}

Mème ouvrage. Deux volumes, reliés en quatre tomes. Le prèmier volume est daté de l'an 1231 de l'hégire ( 1816 de J. C.), le second volume de 1232 .

4 volumes. Papier. $342,342,337$ et 367 feuillets. Hauteur, a a cenlimètres et demi; largeur, 16 certimètres et demi. 17 à 19 lignes par jage. - (Supplément 716.)

\section{4.}

Même ouvrage. Ce volume renferme les deux premiers tiers de l'ouvrage. La seconde partie commence au fol. 102 , et se termine par le chapitre qui, dans l'édi- 
tion de la Société asiatique, est le soixante-buitième. lls. dité de l'an 964 de l'hégire (1556-1557 de J. C.). Le texte est pourvu des voyelles, qui ont été ajoutées après coup.

Papier. 189 feuillets. Hauteur, 21 centimètres; largeur, 15 centimètres. 17 lignes par pagc. - (Ancien fonds 599.)

\section{5 .}

Nême ouvrage. Ce volume renferme la première partie de l'ourviage et se termine par le chapitre qui, dans l'édition de la Société asiatique, est le trente-troisième. Le commencement (les dix premières pages du tome ${ }^{\text {er }}$ du texle imprimé) manque. Ms. écril à Sâfad, en Syrie, el daté de l'an 974 de l'légire (1566-1567 de J. C.).

Papier. 138 feuillets. Hauteur, 21 centimètres; largeur, 15 centimètres. 19 lignes par page. - (Ancien fonds 598 .)

\section{6.}

Table des matières des pages 1 à 158 du ms. $n^{\circ} 1478$. Cette table est de la main de Michel Sabbàgh.

Papier. 10 feuillets. Hauteur, 23 centiniètres; largeur, 17 centimètres. 15 limnes par page. — (Ancien fonds 599 в.)

\section{7.}

rIndication et éclaircissement n, traité de cosmographice ot d'histoire, par Al-Mas'oûdi. 11. de Sacy a donné une notice étendue de cet ouvrage dans le tome VIIl des Notices et Extraits.

Papier. 224 feuillets. Ilauteur, 21 centimètres; largeur, 15 centimètres et deni. a lignes par page. Ms. du xris siècle. - (Supplément 901 , Saint-Germain 337.)

\section{8.}

 tants touchant l'histoire des rois", par Aboû Manșoûr al-Hosaïn ibn Mobammad al-Maréaschì al-Tháálibì, auteur qui vivait au commencement du v viècle de l'hégire, sous le règue du sultan ghaznévide Mạ̣mond ibn Saboktiguin. Cet ouvrage, comnu sous le titre de Ghorar
al-Siyar, est une clıronique universelle, divisée en quatre rolumes, dont le présent ms. contient les deux premiers. Le premier volume renferme l'histoire de la Perse, depuis le règne de Kayomarth jusqu'à la mort de Yazdaguird, fils de Bahrîm, et la guerre qui eut lieu entre Fîroùz et Hormoz, les deux fils de ce prince. L'antique histoire de la Perse est racontée avec beaucoup de détails. Le second volume (lol. $153 \mathrm{v}^{\circ}$ ) conduit le récit jusqu'à la chute de Yazdaguird, fils de Schahryâr. Viennent ensuite les chapitres suivants : histoire des rois prophètes chez les juifs; histoire des Pharaons; histoire des rois du Yémen; histoire des rois arabes de la Syrie, des rois arabes de l'Iràq, des rois des Grees, et une notice trèsdélaillée sur Mahomet. En tête de chaque rolume se trouve une liste de chapitres. Les deux autres volumes, que nous ne possédons pas, renferment l'histoire des quatre califes légitimes, des Omayyades, des Abbasides, d'Aloou Moslim, des Barmécides, des Tahirides, des Samanides, des Hamdanides, des Bouïdes, de Saboktiguîn et de Mahmoùd, fils de Saboktiguì, à qui l'auteur souhaite un long règne. II dit avoir rédigé cet ouvrage sur le désir de son patron, Aboû 'l-Mozaffar Nașr, frère du sultan Maḥmoûd. Ce ms., d'une écriture très-cursive, qu'on arait voulu faire passer pour un volume de l'Hisloire universelle d'llon Klıaldoûn, a été exécuté à Constantinople, vers 1837 .

Papier. 298 fevillets. Hauteur, 25 centimètres; largeur, 18 centimètres et demi. 22 lignes par page. - (Supplément 7424. )

\section{9.}

res traces laissées par les siècles passés", traité de chronologie, par Aboû 'lRaîḥân Moḥammad ibn Ạ̣mad al-Bìroûnî. Dans cet ourrage, l'auteur indique les divers systènes chronologiques des peuples anciens et leurs fètes religieuses. On $y$ irouve un assez grand nombre de tableaux astronomiques et autres, et ringt-cinq miniatures. Les premiers mots de chaque paragraphe sont écrits en caractères coufiques, tantôt à l'encre rouge, tanlôt à l'encre noire. Le texte a tous les points-royelles.

Papier. 171 feuillets. Hauteur, 30 centimètres; largeur, 21 centimètres. 21 lignes par page. IIs. du xru siècle. - (Supplément 713 bis.)

\section{0.}

r Sources des connaissances et branches de l'histoire des califes n, par le cadi 
Aboủ 'Abd Allah Moḷammad ibn Salàma ibn Khadhr alQodhâi (التقضال), mort en 454 de l'hégire (1062 de J. C.). C'est un résumé de l'histoire des patriarches, des prophètes, de Hahomet et des califes omayyades, abbasides et falémides. Plusieurs onglets, portant des renseigruements, les uns en arabe, les autres en turc, sont intercalés dans le volume; ces additions ont été faites par un Turc, vers la fin du $x^{2} n^{e}$ siecle. Les premiers el les derniers feuillels contiennent plusieurs historiettes et anecdotes, apparemment de la mème main.

$2^{\circ}$ (Fol. $123 v^{\circ}$.) Continuation de l'ouvrage précédent, par un anonyme. Ce supplément, qui sarrêle à l'an $9_{2} 6$ de l'hégire, renferme une notice sur la dynastie fatémide. A la fin se trouve une liste chronologique des califes et des souverains musulmans, jusquà Qànșon 'I-Giliauri, dernier sultan mamloue.

Papier. 144 feuillets. Hauteur, 21 centimètres; largenr, 14 centimètres. 15 à 17 lignes par page. Le premier ouvrage est dn xu1" siècle, le second du xvir. - (Ancien fonds $77^{3}$.)

\section{1.}

Hême ouvrage. Le volume se lermine par la mention de l'avènement el de la mort d'Al-Ĵ̣kim bi-Anni'llâh, calife d'Égyple.

Papier. 121 feuillets. Ilanteur, 21 centimètres et demi; largeur, 15 centimètres. 15 lignes par page. Us. du xvi siècle. - (Ancien fonds 761.$)$

\section{2.}

Le Kamil d'Ibn al-Athìr. Ce volume renferme le commencement de lourrage et se termine par lo chapitre intilulé toire dı califat d'Aboû Bakr.

Papier. 151 feuillets. Hanteur, 33 centimètres et demi; largeur, 22 centimètres. 17 lignes par page. Ms. du xix siècle. - (Supplément 7 ho bis, 1.)

\section{3.}

Autre volume du mème ouvrage, commençant par l'an 11 de l'hégire, au chapilre intitulé ى الاسحى, et finissant par l'an 36 de l'hégire, immédiatement avant le chapitre intilule

Papier. 270 feuillets. Ilautenr, 26 centimètres et demi; largeur,
18 centimètres. 21 lignes par page. Mls. du xin' siècle. - (Supplément 7 to bis, II.)

\section{4.}

Autre volunne du même ouvrage, commençant par l'an 36 de l'hégrine, au chapitre intilute , et finissant par l'an 66 de l'hégire.

Papier. 99 feuillets. Ilantenr, 35 centimètres; largeur, 22 centimétres et demi. 1 j lignes par page. Ms. du xıx siècle. - (Supplément 7 to bis, 111.)

\section{5.}

Autre volume du meme ouvrage, renfermant l'histoire des années 66 à 35.3 de l'hégire. Les vingt-six preniers feuillets et quelques leuillets dans le corps du volume ont été ajoulés après coup. Au fol. 27 se trouve un frontispice orné, portant le tilre de l'ourrage, كناب المكامل في النّإ "Le Complet, ouvrage dhistoiren.

Papier. 39 o feuillets. Ilaıteur, 31 centimètres; largeur, 24 centimètres et demi. 31 lignes par page. Mls. du xiv siècle; les vingt-six premiers feuillets et les aulres feuillets ajoutés après coup sont d'une écriture turque du xvi siècle. - (Supplément 740 bis, 1v.)

\section{6.}

Autre volume du même ouvrage, commençant à la fin du premier chapitre de l'an 155 de l'hégire, el finissant par le cinquième chapitre de l'an 248 de l'hégire. Le volume suivant derait commencer par l'avènement d'AlMostain. Le premier feuillet du présent ms., qui manquait, a élé remplacé par un autre arec un titre et une préface apocryphes. Les ehiffres qu'on lit à la fin ont été altérés, et le mol وبه نستعيبر a 11 y a plusicurs lacunes dans le corps du volume. Ms. dalé de l'an 711 de l'hégire (131: de J. C.).

Papier. 205 fenillels. Hauteur, 25 centimètres et demi; largeur, 17 centimètres. 21 lignes par page. - (Supplément 7 /o, 1.)

\section{7.}

Autre volume du même onvrage, commençant à la fin de l'an 227 de l'hégire, et finissant par le chapitre vm de l'an 321 de l'hégire.

Papier. 271 feuillets. Ilauteur, 26 centimétres; Jargeur, 19 centimètres. 23 lignnes par page. Ms. du $\times \mathbf{x}^{\circ}$ siècte. - (Supplément 7 亿́, 11.) 


\section{MANUSGRITS ORIENTAUX.}

\section{8.}

Aulre volume du même ouvrage, commençant au milieu de l'année 296 de l'hégire, el finissant par l'an 369 de f'hégire. Ms. dalé de l'an 666 de l'bégire (1268 de J. C.). Les premiers fenillets manquent.

Papier. 310 feuillets. Iauteur, 26 centimètres; largeur, 17 centimètres et demi. 19 liggnes par page. - (Supplément $7^{4} \mathbf{1}$ bis.)

\section{9.}

Aulre volume du même ouvrage, commençant par l'an $34 y$ de l'hégire, et finissant par le chapitre iv de l'an 620 de l'hégire, qui est la dernière de la présente rédaction de l'ourrage. L'écrilure est très-belle, mais petite et serrée. Le copiste, Ibn a]-Foûtî (الغوطى) Mohammad ibn A hamad al-Schaîbàni, jouissail d'une baute réputation comme calligraphe (royez les deux notices biographiques, à la fin du volume). Ns daté de l'an $6_{9} 1$ de l'hégire (1293 de J. C.).

Papier. 289 feuillets. Ilauteur, 26 centimètres et demi; largeur, 19 centimètres. 26 à 28 lignes par page. - (Supplément 740 bis, v.)

\section{0.}

Aulie volume du mêtne ouvrage, commençant par le chapitre "I de l'an 364 de l'hégire, el finissant par l'an 438 de l'hégire. Il y a quelques lacunes dans l'histoire de l'an 432 .

Papier. a 70 feuillets. Hauteur, 25 centimètres; largeur, 18 centimètres. 19 lignes par page. Ms. du xv ${ }^{\circ}$ siècle. Les demiers feuillets sont modernes. - (Supplément 740,111 .)

\section{1}

Aulre rolume du mème ouvage, commençant par l'an 439 de l'hégrire, el finissant au milieu du clıajitre $v$ de l'an 498 de l'hrogire. La fin du volume manque. Les trois dernières ligues du fol. $2121^{\circ}$ ont été ajoutées après coup. Le feuillet snivant devait commencer par les mots

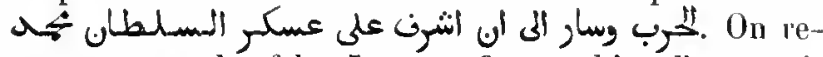
marque entre les fol. 150 et 173 un cahicr d'une écriture assez moderne, qui a été inséré à cette place pour dissimuler une lacune de six années. Ce cahier contient des extraits du Kamil se rapportant aux années 426,427 ,
$623,428,430,431,422,600$ et 210 . Ces dates, dont la pluparl sont écrites à l’encre rouge, ont été altérées.

Papier. 212 fenillets. Hauteur, 25 centimètres et demi; largeur, 18 centimètres, 21 lignes par page. Ms. du xiv siècle. - (Supplément $740, \mathbf{v}$.)

\section{2.}

Autre volume dn nêtme ouvrage. Ce volume, dont les premiers et les derniers feuillets manquent, commence au milieu de l'an 456 de l'hégire, et finit par les premières lignes du chapitre 1 de l'an 507 de l'hégire. Les points diacritiques sont souvent omis.

Papier. ${ }_{10} 6_{7}$ feuillets. Hauteur, 25 centimètres et demi; largeur, 18 centimètres. 21 lignes par page. Ms. du xıv siècle. - (Supplément 741.)

\section{3.}

Autre volume du même ouvragge, commençant par le chapitce $w$ de l'an 527 de l'hégire, et finissant par le chapitre u de l'an 572 de l'hégire. 11 y a, dans ce volume, des lacunes, plusicurs feuillets sont intervertis, d'autres ajoutés pour remplir des lacunes. Un certain nombre de dates ont élé altérées.

Papier, 293 pages. Hauteur, 27 centimètres; largeur, 19 centimètres et demi. 23 liggnes par page. Ms. du sw siècle. - (Supplément $740, v_{0}$ )

\section{4}

Antre volume du même ouvrage, commençant par l'an $5_{72}$ de l'hégire, et finissant par l'an $6_{2} 8$ de l'hégire.

Papier. 349 pages. Hauteur, 27 centimètres et demi; largeur, 2o centimètres. 23 lignes par page. Ms. du xiv siècle. - (Supplément 740, iv.)

\section{5 .}

Miroir du temps, Iraitant de f'histoire des hommes notables $\pi$, corps d'annales et nécrologe, composés par Ibn Kizoghli (Aboû '1-Mozaffar Yoûsof), généralement connu sous le nom de Sibt Ibn alDjauzî. L'auteur, petit-fils de la fille du célèbre docteur Aloû̀ 'l-Faradj 'Abd ał-Raḥmân ibn ał-Djauzî, mourut en 654 de l'hégire ( 1257 de J. C.). Ce volume, le sixième 
d'un très-bel exemplaire, commence par l'an $19^{\circ}$ de l'hégire, el finit par l'an 281. Ms. daté de l'an 971 de l'hégire (1564 de J. C.). Frontispice orné, avec titre en lettres d'or sur un fond bleu.

Papier. 227 fenillets. Hauteur, 31 centimètres; largeur, 21 centimètres. 25 lignes par page. - (Ancien fonds $6{ }^{\prime}$ o. $)$

\section{6.}

Second volume du mème ourrage, commençant par l'an 440 de l'hégire, et finissant au milieu de l'an 517 de l'hégire. Les derniers feuillets manquent et il y a plusieurs lacunes dans le corps du volume.

Papier. 313 feuiltets. Hanteur, 28 cenlimètres; largenr, 18 contimètres et demi. 25 lignes par page. Ms. du $x \nabla^{e}$ siècle. - (Ancien fonds 641.)

\section{7.}

Abrégé de l'histoire des anciens et des rois, ourrage par lequel l'humble serviteur se recommande à la faveur de son maitre», abrégé d'histoire universelle, par Mohammad ibn 'Alì ibn 'Abd al-'Aziz ibn 'Alì ibn Barakit, de Hamâh. Cet ouvrage, composé pour servir de lecture de voyage à l'émir général en chef (isfahsalar), Saîf al-Dìn 'Ali, fils de l'émir 'Tzz al-Din Hasan ilon abi 'Ali, contient, dans le premier volume, aprì̀ un résnmé de l'histoire antéjslamique, l'histoire de Mahomet, des quatre premiers califes et du califat d'Al-Hasan, l'histoire de Mo ${ }^{c} i-$ wiya et des Omayyades et celle des Abbasides jusqu'à la mort d'Al-Mohtadí. Le second volume, commençant au fol. 166 , renferme la suite de l'histoire des Abbasides, jusqu’à l'avènement d'Al-Moqtadir, en 295 de l'hégire. Les folios 179 et suivants, jusquau fol. 182 , contiennent l'histoire des Fatémides. Le dernier feuillet porte la mention de la mort du calife Al-Ràdhî̀. Le reste, c'est-à-dire la plus grande partic du second volume, manque.

Ms. de diverses écritures, dont la plus ancienne est antérieure à l’an 683 de l'hégire (1284 de J. C.), date de quelques actes de vente inscrits au fol. 1 et au fol. $165 \%^{\circ}$.

Papier. ${ }^{1} 89$ feuillets. Hauteur, 23 centimètres; largeur, 15 centimètres et demi. 14 lignes par page. -- (Supplément 728.)

\section{8.}

La Chronique d'Aboû 'l-Fidâ (لمختصد 3 اخبار ألبنثت)
Cet exemplaire porte les corrections de l'auteur et renferme plusieurs feuillets écrits de sa main. (Pour la description détaillée de ce ms., voyez le Recueil des historiens orientaux des croisades, t. I, p. 747.)

Papier. 348 feuillets. Hauteur, 31 centimètres; largeur, at centimètres et demi. 19 à 20 lignes par page. - (Supplément 750 , SaintGermain 101.)

\section{9.}

Quatre feuillets d'une copie du mème ouvrage. Une partie considérable de cel exemplairé a servi à compléter le ms. 1508 . L'écriture de ces feuillets est de la même main que cenx qui, dans le Recueil des historiens orientenx des croisades, $\mathrm{t}$. I, p. $7^{4} 7$, sont désignés par la lettre C.

Papier. 4 feuillets. Hauteur, 29 contimètres et demi; Jargeur, 20 centimètres. 25 lignes par page. Ms. du xvi ${ }^{\circ}$ siècle. - (Supplément 2068.)

\section{0.}

Méme ouvrage. Cet exemplaire s'arrêtait primitivement à la fin de l'an $69^{3}$ de l'hégire; mais une autre main $y$ a ajouté les premiers événements de l'aunće suivante. (Voyez le Recueil des historiens orientaux des croisades, t. I, p. 750.$)$

Papier. 371 feuillets. Hautenr, 30 centimètres et demi; largeur, 23 centimètres. 25 lignes par page. - (Supplément 748.)

\section{1.}

Première partie dn même ouvrage. La copie s'arrête an conmencement de l'an 468 de l'hégire.

Papier. 280 feuillets. Hauteur, a 7 centimètres ; largeur, 17 centimètres et demi. 17 à 26 lignes par page. Ms. de la fin du xiv siècle. Les 80 premiers feuiltets sont d'une main plus modernc. - (Ancien fonds $615 \mathrm{~A}$.)

\section{2.}

Seconde partie du même ouvrage, commençant par l'an 455 de l'hégire et finissant an milien de l'an $7^{\circ} \mathrm{g}$. Les derniers feuillets manquent. Bel exemplaire, du commencement du xiv $v^{\mathrm{c}}$ siècle, écrit du vivant mème de l'au- 
teur. (Voyez le Recueil des historiens orientaux des croisades, t. $1, P .749$.

Papier. 5.30 pages. llauteur, 26 centimètres el demi; largeur, 19 rentimètres. 21 lignes par page. -- (Ancien fonds 615 B.)

\section{3.}

Seconde partie du même ouvrage, commençant par l'an 455 de l'hégire, et finissant par l'an 709 de l'hégire. (Voyez le Recueil des historiens orientnux des croisades, t. I, p. 750.$)$

Papier. 287 feuillets. Hauteur, 26 centimètres; largeur, 18 cenlimètres et demi. 21 lignes par page. Ms. du milieu du xır siècte. (Supplément 749. )

\section{4.}

Premier volume d'une listoire universelle qui porte

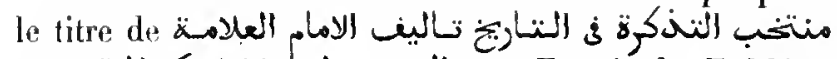
تExtrait du Tadskira, ouvage historique, composé par le savant maître Taqì al-Din About Bakr al-Maqrizìn. Ces mots, inscrits sur le recto du premier feuillet, sont de la mème main que le commencement de la préface, au verso du même feuillet, qui remplace le premier feuillet du ms. qui manquait. L'authenticité du titre ct de cetle préface est très-douteuse, car le reste du ns. est évidemment du ${ } \mathbf{v}^{\mathrm{c}}$ siècle et, par conséquent, antérieur à la naissance d'Al-Maqrìzi. D'ailleurs, on ne voit pas si Maqrízì est désigné comme atuteur de l'Extrait ou du Tadshira. Voici

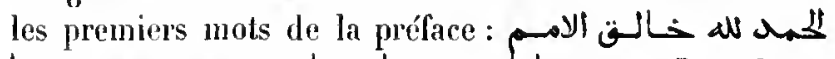

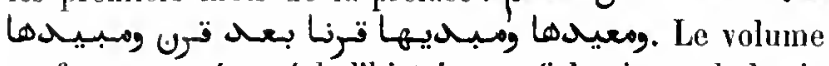
renferme un résumé de l'histoire antéislamique, de la vie de Mahomet et de l'histoire musulmane, depuis l'bégire jusqu'en 555. Au fol. 121 commence la narration d'une série d'événcments divers, survenus depuis la chute des Omayyades, en ${ }_{3} 3_{2}$ de l'hégire, jusqu'en 270 de l'hégire.

Papier. 165 feuillets. Hauleur, 23 centimètres; largeur, 18 centimètres. 15 lignes par page. Ms. du xiv siècle - (Ancien fonds $; 9^{6}$.)

\section{5.}

P'remier roluıne de la Chronique universelle, intitulée (البحلية والنهاية Le commencement et la fin n, d'Ibn Kathîr (Aboû 'l-Fidâ Isınâeil ibn 'Omar), de Damas, mort, selon Hadji Khalfa, en $77^{4}$ de l'hégire (1372-1373 de J. C.). Ce volume commence par la création et finit par le récit du mariage d's $\mathrm{Abd}$ Allah, père de Mahomet.

Papier. 333 feuillets. IJauteur, 30 centimètres; largeur, 20 centi-

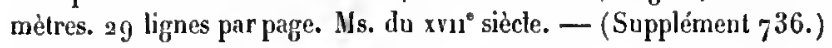

\section{6.}

Dernier volume de la nouvelle rédaction de la chronique d'Ibn Kathîr. Une note, inserite sur le fronlispice, nous apprend que l'auteur de cette rédaclion se nommail Aboù 'l-Abbâs Aḥmad ibn abì Bakr ibn Khalìl ál-Ṭabarìni (الطبرأن), docteur hanbalite, mort au mois de safar de l'an 835 de l'hégire ( 143 I de J. C.). (Voyez, pour d'autres renseignements, le folio 275 du présent ins. et le Recucil des historiens orientaux des croisades, t. I, p. LII et suiv.) Ce ms. commence par l'an 617, et finil avec l'an $7^{3} 7$ de l'hégire.

Papier. ${ }_{277}$ feuittets. Hauteur, 27 centimètres et demi; targeur, 18 centimètres, 25 lignnes par page. Ms. du $x^{e}{ }^{e}$ siècle. - (Supplément 814 , Saint-Germain 112.)

\section{7 à 1523.}

Chronique universelle d'Ibn Khaldoûn. Copie exécutée en 1836-1837, sur l'exemplaire qui se troure dans la bibliothèque d'lbrîhìm Pacha, à Constantiuople.

Le premier volume contient les Prolégomènes.

Le second volume, qui est le troisième de l'ourrage, commence par l'bistoire des Omayyades et s'étend jusqu'à la prise de Baghlıâd par les Tartares.

Le t'oisième volume, qui est le quatrième de l'ouvrage, renferme l'histoire des petites dynasties de l'Orient et de l'Occident.

Le quatrième volune, désigné dans l'explicit comme le cinquième de l'Histoire universelle d'Ibn Khaldoûn, commence par la deuxième section (قسم) d'un ouvrage sur l'histoire d'Égypte. Celte section, cousacrée aux Fatémides, est suivie de la treizieme section, qui traite des Ayyoubides, et des quatorzième et quinzième, consacrées aux deux dynasties des Mamloucs. Ce qui appartient à l'ouvrage d'Ibn Khaldoûn commence au fol. $47 v^{\circ}$. Nous y trourons les notices sur les Zoghba, les Macqil (fol.52 vo), les Dsoûi 'Abd Allalı, les Tha'âliba, les Dsoûï Manșoûr, le faux prophète Hâ-Mìm, la dynastie des Hammoudites, les peuplades de l'Atlas, le Malıdì des Almohades, Qâsim ibn Merà, les Solaïm, etc. Au fol. 71 commence le pre- 
mier chapitre le l'Histoire des Berbères, suivi d'autres chalpitres tirés du mème ouvrage.

Le cinquiène rolume, qui est le sixième de l'ouvrage, commence par la section des tribus arabes de la quatrième race. Vient ensuiłe toute la première partie de l'His. toire des Berbères. Le dernier chapitre est consacré aux Beni Thàbil de Tripoli.

Le sixiène volume, désigné sur le frontispice et dans l'explicit comne le septième de l'ouvrage, commence par le chapitre des Zenâta et finit par le chapitre consacré à l'histoire d'llon 'Alì Ifellousen.

Le septième volume, qui est donné comme le huitième de l'ouvrage, et qui, en réalité, est le cinquiène, commence par l'histoire des Seldjoukides et finit par l'histoire des Benì Doúschì Khàn.

7 vol. Papier. $511,609,559,190,402,339,492$ feuillets. Hautcur, 25 centionètres; largeur, 18 centimètres. 21 lignes par page. (Supplément $742 \mathrm{~B}-\mathrm{H}$.)

\section{4.}

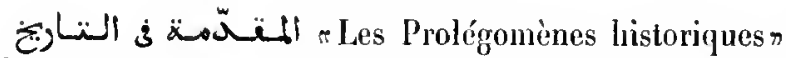
d'lbn Klıaldoûn. Ms. daté de l'an 1 i 46 de l'bégire (1 733 de J. G.).

Papier. ${ }^{5} 51$ feuillets. Hautcur, 22 centimètres; Jargeur, 15 centimètres, 31 lignes par page. - (Supplément $74_{2}$ U.)

\section{5 .}

Second volume de la Chronique universelle d'thn Khaldoûn, commençant par le chapitre qui traite des "peuples du monden, et finissant par le récit de l'avènement d'Al-Hasan, fils d"Ali.

Papier. 240 feuillets. Hauteur, 28 centimètres; largeur, 21 centimètres. 26 lignes par page. Ms. du $x^{\circ} 1^{\circ}$ siècle. - (Supplément 7 4 a K.)

\section{6 .}

Même ourrage, second volume, commençant par le chapitre consacré aux "peuples du nonder, et finissant par le clsapitre qui traite des tribus descendant de Kahlân ibu Saba. Les clıapitres des Mondsirites, des Kindites, des Ghassanides, des Qoraïsch et des quatre premjers califes manquent. (Voyez Notices et Extraits, t. XIX, ${ }^{\text {re }}$ partie, p. xevilı.)

Papier. 113 feuillets. Hauleur, 29 centimètres et demi; largeur, Man. orientaux. - Il.
20 centimètres. 29 liggnes par page. Ms. du xwn siècle. - (Supplíment $742 \mathrm{~J}$. )

\section{7.}

Hême ouvrage, second volume, commencant par lo chapitre des epeuples du monden, et finissant par le récit de l'avènement d'Al-Hasan, fils $d^{\star}$ Ali. Le premier feuillet manque. Il a été probablement enlevé pour faire disparaître l'acte par lequel Șâlih-Bey donna ce volume en waqfà la mosquée de Sidi 'l-Kattânì, près de Constantine.

Ms. daté de l'an 1192 de l'hégire (1 778 de J. C.).

Papier. 197 feuillets. Hauteur, 31 centimètres; Jargeur, 21 centimètres el demi. 33 ligncs par page. - (Supplément $7^{\text {4a Q.) }}$

\section{8.}

Méme ouvrage, troisième volume, renfermant l'hisloire des Omayyades et des Abbasides, jusquà la prise de Baghdàd par les Tartares. En tête se trouve l'autobiographie de l'auteur. Au folio 3 se troure le cachet de SàlihBey et l'acte par lequel il donna ce volume au collège attenant à la mosquée de Sìdì 'l-Kattànì.

Papier. 258 feuillets. Hautcur, 32 centimètres; Jargcur, a 1 centimètres et demi. 23 lignes par page. $M s$. du xvil siècle. - (Supplément $7_{\text {ta }}$ R.)

\section{9 .}

Mème ouvrage, quatriène volume, reufermant l'histoire des petites dynasties de lOOrienl et de l'Occident.

Papicr. 234 feuillets. Hauteur, 28 centimètres; largeur, 19 centimètres et demi. 35 ligncs par page. lls. du xvi1 siècle. - (Supplément 7 h 2 II.)

\section{0 .}

Mème ouvrage, cinquième volume, commençant par l'histoire des Seldjoukides et finissant par l'histoire des Doûschì Khân.

Papier. 2 o 7 feuillets. Ilanteur, 28 centimètres; largeur, 20 centimètres. 35 lignes par page. Ms. du xví siècle. - (Supplément $742 \mathrm{~N}$.)

\section{1.}

Même ouvrage, cinquième volunie, commençant par 
I'histoire des Seldjoukides el finissant par l'histoire des Oltomans. Ms. daté de l'an $119^{2}$ de l'hégire (1778 de J. C.).

Papier. 243 fetillets. Hautenr, 31 centimètres; largeur, 21 centimètres. 33 lignes par page. - (Supplément 742 T.)

\section{2.}

Hême ouvrage, sixième volume, commençant par l'histoire des Arabes de la quatriène race et finissant par le chapitre des Beni Makki, de Gabès (قابس).

Papier. 192 feuillets. Hauleur, 33 centimètres; largeur, a centiwètres et demi. 23 lignes par page. Ms. dı xvı siècle. -- (Supplément 742 S.)

\section{3.}

Même ouvrage, sixiène volume, commençant par la seclion des Arabes de la qualrième race et finissant jar le chapitre des Beni Thâbit, de Tripoli. Aux fol. $211 v^{\circ}$ et suiv. se Irouvent cing chapitres formant le commencement du septième volume de lourrage, volume que le copiste désigne comme le cinquième. Ces chapitres trailenl des Zenàta, de la Kîhina, des Benì lfrẹ, d'Alsoû Qorra et d'Abon Yazîl. Ms. daté de l'an 1199 de l'hégire ( $784-1785$ de J. C. .).

Papier. 217 feuillets. Ilauteur, 31 cenlimètres; largenr, 22 centimètres el demi. 26 lignes par page. - (Supjlément $7^{42} 0$. )

\section{4.}

Mène ouvrage, sixième volume, commençant par la section des Iribus arabes de la quatrieme race et finissant prar le chapilre des Beni Thàbit, de Tripoli. Ms. daté de l'an 1200 de l'hégire (1785-1786 de J. C.).

Papier. $19^{2}$ feuillets. IIauteur, 34 centimétres; largeur, 23 centimètres. 30 lignes par page. - (Supplément $742 \mathrm{~L}$.)

\section{5.}

Mêne ouvrage, septième volume, conmencant par les Zenàta et finissant par le chapitre des e volonlaires de la loi \%. Ms. daté de l'an 1179 de l'hégire (1 766 de J. C.).

Papier. 160 feuillets. Hauteur, 30 centimètres et demi; largeur, 20 centimètres. 31 lignes par pagre. - (Supplément 743 P.)

\section{6.}

Ourrage anonyme, commençant par une esquisse de l'hisloire du monde, jusqu'à la prédicalion de Mahomel, suivie d'un corps d'annales très-alyrégé, qui se ter-

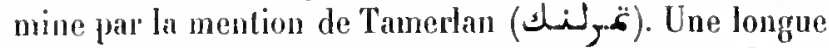
disserlation sur les signes avant-coureurs de la fin du monde sert d'épilogue à l'ouvage. Le premier feuillet manque, ainsi que le dernier. Une préface, ajoutée après coup, donne à cet ouvrage le litre de Dons spiriluels fournissant les dates des connaissances inspirées $"$, litre qui ne convient guère au contenu de cet abrégé historique. En tête de la prélace, el écril de la même main, se trouve le nom de l'auteur: Aboû Zaïd 'Abd al-Raḥmân ibn Khaldoùn. Nous sommes portés à croire que ce premier l'euillet est l'œuvre d'un faussaire.

Papier. 71 feuillels. Hautẹu, 31 centimètres; large:1r, 21 centimètres et demi. 25 lignes par page. IIs. du xvis siècle. - (Supplément g/5.)

\section{7.}

Jardin offrant divers poinls de vue loncliant la connaissance des origines et des finss, par Moḷibh al-Din Abou 'I-Walid Mohammad ihn al-Schiluna. Abrégé d'hisloire universelle, composé

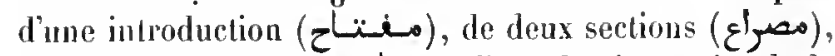

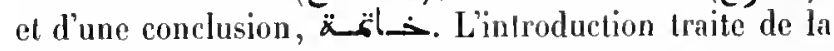
création des cieux et de la terre; la prenière section renferme l'histoire antéislamique; la seconde, l'histoire musulmane, jusquà l'an 806 de l'hégrire. Dans la conclusion, l'auleur énumère les signes qui doirent annoncer la fin du monde. Ce Jésumé d'histoire commence ainsi : all $\omega_{0}$

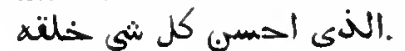

Hs. daté de l'an 860 de J'hégire (1456 de J. C.). Lin tête du rolume se trouvent deux notes, l’une de la main de Galland et l'autre de la main de Dom Berthereau.

Papier. 91 feuillets. Hauteur, 27 centimètres et demi ; largeur, 28 centimètres el demi. 29 lignes par page. - (Ancien fonds 617.)

\section{$153 S$.}

Nême ouvrage. Ms. daté de l'an 983 de l'hégire ( 1575 de J. C.). Frontispice en or el en couleurs. Au commencement et à la fin du volume se trouvent des notes diverses.

Papier. 160 feuillets. Hanteur, 20 centimètres et demi; largeur, 15 centimètres et demi. 23 lignes par page. - (Ancien fonds 774 .) 


\section{9 à 1541.}

Hème ourrage, accompagné d'une traduction fiançaise, exécutée en 1736 et en 1737 , à Constantinople, par Galland, jeune de langues. Le texte arabe est de la maiu d'un scribe orienlal. Le récit s'arrête à l'an 584 de l'hégire.

3 vol. Papier. 26,34 et 39 feuillets de texte arabe, et 157,281 et 302 pages de lexte français. Hauteur, 16 centimètres et demi; largeur, 10 centimètres et demi. 21 lignes par page dans te texte arabe, 19 lignes dans la partie françise. - (Fonds des traductions 83, 84, 85.)

\section{2.}

بان Le Collier de perles, traité dhistoire des peuplesn, par Badr al-Din Maḷmonid at-Aïni, mort en 855 de l'héfrive (1451-1452 de J. C.). Ce volume, le second de l'ouvrage, renferme l'histoire d'Abralıan (Al-Khalil) et des autres patriarches, l'histoire des rois des diverses nations, l'histoire des tribus arabes, et enfin la généalogie de Mahomet. Ms. daté de l'an 1158 de l'hégire (1 745 de J. C. ).

Papier. 325 fenillets. Hauteur, at centimètres; largeur, 15 centimètres et demi. 25 lignes par page. - (Supplément 737. )

\section{3.}

Volume dépareillé du même ouvrage, contenant l'histoire musulmane, depuis l'an $G_{2} 1$ de l'hégrire, jusqu'à l'an 679 de l'hégire. Le premier feuillet, avec le tile, et la seconde page du dernier feuillet sont l'ourre d'un laussaine. (Voyez le Recueil des historiens orientaux des croisades, I. 1, p. xuv.) En tète du volume se trouve une liste des clıpilıes, écrite par Mliclıel Șabbâght.

Papier. s34 feniltets. Hautenr, sti centimètres et demi; largeur, 18 centimètres. 31 lignes par page. Ms. du $x v^{e}$ siècte. - (Supplément 757.$)$

\section{4.}

Volume dépareillé du même ouvrage. Ce volume qui, jusqu'au fol. $168 \mathrm{r}^{\circ}$, est de la main d'd l़mad al-'Aini, frère de l'auteur (royez lol. 99, í la marge, et fol. $134 \mathrm{v}^{\circ}$ ), contient un jourmal très-détaillé des événements de l'Égypte et de la Syric, depuis te commencement de l'an
799 de l'hégire, jusqu'en 832 de l'hégire. Chaque année est suivie d'un obituaire.

Papier. 186 feuillets. Ilanteur, 25 centimètres; largeur, 16 cenlimètres. 3 lignes par page, 23 lignes à partir du feuillet 168 . Ms. du $x v^{\circ}$ siècle. -- (Ancien fonds $68 \%$.)

\section{5.}

( Livre des perles, abrégé d'histoire universellen, par Aboû 'Abd Allah Mo-

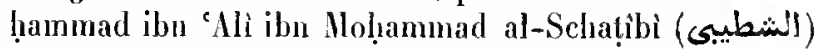
al-Andalosi. Cet ouvrage est divisé en trois sections, dont la première est consacrée à l'histoire antéislamique, la seconde à la vie de Mahomet, et la troisième à l'histoire des dynasties musulmanes, y compris celle des Almohades. Dans un chapitre supplémentaire de sept pages, l'auteur énumère les signes précurseurs de la fin dı monde.

Dans l'ancien catalogue et dans les notices qui sont en tête du ms., eet ourrage est attribué à Jbu Klıaldoûn. - Je ne comprends pas, dit H. de Sacy (Notices et Extraits, t. 11, p. 124 et suiv.), ce qui a pu donner lieu à cette erreur. $\rightarrow$ Les premiers feuillets manquent.

Papier. $17^{4}$ fenillets. Hauteur, 22 centimètres; largeur, 16 centimètres et demi. a 3 lignes par page. Ms. dn $x v^{\circ}$ siècle. - (Ancien fonds 769 , Colbert 5283 .)

\section{6.}

\section{$1^{\circ}$ Le Kitâb al-Djomin d'Al-Schatịibi.}

$2^{\circ}$ (Fol. 176 v.) (فلوفيات "Les Décès", par le khatil ou prédicateur Mḷmad ibn Qoufod (قنی). (La fanille des Benî Qonfod est une des plus notables de la ville de Constantine.) C'est un nécrologe des saints personnages de l'islamisme, par périodes de dix ans, depuis l'an 1 de l'hégire jusqu'en 807 de l'hégire. Nous lisons à la fin du traité que l'auteur lui avail donné le titre de تشرن المطالب s' is l'endroit par excellence oì l'on peut trouver des trésors cachés\%.

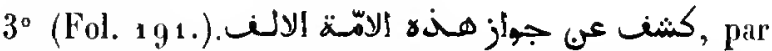
Al-Soyoûti. Dans ce traité, l'auteur prétend démontrer que la nation musulmane doit durer au delà de mille ans.

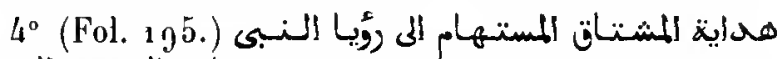
e Guide pour celui qui a un grand désir de voir en songe le prophète Hahomet ", par Zaïl al-

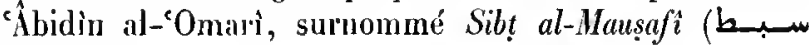
(li).

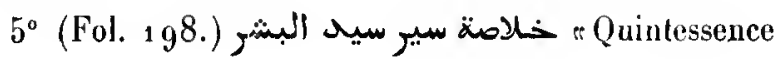
37. 
de l'histoire dur Seigneur du genre humain ", par le mouftì al-llaramaïn Molibb al-Din Alumad ibn 'Abd Allah alTabari. C'est une biographic de Mahomet en vingt-quatre chapitres.

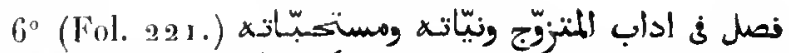
Conrt chapitre sur les deroirs d'un homme qui se marie, sur les intentions quil doit avoil el sur ce quil fera de louable ou de réprébensibler.

$7^{\circ}$ (Fol. aะ4.) Visious du schaikh 'Abd al-Raḥmàn al-

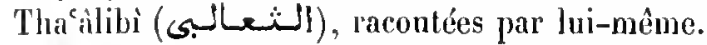

Us. écrit à Fez et daté de l'an 1004 de l'hégire $(1596$ de J. C.).

Papier. 226 feuiltels. Hauteur, 30 cenlimètrcs; largeur 20 centimètres et deıni. Au conmencement 29 ligues par page, puis 26 , puis 24 . - (Ancien fonds 616 , Colbert 3149. )

\section{7.}

Le Kitáb al-Djomán d'Al-Schațibi. Dans cet exemplaire on donne à l'auteur les noms de Schihàb at-Dìn Aḥmad al-Moqrì al-Fàsi. Il y a plusieurs lacunes daus ce volume. Ms. daté de l'an 1051 de l'hégire (1641 de J. C.).

Papier. 160 feuillets. llauleur, 22 centimètres; largeur, 15 centimètres. An commencement 17 lignes par page, puis 23. - (Ancien fonds $7_{2 .}$ )

\section{8.}

Nème onvrage. Le titre complet est indiqué aux folios 59 et $115 \vee^{\circ}$. Ms. daté de l'an 1197 de l'hégire ( 1783 de J. C.).

Papicr. 190 feuillels. Hauleur, 34 centimètres; largeur, 20 centimétres et deini. 25 lignes par page. - (Supplément $7^{55}$.)

\section{9.}

Extraits de divers ouvrages arabes, dont quelques-uns sont accompagués d'une traduction française, le tout de la main de Venture de Paradis. Le premier morceau est liré du Kitàb al-Djomán d'Al-Schatịit. Au fol. $37 v^{\circ}$ commence une série d'observations critiques sur la vie de Mahomet, composée par Sarary.

Papier. 61 feuillets. Hauteur, 30 centimètres; largenr, 23 centimètres. Ms. du commencement du $x_{x}{ }^{e}$ siècle. - (Supplément 2369.)

\section{0.}

م- Abrégé du Montazam et récolte de l'homme assidu », ouvrage composé en 870 de l'hégire (1465 de J. C.), par 'Mlì ibn Madjd al-Dìn alSchâhroudi al-Bisțâmî. La grande chronique unirerselle, intitulée e coordonnén, a pour auteur le célèbre polygraplie et prédicateur Aboû 'l-Faradj ' $A$ bd al-Raḅmàn Ibn al-Djauzi. Hadji Khalfa, en parlant de ce dernier ouvrage, attribne à un nonmé 'Alì ibn 'Atà al-Dìn Molıammad epetit anteur» cet abrégé, dont le présent ms. n'est que le premier volume, renfermant l'histoire du monde, depnis la création jusqu'à l'hégire.

Papier. 260 feuillets. Hauteur, 21 centimètres et demi; largeur, 5 centimètres et demi. 2 lignes par page. Ms. du xvir siècte. - (Ancien fonds $77^{2 .}$.)

\section{1.}

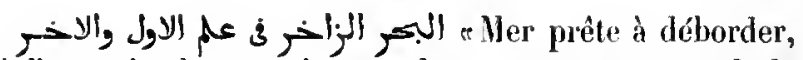
où l'on prise la connaissance du commencement et de la fin », chronique universelle, par Aboû 'I-Maḷâsin Yoûsof ¡bn Taghri Bardi. Le présent volume, le cinquième de l'onvrage, commence par l'an $3_{2}$ de l'hégire, et finit par l'an $7^{0}$ de l'hégire.

Papier. 248 fenillets. Hauteur, 27 rentimètres et demi; largeur, 18 centimètres. 23 lignes par page. Ms. du xx ${ }^{e}$ siècle. - ( A ocien fonds $65_{9}$ A.)

\section{2.}

reurs magrnifiques, cueillies parmi les événements des siècles», par Djalâl alDìn 'Abd al-Raḥmàn al-Soyoûtị. Premier volume d'une chronique universelle, commençant par la création dı monde et finissant par l'an 783 de l'hégire. Le second volume devait contenir l'histoire des Mamloucs circassiens. Ms. daté de l'an 1094 de l'hégire (1683 de J.

Papier. 441 fenitlets. Hautenr, 21 centimètres; largeur, 17 centimètres. 17 lignes par page. - (Supplément 728.)

\section{3.}

Abrégé d'histoire universelle, composé par un anonyme, d'après les ouvrages d'Aboû 'T-Fidà (Ismacil ibn 
'Alì ibn Mạ̣moûd..... ibn 'Omar ibn Schâhinschâhı), d'Ibn al-Monaddjim (Aboû 'Isà Aḥmad), d'Al-Qìdlì al-Hlamawi, auteur du Tarikh al-Mosaffari, d'Ibn Khallikân, d'Al-Ișfahàni, auteur du Djâme wa 'l-Bayân fi Tarikhi 'l-Kä̈rawân, d'Ibn Sa'id, d'lbn Wàșil, auteur du Mlofarridj al-Koroûb et d'Al-Maqrìzi. L'auleur dit aussi avoir mis à contribution les compilations d'Al-Qodbâci et l'Histoire des juges des enfants d'lsraël (الفغر تضاة بنى (أسـرايـل On voit aussi qu'il s'était servi des ouvrages d'Al-Maseoudi. C'est uu abrégé de l'histoire du monde, depuis Adam jusqu’ì la conquête de l’Égypte par les Ottomans. Au fol. $136 \mathrm{v}^{\circ}$ commence une notice sur le Caire, sur les mosquées el les autres monuments de cette ville, sur les pyramides, sur la ville de Jérusalem, sur le torrent d'Arim, sur les fêtes des Coples et sur d'autres suكتناب التناريخ : jets. Le frontispice orné porte le titre de

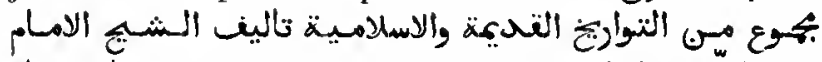

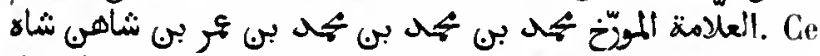
titre inexact a été ajouté après coup. Hs. daté de l'an 973 de l'bégire (1565-1566 de J. C.).

Papier. 197 fenillets. Hauteur, 3o centimètres et demi; largeur, 20 centimètres et demi. 14 lignes par page. - (Ancien fonds 615.)

\section{4.}

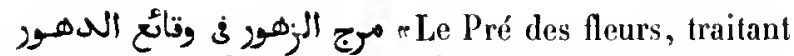
des événements de tous les siècles $n$, par un auteur anonyme. C'est une clironique universelle, depuis la création du monde jusqu'au règne du sultan mamlouc Barqoûq et ses successeurs. Le présent volume, le premier de l'ouvrage, renferme l'histoire des patriarches, de Nabuchodonosor, d'Alexandre, etc., et se termine par une nolice sur les Sassanides et sur Yazdagird. Lauteur écrivait sous le califat d'Al-Mostamsik billàh Aboû 'I-Ṣabr Yac qoùb, de la seconde dynastie abbaside, qui régnait de 903 à 945 de l'hégire ( 1496 à 1539 de J. C.) ${ }^{1}$. Ms. daté de l'an 1038 de l'hégire (1628-1629 de J. C.).

Papier. $3{ }^{4} 9$ feuillets. Ilanteur, 3 i centimètres; largeur, a i centimètres. 13 liggnes par page. - (Ancien fonds 617 A.)

\section{5 .}

Abrégé des annales d'Ibn alBadie", par "Nbd al-Qâdir ibn Djàr Allâlı al-Amìn. Cel abrégé devait se composer de trois parties, mais l'auteur n'a pu en rédigger que la première et la seconde. La preunière parlie remplit treize feuillets el contient me histoire des Sassanides, depuis Ardaschîr, fils de Bàbak, jusqu’à la conquête de la Perse par les Musulmans. La seconde partie commence à l'bégire et donne une esquisse de l'histoire musulmane, année par annće, jusquù l'àènenıent de la dynastie abbaside.

Papier. 140 feuillets. Hauteur, so centimètres; targeur, 14 centi. mètres. 17 lignes par page. Ms, du $\mathrm{xvı}^{\mathrm{e}}$ sièele. - (Ancien fonds 768.$)$

\section{6.}

(ilistoire des dynasties et monuments des temps passésn, par Aboû 'l- Mbbàs A ḷmad ibn Yoûsof ibu A ḥmad al-Dinaschqì, mort en 1019 de l'bégire (1610-1611 de J. C.). Celte chronique universelle se compose d'une introduction el de cinquante-cinq chapitres. Chaque chapitre est divisé en plusieurs sections. Les vingt-sept dernières sections forment un dictionnaire géographique, où les noms de lieu sont classés dans l'ordre de l'alphabet. En tète dn volume se tronve une table des malières très-complète. Premiers mots de la préface : لمه  lets du dernier tiers du volume ont beanconp souffert de l'lumidité. Le dernier feuillet manque.

Papier. ${ }_{267}$ feuillets. Hauteur, 29 centimc̀tı es et demi; targeur, 9 centimètres et demi. 31 lignes par page. Ns. du xvin siècte. (Supplément 75 \%.)

\section{7.}

Mène ouvrage.

Papier. 375 feuillets. Ifauteur, 30 centimètres; largeur, so cenlimètres. 21 lignes par page. Ms. du xwı1' siècle. — (Supplément 753.)

\section{8 et $\mathbf{1 5 5 9 .}$}

Première partie du mème onvrage. Texte arabe, accompagné d'une traduction française, exécutée en 1733 , par Paul Astoin Sielve, chevalier du Saint-Sépulcre et premier interprète de France an Caire. Le texte est de la main d'un scribe oriental.

2 votumes. Papier. 106 feuillets de texte arabe et 386 pages de texte

\footnotetext{
' L'auteur de celle chronique est l'lmåm hanéfite Moḷammad ibn lyâs at-Mị̣rî. H. Z.
} 
français. Hauteur, 30 centimètres; largeur, 20 centimètres et demi. 15 lignes par page dans le texte arabe, 19 lignes dans la partie frangaise. - (Fonds des traduclions 3.)

\subsection{0 .}

e Source de l'histoire et délassement des yeux $n$, ouvrage composé par un descendanı du calife Shoû Bakr, qui portait les noms de Molımmad ilou Hoḷammad ibn abî l-Soroùr ef les surnoms d'M-Şiddíni al-Bakri, et qui était contemporain de Hadji Kalli (royez IJadji Ĺlıalfa, t. 11, p. 264). Ce volume, renfermant huil sections, n'est que la premiere moitié de l'ourrage. On y trouve l'histoire d'Adam et des patriarches, des souverains de la Perse, de la Grèce, de l'Arménie, de Rome, l'histoire de Mahomet, des premiers califes, des Omayyades d'Orient, des Mbbasides de la première el de la seconde race, jusqu'en $9^{5} 7$ de l'hégire. Le second volume devait contenir l'histoire des Omayyades d'Espalgue, des Bouides, des Fatémides, des Seldjonkides, des lyyoubides, des Tures, des Musulmans circassiens et des Ottomans. Ce mns. porte des corrections de la main de l'auteur.

Papier. 256 feuillets. Hauteur, 20 centimètres; largeur, 1/4 centimètres et deni. 15 lignes par page. - ( Ancien fonds 763, )

\section{1.}

مes Délices des yeux et les Nourelles certaines $n$, par Moḷammad ibn abì Bakr al-Şiddiqî. Cet ouvrage se compose d'une introduction et de vingt-quatre chapitres. Les premiers chapitres sont consacrés anx sept races des génies qui habitaient la terre arant Adan. Le dernier chapitre (fol. $122 v^{\circ}$ ), le plus étendu, renferme l'histoire de la dynastie ottomane, depuis 'Othmân Khàn, jusqu'an règne de Mourâd, fils d'Mḥmad 1. Ms. daté de l'an 1199 de l'hégire (1 785 de J. C.).

Papier. 181 fenillets. Ilauteur, 34 centimètres; largeur, 20 centimètres et demi. 25 lignes par parge. - (Supplément 750 .)

\section{2.}

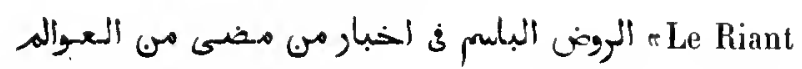

jardin, hisloire des peuples d'autrefois $»$, par un auteur incomnu. On a écrit sur le recto du premier leuillet que c'est

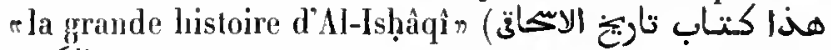
الذبميي ), auleur qui n'est pas mentionné ailleurs. Dans ce rolume, nous trourons d'abord un sommaire de l'histoire des prophètes, puis (fol. 15) l'histoire des quatre premiers califes ef d'Al-Hasan, fils d'Ali; ensuite (fol. 59) l'histoire des Omayyades et celle des Abbasides (fol. 94). Les chapitres suivants traitent des gouverneurs de l'Égypte sous les califes (fol. $165,{ }^{\circ}$ ), des Fatémides (fol. 1 74 ) et des Ayyoubides (fol. $19^{5} \mathbf{v}^{0}$ ). L'histoire du règne d'Al-Màlik al-'Âdil, fils d'Al-Màlik al-Kànil, est précédée d'une dissertation relative à certains cadis du Caire. Après l'histoire d'Al-'̂́dil, l'auteur donne un résumé de l'histoire de l'Égypte, jusqu'en 1032 de l'hégire ${ }_{1} 6_{2} 3$ de J. C.). De nombreuses et intéressantes anecdotes, parfois étrangères au sujet, se trourent mêlées au récit. L'auteur dit (fol. 166) qu'il était né en 9 5 de l'hégire, et qu'il a comnencé cet abrégé historique en 955 ; mais plus loin (fol. $208 v^{\circ}$ ), il dit qu'il lui naquit un fits en 1032 . Ms. daté de l'an 1062 de l'hégire (1623 de J. C.).

Papier. 212 feuillets. Hauteur, 21 centimètres; largeur, 15 centiuètres. 17 à 21 lignes par page. - (Supplément 735 .)

\section{3.}

Fil (ou collier) d'éloiles culminantes, traité qui fait connaitre les fils (ou l'histoire, lil?) des anciens et de leurs successeurs $\leadsto$, ouvrage composé entre les années 1 o 94 et 1098 de l'hégire ( 1683 et ${ }_{168} 68$ de J. C.), par 'Abd al-Mâlik al-'Ișàmi (العصأى). C'est une chronique miverselle qui, eommençant par la création d’ Adam, traite des prophètes, de Mahomet, des quatre premiers califes, d'Al-Ilasan et d'Al-1losainn, des Omayyades, des Abbasides, des Fatémides, des Ayyoubides, des sultans mamloucs et des sultans ottomans. Ce volume se termine par le récit de la mort d'Al-Hasan. Dans la préface, qui commence par les

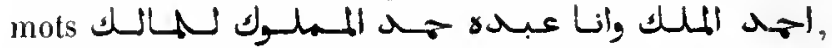
l'auteur donne la liste des nombreux ouvrages qu'il a consultés. Il fait observer que le titre de son ouvrage est un chronogramme indiquant l'année de sa composition.

Ms. daté de l'an 1157 de l'hégire (1744 de J. C.).

Papier. 361 feuillets. Hauteur, 29 centimètres; largeur, so centimètres et demi. ag liggnes par page. - (Supplément 734 .)

\footnotetext{
' Cet ourrage est une nouvelle rédaction du عي-رو الاخـبـ, dont plusieurs chapitres sont reproduits littéralement. H. Z.
} 


\section{4.}

Première partie de l'Histoire ancienne de Rollin (كير)

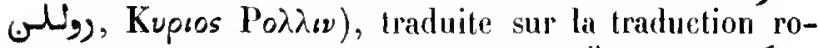
maíque du chancelier Alexandros (الكسندروس قانجيلارى), par le prè̀tre eAbd al-llasị, clief de la communauté chrétienne de Damietle, avec le concours du prè̀tre clsà Petro (بيتتس), natif de Jérusalem (الاورشيمى), qui était alors de passage ì Damiette. Ce travail fut entrepris en 1806 de J. C., sous les auspices de Kir Youkir Basili (كيـر ي-كوكيـ بـاسـيـلى), consul en cetle ville, et achevé en I 808. Le présent ms. se termine par la troisième guerre panique et la notice sur la famille de Masinissa (ميـلة (ماسى نسيسن).

Papier. 284 feuiltets. Hauteur, 23 centimètrus; largeur, 16 centimètres. 27 lignes par page. Us. du vire sièute. - (Supplément 7 13.)

\section{5.}

Arbres généalogiques des patriarches, des prophètes, des califes et des sultans. Le dernier souverain mentionné est le sultan oltoman Mlouștafâ III, fils d'Aḷmad III, qui monta sur te trône en 117 1 de l'hígire $(1758-1759$ de J. C.). Une autre main a ajouté le nom de Sélim, fils de Mouștafâ III, avec la date de son avènement. $A$ la suite des tables, vient une liste de tous les pachas d'Égypte et les dates de leur nomination, depnis l'an 923 de l'hégire jusqu'en 1 I 33 . Une autre inain a contimué celte liste, en y ajoutant dix-neul noms. Les derniers feuillets contiennent la liste eluronologique de tous les grands saints et docteurs de la loi, depuis Aboû ḷanila, jusqu'an schaikh Mollâ Moḷammad صون, mort en 1071 de l'hégire (16601661 de J. C.).

Papier. 51 fenitlets. Hanteur, 1 centimètres et demi; largeur, 16 centimètres. Ms. du xvm siècle. - (Supplénent 756 bis.)

\section{HISTOIRE DISS CALIFES.}

\section{6.}

riécits au sujet de la puissance spiriluelle et temporelle $n$, on liistoire des caliles, depuis la mort de Mahomet, jusqu'ì la mort de Haron̂ı al-Raschîd. Les deux premiers feuillets ne sont pas de la mêne main que te reste du volume. Mais on a laissé en blane le commencement de la prélace, tout en y iuscri-

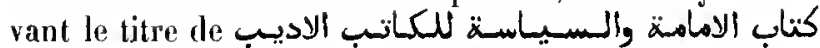

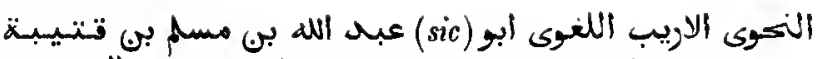

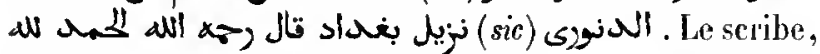
en attribuant cet ouvrage au célèbre Ilbn Qotaïba, ignorait le nom exact de cet auteur (Abou Mohammad "Abd

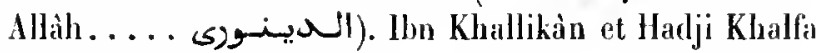
ont ignoré l'existence de cet ourrage. Le titre que nous àons donné en tête de cette notice est mentionné duux fois vers la fin du volume. Hs. daté de l'an 1229 de l'hégire (18,3-18,4 de J. C.).

Papier. 29 3 feuillets. Ilauteur, a centimètres et demi; largeur, 17 centimètres. 17 lignes par page. - (Supplément 5 h3 bis.)

\section{7.}

révénemenls extraordinaires", recueil d'anecdotes et de faits historiques, atlribué au célèbre docteur et prédicateur Aboû 'l-Faradj 'Abd al-Ralimmàn Ibn al-Djauzì. Ciel ourrage se compose de deux parties, dont la première énumère los événements remarifualles de chaque année, depuis l'hégire, jusqu'à l'an 520. La seconde partie, commençant au fol. 67 , et intitulée r Récits extrordinairesn, renferme des aneedotes de tout gen re, provenant de diverses sourees. Le compilateur les rapporte, sans observer ni l'ordro des matières, ni l'ordre chronologrique. La préfice commence Pall ces unots :

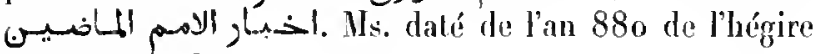
(14-5 de J. C.).

Papier. 155 fenillets. Hauteur, 18 centimètres et demi; largenr, 13 centimètres. 15 lignes par page: - (Supplément $7^{4} 7$, Saint-Germain 363.)

\section{8.}

r Lare qui suffit pour faire connaitre l'listoire des guerres de l'Élu (Mahomet) et des trois (prenier's) califes", onr rage connu sous le titre de سئرة Histoire du Prophète, par A]-Kalâ‘i ". L'auteur, Abon̂ 'l-Rabic Solaïmâu ibn Moùsà al-Kalầi, descendant des Arabes himyarites, élait né en 565 de l'hégire $(1,69-1170$ de J. C. $)$, aux environs de Murcie; après avoir rempli les fonctions de khatib dans la grande mosquée de Valence, il trouva la mort en 634 ( $1336-1237$ de J. C.), sous les nurs de sa ville natale, en combattant les chrétiens. Il a laissé plusieurs ourrages, dont la liste, avee une notice hiographique, tirée du طبنات أبر فوحرن. se trouve en tête du présent ms., qui ne contient que la première partie de l'Ilitifa, c'est-à- 
dire l'histoire de Mahomel, d'après les sources les plus aulhentiques, se terminant par quelques élégies composées à l'occasion de la morl du Propliète. Ms. daté de l'au 909 de théggire ( 1504 de J. C.).

Papier. 255 feuillets. Hauteur, 28 centimètres; largeur, 18 centimètres et demi. 7 lignes par page. - (Ancien fonds 633.)

\section{9 .}

Seconde moitié dr' l'Iktifâ d'Aboû 'l-Rabî́ Solaïmân alKatâi ixemplaire copié à la Meeque, en 885 de l'hégire (1480 de J. C.) '.

Papier. 143 fenillets. llanteur, 27 centimètres; largeur, 18 centimètres el demi. 25 lignes par page. - (Ancien fonds 653.)

\section{0 .}

Fragments d'une histoire musulmane. Le premier feuillet appartient au chapilre qui trate du calife abbaside M1-Táie . Vient ensuite la mention du massacre des delniers Omayyades et de l'arènement des Abbasides. L'histoire très-incomplète dr cetto dynastie se termine par le règne d'Al-Moqtafí. L'auleur parle ensuite des vizirs de ces caliles, puis de l'origine et de l'histoire des Fatémides, jusqu'an règne d'Al-Mostaclì. Plusieurs feuillets sont intervertis.

Papier. 85 feuillets. Hauteur, 18 centimètres; largeur, 13 centimètres. 19 lignes par pagre. Ms. du xum siècle. - (Supplément $7_{26} 6$, Saint-Germain 360.)

\section{1.}

ي : Livre pour les orthodoxes, traitant des mériles des califes \%, traité spécial des mérites des quatre premiers califes, d'Al-I!asan et d'Al-Hosaïn, et des dix compagnons de Mahomet qui avaient reçu de lui l'assurance qu'ils entreraient diuns le paradis. L'auteur anonyme déclare avoir pujsé les matériaux de son ourrage

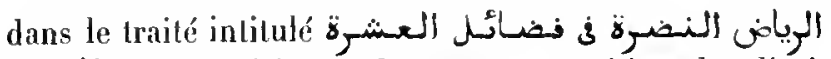
r. qui le paradis fut promis $n$, de Mołibb al-Din Abou Djacfar al-Ṭabari (Aḷmad ibn 'Abd Allah), docteur schaféite de la Mecque, mort, selon Hadji Khalfa, en 694 de l'hé- gire (1294-1295 de J. C.). Il donne, dans la prélace, la liste de ses professeurs et un catalogue des lives qui foumissent les renseignements les plus aubentiques sur les premiers temps de l'islamisne. L'ouvrage com-

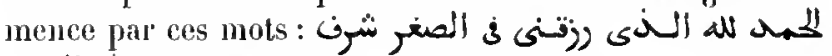
.

Papier. 135 feuillets. Hauteur, 20 centimètres et demi; largeur, 15 centimètres et demi. 17 lignes par page. Ms. du xvn siècle. (Ancien fonds $77^{5}$.)

\section{2.}

ة traitant de l'histoire musulmane depuis l'légires, par Rokn at-Din Bajbars al-Manșoûrì, chancetiel du gouvernement égyptien (jlslo), mort en 725 de l'bégire (1 325 de J. C.). Ce rolume est le cinquième d'un exemplaire qui se composail de onze volumes, et qui avait été donné en waqf ì un établissement religieux par le sultan mamloue Al-Malik al-Zâhir Aboû Sa ìd Barqoùq. 11 commence par l'an 252 de l'hégire, el finit par l'an 322 de l'hégire. L'auteur a puisé la plupart de ses matériaux dans le Kâmil d'lbn al-Alhir.

Ms. revu et corrigé par l'auteur; frontispice orné.

Papier. 234 fenillets. Hauteur, 26 centimètres; largeur, 17 centimètres. 17 lignes par pagre. Ms. du xiv ${ }^{\mathrm{e}}$ siècle. - (Ancien fonds 668.)

\section{3.}

Encyclopédie d'M1-Nowaïri. Le commencement et la fin mawquent. Ce volume renferme les parties suivantes:

1. Fin de l'histoire des rois himyarites, à partir de la mort du second tobbac, As ad Aboú Karib.

2. (Fol. $5 v^{\circ}$.) Histoire des princes de Ḥira, de la race de Kahtân.

3. (Fol. $9 v^{\circ}$.) Histoire de la digue de Marils.

4. (Fọl. 11.) Commencement du cinquième باب du

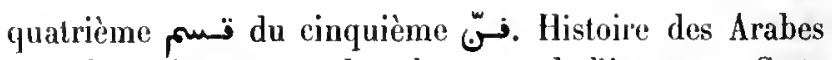
et de leurs journées pendant le temps de l'ignorance. Cette partie se termine par le récit de la journée de Dsoû Qâr, mais les derniers feuillets manquent.

5. (Fol. 40.) Histoire des Phıaraons d'Égypte, à partir

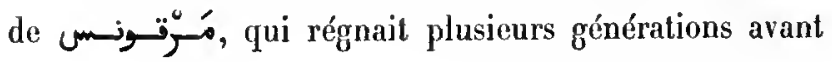

\footnotetext{
1 C'est plutôt la troisième partie de l'ourrage, car le récil commence aư milieu du califat d'Omar. H. Z.
} 
Rayyân ibn al-Walid, le Pharaon du patriarche Joseph. Elle se termine par la notice du roi Tamâir Qoûs (طمايی (توس ), le Pharaon de Moïse, et pas un court appendice, qui s'arrête à l'époque de l'ishamisme.

6. (Fol. 57.) Commencenent du troisième باب du

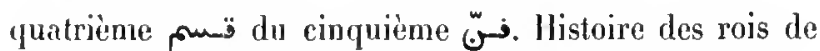
Perse, depuis Kayoůmartı jusqu’à Yazdagird.

7. (Fol. $86 \mathrm{v}^{\circ}$.) Histoire des rois grees, à partir de Philippe, père d'Alexandre, finissant par la liste des Ptolémées.

8. (Fol. 93.) Liste des anciens rois d'Assyrie.

9. (Fol. 94.) Liste des rois chaldéens (sic أUلبوأنبيج).

10. (Fol. $9^{5} \mathrm{v}^{\circ}$.) Liste des empereurs romains, depuis Jules César jusquu’à Dèce.

11. (Fol. $9^{6} \mathrm{v}^{0}$.) Histoire des sept dormants (أمحسب) iquil).

Ce ms. ust considéré comme autographe. Les quarante premiers feuillets doivent être placés à la fin du volume.

Papier. 98 feuiltets. Hauteur, ${ }_{2} 5$ centimètres et demi; largeur, 19 centimètres et demi. 27 tignes par page. - (Ancien fonds 700.)

\section{4.}

Encyclopédie d'Al-Nowaïrî. Ce volume renferme :

1. llistoire des deux dynasties des califes abbasides, depuis l'avènement d'Al-Moqtafì Billâh jusqu'à l'avènement d'A1-Mostaqfî Billâh, de la seconde branche abbaside, qui fut proclamé au Caire, en 701 de l'hégire ( 1320 de J. C.). Au lol. go se trouvent, écrites d'une autre main, quelques notes sur les successeurs de celui-ci, jusqu'en 763 de l'hégire. Mais cette addition ne peut appartenir à Al-Nowaïri, mort en 732 .

2. (Fol. $90 \mathrm{v}^{\circ}$.) Histoire de l'Espagne sous les Omayyades

Les parties de l'Encyclopédie qui se trouvent dans ce volume forment la fin du quatrième باب du quatrième فنّ, et le commencement du cinquième تسّم du mêne titre qu'on lit en tête du volume est faux. dent.

Ce ms. est de la même main que le numéro précé-

Papier. 110 fenillets. Hauteur, 27 centimètres et demi; largeur, so centimètres. 27 lignes par page. Ms. du xuv siècle. - (Ancien fonds 645.)

Max. obiextaux. - 11

\section{5 .}

Encyclopédie d'Al-Nowaïrî. Ce volume commence par le sixième باب du cinquième قسم du cinquième فى. Cette partie renferme:

1. Mistoire de la Mauritanie, depuis la conquête musulmane jusqu'à la clute de la dynastie almohade.

2. (Fol. $68 v^{\circ}$.) Histoire de la Sicile sous la domination musulmane.

3. (Fol. 72.) Histoire de la Crète sous les Musulmans.

4. (Fol. $7^{3} \vee^{\circ}$.) Seprtième باب du cinquième قسم du cinquième $\underset{\sim}{\sim}$, renfermant l'histoire des prétendants de la famille $d^{\prime c} A l i$, sous la dynaslie omayyade.

Il manque un feuillet entre les fol. 3 et 14 , un feuillet entre les fol. 15 et 16, un feuillet entre les fol. 20 et 21. Ce ms., d'après l'explicit, serait autographe : على

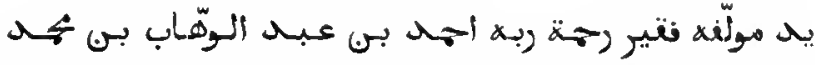

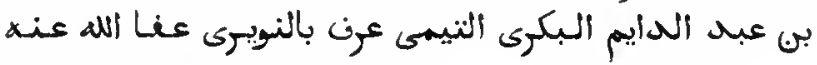

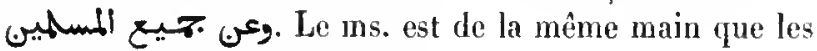
deux numéros précédents.

Papier. 79 feuillets. Hauteur, 27 rentimètres et demi; largeur, so centimètres. 27 lignes par page. Us. du xiv siècle. - (Ancien fonds 702.)

\section{6.}

Encyclopédie d'Al-Nowaïrì. Ce volume commence par l'histoire des prétendants de la famille d'Alì, sous less Abbasides. Suit un récit assez étendu des révoltes des Zendj et des Caranathes; puis (fol. 8a) une courte notice de la révolte des Khâridjites, en 252 de l'hégire ( 866 de J. C.), dans la province de Mossoul. Au folio 86 communce

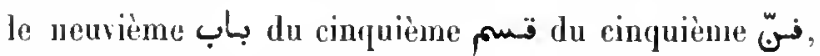
renfermant des notices sur les Samanides, sur les Saffarides (fol. $97 \mathrm{v}^{\circ}$ ) et sur les princes qui régnèrent en Espagne, après la chute de la dynastie omayyade. Après uu résumé de l'histoire d'Al-Mo'tamid ibn 'Abbàd, de courtes notices sont consicrées aux princes qui régnèrent à Saragosse et dans l'Aragon, à Tortose, à Salé, à Dénia et aux Baléares, à Hurcie et à Almeria. La fin du ms. (notice des princes de Malaga et quelques autres) manque. Ce ms. est de la même main que les numéros précédents.

Papier. 108 feuiltets. Hauteur, 27 centimètres et demi; largeur, so centimèlres. 27 lignes par page. Ms. du xıve siècle. - (Ancien fonds 647. ) 


\section{7.}

Extraits de l'Encyclopédie d'Al-Nowaïrì.

1. Histoire des Almohades d'Espagne et d'Afrique, et de la conquête de la ville de Maroc. La narration s'arrête ì la mort du sultan Mboú Hoḷammad ibn 'Abd al-'Aziz ibn Yoûsof ibn 'Alod at-Moúmin. Suivent la liste des souverains almohades et celle des souverains mérinides.

2. (Fol. 14.) Histoire de l'occupation de la Sicile par les Musulmans.

3. (Fol. $14 r^{\circ}$, ligne 11.) Passage interpolé, relatif au sultan ahmohade Aboù Yoûsof Yacqoûb, mort à Salé, en $59^{5}$ de l'lıégire ( $11199^{8-1} 199$ de J. C.).

4. (Fol. 15.) Avìnement d'Aboû 'Abd Allah Mohammad, fils d'Aboủ Yoûsof Yácoûb. Les dernières lignes du recto de ce feuillet sont une interuolation. Il y est question de la Sicile, de la mort du cadi Asad ibn al-Forât, en 213 de l'hégire, de l'avènement de Mohammad ibn abì 'l-Djewârì, et de la mort de Moḥammad ibu 'Abd Allah l'Aghlabite, en 236 de l'hégire.

5. (Fol. 16.) Suite de l'histoire des Musulmans en Sicile.

6. (Fol. 20.) Histoire de la conquête de l'ile de Crète par les Musulmans.

7. (Fol. 21.) Premiers feuillets de l'histoire des prétendants de la famille d"Ali, dont le premier fut Zaid ibu 'Alì.

8. (Fol. 24.) Histoire des guemes qui eurent lieu entre les Tartares et fe sultan Djalail al-Dìn, et listoire des descendants de Djenguiz Khân.ı.

9. (Fol. 43.) Histoire des gourerneurs du Maghreb et des Aghlabites. Les premiers feuillets manquent.

10. (Fol. 56.) Fragment de l'histoire des Fatémides, depuis l'an 437 de l'hégire, jusqu'en 492 . Histoire de la première croisade.

1 1. (Fol. 66.) Fragment de l'histoire des Tartares; conquête de la Syrie par Ghàzàn.

12. (Fol. 68.) Fragment de l'histoire de Tamin ibn al-Mo izz ibn Badis et de ses successcurs; prise de Tripoli d'Afrique par les Franes.

13. (Fol. 75.) Règue d'Aboù Bakr al-Lamtoùnì, et suite de l'histoire des Almoravides.

14. (Fol. 8o.) Extraits de lettres écrites par diverses personnes. Épitre composée par llon Badroûn au nom de la princesse Wellada et autres pièces; épître attribuée ì Aboû Bakr et adressée à 'Ali, fils d'Aboû TTâlib.
15. (Fol. 94.) Fragment de l'histoire des Atabecs de Mossoul, à parlir de la mort de Djamâl al-Dìn, vizir de Qotb al-Dìn Maudoùd.

16. (Fol. 97 \%․) Histoire des Khàrizm Schâlı.

17. (Fol. 1 o6.) Fragments d'épitres.

Papier. 1 is feuillets. Hauteur, 27 centimètres et demi; largeur, 18 centimètres et demi. 29 lignes par page. Ms. de diverses écritures du $x v^{\circ}$ siècte. $-($ Ancien fonds $702 \mathrm{~A}$.)

\section{8.}

Vingt-cinquième volume d'un exemplaire de l'Encyclopédie d'Al-Nowaïrì, contenaut l'histoire des sultans mamloues, à partir de l'avènement d'Al-Málik al-Zủhir Baïbars, en 658 de l'hégire, jusqu'en 701 de l'hégire. La première partie de ce volume est donnée comme autographe, mais les derniers feuillets, à partir du folio 202, ont été écrits en 814 de l'hégire (1411-1412 de J. C.).

Papier. 220 feuillets. Ilauteur, 28 centimètres; largeur, a centimétres. 27 tignes par pazre. - (Supptément 739 .)

\section{9 .}

Vingt-neuvième (avant-dernier) volume d'un exemplaire de l'Encyclopédie d'AI-Nowaïrì. L'exenplaire complet avait été donné en waqf à la bibliothèque fondée par Ml-Mâlik al-Zàhir (Baibars), dans le quartier d'Al-

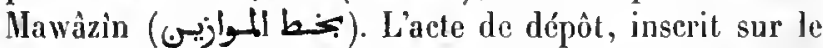
recto du premier feuillet, est daté de l'an 797 de l'hégire ( 1395 de J. C.). Le donateur, nommé Maḷmoûd, était ostadar egrand maitre du palais n de ce prinee. Ge solume commence par l'avènement de Qalawoûu, en $6_{7} 8$ de l'hégire, et finit par l'année 700 de l'hégire.

Ms. daté de l'an $7^{2} 6$ de l'hégire ( 1326 de J. C.). 11 est donné comme autographe.

Papier. 217 feuillets. Hauteur, 26 centimètres et demi; largeur, 17 centimètres et demi. 17 lignes par page. - (Ancien fonds 683.)

\section{0 .}

Annales de l'islamisme n, par Schams al-

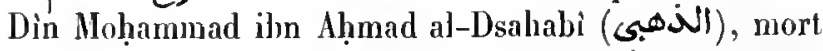
en 748 de l'hégire ( 1348 de J. C.). Ce volúme, sans pré- 
face, commence par la généalogie de Mahomet et renferme l'histoire de Mahomet et des quatre premiers califes, jusqu'à l'an 40 de l'hégire.

Papier. 192 fenillets. Hauteur, a6 centimètres ; largenr, 17 centimètres et demi. 27 lignes par page. $\mathrm{Ns}$. du $\mathrm{xv}^{*}$ siècle. - (Ancien fonds 6.6.)

\section{1.}

Sixième volume d'un exemplaire du même ouvrage, commençant par l'an 301 de l'hégire, et finissant par l'an 400 de l'hégire. Chaque période décennale, dont les événements sont brièvement énumérés, est suivie d'un obituaire, qui est disposé dans l'ordre de l'ajphabet; mais à partir de l'an 350 , jusqu'à la fin du siècle, la distribution par périodes décennales n'est plus observée, et l'obituaire, toujours dans l'ordre alphabétique, est disposé par ordre d'années. Frontispice orné; titre en or et en couleurs.

Papier. 334 feuillets. Hauteur, 27 centimètres et demi; largeur, 18 centimètres et demi. 29 lignes par page. $\mathbf{M l s}$ du $x v^{e}$ siècle. - (Ancien fonds 646 , Colbert 2865 .)

\section{2.}

Autre volume du même ouvrage. Ce volume, probablenent le dixiène de l'exemplaire auquel appartenait le numéro précédent, commence par l'an 581 de l'hégire, et finit par l'an 620 de l'hégire. Il y a une lacune entre les folios 128 et 129 . Frontispice orné.

Papier. ${ }_{2} 6_{7}$ feuillets. IIautenr, 27 centimètres et demi; largeur, 18 centimètres. 29 lignes par page. Ns. du $\mathrm{xv}^{*}$ siècle. -- (Ancien fonds 753 , Colbert 2864 .)

\section{3.}

Index alphabétique des noms des personnages mentionnés dans le ms. précédent, par Hichel Ṣabbàgh.

Papier. 43 feuillets. Ilauteur, 36 centimètres; largeur, 22 centimètres et demi. 26 à 27 lignes par page. - (Supplément 2069.)

\section{4 et 1585 .}

Exemples instructifs four- nis par l'histoire des hommes du passén, corps d'annales et obituaire, depuis la prenière année de l'hégire jusqu’à l'an 700 de l'hégire. Le premier rolıme s'arrête à l'an 444 de l'hégire. Copie datée de l'an 756 de l'hégire ( 1355 de J. C.). Le premier feuillet du premier volume manque. Le premier feuillet du second volume est orné d'un frontispice portant que cet excmplaire était

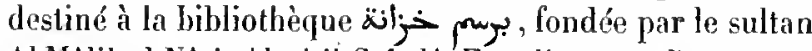
Al-Màlik al-Nâșir $A$ boû 'I-Sa adât Faradj, et que l'ou rrage a pour auteur Schams al-Din Aboû 'Abd Allah Mohammad ibn Aḷmmad ibn 'Othmân ibn Qâinấz (sL) ibn al-Dsahabi. Cette note n’est pas contemporaine de la copie, car le sultan Ml-Majik al-Nàsir Faradj ne monta sur le trône qu'en 801 de l'hégire.

2 vol. Papier. 218 et 237 feuillets. Ilanteur, 21 centimètres; largeur, 15 rentimètres. 19 lignes par page. - (Supplément 746 , SaintGermain 358 et $35 \mathrm{~g}$.)

\section{6.}

Dernier cahier du premier volume de la chronique intitulée عيبون التنوأزي (royez le numéro suivant), contenant le récil des derniers événements de l’an 21 de l'hégire et des événements de l'an 22. Le dernier fenillet porte dans un encadrement les titres des chapitres du Khitat qui traitent des sept premiers califes latémides.

Papier. 8 feuillets. Hauleur, 26 centimètres; largeur, 17 centimètres et demi. so à a 3 lignes par page. Ns. do xiv siècle. - (Supplément 2075 .)

\section{7.}

: Sources historiques», par Ibn Schâkir Fakhr aj-Din Molıammad al-Kotobi ( Selon Hadji Khalfa, cet ouvrage se terminait par l'an 760 de l'hégire. Le présent ms., troisiène volume d'un exenplaire qui devait en aroir dix ou quinze, commence par l'an 80 et se termine par l'an 123 . Cet ouvrage est trèsriche en anecdotes historiques et en notices biographiques. Dans le récit de l'an $9^{6}$ de l'hégire se trouve une longue description topographique et littéraire de la ville de Damas. Les marges du ms. sont couvertes de notes et d'extraits, écrits en ta'liq, en 1051 de l'hégire (164t1642 de J. C.), à Constantinople, par le faqîr Aḷmad (voyez fol. $166 \mathrm{r}^{\circ}$ ), à saroir :

a. Notices biographiques d'un certain nombre de compagnous du Prophète et de plusieurs traditionnistes. Ces notices, tirées du Tahdsîb d'Ibn 
Hadjr al-'Asqalâni et du أستبعلب (d'lbn 'Abd alBarr?), lorment une sorte de dictionnaire, com-

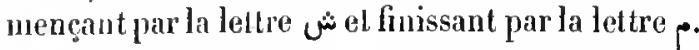

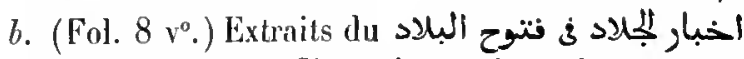
"Hisloire des conflils qui amenèrent la conquête de tant de pays (par les premiers musulmans)", ourrage conposé à Damas, en 884 de l'hégire ( 1479 de J. C.), par Borhân al-Din Ibrâhîm al-

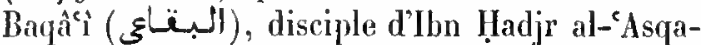
lìnì. Ce traité, qui débute par les exploits de Khàlid ibn al-Walid, en Syrie, et se termine par la mort du calife 'Othmân, fournit des renseignements très-intéressants sur les premières expéditions des musulmans, par terre et par mer.

c. (Eol. $166 v^{\circ}$.) Extrait de l'Encyclopédie d'Al-Nowaïrì, relatil aux premières expéditions des musulmans en Espagne.

Papier. 185 feuillets. Hauteur, 3a centimètres; largeur, 21 centimètres. 19 lignes par page. IIs. du $\mathrm{xv}^{\circ}$ siècle. - (Ancien fonds 638.)

\section{8.}

Mème ourrage, huitième volume de l'exemplaire, dont le numéro précédent est le troisième. Le ms. conmence par une série d'anecdoles concernant le calife abbaside Al-Jla'moûn, morl en 2,8 de l'hégire; le récit s'arrête à la fin de l'an 250 de l'hégire.

Les marges dı ms. contiennent les extraits suivants, écrits par le faqîr Aḷmad :

(t. Hlistoire de l'lispagne, depuis l'avènement des Omayyades jusquà la conquête de ce pays par les Almoravides. C'est un extrait de l'Encyclopédie d'Al-Nowaïrì, onzième section.

b. (Fol. $27 \mathrm{r}^{\circ}$.) Histoire de la Mauritanie, depuis la conquête musulmane jusqu'au règne du souverain almohade Al-Mostansir Billâh Aboû Yacqoûb Yoûsof, fils du sultan Al-Nâsir Mohammad. C'est encore un extrait de l'Encyctopédie d'AlNowaïrì.

Ge ms., de la même main que le précédent, est daté de l'an 963 de l'hégire ( 1556 de J. C.).

Papier. 160 feuillets. Hautenr, 32 centimètres; largeur, 21 centimètres. 19 lignes par page. - (Ancien fonds $638 \mathrm{~A}$.)

\section{9 .}

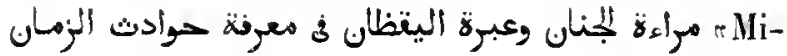

roir de l'intelligence et exemple pour l'homme attentif, faisant connaître les événements du temps", annales et obituaire (dans l'ordre de l'alphabet et dans l'ordre chronologique), par 'Afíl al-Din 'Abd Allah ibn As'ad alYâfíi, mort, selon Al-Sobkî ( Tabaqat al-Kobrâ), en $7_{7}$ de l'hégire ( 1366 de J. C.), ou, selon Ibn Schohba (Classes de doctears schafétites), en $77^{8}$ de l'hégire. Ce uns. renferme la première parlie de l'ouvrage, depuis l'an 1 jusqu'àt'an 399 de l'hégire. Le dernier feuillet manque.

Papier. 299 feuillets. Hauteur, 26 centimètres et demi; largeur, 18 centimètres. 25 lignes par page. $\mathrm{lls}$. du $x v^{e}$ siècle. - (Ancien fonds 637 .)

\section{0 .}

Seconde partie du mème ouvrage, commençant par l'an 401 de l'hégire et firissant par l'an 750 . Un appendice conlient la biographie de quelques saints personnages du Yémen. Ms. écrit en 873 de l'hégire ( 1469 de J. C.), par un arrière-pelit-fils de l'auteur.

Papier. 243 feuillets. flauteur, 27 centimètres; largeur, 17 centimètres et demi. 27 lignes par page. - (Ancien fonds 644.)

\section{1 .}

Seconde partie du même ouvrage, commençant par l'an 402 de l'hégire. Copie exécutée à Bassore, en 1154 de l'hégire.

Papier. 391 feuillets. flauteur, 30 centimètres; largeur, 19 centimètres. 21 lignes par page. - (Supplément 723.)

\section{2.}

Index du Mirât al-Djanân d'Al-Yâfî̀i.

Papier. 41 feuillets. Hauteur, 26 centimètres; largeur, 17 centi-

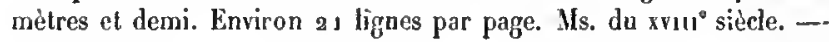
(Supplément 692.)

\section{3.}

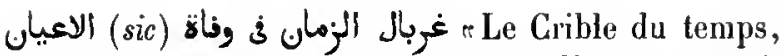
oljituaire des personniges marquants $n$. C'est un extrait du Mirât al-Djanân d'Al-Yâfíi, par Al-Hosaïn ibn al-Rahmân al-Ahdal (qui a la lèvre pendante). Premiers mots 
de la préface : Ms. daté de l'an 1076 de l'hégire (1665 de J. C.).

Papier. 221 feuillets. Hanteur, 29 centimètres et demi; largeur, 20 centimètres. 25 lignes par page. - (Supplément $72 \%$.)

\section{4.}

Abrégé de l'histoire des califes, depuis Aboû Bakr jusqu'à la chute de la dynastie abbaside, suivi d'une collection d'anecdotes lisisoriques et biographiques, dont plusieurs sont très-intéressantes, et de nombrenses

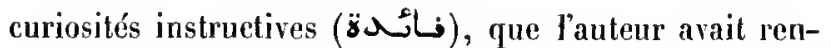
contrées dans ses lectures. Cel ouvrage paraît avoir été composé vers la fin du $x_{10}{ }^{\mathrm{c}}$ siècle. Uls. daté de l'an 1145 de l'hégire ( ${ }_{7} 3_{2}$ de J. C.).

Papier. 163 feuittels. IJautuur, 20 centimètres et demi; largeur, 15 centimètres et demi. 19 lignes par page. — (Supplément 733.)

\section{5.}

$1^{\circ}$. Lاريخ ابر. La Chronique d'lbn al-Forât (Moḷamnad ibn 'Abd al-Raluîm 'Alì ibn al-Ḥasan), docteur hanéfite, mort, selon Hadji Klualfa, en 807 de l'héggire (1404-1405 de J. C.). La partie de l'ourrage contenue dans le présent volume commence par l'an 1 de l'hógire, et se terınine au milieu de l'an 19. Cette copie paraît être une mise au net du brouillon de l’auteur et avoir été écrite pour son usage.

$2^{\circ}$ (Fol. ${ }_{1} 3_{9 .}$ ) Plusieurs feuillets d'un exemplaire, écrit en 675 de l'hégire ( 1276 de J. C.), dı Kâmil d'lın al- $\Lambda$ thìr, se rapportant aux années $179,180,181,194$, 435,436 et 437 de l'hégire.

Papier. 164 feuillets. Ilanteur, 33 centimètres et demi; largeur, 16 centimètres et demi. 25 liggnes par page dans le premicr ouvragre, 19 lignes dans l'article $2^{\circ}$. - (Supplément $7^{43 .}$ )

\section{6.}

Extraits, dont plusieurs sont accompagnés de la traduetion française, de la Chronique d'lbn al-Forât. Ces extraits, copiés et traduits par M. Jourdain, commencent par l'an 664 de l'hégire et finissent par l'an 690.

Papier. 150 pages. Hautenr, 26 centimètres; largeur, 19 centimètres et demi. - (Supplément s162.)

\section{7.}

م نمécréation pour tes hommes, ouvrage contenant les Annales de I'islamismen, par Ibrà-

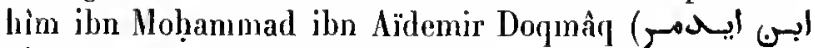
(د), mort en 809 de l'hégrire (1406-1407 de J. C.). Ce volume, le sixième de l'ouvrage, renferme l'histoire des années $6_{2} 8$ à 659 de l'hégire. Ms. autographe. Le commencement manque.

Papier. 137 feuillets. Hauteur, 26 centimètres; largeur, 17 centimètres et demi. 17 lignes par page. - (Supplément 721 .)

\section{8 et 1599.}

Continuation des Annales de l'islamismen, Histoire des années 74 a a 806 de l'hégire, faisant suite aux Annales d'Al-Dsalıabi, par Taqi al-Dìn ilın Qàdhì Sclıohba, mort en 851 de l'hégrire (1447-1448 de J. G.). Comine les Annales d'Al-Dsahabî, l'ouvrage d'Ibn Qàdhì Sclohba est une chronique et un obituaire. Le premier volume de cet exemplaire mène le récit jusqu'à l'an 785 de l'hógire. Les premiers feuillets du premier volume et les derniers du second volume manquent.

Copie datée de l'an 840 de l'hégire (1436 de J. C.).

2 vol. Papier. 287 et 220 feuillets. Hanteur, 28 centimètres; largeur, 18 centimètres et demi. 25 lignes par pagc. - (Ancien fonds 643 et 687 .)

\section{0.}

Premier rolume du mème ouvrage. Un titre absolu ment faux (تاريخ العلامة السخاوى) a ćté ajouté après coup, ainsi que, à la fin, les mots Ms. daté de l'an 849 ( 1446 de J. C.).

Papier. 290 fenillets. Hantenr, 27 centimètres et demi; largenr, 18 centimètres et demi. 85 lignes par page. - (Ancien fonds 754 .)

\section{1 et 1602 .}

Renseignements pour l'homme sans instruction, au sujet des fils du sièclen, par Ibn IIadjr al-'Asqalânî (Alıınad ibn 'Alì). Chronique et obituaire, embrassant toute la période de la vie de l'auteur, depuis 773 de l'hégire, année de sa naissanee, jusqu'en 
850 de l'hégire, environ deux années arant sa mort. Le premier volume se termine par la relation des événements de l'an 811 de l'hégire.

2 vol. Papier. 246 et 279 feuillets. Hauleur, 28 centimètres; largeur, 18 centimètres el demi. 2 1 à 3 । lignes par page. Ms. du $x v^{\circ}$ siècle. - (Aucien fonds 656 et 657.$)$

\section{3.}

P'remier volume du mème ouvrage. Cet exemplaire a élé exécuté pour la bibliothèque d'un grand émir du Caire.

Papier. 245 fenillets. Ifauteur, 28 centimètres; largeur, 19 centimètres. 29 lignes par page. Ms. du $x v^{\circ}$ sièele. - (Ancien fonds 658.)

\section{4.}

Second volume (d'un exemplaire divisé en trois volumes) du même ourrage, commençant par l'an 801 de l'hégire, et finissant par l'an 823 . Ms. daté de l'an 880 de l'hégire ( $147^{5}$ de J. C.). Le premier feuillet est moderne.

Papier. 246 feuillets. Hauteur, 26 centimètres et demi; largeur, 18 centimètres el demi. 21 lignes par page, puis 23 dans la dernière partie du volume. - (Ancien fonds 648.)

\section{5.}

$3^{\circ}$ Abrégé du انباء l'lbn Hadjr al-'Asqalànî, par Moḥammad ibn al-Qàdir al-Damîrì. Le préseut ms. est le brouillon de cet épitomé.

$2^{\circ}$ (Fol. 146.) Extrait du traité mystique intitulé Éclaircissement complet au sujet de la station des témoins sincères $\%$, d'Abd al-Qàdir ilın Hosaïn ilon Moghaïzil (مغيزل), derviche schadsilite (لنماذله). Ce trailé mystique qui, selon Hadji Khalfa, a été composé en 894 de l'hégire ( $1488-1489$ de

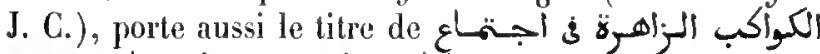
Les Astres brillants, ourrage qui traite de l'uuion qui s'élablit pendant qu'ils sont en élat de veille entre les saints el le Seigneur de ce monde et de l'autrer.

Papier. 150 feuillets. Hauteur, 22 centimètres et demi ; largeur, 16 centimètres. 29 lignes par page. Ms. du $x v^{\circ}$ siècle. - (Ancien fonds 804.)

\section{6.}

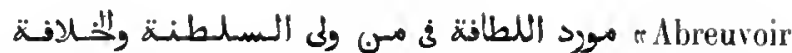
d'agrément ou listoire des sultans et des califes», abrégé d'listoire musulmane, depuis la prédication de Nahomet jusqu'en 872 de l'hégire, par Aloù 'l-Maḷâsin Yoûsof ibn Taghrì Bardi. Premiers mots de la prélace : al $\lambda$,

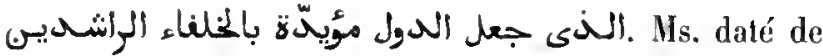
l'an 1011 de l'hégire (1602-1603 de J. C.).

Papier. 357 fenillets. Hanteur, 21 centimètres et demi; largeur, 15 centimètres et demi. 91 lignes par page. - (Ancien fonds 777.)

\section{7.}

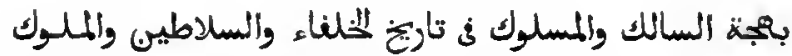
-Amusement du promeneur el charme du chemin, histoire des califes, des sultans et des rois», résumé de l'histoire musulmane, depuis le temps de Mahomet jusqu'en 886 de l'lıégire, par Mohammad ilon Moḷammad ibn Moḷammad al-Dja farì. Cet ouvrage, composé sous le règne du sultan mamlouc Qâitbey, contient entre autres (fol. $98 v^{\circ}$ ) une dissertation sur la peste, plusieurs pièces de vers, et une longue qasîida, intitulée "Les Dernières injonclions de (l'imàm Aboù 'Abd Allâh Mohammad) al-Șarşarì. Ms. dalé de l'an 886 de l'hégire (1481-1482 de J. C.).

Papier. 197 f fuillets. Hauteur, 22 centimètres; largeur, 16 centi-

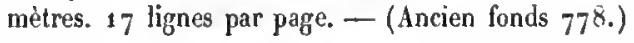

\section{8.}

Couronne des connaissances et histoire des califes", par Moḷammad ibn Mahmoûd ilon abì 'I-Sa'adât..... ibn abì 'l-Djoûd al-Salmoûnì. Ce résumé historique, qui s'arrête à l'avènement de Qåïlbey, sultan d'Égypte, en l'an 872 de l'hégire, est suivi (fol. 83) d'une série de notices sur les cadis des quatre rites qui ont siégé au Caire, depuis la conquête musulmane (fol. $200 \mathrm{r}^{\circ}$ ), et d'une pièce de vers, daus laquelle Djamâl al-Dìn ibn al-Djazzâr, poète égyptien, mentionne les émirs qui ont successivement gouverné l' ligypte; cette pièce, intitulée العتود المرّية في الامولء المصريسة, est suivie d'une continuation, par Djamâl al-Dìn al-Soyoûți. Une autre pièce de vers, composée par Ibn Dẩnyàl (Jis) et renfermant les noms des cadis du Caire, a été égale- 
ment complélée par Soyoûtì. Ns. daté de l'an 899 de l'hégire ( 1494 de J. C.).

Papier. 206 fenillets. Hauteur, 21 centimètres et demi; largeur, 15 centimètres et demi. 21 à 26 lignes par page. - (Supplément 727.)

\section{9.}

Sources de la purelé, renfermant l'histoire des califesn, par Djalâl al-Dìn alSoyoûți. Histoire des califes, qui s'élend jusqu'en $7^{8} 7$ de

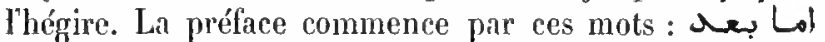
r. C'est l'ouvrage men-

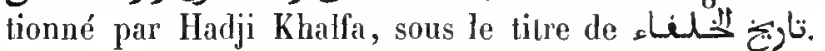
Ms. daté de l'an 1026 de l'hégire ( 1617 de J. C.).

Papier. 249 feuillets. Hauteur, 20 centimètres et demi; largeur, 15 centimètres. 23 lignes par page. - (Supplément 729.)

\section{0.}

Même ouvrage. Ms. daté de l'an 1099 de l'hégire (16871688 de J. C.).

Papier. 210 feuillets. Hauteur, 20 centimètres et demi; largeur, 15 centimètres. 23 lignes par page. -- (Ancien fonds $77^{6 .}$ )

\section{1}

Seconde partie du mème ourrage, commençant au milieu du règne d'Al-Mahdi, troisième calife abbaside. Les premiers fenillets manquent.

Ce ms., dalé de l'an 887 de l'hégire (1482 de J. C.), a été corrigé sous les yeux de l'auteur.

Papier. 146 feuillets. Hauteur, 26 centimètres et demi; laryeur, 17 centimèires. 17 lignes par page. $-($ Ancien fonds 639 .)

\section{2.}

Abrégé de l'Hisıoire des califes d'Al-Soyoûtit. Le titre et le nom de l'auteur ne sont pas indiqués. La próface

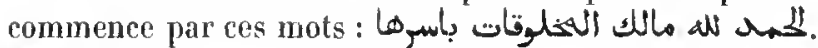
Ms. daté de l'an $119^{8}$ de l'hégire (1784 de J. C.).

Papier. 154 feuillets. Hauteur, 2o centimètres; largeur, $1 /$ centimètres. 21 liggnes par page. - (Supplément 7330. )

\section{3.}

Abrégé de l'Histoire des califes d'Al-Soyoûtị. C'est le mème ourrage que le précédent, et la copie est datée du même endroit et de la mềme année.

Papier. 151 feuillets. Hauteur, 22 centimètres; largeur, 15 centimètres et demi. 21 liggnes par page. - (Supplément 731.)

\section{4.}

Histoire des califes, par Djalàl al-Din al-Soyoûti. C'est une rédaction plus développée du Manahil al-Safá. Le présent ms., qui ne renferme que la première partie de l'ouvrage, embrasse une période de deux cent cinquante-cinq années. La préface, sans bismillahh et sans la

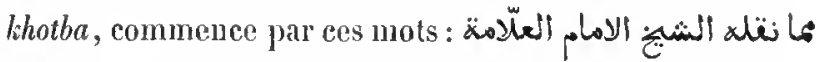

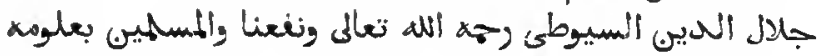

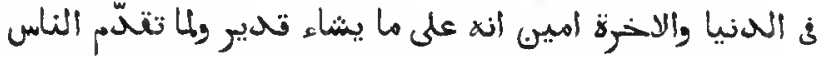

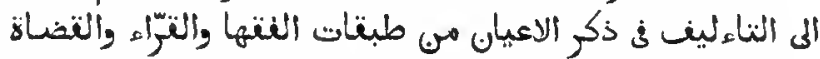

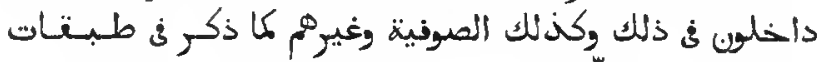

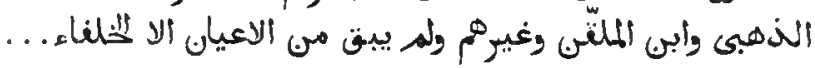

Les rubriques indiquant les années, etc., ont élé laissées en blanc. Les derniers feuillets manquent.

Papier. 307 feuillets. Hauteur, 22 centimètres; largeur, 15 centimètres. 19 liggnes par page. Ns. du $x r^{\circ}$ siède. - (Supplément $73_{2}$.)

\section{5.}

$1^{0}$ is'Histoire mise en vers». Cet opuscule traite des premiers califes, des Omayyades, des Abbasides, des Fatémides, des Ayyoubiles et des sultans manloues d'Égypte, jusqu'à Qâilbey، L'auteur, Schams

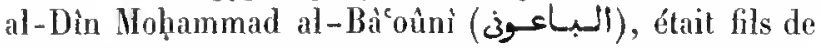
Schihâb al-Dìn, grand cadi schaféite et schaikh al-Islàn. Hadji Khalfa dit que cet ourrage portait encore deux

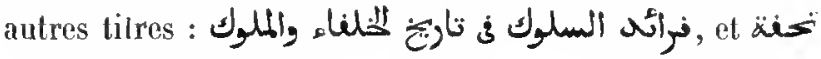
. الظرفاء 3 تاريخ الملوك.

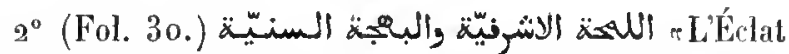
d'Aschraf et le lustre princier", panégyrique en vers d'AlMâlik al-Aschraf Qâïbey, par Noḷammad ibn Yoùsof ibn Ạ̣mad al-Bầoûnî. La fin manque.

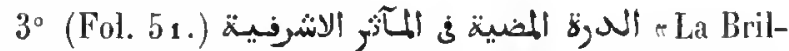
lante perle ou nobles actions d'Al-Mâlik al-Aschrafn, 
autre poème, composé en l'honneur de Qâitbey, par le cadi Al-Saklıâwi.

Ms. daté de l'an 894 de l'hégrire (1489 de J. C.).

Papier. 62 fouillets. Hauteur, 22 centimètres; largeur, 16 cenlimètres. 11 lignes par page. - (Supptément 811 , Saint-Germain 21.)

\section{6.}

Perles rangées sur leurs fils, ou liistoire des califes et des rois», abrégé d'histoire musulmane, par un anonyme du xvi siecle. Cet ouvrage commence par l'histoire de Mahomet et se termine par l'an 903 de l'hégire. Premiers mots de

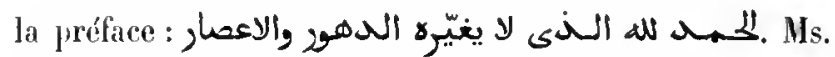
daté de l'an 1047 de l'hégire ( $1637-1638$ de J. C.). Les premiers et les derniers feuillets sont couverts de notes de diverses mains.

Papier. 146 feriltets. Ifauteur, 21 centimètres; largeur, 15 centimètres. 19 lignes par page. - (Ancien fonds $77^{4}$ A.)

\section{7.}

r La Perle précieuse, histoire des califes et des sultans \%. Alrégé d'histoire musulmane, depuis Mahomel jusqu'au règne du sultan mamlouc Qânşoûh al-Ghaurî, qui monta sur le trône en go6 de l'hégire ( 1501 de J. C.). Le nom de l'auteur est inconnu. En tête du rolume se trouve une élégie de seize vers sur la mort de l'émir Yeschhek (يشُبك), le devadûr. Au ver'so du fol. 2 on lit une note sur la construction du nilometre.

Papier. 109 feuillets. Hauteur, 27 centimètres; targeur, 18 centimètres. 25 lignes par page. Ms. du xv' siècle. - (Supplément 758 .)

\section{8.}

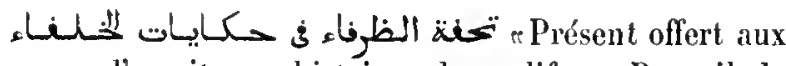
hommes d'esprit, ou histoires des califes $\pi$. Recueil de contes, en géućral assez courts, dans lesquels on fait figurer les anciens califes et les littérateurs célèbres, tels qu'Al-Aṣma'i, Aboû Nowàs, etc. Dans une de ces historiettes (fol. $185 v^{\circ}$ ), l'auteur anonyme parle d'une disette qui eut lieu sous le règne de Qảithey, sultan d'Égypte. Cet ouvrage paraît être différent de celui qui, portant à peu près le mème titre, est attribué par Hadji Khalfa à Mohammatl ibn abî 'l-Soroûr.

Papier. 948 feuillets. Hautenr, al centimètres; largeur, 15 centimètres. s3 lignes par page. Afs. du xviı siècle. - (Ancien fonds 779.)

\section{9.}

Onzième section d'un grand ouvrage historique, dont on ignore le nom de l'auteur. Nous lisons sur la tranche

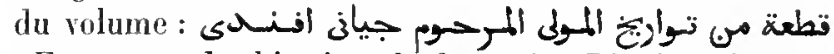
"Fragments des histoires du feu maître Djayânì Efendi ", persounage dont Hadji Khalfa ne fait pas mention dans sa Bibliographic. Cette section renferme les notices biographiques des Compagnons, des Tabic et des docteurs de la troisième génération après Mahomet. Puis viennent des articles concernant les califes omayyades et abbasides, jusqu'à Al-Mo'tazz Billâh. L'auteur nous apprend (fol . $1 \mathrm{v}^{\circ}$ )

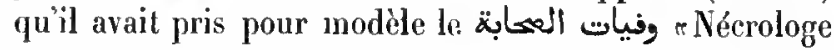
des compagnons $\leadsto$, composé par le savant imâm Al-Hasan ibn Moḥammad al-Ṣaghânî.

Papier. $7^{4}$ feuillets. Hauteur, 27 centimètres; largeur, 18 centimètres. 19 lignes par page. Ms. dn xvn' siècle. - (Ancien fonds 63ə.)

\section{0 .}

$1^{\circ}$ (Fol. $3 v^{\circ}$.) Liste chronologique des califes omajyades, abbasides et fatémites, suivie des noms des souverains ayyoubites, des Mamloues tures et des Mamloues circassiens.

$2^{\circ}$ (Fol. 9.) Qaşî̉a de vingt-cinq vers, attribué à 'Alì et commençant par ces mots :

$$
\begin{aligned}
& \text { لك للممه يا ذا للمبود والنجيد وألعلى }
\end{aligned}
$$

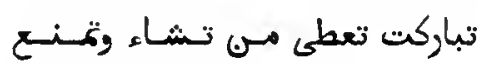

C'est une série d'invocations adressées à Dieu.

$3^{\circ}$ (Fol. $9 \mathrm{v}^{\circ}$.) Commentaire sur la Borda d'Al-Boușirì, par Aboù Schâma 'Abd al-Raḥmân ilon Isma'îl, mort en 665 de l'hégire (1266-1267 de J. C.). Commencement : سبكان من الخغ سبكات وجهم .كياب كجاب الانوار.

$4^{\circ}$ (Fol. $46 v^{\circ}$.) La Borda mise en strophes de quatre vers, c'est-à-dire avec addition de trois vers ou six hémistiches avant chaque vers du poème. En marge, une traduction de la Borda en vers persans. Premier vers :

\section{ما بال تلبك لا ينغك ذا الم بان التصبّر بين البان والعه}

$5^{\circ}$ (Fol. 60 v $^{\circ}$.) Le Bânat $S_{o}{ }^{e} A d$ de Ka $a^{e}$ b ibn Zohaïr. Chaque vers du poème est précédé de trois autres sur la même rime. Premier hémistiche:

$$
\text { اسير شـوق عى المسوأن منفغول }
$$

$6^{\circ}\left(\right.$ Fol. $65{ }^{\circ}$.) Pièce de vers dont voici le premier :

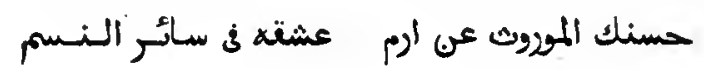




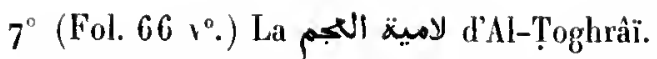

$8^{\circ}$ (Fol. $69 r^{\circ}$.) Les Nawábigh d'Al-Zamakhscharì.

$9^{\circ}$ (Fol. $80 v^{\circ}$.) composé à l'imitation de la Borde, par Hoḥammad ibn Moûsâ al-Naddjâr. Premier vers :

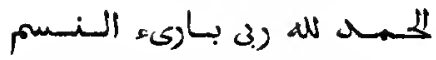

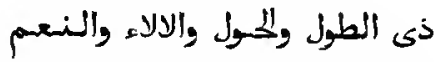

$10^{\circ}$ (Fol. $85 v^{\circ}$.) Le poème d'Avicenne sur l'àme, accompagné de gloses marginales et inlerlinéaires. Premier vers :

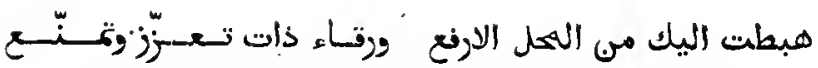

$11^{\circ}$ (Fol. $86 r^{\circ}$.) Quelques pièces de vers sans nom d'anteur.

$12^{\circ}\left(\right.$ Fol. $91 v^{\circ}$.) Le Binat $S 0^{\circ} d d$, arec un commentaire tiré de l'omrage de Djamâl al-Dìn ibn Hischâm.

$13^{\circ}\left(F_{0}\right.$ ol. $106 v^{\circ}$.) Pièce de vers, au nombre de quarante-deux, dont voici le premier :

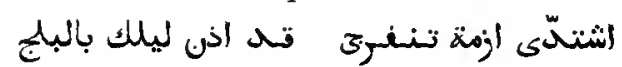

Plusieurs pièces de ce ms. sont datées de l'an 966 de l'hégire (1558-1559 de J. C.).

Papier. 118 feuillets, dont plusieurs sont restés en blane. Hauteur, 21 centimètres et demi ; largeur, 15 centimètres. 25 lignes par page. - (Supplément $₫ 466$. )

\section{1.}

Tableau généalogique des dynasties oltomane, seldjoukide, tartare, etc., depuis Adam, el généalog̣ies des paIriarches, des souverains antérieurs à l'islamisme, des califes, et de la famille de Mahomet.

Rouleau collé sur toile, long de 6 mètres et derni. Mls. du xw1 siècle. - (Supplément 857 bis.)

\section{2 .}

Épître triomphale de Rhodes n. Histoire de la conquête de Rhodes par le sultan ottoman Soläinàn Khàn, en $9_{2}^{2} 8$ de l'hégire $\left({ }_{1} 5_{21-1} 5_{22}\right.$ de J. C.). Cet ourrage, composé par le médecin de ce prince, nommé Ramadhàn, est divisé en ringt sections (فنصل), une introduclion el un épilogue. Le presnier feuillet, contenant le commencement de la préface, manque. L'abbé Tercier a donné un résumé dẹ cet ouvrage dans son Mémoire sur la prise de la ville et de l'ile de

Max. omextali. - II.
Rhodes. (Voyez l'ancien recueil des Mémoires de l'Acadénic des Inscriptions, t. XXVI, p. $7_{2} 8$ et suiv.)

Papier. $17^{4}$ feuillets. Hauteur, 22 centimètres; largeur, 15 centimètres et demi. 10 lignes par page. NIs. dn xvie siècle. - (Aneien fonds 830.)

\section{3 .}

Les Gràces du miséricordieux dont la dynastie oltomane offre de nombreux exemples n, par le Schaïkh al-lstâm Moḥanmad ibn abî 'l-Soroûr al-Bakrì al-Ṣiddiqi. Ce traité, qui forne une section d'une Histoire universelle, intitulée عيهن ألاخبل ون-هـة الابصار, commence par l'histoire dethmân Ier et finit par celle du sultan Mousțafà Ier, fils de Nohammad III. La préface commence par ces mots : من في هز شأ مى عباده نضلا جزيلا

Papier. 43 feuillets. Hauteur, 21 centimètres; largenr, 15 centimètres. s3 lignes par page. Ms. du $\times{ }^{\circ} 1^{\circ}$ siècle. - (Supplément 858

\section{4.}

Les Colliers d'or, traité dans lequel on signale les grands mérites des sultans ottomans n, par Mari (مكى ) ibn Yoûsof al-Mlaqdisi, mort en 1033 de l'hégire (1623-1624 de J. C.).

Papier. 64 feuillets. Hauteur, s a centimètres; largeur, 17 centimètres. 17 lignes par page. Ms. du xvı1 siècle. - (Supplément 857

\section{5.}

La Perle conservée avec soin, traité des événements qui doivent arriver sous la dynastie des sultans ottomans n, par Ḥosain ibn Kamâl. Commentaire sur un poìme rimant en lâ. L'auteur en tire des prédictions par des procédés calbalistiques. La fin manque. Commencement : all الذي اطلع مى. اجتباه مه عباده على كنوز الاسرار.

Papier. 59 feuillets. Hauteur, 31 centimètres; largeur, 1 / centimètres et demi. 19 lignes par page. Ms. du xwir siècle. - (Supplément 2078 .)

\section{6.}

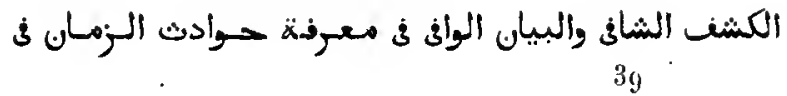


r La Révélation salisfaisante el l'explication suffisante touchant les événements qui doivent arriver sous la dynaslie ollomanen, par le schaïkh "Aldd al-Ghanî al-Nablosi (originaire de Naplouse). L'auteur énumère les événements, lels que les pestes, les famines, etc., qui devaient survenir sous le gourernement otloman, depuis l'an 1107 de l'hégire ( 1695 de J. C. ), jusqu'à l'an 1159 ( 1746 de J. C.). Ces prédictions sont fondées sur le calcul de la valeur des lettres dont se compose l'ouvrage calbalistique intitulé أنشارات eindications $\pi$, du grand écrirain mystique Moḷyì al-Dìn Ibn al-`Arabî.

Papier. 5o feuillets. Ilauteur, as centimètres; largeur, 15 centimètres. 17 lignes par page. Ms. du xvu siècle. — (Supplément 855.)

\section{7.}

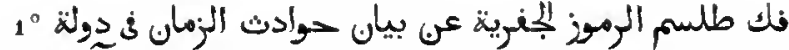
ere du talisman attiché aux énigmes du djafr, pour meltre en évidence les événements qui doivent arriver sous la dynastie ottomanen, par le schaikh Zaïn al-Din 'Abd al-Ghanì al-Nablosi. Dans ce trailé, qui est du mème genre que le précédent, l'auleur prédil les événements des années 1139 ( 1720 de J. C.) à 1284 de lhégire (1868 de J. C.).

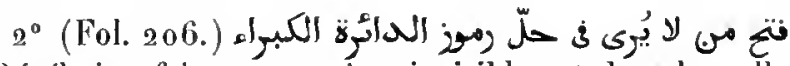
* Révélation faite par un être invisible, et dans laquelle sont expliquées les énigmes du grand tableau circulairen, par ${ }^{\mathrm{C}} \mathrm{Abd}$ al-Ghani al-Nablosi. Ce sont eneore des prédictions touchant la dynastie otlomane que l'auteur prétend avoir tirées du grand tableau circulaire, dressé d'après la première conjonction de Saturne ol de Jupiter, et inséré par Moliyì al-Dìn Ilon al-'Arabì dans son ouvrage intitulé

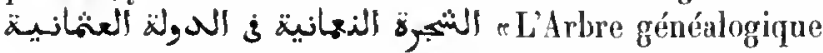
de l'empire oltoman, de No màn n. La dernière de ces prédictions se rapporte à lannée 1296 de l'hégire $(1879$ de J. C.).

Ms. daté de l'an 1139 de l'hégire $(1726-1727$ de J. G.).

Papier. 357 feuillets. Ilauteur, 21 centimètres; largeur, 16 centimètres. 13 lignes par page. - (Supplément 856.)

\section{HISTOHE DES VILLES SAINTES.}

\section{8.}

3) raqiis (Aboù '1-Walid Moḷammad ibn 'Alsd Allah..... ibn al-Walid ibn 'Okba ibn al Azraq..... al-Ghassàni).
L'année de la morl de ce traditionniste n'est pas exactement connue, mais dans son ouvrage il mentionne la date de 244 de l'hégire (858-859 de J. C.). M. Wüstenfeld a publié le texle de cet ouvrage à Leipzig, en 1858 .

Papier. 273 feuillets. Hauteur, 24 cenlimètres; largeur, 1 z centimètres. 19 lignes par page. Ms. dn xu" siècle. - (Ancien fonds 843. Colbert 3697.)

\section{9 .}

Nème ouvrage, seconde partie, commençant par le

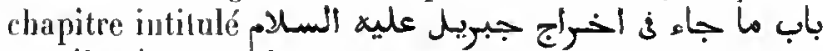
زمزم لام السمعيل عليه السلكام gire (1361 de J. C.).

Papier. 154 feuillets. Hauteur, 25 centimètres et demi; largrur, 17 centimètres. 23 lignes par page. - (Ancien fonds 723. )

\section{0.}

e La Perle précieuse, ou Histoire de Nédine n, par Moḥibb al-Dìn ibn al-Naddjàr (Hoḷammad ibu Malımoùd), morl en 643 de l'hégire (1245-1246 de J. C.). Cet ouvrage se compose de dix-huit

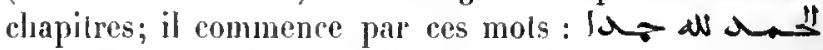
يقتضضى مه احسبانه المزبيه . Ms. daté de l'an 887 de l'bégire (1482 de J. C.).

Papier. 53 feuillets. Hauteur, 96 cenlimètres; largeur, 18 ceńtimètres. 27 lignes par page. - (Ancien fonds $72 \%$ )

\section{1.}

ela Crème des ceuvres et l'essentiel des actesn, hisloire de la Mecque et de Médine, en deux parties. La première parlie, tirée de l'ouvrage d'Al-Azraqi, el consacrée à la Mecque, renferme cinquante-quatre chapitres; la seconde, composée de vingt chapilres, lraite de l'listoire de Malıomet, suivie de la description de son tombeau, et des privilèges de Médine. Le titre, transcrit ci-dessus, est indiqué dans la préface (fol. 2); en lête du volume, on lit te même tilre,

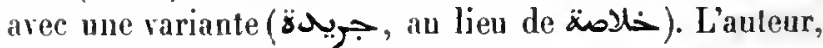
également d'après la préface, se nommait Aboû 'l-IIJasan

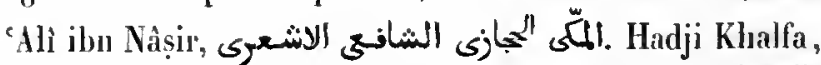
1. III, p. 534, l'appelle Sacd al-Dín al-Isfarâinî. Quoi qu'il en soit, l'auteur nous apprend qu'il a achevé la composition de son ouvrage en $7^{6} 2$ de l'hégire $(1360-1361$ de J. C. $)$. 
A la fin du volume se trouve une tradition transmise par' 'Ali et suivie de son isndd, au sujet de la voie la plus courte pour obtenir la faveur de Dieu. Ms. daté de l'an $9^{61}$ de lhégire ( 1554 de J. C.).

Papier. 81 feuillets. Hauteur, 95 centimètres; largeur, 17 centimètres et demi. 25 lignes par page. - (Ancien fonds $7^{18}$.)

\section{2.}

Mème ourrage. Une note ajoutée après coup au commencement du volume donne, comme nom de l'auteur, Sa d al-Din al-Isfaräini. Mls, daté de l'an $99^{6}$ de l'hégire ( 1588 de J. C.).

Papier. $1_{2} 3$ feuillets. Hauteur, a 1 centimètres; largeur, 14 centimètres et demi. 23 lignes par page. - (Ancien fonds 844.)

\section{3.}

r Guérison du désir de connaitre l'histoire du territoire sacrén, description topographique et historique de la Mecque, par Taqì al-Dìn al-Fàsì. L'ouvrage renferme quarante chapitres, et com-

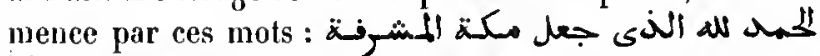
أعظم البلاد شانا la seconde édition, revue et augmentée, du Tolifat al-Kirầm (voyez ci-après, $\mathrm{n}^{0}{ }_{1668}, 3^{\circ}$ ), dı même auleur. Ms. de plusieurs mains, daté de l'an $9^{3} 9$ de l'hégire (1533 de J. C.).

Papier. 256 feuiltets. Hauteur, 26 centimètres: largeur, ${ }_{1} 7$ centimètres et demi. 27 et 28 lignes par page. - (Ancien fonds 722.)

\section{4.}

هuintessence du livre intitulé Renseignements complets au sujet de la résidence de l'Élu (Mahomet), par Noûr al-Dìn Aboù 'l-Ḥasan 'Alì ibn Ahmad al-Saulıoûdi, nort en 911 de l'hégire (15051506 de J. C.). Cet abrégé du Wafâ est divisé en huit sections, saroir : $1^{\circ}$ sur les mérites attachés aux pèterinages; $2^{\circ}$ sur le pèlerinage au tombeau du Prophète; $3^{\circ}$ histoire particulière de Médine, depuis les temps les plus anciens; $4^{\circ}$ histoire de la mosquée; $5^{\circ}$ sur la Moṣallâ et les tombeaux qui s'y trourent; $6^{\circ}$ sur les puits de la ville et sur les fondations pieuses dues au Prophète; $7^{\circ}$ sur les lieux où le Prophète a célébré la prière dans ses voyages et ses expéditions militaires; $8^{\circ}$ sur les rivières, les terrains arides, les chàteaux, les collines et autres licux des envi- rons de la ville. Chacune de ces sections est divisée en plusieurs chapitres. Le quatrième chapitre de la dernière section est rédigé sous forme de diclionnaire alpha-

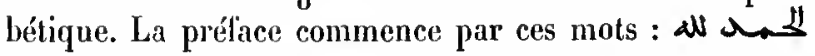

$$
\text { النَى شرّن طابة وشَّتق القلوب لسماع اخبارها المستطابة }
$$

Ms. daté de l'an 973 de l'hégire ( 1565 de J. C.).

Papier. 269 feuillets. Hauteur, 20 centimètres et demi; largeur, 15 centimétres. 19 lignes par page. - (Supplément 763 bis.)

\section{5.}

Mème ourrage. A la fin du volume se trouve, écrit d'une autre main, un poème intitulé تصيدة البسككى, renfermant l'éloge de la ville de Médiue.

Papier. 9/5 feuillets. Hauteur, 23 centimètres; Jargeur, 14 centimètres. 25 lignes par page. Ms. du xvi siecle. - (Ancien fonds 848.)

\section{6.}

Mème ouvrage. Ms. daté de l'an 1131 de l'hégire ( 179 de J. C.).

Papier. a 81 feuillets. Hauteur, 21 centimètres; largeur, 15 centimètres et demi. 23 liggnes par page. - (Supplément 763.)

\section{7.}

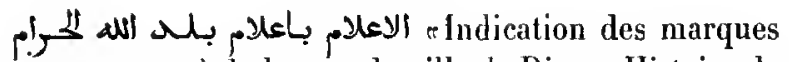
(ou monuments) de la grande ville de Dieu n. Histoire de la Mecque, par Qoṭb al-Dìn Moḥammad ibn Aḥmad, mort en $99^{\circ}$ de l'hégire (1582 de J. C.), ou en $9^{88}$, selon Hadji Khalfa. M. de Sacy a donné une analyse étendue de cet ouvrage dans les Notices et Extraits, t. IV, p. 538. Le texte arabe a été publié à Leipzig, en 1857 , par les soins de M. Wüstenfeld. Ms. daté de l'an 997 de l'hégire (158g de J. C.).

Papier. 210 feuillets. Hautenr, 26 centimètres; largeur, 16 centimètres. 25 liggnes par page. - (Supplément ${ }_{7} 60$.)

\section{8.}

Mème ourrage. Ms. daté de l'an 1002 de l'hégire (1594 de J. G.).

Papier. 370 feuillets. Hauteur, 21 centimètres et demi; largeur, 14 centimètres. 17 lignes par page. - (Ancien fonds 845.) 


\section{9 .}

Nème ourrage. IIs. daté de l'an 1018 de l'hégire (1609 de J. C.).

Papier. 339 feuillets. Hanteur, 21 centimètres; largeur, 14 centimètres. 19 lignes par page. - (Supplément 76 a.)

\section{0.}

Hême ourrage. Ms. daté de l'an 1027 de l'hégire $(1628$ de J. C.).

Papier. 224 feuillets. Hauteur, 21 centimètres; largeur, 15 centimètres. 21 lignes par page. - (Supplément 761 , Saint-Germain 356.)

\section{1.}

$1^{\circ}$ Nême ourrage.

$2^{\circ}$ (Fol. $221 v^{\circ}$. (Exposition de l'étal des saints», par 'Tzz al-Din 'Abd al-Salàm ibn Aḷmad ibn Ghàniun al-Maqdisî. Ce sont des discours mystiques mis dans la bouche de plusicurs grands saints musulmans, depuis Aboủ Bakr jusqu’à Raïhâna (ويحانة).

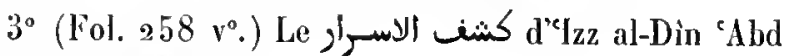
al-Salìm al-Mlaqdisì.

\section{0 (Fol. 292.) Extrait du ميزأن d'Al-Schae rânî.}

Papier. 300 feuillets. Hauteur, 21 centimètres; largeur, 15 centimètres. 19 à 26 lignes par page. Ms. du xvı" siècle. - (Supplément 1887.)

\section{2.}

Histoire de la Mecque de Qoṭ al-Din Mohammad. (Voyez les numéros précédents.) Exemplaire copié à Bassore, en 1740, par les soins d'Otter.

Papier. 212 feuillets. Hauteur, 29 centimètres et demi; largeur, 18 centimètres et demi. 21 liggnes par page. - (Supplément 759.)

\section{IISTOIRE DU YÉNEN.}

\section{3.}

Histoire d'Al-Ràzin. C'est la troisième section de cet ouvrage, la seule qui en existe (voy. Hadji
Khalfa, t. Il, p. 159), et qui forme un ouvrage à part, avec le titre de تاريخ مدينة صنعا اليمى Histoire de la ville de Sạcà du Yémen". Le contenu des autres sections nous est inconnu. L'auteur, Aboû 'l-'Abbâs Aḷmad ibn 'Abd Allah ibn Moḥammad al-Râzî, natif de Șaneà, qui vivait encore en 460 de l'hégire $(1067-1068$ de J. C.), traite d'abord de la ville et des environs de San â, puis des légendes et traditions qui s'y rapportent, et finit par une séric de notices biographiques des personnages des premiers tempss, des Compagnons du Prophète et d'antres personnages remarquables de l'islamisme qui se sont trouvés dans cette ville jusqu'au commencement du $11^{\circ}$ siècle de l'hégire. L'ouvrage commence par ces mots : all

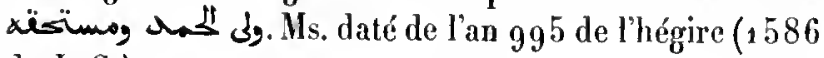
de J. C.).

Papier. 102 feuillets. Llauteur, 29 centimètres; largeur, 18 centimètres. 21 ligries par page. - (Ancien fonds 701.)

\section{4.}

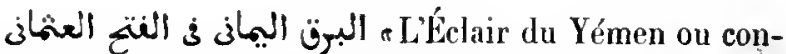
quête de ce pays par les Ottomans n, par Qoṭ al-Dìn Mlọ̣anmad ibn Aḷmad. Cet ouvrage, dédié à Sinân Pacha, grand vizir du sultan Sélim II, est divisé en trois sections et un appendice, contenant l'histoire de la prise de Tunis et de la Goulette par les Ottomans. Commence-

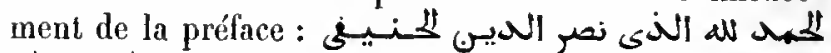
(Voyez, sur cet ouvrage, l'article de M. de Sacy, dans les Notices et Extraits, t. IV, p. 412.)

Papier. 190 fenillets. Hauleur, 21 centimètres; largeur, 15 centimètres. a 3 lignes par page. Ms. du xvi ${ }^{e}$ siècle. - (Ancien fonds 826 A.)

\section{5.}

Mème ouvrage. La copie s'arrête au trente-deuxième chapitre de la troisième section. Ms. daté de l'an 981 de l'hégire $(1573-1574$ de J. C. $)$.

Papier. 87 feuillets. Hauteur, 21 centimètres; largeur, 14 centimètres et demi. 21 lignes par page. - (Supplément 766.)

\section{6.}

Mème ouvrage.

Papier. ${ }_{2} 59$ feuillets. Hauteur, so centimètres et demi; largeur, 14 centimètres. 19 lignes par page. Ms. du xvi1' siècle. - (Supplément 764 .) 


\section{7.}

Mème ourrage.

Papier. 227 fcuillets. JJantenr, 21 centimètres; largeur, 15 centimètres. a 1 lignes par page. Ms. dı Xu1 siècle. - (Ancien fonds 8.8.)

\section{8.}

Même ouvrage. C'est la seconde édition qui a été rédigée sous le règne du sullan Anuralh IIt. Cet exemplaire a été revu et corrigé par l'auteur, qui a écrit lui-nềne son nom en tête du volume, ainsi quil suit : Moḷammad Qoṭb al-Dìn ihn 'Alà al-Dìn al-Nahrawàni al-Makkì al-

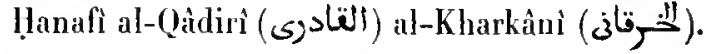

Papier. 293 feuillets. llauteur, 24 centimètres; largeur, 15 centiinètres. 19 lignes par page. Ms. du xvi sièrle. - (Supplément 765.)

\section{9.}

Même ouvrage. Seconde édition.

Papier. 239 fevillets. Hauteur, 21 cenlimetres; largeur, 13 centimètres. ${ }_{7} 7$ lignes par page. Ns. du xvi siècle.-(Ancien fonds 8.66.)

\section{0 .}

Même ouvrağe. Seconde édition.

Papier. 197 feuillets. Hauteur, 20 centimètres et demi ; largeur, 15 centimètres. 21 lignes par page. Ms. du xvı siècle. - (Ancien fonds 827 .)

\section{1.}

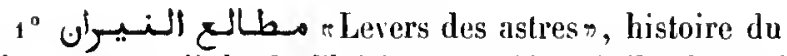
Yémen au $x^{\circ}$ siècle de l'hégire, par Aḥmad ibn Yoûsof ibn Moḷammad Fìroûz. M. de Sacy a donné l'analyse de cet ouvrage dans les Notices et Extraits, t. IV, p. 505.

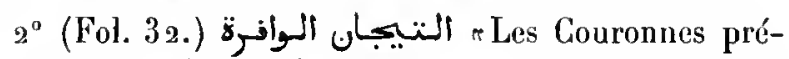
cieuses $»$, histoire du Yémen, en vers, depuis le gouvernement de Rodhwân Pacha jusqu'à l'arrivée de Bahrâm Pacha. (Voyez Notices et Extraits, t. IV, p. 51 o.)

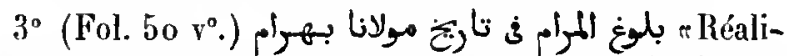
sation du désir quand on veut connaitre l'histoire de Monseigneur Bahrâm», par Moḷammad ibn Yậ̣â al-
Motayyib, docteur lıanéfite, natif de la ville de Zabîd. C'est l'histoire du Yémen sous l'administration de Bahrânı Pacha, depuis l'an 977 de l'hégire $(1569$ de J. C.), jusqu'en 983. (Voyez Not. et Extr., t. 1V, p. 512 et suiv.)

Papier. 109 feuillets. Hanteur, a 1 centimètres; largeur, is centimètres et demi. 13 lignes par page. Ms. du xvi siècle. - (Ancien fonds 829 .)

\section{IIISTOIRE DI LA SYRIE.}

\section{2 .}

"Victoires remportées en Syrie». Histoire de la conquête de la Syrie par les musulmans, roman historique attribué à Al-Wâqidi.

Papier. 207 fenilets. Hauteur, 27 centimètres et demi; largeur, 18 centimètres. 25 lignes par page. - (Ancien fonds 698.)

\section{3.}

Même ouvrage.

Papier. 199 feuillets. Jlauteur, 25 centimètres et demi; largeur, 18 centimètres. 93 lignes par page. Ms. du xvie siècle. - (Ancien fonds 697.)

\section{4.}

Même ouvrage. Ms. daté de l'an 994 de l'légire ( 1586 de J. C.).

Papier. 211 feuillets. Hauteur, 31 centimètres; largeur, 21 centimètres et demi. 25 lignes par page. - (Ancien fonds 696 .)

\section{5 .}

Même ourrage. La rédaction est légèrement différente. Ms. daté de l'an 1009 de l'hégire (1600-1601 de J. C.).

Papier. 234 feuillets. Hauteur, 27 centimètres; largeur; 18 centimètres et demi. 23 lignes par page. - (Ancien fonds 699 .

\section{6 ` 1658.}

Trois volumes dépareillés, désignés comme le troisième, le cinquiène et le sixième d'un exemplaire du 
mêne ouvrage. Coppie datée de l'an $119^{1}$ de l'Jégire ( 1777 de J. C.).

3 volumes. 60,60 et 65 feuillets. Hauteur, a a centimètres; largeur, 15 centimètres el demi. a lignes par page. - (Supplément 779 , II, v, 1.)

\section{9 .}

Volume dépareillé du même ouvragre. Le ms. commence par une courle préface, dont voici les premiers mots : ura الم. Suit un discours, adressé aux Musulmans, et le récit du combat qui eut lien entre Klatid et le patrice Nestor. Ce ms., on le roit, a été copié sur le deuxième ou le troisiène volume d'un exemplaire en tête duquel il a été ajouté une préface apocryphe. En tèle du volume, on lit un titre égalenent

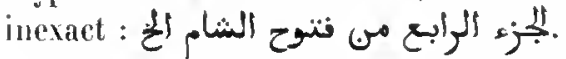

Papier. 62 feuillets. Hauteur, al centimètres; largeur, 14 centimètres el demi. 19 lignes par page; les trois derniers feuillets sont d'une aulre main el portent 25 lignes par page. Ms. du xvil' siècle. (Supplémeni 780. )

\section{0.}

Dernière partie du même ouvrage.

Papier. 203 fenillets. Hauteur, s centimètres; largeur, 17 centimètres. 19 à 2 l lignes par page. Ms. du xv ${ }^{e}$ siècle. - (Ancion fonds 89o.)

\section{1.}

Dernière partie du mène ouvrage. Les derniers feuillets manquent.

Papier. 160 feuillets. Hauleur, a 1 centimètres el demi; largeur, 15 centimètres. 15 lignes par page. Ms. du xvin" siècle. - (Supplément 777 .)

\section{2.}

Autre roman historique, intilulé فتنوح Conquêle

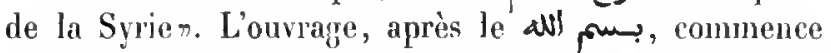

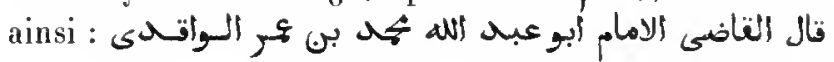

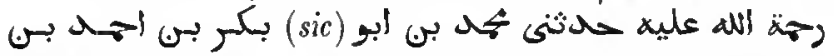
. Suit une longue liste de traditionnistes, quelques mots sur la mort de Nla- homel ol un discours adressé aux Musulmans, par Aboû Bakr, pour les exhorter à la conquêle de la Syrie.

Papier. 222 feuillets. Hauteur, 26 centimètres; largeur, 17 centimèlres. 25 lignes par page. Ils. du xv siècle. - (Supplément 778.)

\section{3.}

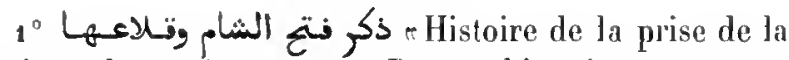
Syrie et de ses forteresses $\%$. Roman historique commen-

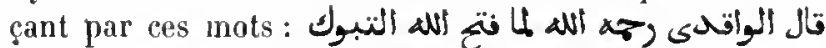

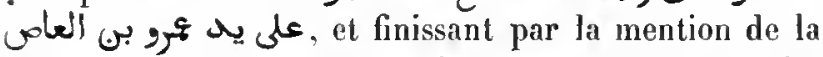
bataille d'Al-Yarınoủk. A la fin, le copiste énumère les noms des lreize premiers sultans ottomans avee les dates de leur avènement au trône. Ces dates ne sont pas toujour's exactes.

$2^{\circ}$ (Fol. 4g.) Extrait du livre intitulé Al-Bostän. Nous y lisons les noms des califes, depuis Aboú Bakr juscquà Al-Mámoûn, fils de Hâroûn al-Raschid.

$3^{\circ}$ (Fol. $49 \vee^{\circ}$.) Histoire de la conquête de l'Égypte et d'autres pays par les Musulmans. Roman listorique, com-

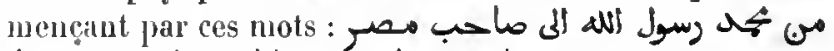

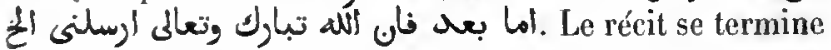
par l'explicalion de la propluétie du Coran, relative à la défaite des Grees et à la victoire qu'ils devaient remporter plus tard.

$4^{\circ}\left(\mathrm{Fol}, 100 \mathrm{v}^{\circ}\right.$.) Histoire des conquêtes musulmanes dans la haute Nésopolamie. Roman historique commen-

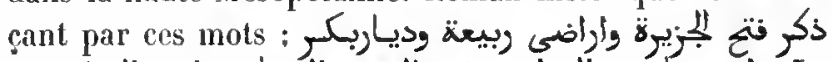

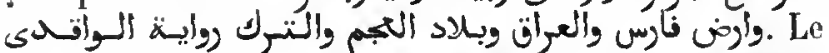
récit se termine par la conquête de l'ile d'Aradus (s/g), sous le califat d"Othmân.

Ms. daté des années 999 et 1002 de l'hégire (1591 et 1594 de J, C.).

Papier. 242 fenillets. Hauteur, a 1 centimètres; largeur, 15 centimètres. 31 à 23 lignes par page. - (Supplément 781.)

\section{4.}

ellistoire abrégée de la conquête de la Syrien, par Aboû Isma il Mohammad ibn 'Abd Allah al-Azdi al-Başì. Cet ouvrage, rédigé sous forme de récits faits par un certain Aboû Isma il al-Bașrî, et précédés chacun d'un isnád à cinq ou six degrés, a été publié par 11. Lees, à Calculta, en 1854 , sous le tilre de Fotooh alSham by Abou Ismail Mohammad, etc. D'après le caractère des récits et des isnâd, cet ouvrage doit être considéré comme un roman historique. (Voyez De Goeje, Mémoires 
d'histoire et de géographie orientales, Leyde, 1864.) Ms. daté de l'an 613 de l'hégire ( 1217 de J. C.).

Papier. 8 a feuillets. Hanteur, 23 centimitres; largenr, 16 centimètres et demi. a 3 lignes par page. - (Ancien fonds 819.$)$

\section{5.}

Histoire abrégée de la conquête de la Syrie, par Aboû Ismaêl Moḷammad ibn 'Abd Allah al-Azdì al-Bașî. Ce sont les mèmes récits que ceux du numéro précédent, mais ils different par leurs isnad. Ms, daté de l'an 764 de l'hégire (1362-1363 de J. C.).

Papier. 148 feuiltets. Hauteur, a 1 centimètres; largeır, 16 cenlimètres. 17 lignes par pagge. - (Ancien fonds 82\%.)

\section{6.}

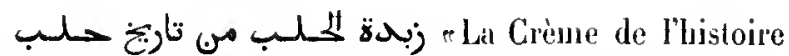
d'slepr, histoire générale de la ville et de la province d'Alep, depuis les temps les plus reeulés jusqu'à l'an 639 de l'hégirc, par Kamâl al-Dìn Aboû Hafṣ 'Onar', surnommé Ibn al-`Adim. Lianteur dit en avoir pris les matériaux dans sa grande histoire de la ville, c'est-à-dire dans le dictionnaire biographique intitulé Boghait al-Talib fi Tarikh Malab. (Voyez, sur cet ourrage, Extraits des historiens arabes des croisades, t. I, introd,, p. wuı.) Ce Ins., daté de l'an 666 de l'hégire (1 268 de J. C.), a été copié sur l'original antograplue.

Papier. 268 fenillets. Hauteur, 25 centimètres; largeur, $17 \mathrm{cen}$ timètres et demi. 17 lignes par page. - (Ancien fonds 728 , Colbert 5158 .)

\section{7.}

$1^{\circ}$ م Traité qui doit exciter le désir de visiter Jérusalem et la Syrie», par Djamâl al-Din Aboû Mahmoûd Aḷmad ibn Moḥamnad al-Maqdisi, mort en 765 de l'hégire (1363-1364 de J. C.). Ce traité que l'auleur dit (lol. $641^{\circ}$ ) aroir achevé ì Jérusalem, en 752 de l'hégire (1351 de J. C.), se compose de deux sections (قسم), dont la première est consarée à la Syrie et la seconde à la mosquée d'Al-Aqșà. Chaque section est divisée en plusieurs cluapitres. A part les nombrenses notices historiques et topographiques tonchant un grand nombre de lieux de la Syrie, et, en particulier, Jérusalem, on trouve, dans cet ouvrage, des ar- ticles sur Malıomel, sur les Compagnons et sur les autres grauds personnages musulmans qui ont habité ou visité la Syrie. A la fin on lit me conrte notice sur Saladin. La pré-

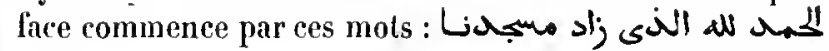

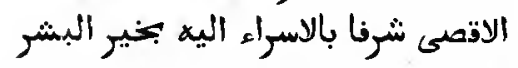

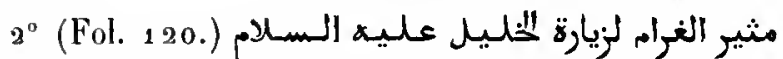
- Traité qui doit exciter le désir de visiter Abrabam, l'ami de Dieu r, par Aboû 'I-Fidâ Ishâaq al-Khalìlì. C'est une histoire d'Abraham el des prophètes, ses successeurs, y compris Mahomet. Elle se compose de viugt-sept chapitres, dont le quinzième traite du tombeau d'Abralıam, à Hébron. Au commencement de la préface, l'anteur nous apprend quil était originaire de Palnıyıe (Al-Tadmori), el que son père, Ibrâhìm, était fils d'Aḷmad ibn Moḥammad ibn Kâmil. La plirase suivante, formant le com-

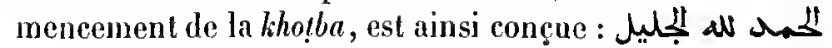

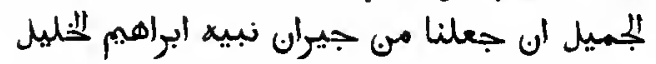

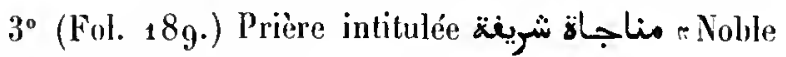
entretienn (de l'àme avec Dieu).

$4^{\circ}\left(\right.$ Fol. $19^{\circ} \mathbf{v}^{\circ}$.) Dialogue, en prose el en vers, entre les villes saintes, la Meeque et Médine, an sujet de la prééminence. Après aroir exposé leurs titres, elles invoquent le jugrement dı grand émir, Saïl al-Dì llboghâ (يـــــ . Ce personnage parait être l'énuir qui se révolta contre le sultan mamlouc Barqoûq, le détrôna eu 1389 , et fut alors nommé général en chef de l'arméc et régent du royaume. Après la restauration de Barqoùq, il lut mis à nort.

$5^{\circ}$ (Fol. 200.) Vers (sentences et conseils moraux, traditions, anecdotes) attribués à 'Alì ibn abì-Ṭàlib.

$6^{\circ}$ (Fol. 204. Privilèges appartenant spécialement ì la plus excellente des créaturesn, e'est-ì-dire à Malıomet, par Siràdj al-Dìn 'Omar,

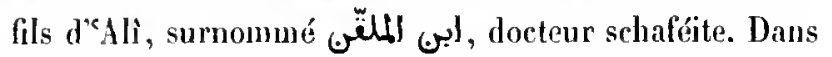
le dernier chapitre, l'auteur énumère les miracles du Prophète. Il dit avoir terniné son ouvrage en 758 de l'hégire ( 1357 de J. C.).

En tête du volume on lit une note au sujet de certains phénomènes atmosphériques et météorologiques qui avaient en lieu en Syrie en 589 de l'hégire ( $1 \mathbf{1}^{3}$ de J. C.), el, écrite de la mème main, une anecdote an sujet de l’imâm Al-Schàfi i, qui aurait épousé dans le Yémen ume femme à deux tètes. A la fin du volume se trouve un talisman au moyen duquel on découvre les oljets volés.

Ms. daté des années 872 et $87^{4}$ de l'hégire $\left(1469^{-}\right.$ $147^{\circ}$ de J. C. .).

Papier. 25 h fenillets. Hauteur, 18 centimètres; largeur, 1' centimètres. 17 lignes par page. - (Incien fonds 841.) 


\section{8.}

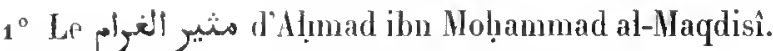
(Voyez l'article 1’ du numéro précédent.)

$2^{\circ}$ (Fol. 65.) Le مثير الغرأم d'Áboû 'l-Fidà Ishâq alKlrabilî. (Voyez l'arlicle $2^{\circ}$ du numéro précédent.) On lit en tête de la copie que l'auteur mourut en 833 de l'hégire ( 1430 de J. C.).

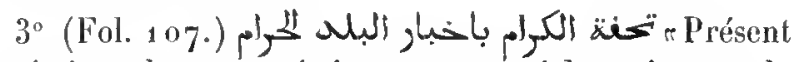
destiné aux hommes généreux, composé de nolices sur la ville sainten. Description historiqne et topographique de la Necque, par Taqì al-Dìn Aboû 'I-Ṭayyib Nohammad al-llasanì ibn Mḷmad ibn 'Alì, cadi malékite, originaire de Fez $(A l-F d s i)$. Cel ouvrage est la première édition de

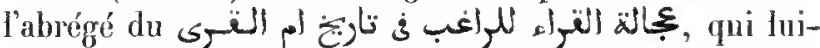

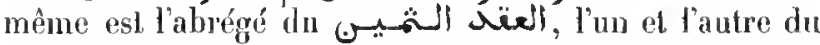
même auteur. La seconde édition de l'abrégé de l’Odjala, consacrée plus spécialement aux biographies, est intilu-

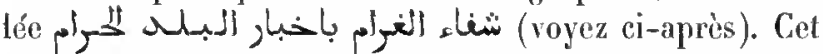
ouvrage renferme vingt-quatre chapitres et se termine par une pièce de ver's de Molı̣mmad iłn abì Bakr ibn Raschìd al-Baghdàdi, sur le pèterinage de la Mecque et celui de Médine. Ce poème al pour litre : النتصـيـد

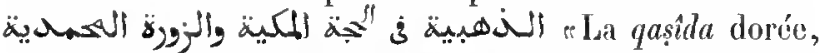
trailant du pèlerinage de la Mecque el de la visite qu'on rend au tombeau de Mlahomet $\%$. Le Tohfat al-Kiram commence par ces mots : : خير ألارض

$4^{\circ}$ (Fol. 201.) Offices $(5 \mid, g l)$, prières et invocations (ج) à réciler dans diverses occasions.

$5^{\circ}$ (Fol. 211.) Prières pour les sept jours de la semaine.

Les lrois premiers ouvrages, écrits de la même main, sont datés de 970 el 971 de l'hégire (1562-1564 de J. C.).

Les deux dernières pièces sont d'une autre main; la première est datée de l'an 991 de l'hégire ( 1583 de J. C.).

Papier. 223 feuillets. Hlauteur, 31 centimètres; largeur, 21 centimètres. 31 lignes par page. - (Ancien fonds 716. )

\section{9.}

Le مثنير الُغرام d'Aḷmad ibn Mohammad al-Maqdisî.

Papier. 137 feuillels. Hanteur, 18 centimètres et demi; largeur, 13 centimètres et demi. 19 lignes par page. Ms. du xvi" siècle. - (Aucien fonds 842.)

\section{0 .}

Histoire de Beyrouth et de la famille Bohtor (بُكْنُ émirs d'Al-Gharb, province située au sud de celte ville. Liuteur, Șaliḥ ilon Yậ̣â, membre de la même famille, composa son ourrage en vue de perpétuer les beaux souvenirs qu'elle arail laissés. Il vivait encore en 840 de l'hégire ( 1437 de J. C.). Une courte esrnisse de l'histoire de Beyroull est suivie de l'histoire des diverses branches de la famille Bohtor et de l'analyse des pièces officielles que ees émirs avaient reçes, soil du gouvernement égyplien, soit du gouvernement de Damas, soit encore des princes francs qui commandaient à Beyroutlı el à Sidon. Les derniers feuillets, renfermant la suite de l'hisloire de l'expédition entreprise en 828 de l'hégire (1425 de J. C.) contre lile de Chypre, manquent. Nombreuses notes marginales.

Papier. 130 fenitlets. Hauteur, 21 cenlimètres; largeur, 15 centimètres el demi. 15 lignes par page. Hs. du xv siècte. - (Ancien fonds 821 , Colbert 4584.)

\section{1.}

م Faniliarité intime avec l'histoire de Jérusatem el d'Héhron n, par Modjìr a]Dìn Aboû 'I-Yomn 'Abd al-Raḥmàn al-eAlìmî (cộl'), cadi hanbalite, mort en $9^{2} 7$ de l'hégire (1521 de J. C.). En tête du volume, te nom de l'auteur, écrit de la main du copiste, se lit ainsi : 'Abd al-Rahmàn ibn Molıammad al-'Omarì at-'Alìmî. Le titre honorifique de Modjîr al-Dîn est omis. Les premiers clapitres de cet ouvrage traitent de la création du monde, de l'histoire d'Adam, d'Abraham, de Moïse, du voyage nocturne de Mahomet, du rétablissement du temple sur l'ordre de Cyrus, de la destruction du temple par Nabuchodonosor, et de sa conquète par les Perses et par 'Omar. Viennent ensuite des notices sur le Mahdî qui doit paraitre vers la fin du monde, sur le dôme de la Sakhra, construit par 'Abd al-Mélik ibn Merwân; sur Haddjâdj ibn Yoûsof et Ibn al-Zobaïr; sur les dimensions de la mosquée Al-Ḥarâm; sur les $T a b{ }^{\tau}$, les pèlerins, les dévots et les ulémas qui ont visité Jérusalen. Suit l'histoire de cette ville, depuis l'an $39^{8}$ jusqu'en 659 de l'hégire (dans cette partie, il est sonvent question des Croisés); la description de la mosquée Al-Aqșà (avec l'indication des dimensions actuelles de cel édifice); l'énumération des mosquées, chapetles et écoles de Jérusalem; les noms des professeurs; la description des environs de Jérusalem; les noms des souverains musulmans qui ont possédé cette ville, ele. Suit l'histoire de la ville d'Hébron, la liste des cadis et 
des émirs, une notice sur le sultan mamlouc Qâitbey, et une série d'annales, depuis l'an 873 de l'hégire, jusqu'à l'an goo. L'auteur dit avoir terminé son ouvrage en 901 de l'bégire ( 4 g5-1496 de J. C.). La préface com-

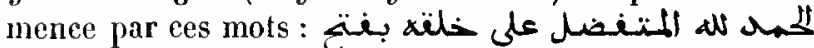
ابواب الرحمة Ce ms. a été copié sur l'exemplaire de l'auteur.

Papier. 411 feuillets. Hauteur, a 7 centimètres; largeur, 18 centimètres. 33 lignes par page. Ms. du xvi siècle. - (Ancien fonds $7^{13}$, Colbert a 868.)

\section{2.}

Même ouvrage. Exemplaire dalé de l'an 962 de l'hégire ( 1555 de J. C.). En tète du volume on trouve la biographie d'un schaikh appelé Ḥasan Baïdemir (بيدمر) al'Adjami, et une pièce de vers rimant en كُ, composée par le Schaikhı al-Islâm Al-"Idjloûnî (الكجلوذ).

Papier. 277 feuillets. Hauleur, 27 centimètres et demi; largeur, 18 centimètres. 17 lignes par page. - (Supplément 784.$)$

\section{3.}

Même ourrage. Exemplaire daté de l'an $9^{6} 9$ de l'hégire ( $156_{2}$ de J. C. $)$.

Papier. 184 feuillets. Hauteur, 32 centimètres; largeur, a 1 centimètres. 31 lignes par page. - (Supplément 785.)

\section{4.}

Même ouvrage. Exemplaire daté de l'an $97^{4}$ de l'hégire (1566-1567 de J. C. $)$.

Papier. 258 feuillets. Hauteur, 26 centimètres; largeur, 18 centimètres. 7 lignes par page. - (Ancien fonds 7 1.)

\section{5 .}

Mème ourrage. Exemplaire daté de l'an $9^{86}$ de l'hégire ( 1577 de J. C.).

Papier. $35_{9}$ feuillets. Hauleur, 27 centimètres et demi ; largeur, 17 centimètres. a 3 lignes par page. - (Supplément 783. )

Mav. oalestacx. - II.

\section{6.}

Même ouvrage. Exemplaire dalé de l'an $99^{8}$ de l'hégire ( 159 o de J. C.). Vignette ornée sur le verso du premier feuillet.

Papier. 285 feuillets. Hauteur, a 1 rentimètres; largeur, 1 / centimètres et demi. s3 lignes par page. - (Ancien fonds 835.)

\section{7.}

Mlême ouvrage. Exemplaire de diverses mains, daté de l'an 1012 de l'hégire (1604 de J. C.).

Papier. 317 feuillets. Hauteur, so centimètres et demi; largenr, 15 centimètres. 2o et 23 lignes par page. - (Ancien fonds 832 .)

\section{8.}

Même ourrage.

On a collé en tête du volume deux feuillets, contenant chacun le texte du poème d'Al-Abìardì, qui est cité par Modjìr al-Dìn, à propos de la prise de Jérusalem par les Franes. Ces vers sont accompagnés d'une paraphrase tatine. Exemplaire daté de l'an 1022 de l'hégire $(1613$ de J. C.).

Papier. ${ }_{239}$ feuillets. Hanteur, 30 centimètres; largeur, 20 rentimètres et demi. 29 lignes par page. - (Ancien fonds 710. )

\section{9 .}

Même ouvrage. En tête de cet exemplaire se trouve une lisle de chapilres. Ms. 'daté de l'an 1062 de l'hégire (1652 de J. G.).

Papier. $27^{3}$ feuillets. Hauteur, 21 centimètres; largeur, 15 ceatimètres et demi. 25 et 27 lignes par page. - (Ancien fonds 831.)

\section{0.}

Même ouvrage.

Papier. 371 feuiltets. Hauteur, a 1 centimètres; largeur, 15 centimètres et demi. 19 lignes par page. Us, du xvu siècle. - (Ancien fonds 83 \%.) 


\section{1 .}

Nlème ouvrage. Ils. daté de l'an 1100 de lhégire (1688-1689 de J. C. $)$.

Papier. 233 fenillets. Hauteur, 28 centimètres; largeur, 16 centimètres. 31 liggnes par page. - (Ancien fonds 712.)

\section{2.}

Même ouvrage. Ms. daté de l'an 1122 de l'hégire (1 710 de J. G.).

Papier. 266 fenillets. llauteur, 21 centimètres; largeur, 15 centimètres. 27 lignes par page. — (Ancien fonds 833.)

\section{3.}

Description de la ville et de la province d'Alep et des lieux voisins. Cette compilation, rédigée probablement au xvi ${ }^{\circ}$ siecle, se compose de passages tirés principalement de l'Histoire d'Aboû 'I-IValid ilon al-Schiḷna; elle est divisée en vingl-cinq chapitres. Le dix-neuvième chapitre et le vingt-cinquième lournissent des renseignements sur plusieurs villes et forteresses de la province de Tripoli et de la frontière septentrionale de la Syrie. Cet exemplaire a été écrit en 1082 de l'hégire $(1671$ de J. C.), par Țoûma ibn Solaïmàn, catholique romain orthodoxe (الاتودكسى)

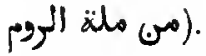

Papier. 98 feuillets. Hauteur, 21 centimètres; largeur, 15 centimètres et demi. 25 lignes par page. - (Supplément 789. )

\section{4.}

DDétices de l'époque, traité sur les érénements qui eurent lieu dans le Liban C'est une histoire des ćmirs du mont Liban de la famille l'Al-Schihàb, depuis l'apparilion de l'islamisme jusqu'à la morl de l'émir Yoùsof, dans la prison de Djazzâr Pacha, en 1205 de l'hégire.

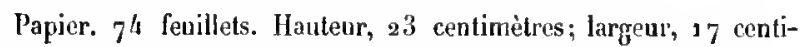
mètres et demi. 99 à 33 lignes par page. - (Supplément 2081.)

\section{5.}

| Écrit dans lequel un proche observateur raconte les événements qui viennent de se passer chez les populations sédentaires (de la Syrie) et chez les Arabes", par Fatḷ-Allah Ibn al-Sâïgh. C'est une chronique de l'occupation de la Syrie par Ibrâlimm Pacha, accompagnée de notices touchant les Anézé (عناز), les Nosairiens et les autres peuples de ce pays. Ms. daté de l'an 1843 de J. C.

Papier. 99 feuillets. Hauteur, 21 centimètres; largeur, 14 centimètres. 14 lignes par page. - (Supplément 947.)

\section{HISTOIRE D'ÉGYPTE.}

\section{6.}

:Conquête de l'Égypte et histoire de ce pays $\pi$, par 'Abd al-Ralımàn ibn 'Abd Allah ibn 'Abd al-Ḥakam iln $A^{c}$ yan, de la tribu de Qoraisch, traditionniste et historien, mort en 257 de l'hégire $\left(870-87^{1}\right.$ de J. C.). Cet exemplaire renferme le texte tel qu'il avait été transmis aux éludiants par Aboû 'l-QQâsim 'Alì ibu al-Ḥasan ibn Khalaf al-Djaulıari al-Azdi. (Voyez l'article publié par M. de Slane dans le Journal asiatique de 1844.) Ms. daté de l'an 585 de l'hégire ( 1190 de J. C.). La plupart des points diacritiques manquent.

Papier. ${ }_{19} 5$ feuillets. Hauteur, 29 centimètres; largeur, 15 centimètres. 21 lignes par page. - (Ancien fonds $7^{85}$.)

\section{7.}

Mème ouvrage. Ms. daté de l'an $77^{6}$ de l'hégire $(1374$ de J. C.).

Papier. $44_{7}$ feuillets. Hauteur, 27 centimètres; largeur, 18 centimètres. 15 lignes par page. - (Ancien fonds 655.)

\section{8.}

r Histoire d'Égypten, attribuée à Moḷammad ilbn Moyassar (ms. مِيْسَر). Le présent ins., qui ne renferme que la seconde partie de l'ourrage, depuis l'an 439 jusqu'à l'an 553 de l'hégire, a élé copié sur un exemplaire que l'historien Al-Maqrìzi avait écrit pour son propre usage, et dans lequel il avait intercalé un extrait d'un autre ouvrage, afin de combler une lacune de cinquante ans quil avait remarquée dans le ms. dont il se servait 
(royez fol. $39 r^{\circ}$ et $52 r^{\circ}$ ). Ce ms. est ponctué d'une manière très-incorrecte.

Papier. 94 fevillets. Hauteur, 31 centimètres et demi; Jargeur, 15 centimètres. 15 lignes par page. Ms. du xwrie siècle. - (Ancien fonds 801 A.)

\section{9.}

r La Conquête de l'Égypten, roman liistorique attribué à Al-Wàqidì. Commencement : قكال

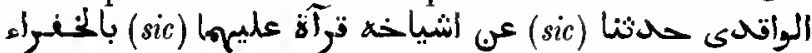
(1'légire (1780 de J. C.).

Papier. 198 feuillets. Hauteur, 21 centimètres et demi; largeur, 14 centimètres et demi. 15 lignes par page. - (Supplément 791.)

\section{0 .}

"Victoires de Bahnasân. Roman historique. Dans cet exemplaile (fol. $20 \mathrm{v}^{\circ}$ ), l'auteur cite parmi ses autorités le célèbre Zamakhsehari, mort en 1143 de J. C. Ms. daté de l'an $97^{5}$ de l'hégire $(1567$ de J. C.).

Papier. 197 feuillets. Hauteur, 31 centimètres; largeur, 15 centimètres. 11 lignes par page. - (Ancien fonds 815.)

\section{1 .}

Même onvrage.

Papier. 148 feuillets. Hauteur, 31 centimètres; largeur, 15 centimètres. 14 à 16 lignes par page. Ms. du xviı é siècle. - (Ancien fonds 814 .)

\section{2.}

\section{Même ouvrage.}

Papier. 190 feuillets. Hauteur, 21 centimètres; largeur, 15 centimètres. 15 lignes par page. $\mathrm{N}$ s. de plusieurs écritures, dont la plus ancienne est dn xv11 siècle. - (Supplément 792.)

\section{3.}

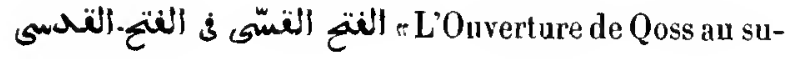

jet de l'ouverture de Qods » (c'est-à-dire, éloquence digne du grand prédicateur Qoss, applirjuée au réeit de la conquête de Jérusalen, par Saladin), par 'Imâd al-Dìn Mboù 'Abd Allah Moḷammad ibn Moḷammad ibn Hâmid... ibn Oloh, xll, al-Iṣlahânî. C'est une histoire de Saladin, depuis la bataille de Tibériade, en 583 de l'hégire, jusqu'à la mort de ce souverain, en 589. Cet ourrage important, écrit en prose rimée, est plein d'archaismes, d'allusions énigmatiques, d'assonances et de jenx de mots, et d'une lecture fort dilficile. L'auteur était secrétaire de Saladin et souvent témoin des événements qu'il raconte. Exemplaire pourvu de points-voyelles, éerit du vivant de l'auteur (sauf les vingt-six derniers feuillets).

Papier. 264 feuillets. Hauteur, a\& centimètres; largeur, 15 centimètres et demi. 19 lignes par page. - (Ancien fonds $\left.7^{1} 7.\right)$

\section{4.}

Mème ouvrage. Dans cet exemplaire, le premier mot dı titre, qui se trouve au recto des feuillets 1 et 168 , est écrit

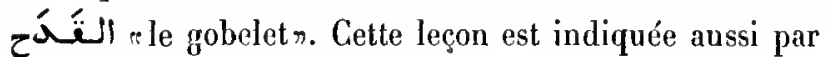
Hadji Khalfa (Bibliogr., t. IV, p. 5o5), qui fait observer qu'elle ne s'accorde pas avec celle qui est donnée par l'auteur lui-même à la fin de la préface. Exemplaire dalé de l'an 600 de l'hégire (1 204 de J. C. ).

Papier. 333 feuillets. Hauteur, 25 centimètres et demi; largeur, 17 centimètres. 17 lignes par page. - (Ancien fonds 714 , Colbert 4204.)

\section{5 .}

Mème onviage.

Papier. $33_{2} 3$ feuillets. Hauteur, 24 centimètres; largeur, 17 centimètres. 19 lignes par page. Ms. du xm ${ }^{\circ}$ siècle (à l'exception des 23 derniers feuillets). - (Ancien fonds $7{ }^{15}$.)

\section{6.}

Même ouvrage. Exemplaire écrit en 629 de Thégire (1231-1232 de J. C.), pour la bibliothèque de Waḷid al-Din Hoddjat al-Islàm al-Salmânì. Points-voyelles. Sur le verso du dernier feuillet, on lit une pièce de vers, composée à l'éloge de Mọaminad (?) Efendi (?) al-'Tmâdì, par 'Abd al-Raḥmàn Moḷammad al-Turkomânì. Cette pièce est datée de l'an 1130 de l'hégire (1 718 de J. C.).

Papier. 160 feuillets. Hauteur, 30 centimètres et demi; largeur, 23 centimètres. 21 lignes par page. - (Supplément 786.) 


\section{7.}

Mêne ouvrage.

Papier. 2/8 feuillets. Hauteur, 26 centimètres; largeur, 17 centimètres. 21 lignes par page. Ms. du xiv siècle. - (Supplément 787.)

\section{8.}

Hème onvrage. Les rimes du texte sont ponctuées en rouge.

Papicr. 272 feuillets. Llauteur, 21 centimètres; largeur, 15 centimètres. 23 lignes par page. Ms. du $\mathrm{N}^{\circ}$ " siècle. - (Ancien fonds 840. .)

\section{9 .}

Même ouvrage. Exemplaire daté de l'an to67 de l'hégire ( 1657 de J. G.). Quelques notes marginales.

$2^{\circ}$ (Fol. $197 \mathrm{v}^{\circ}$.) Sote relative à une controverse qui avait eu lieu en 1071 de l'hégire (1601 de J. C.) entre Moḷammad al-Bảbili et certains théologiens chrétiens.

مـ - Mliroir des réalités, pour servir à faire comprendre le microcosme humain ». Cet ouvrage, qui porte aussi le titre de decin" on rMédecine de l'âme», est, d'après la préface, la traduction d'un traité de philosophie transcendante, composé en langue indienne, par un djogui (جوكى), el intitulé a r Réservoir de l'eau de la vien. Cet ouvrage a été traduit en persan par le cadi Rokn al-Din Mohammad at-Samarcandi, et du persan en arabe par łe célèbre théosophe Molıyì al-Dì Ibn al-'Arabì. Il est divisé en dix chapitres, dont M. de Guignes a donné nue bonne analyse dans les Mémoires de l'Académie des inscriptions et belles-lettres, ancienne série, t. XVI, p. 791.

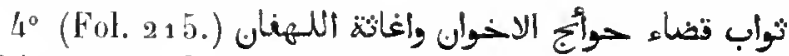
"Récompense de ceux qui rendent service aux frères et qui portent secours à l'opprimés, par Mlobyi al-Din lbn al-'Arabì. L'autenr cite un grand nombre de traditions en laveur de la fraternite universelle.

$5^{\circ}$ (Fol. 225 $\mathrm{v}^{\circ}$.) Éloge de Jérusalem, en vers, par Moḥammad Efendi, qui avait élé cadi de cette ville. Ces vers riment en $s$.

$6^{\circ}\left(\right.$ Fol. $229 \mathrm{v}^{\circ}$.) Autre qașida sur la rime $s$ do mème auteur.

Papicr. 232 feuillets. Hauteur, 21 centimètres; largeur, 15 centimètres. 21 tignes par page. Ms. du xvir siècle. - (Ancien fonds 839.)

\section{0 .}

r Les Deux Jardins, renfermant l'histoire des deux règues , par Aboû Schâma Schiliàb al-Dìn 'Abd al-Rahmàn ibn Ismacil, de Jérusalem, mort en 665 de l'hégire (1266-1267 de J. C.). أزهار الروضتيب Hadji Klıalfa donne à cet ouvrage le titre de "Fleurs des deux jardins ". C'est une histoire des Alabees de Mossoul, de Noûr al-Din et de Salâḷ al-Dìn (Saladin), jusqu'ì l'an 597 de l'hégire. Exemplaire daté de l'an 1121 de l'hégire ( 1709 de J. G.).

t'apier. 29 '4 feuillets. Ilauteur, 33 centimètres el demi; largeur, 23 centimètres et demi. 43 lignes par page. - (Ancien foods 707 A.)

\section{1}

Première partie du même ourrage. Le titre de cet exemplaire a été altéré. Le premier feuillet a été ajouté après coup, ainsi que l'explicit du ms.

Papier. 211 feuitlets. Hauteur, 27 centimètres et demi; largeur, 19 centimètres. 19 lignes par page. Ms. du xıv siècle. - (Supplément 788.)

\section{2.}

rivre qui dissipe les soucis et qui renferme l'histoire des princes Ayyoubides $n$, par le cadi Djamìl al-Dìn Ibn Wâșil (Mohammad ibn Sàlim al-Hamawi), docteur schaféite, mort, selon Hadji Khalfa, en 697 de l'hégire (1297-1298 de J. C.). Le titre qui se trouve en lêle du volume, ainsi que les renseignements qu'on lit au premier feuillet et au dernier, sont faux; ils ont élé ajoutés après coup. Le texte authentique, c'est-à-dire la fin de l'histoire de l'an 530 de l'hégire, commence au second feuillet. Ce volume devait conlenir l'histoire des années 530 à 680 de l'hégire; mais il y a plusieurs lacunes, dont quelques-unes très-considérables, et plusieurs feuillets sont intervertis.

Papier. 442 feuillets. Ilauteur, 28 centimètres; largeur, 19 centimètres et demi. 21 lignes par page. Ms. du xiv" siècle. - (Supplément $7^{25}$.)

\section{3.}

Dernière partie de l'histoire des Ayyoubides de Djamât 
al-Dìn Ibn Wâṣil, commençant par le récit de la mort d'Al-Malik al-Kâmil, sultan d'Égypte, événement qui eut lieu en 635 de l'hégire. L'ourrage se termine par l'expédition d'Al-Malik al-Zàlıir Bäbars et du nouveau calife, Al-Mostansir II, contre la Syrie, en 650 de l'hégire. Eutre les folios 8 et 9 il manque plusieurs feuillets.

$2^{\circ}$ (Fol. 172.) Contimuation de la même histoire, par 'Ali ibn 'Abd at-Rahìn ibn Aḷmad, secrélaire et client

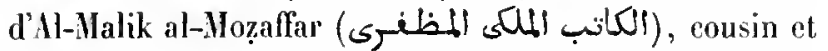
prédécesseur de l'historien Aboù 'l-Fidà, dans la principauté de Ilanâh. Le réeit s'arrète à l'an 695 de l'hégire.

Papier. 216 feuillets. flauteur, 28 centimètres; largeur, 18 centimètres. 33 lignes par page. Ms. de ta fin da XIv siècle. - (Supplément $7_{\text {ha. }}$

\section{4.}

Seconde et troisiènne parties de l'ourrage intilulé - Histoire du sultan al-Malik al-Manșoûr (Qalawoún), pour servir d"illustration anx jours et aux siècles\%. Ce volume renferme le récit des événements des années 681 à 689 de l'hégire, jusquà la mort de Qalawoûn. Le commencement el la fin de la troisième partie manquent. La seconde partie se termine au fol. $147 \mathrm{r}^{\circ}$. Cet ourrage renferme plusieurs pièces diplomatiques. (Voyez Recueil des listoriens oriontaux des croisades, t. I, p. u.v.)

Papier. 376 feuillets. Hauteur, 26 centimètres et demi; largenr, 20 centinètres. 7 lignes par page. Iss, de la fin dı $x 1^{\mathrm{e}}$ siècle. (Supplément 810, Saint-Germain 118 bis.)

\section{5.}

Histoire du sultan mamlouc Al-Malik al-Nàsir, fils de Qalawoûn. Ce volume, dont le commencemeut et la fiu. manquent, contient le récit des événements qui eurent lieu en Egypte, en Syrie et en Cilicie, pendant les années 704 et 705 de l'hégire. L'ourrage, rédigé en prose rimée et du vivant même de ce sultan, n'est qu'un long et rerbeux panégyrique du priuce; mais il renlerme plusieurs faits intéressants et ressemble beaucoup à l'histoire du sultan Qalawoûn, contenue dans le numéro précédent.

Papier. 107 fenillets. Mauteur, a5 centimètres et demi; largeur, 17 centimètres el demi. 9 lignes par page. - (Supplément 839, SainlGermain $9^{4}$.)

\section{6.}

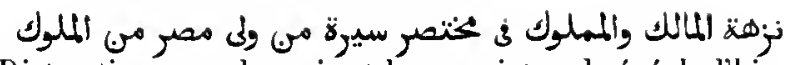
* Distraction pour les rois el leurs sujels, alorégé de l'histoire des souverains de l'Égypte», par Al-Ịasan ibn abî Molıammad 'Alod Allahı al-chboâsì al-Hàschimi, client d'Ml-Malik al-Nâsir, fils de Qalawoùn, et génératement connu sous le surnom d'Al-Safadi. Résumé de l'histoire de l'Égypte, depuis les temps les plis reculés jusqu'au milieu de l'an 711 de l'bégire. Ms. daté de l'an 1012 de l'hégire ( 1603 de J. C.).

Papier. ${ }_{7} 7$ feuillets. llauteur, a 1 centimètres; largeur, 15 centimètres et demi. 19 lignes par page. - (Supptément 823.)

\section{7.}

مes Vertus princières, abrégé de l'histoire de Zàlir », par Schàfie ibı 'Alì ibn 'Abbàs. C'est le résumé, en prose, d'un longr poème, composé par' Hoû 'I-Fadhl 'Albd Allah ibn 'Abd al-Tâhlir', renfermant l'histoire du sultan mamlouc $\mathbf{~} \mathrm{l}$ Malik al-Zàbir Baibars. D'autres mains ont écrit sur les derniers feuillets plusieurs maximes, tant en prose qu'en vers, des traditions de Mahomet, ete. Ms. daté de l'an 716 de l'hégire $(13,6$ de J. C.).

Papier. 160 feuillets. llanteur, 20 centimètres el demi; largeur, 14 centimitres. 3 lignes par page. - (Ancien fonds 803.)

\section{8}

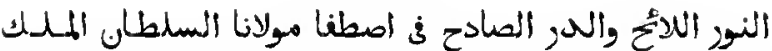
flall "La Lumière brillante et l'anulette des perles, montrant que notre seigueur le sultan MI-Malik al-Șalih jouit de la faveur divinen, par lbrâbim ibn 'Abd al-lial! mân ibn 'Abd Allah al-Qaïsaràni, le Qoraïschite, surnommé $A$-Khâlidi, parce qu'il descendait de Khâlid ibı al-Walid. C'est un panégyrique du sultain mamlouc, AlMalik al-Sitih Ismacil, fils d'Ml-Mảlik al-Nàsir Molıammad et petit-fils de Saïl' al-Din Qalawoûn. L'auteur était secrétaire (كاتب دست) du sultan Al-Malik al-Șảliḷ. Il raconte d'une manière sommaire, mais avec les dates, comment la souveraineté de l'Égypte passa de Noùr al-Dín Molıammad, fils de Zengui, au pelit-fils de Qalıwoûn. Ce volume, écrit avec une rare élégance et de la main de l'auteur, porte un double frontispice, très-artistement exécuté en or et en couleurs; les deux dernières pages sont 
ornées de ta mếme manière. Hs. exécuté entre les années 743 et 746 de l'hégine $(1342-1345$ de J. C. $)$.

Papier. 48 fenillets. Hlauteur, 30 centimèires; largeur, 21 centimètres et demi. 7 lignes par page. - (Supplément 813 , Saint-Germàin 130.)

\section{9.}

(x) Sucrier du sultann, par Aboû 'Abd Allah ibn abi Hadjla ( vrage, dédié au sultan mamlouc Al-Malik al-Nâșir Ḥasan ibn Molammad, se compose de sept chapitres et un appendice, divisé aussi en sept parties, le tout servant à illustrer l'excellence dn nombre sept et son rôle dans l'histoire de l'Égypte. C'est un recueil d'anecdoles en prose et en vers, composé en 757 de l'hégire (1356 de J. C.). La qualrieme section de l'appendice traite des actes criminels commis par le calife fatémide Al-ḷ̂akim bi-Amr lltâlı. Vovez, pour le contenu de l'ouvrage, le Calalogue de la bibliothèque bodléienne, t. II, p. 140. La préface commence

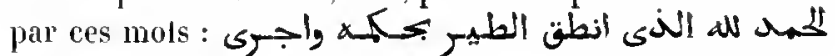

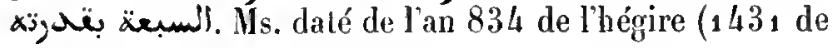
J. C.).

Papier. 115 fenillets. Hauteur, 18 centimètres; largeur, 13 centimètres et demi. 16 lignes par page. - (Ancien fonds 806 , Colbert 6025$.

\section{0 .}

Même ouvrage. Ms. daté de l'an 869 de l'hégire (1465 de J. C.).

Papier. 219 feuillets. Hanteur, 26 centimètres; largeur, 18 centimètres. 17 lignes par page. - (Supplément 818.)

\section{1.}

Mème ouvrage. Mls. daté de l'an 870 de l'hégire (14651466 de J. C.).

Papier. 136 feuillets. Hauteur, 18 centimètres; largeur, 14 centimètres. 17 lignes par page. -- (Ancien fonds 808.)

\section{2.}

Même ouvrage.

Papier. 139 feuillets. Hauteur, 27 centimètres; largeur, 18 centi- mètres et demi. 17 lignes par page. Ms. du xiv siède. - (Ancien fonds 693.)

\section{3.}

Mème ouvrage. Au verso du folio 9 se trouve un planisphère grossièrement exécuté. Ms. daté de l'an 962 de l'hégire (1555 de J. C.).

Papier. 56 fenillets. Hautenr, 28 centimètres; largeur, 18 centimètres et demi. 27 lignes par page. - (Ancien fonds 694.)

\section{4.}

Même ouvrage. Ms. daté de l'an 1061 de l'hégire (1651 de J. G.).

Papier. 120 feuillets. Ilauteur, 21 centimètres; largeur, 15 centimètres et demi. 19 lignes par page. - (Supplément 819.)

\section{5 .}

Même ouvrage. Le dernier feuillet du ms. manque.

Papier. 124 feuillets. Hauteur, 19 centimètres; largeur, 15 centimètres. 17 lignes par page. Ms. du xvı"e siècle. - (Supplément 817.)

\section{6.}

$1^{\circ}$ Même ouvrage. L'appendice est d'une écriture plus ancienne que le reste de l'ouvrage.

$2^{\circ}$ Fol. 110. ( 10. taire sur un poème renfermant des conseils et des maximes de sagesse, par Yoûsof ibn Moḷammad ibn 'Abd al-Djawwâd ibn Khidr al-Scharbini. Le poème et le commentaire sont du même auteur, qui déclare n'y avoir employé - que les quatorze lettres non ponctuées de l'alphabet arabe. Cel ouvrage a été composé en 1098 de l'hégire (1686${ }_{1687}$ de J. C.).

Papier. 150 fenillets. Hauteur, 20 centimètres; largeur, 15 centimètres. 15 lignes par page, puis 21 et 19 dans la première partie; 17 lignes dans la seconde. Ms. de diverses écritures du xviı siècle. (Supplément 817 bis.)

\section{7.}

Le Soukkardân al-Soltân d'Ibn abì Hadjla. Exemplaire 
composé de cahiers de diverses écritures, dont la plus moderne (fol. 128) est datée de l'an $107^{\circ}$ de l'hégire (1659-166o de J. C.).

Papier. 128 fenillets. Hauteur, 18 centimètres; largeur, 13 centimètres et demi. 15 lignes par page. - (Ancien fonds 807 , Colbert 6035.)

\section{8.}

Fragment du même ouvrage, depuis la fin du chapitre nu jusque vers la fin du chapitre vı.

Papier. 49 feuillets. Hauteur, 18 centimètres; largeur, 13 centimètres. 13 lignes par page. Ms. du $x^{e}{ }^{e}$ siècle. - (Supplément 20 76 .)

\section{9.}

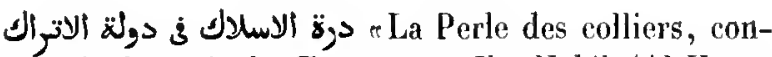
cernant la dynastie des Turesn, par Ibn Habîb (Al-Hasan ibn 'Omar), mort en 779 de l'légire ( 1378 de J. C.). Histoire, sous forme d'annales, des sultans mamloues d'Égyple, depuis l'an 648 de l'hégire, renfermant un grand nombre de notices obituaires. D’après Hadji Klralfa, ces amuales s'étendaient jusqu'à l'an 778 de l'hégire. Mais le présent exemplaire, composé de deux volumes reliés en un seul, s'arrête à l'an 760 . Ms. dalé de l'an 982 de l'hégire ( 1574 de J. C.).

Papier. 300 feuillets. Hauteur, 28 centimètres; largeur, 17 centimètres et demi. 3. lignes par page. - (Ancien fonds 688.)

\section{0 .}

Le premier volume du mène ourrage. Ce volume se termine avec l'anmée 714. Ms. daté de l'an 1026 de l'hégire ( 1617 de J. C.).

P'apier. ${ }_{7} 8$ fenillets. Hauteur, 22 centimètres; largeur, 15 centimètres et demi. 17 lignes par page. - (Supplément 849.)

\section{1.}

ristraits de l'ouvrage historique d'lbn liabìb», e'est-à-dire du Dorrat al-Aslik, arec d'autres extraits. Le ms., un sinıple brouillon, est, paraìt-il, de la main de l'historien Ibn Qâdhî Schohba. L'écriture est assez régulière, mais très-souvent dépourvne de points diacritiques et assez difficile à lire. Il y a des additions marginales d'une autre main. Ms. daté de l'an 8,6 de l'hégire ( 14,3 de J. C., voyez fol. 133 ).

Papier. 270 feuillets. Hautcur, 19 centimìtres; largeur, 14 centimètres. 19 lignes par page. - (Ancien fonds 859.)

\section{2 .}

Résumé de l'histoire musulmane, depuis l'avènement de Mo âwrya ibn abì Sofyàn jusqu'à l'an 783 de l'hégire, alors que Barqoûq plaça İàddji Sạliḷ, fils de Sclracbân, sur le trône d'Égyte. Ce ms. parait être le brouillon de l'auteur. Il y a des lacunes et plusieurs feuillets sont transposés.

Papier. 203 feuillets. Hauteur, 21 centimètres el demi; largeur, 16 centimètres. 12 à 18 lignes par page. - (Supplément 845.)

\section{3.}

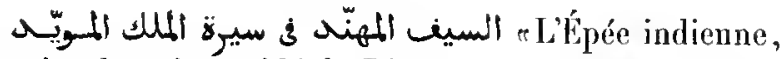
histoire du prince aidé de Dieun, par Aboû Moḷammad Maḷmoûd ilon Aḷnad al-'Aïnì. C'est un long panégyrique du sultan manlouc, Al-Malik al-Mowayyad Aboû 'H-Nașr, qui régnait de 815 à 824 de l'hégire. La partie historique de ce volume commence au fol. $53 \mathrm{v}^{\circ}$, el s'arrète vers la fin de l'année $8 r_{9}$, où l'ouvrage se termine. Le reste contient des louanges, des rèveries astrologiques et un arbre généalogique (fol. $18 v^{\circ}$ ), qui démontre que los Tures sont les ancêtres de la race arabe.

Papier. 60 feuillets. Hautenr, 26 centimètres et demi; largeur, 18 centimètres. 24 el 25 lignes par page. Ms. dı xv siècle. - (Ancien fonds 685.$)$

\section{4.}

$1^{\circ}$ r La Crème de l'ouvrage intitulé Kaschf al-Mamálik, par Khalì ibn Schàdnìn al-Zâhrirì. C'est un tableau topograplrique, historique el politique de l'empire des sultars manlones de l'Égypte, vers l'année 839 de l'hógine, tiré de l'ouvrage du mème anteur,

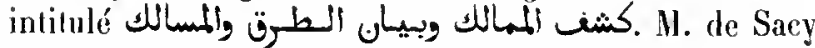
en a publié un extrait dans sa Chrestomathie arabe, t. 11, $\mathrm{n}^{\circ} \mathrm{x}$. Le mème savant nous apprend que l'auteur avait été rommé colonel dans la cavalerie de la garde (أمير الن), en 843 de l'hégire ( 1439 de J. C.). Premiers mots de la

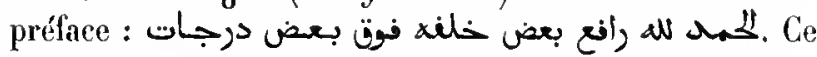
rolume a été écrit pour la bibliothèque du sultan Qâïlbey, par conséquent, entre les années 872 et 901 de l'lrégire. En tête du ms. se troure une note qui constate que 
ce volume a été donné, eu 890 de l'hégire, par ce sultan au collège quil avait fait construire dans la Salarâ. (Voyez S. de Sacy, l.c., 1. 1, p. 194.)

$2^{\circ}$ (Fol. $306 \mathrm{r}^{\circ}$.) Lettre adressée par le sultan Al-

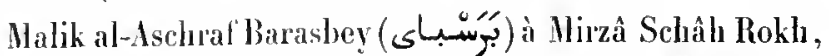
fils de Timoul. Cette pièce a été publiće par N. de Sacy dans sa Chrestomathic arabe, 1. I, p. 71.

Papier. 312 feuillets. Ilauteur, 28 centimètres; largeur, 19 centimè̀res. 10 lignes par page. Ms. du $x^{e}$ siècle. - (Ancien fonds 695.)

\section{5 .}

rices sur les tribus arabes établies en Égypten, par $\Lambda$ ḥmad ibn 'Alì al-Maqrìzì. Hs. copié sur l'autographle et daté de l'an 841 de l'hégire.

Papier. 19 feuiltets. Hauteur, 23 centimètres; largeur, 14 centimèlres et demi. 23 lignes par page. Ms. du xvn' siècle. - (Supplément $79^{3}$.)

\section{6 et 1727.}

rlntroduction à la connaissance des dynasties $n$, histoire d'Égypte, depuis l'avènement des Ayyoubides jusqu'à la fin de l'année 822 de l'hégire, par Taqì al-Dîn Aḷmad ibn 'Ali al-Maqrîzî, mort en 845 de l'hégire (1442 de J. C.). L'auteur donne d'abord de courtes notices sur d'autres dynasties, telles que la dynastie des Bouides et celle des Seldjoukides. Il parle ensuite de Salâlı al-Dìn (Saladin), quil fait descendre de Macadd ibu 'Adnân, puis il entre en matière et rapporte tes événemeuts de l'an 568 de l'hégire el des années suivantes, jusqu'à l'an 844 . Le premier volume finit à la fin de l'au 753 de l'hógire. Copie datée de l'an 1041 de l'héggire (163 I de J. C. .). La dernière partie du second volume, qui présente quelques lacunes, est d'une autre main, et datée de l'an 939 de l'hégire (1533 de J. C.).

2 vol. Papier. 630 et 488 feviltets. Hauteur, ${ }_{2} 6$ centimètres et demi; largeur, 16 centimètres et demi. 25 lignes par page. - (Ancien fonds 672 et 6373 .)

\section{8.}

Dernière partie du même ouvrage, embrassant l'histoire des années $80_{1}$ ì 822 de l'hégire.

Papier. 165 feuiltets. Hauteur, 27 centimìlres et demi; Jargeur,
18 centimètres. 31 lignes par page. Ms. du $\mathbf{x v}^{\mathrm{e}}$ siècte. - (Ancjen fonds 674 .)

\section{9 et 1730 .}

r. Les Arertissements et l'explication au sujet de la topographie et des monuments n, par Taqì al-Dìn Alımad ibn 'Alì al-Mlaqrizî. Exemplaire daté de l'an 874 de l'hégire (1470 de J. C.).

2 vol. Papier. 350 et 368 feuillets. Ilauteur, 27 centimètres; largeur, 19 centimètres. 35 lignes par page. -- (Ancien fonds $673 \triangle$ et в.)

\section{1 et 1732 .}

Mème ouvrage. Frontispice orné dans chacun des deux volumes.

a vol. Papier. 424 et 442 feuillets. Hanteur, 21 centimètres; largeur, 13 centimètres et demi. 29 lignnes par page. Ms. du xv1 siècle. (Ancien fonds 797 et 798 .)

\section{3.}

Même ouvrage. Un grand nombre de feuillets du ms. sont détériorés.

Papier. 517 feuillets. Ilauteur, 26 centimètres; largenr, 16 centimètres. 35 lignes par page. Ms. du $x v^{\circ}$ siècte. - (Supplément 2072.)

\section{4 et 1735 .}

Même ouvrage. Copie datée de l'an 978 de l'hégire ( 1570 de J. C. $)$.

2 vol. Papier. 477 et 518 feuitlets. Hauteur, 21 centimètres; largeur, 15 centimètres. 25 lignes par page. - (Supplément 926 et 926 bis.)

\section{6.}

Même ouvrage. Ms. daté de l'an $9^{81}$ de l'hégire $(1573-$ 1574 de J. C.).

Papier. 588 feuillets. Hauteur, 31 centimètres; largeur, 20 centimètres. 41 lignes par page. - (Ancien fonds 682, Colbert 2840.) 


\section{7 × 1740.}

Même ouvrage.

4 vol. Papier. 331, 279, 350 et 340 feuillets. Hauteur, 21 centimètres et demi; largeur, 14 centimètres. 27 lignes par page. Ms. dı xvi" siècle. - (Ancien fonds $79^{5} \mathrm{~A}$.)

\section{1 i 1743.}

Même ouvrage.

3 vol. Papier. ${ }_{2} 69,{ }_{2} 69$ et ${ }_{2} 35$ feuillets. Hauteur, 30 centimètres; largeur, 20 centimètres. 25 lignes par page. Ms. du xvir siècle. (Ancien fonds $6-3 \mathrm{c}$.)

\section{4.}

1. Premier volume du mème ouvrage, finissant par le chapitre qui traile de l'ère des Perses.

$2^{\circ}$ (Fol. 194.) Nolice chronologique des souverains hafsides.

$3^{\circ}$ (Fol. $19^{4} 1^{\circ}$. ) Courte nolice des peuples nègres

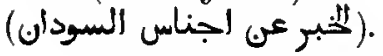

$.4^{\circ}$ (Fol. 1 $96 v^{\circ}$.) Examen des Iradilions qui se rapportent à l'investiture d'Alì par Mahomet près de l'étang

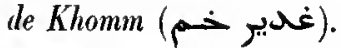

Hs. daté de l'an 881 de l'hégire (1476-1477 de J. C.).

Papier. 197 fenillets. Hauteur, 26 centimètres; largeur, 17 centimètres el demi. 31 lignes par page. - (Ancien fonds 676 .)

\section{5 .}

Premier volume d'un exemplaire du Khițtat de Maqrizi. le commeneement manque. Le volume suivant devait

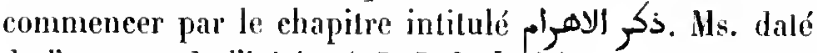
de l'an 921 de l'hégire ( 1515 de J. C.).

Papier. 301 feuillets. Hauteur, 27 centimètres et demi; largeur, 18 centimètres et demi. 17 lignes par page. - (Supplément 2073 .)

\section{6.}

Prenier volume du même ouvrage, se terminant par

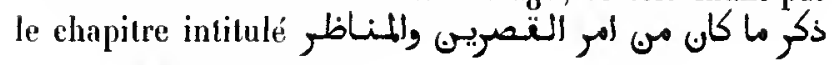

$$
\text { Man. ontentalx. - II. }
$$

A la fin se trouve une courle notice biographique de l'auteur.

Papier. 381 feuillets. Hauteur, 27 centimètres; largeur, 18 centi. mètres. 36 lignes par page. Ms. du xvi siècle. - (Supplément 925.)

\section{7.}

Première moilié du mème ouvrage. Le dernier feuillel manque; mais un savanl musulman a reproduil, dans une très-mauvaise écriture et sur deux feuillels à part, la suite du chapitre qui, du resle, est beaucoup. plus détaillé que celui de l'édilion de Boulày. Le mème savanl a écrit sur les marges de plusieurs feuillets dn volume, notammenl des feuillets 185 à 192 , de longues noles el des éclaircissements historiques, qu'il paraì avoir lirés de son propre fonds.

Papier. 430 feuillets. Ilauteur, 30 centimèlres et demi; largeur, so centimètres et demi. 31 lignes par page. Ms. du viı siècle. - (Supplément 933, Saint-Germain 106.)

\section{8.}

Premier volume du mème ouvrage. Le dernier chapilre a été omis par le copiste. Le volume se terinine par une courte nolice biographique de l'anteur.

Papier. 311 feuillets. Hauteur, 31 centimètres; largeur, al centimètres. 35 lignes par page. Ms. du xvu siècle. - (Supplément 92'́, Saint-Germain 1 08.)

\section{9 .}

Prenier voluue du mème onvrage. Les derniers leuilJets manquent. Le lexle s'arrète an milien de la deseription des bords du Nil, dans la ville de Mișr (page 344. ligne a du premier volume de l'édilion de Boulà(q).

Papier. 488 feuillets. Hauteur, 31 centimètres; largenr, 15 centimètres. 25 liggnes par pagr. Ms. du xvı' siècle. - (Supplément 930.)

\section{0.}

Premier volume du mòme ourrage. Le dernier eluipilre est celui qui trajte des successeurs d'Alexandre dans le gouvernement de l'Égypte. (Voyez l'édition do Boulàq, 1. 1, p. 155.$)$

Papier. 222 feuillets. Hauteur, a6 centimèlres et demi; largeur, 18 centimètres. 23 lignes par page. Ms. dı xur siècle. - (Supplément 927.) 


\section{MANUSCRITS ORIENTAUX.}

\section{1.}

Premier volume du même ouvrage.

Papier. 230 feuillets. Hauteur, 17 centimètres; largenr, 1 a centimètres et demi. a3 lignes par page. Ms. du xvu" siècle. - (Ancien fonds 799 , Colbert 3677 .)

\section{2.}

Nlime ouvrage, second volune d'un exemplaire distribué en trois volumes. Le ms. commence par le chapitre sur Fostàt el finit par celui qui traile de l'hippodrome d'Al-Halik al-Nàsir" (الميشأن الناصعى).

Papier. ${ }_{2} 57$ feuillels. Hanteur, 27 centimètres et demi; largeur, 18 centimètres. 35 liggnes par pağe. Ms. du $\mathbf{x v}^{e}$ siècle. - (Ancien fonds 677 .)

\section{3.}

Second rolume du même ouvrage, commençant par le chapitre sur Fostât (1. I, p. 285 de l'édilion de Boulàq), et finissant par la Rahaba wazîr Baghdald (t. II, p. 50 de la même édition). Le copiste a placé en tête du volume une liste de chapitres, dans laquelle il a intercalé quelques Iradilions relatives an Propliète.

Papier. a 46 feuillets. Ilauteur, 27 centimètres; largeur, 18 centimètres. 31 lignes par page el 29 lignes vers la fin du volume. Ms. du $\mathrm{vv}^{\mathrm{e}}$ siècle. - (Ancien fonds 678 .)

\section{4.}

Second volume du même ouvrage, commençant par le chapitre sur la londalion de la ville du Caire par les Faténides (voyez l'édition de Boulâq, t. I, p. 361), et se terminant par celui qui renferme la liste des sultans mamIoucs (royez l'édition de Boulì, t. II, p. 244, 1. 4).

Papier. 275 feuillets. Hauteur, 27 centimètres; largeur, 18 centimètres et demi. 27 lignes par page. Ms. du xvi siècle. - (Supplément 929.)

\section{5.}

Second volume du mème ouvrage, commençant par le chapitre relatif à la ville de Fosṭậ (voyez l'édition de Boulàq, t. I, p. 33g), et finissant par le chapilre qui traite du pont de la route de Qalyoûb ì Damielten (ibidem, t. 11, p. 171).

Papier. 223 feuillets. Hauteur, 26 centimètres el demi; largeur, 18 centimètres. 31 lignes par page, puis 33 , puis 35 dans le dernier cahier, qui est d'une écriture plus moderne; le dernier feuillet est de la même écriture que le corps du volume. Ms. du xvı siècle. - (Supplément 927 bis.)

\section{6.}

Second volume du même ouvrage, commençant par le chapitre relatif à Fostàt, et se teminant par celui qui traite de l'ile d'Al-Ródha.

Papier. 270 feuillets. Hauteur, 27 centimètres; largeur, 18 centimètres. 31 liggnes par page. Ms. du xvi" siède. - (Supplément 2074.)

\section{7 et 1758 .}

Second et troisième (dernier) volumes du mème ouvrage. Vignetle sur le verso du premier feuillet.

2 vol. Papier. 343 et 347 feuillets. Hauteur, 21 centimètres; lar-

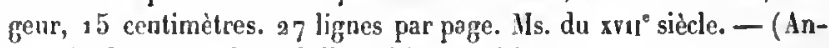
cien fonds 800 et 801 , Colbert 3678 et 3679 .)

\section{9 .}

Dernière partie du mème ouvrage, commençant par le chapitre intitule daté de l'an 887 de l'hégire (1482 de J. C.), est de la main d'Ahmad ibn Moḷammad al-Qastalànî, auteur du traité mystique intitulé المواهب اللدنية.

Papier. 277 feuillets. Hauteur, 26 centimètres; Jargeur, 18 centimètres et demi. $3{ }_{1}$. lignes par page. - (Supplément 923 bis, SaintGermain 105.)

\section{0.}

Dernière partie du même ouvrage, commençant par le chapitre intitulé ذكر حارات القاهرة وظواهوهاه

Papier. 390 feuillets. Hauteur, 31 centimètres; largeur, so centimètres. 31 lignes par page. Ms. du xv1" siècle. - (Ancien fonds 680.)

\section{1.}

Quatrième (dernier) volume du même ourrage, com- 
mençant par la section qui traite des collèges. (Voyez t. II, p. 362 de l'édition de Boulàq.)

Papier. 217 feuillets. Hauteur, 21 centimètres; largeur, 15 centimètres. 21 lignes par page. Ms. du xñ siècle. - (Supplément 92a, Saint-Germain 367 .)

\section{2.}

Troisième (dernier) volume du même ouvrage, commençant par le chapitre intitulé pond à la page 177 de l'édition de Boulâq. Le copiste a ajouté à la fin de l'ouvrage trois courts chapilres, tirés d'une source anonyme, et intitulés

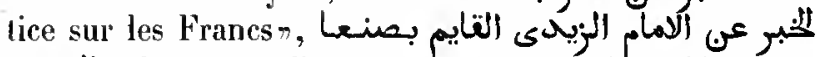
Nolice sur l'imam zaìdite de Șancâ, du Yémen n,

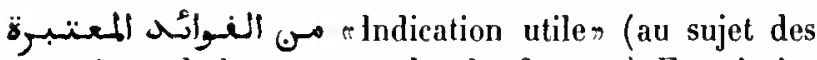
symptômes de la grossesse chez les femmes). Frontispice orné.

Papier. 291 feuillets. Hauteur, a 7 centimètres; largeur, 18 centimètres. 31 lignes par page. Ms. du $x 1^{\circ}$ siècle. - (Ancien fonds 681.)

\section{3.}

Troisième (dernière) partie du même ouvrage, commençant par le chapitre intitulé ذكر المياديب.

Papier. 280 feuillets. Hauteur, 29 centimètres; largeur, 19 cenlimètres et demi. 23 lignes par page. Ms. du xvin' siècle. - (Supplément $9^{2} 5$ bis.)

\section{4 .}

Deux fragments du même ourrage. Le premier fragment, fol. 1 à 438 , correspond au I. II, p. 1 à 324 de l'édilion de Boulàq. Le second fragment, fol. 439 à 587 , correspond au t. I, p. 68 à 285 . Outre ce déplacement de feuillets on y remarque quelques lacunes. Ms. daté de l'année 964 de l'bégire (1557 de J. C.).

Papier. 587 feuillets. Hautcur, 31 centimètres; largeur, 21 centimètres. 35 lignes par page. - (Ancien fonds 679.)

\section{5.}

rillette de fleurs faite dans le Khițat et dans les Monuments r. Abrégé du Khitat de
Maqrî̀î, rédigé par un descendant d'Aboû Bakr (الصدينى), nominé Aboû 'l-Soroûr ibn Moḥammad ibn abì 'l-Soroûr al-Siddiqìi. Cet ouvrage, divisé en trente-quatre chapitres, a été achevé en 1054 de l'hégire (1644 de J. C.), et notre exemplaire, écrit de la main de l'auteur, est de l'an 1058 de l'hégire. La préface commence par ces mots : الكمد الله الذذى اطلع ثنمس مى أفلاك السماء الكمديّة.

Papier. 131 feuillets. Hauteur, 29 centimètres; largeur, 20 centimètres. 3 , lignes par page. — (Supplément 931.)

\section{6.}

Même ouvrage. Les derniers feuillets manquent.

Papier. 104 feuillets. Hauteur, 19 centimètres et demi; largeur, 15 centimètres. 27 lignes par page. Ms. du xvin'e siècle. - (Ancien fonds 802.)

\section{7.}

Prérogatives éclatantes ou avantages possédés par le vieux et le nouveau Cairen. L'auteur de ce résumé ne se nomme pas, mais on voit (fol. $81 v^{\circ}$ ) qu'il avait étudié sous Al-Maqrìzì. Le contenu du livre est suffisamment indiqué par le litre.

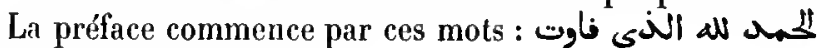
بيم. الببلاد ف نضلها وصغاتها.

Papier. 148 fenillets. Hauteur, 18 centimètres; largeur, 11 centimètres. 17 lignes par page. Ms. du $\mathbf{x v i}^{\circ}$ siècle. - (Ancien fonds 878 , Colbert 6053.)

\section{8 .}

1 Fragments d'une histoire d'Égypte, dont l'auteur a connu la Khitat de Maqrìzî.

$2^{\circ}$ (Fol. 31.) Fragments d'un ourrage composé de plus de seize séances (s) dans cliacune desquelles l'auteur explique, avec de grands détails historiques et littéraires, un verset du Coran.

3० (Fol. 109.) Commentaire sur une prière, par laquelle on demande d'être préservé de péchés, d'erreurs de conduite, etc. Le commencement manque.

Papier. $166^{\circ}$ feuillets. Hauteur, 21 centimètres et demi; largeur, 16 centimètres. 21 à 23 lignes par page. Ms. du svir siècle. - (Supplément 1889.) 


\section{9.}

1 م Agrément pour les hommes ou llistoire des rois el des personnages distingués». C"est mne histoire des sultans mamlones, depuis l'aremement d'Al-Mo'izz Aïbek, en 668 de l'hégire, jusqu'à l’inauguration de Qiütbey, en 872 de l'hégire. L'aucour, donl le nom est resté inconnu, parle en détail des érénenuruts d'Égypte, année par année, et, daus la derniere moitié de son ourrage, presque jour par jour.

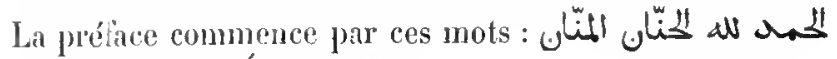

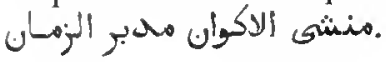

$2^{\circ}$ (Fol. 150.) Premier cahier d'un traité d'astrologie en cing sections (نصل), dont chacune est divisée en plusieurs chapitres (باب). Le commencement manque, et il y a une lacune entre les lolios 158 et 159 .

$3^{n}\left(\right.$ Fol. $160 v^{\circ}$.) Commencement d'une note sur les áments de l'algèore.

Papier. 160 reuillets. Ilauteur, 22 centimètres; largeur, 14 centinuètres et (lemi. 17 à 25 lignes par page. Ecritures diverses. - (Supplément 838, Saint-Germain 365.)

\section{0.}

若 ment, traité renfermant la mention de ceux qui ont rempli les lonctions de calilen, par Aboû 'l-Mlahàsin Yoûsol' ibn Taghri Bardì (en ture, 130 s en 874 de l'bégrire (1469-1470 de J. C.). Ce titre, écrit au verso dı premier leuillet, est répété ar fol. 24 . Le titre كـنـاب

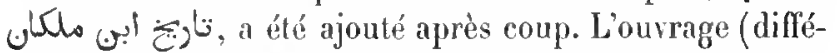
rent du dulls du mène auteur) commence prar ces

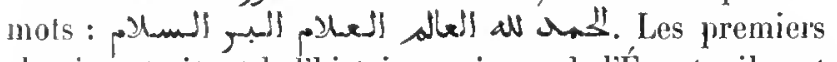
chapitles trailunt de l'histoire ancienne de l'Égypte; il y est question de quelques prophètes, des rois qui ont régné dans ce pays avant le déluge, des Pharaons et des merveilles qui s'y trouvent. A la fin de cette section, l'auteur renvoie le lecteur à l'ourrage d'Al-Qazwini intitulé r. Merveilles de ce monde et de l'autren. La seconde section, précédée du tilre mentionné ci-dessus, comneuce par un clıpitre sur les Arabes qui régnèrent en Égypte avant l'islamisme; viennent ensuite des notices assez conrtes sur Mahomet, sur les quatre califes légitimes, sur les Ornayyades, sur les Abbasides, jusquà Al-Mostakfi, sur les Fatémides, sur les Ayyoûbides et sur les sultans mamloues, jusqu'en 719 de l'hé- gire. L'auteur parle d'une guerre qui eut lieu en Égypte, entre les Musulmans et les Francs. Viennent ensuite des notices sur les vizirs célèbres, à commencer par Yaḷyà ibn Klıâlid le Barınékide. Suit un journal de la dernière année du règne d'Al-Nâsir, fils de Qalawoûn, et de la première année du règne d'Al-Malik al-Manşoûr. Après quelques notices sur ceux des Compagnons et des Tabi qui ont vécu en Égypte, ainsi que sur les grands jurisconsultes, les littérateurs et les poètes, l'auteur reprend l'histoire des sultans mamloues, en commençant par AlMalik al-Șâlih Ismacil, fils d'Al-Nàșir. Les derniers fenillets du colume sont d'une autre main el contiennent la suite de l'histoire des sultans mamloucs, jusqu'à la conquêto ottomane. Une troisiène main a continué l'histoire jusqu'en 932 de l'hégire (1525-1526 de J. C.). Le travail de l'auteur parait s'ètre arrêté à l'an 842 , où il renvie le lecleur à sa contimuation de l'histoire d'Al-Maqrizi (المنيل على تاريخ المتوبزي).

Papier. 109 feuillets. Ifauteur, 23 centimètres; largeur, 15 centimètres. 21 lignes par page. Mts. dn xv' siècle. - (Ancien fonds 795.)

\section{1.}

Brillantes étoiles, listoire des somerains de Miṣr et du Cairen, par Djamâl al-Dîn Aboû '1-Maḥâsin Yoûsof ibn Taghrî Bardi, تغسى s ب. Ce volume contient la première partie de l'ouvrage, c'est-à-dire l'histoire de l'Égypte, depuis la conquête musulmane jusquà l'an 254 de l'hégire. Ia préface com-

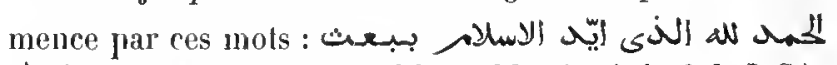
. Ms. daté de l'an 881 de l'lrégire (1476 deJ.C.), mais le premier cahier est d'une écriture dı xvı siècle.

Papier. a 20 feuillets. Hauteur, 27 centimètres et demi; largeur, 18 centimètres et demi. 25 lignes par page. - (Ancien fonds 654.)

\section{2.}

Mème ouvrage. Premier volume, se terminant par l'an 254 de l'hégire. Frontispice très-orné, où on lit que ce volume a été exécuté pour la bibliothèque de Son Excellence (المتُّ) Dhàdjì 'l-Djamâli, inspecteur du domaine

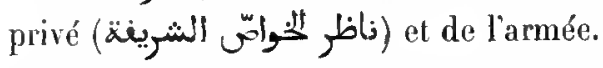

Papier. 219 feuillets. Ilauteur, 26 centimètres; largeur, 17 centimètres et demi. 23 ligrnes par page. Its. du $x v^{e}$ siècle. - (Ancien fonds 659 .) 


\section{3.}

Hème ouvrage. Second volume, commençant à l'an 141 de l'hégire, et finissant par l'an 253 . Ms. daté de l'an 883 de l'hégurire (14 78 de J. C.).

Papier. 228 fenillets. Hauteur, 2 8 centimètres; largeur, 18 centimètres. 17 lignes par page. - (Supplément 815, Saint-Germain 1og.)

\section{4.}

Même ouvrage. Second volume, commençant par l'an 254 de l'hégire, et finissant par l'an 524. Cet exemplaire a été écrit pour la bibliothèque d'un fonctionnaire égyplien, nommé Faradj, qui avait été grand chambellan du sultan mamloue Ml-Malik al-Aschrat Inàl, dont le père, Ized Beg (كودك), avait été émir de mille, c’est-àdire colonel d'un des ingt-quatre régiments de caralerie qui composaient la halqa ou garde impériale. Ms. daté de l'an 885 de l'hégira (1481 de J. C.).

Papier. 228 feuillets. llauteur, a7 centimètres; largeur, 18 centimètres. 29 lignes par page. - (Ancien fonds 66g.)

\section{5 .}

Même onrage. Second volume, commençant par l'an 254 de l'hégrire, et finissant par l'an 524. Ie premier feuillet manque. Ms. daté de l'an 866 de l'héggire (14611462 de J. C.).

Papier. 196 feuillets. Ilanteur, 27 centimètres; largeur, 18 centimètres. 25 lignes par page. - (Ancien fonds 660.)

\section{6.}

Nème ouvrage. Second volume, commençant à l'an 254 de l'héggire, et finissant par l'an 362. Frontispice orné.

Papier. 30 o fenillets. Ilauteur, a 8 centimètres; largeur, 18 centimètres et demi. 13 lignnes par page. Ns. du xv siècle. - (Supplément 815 bis, Saint-Germain 110. )

\section{7.}

Mème ouvagge. Second volume, commenẹant par l'an
255 de l'hégire, et finissant par l'an 524. Ms. daté de l'an 862 de l'hégire ( 1458 de J. C.). Frontispice trèsorne, portant le titre de l'ourrage ainsi que le nom de l'auteur.

Papier. a 70 feuillets. Hanteur, 32 centimètres; largeur, a 1 centimètres et demi. a 3 lignes par page. - (Ancien fonds 671 .)

\section{8.}

Même ouvrage. Second volume, commençant par l'an 362 de l'hégire, et finissant par l'an 524. Frontispice orné.

Papier. 333 feuillets. Ilauteur, 28 centimètres; largeur, 18 cenlimètres. 13 lignes par page. Ms. du xve siècle. - (Supplément 816 .)

\section{9.}

Même ouvrage. Troisième volume, commençant à l'an 524 de l'hégire, et finissant par l'an 675 . Il y a quelques lacunes. Ms. antographe, daté de l'an 860 de l'hégire (1456 de J. C. ).

Papier. 169 feuillets. Hauteur, 23 centimètres et demi; largeur, 16 centimètres. 26 lignes par page. - (Supplément 816 bis.)

\section{0.}

Mème ourrage. Troisième volume, commençant par l'avènement du calife latémide Al-I!àfız 'Abd al-Madjid, en 525 de l'hégire, ot firissant par l'an $67^{5}$, dix-septième année du règne du sultan Al-Malik al-Ẓàhir Baïbars. Ms. daté de l'an 861 de l'hégire ( 1457 de J. C.).

Papier. 227 feuillets. Hauteur, 32 centimètres; largeur, 22 centimètres. 25 lignes par page. - (Ancien fonds 661.)

\section{1.}

Même ouvrage. Troisième volume, commençant par l'an 525 de l'hégire, et finissant par l'an 675 . Ms. copié en 866 de l'hégire (1462 de J. G.) sur le ms. autographe daté de l'an 860 .

Papier. 197 feuillets. Hauteur, 27 centimètres; largeur, 18 centimètres et demi. 25 lignes par page. - (Ancien fonds $67^{\circ}$.) 


\section{2.}

Même onvarge. Troisième rolume, commençant par le récil de l'avènement au trône d'Al-Malik al-Kâmil l'Ayyoubite, en 616 de l'légire, et finissant par l'an 675 . Le premier feuillet ne fait pas parlie de l'ourrage. Hs. daté de l'an 883 de l'hégire ( 488 de J. C.), copié sur le ms. autographe.

Papier. ${ }_{2} 50$ fenillets. Hauteur, 28 centimètres; largeur, 19 centimètres. 17 lignes par page. - (Ancien fonds 661 A.)

\section{3.}

Hême ourrage. Quatrième volume, commençant par l'avènement d'Al-Malik al-Sa ìd Mohammad, fils de Baibars, en 676 de l'hégire, et finissant par l'an 783 . Frontispice orné, portant le nom de l'auteur. Un titre inexact a élé ajouté après coup.

Papier. 229 feuillets. Hauteur, 31 centimètres; largeur, 21 centimètres et demi. 33 lignes par page. Ms. du $x^{*}$ siècle. - (Ancien fonds 663.)

\section{4.}

Même ourrage. Quatrième volume, commençant par lavènement d'Al-Malik al-Sa ìd Mohammad, fils de Baibars, en 676 de l'hégire, et finissant par l'an 745. Ce ms., qui a fait partie du mème exemplaire que le $n^{\circ} 1780$, est daté de l'an 861 de l'hégire ( 1457 de J. C.). Frontispice et titre en or et en couleurs.

Papier, 259 feuillets. Hauteur, 32 centimètres; largeur, 22 centimètres. 25 lignes par pagye. - (Incien fonds 662.$)$

\section{5.}

Même ouvrage. Cinquième volume, commençant par l'arènement d'Al-Lllik al-Kâmil Scha'bân, fils d'Al-Malik al-Nâșir Mohammad, en 746 de l'hégorire, et finissant par l'an 800 .

Papier. 194 feuillets. Hautenr, 27 centimètres et demi; largeur, 18 centimètres et demi. 27 lignes par page. Ms. du $x v^{e}$ siècle. - (Ancien fonds 664.)

\section{6.}

Même ourrage. Volume commençant par l'an 746 de l'hégire, à l'avènement d'Al-Malik al-Kâmil Scha'bân, et finissant par l'an 783 de l'hégoire. D’après le titre, ce volume serait le neuvième d'un exemplaire complet, mais dans l'explicit il est désigné comme le cinquième. On lit dans le même explicit que ce ms. est de la main de Yoùsof lbn Taghrî Bardì al-A tảbeki, c'est-à-dire de l'auteur luimême.

Papier. 224 feuillets. Hauteur, 26 centimètres; largeur, 18 centimètres et demi. 17 lignes par page. Ms. du $x^{\circ}$ siècle. - (Ancien fonds 665.)

\section{7.}

Même ouvrage. Ce volume, qui a fait partic du mème exemplaire que le $\mathrm{n}^{\circ} 1785$, commence par l'avènement d'Al-Malik al-Zàhir Barqoûq, en 784 de l'hégire, et finit par l'an 836. l'rontispice orné, portant le nom de l'auteur. Un titre faux a été ajouté après coup.

Papier. a 29 feuillets. Hauteur, 31 centimètres; largeur, 21 centimètres el demi. 33 lignes par page. Ms. du $x v^{*}$ siècle. — (Ancien fonds 666.)

\section{8.}

Même ouvrage. Ce volume, le septième d'un exemplaire, commence au milieu de la biographie de Barasbey, et renferme l'histoire des années 836 à 856 de l'hégire. Les derniers feuillets manquent. Un feuillet blanc, coté 173 , indique une lacune.

Papier. $19^{3}$ fenillets. Hautenr, 98 centimètres; largeur, 18 centimètres. 25 ligncs par page. Hs. du $x^{\circ}{ }^{\circ}$ siècle. - (Ancien fonds 667.)

\section{9 .}

Même ouvrage. Ce volume renferme l'histoire des années 842 à 872 de l'hégire. La copie n'a pas été achevée.

Papier. 155 feuillets. Hauteur, 27 centimètres et demi; largeur, 18 centimètres et demi. 27 lignes par page. Ms. du xvı" siècle. (Supplément 8og.) 


\section{0.}

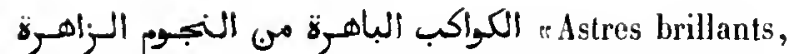
de (l'ouvrage intitulé) Al-Nodjoûm al-Zâhiran. C'est un abrégé du Nodjoûm renfermant l'histoire de l'Égypte, depuis la conquète jusquà l'an 867 de l'hégire, rédigé par l'auteur lui-même. Le présent ms. a été corrigé par l'auteur, et les derniers feuillets, dont il manque un ou plusieurs, sont de sa main. La préface commence par ces

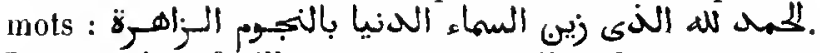
Les premiers feuillets portent une pièce de vers et une lilanie. Au fol. 3 , on lit une courte notice biographique, très-mutilée, el dont l'écriture est celle d'Al.Maqrizi. Ce feuillet a dì appartenir au brouillon d'un des rolumes du Mogaffa.

Papier. 211 feuillets. Hanteur, 22 centimètres; targeur, 16 centimètres. Au commencement 26 , puis 25 lignes par page. Ms. du $\mathbf{x v}^{e}$ siècle. - (Ancien fonds $7^{8} 9$, Colbert 4516.)

\section{1.}

Neuvième volume d'une chronique renfermant l'histoire de l'Égyple el de la Syrie, pendant les années 873 à 877 de l'hégire. Dans l'obituaire qui termine chaque année du récit, les nouns des personuages, accompagnés de longs détails biographiques, sont disposés dans l'ordre de l'alphabet. La fin du volume manque. Les quatre derniers feuillets ne sont pas à leur place. D'après une note, en tête du volume, le titre de l'onrrage serait أنباء الهصر , is et le nom de l'auteur Noûr al-Dìn 'Alì ibn Dàwoûd al-Khatịb al-Djauharì qui, selon Hadji Khalla, a rédigé les annales de l'Égypte, de $7^{86}$ a 870 de Thégire, sous le titre de نزهم النغوس والابحأن.

Papier. 207 feuiltets. Hauteur, 27 centimètres et demi; larrseur, 18 centimètres et demi. 21 à 23 tignes par page. Ms. du xv sièrlc. (Supplément 776.)

\section{2.}

Modèle de trois inscriptions qui devaient ètre placées sur un certain nombre de ponts (قناطر) bâtis par le sultan mamlouc Qiït Bey, en 884 de l'hégire. La seconde et la troisième de ces inscriptions sont reproduites au bas des pages en caractères ordinaires.

Papier. a feuillets. Hauteur, 31 centimètreset demi ; largeur, 29 centimètres et demi. La première inscription a 3 lignes, les deux autres 4 . - (Supplément 2271.)

\section{3.}

La Lune brillante, ou triomphe d'Al-Mllalik al-Nâșirn. C'est un panégyrique du sultan mamlonc Al-Malik al-Nâsir Aboû 'I-Sacadàt Mohammad, fils du sultan Qàit Bey. La préface commence

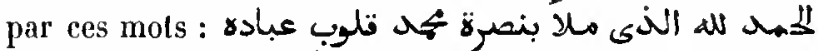

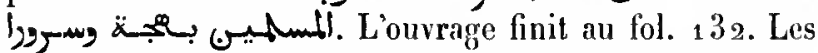
quatre derniers feuillets contiennent un supplément. Ms. autographe, daté de l'an 902 de l'hégire ( 1496 de J. C.), provenant de la bibliothèque du sultan Al-Malik al-Nâsir. Frontispice en or et en couleurs.

Papier. 137 feuiltets. Hauteur, 18 centimètres; largeur, 13 centimètres. 7 lignes par page. - (Ancien fonds 805.)

\section{4.}

CGauseries agréables au sujet de l'Égypte et du Caire», par Djalal al-Dìn al-Soyoûtị. Le texte de cet exemplaire parait ètre celui de la première édition de l'ouvrage. Beaucoup de chapitres manquent, et la série des sultans d'Égypte s'arrête une vingtaine d'années plus tòt que dans d'autres examplaires. Une main africaine a inscrit sur le verso dn dernier feuillet une pièce de (dix-huit) vers, rimant en $ע$, et contenant des observations sur les pratiques religieuses des chrétiens. Cette pièce est attribuée au grand docteur mystique, Moṭyì al-Din Ibn al-'Arabì. Ms. daté de l'an $9^{6} 9$ de l'hégire $\left(1559^{-1560}\right.$ de J. G.)

Papier. 136 feuillets. Hauteur, 21 centimètres; largeur, 15 centimètres et demi. 21 lignes par page. - (Ancien fonds 790.)

\section{5 .}

Mème ouvrage. Exemplaire de la première édition.

Papier. 213 feuittets. Hauteur, 21 centimètres; largeur, 15 centimètres. 21 lignes par page. Ms. du xv1 siècle. - (Ancien fonds 793.)

\section{6.}

Mème ouvrage. Exemplaire de la première édition. Ms. daté de l'an 1072 de l'héguire (1661-1662 de J. C.).

Papjer. ${ }^{1} 1$ feuillets. Hauteur, 24 centimètres et demi; largeur, 3 cenlimètres el demi. 23 lignes par page. - (Supplément 801.) 


\section{MANUSGRITS ORIENTAUX.}

\section{7.}

Le حسى النماضرة d'Al-Soyoûtị̂.

Papier. 431 feuillets. Hauteur, 2a centimètres; largeur, 16 centimètres. 19 à 25 lignes par page. Uls. de diverses écritures; la partie la plus ancienne est du $x^{\circ} 1^{\circ}$ siècle. - (Supplément 8o3, Saint-Germain 366.)

\section{8.}

Nème ourrage. Ms. daté de l'an 970 de l'hégire ( 1563 de J. C.).

Papier. 286 feuillets. Hauteur, 28 centimètres; largeur, 18 centimètres. 27 ligues par page. - (Supplément 802.)

\section{9.}

Nème onvrage. Hs. daté de l'an $99^{2}$ de l'hégire (1584 de J. C.).

Papier. 289 feuillets. Hanteur, 28 centimètres; largeur, 18 centimètres et demi. 35 lignes par page. - (Ancien fonds $65_{2}$.)

\section{0 .}

Mème ouvrage. Ms. daté de l'an 1008 de l'hégire ( 1599 de J. C.).

Papier. 317 feuillets. Hauteur, 3o centimètres et demi; largeur, so centimètres et demi. 31 lignes par page. - (Ancien fonds 649 , Colbert 6go.)

\section{1.}

Mème ourrage. Ms. dalé de l'an 1009 de l'hégire ( 1600 de J. C.).

Papier. 4 co feuillets. Hlauteur, 21 centimètres; largeur, 15 centimètres. 25 lignes par page. - (Ancien fonds 791 .)

\section{2.}

Mème ouvrage. On remarque un grand nombre d'omissions dans cet exemplaire. La copie s'arrête au milieu du chapitre des grandes mosquées. Ms. daté de l'an 1009 de l'hégire ( 1600 de J. C.).

Papier. 334 feuillets. Hauteur, 2i centimètres; largeur, 12 centimètres et demi. 15 lignes par page. - (Ancien fonds 792.)

\section{3.}

Mème ouvrage.

Papier. ${ }_{2} 39$ feuillets. Hauteur, 29 centimètres; largeur, 20 centimètres el demi. 35 lignes par page. Ms. dn $x^{\prime} u^{2}$ siècle. - (Supplément 805.)

\section{4.}

Nême ouvrage.

Papier. 282 feuillets. Hauteur, 30 centimètres; largeur, 19 centimèłres. 29 lignes par page. Ms. du xvm" siècle. - (Supplément 800.)

\section{5.}

Mème our rage. Ms. daté de l'an i i 96 de l'hégire ( 1782 de J. C.).

Papier. $59^{\circ}$ feuillets. Hauteur, 23 centimètres; largeur, 16 centimètres. 21 lignes par page. - (Supplément 807. )

\section{6.}

Première partic du même ouvage, finissant par le chapilre des poètes et des liltérateurs. Ms. daté de l'an 1138 de l'hégire ( 1726 de J. C.).

Papier. 376 feuillets. Hautenr, 23 centimètres; largeur, 16 centimètres. a 1 lignes par page. - (Supplément 806.)

\section{7.}

Seconde partie du même ouvrage. Ms. daté de l'an $9^{62}$ de rhégire (1555 de J. C.).

Papier. 281 feuiltets. Hauteur, 23 centimètres; largeur, 17 centimètres. 21 lignes par page. - (Ancien fonds $79^{4}$.)

\section{8.}

Fragment du même ouvrage, commençant par la fin 
de la lettre alif du Dictionnaire des compagnons de Mahomet qui passèrent en Égypte, el finissant par la liste des grammairiens el des philologues.

Papier. 162 feuillets. Hauteur, a 1 centimètres; largenr, 15 centimètres et demi. 19 lignes par page. Ms. du xvıu' siècle. - (Supplément 2071.)

\section{9 .}

Fragment de mème ouvrage, commençant au milieu du chapitre des traditionnistes el se terminant par le chapitre des poètes et des littéraleurs. II manque plusieurs feuillets an milieu du volume.

Papier. 79 feuillets. Hauteur, 21 centimètres; largeur, 15 centimètres. 26 à 28 lignes par page. Hs. du xviı' siècte. - (Supplément 2070. )

\section{0 .}

Fragment du mème ouvrağe, commençant par l'article du chapitre des jurisconsultes malékites, et se terminant par un des derniers articles du chapitre des traditionnisles célèbres. Les chapitres ne se suivent pas dans leur ordre naturel.

Papier. 218 feuillets. Hauteur, 21 centimètres et demi; largeur, 16 centimètres. 21 lignes par page. Vs. du xv $1^{\circ}$ siècle. - (Supplément 808.)

\section{1.}

$1^{\circ}$ Abrégé du llosn al-Moluchlhira d'Al-Soyoûṭi. Ce résumé est altribué à Aboù Hiànid al-Maqdisi, docteur hanbalite.

$2^{\circ}$ (Fol. $831^{\circ}$.) Notices diverses sur l'Égypte, formant

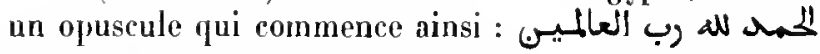

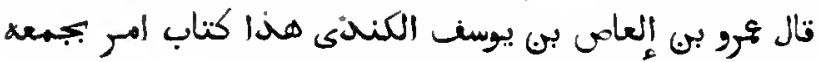

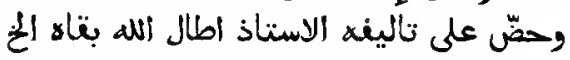

Ms. daté de l'an 1189 de l'hégire ( 1775 de J. C.).

Papier. 100 fenillets. Hanteur, 23 centimètres; largeur, 15 centimètres et demi. 3 lignes par page. - (Supplément 804.)

\section{2.}

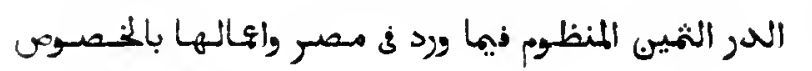
Mas. ontentaux. - H.

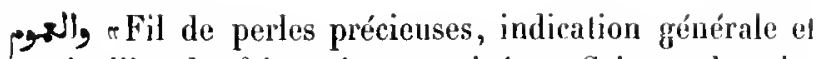
particulière des faits qui sont arrivés au Caire et dans les provinces n, par Al-Khațib al-Djauharì ( ${ }^{2} A$ lì ibn Dàwoûd). Cel opuscule est divisé en vingt chapitres. Ms. daté de l'an 1019 de l'hégire $(1611$ de J. C.).

Papier. 44 fenillets. Hauteur, 21 centimètres el demi ; largeur, 15 cenlimètres. 11 lignes par page. - (Supplément 812.)

\section{3.}

Même ouvrage.

Papier. 80 feuillets. Hauteur, 21 centimètres; largeur, 14 centimètres

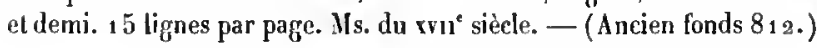

\section{4.}

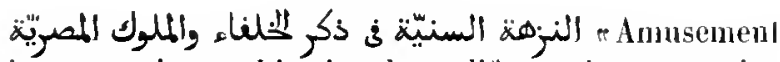
qui a son prix, ou histoire des califes et des soureraius de l'Égypten. Résumé historique composé de courles notices sur les émirs et les souverains qui ont gouverı́ l'Égypte. L’auteur, Hasan al-Ṭoloùi, ou, d'après Hadji Khalla, Hasan ibu Hosaïn ibn Aḷmad, naquit en 832 d" l'hégire (1428-1429 de J. C.). Hadji Khalla dil que l'ouvrage s'arrête à l'an 909; mais on voil par notre exemplaire qu'un anonyme l'a continué jusqu'à l'an 982 de l'hégire, alors que le paclıa oltoman, llazrat Masị̀, ful chargé du gouvernement de l'Égypte. A la suite de cet ouvrage se trouve, écrite de la mène main, une copie ipparemment tronquéc de la dépèche adressée par Scliàlı Ismacil au sultan Al-Ghauri, avec la réponse de celni-ci. Le fenillet de garde du conmencement porte uue prière quion doil réciter aprés la lecture de la quatre-ringlquatorième sourate du Coran. I la fin du volume se trouvent quelques recettes médicales.

Papier. 90 feuillets. Hauteur, 21 centimètres; largeur, 15 centimètres. 11 lignes par page. Ms. du xvi siècle. - (Ancjen fonds 780. )

\section{5.}

$1^{\circ}$ Mème ouvrage. Cel exemplaire se termine par l'arlicle sur Toumin Bey.

$2^{\circ}$ (Fol. $26 v^{\circ}$.) Lettre de Qalawoùn, répondant à une lettre de Takôdâi, roi des Moghuls.

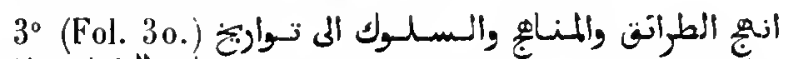
(الانبيباء ولخفلناء والملوك roies et des routes pour arriver à la connaissance de l'his- 
toire des prophètes, des califes et des rois n, par Noḅammad ibn Molanmmad al-Djalfari, locteur schaféite. Le présenl ms. contient la prenniere pallie dr l'ouvrage, qui est un résumé de l'histoire universelle, depuis Adam jusyừ l’an 70 de l'hŕgire. L'auteur indique dans la prélace les sources oǹ il a puisé, et particulièrement l'ouvrage du

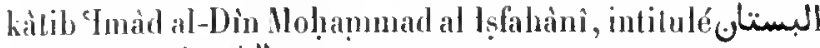
(l) Jardin, renl'rmant l'hisloire du remprs". La prélace se trmine par une notice sur Tmàd al-1)in et un extrail de l'introduction de son ouvage, et à la lin de colte premiere partie de l'anvage se lrouvent $\left(\right.$ lol. $\left.61 \mathrm{v}^{\circ}\right)$ quelques exlriils du Bostân, et une pièee de vers dans linumlle l'uuteur, Moliammad al-Dja'fari te Schalcite, dit avoir leminé son ouvrage en 875 de l'hégiro (1470-1471 de J. C.). Premiers mots de la pré-

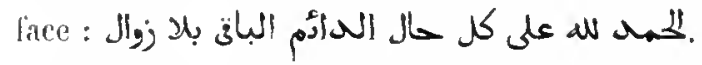

$4^{\circ}$ (Fol. $65 v^{\circ}$.) Autre partie du mème our rage, commencant par une prélace dont les premiers mots sont:

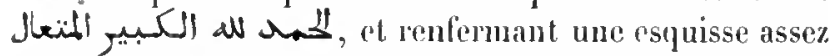
ronfuse de l'hisloime antéislanique, quelques extraits de la qasîda d'flm 'Abloưn et d's nolices sur yuelques compagnons de Mahourel, nommés dans ce poème.

$5^{\circ}$ (Fol. 11.) Autre partie du mème onrage, qui commence également par une prélace et renferme une hisloire de Malromet, des calilis el de l'Égypte, jusqu'à rannée 874 de l'hégire. On y trouve aussi des notices abrégées sur les Tahérides, les Bouides, les Aghlabides el les Omayyades d'Espagne.

Ils. daté de l'an 948 de l'hégire (1541-1542 de J. C. .).

Papier. 228 fenillets. Hanteur, 18 centimètres et demi; largeur, 14 centimètres. 19 à 2 , lignes par page. - (Ancien fonds 783.)

\section{6.}

$1^{\circ}$ Sur les avantages dont jout l'Egyple el sur l'bisloire de ce pays. En tíle dn ms. on lit un titre ainsi

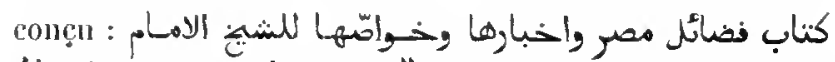

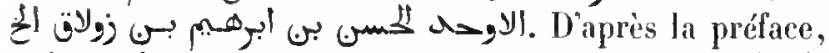
قال النّيخ

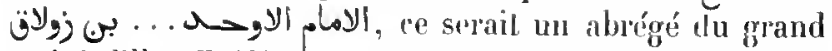
l.aịlé d'tbn Zoûlàg, morl en 387 de l'hégire (997 de J. C.). A part quolques indicalions lopographiques et quelques pièces en prose el en vers à la louange de l'Égyple, cel opuscule ne renferme que des fables; in des premiers chapitres Lraile des rois qui gouvernaienl l'Égyple après le délugre.

$2^{\circ}$ (Fol. 50.) فتّوح اللمهن, roman historique de la conquête du Yémen par les armes d'Ali, fils d'Aboû Tâlil.
L'auleur est nommé Aboû 'I-lịasan 'Alì ibn Ahmad alBakri. Les derniers l'euillels manquent.

Papier. 88 feuillets. Hauteur, al centimètres; largeur, 14 centimètues. 15 lignes par page dans le premier ouvrage et 17 dans le second. Ms. du $x 1^{e}$ siècle. - (Supplément 790.)

\section{7.}

ت. Histoire de l'Égypte el de ses droils à l'ixectlence, par lon Zoûlitr". (Voyez le numéro précédput.) La prélace commence par ces mots : اعم أبها المسامع وفتنى الفه وأياك أطاعته أن مصسر كانست مسن

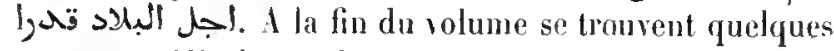
receltes médicales en langue turque, ainsi qu'une amulelle. Ms. Laté de l'an 1073 de l'hégire (1662-1663) de J. C.).

Papier. 93 feuillets. Hauteur, 21 contimètres: largeur, 1' centimètres el demi. 13 liggnes par page. - (Supplément 820, Saint Germain 308.)

\section{8.}

Courle descriplion topographique el historique de l'Eigyple, attribuée ì Ibn Zoûlàq, commencant par ces

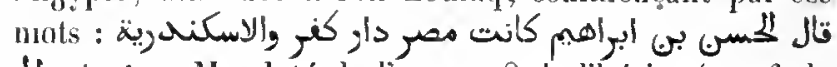
أخسنيف. Ms. daté de l'an 1118 de l'hégire (1 706 de 1. C.).

Papier. 45 feuillets. Hauteur, 20 centimétres et demi; largeur, 13 centimètres. 21 lignes par page. - (Supplément 821 .)

\section{9 .}

$1^{\circ}$ Horrgé de linsloire de l'Égypte, depuis les temps les plus anciens jusquà la conquèle de ce pays par les Otto-

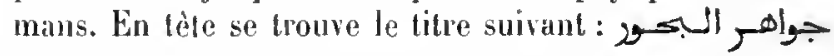

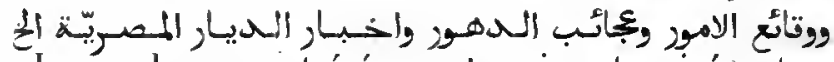
"Joyaux des mers et événements qui sont arrivés, etc." D'après ce tilre el les indicalions de Hadji Klıalfa, on a cru (que c’élail l'ourrage d'lbràhìm ibn Waṣif Schàh; mais cel auleur est cilé (fol. L1) lui-mème parmi les sources.

$2^{\circ}$ (Fol. 89 ト $^{\circ}$.) Recuéik de lágendes relatives à Mahomel.

Le premier ouvage est daté de l'an 1033 de l'hégire ( $1633-1634$ de J. C.), le second de l'an $103 a$.

Papier. 121 feuillets. Hauteur, 21 centimètres; largeur, 15 centimètres. 19 lignes par page dans le promier ouvrage, 11 lignes clans le second. - (Ancien fonds 781.$)$ 


\section{0 .}

جوأهر البكور ووقائع اللامـو2 Joyaux des mers et événements qui sont arrivés». Résumé de l'histoire d'Égypte, différent de l'ourrage contenn daus le numéro précédent, mais également attribué à Ibrâhìm ibn Waṣil Schàh, bien que cet auteur soit cité parmi les sources (royez fol. $19 v^{\circ}$ ). Cet ourage commence par un chapitre sur les avantages dont jouit l'Egypte, et donne ensuile de courtes notices des souverains qui y ont régné, depuis les temps les plus anciens jusqu'ì la conquète de ce pays par les Ottomans. La préface commence pall tes mots :

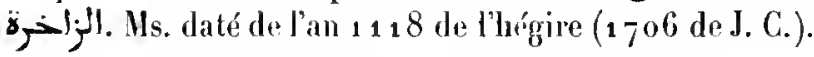

Papier. 128 fenillets. Ilanteur, 20 centimètres et demi; largeur, 5 centinètres. 13 lignes par page. - (Supplément 847.)

\section{1}

Histoire des souverains d'Égypte, ouvrage rédigé sons forme d'annales et attribué à Ibn Asbàt (أبس أسـبـاط), llamza ibn Alymad al-Gliarbi. Ce volume, dont les premiers feuillets manquent, commence au milieu de l'an 526 de l'hégire. Ns. daté de l'an 1080 de l'hégire ( $669-$ 1670 de J. C. ).

Papier. 218 feuillels. Hauteur, 30 centimètres; largeur 19 centimètres et demi. 21 ligoes par page. - (Supplément 720.)

\section{2 et 1823.}

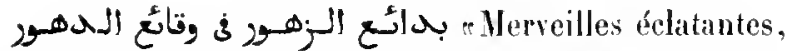
traité sur les événements des sièces $»$, par Mohammad ibn Alumad ibn lyàs, docteur hanéfite et auteur de la cosmo-

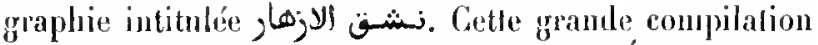
présente, après quelques généralités sur l'Égy pte et sul les anciens rois de ce pays, les anmales de l'Égypte, depuis la conquèle musulmane jusqu'à la fiu de l'anmée 928 de l'hégire. Le premnier volume se compose de deux parties, dont la première renferme l'histoire de l'Égypte, jusqu’à l'avènenent de la dynastie mamlouc circassienne; les derniers feuillels de cette partie manquent. La seconde partie du mène volume est d'une antre écrilure; elle commence (fol. 217) par l'listoire des Mamlones circassiens et s'arrête à la fiu de l'année 857 de l'hégire. Dans cette partie, l'auteur rapporte les événements mois par mois. Le second volume commence par l'an 858 de l'hégire, et finit par l'an 928. Dans cette partie, l'auteur raconte les événements mois par mois et souvent jour par jour. La copie est datée de l'an 1118 de l'hégire ( 7 o61707 de J. C.).

Papier. 333 feuillets. Hauteur, 29 centimètres; largeur, 18 centimètres. 31 lignes par page. Ns. do xv111 ${ }^{\circ}$ siècle. - (Ancien fonds 595 A ef в.)

\section{4.}

तChoses à remarquer parmi les événements des siècles $n$, histoire d'Égypte, par Hohamumad ibn Aḷmad Ibn lyàs. Le présent ms., nemiène volume de l'ouvrage complet, et qui renferme le récit des événements des aunées 891 à 912 de l'hégire, a été copié en 1 1 27 de l'hégire (1715 de J. C.), sur l'autographe daté de l'an 914 de l'hégire (1508 de J. C.).

Papier. 167 feuiltets. Hauleur, 88 centimètres et demi; largeur, 17 centimètres. 29 lignes par page. - (Ancien fonts 686.)

\section{5 .}

Mểne ourragı. Ce volnne, qui est le onzième d'un exemplaire, a dû commencer par l'an 922 de l'hégire, mais les premiers feuillets manquent; il se temine par les événements de l'an 928 de l'hégire. Lo ms. sur lequel le prósent volume a ćté copié était daté de l'an 934 de l'héfire (1 528 de J. C.) ' ${ }^{\text {. }}$

Papier. 340 fevillets. Ilauteur, 27 centimètres el demi; largeur, 18 centimètres. 15 lignes par page. Ms. du xvi" siècle. - (Ancien fonds 689 .)

\section{6.}

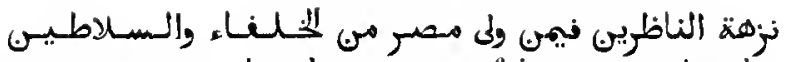
" Anusement pour les observateurs, faisant connaitre les caliles et les sullans qui ont régné en Égypter, par Marcî ( $\xi-0)$ ibn Yoùsof al-Maqdisi, docteur hanbalite. (Le ms. porte Yousof ibn Mari, mais c'est une faute du scribe.) Selon Hadji Khalfa, cet auteur mourut en 1033 de l'hégire ( 1623 de J. C.). Il acheva son ourrage en 1007 de l'hégire. C'est un résuné de l'histoire de l'Égrpte.

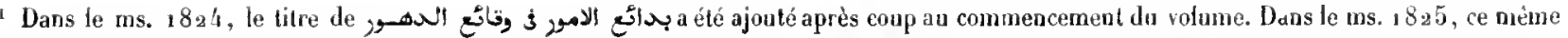

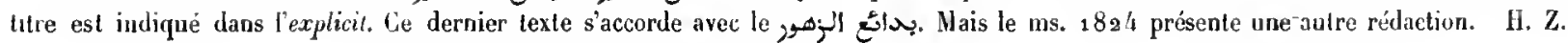


depuis la conquète musulmane jusqu’à l'avènement du sultan olloman, 'Othmàn, fils d'Aḷmad. L'ouvrage com-

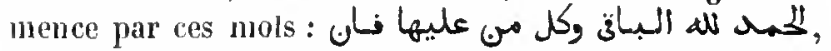
et se termine par un chipitre sur les devoirs du souverain. Au commencement et à la fin du volume se trouvent un assez grand nombre de notes diverses, en arabe et en l'rançais, de la main de Venture de Paradis.

Pajier. 86 feuillets. Hanteur, 21 centimètres; largeur, 16 centimítres. 21 lignes par page. Ms. du xvi" siècle. - (Supplément 833.)

\section{7.}

Mème ourage. Ms. daté de l'an 1034 de l'hégire (16 44 de J. C.).

Papier. 163 feuilleis. Hauteur, 21 centimètres; largeur, 14 centimètres. 11 liggnes par page. - (Ancien fonds 786. )

\section{8.}

Mène ouvrage. Ms. daté de l'an 1067 de l'luégire $(1657$ de J. C.).

Papier. 119 feuillets. Hautcur, 21 centimètres et demi; largeur, 15 centimètres. 17 ligues par page. - (Supplément 837.)

\section{9 .}

Mème ourage. Hs. daté de l'an 1076 de l'hégire ( 1666 de J. C.).

Papier. 69 feuillets. Hauteur, 21 centimètres; largcur, 15 centimètres. 19 lignes par page. - (Supplément 834.)

\section{0.}

Mlème ourrage. $\Lambda$ la fin du volunse se trouvent deux traditions relatives aux derniers moments de la vie de Mahomet.

Papier. $9^{5}$ feuillets. Hauteur, 20 centiujètres et demi; largeur, 15 centimètres. 17 lignes par page. Ms. du xviı siècle. - (Supplément 835.)

\section{1.}

Même ouvrage. La fin manque.

Papier. 54 feuillets. Hauteur, 20 centimètres; largeur, 14 centimètres et demi. 21 lignes par page. Ms. du xvme sièrle. - (Supplément 836.)

\section{2.}

$1^{\circ}$ Histoire de la conquête de l'Égypte par le sultan ottoman Sélim Khân, et de la chute de la dynastie des Mamloucs circassiens. L'auteur, d'après la préface, serait Molıanmad al-Zanbalì (لزّنبل) al-Rammâl al-Mahalli, mais dans d'autres exemplaires il est appelé Aḷmad ibn Zanbal al-Rammâl al-Mlahalli ou al-Haḷlâwî. Le récit se termine par le second avènement du sultan ottoman, Mouṣtafâ I Ier, en 1031 de l'hégire (1622 de J. C.). L'auteur dit dans sa préface, après le bismillah : وبعـ فــ

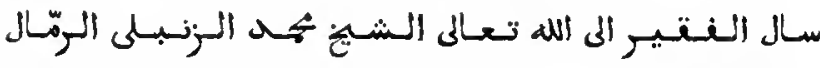

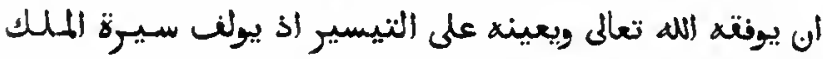

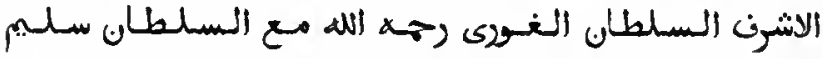

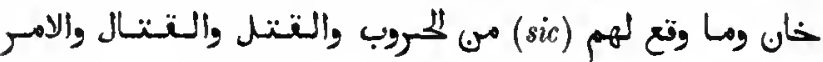

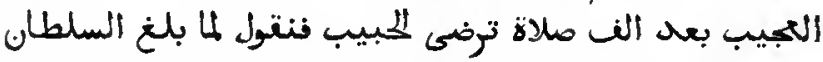

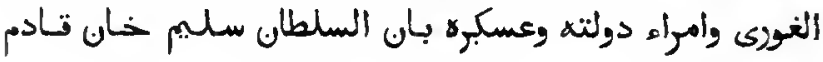

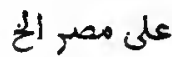

$2^{\circ}$ (Fol. 118.) Fragment (الباب العاشر), renfermant les noms et l'histoire des pachas qui gouvernèrent successivement l'Égypte, depuis la conquête de ce pays par le sultan Sélim jusqu'en 1028 de l'hégire ( 1619 de J. C.).

$3^{\circ}$ (Fol. 149. .) Chapilre de l'Histoire des califes d'AlSoyoụti, dans lequel cet auteur expose que la fin de chaque siècle était toujours signalée par un événement très-grave.

Papier. 150 feuillets. Hauteur, 31 centimètres et demi; largeur, 16 centimètres. 17 et 19 lignes par page. Ms. de deux écritures, dont la plus ancienne est du xvi! siècle, et l'autre de l'an $119^{8}$ de l'hégire (1783-1 784 de J. C.). - (Supplément 794.)

\section{3.}

Méme ourrage que l'article $1^{\circ}$ du numéro précédent. La rédaction est différente. Ms. daté de l'an 1030 de l'hégire (1620-1621 de J. C.).

Papier. 139 fenillets. Hanteur, 20 centimètres et demi; largeur, 14 centimètres et demi. 17 lignes par page. - (Supplément 796.)

\section{4.}

Mème ouvrage. Ms. daté de l'an 1066 de l'hégire (16551656 de J. C.).

Papier. 168 feuillets. Hauteur, 15 centimètres et demi; largeur, 10 centimètres et demi. 13 lignes par page. - (Ancien fonds 880.) 


\section{5.}

Nême ouvrage. Ce ms. présente la mène rédaction que le $\mathrm{n}^{\circ}{ }_{1834}$, mais daus la préface on lit le nom de l'auteur ainsi : Moḥammad ibn Zanbal al-Rammâl alMalılàứ; et dans le titre on lit : Ahmad ibn Zanbal alMahlầì al-Rammàl. Ms. daté de l'an 1083 de l'léeggire ( 1672 de J. C.).

Papier. 81 feuillets. Hauteur, 21 centimètres; largeur, 15 centimètres et demi. 21 lignes par page. - (Ancien fonds 809.)

\section{6.}

Nềne ourrage. Ms. daté de l'an 1179 de l'hégire ( 1765 1766 de J. C.).

Papier. $19^{4}$ feuillets. Hauteur, 21 centimètres; largeur, $1 / 4$ centimètres et demi. 17 lignes par page. - (Supplément 797.)

\section{7.}

Hême ourrage. Ms. daté de l'an $1186^{\circ}$ de l'hégire $\left(177^{2-1} 77^{3}\right.$ de J. C. $)$.

Papier. 73 feuillets. IIauteur, a a centimètres; largeur, 15 centimètres. 25 lignes par page. - (Supplément 795.)

\section{8.}

Mème ouvrage. Exemplaire écrit par Michel Șabbâgh, en 1809 , et copié sur un ms. daté de l'an 1081 de l'hégire $(1670-1671$ de J. C. $)$.

Papier. 132 feuillets. Hanteur, ao centimètres; largeur, 15 centimètres. 14 lignes par page. - (Supplément 798.)

\section{9 .}

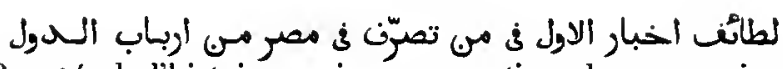
"Beaulés de l'histoire ancienne ou notices des souverains qui ont régné sur l'Égypten, ouvrage composé en 1031 de l'hégire (1622 de J. C.), sous le règne du sultan ottoman Mouștafà Ier, fils de Mahomel III, par Moḥamınad ibn 'Abd al-Mo'tî al-Istyàqi. L'introduction renferme des considérations générales sur l'Égypte, et quelques nolions sur l'histoire de ce pays avant l'islamisme; viennent en- suite dix chapilres consacrés à l'histoire de ce pays, depuis le califat d'Aboû Bakr jusqu'en 1032 de l'hégire. Un appendice contient des exlortations religieuses, des conseils et des anecdotes toucluant les rois et les princes. Copie exécutée en 1040 de l'hégire ( 1630 de J. C.), sur le ins. de l'auteur.

Papier. 230 feuillets. Ilauteur, 26 centimètres; largeur, 16 centimètres et demi. 19 lignes par page. - (Supplément 8ะ9.)

\section{0 .}

Même ourrage. Ms. daté de l'an 1045 de l'hégire (1636 de J. C.).

Papier. 248 feuillets. Hautenr, 21 centimètres et demi; largeur, 15 centimètres. 19 lignes par page. - (Supplément 825.)

\section{1.}

Même ouvrage. Ms. daté de l'an 1052 de l'hégire ( 1643 de J. C.).

Papicr. 236 feuillets. Hauteur, 21 centimètres; largeur, 13 centimètres et demi. 19 lignes par page. - (Supplément 830.)

\section{2.}

Mème ourrage. Ms. daté de l'an 1074 de l'hégire $(2664$ de J. C.).

Papier. 191 feuillets. Hauteur, 20 centimètres et demi; largeur, 15 centimètres. 25 lignes par page. - (Supplément 8.6.)

\section{3.}

Même ourrage. Ms. daté de l'an 1080 de l'hégire ( $1669^{-1} 670$ de J. C. $)$.

Papier. 244 fenillets. Hauteur, 20 centimètres; largeur, 16 centimètres. 23 lignes par page. - (Ancien fonds 782.)

\section{4.}

\section{Même ouvrage.}

Papier. 208 feuillets. Hauteur, 21 centimètres; largeur, 15 centimètres. 19 lignes par page. Ms du xvin siècle. - (Ancien fonds $782 \mathrm{~A}$.) 


\section{5.}

Mème ouvrage.

Papier. 184 feuillets. Hantenr, 21 centimètres; largeur, 15 centimètres. 25 lignes par page. Ms. du xvic siècle. - (Ancien fonds $7^{8} 7$.)

\section{6.}

Mème ourrage.

Papier. 176 feuillets. Hauteur, 91 centimètres et demi; largeur, 15 centimètres. a 3 liggnes par page. Écritures diverses du $x^{\circ} n^{\circ}$ siècle. - (Supplément 827.)

\section{7.}

Hème ouvage. Cet exemplaire porte le titre suivant: Bacage de fleurs d'Ishàq, on l'on traite de ceux qui ont gouverné l'Égyple?.

Papier. 100 feuillets. Hauteur, 21 centimètres; largeur, 15 centimètres. 21 lignes par page. Ms. du xvi siècle. - (Ancien fonds 788.$)$

\section{8.}

\section{Mème ourrage.}

Papier. 166 feuillets. IJauteur, 21 centimètres; largeur, 17 centimètres. a 3 lignes par page. Ms. de deux écritures, dont l'une est du ivil' siècle, l'autre de l'an 1152 de thégire $(1740$ de J. C. ). - - (Supplément 828.)

\section{9.}

Mème ounage.

Papier. 193 feuillets. Hauteur, 21 centimètres; largeur, 15 centimètres. 21 lignes par page. Ms. de plusieur's écritures, dont la plus ancienne est du swil' siècle.- (Supplément 834.)

\section{0 .}

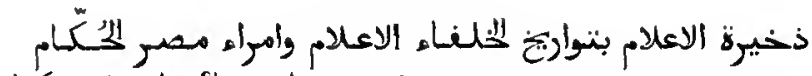
Trésor de renseignements au sujel des caliles éminents et des émirs qui ont gouremé l'Egypte, arec ta liste des cadis qui ont administré la justice dans ce pays", par Alumad ibn Sacd al-Din alGhomrì al-'Othmânì. Histoire de l'Égypte, en vers, depuis la conquête musulmane jusqu'à l'an 1o ho de l'hégire, suivie de la liste des cadis. Premier vers:

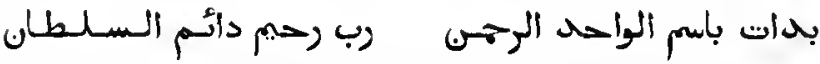

Papier. 220 feuillets. Hauleur, 22 centimètres; largeur, 15 centimètres. 21 lignes par page. - (Supplément 832.)

\section{1:}

Même ourrage. Ms. daté de l'an $117^{8}$ de l'hégire ( 1765 de J. C.).

Papier. 183 feuillets. Hauteur, 22 centimèlres; largeur, 16 cenlimètres. 26 lignes par page. - (Supptément 831.)

\section{2.}

الكوأكب السائرة ف أخبار مصر والقاهرة marchent, histoire de l'ancien et du nouveau Cairen, par Schams al-Dìn Moḥamnad ibn abì 'l-Soroûr al-Bakrì alȘiddiqi (descendant du premier calife, Aboû Bakr alSiddị). C'est une description topographique de l'Égyple, accompagnée d'une listoire de ce pays. La partie historiqué commence par la mention des rois qui régnèrent en Égypte avant le déluge, et se termine à l'an 1063 de l'hégire. L'ourrage est divisé en vingt chapitres, dont la liste est placée à la fin de la préface. Commencement :

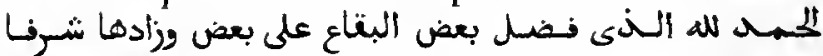
وتبكيكل M. de Sacy a donné une analyse de cel ouvrage dans le premier volume des Notices et Extraits, p. 165 et suiv. (Les patronymiques البكرى الصدّيتق y sonl expliqués par adescendant de Moḷammad Baker (الباقي) et de Djafar Sadikn.) Ms. daté de l'an 1055 de l'hégire (1645 de J. C.), mais corrigé quelques années plus tard par le même copiste (voyez fol. 74 et $89 \mathrm{v}^{\circ}$ ).

Papier. ${ }_{1} 7^{5}$ feuillets. Hauteur, 20 centimètres; largeur, 15 centimètres. a 2 lignes par page. - (Ancien fonds 784.$)$

\section{3.}

Comment furent lancés les coups de foudre daus laflaire des Șandjaq-Beys n, par Ibrâhîm ibn abì Bakr al-Ṣâlihị. C'est un récit trèscirconstancié de la révolte des Șandjaq-Bejs contre le gouvernement du pacha turc, en 1071 de l'hégire. L'ou- 
vage est divisé en cing parlies. La première partic ou lintroduction renferme des généralités sur la prédeslinalion; le premier chapitre traile des versets du Coran que les loonmes doivent méditer, le second de la date de cette rérolte, el le troisième de la révolle de Moḷammad Bey dans la Haute Égypte, en 1069 de l'hégire; la cinquième partie renferme des considéralions morales el rejigienses silr les malheurs (مصائب) qui allligent les liommes. Ms. dalé de l'an $107^{1}$ de l'hégire (1660-1661 de J. C.).

Papier. 86 fenillets. Hauteur, 21 centinètres; largeur, 15 centimètres. 19 lignes par page. Le premier cahier est d'une autre main et purte 25 lignes par page. - (Supplément 843.)

\section{4.}

Hisloire abrégée des sultans ollomans el des pachas de l'Égypte, jusqu'à l'an 1084 de l'hégire. Les dernier's feuillets de ce volume sont converls de noles de la main de Venture de Paradis.

Papier. 230 fenillets. Hauteur, 2 i centimètres; largeur, 16 centimètres. 14 à 16 lignes par page. Ms. du xwm siècle. - (Supplément 84 4.)

\section{5 .}

Fragment d'une histoire des sullans oltomans el des pachas turcs élablis en Égyple. Les premiers cahiers (probablement six), et plusieurs feuillels à la fin, manquent. Ie ms. commence au milieu de l'hisloire de Mohammad II, fils de Mourid, conquérant de Conslantinople. Le deruier article est consacré au règne de Solaïmàn ibu Jbràhìn Khàu, qui monla sur le trône en 1099 de l’hégire. L’hisloire des pachas de l'Égyple (fol. 3o) est indiquée conme le qualrième chapitre (باب) de l'our rage. Le récil s'arréle? à l'an 1120 de l'lıégire.

Papier. 78 feuillets. Hlanteur, al centimètres et demi; largenr,

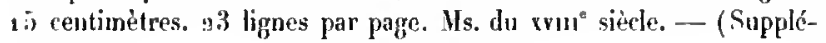
ment 2077 .)

\section{6.}

Récil de ce qui sesl passé en Égyple, depuis l'an $119^{\text {t }}$ de l'hégire jusqu'en 1198 . Onvrage sans litre, ni préface, ni nom d'inteur. Les premiers et les derniers feuillets sont endommagés par l'lumidilé.

Papier. 32 feuillets. Hauteur, 17 centimètres; largenr, 16 centimétres et demi. 5 lignes par page. - (Supplément 848.)

\section{7.}

Hisloire de l'expédition française en Égypte, par un clurétien de l’Orient, appelé Nicolas le Turc (نقولا التهك). L'onvrage commence par une esquisse de la Rérolution francaise el de la mort de Louis XVI. Cette relation a été publiée en arabe et en français, par M. Desgranges ainé. Ce ms., daté de l'an 1826 de J. C., a élé écrit pour le chancelier du consulat français, à Danas.

Papier. 58 feuillets. Hauteur, 22 centimètres et demi; largẹr, 6 centimètres. 28 lignes par page. - (Supplément 842.) .

\section{8.}

- Aide-inémoire des gens inlelligents, sous forme d'abrégén, récit des événements qui se passèrent en Égypte, depuis l'an 1120 de l'hégire jusqu'à l'expédilion f'rançaise, par le schaïklı Isma il Khasclıàb (خشاب) , secrétaire du divan du Caire sous l'administration française.

Papier. 96 feuillels. Ilauteur, 19 centimètres et demi; largeur, 13 centimètres et demi. 17 lignes par page. -- (Supplément 850.)

\section{9.}

Vie de Mouràd Bey, émir mamloue d'Égyple, mort en 12 1 4 de l'hégire, pendant l'occupation française. Ms. daté de l'an 1216 de l'hégire (1801 de J. C.).

Papier. 30 feuillets. Hauteur, a a centimètres et demi; largeur, 16 centimètres. 15 lignes par page. - (Supplément 2084.)

\section{0 .}

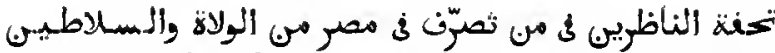
"Présenl pour les observaleurs, indiquanl les préfets el les rois qui onl gourerné l'Égyptes, par 'Abd Allalı ibu Ilidjâzi, généralement connu sous les noms d'll-Sclıar-

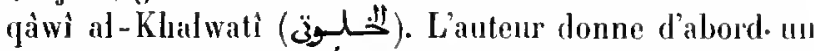
résumé de l'histoire d'Égypte, depuis l'époque de Mahomet jusqu'an reggne du sullan ottoman Sélim JlI. II lermine (fol. $571^{\circ}$ ) par le récil de l'expédilion francaise en Égypte, depuis l'an 1213 de l'hégire jusquian départ des Français. Ms. copié sur l'original qui élait daté de l'an 1 . 28 de l'hégire (1813 de J. C.).

Papier. 64 feuillets. Ilauteur, 23 centimètres et demi; largeour, 16 centimètres. a lignes par page. - (Supplément 82.) 


\section{1 i 1863.}

Reuseignements intéressants, en fait de nolices biographiques et récits historiques", par "Abd al-Raḷmân ibn Hasan al-Djabartì (3) docteur hanéfite. Ce corps d'innales et d'articles nécrologiques commence par le xil siècle de l'bégire, et se termine par l'annéc 1220 . L'auteur passe rapidement sur les événements des premières années, mais il traite avec plus de détails les années suivantes, et, vers la fin, il consacre un chapitre spécial à chaque mois de l'année. Dans la préface, il domne la liste des nombreux ourrages quil a mis à contribution, et ce n'est qu'après une assez longue introduction, renfermant des généralités sur l'histoire de l'Egypte, qu'il aborde le sujet principal de son ourrage. La préface commence par ces mots : a d W

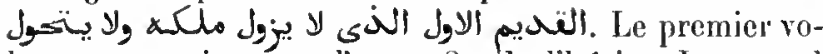
lume se termine arec l'an 1189 de l'bégire. Le second volume, d'une main plus moderne, commence par l'an 1190 de lluégire, et finit par l'an 1212 . Le troisième volume commence par l'an 1213.

3 volumes. Papier. 473,869 et 426 feuillets. Hauteur, 2 a centimètres; largeur, 15 centimètres et deni. 95 tignes par page. - (Supplément 840.)

\section{4 à 1866.}

Mène ourrage. Cet exemplaire a été copié sur le ms. de l'auteur. La division des volumeśs est la même que celle de l'exemplaire précédent.

$3 \mathrm{vol}$. Papiec. Ite tone I renferme 59.3 fenillets. Hauteur, 23 centimètres; largeur, 16 centimètres. 21 lignes par page. Le tome If, du mène format, a 423 feuillets. Le tome $111, .402$ feuillets. Hauteur, a 4 centimètres; largeur, 16 centimètres et demi. 25 lignes par page. - (Supplément 84\%.)

\section{HISTOIRE DE LAFRIQUE ET DE L'ESPAGNE.}

\section{7.}

$1^{\circ}$ Histoire de l'Espagne par Mollammad ibn 'Omar Ibn al-Qoûtịa (ابع) النقوطية). Le récit commence par la conquête arabe et sc termine au règne $d^{\prime} A b d$ al-Rah-

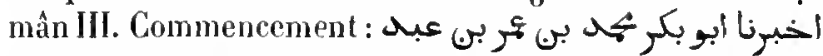

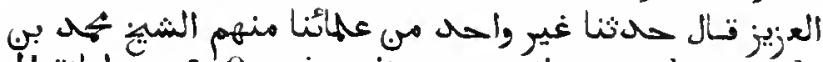
أل

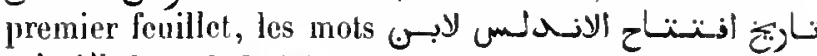
التوطية. Ibn al-Qouttịya, descendant de Sara, petite-fille de Witiza, avant-dernier roi goth, naquit à Cordoue et mourut dans cette ville en 367 de l'hégire ( 977 de J. C.). (Voyez te Dictionnaire biographique d'lbu Klallikîn, I. HI, p. 79 de la traduction anglaise, el une analyse de l'ouvrage dans l'introduction au Bayân, édition de M. Dozy, p. 28 et suiv.)

$2^{\circ}$ (Fol. $51 v^{\circ}$.) Autre relation de la conquête de l'Espagne par les Arabes et histoire des chefs qui ont gouverné ce pays. Le récit s'arrète au règne d"Abd al-liahmàn III. Voici le litre que le copiste a inscrit en lête

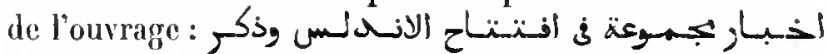

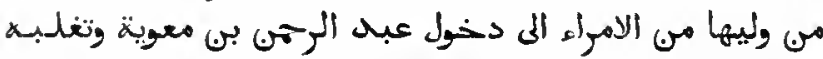

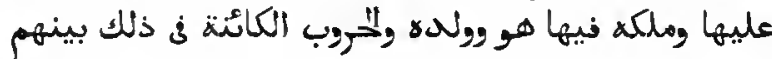

Papier, 118 feuillets. Hauteur, 96 centimètres; largeur, so centimètres. 15 lignes par page. Ms. du xvi siècle. - (Ancien fonds 706 .)

\section{8.}

الانيس المطرب رون الترطاس ف أخبار ملوك المغيب وتساريخ

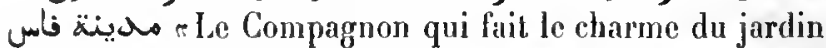
de Qarțâs, ou Histoire des rois de la Mauritanie, ainsi que de la ville de Fezn, par Ibn abî Zare ( j $^{2}$ Aboû 'l-Hasan Alì iln Moḷammad. Tel paraît ètre le véritable titre de cet important ourrage, qui a été traduit en allemand par Dombey, en portugais par le P. Moura, en français par Beaumier, et publié, avec une traduction latine, par Tornberg. Le jardin public appelé Qartâs avait été créé dans le voisinage de Fez par Zirì ibn 'Atìya, souverain de cette ville et chef de la grande tribu des Maghrawa, qui porta lui-même le surnom de Qarțàs et dont le règne se prolongea jusquien $3_{91}$ de l'hégire. Dans quelques exemplaires, la prélace, qui commence par les mots an

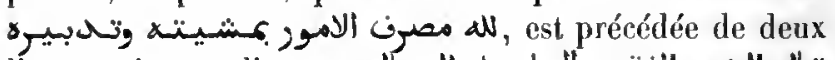

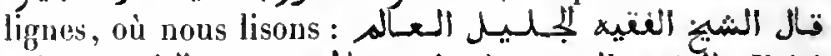
لفال r Voici ce que dit le professeur et légriste très-illustre et très-savant, le docte traditionniste Aboû Mohammad Sàlị̣ ibn 'Abd al-Halìn, maintenant décédér. On croit cependant que cette indication est fausse, et on a fait la remarque qu'Thn Khaldoùn, toutes les fois qu'il cite le Qartâs, l'attribue à Ibn abì Zerae. Telle est aussi l'opinion de Hadji Khalfa (édition de Flügel, t. I, p. 489). Dans quelques

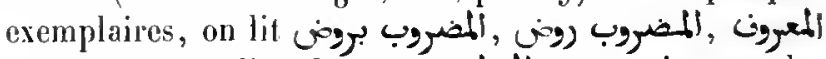

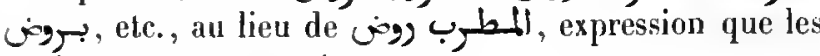
copistes ne comprenaient pas.

Ce volume, yui a appartenu à Petis de Lacroix, est interfolié. Ms. daté de l'an 971 de l'hégire ( 1563 de J. C.).

Papier. 135 feuillets. Hauteur, 26 centimètres et demi; largeur, 20 centimètres. 31 lignes par page. - (Supplément 853.) 


\section{9.}

Mème ouvrage. Ils. dafé de l'an 1100 de l'hégire (1689 de J. C.).

Papier. 22: feuillets. llauteur, 28 centimètres; largeur, 20 centinètres. 20 à 22 lignes par page. — (Supplément 853 ter.)

\section{0 .}

Commencenent du mème ouvrage. Ms. daté de l'an 1028 de l'bégire ( 16 ig de J. C.).

Papier. 9 feuillets. Hauteur, 37 centimètres el demi ; largeur, 25 centimètres. 24 à 26 lignes par page. - (Supplément 853 bis.)

\section{1.}

1. Collier de perles brillantes", opuscule dans lequel on démontre l'authenticité de la généalogie d'ldris, fondateur de la dynaslie des Idrisides. Liauteur raconte l'histoire de ce prince, et, après avoir donné une courte description de Fez, il traite des diverses branches de la famille d'Idris. Ia prélace commence par ces

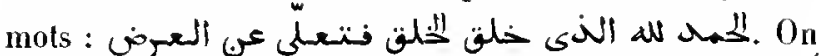
كتناب القرطاس : lit, en tèle de la prélace, le litre suivant

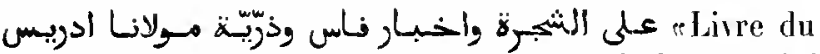
Qartâs sur l'arlıre (?) el histoire de Fez ef de la postérité de notre seigneur Idris r, et le nom de l'autem. Djalàl al-Din 'Abd al-Raḷmân al-Soyoùti. L'explicit donne à peu près le même titre, mais dans la prélace on lit celui qui est transcrit ci-dessus.

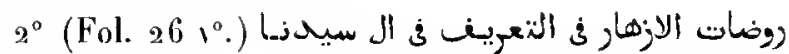
r Jardins de lleurs pour la commaissance des descendants de notre seigueur Molammad, l'élu de Dieun, par le chérif lloḥmmad, fils d'Aḷmad al-Talirài

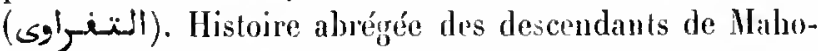
met, et surtont des ldrisides, et généalogie d'un grand nombre de familles africaines dont l'origine remonte à Idrîs. Cet opuscule est daté de l'an $11_{6} 6_{2}$ de l'hégire.

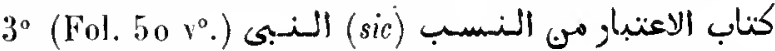
r. Considérations sur la progéniture du Prophète élu». Sur les ldrivides et les généalogies des diverses branches de ectte fimille. Opuscule tiré d'un écrit laissé par Sidi 'Alud Allah al-Bakri.

$4^{\circ}$ (Fol. $60 v^{\circ}$.) Autre opuscule, portant te même titre que le précédent et traitant du mème sujet, par Aboû 'l-'Abbàs Aḅmad ilı 'Alud Mllah al-Bakrî.

Mas. orientalX. - II. $5^{\circ}$ (Fol. $70 \vee^{\circ}$.) Le Qartîs. La préface esl omise, et il y a quelques lacunes dans le corps du texte. La copie es! datée de l'an $11_{1} 1$ de l'hégire (1748 de J. C.).

Papier. 233 feuillets. Hauteur, 21 centimètres; largeur, 15 centinètres et demi. 2 a lignes par page. Ms. du xwı1' siècle. - (Supplément 854.)

\section{2.}

Copie authentique de la généalogie des Idrisides, et un acte de notoriété constatant qu'une certaine personne appartenait à cette famille. Pièce dressée à Alger, vers l'an $117^{3}$ de l'hégire $\left(17^{5} 9^{-1} 7^{60}\right.$ de J. C. $)$.

Rouleau de papier. Hauteur, 1 mètre 50 centinètres; largeur, $2 / 4$ centimètres et demi. - (Supplément 2345.)

\section{3.}

$1^{\circ}$ مobes de couleur, ou histoire de la ville de Maroc. Abrégé de l'histoire de cette ville, depuis sa fondation par Yoúsof ibı Tàschifìn, jusqu'à l'an 783 de l'hégire. On ne sait pas ce qui a pu domer naissance à l'erreur qui, dans l'ancien catalogue, a lait altribuer cet ouvrage ì Ibn Batouṭ.

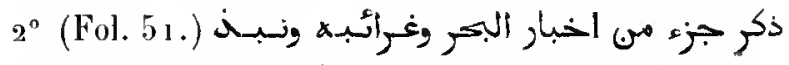
Exposé des merveilles de la mer el de l'histoire d'Adan et de ses descendants". La uner dout il s'agit ici est celle de la C'hine et de l'Inde. L'auten parle des iles, d'Adam et des patriarches, de Dsou 'l-Qarmain, de Methusalem el des descendants de Noé.

IIs. daté de l'an $99^{6}$ de l'hégire ( 1590 de J. C.).

Papier. $19^{2}$ pages. llauteur, 21 centimètres; largeur, 15 centjmètres. 21 lignes par page. - (Aneien fonds 825 , Colbert $\left.529_{6} 6.\right)$

\section{4.}

Histoire des Almohades Hafṣides. Cet ourrage, allribué à Aboû 'Aldd Allalı al-Zarqaschi, conmence par une. nolice touchant l'origine du Mahdi lbn Toimert el unc. courte esquisse de l'histoire des sultans almolıades. L'histoire des liafsides s'arrête à l'avènement de Molammad al-Manṣoûr, fils d'Aboù Fàris 'Al)d al-'Axiz, en 839 de l'hégire (1435 de J. C.).

Ms. daté de l'an 1 1 33 de l'hégrire ( $17^{21}$ de J. C.).

Papier. 113 feuillets. Hauteur, 21 centimètres; largeur, 16 centimètres. 19 lignes par page. - (Supplément 852.) 


\section{5 .}

(Fil de perles "L'or, tritécle la noblesse des Beni Ziyàn", par Nolammad iln "Abd Allalı llon 'Ald al-Djatil al-Tanasi, mort en 899 de l'hégrire ( 149 de J. C.). Cet ourrage, composé an l'honneur des "Ald al-Wadites, souverains de Tlemcen, sous le rè̀gne d'Al-Notawakkil (Aboù 'Abd Altalı Hoḷammad ilon Noḷammad ibn abì Thàlsil ibn abì Tìschifin), est divisé en cinq sections (قسم), dont la première lraile de la gónéalogie de ce sultan et de l'origine illustre de la famille des Ziyanides; la seconde section traile des qualilés qui conviennent à un sourerain; la Iruisième se compose d'aneclotes piquantes et de traits j'espril; la qualrième est une anllhologie en vers et en prose; la cinquième est un traité de morale ( rovez Journal asiatique, callies' d'oclobre 1849 et cahier' de décembre 1851 ). Le présent ms. ne renferme que les deux premières sections de l'ouvrage. La préface commence par.

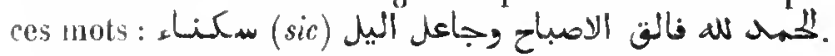

Papier. 152 fenillets. Hauteur, 26 centimètres et demi; laryeur, so centimètres. 25 lignes par page. Ms. du x F $^{\mathrm{a}}$ sièele. - (Aneien fonds $7^{\circ 3}$, Colbert 3103.)

\section{6.}

Nème ourrage. A la fin se troure un court précis historique des origines du peuple arabe, race à laquelle la lamille berlyère des Benî Ziyàn prétendait apparlenir; puis viement quelques qasida el autres pièces de vers, romposées par le sultan Aboù llammoù, 1 naslie d"Albd al-Wàd. Ms. daté de l'an 1167 de l'hégire ( 1763 de J. C.). Le premier feuillet mantue, ainsi que queluues levillets à la fin.

Papier. 280 feuillets. Hauteur, a 7 centimètros el demi; largeu", 17 centimètres el demi. 31 lignes par page. -- (Supplément 85. 1er.)

\section{7.}

Épisades de la conquète de l'Afrique jar les Otlomans. Hs. dalé de l'an 1265 de l'hévire (1849 de J. C.).

Papier. 35 fenillels. Hauteur, 2.3 centimètres; largeur, 18 centimètres. 1 lignes par page. - (Supplément 2448.)

\section{8.}

سيرة اللجاهد خير الدير. Vie de Khaïr al-1)in Barberousse. Cel ourrage (qui n'est pas le mème que celui dont la traduclion française a cété publicée par MII. Sander Rang el Ferdinand Denis, d'après un ms. de la Bihliothèque

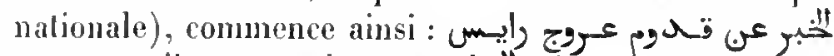

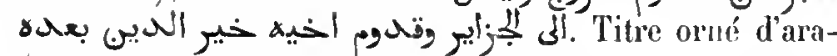
besques de diverses couleurs.

Papier. 114 feuillets. Hanteur, 25 centimètres; largeur, 19 centimitres. 19 lignes par page. Is. du xvi̊ siècle. - (Supplément 852 bis.)

\section{9 .}

Histoire de la conquète de l'Afrique ${ }^{1}$. Ms. daté du mois d'oclobre 1866 .

Papier. 6o feuillets. 11 auteur, 24 cenlimètres; largeur, 18 ceulimètres. 2a lignes par page. - (Supplement 2429.)

\section{0 .}

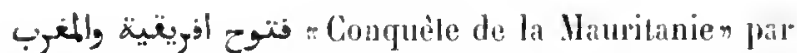
les Ilusulmans, rontan historique en deux parties. L'ouvrage est altribué à un auteur nommé Aboù 'l-IJasan Bakrì.

Papier. 17 fenillets. Hauteur, 25 centinètres; largeur, 18 centimètres. 29 lignes par parze. Its. du xvi" sièele. - (Supplément 234.)

\section{1.}

ف Conquète de la Mauritanie " par les Husulmans. Roman historique plein d'anachronismes, en deux parties?. Ils. daté de l'an 1148 de l'hégire (1 735 1736 de J. C.).

Papier. 335 feuillets. llauteur, 21 centimètres; largenr, 15 centimètres et demi. 17 lignes par page. - (Ancien fonds 8.4.)

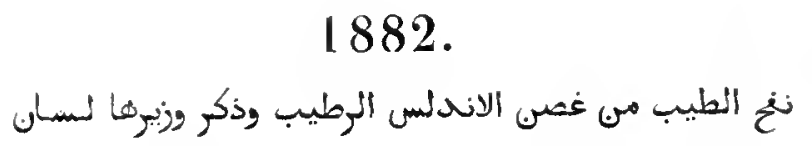

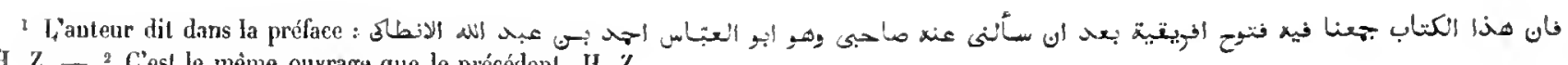
H. Z. - ${ }^{2}$ C'esl le mème ourrage que le précédenI. II. $Z$. 
Odeur suave du rameau verdoyant de l'Espagne et biographie de lisin al-Din iłn Khatịl, vizir espragnol». Histoine politique et littéraire de l'Espagne, part Iḷmad ibn Mohanmmad al-Maqqari, mort au Caire, on 10 la de l'hégire ( 163 i de J. C.). Lonvrage se compose de deux partics, dont chacune est divisée en deux volumes. La première partie est consacrée à l'Espagne el lit seconde au vizir Lisin al-Din. Une traduction anglaise de la première partie a cité publiće par M. de Gayangos; le texte arabe de la mème partie a été impriné à Leyde, et une édition complète des deux parties a paru en Égypte. Dans l'introduction de l'édition de Leyde, M. Gustare 1)ugrat a donué un aperçu général de l'ouvrage "t une vie de l'auteur. Le présent ms. renlerme les cinq premiers lisres de la premiere partie.

Papie:. ali8 feuillets. Ilauteur, 30 cenlimétres; largeur, 19 centimètres el demi. 33 liģnes par pagre. Ms. dn xrü siècle. - (Incien londs 704 , Coibert 3150.$)$

\section{3.}

Première partic du même ourrage qui, dans cet exem-

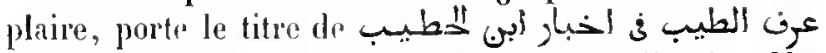
-Odeur des parfuns, ou histoire d'lbn al-Khatibs. Ms. daté de l'an 1080 de l'hégire ( 1669 de J. C.).

Papier. a 4 fentillets. Janteur, ag centimètres; largeur, 19 centimètres. 25 lignes par page. - (Ancien fonds 7 43.)

\section{4.}

Second volume de la première partie ot premier volume de la seconde partie du mème ourrage.

Papier. sgo feuitlels. Hauteur, 30 cenlimètres; largeur, 20 centimètres et demi. 3 I tignes par page. Ms. du xvi siècle. - (Ancien funds 758 , Cutbert 3.5 .2 .)

\section{5 .}

Second volume de la première partie du mème ouvrage.

Papier. 268 fenilfets. Ilanteur, 30 centimètres; largeur, 19 centjmètres et demi. 33 lignes par page. $\mathbf{~ l s , ~ d u ~ x v n ' ~ s i e ̀ c l e . ~ - ~ ( A n c i e n ~}$ linds 705 , Coltert 3151 .)

\section{6 .}

Seconde partic du mème ouvrage. Ms. daté de l'an 1039 de l'hégire (1629-163o de J. C.).

Papier. 238 fenillets. Hauteur, 30 centimètres; targeur, so centi- mètres el demi. 33 lignes par page. - (Ancien fouds $75_{9}$, Colber 3153.)

\section{7.}

أ ile Compagnon agréable, traité de l'histoire d'Alique et de Tunisn, par Aboù 'Jbd Allah Mohammad ibn abî 'l-Qàsim al-lóo aünì (الرعينى), généralement connu sous te nom d'Jlbn abi Dinàr.a1-Qaïrawàni. Cet ouv'age, divisé en luuit sections, a été achevé en 1092 de l'hépgire (1681 de J. C.). La première section traite du nom de umig, la seconde du nom de أفريقية, la troisième de la conquète de ces pays par les Musulmans, la quatrième des caliles falémites, la cinquième du gourernement des émirs sanhadjiens, la sixième de l'histoire des Hafsides, la septième de lhistoire des Ottomans, et la huilième, intitulée appendice (ä $\ddot{z}$ ), divisée en quatre chapitres, renlerme des notices diverses sur Tunis. La préface commence par ces mols : a d

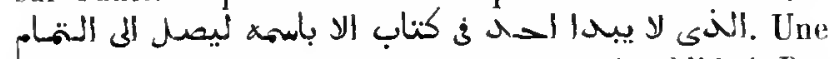
traduction lrançaise de cet ouvrage, a été publiće ì Paris, en 1845 , par MM. Pellissier et Rémusat. Ms. daté de l'an 1145 dél'hégire ( 1733 de J. C.).

Papier. 1'12 feuillets. Ilauteur, 24 centimètres; largeur, 77 centimètres et demi. 2 s tignes par page. - (Supplément 851.)

\section{8.}

Histoire des 'Obädites, par Aboû 'Mbdaltalı Mohammad ibn IIammid. (Voyez Journal asiat., 1852, i. II, p. 470). Ms. dalé de l’an 1868.

Papier. 33 feuillets. Hauteur, 20 centimètres; largeur, 15 centimètres. 18 lignes par page. - (Supplément 2456.)

\section{9.}

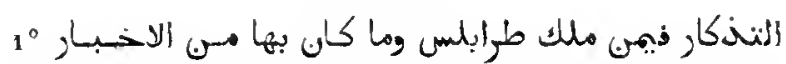
"L'Aide-mémoire, renfermant l'histoire de Tripoli et des souverains qui y ont régnćs, commentaire historique d'un ćloge poétique de cette ville, composé par Aḷmad ibu 'Albd al-Diiim al-Anșâlì. Lianteur du commentaire, Moḷammad ibn Khalil Ghalboù (غلبون), nons donne l'histoire de Tripoli, depuis la conquète nusulmane jusqu'au

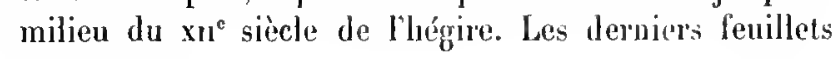
manquent.

$3^{\circ}$ (Fol. 120.) Notice sur Tripoli, par le royageur 
Mohammad ibn Mohammad al-Abrari, qui arait visité celte ville en 688 de thégrire ( ${ }_{2} 89$ de J. Ć.).

$3^{\circ}$ (Fol. 122.) Deux copies d'une pièce de vers d'un anonyme, renfermant l'élogge de Tripoli, pour répondre à une satire composée par un voyageur, natif de l'Orient.

Papier. 126 feuillels. Hauteur, so centimètres et demi; largeur, 15 centimètres et demi. Ms. du xvme siècle. -- (Supjlément 2343.)

\section{0.}

Histoire alnégée de la régence de Tripoli, depuis l'an 958 de l'hégire, et de la conquête du Fezzà. Texte arabe et traduction lrançaise, suivic de la traduction française de l'histoire du règne d“Ali Caramanli, pacha de Tripoli de Barbarie. Ces pièces, traduites en francais par un ancien vice-consul de lirance en cette résidence, ont été copiées par M. de Slane, en 1845, sur l'original, conservé dans la Bibliotheque de Malte.

Papier. 3 a pages. Hauteur, 23 centimètres et demi ; largeur, 16 centimètres et demi. - (Supplément 850 bis.)

\section{1.}

Monographie de la ville de Ghadàmès. Commencement :

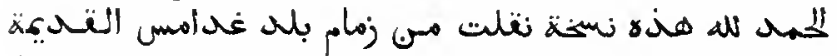
نصّ. Ms. dalé de l'an 1181 de l'hégire (1 1767 de J. C.).

Papier. 7 feuillels. Hauteur, 20 centimètres; Jargeur, 15 centimètres el demi. 17 et 18 lignes par page. - (Supptément 2083.)

\section{2.}

$1^{\circ}$ Histoire de la ville de Glıadàmès, précédée de conseils moraux ef religieux. Manvaise compilation, faite probablement par un Turc, el datée de l'an 1181 de l'hégire $(1767 \text { de J. C. })^{1}$.

$2^{\circ}$ (Fol. 1 o.) Histoire de la ville de Tripoli d'Afrique qui se termine par le récit des conquêtes de Dseraghoût Pacha. Copic exécutée en 1809 , par le chancetier du consulat de France (أنا كنسائي النوانصيس

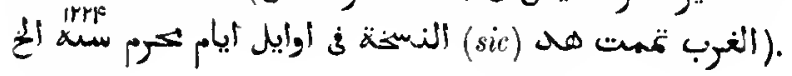

$3^{\circ}$ (Fol. $29 \mathrm{r}^{\circ}$.) Modèles de lettres au sultan et à d'iutues personnages.

$4^{\circ}$ (Fol. 5 ..) Recueil d'apophthegmes at tribués à Aristote. A la fin se trouvent quelques maximes $\mathrm{d}^{\prime \prime} \mathrm{Al}$ bd alMalik ibn al-Marwàn.

$5^{\circ}$ (Fol. 64.) Histoire de Maulày Solìmàn, empereur du Maroc, depuis l'an 1202 de l'hégire $\left(17^{8} 7^{-1} 788\right.$ de J. C.).

$6^{\circ}$ (Fol. $72 v^{\circ}$.) Notice topographique et historique de la ville de Fez, tirée d'un ourrage d'Ahmad ibn 'Abd Allah al-Bornoûșì.

$7^{\circ}$ (Fol. 82.) Généalogie des familles de l'Afrique occidentale, qui descendaient d"Alì ibn abì Tâlib.

Papier. 93 feuillets. Hauteur, 32 centimètres; largeur, 21 centimètres et demi. Mts. de diverses écritures du xvmi' siècle. - (Supplément $19^{5} 4$.)

\section{3.}

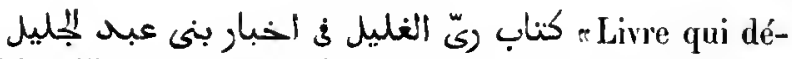
saltèro l'homme altéré, histoire de la famille d'Abd alDjalil $\pi$, souverains du Fezzân, par Mohammad "Abd atDjalil, fils dı dernier sultan de ce pays. Ms. exécuté par l'auteur, à Paris, en 1862.

Papier. 103 feuilleis. Hauteur, 28 cenlimètres; largeur, 29 centimètres et demi. 16 lignes par jage. - (Supplement 850 ter.)

\section{HISTOIRE DES CONTIELS ORIENTALES.}

\section{4.}

Histoire du sultan ghaznévite Yamin al-Daula Mal!moùd ilon Soboktegnìn, par Abon̂ 'l-Naṣr Moḥammad ibn 'Abd al-Djabbâr al-'Otbì. Cet ourrage, connu sous le titre

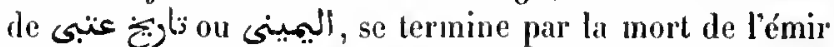
Naṣr, frère du sultan Maḥmoûd (en 412 de l'hégire?), et par l'éloge de ce prince, rédigé sous forme de lettre adressée à tous les personnages distingnés des pays qui s'étendent depuis l'extrême Orient jusqu'au fond de l'Mrâq. C'est dans cette pièce que l'autenr indique ses noms, que nous avons transcrits ci-dessus. L'ouvrage d'Al-'Otbì est écrit dans un style très-recherché, inintelligible sans l'aide d'un commentaire ou de gloses. Aussi les marges de ce ms. sont-clles chargées de notes et d'éclaircissements, les

\footnotetext{
1 C'est le mème ourrage que le numéro précédent. La date de 1181 de l'hégire, qu'on lit à ta fin des deux exemplaires, est celle du ms. original. L'auteur se nomme également à la fin : Mouștafa Khòdja ibn Qàsim al-Miṣri. H. Z.
} 
uns à l'enerc noire, les autres écrits en rouge. Ces derniers sont datés de l'an 668 de l'hígire $(1269-1270$ de J. C.). Plusicurs onglets, portant des notes d'une écriture très-moderne, sont inter'calés dans le volume. La préface

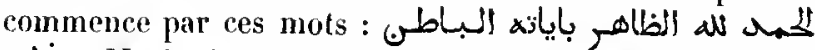
vili. M. de Sacy a inséré, dans les Notices et extraits, t. IV, p. 325 , une analyse tries-détaillée de la traduction persane de cet ouviage. Ms. daté de lan $6 y_{7}$ de l'hégire (1 220 de J. C.).

Papier. 322 feuiltets. Hauteur, 20 centimètres et demi; largeur, 15 centimètres. 19 lignes par page. - (Supplément 770.)

\section{5 .}

Mème ouvrage. Ms. daté de l’an 666 de l'hégire (1 268 de J. C.). Notes marginales. En tète du volume se trouve le célèbre poème d'Avicenne sur l'àme.

Papier. 218 feuillels. Hauteur, 29 centimètres el demi; largeur, 18 centinètres el demi. 18 lignes par page. - (Supplément $77_{1 .}$ )

\section{6.}

Le Livre des Rois d'Aboû I-Qàsim Manṣoùr al-ḷasan al-Ṭoûsì al-Firdoùsì, traduit du per'san, par Al-Fat!̣ ibn 'Alí ibn Moḷammad al-Bondàr'̀, d'lspahàn, anteur d'une histoire des vizirs seldjoukides, qui reproduit dins un style plus simple l'ourrage d'Imàd al-Din al-Iṣfahàni. Cette traduction, qui n'est qu'un abrégré du texte persan, a été exécutée sous le règne d'Al-Malik al-Moćaz̧am, fils d'Al-Mlalik al-'Ádil, sultan ayyoubite de Damas, c'està-dire entre les années 615 et 624 de l'hégire, et non, comme on lit daus Iladji Khalfa, en 675 de l'hépire. Dans ce volume, l'ordre des cahiers est interverti; mais une note qu'on lit en tète du volume indique comment on peut le rétablir. C'est par mégarde que le copiste de la dernière partie de l'ourrage écrit le nom du traducteur' : Aboù 'l-Faṭ̣ 'Isà ibn 'Alì ibn Moḷanmad al-lṣfahàni (fol. 199, 319 ), et ailleurs (fol. $258 v^{\circ}$ ), Ml-Fatl ibn Khàkàn.

Papier. 320 feuillels. Itauteur, 28 centimètres; largeur, 15 centimètres et demi. 25 et 27 lignes par page. La première partie parait ètre du $x v^{\circ}$ siècle; la seconde est datée de l'an 1039 de l'hégrire (16291630 de J. C.). - (Ancien fonds 6.4.)

\section{7.}

Seconde moitié du méme ouvrage. Ils. daté de l'an 75 h de l'hégire ( 1353 de J. C.). Les deux premiers leuillets sont d'une main moderne.

Papier. 228 feuillels. Hauteur, 27 centimètres; largeur, 18 centimètres el demi. 19 lignes par page. - (Ancien fonds 695.)

\section{8.}

Histoire des Atabecs de Mossoul, par 'Jzz al-Din 'Alì ibn el-.Ithir, auteur de l'histoire universelle inlitulée $A l$ $K a$ amil. Une analyse tr'ès-étendue de cette monographie, par M. de Guignes, se trouse dans les Notices et extraits, t. I, p. 542 et suiv. L'ourrage a été publié dans le tome IJ du Recueil des historiens arabes des croisades.

Papier 231 fenillets. llauteur, go centimètres; largeur, 14 centimètres et demi. 13 lignnes par page. NIs. du xvu" sièele. - (Ancien Fonds 818 , Colbert 4995.)

\section{9 .}

Histoire du sultan Djalàl al-Dìn Mankoubirti (Dieu donné)", roi du Kharizm, par Schilıàb al-Din Moḷammad ibn Alımad 'Alì alNasawì (لنسموى), secrétaire de ce solverain. Cet onvrage, composé en 639 de Thégire, a beancoup servi à M. DOhsson, fils, ponr la rédaction de son Histoire des Mongols (royez à la page $n$ de l'Exposition du premier volume). On remarque à la page 3 i 4 cing lignes d'écriture en langue et en caractères mongols, suivies des mots arabes Ceci est la leltre (on l'écriture) de l'ímir Saif al-Din, lieutenant gouverneur d'Ml-Karak». Ic feuillet qui porte ces lignes est un bout de roulean yui parait avoir contenu une dépèche officielle et n'a aucun rapport a vee le texte d'Al-Nasawi. Ms. daté de lan 660 de l'hégire (1 262 de J. C.).

Papier. 337 pages. Hauteur, 21 centinètres; largenr, 14 centimètres. 15 lignes par page. - (Ancien fonds 8'19.)

\section{0.}

Histoire de Tanerlan, par Al!mad ibn Nohammad ibn

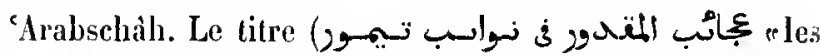
Merveilles de la destinée dans les aventures de Tìmoǹr $r$ ) manque dans cet exemplaire. I la suite de l'ourage 
(fol. $17^{3} v^{\circ}$ ) se trouse l'auto-biographie de l'auteur. Exemplaire daté de l'an 843 de l'hégire (1440 de J. C.).

Papier. 1,8 feuillds. Hauteur, so centimètres el dem; largenr, 15 centimetres. 19 lignnes par page. - (Ancien fonds 8rio.)

\section{1.}

Mème onrage. Lin téte se troure la liste des chapilues, el au fol. $1_{28} 3^{\circ}$, la fignre de l'échiquiar, inventé par Tamerlan. Ils. dalé de l'an 855 de l'llégire (1451 de J. C.).

Papier. ${ }^{3} 39$ feuillets. Hauteur, 26 centimètres et deni; laryeu", 18 cenlimèt:es. a a el a lignes par page. - (Supplément 775.)

\section{2.}

Mème ouvrage. A la lin du volume se trouvent les Visjons d'Al-ḷàrilh ibn Nabhàn (نبها).

Papier. 234 fenillels. Jlanteur, 27 centimètres; largeur, 18 conlimères. 15 lignes par page. Ns. du $\mathrm{w}^{\mathrm{e}}$ siecle. - (Ancien fonds $7^{\circ} \mathrm{g}$, Colbert 28.6 .)

\section{3.}

$1^{\circ}$ Mème ouvrage. La fin mangue (à partir du cinfrième chapitre, page 416 du tome I' de l'édition de Manger).

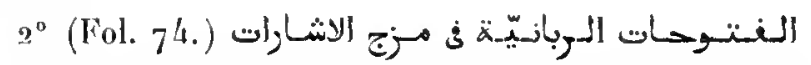

"Révélalions divines au sujet du mélange des Indications de Hamadìn». Commentaire du traité unystique de Bàbâ Ṭâhir al-llamadânì, composé en 889 de l'héģive (1484 de J. C.).

$3^{\circ}$ (Fol. 101.) Maximes de Bàbà Tịhir al-llamadànî.

$4^{\circ}$ (Fol. $108 \vee^{\circ}$.) La Borda d'Al-Bouṣirì en takhmis.

Papier. 143 feuillets. Hauteur, 27 centimètres; largeur, 18 centimétres. Hs. de diverses éeritures. Les articles $2^{\circ}$ et $3^{\circ}$ sont datés de l'an 89o de l'hérgire ( 1485 de J. C.) - (Ancien fonds 708.)

\section{4.}

Histoire de Tamerlan d'Ibn 'Aralısclıălı. Les marges d'un certain nombre de leuillets sont couvertes de longs "atraits de divers ouvrages, tels que la Géograplice d'Idrìsì (fol. 3o), etc. Mais l'écriture de ces exlraits est presque indéchiffrable. Ms. daté de l'an 1013 de l'hégire (1605 de J. C.).

Papier. $19^{5}$ feuillets. Hautemi, 21 centimètres et demi; largeur, 16 centimètres. 21 lignes par page. - (Supplément 774.)

\section{5 .}

Même ouvrage. Ms. daté de l'an 1157 de l'hégire ( 145 de J. C.).

Papier. 205 feuillets. Hlauteur, 21 centimètres; Jargeur, 15 centimètres et demi. 2 i lignes par page. — (Supplément 773.)

\section{DIVERS}

\section{6.}

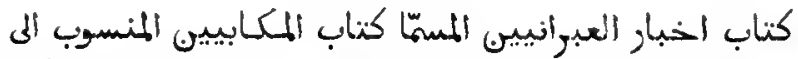

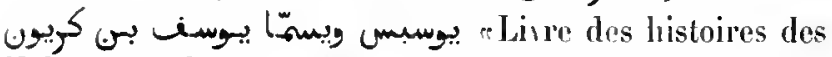
Ilébreux ou livre des Haccabées, altribué à Josippos ou Jozeph ben Gorion\%. (Voyez, sur cet onvage, J. B. de Rossi, Dizionario storico degli antori ebrei, arlicle Gorionide, et Hadji Klıalfa, t. ll, p. 121). Ms. daté de l'an 1057 des martyrs, 7 /3 de l'hégire (1341 de J. C.).

Papier, 120 fenillets. Hautenr, 25 centimètres; largeur, 17 centimètres. 21 lignes par page. - (Ancien fonds 330.)

\section{7.}

Relation des victoires de Louis XIV sur les Hollandais, en arabe, suivie de la fable du Soleil et des grenouilles (le soleil désigne le roi de France et les grenouilles les Hollandais), et accompagnée d'une traduction française. Ms. exécuté à Alep, en 1672 de J. C.

Papier. 27 feuillets. IJauteur, qo centimèlres el demi ; largeur, 16 cenlimètres. 17 ligues par page. - (Supplément 2163.)

\section{8.}

Hême ouvrage, texte arabe et traduction française. Ms. exécuté à Alep, en 1673 de J. C., par Jean François La Croix, fils de l'interprète Pétis de La Croix.

Papier. 34 fenillets. Hauteur, 20 centimètres et demi; largeur, 15 centimètres el demi. 17 ذ̀ 22 lignes par page. - (Ancien funds 851 , Colbert 3777.) 
VII.

\section{BIOGRAPHIE.}

\section{VIES DES PATRIRCIILS ET DES PROPIITTES.}

\section{9 .}

:Histoire des prophètes n, par Aboú I-llasan Moḷmmad ibn 'Abd Allah al-Kisà'i. (Voyez Hadji Khalfa, t. III, p. 174.)

Рapie:: 174 feuillets. Hauteur, 25 centimitres; largeur, 16 centimètres et demi. 23 lignes par page. Hs. du $x^{e}$ siècle. - (Supplément 632.$)$

\section{0.}

Hème ourrage. A la fin du ms. on lit une prière, une Iradition et'une pièce de (Irenle-six) ver's, citée par Ibn 'Abbàs comme un des praumes de David (سورة من المزبور).

Papier. 309 feuillets. Ilauteur, 19 centimètres; largenr, 14 centimètres et demi. 17 lignes par page. Ms. du xvi siècle. - (Supplément 631.)

\section{1}

llème ourrage. Le premier feuillet manyue; d'autres, surtout ver's la fin, ont été ajoutés après coup. Beaucoup de notes marginales en lalin.

Papier. 192 feuillets. Ilanteur, al centimètres; largenr, 18 centimètres et demi. a1 lignes par page. Ms, du $\mathrm{rv}^{*}$ siècle. -- (Ancien fonds 6a2.)

\section{2.}

\section{Vème onvarige.}

Papier. 213 leuillets. Hauteur, 27 centimitres; largeur, 17 centimètres. 25 lignes par page. Ms. du $\mathbf{v i}^{\mathrm{e}}$ siècle. - (Supplément 633.)

\section{Hème ouvrage 1 .}

\section{3.}

$2^{n}$ (Fol. 165.) extrail de l'histoire des prophètes d'Al-Tha'lahì, renfermant les actes des apôtres envoyés à Antioche, ainsi que Dieu l'a dit dans le Coran (xxxr, 12 et suiv.). Ce récit n’a pas été rapporté par Al-Kisàì."

$3^{\circ}$ (Fol, 173.) Histoire du prophète Simćon.

$4^{\circ}$ (Ibill.) Histoire des gens du Fossé (المحاب الاخدود, Coran, Lxxxr, 4).

$5^{\circ}$ (Fol. 174.) Histoire des gens de l'Éléphant (Co. ran, cv, 1).

$6^{\circ}$ (Fol. ${ }_{7} 7^{6}$.) Sur les mérites de l'ange Gabriel.

$7^{\circ}$ (Fol ${ }_{1} 77^{v^{\circ}}$.) Aventure de Moüse dans l'ile merveilleuse.

$8^{\circ}$ (Fol. 183.) Des droits de la femme sur le mari.

$9^{\circ}$ (Fol. $1831^{\circ}$.) Des droils du père sur le fils.

$10^{\circ}$ (Fol. $185 v^{\circ}$.) Des droits du mari sur la femme.

$11^{\circ}$ (Fol. $18_{7} 1^{\circ}$.) Des droits qui dérivent des liens du sang.

$12^{\circ}$ (Fol. 188.) Des droits réciproques des roisins.

$13^{\circ}$ (Fol. $192 \mathrm{~V}^{\circ}$.) Histoire de la conférence qui avait eu lieu entre guelques moines de Syrie et le calife Aboù Bakl.

$14^{\circ}$ (Fol. 195.) Histoire d'Aboù Yazid al-Bostàmi et da moine.

$15^{\circ}$ (Fol. 196. كتاب البعث والكنشور. Sur la résurrec-

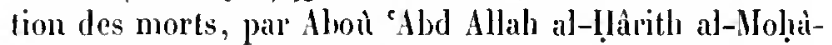
sibi \%. (Voyez Ibn Khallihàn, Iraduction anģaise, t. I, p. 365.)

$16^{\circ}$ (Fol. 203.) Conscils adressés par le Prophète à Ali.

$17^{\circ}$ (Fol. 207.) Conseils de Loquàn à son fils.

$18^{\circ}$ (Fol. 207 v $^{\circ}$.) Prière de la Cuirasse (s) (s) als), arec un commentiire. Opuscule attribué à Djaefar alȘàdì.

Ms. exéculé ì la Mecyue, l'an 1004 de l'hégire $\left(159^{6}\right.$ de J. C.).

Papier. 2 13 feuillets. Ilauteur, 30 centimètres et deni; largeur, 21 centimètres. 25 lignes par page. - (Ancien fonds 620.)

\section{4.}

Histoire des Prophèles d'Al-Kisà'i. Ms. daté de l'an 10 a 6 de l'hégire ( 1607 de J. C.).

Papier. 190 feuillets. Hauteur, 21 centimètres; largeur, 15 cenlimètres. 27 lignes par page. - (Ancien fonds 76 ł.)

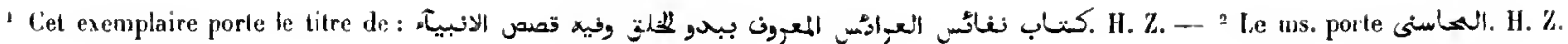




\section{MANUSCRITS ORIENTAUX.}

\section{5}

Mème ouvrage.

Papier. 145 feuillets. Hauteur, ao centimètres et demi; largenr, 15 centimétres et demi. a.) lignes par page. Ms. du xvir siècle. -(Supplément 579.)

\section{6.}

1. Mème omrage. Quelques-unes des légendes qui, dans d'antres exemplaires, se trowrent à la suite de l'ourrage, sont, dans le présent ms., intercalées dans le texte.

$2^{\circ}$ (Fol. 194.) Choix d'anecdotes concernant le Prophìte.

Ms. daté de l'an 1076 de l'hégirie ( 1666 de J. C.).

Papier. 2a2 feuillets. Hauteur, 29 centimètres; largeur, 21 ecntimètres. 25 lignes par page. - (Aneien fonds 6210 )

\section{7.}

تصص الانبياء d'Al-Kisầi. La copie n'est pas achevée. Le commencement manque ${ }^{1}$.

Papier. ${ }_{1} 76$ feuillets. Hauteur, so centimètres et demi; largeur, 15 centimètres. 13 lignes par page. Ms. du xvıl siècle. - (Stupplément 2058.)

\section{8.}

Histoire des patriarches et des prophètes (ائسسن)

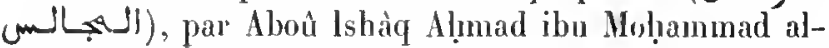
Thálabi, mort en 427 de l'hégire (1 035-1 036 de J. C.). La fin manque. Quelques feuillets sont intervertis et tout le ms. a sonfferl de l'humidilé.

Papier. $19^{2}$ feuillets. Hauteur, 24 centimètres et demi; largeur, 17 centimètres el demi. 25 lignes par page. Hs. de la fin du $\mathbf{x i}^{\circ}$ sièele. - (Ancien fonds s56.)

\section{9.}

Mème ouvrage. En tête du rolume se trouve la liste des chapitres. Ms. daté de l'an 1124 de l'hégire (1712 de J. C.).

Papier. 332 feuillets. Hlanteur, 22 centimètres et demi; largeur, 15 centimètres. 23 lignes par page. -- (Supplément 628.)

\section{0 .}

Premier volume dı même ouvrage.

Papier. 168 feuillets. Hauteur, 2a centimètres; largeur, 15 centimètres. 25 lignes par page. Ms. du $\mathbf{v v}^{\circ}$ sièele. - (Supplément 629.)

\section{1.}

Second volume du même ouvrage. Ms. dalé de l'an 869 de l'hégire ( 1 s65 de J. C.).

Papier. 199 feuillets. Hlauteur, 36 centimètres ef demi; largenr, 18 centimètres. 15 lignes par page. - (Ancien fonds 623.)

\section{2 .}

Second volume du même ouvrague.

Papier. 131 feuillets. Hauteur, 25 centimètres et demi; largeur, 17 centimètres. 17 lignes par page. Ms. du xvi siècle. - (Supplément 63o.)

\section{3.}

Premier volume d'un قصص الانبيسبـاء ou hisloire des prophètes. Cet ourrage est divisé en séances (umlș) et en chapitres (باب). Le présent ms. se termine par la mort de Josué. La préface commence par ces mots : all Mr H  que l'auteur se nommait Aboû Ishât Aḷmad ibn Moḥammad al-Thálabî; mais d'après une note, écrite d'une aulve maiı, qu'on lit en tête du volume, cette histoire des prophètes présente le texte de d'Al-Tha labì, combiné arec celui d'Al-Kisàì. Ms. daté de l'an 999 de l'hégire $(1590-1591$ de J. C.).

Papier. 391 feuillets. Hauteur, a 1 centimètres; largeur, 16 centimètres. 21 lignes par page. - (Ancien fonds 767 , Colbert 5001.)

\footnotetext{
${ }^{1}$ C'est, en effet, un exemplaire de l'ouvrage de Kisầ'i. Le ms. commence au milieu de l'histoire d'Abraham et finit au milieu de l'histoire de Moïse. Il manque quelques feuillets dans le corps du volume. H. Z.
} 


\section{4.}

Histoire des prophètes (قصص الانسبيـاء), depuis Idrìs jusqu’à Mallomet. Une note, à la fin de l'ourrage, qui est div isé en ingt-sept ehapitres, nous apprend que l'auleur, dont nous ignorons le nom, a terminé son travail en 81 h de l'hégire ( 1411 de J. C.). Ms. daté de l'an 1145 de l'hígire ( $7^{3} 2_{-1} 733 \mathrm{de}$ J. C. .). Le premier feuillet manque. Il a été remplacé par un autre qui contient une prélace rédigée après coup.

Papier. $9^{3}$ feuillets. Jlanteur, 31 centimètres; largeur, 15 centimètres. 17 lignes par page. - (Supplément 635.)

\section{5 .}

Histoire des prophètes (قصص الانبياء). Volume mutilé au commencement et à la fin. Le premier chapitre com-

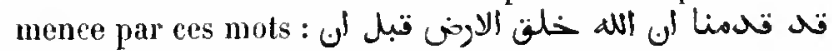
Au verso du dernier fenillet, l'hisloire

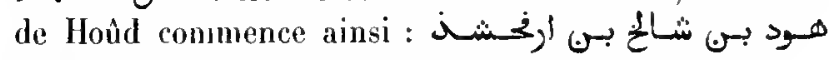

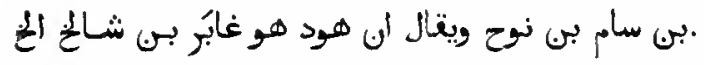

Papier. 76 feuillets. Hauteur, a centimètres; largeur, 1.5 centimètres. 25 lignes par page. Ils. du wrı siècle. - (Supplément ti3o bis.)

\section{6.}

Les Passages intéressants de l'histoire des prophètes", par un auteur inconnu. L'ouvrage, divisé en seize chapilres, commence ainsi : (الاول فلا ثيء قتبـله (1779 de J. C.).

Papier. 218 feuillets. Hauteur, a a centimètres et demi; largeur, 16 centimètres. 7 à 1 I lignes par page. - (Supplément 63\%.)

\section{7.}

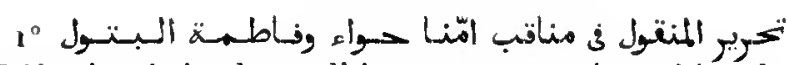
- Rédaction écrite des traditions concernant les mérites de notre mère tive et de Fàtima la viergen, par Noûr al-Din 'Alî ibn Noḷammad lbn al-Sabbàgh al-Mlatiki. Ourage schiite, divisé en trente chapilres, dont la composition a été terminée en 1025 de l'hégire $(1616$ de J. C.). Le premier feuillet manque.

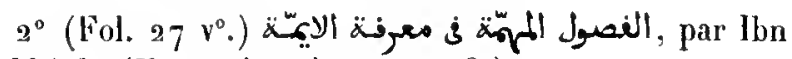
Șabbàgh. (Voyez ci-après, $1^{\circ}$ 2023.)

Mar. omextaux. - It.
Ms. daté de l'an 1038 de l'hégire ( 1628 de J. C.). Le dernier cahier est d'une écriture plus récente.

Papier. ${ }_{157}$ feuillets. Hauteur, 19 centimètres; largeur, 10 centimètres. 27 lignes par page. - (Ancien fonds 881.)

\section{8.}

- Histoire de Noé et de la tour de Babel. Le commencement manque.

Papier. 6 feuillets. Hauteur, 20 centimètres; largeur, 13 centimètres et demi. 5 lignes par page. Ms. du .svi sièele. - (Supplément a 68 .)

\section{9 .}

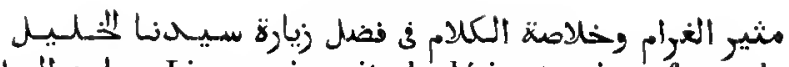
ماليه المسلام crème du langage, montrant les mérites attachés au pèlerinage lait au tombeau de notre seigneur Abraham",

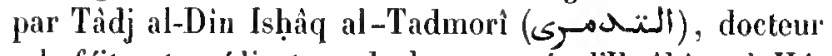
schaféite et préclicateur de la mosquée d'Ibrâhìn, à Hébron. Cel ouvrage, divisé en vingt-sept seclions et trois sections supplémentaires, traite non-senlement d'Abraham, Inais aussi d'Ismael, d'Isaae, de Jacob, de Joseph et de Loth. Dans le présent exemplaire, le nom de l'autenr est écrit ainsi : Isḥâq ibn Ibrâhìm ibn Aḷmad ibn Moṭammad ibn Kàmil التبرe mais on remarque que la dénomination etlmique a été altérée. Ms. daté de l'an 1063 de l'hégire ( 1653 de J. C.).

Papier. 147 fenillets. Hauteur, so entimètres et deni; largeur, 14 centimètres et demi, 13 lignes par page. - (Supplément 617.)

\section{0.}

Nème onvrage. Ms. daté de l'an 1084 de l'hégire $(1673$ de J. C.).

Papier. 202 feuillets. Hauteur, 21 centimètres; largeur, 15 centimètres. 17 lignes par page. - (Supplément 616.)

\section{1.}

Recueil de légendes musulmanes, à savoir :

1. Histoire d'Abraham, par Ibrâhim ibn 'Abd al-Ra!!mân, surnommé Ibn al-Karaki أبن الكرك 
2. Entretiens de Moise arec Dieu (fol. $18 r^{\circ}$ ).

3. Questions qu'c Abd Allah ibn Salàm avait adressées an Prophète (fol. 32 ).

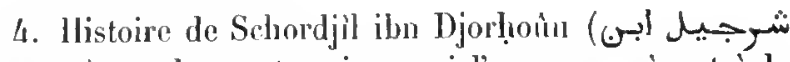
جرحون llecque et qui se convertirent lous à l'islamisme (fol. 52).

5. Conseils (وصيّة) que le Prophète avait addessés à 'Omar ilm al-Khat!iil) (fol. $581^{\circ}$ ).

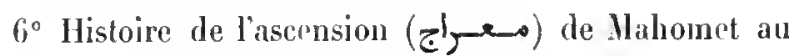
ciel, pall Aboù 'l-l!isan al-Bakrì (fol. $\left.701^{\circ}\right)$.

7. Histoire des gens de la Caverne (les sept dormants) (fol. $\left.911^{\circ}\right)$.

8. Histoire de la Line fendue par Mahomet ( fol. $\left.101 \mathrm{v}^{\circ}\right)$.

9. Histoire de Tamìn al-Dàrì, qui avait été enlevé par un démon et qui était resté abseut du monde pendant quelques années $\left.\left(f_{0}\right] .105 v^{\circ}\right)$.

10. Histoire dill-lyaddjàdj ibn Yoùsof et du jeune homme (الصبى), qui n'était autre que llon al-Ịlaniffyya (fol. 118).

11. Histoire d'Al-l!addjàdj et d'Al-Rabica ibn ḷatim (fol. 127).

12. Prière efficace qui avait préservé Anas ilon Malik de la colère d'Al-ḷadljàdj (fol. 143).

13. Histoire d'une femme juive qui arait perdu s!'s deux fils et qui arait eu une de ses mains coupée par ordre du roi. Un ange lui rendit tout ce qu'elle avait perdu (fol. $\left.144 \mathrm{v}^{\circ}\right)$.

14. Histoire d'Aboù 'Abd Allah al-Audalosi (fol. 145).

15. Histoire d'Al-Khidr (fol. $148 v^{\circ}$ ).

16. Histoire des chamelles qui araient adressé la parole au Prophète (fol. 150).

17. Histoire de Malik ibn Dinàr et d"Abd al-Rạımân ibn Moḷammad (fol. 157).

18. Histoire d'un jeune lomme de llédiue et du Prophète (fol. 161 ).

19. Histoire de l'expédition d'Al-Rabàb et de ce qui

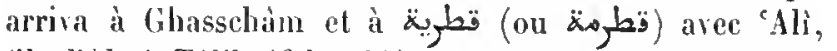
lils d'Aboû TTiilib (fol. 164).

20. Conıersion de Dhirâr ibn al-Azwarr, par 'Alì, fils d'Aloû Țälib (fol. 17 1).

21. Histoire du patriarche Joseph (fol. 191).

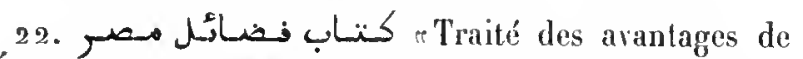
l'Égypten, par Al-ḷasan ibn 'Abd Allah al-Ṣafadi; com- pilation, dont la première moitié est un recueil de fables et la dernière un résumé de l'histoire d'Égypte, depuis la conquête musulınane jusqu'en 711 de l'hégire (fol. 211 ).

23. Histoire de Ho àds ibn Djabal, de son expédition dans le Yémen et de la mort du Prophète (fol. 253).

Papier. 265 feuillets. Hlauteur, 21 centimètres; largeur, 15 centimètres et demi. 17 lignes par page. Ms. du xvir siècte. - (Supplément 618.)

\section{2.}

$x^{\circ}$ llistoire d'Abraham el du marchand.

$2^{\circ}$ (Fol. $5 r^{\circ}$.) Histoire de Job.

$3^{\circ}$ (Fol. $29 \mathrm{r}^{\circ}$.) Ilistoire des sept hommes pienx ef d'un roi d'lsraël.

$4^{\circ}$ (Fol. 43 1\%) Extrait du "Poème militaire",

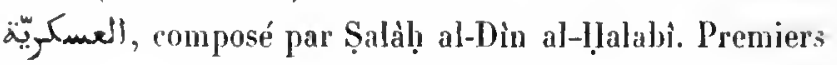
vers :

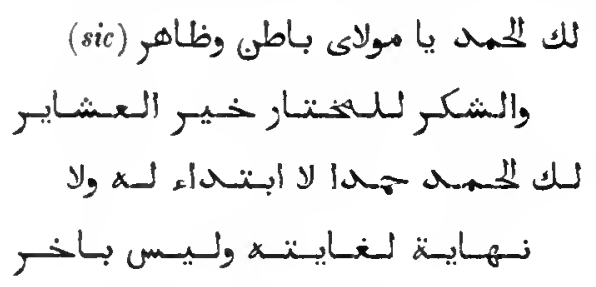

$5^{\circ}$ (Fol. 56.) La Khamriyya d'Omar ilın al-Fàridh. Incomplet.

$6^{\circ}$ (Fol. 61.) Dialogue entre la plume et l'épée, cu vers.

$7^{\circ}$ (Fol. $\left.63 r^{\circ}.\right)$ Histoire de Yohanná al-Şạigh

$8^{\circ}$ (Fol. 7 i.) Histoire de Salomon et de la reine de Saba.

$9^{\circ}$ (Fol. 8o.) Histoire d’eïn al-Zamân et de Săfî alRạ̣màn.

$10^{\circ}$ (Fol. $831^{\circ}$.) Histoire de Salmàn le Persan.

$11^{\circ}$ (Fol. $95 v^{\circ}{ }^{\circ}$ ) Histoire d'Abej.

$12^{\circ}$ (Fol. $9^{8}$.) Histoire du prophète Șâliḷ.

$13^{\circ}\left(\right.$ Fol. $103 v^{\circ}$.) Histoire du prophète Isaïe.

$14^{\circ}$ (Fol. $1051^{\circ}$ ) Histoire de Loth.

$15^{\circ}$ (Fol. 115.) Histoire de Noḥammad Ibn al-Hìschimi.

$16^{\circ}$ (Fol. 120.) Histoire de Moḥammad Ibn al-Nobàrak. 
$17^{\circ}$ (Fol. 123.) Panégyrique des saints, en vers.

Papier. 129 feuillels. IIautenr, 16 centimètres et demi; largenr, 11 centimètres. 11 lignes par page. Ms. du xvi' siècle. - (Supplément 2.11.)

\section{3.}

Fleur du calicen. Histoire du patriarche Joseph, par Aboû Ishâą Ibrâhìm al-Ausì al-Anșârì. Cet ourrage, divisé en dix-sepl séances on discours, et conlenant un grand nombre de rersets du Coran, de traditions, de reffexions morales, d'anecdotes édifiantes, de pièces de vers et de morceanx en prose rimée, a probablement été composé au $x \mathrm{II}^{\mathrm{C}}$ on au xure siècle.

l'apier. 129 fenillets. Hauteur, ag centimètres el demi; largeur, 21 centimètres et demi. 31 lignes par page. Ms. du svi" siècle. - (Supplément 6.2.)

\section{4.}

Mème ouvrage. Ms. daté de l'an 1082 de l'hégire $\left(167_{1}-\right.$ 1672 de J. C.).

Papier. 124 fenillets. Ilauteur, 20 centimètres; largeur, 15 centimètres. 21 lịnnes par page. - (Ancien fonds 766. )

\section{5 .}

Même ourrage, alec une préface entièrement différente. On remarque anssi quelques légers changements dans le corps de l'ourrage.

Papier. 149 feuillets. Hanteur, 31 centimetres et demi; largeur, 15 centinètres et demi. Au commencement, 17 lignes par page, puis 15 lignes. Ms. da xw" siècle. - (Ancien fonds 765 .)

\section{6.}

\section{Même ouvrage.}

Papier. 448 fenillets. Ilauteur, 21 centimèlres; largeur, 15 centimètres. 13 lignes par page. Ms. dı xиı' siẻcle. - (Supplément 622.)

\section{7.}

Même onvrage. En têle dı volume on lit le titre suivant: نشثر الاككام في قصة بوسف الصديق عليه المسلم.

Papier. 137 feuillets. IIauteur, $\$ 1$ centimètres et demi; largeur,
16 centimètres. 21 lignes par page. Ms. du xvı" siècle. - (Supplément 3054 .)

\section{8.}

Même ouvragge. Ms. daté de l'an 1 I 97 de l'hégire (1 686 (le J. G.).

Papier. 218 feuillets. Hauteur, 23 centimètres; Iargeur, 16 centimètres. 17 lignes par page. - (Supplément 620.)

\section{9 .}

Histoire de Joseph, depuis sa jeunesse jusqu'an moment où son père, ayant recourré la vue, vint le rejoindre en Égypte. Lanteur' spapuie sur le texte du Coran, en le déreloppanl et en y ajoutant un grand nombre d'anecdotes et de pièces de vers. Les premiers feuitlets manquent. Ms. daté de l'an $97^{3}$ de l'hégire (1566 de J. C.).

Papier. 83 feuillets. Hauteur, 2 a centimètres ; lirgenr, 15 centimètres. 17 à so lignes par page. - (Supplément 1981.)

\section{0 .}

Histoire de Joseph, en vers. Ouvrage altribué à un nommé Ibn 'Tsà. P'remier vers :

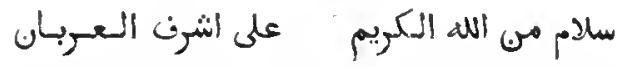

Papier. 133 fenillets. Hauteur, 16 centimètres; largeur, 10 centimètres. 12 a so lignes par page. Ms. du xviI' siècle. - (Supplément $2 n 56$.

\section{1 .}

Histoire de Joseph, par Mohammad ibn al-'Abbàs ibn A hmad al-Moqri. Cet ouvrage commence par ces mots : 年 l'an 1160 de l'hégire ( $17^{4} 7$ de J. C.).

Papier. 143 fenillets. Hauteur, 22 centimètres; largeur, 15 centimètres. 3 lignes par page. - (Supplément 625.)

\section{2.}

Histoire de Joseph et de Zoulaikhà, d'après le texte 
du Coran et les traditions, contenant de nombreuses anecdotes plus ou moins édifiantes. Commencement: 岸. La préface ne mentionne ni le titre, ni le nom de l'auteur. Un titre, ajouté après coup en tèle du volune, nomme comme anleur ule schaïkh Al-ljandànin. Ms. dalé de l'an 138 de l'hégire (1 726 de J. C.).

Papier. 124 feuillets. Hauteur, 28 centimètres; largeur, 18 centimètres. 19 lignes par page. - (Supplément 623.)

\section{3.}

llème ouvrage. Le commencenent et la fin manquent.

Papier. 117 feuillets. Ilanteur, 18 eentimètres; largeur, 13 centimẻlres. 13 lignes par page. Ms. du xvi ${ }^{e}$ siècle. - (Supplément 624.)

\section{4.}

Hisloire de Moïse, composée en grande parlie de récils que l'auteur dit avoir tirés d'Al-Ṭabarí.

Papier. 239 feuillets. IIauteur, 16 centimètres et demi; largeur, 11 cenlimètres. 13 lignes par pagre. Ms. du xvir siècle. - (Supplément 2057 .)

\section{5.}

Recueil de légendes musulmanes, contenant les entretiens de Moïse avee Dieu, l'histoire de Jésus et de sa mère, la prière d'lbn Ṭoûloûn, invoquant des bénédictions sur le Prophète, l'histoire du juif Naşoûh (تصوح) et de la brebis, et l'histoire des SepL Dormants, le tout d'après les tradilions de Djáfar al-Ṣadiq, Wahb ibn Monabbih et Ką al- $\Lambda$ ḷbàr.

Papier. 95 feuillets. Hauteur, 22 centimètres; largenr, 15 centimètres. 11 lignes par page. Ms. du xvme siècle. - (Supplément 615.)

\section{6.}

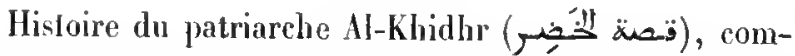
mençant par ces mols : et en couleurs.
Papier. 53 fenillets. Hauteur, 27 centimètres; largeur, 18 centimètres. 5 lignes par page. Ms. du $\mathrm{xv}^{\circ}$ siècle. - (Supplément 627.)

\section{7.}

Hisloire d'Idris, d'après Ilon 'Abhàs.

Ce ms. vient de la Bibliothèque du sullan Qìnșoûlı al-Ghaurî.

Papier. 18 feuillets. Hauteur, 28 centimètres; largeur, 18 centimètres. 5 lignes par page. Ms. du $x^{e}$ siècle. - (Ancien fonds 129.)

\section{VIE DE MAIIOMET.}

\section{8.}

"Vie du Prophèten, par Mohammad 'Alıd al-Mảlik Ihn Hischâm. Cet exemplaire porte des correclions, des grloses et des notes marginales. Le texte, d'après II. de Sacy, est très-correct. M. Wüstenfeld ne parait pas s'en ètre servi pour son édition, imprimée à Grottingue, "n 1858. Ms. daté de l’an 1059 de l'hégire (1649 de J. C.).

Papier. 274 feuillets. Hauteur, 30 centinètres et demi; largeur, 21 centimètres. 33 lignes par page. - (Aucien fonds 629.)

\section{9.}

Mème ouvrage. Ce volume, renfermant le premier tiers de l'ouvrage, est composé de cahiers ayant appartenu ì plusieurs exemplaires, tous de la mêne époque. Le texte s'arrèle an milieu d'une phrase '.

Papier. ${ }_{1} 76$ feuillets. Ilauteur, 25 cenlimètres et demi; largeur, 19 centimétres. 9 à 19 lignes par page. Ms. du xin ${ }^{e}$ siècle. - (Supplément 613.)

\section{0.}

Le Sirat al-Rasốl d'llon Hischâm. Volume renfermant tout l'ouvrage, mais les deux premiers feuillets manquent. Ms. daté de l'an 781 de l'hégire ( 1379 de J. C.) ${ }^{2}$.

Papier. 184 feuillets. Ilauieur, 24 centimètres el demi; largeur, 19 centimètres. 25 lignes par page. - (Supplément 614.)

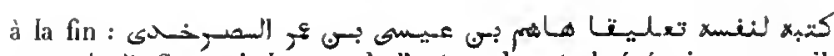

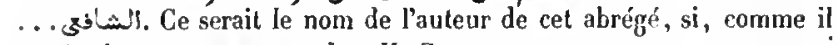
paraît, le ms. est autographe. II. Z.

\footnotetext{
${ }^{1}$ Ce ms. ne contient que des fragments de l'ouvrage d'Ibn Hischâm, complétés par plusieurs ebapitres d'une autre vie de Mahomet. II. Z.

Ce n'est qu'un abrégé du Sirat al-liasoül d'Ibn Hischâm. On lit
} 


\section{1 .}

$1^{\circ}$ Lettres adressées par Mahomet à divers souverains et grands personnages.

$2^{\circ}$ (Fol. 4.) Nole sur les Hotazéliles.

$3^{\circ}$ (Fol. $4 \mathbf{v}^{\circ}$.) Note sur le Coran.

$4^{\circ}$ (Fol. 5.) Liste de plusieurs compagnons de Mabomel.

$5^{\circ}$ (Fol. 6.) Épî̀tre des chréliens de la Syrie au calife 'Omar.

$6^{\circ}\left(\right.$ Fol. $7 v^{\circ}$.) Sur les premiers copistes du Coran.

$7^{\circ}$ (Fol. 8.) Sur la chronologie. Extrait de la Chronique d'lbn al-Djauzi.

Papier. $g$ feuillets. Hauteur, 23 centimètres; largeur, 16 centimètres et demi. 23 à 25 lignes par page. Ms. du xvin' siècle. - (Supplément 504.)

\section{2.}

rFlambeau de nouvelles\%. Sentences attribuées à Hahomet, au nombre de nille. Ce recueil a pour auleur, Moḷammad ibn Satamat ibn l!akmoùn (- al-Qorlhâi, cadi schaféile, mori en 457 de l'hégire ( 1062 de J. C.). Clıaque sentence est survie d'un commenlaire assez détaillé, en persan. La frélace du compilateur, rédigée en arabe, se Irouve sur la marge du fol. $4 r^{\circ}$. Celte collection de maximes est très-imporlante pour faire connaitre te caraclère de Mahomet el

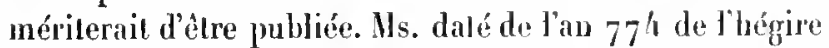
$\left(1372-137^{3}\right.$ de J. C.). Le texte esl écrit à l'encre rouge, le commentaire à l'encre noire.

Papier. 177 feuillets. Ilauteur, s4 centimètres; largeur, 17 centimètres. 19 lignes par page. - (Ancien fonds 4\%9.)

\section{3.}

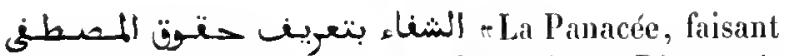
connaîlre les mérites de celui (Mahomel) que Dieu avait spécialement choisi s, par le cadi Aboù 'I-Fadhl 'Tyàdh ibn Hoủsâ a1-Yạ̦şobi. On tronve dans Hadji Khalla, t. IV, p. 56, le tableau du contenu de ce célèbre ouvrage.

Papier. ${ }_{2} 62$ feuillets. Hauteur, 21 centimètres; Jargeur, 14 centimètres. 19 lignes par page. Ms. du xw1 siècle. - (Supplẻment 185.)

\section{4.}

Mème onvrage. Les derniers feuillets sont délériorés par l'humidilé.

Papier. 13.5 feuillets. Ilauteur, 99 centimètres; largeur, 21 centimètres. 3o liggnes par page. Ms. du xvi siècle. - (Supplément 487. )

\section{5 .}

Mèune ourrage. Exemplaire dalé de l'an 1126 de l'bégire (1 714 de J. C.). Le lexte des deux premières pages est enlouré d'ornements en or el en couleurs.

Papier. 326 feuillets. IJauteur, 17 centimètres et demi largeur, 11 centimètres. 19 liggnes par page. - (Supplément 486.)

\section{6.}

Méme ouvrage. Ms. dalé de l'an 1153 de l'hégire ( 17 ho de J. C.).

Papier. 328 feuillets. JJauteur, 22 centimètres; largeur, it centimères et demi. 17 lignnes par page. - (Supplément 488.)

\section{7.}

1 Commenlaire perpéluel dı slì du cadi 'Tyàdh, par le schaïk 'Abd al-Raoûf al-Manâwí, dernier ḥdfz

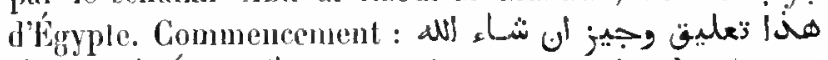
تعالى على كتاب النشغاء. La copie esl restée inachevée.

$2^{0}$ Fo1.103.) Explicalion des termes cmployés dans te stiun, jar Mhmad ibn Noḷammad al-Schononnî (जُ gire $\left(1467_{-1} 468\right.$ de J. C.). Copie datée de lan 898 de l'hégire (1493 de J. C.).

Papier. 144 feuillets. Ilauteur, 21 centimètres; Jargeur, 11 if centi-, métres. Les pages du premier ouvrage, dont l'écriture est du xvi" sièele, ont 25 lignes el celles du second 25 et 26 lignes. - (Ancien fonds 397.)

\section{8.}

Première moitié d'un conmentaire sur le شle du cadi 'Iyàdh, par 'Alî ibn Sol!̣in al-Qârî, qui a commencé cet ourrage en 1013 de l'hégire (1604-1605 de J. C.), el 
a terminé celle première partie en $1020(1611-1612$ de J. C.). Ms. daté de l'an 1148 de l'hrógire $(1735-1736$ de I. C.).

Vélin. 478 fevillets. Hauteur, 39 centimètres; largeur, a centimètres et demi. 31 lignes par page. -- (Supplément 489.)

\section{9 .}

- Les meitleures annonces concermant le meitleur des hommes, recueil de prophéties relatives à la vemue de Mahomet, par Ibn Zafar (Moḷanmad ibu abì Mol!amnad), auteur sicilien. La première section renterne les prophélies qui se rencontrent dans les linres sain!s; la seconde, les prophéties des grands

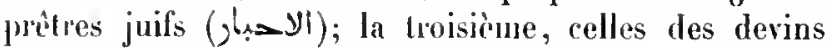
arabes; la quatriène el dernière, les prédictions des

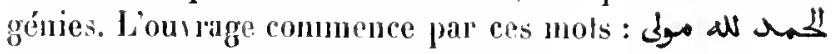
الوليائه الرمعة والتخكي.

Ms. daté de l'an 724 de l'hégire (1.324 de J. C..).

papier. 92 fenillets. Hauteur, a 7 centimètres; largeur, 19 centimètres el demi. 13 lignes par page. - (Supplément 586.)

\section{0 .}

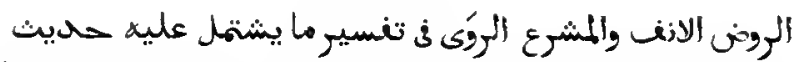

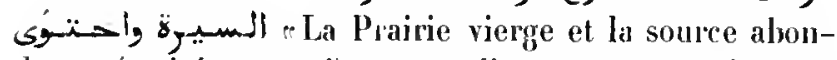
dante, (traité composé) pour expliquer re que contiennent les tradilions sur la vie du Prophète et ce qu'elles renferment d'obscur". Commentaire plilologique, étymologique, historique et généalogique sur listoire du Prophète d'Abou Bakr Moḷammad ibn Istạa al-Moțtalibi, par Aboû 'I-Qàsim 'Abd al-Raḷmàn ibn "Abd Allah alSohaïli, nort en 58 , de l'hégire $(1,85-1186$ de J. C.). Liauteur dit daus la préface qu'il a composé cet ourage en 569 de f'luégire ( $1173-1174$ de J. C.). L'ouvrage com-

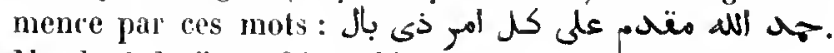
Ms. daté de l'an $9^{84}$ de l'liégire ( 1576 de J. G.).

Papier. 332 feuillets. Hauteur, 27 centimètres; largeur, 15 centimètres. 29 lignes par page. - (Supplément 6o\%.)

\section{1.}

Première partie du mème ouvrage.

Papier. ${ }_{175}$ feuillets. Hauteur, 26 centimètres et demi; largeur, 17 centimètres. 25 lignes par page. Ms. du xıv ${ }^{e}$ siècle. Les cinq derniers feuillets sont d'une écriture plus moderne. - (Supplément 6051. )

\section{2.}

Première partie du même ouvrage. Ms. daté de l'an 783 de l'léggire ( 1382 de J. C.).

Papier. ${ }_{199}$ feuillets. Ilauteur, 25 centimétres et demi; largeur, 17 centimètres et demi. 21 lignes par page. - (Supplément 6o6.)

\section{3.}

Seconde partie du mème ouvrage, commençant par le clapitre de l'Hégire. Ms. de plusieurs écritures, dont la plus récente est de l'an 1116 de lhégire (1705 de J. C.).

Papier. 206 feuillets. IIauteur, 98 centimètres et demi; largeur, 19 centimètres. 21 lignes par page. - (Supplément 605 11.)

\section{4.}

1. Trois fragments (le prenier feuillet, un feuillet du milieu ef le dernier feuillet) du vingt-cinguiène cahier

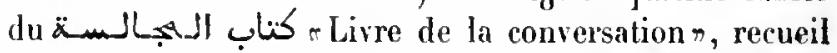
d'anecdotes et des traditions provenant de Mahomet. Le recto du fol. 1 et le verso du fol. 2 portent des certilicats qui constatent que certains personnages avaient étudié ce livre sous un prolesseur autorisé.

$2^{\circ}$ (1Fol. 4.) Explication de la Somnas (roy. fol. 10, 20, 30, elc.). Le présent ms., qui n’est que le premier volume de l'ourage et dont le commencement (treize cahiers et les deux premiers feuillets du quatorzième) manque, renferme l'exposition des lois canoniques relatives à la prière et tes traditions de Mahomet, sur lesquelles ces lois sont fondées.

Ms. daté de l'an 622 de l'hégire (1 225 de J. C.). Les points diacritiques manquent souvent.

Papier. 159 feuilfets. Hauteur, 84 centimètres; largeur, 16 centimètres. 21 lignes par page. - (Ancien fonds 468.)

\section{5.}

r. Les Perles magnifiques», par Badr alDìn Moḷammad ibn Ayyoûb al-Tâdsifi (النlis), docteur lanéfite, natif d'Alep. C'est un commentaire sur une vie de Mahomet en vers (rimant en r. La Prairie charmanten. Le présent ins. ne con- 
tient que la seconde partie de l'ouvrage. Il commence par neuf vers qui traitent du combat de Badr, suivis d'un long commentaire avec la liste des Musulmans qui avaient assisté à ce combat. La suite du poìme se troure au folio 18 , puis aux fol. $29 \mathrm{r}^{\circ}, 35,43,55 \mathrm{v}^{\circ}, 7^{\circ} \mathrm{v}^{\circ}$, $88 v^{\circ}, 106$. Le dernier passage est relatil aux dix-sept expéditions militaires auxquelles Malomet n'avait pas assisté. On trouve de nomlureux détrails sur ces expéditions, ainsi que sur la prise de la Mecque et sur l'expédition de Khaibar. L'auteur du commentaire explique, à la fin de chaque article, le sens des mots peu connus tui se rencontrent daus les tradilions reproduites par lui. Le volume se lermine au milien du récit de l'expédition d'Osàma ilon Zaïd en Palestine.

Papier. 118 feuillels. Ilauteur, 25 cenfimètres el demi; largeur, 18 centimèlres el demi. ${ }_{2} 5$ liģnes par page. Ms. du xıv siècle. (Supplément 610.)

\section{6.}

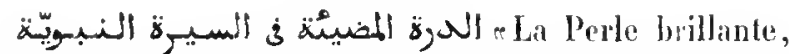
histoire du Prophèter. Tel est le ritre que Hadji Khalfa donne à cet ouvrage, qui traite de Hahomet, de ses divers noms, des membres de sa famille; des lettres quil envoya à plusienrs princes, de ses moeurs, do ses miracles, de ses compagnons, etr. Le présent exemplaire porte en léte le nom de l'autemr, Aboù Moḷamuad 'Abd al-Grlani ibn 'Abd al-Wahid al-Maydisì, et commence par ces mots : n'est pas iudiqué. Ms. daté de l'an $7_{3} 3$ de l'hógire 1332 de J. C.).

A la fin du volume se trouve une ligne d'ćcriture secrète en chifhes indiens.

On a relié en tète de co volume trois pières de diverses mains, en earactères maghrebins. La première est une généalogie spirituelle dressée par Moḷammad ibn Moḷammad ibn Sassir qui, en commençant par son maitre et iniliateur, émunère tous les doctenrs soufis, jusgüì 'Alì, fils d'Aboù Tàlib, qui ont transmis la doctrine. lal seconde pièce est un acte par lequel le nonnó Yoúsol'ibn Moḷammad ilon Molammad ibn Násir constitue son parent, Moḷammad ibn Nạsir ilın Ghalboùn, chef de la branche nasérionne des deriches schadsilites b́laljlie dans le Rabàt al-Scluaikh, au Caire. Cette pièce est datée de l'an 1162 de l'héggire (1749 de J. C.). La troisième pièce, portant la mểne date, est une note de Yoùsof ibn Mohammad ibn Moḷammad ibn Kìsir, qui indique à Moḷammad ibn Nàșir ibn Ghalboủn les diverses prières et invo- cations quil doit prononere charue jour, ef le nombre de fois que chaque invoration doit être répétée.

Papier. ${ }_{17}$ feuillefs. Hauteur, 24 centimètres; Jargrur, 17 centimistres. 27 lignes par page. -- (Supplément 6r1.)

\section{7.}

Sourees de: traditions lonchant les expéditions (de Mahomet), ses belles qualités et ses acles", par Ibn Sayyid al-Vàs Molyammad ibn Molyammad ibn Mol!ammad ibn Al!mad alYámarì al-Ralici (اليجا), surnommó Fal! al-Din et $A$ boù 'I-Fall!, originaire d'Espagne, mort en 734 de l'hégire (1333-1334 de J. C. .). L'auteur a fait pré́rédri son ouvrage de quelques dissertalions, dans lestuelles il parle de ses principales antorités, et surtout d'Ibn Isḷà ol d'Ml-Wànidì. On voil par la liste des chapitres, en tèt. du volume, que ret ouvrage est fon des plus comples: sur la vie de Malıomel. Ms. daté de l'an 1095 do l"higire $(168: 3-1684$ de J. (.).

Papier. 164 feuillets. IJauteur, 22 centimètres; largeur, 15 centimètres. 21 lignes par page. — (Ancien fonds 771 .)

\section{8.}

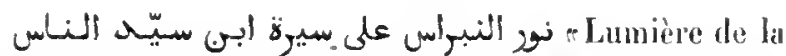
lampe pour éclaircir la biograplie (de Mahomel) d'lbn Sayyil al-Xìs *, par Borhain al-Dìn Ibràlìm ibn Khalì al-flalabì, sumommé Sib! Ibn I'djami, mort en 84 1 de l'hégire (1437-1438 de J. C. $)^{1}$.

Papicr. 540 fenillets. Hanteur, 31 centimètres; largeur, 15 centimétres el drmi. a lignes par page. Mls. du xvir siècle. — (Supplẹment 603 ter.)

\section{9.}

La seconde partie du mène ouragre. Ms. daté de lan 1059 de l'hégrire (1649 de J. (i.).

Papier. 528 fenillels. Ilauleur, 31 cenlimètres; largeur', 15 conlimètres. 2 l lignes par page. - (Supplément 603 ter $\mathrm{nl}$.)

\section{0 .}

Ralfermis-

\footnotetext{
' Le ms. porle le litre de كتاب حاثنية نوز النبورس Il ne conlient que la première partie de l'ouvrage. IJ. Z.
} 
sement des nouds (ou poignets) de la foi, en montrant l'excellence du favori de Dien ". Relation des miracles el des mériles de Mahomet, par Hibat Allah ibn 'Mbd alRaḷmàn, surnommé Ibu al-Bàrizi, nort en 738 de l'hégire $1337-1338$ de J. C.). Le présent ms. contient les dew premières dos quatre parlies (u,f) qui composent l'ourrage. La préface, qui commence par les mols on

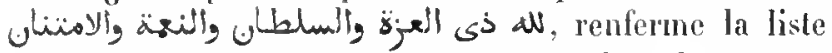
des scctions, des chapitres et paragraphes des quatre parties. Dans une note qui termine le rolume, l'anteur, après une profession de loi, suivie de l'éloge de Mahomet, déclare que sept cent trente el quelques années s'étaient écoulées depuis l'hégire jusqu'à l'époque où il écrivait. Ms. daté de l’an 769 de l'hégire ( 1368 de J. C.).

Papier. 27 3 feniflets. Hauteur, 27 centimèlres et demi; larzenr, 1 . centimètres et demi. 19 lignes par page. - (Ancien fonds 630.)

\section{1.}

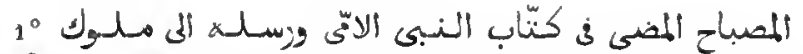

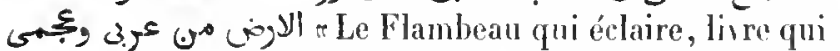
traite des secrétaires dı Prophète illettré et des envoyés qu'il expédia aux princes de la terre, arabes et étrangers $n$,

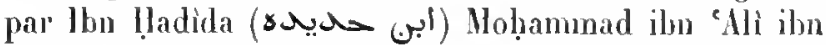
Aḷmad al-Anșârì al-K'hazradjì, qui dit avoir achevé son Irarail en 779 de l'hégire ( 1378 de J. C.). La préface est suivie d'un chapitre sur la-généalogie de Mahomet et sur les divers noms et titres par lesquels on le désignait. La dernière partie de l'ourrage, qui a été composée d'après les meilleures sources, contient, dans l'ordre de l'alphabet, les noms de toutes les personnes à qui il avait fait ćcrive et les noms de toutes celles qui lui avaient adressé des lettres. Copie datée de l'an 923 de l'hégire (15 77 de J. C.).

$3^{\circ}$ (Fol. $\left.78 v^{\circ}, 79.\right)$ Deux éloges, adressés, l’un à Aboù Bakr et l'autre à 'Omar.

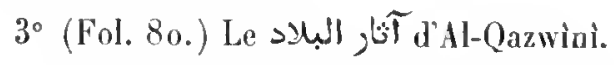

Papier. 227 fenillets. Hauteur, 26 centimètres; largeur, 17 centimètres. Écritures diverses du $x^{\circ} 1^{\circ}$ siècle. - (Supplément 658.)

\section{2.}

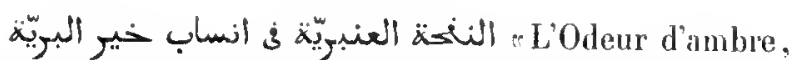
généalogie du meilleur des êtres créés\%. Généalogies de Mahomet, de ses descendants et de ses collatéranx, y compris les imams, les califes abbasides et les califes onaygades, et des principales branches des tribus arabes, par Shoù '1-Fadhâil Moḥammad, fils d'Aboû 'l-Fotoûh, fils d'Aboû 'l-Yomn Solaïmân. L'auteur, qui fait remonter sa propre origine à Al-IJosain, petit-fils de Malıomet (voyez fol. $3 r^{\circ}$ ), a dédié son ouvrage à un prince du Yémen, quil appelle Molammad al-Mahdi, fils d'AlNàsir li-Dín Illâh, fils d'Aḥmad, qu'il fait descendre de Tabàtaba, fils d'lsma'il, arrière-petit-fils d'Al-ḷasan ibn 'Alì ibn abî Țàlib.

Papier. 115 feuillets. Hautenr, 21 centimèlres; largeur, 15 centimèlres. 15 lignes par page. Ms. du xviı siècle. - (Ancien fonds 853.)

\section{3.}

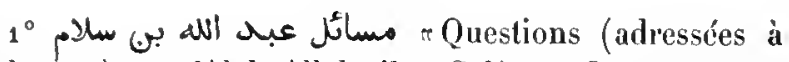
Mahonet) par 'Abd Allah ibn Salâmn. Ouvrage apo. cryphe. Ces questions concernent la cosmographie, la physiologie, etc.

$2^{\circ}$ (Fol. $22 \vee^{\circ}$.) Recueil de prières attribuées à plusicur's saints personnages.

3० (Fol. 63.) Inıocation appelée prilg prit.

$4^{\circ}$ (Fol. $88 v^{\circ}$.) Oraison $(\underset{ن}{-})$ d'Aboû l-Ṣafà Aboû Bahr' ibn abì 'I-Waqt Dảoûd, soufi hanbalite.

$5^{\circ}$ (Fol. $951^{\circ}$.) Explication légendaire de la sourate de l'éléphant (تعبير سورة الغبل وتصة أمحابي).

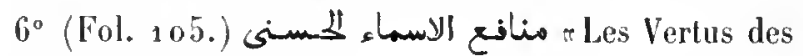
saints noms de Dieu».

Papier. 111 feuillets. Hauleur, 17 centimètres et demi; largeur, 13 centimètres. 1 lignes par page. Hs. du $x^{\circ}$ siècle. - (Supplément 483.)

\section{4.}

1 م مueslions adressées par 'Abd Allah ibn Salàm, au Prophète. Autre rédaction de l'ourrage contenu dans le numéro précédent $\left(\operatorname{article~}_{1}^{\circ}\right)$.

$2^{\circ}$ (Fol. $7^{h} v^{\circ}$.) Autres questions en turc.

$3^{\circ}$ (Fol. 78.) Prière attribuée à Aboù 'l-Ḥasan al-Schâdsili, servant de talisman contre les dangers de la mer

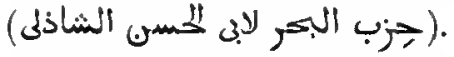

$4^{\circ}$ (Fol. 81.) Conseils moraux. Trois chapitres inti-

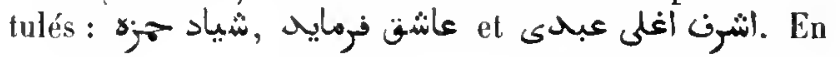
ture.

Papier. 83 fcuillets. Hauteur 26 centimètres et demi; largenr 17 centimètres et demi. 11 lignes par page. Mls. du xvil $^{\mathrm{e}}$ siècle. (Ancien fonds 358.) 


\section{5.}

Histoire des expéditions de Mahomel, depuis le combat du Fossé jusqu'à l'expédition d'Al-ḷonain. Sans préface, ni titre. Le titre qu'on lit en tète du volume, بهوع غزولة a élé ajouté après coup. L'auleur cile quelquefois la

Papier. 77 feuiltets. Ilauteur, a a centimètres; largeur, 16 centimètres. 33 à 36 lignes par page. Ms. du xvü siècle. - (Supplément 591 .)

\section{6.}

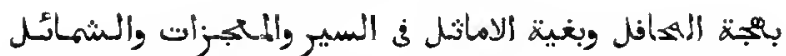
"Ornement des réunions el souhait des hommes distiugués, traitant de l'histoire (de Mahomet), de ses miracles et de ses qualités o, par Yahyà ibn abî Bakr a!'Amirì (s solell), mort en 893 de l'hégire (1 488 de J. G.). Cel ourrage est divisé en Irois sections. Ns. daté de l'an 957 de l'hégire (1550 de J. C.). Il est dit, dans une note, quill a été collationné et corrigé trois fois. Premiers mots :

Papier. 230 fenillets. Hauteur, at centimètres et demi; largeur, 15 centimètres et demi. 20 lignes par page. - (Supplément 58\%.)

\section{7.}

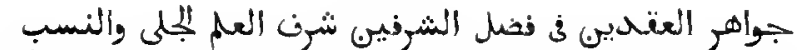
"Les Perles des deux colliers, concernant les mérites des denx illustralions, celle de la profonde érudition et celle de la liante naissancén, par le chéril' 'Alì al-Samboûdi. (Voyez Hadji Khalfa, 1. Il, 1. 643). Ms. daté de l'an 1120 de l'hégire (1 708 de J. C.).

Papier. 277 feuillets. Hauteur, a1 centimitres et demi; largeur, 15 centimètres. a 3 lignes par page. - (Supplément 491.)

\section{8.}

Première partie du sive des miracles el des qualités spécialesn, ouvage désigué ordinairement par le titre de édition du Khasạạss, par Djalál al-Dìn al-Soyoûlì. Ciest un vaste recueil de traditions et de récits plus ou moins anthenliques concemant les miracles de Malıomet et les dons spéciaux dont Dieu l'avait farorisé. L'auteur a com- posé aussi un abrégé de cet onvrage sous te titre de ی présent excmplaire est de deux écritures, dont la première, du folio 3 an folio $16_{2}$, parait etre de la main de l'auteur. Les autres leuillets, au nombre de cent quinze, viennent de la seconde partie d'un autre exemplaire divisé en quatre sections. Céte seconde partic se

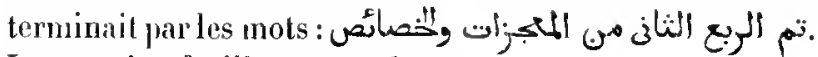
Le premier feuillet est moderne.

Papier. 277 fenillets. Hauteur, 27 centimètres et demi; largeur, 18 centimètres. 3, lignes par page. Ms. du $x v^{\circ}$ siècle. - (Supplément 505.)

\section{9 .}

Prenier volume du المواهب - Dons venus directement de bieu (et qui se sont manifestés) dans les actes de la meilleure des Créatures m, par Schihåb al-Dín Aḷnad ibn Moḷammad al-Qastallini, mort en $9_{2} 3$ de l'hégire (1517 de J. C.). C'est une hisloire de la vie et des mirarles de Mahomel. Ms. daté de l'an 1008 de l'hégire ( 1696 de J. C.).

Papier. 944 feuillets. Hlauteur, 29 centimètres et demi; largeur, 21 centimètres. 31 lignes par page. - (Supplément 492.)

\section{0.}

(ئlire en cinq parlies, traitant de l'histoire de l'àme tròs-précieusen, c'est-à-dire de Mahomel, par IIosaïn ibn Moḷammad ibn al-llasan al-Diyàrbakri, docteur malékite, mort, d'après Hadji Khalfa, vers l'an $\mathbf{9 6 6}$ de l'hégire (15581559 de J. C.). L'our rage est divisć en ciny parties : une introduction, trois خاتزة (colonnes) et une premicr s, renferme tout ce qui concerne Mahomet, ilepuis la création de sa lumière prophétique jusqu’à sit naissance; le second donne la biographic du Prophètr, depuis sa naissance jusqu'à thégire, et le troisième, depuis l'hégrire jusqu’à sa mort. Ces loj sont subdivisés en chapitres (باب), en seclions (نصاب) et en stations renferme les listes des esclaves, des alfranchis, des cadis de Mahomet, etc., ainsi que l'histoire des quatre premiers califes et un résumé de l'histoire musulmase jusqu'à la conquête de l'Égyple par les Ottomans. La prélace commence par ces mots : لـ كadji Khalla mentionne l'avis de certaines personnes d'aprìs lequel le véritable titre de ce livre serait كميس qui est un 
des noms de la Mecque. Dans quelques mss. el dans l'édition du Caire on lit النغس نغيس liè lie le plus précieux $\leadsto$, au lien des nols du lilre النغس النغيس (1s. daté de l'an 1066 de l'hégire ( 1656 de J. C.).

Papier. 419 feuillets. Hauteur, 29 centimètres; largeur, so centimètres. 35 lignes par page. - (Ancien fonds 635.)

\section{1 .}

Les deux premiers livres du même ouvrage. Ms. dalé de l'an 1106 de l'hégire ( 1695 de J. C.).

Papier. 410 feuillets. Hauteur, 11 centimètres; largeur, 15 centimètres. An commencement ${ }_{2} 3$ lignes, puis 18 lignes par page. (Supplément 607.)

\section{2.}

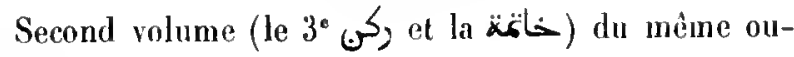
rrage.

Papier. 436 feuillets. Hauteur, aq centimètres; largeur, 20 centimètres et demi. als lignes par page. IIs. du xvi" sièele. - (Supplément 607 bis.)

\section{3.}

Second volume, d'un exemplaire distribué en trois volımes, du mêne ouvrage.

Papier. a 38 feuillets. Hauteur, 3o centimètres et demi; largeur, 21 centimètres. 27 lignes par page. Ms. du xvm" sièele. - (Supplément 608.)

\section{4.}

rive des lumières, et comment Dieu créa son prophèle choisin. Histoire de Mahomel, suivie de la relation de ses miracles. L'onvage renferme un grand nombre de tradilions.

Papier. 80 feuillets. Hauteur, 25 centimètres; largeur, 18 centimètres et deıni. 21 à 38 lignnes par page. Ms. du xvie sièele. - (Supplément 612.)

\section{5.}

مistoire du voyage nocturne de Mahomet et de son ascension au cieln, ouvrage altribué à un docteur schaféite, d'Alexandrie, nommé Nadjm al-Dìn Noḷammad ibn Aḷmad al-Ghäți, mort en 984 de l'hégire $(1576-1577$ de J. C. Voyez Hadji Khalfa, t. IV, p. 84). En tète du volume on lit un titre ainsi conçu : كتاب الادتهانج (sic) Ms. dalé de l'an $9^{8} 7$ de l'hégire (1579 de J. C.).

Papier. 76 feuillets. Hauteur, a centimètres; largeur, 15 centimètres. 23 lignes par page. - (Supplément 588.)

\section{6.}

C Commenlaire sur le Récit de l'ascension n. L'iristoire de l'ascension de Mabomet au ciel, dont le texle est écrit à l'encre rouge, a pour auteur Nadjm al-Din al-Ghaitti, mais ce texte differe beaucoup de l'ouvrage altribué à cet auteur et contenu dans le numéro précédent. Le commentaire, écrit à l'encre noire, est attribué à un docteur schafćite, nommé Hasan al-Hadàbighì (ابلغابل al-Azharì. Ms. daté de l'an 1192 de l'hégire ( 1778 de J. C.).

Papier. 79 feuillets. Hanteur, 21 centimètres; largeur, 16 centimètres. 19 lignes par page. - (Supplément 589.)

\section{7.}

Toies de bonne direction et de rectitude, histoire du meilleur des servileurs", par Moḥammad ibn Yoûsof' ibnn 'Alì al-Schâmì, nalif de Damas. Cet ourrage, plus connu sous le titre de سيرة النثايى , est une histoire très-détaillée de Mahomet, de ses guerres, de ses habitudes, de ses miracles, etc. La rédaction de cet ourrage a élé terminée en 999 de l'hégire ( $55_{90-1} 59_{1}$ de J. C.), ainsi que nous l'apprenons par la souscription du ms. ${ }^{9} 9^{6}$, qui en renferme le dernier volume. Cependant on lit dans Hadji Khalfa (t. III, p. 380) que l'auteur est mort en 942 de l'hégire.

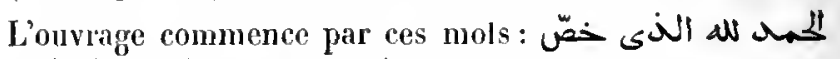

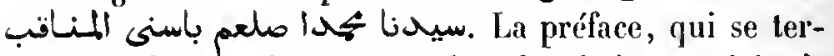
mine par la liste des auteurs dont les écrits onl été mis à contribulion, est suivie de la liste de chapitres qui remplit près de soixante pagoes. Ces chapitres, classés dans l'ordre des matières, sont rangés sous cent huit titres ou sections (بوابع). Le présent volume, le premier de l'ourrage, se lermine par la onzième section, intitulée بهؤ أسلام الانصار. Ils. daté de l'an 1061 de l'hégire $(1651$ de J. C. $)$.

Papier. 482 feuillets. Hauteur, 27 centimètres; largeur, 19 centimètres. 31 lignes par page. - (Supplément 6oo.) 


\section{8.}

Nème ouvrage, premier volume. Le ms. s’arrête au septième chapitre de la neuvième section, intitulé ابواب بعض الاموز الككاينة بعد بعثه . La préface et la lisle des chapitres manquent.

Papier. 271 Seuillets. Hauteur, 30 centimètres et demi; largeur 1 centimètres. 31 lignes par page. - (Supplément 602.)

\section{9 .}

Autre volume du même ouvrage. Ce ms. renferme la Ireizième seclion el les seelions suirantes, jusqüau seizième chapilı de la dix-huilième section.

Papier. 446 feuillets. Hauteur, 29 centimètres et demi; largeur, 19 centimètres. 35 lignnes par page. - (Supplément 603 11.)

\section{0.}

Autre volume du même ouvrage, commençant par le vingt-troisiène chapitre de la séizième section, intitulé باب المغازى التى غزى فيه النبى بـنانس

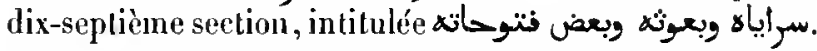

Papier. 335 fenillets. Hauteur, 29 cenlimètres; largenr, 20 centimètres et demi. 31 lignes par page. - (Supplément 6oo bis A.)

\section{1 .}

Aulre volume du nême ouvrage. Les premiers feuillets manquenl. Le ms. commence au milieu du premier

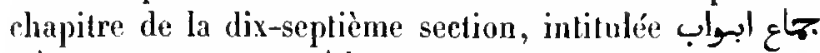
ret se termin' par la quarante-

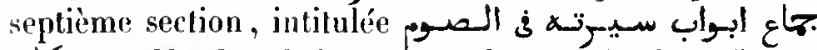
والاعتكان. Ms. daté de l'an 997 de l'héggire ( 1589 de J. Ć.), éerit probablement du vivant de l'anteur.

Papier. 527 feuillets. Hauteur, 23 centimètres; largeır, 17 centimètres. 29 lignes par paģe. -- (Supplément 60.3 bis.)

\section{2.}

Autre volume du mème ouvrage, commençant pir le seizième chapilre de la dix-huitième section, et se ter- minant par le troisième chapitre de la quarante-lroisieme seclion.

Papier. 3oo feuillets. Hauteur, 27 centimèlres et demi; largeur, 18 centimètres et demi. 31 lignes par page. - (Supplément 603111.)

\section{3 .}

Autre volume du même ouvrage, commençant par la dix-luuitième section, intitulée الـوفسود, et finissant

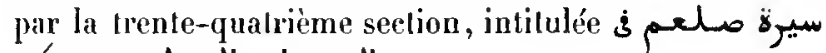
.

Papier. 307 feuillets. Hauteur, 29 centimètres el demi; largeur, so centimètres el demi. 31 lignes par page. - (Supplément 6oo bis B.)

\section{4 et 1995 .}

Deux rolumes du même ouvrage, commençant par la

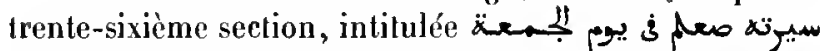
مائزانغ وليلنها صعـ Copie datée de l'an 1063 de l'hégire (1653 de J. C.).

2 vol. Papier. 223 el 255 feuillets. Hauteur, 27 centimètres; largeur, 19 centimètres et demi. 31 lignes par page. — (Supplémen 601. )

\section{6.}

Dernier volume du même ouvrage, commençant par la

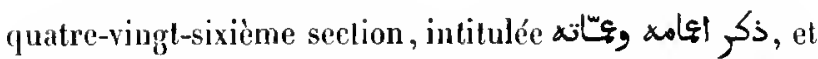

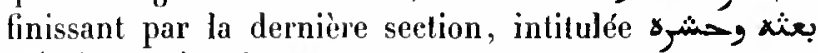
. واحواله يوم التيامة. Ms. daté de l'an 1114 de l'hégire (1702-1703 de J. C.).

Papier. 301 fenillels. Hauleur, 29 centimètres et demi; largenr, 19 centimètres. 31 lignes par page. - (Supplément 600 bis C.)

\section{7.}

oDiscours magnifiques à la louange de la meilleure des créatures $\%$, hisloire de Mahomet, en soixanle-douze discours, rédigée en vers,

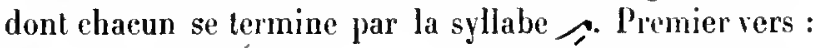

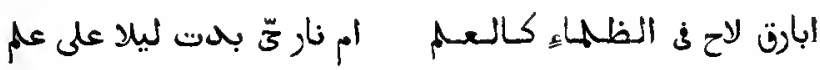

Le présent ms. renferme les trente-six premières sec- 
tions de l'ourrage qui, par l'ordre des chapitres el par leur contemu, ressemble aux compilations du mème yenre en prose. Le copiste, autenr de la prélace, qui est écrite dans un style très-u'cherché, nous apprend que ce poìme a élé composé par un militaire de haut lang de l'armée oltomane, le colonel 'Othmàn bey, fils du colonel Ali Bey. Cette préfice a été écrite du vivant de l'auteur, au mois de scha'bàn 1029 (juillet 1620 de .. C.).

Les soixante-dix-huit prenicess feuillets de ce ms. sont cowerts, sur les marges et entre les lignes, dun certain nombre d'extraits érits d'une petite écribre orientale, tris-serréce et mal forméx, au point d’être illisible en plusieurs androits. Cie sont des documents relatifs a l'histoine musulmane, depuis la seconde année de l'hégrine, jusquà la conquête de l'Égyple par Noûr at-Din, qu'uu sarant a lénnis pour son prople usage. Limn des ourrages qui a fourni ces extraits est le vere

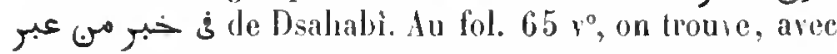
queleques modifications, le récit de Bahà al-1)ìn ilsn Schaddad, touchant la bistaille de llit!m, qui amena la prise de Jérusalem par Saladiı. Les lenillets suivants contiennont des extrits relalil's aux Musulmans d'Espagne; il y est question d'lhn Mardanisch (Mortimus), prince do Saragosse, de la mort du sultau Yonsof, sous Les murs de Santarem; puis d'un certain produit maritime, dout on tissait des étoffes magrnifiques. Ces rérits sont suivis d'autres extraits, relatil's aux événements de l'lispagne jusquau commencement du vm siècle de lhégire. An fol. 83 on trouve une troisieme série d'extraits relatifs à l'Espagne, qui paraissent avoir été empruntés à l'ouvrage de Lisin al-Din ibn al-Khatily, vizir de Grenade, intitule الاحاطة في تاريخ غرناطة. Aux fol. $9^{5}$ "t $9^{6}$, on lit plusicurs notes, notamment le récit de la conquète de Cimdie (كاني) par le sultan oftoman Ibràhim, en 1055 de l'hégire (: 645 de J. C. La date de 1.94 a élé ćcrite par errem pour 1.00). D’autres notes, qui paraissent ètre d'mue main plus moderne, se rapportent à certains érénements qui eurent lieu à Malte, dans linde, an Maroc el en Tunisie, au cours du $x^{2}{ }^{\mathrm{e}}$ et du $x^{2} n^{e}$ siccle. Au fol. 265 comnence une nouvelle série d'extraits, lirés d'un ourage plilologique dont le titre,

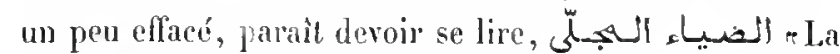
Lumière qui éclaires. Le feuillet de garde du commencement contient un long passage, presque illisible, où on parient toutelois à déchiffrer une note sur l'adjectif ethnique 5 , titre d"Abd al-Mou'min, l'Almohade; une autre sur le mot - employé pour désigner un certain recueil de prédictions; on y lit aussi le nom de Mo-

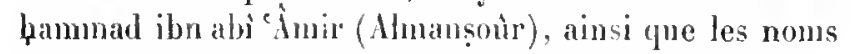
de plusieurs villes d'Espagne. Le verso dn mème feuil- let contient un fraggment qui parail se rapporter à l'his. toire des premiers Omayyades. Au rerso du fol. 287 on lit une épitre dans laquelle on examiue une question de doggme. Au fol. 81 se trouve une note de Soyoûtì ('Abd'alRaḷmàu ibn abi Bakr), datée de 868 de l'hégrire, et en tète dn lol. 79, une nole datée de l'année mếme où ce volume a été écrit, certifiant qu'un nommé Al-Maqqarì (ى) Mḥmad ibn Moḷammad, natif du Maglıreb, qui s'ćtait établi au Caire, donnait son approbation à l'ouvrage. Aux fol. $142 v^{\circ}$ el $143 \mathrm{r}^{\circ}$ se troure un dessin représentant les sandales de Mahomet.

Papier. a 88 feuillets. Hauteur, 30 centimètres; largeur, 21 centimètres. 19 lignes par page. - (Suppléraent 6og.)

\section{8.}

Parole véritable et belle au sujet de l'ascension de Son Éminence (Mahonel) au riel». Poème d'environ dix-sept cents vers, qui liment en mîm, précédé d'une préface, également en vers, qui riment en aï. L'auteur, qui n'est désigrné que par le surnom d'Al-Bakrì, nous apprend que le présent ourrage n'est qu'un extrait et un abrégé d’un grand poìme composé par lui el intitulé rLe disconrs précieux, a la louange de la meilleure des créatures".

Papier. 85 fenillets. Hauteur, 21 centimètres; largeur, 14 centimẻtres. 11 lignes par page. NIs. du rrı" siècle. - (Supplément 587.)

\section{9 el 2000.}

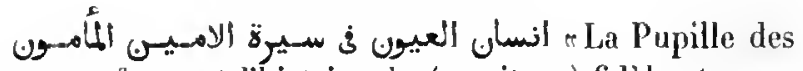
yeux, renfermant l'histoire du (serviteur) fidèle et constant", par Noûr al-Din 'Ali al-Halabi, mort, sclon Hadji Klialla, en 1044 de l'hégire (1634-1635 de J. C.). Cet ourrage est aussi connu sous le titre de السيرغ كلمبيّة. Ms. daté de l'an 1091 de l'hégire (1680 de J. C.).

a vol. Papier. 298 et 31 \% feuillets. Hauteur, 21 centimètres; largeur, 15 cenlimètres. 21 lignes par page. - (Supqlément 596.)

\section{1 .}

Première partie du même ourage. Ms. daté de l'an 1115 de l'hégrire (1703-1 704 de J. C.). Plus d'une centaine de feuillets, a partir du fol. 42 , sont d'une écriture du $\mathbf{x i x}^{\mathrm{e}}$ siècle. 
Papicr. 453 feuillets. Hautcur, 31 centimètres; largeur, 21 centiıètres. a9 à 32 lignes par page. - (Supplément 597.)

\section{2.}

Première partie du mème ouvrage. Les derniers feuillets sont d'une autre main que le reste du ms., et la copie s'arrête an milieu d'une plırase.

Papier. 310 feuillets. Hanteur, 21 centimètres; largeur, 15 centimètres. 21 lignes par page. Ms. du xvi" siècle. - (Supplément 595.)

\section{3.}

Première partie du mème ourrage. Ms. daté de l'an 1162 de thégire ( 1749 de J. C.).

Papier. 459 feuillets. Hauteur, a a centimètres; largeur, 16 centimètres. a lignes par page. - (Supplément 5.99.)

\section{4.}

Seconde partie du même ouvrage. Ce ms. a été complété au moyen de caliers provenant de différents exemplaires.

Papier. 459 feuillcts. Hauteur, 3 , centimètres; largeur, 21 centi-

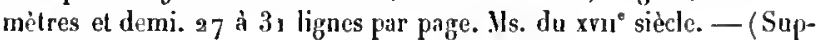
plément 594.)

\section{5}

Seconde partie du mème ouvrage.

Papier. 450 feuillets. Hauteur, a centimètres; largeur, 16 centimètres. 17 lignes par page. Ns. du xvm ${ }^{\mathrm{e}}$ siècle. - (Supplément $59^{5}$ bis.).

\section{6.}

Abrégé du أنسان العيون, composé en 1104 de l'hégire (1692-1693 de J. C.), par un anonyme. En tète du كتاب كنتـصـر المسيـرة : volıme on lit le titre suivant

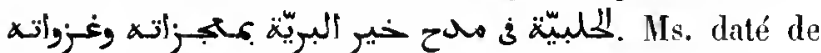
l'an 1112 de l'hégrire (1700-1701 de J. C.).

Papier. 457 fcuillets. Hauteur, 20 centimetres et demi; largeur, 15 centimètres. 19 lignes par page. - (Supplément 598.)

\section{7.}

Dictionnaire alplabétique renfermant des éclaircissements sur les hommes, Jes tribus, les lieux, les expéditions militaires dont il est fait mention dans les biographies de Mahomet, notamment dans le سيبة النببويّة et le دلائل الزيرات. La copie s'arrête au milieu de l'arlicle . 11 y a de nombreuses lacunes dans le corps du volune, et plusieurs pages sont restées en blanc. Cet (xemplaire, d'un ouvage qui aurait pu être très-ulile, a été évilemment transcrit et disposé pour recevoir les additions de l'auteur. Le litre de l'ourragre et le num de l'auleur sont inconnus.

Papier. 357 feuillets. Hautcur, 21 centimètres el demi; largeur, 11 centimetres et demi. 28 liggnes par page. Mls. du xvur siècle. (Supplément 697.)

\section{8 .}

- Bouquet pour ceux qui désirent connaitre les miracles du prince des apótres, par "Abbàs ibn Aḷmad ibn 'Abd alKarim al-lladdàd al-Marḥoûmi, le Schaféite. Ce recueil émumère, non seulement les miracles attribués à Mahomel, mais aussi les faits merveilleux touchanl les quatre premiers calites, les chels des quatre écoles de jurisprudence, el les fondateurs des divers ordres de delviches. Ms. autographe, daté de l'in 1187 de l'hégire (17731774 de J. G. ).

Papier. 105 fenillels. Hautenr, 23 rentimèlres; largeur, 16 centimètres. 19 liggnes par page. - (Supplément 49o.)

\section{9}

$1^{\circ}$ Traité des miracles de Mahomet. Commencement:

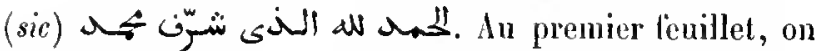

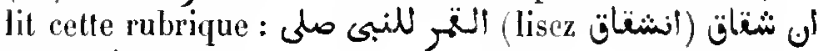
gw gle avl.

$2^{\circ}$ (Fol. $41 \mathrm{v}^{\circ}$.) Histoire d'Aboù Yazîd al-Basṭàmì et du moine.

$3^{\circ}\left(F_{0} .54 v^{\circ}\right.$.) Histoire de l'Arabe du désert et de sa femme.

$4^{\circ}$ (Fol. 61.) L'Arbain d'll-Nawawi.

$5^{\circ}$ (Fol. $\left.89 v^{\circ}.\right)$ Description de la personne ( du Propliète.

$6^{\circ}\left(\right.$ Fol. $9^{4} v^{\circ}$.) Dissertation sur le sacrifice, sur les 
délauls corporels qui rendent un animat impropre pour le sacrifice, et sur quelques points relalifs au mariage et all divorec.

Papier. 106 feuillets. Hauteur, 29 centinètres et demi; laryeur, 16 centimétıes. 13 liģnes par page. Ms. du xrü siècle. - (Supplément 585.)

\section{0.}

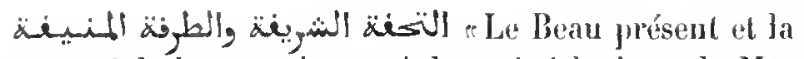
nonveauté de haule aleur\%. Arbse généalogique de Mahomet et de tous les membres de sa famille, par Je schérif el gónéalogiste Hbou 'J-(yàsin Noḷammad ibu al-ḷasan ibn edi ibn al-l!osin̈ı al-Djowânì. $\mathrm{A}$ la fin des tables se lrounc la leprésentation des sandales de Mahomet, snivie de la liste de ses expéditions militaires, de la description do sa personne, de l'énumélation de ses miracles, de ses armes et do ses montures, et du l'écit de sa mort. Ms. daté de l'an 1163 de l'hégire 1750 de J. C.).

Papier. 26 feuillels. Ilauteur, 32 centimètres; largeur, 22 centimètres et demi. 5 lignes par page. - (Supplérnent $\left.59^{3}.\right)$

\section{MES DES COMPAGNOXS DU PROPHETE.}

\section{1.}

e Le Grand dictionnaire d'Al-Ṭabarânì (Aboû̉ 'l-Qàsim Solaïnân ibn Ạ̣mad ibn Ayyoûb)". Le présent ms. est le sixième et dernier volume de cet ourrage; mais les fojios 1 à 19 appartiennent au commencement d'un autre volume, pent-être du quatrième. Bien yue, d'iprès le litre, l'auteur ait rangé les noms dans l'ordre de f'alphabet, cet ordre n'est pas régulièrement suivi. Peut-ètre les feuillets du ms. ont iłs été intervertis, surtout dans li parlie du volume comprise entre les folios zo et 92. Au lol. $937^{\circ}$ commence la section intitulée

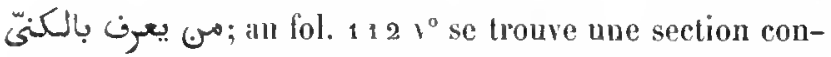

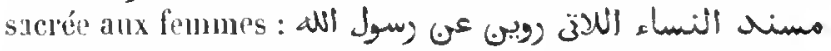

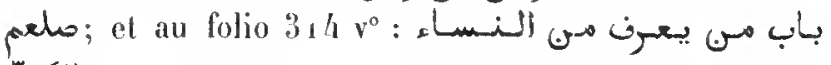
بالمنّ. Dans ces sections, l'ordre alphahétique est mieux observé. On lit an verso du premier lenillel, la copie d'un certificat d'audition le lecture, daté de l'an 771 de l'hégine (1369 de J. C.), et au verso du dernier feuillet deux certificats de lecture autographes.

Ms. daté de J'an 728 de l'hégire $(1327$ de J.' C.).

Papica. 336 feuillets. Hauteur, 27 centimètres; largeur, 17 centimètres. 29 lignes par page. - (Supplément 663.)

\section{2.}

r Notices liographiques des Anciens", par $\Lambda$ boû 'l-Qàsim Isma'i\} ibn Moḷammad ibn al-Fadhl al-Taimi, surnommé Al-luaifiz al-Ișfahânì. Cet ouvrage traite des principaux Compagnons de Mahomet, des Tábi ốn et de plusieurs saints per'sonnages. Les dernier's articles du volume sont consacrés à Ibn Manda (Aboû 'Mbd Allah), à lla'mar (Aboû Manșoûr) et au père de l'auleur. La préface commence par ces mots : as un .كيى الاموات وسامع الاصوات . Fn tềte du volume se trouve la table des notices arec l'indication des pages. D'après Hadji-Khalfa (tome II, p. 256 ), l'auteur de cet excellent répertoire est mort en 535 de l'bégire (1 140-1 1 4 de J. C.).

M. daté de l'an 894 de l'hégire (1489 de J. C.).

Papier. a 48 feuillets. Hauteur, a 6 centimètres; largeur, 17 centiinètres et demi. 21 lignes par page. - (Supplément 693.)

\section{3.}

Dictionnaire des noms des Compagnons de Mahomet et des Tabioin, avec l'indication des ouvrages dans lesquels ces noms se rencontrent. Cet exemplaire, qui est autographe et qui porte les corrections et additions de l'auteur, les unes à la marge, les autres sur des onglets, est daté du mois de rabì'a prenier de l'an 712 de l'hégire (juillet-aout 1312 de J. C.). Comme le premier feuillet manque, on ne pent indiquer arec certitude ni le titre de l'ourrage, ni le nom de l'auteur; mais it est probable que le présent ms. est le brouillon du Tadjrid (التتميح في اسماء النهابة) du célèbre polygraphe Schams al-Dîn Mlọammad ibn Ahmad al-Dsalıabi, mort en 748 de l'hégire $\left(1347^{-1} 348\right.$ de J. C. $)$.

Papier. 438 feuillets. Hauteur, 19 centimètres; targeur, 14 centimètres. 13 à 18 tignes par page. - (Ancien fonds 379.)

\section{4.}

r Splendeur des histoires", par Yáqoûb ỉn 'Aṭà Allâlı al-Roûnî al-Qaramâni, mort el 833 de l'hégire (1429-143o de J. C.). Cet opuscułe se compose d'ume introduction, de trois grands chapitres et d'une conclusion. L'introduction traite des prophètes antérieurs à Nahomet; le premier chapitre, de Mahomet; le second, des membres de la famille de Mahomet et des dix Compagnons prédestinés au Paradis; le troisième, des Com- 
pagnons. La conclusion contient de courtes notes biographiques sur les grands docteurs de l'islamisme, depuis Aboû Hanifa jusqu'à Aboû IIàmid al-Ghazâti. Ms, daté de l'an 985 de l'hégire $(1577-1578$ de J. C. $)$.

Papier. 5o feuillets. Hauleu', 21 centimètres; largeur, 14 centimètres. 21 lignes par page. - (Supptément 636.)

\section{5.}

Volnme sans titre, renfermant une histoire des prophèles, une notice sur Mabomet, sur sa famille et sur ses principaux Compagnons, et une série de notes sur les grands docteurs de l'islamisme, depuis Abou Itanifa. Le dernier nommé de ces docteurs est Aboì llàmid atGhazàli, mort en 505 de l'hégire (1111 de J. C.). La préface commence par ees mots : أهذا وما كنّا لنهتيلى . Le nom de l'antenr n'est pas indi'Tué ${ }^{\text {. }}$.

Papier. 92 feuillets. Hauteur, 19 centimètres; targen", 13 centimètres et demi. 15 lignes par page. IIs. dn xv' siècte. - (Supplément 592.)

\section{6.}

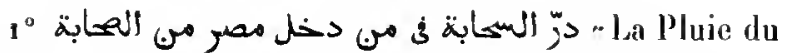
nuage, traité ren Fermant la mention des Compragnons (de Mahomel) qui sont venus en Égypter, par Al-Soyoutti. A la suite de ce dictionnaire, disposé dans l'ordre de l'alphabet, l'auteur énumère, en ajoulant quelques délails biographiques, les grands imàms áppetés lesquels figure Al-Schàfíl. Il termine son traité par une série de nolices consacrées aux docleurs schaféites les plus distingués qui ont habité l'Égypte, et dont la dernière est dalée de l'an 825 de l'hégire. Dans cette partie, les personnages sont désignés par leurs patronymiques .ou par leurs tilies honorifiques. La préface commence par ces mots : كثيرا

$2^{\circ}$ (Fol. $53 \quad{ }^{\circ}$. ) Abrégé du traité mystique d'Aboù

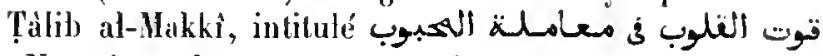
* Nourriture des coeurs, ou mànière de se conduire envers le bien-aimén. Ce sont des extraits relatifs aux devoirs du musulman, des instructions morales et religieuses, des anecdotes et des légendes édifiantes. Il y a une lacune entre les folios actuellement colés 74 et 75 . La préface

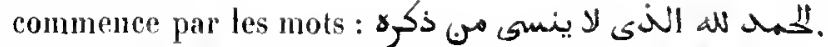
Abont Tàlib Moḷammad ibn 'Ali ibn 'Aḷya al-Makki est mort à Baghidàd, en 386 de l'hégire ( 996 de .I. C. $)$.

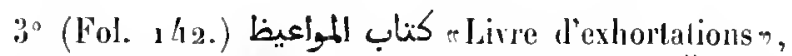
par Al-IJosaïn ibn Mohammad al-l!annàtì (blill), onvrage qui traile des mérites des musulmans les plus distingués par leur veriu et leur piété. C'est une série d'extraits de cet ouvrage commencant par le calife Aboû Bakr, puis riennent des notices sur 'Omar, 'Othmàn, Fàtima, Al-Hasan, Al-l!osaïn, Al-Qoschaïri, Abd al-Qàdir alDjilàni et quelques autres ascètes.

$4^{\circ}$ (Fol. 17 r veauté des mystères el mine des lmmières $\%$. Dissertalion sur le grand docteur soufi, "Abd al Qd̀dir al-Djilài, el quelques notices sur quelques autres docteur's mystiques. Le traité commence par un paragraphe écril à l'encre rouge, dont

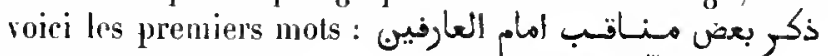

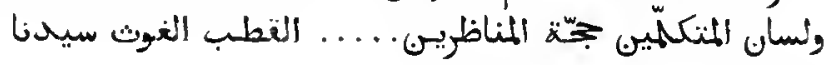

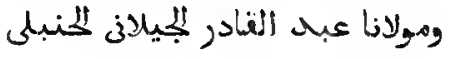

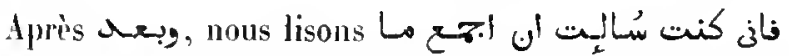

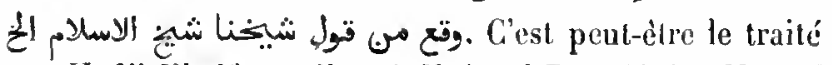
que Hadji Khalla atribue ì Nour al-Din c Jli ibn Yoùsof al-Lakhmi, docteur schaféite, qui l'aurait composé, à la Hecque, en 660 de l'hégire (1261-1262 de J. C.).

Ce ms., lont entier de la mène main, est daté de l'an 943 de l'hégire ( 1536 de J. C.).

Papier. 205 feuillets. Hlauteur, 27 centimètres; largeur, 18 centimètres et demi, 21 lignes par page. - (Ancien fonds 650. )

\section{7}

م Lumières brillantes et flenrs odlorantes $\%$. liecueil de notices instructives et d'anecdotes édifiantes, tirées des commentaires d'lbn Iadjr el d'Al-Schobrahliti sur l'Arba in d'Al-Nawawi,

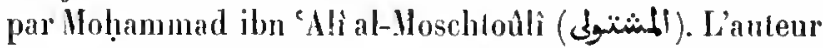
s'occupe surtout de ce qui peut filire apprécier les hauts mériles des Compagnons et de leurs successeurs immédiats. La préface commence par ces mots : all do xils J

Papier. 28 2 fevillets. Hautenr, a a centimètres; largeur, 16 centi-

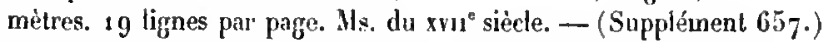

\footnotetext{
1 C'est le mème ouvrage que le précérlent. H. Z.
} 
4. VIES DES DESGENDANTS D"eALÎ.

\section{8 .}

Sources de l'histoire d'Al-Ridhà r,

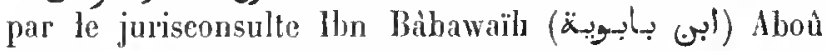
Djiıfar Mohanmad ibn 'Alì ibn al-ḷtosain ibn Moûsâ al-Qommi, mort à Raï (s ( $y^{i l)}$, en 381 de l'hégire (991$99^{2}$ de J. C.). (Sur le père de l'auteur, l'un des grands jurisconsultes de la seete schiile, qui arait composé deux cents ouvrages, voyez le Fihrist, édit. de Flügel, page 144.) Cet ourrage est un recueil de toutes les traditions qui se rapportent à 'alli ibu Moùsâ al-Ridhâ, l'uı des douze imâms. Il est divisé en soixante et dix chapitres, mais l'auleur déclare dans la préface, à deux reprises, que le nombre des chapitres était de cent quatre-ringt-treizc. La

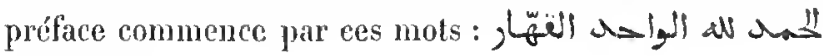

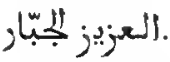

$2^{\circ}\left(\right.$ Fol. $207 \mathrm{~V}^{\circ}$ (مéclarations authentiques au sujet des douze imàms?. Ces déclaralions sont cetles des Compagnons de Mahomet et les propres déelarations des imàms. Le nom de l'auteur (probablement Ibn Bàbawaïh) n’est pas mentionné.

Ms. daté de l'an 1086 de l'hégire $(1675$ de J. C. $)$.

Papier. 257 feuillets. Hauteur, 28 centimètres; largeur, 17 centimètres. a 5 lignes par page. - (Supplément 651.)

\section{9 .}

Les Joyaux de prix, traitant de l'origine et des actes surnaturets d'Al!mad', c'est-à-dire d'Aboû 'l-'Abbàs Ahmad ibn 'Alì alBadawi (البح). Ce saint personnage, descendant d'Al-

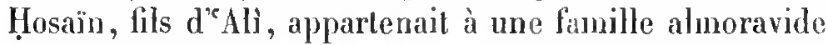
(مـــ qui énigra de Fez, en 603 de l'hégire (1 2061207 de J. C.), et s'établit à la Meeque. Mḷmad ayant embrassé la vie dévote, se rendit dans l'Tràt, puis, en 634 de l'hégire ( $1236-1237$ de J. C.), en Égyple et demeura dans le voisinage de Tandtà (bi) jusquà sa mort, en 675 de l'hégire ( 1276 de J. C. . Son tombeau est encore aujourd'hui un lieu de pèlerinage très-fréquenté. Cet ouvrage, composé par Zaïn al-Dìn ' $A$ bd al-Ṣamid, prédicateur attaché au mausolée d'A humad al-Badawì (المالى بالمتام الآهی), est divisé en cinq rhapitres, précédés d'une préface et suivis d'une conclusion qui renferme plusieurs poèmes d'Al-Badawî, elassés d'après l'ordre alphabétique des rimes. Lial préface commence

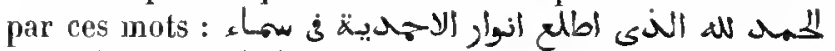

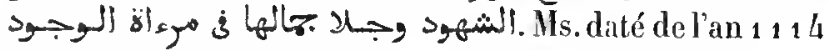
de l'hégire ( 1703 de J. C.).

Papier. 147 feuillets. Hauteur, 21 centimètres; laryeur, 15 centjmètees, 19 lignes par page. - (Supplément 643.)

\section{0 .}

Premier feuillet d'un opuscule sur les mérites de Sidi Aḥmad al-Badawî.

Papier. 1 feuillet. Hauteur, so centimètres; largeur, 12 centimetres. 18 lignes par page. Ms. du xvi1 ${ }^{\circ}$ sièele. - (Supplément 2270.

\section{1 .}

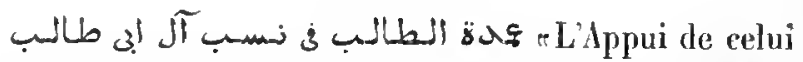
qui cherche à connaìtre les généalogies des descendants d'Alì ibn abì Țàlibr. Selon Hadji Khall'a, cet ourrage aurail été composé par Djamål al-Dìn ibn al-Ḥosän ibu 'Oq ba al-Hatabì, pour ètre offert à Tamerlan; l'auteur, mort en 828 de l'bégire (1424-1425 de J. C.), se serait prineipalement servi des ouvrages d'Al-Soûfì (Aboù T-Hasan 'Alì ibu Moṭammad et d'Al-Bokhầì ( Aboù Nâșir Sabl ibn 'Abd Allah). Dans notre exemplai'e, l'anleur, qui ne se nomune pas, dit avoir composé son ouvrage sur la demande du chérif Djalàl al-Dìn al-Ḥasan ibn 'Alì, descendant $d^{\text {'c }}$ lì à la vingt-deuxième génération. $A$ la fin $\left(\right.$ fol. $\left.2311^{\circ}\right)$ se trouve un ehapitre sur la terminologie ct les sigles employés par les généalogistes, puis un autre ehapitre sur le mème sujet, par un certuin Al-Așîli (الاصيلى), nalif d'Aṣila (Ariille), près de Tanger. En tête du volume, on lit une note, d'après laquelle l'ouvrage entier aurait élé composé par 'Aldd Allah ibu Ibrâhìm al-Aṣ̂ili, mort en $79^{2}$ de l'hégire ( $133_{9}$ o de J. C.); mais, comme l'auteur de cette nole ajoule qu'Al-Dâraq̣otnî (mort, comme nous le savons, en 385 de l'hégire, avait fail l'éloge d'Așili, on voit qu'il n'y a pas lieu d'en tenir comple.

Ms. daté de l'an 938 de l'héforire ( 1532 de J. C.).

Papier. 237 feuillets. Hauteur, 27 centimètres; largeur, 18 centimètres. 16 lignes par page. - (Ancien fonds 636.)

\section{2 .}

r Chapitres importants pour la connaissance des imàmsn, par 'Alì ibn Moḥam- 
mad Ibn At-Ṣabbàgh docteur malékite, né à la Mecque, mort en 855 de l'hégire ( 1451 de J. C.). Cet ouvrage, qui iraite spécialement des douze imàms des Schiites, commence par ces mots : $ح^{\text {Ut }}$

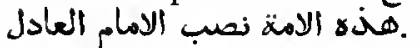

Ms. daté de l'an 1010 de l'hégire (1601 de J. C.).

Papier. 163 feuillets. Hauleur, 21 centimètres; largeur, 15 centimètres. 19 ligues par page. - (Ancien fonds 852.)

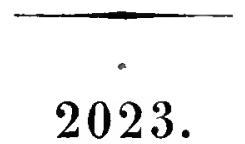

Même ouvragoge.

Papier. 91 fenillets. Hauleur, 21 centimètres; largeur, 15 centimètres. 21 à 27 lignes par page. Ms. du xvu siècle. - (Supplément 650.)

\section{4.}

Mème ourrage. Ms. daté de l'an $\log _{5} 5$ de l'bégire (1684 de J. C.). A la fin, on lil une qașida du kàtib Ibn Rozaïq (رزيق) al-Baghdàdi, dont voici le premier vers :

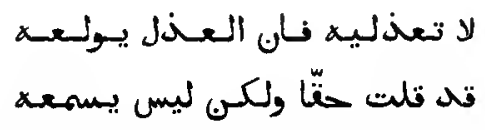

Papier. 154 feuillets. Hauleur, 29 centimèlres et demi ; largeur, o centimètres. 19 lignes par page. - (Supplément 649.)

\section{5 .}

Traditions relatives aux quatre premiers califes et aux descendants $\mathrm{d}^{\top} \mathrm{Ali}$. Cet ouvrage a été composé vers 950 de l'lé́gire ( $154_{7}$ de J. C.), à la Mecque.

Papier. 196 feuillets. Hauteur, 21 centimètres; largeur, 15 centimètres. a 3 lignes par page. - (Supplément a 140.)

\section{6.}

Les opuscules de Mar'i ibn Yoûsof ibn abi Bakr alMaqdisî, docteur hanbalite.

10 Notions rares et précieuses, au sujet d'Al-Mahdi, l'imâm attendu $\pi$, traité historique en neul chapitres. L'auteur dit avoir achevé cet ouvrage dans la mosquée d'Al-Azhar, au Gaire,

Mav. orientaux. - II. en 1022 de l'hégire ( 1613 de J. G.). Commencement de

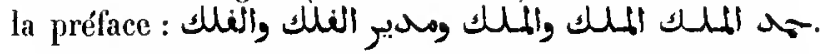

$2^{\circ}$ Fol. 23. (Examen des différentes opinions concernant la pester. L'auteur discute vingt questions qui se rapporlent à ce sujet. Com-

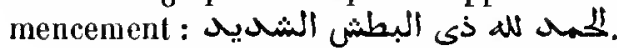

30 Fol. 63. Consolation pour celui qui est aflligé de la perte de ceux quil ainen. Sur les causes de la peste et sur le bien qu'elle produit en raffermissant les àmes contre le mallieul.

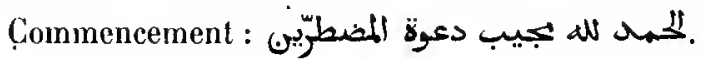

$4^{\circ}$ (Fol. 82.) Nourrilure des âmes par la conversation et la plaisanterien. Sur ce qui est permis en fait de plaisanteile et ce qui est

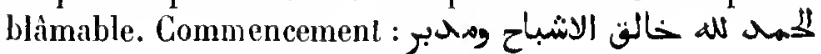
حألإ.

50 (Fol. 9. 9. (6axines de sagesse à l'usage des princes et scnlences belles comme des fleurs \%. Conseils et avertissemenls adressés aux rois, aux vizirs, aux chambellans el aux courtisans. Commen-

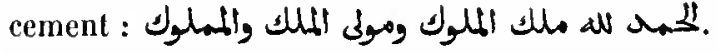

Papier. 114 fenillets. Hauteur, 21 centimètres et demi; largeur, 15 centimètres. 21 liggnes par page. - (Supplément 65.)

\section{VIES DES SAINTS ET DES SOUFIS.}

\section{7.}

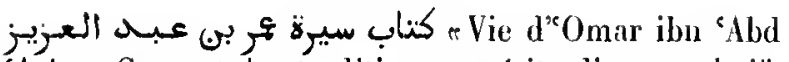
al-Aziz». Ce sont des tradilions el récils divers, relatils surtoul à la vie privée de ce catife. Ms. daté de l'an 1017 de l'hégire ( 1609 de J. C.).

Papier. 71 feuillets. Hauteur, 21 centimètres; largeur, 15 centimètres. 19 lignes par page. - (Supplément 2439 .)

\section{8.}

م حلية الاولياء وطبقة الاصفياء Parure des saints et liste d'hommes purs", par Aboû No'aïm Aḥmad ibn 'Abd Allah al-Iṣfahàni, mort en 430 de l'hégire ( $1038-1039$ de J. C.). C'est un recneil de toules les tradilions, précédées de leurs isnad, qui concerment les Compagnons, les Tabíoûn, les successeurs de ceux-ci, et les personnages les plus remarquables par la saintelé de leur vie. Le présent ms. est le second volmne de l'ouvrage; il conmence par l'article $\mathrm{Mo}_{0}$ âds ibn Djabal, et finit par les premières lignes de la notice sur Khobaïb ibn Yasâf. Les 
derniers fenillets manquent. Les folios 235 ì 244 ne sont pas à leur place et paraissent appartenir à l'arlicle Móàds ibn Djabal.

Papier. 2h/4 feuillets. Hauteur, 23 centimètres; largeur, 17 centimètres. 13 lignes par page. Ms. du xiv siècle. - (Anrien fonds 381.)

\section{9 .}

Neuvième volume du même ouvrage.

Papier. 179 feuillets. Hauteur, 25 centimètres; largeu; 17 centimètres. 22 à 26 lignes par page. Hs. du xiv siècle. - (Supplément $(; / 4.7$.

\section{0 .}

حلـيـة QLa Quintessencen, abrégé du صغوة الصغوة الاولمياء d'Aboù No'aïm al-lẹfahânì, par Aboû 'l-Faradj'Abd

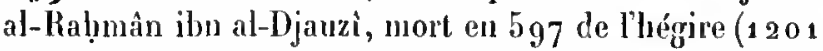
de J. C.). Ces notices biographiques sont classées, pour chaque provinee, dans l'ordre chronologique. Le présent ms., qui est le second volume de l'ourage, commence au milien de la troisième classe des Compagnons de Malıomet, nalifs de Médine. Suivent des nolices sur les Tábi oûn de Médine, de la Mecque, du Ṭaiif, du Yémen et de Baghdìl. Ms. daté de l'an 717 de l'hégire ( 1317 de J. (i.).

Papier. 230 fenillets. Hauteur, 36 centimètres et demi; largenr, 19 centimetres. 19 lignes par page. - (Ancien fonds 738.$)$

\section{1 .}

Troisième volume du même ourrage, commençant par la nolice sur lbı Samoûn, dévot de Baghdàd, mort cn 387 de l'bégire ( 997 de J. C.). Viennent ensuite des nolices sur plusieurs autres dévots, hommes et femmes, de la mème ville, puis des villes de Madàin, de Wàsit et de Konfa. Le volume se termine par la notice sur Mostim ibn Yasir, morl en 100 ou 101 de l'hégire.

Papier. 168 feuillets. Hantenr, 35 centimètres; largeur, 17 centimètres. 18 lignes par page. Ns. du xıv siècle. - (Ancien fonds $7^{3} 9$.)

\section{2.}

Réunion des amis et aide-mémoire des gens de ceurn, par Moḷammad ibn Ḥasan ibn 'Abd Allah al-Ịosaïnì, morl en 776 de l'hégire $(1374-1375$ de J. C. ). Recueil de nolices sur les Compa- guons, les Tàbiéoun et les personnages les plus remarquables par leur piété et par la sainteté de leur vie. Le présent ms., premier volume de l'ouvrage, commence par la vie d'Aboû Bakr et finit par celle de Solyân al-Thauri. It renferme cent trois articles, dont les titres sont indiqués sur le feuillet de garde. Le second volume devait contenir trois sections, dont la première traite des femmes distingucées par leur sainteté; la seconde, de certains dévots dont on ignorait les vrais noms, et dont la troisième renferme deux notices biographiques, celle de Noûr al-Dìn el celle de son sucresseur, Șalàṭ al-Dìn (Saladin). L'auteur déclare que son ouvrage n'était qu'un abrégé du صغوة الصغوة d'Aboû 'l-Faradj 'Abd al-Raḷmân ibn alDjauzi, ourrage qui, lui-même, n'est qu'un extrait du حلية الاونياء d'Aboù Noóaïn al-Iṣfahıàni. Hadji Khalfa donne à l'ouvrage de Mohammad al-liosainni le titre de rollection de renseignements sur les miérites des saints $\%$. En tête du volume se trouse le dix-neuvième feuillet d'un traité de mélaphysique. Ms. daté de l'an 994 de l'hégire (1586 de J. C.).

Papier. 140 feuillets. Hauteur, 31 centimètres et demi; largeur 21 centimètres el demi. 35 lignes par page. - (Supplénıent $65_{9}$.)

\section{3.}

La Fleur odorinte, ourrage trailant de ceux qui ont évité le péché el les turpiludes \%. Ce trailé de morale, qui se compose d'histoires de quelques saints, de traditions, d'exhortations et de pièces de vers, est attribué au célèbre prédicateur et polygraphe Aboû '1-Faradj 'Abd al-Rạ̣mân ibı

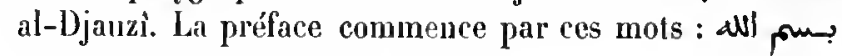
ابتهاءى وبكتابه اتتحأهى وبنبيّه أهتحأىى.

Papier. 52 feuillets. Hanteur, 21 centimètres; largen:, 15 centimètres. 23 lignes par page. Ms. du $x \mathbf{1}^{\circ}$ siècle. - (Supplément 64.4.)

\section{4.}

Autre rédaction du mème ourrage. En tête du volume on lit deux prières, et à la fin un sermon et une prière.

Papier. 9o feuillets. Hauteur, 21 centimètres; largeur, 16 centimàlres. 15 lignes par page. Ms. du xvı' siècle. - (Supplément 645.)

\section{5.}

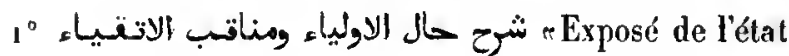


des saints personnages et mérites des hommes pieuxn. Anecdoles concernant les principaux saints de l'islamisme.

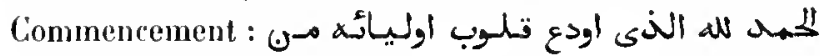
لطيغ حكته النمرأ.

$2^{\circ}$ (Fol. 29.) Deux feuillets détachés d'un recueil d'anecdotes, dont un chapitre est intitulé قيل في التقلم الميغ منتشورا plume et de l'épéer.

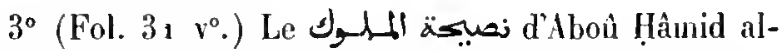
Ghazàli, traduit du persan en arabe par un anonyme.

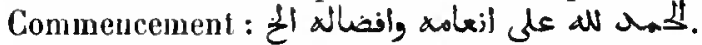

Papier. 103 feuillets. Hauteur, 2a centimètres; largeur, 15 centimètres. 19 lignes par page. Ms. du xviri siècle. - (Supplément 2055.)

\section{6.}

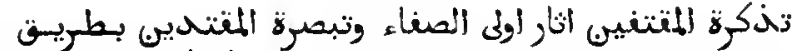
ride-ménoire de ceux qui marchent sur les traces des gens de la pureté et indicateur pour ceux qui suicent la voie d'Aboù ' $I-$ Wafà Tàdj al'Àrifin (Couronne des hommes qui ont obtenu la connaissance parfaite de Dieu)r. Cet ouvrage, qu'on désigne

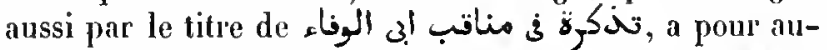
teur un nommé Schibîb al-Dìn Aḥmad ibn 'Abd al-Mon'im al-Schabrisi al-Wàsiti. C'est une histoire très détuillée de Tádj al-Àrifin Aboù '1-Wafà Moḷammad, saint personnage qui était parvenu à une très-laate station dans la vie spirituelle. Né à Koùsàn, ville située dans cette partie du Kurdistân qui touche an Zảb supérieur, il mou-

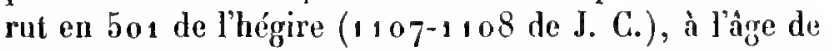
quatre-vingt-trois ans. La seconde partie de l'ouvrage traite des parents d'Aboù 'l-IVafà, de son directen' dans la voie spirituelle, le schaikh al-Schanbakî (النُنبكى) et de ses disciples. On y trouve beancoup d'exhortations, de poésies morales el d'anecdotes édifiantes. Le présent ms. se compose de deux volumes, reliés ensemble; mais le dernier feuillet du premier volume manque. Ms. daté de l’an 878 de l'hégire (1473-1474 de J. C.).

Papier. 189 feuillets Hauteur, 27 centimètres; largeur, 18 centimètres. 29 lignes par page. - (Supplément 642.)

\section{7.}

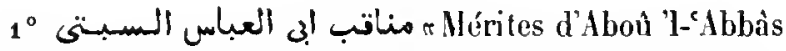
(Ahmad ibn Djaćfar) al-Sabtì», par Yoủsof ibn Yaḥyâ ibn 'Îsâ al-Schàdsili. Aboù 'l-' Abbàs al-Sabtì, mentionné dans les Prolégomènes d'lbn Khaldoûn, était né à Ceuta et est mort dans cette ville, en 601 de l'hégire (1204-1205 de
J. C.). Copie datée de l'an 1152 de l'hégice $\left(17^{3} 9 \cdot 1740\right.$ de J. C.).

$2^{\circ}$ Fol. 3o. (Guide pour l'aspirant vers la voie louable", par Molyanmad al-Bakrì.

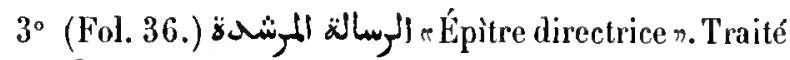
de soufisme.

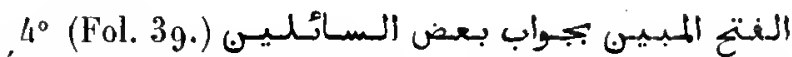
"Éclaircissements en réponse à un questionneur $r$. Traité de soufisme, par le schaïkh Moḥammad ibn abì 'l-ḷ̂osaïn al-Ṣiddìnì.

5 Fol. 42. (لمسالة النفاصوية Traité de soufisme, par le même auteur.

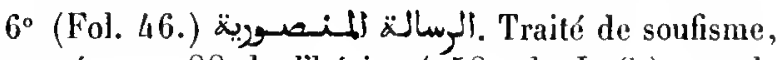
composée en $9^{88}$ de l'hégire ( 1580 de J. C.), par le mème.

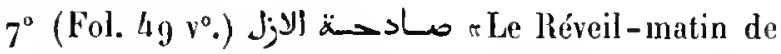
l'éternitén, par le mème.

Papier. 58 fenillets. Hauteur, 19 centimètres; Jargeur, 13 centinètres et demi. 17 d̀ 19 lignes par page. Ms. du xrute siècle. - (Supplément 641.)

\section{8.}

Splendeur des mystères et nines de lumières \%. Histoire, discours et miracles du grand saint nusulmau, Mohyì al-Din 'Abd al-Qàdir alDjillì ou al-Djîlâni, pall' 'Alì iłn Yoûsof ibn Djarîr (ou Hariz? (حوي,) ibn Micdhid ibn Fadhl. (Voyez sur' 'Abd alQidir al-Djiłài, le Dictionnaire d'lbn Khatlikàn, traduction anglaise, t. Il, p. 172.) Cet ouvrage a été composé après l'an $67^{1}$ de l'hégire (Préface, fol. $2 v^{\circ}$ ). La seconde partic traite de l'histoire des docteurs les plus distingués dans l'ordre des derviches soufis fondé par AlDjilànì. Commencement : استغتح بنب العون بايهى محاميح عز

Ms. daté de l'an $99^{8}$ de l'hégire ( 1590 de J. C.).

Papier. 282 feuillets. Hauteur, 21 centimètres; targeur, 15 centimètres et demi. 21 tignes par page. - (Supplément 1959.)

\section{9 .}

Même onvrage. $\Lambda$ la fin on lit une épitre adressée par 'Abd al-Qàdir à un de ses disciples.

Ms. daté de l'an 1008 de l'hégire ( 1600 de J. C.).

Papier. 252 feuitlels. Hauteur, 28 centimètres; targeur, 21 centimètı es. 19 ligaes par page. - (Ancien fonds 744.) 


\section{0.}

C Jardin de plantes odoranles, renfermant des récits concernant les hommes saints \%, par 'Alyd Allah ibn As'ad al-Yäfici al-Yamani, morl, selon Iirdji Khalfa, en 768 de l'hégrire (1366-1 367 de J. G.). L'ouvrage est divisé en cinq chapitres qui conliennent des histoires édifiantes, des légendes et des pièces de ver's, au nombre de cing cents, se rapporiant aux ancieus patriarches el aux saints personnages de l'islamisme. L'auteur dit dans la préface quiil avait donné à

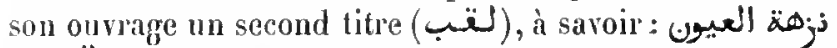
Délices des yeux qui contemplent (Dieu) et cadeau pour les cours qui sont en si présencen. Hs. daté de lan 909 de l'luégire (1503 de J. C.)

Papier. 291 feuillets. Hauteur, 22 centimètres; largeur, 15 centimètres et demi. 17 lignes par page. - (Ancien fonds 854.)

\section{1.}

Mème ouvrage. Ms. daté de l'an 1122 de l'hégire ( 1710 de J. C.).

Papier. 154 feuillets. Hauteur, 30 centimètres; largenr, a 1 centimètres. 34 lignes par page. - (Supplément 638.)

\section{2.}

10 "Vies des saintes femmes vertueuses et croyantes $»$, par Taqi al-Dín Aboû

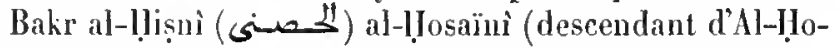
sitin). Louvrage est suivi de deux appendices, dont le

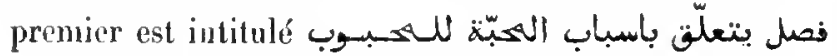
"Trailé sur les causes qui conduisent à l'amour de Dieu",

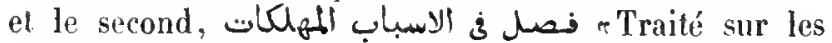
causes qui amènent la perte de l'àmen. C'est un exposé des vertus et des vices.

سمبر السـالم كies de eeux qui ont marché dans le plus excellent des sentier's $n$, par Taqî al-Din al-ḷlișni. Ce sont des conseils et des exhortations.

Le mis. porle la date de 875 de l'hégire ( 147 de J. C.) (voyez fol. 83 ), mais il parail ềlre du xy e siècle.

Papier. 90 fevillets. Hauteur, 21 centimètres el demi; largeur, 15 centimètres et demi. 21 lignes par page. - (Ancien fonds 855.)

\section{3.}

Traité des mérites éminents du célèbre ascète Dsoû 'l-Noûn al-Miṣrì (Aboù 'l-Faidhl Thaubân ibn lbrâhìm), né à Iklımìm, en Égypte, et mort dans ce pays, d’après Aboû 'l-Maḷâsin, en l'an 245 de l'hégire $(859-860$ de J. C.). Le premier feuillet manque et le recto du second feuillet a élé recouvert d'un feuillet contenant une préface apocryphe, précédée d'un litre où on lit encore ces

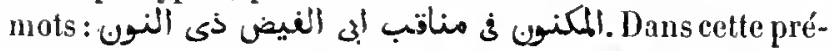
face, l'onvrage est attribué à un certain Mlḷammad ibn

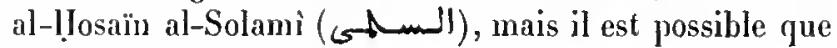
l'auteur soit Al-Soyoûtì.

Ms. daté de l'an $99^{4}$ de l'hégire (1586 de J. C.).

Papier. 62 feuillets. Ilauteur, 21 centimètres; largeur, 15 centimètres. 21 lignes par page. - (Supplément 640.)

\section{4.}

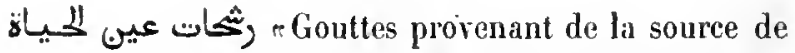
la vie ", par 'Alì, fils de Ḥosain Wảiz al-Kàschifí. Cet ouvrage, composé en persan, en 909 de l'hégire (15031504 de J. C.), a été traduit en arabe, en 1029 de l'hégire (1620 de J. C.), par Tàdj al-Din ibn Zakariya ibn Soltàn, derviche de l'ordre des Naqschbendis. Ce sont des notices biographiques sur les derviches les plus re-

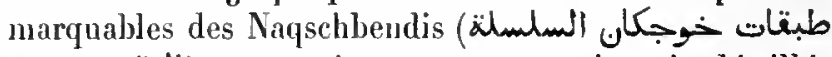
النتشنبنديسة), se terminant par une notice très-détaillée (fol. 135 et suiv.) sur le klıdja Nâsir al-Dìn 'Obaïd Allâh

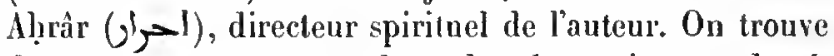
dans cet ourrage un grand nombre de naximes et de réflexions morales, recueillies parmi les religieux de cette confrérie et porlant chacune le titre de $\ddot{x}$; "goutter. La préface du traducteur commence par ces mots : له alle de

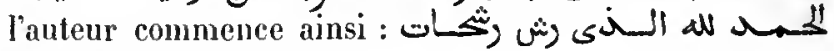
㺼

Ms. daté de l'an 1119 de l'hégire (1 707 de J. C.).

Papier. 202 feuillets. llauteur, 22 centimètres et demi; largeur, 15 centimèires. 25 lignes par page. -- (Supplément 664.)

\section{5 .}

م لوأح الانوار خ طبنات الاخيار dent ou classes d'hommes saints », par 'Abd al-Wahhâb ibn Aḷmad al-Sclua rûuî. Notices des dérots, des ascètes 
et des soufis de l'islamisme des neuf premiers siècles de l'hégire. Ces notices, qui sont an nombre de plus de quatre cents, ne contienment ordinairement que les traits de sainteté qui distinguaient les personnages et les paroles et maximes qu'on leur atiribuait. La préface commence par

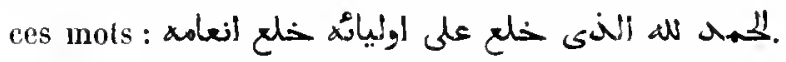

Is, autographe, daté de l'an 952 de lhégire (1 545 de J. C.), sauf $7^{5}$ feuittets, ajoutés en $119^{1}$ de l'hégire (1777 de J. C.).

Papier. 301 fenillets. Ilauteur, 19 centimètres et demi; largeur, 15 centimètres. 23 à 24 lifnes par page dans la partie ancienne, 30 à 3a dans la partie moderne. - (Supplément 646.)

\section{6 .}

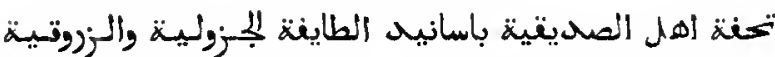
"Cadeau offert aux lommes integres, renfermant la fifiation des docteurs appartenant à l'ordre d'Al-Djozoûti et d'Al-Zarroû $\rceil$ n, ouvrage composé en 1 o go de l'łégire ( 679 de J. C.), par Moḷammad al-Mahdi ibn Mḥmad al-Fàsi. Al-Djozoưlì (Mohammad ilon 'Abd al-Rạımân ilon abì Bakr), et Al-Zalrounq ( l!mad ibn Aḷmad al-Bornosì alFàsì), avaient été les chufs dime branche de l'ordre des derviches schàdsilites du Maghreb, au viı siècle de l'hégire. Ce Iraité renferme une notice sur ces deux schaikhs et la liste chronologique de leurs disciples.

Ms. daté de l'an 1228 de l'hégire (1813 de J. C.).

Papier. 48 feuiltets. Ilauteur, 21 centimètres et demi; largeur, 15 centimètres et demi. 25 lignes par page. - (Supplément 642 bis.)

\section{BIOGRAPHIES GÉNÉRALES.}

\section{7.}

Fragments de généalogies arabes, probablement du - Collection des généalogies », de Hischàm ibn Mohanmad al-Kalbi. En comparant le texte de ces fragments avec le Kitúb, al-Ma'ârif d'Ibn Qotaïba, on reconnait que cet auteur s'en était servi, en faisant quelques changements dans la rédaction. Ce ms., écrit en caractères coufiques, est probablement de la fin du $n^{e}$ siècle de l'hégire. Les traits diacritiques sont contemporains du texte.

Vélin. 13 feuillets. Hauteur, 22 centimètres; largeur, a 9 centimètres et demi. 13 à 15 lignes par page. - (Supplement 655 lis.)

\section{8.}

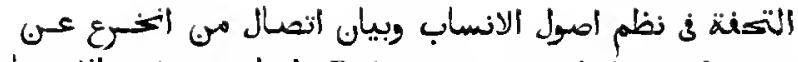
م Présent pour servir à coordonner les principes de la science généalogique et pour faire reconnaitre la filiation des persomnages distingués qui ont perdu les traces de leur origine ${ }^{2}$ Génćatogies des trilsus arabes, composées par un schaléite, descendant d'Al-Ha-

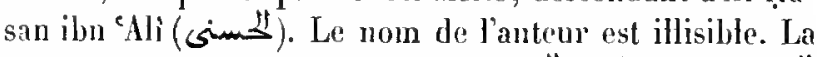

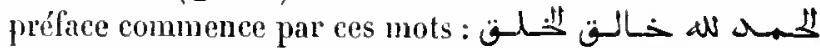
. Le ms., daté de l'an 659 de lhégire (1261 de J. C.), est antographe. L'écriture est dépourvue de joints diaeritiques.

Papier. 204 fenillels. Hauteur, 20 centimètres; largeur, 14 centimètres. 17 lignes par page. - (Supplément 655 ter.)

\section{9}

Tout ce dont on peut aroir besoin pour bien connaître les génćalogies des Arabes", par Mot!ammad ibn N!̣mad ibn "Nbd Allalı alGalqaschandi (né à Qałqaschand, près du Caire) alSehâfici. Lauteur dit dans ta préface quil a composé ce volume pour l'usage de Zain al-Dìn Aboû 'L-Djoûd Baqr (ب̈) ibn Râschid al-Zaini, grand émir des Arabes nomades des contrées orientales et occidentales. L'onrrage commence par une introduction, divisće en cinq chapitres, qui traite des connaistances récessaires à quiconque veut s'oceuper des généalogies. Le quatrième chapitre énumère les localités que les Arabes oceupaient dans les temps anciens. Vient ensuile une section inti-

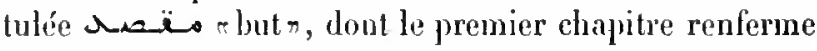
la généalogie dn P'rophète. La seconde partie de l'ourrage est un dictionnare alphabétique, renfermant les noms des diverses branches de chaque tribu. La conclusion, divisée en einq chapitres, traite des croyances religienses des Arabes avant l'islamisme, des discussions qui eurent lien entre les tribus, an sujet de leur noblesse, de leurs journées et combats, de certains feux qu'elles allumaient et de leurs foires et autres réunious. Ce ms., autographe, est dalé de l'an 846 de t'hégire (1/42-1443 de J. C.). A la fin du volume se trouve la signature de Schams al-Din Moḷammad ilon Qàsim al-Zaïnì, petit-fils de l'émir pour lequel Al-Qalqaschandi a composé cet ouvrage.

Papier. ${ }_{18} 8$ feuillets. Hauteur, 26 centimètres et demi; largeur, 18 centimètres. 21 lignes par page. - (Supplément 655.) 


\section{0.}

r Les Décès des hommes illustres et renseignements sur les enfants des sièclesn, diclionnaire biographique, par Schams al-Din Aḷmad ibn Nohammad lbn Khallikìn, mort en 681 de l'hégire (1 $28_{2}$ de J. C.). Ce volume renferme les passages qui ne se trouvent pas dans tous les exemplaires.

Ms. daté de l'an $99^{2}$ de l'hégire (1584 de J. C.).

Papier. 516 fenillets. Hauteur, 29 centimètres et "demi; largeur, so centimètres. 39 lignes par page. - (Ancien fonds 730. )

\section{1.}

Même ouvrage.

Papier. 310 feuillets. Hauteur, 35 centimètres; largeur, 21 centimètres. 33 lignes par page. Ms. du xvi $^{\circ}$ ou du xvı siècle. - (Supplément $70 \%$ )

\section{2 et 2053.}

Premier et troisième volumes d'un exemplicire du mème ouvragge. Le premier volume finit par la lettre J; l'autre volume commence par l'article $J^{0}$ g, et se termine par la vie de Yoûsof ibu Hâroûn al-Kindì, suivie d'une notice biographique de l'auteur.

3 vol. Papier. 354 et 266 feuillets. Hauteur, 27 centimètres et demi; largeur, 19 centimètres. 21 lignes par page. Ms. du xvis siècle. - (Ancien fonds $7^{5} 1 \mathrm{~A}$.)

\section{4.}

Première partie du même ouvrage. Ce volume, qui s'arrête à la lettre w, a été collationné sur trois inss. et porte plusieurs additions, les unes en inarge, les autres sur des onglets.

Papier. ${ }_{2} 51$ feuillets. Hauleur, 18 centimètres; largeur, 14 centimètres. 21 lignes par page. Ms. du $x^{\circ}$ siècle. $-($ Ancien fonds 864.)

\section{5.}

Première partie du même ouvrage, se terminant par l’article غيلان بر عتبة. Au cơmmencement et à la fin du volume se trouvent deux courtes notices sur l'auteur et quelques recettes talismaniques.

Papier. 364 feuillets. Hauteur. 26 centimètres et demi; largeur, 15 centimètres. 27 à 33 lignnes par page. Ms. du xvo siècle. - (Supplément 700.)

\section{6.}

Première partie du mêne ourrage, s'arrètant au commencement de la leltre $\Lambda$. Ms. daté de l'an 1048 de thégire ( $1638-163_{9}$ de J. C. $)$.

Papier. 220 feuillets. Hauteur, 21 centimètres; largeur, 15 centimètres. ${ }_{7}$ lignes par page. - (Supplément 701.)

\section{7.}

Première partie du même ouvrage, se terminant par l'article ظافر بـ التقاسم. Ns. daté de l'an 1065 de l'hégire (1655 de J. C.).

Papier. ${ }^{6} 67$ feuillets. Hauteur, 29 centimètres et demi; largeur. go centimètres. 25 lignes par page. - (Ancien fonds $7^{31}$.)

\section{8.}

Mềne ouvrage, volume commençant par le prenier

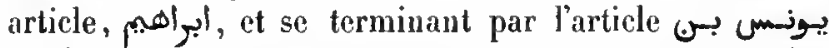
aـ. Le post-scriptum de l'auteur est omis. On a joint au volume une table des matières, écrite par Nichel Șabbâgh.

Papier. 434 feuillets. Hautenr, 32 centimètres; largeur, 21 centimètres. 43 lignes par page. Mis. du $x^{\circ}$ siècle. - (Supplément 702.)

\section{9.}

Second volume du inême ouvragge, commençant par la lettre $\varepsilon$ et finissant par la lettre $J$.

Papier. 203 feuillets. Hauteur, 26 centimètres; largeur, 18 centimètres et demi. 21 lignes par page. Ms. du $x_{1 v^{\circ}}$ ou du $\mathbf{x v}^{\circ}$ sièele. (Supplément 705.)

\section{0.}

. مختسصر الانسباء. Abrégé du Dictionnaire biographique 
d'lbn Khallikàn (dont le second titre est انسبـاء ابسنسـاء) (الزمان). L'auteur, 'Alî̀ ibn Ya'qoûb ibn 'Alì ibn al-Wall ibı̊ al-Bàrizî, natil de H̦amailı, dit, dans une note finale, quiil a terminé cet ourrage le dernier mois de l'année 751 de l'hégire (janvier 1351 de J. C.). Le ms., probablement autograple, est d'une belle ćcriture cursive; les points diacritiques sont très-sourent omis, et l'encre est presque effacée en plusieurs endroits par l'humidité. La préface commence par ces mots :

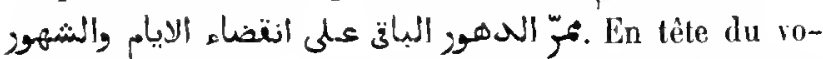
lume se troure nue liste des notices qu'il renferme, et a lal fin une copie du لامية النجم d'Al-Ṭoghraiï, un extrait du Kitâb al-Mádirif d'llbm Qotaiba; et quelques notes peu importantes.

Papier. I 38 feuillets. Hauteur, 27 centimètres et demi; largeur, so centimètres et demi. 26 à 41 tignes par page. Hs. du xiv siècle. - (Supplément jo3.)

\section{1 .}

تنال كتاب وفيات الاعيار. Continuation du Dictionnaire biographique d'llon Khallikàn, par Al-llowaffaq Fadbl Mlah ibn abì 'I-Fakh" al-Șaqấi. Cet ouvrage denferme des notices, disposées dans l'ordre de l'alphabet, sur les personnages remarquables de l'sigy,te et de la Syrie, morts entre les années 660 et 715 de lhégire, ainsi qu'un nécrologe des années 717 à 725 de l'héggire. Ce ms. a appartenu à Khalil ibn Aibek al-Şafadi, comme on le voit par une note, prohablement antoggraphe, en tête du volume.

Ms. daté de l'an 733 de l'hégire (1332-1333 de J. C.).

Papier. 100 feuillets. Hauteur, 25 centimètres; targeur, 18 centimètres. 21 lignes par page. - (Aneien fonds 732.$)$

\section{2.}

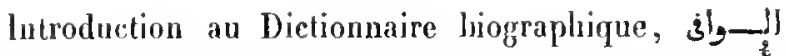

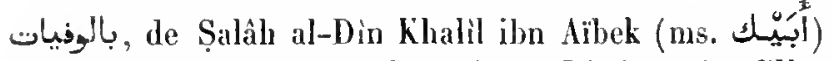
al-Şaladi. Ce dictionnaire fait suite au Dictionnaire d'lbn Khallikàn. Hadji Klralfa, à l'article بـ place la mort de Klaalil ibu Aỉbek en l'an 749 de l'lȩ́rire (1348-1349 de J. C.); mais, à l'artirle الوأi, il indique l'an 764 . Dans le long article que l'auteur d'Al-Manhil al-Șífi a consacré à Khalil ibn Aillek, nous lisous (ms. arabe de a Bibliotlièque nationale, $\mathbf{n}^{\circ}{ }_{20} 7^{\circ}$, fol. 59 ), qu'il mourut à Damas, le 10 schawwâl de l'an 764 .

Papier. ${ }_{2} 7$ feuillets. Hauteur, 26 centimètres; largenr, 19 centi-

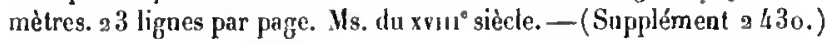

\section{3.}

Copie moderne du ms. précédent.

Papier. 34 feuillets. Hauteur, 30 centimètres; largeur, a3 centimètres. sa lignes par page. - (Supplément s431.)

\section{4 .}

Volume dépareillé du Dietionnaire biographique de Khalil jbn Aïbek al-Șafadi. Le nom de l'auteur est écrit,

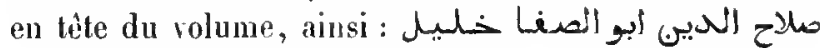
. Ce volume, écrit du visaut de l'auteur, renferme, d'après la souscription, la luitiome خاتون بنت

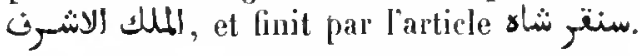

Papier. 197 feuiltets. Hauteur, 27 centimètres; Iargeur, 19 centimètres. 25 lignes par page. - (Supplément jo6 bis.)

\section{5.}

Antre volume dn mème ourrage. Les premiers feuillets mancuent. Ce volume qui, d'après la souscription, renferme la quinzième partie, commence par l'article سعيد

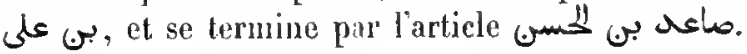

Papier. $18_{7}$ feuillets. llauteur, 28 centimètres el demi; largeur. 18 centimètres et demi. 19 lignes par page. Ns. du xuv siècte. (Supptément jo6.)

\section{6.}

Autre volume du mème ouvrage, renfermant trois parties : la quinzième, la seizième (fol. 99) et la dix-septième (fol. 203). Le premier article est عبادة بن الصامت (c)

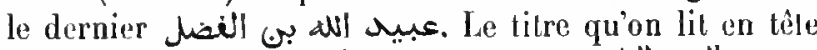

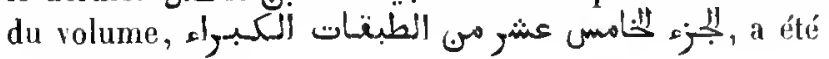
ajouté après coup.

Papier. 307 feuillets. Hlauleur, 39 centimètres; largeur, su centimètres. 29 lignes par page. Ms. du xvu' siècle. - (Supplément 2432.)

\section{7.}

Roucoulement des tourterelles qui eut lieu entre celui qui avait commencé 
(la correspondance) el celni qui lui avait répondus. Notices biographiqutes dos littérateurs avec lesquels l'auleur, Khalil ibn lïlek al-Silfadi, avait élé es correspondance. Ms. dalé de l'an 1004 de l'hégire (1596 de J. C.).

Papier. 949 feuillets. Hauteur, 20 centimètres el demi; largeur, 14 centimètres. 25 Jignes par page. - (Supplément 698.)

\section{8 : 2072.}

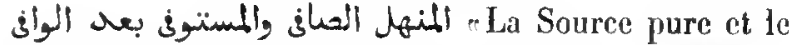
complément du Supplément s, par l'émir Aboû 'l-Malıìsim Yousof ilon Taghri Bardi. Diclionnaire biographique qui fait suite au Dictionnaire de Khalil ibn Aibek al-Ṣafadi. Le présent exemplaire, dont le sixième et dernier volume manque, a été transcrit pour l'usage de l'auteur.

Le tome I commence par la liographie du sultan mamlouc 'Tzz al-Din Aibek, et finit par le nom de أقطوأن.

Le tonte II commence par le nom de $s_{y}$ et finit par le nom de ${ }_{\text {r }}$.

Le tome Ill commence par le nom de Jü a et finit par le nom de $a$ sb.

Le tome IV commence par l'article

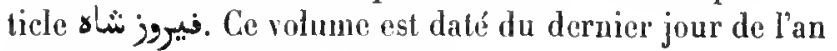
855 de l'hégire (1452 de J. C.).

Le tome V commence par le nom de 1 , et finit par l'article Moḷammad ibn Mohammad. Ce volume est daté du commencement de l'au 856 de l'hégire (février 1452 de J. C.).

On a ajouté à charque volume la liste des notices qu'il renferme. Ces tables sont de la main de Michel Şabbâgh.

5 vol. Papier. $210,207,194,223$ et 207 feuillels. Hauteur, a 7 cen. limèlres; largeur, 19 centimètres. 23 ligues par page. - (Ancien fonds 747 à 751.$)$

\section{3.}

Table des articles contenus dans le premier volume du ill Jion.

Papier. 14 feuillets. Hauteur, a a centimètres; largeur, 17 centimètres. 29 lignes par page. Ms. du xix $x^{\circ}$ siècle. - (Supplément 2280.)

\section{4.}

Volume détaché d'un nécrologe disposé par périodes de dix ans. Le présent ms. renferme la trente-sixième ef la trente-septième période. Chaque période commence par une table, divisée en sept comparliments, dont te premier reuferme le non du calife régnant; le second les noms des cadis morts dans cette période; le troisiène les noms des légistes; le quatrième ceux des lecteurs; le cinquième ceux des traditionnistes; le sixième ceux des soufis, et le septième ceux des hommes de leltres. Ces notices nécrologiques sont suivies de l'énumération des. événements politiques ou autres de la période de dix ans. Il parait, d'après le catalogue de la Bibliothèque royale de Munich, page 142, qu'au moins une partie des Annelles de l'islamisme d'Al-Dsahabi était rédigée par périodes de dix ans. L'ouvrage donl le présent rolume n'est qu'un fragment, a été composé postérieurement au vı siècle de l'hégire; car le Dictionnaire biographique d'Ibu Khallikản y est cité (fol. $45 \mathrm{v}^{\circ}$ ).

Papier. 75 feuillets. Hauteur, 26 centimètres; targeur, 16 centimètres. 17 liggnes par page. Its. du xiv" sièele. - (Supplément 694.)

\section{5.}

Ambiguités des noms propres d'hommes et des patronymiquesn, dictionnaire orthograplique de noms propres, par Schams al-Dìn Moḷanmad ibn Ạ̣mad at-Dsahabi, mort en 748 de l'hégire (1347-1348 de J. C.). Ce volume, copié du vivant de l'auteur et lu en sa présence, est accompagné de six certificats de lecture el d'audilion.

Papier. 234 fenillets. Hauteur, 19 centimètres; largeur, 13 centimètres el demi. 19 liggnes par page. Ms. du xiv ${ }^{\circ}$ siècle. - (Ancien fonds 862. .)

\section{6.}

Notices biographiques, tirées des dictionnaires et de la Chronique d'Al-Dsahabi, et transerites pour son propre usage par Ibn Qâdhî Schohba :

1. Notes biographiques.

2. (Fol. 44.) Articles nécrologiques des années 741 à $77^{6}$ de l'hégire.

3. (Fol. $66 r^{\circ}$.) Notices biographiques de docteurs schaféites et autres, tirées du مأكم الكبير d'Al-Dsahabî.

4. (Fol. 143.) Biographies des docteurs schaféites, tirées du même ouvrage. Elles se rapportent aux années 640 à 699 de l'hégire. 
5. (Fol. $183 v^{\circ}$.) Biographies de personnages marquants des années 640 à 700 de l'hégire, tirées de la Chronique d'Al-Dsahabî.

Ms. autographe, dépourvu de points diacritiques.

Papier. 284 feuillets. Hauteur, 18 centimètres et demi; largeur, i4 centimètres. 19 ligres par page. Ms. du $8 v^{\circ}$ siède. - (Ancien fonds 872. )

\section{7.}

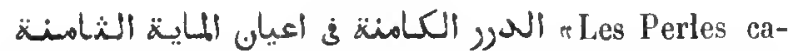
chées, notices biographiques des personnages marquants du vıI' sièclen, par Schihâb al-Dìn Ạ̣mad ibn 'Alì ibn Hadjar al-'Asqalànì. Les noms sont disposés dans l'ordre de l'alphabet. Le présent volume, le premier de l'ourage, finit par l'arlicle عطيّة. L'auteur énumère ses sources, dans une courte préface, qui commence par ces mots :

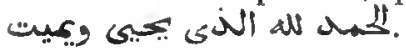

Papier. 228 feuillets. Hauteur, 27 centimètres; largeur, 18 centimètres. 29 lignes par page. Ms. du sv siècle. - (Supplément 675.)

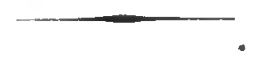

\section{8.}

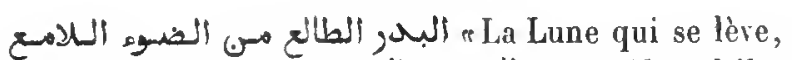

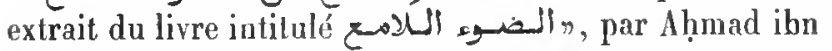
Mohammad ibn 'Abd al-Salâm al-Manoûfí. L'ouvrage intitulé الضوء l, de Schams al-Din al-Sakhấwî, est un dictionnaire biographique des hommes illustres du $\mathrm{Ix}^{\mathrm{e}}$ siècle de l'hégire. Ibn 'Abd al-Salâm dit avoir rédigé cet abrégé, qui ne renferme que les articles les plus importants de l'ouvrage de Sakhâwi, en 9o5 de l'hégire (1499-1500 de J. C.), à la Meeque. Conimence-

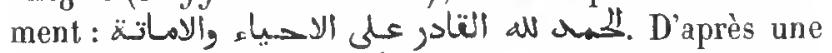
note qu'on lit au verso du dernier feuillet, ce ms. est antérieur à l'an $9^{41}$ de l'hégire (1534-1535 de J. C.). Notes marginales, dont quelques-unes très-étendues.

Papier. 88 feuillets. Hauteur, 27 centimètres et demi; largeur, 18 rentimètres et demi. 29 lignes par page. - (Supplément 2080.)

\section{9.}

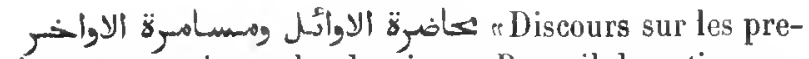
miers el causerie sur les derniers n. Recueil de notices sur les personnages qui, les premiers ou les derniers, ont. accompli certains acles. Liauteur, désigué sur le frontispice par les noms d' 'Alì Qàrì (مولى على قارى), dit avoir

$$
\text { Man. orientaus. - } 11 \text {. }
$$

pris pour base de son travail l'ouvrage d'A1-Soyoùti sur le même sujet; il en a fait d'abord un abrégé, puis il a ajouté de nouveaux renseignements. La préface commence

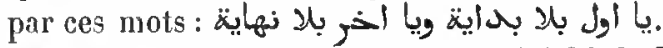

Ms. dalé de l'an 996 de l'hégire ( 1588 de J. C.).

Papier. 155 feuillets. Hauteur, 21 centimètres et demi; largeur, 15 centimètres. 19 lignes par page. - (Supplément 653.)

\section{0.}

Autre rédaction du même ouvrage, commençant par ces mots : باسِ الاول الاخر المباطى الظاهر. On lit en tête du

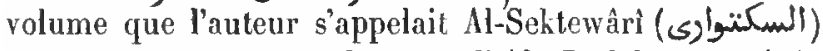

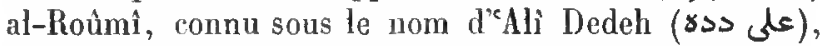
schaïkh d'Aiya-Soufia (Sainte-Sophie), à Constantinople.

Ms. daté de l'an 1125 de l'leégire (1713 de J. C.).

Papier. 258 feuillets. Hauteur, 21 centimètres; largeur, 15 centimètres. 23 lignes par page. - (Supplément 654.)

\section{1.}

Recueil de nolices biographiques des personnages les plus célèbres de l'islamisme. Ces articles, généralement très-courts, ne sont disposés ni dans l'ordre de l'alphabet ni dans l'ordre chronologique. Le ms., d'une assez bonne écriture, apparemment européenne, n’a pas été achevé. Le premier article, consacré à Mahomet et rédigé évidemment par un clırétien, ne renferme que les principales dates de la vie du Prophète; le second article Iraite d'un docteur musulman, né à Amasia, en 864 de l'hégire (1459-1460 de J. C.).

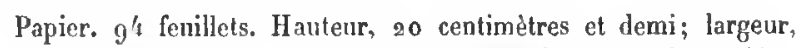
15 centimètres et demi. 14 lignes par page. Ms. du xvin' siècle. - (Ancien fonds 865.)

\section{2.}

Dictionnaire biographique des savants musulmans, composé, en arabe et en français, par Armain, d'après les notes marginales qui se trouvent dans l'exemplaire du , الاخديـار de la Bibliothèque nalionale. Ms. autographe.

Papier. 65 feuillets. Hauteur, 32 centimètres et demi; largeur, 21 centimètres, 20 lignes par page. Ms. dn xvin siècle. - (Supplément 2291.) 


\section{3.}

"La Crême des renseignements sur les personnages marquants du $x^{\circ}$ siècle». Dictionnaire hiographique, disposé dans l'ordre de l'alpliabet, par Moḷammad Amîn, surnommé Al-Aınin alSchàmì ct al-- mîn al-Mohibbî, fils de Mohilib al-Dìn ibn abi 'l-Fadhl. L'anteur, dont le nom ethnique était Al-'Olwàni, originaire de la ville de Hamâh, est mort à Damas, en 1111 de l'hégire ( 1699 de J. C.). Ces renseignements se tronvent écrits sur le recto du premier feuillet du volume. Ms. daté de l'an 1106 de l'hégire $(169 / 1-1695$ de J. C.).

Papier. 6.5 fenillets. Hauteur, 30 centimètres et demi; largeur, 18 centimètres et demi. 33 lignes par page. - (Supplément 6-6.)

\section{BIOGRAPIIES SPÉCIALES.}

\section{4.}

rive faisant connaitre l'histoire des grands lecteurs, biographies classées dans l'ordre cluronologiquen, par Scliams al-Din Aboû 'Abd Allah Mohammad ibn Aḷmad ibn 'Othmân ibn al-Dsahabi, mort en 748 de l'hégire (1347-1348 de J. C.). L'ouvrage commence par l'article 'Othnân ibn "Affàn, el se termine par une notice sur un lecleur espagnol, lbn al-Zayyàt Aḷmad ibn al-Hasan al-Kalà'i, de Velez (ب̂ش), mort vers 730 de l'hégire (1329-1330 de J. C.). Ce ms., écrit du vivant de l'auteur (roy. au fol. $1 \mathrm{v}^{\circ}$, ligne 3 , les mots all 8,5 ), a été collationné sur l'exemplaire de l'auteur.

Papier. 2/a feuillets. Hauteur, 27 centimètres; largeur, 18 centimitres et demi. 23 lignes par page. - (Ancien fonds 742 .)

\section{5.}

Questions adressées par Aboù 'Obaid Mlohammad ibn

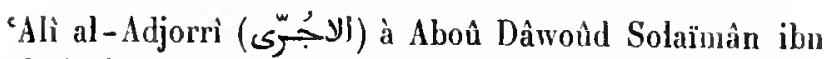
al-Asch ath al-Sidjistảni, célèbre traditionniste, mort, selon Ibn Khallikân (vol. 1, p. 590 de la traduction), en $27^{5}$ de l'hégire. Ces questions sont relatives aux différents traditionnistes et à l'authenticité de leurs tradilions. C'est le texte dicté par le haff: A ḥmad ibn Moḷaminad al-Silafi, mort en 576 de l'hégire ( 1180 de J. C.), ì ses auditeurs (voyez lbn Khallikân, tome I, p. 86). Ce volume, le second d'un exemplaire qui devait se compo- ser d'au moins trois volumes, renferme la quatrième section de l'ouvrage et la cinquième, consacrée aux traditiomnistes d'Aïla, de Damas, d'Édesse, des frontières de la Syrie, de Ramla, de Harràn, de la Mésopotamie septentrionale, de Raqqa, de Mossoul et de Baghdâd.

$A u$ fol. 17 on lit un certificat de lecture qui commence

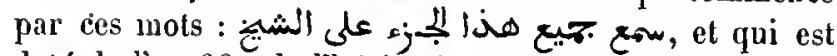

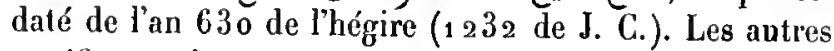
certificats qu'on trouve dans le volume ont été copiés dans le ms. original.

Papier. 68 feuillets. Hauteur, 19 centimètres et demi; largeur, ${ }_{1} 3$ centimètres et demi. 17 lignes par page. Ns. du xuI' siècle. - (Ancien fonds 866. )

\section{6.}

Dictionnaire des traditionnistes, par 'Abd Allah ibn 'Abd al-Raḥmân ibn Djozayy, qui a achevé ce volume en 562 de l'hégire ( 1167 de J. C.). C'est une nouvelle édition de l'ouvrage cité par Hadji Khalfa, sous le titre de اسمبـاء (Noms des hommes dont l'autorité est citée dans le Sahih d'Al-Bokhàrîn, et qui a pour auteur 1lıoù Nași A ḅmad ibu Moḥammad al-Kalâbâdsì, mort en 398 de l'hégire (1007-1008 de J. G.). Ms. autographe.

Papier. 164 feuillels. Ilauteur, 26 centimètres et demi; largenr, 17 centimètres et demi. 25 lignes par page. Ms. du $x u^{\bullet}$ siècle. (Ancien fonds 736 .)

\section{7.}

Volume dépareillé (le vingtième d'un exemplaire divisé en quarante volumes) d'un dictionnaire des traditionnistes. Les premiers feuillets manyuent. Le ms. commence au milien de la notice sur Ilon abì 'l-'Aschrìn 'Abd al-llamid ibn Habib, et se termine par la notice sur ${ }^{\circ} \mathrm{Abd}$ al-Raḥmån ibn 'Abd Allah Aboû 'I-Miṣbạ al-Hamadàni, surnommé al'aveugle de Hamadànn. La date la plus récente que l'on rencontre dans le présent volume est celle de 661 de l'hégire (voyez fol. $78 \mathrm{v}^{\circ}$ ).

Papier. ${ }_{2} 3$ feuillets. Hauteur, 25 centimètres et demi; largeur, 16 centimètres et demi. 26 à 29 lignes par page. Ms. du sule siècle. - (Ancien fonds 735 .)

\section{8.}

Commentaire sur l'ouvrage d' $\Lambda$ bd al-Ghani, intitulé

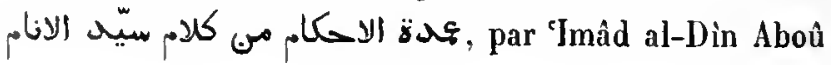


'I-Ẓihir Ismacil ibn Tâdj al-Dìn al-ḷaqq ạt-Kâlib ibn Scharaf al-Dìn Sacid, rénéralement connu sous le nom patronymique d'Ibn al-Athir, morl, selon Hadji Klsalfa, en 699 de l'hégire (1299-1300 de l'hégire). Premier's

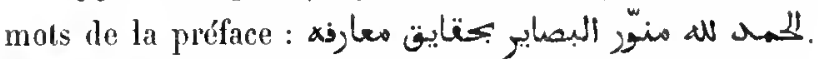

Ms. daté de l'an 742 de l'hégire (1341 de J. C.).

Papier. 242 feuillets. Hanteur, 26 centimètres; largeur, 18 centimètres. 25 liggnes par page. - (Supplément 661 .)

\section{9 .}

remaniement de l'ouvrage intitulé Traité complet pour faire counaitre les noms des tradilionnistesn. Lourage intiluté Jكاك a pour auleur Mohibb al-Dìn al-Naddjầ ibn Mạ̣moûd al-Baghdâdì, molt en 643 de l'hégire (1 245-1246 de J. C.), et la nouvelle édition, Djamàl al-Dìn Aboù ' 1 -Haddjâdj Yoûsof ibn al-Zakì 'Abd al-Raḷnân ibı Yoûsof al-Mizzi (de Mizza, village près de Damas), mort en 742 de l'hégire (1341-1342 de J. C.). Le présent volume, qui renferme la troisiène parlic de l'ourrage et la qualrième, commence au milieu de la notice sur Al-Hosain, fils d' $\mathrm{Ali}$, et se termine par la nolice sur Solaïmân ibn Sofyâu.

Papier. 324 fenillets. Hauteur, 30 centimètres; largeur, 20 centimètres et demi. 3o lignes par page. Ms. du søn" sièrle. - (Supplément 665.)

\section{0.}

Autre volume du même ouvrage. Les preniers feuillets manquent. Le ms. commence au milieu de la nolice sur Sacid ibn 'Abd al-'Aziz et finit par la notice sur' ${ }^{\circ}$ Inir ibu abì 'Ảmir al-Aschrarì. Une note marginale du copiste (fol. 70 ) nous apprend que la première partie du présent volume formait le fascicule $9^{5} \mathrm{du} \mathrm{ms}$. original.

Ms. daté de l'an 746 de l'hégire (1345-1346 de J. C.).

Papier. 238 fevillets. Hauteur, 27 centimètres et demi; largeur, 19 centimètres. a 7 lignes par page. - (Supplément 667.)

\section{1 .}

Autre volume du même ouvrage. Ms. autographe, renfermant les fascicules $152,153,154,155,157$ et 158 de l'ouvrage. Le volume commence par la notice sur 'Ammâr ibn Naṣr al-Sacdì, et finit au milieu de la notice sur 'Amr ibn Morra al-Djoliani. A la fin de cliaque fascicule se trouvent plusieurs certificals d'audition, dont quelques-uns, écrits de la main de l'auleur, portenl la date de 71 h de l'hégire $(13,1-13,5$ de J. C. $)$.

Papier, 166 feuillets. Hauteur, a7 centimètres et demi; largenr, 19 centimètres. 23 lignes par page. Ms. du xiv" siècle. - (Supplément 666.)

\section{2.}

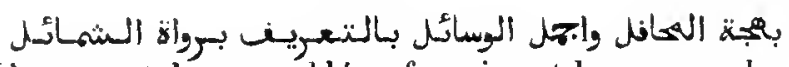
"L'ornement des assemblées, fournissant les moyens les plus complets pour parvenir à la connaissance des traditionnisles dont l'aulorité est citée dans le Schamäil (d'AlTirmidsì)", par Aboû 'l-Imdàd Ibràhim al-Loqânì, docleur malékile, mort en 1041 de l'hégire (1631-1632 de J. C.). Premiers mots de la prélace : sذلll ar.j

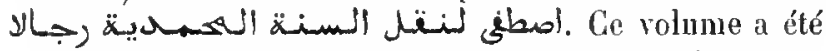
écrit par le fils de l'auteur en 1049 de l'hégire $(1639$ de J. C.).

Papier. 122 feuillets. Hauteur, 21 centimètres; largeur, 15 centimètres. 20 à 23 lignes par page. - (Supplément 66\%.)

\section{3.}

-Classes des jurisconsultesn, par le cadi Scliams al-Dìn al-'Othunâni al-Ṣafidi. Nolices biographiques des principaux docteurs musulmans, dans l'ordre chronologique, depuis Milnomet jusque vers le milicu du vul siècle de l'hégire. Ms. surchargé de corrections de la main de l'auteur.

Papier. 158 feuillets. Ilauteur, 26 centimètres et demi; largeur, 19 centimètres. 19 lignes par page. Ms. du xuv' siècle. - (Ancien fonds 755 .)

\section{4.}

Pages rendues éclalautes par les mérites d'Aboû Hanifa r. Eloge d'Aboù Hanifa, par Djalàl al-Dìn al-Soyoûtị. Commencement : hat 年. Il y a une lacune considérable entre les folios actuellement cotés 3 el 4. Ms. daté de l'an 1245 de l'hégire $(1829$ de J. C.).

Papier. 5 fouillets. Hauteur, 21 centimètres et demi ; largeur, 1 i centimetres et demi. 21 lignes par page. - (Supplément a085.) 


\section{5.}

Dernières pages d'un traité sur les mérites (منساقب) du grand imâm Aboû Ịanîifa.

Papier. 4 feuillels. Hauteur, 13 centimètres et demi; largeur, a I centimètres. 15 lignes par page. Hs. du rrm siècle. — (Supplément a 26.)

\section{6.}

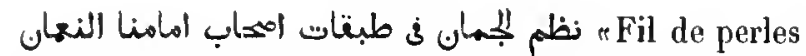
ou biographies disposées par classes des disciples de nolre imâm (Aboû Ịanîfa) al-Nocmân», par Ibrâhìm ibn Mohammad ibn Aïdemir al-'Alàyì ibn Dợmâq, mort en 809 de l'hégire (1406 de J. C.). Ce volume, le premier de l'ouvrage, est consacré exclusivement à l'éloge d'Aboû Ilanîla, à l'histoire de sa vie et à un résunté de ses doclrines. It est de la main de l'auteur et daté du mois de scha bân $79^{5}$ de l'hégire ( $139^{3}$ de J. C.). La tecture de ce volume inspire une vive admiration pour le caractère sage et conciliant d'Aboû țanîfa. La préface commence

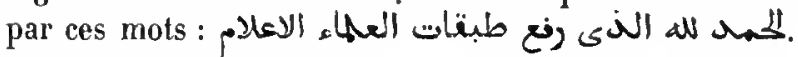

Papier. 154 feuillets. Hauteur, 25 centimètres et demi; largeur, 16 centimètres et demi. 21 lignes par page. - (Ancien fonds 741.$)$

\section{7.}

Première partie d'une histoire des docteurs hanéfites,

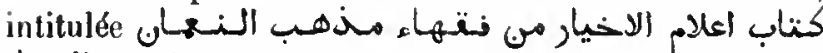
Indication des princıpaux jurisconsultes de l'école (d'Aboû Ḥanîfa) al-Nocmân», par Mohammad ibu Solaimân al-Kafawi, auteur du $\times y^{\circ}$ sic̀cle. (La date de 920 de l'hégire est inentionnée au fol. $214 \mathrm{v}^{\circ}$ du présent ms.) L'ouvrage commence par une préface (عنولن), suivie d'un chapitre intitulé برهان "la preuve", qui traite de la grande utililé de l'élude du droit; vient ensuite un chapitre sur tes prophètes (الركان); puis l'article de Mahomet, سطان الكنتايبب , chef des classes de jurisconsultes, le corps des Compagnons, le corps des تابــ avec l'arrière-garde (سان), le corps des hanéfites. Un iudex, qui a été achevé par M. de Slane, se trouve à la fin du volume.

Papier. a 6 feuillets. Hauteur, 30 centimètres; largeur, 19 centimètres et demi. 29 lignes par page. Ns. dn $x v^{\circ}$ siècle. - (Supplément 699.)

\section{8.}

Continuation de la fondation ( $\mathrm{du}$ monument qui doit conserver le souvenir) des hauts mérites d'Ibn Idrîs". Notice très-détaillée sur l'imâm Al-Schâfíi (Mohammad ibn Idrîs al-Moṭlalibî) et sur ses élèves, par Ahmad ibn 'Ali ibn Hadjar al'Asqalânî. L'auteur a terminé son travail en 835 de l'hégire ( 1432 de J. C.). Dans la préface, il donne les titres des ourrages antérieurs sur le méme sujet.

A la fin du volume se trouve un éloge de l'imâm AlSchâfi i, en vers, par Schams al-Din Mohammad al-Nawâdji, mort en 859 de l'hégire (1455 de J. C.).

Ms, daté de l'an 879 de l'hégire $(1474$ de J. C.).

Papier. $9^{8}$ fenillets. Hauteur, 18 centimètres et demi; largeur, 13 centimètres. 15 lignes par page. - (Supplément 660.)

\section{9.}

"Mérites de l'imâm al-Schâfici ”. Ourrage anonyme, divisé en dix chapitres. La préface com-

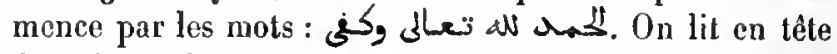
du volume deux pièces de vers, ajoulées après coup, et dont la seconde est attribuéc à Ibn Sanâ al-Molk (Hibal Allahı ibn Djáfar), poète dont Ibn Khallikân nous a donné la vic (vol. HI, p. 589 de la lraduction). A la fin du ms. se lrouvent figurés certains sigles que Dieu, dit-on, avail rérélés au propliète Jérémic, et une prière attribuée à $\mathrm{Ka}{ }^{\mathrm{C}} \mathrm{b}$ al-Alibar. Ce ms. porle au fol. 1 ter un acte de wayf, daté de l'an 1063 de l'hégire (1653 de J. C.).

Papier. 75 feuillets. Hauleur, 21 centimétres; Jargeur, 15 centimètres. 15 lifgnes par page. Ms. du xvu' siècle. - (Ancien fonds 856.)

\section{0.}

"Classes des docteurs schaféites », par Tàdj al-Dìn 'Abd al-Wahłâb ibn 'Alì ibn 'Abd al-Kafì al Sobkì al-Khazradjì, mort en $77^{1}$ de l'hégire (1369-1 370 de J. C.). On lit dans Hadji Khalfa qu'lbn al-Sobkì a composé trois traités sur le même sujet : le grand, dont nous avons ici le premier volume, portant en mirge les corrections de l'auteur, le traité moyen (الطبتات الموسطى)),

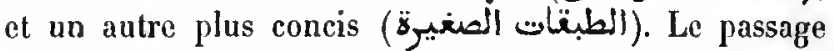
reproduit par Hadji Khalfa (t. IV, p. 139 et suiv.), se trouve, arec quelques différences, au fol. $3_{9}$ de notre exemplaire, qui renferme les notices biographiques des docteurs des premières classes (jusqu'au commencement du $v^{\circledR}{ }^{\circledR}$ siècle de l'hégire). Les noms des personnages, en tête des articles, ont été laissés en blanc.

Papier. a 11 feuillets. Hauteur, 27 centimètres et demi; largeur, 18 centimètres. 31 lignes par page. Ms. du xıv siècle. - (Ancien fonds 737 , Colbert 1804.) 


\section{1.}

Dernier volume des Classes des docteurs schaféites, par Tàdj al-Din al-Sobki. On lit à la fin, le titre de الطبتقات الكبرى للسبكى, mais ce volume ne parait pas appartenir à la grande édition de l'ouvrage. Le ms. commence par une très-longue notice sur Taqì al-Dìn Aboû ' $\mathrm{H}$-Ḥasan ibn 'Alì ibn Tammâm al-Sobki, probablement le grandpère de l'auteur. Cet article remplit plus de la moitié du iolume. Suivent des notices sur d'autres personnages portant le nom d $d^{`}$ Alî, et sur les différents personnages appelés 'Omar, Mahmoûd, Yahyà et Yoûsof. Un chapitre, tiré de la grande édition et placé à la fin du volume (fol. 145), renferme un certain nombre de prières que Tàdj al-Dîn al-Sobkî avait recueillies de la bouche de plusieurs grands doeteurs de l'islamisme.

Ms. daté (fol. 144 ) de l'an 856 de l'luégire (1453-1453 de J. C.).

Papier. 155 feuillets. Hauteur, 19 centimètres; largeur, 14 centiunètres. 15 lignes par page. — (Ancien fonds 860.)

\section{2.}

C Classes des docteurs schaféites, par lbn Qâdhì Schohbas (Taqì al-Dìn Aboû Bakr ibn Aḥmad ibn Moḷammad), de Damas, mort en 851 de l'hégire $(1447.1448$ de J. C. $)$. L'ouvrage est divisé en vingt-neuf chapitres, qui suivent l'ordre clıronologique, et daus chaque chapitre les articles biographiques sont classés daus l'ordre de l'alphabet. Le dernier chapitre contient les notices des docteurs morts vers le milieu du $1 \mathrm{x}^{\mathrm{e}}$ siècle de l'hégire. A la fin se trouvent les tables des noms, des patronymiques qui commencent par إبو, des titres honorifiques, des appellations ethniques et des sobriquets de la forme de efils d'un tels (إبهى), et une table des auteurs désignés par les titres abrégés de leurs ourrages, par exemple : صـاحسب ,صاحب الارتبـاد النتستويسب. Ms. exécuté à la Mecque, en 882 de l'hégire (1477-1478 de J. C.).

Papier. ${ }_{7} 3$ feuiflets. Hauteur, 19 centimètres; largeur, 15 centimètres et demi. 33 lignes par page. - (Aucien fonds 861.)

\section{3.}

Notices biographiques de toutes les personnes dont les noms sont mentionnés dans l'Abrégé de droit malékite

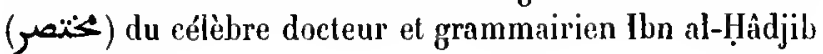

Aboù 'Anr 'Othmàn iln abì Bakr, mort en 646 de l'lıégire (1 249 de J. C.). (Voyez Hadji Khalfa, t. V, p. 441 , et $t$. VI, p. 178.) Il est question dans eet ouvrage des prophètes, de Mahomet, des quatre premiers califes, des compagnons, des tâbiónin, des grands docteurs de l'islamisme, et surtout de Malik et de ses diseiples. On y trouve aussi beaucoup d'indications utiles pour l'explication du texte de l'Abrégé, et une notice biographique sur d'Ibn al-Hâdjib.

Papier. 45 fenillets. Hauteur, 87 centimètres; largeur, 17 centimètres et demi. 29 lignes par page. Ms. du xvie siècle. - (Supplément 66g.)

\section{4.}

(riographie d'Aboù 'l-Abbàs A ḥmad ibn Tä̈miya al-Ilarrânî̀. Ce docteur, né à Harrân, en $66_{1}$ de l'hégire $(1262-1263$ de J. C. ), était šchaikh al-Islàm, avee le titre de Taqi al-Dìn, à Damas, où il mourut en $7_{2} 8$ de l'hégire $\left(13_{27}-1328\right.$ de J. C.). Dans cet ouvrage, on trouve de nombreux extraits de sa correspondance littéraile et théologique, ef au fol. $38 \mathrm{v}^{\circ}$, une dissertation sur l'irresse, فصل في المسكر

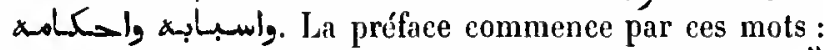

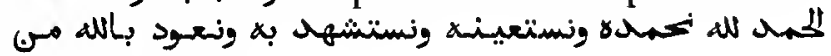

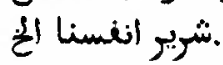

Papier. 48 feuillets. Hauteur, 18 centimètres; largeur, 13 centimètres. 3/ı lignes par page. Ms. dı $\times v^{\circ}$ siècle. - (Ancien fonds 858.)

\section{5.}

م Joyaux et perles, biographie du schaïkh al-Islàm Ibn Hadjar $»$; par Schams al-Dìn Aboû 'l-Khaïr Moḷammad ibn 'Alì al-Sa-

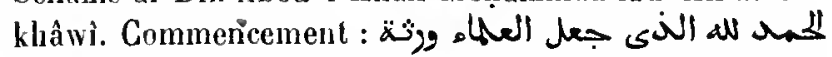
.الانبياء. L'introduction, dans laquelle l'auteur expose trèslonguement la signification des termes schaikh al-Islâm, mohaddith et hafir, est suivie de dix chapitres : $1^{\circ}$ sur la généalogie et la naissance d'lbn Hadjar. (On lit, fol. $14 \mathrm{v}^{\circ}$, ligne 6 , que ce nom doit se prononcer avec un fatha sur le $h \hat{a}$, ainsi que sur le djim); $2^{\circ}$ histoire de sa jeunesse et de ses premières études; $3^{\circ}$ sur les maîtres dont il reçut les leçons; $4^{\circ}$ sur son enseignement; $5^{\circ}$ sur ses ouvrages; $6^{\circ}$ sur ses compositions en prose et en vers; $7^{\circ}$ sur son earactère; $8^{\circ}$ liste de ses élèves; $9^{\circ}$ sur sa dernière maladie et sa mort; $10^{\circ}$ sur les élégies composées à l'oceasion de sa mort. 
Ms. exécuté en 871 de l'hégire (1466 de J. C.), du vivant de l'auteur. Les points diacritiques manquent souvent.

Papier. 298 feuillets. Hauteur, 27 cenlimètres el demi; largeur, 18 centimèlres el demi. 31 lignes par page. - (Supplément 690.)

\section{6.}

Fleurs des prairies, ou Histoire du cadi 'Iyâdh n, par A ḷmad al-Maghribi, neveu d'Aḷmad ibn Moḷammad al-Maqqarì, auteur de l'Histoire politique et littéraire de l'Espagne et de la Vie d'Ilon alKluatils. L'ourrage se compose d'une préface et de huit grauds clapitres, dont le premier, intitulé rla Rosen, traite de l'origine d'lyâdh; le deuxième, intitulé "la Camomilter, de son adolescence; le troisiène, intitulé trième, intitulé المنثئ ta Girofléen, traite des pièces en prose et en vers composées par lui; $5^{\circ}$ le cinquième, intitulé la kose musquée on l'églantinen; de ses ouvrages; le sixième, intitnlé الإس cle Myrten, de sa mort; le septième, intitulé tient un exposé de ses mérites, et le luvitième, intitulé cle Nénupharn, renlerme les éloges qu'on a fait de ce docteur. Le présent ms. ne contient que les quatre premiers chapitres. Un certain nombre de vers inscrits sur les murs de l'Allambra sont tirés des poésies qu'on lit dans cet ouvrage. Notre auteur, à l'imitation de son oncle, dans la vie d'Ibn al-Khatỉb, a consacré la plus grande partie de son ouvrage à différents sujets plus ou moins étrangers à la biographie d'Tyâdh. Commence-

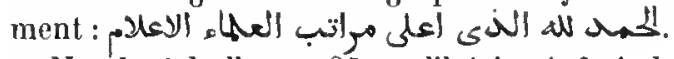

Ms. daté de l'an 1085 de l'hégrire (1674 de J. C.).

Papier. 368 feuillets. Ilauleur, 29 centimètres; largeur, 20 centimètres. 31 tignes par page. - (Ancien fonds $1377 \cdot$ )

\section{7.}

re La Meillenre voie pour arriver à la connaissance de l'histoire des Barmécides n, par Yoûsof ibn Moḷammad al-Mìlawi (المبل/ى). C'est une histoire bien faite, et, d'après la préface, le premier ouvrage composé sur ce sujet. La préface commence par les

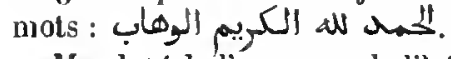

Ms. daté de l'an 1019 de l'hégire (16 $60-1611$ de J. C.).

Papier. 109 feuitlets. Hauteur, 17 centimètres; largeur, 10 cenlimètres el deni. 19 lignes par page. - (Supplément 7 10.)

\section{8.}

Renseignements pour le public, au sujet de ce qui est arrivé aux Barmécides de la part des Abbasides", par Mohammad

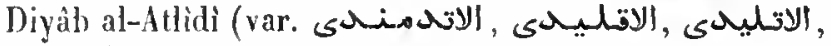

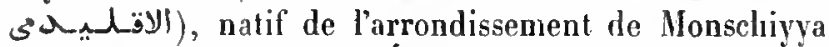
al-Khaṣib, dans la haute Égypte. Le récit commence au califat d"Omar ibu al-Khațâb et se termine au règne d'Al-Mo'taşim. Cette compilation est du genre des romans historiques. La préface commence par ces mots :

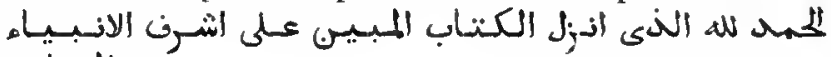
(ألمسلبي.

Papier. 134 feuiltets. Haulcur, 22 centimèlres; largeur, 15 cenlimètres. 2, lignes par page. Ifs. du xvı' siècte. - (Supplément 708.)

\section{9 .}

Mème ouvrage. Ms. daté de l'au 1120 de l'hégire (17081709 de J. C.).

Papier. 170 feuillets. Hauleur, 21 cenlimètres; largeur, 15 centimètres. 18 à 21 lignes par page. - (Supplément 707.)

\section{0}

Mêne ourrage.

Ms. daté de l'an 1149 de l'hégire $(1736-1737$ de J. C.).

Papier. 153 feuiltets. Hauteur, 21 centimètres et demi; largeur, 16 centimètres. 21 tignes par page. - (Supplémenl 709.)

\section{1 .}

Histoire de la fanille Baschîr, émirs du Liban. L’introduction, qui porte le titre spécial de : غر, arnements éclatants des belles, ouvrage renfermant la mention des hommes des temps passés (littéralement : des enfants du temps) $\pi$, nous apprend que la tribu arabe des Makhzoûm s'établit dans le Haurân, lors de la conquête de la Syrie par les Musulmans. Au $\mathrm{vl}^{\circ}$ siècle de l'hégire, la fainille (JI) de Schihâb, branche des Makhzoûm, aida Noùr al-Din et Salâh al-Dìn dans leurs guerres contre les Croisés, el obtint la pernission de s'établir dans le Wâdì al-Taïm, canton situé au nord 
de Banyàs et traversé par le Jourdain. Après un intervalle de plusieurs sic̀cles, pour lesquels l'ouvrage ne lournit aucun renseignement, les Schihàb contractèrent une alliance avec Fakhr al-Din al-Mánì (le célèbre Facardin), et les deux tribus, les Sclibâl) et les Ma ni, se soutinrent mutuellement, jusqu'à ce que le chef des Schihàb, Baschìr, fils de Manșoûr, oblint de la Porte Ottomane le gouvernement dı Liban. Suit une courte hisloire de la fa. mille Baschì', hisłoire quj s'arrête à l'an 1204 de l'hégire (1789-1790 de J. C.). Au tol. 9 du volume commence la seconde partie de l'ouvrage, intitulé so ف. C'est Thistoire de la famille Baschîr, depuis l'an 1109 de l'hégire jusqu'à la fin de l'an 1241.

Papier. 149 feuillets. Hauteur, 31 centimètres; largeur, 21 centimètres. 24 lignes par page. Ms. du xix siècle. - (Supplément 711.)

\section{2}

L Hisloire des philosophesn, ouvrage qui serait plus exactement inlitulé naire des philosophesn, car les notices biographiques sont disposées dans l'ordre de l'alphabet. L'auleur, nommé dans la préface el dans la note finale, Mohammad ibn "Alì ibn Molammad al-Khatibì al-Zauzanì, dit aroil" ternumé son onvrage en 647 de l'hrírire (1249 de J. C.). C'esl à tort que l'on a considéré ce dictionnaire commo un abrégé du Tabaquit al-IIokanù du vizir "Alì ibu Yoùsol al-Qifị, mort en 646 de l'hégire (1 248-1249 de J. G.).

Ms. dalé de l'an $177^{\circ}$ de J. C.

Papier. 178 fenillets Hauleur, a 2 centimètres; largeur, 15 centimètres. a 1 lignes par page. - (Supplément 672.)

\section{3.}

Sources d'iniormations au sujet des médecins des diverses classes $"$, par Howalfiq al-Din Ahmad ibn al-Qàsim ibn Khalifa ibn Yoûnos ibn abì 'l-Qàsim al-Khazı'adjì al-Sal'dì ibn abì Oșaïbi'a, mort en 668 de l'hégire $(1269-1270$ de J. C.). Pour la liste des chapitres, on peut consulter l'ouvrage de M. Wüstenfeld, Arabische Acrzte, elc., et le Calalome de la Bibliothèque Bodléienne, L. II, P. 131 et suiv. La préface com-

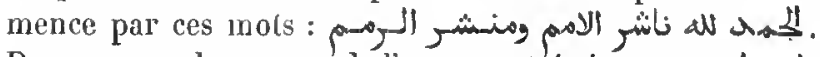

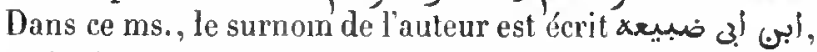
mais c'est une erreur de copiste. Il y a plusieurs lacunes.

Ms. daté de l'an 1245 de l'hégire (1830 de J. G.).

Papier. ${ }_{2} 7^{3}$ feuillets. Hauteur, 3 o centimètres; largeur, 20 centimètres. 33 lignes par page. -- (Supplément 673.)

\section{4}

Mème ouvrage. Dans cel exemplaire, le surnom de l'auteur est écrit ابر (إق) ضبيعه , comme dans le ms. précédent.

Ms. daté de l'an 1262 de l'hégire (1846 de J. C.).

Papier. 313 feuillets. Hauteur, 22 centimètres et demi; largeur, 15 centimètres. 31 lignes par page. - (Supplément 673 bis.)

\section{5 .}

Les deux premiers volumes du même ouvrage. La copie se termine par la nolice sur Aboû 'l-Faradj Yahyâ Ibn al-Talmid. Sans points diacritiques.

Papier. 170 feuillets. Hanteur, 26 centimètres; largeur, 17 centimètres. 25 à a 7 lignes par page. Ms. du xiv siecle. - (Ancien fonds 757 .)

\section{6.}

Premier volume du même ouvrage, se terminant an milieu de la huilième section, par la notice sur Gabriel ibm Bakhlischou'. Le fol. 101, qui n'appartient pas à louvrage, contient quelques recettes pliarmaceutiques en caractères syriaques, mais en langue arabe.

Papier. 131 fenillets. Hauteur, a 6 centimètres et demi; largeur, 18 centimètres. 17 lignes par page. IIs. du $x^{0}{ }^{\circ}$ siècle. - (Supplément 674.$)$

\section{7}

Les sept premières sections et le commencement de la luitiente section du méne ouvrage. Les derniers feuillets manquent.

Papier. 138 feuillets. Hauteur, 26 centimètres et demi; largeur, 17 centimètres. 17 lignes par page. Ms. du xit $7^{\circ}$ siècle. - (Ancien fonds 756. .)

\section{8.}

Rédaction abrégée du même ouvrage.

Papier. 111 feuillets. Hauteur, 17 centimètres et demi; largeur, 12 centimètres et demi. 19 lignes par page. Ms. du xwì siècle. - (Ancien fonds 873.) 


\section{9.}

o Dictionnaire biographique des grammairiens arabes". C'est le ms. autographe du dictionnaire moyen, طبقات النهاة الوسطى, de Djalàl al-Dìn alSoyoûtì (voyez aux fol. $146,1491^{\circ}, 193,19^{8,221} \mathrm{v}^{\circ}$ du présent ms.). L'ouvrage commence par les auteurs portant le nom de Moḷammad; puis suivent ceux du nom d'Alımad, et les autres noms, disposés dans l'ordre de l'alplıabet. Le volume se termine par des chapitres sur les prénoms, surnoms, synonymes, etc. Les quatorze premiers feuillets de cet exemplaire manquent, ainsi qu'un ou deux feuillets ì la fin. Le volume commence par la nolice sur Moḥammad ibn Abân al-Lakhmî, de Cordoue.

Papier. 238 feuillels. Hautcur, a 6 centimètres; largeur, 17 centimètres. a 7 lignes par page. — (Supplément 683.)

\section{0.}

1 Biographies des professeurs d'Abd Allah ibn Moḅammad al-Schobrâwî, docteur schaféile. 'Abd Allah a1Scliobrâwî, auteur de cet opuscule, écrivait vers l'an 1142 de l'hégire (1 $7^{2} 9^{-1} 7^{30}$ de J. C.).

$2^{\circ}$ (Fol. 22 vº) عنوان البيان وبستان الاذهـان. Recueil d'apologues et d'anecdotes, en sept sections (oslôib), par

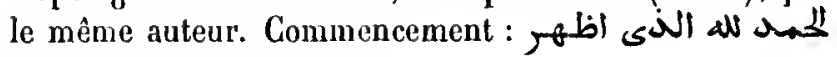
مى مكنونات اسرأو كنهوز

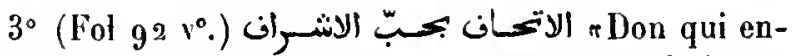
seigne à aimer les descendants de Mabomet n, en huit seclions, par le même auleur. Commencement: als ${ }^{2}$

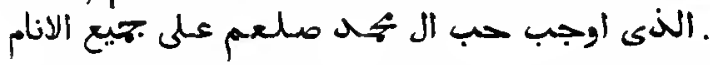

$4^{\circ}$ (Fol. $208 v^{\circ}$.) Commentaire d'A Abd Allah al-Schobrâwì, sur la qașida d'Aḥmad ibn Mascoûd, chérif de la Mecque, qui vivait vers le milieu du xvil siècle de J. C. Le commenlaire est précédé d'une notice sur ce person-

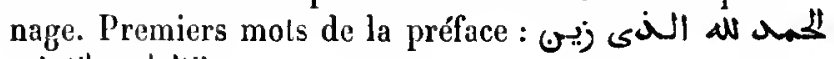
الالبباب بالاداب.

$5^{\circ}\left(\right.$ Fol. $26_{7} v^{\circ}$.) Dissertation sur la profession de foi,

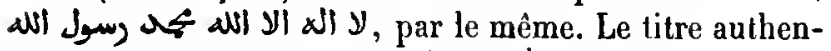

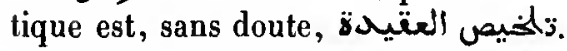

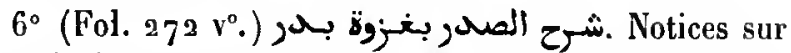
les principaux compagnons de Mahomet qui avaient assislé au combat de Badr, par le mème. Commencement:

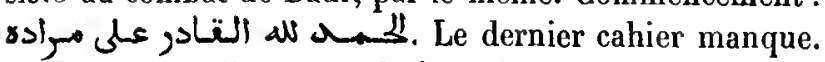
Toutes ces pièces sont de la main de l'auteur. La cin- quième est datée de l'an 1049 de l'łégire $(1639$-1640 de J. C.).

Papier. 284 feuiltets. Hauteur, a a à 23 centimètres; largeur, 15 cen. timètres el demi. 27 lignes par page. - (Supplément 1890.)

\section{1.}

r Histoire des enfants célèbres n, par Schams al-Dìn Moḥammad ibn Zafar, auteur sicilien. Ms. daté de l'an $9^{30}$ de l'hégire ( ${ }_{1} 5_{2} 3$ de J. C.). Celte date a été altérée après coup.

Papier. 79 feuillets. Hauleur, 27 centimètres et demi; largeur, 18 centimètres. 17 lignes par page. - (Supplément 679.)

\section{2.}

\section{Même ouvrage.}

Papier. 55 feuillets. Hauteur, 27 centimètres et demi ; largeur, 18 centimètres et demi. 21 lignes par pagc. Ms. du rvı siècle. - (Supplément $67^{8}$.)

\section{BIOGRAPHIES LOCALES.}

\section{3 à 2126.}

rLe Collier de baut prix, renfermant l'histoire du territoire sacré de la Mecque n, par le docleur malékite Taqî al-Dîn Aboû 'l-Taiyib Mohammad ibn Aḥmad al-Fâsî al-Hasanì, mort en 831 de l'hégire (1428-1429 de J. C.). C'est un dictionnaire biographique des Mecquois les plus distingués et des personnages qui ont résidé à la Mecque ou qui ont rendu des services à celte ville. En tête se trouve une courte histoire de la Mecque, avec l'indication des ouvrages que l'auteur a consultés. Cette esquisse historique se termine à l'an 829 de l'hégire (1425 de J. C.). L'article sur Mohyî al-Dìn lbn al-'Arabì (fol. $196 \mathrm{v}^{\circ}$ ) renferme les falwâ déclarant impies les doctrines panthéistes du فصوص S.

Ms. écrit à la Mecque, en 891 de l'hégire (1486 de J. C.).

4 vol. Papier. $273,277,243$ et 208 feuillets. Hauteur, 27 centimètres et demi ; largeur, 18 centimètres. 25 lignes par page. - (Ancien fonds $719,7^{20}, 7^{21}, 863$.) 


\section{7.}

Histoire biographique du Yémen, depuis Mahomet jusqu'à l'an 736 de l'hégire, renlernant des notices sur tous les personnages remarquables qui ont séjourné dans cette province. L'auteur dit avoir puisé une grande partie de ses renseignements dans l'Histoire yemenite d'Ibn Samoura (wor), dans l'Histoire de Șancà, d'Ibn Djarì̀, dans le Mofid, histoire de la ville de Zabid, et dans le Dictionnaire Jiographiłpue d'Jbn Khallikàn. La préface com-

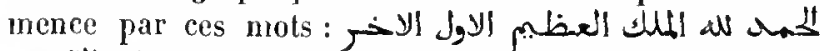
pall. C'est l'ouvrage que Hadji Khalfa mentionne sous

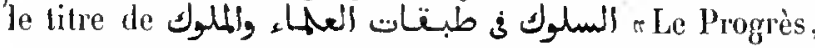
indication des classes des ulémas et des rois $n$, et dont l'auteur est le cadi Aboû 'Abd Allah Yoùsof ibn Ya'goûb, connu sous le litre de Bahâ al-Din (stolif) al-Djanadi.

Ms. daté de l'an 820 de l'hégire (1417 de J. C.).

Papier. 207 feuillets. Hanteur, 33 centimèlres el demi; largeur, 25 centimètres et demi. 31 lignes par page. - (Supplément 767. )

\section{8 .}

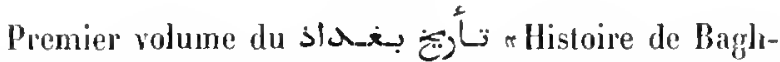
dåd r, par Aboù Bakr Alımad ibn 'Ali ibn Thàbit al-Khatỉb al-Baghdàdi, mort en 463 de l'hégire (1071 de f. C.). Ce dictionnaire biographique commence par une description de la ville de Baghdad et des lienx envirommants, divisée en plusieurs chapitres, qui traitent des sujets suivants: 1. Examen de la question de saroir, s'il est promis de vendre les terrains de Baghldâd (c'est-ì-dire si cette ville a été prise d'assaut ou par capitulation: dans le premier cas, ces terrains n'appartiennent pas aux particuliers, mais à l'État); - 2. notice sur le Savâd ou la campagne de Baglidàd, el comment le cadife 'Omar en disposa; - 3. sur la question de savoir si la rente des terrains dans le Sawad est permise; - 4. sur les sept climats et sur la positiou de la ville de Baghdaul; 5. tradilions concernant les défauts de la ville et des habitants de Barghdâd; - 6 . traditions renfermant l'éloge de cetle ville; - 7. plusicurs traditions à la louange de Baghdàd; - 8. sur les deux flenses de Baghdad, le Tigre et l'Euphrate; - 9. sur les premiers cultivateurs du Sawàd; - 10. sur l'origiue du nom de Baglıdàd; sur la part que le calife Aboù Djat far al-Mansoûr prit à la fondation du noureau Baghdàd; - londation de Baghdad (Madìnat al-Salàm); - 11. mème sujet; - 12 . rues et places de Bighldad; - 13 . le palais du calife, la citadelle et le pavillon de la couronue (التاج); - 14 . sur le palais du sultan (álll jo); - 15. sur les canaux de

Mav. onientaux. - 11 .
Baghdàd et les lieux roisins; -16 . sur les anciens ponts de Baghdàd; - 17. dimensions de Baghdảd en Jongueur et en largeur; - 18. tombeaux musulmans les plus remarquables: - 19. notice sur la ville d'AJ-Madäin; 20. prédictions de Mahomet, touchant la conquète de cette ville. Suit (fol. $41 v^{0}$ ) la liste des compagnons de Mahomet qui assistèrent ì la conquète d'Al-Madiiön. Des nolices assez délaillées sont consacrées à quelques-uns de ces personnages (fol. $451^{\circ}$ ), ì savoir : Sa d ibn abi Waqqàs, 'Abd Allah ibn Naśôud, 'Ammàr ibn Yàsir, Aboû A yyoûb al-Anșàn', 'Otba iln Ghazwìn, Aboû Mas'oủd al-Badrì, Aboù Qatàda '1-Aușârì, Ilodsaifa ibn al-Yamàn, Salmån al-Fàrisi, 'Abd Allahi ibn 'Omar ibn.al-Khattàb. "Abd Allah ibn 'Abbàs, Thàbit ibn Qaïs, Al-Barà ibn 'Ázils, Qaïs ibn Sacd ibu 'Obada, 'Othmàn ilon Honail, Aboù Sa id al Khodri, 'Abd al-halımàn ibn Somra, Aboù Barza al-Aslami, 'Jyidh ibn Ghànim al-Fihrì, Qorza ibn Ka`b, Naifi ibn 'Otba, Somra ibn Aboù Laïlà al-Anșâri, Djarir ibn 'Abd Allah, 'Adí ibn llàtim, Al-Moghira ibn Scho'ba, 'Orwa ibn abì Dja'd, 'Omar ibn abî Salama, Baschìr ibn al-Khaşisiya, Hischàm ilm 'Otba, Al-Asch"ath ibn Qaïs, Wâil ibn llodjr, Címir ibn Wàthila, Aboû Djolyaila al-Sowaí, Khâlid ibn 'Orfola, Dhiràr ibn alKlıt!̣ab, Solämàn ibn Şorad, Nl-Sảib ibn al-Ayrac, labib ibn Rabiea, Yazid ibn Nowaïra, les fils de Bodaï, 'Abd Allah ibn Khabbàb, Jyàth ibn 'Amr, Mocawiya ibı abi Solyàn, Bosr ibn abì Mrṭi ou Jbn Irțà. Le dictionnare biographique commence an fol. $66 v^{\circ}$. 11 contient des nolices sur les califes, les descendants du Prophète, les grands personnages, les cadis, les traditionnistes, les lecteurs, les ascètes, les homures pieux, las liltératen's et les poètes, en somme sur tous les houmes remarqualıles nés à Baghidact on qui y araient demeuré. Il commence par les personnages appelés Molımmad; les autres noms sont disposés dans l'ordre de l'alplabet; les patronymiques se trourent ì la fin. Le premier article est consacré à Molıammad ibn Islàic ibn Yassàr. Le présent ms. se termine par la notice de Holammad ilon al-llasan ibn Schaïk al-lșfahảni.

Ce ms., qui a élé collationué arec soiu, est daté de l'an 633 de l'hégire (1 $235-1236$ de J. C.).

Papier. 185 feuillets. Iauteur, 26 centimètres; largeur, 18 centimètres. 25 lignes par page. - (Supptément 68\%.)

\section{9 .}

Second rolume du méme ourrage. Les premier's feuillets manquent. Le ms. commence au milieu de la nolice de Holuammad ibn Kathir al-Fibri, et finit par celle d'Alımad ibn 'Obaïd al-Saffàr. 
Ms. daté de l'an 635 de l'hégire (1 238 de J. C.).

Papier. 152 fenilleť. Hauteur. 26 centimètres; largeur, 18 centimètres. 25 lignes par page. - (Supplément 684 bis.)

\section{0}

Volume dépareitlé du même ouvrage. Le ms. commence par la notice de Șàliḅ ibn Noṭammad ibn 'Amr (Abou' $1-\Lambda$ scliras al-Azdi), et finit par celle d' $\mathrm{Abd}$ al- $\mathrm{Aziz}$ ilon Mohammad al-Motariziz.

Le mis, est pourvu des points-ıoyelles.

lapier. 177 feuiltets. Hauteur, 29 centimètres; largeur, 19 centimètres. 27 lignes par page. Ns. du $x$ vir $^{\mathrm{e}}$ siècle. - (Supplément 685.)

\section{1 .}

Vingl-Luitième volume du mème ourage. Les premiers leuitlets manquent. Le ms. commence par la nolice d"cllì iln Moḷammad al-Dàmaghı̀ni, grand cadi, et finit par celle d'Al-Fidhl ibn Molnammad ibu Sì id al-lladdid.

Ils. Jaté de l'an 748 de l'hégrire ( 1347 de J. C.).

Papier. 145 fenillets. Hauteur, 36 centimetres; largenr, 19 centimètres. 17 lignes par page. - (Supplément 686.)

\section{2.}

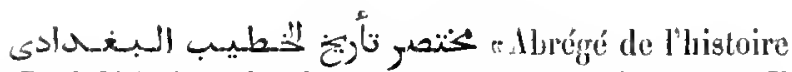
de Baghdàd du Khalihs, par un auteur inconnu. II manque quelques feuillets à la fin et au milieu; plusieurs autres sont intervertis. Ms. aulographe.

Papier. 180 feuillets. Ilanteur, 24 centimètres el demi; largeur, 16 centimètres. 17 à 21 lignes par page. $\mathrm{Vs}$. du $\mathbf{x i v}^{*}$ siècle - (Ancien Fonds (634.)

\section{3.}

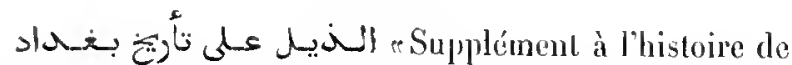
Baghlıdà. C'est un supplément au diclionnaire biographique d'Aboù Sacd 'Abd al-Karim al-Sameàni, par Moḥimmad ibn Saèd ibn al-Dobaïthì al-IVâsiḷi, mort en 637 de l'hégire ( 1239 de J. C.). Le présent nus. renferme la seconde partie de lourrage, commencant par te nom d'Aḷmad el finissant par la notice de lladdjàdj ibn
'Alì. (Voyez sur Samª̂ni et Ihn al Dobaithì, le Dictionnaire biographique d'lbn Kliallikàn, t. II, p. 156 et t. IH, p. 102 de la traduction anglaise).

Papier. 211 feuillcts. Hauteur, 25 centimètres; largeur, 17 centimètres, 21 lignes par page. Mss, du xil siècte, écrit probablement du vivant de lauteur. - (Ancien fonds 745 .)

\section{4.}

e Bouquet pour les hommes intelligents et éclat de la vie mondaines, ou, d'après la souscription du volume, ريكانسة النحماء وسماهم B Bouquet pour les gais convives el orange parfunée pour les leltrés $\pi$, recueil d'observations critiques, d'anecdoles, de pièces de vers et de notices biographiques, le tout rédigé dans un style encore plus recherehé et plus fleuri que celui de llarìr. L'ourrage est divisé en deux sections, dont la première contient des notices sur les savants et les hommes de lettres que l'auteur' avait rencontrés en Syrie; la seconde traite de ceux qu'il arait connus en Égypte. Au fol, 18 se tromre, sous lorme de leltre, une notice rédigée par l'auteur sur ses études, et au fol. 184 la liste de ses ouvrages, parmi lesquels on remarque un recueil de poćsies (divan), une collection de gloses sur le commentaire du Corm d'Al-Baïdhàwì, collection qui remplissait plusieurs volumes; un traité intitule

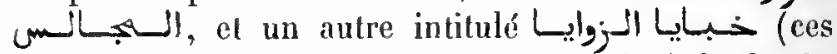
deux ouvrages ont été imprimés au Caire). A la fin dı volume, on lit une pièce de rers portant le titre de

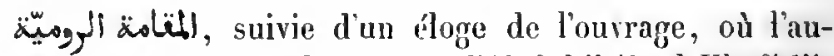
teur est désigné par le surnom d'Al-Schihàb al-Khafàdjì, probablement forme abrégée de Schilıâb al-Dìn A ḥmad ibn Molıammad al-Khafädji. Cel auteur égyptien est mort en 1069 de l'hégire (1658-1659 de J. C.). Une table des matières, ajoutée après coup, se trouve en tète du volume. Celte table, d'ailleurs très-détaillée, a ćlé complétée par une autre, écrite à la fin du volume.

Ms. daté de l'an 1080 de l'hégire $(\mathbf{1 6 6 9 - 1 6 7 0}$ de J. C.).

Papier. $19^{5}$ feuillets. Hanteur, 24 centimetres et demi; largeur, 15 centimètres. 25 lignes par pages. - (Supplément 670.)

\section{5.}

Même ouvrage. Le nom de l'auteur, Schihâb al-Khalìdjì, grand cadi, se troure en tête du volume. Cet exem- 
plaire se termine par une autre maqáma et par quelques remarques littéraires dues à l'auteur.

Ils. daté de l'an 1082 de l'hégire $(1672$ de J. C.).

Papier. 325 feuillets. Itauteur, 21 centimètres; largeur, 15 centimètres. a lignes par page. - (Supplóment 671.)

\section{6.}

Mème ourrage. Les derniers feuillets manquent.

Papier. 222 fenillets. Hautenr, 20 cenlimètres et demi; targeur, 15 centimètres et demi. 25 fignes par page. Ms. du xvir siècle. (Supplément 1/12.)

\section{7.}

مistoire de Damas d'lbn 'Asikirr. Dictionnaire biographique de la ville de Damas, rédigé sur le modèle du Dietionnare biographique de Baghdâd. Dapres lon Khallikin, l'onvage d'Ali ibn

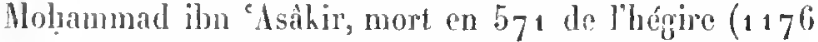
de J. C.), se composait de quatre-viugt parties ou volumes; mais l'exemplaire de la bibtiothégue d"e t tef Pacha, à Constantinople, ne remplit que sept rolumes in-folio, dont chacum est divisé en trois sections. lue présent ms. est le dernier volume de l'ourage. Les premiers et les derniers feuillets manquent. Le volume commence au milien de la notice de Yazid ilon Yazid ibn Djabir. Après la lettre $\varsigma_{s}$, qui finit par l'article Yoûnos al-Madinì alKàtib, viennent les notices des personues généralement désignées par leurs patronymiques. Cetle partie commence far Aboì Almad. Le ms. s'arrète au commencement de l'articte Aboû Moḷammad ibn al-'Abbis al- 'Altì'.

Pafrier. 234 fenillets. Hauteur, 22 centimetres; largeur, 13 cenlinètrs. 23 liggnes par page. Its. du $x^{*}$ siécle. - (Supplément 687.)

\section{8}

بغية L'objet que doit rechercher celui qui désire connaitre l'histoire d'Alep». Dictionnaire biographique de la ville d'Alep, par le cardi Kamâl al-Dìn Aboù Hafṣ e Oual ibu abì Djarâda, connu sous le nom d'lbu al-'Adim. Le présent ms., qui parait être le second ou le troisime volume de l'ourrage, commence au milieu de la notice d'Is!̣ây ibn Mansoutu, et finit par la notice d'Omayya ibn 'Abd Allah l'Omayyade.
Ms. exécuté au Gaire, en 814 de l'hégire $(1412$ de J. C.), d'après le ins. de l'auteur.

Papier. 308 feuillets. Itauteur, 27 centimètres; largeur, 18 centimìtres. 25 liggnes par page. - (Ancien fonds 726 .)

\section{9.}

مل Perles choisies pour compléter l'histoire d'Alep\%. Supplément au Diction-

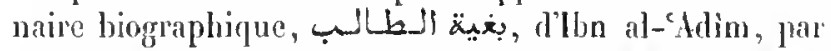
'Ali ibn Hoḷammad al-Djibrìnì, surnommé Khaṭib al-Kâsiriya, mort en 843 de l'hégire (1439-1440 de J. C.). Le présent ms. est le troisième volume d'un exemptairo écrit pour l'usage de l'auteur. Les points diacritiques sont très-sourent omis; un assez grand nombre d'articles ont été laissés en blane, et les marges portent plusieurs additions et corrections, probablement de la main d'Al-Djibrini. Les vingt-cinq premiers feuillets manquent (royez les noles en lête des fol. $66,76,86)$. Les fol. 1, 10 , $11,12,135$ ont été ajoutés après coup et ne fout pas partic de louvrage. Le texte authentique commence au lol. 2, où l'on troure la nolice d'Abd al-Karim ibn 'Abrl al-Malik al-Djanadi. Le volume se termine par l'article Moḷammad ibn Tammàm al-Himyarì. Le quatrième volume devait commencer par l'articte Nolnammad ibu Djäbir, de Cadix.

Papier. 150 feuillets. ttautour, 36 centimètres et demi; largeur, 17 centimètres et demi. 2.3 à 25 lignes par page. Ms. du $x^{e}$ siccle. - (Supplément 688.)

\section{0.}

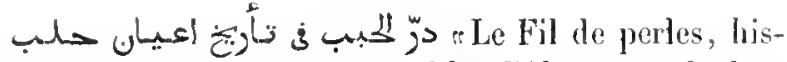
loire des personnages remarquables d'Alep", par le docteur hanéfite lbn al-lianbalì Moḷammad ibn Ibràhin,

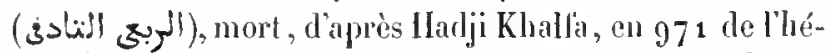
grire (1563-1564 de J. C.). Ce dietionnaire biographique des contemporains de l'auteur', commence par lbrilım. Larticle umigt suivi des noms patronymiques, Dans la préface, l'anteut énumère ses autres onrrages snl' l'histoire politique et biographique d'Alep.

Ce ms., daté de l'an 985 de l'hégire $(1577-1578$ de J. C.), a été collationné sur l'exemplaire de l'auteur.

Papier. sos feuillets. Hantenr, 36 centimetres ef demi; largeur, 16 centimètres ef demi. 33 lignes par page. - (Ancien fonds 797.) 


\section{1}

Nlème ourrage.

IIs. daté de l'an 999 de l'hégire (1 $590-1591$ de J. C.).

l’apier. 238 feuillets. Hauteur, 27 centimètres et demi; targeur, 19 centimètres. 27 lignes par page. - (Ancien fonds 795.)

\section{2.}

llême ouvrage.

Ns. daté de l'an 1010 de l'hégire ( 1601 de J. C.).

Papier. 310 feuillets. Hauteur, 30 centimètres; largeur, 30 centimètres et demi. 5 lignes par page. - (Supplément $68 \mathrm{~g}$.

\section{3.}

l'ragment du mème ourrage.

Le ms. commence au milieu de la notice du grand cadi 'Tzz iel-Dìn al-Roùmì 'Abd al-'Azìz ibn Zaïn al-'Ábidìn.

Papier. 131 feuiltels. Hauteur, 26 centimètres et demi; largeur, 17 centimètres et demi. 25 lignes par page. Ms. du $871^{\circ}$ siècle. (Ancien fonds 799.)

\section{4.}

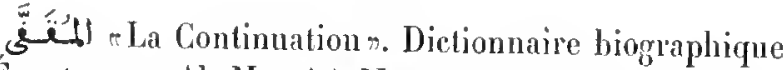
d'Égyple, par A\}-Maqrìzi. Ms. autographe. Ce volume, dont plusieurs feuillets sont transposés, commence (fol.5)

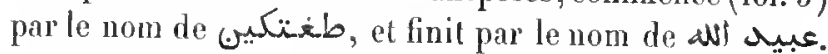

Papier. 260 feuillets. Hauleur. 35 centimètres; largeur, 16 centimètres. 97 lignes par page. - (Ancien fonds 675.)

\section{5.}

en Secours contre la langueur et asyle de la pićlć (?)", par 'Imâd al-Din Mohammad al-Ișfahânî, mort en 597 de l'hégire (1 201 de J. C.). C'est une histoire, en prose rimée, des vizirs des souverains seldjoukides. Le dernier tiers de l'ourrage est consacré au l'écit des événements qui eurent lieu du temps de l'auteur. La préface commence par ces mots : aN W

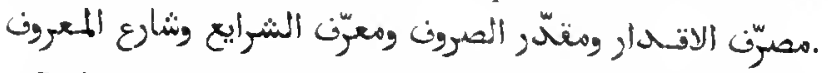

Papier. 328 feuillets. Hauteur, so centimìtres el demi; targeur, 14 centimèlres. 31 lignes par page. Ms. du xvı" siècle. - (Supplé-
ment 772 .)

\section{6.}

زبحهة النصوة ونخبة المعصرة. Abrégé de l'ouvrage précédent, par Al-Fat!̣ ibn 'Alì ibn Mlolammad Al-Bondârì.

Ce ins., daté de l'an 660 de l'hégire ( 1261 de J. C.), a été copié sur l'autographe. Titres de chapitres en lettres d'or; frontispice en or et en couleurs.

Papier. a 08 fenillets. IIauteur, 3 a centimètres; largeur, 15 centimètres. 13 lignes par page. - (Ancien fonds $7^{6} 7 \mathrm{~s}$.)

\section{7.}

1 × Anecdotes au sujet des vizirs égyptiens, mes contemporains n. Aulobiographie du célèbre poète Nadjm al-Dîn 'Omårat al-Yamani (مأز أليمنى). L'anteur parle surtout de ses rapports arec les vizirs Razzìq (on Rozaïq) ibn Șâlih, Dirghàm (ض-رغـام) et Schâwur. Il a rédigé ces mémoires peu de temps après la mort de Schàwur (vojez fol. 3o), et, comme lui, il mourut victime de la politique ombrageuse de Saladin. (Voyez le Dictionnaire biographique dilsn Khallikân, tome If, p. 367 et suiv. de la traduction angraise.) Commencement : كمها

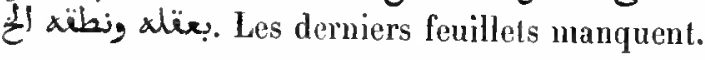

$2^{\circ}$ (Fol. 41.) Le divan d'Aboû 'l-Fadhl Badi' al-Zamàn al-Hamdàni, l'auteur des تlole (voyez fol. $50,67,81$ ). Ce recueil renferme une pièce de vers composée de mots dont les lettres sont alternativement ponctuées et non ponctuées et qui, sans doute, a servi d'exemple à Harirì, dans la vingt-sixième maqâma. Les premiers feuillets manyuent.

Papier. 93 feuillets. Hauteur, 22 centimètres; largeur, 15 centimètres. 17 liggnes par page dans le premier ouvrage, 30 dans le second. IIs. du xu' siècle. - (Ancien fonds 810.$)$

\section{8.}

L'L'Ascendant heureux, contenant les noms des personnages distingués du Șa îd ", dictionnaire biographique des hommes remarquables de la haute Égypte, précédé d'une description de celte province. Cet ouvrage a été composé sur la demande d'un savant, né à Grenade, nommé Athîr al-Dìn Aboû Haiyân Moḥammad ibn Yoûsof, précepteur de l'auteur, dont le nom, d'après Hadji Khalfa, était Kamâl al-Dìn Aboû 'l-Fadhl Djacfar ibn Tha'lab a\}-Odfawi, mort en 748 
de l'hégire ( $347-1348$ de J. C.). L'ourrage a été achevé en 7 to de l'hégire.

Ms. daté de l'an 1061 de l'héggire (1651 de J. C.)

Papier. 329 feuillets. Hauteur, a centimètres et demi; largeur, 15 centimètres et demi. 17 lignes par page. - (Supplément 799.)

\section{9.}

ونع الاصر عى قضساة مصصى Dictionnaire biographique des cadis du Caire, par Aḷmad ibn 'Ali ibn Iladjar al'Asqalâni. L'auteur dit avoir' disposé dans l'ordre de l'alphabet les noms des fonctionnaires, qui étaient énumérés dans l'ordre chronologique et sans ancun éclaircissement, dans un poème composé par Sehams al-Din Moḷammad ibn Dànyâl (s), et dont le texte se trouve au commencement. La préface renferme la liste des ourragres que l'auteur avait consullés; elle commence par ces mols :

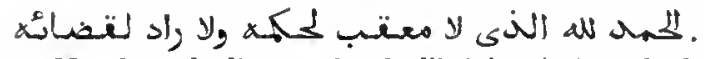

Ms. daté de l'an 1031 de l'hégire (1622 de J. C.).

Papier. 147 feuillets. Hauteur, 29 centimètres; turgeur, 19 centimètres. 31 lignes par page. - (Supplément 69 ^.)

\section{0.}

ripplément au Livre des cadisn, ouvrage composé par Schans al-Din Aboù 'l-Khaïr Moḷammad ibn 'Abd al-Rahmañ al-Sakhiwi, pour servir de suite et de supplément à l'Hlistoire des cádis d'Égypte d'lon lladjar al-'Asqalinî (royez le numéro précédent). L'auteur a suivi l'ordre alphahétique dans ce

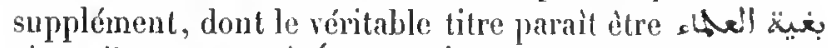
بئئir des savants et des érudits, servant d'appendice au livre de mon professeur sur les cadisn.

Papier. 113 feuillets. Hauteur, 27 centimètres; largeur, 18 centimètres et demi. 29 tignes par page. Hs. du $x^{\circ}{ }^{\circ}$ siecle. - (Ancien fonds 690 .)

\section{1 .}

وفسع Abrégé du supplément du الأصى (voyez les deux numéros précédents), par le nommé 'Alî ibu abî 'l-Lotí. Commencement : all t

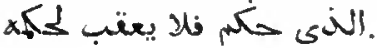

Ms. daté de l'an 900 de l'hégire (1494-1495 de J. C.).

Papier. 134 feuillets. Hauteur, 18 centimètres; largeur, 14 centimètres. 19 lignes par page. — (Ancien fonds 811 .)

\section{2.}

Les Étoiles brillantes, résumé de l'histoire des cadis du vieux el du nouveau Caire», par Djalâl al-Din Yoùsof ibn Schahìn, docteur hanéfite, petit-fils, par sa mère, d'lbn lladjar al-'Asqalìni (سبط أبر (س) une liste de patronymiques, de sobriquets et de noms ethniques.

Ms. revu et corrigé par l'auteur qui, selon Hadji Khalfa, était né en 828 de lihégire (1424-1425 de J. C.).

Papier. 119 feuillets. IIauteur, a 8 centimètres; largeur, 19 centimètres. 29 lignes par page. - (Ancien fonds 691 .)

\section{3.}

ofardins des àmes", histoire biographique de Qaïra wấn et d'Ifrìjiya (la Tunisie et les contrées voisines), depuis la conquête de ce pays jusqu’à l'an 356 de l'hégire, par Aboû Bakr 'Abd Allah ibn Mohammad al-Maliki. L'auteur déclare que, dans ce rolume, il s'oecupe principalement des doetem's de la loi it des dérots; mais dans ces notices, donl quelques-nnes sout l'orl étendnes, on rencontre parfois des renseignements importants sur l'histoire du pays.

Ms. mutilé an commencement et à la fin, el dalé de l'an 729 de l'hégrire $(1329$ de J. C. $)$. Le copiste a eu sous les yeux deux exemplaires de l'ouvrage, l'in portant la date de 544 de l'hégire (1149-1 150 de J. C.), l'autre celle de 601 (1204).

Papier. 108 feuillets. Hautenr, 35 centimètres; largeur, 26 centimètres. 35 lignes par page. - (Ancien fonds 752.)

\section{4.}

Biographie des lommes illustres de Qaĭranâı, par 'Abd al-Rahmàn ibn Nohammad ibn "Abdallah al-Anşàri, surnommé Al-Dabhàgh. Première partic ${ }^{\text {. }}$

Papier. 198 feuillets. Hauteur, so centinetres; largeur, 14 centimètres. 23 liggnes par page. Ms. du xvm1 siècle. - (Supplément a4.6.)
1 L'ourrage, d'après la préface, porte le titre de 3 هeron. Le nom de l'auteur, tel qu'il est transcrit ci-dessus, est égatemement indiqué dans la préface. Mais le présent ms. est une édition commentée et augmentée par un écrivain de Qaïrawân, nommé lbn Nâdjî. Le texte du premier auteur et celui de l'éditeur sont distingués par les nots قلت el. H. Z. 


\section{5.}

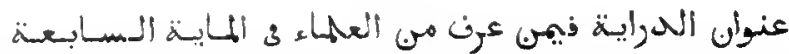
eprincipes du saroir, trailaut des ulémas qu'on connaissail à Bongie au vir sicele de l'hégirer. C'est un recueil de notices liograplitiues, dont l'auteur, Aboû ']-Chbàs Mlınad, appartenait à la famille des Ghobrinì (الغبوينى), famille qui tient encore une place distinguée dans la magristrature musulmane de l'Algérie. Au folio $108 v^{\circ}$ se trouve une esquisse des diverses sciences qui se rattachent au droit musulman.

Papier. 11 g̣ feuillets. Ilauteur, 21 conlimètres; largeur, 14 cenlimètres el demi. 2. lignes par pağe. Ms. du xvi siècle. - (Supplément $706 \mathrm{ter}$.)

\section{6.}

Le sixième volume du dictionnaire biographique intitulé

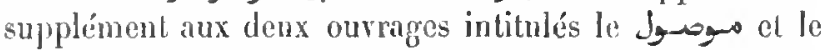
atwe. Cet ourrage renferme des notices sur les personnages remarquables de l'kspagne musulmane qui araient

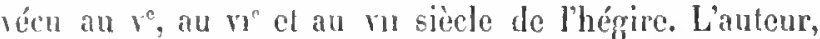
Hohammad ilın Mohammad ilın 'Abd al-Malik al-husì al-Anşàrì al-Marrâkoschì, qui était grand cadi (تهاخى 8hill), peut-être de Cordote, a achevé son travail postéricurement ì l'an 675 de l'hégire (1 $27^{6-1} 277$ deJ.C.), ainsi qu'on lit au fol. $17^{6} \mathrm{v}^{\circ}$. Le ms. a été écrit après la mort de l'auleur; car dans l'explicit son nom est suivi de la formule groun autre côté, me nole en écriture cursive sur le verso du dernier fenillet, nous apprend qu'un certain Hohammad ibn Ibrithim al-Khazradji, arail terminé d'éturlier ce volume an mois de dsou'l-ta $a^{e}$ da 768 (juillet 1367 de J. C.). 11 est done permis de supposer yuc ce ms. a été écrit dans la première moilié du $\mathrm{x}^{\circ}$ siècle, et que l'autenr est mort vers la fin du sure. Ce sixieme volume commence par le nom de Nohammad ibn Almal et finit par Mohammad ibn 'Ali. On y trouve entre autres allicles très-intéressants, une notice sur Averroès ( $/$ bn Roschd), dont le commencement mancue (lol. $7 r^{\circ}$ ). Il y a encore d'autres lacunes. Le mot ألصأ titre du dictionnaire biographique de l'Espagne d'lbn Baselikowill, signilie, en arabe, raddition" on "don"; mais, dans le langage lechnique des grammairiens, il désigne le "conjoint", c'est-ì-dire le pronom

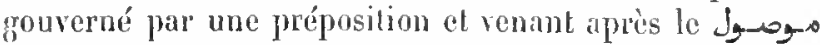
ou pronom rejatif. En effet, l'ouvrage d'lbn Baschkowil est le complément d'un ourrage semblable, intitulé الموصول
- le conjoint $\pi$, probablement celui dont l'auteur est Aboù 'l-Walid 'Abd Allah ibn al-Fàradhi.

Papicr. 205 feuillets. Ilauteur, 23 centimètres; largeur, 16 centimètres. 25 lignes par page. - (Supplément 682, Saint-Germain 361. )

\section{7.}

Les Fleurs de Nómân, classes des ulémas de l'empire ottoman», par Ṭiseh ibn Kopri-Zidè (Aḷmad ilon Moṣtafã), mort en 968 de l'hégire (1560 de J. C.).

Papier. 143 feuillels. Hauteur, a centimètres et demi; largenr, 14 cenlimèlres. 25 lignes par page. Ms. du svie siècle. - (Ancien fonds 868.)

\section{8.}

Même ourrage.

Exemplaire dáté de l'an 980 de l'hérgire $(1572-1573$ de J. C.).

Papier. 2a/t fenillets. Hanteur, 21 centimètres el demi; largeur, 15 conlimetres. 7 lignes par page. - (Ancien fonds 86..)

\section{9.}

Mime ourrage.

Papier. 297 feuillets. IJanteur, a 1 centimètres el demi; largeur, 16 centimètres. 19 lignes par page. Ms. dn $x^{\prime}{ }^{e}$ siècle. - (Ancien fonds 870. .)

\section{0.}

Nème ourrage. En tête de ce volume se trouve une table des matières, et à la fin une courte notice sur l'auteur, par son élère, Moḥammad ibn Moḷammad QàdhìZidde.

Exemplaire daté de l'an 999 de lhégire (1591 de J. C.).

lapier. 157 feuillels. Hauteur, a 1 centimètres; largeur, 13 centimètres et demi. 25 lignes par page. - (Ancien fonds 871 ).

\section{1.}

Mème ourrage. Texte arahe et traduction française 
abrégée. La copie arabe est datéc de l'an 1001 de l'hégire $(1593$ de J. C. $)$.

Papier. 155 feuillets de texte arabe et 180 feuillets de texte français. Hauteur, 20 centimètres; largeur, 18 centimètres el demi. 21 lignes par page dans le texte arabe, 17 lignes dans la partie française. (Fonds des traductions 51.)

\section{2.}

Hême ouvrage.

Papier, 163 feuillels. Hauteur, a 1 centimèlres; largeur, 15 centimètres et demi. 20 à 23 lignes par page. MIs. du xvie siècle. - (Supplément 695.)

\section{3.}

(العبا Collier de perles bien rangées, traitant des sarants distingués de l'empire oltomans, par 'Ali ibn Bàlì (بإ), surnommé Tchennaq (une suite à l'ourragó que Lutfi Bego Zàdè arait composé pour servir de supplément an Schaquäiq al-Nómaniyya de Tiàsch iłn Kopri-Zàdè. En tête du mıs. se trouve une liste des savants morts sous les règnes du sultan Solämân, du sultan Sélìn et du sultan Mourâd. Les feuillets de garde sont courerts de notes et d'observations diverses, les unes en arabe, les autres en turc.

Papier. 107 feuillets. Itapteur, 20 centimètres el deni; largeur, 1 a centimètres. 19 lignes par page. IIs. du xri siècle. - (Supplément 680.)

\section{4.}

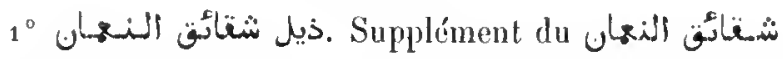

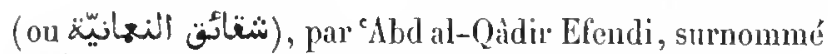
"menteurn, mort en 1000 de lhégire (1591$159_{2}^{2}$ de J. C.). Cet exemplaire n'a pas de préface et

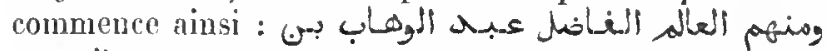

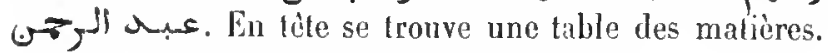

$2^{\circ}$ (Fol. 68.) Autre supplément du le cadi 'A schic Tschedebi. Les derniers feuillets manquent. En tête se troure une table des natières. La préface commence par ces mots : تبارك النَى نزل النوقان.

Papier. 97 feuitlels. Haulenr, 21 centimètres; largeur, 13 centimèlres. 19 à 21 lignes par page. Écritures diverses du xvi1 siècle. (Supplément 696.)

\section{5.}

-0uverture de l'existence et déploiement de la générosité, offrant les louanges de Mạ̣moûd Pachan. Panégyrique en vingt-quatre chapitres de Mahmoûd Pacha, gouverneur d'Egypte, sous le règne du sultan Sélim (1566 à 1574 de J. C.), par Ramadhân ibn cîmir ibn 'Alì. A la fin, l'auteur a ajouté deux qașidas : la première se compose de quatrains, dont les trois premiers vers commencent et finissent par la mème lettre de l'alphabet, à commencer par l'élif; le quatrième vers est un refrain, dont

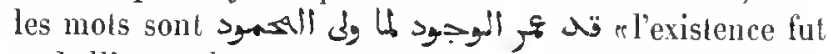
embellie sons le gourernement de Mahmond». La seconde qasida est écrite sur les còtés el dans lintérieur d'une enfilade de cercles. Le présent ms., accompagné d'aposlilles en prose rimée dont chacune est écrite de la main d'un docteur parmi les ulémas, est l'exemplaire original offert par l'auteur au pacha.

Papier. 36 fouillets. Hautenr, 40 centimètres; lúrgeur, 37 centinètres et demi. 19 liggnes par page. Ms. du $581^{\circ}$ siècle. - (Ancien fonds 760. )

\section{6.}

IListoire d'Al Whad Pacha Al-Djazzàr (le boucher)», ourrage composé en 1225 de l'hégire ( 1810 de J. C.), pour laire partie d'une grande histoire universelle, que l'auteur anonyme arait l'intention d'écrire.

Papier. 98 leuillets. llaulenr, as centimètres; laryeur, 16 rentimètres. 19 ligunes par page. - (Supplément 712.)

\section{VIII.}

\section{COSHOGRAPHIE ET GÉOGRAPHIE.}

\section{COSHOGR IPIHE.}

\section{7.}

Cadean pour les esprils éclairés", pal Moḷammad ilon 'Abd al-Rályim al-Qaïsi, de Grenade, mort en 565 de l'hégire (1 169 -1 170 de J. C.). Cet ouvrage traite des merveilles du monde. Liauteur décrit les 
choses remarquables qu'il a observées dans ses royages el reproduit les descriptions plus on moins fabuleuses, tirées d'autres sources. Il dit aroil composé ce livre, se Jouvaut à Mossoul, en 55 ; de l'hégire, sur la demande de son ami $\Lambda$ boû-IJafs 'Omar al-Ardabili. L'ourrage est divisé, à part l'intjoduction, en quatre seclions (أبواب), donl roici les rubriques : $1^{\circ}$ Description du monde et de

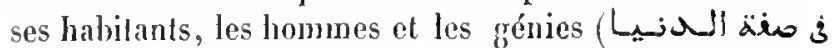

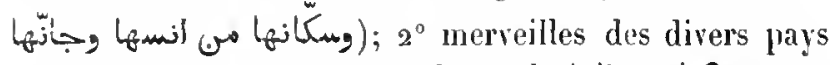

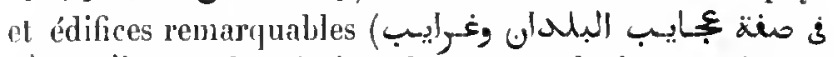
(l) ; $3^{\circ}$ description des mers, de leurs animaux extraordinaires, et ce qu'elles produisent en fait d'ambre gris et de poix; indication des diverses especes de naphte el des subslances inflammables qui se trourent dans les

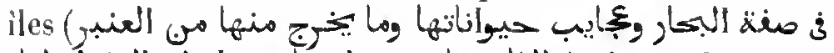

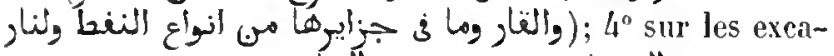

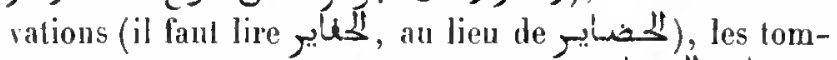

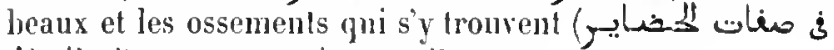

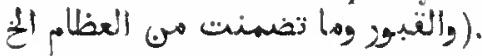

Papier. 10 h feuillets. Ilantenr, 13 centimètres; largeur, 12 centimètres et demi. 11 lignes par page. Ms. de diverses écritures, dont la plus ancienne parait ètre du xü siècle. - (Ancien fonds 586 , Colbert, 6002.)

\section{8.}

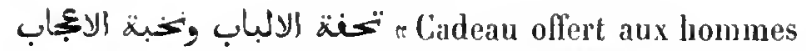
intelligents et choix de merveilles $n$, par Moḷammad ibn 'Abd al-Raḥim al-Qaïsì, de Grenade. Méme ouvrage que le précédent. Quelques dessins grossièrement exéculés sont intercalés dans la partie relative aux édifices fabuleux.

Papier. 46 fenillets. Ilauteur, 21 centimètres et demi; largeur, 15 centimètres. 21 lignes par page. Mls. du $x \times 1^{\circ}$ siècte. - (Ancien fonds 954 .)

\section{9.}

Mème ouvrage. Ms. interfolié, contenant un commencement de lraduction par Pélis de la Croix.

Papier. 56 feuillets. Ifauteur, 20 centimètres et demi; largeur, 15 centimètres. 21 à 23 liggnes par page. Ifs. du wrir siècle. - (Supplément 861.)

\section{0 .}

Même ouvrage, avec un litre un pen différent: تحكنـ r Cadeau pour les hommes intelligenls et (traité) qui excite l'admiration".
Ms. dalé de l'an 1140 de l'hégire (1728 de J. C.).

Papier. 94 feuillets. Hauteur, 21 centimètres et demi ; targeur, 15 centimètres. 13 lignes par page. - (Supplément 863.)

\section{1.}

Mème ourrage. Le litre se lit ainsi : "Cadeau pour les hommes iutelligents, objet choisi et digne d'ètre offert aux honumes de mérite\%.

Papier. 59 feuillets. Hauteur, 22 centimètres et demi; largeur, 16 centimètres. 19 lignes par pare. Ms. du xrme siècle. - (Supplément 862.)

\section{2.}

-Cadeau composé de merveilles et noureauté renfermant des choses élranges n. Cet ouvrage, divisé en quatre sections ou discours (maqualât),

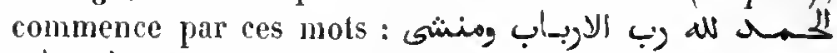
السنياب. La première section traile, en deux cliapilres, des choses célestes et des choses terrestres, du ciel et de la terre; la seconde seclion, des merveilles du monde, du temps, des nuits et des jours; la troisième, des merveilles des mers, des fleures, des sources, des montagnes, etc.; la quatrième traite des minéraux, des planles et des animaux. Les deux dernières parties renferment nne sorte de dictionnajre géographique et une nomenclature des minéraux. Plusieurs pièces de rers, en général assez courtes, et dont la plupart portent des noms de poìtes qui vivaient sous le règne des $A$ bbasides, sont insérées dans le texte. Hadji Klıalfa nous apprend que cette compilation a pour auteur lbn al-Athir al-Djazarî. Mais il y avait trois frères qui portaient ce nom.

Il $\mathrm{y}$ a une lacune entre les feuillets 103 et 104 , et une autre entre les feuillets 147 et 148 .

Ms. dalé de l'an 684 de l'hégrire (1285 de J. C.).

Papier. 189 feuillets. Ilauteur, 26 centimètres et demi; largeur, ${ }_{1} 7$ centimètres. 25 lignes par page. - (Ancien fonds go3.)

\section{3.}

Merveilles des choses crééesn, par Zakarìya ibn Moḷammad ibn Mạ̣moûd al-Qazwînì, mort en 682 de l'hégire ( 1283 de J. C.). Voici le titre qu'on lit en lête du présent ms. et qui diffère de celui qui se كتاب فيه عئايب المخلوقات : trouve dans d'antres excmplaires 


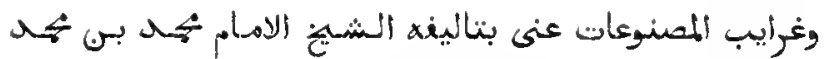

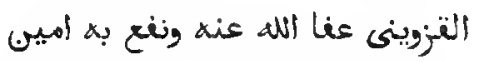

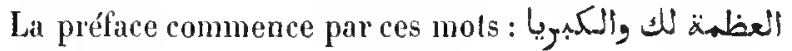
يا تابيم النذأت

Papier. 293 feuillets. Hauteur, 27 centimètres el demi; largeur, 19 centimètres et demi. 17 lignes par page. Ms. du xiv siècle. - (Ancien fonds 898 .)

\section{4.}

Hème ouvrage.

Ms. daté de l’an 93o de l'hégire (1524 de J. C.).

Pinpier. 3 a a feuillets. Hauteur, 18 centimètres et demi; largenr, th centimètres. 15 lignes par page.- (Ancien fouds 958.)

\section{5.}

Hème ourrage.

Hs. daté de l'an 986 de l'hégire ( 1578 de J. C.).

Papier. 227 feuillets. Hanteur, a 1 centimètres et demi; largeur, 15 centimètres el demi. 21 lignes par page. - (Supplément 86'.)

\section{6.}

Hême ouvrage. Le premier leuillet manque.

Papier. 344 feuillets. Hanteur, 21 centimètres; largenr, 14 centimètres et demi. 21 lignes pas' page. Ms. dn xvr sièele. - (Supplément 867 .)

\section{7.}

Mème ouvrage. Le copisle, un chrétien maronile, a

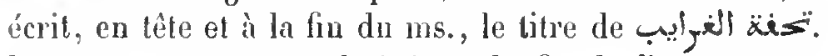
Le texte est soutent alorégé, el la fin de l'ourage est omise,

Papier. 165 feuillets. Hauteur, 29 centimètres; largeur, 19 centimètres. 23 lignes par page. Ns du xwn" siècle. - (Ancien fonds goo.)

\section{8.}

Méme onvrage. Ms. orné de figures coloriées, représen-

$$
\text { Max. oniextalx. - It. }
$$

lant les aninanx et les plantes décrits dans le texte. 11 est daté de l'an 1176 de l'hérgire (1 $7^{62-1} 7^{63}$ de J. C.).

Papier. 380 feuillets. flanteur, 30 centimètres et demi; largeur, 21 centimètres. 23 lignes par page. - (Supplément 866.)

\section{9.}

Premier colume du nême ourrage. La copie s'urrète au chapilre des oiseaux, article

Papier. 162 feuillets. Hauteur, so centimètres; largeur, 13 centimètres et demi. 27 à 29 lignes par page. Ms. du xn" siècle. - (Supplément $208 \%$ )

\section{0.}

Extrait du même ouvrage, chapitre des animaux.

Papier. 17 feuillets. Hauteur, $1 /$ centimètres; largeur, 10 centimètres et demi. 13 lignes par page. -- (Ancion fonds 983.)

\section{1.}

r La petite édition des merveilles de la création", ourrage anonyme, commençant

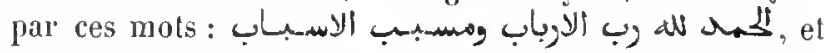
ayant beaucoup d'analogie arec l'ourrage d'Al-Qazwini en ce qui concerne l'ordomnance du sujet. L'auteur dit

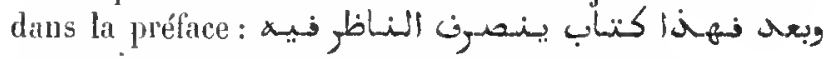

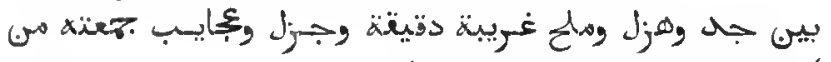
كنب علدة وزتبتنه على إبوابب ألخ

Ms. daté de l'an 1122 de l'hégire (1710 de J. C.).

Papier. 152 feuillets. Hauteur, 22 centimètres: largeur, 14 centimètres et demi. 23 lignes par page. — (Supplément 868.)

\section{2.}

1. Abrégé du Cette rédaction siaccorde lantòt avec la grande édition, tantôt arec l'abrégé contenu dans le numéro précédent. La préface qu’on lit en tête est apocryphe; elle a ćlé ajoutée après coup. Le الباب ألاول ف ألانثار ألعالوية : texte commence par ces mots فن Le second chapitre (fol. 10 ) commence ainsi : الdباب الثناظ ف 
والمزمان واللياني والايام الما النشهور فالنههور عبارة عمى التزمان

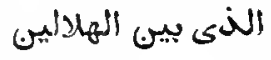

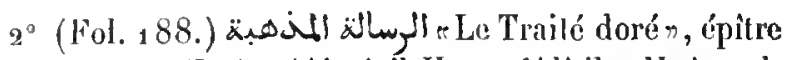
dans laquelle l'Intù ( $A$ boù 'T-Hasan 'Ali ibn Hoùsa alRidla) donne au calife Ml-Ma'moùn des instructions pour la conservation de sa santé. La copie s'arrête an milien d'une phrase.

$3^{\circ}\left(\right.$ Fol. $197 \mathbf{r}^{\circ}$.) Recettes médicales. Les derniers fenillets sont restés en hlanc.

Papier. 199 feuillets. Ilauteur, 21 centimètres; largeur, 15 centimètres. 15 lignes par page. Ms. du xvi siècle. - (Supplément 865, Saint-Germain 398 .)

\section{3.}

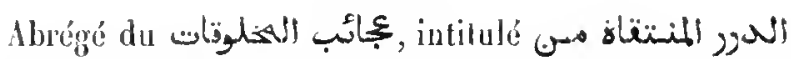


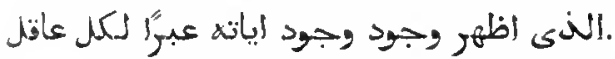

.ls. dalé de l'an 872 de l'hégire ( 1467 de J. C.).

Papier. 193 feuillets. Hauteur, 26 centimètres; largeur, 18 centimetres. 21 lignes par page. - (Ancien fonds 9go A.)

\section{4.}

Traité des merveilles r, par un anonyme qui parait aroir vécu vers la fin du vic siccle de l'hégire. La préface commence par ces mots : a_

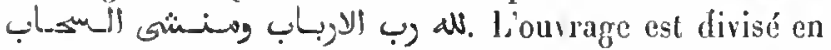
'fuatre serlions, el traite : $1^{\circ}$ des pierres; $2^{\circ}$ des plantes; $3^{\circ}$ des villes; $4^{\circ}$ des pays, des mers, des leures et des montagnes, elc.

Papier. $7^{6}$ feuillets. IJanteur, 21 centimètres el demi; largenr, 12 centimetres el demi. Euviron 27 tignes par page. Ns. de diverses écritures du $x^{\mathrm{e}}$ siècle. - (Ancien fonds 956.)

\section{5.}

Traité de cosmograplice, consacré principalement à la deseription des océans. Le premier feuillet manque. A la fin de la préface, l'auteur dit qu'il a puisé ses matériaux dans les ourrages d'Al-Qazwîni, d'Al-Mascotidi ef d'autres. Il a divisé son ouvrage en trois chapitres (قتول), dont le

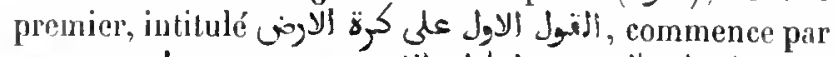

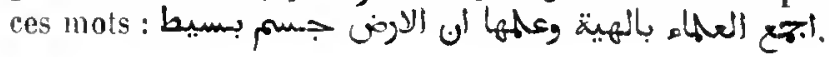

Le second chapitre est intitulé التول ألثان على كرة الماء

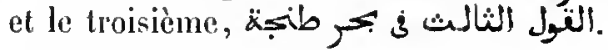

Papier. 25 feuiltets. Hauteur, 22 centimètres; largeur, 1 /s centimètres. 21 lignes par page. Ms. du xv11" sièc!e. - (Supplément 3267.$)$

\section{6.}

Manuel de cosmographic, par Ishâq ilon al-ḷasan ibn al-Zaiyât. L'auteur dit que les latiludes se comptent, vers le nord et vers le sud, et les longitudes rel's louest et vers l'est, à partir de l'ile d'Arìn (الريب(), qui est le centre du monde. Il parle ensuite des sept climats, des phases de la lune $\left(f_{0}, 3_{2} \mathrm{v}^{\circ}\right)$, des éclipses, des étoiles fixes et des constellations, et des hourrasques (بـوارح) qui accompagnent les levers des vingt-liuit mansions de la lune. Suit une ardjoûza de vingt-liuit vers sur la direclion de la qibla dans les diverses contrées musulmanes. Le fol. 44 porte un dessin représentant l'orientation de la lacba. Au feuillet suivant commence un Iraité de gnomonique, suivi de tables indiquant la longueur des ombres, les levers des signes du zodiaque, les positions des étoiles, etc.

Papier. 75 fouillets. Hạteur, 34 centimètres; largeur, 17 centinèेtres. 17 à 19 lignes par page; quelques feuillets sout intervertis. Nls. du xive siècle. - (Supplément 956, Saint-Germain 142.)

\section{7.}

r Chlioix de ce que le monde nous offre en fait de merveilles de la terre et de la mern, par Schams al-Din Aboû 'Ald Allah Mohammad ibu abî Țìlib al-Anșầì al-Dimaschqî, mort en 727 de l'hégire (1 $3_{2} 6-13_{27}$ de J. C.). C'est une compilation faite sans critique, mais qui offre quelques bons renseignements. l'ouvrage est divisé en neuf sections (royez la traduction de la Géographie d'Abou 'l-Féda, de M. Reinaud, p. GL, et le Catalogue de la bibliotheque de Leyde, t. I, p. 134). Quelques figures mal dessinées et grossièrement coloriées sont intercalées dans le texte. Le premier feuillet manque.

Ms. daté de l'an 845 de l'hégire (1441-1442 de J. C.).

Papier. 148 feuillets. Hauteur, 27 centimètres el demi; largeur, 18 centimètres. 29 lignes par page. - (Ancien fonds 581.)

\section{8}

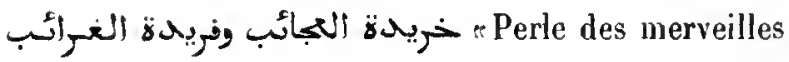


et joyau des raretés", traité de cosmographie, par Aboû Hafs s ${ }^{\circ}$ Omar ibn Mohammad ibn al-Wardi, mort en $7^{4} 9$ de thégire ( 1349 de J. C.). Un planisphère d'environ vingl-cinq centimètres de diamètre, représente la partie habitée de la terre el occupe le verso du folio 2 el le recto du folio 3 . Au verso du folio 25 se trouve un tablean carré qui montre l'orientalion des villes et des pays du territoire nusulman, par rapport au temple de la Mecque. (Voir, sur cet ouvrage, De Guignes, dans les Notices et Extraits, I. II, p. 19 el suiv.) L'ourrage est suivi d'une pièce de vers, dont quelques hémistiches et beaucoup de mols sont restés en blanc, et dans laquelle sont énumérés les événements qui aurout lieu au jour du jugement dernier. Au folio 93 , on voil larbre généalogique d'un personnage نوفل بـ عبد qui descendait de مطرن بر كبريت منان.

Ms. daté de l'an 883 de l'hégire ( 1479 de J. C.).

Papier. $9^{3}$ feuillets. Hanteur, 28 centimètres; largeur, 20 centimètres. 25 lignes par page. - ( 1 ncien fonds $\left.577^{\circ}\right)$

\section{Nème ourrage.}

\section{9.}

Is. daté de l'an 885 de l'hégire (1480 de J. C.). Le premier feuillet, ainsi que celui qui précédait le poème qui forme l'appendice, manquent.

Papier. 113 feuillets. llauleur, 26 centimètres ; largeur, 17 centinètres el demi. 25 lignes par page. - (Supplément 888.)

Mème ouvrage.

\section{0.}

Ils. daté de l'an 928 de l'hégire ( 1522 de J. C.).

Papier. 110 feuillets. llauteur, 32 centimètres et demi; largeur, as centimètres. 25 lignes par page. - (Supplément 9oo.)

\section{1.}

Mème ouvrage.

Ms. daté de láan $99^{2}$ de l'hégire ( 1584 de J. C.).

Papier. 162 feuillets. Hauteur, 22 centimètres el demi; largeur, 15 centimétres. 22 à 25 lignes par page. - (Ancien fonds $59_{9} 3$.)

\section{2.}

Mème ourrage. Outre les appendices qui se trouvent dans d'autres exemplaires, ce volume conlient plusieurs morceaux de poésie religieuse, dont le prennier, intitulé

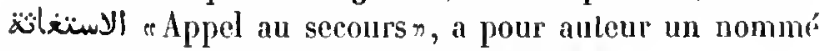
Aḷmad, derviche de l'ordre des Khalwaiti.

Ms. daté de l'an 1000 de l'hégire (1591-1592 de J. C. $)$.

Papier. ${ }^{2} 79$ feuillets. Hauteur, 21 centimètres; largeur, 14 centimètres el dlenii. 15 lignes par page. - (Ancien fonds $59^{4}$.)

\section{3.}

Mème onvrage.

Ms. daté de l'an 1005 de l'hégire ( $1596-1597$ de J. C.).

Papier. 163 feuillets. Hauteur, 21 centimètres; largeur, 15 cen!imètres. 19 lignes par prige. - (Ancien fonds 588.)

\section{4.}

Hême ouvrage. C'est par erreur que, dans le titre, louvrage est attribué à Qazwini.

Ms. dalé de l'an 1020 de l'hégire (1611 de J. C. .).

Papier. 242 feuillets. Hauteur, 20 centimètres; largeur, 11 centimètres el demi. 19 liggnes par page. - (Ancien fonds 591.)

\section{5.}

Mème ouvrage.

Ms. daté de l’an 1020 de l'hégire $(1611$ de J. C. $)$.

Papier. 16 亿 feuillets. Hanteur, so centimètres et demi; largeur, 15 centimètres. 21 lignes'par page. - (Supplément 897.)

\section{6.}

Mème ouvrage.

Ms. daté de l'an 1021 de l'hégire (1612-1613 de J. C.).

Papier. 155 feuillets. Hauteur, 18 centimètres; largeur, 10 centimètres et demi. 21 lignes par page. - (Ancien fands 601.)

\section{7.}

Mème ouvrage.

Ms. de deux écritures. La partie plus récente a été écrite en l'an ${ }_{1037}$ de l'hégire ( $1627_{-1628}$ de J. C.).

Papier. 213 feuillets. Hauteur, 20 centimètres; largeur, 15 centimètres. 19 lignes par page. - (Ancien fonds 592 ) 


\section{8.}

Hène ourrage.

A la fin du volume ou lit une note sur la manière de deviner l'issue d'un combat, et une pièce de vers sur' le jeu d'échecs, par le chérif Ibn al-Habbàriya (ألهيّارية).

Papier. 210 feuillets. Hauleur, 22 centimètres; largeur, 15 centimètres. 17 lignes par page. Ns. du xvile siècle. - (Ancien fonds 590.$)$

Nlème ouvrage.

\section{9.}

A la fin du volume, on lit l'histoire d'Og, tirée, dit le copiste, de l'ourrage d'Aboù 'Obaïd al-Bakrì, intitulé

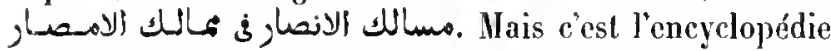
de Schilhàb al-Dìn al-'Omarì qui porte ce titre.

Papier. 1 g feuillets. Hauteur, 23 centimètres el derni; largeur, 17 cenlimèlres et demi. 23 lignes par page. Ms. du xvi siècle. (Ancien fonils 589 , Colbert 5298 .)

lème ourage.

\section{0.}

Papier. 278 feuillets. Hauteur, 21 eentimètres; largeur, 15 rentimèrres. 1 / lignes par page. Ms. du xvn sièele. - (Supplément 1906.)

\section{1}

Même ouvrage.

Papier. 185 feuillets. Hauleır, 20 centinètres el demi; largeur, $1 /$ centimèlres. 19 lignes par page. Ns. dn svı siècle. - (Supplément $89^{6}$.)

Hème ourrage.

\section{2.}

Hs. daté de l'an 1090 de l'hégire ( 1679 de J. C.). Papier. 145 feuillels. Hauteur, 21 cenlimètres; largeur, 15 centimètres el demi. 21 lignes par page. - (Supplément 898 .)

\section{3.}

Nême ouvrage.

Papier. 118 feuillels. Hauteur, 29 centimètres el demi; largeur, s 0 centimètres. 25 lignes par page. Ms. du xvi1 è siècle. - (Supplćment 899 .)

\section{4.}

1 Même ouragge.

$2^{\circ}$ (Fol. 147 vº -Objet des désirs des étudiants, commentaire sur le Souhait des calculateurs ». L'ourrage commenté est le traité d'aritlımélique de Mohammad ibn Aḥmad Ghàzì, commençant par ces mots : تلوبنا

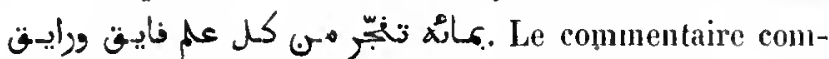

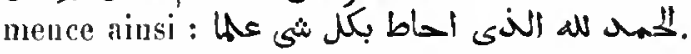

Papier. 255 feuillets. llauteur, 20 centimètres et demi; largenr, 15 centimètres. Le premier ouvrage parte so lignes par page, le serond 32 lignes. Ms. du xvı siècle. - (Supplément a341.)

\section{5}

Fragments de la première parlie du Kharidat al-'Adjaiib d'Ibn al-Wardi.

Papier. 37 feuillets. Hauteur, 21 centimètres; largeur, 15 centimètres. 17 lignes par page. Ns. du xme sièele. -- (Supplément a 100.)

\section{6.}

Table de la cosmographie d'Ibn al-IVardi. Cette table a été dressée sur le ms. $219^{8}$, par Michel Șabbàgh.

Papier. 2 pages. Hanteur, 23 centimètres cl demi; largeur, 18 centinièlres. 15 lignes par page. - (Supplément 2101 .)

\section{7.}

Le Parfun des fleurs, trailé des merveilles des diverses régions ", par Moḥammad ilın Ahmad ibn Aiyâs. Dans cette cosmographie, l'auteur parle d'abord des villes, des pays, des mers et des iles, des fleuves et surtout du Nil, des sources (عيمون) remarijuables, des puits (بير) et des montagnes. Suit une nolice sur les pyramides, une autre sur les fêtes des Coptes, puis quelques obserrations sur le calendrier copte et sur les noms des mois chez les Arabes, les Coptes et les Persans. L'auteur a achevé son travail en 922 de l'hégire ( 1516 de J. C.). (Voyez, sur cet ouvrage, une nolice de Langlès, dans le tome VIll des Notices et Extraits.)

Ms. daté de l'an 1018 de l'hégire ( 1609 de J. C.).

Papier. 356 feuillets. Hauteur, go centimètres et demi; largenr, 15 centimètres. 19 lignes par page. - (Supplément 905.) 


\section{8 .}

Nème ouvrage.

Ms. daté de l'an 1044 de l'bégire ( 1634 de J. C.).

Papier. 410 pages. Hanteur, 25 centimètres et demi; largeur, 8 centimètrus. 29 lignes par page. - (Supplément $9^{\text {at. }}$ )

\section{9 .}

Mème ouvrage.

Hs. daté de l'an 1115 de l'hégire (1703 de J. C.).

Papier. 380 feuillets. Janteur, a 3 centimètres; largeur, 16 centimètres. 19 lignes par page. - (Ancien fonds 595.$)$

\section{0}

Fragment dı même ouvrage.

Ms. daté de l'an 1110 de l'hégire ( 1699 de J. C.).

Papier. 54 feuillets. Hauteur, a1 centimètres; largeur, 15 centimètres et demi. 93 lignes par page. - (Supplément go6.)

\section{1}

Table de la cosmographie d'lbn Aiyàs. Cette table a été dresséc sur le ms. 2209, par Michel Sabbaigh, en 1808.

Papier. 48 feuiltets. Hauteur, 23 centimètres et demi; largenr, 18 centimètres. 15 lignes par page. - (Supplément a 109. )

\section{2}

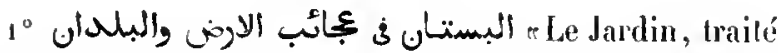
des merveilles de la terre el des pays n, par Salàmisch

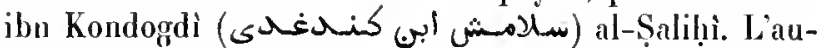
teur dit dans la préface quil a recueilli les natériaux de son ourrage dans les livres de ses devanciers, et il énumère les titres d'une dizaine de ces traités. Ces extrails sont classés en sept chapitres qui traitent : $1^{\circ}$ des sphères rélestes; $2^{\circ}$ de la terre et des climats; $3^{\circ}$ des mers, des îles et de leurs merveilles, des lacs, des sources el des flenves; $4^{\circ}$ des montagnes, des puits et des qualités merveilleuses des pierres précieuses; $5^{\circ}$ des divers pays et peuples du monde; $6^{\circ}$ des animaux, des génies, des plantes et des merveilles des êtres créés; $7^{\circ}$ des monuments anciens, des grands édifices, des rois et des magiciens, ainsi que des talismans. Cette compilation de fables parait aroir élé rédigée, au xvie siècle, en ligyple.

$2^{\circ}$ (Fol. 35.) Extrail du Dìn ibn al-Schiḷna (rojez ci-dessus, $n^{\circ} 1537$ ). C'est un résumé des principaux liails de lhistoire miverselle, qui se termine par un lableau des événements qui annonc:ront la fin du monde.

$3^{\circ}$ (Fol. $40 r^{\circ}$.) Notes, les unes en arabe, les aumes en turc, relatives aux lioux oǹ il y a des trésors cachés.

Is. daté (l'ol. $\left.341^{\circ}\right)$ de l'an $9^{45}$ de l'légorire $(1539 \mathrm{de}$ J. C.).

Papicr. 41 fenillets. Ilauteur, 20 centimètres et deni; largoun, 15 centimétres. 25 lignes par jage. - (Supplément 903.)

\section{GÉOGRAPHE GÉxÉRAL:}

\section{3}

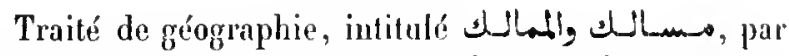
"Abd Allah ibn 'Alod Allah ibn Khordàdbeh. Ce Iraité, qui date de la seconde moilié da $x^{2}$ siècle de l'ère chrétiemne, a été publié et tradnit par M. Barbier de Heynard, dans le Journal asiatique de l'année i 865 . Le présent exemplaire a été copié à Constantinople.

Papier. 5/ feuillets. Ilauteur, 20 centimetres; largeur, 1/ centimètres. 15 lignes par page. Ms. du xı siècle. - (Supplément 89.5 bis.)

\section{4.}

Traité de géographie, accompagné de carles. Ourrage anonyme, dédié à Saif al-Daula ilun llandàn, sourerain de la Syrie et de la Mésopotamie, mort en 356 de l'hégire ( 967 de J. C.). La préface commence par ces mots : Après l'éloge de Saif al-Daula, et l'exposé du plan suivi par l'auteur, on troure la liste des cartes, dont chacune est accompagnée d'une description détaillée, ì sar oil : $1^{\circ}$ l'lrabie; $2^{\circ}$ la mer de la Perse on l'Océn indien; $3^{\circ}$ la llan-

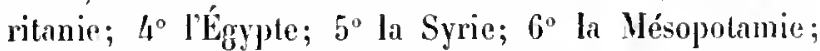
$7^{\circ}$ l'Iràq; $^{\circ}$ le Khouzistàn; $9^{\circ}$ le Fars; $10^{\circ}$ le Kirmàn ;

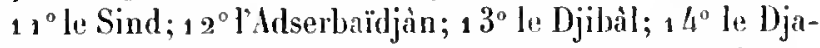
bal, le Daïlam et le Tabaristàn; $15^{\circ}$ la mer de Tabaristản (la mer Caspienne); $16^{\circ}$ le désent qui sépare le Fars du Khorâsàn; $17^{\circ}$ le Sidjistàn; $18^{\circ}$ le Tokhâristân

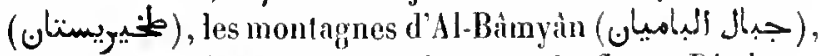
le Toùs et le Koùhistàn; $19^{\circ}$ le cours du fleuve Djaïhoun (l'Oxus). 
Le ms. renferme dis cartes suivantes :

Fol. 3. Tracé de l'hémisphère seplentrional (sans la nomenclature).

Fol. \. Tracé de la mer indienne, an sud de l'Arabie.

Fol. 5. La mer indienne, l'Aralie el le cours inférieur dris'Euphiale.

(La carle el la description de la Hauritanic et le commenc ment de la description de l'Arabie manguent.)

Fol. 10. la Méditerranér.

Fol. 12. La basse Égypla.

Fol. $13 r^{\circ}$. Le cours supérieur du Nil.

Fol. 18. La Mésopolamie.

Fol. $211^{\circ}$. Letrât.

Fol. $241^{\circ}$. Le Khoûzistîn.

Fol. $25 \mathrm{r}^{\circ}$. Le Kirmàn.

Fol. $29 \mathrm{r}^{\circ}$. Le Fars.

Fol. $30 v^{\circ}$. Le: Sind.

Fol. 32. L'Arménie, l'Adserbaidjàn et l'Arràn.

Fol. 34. Le Djibii].

Fol. 36. Le bjabal el le Tabaristàn.

Fol. 37. La mer des Khazar (la mer Caspienne).

Fol. $39 v^{\circ}$. Le désert qui sépare de Fars el le Khorèsân.

Fol. 42. Le Sidjistàn.

Fol. $45 r^{\circ}, 46 r^{\circ}$. Le Khoraisân.

Fol. 53. Planisphiere oval.

Ce manuel de géographie qui a été sourent copié, a élé interpolé à clraque nouvelle copie. La plupart de ces addilions sont du vie siècle de l’hégire, la plus récente porte la date de 858 , date qui contredil une note ajoutée

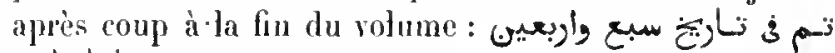

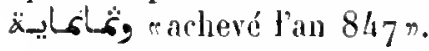

Le litre de l'ourrage est inconmu. Denx titres diffeI'enls, qu'on lit au commencement du ms., paraissent apocryphes. On peut supposer que ce Irailé a eu pour autem $\mathrm{A}$-Istakhri; mais il differe en plusieurs points du lexte litloggraphié el pubtié à Gotha, en $\mathbf{1} 839$, par les soins du Dr J. H. Möller. Le présent ms. est pourvu d'une table, de la main de Mielıel Sabbigh.

Papier. 53 feuillets. Hauteur, 35 centimètres; lirgeur, 26 centimètres et demi. 23 lignes par page. Ms. du xv1 sièrte. - (Ancien fonds 583.)

\section{5.}

e Roules el royaumes », traité de géographic, par Ibn I!auqa\}. Is. copié sur le ms. de Leyde, par MII. Langles et Jourdain.

Papier. 256 pages. Hauteur, 26 centimètres el demi; largeur, 21 centimètres et demi. 27 lignes par page. - (Supplèment 885.)

\section{6.}

Cinfuante-six passages de la géographie d'Ibn Hauqal qui, dans la copic coutenue dans le numéro précédent, araiênt été omis. Ces morceaux, écrits de la main de Michel Șabbàgh, ne se suivent pas dans l'ordre du texte.

Papier. 56 feuillets. Hlauteur, a 1 centimètres et demi; largenr, 16 centimètres. - (Supplément 885 bis.)

\section{7.}

Table de la Góographie d'lbn llauqal, faite sur le ms. 2215 , par Miclıel Șabbàgh.

Papier. 18 feuillels. Hauteur, 29 centimètres; largeur, 16 centimètres et demi. Environ a lignes par page. - (Supplément 885 ter.)

\section{8.}

Fraguent de l'ourrage intitulé كلمh' Routes et royaumes", par 'Abd Allah ilon 'Abd al-'Azìz Aboû 'Obaïd al-Bakıí. C'est probablement la dernière partie du second rolume de l'ourrage. Plusieurs feuillets manquent dans le corps du volume, ainsi que les derniers cahiers, qui contenaient la description de l'Espagne, dont il ne reste que te commencement. M. de Slane a pubtié le texte de ce ms., après l'ayoir corrigé au moyen d'un sceond exemplaire qu'il avait découvert à Alger. Le frontispice el le titre qui occupent le premier feuillet sont apoeryphes.

Papier. a 56 feuillets. Hauteur, 26 centimètres et deni; largenr, 18 centimètres. 21 lignes par page. Ms. du xü siècle. - (Ancien fonds 580. .)

\section{9.}

r Traité des moṇtagnes, des lieux et des sourees", par Aboû 'l-Qâsim Mạ̣moûd Zamakhscharî. Dictionıaire des noms géographiques contenus dans les anciennes poésies arabes. Cet ouvrage a été imprimé à Leyde, en 1856.

Exemplaire copié par Michel Ṣabbâgh, en 1811, sur le ms, de Leyde, $n^{\circ} 7^{3} 9$.

Papier. 38 feuillets. Hauteur, 29 centimètres; largeur, 30 centimètres el demi. 21 lignes par page. — (Supplément 889.) 


\section{0 .}

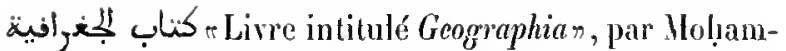
mad ibn abi Bakr al-Zohri. L'auteur dit qu'il a copié ce r'ésumé sur un exemplaire de la Géographie d'Al-Qomâr (النقاوى), qui avait copié le sien sur l'exemplaire de l'ouvrage que soixante-dix phitosophes avaient composé pour Al-Ifamoûn, fits de Haroûn al-Raschìd. Cela paraìt signifier qu'Al-Qomârì avait donné une nouvelle édition de la Géographic d'Al-Ma'moùn, et que Ibn abi Bakr a l'emanié l'édition d'Al-Qomàrí. On lit au fol. $40 r^{\circ} \mathrm{du}$ présent ms. que l'autenr se trourait à Grenade, en 532 de l'hé-

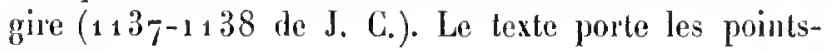
royelles.

Papier. 58 fenitlets. Hauteur, 21 centimètres; largeur, 13 centimètres el demi. 18 lignes par page. Ms. du $x_{y 1^{\circ}}^{\circ}$ siècle. - (Ancien fonds 596 , Colbert $5_{97}$ 4.)

\section{1 .}

م Ammsement pour qui désire parcomrir les différentes parties du monde». C'est le célèbre traité de géographie, composé par Idrìi , vers le milieu du xn siècle, à la cour de Roger 11 , roi de Sicile. Les premiers feuillets sont en partie détériorés; le dernier feuillet, renfermant la dixième section du septième climat, manque; d'antres feuillets dans le corps du volume ont été raccommodés et présentent des lacunes. Cet exemplaire renferme un planisphère dessiné arec soin et soixante-liuit cartes, représentant chacune ta dixième section d'un climat, également fort bien dessinées et coloriécs. Ce sont probablement, de toutes les cartes arabes, les mieux exécutées. Deux cartes, celles de la prenière et de la seconde section du septième chimat, manquent.

Papier. 352 fenillets. Hauleur, 26 centimètres; largeur, a 2 centimè̀res. 23 lignes par page. Ms. maghirelsin du xm" siècle. - (Supplément 893.)

\section{2 .}

1 Hểne onviage. Exemplaire dépourvu de cartes, exéculé en 744 de l'hégrire (134h de J. C.), à Coimbre (تمرية). Les deux preniers feuillets sont du xvn' sicele.

$2^{\circ}$ (Fol. $236 \vee^{\circ}$.) Le dix-huitième chapitre de l'ouvragge d'Aboû 'I-Raịlyân al-Bìroûnì sur l'Inde. Copie moderne.

Papier. ${ }_{3} 38$ fenillets. Hanteur, 3 o centimètres et demi; largeur, 31 contimètres. 25 à 29 lignes par page. - (Supplément 893 .)

\section{3 .}

Abrégé de la Géographie d'ldrìsì. C'est probablement l'exemplaire d'après lequel a été imprimé le texte publić ì Rome, vers la fin du xw $x^{c}$ siècle. Un tilre apocryphe, ajonté après coup au commencement du volume, a été reproduit dans l'edition.

Ms. daté de l'an 944 de l'hégire (1538 de J. C.).

Papier. 101 feuillets. Hautenr, 21 centinètres; larmeur, 15 centimètres. 25 lignes par page. -- (Supplément 89!, Saint-Grrmaiu 334 ter.)

\section{4}

Table des matieres de l'abrégés de la Gróographie d'ldrisi. Cetle lable est de la main de Mirhel Sabbaght. Elle paraìt avoir été destinée ì un exemplaire paginé du texte imprimé.

Papier, 121 fenitlets. Hauteur, 23 centimètres; largeur, 17 centimètres et demi. 15 liggnes par page. - (Supplément 895.)

\section{5 .}

Traité de géographie. Les premiers feuillets manquent. Le ms. commence par la description du mont Aboù Qobaïs et d'autres lieux des environs de la llecque; vient 'nsuite une notice sno ta ville de Módiue, puis un article sur l'Égypte, suivi d'un traté sur l'A frique, depuis la vallée dn Nil jusquà l'océan Atlantique. L’antenr, qui virail sous la domination des catifes Almohades, dit qu'il a rédigé cet ourragre en 586 et 587 de l'hégrire ( 1190 et 119 1 de J. G.).

Ms. daté de l'an 1143 de l'hégire $(1730-1731$ de J. C.).

Papier. 97 fenillets. Ilanteur, 32 centimètres; largeur, 21 centimètres. 26 lignes par pağe. - (Supplément 906 bis.

\section{6 à 2231 .}

follow Grand dictionnaire géographique de Yàqoùt al-llamawi. Cet onvage a été publié par M. IVüstenl'eld. Copie exécutée d'après les mss. de Constantinople, rers 1850 .

6 vot. Papier. 552, 332, 321, 527, 501, 580 fenillets. Lauleur, 30 centimètres el demi; largeur, 19 centimètres et demi. 17 ligsnes par parge. -- (Supplément 886.) 


\section{2 .}

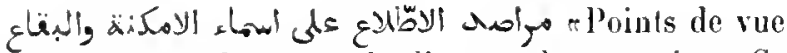
d'oủ lon apercoil les nonns des lieux et des contrées\%. Ce

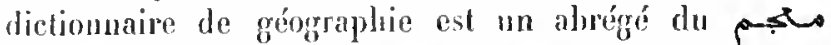

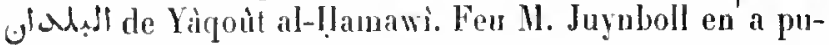
blié unc édilion arec des notes. Daus la préface du traité

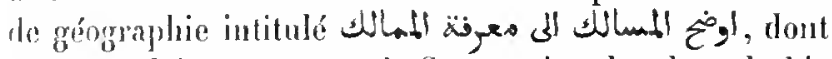
nu exemplaire se trouve à Constantimople, dims la bibliothèque londée par Ràghib Pacha, on lit que l'auteur du ofo se nommait Tingi al-Din 'Abd al-Moûmin ibn "Mld al-llaył. Ms. copić en 1810 , sur le ms. de Leyde, $11^{\circ} 724$, par Nichel Sabbàgh.

Papier. 35 , fonillets. Hauteur, a 8 centimètres el demi; largeur, 30 renlimètres el demi. a l lignes par page. - (Supplément 89٪)

\section{3.}

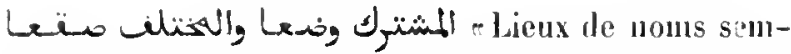
blables et de positions différentesn, dictionnaire d'homonymes géographiques, par Yàgoût al-Hamawi. Get ouvrage a été publié par II. Wüstenleleld. Hs. copié en 1811 , sur le ms. de Leyde, $n^{\circ} 725$, par Michel Sabbàgh.

Papier. 114 feuillets. Ninuleur, 38 centimetres et deni; largeur, 20 centinètres el demi. 21 lignes par page. - (Sujplément $89^{\circ}$.)

\section{4.}

$1^{\circ}$ Traité de géographie générate, par 'Ali ibn Sil id al-Maghribi. Copie datée de l'an 714 de l'hégrire (13141315 de J. C.), ayant appartenu au célèbre Aboù 'l-Fidâ, prince de Hamâh.

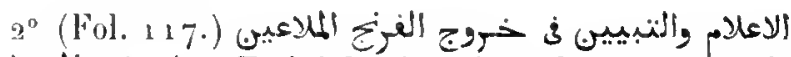

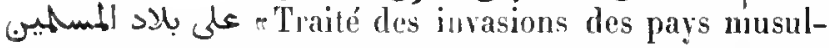
mans par les maudits Francs\%. Histoire abrégée et très sommaire des Croisades, depuis la première arrivée des Croisés eu Syrie jusquà leur expulsion définilive de ce pays, par Alumad ibn 'Alí ibu al-I!arivi. Exemplaire autographe daté de l'an 926 de l'hégire (1520 de J. C.).

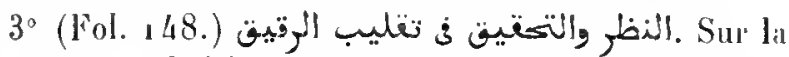
maniere de choisir el de gomerner des esclases, par Mohammad ihn Ibrâhîm ilon Sảid ibn al-Akfaini al-Ansàri. Exemplaire incomplet et interpolé, qui paraìt dafer du $x^{\mathrm{e}}$ siècle. Écriture sourent dépourve de points diacritiques.

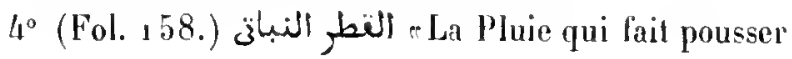

les plantes r, clıoix d'extraits du diran d'lbn Nobâta Djamâl al-Dìn Moḷammad, poète de la cour d'Aboû 'l-Fidà. Ce recueil a été composé par l'auteur lui-ınême. Commencement : بل Lol. Copie datée de l'an 732 de l'hŕgire (1332 de J. C.).

$5^{\circ}$ (Fol. 201.) Plusieurs pièces de vers, entre autres le commencement d'une élégie d'Ibn Nobâta sur la mort d'Aloù 'l-Fidà.

Papier. 202 fcuillets. Hauteur, 18 centimèlres; largeur, 13 centimètres. Écritures diverses. - (Supplément 1905.)

\section{5 .}

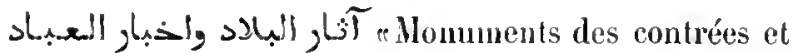
notices des habitants». Première édition du Diclionnaire de géographie de Zakariya ibn Moḷammad ibu Mạımoûd al-Qazwini. Cet ourrage a été pulblié par M. Wüstenfeld. Le présent exemplaire est incomplet et s'arrète à la lettre şad dı septième climat. Un index général est placé en tête du volume; un autre index, de la main de Hichel Sabbâgh, se trouve à la fin.

Papier. 25๊a feuitlets. Haulcur, 30 centimètres; largeur, 18 centimètres et demi. 23 lignes par page. Us. du xvi" siècle. - (Ancien fonds 899. )

\section{6 .}

Mêne ourrage. En tềte de cet exemplaire se Irouvent quelques détails biographiques sur l'auteur, empruntés au Tabaqât d"sbd a]-Raoul" al-Manâwì. Il y a aussi un index des principaux personnages.

Papicr. 216 feuillets. Hauleur, 21 centimètres; largeur, 15 centimètres et demi. 19 tignes par page. Ns. du xwn siècle. - (Ancien fonds 957 .)

\section{7.}

أن Merreilles des pays", par Qazwìni.

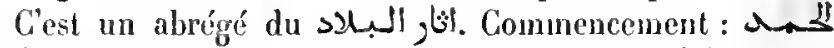
卉 L'auteur est désignć par les noms d'Aboù Zakarîya Molıanmad ibn Moḷammad al-Qazwîni. La division du Dictionnaire géographique par elimats n'est pas bien iudiquée; aucune marque ne distingue les noms de lieux placés en tète de chaque article; mais, en revanche, il y a 
beaucoup de rubriques tout à fait inutiles. La fin manque. Le texte s'arrête au unilieu de l'article تزوين.

Papier. 131 feuillets. Hanteur, 37 centimètres el demi; largeur, 18 centinètres. 22 ì $9 / 4$ tignes par page. Ms. du xw1 ${ }^{\circ}$ siècle. - (Supplément 916 , Saint-Germain $9^{4}$.)

\section{8.}

Mème ourrage. La préface commence ainsi : A wall

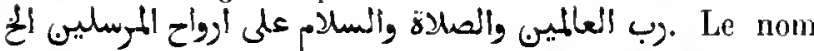
de lauteur est indiqué ainsi : Zakarìya ilon Moḷammad ibn llạımoûd al-Qazwini.

Papier. at5 feuillets. Hanteur, 21 centimètres; largenr, i 5 centimètres el demi. Au commencement 19 lignes, puis 3 I lignes par page. Ms. de diverses écritures du xvu" siècle. - (Supplément 917, SaintGermain 397. )

\section{9 .}

"Tableau synoptique des pays", traité de géographie comparée, par Aboû 't-Fidà (Al-Malik alMowaïyad 'Imàd al-Dìn Ismacil), prince de Hamâh. Cet exemplaire est l'un de ceux dont MII. Reinaud et de Slane se sont servis pour leur édition du texte arabe, pubhíe pour la Société asiatique, en 1840.

Papier. ${ }_{2} 5$ feuiltets. Hauteur, 27 centimètres; largeur, 18 centimètres. 23 lignes par pagre. Its. du $x v^{\circ}$ siècle. - (Ancien fonds 578. )

\section{0.}

Vêne ouragge. Ms. copié sur l'exenplaire de la bibliothèque de l'université de Leyde, en 1655 de J. C.

['apier. 289 feniltets. Hauteur, 32 rentimètres; largeur, 21 centimètres. 31 lignes par page. - (Ancien fonds 579 .)

\section{1 et 2242.}

Mème ourrage. Ms. copié par G. Schickart, professeur dhébreu à Tubingue, au $x^{2} u^{\mathrm{e}}$ siecle, sur le ins. arabe, $\mathrm{u}^{\circ} 1265$, de la Bibliothèque impériale de Vienne. Ontre le texte arabe, on trouve des notes et quelques passages traduits en latin, le tout de la main de Schickart. Le rerso de chaque feuillet est resté en blanc.

a vol. Papier. a 40 el 624 feuillets. Hauteur, ao centimètres; largeur, 17 centimètres. 16 à 20 lignes par pagre. - (Aucien fonts 587.)

MAx. orientact. - II.

\section{3.}

Extrait du même ourrage. Copie faite à Paris, sur to ms. 2239 , par Pierre Dippy, d'Alep, et datée de l'an 1696 de J. C.

Papier. 1 o6 feuillets. Hanteur, 28 centimètres et demi; largenr, so centimètres. 15 lignes par page. -- (Supplément 2098.)

\section{4.}

Divers passages du mème ourrage, copiés et traduits en français, par M. Solvel. A ces fragments se trouve joint un exemplaire du er Abulfeda Africa ", publié pra Eichhorn.

Papier. 53 feuitlets. Hauteur, ag centimètres; largenr, a a centimètres. Hs. di xix siècle. - (Supplément 2502.)

\section{5 .}

Liste des chapitres et darticles divers du Taqwim alBoldân, d'àprès le ms. 2239 , de la main de Michel Șabbàgh.

Papier. to pagcs. Hanteur, s3 centimètres el demi; largeur, 18 centimètres. 16 lignes par page. Ms. du xir siècle. - (Supplísment 2099.)

\section{6 .}

Sommaire des renseignements concernant les merreilles des divers pays \%. Traité de géographie qui commence par une courte introduction et renferme des notices sur les lieux les plus remarquables de chacun des sept climats. Les noms sont disposés dans l'ordre de l'alphabet. L'iuteur, 'Abd al-Raschìd Sălih ibn

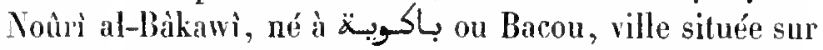
les bords de la mer Caspienne, dit, dans l'article consacré à cette ville, que son père était mort en 806 de l'hégire (1403-1404 de J. C.). Dans la préface de notre exemplaire, te nom ethmique de l'auteur est écrit swghl.

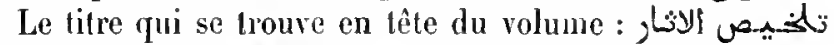
, وعايب ألملك التقهيار , n'est pas exact; le copiste a mal lu

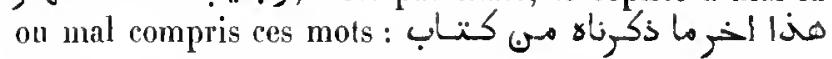
, qui terminent le traité. II. de Guignes a donné une nolice de cet ourrage dans le second volume des Notices et Extraits.

Au fol. 75 , on lit une pièce de vers rimant en $\alpha \dot{s}$, et attribuée à un schaïkh égyptien, nommé Moḥanmad al- 
Bakrî. Au fol. $7^{6}$ se troure une nolice sur le poèle AlMotanabbì. Ms. daté de l'an 1023 de l'lúgine (1614 de J. C.).

Papier. 77 feuillels. Ilauteur, 2 s centimètres; largeur, 15 centimòtres. 19 lignes par page. - (Ancien fonds 585 , Colbert 5299.)

\section{7.}

Mềme ourrage. Copie exécutée sur le ms. précédent par llichet Sabbigh.

Papier. 24 feuiltets. Hanteur, 32 centimetres et dem; largeur, 2 o centimètres el demi. 1 a lignes par page. Ms. du xrx" siècte. - (Supplément 887\%)

\section{8.}

Traité de geographie, sans prélace ni nom d'auteur, renfermant des notices sur la ville de Médine, sur le Nedjd, sur le Yémen, sur Zabìd, sur Şanèà, sur Aden, elc.; puis un arlicle sur l'Inde, un autre sur Qomar, et une notice sur le pays des Francs et sur les iles de la Méditerranée. Les noms de licux qui devaient être écrils à l'encre rouge sont presque tous restés en blanc. L'onrage est rempli d'histoires falunleuses. Les derniers feuillets manquenl. Les deux titres qu'on lit ê tête du volume sont apocryphes.

Papier. 38 feuillets. Ilauteur, so centimètres et demi; largeur, 15 centimètres. 19 lignes par page. Ms. du xwi1 sjècle. - (Supplément 9,4.)

\section{9.}

Traité de géographie et d'astronomie. C'est une traduclion de l'ouvrage de Chrysanthus Notaras, Ei $\sigma \alpha \gamma \omega \gamma \eta \dot{\eta}$ \&is

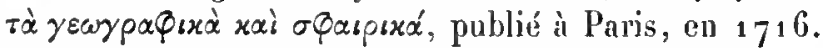
Notaras, patriarche de Jérusalem, avait éludié les mathématiques à Paris, sous Cassini. La Iraduction arabe est sans préface, mais en têle de la lisle des chapitres qui se trouve au commencement du rolume, on lit le nom de l'auteur : "Chrysanlhus Notara, archimandrile et successeur au siége apostolique de Jérusalemr. Les figures géométriques sont tracées au crayon.

Papier. 118 fenillets. Hauteur, 34 centimètres; largeur, 2.3 centimètres. 27 lignes par page. Ms. du xvıu sièdle. - (Supplénent $0_{13 .}$ )

\section{GEOGRAPIIE SPÉCIALE.}

\section{0 .}

$1^{\circ}$ Traité de Ḥasan al-Başri sur l'excellence de la ville de la Mecque.

20 (Fol. 23.) Calendrier romain, copte et persan.

$3^{\circ}$ (Fol. 84.) Traité des talismans, attribué à Apollonius de Tyane.

Papier. 134 feuillets. Hauteur, 15 centimètres; largeur, 10 centimètres. 10 d 13 lignes par pagoe. Écritures diverses dı $x \ngtr u^{e}$ siècle. (Supplément 1941.)

\section{1 .}

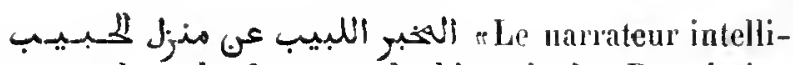
gent, touclıant la demeure du bien-aimèn. Description de la ville de Médine, composée après l'an 860 de l'hégire (1456 de J. C.). Le commencement el la fin manquent.

Papier. 165 feuillets. Hauteur, 21 centimètres; largeur, 15 centinètres. 16 dे 21 lignes par page. Ms. du xvis siècle. - (Supplément 2418 .)

\section{2 .}

$1^{\circ}$ a des Pierres précieuses, traité des privilèges de la ville de Médine», par le chérif Mohammad al-Ḥosaïnì, surnommé Kibrît (كبـ- Gel ourrage, écrit en prose rimée entremôlée de vers, renferme la description de Médine el de ses environs. L'auteur l'a terminé en 1048 de l'hégire (1639 de J. C.). Cette copie est datée de l'an 1078 de l'hégire ( 1667 de J. C.). Une notice biographique de l'auteur, mort en $107^{\circ}$ de l'hégire (1660 de J.C.), se trouve au fol. $1 \mathrm{v}^{\circ}$ et au fol. $2 \mathrm{r}^{\circ}$.

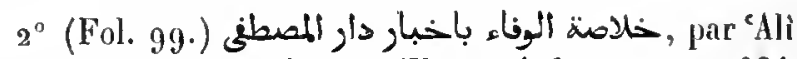
ibn al-Hosaîn a]-Samhoûdi. (Voyez ci-dessus, $n^{\text {os }} 1634$ et suiv.) La copie est datée de l'an 1079 de l'hégire ( 1668 de J. C.).

Papier. 307 feuillets. Hauteur, 23 centimètres; largeur, 15 centimètres. 29 lignes par page. - (Supplément 918.)

\section{3.}

$1^{\circ}$ Description de Damas. Ourrage anonyme, divisé 
en six chapitres, dont le premier traite de la Syrie; lo second, de Damas; le troisième, de la grande mosquée de Damas; le quatrième, qui est te plus long, renferme des notices sur les prophètes, les compagnons de Mahomet, les ulémas et les ints qui ont été enterrés sur le terriloire de Danas; le cinquièmo chapitre traite des monuments sacrés de la ville, ot le sixième, des grands événements qui auront lieu à Damas lors de la consommation des siècles. La préface conmence par ces mots:

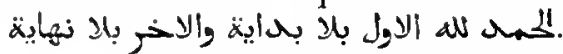

$2^{\circ}$ (Fol. $47 \mathrm{r}^{\circ}$. (Récréation pour les hommes ou beautés de lis Syrien, par "Abd Mllah ibn Nolammad al-Badri, auteur qui vivait encore en $82_{1}$ de l'hégire ( 1418 de J. C.). C'est un recueil de passages de divers auteurs sur les productions et les beautés de la Syrie, et principalement de Damas, aree une liste des saints personnages qui y sont enterrés. Premiers mots de la préface : لألماء تشاهة خضراء.

Ils. daté de l'an 1043 de l'héggire (1633-1634 de J. C.).

Papier. $9^{3}$ fenillels. Hanteur, 2 I cenlimèlres; largeur, 15 cenlinètres. 27 lignes par page. - (Ancien fonds 823. )

\section{- 2254 .}

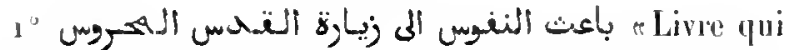
excite clans l’àme le désir de visiter Jérusalem la bien gardée", par Borhàn al-Dìn al-Qaziwi (النزالوى), ou, seIon Hadji Khalfa, Al-Fazàri (النزال), docteur schaféite. C'est une sorte de guide din pèlerin. Ml. de Gruigres en a donné l'analyse dans les Notices et Extraits, tome III, pages 605 et suiv.

2" (Eol. 62.) Prières et litanies.

$3^{\circ}$ (Fol. $66 \mathrm{v}^{\circ}$.) Notes de direrses mains, un langrue timerpir.

$4^{\circ}$ (Fol. $68 r^{\circ}$.) Traditions et légendes, en ture.

$5^{\circ}$ (Fol. $791^{\circ}$.) Notes en arabe sur des questions se rapporlant aux purifications, suinips d'extraits divers en l.tire.

$6^{\circ}$ (Fol. $841^{\circ}$.) Poème en l'honneur de Mahomet, en tur. Premier vers:

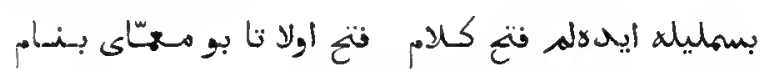

$7^{\circ}$ (Fol. $100 \mathrm{r}^{\circ}$.) Arba ${ }^{\hat{\imath}} \mathrm{n}$ de Molanmad ibu abi Bakr. Il n'y a que vingl-cinq traditions.

$8^{\circ}$ (Fol. $1311^{\circ}$.) Recetles médicales, en turc.

$g^{\circ}$ (Fol. $132 r^{\circ}$.) Généalogie des sultans ottomans, en vers turcs. Gette gêncialogie s'arrête à l'an 1099 de l'hégire ( 1687 de J. G.).

$10^{\circ}$ (Fol. 134.$)$ Histoires édifianles, en langue turẹuc,

$11^{\circ}$ (Fol, 137.) Notes diverses et vers en langue turque.

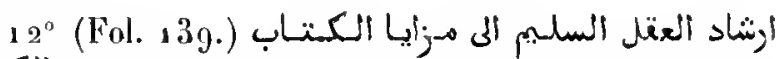
بDirection de la saine intelligence vers les excellences du noble livre $r$. C'est un commentaire sur la préface du commentaire du Corin d'Aboù Sa'oûd ibn Moḷammad al-'Imâdi, par Moḥammad al-ḷısaïnî, surnommé Buzurg-Zidè. En arabe. Exemplaire parafé par l'auteur' en 1007 de lhégire ( 1598 de J. C. $)$. Le commencement manque.

$13^{\circ}\left(\right.$ Fol. $160 v^{\circ}$.) Extraits d'un commentaire sur le traité de grammaire, intitulé Al-Miftâh.

Papier. 163 fenillets, plus 36 feuillets restés en thanc. llauteur, 19 centimètres et demi; largeur, 14 centimètres.Ms. de diverses écri tures du $x^{\circ}{ }^{\circ}$ et du $\mathrm{xrI}^{e}$ siècle. -- (Ancien fonds 837. )

\section{5 .}

CGadeau pour" les hommes d'élite, traitant des prérogatives de la mosquée la plus ćloignée», c'est-ì-dire de la ville de Jérusalem, par Moḷammad ibn Aḷmad al-Minlıâdjî al-Osyon̂ți, docteur scliaféite d'Égypte, mort en go6 de l'hégire (15001501 de J. C.). Selon Hadji Khalfa, le nom de l'auteur était Kamâl al-1)in Noḷammad ilon abì Scharif. L'auteur avait visité Jérusalem en 874 de l'héggire ( 147 o de J. C.). L'ou rage, composé en 875 de l'hégire, renferme dix-sept (hapitres: $1^{\circ}$ sur les divers noms de cette ville; $2^{\circ}$ sur ti construction du temple par David et Salomon; $3^{\circ}$ sur les vertus de la Pierre (Al-Sakhra); $4^{\circ}$ sur le mérite particulier des prières faites à Jérusalem; $5^{\circ}$ sur les vertus de l'eau qui sort de la base de la Pierre; $6^{\circ}$ sur le voyage nocturno de Hahomet; $7^{\circ}$ sur le mur qui entoure la mosquéc; $8^{\circ}$ sur les puits et les sources qui se trouvent près de la mosquéo; $9^{\circ}$ sur la prise de la ville par le calife 'Onnar; $10^{\circ}$ énumération des prophètes qui y sont entrés; $11^{\circ}$ sur Abrahan; $12^{\circ}$ sur la tentation d'Abraham; $13^{\circ}$ sur la caverne dans laquelle it est enterré; $14^{\circ}$ sur Ismaél; $15^{\circ}$ histoire de Loth; $16^{\circ}$ sur ce quon dit du tombeau de Moïse; $17^{\circ} \mathrm{sut}$ les prérogatires de la Syrie. La préface commence par ces

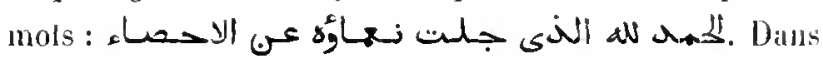
cette préface, l'auteur indique les ourrages sur le même sujct qu'il a consultés. N. de Guignes a publié une notice de cet ouvrage dans le Recueil das Notices et Extruits, t. III, p. 610 . 
Ms. dalé de l'an $97^{3}$ de l'hégire ( 566 de J. C.).

Papier. 154 feuillets. Hauteur, 21 centimèlres; largeur, 15 centimètres. 21 à 23 lignes par page. - (Ancien fonds 836.)

\section{6.}

Nème ouvrage.

Ms. daté de l'an $9^{8} 1$ de l'liégire ( 1574 de J. C.).

Papier. 129 feuillets. Ilauteur, 21 centimètres et demi; largeur, 15 cenlimètres. 25 lignes par page. - (Supplẻment $9{ }^{19}$, Saint-Germain 35\%.)

\section{7 .}

Mème ourrage.

Is. daté de l'an 993 de l'hégire (1585 de I. C.).

Papier. 10 .' feuillets. Ifaulenr, a centimètres et demi; largeur, ,j centimètres et demi. s 3 à 36 lizgnes par page. - (Ancien fonds 838.)

\section{8 .}

r La Crême de l'exposilion détaillée des provinces el du tableau des chemins et des roules n. Tablenu de l'Égypte, par Khalil ibn Schẩhìn al-Záahirì. Cetle copie est antérieure à l'an $87_{7} 6$ de l'hégire ( $14_{7}$ de J. G.). Le premier feuillet manque.

Papier. 65 fenillets. Hauleur, 37 centimètres et demi ; largeur, 18 centimèlres. 22 lignes par page. - (Supplément 921.)

\section{9.}

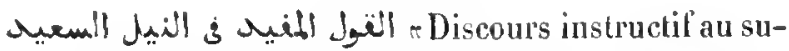
jet du Nil bienfaisantr, par Djalal al-Dìn al-Maḷalli. G'est un petil recueil de versets dı Coran, de tradilions de Mahomel, de passages d'Al-Hascoudì et de quelques aulres écrivains, le loul se rapporlant au Vil. Conmen-

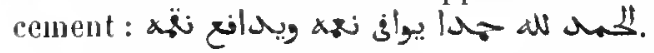

Papier. 39 feuillets. Ilauteur, 15 centimètres; Jargeur, 10 centimètres. 7 lignes par jage. Ms. du xvi siècle. - (Supplément 933.)

\section{0.}

Même ouvrage. Un titre, ajoulé après coup, donne le nom de l'auteur ainsi : Schilıâb al-Dìn Aḷmad ibn 'Imàd al-Aqfahisi. La fin manque.

Papier. 65 pages. Hauteur, 21 centimètres; largeur, 14 centimètres. 13 lignes par page. Ms. du xü siècle. - (Ancien fonds 813 , Colbert 4985 .)

\section{1 .}

Réussite (préparée) pour celui qui clierclie des renseignements sur les crues du Nil \%. C'est la liste des hauteurs que les eaux du Nil ont alteintes, depuis les premières années de l'hégire jusqu'à l'an 874 ( 1470 de J. C.), précédée d'une notice sur les nilomètres des différentes époques, el d'une liste des années où le fleure n'avail pas atteint la hauteur requise pour la prospérité du pays. Cet ouvrago a été composé par un nommé Schihaib al-Dìn Alımad al-l!idjâzì. Ms. autograple. En tète du volume se trouve une inlrodıction de trois pages, écrite diune autre main.

Papier. ${ }_{169}$ fenillets. Hauteur, 15 centimètres; largeur, 11 centimètres. 16 lignes par page, rouges et noires alternativement. - (Ancien fonds $879 \cdot$ )

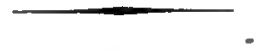

\section{2.}

Terrier d'Ésypte, copié, probablement en 827 de l'hégire (1423-1424 de J. C.), sur un rôle dressé en 777 de l'héggire $(1375-1376$ de J. G.). Le revenu de chaque village est indiqué sur le pied de l'éraluation faite en 777 , avec les changeurents survenus postérieurement à cette dale et avec les noms des proprićtaires ou apanagistes qui en jouissaient en la même année 777 , et les noms des personnages qui les tenaient, soit à titre de $v$ aqf ou fondation pieuse, soit conme apanagistes ou comme acquéreurs à l'époque de la confection du présent registre. On trouve aussi à claque article le nombre de فـ ou arpents qui étaient distraits du territoire de cliaque village, comme formant le fonds des وزقات pensions. (Voyez S. de Sacy, Abdallatif, pages 585-586.) Le litre qui se trouve en têle du volume est apocryphe.

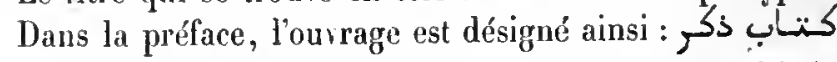

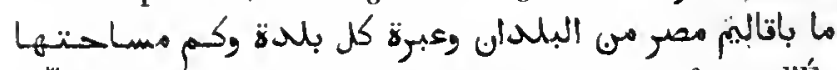
في أن Indication de tous les villages que renferme l'Égypte et du nombre des feddán dont le territoire de chaque village se compose.

Papier. 120 feuillets. Hauteur, 27 centimètres el demi; largeur, 18 centimètres. 23 lignes par page. - (Ancien fonds 693.) 


\section{3.}

$1^{\circ}$ Copie des tables statistiques contenues dans le uns. précédent, de la main du docteur Piques, accompagné de notes et de la transcription des noms.

$2^{\circ}$ Liste alphabétique de tous les villagges d'Égypte, d'après les tableaux des différentes provinces. Dans cette liste, les noms sont écrits en caractères européens. (Voyez l'Abdallatif de S. de Sacy, page 587).

Papier. 50 feuillets el 204 pages. Ifauteur, 28 centimètres; largenr, 18 centimètres. - (Supplément 20\%9.)

\section{4 .}

Nomenclature des villages ou arrondissements agricoles de chaque province de l'Egypte. Au-dessis de chaque nom

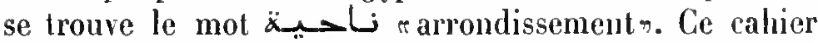
(دنتى) a probablement appartenu au bureau de l'administration territoriale.

Papier. 11 feuillets. Hanteur, 32 centimetres; largeur, 21 centimètres. Ms. du svme siècle. - (Supplément 93ః.)

\section{5 .}

年 Le Cadeau magnifique, indiquant les vestiges des rues dn Cairen. Description topographique du Caire, par $\hat{A} q$-Boghà al-

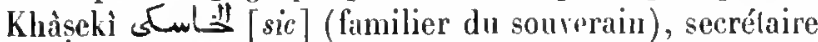
du sultan Al-Mllalik al-Aschraf Qìnșoù 'l-Ghamì. Qànșoù 'I-Ghaurì monta sur le trỏne en 906 de l'hégire (1500 de J. C.), et mourut en combattant les Turcs ottomans, en 922 de l'hégire ( 1516 de J. C.). Cet ouvrage, composé plus de cinquante ans après la mort d'Al-Maqrizì, contient la description el l'histoire des rues (quartiers (bطخ), des passages et des ruelles (الن)

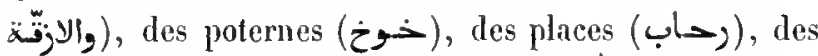
bazars (أسوانة) et des petils marchés (سوبتان). Dans la seconde parlie, qui forme à peu près la moitié du volume, l'auteur Iraite des environs (ظواهى) du Caire, des maïlan,

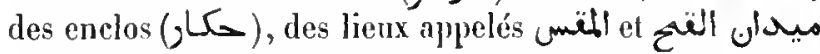

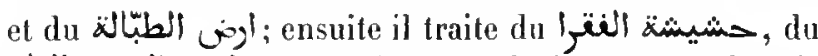

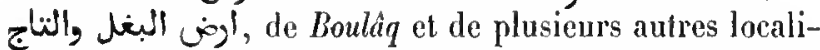
tés; puis des canaux et des ponts, et termine par le pont de Gizé. L'auteur paraît avoir mis à contribution le Khịtat ou description topographique du Caire d'Al-Maqrìi. Ms. autographe.

Papier. 145 feuillets. Hauteur, 24 centimètres; largeur, 15 centimètres el demi. 25 lignes par page. - (Supplément 920.)

\section{6.}

rL'Éloile de Raudlan, par Djalil alDìn 'Abd al-Ralumân al-Soyouttii. Traditions et autıes extrails, en prose et en vers, se rapportant plus ou moins directement à lìle de Raudha, située en fiace du Caire, et qui traitent des productions de ce lieu de délices, du nilomètre, du cours du $\mathrm{Nil}$, dont on trouve une carte. Il y a aussi quelques maqiant et autres morceaux liltéraires de la composition de Soyoùti. L'ourrage, qui a été achevé en $89^{5}$ de l'hégire (1489-1490 de J. C.), com-

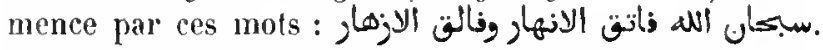

Papier. 244 feuillets. Ifauteur, 26 centimètres; largeur, 16 centimètres. 23 lignes par page. Ms. dı $\mathrm{xv}^{\circ}$ siècte. - (Ancien fonds 651.)

\section{7.}

Même ouvrage, précédé d'une liste des chapitres.

Papier. a 28 fenitlets. Hauteur, a 4 centimètres; targeur, 13 centimètres et demi. 25 lignes par page. Its. du $x^{\circ} 1^{\circ}$ siècle. - (Supplément $9^{38 .)}$

\section{8 .}

Même ouvrage.

Papier. 134 feuillets. Hauteur, 28 centimètres et demi; largeur, 19 centimètres et demi. 3 1 à 35 lignes par page. Mis. du xvi" siècte. (Supplément 937.)

\section{9 .}

Nême ourrage.

Ms. daté de l'an $9^{8} 9$ de l'hégire ( 1581 de J. C.).

Papier. 372 feuiltets. Hauteur, 21 centimètres; targeur, 16 centimètres. 17 lignes par page. - (Supplément 939 , Saint-Germain 370. )

\section{0 .}

Même ourrage. Ms. dité de l'an 1016 de l'hégrire ( 1607 
de J. C.). II y a une lacune entre les folios actuellement cotés 101 et 102.

Papier. 277 Ceuitlels. llauteur, 21 centimètres; largeur, 15 centimètres. 2 1 lignes par page. - (Supplément 935 , Saint-Germain ?1 6.)

\section{1 .}

Wểne: ourragoge.

Papier. 283 fenillels. Hlauleur, 23 centinùtres; largenr, 17 centimètres. 25 liggnes par page. IIs. du xux siècle. - (Supplément 2434.)

\section{2 .}

Le premier volume du mème ourage.

Papier, 162 fenillets. IIauteur, 21 centimètres et demi; largeur, $1^{1}$ ceutimètres el demi. 19 à 21 lignes par page. Ms. da xvil siècle. - (Supplément 936.)

\section{3.}

Dialogue sur le nitomètre de l'jle de Raudha, composé par Legrand, drogman de l'aunbassado française à Conslantinople.

Papier. 5 pages. Ilanteur, 23 centinètres; largeur, 17 rentimìtres. 17 lignes par page. - (Supplém a no 6 6.)

\section{4.}

r Lumière de l'exallation des lieux sacrés (?), éclaircissements sur les mysteres des pyramidesn, par le chérif Djamàl al-Dìn Aboû Djacfar Mohammad ibn 'Abd al-'Aziz al-Idrisì qui, d'après Hadji Kliatfa, anrail composé cet ourrage en 623 de l'hégire (1 2 26 de J. C.), pour Ml-Malik al-Kâmil Mo!̣ammad ibn Khalì. Mais le pire de ce prince sappelait, non pas Khalil, mais Nolyammad. Selon Hadji Khalfa encore, la préface commencerail par ces mots : all andill أبنا

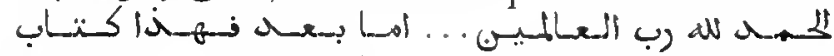

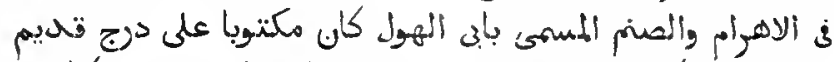

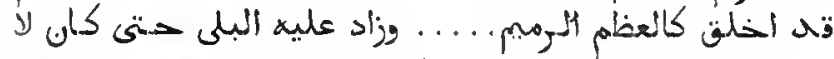

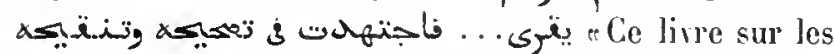
pyramides el sur l'idole nommé le Pére de l'éponturante (le Sphimx), se trouva écrit sur un vieux roulean, semblable à un os qui lombe en poussière, et tellement détérjoré par la vélusté qu’à peine pouvait-on le lire. J'ai l'ait mes efforts pour le rétablir, etc.n L'auteur nous apprend (fol. $20 v^{\circ}$ ) qu’à l'époque où il écrivait, la citadelle dı Caire, appelée le Châtean de la montagne, était la résidence du sultan Ahou Bakr Khalil, fils d'Al-Malik alAfdhal Nadjm al-Din Amîr al-Moumminin. Mais il n'y a jamais eu de sullan de ce nom, et aucun sultan ne porta le litre d'Amîr al-Moûminin avant la conquête de l'Égypte par les Ottomans. En conséquence, cet ourrage a dû ếtre rédigé à une époque oì les titres de sultan et d'Amîr alMoúminin étaient regarlés comme inséparables. Une note, en tête du volume, de la même main que le texte, nous apprend qu'un savanl grammairien, appelé 'Abd al-Qâdir ibn 'Omar al Baghdàdi, a tiré le contenu de ce volume

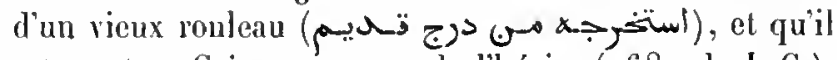
est mort au Caire, en $10 g_{2}$ de l'hégire (1681 de J. C.). Ge renseignement paraît également apocryphe. Les yuatre exemplaires de l'ouvrage, conservés à la Bibliotliéque na【ionale, sont tous écrils de la mème main et datés de 1232011233 de l'hégire (1816-1818 de J. C.). Par conséquent, c'est ì cette date que l'ouvrage à dû être mis en rente pour la première fois. Il renferme sepl chapilres : $1^{\circ}$ ce que les anciens ont dit des pyramides; $2^{\circ}$ ce que les sarants ont racouté des merreilles du monde; $3^{\circ}$ désignation du lieu où se trourent les pyramides: $4^{\circ}$ sur l'origine lu nom des pyramides et l'époque de leur con struction; $5^{\circ}$ sur le but de leur construction; $6^{\circ}$ sur ce que les savants égyptiens ont dit dans leurs lives, au sujet des merveilles des pyramides; $7^{\circ}$ passages en prose el en vers se rapportant aux pyramides.

Ms. daté de l'in 1232 de l'hégire (1817 de J. C.).

Papicr. 106 feuillets. Ilanteur, 22 centimètres et demi; largeur, 16 centimètres. 17 tignes par page. - (Supplément 941 bis.)

\section{5 .}

Même ouvi'age.

Ms. dalé de l'an 1232 de l'hégorire (1817 de J. C.).

Papier. 115 feuillets. IIanteur, 24 centimètres; largeur, 15 centimètres. 19 lignes par page. - (Supplément $9^{\text {fo. }}$ )

\section{6 .}

Même ourrage.

Ms. daté de l'an 1233 de l'hégire (1817 de J. C.).

Papier. 99 feuillets. Ilauteur, 22 centimètres et demi; largeur, $1 / 1$ centimètres. 17 lignes par page. - (Supplément 941.) 


\section{7.}

Nème ouvrage.

J. C.).

Ms. daté de l'an 1233 de l'hégire $(1817-1818$ de

Papier. 103 feuillets. Hauteur, 23 centimètres; largeur, 16 centimètres. 15 liggnes par page. - (Supplément 942.)

\section{8 .}

Porlulan de la mer Méditerranée, par 'Ali ibn Ahmad ibn Mohammad al-Scharqi, de Sfax (Ji), en Tunisie. Cet atlas, dressé sur huil feuillets de carton el daté de l'an 958 de l'hégire ( 1551 de J. C.), commence par un calendrier solaire. Viennent ensuite : $1^{\circ}$ un plan du temple de la Mecque, avec l'orientation des divers pays musulmans; $2^{\circ}$ un planisphère général; $3^{\circ}$ carte des côtes de l'Lspagne et du pays situé au sud du détroil; $4^{\circ}$ carte des côtes de la mer Noire; $5^{\circ}$ carte des cótes méridionales de l'Asie-Mineure, de celles de la Syrie et de l'Égypte jusqu'à Ia Cyrénaïque; $6^{\circ}$ carte de la Grèce, de l'archipel, de l'ile de Grète et de la còte africaine, située vis-à-vis; $7^{\circ}$ carte de la Cyrénaique, de la Tripolitaine, de la Tunisie el de la Sicile; $8^{\circ}$ tableau circulaire, représentant la longueur du jour pour chaque mois de l'année solaire dans le quatriène climat; $9^{\circ}$ calendrier agricole pour chaque mois de l'annce solaire. Cet allas est un beau monument de la cartographie chez les Arabes au $\times \mathrm{XI}^{\mathrm{e}}$ siècle. La nomenclature est très-riche.

Hauteur, 25 centimètres; largeur, 20 centimètres. - (Ancien fonds 847.)

\section{9 .}

Carte du Schoṭ al-'Arab (تُطب), c'est-à-dire de la partie inféricure du cours de l'Euphrate et du Tigre. Lal nomenclature de celle carte est très-riche, mais difficile à lire. Le dessinateur a mal orienté son travail : il lait couler les deux fleures de l'ouest à l'est. Ce document parail être du commencement du $\mathrm{xix}^{\mathrm{e}}$ siècle.

Hauteur, 1 mètre $9^{t}$ centimètres; largeur, $5_{2}$ centimètres. (Supplément go2.)

\section{0 .}

Quatre-vingt chapitres sur l'Inde el sur les sciences des Indiens, les doctrines philosophiques, les théories cosmographiques, etc., par Aboù 'l-Raịhàn Moḷammad ibn Aḷmad al-Bìrouni. On connaît les renseignements précieux que ce trajté, appelé ordinairement Tarilkh alHind, a fournis à M. Reinaud pour son Mémoire sur IInde. (Voyez Mémoires de TAcalémie des inscriptions et belles-lettres, I. XVIII, $2^{\mathrm{e}}$ partie. - Voyez aussi l'introduction à la traduction de la Géographie d'Abou 'l-Féda, p. xev el suiv., el le Journal asiatique, année 1 844.) La préface commence

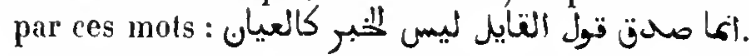

Papier. 165 feuillets. Ilauleur, 24 centimètres et demi ; largeur. 15 cenlimètres et demi. 31 lignes par page. $\mathrm{IIs}$. du xruı siècle. (Supplément 93१.)

\section{VOYAGES.}

\section{1 .}

1 Renseignements sur la Chine et sur l'Inden. Tel parait etre te vrai titre (roil' fol. 24 ) de l'ouvrage don la traduclion a été publiée pat. Renaudot sous le titre de Aneiennes relations des Indes et de la Chine, de deux voyageurs makomélans qui y allerent dans le I. e $^{e}$ siècle de notre ère. Le texte, imprimé par les soins de M. Lanģłès, a été publić en 1845, arec ume nouvelle traduction, par M. Reinaud. Comme les premiers feuillets du ms. manquent, un des anciens possesseurs, homme peu instruit, les a remplacés par une introduction apocryple avec le titre imaginaire de (ou séric) de dates $\pi$. M. Rcinaud, bien quil eût reconnu la fraude, a adopté ce titre, en le traduisant par "Chaine des chroniques n. Le mème savant suppose que la première partic de l'ourrage renferme le rúcil d'un nommé Solaïmàn, gui arail lait plusieurs voyages dans l'Inde et en Chine, el que la seconde partie n'était qu'un supplément rédigé par un nommé Aboû Zaïd al-l!asan, de Siraf, qui n'avait jamais visité ces pays. La copie est du xue siècle.

$2^{\circ}$ (Fol. 57.) Tableau des dimensions, en chiffres diwâni, de quelques places fortes de la Syrie. Écrilure du xil ${ }^{\circ}$ siècle.

$3^{\circ}$ (Fol. 58.) Notice rédigée en 54h de l'hégire (1 169 de J. C.), peu de temps après la morl du sultan Noùr alDin, fils de Zengui, sur les dimensions de plusieurs forteresses des Etats de ce prince, avec la mention des distances d'une forleresse ì une autre. Linsi que dans la pièce précédente, les nombres sont exprimés en caraclères diruint. Cette notice a élé impriméc, mais pas toujour's correclement, à la suile de l'édition du II. Langlès. Écriture du $x_{1}^{e}$ siècle. 
$4^{\circ}$ (Fol. 63.) Traduction du traité De Caelo, d'Aristote, accompagné de gloses marginales. Le commencement et la fin manquent, ainsi que plusieurs feuillets an milieu. Quelques feuillets sont transposés. Écriture du $\mathrm{xI}^{\mathrm{e}}$ siècle.

$5^{\circ}$ (liol. 125.) Commencement d'un traité, rédigé sous forme de Questions et réponses, sur la construction et l'usage des membres du corps lnmain. Cette partie traite de la main el du bras. Les Réponses paraissent être fondées sur les enseignements de Gallien, dans son traité De usu partium; mais, de même que les Questions, elles sont trèsroncises. Le premier feuillet manque, et le second feuillet, contenant la suite de la préface, ne fournit ancune indication qui puisse faire reconnailre le titre du lise et le nom de l'auteur. A u reste, ce questionnaire differe complétement de celui de llonaïn ilon Isṭàq. L'écrilure, qui parait être du $x^{\circ}$ siècle, est dépourvue des points diacriliques, et ressemble au premier neskti, celui qui a remplacé dans les livres l'écriture confique. Le dermier fenillet a élé ajouté après coup et n’appartient pas à l'ourage.

Papier. 148 fenillets. Hauteur, 18 et 19 centimètres; largeur, 8 centimètres el demi et 9 centimètres. Écritures diverses du $v^{\circ}$ et du xıt siècle. - (Ancien fonds 597 , Cotbert 6oó.)

\section{2.}

Relations de royages dans J'Inde et la Chine. Copie de l'article $1^{n}$ dı ms. jrécédent, de la main de Renaudot.

Papier. 21 feuillets. Hauteur, 25 centimètres; largeur, 18 centimètres. 24 à 26 lignes par page. Ns. du xw1 ${ }^{\circ}$ siècle. - (Suppléminl gog 5.)

\section{3.}

ى) Noyage d'Al-Abdarin. C'est la relation d'un voyage fail en 688 de l'hégrire ( 1289 de J. C.), de l'Océan Atlautique à la Mecque, par Moḷammad ibn Nohammad al- 'Alodari. M. Cherbonneau en a publié une analyse dans le Journal asiatique (année 1854).

Ms. dalé de l'an 745 de l'hégire ( 1345 de J. C.). Les deux premiers feuillets sont modemes.

Papier. 151 feuillets. Hauleur, 23 centimètres; largeur, 17 centimètres. 23 lignes par page. - (Supplément 911 ter.)

\section{4.}

Relation des royages d'Ahoù Dolaf, d'après le Mocljam
al-Boldan de Yàqoùt, par l'abbé Renaudot. A la fin se trouve une notice de Yàqoût sur la Chine.

Papier. 18 feuillets. flauteur, 21 centimètres et demi; largeur, 16 centimèlres. 2 à 16 lignes par page. Ms. du xvar siècle. - (Supplément 2094.)

\section{5 .}

Voyage du schaiklı Aboû Moḷammad 'Alıd Allah alTìdjùni dans la régence de Tunis, pendant les années 706 , 707 et 708 de l'hégire ( 1306 à 1309 de J. C.). M. Alplionse Roussean a publié une traduction de celte reJation, dans le Joumal asiatique, année 1852. La pré-

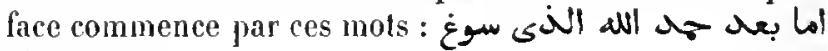
علغوارن

Papier. 163 feuillets. Hanteur, 21 centimètres; largeur, 15 centimètres et demi. 19 lignes par page. - (Supplément 91 1 bis.)

\section{6.}

d Couronme pour la tête, contenant les signalements des docteurs du Levantn, par le cadi Aboû 'l-Baqâ Khàlid ibn 'Îsa al-Balawì, auteur du $x^{-e}$ siècle, né à Cantoria, sur l'Almanzora, province de Grenade (تنتورية مي حصسون المنصدوة). C'est la relation d'un royage, exécuté dans les années 736 et suivantes de l'hégire, à travers l'Afrique, depuis l'Espagne jusqu’à la Necque el à Médine, et de Nédine en Espagne. L'auleur raconte, dans un slyłe très-recherché et très-prétentieux, ses entretiens arec les sarants qu'il arait rencontrés dans ees divers pays, et donne de longues notices, biographiques et littéraires, de ces personnages. Il a fait lni-même plusieurs copies de cet ouvrage, et a terminé la dernière en 771 de l'héggire ( 1309 de J. G.), à Purchena (برشناكة). En tête du volume se trouvent quatre feuillets, dont le premier porte quelques gloses et la copie d'une lettre adressée par le calife 'Omar à Sa'd ibn abî Wagqìs. Les feuillets suivants contiennent : une lettre d'Albd al-Raḷmmân ỉon Ghânim à 'Omar; une lettre d'Al"Abbàs à son fils, "Abd Allah; une lettre du calife abbaside Al-Qàïm bi-Amr Hllahh, renfermant de vives plaintes contre Al-Besàsirí; enfin une lettre, dans laquelle 'Abd al-Raḥmân al-Nàsili, calife omayyade d'Espagne, ordonne au prédicateur de la grande mosquée de Cordoue de le désigner par le titre d'Amîr al-Mônninín. On lit ensuite une notice sur l'auteur de ce royage, tirée de l'Ihâata d'Tbn al-Khațîlb, suivi d'éloges, en prose el en rers, de l'admirable style de 
cette narration. Toutes ces pièces sont de la mène main que l'ourrage principal.

Ms. exécuté en l'an 1245 de l’hégire (1830 de J. C.).

Papier. 113 fenillets. Hauteur, 21 centimètres; largeur, 15 centimètres. 24 à 26 lignes par page. - (Supplément 912 bis.)

\section{7 .}

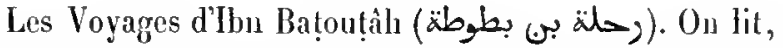
en tête du volume, un titre apocryphe, ajouté après

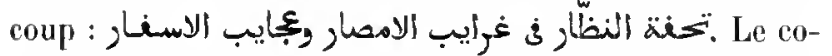
piste luj-mème a désigné l'ourrage (fol. $1111^{\circ}$ ) par un

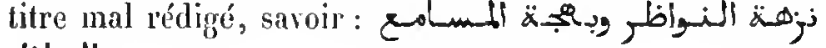
(والنواظظ.

Papier. 206 fcuillets. Hauteur, 88 centimètres; largeur, 19 centimètres et demi. 88 lignes par page. IIs. du xvir siècle. - (Supplément 909.)

\section{8.}

Mème ouvrage. Le premier feuillet et les deux derniers manquent.

Papicr, 160 feuiltets. Hauteur. 30 centimètres; largeur, so centimètres et demi. 27 lignes par page. Ms. du xvi ${ }^{\circ}$ siècle. - (Supplément 911.$)$

\section{9 .}

Mème ouvrage.

Ms. daté de l'an 1180 de l'héguire (1 766 de J. C.).

Papier. 153 feuillets. Hauteur, 30 centimètres; largeur, 20 centimètres et demi. 31 lignes par page. - (Supplément 910.)

\section{0.}

Première partie du même ouvrage.

Ms. daté de l'an 1134 de l'léegrire (1721 de J. C.).

Papier. 200 feuillets. Hautenr, 31 centimètres; largeur, a 1 centimètres. 20 lignes par page. - (Supplément 908.)

\section{1 .}

Seconde partie du même onrrage. Ce volume a été Mav. orientaux. - 11 . écrit par Ibu Djozayy, sous la dictéc de l'auteur; il est daté de l'an $7^{5} 7$ de l'hégire (1356 de J. C.). Quelques feuillets sont plus modernes.

Papier. 110 fenillets. Ilauteur, 27 centimètres et demi; largeur, 20 centimètres et demi. 23 lignes par page. - (Supplémeal 907.)

\section{2 .}

Renseignements utiles sur les bases el les principes de la science nantique ». Traité de warigation, composé en 895 de l'luégire (1490 de J. C.), par un marin nommé Schilıâb alDìn Aḷmad ibn Màdjid ( $u_{\text {C }}$ ) ibn Mohammad. . . ibn

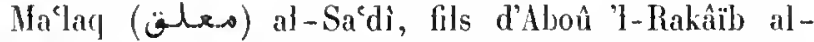
Nadjdì, et divisé en douze sections, dont ła première traite de l'origine de la navigation et du progrès de cet art depuis les temps de Noé. Les sections suivantes traitent des nuansions de la luue, des constellations du zodiaque, des priucipales étoiles, de la navigation du Golfe persique et de l'Océan indien, des côtes de la péniusule arabique,

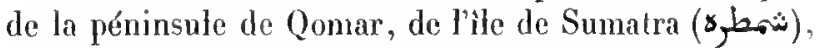

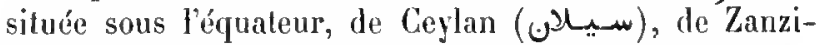
bar, etc.; des vents, des typhons, des moussons (مسأw o). L'auteur parłe de l'usage de la boussole, qu'il appelle "r maison de l'aiguillen. Le style de l'ouvrage est très-prolixe et chargé de termes lechniques, dout le sens n'élait comnu qu'aux navigateurs de la mer indienne.

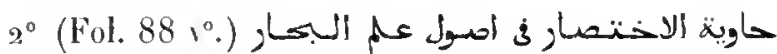
"Traité abrégéé des principes de la science des mers\%. Ardjoúza sur le même sujet el par le même auteur, fon Mlidjid.

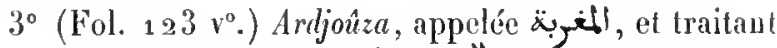

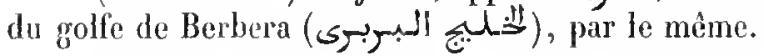

$4^{\circ}$ (Fol. 128.) Ardjoûza sur la manière de trouver la direction de la Hecque, quel que soit le pays où l'on se trouve. Ourrage du même auteur.

$5^{\circ}$ (Fol. 137. ) Ardjoúza renfermant la description de la côte arabique du Golfe persique, par le nême.

$6^{\circ}\left(\right.$ Fol. $\left.139 r^{\circ}\right)$ Quelques autres poèmes d'lbn Mâdjid sur des matières analogues aux précédentes, et une ardjoûza (folio 163) sur les mausions de la lune, allribuée au calife 'Alí, fils d'Aboú Tâlib.

Ms. daté (fol. $88 r^{\circ}$.) de l'an 984 de l'hégyire $(1576$ de J. G.).

Papier. 183 fenillets. Hauteur, 27 centimètres et demi; largenr. 18 centimètres. 19 lignes par page. -- (Supplément 891 bis.) 


\section{3.}

Relation d'un royage en Syrie, en Égypte et à Constantinople, par le cadi hanćfte Moluiblo al-Din ibn Taqi al-Din ibu Dâwoud. Parli de Damas, en $97^{8}$ de l'hégire ( 1571 de J. C.), Molnibb al-Din accompagna le grand cadi ¿ Jérusalem, afin d'enlever aux chrétiens une ancienne nosquée, enclavéc dans une église; il passa ensuite en Égypte, où il devint cadi de Foûwa; plus tard, il fut nommé cadi de Qadmoùs, en Syrie. Rentré à Damas, en 981 de l'hégire ( 1573 de J. C.), il partit l'année suivante pour Constantinople, où il assista à l'avènement du sultan Amurath. Il devint ensuite cadi de Macarrat al-Nocmàn, en Syrie. Dans ce récit, écril avec une certaine élégance, l'auteur raconte ses entrevues arec les docteurs et les littérateurs des diverses villes qu'il arait traversées, et il repporte diverses correspondances ol autres pièces littélaires.

Ms. daté de l'an 1017 de Thégire (1609 de J. C.).

Papier. 42 feuiltets. Ilauteur, 16 centimètres; largeur, 10 centimètres et demi. 29 à 34 tignes par page. - (Aucien fonds 602.)

\section{4.}

"Voyage d'liver et d'été", par Hoḷammad al-Ilosaïnî, fils du chérif 'Abd Allah, surnommé auteur, كبربت. Dans celte relation, composée en prose rimée entremêlée de vers, l'auteur, qui était né à Hédine et qui écrivait sous le règne du sultan ottoman Hourìd Khlìn (Amurath IV), vers l'an 10 ho de l'hégire (163o de J. C.), raconte toul ce quil avait vu ou applis d'intéressant dans un long voyage. Il avait d'abord fait le p̀lerinage de la Mecque; puis il était parti de nouveau et avait visité l'Egypte, Conslantinople, l'Asie-Mineure et la Syrie. l'ouvrage est rédigé dans un style très-recherché.

Ms. daté de l'an 1241 de l'hégire $(1826$ de J. C. $)$.

Papier. 124 feuillets. Ilauteur, 21 centimètres; largeur, 15 centimètres. 23 lignes par page. - (Supplérnent 912.)

\section{5 .}

Cahier renfermant un extrait d'un voyage en italien; un firman turc, en caractères curopéens, aice une lraduction hollandaise interlinéaire; d'autres pièces du nême gọnre, avec tradıction interlinćaire en français; un extrait de la bible anglaise, imprimée à Cambridge, eı 1677 ; des notes et comptes commerciaux; le texte arabe de quelques passages des psaumes, avec une traduction latine. Le tout écrit par un Européen.

Papiel. $7^{8}$ feuittets. Hauteur, 21 centimètres et demi; larģeur, 16 centimètres et demi. Ms. du xvi siècle. - (Supplément 2082.)

\section{6 .}

Relation de la mission de Mohammad Efendi à la cour de France, en 1720 de J. C. L'ambassadeur parte à la première personne, mais son récit est beancoup moins développé que celui qu'il a composé en langue turque.

Papier. 23 fenillets. Hauteur, 21 centimètres; largeur, 15 centimètres. a 2 lignes par page. Ms. du xvin siècte. - (Supplément 9/4.)

\section{7.}

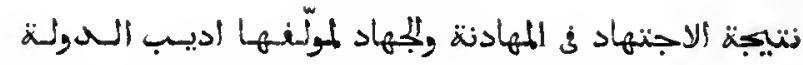

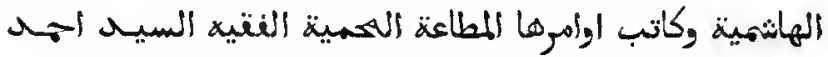

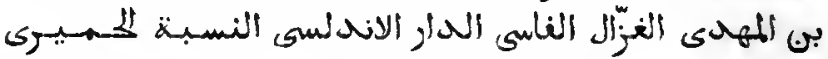
ئ Le Fruit des efforts dans la négociation d'un traité de paix el dans la guerre sainte, par le littérateur de la dynastie hasschimide (du Maroc) et le secrétaire de ses commandements obéis et respectés, le jurisconsulte Sidi Aḷmad ibn al-Malıdi al-Ghazzâl alFàsî (domicilié à Fez), originaire d'Espagne et himyarite de race. Puisse-t-il se trouver dans la compagnie des justes au jour de la résurrectionn. C'est la relation d'une mission diplomatique près de la cour d'Espagne, en 1179 de l'hégire $(1765-1766)$, dont fut chargé le susdit Sìdì Aḷnad par Aboû 'Abd Allah Moḷammad ibn 'Abd Allah, empereur du Maroc. Dans ce récit, l'auteur fait la description des illes qu'il arait traversées, lors de son voyage, depuis Ceuta jusquà Madrid et à l'Escurial.

Papier. 90 feuiltets. Hauteur, 20 centimètres; largeur, 14 centimètres. 23 lignes par page. Ms. du xvme siècte - (Supplément 9 43. )

\section{8 .}

Mémoire de Fath Allah ibn al-Ṣäigh, d'Alep, chrétien du rite latir, sur ses royages dans les déserts de la Syrie et chez les Bédouins, pendant les années 1810,1811 , 1812 et 1813 . Fatl Allah arait accompagné, en qualité d'interprète, un Piémontais nommé Théodore Lascaris, 
qui était chargé, dit-on, par Napoléon [er, d'explorer les pays entre la Syrie et les frontières de la Perse, et de lier des relations politiques avec les tribus nomades de cette région. C'est le récit dont M. de Lamartine a publié une traduction dans son Voyage en Orient. En tête du rolumo se troure un tableau renfermant les noms des tribus et le nombre de tentes ou familles dont chacune d'elles se compose.

Papier. 129 feuillets. Hauteur, 21 centimètres et demi; largeur, 15 centimétres. 22 à 25 tignes par page. Its. du xix siècte. - (Supplément 9/5.)

\section{9.}

Extrail du mémoire d'Ibn al-Ṣaigh (voyez le numéro précédent), traduil en arabe, par Fulgence Fresnel (فلمجنس فينال), d'après la traduction française de M. de Lamartine, et accompagné d'observations criliques par le schaikh Ahmad ibn Raschid al-Hanbali. Ce docteur relève les nombrenses erreurs et les mensonges d'lbn alSâigh.

Exemplaire de la main du schaikh Mollammad 'Tyàd al-Tantàivi.

Papier. 9 fcuillets. Hauteur, 22 centimetres et demi; 1argenr, 15 cen. timètres et demi. a lignes par page. - (Supplément 946.)

$1 X$.

\section{ENCYCLOPÉDIES.}

\section{0.}

Mell

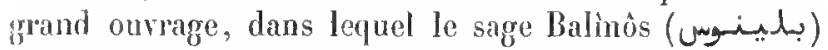
a exposé tous les mystères de la création, et dont la

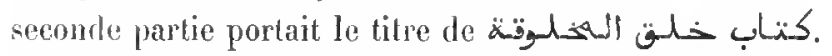

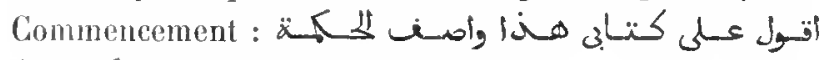

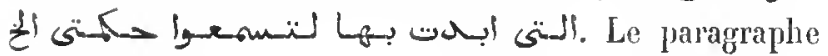

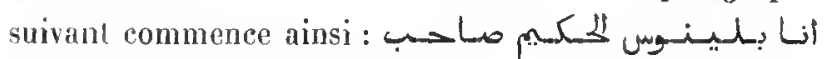

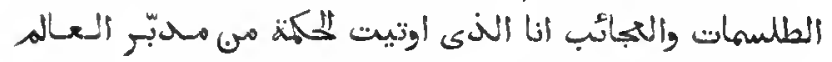

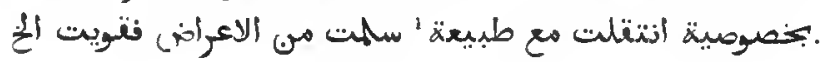

A Ia fin de l'ouvrage, le traducteur s'exprime ainsi :

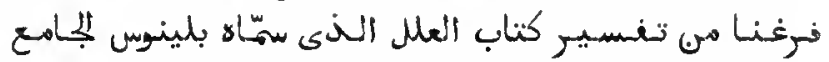

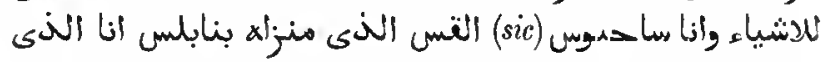

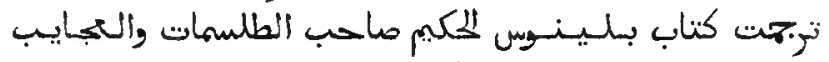

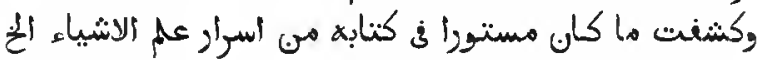

On voit, par ces extraits, que nous arons ici l'onvage

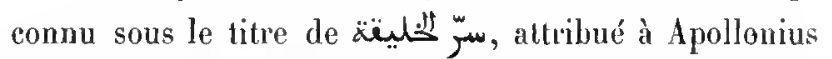
de Tyane, dont M. de Sacy a publié une notice étendne, (Voyez Notices et Extraits, i. IV, p. 107 et suiv.)

Papier. 149 fenillets. Hautenr, 33 centimètres el demi; largeur, 25 centimètres et demi. 19 lignes par page. Ms. du xu" sièclo:- (Supplément $1097^{\circ}$ )

\section{1.}

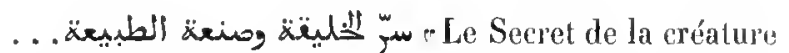
el l'art de la nature", par ele sage Balanyâs (Apollonius de Tyane), maître en fait de talismans, de merreilles et de choses extraordinairesn. Commencement:

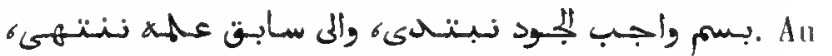
fol. $19 \mathrm{v}^{\circ}$ se trouve un autre ouvrage du même genre,

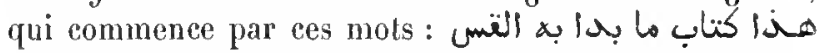

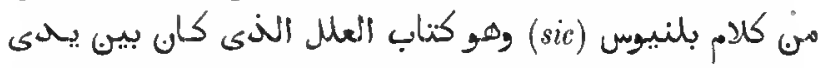

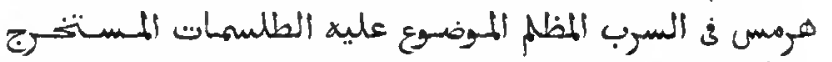

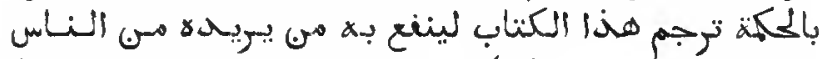

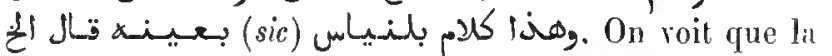
rédaction de cet exemplaire du Sirr al-Khaliqa diffère beaucoup du texte, d'après lequel M. de Sacy a écrit sa notice (royez le numéro suivant) ${ }^{2}$.

Papier. $9^{5}$ feuillets. Hauteur, ${ }_{2} 6$ centimètres et demi; largeur 18 centimètres. 21 lignes par page, Ms. de ta fin du xiv siècle. (Supplément 1096 .)

\section{2.}

r Lo Secret de la créature», (Voyez Notices et Extraits, tome IV, page 107 , l'article de M. de Sacy.) Ms. daté de l'an 958 de l'hégire $(\mathbf{1 5 5}$ i de J. C.).

Papier. 117 feuiflets. Hauteur, 19 centimètres; largeur, 13 centimètres et demi. 23 lignes par page. - (Ancien fonds 959 , Colhert 6187$.

\footnotetext{
'Le ms. porte هع طبيعة 'طيفة. H. Z.

3 Il y a des différences entre les diverses copies de l'ouvrage; mais los passages ci-dessus transcrits se trouvent aussi dans le ms. 2302.
}

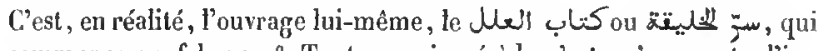
commence au fol. $19 v^{\circ}$. Tout ce qui précède n'est quiune sorte d'introduction. It en est de mềme dans les autres exemplaires. H. Z. 


\section{3.}

"Traités des frères de la puretén. Ces traités, au nombre de cinquante-et-un, forment une sorte d'encyclopédie, dont le contenu est suffisamment connu par la notice de M. Flügel (voyez Zeitschrift der Deutschen Morgenländischen Gesellschaft, 1859 , tome XIII, pages 1-43), et dont quelques chapitres ont été publiés par M. Dieterici. C'est à tort qu'on a écrit sur la tranche de ce rolume le nom d'Al-Madjrititi.

IIs. daté de l'an 1020 de l'hégire $(1611$ de J. C.).

Papier. 539 fenillets. Hauteur, 27 centimètres et demi; largeur, 16 centimètres. 31 lignes par page. - (Supplément 1845.)

\section{4.}

Mème ouvragge.

Exemplaire dalé de l'an 1065 de l'hégire (1654 de J. C.). Les figures sont restées en blanc. En tête du rolume se tronve une vignetle coloriće et dorée; lè frontispice, en or el en couleurs, est resté inachevé.

Papier. 488 feuiltets. Hauteur, 29 centimètres et demi; largeur, so centimètres et demi. 31 lignes par page. - (Ancien fonds 1105 , Colbert $239^{3}$.)

\section{5.}

Mène ouvrage !

Ms. daté de l'an 1153 de l'hégire (1 740 de J. C.). En tète, se trouve une vignette en or et en couleurs.

Papier. 414 feuillets. Hauteur, 31 centimètres et demi; largeur, 19 centimètres ot demi. 31 lignes par page. - (Supplément 1844.)

\section{6.}

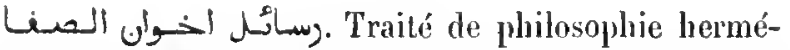
tique, par Al-Madjrịî (Moslima), mort en 398 de l'hégire. Cet ouvrage, dont nous avons ici la première partie,

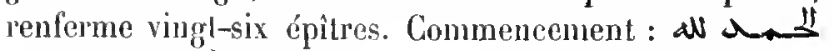

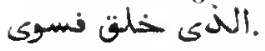

Papier. 66 feuillets. Hanteur, 23 centimètres el demi; targeur, 16 centimètres et demi. a 3 lignes par page. Ms. du xv ou du xvi" siècle. - (Supplément 1846.)

\section{7.}

1 Extrait de l'Ikhwän al-Safá d'Al-Madjriți.

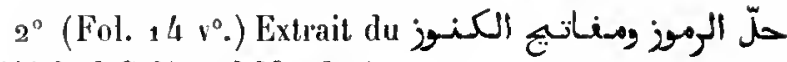
d"Mbd al-Salàm al-Maqdasí.

$3^{\circ}$ (Fol. 19.) Le Maqsoûd, traité de grammaire.

$4^{\circ}$ (Fol. $31 v^{\circ}$.) L'Adjarrotimiyya.

$5^{\circ}$ (Fol. 99.) Traité de la foi et du repentir (

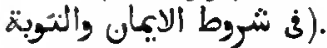

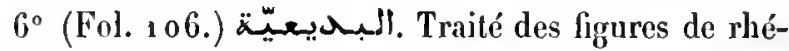
torique, par le schaikh Șafí al-Dìn 'Abd al-'Azîz ibn Sarâyâ.

$7^{\circ}$ (Fol. 168.) Un Isagoge qui commence par ces

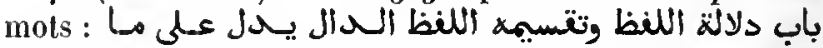

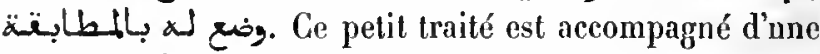
traduction latine, placée en regard.

$8^{\circ}$ (Fol. 180.) l'Isagroge d'Athir al-Din al-Abhari.

$9^{\circ}$ (Fol. $184 \mathrm{v}^{\circ}$.) Commentaire du schaikh Hosâm alDìn Kànî (ms. كات $)^{2}$ sur l'Isagroge d'Al-Abharî.

Papier. 205 feuillets. Hauteur, 19 centimètres; largeur, 12 centimètres et demi. 15 à 20 lignes par page. Ms. du xvi' siècle. — (Supplément $184 \%$.)

\section{8.}

Traité sur la musique, formant le cinquième traité de la grande collection intitulée Rasail Ikhwán al-Safa. L'auleur était originaire de Madrid (النجيطي) , et se nommait

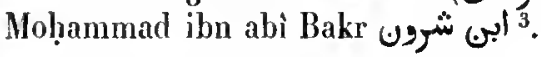

Papier. 47 feuillets. Hauteur, 21 centimètres; largeur, 15 centimètres. 18 lignes par page. Ms. du xvit siècle. - (Ancien fonds 1215.)

\section{9 .}

$1^{\circ}$ Extraits du Rasäll Ihhwân al-Safá. Un de ces extraits est relatif aux charmes et à la magie.

$2^{\circ}$ (Fol. 123.) Tableau chronologique des Ayyoubides et des sultans mamlouks jusqu'à l'an 740 de l'hégire.

\footnotetext{
1 Dans le titre, écrit sur la tranche, l'auteur est nommé باتهـ العأملى. H. Z.

${ }^{2}$ La forne كات كات est cependant généralement admise. H. Z.
}

3 Telle est, en effet, l'indication du titre qui se trouve en tête du ms. Mlais, dans les deux mss. précédents, on ne lit aucun nom d'auteur. H. Z. 
$3^{\circ}$ (Fol. 197.) Letire adressée par le sultan Saladin au vizir Râschid al-Dìn el réponse de celui-ci.

Papier. 129 feuillets. Hauteur, 20 centimètres; largeur, 13 centimètres et demi. 15 liggues par page. Ms. du xvi siècle. - (Supplément 109 l.)

\section{0.}

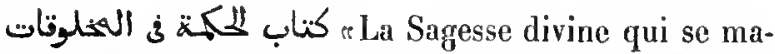
nifeste dans les êtres créésn, par d'Aboû Hâmid Hoḥanmad ibn Moḥammad ibı Mohammad al-Ghazâli. Les cieux, le soleil, la lune el les étoiles, la terre, la mer, l'eau, l'air, le feu, l'homme, les oiseaux, les quadrupèdes, les abeilles, les fourmis, les araignées, les vers à soie, les mouches, les poissons, les plantes forment la matière de dix-huit chapilres. Ouvrage bien conçu, bien exécuté, écrit dans un style simple, et tout à fait digne d'Al-Ghazâli.

Ms. daté de l'an 925 de l'hégire ( 1519 de J. C.).

Papier. 53 feuillets. Hanteur, 21 centimètres; largeur, 15 centimètres. 19 à 21 lignes par page. - (Ancien fonds 4ag.)

\section{1.}

rIntroduction aux sciences n, par Aboû Hâmid al-Ghâzalí. Cet ourrage se compose de sept chapitres qui traitent : $1^{\circ}$ de l'excellence de la science; $2^{\circ}$ de la rectitude de l'intention dans la poursuile de la science; $3^{\circ}$ des signes qui distinguent les mondains parmi les savants de ceux qui pensent ì la vie future; $4^{\circ}$ des sciences les plus importantes et de leurs divisions; $5^{\circ}$ des règles à observer dans les discussions scientifiques; $6^{\circ}$ des devoirs du précepteur et de l'élève; $7^{\circ}$ des dons d'argent que les savants peuvent accepter du sultan ou souverain temporel. 11 y a une lacune entre les folios actuellement colés 5 et 6 . La préface commence par ces mots : M, 情. On a écrit sur le feuillet de garde une qasîda, dans laquelle le poète dépeint les souffrances du peuple et invoque l'aide de Dieu. En voici le premier vers :

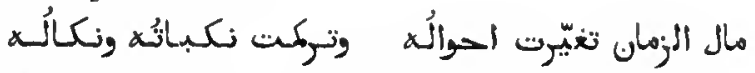

Ms. daté de l'an 873 de l'hégire (1469 de J. C.).

Papier. 46 feuillets. Hauteur, 21 centimètres; largeur, 15 centimètres et demi. 21 lignes par page. - (Ancien fonds 918.)

\section{2.}

1 × Traité qui enseigne (lit- téralement : enseignement) à l'étudiant la manière d'apprendren, par Borhân al-Dìn al-Zarnoûdjî.

Papier. 48 feuillets. Hauteur, 17 cenlimètres; largeur, 10 centjunètres. 11 liggaes par page. Ms. de la fin du $x^{*}$ siècle. - (Supplément 533.)

\section{3.}

Mème ouvrage.

Exemplaire daté de l'an $9^{52}$ de l'hégire (1545-1546 de J. C.) Notes marginales.

Papier. 34 feuillets. Hauteur, 16 centimètres et demi ; largeur, 11 centimètres et demi. 13 lignes par page. - (Ancien fonds 516.)

\section{4.}

$1^{\circ}$ Même ouvragoge.

Exemplaire daté de l'an 988 de l'hégire ( 1580 de J. C.). Quelques gloses marginales.

$2^{\circ}$ (Fol. 17.) Sur le partage des successions, par

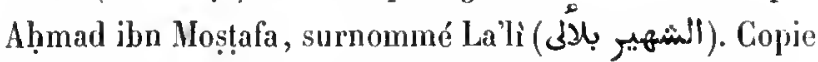
exécutée par l'auleur, en 971 de l'hégrire ( 1564 de J. C.). Le commencement manque.

$3^{\circ}$ (Fol. 34.) Fragment d'un commentaire du Coran, en langue turque.

Papier. 34 feuillets. Jlauteur, 20 centimètres; largeur, 13 centimètres et demi. - (Ancien fonds 515.)

\section{5.}

$1^{\circ}$ Le Ta'lim al-Mota'allin d'Al-Zarnoûdjì.

$2^{\circ}$ (Fol. $30 v^{\circ}$.) Le Pend-Nàmé d’eAtlàr, en persan.

Papier. 61 feuillets. Hauteur, 20 centimètres et demi; largeur, 14 centimètres. 15 lignes par page. Ms. du xvi" siècle. - (Supplément 1880.)

\section{6.}

$1^{\circ}$ Le Ta'lim al-Motáallim d'Al-Zarnoûdjì. Notes nuarginales et interlinéaires.

$2^{\circ}$ (Fol. $28 v^{\circ}$.) Conseils moraux et religieux, adressés par l'imâm Aboû Han îfa à son fils Hammâd. Commencement : يا بنى أرشحك المه تعاله واليّلك أوصيك بوصايك.

$3^{\circ}\left(\right.$ Fol. $30 v^{\circ}$.) Conseils adressés par l'imâm Aboû Hanîfa à son disciple, Aboû Yoûsof Yáqquâb. Commen-

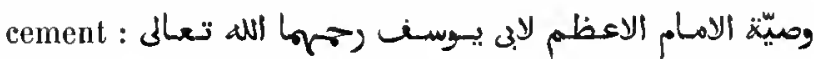
. 
$4^{\circ}$ (Fol. $37 \mathrm{v}^{\circ}$.) Conseils d'Aboû IIanifa, renfermant un résumé de la doctrine musulmane. Commencement: الايمان أقرار بالنسان وتصديقن بالجنان

$5^{\circ}$ (Fol. 40.) Sur les expressions incorrectes dont l'emplai doit être évité dans la rédaction des pièces nota-

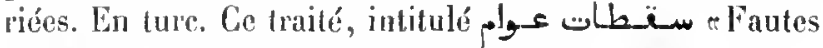
vulgairesn, a pour auteur un nommé Aboû Maseoûd.

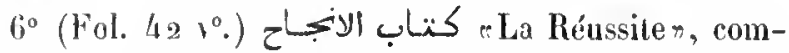
mentaire sur le traité de grammaire inlitulé holy-all (royez ci-après, article $8^{\circ}$ ), dont le texte est reproduit littéralement.

$7^{\circ}$ (Fol. 78.) Analyse grammaticale des sourates 1, cris et suivantes du Coran, par Khâlid ibn 'Abd Allah al-Azhari.

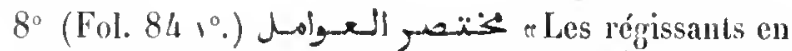

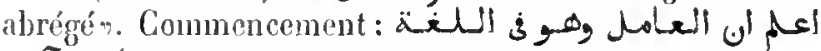

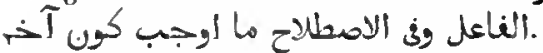

Papier. 90 feuillels. Hauteur, 20 eentimètres et dcmi; largeur, 12 centimètres. 19 à 21 lignes par page. Ms. du xrn siècle. - (Supplément 531.)

\section{7.}

$1^{\circ}$ Le Ta'lim al-Mota allim d'Al-Zarnoudji. Notes marginales.

$2^{\circ}\left(\mathrm{Fol} .58 v^{\circ}\right.$.) Traité élémentaire de la doctrine musulmane. En turc.

Papier. 84 feuillets. Hauteur, 21 contimètres et demi; largeur, 14 centimètres et demi. Écritures diverses du xvu" siècle. - (Supplément 532.)

\section{8.}

$1^{\circ}$ Le Tálim al-Mota allim d'Al-Zarnoûdjî.

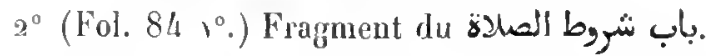

3० (Fol. 88.) Traité des éléments de la religion musulmane, sous forme de Questions et Réponses. En turc.

Papier. 106 fenillets. Hauteur, 14 centimètres cl demi; largeur, 10 ceutimètres el demi. $g$ lignes par pagre. Ns. du xvı" siècle. - (Supplément 3153. )

\section{9.}

Le Tálim al-Mota allim d'Al-Zarnoûdjî. Exemplaire incomplet et très incorrect, écrit par un Européen.

Papier. 56 feuillets. Hauteur, 17 centimètres; largeur, 11 centimètres et demi. 20 lignes par page. - (Ancien fonds 570. )

\section{0 .}

Commentaire d'lbn Ismáil sur le Ta lim al-Motacallim.

Papier. 125 pages. Hauteur, 21 centimètres; largeur, 13 centimètres et demi. 21 lignes par page. - (Ancien fonds 976.)

\section{1 .}

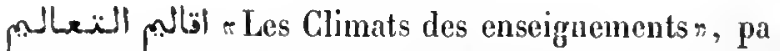
le cadi $A$ h!mad ibn Khalil al-Khouwaïyi, mort en 693 de l'hégire (1 293-1294 de J. C.). L'ouvragge traite, en sept sections, de sept sciences, et chaque section est suivie de sept anecdotes. Les sciences sont : l'exégèse du Coran, les traditions (fol.56), la jurisprudence (fol. 82 ), et la science appelée الادب, qui comprend la littérature (fol.126), la médecine (fol. $17^{\circ}$ ), l'astronomic (fol. 181), la géométrie et l'arithmétique (fol. 187). La classificalion par sept paraissait très-naturelle aux Musulmans, qui comptent sept cieux, sept terres, sept mers, sept jours de la semaine et sept versets dans la première sourate du Coran. Lourrage commence par ces mots : الانتياء رلزق الأحياء وأضع الارنى ورأفع السهاء

Papier. 202 Seuillets. Hauteur, 18 centimètres; largcur, 13 centimètres. 19 lignes par page. Ms. du xv sièdle. - (Ancien fonds 261 .)

\section{2 .}

$1^{\circ}$ Extraits du أتالمي التنعالم du cadi Schams al-Dìn ibn al-Khouwaïyî.

$2^{\circ}$ (Fol. $\left.60 v^{\circ}.\right)$ Liste des traditions dépourves d'isnâd, lapportées dans le أحياء علوم الميب d'Al-Ghazâli.

$3^{\circ}$ (Fol. 1 o6.) Traditions tirées d'un ouvrage qui traite des mérites de la ville sainte.

$4^{\circ}$ (Fol. $109 \mathrm{r}^{\circ}$.) Autres traditions sur le mème sujet.

$5^{\circ}$ (Fol. $119 \mathrm{v}^{\mathrm{o}}$.) Sur une parole de Mahomet, relative à la femme reuve ou divorcée.

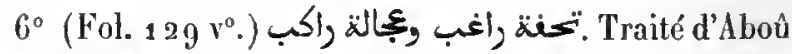
'I-Macâli Moḷammad ibn 'Alì al-Anșâri, sur certaines questions qui se rattaclient aux devoirs du pélerinage.

$7^{\circ}$ (Fol. 136.) Traité du même auteur sur l'autorité des paroles des grands docteurs de la loi.

$8^{\circ}$ (Fol. $145 v^{\circ}$.) Recueil de Questions et Réponses relatives an droit. 
$9^{\circ}\left(\right.$ Fol. $154 v^{\circ}$.) Poème d'Avicenne sur l'Àme, avee un commentaire perpétucl.

$10^{\circ}$ (Fol. $158 v^{\circ}$.) Recueil de traditions diverses.

$11^{\circ}\left(F_{0} l_{1} 168 v^{\circ}{ }^{\circ}\right)$ Autres recueils du même genre.

$12^{\circ}$ (Fol. 175.) Exposé de la doctrine musulmane, en vers, par Ibn abî 'l-Aswad.

Papier. 184 feuillets. Hauteur, 18 centimètres; largeur, 13 cenlimèlres. Écritures diverses du xvi" siècle. - (Supplément 1853.)

\section{3 .}

Recueil de matières diverses (pour servir de) consolation à l'homme afligén. Cet ouvrage qui, selon Hadji Khalla, a pour autenr un écrivain nommé Nadjm al-Dìn Aḷmad ibn ḷamdàn ibn Schabìb al-Harrânî, mort en 695 de l'hégigire ( 1295 de J. C.), est divisé en plusieurs livres (مـتالات). Le pre-

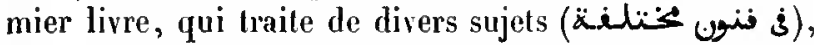
commence par quelques sentences, tirées des livres sacrés, plusieurs traditions attribuées à Mahomet, des phrases toutes faites sur divers sujets, etc. Le second livre traite des choses célestes et des choses terrestres (الاثناز

(العلويّة والسنليّة), telles que la sphère, les constellations, les éclipses, les anges, les éléments, les jours et les mois, les saisons, la prospérité et l'adversité, la générosité, la pauvreté, l'amour du pays natal, ete. Le quatrième livre traite, d'une manière très-concise, des mers, des îles, des fleuves, des sources, des montagnes, des pierres précieuses, des villes, des pyramides, des souverains de l'ancienne Égypte, des peuples de la terre, des monstres, ete. Il manque un feuillet entre les folios actuellement cotés 132 et 133 .

Papicr. 152 feuiltets. Hauteur, 26 centimètres et demi; largeur, 17 centimètres. 17 lignes par page. Ms. du xvi ${ }^{\circ}$ siècle. - (Aneien fonds 367. )

\section{4.}

recueil de Rasehìdn, opuscules de Raschìd al-Dìn, vizir des sultans mongols de la Perse et historien de cette dynastie. Ces traités sont elassés sous quatre rubriques, à savoir : التموضيكات Éclair-

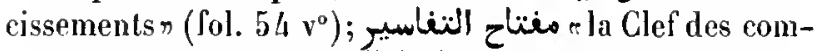
mentaires "(fol. 168); السلطانية (fle Sultanien n (fol. 207 ),

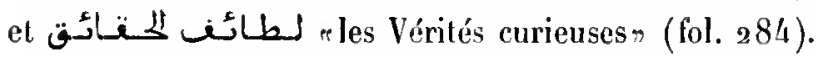
En tête du volume se trouvent les attestations de soixante- dix doeteurs qui rendent témoignage de l'orthodoxie des principes énoncés par l'auteur. Les nombreux opuseules réunis dans ce volume traitent de questions théologiques et philosophiques, des commentateurs du Coran, des généalogies, des patriarches, des prophètes, de Mahomet, des califes d'Orient et d'Égypte, des docteurs et des saints personnages qui ont illustré les premiers siècles de lisłamisme, etc. M. Quatremère a donné une notice très-étendue sur Raschìd al-Dìn et sur ses ouvrages, et une description du présent ms., dans l'introduction à l'Histoire des Mogols de la Perse. (Collection orientale, t. I, préface, p. I et suiv., cxiv et suiv.)

Les titres des sections sont encadrés dans des arabesques. Le copiste, surnommé Zoûd-Navis (زود نويس) ilc tachygraphen, a terminé ce volume après un trarail de trois années, en $7^{1} 0$ de l'hégire $\left(\begin{array}{lllll}1 & 3 & 0 & \text { de J. C.). }\end{array}\right.$

Papier. 375 fenillets. Hauteur, 5a eentimètres; largeur, 36 centimètres et demi. 15 lignes par page. - (Ancien fonds 356.)

\section{5.}

Sentiers à parcourir des yeux, dans les royaumes à grandes capitales". grande encyclopédie géographiqque, historique et biographique, par Schihàb al-Dìn al-'0marì (A humad ibn Yaḷya ilon Fadhl Allah), de Damas, mort en 749 de l'hégire (1346-1349 de J. C.). Le présent volume renferme la troisième section de l'ourrage, qui traite de l'Inde, $d u$ Sind, de l'empire de Djenguiz-Khàn et de ses descendants, de l'empire du grand Khàn, des princes du Touràn et de ceux de l'Tràn. L'auteur parle ensuite du Guilin, des Curdes, des Lòr, des Schoûl et des Schebankera, des principautés turques de l'Asie Nineure, des empires de Trébizonde et de Constautinople, de l'Égyple et de la Syrie. MI. Quatremère a donné une excellenle notice de ce ms. arec de longs extraits, dans le treizième volume des Notices et Extraits. L'écriture de ee ms. est souvent dépourvue de points diacritiques.

Papier. 231 feuillets. Hauteur, 37 centimètres; largeur, 18 centimètres et demi. 17 lignes par page. Ifs. du $x v^{e}$ siècle. - (Aneien fonds 583.)

\section{6 .}

Hème ourrage.

Ce volume, le quatorzième d'un exemplaire, renferme de courtes notices, écrites dans un style assez prétentieux, sur les poc̀tes des temps antérieurs ì l'islamisme et sur 
ceux des premiers siècles de l'hégire, et de nombreuses pièces de vers.

Papier. 177 feuillets. llauteur, a 7 centimètres et demi; largeur, 18 centituètres et demi. 17 lignes par page. Ms. du $x^{e}$ siècle. (Ancien fonds 1371. )

\section{7.}

Nlène ourrage.

Co: volume, le dix-septième d'un exemplaire, renferme des notices sur les poc̀tes maghrebins, depuis le commencement du $1 v^{\mathrm{e}}$ siècle de l'hégire jusquä l'époque où vivait l'auleur, qui, dans sa préfice, reconnaìt avoir fait de uomlureux e'mprunts au Moghrib d'llon Sa'id, célebre aureur espagnol. Un index des poìtes mentionnés se troure eu tète du volume. Le ms. porte des additions et des corrections de la main de l'auteur.

Papier. 218 feuillets. Hauteur, 30 centimètres et demi; largeur, 21 centimètres. 19 lignes par page. Ms. du xuv siècle. - (Ancien fonds 1372. )

\section{8.}

Nêne our rage.

Ce volume, le vingt-troisième d'un exemplaire, renferme un alorégé des annales de l'islamisme, depuis l'an 541 jusquà l'an 744 de l'léegire.

Le présent ins., écrit du vivant de l'auteur, ou peu de temps après sa mort, a a ait appartenu, en 761 de l'hégire ( 1360 de J. C.), à un nommé Nlohammad, fils d'îsa, fils de Dâwoud, fils de Schirkoulı, fils de Moḷammad, fils du célèbre vizir d'Égypte Schìr. Un acte de waqf, iuscrit sur le frontispice du volume et dalé de l'an 797 de l'hégire ( 1395 de J. C.), nous apprend qu'un nommé Maḷmoûd, grand-maitre du palais (أستاداد) dı sultan mamlouk Al-Malik al-Zàhir Barcouc, avait donué les vingt-trois premiers volunes de cet ourrage, à l'exception du vingtet-unième, au collège situé daus le quartier d'Al-Mawàzìn (الموازيب), an Caire. Titre en lettres d'argent, avec encadrement en or et en conleurs.

Papier. 150 feuillets. Hauteur, 27 centimètres; largeur, 19 certimètres. 2.3 lignes par page. Hs. du xive siècle. - (Ancien funds 642.)

\section{9 .}

Mème ourrage.

Ce volume, le vingt-lroisième d'un exemplaire, com- mence par un chapitre intitulé "Troisième espèce des

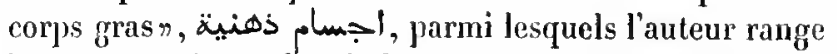
le mercure, le soufre, le baume momie et l'ambre gris. Ce chapitre est suivi d'une esquisse de l'histoire universelle, depuis la création du monde jusqu'au califat d'Ali, fils d'Aboû TTâlib. L'auteur parłe ensuite des douze inâms et des autres descendants d'chlì, jusqu'à ceux de la cinquième génération; mais, au fol. 208, il suspend son récit pour reproduire une quantité de beaux vers, composés par le chérif II-Ridhà. La suite de la généalogie des Alides derait se trourer dans le vingt-quatrième volume.

Papier. 235 feuillets. Hauleur, 27 centimètres et demi; largeur, 18 centimètres et demi. 2 1 lignes par page. Ms. du $x^{\circ}$ siècle. (Ancien fonds 904.)

\section{0 .}

10

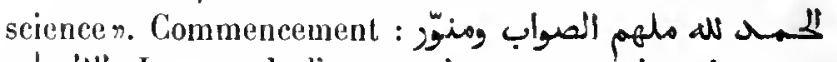
الالمباب. Le nom de l'auteur n'est pas mentionné.

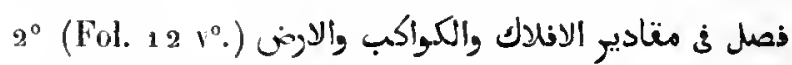

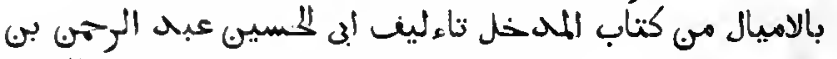
rihapitre sur les dimensions, calculées en milles, des splù̀res, des étoiles et de la terre, extrait de l'Introduction (à l'astronomie) d'Aboù '1-Hosaïn ibn 'Omar 'Abd al-Rahmâna al-Ṣoûfî".

$3^{\circ}$ (Fol. 14.) Note d'Athìr al-Din aj-Abharì sur la mauière de procéder, en astrologie, pour décourrir l'époque de la maissance d'un individu dont le jour natal est inconnu.

$4^{\circ}$ (Fol. 15.) Note sur la signification du mot $\boldsymbol{c}^{\circ}$.

50 (Fol. $15 v^{\circ}$.) التول في الطبـيعات physiquen, formant la seconde partie du traité général

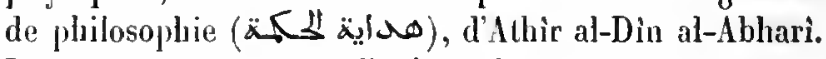
Le texte est accompagné d'un grand nombre de notes marginales et interlinéaires.

$6^{\circ}\left(F_{01} .44 v^{\circ}\right.$.) Deux notes de Nașir al-Dìn al-Ṭoûsì. La première explique comment le multiple émane de l'unité, hien que rien ne puisse émaner de l'unité, excepté l'unité. La scconde indique les jugements que l'on peut tirer de la lune, dans chacune des six dispositions que lui attribue l'astrologie. Suivent d'autres notes sur les influences des sept planètes, sur les coujonctions de la lune et sur les jugements que l'on peut tirer du jour dans lequel la lune entre dans l'une oul dans l'autre de ses vingthuit mansions. 


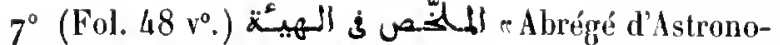
mien, par Nlahmoûd ibn Moḥammad al-Djaghmini alKhowârazmî. Le texte est accompagné de notes marginales et interlinéaires. La préface commence par ces mots :

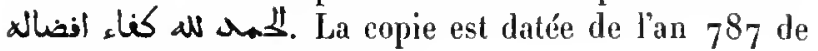
l'hégire (1 $385-1386$ de J. C.).

$8^{\circ}$ (Fol. $83 v^{\circ}$.) Deux chapitres du traité d'astronomie de Naṣir al-Din al-Ṭoûsì, intitulé żs moirer. Le premier chapitre contient l'explication des termes techniques employés dans la géométrie; le second traite de la méthode pour mesurer les surlaces planes.

$9^{\circ}$ (Fol. $9^{3}{ }^{\circ}{ }^{\circ}$.) Principes de géométrie, avec figores. Pièce datée de l'an 788 de l'hégoire.

$10^{\circ}$ (Fol. $100 \mathrm{v}^{\mathrm{n}}$.) Traité d'arithmétique.

$11^{\circ}$ (Fol. $105 v^{\circ}$.) Tables de mulliplication et (quelques règles d'arithmétique.

$12^{\circ}$ (Fol. $1061^{\circ}$ ) A Assimilation dans l'art du calcul n, traité d'algèbre, précédé d'un clrapitre sur la réduction des fractions. Selon Iladji Khalfa, l'auteur de ce traité se nommait Siràdj al-Dìn Aboû Ṭilhir Noḷammad al-Sadjàwandì ?

$13^{\circ}\left(\right.$ Fol. $108 \mathrm{v}^{\circ}$.) Introduction ì un traité d'aritlméétique.

$14^{\circ}$ (Fol. $1091^{\circ}$.) Suite de l'article $12^{\circ}$.

Papier. 116 feuillets. Hauteur, 19 cenlimètres el demi; targeur, 13 centinètres el demi. Diverses écritures dı xv siècle. - (Ancien fonds 922, Colbert 6028.)

\section{1 .}

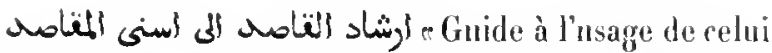
qui se dirige vers le but le plus élevén, par Moḷammad ibn lbrähìm ibu Sấid al-Anșârî al-Sakhâwî, mort en $7^{4} 9$ de l'hégire (1347-1348 de J. C.). Dans cette petite encyclopédie, l'auteur parle brièvement de toutes les sciences. Chaque notice est suivie de lindication des ouvrages qui traitent du sujet. Cet ouvrage a été injurimé ¿ Calcutta, dans le vingt et unième cahier de la Bibliotheca indica, et traduit en allemand par M. Haarbrücker (Berlin 1859). Premiers mots de la préface : als a

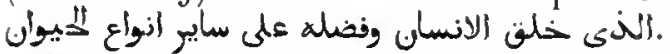

Ms. daté de l'un 779 de l'hégire ( 1377 de J. (.).

Papier. 65 feuittets. Hauteur, 23 centimètres; largeur, 15 centimètres et demi. 17 lignes par page. - (Supplément 2165.)

\section{2 .}

Mème ourrage.

Papier. 77 feuillets. Hauteur, 18 centimètres; targeur, 13 centimètres. 13 lignes par page. Ms. de la fin du xví siècle. - (Ancien fonds 920.)

\section{3 .}

Hème ourrage.

Ms. daté de l'an 1023 de l'hégire ( 1614 de J. C.). A la fin se trourent quelques prières.

Papier. 13 feuiltets. Hauteur, 21 centimètres el demi; largeur, 15 centimètres el demi. a l lignes par page. - (Supplément 13\%0.)

\section{4.}

(Qui communique des connaissances et qui dissipe les soucis", recueil de notions sur des sujets divers, par Djamâl al-Dìn Aboû 'Abd Alłah Noḥammad ibn Aḷmad al-Qazwini. Commencement:

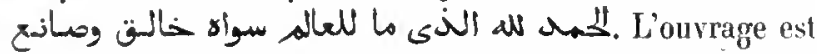
divisé en trente-denx seetions, dont voici les rubriques:

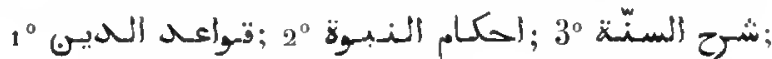

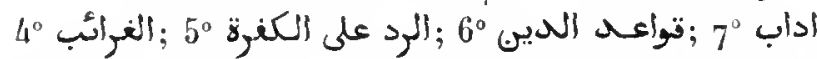

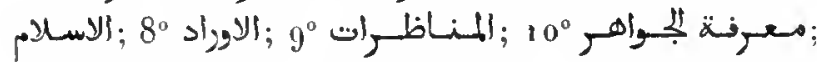

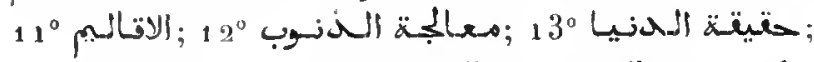
$14^{\circ}$ المكارم $17^{\circ}$

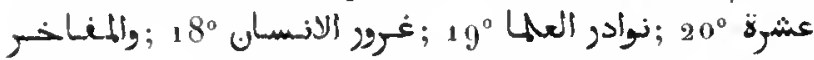

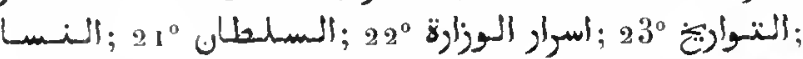

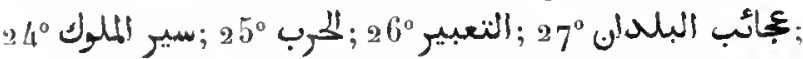

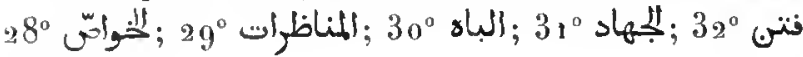

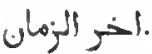

La date, un peu eflacée, yu'on lit à la fin du ins., parait être l'an 823 de l'hégire (1420 de J. C.) $)^{2}$.

Papier. 278 feuillets. Hauteur, 19 centimètres; largeur, 14 centimètres. 19 lignes par page. - (Ancien fonds 519.)

\section{5.}

Nème ourrage.

Le chapitre sur les fractions fail partie intégrante du traité d’Aboû-Tâhir. H. Z. - ${ }^{2}$ Le ms. paraîl ềtre du rvı๋ siècte. H. Z. Mas. onextacx. - Il. 
Is. daté de l'an 1081 de l'hégire $(1670$ de J. C.).

Papier. 1/66 feuillels. Hauteur, 26 centimètres et demi; targeur, 17 centimètres. 3 1 lignes par page. - (Supplément 1851.)

\section{6.}

llème ouvrage. Le titre de cet rxemplaire porte que lanteur se nommait thoù 'Abd Allah Mlohammad alKhowârazinì.

Ms. daté de l'an 1126 de l'hégire (1 714 de J. C.).

Papier. 233 feuillets. Hauteur, 25 centimètres; largeur, 19 centisnètres et demi. 19 à 2 i lignes par page. - (Supplément 1851 d.)

\section{7.}

llème ouvrage.

Us. daté de l’an 1298 de Thégire (18,3 de J. C.). II y a une lacune entre les folios actuellement cotés 89 at 90 .

Papier. 253 feuillets. Hauteur, 22 centimètres et demi; largenr, 16 centimetres. a l lignes par page. - (Supplément 2164.)

\section{8.}

Odeurs de musc, ou révélatious laites à la Mecque», encyclopédie à l'usage des soulis, qui renferme des renseignements littéraires, des disserlations philosophiques at surtout mystiques, par 'Abd al-Rahnàu iln Moḷammad al-Ḥanafi al-Bastânù. Lianteur a acheré cette première partie, qui contient l'ente chapitres (l'ouvrage entier se compose de cent chapilres), au mois de dsoùl-lịddja de l'an 844 de l'hégire ( 1441 de l. C.).

Papier: 275 feuillets. Hauteur, 20 centimètres et demi; largeur, 1 a centimètres et demi. 19 liggnes par page. Ils. du wrie siècle. - (Ancien fonds 877 .)

\section{9 .}

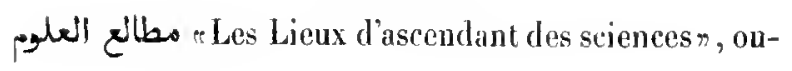

vrage composé de vingt livres, dont le présent ms. renferme dix-neuf, qui lraitent des flexions grammaticales, de la syntaxe, de la rhétorique, de la logique, de la prosodie, de la controverse, de la théologie scolastique, de la jurisprudence, du partage des suecessions, de la théologic dogmatique, de la physique, de la métaphysique, de l'astronomie, de la géométrie, des corps sphériques, de la géomancie, de l'usage de l'astrolabe, de la musique. Cet ourrage a été composé sur la demande d'un grand personnage, nommé Schaikh-Zàdè. Commencement :

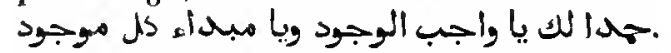

Papier. 205 feuillets. Hauteur, 17 centimètres; largeur, 12 centimètres et demi. 8 lignes par page. - (Ancien fonds 1325.)

\section{0.}

Perle des plongeurs et trésor de spécification, traité de la connaissance des qualités $»$. C'est une sorte d'encyclopédie, dans laquelle l'auteur anonyne traite successivement des divers règnes de la nature, des drogues, des pierres, des maladies, des boissons, etc. La section des drogues et des simples est rédigée dans l'ordre alphabétique. Le dernier tiers de l'ouvrage est consacré aux talismans, à la cabale et à la divination?

Papier. 202 feuillets. Hauteur, 31 centimètres; largeur, so centimètres et demi. 27 lignes par page. Ms. du xvi siècle; mais certaines parties sont plus récentes. - (Supplément 1119.)

\section{1.}

Encyclopédie des sciences musulmanes, grand ouvrage sans titre ni nom d'auteur. Commencement : at حم

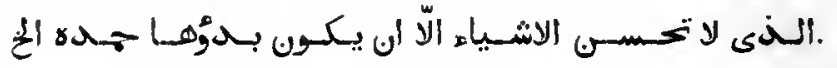

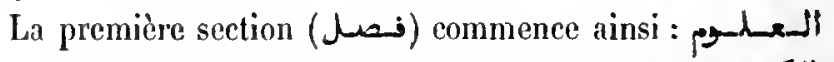

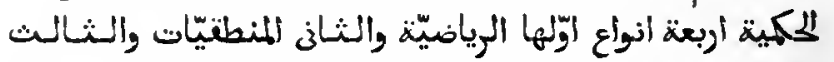

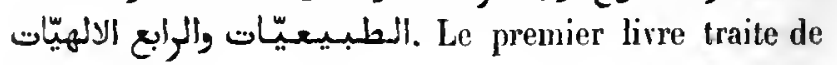
l'arithmétique.

Ms. daté de l'an 1228 de l'hégire (1813 de J. C.).

Papier. 339 feuillets. Hauteur, 30 centimètres; largeur, 25 centimètres et demi. 31 lignes par page. - (Supplément 1849.)

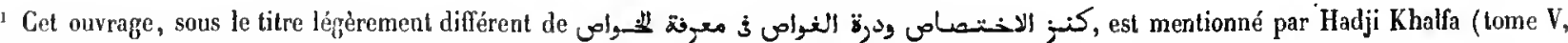
p. :46), qui indique aussi le nom de l'auteur : Aidamir ibn 'Alî́ ibn Aỉdamir aj-Djildakî. It. Z.
} 


\section{2 i 2344.}

Même ouvrage.

3 vol. Papier. 413, 414 el 393 feuillets. Hauteur, 23 centimètres; largeur, 16 centimètres et demi. 19 lignes par page dans le premier volume, 17 dans le deuxième et le troisième. Ms. du commencement dn xix sièclé. - (Supplẻment 1850 I-III.)

\section{5.}

ذكر العاتل وتنبيه الغـافـل Loup d'oil général sur les scionces et la civilisation, par l'émir " $A$ bd al-Qkidir ( $A b d$ el-Kader). Un feuillet du journal te Moniteur, contenant un rapport de M. Reinaud sur cel ourrage, qui a été traduit par M. Dugat, est joint au volume.

Ms. écrit par un Maghrebin, sous les yeux de l'iuterur, ot daté de l'an 1855 de J. C.

Papier. 38 feuillets. Hateur, 24 centimeilres et deni; largenr, 17 centimètres. 2, lignes par page. - (Supplément 1953.)

\section{$\mathrm{X}$.}

\section{PHILOSOPHIL.}

\section{6.}

LOOrganon, la Rhétorique at la Poétique d'Aristote, et 1'Isagroge de Porphyre. Ces versions sont dues i plusicurs trarlucteurs. Il ne peut rester aucun doute sur letir origine; car les mots elraduit du syriaque" sont répétés dans phosieurs rubriques. On voit, du reste, par les nonlyreuses notes interlinéares et marginales que porle le manuscrit, qu’il existait, dès le $x^{\mathfrak{e}}$ siècle, plusieurs Iratuctions des différents ouvrages d'Aristolo, el que les traductions failes il la hàte sous les caliles M-Mamoùn et Al-Moutawakkil ont été revies plus tard, corringés sur le texte syriaque on grec, ou mème exécutées ì nouvean. Le live des Réfutations des sophistes se présente, dans notre ms., dans quatre traductions différentess (royez S. Munk, Mélanges de philosoplie juive at arabe, page 313). Une partic des notes qui courrent les marges de ce volume sont tirées des commentaires yne Ilasan ben Sawar, auleur chrélien du $x^{\text {e }}$ siecle, disciple de Yalya ben 'Adi, avait écrits sm l'Organon d'Aristote. Ce ms. a été collationné at corriggé en 418 de l'hégire (1027 de J. C.). L'écriture des feuillets $147-172$, est plus soignée que dans le reste du ms. Un certain nombre de passages sont devenus illisibles.

Papier. 380 feuillets. Hauteur, 43 centimètres; largenr, 30 centimètres. 21 à 35 lignes par page. - (Ancien fonds $882 \mathrm{~A}$.)

\section{7.}

Lo traité intitulé $\Theta \varepsilon \sigma \lambda c \gamma i ́ \alpha$, altribué à dristote. Com-

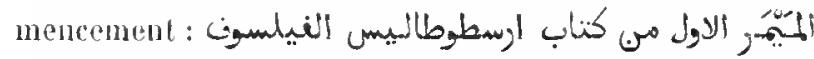

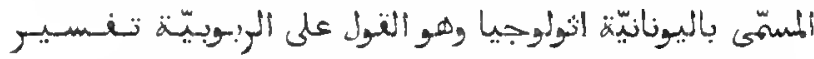

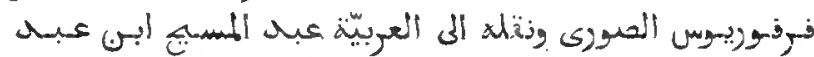

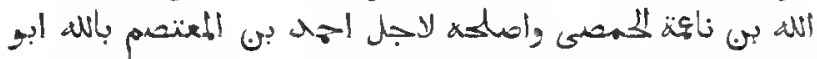
Premiel discours du livre. d'Aristote le philosophe, (livie) intilulé, en grece, Theologia, ce qui signifie discours sur la divinilé, expliqué pas' Porphyre de Tyr, et traduit en a abe par ${ }^{e}$ Mbor al-Masilu, fils d'Abd Allal, fils de Nicima, d'Émesse. Ce lrarail a élé l'avisé pour l'usage d'Almmad, fils (du calife) Al-Mo'lasim Billâlı, par Mboù Yoûsof' Yá'joûb ibn Islàiq al-Kindì. Ciet ourrage se compose de dix chaj)itres, ou mä̈mar, mot yui, en syriaque, signilie ediscoums Écriture cursive, dépouriue, en général, de points diacritifues.

Papier. 87 feuillets. Hanteur, 25 centimètres; largeur, 15 centimètres. 15 liq̧nes par page. Ms. du xvit siècle. - (Supplément 1343.)

\section{8.}

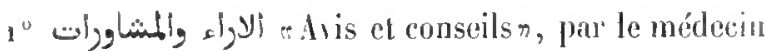
Aboù 'I-llasan 'Mli ibu Mḷmad (Ibn Hobàl). Cette disserlation, divisée en vingt ot un chapitres, l'aite du jugrement, de ce qui le forlifie el de ce qui l'allaiblit, de lit maniere de se lormer un atris et de chercher des conseils, atc. Commencentent :

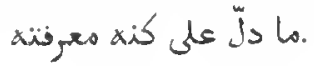

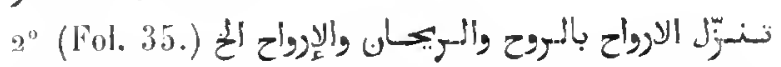
"bescente des esprits au moyen de l'àme, des parlum et des fumigations, etc. $n$, recueil de poésies mystiques, de Molyyi al-Dín ibn al-'Arabi. Cel ouvrage porte ansni

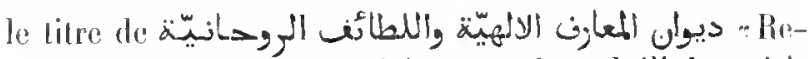
cueil de commaissances divines et de subtilités spirituelles\%. Commencement :

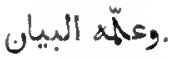

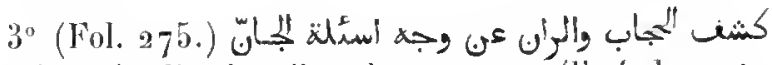
e'Trité qui enlère le voile et la couverture (littéralenenl : la guètre) qui couvrent les questions des génicsn, par "Abd 
al-Wahhåb ibn A hẹmạd $A$-Scha'rùnî. L'auleur répond à une série de questions que lui avaient adressées certains vrais croyants de la race des génies. Commencement:

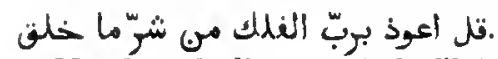

Ms. daté de l'an 1093 de l'hégire (1682 de J. C.).

Papier. 300 feuillets. Hauteur, 25 centinètres; largeur, 15 centimètres. 27 dे 29 lignes par page. - (Supplément 2154.)

\section{9.}

Seconde parlie du commentaire de Qoth al-Din Malu-

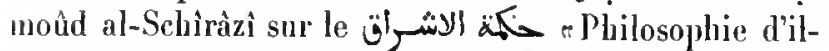
luminisme», du célèbre théosophe Al-Sohrawardi, qui a élé mis à mort à Alep, en $19^{1}$ de J. C., sur l'ordre du sullan Saladin. (Voyez lbn Khallikin, l. 1V, page 153 de la traduclion anglaise).

Ms. dalé de l'an 750 de l'hégire ( 1350 de J. C.).

Papier. 210 feuillets. Hauteur, 17 centimètres et demi; largeur, 13 centimètres. 17 lignes par page. - (Supplément 1337. )

\section{0.}

régles de la discussion », par Schams alDîn Mlọammad al-Samarqandì. Traité de dialeclique qui

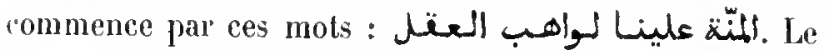
lexle est accompagné d'un commentaire perpétuel et d'un grand nombre de gloses, tant marginales qu'iuterliméaires.

$2^{\circ}\left(F_{0} l .47 r^{\circ}\right.$.) Le même ouvragre, sans commentaire ni gloses.

3० Prière qui sert d'amulette $(j,-)$, el qui protège contre la colère des princes el contre beaucoup d'autres dangers.

Papier. $6_{7}$ feuillets. Hauteur, 20 centimètres; largeur, 14 centimètres. 13 lignes par page dans le premier traité, 7 lignes dans te second. Ms. du xvit siècle. - (Ancien fonds 931 .)

\section{1.}

$1^{\circ}$ Gloses de Sinân al-Dìn Yoûsof al-Roûmî pour élucider certains passages du commentaire de Kamâl al-Dìn Mascoûd al-Schîrwânî sur le le
Din al-Samarqandì. Premiers mols : فضلة على مه بنثاء.

$2^{\circ}$ (Fol. 16.) Commentaire de Maśoûd sur le إدأب ثs?ll de Schams al-Dìn al-Samarqandì. Beaucoup de gloses marginales. Les derniers feuillets manquent.

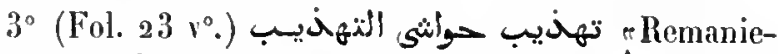
ment des gloses du Tahdsîbr, par Zaïn al- Ẩbidìn ibn Yoûsof al-Kourànî. Le Tahdsîb est un traité de logique et de théologie scolastique, dont l'auteur est Sa'd al-Din alTaftâzànì. Premiers mots de la préface : يـا مس. وفنقسنـا لتههi. La fin manque.

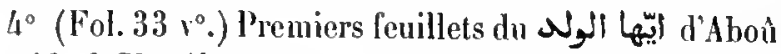
!làmid al-Ghazâlì.

Papier. 36 feuillets. Hauteur, 21 centimètres; largeur, 14 centi-

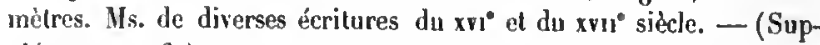
plément 2116.)

\section{2 .}

Cahier détaché d'un traité de métaphysique. Chaque paragraphe est intitulé 8 raprincipes. L'auteur traite de l'union de l'àme et du corps, de l'immortalilé de l'âme (بناء النغن), de l'infériorité des plaisirs des sens comparé à la voluplé de la contemplation de la majesté divine, ete.

Papier. 10 feuillets. Hauteur, 15 centimètres et demi; largeur, 8 centimètres el demi. 16 ligues par page. Ms. du xu1" siècle. - (Supplément 2157.)

\section{- 2353 .}

1 Commentaire d'Al-Fanàrì sur l'Isagoge d'Athìr alDìn al-Abluarì.

$2^{\circ}$ (Fol. $22 v^{\circ}$.) l'Isagoge d'Al-Abharî.

$3^{\circ}$ (Fol. oo.) Commentaire de Hosàm al-Dìn al-Kânî ${ }^{1}$ sur l'Isagoge d'Al-Abharì.

Le dernier de ces traités est daté de l'an 911 de l'hégire (1505-1506 de J. C.).

Papier. 36 feuillets. Ilauteur, 18 centimètres; largeur, 13 centimètres. Diverses écritures du $x^{\circ} 1^{\circ}$ siècle. - (Ancien fonds 937.)

\section{4.}

$1^{\circ}$ Commentaire d'Al-Fanârî sur l'Isagogoge d'Athîr alDìn al-Abharî.

\footnotetext{
I La forme exacte de ce nom esl Al-Kâtí. Yoyez ci-dessus, p. 404, note 2. H. Z.
} 
$2^{\circ}$ (Fol. 49.) L'Isagoge d'Al-Abharì. Le commencement inanque.

$3^{\circ}\left(\right.$ Fol. 56 v$^{\circ}$.) Commentaire d'Al-Kànì sur l'Isagrogre d'Al-Abharì.

Papier. 99 Peuillets. Hauleur, 15 centımètres; largeur, 10 centimètres et demi. 15 lignes par page. Ms. du svis" siècle. - (Ancien fonds 977.)

\section{5.}

Commentaire d'Al-Fanârì sur l'Isagogoge d'Athì' al-Din a1-Abharì. Quelques gloses marginales.

Papier. 94 feuillets. Hanteur, 23 centimètres; largeur, 17 centimètres. 9 lignes par page. Ms. du xvnı sièrle. - (Supplément a 330.)

\section{6.}

$1^{\circ}$ Gloses (de Mohyì al-Dìn al-Tülischî?), pour élucider quelques jassages du commentaire d'Al-Kânî sur le commentaire de l'Isagoge d'Athîr al-Din al-Ablarì. Com-

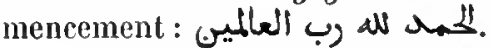

$2^{\circ}$ (Fol. $7^{8} v^{\circ}$.) Commentaire d'Al-Kànî sur l'Isagogoge d'Al-Ablıarì.

$3^{\circ}$ (Fol. $103 v^{\circ}$.) L'Isagoge d'Athìr al-Dîn al-Abharì.

Ms. daté de l'an 1091 de l'hégire ( 1680 de J. C.).

Papier. 108 feuillets. Hauleur, 20 centimètres; largenr, is centimètres. 17 lignes par page. - (Supplément 1 329.)

\section{7.}

$1^{\circ}$ Commencement du commentaire d'Ml-Kànì sur l'Isagoge d'Athir al-Din al-Ablsari.

$2^{\circ}$ (Fol. 12.) Sur l'art de décourrir les trésors cacliés. Ce traité renferme un assez grand nombre de passages en chiffres et en caractères de convention. Le premier feuillet manque. Il a été remplacé par un autre qui se trouve, par erreur, en tẻte du volume. Sur ce feuillet,

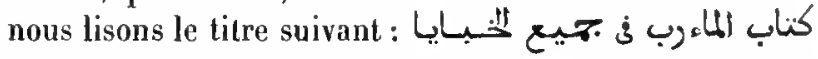
(livre des choses nécessaires, traitant de tous les trésors cachés, des puits et des lieux à explorer'n. Le copiste ajoute que ce traité est la reproduction du livre du sage Hermès, le philosophe, livre qui se trouvait à Miṣı, dans la bibliothèque du Pluaraon. $3^{\circ}$ (Fol. 5g.) Sur les vertus des leltres de l'alphabet et sur la construction des wiqf. ou carrés magiques, pour servir de talismans.

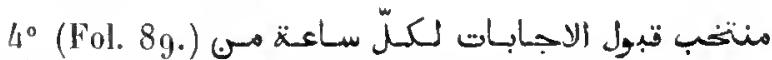
r Extrait de l'ourrage intitulé d'Obtention de réponses pour chacune des heures", traité cabalistique et mystique, renfermant les oraisons pour chaque lseure de la journée. L'auteur cite quelquelois l'autorité d'Aboû "l-c'thbảs al-Boûni.

$5^{\circ}$ Fol. 106. (06) Sullisant, qui traite de la prosodie et des rimes $\%$, par Alımad

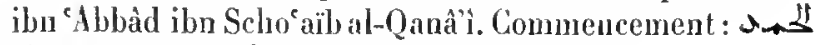

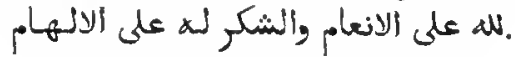

$6^{\circ}$ (Fol. 115.) Quatre feuillets, contenant la fin de l'Isagoge d'Al-Abluarì.

$7^{\circ}$ (Fol. 119.0 . Spécimen d'astronomien, par Dàwoud le inédecin. C'est plutôt un traité d'astrologie médicale.

$8^{\circ}$ (Fol. $1321^{\circ}$. ) Pronosties qu'on pent tirer, pour les maladies, des jours de la semaine et des mois.

$9^{\circ}$ (Fol. $133 v^{\circ}$.) Trailé des charmes el des paroles magiques appelées طبه

$10^{\circ}$ (Fol. 143.) Traité de inagie naturelle (سميل) et des talismans.

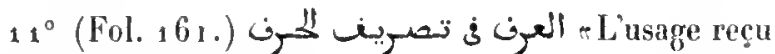
en ce qui concerne l'emploi des lettres n. Traité de divination et de talismanique.

$12^{\circ}$ (Fol. 175. (750. Cercle des lettres de l'alphabet $\%$. Traité cabalistique, attribué à Helmès le sage, dans lequel sont exposées les propriétés secrètes des vingt-huit lettres.

$13^{\circ}$ (Fol. 2o6.) Modèle d'écriture arque. Feuille pliée.

$14^{\circ}$ (Fol. 207.$)$ Prière.

$15^{\circ}$ (Fol. $207 \mathrm{v}^{\circ}$.) Traité sur les vertus des lettres, attribué à Hermès trismagiste et transmis par Al-Khowârazmi. Quelques figures et talismans.

$16^{\circ}$ (Fol. 214.) Sur les vertus du sceau d’Aboû Hàmid al-Ghazâlî. Cette pièce, qui est de la même écriture que l'article précédent, est datée de l'an 1063 de l'hégire ( 1653 de J. C.).

$17^{\circ}$ (Fol. 218.) Les sept horoscopes des anges.

$18^{\circ}$ (Fol. 223.) Deux carrés magiques.

Papier. 255 feuillets. Hanteur, 22 centimètres; largeur, 15 centimètres. Écritures diverses du xvı et du xvi" siècle. - (Ancien fonds 929.) 


\section{8.}

$1^{\circ}$ Gloses de Molyyî al-Din sur te commenlaire de l'Lsagoge d'Al-Abharì par Al-Kùní.

$2^{\circ}$ (Fol. 73. (أنحليب ' Sur la manière de discnler les questions mélaplyssiques, par Moḷammad ibn Waìz ibn Walìdjàn de Marcasch. Cette dissertation est suivie d'un commenlaire du mème auteur. Commence-

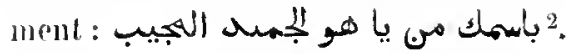

Papier. 77 fenillets. Itauteur, 20 cenlimètres; largeur, 19 centimètres. 17 lignes par page. Ms. dı xvin' siècle. - (Supplémenl 1 331.)

\section{9 .}

$1^{\circ}$ Gloses sur le commentaire de l'lsagoge d'Al-Abliar', 1 lal Il-Kài. Commencement : ك. Cost peul-ûtre l'ourrage que Iladji Khalfa (t. I, 1) 503) altribue ì AlBardaci.

$2^{\circ}\left(F_{0} .21 v^{\circ}\right.$.) Conmentaire d'Al-Kànì sur l'lsagoge d'Al-Abhari. Les premières pages de cet exemplaire portent un grand nombre de notes marginales.

$3^{\circ}$ (Fol. $46 r^{\circ}$. ) L'Isagoge d'Athìr al-Din al-Abharì.

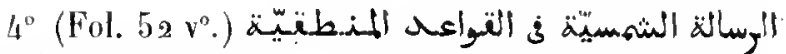
- Traité sur les principes de la logique, dédié à Schans al-Dinn, par Nidjun al-Dín 'Omar ibn 'Ali al-Kitihi alQazwìni, disciple de Nișir al-Dìn al-Ṭonsî. Cel ouvrage 'se compose d'une introduction, de trois discours et d'un appendice. Lintroduction traite de la nature (ماهيّة) d la logique; le premier discours, des termes simples

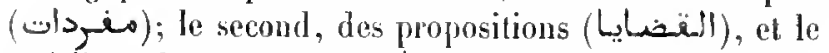
troisième du syllogisme (ân). La copie s'arrête au milicu du second discon's.

$5^{\circ}$ (Fol. 62 1\%.) Commentaire anonyme sur la Schamsiya de Nadjm al-Din al-Kàtibì. Nombreuses gloses marginales. Il y a une litcune entre les leuillets 114 ot 115 .

Volume écrit en entier de la même main, en $9^{54}$ de l'hégire (1547 de J. C.).

Papier. 121 feuiltets. Hauteur, 22 centimètres; largeur, 15 centimètres. 1 lignes par page. - (Ancien fonds ga6.)

\section{0 .}

Commentaire sur les deux dernières parties de la $\mathrm{Hi}$ díya d'Athìr al-Dín al-Abhari, par Maulànà Zàdé Aḷmad ilon Maḷmoût al-llarawì. La هـ ou, d'après Hadji Khalfa, visée en trois parties, dont la première est consacrée à ła logique, la seconde à la physique et la troisième à la métaphysique (الإنَّ). L'ourage est rédigé sous forme de Questions et Réponses. La préface commence par ces

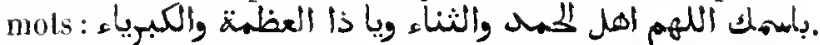
A la lin du volume on lit: $1^{\circ}$ une explication du terme philosophique hyle (المهيولى); $2^{\circ}$ la prière des funéraillles. Les premières pages du texte sont couvertes de gloses marginales et interlinéaires.

Papier. 107 feuillets. Hauteur, a 6 centinètres et demi; largeur, 18 centimètres. 16 lignes par page. - (Ancien fonds goa.)

\section{1 .}

Mène ouvragge.

Le commencement nuanque (le folio actuellement colé 1 correspond au fol. $411^{\circ} \mathrm{du}$ mis. précédent). A la fin, on lit une dissertation sur les divisions de la science philosophique, une courte nolice sur Socrate, le maître de Platon, et l'explicaliou de quelques ternes de métapliysigue.

Papier. 83 feuillels. Hauteur, 18 centimètres et demi; largeur, 13 centimètres el demi. 15 lignes par page. -- (Ancien fonds 960 .)

\section{2 .}

$1^{\circ}$ Explication du commentaire de Maulàná Zadè sur la Ilidâya d'Al-Abharì. La préface conuence par ces mots :

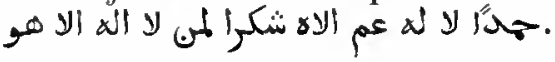

$2^{\circ}$ (Fol. $411^{\circ}$.) Commentaire amonyme sur la seconde et sur la troisième section de la llidáya d'Al-Abharî. Com.

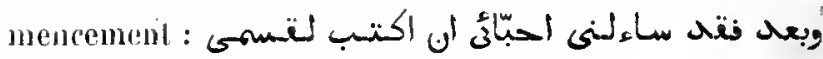

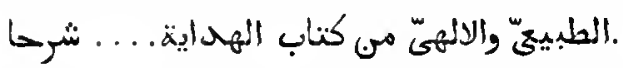

Papier. 80 feuittels. Hauteur, 22 centimètres; largeur, 13 centimètres et demi. a1 lignes par page. Ms. du $v^{6}$ siècle. - (Ancien fonds $9^{2} 8$.)

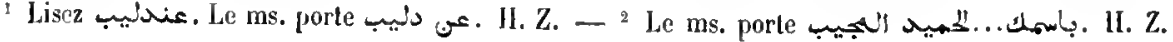




\section{3.}

Commentaire sur la Hidiya d'Alhir al-Din al-Abharì, par lịosaïn ibn Mo'in al-Din al-Maïbodsì. Ce cominentaire a élé composé en 880 de l'hégire (1476 de

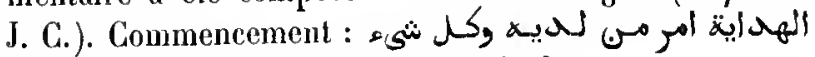
. Nombreuses gloses marginales.

Papier. 165 feuillets. Hauteur, 2o centimètres; largeur, 13 centimètres et demi. 12 lignes par page. Nls. du $x^{e}$ siècle. - (Ancien fonds $9^{30 .}$ )

\section{4.}

Gloses de Schams al-Din Hoḷammad, surnommé Moslih al-Dìn al-Lârî sur la Hidaya d'Alhîr al-Dìn al-Abharì.

Ms. daté de l'an 1075 de l'hégrire (1665 de J. C.).

Papier. 77 feuillets. Hauteur, 20 centimètres; largeur, $1 / 1$ centimètres et demi. 28 lignes par page. - - (Supplément 2 ๑०.)

\section{5.}

Volume composé de soixante-lıuit fragments de manuscrits et d'ouvrages différents, de diverses écritures, portant presque tous, en marge, des gloses dont la plupart sont de la même main et en écrilure tálíq. Ces fragments se composent en général d'un très petit nombre de feuillets, et quelquefois même d'un seul. Plusicurs sonl des commentaires renfermant quelques mots seuleinent du texte; aussi serait-il très difficile de reconnaitre les ouvrages commentés. H. Anari, qui a examiné avec grand soin cette collection de feuillets détachés, a indiqué les divers sujets dont ils trailent, ainsi qu'i\} suit :

$1^{\circ}$ Logique et métaphysique. Fol. $12 \mathrm{v}^{\circ}$ : Commentaire sur deux chapitres de la Hidaya d'Athir al-Din al-Ablari. Fol. 347 : Fin du traité d'Aloû ḷìmid al-Ghazâlì, qui a

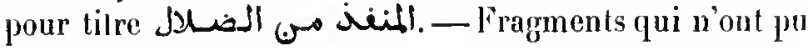
ètre identifiés : fol. $11,13,20,37,52,59,61,66$, $93,106,116,118,122,128,134,140,168,176$, $177,184,215,239,245,261,263,265,279,289$, $29^{\circ}, 29^{5}, 304$.

$2^{\circ}$ Théologie. Fol. 330 : Le second feuillet de l'introduction à un poème composé par cìmir ibn cÀmir al-Baṣri, intilulé vingt-deux vers, formant te commencement du poème et portant le tilre de الانثارة الاوله ف النتوحيد Lal première indication touchant la confession de l'unité de Dieu- Fragments qui noont pu être identifiés : lol. 21, 27, $36,200,204,225,242,248,272,296,331$.

$3^{\circ}$ Grammaire. Fol. 4, 10,39, 58, 117, 144, 145 , $146,152,179,195,227,231,343,308,310$.

$4^{\circ}$ Jurispmudence. Fol. $205,207,213,243,308$.

$5^{\circ}$ Traditions des premiers califes. Fol. 336.

$6^{\circ}$ Cosmogonie. Fol. 19.

$7^{\circ}$ Gnomonique. Fol. 1 : Premières pages d'un traité d'Aboù 'l-Fadhâil 'Alod al-'Azìz Moḥammad al-IVafài, nowaqqit (indicateur des hıeures des pric̀res, ou plulòt loologer), de la mosquée d'Al-Mowaiyidi, de la mosquée d'Al-Azhar et d'autres mosquées. Le titre de l'ourrage manque.

$8^{\circ}$ Commentaire d'un commentaire. Fol. 260.

$9^{\circ}$ Fragments de prières.

Papier. 347 feuillets. Hauteur, 19 centimètres; largeur, 13 centimètres. - (Ancien fonds $2 g^{5}$.)

\section{6.}

La seconde et la troisième partic du commentaire de Naṣir al-Din al-Ṭoùsî sur l'ouvrage d'Avicenne intilulé iأil.

Papier. $17^{5}$ feuillets. Ilanteur, a a centimètres; largeur, 19 centimètres. 29 lignes par page. IIs. du xv' siècle. - (Supplément 2513.)

\section{7.}

Trailé de métapliysique, faisant suite à un Irailé de pliysique et portant, d'après l'explicit, le titre de

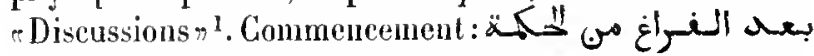

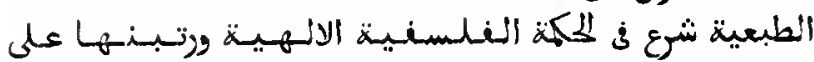

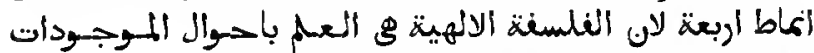

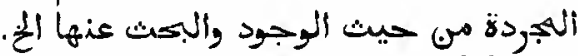

lìn têle du volume se trouvent plusieurs alphabets imaginaires.

Ms. dépourvu de points diacriliques, excepté dans les trois premières pages.

Papier. 192 feuillets. Hauteur, so centimètres et demi; largeur, 13 centimètres et demi. 17 lignes par page. IIs. du svil siècle. (Supplément 1338.)

\footnotetext{
1 Comparez Hadji Khalfa, t. I, p. 3os. H. Z.
} 


\section{8.}

Régularisation des bases, pour servir de conmenlaire au Tadjrîd al"Aquiids. Le مiئll "Exposé du dogmen, on Exposé de la mćtaphysiquen, de Nașir alDin al-Tousì est un traité de logique, de physique et de métaphysique. Le commentaire commence par ces mots :

. Le nom de l'auteur n'est pas indiqué. Il est fort doutenx que ce soit le commenlaire d'Al-Iṣlahànî, dont le nom est mentionné dans la prélace avec des louanges qu'un auteur ne se donnerail pas.

Papier. $3: 44$ feuillets. Ilanteur, 18 centimètres; largeur, 13 centimètres. 19 lignes par page. Ms. dı xvi siècle. - (Ancien londs 933.)

\section{9 .}

$1^{\circ}$ Explication des passages obscurs et énigmatiques du grand commentaire d'Al-Djordjânî, qui sert à élucider le conmentaire d"Abd al-Ralımån ibn Aḷnad al-lṣfahànì

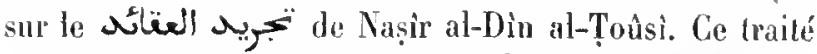
a été composé sous le l'ègne du sultan olloman Molıammad II, entre les années 1453 al 1481 , ainsi qu'on dic

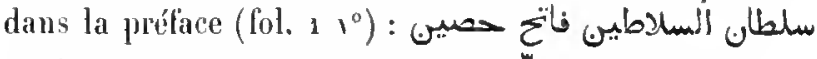

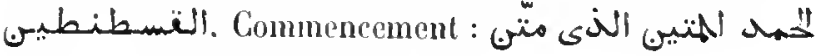

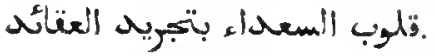

$2^{\circ}$ (Fol. $11 v^{0}$.) Commencenent du commentaire d'AlTaḥtànì (Qọ̣bal-Dìn Moḷanmad ibn Moḷammad al-Kàzî), mort en 766 de l'hégire (1364-1365 de J. C.), sur le d'Al-Ormawì. Commencenent : all our فيّامن ذوارن ألعوارن.

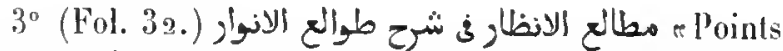
d'ohservalion pour servir de commentaire au traité de mélaphysique intilulé Tawâlic 'l-Amwấr (d"Abd Allah ibn "Omar al-Baïlihâwi)", par' Schams al-Dìn Aboû '1-Thanì Maḥmoud ibn 'Abd al-lialınèn al-Iṣfatıini. Ce n'est qu'un fragnent, dont le premier fenillet manque. Je texte est surcliargé de gloses et de notes.

$4^{\circ}$ (Fol. 41.) Fragment d'un commentaire sur un commentaire d'un trátité de métaphysique.

$5^{\circ}$ (Fol. 5 1.) Fragnent d'un commentaire sur un ourage qui traite de la matiere prenière, de la forme, dı corps, du mourement et du repos, elc. $6^{\circ}$ (Fol. 64.) Fragment d'un autre commentaire sur le même traité de métaphysique.

$7^{\circ}$ (Fol. $7^{2} 1^{\circ}$.) Explication d'un commentaire sur la prélace (ديباجة) du trailé de grammaire inlitule مصباجة

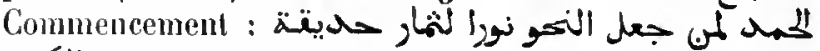
plist. La fin manque.

$8^{\circ}$ (Fol. 92.) Fragment d'un commentaire sır un traité de granmaire. Il est question des pronoms.

$9^{\circ}$ (Fol. 100.) Fragonent du (raité) de Rokn al-Dìn al-Istiràbàdsi, mort en $7^{1} 7$ de l'hé-

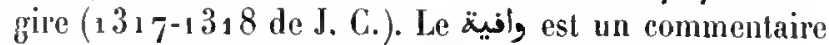

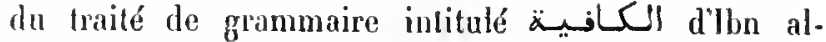
Hàdjib. La copie est datéo de l’an 869 de l'hégire (14641465 de J. C.).

$10^{\circ}$ (Fol. $\left.1151^{\circ}.\right)$ Conseils adressés aux jeunes gens (jui cherchent à sinstruire.

Papier. 118 feuillets. Hauteur, 18 centimètres; largeur, 13 centimètres et demi. Écritures diverses. - (Aucien fonds 925.)

\section{0 .}

 pour la découverte de la véritén, par Aboû 'l-Hasan 'Ali ibn 'Omar Al-Kìlibi, mor't vers l'an 65 o de l'hégire ( 1252 1253 de J. C.). La prenière des trois parties (قـسمم) dont se compose cet ourrage est consacrée à la logique, la seconde ì la physique et la troisième à la métaphysique. Ces parties sont divisées en discour's (älio), dont chacun contient plusienr's chapitres. Ia seconde partie commence an fol. $110 \mathrm{r}^{\circ}$, el la troisieme au fol. $130 \mathrm{v}^{\circ}$.

Ms. daté (au fol. 110 ) de l'an 863 de l'hégire $(\mathbf{1 4 5 9}$ de J. C.).

Papier. 151 feuillets. Hanteur, 18 centimètres; largeur, 13 centimètres. 21 lignes par page. - (Ancien fonds 93a..)

\section{- 2371 .}

$1^{\circ}{ }^{\circ}$ Schams al-Din, sur les priucipes de la logiquen, par Nadjun à-Dìn 'Omar al-Qazwìnì al-Kâtibì (Voyez cidessus, $n^{\circ} 2359,4^{\circ}$ ).

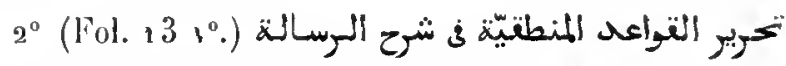

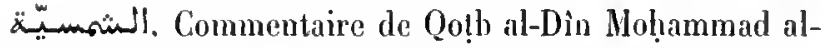
Râzî sur la Schamsîya d'Al-Kütibì. Commencement : ol 
ابهى درر تنظم ببنان البيان وأزهر زهر ينشر ف أردان الاذهـان 常

Papier. 211 feuillets. Hauteur, as centimètres el demi; largeur, 16 centimètres. L'écrilure du premier ouvrage est du xvı1 ${ }^{\circ}$, celle du serond, du xrm" siècle. - (Supplément 1323.)

\section{2.}

$1^{\circ}$ La Schamsîya d'Al-Kàlibì. Copie datée de l'an 1085 de l'légire (1674-1675 de J. C.).

$2^{\circ}$ (Fol. 3o.) Le Talkhîs al-Mifhâh.Copie du xrıc siècle, de diverses mains.

Papier. 113 feuillets. Hauteur, 21 centimètres; largeur, 13 centi-

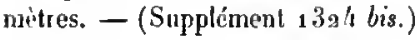

\section{3.}

1 Le Talerir al-Qavấid ou commentaire de Qoṭb alDìn al-Ràzì sur la Schamsíya d'Al-Qazwìnî. La copie est datée de l'an $7^{6} 7$ de l'hérire (1365-1366 de J. C.). Nombreuses notes marginales.

$2^{\circ}$ (Fol. $83 v^{\circ}$.) Commentaire sur la Schansîya, com-

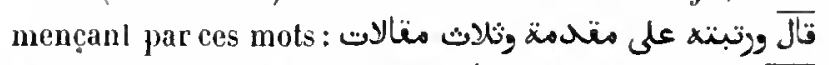

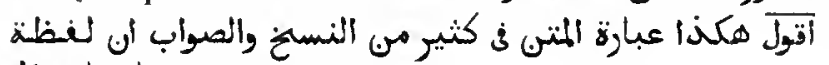

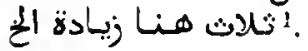

En lêle du volume, on lit des notes diverses, des traditions, des pièces de vers, dont quelques-unes en persan, des observations grammaticales, etc.

Papier. 131 feuillets. llauteur, 21 centimètres et demi; largeur, sa centimètres et demi. - (Ancien fonds 940.$)$

\section{4.}

Dépouillement des principes de la logique, pour servir de commentaire au traité inlitulé Al-Schamsîya. La prélace commence par ces mols : أن ابهى دور تنظم بينان اللبـيان Notes marginales, en caraclères nuicroscopiques?

Papier. 151 feuillets. Hauteur, 18 centimèlres; largeur, 11 centimètres. 17 lignes par page. Ms. du xvie siècle. - (Ancien fonds 978.)

\section{5 .}

Le Tahrir al-Qawáid de Qoṭb al-Din al-Ràz. Notes marginales et interlinéaires.

Papier, 215 feuillets. Hauleur, 23 ccntimètres et demi; largeur, 16 centimètres ot deni. 11 lignes par page. Ms. Ilu xvi" siècle. (Supplèment 1324.)

\section{6.}

Mème ourragoe.

Exemplaire dalé de l'an 1236 dè l'hégire $(1821$ de J. C..).

Papier. 298 feuillets. Hautcur, 19 centimètres et demi; largeur, 12 centimètres. 13 lignes par page. - (Supplément 1325.)

\section{7.}

$1^{\circ}$ Commentaire d'Alı̣mad ibn 'Abd al-Fatlâl Ml-Mlalawì sur la prélace ¿du Tahrîr al-Qawie id de Qo!̣ al-Dïı al-Ràzî.

$2^{\circ}$ (Fol. $24 v^{\circ}$.) Le Taleîr al-Qawacid de Qoṭb al-Din al-Ràzì.

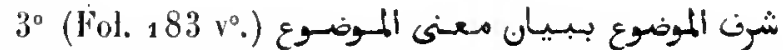
* Noble sujet à trailer, ì savour la signification du termo objet n, par Aboù 'l-Ilorschid Khalil al-Mâlikî. Il s'agyit de la signification du mol objet, qui s'emploie dans la Schan-

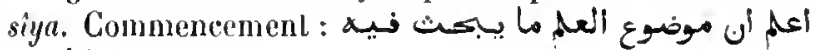
عب عوارضه الخذاتية

Papier. 186 feuillets. Hauteur, 22 centinètres; largeur, 16 centimètres. Écritures diverses du xvin" siècle. - (Supplément 13a6.)

\section{8.}

Gloses d'Alımad al-Abîwardì sur le commentaire du Taltrir al-Qawdeid par Djordjânì. Commencement : Mall

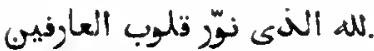

Ils. daté de l'an 895 de l'hégire (149o de J. C.).

Papier. $19^{3}$ feuillets. Hauteur, 19 centimètres; largeur, 12 cenlimètres. 21 lignes par page. - (Supplément 1327.)

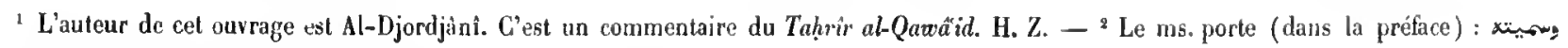

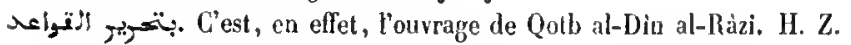

Mas, orientaur. - II 


\section{9.}

Commentaire sur la Schamsîya. Commencement: u.

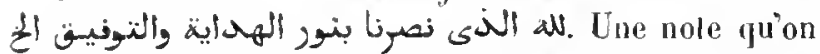
lit à la fin du volume nous apprend que cel exemplaire

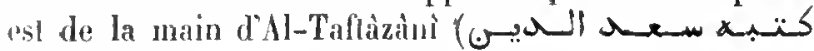
j)(inimll).

Papier. $9^{8}$ feuillets. Hauteur. 17 centimetres et demi; largecur, u centimètres et demi. 21 lignes par page. Ils. du $x v^{*}$ siède. (Ancien fonds 942.)

\section{0.}

Commentaire sur la Schamsinya. Commencement : u.S

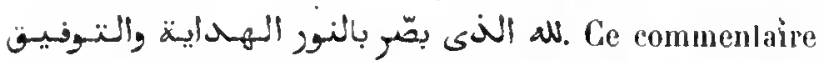

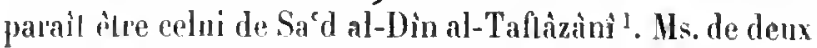
ŕcrilures, daté de l'an 877 de l'hégire (1 473 de J. C.).

Papier. ${ }_{119}$ feuillets. Hanteur, 8 centimètres el demi; largeur, 13 centimètres demi. 5 lignes par page. - (Stapplément 1328.)

\section{1 .}

$1^{\circ}$ Gloses sur la Schansiya. Une note yu'on lit au commencement, attribue ces gloses au docteur connu sous le snrnom d'Al-Saïyid al-Scharif, c'est-à-dire 'Alì ilm Molıammad al-Djordjunîi. L'ouvrage commence pal ces

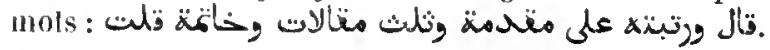

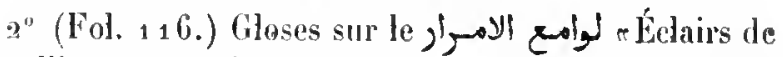
l'iutelligence-, qui est un commentaire sur le traité de logique intitnlé

Papier. 235 feuillets. Hauteur, s 1 centimètres et demi; largeur, 15 centimètres. Environ 20 lignes par page. Ms.du we siècle. - (Anrien fonds 9.38 .)

\section{2.}

Commenlaire sur la Schamsîya, accompagné de gloses. Ce ms. avail appartenu à Sammaise.

Papier. 6o feuillets. Hauteur, 19 centimétres; largenr, 14 centimètres. 16 lignes par page. - (Supplément 1930.)

\section{3.}

Commentaire sur le Schamsiya. Commencement : J

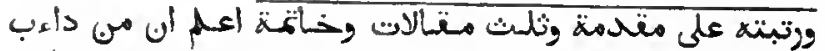

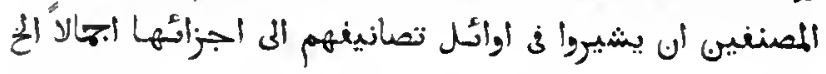

Papier. 77 feuillets. Hauteur, 17 centimètres; largeur, 13 centimètres et demi. 17 lignes par page. Ms. de différentes ćcritures du xvi siècle. - (Anrien fonds 941.$)$

\section{8 个.}

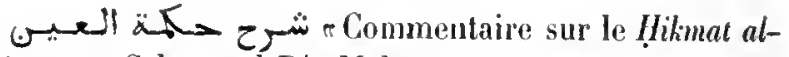
'Ainn, par' Schanıs al-Din Moḷammad ilon Mobàrakschàlı, al-Bokhàrì. L'ouvrage commenlé a pour anteur Nadjm al-Din Aboù Bakr ibn 'Omar al-Kálibi al-Qazwini, qui s'est proposé de mellre au grand jour la doctrine (حكية)

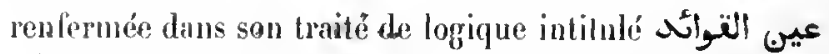
"Source des principes» et qui l'a complété par ce Iraité de métaphysique el de physique. Commencement du

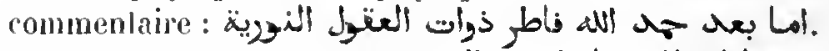

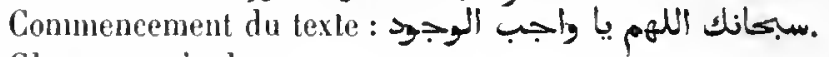
Gloses marginales.

Us. daté de l'an $9^{50}$ de l'hégire ( 1543 de J, C.).

Papier. 156 feuillets. Hauteur, 18 centimètres et demi; largeur, 13 cenlimòtres. 15 lignes par page. - (Supplément 9156.)

Vème ouvrage.

\section{5 .}

$2^{\circ}$ (Fol. $311^{\circ}$.) Gloses de Mirzaidjàn sur le $\ddot{a}$ cell. La fin manyue.

$3^{\circ}$ (Fol. g6 $v^{\circ}$.) Gloses d'un anonyme sur le même

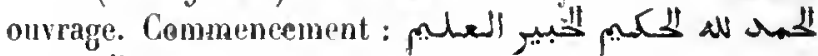
الانبهil.

$4^{\circ}$ (Fol. $1021^{\circ}$ ) Gloses de Nonlà Haïdar ( (حيار) sur le mêne ourrage.

$5^{\circ}$ (Folv 114 $v^{\circ}$ ) Gloses d'un anonyme sur lè même ouvrage.

$6^{\circ}$ (Eol. 126.) Dernier cahier d'un recueil de gloses sur' le même ouvrage. La copie n'est pas terminée.

La plupart des Iraites contenus dans ce volume sont

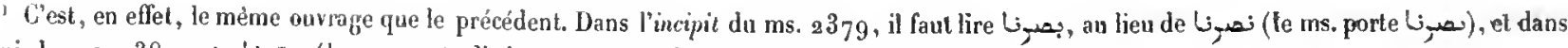

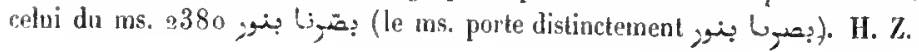


de la unème ćcriture. Nombreuses gloses marginales, disposées ordinairement en deux colonnes.

Papier. 133 feuillets. Hauteur, 22 centimèlres; largeur, 16 centimètres et demi. 19 lignes par page daus le premier et le second traité, 33 lignes dans le troisième, le qualrième et le cinquième trailé. Ms. du wru' sicicle. - (Supplément 1327 bis.)

\section{6.}

$1^{\circ}{ }^{\circ}{ }^{\prime}$ gique, par Sirâdj al-Din Moł̣anmad ibn abì Bakr alOrmawi. Commencement : ألائك On lil sur le second feuillet une note en langue Iurque, datée de l'an 1662 de J. C., portant que Barihéleny d'Herbelot a fail don de ce volume ì un nommé Des Vallès? (ديسس والـيـس (د) La copie elle-même est probablement de la main de d'Herbelol.

$2^{\circ}$ (Fol. $51 v^{\circ}$.) Senlences, maximes et pièces de vers, les nmes en arabe, les autres en persan et en turc.

$3^{\circ}$ (Fol. 58.) Pièce de vers en langue turque.

Papier. 6o feuillets. Hauteur, 16 centimètres; largeur, 10 centimètres et demi. 8 lighnes par page. Ms. du xvue sièele. - (Supplément 133.)

\section{7.}

Premières pages du al-Ormawî.

Papier. 16 pages. Hauteur, 23 cenlimètres; largeur, 18 centimètres. Écriture européenne du xri๋ siècle. — (Supptément 2259.)

\section{8.}

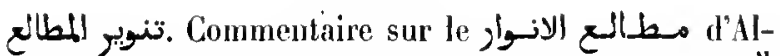
Ormawi, attribué à l!âdji Paclıa. Commencement : لمهن

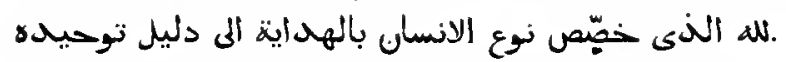

Papier. $19^{8}$ fenillets. Hauteur, 22 centimètres et demi; largeur, 1 2 centimètres et demi. a 5 lignes par page. Ns. du xv' sièrle. - (Supplément 1333.)

\section{9 .}

Le مطالع ألانظار de Schams al-Din al-lṣfalıânî̀. (Voyez (i-dessus, $n^{\circ} 236_{9}, 3^{\circ}$.)
Ms. daté de l'an 898 de l'hégire (1492-1493 de l. C.).

Papier. 210 feuillets. Hauteur, 17 centinètres et demi; largeur, 11 centimètres. 25 lignes par pagae. - (Supplément 2155.)

\section{0.}

Commenlaire du Saïyid al-Scharîf al-Djordjânî sur le

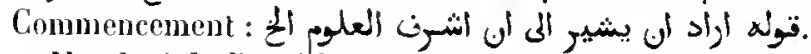

Ms. daté de l'an 881 de l'hégire (1 476 de J. C.).

Papier. 38 feuillets. Hauteur, 19 centimètres; largeur, 14 centimètres. 21 lignes par page. - (Ancien fonds 939 .)

\section{1 .}

Gloses de Mìrzàdjàn IIabỉb al-Sehìràzi sur te com-

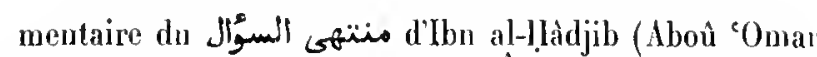
'Othmàn), par Adhod al-Dìn al-ìdjì. Commencement :

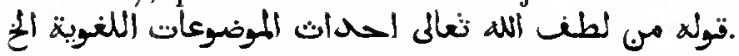

Papier. 233 feuillets. Hauteur, 18 centimètres; largeur, 12 centimètres et demi. 21 lignes par page. Ms. de diverses écritures du $\mathrm{x} v{ }^{\circ}$ siècte. - (Supplément 3336 .)

\section{2 .}

res Stations n, traité de philosophie scolastique appliquée aux dogmes de la religion musulmane, par le cadi 'Adhad al-Dìn 'Abd al-Raḥmân ibn Aḷmad alIdjì. Cet ouvrage se compose de six parties ou stations, divisées en plusieurs مرصد (lieux d'observation), et chaque مر on points de vue). La prenière station sert dintroduction à l'ourrage; la seconde Iraitc. des universaux; la lroisiène, des aceidents; la quatrième, des substanees; la cinquième, de la nature de Dieu, el la sixième, des dogmes. II. Soerensen a publié le lexte des deux dernières stations, avec le commentaire d"slì ibı Moḷammad al-Djordjâní.

Hs. daté de l'an 782 de l'hérgire (1381-1382 de J. C..).

Papier. 160 feuiltets. Ilauteur, 24 centimètres el demi; largeur, 15 centimètres. 25 lignes par page. - (Ancien fonds 883.)

\section{3.}

Commentaire d'Al-Djordjânî sur le هـواتفغ d'Al-Îdjî. 
Exemplaire écrit à Héral, en $9^{02}$ de l'hégire $(1495$ de J. C.), pour le vizir 'Alî Schîr. Ms. dépourru de points diacritiques. Le premier feuillet a élé ajouté après coup; mintre ce feuillet et le suivanl il $y$ a nne lacune considérable.

Papier. 249 feuillets. Hauteur, 25 centimètres; largeur, 18 rentimètres. 30 lignes par page. $\rightarrow$ (Supplénent 1320 bis.)

\section{4.}

Hême ourage.

Ms. daté de l'an 1168 de l'hégire $(1750$ de J. C.).

Papier. $79^{\circ}$ leuillets. Hauteur, 2 a centimètres; largeur, 17 centimèlres. s.3 lignes par page. - (Supplément 1320.)

\section{5.}

Commentaire sur le eco d'Al-ìdji, par un ano-

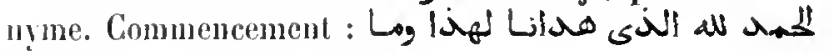

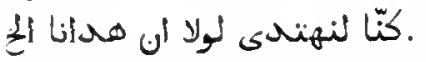

Papier. 399 feuillets. Hauteur, 21 centimètres et demi; largeur, 16 centimètres. 23 lignes par page. Ns. du xvur siècle. - (Supplément 1321.)

\section{6.}

Commentaire d"Ald Allah ibn Fadhl Mllah al-Khabịṣi,

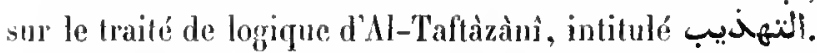

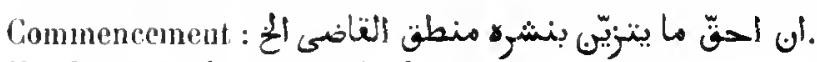
Yombreuses gloses marginales.

Papier. 88 feuillels. Hauteur, 2 h centimètres; largeur, 17 centinètres. 11 lignes par page. Ms. de deux mains différentes du vиit siẻcle. - (Supplément 1322.)

\section{. 2397.}

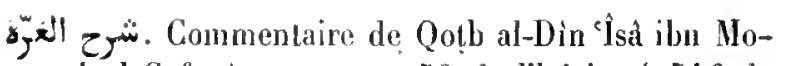
ḥanmad al-Şafawi, morl en 953 de l'hégire ( 1546 de 1. C.), sur le traité de logique de Noùr al-Din Nohammad Al-Djordjânî, intitulé الغترّ 3.

Uls. daté de l'an 1077 de l'hégire (1667 de J. C.).

Papier. 76 feuillets. Hauteur, 21 centimètres; largeur, 14 centimètres et demi. 21 lignes par page. - (Ancien fonds 917.)

\section{8.}

Le Tahâfout du mollâ Hoṣtafà ibn Yoûsof al-Borsawi Khwâdja Zidè, mort en 893 de l'hégire (1488 de J. C.). Cel ourrage, imité du تهافت اللناسنغة eChute des philosophes", d'Al-Ghazâlì et composé sur l'ordre du sullan ottoman Nohammad II, fils d'Amourathe II, renferme, en vingt-deux chapitres, la réfutation des opinions impies professées par les philosophes. Copie exéculée e'n 928 de l'hégire (1521 de J. C.), sur le ms. de l'auteur. Quelques feuillets manquent.

$2^{\circ}$ (Fol. $1_{2} 5 \mathrm{v}^{\circ}$.) Mélanges théologiques et mélaphysiques : $1^{\circ}$ Examen de la question de savoir si la taşliya (صلى إله عليه وسميم), jointe au nom du prophète Malomet, cst supérieure à celle qui accompagne le nom du patriarche Abraham; $2^{\circ}$ dissertation sur lindividualité

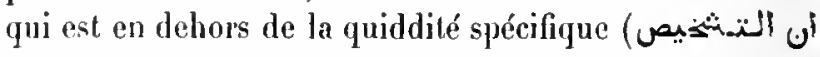

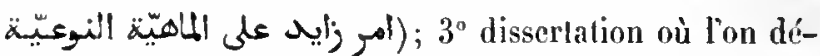
monlre que l'homme possède une faculté raisonnable et d'autres lacultés, sur lesquelles s’impriment les images

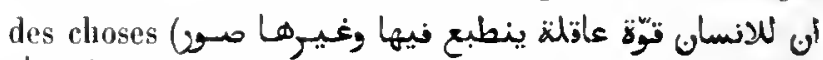
الاشياء ); $4^{\circ}$ commenlaire sur une proposition qui se trouve dans l'ourrage intitulé

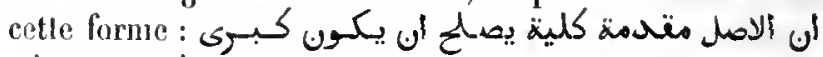
أصغتى سهالنة. Suivent d'autres gloses sur le même livre.

$3^{\circ}$ (Fol. $147 v^{\circ}$.) Commentaire de Vlìr Șadr al-Dìn Nohammad al-Schìrâzi mort en 898 de l'hégire (14921493 de J. C.), sur le traité de métaphysique intilulé (Comment démontrer l'existence de l'ètre nécessaire?

$4^{\circ}$ (Fol. $165 v^{\circ}$.) Gloses de Djalàl al-Dìn al-Dauwìnì sur le traité de logique intilulé al-Din Mlọ̣ammad al-Ormanî. Cel opuscule est daté de l'an $9^{2} 8$ de l'hégire (1521-1522 de J. C.).

Papier. 196 feuillets. Hauteur, 20 centimètres. et demi; largeur, 13 centimètres. Écritures diverses du xvi" siècle. - (Ancien fonds 923.)

\section{9.}

$1^{\circ}$ Gloses sur le تهافت de Khıwidja Zàdè, par Ibn Kamâl-Pacha.

$2^{\circ}$ (Fol. 75.) Gloses du mème auteur sur le كائكات.

$3^{\circ}$ Gloses du même auteur sur le الثبات الـواجبـ de Djalàl al-Dìn al-Dauwầnì.

Papier. 130 feuillets. Hauteur, 21 centimètres et demi; largeur, 13 centimètres et demi. 21 lignes par page. Écritures diverses du $\mathrm{xv}^{\mathrm{e}}$ iècle. - (Ancien fonds $9 \mathrm{3}^{4}$.) 


\section{0.}

$1^{\circ}$ Gloses de Hohammad ibn Yoùsof al-Sanoủsi sur

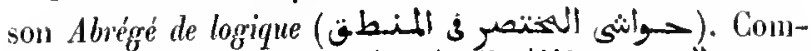
mencement : Copie du xvur siècle.

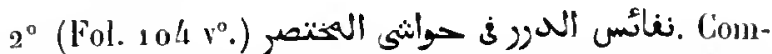
mentaire de l'ouvrage précédent, par Al-Hasan ibn Mas-

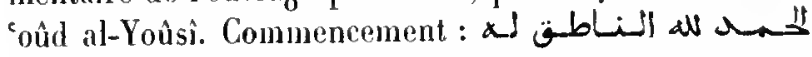
بالوبوبيّة الثره الظاهـ Copie datée de l'an 1162 de l'hégire ( 1749 de J. C.).

Papier. 251 feuillets. llautcur, 22 centimètres; largeur, 16 centimètres el demi. 23 et 29 lìnes par page. - (Supplément $13 \%$ '.)

\section{1.}

Commencement du commentaire d'Al-Sanoûsì sur son trailé de logique.

Papier. 10 feuillets. Hauteur, 23 centimètres; largenr, 16 centimètres et demi. 25 lignes par page. Ms. du xviı siècle. - (Supplément 2.159.$)$

\section{2.}

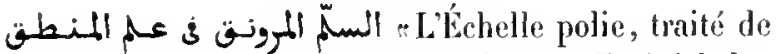
logiquen, par 'Abd al-Ralımin ill-Akhdhari. Traité de logique, en ver's, accompagné d'un commentaire par le même auteur. Premier ver's:

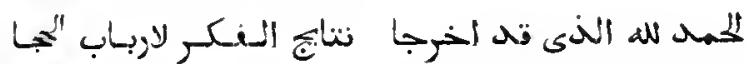

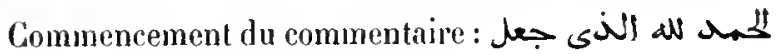

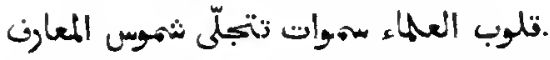

Papier. 2 a feuillets. Hauteur, 21 centimètres; largeur, 15 centimètıes. a 3 lignes par page. Ms. du vvı ${ }^{\circ}$ siècle. - (Supplément t 3 i 7. .)

\section{3.}

Commentaile sur le سلّ المورونسق d"Abd al-Ral!min alAkhdhari, par Alımad al-Malawi. Commencement : هم

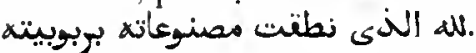

Ms. daté de l'an 1192 de l'héggire (1 778 de J. C.).

Papier. ${ }_{1} 9^{4}$ fenillets. Hanteur, 23 centimètres et demi; largeur, 16 centimètres et demi. 23 lignes par page. - (Supplément 1318.)

\section{4.}

Abrégé du commentaire précédent, par l'auteur luimême. Commencement :

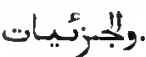

Us. daté de l'an 1143 de l'hégire ( 730 de J. C.).

Papier. 48 feuillets. Hauteur, 31 centimètres et demi; largeur, 16 centimètres. 23 lignes par page. - (Supplément 1319.)

\section{5.}

1. Les Questions des grénies dévoilées", par " $M$ bd al-Wahıth al-Schacràni. Copie datée de l'an 1030 de l'hégire ( 1612 de J. C.).

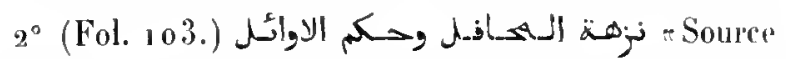
d'agrément pour les réunions et maximes des anciens". liecueil d'anecdotes en prose et en rers, en dix chapilres. Chaque chapitre contient dix anecdotes. Le chapilre dixième traite de l'écriture coufiupe et de certains alplat-

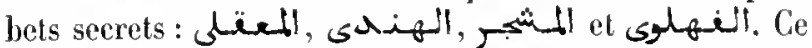
dernier, dit l'auteur, est un alplabet de convenlion, liré de l'alphabet arabe. Le luitieme chapitre indirue divers artifices employés clans la composition des vers, comne dans le vers suivant :

$$
\text { مودتغ تـدوم لكل هول وهل كل مـودتس تـدلوم }
$$

que l'on peut lire de droite à gauche et de gauche à droite. Commencement de la prélace : جلى جبعie datée de l'an 1020 de l'hégine.

$3^{\circ}$ (Fol. 160.) Quatre pièces de vers. La première est attribuée à Al-Așna í la seconde est de Borhàn al-Dï al-Qirați ; la troisième a été récitée en la présence du sultur Baresbai par Molıammad al-Hakim; la quatrième commence ainsi :

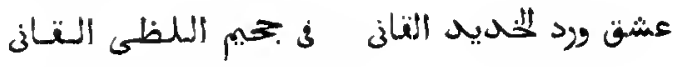

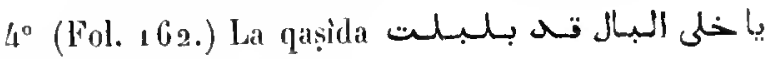

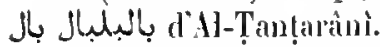

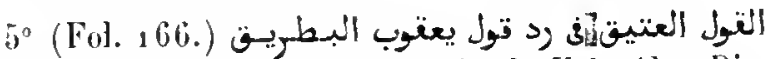
- Beau disconrs pour réfuter le patriarche Ya'qoûb». Dissertation composée à Constantinople par un nommé Mohammad ibu 'Alì, pour' démontrer a patriarcle la supériorité de l'islamisme sur la religion clurétienne. Copie datée de l'an $117^{5}$ de l'hégire $\left(17_{2}\right.$ de J. C.).

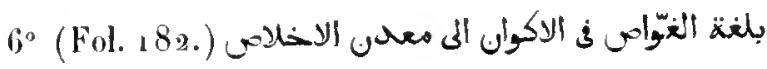


(se qui suflit pour celui qui plonge dans (la mer des) ètres afin d'alleindre la mine de la sincérilé dans la connaissance de l'lomme \%. Ourrage mystique de Molyyi al-Dìn jbu al- ${ }^{\complement}$ Aralui.

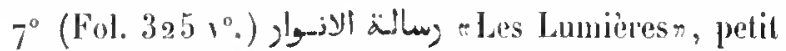
Iraité myalique de Molıvi al-Din Hon al- Trabi. Commen-

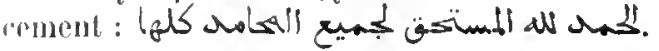

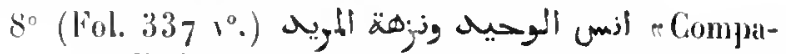
funon du solilaire el amusement pour l'aspirant», traité (w morale, jar Mbou Hadyan (Boû Hedin) Schocaib, de Themen.

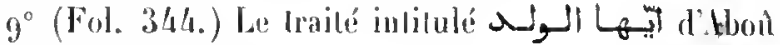
llàmid al-Ghazalì.

Papier. 363 feuillets. Ilanteur, a1 centimètres; largeur, 14 centimètres et demi. Écritures diverses du xrue et du xrmi siècle. - (Supplément 2.333.)

\section{6.}

10 Trailé sur la science de la balance, science quion désigne par le

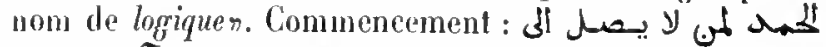

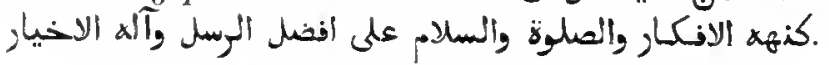

$2^{\circ}\left(F_{0} .14 \%^{\circ}\right.$.) Gloses relatives an commentaire de Hosàm al-Dìn al-Kinî sur l'Isagoge d'Athìr al-Dìn al-

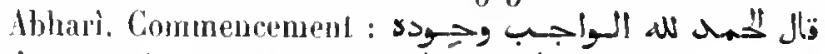

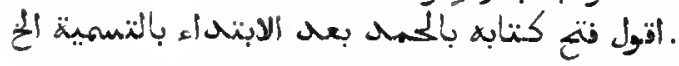

Papier. 56 feuillets. Hauteur, 19 centimètres et demi; largenr, 12 centimètres. 17 lignes par page dans le premier traité, 19 lignes dans le second. Ms. du xw" siecle. - (Aneien fonds 921.)

\section{7.}

Conmenlaire sur un traité de métaphysique. Le commencenen! manque.

Le premier feuillet conlient te commencement d'une prière, amplification de la première sonrate du Coran.

Papier. 54 feuillets. Hauteur, 21 centimètres; largeur, 14 centimètres. 16 lignes par page. Ms. du un $^{\circ}$ siècle. —(Ancien fonds 30\%.)

\section{8.}

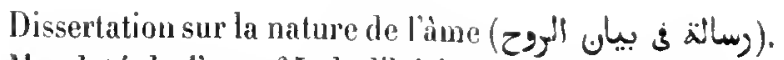
Ms. daté de l'an 965 de J'hégire (1558 de J. C.).

Papier. 3 pages. Hauteur, 20 centimètres; largeur, as centimètres et demi. 25 lignes par page. -. (Supptément 2257 .)

\section{9.}

Gommentaire sur un trailé de logique. Le commencement manque. Liouvrage commenté se termine par un appendice qui commence par ces mols : ألموضسوعات.

Ms. daté de l'an 972 de l'hégire (1564 de J. C.).

Papier. 4́ feuillets. Hauteur, 17 centimètres; largeur, 10 centinietres et denif. 19 lignes par page, et à partir du fol. 31, 17 lignes. - (Supplément 1335.)

\section{0.}

$1^{\circ}$ Giloses sur un commentaire d'un traité de logrique.

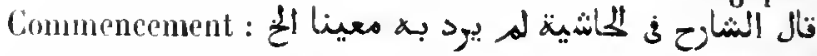

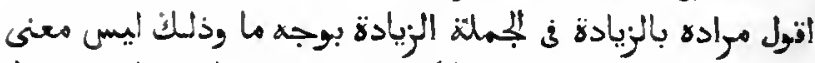

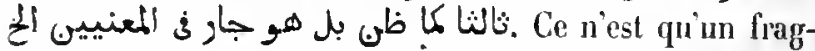
ment de l'ourrage, et il y a de nombreuses lacunes dans le corps du texte.

$2^{\circ}$ (Fol. 45.) Extrait d'un traité sur les traditionnistes, commençant par les mots : باب حلاوة الايان. Le

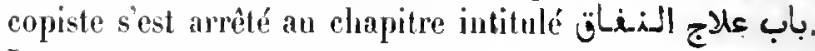
Le commencemenl mánque.

Papier. 55 feuillets. Hauleur, 14 centimètres; largeur, 9 centimètres. 13 et 14 lignes par page. Ils. du xviª siècle. - (Supplément 2158.)

\section{1 .}

Gloses sur un traité de mélaplaysique. Commencement:

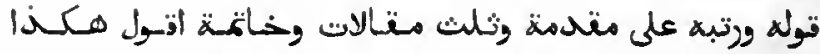

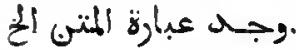

Papier. 88 feuillets. Hauteur, 18 centimètres; largeur, 11 centimètres et demi. 17 lignes par page. Ms. du xviı' siècle. - (Suppléinent 1330. )

\section{2}

Gloses sur un commentaire d'un traité de métapliy-

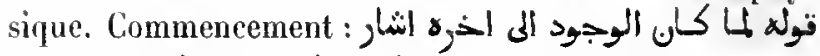

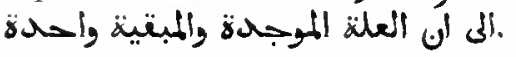

Papier. 26 feniflets. Hauteur, 16 centimètres; targeur, 17 centimètres et demi. 26 lignes par page. Ms. du xwı siècle. - (Supplément 2958 .) 


\section{3.}

Commentaire sur un traité de logiqur. Le commencement et la fin manquent.

Papier. 5y feuillets. Hauteur, 21 centimètres; largeur, 14 centimètres. 18 lignes par page. Vls. du xuit siècle. - (Supplément 3265.)

\section{4.}

Fragment dinn commentaire sur un traité de logique. Nombreuses notes marginales.

Papier. so feuillets. Hauteur, 21 centimètres; largeur, 13 centimètres et demi. \ lignes par page. Ms. du xw" siède. - (Supplément a 266 .)

\section{5.}

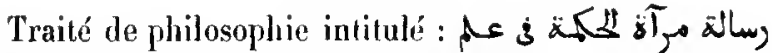
äl par Karìm ibn Ibràhìn. Ns. daté de l'an 1264 de l'hégire ( 1847 de J. C.).

Papier. 107 feuillets. Hauteur, s 1 centimètres; targenr, 15 centimètres. 20 lignes par page. -- (Supplément $\$ 514$. )

XI.

\section{MORALE ET POLITIQUL.}

\section{6.}

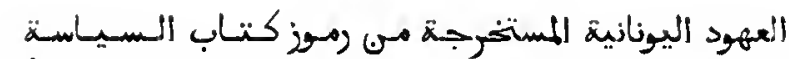
(- Préceptes grecs, tirés des énigmes contenues dans te Livre de la politique de Platon $n$, par Al!mad ibn Yoûsof ibn Ibrâhìm. Traité de morale et de politique, divisé en trois chapitres, contenaut les préceptes du roi grec Hadrien à son fils, ceux du vizir à son fils et ceux de l'homme du peuple à son fils. Commencenent : لl

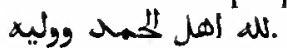

Papier. 56 fenillels. Ilanteur, 24 centimètres et demi; largenr, 16 centimètres. 15 lignes par page. Ms, da xiv siecle. - (Ancien fonds 885.)

\section{7.}

: Le Secret des secrets", traité de politique attribué à Aristote. L'ouvage commence par une prélace, dans laquelle le traducteur, Yoûlanmi ibn al-Batring (Johannes Patricius, surnomme $A l$-Tardjomán relinterprète $n)$, s'adressant au calife tmir al-Iloùminin (il s'agit d'AlMa'moủn l'Abbàside), déclare que, suivant ses ordes, il arait lait des recherehes pour décomvir le live du Secret des secrets, ouvrage composé par Aristote, fils de Nicomaque (زيقوماخوس), pour son diseiple, le très grand roi Alexandre, fils de Philippe, surnommé Dson'l-(arnaï. Il ajoute quaprès avoir visité tous les grands temples (هيlك), où les pliblosophes aviliml coutume de placer

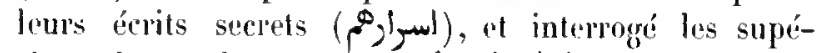
ricurs de tous les couvents (عظملاء الوهبل), il était venu au temple du Soleil, édilice que s'était construit lisculape le Sage (selon un autre ms., Hermes le Grand), et que là il avait trouvé le traité tant désiré. Revenu à la cour, il arait commencé, sous les auspices du calif" (بسعد أميو المونيه), à traduire cet écrit du grec en la-

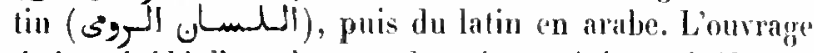
élait précédé d’une lette, adressée par Aristote ì Hexandre, el contenant la liste des discour's (مقالة), au nombre de dix, dout se compose l'ourragra. Nous donnons ici les titres de ces discours, en les abrégyeant.

1. (Fol. $31^{\circ}$.) Sur les diverses catrgories de ruis. - 11 y a quatre catégories de rois : le roi magnifique pour lui-mènu et libéral envers ses sujets: le roi matruifique pour luimème ef parcimonieux à l'égard de ses sujets; le roi parcimonienx pour lui-mène et à l'égand de ses sujets; le roi parcimonieux pour lui-méme et libéral à l'égard der ses sujets."

2. (Fol. 5 + $^{\circ}$.) Sur la copduite qui convient à un roi. ¿O Alexandre! te roi qui med sa royanté an service de la religion est digne de régner; le roi qui met la religion au service de la royauté méprise ce qui esl convenable at ell sera la victime. ?

3. (Fol. 27.) Sur la forme de la justice. ot Mexandre! la justice est un des plus nohles atlributs du Créateur, el le roi à yui Dien a confú la garde de ses semiteurs est comme un simple instrument, etc. $\pi$

4. (Fol, 28.) Sur les vizirs et leur nombre, etc. "O) Alexandre! fais bien attention an sous de ce discours. qui est, sache-le bien, de la plus laante importance, ete."

5. (Fol. 33 r.) Sim les turivains de la chancellerie. o $\hat{O}$ Alexandre! tu dois mettre beaucouj, de soin dans le choix des écrivains de tes juieces olliciclles; ce sera là la plus larte prenve de ton intelligence, ete.

6. (Fol. 34.) Sur le choix des ambassadeurs. Sache, Alexandre, puisse Dieu te laroriscr! qu'on pent apprécier', d'après le caractèro de l'envoyó, l'introlligence de celui qui l'a chargé de sá nission, etc." 
7. (Fol. $341^{\circ}$.) Sur les gouvemeurs des provinces et sur les perceptenrs. "Tu sais bien, $\hat{o}$ A Jexandre! que tes sujets ............ sont le soulien de ta puissance, etc.

8. (Ibid.) Sur les généraux et sur larmée. ¿Ô Alexandre? l'armće est la crême de l'empire, l'éclat du royaume, etc.n

9. (Fol. $35{ }^{\circ}{ }^{\circ}$.) Sur lart de la guerre. "O Alexandre! ne fais pas la guerre en personne, etc."

10. (10l. $38 \mathrm{r}^{\circ}$.) Sur la talismanique, l'astrologie, la manière de gagner les esprits, les propriétés des pierres et des plantes, etc. "Tu sais, d'après ce que je t'ai plusieurs fois exposé, que la subslance du monde supérieur el du monde inféricur, de près et de loin, est unique et ne varic pas, en lant que substance; les variations ne proviennent que des accidenls, etc.

II est crrtain que cel omrage n'est pas d'Aristote, et Yon̂ṭanni (ou Yạ̣yà) ibu at-Baṭì n'en est probablement ni lo Iraducteur, ni l'auteur.

Papier. 15 feuillets. Haulcur, a 1 cenlimètres; largeur, 14 cenlimètres el demi. 31 liggnes par page. Ms. du xvu' siècle. - (Supplémerit 5'0.)

\section{8.}

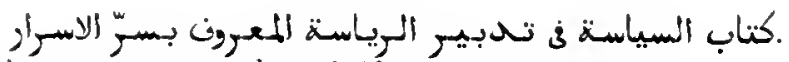
Mème ourrage que le précédent.

Ms. daté de l'an 1037 de l'hégire (1627 de J. C.).

Papier. 61 feuillets. Hauteur, a 1 centimètres et demi; largeur, 15 centimètres. 17 lignes par page. - (Ancien fonds 9.44.)

\section{9.}

$1^{\circ}$ Mème ouvrage.

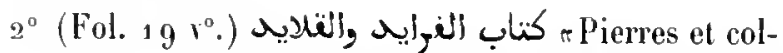
liers", par lloḷammad ibn al-ḷosain al-Ahwài. Recueil de maximes et d'expressions proverbiales, divisé en 'huit sections, dont la premiere traite de la dévotion; la seconde, de la science; la troisième, de l'arantage du silence; la quatrieme, de la conduito vertueuse; la cinquiène, de la culture de l'esprit; la sixiène, des belles qualités de l'àme; la septième, de la bome administration de l'Étal, et la builiène, de la correction el de la précision du style. Les derniers feuillels de li liuilieme section manquent.

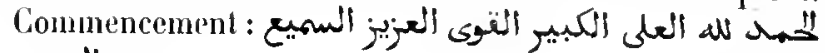
البحيبر.

$3^{\circ}$ (Fol. 4o.) Abrégé du 'Adjaib al-Makhlộquit d'Al-
Qazwînì. Les premiers feuillets, ainsi que plusieurs autres dans le corps de l'ouvrage, manquent.

$4^{\circ}$ (Fol. $167_{r^{\circ}}^{\circ}$ ) Pièces direrses. (Prière d'un opprimé se plaignant de l'oppresseur; quelques vers détachés; indication de la vateur numérique des lettres de l'alphabet; sirr l'exaltation, شُنَ, des astres, elc.)

$5^{\circ}\left(\right.$ Fol. $169 \mathrm{v}^{\circ}$.) Tableau des madadies et des remèdes.

$6^{\circ}$ (Fol. 180.) Tableau des jours lastes el nélastes.

$7^{\circ}$ (Fol. $1851^{\circ}$.) Vers altrihués à l'imàm Al-Schâfî̀ d. ì d'autres.

$8^{\circ}$ (Fol. 187.) Copie d'un document officiel, en écritur' de bureau.

Papier. 188 feuillets. Hauteur, 21 centimètres; largeu;, 15 centimìtres. 13 à so lignes par page. Ms. du xü siècle. - (Ancien fonds 945 .)

\section{0 .}

$1^{\circ}$ Le Sirr al-Asrâr. (Voyez les numéros précédents.) Copie datée de l'an 1102 de l'hégire $(1690-1691$ de J. C.).

$2^{\circ}$ (Fol. $\left.57 \vee^{\circ}.\right)$ Recueil de paroles attribuées à Mahomel el tirées du rrcueil d'H-Raschidi (ديوأن الرشيهى).

Papier. 60 fenillets. Hanteur, 20 centimètres et demi; largeur, 15 cenlimètres. Écritures diverses du xvir siècle.--(Supplément 542.$)$

\section{1.}

Le Sirr al-Asrâr. Cel exemplaire ne renferme que huit discours, le copiste ayant suppriné te cinquième et le septième. La rédaction du huitième discours (le dixième des autres exemplaires) présente de notables différences, quoique les titres soient identiques.

lls. daté de l'an 1144 de l'lıégire $(1732$ de J. C.).

Papicr. 45 fcuillets. Hauteur, 16 centimètres; largeur, 10 centimètres et demi. 15 lignes par page. - (Supplément 543)

\section{2.}

. Aس الاسـرار . Autre rédaction du fol. $24 \vee^{\circ}$ commence un discours do Platon, adressé aux Éphésiens, sur la vanité des richesses, et plus loin, (fol. 62), une lettre adressée par Alexandre à Porus, sollverain de l'Inde. 
Le titre du ms., très orné, nous apprend qu'il a été écrit pour la bibliothèque et du vivant de la princesse Dilschâd (Sلنياد خـاتسون) Nous savons par le Gulschen al-Kholafa, histoire de Baghdàd, de Nezmi-Zàdè, qu'une princesse Dilschad avait pour mari le schaikh llosain Ilkhâni, gouverneur de cette ville, qui est mort en $7^{5} 7$ de lhégire (1356 de J. C.).

Papier. 90 feuillets. Hanteur, 25 centimètres et demi; largeur, 28 centimètres. 9 lignes par page. - (Supplément 541.)

\section{3.}

rVoie qui mène ì l'éloquencen, recueil de discours, d'épitres et de maximes attribués ì 'Mli, fils d'Aboû Trìlib. D'après le titre, qui se trouve en tète de l'ourrage, l'auteur de cette compilation est reelui qui a devancé tous ses compétiteurs dans la carrière de l'excellence, celui swr lequel Dieu a inprimé le cachet de sa satisfaction, ì savoir 'Alì al-Mourtadhâ, sur' qui soit le sa-

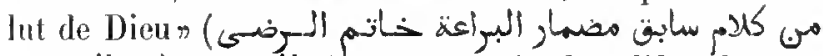

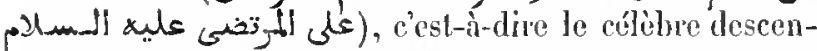
dant d"Alì, le chérif" "Ali al-Mourtadìa, mort en 448 de I'hégire (1 057 de J. C.). Ibn Khallikìn, dans son Dictionnaire biographique, (tome $\mathrm{II}$, page 236 de ta traduction anglaise), nous apprend qu'on a nió l'authenticité de ces pièces el supposé que le chérif luj-mème en fiut l'auteur. On peut aussi consulter à ce sujet le Dictionnaire bilbliographique de Hadji Khalla, tome VI, pages 406 et 408 . Commencement :

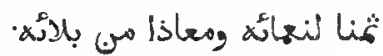
Ms. daté de l'an 735 de l'luégire (1334 de J. C.).

Papier. 351 fenillets. Hauteur, a6 centimètres; largeur, 17 centimètres. 12 lignes par page. - (Ancien fonds 1563.)

\section{4.}

ronseils aux princesn, traité de morale el de politique, par Abou Hàmid al-Ghazâli. Cet ourrage, dédié an sultan seldjoukide Molınmmad ilm Malik Schàls, renferme sept clapitres, précédés d'ıne longue introduction. Une analyse en est domée dims le Catalogue des mss. de la bibliothèque bodléienne, tomell, page 99. La préfice, commence par ces mots : all $ح$ لغ Elle nous apprend yue cet ouvrage avait été primitivement composé en langue persame, puis traduit en arabe. Le nom du traducteur u'est pas mentionné.

l'apier. ${ }_{12}$ fenillets. Hauteur, 23 centimètres et demi; largeur, Mas. oriertacx. - Il.
16 centimètres. 13 à 15 lighnes par page. Ms. du $x i v^{e}$ ou du $x v^{*}$ siècle. - (Supplément 549.)

\section{5.}

$1^{\circ}$ Mème ourrage. Les premiers feuiltets de cet exemplaire ont été transposés lor's de la reliure. Is doivent $\mathrm{s}$. placer dans l'ordre suirant : 1,24 à $29 ; 3$ à $15 ; 2,16$ à 23,30 à 65 .

$2^{\circ}$ (Fol. 66.) Les Tárifat d'Al-Djordjànî. Nonbreuses notes marginales. La copie s'arrête à l'un des premiers articles de la lettre djim.

Papier. 83 feuillets. Hantenr, 23 centimètres et demi; largeur, 17 centimètres. Le premier ouvrage est du $\mathbf{x v}^{\mathrm{e}}$ siècle, le second du xvu $\mathrm{r}^{\mathrm{e}}$. - (Aneien fonds 894.)

\section{6.}

Le Nașîhat al-Moloûl d'Al-Ghazâli. La prélace con-

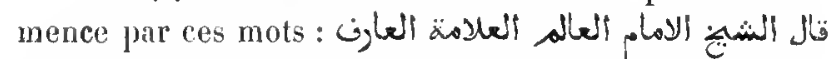

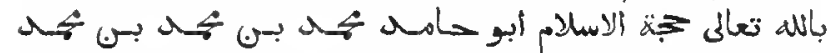

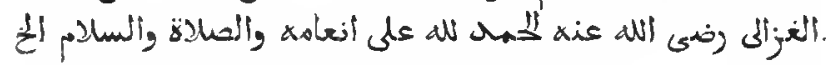
Par conséquent, il faudrait conclure que Ia traduction est d'Al-Ghazâli lui-même. Mais ce passage ne se trour pas dans les antres mss. Dans la préface, l'ourrage est

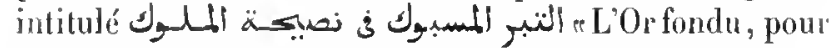
servir de conseils alux princes $»$. Cependant nous devons faire remarquer que le premier feuillet, qui contient ces passages, a été ajouté apr'ès couj.

Papier. 66 feuillets. Ilauteur, an centimètres el demi; largeur, 14 centimètres et demi. 33 lignes par page. Ms. du xrie sièle. - (Supplément 550.)

\section{7.}

Hème ourrage. Le titre de cet exemplaire est le mème que celui que l'on trome dans la préfice du numéro précédent.

Papier: 141 feuillets. Hauteur, 22 centimètres el demi; largeus, 16 centimètres. 15 lignes par page. Ms. du xvi siẻcle. - (Supplément 552.)

\section{8.}

Hême ourrage. La préface commence par ces mols :

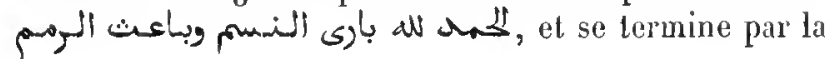


liste des chapitres. 11 niest pas dil que l'ourrage est traduit dı persan. Linlrodnclion commence pas ces mols :

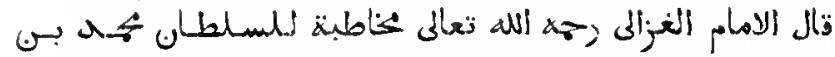

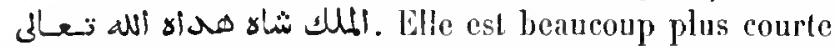
que celle des deux numéros précédents et présente une rédaction différente. Le texte des sept chapitres est à peu près le même que dans les autres mss.

Papier. 69 feuillets. Hauteur, a 1 centimètres; largeur, 14 centi-

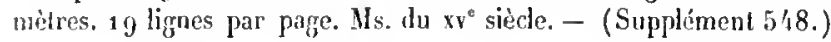

\section{9.}

Hème ouvrage. Il est dit, au commencement de la préface, que lourage, composé primitivement en persan, a ćté traduit en arabe par un nommé Aboû '1-1Jasan 'Alî ibn al-Mobàrak ilon Mauhoub, sur l'ordre de

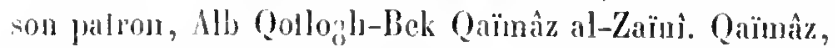
"Yrand amateur des belles-lettres, était premier ministre le Saif al-I)in Ghài ibn Maudoùd, atabec de Mossoul, al de son successeur ' Tzz al-Dìn Masoùd. Il est mort en 595 de l'hégrine ( 199 de J. C.). Sa vie se lrouve dans le Diclionnaire biographique d'lbu Khallikin, lome II, page 510 de la traduclion anglaise.

Hs. daté de l'an 1210 de l'hégire (1796 de J. C.).

Papier. 142 feuillets. Hauteur, 22 centimètres; largeur, 16 centimidres. 21 lignes par page. - (Supplément 551.)

\section{0.}

Premies cahier d'us cxemplaire du mème ourage. Le preuier feuillet manque.

Papier. 19 feuillels. Hauteur, 21 centimìtres; largeur, 15 centimetres. 15 lignes par page. - (Supplément 2051.)

\section{1.}

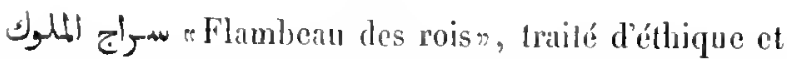
de polilique, à l'usage des princes, en soixante-quatre seclions, par Aboû Bakr Mol!ummad ibn al-Walid al-Ṭorfouschì al-Qoraschi, mort à Tlemeen, en 520 de l'hégire ( 1126 de J. G.). La préface commence par ces mols :

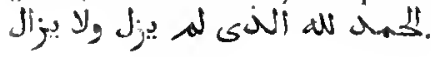

Le copiste, par esreur, a écrit le nom de l'auteur : Abotíl-Walid ibn Roschd (Averroès). Frontispice orné.

Ms. daté de l'an 786 de l'hégire (1384 de J. C.).

Papier. a 81 feuillels. Hauteur, 26 centimètres; largeur, 18 centimètres et demi. 17 lignes par page. - (Ancien fonds 887.)

\section{2.}

Hême ouvage. Exemplaire pourvu des points royelles.

Ms. daté de l'an 801 de l'luégire (1398-1399) de J. C.).

Papier. 167 feuillets. Hauteur, 24 centimitres; largeur, 16 centimétres. a 3 lignes par page. - (Supplément 545.)

\section{3.}

Mème ouvrage. Le litse inscrit dans une vignette richement ornée, partic en caractères confiques, partie en ca-

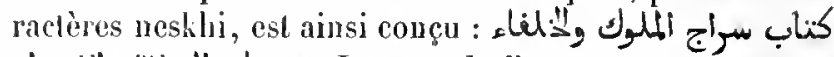
أ. Le mom de l'auteur est écrit Abou

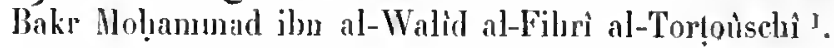

Papier. 273 feuillets. Hauteur, 29 centimètres; largeur, a a centimètres. 17 lignes par page. Ms. du commencenient du $\mathbf{x v}^{\mathrm{E}}$ siècle. (Ancien fonds 892, Colbert 3148 .)

\section{4.}

Mème ourrage.

Is. daté de l'an 841 de l'hégire ( 1437 de J. C.).

Papier. 246 feuillets. Ilauteur, 27 centimètres; largeur, 18 centimitres. 15 lignes par page. - (Supplément 5 '7.)

\section{5.}

Nème ouvrage.

Tex'e soigneusement corrigé el pousvu des points vayelles. Frontispice orné.

Papier. 263 feuillets. Hauteur, 31 centimètres; largeur, 21 centimètres. 17 lignes par page. Mls. du xve siècle. - (Supplément 546.)

\footnotetext{
l Le ms. porte الطوسوسى. H. Z.
} 


\section{6.}

Mème ouvrage.

Ms. daté de l'an 870 de l'hégrire (1466 de J. C.).

Papier. 230 feniltets. Ilauteur, 28 centimètres; largeur, 18 centimètres. 19 tignes par page. - (Ancien fonds 889.)

\section{7.}

Vème ouvrage. Vignette ornće.

Hs. daté de l'an 1007 de l'hégire (1598-1599 de J. C.).

Papier. 221 feuilfets. Ilauteur, 27 centimètres; largeur, 16 centimètres et demi. 21 lignes par page. - (Ancien fonds 888.)

\section{8.}

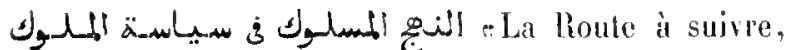
traité d'administration politique à l'usage des princess, par "Alud al-Raḷmàn ibn Naṣ ibn "Abd Mlah. Cet ouvage, composé pour le sultan Saladin, commence par

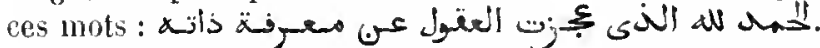
11 est disisé en vingl chapitres (ب) : $1^{\circ}$ il laut aux sujets un roi juste; $2^{\circ}$ une bonne éducation est nécessaire aux rois; $3^{\circ}$ bases d'une bonue éflucation; $4^{\circ}$ les bases de l'État; $5^{\circ}$ qu'il faut se distinguel par des nobles qualités; $6^{\circ}$ yu’il ne faut pas contracter des défauts; $7^{\circ}$ sur la place qu'un souverain cloit tenir quand il sort à cheval, accompagné de ses grands ofliciers, et quand il tient ses sćances soleunelles; $8^{\circ}$ qu’il est nécessaire de prendre conseil; $9^{\circ}$ qualités requises dans un conseiller; $10^{\circ}$ principes dadministration politique; $11^{\circ}$ sur la haute cour de justice présidéc par le souverain; $12^{\circ}$ sur les qualités requises dans un courtisan; $13^{\circ}$ sur les intriognes et les complots anxquels un souverain est exposé; $14^{\circ} \mathrm{co}$ quil faut à un souverain pour administrer et commander la lorce armée; $15^{\circ}$ sur les divoir's des soldats engagés dans la guerre sainfe; $16^{\circ}$ que les soldats ne doivent pas reculer

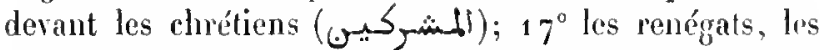
brigands et les coupeurs de route doivent être punis de mort; $18^{\circ}$ sur le partage du butin; $19^{\circ}$ ce qu'un souverain doit faire quand il entreprend une expédition; $20^{\circ}$ qu'il doit écouter et bien accueillir les exlıortations picuses.

Papier. 01 feuittets. Hauteur, 20 ecntimétres; largeur, 15 centimètres. 19 tignes par page. Its. du svil sièfle. - (Supplément 553.)

\section{9.}

re Règles à observer par celui qui marelıe dans la bonne voien, par un auteur anonyme. C'est un traité d'éthique, composé d'un grand nombre do maximes en prose el en vers, classées dans l'ordre des matières, el divisées en soixante chapilres, appelés gun "abreuvoirs $\%$. Un des derniers chapitres, le cinquante-cinquiène,

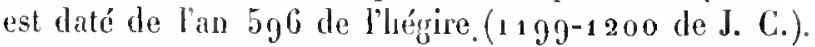
Les différents cxemplaires de cet ourrage dérivent d'ume copie, faite sur l'autographe, par un habitant d'Espagne, nommé 'Abd al-Mon'iun ibn 'Omar ibn Hasanì al-Djilyâni (de Djiliana, chàteau-fort des environs de Cadix), mort (n 602 de l'hégire $(1205-1206$ de J. C.), ou en 603, qui, entre autres ourrages, arait écrit mne relation de voyages en Orient. Cel écrivain dit, au commencement

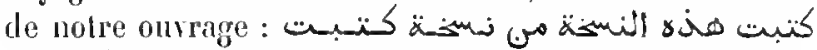
"Ilil écril cel exemplaire d'après un autre qui étail de la main de l'auteur\%. C'est done à tort que IIadji-Khalfa (t. 1, p. 219), attribue cel ouvage à 'Mbd al-llon im al-Djilyin.

Papier. 98 fenillets. ttauteur, 18 centimètres; largeur, 12 centimètres. 15 lignes par page. - (Incien fonds 979.)

\section{0.}

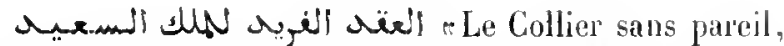
destiné au roi fortuné", c'est-à-rlire à Ml-Malik al-Sarid Nadjum al-Din Ghâzi, fils d'Ortor Arslàn, souverain de Màridin. L'autcur, Moḷammad ibn Talha al-Qoraschî al"Adawi, mort, selon lladji Klatfa, en 652 de l'hégir" (1254 de J. C. ), désigne le prince par les ternes

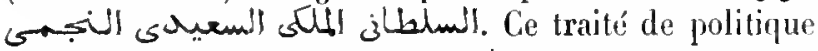
est divisé en quatle parties (öscla) : la première traik de la nécessité des bonnes mours; la seconde, de l'administration de l'État; la troisième, de la toi el de la religrion; la quatrième renlerme des renseignements supplémentaires, dont un certain nombre sous lorme do Qurstions el répouses.

Ms. daté de l'an 805 de l'hégrire (1402 de J. C.).

Papier. 139 feuillots. Ilizuteur, a 6 centimètres; largenur, 17 centimèrres. 23 lignes par page. - (Aneion fonds 890. )

\section{1.}

(Tableau) des qualités requises dans un sultan et des dynasties musul- 
manes", par llohammad ibn 'Alì ibn Tabâtabà (طباطب),

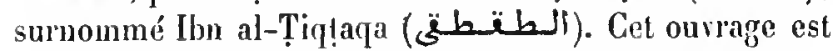
connu aussi sous le litre d'Al-Fakhrî, parce que, dit-on, il a été composé en l'honneur d'un prince de Mossoul, nommé 'Îsá ibn Ibrâhùm el suruommé Fakhr al-Dì. II a céé publié à Gotha, en $\mathbf{1} 860$, avec une introduction crilique en allemand, par M. Alılwardt. Une note à la fin du volume, de la main de l'auteur, nous apprend que cet exemplaire a été écrit à Mossoul, en 7.01 de l'hégire ( 1302 de J. C.). Texte pourvu des points royelles.

Papier. 3 1 1 feuillets. IJauteur, a' 4 centimètres; largenr, 16 centimètres. 13 lignes par page. - (Ancien fonds 895. )

\section{2.}

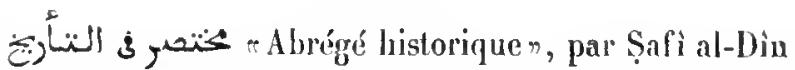
Joḷammad ibn 'Alì al-liasani, connu sous le nom d'llon الاداب البأ المسلطبانيـة qui forne la première partie de l'ouvrage listorique qui porte le titre d'Al-Fakhri. (Voyez le numéro précédent.)

Ms. daté de l'an 711 de l'héggire (1311-1312 de J. C.).

Papier. 57 feuillets. Ifauteur, 17 centimètres; largeur, 19 centimètres. 13 lignes par page. - (Ancien fonds 98.)

\section{3.}

Administration conlorme à la loi divine et devant être également avanlageuse au pasteur (au souverain) et au troupean (aux sujets)". Traité de politique, par Taqì al-Dìn Alumad ibn Taïmìn, célèbre doctenr lanbalite du vuñ siècle de l'hégrile.

Ms. daté de l'an 876 de l'hégire ( 1471 de J. C.).

Papier. 57 feuillets. Hautenr, 19 centimètres; largeur, 13 centimètres et demi. 13 à 20 lignes par page. - (Ancien fonds 980 .)

\section{4.}

Mème ourage. Les derniers feuillets manquent.

Papier. 73 feuillets. Ilauteur, 18 centimètres; largenr, 13 centimètres. 15 lignes par page. Ms. du xvi sièele. - (Ancien fonds $9^{46}$.)

\section{5.}

Cadeau pour les Tures, dans lequel on expose ce qui doit se faire dans l'administration d'un royaume", ouvrage attribué à Ibn al- Tzz, docteur hanéfite et auteur d'un commentaire sur la IVidúya. Cet ouvrage, divisé en douze chapitres, a été composé en 753 de l'hégire, alors que la dynastie des Mamlouhs turcs régnait en Égyte. Dans le premier chapitre, l'auteur démontre, à l'encontre de l'opinion d'AlSchaifici et d'autres docteurs, que le sultanat peut être exercé jar un Turc, et que, pour remplir cette dignité, la qualité de Qoraïschite n'est pas obligatoire. Les autres sections contiennent des instructions touchant la surveillance qu'il faut exercer sur les grands fonctionnaires et les cadis; le bien-être des sujets; linspection des waqf, des digues et du Bait al-Mal; les confiscations, les cadeaux recus des puissances étrangères; les brigands et les insurgés, et la guerre contre les infidèles.

Papier. $9^{1}$ fenillets. Hauteur, 18 centimètres; largeur, 13 centimètres et demi. 9 Jignes par page. Ms. du $\mathrm{xv}^{\mathrm{e}}$ sidcle. - (Ancien fonds $9 / 7$. )

\section{6.}

$1^{\circ}$ Même ouvrage. L'anteur est nommé en tête du volume : le grand cadi Borhàn al-Din lbràhim ibn 'Alì alTar'soûsì al-Hanafi.

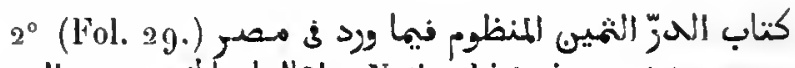
. Notice historique et topographique sur l'Éggpte, par le schaïklı CAlì ibn Dàwoud alKhațib!.

$3^{\circ}$ (Fol. 54.) Traité sur les terres de dime et les teries de kliaradj.

$4^{\circ}$ (Fol. 65.) Traditions ${ }^{2}$.

$5^{\circ}$ (Fol. 8o.) Traité des degrés de parenté.

Papier. 87 feuillets. Hauteur, so centimètres; Jargeur, 15 centimètres. Écritures diverses du $x^{\prime} u^{e}$ et du xvin' siècle. -- (Supplément 1927.)

\section{7.}

$1^{\circ}$ مeنم in Qui ramène les laveurs (divines) et qui met lin aux châtiments», traité de mo-

\footnotetext{
2 Voyez ci-dessus, $n^{\circ 5} 1812$ et 1813 . II. Z. - - ${ }^{2}$ Ce sont des traditions sur les merveilles de l'Égypte. Ce traité porte le titre de : كتاب بذك

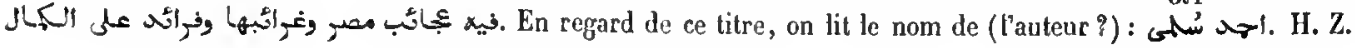


rale, par Tàdj al-Din al-Sobki ("Alì al-Walıhàb ibn 'Ali). L'auteur énumère les devoirs que chaque homme doit remplir, seion sa position dans la société. C'est en s'appliquant à remplir ces obligations sociales et religieuses qu'on obtient la faveur divine. L'ouvrage reuferme plus de cent dix exemples (مثنال), dont chacun est consacré à un emploi ou ì un métier.

$2^{\circ}$ (Écrit sur les marges des feuillets 2 à 25.) ســ (المالك ف تحبيـ الممالك (Voyez le no 2448 ci-après.) Ce n'est qu'un extrait de l'ourrage. Une partie des tablearx sont insérés dans le texte.

Les deux ouvrages sont ornés, au commencement, d'une vignette en or et en couleurs.

30 Fol. 63. (Conseils adressés aux rois", par Aboù 'l-ḷasan 'Alî ibn Moḷammad ibn luabìts al-Mlàwardi, mort à Bagdhàd, en 450 de l'hégire (1058 de J. C.). Dans ce traité, qui se compose de dix sections $(b \hat{a} b)$, l'auteur traite de l'administration de l'État et de ce qui amsène la ruine ou la prospérité d'un empire. La préface commenee par ces mots : بمد الف نغتنح وعلي نتوكل وبx نستعيى.

Ms. daté de l'an 1007 de l'hégire ( 1598 de J. C.).

Papier. 158 feuillets. Hauteur, 25 centimetres et demi; largeur, 14 centimètres et demi. 25 lignes par page. - (Ancien fonds $89^{3}$.)

\section{8.}

r Voie que le souverain (l'homme) doit suivre dans le gouvernement de ses titats (les facultés intellectuelles)", par Ibn abì 'I-Rabie (A!!mad i]n Hohammad). C"est un traité de morale composé sur le modèle de certains traités de médecine, l'auteur avant voulu faire pour l'àme ce que les auteurs de ces traités avaient fait pour le corps. L'ourrage est divisé en quatre sections, dont la première, formant l'introduction, traite de la supériorité de l'lomme; la seconde des facultés de l'âme, des vertus et des vices; la troisième des connaissances acquises par l'intelligence et de leur application; la quatrième de la vie sociale et de l'administration politique. L'auteur a combiné toutes ces facultés et toutes ces connaissances sous forme de tableaux, et en a rempli la majeure partie du volume. Premiers mots de la pré-

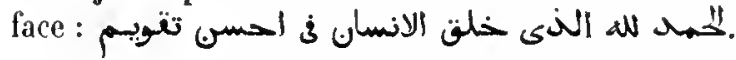

Papier. 44 feuillets. Hauteur, 28 centimètres; largeur, 18 cenlimètres. Ms. du xv $v^{\circ}$ siècle. - (Ancien fonds $89^{6}$.)

\section{9.}

كتاب البركة . Traité sur les avantages du trarail I.

Iss. daté de l'an 1086 de l'hégire $(1675$ de J. C.).

En tête du volume se trouve un poème à la louange de Dien.

Papier. 126 feuillets. Ilauteur, 23 centimètres; largeur, 17 centimètres. 23 lignes par pag̊. - (Supplément 1932.)

\section{0.}

$1^{\circ}$ Ms. sans titre ni préface, renlermant un grand nombre de discours sur divers sujets, tels que la nature de l'homme, le sowrenir, l'invocation, la jalousie, l'avitrice et la prodigalité; des conseils anx aspirants, une liste

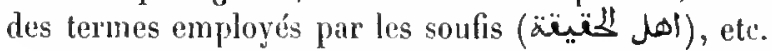

$2^{\circ}$ (Fol. 45.) Une antre partie du mème ouvrage.

$3^{\circ}$ (Fol. 79.) Fragrnents d'un traité des origines, rédigé au point de vue mystique.

$4^{\circ}$ (Fol. $84 v^{\circ}$.) Commentaire de Molammad ibn lbràhî̀m al-Bakrì al-Roùdi sur le recueil de maxinnes (كتبا مكإ) de Tàdj al-Din al-Sihandarì (Ahmad ibn Hoham-

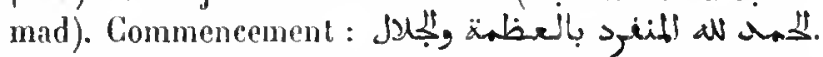

Papier. 9h fenillets. flauteur, a 1 centimètres; largeur, 13 centimètres el demi. 23 lignes par page. Ifs. du xvie siècle. - (Supplément 1315.$)$

$$
2451 .
$$

بنل النصائح النثرأعية فيما على المسلطان وولات الامور وسايـ

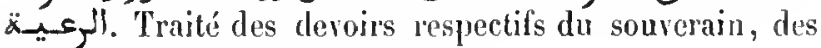
hommes en place et du peuple?

Ms. daté de l'an 1056 de l'hégrire ( 1646 de J. C.).

Papier. 129 feuillets. Houteur, 19 centimètres; largeur, 1 t centimètres. 19 liggnes par page. Ms. du six siècle. - (Supplément 544.)

X11.

\section{ADVINISTRATION.}

\section{2.}

r Traité de limpôtn, par le cadi $A$ boù Yoûsof Yaíqoûb ibn Ibrâhim, docteur hanéfite, mort en

${ }^{1}$ L'auteur de cet ouvrage est Djamât al-Dín Moḷammad ibn abi-Zaid 'Abd al-Raḷmân al-Ḥabaschi. H. Z. _- ${ }^{2}$ L'anteur est nommé à la tin : Moụ̣ibb al-Dín Moḥammad Aboủ H̦âmid at-Naqdisì al-Schàfíi. H. Z. 
182 de l'hígire (798 de J. C. $)$. Cet ourregge a été composé sur la demande du calife Ml-tlidi ou de Haroûn al-Raschid. Il renferme une série de conseils et d'opinions juridiques au sujet de la manière dont it fant percevoir l'impồt sur les récoltes (liharấlj), la dìme des troupeaux ('oschr), ta dime aumônière (sadaquit), le tribut personnel imposé anx non musulmans (djavali), etc. On trouve une notice très-intéressante sur le grand cadi Aboû Yoûsol daus le Dictionnaire biographique d'Ibn Khallikàn (tome IV, page 272 de la traduction anglaise). Con-

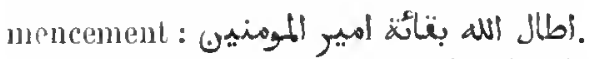

Ns. claté de l'an $119^{5}$ de l'hégire $(1-81$ de J. C.).

papier. 101 feniltels. Hatıteur, 21 centimètres el demi; largeur, 15 centimètres el demi. 23 lignes par page. — (Supplément 2339.)

\section{3.}

Heme ourrage.

Ns. copié à Constantinople vers 1840 .

P'apier. 140 feuiltets. Ilauteur, 24 rentimètres el deni; largeur, 16 centiniètres el demi. 1 j lignes par page. - (Supplément 552 lis.)

\section{4.}

e. Exposition des règlements touchant limpôt appeté kharidj", par dboû "l-Faradj 'Alu al-Ralunàn ilı Alımad ibn Radjab, docteur' hanbalite. Lianteur, sur lequel nous ne possédonsaucun renseignement, cite plusiemrs fois un jurisconsulte qu'il désigne par les noms d'Aboû 'l-'Abbàs ibu Tainniya. Taqi a]-Din Aboû 'l- Albbàs Aḅmad ibn Taümîya, docteur hanbalite, est mort en 728 de l'hégire (1337 de J. C.). Pàr conséfuent, on peut supposer que l'Istikhrâdj a été composé rer's la fin du xive siède. Voici la liste des chapi'res de cut important ourrage :

1. Sur le sens propre el primitif du not hharidj, is

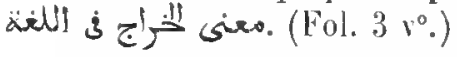

2. Palssages de la soma dims lesquels il est fait men-

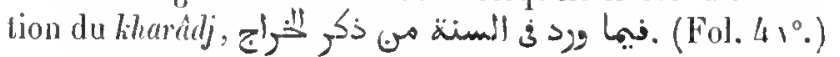

3. Principe sur lequel cet impôt est fondé; qui fut le premier qui l'établit sous la domination musumane, s

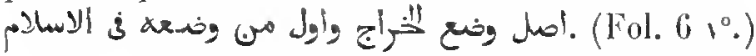

4. Des terres qui doivent âtre soumises au kharâdj ou

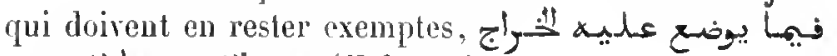
هo. (Fol. 10.)

5. Examen de la question de saroir si le hharâdj est

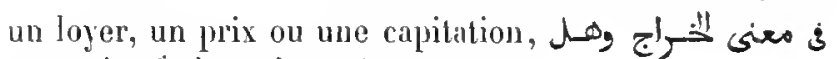
هو أجرة أوتمى او جزية (Fol. 39 ro.)
6. Énumération des pays soumis au kharadj par le

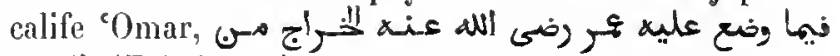
(Fol. $41 \mathrm{r}^{\circ}$.)

7. Sur la quotité du kharâdj, جأ (Fol. 65.)

8. Dioits et devoirs des propriétaires dont les terres sont soumises au khardij, حكم تصسرفسات أربـاب ألاوضن (Fol. 78.)

9. Droits et devoirs de l'Imâm (souverain spirituel et temporel) à l'égard des terres conquises par la force des allmes et rapportées ensuite dans la catégorie du butin,

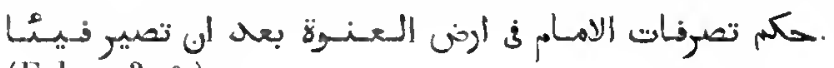
(Fol. $1131^{\circ}$.)

10. Du carnctìre de l'argent provenant du kharidj et de l'emploi qu'on doit lui donner, x-jolog. (Fol. i2 5 .)

IIs. copié à Constimtinople, vers 1840.

Papier. 140 feuillets. Hlautenr, 24 centimètres; largenr, 16 centi mètres. 17 lignes par page. - (Supplément 552 ter.)

\section{5.}

Comptes rendus des séances du Divan du Caire, en l'an IX de la République française. C'est probabtement une copie du registre original.

papier. 44 feuillels. Hauteur, 23 centimètres; Jargeur, 14 centimètres el demi. 15 lignes par page. — (Supplément 2103.)

\section{6.}

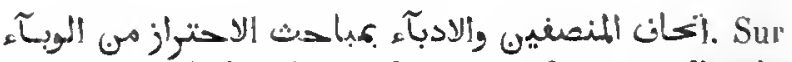
les mesures sanitaires à prendre contre la peste, d'après le Coran, les triditions, etc., par Sidì Hamdìn, d'Alger. L'auteur a rédigé cet ourrage après avoir séjourné à $\mathrm{Pa}$ ris et avoir pris connaissance des moyens prérentifs employés en Europe.

Papier. 30 feuillets. llauteur, 29 centimètres; largeur, 17 centimitres. a l lignes par pagre. Ms. du xıx siécle. - (Supplément 544 bis.)

XIII.

\section{MATHÉMATIQUES.}

\section{7.}

Recueil de cinquante et un traités de mathématique. La liste des ourrages contenus dans ce ms. a été publiée 
par. M. Wrepcke, dans le tome XIV des Mémoires présentés par divers savants à l'Académie des sciences.

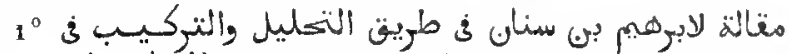

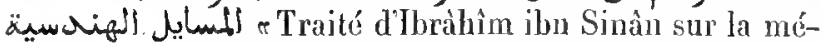
thode de l'analyse et de la synthèse dans les problèmes géométriques\%. Copié à Schìrâz, au mois de rabì premier de l'an 358 de l'hégire (février 969 de J. C.), par Alumad ibn Nohammad ihn 'Abd al-Djatîl al-Sidjzì.

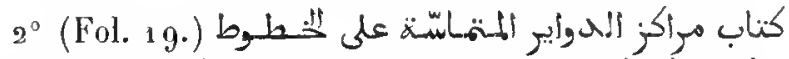

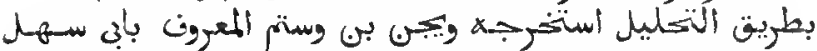

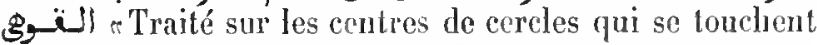
sur des lignes (dounées), d'après la méthode de l'analyse, par Wídjan ibn Wastam, connu sons le nom d'Alyoû

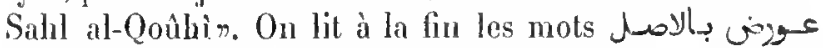
" a été collationné avec le ms. autographe". M. Wopcke a douné une analyse de ce traité dans l'Algèbre d'Omar Alkhayyami (page 55, note).

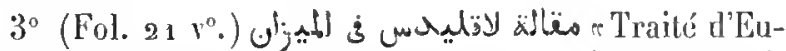

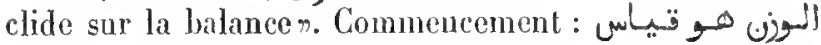

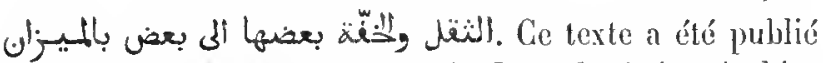
et traduit par M. Woepcke dans le Journal asiatique (cahier de septembre-octolore 1851 ).

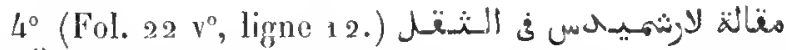
"Traité d'A i'climimede sur la pesanteur et la légìretén. Ce sont les énoncés des propositions du premier lirre et de la prenière proposition du deuxième livre du traité d'Archimède, De ïs qui in humido veluntur (édition d'Oxford, page 333 et suiv.).

50 (Fol. 23 r.o.

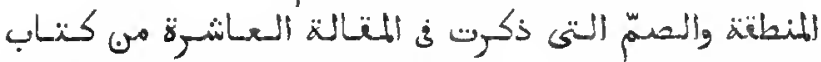

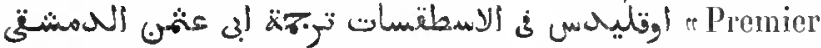
livre du traité de ..... (Pappus?) sur les quanti'és rationnelles et sourdes dont il est fait mention dans le dixieme live de l'ourrage d'liuclide sur les Éléments, traduit par Aboû 'Othmân, de Damas». M. Woepreke a publić un extrait de ce traité daus son Essai d’une restitution des travaux perdus d'Apollonius sur les quantités irraliomelles. (Mémoires de l'Académie des sciences, savants étrangers, 1. XIV.)

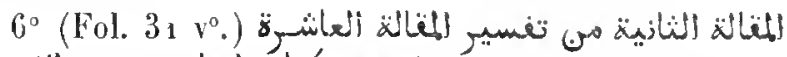
的 Sccond livre du commentaire du dixiène livre des Éléments d'Fuclider. Traduit par Aboû 'Othmùn, de Danıs, et copié par Aḷmad ibn Mohammad ibn 'Abd al-Djalil, an mois de djomida Ier de l'an 358 (avril 969 de J. C.).

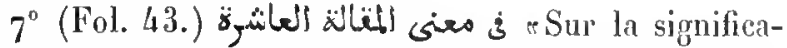
tion du dixième livre (d'Euclide)". Cet opuscule com-

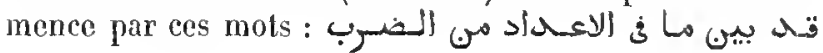

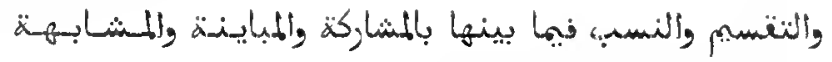

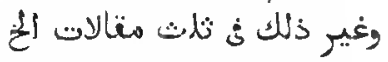

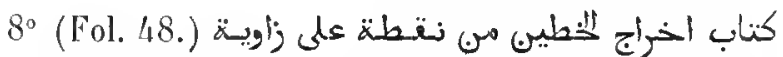

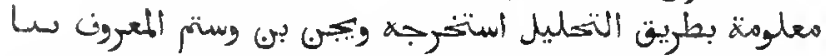

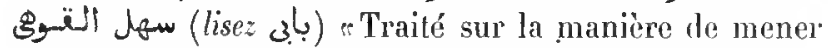
deux lignes issues d'un point et renfermant un angle donné, d'après la méthode de l'analyse, par Widjan ibn Wastan, comnu sons le nom d'Aboit Sahl al-Qouhin'. Collationné sur le nis. au'ograple. M. Wopcke a donné une analyse suecincle de ce traité dans soll édition de l'Algèbe d' Omar al-Khayyami (page 55 de la traduction francaise).

$9^{\circ}$ (Fol. 51.) Traité sur l'ohjet et le contenu des Étéments d'Euclide, devant servir de préface à unc édilion de cet ourrage. Commonrement : أن ألغر

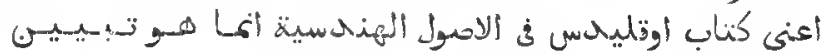

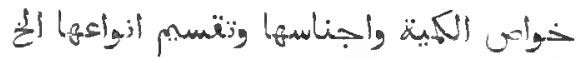

$10^{\circ}$ (Fol. $52 r^{\circ}$.) Lettre d'Almad ihn Molammad ibn 'Abd al-Djalil sur la solution d'un problème liné de l'ouvrage de Yôhannà ibu Yoùsof, relatif à la division d'une ligne droite en deux parties égales, et indication de ler-

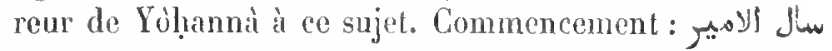

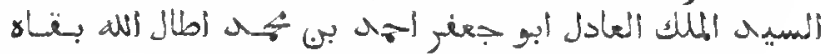

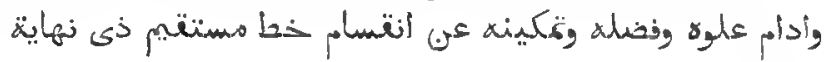
بنصغين.

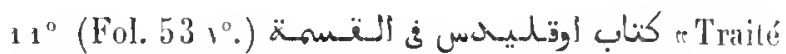
d'Euclide sur la dirision (des linnes planes) r. M. Woxpcke a publié une traduction de ce traité dans le Journal asialique (cahier de septembre-octolne 1851 ).

$12^{\circ}$ (Fol. 56.) Quatre formules astronomiques, dont

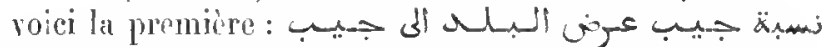

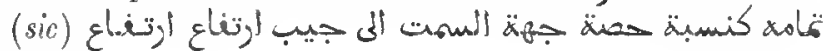

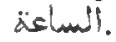

$13^{\circ}$ كol. 56 vo.0

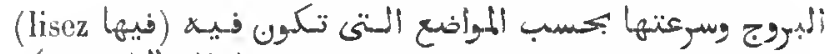
"Traité de Thàbit (ibn Qorral) sur" la relardation du unouxement dans la sphère des signes et sur son accélération suivant les points de l'excentrique on se troure (le corps en mourement) \%.

$14^{\circ}$ (Fol. 59.) Fragment relatif à la théorie du mouvement de la lune. Copie datée de Schì̀àz, du jeudi 30 rabie second 359 de l'hégire (1 o mars 970 de J. C.).

150 (Fol.601\% reraité d'Aboû 'I-Illasan Thâbit ibn Qorra le Sabéen, sur la composition des rapports ". Ce traité est divisé en trois chapitres. Daus l'explicit, on lit qu'il a été 
copić par Aḷmad ibu Moḥammad ilon 'Abd al-Djalil sur l'exemplaire de Nazill ibn Ýomn (نظيغ بر يكم), nédecin chrétien, à Schî́râz, le 29 dı mois de djomàda second, de J'an 359 (mai 970 de J. C.).

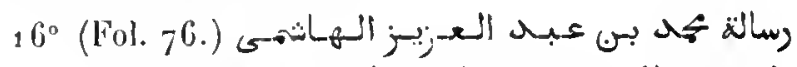

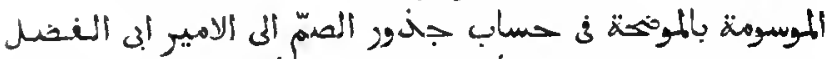

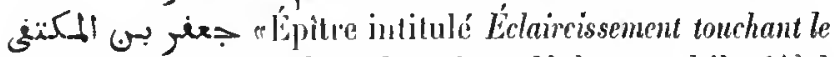
calcul des racines sourdes, adressé par Moḷammad ibn 'Abd "al-Azìz al-Hàschimì à l'émir Aboù 'l-Fadlıl Dja far', fils d'Al-lloktafi (le calife abbaside)». Coppé à Selin̂̀àz, sur Pexemplaire du médecin Nazif ibn Yomn. M. Wopeke a publicé la traduction de ce traité dans le Journal asiatique (calier de septembre-octobre 1851 ).

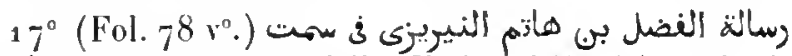
âlièn "Traité d'Al-Fadlıl ilsn Hàtim al-Närizî sur l'azimuth de la Qiblar.

18 (Fol. $80 \%^{\circ}$ (F) هilo

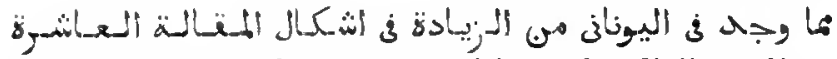
"Additions à quelpues propositions du dixiène live (d'lunlide), existant en langue orecyue el traduites par Nazîf ilm Yomu, le médeciu». Ce sont denx démonstrations, l'une de la première el l'autre de la sixième proposition du dixième lirre d'Euclide, à savoir : la première démonstration de la premiere proposition el la première démonslration de la sixième proposition (avec quelques différences) de l'édition d'Oxford. Comparez le passage du Tàilih al-lloliama, rapporté par Casiri, tome I, page 340 , col. $a, 1.14$ et suiv, et page $341,1.22$ et suir.

$19^{\circ}$ (Fol. 82.) Sur la formation des triangle s rectangles en nombres raliomels ou entiers. Le. deux dernières pages et la parlie inférienre du fol. 85 contiennent les tables. Le commencement manrjue.

$20^{\circ}\left(F_{0}\right.$ l. $86 \mathrm{r}^{\circ}$.

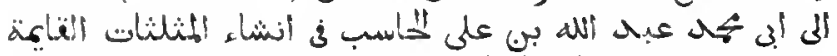
Traité adressé par le schaïkh Ahoù Dja far Moḷammad ibn al-Ḥosaïn à Aboù Mohammad 'Abd Mllah ilsn 'Ali, le calculateur, sur" la formation dés trianghles rectangles ayant des côtés ratiomels, el sur l'ulilité qu’offre leur connaissancen. Cupie collationnée aree le ms. autographe.

$21^{\circ}$ (Fol. 93.) Formules astronomitues pour trourer les azimuths, les levers des signes du zodiarue dans la sphere droile, la jongueur des heures el l'amplitude ortive.

$22^{\circ}$ (Fol. $9^{3} r^{\circ}$.) Quelques recettes médicales, dont la première indique la préparation d'une panacée appelée ilis_. Au milieu de ce morcenu, on trome intercalées (fol. $g^{4} 1^{\circ}$ ) les observations de quelques conjonctions, qui ont élé cilées et traduites par Caussin de Perceral, père, dans son Mémoire sur les tables d'Ihn Younis (Notices et extraits, t. VII, p. 238 ).

$23^{\circ}$ (Fol. $9^{5}$, I. 9.) Sur la manière de prendre les lıauteur's égales sur le dos (b) de l'astrolabe.

$24^{\circ}$ (Fol. $9^{5} r^{\circ}$ (.) "Traité de Thàbit ibn Qorra sur la mesure des corps paraboliques". Copic datée du mois de rabi premier de l'an 358 (férier 969 de J. C.).

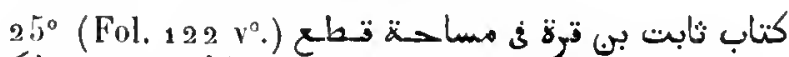

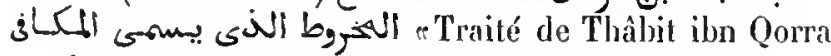
sur la mesure de la parabolen.

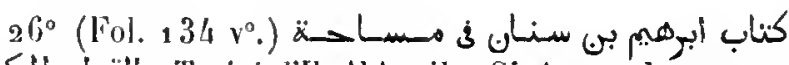
ill 'Thaité d'lbràhim ibn Sinàn sul la mesure de la paraboler. Copie datée du mois d'ardibihischt de l'an $338 \mathrm{de}$ Yazdadjird (arril-mai ${ }_{9} \mathrm{G}_{9}$ de J. C.).

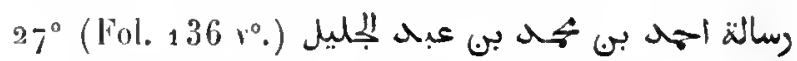

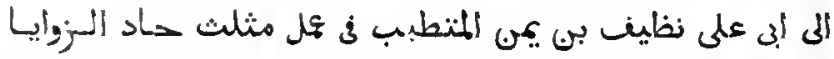

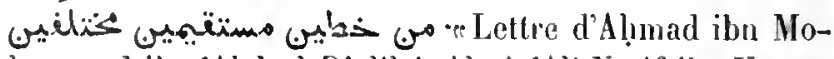
lıammad ibn 'Abd al-Djalìl à Alooú 'Ali Nazilf ibn Yomn, le médecin, sur la construction d'uu triangle acutangle au moyen de deux lignes droites inégalesn. Copie datée

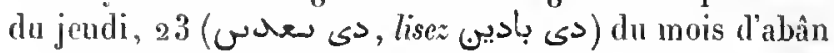
de l'an 302 de Yazdadjird (octobre 970 de J. C.).

$28^{\circ}$ (Fol. $137 \mathrm{r}^{\circ}$.) Lettre d'Aḷmad ibn Sloḷammad ibn 'Alyd al-Djalìl au schaỉh Aboì '1-l!osaïn Molammad ibn 'Ald al-Djalil sur les sections produites dans les paraboloïdes el hyperboloïdes de révolulions. Le texte arabe

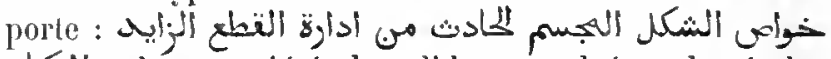
ill, eles propriétés du solide engendré par la révolution de l'hyperbole et de la paraboles. Copie datée dı lundi, 2 (rim-roni) de Balıman de l'an 342 de Yazdadjird (janvier $3_{72}$ de J.C.).

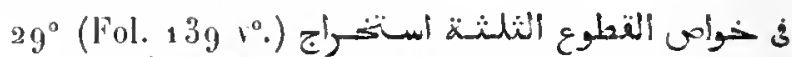

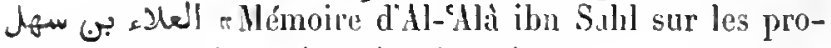
priétés des trois sections (coniques)r.

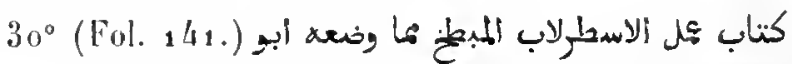
wi (Traité sur la construction de l'astrolabe mob!akh (à projection stéréographique?), par Aboù Djalefar Aḷmad ibn "Albd Allah\%.

$31^{\circ}$ (Fol. 151.) Traité d'Aḥmad ibn Molıammad ibn 'Abd al-Djalil sur les solutions de dix problemes que lui arait proposús un géomére de Scliriz.

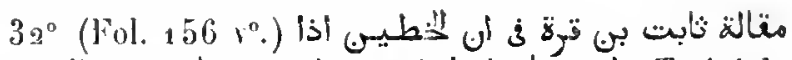

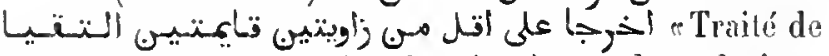
Thàbit ibn Qorra sur (ce théorème) que deux droites, menées de manière à renfermer (avec une tro:sième) moins de denx angles droits, se rencontrentr. La copie 
est datée de Schîrâz, du mercredi, $27^{e}$ jour du mois de rabi' second de l'an 359 de l'liégire ( 9 mars 970 de J. C.).

$33^{\circ}$ (Fol. 160 .) Une construetion de la trisection de l'angle.

$34^{\circ}$ (Fol. 161.) Traité relatif à la théorie des quantités irrationnelles, reproduisant, à quelques légères modifications près, les propositions 7 et 8 , et une partie du corollaire de la proposition 9 du dixième livre d'Euelide, telles qu'elles se troureni dans l'édition d'Oxford. Le commencement manque. Ce fragment parait être la suite de l'article $18^{\circ}$ ci-dessus.

$35^{\circ}$ (Fol, 161 V . . Problèmes subtils et élégants sur les nombresn.

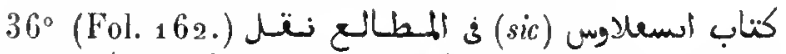

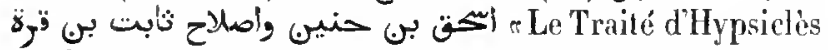
sur les ascensions, traduit par Ishâq ibn llonaüu, et revu par Thâbit ibn Qorra".

$37^{\circ}$ (Fol. 164.) Lettre d'Abou 'l-Hasan Thâbit ibn

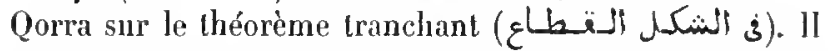
s'agit de la première proposition du troisieme live des sphériques de Menelaus, proposition nomnée ordinairement réggle d'intersection, employée par Ptolémée jour calculer sa table de cordes.

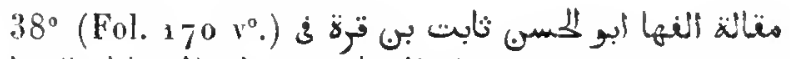
أل eTraité d'Abou 'l-Ilasan Thâbit ibı Qorra sur la manière de lı'onrel les nombres aimables, d'après une néthode faciler. Voyez, sur les nombres aimables, la note de H. de Slane, il la page 178 du tome $I I I$ de la traduction des Prolégomènes d'Hbn Khaldouin (Notices et extraits, $1 . \mathrm{XXI}, 1^{\text {re }}$ partic). 11. Wropcke a donné une analyse de ce traité dans le Journal asiatique, calier d'octobre-novembre 1852 . La copie est datée de Schirriz, de la fin du mois de khordàd de l'an 338 de Yazdadjird (juin $9^{6} 9$ de J. C.).

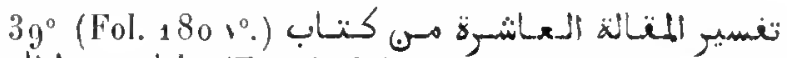
(Extrail du) commentaire d"Al-Màilıài sur le dixiène livre d'Euclide".

$40^{\circ}$ (Fol. $181 v^{\circ}$, l. 4.) Démonstration diun problème de géométrie.

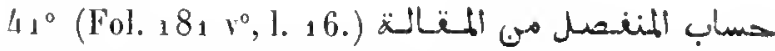

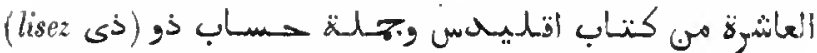
exposé du calcul des apotomes, firé du dixième livre d'Euclide, et calcul des droites à deux noms $\%$. La copie est datée de Schîrâz, de la fin du mois de seha'bûn de l'an 358 de l'hégire (juillef 969 de J. C.).

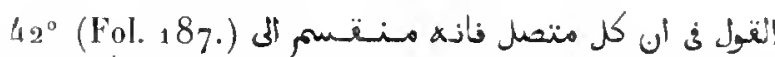
Discussion de la proposition que tonte quantité continue est divisible à l"infini".

Man. orientalx. - It

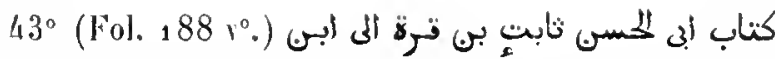

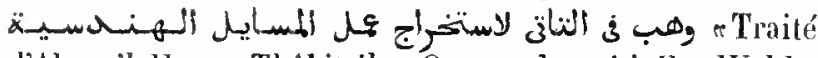
d'Abou 'I-Hasan Thábit ibn Qorra adressé à Hon Walıb, sur la manière de trouver la construction des problèmes géonétriques

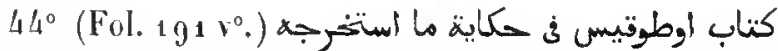

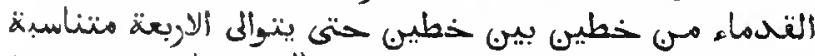
Traité d'Eutocius, rendant compte des solutions, données par les anciens, du problème de la détermination de deux lignes entre deux autres lignes, de telle sorte que ces quatre lignes soient en proportion continne. Traduit par Thâbit ibn Qorra". C'est un extrait du commentaire d'Eutocius sur la deuxième proposition du second livre du Traité de la sphère et du cylindre d'Archimède.

$45^{\circ}$ (Fol. $192 V^{\circ}$.

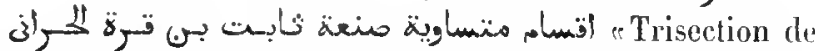
l’angle rectiligne, par Thâbit ibn Qorra al-Harrâni.

كن

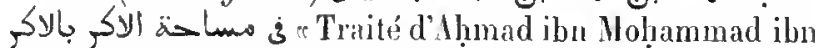
"Abd al-Djahil sur la mesnre des spheres au moyen des splieress.

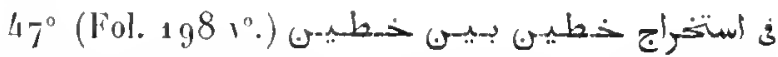

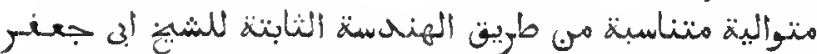
: Sur la construction des deux moyennes proportionnelles par la méthode de la géométrie fixe. T'raité composé par le schaikl Aboù Djáfar ibn Moḷamnual ibn al-l!osainn. La géonnétre fixe est peut-ĉtre la géométrie théorique, et lopposé de la géométrie mobile ou empiripjue.

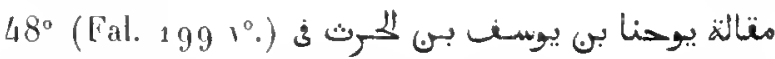

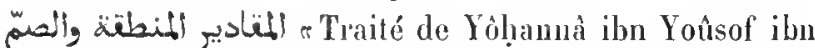
al-llàith sur les quantités lationnelles et irrationnelles

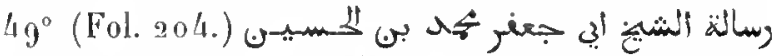

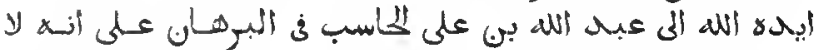

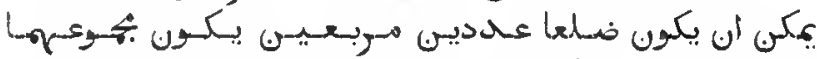

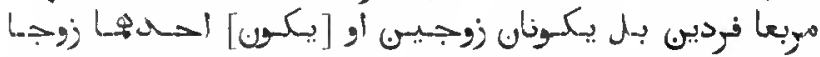

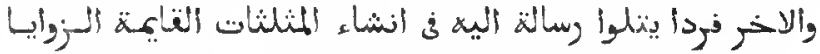

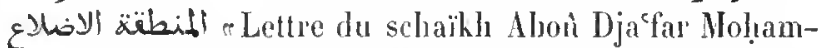
Inad ilon al-Ịosain à 'Abd Allah ibn 'Ali, le calculateur, sur la démonstration du problème que la somme de deux carrés ne peut pas être un carré, si les racines des deux premiers carrés sont des nombres impairs. Pour que cette somme soit un carré, il faut que les racines des deux premiers carrés soient des nombres pairs, ou bien que l'une soit un nombe pair et l'antre un nombre impair. Cette lettre est suivie d'une autre, adressée au même, sur la 
construction des triangles rectangles en nombres rationnels $\%$.

$50^{\circ}\left(\right.$ Fol. $215 \mathrm{v}^{\circ}$.) Liste des traités contenus dans le présent volume. Il ressort de cette table que quelques pièces ont élé transposées à l'époque déjà ancienne où le volume a été relié.

$51^{\circ}$ (Fol. 217. ) Diverses propositions relatives it la théorie des quantités irrationnelles.

Ce précieux ms. est écrit presque tout entier de la main d'Fbn "Abd al-Djałil al-Sidjzì (de Sidjistân), mathématicien distingué, qui florissait au $\mathrm{x}^{\mathrm{e}}$ siècle. L'écriture est très-régulière et les figures, dont il y a un assez grand nombre, sont tracées avee beancoup de soin. Les quatre derniers feuillets sont plus modernes.

Papier. 219 fenillets. 1lauteur, 18 centimètres; largeur, 13 centi. mètres el demi. 25 à 31 lignes par page. - (Supplément 952 bis.)

\section{8.}

$1^{\circ}{ }^{\circ}$

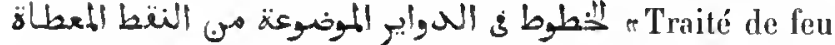
Aḷmad ibn Moḷammad ibn 'Abd al-Djalil sur les lignes menées dans des cercles donnés par des points donnés\%. (Voyez l'analyse de ce traité, par A. Sedillot, dans les Notices et extraits, t. XHI, 1). 143.)

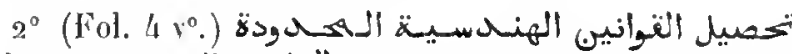

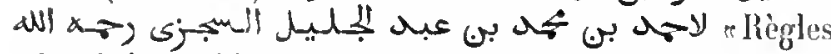
géométriques bien précises (?), Irouvées par feu Aḷmad ibn Moḷammad ibn 'Abd al-Djalil al-Sidjzîn. (Voyez Notices et extraits, t. XIII, p. 139.)

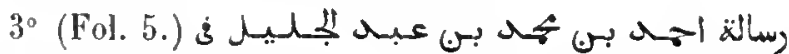

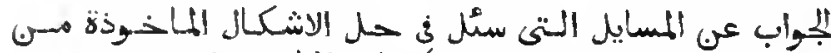
كettres d'Al!mad ibn Mollammad ibn "lbd al-Djalil, répondant aux questions qu'on lui avait adressées sur la solution des propositions (littéralement: des figures) tirécs du Livre des Lemmes d'Archimèden. (Voyez Notices et extraits, t. XIII, 1). 136.)

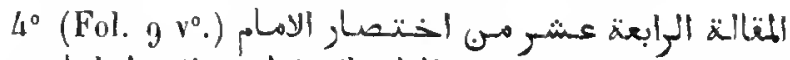
(Quatorzième chapitre de l'épitomé des Éléments d'Euclide, par l'imâm al-Mozaffar al-lsferledir.

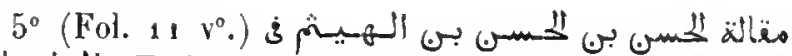
"Traité d'Al-luasan, fils d'A1-Hasan, fils d'MlHaïtham, sur les connus (géométriques) \%. (Voyez Journal asiatique, calier de mai 1834.$)$

$6^{\circ}($ Fol. 26 ํ.) Propositions de trigononétrie splıé- rique, pour servir à lintelligence de l'Almageste, par le

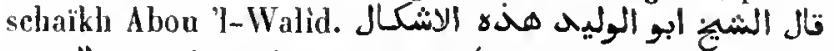

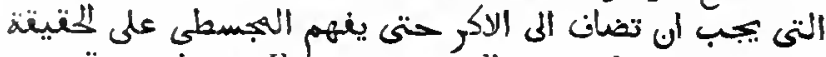

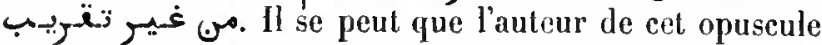
soit le célèbre philosophe Averroès (Abou 'l-Walid ibn Rosehd), qui a composé un abrégé de l'Almageste, dont la Bibliothèque possède la Iraduction hébraïque. Il est rrai qu'Averroès est ordinairement désigné par le titre d'Al-Qadhî; mais comme, à l'époque où ce ins. fut écrit, il était âgé de cinquante-six ans, le titre d'Al-Schailih s'explique facilement.

$7^{\circ}$ (Fol. 28.) Traité d'algebre d'Al-Khaîyàmì.

H. Wœpcke a publié le texte et la traduction de cet opuscule en 1851 . La copie n’est pas aclievée.

Ce ins., écrit par un géomètre pour son propre nsage, est daté de l'an 539 de l'hégire (1144-1145 de J. C.). Les nombreuses figures géométriques sont dessinées avec soin.

Papier. 32 feuillets. Hauteur, 27 centimètres; largeur, 16 centimètres et demi. 30 à 37 lignes par page. - (Ancien fonds 1 104.)

\section{9 .}

ة Traité d'algèbre, intitulé AlFakhrì, par Abou Bakr Mohammad ibn al-Hasan alKarkhî (j) biographique d'Ibn Khallikân, vol. HII, page 279 de la traduction anglaise. M. Wopcke a publié, en 1853 , une description de ce ms. el une analyse très-détaillée de l'ouvrage.

Papier. 108 feuillets. Ilauteur, 31 centimètres; largeur, 14 centimètres. 21 lignes par page. Hs. du xiv' siècle (à l'exception du feuillet 88 et du dernier cahier qui paraissent être de la fin du $\mathbf{x v}^{*}$ siècle). - (Supplément 952.)

\section{0.}

r Révision (du traité) de l'Optique». I1 s'agit sans doute du traité d'Al-Hasan ibn al-Haitham, géomètre égyptien qui vivait encore en 432 de l'hégire (1 040-1041 de J. C.). (Voyez les Prolégonènes d'Ibn Khaldoûn, traduction, tome I, page 111 , fin de la note, et tome III, page 144). L'auteur du Kitâb al-Hokama lui a consacré un article de plus de deux pages (fol. $73 v^{\circ}$ ). Les figures géométriques sont hien exécutées.

Papier. 26 feuillets. Hauteur, 21 centimètres; largeur, 15 centimètres. 9 lignes par page. Ms. du $x^{\circ}{ }^{\circ}$ sièele. - (Ancien fonds 1130. ) 


\section{1.}

r Mémoire dill-Khaìyâmi sur l'algèbren. (Voyez ci-dessus, $\mathrm{n}^{\circ} 2458,7^{\circ}$.)

Ms. daté de l'an 626 de l'hégire (1229 de J. C.).

Papicr. 25 feuillets. Hauteur, 18 centimètres et demi; largeur, 13 centimètres et demi. 19 lignes par page. - (Ancien fonds 1136. )

\section{2.}

Collection d'opérations cadastrales (littéralement : gourernementales) et de principes de calculs employés dans les bureaux de l'administrations. Cet ourrage, qui est un traité de calcul et de ses diverses applications, est divisé en trois parties. Le présent ms. ne contient que la fin de la seconde partie et la troisième partie. L'auteur est peut-être l'imàm Aboû 'Abd Allah Mḷmad ibn al-ḷosaïn al-Schaqqàq, qui est mentionné au fol. 144. Parmi les ouvrages eités, on remarque celui d'Al-Karkhî̀ et le كتاب

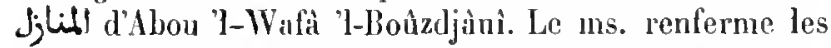
chapitres qui traitent des ventes, des baux à loyer, de la mesure des surfaces planes, des surfaces courbes el des solides, de l'arithmélique des fractions, du calcul des proportions et de l'algèbre. Entre autres renseignements très curicux, on trouve un chapitre sur les huit espèces de cou-

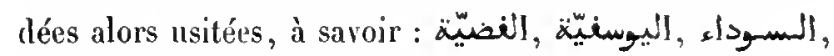

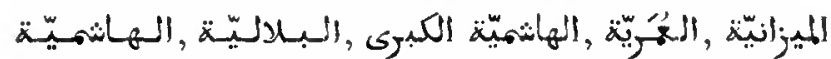
(fol. $\left.155 v^{\circ}\right)$. La place des figures est restée en blanc. Ms. daté de l'an 734 de l'hégirire (1333 de J. C.).

Papier. 188 feuillets. Hauteur, 26 centimètres; largeur, 18 centimètres. 15 lignes par page. - (Ancien fonds 1106 , Cotbert 4186. )

\section{3.}

$1^{\circ}$ Traité d'arihmélique pratique, intitnlé, dans la

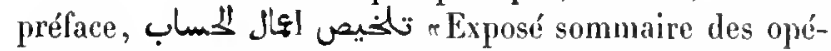
rations du calcul», et qui paraît être le célèbre our rage d'lbn al-Bannâ. D'après M. Wœpeke, ce ne serail qu'un commentaire du Talkhîs. (Voyez Journal asiatique, férriermars 1862 , page 108.) Ce traité est suivi d'un recucil de problèmes qui occupe vingt-quatre feuillets. Commence-

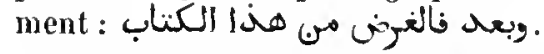

$2^{\circ}$ (Fol. 77 vº (Explication du texte de la Sakhâwiya, effectuée par la grâce du
Seigneur de toutes les créaturesn, par le doctenr schaféite Hosain ibn Moḷammad al-Mal!alli. Le traité d'arithunétique intitulé tantòt Al-Risâlat al-Sakhâwiyat : le Traité de Saklıàwì, et tantòt Mokhtaşar fi 'ilm al-ḷisâb - Abrégé d'arilhméliquen, a pour auteur 'Abd al-Qàdir al-Sakhâwî. Le Iraité du Mokhtaşar est ćcrit à l'encre rouge. Cet onvrage se compose d'une introduction, de onze chapitres el d'un appendice. La liste des chapitres a été publiée par M. Wopcke dans le Journal asiatique (férrier-mnars 1862 , page 109$)$.

30 (Fol. $123 v^{\circ}$.) science du ealcul déroiléen, par Abor I-llasan Ali ibu Moḷammad al-Qaliṣadi. C'est un commentaire du traité

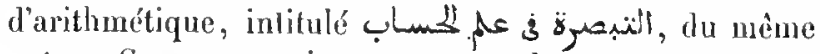
anteur. Ce commentaire se compose de quatre sections et d'un appendice. (Voyez Journal asiat., février-mars 1862 , page 110.$)$ L'auteur, qui appartenait à une famille qorai-

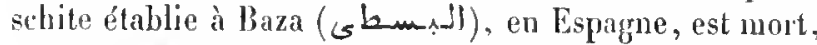
selon Al-Maqqà, vers l'an 851 de l'hégire $\left(1447^{-1} 448\right.$ de J. C..).

Papier. 179 feuillets. Ilauteur, 21 centimètres; largeur, 16 centimèlres. 2o à 25 liggnes par page. Écritures diverses du xvmı siècle. - (Supplément 951 ter.)

\section{4.}

$1^{\circ}$ Commentaire sur le Tallhị d'lbn al-Bannâ, par 'Ali ibn Moḷammad ibm Mọ̣anmad ibn 'Mlì al-Qalaṣâdi. Le commentaire est précédé d'une courle invocation, qui commence par ces mots: بل بـi.

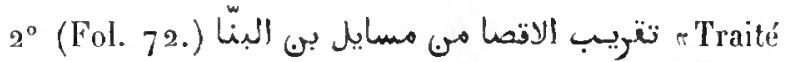
qui faciliteri l'intelligence des questions les plus difficiles traitées par Ibn al-Bannà ». Commentaire du Talkhiş d'lbn al-Bannà, par un auteur anonyme qui dit en avoir composé un autre plus étendu.

Papier. 129 fenillets. Hautenr, 21 centimètres; largenr, 16 centimètres. Écrilures diverses du xw1 siècle. - - (Supplément 951 bis.)

\section{5.}

CRévision des Liléments d'liuclide , par Nașir al-Din Moḷamunad al-Ṭ̂ousi (royez Hadji Klaalfa, t. 1, p. 383). La prélace du texte arabe d'Euclide, inprimée à Roune, est tout à fait différente de la préface du présent nıs., dont les premiers mots ont élí cités par Hadji Khalfa. Commencement : s jl al andil 


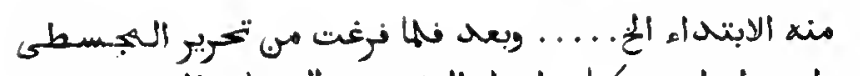

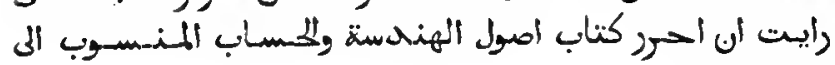

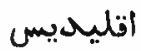

Ms. écrit à Schìrâz et daté du morcredi, 22 ṣafar de l'an 698 ( 1298 de J. C.).

Papier. 208 fenillets. Ilauteur, 13 centimètres; targeur, 8 centimètres. 19 lignes par page. -- (Ancien fonds 12 6. .)

Nème ourrage.

\section{6.}

$2^{\circ}$ (Fol. $197 v^{\circ}$.) Une note du mème Nașin al-Dín sur la musirjue.

Figures nombreuses et bien exćcutées; beaucoup de uotes marginales de la mème main que le texte.

Papier. 198 fenillets. Ilanteur, 21 centimètres; largenr, 1 a centimètres. 17 lignes par page. Ms. du $x v^{\circ}$ siècle. - (Ancien fonds 11 29.)

\section{7.}

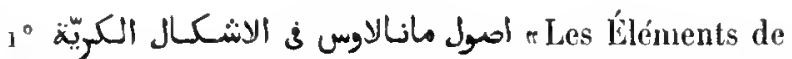
Menełaus, traité des figures sphériques:. C'est une traduction des Sphériques de Menelaus, remaniée par Nașir al-Dìn al-Tonsis. Un extrait de ła préface se trouve dans Hadji Khalfa. Les chapitres ou livres de la présente rédaction ne sont ni composés, ni distribués comme dans l'édition latine, qui a été faite sur un texte arabe.

$2^{\circ}$ (Fol. $56 v^{\circ}$.) Extrait du faites à l'Optique (d'Euclide)n, par Ya áquâb ibn Ishâaq al-Kindi.

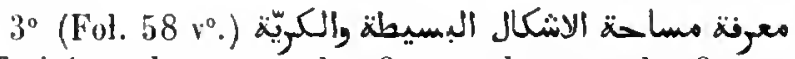
"Traité sur la mesure des figures planes et des figures sphériques n, composé par les filts de Moûsâ: Moḷanmmad, Al-llosainn et Aḷuad. Ce traité renferme dix-sept figures ou propositions.

$4^{\circ}\left(F_{01.6} 68 r^{\circ}\right.$. Révision du Kitâb al-Majroûdhât n. Le traité de géométrie intitulé كتاب Problèmes à résoudren, est de Thâbit ibn Qorra.

$5^{\circ}$ (Fol. $73 r^{\circ}$.) Discussion des postulats (مصادرات d'Euclide, par Naşir al-Dìn al-Ṭousì.

$6^{\circ}\left(\right.$ Fol. $87 v^{\circ}$.) Lettre au sujet du traité précédent, adressée à l'auteur par 'Alamı al-Din Qaĭsar ibn 'Abd alQàsim al-Ḥanafî, ingénieur mathématicien au service des princes ayyoubites de Đ̣amâh. $7^{\circ}$ (Fol. 89.) Note (وسمالع) d'Al-Fadh ibn llâtim al-

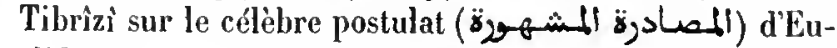
clide.

$8^{\circ}$ (Fol. 9o.) Conmentaire de Nașir al-Din al-Ṭoùsì sur le traité d'Arclimède, intitulé " La Sphère et le cylindren, الككرة والاسطوانة. Hadji Klıalfa a reproduit, dans son Dictionnaire, la partie la plus importante de la préface de ce commentaire.

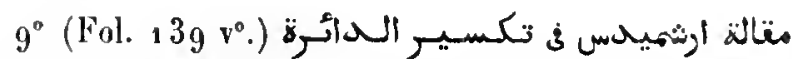
"Traité de la Mesure du cercle d'Archimède".

$10^{\circ}$ (Fol. $143 v^{\circ}$.) Trailé en cinq clıapitres sur le

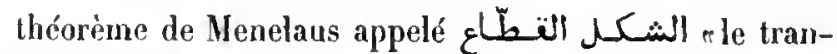
chant", e'est-à-dire la rígle d'intersection. Cet opuscule

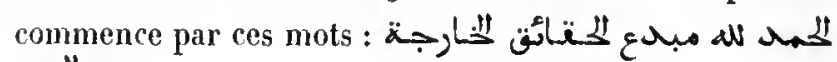

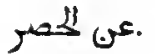

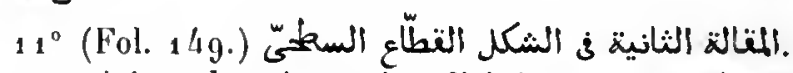
Autre traité sur le mème sujet, divisé en onze sections, dont la septième, la huitième, la neuvième et le commencement de la dixième manquent.

$12^{\circ}\left(F_{01 .} 155 v^{\circ}\right.$.) Troisième opuscule sur le mème sujet.

L'auteur de ces trois traités est probablement Nașir ałDìn al-Ṭoûsì.

$13^{\circ}$ (Fol. 195.) Extrait d'un traité de Thâhit ibn Qorra sur le même sujet.

$14^{\circ}$ (Fol. 196.) Sur la proposition qui enseigne que la somme des carrés de deux nombres ne peut être un carré, si ces deux nombres sont impairs.

${ }_{1} 5^{\circ}$ (Fol. $19^{6} \vee^{\circ}$.) Dissertation d'lbn Yoûnos sur le mềne sujet.

$16^{\circ}$ (Fol. $197{ }^{\circ}$.) Éclaircissements d'Al-Mâhânî sur la théorie des proportions exposée par Euclide dans le cinquième livre des Éléments.

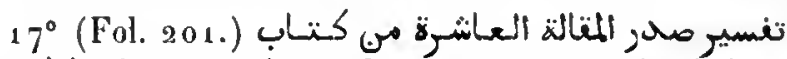
Commentaire sur le conmencement du dixième livre d'Eucliden, par dboû Dja far al-Klıâzin.

$18^{\circ}$ (Fol. 207.) Extrait du commentaire d'Al-Ahwàzì sur le dixième livre d'Euclide.

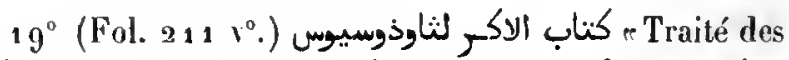
Sphères de Théodosen. Trois sections, renfermant cinquante-neuf figures ou propositions.

$20^{\circ}$ (Fol. $232 r^{\circ}$. "Révision du traité de la Sphère en mouvement d'Autolycus (par Thâbit ibn Qorra)n. Dix-neuf propositions.

L'écriture de ce ms. est souvent dépourrue de points 
diacritiques. Les nombreuses figures sont tracées avee soin.

Papier. 935 feuillets. Hauteur, 23 centimètres; largeur, 14 centimètres. 14 tignes par page. Ms. du xv' siècle. - (Supplément 955 bis.)

\section{8.}

1 Remaniement des traités de Théodose sur les sphères», par Moḷyì alDin Yalyaa ibn Moḷammad ibn abì Schokr al-Maghrabi. Cette copie, datée de l'an $9^{0} 6$ de l'hégire (1500 de J. C.), a été exécutée d'après un ms. du vo siècle de l'hégire. Le texte est accompagné d'un grand nombre de figures dessinées avec soin.

$2^{\circ}$ (Fol. $291^{\circ}$.) Traité de pneunatique, attribué à Archimède, touchant le mécanisme des automates, des orgues, des clepsydres, etc. Commencement : تال ارثنهينس

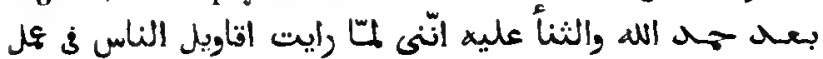

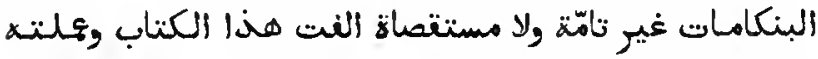
لأ gures sont interealées dans le texte. Les points diacritiques sont rares. La fin manque.

$3^{\circ}$ (Fol. 46.) Fragnent d'un traité de géométrie. On trouve d'abord la fin d'un chapitre sur la mesure des polygones réguliers; puis viennent des chapitres très-courts sur la mesure des solides, sur les poids comparés des diverses substances minérales, sur la splière, sur le nivellement. Suit la quatrième section (مغالة) de l'ourrage, commençant par un chapitre sur l'algèbre, dont il ne reste que les premières lignes.

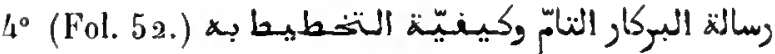
"Trailé du compas parfait et de la manière de s'en servir», par Mohammad ibn al-Hosaïn. C'est la description et la théorie du compas parlait, au moyen duquel on peut tracer toutes les sections coniques. Ce traité a été présenté par l'auteur an sultan Saladin. Il a été publié avec une traduction française par M. Wopcke, dans le tome XXIII, $1^{\text {ro }}$ partic, des Notices ct extraits. La copie est datée de l'an 768 de l'hégire ( 1367 de J. C.).

Papier. 63 feuiltets. Hauteur, 16 centimètres; largeur, 8 centimètres et demi. 21 à 23 lignes par page. Écritures diverses du xıv et du $\mathrm{xv}^{*}$ siècle. - (Supplément 955.$)$

\section{9.}

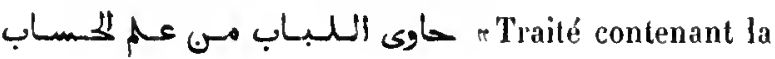

moëlle de la science de l'arithmétiquen, par Taqî al-Dìn al-ḷanbalì, fils du schaïkh 'Tzz al-Dìn. Cet ouvrage se compose d'une introduction, de trois d'un appendice. Chacune de ces sections est divisée en chapitres. Lintroduction renferme des notions générales; le premier تطب traile de la numération et de l'arithmétique des nombres entiers; le second, du calcul des fraclions; le troisième, des définitions; l'appendice, de la preuve des calculs, des proportions et des questions se rallachant aux quatre opérations fondamentales. Com-

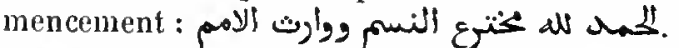

Ms. daté de l'an 812 de l'hégire ( 1409 de J. C.).

Papier. 43 feuillets. Hauteur, 25 centimètres et demi; largeur, 16 centimètres et demi. 23 lignes par page. - (Supplément 951.)

\section{0.}

Traité d'arithmétique, par 'Abd Allah ibn Moḷammad ibn al-Khawwàm. En tête du solume on lit ce litre : لكرسالة

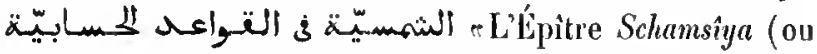
solaire?) sur les principes du calcnl $n$. Cet ouvrage traite, en outre, des éléments de la géométrie, de la mesure des surfaces, des principes de l'algèbre et de la réparlition des surcessions. La copie a élé exécutée đlu vivant de l'auteur.

Papier. 88 leuittels. IJanteur, 20 centimètres et demi; largeur, 15 centimères. 11 lignes par page. Ms. du xiv" siècle. - (Ancien fonds 1 133.)

\section{1.}

吾 liquen, par Schihails al-Dìn Alımad ihn al-Haìm, avee le commentaire de Sibt al-Màridinì (Mohammad ibn Moḷammad ibn Aḷmad ibn Molıanmad). Le texte, écrit à l'encre rouge, commence par le bismillah, et le commen-

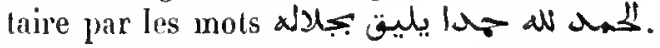

Papier. 44 feuillets. Ilauteur, 23 centimètres; targeur, 17 centimètres. 17 lignes par page. Hs. de la fin du xvm ${ }^{\bullet}$ siècle. - (Supplément 950.)

\section{2.}

- Le même traité d'Ibn al-IIäim, avec le commentaire d'Alımad ibn Moûsà ibn "Abd al-Ghaffàr al-Mìliki. 
Ibn al-Hàim est mort en 887 de l'hégire ${ }^{2}$. Le commentateur a composé son ourrage à la Mecque, en 920 de l'hégire ( 1515 de J. C.). Commencement du commentaire:

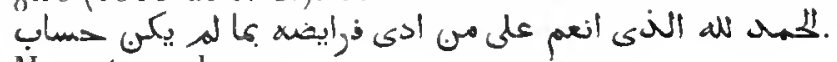
îs. autographe.

$2^{\circ}$ Fol. 56. (Frithmétique pour les

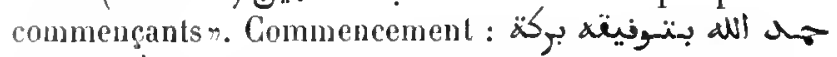
x. 10 of.

Papier. 63 feuillets. Llauteur, 19 centimètres; largeur, 14 centimètres. - (Ancien fonds 1135.$)$

\section{3.}

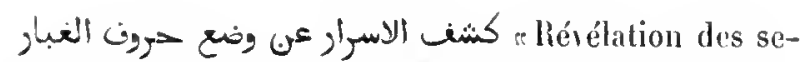
crels dims l'emploi des caractères ghobârn, par 'Alì ibn Mohammad al-Qalașàdi, d'Espagne. C'est un traité sur' l'application des chiffres décinaux au calcul par écrit. Fen M. Wopcke en a donné une analyse complète dans le Journal asiatique (cahier d'octobre-novembre 1854). L'anteur dit dans la préface que cet ourage est l'abrégé d'un autre qu'il a composé, sur le mème sujet, sous le

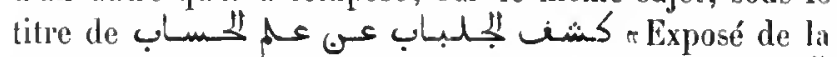

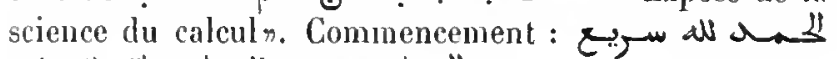

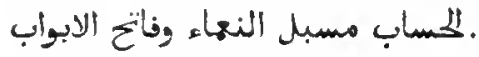

Papier. 40 feuillels. Hauteur, 21 centimètres; largeur, 15 centimètres. 19 lignes par page. Ms. dı $w_{1}^{e}$ siècle. - (Ancien fonds $113 \%$.)

\section{4.}

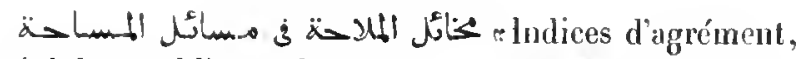
lraité des problèmes des mesures», par Mohammad ibn Hrâhim ibn al-Hanbali, mort en 971 de l'hégire (voyez lladji Khalfa, tome $V$, page 1 91). C'est un commentaire

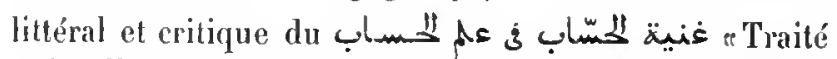
qui suffit au calculateur pour connaîlre la science du calcul», de Djamâl al-Dîn Aḷmad ibn Thâbit, qui expose les connaissances nécessaires pour évaluer les mesures des surfaces et des solides.

Ms. daté de l'an $9^{6} 1$ de l'hógire (1554 de J. C.).

Papier. 53 feuillets. Hauleur, 19 cenlimètres; largeur, 13 centimètres el demi. 27 lignes par page. - (Ancien fonds 1131.)

\section{5.}

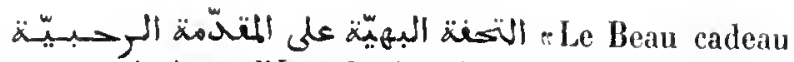
(commentaire) sur l'Introduction d'Al-Rahabi", par Aboù Moûsâ ibn Qâsim al-Maghrabi. L'ourrage commenté, dont lauteur était Aboû 'Abd Allah Mohammad ibn 'Alì ibn Aḷmad, est une ordjoúza qui traite du partage des succes-

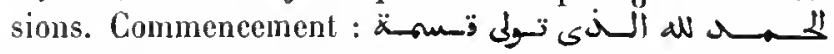

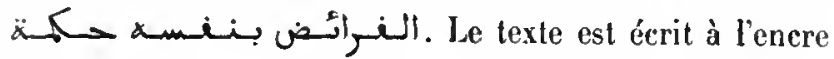
rouge.

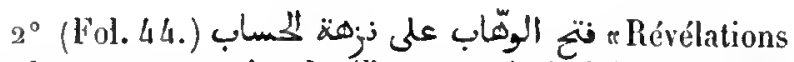
du donateur au sujet de (l'ouvrage intitulé) Récréations arithmétiques $»$, c'est un commentaire sur l'abrégé d'un traité d'arithmétique, intitulé "Guide de l'art du ealcul\%. Cet ouvrage, ainsi que son ahrégé, sont du même auteur, dont le nom est resté inconnu. Le نزهة لهـساب, qui se compose d'une introduction, de deux chapitres et d'un appendice, traite de la notation arithnótique, des diverses opérations qu'on peut faire arec les nombres entiers, du caleul des fractions et de l'art de dégager l'inconnue. Le texte est écrit à l'encre ronge. Le commentaire a été rédigé en 1029 de l'hégire ( 1620 de J. C.), et complété en 1039 de l'hégire. Le présent exemplaire, copié sur celui de l'auteur, est daté de lan 1091 de l'hégire (1680 de J. C.). L'auteur du commentaire est nommé à la fin : 'Alì ibn abì Bakr ibn al-0jamâl at-Anșàrì.

$3^{\circ}$ (Fol. 100.) Commentaire du schaïkh Badr al-Dìn Sibt al-Mâridìnì sur le traité des successions intitulé

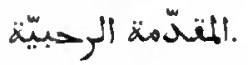

$4^{\circ}$ (Fol. $120 \mathrm{v}^{\circ}$.) Traité de Schihâb al-Din Ibn alHaiim sur la solution de certaines questions qui se présentent lors du partage des successions et que l'on désigne par le terme منابيخأ. Il y a plusieurs tableaux dans cet opuscule.

$5^{\circ}\left(\right.$ Fol. $132 v^{\circ}$.) Traité d'arithmétique pratique, par Schihâb al-Dìn Ibn al-Häim (Ạ̣mad ibn Moḥammad ibn 'Hli ibn 'Imâd).

(Voyez, sur ces traités, un article de II. Wœpcke, dans le Journal asiatique, cahier de févijer 1862.)

Papier. 168 feuillets. Hauteur, 20 centimètres; largeur, 14 centimètres et demi. Écritures diverses du svi" sièele. - (Supplément 950 bis.)

\footnotetext{
1 C'est la date que donne Hadji Khalfa, t. V, p. 331, et qui renferme une erreur. Le mème auteur, dans un autre passage, t. VI, p. 494, indique la date de 8,5 . H. Z.
} 
XIV.

\section{MÉCANIQUE.}

\section{6.}

, Le Collier de prix, qui traite de tout ce qui se rapporte aux balancesn, par Ḥasan ibn Ibrâłhìn al-Djabarti. C'est un traité systématique et détaillé sur les poids et mesures. L'auteur y a joint plusieurs tables. Commencement :

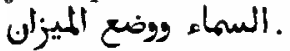

Papier. 48 feuillels. Hauteur, 22 centimètres; largeur, 15 centimètres. 23 lignes par page. Ms. du xvın siècle - (Supplément g85.)

\section{7.}

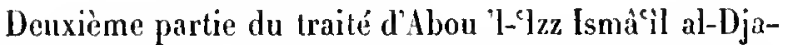
zarì, sur l'emploi de l'eau pour donner du mouvement aux automates, pour faire rendre des sons musicaux à des boyaux, ete., et sur la manière de laire sortir plusieurs liqueur's d'un même vase, etc. ll y a un assez grand nombre de plans et de figures coloriées, qui représentent la construction intéricure de ces automates et de ces vases merveilleux. Cet ouvrage a été composé en 602 de l'hégire ( 1206 de J. C.).

Ms. daté de l'an 890 de l'hégire (1485 de J. C.).

Papier. 112 pages. Hauteur, 27 centimètres; largeur, 18 centimètres el demi. ag lignes par page. - (Ancien fonds 1577.$)$

\section{8.}

Traité d'horlogeric (علم البــامـاتC), par Taqi al-Din Moḅammad ibn Ma'roûf, ministre de la loi daus l'arron-

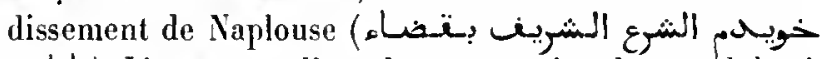
(نابلس). L'auteur explique la construction des pendules à poids et des pendules à ressorts. Des dessins explicatifs, bien exécutés, en assez grand nombre, scrvent ì lintel-

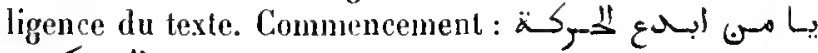
. والـسـكسوت.

Papier. 85 feuillets. Hauteur, a 7 centimètres el demi ; largeur, 17 cenlimètres et demi. 13 lignes par page. Ms. du xví siècle. - (Ancien fonds 1121.)
XV.

\section{MUSIQUE.}

\section{9.}

rLe Traité dédié à Scharaf al-Din sur les rapports combinés $\%$. Cet ourrage, qui traite de la musique et du chant, a été composé pour Scharaf al-Din Hàroùn, fils de Mohammad ibn Moḥammad al-Djoùfí, qui élait vizir du dernier calife de Baghtdâd. Hadji Khalfa, sur l'autorité du ḷabîb al-Siyar de Khondemir, raconte que, lors de la prise de Baghdad par les Tartars, Houlagou, charmé du talent de Scharaf al-Din comme jouenr de luth, lui fit rendre tous ses biens. L'ourrage, qui renferme beaucoup de termes techniques,

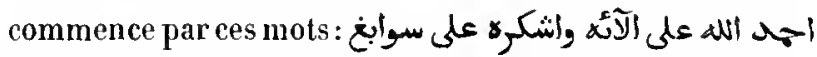

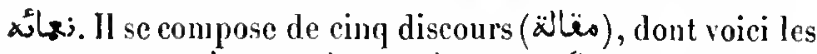

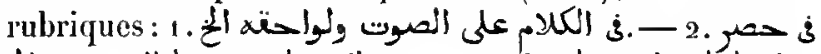

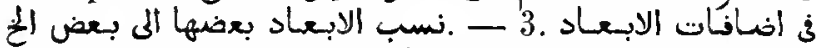

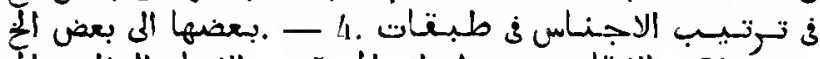
. L'auteur dit quili a suivi la voie frayée par les anciens philosopbes grecs, mais que son traité renferme des renseignements qu'on ne trouve ni chez les auteurs anciens, ni chez leurs successeurs. Il y a un grand nombre de lables et de figures qui paraissent indiquer des accords et des intervalles harinoniryues.

Is. daté de l'an 897 de l'hégire (1491 de J. C.).

Papier. 56 feuillets. llauteur, 23 centimètres; largeur, 13 centimètres. 19 lignes par page. - (Supplément 98\%.)

\section{0.}

$1^{\circ}$ م Traité qui fait connaitre les modes de la musique», par Schams al-Din al-Ṣaïdàwì, de Damas. Ce traité est composé en vers. Les termes de l'art sont exprimés en persan. Commencement : גa

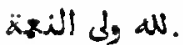

$\Lambda$ la fin se trouvent plusieurs tableaux et diagrammes.

$2^{\circ}\left(F_{0}{ }^{\prime}{ }_{9} v^{\circ}.\right)$ Deux pièces en prose rimée, dans lesquelles l'auteur anonyme exprime les sentiments que lui inspirent les divers modes de la musique. Viemnent ensuite: $1^{\circ} \mathrm{un}$ panégyrique de Malıomet, en prose rimée, par un nommé Al-Bábili; $2^{\circ}$ deux morceanx en jrose rimée, dans lesquels un eertain 'Alì ibn abi 'l-Wafà ra- 
conte les peines de l'amour (divin); $3^{\circ}$ un poëme sur le même sujet, par le même auteur.

Papicr. 95 feuillets. Ilauteur, 21 centimètres; largeur, 17 centimètres. 17 lignes par page; 11 à 13 lignes dans l'article $\mathrm{a}^{\circ}$. Ms. du wi" siècle. - (Aneicn fonds 1214.)

\section{1.}

Tableau synoptique des douze lons ou modes principaux du système musical des Arabes, et en général des Orientaux. En arabe, en italien et en francais.

Papier. 13 feuillcts. Hauleur, 56 centimètres; targeur, 40 centimètres. Ms. du xIs" siècle. - (Supplément 2371.)

\section{XVI.}

\section{ASTRONOMIE.}

\section{2.}

(النجسطى لبطلميوس :L'Almageste de l'toléméen. Com-

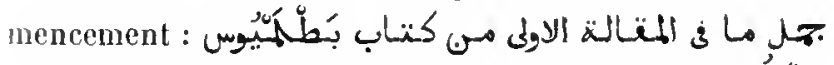

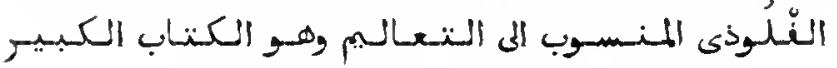

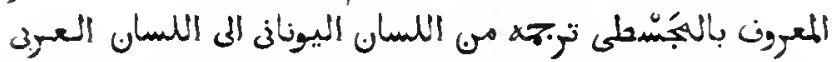

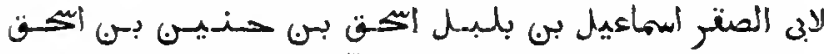
Contenu de la première section du livre de Ptolémée al-Feloûdsî, surnommé le Mathématicien. C'est le grand ourrage appelé l'Almageste. Traduit du grec en arabe pour Abou 'ş-Ṣaq lsmâcil ibn Boulboul, par le médecin Isḥâq ibn Honaïn ilın lsḥàq, et corrigé par Thâbit ibn Qorra al-llarrânìn. Suit la liste des chapitres. On sait que les premiers traducteurs arabes ont transcrit sous la forme le prénom Claudius, mol que les copistes ont changé en الغنالفوذى Alou 'ṣ-Ṣaqr, vizir d'Al-Nowaffaq, frère du calife AlNólamid, a été mis à mort en 278 ou 279 de l'hégire $\left(89^{1}\right.$ de J. C. $)$. Ce volume renferme les six premières sections de l'ourrage.

Ms. daté de l'an $61 \delta$ de l'hégire (1221 de J. C.).

Papier. ${ }_{3} 31$ feuitlets. Hauleur, 25 centimètres; largenr, 19 centimètres. 24 lignes par page. - (Ancien fonds 1107 .)

\section{3.}

LiAlmageste de Ptolémée. Sept parties (maqâlât), dont la première est incomplète au commencement. Les figures sont dessinées avec soin. Les tables sont restées en blanc.

Papier. 166 leuillets. Hauteur, 23 centimètres el demi; targeur, 18 centimètres. 24 à 25 lignes par page. Ms. du xv siècle. - (Ancien fonds 1139. )

\section{4.}

$1^{\circ}$ Abrégé de l'Almageste de Ptolémée, par Avicenne.

$2^{\circ}$ (Fol. 144.) Les Éléinents d'Euclide. Cette traduclion abrégée se compose de quinze livres (متالات).

Le texte des deux ourrages est presque entièrement dépourvu de points diacritiques. Dans l'un et dans l'autre, les figures n'ont été exécutées qu'au commencement.

Le volume est tout entier de la mème main et daté de l'an 683 de l'hégire (1284-1285 de J. C.).

Papier. 221 feuillets. Hauteur, 34 centimètres; largeur, 13 centimètres. al lignes par page. - (Supplément 2097.)

\section{5.}

Remaniement de l'Almagester, par Naṣir al-Dìn Noḷammad ibu Moḷammad al-Ṭoûsî. (Voyez Hadji Khalfa, tome $V$, page 387 .) On lit en tête du présent ms. un titre apocryphe, d'après lequel l'auteur de l'ouvrage serait Mohammad ibn Schàkir. Commencement:

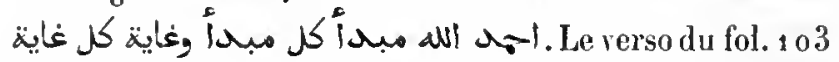
porte une note en écriture cursive, où l'on troure la liste des nombrenx traités de mathématiques qui ont été remaniés par Naṣìr al-Dìn al-Ṭoûsî.

Papier. 103 feniltets. Hauteur, 36 centimètres; largeur, 23 centimètres. 29 tignes par page. Ms. du $\mathbf{x v}^{\bullet}$ siècle. - (Ancien fonds 1108 ).

\section{6.}

(زيج الاستاد بrال الميسن. Tables astronomiques de Djamâl al-Dìn Abou 'l-Qấsim ibn Maḷfoûz, astronome de

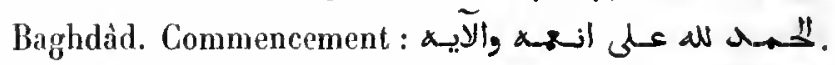
Dans la première partie de ce manuel d'astronomie, lauteur traite des ères et indique le moyen d'établir la concordance des années musulmanes avec les années des Coptes, des Grecs, des Perses et des Sabéens. Il donne ensuite une clronologie des califes, jusqu'à la morl d'Al-Mostaeșim; puis il traite des signes du zodiaque, et donne les tables des apogées $(ا و ج س ا ت)$ du soleil, de la lune, des cinq planètes, des comètes et des étoiles fixes. 
Il traite aussi des mouvements, direct et rétrograde, des cinq planètes, de la mesure de l'arc diurue et des lables de hauteurs pour la latitude de Baghdid. On Irouve ensuite : la liste des éclipses du soleil el de la lune, avec des tables; la table des levers des signes pour la latitude de Baghdàd et pour d'autres latitudes; la liste des sept climats; une table des longitudes et des latitudes des différentes villes; des tables des latitudes de Saturne, de Jupiter et de Mars; une table pour trouver I'ascendant d'une année quelconque; les mansions de la lune; les conjonctions de la lune arec différentes étoiles; le calcul de nativités; des thèmes et des tables genethliaques; les lever's des signes dans la sphère droite; une table d'aspects; une table des sinus; le calcul de la déclinaison du soleil et de la latitude de la lune; une table pour trouver la quantité de l'arc diurne parcouru par le solcil et pour déterminer les heures égales. Cetle dernic̀re table est in-

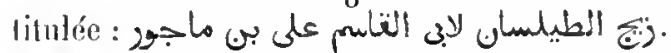

Ils. dalé de l'an 684 de l'hégire (1285 de J. C.). Un

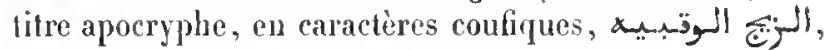
" été ajouté après coup, en tête du volume.

Papier. 225 feuillets. Hauteur, 26 centimètres; Jargeur, 18 centimètres. 17 lignes par page. - (Ancien fonds 605.)

\section{7.}

$1^{\circ}$ كناب الاصط Sur l'astrolabe et son cmploi, par Ibou 'I-ḷasan Koủschyân' ibn Labbân ibn Bischabrì alDjîlì.

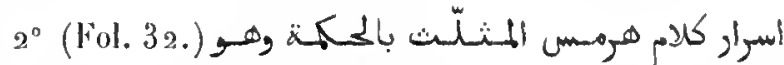

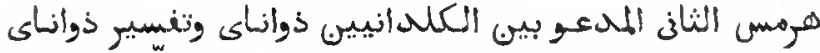
arismériste, qui est Hermès 11, appelé chez les Chaldéens Dsovainaii, nom qui signifie saneur du genre humain \%. Traité d'astrologie, ilve quelques tables.

$3^{\circ}$ (Fol. 3.) Traité des conjonclions, par le magre Djâmàsb\%.

4 Fol. 56. ( Traité des conjonctions n, par « Zarâdouscht le sage, chef des écrivains des miges

Ms. daté de l'an 699 de l'hégire (1300 de J. C.).

Papier. 105 feuillets. Hauteur, 25 centimètres; fargenr, 17 centjmètres. 15 liggnes par page. - (Supplément 1901.)

\section{8.}

Catalogue des étoiles, par 'Abd al-Ralınân ibn 'Omar Mas. orientati. - II.
al-Şoûfi, ourrage connu sous le titre de

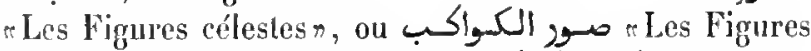
des éloilesn, on encore ćtoiles fixes». Ce dernier tilre est donné par l'auteur du Tawårikh al-Hokamâ. Ce traité renlerme les figures des constellations el l'énumération des étoiles qui composent chaque constellation. Les figures, dessinées au simple trait, sont doubles, l'une représentant la constellation telle qu'elle paraît sur la volite céleste, l'autre, renıersée de droile à ganche, représentant la même constellation, telle quon la trouve dessinćc sur les globes (j 8̌Sil). Dans l'Histoive de lastronomie du moyen-age, de Delambre, il est dit par crreur (page 204 ) que les doubles figures sont, les unes pour les cartes et les autres pour les globes. Chaque figure est précédée de sa description at suivie de la liste des étoiles dont elle se compose et de lenrs latitudes et Iongitudes. Claque éloile est accompagnée de son numćro, dans les ligures et dans la table. l'anteur indique aussi les étoiles qui se Irouvent en delors des constellations. Ce catalogrue raisonné a été composé postérieurement à l'an 335 de l'hégire $(947$ do J. C.), et dédié au sultan bouïde 'Adhod al-Daula Fenna Khosrou, qui monta sur le trône en 338 de l'hégine. Lauteur, 'Abd al-Raḷmân ibu 'Omar ibn Moḷammad ibn Sahl al-Şoûlì, grénéralement connu sous le nom d'Abou 'l-llosaïn, naquit à heï, en 29 ' de l'hégire (9o3 de J. C.), et mourut en $37^{6}$ de l'hégire ( 986 de J. C.). Employé par "Arhod al-Daula en qualité de prol'esseur d'astronomie, il enseigna ì ce prince les noms et les positions des étoiles fixes. Caussin de Perceval, père, a donné une nolice sur cet ourrage et un extrait considérable de la préface, dans le recueil des Notices et Extraits, t. XII, pages 236 et suiv. L'ouvagre complet a été publié récemunchl on Russie.

Le dernicr feuillet du ms, ne fait pas partie de l'onrage. Il contient la recette d'une lotion qui fait disparaitre la lèpre blanche.

Papier. 151 feuillets. Hauteur, 29 centimètres et demi; largeur, yo centimètres. 35 lignes par page. Ms. du siv siècle. - (Ancien fonds 1111.)

\section{9.}

$1^{\circ}$ Mème ourrage.

$2^{\circ}$ (Fol. 171.) Quelgues maximes détachées.

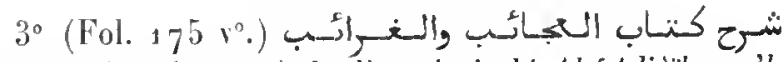
"Traduction (turtue) du livre intitulé $A l$-'Adjaib wa ' $l$ -

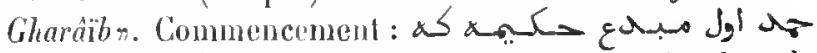
أسمان بنياد تُ C'est un traité de cosmogonie, dans le genre de celui d'Al-Qazwini. L'introduction, en quatre 
chapitres, est suivie d'un premier discours (المعاباتة اللماولى),

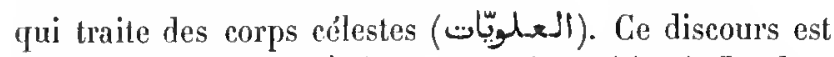
divisé en chapitres (نظ) el en sections (نصليّ). La dernière section de cet exemplaire est consacrée aux merveilles de l'anncée. C'est peut-être l'ourrage qui est mentionné sous le même titre par Hadji Klıalfa, qui a été traduit en ture par Al-Soroûrî et qui renferme dix discours. En effet, le troisiène discour's de la traduction d'AlSoroûrì traite du temps. Mais notre exemplaire ne contient que trois discours.

Papicr. 229 feuillets. Hauteur, 27 centimètres; largeur, 18 centimètres et demi. Le premier ouvrage, écrit au $x_{1} v^{6}$ siècle, a 17 lignes par page; le troisième, écrit au xvı" siècle, a 19 lignes. - (Ancien fonds 11113. .)

\section{0.} Șoûfì.

Catalogue des étoiles fixes, par 'Abd at-Raḥnân al-

Ms. daté de l'an 922 de l'hégire ( 1516 de J. C.). Les figures sont dessinćes au trait; mais il en manque un assez grand nombre, dont la place est restée en blanc.

Papier. 155 feuitlets. Hauteur, 28 centimètres; largeur, 21 centimètres. 19 lignes par page. $-($ Ancien fonds 1110.$)$

Nême ouvrage.

\section{1.}

Ms. daté de l'an 1183 de l'hégire (1 $77^{\circ}$ de J. C.). Les figures sont dessinées avec beaucoup de soin.

Papier. 182 feuiltets. Hauteur, 23 centimètres et demi; largenr, 15 centimètres. 17 lignes par page. - - (Supplément 964. )

\section{2.}

Nême ouvragege.

En lête du volume se trouve une ordjoûza, poème en vers innénoniques, qui contient la description des différentes constellations. Les figures sont dessinées arec soin et coloriées; les étoiles sont indiquées (sans leurs numéros) par des petits ronds dorés.

Papier. 295 feuiltels. Ilauteur, 22 centimètres; largeur, 15 centinètres. 23 lignes par page. Ms. du Xmu' siècle.-(Supplément 964 bis.)

\section{3.}

Traité de l'astrolabe et de son emploi, par 'Abd al-
Raḷmân iłon 'Omar ał-Ṣoûfî, divisé en trois cent quatrevingt-six chapitres, dont la plupart sont consacrés à des problèmes astronomiques. L'ouvrage cominence par une dédicace adressée à un grand personnage dont le nom n'est pas indiqué.

Ns. daté de l'an 1283 de l'hégire $(1866$ de J. C.). Vignettes en or et en couleurs; les deux premières pages sont ornées d'arabesques en or.

Vélin. 183 feuillets. Hauteur, a 2 centinètres et demi; largeur, 13 centimètres et demi. 18 lignes par page. - (Supplément 196\%.)

\section{4.}

"L'Almageste d'Abou "'l-Wafâ al-Boûzdjânî̀. Ce ms., dout le commencement et la fin manquent, renferme les sept premiers livres de l'ourrage; les autres devaient se trouver dans un second volume. En effet, nous lisons sur la tranche inférieure du manuscrit : ب Premier volume de l'Almageste d'Al-Boìzdjânî \%. Chaque livre (مقالم) est divisé en sections (نوع) ct en chapitres (فُعل), ct précédé d'une table des inatières. L'auteur, Abou 'IWalî̀ Hoḷammad ibn Moḷammad al-Boûzdjàni (né à Boûzdjàn, petite ville du Klıorâsân, située entre Hérat et Naïsâboûr), est mort en 387 de l'hégire ( 997 de J. C.), à l'àge de cinquante-neul ans. (Voyez le Dictionnaire biographique d'Ibn Khallikin, t. III, page 320 de la Iraduction anglaise.) II. Am. Sédillot a traité de l'Almageste d'Abou 'I-Wafà dans son ouvrage intitulé Matériaux pour servir à l'histoire comparée des sciences mathématiques ehez les Grecs et les Orientaux, p. 42 et suiv.

Papier. 107 feuillets. Hauleur, 20 centimètres; largeur, 16 centimètres. 19 lignes par page. Ms. du xut siècle. - (Ancien fonds 1 138.)

\section{5.}

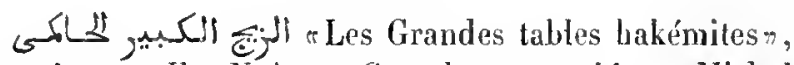
dressées par Ibn Yoưnos. Ce volume, copié par Michel Sabbàgh, sur le ms. 1057 de la bibliothèque de l'universilé de Leyde, ne renferme que la première moitié de l'ouvrage. M. Caussin de Perceval, père, a traitć de cet ouvrage dans le tome VII des Notices et Extraits. (Voyez aussi Delambre, Histoire de lastronomic du moyen-âge, p. 76 et suiv.)

Papier. 208 feuillets. Hauteur, 28 centimètres et demi; largeur, a 2 centimètres. 21 lignes par page. Ms. du xixe siècle. - (Supplément $9^{65 .)}$ 


\section{6.}

$1^{\circ}$ (Fol. 10.) Fragments des Tables hakémites d'Ibn Younnos. On trouve une partie du chapitre v, puis les chapitres vı, x, xı, Lxxum, Lxxix, Lxxx, Lxxxı, xvmı ct plusieurs autres, qui ne se suivent pas dans l'ordre incliqué par l'auteur. (Voyez Notices et Extraits, tome VII, page 82 et suiv.) M. Sédillot, père, avait communiqué un extrait de ce ms. à M. Delambre, qui l'a publić dans son Histoirc de l'astronomie du moyen-âge, page 125 et suiv.

$2^{\circ}$ (Fol. 95.) Tables astronomiques, dont quelquesunes sont attribuées à 'Alud al-Raḥmàn al-Ṣalị̣ì, et d'autres à Olough-Beg.

En lête dı volume se trouvent quelques notes, en ćcriture cursive, sur l'histoire et la pratique de l'art de l'écriture, et un modèle d'écriture, lettres isolées et syllabes, ćcrites sur les marges de denx fenillets d'une table astronomique. Puis viennent six feuillets de tables astronoiniques qui, probablement, font partie des tables $d^{\prime c}$ Abd al-Raḥmàn al-Ṣalị̣i; enfin deux tables, composées en 973 de l'hógire ( 1566 de J. C.), au moyen desquetles on trouve la concordance de lannéc musulmane avec l'annéc copte. Ces deux tables n'embrassent que les six premiers mois de l'année musulmane.

Papier. 131 feuillets. Hauteur, 27 centimètres et demi; largeur, 18 centimètres. 25 lignes par page. Écritures diverses. - (Ancien fonds 1112. .)

\section{7.}

Hanuel d'astronomie, accompagné de figures el suivi d'un traité sur l'astrolabe. Commencement عان all all عطائه وكاشنف غطابيه C'est la traduction d'un ourrage persan, à savoir les Éléments d'astronomie d'Abou 'IRaịḷân Moḥammad ibn Ạ̣mad al-Bìrounnî.

Papicr. 85 feuillets. Hauteur, 20 centimètres el demi; largecur, 14 centimètres. 22 lignes par page. Ms. du xvir siècle. - (Ancien fonds 584, Colbert 5958 .)

\section{8.}

$1^{\circ}$ Traité sur les divers genres d'astrolabes et sur leur usage, par Abou 'l-Raïhìn Mohammad al-Bîroûnì. Lou- vrage est divisé en vingt chapitres (bâb), et chaque chapitre en sections $(f a s ̧ l)$. Les figures nont pas été exécutées.

$2^{\circ}$ (Fol. $65 \mathrm{v}^{\circ}$.) Traité sur l'usage de l'astrolabe, par 'Abd al-Rahmân ibn 'Omar, géuéralement connu sous le nom d'Abou 'l-Hosaïn al-Soûfí. Les figures manquent.

Papier. 177 fenillets. Hauteur, 18 centimètres; largeur, 12 centimètres et demi. 17 lignes par page. $\mathrm{Hs}$. du $x \mathbf{x}^{\circ}$ siècle. - (Ancien fonds 1159. )

\section{9.}

(1) :La Dernière limite de la connaissance en ce qui concerne les divisions des sphères\%. Manuel d'astronomie, par Al-Khiraqi, auteur qui est mort en 533 de l'hégire $(1138-1139$ de J. C. $)$. Selon Hadji Khalfa, l'auteur se nommait Moḷammad ibn Al!mad al-llosainì mais en tète de notre ms. on lil les noms d'Alon̂ Moḷammad 'Abd al-Djabbâr ibn 'Abd alDjabbàr ibn Molnammad al-Thâbili al-Khiraqi ". Cet on-

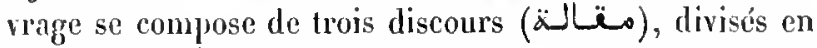
chapitres (باب) et en sections (ذصال). Le premiel discours traile de l'astronomie proprement dite; le second (fol. $7^{2}$ ), de la géographie astronomique, et le troisième (Col. 103 ), de la chronologie. Commencement : $\sim \rightarrow$ B

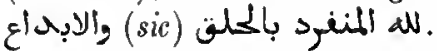

Ms. daté de l'an 633 de l'hégire ( 1237 de J. C.).

Papicr. 156 feuillets. Hauteur, 25 centimètres; largeur, 16 centimètres, 21 lignes par page. - (Ancien fonds 1115, Colbert 4377.)

\section{0.}

1 o 1 - Mbrégé d'astrononien, par Mal!moûd ibn Mohammad ibn 'Omar al-Djaghminî. Commen-

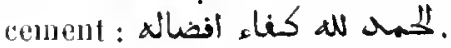

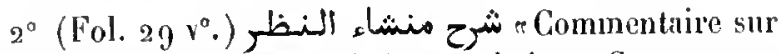
l'ourage intitulé Produit de la spéculationn. Cet ourrage traite des matières théologiques qui ont domé lieu à des controverses. L'auteur du منشاء النظظ, Borhân al-Dìn alNasafi, est mort, selon Hadji Khalfa, en 684 de l'hégire (1 $285-1286$ de J. C.). Le commentaire commence par

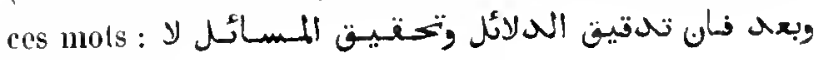

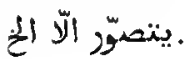

\footnotetext{
' Ms. 3. H. Z.
} 
$3^{\circ}$ (Fol. $62 r^{\circ}$.) Antre commentaire sur le mème on-

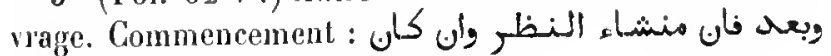

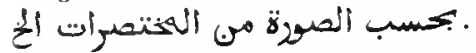

$4^{\circ}$ (Fol. $9^{5} \mathrm{v}^{\circ}$.) Traité de géométrie ćlémentaire, avec figures, fondé sur les Éléments d'Euclide. La dernière proposition est celle du carré de lihypoténuse égal à la somme des carrés des côtés.

$5^{\circ}$ (Fol. $109 \mathrm{v}^{\circ}$.) Commencement d'un traité intitulé - Sur les propriétés des lettres de l'alphabet $n$.

$6^{\circ}\left(F_{0}\right.$ l. 1 10.) Dernière page d’un traité de diétélique.

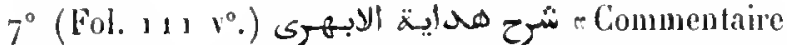
sur la Ilidaya d'Al-Abharì. Ce commentaire n'embrasse que la plysique et la métaplysique. Commencement:

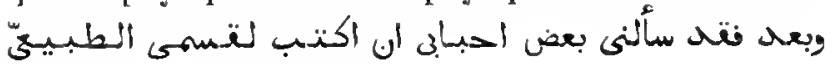

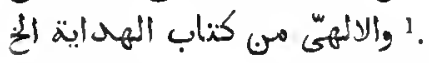

$8^{\circ}$ (Fol. $182 v^{\circ}$.) Recettes pour faire des tisanes.

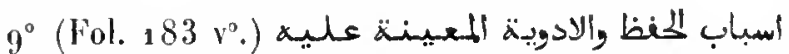
"Traité sur la mémoire et les remèdes à employer pour la fortifier's.

$10^{\circ}$ (Fol. $19^{2} \mathrm{v}^{\circ}$.) L'Isagoge d'A thir al-Din al-Lhari.

Ils. daté de l'an 806 de l'hégire (1404 de J. C.).

Papier. 197 feuillets. Hauteur, 27 centimètres; largeur, 18 centimètres et demi. 15 lignes par page. - (Ancien fonds 1114.)

\section{1 .}

Le ماكّّص في الهيئة d'Al-Djaghmini.

Is. daté de l'an 896 de l'hégire (1490-1491 de J. C.).

Papier. 58 feuillets. Ilanteur, 22 centimètres; largeur, 15 centimètres et demi. 19 liģnes par page. - (Ancien fonds 1153.)

\section{2 .}

$1^{\circ}$ Même ouvrage.

$2^{\circ}$ (Fol. 26.) Tables pour trouver le complément de l'axe qui fixe l'heure de la prière du ber.

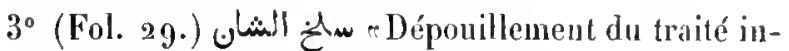
titulé Kitab al-Schán (Livre de l'affaire) ". L'auteur du كتناب
Uîn, le célebre théosophe Mohyì al-Dìn Ibn al-'Arabi, prétend expliquer le passage du Coran : شأر. Nous avons ici un abrégé de l'ouvrage, accompagné de plusieurs tableaux circulaires, an moyen desquels on peut trouver l'affaire de chaque jour de la semaine.

$4^{\circ}$ (Fol. $\left.35 \%^{\circ}.\right)$ Pièce de (cent huit) vers, dont roici le premier :

$$
\begin{aligned}
& \text { بحأت باسم الله في نظمم حسمس } \\
& \text { اذكر مـا جربـت ف طسول الزمهان }
\end{aligned}
$$

Le sujet de cette pièce nous échappe; mais il y a un endroit où il est question d'un collyre, et, plus loin, de la composition d'une eau merveilleuse.

$5^{\circ}$ (Fol. $39 \mathrm{v}^{\circ}$.) Ordjoûza sur les angures que l'on peut tires des rencoutres et des objets quon roit par accident. Le poème est divisé en chapitres, dont chacun est consacré à un objet particulier.

$6^{\circ}\left(l^{\circ} 0 l .51 v^{\circ}.\right)$ Sur les moyens employés pour déterminer l'azimut de la qibla. Ce traité se compose d'une introduction et de huit chapitres. Commencement : لـ . W.

$7^{\circ}$ (Fol. $59 v^{\circ}$.) Traité de Sibț al-Mâridinì sur l'emploi du quart de cercle à sinus. Introduction et cinq chapitres.

$8^{\circ}$ (Fol. $661^{\circ}$.) La qașida d'Avicenne, avec un commentaire. Ce poime nystique commence par ces mots :

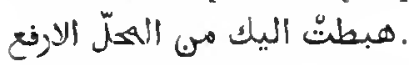

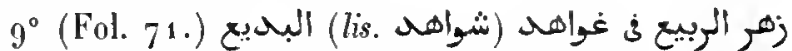
"Fleurs du printemps, pour servir d'illustrations du heau style», traité de rhétorique en quarante-trois chapitres, par Nàșir al-Dìn Moḷammad ibn Qorqamâs, mort, selon lladji Khalifa, en 882 de l'hégire (1477-1478 de J. C.).

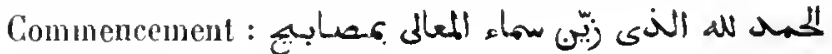

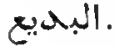

$10^{\circ}$ (Fol. $1071^{\circ}$.) Les Cent paroles ou maximes (ماية ¿®S) d'Ali, fils d'Aboû Tâlib, l'apportées par Djáfar alSidiq d'après la tradition de ses aïeux.

$11^{\circ}$ (Fol. 109.$)$ La qasida intitulée Toghnaii, avec le commentaire de Djamâl al-Din Mohammad ibn 'Omar al-Hadhramí. Le commentaire est très

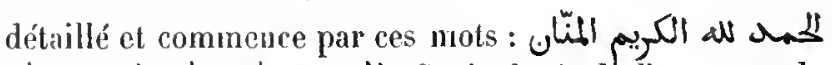

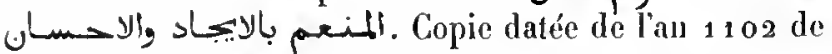
l'hégire $(1690-169$ de J. C.).

$12^{\circ}$ (Fol. $134 \mathrm{v}^{\circ}$.) Prières pour claque jour de la semaine.

\footnotetext{
${ }^{2}$ Comparez ei-dessus, $\mathrm{I}^{\circ}$ 2362, $2^{\circ}$. II. Z.
} 
$13^{\circ}$ (Fol. 136.) Litanie (טـــ/ du schaikh Al-Sanoûsî.

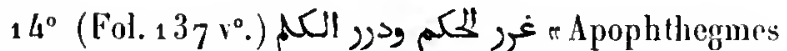
brillants et maximes précieuses $\%$, recneil de maximes atlribuées à 'Alì, fils d'Aboù Tálib, et elassées dans l'ordre alphabétique, par 'Abd al-Wâhid al-Âmidi al-Tamimí. Commencement : : La fin manque, et il y a des lacunes dans le corps du texte.

Papier. 159 fcuillets. Hauteur, 21 centimètres ; largeur, 15 cenlimètres et demi. Écritures diverses du xvi et du sru ${ }^{e}$ siècle. - (Ancien fonds 1, 40.)

\section{3.}

Le ملفّ d'Al-Djaghminì, arec le commentaire composé pour Oloûgh-Beg, en 8,5 de l'hégire (1412-1413 de J. C. ), par Hoûsâ ibn Mạ̣moûd Qàdlî̀ Zàdè al-Roûni. Notes marginales et figures astronomiques. Ms. daté de l'an 1000 de l'hégire ( $15 g_{1}$ de J. C.).

Papier. 8z feuillets. Hauteur, a 1 centimètres et demi; largeur, 15 centinètres. 19 lignes par page. - (Aucieu fonds 600.)

\section{4.}

$1^{\circ}$ Même ouvrage.

Copie datée de l'an 1016 de l'hégire ( 1607 de J. C.).

$2^{\circ}$ (Fol. $24 v^{\circ}$.) Commentaire de Moûsì ibn Maḷnoùd Qâdhî-Zàdè sur le vãّ d'Al-Djaghıminini.

Copie datée de l'an 1016 de l'héggire.

30 (Fol. 116 vo.) هيعة النغوغان. Traité d'astronomie en trente chapitres, par Abou 'L-Abbàs Aḷmad ibn Mohammad ibn Kathìr (ms. بـشيـ) al-Farghânì. C'est probablement l'ouvrage que l'on désigne sous le titre de ه res trente sections r. Commencement :

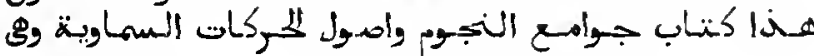

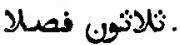

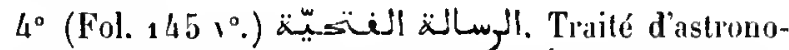

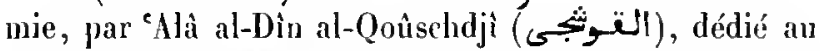
sultan oltoman Moḷammad II, surnommé Abou 'l-Fall.

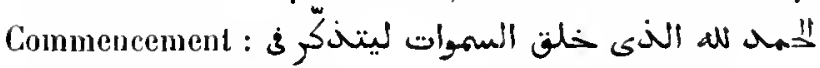

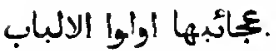

Copie datée de l'an $117^{\prime}$ de l'hégire $\left(1760 \cdot 17^{6} 1\right.$ de J. C.).

$5^{\circ}$ (Fol. $17^{4} v^{\circ}$.) Commentaire sur le traité précédent, par Miram (ميسمر) Tchelebi, petil-fils d'Al-Qoûschdjì. Louvrage est dédié au sultan Sélim, fils de Baya-

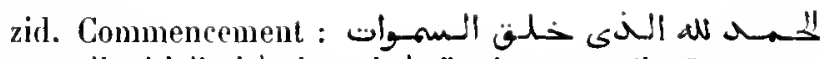

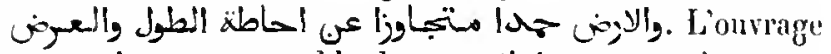
se termine par une table des quantités astronomiques.

(Voyez, sur ce ms. et sur les diverses traductions de l'Astronomie d'Al-Farghảni, la nolice de M. Wopcke dans le Journal asiatique, cahier de févier-mars 1862 , p. 112 et suiv.)

Papier. 268 feuillets. Hanteur, 20 centimètres et demi; largeur, 15 centimèlres. Écritures diverses. - (Supplément 95/ bis.)

\section{5.}

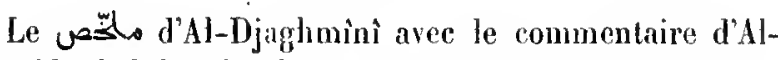
Sayyid al-Scharif 'Alì al-Djordjânì. Commencement :

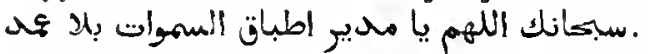

Papier. 122 fenillets. Hauteur, 22 centimètres; largeur, 12 cenlimètres. 17 lignes par page. Ms. du xvm ${ }^{\circ}$ siècle. - (Ancien fonds 115 s.)

\section{6.}

- Traité sur les cadrans solaires sans direction dé terminée et perpendiculaires à l'horizon, et sur leur enploi, par Abon 1-lath Sacid ibn Khafif al-Samargandi.

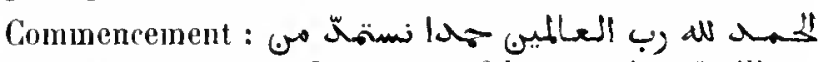

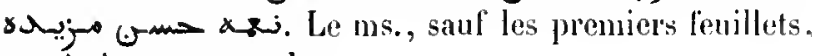
parait étre autographe.

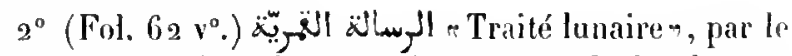
seluaikh Aboû Yoûsof. Inslructions pour calculer des nalivités el pour tirer des horoscopes d'après la position de la lume.

Papier. 65 feuillets. Hauteur, 18 centimètres; largeur, 19 centimètres. 17 lignes par page. Us. du ruv siècle. - (Ancien fonds 1220 , Colbert 6o6o.)

\section{7 et 2508 .}

Recueil de principes et de résultats $\%$, traité théorique et pratique de gnomonique et des instrmmenls astronomiques, par Al-llasan ibn 'Alì ibn 'Omir al-Marrâkoschì, auteur' du xum' siècle. Cet onnage a été traduit en français par J. J. Sédillot, sous le titre de Traité des instruments astronomiques des Arabes. Paris, $1834-1835$.

2 vol. Papier. 18 2 et 195 feuillets. Hauleur, 2 a centimètres; largeur, 16 centimètres el demi. 21 lignes par page. Us. du xiv siècle. Les derniers feuillets de claque volume sont d'une main plus récente. - (Ancien fonds 1147 ef 11/18.) 


\section{9 .}

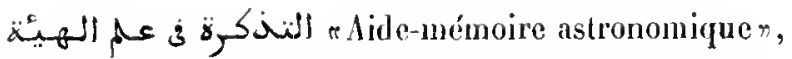

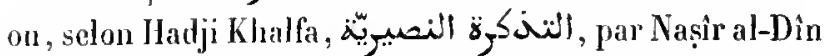
Moḷammad al-Ṭousi. L'ourrage est divisé en quatre sections (bâb), qui sont divisées en chapitres (faşl). La première seclion traite des connaissances préliminaires et dome lexplicalion des termes techniques; la seconde (fol. 6), composée de quatorze chapitres, traite des corps célestes; la troisième (fol. 52), en douze chapitres, de la terre, et la quatrième (fol. $7^{2}$ ), en sept chapitres, des distances et des masses des corps célestes. Cet exemplaire, daté de l'in 791 de l'hégire ( 1389 de J. C.), renferme plusieurs figures tracées arec soin. Le texte est accompagné de notes marginales et interlinéaires, et il y a deux notes détachées, aljoutées après coup (fol. 6 bis et 7 bis), dont l'une domne un extrait du Lamac, ouvrage altribué à Al-Djaghminini.

Papier. 83 feuillets. Hauteur, a a centimètres et demi; largeur, 15 centimètres et deni. 15 liggnes par page. Ms. du xiv sièete. (Supplément 962.)

\section{0.}

توضيح التخكرة Commentaire de l'ouvrage précédent, par Al-ḷasan ilm Moḷammad al-Naisâboûri, surnommé Nizim. L'auteur dit avoir composé ce commentaire en 711 de l'hégire ( $3_{1}{ }_{1}$ de J. C.). Un grrand nombre de figures géométriques sont intercalées dans le texte.

Papier. 255 feuillets. Ilauteur, so centimètres; largeur, 10 ecnlimètıes. 16 lignes par page. Ms. du xiv siècle. - (Supplément 963.)

\section{1.}

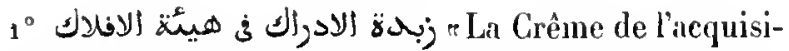
tion, touchant la forme des sphères $n$, triité élémentaire d'astronomie, par Nașìr al-Dìn Mloḥammad al-Ṭoûsî.

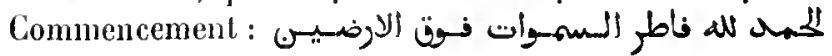
واجاعلها عبرة للناظربي المتنوسّمين.

$2^{\circ}$ (Fol. $21 v^{\circ}$.) Gloses sur le texle arabe du سى فصل de Nașir al-Dìn al-Ṭousì. L'auteur, 'Abd al-Wàhid ibn Mohammad, a composé ce commentaire en 797 de l'hégire $\left({ }_{1} 3_{9} 5\right.$ de J. C. $)$.

Papier. 68 feuillets. Hauteur, a 2 centimètres; largeur, 16 centimètres. 21 liggnes par page. Ms. du $\mathbf{x u}^{\mathrm{e}}$ siècle. - (Aneieu fonds ${ }_{11} 51$.)

\section{2.}

"Trente chapitres», éphémérides astronomiques, par Naṣir al-Dìn al-Ṭoùsî, texte arabe, accompagné d'un commenlaire, par un anonyme. On lit dans le commentaire, après la doxologie : أما بعد فال

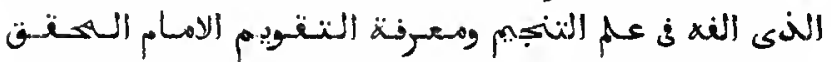



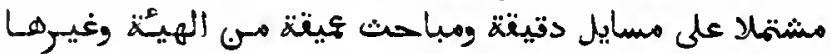

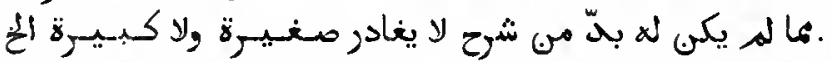
On trouve quelques délails sur l'ouvrage d'Al-Toûsî dans le tome II du Catalogue des manuscrils de la bibliothèque Bodléienne, page 30o. Hadji Khalfa a meutionné cet ouvrage dans son Dictionnaire bibliographique, tome III, page 642. D'après une nole qui se tronve en tête du ms., celui-ci avait appartenu à Mouley Zìdàn, empereur du Maroc, au commencement du xvil siècle : مى كتب عبد

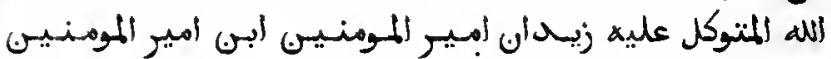

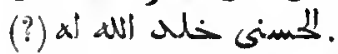

Papier. 64 fenillets. Ilauleur, 18 eentimèlres; largeur, 13 centimètres, ${ }_{7}$ ligues par page. Ms. du $x^{\circ}{ }^{\circ}$ sièele. - (Ancien fonds 1 140.)

\section{3.}

Tables astronomiques. Ourrage sans titre ni nom d'auteur, divisé en quatre parties : $1^{\circ}$ sur les ères et les fêtes; $2^{\circ}$ sur les mouvements des corps célestes, avec tables; $3^{\circ}$ sur l'usage des tables pour déterminer les positions des corps célestes; $4^{\circ}$ tables supplémentaires pour faciliter les calculs. Les derniers feuillets manquent. Un titre apocryphe, qu'on lit au commencement, attribue l'ouvrage à lbn Yoûnos. Le second feuillet, qui est le premier de l'ouvrage, est d'une main plus moderne. Le folio 94 est couvert de notes astronomiques.

Papier. $9^{4}$ feuillets. Hauteur, 21 centimetres; largeur, 14 centimètres et demi. 23 lignes par page. Ms. du xun siècle. - (Supplément 966 .)

\section{4.}

Deux séries de Tables astronomiques, dont la première indique les heures temporaires et équinoctielles, Ja longueur des ombres du cadran et l'altitude de l'aşr pour cliaque degré de hauteur du soleil, et pour chaque degré de latitude; la seconde série donne l'ascendant et le lieu de l'ascendant des principales étoiles du zodiaque pour 
chaque degré de hauleur. Il n'y a pas de préface. Une rubrique quion lit an commencement el qui, probablement, est de la mème main que le reste du ms., nous apprend que ces tables, intitulées بables du capuchon $\pi$, sont nocturnes el diurnes, qu'elles n'indiquent que les heures et qu'elles ont été écrites le qualrième jour du mois de djomádà premicr de l'an $6_{1}$ a de l'hégire (3, aoutt 1215 de J. C.). Voici le lexte de cello

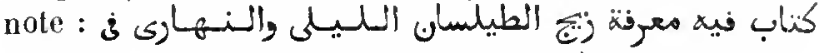

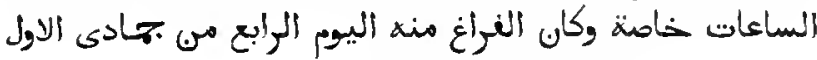

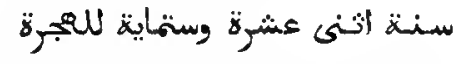

Papier. ${ }^{49}$ feuillets. Hauteur, 22 centimètres et demi ; largeur, 18 centimètres. - (Supplément 958.)

\section{5 .}

Traité d'astronomie mathématique, en ringt-deux chapitres (ä), sans prélace ni nom d'auteur. Un titre qui a été collé après coup sur le premier feuillet porte que

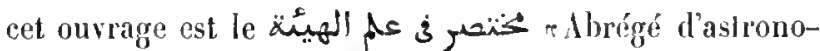
mien, d'Athir al-Din al-Mofaddhal ibn 'Omar al-Abhari' . Al-Abharì, mort vers l'an 700 de l'hégire (1300-1301 de J. C.), n'est connu que par un abrégé de lsagoge de Polphyre. Contenu des vingt-deux chapitres: $1^{\circ}$ Notions préliminaires, neuf figures; $2^{\circ}$ sur la forme des cieux el de la terre; $3^{\circ}$ sur les sinus et les cordes, six fignres; $44^{\circ}$ sur les ombres, deux figures; $5^{\circ}$ sur les propriélés des triangles sphériques, cinq figures; $6^{\circ}$ sur l'obliquilé de l'écliplique, sept figures; $7^{\circ}$ sur la latitude du ticu el la longueur des jours, sept figures; $8^{\circ}$ introduction à la connaissance des diver's mouvements des étoiles, sept figures; $9^{\circ}$ sur l'observation des étoiles et sur la canse de l'irrégularité de leurs mouvements, cinq figures; $10^{\circ}$ sur tes changements des mourements des étoiles dans la sphère de rérolution, huit ligures; $11^{\circ}$ sur les changements des mourements des étoiles dans l'excentrique, qualre figures; $12^{\circ}$ sur les mouvements et les sphères du soleil, seize figures; $13^{\circ}$ sur les mouvements et les sphères de la lane, sept figures; $14^{\circ}$ sur les mouvements at les splieres des astres supéricurs, trois figures; $15^{\circ}$ sur les mourements et les sphieres de Vénus et de Mercure, deur figures; $16^{\circ}$ sur les mouvements directs et rélrogrades des cinu astres, quatre fignres; $17^{\circ}$ sur la latitude des étoiles, deux figures; $18^{\circ}$ sur la latitude des étoiles fixes; $19^{\circ}$ sur l'ascendanl, cinq figures; $20^{\circ}$ sur les aspects de la lune
(3), huit figures; $21^{\circ} \mathrm{sur}$ les éclipses, trois figures; $22^{\circ}$ sur les problemes (J歽) qui restent ¿ indiquer, cing figures; conclusion : sur l'ordre des sphères.

Les nombreuses figures sont dessinées arec soin.

Papier. 67 feuillets. Ilauteur, 26 centimètres; largeur, 17 centimètres et demi. 21 lignes par page. Ns. du $x v^{e}$ siècle. - (Supplément $9{ }^{5} 7$, Saint-Germain 14..)

\section{6.}

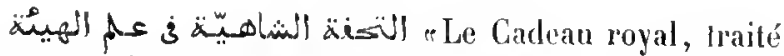
d'astronomier, pal Mạ!moùd ibn Mascoûd al-Schìràzì, vizir du prince Modjir al-Dìn Tảdj al-lshàm Amir-Schàh, fils de Hotazz, lils de Tàhil. L'ouvrage est divisé en quatre parties, dont la première contient des notions

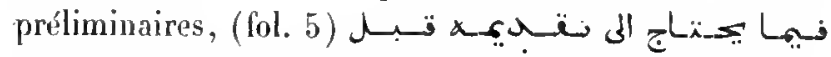
في هئية , المثروع

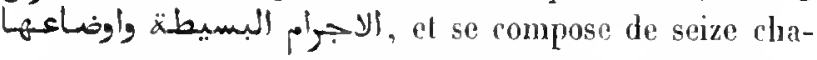
pitres; la troisième (fol. $711^{\circ}$ ) traite de la terre, هئ

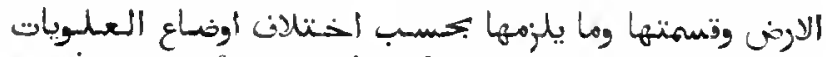

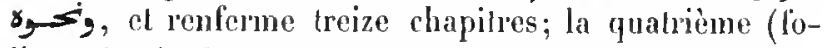
lio $103 \mathrm{r}^{0}$ ), des distances et des masses des corps célestes. Un assez grand nombre de diagrammes accomparnent le texte. Selon Hadji Khalfi, l'auteur est mort en 710011720 de l'luégire ( 31 o ou 1320 de J. C.). Commen-

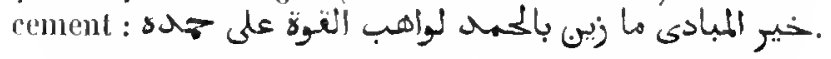

Copie exéculée à Sivàs, en 68 4 de l'hégire (1 285 de J. C.), du vivant de l'ituteur.

Papier. 118 feuillets. Hauteur, 25 centimètres; largeur, 20 centimétres. 21 lignes par page. - (Supplément a3.j.)

\section{7.}

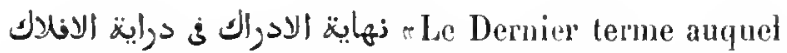
on puisse atteindre dans la connaissance des sphères célestes ", traité d'astronomie, par Qoṭ al-Dìn al-Malumond iłn Mascoûd al-Schìràzi. Cel ouvrage est divisé en quatre parlies. La première partie expose les connaissances néressaires pour celui qui reut aborder le sujel; la seconde traite des corps célestes; la troisième, de la terre et de ses divisions; ta quatriène, des distances ut des masses

'Le premier feuillet a été réparé, nais le titre appartient au ms. et il est de la main du copiste. H. Z. 


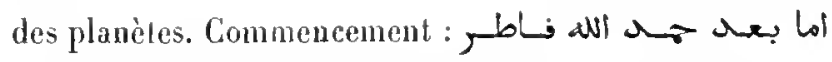

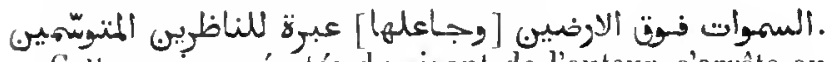
Celte copie, exécutée du visant de l'auteur, s'arrête au milieu de la troisième section. L'écriture, en majeure parlie, est dépourve des points diacritiques; les figures sont dessinées aver soin.

Papier. 126 feuillels. Hauteur, 17 centimètres; largenr, 13 centimètros. 23 à 29 lignes par page. - (Ancien fonds 1150.$)$

\section{8.}

Mème ourragge.

Ms. daté de l'an 1200 de l'hégire $(1785-1786$ de J. C.).

Papier. 284 feuillets. Ilauteur, 24 centimètres; largeur, 14 centimètres et demi. 15 lignes par page. - (Supplément 969. )

\section{9.}

$1^{\circ}$ Premier et dernier fenillel du traité d'Abd al-

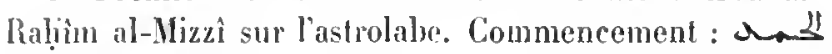

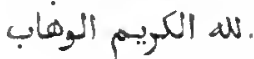

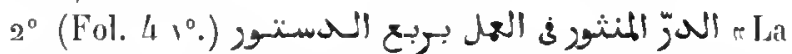
Perle délacliée, indiquant l'usage du quart de cercle appelé destoûr $n$, trailé d'astronomie pratique, appliquée j̀ la détermination des lieures, en soixante chapitres, par Sibṭ al-Màridinî. Commencement :

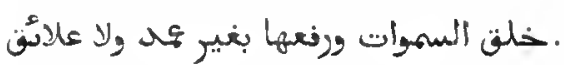

30 Fol. 52. 2. Ourrage où l'on trouve indipué la manière d'opérer arec le quart de cercle a sinusr, par Badr al-Din Molımmad ibu Mohammad ibn Aḷmad, mouraqqit de la mosquée d'Al-Azhar, connu sous le nom de Sibt al-Maridini, mort en 934 de l'hégire (1527-1528 de J. C. ). C'est un traité complet d'ashonomie pratique, en cent rinquante chapitres.

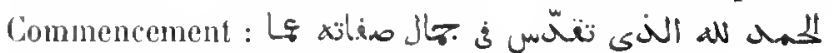
. Les derniers fuillets manquent.

$4^{\circ}$ (Fol. 1 13.) Notes diverses, relatives à l'astronomie.

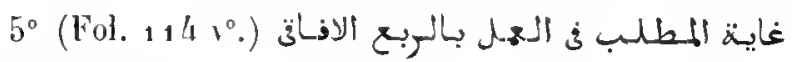

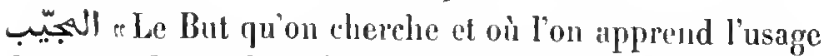
du quarl de cercle universel à sinus\%. Liourrage est divisé en trois sections (fenn). Le nom de l'auteur est inconnu. Commencement: : Eئ. Entre les folios 167 et 170 se trouve intercalé le traité suivant: $6^{\circ}$ (Fol. 1 68.) Une ordjoúza sur l'astronomie, par Abou 'l-Khaïr, fils du cadi Aboù Sa'oûd. La fin de cette pièce de vers se trouve au fol. $19^{5}$.

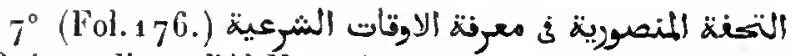
"Présent digne d'Al-Mllanşoûr et enseignant à reconnaitre les lieures fixées par la loi (pour la prière)." Traité sur l'astrolabe, en vingt chapitres, par Badr al-Din Mohammad ibn Moḥammad al-Màridînì. Nous ignorons si le non de Manşoûr "le victorieux", mentionné dans le titre, désigne le sultan ottoman Sélim, le conquérant de l'Egypte, ou un autre prince. Cet exemplaire a été écrit en l'an 897 de l'hégire el corrigé sous les yeux de l'auteur.

$8^{\circ}$ (Fol. $195 v^{\circ}$.) Traité ( faṣl) en douze chapitres sur l'usage du quart de cercle appelé وبع المتنطرات

$9^{\circ}$ (Fol. $2021^{\circ}$.) Traité (faşl) en dix chapitres, sur l'usage du quart de cercle à sinus.

$10^{\circ}$ (Fol. $213 \mathrm{r}^{\circ}$. ) Opuscule en treize chapitres, sur l'usige d'un instrument astronomique ayant la forme d'un demi cercle, dont la circonférencè est divisée en quatrevingt-dix parties égales et le rayon en soixante parties. Conmencement:

$11^{\circ}\left(\right.$ Fol. $217 v^{\circ}$.) Traité en dix-huit chapitres sur un instrument astronomique, ressemblant beaucoup à celui qui est décrit dans l'article précédent et appelé الغيب, par Schams al-Din al-Ghazoûli.

Papier. 2 as feuillets. Hauteur, 18 centimètres; largeur, 13 centimètres et demi. Écritures diverses du $\mathrm{r}^{\circ}$ siècle. - (Ancien fonds 1158.$)$

\section{0 .}

$1^{\circ}$ Les huit premiers feuillets (cotés A, B, etc.), d'un Iraité d'astronomie en quatre sections, dont la première traite des ères; la seconde, des mouvements des astres; la troisième, des opérations usitées pour observer ces mouvements, et la quatrième, des calculs qui lacilitent ces opérations. Ce fragment renlerme une partie de la première section. Il n'y a pas de préface. Un titre ajouté apres coup, بles Tables techniques (?) d'Ibn Yoûnos $\pi$, est apocryphe, car le flball a pour auteur un calculateur nommé Moluammad ibn Moḷammad al-Fàriqî.

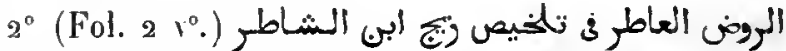
"Le Jardin parlumé, sommaire des tables d'lbn al-Schàtir's, par Mohammad ibn 'Ali ibn fbrâhîm, surnommé lbn Zarin al-Khaïri. C'est une collection de tables précédées d'une introduction. Elle se termine par une table des latitudes et longitudes et une table des sinus. A la 
fin du volume on troure deux tableaux circulaires, dont l'un représente l'orientation des divers pays vers la

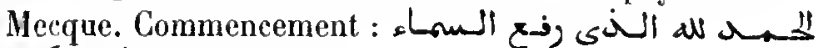
بتحرته ودبر الانلكك بككنه

Papier. ${ }_{7} 5$ feuillets, plus les fenillets $\mathbf{A}$-H préliminaires. Hauteur, 18 centimètres et demi; largeur, 12 cenlimètres et demi. 17 lignes par page. Ats. du xiv" siècle. - (Ancien fonds 1144.$)$

\section{1 .}

$1^{\circ}$ Deux fragments (le commencement et la fin) de

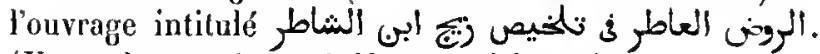
(Voyez le numéro précédent, article $3^{\circ}$.)

$9^{\circ}$ (Fol. 11.) Deux tables, dont l'une fait commaitre la concordance de l'annće lunaire avec l'annće solaire, et l'autre (à une minnte près), les positions du soleil, jusqu'à la fin de l'an 1000 de l'hégire. L'introduction commence par' ces mots : فيساء

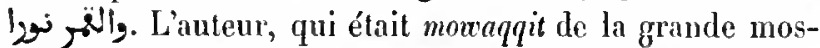
quée de Damas, se nommait Mlọammad ibn Moḥammad ilon abi Bakr al-Tizini (التينينى).

$3^{\circ}$ (Fol. 19.) Tables du soleil, de la lune et des planètes, table d'élections (أختيبارأ), tables de jugements astrologiques, elc.

$4^{\circ}$ (Fol. 91.) Mélange d'astronomie, d'astrologie et de chronologie.

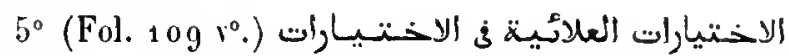

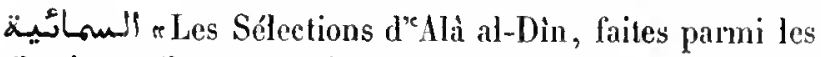
b́lections célestes $\pi$, traité d'astrologie composé originairement en persan, par' Fakhr' al-1)in 'Omar al-Râzì pour le sultan 'Alà al-Dìn Mohammad ibn Khwarizm-Sehâh, et traduit en arabe par un anonyme. Commencenrent : Un ألمالم

$6^{\circ}$ (Fol. $124 v^{\circ}$.) Traité sur les vertus secrìtes des lettres de l'alphabet.

$7^{\circ}$ (Fol. 129.) Calendrier perpétuel, intitulé :

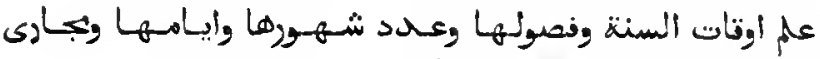
النشمس في بروتها

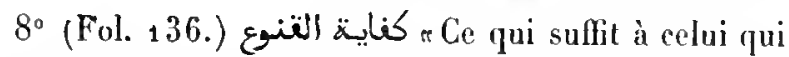
se contente de peu», traité sur l'usage du quart de cercle appelé الوبـ المبع , par Badr al-Dìn Molımmad Sibt al-Màridini.

$9^{\circ}$ (Fol. 137 Vo.) r Les Étoiles brillantes, traité sur l'usage du quart de cercle à sinusn, par Aboû Horaïra 'Abd al-Raḷmân Mas. orientaux. - Il.

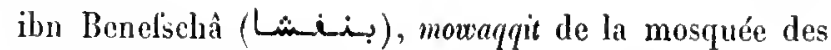
Omayyades, à Damas.

$10^{\circ}$ (Fol. $139 v^{\circ}$.) Deseription d'un astrolabe appelé دائرة المعدّ, et instructions pour son usage, par l'inventeur de cet instrument, 'lzz al-Din 'Abd al- $A z i z$ al-Wafäi, motraqqit de la mosquée de Damas. (Vojez ci-après, $n^{\circ} 2544,7^{\circ}$.)

En tête du volume on trowve une recette pour faire de l'enere noire, et quelques extraits d'un traité d'astrologie, par Abou 'l-ḷasan Koûsclyaùr ibn Labbàn ibn Bàschahrì al-Djilì.

Papier. 154 fenillets. Hauteur, 31 centimètres et demi; largeur, 17 centimètres. Écritures diverses du $\mathrm{xv}^{\circ}{ }^{\circ}$ siècle.-(Ancien fonds 1128.$)$

\section{2 .}

Tables du solcil, de la lune et des planètes, par "Alaï al-Dîn Ibn al-Schâțir. Le commencement manque. Le prenier levillet du ms. porte le titre de جله

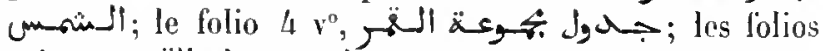

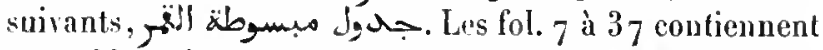
une table qui parait se rapporter à la lune. Au fol. $371^{\circ}$ commencent les tables de Saturne; au fol. $61 \mathrm{v}^{0}$, celles de Jupiter, dresscées d'après les observations liaites au Caire, long. $54^{\circ} 30^{\prime}$; au fol. $66 \vee^{\circ}$, les tables de llars; at fol. $801^{\circ}$, celles de Vémus; au fol. $931^{\circ}$, celles de Mercure. Toutes ces tables ont été dresscées d'après des observations faites au vieux Caire par 'Aliï al-Dìn ibn al-Schâtir, de Damas, mort, d'après Hadji Khalfa, en 777 de l'hégire $(1375-1376$ de J. C. $)$. Les sept demiers feuillets du volume renferment les أبهات du soleil et de la lune, dressés par un calculateur qui a écrit de sa propre main, en caractères cursifs, une noteque nous lisons ainsi : o

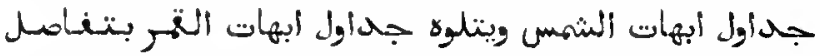

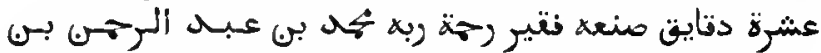

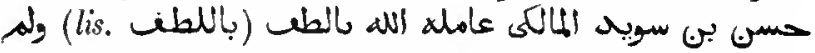

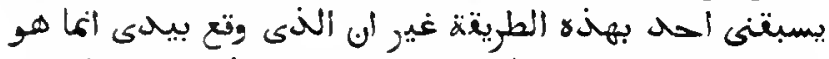

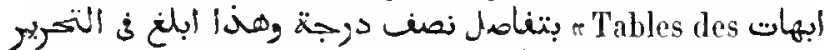
du soleil, suivies des tables des sées pour loutes les dix minutes, par l'humble serviteur du Seigrneur, Moṭanmad, fils d'elbd al-Rahnuân, fils de !lasan, fils de Sowaïd al-Mâliki, que Dien le traite avee bonté! Personne ne m'a surpassé dans cette voie (ou gemre de (ables), car les tables qui me sont tombées entre les mains n'étaient dressées que pour claque demi-degré; mais celle-ci offre une plus grande exactituden.

Papier. 113 feuillets. Hantenr, 25 centimètres et demi; largeur, 17 centimètres. Ms. du $x \mathbf{x i}^{\mathrm{e}}$ siècle. - (Ancien fonds 607.) 


\section{3.}

Tables astronomiques, précédées d'une introduction, où l'auteur traite de la concordance des ères et des opérations par lesquelles on détermine les positions des planètes, les heures, les éclipses, etc. Le commencement manque.

Quatre feuillets provenant d'un ms. arménien ont été reliés au commencement et à la fin du volume.

Papier. 107 fevillets. Hauteur, 24 centimètres; largeur, 17 centimèlres. Dans l'introduction, environ 23 lignes par page. Ms. du xiv" siècle. - (Ancien fonds 1143, Colbert 4202.)

\section{4.}

$1^{\circ}$ Sur l'usage du quart de cercle astronomique», par Ạmad ibn Khalil al-Fàklıû́rì.

$2^{\circ}$ (Fol. 8.) Observations apparemment astrologiques relatives aux premiers mois de l'année copte. Cette pièce porte le titre apocryplie de وسالة ف المعل بالاسطرلب.

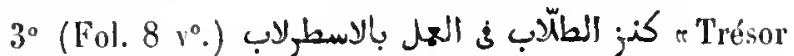
pour ceux qui cherchent, traité sur l'usage de l'astrolaben, par le sclıäkl Nâsir al-Din ibn Samoounn. C'est une compilation faite d'après le traité d'Abou 'l-Ṣalt, d'après l'abrégé de ce mème traité, par Ml-Marrâkoschi, et d'autres ouvrages. Le présent opuscule est divisé en quatre chapitres $(b a ̂ b)$, dont chacun renferme cinq sections $($ fassl).

Ces trois pièces sont de la même main.

$4^{\circ}\left(\right.$ Fol. $21 \mathrm{v}^{\circ}$.). Sur l'astrolabe et son emploi. Ce traité se compose de quatre discours (ôlon), dont chacun est divisé en plusieurs sections (فصلم). Le texte est accompagné de tables, de figures et de notes marginales. Le premier feuillet manque; l'écriture du recto du second feuillet est effacée en plusieurs endroits.

$5^{\circ}\left(F_{0}\right.$ l. $85 v^{\circ}$.) Sur l'astrolabe et son emploi. Traité sans titre ni nom d'auteur, divisé en vingt sections

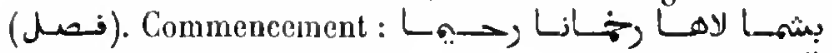
(c'est la forme syriaque du Bismillah) ح w W

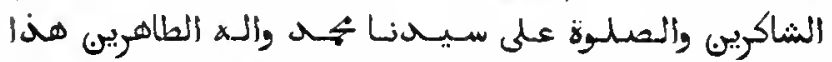

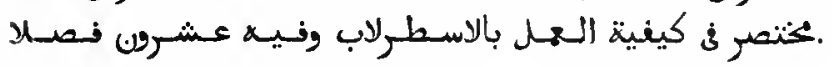
Quelques figures. La copie est datée de l'an 815 de l'hégire (1412 de J. C.).

$6^{\circ}$ (Fol. $9^{6 .)}$ Explication du bissexte. En turc.

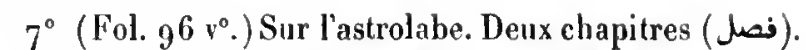

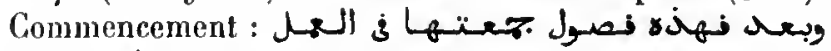
. Cet opuscule, copié l'an 8.5 de l'hégire, est de la même main que l'article $5^{\circ}$.

$8^{\circ}$ (Fol. 102.) Sur l'usage de l'astrolabe. Même écriture el même date que dans l'article précédent.

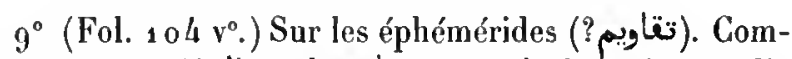

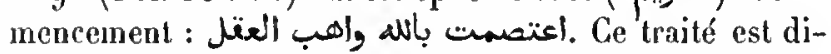
visé en trente chapitres (فصل), mais la fin du chapitre v, les chapitres vı et vı, le commencement du chapitre vuı et les treize derniers ehapitres manquent. Le premier chapitre énumère les valeurs numériques assignées à chaque lettre de l'alpliabet; le deuxième, les jours de la semaine; le troisième traite de l'année arabe; le quatrième, de l'année des Grecs; le cinquième, de l'année des Perses; le neuvième, de la durée des révolutions du soleil, de la lune et des planètes; le dixième, du zodiaque; le onzième, des beures du jour et de la ıuit; le douzième, des aspects réciproques des planètes; le trei-

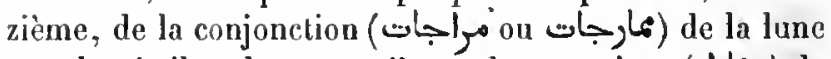
avec les étoiles; le quatorzième, des mansions (منار) de la lune; le quinzième, de l'apparition et de la disparition des étoiles; le seizième est intitulé dix-septième traite des maisons (بيوت) des étoiles. L'écriture est presque partout dépourvue de points diacritiques.

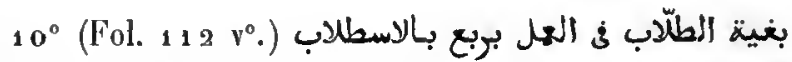
(sic) «Le Traité souhaité des amateurs, ayant pour sujel l'usage de l'instrument appelé le quart d'astrolaben, par Aḥmad ibn Ibrảhîn ibn Khalil al-Halabì. Commence-

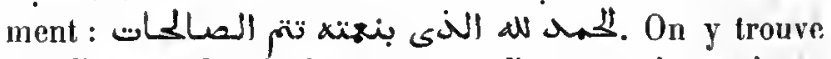
l'explication de plusieurs termes d'astronomie pratique. La fin manque.

$11^{\circ}$ (Fol. 120.) Notes et dissertations astrologiques et cabalistiques, dont l'une est intitulée le Livre de Daniel ( fol. $124 \mathrm{v}^{\circ}$ ). Ces textes, d'une écriture moderne, renferment de nombreuses fautes d'orthographe.

Papier. 127 feuitlets. Hauteur, 18 centimètres el demi ; largeur, 13 centimètres. 2 I lignes par page. Écritures diverses du $x_{1 v^{\circ}}$ et du $\mathrm{xv}^{\circ}$ siècle. - (Ancien fonds 613.$)$

\section{5 .}

1 Tables trigonométriques et astronomiques, calcu-

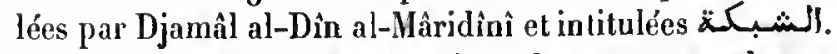
La première table donne les sinus des arcs pour chaque minute du cadran. 
$2^{\circ}$ (Fol. 37.) Catalogue d'étoiles fixes, avec l'indication de leurs positions.

Papier. 54 feuillets. Hauteur, 19 centimètres; largeur, 13 centimètres. Ms. du xv' siècle. - (Ancien fonds 1155, Colbert 60o6.)

\section{6 .}

年 tions relatives aux sept planètes $\%$. Tables astronomignes, calculées pour la latitude du Caire, par Schihâb al-Dìn Ahnrad ibn Gholàm Allah, connu sous le nom d'Al-Koủm al-Rîsclî, mowaqqit de la mosquée d'Al-Malik al-Mowayyad (fondée au Caire, près de la porte de Zowaila, en 818 de l'hégire, par le sultan mamlouc Al-Malik alMowayyad Aboû Naṣr Schaïkh al-Mạmmoûdî). Dans l'introduction, l'auteur dit que ce traité est un abrégé commode et ulile d'un grand ouvrage qu'il avait composé,

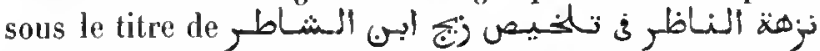
"Délices du lecteur, rédaction abrégée des Tables d'lbn al-Schàtir $\%$. Il donne des instructions pour l'emploi des tables, qui font connaitre la concordance des ères et des dates, les fìtes, les positions des planètes, les mouvements direets et rélrogrades, les plus grandes hauteurs dı soleil et les heures équinoctielles, les points de lever des signes du zodiaque, selon les différents pays, les conjonctions et oppositions, les éclipses, les occultations des eing planètes, les conjonetions des planètes, cte. Une des dernières tables donne les latitudes et longitudes de plusieurs villes, ainsi que l'azimut de la qibla.

Ms. daté de l'an 1,46 de l'hégire (1 733 de J. C.).

Papier. 53 feuittlets. Hauteur, 33 centimètres; largeur, 16 centimètrcs. - (Supplément 960.)

\section{7 .}

Même ouvrage. Copie datée de l'an 1177 de lhégire ( 1764 de J. C.).

Papier. 48 feuillcts. Hauteur, 31 centimètres; largeur, 21 centimètres. - (Supplément 959.)

\section{8 .}

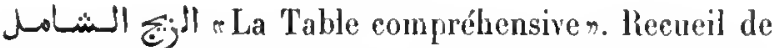
tables astronomiques, par un auteur anonyme, dont voici la prélace (corrigée d'après le ms. 2530) : $\lambda_{-1}$

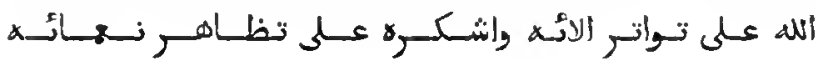

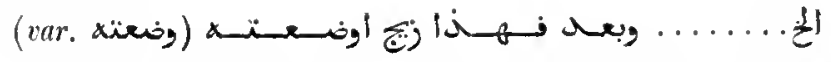

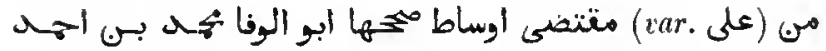

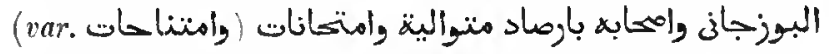

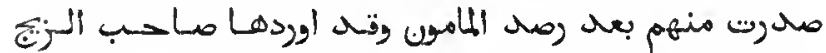

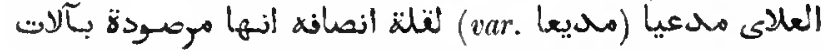

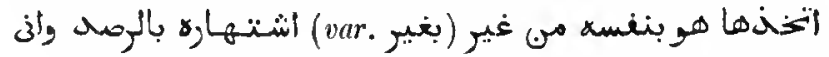

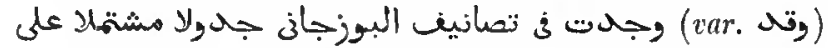

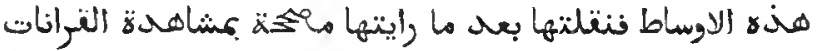

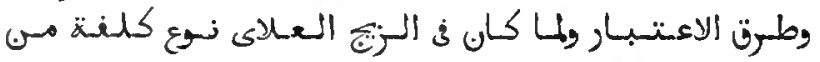

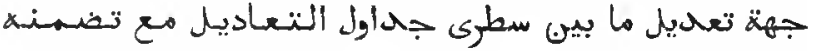

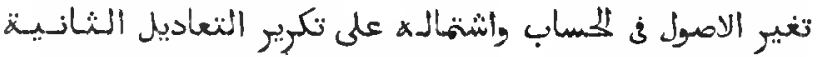

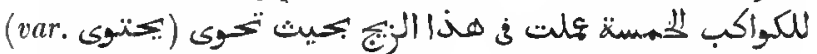

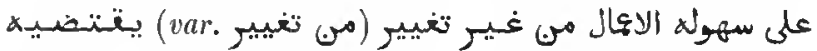

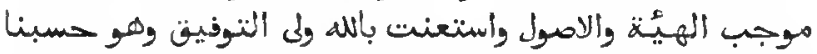

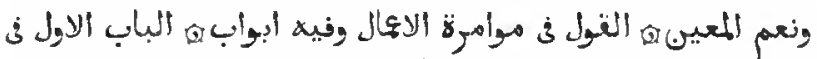

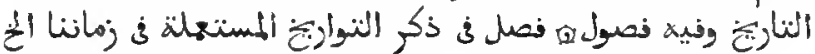
"Je loue Dieu de ses nombreux bienfaits et je le remercie de la manifestation de ses gràces, ete. J'ai dressé ces tables, conformément aux résultats moyens dont Abou 'l-Wafí al-Boùzdjàni et ses compagnons avaient constaté l'exactitude par des observations répétées et par des expériences dont ils furent les auteurs, (et cela) à la suite des observations d'Al-Hamoûn. Ces résultats moyens avaient ćlé publiés par l'anteur du Zidj al-'Alâi (voyez la Bibliographic de Hadji Khalfa, t. III, p. 567), qui, dans sa déloyauté, disait les avoir obtenus lui-mêne à l'aide d'instruments de son invention, el (cela) bicn quil fût peu connu comme observatẹr. Ayant trouvé, moi, parmi les traités d'Al-Bouzdjâni, une table renfernant ces résultats moyens, je les ai reproduits (ici), après les avoir vérifiés par l'observation des conjonetions et par d'autres modes d'examen. Comme le Zidj al-Aläi offrait un certain inconsénient, par rapport à la manière dont lantenr arail fait correspondre l's deux colonnes d'ěquations, et qu'on y remarquait des changements dans les formes de calcul usuelles, ainsi que la répétition des équations du second ordre pour chacune des cinq planètes, j’ai rédigé cette table de manière à en faciliter l'emploi et sans rien changer aux règles essentielles de l'art astronomique. Je demande à Dieu son secours et sa faveur; lui seul me suffit, et il est le meilleur des soutiens! Discours sur l'emploi des Tables, en plusicurs cliapitres. Chapitre ${ }^{\text {cr }}$, sur la chronologie, en plusicurs sections. Scetion: sur les ères employées de notre temps, etc.

Dans ce discours, qui est assez court, l'auteur traite des ères et de l'emploi des tables pour la solution des problènes. La prenière table domne les sinus et les sinus 
verses; une autre indique les ombres du cadran; une aulre (fol. $19 \mathrm{r}^{\circ}$ ), la latitude et la longitude de plusieurs villes. Le reste du volıme est consacré aux tables du soleil, de la lune et des cinq planètes. Toutes ces tables, ì l'exception des deux derniers feuillets, sont écrites avec beaucoup de soin et paraissent être du $\mathrm{xv}^{\mathrm{e}}$ siècle. L'introdnction est d'une autre main et paraît dater du xvie siècle. Une table supplémenlaire, écrite an verso du premier feuillet, porte la date de 882 de l'hégire (1477 de J. C.). Le titre quion lit en tète du uns. et qui désigne ces tables comme les Tables d'Al-Ma'moun, est apocryphe. Dans l'introduction, le nom d'Abou 'l- Wafà a été effacé el remplacé par celui d'Al-Ma'moûn.

Papicr. $7^{3}$ feuillets. Hauteur, 31 centimètres; largeur, 21 centimètres. 27 lignes par page. - (Ancien fonds 606 , Colbert 749.$)$

\section{9 .}

Même ouvrağe. Lintroduction est d'une autre main que les tables.

Papier. $7^{6}$ feuillets. JJauteur, 22 centimètres; largeur, 14 centimèlres. Dans l'introduction, 17 lignes par page. Ms. du $\mathbf{x v}^{\circ}$ siècle. Ancien fonds 1141.)

\section{0 .}

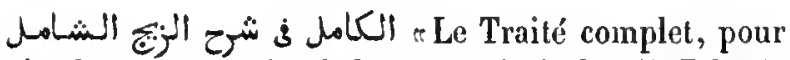
servir de commentaire à l'ouvrage intitulé Al-Zidj al-

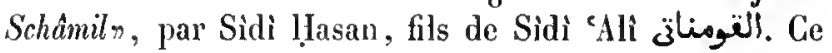
commentaire, assez étendu ef renfermant lui-même des figures et des tables, a été composé en 822 de l'hégire ( 1419 de J. C.), sous le règne et sous les auspices du sultan ottoman Moḷammad, fils de Bayazet, fils d'Amurath.

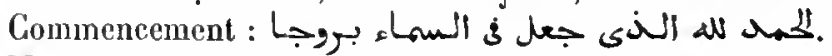
Ms. daté de l'an 1121 de l'hégire $\left(17^{\circ} 9^{-1} 710\right.$ de J. C.). On a altéré ce chiffre en changeant IIrI en $\mathrm{Ar}$.

A la fin se trouvent des noles et extraits divers, les uns en arabe, les autres en turc, parmi lesquels on remarque un poème religieux composé de cinquante quatrains, par

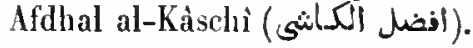

Papier. 118 feuillets. JJauteur, 18 centimètres; largeur, 13 centimètres et demi. 15 liģnes par page. - (Ancien fonds 608.)

$$
\begin{aligned}
& 2531 .
\end{aligned}
$$

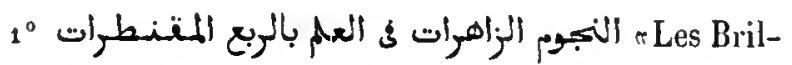

lantes étoiles, trailant de l'usage du quart de cercle ap-

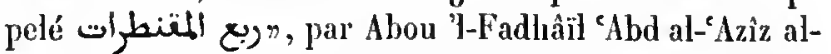
Wafài. L'auteur dit avoir rédigé cet ouvrage, divisé en vingl-cinq chapitres, à l'aide des deux traités de Schams al-Dín Moḷammad al-Mizzî et de Djamâl al-Dìn 'Abd Allah al-Mâridìni.

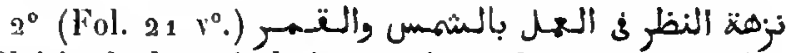
- Plaisir de la spéculation, traitant des opérations (de calcul) relatives au soleil et à la lune", par le même auteur. Cet ouvrage est également divisé en vingt-cinq chapitres, précédés d'une introduction et suivis d'un appendice. Lintroduction traite des lignes tracées sur le quart de cercle et de leurs noms; l'appendice, des heures de la prière et de l'observation de la nouvelle lune. Cet opuscule est accompagné de trois tables.

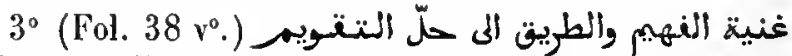
"Ce qui suffit pour l'lomme intelligent, et manière de résoudre les problèunes au mojen des tables», par Abou 'l-c Abbâs Schilıâb al-Dìn A ḥmad lbn al-Madjdì. Cet opuscule renferme trois chapitres : $1^{\circ}$ sur les années et les fètes; $2^{\circ}$ sur le calcul des lieux des sept corps célestes; $3^{\circ}$ sur les conjonctions, les oppositions, les ascendants, etc.

$4^{\circ}$ (Fol. 8o.) Autre traité sur le mềne sujet. Suivent trente-trois pages de tables, dont les dernières sont attribuées à Ibn Yoủnos.

Ms. daté de l'an $88_{7}$ de l'hégire ( 1482 de J. C.).

Vélin. 131 feuillets. Hautcur, 2o centimètres et demi; largeur, 15 centimètres et demi. 20 lignes par page. - (Supplément $9^{67}$, Saint-Germain 387.)

\section{2.}

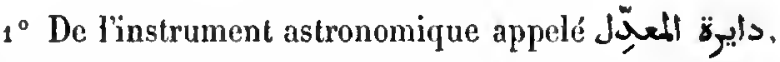
et instructions pour son usage, par 'Abd al-'Azìz al-Wafâi, inventeur de cet instrument. Copie datée de l'an 911 de l'hégire (1505-1506 de J. C.).

$2^{\circ}\left(\right.$ Fol. $20 \mathrm{v}^{\circ}$.) De l'instrument astronomique appelé

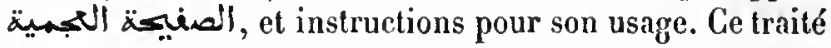
se compose d'une introduction, de quinze chapitres et d'un appendice.

Papier. 39 feuillets. Hautcur, 16 centimètres; largeur, 10 centimètres ct demi. Dans le premier traité, 11 lignes par page; dans le seond, 15 lignes par page. - (Ancien fonds 1219.)

\section{3.}

"Guide de celui qui dé- 
sire conuaitre les principes des problèmes (astronomiques)", par Schilaâb al-Dín Aḥmad ibn Radjab (ms. ( ) al-Ṭanboghà, mort en 850 de l'légire (1446-1447 de J. C.). C'est un conmentaire du traité d'astronomie mathématique et pratique d'Aboû 'Abd al-Raḷmân 'Abd Allah al-Mâridinì (dans Hadji Khalfa, l'auteur est nommé Djamâl al-Dîn Mọ̣ammad ibn Moḷammad al-Mlàridinî), intitulé pillées ou manière de se servir du quart de cercle appelé 20توs, et qui est une théorie des opérations astronomiques au moyen desquelles on détermine les heures de la prière. Le lexte commenté est reproduit en entier, plırase par phrase. Al-Tanboghâ développe et explique tous les problèmes que Al-Ilàridini, son précepteur, arait employés sans en donner la démonstration. Le commentaire, renfermant plusieurs tables et un grand nombre de figures très bien exécutées, commence par ces mots :

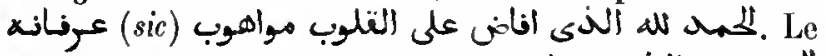

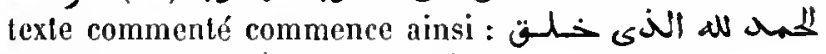

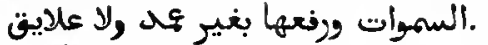

Ms. daté de l'an $99^{4}$ de l'hégrire ( 1586 de J. C.).

Papier. 150 feuillets. Hauteur, 30 centimètres et demi; fargeur, 19 contimètres et demi. 31 lignes par page. - (Ancien fonds 1 103.)

\section{4.}

"Talsles astronomiques d'Oloûgh-Begn, traduites du persan en arabe par Yalıya jbn 'Alì al-Zamâi ou Al-Rafâi i, sur la prière d'un mathématicien distingué, nommé Schams al-Din ibn abj 'l-Fatlı al-Ṣon̂fi. Dans le texte original, les quatre discours qui forment les prolégomènes, sont placés l'un à la suite de l'autre; mais, dans cette traduction, claque discours est suivi des tables auxquelles il se rapporte. Les prolégomènes ont été traduits du persan en français par 11 . Sédillot, Paris, 1853. Ce ms. contient les prolégomènes et la majeure partie des tables; la copie n'a pas été achevée. Com-

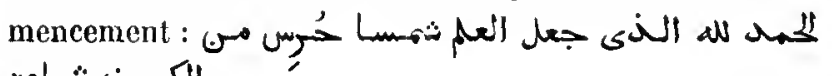

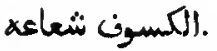

Papier. 102 feuiflets. Hauteur, 30 centimètres; fargeur, 18 centimètres et demi. 23 lignes par page. Ms. du $\mathrm{xvr}^{\circ}$ siècle. - (Ancien fonds $1,1,6$.)

Même ouvrage.

\section{5 .}

Ms. daté de l'an 1097 de l'hégire (1686 de J. C.).

Papier. 190 feuillets. Llauteur, 25 centimètres; largeur, 15 contimètres et demi. 29 lignes par page. - (Supplément 968. )

\section{6 .}

Tables astronomiques d'Oloûgh-Beg, adaptées à la longitude $41^{\circ} 45^{\prime}$, du méridien des îles Fortunées, et précédées d'une introduction qui commence par ces mots :

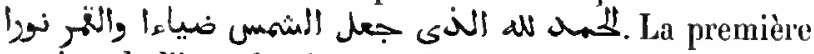
section de l'introduction renferme six chapitres et traite de la manière de déterminer par le calcul les places des planètes; la secoude, en huit chapitres, des procédés qui font connaitre les places du soleil et de la lune, les éclipses, etc. Cet ouvrage a été évidemment composé pour la longitude de Tunis. Une note d'une main européenne l'attribne à un savant de Tumis, nommé Mohammad Sandjakdâr al-Scliarîf.

Papier. 48 feuillets. Hauteur, 25 centimètres et demi; largeur, 19 centimètres et demi. 28 lignes par page. Ms. du xvu1" siècle. (Supplément 968 bis.)

\section{7 et 2538 .}

re Don le plus précieux pour déterminer les positions des astres $\%$. Tables des mouvements des sept planètes et des nouds de la lune, construites pour la longilnde du Caire, d'après l'ourrage d'Oloûgh-Beg, par Kodhwàn Efendi. Les tables sont précédées d'un avertissement de dix pages qui enseigne la manière de s'en servir. L'auteur, qui vivait encore en 1115 de l'hégire (1 703 de J. C.), allirme que la longitude du Caire est au $55^{\circ}$ degré, à compter du livage de l'Océan atlantique. Partout, dans cet exemplaire, le nom d'Oloùgh Beg est écrit كبل؛

2 vot. Papier. 197 et a a feuillets. Hauteur, a 2 centimètres et demi ; fargeur, 16 centimètres el demi. Ms. du svun' siècle. - (Supplément 970 bis.)

\section{9 .}

Tables astronomiques, tirées de l'ourrage de Rodhwàn Efendi:

a. Tables des nouvelles lunes pour les années 1115 à 1130 de lliégire.

b. Tables de Mercure, pour les mèmes années, cal-

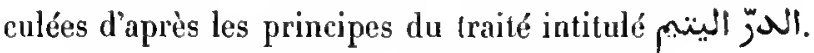

c. Tables de Saturne pour les mèmes années.

d. Tables du soleil pour les années 1116 à 1121 .

e. Tables de Mercure pour les années 1115 à 1121. 
f. Tables de Mars pour les années 1115 à 1121.

g. Tables des nœuds (? à 1120 .

1. Tables de la lune pour les années 1116,1119 , 1121.

i. Tables du soleil pour l'année 1115 .

j. Tables de Vénus pour les années 1115 à 1121.

k. Tables des nœuds pour l'année 1115 .

Il y a une lacune de six feuillets dans les tables de Satirne.

Les folios 22, 44 et 46 sont interverlis; le folio 45 porte un lableau circulaire représentant les signes du zodiague avec leurs levers ignés, aériens, terrestres et aqueux; sup le verso est un tableau semblable, indiquant les jours de la bonne el de la mauvaise influence de chaque planète.

Ms. daté de l'an 1125 de l'hégire (1703-1704 de J. C.).

Papier. 47 feuillets. Hauteur, 21 centimètres et demi; largenr, i 6 centimètres. - (Supplément 970.)

\section{0 .}

1 Notes détachées, tableaux et figures touchant l'astronomie.

$2^{\circ}$ (Fol. $7 v^{\circ}$.) Traité d'astronomie pratique, pour servir d’introduction à une série de tables, calculées d’après les positions moyennes, telles qu'Abou 'I-IVafà Mohammad al-Boúzdjânî les avait déterminées au moyen d'observations répétées.

$3^{\circ}$ (Fol. 16.) Formulaire merveilleux", par Nàșir al-Dín ibn 'Îsâ ibn al-ḷiṣhafì (de ḷịṣn Kaifa). L'auteur se propose de simplifier et d'abréger les calculs astronomiques au moyen d'une série de tables rédigées pour cet objet.

$4^{\circ}$ (Fol. 17.) Tables de la lune et des planètes, les mêmes, peut-être, qui devaient accompagner le traité précédent.

$5^{\circ}$ (Fol. $29 \mathrm{v}^{\circ}$.) Collection complète de tables astronomiques, précédées d'une table de sinus et de sinusverses. Ces tables sont dressées arec beaucoup de soin.

Papier. 99 feuillets. Hauteur, 3 o centimètres et demi; largeur, s 1 centimètres. Ms. du xv'siècle. - (Ancien fonds 1109 , Colbert 680.)

\section{1 .}

1 م Artifices pour faciliter le calcul des degrés et des minutes $n$, par Mohammad Sibt al-Mâridinî. Commencement : W W ג דה المناك.

$2^{\circ}$ (Fol. 20.) Dernier cahier d'une ordjoûza sur l'art de dire la bonne aventure.

$3^{\circ}$ (Fol. 28.) Le poème d'A vicenne sur l'àme, avec un commentaire perpéluel.

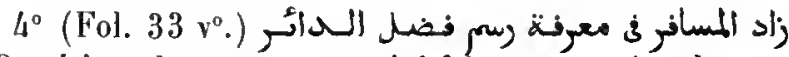
"Provisions du voyageur, traité faisant connaitre la manière de tracer le surplus du dâiir $\%$, par Schihâb al-Dìn Athmad al-Madjdi. Cet ouvrage enseigne la projection des surplus sur les plans horizontaux, perpendiculaires ou obliques. Le dâir est la distance de l'astre à l'horizon, comptée sur sa parallèle; le surplus est la distance de l'astre au méridien, prise sur la même parallèle. C'est un traité de gnomonique.

$5^{\circ}$ (Fol. $43 r^{\circ}$.) Tables de latitudes et de longitudes, tirées des tables astronomiques d'châ al-Dìn ibn al-Schâtir, de Damas.

$6^{\circ}$ (Fol. $48 v^{\circ}$.) Traité de Badr al-Din al-Mâridìnî sur l'emploi du quart de cercle appelé ربع المتنطرات.

Ms. de diverses mains, daté de l'an 1150 de l'hégire $\left(17^{3} 7^{-1} 7^{38}\right.$ de J. C. $)$.

Papier. 54 feuillets. llauteur, 21 centimètres; targeur, 15 centimètres. - (Supplément 1904.)

\section{2.}

I Satisfaction suffisante relativement à la manière de se servir du quart de cercle, appelé dés d'une introduction renfermant l'explication des termes de l'art'.

$2^{\circ}$ (Fol. $14 v^{\circ}$.) Description du quart de cercle à sinus et instructions pour son usage, d'après les ouvrages d'Aboû 'Abd Allah Mohammad al-Mâridinî. Cet instrument était aussi appelé pivot central $\left.(م)^{\circ}\right)$, était nommé $j^{3}$. Dix-sept chapitres, précédés d'une introduction.

'L'auteur de cet ourrage est Moḥammad Siḅ̣ al-Mâridinî (comp. Hadji Khalfa, t. V, p. 223 el suiv.). H. Z. 
3० (Fol. 34.) Explication des lignes tracées sur l'astrolabe nommé zُأحات ذات

$4^{\circ}$ (Fol. $47 \mathrm{r}^{\circ}$.) Description de la sphère arnillaire

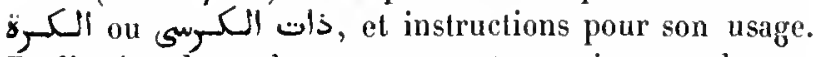
Explication de quelques termes astronomiques en langue lurque.

$5^{\circ}\left(\right.$ Fol. $69 \mathrm{r}^{\circ}$.) Notes et observations diverses.

Papier. 76 fenillets. Hauteur, 16 centimitres; largenr, 11 centimètres. 15 lignes par page. Ms. du xrm1 siècte. - (Supplément 971.)

\section{3.}

Figures des lignes horaires (?) dans les cadrans déclinants et horizontaux . Traité de gnomonique, par Badr al-Dín Hasan ibn Khalil ibn 'Alì ibn Mazroû' al-Ṭobnì (de Ṭobna, en Algérie). Ms. de la main de l'auteur et portant ses corrections. L'ouvrage a été terminé en 882 de l'hégire (1477-1478 de J. C.), mais il avait été commencé quelques années auparavant. On y trouve les figures des lignes horaires et les tables.

Papier. 59 feuillets. Hantenr, 18 centimètres; largeur, 13 centimetres et demi. 19 lignes par page. - (Ancien fonds 282.)

\section{4 .}

10 Traité sur l'usage du quart de cercle à sinus», par Ghars al-Din, fils de Schihab alDin Ahmad al-Naqîb. Vingt chapitres, précédés d'une introduction. Commencement : نلها كار عم الوقت منح وبا 2الية

$2^{\circ}$ (Fol. $8 v^{\circ}$.) Sur l'usage de l'iustrument astronomique appelé النشكازية. Dix chapitres, précédés d'une in-

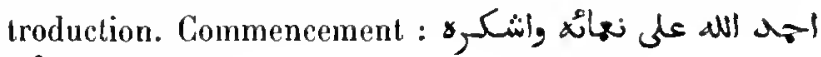
على توالى الآنم

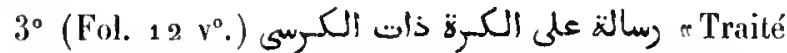
sur le globe soutenu par un horizon comme un support (sphère armillaire) r. Vingt-trois chapitres, précédés d'une

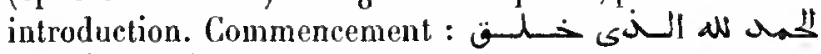
ألسموات والاون ونصب فيها ايات لمتنكسيس.

$4^{\circ}$ (Fol. 2 1.) Note sur la manière de trouver les positions des planètes dans le zodiaque.

$5^{\circ}$ (Fol. $21 \vee^{\circ}$.) Traité sur l'astrolabe, en quatorze chapitres, par Athì al-Din al-Abhari. Lauteur explique d'abord les différentes parties de cet instrument et les lignes qui y sont tracées, puis il enseigne la manière de s'en servir.

$6^{\circ}$ (Fol. $27 \mathrm{v}^{\circ}$.) Traité en persan sur la manière de trouver le däir et son augment, ainsi que l'altitude du soleil, l'heure étant donnée; sur les heures égales et inégales; sur la manière de trouver la longueur de l'ombre, la hauteur étant donnée, et viee-versa; sur les ascendants et les coascentants.

$7^{\circ}$ (Fol. $41 v^{\circ}$.) Traité d"s Abd al-'Azìz al-Wafäi, mowaqqit de la grande mosquée Al-Howaïyadi, mort en 876 de l'légire (1471-1472 de J. C.), sur un instrument astronomique de son invention et sur ses divers emplois. C'est un compas azimutal accompagné des

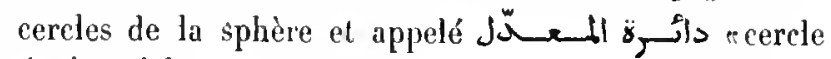
équinoctiel $\%$.

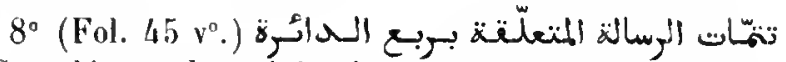
"Complément du traité qui concerne le quart de cerclen. En turc. Ce sont les chrapitres vı à xxx du traité sul' l'emploi du quart de cercle, intitulé fit pour déterminer l'heure -, et attribué ici a Al-Salani le mowaqqit, par Hadji-Khalfa à 'Abd al-'Aziz al-Wafäi.

$9^{\circ}$ (Fol. $56 v^{\circ}$.) Explication du passage de Ptolémée (au commencement du sixième livre de l'Almageste), contenant la description de la sphère armillaire (sالت إن), passage qui avait été mal rendu par les traducteurs arabes. Lauteur, $A$ bou Yoùsof Yáqoúbibn Ishàq al-Kindì. décrit toutes les parties de linstrument.

$10^{\circ}\left(\mathrm{Fol} .60 \mathrm{~V}^{\circ}\right.$.) Traité d'un auteur anonyme qui se trouvait à Damas, en 650 de l'hégire (1252-1253 de J. C.), sur plusieurs instruments d'observation, construits par lui-mềne, tels qu'un quart de cercle mural, un as-

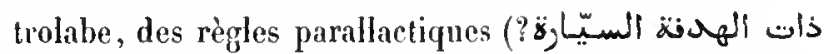
ou ذات الثنبيتيب), l'instrument à sinus et à siuus verses

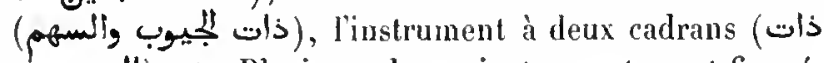
(الربعسبـ), etc. Plusieurs de ces instruments sont figurés dans le texte.

$11^{\circ}$ (Fol. $79 v^{\circ}$.) Traité du globe, de ses cercles et de son usage. L'auteur anonyme dit, au conmencenent

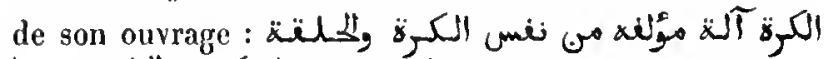

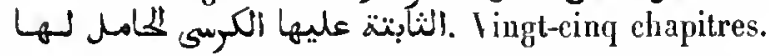

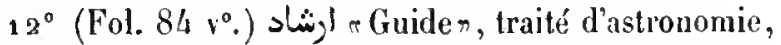
en persan. Cinquante chapitres. Cet opuscule renferme quelques tables. Nombreuses note; marginales en langue persane.

$13^{\circ}$ (Fol. 107.) Chapitre sur la Qibla et sur les heures. Quelques figures.

$14^{\circ}$ (Fol. $110 \mathrm{v}^{\circ}$.) Traité, en turc, sur la manière de déterminer le signe du zodiaque, dans lequel se trouve 
le soleil, et le degré de ce signe, par Moștafâ, mowaqqi du sultan Sélim-Khàn. Cet opuscule se termine par une table d'heures.

$15^{\circ}$ (Fol. $120 \mathrm{~V}^{\circ}$.) Traité d'Abou'l-Fadłâil 'Izz al-Dîn 'Abd al-Azìz al-Wafäi, docteur schaféite et mowaqqit de la mosquéc Al-Mowaïyadî, reproduisant, arec des additions el des corrections, le contenu des deux traités sur le ربع المتنطبات de Seliams al-Din Mohammad al-Mizzî, et de Djamâl al-Dìn 'Mbd Mllah al-Mâridinî '. L'auteur a aclıevé son travail dans la Raudha du Caire, en 843 de l'hégire ( 1439 de J. C.). Copic exécutée à Constantiuople, en 1012 de l'hégire (1604 de J. C.).

Papier. 141 feuillets. Hauteur, a centimètres et demi; largeur, ${ }_{15} 5$ centimètres. Écrilures diverses du $\mathrm{xvI}^{\circ}$ et du $\mathrm{xw1}^{\circ}$ siècle. - (Ancien fonds 1157. )

\section{5.}

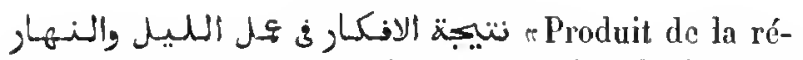
flexion, cn forme de procédé (pour déterminer les heures) de la nuit et du jour\%. Tables horaires, dressées au xrre siecle, pour la latitude du Caire, par Moḷammad ibn 'Omar ibn Șàdiq ibn 'Omar al-Bakri, connu sous le nom de Al-Fawìnîsi (لنفوأنسيسىى). Dans la préface, l'auteur indique les principes d'apres lesquels il a calculé ses tables; il donne ensuite pour chaque mois de l'année solaire quatre tables, dont deux pour le jour et deux pour la nuit. Les tables du jour se composent de vingtdeux colonnes (renfermant treize cases), appelées Jlä "procédés", à savoil" :

1. Les inois de l'année copte.

2. Les mois de lannée grecque.

3. Le degré occupé par le soleil dans le signe du zodiaque.

4. La quantité de l'are semi-diurne (المائر عند طلوع) (ii).

5. L'amplitude ortive (سعة اللمشترة).

6. Hauteur du soleil dans le premier vertical.

7. Hauteur du soleil dans le vertical de la Mecque.

8. Larc du cercle diurne, compris entre l'horizon

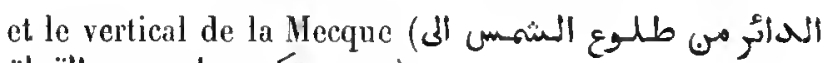

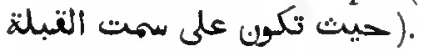

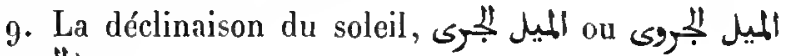
(? $(s) \div 3$.
10. La plus grande hauteur du soleil.

11. La longueur en doigts de l'ombre du cadran horizontal au moment où le soleil quitte le méridien (לابع) (ظلّ الزوال المبسيوطا

12. La longueur en doigts de l'ombre du cadran verlical (اللنكوس), au moment où le soleil quitte le méridien.

13. L'équation du midi.

14. La moitié de l'are diurne.

15. Le nombre d'heures égales (عاءد) ساتن المستوية).

16. Les heures temporaires (أزمان ساعانِ).

17. La longueur de l'arc diurne au moment ou le soleil

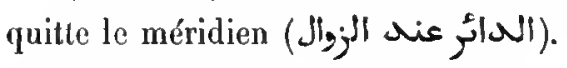

18. Le temps écoulé depuis le moment où le soleil

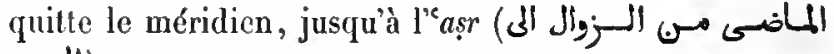
jadl).

19. L'are parcouru par le solcil, depuis te lever jusqu’à l'cașr.

20. La hauteur du soleil au commencement de l'așr.

21. Sa lıauteur à la fin de l'a asr.

22. Le temps écoulé depuis l'aṣr jusqu'au coucher du soleil.

Les tables de la nuit sont disposées en onze colonnes, it savoir :

1. Les mois de l'annéc copte.

2. L'arc parcouru par le soleil jusqu'à son coucher $(\dot{\xi})$.

3. L'arc au moment de la disparition du crépuscule (ألمأر عنح غياب النغنق).

4. L'argument du crépuscule moyen lors de la dispari-

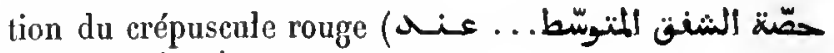
(غياب النشفن الآتر).

5. L'arc nocturne en totalité.

6. Le nombre d'heures égales.

7. L'arc parcouru par le soleil, depuis son coucher

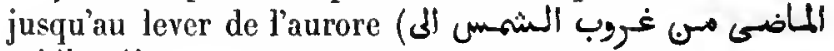
(طلوع الفئر).

8. L'arc semi-nocturne (لهائر عنه نصف الميل).

9. Cliffre pour trouver l'heure de l'aurore moyenne,

1 Voyez ci-dessus, $n^{\circ} 2531,1^{\circ}$. H. Z. 
lorsque telle étoile du zodiaque est sur le méridien

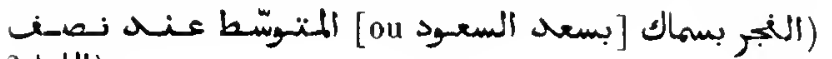
? Jli).

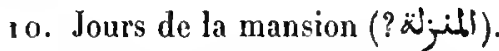

11. L'are au moment de l'aurore.

12. L'argument de l'aurore moyenne au lever de l'aurore.

Ce rolume a été écrit et corrigé par l'auteur.

Papier. 7 I feuittets. Hauteur, 26 centimètres; largeur, 18 centimètres. - (Aucien fonds 603.)

\section{6.}

$1^{\circ}{ }^{\circ}$ Révélations sur l'art de tracer les (lignes et divisions des) quarts de corelen, par Aboû 'Abd Allalı Mohammad ibn Mlohammad... ibn al'Aț̣âr al-Bakrì. C'est surtont une deseription dı quart de

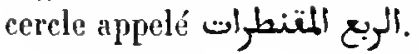

$2^{\circ}$ (Fol. 21 vo.) Cadeau offert à lhomme intelligent et souhaité par l'homme avisé $\%$ Sur la manière de trourer le quart de cercle et le sinus, par "Abd Allah ibn Aḷmad al-Maqdisì al-llanbali.

Copie datée de l'an 1009 de l'hégire (1601 de J. C.).

$3^{\circ}$ (Fol. $3{ }_{1} \mathrm{r}^{\circ}$.) Tables pour servir à la construction du quart de cerele appelé ألربع ألتنطرأت, d'après Al-Farghânì et Al-Halabi.

$4^{\circ}$ (Fol. 47.) Sur la construction du quart de cercle appelé

$5^{\circ}$ (Fol. $52 \mathrm{v}^{\circ}$.) Traité sur la construction des astrolabes, accompagné de figures, par Aḷmad ibn Moḷanmad ibn Kathìr al- Farghånî. Cet opuscule est daté de l'an 1107 de l'hégire (1695-1696 de J. C.).

Papier. 91 feuillets. Hanteur, 21 centimètres; fargeur, 15 centimètres et demi. Écritures diverses da xrü siècle. - (Supplément 97 bis.)

\section{7.}

1. Instructions pour faire un cadran solaire horizontal\%.

$2^{\circ}$ (Fol. $4 \mathrm{v}^{\circ}$.) Traité sur l'usage du quart de cercle appelé الكبع النجيّب le cadran ì sinus n. Cet opuscule est attribué à Al-Màridini et daté de l'an 979 de l'légire (1572 de J. C.).

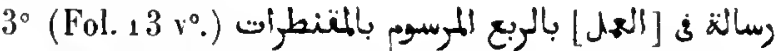
Mlax, orientauX. - II.
}

"Traité sur l'usage du quart de cerele sur lequel sont tracés les cercles de progression", par Schihàb al-Dìn Aḷmad ibn al-Madjdi.

$4^{\circ}$ (Fol. $21 v^{\circ}$.) Sur l'usage du quart de cercle à sinus, par A ḥmad ibn 'Abd Allah al-Màridinì.

$5^{\circ}$ (Fol. $26 \mathrm{v}^{\circ}$.) Sur l'emploi du quart de cerele à sinus pour trouver l'heure de la journée, par Ghars al-Dìn al-Naqib, fils de Schitıàb al-Dìn Alumad ilın al-Madjdi.

$6^{\circ}$ (Fo1. $33 \wedge^{\circ}$.) Traité de l'astrolabe, par Schams alDìn Moḷammad ibn Alımad al-Mizzì. Le premier clapitre (فــ contient la description de cet instrument; les autres, au nombre de neuf, indiquent l'emploi de l'astrolabe pour la solution des problèmes. Cet opuscule est daté de l'an 980 de l'hégire ( 1572 de J. C.).

$$
7^{\circ} \text { (Fol, } 43 \text { vº) }
$$
"Énonciation précise pour rendre clair l'emploi du quart de cercle appelé mad ibn Ahmad al-Azhari a1-Khàniqui. Il s'agit probablement de linstrument qui a été décrit par Al-lasan ibn 'Alì ibn 'Omar al-Marrikosehi, sous le nom de ong. (Is. arabe $n^{\circ}{ }_{2} 508$, page 42.) Cie petit traité est suivi de onze pages de notes sur le mème sujet.

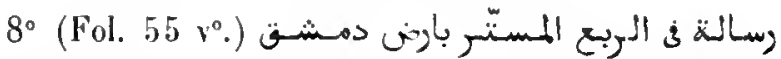
- Traité sur le quart de cercle appelé le territoire de Damasn, par Moûsâ ihn Alumad al-Khalili, movaqqit de la grande mosquće de Damas.

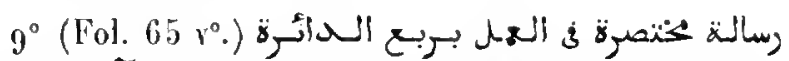
. Traité concis sur l'usage du quart de cercle qui porte les

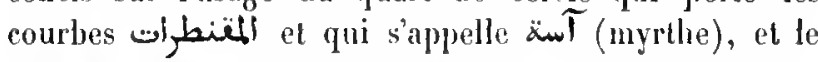

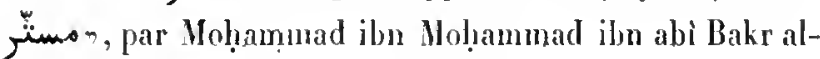
Tizini.

$10^{\circ}$ (Fol 72.) Traité sur l'usage de l'astrolabe, appelé safiha d'Arzachel (الصنيكة الزئية).

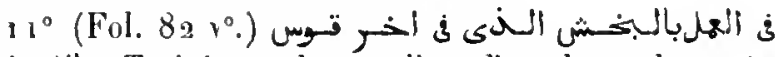

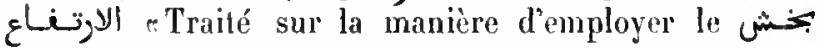
qui est à l'extrémité de l'are de hautemr. Cet instrument servait aux mèmes usages que l'astrolabe.

$12^{\circ}$ (Fol. $85 r^{\circ}$.) Sur l'art de déterminer les heures de la prière, la direction de la Meeque, etc., par Moúsà ibn Moḥammad al-Khalìlì, mowaqqit de la grande mosquée de Damas. L'autem traite d'abord des sinus et des sinus verses. Les derniers leuillets manquent.

$13^{\circ}$ Fol. 92. (2. Éloignement de l'incertitude, touchant l'usage de l'astrolabe à sinus ๓, par Moḷammad ibn Aḷmad al-Mizzi. 


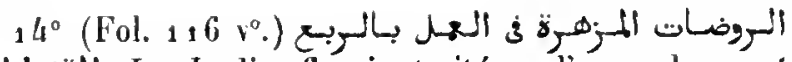

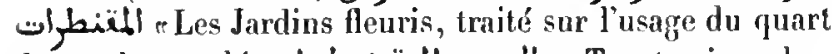
de cercle appelé pitres (باب), attribués ì l'auteur du traité précédent.

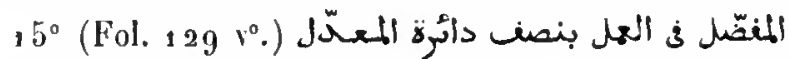
- Le Prééminent, traité sur l'asage du demi-cercle (ou astrolabe) méridional $\%$

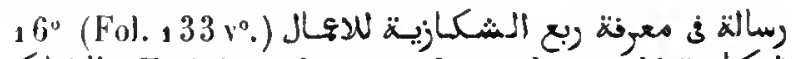

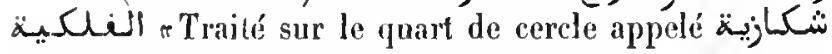
et sII' son usagen. Cet opuscule est attribué a Moḥammad ibn abi Bakr al-Tizâi. Vingt chapitres (باب), précédés d'une introduction.

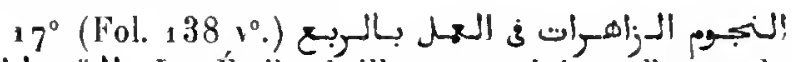
eles Étoiles brillantes, traitó sur l'usage du

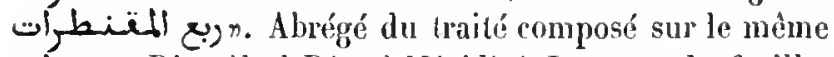
sujet par Djamàl al-Dìn al-Màridimî. Le verso du fenillet 142 avait été laissé en blanc par mégarde. Le copiste y a écrit plus tard le titre ef le commencement du traité.

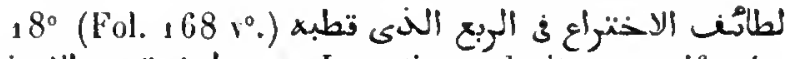
r. Inventions adroites, manifestées dans le quart de cercle dont le pơle est à l'extrémité de l'arc de hauteur $»$, par Moḷammad ilon Sibț al-Màridinì. (La hautenr signifie le pồle de l'horizon.)

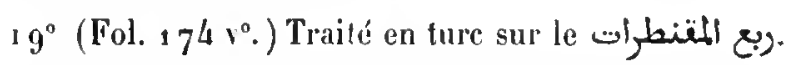

$20^{\circ}\left(\right.$ Fol. $183 \mathrm{v}^{\circ}$.) Tables indiquant les jours initiaux de chaque mois pour les années 972 à 1001 de l'hrégire.

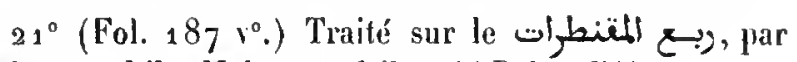
Moḷammad ibn Moḥammad ibn abì Bakr, d'Alep.

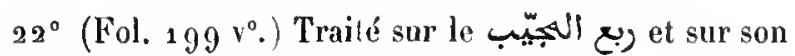
utilité pour déterminer les heures de la prière. Cet opuscule est du même auteur que le précédent. 11 se compose de vingt chapitres et d'une courte introduction.

$23^{\circ}$ (Fol. 211.) Traité sur l'instrument astronomique

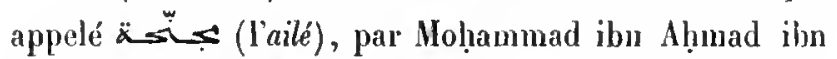
'Abd al-Ralyim al-Mizzi. La fin manque.

On trouve à la fin du volume quatre tableaux numériques qui paraissent être des carrés magiques.

Papier de diffërentes couleurs et vélin. 225 feuillets. Hauteur, 21 centimètres et demi; largeur, 14 centimètres el demi. Écritures diverses du rvie siècle. - (Ancien fonds 6.3.)

\section{8.}

Introduction à l'art de déterminer les heures de la prièren, par Hohammad iłn Idrìs.
C'est un traité sur la manière de trouver l'heure du jour au moyen d'observations astronomiques.

Papier. 28 feuillets. Hauleur, 20 centimèlres; largeur, 15 centimàtres. 15 lignes par page. Ms. du xvn" siècle. - (Supplément 954.)

\section{9.}

$1^{\circ}$ Manuel d'astronomie en soixante chapitres, à l'u-

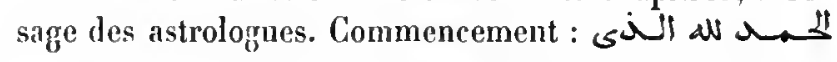

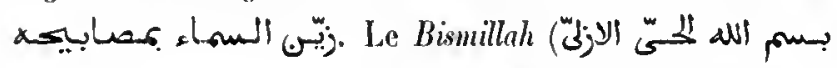

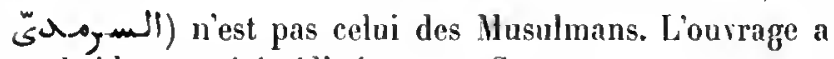
probablement été rédigé par un Copte.

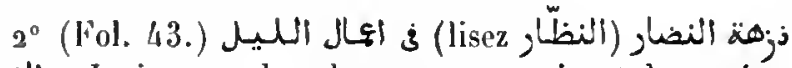

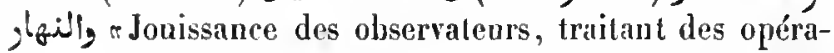
tions (astronomiques) de nuit et de jour $\%$. L'écrivain anonyme prétend expliquer l'emploi des astrolabes, des globes et autres instruments astronomiques; mais, an lieu de remplir ce programme, il offre au lecteur une esquisse de cosmographie, un chapitre sur les mansions de la lune, et un autre sur les levers des signes du zodiaque.

$3^{\circ}$ (Fol. 59.) Tableau pour trourer le commencement de chaque mois du calendrier arabe, suivi du calendrier général de l'année solaire et de trois tableaux, dont l'un est pourva d'un disque mobile pour trouver la concordance des années solaires et lunaires.

IIs. daté des années 1075 el 1076 de l'hégire (16641666 de J. C.).

Papier. 63 feuiltets. Hauteur, 20 centimètres; largeur, 14 centimètres. 15 lignes par page. - (Ancien fonds 1146 , Colbert 4541.)

\section{0.}

$1^{\circ}$ Sur la manière de déterminer la direction de la qibla et les heures de la journée. Commencement:

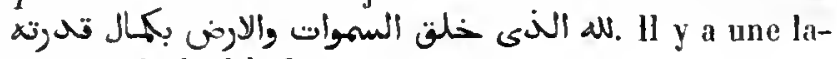
cune après lo fol. 3 .

$2^{\circ}\left(F^{\prime} o l .6 v^{\circ}\right.$.) Sur le quart de cercle à sinus. Vingt

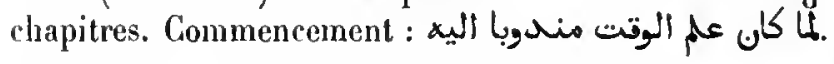

$3^{\circ}$ (Fol. 17.) Sur la manière de déterminer les heures de la prière. Exposé des principes géométriques, par l'auteur d'un traité d'astronomie intitulé المطلد. C'est pent-être l'ourrage de Sib! al-Màridinì.

$4^{\circ}\left(\mathrm{Fol}_{2} 27 \mathrm{v}^{\circ}\right.$.) Description du quart de cercle à sinus et instructions pour son usage. Vingt chapitres. Commencement : هذها رسالة ف الملا بالربع الهيّيب. 


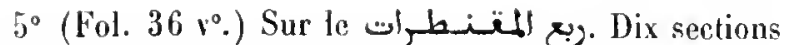

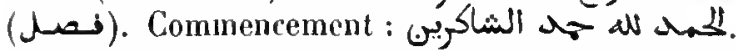

6० (Fo1. $44 v^{\circ}$.) Sur le ربع المتنطات : En turc. Quinze cluapitres, précédés d'une introduction.

$7^{\circ}$ (Fol. $50 v^{\circ}$.) Les cinq premières pages d'un trailé

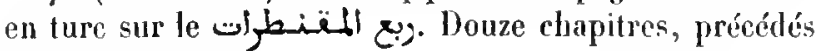
d'une inlroduction.

$8^{\circ}$ (Fol. 53.) Les quatre derniers chapitres d'un traité d'astronomie pralique, en langue turque. L'ouvage complet renfermait vingt-cing chapitres. Le vingt-deuxième chapitre commence par ces mots :

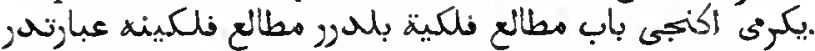

Papier. 57 feuillets. Hauteur, 15 rentimètres; largeur, 10 centimètres el demi. Écrilures diverses du xwn' siècle. - (Ancien fonds 1218 , Colbert 650\%.)

\section{1.}

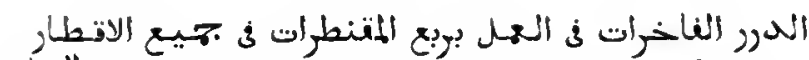
r Les Perles brillantes, traité sur l'usage du quart

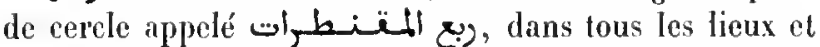
toutes les directionsn, par Al!unad al-Scharqi, de Slax (الصناتُ), en Tunisie, attaclué à la mosquéc d'll-Azhar', au Caire. Cet opuscule est divisé en lingl chapitres, précédés d'une introduction. Il a été composé en 1087 de l'hégire. L'auteur l'a mis au net en $109^{3}$ de l'hégire ( 1682 de J. C.).

Ms. autographe.

Papier. 28 feuillets. Haulenr, 20 centimètres; largeur, 1/1 ceatimètres el demi. 19 lignes par page. — (Supplément 961. )

\section{2 .}

Talsle astronomique qui indique l'augment dı dair

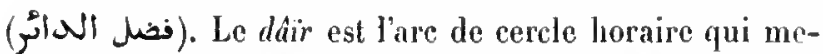
sure la partie écoulée du jour, et l'augment, ou plutôt l'excès (فضل), est l'excès de l'arc semi-diurne sur le dair. (Vovez Delambre, Histoire de l'astronomie du moyen-agre, p. i1 1, $118,187$.$) Cetle Lable est calculée pour chaque$ minute du degrré, jusqu'à $60^{\circ}$.

Papier. 182 feuillets. Hauteur, 28 centinètres el demi; targeur, 10 centimètres el demi. 61 tignes par page. Ms. du $\backslash$ vi" siècle. - ( $\mathrm{An}$ cien fonds 11.17 .)

\section{3.}

Souhait de l'àme, toucliant la solution (des problèmes relatifs à la position) du soleil \%. Tables astronomiques, scrvant à déterminer les hemes de la prière, par Mohammad ibn Moḷammad al-

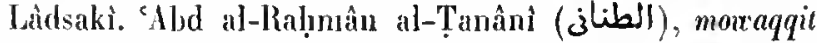
de li mosquée d'Al-Azhar, au Caire, y a joint une courte introduction, dans laquelle il traite de la notation par chiffres et par lettres, de la concordance des ères et de l'emploi de ces tables, calculées pour la longitude $44^{\circ}$, 45', ì partir de l'océan Atlantique, et pour les années 1059-1 104 de l'hégire $(1649-1693$ de J. C.).

Papier. 19 feuillets. Hauteur, 21 centimètres; targeur, 15 centimètres. Ms. du xvure siècle. - (Ancien fonds 1 156.)

\section{4 et 2555 .}

L'Astronomie de Lalande, traduite en arabe sur l'édition italieune, par un nommé Basili Fakhr (بأسيلى فَر).

Ms. daté de l'an 1808 de J. C.

a vol. Papier. 111 et 102 feuilhets. Hauteur, 30 cenlimètres et demi; Jargeur, 21 centimètres. 27 lignes par page. — (Suppłément 953.)

XVII.

\section{CALETDRIER.}

\section{6.}

Traité sur les quatre saisons de l'anuée, attribué à Hippocrate. Lourrage, divisé en treize sections, dont la dernière est restée inaclievée, commence par ces mots :

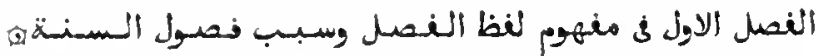

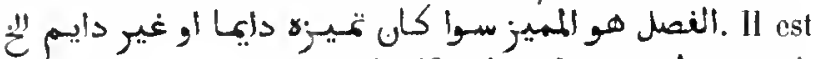
probable que la double signification du not فصول saisons el aphorismes, a fait croire que nous avions ici un exemplaire des Aphorismes du grand médecin grec.

Papier. 39 feuiltets. Hauteur, so centimètres et demi; largeur. $1 /$ centimètres. 17 lignes par page. MIs. du xvil $^{\circ}$ siècte. - (Supplément 998.)

\section{7.}

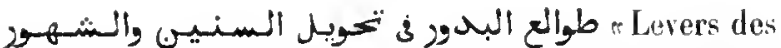
pleines lunes, traitant de la comersion des années et des moisr, par Son Excellence (ï) Abou 'l-Bakî ibn 
al-Djaïàn al-Badrì. L'auteur expose le système employé dans les bureaux de la guerre et dans ceux de la chancellerie, en Égypte, prour convertir les années lunaires en années solaires. Il y ajoute la copie d'un règlement promulgué par le sultan à ce snjet et devant s'appliquer à l'an 835 de l'hégire (1431-1432 de J. C.).

'Titre orné. Ce volume était probablenent destiné à un haut personnage.

Papier. 24 feuillets. Hauteur, 23 centimèlres; largeur, 16 centimètres. 7 lignes par page. - (Ancien fonds 611 .)

\section{8.}

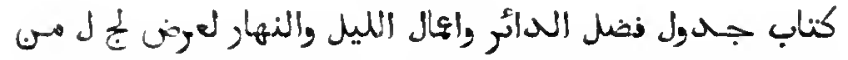

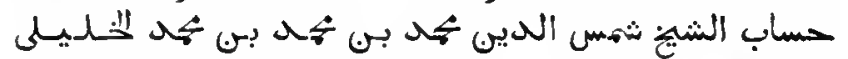

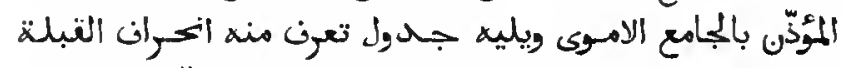

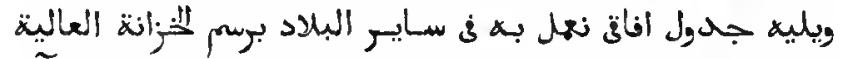

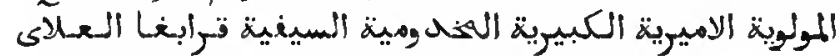

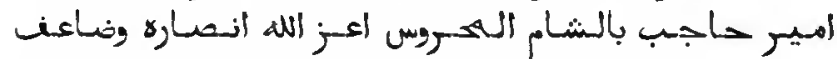
" d'ar's, de pratiques prour la nuit et te jour, pour la latitude $33^{\circ} 30^{\prime}$, d'apres les calculs du schaikh Schams al-Din Molıammad, fils de Mohammad, fils de Mot!am-

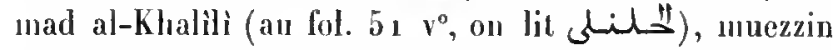
de la mosquée Omayyade (de Damas); suit une table qui fait connaîlre l'azimut de la qibla; puis une table d'angles liorizon taux, avec laquelle nous pouvons opérer dans tous les pays. Volume destimé à la bibliothèque du liant et puissant seigneur makhdoumien et seifien, Qarảboghâ 1-'Atài, grand-chambellan de Damas, la bien gardée; que Dieu lni accorde des victoires éclatantes et augmente sa puissance, etc.!r

Ce volume renferme les opuscules suivants :

$1^{\circ}$ Commencement d'un traité sur la concordance des années de l'hégire el de l'ère des Séleucides. Lc copiste ayant trouvé un autre ouviage sur le même sujet, qu'il appréciait davantage, a collé les deux premiers feuillets ensemble, et commencé la transcriplion du traité suivant.

$2^{\circ}$ (Fol. 1 bis $1^{\circ}$.) Deux tables dressées par Mohanmad ibn Molıammad ibn abi Bakr al-Tizini, mowaqqit de la grande mosquée de Damas. La première de ces deux tables donne la correspondance des années 851 à 1001 de l'hıégire avec les années 1789 à 1904 des Séleucides.

30 (Fol. 9 v vables intitulées

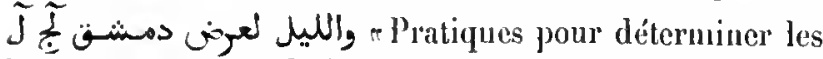
lieures du jour et de la nuit, calculées pour la latitude $33^{\circ} 30^{\prime}$, qui est celle de Damasn. Chacune de ces tables occupe en largeur deux pages, et renferme seize colonues, dont les titres sont généralement les mêmes que ceux de la table contenue dans le (Voyez $\mathrm{n}^{\circ} 2545$.)

$4^{\circ}$ (Fol. $151^{\circ}$.) Levers des signes du zodiaque lors de la disparition du crépuscule et lors de l'apparition de l'aurore, calculés pour la latitude de Damas.

$5^{\circ}$ (Fol. $18 \vee^{\circ}$.) Liste d'étoiles fixes, avec leurs levers, etc., d'après te schaikh 'Alâ al-Dîn ibn at-Sclıâkir.

$6^{\circ}\left(F_{0} .20 v^{\circ}.\right)$ Ares de hauteur et leurs compléments, calculés pour toutes les latitudes, depuis l'équateur jusqu'au $80^{\circ}$ degré.

$7^{\circ}$ (Fol. $40 \mathrm{v}^{\circ}$.) Tables pour trouver la hauteur du soleil, étant donnée l’heure du jour.

$8^{\circ}$ (Fol. $51 v^{\circ}$. ) Latitudes, longitudes ef azimuts (انحكرافات) de la qibla pour quelques villes de l'Arabie et de l'Égypte, et pour les principales villes de la Syrie.

$9^{\circ}$ (Fol. 52.) Latitudes des licux situés sur la route qui conduit de Damas à la Hecque.

$10^{\circ}$ (Fol. $52 \mathrm{v}^{\circ}$. ) Tables pour trouver ta direction de la qibla, calculées pour tontes les latitudes, du $10^{\circ} \mathrm{de}-$ gré au $56^{\circ}$.

$11^{\circ}$ (Fol. 61 ro.) Tables calculées pour toutes les lalitudes, jusqu'au $55^{\circ}$ degré, et servant à déterminer les licures de la prière et la direction de la qibla. Il y a une notice préliminaire portant la date de 811 de l'hégire.

$12^{\circ}$ (Fol. $92 v^{\circ}$.) Table des sinus du tartib (بـيسب (التنتينب pour toutes les hauteurs, jusqu'au $49^{\circ}$ degré. Le sinus du tartib (ou de la directrice) est celui de l'angle formé par la verticale de l'astre observé et par la verticale de la qibla.

$13^{\circ}$ (Fol. $104 v^{\circ}$.) Levers des signes du zodiaque dans la splière droite.

Ms. daté de l'an 811 de l'hégire (voir fol. 62 et $105 \mathrm{v}^{\circ}$ ), bien que les premières tables soient catculées pour les années 851 et suivantes.

Papier. 105 feuitlets. Hauteur, 57 centimètres; largeur. 14 cenlimètres. - (Ancien fonds 604.)

\section{9.}

$1^{\circ}$ Collier (ou licou) pour le cheval rétif, et exposé des principes qui forment les bases des épactes\%. Traité anonyme sur la concordance de l'année musulmane avec l'année solaire. 


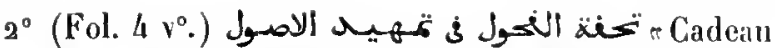
destiné aux hommes éminents, et servant à faciliter la connaissance des principes tronomie nautique, par Solaïmân ibn Aḷmad ibu Solaïmân al-Mahrî, qui, selon M. Reinaud (Géographie d'Abou ' $-F$ édd, p. cLvi), aurait composé ce traité en 917 de l'hégire ( 1511 de J. C.).

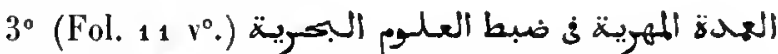
"L'appui de Mahrî pour bien acquérir les connaissances nautiques", par Solaïmân ibn Aḥmad al-Mahrì. Ce traité de navigation théorique et pratique, commence par l'explication de plusieurs termes employés dans la

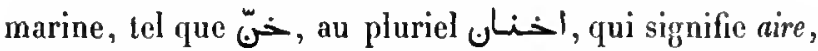
trente-deuxième partie du cercle de l'horizon. On y trouve d'intéressantes instructions sur la navigation de la mer Rouge, de l'océan Indien et des mers de la Chine. L'opuscule est daté de l'an $9^{6}$ I de l'hégire ( 1554 de J. C.).

$4^{\circ}$ (Fol. $59 v^{\circ}$ ) المنهاج الفلخد "Noble voie pour arriver à la connuissance de la grande mern, traité de navigation, par Soliümân ibu Aḷmad al-Mahrì al-Mohammadi. Après avoir expliqué quelques termes d'astronomie nautique, l'auteur décrit les paragres de Socotora, de Ceylan et d'autres iles de l'océan Indien. Il parle des cyclones, des vents, des signes auxquels on reconnaît les côtes des divers pays, et doune ensuite des directions pour naviguer d'un port à un autre dans l'océan Indien.

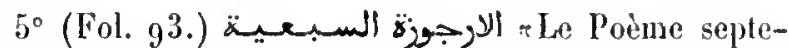
naire, par Schilıàb al-Din Alımad iłon Mâdjid ibn Molıammad ibn ${ }^{\circ} \mathrm{Omar}$ al-Sa'di. Ce poème didactique, composé de trois cent six vers, traite des sept genres de connaissances nécessaires à un marin. La rime est en 3.

$6^{\circ}$ (Fol. $\log \mathrm{v}^{\circ}$.) Autre poène dı même auteur, composé de trente-trois vers, sur l'astronomic. La rime est en 3. La pièce est datée de l'an 865 de l'lıégire (14601461 de J. C.).

$7^{\circ}$ ) Fol. 11 1. (1) مa Direction en vers , par le mêne auteur. Instructions pour la navigation de la mer des Indes et de la mer Rouge. Cent cinquante-cing vers.

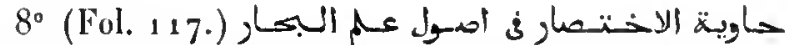
"Abrégé universel des principes de la connaissance des mers $"$, par le même auteur. Poène de près de mille vers, divisé en onze sections et précédé al'une prélace en prosa. La fin de la première section, qui forme l'introduction, et toule la seconde section manquent. La troisième section traite des diverses ères; la quatrième, des phénomènes du ciel; la cinquième el les suivantes, de la navigation des còtes de l'Arabie, de l'Inde, de Sumatra et des îles roi- sines. Dans cette pièce, l'auteur est désigné ainsi : AlMo allim Ahmad ibn Màdjid ibn Moḥammad ibn 'Amr ibn Fadhl ilın Dowik, du Nadjd.

$9^{\circ}$ (Fol. 155.) Commentaire du royez cidessus, l'article $2^{\circ}$ ), par l'auteur lui-mêne, Solaünàn ilon Aḷmad al-Mahrì. Le texte est écrit à l'encre rouge.

Toutes ces pièces sont de la inême main.

Papier. 187 feuillets. Hauteur, 22 centimètres; largeur, 15 centimètres. 15 lignes par page. Ms. du xriı" siècle. - (Ancien fonds 609.)

\section{0 .}

$1^{\circ}$ Commentaire sur le traité intitulé $\ddot{x} \rightarrow$ ga_l, par 'Abd al-Rạ̣mân a1-Tàdjoùrì. (Voyez ci-après, article 3º)

$2^{\circ}$ (Fol. 10.) Tables de concordance des années $9^{3} 7$ à 1029 de l'hégire el des années correspondantes de l'ire des Coptes.

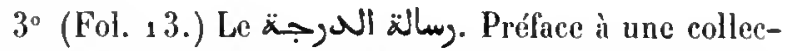
tion de tables servant à trouver la concordance des années solaires et lunaires, par le schaikh Honaïd (الهنيا)).

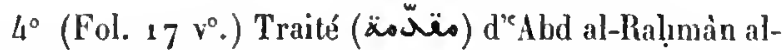
Tàdjoûrì, sur la manière de déterminer les quatre saisons, les heures de la muit, les heures de la prière et la direction de la qibla.

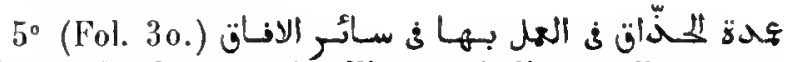
"Appui des hommes intelligents, indiquant l'usage du (quart de cercle à sinus?) dans toutes les contréesn.

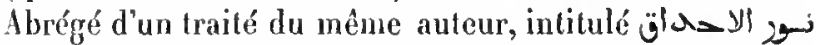
"Lumière des yeux $\%$. La présente dissertation renlerme les règles, sans démonstration. Commencement : al a

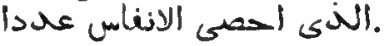

$6^{\circ}$ (Fol. 32.) Le vingt-sixième chapitre (بـاب) du , وصيلة الطلّاب , traité d'astronomie de Sibṭ al-Mâridìnì.

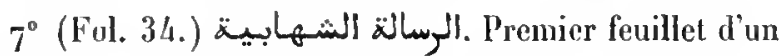
traité en vingt chapitres sur l'usage du quart de cercle ì sinus, par Moḥanmad Sibṭ al-Mâridinì.

$8^{\circ}$ (Fol. 35.) Autre traité sur le même sujet. Deux cent cinq chapitres. Les feuillets sont intervertis. Le commencement et beaucoup d'autres feuillets manquent.

$9^{\circ}$ (Fol. 69.) Traité sur l'astrolabe, par 'Alì ibn Moliammad al-Naqqásch ( le graveur $n$ ). Cent cinquante cha-

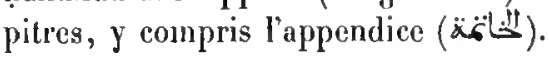

$10^{\circ}$ (Fol. $132 r^{\circ}$.) Traité d'eAbd al-Ralumàn al-Tàdjoûrì sur l'usage astronomique de la boussole (لبيـت الابرة:). 
$11^{\circ}$ (Fol. $148 r^{\circ}$.) Tableaux qui donnent l'argument des latitudes, depuis le $10^{\circ}$ degré jusqu'au $56^{\circ}$.

$12^{\circ}$ (Fol. 160.) Tables de longitudes et latitudes.

$13^{\circ}$ (Fol. $1641^{\circ}$.) Dissertation, en turc, sur la longiiude et la latitude.

$14^{\circ}$ (Fol. $171^{\circ}$.) Sur la inanière de marquer au cadran les signes de l'augment du driïr. (Voyez ci-dessus, $\left.\mathrm{n}^{\circ} 2552.\right)$

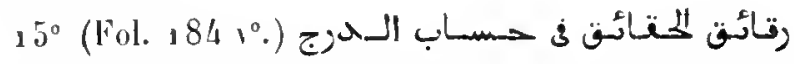

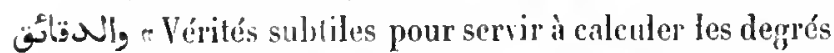
et les minutes $\pi$, par Molıanmad Siltt al-Màridìn. L'auteur enseigne, au noyen des lettres de l'alphabet emplovées numéliquement, te حساب بهم, c'est-à-dire les calculs faits.

${ }_{16}^{\circ}\left(\right.$ Fol. $204 v^{\circ}$.) Description des pièces et des lignes dont se compose l'astrolabe et instructions pour son usage.

$17^{\circ}$ (Fol. 236.) Fragment d'un traité d'astronomie sphérique et de l'usage des horonomes. La fin manque.

$18^{\circ}$ (Fol. 259.) Fin du huitième et commencement du neuvième chapitre d'un traité d'astronomie. Ces fragments renferment la démonstration des règles qui servent à calcuter la position dı soleil et des cinq planètes.

La plupart des pièces contenues dans ce ms. sont de la mềne main.

Papier. 268 feuitlets. Hauteur, 21 centimètres; largeur, 15 centimètres. 19 à 23 tignes par page. Ms. du xvil1 siècte. - (Supplément 2092.)

\section{1.}

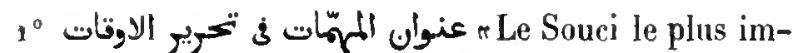
poutant, de la manière de déterminer les lıeures (de la prière) \%. La première partie indique les règles pour établir la concordance des années 958 à 1115 de l'hégire arec les années correspondantes de l'ère des Coptes. L'auteur inconnu déclare s'ètre servi des tables contenues

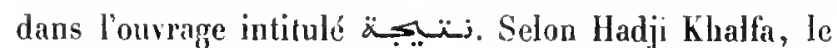
r Produit de la réflexion, indiquant les opérations (de calcul) pour déterminer les heures du jour el de la nuit", a pour' auteur Mohammad ibn 'Omar al-Qawànisì; mais le sarant bibliographe ne connaissait l'ouvrage que par un catalogue?. Après avoir indiqué comment on détermine la hauteur du soleil pour la latitude dn Gaire, l'auteur montre, dans la seconde partic (fol. 7), comment se fait la mème opération pour les autres lieux. En tête du volume se trouve un titre apocryphe.

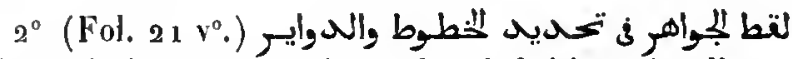
- Amas de joyaux, fournissant les définitions des lignes et des cercles (de la sphère)", écrit pour l'usage de ceux qui veulent apprendre l'art de déterminer les heures de la prière.

$3^{\circ}$ (Fol. $33 \mathrm{v}^{\circ}$.) Traité de trigonométrie et du calcul des henres, rédigé en vers et divisé en vingt-trois chapilres.

$4^{\circ}$ (Fol. $37 \mathrm{v}^{\circ}$.) Aboû 'Alì ibn abi 'l-Ịo-saïn al-Ṣoûfi.

$5^{\circ}$ (Fol. $45 r^{\circ}$.) Tabtes des levers des étoites et de leurs culminations, par le schaikklı Moștafa 'l-Khaïyât.

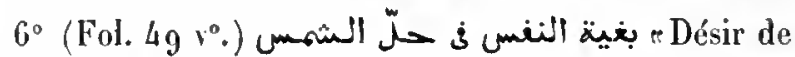
l'àme, touchant la manière de calculer la place du soleil $»$. En tête se trouve un titre apocryphe.

Papier. $5_{2}$ feuillets. Hauteur, 21 centimètres; largeur, 16 centimètres. 2 I lignes par page. Ms. du xrm siècle. - (Supptément 979.)

\section{2.}

$1^{\circ}$ Calendrier de l'année copte. La longueur, en degrés, des jours de chaque mois, ainsi que la croissance et la décroissance des eaux du Nil y sont spécialement indiquées.

$2^{\circ}$ (Fol. $9^{\circ}$.) Traité anonyme sur les années musulmanes et les années coptes, comprenant l'énumération des jours de fète, des jours fasies et néfastes, des mouvements des planètes, des conjonctions, des mansions de la lune, des influences astrologiques des planètes, et quelques notions sur les Nativités. Un certain nombre de chapitres est consacré à la chute de la goutte (نزول النـتنطة), phénomène sur lequel on peut consulter l'Abdallatif de M. de Sacy. Vers la fin du traité, on trouve plusieurs sceaux ou carrés magiques.

$3^{\circ}$ (Fol. 54.) Feuillet qui paraît aroir appartenu à un recueil de recettes médicales. La plus grande partie du lexte est écrite en chiffres el en caractères de convention.

$4^{\circ}$ (Fol. 56.) Traité des Nativités. L'auteur, désigné par l'appellation de par citer l'autorité de Hermès et d'Aristote.

1 Voyez ci-dessus, n² 2545. H. 2 . 
$5^{\circ}$ (Fol. 83.) Traité des vertus des quarante noms sacrés : مصميت , سموطيثيا, شعيثا, ete.

$6^{\circ}$ (Fol. $\left.9^{3} \vee^{\circ}.\right)$ Traité de géomancie, en vers, avec un commentaire. On y trouve les figures et les valeurs des diverses combinaisons de points dont il est fait mention dans les Prolégomènes d'lbn Khaldoûu.

$7^{\circ}$ (Fol. 113.) Traité sur la divination au moyen de la géomancie et des tableaux cabalistiques appelés الزيارج. On y trouve également les groupes de points en usage dans la géomancie, avec leurs noms, etc.

$8^{\circ}$ (Fol. 195.) Recueil de charmes, de prières et de conjurations. La première de ces conjurations a pour effet de mainlenir la bourse toujours remplie d'argent. L'anteur se nommait Badr al-Dìn al-Noûhàni.

$9^{\circ}$ (Fol. $211 r^{\circ}$.) Traité en rers sur les influences des lettres de l'alphabet et sur l'hygiène, suivi d'un autre, rimant en ali, sur les convenances qu'il faut observer dans le commerce conjugal (عالم ibn Montaṣer.

$10^{\circ}$ (Fol. $217 \mathrm{~V}^{\circ}$.) Traité de médecine, en soixante. sept chapitres. L'auteur déclare y aroir inséré toutes les doctrines du sage Hippocrate, à qui les arlres avaicnt adressé la parole pour Jui apprendre leurs qualités et leurs vertus. Le copiste a laissé quelques chapitres en blanc.

$11^{\circ}$ (Fol. 227.) Ordjoúza attribuée à Avicenne, sur l'art d'appliquer les ventouses.

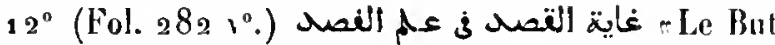
à atteindre, touchant l'art de saignern, piece de vers attribuée à Avicenne.

${ }_{1} 3^{\circ}$ (Fol. 285.) Autre copie de la pièce de vers sur le commerce conjugal. (Voyez ci-dessus, article $9^{\circ}$.)

$14^{\circ}$ (Fol. 287.) Recettes, tirées du livre intitulé حيوة , 20ur produire l'obésité et pour exciter l'amour sexuel.

$15^{\circ}$ (Fol. 289.) Conseils, en vers, sur l'entretien de la santé dans les quatre saisons de l'année, attribués à Avicenuse, suivis de deux pièces de ver's: l'une traite de la préparation d'un certain aphrodisiaque; dans l'autre il est question d'un roi, désigné par le titre d'Al-Malik al-Imâm, qui consulte le calife 'Mlì sul' sa santé et qui est favorisé d'une réponse $d^{\top} A l i$.

${ }_{16}^{\circ}$ (Fol. 294.) Recette attribuée an schaikh Diwond al-Anțakî pour composer un certain électuaire (م-جبـون) aphrodisiaque.

$17^{\circ}$ (Fol. $29^{4} v^{\circ}$.) Traité sur les artères du corps

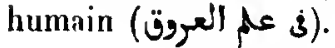

$18^{\circ}$ (Fol. 297. ( La Médecine du Prophèten, par Mohammad ibn 'Abd al-Wạlid al-Maqdisì.

19 (Fol. 299.) Notions médicales, tirées d'une lettre adressée par Chosroès (1ك) à César, roi des peuples non arabes (ألنجم).

$20^{\circ}$ (Fol. $326 \vee^{\circ}$.) Dissertation sur les signes précurseur's de la mort, par Mohammad ibn abì Tảlib al-Ansàrì, supérieur d'une corporation de soufis, à Damas. Lia liste de ces symptómes, au nombre de vingt et un, est empruntée, dit-il, à Hipjocrate.

$21^{\circ}$ (Fol. $3291^{\circ}$.) Traité en vers sur les présages que l'on peut tirer des monvements involontaires (ikhtilddj) des membres du corps humain.

22" (Fol. 343.) Commenlaire du schaïhls Aḷmad ibn 'Îsà sur la pièce de vers du schajkh soufi Noùr al-Din alDimyali, touchant tes noms de Dieu.

$23^{\circ}$ (Fol. $\left.359 v^{\circ}.\right)$ Prière efficace (لمعاء المستخباب), en vers.

Papier. 364 feuillels. Hauteur, 15 centimètres el demi; largeur, 10 centimètres et demi. As. du xw' siècle. - (Aneien fonds $614, \mathrm{Col}-$ bert 65 :4.)

\section{3.}

$1^{\circ}$ Catendrier de Paunée cople, dressé par un musulman. Les jours des mois sont rangés en colomnes et accompagnés de diverses indications, telles que les lêtes musulmanes et coptes, anniversaires d'événements mémorables, levers des constellations, etc. Commencement :

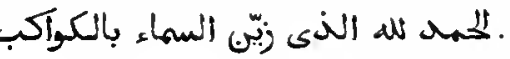

$2^{\circ}$ (Fol. $17 v^{\circ}$.) Autre calendrier de l'année copte. Aux indications ordinaires est jointe la durée de chaque jour. Ce calendrier est également d'un auteur musulman. A la fin se tromient les noms des vingt-huit mansions de la lune.

Papier. 40 feuillets. Hauteur, 20 centimètres et demi; largeur, 14 centimètres. Le presnier opuscule a 15 lignes par page; le second. $2 t$ lignes. Mfs. du xvı" siècle. - (Supplèment $9^{81 .)}$

\section{4.}

Concordance des calendijers arabe, grec et copte.

Papier. 18 feuillets. Hauteur, 29 centimètres; largeur, 19 centimètres. Ms. du xv1" siècle. - (Supplément 974.) 


\section{5.}

Calendrier qui indique les plénomènes naturels, célestes el terresires, particuliers à chaque jour de l’année solaire. Les onze premiers jours du mois de janvier manquenl; ils ont été omis par le copiste.

Papier. 134 fenillets. Hauteur, 16 centimètres; largeur, 10 centimètres et demi. 15 lignes par page. Ms. du xvi1" siècle. - (Supplément 972.)

\section{6.}

1 Calendrier de l'année solaire, avec l'indication des phénomènes de la nature, des grands événemenls, etc., et précédé d'un clıapitre sur la division de l'annéc en saisons ct en mois. Plusieurs blancs laissés dans le texte deraient probablement recevoir les figures de certains groupes d'étoiles. La fin, à partir dı 15 novembre, manque.

$2^{\circ}$ (Fol. 40.) Traité d'astronomie en vers, accompagné d'un commentaire. Vingt clapitres. Les trois premiers chapitres et le commencement du quatrième manquent.

Papier. 54 feuillets. Hanteur, 21 centimètres; largeur, 15 centimètres et demi. 23 lignes par page dans le premier traité, 21 lignes dans le second. Ms. du xviı siècle. - (Supptément 980.)

\section{7.}

Tableaux au moyen desquels on trouve la concordance des dales coptes et musulmanes el qui ont pour argument les noms des sept dormants. En lête se trouve unc préface en langue turque. Traité composé en 1118 de l'hégire (1706-1707 de J. C.). Commencement : باعست

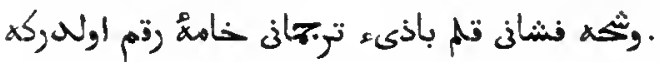

Papier. 15 feuiltets. Hauteur, 2.3 centimètres el demi; largeur, 15 centinètres et demi. MIs. du xvin siècle. - (Supplément 2091.)

\section{8.}

$1^{\circ}$ Explication de certains termes employés dans l'ouvrage d'Al-Soûsî, intitulé ciêl', et qui traite de la concordance de l'année lunaire et de l'annéc solaire, par Mohammad jbn 'Abd al-'Azì ibn abî̀ Bakr al-Djozoûlì alYa'qoûbî al-Resmoûkî. Cet opuscule a élé composé à Bedja, on Tunisie, en 1143 de l'hégire ( 1730 de J. C.). $2^{\circ}$ (Fol. $30 \mathrm{v}^{\circ}$.) Note sur la date de la naissance de Mahomet, suivie de notes cabalistiques.

$3^{\circ}$ (Fol. $32 v^{\circ}$.) Commentaire d'Aboû Zaïd 'Abd alRał̣màn الزيرن surle Moqna' (متئill), trailé en vers techniques d'Aboû Moqra' (متّ), qui enseigne la manière de trouver les jours et les mois de l'année lunaire correspondant au $1^{\text {er }}$ janvies de l'annéc solaire et aux fêtes chréliennes.

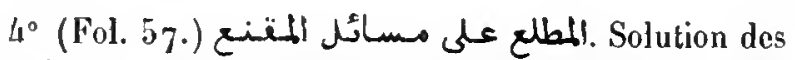
questions auxquelles donne lieu le trailé intitulé $A l$ Moqnae, par Moł!ammad ibn Sacid Al-Marei (iأ).

$5^{\circ}$ (Fol. 67.) Traité d'astrologie, par Mohammad ibn Aḷmad al-Dhakhrî (الغحكى), d'Alger.

$6^{\circ}$ (Fol. 80.) Traité de médecine intilulé نl Le Don agréabler.

$7^{\circ}$ (Fol. 9o.) Autre dissertalion médicale.

$8^{\circ}$ (Fol. 91.) Sur les vertus de certains fruits et de certaines plantes.

$9^{\circ}$ (Fol. 97.) Traditions touchant les mérites des cultivateurs de la terre.

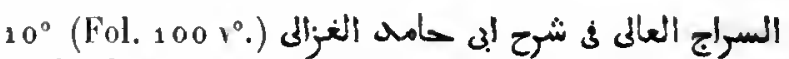
"Le Flambeau ćlevé, pour l'explication d'Aboù Ịâmid al-Ghazâlir. Traité de cabale et de magie.

$11^{\circ}$ (Fol. $119 \mathrm{v}^{\circ}$. ) Commentaire sur la qașida de Molaanmad jbı Sacid al-Soûsì.

$12^{\circ}$ (Fol. $127 r^{\circ}$. ) Commentaire sur l'ordjoûza cabalistique d"Omar ibn 'Abd al-Raḥmân al-Djizqâi ( Cette pièce est datée de l'an 1222 de l'hégire (1807 de J. C.).

${ }_{1} 3^{\circ}$ (Fol. 145.) Notice biographique sur 'Alì ibn abî

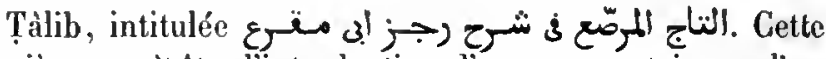
pièce parait être l'introduction d'un commentaire sur l'ordjoúza, intitulé Al-Moqna'.

$14^{\circ}\left(\right.$ Fol. $\left.19^{6} \mathrm{v}^{\circ}.\right)$ Traité sur le grand-øuvre.

$15^{\circ}$ (Fol. 204.) Traité d'alchimie.

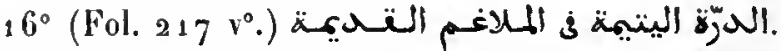
Traité d'alchimie qui, suivant la préface, a élé copié sur un très ancien livre, renfermant tous les secrets du grand art, et qui avait été transmis par un propliète à l'autre. L'original avait été trouvé en Égypte et traduit du syriaque en arabe.

Papier. 266 feuillets. Hauteur, 24 centimètres et demi; Jargeur, 17 cenlimètres. 26 à 34 lignes par page. Ms. du xrint siècle. - (Supplément 1902.) 


\section{9.}

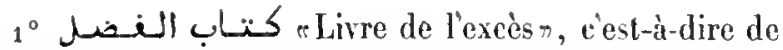
l'excès de l'année solaire sur l'année lunaire. Il s'agit du procédé au moven duquel on trouve le jour de Pâques. Ce traité, composé par un chrćtien copte, est précédé d'une prière el d'une note sur le sens du mot fadhl. En tête se trouve une liste de chapitres. Le texte est accompagné de plusieurs tables astronomiques.

$2^{\circ}$ Fol. 82. (Exposé de la manière de vérifier le temps de la Pàque de notre Seigneur le Messien. Traité composé en Egypte, sous la domination turque, par un mufti hanéfite nommé llohammad ibn Youtsof, de Damiette. Commencement : da

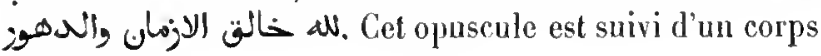
de tables.

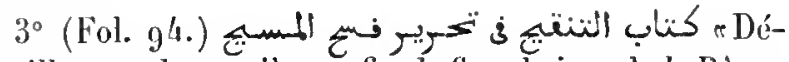
pouillement des matières, afin de fixer le jour de la Pàque du Messier, par Mohanmad ibn Mohammad ibn abi '1Khaïr al-Hasani l'Arnénien, le Malékite, mowaqqit de la mosquée d'Al-Azhar, au Gaire. Commencenient : Us النهم يا مى تغّّد بالابحاع والاختراع . Cet opuscule est suivi d'uu corps de tables et précédé d'une approbation signée : Solä̈mâı ibn llamza, astronome hanéfite et ottoman

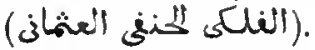

Papier. 106 feuillets. Hauteur, 21 centimètres; largeur, 15 centimères. 14 à 16 lignes par page. Ms. du xrmi siècle. - (Supplément 977 , Saint-Germain 385.)

\section{0.}

$1^{\circ}$ Almanach pour l'année solaire commencaut à l'équinoxe du printemps de l'an 980 de l'hégire $(1573$ de J. G.). Dans I'introduction, l'auteur traite de l'influence des planètes, de leurs aspects el de la concordance des différentes ùres pour l'an 980 . On y remarque quelques figures astrononiques. A la fin se troment des tables de pronostics, de jugerments et d'élections.

$2^{\circ}$ (Fol. $161^{\circ}$.) Almanach du même genre, en langue turque, calculé pour l'an 983 de l'hégrire $(1575-1576$ de J. C.). L'auteur s'étend très-longuement sur la bonne fortune qui farorise le règne du sultan Amurat, fils de Sélim.

Papier. 28 feuillets. Hauteur, 27 centimètres et demi; largeur, 19 centimètres. - (Supplément 978 , Saint-Germain 148.)

Max. omestaux. - It.

\section{1.}

1 0 Calendrier de l'année arabe lunaire ( 1015 de l'hégire) $)$, par Molıammad ibn Mansoûr, descendant du sultan mamlouc Ml-Nàsir, fils du sultan Qalàwoûn.

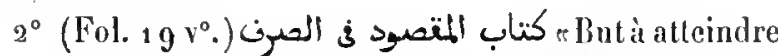
en ce qui regarde les inflexions grammaticales $\%$. Com-

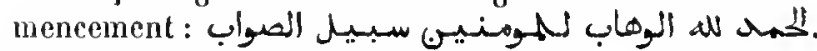
L'auteur y expose la conjugaison et les formes du verbe.

$3^{\circ}$ (Fol. $22 \vee^{\circ}$.) Paradigmes des diverses inflexions du verbe de la première forme. Chaque inflexion devait être accompaguée de sa désignation technique; mais le copiste n'a donné ces indications que pour les deux premières pages.

$4^{\circ}$ (Fol. 37.) Recueil d'anecdotes et de traditions touchant la religion et le droit.

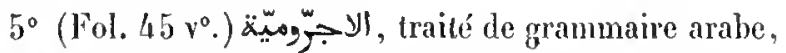
par Mohammad ibn Dâwoud al-Ṣanhâdjì. Copie datée de l'an 1039 de l'hégire $(1629-1630$ de J. C. $)$.

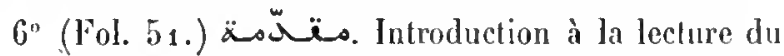
Coran, par Moḷammad ibn al-Djazari, docteur schaféite. C'est un traité en vers. T'exte ponctué. Les feuillets sont renver'sés.

$7^{\circ}$ (Fol. 53 \} ^ { \circ } \text { .) Règles pour la prononciation du noûn } et de l'alif, surtout dans la lecture du Coran, par le schaikh

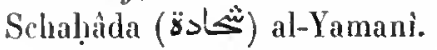

$8^{\circ}$ (Fol. $58 v^{\circ}$.) Les régissants grammaticaux. Com-

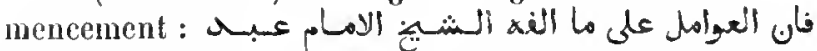

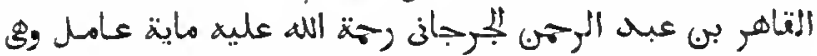

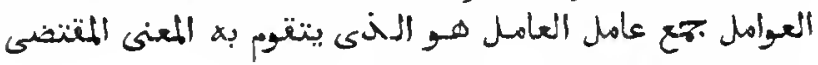

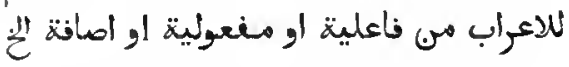

$9^{\circ}$ (Fol. 63.) Le ألاعراب d'Al-llarîrì. Copie dépourvue de points-royelles.

Papier. 66 feuillets. Ilanteur, 21 centimètres; largeur, 15 centimètres. Écritures diverses do xvir sièele. - (Ancien fonds 610, Cotbert 5201.)

\section{2 .}

Calendrier astronomique et ast rologique pour l'an 1040 de l'hégire $(1630-1631$ de J. C. $)$.

Tables et préface en diverses couleurs.

Papier. 2 a feuillets. Hauteur, 29 centimètres; largeur, 20 centimètres. - (Ancien fonds 11119.$)$ 


\section{3.}

Calendrier arec diverses prédictions pour l'an 1053 de l'hérire (1643-1644 de J. C.). Le calendrier est précédé d'une introduction générale et de deux dissertations, dont la première traite de la concordance de l'an 1049 de l'hérgire arec l'annće solaire correspondante, et la seconde, du cycle des Mongols. On y remarque quatre figures circulaires dessinces avec soin.

Papier. 14 fevillets. Hauteur, 29 centimètres et demi; largeur, 20 centimètres et demi. 33 lignes par page. - (Ancien fonds 1120 , Colbert 18,5.)

\section{4.}

Calendrier pour l'an 1163 de l'hégire $\left(17^{4} 9^{-1} 7^{5}\right.$ o de J. C.), dédić au sultan ottoman Maḷınoùd et précédé d'une longue introduction, d'une table d'élections (اختيارات), d'une dissertation sur les éclipses, d'une autre sur les influences des corps célestes, et d'une table qui indique les apparitions de la nouvelle lune. Suivent les tableaux ordinaires, dont chacun est accompagné d'une colonne de prédictions.

Papier. 17 feuillets. Hauteur, 29 centimètres; largeur, 20 centimètres. - (Supplément 2093.)

\section{5.}

Concordance de l'année lunaire 1214 de l'liégire avec l'année solaire (1797-1 $79^{8}$ de J. C.).

1'apier. 12 feuillets. Hanteur, 16 centimètres et demi; largeur, 16 centimètres. 15 à 18 lignes par page. - (Supplément ${ }_{2} 3_{7} 3$.)

\section{6.}

Almanach de l'année solaire 1806-1807 de J.C., qui correspoud à l'année 1221-1232 de l'hégire.

Papier. 10 feuillets. Hauteur, 16 centimètres et demi; largeur, 11 centimètres. 17 lignes par page. - (Supplément 982.)

XVIII.

ASTROLOGIE.

\section{7.}

1 ㄴ. Livre liermétique (كتاب هرمس), composé de deux parties, dont la première, intitulée الأسنتُوطاس, traite de la cosmogonie, du macrocosme et du microcosme; la seconde, des ètres spirituels (الروحانيات) et notamment, sous forme d'un dialogue entre Hermès et Aristote, des heures favorables ou défavorables de chaque jour de la semaine et des spiritualités des astres et des conjonctions. Le titre الستنـوطـاس rappelle celui des traités ஐpòs Tát attribués ì Hermès.

$2^{\circ}$ (Fol. 104.) Recetles pour conmposer des onguents magiques, tirées du Livre des lois (كتاب المنـوأمسيس) de Platon.

Au premier feuillet se trouve le toghra d'un sultan.

Papier. 105 feuillets. Hauteur, 21 centimètres; largeur, 15 centimètres et deni. 13 lignes par page. Ms. dn $x^{\circ}{ }^{\circ}$ siècle. - (Ancien fonds 1167 .)

\section{8.}

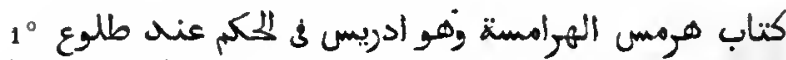
年 Le Livre d'Hermès des Hermès, qui est le même qu'Idris, sur les jugements que l'on peut tirer des levers de Sirius yemeniten. Traité d'astrologie attribué ì IIermès Trismégiste, qui expose les influences exercées par Sirius dans chaque signe du zodiaque. Il est dit dans la préface quill a été traduit par Aristote, du Livre des secrets (الكتاب المخكون ف الاستراز), ouvrage écrit

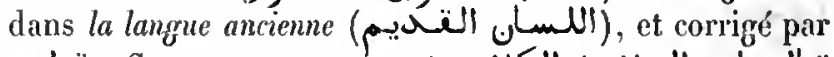
تال عليه السلام ف الكلام عنده : Commencement. نتطويه

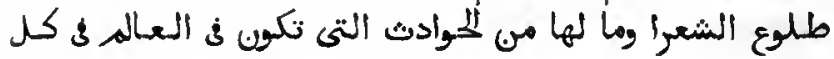

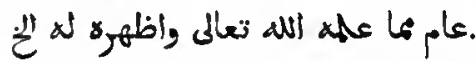

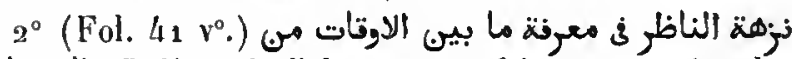
م الـد Délices de l'observateur, faisant connaître les ares compris entre les heures n, par le mowaqqit Schihâb al-Dìn 'Albd al-Qâdir ibn Aḥmad al-'Adjmâwî̀ (ألجمان). Ce sont les mesures, en degrés et en fractions de degrés, des ares de cercle compris entre les cercles horaires, pour chaque jour de l'année solaire. Commencement : av sals

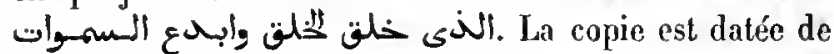
l'an 1024 de l'hégire (1616 de J. C.).

Papier. 96 feuillets. Hauteur, 20 centimètres; largeur, 15 centimètres. 15 lignes par page dans la première pièce, 23 dans la seconde. - (Ancien fonds 1171.)

\section{9 .}

$1^{\circ}$ Traité d'astrologie attribué à Hermès Trismégiste. (Voyez l'article $1^{\circ}$ du numéro précédent). Copie datée de l'an 1064 de l'hégire (1653-1654 de J. C.). 
$3^{\circ}$ (Fol. $141^{\circ}$.) Traité d'astronomie, sans préface ni titre, contenant la description des mansions de la lune et celle des constellations, ainsi que des notices sur la manière de déterminer l'heure dı jour et de la nuit, sur la manière de dresser la qibla el sur l'année solaire, commençant au mois d'octobre (اكتتـوبر). Les dernier's chapitres traitent des fou levers d'étoiles qui influent sur l'atmosphère; de l'ère du Dsou 'I-Qarnaïn; de l'année des chrétiens de Syrie; de l'année des Coptes; des saisons; des nuages el des éclairs.

Papier. 49 feuillets. Hauteur, 21 centimètres; largeur, 15 centimètres. 95 lignes par page dans le premier opuscule, 19 dans tc sccond. Écritures diverses du xwı siècle. — (Supplément 983.)

\section{0 .}

1. Traité d'astrologie attribné à Hermès Trismégiste. (Voyez les deux numéros précédents.)

$2^{\circ}$ (Fol. 17. (Chapitre sur l'ascendant des années de l'univers". 11 y est question des influences exercées par les diverses planètes dans chaque signe du zodiaque.

30 (Fol. 19 \% .) (Traité des conjonctions des astres $\pi$, par $\Lambda$ boû Maéschar (Albumasar) ibn Moḷammad al-Balklıi.

$4^{\circ}$ (Fol. 36.) Chapitre sur les obligations $(\dot{\infty}, \mathbf{3})$ de diverse nature imposées par la loi, par Sidì Moḷammad al-Bakri.

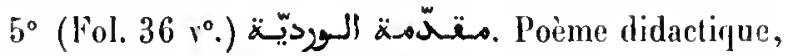
en vers du mètre radjaz, sur linterprétation des songes, par 'Omar ibn al-Wardi.

Ms. daté de l'an 1021 de l'bégire ( $1709-1710$ de J. C.).

Papier. 63 feuillcts. IIauteur, 21 centimètres; largeur, 15 centimètres. 17 à so lignes par page. - (Ancicn fonds 1137.)

\section{1.}

Traité sur l'inllnence que les corps célestes exercent dans les affaires du monde. C'est probablement le كتاب r Les Périodes et les Milliers d'années

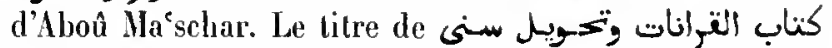
العالم, qu'on lit en tête dums., est apocryphe. L'ouviage se compose principalement de tableaux. Commencement: ان وجود دلايل الاثثخام العلوية في الاثثخام السفلـيـة بسوجه

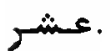

Papier. 66 fenillets. Hauteur, ${ }_{2} 5$ centimètres; targeur, 16 centimètres et demi. Ms. du xiv siècle. - (Supplément 1133. )

\section{2.}

$1^{0}$ Traité sur les influences des planètes et des signes du zodiaque, attribué à Aloû Macschar, et précédé d'une introduction qui commence par ces mots : لذال .خلق الانسسان مس. ط' L'ouvrage lui-même commence

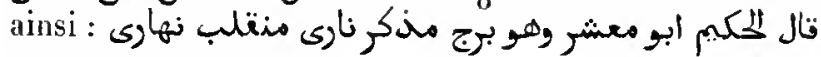

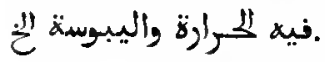

$2^{\circ}$ (Fol. $45 \mathrm{r}^{\circ}$.) Autre traité du même genre, atlribué aussi à Aboû Måschar.

Papier. 81 feuillets. Hauteur, 28 centimètres et demi; largeur, 20 centimètres. 19 lignes par page. Ms. du $x y^{\circ}$ siècle. - (Supplément 1135 lis.)

\section{3.}

Traité des nativités, attribué à Aboû Ma'schar et renfermant de nombreux dessins coloriés, dont les quatre premiers représentent Satan el d'autres démons. Les dessins qui snivent représentent les figures des signes du zodiaque, les phases de la lune personnifiées, el d'autres formes bizarres. Les preuiers feuillets manquent. Les deux derniers feuillets, d'une main plus moderne que le reste du ms., sont datés de l'an 700 de l'hégire (1 300 de J. C.).

Papier. 37 feuiltets. IIauteur, 36 centimetres; largeur, 26 centimètres et demi. Environ 27 lignes par page. - (Supplémsent 1126 bis.)

\section{4.}

e Traité des nativités $\pi$, attribué à Abon Máschar. Il y est question des inlluences planétaires, des lalismans et des sigues du zodiaque, représentés par

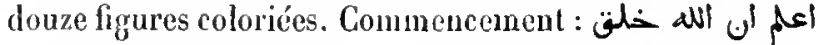

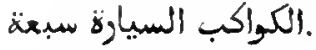

Papier. 51 feuillets. Hauteur, a1 centimètres et demi; largeur, 15 centimètres et demi. 15 liggnes par page. Ms. du xvi" siècle. (Ancien londs 1165. .)

\section{5.}

Traité des nativités, par le Ilakîm, titre qui, probablement, désigune Aboû Macschar. Chacun des douze discours Iraite d'un signe du zodiaque. Des figures coloriées représentent ces signes.

Papier. g34 feuillets. Hauteur, 31 centimèlres; largeur, 21 centimètres el demi. 6 à 8 liggnes par page. Vls. du $x{ }^{\circ}$ siècle. - (Supplément 1130.) 


\section{6.}

Trailé des nativilés, attribué à Aboû $\mathrm{Ha}^{\mathrm{e}}$ schar. Com-

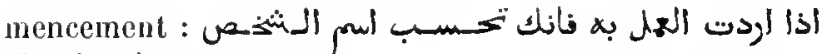
¿t dol poly.

Ms. daté de l'an 1057 de l'hégire (1647 de J. C.).

Papier. 73 feuillets. Hauteur, 26 centimètres et demi; largeur, 18 centimètres et demi. 17 lignes par page, - (Supplément 1132.)

\section{7 .}

Traité des nativités, attribué à Aboû Ma'schar, et précédé d'une courte notice sur les douze signes du zodiarjue.

IIs. daté de l'an 1088 de l'hégire (1678 de J. C.).

Papier. 124 feuillets. Hauteur, 15 centimètres et deni; largeur, 10 centimètres. 11 lignes par page. - (Supplément 1135.)

\section{8.}

الحكام تحكويل سنى المواليـد Jugements fournis par la conversion des années des naissances n, grand traité d'astrologic, par Aboû Ma'schar. Commencement : تسال أبسو

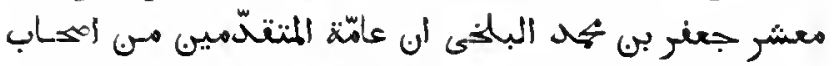

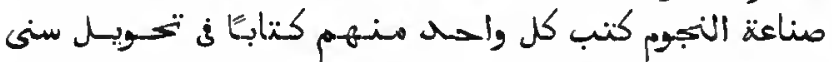

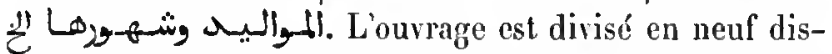
cours. En tête se trouve une longue inlroduclion, comهençant par ces mots : هـ ذا كتناب أبو (sic)

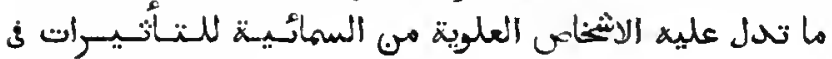
الاثشياء المسنلية

Ms. daté de l'an 609 de l'légire (1212 de J. C.).

Papier. ${ }_{19}^{8}$ feuillets. IIauteur, 27 centimètres; largeur, 18 centimètres et demi. 19 lignes par page. - (Supplément 1133.)

\section{9 .}

-Introduction à l'astrologie judiciairen, ourrage composé, selon Hadji Khalfa, en 357 de l'hégire ( 968 de J. C.), par Aboû Naṣr alQommî al-Ḥasan ibn 'Alì. Ce trajté, dédié au prince bouïde Fakhır al-Daula Schâlıânschâh, est divisé en cinq discours (متالات), dont chacun renferme plusieurs chapitres (ذصول). On y trouve les éléments de l'astronomie, quelques figures et un petit nombre de lables, avec des ins. tructions sur la manière de connaître l'arenir au moyen de jugements tirés de la position des corps cétestes. Chaque maqála commence par le alli بس écrit en gros caractères coufiques d'un genre très-fantastique. La date de 595 qui se trouve à la fin de la première maqâla (fol. 39 ), est probablement celle de l'exemplaire-dont le présent ms., daté de l'an 704 (১ذ) de l'hégire (1304-1305 de J. C.), est la copie.

A la fin du ms. se trouve une dissertation, en cinq pages, par Scharîf al-Dìn Mohammad ibu Mohammad ibn 'Omar' al-Djaghminî, sur les influences fortes et faibles des étoiles (قوى الركواكب وضعنها).

Papier. ${ }_{178}$ feuillets. Hauteur, 20 eentimètres et demi; largeur, 11 centimètres el demi. 19 lignes par page. - (Supplément g6 1 bis.)

\section{0 .}

م logie judiciairen, par 'Alì ibn abi 'l-Ridjâl al-Schaỉbâni. L'ourrage est divisé en huit partics et chaque partie en plusieurs chapitres. En tête du volume se trouve un index, remplissant quinze pages. Commencement : دم

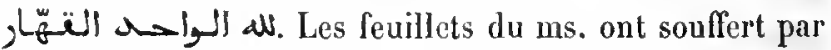
l'lıumidité.

Papier. 352 feuillets. Hauteur, 26 centimètres; largeur, 15 centimètres. 23 tignes par page. Ms. du xvu siècle. - (Supplément 1127.)

\section{1.}

لLL Complet». L'auteur de ce traité d'astrologie prétend déduire de certains thèmes dressés par lui et dont il donne les figures, les événements passés et futurs, depuis les temps les plus reculés jusıju'à la fin de la vingtième année du vil siècle de l'hégire. $A$ partir du milieu du $v^{\circ}$ siècle, les indicalions fournies par les thèmes se rapportent à des événements futurs, circonstance qui détermine l'époqne où vivail l'auteur.

Papier. 107 feuillets. Hauteur, 28 centimètres et demi; largeur, 15 centimètres et demi. 21 lignes par page. Ms. du xil" siècle. - (Supplément 1129.)

\section{2.}

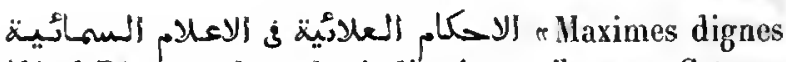
d’Alà al-Dîn, touchant les indications célestesn. Cet ou- 
vrage, divisé en neuf chapitres, traite des اختيلرأر Elections, c'est-à-dire des heures propices pour entreprendre une affaire. Il a été composé originairement en persan, par Fakhr al-Dìn al-Kàzì (Hoḥammad ibn 'Omar) et dédić au sultan 'Alà al-Dìn Moḥammad Khwìriznı Schâh, fils de Tukusch (تكش) mort en 596 de l'hégirire. Il a été traduit en arabe par l'auteur lui-même. Le ms. est daté de l'an 678 de l'hégire (1279 de J. C.).

Papier. 57 feuillets. Hauteur, 22 centimètres et demi; largeur, 15 centimètres et demi. 15 lignes par page. - (Ancien fonds $117^{\circ}$, Colbert 4710.$)$

\section{3.}

$1^{\circ}$ d'sur la manière d'établir des jugements d'après la conversion des années de l'universs. Traité conplet d'astrologie judiciaire, par Yaḅyà ibn Noḥammad ilon abí Schokr al-ILaghrabì.

$2^{\circ}$ (Fol. $89 \gamma^{\circ}$.) Poème dont tous les vers riment en ili, sur les pronostics que l'on pent tirer de la position de Saturne dans les différents signes du zodiaque.

$3^{\circ}\left(F_{0} l .9^{4} v^{\circ}\right.$.) 2 a Sage, se rapportant aux positions de Sirius dans les différents signes du zodiaque.

$4^{\circ}\left(\right.$ Fol. $104 v^{\circ}$.) Notes et tables astrologiques.

Papier. 107 feuillets. Ilauteur, 31 centimètres; targeur, 15 centimètres. 23 tignes par page. $\mathbf{~ l l s . ~ d u ~} \mathrm{xv}^{\circ}{ }^{\circ}$ siècte. - (Ancien fonds 1161.$)$

\section{4 .}

Traité d'astrologie judiciaire, en vingt-trois chapitres, attribué à Moḷyì al-Din Ibn abì Schokr al-Maghrabì. C'est proballement l'ouvrage que Hadji Khalfa, t. II, p. 560 , mentionne sous le titre de r. Le Petit recueil भ. Suivent quelques tibleaux indiquant les jour's que les aspeets des diverses planètes rendent propices ou dél'avorables.

Papier. 140 feuillets. Llauleur, 19 centimètres; targeur, 14 centimètres. 15 lignes par page. Ms. du xv1 ${ }^{\circ}$ siècle. - (Ancien fonds 1142.$)$

\section{5.}

$1^{\circ}$ Source des vérités, traité qui enseigne tout ce qui peut s'apprendre en ce qui concerne la comnaissance des procédés». Traité d'astrologie et de magie, dont l'anteur est désigné par le surnom d'Al-Djili, natif du Guîlàn, et qui traite des noms des esprits des sept planètes, des vertus secrètes des chiffres indiens et des chiffres arabes, des tour's de magie blanche, de la talismanique, des alphabets magiques, etc.

$2^{\circ}$ (Fol. 59.) كتاب ba Traité sur les influences des astres, attribué à

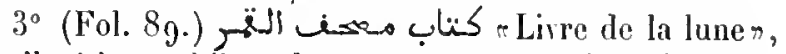

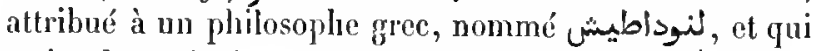

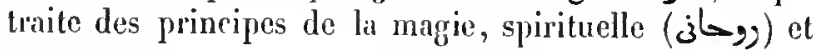
terrestre.

$4^{\circ}\left(\right.$ Fol. $\left.1041^{\circ}\right)$ (بvive des opérations magiques qui se font au mojen d'un chevrean?.

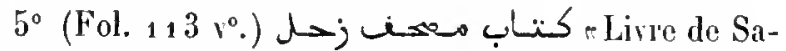
turnen, altribué au sage لنوداطيش, et qui traite des tillismans qu'on peut confectionner sous l'inliuence de cette planète.

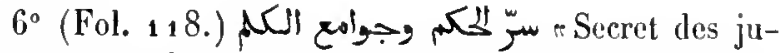
gements et collection des sentences", traité de cabale et et de divination, par $A$ bou 'l- $A$ bbàs al-Boûnì. Conmmencement :

$7^{\circ}$ (Fol. $136 v^{\circ}$.) Traité de magie naturelle et de prestiges (النّعبده والمسيهيميا). Ce traité renferime un grand nombre de signes cabalistiques et d'alphabets de convention.

$8^{\circ}$ (Fol. $148 v^{\circ}$.) Traité de divination el d'opérations magiques, attribué ì Aristote.

Ms. daté de l'an 1041 de l'hégire (1631-1632 de J. C.).

Papier. 15 ' fenillets. Hauteur, 21 centimètres; largeur, 15 centimètres et deni. 17 lignes par page. - (Aneien fonds 1154 , Colbert 4986.$)$

\section{6.}

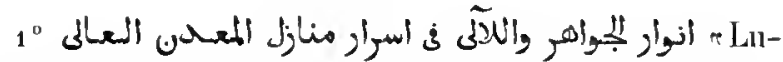
mières des pierreries et des perles, sur les secrets des slations (gangues) de la mine supérienrer. Cet ourrage traite des influences que les splières célestes et les mansions de la lune exercent sur les choses de ce monde. II a été composé en 867 de l'hęrire (1462-1463 de J. C.). Commencement : نور نورا

$2^{\circ}$ (Fol. $217 \mathbf{v}^{\circ}$.) Extraits du chapitre qui traite de la magie, des incantations, etc., de l'ou rage intitulé لئر أخوان الصنا.

Us. daté (fol. $215 \mathrm{v}^{\circ}$ ) de l'an 971 de l'hógire (1565 de J. C.).

Papier. 286 feuiltets. Ulautenr, 23 centimètres; largeur, 15 centimètres et demi. 17 à 21 lignes par page. - (Supplément 1128.) 


\section{7.}

Ornement (de l'esprit) du causeur, lraitant des pronoslics qu'on peut lirer d'une foule d'événements", par Moḷammad ibn "Mlì al-Schobrìmolsi. Ce traité de prédictions $\left(\boldsymbol{\beta} l_{0}\right)$ se compose d'une introduction à la chronologie et de deux chapilres, l'un se rapportant aux jours de l'année (arabe, copte et grrecque), et l'autre aux phénomènes de la na-

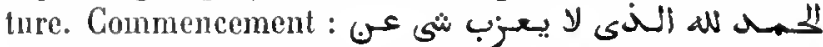
ants.

Le urs. a été écrit avant la mort de l'auteur.

$A$ la lin du volume se trouve la recette d'un aphrodisiaque.

Papier. 82 feuillets. IIauteur, 21 centimètres; largeur, 15 centi-

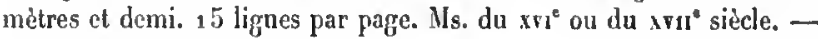
(Supplément 973.)

\section{8.}

Jugrements d'après les stations (de la lune)." Traité d'astrologie, composé de trente tableaux doubles et de huit tableaux supplémentaires. Les six premiers tableaux et la moitié du septième manquent.

Papicr. 28 feuillcts. Hauteur, 24 centimètres; Jargeur, 18 centimètres. Mls. du xv1 siècle - (Supplément 1126.$)$

\section{9.}

$1^{\circ}$ Commentaire sur un iraité d'astrologie touchant les aspects et les influences des planètes. Le commencement manque.

$2^{\circ}$ (Fol. $17 \mathrm{v}^{\circ}$.) Tables dressées par Fakhr al-Din alRàzî, donnant la description des esprits qui président à chaque degré de chaque signe du zodiaque, arec l'indication de leurs influences et des fumigations qu'il convient d'employer'.

Papier. ${ }_{7} 7$ fenillets. Hauteur, 22 centimètres; Jargeur, 15 centimètres et demi. Ms. du xvı" siècle. - (Supplément 2089.)

\section{0.}

$1^{\circ}$ Traité d'astrologie en cent trente-sept chapitres, par 'Omar ibn Ferdjân al-Tîrân 1. Il n'y a pas de préface. $2^{\circ}\left(\right.$ Fol. $5 \mathbf{r}_{1} \mathbf{v}^{\circ}$.) Traité des vertus secrètes des lettres de l'alphabet et de leur emploi dans le Djafr (남).

$3^{\circ}\left(F_{01} .801^{\circ}.\right)$ Notes sur les lettres males et les lettres femelles.

$4^{\circ}$ (Fol. $83 \mathrm{v}^{\circ}$. ) Instructions pour l'emploi d'un tableau de divination.

Papicr. $9^{3}$ feuillets. Hauteur, 20 centimètres et demi; largeur, 14 centimètres. Écritures diverses du xrin' siècle. - (Supplémert 1891.)

\section{1}

10 Sur les influences qu'exercent les diverses planètes dans chaque signe du zodiaque. Ouvrage sans titre, ni préface.

$2^{\circ}$ (Fol. 77.) Autre traité du même genre, accompagné de tables, dont une table de latitudes et de longitudes. Commencement : "

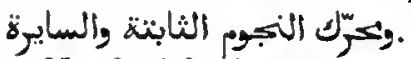

Ms. daté de l’an 1036 de l'hégire (1626 de J. C.).

Papier. 180 feuitlets. Hauteur, 21 centimètres; largeur, 14 centimètres et demi. 15 à 17 lignes par page. - (Ancien fonds 1162.)

\section{2.}

$1^{\circ}$ Notes cabalistiques et astrologiques, dont quelques-unes en langue turque.

$2^{\circ}$ (Fol. 7.) Traité d'astrologie, en turc, renfermant un grand nombre de tables astronomiques et de diagrammes.

30 (Fol. 45.) العرن ف تصريغ المبر. Traité de cabale, par Ibn abi 'l-Fatḥ al-Ṣoûfî̀.

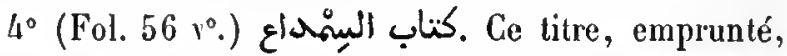
dit l'auteur, à la langue syriaque, signifie les signes et les indications (العلامات والهلايل). C'est un traité d'astrologie, fondé, toujours d'après l'auteur, sur les doctrines d'Hermès le sage, de Daniel, de Dsou 'l-Qarnaĩn et d'Alexandre. II se compose de vingt-deux chapitres.

$5^{\circ}\left(\mathrm{F}_{01 .}{ }_{0} 09 \mathrm{r}^{\circ}\right.$.) Traité des Élections astrologiques.

$6^{\circ}$ (Fol. 1 1 4.) Traité sur la construction et l'emploi du Zäirdja.

$7^{\circ}$ (Fol. 117.$)$ (المنتخب. Traité de géomancie.

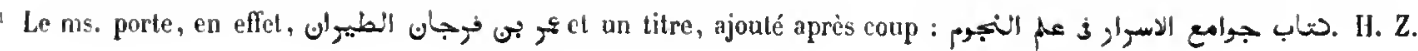


$8^{\circ}$ (Fol. $120 \mathrm{r}^{\circ}$.) Notes sur la science de la cabale (c)

$9^{\circ}$ (Fol. 128.) Sur le commencement et la fin du ınonde. Ce traité renferme une Jongue qasida qui, dit-on, avait été composée pour un tobba régnant à Yathrib et qui a été découverte par 'Othmàn ibn 'Affàn. Ce joème,

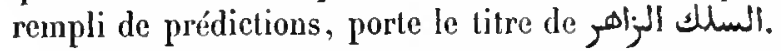

$10^{\circ}$ (Fol. 136.) (13) Noms des ctels des trésor's n, c'est-à-dire noms des esprits qu’il faut invoquer dans la reclierche des trésors cachés. Ce traité renferme une formule de conjuration et phusienrs formules de talismans, etc.

Papier. 156 feuillets. Ilauteur, 20 centimétres et demi; largeur,

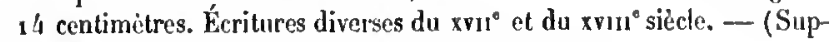
plément 1892.)

\section{3.}

Éphémérides, pronostics et thèmes astrologiques pour l'an 1130 de J'héggire ( 718 de J. C.), scizième annéc du règne du sultan ottoman Aḷmad Klı̀̀n, fils de Moł̣ammad Khàn. Les tables, qui paraissent d̀tre incompletes, sont précédées d'une introduction qui traite de la chronologie et de l'astrologie.

Papier. 10 feuillets. Ilauteur, 22 centimètres; largeur, 15 centimètres et demi. Iss. ln xrm siècte. - (Supplément 975.)

\section{4 .}

Éphémérides, pronostics et thèmes astrologiques pour l'an 1133 de Thégire $\left(17^{20-1} 7^{21}\right.$ de J. C. $)$, dix-lıuitième du règne dı sultan ottoman Aḷmad Klẩn, fils de Mohammad Khàn. La premièle table domne l'explication des mourements involontaires qui se manifestent dans les membres du corps, science appelée عيم الاختلإ.

Papier. 18 feuillels. Ilauteur, 32 centimètres; largeur, 21 centimètres et demi. Ms. du xvi11" siècle. — (Supplément 976.)

XIX.

\section{SCIENCES OCCULTES.}

\section{ALCIIIHIE.}

\section{5.}

1 م Ises (douze) chapitres d'Ostancs le sagen. Traité de la pierre philosophale. Il est dit dans la préface que cet otrrage, écrit dans la langue de l'auteur (la langne pehlevie?), a été traduit en grec,

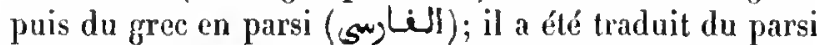

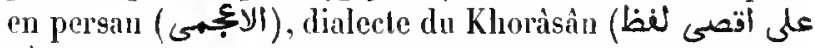
), par un nommé Ibn 'Omar, et ce texte a été l'ơriginal de la version arabe. Ces renseignements ne méritent ancune créance. Quant an mage Ostanès, il était, dit-on, disciple de Zoroastre; d'autres le font contemporain de Xerxès ou bien d'Alexandre le Grand. Quoį̣u’il en soit, le texte gree de certains opuscules chimiques attribués à Ostanès on Hostanès, existe encole. (Voyez la Bibliotheca graca de Fabricius, t. I, p. 106 de l'édition de Harless.) La copie est datée de l'an 738 de l'hégire (1337 de J. C.). Plusieurs leuillets sont intervertis et il $\mathrm{y}$ a quelques lacunes.

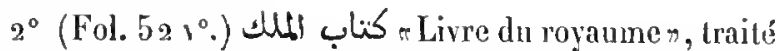
d'administration politique, londée sur l'alchinie. D'après une note qui se troure en tête, cet opuscule serait le hnitième des cinq cents ourrages composés par le scliaikh soufi Aboù Moûsì Djùbir ilm Haiyàn (le célèbre Géber).

$3^{\circ}$ Fol. 58. (Fe Petit traité de la Miséricorde $\leadsto$, traité d'alchimie, par Djàbri ibn Haiyàn, commençant par un dialogue entre l'anteur et son maître.

4 (Fol. 62.) Traité d'alchimic divine, attribué au sage Ostanès. Trente-deux chapitres, précédés d'une longne introduction. Lourrage, ainsi qu'on le roit par les

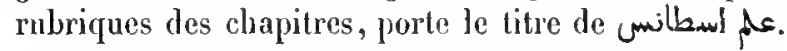

Papier. 142 feuillets. Ilauteur, 18 centimètres et demi; largeur, 13 centimètres et demi. Écritures diverses du xı ${ }^{\circ}$ sjècte. - (Ancien fonds 972.)

\section{6 .}

Vingt-et-ın traités d'alchimie, par Djàbir ibn Haiyàu. Le premier opuscule traite de l'or; le second, de l'argent; le troisième, dı cuivre; le quatriène, du fer; le cinquième, de l'étain (slêl); le sixième, du plomb, etc. On y remarque deux traités sur les rertus secrètes des lettres de l'alpliabet, un sur les diverses catégories t'êtres (? العوالم ; deux autres sur la pierre philosophate, el deux autres sur les combinaisons chimicpues. Les derniers fenitlets manquent. Le folio 163 n'appartient pas ì l'ouvrage.

Papier, 163 feuillets. Ilauteur, 21 centimètres et demi; largeur, 13 centimètres et demi. 16 lignes par page. Ms. du svie siècle. (Supplément 1080.)

\section{7.}

r Secret de la philosophie (hermétique) pour servil de commentaire alu Livre de la 
miséricorle (de Géber)». Ce commentaire est attribué au

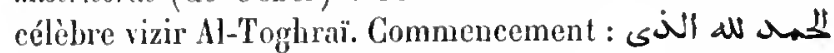

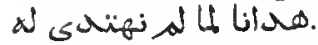

A la fin du volune se trouve la note d'un adepte qui donne la composition de la pierre philosophale. Il déclare que la première opération avait manqué, l’opérateur ayant chauffé trop fort, el que, faute d'argent, il n'a pu la recommencer.

Papier. 160 fenillels. Ifauteur, 21 centimètres; largón, 14 centimètres el demi. 17 liģnes par page. Ms. du xru' sièele. - (Supplément $107^{3 .)}$

\section{8 .}

" Recelles approuvées, provenant de Dsou 'l-Noûn d'lkhmim (Al-Mișrì)n, célèbre ascète ct saint musulınan, médecin et alchimiste, mort en 245 de l'hégire $(859-860$ de J. C. $)$. C'est une collection de recettes médicales el chimiques, de charmes, de talismans, dinrocations magiques, ete.

Ms. daté de l'an 1000 de l'hégire (1591-1592 de J. G.).

Papier. 91 fevillets. Hauteur, 20 centimètres; largeur, 14 centimètres. 21 lignes par pagre. - (Ancien fonds 1083.)

\section{9 .}

$1^{\circ}$ Commentaire de Moḷammad ibn Amyal al-Tamimì

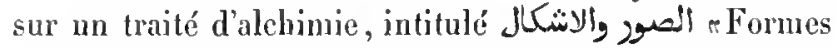
et figures $\%$, composé par un personnage désigné par le titre d'Al-Makim ele sage, le philosopher. Le commentateur prélend expliquer ces formes et figures mystérieuses qui étaient au nombre de dix, sans les reproduire; il en parle comıne si le lecteur les, avait sous les yeux, et il ajonte : eJ'en donne ici l'explication, sans la cacher par jalousie (ب) ) r. Cette explication consiste en rèveries cabalistiques et en pièces de vers peu intelligibles. A la fin se trouvent plusieurs poèmes composés par le tlakim.

$2^{\circ}$ (Fol. 44.) Note sur les Formes et figures, par Ibn Amyal.

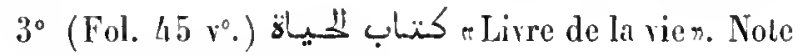
sur une opération d'alchimie.

$4^{\circ}$ (Fol. $47 \mathrm{r}^{\circ}$.) Pièce de vers sur la pierre philosophale, attribuce à Dsou 'l-Noûn al-Miṣrì.

Papier. 51 fenillets. Hauteur, 20 centimètres el demi; largeur, 14 centimètres et demi. 25 lignes par page. Ms. du xvi1 siècle. (Supplément $107^{4}$ bis.)

\section{0.}

1 Dissertation de Molyammad ibn Amyal al-Tamimî sur certaines figures d'ètres ailés et d'hommes qui étaient représentés sur le plafond et les murs d'un temple de Boûșir qui, dit-on, arait été la prison du patriarche Joseph. Ces figures, représentées d'une façon rudiunentaire, sont expliquées dans une qașida appelée Épître du soleil à la lune (voyez le numéro suirant), suivie d'un commentaire très étendu, qui traite surtout de la pierre philosophale.

$2^{\circ}$ (Fol. $77 r^{\circ}$.) Pièce de vers sur la pierre philosoplale, dont voici le premier :

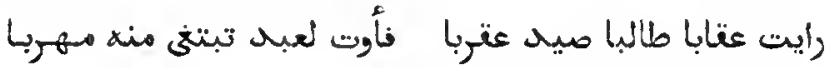

Papier. 79 fenillets. IIauteur, 21 centimètres; largeur, 16 centimètres. 19 lignes par page. Ms. du xvi siècle. - (Aneien fonds $117^{8}$, Colbert 4988.)

\section{1 .}

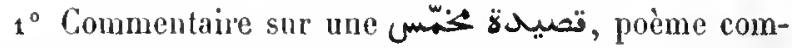
posé de strophes, dont chacune renferme cing vers. Ce

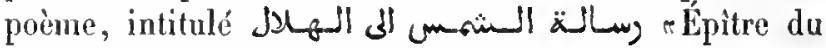
soleil à la lunen, traite de l'élixir et de la pierre philosopbale. C'est le même que celui qui est mentionné par Hadji Khalfa, sous le titre de " Eau de la feuille et de la terue stellairen. Premier vers:

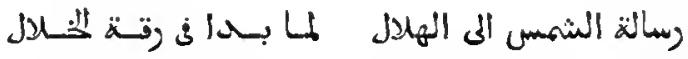

L'auteur du poème se nommait Aboû 'Abd Allah Moḷammad ibn Amyal al-Tamimi. Le commencement et la fin du commentaire manquent.

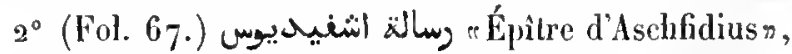
sur l'emploi de la pierre philosoplate. Commencement:

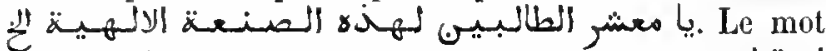

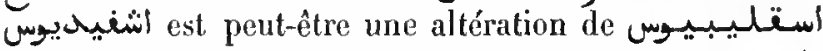
"Asclepius", nom de l'écrivain hermétique dont Fabricius parle dans sa Bibliotheca graca, tome I, page 64 de l'édition de Harless.

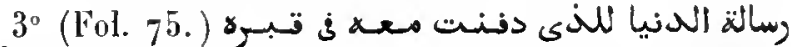
"Epitre de la fortune à celui avec lequel elle avait été enterrée dans le même tombeau r. Traité de philosophie hermélique.

40 (Fol. 81.) Traité d'alchimie, intitulé العي ملكنسب

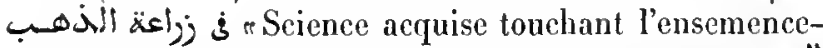

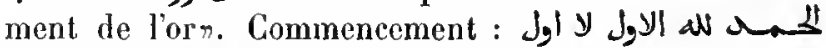

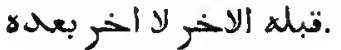


$5^{\circ}$ (Fol. $109 v^{\circ}$.) Notes et récits au sujet de l'élixir, etc.

Papier. 112 feuiliels. Hauteur, g4 centimètres; largeur, 15 centimètres et demi. Écritures diverses du $x v^{\circ}$ siècle. — (Ancien fonds 975 , Colbert 4990.)

\section{2.}

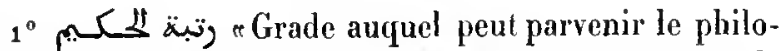
sophen, Iraité d'alchimic, par Maslama ibn Ahmad alMadjriți (né à Madrid), astronome distingué, mort en 398 de l'hégire (1007-1008 de J. C.). (Voyez Prolégoménes d'Ibn Khaldoun, traduction de M. de Slane, t. IIl, p. 173 , note.) Dans le premier chapitre, l'auteur examine les ourages de ses devanciers, à partir d'Euclide et de Ptolémée; dans le second, il traite de la pierre employée dans les

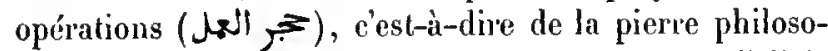
phate; dans le troisième, de la préparation de l'élixir (الاكسير), et dans le quatrième et dernier, de la solution des énigmes employées par les alchimistes. Commence-

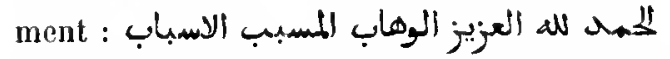

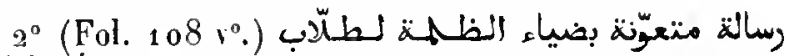
¿كاك ếpitre qui aide à dissiper les ténèbres pour ceux qui cherchent la science . Traité d'alchimie.

Papier. 117 feuillets. Hauteur, 21 centimètres et demi; targeur, , 6 centimètres. 17 lignes par page. Ms. du $\mathrm{xri}^{e}$ siecle. - (Ancien fonds $97^{3 .}$ )

\section{3.}

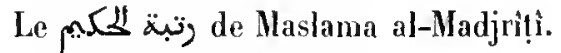

La fin du ms. manque.

Papier. 138 feuillets. Hauteur, 19 centimètres; largeur, 11 centimètres. 18 lignes par page. Mls. du xwı" siècle. - (Supptèment 1078.)

\section{4.}

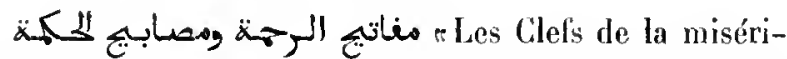
corde et les lumières de la sagessen. Première partie d'un traité d'alchimie el de la pierre philosoplale, par le vizir Al-Hosaïn ibn 'Alì al-Ṭoghräi, qui ful mis à mort en 515 de l'hégire ( 11121 de J. C.). L'auteur déclare dans la préface que son livre est destiné à ceux qui ont déjà la connais-

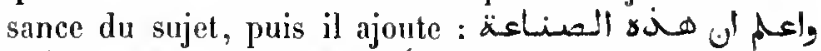
政 qu'il est réel; cela est incontestablen. L'ouvrage se com-

\footnotetext{
MN. oRiExtaUt. - II.
}

pose de deux parties (متالة), dont le présent volume renferme la première.

Ms. daté de l'an $9^{34}$ de l'hégire (1528 de J. C.).

Papicr. 123 feuillets. Hauteur, 18 centimètres; targeur, 13 centimètres et demi. 21 lignes par page. - (Ancien fonds 974 , Colbert 6147.)

\section{5 .}

مe Flambeau qui éclaircit les secrets de la science de la clef n, traité d'alchimie attribué à 'Izz al-Dìn Aïdamir ibn 'Alì al-Djildakî. (Voyez Notices et Extraits, t. IV, p. 108.) "La clef dont il s'agit,

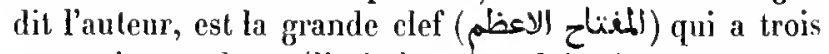
cent soixante dents (litléralement : doights), et au moyen de laquelle on peut ouvrir toutes les portes du grand art et trouver le sens des expériences énigmatiques qui s’y emploient \%. L'ouvrage est divisé en quatre parties el chaque partie en plusieurs chapitres qui, tous, commencent par le bismillah.

Ms. daté de l'an 973 de l'hégire (1565-1566 de J. C.).

Papier. 145 feuitlets. Hauteur, 27 centimètres; targeur, 17 centimètres et demi. 25 lignes par page. - (Ancien fonds go5, Colbert 3699.)

\section{6.}

Premier yolume du méme ourrage.

Ms. daté de l'an $\log _{4}$ de l'hégire ( 1683 de J. C.).

Papier. 849 feuillets. Hauteur, 17 centimètres; largeur, 11 centimètres. 15 lignes par page. - (Ancieu fonds $9^{84 .}$.)

\section{7.}

-Les Secrels de la combinaison. rendus intelligibles", par Aïdamir ibn 'Alì al-Djildakì.

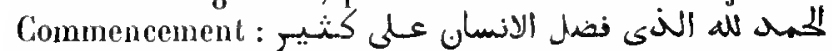
. Ce traité d'alchimie fait suite à un grand ouvrage du mème auleur sur le mêne sujet. Le ms. commence, après la préface, par la quatrième section (فصل) du quatrième livre (باب) de la première division (قسم) du troisième volume. Ce chapitre est intilulé : eProduil. des corpus imparfaits traités au noyeu des parties combinées provenant de métaux, de plantes at d'animaux". La fin inanque.

Papier. 118 feuillets. llauteur, 20 centimetres el demi; largeur, 15 centimètres. 19 lignes par page. Ms. du rril' siẻcle. - (Sıpplément $21: 0$. 


\section{8.}

$1^{\circ}$ La quatrième partic du même ouvrage, où l'on Irouve la description diun grand nombre d'opérations chimiques, faites en vue de la pierre philosopluale, et une quinzaine de balances cabalistiques qui se rapportent aux corps célestes.

$2^{\circ}$ (Fol. $143 \mathrm{r}^{\circ}$.) P'lusieurs recettes d'alchimie, de diverses écritures.

Papier. 150 fonillets. Hlauleur, 21 centimètres; largeur, 15 centiıètres. 25 liggnes par page. Ms. tu xvi siècle. - (Supplément 1079.)

\section{9 .}

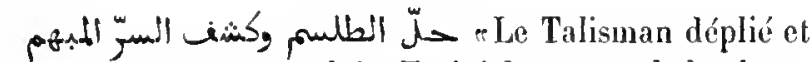
découverte du secret cachén. Traité des vertus de la pierre philosophale, par Abou 'l-chbbàs Aḷmad al-Glıomri.

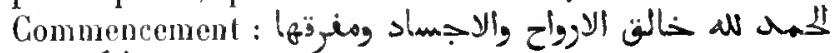

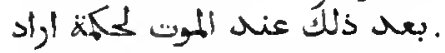

Papier. 36 feuillets. Hauteur, 31 cenlimètres; largeur, 16 cenlimètres. 27 lignes par page. Ils. du xv1 siècle. - (Supplémen1 1069.)

\section{0 .}

1 Mème ourrage.

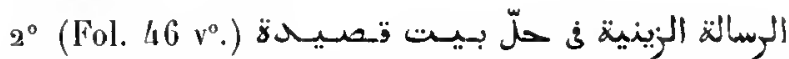
النونية. Explication d'un vers d'une qaṣida d'Aboù Amyal sur la pierre philosophale.

$3^{\circ}$ (Fol. $51 v^{\circ}$.) Traité dédié à lbràhìm Pacha, vizir du sultan Amurath, et contenant le compte-rendu de quelques opérations alchiniques.

$4^{\circ}$ (Fol. 57.) Recette pour traiter la pierre qu'on désigne sous le nom de

$5^{\circ}$ (Fol. $58 \vee^{\circ}$.) Épitre sur le grand-ceurre, adressée au sultan ottoman Solaïmàn par un adepte nommé Maghousch al-Maghrabì (a) (مغون)

$6^{\circ}$ (Fol. $63 \mathrm{v}^{\circ}$.) Traité d'opérations alchimiques, intitulé كناب الاصول بهابي الموصول

$7^{\circ}$ (Fol. $9^{4} \mathrm{v}^{\circ}$.) Autre traité sur le mème sujet.

$8^{\circ}$ (Fol. 134.$)$ Note sur la pierre philosophale.

$9^{\circ}$ (Ibid.) Autre traité d'alchimie. L'auteur y a inséré une lettre du vizir AI-Toghrâi sur le même sujet. Con-

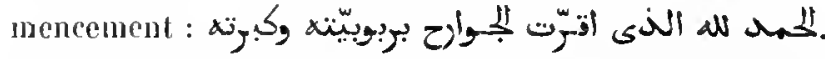

Papier. 153 feuillets. Hauleur, 21 cenlinètres; largenr, 14 centimètres et demi. 25 lignes par page. Ms. de diverses écritures du svu1 siècle. - (Supplẻment $189^{5}$.)

\section{1 .}

$1^{\circ}$ Commentaire d'un anonyme sur le حلّ اللطلمس dont l'auteur est nommé ici Moḷammad al-Ghomri.

$2^{\circ}$ (Fol. 64.) Extraits du نهاية اللملب d'Al-Djildaki et des ourrages d'alchimie les plus célébres. Un index des extraits, qui sont au nombre de quatre cent quatrevingt, se trouve au commencement.

Papier. 257 feuillets. Hauteur, 26 centimètres et demi; largeur, 13 centimetres et demi. 39 lignes par page. Ms. du xü sjècle. (Supplénent 1089.)

\section{2 .}

a Divan de paillettes d'orn². Premières lettres d'un recueil de poésies ayant pour sujet l'alchimic. Le premier fenillet manque.

Papier. 26 pages. Ilauleur, 23 centimètres et demi; largeur, 17 centitimèt es et deni. 18 à so lignes par page. Ms. du xvi" siècle. - (Supplément 1527. )

\section{3.}

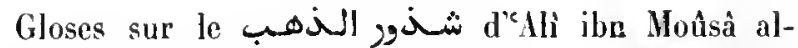
Andalosì. A la fin du ms. se trouve un poème sur le grand ceuvre.

Ms. daté de l’an 1087 de l'hégire ( 1676 de J. C.).

Papier. 19 feuiltels. Hauteur, 91 cenlimètres et demi; largeur, 17 centimètres. 23 lignes par page. - (Supplément 1070. )

\section{4 .}

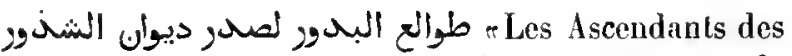
pleines lunes, pour accompagner le commencement de l'ouvrage intitulé Diwân al-Schodsoûrn. Ce sont des gloses composées par 'Alì Tehelebi pour expliquer une phrase

1 Ce titre ne se trouve pas dans le ms., qui est une copie moderne du شخور الخذهب. II. Z. 
cabalistique de trois lignes, qu'Abou 'l-Ḥasan al-Anșârî avail placée en tête de son traité dalchimie, intilulé Dîwân al-Schodsoûr. Commencement : زيّيّ . السموأت بانوار اللطسوألع

Papier. 82 feuillets. Hauteur, 21 eentimètres; largẹtr, 15 centimè̀tres. $\mathbf{3}$ lignes par page. Ms. du xviı siècle. - (Supplément 1071.)

\section{5 .}

$1^{\circ}$, Perles el pierreriesn, trailé sur te grand ouvre qui, dit l'auteur, 'Alî ibn abî Bakr ibn Aḷmad al-Ṣáliḅi, est appelé alchimie (lo par le vulgaire, et philosophic (2⿺辶ا木 $)$ par les adeptes.

$2^{\circ}$ (Fol. 16.) Recucil de receltes d'alchimic.

$3^{\circ}$ (Fol. 41. (1) "Flux de lumières", traité

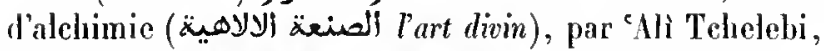
suruommé Al-Móallim al-djadid «le nouveau maîtren.

$4^{\circ}$ Fol. 51. Solution des éuigmes et clefs des trésors $\pi$. Traité d’alclimie.

$5^{\circ}$ (Fol. $55 \mathrm{r}^{\circ}$.) Épitre attribuce à Socrale sur l'art divin.

$6^{\circ}$ (liol. $57 v^{\circ}$.) Piece de dix-sept vers sur les qualilés de l'élixir d’or (خوأم الاكسيـ النذهب), par Géber, suivi d'un commentaire et d'une autre pièce de vers sur

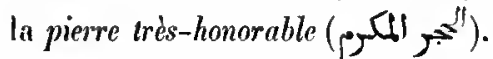

$7^{\circ}$ (Fol. 61.) Traité anonyme sur l'art divin.

$8^{\circ}$ (Fol. 74.) Traité du maître (4تاد) Dâwoud ibn Khalîl al-Antakì sur l'oiseau (الطاير) ou l'aigle (عتاب), pierre philosophale ainsi nommée, parce qu'elle s'mvole el emporte ce qui est combinć avec elle.

$9^{\circ}$ (Fol. 83.) Autre traité sur l'art divin.

$10^{\circ}$ (Fol. $87 v^{\circ}$.) Commenlaire sur le poème d'Aboû Yaḷyâ Zakarîyâ al-Marrâkoschì qui traite des vertus de l'aigle (عتاب), appelé aussi l'esprit des esprits.

Ce uns. est de la main d'Aṭmad Tehorbadji, janissaire de Damiette; il est daté des aunées 1198 et 1199 de l'bégire (1 $783-1785$ de J. C.).

Papier. $9^{3}$ fenillets. Ifanteur, 17 centimètres el demi; largeur, 24 centimètres. 20 lignes par page. - (Supplément 1072.)

\section{6.}

r Fruit de la bonne direction et manière de mélanger les âmes avec les corps $\pi$. Traité d'alchimic qui, dit l'auteur anonyme, enseigne la

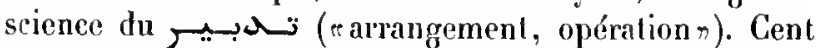
trente-six chapitres. Commencement :

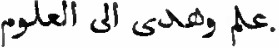

Papier. 184 feuillets. Hauteur, 21 centimètres; largetur, 15 centimètres. 21 lignes par page. Mls. du xru' siècle. - (Supplément 1069 bis.)

\section{7.}

1 Traité d'alchimie, sans titre.

$2^{\circ}$ (Fol. 130.$)$ Traité sur les verlus secrètes des planles qui portent les nonis des sept planèles et des sept mélaux.

Ms. dalé de l'an 1196 de l'hégire $(1782$ de J. C.).

On lì, en tête du volume, la description de quelques amulettes.

Papier. 180 feuillets. Ifauteur, 17 centimètres et demi; largeur, 12 centimètres. 18 lignes par page. - (Supplément $107^{4}$.)

\section{8 .}

Trailé d'alchimie. L'auleur emploie, en s'adressant alt

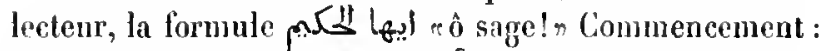

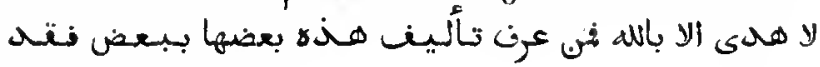

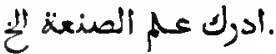

Papier. ${ }_{157}$ feuillets. Hauteur, a 2 centimètres et demi; largeur,

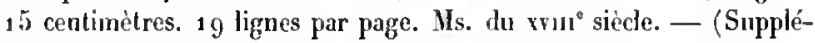
ment 1076. )

\section{9 .}

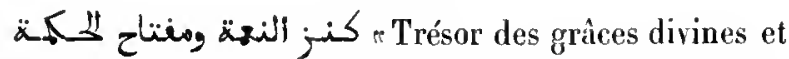
clef de la sagesser. Traité d'alchimie. Commencement:

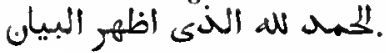

Au commencement el ì la fiu du uns. se trouvent un grand nombre de receltes d'alchinie.

Papier. 81 feuillets. Hauteur, 21 centimètres; largeur, 15 centimètres. 19 lignes par page. Ms. du xvin ${ }^{\circ}$ siècle. - (Supplément 1081.)

\footnotetext{
1 Comparez Hadji Klıalfa, t. IV, p. 18. H. Z.
} 
2. MAGIE.

\section{0.}

كتاب أندهريون البابلى في علاجات بلمّ والاوجاع والامبامن "Traité d'Andahrioúsch le Babylonien, sur les noyens de gouérir les personnes possédées, les donleurs et les maladies . Recueil de charmes, d'inrocalions et de talismans.

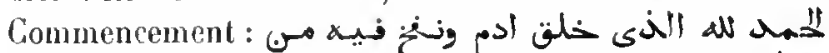

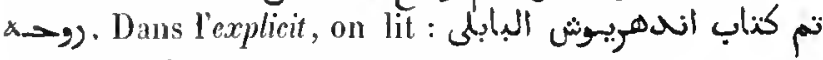

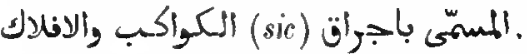

Papier. 12 fenillets. Hauteur, 15 centimètres et demi; largeur, 10 centimètres et demi. 18 lignnes par page. Its. du xv' siècle. - (Ancien fonds 1226.)

\section{1.}

Trailé de géomancie, altribué au propliète Idris et commencant pal un tableau de seize figures que l'on obtient en marquant quatre lignes de points sur le sable.

Papier. 80 fenillets. Hauteur, 21 centimètres; largeur, 16 centimètres. 15 liğnes par page. Ms. du xvm siède. - (Supplément 1111.)

\section{2.}

Autre traité de géomancie, également attribué à Idrìs.

Papier. 37 feuillets. Hauteur, 22 centimètres; largeur, 15 centimètres. 18 lignes par page. Ms. du xvm" siècle. —(Supplément 1113.)

\section{3.}

T'raité de diviualion, attribué au prophète Daniel, indiquant les pronoslics qu'on peut lirer du tonnerre et des éclair's.

Papier. 74 feuillets. Hauteur, 16 centimètres; largeur, 10 cenlimètres et demi. 11 lignes par page. Ms. du xvi' siècle. - (Supplément 1109.$)$

\section{4.}

Traité de Seherdsim l'Indieme sur la science de la magien. Lourrage conmence par la liste des noms des esprits préposés aux sept astres et dont on invoque le concours pour opérer

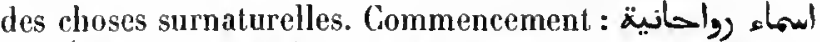

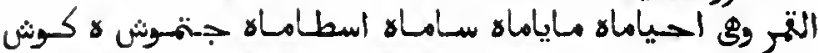

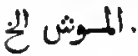

Papier. 57 feuillets. Hauteur, 20 centimètres et demi; largeur, 15 centimètres. 15 lignes par page. Ms. du xvi" siècle. - (Ancien fonds 1195 .)

\section{5 .}

Même ouvrage.

Ms. écrit à Paris, en 1677 .

Papier. 170 pages. Hauteur, 19 centimètres; largeur, 13 centi mètres. 12 lignes par page. - (Supplément 1095 , Saint-Germain 1095.)

\section{6.}

(5) :Les Grands phylactères (?)) n. Traité de magie (المسجمية) el de cabale, attribué à Aristotc.

Papier. a f feuillets. Hauteur, a centimètres et demi; largeur, 14 centimètres. 15 lignes par page. Ms. du xrö siècle. - (Supplément 2111.)

\section{7.}

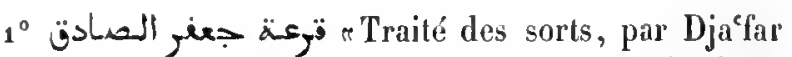
al-Sådiq \%. Les questions doirent d'abord se réduire à un groupe de trois lettres, el ce groupe sert à indiquer le paragraphe qui renferme la réponse el qui se compose de versets du Coran et de tradilions. Le chapitre qui traite de la manière de réduire les questions à trois lettres manque. Dans le présent ms., on trouve les groupes trilitìres formés par les diverses combinaisons des quatre premières lettres de l'alphabet. Le $\mathrm{ms}$. commence par la prière qu'il faut réciter avant de consulter ce traité des sorts.

$2^{\circ}$ (Fol. $15 \mathrm{v}^{\circ}$.) Calendrier de l'année julienne.

$3^{\circ}\left(\mathrm{Fol} .21 v^{\circ}.\right)$, Amulette maritimen, par Abou 'l-Hasan al-Schâdsili. C'est une prière à l'usagè des marins. (Voyez Hadji Khalla, 1. 1II, p. 57.)

$4^{\circ}$ (Fol. $24 \mathrm{v}^{\circ}$ ) Indication des fortuna ( pluriet (كراتنيس(1) ou coups de vent qui surviennent dans chaque mois de l'année julienne.

$5^{\circ}\left(\right.$ Fol. $25 \mathrm{v}^{\circ}$.) Liste des mois de l'année arabe et diverses prieres.

$6^{\circ}$ (Fol. $26 v^{\circ}$.) التبرطبية La Cordouane n, poème des- 
liné à être appris par les enfants el qui traite des devoirs dı musulman.

$7^{\circ}$ (Fol. $30 v^{\circ}$.) en vers. Chaque hémistiche commence par سبكان دع.

$8^{\circ}$ (Fol. 32.) Notes diverses.

$9^{\circ}$ (Fol. 34.) La Borda d'Al-Bousịiri.

$10^{\circ}$ (Fol. 44.) Conte moral. Commencement : وפى أن

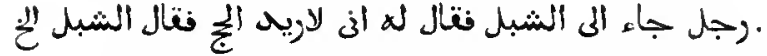

$11^{\circ}$ (Fol. 46.) Traité sur l'utilité qu'on peut lirer des diverses parties du corps de certajns animaux, à commeneer par le loup.

$12^{\circ}$ (Fol. 5o.) Prières et notes diverses.

$13^{\circ}$ (Fol. 53.) Prière, commencant par ces mots : اللاهم الن أعوذ بك مى الكسل والكهزم والمغوم والمأثم

$14^{\circ}$ (Fol. 55.) Qualre ou poèmes en l'honneur de la naissance de Mahomel.

En tête du volume se trouvent des versets du Coran dont on fait usage dans les sciences occulles.

Papier. 6o feuillets. Hauteur, 19 centimètres; largeur, 13 centimètres. Environ 16 lignes par page. Écritures diverses da $x v^{\circ}$ siècle. - (Ancien fonds 1204.$)$

\section{8.}

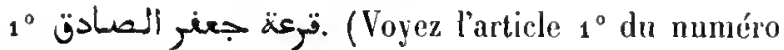
précédent.)

$2^{\circ}$ (Fol. $15 \mathrm{v}^{\circ}$.) Énumération des heures favorables et défarorables des sept jours de la semaine.

$3^{\circ}$ (Fol. ${ }_{1} 6 v^{\circ}$.) Énumération des jours de chaque mois (du calendrier romain) où il doit tomber de la pluie

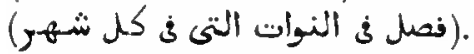

Papier. a feuillets. Hauteur, a centimètres; largeur, 1/ centimètres. 18 lignes par page. Ms. du $\mathrm{xvr}^{\circ}$ siècle. - (Ancien fonds 438 , Colbert 6118 .)

\section{9.}

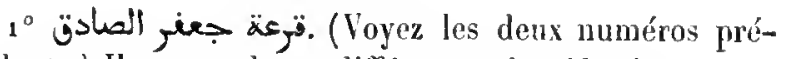
cédents.) II y a quelques différences de rédaction.

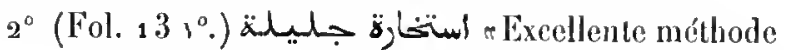
pour consulter le sort (au moyen de versets du Coran)".

$3^{\circ}$ (Fol. $39 v^{\circ}$.) Présages que l'on peut tirer de la position de la lune, lorsqu'on entreprend un royage.

$4^{\circ}$ (Fol. 4o.) Tables pour trouver la position de la lune dans le zodiaque, ainsi que le mois et le jour de l'année solaire. D'autres tables, dressées pour chaque signe du zodiaque, font connaitre la significalion de certains présages.

$5^{\circ}\left(F_{0} l .60 v^{\circ}\right.$.) Tables tirées par $r$ le pluilosophe indien" du tableau de la vie et de la mort.

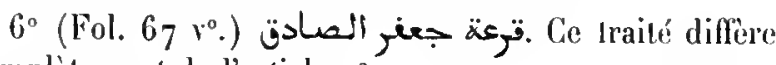
completement de l'article $1^{\circ}$.

Ms. daté (voy. fol. 13) de l'an 1041 de l'bégire (1631-1632 de J. C.).

Papier. 83 feuillets. Hauteur, 20 centimètres; largeur, 15 centimètres. 18 lignes par page. - (Ancien fonds 1205.)

\section{0.}

rLes Sorts de Ma'mounn. Tables dressées, dit-on, par le calife Aboù Moḷammad (sic) 'Abd Allah al-Mla'moûn, fils de Hàroûn al-Raschìd, pour faire connaitre d'avance l'issue, bonne ou mauraise, d'un projet qu'on veut exécuter. L'ouvrage se compose de plusicurs cereles, de quelques tables se rapportant aux planètes et aux stations de la lune, de vingt grands corcles ì rayons, couverts d'inseriptions, et de plusieur's colonnes de disliques lirés des ourrages des grands poètes, parmi lesquels l'auteur fait figurer, malgré l'anachronisme, AlNolanabbì el Al-Harirì.

Papier. 48 fenillets. Ilauteur, 25 centimètres et demi; largeur, 18 centimètres. Ms. du $\times v^{\mathrm{e}}$ siècle. - (Supplément 1093. )

\section{1 .}

Tables analogues aux précédentes. A la fin, on lit le? mène litre : قرعة ألمألمونية

Papier. 34 feuillets. Hauteur, 31 centimètres; largeur, 15 centimètres. Ms. du xví siècle. - (Supplément 1129. )

\section{2}

Trailé de cabale el de divination, intitulé

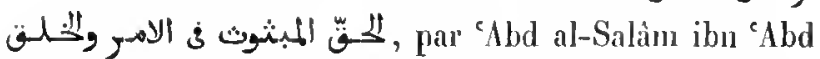

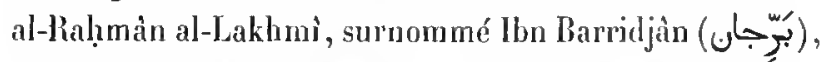
mor't, dans la ville de Maroc, en 536 de l'trégire (1 1411142 de J. C.). L'auteur explique l'étymologie et les ver- 
lus miraculeuses des quatre-vingt-dix-neuf noms de Dieu. Cet ouvage est divisé en trois sections.

M!s. daté de l'an $9^{83}$ de l'hégire $(1575-1576$ de J. C.).

Papier. 276 feuillels. Hauteur, 23 centimètres; Jargeur, 17 centimètres. 19 ligues par page. - (Supplément 243.)

\section{3.}

. Médication spirituelle, au moyen du Coran du Miséricordieux n, par Abou 'l-Ilasan 'Alì ibn Moùsà, de Grenade, comnu sous le nom d'Al-Schodsoûrî, parce yuii] avait composé nn ouvrage sur

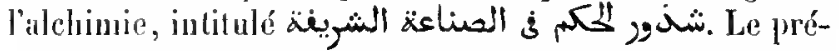
sent onrage traite des mystieres des lettres de l'alphabet, puis des talismans. H est divisé en buit chapitres, précédés de denx introductions. Le trosiène chapitre traite des mystires du sceau trimgulaire attribué à Abou llàmid al-Ghazàlì.

Papier. 94 feuillets. Hauteur, 21 centinètres et demi; largeur, 15 centimètres. 21 lignes par page. Ms. du xwit siècle. - (Ancien fonds 117.7.)

\section{4.}

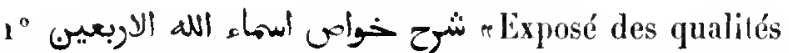
inhérentes anx quarante noms de Dieur, traité fondé, dit-on, sur les leçous de Schilıàb al-Dìn Ahmad al-Sohrawardi, docteur soufi du xus siècle. On rapporte, d'après celte autorité, que, lorsqu'un lomme connait l'usage de ces quarante noms, il pent commander aux esprits, aux anges, aux génies, aux hommes, aux cieux, à ła terre, aux bêtes sauvages el aux oiseanx. Mais, pour les employer avec succès, il faut rempiir liuit conditions, dont la première est de croire fermement à la puissance de ces noms. Commencement : لمه

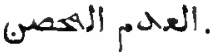

$2^{\circ}$ (Fol. $36 \vee^{\circ}{ }^{\circ}$ ) Autre commenlaire sur le même traité d'Al-Sohrawardi.

Papier. 54 feuillets. Hauteur, a 1 centimètres; largeur, 15 centinètres et demi. 17 lignes par page. -- (Ancien funds $119^{4 .}$ )

\section{5 .}

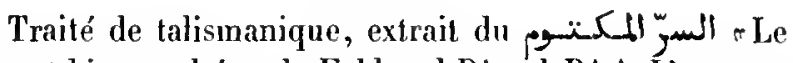
Secret bien cachér, de Fakhr al-Din al-Ràzî. L'ouvrage commence par une déclaration sur les avantages de cette science (S) qui, dit.il, nous fait connaitre les mystères dn monde supérieur et ceux du monde inférieur. 11 y a quelques chapitres sur l'astrologie et un calendrier des jours fastes et néfastes. Le premier feuillet manque.

Papier. 245 feuillets. Hauteur, 23 centimètres; largeur, 13 centinètres. 17 lignes par page. Ms. du $\mathrm{m}^{\circ}$ siècle. - (Ancien fonds 1039.$)$

\section{6.}

Traité d'Abou 'l-'Abbâs al-Boûnì sur les mystères des lettres de l'alphabet et sur les vertus des noms de Dieu. Abou 'l- Abbâs Aḷmad ał-Boûnì (né à Bone), est mort en 622 de l'hégire (1 225 de J. C.). Commencement : (ل) Un titre, rjouté après coup, qui se trouve en tête du rolume,

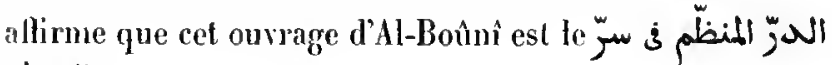
plill.

Papier. 59 feuillets. Flauteur, 18 centimètres et demi; largeur, 13 centimètres et demi. 15 lignes par päge. Ms. du xw1 siècle. (Supplément 1087.)

\section{7.}

Soleil des connaissances (mystiques) et dons précieux $\pi$, grand ouvrage sur la cabale, les tatismans, les carrés magiques, etc., par Abou 'J-'Abluâs Aḷmad al-Boûni. C'est la première édition de l'ourage qui est moins étendue que la seconde. Le frontispice, portant le titre et le nom de lauteur, est orné d'arabesques.

Papier. 148 feuillets. Hanteur, 25 centimètres; largeur, 17 centimétres. 17 lignes par page. Ms. du xü siècje. - (Ancien fonds 363.)

\section{8.}

Même ourrage. Exemplaire de la première édition, daté de l'an 847 de l'hégire (1443 de J. C.). Le premier feuillet manque.

Papier. ${ }^{3} 37$ feuillets. Hauteur, 26 centimètres; largeur, 17 centimètres et demi. 17 lignes par page. - (Supplément 1091.)

\section{9.}

Même ouvrage. Exemplaire de la première édition, laté de l'an $9^{13}$ de l'hégire ( 1508 de J. C.).

Papier. 108 feuillets. Hanteur, 37 centimètres; largeur, 18 centimètres. 17 tignes par page. - (Ancien fonds 1122 , Colbert 3700 ) 


\section{0.}

Première partie de la grande édition du même ouvrage.

Papier. 227 feuillels. Hauteur, 29 centimètres; largeur, 19 centimètres et demi. a6 lignes par page. Ms. du $x^{2} v 1^{\circ}$ sièele. - (Ancien fonds 378. )

\section{1 .}

Seconde partie de la grande édition du même ouvrage.

Papier. 256 feuillets. Hauteur, 29 centimètres et demi; largeur", 20 centinuètres. 25 lignes par page. - (Ancien fonds 1123 .)

\section{2 et 2653.}

Mème ouraģa, écril par un Européen. Le commencement est accompagné d'une version latine interlinéaire. La copie est datée de l'an 1711 de J. C.

2 vol. Papier. 579 et 605 feuillets. Hauteur, 37 centimètres et demi; largeur, 24 centimètres. Envirun 16 lignes par page. - (Supplément 1088 I, II.)

Même ourrage.

\section{4.}

Papier. 348 feuillets. Ilauteur, 29 centimètres; largeur, 20 centimètres. 29 lignes par page. Ms. du xviı" siècle. - (Supplément 1089.)

\section{5.}

Mème ouvrage. Exemplaire daté de l'an 1188 de l'hégire (1774 de J. C.). En tète, une vignette assez bien exécutée.

Papier. 509 feuillets. Hauteur, 32 centimètres; largeur, zo centimètres. 27 lignes par page. - (Supplément 1090.)

\section{6.}

(الاصول والـضـ Les Principes et les règles", traité des sciences occultes atribué à Schibàb al-Din Ahmad

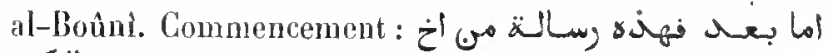

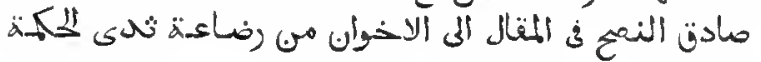

Papier. 110 feuillets. Ilauteur, 15 centimètres et demi; largeur,
10 centimètres et demi. 13 lignes par page. Hs. du Ivi $^{e}$ siècle. (Ancien fonds 1231, Colbert 6503.)

\section{7.}

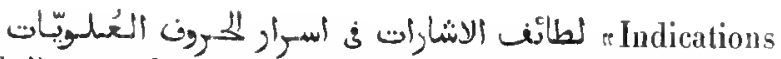
subtiles touchant les vertus secrìtes des letlıes de lalphabet célesten. Traité de cabale et de talismanique, par Abou 'l-cAbbàs al-Boûnî. Commencement : s jl all ana

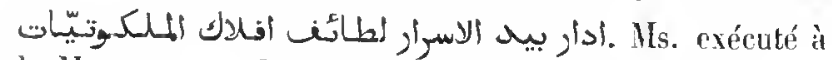
la Mecque, en 784 de l'hégire (1382-1383 de J. C.).

Papier. 66 fenillets. Hauteur, 25 centimètres et dani; largenr, 17 centimètres. 21 lignes par page. - (Ancien fonds 364.)

\section{8.}

Mème ouvrage.

Papier. $9^{3}$ fenillets. Hauteur, 19 centimètres; largeur, 14 cenlimètres. 17 lignes par page. Ms. lu xv sic̀cle. - (Aneion fonds 1185.)

\section{9 .}

Amulette composée par Al-Boùni. Cette pièce est écrile sur une bande de papier insérée dans un petit étui de cillton.

Papier. Longueur, 1 mètre 55 centinètres; largeur, 8 centimètres et demi. Ms. du xvi e sièela. - (Supplément a115.)

\section{0.}

Clefs des nystères des lettres et flambeaux des lumières des vasesn. Ce traité est à tort altribué à Abou "l- Abbàs Aḅınad alBoùni, qui est mentionné dans la préface aree d'autres écrivains ayant trailé de ce sujet. Son nom est accon-

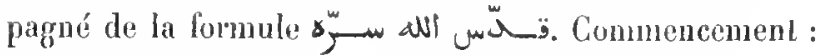

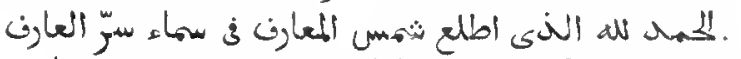

Au commencement et à la fín du volume (lol. 1 à 16 et $\log$ a 134 ) se trouvent des extrails el des fragments, en général Irès mal écrits, se rapportant tous à la cabale.

Ms. daté de l'an 1096 de l'hégire ( 1685 de J. C.).

Papier. 134 feuillets. Hauteur, 20 centimètres; largeur, 15 centimètres. 1 g lignes par page. - (Supplément 1105. ) 


\section{1 .}

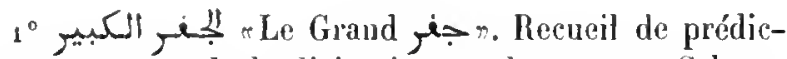
tions au moyen de la divinalion par lettres, par Schams al-Dîn Hohammad ibn Sàlim at-Khallàt. L'auteur dit anoir puisé les matériaux de celte compilation dans les Iraités d'At-Kindi, de Kamàl al-Din Moṭanmad al-Bastàmi, de Nolı̣ì al-Din Ibn al-'Arabî et d'Abd al-Ḥaqq ibn Saba'in. Il a eu enire les mains l'ourrage de ce dernier en 735 de t'bégire $(1325$ de J. C.). Chaque chapitre de ce recueil lorme un ourrage séparé. Au fol. $11 \mathrm{~V}^{\circ}$ se trouve la likotba prononcée, dit-on, par'Ali, fils d'Aboù Tálib, devant les lıabilants de Koùfa; au fol. 21, la litanie des symloles d'Ali, dont les premiers sont : أنا سّر الاسبراز

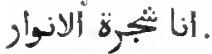

$2^{\circ}\left(\right.$ Fol. $461^{\circ}$.) Sur les mystères des lellres. Ge lraité parait faire parlie de l'ourrage précédent. C'est le mème opuscute que l'article $9^{\circ}$ du $\mathrm{n}^{\circ} 2669$.

$3^{\circ}$ (Fol. $49 r^{\circ}$.) Plusieurs figures talismaniques, servant à illustrer le texte d'un traité de prédictions de Motıyì al-Din Ibo al- Arabi.

$4^{\circ}\left(F_{0} .6, v^{\circ}.\right)$ expériences", par Aricenne. Poòme sur t'rmploi, cn médecine, de la thériaque, des latismans, des charmes et des influences astrologiques. premiers vers :

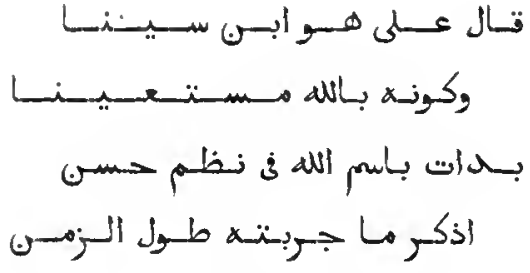

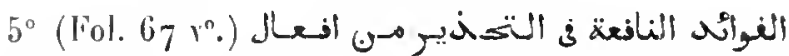
مضرّة (Nolions uliles, on avertissements, au sujet de certains actes muisibles\%.

$6^{\circ}$ (Fol. $69 r^{\circ}$.) Dialogue entre Malsomet et Satan et quelques traditions du Prophète.

$7^{0}$ (Fol. $74 v^{\circ}$.) Questions adressées à Hahomet par 'Abd Altah ibn Salàm.

$8^{\circ}$ (Fol. 79.) Fragunents de poésies retigieuses.

$9^{\circ}$ (Fol. 80 vo.) Histoire de la chemise d'Al-Bahloûl (القيص (البهانول et du calile Hàroùn al-Raschid.

$10^{\circ}$ (Fol. 88.) Traité sur l'exceltence dı nom de Joseph (يوسن). Le commencement mantue. On remarque dans cotte pièce des carrés magiques, un tableau circulaire et l'imitalion de quelques hiéroglyphes égyptiens. $11^{\circ}$ (Fol. 93.) Notes et extraits sur l'art de ta divination.

$12^{\circ}$ (Fol. 101.) Divers autres fragments sur te même sujet.

جنس الكبير $13^{\circ}$ (Fol. $104 v^{\circ}$ ) Autre exemplaire du de Mlọammad iłon Sâtim ał-Khallâl.

Papier. 134 feuillets. Hauteur, 20 centimètres et demi ; largeur, 15 centimètres. Ms. de diverses écritures du xrı siècle. - (Aucien fonds 1174. )

\section{2.}

Recueil de charmes, d'incantations et de receltes magiques, commençant sous forme d'un conmentaire sur un trailé dont le nom n'est pas indiqué. Il est dil que le comınenlaire a été composé par Abou 'J-Abbâs alBoûni, mais cet écrivain est cité.tui-même, fol. $5 v^{\circ}$.

Papier. 78 feuillets. Hauteur, 22 centimètres; largeur, 15 centimètres et demi. a l ligues par page. Ms. du xrü sjècle. - (Ancien fonds 1176. )

\section{3.}

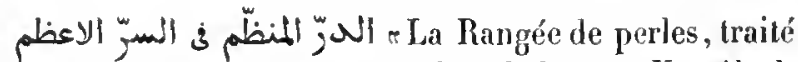
sur le grand secret», ourrage de cabale, par Kanàl atDìn Aboû Sìlim Hoḷammad ibn Ṭatha, mort en 652 de

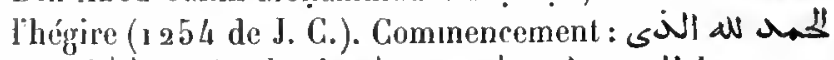
أطلع مه أجتباه مه عباده الابرأر على خغايا الاسرأ

Papier. 80 feuillets. Hauteur, al centimètres et demi; largeur, 15 centimètres. 21 lignes par page. Ms. du $x^{\circ}$ siècle. - (Ancien fonds 420.)

\section{4.}

Nème ourrage.

Ms. daté de l'an $9^{3} 9$ de l'hégire ( $1532-1533$ de J. C. $)$.

Papier. 143 feuillets. Hauleur, 19 centimètres et demi; largeur, 14 centimètres. 13 lignes par page. - (Supplément 1120 .)

\section{5.}

Nême ourrage.

Papier. 88 jeuillets. Hauteur, 31 centimètres et demi; largeur, 21 centimètres et demi. Ms. de deux écritures, dont la plus ancienne est du $\mathrm{xvi}^{\mathrm{e}}$ siècle. - (Supplément 1099.) 


\section{6.}

Même ouvrage.

Papier. 142 feuillets. Hauteur, a centimètres et demi; largeur, 15 centimètres et demi. 3 lignes par page. Ms. du xvı siècle. - (Ancien fonds 1192.)

\section{7.}

Même ouvrage.

A la fin de cet exemplaire se trouvent plusieurs tableaux magiques, composés de cercles et de parallélogrammes.

Papier. 1 to feuillets. Hauteur, 21 centimètres; largeur, il centimètres et demi. 17 lignes par page. Ms. du xvis' siècle. - (Ancien fonds $77^{\circ}$.)

\section{8.}

$1^{\circ}$ Même ourrage.

$2^{\circ}$ (Fol. $17 \mathrm{v}^{\circ}$.) Traité sur la durée dn monde. Com-

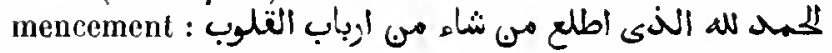
. Ce traité est suivi de quelques dissertations et poèmes sur la divination par lettres, et d'une vingtaine de figures cabalistiques.

Papier. 88 feuillets. Hauteur', a o centimètres; largeur, 14 centimètres et demi. 21 lignes par page. Ms. du xwı* siècle. - (Supplément 1103.)

\section{9 .}

1 Explication des mystères renfermés dans le جند, ou livre de prédictions qui élaient écrites sur une planche

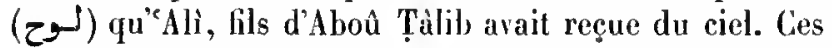
prédictions se rapportent à la série des princes qui devaient régner sur l'Égypte. L'auteur, Kamâl al-Dìn Moḥammad ibn Talḅa, a pris pour base de son commentaire la valeur inystique des lettres de l'alphabet. Une qasida d'une quarantaine de vers est intercalée dans la préface, qui

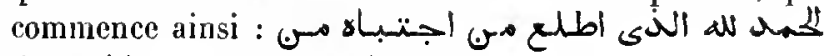
I عباده الابرار على خبايا الاسرار

$2^{\circ}$ (Fol. $10 \mathrm{r}^{\circ}$.) Prédiclions au sujet des gorands événements qui doivent arriver jusqu'à la fin du monde. Com-

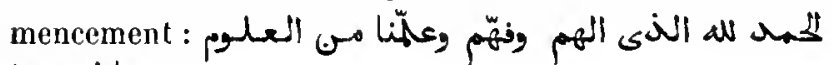
مالم نما مالم
30 (Fol. 16.) Chapitre extrait du جفب الكبير de Mloḥammad ibn Sàlim al-Khallâl, renfermant un sermon prononcé devant les habitants de Koûfa par 'Alì, fils

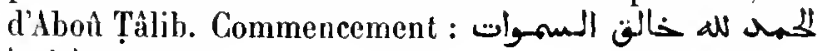

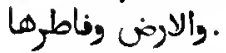

$4^{\circ}$ (Fol. 27.) Prédictions. Commencement : a d a

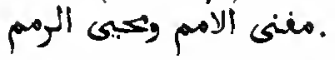

$5^{\circ}$ (Fol. 31.) Aulre chapitre du même genre. On y remarque de singulières combinaisons de lettres, des mots renversés, etc.

6* (Fol. 42.) Prédiction relative à la fin du monde, annoncée pour le $\mathrm{x}^{\mathrm{e}}$ siècle de l'hégire ( $\mathrm{xv}^{\mathrm{e}}$ siècle de J. C.).

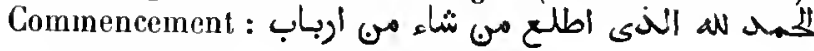
.القلوب على حتائق الغيوب.

$7^{\circ}$ (Fol. 47.) Prédictions relatives à la fin du monde. La grande ville de Rome sera prise par les Musulmans, sept ans avant l'apparition de l'Antéchrist, puis viendra la grande catastrophe. Commencement : أطلع شنموس الغيوب من حنادس النلوب.

$8^{\circ}$ (Fol. $56 \mathrm{v}^{\circ}$.) Autres prédictions. Commencement :

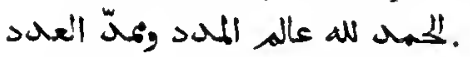

$9^{\circ}$ (Fol. $7^{4} \vee^{\circ}$.) Trailé sur les nystères des lettres. On y trouve des lettres et des mots répétés plusieurs fois, et des mots renversés. Commencement : أعم أن سمَ

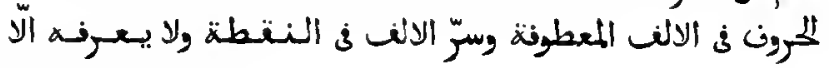

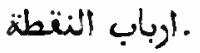

$10^{\circ}$ (Fol. $84 v^{\circ}$.) Prédictions et renseignemenls, en prose et en vers, touchant l'Égypte et ses merveilles. Conmencement : فار مصرا شانها عيبب وسرّها غريب.

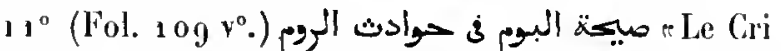
du líbou, touchant les grands événements de l'empire romain n, poème rimant en $J$, composé de plus de cent vingt vers. Dans cette pièce, l'auteur, Moḷyì al-Dìn Ibn al-'Arabi, prédil, an moyen des lettres de l'alphabet, les grands événements de l'avenir. Premier vers :

$$
\text { ناهيك يا منزل الاحباب هـى ظلهل }
$$

Ce poème est suivi de prédictions, de pièces de vers, d'une vingtaine de figures talismaniques, dont chacune occupe une page, et d'explications tonchant la valeur mystique des lettres.

${ }^{1}$ Ce traité, en effet, est le premier du الحز المنظظم. Les articles suivants font partie du méme ouvrage. H. Z.

Mas. orientaur. - II. 


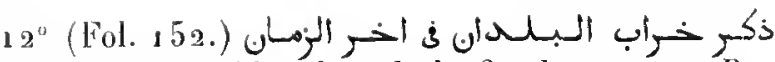
- Destruction des villes, lors de la fin des tenups r. Recueil de lraditions sur la fin du monde.

$13^{\circ}$ (1 ol. 156.) Recueil de prédictions, renfermant quelques pièces de vers atlribuées à Mohỵî al-Din lbn at-Arabi. Cies vers sont accompagnés d'un commentaire. Premier vers de la première pièce:

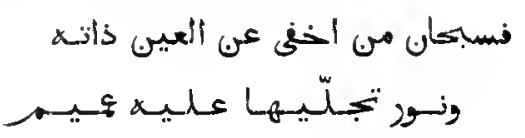

$14^{\circ}$ (Fol. $\left.166 v^{\circ}.\right)$ Le جن ج) du schäkh Molyyì al-Din lbn al-Arabi. Traité sur les verłus des leltres, accompagné d'une grande quantilé de tableaux, de carrés ma-

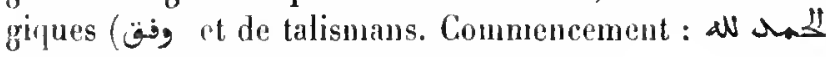

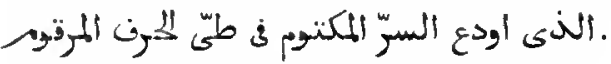

'loutes ces pièces sont de la même main. Le ms. est daté de l'an 1026 de l'hégire ( 1617 de J. C.).

Papier. a 43 feuillets. Ilauteur, 21 centimètres; largeur, 15 centimètres et demi. 1 ì so lignes par page. - (Ancien fonds 1173.)

\section{0.}

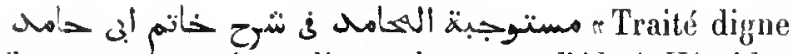
d'éloges, servant à expliquer le sceau d'Aboû Ḥàmid». L'auteur, Molıammad ibn 'Otlımàn el-Anșàrì, donne l'explication des carrés magiques et des lettres mystiques qu'on voyait sur un certain sceau d'Aboû Hàmid al-Gha-

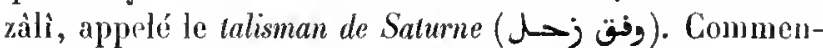

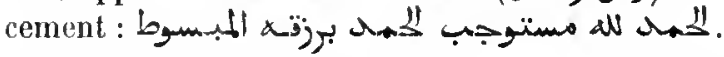

Papier. 68 feuillets. Hauteur, a 1 cenlimitres; largeur, 15 centimètres et denii. 17 à 19 lignes par page. Ms. du xvic siècle. -- (Ancien fonds 1160. .)

\section{1.}

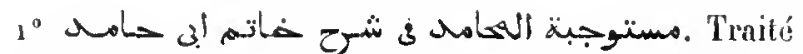
cabalislique, renlemant l'explication du sceau d'Aboù llànid al-Gluazali.

$2^{\circ}$ (Fol. 137.) Trailé sur un charne on talisman (تســــ par la vertu duquel on triomplue de son elunemi.

Papier. 186 feuillets. Haulcur, 13 centimètres; largeur, 9 centimètres. g lignes par page. Ms. du xvü siècle. - (Supplément 1084.)

\section{2.}

Traité sur les carrés magriques. En lète se trouve un chapitre sur le scean d'Aboû ḷànid al-Ghazâli.
Ms. daté de l'an 997 de l'hégire ( 1589 de J. C.).

Papier. 59 feuillets. Hauteur, 21 contimetres et demi; largeur, 16 centiniètres et demi. 15 lignes par page. - (Ancien fonds 1187.)

\section{3.}

e Sources des vérités et exposilion des procédésn. Cet ouvrage, divisé en trente chapilres et attritué à un auteur nommé Maïmoûn, vivant sons le règne d'Al-Madik al-Z̆âhir Rokn al-Dîn, esı un traité de magie et de prestidigilation. Il renferme un grand nombre de recettes pour opérer des prodiges et pour fasciner et tromper te public. Commencenent :

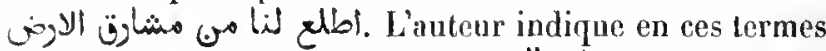

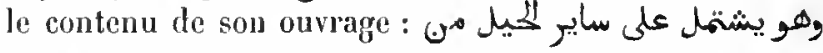

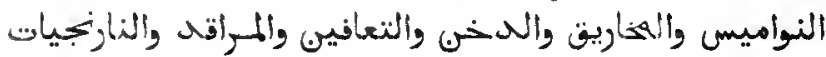

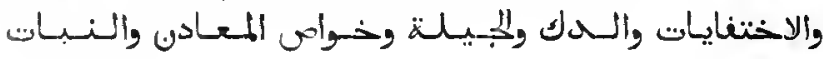

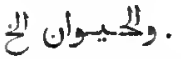

Papier. 72 fenillets. Hautcur, 21 centimẻtres; Jargeur, 15 centimètres et demi. 10 à 12 lignes par page. Ns. du xvi siècle - (Ancien funds 1201 .)

\section{4.}

Mème ouvrage.

Papier. ${ }_{2} 3$ fenillets. Hauteur, a 1 centimètres et demi; largeur, 15 centimètres et demi. 17 lignes par page. Ms. du xvus siècle. (Supplément 990.)

\section{5.}

1 Clefs des secrets des connaissances des prophèlesn (voir fol. $44 \mathrm{v}^{\circ}$ ). Recueil de vingt-quatre alphabets, tous imaginaires, à l'exception d'une sorte d'alphabet hébreu. Ce recueil a été composé en 703 de l'hégire (1303-1304 de J. G.), s’il faut en croire la déclaration de l'auteur anonyme, qui cite deux autres de ses ouvrages, l'un intitulé الاعلام بغك المنتخ

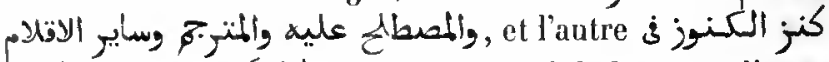

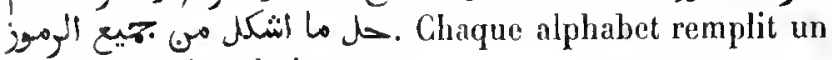
lableau de vingt-huit cases.

$2^{\circ}$ (Fol. $48 \mathrm{v}^{\circ}$.) Pièce de vers, accompagnée d'un commentaire et de tables, sur les verlus secrèles des lettres de l'alphabet.

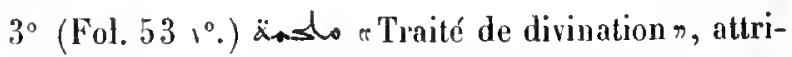
bué ì Mohyî al-Dìn lbu at-'Arabì. Il est dit que, par l'emploi habile d'une table à cases circulaires, qui romplit une page et demie de ce traité, on pourra trouver les 
noms des Turcs qui doivent gouveruer l'Égypte. Commen_

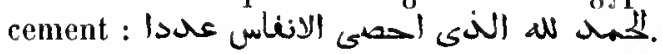

$4^{\circ}$ (Fol. 58.) Tables de divination.

Ms. daté de l'au 1005 de l'hégire $(1596-1597$ de J. C.).

Papier. 6o feuillets. Hauteur, 26 centimètres; targeur, 16 centimètres. - (Ancien fonds 1124.)

\section{6.}

Mème ouvrage que l'article $1^{\circ}$ du nunéro précédent, dans une rédaction amplifiée. Le premier feuillet manque. Des alphabets fantaisisles ont été ajoutés; après coup, an commencement et à la fin du volume.

Papier. 126 feuillets. Hautenr, 21 centimètres; largeur, 15 centimètres. Ms. du $\mathrm{xvi}^{\circ}$ siècle. - (Ancien fonds 1180, Colbert 4989 .)

\section{7.}

$1^{\circ}$ Fraginent d'un traité de divination intitulé J_a-ج , el renfermant plusieurs tables.

$2^{\circ}$ (Fol. 6.) Ordjouza sur l'emploi de ces tables, par Schilıâh al-Din al-Faỉyoûmî.

$3^{\circ}$ (Fol. 9.) Notes et extraits se rapportant aux divers procédés de divination. L'écriture cursive de la plupart de ces passages est difficile à déchiffrer.

$4^{\circ}$ (Fol. 38.) Poème en l'lonneur de Mahomet, attribué à Ị̂assân ỉn Thâbit. Comunencement :

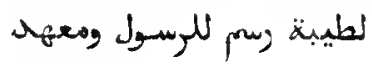

$5^{\circ}$ (Fol. $39 v^{\circ}$.) Sermon.

$6^{\circ}$ (Fol. $42 v^{\circ}$.) Brouillon d'une hiographie de Mohammad ihn Ismấil al-Bokhàrî, suivi de quelques traditions.

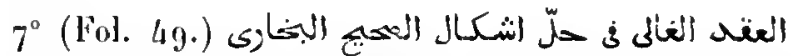
"Le Collier de prix, explication des lermes obscurs qui se rencontrent dans le Sahih d'Al-Boklıârìn. L'autenr, Alumad al-Kordi, avait recueilli ces gloses de la bouche d'lbrâhîm al-llalabì. Ce traité n’a pas de préface; les derniers feuillets manquent.

30 "Plaisir des yeux, Iraité du fatha, de l'imala et de l'intermédiaire entre ces deux sons \%. Cet opuscule est le résumé des opinions des sept Lecteurs, touchant les modifications que subit le son de la lettre alif dans la récitation du
Coran. L'auteur, Abou 'l-Baqà 'Alì ibn 'Othmàn Ibu alQîsịh al-'Odsrì, est mort en 801 de l'hégire $(1398-1399$ de J. C.). La copie est datée de l'an 973 de l'hégire ( 1566 de J. C.).

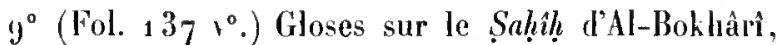
recueillies par le cadi ' $I z z$ al-Din 3 , dans un ms. qui avail appartenu à Scharaf al-Dìn al-Auṣârì. Texte pourvu des points-royeltes.

$10^{\circ}$ (Fol, $491^{\circ}$ ) Gloses sur le Salıih d'Al-Bokhârì, recueillies de la bouche du traditionniste Abou 'J-Waqt Ibrâhim ibu Mohammad ibn Khalil. Texte pourvil des points-voyelles.

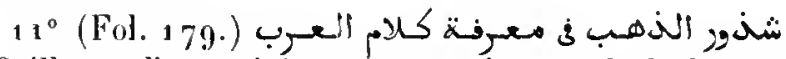
"Paillettes d'or, traité sur la connaissance de la langue araben, par Djamâl al-Dìn ibn Hischâm al-Anșàrì. Lıa préface, citée par Hadji Khalfa (lome IV, page 18), manque.

$12^{\circ}\left(F_{0}\right.$ ol. $\left.186 \mathrm{v}^{\circ}.\right)$ Quelques gloses sul le traité précédent, et d'autres notes, principalement grammalicales.

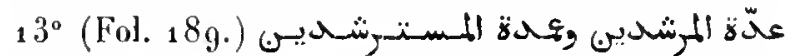
- Approvisionnement de ceux qui sont bien dirigés et soutien de ceux qui cherclient la bonne directions, par Aḷmad ibn abì Bakr ibn Moḷamnad al-liaddàd. Nous n'en arons ici qu'un extrail, dans lequel se trouve la solution de quelques questions relatives à la transmission de la خرقة (d'un prieur de soufis à son disciple).

$14^{\circ}$ (Fol. $1911^{\circ}$.) Extrait d'un traité de soufisme.

$15^{\circ}$ (Fol. 195.) Sur l'âme.

$16^{\circ}\left(\right.$ Fol. $\left.19^{6} \mathrm{v}^{\circ}.\right)$ Notes diverses.

$17^{\circ}$ (Fol. 197.) Fragment d'un brouillon d'un traité de théologie et d'un traité sur la peste.

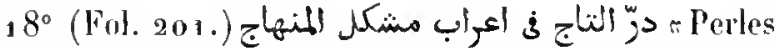
de la couronne, ourrage dans lequel se trouve l'éclaircissement des difficultés du Minhadj al-Tálibinn, par Djalâl al-Dìn 'Abd al-Raḷmân al-Soyoûtị. Commencement :

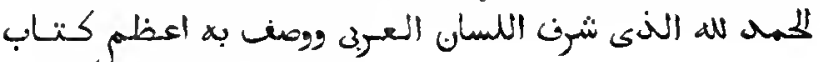
. أكرم نبى . La fin manque.

$19^{\circ}$ (Fol. 209. ) Questions et réponses touchant une tradition rapportée dans le Salîh d'Al-Boklhârì.

$20^{\circ}$ (Fol. 214 .) Fragment d'un poène en l'honneur de Naliomet.

$21^{\circ}$ (Fol. $214 \mathrm{v}^{\circ}$.) Recueil de notes, de traditions et de renseignements au sujet des ventes el des opérations commerciales. On y trouve une notice sur les calendriers arabe et syriaque.

Papier. 221 feuillets. Hauteur, 19 cenlimètres; largenr, 14 centimètres. Écritures diverses du $\mathbf{x v}^{\circ} \mathrm{ct} \mathrm{du} \mathbf{v v} \mathbf{1}^{\bullet}$ siècle. - (Ancien fonds 1206 .) 


\section{8.}

Explicalion des mystères renfermés daus le cercle qui fait partie de l'arbre généalogique de la famille hanéfite de l'enpire oltomaum. Ce recueil de prédictions inintelligibles est altribué à Mohyyì al-Dìn ibn al-'Arabî (comparez ci-dessus, $\left.n^{\circ} 1627,2^{\circ}\right)$; le commentaire a pour auteur $\mathrm{Al}$ Salitı al-Din Khalíl ibn Aibak al-Safadì, mort en 764 de l'hégire (1362-1363 de J. C.). Commencement: u-as

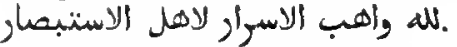

Papier. 34 fenillets. Hauteur, 21 cenlimèlres; largeur, 15 centimètres, 11 lignes par page. - (Ancien fonds 1169 -)

\section{9 .}

1" Hème ourrage. Copie datée de l'an 1060 de l'hégire (165o de J. C.).

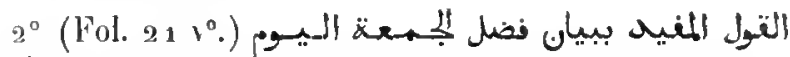
(لم) Discours instructif dans lequel on expose l'excellence du vendredi, jour de surcroìt. Dans cette monographic, l'anteur, Hanif al-Dìn 'Nbd al-Ralunân al-Morschidi al 'Omari, traite d'abord des jours, des nuits et des heures; puis de la dérivation et du sens du mot äez; il montre ensuite pourquoi il ne convient pas de jeûner le vendredi. Vient un chapitre sur les mér'ites du jour de rendredi el une qasida sur le mềme sujet. L'ourage se lermine par un appendice renlermant des traditions, des inecdotes, elc. Lauteur cite quelquefois les écrils de Djalàl al-Din al-Soyoutit. Commencenent :

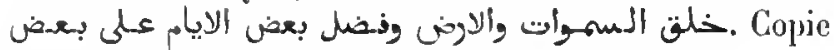
datée de l'an 1060 de l'hérgire (1650 de J. C.).

$3^{\circ}$ (Fol. $40 r^{\circ}$.) Dissertation de Moḷammad Amin alBokhàri, vulgairement appelé Amir Pâdischà, sur J'opinion de certains docteurs schaféites qui enseignaient que le pélerinage de la Heeque efface également les péchés mortels el les péchís véniels. Commencement: W W W

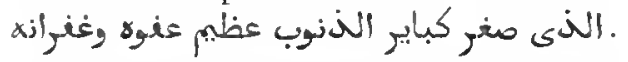

$4^{\circ}$ (Fol. $491^{\circ}$.) Traité en dix chapitres sur les méviles respectil's des villes de Jérusalem, de la Mecque et de Médine. La prélace est en arabe, le reste de l'ouvragge est en ture.

Ciopie datée de l'an 1059 de l'bégrire (1649 de J. C.).

Papier. 100 feuillets. Hauteur, 21 centimètres; largeur, 15 centimètres. Écrilures diverses dn xw ${ }^{\circ}$ siècle. - (Ancien fonds 1191.$)$

\section{0.}

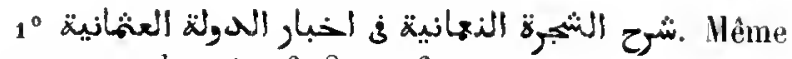
ouvrage que les $n^{\text {os }} 2678$ el $2679,1^{\circ}$.

$2^{\circ}$ (Fol. 16.) Traité de divination au moyen des vertus secrètes des lettres de l'alphabel. Commencement:

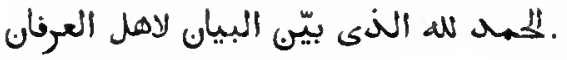

Papier. 47 feuillets. Hauteur, 32 centimètres; largeur, 9 centi-

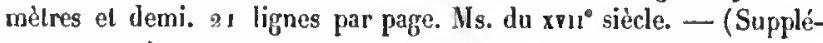
ment 110101 .)

\section{1 .}

Source de lumières et collection de secrets\%, traité sur les vertus mystiques des lettres de l'alphabet et des noins des animaux et des plantes. Il est dit dans la préface que l'alphabet universel, révélé par Dieu à Adam, se composail de vingl-lıuit lettres. Commencement: : Selon Hadji Khalfa, l'auteur se nommail Djamal al-Dîn Yoûsof, né à Nedroma, ville de la province d'Oran.

Ms. daté de l'an 853 de l'hégire (1449-145o de J, C.).

Papier. 194 feuillels. Hauteur, 16 centimètres; largeur, 13 centimètres. 15 lignes par page. - (Ancien fonds 1181 , Colbert 6049.)

\section{2 .}

Mème ouvage. Il est dit à la fin que ce traité a été composé en 786 de l'hégire (1384-1385 de J. C.), et que le présent exemplaire a été copié sur l'autograplie, en 862 de l'bégire (1457-1458 de J. C.) '

Papier. 123 feuillets. Hauteur, 18 centimètres; largeur, 14 centimètres. 19 lignes par page. - (Anejen fonds 1184. )

\section{3.}

Hème ourrage.

Ms. daté de l'an $99^{5}$ de l'hégire ( 1587 de J. C.).

Papier. 117 feuillets. IIauteur, 21 cenlimètres et demi; largeur, 1 is cenlimétres. 19 lignes par page. - (Supplément 1086.)

\section{4.}

1" Traité de divination, sans litre ni nom d'auteur,

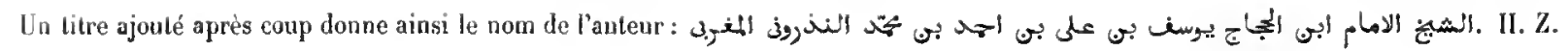


composé au Maghreb, sous les auspices du sultan mérinide, Aboû Fâris 'Abd al-'Azì, qui régnait vers la fin du $x_{1} v^{e}$ siècle de notre ère. L'auteur était probablement Abou ']-'Abbås Ahmad al-Siblì. Commencement : A. L

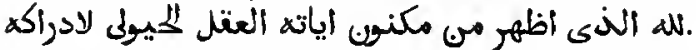

$2^{\circ}$ (Fol. $20 \vee^{\circ}$.) Traité d'Aboû Zaïd 'Abd al-Raḷ̣nân Ilın Klıaldoûn sur le même sujet. Cet opuscule est emprunté en grande partic aux Prolégromènes du mênre auteur. (Voir Notices et extraits des manuscrits, $t$. XXI, ${ }^{\text {re }}$ partic, p. 199 et suiv.)

$3^{\circ}$ (Fol. 31.) Traité anonyme sur le même sujet, inlitulé (Chemins pour ceux qui marchent (vers la perfection) el trésor des

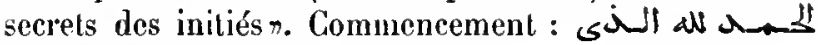
نوّز قلوب عبادها بذكره

$4^{\circ}$ (Fol. 53.) Traité anonyme sur le mène sujet, com-

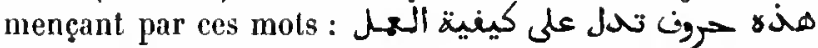

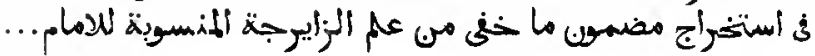
السبنتى

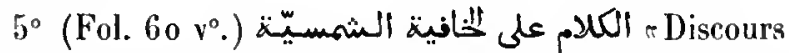
sur les mystères cachés dans (le poème astrologique intitulé) la Schamsiya. n L'auteur trite des vertus secrètes des lettres el de lcur emploi dans l'évocation des anges.

$6^{\circ}$ (Fol. $63 v^{\circ}$.) Explication des noms qui se trouvent dans la Zaïdja.

$7^{\circ}$ (Fol. 64\% $\%^{\circ}$ ) Traité de Moḷammad ibn M!̣mad sur le progrès du soleil à travers les signes du zodiaque, pour chaque mois de l'anuéc solaire des Latins.

$8^{\circ}$ (Fol. 65 v $^{\circ}$ ) Traité sur la Zäirdja d'Al-Sibti, par

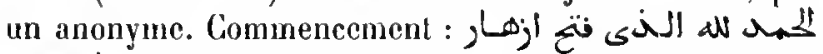

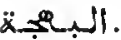

$9^{\circ}$ (Fol. $7_{2} v^{\circ}$.) Traité sur les vertus des lettres el de lcur emploi dans la Zäirdja.

$10^{\circ}$ (Fol. 75.) Trailé sur l'emploi de la Zäirdja, lorsqu'on veut obtenir une réponse à une question.

$11^{\circ}$ (Fol. 81.) Traité sur le mème sujel, par 'Abd alIlaqq ibn Ibràhìn ibn Sab`in, de Nurcie, en Espagne.

$12^{\circ}$ (Fol. 85.) Traité en vers sur les dates el les époques, et sur leur application à la Zâirdja.

$13^{\circ}$ (Fol. 88.) Adjuration adressée aux esprits célestes.

$14^{\circ}$ (Fol. 9o.) Illustration des diverses manières d'opérer sur la Zairdja. Commencement :
. Au commencement se trouve un titre, ajouté après coup : مrincipes des intelligencesn, où l'ourrage est attribué à Mohyî al-Dìn ibn al-'Arabî.

$15^{\circ}$ (Fol. 128 .) Explication d'un certain emploi de la

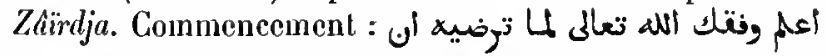

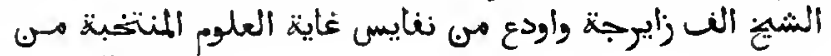

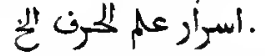

$16^{\circ}$ (Fol. 139.) Poème sur l'emploi de la Zäirrdja, par

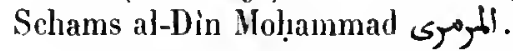

$17^{\circ}$ (Fol. $1421^{\circ}$.) Notes sur le mème sujet, les unes en prose, les autres en vers.

Papier. 165 feujllets. Hanteur, 21 centimètres el demi; largenr, 15 centimètres et demi. 25 lignes par page. Ms. du xvire siècle. (Ancien fonds 1188. )

\section{5.}

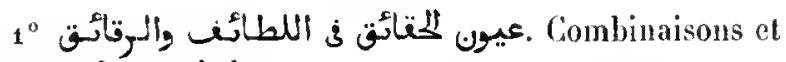
recettes de magie ${ }^{1}$.

$2^{\circ}$ (Fol. $193 v^{\circ}$ (كتاب عه اللهيـيل. Sur les noins mystiques des planètes el sur la manière de s'en servir pour composer des talismans.

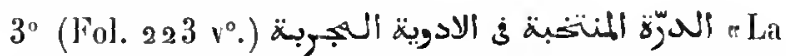
Perle choisic, trinité des remèdes éprquvés». Receltes el anuleltes. Cet ouvrage a été composé sur le désir du sultan Al-Malik al-Mowayyad (Abou ']-Fidâ?). Commen-

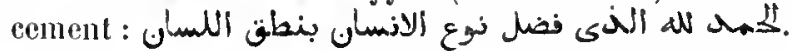

Ms. de denx mains différentes, daté de l'an 1066 de l'hégire (1655-1656 de J. C.).

Papier. 29o feuillets. Hauteur, 22 centimètres; largeur, 16 centimètres. 13 lignes par page. - (Supplément 1898.)

\section{6.}

r Révélation des mystères des lettres et indication des sens contenus dans les vases . Traité complet sur les vertus secrètes des leltres de l'alplabet, par 'Alod al-Ralumàn ibn Mlọammad ibn 'Alì al-Bestâni, mort, selon lladji Khalfa ( $\mathrm{t}$. V1, 1. 360), en 843 de l'hégire (1439-1440 de J. G). L'lutroduction contient une longue liste d'ouvrages relatil's au mène

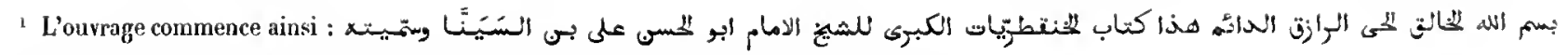

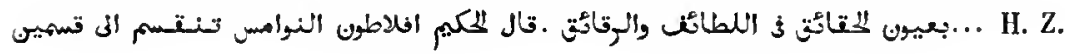


sujet. Au folio 68 se troure la figure de la sandale de Mahomel; au folio $7^{6}$, la géuéalogie du Prophète depuis Adam; an lolio 110 , li liste des persomages qui ont successivement transmis celle doctrine cabalistique; au folio $1981^{\circ}$, une série de courtes notices biographiques sur les priucipaux saints et ascètes musulmans. Com-

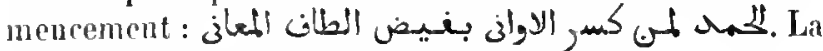
fin maniue.

Papier. 216 feuillets. Hauteur, 15 centimètres; Jargenr, 11 centimetres. 19 lignes par page. Ms. du xvi' siècle. — (Supplément 1098.)

\section{7.}

1 م Trésor des mystires des lettres de l'alphabet el lumieres pénétranles de Hahomel"; Iraité de cabale, par 'Abd al-Ralymân ibn Moḷammad Al-Bas!àmi. Commencement : Uم .

$2^{\circ}$ Fol. 7. (مصف Description d'uu remède contre la peste, par le même. Commen-

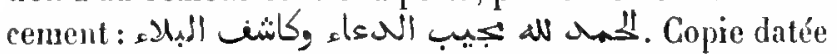
de l'an 832 de l'hégire (1428-1429 de J. C.).

$3^{\circ}$ (Fol. 1 8.) Album de diverses écritures, renfermant des pièces de vers en persan et en turc.

Papier. 80 feuillets. Hauteur, 17 centimètres; largeur, 1 a centimètres. Écritures diverses. - (Supplément 1893.)

\section{8 .}

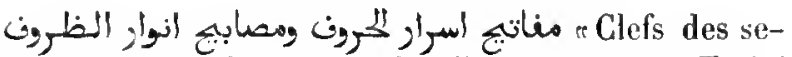
crets des lettres et lampes des lumières des vases $\%$. Traité sur les vertus mystiques des lettres de l'alphabet, sur les talismans et sur les carrés magiques, attriluué à 'Abd al-

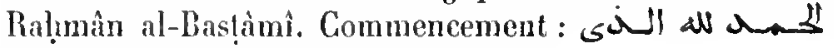

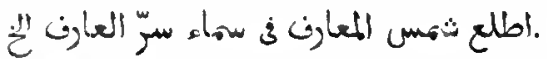

Ils. dalé de l'an $99^{2}$ de l'hégire (1584 de J. C.).

Papier. $9^{8}$ pages. Hauteur, 21 centinè̀tres et demi; largeur, 15 cenlimètres el demi. 20 lignes par page. - (Ancien fonds 1320.)

\section{9 .}

, the Soleil des régions, traité sur' la science des lettres et des talismans", par 'Abd al-Raḷmẩn al-Basțâmî. Ouvrage divisé en cinq sections $(f a s ̧ l)$. La préface reuferme une longue liste d'ouvrages que l'autenr dit aroir mis à contribution. Aux fait. ho $v^{\circ}$ et $/ 1 \mathrm{r}^{\circ}$, se troure un tableau général des soixonte sciences cultivées par les musulmans. Commencemént: all

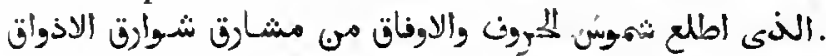

An premier feuillet se trouve un acte de vente daté de l'an 1014 de l'hégire $(1605-1606$ de J. G.).

Papier. a 66 feuillets. Hauteur, 21 centimètres el demi; largeur, 16 centimètres. 21 lignes par page. - (Ancien fonds 1177. )

\section{0 .}

1 م llaité des médicaments qui réunissent (toutes les verlus) n, par 'Abd al-Rạ̣mân ibn Moḥammad a\}-Basțàni. Dans ce traité, divisé en dix chapitres, qui a été composé en 834 de l'hégire ( 1430 de J. C.), l'auteur expose, d'après lestraditions provenant de Nahomet et des anciens musulmans, les nombreuses vertus de certains remèdes,

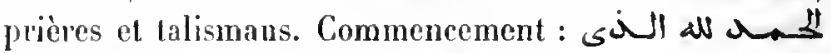
الثهد اخلاد اولياءه خوالم الدعيته الكبانية.

$2^{\circ}$ (Fol. 68.) Traité sur la prière, par le même auteur. L'ouvrage est divisé en quatre sections (باب), dont cliacune renferme plusieurs chapitres. C"est principalement un recueil de traditions ayant rapport à ce sujet.

Ms. écrit probablement du vivant de l'auteur.

Papier. 97 fenitlets. llauteur, 18 centimètres et demi; largeur, 13 centimètres et demi. 19 lignes par page. Ms. du x* siècle. - (Ancien fonds 1087 .)

\section{1.}

Choix de prières et remèdes approuvés $\%$. Traité sur la peste et son traitement. an moyen d'amulettes et de carrés magiques, en six chapitres, par 'Abd al-Raḥmâu ibn Họ̣ammad al-Bastâmî. Les derniers feuillels manquent. A la fin du volume se tronve un dessin représentant le nom de Mahomet écrit dans les deux sens et entouré de passages du Coran, etc.

Papier. 52 feuillets. Ilauteur, a a centimètres et demi; largeur, 16 centimètres. 21 lignes par page. Ms. du xvur siècle. - (Supplément 1052.)

\section{2.}

re secret caché et le trésor scellé $\gg$, trailé de magie, d'astrologie, de talismans, etc., par Moḷammad ibn 'Îsâ al-Andalosî. Les deux premiers feuillets du volume contiennent la liste des chapitres. 


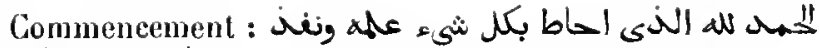
x

Ms. daté de l'an 1130 de l'hégire (1718 de J. C.).

Papier. ${ }_{2} 3$ feuiltets. tlauteur, 20 centimètres et demi; largeur, 15 centimètres et demi. 21 liggnes par page. - (Supplément 1121.)

\section{3 .}

$1^{\circ}$ Résumé de ce que le savant docteur, Aboù Zä̈d 'Abd al Raḥmân ibn Khaldoûn, a écrit au sujet de la manière d'opérer sur la Zärdja d'Al-Sibti.

$2^{\circ}$ (Fol. 4 vo.) Quatrième partie du مiاسيب التيسيرية, qui explique la Záïrdja d’Al-Sibtî.

$3^{\circ}$ (Fol. 6 vo.) Le ze do du sehä̈h Schihâh al-Dìn Aḷmad al-Mlarrâkoschi. Dissertalion sul la manière de "poser les cordes universelles n وضع الاوتشار )

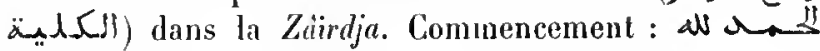

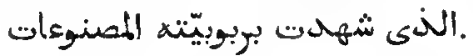

$4^{\circ}$ (Fol. 17.) Extrait du mêne ourrage. Il s'aggit des cases (يميوت) furmées par les douze cordes de la Zärilja d'Al-Sibti qui se compose de cent trente cases en lougueur.

Papier. 37 feuillets. Hauteur, 18 centimètres; targeur, 13 cenlimètres. 23 lignes par page. Ms. du xvi sièele. - (Ancien fonds 1166 .

\section{4.}

Traité de divination au moyen du tableau cabalistique

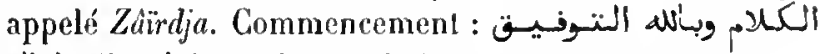

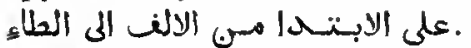

Ms. daté de l'an 1008 de l'hégire ( 1599 de J. C.).

Papier. 48 feuilfets. Hauteur, 21 centimètres; largeur, 15 centimètres. 17 lignes par page. - (Supplément 1117.)

\section{5 .}

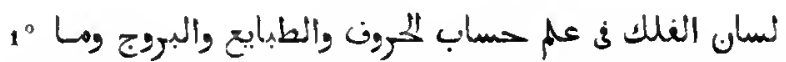
بr Langage de la splière, traité où on enseigne le calcul des lettres, des natures, des signes du zodiaque, ete. n. Tel est le titre qui se trouve en tète du volume. L'auteur dit, dans la préface, qu'i] s'attache surtout à expliquer les quatre tableaux remplis d'obseurités qui composeut la Zäirdja d'Al-Sibti. C'est un traité de divination au moyen des lettres de l'alphabet, des éléments cosmiques et des constellations. Commencement : If

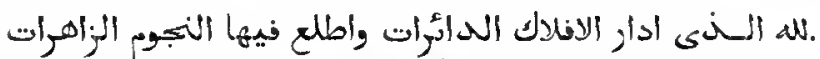
Copie datée de l'an 1075 de l'héçire ( 665 de J. C.).

$\left.2^{\circ}\left(F_{0}\right]_{0} 6 v^{\circ}.\right)$ Autre traité de divination, sans titre. Lautem expose d'abord les vertus mystiques de chaque lethe de l'alphabet, puis il montre lapplicalion de son système an moyen diun grand nombre de tables.

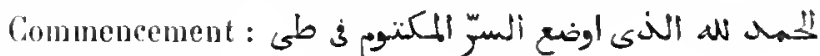

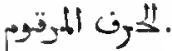

P'apier. 183 fruillets. Hauteur, 21 centimètres et demi; largeur, $1 j$ centimètres et demi. Écritures diverses dı wru siècle. - (Aneien fonds $11(j 6$.

\section{6.}

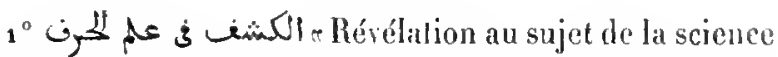
des lellresn. Ce trailé, sur le sens myslique des letlres de l'alphabot, ronferme dos carrés magiques, des fignres planétaires et de nombreuses combinaisons de lettres. Il se compose de quatre chapittes : $1^{\circ}$ sur la connaissance de la sphère; $2^{\circ}$ sul la science des lettres; $3^{\circ}$ sur les connais-

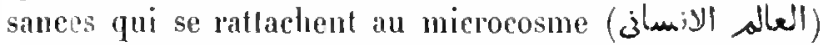
$4^{\circ}$ sur les quatre sciences indépendantes d'aul'es seiences; et dont la première est celle de la Zaïrdja. Commencement:

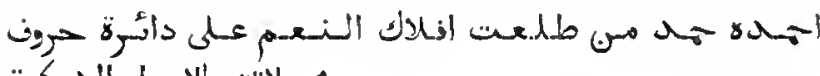
هيولاته بالاسرار المركية

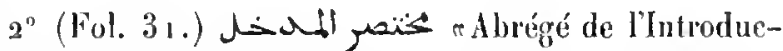
tion \%. Trailé d'astrologie, en sept chapitres. L'Introduction est celle d'Aboù Hacschar.

Papier. 77 feuillets. Ilauteur, 21 centimètres; Jargeur, 15 centimètres el deni. Écritures diverses du xvu ${ }^{\circ}$ siècte. -- (Ancien fonds 1163. )

\section{7.}

1 Trailó sur les figures de la géomancie (ضرب ألمالم) et sur leur signification pour les diverses circonstances de la vie. Lianteur cite les opinions de plusieurs maitres dans cet art, tels qu'Hermes, Al-Barbiri, Al-Kordi, Tomtom et d'autres personnages imaginaires. (Vovez, sur Ja géomancie arabe, la traduction des Prolégomènes d'lbn Khaldoûn, t. 1, page 238.)

$2^{\circ}$ (Fol. $531^{\circ}$.) Traité de cartomancie, par lo schaïht Abou 'l-Qàsim al-Anșàrì.

3. (Fol. $\left.57 v^{\circ}.\right)$ Principes génélaux de la géomancie.

$t^{\circ}$ (Fol. jo $v^{\circ}$.) Traité de divination au moyen des letres de l'alphabet, par Abou l-Faradj al-Kindi. 
$5^{\circ}\left(F_{0}\right.$ l. $\left.74 \%^{\circ}.\right)$ Diver'ses tables à l'usage des géomanciens.

$6^{\circ}$ (Fol. $80 \vee^{\circ}$.) Pò̀me en strophes de cinq hémisliches, dont le second se termine régulièrement par la lettre djim. Il parait renfermer des conseils moraux adressés à un musulman.

Papier. 88 feuillets. Hauleur, 26 centimètres; largeur, 18 centimètres. 11 à 15 lignes par page. Ms. du $\mathbf{s v}^{\mathrm{E}}$ sièele. - (Ancicn fonds 1125.)

\section{8.}

1 "Ascendants de lilluminatiou, traité sur la composition des carrés magiques $\pi$,

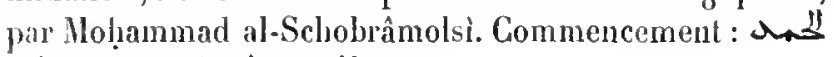

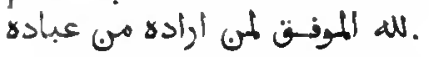

$2^{\circ}$ (Fol. $74 \%$.) Traité d'Al-Schobrâmolsî sur un talisman très puissant que l'on obtient par la connaissance du sens mystique des letlres. Commencement : فصل 3 :

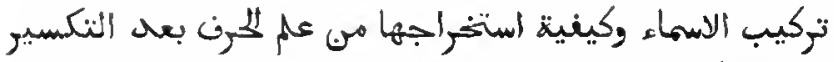

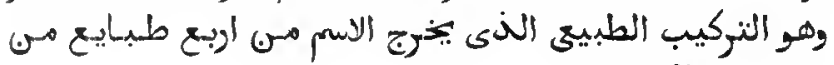
نار وهوا ومآ وتراب

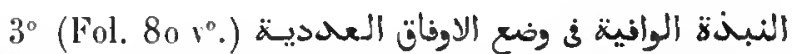
" Morceau qui suffit pour faire connaitre la composition des carrés magiques à chiffres numériques», par Al-

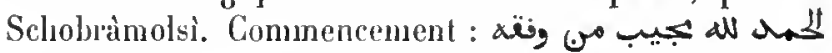
allymed.

Papier. 103 feuillets. Hauteur, a centimètres; largeur, 15 centimètres et demi. Ĺcrilures diverses du x vu sièele. - (Ancien fonds 1186.)

\section{9.}

Trailé de géomancie, que l'on dit avoir été transmis par le patriarche Idris à Tomtom (طم) l'Indien, et par celui-ci à Aboû Mlọammad al-Zanâti, par ce dernier à un autre llaghrebin, et ainsi de suite, jusquà ce qưil parvint à la connaissance d'Ilbrâhîm ibn Nâfic alŞàliḥi. Celui-ci a remanié et publié l'ourrage, en y ajoutant les éclaircissements et renseignements nécessaires. C'est ce Iravail que renferme le présent ms. Commen-

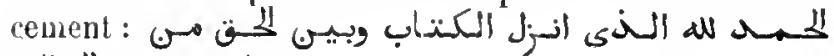
.

Papier. $9^{4}$ feuillets. Hauteur, 21 centimèlres et demi; largeur 15 centimètres et demi. 17 lignes par page. Ms. du xvi' siède. - (Ancien fonds 1196. .)

\section{0.}

$1^{\circ}$ Recueil de formules pour servir d'amulettes et de charmes. Ce sont des lettres répétées plusieurs fois ou combinées avec d'autres, des mots et des phrases n'offrant aucun sens. A ces pièces sont joints des talismans, des carrés magiques, des lignes de chiffres et d'alphabets imaginaires, etc. L'ouvrage, qui paraît être du $x^{\mathrm{e}} \mathbf{1}^{\mathrm{e}}$ siècle, commence par une invocation attribuée à 'Ali.

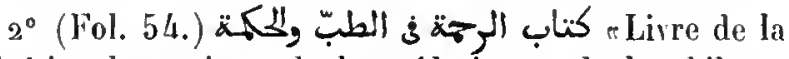
miséricorde, Iraitant de la médecine et de la philosophien, par Mahdi ibn 'Ali al-Ṣonbori, mort, selon Hadji Khalfa, en 815 de l'hégire (1412-1413 de J. C.). Ce traité se compose de cinq chapitres : $1^{\circ}$ sur la nature (طبيعة) en général; $2^{\circ}$ sur la nature des aliments; $3^{\circ}$ sur ce qui convient au corps en état de santé; $4^{\circ}$ sur le traitement des maladies qui affectent l'un ou l'autre des membres du corps; $5^{\circ}$ sur le traitement des maladies communes à toutes les parties du corps. Commencement:

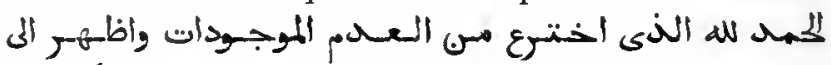
الوجبرد الكاينات. Les trois derniers chapitres et une partie du second chapitre manquent.

$3^{\circ}$ (Fol. 63.) Traité d'astrologie. Le commencement manque.

Papier. 136 feuiltels. Hauteur, 2o centimètres el demi; largeur, 15 centimètres. 16 ligues par page. Ms. du rvu' siècle. - (Aneien fonds 1175. )

\section{1.}

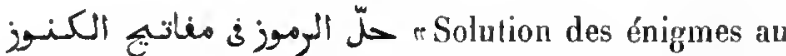
sujet des clés des trésors. Tel est le titre qui se trouve en lête du ms., qui renferme un traité sur les vertus secrètes des lettres de l'alphabet, sur les talismans et les charmes. En tête de la préface se trouve un autre

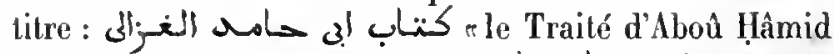

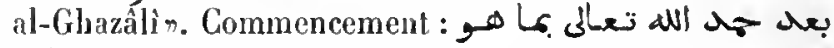
. أهـلمة.

Papier. 31 feuittets. Hauteur, 22 centimètres; largeur, 26 centimètres. 25 à 39 lignes par page. Ms. du xvi' siècte. - (Ancien fonds 1200.)

\section{2.}

Recueil de formules de conjuration, de talismans, d'amulettes et d'inrocations.

Papier. 134 feuittets. Hauteur, 17 centimètres el demi; largeur, 11 centimètres et demi. 15 à 19 tignes par page. Ms. du xvi siècle. (Ancien fonds 1233.)

\section{3.}

r Solution d'énigmes 
et explication des alphabets et des talismans $\leadsto$. Ce traité renferme vingt-neuf alphabets, dont à peine un seul est authentique.

Papier. 6, fẹilletx. Hauteur, 16 centimètres; largeur, 11 centimètres. I lignes par page. Ms. du xvi siècle. - (Ancien fonds 1 22\%.)

\section{4.}

Recueil de charmes, de talismans, de combinaisons de lettres, de notices sur les vertus des divers noms des patriarches, à commencer par Moïse, d'opérations magi-

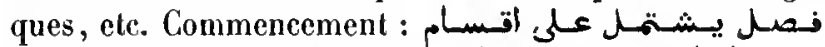

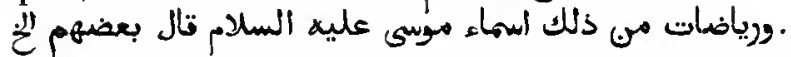

Papier. 48 feuillets. Ilauteur, 21 centimètres; largeur, 15 centimètres. 17 à 19 lignes par page. Als. du $x^{e} 1^{e}$ siècle. - (Ancien fonds $1 \mathrm{~g} 8$.

\section{5.}

$1^{\circ}$ Recueil d'anulettes, d'invocations, de charmes, de recettes magiques pour opérer soit Je bien, soit le mal. Exemplaire écril de la main de l'auteur, A ḥmad الطنبنغاوى, el daté de l'an 1045 de l'hégire (1635-1636 de J. C.). Le commencement manque.

$2^{\circ}$ (Fol. 187. .) Deux cahiers très mal écrits qui paraissent être un supplément à l'ourragre précédent.

$3^{\circ}$ (Fol. $508 v^{\circ}$.) Collection de charmes et de recettes.

Papier. $5{ }_{2} 3$ feuillets. Ilauteur, 21 centimètres; largeur, 15 centimètres et deni. Écritures diverses du $x^{2} 11^{\circ}$ siècle. - (Ancien fonds 1203.)

\section{6.}

rLes Grands sorts\%. Reeueil de tables dont les combinaisons se rapportent aux mansions de la lune, aux noms des villes, des pays, des oiseaux, des savants, des époques, des groupes de points qui sobliennent par la géomancie, etc. Chacune de ces tables contient dix-huit réponses, rangées en deux colonnes. Pour s'en servir, il faut commencer par opérer sur certains cereles astrologiques placés en tête de l'ourrage. L'auteur ne se nomme pas dans la préface, mais, d'après le titre, écrit de la main du copiste au commencement, il était né en Égyple, et se nommait Moḥammad ibn 'Omar al-Bahịinì al-Mahallì.
Ms. daté de l'an 1076 de l'hégire (1665-1666 de J. C.).

Papier. 14 feuillets. Ilauteur, 21 centimètres; largeur, 15 centimètres el demi. - (Ancien fonds 1197, Colbert 4640.)

\section{7.}

(Ce qui facilite les recherches». Tel est le titre qui se trouve en tête du ms. C'est un traité sur les verius secrètes des noms et des lettres de l'alphabet. L'auteur, Mohammad ibn Mohammad ibn Yacqoûb alKoûmi al-Toûnisì ${ }^{1}$, traite surtout des leltres, dans l'ordre de l'alphabet. Commencement : خير ما صدر بx اللعهن

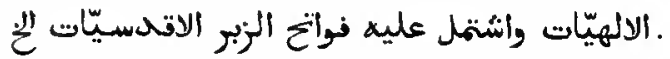

Papier. 48 feuillets. Hauteur, 22 centimètres et demi ; largeur, 15 centimètres el demi. 2 lignes par page. Ms. du xvı" siècle. (Ancien fonds 1189. .)

\section{8.}

$1^{\circ}$ Prédictions fondées sur la valeur secrète des lettres de l'alphabet et sur l'influence des sphères célestes.

$2^{\circ}$ (Fol. $35 \mathrm{v}^{\circ}$.) Prédictions touchant l'empire ottoman, pour les années 1084 à $119^{6}$ de l'hégire.

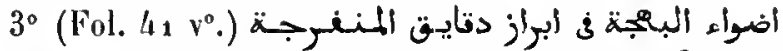
-Lumières de la beauté, pour faire ressortir les finesses de la Monfaridja». Commentaire de la قصيدة المننوجة. La préface du commentaire a été laissée en blanc. Copie datée de l’an 1162 de l'hégire (1 749 de J. C.).

Papier. 65 feuillets. Hauteur, 2 a centimètres; largeur, 15 centimètres et demi. Écritures diverses. - (Supplément 1125.)

\section{9 .}

r Soleils des lumières et trésors des secretsn, traité de cabale en treute chapitres, par Ibn al-ḷaddj al-Tilimsânì. Commencement : U. \ֶ

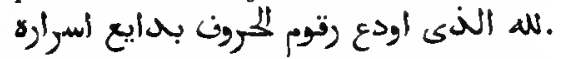

Papier. 186 feuillets. Hauteur, so centimètres et demi; largeur, 15 centimètres et demi. 19 à 25 lignes par page. Ms. du xwr siècle. - (Supplément 1085 bis.)

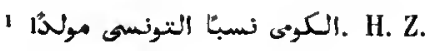




\section{0 .}

Nème ouvrage.

Ms. dalé de l'an 1164 de l'uégire (1750 de J. C.).

Papier. 149 feuillets. Ilautcur, 22 centimètres; largeur, 16 centimètres. a 3 ligncs par page. - (Supplément 1085.)

\section{1.}

"Thème de mativité unique, se rapporlaut à la lellre fortunéen, traité de cabale, par un derviche éryptien nonmé Molıammad ibn 'Alî Kamâl al-Din al-Anstîni. L'auteur expose l'excellence

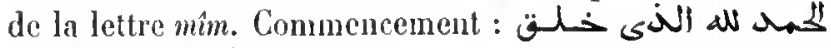

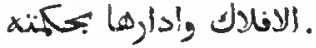

Papier. 56 feuillets. Hanteur, 21 centinètres; largeur, 15 centimètres. 17 liggnes par page. Mts. du xvı" siècle. - (Supplément i116.)

\section{2.}

Figures circulaires et tables divinatoires. Le commencement et la fin manquent.

Papier. 20 feuillets. Hauteur, 21 centimètres; largeur, 17 centimètres. Its. du xu" siècle. - (Supplément aogo.)

\section{3.}

Trailé anonyme, composéprobablement au xv11 siècle, qui renferme un grand nombie de talismans, de cluarmes, d'amuleltes et de remèdes. Ce sont d'abord certains versels du Coran, ensuile des prières, des invocalions, des carrés

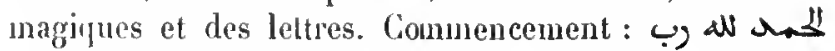
العالميب. التوى المبيمين.

Papier. 99 feuillets. llauteur, 2 i centimètres; largeur, 15 centimètres et demi. 17 lignnes par page. Ms. du $\mathbf{x r u}^{\circ}$ siècle. - (Ancien fouds 1190. .)

\section{4 .}

$1^{\circ}$ Divers fragmenls, contenant des imocalions, des remèdes magiques, des talismans, cle.

$2^{\circ}$ (Fol. $14 \mathrm{r}^{\circ}$. ) Trailé sur sepl noms qui possident un grand pouvoir magique. L'auleur prétend que ce texte qui remonterait à 'Ali, fits d'Abou Tàlib, lui aurait été transmis par l'imân Aboû ḷàmid al-Ghazâlì.

$3^{\circ}$ (Fol. $84 v^{\circ}$. ) Pièces de diverses mains, renfermant des conjurations, des talismans, des alpliabets magiques, elc.

Papier. 105 feuillets. Hauteur, 16 centimètres; largeur, 11 centimètres. Nls. du xru* siècle. - (Ancien fonds 1222.)

\section{5.}

.ترعة الانبياء Sorls et charmes fondés sur les noms des patriarches et des prophètes, depuis Adam jusqu’ì Mahomet.

Papier. 57 feuillets. Hantenr, 10 centimètres et demi; largeur, 7 centimètres et demi. 11 lignes par page. Us. du xvi" siècle. (Ancien fonds 1225.)

\section{6.}

1. Traité sur les figures de points qu'on obtient par la géomancie, suivi d'un poème sur le même sujet.

$2^{\circ}$ (Fol. 41 、o.) Lc تسكيى. du schaikh Abou 'l-Khaïr. Trailé de géomancie.

$3^{\circ}$ (Fol. 47.) Autre trailé sur le même sujet.

$4^{\circ}\left(\right.$ Fol. $101 v^{\circ}$.) Diverses dissertations sur le même sujet.

$5^{\circ}$ (Fol. $1131^{\circ}$. ) Trailé sur les figures de la géomancie, par Naṣir al-Din Mọ̣ammad al-Ṭoûsì, traduit du persan, par 'Abd al-Moḷsin Aḷmad ibn al-Mahdi. Il

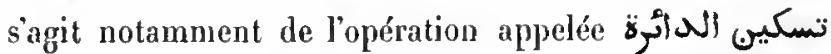
"garnir les cases du cercle ". La cojie est datée de l'an 1056 de l'hégrire (1646 de J. C.).

$6^{\circ}$ (Fol. $151 v^{\circ}$.) Traité sur les rapports qui existent entre les letires de l'alphabet et les quatre éléments, etc. (ف) بيالن ألنسبة).

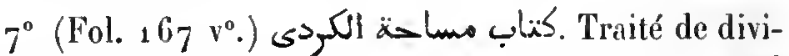
nation, accompagné de tableaux, par Aḷnad ibn Aḷmad al-Kordì. L'auteur indique certains rapports entre les procédés de l'arithmétique et les influences des quatre éléments.

$8^{\circ}$ (Fol. $19 \mathrm{~V}^{\circ}$.) Cluapitre sur la géomancie et les quatre éléments.

$9^{\circ}$ (Fol. $203 \mathrm{r}^{\circ}$.) Traité de divination, commençant par quatorze cercles qui fournissent la clef au moyen de 
laquelle on peut consulter une série de tables renfermant les réponses aux diverses questions.

$10^{\circ}$ (Fol. $228 \mathrm{v}^{\circ}$.) La قرعة de Dja far al-Sàdiq, traduite en langue turque. Les tableaux et les cercles sont assez nombreux. Cetle traduction est dédiée au sultan oftoman Mohammad-Khàn, fils de Mourâd-Khàn.

$11^{\circ}$ (Fol. $252 v^{\circ}$.) Pièces de vers en ture, au nombre de cinquante-six, dont cluacune contient vingt lignes et porte en tète le nom d'un des grands poites arabes. Le recueil entier parait lormer un livre de sorts (فLلمالمها).

l'apier. 283 fenillets. Hauteur, a1 centimètres et demi; largeur, 15 centimètres et demi. Écritures diverses du xrn siècle - (Ancien fonds 1209.)

\section{7 .}

rivre des Plyylactèresn. Traité divisé en onze sections et cent chapilres, sur les lalismans et sur l'emploi de la cendre animale pour les opérations de la magic blauche et noire.

Ms. daté de l'an 1063 de l'hégire ( 1653 de J. C.).

Papier. 13 feuillets. Hauteur, 21 centimètres et demi; largeur, 15 centimètres et demi. 17 lignes par page. - (Ancien fonds 1208.)

\section{8.}

$1^{\circ}$ (Fol. $1 v^{\circ}$.) Tables de la valeur numérique des lettres de l'alphabet dans les deux systèmes appelés

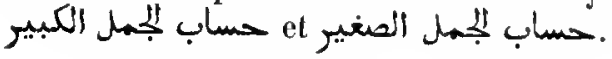

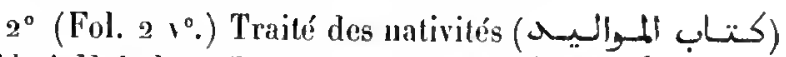

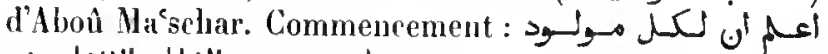

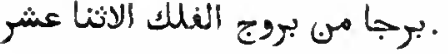

$3^{\circ}$ (Fol. 44.) Notes supplémenlaires au traité précédent.

$4^{\circ}$ (Fol. 46.) Notes sur les heures propices de chaque jour de la semaine, sur les signes du zodiaque et sur le grand nom de Dieu; Lalismans (وفق ), prières, etc.

50 (lol. $68 v^{\circ}$.) Prière réminemment efficaces.

$6^{\circ}$ (Fol. $79 \mathbf{v}^{\circ}$.) Charmes et prières.

$7^{\circ}$ (Fol. 90.) Anulelte appelée Secret des secrets (سمّ (ألاسبر').

$8^{\circ}$ (Fol. $9^{3} v^{\circ}$.) Qașida composée de plus de cent vers, pour servir d'amulette. La rime est en ).

$9^{\circ}$ (Fol. $99 \mathrm{v}^{\circ}$.) Chapitre sur les talísmans.

$10^{\circ}$ (Fol. 11 4.) Traité attribué à l'imâm هومس بيطموس, sur les vertus secrètes des lettres de l'alphabet. Commen-

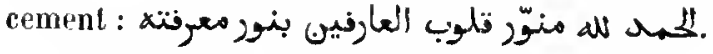

$11^{\circ}$ (Fol 149.) Traité sur les dix noms mystiques que Dieu a révélés à Moïse. Il y a un chapitre sur les تهاطيل et sur les heures propices des jours de la semaine.

$12^{\circ}$ (Fol. 156.) Chapitre sur l'art de déterminer lequel de deux combattants sera le rainqueur (3)

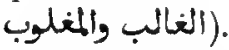

$13^{\circ}$ (Fol. 161.) Sur les pronosties que l'on peut tirer de chaque mois de l'année solaire; anıulettes, prières, etc.

${ }_{14}^{\circ}$ (Fol. 180.) Sur les pronosties que l'on peut tirer du tremblement involontaire d'un nembre quelconque du corps (جلاخ'

15 (Fol. 211.) Traité sur les vertus mystiques des lettres.

Chacun de ces traités renferme nn grand uombre de talismans, d'amulettes et de notices sur les diverses manières de deviner.

Ms. tout entier de la méme main, daté de l'an 1052 de l'bégire (1642-1643 de J. C.).

Papier. 219 feuillets. Hauteur, 21 centimètres et demi; largeur, 15 centimètres et demi. 17 lignes par page. - (Ancien fonds 1168.)

\section{9.}

Fragments d'un ouvrage où sont indijués les versets du Coran qui peurent s'employer comme amulettes. L'auteur se désigne par le titre de pكبر.

Papier. 9 feuiflets. Hauteur, 26 centimètres; largeur, 17 centimètres. \& 5 lignes par page. Ils. du xvı" siècle. - (Supplément 2050.)

\section{0 .}

Sur la manière de consulter le sort au mojen du Coran; sur le choix des heures favorables pour s'engager dans une entreprise; sur la composition des amulettes, etc.

Papier. 24 fevillets. Hautenr, 34 centimètres et demi; largeur, 18 centimètres. Ms. du $\times$ viı siècle. - (Ancien fonds 279.)

\section{1 .}

$1^{\circ}$ Fâl-námé, en arabe, arec une traduction interlinéaire en latin. 
$2^{\circ}$ (Fol. 4.) Dissertation sur la prononciation de cerlaines lettres dans la lecture du Coran, accompagnée d'un essai de traduction interlinéaire en latin.

$3^{\circ}$ (Fol. 6.) Vocalsulaire de quelques mots arabes avec leurs équivalents, partie en latin, partie en italien.

Papier. 7 feuillets. Hauteur, a 1 centimètres et demi; largeur, 14 centimètres et demi. Hs. du xv1 $1^{\circ}$ siècle d'une main européenne. (Supplément 2113.)

\section{2 .}

Amulette à compartiments, très-bien écrite et ornée. On trouve d'abord plusieurs carrés magiques, puis quetques poèmes religieux, parni lesquels la Borda de Boușîîi. Entre les deux bordures sont écrits plusieurs morceaux du Coran et d'autres textes pieux. Au verso on lit

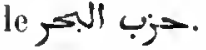

Papier. Longueur, environ 3 mètres; largeur, 6 centimetres et demi. Ms. du xvi' siècle. - (Supplément 2169.)

\section{3.}

$1^{\circ}$ Traité de géomancie, avec quelques notes marginales.

$2^{\circ}$ (Fol. $76 v^{\circ}$.) Diverses notes sur le même sujet, en langue turque.

Papier. $9^{4}$ fevillets. Hauteur, 21 centimetres et demi; largeur, 12 centimètres. 19 liggnes par page. Ms. du xvu* siècle. - (Supplément 1194 .)

\section{4.}

Traité sur les propriétés extraordinaires d'une certaine figure qui sert à faire connaitre les événements de l'avenir. Cette figure est un cercle inscrit dans un carré et entouré de lettres de l'alphabet arabe. Conmence-

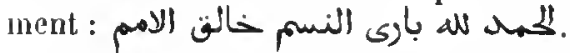

Papier. 26 feuillets. Hauteur, 31 centimètres; largeur, 13 centimètres et demi. 19 lignes par page. Ms. du xvic siecle. - (Supplément 1106 .)

\section{5 .}

$1^{\circ}$ Tables de prédiction. En tête se trourent douze cercles qui servent de clefs à ces tables.

\section{$2^{\circ}$ (Fol. $25 \mathrm{v}^{\circ}$.) Traité de géomancie.}

Papier. 33 feuillets. Hauteur, 23 centimètres; largeur, 16 centimètres. Ms. du xru⿰ siècle. — (Supplément 1 108.)

\section{6 .}

1 - Recueil d'alphabets magiques.

20 (1'ol. 35.) Le (Voyez ci-dessus, $1^{\circ} 267^{5}, 1^{\circ}$ et $267^{6}$.)

Papier. 84 feuillets. IIauteur, 21 centimètres; largenr, 15 centimètres et demi. Ms. da xv11" siecle. - (Ancien fonds 1182.)

\section{7.}

$1^{\circ}$ Recueil d'alphabets magiques.

$2^{\circ}$ (Fol. 9.) Éléments de géomancie (علم خرب الرمل (

3 (Fol. 35 vialogue dans lequel la plume et l'épée se disputent la préémi-

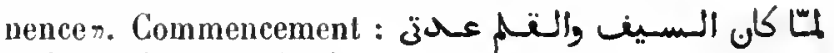
الحول وعدة التول والعيل :

$4^{\circ}$ (Fol. $39 v^{\circ}$.) Traditions attribuées à Ibn 'Abbâs et se rapportant au dernier Jugement.

Ms. daté de l'an 1178 de l'hégire (1667-1668 de J. C.).

Papier. 42 feuillets. Hauteur, 21 centimètres et demi; largeur, 15 centimètres. 19 à 25 lignes par page. - (Ancien fonds 1183.$)$

\section{8.}

Traité sur la valeur mystique des lettres, sur les talismans, les invocations, les formules magiques, etc. Compilation rédigre sans plan, ni ordre. Commencement:

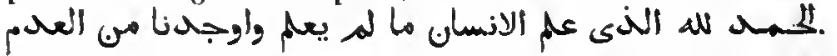

Papier. 165 feuillets. IIauteur, 21 centimètres; largeur, 15 centimètres et demi. 17 lignes par page. Ms. du xviı siecle. - (Ancien fonds 1193. )

\section{9 .}

$1^{\circ}$ Traité sur les vertus secrètes des noms de Dieu, avec un commentaire.

$2^{\circ}$ (Fol. $31 v^{\circ}$.) Traité de cabale.

$3^{\circ}$ (Fol. 38.) Traité sur les vertus secrètes des lettres de l'alphabel, par Moḷammad المرجان . Le texte est accom- 
pagné d'un commentaire. Le commencement et la fiı manquent, ainsi que plusieurs feuillets au milieu.

Papier. 152 feuillets. Hautcur, at centimètres et demi; largeur, 14 centimètres el demi. 24 à 26 lignes par page. Écritures diverses du $8 v i i^{\circ}$ siècle. — (Supplément 2 263.)

\section{0 .}

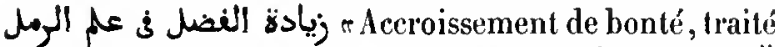

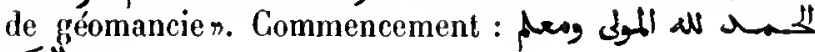
مrel.

Papier. 62 feuillets. Hauteur, 20 centimètres; largeur, 14 centimètres et demi. Environ 13 lignes par page. Mls. du xwı" siècle. (Supplément 1112.)

\section{1.}

Traité de géomancie. Commencement : اعلم إيدك الله . بروح مis

Papier. 91 feuiltets. Hauteur, 21 centimètres; largeur, 15 centimètres. 17 lignes par page. Ms. du xvi" siècle. - (Supplément 1115 .)

\section{2.}

م Flèches attachées (?), traité sur l'abacus à cinq cases de côté, dont la case centrale est vide n, par Moḷammad al-Fásí. L'auteur montre comment il faut reniplir la case centrale d'un certain abacus, au moyen duquel on se met en rapport avec les êtres surnaturels. Commencement : لـ

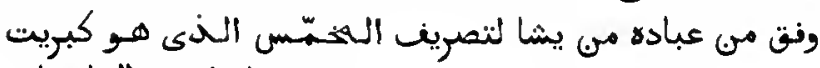

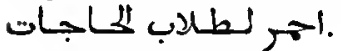

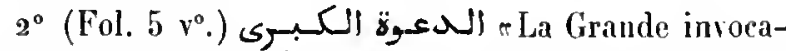
lion n, appelée aussi In Ingrocation adressée aux

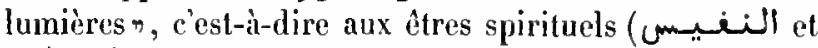
(معشثر الازولح الروحانية). Il est dit que, par le concours de ces êtres spirituels, on obtient le pouvoir de commander aux anges rebelles et anx démons (المردة والعغاريت (الميت ). Cette conjuration est suivie d'instructions sur son emploi.

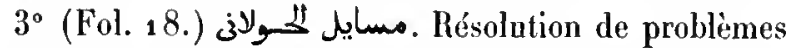
touchant la divination et les vertus secrètes des lettres de l'alphabet, par Aboù Bakr ibn Baschîr al-Ḥanlàni. Cet extrait est accompagné de plusieurs pièces du mène genre, lirées des écrits d'Abou 'l- Abbâs al-Boûni el du livie d'Aboû ḷâmid al-Ghazâlì.
4\% (Fol. 25 、..) Amulette de la laveuse des femmes mortes\%, charme pour se faire aimer, qui avail été trouvé sur le corps d'une négresse passionément aimée par le calife Hàroûn al-Raschìd et au moyen duquel la laveuse obtint le mème amour.

$5^{\circ}$ (Fol. $32 v^{\circ}$.) Collection de charmes, de talismans et d'invocations. Cette pièce el les deux pièces qui précèdent paraissent faire partie du دعوة الانوار. (Voyez cidessus, article $2^{\circ}$.)

$6^{\circ}$ (Fol. $901^{\circ}$.) Autre traité sur l'emploi de l'abacus à cinq cases de côlé, dont la case centrale est vide.

$7^{\circ}$ (Fol. $107 v^{\circ}$.) Autre traité sur le même sujet inti-

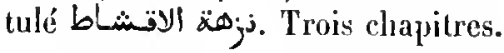

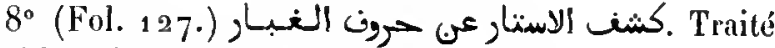
d'aritlımétique et de l'extraction des racines, suivi d'un petit traité d'algèbre.

$9^{\circ}$ (Fol. 165.) Traité en vers sur l'emploi d'une certaine zâirdja. Tous les vers de cette pièce riment en lá. Suivent quelques éclaircissements.

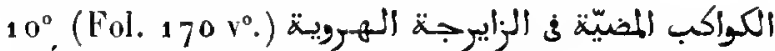
- Les Étoiles brillantes, traité sur la zäirdja d'Al-Harawì. C'est un poème didactique, rimant en $l a$, suivi d'un commentaire.

$11^{\circ}$ (Fol. $176 \%^{\circ}$. ) Traité de géomancie.

Ms. tout entier de li mème main el daté de l'an $107^{4}$ de l'hégire (1663-1664 de J. C.).

Papier. 18 , feuillets. Hauteur, 20 centimètres; targeur, 15 centimètres. a 3 lignes par page. - (Ancien fonds 1179 , Colbert 4984.)

\section{3.}

t ta Perle brillante, traité qui enseigne l'art de décourrir ce qui est cachén. Traité de géomancie, composé par un derviche de Damiette, nommé Aḷmad ibn 'Abd al-Barr, et divisé en cinq seclions, suivies d'un appendice. Commencement : سبكانك عالم لإنيّات وبليّيّات.

Papier. 117 feuillets. Hauteur. 21 centimètres; largeur, 15 centimètres. 19 tignes par page. Ms. dı xwìe siècle. - (Supplément 11 18.)

\section{4.}

Traité de géomancie. Hs. daté de l'an 1191 de l'hégire ( 1777 de J. C.).

Papier. 37 fevillets. Hauteur, 16 centimètres et demi; largeur, 11 contimètres. 15 et 16 lignes par pare. - (Supplément 1114.) 


\section{5 .}

$1^{\circ}$ Explication d'une amuletle divisée en vingl-cinq cases.

$2^{\circ}$ (Fol 7.) Traité imprimé, dans lequel un juif de Constanlinople parle de la venue du Messie et de la prophétie de Daniel. A la fin se trouvent quatre planches de figures et une carte représentant les pays occupés par les descendauts de Noé.

Papier. 35 fcuiltets. Hauteur, 19 centimètres; largeur, 13 centimètres et demi. - (Supplément 1100.)

\section{6.}

äalo ou livre de prédictions pour les sept jours de la semaine, au mois de moliarran.

Papier. 4 feuillets. Hauteur, 16 centinè̀lres; largeur, 10 centimètres et demi. g lignes par page. Ms. du xrou siècle. - (Supplément 1123.)

\section{7.}

Traité de divination.

Papier. 13 feuillets. Hautcur, 21 centimètres; largeur, 15 centimètres. 13 lignes par page. Ms. du svm" siècle. - (Supplément i 083.)

\section{8.}

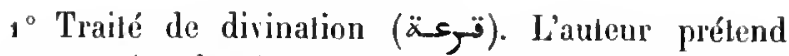
faire connaitre les érénements qui surviennent chez les divers souverains du monde. L'ourrage esl accompagné de tableaux.

$2^{\circ}$ (Fol. 43.) Art de calculer le cours d'une maladie, lorsqu'on connaît le jour où la maladie a commencé.

$3^{\circ}$ (Fol. 61.) Traité sur les influences des planètes.

$4^{\circ}$ (Fol. $77 r^{\circ}$.) Prière.

$5^{\circ}\left(F_{0} 01.78 v^{\circ}\right.$.) Traité qui fait connaitre les jours néfastes.

$6^{\circ}$ (Fol. 82.) Calendrier solaire avec prédiclions.

$7^{\circ}$ (Fol. 89.) Conte des cinq pommes.

$8^{\circ}$ (Fol. 92.) Dialogue d'Al-ṭaddjàdj et du jeune homme. $9^{\circ}$ (Fol. 99.) Entretien de Jésus arec le cràne.

$10^{\circ}$ (Fol. $104 v^{\circ}$.) Histoire de Job.

$11^{\circ}$ (Fol. 111.) Légende sur la fuite de Malıomet et sur la prise de la Mecque.

$12^{\circ}$ (Fol. $126 \mathrm{v}^{\circ}$.) Histoire de la mort d'Al-Hosain, fils d'Ali.

$13^{\circ}$ (Fol. 137. ) Conte du Château d'or.

Ms. daté de l'an 1176 de l'bégire $\left({ }_{1} 7_{2-1} 763\right.$ de J. C.).

Papicr. 149 feuillets. Hauteur, 18 centimètres el demi; largeur, 13 centimètres. 13 liggnes par page (à l'exception de l'article $1^{\circ}$ qui contient zo lignes). - (Supplément 1894.)

\section{9.}

Explication cabalistique des noms de Dieu. Le commencement et la fin manquent.

Papier. 58 feuillets. Hauteur, 16 centimètres; largeur, 10 centimètres et demi. 9 lignes par page. Ms. du xvirie siècle. - (Supplément 2112.)

\section{0.}

Fragment d'un trailé, divisé en plusieurs sections (مـــ), qui fait connaitre les charmes, amulettes, prières et médicaments qui servent ì préserver de la peste et d'autres maladies.

Papier. 22 feuillets. Hautenr, 15 centimètres et demi; largeur, 11 centimètres. 20 à 22 lignes par page. Ms. du xvu" siècle. - (Supplément 2262.)

\section{1 .}

$1^{\circ}$ Deux fragments d'un traité sur les moyens de guérir les maladies par des talismans et par ta lecture de certains passages du Coran, ainsi que par l'emploi de certaines plantes.

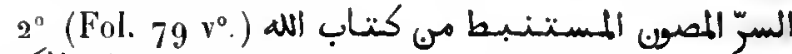
ن isecret bien gardé, tiré du livre de Dieu qui est resté cachén. Versets du Coran que l'on emploie comme amuletles. Ce recueil est attribué à Aboû Moḥammad ibı Ịầmid al-Ṭoûsî al-Ghazâlì.

$3^{\circ}$ (Fol. 95 vo.) "Voile des régions (c'est-à-dire amulette proleclrice dans toutes les régions du monde) d'Al-Fodhaïl ibn 'Iyâdh.» AlFodhail ibn 'Yyàdh était un saint musulman qui vivait 
du temps de Hàroùn al-Rasclìd et qui avait été brigand dans sa jeunesse. (Voyez Ibn Khallikàn, t. II, page 478 de la Iraduction anglaise.) Dans ce traité, l'auteur inroque de la manière la phos solennelle les anges et le: esprits purs et sainls et leur demande de protéger quiconque portera sur lui cet écrit en guise d'anuletle.

$4^{\circ}$ (Fol. 109.) Nodèles de charmes et d'amulettes pour guérir les maladies et pour écarter les malheurs. La fin manque.

Papier. 151 feuillets. Inatcur, 15 contimetres; largeur, 10 centimètres. 12 lignes par page. Is. du xvü siecle. - (Aucien fonds 1099 .)

\section{ONIROCRITIQUE.}

\section{2.}

rLituterprétation des songesn. Cie traité, divisé en cinquante chapitres, dont ła liste se troure au commencement, est attribué à Noḥanmad ibn Sirìn, célèbre traditiouniste, mort en 110 de l'hérgire (729 de J. C.). (Voyez lbn Khallikân, t. IJ, page 586 de lit traduc-

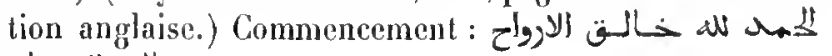
وفالق الاصبيح.

Papier. 76 fenillets. Hautenr, 21 contimètres et demi; largeur, 15 centinietres. 25 lignes par page. Ms. du $\mathrm{xvi}^{\mathrm{e}}$ siècle. - (Anrien fonds 1210 , Colbert 4573.$)$

\section{3.}

Mème ouvrage. Le commencement manque.

Ms. daté de l'an 1123 de l'hégire (1711 de J. C.).

Papier. 39 feuillets. Hlauteur, 20 centimètres el demi; largenr, 15 ceutimètres et demi. 25 lignes par page. - (Supplément a114.)

\section{4.}

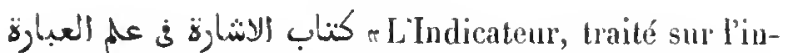
Lerprétation des songes $n$. Cel ouvrage, divisé en cinquante chapitres, est attribué ì Noḷannad ibn Sirǹn; mais il differe beaucoup de l'ouvrage précédenl. Conmencement : quent.

Papier. 127 feuillets. Hauteur, 20 centimètres; largeur, 14 centimètres. 21 lignes par page. Ms. du $871^{\circ}$ siècle. - (Ancien fonds 1 a 1 2.)

\section{5.}

اللقادرى 3 النتعبير. Trailé de l'interprétation des songes composé en 397 de l'llégire (1007 de J. C.), par Aboù Sacid Naṣr ibn Ya qoû̉, al-Daïnawarì et dédié au sultan abbaside Al-Qidir Billàh. Commencenent : أسهـهـود

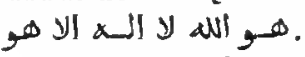

Ms. daté de l'an $119^{6}$ de l'hégire $(1782$ de J. C.).

Papier. 206 feuillets. Hauteur, 32 centimètres el demi; largeur, 2 centimètres. 19 lignes par page. - (Supplément 1144.)

\section{6.}

Satisfaction pour celui qui cherche l'intesprélation des songes n, par ‘dli iłn Sa'id al-Khaulànì al-Q Qașàn.

Papier. 4h feuillets. Hauteur, 20 centimètres et demi; largeur, 14 centimètres. 15 lignes par page. Ms. du xvi”' siècle. - (Supplément 1143.)

\section{7.}

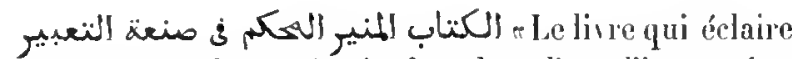
et qui rend (le lecteur) très fort dans l'art d'interpréter Jes songes", jar Abou "1-Fadtıl Ismà il al-Maușili. Commencement: : La copie r'a pas été achevée.

Papier. 185 feuillets. Hauteur, 30 centimètres et demi; largeur, 21 centimètres. 33 lignes par page. Ms. du xvi siècle. - (Supplément 11/2.)

\section{8.}

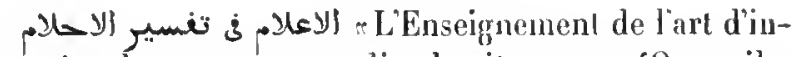
terprétrr les songess, en dix cluapitres, par 'Omar ibu

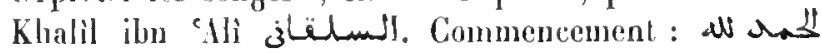

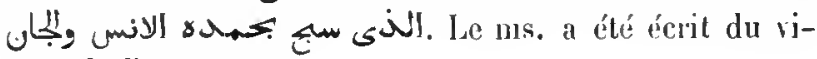
vant de l'auteur.

Papier. 145 feuillets. Ilauteur, 20 centimètres et demi; largeur, 16 centimètres. 9 lignes par page. Ms. du xrir siècle. - (Ancion fonds 1213. .)

\section{9.}

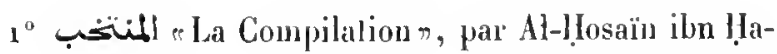
sau ibn Jbràlı̀m al-Kha\}iłì al-Dàrì. Traité d'onirocritique, 
en cinquante-neuf chapitres. Commencement : del فان علم الزويا مى اجل العلوم نغعا

$2^{\circ}\left(\right.$ Fol. $162 v^{\circ}$.) Nole en langue turque, lirée d'un traité de divination.

$3^{\circ}\left(\mathrm{Fol}, 163 \gamma^{\circ}\right.$.) Les quinze discours qui forment le commencement du traité d'onirocritique intitulé التادي Le quinzième discours renferme la liste clironologique des principanx interprètes des songes.

Papier. 171 feuillets. Hauteur, 25 centimètres et demi; largeur, 16 centimètres. 25 liggnes par page. - (Supplément 1140.)

\section{0 .}

Trailé d'onirocritique, par Ibràhîm ibn Yaḥyâ ibn Ghannûn, docteur hanbalite, né en Egypte. Les matières sont disposées dans l'ordre de l'alphabet. Ce dictionnaire est précédé d'une introduction composée de quatorze dissertations assez courtes. Commencement :

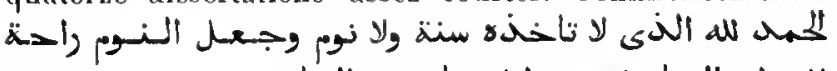

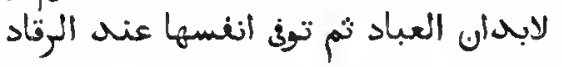

Papier. 186 feuillets. Hauteur, 21 cenlimètres; Jargeur, 15 centimètres. 20 lignes par page. Ns. du xrie siècle. - (Supplément 1139.)

\section{1}

Même ourrage. Cet exemplaire, qui a été écrit en 833 de l'héggire (1430 de J. C.) pour la bibliolhèque d'une princesse égyptienne, fille d'Al-Mâlik al-Manșoûr et petite-fille d'Ál-llâlik al-Zâhir (Tchaqmaq), sultan mam-

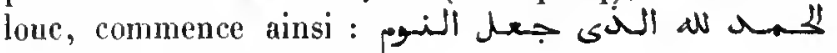

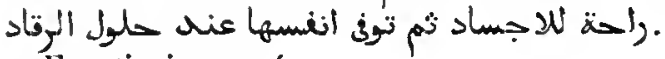

Frontispice orné.

Papier. 189 feuillets. Hauteur, 25 centinètres et demi; largeur, 16 centimètres et demi. 19 liggnes par page. - (Supplément 1141.)

\section{2.}

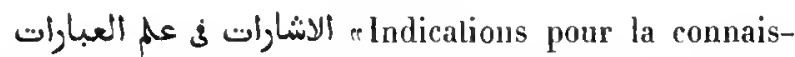
sance des significations $n$, traité d'onirocritique en qualrevingt sections (bâb), par Khalìl ibu Schâhìn al-Z̨âhirì.

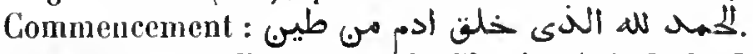

Ms. daté de l'an 1109 de l'hégire $(1698$ de J. C.).

Papier. 276 feuillets. Hauteur, 3o centimètres; largenr, 19 centimètres el demi. 25 lignes par page. - (Supplément 1145.)

\section{3.}

rexcellent traité d'interprétation et de noble explication n, traité d'onirocritique, par Moḷammad ibn al-Môlâ Qoṭb al-Dìn. Com-

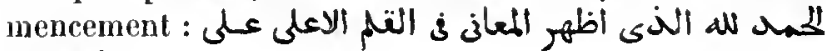

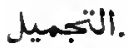

Papier. 241 feuillets. Hauteur, 24 centimètres et demi; largeur, 15 centimètres. 7 lignes par page. Ms. du xvi siècle. - (Supplément 1138. )

\section{4.}

Traité d'onirocritique, attribué à Schihàb al-Dîn al-

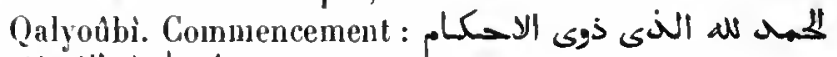

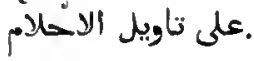

Papier. 299 fenillets. Hauteur, 21 centimètres et demi; largeur, 15 centimétres. 33 liggnes par page. Ms. du xvi" siècle. - (Supplément 1137 bis.)

\section{5.}

rLe Trésor, l'arenir révélé aux clairvoyants \%. Traité complet d'onirocritique divisé en huil sections, dont chacune renferme

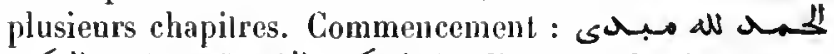
الحكام التحرة ف دلايل النكرة . La liste des chapitres commence au verso du second feuillel.

Ms. daté de l'an $99^{6}$ de l'hégire ( 1588 de J. C.).

Papier. 194 feuillets. Hautenr, 30 centimètres et demi; largeur, 21 centimètres. 27 lignes par page. - (Ancien fonds 1126.)

\section{6.}

Traité d'onirocritique, divisé en dix-neuf sections ( $f a s l$ ), dont chacune se compose de plusieurs chapitres $(b a ̂ b)$. La dernière section est divisée en cent trentequalre chapitres, mais la copie s'arrête au quatre-ringtdouzième. Le commencement manque.

Papier. 207 feuillets. Hauleur, a 4 centimètres; largeur, 16 centimètres. 21 lignes par page. Ms. du xvi siècle. - (Supplément 1136.)

\section{7.}

Traité général d'onirocritique, en ver's. Le commence- 
ment et la fin manquent. $\Lambda$ la fin du ins. se trouvent les deux dernières pages d'un traité de divination du genre appelé ikhtiladj.

Papier. 181 feuillets. Hauteur, 21 centimètres et demi; targenr, 15 centimètres. 15 lignes par page; dans les derniers feuillets, qui sont d'une autre main, on compte 17 à 20 ligṇes par page. Ms. du xrII" siècle. - (Supplément 1137.$)$

\section{h. PIYYSHONOMIQUE.}

\section{8 .}

$1^{\circ}$ ) sic) Traitá de l'llhtildd, c'est-à-dire des pronostics que l'on peut tirer des mouvements involontaires des différents miembres du corps.

$2^{\circ}$ (Fol. 5 ‥) Abrégé du traité d'Abou 'l-Isląi atKirmànì snr l'interprélation des songes, par Moḷammad ibn 'Ali, le Sicilien et JEspagnol, désigné ordinairement

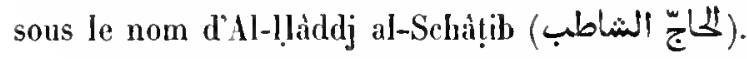

$3^{\circ}$ (Fol. 52.) Histoire de la Chamelle el de quelques miracles opérés par le Prophète.

$4^{\circ}$ (Fol. $\left.63 \gamma^{\circ}.\right)$ Histoire de la lune qui se sépara en deux moiliés (انسنتشاق الثمى) et du miracle opéré par le Prophète.

$5^{\circ}$ (Fol. $75 v^{\circ}$.) Récit de quelques miracles du Prophète, d'après la slì du cadi 'Iyàdll.

$6^{\circ}\left(\right.$ Fol. $85 \mathrm{v}^{\circ}$.) Le Hizb al-Bahr r Amulette pour préserver contre les dangers de la mern, par Abou 'H-Hasan at-Schâdsiti.

$7^{\circ}$ (Fol. 87. (Profession de t'milé de Dien sous forme de prièrer.

$8^{\circ}$ (Fol. 88.) Traité de géomancie.

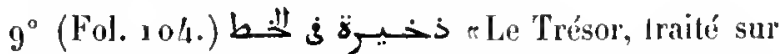
la science de l'alignement $\pi$, par Aboû 'Amrín al-Zanàlí. C'est encore un traité de géomancie, qui se termine par l'énumération des sorts que l'on tile des signes du zodiaque.

$10^{\circ}$ (Fol. $114 \mathrm{v}^{\circ}$.) Opuscule contenant des paroles attribuées à Mahomet. Commencement : لذإل

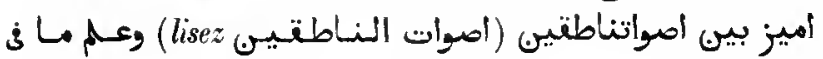

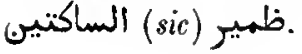

$11^{\circ}$ (Fol. $120 \mathrm{~V}^{\circ}$.) La قوع d'Aboû Djáfar al-Sâdiq.

$12^{\circ}$ (Fol. 128.) Note sur les jour's néfastes des mois de l'année solaire.

alsa. oriextavy. - Il.
${ }_{13} 3^{\circ}$ (Fol. 131.) Recueil de sorts tirés des noms des vingt-cinq prophètes, depuis Adam jusqu'à Mahomet. La fil manque.

Ce recueil, écrit par un Maghrebin illettré, est daté (fol. $51 \mathrm{v}^{\circ}$ ) de l'an 1015 de l'hégire (1607 de J. C.).

Papier. 163 feuillels. Hanteur, 20 centimètres el demi, largour, 14 centimètres. 18 lignes par page. - (Incien fonds 1211.)

\section{9.}

Traité de physionomique, par le soufi Molyammad ibn abî Țàlib al-Anșârî, de Damas, mort en $7^{3} 7$ de l'hégire (1336-1337 de J. C.). Commencement : 1 d ג . Selon Hadji Khalfa, ce traité

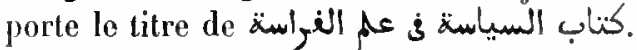

Ms. daté de l'an 1075 de l'hégire (1664-1665 de J. C.).

Papier. 44 feuiltets. Hauteur, 21 centimètres et deni; largeur. 15 centimètres et demi. 31 lignes par page. - (Ancien fonds 963.)

\section{0 .}

埧 Amusement de société, traité de la physionomie de l'hommen. Ce traité, attribué au schaikh Zaïn al-Dìn al-'Omarì, se compose d'une introduction, de quatre-vingt-dix paragraphes ef d'un appendice. L'auteur indique les inductions qu'on peut tirer de l'examen des divers membres du corps de I'homme. Il y a aussi un chapitre sur la chiromancie.

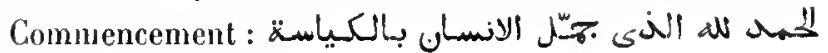

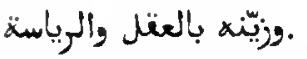

Papier. 36 feuillets. Hauteur, 21 centimètres et demi; targeur, 15 centimètres. 21 lignes par page. Ms. du xv1 siècle. - (Ancien fonds 961.$)$

\section{1.}

1. Traité de l'Ikhtilidj, attribué à Moḷammad ibn Ibrâhîm ibn Mohammad ibn Hischàm.

$2^{\circ}$ (Fol. $25 \mathrm{v}^{\circ}$.) Itinéraile du pèlerin, depuis la Mecque jusqu'au Caire, par Schams al-Din Moḷammad ibn Aḷmad, moueddin et mowaqqit. Commencement :

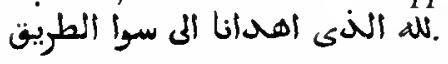

$3^{\circ}$ (Fol. $57 v^{\circ}$.) Traité du Vainqueur et du vaincu. Traité de cabale attribuéà tristote. Le vainqueur sera celui 
dont le nom, d'après la valeur numérique des lettres, représente le chiflie le plus élevé.

$1^{\circ}\left(\right.$ Fol. 6/4 $\mathrm{v}^{\circ}$.) Hisloire de l'entretien de Jésus-Christ avec le rrine (ärộ).

Papier. 79 ferillets. Hauteur, 19 centimètres et demi; targeur, I' centimètres et demi. 11 lignes par page. Ns. du xvi' siècle. (Ancion fonds g64.)

\section{2.}

Bases de lautorité du maitre, traité de physionomiquen, par Mohammad ibn

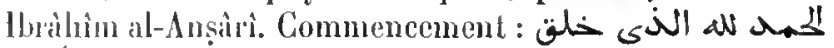
x. الانساu وكر. Cette copie a élé corrigéc par l'auteur.

Papier. 32 fenillets. Hlauteur, 21 centimètres et demi; largeur, 1.) centimetres. 2.3 lignes par page. - (Ancien fonds 962.)

\section{RECHERCHE DES TRÉSORS.}

\section{3.}

$1^{\circ}$ Présenl offert au chereheur, indiquant la manière de faire disparaitre les dangers qui entonrent les trésors cachés\%. Recueil d'invocations, de lormules magigues et d'amuletles, dont quelques-unes sont altribuées à Mboù Ilàmid al-Ghazalli. Commencement : أقسهت عليكم إيتها المائكة المكرأ

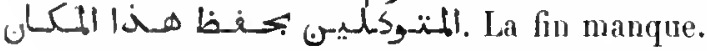

$2^{\circ}$ (Fol. G1.) Charmes, talismans et receltes pour faire des opérations magiques, etc. Plusieurs de ces pièces sont empruntées aux ourrages d'Al-Boûnî. Le commencement manque.

Papier. 101 feuillets. Ilauteur, 21 centimétres et demi; largeur, $1 / 4$ cenlimètres et demi. Fécritures diverses du $\mathbf{w v}^{\circ}$ siècle. - (Ancien fonds 1202. .)

\section{4 .}

ك S Traité de la dernic̀re nécessilé, qui indique les avantages que l'on peul oblenir, les trésors cachés el les licux où ces trésors se trouventn. L'auteur a tracé sur les marges de son ouvage un grand nombre de caractères talismaniques el de figures d'hommes el d'animaux. La fin manque.

Papier. 100 feuillets. Ilauteur, 19 centimétres; largeur', 13 centimètres. 21 lignnes par pago. - (Ancien fonds 816.$)$

\section{5.}

r Recueil d'indications ». Il s'agit des lieux d'Égypte où se trouvent des trésors caclıés, et des moyens à l'aide desquels on peut en obtenir possession.

Papier. 147 fevillets. Hautenr, 16 centimètres; largeur, 10 centimètres. 15 lignes par page. Nls. du xvi" siècle. - (Ancien fonds 817.)

\section{6.}

Préservatif des dangers auxquels on s'expose dans la recherche des trésors cachés $\%$. Cet ourrage renferme des talismans, des iuvocations, des charmes et des amulettes qui doivent préserver le porteur contre les génies. Commencement :

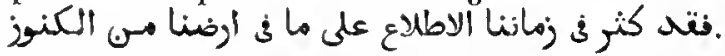

Papier. 63 feuillets. Hauteur, 21 centimètres et demi; largenr, 15 centimètres. 15 à 20 lignes par page. Mls. du xvi siècle. - (Ancien fonds 1199.$)$

\section{7.}

$1^{\circ}$ Charmes et ineantations à l'usage de ceux qui cherchent des trésors cachés.

$2^{\circ}$ (Fol. $74 v^{\circ}$.) Traité sur les vertus de l'invocation appelée la grande Invocation du désertr. Soixante-douze chapitres, en général très courts.

$3^{\circ}$ (Fol. 98.) Texte de ela grande Inrocation du désert $\pi$.

$4^{\circ}\left(\right.$ Fol. $101 \mathrm{v}^{\circ}$ ) Texte de $\mathrm{rla}$ petite Invocation du désert $\leadsto$.

Papier. 104 fenillets. Hauteur, 22 centintètres; largeur, 15 centimètres et demi. 19 lignes par page. Ms. du svu" siècle. - (Suppléunent 1110.$)$

X.

HISTOIRE NATURELLE.

I. TRAITÉS GËYÉRAUX.

\section{8.}

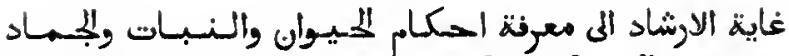
"La direclion vers la connaissance de ce dont l'usage est 
licite ou illicite en fail d'animaux, de planles et de minéraux „. Dictionnaire d'histoire naturelle, par le schaïk 'Abd al-Ra'ouf at-Monàwì, docteur schaféile. Les articles sont disposés dans l'ordre de l'alphabet et offrent des renseignements intéressants ainsi que de bonnes notes philologiques. Cet ouvrage mériterail d'ètre publié. Com-

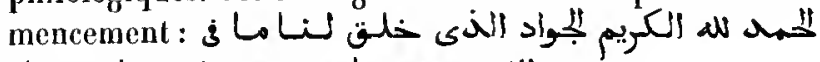

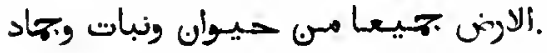

Ms. écrit par le fils de l'auteur et annoté par l'auteur' lui.même.

Papier. 1 to feuillets. Hauteur, 21 centimètres et demi; largenr, 15 centimètres. 25 lignes par page. Us. du xvi siècle. - (Supplément 859.)

\section{9 .}

Mème onvrage.

Ms. daté de l'an 2229 de l'hégrire (18,4 de J. C.).

Papier. $34_{1}$ feuillets. Hauteur, 23 centimètres; largeur, 16 centimìtres et demi. 23 lignes par page. - (Supplément 86o.)

\section{0.}

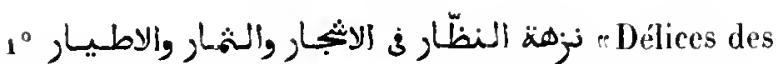
spectateurs, traité des arbres, des fruits et des oiseaux $»$. L'auteur parle des arbres et des plantes qui sont utiles à l'homme, et des qualités utiles ou nuisibles des diverses parties de certains quadrupèdes et de certains oiseaux.

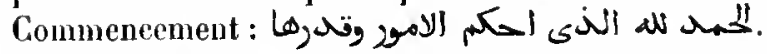

$2^{\circ}$ (Fol. $3_{9} \mathrm{v}^{\circ}$.) Recueil d'apoplitlegmes, par Raschid al-Din ibn Mohammad al-'Omari, sumommé Hl-Wațat, mort en 573 de l'hégire ( 11 7 $77^{-1} 17^{8}$ de J. C.). Ce recueil se compose de cinq séries. La première porte le titre

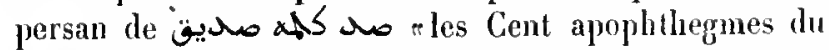
calife Aboû Bakrn; la seconde (fol. $62 \vee^{\circ}$ ) renferme les - Maximes du calife 'Omar"; la troisième (fol. $9^{1} \mathrm{r}^{\circ}$ ),

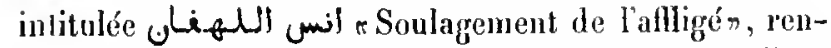
ferme cent maximes du calife 'Othmanin; la quatrième (fol. $112 \mathrm{v}^{\circ}$ ), cent maximes du calife 'Mli, el la cinquième,

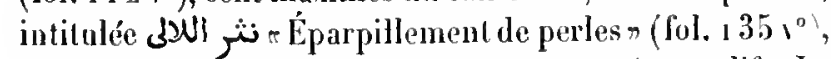
une centaine de proverbes attribués au même calife. Le compilateur a fail suivre clracune de es maximes d'un commentaire en langue persane. L'ourrage est dédié au sultan de Khârizm, Mạ̣moûd, fils d'll-A r'slàn, qui régnait de 568 a 588 de l'hégire.

La copie est datée de l'an 913 de l'hégire ( $1507-1508$ de J. C.).

3 (Fol. 157. ( cieuses, par Schihâb al-Dìl Aḷmad ibn Yoùsof al-Tifäschì. Frontispice très bien exécuté en or et en couleurs. La copic est datće de l'an $8{ }_{2} 6$ de l'hégire $\left({ }_{1} 4_{2} 3 \mathrm{de}\right.$ J. C. $)$.

$4^{\circ}$ (Fol. $222 \vee^{\circ}$.) Traité des épidémies et de la peste

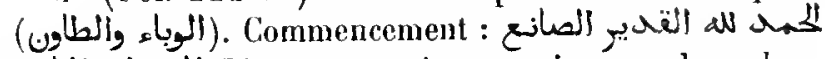

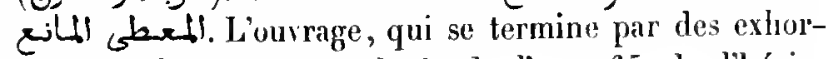
lalions religieuses, est datée de l'an 765 de l'hécgire (1364 de J. C.).

$5^{\circ}$ (Fol. 254.) Note du schaikh Abou 'l-llawâhib alTounisî sur certaines négligences que les fidèles commellent dans l'exécution de leurs deroirs religienx.

Papier. 255 feuillets. Hauteur, 17 centimètres et demi; largeur, 13 centimètres. Écritures diverses. -- (Ancien fonds 969.)

\section{1.}

Volume dépareillé d'un trailé d'histoire natmrelle. Ayant

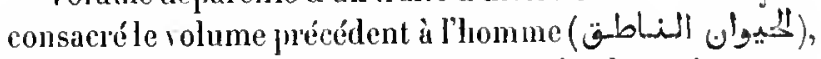
l'auleur traite, dans la première parlie du présent volume, des animaux et, dans la seconde partie, qui renferme des figures coloriées, des plantes. Il a suivi, dit-il, prineipalement le جام d'lbn al-Bätảr. L'arrangemenl des articles, dont la liste se troure en tìte, est alphabétique, mais on y remarque des irrégularités. Un titre apocryphe qui altribue l'ouvrage à Ibn al-Baịtàr, a élé ajouté après coup.

Papier. 277 feuillets. Hanteur, 86 centimètres et demi; largeur, 18 centimètres et deuni. 17 lignes par page. Its. du xiv siècle. - ( $\mathrm{An}-$ cien fonds 1037. )

\section{MINRRALOGIE.}

\section{2.}

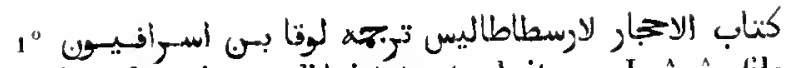
- Le Lirre des pierres d'Aristote, traduit par Loûqẩ, fils. de Sérapion \%. Ce sont, dit le tradıcteur, des extraits d'un ourrage d'Aristote renfermant la descriplion de sepl cents espéces de pierres, ainsi que des détails sur leul composition (هو, (أهر)), leur couleur, leur genre et les mines où elles se trouvent (s) ols ). Dans celte traduclion, nous remarquons huit articles consacrés aux différentes especes d'ainants (umbieico) : l'aimant d'or, d'argent, de plomb, de cheven $x$, de chair, etc., dont chacun a des vertus singulières. lioriginal gree est probablement le traité $\Pi \varepsilon \rho i \lambda_{l} \theta \omega \nu \delta_{\imath} \alpha \varphi_{\circ} \rho \tilde{\alpha} s$ faussement altribué à Aristole. 
$2^{\circ}$ (Fol. $36 \mathrm{v}^{\circ}$.) Traité des sigles planétaires qui s’inscrivent sur les chalons de bagues pour servir d'amulettes.

Mls. daté de l'an 730 de l'hégire $(1329$ de J. G.).

Papier. 45 feuillets. Hauteur, 17 centimètres et demi; largeur, 12 centimetres. 13 lignes par page. - (Supplément 876.)

\section{3.}

r Traité des pierres précieuses", par Aboû 'Abd Mllah Mḷmad ibn Yousof al-Tifàschì (né il Tipasa, ville de la province de Conslantine, en Algérie), mort en 65 I de l'hégire (1272-1273 de J. C.). L'auteur décril vingl-cinq espèces de pierres fines et en indique les qualités ainsi que la valeur.

Cel ouvrage a été publié à Florence, en 1818. Mais le présent ins. présente un assez rrrand nombre de variantes.

Papier. 83 feuillets. Ilauleur, 18 cenlimètres et demi; largeur, 14 contimètres. 13 lignes par page. Ils. du vule siècle. - (Supplément 880. )

\section{4.}

Sìme ouvrage. Cet exemplaire porle le titre de

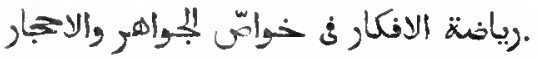

Papier. 67 feuillets. Hauteur, 17 centimètres; largeur, 13 ceutimèlres. 15 lignes par page. Ms. du $\mathrm{xv}^{\mathrm{e}}$ siècle. - (Supplément 2534.)

\section{5 .}

$1^{\circ}$ Mème ouvrnge. Cet exemplaire porte le titre de r. Les l'erles brillanles, sur les vertus des pierres précieuses».

$2^{\circ}$ (Fol. 75. 5. Livre des propriétés des pierres, attribué à ḷonaïn ilon Isḷàq. C'est un trailé sur l'usage des pierres précicuses comme talismans et roume annulettes. Des figures bizarres, dessinées au trait et représentant des hommes et des animaux, sont intercalées dans le texte.

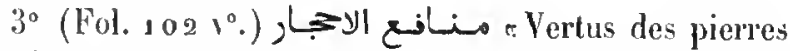
préeieuses $\%$. Ce traité, qui renferme des figures, est altribué à un certain 'Oṭârid (Mereure), fils de Mọ̣ammad. II aurait été composé d'après les ouvrages d'Hemines trismégiste qui sont compris sous le tilre de وجاينى et qui traitent des pierres, des arbres et des plantes. Au lieu de

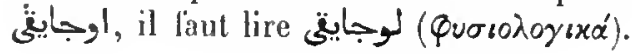

$4^{\circ}$ (Fol. 13 v $^{\circ}$. ) Trailé sur les vertus magiques des pierres, en seize chapitres. La fin manque.

Papier. 173 feuillets. llauteur, 17 centimètres et demi ; largeur, 13 centimètres. 13 lignes par page (dans les deux derniers opuscules, 11 lignes par page). Mls. du xv" siècle. - (Supplément 878, SajntGermain 401.)

\section{6.}

$1^{\circ}$ Traité des pierres précieuses d'Al-Tífàschì.

$2^{\circ}$ (Fol. $25 v^{\circ}$.) Autre traité des pierres précieuses,

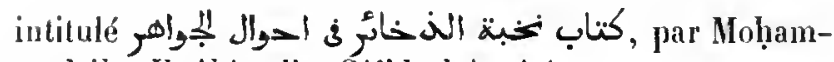
mad ibn Ibrîhìm ilun Sàid al-Ansânì.

$3^{\circ}$ (Fol. 3o.) Autre traité des pierres précieuses. Trente ehapitres et un apjendice. En inarge on lit le titre de كتناب نزهة الابصار.

$4^{\circ}$ (Fol. $38 v^{\circ}$ ) Extrait de lourrage intitulé flo الغكى ومناهُ العبر, sur les pierres préeieuses.

50 (Fol. 49.) Extrait du ع بائب النحلوقات, sur les minéraux et les pierres précieuses.

$6^{\circ}$ (Fol. 64.) Ordjoiza, en quatre parties, intitulée

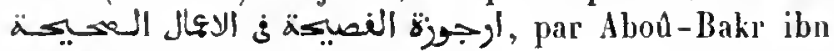
Yalỵà al-Kàtib al-Khiràt.

$7^{\circ}$ (Fol. 71.) Extrail de l'ourrage intitulé .اسكرا, النكاح

$8^{\circ}$ (Fol. $72 v^{\circ}$.) Recucil de recettes, par lbn-Rasoûl al-Ghassâni. Sept chapitres.

$9^{\circ}$ (Fol. $103 \mathrm{v}^{\circ}$.) Dissertation médicale intitulée sy?

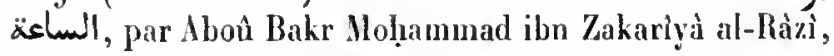
suivic d'autres extraits relatifs à la médecine.

Papier. 118 feuillets. Hauteur, a a centimètres; largeur, 16 centimètres. 95 lignnes par page. Ms. du $\mathrm{rvi}^{\mathrm{e}}$ siècle. - (Supplément 19.51.)

\section{7.}

Traité des pierres précieuses, par Aḷmad ibn Yoùsof al-Tífàschì.

Papier. 42 feuillets. llauteur, 26 centimètres et demi; largeur, 14 centimètres et demi. 25 lignes par page. Ms. du xwit siècle. (Supplément 881.)

\section{8.}

rileurs des pensées, traité des pierres précieuses \%. Tel est le titre inscrit sur ce v- 
lume; mais seuls les quatre premiers feuillets et le dernier appartiennent à l'ouvrage d'Al-Tifàschì. Le reste dı ms. contient deux ouvrages, en turc : le premier, dont le commencement manque, expose les privilèges de la ville de Médine; le second, dont li fin manque, les privilèges de Jérusalem. La première de ces pièces est datée de l'an 920 de l'ı́́gire (1514-1515 de J. C.).

Pnpier. 65 feuiflels. Hauleur, 18 centimètres; largeur, 13 centimètres. $\leadsto$ lignes par page. Ms. du xv' siècle. - (Ancien fonds 846.)

\section{9.}

r Trésor des marchands, sur la connaissance des pierres précieuses $»$, par Baïlak-Qabdjàqì (بيلك قبكاق), ouvrage dédié au prince de ḷamât, Al-Màlik al-Manșoûr H, fils d'Al-Màlik al-Mozaffar 11 el oncle de l'historien et géographe Abou 'H-Fida. Ce traité est divisé en trenta sections (ö), dont la liste, ainsi que celle de leurs subdivisions, occupe les folios $4 v^{\circ}$ ¿ 13 . La préface commence par la mème phrase que l'ouvrage d'Al-Tífàschì.

Volume écrit de la main de l'auteur et daté de l'an 681 de t'hégire ( 1282 de J. C.).

Papier. 88 feuillels. Hautcur, 21 cenlimètres el demi; largeur. 15 centimètres. 15 lignes par page. -- (Ancien fonels $97^{\circ}$.)

\section{0.}

r Secret des secrets, louchant la connaissance des pierres précienses". Commencenent : .

Papier. 64 feuiltels. Haulcur, 21 centimètres et demi; largenr, 15 centimèlres et demi. 15 lignes par page. MIs. du wni siècle. (Supplément 879.)

\section{BOT AMIQUE.}

\section{1 .}

Dictionnaire de botanique, sans titre ni préfice, composé de deux sections, dont la première est consacrée anx arb)res, la seconde anx autres plantes. Ie présent ms. est l'exemplaire de l'auteur qui a ajouté, à la marge, plusieurs notes qu'il se proposait de faire rentrer dans le texte. Les matériaux de ce dictionnaire sont tirés de l'Agriculture nabatéenne el des autres traités qui portent le nom d'lhn Wạ̣schiya, de l'Agriculture d'lbı Bassàl, du Livre des plantes d'Aboû Hanîla al-Daïnawatì, de l'Agriculture des Grees et du ما لا يسع.

Papier. 23 fenillets. Hauteur, 35 centimètres; largenr, 24 centimètres. 37 lignes par page. Ms. du swri siècle. - (Ancien fonds $9{ }_{1} 6$. .)

\section{ZOOLOGIE.}

\section{2 .}

Traité de zoologie, arec des figures, par 'Abd Mllah ibn Djibril ibn Bakhtyaschoû ${ }^{\complement}$. Les figures sont très nombrenses, mal dessinées et coloriées, mais représentant passablement les animaux décrits dans le texte. Après awoil parlé de l'lomme, l'auteur décrit les animaux domestiques, les bêtes sauviges, les oiseanx, queltues poissons et simuiens, et quelques insectes. En tète du volumr,

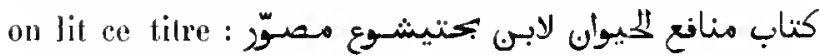
- Traité des avantages quon peut tirer des animanx, ourrage orné de figures, composé par lbn Bahhlyaschon' $n$. A la fin on lit que cet ouvrage est un extrait d'un

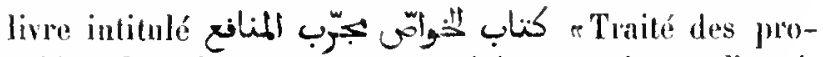
priétés dont les avantages ont été constatés par l'expérience?.

Ms. daté de l'an 700 de l'hégrire (1300-130 1 de J. (i.).

Papier. 58 feuillets. llauleur, 20 centimètres; largeur, 14 centimètres. 15 liygurs par page. - (Ancien fonds 1077. )

\section{3.}

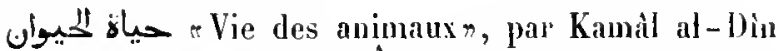
Moḷammad ibn Moûsì ibn 'Îsâ al-1)amîri, docteur schàféite, mort en 808 de l'légire (1405-1406 de J. C.). Exemplaire complet de la première édition ${ }^{2}$.

Ms. daté de l'an 773 de l'hégire $(1372$ de J. C.).

Papier. ${ }_{7} 8$ feuillets. Hauleur, 25 centimètres ot demi; largeur, 15 centimètres et demi. 25 lignes par page. - (Ancien fonds 908.)

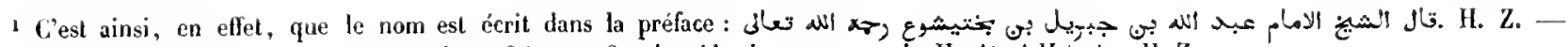
2 Ce ms. renferme, ainsi que tes $n^{\circ 3} 2784,2788$ el 2789 , la rédaclion moyenne du Ḥayàl al-ḷaiwàn. Il. $Z$. 


\section{4.}

Mêne ouvrage.

Ms. daté de l'an 817 de l'hégire (1414-1415 de J. C.).

Papier. 275 feuillets. Hauteur, 28 centimètres et demi; largeur, 18 centimètres. 24 à 27 lignes par page. - (Ancien fonds 910.)

Mème ourrage.

\section{5}

Ms. daté de l'an $9{ }^{1} 7$ de l'hégire ( 1511 de J. C.).

Papier. 346 feuillets. Hauteur, 18 centimètres; largeur, 13 centimètres. 21 lignes par page. — (Supplément 872, Saint-Germain 399.)

Même ouvrage.

\section{6 .}

Ms. daté de l'an 974 de l'hégire ( 1567 de J. C.).

Papier. 398 feuillets. Hauteur, 31 centimètres; largeur, 21 centimètres. 23 lignes par page. - (Supplément 873 ter.)

Même ourrage.

\section{7.}

Papier. 294 feuillets. Hauteur, 30 centimètres; largeur, so centimèlres. 35 à 37 lignes par page. Ms. de diverses écritures du $x v 1^{\circ}$ et du $\mathrm{xrr}^{\circ}$ siècle. - (Ancien fonds 911.)

\section{8.}

Même ouvrage.

Ms. daté de l'an 1007 de l'hégire (1598-1599 de J. C).

Papier. a 08 fenillets. Hauteur, 3 a centimètres; largeur, a a centimètres. 29 tignes par page. - (Ancien fonds 907.)

\section{9.}

$1^{\circ}$ Même ouvrage. Copie datée de l'an 1008 de l'hégire ( 1600 de J. C.).

$2^{\circ}\left(\right.$ Fol. $150 \mathrm{v}^{\circ}$.) Histoire de Kalila el Dimna. Copie datée de l'an 1041 de l'hégire $(1631-1632$ de J. C. $)$.

Papier. 344 feuillets. Hauteur, 21 centimètres; largeur, 14 centimètres et demi. 23 lignes par page. - (Ancien fonds 965.)

\section{0 .}

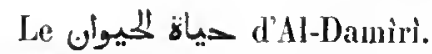

Ns. daté de l'an 1077 de l'héggire ( $166_{7}$ de J. C.).

Papier. 494 feuillets. Hauteur, 30 centimètres; largeur, a 1 centimètres. 27 lignes par page. - (Ancien fonds 906.)

\section{1.}

Première parlie du même ourrage, se terminant par la lettre $\infty$. Titre et vignettes en or et en couleurs.

Papier. 304 feuillets. Hauleur, 97 centimètres et demi; largeur, 21 centimètres. 26 lignes par page. Ms. du xiv siècle. - (Ancien fonds 909 .)

\section{2 .}

Première partie du même ourrage, se terminant par la lettre ش. En tête se troure une vignette en or et en couleurs.

Papier. 215 feuillets. Hauteur, 3 1 centimètres; largeur, a 1 centimètres. 35 lignes par page. Ms.du avı" siècle. - (Supplément 2086.)

\section{3.}

Première parife du même ourrage. Ce rolume devait se terminer avec la lettre ش; mais pour le faire accorder avec un autre volume qui commençait par celte lettre, on a enlevé du présent ms. plusieurs feuillets et collé sur le dernier feuillet un morceau de papier blanc avec un explicit.

Papier. 333 feuillets. Ilanteur, 30 centimètres; largeur, 20 centimètres. 29 lignes par page. Ms. du xvi" siècle. - (Supplément 870.)

\section{4.}

Première partie du même ouvrage, se terminant par la lettre w.

Papier. 219 feuillets. Ilanteur, 31 centimètres; largenr, 20 centimètres. 33 lignes par page. Ms. du xvu siècle. - (Supplément 871.)

\section{5 .}

Première partie du même ouvrage, se terminant par 


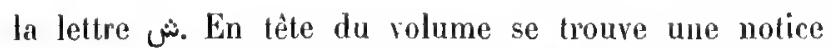
biographique de l'auteur, tirée du coll li d'Al-Qastalànî.

Papier. 540 feuillets. Hauteur, a a centimetres; largeur, 16 centimètres. 23 lignes par page. Ms. du xvur siècle. - (Sppplément 873.)

\section{6.}

Seconde partie du même ouvrage, commencanl par la lettre $\infty$.

Ms. daté de l'an 1171 de l'hégire ( 1758 de J. C.).

Papier. 487 feuillets. llauteur, 21 centimètres; largeur, 15 centimètres. 19 ligones par page. - (Supplément 873 bis.)

\section{7.}

Seconde partie du même ouvrage, commençant par la lettre

Ms. daté de l'an 1227 de l'hérire (1 812 de J. C.).

Papier. 2/4 feuillets. Hautleur, 36 cenlimètres; largeur, a 3 cenlimètres. 33 lignes par pages. - (Supplémeni $87_{0}$ bis.)

\section{8.}

L'édition abrégée (rédigée par l'autenr lni-mème) dı même ouvrage.

Ms. dalé de l'an 1064 de l'hégire (1654 de J. C.).

Papier. 228 fenillots. Jauteur, so centimètres et dermi; largeur, 14 centimitres. 21 ligrnes par page. - (Supplément 875.)

\section{9.}

- Beautés du livre intitulé Wayất al-llainwân». Abrégé du dictionnaire d'Al-Damîri, par le docteur hanélite Moḷmmad ibn 'Abd alQâdir ibu Mohammad at-Damirî. L'autemr ayant voulu surtout reproduire les passages brillants et curicux, n'a eu garde d'omettre la longue et célèbre digression de l'article jol rloien, qui renferme une histoire des califes el où l'autem démontre que le sixième calife de chaque dynastie avait été détrôné. Commencement : لإلق

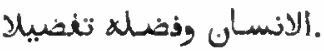

Ms. daté de l'an 1048 de l'hégire (1638 de J. C.).

Papier. 318 feuillets. Hautenr, 25 centinètres; largeur, 17 contimètres et demi. 27 liłnes par page. - (Supptément 874.)

\section{0 .}

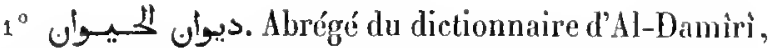
par Al-Soyoûți. Cependant ce dernier auteur a fait quelques additions au trarail de Damirì et y a joint un sup-

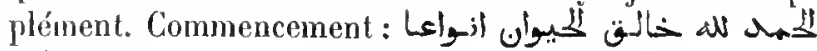
xelises.

$2^{\circ}$ (Fol. $188 \gamma^{\circ}$.) Traité sur l'exceltence dn jour de rendredi, par le Al-Soyoûtî.

30 (Fol. $196 r^{\circ}$ ) (li, jar A]Soyoụtị. Dans cette dissertation, l'auteur démontre que l’imàm Aboû flanifa a rapporté deux tradilions sur l'autorité de l'imâm Al-Sclıàfı̀i

$4^{\circ}$ (Fol. $198 v^{\circ}$.) Notes d'Al-Soyoûtî sur divers sujets, tirées d'un traité en vers, qui renfermait plusieur's anecdotes et d'autres renseignemenls. Le litre de ces

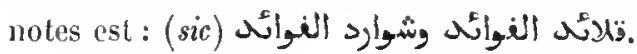

5* (Fol. 202.) (البl. Sur certaines décisions du Prophète, par le mème auteur.

$6^{\circ}\left(\right.$ Fol. $209 r^{\circ}$.) la transmission de la robe du soufi dont il avait été luimème revètu par Kamill al-Dìn al-Misrì ef qui remonto à Ibn al-Tauwîzi.

$7^{\circ}($ Fol. 211 vo.) Dissertation d'Al-Soyoûtì dans laquelte if démontre qu'Al-llasan alBaṣri arait reçu d'Ali, fils d'Aboû Ṭalib, la robe du soufi.

$8^{\circ}$ (Fol. $2131^{\circ}$.) Extraits de l'ouvrage intitulé

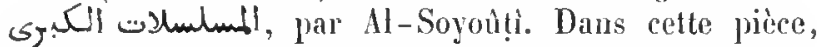
l'auteur rapporte plus de trente des traditions appelées مسرامسكات

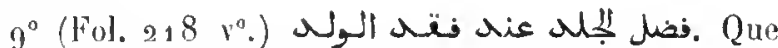
lon doil supporter avec fermeté et résignation la perte de ses enliants, par le mème.

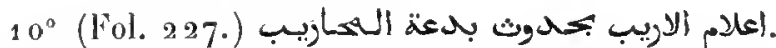
Dans celte pièce, Al-Soyoûlî démontre que l'usage des mileráb dans les mosquées est une innovation et qu'il n'existait pas du vivant de Mliomet.

$11^{\circ}$ (Fol. 23\%. (ST. Sur les lois relatives aux eunuques, par Al-Soyoûtî.

$12^{\circ}$ (Fol. $235 \vee^{\circ}$.) Sur l'usage qui s'est conservé ì la Mecque de nourrir des pauves pendant sept jours au nom d'une personne qui vient de mourir, par le mène auteur.

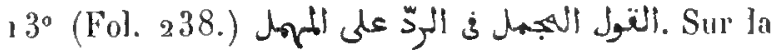


prononciation du mot dans un passage de la \&li du cadi 'yâdh, par le même.

$14^{\circ}$ (Fol. 241.) Recueil de tradilions relatives aux eufants, par le même.

$15^{\circ}$ (Fol. $244 r^{\circ}$.

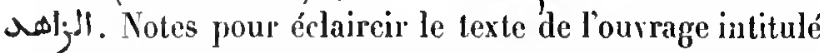
les Soixante questims (المتيى مسئلة) et qui traite des devoirs du Musulman.

$16^{\circ}\left(\mathrm{Fol} .266 \mathrm{v}^{\circ}\right.$ () Prophèten, par Djałàl al-Dìn Moḥammad iłn Aḷmad alMalıalli.

$17^{\circ}$ (Fol. $2731^{\circ}$.) Dictionnaire alphahétique des productions de la terre, au sujet desquelles il existe des

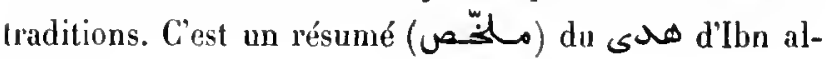
Qayiu !.

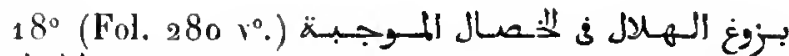
لـ Traité d'Al-Soyoûtî sur les soixante-dix qualités dont la possession donne le privilège d'être placé à l'ombre du trône de Dieu.

$19^{\circ}$ (Fol. $284 v^{\circ}$.) Classes des Iraditionnistes, depuis Mahomet jusqu'à l'époque d'Ibn Hadjar al-'Asqalâni, par Al-Soyoûțî.

$20^{\circ}$ (Fol. $366 \mathrm{v}^{\circ}$.) Dictiommaire de patronymiques, abrégé du Lobáb d'lbu al- $\Lambda$ thî̀r, par $\Lambda \mathrm{l}$ Soyoûti.

$21^{\circ}$ (Fol. $423 v^{\circ}$.) Liste de ses ouvrages, par AlSoyoûtị.

$22^{\circ}$ (Fol. $\left.427 r^{\circ}.\right)$ Liste des ouvrages qu'Al-Soyoûți avail éludiés sous la direction de ses professeurs.

$23^{\circ}$ (Liste $444 r^{\circ}$.) Liste des califes qui ont transmis des tradilions.

$24^{\circ}$ (Fol. $446 r^{\circ}$. ) Sur les signes précurseurs de la fin du monde (أشراط (لماعة)

Ms, dalé de l'an $9^{4} 9$ de l'hégire (1542 de J. C.).

Papier. 465 fenillets. Ilauteur, 29 céntimètres; largeur, 20 centimètres el demi. 31 lignes par page. - (Supplément 1920.)

\section{1.}

مغنى Traité qui dispensera les amis d'avoir recours au ḷayât al-Haïzân. Abrégé

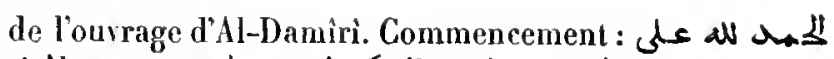
. ا انسعم واوله والنشكر له سبكانغ وهو نعم المولى

Papier. 32 feuillets. Hauteur, 21 centimètres; largeur, 15 centimètres. 16 à 19 lignes par page. Ms. du xviı siècle. - (Ancien fonds 967$.

XX I.

\section{AGRICULTURE.}

\section{2.}

هـ Abrégé d'agriculture $n$, attribué au philosophe Dénocrite (ديمتراطيس المغيلـسيون). C'est un manuel pour le cultivateur renfermant des notions utiles sur la culture des céréales, des arbres fruitiers et des légumes, et des observation sur l'éducalion des animaux domestiques. On lit en tête du ms. ces mots : Abrégé dagriculture d Ibn Ouahchiya. Mais le nom d'lbn Walıschìya n'est mentionné nulle part dans le texte. Les premiers feuillets présentent quelques lacunes.

Papier. $30^{\circ}$ feuillets. Hauteur, 26 centimètres; largeur, 17 centimètres et demi. 29 tignes par page. Ms. du xvi siècle. - (Ancien fonds 9 14.)

\section{3.}

r L'Agriculture nabatéenne n, traduite, d'après le titre de la seconde partie (fol. 94), de la langue des Chaldéens (نمانيين), en arabe, en 291 de l'hégire (9o3-go4 de J. C.), par Aboû Bakr ibu (sic) Ahmad ibn 'Ali, généralement conmu sons le nom d'Ibn Wahschîya. (Voyez, au sujet de cet ouvrage apocryphe, l'article de M. Renan dans le t. XXIV des Mémoires de l'Académie des inscriptions; le travail de M. Gulschmidt dans te t. XV du Jourual de la Société orientale d'Allemagne; Je Guide des égarés, de M. Munk, t. III, et le résumé que M. Chwolson en a donné dans les Mémoires de l'Académie de Saint-Pétersbourg, Savants étrangers, t. VIII, p. 443-446.)

Ce volume renferme la seconde moitié de la première partie de fouvrage, et toute la seconde partie. La copie est datée de l'an 1043 de l'hégire (1634 de J. C.).

Papier. 300 feuillets. Hauteur, 29 centimètres; largeur, 19 centiniètres et demi. 25 lignes par page (vers la fin du volume, 23 et 24 lignes). - (Ancien fonds 913 .)

\footnotetext{
${ }^{1}$ Cet exIrail, comme le précédent, qui est également tiré du هی, a pour auleur Djalât al-Dín al-Mahalli. H. Z. - "L’auteur de ce traité est J'imâm Al-Sarakhsî. H. Z.
} 


\section{4.}

r Live de l'agricultures, par Aboû Zakarìya Yaḷyå ibn Moḷammad ibn Mḷmad ibn al'Auwàm. Le présent ms. renferme les seize premiers chapitres de l'ourrage; mais il y a trois lacunes.

Papier. 98 a feuiltets. Hauteur, 27 centimètres; largeur, 18 cenlimètres et demi, 19 lignes par page. Mts. du xur siècle. - (Ineien fonds 912.$)$

\section{5.}

ä Abrégé d'agriculturen. L'auteur anonyme dit qu'aux notions acquises par sa propre expérience, il a ajouté celles que hui fournissaient l'Agriculture d'Ibn Wahschiya et l'Agriculture des Grecs (مول/). II cite aussi l'autorité d'Ibn al-Baițìr (roir [ol. $52 \mathrm{v}^{\circ}$ ), célébre botaniste, mort en 646 de l'hégire ( 1248 de J. C.).

Papier. 110 fenittets. Hauteur, 27 centimètres; largeur, 18 centimètres. 13 lignes par page. Its. du xiv sièele. - (Aneien fonds 915.)

\section{6.}

Traité d'agricuiture et d'élevigge d'animaux domestiques. Ournge sans tilre, ni nom d'auteur. Les indications qui se Irouvent au verso du premier et du second feuillet sont inexactes. L'auteur ne s'est pas serri de l'Agriculture nabatéene, il ne la cite pas une seule fois, et le personnage nommé Mboù Bakr ibn Yalyyà ibn Yoûsof ibn Qorquàs (قرقساس) al-Khamrà wì est celui qui avait fait

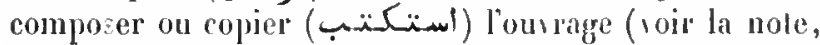
fol. $1441^{\circ}$ ). L'auteur inconnu dit que le conlenu de ce laité a été puisć dans les lirres des Grecs rt dans les tré-

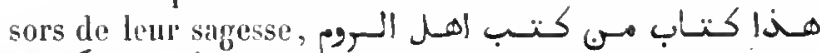
مونظ Dans la prélace, qui remplil quarante pages et qui forme un traité sur l'utilité de l'agriculture et de l'élevage des animaux domestiques, il cite très souvent sui, parait-il, attribuait une grande influence à la planète Jupiter. Suivent plusieurs chapitres très courts sur les bons et les mauvais terrains, sur les engrais, sur la découverte des sources cachées, sur les semences, sur les insectes nuisibles, sur les plantations des vignes, sur les plantes et les jardius. Vient ensuite une série d'articles sur charque plante et ehaque animal intéressant l'économie domestique. Commence-

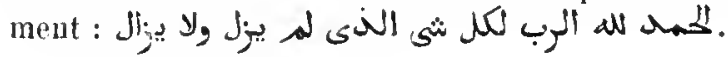

$$
\text { Mis. onievtact. -- } t \text { t. }
$$

Ms. daté de l'an 959 de l'hégrire ( 552 de J. C.).

Papier. 116 feuilets. llanteur, 17 centimètres et demi; largeur. 13 centimètres et demi. 11 lignes par page. - (Supplément 88.)

\section{7.}

طـيسبـغنـا Traité d'agriculturen, par

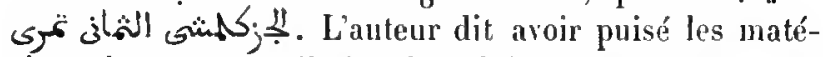
riaux de cette conppilation dans l'Agriculture (nabaténne) d'Ibn Waḷschiya, dans l'Agriculture des Grecs $(\ddot{x} \rightarrow)$. (l), ut dans les commaissances pratiques quil s'était lui-mèue acquises. La préface traite en plusicurs chapitres des lerres et de leurs quatités, des snisons, des vents et des cultures appropriées à chaque nois de l'année copte. Vient ensuite une súpie de notices sur les arbres rt les plantes les plus utiles a l'homme. Commencement : 情 "س

Ms. daté de l'an 1019 de lhégire (1610-1611 de J. C.).

Papier. 82 feuillels. Hautenr, a 1 centimètres; largenr, 15 centimètres. 19 lig̣nes par page. - (Supplément 883.)

\section{8}

\section{Mène ouvrage.}

Popier. 9's feuillets. llantenr, 18 eentimètres; largeur, 11 centimitres. 21 lignes par page. Uls. du xvı ${ }^{e}$ siècle.-(Supplément 883 bis.)

\section{9.}

Trailé d'agriculture, sans litre ni nom d'auteur, divisé en neuf chapitres, saroir: $1^{\circ}$ sur la nature des plantes; $3^{\circ}$ sur les terres et les funiers qui leur conviennent; $3^{\circ}$ sur la culture des céréales et autres graines (تطان); $4^{\circ}$ sur la culture des légumes; $5^{\circ}$ sur la culture des plantes dont les fruils sont renlermés dans une coque; $6^{\circ} \mathrm{sur}$ la culture des plantes qui portent des fruits à noyaux; $7^{\circ}$ sur la cullure des plantes dont le fruit n'a ni coque, ni noyau; $8^{\circ}$ sur la culture des plantes ordorantes; $9^{\circ}$ sur les arbres à manne et à gomme. Commencement: لإ.

lls. daté de l'an 1057 de l'hégire (1647 de J. C.).

Papier. 1 a 2 feuillets. Hauteur, an centimètres; largeur, 15 centimètres. 21 lignes par pagé. - (Supplément 884, Saint-Germain 403.) 
XX II

IIPPOLOGIE ET HIPIATRIQUE.

\section{0.}

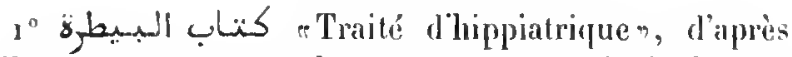
différents ouvrages en langue prrecque, principalement celui de Theomnestus ("ناومنيطيس), Ulis titre yni se tronve en tèle du ms. altribue cette compilation à ḷ̣onainn ibu Iș̣àty.

$2^{\circ}$ (Fol. $46 v^{\circ}$.) Traité des maladies des cheraux, en

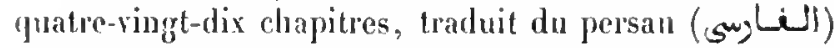
en arabe. Un titre qu'on lit en tele attribue cet onrage à Thàbit ilon Qorra.

Ms. daté de l'an 750 de l'hépire ( 13 彳 9 de J. C.).

Papier. 170 feuiltets. Hauteur, 26 centimètres et demi; targenr, 18 centimètres. 17 lignes par page. - (Ancien fonds 1038.$)$

\section{1 .}

$1^{\circ}$ Traité d'hippiatrique, fondé sur les pratiques de Qanbar (قنب), palefrenier d'Mli, fils d'Ahoû Țàlib.

$2^{\circ}$ (Fol. $2 / 11^{\circ}$.) Autre traité dihppiatrique.

$3^{\circ}$ (Fol. 100.) Histoire d'Aboù Yazid al-Bastàmi, qui convertit tous les moines d'un couvent ì l'islamisme.

Papier. 113 feuillets. IIauteur, 15 centimètres; targeur, 10 centimèires. 11 lignes par page. Ifs. du xvi" siècle. - (Supplément 1900.)

\section{2}

Traité d'hippiatrique. Le commencement et la fin manquent. L'ourrage, qui se compose principalement de recettes, était sans doute considéré comme classique; car on voit sur les marges un grand nombre d'additions, d'une trìs loelle écriture, faites à une époque déjà ancienne.

Papier. 211 feuillets. Hauteur, 27 centinè̀res et demi; largeur, a o centimètres el demi. 1 lignes par page. Ms. du su' ou du xuा siècle. - (Supplément 997 bis.)

\section{3.}

مئ Le Mal mis à décou- vert, traité des maladies des chevauxn. Ce titre que l'auteur lui-même avait donné à son ouvrage, a été rem-

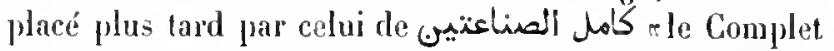
en ce qui regarde les deux arts n (à savoir : l'hippologie et

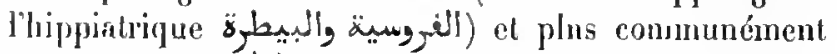
par celui de الناصر, parce que l'auteur, Badr al-Dín ibn Bakr, maréchal vélérinaire employé au service du sultan manlonc Al-Nalik al-Nàșir, fils de Qalawoun, l'arail composé pour plaire à son souverain. L'ourrage commence par ces inots:

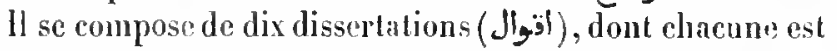
divisée en plusieurs chapitres. Il est inutile de reproduire les titres de ces chapitres, qui se trouvent rapportés dans la traduction publiće par le docteur Perron (Paris, 1852 1860 , trois vol. in- $\left.8^{\circ}\right)$. 11 est dit, dans la préface, que cet ourrage renferme tontes les connaissances nécessaires pour celui qui veut apprendre la science vétérinaire, l'art d'ćlever et de dresser les chevaux, et l'art de l'écuyer

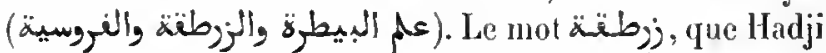

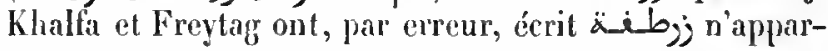
tient pas à la langue aribe; il a dù ètre emprunté à l'étranger. Le docteur Perron cite (tome II, page 429), un passage de la pharmacopée du célèbre médecin Dàoûd, d'Antioche, d'après lequel r beaucoup de Rouns (ou écrivains d'Lurope) ont traité des animaux en traitint de l'agriculture, et ont donné à ce genre de composition te nom de zortokian. Le docteur Perron ajoute: $₫$ C'est donc te res rustica, la maison mustique, le predium rusticum! Les Arabes auraient-ils donc entendn les nots res rustica et auraient-ils en le malheur d'en faire zortoka?" Un copiste arabe a pu, en effet, en déplaçant

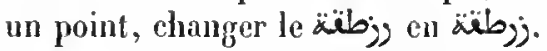

Is. daté de l'an 875 de l'hégire ( 1471 de J. C.).

Papier. 151 feuiltets. Hauteur, 26 centimètres et demi; largeur, 17 centimètres et demi. D'abord 15 lignes, puis 16 lignes par page. - (Supplément 994.)

Mème ouvrage.

\section{4.}

Ms. daté de l'an 1077 de f'hégire (1666 de J. C.).

Papier. 229 feuiltets. Hauteur, 21 centimètres; largeur, 15 centimètres. 7 lignes par page. - (Ancien fonds 1095.)

\section{5 .}

T'raité sur la manière d'élever les cheraux, de fes dresser, de les monter et de les soigner en cas de maladie. Le titre et le nom de l'anteur de l'ourrage restent inconnus, car le premier et le dernier feuillet du ms. 
manquent. Le second paragraphe de la préface commence

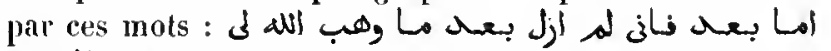
مـ Lourage commence par non chapitre sur la gruerre sainte. Suivent des fragments de poc̀mes à la louange des chevaux, des observations sur la manière de connaitre les qualités d'un cheval, un chapitre sur les coulenrs et les marques par lesquelles un cheval se distingue, des instructions pour le caralier et pour ceux yni dressent les clıevaux, des obsemalions sur la propagation de l'espece et sur la ferrure, l'indication des délauts corporels et des maladies, enfin une longue dissertation sur les symptômes des maladies et sur les remedes qu'on doit employer daus chaque cas.

Papier. 145 feuillets. Haulenr, 30 centimètres; largenr, 21 centimètres. 17 lignes par page. Ms. du $x v^{e}$ siècle. - (Supplément 995.)

\section{6.}

(De l'excellence de la ruce cheralinen, par Scharaf' al-Din 'Abd al-Moumin al-Dimyàti, mort en 705 de l'hégire ( $305-1306$ de J. C.). L'auleur a rassemblé et classé toutes les traditions dans lesquelles Hahomet a lait mention des cheraux. Chayue tradition est précédée d'un isnâd, souvent très long. L'ourrage se compose de huit clıpitres : $1^{\circ}$ sur les mérites des chevaux employés dans la guerre sinite; $2^{\circ}$ sur la défense touchant la rastration et la mulitation des chevaux; $3^{\circ}$ sur le choix des chevaux pour la guerre sainte (أرتباط) at sur la couleur que l'on doit préférer; $4^{\circ}$ qu'il laut se méfier des marques de mauris augure dans les cheraux et du J شَ, terne qui signifie un cheval dont l'un des pieds de devant et le pied opposé de derrière sont blanes; $5^{\circ}$ sur la défense de concourir pour des prix, si ce riest avec des cheraux ou des chameaux, ou au tiu

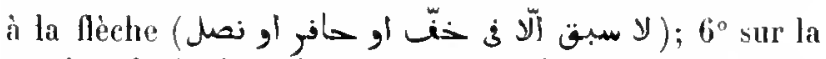
portion du butin qui revient au cavalier; $7^{\circ}$ sur l'exemplion de limpòt dont jonissent les cheraux des Musulmaus; $8^{\circ}$ sur les noms particuliers des montures qui appartenaient à Mahomet.

Ms. daté de l'an 850 de l'hégire (1446-1447 de J. C.).

Papier. $9^{3}$ fenillets. Hanteur, 18 centimètres; largeur, 14 centimètres. 17 lignes par page. - (Supplément 992.)

\section{7.}

Traité des chevaux, sans titre ni nom d'auteur. Un titre quón lit en têle du volume est aporryphe. L'ouvrage commence par une série de traditions dans tesquelles Malromet a parlé des chevaux; puis vient un poème rimant en ri, qui avait été récité, dit-on, par un inconnu devant le sultan Salaị al-Dìn (Saladin) Yoûsof ibn Aiyoûl.. Dans cette pièco, dont chacpue vers est accompagné d'un commentaire, l'auteur décrit les marques et les qualités d'un lson cheval. An fol. $14 \mathrm{v}^{0}$ se trouve la figure d'uu cheral noir, accompagnée des noms de toutes les parties de l'animal; au fol. 18, la représentation d'une jument et de son poulain; au fol. 19, la figure d'un cheral blanc qui parait gravir une côte vapide; au fol. 20 , la figure du İaïzoum (حيزوم), d'hippogriffe qui servait de monture ì l'ange Gabriel. Vient ensuite une description anatomique du cheval, accompagnée de trois figures, dont l'une est la représentation très rudimentaire et très incorrecte d'un squelette; puis, un traité d'hippiatripue en vers dont la rime est en ri. Chaque vers est suivi d'un commentaire. Ce poème renferme les noms des défauts et des maladies des chevaux et des instructions sur l'entrainement, sur le traitement des maladies, sur les armes défersives et les armes offensives du cavalier, sur les harnais et sur les combats. Cet ourage dont plusieurs passages sont rn prose riucée, paraît avoir été composé en Egrypte. vers la fin du $x^{\mathrm{e}}$ siècle.

Ms. daté de l'an 1180 de l'hégire ( 1670 de J. C.).

Papier. 100 feuiltets. Hanteur, 33 centimètres; largeur, 22 centimètres. 13 lignes par page. - (Supptément 993.)

\section{8.}

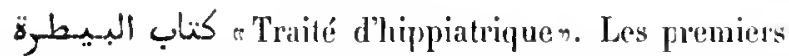
feuillets manquent. Le ms. commence par ces mots : عيوب "ل passer le volume pour complet, on a inscrit sur le premier feuillet le bismillah.

Papier. 86 fenillets. Ifauteur, 21 centinètres; largeur, 15 centimètres et demi. 11 lignes par page. Ms. du xvi siecle. - (Supplément 997 , Saint-Germain 210 ter.)

\section{9.}

Seconde partie d'un traité sur le dressage des chevaux, renfermant un grand nombre de dessins, tracés à la plume, dont quelqnes-uns représenteut des éperous. On a ajouté, après coup, en tête du volume, en gruise do titre, une note de douze lignes, dont voici les trois pre-

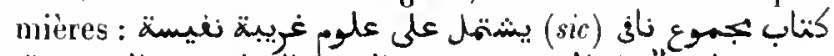

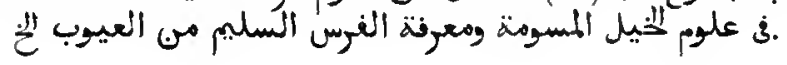


Papier. 243 feuilfets. Ilauteur, 18 centimètres et demi; largeur, 13 centimètres et demi. Ms. de deux mains différentes du $x v^{\circ}$ siècle. - (Ancien fonds 1578.)

\section{0 .}

r Discours suflisants et chapitres salisfaisants n, Irailé complet du cheral, par un auleur anonyme. Cet ourage se compose de six discours (ق) , divisés en sections : le premier, sm l'excellence de la race chevaline; le second, sur la conformation, les couleurs, les qualilés et les délauts du cheval; le troisiemo, sur les poulains, leur éducation et leur dressage; le qualriume, sur les causes et le traitement de leurs maladies; le cinquième, sur les cheraux les plus célibres des temps anciens, arant et après la promulfration de l'islamisme, arec la mention de leurs noms; le sixième, sur les bêles de somme, les mulets, les chevaux de la Porse et ceux du Yémen. Commencement:

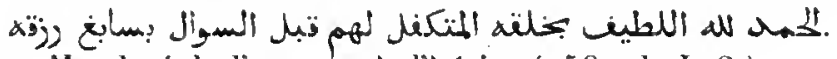

Hs. daté de l'an 990 de l'hégire (1582 de J. C.).

l'apier. 93 feuillets. Ilauteur, 23 centinètres; largeur, 16 centimictres et demi. 25 lignes par page. - (Supplèment 996, Saint-Germain a to bis.)

\section{1.}

\section{Nème ourrage.}

Papier. 1 to feuillets. Mauteur, 21 centinètres; largeur, 15 centimètres. 2 o lignes par page. Is. du xvu" siècle. - (Supplément 9498.)

\section{2 .}

Traité d'hippiatrique, en vingt-huit clapitres (بن), sur la manière de lrailer autant de maladies. Le commen. rement et la fin manquent.

Papier. 67 feuillets. Ilauteur, 15 centimètres; largeur, 10 centimètres. 9 lignes par parge. Ms. du xrı" siècle. - (Supplément 2088.)

\section{XXIII.}

\section{EQUITATION, GHASSE, ART MILITAIRE.}

\section{3.}

Premier et dernier feuillet d'un traité d'Aboú 'Abd- allah Mohammad ibn Yaequâb ibn akhì Khozâm, sur la guerre sainte, l'équilation, les maladies des chevaux, etc.

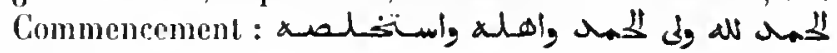

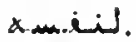

Ms. daté de l'an 1063 de l'hégire (1653 de J. C.).

Papier. a feuillets. Hauteur, 29 cenlimètres; largeur, so centimètres el deni. 17 ligues par page. - (Supplément 2105. )

\section{4.}

rLe Trésor où se tronvent réunies les diverses branches (de l'art)», par Ibn akhî Khozìm. Traité de l'art militaire, renfermant les écoles de peloton, de cavalier, de fantassin, d'archer et d'arbaléIrier. Lin grand nombre de figures coloriées et assez bien dessinées sont insérées dans le texte. Comme tous les ouvrages arabes sur le mème sujet, ce Irailé renferme un grand nombre de termes tecliniques el de termes de commandemenl. Commencement :

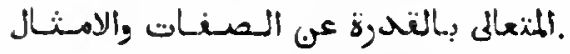

Ce ms. a été exécuté en 875 de l'lıégire (1470 de J. C.), pour un grand persomage de la cour des sultans uamloucs, dont le nom a été soigneusement ellacé du frontispice, qui est trìs orné. On y a tontefois laissé subsister les derniers mots renfermés dans le médaillon cen-

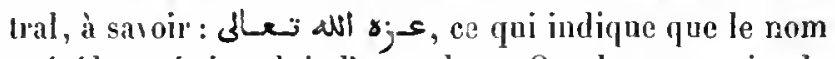
précédent était celui d'un sultan. Or, le souverain de l’Égypte à celle époque élait Qaïbaï.

Entre les folios actuellement colés 1 et 2 , il manque plusieurs fenillets.

Papier. 9o feuillets. Hauteur, 3o centimètres; largeur, 20 centimètres. 15 ligaes pa: pagc. - (Supplément 988 bis.)

\section{5.}

1 " altribué à Nadjnı al-Din liasan al-Rammâl al-Aḷdab, mort en $69^{4}$ de l'hégire $\left(129^{5-1} 29^{6}\right.$ de J. C. ), personnage dont le père el le grand-père sétaient distingués par leur habileté dans cet art. L'ouvrage commence par lexplication de vingl mouvements que le cavalier doit savoir exéculer avec la lance $\left(0{ }^{2}\right)$. Suit la deseription des vingl-six mourements du combat singu-

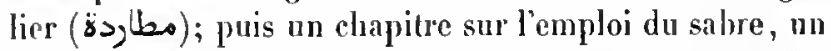
autre sur l'umploi de la masse d'armes (F); la descriplion de cinquante-lıuit mowrements que l'on peut exécuter avec la lance; la description dun miroir ardent, 
employé par Alexandre le Grand; cnfin un traité assez étendu sur les feux d'artifice employés à la guerre et sur les machines employées pour les lancer. Cette partie de l'ourrage est accompagnée de nombrenses figures. La

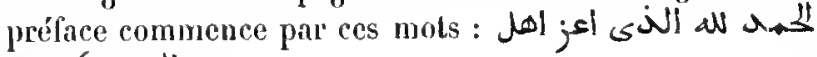
طاعتن وكرمهمم.

$2^{\circ}$ (Fol. $109 \mathrm{v}^{\circ}$.) Traité sur le maniement de la lance, où l'auteur, apparemment le mème que celui de l'ar-

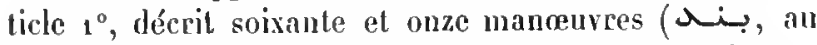
pluriel بنود). Dans le paragraphe fiual, il donne la nomenclature des vingt-cing parades (تمبرد s'exécutent arec la lance, mais il ne les décrit pas.

Papicr. 121 feuillets. Hauteur, 27 centimètres; largenr, 18 centi-

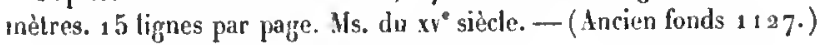

\section{6.}

$1^{-}$Dessins au trait qui devaient probablensent accompagner un traité sur l'école du peloton.

$2^{\circ}$ (Fol. $29 \vee^{\circ}$.) Traité d'équitation militaire portant le titre de كتاب النتزون لارباب الفنتون. C'est, sauf quelque; variantes el omissions, le même ourage que l'article $2^{\circ}$ du numéro précédent, mais l'auteur, dans cet cxemplaire, est appelé Al-Ostàd Nàsir al-Dín ibn al-Taràblosî.

$3^{\circ}$ (Fol. $541^{\circ}$.) Traité de l'art militairc. C'est le même ouvrage que le $\mathrm{n}^{\circ}{ }_{2} 8_{2} h$, mais le litre manque dans cet exemplaire.

Nombreuses figures coloriées.

Ms. daté de l'an 986 de l'hégrire (1578-1579 de J. C.).

Papier. 112 feuillets. Hauteur, 28 centinètres el demi; largeur 19 centimètres. 21 lignes par page. - (Ancien fonds 1138. )

\section{7.}

$1^{\circ}$ Description technique des soixante-douze mancuvres (بن) qui se font avec la lance, d'après le système

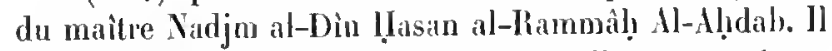
manque un feuillet entre les folios actuellement cotés 12 el 13.

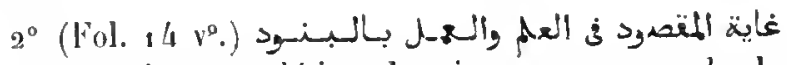
"Tont ce qu'on peut désirer de miemx pour appcendre la théorie el la pratique des manouvres avec la lances, par

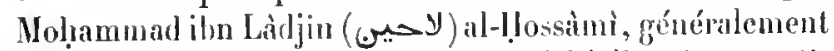

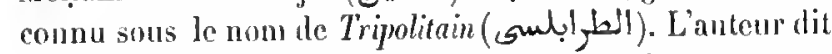
que ces manourres, an nombre de soixante-donze, appartiennent au système de Nadju al-Din al-Aḷdab; mais les descriptions qu'il en doune ne s'accordent pas aver celles qui se trouvent dans l'opuscule qui précède. Commence-

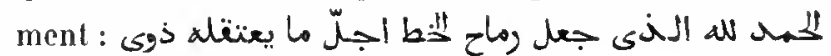

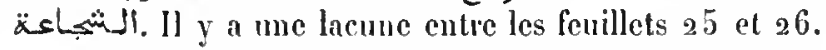

$3^{\circ}$ (Fol. 26.) Traité de pyrotechnie militaire, indiquant la composition des matières inflammables dont on

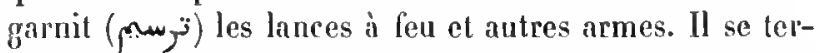
mine par vingt-et-un chapites, très courts, sur le manienteut du cheval, suivis de quelques recettes pour la composition des feux d'arlifice. Le commencement et la lin manquent.

Papier. 51 feuillets. Haateur, 31 centimètres; largeur, 22 centinètres. 15 liģnes par page. Ms. du $x v^{\circ}$ ou du $x w^{e}$ siècle. - (Supy)lément 991.)

\section{8.}

Terme mis aux questions et anx souhaits touchant la manière d'apprendre l'épuitations. Onrrage du genre de cenx que l'on appelle maintenant Écule du cavalier et dont l'anteur' est resté inconnu. Le premier lenillei manque. Le nus. commence par un trailé sur les mérites et sur la pratique de la gurre sainte (djihid), en donze chapitres. Viennent ensmite (fol. 16) plusiemrs chipitres sur l'are, sur la lance et sur la manière de s'en servic. L'auteur a puisé ses renseignements dans le Kitâb al-Bonoúd "Traité des manourres avec la lances de Nadju al-Din, et il donne la description des soixante-douze de ces exercices. Plus loin, il parle des exercices du cheral, de linstruction des fantassins, de la manière de conper et de passer les rivieres, du combat singulier (oj, ot des diverses pratiques et usages de la guerre.

Papier. 177 feuillets. llauteur, 2 centimètres; Jargeur, 14 centimètres. 25 lignes par page. Its. du $x^{e}$ siècle. - (Supplément 210

\section{9 .}

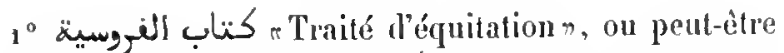

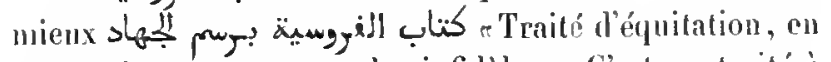
vue de la guerre contre les infrdèles\%. C'est un traté à l'usage des cavaliers, pour apprendre l'escrime à li lince

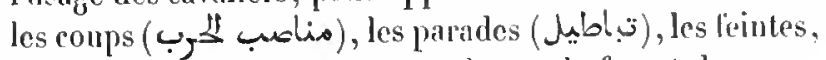
le maniement des ames, pour lancer le feu et des massues, ctc. L'auteur n'est pas nommé.

$2^{\circ}$ (Fol. 25.) Signes distinctifs de l'homme intelligent et du sot. 
$3^{\circ}$ (Fol. 26.) Passages du Coran et traditions relalives ù la guerre sainte, accompraguées de prières el d'observalions sur lescrime à cheral. Cel opuscule qui, comme le précédent et les trois autres qui sujent, paraissent

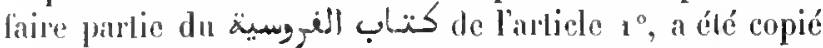

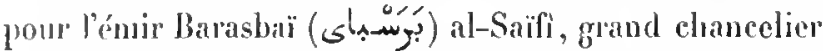

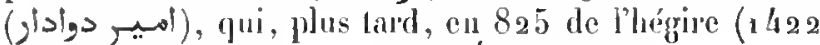
de J. C.), monta sur le lrône d'Égypte.

$4^{\circ}$ (Fol. 30.) Description lechnique de soixante-douze manouves (ais) que l'on cxécute avec la lance.

$5^{\circ}$ (Fol. 43.) Énumération des vingl-cinq leintes

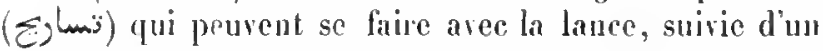
cluapilre sur les noms qui désignent cette arne el d'un aulje sur les mourements qui s'exécutent avec la lance

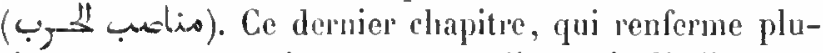
sjeurs vers, se termine par mue priere qui, dit lanteur, ne manque jamais d'être exancéc. L'auleur donne ensuite plusieurs receltes de feux d'arlifice employés ì la guenre.

$6^{\circ}\left(F^{\circ} 01.54 v^{\circ}.\right)$ Trailé des leux d'arlilice qui s'enploient il la gucrere.

M. Reinaud s'esl servi de ces deux dernjers opusenles pour son ouvrage sur la poudje à canon.

Papier. 96 feuillets. Ilauteur, 22 centimètres; largeur, 15 centjmètres et demi. 19 lignes par page. Ms. du xvi" siècle. - (Supplémerit $9^{\text {S8.) }}$

\section{0.}

كتناب في علم الغوسينة Traité d'hippologic, d'hippiatrique el de l'art de l'équitation.

t’apier, 118 feuillets. Hauteur, 18 centinètres; largeur, 14 centimètres. g lignes par page. Ms. du xuxe sièce. - (Supplément 2499.)

\section{1 .}

Traité de fauconneric, sans lilre ni préface, com-

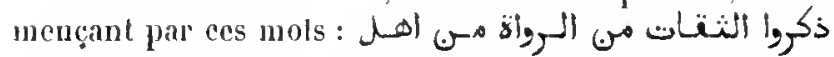

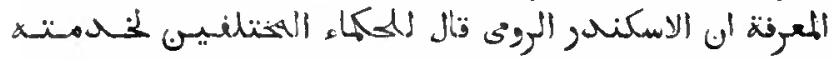

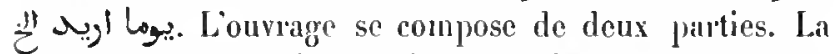
plemière partie, traile, en cinquante-deux cliapilres assez courls, de la nanjère d'élever el de dresser les fiucons; la seconde partie, en soixanle-trois chapitres, des maladies de ces oiseanx et des remèdes. En tẻle du volume on lit un titre qui ne parait pas authentique:

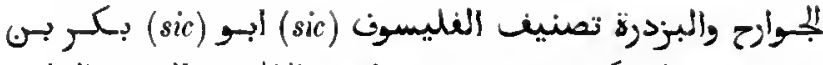

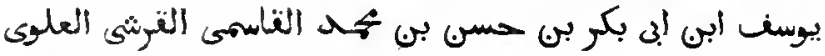
¿ل

Ms. daté de l'an 848 de l'liégire (1444 de J. C.).

Papier. 108 feuillels. Hauteur, 26 centimètres, largeur, 17 centimètres et demi. 15 lignes par page. - (Supplément 987.)

\section{2 .}

$1^{\circ}$ Se lit "Traité qui familiarise les gr'ands avec les animaux du désert». Traité de chasse, composé en $77^{3}$ de l'hégire ( 1371 de J. C.), par Moḷam-

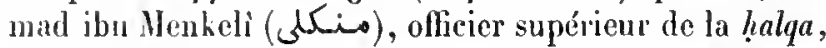
ou garde particulière du sultan mamlouc Al-Malik alAscliraf Sclıa'bin. L'auteur traite d'abord des viandes permises el des viandes défendues, puis des bètes faures, des oiseaux et des crocodiles, en faisant connaitre lcurs lrabitudes el les diverses manières de les prendre. Com-

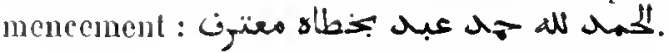

$2^{\circ}$ (Fol. $54 r^{\circ}$.) Traité des maladies des faucons el des cliens de cluasse, attribné à un philosophe grec, nommé Capadanios(?). Commencement : تال

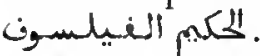

Ms. daté ( fol. $531^{\circ}$ ) de l'an 923 de l'hégire $\left({ }^{5} 17\right.$ de J. C.).

Papier, 6o Penillets. Hautrur, 18 centimètres et demi; largeur, 13 centimètres et demi. a lignes par page dans le premier traité, 1) lignes dans le second. - (Supplémenl 986.)

\section{3.}

x ب Pò̀me sur l'art de tirer des fleches, arec un commentairen, le lout conposé par Taïboghiâ al-Aschrafi surnommé A]-Baklamis a\}-Yoûnànì. Le poème, qui se compose de cent cinquante vers, rimant en âmi, est séparé du commentajre. Commencement :

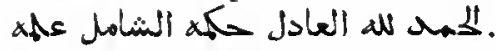

Papier. 77 feuillets. Hauteur, 21 centimètres et demi; largeur. 15 centimètres et deıni. 15 lignes par page. Ms. du xvi1 siècle. (Supplément 989.)

\section{4.}

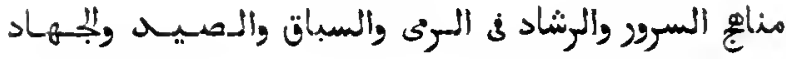


"Voics de la gaieté et de la bonne conduite, traité sur le tir, les courses, la chasse et la guerre saintes, par Zaïn al-Din 'Abd al-Qidir ibn Alımad ibn 'Alì al-Fàguilui

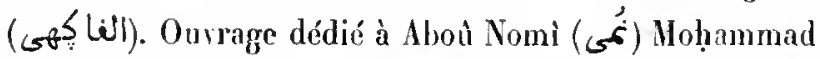
ihn Barahil, chérif de la Mecque, à l'oceasion d'une démonstration faite par les infidèles (les Portugais?) contre le territrire sacré de cette ville, an mois de dsou 'l-qa'da de l'an 947 (février-mars 1541 de J. C.). Dans la première section (Jصë), l'autemr expose les mérites de la guerre sainte; dans la seconde, il raconte d'une manière sommaire les expéditions de Malıonet; dans la troisième, il parle des courses de chevaux et de chameaux. La quatrième seetion traite de I'art de tirer de l'are, et la einquième est consacréc à la chasse. Les trois dejuières sections renferment des observations philologiques, des expressions proverbiales, des ver's, des notices sur les animaux domestiques, sur les diverses espèces de gibicr et sur les quadrupèdes et oiseaux qu'on dresse pour la chasse. L'éloge de eet ouvrage, par le scluaikh Schilıâb al-Din Aḷmad ibı Hadjar al-Haïthami, doctemr schaféite, a été ajouté après coup.

Ms. daté de l'an 1009 de l'hégire (1600 de J. C.).

Papier. 114 feuillets. Hauteur, 27 centimètres et demi; largeur, 18 centimètres. 27 lignes par page. - (Supplément 477.)

XXIV.

MÉDECINE.

\section{5 .}

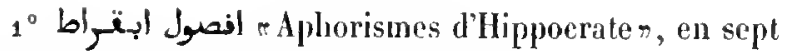
livres, traduits par Honaïn ibn Ishầ].

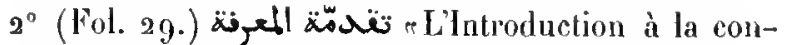
naissance . C'est le Traité des pronosties d'Hippocrate, traduit par I!lonaïn ibn Ishàq.

$3^{\circ}$ (Fol. 49.) Commentaire sur l'ourrage précédent, rédigé, d'après les leçons du médecin Mohaddsib at-Dìn 'Abd al-Raḷmân ibn 'Ali, par son élève, Bade al-Din at-Mozallar, fils du eadi de Baalbec. La préface de Badr al-Din est curicuse; on la trouve, texte et traduction, dans le Catalogue des mss. de la Bibliohèque Bodléïenne, tome II, page 167 .

Papier. 147 feuiltets. Hauteur, 16 centimètres; largeur, 1 a centimètres. 12 lignes par page. Ms. du xim ${ }^{\circ}$ siècle. - (Ancien fonds 1040 , Colbert 6505.)

\section{6.}

A Aphorismes d'Hippocrale ", recueillis dans ses ourrages et classés en douze sections (famn), par بوس بـ. La première section renferme des conseils et commence par l'aphorisme: la vie est courte, etc.; la seconde se rapporte aux symptòmes; la troisiène aux maladies; la quatrième aux erises; la cinquième aux évacuations; la sixième au régine; la seplième anx époques de l'ammée et aux pays; la huitième à l'air; la neuvième aux maladies ehroniques; la dixiène anx effets divers des applications chaudes et froides; la onzieme aux maladies des femmes, et la douzieme au tratement. Celte collaction d'aphorismes differe beaucoup du recucil dont nous possédons le texte irea; elle est plus concise et offre ees maximes dans un autre ordre. Un des anciens possesseurs dn ms. a inserit en marge, en regard de chapue aphorisme, un remoi it la page d'un ms. qui parait avoir renfermé les ouves conplètes d'flippocrate.

Papier. 41 feuillets. Hauteur, 91 centimètres et demi; largeur, 15 centimètres et demi. Ns. du $\mathrm{xv}^{\circ}$ siècle. - (Supplément 998 bis.)

\section{7.}

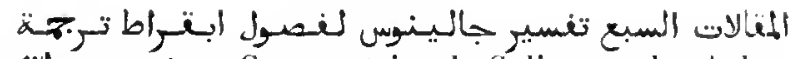
. حنيبر بر. Commentaire de Galien sur les Aplorismes d'Hippoerate, en sept livres, traduit en arabe par llonaïn ibn Ishâq. Il y a une lacune de dix leuillets entre. les folios actuellement cotós $6_{1}$ et $6_{2}$.

J. C.).

Copie datée de l'an du monde $6735(1227-1228$ d?

Papier. 1 is feuillets. Hanleur, 24 centimètres et demi; largeur, 16 centimètres. 24 ì 29 lignes par page. - (Ancien fonds 985.)

\section{8.}

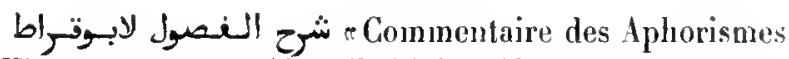
d'Hippocraten, par Abon 'I-Qàsim 'Abd al-Raḥmâu ibu 'Alî ibn abì Sàdiq, de Naïsâpoûr, disciple d'Avicenne. Ce. commentaire, qui a élé composé en 460 de l'hégire (1 068 de J. C.), est très détaillé; le texte qui l'accompagne est conforme au texte grec. Commeneement : ג sulol sart. Aux folios $1 v^{\circ}$ et $21^{\circ}$, on lit un extrait d'un traité sur les purilications.

Papier. 156 feuillets. Hauteur, ${ }_{2} 5$ centimètres; largeur, 17 centi- 
mètres et demi. 19 lignes par page. Ms. du xu1 ${ }^{\circledR}$ siècle. - (Supplément 999 .)

\section{9.}

Même oưrage. Le texte des premniers feuillets est accompagné de quelques gloses en persan.

Papier. 161 feuillets. Hauteur, 22 centimètres; largeur, 16 centimètres. 19 lignes par page. Ns. du $x v^{\circ}$ sićcle. - (Ancien fonds 1041.)

\section{0}

Hềne ouvrage.

Ms. daté de l'an 977 de l'hégire ( 1569 de J. C.).

Papier. 137 fenillets. Hauteur, 16 centimètres et demi; largeur, 13 centimètres. 21 liggnes par page. - (Ancien fonds 1096 .)

\section{1.}

A A A erlissements pour les intelligences, renfermant la solution des diflicultés qui se présentent dans les Aphorismes (d'Hippoerate) s, par Nadjm al-Din Aḷmad, surnommé Ibn alMaufäl, savant médecin, qu'on désigne aussi par le surnom d'fbu 'Olwìn, mort à Damas, en 652 de l'hégire (1 254 de J. C.). Cet exemplaire se termine par quelques observations sur la septième et dernière section des Apho-

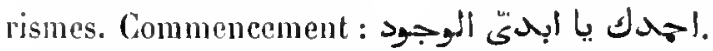

A la fin se trouve unc dissertation dı même anteur sur quelques passages obscurs de l'ouvrage de Honaïn ibn Isllâin, intitulé

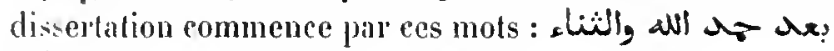
se.

Ms. daté de l'an 678 de l'hrógire (1 280 de J. C.).

Papier. 5.3 fevillets. Hautenr, 18 centimètres et demi; largeur, 12 centituètres et demi. 19 lignes par page. - (Supplément 1000, Saint Germain 56\%.)

\section{2.}

(ل) Livre des Plineipes, pour

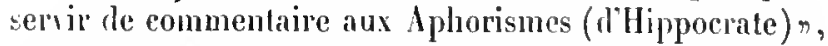
par' Amin al-Danla Abou 'l-Faradj Ya quoûb ibu Ishàq, médecin chrétien, désigné ordinairement par le sobriquet d'Ibn al-Qoff, mort en 685 de l'hégire (1 286 de J. C.).

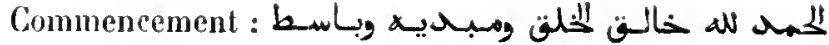

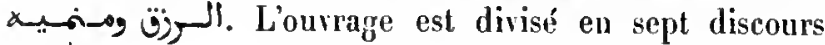
(مقالات).

Ce ms., divisé en deux parties, est daté de l'an 1447 de l'hégire ( 1734 de J. C.).

Papier. 367 feuillets. Haufeur, 31 centimètres; largeur, 20 centimètres. 39 lignes par page. - (Supplément 2348.)

\section{3.}

Commentaire sur les Aphorismes d'Hippocrate, parIbn al-Nafis, médecin de Baghdàd, qui vivail au xı11 siècle.

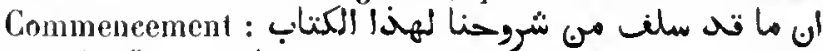

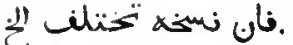

Ms. daté de l'an 887 de l'hégire (1482 de J. C.).

Papier. 153 fenillets. Hauteur, 18 centimètres el demi; Jargeur, 14 centimètres. 17 lignes par page. - (Ancien fonds 1042 , Colbert 6001.)

\section{4.}

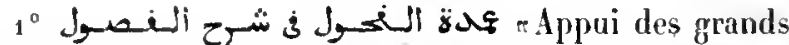
mailres dans l'explication des Aphorismes d'Hippoeraten, traité composé au commencement du xw siecle, par "Ibd Allah ibn "Abd al-'Azìz ibn Mloûsâ al-Siwàsì. Chaque

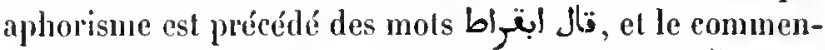
laire qui l'accompagne porte en tête le mot التنفسير. Com-

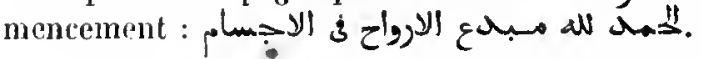

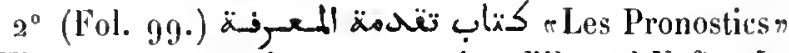
d'Hippocrate, arce le commentaire d'Hon al-Nafis. Le commencement manque.

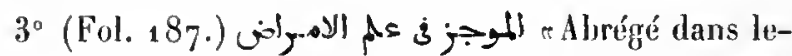
quel on traite de lia conuassance des madadies $\%$. Traité

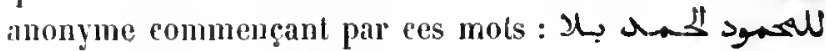

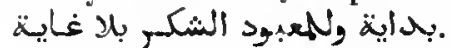

Ms. daté de l'an $7_{1} 7$ de l'hégire $\left(3_{1} 7^{-1} 318\right.$ de J. C.). Les points diacritiques sont rares.

Papier. 235 feuillets. Hauteur, 13 centimètres; largeur, 9 centimètres et demi. 15 lignes par page. - (Supplément 1001. )

\section{5.}

Commentaire de Galien sur le كتاب الاسابيع r Le Lirre des septenaires" dHippocrate, ourrage traduit en arabe par Honaïn, fils d'Isṭâq. Copié par M. L. Leelerc sur le 
ms. $n^{\circ} 802$ de la bibliothèque de Munich, qui est daté de l'an 471 de l'hégire (1079 de J. C.).

Papier. 119 fenillets. Llauteur, 2a centimètres ut deni; largeur, 17 centimètres. 2 a lignes par page. - (Sujplément 2391.)

\section{6.}

Lo deuxième et le sixiène live du Trailé des ćpidémies dHippoerate, avec le commentaire de Galien. Lo fout traduit, partic du texte frec, partie du lexte syriaque, par llonain ibn Istàq. Le présent volume est une copore moderne du ms. de la Biblioblueque dmbrosienne, à Vlilan.

Papier. 31g feuillets. Ifauteur, a 8 centimètres; largeur, a 1 centimitres et demi. 17 lignes par page. Is. du xis siccle. - (Supplément 1002 ter.)

\section{7.}

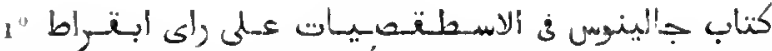
-Traité de Galien sur les Élémenls, d'apries l'opinion d'Hippocrates, traduction de llonaïn ibn Ishà, avec les éclaircissements (تنصيل) du médecin Aḷmad ibn Mohammad, surnommé Ibn al-Ascheath, mort en 360 de l'héfrire $(970-971$ de J. C. $)$.

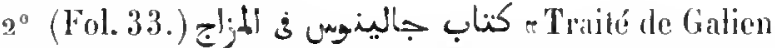
sur le Iemperaments, traduit par Ilonaïn ibn Istiv, arec les colaircissements d'Hon al-Asch'alh. D'apres te lilre qui se troure en tèle el la dirision adoptée par le copiste, l'onbrage se compose de six scetions, tandis que te lexte grec n'en a que Irois. En effet, Ihn al-Ascheath, dans une motice qui remplil quate pages, nous apprend quil a ru devoir rultarher ì louvrage quil éditail trois aulres upuscules de Gatien, en se tondanl sur te passige, à la fin de la denxiène seclion, oǹ l'auleur promet de eompléter bientot ses éludes sur te tempérament. Ce sont: $1^{\circ}$ (lol. 106$)$, le traité sur le tempérament anormal

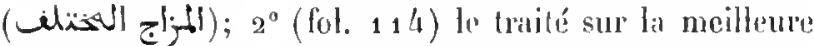

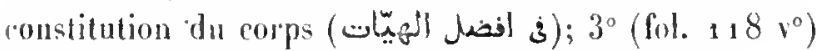

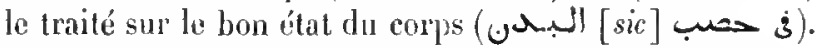

Ms. daté de l’an 614 de l'léggire ( 1217 7-12 18 de J. C.).

Papier. 1 o feuillets. Hauteur, a/ centimètres; taryour, 17 centirnètres. 19 tignes par parge. - (Ancien fonds 987.$)$

\section{8.}

$1^{\circ}$ Commentaire d'Abou 'l-Faradj 'Abd Allah ibn atNax. onestalx. - II.
Taiyib, médecin chrétien, mort en 435 de l'hégire (1 o4?)-1044 de l. C.), sur le traité de Galien, intiulés - Les Élóments d'ilprès l'opinion d'Hippocrater.

$2^{\circ}$ (Fol. $35 \nvdash^{\circ}$.) Commenlaire du méme anteur sur lo traité de Galien, intituté "Traité dn tempériment".

Hs. daté de l'an 415 de l'hégrire (1024 de J. C.), éerit du vivint de liateur.

Papier. 139 fenillets. Hauteur, 17 centimètres el demi: largeur, 11 centimètres. 20 lizrnes par page. - (Ancien fonds 1097 , Colbert 6065.)

\section{9.}

Le Traité des plantes de Dioscoride, traduction d'Étienne, revue par llonaï ibn lshiq, pour Hol!ammad

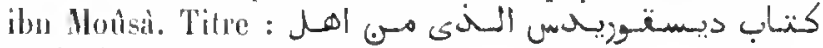

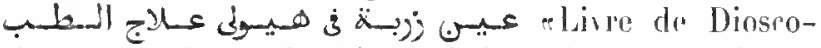

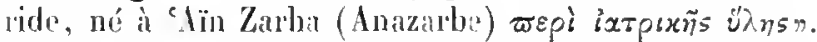
Dans une note, placée an tête du ms., le copisle déchare que les figures qui devaienL accompagnex cel "xemplaire formaicul un rolume à part. Les marges de ce précicux ms. sont courertes de notes de diverses mains. Pour plus de renseignements, royez l'article inséré par M. Loclerr. dans le Journal asiatique, cahier de janvier $186_{7}$.

Hs. daté de l'an 616 de lhégire (1219 de J. C..).

Papier. 113 feuillets. Ilauteur, 33 centinètres et demi; largeur, 95 centimètres el demi. 23 lignes par pagre. - (Supplément 1067.)

\section{0.}

Quelques parties du traité des plantes de Dioscoride. Les feniltets se suivenl dans le plus grand désordre. Le verso du premier feuillet porte la ligure d'une plante

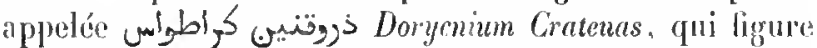
alu $1 V^{\text {e }}$ lives de Dioseoride; le feuilled suivant donme la fin de l'aticle Mandragore, puis l'article Aconit. Lo lenillet qui est naintenant le dernier du volume contient l'article

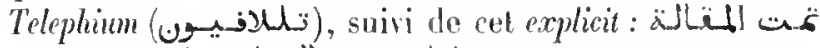

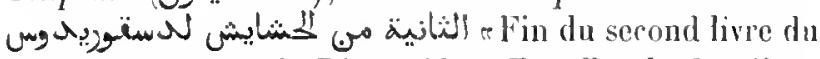
'Traté des plantes de Dioscoriden. En effet, le denxiènes livre du texte gree se termine par le Telephium. Un titre apoeryplie, ajouté après coup en tête du volume, كتباب اله

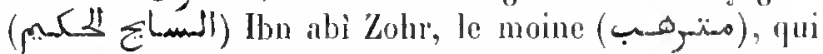
était père de Tomtom l'hndien et, ayant royagé dans les quatre climats du monde, arait composí son liver sous la dynastie des Omayyades, en 125 de l'bégriler, à l'aid d'un ouvrage de Salomon, fils de David. 
Us. cxécuté en Espagne et orné de figures coloriées.

Papier. 235 fenillets. Maulen', 24 contimètres el demi; largen; 8 centimètues el drmi. 18 tignes par page. Ms. du xir siècle. -- (Ancien fonds g68, Colbut 1205.$)$

\section{1.}

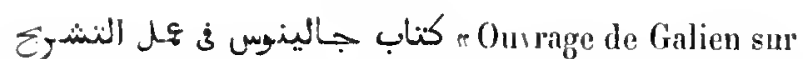
lanatomic , traduction de Ilonaïn ilon Isḷâq. Ce sont les sin demicrs lirres $(\mathrm{IX}-\mathrm{XV})$, dont le texte gree est perdu, du traité De anatomicis administrationibus. Cette copie a étć hate sur le m: nDLXX de la bibliotheque Bodléienne, par les soins da docteur Diremberg.

Papicr. 116 fenillets. llauteur, a 4 centimètres; largeur, 19 centimélr's et demi. 23 lignes par page: - (Supplément 1009 bis.)

\section{2 .}

Le commencement du dixiène discours (متصال) de (ialion sur l'auatomie.

P'ajicr. 4 parges d'écriture enropécnuc. Houtcur, 21 centimètres; largeur, 15 centimètres of demi. 15 ì 16 lignes par page. - (Supplément 2260.)

\section{3.}

كتانب جالينوس ف منافع الاعضشاء Traité de Galien sul" les usages des memlores du corps (De usu partium)r, tradui par Honaïn ihn lshày. Dix-sept sections.

Is. daté de l’an 682 de l'hégire (1 283-1284 de J. C.).

Papier. 301 feuille's. Itanteur, 25 centimètres ct demi; largeur, ti centimètres el demi. 23 lignes par page. - (Ancien fonds 988 .)

\section{4.}

"Commentaire sur le traité De usu partium o de Galien, par 'Abd al-Raḷmàn ibn 'Alì ibn abì Sâdiq. Le commentateur a modifié le texte, tantôt par des additions tirées des autres écrits de Galien, tantôt par des suppressions. A la fin se trouve une courte notice sur lbu alıì Sạdiq, tirée de l'/listoire des médlecins d'Ibn alui Oșaihica.

Ms. daté de l'an 885 de l'luégire (1480 de J. C.).

Il y a une vignette en tète de l'ourrage (fol. $1 v^{\circ}$ ). Le titre est écrit en caractères coufiques.
Papier. 516 feuiltets. llauteur, 21 centimètres el demi; largeur, 12 cenlimètres et demi. 21 lignes par page. - (Ancien fonds 1044.)

\section{5.}

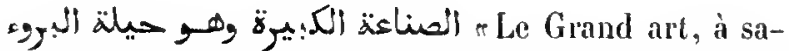
voir, la méllode de guérir $n$, traduit du grec par Honaïn ibn Js!̣iq. Co sont les quatre preniers livres et une partie cousidćrable du cinquième du grand ouvrage de Galien, intitule De Methodo curandi. Au fol. 138 , dans le corps même du texte, on lit une note de Honaïn, signalant une variante des manuserits grees quil arait sous les yeux. Les derniers feuillets du ms. manquent, et il y. a une lacune d'un on de deux feuillets entre les folios actucllement colés 1 et 2 .

Pajier. 1/2 feuillets. Hanteur, 26 centimètres; largeur, 17 centimètres et demi. 23 tignes par page. Ms du xıv siècle. - (Supptíment 1077 .)

\section{6.}

Fragnents des traités de Galien, intitulés De Compositione medicamentorum sccundum locos, et De Compositione melicamentorum per genera. Los Arabes désignent généralement le premier de ces traités par un titre syriatue, Miamir, qui signifie rles discours"; ils conservent au

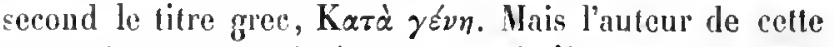

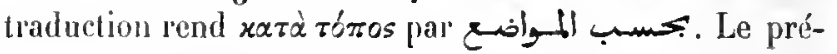
sent ms. a ćté examiné et annolé par feu le Dr Daremberg et par N. Renan. Il manque le commeneement, la fin et plusieurs calliers au milieu. Un certain nombre de feuillets sont mutilés, d'autres transposés et renversés; écriture naghlurebine-espagnole.

Papicr. 71 feuillets. Hanteur, 26 centimètres; largeur, 19 centimètres el deni. थa à 24 lignes par page. Ils. du xiv siècle. - (Supplément 1058.)

\section{7.}

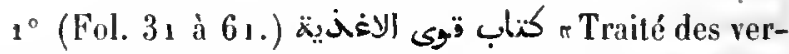
tus des aliments *. Traduction du П de Galicn. G'est la dernière partie du second livre et le troisième livre complet.

$2^{\circ}$ (Fol. 1 à 30 el 6 1 à 1 36. "Trailé des médicaments simples ". Traduction du Пврі

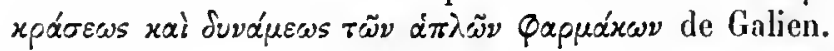
Les folios 1 à 30 sont intervertis; ils doivent ètre placés entre les feuillets 8 o et 81 . 
Papicr. 139 fevittets. Hauturur, 18 centimètres et demi; largeur, 13 contimètres. 17 lignes par page. Ms. du xiv siècte. - (Ancien fonds 1073 .)

\section{8.}

مت Traití de Galien sur

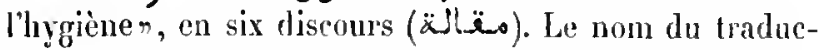

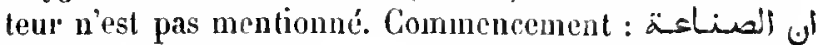

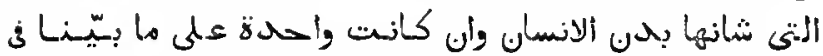

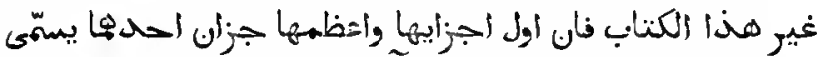

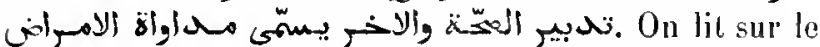
verso du premier feuillet, en écriture grecque du xiv siè-

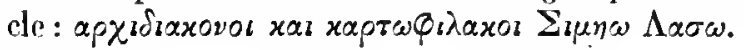

Papier. ${ }_{1} 58$ feuillets. Hauteur, 25 centimètres; largeur, 16 centimètres et demi. 19 lignes par page. Ms. du xiv" siècte. -- (Ancien fonds $9^{86 .)}$

\section{9 .}

Sept traités de Galien, traduits en arabs par Mbon Yazid Honaïn ibn Ishàq. Le premier est intitulé : في فرق (لطب il), De sectis, ad eos qui introducuntur. Le pre-

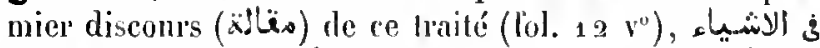
(De causis et morbis), correspond au traité De morborum diffevenuï; la seconde maqala (fol. 23), an De morborum causis; la troisieme (fol. 33), au De symptomatum differentiis; la quatrième (lol. $431^{\circ}$ ), la cinquiène (fol. 66) et la sixieme (fol. 72 ), aux hois lives du De symptomatum causis. On lit sur le recto du premier feuillet une note qui est tries probablement de la main d'Aviceme et qui ost ainsi conçue : (Est passé en la possession du paurre !losaïn ilon 'Mbd Allah ibu Sinà, le médeein, l'an 407"(1016-1017 de J. C.).

Papier. 86 feuillets. IIauteur, 28 centinètres et demi; largeur, a o centimètres. 28 lignes par page. Ms. du commencement du $\times 1^{\circ}$ siècle. (La date 232 qui se lit au fol. 11 et au fol. $86 \mathrm{v}^{\circ}$ a été substituée à la date véritable qui avait élé grattée.) - (Supplément 1002.$)$

\section{0.}

$1^{\circ}$ Traité de Galien sur

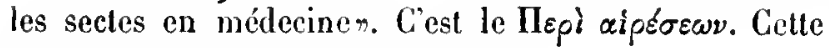
Iraduetion est de Họonaïn ibn Ishàq. $3^{\circ}$ (Fol. 14 vo.) (Traité du petil

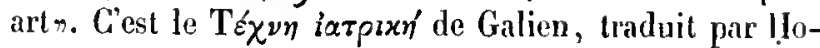
naïu ibu Isṭàq.

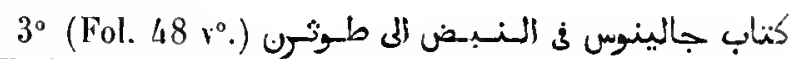
"Traité de Galien sur le pouls, adressé à Thentra", traduit par I!onaïn ibn Ishàt.

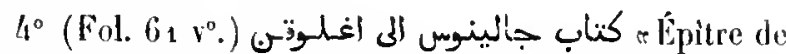
Galien ì Glaueon, , en deux sections. Traduction de Ilonaïn ibn Isḷâq.

Ms. copié par un médecin samaritain en 676 de l"hé. gire ( 1277 de J. C.).

Papicr. 110 feuillets. Hanteur, 21 centimètres; largeur, 14 centimètres et demi. 21 lignes par pare. - (Ancien fonds 1043.)

\section{1 .}

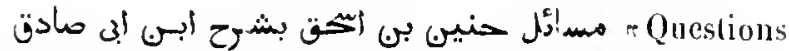

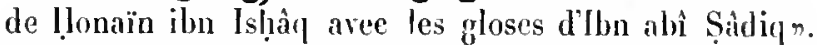
Dans ce trailé, cliaque question est précédée des mots مل3, et la glose qui y correspond, dn mot قــ. C'est un manuel de médecine, rédigé sous forme de Questions

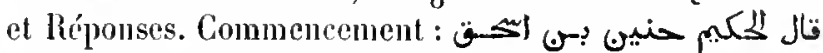

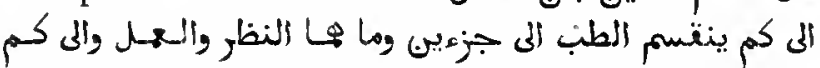
. La glose de ee passage com-

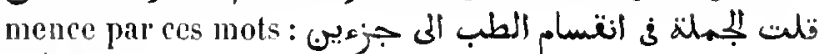
jit Lol xil.

Papier. 33 feuillets. Ilauteur, 26 centimètres ot demi; largeur, 18 contimètres. 2a lignes par page. Ms. du uv" siècle. - (Ancien fonds 1031.$)$

\section{2.}

Second volume du commentaire d'Jbn abî Ṣâdic alNaisiljoùri sur les Questious de Honaïn.

Ms. daté de l'an 686 de l'hégire (1 288 de J. C.).

Papicr. 185 fcuillets. Lfauteur, 23 centimètres et demi; largeur, 16 centimètres. 21 lignes par page. - (Ancien fonds $109^{\circ}$, Colbert $115 \%$.)

\section{3.}

"Questions médicales de ḷonaï ibn Ishàq", aree le commentaire d'un auteur inconmu. Dans cet ouvrage, chaqque question est précédée du mot النفصّ, et l'explication qui y correspond porte en tête le 
mol التنغسير. Ce n'est done pas loou rage d'Jbn abi Ş̣idiq. Je commencement mantue ${ }^{1}$

Papier. 164 feuillets. Hauteur, 25 centimèlres; largeur, 16 centimèlres. ${ }^{g}$ ligncs par page. Ms. du xü siècle. - (Supplément 1003. Saint Getmain 168.)

\section{4.}

Traité de médecine, sous forme de Queslions et Répouses. Le commencoment et la fin manquent. Les Queslions sont écrites à l'encre rouge. Ite titre, ajouté après coup, en téle du volume, et la nole qui se trouse à la fin arre la ditte $9^{65}$, sont apocryphes.

Papier. 126 feuillets. Hauteur, 17 centimètres; largeur, 13 centimètres. 13 lignes par page. Ms. du au" siecle. Les feuillets go à 194 sont d'une cicrilure plus moderne et portent 10 a 12 lignes par page. (Ancien funds 1081 , Golbert 6061.)

\section{5.}

$9^{0}{ }^{0}$ liazi. D’apres le titre, ce serait le rélèbre médeciu Houl Bakr Molyammad ibn Zakariyà al-Rizi. L'auteur traite d'abord de la crúation, puis des éléments, des humeurs du corps humain, des maladies, des membres du corpos. Lomrage est probablement apocryphe.

$2^{\circ}$ (Fol. 6.) Jiagment d'un traité de musitjuá, avec plusicurs tableanx.

$3^{\circ}$ (Fol. 24.) Fragment d'un traté d'astronomic, en langue turque.

$4^{\circ}$ (Fol. 26.) Fragment d'un traité d'astronomie élémentaire, en arabe.

$5^{\circ}$ (Fol. 28.) Frament astrologique. Il y est question des mois de divers peuples, des étoiles, des planètes, de l'pxaltation ( 6, wi) des planètes, de leur déjection (b, ه), de leurs influences, ele.

$6^{\circ}$ (Fol. 36.) Quelques pages d'une anthologie en prose el en rers, où il est trailé de l'amour et eles seatiments quil inspure.

$7^{\circ}$ (Fol. 4o.) Fragment d'un traité sur la manière de tirer d's réponses d'un tableau cabalistique.

\footnotetext{
- C'est hien le mème ourrage que le $\mathrm{n}^{\circ} 286$ a qui, également, présente toujours les rubriques النفسير t' Ces mss. renferment, l'un et l'autre, les sections 7 à 10 . Quant au ms. 2861, c'est un onvrage diffírent. 11 parait ètre complet et porte cet explicit : تم كتئب
}

$8^{\circ}$ (Fol. 49.) Fragment d'un traité d'astrologie.

$9^{\circ}$ (Fol. 51.) Fin d'un petit traité d'astronomie élenentaire.

$10^{\circ}$ (Fol. 56.) Note sur certains phénomènes que l'on explique par l'optique. Cette pice et la suivante sont d'une écriture turque cursive très dillicile à lire.

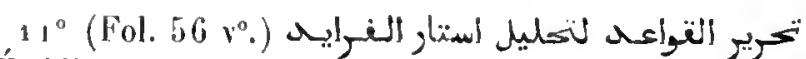
- Établissement des bases pour servir à dénoncr les voiles (c'est à dire à éclaircir les diflicultés) du Feraid ". L'onvrage conmenté est un traité d'astronomie attrilyué à Al-Djaghhmîni. La fin manque.

$12^{\circ}$ (Fol. $66 v^{\circ}$.) Petit trailé sur le quart de cercle apluelé

$13^{\circ}$ (Fol. $7^{\circ}$.) Dernières pages diun traité sur te chant.

Papier. 75 feuillets. Hauteur, 18 centimètres; largeur, 13 centimêlres et demi. Écritures diverses du $x v^{\mathrm{e}}$ el du $\mathrm{xvi}^{\mathrm{e}}$ siècle. - (Aucien fonds 105\%, Colbert 6007.)

\section{6.}

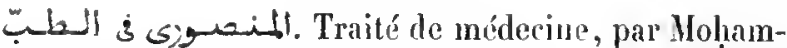
mad ibn Zakariyâ al-Rázì. Cel ouvrage se compose de dix lincis (متالات). Le nombre des chapitres (فصول) est de qualre cent trente-neuf, tont la liste se tronve au commencement du rolume. On dit que l'auteur a choisi le titre de sزs pour faire honneur à un émir samanide, nommé :H-Manşoûr; mais rien dans la préface de notre exemplaire ne confirme ce renscignement.

Papie: 187 fenillets. Hanteur, 27 centimètres et demi; largeur, 18 centimètres. 2 lignes par page (à la fin du volume 31 lignes). Ms. du xive siècle. - (Supplément 1005.)

\section{7.}

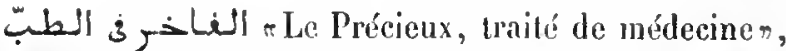
par Hoḷammad ibn Zakariyâ al-Râzì. Dans cet ourrage, dont le présent ms. ne renferme que le premicr volume, lauteur expose les opinions des anciens philosophes an sujet des aliments et des remiedes, el indirjue la manière de traiter les diverses maladies qui afligent l'homme, depuis le sommet de la tête jusquà la plante des pieds.

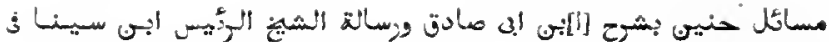
كاية الناتق حوالثى : En tite, on lit un tilre ajouté après coup

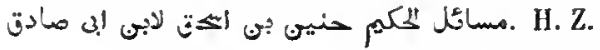




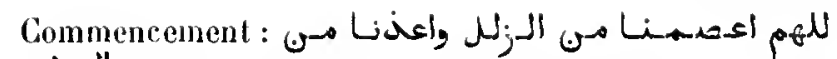
Nb. N.

Papier. 238 fouillets. IIauteur, 25 centimètres; largeur, 17 centimètres. 19 lignes par page. Mls. dn $x_{1} v^{\circ}$ siècle. (Le premier feuillet et le dernier sont plus modernes.) - (Supplément 1004.)

\section{8.}

$1^{\circ}$ من Trailé des correctif's des aliments $\leadsto$, par Aboû. Bakr Mohammad ibn Zakariyà alRàzì. Copie dalée de l'an 718 de l'hégire $\left({ }_{3} 18\right.$ de J. C.).

$2^{\circ}\left(\right.$ Fol. $\left.192{ }^{\circ} \%\right)$ "Lettre qui arait été trouvée dans te tombeau d'Hippocraten.

$3^{\circ}$ (Fol. 194.) Diagnostics emprunlés à Galieus.

Papicr. $19^{5}$ fenillets. Hanteur, 24 centimètres et demi; largeur, 16 centimètres et demi. 15 lignes par parge. - (Supplément 1 065.)

\section{9.}

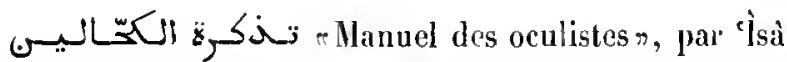
ihn 'Ali, médecin chrélien de Baghdàd, au $\mathrm{x}^{\mathrm{a}}$ siècle de notre ère. Ce traité se compose de trois discours : le premier, sur la conslitution el l'anatomie de l'œil; le deuxième, sur les maladies de l'œil qui se manifestent extérieurement; le troisième, sur les maladies cachées qui affectent cet organe. Dans cet ourrage, l'auleur s'adresse à un ami qui lui avait fait plusieurs questions au sujet de ces maladies et de lenr traitement.

Ms. daté de l'an $8_{92}$ de l'hégire (1487 de J. C.). Le premier calicur est d'une main plus moderue.

Papier. 196 feuillets. IIauteur, 17 centimètres el demi; largenr, 12 centimètres. $t / 4$ lignes par page. - (Ancien fonds 1100. )

\section{0.}

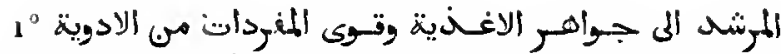
"Guide à la connaissance des substances dont se composent les aliments et des vertus des médicaments simples $r$, ouvrage très élendu, dont le présent ms. ne renlerme que qualre livres ou discours; le onzième, où l'auteur traite des gonnmes et des mannes; le douzième, consacré aux substances terreuses el aux minéraux; le treizieme, qui lraile des pierres qui se fondent au feu, et le quatorzième où t'on liroure des notices sur les poudres minérales employées pour la toilette. Cut ouırage est attribué à Al-Tamimi, probablement Moḥammad ibn Ạ̣mad ibn Såid, né à Jérusalem, qui vivait dans la seconde moitié du $1 v^{e}$ siècle de l'hégire. (Voyez Wüstenfeld, Arabische Aerzte, p. 57.)

$2^{\circ}$ (Fol. 128 .) Traité sur les quatre humeurs et sur les aliments, attribué à Abon Moluammad 'Abd al-latî́f ibn Yoûsof al-Baglıdàdi, auteur de la Relation de l'Égypte. L'ouvage n'a pas de préface et commence par ces mots :

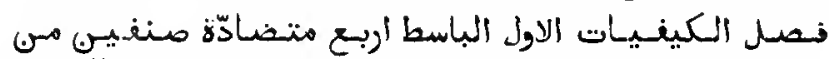

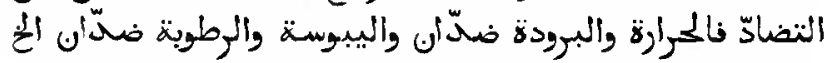

Ms. dlaté de l’an 947 de l'hégire (1 540-1541 de J. C.).

Papier. ${ }_{7} 7^{3}$ feuillets. Hanteur, $2:$ centimetres; largeur, 16 centimètres. 17 lignes par pagø. - (Ancien fonds 1088.)

\section{1.}

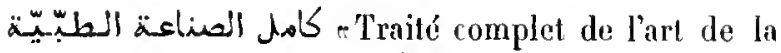
mérlecine $\rightarrow$. Vingt sections (älo), divisées en chapitres (باب). Les dix premières seclions sont consacrées à la théorie, et les dix dernières à la pratique de l'art. Liauteur, 'Alì ibn 'Abbìs al-Madjoûsi, nć à Arradjân, élait disciple d'lboû Màhir (olo) Moûsì ibn Saĩyâr. Il mourul en 384 de l'hégire $\left(99^{4-995}\right.$ de J. C.). L'ourrage a été composé sous les auspices d'Tdhod al-Dauta le Bouïde; c'est ponrquoi il est désigné sous le titre de المعضضى on sulf rle royals.

Le présent ms. renferme les dix premières sections.

Papier. 189 f feuillets. Hauteur, 35 centimitres; largeur, a 7 centimètres. 27 lignes par page. IIs. du viı ${ }^{\mathrm{e}}$ siècle. - (Ancien fonds 1012.$)$

\section{2 .}

Les einq premières sections du mềne ourrage.

Ms. daté de l'an 705 de l'hégire ( 1306 de J. C.).

Papier. 255 feuillets. Hauteur, 25 centimètres; largeur, 17 centimètres. 18 lignes par page. - (Ancien fonds 1011.)

\section{3.}

Les cing premières sections du nuème ouvrage. Les derniers feuillets manquenl.

Papier. 155 feuillets. Hauteur, 26 enntimètres et demi; largeur, ${ }_{9} 9$ ecntincitres el demi. 23 lignes par page. $1 /$ s. du xiv siècle. - (Ancien fonds 1013.) 


\section{4.}

Les cinq dernières seclions de la première partic du uêtme ouvrage.

Ms. daté de l'an 595 de l'lıégire ( 1199 de J. C.).

Papier. 186 feuillets. Hauteur, 26 centimèt es et demi; largenr, 18 centimitres et demi. 27 lignes par page. - (Aneien fonds 1060 , Collert 4273.$)$

\section{5.}

Les quatre dernières seclions de la première partie du niême ourlage.

Papier. 80 feuillets. Hauleur, 25 sentimètres et demi; largeur, 18 centimètres. 29 lignes par paģe. Hs. dn $\mathrm{m}^{\circ}$ siècle. - (Aneien fonds 1016.$)$

\section{6.}

Les cinf premières sections de la seconde partie du même ourrage.

Ms. daté (lol. $240 \mathrm{v}^{\circ}$ ) de l'an 1056 de l'hérrire (1646 de J. C.).

Papier. 311 feuillets. Hantenr, 21 centimètres; largenr, 15 centimètres et demi. 23 lignes par page. - (Ancien fonds 1059 .)

\section{7.}

Les Lrois premieres seclions de la seconde partie du même ourrage. A la fin du solume se lrouve une nole de denx pages cl demie, en langue persane, str le traitement des éruplions culanés.

Palpie;, a 45 fevillels. Ilanteur, 2 a centimètres; largeur, $1 / 4$ centimèires. 20 lignes par pagre. Ms. du $x^{\circ}$ siècle. - (Ancien fonds 1061 , Colbert 4 73 3.)

\section{8.}

Les deux premières sections de la seconde partic du mêne ouvrage.

l'apier. 317 feuillets. Hauteur, 24 centimètres et demi; largeur, 16 centimètres. 16 à 18 lignes par page. Ms. du xi ${ }^{e}$ siècle. - (Ancien fonds 1062, Colbert 4118.)

\section{9.}

Les quatre dernières sections de la seconde partie du même ouvrage.

A la fin on lit plusieurs recettes, dont la première est celle des paslilles de violette.

Ms. daté de l'an 611 de l'hégire (1214 te J. C.).

Papier. 238 feuillets. IJauteur, $2 / \mathrm{h}$ centimctres et demi; largeur, 16 centimètres et demi. 23 lignes par page. - (Ancien fonds 1015.)

\section{0.}

Dixième section de la scconde partie du mème .ouvrage. Gette section traite de la pliarmacopée, en particulier des médicaments composés.

Papier. 125 fenillets. Ilauteur, 25 centinèlres; largeur, 16 centimètres. Écritures diverses, dont la plus ancienne est du xu1 sièele. (Ancien fonds 101\%, Colbert 4582.)

\section{1.}

r Le Livre des cent (chapitres) sur la médeciner, par Aboû Sahl 'Îsà ibn Yaḷyâ al-Masîhị, médecin chrétien du Khorîsân el maìtre d'Aicenne, mort vers l'an 3 go de l'hégire (1000 de J. C.).

Papier. 256 feuillets. Ilanteur, 28 centimètres; largeur, a 1 centimètres el demi. 29 ligunes par page. Ms. du $\mathbf{x v}^{\circ}$ siècle. - (Ancien fonds 1010. .)

\section{2.}

$1^{\circ}$ Les vingt premiers liıres dı même ouvrage. Au fol. $14 v^{0}$ commence l'énumération des matières contenues dans chacun des cent livres. Copie datée de l'an 582 de l'hégire (1 186 de J. C.).

$2^{\circ}$ (Fol. 200.) Les livres XXI à XXX du même ouvage. Copie du $\mathrm{Xv}^{\circ}$ siècle.

Papier. 217 feuillets. Hauteur, $2 j$ centimètres; largeur, 17 centimètres. 13 lignes par page (dans la seconde partie 3 , lignes). (Ancien fonds 1009 , Colberl 2872.)

\section{3.}

لالاواشى النهانية والمقاصد الطبية على كتاب المائز لمسيكى 
"Gloses de No màn et indicalions médicales se rapporlant au Lirre des cent chapitres d'Al-Masihin, par Xocmân ibn abì 'l-Ridlaì al-Isrâilì. Commencement : ha.

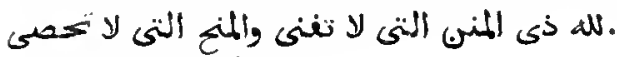

Ms. aulographe.

Papier. 206 fenillets. Hauteur, 25 centimètres; largeur, 16 centimètres el demi. 2 I lignes par pare. Ms. du xiv siecle. - (Supplément 1024.)

\section{4.}

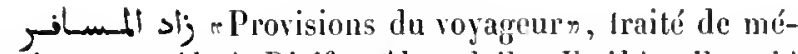
decine, par Áboù Dja far Aḷmad ibn Ibràlum ibn abì Khảlid, surnommé Ilon al-Djazzair, médecin né à Qaï'awàn, morl vor's l'au $39^{5}$ de l'hégrire $(1002-1003$ de J. C.).

Ms. moderne d'une bonne écriture curopéenne, copié sur un ms. de la Bibliollì̀que de Dresde.

Papier. 339 feuillets. Ilauteur, 31 centimètres et demi; largeur, so centimetres. 19 lignes par page. - (Supplément 1008. )

\section{5 « 2891.}

Le Canon d'Avicenne. Le premier et le second volume renferment le prenier livre; le troisième volume conlient la parlie du second lirre qui forme le diclionnaire des simples (commençant par غافو Larlicle ${ }^{\prime}$ (غ manque). Le quatrieme volume comnence par le second discours du dixiène fam di troisième livre (page rac du lexte imprimé), el se lermine par le dernier arlicle du second discour's du treizième famn du troisième line (page rel du laxle imprimé). Le cincuiène volume commence par le premier discours du treiziente fann du troisième livre (page kru du lexte imprimé), et se termine par le dernier arlicle du second discours du quinzieme fann du troisième line (page ren du lexle imprimée). Le sixième volume, dont le commencenent manque, renferme le quatorieme et le quiuzieme famn du troisiome livre. Le sepliène volume reulerme la fin du troisième livre el le commencemenl du quatriène. La copie s'arrète au milieu du cinquième discours du sixième fann (p. 1:s du texte imprimé).

Ms. dalé de 593,596 et 597 de l'hégire $(1196,1200$ el 1201 de J. C.).

7 volumes. Papier. 229, 247, 232, 206, 317, 197 et 213 feuillets. Hanteur, 33 centinètres; largeur, 15 centimètres. 15 lignes par page. - (Supplément 1006 A-G.)

\section{2.}

Même ouvrage. Premier et second livres et première partic du troisieme livre.

Ms. daté de l'an 714 de l'bégire (1314 de J. C.).

Papier. 307 feuillets. IIauteur, 36 eentinètres; largeur, 25 centimètres. 31 lignes par page. - (Supplément 1007.)

\section{3.}

Nême ourage. Premiel el second livres. Les premiers feuillets manquent; le lolio actucllement coté 1 correspond à la page ry du texte imprimé.

Papier. 215 feuillets. Hauteur, 22 centimètres et demi; largenr. 30 centimèlres et demi. 25 lighnes par page. Ns. du xuv sièele. - (Ancien fonds $99^{5}$, Collhert 2814 .)

\section{4.}

Hène ouvragye. Premier lirre. Ce ms. est composé de cahiers et de feuillets de diverses écrilures, dont la plus ancienne, celle des feuillets 17 a 125,133 à 231 est probablement dn $\mathrm{xu}^{\mathrm{e}}$ siccle.

Papier. 326 fevillets. Hautenr, a5 eentimètres; largeur, 17 rentimètres el demi. - (Ancien fonds 989 .)

\section{5.}

Mème ourage. Premier livre. Le commencement manque.

Ms. dalé de l'an 620 de l'hégire $(1223$ de J. C.).

Papier. 96 feuillets. IJauteur, $2 / 1$ centimètres; largeur, 17 centimètres. 17 lignes par page. - (Supplíment 1oog.)

\section{6.}

Mème ou rage. Premier livre.

Papier. 236 fenillets. Hauleur, 24 centimètres; largeur, 16 centimètres. 19 lignes par page. Ms. du xu1 sièele. - (Ancien fonds $\left.99^{\circ}.\right)$ 


\section{7.}

Mème onvrage. P'remier livre, accompagné d'une traduclion latine. La copic et la lraduction sout de la main de Ramusio el très incorrectes.

Le ms. est daté de Damas, de l'an 1485 de J. C, mais l'écriture est du $x_{v y}{ }^{\mathrm{e}}$ siècle.

P'apicr. 350 feuillets. Hauteur, 22 centimètres; largeur, 15 centimètres. - (Ancien fonds 1048.)

\section{8.}

Nème ouvrage. Deuxième partie du premier livre. Le volume commence à la deuxiène djomla du second talim du deuxième fam.

Ms. daté de l'an 617 de l'hégire (1220 de J. C.).

Papier. 185 feuillets. Hauteur, 27 centimètres ct demi; larrreur, 18 centinètres. 17 lignes par page. - (Ancien fonds 992.)

\section{9 .}

Mème ourage. Deuxième livre, renfermant le dictionnaire des médicaments simples.

Ms. daté de l'an 609 de l'hégire (1212-1213 do J. C.).

Papier. 332 feuillets. Hauteur, 25 centimètres et demi; largeur, 17 centimètres et demi. 15 lignes par page. -- (Ancien fonds $99^{\prime / .}$ )

\section{0.}

Mèunc vurage. Fragments dı troisième at du quatrième livre.

Papier. 345 feuillets. Hauteur, 23 centimètres; largeur, 14 centimètres et demi. Environ 15 lignes par page. Ms. du xir siècle. (Ancien fonds 104.)

\section{1.}

Mème ourrage. Troisième liıre.

Papier. 284 feuiltets. Hautcur, 25 cenlimètres; largeur, 20 centimètrẹs. 25.5 lignes par page. Ms. du xure siècle. - (Supplément 1011.)

\section{2.}

Mème ourrage. Ce volume renferme les dix-neuf premiers fann du lroisième livre.

Papier. 320 feuillets. Hauleur, 33 centimètres et demi; largenu, a 6 centimétres, 25 lignnes par page. Ms du xin' siècle. Le dernier calier est d'une écriture moderne. - (Ancien fonds 996 , Colbert 2815 .)

\section{3.}

Méme ouvrage. Ce volume renferme les neuf premiers fann du troisième livre.

Ms. daté de l'an 522 de l'hégire ( 1128 de J. C.).

Papier. 253 feuiltets. Hauteur, 19 eentimètres et demi; largeur, 16 centimètres. 17 lignes par page. - (Supplément 1012.)

\section{4.}

llème onrage. Ce volume renferme les neuf premiers fann du Iroisième livre.

Papier. 121 fenillets. Hauteur, 28 centimètres; largeur, 20 centimètres. a 3 lignes par page. Ms. du xir' siècle. - (Ancien fonds 997 , Colbert 2870. .)

\section{5.}

Mème ouvrage. Ce volume renferme plusieurs fann du troisiène live. Le neuvieme fann, commençant par le chapitre sur l'anatomic du corps, est suivi (lol. 18) du onzième fann, intitulé ألثها is, puis (fol. $22 v^{\circ}$ ) du douzième, etc., jusqu'au dix-huitième.

Papier. 248 feuillets. Ilauteur, 28 centimètres; largeur, 21 centimètres el demi. 19 lignes par page. Ms. du xu siècle. - (Ancien fonds 993.)

\section{6.}

Mème ouvrage. Ce volume renferme les fann $\mathrm{x}$ à xv du troisième livre.

Ms. daté de l'an 524 de l'hégire (1 130 de J. C.).

Papier. 182 Ceuillets. Hauteur, 24 centimètres; largeur, 16 centimètres. so lignes par page. - (Supplément 1010.) 


\section{7.}

Mlème ouvrage. Troisième livre. Le commencement manque. Le ms. commence au milieu de la première maqâla du Ireizième fann du troisième livre (page kry du texte imprimé), et il y a une lacune d'un feuillet entre les folios actuellement cotés 312 et 313 .

Ms. daté de l'an 542 de l'bégire (1 147-1148 de J. C.).

Papier. 313 fenillets. Hautcur, 31 centimètres; largeur, 24 centimètres. 18 lignes par page. - (Supplément 10 13. )

\section{8.}

Même ourrage. Le ms. commence par la seconde $m a-$ qâla du quinzième fann du froisième livre, et finit par le vingt-deuxième fann du même livre.

Ms. daté de l'an 737 de l'hégire ( 1337 de J. C.).

Papier. 333 feuillets. Hauteur, 19 contimètres ct demi; largeur, 24 centimètres. 13 lignes par page. - (Supplćment 1028.)

\section{9.}

Hême ouvrage. Troisième livre, fann xvı à xxur.

Ms. daté (fol. 135$)$ de l'an 576 de l'hégire $(1181$ de J. C.). Les folios $132,133,134$ et 279 sont d'une écriture plus moderne.

Papicr. 279 feuillets. Hauteur, 24 centimètres; largeur, 17 centimètres. 15 lignes par page. - (Aneien fonds 1000 , Colbert 5 202.)

\section{0.}

Mème ouvrage. Troisième livre, fann xvill à xxıl.

Papicr. 114 feuillets. Hauteur, 27 centimètres et demi; largeur, 28 centimètres. 23 d̀ 27 lignes par page. $\mathrm{Ms}$. du $\times \mathrm{xr}^{\circ}$ siècle. - (Ancien fonds 991.)

\section{1.}

Mème ouvrage. Quatrième volume d'un exemplaire complet, renfermant le quatrième et le cinquième livres de l'ouvrage.

Papier. 286 feuillets. Hauteur, 25 contimètres; largenr, 17 cenlimètres. 24 lignes par page. Ms, du xi1' siècle. - (Ancien fonds $99^{8}$, Colbert 2871.)

Mix. orientaux. - 11 .

\section{2.}

Même ouvrage. Qualrième et cinquième livres.

Ms. daté de l'an 632 de l'hégire (1234 de J. C.) ; mais ce chiffre a été changé, après coup, en 232 .

Papier. 190 feuillets. Hauteur, 25 cenlimètres; largeur, 17 centimè̀res. 27 lignes par page. - (Supplément 1014.)

\section{3.}

Mème ouvragge. Ce volume commence par la seconde maqûla du troisième fann du quatrième liıre, et finit par la neuvième maqála de la seconde djomla du cinquième livre.

Ms. daté de l'an 619 de l'hégire (1222 de J. C.).

Papier. 296 feuillels. Hauteur, 25 centimètres ot demi; largeur, 17 centimètres. 19 lignes par page. - (Supplément 1016.)

\section{4.}

Même ourrage. Ce volume renferme le sixième et le seplième fann du quatrième livre. Le commencement manque.

Papier. 97 feuillcts. Hauteur, 25 centimètres et dcmi ; largeur, ${ }_{7} 7$ centimètres. 19 lignes par page. Ms. du xıv siècle. - (Supplément 1006 11.)

\section{5.}

Même ouvrage. Cinquième livre.

Ms. daté de l'an 725 de l'hégire (1 326 de J. C.).

Papier. 120 feuillets. Hauteur, 25 centimedres et demi ; largeur, ${ }_{1} 7$ centimètres el demi. 19 lignes par page, - (Supplément 1006.$)$

\section{6.}

Même ouvrage. Cinquième livre. Des gloses persanes, donnant la traduction de certains mots et même de certains passages sont placés en plusieurs endroits entre les lignes.

Papier. 222 feuillets. Hauteur, 25 centimètres ct demi; largeur, 17 centimètres. 9 lignes par page. Ms. du $x \mathrm{v}^{\circ}$ siècle (le dernier feuillet est moderne). - (Ancien fonds 999.) 


\section{7.}

$1^{\circ}$ Ahrégé du Canon d'Avicenne, par Scharaf al-Din al-îlàqi, disciple d'Avicenne. Commencement : als and الغنيى المبيد.

$2^{\circ}$ (Fol. $66 \vee^{\circ}$.) Commentaire sur l'abrégé d'Al-îlàqì,

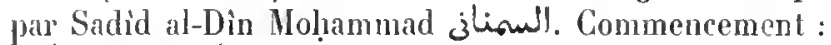

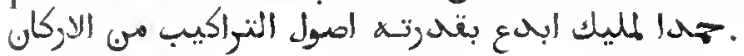

Ns. daté de l'an 759 de l'hégire (1358 de J. C.).

Japier. 212 feuillets. Ilauteur, 17 centimètres; Jargeur, 14 centimètres. Dans le premier ouvrage 17 lignes, dans le second 21 lignes par page. - (Supplément 1019.)

\section{8.}

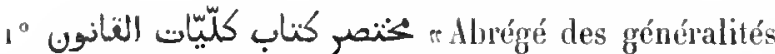
du Canon (d'Avicenne)", par Nadjm al-Din Aḷmad ihn Noḥammad al-Lohoûdi (النُبودي), anteur du xu1 siècle.

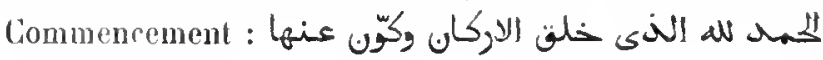

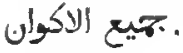

Copie autographe, portant des corrections.

$2^{\circ}$ (Fol. 36.) Traité d'Al-Mokhtâr ilon al-Hosain ibm 'Abdoûn ibn Boṭlàn sur les majadies des moines et des personues qui demenrent loin des villes. Cet ourrage se compose de quarante-rleux chapitres, dont la liste occupe les premières pages. Nous n'avons ici que les quatre premiers chapitres et le commencenent du cinquième.

$3^{\circ}$ (Fol. 42.) Fragments du Canon d'A vicenne. Ce sont des extraits des lettres alif, djim et dal du Livre des simples.

$4^{\circ}$ (Fol. 56.) Fragment du Continent (s) إك) de Rhazès, section des fières.

$5^{\circ}$ (Fol. 95.) ب. Manuel des oculistesn, far' 'Alì ibn 'Îsâ, oculiste chrétien du me siècle de l'hégire. Fragment qui donne la fin de la seconde partie de l'ouvrage, et la liste des chapitres et quelques fuillets détachés de la troisième partie.

$6^{\circ}$ (Fol. 106.) Fragnent du commentaire d'Averroès sur l'Orljoûza d'Avicemne.

$7^{\circ}$ (Fol. 155.) Fin du troisième discours et commencement du quatrième, avec la liste des chapitres, du كنّانث de Yộhannẩ ibn Sérapion.

$8^{\circ}$ (Fol. 171.) Fragments d'un recueil de Vies de quelques saints musulmans.

$9^{\circ}$ (Fol. 183.) Fragments de plusieurs seclions d'um traité de médecine. Écriture cursive, probablement celle de l'auteur.

$10^{\circ}$ (Fol. 190.) Fragunent d'un traité de médecine. Il y est question des maladies de la peau, de la vessie, des reins, etc.

$11^{\circ}$ (Fol. 201.) Traité des pierres, extrait de l“Adjâib al-Makhloûquit de Qazwînì. Les feuillets sont intervertis.

$12^{\circ}$ (Fol. 207.) Fragonent d'un traité de médecine. I1 $y$ est question des vers intestinaux, des hernies, des coliques, etc.

$13^{\circ}$ (Fol. 223.) Notes d'un médecin sur les maladies qu'il a soignées, extraits de ses lectures et diverses recettes. Le tout est écrit sans ordre et d'une écriture mal formée.

Papier. a 53 feuillets. Hauteur, s 3 centimètres et demi; largeur,

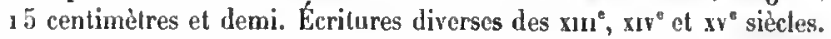
- (Ancien fonds 1056.)

\section{9.}

C Compendium de médecinem. Abrégégé du Canon d’Avicenne, par Ibn al-Nafis ("Alà al-Din Abou 'L-Ilasan 'Ali ibn abi 'l-Ḥazm al-Qoraschì), mort vers la fin du $\mathrm{x} 1 \mathrm{u}^{\circ}$ siècle. L'ourrage est divisé en quatre sections : $1^{\circ}$ la théorie et la pratique; $2^{\circ}$ les médecins et les aliments; $3^{\circ}$ les maladies locales et leur traitement; $4^{\circ}$ les maladies qui affectent tout le corps et leur traitement.

Is. daté de l'an 738 de l'hégire ( 1337 de J. C.).

Papier. $19^{8}$ feuillets. Hauteur, a centimètres; largeur, 14 centimètres. 17 lignes par page. - (Ancien fonds 1050, Colbert 5953.)

\section{0.}

Mème ouvrage. Nombreuses notes marginales aux premiers feuillets. Les feuillets de garde portent diverses notes, les unes en arabe, les autres en turc.

Is. daté de l'an 785 de l'hégire ( 1383 de J. C.).

Papier. 224 feuillets. Ilauteur, 19 centimètres et demi; lárgeur, 14 centimètres. 11 à 13 lignes par page. - (Ancien fonds 1051.)

\section{.2921.}

Mème ourrage.

Ms. incomplet et composé de cahiers de diverses écritures. Un titre apocryphe désigne l'ouvrage comme un 
commentaire du Moûdjiz, et affirme que le ms. appartenait à la bibliothèque du sultan Tchaymaq.

Papier. 120 feuillets. Hanteur, 21 centimètres et demi; largeur, 15 centimètres. Environ 19 lignes par page. - (Supplément 1 033.)

Mème ourrage.

\section{2.}

Nls. daté de l'an 963 de l'hérgire (1556 de J. C.).

Papier. 195 feuillets. Jlauteur, 18 centimètres; largeur, 13 centimètres et demi. 15 lignes par page. - (Ancien fonds 1057.)

Nème ouvrage.

\section{3.}

Ms. daté de l'an 1122 de l'hégire $\left(17^{11}\right.$ de J. C.). II y a beaucoup de notes au commencement et à la fin.

Papier. 192 feuillets. Hauteur, 19 centimètres; largeur, 15 centimètres. 15 lignes par page. - (Supplément 1962.)

\section{4.}

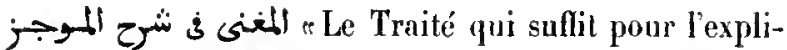
cation du texte du Moûdjiz», par Sadid al-Dìn al-Kàzaroûnî, médecin du xiv ${ }^{\mathrm{e}}$ siècle. Lo texte du Moúdjiz, divisé en paragraphes, se troure presque en entier dans cet

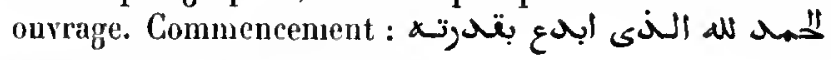

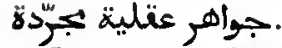

Le texte du Moûdjiz est écrit à l'encre rouge.

Papier. 258 feuillets. Hautcur, 28 centimètres; largeur, 17 centimètres. 31 lignes par page. Ms. du xıv sièele. - (Ancien fonds 1005 , Colbert 2873.)

\section{5 .}

Mème ouvrage.

Exemplaire écrit à Mâridín, et daté de l'an $79^{1}$ de l'hégire ( 1389 de J. C.).

Papier. ${ }_{2} 5$ fenillets. Ilauteur, 26 centimètres et demi; largeur, 18 rentimètres et demi. 37 lignes par page. - (Ancien fonds 1006.)

\section{6 .}

Même ourrage.

Ms. daté de l'an 946 de l'leégire ( 1539 de J. C.). Le commencement manque.
Papier. a 30 feuillets. Hauteur, 21 centimètres et demi ; largeur, 15 centimètres et demi. 19 lignes par page. - (Supplément 1035.)

\section{Neme ouvrage.}

\section{7.}

Ms. daté de l'an 968 de l'hégire (1564 de J. C.).

A la lin du $\mathrm{ms}$. se trouvent des notes diverses, des réflexions morales, des prières, des recettes, des extraits d'lbn al-Baịtâr, etc. Quelques-unes de ces notes sont en persin.

Papier. 315 feuillets. Hauteur, 31 centimètres; largeur, 21 centimètres. 23 lignes par page. - (Ancien fonds 1004.)

Mlème ouvrage.

\section{8.}

A la fin du volume se trouvent un grand nombre de notes et d'extraits, dont quelques-uns en langue turque.

Papier. 150 feuillets. Hauteur, 21 centimètres; largeur, 14 centimètres. 15 lignes par page. Ms. du xvi siècle. - (Ancien fonds 1045.$)$

\section{Mème ouvrage.}

\section{9 .}

Papier. 510 feuillets. Hauteur, 21 centimè̀res; largeur, 15 centimètres. 19 lignes par page. Ms. du $x^{\circ}{ }^{\circ}$ siècle (les premiers feuillets sont plus anciens). - (Supplément 1034.)

\section{0 .}

Second volume dn commentaire sur le Moûdjiz d'lbn al-Nafis, par Maḷmoûd ibu Aḥnad Ml-Amschâtị, morł en 810 de l'hégire (1407-1408 de J. C.).

Ms. daté de l'an 1126 de l'hégrire (1714-1 715 de J. C.).

Papier. $36_{3}$ feuilfets. IJauteur, 31 centimètres; largeur, a a centimètres. 17 lignes par paģe. - (Supplément 1020.)

\section{1.}

Conmentaire anonyme sur le Moûdjiz d'lbu al-Nalìs. Le texte du Moûdjiz est reproduit en entier. 11 n'y a pas de préface.

Ms. dépourva de points diacritiques.

Papier. 599 feuillets. Hauteur, 18 centimetres; largeur, 14 centimètrus. 21 lignes par page. His. du rvo siècle. - (Supplément 103\%.) 


\section{2.}

Commentaire de Mohammad ibn Ahmad, d'Andrinople (الادونوى), surnommé Ibn al-A!̣âr, sur les gloses de Nafis ibn Cwadh al-Kirmânì expliquant les passages difficiles de l'épilomé du Canon d'Avicenne d'lbn al-

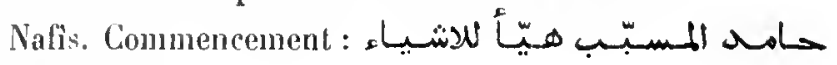
أسمسبـابـا

Ms. daté de l'an 976 de l'hégire ( 1569 de J. C.).

Papier. 60 feuillets. Hanteur, 20 centimètres et demi; largeur, 15 rentimètres. 23 lignes par page. - (Ancien fonds 1089 .)

\section{3.}

كختِعr. Abrégé du Canon d'Avicenue. Première moitié du second livre, renfermant le dictionnaire des simples, jusqu'à l'article غرب. L'auteur de cet abréçé se nomme Nidà ibn 'Îs iln al-Hâddj Nidâ ibn

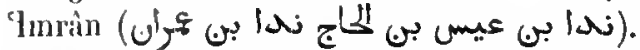

Ms. allographe, daté de l'an $99^{\circ}$ de l'luégire ( 1582 (le J. G.).

Papier. 109 feuillets. Hauteur, \& 1 centimèlres et deni; largeur, 15 centimètres et demi. 15 lignes par page. - (Ancien fonds 1052 , Collert 4560.)

\section{4 .}

$1^{\circ}\left(\right.$ Fol. $2 v^{\circ}$.) Commentaire sur le premier livre du Canon d'Airicenne. Commencement : Wh tor

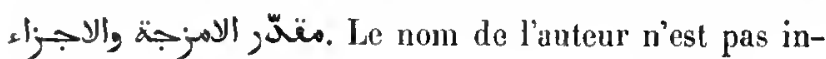
liciné ?.

$2^{\circ}$ (Fol. 128.) Traité anonyme où l'on examine, au point de vue de la mélaphysique, l'inllnence de la prière sur l'esprit et sur le corps.

Hs. daté de l'an 635 de l'hógire ( 1238 de J. C.). Les points diacriliques sont souvent omis. En tête du volume on lit la fin d'une dissertation sur les sphères et sur la première intelligence; ce texle renforme des prières et des invocations adressées à Dieu.

Papier. 130 feuillets. Hauteur, 23 centimètres et demi ; largeur, 16 centimètres et demi. 23 lignes par page. - (Ancien fonds 1001.)

\section{5 .}

Commentaire sur le premier livre du Canon d'Avicenne. C'est le mêne ouvrage que l'article $\iota^{\circ} \mathrm{du}$ numéro précédent.

Ms. daté de l'an 710 de l'hégire $(1310-1311$ de J. C. $)$.

Papier. 196 feuillets. Hauteur, 16 centimètres; largeur, 12 centimètres. 20 lignes par page. - (Supplément 1015.)

\section{6.}

Explication des difficultés qui se trouvent dans le Canoun, par A ḥmıd ibn abì Bakr ibn Mohammad al-Nakhdjowânî, mort à Alep, vers le milien du $x_{11}{ }^{e}$ siècle. Ce sont des gloses sur le commentaire du Canon d'Avicenne, par Fakhr al-Din al-Ràzí. Commen-

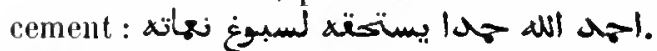

Ms. sans points diacritiques, qui a été collationné en l’an 651 de l'hégire (1253 de J. C.).

Papier. 128 fenillets. Hauteur, 21 centimètres et demi; largeur, $1 /$ centimètres et demi. 15 lignes par page. - (Ancien fonds 1053.)

\section{7.}

Commentaire sur le كلِّبّان du Canon d'Avicenne, accompagné d'exlıaits du traité composé sur le même sujet par Fakhr al-Dìn Molımmad ibn 'Omar al-Rảzì. Cet ouvrage a pour auteur Abou 'l-Fadhâil Mọ̣ammad ibn Nàmwer al-Khoùnadjî, docteur schaféite, mort, selon Hadji Khalfa (t. II, p. 623), en 649 de l'bégire (12511252 de J. C.), ou en 646, selon Wüstenfeld (Arabische Aerzte, $\mathrm{n}^{\circ}$ 239). Commencement :

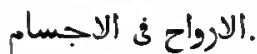

Ms. daté de l'an 671 de l'hégire ( 1273 de J. C.).

Papier. 97 feuillets. Hauteur, 16 centimètres; largeur, 12 centimètres. 20 lignes par page. — (Supplément 1015 bis.)

\section{8.}

Mème ourrage.

Ms. daté de l'an 732 de l'hégire $(1332$ de J. (c.) ).

papier. 11 a feuillets. Hauteur, a 3 centimètres et demi; largeur, 15 cenlimètres et demi. 23 lignes par page. - (Supplément 1017.)

1 Ce commentaire est, parait-il, de Fakhr al-Dîn Moḷammad ibn 'Omar al-Ràż. H. $Z$. 


\section{9.}

Commentaire sur les parties anatomiques du Canon d'Avicenue, par ${ }^{\complement} M l a ̂$ al-Dìn ibn al-Nafìs. L'auteur dil qu'il avait réuni tous les passages sur l'anatomie qui sont dispersés dans les trois premiers livres du Canon, afin de former un traité régulier sur le sujet. Commencement:

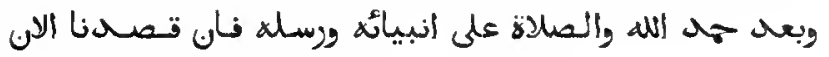

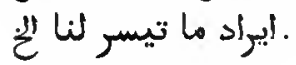

Cette copie a probablement été écrite du vivant de lauteur.

Papier. 118 feuillets. Hautenr, 25 centimètres el demi; largetrer, 17 centimètres. 99 lignes par page. - (Ancien fonds 1002 , Colbert 2869.)

\section{0.}

Prenier volume du commentaire de Qo!̣ al-Din Mal?moûd ibn Mascoûd al-Schiratzi sur le Canon d'Avicenue. On lit, au tol. 3, qu'en l'an 681 de l'hégire (12821283 de J. C.), l'auteur était occupé à rassembler les matériaux de son ouvrage. Il mourut en 710 de l'trégije (1310-1311 de J. C.). Le commentaire commence par

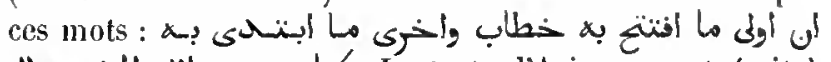

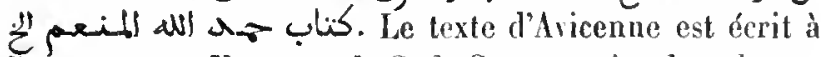
l'enere rouge. Une note de S. de Sacy, en tète du volume, constate que l'on y trouve la préface du Canon, ainsi que les dix prenières pages et trois lignes de la onzième page de l'édition de Rome, et, de plus, les pages 33 , $34,35,36$ et quatorze ligones de la pago 37 de la même édition. Un traitś des fières, en quinze chapilres, termine le volume. L'auteur expose les raisons qui l'out déterminé à insérer ce trailé dans son commentaire.

Papier. 335 feuillets. Hauteur, 26 centimètres et demi; largeur, 20 centimètres et demi. 25 lignes par page. MIs. da la fin du xiı" siècle. - (Ancien fonds 1003, Colbert 2863.)

\section{1.}

a Éclaircissement des obscurités du Tanqihs, par Fakhr al-Din al-Khodjandi. Dans ce trinité, l'auteur donne le sommaire d'un onvrage qu'il avait publié sous le titre de تنفي اكلمنون, et qui est un extrait d'un abrégé, intitulé par un auteur inconnu. (Voy. Hadji Khalfa, t. II, p. 451 , et t. IV, p. 501). Le présent onvrarge commence par ces

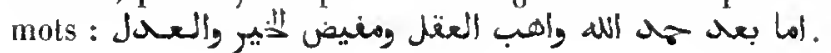

Aux premières pages, il y a un grand nombre de notes marginales. Én tèle du volume se trouve un assez long article sus la vraie définition de la seience de la médecine.

Papier. 102 fcuillets. Hauteur, 20 centimètres et demi; largeur, 13 centimètres el demi. 13 lignes par page. IIs. du xvi siècte. (Ancien fouds 1049, Colbert 4975.)

\section{2 .}

$1^{\circ}$ Ordjoúza d'Avicenne sur la médecine. Commencement :

$$
\begin{aligned}
& \text { يـا سـايسلى عـى محــة الاجبـســاد }
\end{aligned}
$$

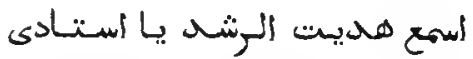

$2^{\circ}$ (Fol. $5 r^{\circ}$.) Antre Ordjoúza sur le même sujet. Commencement :

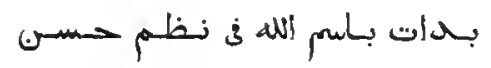

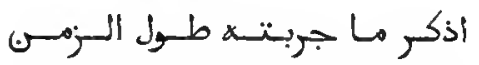

$3^{\circ}$ (Fol. 11.) Ordjoúza sur le mène snjet, conposéx: au commencement du xuve siècle, par Abumad ibn flasan al-Khatib.

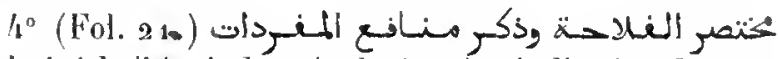
"Abrégé de l'Agriculture (nabatéenne) et indication des vertus des simples $\%$. Notices sur les plantes utiles, par "Ali ibn İasan ibn Mohammad al Zaitounni al-`Auli.

$5^{\circ}$ (Fol. 62.) Nolices sur les médicaments simptes. tirées d'un ourage composé par Lṣài ibn Solaümàn. d'aprés les écrits de Galien et d'autres autem's anciens. L'auleur de cet extrail se nomme Hohammarl ibu $\mathrm{Ab}$ mad ibn cïscha (?) al-Zaïtoûnì al-Aufi.

$6^{\circ}$ (Fol. 108. ) Prières.

La plus grande partie de ce volume est de la main do Moḷammad ibn Aḷmad al-c Aufi.

Papier. 113 feuillets. Hanteur, 18 centimètres; largeur, 13 centiurètres el demi. 15 à zo lignes par payge. - (Ancien fonds $1093, \mathrm{Col}$ bert 6005.$)$

\section{3.}

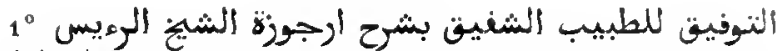
Satisfaction donnée au médecin plein d'humanité et qui consiste en un commentaire sur l'Ordjoita du schaikh et ra'is qui nous guide dans te cheminr. (ie commentaire a été composé en 988 de l'héúcire (1580 do 
J. C.), par Mohammad ibn Ismấil ibn Moḷammad. Com-

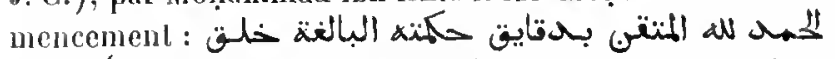
كا كل شن Le dernier chapitre renferme de courtes notices liographiques sur les médecins dont les noms sont mentionnés dans le poème d'Avicenne.

$2^{\circ}$ (Fol. 203.) L'Ordjoúza d'Avicenne sur la médecine.

$3^{\circ}$ (Fol. $250 v^{\circ}$.) Ordjoûza sur les maladies de l'œil.

$4^{\circ}$ (Fol. $260 \mathbf{v}^{\circ}$.) Ordjoûza énumérant les veines sur lesquelles on peut pratiquer la saignée.

Le premier traité contenu dans ce volume a été copié sur le ms. antographe, probablement au xvill siècle; le second traité est daté de l'an 1185 de l'hégire (1771$177^{2}$ de J. C.).

Papier. 26, fenillets. Hauteur, a centimètres ; largeur, y a centimètres. 23 lignes par page dans le premier traité, 15 lignes dans les antres. - (Supplément 1022.)

\section{4.}

r Le Précieux collyre pour éclaircir les yeux (ou les 'ain, c'est-à-dire les vers rimant en 'aï) du Ra'îs\%. C'est un commentaire sur le célébre poème d'Avicenne (العينية), qui traite de l'union el de la séparation du corps el de l'àme, par le médecin Dàoûd, d'Antioche, mort en 1008 de l'hégire (15991600 de J. C.). Commencensent : تقدس نور الانسوار عـى . حصر المرايا.

Ms. daté de l'an 1200 de l'hégire ( 785 de J. C.).

Papier. 63 feuillets. Hauteur, so centimètres el demi; largeur, 15 centimètres. 21 lignes par page. - (Supplément 1963.)

\section{5.}

r Entretien de la santén, traité d'lyygiène par Abou 'l-I!asan Bawàninn (بوأنير) ibn al-Hasan ibn alḷasan ibn 'Abdoùn (Ibu al-Bollàn), surnommé Al-Mlokl1târ, médecin chrétien de Baglidad, mort en 444 de l'hélire (1055-1 053 de J. G.). L'auteur expose, en plusieurs tableaux synoptiques, les propriélés des aliments, de l'air, des vềtements, etc. Commencement: ان الانسسان 3 أكثر احواله شبيه بحال الثتى

Ms. daté de l'an 1014 de l'hégire (1605 de J. C.).

Papier. 21 feuillets. Hauteur, 32 centimètres; largeur, a centimètres et demi. - (Supplément 1061.)

\section{6.}

$1^{\circ} ج^{2 l}$ a téclaircissement de la voie qui conduil à la thérapeutiquen, par Tâahir ibn Ibrăhîm ibn Mohanmad, médecin persan du xi ${ }^{\mathrm{e}}$ siècle. Ce traité a été composé à la demande du cadi Abou '1-Fadbl Mohammad

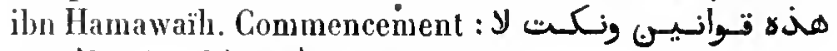

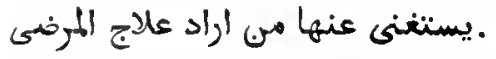

$2^{\circ}$ (Fol. 30 bis.) Médicaments simples mentionnés dans la تِ et classés ici selon leur nature et leur emploi. Notes marginales en persan.

$3^{\circ}$ (Fol. 34.) Traité de pharmaceutique, par Badr

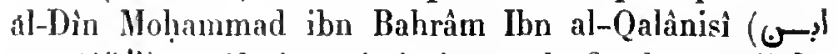

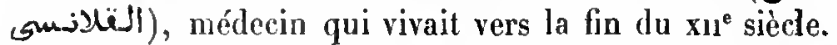
Quarante-neuf chapitres. Commencement : القياد القاهر العزبز التقادر.

$4^{\circ}$ (Fol. $145 v^{\circ}$.) Traité d'Hippocrate sur la mort, traduit en arabe par Yahyyà ibn al-Batrì̀q.

$5^{\circ}\left(\right.$ Fol. $147 v^{\circ}$.) Sur le régime quil faut prescrire

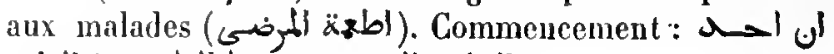

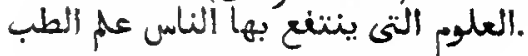

$6^{\circ}$ (Fol. $164 v^{\circ}{ }^{\circ}$ ) Recettes.

$7^{\circ}$ (Fol. ${ }^{16}{ }_{7} r^{\circ}$.) Petit dictionnaire alphabélique des simples, suivi d'un chapitre sur les purgatifs. Au verso du premier feuillet on lit, écrit de la même main que les ru-

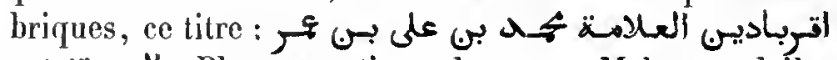
Pharmaceutique du savant Mohamnad ibn 'Alì ibul 'Omar al-Samarqandìn.

$8^{\circ}$ (Fol. 185.) Recueil de recettes et de remèdes. D'après une note, qu'on lit au commencement, ce serait la Pharmaceutique d'Al-Nadjibî. Il n'y a pas de préface. Le premier article est intitulé حب التوتايا.

$9^{\circ}\left(\right.$ Fol. $244 \mathrm{r}^{\circ}$.) Recueil de notes dont l'auteur est le médecin qui a écrit ce volume. On y trouve des recettes, des extrails de divers ourrages, des observations sur les résulats qu'il a obtemns lui-mème en employant tel ou tel Iraitement, etc.

$10^{\circ}$ (Fol. $278 \mathrm{v}^{\circ}$.) Deux traités en langue persane, sur les pronostics qu'on peut tirer des mois de l'année. Le premier traite de l'année arabe, le second du cycle des Tures, à commencer par les années de la Souris et de la Vache.

Is. tout entier de la même main et daté de 859 et 860 de l'hégire (1455-1456 de J. C.).

Papier. 289 fenillets. Hauteur, 27 centimètres; largeur, 18 centimètres. 21 lignes par page. — (Ancien fonds 1022 , Colbert 4103.$)$ 


\section{7.}

1 م Tableaux synopliques des (maladies du) corpsn, par Abou 'Alì Yahyyâ ibn 'Îsà ibu Djazla, de Baghdàd, mort en 493 de l'hégire ( 1100 de J. C.). Ce traité, qui a été composé pour la bibliothèque du calife abbaside A1-Moytadi, nous offre une série de tableaux, à plusieurs colonnes, accompagnés de notes marginales. Les colonnes de droite indiquent les caractères particuliers de chaque maladie, celles de gauche lo traitement.

$2^{\circ}\left(F_{0}\right.$. $\left.49 v^{\circ}.\right)$ Deux extraits: to premier est tiré du Continent (Al-Hâtwî) d'Al-Râzì, le second de la Kholísa de Ju ibn Ishàq al-Ardabìlì.

$3^{\circ}$ (Fol. 5 2 vº ( Tableaux synoptiques pour l'entretien de la santén, par Abou 'l-llasan al-Mokhtâr ibn al-Hasan ibn 'Abdoûn ibn Botlàn.

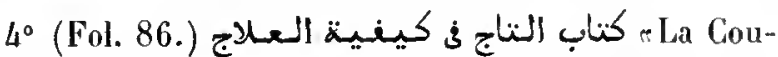
ronne, traité sur la manière de guérir les maladies n, par 'Abd at-Wâhid ibn 'Abd al-Razzâq, prédicateur de la

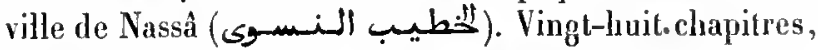
dont le troisième et le dernier sont en langue persane.

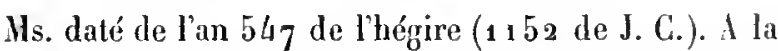
fin du volume se troure un cahier d'une grossière écriture maghrebine, renfermant quelques fragments du Coran.

Papier. 135 feuiltets. Hauteur, 3 i centimètres; largeur, a a centimètres el domi. - (Ancien fonds 1020 .)

\section{8.}

- Le sentier de l'indication, faisant connaitre ce qui est à l'usage de l'hommen, par Aboû 'Mlì Yalyấ ibn Djazla. Kotices, rangées dans l'ordre de laphabet, sur toutes les substances animales, végét:les et minérales qui peuvent servir à l'homme, soit comme aliments, soit comme remedes. Commencement :

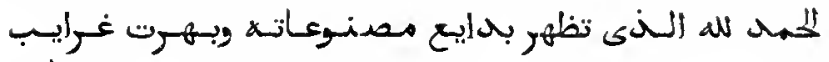

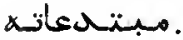

Us. de diverses mains, dont la partie la plus considérable et la plus ancienne est datée de l'an 6 1 a de l'hégire (12 16 de J. C. ).

Papier. 220 fenillets. Hlauteur, 23 centimètres; largeur, 17 centimètres et demi. a. liggnes par page. - (Supplément 10 \%6.)

\section{9.}

Mème ouvrage.

Ms. daté de l'an 615 de l'hégire (1218 de J. C.).

Papier. 203 feuittets. Ifauteur, 30 centimètres; targeur, 14 centimètres. 19 lignes par page. - (Ancien fonds 1035.)

Même ouviage.

\section{0.}

Ms. daté de l'an 674 de l'hégire ( $127^{5}$ de J. C.). Les fenillets 25 à 52 sont d'une époque assez moderne.

Papier. 361 feuillets. Hauteur, 30 centimètres el demi; largeur, 23 centimètres el demi. 15 lignes par page. - (Ancien fonds 1021.)

\section{1.}

Mème ouvrage.

Ms. daté de l'an 946 de l'lıégire (1540 de J. C.).

Papier. 345 feuillets. Ilauteur, 22 centimètres; largen, 16 centimètres. 15 à 17 lignes par page. - (Ancien fonds 1078. )

\section{2.}

Mène ouvrage.

Ms. daté de l'an 1058 de l'hégire ( 1648 de J. C.).

Papier. 294 feuitlets. Hauteur, 22 centimètres; largeur, 15 centimètres et demi. 21 ligucs par page. - (Ancien fonds 1079.$)$

\section{3.}

oDisconrs sur les opérations mat muellesn, traité de chirurgic en trois parties, par Abou 'l-Qàsim (Albucasis des traducteurs latins) Khalai' ibn 'Mbbàs al-Zahrivi, médecin espagnol, mort en 500 de l'hégire ( 1 1 o6-1 107 de J. C.). Ce traité lorme la trintième et derniòre section du grand ouvrage sur la méde-

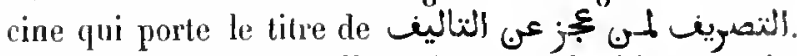

Ce volume, d'une belle écriture maghrebine, contient des figures d'instruments assez bien dessinces; le dernier cahier et la préface particulière que l'auteur avail composée pour ce traité sont d'une mán plus moderne.

Papier. 112 fcuitlets. Hauteur, 27 centimètres et demi; largenr, 2 o centimètres et demi. 27 lignes par page. Ms. du wr" siècle. - (Supplément 1059.) 


\section{4.}

$I^{\circ}$ Dictionnaire des divers corps et substances et de leurs vertus. Ce recueil, formé d'extraits d'une trentaine d'auteurs, dont les noms sont indiqués ì la première page, arec les sigles par lesquels ils sont désignés, dans la suite de l'ourrage, est attribué à Lbou 'l-'Alà Zohr, médecin espagnol. Voici ce qu'on lit immédiatement après le bis-

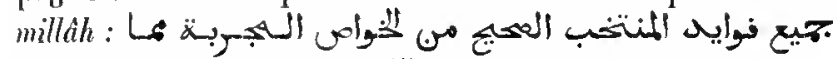

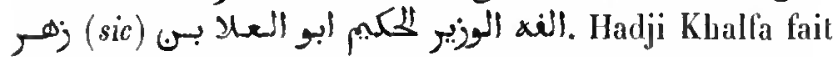
mention de ce traité dans sa Bibliographie (t. V, p. 383). (Voyez aussi le Catalogue de la Bibliotheqque de Leyde, 1. III, p. 249.)

$2^{\circ}\left(F_{01} 106 v^{\circ}\right.$ ) كن r Le Livre de Mehârìn, personnage nommé dans la préface du traité précédent. On y trouve l'indication des vertus médicales qu'on a reconmues dans les diverses parties du corps humain et des corps des animaux. Cette compilation commence

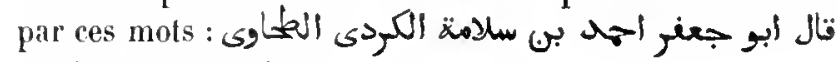

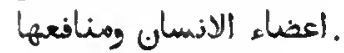

$3^{\circ}$ (Fol. 113.) Charmes et anulettes qu'un certain 'Abd Allah iln Salàm prétend avoir trouvés dans le Pentiteuque.

Ms. daté de l'an 5 go de l'hégire (1 194 de J. C.).

Papier. 116 leuiltets. Hauteur, 23 centimètres et demi; largeur, 16 centimètres et demi. 15 lignes par page. - (Ancien fonds 1076 .)

\section{5 .}

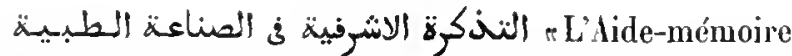
aschrafite pour l'art de la médecinen, traduction arabe du

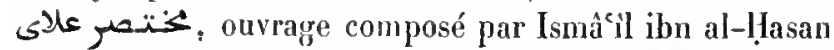
al-Djordjânì pour 'Alà al-Dìn Alp Arstàn Mohammad. Al-Djordjàni mourut vers l'au 530 de l'bégire (1 135 de J. C.). Le traducteur, dont le nom reste à découvrir, a dédiés son travail à un prince qui portait le titre d'Al-Malik al-Aschraf. Une lacune entre les deux premiers feuillets dı ms. nous empêche de reconnaître le nom de ce persounage. C'est peut-être Al-Malik al-Aschraf Moûsà, fils d'Al-Malik al-'Âdil et neveu de Saladin. Commencement :

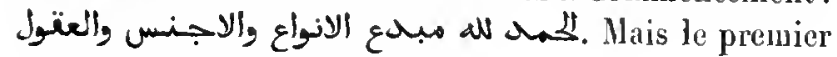
leuillet a été ajouté après coup.

Papier. 104 feuiltels. Hauteur, 24 centimètres; targeur, 15 centimètres et demi. 17 lignes par page. Ms. du xu' siècle. - (Ancien onds 1019. )

\section{6 .}

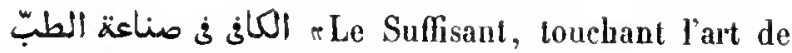
la médecine , traité de médecine pratique, par Aboû Naṣr 'Adnàu iłn Naṣr al-'Aïn-Zarbî, médecin du calife fatémide Al-Ẓâfir bi-Amr Illàh. L'auteur, après quelques observations sur l'influence de l'air, de l'alimentation, du repos et du mouvement, etc., consacre la plus grande partie de soll ouvrage à la thérapeutique.

Ms. daté de l'an 953 de l'luégire (1546 de J. C.).

Papier. 184 feuittets. Hauteur, 23 centimètres; largeur, 16 centimèlıes et demi. 18 lignes par page. - (Ancien fonds 1067 , Colbert 4.1.)

\section{7.}

بط tous les autres n, par' Abou 'l-Ilosain Sa'id ibn Hibat Allah ibn al-Hasan, médecin du calife abbaside Al-Moqtadir, nort vers le milicu du xı siècle de J. C. Louvrage se compose de tableaux, où sont indiquées les maladies, lent's causes, leurs symptomes el leur traitement. Com-

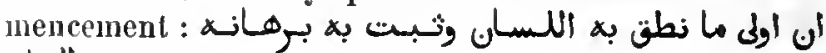
s.

Ms. daté de l'an 597 de l'légoire (1 201 de J. G.).

Papier. 103 feuillets. Hauteur, 20 centimètres et demi; largeur, 15 centimètres et demi. - (Ancien fonds 1075 , Colbert 4651 .)

Mème ouvrage.

\section{8.}

Papier. 104 feuiltets. Hauteur, 28 centimètres et demi; largeur, go centimètres et demi. Ms. du $x v^{\circ}$ siècle. - (Ancien fonds 1007. )

\section{9.}

ise Juste milieu pour la guérison des esprits et des corps", traité de médecine en sept discours (maqúlat), composé par 'Abd alMalik ibn Zohr (Avenzohar) ibn 'Abd al-Malik, et dédié au priuce almoravide, lbrâhìm ibn Yoûsof ibn Taschefin. Dans l'explicit, l'auteur promet de faire suivre cet ouvrage d'un second volume. Écriture sans points diacritiques; le premier cahier est d'une main plus moderne.

Papier. 141 fenillets. Hauteur, a a centimètres el demi; largeur, 15 centimètres. 19 tignes par page. Ms. du sv1 $^{\circ}$ siècle. - (Supptément 1057 .) 


\section{0.}

i Traité des aliments et de l'hygiène, par Aboû Marwân 'Abd al-Malik ibn Zohr. C'est l'Abomeron Avenzohar قال عبد : de l'ancienne traduclion latine. Commencement

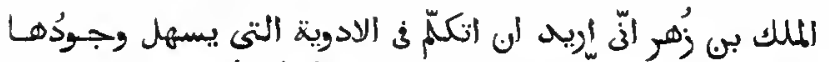

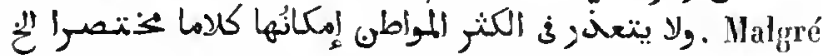
cette déclaralion, l'auteur s'occupe principalenent des aliments, de la chair des animaux el de l'hygiène. Copie

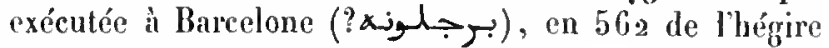
(1 166 de J. C.).

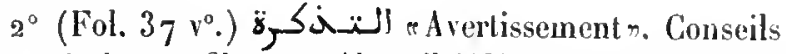
adressés à son fils, par Abou 'l-cAlà Zohre, fils d'Aboù Marwån 'Abd al-Malik ibn Zohr, et se rapportant à la pralique de la médecine. Chaque conseil commence par le mot تن r souviens-toin. Cette pièce n'a pas de préface.

$3^{\circ}$ (Fol. $42 \mathrm{v}^{\circ}$.) Recueil de recettes, par un anonyme, probablement par un des nombreux membres de la famille Zolır. Commencement : ذكر الادوبة اللتى تُختِكي

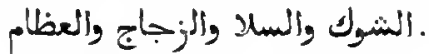

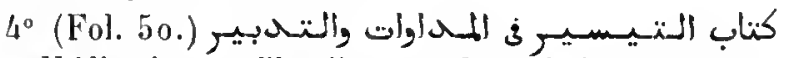
"Isa Médication el l'hygiène rendues faciles", par le

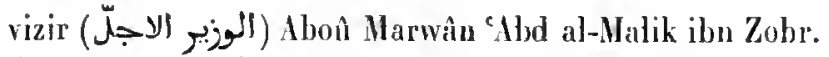
Cel onvrage, très élendu, conmence par une note de

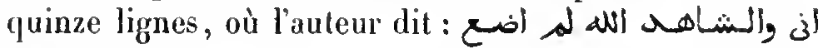

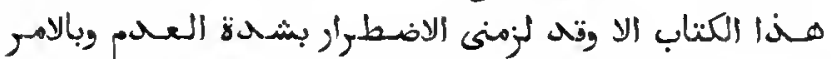
لثلك. La préface commence par ces mots :

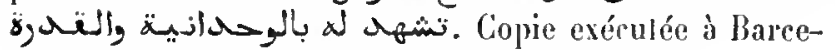
lone, en 561 de l'hérgire $(1165-1166$ de J. C.).

Le ms. tout entier est de la mème main.

Papicr. 201 feuillets. Hauteur, 25 centimètres et demi; largeur, 19 centimètres et demi. 2 lignes par page. - (Ancien fonds 1028.)

\section{1 .}

Produits intellecluels qui conduisent vers les voies plilosopliques $n$, traité de médecine, par Mbô 'Abd Allalı Moḷammad ibn Alımad al-Albì'i (الالبيد, né à Elvira, en Espagne?). Cet ouvrage, qui est silus prélace, Iraite des devoirs d'un pharmacien et des instruments dont celui-ci a besoin pour ses nanipulations; puis des verlus des divers minéraux el drogues, des saisons de l'année, des jours de la semaine el des quat'e lumeurs, des nualadies provenant du dérangrement des liumcurs et des maladies qui affectent les divers membres du corps. On tromve ensuite

$$
\text { Mas. qmeatal. - II. }
$$

des instructions pour la préparation des loochs, tisanes, pastilles, poudres, élecluaires, elc. L'ouvrage se termine par des observations sur les vertus de certains produits végétaux et par un recueil de recetles.

Ms. daté de l'an 612 de l'bégire ( 1216 de J. C.).

Papier. 130 feuitlets. Hauteur, 21 centimètres; largeur, 13 centimètres el demi. 15 à 17 lignes par page. - (Ancicn fonds 1068.)

\section{2 .}

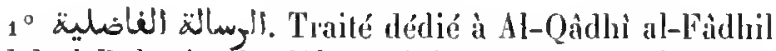
('Abd al-Ralymàn ibn 'Alì), ministre du sultan Saladin, par Aboù 'Imràn Moûsâ ibn 'Obaïd Allalı, de Cordone, nieux conuu sons le nom de Ibn-Maimoun ou Mä̈nonide. Cet écrit se compose de deux parties (نوع), dont chacme est divisée en plusieurs clapilres. La prenière partie traite des piquires des repliles, la seconde, des empoisomnements. Cie traité a été composé au Caire, en 575 de l'hérgire ( 1180 de J. C.).

$2^{\circ}$ (Fol. 34.) (Qllestion sur les églises r. Il s’agit des églises que les chréliens possédaient au Caire et qui avilient été fermées par l'autorité musulmane. Les chréliens ayant réclamé, le cas lut soumis au docteur hanbalite Taqì al-Dìn ibn Taïniya al-Ịtarrânì, qui approuva la mesure prise par le gouvernement. Ce traité renferme la Question in extenso, ainsi que la Réponse.

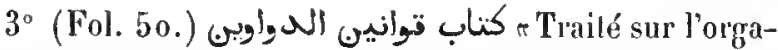
nisation des bureaux $\%$. 11 s'agit des bureaux de l'administration financière en Egypte, au xin' siècle. Le traité se compose de dix chapitres : $1^{\circ}$ sur les écritures et les écrivaius; $2^{\circ}$ sur les devoirs des écrivains; $3^{\circ}$ sur le persounel des bureaux; $4^{\circ}$ sur les voies et moyens (- Holefl

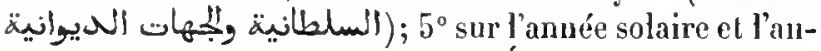
née lunaire; $6^{\circ}$ sur les terres de l'Égypte et leurs divers caractères; $7^{\circ}$ sur les cauaux et les chaussées (2-ج) ; $8^{\circ}$ sur le cadastre; $9^{\circ}$ sur la valeur relative des divers produits de la terre; $10^{\circ}$ sur la question de savoir si les r'èglements de l'administration s'accordent avec les préceptes de la loi. Le premier feuillet de cet ourrage instructif manque, ainsi que quelques feuillets au milien.

Copie datée de l'an 651 de l'hégire (1 253 de J. C.).

Papier. 97 feuillets. Itauteur, 17 centimètres; largeur, 12 centi-

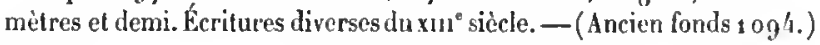

\section{3.}

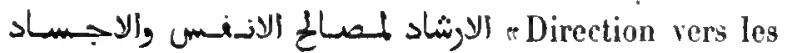
67 
choses utiles pour l'àme et le corps», traité de médecine, en quatre sections (maqdald), par Abou 'L-Makàrim Hibat Allah ibn Djamí (جي) al-Isräili. L’auteur étant mort avaut d'avoir mis son ouvrage au net, son fils, Abou 'l-Ṭâhir Ismà'il, surnommé Sanìa 'l-llolk (صنيعة كll), s'acquitta de cette tâche.

Papier. 307 feuillets. Hauteur, 29 centimètres et demi ; largeur, so centimètres. 21 liggnes par page. Ms. du Xvi sièele. - (Supplément 1063.)

\section{4.}

Traité de la thériaque.

Ms. daté de l'an 595 de l'hégirc. Nombreux olnements ot miniatures. Le premier feuillet manque.

papier. 73 fenillets. Hauteur, 37 centimètres; largeur, 29 centimètres. - (Supplémeat a433.)

\section{5 .}

1 مة Tables synoptiques des médicaments simplesn, par lbràhîm ibn abì Sacid al"Hî̀, médecin maglırebiı. L'ourrage renferme une introduclion et scize tableaux doubles, dans lesquels les noms des simples sont inserits suivant l'ordre de l'alphabet أب avec l'indicalion de leurs vertus et de

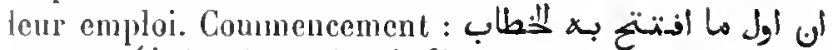

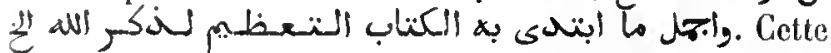
copie est probablement du commencement du $\mathrm{xv}^{\mathrm{e}}$ siècle.

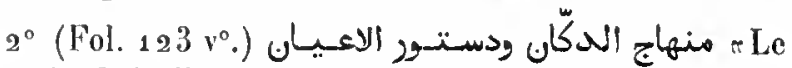
Chemin de l'officine et le guide pour les hommes distingués ", lraité de plrarmaceutique en vingt-cinq chapitres. L'auleur, Abou 'l-Mlonâ (لن) ibn abì Naṣr ibn Haffàz. (bانـ ) généralement connu sous le nom de Kỏhén le drogriste (الكوهين (العطّ), nous apprend dans sa préface fu'il demeurait au Caire, en 658 de l'hégire (1 260 de

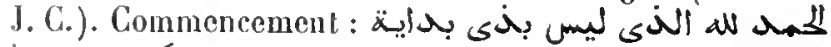
. Cيكور مسبورقا Copic daléc de l'an 932 de l'hégire (1526 de J. C.).

Papicr. 233 feuillets. ILauteur, 26 centimètres et demi; largeur, ${ }^{2} 7$ centimètres et demi. - (Ancien fonds 1027 .)

\section{6.}

Le Taqwìn al-Adwiya d'Ibn abî Sacid al-'Mlài.

Papicr. 134 feuillets. Ilauteur, 26 centimètres; largeur, 16 centimètres. Ms. du xvi siècle. - (Aucien fonds 1 032.)

\section{7.}

$1^{\circ}$ Même ouvrage.

$2^{\circ}$ (Fol. 150.) Sur la préparation des potions. Extrait du Schafa de Haddji Pacha.

$3^{\circ}$ (Fol. $150 v^{\circ}$.) Chapitre sur les poids et mesures.

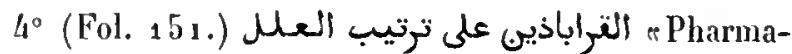
copéc rangée d'après les maladies . Ce traité est attribué à Nadjìb al-Din al-Samarqandi. (Voir fol. $149 v^{\circ}$.)

Papier. 200 feuillets. Hauteur, 21 centimètres et demi; largeur, 16 centimètres. Ms. du $x^{\circ} i^{\circ}$ siècle. - (Supplément 1030. )

\section{8.}

Le Taqwîm al-Adwiya d'tbn abì Sacid al-cAlà'ì.

Papier. 149 feuillets. Hanteur, 23 centimètres; largeur, I 6 centimètres et demi. Ms. du xvü siècle. - (Supplément 1041.)

Méme ourrage.

\section{9.}

Papier. 133 feuillets. Hauteur, 22 centimètres; largeur, 14 centimètres et demi. Mts. du xvir siècle. - (Supplément 1041 bis.)

\section{0.}

Troisième livre de la troisième section du traité de

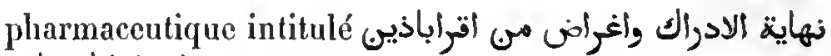
الانتوإباذينات, par Dà'oûd ibn Nâșir al-Aghbari (الاغبراكي), né à Mossoul et établi à Ḥiṣn Kaîfa. D'après la préface, cet ouvrage, qui porte aussi le titre de dolefli, a été composé pour la bibliothèque du sultan Fakhr al-Dîn Solaïmàn, fils dı sultan Schihàb al-Dìn Ghàzì, fils de مولانا السلطان فنـ الملـوك ابـو : Mohammad l'Ayyoubite

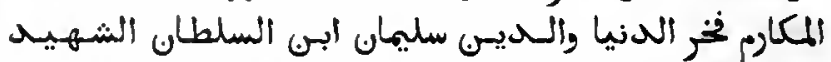

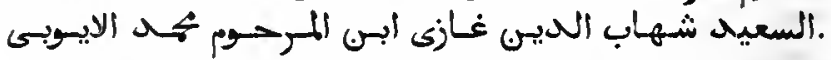
Le présent exemplaire a été écrit en 826 de l'hégire (1423 de J. C.), par 'Îsâ ilon al-Aghlbarì, frère utérin de l'auteur (شقيق مؤلغx). Nous ne savons quel est ce sultan ayyoubide $\mathrm{du} \mathrm{Ix}^{0}$ siècle de l'hégire. Les princes de cette dynastie portent généralement le titre de Ml-Malik al'Âdil. Au commencement et à la fin du ms. se trouvent 
un grand nombre de notes, un traité sur les aplirodisiaques, etc.

Papier. ${ }_{2} 48$ feuillets. Hauteur, 28 centimèlres; largeur, 18 cen(imètres. 16 ligoes par page. - (Ancien fonds 1036.$)$

\section{1 .}

r Livre des causes et des symplômes », Iraité de médecine, par Nadjib al-Din Moḥmmad ibn 'Ali al-Samarqandi, qui ful tué, en 619 de l'Irégire (1 222 de J. C.), lors de la prise de Hérat par les Mongols.

Papier. 201 fevillets. Hauteuc, 24 centimètres et demi; largeur, 16 centimètres et demi. 17 à 19 lignes par page. Il s. du xu1 siècle. - (Ancien fonds 1018, Colbert 4981.)

\section{2 .}

Nême ouvrage.

Ms. daté de l'an 700 de l'hégire (1300-1301 de J. C.).

Papier. 119 feuillets. Hauteur, 23 centimètres et demi; largenr, 16 centimètres. 21 lignes par page. - (Aneien fonds 1063.)

\section{3.}

Mème ouvrage.

Ms. daté de l'an 753 de l'hégire ( 1352 de J. C.). Nonlireuses notes marginales.

Papier. 199 feuillets. Hauteur, 18 centimètres et demi; largeur, 11 centimètres. 17 lignes par page. - (Ancien fonds 1098.)

\section{4.}

Mème ourrage.

Papier. 151 feuillets. Hanteur, 21 centimètres; largeur, 15 centimètres et demi. 21 lignes par page. - (Ancien fonds 1064, Collsert 4653.)

\section{5 .}

Traité de médecine, sans titre ni nom d'auteur. Com-

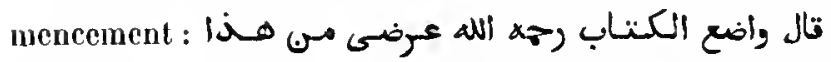

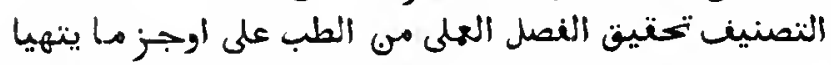

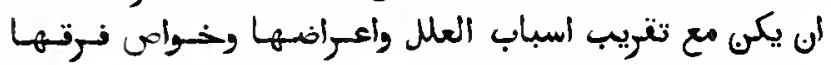
. Après cette courte préface suivent immédiatement les articles consacrés à la description et au traitement de chaque maladie, en commençant par l'alopécie (داء الثعلب). C'est à tort qu'on a pris cet ouvrage pour le Kitâb al-Asbâb de Nadjib al-Din al-Samarqandì.

Ms. daté de l'an 627 de l'hégire (1 230 de J. C.).

Papier. 183 feuillets. IInuteur, a 3 centimètres et demi; largeur, 16 centinetres et demi. 23 lignes par page. - (Ancien fonds 1065 , Colbert 5204.)

\section{6.}

recueil de remèdes", par 'Abdallah ibu - Alumad ibn al-Baịtàr, célèhre botaniste de Malaga. C'est un dictionnaire des simples.

Ms. daté de l'an 1033 de l'hégire $(1614$ de J. C. $)$.

Papier. 401 fevillets. Hauteur, 3o centimètres et demi; largenr, so centimètres et demi. 97 lignes par page. - (Aneien fonds 1093.)

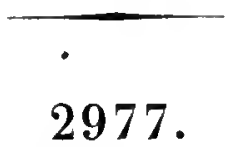

Mème ouvrage. Premier volume, se terminant par la lettre sîn. A la fin du ms. le titre de l'ouvrage est donné

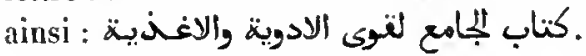

Papier. a 79 feuillets. Hauteur, 25 centimètres et demi; largeur, 17 centimètres. 23 à a lignes par page. Ms. do $x_{1} v^{e}$ siècle. - (Supplément 1025.)

\section{8.}

Même ouvrage. Premier volume, se terminant par l'arlicle سمات̈. Ce volume, très bien écrit, porte souvent en marge les équivalents en caractères grecs, syriaques et coptes.

Papier. $3_{21}$ feuillets. Ifauteur, a 5 centimètres et demi; largeur, 19 centimètres. a 3 lignes par page. NIs. du xv' siècle. - (Ancien fonds 1071.$)$

\section{9.}

Même ouvrage. Premier volume, renfermant les cinq premières lettres de l'alphabet. Le premier feuillet manque.

Papier. sa 1 feuillets. Hanteur, 25 centimètres; largeur, 17 centimètres. 21 lignes par page. Ms. du xiv $^{\circ}$ siècle. - (Ancien fonds 1025 , Colbert 4220.) 


\section{0.}

Mème ouvrage. Premier volunce, finissant par la letire $\tau$.

Papier. 216 feuillets. IIauteur, a 6 centimètres; largeur, 18 ceutimètres, 19 lignes par page. Ns. du $x v^{*}$ siècle. Les 20 premiers feuillets sont plus moderues. - (Supplément 1026.)

\section{1 .}

Même ouvrage. Second volume d'un exemplaire complel, contenant les lettres $\boldsymbol{e}^{\grave{a}}$ ).

Papier. 2.53 fenillets. Ilautcur, 24 centimètres; largeur, 16 centimètres et demi. Environ 5 ligues par page. Ms. du xu1" siècle. Les 30 derniers feuillets sont du xiv siècle. - (Ancien fonds 1074 , Colbert 4221.$)$

\section{2.}

Même ouvrage. Ce volume commence par la lettre $خ$ et finit par la lettre w.

Papier. 182 feuillets. Hauleur, 26 centimètres; Jargeur, 17 centimètres et demi. 23 lignes par page. Iss. du xiv" siècle. Les derniers feuillets sont plus moderues. - (Supplément 1026 bis.)

\section{3.}

Nème ourrage. Volume commençant par la lettre w el finissant par la lettre $\varsigma$.

Papier. 211 feuillets. Hauteur, 27 centimetres et demi; largeur, 18 centimètres et demi. 25 ligues par page. Ifs. du xv siècle. Les douze derniers feuillets sont plus modernes. - (Supptément 1028.)

\section{4.}

Hême ouvrage. Cie volume commence par la lettre ش et finit par la lettre 5 .

Ms. exéculé en 668 de l'hégire (1 270 de J. C.), par un nıédecin nommé eAbd al-Salâm ibn 'Othmàn ibn Ṭarkhân. 11 a été collationné plusieurs fois. Les points diacritiques sont souvent omis. Qualre feuillets, vers la fin du volume, sont d'une écrilure plus moderne; il en est de même des fenillets $2,3,4$ et 5 .

Papier. 219 feuillets. Hauteur, 25 centimètres; largeur, 17 centimètres. 21 lignes par page. - (Supplément 1025 bis.)

\section{5.}

Même ouvrage. Ge volume commence par la lettre ش et finit par la letlre 3.

Papier. 279 fenillets. Hautcur, 24 centimètres; largeur, 17 centimòtres. 19 lignes par page. Ms. de diverses mains du $\mathbf{x i v}^{\circ}$ siècle. (Supplément 1026 ter.)

\section{6.}

Mêmc ouvrage. Volume commençant par la lettre io et finissant par la lettre $s$. Les noms des substances sont reproduits en marge.

Ns. daté de l'an 1047 de l'hégire ( 1637 de J. C.).

Papier. 323 feuillets. Hauteur, 21 centimètres; largeur, 15 centimètres. 21 ligues par page. — (Supplément 1027.)

\section{7.}

Mềme ouvrage. Volume commençant par la letıre قet finissant par la lettre $s$. Le titre et le nom de l'auteur sont écrits en lettres d'or et entourés d'arabesques.

Papier. 209 feuillets. Hauteur, 26 centimètres; Jargeur, 17 centimètres et demi. a 3 lignes par page. Ms. du xuı siècle. - (Ancien fonds 1026, Colbert 4242.)

\section{8 .}

Même ouvrage. Ce volume commence par la lettre et se termine par la lettre s.

Papier. 240 feuillets. Hauteur, 26 centimètres; largeur, 17 centimètres et demi. 19 lignes par page. Ms. du $\times 10^{\circ}$ siècle. Les 32 premiers fevillets sont plus modernes. - (Supplément 10964.)

\section{9 .}

Extraits du mème ouvrage.

Papier. 4 feuillets. Hauteur, 32 centimètres et demi; largeur, 2o centimètres. 22 à 25 lignes par page. $\mathrm{Ms}$. du xix siècle. - (Supplément 2261.)

\section{0.}

r Traité qui suffit pour faire con- 
naitre les médicaments simples", par 'Abd Allah ibu Alımad ibn al-Baițàr. Truité de pathologie spéciale et de malière médicale, divisé en vingt sections, qui traitent successivement de la tète, des yeux, des oreilles, des narines, de la bouche, de la gorge, de l'estomac, du foie el de la rate, des inteslins, de l'anus, des reins, de la vessie, du membre viril, de la matrice, des articulations, des blessures et des ulcères, des lumeurs, des fards, des fières, des poisons, enfin des propriétés de certains simples qui ne sont pas employés comme remèdes. Com-

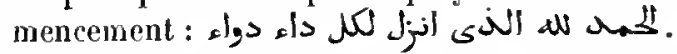

Papier. $3{ }_{1} 3$ feuillets. Hauteur, 54 centimètres; largeur, 25 centimètres el demi. 21 lignes par page. Ms. du xur' siècle. -- (Ancien fonds 1008.)

\section{1.}

Première partie dı mème ouvrage.

Exemplaire écrit à Damas, en $69^{5}$ de l'hégire $\left(129^{6}\right.$ de J. G.).

Papier. 293 fenillets. Hauteur, 24 centimètres et demi; largeur, 17 centimètres. 7 lignes par page. - (Supplément 1029.)

\section{2.}

1 o La Perle choisie, traité des remèdes approurésn, par le cadi $\Lambda$ boù Bakr a1-Fàrisi. Douze chapitres. L'auteur, parmi d'autres remèdes, recommande particulièrement plusieurs amulettes, charmes et talismans dont il donne les modeles. Il dit, dans la prélace, avoir conposé ce traité sur la demande d'un sultan quil appelle M-Malik al-Mowaïgad Dàoùd, fils du sultan Al-Malik al-Mozaffar, fils du sulIan Al-Malik al-Ilanșoûr. (On ne devra pas confondé ce prince avec le sultan de Hamàh, Abou 'l-Fidà, historien ef géographe, qui se nommait Ismâil, et n'était pas fils, mais petit-fils d'Al-Mlalik al-Mo?.affar ll). Commencement :

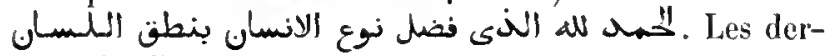
niers feuillets manquent.

$\therefore 2^{\circ}$ (Fol. 95.) Prière efficace qui préserve l'homme de tons les max. En marge, on trouse, écrites d'une autre main et en petits caractères, des instructions pour la manipulation des diverses substances minérales, végétales et animales,

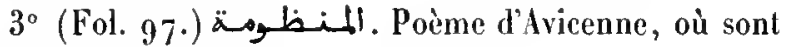
résumés les principes de l'art inédical. $4^{\circ}$ (Fol. $\left.108 \mathrm{v}^{\circ}.\right)$ Recettes pour composer certains électuaires, etc.

Papicr. 109 feuillets. Hauteur, 17 centimètres et demi; largeur, 13 centimètres. 3 lignes par page. Ms. du $x v^{*}$ siècle. - (Ancien fonds 1085 .)

\section{3.}

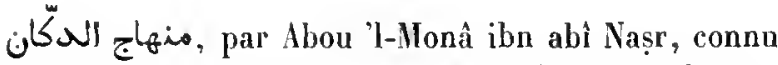
sous le nom de Kôhên al-`Attàr. (Voyez ci-dessus, $\left.\mathrm{n}^{\mathrm{0}} 29^{65}, 2^{\circ}\right)$.

Papier. ${ }_{2} 52$ fenillets. Ilauteur, 23 centimètres et demi; largeur, 15 centimètres et demi. 16 lignes par page. Ms. du xm" siècle, écrit probablement du vivant de l'auteur. - (Ancien fonds 1086. )

\section{4.}

Même ouvraģc.

Papier. 147 feuillèts. Jauteur, 25 cenlimètres; largeur, 18 centimètres. 19 ligones par page. Ms. du xıv' siècle. Les dix-sept premiers feuillets sont plus modernes. - (Supplément 1066.)

\section{5.}

Mème ourrage.

Papier. 97 feuiltets. Hautenr, ag centimètres et demi; largeur, 2o centimètres. 33 lignes par page. Ms. du xw1" siècle. - (Ancien fonds 1033 , Colbert 1756. )

\section{6.}

Fragments du même ouvrage. C'est une partie considérable du vingt el uniène chapitre, précédé d'une liste alphabétirque des succédanées, et une parlie du vingtdeuxiène chapitre, qui traite des poids et des mesures.

Papier. 40 feuillets. Hauteur, 27 centimètres; largeur, 18 centimètıes. 17 lignes par page. Ms. du xiฑ siècle. - (Supplément 2106.)

\section{7.}

ارجـ أز chrétien copte nommé Mofaddlual ibn Màdjid ibn alBischr. L'auteur a donné à son ourrage te titre de 
لـeل Moyen d'apaiser la soif (de connaissances médicales) et l'avantage de boire une seconde fois ${ }^{\circ}$. Commencement :

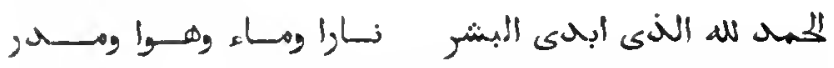

Ms. aulographe, daté de l'an $66_{7}$ de l'hégire (1 a 68 1269 de J. C.).

Papier. 137 feuillets. Hauteur, 21 centimètres et demi; largeur, 16 centimètres. 13 lignes par page. - (Supplément 1021.)

\section{8.}

$1^{\circ}$ Même ourrage.

$2^{\circ}$ (Fol. $109 \mathrm{v}^{\circ}$.) Commencement de l'épître sur les maladies des yeux, par' 'Îsâ ibu 'Alì, médecin du $\mathrm{Ix}^{\mathrm{C}}$ siècle.

$3^{\circ}$ (Fol. 117. .) Traité sur les proptriétés profilables ou nuisibles des choses crées : de l'homme, des animaux, des plantes et des jierres. Il manque, au commencement, un feuillet, et à ta fin il en manque plusieurs. Le pre-

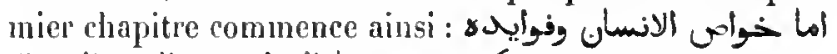

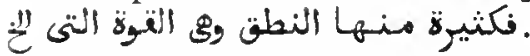

Papier. 184 fenillets. Hauteur, 16 centimètres; largeur, 13 centimètres. Écritures diverses. - (Supplément 1031.)

\section{9.}

"Le Suffisant, traité des collyres», par Khalifa ibn abi 'l-Malatsin. Cet ourrage traite de l'anatomie de f'cil, des maladies des yeux et de l'art de l'oculiste. Plusieurs chapitres sont disposés en deux colonnes.

Ms. daté de l'an 674 de l'hégire (1 $27^{6}$ de J. C.).

Papier. 248 feuillets. Hauteur, s lu centimètres et demi; largeur, 16 centimètres. 21 à 27 lignes par page. - (Supplément 1043.)

\section{0 .}

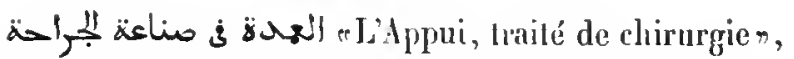
par Abou 'J-Faradj Ya'(yoûb ilon Isḷât ibn al-Koff, médecin clurétien melkite, mort en $6 \dot{85}$ de l'hégrire (1 286 ${ }_{12} 87$ de J. C. ). Cet ouvrage se compose de vingt sections (maqâlât), dont chacune est divisée en plusieurs chapitres

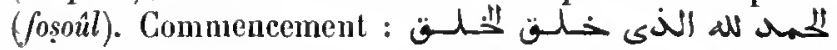
هieris.

Papier. 423 feuillets. Hauteur, so centimètres et demi; largeur,
15 centimètres et demi. 2 lignes par page. Ms. du xvin' siècte. - (Supplément 1023.)

\section{1 et 3002.}

Traité de médecine qui, comme le Moghnî d'ibn alBaị̂âr, énumère les diverses maladies et les simples que l'on emploie pour les guérir. L'ourrage, dont l'auteur est كتاب

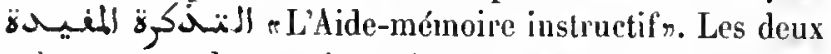
rolumes sont les parties, séparées par erreur, d'un seul et mème nıs. Il y a plusieurs lacunes et interversions de feuillels.

Ms. daté de l'an 658 de l'hégire (1 260 de J. C.).

2 vol. Papier. 152 et 96 feuillets. Hauteur, 25 centimètres et demi; largeur, 18 centirnètres, 21 lignes par page. - (Ancien fonds 1094 et 1034.)

\section{3.}

Abrégé de l'Aide-mémoire d'Al-Sowaidi, composé en 953 de l'hégire ( 1546 de J. C.). Com-

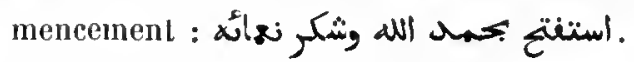

Papier. 166 fevillets. Hauteur, 21 centimètres et demi; largeur, 16 centimètres. a 3 lignes par page. Ms.du xvi1 siècle. - (Supplément 1054.)

\section{4.}

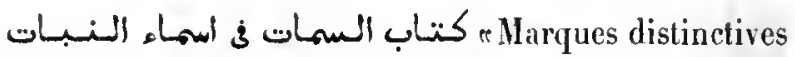
(appliquées) aux noms des plantes 7 . Dictionnaire des simprles. Les articles sont disposés selon l'ordre de l'alphabet $\lambda$. On y trouve assez sourent des synonymes grecs, latins et berbères. Ce ms. est de la main de l'auteur, qui a introduit beaucoup de changements et de corrections dans son ouvrage. Ise premier et le dernier feuillet manquent. Un copiste musulman du xvm" siècle a essayé de reproduire la préface d'après un feuillet détérioré, mais il n'a pu en déchiffrer que les buit premières lignes et la fin de la neuvième. Cette préface commence ainsi :

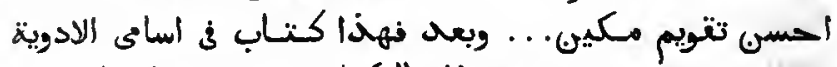
.... . . Le mêne copiste a écril le titre, en tête du volume, en faisant observer que ce ms. était de la main de l'auteur, le savant schaỉkh Ilırâhîm ibn Aḷmad ibn Tarkhân. D'après Hadji Khalfa (t. II, p. 260), Ibrâhîn ibn Țarkhân al- 
Sowaïdi, mort en $69^{\circ}$ de l'hégoire ( 1291 de J. C.), se nommait Ibrìlıim ibn Mlọammad.

Papier. 307 feuillets. Hauteur, 24 centimètres el demi; largeur, 17 centimètres. 15 lignes par page. - (Supplément 877.)

\section{5.}

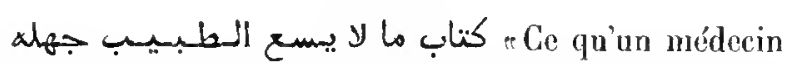
ne doit pas ignorer», par Djamal al-Din Yoùsof ibn Ismâil, ibn al-Kolbi al-Djowainin, médecin de Baghdaid. Cet ouvrage se compose de deux parties, dont l'une traite des médicaments simples, l'autre des médicaments composés. Le présent ms, renferme la première partie, qui a été terminée en 711 de l'hégire $(1311$ de J. C.). La pré-

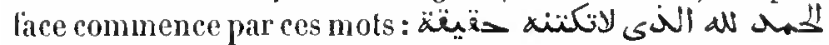

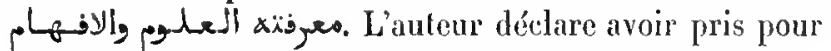
modèle l'ourrage d'llon al-Baitầ sur le même sujet.

Ms. daté de l'an 913 de l'hégire (1507 de J. C.).

Papier. 311 feuillets. Hauteur, 27 centimètres; largeur, 18 centimètres el demi. 23 lignes par page. - (Ancien fonds 1030 , Colbert 2874 .)

\section{6 .}

Hême ourrage. Première partie.

Papier. 304 feuillels. Ilanteur, 21 centimètres el demi; largeur, 15 centimètres el deni. 25 lignes par page. 11 , du xvi siëcle. (Ancien fonds 1072. )

\section{7.}

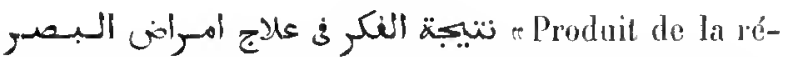
flexion sur le traitement des maladies de la vuen, par Fatly al-Din Aḷmad ibu 'Othuàn al-Qaïsi. L'ourrage se compose de quinze chapitres. Commencement: w W L

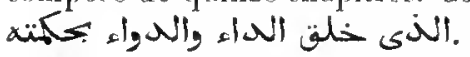

Ms. daté de l'an 850 de l'hégire (1446-1447 de J. C.).

Papier. 90 fenillets. Hauteur, 21 centimètres; largeur, 15 centimètres el demi. 17 lignes par page. - (Supplément 1044.)

\section{8 .}

-Lumière des yeux et Recueil d'observations diverses(?)». Traité d'ophthalmologie, composé par un praticien pour l'instruction de son fils,

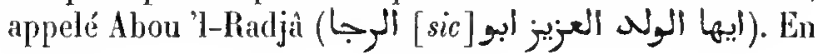

tète du volume, on lit le nom de l'antenr ainsi : Salàḷ al-Din ibn Yoùsof al-Kaḥ!̣âl (l'oculiste), de Hamâh. Les dix chapitres (maqâla) de l'onvrige sont divisés en sections $(b a b)$. L'anteur y traite de l'anatomie de l'oil, de la vision, des opérations el des instruments dont on se sert; il donne les dessins de ces instruments. Le dixième chapitre renferme les noms el la description des simples qu'on emploie pour guérir les maladies des yeux. Celte liste est disposée dans l'ordre de l'alphabet. Commence-

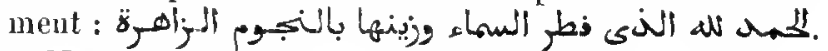
Ms. daté de l'an 1126 de l'hégire (1 714 de J. C.).

Papier. 178 fenillets. Hauteur, 3 a centimètres; largeur, a 1 centimètres el demi. 27 lignes par page. - (Supplément 1 o'12.)

\section{9 .}

r. Causes des maladies et leurs symptômes». Ce titre est commun à plusieurs ouvrages; le commencemenl du présent exemplaire manque el il n'a pas été possible de lidentifier. Il se compose de denx parties: la première est consacrée aux maładies et la seconde aux symptòmes. Le premier paragraplie (fol. $11^{\circ}$ ) conmence

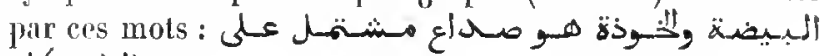

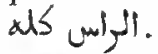

Ms. daté de l’an 731 de l'hıégire $\left(133_{1}\right.$ de J. C.).

Papicr. 147 fenitlets. Ilauteur, 18 centimètres; largeur, 13 centimètres. 11 liggnes par page. - (Supplément 1036.)

\section{0 .}

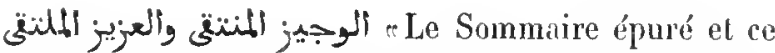
qui est précieux ramassér, par Schihâb al-Dìn Aḅmad ibon Yousôl al-Safadi, médecin du xıre siècle. L'auteur raconte, dans un style llemi el en prose cadencée, l'entretien d'un sultan avec dix phitosophes (ف) (ف) au sujet de la médecine et les faits singuliers dont ces personnages avaient été les témoins. Cotte copie, d'après une note qu'on lit en tête, est la deuxiéme écrite de la main

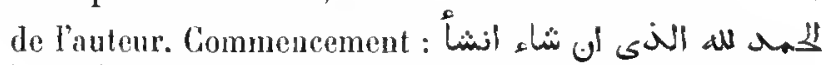

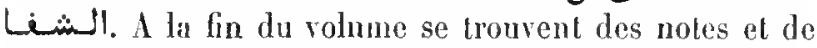
courtes anecdotes se rapportant ì des personnages historiques.

Ms. autographe, daté de l'an 742 de l'hégire (1341 de J. G.).

Papier. 62 feuillets. llauteur, 22 centimètres; largeur, 15 centimètres et demi. 17 lignes par page. - (Ancien fonds 1055, Colberl 4729 .) 


\section{1.}

• r Acte de eelui qui emploie son habileté (ou son talcut médical) en faveur de cehii quil aimen, traité de médecine, par le célèbre vizir espagnol, Lisàn al-Dìn ibn al-Khatîb (Moḥammad ibn 'Abd Allah), qui fut mis à mort en $77^{6}$ de l'hégire $\left({ }^{3} 3_{7}^{4}\right.$ de J. C.). Cet ourrage est dédié au prince mérinide, Aboû Sâlim, frère d'Aboù 'Inân, qui lut proclamé sultan du Maroe en 760 de l'héririre ( 1359 de J. C.). Il se compose de deux parties, l'une consacrée anx maladies qui affectent tout le corps, la seconde aux maladies spéciales. L'auleur a choisi comme titre une expression proverbiale, usitée de son temps, el rui signifie : rll a agi comme ayit celui qui emploic de l'adresse à l'égard de la personne qu'il aimen, et qui se retrouve sous une autre forme, dims Al-Maïdâni, où on lit, t. Il, p. 668

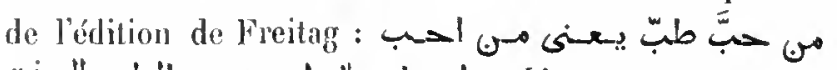

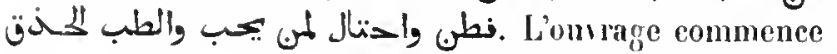

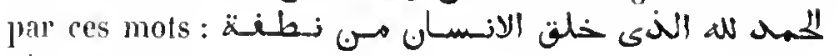
ج.

Ms. daté de l'an 894 de l'hégire ( 1489 de J. C.).

Papier. 197 feuillets. Ilauteur, 22 centimètres; largeur, 14 centimèlres et demi. 19 lignes par page. - (Ancien fonds $107^{\circ}$, Colbert 5200$.

\section{2.}

 mèdes contre les douleursn, par Khidr ibn 'All ilsn atKhattâb, surnommé l!âddji-Pacha (حاخ باش). Ce traité de médecine est dédié au sultan 'Îsà, fits de Molnammad, fils d'hïdin (إيـحيـ(). Aidin, l'un des chef's tures qui se rendirent indépendants après la chute des Seldjoukides et avant l'élablissement de la dynastie ollomane, régna sur la Carie et li Lydie, pays qui forment encore la province d'Aidin (Aidin-Ilé). Son fils Mlọammad régna après lui ct cut pour successeur son fils 'Îsá, ainsi qu'il ressorl de la dédicace de Ilàddji-Pacha. L'ouvrage a élé composé en 78 a de l'hégire ( $380-138$ t de J. C.). 11 esl divisé en quatre sections : $1^{\circ}$ principes généraux; $2^{\circ}$ boissons et médicaments; $3^{\circ}$ maladies spéciates; $4^{\circ}$ maladies géné-

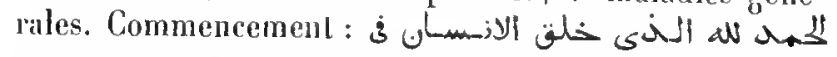

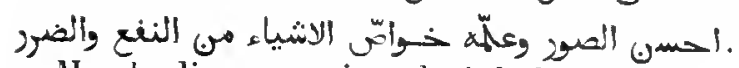

Is. de diverses mains, daté de l'an 914 de l'hégire ( 1508 de J. C.).

Papier. 466 feuillets. Hauteur, 26 centimètres; largeur, 18 centimèires. 25 à 32 lignes par page. $-($ ( nacin fonds 1017.$)$
Mème ouvrage.

\section{3.}

Ms. daté de l'an 973 de l'hégire ( 1566 de J. C.).

Papier. 465 feuillets. Hauteur, 27 centimètres; largeur, 18 centimètres. 35 lignes par page. - (Supplément 1060.)

\section{Mème ouvrage.}

\section{4.}

Papier. 311 feuillets. Hauteur, 30 centimètres; Iargeur, 21 centimètres. 33 lignes par page. Ms. du xvir siècle. - (Supplément 1060 bis.)

\section{5.}

Traité de médecine en vingt-cinq chapitres, composé vers la fin du vun ou au commeneement du $1 \mathrm{x}^{\mathrm{e}}$ siècle de l'hégire (l'auleur se trourait à Jérusalem en $79^{\circ}$ de l'hégire). Le premicr chapitre traite des qualités requises dans un médecin; le second, de la conduite du médecin ']uand il se présente chez un malade; le troisième, des causes des maladies qui affectent les articulations; le dernier chapitre (fol. $175 \mathrm{v}^{\circ}$ ) est intitulé : 3

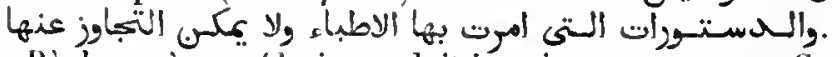
r Règles qu'un médecin ne doit jamais transgresser . Ce chapitre est beaucoup plus long que les autres. C'est à

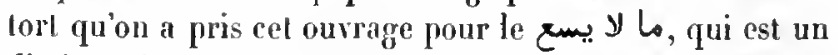
dictionnaire des simples. Le commencement et la fin du ms. manquent.

Papier. 299 fenillels. Hauteur, 3o centimètres; largeur, 18 centimèlres. 17 lignes par page. Ms. du xvi siècle. - (Aneien fonds 1029. )

\section{6.}

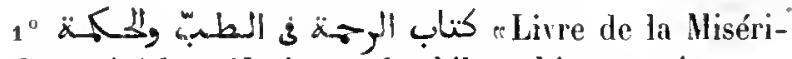
corde, traité de médecine ct de philosophien, en einr sections. En tête du ms. on lit que l'auteur se nommait Schihaib al-Din Al!mad ibn Zerdouk(?). D'iprès Hadji Khalfa) I. III, p. 351), l'auten' est Mahdi ibn 'Ali al-Ṣo-

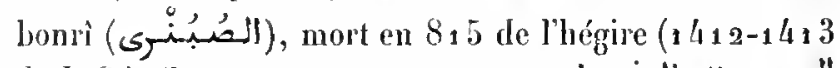

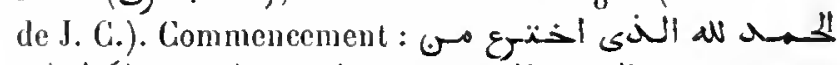

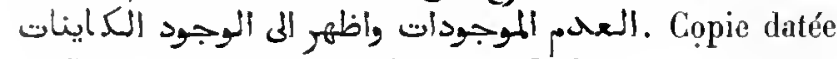
de l'an 1118 de l'hégire ( 706 de J. C.).

$2^{\circ}$ (Fol. $40 v^{\circ}$.) Traité de médecine, en dix sections (bâb), dont chacune est divisée en plusieurs chapitres. 


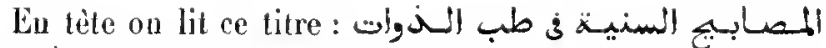
enes Lumières précieuses sur l'art de gouérir les êtres liumajus", et le nom de l'auteur Schiluàb al-Dìn

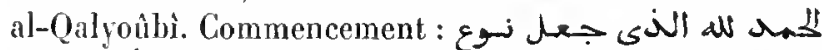
الانسيان كما انسواع. Copie datée de l'an $109^{3}$ de l'hégire (1682 de J. C.).

$3^{\circ}$ (Fol. $92 v^{\circ}$.) Vers attribués ì l'imâm Al-Schafíi.

$4^{\circ}$ (Fol. 94.) Parotes attribuées à Hahomet.

$5^{\circ}$ (Fol. $95 v^{\circ}$.) Abrégés du traité de thérapeutique

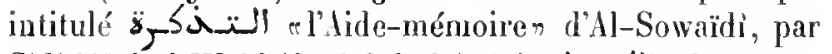

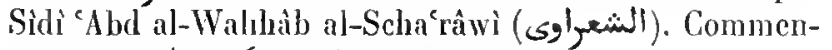
cement: أستفتح بحمد الله وشكر نهائ.

Papier. 213 feuillets. Hauteur, 20 centimètres et demi; largeur, 16 centimètres et demi. Écritures diverses. - (Supplément 1045.)

\section{7.}

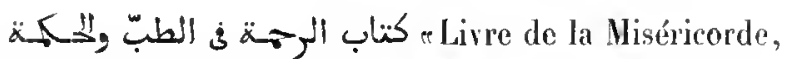
Iraité de la science médicalen. Même ouvrage que l'article $1^{\circ}$ du numéro précédent.

Papier. 47 feuillets. Hauteur, 24 centimètres; largenr, 15 centimètres et demi. 19 lignes par page. Ms. du $x^{\circ} 0^{\circ}$ siècle - (Supplément 2352 .)

Mème ourrage.

\section{8.}

Papier. 117 fenillets. Hauteur, 20 centimètres; largeur, 15 centimètres. Écritures diverses du xix siècle. - (Supplément 2357.)

\section{9.}

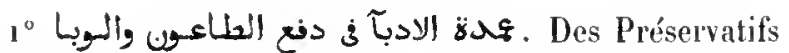
contre la peste, par Schiluâb al-Dìn ibu Aḷmad alSchosclitarí.

$2^{\circ}$ (Fol. 95 vº) La La لاميّة الع.

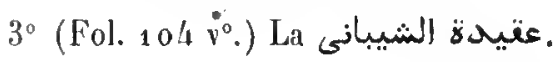

$4^{\circ}$ (Fol. $115 \vee^{\circ}$.) Traité sur l'excellence des chevaux, par Walì al-Din al-'Irâqì.

$5^{\circ}$ (Fol. $172 v^{\circ}$.) Qaṣida d'Ismàîl ilon al-Mloqrì alYamauî.

$6^{\circ}$ (Fol. 18ı.) Des idées d'Aristote qu'on retrouve dans les poésies d'Al-Motanabbi.

$$
\text { Ma. ontertak. - if. }
$$

$7^{\circ}\left(\right.$ Fol. $\left.200 \mathrm{v}^{\circ}.\right)$ Recueil d'extraits en prose et en vers.

Papier. 271 feuillets. Hanteur, 18 centimètres; largeur, 13 centimètres. 7 lignes par pagé. Ms. du $x \mathrm{v}^{\mathrm{e}}$ siècle. - (Supplément 1943.)

\section{0 .}

Traité qui lacilite l'emploi des enseignements utiles qui sont fournis par la médecinen, par Ibràhim ibn 'Alì ibn abì Bakr al-Azraq. Cinq sections, dont la première contient quelques notions de pliysinue, considérées au point de vue de l'art de guérir; la deuxième traile de la nature et des propriétés des aliments et des médicaments; la troisième, de l'hygiène; la quatrième, des maladies qui n'affectent qu'une parlie du corps; la cinquième, des maladies qui affectent tout le

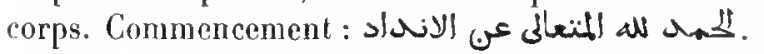

Papier. 161 feuiltets. Hauteur, a 1 centimètres; largenr, 15 centimètres et demi. 23 lignes par page. Ms. du xvir siècle. - (Supplément 1048.)

\section{1.}

Même ouvrage.

Papier. ${ }_{7} 5$ feuillets. Hauteur, 21 centimètres; largeur, 15 centimétres, 31 lignes par page. Ms. du xvn' siècle. - (Supplément 1040.)

\section{2 .}

Traité de médecine que l'auteur inconnu présente conme le résumé du مغني d'Al-Zobaïdi. Les sections de ce traité sont les mèmes que les cinq sections du Tashîl, el c'est à ce dernier traité que le compilateur a cmprunté une partie de ses matériaux. Le présent rolume porte en tête le titıe de

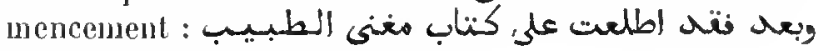
"و

Papier. 148 feuillets. Hauteur, 21 centimètres; largeur, 15 cenlimètres et demi. Environ 23 lignes par page. Ms. du xvit siècte. (Supplément 1050.)

\section{3.}

enédicaments de l'officine r. Traité sur la composition des sirops, des électuaires, des condi- 
ments, des pastilles, des onguents, etc. Commencement:

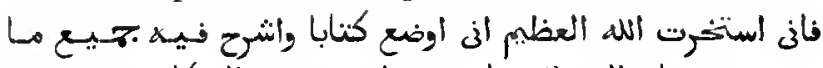

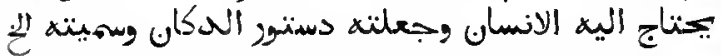

papier. 62 feuillets. Ifateur, 15 centimedres; largeur, 11 centimètres. 11 lignes par page. Ms. du xve siècle. - (Ancien fonds 1101 , Collert 6601.)

\section{4.}

Traité des empoisonnements, attribué à un médecin nommé Djamàł aJ-Din 'Ald Mllah ibn 'Ali ibn Ayoub, de Damas (voy. Hadji Khalfa, t. VI, p. 343, 344). Le titre de ret ouvrage est incerain. On lit deux titres différents en

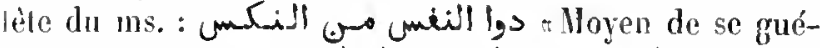

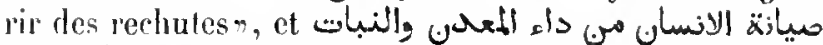

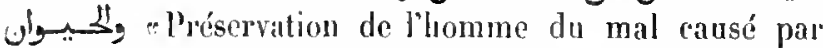
les minéraux, les plantes et Jes animaux \%. L'ouvrage est divisé en trois sections, dont la prenière traite de l'introduction du poison dans le corps; la seconde des animanx dont la picpure est dangereuse, ot la troisième des remèdes.

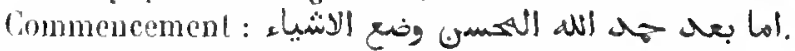

H. daté de l'an 900 de l'luégire (1494 de J. C.).

Papier. 38 feuillets. Ilauteur, 32 centimètres et deni; largeur, 16 centimires et demi. 23 lignes par page. - (Ineien fonds 108\%.)

\section{5 et 3026 .}

Commentaire sur le traité de médecine intitulé äsidl, et attribué par Hadji Khalfa à un autrur égyptien nommé Ibn abi Soroùr al-Sàwi al-Isràili. Le commentaire, intitulé

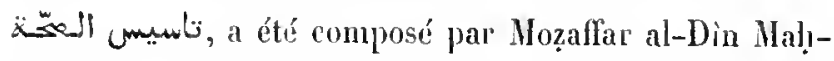

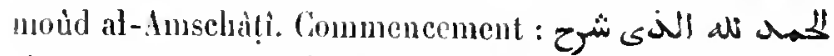
.

2 vol. Papier. 263 et $25 y$ feuillets. Hauteur, a centimètres; largreur, 15 centimèlres. 23 lignes par page. Ms. du xvile siècle. - (Supplénent 1960 el 1961 .)

\section{7.}

Traité sur la véritalsle nature de Ia peste", par Moḷammad ibn abi 'l-îs, médecin espa-

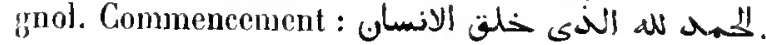

Papier. 11 feuillets. Hlauteur, a 1 centimètres et demi; largeur, 15 centimétres et demi. a 3 à a 5 lignes par page. Ils. du xusı" siècle. -(Supplémeut 1053.)

\section{8 .}

$1^{\circ}$ Remèdes pour les divers dérangements du corps, c'est-ì-dire, l'après l'auteur anonyme, pour toutes les ma-

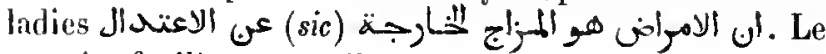
premier fenillet est mutilé, de sorte qu'il ne reste du titre

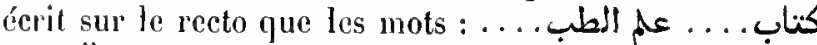

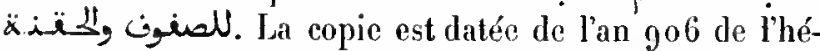
gire (1 501 de J. C.).

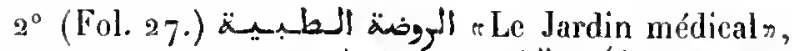
abrégé du livre intitulé pour eclui qui reste chez soi et provision pour celıi qui royage". C'est un résumé des principes de la science médicale, par 'Obaïd Allah ibn Djibril ibn 'Abd Allah ibn Baklıtyaschoùe, médecin du calife abbaside Al-Mottaqî. Labrégé est du mème auteur. Ce traité devait contenir cinquante chapitres, mais notre exenuplaire finit par le quarante-cinquième. Les premiers clapitres traitent des eatégories logirjues; viennent ensuite jes clsapitres sur le corps, les éléments, le tempéranent, le mélange, la force, l'acte, l'esprit, l'àme, l'intelligence, etc.

$3^{\circ}$ (Fol. $59 \mathrm{r}^{\circ}$.) Questions et réponses philosophiques et médicales, par Aboû Sa id Manşoûr ibn 'Îsâ ce l'ascète des savants, de la capilate du Sind" (6)

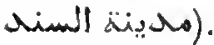

Les deux dernières pièces sont datées de l'an 867 de l'hégire ( $147^{3}$ de J. G.).

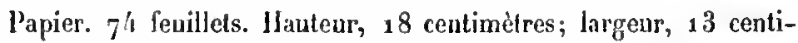
mètres et demi. - (Ancien fonds 1066 , Cotbert 6062.)

\section{9 .}

1 Recueil de receltes médicales, dont les deux premières concernent la préparation d'une panacée éprou-

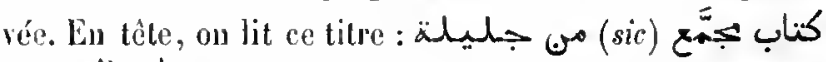
r Recueil des remèdes éprouvés, par Al-Qaïsoùnî". Ce traité n'a pu être composé arant le milieu du $\mathrm{rI}^{\circ}$ siècle de l'hégire, car Ibn al-Baị̂àr y est cité.

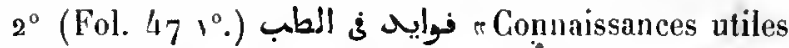
en fait de médecine", lirées de l'ouvrage de Galien, intitulé

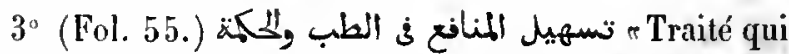
lacilite l'aequisition des connaissances utiles en médecines, par Ibrảhìm ibn 'Abd al-Raḅmàn al-Azraqî. Le présent ms. ne renferme que la première partie de l'ouvage.

Papier. 73 feuillets. Hauteur, 21 centimètres; largenr, 14 centi- 
mètres et demi. 19 lignes par page. Ms. du xvue siècle. - (Ancien fonds 1082.)

\section{0 .}

1. Manuel de thérapeutique. Le commencement manque. Un titre apocryphe, avec le nom d'lbn al-Bailâr, a

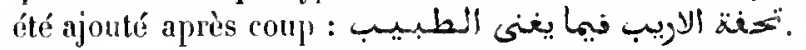

$2^{\circ}$ (Fol. 32.) Traité de thérupeutique, en dix-neuf chapitres, dont le premier et te commenecment du second manquent.

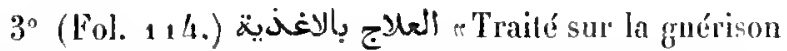
des maladies au moyen des aliments n. Commencement:

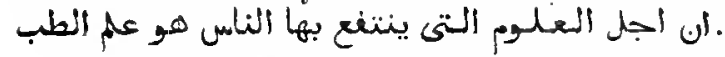

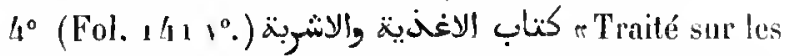
substances alimentaires el les boissons\%. Commence-

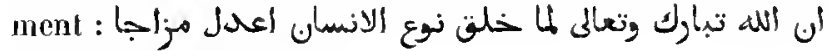

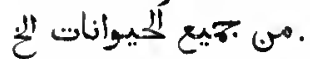

Le ms. parait ène tout entier de la mème main. On lit à la fin du volume une note apocryphe diapris laquell. il aurait été collationné en 701 de l'hégire (1310-1311 J. C.).

Papier. 219 feuillets. Ilauteur, a 4 centimetres; Jargeur, 16 centimètres et demi. 20 liggnes par page. Ms. du xvi siècle. - (Supplément 1056 .)

\section{1 .}

له dide-númoire pour les hommes intelligents et reeneil de choses admirablesn, par le sclıaikh Dâ'oud ibn 'Omar al-Antàhì, mort en 1005 de l'hégire $(1596-1597$ de J. C.). Traité de médecine, composé d'une introduction, de quatre sections (باب) et d'un appendice. La seclion la plus importante et la plus étendue renferme un dictionnaire alphabétique des médicaments simples. Commencement :

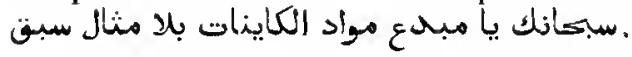

Papier. 490 feuillets. Hautenr, a 1 centimètres; largeur, I/ rentimètres et demi. 3 , à 33 lignes par page. Ms. du xviı siècle. - (Ancien fonds I 058 .)

\section{2.}

Mème ouvrage.

Papier. 36, feuillets. Hauteur, 21 centimètres; largeur, 15 centimètres et demi. 25 lignes par page. Ms. du xvio' siècte; quelques feuitiets sont plus modernes. - (Supplément 1029 bis.)
Mênue ouvrage.

\section{3.}

A la fin se trouve une longue note sur le sassafras (c)iolioli).

Papier. 304 fuillets. Hanteur, $3_{1}$ centimètres; largeur, a centimètres et deni. 29 lignes par paģe ( 30 lignes à partir du feuiltet 201 ). lls. du Xvile siècle. - (Supplèment 1958.)

\section{4.}

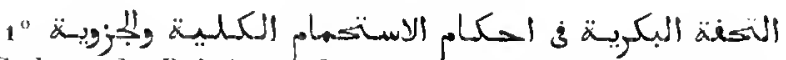
"Cadeau de Bahri, renfermant des reggles grénérales et particulières au sujet de l'usage des bains n, par le schaikh Dàond d'Antioche. Ce traité est dédié à un saint personnage, nommé Sìdi Moḷammad al-Bakn'j. Commen-

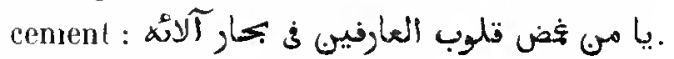

$2^{\circ}$ (Fol. $17 \vee^{\circ}$.) Sur les maladies des yeux, par le mème auteur.

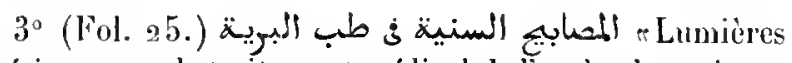
précieuses sur le traitement nédical de l'espèce humaine". Maunel de médecine, par Schiháb al-Dìn al-Qalyoubi. Commencement : الكمل ألانوأlop.

Papier. 88 fenillets. Hauteur, 21 centimetres; largeur, 16 centimètres. Écritures diverses du xvir ${ }^{e}$ siècle. - (Supplément a $o^{\prime}{ }^{\circ}$.)

\section{5 .}

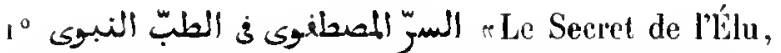
ou médecine du Prophèten, par Noûr all-Din Mbou 'l-lla-

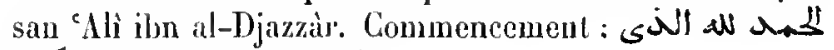
تاهت العنقول ف طب حكثنه

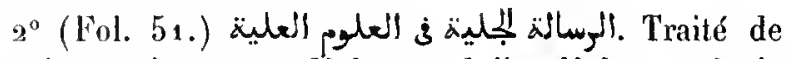
morale mystique, par Molıammad ibn Mol!ammad alAsadi. Commencement : plecl.

Papier. 60 feuillets. Hauteur, 28 centimètres; largeur, 20 centimètres. Écrilures diverses du xvı" ${ }^{e}$ siècle. - (Supplément 1897.)

\section{6.}

Guide suffisant pour l'homme intelligent en l'absence du médecin n, par Hasan ibn Hosaïn al-`Aqqâd (sieli), de Damas. Ciet ouırige 
n'est pas un manuel pratique, comme le titre nous le donne à entendre, mais un traité complet sur la théorie de la médecine. Le présent nis. ne renferme que la première moitić de l'ourage, et la copre n'est pas acherce. Conmencement: :

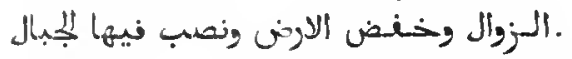

Papier. 118 fenillets. Ilauteur, so centimètres et demi; largeur, 15 centimètres. 19 lignes par page. Ms. du xvil' siècle. - (Ancien fonds 10 So, Collsert 4652.)

\section{7.}

Mćlanges d'hygiène, de physiologie et de morale. Cet ourrage, sans titre ni non d'anteur, commence par une aneclote au sujet d'Al-llâkim bi-Amr Hlâh et des quatre mille médecins qu'il avait réunis auprès de lui. On y trouve anssi les conseils d'Aristote à Alexandre, ceux de Barzawaïh, d'Ml-ḷasan al-Baṣrì, etc.

Ms. daté de l'an 1124 de l'hégire ( 1615 de J. C.).

Papier. 116 feuiltets. Itauteur, 21 centimètres; largeur, 15 centimètres. 33 lignes par page. - (Supplément 1039.)

\section{8.}

$1^{\circ}{ }^{\circ}$ aliments pour celui qui est chez luin. Traité de médecine, par un auteur anonyme. Commencement :

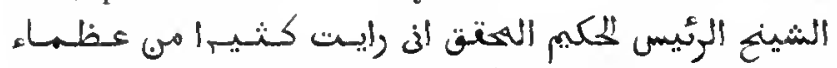

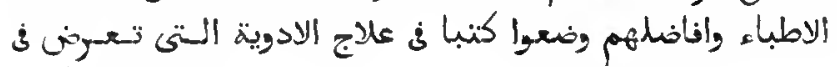

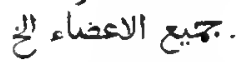

$2^{\circ}$ (Eol. $56 v^{0}$.) Traité du pouls, par Molianmed ihn

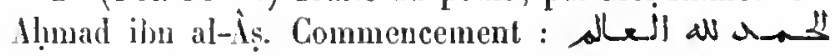
(بألسبا:ب Copie datée de l'an 1052 de l'hégire (1642 de J. C.).

30 Fol. 62. (F) Traité en vers sur la médecinen, par Aricenne. La fin manque.

Papier. $7^{0}$ feuillets. Hautenr, a 1 centimèlres et demi; largeur, 15 centimitres et demi. Écritures diverses du $\mathrm{xwn}^{\mathrm{e}}$ siècte. - (Ancien fonds 1046, Colbert 4548.)

\section{9 .}

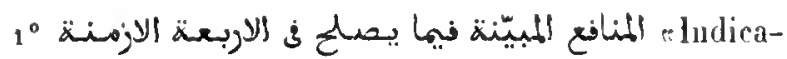
tions claires et utiles, au sujet de ce qui convient au corps dans les qualre saisons de l'année", traité d'lyy- giène en luit chapitres, par un anonyme. Commence-

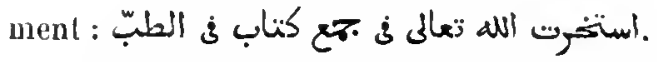

$2^{\circ}$ (Fol. $28 v^{\circ}$.) Remède contre l'impuissance (ضسعi , الانتئin).

$3^{\circ}$ (Fol. 3o.) Chapitre sur l'acte conjugal.

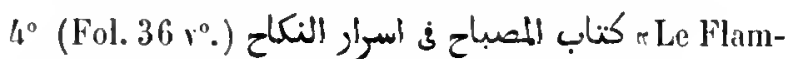
beau, traité sur les secrets de l'acte conjugaln.

$5^{\circ}$ (Fol. 61.) Sur la composilion d'électuaires et de pilules.

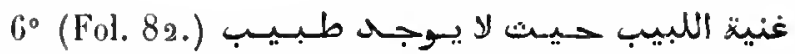
*Traité qui suffit à l'bomme intelligent quand on ne troure pas un médecinn.

$7^{\circ}$ (Fol. 87.) Conseils d'Hippocrate adressés à són fils.

$8^{\circ}$ (Fol. $9^{8} \mathbf{v}^{\circ}$.) Sur les quatre saisous, sur les tempéraments el sur certaines maladies.

$9^{\circ}\left(\right.$ Fol. $103 \%^{\circ}$.) Ordjoûza sur la médecine, attribué ì Avicenne. Premiers rers :

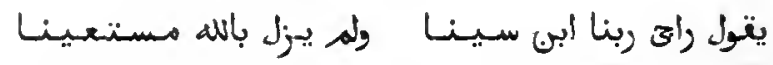

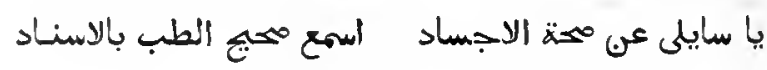

$10^{\circ}$ (Fol. $107 \mathrm{v}^{\circ}$.) Autre ordjoûza sur la médecine.

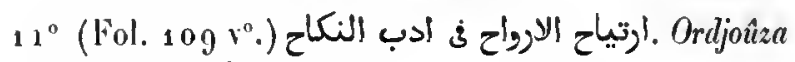
sur l'acle conjugal.

$12^{\circ}$ (Fol. $1111^{\circ}$.) Traité en prose sur le même sujet, renfermant plusieurs anecdotes et historiettes.

$13^{\circ}$ (Fol. 125.) Électuaires et talismans fortifiants.

${ }_{14} 4^{\circ}$ (Fol. $127 \mathrm{v}^{\circ}$.) Recettes pour la toilette des femmes, charmes, aphrodisiaques, etc.

$15^{\circ}$ Fol. 138. جامع المستّات فيما للنغس مو. المنوحات Traité des plaisirs physiques, en sept cliapitres.

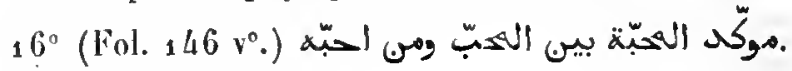
Sur les aplırodisiaques.

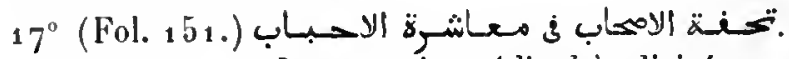
Traité érotique, en douze sections (djomla), divisées en plusieur's chapitres $(b \hat{b} b)$. Une des deruieres sections traite des convenances sociales.

$18^{\circ}$ (Fol. $259 r^{\circ}$. (Fناب المرتانم ف علم الابوال والانباض Traité sur les urines et le pouls.

$19^{\circ}$ (Fol. 264.) Ordjoûza sur les aliments et les boissons qui nuisent à la faculté génératrice.

$20^{\circ}$ (Fol. 267 v $^{\circ}$.) Suite du traité intitulé الاجئب (sic). 
$21^{\circ}$ (Fol. ${ }_{2} 69 \mathrm{v}^{\circ}$.) Ordjoú:a sur la médecine.

Volume écrit de la même main et daté de l'an 1113 de l'hégire (1702 de J. C.).

Papier. 27a fevillets. Hauteur, 21 centimètres; largeur 15 centimètres. 17 lignes par page. - (Supplémenl 1064.)

\section{0 .}

Manuel contenant des recettes et des extraits de divers traités de médecine, surtout du Kitâb al-Irschâd. Nombreuses notes marginales en arabe, en persan et en ture.

Papier. 66 feuillets. Hauteur, 29 centimètres; largeur, 19 centimètres et demi. Environ 31 lignes par page. Ms. du xvir sièele. (Supplément 2107. )

\section{1.}

$1^{\circ}$ Quinzième chapitre (bab) d'un traité de médecine. Ce chapitre traite des maladies des paupières.

$2^{\circ}$ (Fol. 29.) Prière chrétienne.

$3^{\circ}\left(F_{0} .30 v^{\circ}\right.$.) Huit feuillets qui paraissent laire partic du mème traité que l'article $1^{\circ}$.

$4^{\circ}$ (Fol. 38.) Histoire d'un jeune homme qui vend son père et sa mère et qui les rachète ensuite.

$5^{\circ}$ (Fol. $63 \vee^{\circ}$.) Prière de Carpien, intitulée, par erreur', Histoire de Cyprien et de Justine (وصة كبـريانسوس) (ويرستيه (10). tienne.

$6^{\circ}$ (Fol. $7^{3} r^{\circ}$.) Des choses défendues par la loi chré́-

$7^{\circ}$ (Fol. 80.) Sur la gloire du Paradis, extrait de la seconde partie du lb:" خلإ, traité chrétien.

$8^{\circ}$ (Fol. 85.) Prière.

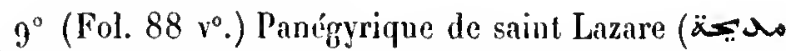
زلـ), suivi de quelques autres morceanx du mème genre.

$10^{\circ}$ (Fol. $103 \mathrm{v}^{\circ}$ ) صلغ الغروب. Prières du soir.

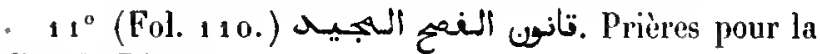
fête de Pàque.

Papier. 118 feuillets. Hauteur, 15 centimètres; largeur, 10 centimètres et demi. Its. de diverses mains du xvı" siècle. - (Supplément 1899.)

\section{2 .}

م Traité sur la préparation des collyres et des poudres pour les yeux $\gg$. Recueil de recetles dont la première enseigne la composition du collyre appelé basilicum (صفنة كاكل الباسليتون).

Papier. $7^{3}$ pages. Hauteur, 16 centimètres; largeur, 10 centimètres et demi. 15 lignes par page. Ms. du w $\mathbf{w 1}^{e}$ siècle, d'une main enropéenne. - (Ancien fonds 1102.)

\section{3.}

Se Rang de perles, sur l'art médical et ses diverses branches $\%$ Quatre-vingt chapitres (bib), par un auteur anonyme.

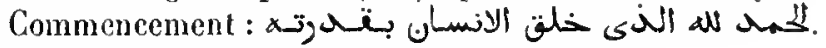
En tète du ms. se trouve un titre apocryphe.

Papier. 120 feuillets. Hauteur, 21 centimètres et demi; largenr, 16 centimètres. 21 lignes par page. Ms. du xvit siècle. - (Supplément 1055.)

\section{4.}

1. Flambeaux de prix, tomehant le traitement des maladies de l'hommen, par Schihàb al-Din al-Qalyouibi, docteur schaféite, mort. selon Hadji Khalfa (t. V, p: 153), en 1069 de l'hégire (1658-1659 de J. C.).

$2^{\circ}$ (Fol. 66.) Explication des noms des drogues mentionnées dans l'ouvrage précédent.

Ms. daté de l'an 1132 de l'bégire $(1719-1790$ de J. G.).

Papier. 72 feuillets. Hauteur, 21 centimètres et itemi; largeur, 15 centimètres et demi. 19 lignes par page. - (Ancien fonds 1069.)

\section{5.}

(llédecine du Prophìtes, par Holım-

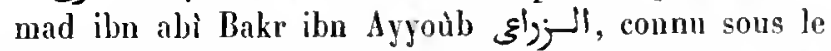

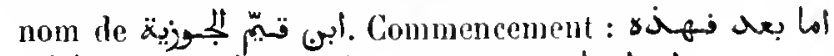

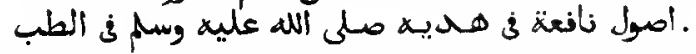

Papier. 246 pages. Hauteur, 23 cenlimètres; Jargeur, 16 centimètres. a 7 ligues par page. Is. dı xıx siècle. - (Supplément 1061 bis.) 


\section{6.}

1" Traité de l'art médical, en dix sections (maqualat). L'auteur dit aroir l'ecueilli los éléments de son ourrage dans les écrits de ses prédécesscurs.

$2^{\circ}$ (Fol. ${ }_{2} 6 \mathrm{r}^{\circ}$.) Commentaire sur une maxime de Mahomet au sujet de l'estomac.

$3^{\circ}$ (Fol. 29.) Dernier fenillet d'un traité sur les tempélinnents.

papicr. 29 fenillets. Hauteur, 21 centinctres; largeur, 15 centimìtres. 15 lignes par page. Ns. du xvm ${ }^{\mathrm{e}}$ siècle. - (Supplément 1051.)

Recueil de recetles.

\section{7.}

A la fin du volume, on lit une note, écrite d'une autre main, d'après laquelle ce ms. aurait été exécuté en 1758 .

Papier. 41 feuillels. Hauteur, 20 centimètres; Jargeur, 15 centimétres. 19 lignes par page. - (Supplémeni 3430. )

\section{8 .}

1 Sixième section (ب) d'un traité de médecine. Celte section contient une tiste de remèdes simples, rangés dans l'ordre de l'alphabet. Elle est suivie de neuf autres sections, reufermant des recettes, et d'mu appendice.

$2^{\circ}$ (Fol. 2 r $\mathrm{r}^{\circ}$.) Recueil de recettes, de charmes et de lalismans.

Papier. 155 feuillets. Hauteur, s3 centimétres et demi; largenr, 16 centimètres el demi. 21 lignes par page. - (Supplément 1047.)

\section{9 .}

Traduction abrégóe du tritité de matière médicale de Barlhélemy. Co volume est de la main de Molıammad ilon Hansoûr, élèe de l'école d'Hou Zabel.

l'apier. largeur, 1 a centimètres. Ns. du $x x^{e}$ siècle. - (Supplément 1 063.3.)

\section{0 .}

Cahier's de notes écrites par les élèves en médecine de l'école des femmes, fondée en Éggpte par le Dr Clot Bey.

Papier. 135 feuillels. Hauteur, 25 centimètres; largeur, 17 centimètres. - (Supplément 1064 bis.)

\section{XXV.}

\section{OUTRGES EROTIQUES.}

\section{1 .}

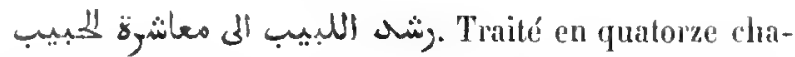
pitres sur l'amour sexuel. Selon Hadji Khalfa, ce livre

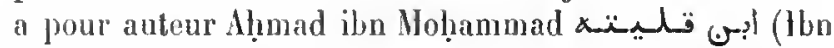
Folaita?), inort en 231 de l'hégire (845-846 de J. C.).

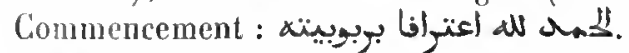

. Ms. daté de l'an $99^{2}$ de l'hégire ( 1584 de J. C.).

Papier. 113 feuillets. Hauteur, 21 centimètres; largeur, 14 centimètres. 17 lignes par page. - (Supplément 1828.)

Mòne ourrage.

\section{2.}

Ms. daté de l'an $1{ }^{6} 69$ de l'hégire (1756 de J. C.). Le premier feuillet nanque.

Papier. 98 feuillets. Hauteur, a a centimètres et demi ; largeur, 16 centimètres. 18 à 20 lignes par page. - (Supplément 1829.)

\section{3.}

rixposition de secrets, en ce qui regarde l'union conjngales, par 'Abd at-Raḥmân ibn Naṣr al-Schìrùzì, médecin d'Alep, mort en 565 de l'hégire ( $117^{\circ}$ de J. C.). L'auleur traite surtont des aphrodisiaques.

Ms. daté de l'an 980 de l'hégire $(1572-1573$ de J. C. $)$.

Papicr. 55 feuillets. Janteur, 17 centimètres el demi; largeur, 13. centimètres. 15 lignes par page. - (Ancien fonds 1091 .)

\section{4.}

مistraction pour les amis, où il est question des rapports familiers des bien aimésn, par Al-Schamou'al (المَ) ibn Yalyà ibn 'Alt al-Maghrabi. Dius les soixante chapitres de ce traité, l'autenr examine toutes les questions qui se rapportent de près ou de loin à l'amour sexuel (علماه/l), et rapporte beaucoup d'anecdoles et de pièces de vers. La préface com- 


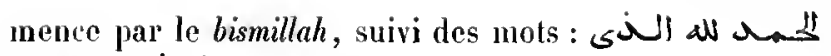
islo lo

L'ouvrage a été divisé par le copiste en trois parties distinctes. (Voir fol. 85 et $147 \mathrm{v}^{\circ}$.) Les derniers feuillets manquent.

Papier. 184 feuillets. Hauteur, 17 centimètres el demi; largeur, 13 centimètres. 15 lignes par page. Ms. du xve siècle. - (Ancien fonds 1092 , Coibert 6486.)

\section{5 .}

Délices des cœuls, conlenant des choses qui ne se trouvent dans ancun liven, par Ahmad al-Tifìschi. Dix rlapilres. Commen-

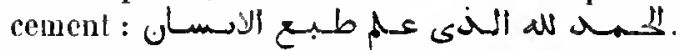

Papier. 118 feuillets. Hauleur, a 1 centimctres; largeur, 15 centimètres. 7 lignes par page. Ms. du xv" sièele. -(Supplément 1805.)

\section{6.}

(جوع السنـيج اله صبـاه lards", Irailé érotique en trente chapitres. (Voy. IIadji

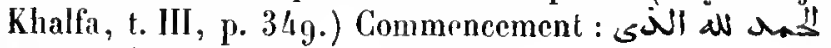
.

Ms. dalé de l'an 1063 de l'hégire (1653 de J. C.).

Papier. 210 feuillets. Hauteur, 20 centimètres et demi; largeur, 14 centimètres et demi. 17 lignes par page. - (Sujplément 1823.)

\section{7.}

Mème ouvrage. Dans le titre, l'auteur est nommé Abou 'L-Barakât Schams al-Dìn Mohammad al-Tífàschì.

Papier. 98 feuiliets. Hauteur, 21 centimètres el demi; largeur, 15 centimètres. 23 lignes par page. Ms. du xvin' sièce. - (Supplément 1894 .)

\section{8.}

كتاب Mème ouvrage. Cet exemplaire porte le titre de

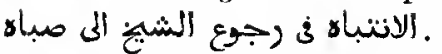

Ms. dálé de lian 1127 de l'hégire (1 715 de J. C.).

Papier. 1 a 8 feuillets. Hauteur, 21 centimètres; largeur, 15 centimètres. 21 lignes par page. - (Supplément 1895.)

\section{9 .}

Sceonde moitié du même onvrage.

Ms. daté de l'an 1142 de l'hágire (1 730 de J. C.).

Papier. 131 feuillets. Hauteur, 21 centimètres et demi; largenr, 15 centimètres. 16 lingres par page. - (Supplément 1827.)

\section{0 .}

1 Antre rédaction dı même ouvrage, divisée en

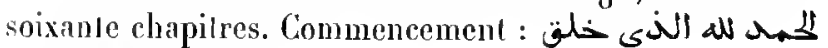

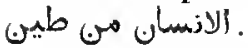

$2^{\circ}$ (Fol. 121.) Alorégé de l'ouvrage érotique, intilulé

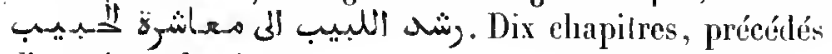
d'une introduction.

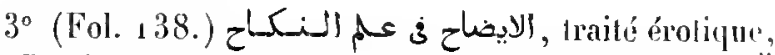
par Djalail al-Dìn al-Soyoùit. Commencement : w and

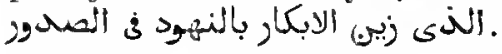

Papier. 145 feuillels. Hauteur, 23 centimètres el demi; largenr, 1fi centimètres el demi. 25 lignes par page. Ms. du xvu' siècle. (Supplément 1826.)

\section{1 .}

, Trailé sur l'anour sexucl, par 'Abd Allah ibn Molıammad al-Tidjânî. L'ourrage renlerme vingt-cinq chapitres. Commeneement : at Tan

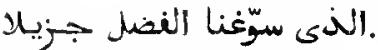

Mls. daté de l'an $9^{3} 7$ de l'hégire (153o de J. C.).

Papier. 221 feuillets. Ilantenr, so centimètres et demi; largenr. 15 centimètres el demi. 17 lignes par page. - (Supplément 1820.)

\section{2 .}

Mème ouvrage, altribué, dans cet exemplaire, à Sehiluàb al-Din M!̣mad, de Bougie (البجائي).

Papier. 159 feuillets. Ilanteur, so centimètres; largeur, 15 centimèlres. 19 à 22 lignes par page. Ms. du xvıı siècle. - (Supplément 1821 .)

\section{3.}

Même ouvrage.

Papier. 186 feuillets. Hauteur, so centimèlres el demi; largeur, 
15 centimètres. 17 à 19 lignes par page. Ms. de deux écritures, dont la plus ancienne est du xwr" siècle. - (Supplément 1819.)

\section{4 .}

Mème ouvrage. La copje n'est pas achevée. Le premier callier est copié trois fois.

Papier. 79 feuillets. Hauteur, 24 centimètres; largeur, 17 centimètres. 19 el a 5 lignes par page. Ms. du xrue sièrle. - (Supplément 2416.$)$

\section{5 .}

Traité érolique, par Ibrîhim ibn ‘Omar at-Beqầî. Cel excmplaire porte de nombreuses additions de la main de l'auteur.

Papier. 247 feuillets. Hauteur, 27 centimètres; Jargeur, 18 centimètres. 31 lignnes par page. Mts. du xv sièele. - (Supplément 1818.)

\section{6.}

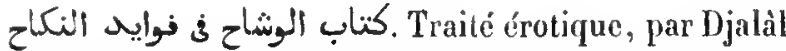
al-Din al-Soyoûti. On y trouve une liste des synonymes qui désignent les parties sexuclles, etc., bcaucoup d'anccdotes se rapportant à des personnages historiques, et des morceaux de vers de divers poètes. Commencement : La fin manque. Nombreuses notes marginales.

Papier. 50 feuillets. Hauteur, a centimèires; largeur, 16 centimètres. 23 à a 7 lignes par page. Ms. du xv1 siècle. - (Supplément 1 833)

\section{7.}

Mème ouvrage. A la fin se trouve l'explication des termes rares employés dans la prélace.

Papier. 99 feuillets. Hauteur, 21 centimètres el demi ; largeur, 15 centimètres. Au commencement 97 lignes, puis 21 lignes par page. Écri-

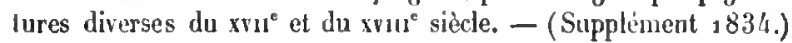

\section{8 .}

نوأضر الايك في نوأدر اللنيك Ouvrage érolique, par Djalà]

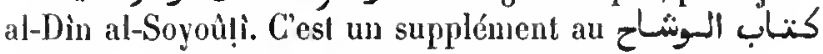

du même auteur. Commeneement : على عباده النيب. أصطن

Papier. 97 feuillets. Hauteur, 21 centimètres et demi; largeur, 15 centimètres. 3 liggnes par page. Its. du xvı' siècle. — (Supplément 3835.$)$

\section{9 .}

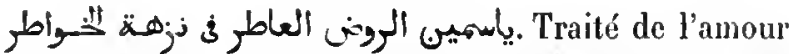
sexuel en vingt-et-un chapitres, par Moḷammad ibn

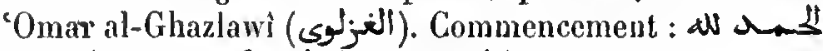

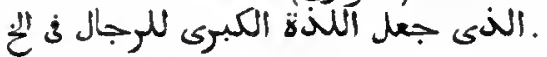

Papier. 4a feuillets. Hlauteur, a a centimètres; largenr, 15 centimètres et demi. a lignes par page. Ms. du svir siècle. - (Supplément 1816.)

\section{0 .}

$1^{\circ}$ Même ouvrage. L'auteur, dans cet exemplaire, est nommé Moḷammad al-Nafzâwi.

$2^{\circ}$ (Fol. $38 v^{\circ}$.) Histoire des Sept dormants.

$3^{\circ}$ (Fol. 48.) Histoire de Zaïd et d'Al-Kahlà. Conte renfermant de nombreuses pièces de vers.

$4^{\circ}$ (Fol. 95.) Histoire de Bisehr et de Hind.

$5^{\circ}$ (Fol. 1 o3.) Histoire de la belle Tawaddoud.

Ms. daté de l'an 1221 de l'hégire (1807 de J. C.).

Papier. 198 feuillets. Hauteur, a2 centimètres et demi; largeur, 16 centimètres. 19 lignes par page. - (Supplément 1817. )

\section{1 .}

نـزهة الابصار والاسماع في الخبلر ذوات النفناع. Traité érotique en dix chapitres, par le schaikh Badr al-Dîn ibn Sàlim ibn Noḷammad Tâbi al-Şiddìq. Commencement :

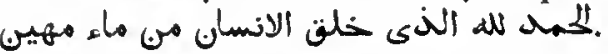

papier. 125 feuillels. Hauteur, 20 centimètres et demi; largeur, 15 centimètres. 21 lignes par page. Ms. du xru⿰ ${ }^{\circ}$ siècle (mais le dernier calsier a été éerit en 1221 de l'hégire, 1806 de J. C.). - (Supplément 1830.)

\section{2 .}

Mème ouvrage.

Ms. daté de l'an 1147 de l'hégire (1 734 de J. C.).

Papier. 115 feuillets. Hauteur, a1 centimètres el demi; largeur, 15 centimètres. a 3 tignes par page. - (Supplément 1831.) 


\section{3.}

Mème ouvrage.

Ms. daté de l'an 1212 de l'hégire (1797 de J. C.).

Papicr. 93 feuillets. Hauteur, 21 centimètres; largeur, 15 centimètres et demi. so à 33 lignes par page. - (Supplément 183æ.)

\section{4 .}

Trailé érolique, intitulé لوعهة المثاكى ودمعة الباكياك. Une note, ajoutée après coup, au commencement, nous apprend que l'ouvrage a élé composé par Al-Ṣafî al-Ḥilli, et qu'on le désigne aussi par le titre de رسالة الانثــوأت

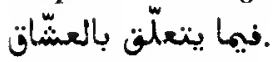

Papier. 51 fenillets. Hauteur, 2 a centinètres; largeur, 15 centimètres et demi. 15 lignes par page. Ms. du xvư siècle. - (Suppléunent 1808.)

\section{XXVI.}

POÉSIE.

\section{1. - DHANS ET QASİDAS.}

\section{5 .}

1 La La لاميّة العرب d'Al-Schanlarâ. Noles marginales et interlinéaires.

$2^{\circ}$ (Fol. $7 \mathrm{v}^{\circ}$.) Takhmis de la Mocallaya d'Anro'lqaïs, en l'honneur du Prophèle el de ses Compagnons, par "Alà al-Dín, fils de Schams al-Dìn Mohammad, fils d'HlRidhà al-Hosaïnì al-Moủsawì al-Toùsì (descendant d'AlHosain, fils dedli, par l'imâu Moûsà al-Kàzim). Les indicatious du titre pourraienl faire croire que mous arons ici un ouvrage composé par le dixième imàn, 'Alì alHàdi, fils de Moḥammad al-Djauwâd, fits de 'Alì al-RiIhà, fils de Moúsâ al-Kàzim; mais les liłres honorifịues d'Ala al-Din et de Schams al-Dín n'ont jamais été appliqués anx donze imàms. Ce taklunts et les huit autres qui suivent portent le titre de مـبـ o le rainqueur des adversaires?.

$3^{\circ}$ (Fol. $171^{\circ}$.) Takhmis de la Móallaqa de Ṭarala, fils d'Al-'Abd, par le même auteur.

$4^{\circ}$ (Fol. $29 \mathrm{v}^{\circ}$.) Talhmis de la Mocallaqa de Zohaïr ibn abì Solmâ, par le même.

Mas. onievtác. - H. $5^{\circ}$ (Fol. 37.) Takhmîs de la Mocallaqa de Labîd, par le mểne.

$6^{\circ}$ (Fol. $47 \mathrm{v}^{\circ}$.) Talilumis de la Mocallaqa d"Mutara, par le mème.

$7^{\circ}$ (Fol. $54 \mathrm{v}^{\circ}$.) Takhmis de la Mocallaqa d'Al-Hirlh $\left(\circlearrowleft-\frac{1}{2}\right)$ ibn Hilliza, par le mème.

$8^{\circ}$ (Fol. $59 \mathrm{v}^{\circ}$.) Takhmis de la Mo allaqa d's Amr ibn Kollhoûm, par le même.

$9^{\circ}$ (Fol.6g.) Takhmîs de la qașìda d'Al-A'schà Maïmoûn ibn Qaïs ibn Djandal, par le même.

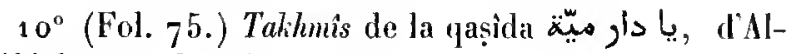
Nâbighlı, par le même.

$11^{\circ}$ (Fol. 79.) La qașida d'Abid ibn al-Abıas, qui conmence par ce vers :

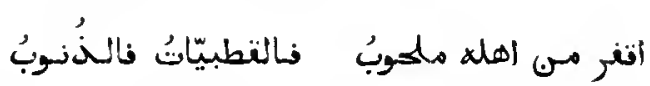

Ms. daté de l'an $99^{4}$ de l'hégire (1586 de J. C.).

M. de Sacy a donné une notice de ce ins. dans les Notices et extraits, t. IV, p. 3og et suiv.

Papier. 8 fenillets. Hauteur, $1 / 1$ centimètres; largeur, 16 centimètres et demi. 15 à 16 lignes par page. - (Ancien fonds 1/15.5, Colbett 4979 .)

\section{6.}

La Lâmîyat al-'Arab d'Al-Schanfarâ, suivi des sept Mo-

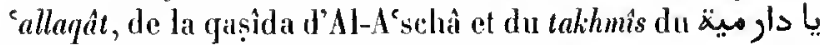
d'Ml-Nâbigha. Le volume se termine par la qașida d'elbìd ibu al-Abras.

Ce ms. est une mauvaise copje, exéculée à Paris, du mis. précédent.

Pipicr. $9^{3}$ feuillets. Hauteur, 18 centimètres et demi; largeur, 14 centimètres. 3 lignes par page. - (Supplément 14a6.)

\section{7.}

La Lâniyat al-Arab d'Al-Schanlärä, avec le commenlaire d'Al-Zamakhscharì. On lit en lète du ms. : lio

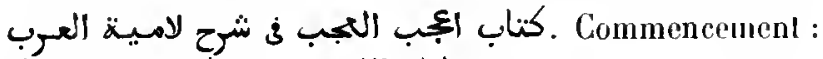

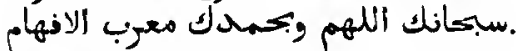

Ms. copié à Alger, vers 1849 de J. C., par un Européen, élevé an Caire.

Papicr. 66 fenillets. Hauteur, 38 centimètres; largeur, 31 centimètres et demi. - (Supplíment 1/126 bis.) 


\section{8.}

$1^{\circ}$ La qașida appelée avec le commentaire d"Abd Allalı ibn Fakhr al-Din al-

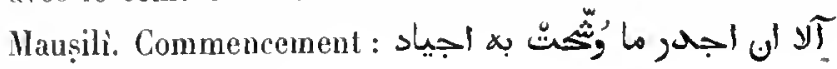
مياد الانفاظ والمبان

$2^{\circ}\left(F_{0}\right.$. $63 \mathrm{v}^{\circ}$.) Commentaire sur te même poème, par Moḷammad ibn Ilomaïd al-Kafawî. Commencement :

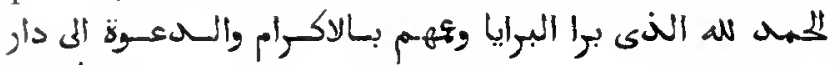
indit.

Ms. dalé de l'an 1178 de l'hégire $(1764-1765$ de J. C.).

Papier. 114 feuillets. Hauteur, 30 centimètres et demi; largeur, 13 centimètrcs. 19 lignes par page. - (Supplément 1428.)

\section{9 .}

Le بانت avec gloses inlorlinéaires.

Copie de Michet Sabbàgh datée du 9 thermidor an XI de la République française.

Papier. 6 fenillets. Hauteur, 5 o centimètres ; largeur, 36 centimètres. 5 lignes par page. - (Supplément 14.9.)

\section{0.}

$1^{\circ}$ Takhmis de la mème qaṣida, par Schams al-Dìn

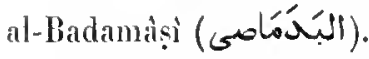

2 (Fol. 13.) Takhmis de la Borda d'Al-Boûsîni, par un anonyme.

Le premier ourrage est dalé de l'an 1190 de l'hégire ( 1776 de J. C.); le second de l'an 1054 de l'hégire (1 645 de J. C.).

Papier. 40 feuillets. Hauteur, 29 centimètres et demi; largeur, 21 centimètres. - (Supplément 1431.)

\section{1 .}

Commentaire d'Ibn Hischàm al-.Inṣârì (Djamàl al-Dìn

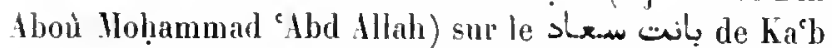
ibn Zohä̈. Commencemenl du commentaire :

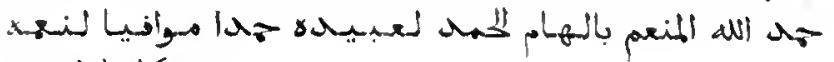
.
Ms. daté de l'an 983 de l'hégire ( 1576 de J. C.).

Papier. 87 feuillets. Hauteur, 19 centimètres; largenr, 14 centimètres et demi. 16 à 20 lignes par page. - (Supplément 1430.)

\section{2 .}

Divan d'Ali ibn abî Țàlil. Dans cette compilalion, les pièces de vers sont disposées d'après l'ordre alphabétique des rimes. L'éditeur, Sádì ibn Tàdji, qui en a achevé la rédaction en 897 de l'hégire (1492 de J. C.), a mis en tête une préface en prose et, à la fin, un appendice également en prose, donnant à la collection le titre de

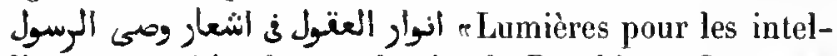
ligences, poésies du mandataire du Prophète \%. Commen-

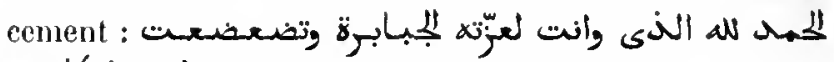
هون عظمته الاكاسـرة : Premier vers du divan :

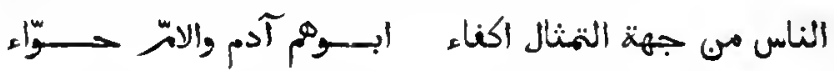

Papier. 69 fenillets. Hauteur, 17 centimètres et demi; largeur, 12 centimètres. 15 lignes par page. Ms. du $x^{e}$ siècle. - (Ancien funds 1483.)

\section{3.}

Même ouvrage, accompagné, sur les marges, d'une traduction persane en vers. Les feuillets 47,48 et 49 portent une invocation adressée à Dieu el une autre adressće aux hommes du monde invisible (رجال الغيب), c'està-dire aux esprits appelés تطب ,غوت ,اوتاد, etc. Celte pièce est précédée d'une introduction en turc, suivie d'un cercle chargé de signes cabalistiques.

Ms. daté de l'an 966 de l'hégire ( 1559 de J. C.).

Papier. 49 feuillets. Hauteur, 2a centimètres; largeur, 14 centimètres et demi. 23 lignes par page. - (Ancien fonds 1423. )

\section{4.}

Les Poésies de Hassân ibn Thâbit. Commencenent:

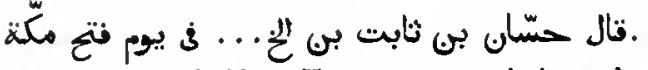

Papier. 105 feuillets. Hauteur, a 31 centimètres; largeur, 15 centimètres. Ms. du xvì siècle. - (Supplément 1432.)

\section{5 .}

Divan d'Aboû Tammâm (Habîb ibn Aus al-Ṭâi). Les, 
poésies contenues dins ce recueil sont divisées en sept

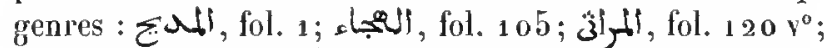
Jil, fol. 134 r ; الاوصان ; fol. fol. 156 ; النتر, fol. 161 . Les pièces de vers qui composent chacune de ces sections sont disposées suivant l'ordre alphabétique des rimes.

Ms. daté de l'an 1234 de l'hégire (1818 de J. G.).

Papier. 164 feuillets. Hanteur, 29 centimètres; largeur, 15 centimètres. 23 lignes par page, à doubtes colonnes. - (Supplément 2292.)

\section{6.}

Divan d'Aboû 'Obàda Walîd ibn 'Obaid al-Bọ̣torì, mort en 284 de l'hégire ( 897 de J. C.). (Voyez le Dictionnaire biographique d'Ibn Khallikân, t. HII, p. 657.) Les pièces de vers sont classées suivant l'oldre alphabétique des rimes. Le présent ms. se compose de deux parlies; la fin de la première partie, à savoir un certain

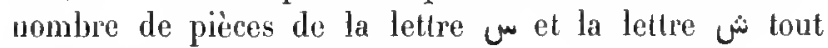
entière, manque.

Ms. daté de l'an 610 de l'bégire (1213 de J. C.).

Papier. 43a feuillets. Hauteur, 26 centimètres et demi; largeur, 18 centimètres. 19 lignes par page. - (Aneien fonds $139 \%$ )

\section{7.}

Divan d'Abd Allalı ibn al-No'tazz, édition d'Abon 'l'Abłâs at-Soûlì. Dix seclions, dans chacune desquelles les pièces de vers sont classées dans l'ordre alphabétique

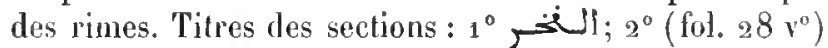
ألغ ألغجا (fol.

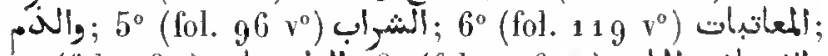

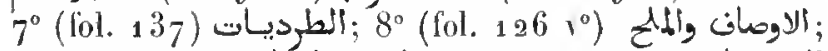

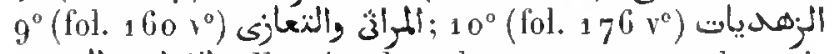

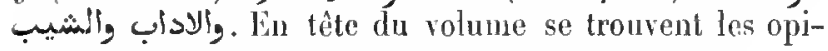
nions de diflérents auteurs au sujet de ce recueil.

Ms. daté de l'an 1007 de l'luégire (1598-1599 de J. C.).

Papier. 158 fenillets. Ilauteur, 29 centimètres; largeur, 15 centimètres et demi. 23 lignes par page. - (Ancien fonds 1439. )

\section{8 .}

$1^{\circ}$ Lat Maqşoûra d’lbn Doraïd. Chaque vers est accompagné d'un commentaire. Commencement : w a d If ألظاهر أحسانه ألباطه برهانه العظيم آلأوه لجسميم نهاوه
Copie datée de l'an 844 de l'hégire (1440-1441 de J. C.).

$2^{\circ}$ (Fol. 37.) La qaṣìda d'Al-Ṭanțarânì, accompagnée de nombreuses głoses.

Copie datée de l'an 846 de l'hégire (1442-1443 de J. C.).

$3^{\circ}$ (Fol. $49 \mathrm{~V}^{\circ}$.) Les Cent régissants d'Al-Djordjânì, texte fégèrement remanié. Commencement : أعـام أن

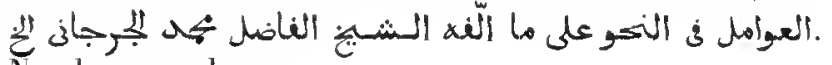
Nombreuses gloses.

Copie datéc de l'an 844 de l'hégire.

$4^{\circ}\left(\right.$ Fol. $54 \mathrm{v}^{\circ}$.) Notes et observations grammaticales, suivies de quelques vers en persan.

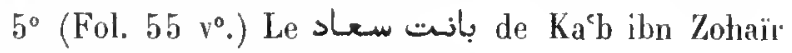
accompagné de nombreuses gloses.

Copie datée de l'an 845 de l'luégire.

$6^{\circ}$ (Fol. $\left.721^{\circ}.\right)$ Traité de métrique, en vers persans, par Aboû Naṣr Farâhì (فرأف). Nombreuses gloses en arabe.

Papier. 87 feuillets. Hauteur, 23 centimètres; largeur, 14 centimètres. Écritures diverses. - (Aneien fonds 1454.$)$

\section{9 .}

Commentaire sur la Maqsotura d'Thn Doraïd. Le premier feuillet manque. Commencement de l'explication

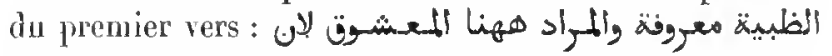

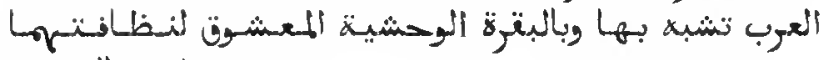

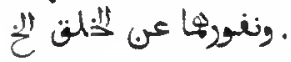

Papier. 52 feuillets. Ilauteur, 23 centimètres et demi; largeur, 14 centimètres. 25 lignes par page. Ms. du xvrie siècle. - (Supplément 2174.)

\section{0 .}

Analyse grammaticale de la Maqșoûra d'Ilın Doraïd ^, ouvrage attribué au scliaikh ` 17.

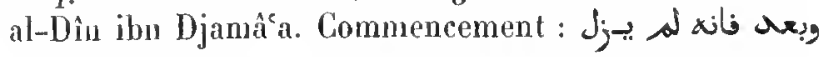

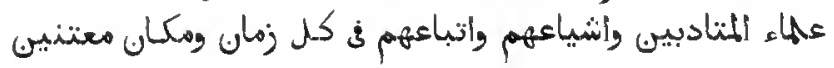

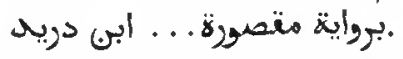

Papier. 69 feuillets. Hauteur, 17 centimètres; largenr 13 centimètres. 15 liggnes par page. Ms. du xiv siècle (les 9 premier feuillets sont plus modernes). - (Supplément 1433.)

\section{1 .}

Bivan d'Aḥmad ibn al-Hosaïı al-Molanabbì. Les 
pièces de vers sonl disposées dans l'ordre chronologique. Les ver's sont rocalisés. Noles marginales et interlinéaires.

Ms. dalé de l'an 660 de l'hégire (1262 de J. C.). Les deux prenières pages sont olnées.

Papier. 315 fenillets. Hantenr, 24 centimetres et demi; largcur, 17 centimetres. 15 ligues par page. - (Ancien fonds 1428 , Colhert 1765.$)$

\section{2.}

Même ouvrage. Les pièces sont disposées dans l'ordre chronologique. A la fin du volume, le copiste a reproduit plusieurs certificats qui constatent l'authenlicilé du texte adoplé par lui.

Ms. daté de l'an 1013 de l'hégire (1604 de J. C.). Texte rocalisé.

Papier. 181 feuillets. llauteur, 24 centimètres; largeur, 15 centimetres. 17 lignes par page. - (Ancien fonds 1430.)

\section{3.}

Mème outrage. Les pièces sont disposées dans l'ordre rhronologinue. Tous les rer's sont vocalisés.

Hs. dalé de l'an 1017 de l'lıégrire (1608-1609 de J. C.). Frontispice orné; la première page porte une jolie vignelle dorée ot coloriée; en margó de la même page et de la suivante, on remarque trois ronds également dorés et roloriés.

Papier. 179 feuillets. Hauteur, s3 centimètres el demi; largeur, 15) centimetres et demi. ${ }_{7}$ lignes par page. - (Ancien fonds 1427.$)$

\section{4.}

lène ouvrage dans l'ordre chronologique.

Ms. daté de l'an 114 a de l'hégrire (1728 de J. C.). Nombreuses noles marginales.

Papier. 122 feuillets. Hauleur, 22 centimètres; largeur, 15 centimètres. Environ 2 / lizgnes par page. -- (Supplément 148\%.)

\section{5.}

Mème ouvrage dans l'ordre chronologique.

IIs. daté de l'an 118, de l'hégire (1768 de J. C.). Texte à deux colonnes.
Papier. 146 feuillets. Hauteur, 21 centimètres; largeur, 13 centimètres. so lignes par page. - (Supplément 1487.)

\section{6.}

Mème onvage. Les pièces de vers sont disposées dans l'ordre alpluabétique des rimes.

Papier. 202 feuillets. Hauteur, 27 centimètres et demi; largeur, 18 centimètres et demi. 15 lignes par page. Us. du xrve siècle. (Ancien fonds 1399 .)

\section{7.}

Mème ouvrage. Les pièces de vers sont disposées dans l'ordre alphabélique des rimes. Le premier feuillel porte une courte nolice sur le poète el la liste de ses commenlateurs. Texte vocalisé. Les marges el les entrelignes sont couvertes de gloses empruntées au commentaire d'Al- Wạhḷidi.

Papier. 175 feuillets. Hauteur, 21 centimètres; largeur, 13 centimètres. 7 lignes par page. Ms. du xv" siècle. - (Ancien fonds,$f_{29}$.)

\section{8.}

$1^{\circ}$ Mème ouvrage. Les pièces de vers sont disposées dans l'ordre alphabétique des rimes. Nombreuses notes marginales.

$2^{\circ}$ (Fol. $132 v^{\circ}$. ) Divan d'Al-Sarì al-Raffà. Cette collection consiste principalement en éloges. L'auteur mourut à Baghdid, entre les années 360 el 370 de l'hégire (970-980 de J. C. ). lbn Khallikân lui a consacré un. article dans son Dictionnaire biographique (t. 1, p. 559 de la traduclion).

$3^{\circ}$ (Fol. $210 v^{\circ}$.) Divan d'Alımad ibn al-Qàsim alAndalosì ibn Khaloûf (إبر خلون). Celte collection renferme des poésies en l'honneur du roi (الملـلك) ou sultan 'Othmàn, el une pièce de vers à la louange d'un prince, nommé Al-Malik al-Maseoûd.

Papier. 229 feuillets. Hauteur, 25 centimètres et demi; largeur, 14 centimètres et demi. 25 lignes par page. Ms. du xur siècle. (Ancien fonds 383. .)

\section{9 .}

Le divan d'Al-Molanabbì. Les pièces de vers sont dis- 
posées dans lordre alphabétique des rimes. Il y a une courte préface, qui commence par ces nols : al M.Jl

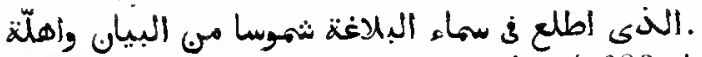

Ms. daté de l'an 1094 de l'hégire (1683 de J. C.).

Papier. ${ }_{13}{ }_{1}$ feuillets. Hauteur, 25 centimètres; largeur, 13 centimètres et demi. 93 tignes par pare. - (Supplément 1488.)

\section{0.}

Commencement du même ouvage. La copie s'arrête au milieu de la lettre $b \hat{a}$.

Papier. 26 feuillets. Hauteur, 32 centimètres; largeur, so centimètres et demi. Ms. du xun" siècle. - (Ancien fonds 1383 1.)

\section{1 a 3103.}

خول- Commentaire sur les poésies d'Al-Motanabbì, disposées dans l'ordre alphabétique des rimes, par le khatiib Aboû Zakarîya Yaḥyâ iln 'Ali Al-Tibrizì, mort

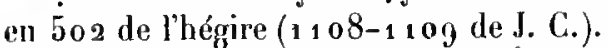

Plusicurs feuillets du second volume, depuis le fol. 60 jusqu'au fol. 83, ont été rongés par les vers.

3 vol. Papier. 208, 186, 185 feuillets. Hauteur, 23 centimètres;

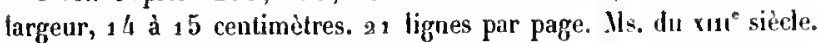
$-($ Ancien fonds $1431,1433,1433$.

\section{4.}

Seconde partie du mème ouvrage, de la main de Michel Șabbàgh.

Papier. 116 feuillets. Hauteur, a 1 centimètres; largeur, 14 centimètres. 15 lignes par page. Ms. du vix $x^{e}$ siècle. - (Supplément 1490.$)$

\section{5 .}

Commentaire du divan d'Al-llotanabbì, par un auteur qui dit avoir étudié ce recueil en 599 de l'hégire (1202-1203 de J. C), et mis à contribution les ouvrages de tous ses devanciers. Ce commentaire, très bien com-

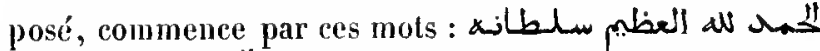

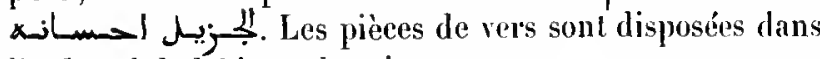
l'ordre alplabétique des rimes.

Papier. 480 feuillets. Hauteur, 25 centimètres; largeur, 16 centimètres. 35 lignes par page. Ms. du $x v^{\mathrm{e}}$ siècle. - (Supplément $\mathrm{t} / 485$. )

\section{6.}

Premier rolume d'un commentaire sur le divan d'AlIIotanabbi. Les premiers feuillels manquent. Les pieces de vers sont disposées dans l'ordre chronologinue.

Papier. 19 f feuillets. Hauleur, 25 centimètres; targeur, 17 centimètres et demi. 19 lignes par page. $\|_{4}$. du $\mathbf{v v}^{\circ}$ sièrle. - (Supplément 1486.)

\section{7.}

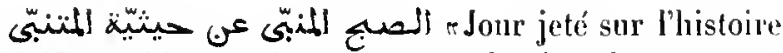
d'Al-Motanabbi ", traité crifique sur la vie el les ouvrages d'Al-Motanabbi, par Youssof al-Badìi. Commencement: سبكان النى زيّه رياه النضايل بازهار الادب الغض

Mls. daté de l'an 1 166 de l'hégire (1 7,3) de J. (.).).

Papier. 154 fenillels. Hauteur, 21 centimètres el deni ; largeur, 14 centimètres. 19 lignes par page. -- (Supptément 1/191.)

\section{8.}

. ديوأن أبر. هان Diran d'Abon l-Qìsim Molıammad ibn Hânî, surnommé le Molanabbî de la Mauritanie. Pour la vie de l'auteur, qui fut tué en 362 (973 (le J. C.), à l'àge d'environ quarante ans, royez le Dictionnaire biographique d'Ibn Khallikân, t. III, page 1 23. Dans cette collection, les pieces de rers sont disposées dans l'ordre alphabétique des rimes. Commencement : لذإلى

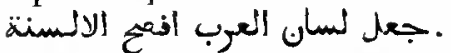

Mls. daté de l'an 858 de l'légire (1 454 de J. C.).

Papier. 189 feuillets. Hauteur, 18 centimèlres et demi; largenr, 15 centimètres. 11 lignes par page. - (Supplément 1506 .)

\section{9.}

قال : Divan d'Abou 'l-cllà al-Macarlì. Commencemen1

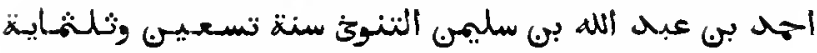

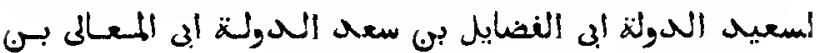

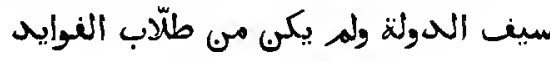

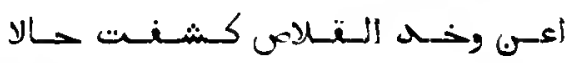

$$
\begin{aligned}
& \text { وهم عنح الضلام (الظللم .lis) طلبت مـالا }
\end{aligned}
$$

C'est le reeucil qui, dans d'antres exemplaires, porte le titre de 
Ms. dalé de l'an 1066 de l'hégire (1656 de J. C.).

Papier. 221 feuillets. Hauteur, 21 cenlimètres; largeur, 1 1 centimùtres et demi. 13 à 16 lignes par page. - (Supplémeut 1439.)

\section{0.}

Hème ouvrage. Commencement de la préface : Lot

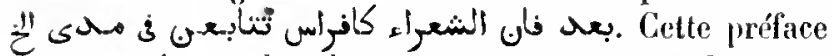
ct un cerlain nombre de rers sont accompagnés de gloses composées par l'anleur.

Les derniers feuillets manquent.

Papier. 154 fenillets. Hauteur, 23 centimètres el demi; largeur, ${ }_{16} 6$ centimètres et demi. 15 lignes par page. Ms. du xiv siècle. (Supplément 1440. )

\section{1 .}

"Lllmière de l'élincelles, commentaire d'Abou 'l-êlâ al-Ma'arrì sur son divan intitulé لز Le commenlaire, très développé, renferme beaucoup d'exemples lirés d'autres poètes. Commencement :

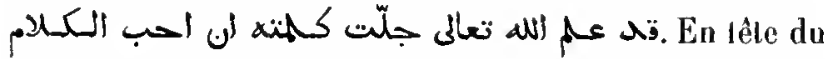
volume, on a relié un calier de dix feuillets, contenant des renseignements sur Abou 'T-Firâs al-Hamdànì et la nolice consacrée à ce poèle par Aboû Mansoûr al-Thacàlihì, dans le Yatimat al-Dahr. Ce cahier, d'écriture très cursive, est daté de Constantinople, 1060 de l'hégire (1650 de J. C.).

Papier. 93 feuillets. Hauteur, 26 centimètres; largeur, 16 centimètres et demi. 25 lignes par page. Ms. du $\mathbf{x v}^{*}$ siè̀le. - (Ancien fonds 1 tog.)

\section{2 .}

Commentaire d'Aboù Zakarîya Yaḥyâ al-Tihrîzì sur

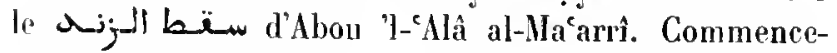

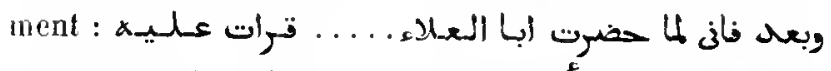

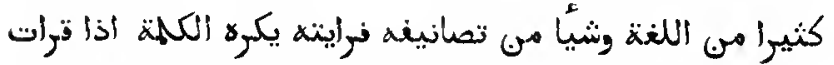

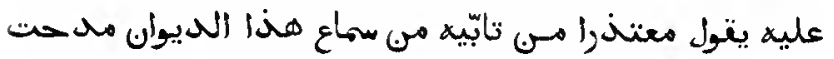

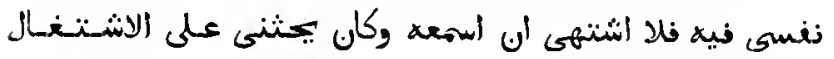

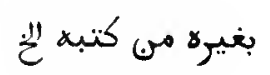

Ms. daté de l'an 632 de l'héggire ( 1235 de J. C.).

Papier. 559 pages. Hauteur, 24 centimètres et demi; largeur, 16 centimètres et demi. 17 lignes par page. - (Supplément 1 行.)

\section{3.}

Divan de Zaïn al-Din eAbd al-lialî́m al-Bor'i. C'esl un recneil de poésies religicuses et mysliques.

Ms. daté de l'in 1025 de l'hégire (1616 de J. C.).

Papier. 120 feuillets. Hauteur, 21 centimètres; largeur, 15 centimetres. 17 lignes par page. - (Supplément 15 15. .)

Mème ouvrage.

\section{4.}

Papier. 131 fenillets. Hauteur, 20 centimètres et demi; largeur, 15 centimètres. 25 lignes par page. Ms. du xvir siècle. - (Supplément 1508 .)

\section{5 .}

Nême ouvrage. Cet exemplaire est incomplet; il s'arrête à la quatrième pièce des poćsies mystiques.

Papier. 76 feuillets. Hauteur, so centimètres et demi; largeur, 15 centimètces. 21 lignes par page. Ms. du xvıt siècle. - (Supplément 1509.)

\section{6.}

Commentaire sur la qașida d'Aḥmad ibn 'Abd alliazzâq al-Ṭantarâni. Le commentaire, sans préface, com-

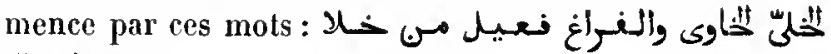

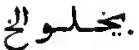

Hs. daté de l'an $117^{8}$ de l'hégire (1764 de J. C.).

Papier. 36 feuillets. Hauteue, 16 centimètres; largeur, 11 centimètres. 11 lignes par page. - (Supplément 1472.)

\section{7.}

Divan d'Abou 'l-Mozaffar Mlọammad ibn Ahınad alAbîwardî, de la famille des Omaïyades, mort à Jspahan, en 507 de l'hégite (1113 de J. C.). (Voyez le Dictionnaire biographique d'Ibn Khallikân, t. III, p. 144.) Le présent mis. ne renferme qu'une parlie du divan, à savoir les اللعـاتهيـات ou poésies composées à l'éloge de plusieurs grands personnages de l'črâq, et les ou fragments d'antres poésies, composées

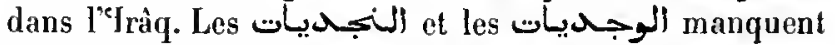
à cette collection. Les feuillets de garde sont couverts de 
notes, de maximes et d'extraits poétiques. Conmencement

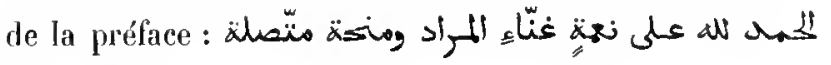
slustis.

Ms. daté de l'an 724 de l'hégire (1324 de J. C.). Nombreuses gloses marginales et interlinéaires.

Papier. 203 feuillels. Hauteur, 25 centimètres et deni; largeur, 17 centimètres. 13 lignes par page. - (Ancien fonds 1398.)

\section{8.}

$1^{\circ}$ Takhmis du poème intitulé $\ddot{x} ج$ oن d'Abou 'l-Fadhl Yousof ibn Mohammad al-Nạ̣wì. Premies hémisticlıe :

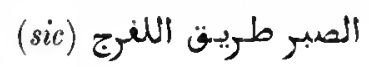

$2^{\circ}$ (Fol. g.) Plusieurs pièces de ver's, dont l'une, composée de six vers, comnence ainsi :

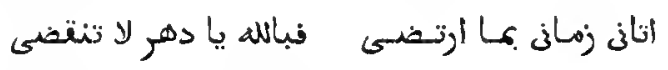

La seconde, de dix rers, commence ainsi :

$$
\text { أعـاتبه اذأ غنل المقتيب وأساله لجوأب فلا يجيب }
$$

La troisième, qui est plus longue, commence aiusi :

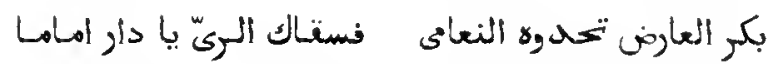

Le quatrième, de vingt-six vers, commence ainsi :

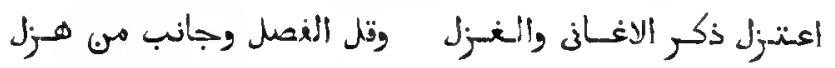

$3^{\circ}$ (Fol. $11 v^{\circ}$.) Histoire de la ville d'airain (ג丷aئ (I), fondée par Salomon, fils de David. C"est un conte populaire, différent de celui qui se Irouve dans quelques édilions des Mille et une Nuits.

$4^{\circ}$ (Fol. $22 v^{\circ}$.) Histoire d'un pieux cadi et d'un voleur.

$5^{\circ}$ (Fol. $24 v^{\circ}$.) Histoire d'Alexandre et d'Aristole, lor'squ'ils allèrent à la conquête de l'Inde, après avoir londé Alexandrie et conquis la Syrie et la Mauritanie.

$6^{\circ}$ (Fol. 26.) Histoire du calife Hàroûn al-liaschı̂d et d'uu Arabe du désert, se rencontrant à la Hecque.

$7^{\circ}$ (Fol. $28 \vee^{\circ}$.) Poésies composées au $x^{\circ}$ siècle de l'hégire, par Abou 'l-Wafì al-'Ordhî (ألعوضى), schaiklı alIstân de la ville d'Mlep.

$8^{\circ}$ (Fol. $3 r^{\circ} v^{\circ}$.) Histoire de Jésus-Christ et do deux hommes, dont l'un était perclus, l'autre aveugle.

$9^{\circ}$ (Fol. 33.) Histoire de la rencontre d'Aboû Yazîd
el-Besțini avec un moine, fors de son quaraute-neuvièue pèlerinage à la Hecque.

$10^{\circ}$ (Fol, $361^{\circ}$.) Histoire de Moïse et de Khidhr.

$11^{\circ}$ (Fol. 38.) Paroles et l'écils d'un saint personnage nommé Nolıammad at-Kitäbî.

$12^{\circ}\left(F_{0} .41 v^{\circ}\right.$.) Histoires merveilleuses, dont la première est colle de Noïse et de l'ange de la mort.

$13^{\circ}$ (Fol. 42.) Histoire de Hâroûn al-Raschîd et de Sofyin al-Thaurí

$14^{\circ}$ (Fol. 44.) Récits touchant la manière dont divers personnages furent accueillis par les premiers califes. La premièue histoire est colle de Djabala ibn alAïham en présence d"c Omar ibn al-Khattâb.

$15{ }^{\circ}$ (Eol. $491^{\circ}$ ) Histoire de la conversion d'omal à l'islamisme.

$16^{\circ}\left(\right.$ Fol. $53 v^{\circ}$.) Histoire du pécheur Kablil et du citlife Hàroûn al-Raschîd.

$17^{\circ}\left(l^{\circ} \mathrm{ol} .63 \mathrm{~V}^{\circ}.\right)$ Anecdotes concernant les califes $\mathrm{Al}-$ Ma'moûu et llẩoûn al-Rasclı̂̀d, etc.

$18^{\circ}\left(F_{0} .68 v^{\circ}\right.$.) Histoire de la colombe d'or et de la fille du roi, conte attribué à $K_{a^{c}}{ }^{c}$ al-Aḷbâr.

$19^{\circ}$ (Fol. $\left.80 v^{\circ}.\right)$ Fragnients poétiques.

$20^{\circ}$ (Fol. $86 v^{\circ}$. ) Pièce de vers d'lbn al-Djazzì ì l'élogoge d'Lbou 'l-Wafà al-Ordhì.

$21^{\circ}$ (Fol. 87.) Autres poćsies.

$22^{\circ}$ (Fol. 88.) Énigme en vers, par Abou'l-Walä 0 mar al-'Ordhî̀. Premiel vers :

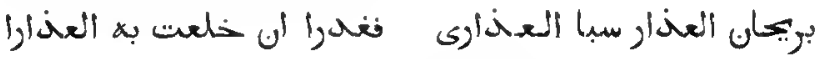
$23^{\circ}$ (Fol. $89 \mathrm{v}^{\circ}$. ) P'oésies diverses.

Papier. $9^{8}$ feuillets. Itauteur, 21 centimètres; largeur, 14 eentimètres. Ms. du vvi" siècle. - (Ancien fonds 1495.)

\section{9.}

Pluie abondante de littérature, commentaire sur la Lamiyat al'Adjam», par Klıalíl ibn Aibak al-Şafadi. Liauteur a inséré dans son commentaire de noubreux extraits et diverses listoriettes. La préface seule remplit vingt-neut

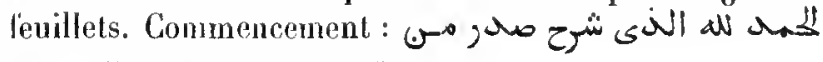

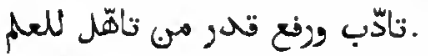

Ms. daté de l'an 818 de l'héggire (1415 de J. C.).

Papier. 150 feuillets. Hauteur, 27 centimètres et demi; largeur, 18 centimètres et demi. 21 lignes par page. - (Ancien fonds 1393. ) 
Hème ouvrage.

\section{0.}

Ms. Saté de l'an 1004 de l'hégire $(1595-1596$ de .. C.). Entre les folios aciucllement cotés 1 at 2 , il manque quelques fenillek.

Papier. 188 feuillets. Hanteur, 23 centimètres et demi; largeur, ifi centimètres et demi. 19 lignes par page. - (Ancien fonds 1481.)

Mème ouvaguge.

\section{1 .}

Ils. daté de lian 1144 de l'hégrire ( 1732 de J. C.).

Papier. 402 feuillets. Hanteur, a 8 centimètres; largeur, 18 centjmètres. 19 lignes el, à partir du fot. 78,95 lignes par page. - (Supplément $11,76$.

\section{2.}

Abrégé du commentaire d'Al-Safadì sur la Lâmîyat al'Adjam dlAl-Ṭoghhâ'i, par Kaunâl al-Din al-Domaiurì

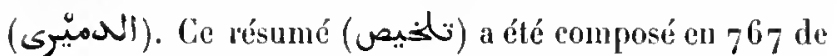
lhégire (1366 de J. C.). Les prélices des deux ourrages commencent par la même phrase; mais elles dillerent pour le reste.

Ms. daté de l'an 1027 de Thégire (1618 de J. C.).

Papier. 81 feuillets. Hauteur, 21 centimètres; largeur, $1 / 4$ rentimétres. 19 liggnes par page. - (Supplément 1475 .)

\section{3.}

Autre abrégé du commentaire d'Al-Ṣafadi sur la Lâmîyat al-Adjam d'Al-Toghửî.

Ms. dillé de l'an 1198 de l'luégire (1 784 de J. C.).

Papier. 59 feuillets. Hauleur, 21 cenlimètres; largeur, 16 cenlimètres. 21 lignes par page. - (Supplément 1473.)

\section{4.}

1. Critique du commentaire d'Al-Ṣafadi, par Mohamnad ibn abì Bakr Ibn at-Damàmini. Cet ouvrage a été composé en 794 de l'hégire ( 1392 de J. C.). Commencement : L L

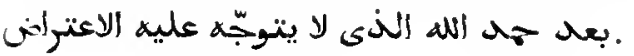

$2^{\circ}$ (Fol. 45.) Description d'une amulette très eflicace.

$3^{\circ}$ (Fol. $47 \mathrm{r}^{\circ}$.) Première partie d'un recueil d'histoliettes et de pièces de vers touchant l'amour. Commen-

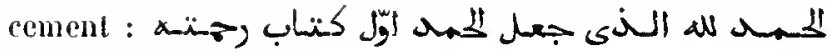

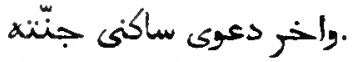

$4^{\circ}$ (Fol. 6o.) Seconde partie du même recueil, com-

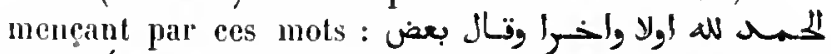

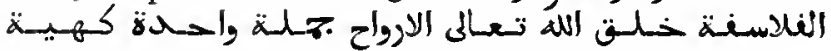

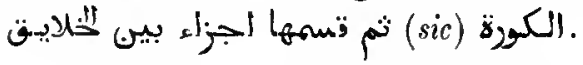

$5^{\circ}$ (Fol. $771^{\circ}$. ) Troisième partie du même ouvage.

$6^{\circ}$ (Fol. 95.) Quatrième el dernière partie du mêsne ouvrage.

Ms. daté de l'an 10 7o de Thégire (166o de J. C.).

Papier. 116 feuillets. Hauteur, 20 cenlimètres el demi; largeur, 15 centimètres. 23 à 25 lignes par page. - (Supplément 1477.)

\section{5 .}

eraité qui permettra aux bons esprits de voir combien la pleine lune est penchée vers son couchant r. Réfutation du نزول الغيت d'lbn at-Danamini, par 'Alà al-Dìn 'Alì ibn Mohammad ibn Aqbar's, docteur schaféite du Caire, mort en 862 de l'hégire (1457-1458 de J. C.). (Voyez Hadji Khalfa, t. V, p. 254.$)$ Le nom ture قبوس signifie es la panthère blan-

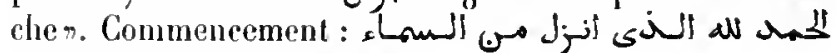

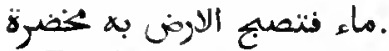

En tête du volume se trouvent diverses notes.

Papier. 105 feuittels. Hauteur, 18 centimètres; largeur, 13 centimètres et demi. 19 lignes par page. Ms. du $x \mathbf{v 1}^{\circ}$ siècle. - (Supplément 1474 .)

\section{6.}

Divan d'Aboû Isḥâq Ibrảhîm ilon 'Othmân ibn Mọ̣ammad al-Kalbì al-Aschhabî al-Ghazzì.

Copie datée de l'an 650 de l'hégire (1253-1254 de: J. C.).

Papier. 167 feuitlets. Hauteur, as centimètres; targeur, 16 centimèlres. 17 lignes par page. - (Supplément 2483.)

\section{7.}

Commentaire d"Abd al-Malik ibn 'Abdallah ibn Bad. roûı sur le poème appełé äالبنأبن, d'Ibn 'Abdoûn. 
Ce ms. qui, dit-on, est de la main de Khalì ibn Aỉbak al-Ṣafadì, est daté de l'an 717 de l'bégire (1319 de J. G.).

Papier. 25 a pages. Hauteur, 23 centimètres; largeur, 17 centimètres. 17 lignes par page. - (Supplément 1502.)

Même ouvrage.

\section{8.}

Papier. 13 o feuillets. Hauteur, 20 centimètres et demi; largeur, 13 centimètres et demi. 17 lignes par page. MIs. du xv siècle. - (Ancien fonds 1487. )

\section{9.}

$1^{\circ}$ Même ouvrage.

$2^{\circ}$ (Fol. $116 v^{\circ}$.) Texte de la qașîda d'Jbn 'Abdoûn.

تخكرة الاويب وتبـصرة r Mémorial de l'homme intelligent et avertissement pour l'lomme de lettresn, par Madjd aJ-Dìn Moḷammad ibn Aḷmmad ibn abî Schâkir al-Irbili, qui vivait encore en $67_{7} 6$ de l'hégire ( 1277 de J. C.). Commencement :

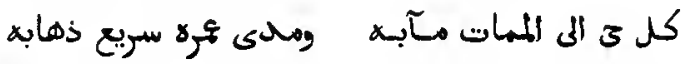

Ms. daté de l'an 1031 de l'hégire (1621-1632 de J. C.).

Papier. 122 feuillets. Hauteur, 22 centimètres; largeur, 16 centimètres. 19 lignes par page. - (Ancion fonds 1478.$)$

\section{0.}

Commentaire d'Ibn Badroùn sur la qaṣîda d'Ibn 'Abdoùn. Le ms. est de plusieurs mains et daté de l'an 1043 de l'hégire (1633-1634 de J. C.).

Papier. 132 feuillets. Hauteur, 20 centimètres et demi; largeur, 14 centimètres. Au commeneement 17 lignes, puis 23 lignes par page. - (Supptément 1500.)

\section{1.}

1 . Nême ouvrage.

$2^{\circ}$ (Fol. 136.) Le سلوان d'lbn Zafar.

Papier. 208 feuillets. Hauteur, 29 centimètres; largeur, 18 centimètres et demi. a 1 lignes par page. Ms. duxw1 ${ }^{\circ}$ siècle. - (Ancien fonds 1/11.)

Man. orientaux, - 11.

\section{2.}

Commentaire d'Ilon Badroûn sur le poème d'Ibn 'Abdoûn.

Papier. 119 feuillets. Hauteur, 22 centimètres; largenr, 15 centimètres et demi. a 3 lignes par page. Ms. du xvme siècle. - (Supplément 1501.)

\section{3.}

Même ouvrage. On lit à la fin du volume que le titre du poème était ألبمامة (sic), et aussi

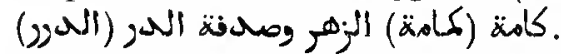

Papier. 138 feuillets. Hautenr, 2 a centimètres; largeur, 16 centimètres. 21 lignes par page. Ms. du xvme siècle. - (Supplément 1499.$)$

\section{4.}

$1^{\circ}$ exemples instructifs que les hommes intelligents peuvent Irouver dans l'histoire des grands rois $\%$. Commentaire sur les vers historiques du poème d'Ibn 'Abdoûn, par le cadi 'Tunùd alDìn Ism âcîl ibn Aḥmad ibn Moḷammad Jbn al-Athìr d'Alep, mort, selon Hadji Khalfa, en 699 de l'lıégire (1 299-1300 de J. C.). Ce commentaire s'arrète au quarante-deuxième vers du poème: Commencenent : لـا

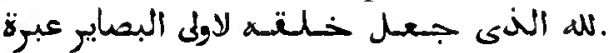

$2^{\circ}$ (Fol. $84 v^{\circ}$.) Suite du poème d'Jbn 'Abdoûn (يل العبشهونينة), composée et commentée par le même Ismit il ibı al-Atlıîr. Premier vers :

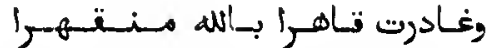

$$
\begin{aligned}
& \text { بالغلع والثثمل يشيب الصنو بالكلدر }
\end{aligned}
$$

(Voyez l'édition du commentaire d'Ibn Badroûn, publiée en 1846 , par M. Dozy, préface, page 25 et suir. 31 et 36.$)$

Papier. 120 feuillets. Hauteur, 2 i centimètres; largeur, 13 centimètres et demi. 2 l lignes par page. MIs. du xviul siecle. - (Supplément 1505.)

\section{5.}

Divan d'Aboû Ishâq Ibràhìm ibn abi 'l-Fath Khafâdja, mort en 533 de l'hégire ( $113_{9}$ de J. C.). Plusieurs des pièces de vers contenues dans ce rolume sont pré- 
rédées d'une introduction en prose. Commencement de

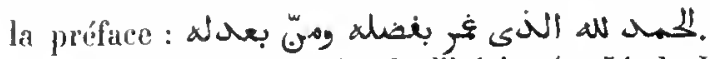

Ms. daté de l'an 1167 de l'lrégrire (1754 de J. C.).

Papier. 67 feuillets. Hauteur, 24 centimètres et demi; largeur, 15 centimètres. 29 lignes par page. - (Supplément 1518. )

\section{6 .}

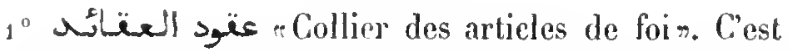
une pièce de vers dans laquelle un auteur anonyme (peut-ètre Șadid al-Din al-Bokhầì), expose les doctrines de l'islamisme. L'ouvrage a été composé en 560 de l'hégire (1 165-1 166 de J. C.). Premier vers :

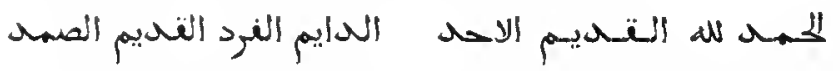

$2^{\circ}$ (Fol. $29 v^{\circ}$.) Instructions morales et religieuses. Chaque paragraphe se compose de cinq vers. Le premier paragraphe rime en alif, le second en $b A$, et ainsi de suile, jusqu'à la fin de l'alphabet. Cet ouvrage, faussement attribué à Al-l!osaï ibn 'Alì ibn abî Ṭalib, a probahlement pour auteur Nadjm al-Din 'Omar al-Nasafi. Prenier vers :

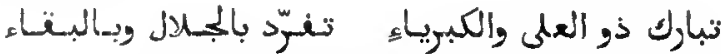

$3^{\circ}$ (Fol. 35.) Chapitre d'arithmétique, suivi de quelques tradıtions relatives à Mahomet.

Is. laté de l'an $77^{4}$ de l'hégire (1372 de J. C.).

Papier. 37 feuillets. Hauteur, 17 centimètres; largenr, 12 centimètres et demi. 15 à a 0 lignes par page. - (Ancien fonds 1418.)

\section{7.}

$1^{\circ}$ Celliel des articles de foi r. (Voyez l'arlicle $1^{\circ}$ du numéro pl'écédent.)

$2^{\circ}$ (Fol. $29 v^{\circ}$.) Instructions morales et religieuses en strophes de cinq vers, par Nadjum al-Din 'Omar al-Nasafí. (Voyez l'article $2^{\circ}$ du numéro précédent.)

$3^{\circ}$ (Fol. 36.) Commenrement du divan alphabétique des poésies d'Al-Motanabbi.

Hs. daté de l'an 1680 de J. C.

Papier. 46 feuillels. Hanteur, 19 centimètres; largeur, 12 centimètres et demi. 15 à 18 lignes par page. - (Supplément 1489.)

\section{8.}

1 م ع Collier des articles de foi». (Voyez les deux numéros précédents.) $2^{\circ}$ (Fol. $3_{1}$.) Les instructions morales et religieuses de Nadjun al-Din 'Omar al-Nasafí.

Ce ms. paraît avoir été copié, ainsi que la première partie du numéro précédent, sur le $\mathrm{n}^{\circ} 33_{136}$, dont la date est reproduite à la fin.

Papier. 36 feuillels. Hauteur, 21 centimètres; largeur, 14 centimètres. 7 lignes par page. Ms. du $\mathrm{xrm}^{\circ}$ siècle. - (Supplément 1931.)

\section{9 .}

Divan d'Abou 'l-Fotoṇt Naṣr ibn Makhloûf ibn Qalàqis, mort en 567 de l'hégire ( 1172 de J. C.). La Vie de ce poète se troure dans le Diclionnaire biographique d'Ibn Khallikân (t. III, p. 537 de la traduction angliise).

Ms. daté de l'an 1023 de l'héggire $(1614$ de J. C.). Frontispice orné, vignette sur le verso du premier feuillel.

Papier. 119 feuillets. Hlauteur, 23 centimètres; largeur, 14 centimètres. 16 à 18 lignes par page. - (Ancien fonds 1446.)

\section{0.}

recueil de l'enjolivement, , c'est à dire des poèmes enjolivés. C'est une collection de qasîdas enchevétrées les unes dans les antres et présentées sous forme d'arbres, de cercles entre-croisés, d'échiquiers, de colonnes et autres figures plus ou moins bizarres. Pour les écrire on a employé des encres de diverses couleurs, noire, rouge, verte et jaune. L'auteur, 'Abd al-Non'im ibn 'Omar ibn Ḥassân al-Ghassâni, né à Djilyâna, près

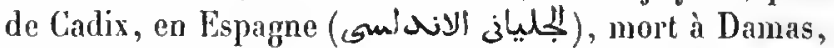
en 602 de l'hégire (1 205-1 206 de J.C.), dil, dans la préface, aroir composé cet ouv'age singulier sur le désir du sultan Saladin qui, se tronvant à Jérusalem, en 588 de l'hégire (1 $19^{2}$ de J. C.), lui avait ordonné de célébrer en vers les événements de son règne. Cet ordre donna naissance à dix divans, dont le présent recueil est le sixième. L'auteur' a eu soin d'écrire à part le texte de chaque pièce de vers, pour en rendre possible la lecture. Au reste, ces pièces n'offrent aucun intérêt, ni historique, ni littéraire. Le kâtib 'Imàd al-Dìn, dans la Kharida, en parlant des divers genres d'ornements on figures de rhétorique

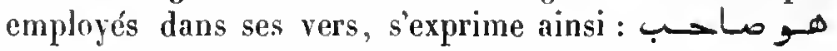

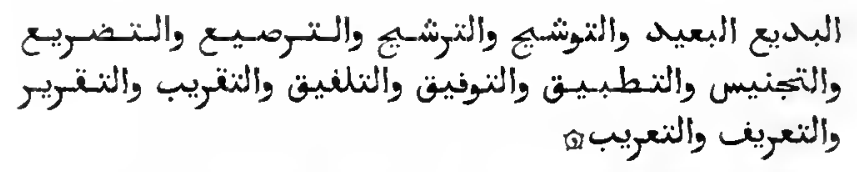

Papier. 69 feuillets. Hauteur, 40 centimètres et demi; largeur, 28 centimètres. 19 lignes par page. Ms. du $\mathbf{x v u}^{\circ}$ siècle. - (Ancien fonds 1394 .) 


\section{1.}

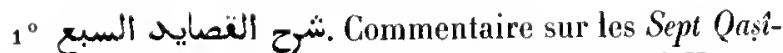
das d"Sllì ilon Moḥammad ibn 'Abd al-Șamad al-Hamadânî al-Sakhâwî, par Schilıâb al-Dìn 'Abd al-Raḷmân ibu Ismâ‘̂̂l Ibn al-Maqdisî, docleur scluaféite. Ces poèmes, composés vers la fin dı vı siècle de l'hégire, en l'honneur

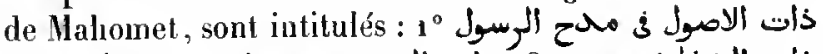

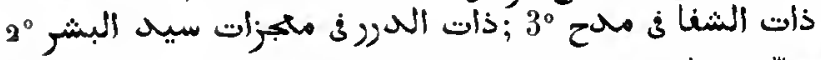

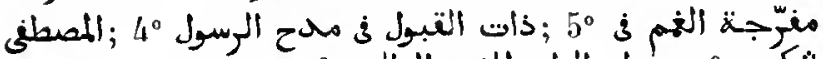

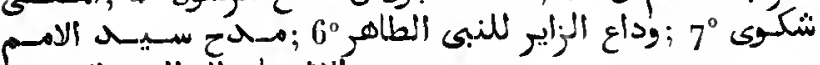

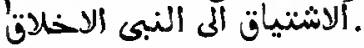

Le commentaire a été rédigé en 642 de l'hégire (1244 de J. C.).

Exemplaire copié en 654 de l'hégire (1256 de J. C.), sur le ms. de l'auteur.

$2^{\circ}$ (Fol. 178 v $^{\circ}$.) Qașida en l'honneur de Malıomel, par Abou 'l-Khattâb 'Omar ilon al-Ḥasan ilon Diḷya (أبسى) د (دينة . Ce poème se compose d'environ quatre-vingt vers, rimant en $d i$.

Papier. 180 feuillets. Hauteur, 19 centimètres et demi; largeur, 14 centimètres. go à 25 lignes par page. Ms. du xvur" siècle. - (Aneien fonds 1476. .)

\section{2.}

Divan de Bahrâm Schâh, fils de Farrouklı Schâh. L'anteur, petit-neveu de Saladin, était sultan de Bablbek et portait le titre d'Ml-Malik al-Amdjad. Il fut assassiné en 627 de l'hégire $(1229-1230$ de J. C. $)$. Toutes ces pièces de vers, dont la première a été composée en 604 de l'hégire ( 1208 de J. C. ), traitent des femmes et dı courage guerrier (النسب والتغزل ولإماسة).

Papier. 130 feuillets. tlauteur, 21 centimètres; targeur, 15 centimétres. ${ }_{7}$ lignes par page. Ms. du xvn'e siècle. - (Supplément 1497.)

\section{3.}

Divan de Scharaf al-Din Ahoû Hafṣ 'Omar Ibn al-liàridh, mort en 632 de l'hégire (1235 de J. C.). Ce recueil é été édité, cent ans apl'ès la mort du poète, par son petit-fils (س-بـe), nommé 'Alì ; car, dans la préface que cclui-ci a placée en têle, il dit qu'il se trourait an Caire vers 730 de l'hégire. (Voyez, sur cette édition, la Chrestornathie de M. de Sacy, $2^{e}$ édition, t. IIl, p. 132.)

Papier. 108 feuillets. Hauteur, 18 centimètres; largeur, 13 centimètres et demi. 3 lignes par page. Ms. du xun' siècte. - (Ancien fonds 1460. .)
Mème ouvrage.

\section{4.}

Fn tète de ce ms. se trouve un frontispice très bien dessiné et exécuté en or et en conleurs; mais le titre, dessiné dans la partie supérieure de cet ornement, n'oflie aucun sens. On y lit que ce rolume avait élé écrit par un nommé Mohammad 5 لـ et dans l'explicit on a effacé le surnom du véritable copiste pour le remplacer, très unaladroitement, par celui-ci. Mais ce titre orné n'est qu'une pièce rapportée.

Papier. 108 feuillets. Hauteur, 26 centimètres et demi; largeur, 17 centimètres. 13 lignes par page. Ms. du xiv ${ }^{\circ}$ siècte - (Ancien fonds 1395.$)$

\section{5.}

Même ouvrage.

Exemplaire copié sur le ms. de l'auleur, et daté de l'an 813 de l'hégire ( 1410 de J. C.).

Papier. $7^{6}$ feuillets. Hauteur, 21 centimètres; largeur, 15 centimètres et demi. 17 ligges par page. - (Ancien fonds 1425, Colbert 4711.)

\section{6.}

$1^{\circ}$ Mème ouvrage.

Copie du xıv siècle. Le premier feuillet manque.

$2^{\circ}$ (Fol. $9^{4}$.) Invocalion mystique, par Raslân $\left(\omega^{3 / 2}\right)$ ibn Yacqoûb ibn al-Dja'fari, de Damas.

$3^{\circ}$ (Fol. $97 \vee^{\circ}$.) Extraits du divan d'Ibn al-Dja fari.

$4^{\circ}\left(\right.$ Fol. $\left.105 v^{\circ}.\right)$ Autres extraits.

$5^{\circ}$ (Fol. $106 \vee^{\circ}$.) Plusieurs pièces de vers altribuées au schaïkh Yoûnos al-Rifài î (ألوفاقى).

$6^{\circ}$ (Fol. $\left.1111^{\circ}.\right)$ Quelques pièces de vers, par un allteur dont le nom n'est plus lisible.

Les articles $2^{\circ}$ à $6^{\circ}$ sont d'uue mauvaise écriture du $\mathbf{x} \mathbf{v}^{\mathrm{e}}$ siècle.

Papier. 112 fenillets. Hauteur, 25 centimètres et demi; largeur, 17 centimètres. - (Ancien fonds 1397.)

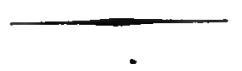

\section{7.}

Divan d'Aboû Hafṣ e Omar lbn at-Fâridh. Le premier 70 . 
leuillet manque. Il a été remplacé par un autre, qui contient le commencement d'une préface apocryphe.

Papier. 168 feuillets. Hauteur, 21 centimètres; largeur, 15 centimètres. 12 lignes par page. Ms. du $x^{*}$ siècle. - (Supplément 1447 bis.)

\section{8.}

$1^{\circ}$ Même ouvrage.

$2^{\circ}$ (Fol. 67.) Premier cahịer d'un trailé sur l'excellence de la science. Ce sont, en majeure partie, des extraits du Coran et des paroles attribuées à Mahomet.

Ms. daté de l'an 947 de l'bégire (1541 de J. C.).

Papier. 71 feuillets. Hauleur, 25 centimètres; largeur, 18 centimétres et demi. 19 lignes par page. - (Ancien fonds 1396.$)$

\section{9.}

Divan d'Jbn al-Firidh.

Papier. 78 fenillets. Ifauteur, 20 centimètres; largeur, 1 a centimètres. 7 ligaes par page. Ms. da $x^{1}{ }^{e}$ siècle. - (Ancien fonds 1 42 4.)

\section{0.}

\section{Même ouvrage.}

Papier. 7 feuillets. Hauteur, 20 centimètres; targeur, 15 centimètres. 27 lignes par pagge. Ms. du xvi siècle. - (Supplément 1/45.)

\section{1.}

Même ouvragè

Uls. dalé de l'an 993 de l'hégire (1 585 de J. C.).

Papier. 109 feuillets. Hauteur, 25 centimètres et demi; largeur, 16 centimètres. 13 lignes par page. - (Supplément 1442.)

\section{2.}

Mème ouvrage.

Les qualre dernières pages du iolume sonl. couvertes d'extraits divers, dont un, en persan, est d'Abd al-Ralımân al-Djâmî.

Ms. daté de l'an 1023 de l'hégire (1615 de J. C.).

Papier. 76 pages. Hauteur, 20 centimètres; largeur, 12 centimètres. 19 lignes par page. - (Suppténent 1446. )
Même ouvrage.

\section{3.}

Ms. daté de l'an 1029 de l'hégire (1620 de J. C.). La partie inférieure du volume a souffert de l'lumidité et a été rongée; mais le texte est demeuré intact.

Papier. 85 feuillets. Hauteur, so centimètres et demi; largeur, 15 centimètres. 16 lignes par page. - (Ancien fonds $1 / 167$, Cotbert 438..)

\section{4.}

$1^{\circ}$ Même ouvrage.

Copie datée de l'an 1044 de l'hégire (1635 de J. C.).

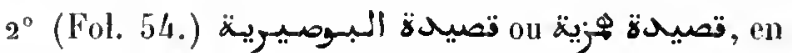
l'homneur de llahomet, par Al-Boûsîrì.

3० (Fol. 64 vº$^{\circ}$ ) La Borda d'Al-Boûșîî.

$4^{\circ}\left(\right.$ Fol. $68 v^{\circ}$.) Pièces de vers de divers autenrs, dont la plupart ont un sens mystique.

\section{$5^{\circ}$ (Fol. $84 v^{\circ}$.) L'Arba'in d'Al-Soyoûtị.}

Papier. 85 feuillets. Hauteur, 20 centimètres; largeur, 12 centimètres et demi. Écritures diverses. - (Supplément i 4 i 8. .)

\section{5.}

Divan d"Omar Ibn al-Fâridh. Le copiste a omis l'introduction et les commentaires sur les premiers poèmes, jusqu'au fol. 52 .

Papier. 68 feuillets. Hauteur, a 1 centimètres; largeur, 14 centimètres et demi. 5 lignes par page. Ms. du xwi siècle. - (Supplément 1/44.)

\section{6.}

$1^{\circ}$ Même ouvrage.

$2^{\circ}$ (Fol. 66.) Deux qașidas d"cAbd al-Rahim al-Bor ${ }^{c} 1$. (Voyez ci-dessus, $n^{\circ} 3113$. .)

$3^{\circ}$ (Fol. 6g.) Extrait de la qạ̣ida d'Al-Bouṣînî.

$4^{\circ}\left(\right.$ Fol. $7^{2} \mathrm{v}^{\circ}$.) Dialogue mystique, tiré du livre intitulé كناب التبلّياتِ

$5^{\circ}$ (Fol. $7^{3} v^{\circ}$.) Onze vers du schaïkh Mohammad alBakrî, dont voici le premier :

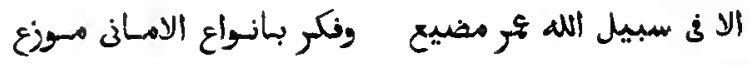


$6^{\circ}$ (Fol. 74.) Quelques pièces de vers en turc et en arahe.

Les trois premiers articles sont de la mème main et datés de l'an 1056 de l'héggire (1646 de J. C.).

Papier. $7^{4}$ feuillets. Hauteur, 18 centimètres; largeur, 11 centimètres et demi. 21 liggnes par page. - (Supplément 1447.)

\section{7.}

Commentaire de Hasan al-Bourîni, mort, selon Hadji Khalfa (tome IlI, page a 48 ), en 1024 de l'hégire ( 1615 de J. C.), sur le divan d'Omar Ibn al-Firidh. Ce commentaire, dit M. de Sacy, est très instructif. Le mème savant fait observer que le poème intitulé تائيسة في التصدّون

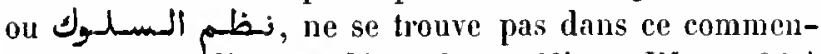

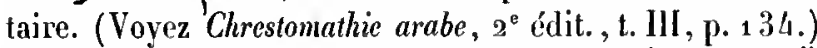

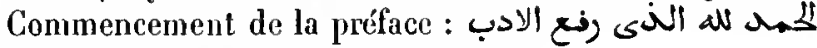

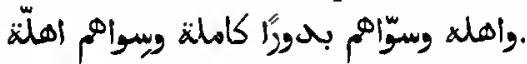

Ms. daté de l'an 1030 de l'héguire (1621 de J. C.).

Papier. $33 \mathrm{~g}$ feuillets. Hauteur, 20 centimètres; largeur, 14 centiet demi. 21 lignes par page. - (Ancien fonds 1479.)

\section{8.}

Mème ouvrage. La préface n'est pas la mème que celle de l'exemplaire précédent. La copie n'est pas terminée; elle s'arrête au passage qui correspond au fol. $3{ }_{1} 6 \mathrm{du}$ numéro précédent. Commencement : जذالذ all und أورد احمبّاه مناهل الصنا C.

Papier. 271 feuillets. Hauteur, 26 centimètres; largeur, $1 / 4$ centimètres et demi. 23 liggnes par page. Ms. du xvi1 sièele. - (Supplément 1443.)

\section{9 ะ 3162.}

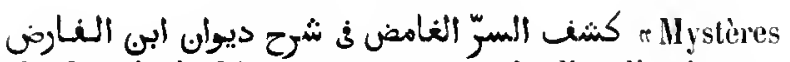
profonds mis à décourert, pour servir d'explication au Divan d'Ibn al-Fàridlı n, par 'Abd al-Ghanì ibn Ismà îl al-

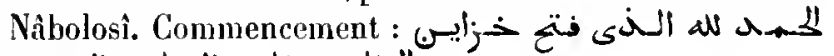

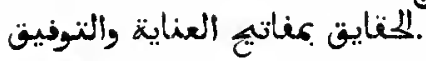

Ms. daté de l'an 1232 de l'hégire ( 1817 de J. C.).

4 volumes. Papier. $390,390,390$ et 384 feuillets. Hauteur, 29 centimètres et demi; largeur, 16 centimètres et demi. 19 lignes par page. - (Supplément 1449 , l-IV.)

\section{3.}

نمeaux visages dévoilés, pour (montrer) les pensées exprimées dans le نظمة

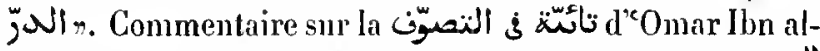

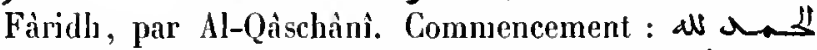

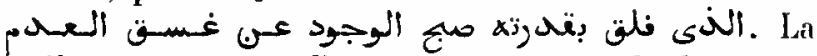
préface se compose d'un avant-propos et de deux sectjons. La première section traite des connaissances et contient cinq chapitres (fasl), dont voici les litres :

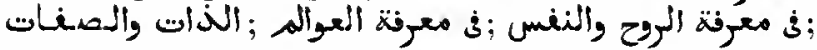

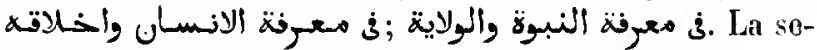
conde section renferme aussi ciulf chapitres, à savoir :

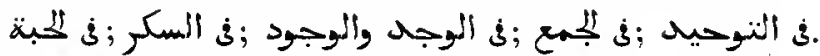

Ms. daté de l'an 1041 de l'léegire ( 1631 de J. C.).

Papier. 187 feuillets. Hauteur, 21 centimètres; largeur, 15 centimètres. 17 lignes par page. - (Supplément 1452.)

\section{4.}

Second volume d'un commentaire sur la grande Täiya d"Omar Ilon al-Fàridh. Le premier et le dernier feuillet manquent; ils ont été remplacés par deux autres, dont l'un renterme une introduction apocryphe, l'aulle un explicit dans lequel ce commentaire est douné comme étan! le célibre commentaire intitulé كill Le premies vers commence par وجانب جناب المورل, et son commen-

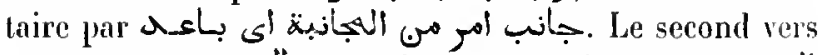

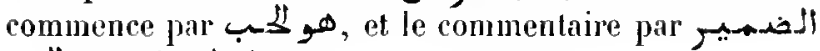

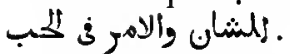

Papier. 12 a feuillets. Hlauteur, a 1 centiniètres; largeur, 15 centimètres. 15 lignes par page. Ms. du vmo siècle. - (Supplément 1451 bis.)

\section{5.}

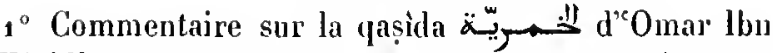
al-Fàridh, par Dâoủd ibn Malımoûd al-Qaịsarì, mort en $7^{51}$ de l'bégire (1350-1351 de J. C.). Commence-

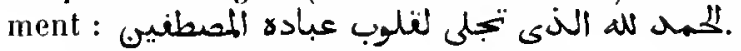

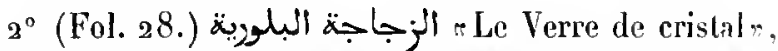
commentaire sur la Khamriya, par Hollammad jlyn Moḷammad al-'Omarî̀ al-Qaṣìrì. Commencement : د-3

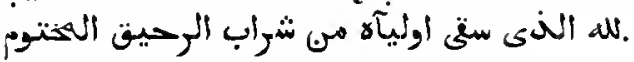

l'apier. 56 feuillets. Itauteur, 23 centimètres; largeur, 16 centimètres et demi. 21 lignes par page. Ms. du wrin siècte. - (Supplément 1451.) 


\section{6.}

Conmentaine sur la Khamrîya d'Omar lbn al-Fàridh. Le second feuillet, renfermanl le titre et peut-être le nom de l'auleur, manque. Commencement : w a H

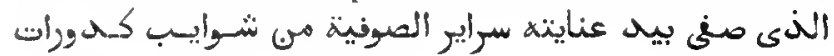

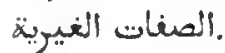

Ms. daté de l'an 1128 de l'hégire (1716 de J. C.).

Papier. 75 feuillets. Hauteur, 21 centimètres; largeur, 15 centimètres. 17 lignes par page. - (Supplément 1450 .)

\section{7.}

ت Interprète des désirs $n$, poésies mysliques de Nolyyî al-Dìn lbn al-'Mrabí, avec le commentaire dı nème auleur.

Papier. 1/7 feuillets. Hauteur, 21 centimètres el demi; largeur, 15 centimètres. 17 ligues par page. Ns. du $x^{\circ}$ siècle. Les 42 premiers feuillets et les 20 derniers sont d'une main plus moderne. (Supplément 1580 bis.)

\section{8 .}

Nème ouvrage.

Ms. daté de l'an 999 de l'hégire ( 1591 de J. C.). Le premier leuillet manque.

Papier. 102 fenillets. Hauteur, 20 centimètres et demi; targeur, 15 centimètres. 21 lignes par page. - (Supplément 2047.)

\section{9 .}

Mème ouvrage. La copie n'est pas acherée. Le premier lenillel manque.

Papier. 100 fenillets. Hauteur, 21 centimètres; largeur, 15 centimètres. 19 à 21 lignes par page. Ms. du xvil siècle. - (Supplément 1580.)

\section{0.}

Même ouvrage.

Ms. daté de l'an 1183 de l'hégire (1769 de J. C.).

Papier. 107 feuillets. Hanteur, 23 centimètres; largeur, 17 centimètres. 23 lignes par page. - (Supplément 1579.)

\section{1 .}

$1^{\circ}$ Poésies religieuses, intitulées الميوان الصغير, par Molyyì al-Dín Ibn al-'Arabì. 11 y a vingt-neuf pièces, selon le nombre des lettres de l'alphabet, en y complant le lim-alif. Chaque pièce se compose de dix vers qui tous cominencent et finissent par la même lettre de l'alphabet, depuis alif jusqu'à yâ. Cette collection est suivie d'un appendice en vers du même auteur et de deux autres pièces peu étendues.

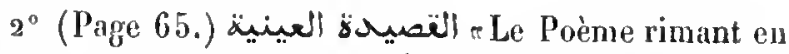

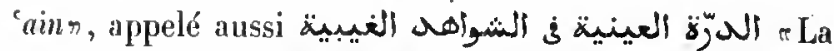
Perle, limant en 'ain, trailant des témoignages occultesn, poème mystique de plus de cinq cents vers, par 'Abd al-Karim al-Djîli. Premier vers :

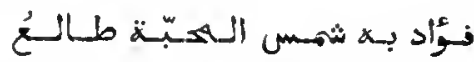

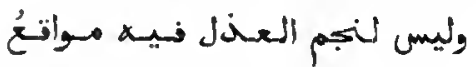

3० (Page 166.) Divan d'Aboû 'Abd Allalı Mohammad al-Ḥanalì. Poésies nyystiques.

$4^{\circ}$ (Page 182.) Extraits du divan d'Mlî Abou 'l-Wafâ. Poésies mystiques, classées d'après l'ordre alphabétique des rimes.

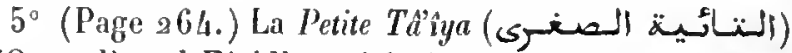
d`Omar lín al-Fâridh, suivie (page 273), de la Táiya sur le souffsme (التنائية ف النصوّن). Les deux qașidas sont réunis l'une à l'autre par trois vers formant la transition.

$6^{\circ}$ (Page 343.) Un Mokhammas de douze stances. Commelicement :

\section{قد قابلوا تلبى ولم ياتجنبوا}

$7^{\circ}$ (Page 346.) Prière ellicace.

$8^{\circ}$ (Page 365.) Dissertation sur la foi.

حجباب النتوابع وام .

$10^{\circ}$ (Page 392.) Autre amulette (نُشَّر).

$11^{\circ}$ (Page $39_{5}^{5}$.) Pièce de vers dont voici le premier :

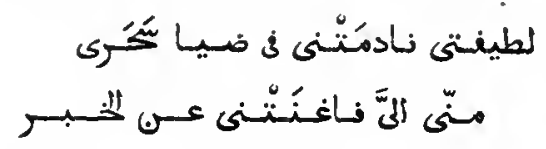

$12^{\circ}$ (Page 397.) Autre pièce de vers, dont voici le premier :

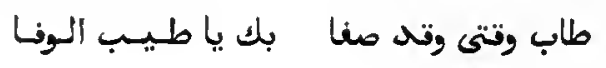


ı $3^{\circ}$ (Page 398 .) Qasîda d'Avicenne sur l'àme.

$14^{\circ}$ (Page 400.) Pièce de vers, commençant ainsi :

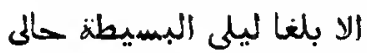

15\% (Page 401.) Poème attribué à 'Abd a]-Qàdir alGuîlànî (j)كيلان). Premier vers :

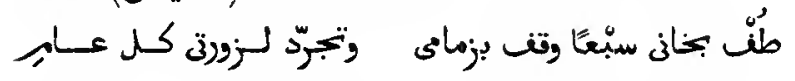

${ }_{16^{\circ}}$ (Page 403.) Autres vers, prières et charmes.

Papier. 414 pages. Hauteur, 18 centimètres et demi; largeur, 13 centimètres. Ms. du xvi sièele. - (Ancien fonds 1 4 /4.)

\subsection{2.}

1 - Les

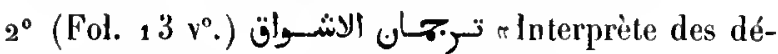
sirs n, poésies mystiques du mème auteur.

Papier. 38 feuillels. Hauteur, 21 centimètres; largeur, 13 centimètres el demi. 15 lignes par page. Ms. du xvi siècle. - (Aneien fonds 1453.)

\section{3.}

Divan, sans préface. Les pièces de vers sont rangées dans l'ordre chronologique. La première qui porte une date, est à la louange de Djildak al-Taqawî, gouverneur d'Alexandrie, en 605 de l'légire (1208-1209 de J. C.). Une des dernières renferme des félicitations adressées, en 655 de l'hégire ( 1257 de J. C.), au sultan mamelouk, Al-Malik al-Manşoûr Noûr al-Din 'Ali, fils d'A]Małik al-Mocizz Aibak. L'auteur de ce recueil, Bahà alDin Zohaïr ilon Mohammad al-Mohallabì al-'Ataki, né à la Mecque, en 581 de l'liégire ( 1186 de J. C.), mourut de la peste, au Caire, en 656 de l'hégrire (1 258 de J. G.). Ibn Khallikân, qui l'avait conno, en a donné une notice daus son Dictionnaire biographique (voyez. t. I, page 542 de la traduction).

Ms. daté de l'an 966 de thégire ( 1559 de J. C.).

Papier. 95 feuillets. Hauteur, 21 centimètres et demi; largeur, 14 centimètres. 17 lignes par page. - (Ancien fonds 1448.)

\section{4.}

Noblesse du portique de l'éloquence, faisant voir la noblesse de la maison du Sahịb al-Diwân r. Reeueil de qașidas et d'épîtres, la plupart à la lonange d'Al-Ṣahhib al-Sa id Bahà al-Dì Moḥammad, ministre des finances, dans le Khoràsìn, sous le règne de Doustehì, fils de Djenguiz-Khàn. An fol. 52 se trouve une pièce composée en l'honneur de son fils, 'Alì al-Dìn 'Ațà Malik al-Djowainni, auteur de l'histoire des Mongols, intitulée Djihân-Kouschaii, qui, après la chute dı khalifat, devint vizir de Houlagou. Au fol. 83 se trouvo une pièce composée en 631 de l'bégire (1 233-1234 de J. C.). Le recueil commence, après une préface, écrite dans un style très fleuri, qui remplit douze pages, par une qașîda en l'honneur d'Al-Nostanșir Billàh. L'anteuı' de ce divan était grand cadi et portait le titre de $\mathrm{Nizim}$ al-Din. Son nom n'est pas mientionné dans le volume.

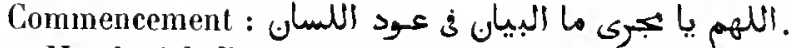

Ms. daté de l'an $7^{3} 7$ de l'hégire ( $336-1337$ de J. C.). Les points diacritiques manquent souvent. On roit les restes d'un médaillon au premier feuillet.

Papier. 141 feuillets. Hauteur, 27 centimètres; largeur, 18 centimètres et demi. 19 lignes par page. - (Supplément 1531.)

\section{5.}

Commentaire d'Aboù 'Abdallah Mohammad ibn Allmad, de Grenade, sur la Maqsoúra et d'antres poésies d'AJon̂ Hasan ḷàzim jbn Moḷammad ibı ḷasan ibn Hàzim al-Anșìli.

Ms. daté de l'an 1120 de l'hégire (1708 de J. C.).

Papier. 246 feuillets. Hauteur, 27 centinètres; laryeur, 16 centimètres. 35 lignes par page. - (Supplément 2347 .)

\section{6.}

. دبوأن المتهـ Diran dn schaikh Scliams al-Dìn Molıammad ibn Solaïmân, de Tlemcen. Les pièces de ver's sont disposées dans l'ordle alphabétique des rimes. En tềte se trouvent deux maqámat dı même auteur, dont la première commence par ces mots : حكى بعض رواة الاخذبار

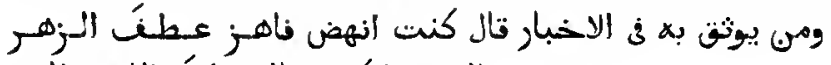

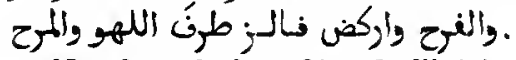

Ms. daté de l'an 857 de l'hégire (1453 de J. C.).

Papier. $7^{3}$ feuillets. Hauteur, 18 centimètres; largeur, 13 centimètres et demi. 17 lignes par page. - (Aneien fonds 1451.)

\section{7.}

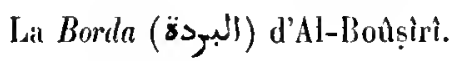


Les hémistiches en tête, en bas et au milieu de chaque page sout écrils à l’encre rouge. Vigunette ornée au commencement.

Papier. 16 fenillets. Hanteur, 18 centimètres; largeur, 11 centimètres. 11 lignes par page. Ms. du xvi" siècle. - (Ancien fonds 1484.)

\section{8.}

Même ourrage, écrit sur un rouleau, ì l'encre rouge sur un fonds doré, en lignes obliques. Les premiers plis du rouleau, qui útait destinć à servir d'amulette, présentent des groupes cabalistiques, où l'on remarque quelques mots lures. Des passages du Coran sont écrils en marge.

Papier. Hauteur, 3 mètres 25 centimètces; largeur, 4 centimètres. Its. du xvi siècle. - (Supplément 1457 bis.)

Hème ouvrage.

\section{9 .}

Ms. daté de l'an 1021 de l'hégire $(1612-1613$ de J. C.). Les deux derniers feuillets contiennent des invocations à Mahomet, en turc.

Papies. 23 fouillets. Hauteur, 21 centimètres; largeur, 13 centimetres et demi. 8 lignes par page. - (Supplément 1457.$)$

Mème ouvrage.

\section{0.}

Ms. daté de l’an 11117 de l'hégire (1 705 de J. C.).

Papier. 2 a feuillets. Hauteur, 29 centimètres; largeur, 19 centimètres. 8 lignes par page. - (Supplément 1456.)

Hême ouvrage.

\section{1.}

Chaque hémistiche occupe une ligne; les lettres sont en blanc sur des fonds verts, rouges, noirs, jaunes.

Papier. 27 feuillets. IJauteur, 18 centimètres el demi; largeur, 13 centimètres. 6 lignes par page. - (Supplément 1456 bis.)

\section{2 .}

تLes Étoiles brillantes, panégyrique de la meilleure des créatures n. C'est le tilre de la Borda d'Al-Boûsînì désignant ici le texte de ce poème transformé en talkmîs par Ibn al-Qabâqabì, auteur qui, selon Hadji Khalfa (t. IV, p. 528 ), est mort en 849 de l'hégire (1445-1446 de J. G.).

Frontispice orné. Chaque strophe est accompagnée de deux ronds on or el en couleurs.

Papier. 28 feuillets. Hauteur, 35 centimètres; largeur, 35 centimètres. 12 lignes par page. Ms. du $x v^{\circ}$ siècle. - (Ancien fonds 1380 .)

\section{3.}

Takhmis de la Borda.

- Ce ms., daté de l'an 866 de l'hégire (1462 de J. C.), a élé exécuté pour le sultan mamelouk Aboû Saeid al-Illa-

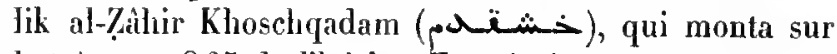
le trône en 865 de l'hégire. Frontispice en or et en couteurs.

Papier. 3o feuillets. Hauteur, 3o centimètres; largeur, a t centimètres. 3 lignes par page en gros caractères, 9 lignes en petits. - (Supplément 1460.$)$

\section{4.}

Takhmis de la Borda, avee quelques gloses.

Papier. 43 fenillets. Hautenr, 21 centimètres el demi; largeur, 15 centimètres. Chaque page contient trois lignes en noir, six en rouge, et quatre demi-lignes latérales en vert. Ns. du xvi siècle. (Supplément 1454.)

\section{5.}

$1^{\circ}$ Takhmis de la Borda, commençant par cet hémistiche:

$$
\text { ما بال تلبكّك لا يـنــلّك ذا اله }
$$

- $2^{\circ}$ (Fol. 25.) Taschtir (تشطير) de la Borda, par Aḷmad al-Dalandjâwì (s) Le genre taschtîr consiste dans l'insertion de deux hémistiches entre le premier et Je second hémistiche de chaque vers de l'original. Le premier hémistiche intercalé porte la rime, le second sert de premier hémistiche au second hémisliche du poème original.

Les hémistiches forment deux colonnes; ceux de la Borda sont écrits à l'encre rouge et les autres en noir.

Papier. ${ }_{7}$ fenillets. Hauteur, 29 centimètres; largeur, 19 centimètres et demi. Le premier ouvrage a 4 lignes par page en gros caractères et 12 en petits; le second ourrage porte $g$ lignes par page. Is. du $x$ vil1 siècle. - (Supplément i $459^{\circ}$ ) 


\section{6.}

Tasbie de la Borda, par Moḥammad ibn Wafì. (Voyez lladji Khalfa, t. IV, p. 532.) Dans le genre tasbic, avant chaque vers du poème original, on ajoute cinq hémistiches nouveaux, ayant la même rime que le premier hémistiche du poème. Commencemeul. :

$$
\text { أله أعـام ما بالقلب مب الم }
$$

Papier. 64 fenillels. Ilauteur, 15 centimètres et demi ; largeur, 10 eentimètres. 9 lignes par page. Ms. du $x{ }^{e}$ sièele. - (Ancien fonds 1/85.)

\section{7.}

Conmentaire sur la Borda, par 'Alì ilon Hbrahim ibn Idrîs al-Antâkì. L'anteur s'attache à faire ressortir les vertus secrètes de ce poème par l'enploi de ligures cabalistiques, de charmes et d'alphabets magiques. C'est phulòt un traité de. divination quiun commentaire.

Ms. daté de l'an $119^{6}$ de lhégire ( 782 de J. C.). Vignelle en lète de l'ourrage.

Papier. 348 feuiltels. Hauteur, 28 centimètres; largeur, 18 centimètres. 7 lignes par page. - (Supplément 1463.)

\section{8.}

Première parlic du commentaire sur la Borda, par Aboù 'Abdallah Mlohammad ibn Aḷmad Ibn Marzoûg al-Tilimsinì.

Papier. 193 feuillets. Hauteur, s9 centimètres ; largeur, a I centimètres. 23 lignes par page. Ms. du xvin" siède. - (Supplément z 495 .)

\section{9.}

r. L'Odeur du bien-aimé », commentaire sur la Borda, par Djalàl al-Dìn Aboù Tîhir lḷmad alKhodjandi, mort à Médine, en 802 de l’hégire (1400

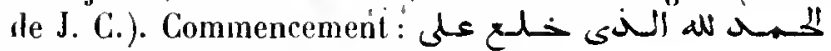

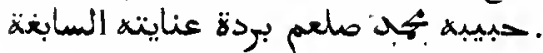

Ms. daté de l'an 846 de l'hégire (1442-1443 de J. C.).

Papier. 253 fenillets. Hauteur, 23 centimètres; largeur, 1 a centimètres. 25 lignes par page. - (Supplément 1455.)

\section{0.}

Délices des aspirants Mav. oliextaux. - II. et don pour les solliciteurs n, commentaire sur la Borda, par Aḷmad ilon Mlọammad ibn abî Bakr, auteur dı $x v^{\circ}$ siecle. Commencement: Ms. daté de l'an 1006 de l'hégire (1597 de J. C.).

Papier. sog feuillets. Hauteur, 19 centimètres; largeur, 13 centimètres el demi. 11 lignes par page. -- (Supplément 1458.)

\section{1.}

$1^{\circ}$ Commentaire sur la Borda, par Djalâl al-Dîu alMaḥalli.

$2^{\circ}$ (Fol. 2 i $v^{\circ}$.) Extrait de l'ouvrage du schaïkh Ibrà-

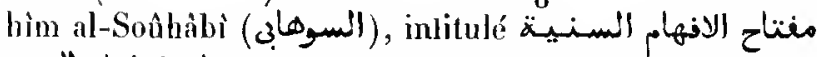

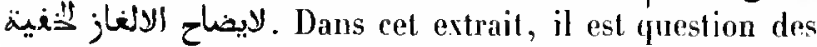
subtilités et des dilficultés de la langue arabe.

Papier. 43 fenillets. Hauteur, ao centimètres; largeur, 15 centimètres. Écritures différentes du $\mathbf{x v}^{\circ}$ siècte. - (Supplénent $19^{4}{ }^{4}$.)

\section{2.}

Commentaire sur la Borda, par Khàlid al-Azbarì.

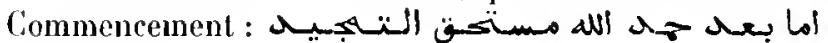
.

Papier. 58 feuillets. Hauteur, 21 eentimètres el demi; largenr, 15 centimètres et demi. 21 lignes par page. Ms. du imiı siècle. (Supplément 1464.)

\section{3.}

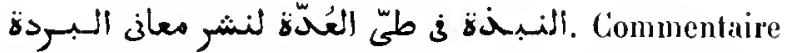
sur la Borda, par Moḥammad ibn Hasan al-Baramoûnì

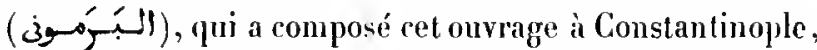
pendant qu îl était logé dans un des télii fondés par Bayazìd

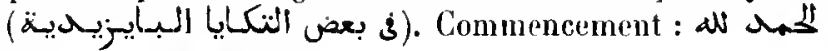
.

Papier. 77 feuillets. Ilautcur, go centimètres et demi; largeur. 15 centiunètres. Ms. du xvı' siècle. - (Supplément 1463.)

\section{4.}

Commentaire sur la Borda. Le commencement est presque complètement effacé.

Ms. daté de l'an 1163 de l'hégire ( 1750 de J. C.).

Papier. 119 feuillets. Hauteur, so centimètres; largeur, 13 ceutimètres. 21 lignes par page. - (Supplénenul 1461.) 


\section{5.}

La Hamrîya d'Al-Boùsirì. (Voyez ci-dessus, $11^{\circ} 3$ 154, $\vartheta^{\circ}$.) Nombreuses notes marginales.

Papier. so feuillets. Ulauteur, a I centimètres et demi; largeur, 15 centimètres. 13 à 15 lignes par page. Ms. du xvu siècle. - (Supplément 1468.$)$

\section{6.}

Takhmîs de la Ilamzíya d'Al-Boûșirì. Premier hémistiche :

$$
\text { يا على العليا لنيك أعتـلاء }
$$

Ms. dalé de l'an 1163 de l'hégire (1750 de J. C.).

Papier. 62 feuillets. Hauteur, 25 centimètres et demi; largeur, 16 centimètres. 12 lignes par page. - (Supplément 146@̊)

\section{7.}

مُ Dons provenant de la Iecque, pour servir de commentaire à la Hámzíya, par Schihảb al-Dìn Ahmad ibn Iladjar, mort, selon Hadji Khalfa (1. IV, 1) 577), en $97^{3}$ de l'hégire (1565-1566

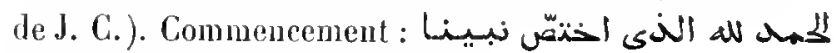

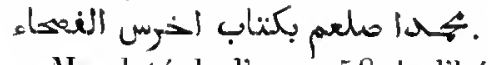

$\mathrm{M}_{\mathrm{S}}$. dalé de l'an 1058 de l'hégire (1648 de J. (.).).

Papier. 281 feuillets. Hauteur, 21 centimetres; largeur, 15 centimétres. 21 lignes par page. - (Supplément 1467.)

\section{8.}

$1^{\circ}$ Commenlaire sur la Hamziya, par Molnammad ibn 'Abd al-Mon im al-Djaudjari. Commencement : al on

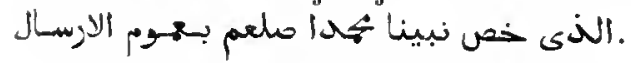

$2^{\circ}$ (Fol. $851^{\circ}$. ) Talihmis d'une qaṣida de quarante vers

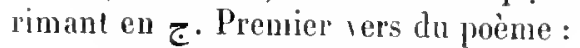

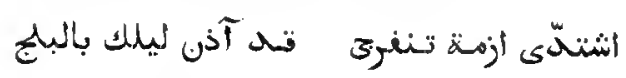

(Comparez ci-dessus, $n^{\circ} 1620,13^{\circ}$.)

$3^{\circ}$ (Fol. $87 \mathbf{v}^{\circ}$.) Qașida attribuée à l'imàm Al-Ghazàli el intitulée ألمنفوجة Commencement :

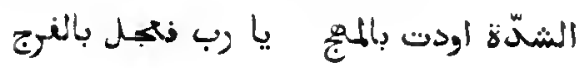

$4^{\circ}$ (Fol. $88 v^{\circ}$.) Commentaire sur la Borda d'Al-Bôtsìnî, par Schaïkı-Zàdè (Mohyyi al-Dìn Mohammad ibn Moș̣alà), morl en $9^{5} 1$ de l'hégire (1544-1545 de J. C.).

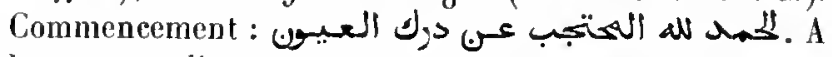
la marge on lil une Iraduction du poème en vers persans. L'explicit nous apprend que ce commenlaire est connu sous le litre de ألمسالة الطوازية ف ملح خير المبرية

La copie est datée de l'an 1027 de l'hégire $(1618$ de J. C.).

$5^{\circ}$ (1'ol. 124.) Le بانت سعاد de Kåb ibn Zohaïr.

6० (Fol. 125.) Qașida intitulée سيغ النصر , par Mohammad ibn Nâsir ş, Nl. Premier vers :

$$
\text { با وبنا اللعلى يا وهاب سجكانك اللمهم يا تواب }
$$

$7^{\circ}$ (Fol. $125 v^{\circ}$.) Qaṣida dont voici le commencement :

$$
\text { سمعت سويجيع الاتلات غنا }
$$

Papier. 126 fenillets. Jlauteur, 29 centimètres; largeur, 20 centimètres. Écrilures diverses du xv" siècle. -- (Supplément ${ }_{1470 .}$ )

\section{9.}

Takhmis de la Lamiya de Zaïn al-Dìn (ou Șirâdj al-Dìn) Aboû llafș 'Omar ilm al-Wardi, morl en 749 de l'hégire (1349 de J. C.). La qaşida, qui porte le titre de نص Conseils pour nos frères el guide pour nos amis $\%$, commence par ce vers:

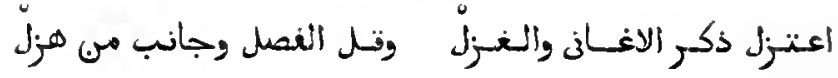

Commencement du takhmis :

$$
\text { أيها المغرون وافاك الاجهل }
$$

Papier. 8 fenillets. Hauteur, a a centimètres; largeur, 15 centimètres el demi. 20 lignes par page. Ms. du xrui siècle. - (Supplément 1589.)

\section{0.}

$1^{\circ}$ Takhinis de la Lâmiya d'Ibn al-Wardi, par Yoúsof at-Maghrabl. Ce talihmîs a été composé en 1020 de l'hégire (1611-1612 de J. C.).

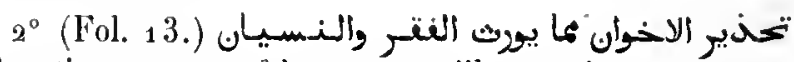
"Avertissement aux frères pour quils se préservent contre ce qui amène la paurreté et l'oublin, traité de morale, par Borhàn al-Din Ibrâhîm ibn Maḥmoûd at-Dimaschgi.

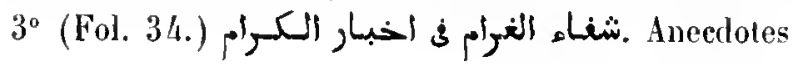


touchant les hommes généreux. Huit chapitres. Com-

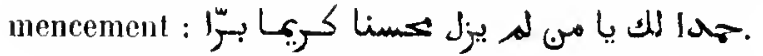

$4^{\circ}$ (Fol. 54 v.) Notes et extraits en prose et en vers.

$5^{\circ}$ (Fol. 57 v $^{\circ}$ ) Taschtîr de la Lamíyat al-Adjam de Toghrầi, par lbràhìm ibn Moḥammad al-Anșâri. Premier rers :

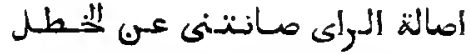

$$
\begin{aligned}
& \text { وتشجمة لالم مسلّتسنى عسى الـزلهل }
\end{aligned}
$$

(Ce genre de poème est appelé aussi تصدير وتكبيز).

$6^{\circ}$ (Fol. 64.) Autre taschtịir du même poème. Premier vers :

$$
\begin{aligned}
& \text { اصالة الرأى صانتتنى عسى فـــل } \\
& \text { وتــوة المعـزم قــادتـنى اله الامــل }
\end{aligned}
$$

$7^{\circ}$ (Fol. 69.) Notice biographique d'Al-Toghrà î, suivie de quelques extraits de ses poèmes.

$8^{\circ}$ (Fol. $7^{3} v^{\circ}$.) Demande d'une licence d'enseigner (idjåa), rédigée partie en prose, partie en vers, et texte de l'idjâza, également en prose et en vers.

$9^{\circ}$ (Fol. 8o.) Extraits en prose et en vers.

Papier. 82 feuillets. Hauteur, 23 centimètres et demi; largeur, 13 centimètres. 17 à 19 lignes par page. Ms. du xvi' siècle. - (Supplément 1478. )

\section{1.}

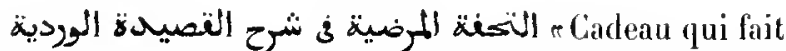
plaisir, explication de la Qasida (al-Lâmiya) d'Jbn alWardì, par Abon 'L-Jkhlâs al-Ghanîmi. La préface com-

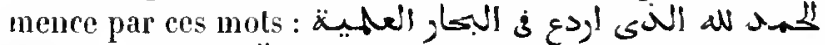
8) Elle contient une notice sur Ibn alWardi et une liste de ses ouvrages. Le Kharîlat al- ${ }^{\circ}$ Adjailb n'y est pas inentionné.

Ns. daté de l'an 1123 de l'hégire $(1711$ de J. C.).

Papier. 147 feuillets. Hauteur, 21 centimètres; largeur, 15 centimètres. 21 lignes par page. - (Supplément 1588.)

\section{2 .}

re Doux parlum, commentaire sur la Qasida d'llı al-Wardi», par "Abd al-Wahlıàb ibn Nohammad al-Khatib ibn al-

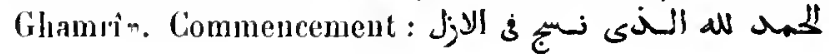

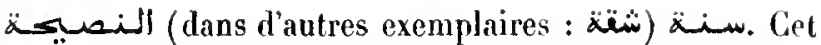
ouvrage a été composé en 1030 de l'hégire (1630 de J.C.).

Ms. daté de l'an 1037 de l'hégire ( 1628 de J. C.).

Papier. 155 feuillets. Hauteur, 22 rentimètres; largeur, 16 centimètres. 19 lignes par page. -- (Supplément 1587.)

\section{3.}

\section{Nême ouvrage.}

Papier. 57 feuillets. Hauteur, 22 centimètres; largeur, 16 centimètres. 23 lignes par page. Ms. du xvm ${ }^{\circ}$ siècle. - (Supplément 1590. )

\section{4.}

$1^{\circ}$ Mème ourrage.

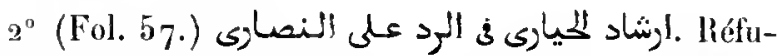

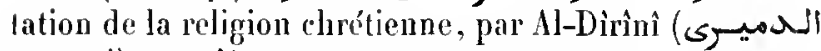

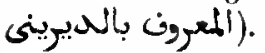

اوحد ألاولي أOا de Molıyî al-Dìn Ilın a]-'Arabi.

$4^{\circ}$ Fol. 65. 65. Traité de grammaire en vers sur les particules et les mots appelés مثالثنات, par 'Alì al-Miṣì.

$5^{\circ}$ (Fol. 68.) Traité de grammaire en vers sur les proposilions, par le schaiklı Al-Madjroûd (لجمورد).

$6^{\circ}$ (Fol. 71.) Commentaire de Nadjm al-Din Mohammad ilon 'Adjloùn sur la 'A pida d'Al-Schaibàni.

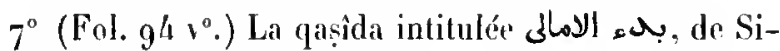
rêdj al-Dìn 'Alì ibn 'Othuıàn.

Ms. tout entier de la mème main, daté de f'an 1171 de l'hégire ( 1758 de J. C.).

Papier. 98 feuillets. Ilauteur', 23 centimètres; largeur, 15 centimètres. ${ }_{7} 7$ liģnes par page. - (Supplément 1926.)

\section{5 .}

Divan de Safï al-Dìn 'Abd al-'Aziz ibn Saràyì alIJilli. Dans la préface, l'auteur expose les motif's qui le porlèrent à réunir ces pièces et à en former un divan (royez le texte et la traduction de ce passage dans le Catalogue de la Bibliothèque bodléienne, I. II, P. 302). Cies pièces de vers sont divisées, d'après leurs sujets, en douze. sections. Dans la onzième, on trouve une pièce composée de plus de soixante-dix vers, renfermant beaucoup do 
mols appartenant ì une Iangue étrangère (لغة ألغوب). Les équivalents arabes sont écrits dans les entre-lignes. Selon Iladji Khalla, ce poète est nort en 75 g do l'hégire ( 1358 de J. C.).

Papier. 265 feuillets. Inateur, a a centimètres; largeur, 14 centimètres. 19 ligrnes par page. Ms. dont la partie ancienne parait ètre du $x v^{\circ}$ siècle; il a été restauré vers la fin du xvu" siècle. - (Ancien fonds 1449.)

\section{6.}

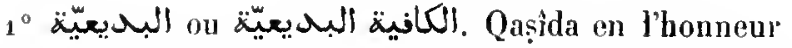
du Prophèle, en cenl quarante-cinq vers, dont chacum offre un exemple d'une figure de rhétorique (بגيع), par Şafì al-Din al-ḷilli. Le poème est accompagné d'un commenlaire du méme auteur. Commencement : al and

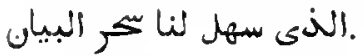

$2^{\circ}$ (Fol. 70.) Lettres de divers Exivains, données comme modiles de slyle.

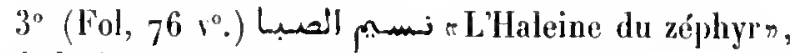
anthologic en prose et en vers, par Hasan ibn Habîb alIIalabi. Ce recueil est divisé en trente chapitres. Com-

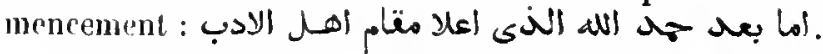

$4^{\circ}$ (Fol. $148 v^{\circ}$.) Badíiya en l'honneur de Mahomet, par Aboù Bakr ilun cllì ibn Hiddja al-llamawì. Premier rer's :

$$
\begin{aligned}
& \text { له ف ابتح| مدحكم يـاعسب ذي سملم }
\end{aligned}
$$

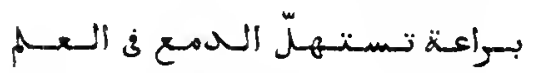

$5^{\circ}$ (Fol. $\left.15_{2} \vee^{\circ}.\right)$ Badíya, par Ismacil ibn al-Ḥosaîn. premier vers :

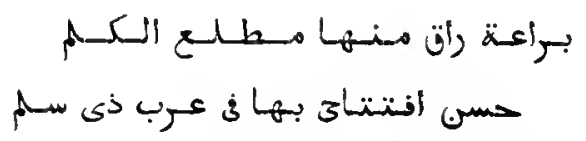

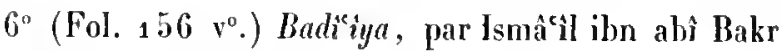
al-Moqri. Premier ver's :

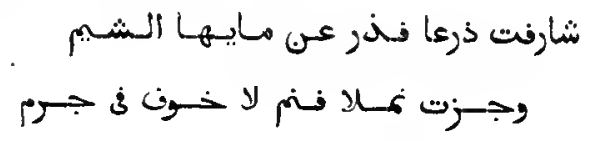

Papier. 164 feuillels. Hanteur, 21 centimetres ef demi; largeur, 13 centimètres et demi. 19 lignes par page. Ms. du xvı ${ }^{e}$ siècle. - (Supplément 1584.)

\section{7.}

$1^{\circ}$ La Badiềya de Safì al-Dìn a1-Hilli. $2^{\circ}$ (Fol. $2 v^{\circ}$.) La Badína d'Aboù Bakr ihn 'Alî ibn Hiddja al-llamawi.

$3^{\circ}$ (Fol. 4.) La Badíîya d’Abd al-Ralımàn ibn abì Bakr al-Soyouttî. Chaque vers est suivi d'un commenlaile. Premier vers :

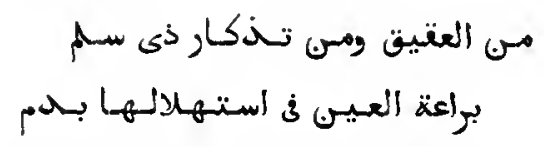

Papier. 8 feuillets. Hauteur, 35 centimètres; targeur, 11 centimètres et denii. 58 à 74 lignes par page. Is. du xvü siècle. - (Supplément 1/49t.)

\section{8.}

Divan de Mohammad Wafà, soufi el derviche de l'ordre de Schàdsili. IIadji Khalfa menlionne ce poète mystique dans plusieurs endroits de son ourrage (t. 11 , p. 276,652 , t. IV, p. 48 et t. V, p. 39 ); mais il n'indique pas à quelle époque il vivait.

Papier. 138 feuillets. Haulcur, 21 centimètres; largeur, 15 centimètres et demi. 19 lignes par page. Ms. du xvn'e siècle. - (Supplément $152 \%$.)

\section{9 .}

Divan de Borhân al-Din Ibrâlı̂̉m ibn 'Abdallah alQirrịi. La prélace, écrite en slyle fleuri, et remplissant dix pages, renferme un éloge de la poésie. Le premier feuillet inanque.

Papier. 101 feuillets. Hanteur, 21 centimètres; largenr, 15 centimètres. 2 I lignes par page.Ms. du xnm" siècle. - (Supplément $15{ }_{17}$.)

\section{0.}

Divan de Faklı' al-Din 'Abd al-Rahmàn Ibn Makànis, * vizir de l'Égypte et de la Syrie ^. On y trouve une qasîda adressée au sullan Al-Malik al-Zảhir Barkouk, qui régnait de 784 à 792 de l'hégire (1382 à 1391 de J. C.);

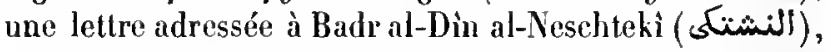
datée de l'an 784 de l'hégire; une autre, adressée à Yelboghà al-Nàsiri, lientenant-gouverneur d'Alep, est peutètre de la même époque. Ce recueil a été formé par le fils

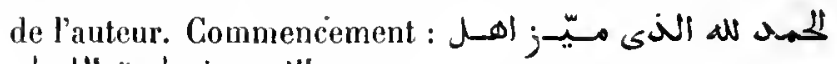
الادب بغصاحة النساب

Papier. 196 feuillets. Hauteur, 18 centimètres; largeur, 13 centimètres et demi. 13 lignes par page. MIs. du $x v^{\circ}$ siècle. - (Ancien fonds 1442.) 


\section{1.}

Mème ourrage.

Papicr. 157 feuillets. Hauteur, a centinètres; largeur, 16 centimètres. 13 lignes par page. - (Ancien fonds 1443.)

\section{2.}

Divan de Schihâb al-Dìn Aḷmad iłon Moḥammad alHàim (l'égaré) al-Salamì al-Manṣoutrî, descendant d'Al'Abbàs ibn Mirdàs. L'auteur a publié ce divan au Caire, en 825 de l'hégire ( 1421 de J. C. $)$.

Papier. 101 feuillets. Hauteur, 31 centimètres; largeur, 15 contimètres et demi. 19 lignes par page. $11 s$. du xv' siècle. - (Ancien fonds 1440.)

\section{3.}

La Badi'iya d'Aboù Bakr ibn !̣iddja, avec un commen-

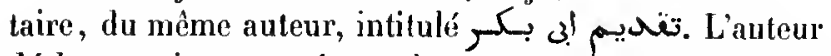
déclare avoir composé ce poème en prenant pour modèle la Borda et en adoptant la même mesure et la même rime, d'après les recommandations de son maitre (مولانا) Mohammad al-Bàrezî. Il donne successivement des exemples de toutes les figures de rhétorique. Il dit, à la fin de l'ouvrage, quil a reproduit toutes les élégances de style que l'étudiant de la belie littérature pourrait désirer. Les citations des poètes sont si nombreuses dans ce commentaire et les renseignements philologiques si abondants, que le célèbre Ibn Ḥadjar le regardait comme un véritable trésor. (Voyez Hadji Khalfa, t. II, p. 34.) Cet onvrage a été achevé en 826 de l'hégire (1423 de J. C.).

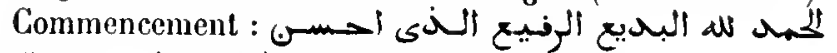

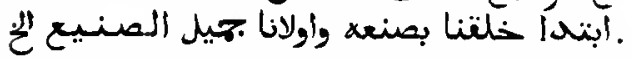

Papier. 216 feuillets. Hauteur, so centimèlres; largeur, 15 centimètres. 21 lignes par page Ms. du $x v^{\circ}$ siècle. - (Supplément 1581.)

\section{Même ouvrage.}

\section{4 .}

Ms. daté de l'an 980 de l'hégire ( ${ }_{1} 57_{2}$ de J. C.).

Papier. 33a feuillets. Hauteur, 28 centimètres; largcur, 18 centimètres. 29 et 31 lignes par pagc. - (Ancien fonds, 382 .)

\section{Même ouvrage.}

En tète se trouve un index des figures de rhétoripne.

Papicr. $13_{2}$ feniflets. Hanteur, 29 centimètres; largeur, 2 t centimètres. 37 lignes par pagc. Ms. du xvi sic̀cle. - (Ancien fonds 1408.)

Mème ourrage.

\section{6.}

Ms. daté de l'an $99^{6}$ de l'hégire (1588 de J. (i.).

Pipier. 210 fcuillets. Hautcur, 31 centimètres; largeur, 20 centimètres et demi. ag lignes par page. - (Ancien tonds 1381.)

\section{7.}

Seconde partie du mème ouvrage.

Papicr. 208 feuillets. Hauteur, 21 centimètres et demi; largeur, 15 centimètres. a 1 lignes par paģe. Ms. du $\mathrm{ww}^{\mathrm{e}}$ siècle. - (Incien fonds 1412.)

\section{8.}

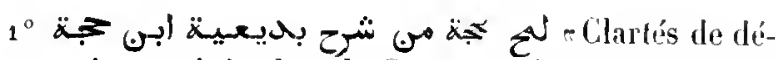
monstration, puisées dans le Comnenlaire de la Badiina l'lbn lliddjas, par Moḷammad ibn lḷmad al-Samnoùdi. auteur du $\mathrm{xv}^{\mathrm{e}}$ siècle. Commencement : • صدورنا بتموفبته ألبليع الملاسلام

$\Lambda$ la fin dn ms. se trouvent quelques pièces écrites de diverses mains, qui paraissent être des préfaces à des traités de rlétorique.

Papier. 120 feuillets. Hauleur, 18 centimètres; largeur, 13 cenlimètres et demi. 17 lignes par page. Its. du vvi siècle. - (Aucien fonds 1475.$)$

\section{9.}

Divan de Schihàb al-Dìn Aḷmad ibn Iladjar al- Isqalànì, mort en 852 de J'hérgire (1448-1449 de J. C.). Ces poésies sont distribuées en sept sections : $1^{\circ}$ النبوريات

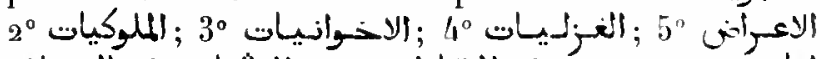

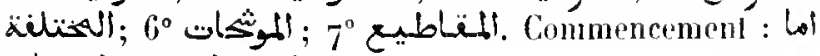
بعد أجد الله على احسانه

Papicr. 110 fevillets. Hauteur, 18 centimètres; largeur, 14 centimètres. 15 lignes par page. Ms. du $x v^{\circ}$ siècle. - (Ancien fonds $1 / 41$, Colbert 4987 .) 


\section{0 .}

"Live pour amuser les eaprits el cérider les fionts soucieux». Divan d’ Alî ibn Soûdoñn al-Baschbaghàwi. Ces pièces sont classées en rinq chapilres, selon les sujets. Commencement : لـ و

Ms. dití de l'an 988 de l’hégrire (1580 de J. C.).

Papier. 133 fcuillcts. Itautenr, 20 centimètres; largeur, 15 centimètres. 13 lignes par page. - (Supplément 1511.)

\section{1 .}

Divan de Kbalíl ou K'halîli, commençant, sans préface, parr un porme moral et mystique de plus de douze cents vers, ayant la méme rime, el dont voici le premier :

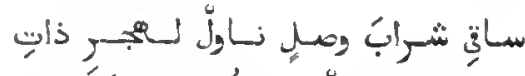

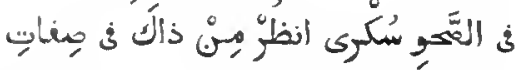

La pièce suivante est du même genre et commence par ce ver's:

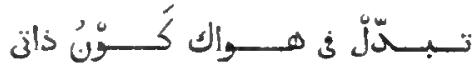

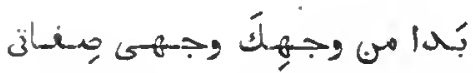

Viennent ensuite plusieurs ghazals, dans lesquels l'auteur, en finissint, jone presque toujours sur les diverses significations du mot lihalil, et un certain nombre de quatrains. Par des rubriques inserites sur les feuillets $87 v^{\circ}$ at 88 recto, on roit que l'auteur était mort

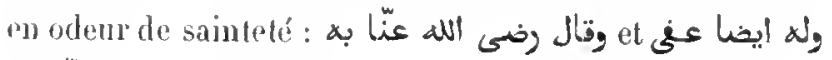
xu Lis avl.

I’apier. 105 feuillets. Itauteur, 21 centimètres; largeur, 13 centimètres. 15 lignes par page ( 11 lignes à partir du fol. 88). - (Ancien fonds 1158.$)$

\section{2 .}

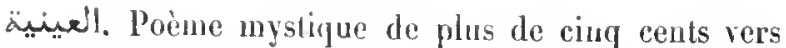
rimant en 'ä̈, par 'Abd al-Karìm al-Djilì. Premier vers:

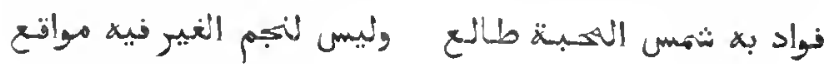

A la fin du ms. se trouvent des fragments de trois qasildas, sans titres ni noms d'anteurs.

Papier. 16 feuillets. Hlauteur, 21 centimètres et demi; largenr, 15 centimètres et demi. 19 liğnes par page. - (Supplément 14.92.)

\section{3 .}

$1^{\circ}$ Takhnis de l'Aimîya d"Abd al-Karim al-Djîlì, pa Abou 'l-Fatlı Sirṭàn s, Schernoúbi. La préface, en prose, remplit plus de onze

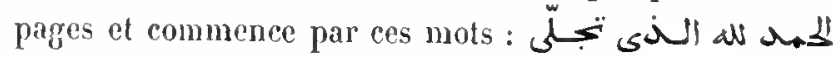

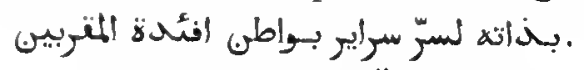

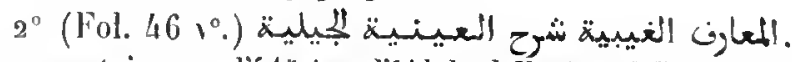
Commentaire sur l's Ainîya d'cAbd al-Karìm al-Djîlì, par' 'Abd al-Ghanî al-Níłolosî. Commencement : âN U.B

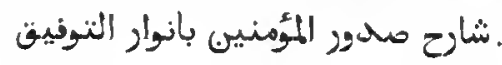

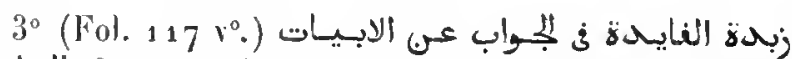

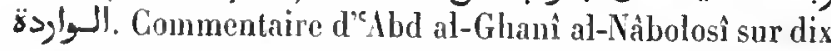
vers composés par lui, pour interpréter le sens mystique de quatre vers de Moḷyì al-Dìn Ibn al-'Arabî.

$4^{\circ}$ (Fol. $\left.122 V^{\circ}.\right)$ Commentaire d'eAbd al-Ghanî alNäbolosî sur un traité mystique du schaỉhl Arslàn, de

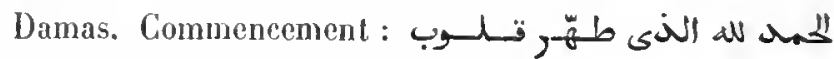

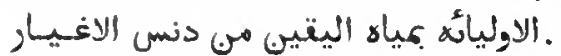

Papier. 1 go feuiltels. Hauleur, a 1 centimèlres; largeur, 15 centimètres. 2 lignes par page. - (Supplémenl 1493.)

\section{4.}

inspiralion du miséricordieux, fouruissant l'explication du poème sur les tombeaux ». Commentaire d'Ahmad ibn Khalì al-Sobkî sur l'Ordjoñza de Djalâl al-Dìl al-Soyoûṭi, intitulée : التنثبيت e Traité pour raffermir le coeur lors de la visite nocturue». Selon Hadji Khalfa, l'auteur du commentaire est nort en 1037 de l'hégire $(1627-1628$ de J. C.). Commencement :

Ms. daté de l'an 1201 de l'hégire (1 787 de J. C.).

Papier. $19^{4}$ feuillets. Hauleur, 16 centimèłres; largeur, 11 centimètres. 11 lignes par page. — (Supplémenl 1585.)

\section{5 .}

- Voie de la source pour éloigner la soif . Tálya sur la viè dévote, texte el commentaire, par 'Abd al-Qâdir jon 'Omar ibn Habìb al-Ṣafadi, mort en 915 de l'hégire ( 1509 de J. C.). Un autre soufi, nommé 'Alì ibn 'Ațiya al-Hamawì 'Alwân, mort en 922 de l'hégire (1516 de J. C.), a commenté, à son tour, le 
poème d'Al-Safadi, et a placé en tête de son Iravail une longue notice sur l'auteur. (Voyez Hadji Khalfa, t. III, p. 609 .)

Ms. dalé de l'an 995 de thégire ( 1587 de J. C.).

Papier. 139 fenillets. Hauteur, a 1 centimètres; largeur, 15 centimètres et demi. 23 à 25 lignes par page. - (Ancien fonds 1457.$)$

\section{6 .}

r Signe de la faveur divine qui nous a fait aperceroir le sens de la réunion el de la séparationn, par Nadjm al-Din Mohammad ibn Mohammad al-Ghazzì al-Ämirí. C'est un commentaire sur quatre vers mysliques, composés par 'Alì ibn 'Aḷya 'Alwìn, et dont voici le premier :

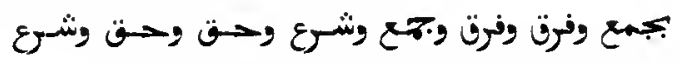

Papier. 10 feuillets. Hauteur, 21 centimètres et demi; largeur, 15 centimètres et demi. 21 lignes par page. Ns. du xriut siècle. (Supplément 1577.)

\section{7.}

R Rirílalions précieuses et secrets cachés $n$, recueil de poésies mystiques, de discours el de lettres, par le schaïhl Aḷmad ibn 'Alwìn.

Papier. 121 feuillels. Hauteur, s 1 centimètres; largeur, 15 centimètres. 17 à a 4 lignes par page. Hs. du xvu" siècle. - (Supplément 1519.)

\section{8 .}

Divan d'Izz al-Dìn 'Abd al-'Aziz al-Zammamì al-Ilakki, mort en 963 de lhégire (1555-1556 de J. C.). Ces poésies sont réparties en lrois sections : $1^{\circ}$ à la lonange du Prophèle; $2^{\circ}$ (fol. 62 ) à la lounge des savants docteurs

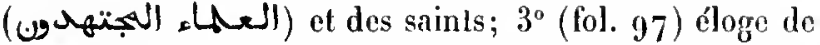
la Mecque, du territoire sacré, du llidjâz, elc. Dans la première pièce de la troisième seclion, l'auteur a inséré un itinéraire de Moka (Lال الà la Mecque.

Ms. de la main du petit-fils de l'anteur (royez fol. 1 et 110$)$. Vignelte au verso du fol. 1.

Papier. 110 feuillets. Hauteur, 22 centimètres; largeur, 14 centimètres et demi. 19 lignes par paģe. Ms. du $\mathrm{rv}^{\circ}$ siècle. - (Ancien fonds , 456.)

\section{9 .}

Divan d'Aboû Bakr Moḥanmad ibn abi '-ḷasan Zaïı al- Âbidìn al-Bakrì al-Ṣiddìqí. C'est un recueil de poúsies mystiques. L'auleur vivajt vers le milieu du xv1 ${ }^{\circ}$ siècle; car l'une de ces pièces de vers a élé composée en 957 de l'hégire (royez fol. $481^{\circ}$ ). Commencemenl: $\lambda_{\text {a }}$. آله ناقتش آيات الاحلديّة بعحايف ألارواح

La fin manque.

Papier. 83 feuillets. llanteur, so centimetres; largenr, 1/4 centimètres. 2. lignes par page. Ils. du xv11 siècle. - (Supplément 1514 .

Hème ouvigge.

\section{0.}

Papier. 128 feuillets. Hauteur, 25 centimetres; largeur, 18 centimétres. 13 lignes par page. Is. du xvi ${ }^{e}$ siècle. - (Supplément 1516 i.)

\section{1 .}

Extraits du divan de Moḷamnad al-Bakrì Zain alcíbidìn.

Papier. 3o feuillets. IIanteur, 21 centinètres; largecur, 15 centimètres et demi. 1 /4 à 18 lignes par page. Ms. du rwu' siècle. - (Sup)plément 1515.)

\section{2.}

Autres extrails du divan de Holanmmad al-Bakri Zaïn al-ibidin.

Papier. 6a feuillets. Ilautenr, 30 centimc̀tres; largeur, 15 centimètres. 9 à 16 liggnes par page. Ms. du $x^{\prime} 1^{\circ}$ siècle. - (Ancien fonds 1469 , Colbert 5ao6.)

\section{3 .}

Divan des poésies mysliques d'Ahmad ihn Zaïn al-

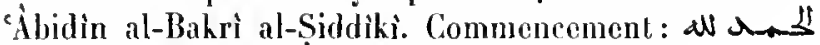
النزى جعل ربامز الادب نزهة النغوس وتحنة الاحبياب.

Ce ms. a élé écrit du vivant de l'auleur.

Papier. 46 feuillets. Hauteır, 19 centimètres et demi; Iargeur. 14 centimètres. 13 liggnes par page. - (Sipplément 2018.)

\section{4.}

Divan d'Abd al-Wahluab al-Schacrini. Commencement de la préfice : أهد مه نصب ديسوأن مسوأكب عـوأزف 


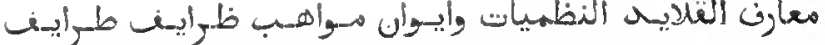

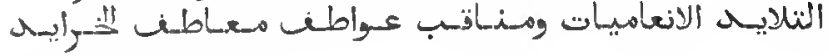
"ل

Le uns. est daté, à la fin, de l'an 942 de thégyire ( 1535 de .l. C. ); mais te premier el le dernier feuillet ont été ajoutés après coup.

Papjer. 334-feuillets. Ilantenr, 26 centimetres; largeur, 15 centimetres. 21 lignes par page. - (Supplément 1530.)

\section{5 .}

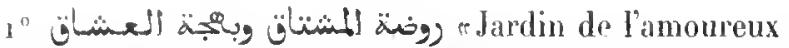
el délices des amants\%. Divan de Molrammad ibn Ahmad

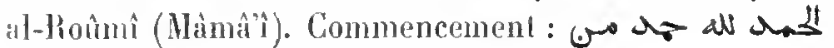

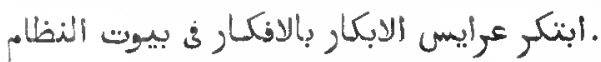

$2^{\circ}$ (Fol. $59 \mathrm{~V}^{\circ}$.) Piéces de rers et notes de diverses mains.

$3^{\circ}$ (Fol. $65 \mathrm{r}^{\circ}$.) Divan composé de quelques pièces de vers ef d'un grand nombre de morceaux en prose

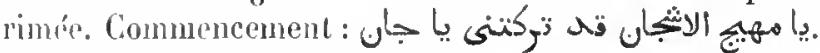

$4^{\circ}$ (Fol. $\left.8 y.\right)$ Noles et extraits, en vers et en prose, de diverses mains.

Papicr. 97 fouillets. Hautenr, 20 centimètres et demi; largeur, 14 centimetres el demi. Écrilures diverses du xvur siècle. - (Supphément 1525.)

\section{6.}

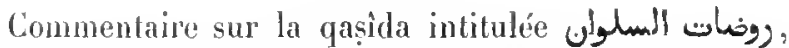
composée en g86 de l'hégire, par Abou 'L-Qâsim ibn Molıammad ibn 'Abd al-Djabbân' ibn Aḷmad (de Figuig).

Ms. daté de l’an 1024 de lhégire (1790 de J. C.).

Papier. $9^{6}$ feuilfets. Ilauteur, 19 centimètres; largeur, 15 centimètres. 25 lignes par page. - (Supplément 2452.)

\section{7.}

Divan d'un auteur inconnu. Ce sont des poésies mysliques, classées dans l'ordre alphabétique des rimes. Le commencement et la fin manquent. Au fol. $9^{8} \mathrm{r}^{\circ}$ on lit le rakhmis d'une qașida de Tàdj al-Dìn ibn 'Atà-allah, derviche schâdsilite, mort en 709 de l'hégrire $(1309$ de J. C.).

Papier. 177 feuiltets. Hauteur, 20 centimètres et demi; largeur, 13 centimètres et demi. 15 tignes par page. Ms. du xvm ${ }^{\mathrm{e}}$ siècle. (Supplément 2176.)

\section{8 .}

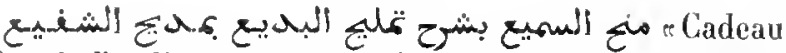
offert à l'auditcur, pour servir d'explication au Tamlihh. al-Badle, poème à la louange de notre intercesseur (Mahomet) \%. C'est l'alrégé du commentaire d"Abd al-Rahmìn al-Homaïdì sur sa Bâdîiya. Commencement de la

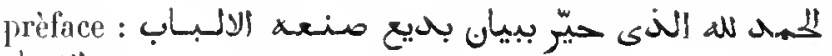
.

Premier vers du poème :

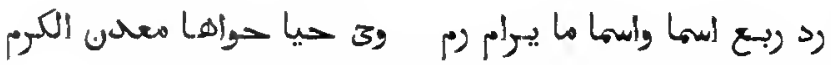

Ms. daté de l'an 1009 de l'hégire (1601 de J. C.).

Papier. 150 feuillets. Hauteur, so centimètres et demi; largeur, 15 centimètres. a1 lignes par page. - (Supplément 158s.)

\section{9.}

Pensées originales el tournures mises en r'éserve $\pi$. Divan d'Ibrâlıim ibn Aḷmad ibn Hoḥammad Ibn al-Mollâ. Les premières de ces poèsies sont datées de l'an 987 de l'hégire (1579 de J. C.), et les dernières de 1017 (1608 de J. G.). Com-

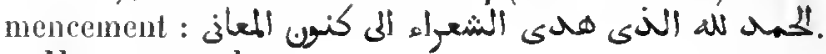
Ms. autographe.

Papier. 265 feuillets. Hauteur, a centimètres et demi ; Jargeur, 15 centimètres et demi. 18 à a 5 lignes par page. - (Supplément 1513. )

\section{0 .}

r Souhait du précepteur et satisfaction de l'étudiant, commentaire sur la Qaşî̉an. La qaṣida est celle qui a été composée

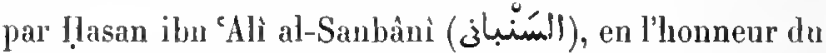
sultan Aïman (أهى), fils du sultan 'Abd al-Hosaïn ibn

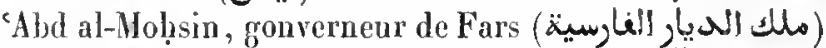

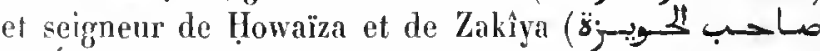
a_-Sزl'). L'auteur a employé dans cette qașida beaucoup de mots d'un usage rare. C'est pourquoi son fils, qui ne se nonme pas, a composé le commentaire. Premier vers du poème:

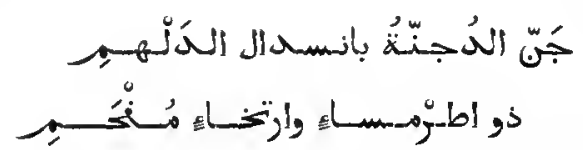

Commencement de la préface : مصاقع هuarante-six feuillets, placés cn tête dı 
volume, renferment la liste des mots dont l'explication est donnée dans le commentaire. Les lignes de cette liste sont disposées en forme de filet.

La fin manque.

Papier. 195 feuillets. Hauteur, so centimètres et demi; largeur, 15 centimètres. 18 lignes par page. Ms. du xvi siècle. - (Supplément 1594 .)

\section{1.}

Divan d'un saint personnage, appelé Al-Saîid Hảtim. Plusieurs des pièces contenues dans ce recueil sont datées de l'an 1009 de l'hégire (1600 de J. C.). Commence-

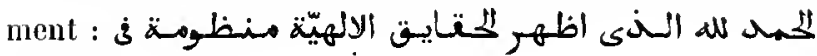
. جيد الوجود :

Papier. $19^{4}$ feuillets. Hauteur, 21 centimètres; largeur, 14 centimètres et demi. 19 lignes par page. Ms. du xv $11^{\circ}$ siècle. - (Supplément 1531 .)

\section{2.}

romment, en regardant des deux yeux, on pénètre le sens des deux vers intitulés Al-Raqmataïn \%. Dans ce traité, l'auteur, Aḷmad ibn Mohammad ibn 'Alì ibn Zighlàn (jeبـ) al-Mlaghribî, indique quarante explications mystiques des vers suivants :

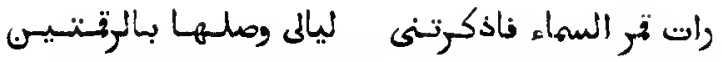

$$
\begin{aligned}
& \text { كلانسا نـاظبر تــرا ولكسى رايت بعينها ورات بعينى }
\end{aligned}
$$

-Voyant la lune dans le ciel, elle me fit ressouvenir des-nuits où nous nous rencontrions à Al-Raqmataïn.

- Chacun de nous voyait une lune, mais je la royais avec les yeux de cette femme et elle la voyait arec les miens?.

Ms. daté de l'an 1034 de l'hégire (1625 de J. C.).

Papier. 30 feuillets. Hauteur, so centimètres; largeur, 14 centimètres. s1 lignes par page. - (Supplément ${ }_{15} 7_{6}$.)

\section{3.}

r Secours venant de Dieu et victoire prochainer, commentaire Irès diffus d'Al-Schaloûbîn sur un poème composé en l'honneur de Mahomet par le derviche Moștafí ibn Qísim ibn 'Abd al-Karîm, de Tripoli de Syrie, qui vivait encore en 1032 de Max. obiextacx. - it. thógire (1622-1623 de J. C.), et dont la biographie se trouve au fol. $9^{6} \mathrm{v}^{\circ}$ de ce volume. Commencement :

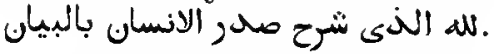

Commencement du poème :

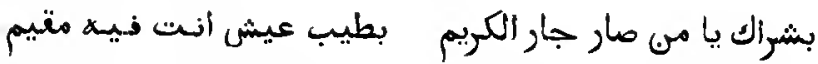

Papier. a0 1 feuillets. Hauteur, 17 centimètres et demi; largeur, i 1 centimètres et demi. 2a lignes par page. - (Ancien fonds 1486.)

\section{4.}

1 مévélation du Seigneur des Créatures, pour scrvir de commentaire à la qașilla d'Al-Mlaqqarì s, par Schihâb al-Dîn Ahmad ibn 'Alì al-Sandoûbî. C'est la qașida que Schihâb al-Dîn A ḥmad al-Maqqarì a mise en tète de son histoire de l'Espagno

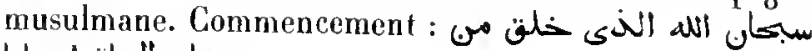
.

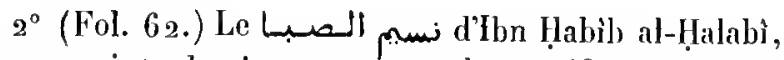
avec une introduction contenant des certificals d'approbation émanant de Tàdj al-Dìn al-Sobkì et d'autres savants.

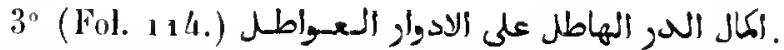
Observations d'Al-Qàbisî sur une qașìda de Yoûsof alScharbini. La qașilla entière, ainsi que le taschtir ajonté par le fils du poète, sont reproduits. La qașida commence par ce vers :

$$
\text { اطوح التوهم ودع is الكسل واسال ألعالم اصلاح المهل }
$$

$4^{\circ}$ (Fol. $121 v^{\circ}$.) Les saints peuvent-ils, après leur mort, intervenir dans la destinée de l'homme? Question discutée en la présence du grand vizir 'Abd al-Rahmàn Paclaa, sur laquelle ont opiné Aboû Saed al-Taftàzânî et d'autres docteurs. Commencement :

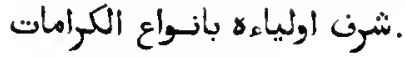

$5^{\circ}\left(\right.$ Fol. $132 v^{\circ}$.) Explication d'une énigme proposée par Taqî al-Din Aḷmal ibn Moḥammad al-Maqrîzî.

6* Fol. 137. Exposé de la doctrine lianéfite au sujet de la transmission de la noblesse chez les chérifs, par 'Omar Agha. Commencement : حها لم. تنزئ عر. الانساب.

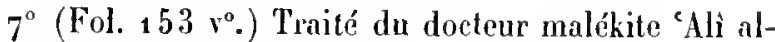
Adjhoûrì (الاججهورى) sur le jour d"Âschoùrâ.

80 (Fol. $176 \mathrm{v}^{\circ}$. ) Fatwa d"Abd al-Mon'im al-Ṭin. djànî, au sujet des فنوحات de Mohyî al-Dìn ibn al-'Ar'abì.

$9^{\circ}\left(\right.$ Fol. $\left.178 v^{\circ}.\right)$ Notes et extraits divers. 
Ms. dalé (Fol. 120 ) de l'an 1155 de l'hégire ( 1742 de J, C.).

Papier. 182 feuillets. Hauteur, 22 centimètres; largeur, 15 centiwè̀res et demi. 22 à 25 lignes par page. - (Supplément 1857.)

\section{5.}

Les Astres brillanls, commenlaire sur la qașida d'Al-Maqqarîn, par Ahmad Éfendi al-Adhanî (الادثي), mul'i de Damietle.

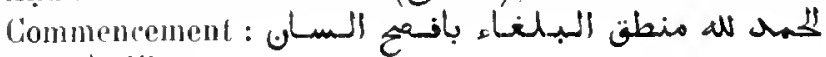
(lis. نلvil).

Papier. 44 a feuillets. Hauteur, 22 centimètres et demi; largeur, 16 centinètres. 19 à as lignes par page. Ms. du xvin" siècle. - (Supplément 1534.)

\section{6.}

Divan de Falṭ Allah al-ḷalabî ibn al-Naḥ̣̣às, mort en 1052 de l'hégire ( 1642 de J. C.).

Papier. 51 feuillets. Hauteur, 21 centimètres; largeur, 15 centimètres et demi. 15 lignes par page. Us. du xvm" siècle. - (Supplément 1510.$)$

\section{7.}

1. Divan d"Alod al-Rạ!màn Efendi. Commencement:

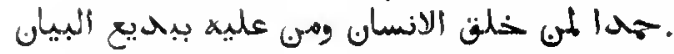

$2^{\circ}$ (Fol. 65.) Divan de Faḷ̣ Allah ibn al-Nạ̣hàs. La préface, qui manque dans le numéro précédent, commence par res mols :

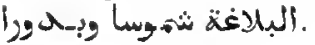

IIs. dalé de l'an 1089 de l'hégire (1678 de J. C.).

Papier. $9^{3}$ fenillets. Jjauteur, 21 centimètres et demi; largeur, 13 centimètres. 27 lignes par page. - (Supplément 1526 .)

\section{8.}

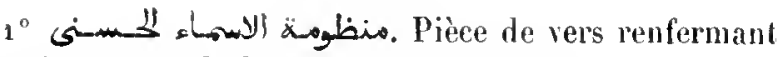
les sainls noms de Dieu. Commencement:

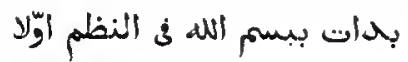

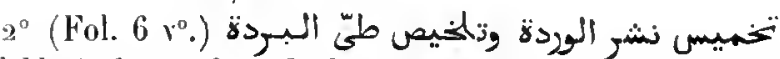
- Takhmís du parfum de la rose et explication des idées renfermées dans la Bordar, par Mohammad ibn A hmmad
al-Sakhâwî. Commencement: Premier hérnistiche :

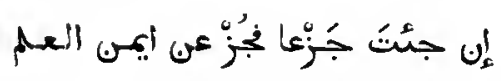

$3^{\circ}$ (Fol. $65 v^{\circ}$.) Aulre takhmîs de la Borda, par Aboû Bakr ibn Ịliddja al-Ịamawî. La préface, bien qu’elle soit en prose, est écrite en forme de takhmis. Commencement dı poème :

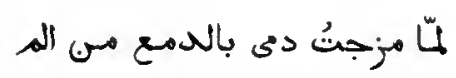

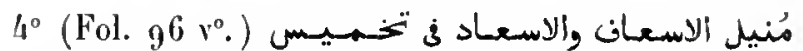

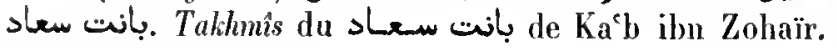
Premier hémistiche :

$$
\text { أسير'شوق عن. السسلوان معتول }
$$

Ce poème est précédé d'une préface en prose de huit pages.

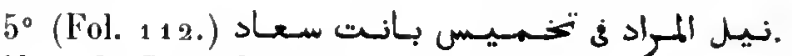
Takhmîs du Banat $S_{o}{ }^{c} a d$. Premier hémisliche:

$$
\text { قل للعواذل مهها شئتموا قولوا }
$$

$6^{\circ}$ (Fol. 123 v. $^{\circ}$ ) Commentaire du Bânat $S_{0}^{e} a ̂ d$, par

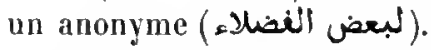

$7^{\circ}$ ( Fol. $139 v^{\circ}$.) Texte du Banat $S_{0}^{c} d d$, sous le titre

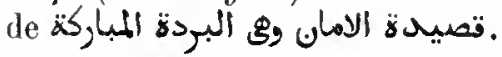

$8^{\circ}$ (Fol. $143 v^{\circ}$.) Qaṣida en l'honneur de Mahomet. Commencement :

$$
\begin{aligned}
& \text { شكوا الدموعُ فان الصبّ منشغولُ }
\end{aligned}
$$

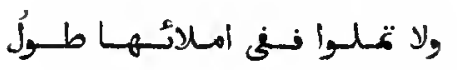

$9^{\circ}$ (Fol. 147 V $^{\circ}$ (ب) Badíýa de Sehábân ibn Mọ̣ammad al-Qoraschî. Commencement :

$$
\text { دع عنلك سَلْعًَا وسلْ عه. ساكه لِّرم }
$$

$10^{\circ}$ (Fol. $167 v^{\circ}$.) Badîîya d'Al-Ṣafi al-Hillî. (Voyez ci-dessus, $\mathrm{n}^{\circ} 3206,1^{\circ}$.)

$11^{\circ}$ (Fol. 177 v $^{\circ}$.) Badǐiya d"Abd al-Rạ̣mân al-Ḥomaïdî. (Voyez ci-dessus, $n^{\circ} 3238$.)

Ms. daté de l'an 1079 de l'hégire ( 1669 de J. C.).

Papier. 181 feuillets. Hauteur, 21 centimètres; largeur, 15 centimètres et demi. 1 à 21 ligneś par page. - (Supplément 1465.)

\section{9.}

Divan de Fatḷ-Allah ibn Mạ̣moûd al-Baïloûnî 
d'Alep, qui vivail dans la première moitié du xvin' siècle. Ce sont des poésies religieuses et mystiques. Ia fin manque.

Papier. 259 feuillets. Hauteur, 21 centinètres; largeur, 14 centimètres. 19 lignnes par page. Ms. du xvü siècle. - (Supplément 1507.)

\section{0.}

$1^{\circ}$ (Pièce de vers) renfermant des proverbes , ou ب. exarfun d'ambre gris n. Qaṣida dont chaque vers renferme une maxime de morale, par Schihâb al-Din Aḥmad al-Khafìdjî al-Miṣrì.

$2^{\circ}$ (Fol. $18 v^{\circ}$.) Poème sur la conquète de l'ile de Crète par le vizir Ahmad. Dans les derniers rers se trouve la date de 1080 de l'hégire ( $1669^{-1} 670$ de J. C.).

$3^{\circ}$ (Fol. $25 v^{\circ}$.) Traité en vers sur l'usage du quart de cercle.

$4^{\circ}$ (Fol. $36 \mathrm{v}^{\circ}$.) Traité de musique. Celte pièce est datée de l'an 1083 de l'hégire $(1672$ de J. C.).

$5^{\circ}$ (Fol. $43 v^{\circ}$.) Traité de géomancic, par 'Askar (عسكא) al-Halabi.

$6^{\circ}$ (Fol. $47 v^{\circ}$.) Commentaire d'Askar al-Halabî sur cette maxime: Dicu a versé ses grâces de trois manières, à savoir : sur les langues des Arabes, sur les cerveaux des Grecs el sur les mains des Chinois.

$7^{\circ}$ (Fol. $54 v^{\circ}$.) Poésies diverses.

Papier. 76 feuiltets. Hanteur, 19 centimèt'es et demi; largeur, 12 centimètres et demi. 17 à 21 lignes par page. Us. du xviı" siècle. (Supplément 1843.)

\section{1 .}

1. Qașida attribuée à un saint personnage nommé 'Alì al-Màkhoúsi (الماخوسى). Premier vers :

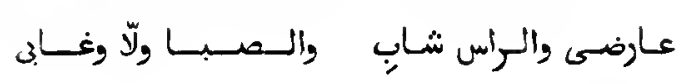

$2^{\circ}$ (Fol. 3.) Pièce de ver's composée par Yoûsol ibn

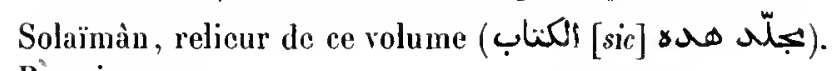
Premier vers :

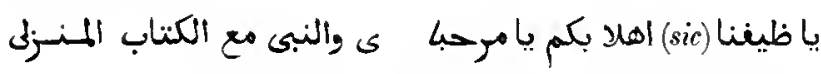

$3^{\circ}$ (Fol. 4.) Conte de l'oisean et dn schaïkh Wahhàsch (وهّانش). Histoirc, en prose el en vers, d'un oiseau mystérieux qui adresse au schaïklı des exhortations morales et religieuses.

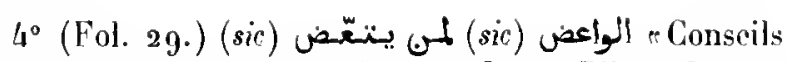
pour celui qui est disposé à en profitern. Pièces de ver's attribuées au roi David, à Salomon, à 'Mlì ibn abì Ṭàlib et à d'autres moralistes.

$5^{\circ}\left(F_{0} .51 v^{\circ}\right.$.) Divan d'Ibn Ismâill ibn 'Alì ibn Ibrìhîm, de la province de Lataquié. Les pièces de vers sont disposées dans l'ordre alphabétique des rimes. Premier vers :

$$
\text { سالبدى نظاى باسم مه سار على اللهـوال }
$$

$6^{\circ}$ (Fol. $7^{3 .}$ ) Autre recueil de poésies du mème auteur.

$7^{\circ}$ (Fol. 1 o4.) Poésies altribuées par le copiste à Háasan ibn Hànì Aboù Nowàs, qưil présente comme étant

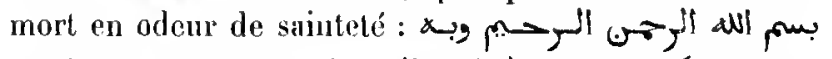

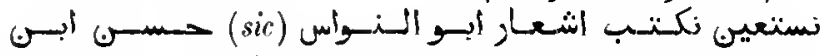
هان تحس الله روحه Plusieurs de ces pièces sont, en effel, assez libres pour ètu'c d'Aboù Nowâs; elles ont pour sujet le vin ef les échansons.

$8^{\circ}$ (Fol. 114.) Poésies de Schihâb al.Dìn ibn Ibràlıìn ibn Solaïmàn الرفأ Chaque pièce se compose de donze vers. Dans la première tous les vers commencent et finissent par un alif; dans la seconde ils commencent et finissent par un bia, et ainsi de suite, jusqu'à la fin de l'alpluabet.

$9^{\circ}$ (Fol. 129.) Correspondance poélique cntre ce mème Schilıảb al-Dìn et un certain 'Abd al-Rahmàn, ha-

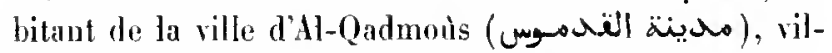
lage près diun chàtean-fort qui, du temps des Croisades, apparlenait aux Ismaéliens de la Syrie.

$10^{\circ}$ (Fol. $131 v^{\circ}$.) Poćsies disposées dans l'ordre alphabétique des rimes et altribuées à Abou Nowàs. Ce divan commence par cette phrase singulière : نبتحى على

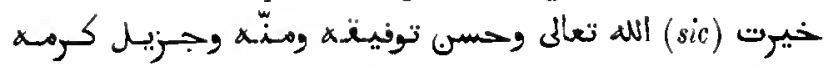

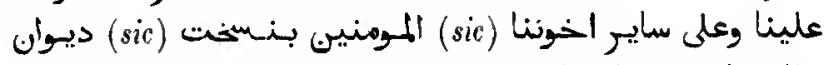

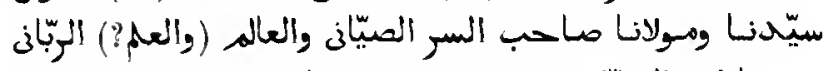

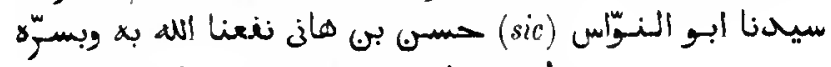

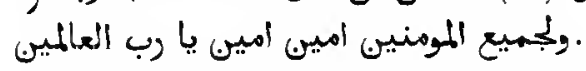

$11^{\circ}$ (Fol. $200 \mathrm{v}^{\circ}$.) Histoire du schaïh ı Ḥàtim al-Ṭaı-

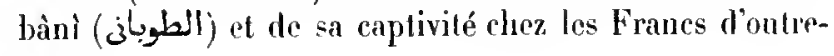
mer.

$13^{\circ}$ (Fol. 203 v $^{\circ}$ ) Qașida du schaikh Ḥàtim al-1)jidilì (يلى), renlermant plus de deux cents vers, dont voici le premier :

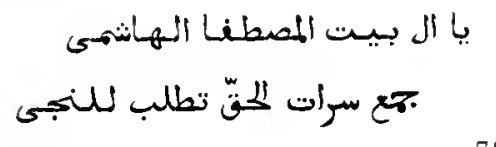


$13^{\circ}\left(F_{0}\right.$. $211 v^{\circ}$.) Vers composés par le schaïh lbrâlîm, fils du cadi de Balbek. C'est un molhammas (us ), une suite de strophes, composées chacune de "ing hémistiches. Il y a plus de cent strophes. Commencement :

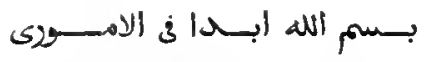

$$
\begin{aligned}
& \text { واهم رب عالم في الضضهميسرى }
\end{aligned}
$$

$14^{\circ}$ (Fol. $222 v^{\circ}$. ) Pièce de vers, par Solaïmàn ibn Yoûsof. Premier ver's :

$$
\text { نيا مه بلت مه سترها ألغـاقة }
$$

$15^{\circ}$ (Fol. $2231^{\circ}$.) Deux autres pièces de vers.

Ms. daté de l'an 1064 de l'hégire (1654 de J. C.).

Papier. 294 feuillets. Hlauteur, 21 centimètres; largeur, 15 centimètres. 15 lignes par page. - (Ancien fonds 1438.)

\section{2.}

Éloignement des diflicultés que présente la qaṣida d'Ibn 'Aroùs n. Commen-

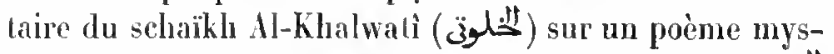
lique d'lbn 'Aroùs al-Maghrabî. Commencement : لِّ .

Papier. 6/4 feuillets, Hauteur, 20 centimètres; largeur, 14 centimètres. ${ }_{7} 7$ liznnes par page. Ms. du xvur siècle. - (Supplément 1 593 .)

\section{3.}

Directions (côtés vers lesquels on doit se tourner) afin d'acquérir la connaissance

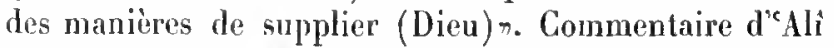
ibn $\mathrm{rrfa}^{c}$ Ràs al-Maghrebì, sur la qaṣîda mystique de Solaïmàn ibn Thåbit. La qậ̀da commence par ce vers :

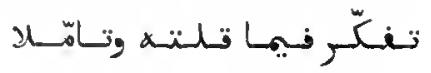

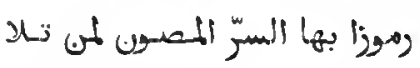

Papier. 38 feuillets. Hanteur, 21 centimètres; largeur, 15 centimètres. 21 lignes par pagge. Ms. du xrü siècle. - (Supplément 1578.)

\section{4.}

Divan d'un poète inconnu. Le premier cahier manque et le dernier feuillet est mutilé.
Papier. 172 feuillets. Ilauteur, 20 centimètres et demi; largeur, 14 centimètres et demi. 24 à 28 lignes par page. Mts. du xwu' siècle. - (Supplément 15 2 3 .)

\section{5 .}

r Fleurs du printemps, trailé des diverses figures de rhétoriquen. Poème du genre de Badílya avec commentaire, par Sadr al-Din 'Ali, fils d'Ạ̣mad, fils de Moḥammad ibn Ma'ṣoùm. L'auteur s'est proposé de surpasser la Badiciya d'Ibn Hiddja. Commen-

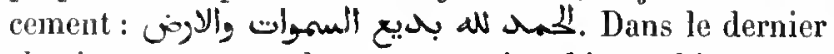
chapitre, on trouve de courtes nolices biographiques sur Al-Ṣafî al-llillî̀, llun Djâbir al-Andalosî, Aboû Djacfar alGharnâtî, 'Izz al-Dìn al-Mauṣilì, Ibn Ḥiddja al-Hamawî Scharaf al-Dìn al-Moqrî, Djalâl al-Dìn al-Soyoûtì, Wadjilı al-Dîn al-'Alawì el 'Abd el-Qâdir al-Tabarî, auteurs de poèmes reproduisant les diverses figures de rliétorique.

A la fin se trouvent quelques poésies portant ce titre:

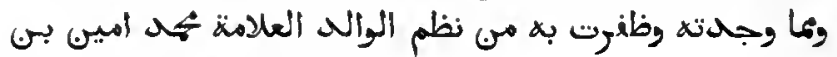

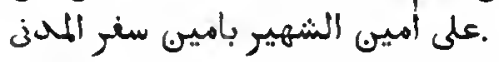

Ms. daté de l'an 1146 de l'hégire $(1733-1734$ de J. C.).

Papier. 3 40 feuillets. IIauteur, 22 centimètres et demi; largenr, 17 centimètres. 25 lignes par page. - (Supplément 1552.)

\section{6.}

re Divan des divans et le bouquet des bouquetsn. Recueil de poésies mystiques, par 'Abd al-Ghanî ilon Ismâcîl al-Nâbolosî.

Papier. 272 feuillets. Hauteur, 22 centimètres; largeur, 16 centimètres et demi. 23 lignes par page. Is. du xvıı siècle. - (Supplément 1496 .)

\section{7.}

1 Qaṣ̂da rimant en Ari, accompagnée d'un commentaire. Ce poème a été composé en l'honneur d'un vizir qui n'est pas nommé, mais qu'on suppose être Keuprili-Zâdè Moṣtafì, fils de Moḷammad Keuprili. En

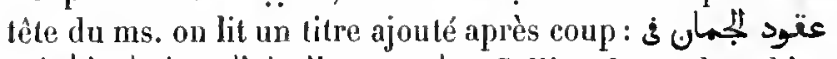
Collier de perles, histoire du vizir du sultan Solaümàı, par Al-ḷalabîn.

$2^{\circ}$ (Fol. 25.) Neuf traités grammaticaux (risala) : le 
premier est d'Al-Qouchdjì; le second (fol. 30 : الرسـالـ ( ficultés qu'on avait signalées dans le traité précédent. Le troisième traité (fol. 33 ) a pour auteur lbrâhiu ibn Moḷanmad ibn 'Arabschah al-Isferâïnî̀; le quatrième (fol. 42) est d'Abou 'l-Faṭh ibn Makhdoûm al-Hasaní; le

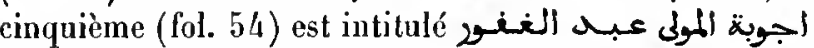
() $\mathrm{UUl}$; le sixième (fol. $57 \mathrm{v}^{\circ}$ ) a pour auteur Mohanmad Amira (8ـاك), surnommé Amîr-PAdischâh; le septième (fol. 64 $\mathbf{v}^{\circ}$ ) est attribué (fol. 25 ) à un professeur de Hérat, appelé Fakhr al-Dîn; le huitième (fol. 70 ), à un auteur nommé Fatḥ Allah, et le neuvième (fol. 77), à Schihâb al-Dìn al-Khafàdjît.

Papier. 91 feuiltets. Hauteur, 31 centimètres; largeur, 15 centimètres. 21 à 23 lignes par page. Ms. du xvil siècle. - (Ancien fonds $8 ; 6$.)

\section{8.}

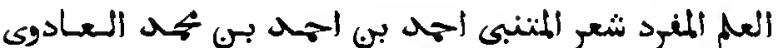
"Le Signal unique, poésies du Motanabbî (de l'époque), Ạ̣mad ibn Ạ̣mad ibn Moḥammad al-c Àdawì n, auteur qui vivait dans le Yémen vers la fin du $\mathrm{xvr}^{\mathbf{e}}$ siècle et pendant le premier quart du sviri . Ce divan commence par quelques qasîdas religieuses, suivies de plusieurs autres à la louange de certains princes descendants d'Al-Motawakkil cala 'Hâh, dernier calife (أميب المومنيم) de la seconde branche des Abbassides, qui lut déposé par le sultan ottoman Sélim, et mourut en Égypte, en 945 de l'hégire (1538-1539 de J. C.). Les fils de ce calife s'étant retirés dans le Yémen, s'établirent, dit-on, à Sancâ, à Sa'da et dans d'autres parties de ce pays. L'un se nommait Nohammad, fils d'Al-Motawakkil, Amîr al-Moúminin; un autre Hosâm al-Islàm al-Moḷassin, fils de l'Amír alMoûminin, et frère de Dhiyâ al-Dìn Yoùsof. On nomme aussi leur parent Scharaf al-Islâm al-Hasan, fils d'Amir al-Moûminîn Al-Qdisim ibn 'Alì, dont le fils s'appelait Aḷmad. Ces personnages paraissent avoir exercé l'autorité comme califes, dans cette partie de l'Arabie, et avoir régné de l'an 1094 de l'hégrire $(1682-1683$ de J. C. $)$, à l'an 1114 de l'bégire (1702 de J. C.), et peut-être plus longtemps. En l'an 1112 , un de ces souverains accueillit arec de grauds honnenrs une ambassade envoyée par le sclıalı de Perse, le sultan Al-I!osaïn, fils de Schàh'Abbàs.

Ms. daté de l'an $179^{2}$ (sic). Le premier fenillet manque. La première partic du volume, jusqu'au fol. 59 , est en très mavais état, l'encre ayant détrint le papier.

Papier. 179 fenillets. Hauteur, 20 centimètres; largeur, 16 centimètres. 15 à 19 lignes par page. - (Supplément 1524 .)

\section{9 .}

$1^{\circ}$ Divan de Mohammad ibn 'Ali ibn J!aidar al-110saïni, poète qui florissait dans les premières aunées dn $\mathbf{x u}^{\mathrm{e}}$ siècle de l'hégire. Ce sont des poésies religieuses et des panégyriques.

$2^{\circ}$ (Fol. $31 v^{\circ}$.) Divan de Șady al-Dîn 'Ali ibn Aḷmad al-Hiosaïnì. Ce recueil, intitnlé الكحيت الهيتوم, commence par une Baditiya. Une pièce de vers (fol. 57) est datée de l'an 1078 de l'hégire ( 1668 de J. C.).

Ms. daté de l'an 1161 de l'hégire (1 748 de J. C.).

Papier. 127 feuitlets. Hanteur, 2 a centimètres et demi; largeur, 15 centimètres et demi. Environ 23 lignes par page. - (Supplément 1512.)

\section{0.}

Divan d'Aḷmad al-Dolandjàwî (s, 1123 de l'hégire (1711 de J. C.). Le recueil commence par un taschtir de la Borda.

Ms. daté de l'an $117^{1}$ de l'hégire (1758 de J. C.).

Papier. 126 fenillets. Hauteur, a 1 centimètres el demi; targeur, 16 centimètres. 15 lignes par page. - (Supplément 1520.)

\section{1 .}

$1^{\circ}$ Divan d'un saint persomnage, dont le nom niest pas indiqué. Le commenceunent manque.

$2^{\circ}$ (Fol. 12.) Divan d'un saint personnage, nommé Mostafí, descendant des deux faunilles d'Al-Ilasan et d'AI-

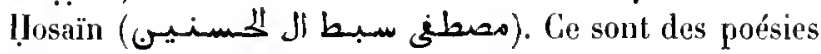
mystiques. La première de ces pièces est une maqsoûra on poème dont les ver's se terminent par un alif bref, qui est intitulée لخيام مa Maqsoûra du poète est une belle soigneusement cachée dans sa tente $\%$.

Ms. daté (fol. 12) de l'an 1151 de l'hégire (1738${ }_{1739}$ de J. C.). C'est aussi la date de la composition du recueil.

Papier. 91 feuillets. Hantenr, 20 centimètres et demi; largeur, 16 centimètres. 21 lignes par page. - (Supplément 2175.)

\section{2 .}

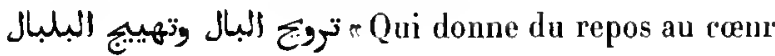


el yni réveille les soucis-. Divan de poésies mystiques d' 'Abd al-hahmàn ibn Hoștafà al-'Aïdaroûs. Commen-

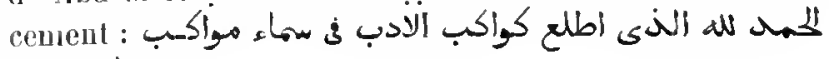

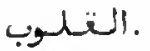

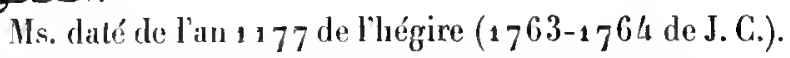

Papier. 106 feuillets. llauteur, 21 centimètres; largeur, 16 centimètres. 19 ligơnes par page. - (Supplément 1495.)

\section{3.}

Divan de ḷosaïn ibn 'Abd al-Schokoùr. L'anteur dit que ces poésiés lui avaient été inspirées par la lecture

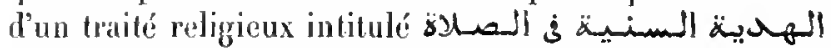
il cadeau de prix, traité sur la prière orthodoxe ñ.

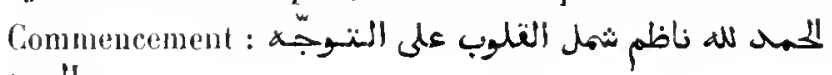
xil.

lls. daté de l'an 1188 de l'hégire (1774 de J. C.).

Papier. 151 feuillets. Hauteur, 22 centimètres; largenr, 16 centimètres. 19 lignes par page. - (Supplément 1529.$)$

\section{4.}

$1^{\circ}$ Qiscîda rimant en $r \hat{a}$, sur les sentiments qu’inspire la contemplation des tombeaux. Premier vers:

$$
\text { با رب صلى على اللختنار كـنـز الـوزا }
$$

$2^{\circ}$ (Fol. 6.) Qasî̀das en l"honneur du Propliète, etc.

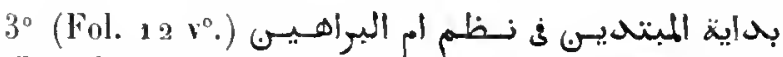
- Début des commencants, ou l'Omm al-Barahîn mis en

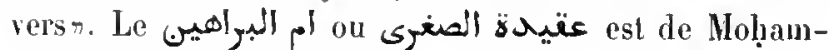
mad ibn Yoûsol" al-Sanoúsî.

$4^{\circ}$ (Fol. 17.) L'Aqida ou profession de foi d'chlì, fils d'Abon Tálib.

$5^{\circ}$ (Fol. 18.) Instructions religieuses pour une retraite de vingt-et-un jours. On doit commencer par lire la sou-

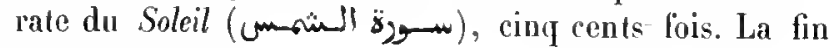
manque.

$6^{\circ}$ (Fol. $\left.211^{\circ}.\right)$ Ordjoùza sur l'orthographe coranique

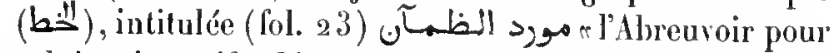
celui qui a soifr. L'auteur dit avoir puisé ses renseignements dans le Moqni d'Aboû 'Annr al-Dânì, daus l' Aqîla d'lbu Ferro al-Schâtibì, et dans le traité d'un schaỉklı qu'il désigne par le surnom d'Aboû Dâ'oûd. Commencement :

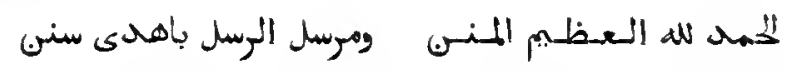

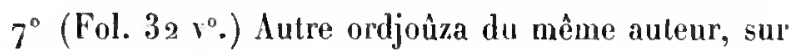
les lecons (الضبط) du Coran, composée en 697 de l'léegire (1297-1298 de J. C.). Elle porte le titre de y ull

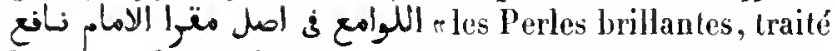
basé sur le systeme de lecture coranique enseigné par l’imâm Nâfín. Un supplément traite des divers organes de la bouche qui servent à la formation des lettres (ج) (2)

$8^{\circ}\left(F_{0} .43 r^{\circ}\right.$.) Ordjoûza sur la manière de déterminer la qibla, ou direction de la Mecque, dans tous les pays, par lbn Mâdjid. En tête se trouve une introduction en prose.

Papier. 52 fenillets. Hauteur, 23 centimètres; Jargeur, 16 centimètres. Écritures diverses du xvi" siècle. - (Supplément 2179 )

\section{5 .}

Aspirations des àmes vers l'odeur du nareissen. Divan renfermant des qașidas et des épigrammes qui, toutes, ont une seule et même rime, écrite en lettres d'or : الربيع الن . . Une seule qa-

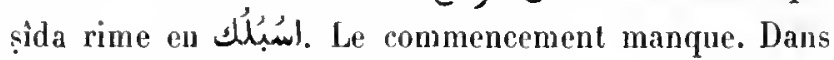
les premièreś pièces, il esl question des vicissitudes d'une guerie entre le printemps et l'hiver.

Papier. 128 feniltets. Hauteur, 26 centimètres; largeur, 16 centimètres et demi. 17 lignes par page. Ifs. du xvu1" sièele. - (Supplément 1592.)

\section{6.}

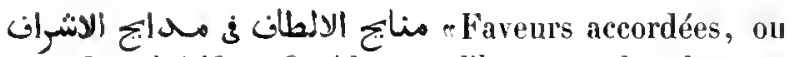
Élog̣es des chérifsn. Qaṣidas en l'honneur des descendants de Nahomet, par le schaikh 'Abd Allah ibn Moḷammad ibn cÂmir al-Schobrìî.

Ms. écrit en 1192 de l'hégire (1778 de J. C.), probablement sous les yeux de l'auteur.

Papier. 68 feuillets. Jtanteur, 22 centimètres; largeur, 16 centimètres. 17 lignes par page. - (6upplément 1568.)

\section{7 et 3268 .}

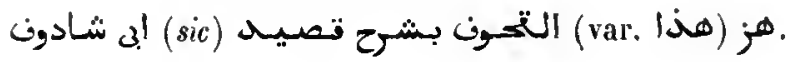


Qașida satirique, avec commentaire, par Youssof ilon Moḷammad ibn "Abd al-ljawâd al-Scharbinì. Commen-

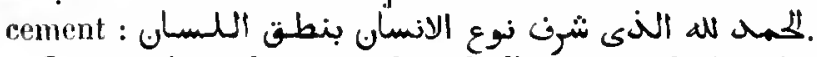

Le premier volume est daté de l'an 1 167 de l'hégire ( 1754 de J. C.), le second est de deux mains différentes.

3 vol. Papier. 157 et 136 feuillets. Hauteur, 20 eentimètres; largeur, 15 centimètres. - (Supplément 1620, 1 et H.)

\section{9.}

Même ouvrage.

Ms. daté de l'an 1224 de l'hégire (1809 de J. C.).

Papier. 28 a feuillets. Hauteur, 23 cenlimètres et demi; largeur, 16 cenlimètres el demi. 21 lignes par page. - (Supplément 621.$)^{\text {. }}$

\section{0 .}

Commencement du mème ourrage.

Papier. 11 feuillets. Hanteur, so centimètres; largeur, 1 is centimètres. 16 à 21 lignes par page. Ms. du vwri siècle. - (Supplément 2 a 85 .)

\section{1.}

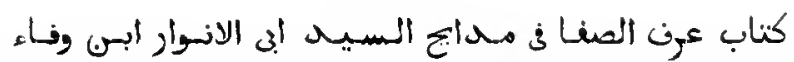
"Don fail avec sincérité, composé des éloges d'Ábon 'lAnwàr ilıı [Mohammad] ibn Wafà", par Abou 'l-Fauz Ihràhìm al-Sandoûbî. Ce recueil, composé du vivant du saint personnage, a été mis par écrit postérieurement à l'an 1204 de l'hégire $(1789$ de J. (i.).

Papier. ${ }_{2} 57$ feuillets. Ilantenr, a 2 centimètres; largeur, 16 centimètres et demi. 15 lignes par page. Ms. du rvur sircle. - (Supplément 1571 .)

\section{2.}

Recueil des poésies et des maquamât de Naqoủlà (Nicolas) al-Tourki, l'auteur de l'llistoire de l'expédition francaise en Égypte. Plusieurs de ces pièces ont élé composées dans les prenières anmées du $\mathrm{xu}^{\mathrm{e}}$ siècle. La fin du volume manque.

Papier. 157 feuillets. Hauteur, a a centimètres; largeur, 15 centimètres et demi. 23 lignes par page. - (Supplément 1528.)

\section{COLLECTIONS ET ANTHOLOGIES}

\section{3.}

Les ceurres complètes des Six Poètes, à savoir : Amro 'H-Qaïs, Al-Nâbigha, 'Alqama, Zohaï', Tarafa el 'Antara.

Ms. dalé de l'an 571 de l'hégire $\left(1+7^{6}\right.$ de J. C.). Grande et belle écriture maghrebine-espagnole; gloses marginales et interlinéaires.

Papier. 105 feuillets. Hauteur, 26 centimètres et demi; largeur, 18 centimètres et demi. 13 lignes par page. - (Supplément, $1 / 25$.

\section{4.}

Commentaire sur les Six Poètes, par Yoûsol al-Schanlamarì. (Voyez l'introduction au Diwan d'Amro 'lkais, pa'

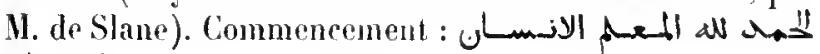
السبـيان.

Us. maghrebiu. En tête de la première page se trouve un titre et un fleuron marginal bien exécutés en or el en couleurs.

Papier. 297 feuillets. Hauteur, 29 eentinètres et demi; largeur, 20 centimètres. 25 lignes par page. VIs. du $\mathbf{w}^{e}{ }^{e}$ siècle. - (Supplé ment 1424.)

\section{5 .}

Poèmes appelés Vocallaqàt, accompagnés d'un commentaire. En tète se trouve la mocallaqa d'Aur ibn Kolthouns, précédée d'une introduction historique. Viennent ensuite les móallaqat de Zohaï ilon abî Solmà, d'Alllìrill ilın flilliza, d"entara ibn Mơàwiya ibn Schaddàd, de Naïmoùn ilon Qaïs al-Aeschit, qui commence par ce vers :

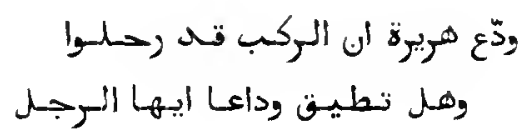

Suivent le poëme يُّيّة de Nàbigha al-Dsobyànî. la móallaqa de Tarafa lbn al-'Abd, celle d'Amro'l-Qaïs alKindí, et la mocallaqa de Labid ibı Rabíca.

Ms. daté de l'an 1073 de l'lségire (1662-1663 de J. C.).

Papier. 66 feuillels. Ilauteur, 30 centimètres; largeur, 19 centimètres et demi. Le nombre de lignes par page varie beancoup. (Supplément 1422.) 


\section{6.}

$1^{\circ}$ Les Sept móallaqût, avec le commentaire d'Al-lyosaïn ibn Ahmad al-Zauzanî.

$2^{\circ}$ (Fol. 56.) La Maqșoûra d'Ibn Doraïd, avec un commentaire.

$3^{\circ}$ (Fol. 78.) Maximes des anciens Arabes, avec un commentaire.

Papier. 89 fenillets. Hauteur, 19 centimètres et demi; largeur, 13 centimètres. 37 lignes par page. Ms. du xvı1 siècte. - (Supplément 1/291.)

\section{7.}

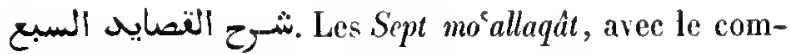
mentaire d'Al-Zauzani.

Ms. daté de l'an $9^{82}$ de l'hégrire ( 1575 de J. C.).

Papier. 148 fenillets. Ilanteur, a 1 centimètres et demi largeur, 15 centimètres et demi. 17 lignes par page. - (Ancien fonds 1416.)

\section{8.}

Mème ouvrage.

Ms. dalé de l'an 1043 de l'hégire (1634 de J. C.).

Papier. 102 fenillets. Hauteur, go centimètres et demi; largeur, 15 centimètres. 19 lignes par page. - (Ancien fonds 1417.$)$

\section{9 .}

Les Sept mosallaqâ (Ilight (السبع), avec le commentaire

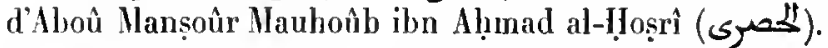

Ms. daté de l'an 1113 de l'hégire (1 701 de J. C.).

Papier. 54 fenillets. Hauteur, 21 centimètres et demi; largenr, 16 centimètres. 17 lignes par page. - (Supplément 1420. )

\section{0.}

Commentaire très étendu sur les Sept móallaqát et sur le يـ دار مار ميّة d'Al-Nâbigha. L'ouvrage commence, sans préface, par l'histoire de la mocallaqa d'Amro 'l-Qaïs.

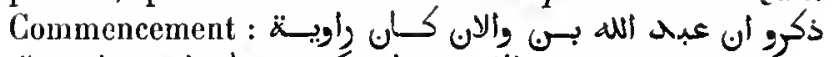

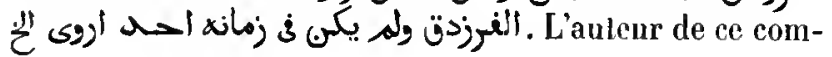

mentaire, qu'on suppose être Aboú Zakariya Yahyâ alTibrìzî, cite très souvent l'autorité d'un nommé Aboû Djâbir et d'un certain Abou Sa id al-Dharìr.

Ms. daté de l'an 616 de l'léggire (1 21 9-1220 de J. C.).

Papier. 320 fenillets. Hauteur, 25 centimètres; largeur, 17 centimètres. Environ 20 lignes par page. - (Supplément 1423.)

\section{1 .}

La İamàsa d'Aboû Tammâm Habỉb ibn 'Aus al-Ṭâïi.

Ms. daté de l'an $6_{27}$ de l'hégire (123o de J. C.). Les neuf premiers feuillets sont d'une écriture moderue.

Papier. 403 feuillets. Hauteur, 25 centimètres; largeur, 17 centimètres. 13 lignes par prage. - (Supplément 1434.)

\section{2.}

Mème ouvrage.

Ms. de deux écritures, dont la plus récente est de l'an 1157 de l'hégire ( 1744 de J. C.). I y a une vignette en or et en couleurs sur le verso du premier feuitlet.

Papier. ${ }_{159}$ feuillets. Hauteur, 2 a centimètres; largeur, 15 centimètres. 15 liğnes par page. - (Supplément 1438.)

\section{3.}

La Hamâsa avec le grand commentaire d'Al-Tibrizî. (كتاب شثح لنماسة الكسبيـر). Ce volume renferme la première section de l'ouvrage et la plus grande partie de la seconde. Il se termine par le poème qui rime en $l e$ et qui a pour auteur Yahyầ ibn Ziyâd al-Hàrithî. (Édilion de Freylag, page $\mu_{4}$.).

Papier. ${ }_{159}$ fenillets. Hauteur, a9 centimètres; largeur, 18 centimètres. 35 lignes par page. Ms. du xvi" siècle. - (Supplément 1437.)

\section{4.}

La Hamàsa avec une portion du commentaire d'Al-Tibrîzî. Copie exécutée par Michel Șabbâgh, d'après les mss. $3_{2} 8_{1}$ et $3_{2} 83$.

Papier. 317 feuillets. Hauteur, 29 centimetres; largeur, 21 centimètres et demi. 21 lignes par page. Ms. du xix siècle. - (Supplément 1436.) 


\section{5 .}

Arertissement au sujet de l'analyse grammatiralen. Commentaire grammatical sur la Hamàsa, par Ibn Djinni. Les soixante premiers leuillets manquent. La suite de ce commentaire, qui formait un ouvrage ì part, devait contenir l'explication des noms des poètes.

Papier. 245 feuillets. Hauteur, 26 centimètres et demi; largeur, 19 centimètres. 15 lignes par page. Ms. du vve siècle. - (Supplément 1435.)

\section{6.}

"Poèmes des Hodsaillites", recueillis et mis en ordre par Aboú Sa jd al-Hasan ibn al-Hosaïn al-Sokkarî, mort en 275 de l'hégire (888-889 de J. C.). C'est la seconde moitié de l'ouvrage.

Papier. 195 feuillets. Hauteur, 93 centimètres; largeur, 18 centimètres. 10 lignes par page. Ms. du vi" siècle. - (Supplément 1427.)

\section{7 à 3289.}

rLe Collier sans pareil $\pitchfork$, anthologie philologique, historique et poétique, composée par Ahmad ibn Moḷammad, surnommé Ibn 'Abd Rabbihi, de Cordoue, mort en $3{ }_{2} 8$ de l'hégire ( 940 de J. C.). (Voyez la traduction d'lbn Khallikàn, t. I, p. 92.) Dans la prélace, l'auteur indique le contenu de son ourrage, qu'il avait divisé en vingt-cinq doubles chapitres (kitab), dont chacun porte le nom d'une pierre précieuse. La notice sur Ies califes commence au fol. $221 v^{\circ}$ dil second rolume. L'histoire des Omaïyades d'Espagne, qui commence an folio $335 \mathrm{r}^{\circ} \mathrm{du}$ mème volume, se termine par un poëme du mìtre redjez, dans lequel l'auteur déerit, année par année, jusqu’à l'an 322 de l'hégire (934 de J. C.), les expéditions entreprises par 'Abd al-IRaḥmân al-Nâșir.

Us. daté de l'an 1250 de l'hégire (1835 de J. C.). Il a appartenu à M. Fresnel, qui y a fait plusieurs correclions.

3 vol. Papier. $331,350,397$ feuillets. Hauteur, 24 à 25 centimètres; largeur, 16 centimètres. 25 tignes par page. - (Supptément 1418 bis, 1-III.)

\section{0.}

Fragment du même ouvrage, à savoir la fin du chaNax. ontertaux. - II. pitre sur les Journées des Arabes, les chapilies sur les poètes, la poésie, la prosodie et la musique (fol. $961^{\circ} a$ $219 \mathrm{v}^{\circ}$ du ms. $3{ }_{2} 89$ ). Ms. maghrehin espagnol.

Papier. 72 feuiltets. Hauteur, 23 centimètres et demi; largeur, 17 centimètres et demi. 27 lignes par page. Ns. du xur siècle. (Supplément 1418.)

\section{1 .}

Onzième partie du même ouvrage. C'est la section qui est consacrée à la science et aux belles-lettres et intitulée تليافوتة le Rubis".

Ms. daté de l'an 592 de l'hégire ( $119^{6}$ de J. C.).

Papier. 135 feuillets. Hauteur, 26 centimètres; largeur, 16 centimètres et demi. 19 lignes par page. - (Supplément 1732. )

\section{2 × 3295.}

Le كتاب الاغان d'Abou '1-Faradj al-Jṣfahànî. Commen-

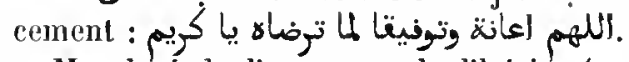

Ms. daté de l'an 1207 de l'hégire (1793 de J. C.).

La liste des chapitres, de la main de Michel Șabbâghh, se trouve en tête de chaque volume.

4 vol. Papier. $390,369,490,374$ feuittets. Habteur, 31 centimètres; largeur, 21 centimètres et demi. 35 lignes par page. - (Supplément 1424 1-IV.)

\section{6.}

Commencement du même ouvrage. Ce fragment se termine par les premières lignes de la notice sur العرّ. Vignelte en or et en couleurs en tête dn ms.

Papicr. 53 feuillets. Ilauteur, $3_{2}$ centimètres et demi; largeur, 21 centimètres. 45 lignes par page. Ms. du xvı' siècle. - (Supplément 1417. )

\section{7.}

Fragment du même ouvrage, commençant au milieu de la notice sur Ibrâhîm al-Mauṣilì, et se terminant par la notice sur Al-Moraqfisch al-Asgriar (ms. 3292, fol. $322 \vee^{\circ}$ à 3293 , fol. 11 ). Il y a quelques lacunes et plusieurs feuillets sont intervertis.

Ms. maghrebin espagnol.

Papier. 193 feuillets. Ilauteur, 27 centimètres; largeur, 18 centinètres. 17 lignes par page. Ms. du xur' siècle. - (Supplément 1415.) 


\section{8.}

Le sixième volume (uـh) d'un exemplaire du mềne ourrage, commençant par la notice sur Doraid Ibn alSimna et se terminant par celle de zu山l ابو

Papier. 178 feuillets. Hauteur, a9 centimètres; largeur, 19 centimètres et demi. 27 lignes par page. Hs. du xiv" siècle. - (Supplément 1416.$)$

\section{9 .}

"Traité du vin», anthologie en prose et• en vers, d'Ábou 'l-'Abbâs "Abd Allah Ibu al-Mo'tazz. Ce sont des extraits de plusieurs auteurs touchant la vigne, les raisins, les diverses espèces de vins, les coupes, les vases, les effets de cette liqueur, ete. D'après la préface, cet ouvrage derait se diviser en quatre sections, mais dans le présent ms. cette division n'a pas été observée. On

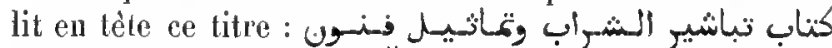

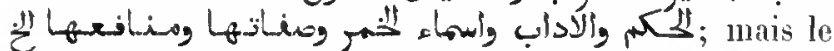
vrai titre est indiqué au lol. 3, ligne 10 . Commence-

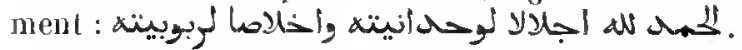

Plusieurs feuillets manquent, surtoul vers la fin.

Papier. 51 feuillets. Hantenr, 33 centimètres; largenr, 15 centimètres. 3 lignes par page. Ms. du xne siècte. - (Ancien fonds 1473. )

\section{0.}

Extraits des poésies d'Al-Bohtorì et d'Al-Motanabbì. II n’y a ni préface, ni explicit.

Papier. 140 feuillets. Hauteur, a 5 centimètres; Jargeur, 18 centimètres et demi. 17 lignes par page. Ms. du xiv siècle. - (Supplément 1483.)

\section{1 .}

in Manuet du conviven, recueil d'anecdotes et de pièces de vers composé par Abou 'l-Falh Mạ̣moûd lbn al-Sindì al-Kàtib, surnommé Kischâdjim (بسى)

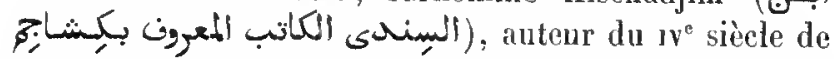
l'hégire. La préface, dans laquelte l'auteur explique l'objet du traité, est suivic d'un assez grand nombre de cha-

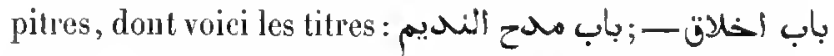

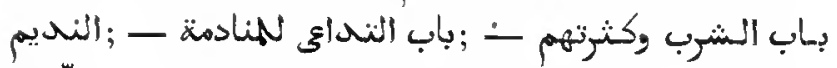

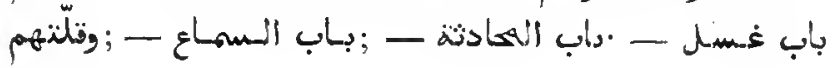

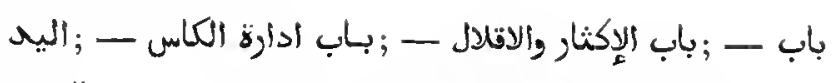

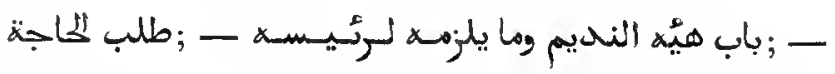

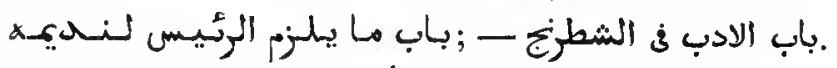

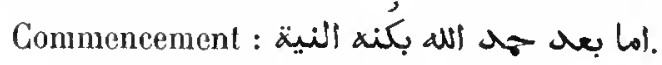

Frontispice portant le titre et le nom de l'auteur en lettres d'or.

Papier. 77 feuillets. Hauteur, 22 centimètres; largeur, 14 centimètres et demi. 7 lignes par page. Ms. du $\mathbf{x i v}^{\circ}$ siècle. - (Supplément 1347 .)

\section{2.}

تطب السمبرو 3 2Le pivot de la joie on Description des boissons et des vins » par Ibrâhîm ilon al-Qâsim ibn ał-Raqîq al-Qaïrawânî, auteur du $x^{e}$ siècle. Cette anthologie renferme de nombreuses historiettes, en prose et en vers, sur les califes et sur d'nutres grands personnages de l'islamisme qui aimaient le vin. Commence-

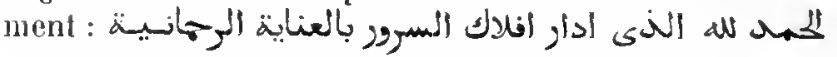

Papier. 263 feuillets. Hlauteur, 17 centimètres; largeur, 13 centimètres. 17 à 20 lignes par page. IIs. du xiv siècłe (un certain nombre de feuillets sont plus modemes). - (Supplément 1068.)

\section{3.}

Analyse grammatieale de certains vers dont la construction était embrouilléen, ouvrage attribué à un certain Al-Românî, peut-être 'Alì ibn 'Îsầ le grammairien, mort en 384 de l'hégire. La préface ne fait mention ni du titre de l'ouvrage, ni du nom de l'auteur, mais ils sont écrits en tête du volume de la main même du copiste. Commencement : مبا بعد

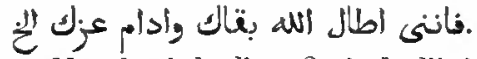

Ms. daté de l'an 804 de l'hégire (1402 de J. C.).

Papier. 167 feuillets. Hauteur, 18 centimètres; largeur, 14 centimètres. 13 lignes par page. - (Supplément 1591.)

\section{4.}

"Compagnon du solitaire", anthologie en prose et en vers, par Aboû Manşoûr "Abd al-Malik alTha'álibî, de Naïsâboùr, mort en 429 de l'hégire (1037-

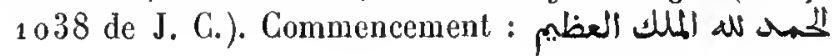


الهى ليس كثلة ثنى وهو السميع البصيى Le premier feuillet, qui donne le titre, et le second feuillet ont été ajoutés après coup.

Papier. 118 feuillets. Hauteur, 21 centimètres; largeur, 17 centimètres. 10 lignes par page. Afs. du xiv's siècle. - (Ancien fonds 1594.)

\section{5 .}

1 م Livre pour celui qui n'a personne pour l'amuser», par Aboû Manșoûr 'Abd alMalik al-Tha âlibi. Cette anthologie, en prose et en vers, se compose de sept parties : la première a pour sujet J'éloquence et l'écriture; la seconde se rapporte aux sajsons de l'année; la troisième, aux nuits et aux jours; la quatriène, aux termes que l'on emploie en courtisant les femmes; la cinquième, aux boissons enivrantes; la sixième, à la fraternité, et la septième à des sujets di-

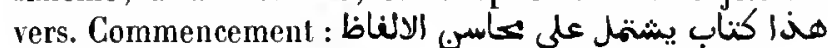

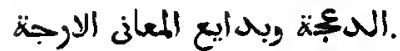

$2^{\circ}$ (Fol. 45.) Recueil de sentences d'une concision sans égale , par le même auteur. Dix chapitres : $1^{\circ}$ paroles du Coran; $2^{\circ}$ paroles du Prophète; $3^{\circ}$ paroles des quatre califes légitimes; $4^{\circ}$ paroles des rois qui ont vécu avant l'islamisme; $5^{\circ}$ paroles des rois et des émirs nusulmans; $6^{\circ}$ paroles de vizirs; $7^{\circ}$ paroles d'écrivains et d'hommes éloquents; $8^{\circ}$ maximes de philosophes, de sages, d'ascètes et de savants; $9^{\circ}$ bons mots de beaux esprits; $10^{\circ}$ sentences de poìtes. Commen-

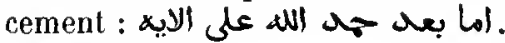

J. C.).

Papier. 128 feuillets. Hanteur, 24 centimètres et demi; largeur, 16 centimètres. 17 lignes par page. - (Ancien fonds 1404.)

\section{6.}

مeautés les plus remarquables", choix de beaux morceaux de prose et de rers. Ce recueil, rédigé, dit-on, par Al-Tha àlibi, se compose de deux

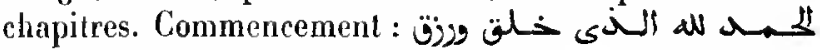
. Quelques cahiers du ms. sont intervertis et il $y$ a des lacunes. La fin manque.

Papier. $19^{3}$ feuillels. Hauteur, 20 centimètres; largeur, 14 centimètres. 21 lignes par page. Ms. du xvi1' siècle. - (Supplément 1653.)

\section{7.}

Anthologie poétique, divisée en quinze sections, à sa- voir : $1^{\circ}$ l'écriture; $2^{\circ}$ les félicitations; $3^{\circ}$ les condoléances; $4^{\circ}$ les nobles qualités; $5^{\circ}$ l'intercession; $6^{\circ}$ la reconnaissance et la louange; $7^{\circ}$ les reproches et les excuses; $8^{\circ}$ la satire et le blàme; $9^{\circ}$ plaintes dans l'adversité; $10^{\circ}$ maximes et apophthegmes; $11^{\circ}$ expression des sentiments fraternels; $12^{\circ}$ les compliments que l'on adresse au sultan; $13^{\circ}$ la prison, la ruine et l'élargissement; $14^{\circ}$ la dérolion; $15^{\circ}$ la prière. L'auteur dit avoir puisé ses matéliaux dans les ouvrages des poètes antéislamiques, des poètes du temps de Mlahomet (اللكضرم-يم) , des musulmans anciens et modernes, etc. Il donne ensuite les nom. des poètes appartenant à chacume de ces classes. Com-

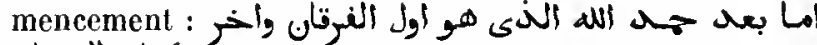

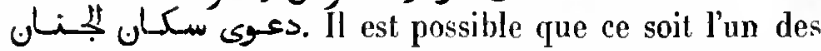
nombreux ouvrages d'Al-Tha àlibi, mais rien ne prouve كتباب مـنـتخهـب : l'authenticité du titre qu'on lit en tête المنتخل انتخبه الرئيس المامل الفاضل أبسو منصور عبد الملك المبك

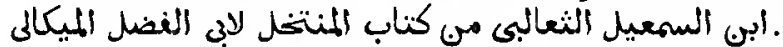

Papier. 111 feuillets. Hauteur, 21 centimètres; largeur, 14 centimètres et demi. 17 à 27 lignes par page. Ms. de diverses éiritures du $x \nabla 1^{\circ}$ et do $x^{\circ} 1^{\circ}$ siècle. - (Ancien fonds 1474.$)$

\section{8.}

مa La Perle du temps, traité sur les mérites des gens de ce sièclen, anthologie poélique et biographique, par Aboû Manșoûr 'Abd alMalik al-Tha'àlibì. L'ouvrage est divisé en quatre sections. Le titre, qui n'est pas mentionné dans la préface, esL reproduit à la fin de chacune des trois premières sections. La liste des auteurs dont il est traité dans cel ouvrage a été publié par M. Dieterici dans le livre intitulé Mutanabbi und Scifuddaula, Leipzig, 1847. Commencement :

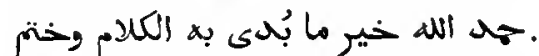

Ms. daté de l'an $9^{8} 9$ de l'hégire ( 1581 de J. C.).

Papier. $59^{3}$ feuillets. Hauteur, 30 centimètres; targeur, 18 centimètres. 27 à 29 lignes par page. - (Supplément 1406. )

Même ouvrage.

\section{9.}

Ms. daté de l’an 1047 de l'hégire $\left({ }^{6} 637\right.$ de J. C. $)$.

Papier. 510 feuillets. Hauteur, 30 centimctres; targenr, 20 centimètres. 29 lignes par page. - (Ancien fonds 1370 .)

\section{0.}

Fragments du mème ouvrage, à savoir : la lin du hui- 
tième chapitre de la première section; quelques feuillets du dixième chapitre; le septième et le huitième chapitre de la seconde section. Il y a de nombreuses lacunes.

Papier. 88 feuillets. Hauteur, 20 centimètres; largeur, 15 centimèlres. 19 lignes par page. Ms. du xvi siècle. - (Supplément 1409.)

\section{1 .}

Les six premiers chapilres de la seconde section du même ourrage. Les derniers feuillets manquent.

Papier. 112 fenillets. Hauteur, 2 a centimètres; largeur, 15 centimètres. 15 lignes par page. Ifs. du xiv siècle. - (Supplément 1407.)

\section{2.}

Quatrième partie du même ouvrage.

Ms. daté de l'an 1026 de lhégice (1617 de J. C.).

Papier. 139 feuillets. HJauleur, 28 centimètres; largeur, 17 centimètres. 25 lignes par page. - (Supplément 1408.)

\section{3.}

مa Belle statue du palais et exlraits poétiques, des contemporains n, anthologie composée pour servir de complément au Katimat alDahr, d'Al-Tha'âlibì, par 'Alì ibn al-llasan ibn abî Taïyib a)-Bàkharzì, qui fut assassiné en 467 de l'hégire $(1075$ (le J. C.), dans le Báklarz, canton des environs de Naïsipoûr. Sa Vie se trouve dans le Dictionnaire biographique d'Ilsn Kliallikản, 1. II, p. 323 de la traduction anglaise.

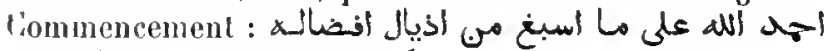

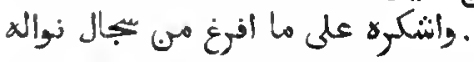

Papier. 308 feuillets. Hauteur, 91 centimètres et demi; largeur, 13 centimètres. 19 ligues par page. Ns. du xvı siècle. - (Supplément $1 / 10$.

\section{4.}

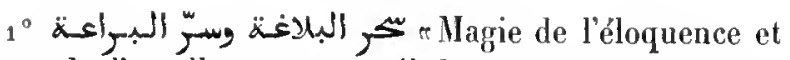
secret de l'excellence», recueil des expressions et lournures de langage les plus élégantes de la langue arabe, par Aboù Manșoûr 'Abd al-Malik al-Tháâlibí. Il y a quatorze chapitres : $1^{\circ}$ le Prophète et son livre; $2^{\circ}$ lemps 't lieux; $3^{\circ}$ l'homme depuis sa naissance jusqu'à la vieillesse; $4^{\circ}$ les mets et les boissons; $5^{\circ}$ prose et vers; $6^{\circ}$ les louanges; 7 . les vices et les méfaits; 8 . la visite des ma- lades; $9^{\circ}$ cadeaux et compliments; $10^{\circ}$ consolation des affligés; $11^{\circ}$ sentiments fraternels; $12^{\circ}$ choses qui se rapportent à la royauté; $13^{\circ}$ divers événements de la vie; $14^{\circ}$ proverbes et maximes. Commencement : أر بعد فا

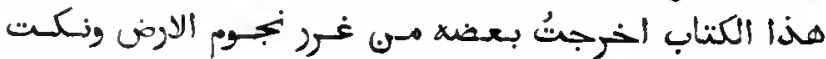

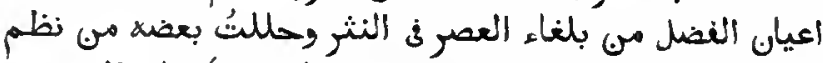

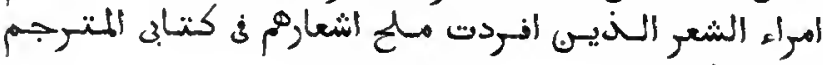
بيتهمة المهي

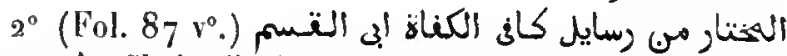
Choix d'épitres composées par Abou 'l-Qâsim ibn 'Abbâd, surnommé lence ) ᄁ. Les épilres et dépêches d'Ảbou 'l-Qàsim Ismâể ibn 'Abbàd Al-Sakib, vizil' des sultans bouïdes Mowaïyad al-Daula et Fakhr al-Daula, étaient renommées pour l'originalité el l'élégance de leur style. L'auteur de la présente collection a choisi dans chacun des vingt volumes dont se compose la correspondance officielle du célèbre vizir, dix épîtres écrites en prose rimée et d'un style très-recherché. Il y a vingt chapitres : $1^{\circ}$ bonnes nouvelles el conquêtes; $2^{\circ}$ actes d'investiture; $3^{\circ}$ lettres de gràce et de prolection, diplômes, concordance de l'année solaire avec l'année lunaire; $4^{\circ}$ protection des pèlerins, entretien des édifices publics et garde des frontieres; $5^{\circ}$ pour se concilier la bienveillance des religieux; $6^{\circ}$ reconciliation et apaisement des querelles; $7^{\circ}$ louanges et témoignages de respect; $8^{\circ}$ blàme et réprobation; $9^{\circ}$ félicitalions; $10^{\circ}$ condoléance; $11^{\circ}$ fraternité et anilié; $12^{\circ}$ reuseignements; $13^{\circ}$ réprimandes pour faits de négligence; $14^{\circ}$ rentréc en grâce; $15^{\circ}$ intercession; $16^{\circ}$ recommandations adressées aux fonctionnaires publics; $17^{\circ}$ exhortations; $18^{\circ}$ passages détaclıés, visas; $19^{\circ}$ jeux d'esprit; $20^{\circ}$ sujets divers.

$3^{\circ}\left(\right.$ Fol. $202 \mathrm{v}^{\circ}$.) Onzième partie de la collection des dépèches rédigées par Aboû Ishạq Ibrâhìm ibn Hilàl alŞâbî, secrétaire du sultan bouide Samsâm al-Daula Aboû Kâlidjàr, et adressées à divers personnages marquants. La plupart de ces pièces sont datées de l'an 375 de l'hégire $\left(9^{85}-9^{86}\right.$ de J. C. ). Le ms. arabe $n^{\circ}{ }_{2} 62$ de la Bibliothèque de Leyde renferme la troisième partie de ce recueil. Aboû Isḷâq al-Ṣâbî est mort en 384 de l'hégire (994 de J. C.). (Voyez le Dictionnaire biographique d'Ibn Khallikân, t. I, p. 31 de la traduction anglaise.)

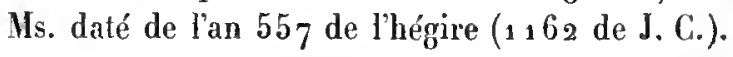

Papier. 299 feuillets. Hauteur, 25 centimètres; fargeur, 17 centimètres. 23 lignes par page. - (Ancien fonds 1405.)

\section{5.}

. Commentaire sur l'épître d'Abon 
'1-Walid Ahmad 1bn Zaïdoûn, par Djamâl al-Dìn Mohammad ibin Nobâta. (Voyez Hadji Khalfa, t. III, p. 358.) Plusieur's extraits de ce commentaire, arec la traduction latine de Reiske, ont été publiés dans l'ouvrage intitulé Additamenta ad historiam Arabum ante Islamismum, par Rasmussen.

Hs. daté de l'an 1161 de l'bégire ( 1748 de J. C.).

Papier. 127 feuillets. Hanteur, 23 eentimètres el demi; largenr, 14 centimètres et demi. 27 lignes par parge. - (Supplément 1504 bis.)

\section{6.}

Commentaire de Șalậ al-Dìn Aïbak al-Ṣafadì sur l'épitre d'Ibn Zaïdoûn, adressée à Ibn Djahwar, roi de Cordone. On trouve au folio 3 une notice biographique d'Ibn Zaïdoûn et au fol. 11, le texte de l'épitre. Ce commentaire, comme d'autres du même auteur, est très diffus. Commencement : L plets.

Ms. daté de l'an 1043 de l'hégir'e (1633-1634 de J. C.).

Papier. 18 \& feuillets. Hautenr, so centimc̀tres et demi; largeur, 15 centimètres. 19 lignes par page. - (Supplément 1504.)

Mème ouvrage.

\section{7.}

Ms. daté de l'an $117^{4}$ de l'hégire (1761 de J. C.). Le premier cahier, qui manque, a été remplacé par un feuillet portant une préface apocryphe.

Papier. $19^{2}$ fenillets. Hauteur, 21 centimètres; largenr, 14 contimètres. 19 lignes par page. - (Supplément 1503.)

\section{8.}

Colliers d'or, on beaux traits des hommes illustresn, anthologie des poètes musulmans d'Espagne du xi ${ }^{e}$ et du xü siècle, par Aboù Nast al-Fatḥ ibn Moḥmmad al-Qaïsî, de Séville, connu sous le sobriquet d'Ibn Khâqân, mort au Naroc, en 535 de l'hégire ( $1140-1141 \mathrm{de} \mathrm{J}, \mathrm{C}$. ). Cet ouvrage, dont le styte est fort admiré, bien qu'il soit difficile de l'apprécier sans l'aide d'un commentaire, est divisée en quatre parties: $1^{\circ}$ les princes; $2^{\circ}$ les vizirs; $3^{\circ}$ les cadis et les ulémas; $4^{\circ}$ les hommes de lettres et les poètes.

Ms. daté de l'an 883 de l'hégire ( 1478 de J. C.).

やapier. a 31 fenillets. Hanteur, a6 centimètres et demi; largeur, 8 centimètres. 21 lignes par page. - (Ancien fonds 734 .)
Mème ouvrage.

\section{9.}

Ms. daté de l'an 1013 de l'hégire (160\%-1605 de J. C.).

Papier. 219 fenillets. Hautcur, 19 centimètres; largeur, 11 centimètres et demi. 19 lighnes par page. -- (Ancien fonds 1415.)

Mème ourrage.

\section{0.}

Ms. de plusieurs mains, daté de l'an 1164 de l'hégire ( 1750 de J. C.). Entre les folios actuellement cotés 14 et 15 et les folios $35 \mathrm{et} 36$, il manque quelques feuillets.

Papier. 12 feuillets. Hauteur, 31 centimètres et demi; largeur, 21 centimètres. 19 lignes par page. - (Supplément 677.)

\section{1 .}

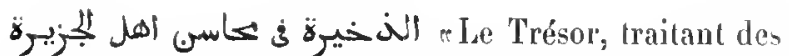
choses qui font honneur aux habitants de la péninsule (espagnole)n, par Abou '1-Hasan 'Mli ibn Bassàm, mort en 542 de l'hégire (1147-1 448 de J. C.). Anthologie poétique et historique, divisée en quatre sections, dont le présent volume renferme la première. Le premier feuillet manque.

Papicr. 263 fenillets. IIanteur, $3 i$ centimètres et demi; largeur, 2 centimètres. 23 ligues par page. Ils. du xuñ $^{2}$ siècle. - (Supplément 23.93.)

\section{2 et 3323 .}

Denxième et troisième partie du même ouvrage, copiées sur le ms. de la Bibliothèque Bodléienne et le ms. de la Bibliothèque de Gotha.

2 vol. Papier. 265 et 263 fenillets. Hauteur, 22 centimètres; largour, 17 centimètres. - (Supplément 2450-2451.)

\section{4.}

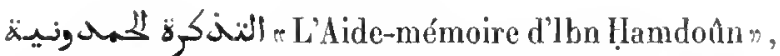
grand recueil de notes historiques et littéraires, d'anecdotes et de morceaux de poésie, par Abou 'l-Macàli Molıammad ibn al-Hasan ...... ibn Hamdoùn, sul’nommé Kafi ' $l$-Kofát cle capable par excellencen. La biographie de l'auteur, qui était employé daus les bureaux 
du califat, à Baghıdàd, pendant la première moitié du $\mathrm{xu}^{\circ}$ siècle, et qui est mort en 562 de l'hégrire $(1167$ de J. C.), se troure dans le Dictionnaire d'Ihn Khatlikàn, I. III, p. 90 de la traduction anglaise. Le présent volume, le onzieme de l'ouvrage, renterme quatre chapitres (ب), dont cluacun est précédé d'une préface et forme un traité à parl, à savoir : chapilre xull. Tours d'adresse et tromperies; - chapitre xum. Les épithites, les insinuations, les énigmes, les logogriphes et les allusions détournées; - chapitre xurv. Le vin et les parties de débauche; - chapilı xur. Le chant, les chanterr's et les musiciens. Il y a une lacune entre les folios actuellement colés 2 el 3.

Papier. 200 feuillets. Hanteur, 23 contimètres et demi; largeur, 16 centimètres. 13 lignes par page. Ms. du xute siècle. - (Aneien fonds 1 (j02.)

\section{5 .}

Choix d'anecdotes et de pièces de vers r, recueil de notices instruetives en cinquante chapitres. L'auteur, qui ne se nomme pas, dit que soll ourrage est un remaniement et un abrégé de l'an-

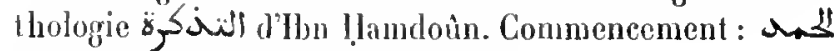

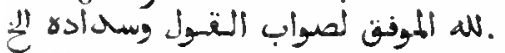

Ms. daté de l'an 1121 de l'bégire $\left(1709^{-1} 7^{10}\right.$ de J. C.).

Papicr. 176 feuillets. Hauteur, 21 centimètres et demi; largeur, 15 centimètres. 23 tignes par paģe. - (Supplément 184a.)

\section{6.}

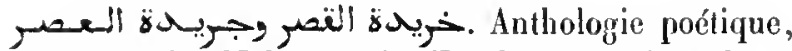
par 'Imid al-Din Mollammad, d'Ispahan. Premier volume de l'ourage, qui commence par les poètes de l'Irâq et se termine par un article sur Al-I!arîn', l'auteur des Ma-

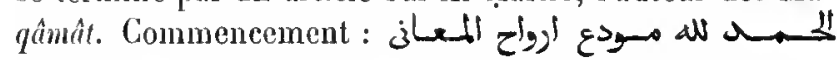

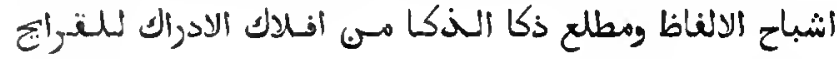

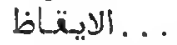

Papier. ${ }_{9} 5$ feuillets. Hauteur, 21 centimètres et demi; largeur, 14 rentimètres el demi. 25 lignes par page. Ms. du xvir siècle, de direrses mains. - (Ancien fonds 1447.$)$

\section{7.}

Autre volume du même ouvrage, commençant au inilieu de la notice d'Ibn al-Khâzin al-Baghdâdì et finissant par la notice d'Al-Ịosaïn ibn Thâbit, poète du vi siècle de l'hégire.

Papier. $19^{2}$ feuillets. Hauteur, 24 centimètres et demi; largeur, 15 centimètres. 21 lignes par page. Ms. du xi11' siècte. - (Ancien fonds 1373. )

\section{8.}

Autre volume du même ourrage, contenant les poètes d'Égypte et ceux de la Palestine.

Le commencement manque. A la fin du ms., on a ajouté après coup, pour tromper le lecteur, cette note:

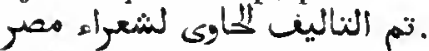

Ms. daté de l'an 642 de l'hégire (1245 de J. C.).

Papier. 201 feuillets. Hauteur, 24 cenlimètres; largeur, 16 centimètres. 17 lignes par page. - (Ancien fonds 1374. )

\section{9 .}

Autre volume du même ourrage, contenant les poètes de la Syrie, de la Mésopotamie, du Ḥidjâz et du Yemen.

Papier. 286 feuillets. IJauteur, 22 centimètres; largeur, 15 centimètres. 23 lignes par page. Ms. du $x_{1}{ }^{e}$ siècte. - (Ancien fonds 14 14.)

\section{0.}

Autre volume du même ouvrage, commençant par les poètes de la Sicile et fiuissant par ceux de l'Espagne. Ce ms. est le onzième rolume d'un exemplaire qui devait en aroir douze; car on lit, à la fin, cette note écrite de la main

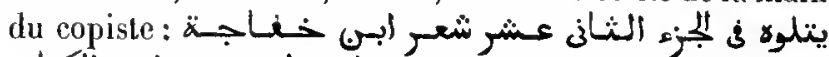

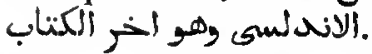

Papier. $19^{8}$ feuillets. Hauteur, ${ }_{2} 6$ centimètres et demi; largeur, 18 centimètres. a I lignes par page. Ms. du $\times 7^{\circ}$ siècle. - (Ancien fonds 1375 .)

\section{1.}

Dernier volume du même ouvrage, contenant les poètes d'Espagne. Le ms. commence par la notice d'Ibn Khafädja el se termine par celle d'lbn al-Meșiṣî.

Papier. 217 feuillets. Hauteur, 27 centimètres; largeur, 17 centimètres et demi. 17 lignes par page. Ms. du xiv* siècle. - (Ancien fonds 1376. .) 


\section{2.}

Dernier volume du même ouvrage, consacré aux poètes d'Espagne.

Papier. 62 feuillets. Hantenr, 25 centimètres et demi; largeur, 17 centimètres et demi. 27 lignes per page. Ms. du xvi siècle. (Supplément 1411.)

\section{3.}

"Gemmes en fait de plurases et colliers pour (orner) les intelligences $\%$, recueil de beaux passages tirés des lettres adressées à Ibn Sanci al-.Molk ef à son père par Al-Qâdhî al-Fâdhil 'Abd al-Ralıìn al-Baïkànî et son fils, A1-Qàdhì al-Asclıraf. Le rédacteur de cette anthologie, qui y a inséré quelques extraits de de ses propres lettres et plusieurs poèmes de sa composition, était considéré comme le premier poète de son temps. Il remplissail les fonctions de cadi au Caire, sous le règne de Saladin, et portait le titre honorifique d'AlQâdhì 'l-Sacid. Il mourut en 608 de l'hégire $(1212$ de J. C.). Sa Vie se trouve dans le Dictionnaire d'Ibn Khallikân, t. III, p. 589 de la traduction. Le mème ourrage, t. II, p. 111 , renferme une notice sur Al-Qàdhì al-Fàdhil. On lit dans le présent recueil quelques passages qui se rapportent anx guerres contre les Croisés et à la prise de la ville d'Acre. Commencement : .

Papier. 96 feuillets. Hauteur, 20 centimètres; largeur, 14 centimètres et demi. 11 tignes par page. Ms. du xıv siècle. - (Ancien fonds 1586. )

\section{4.}

Choix de poésies érotiques de divers autenrs, depuis Aboû Nowâs jusqu'à Moḥyì al-Dìn Ibn al-`^rabî.

Le commencement et la fin manqnent.

Papicr. 33 feuillets. Hauteur, 15 centimètres; largeur, 10 centimètres et demi. 13 tignes par page. Ms. du xrı' siècle. - (Supplément 2049.)

\section{5.}

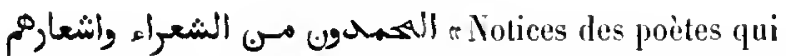
porlaient le nom de Mohammad et exemples de leurs poésies", ouvrage posthume du Qàdhi al-Akram "Ali ibn
Youlsof iln al-Qiftì. Les poc̀tes sont énumérés d'après l'ordre alphabétique des noms de lem's pères. Le ms. s'arrête à l'article Mohammad ibn Sacid. L'auteur, né à Qift, dans la haute Egypte, en 568 de l'hégire (1 $17^{3-}$ $117^{4}$ de J. G.), est mort en 646 de l'hégire (1 248 de J. C.).

Ms. daté de l'an 1157 de l'hégire (1744 de J. C.).

Papier. 130 feuillets. Hauteur, 2 a centimètres et demi; largeur, 15 centimètres el demi. 21 liggnes par page. - (Supplément 681.)

\section{6.}

Recueil d'anecdoles et de pièces de vers. Le commencement et la fin manquent, ainsi que quelques feuillets an milieu. Au fol. 37 se trouve un clapitre intitule wوالات

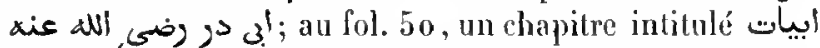

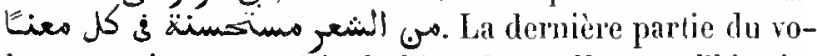
lume contient une série de légendes, telles que l'histoire de Moïse et de Khidr, la justification d'dïscha, l'histoire d'Alraham, celle des Sept dormants, etc.

Papier. 19 feuillets. IIauteur, 28 centimètres; largeur, 19 centimètres. 2 I lignes par page. Ms. du $\times 11^{e}$ siècle. - (Supplément 2188.$)$

\section{7.}

(llaximes de sagesse exprimées en divers styles $\%$, recueil de vers tirés des ouvres des poìtes anciens et modernes et disposés, par ordice de matières, en seize chapitres. L'auteur anouyme de cette compilation l'a dédice an sultan M-Walik al-Moªddham Ghiyàth al-Dìn, r adversaire des infideles et des polythéistes,..... vainqueur des adoratenrs des crois (SUf)

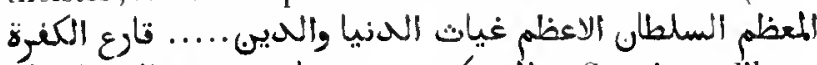
. والمشتوكيه. .... Ces titres d'honneur ne peurent appartenir qu’à H-Malik al-Mo addham Ghiyàth a1-Dìn Toûràn-Schàh, souverain aïyoubide et vainqueur de saint Louis. L'ourrage aurait donc été composé dans les premiers mois de l’an 1250 de J. C. Saint Louis fut fait prisonnier le 8 février I 250 , et ToùrinSchàh fut assassiné le 5 avril de la mème année.

Ce ms. était destiné à da bibliothèque du sonverain dont nous venons dindiquer les principaux titres. Le frontispice orné est mutiló, ainsi que la marge supérieure du fenillet suivant.

Papier. 47 feuillets. Hanteur, 30 centimètres et demi; largeur, 2 a centimètres et deni, 9 lignes par payc. - (Supplément 1359.) 


\section{8.}

1 Même ouvrage. Copie exécutée en 1028 de l'hégire (1619 deJ. C.), d'après un exemplaire daté de l'an 668 de l'hégire.

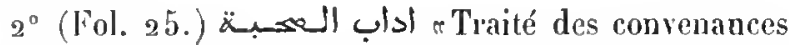
sociales r, attribué soit à ' $\mathrm{Abd}$ al-Ralımân ibn Ahmad al-

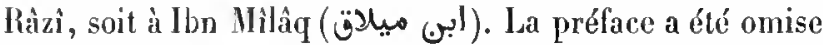
par le copiste. Cette copie, également datée de l'an 1028 de l'hégire, est d'une autre main que l'article $1^{\circ}$.

Ces deux traités sont détachés d'un volume qui, primitivement, eu renfermait six.

Papicr. 4o fenillcts. Hauleur, a 1 centimèlres; largeur, 15 centimètres. - (Supplément 1583.)

\section{9.}

Album composé au vil siècle de l'hégire et renfermant uu grand nombre de morceaux en vers et en prose qui, presque tous, appartiennent à des auteurs de l'époque.

Les premiers feuillets manquent.

Ms. dalé de l'an 874 de l’hégire (1469-1470 de J. C.).

Papier. 74 feuillets. Hauteur, 18 centimètres; largeur, 13 centimètres. 12 à 18 lignes par pago. -- (Supplément 1564.)

\section{0.}

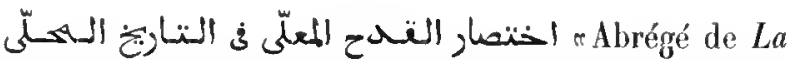
Flèche qui gagne le prix, ouvrage historique, rédigé en style omér. Le لئل sacré par Abou 'I-Ịasan 'Mlî ibn Moûsâ ibn Sa'id, auteur musulman d'Espagne, mort en 685 de l'hégire (1 286 de J. C.), à l'histoire littéraire de son pays et de la Mauri-

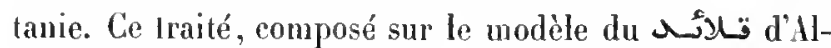

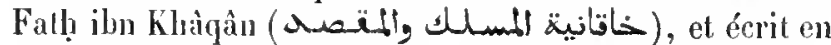
un style tres recherché, renferme des notices sur quelques personnages d'Espagne qui viraient dans la première moitié du vi siècle de l’hégire. Le présent abrégé, rédigé jar Aboû 'Abd Allah Moḥammad ibn 'Abd Allah ibı Djalìl, est dédié au prince Aboû Zakarîya, fils du calife hafside Al-Mostanșir Billâh. A la suite d’une préface, éerite dans un langage très recherché et très obscur, on trouve la notice biographique d'lbn Sa id, désigné par les surnoms d'Abou 'l-Ḥasan ibn abî 'Imrân.

Papier. 70 feuillets. Hauleur, 25 centimètres el demi; largeur, 17 centimètres et demi. 27 lignes par page. Ms. du xir siècle. (Aucien fonds 746 .)

\section{1.}

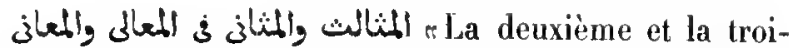
sième corde du luth, traité renfermant des pensées élevées et de nobles idées $\%$. Recueil de morceaux en prose et en vers, dédié au sultan de llamâh, Al-Malik alAfdhal Mohammad, fits d'Al-Malik al-Mowaïyad Abou 'H-Fidà, l'historien et géographe, par Șafì al-Dîn 'Abd al-

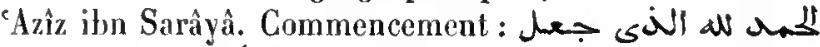

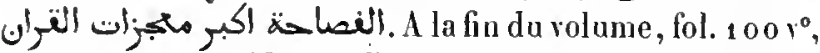
se trouve $1 \mathrm{n}$ certificat délivré par l'auteur de l'ouvrage à un de ses élèves. Cette pièce est datée de l'an 743 de l'hégire, et porte la signature d'Ibn Sarâyâ. Les feuillets actuellement cotés 101 et 102 ne sont pas à leur place.

Papier. 102 feuillels. Hauteur, 26 centimètres et demi; largeur, 18 centimètres et demi. 11 lignes par page. Ms. du xiv siecle. (Supplément 1553.)

\section{2 .}

ج. Perles du discours $n$, choix d'extraits en prose et en vers, par Mohammad ibn Mohammad ibn Scharaf al-Zara'ì, docteur schaféite. L'auteur déclare avoir achevé son travail en 744 de l'hégire $(1343$ de J. C.). Les divers passages, empruntés aux meilleurs poètes et prosateurs musumans, sout classés, d'après leur contenu, en quatorze chapitres. En tête du ms., audessus du titre, un lecteur qui avait collationné le rolume كتناب جوأهر المكلام ف فـنسور : avec un autre ms., a écrit

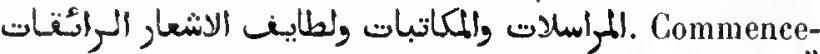
ment de la préface :

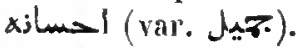

Papier. 92 feuillets. Hauteur, 28 centimètres; Jargeur, 18 centimètres et demi. 15 lignes par page. Ms. du xv ${ }^{e}$ siècle. - (Ancien fonds 1576 .)

\section{Même ouvrage.}

\section{3.}

Papier. 86 feuillets. Hauteur, 19 centimètres; largeur, 13 centimètres et demi. 17 lignes par page. Ms. du $\mathbf{x v}^{*}$ siècle. - (Ancien fonds 1611.)

\section{4.}

م Source de renseignements utiles et collection d'observations précieuses n, anthologie de morceaux en prose et en vers, pour servir de manuel de style et de belles-lettres, par Djamâl al-Dîn Moḥammad ibn Mọ̣ammad ibn Nobàta, auteur égyptien, mort 
en 762 de l'hégire ( 1360 de J. C.). Commencement :

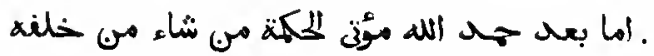

Papier. 136 feuillets. Hautenr, 22 centimètres; largeur, 15 centimètres. 7 lignes par page. Ms. du xvin" siècle. - (Supplément 1558. )

\section{5 .}

exposition et avertissement touchant la description et la comparaisonn, traité de la métaphore et de la comparaison, sorte d'antbologie poétique, par Khalìl ibn Aïbak al-Safadi. Le présent uns. renferme le premier volume de l'ouvrage,

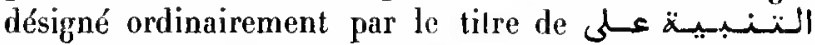
in

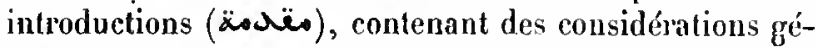
nérales, occupent les folios 4 à $32 \mathrm{v}^{\circ}$, et 33 à $53 \mathrm{v}^{\circ}$. La première est divisée en dix chapitres (فصل), la seconde en ringt-quatre. Suivent soixante-cinq sections (تنبيه), dont chacune, consacrée à un sujet particulier, renferme les compositions poétiques qui s'y rapportent, et dent voici les rubriques :

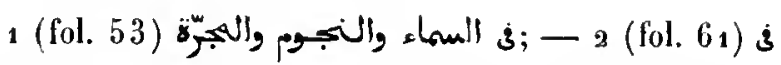
-

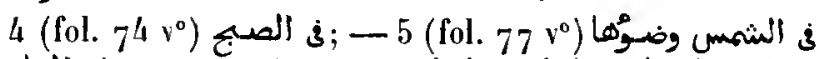
- -

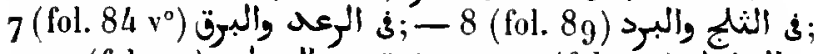

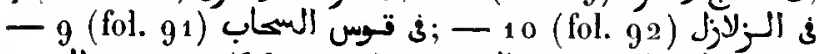

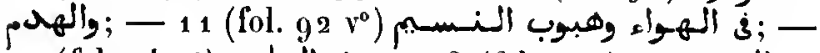

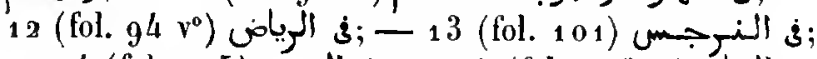
- 14 (fol. 105 ) ألـون - 16 (fol. $109 \mathrm{v}^{\circ}$ (fol. 110 ) (fol. 112 )

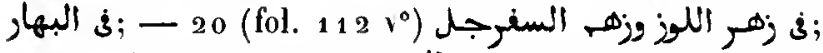
ف

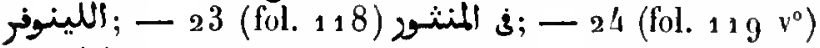
(fol. 121 )

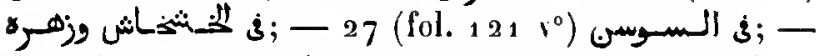

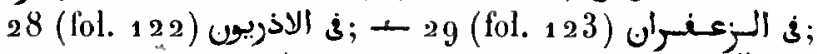

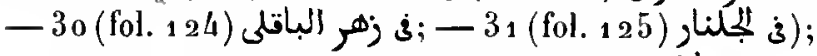

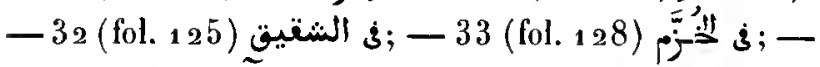

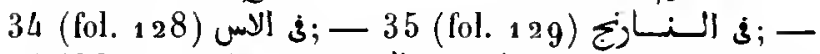

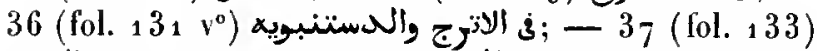

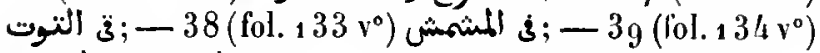
- -

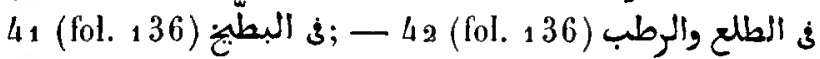
(fol. $138 v^{\circ}$ ) - 43 (fol. 139)

Man. orientaux. - ll.
;

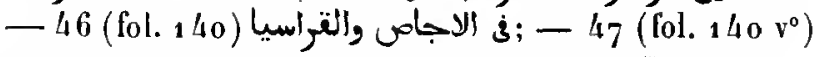
-

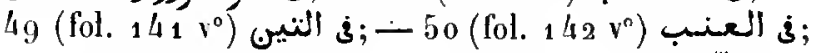
ف

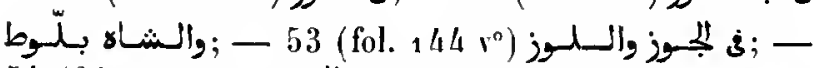
ف قصسب (fol. 145)

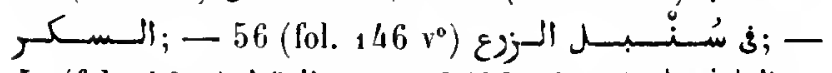
57 (fol. $146 \mathrm{v}^{\circ}$ ) - 59 (fol. $148 v^{\circ}$ ) 60 (fol. $150 \mathrm{v}^{\circ}$ ) ف ف ف الاطيار (fol. $155 \mathrm{r}^{\circ}$ )

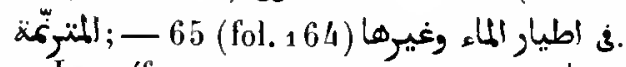

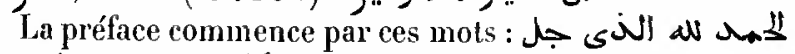

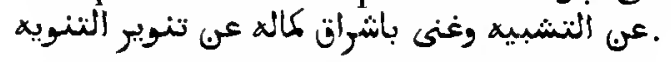

Papier. 167 feuillets. Hauteur, ag centimetres; largeur, 15 centimètres et demi. 17 lignes par page. Ms. du xur siècle. - (Ancien fonds 1584.)

\section{6.}

Brouillon (تعلبغة) autographe du troisième volume d'un dictionnaire des poètes des $v^{c}, v^{e}$ et $v_{11}^{e}$ siècles de l'hégire, par le grand cadi ${ }^{\top} \mathrm{Izz}$ al-Din 'Abd al-'Azìz

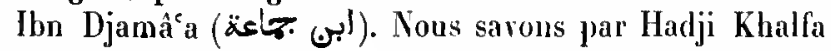
(t. II, p. 286 et I. VI, p. 132, 477), que ce personnage, mort en 767 de l'hégire (1365-1366 de J. C.), était fils de Badr al-Din Moḷammad, qu'il portait les noms ellniques d'Al-Hamawi (né à ḷanàh) et d'Al-Dinaschqii, (habitant de Damas) et quil était docieur scliaféite. $\mathbf{\Lambda}$ Maqqari, dans son grand ouvrage sur l'Espagne, cite ce نزهة الالبّاء - Délices des hommes intelligents 7 . Les notices se conıposent ordinairement de quelques ver's dı poète suivis d'un commentaire. Le présent ms. contient les lettres $\tau$ à w. L'écriture est si cursive qu’à moins de connaître le sujet, il est difficile de la déchiffrer. Les points diacritiques sont presque toujours omis.

Ms. daté de l'an 756 de l'hégire ( 1355 de J. C.).

Papier. 134 feuillets. Hauteur, 27 centimètres; largeur, 17 centimètres et demi. 20 à 3 o lignes par page. - (Ancien fonds 1378 .)

\section{7.}

1 o Centre de la circonfe$7^{4}$ 
rence qui renferme les littérateurs de Grenaden, abrégé de l'ouvrage intilulé الاحاطة بتاريخ غرناطة, du célètsre vizir Lisîn al-Din ibn al-Khațîb. Cet abrégé, rédigé par l'auteur lui-même, est une anthologie poélique, fournissant quelquefois des dates el des indications hisloripues. Il commence par une notice sur Mohammad ibn Yalyyì al-Ghassinìi al-Badjì. Commencemenl: : .

$2^{\circ}$ (Fol. 151.) Autobiographie du vizir Lisân al-Dìn, accompagnée d'extraits de ses poésies et de ses lettres.

$3^{\circ}$ (Fol. $275 v^{\circ}$.) Épitre de grand apparat, adressée par le vizir Lisân ad-Dîn au sullan de Grenade, qui hui avait envoyé une lettre cl un magnifique cadeau. Le iexte de celle pièce est donné d'après l'historien lbu Klıaldoûn, qui l'avait apprise par coeur.

Ms. daté de l'an $99^{6}$ de l'hégire ( 1587 de J. C.).

Papier. 284 feuillets. Hautenr, 21 centimètres et deni; largeur, 15 centimères et demi. 23 lignes par page. - (Ancien fonds 867.)

\section{8.}

"Divan de l'amour passionnén, par Aḷmad ibı Yaḷyà ibn abì Hadjala, de Tlemcen, mort, sclon Hadji Khalfa, en $77^{6}$ de lhégire (1374-1375 de J. C.). C'est un traité complet smr l'amour. II est divisé en trenle cliapilres, dans lęsquels l'auteur a inséré les plus beaux vers des poèles antérieurs el les anecdotes les plus louchanles et les plus intéressantes qui s'y rapportent.

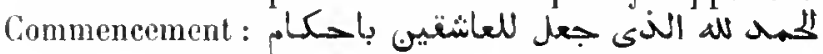

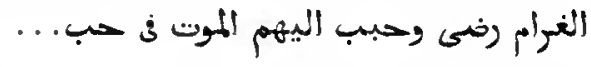

Ce ms. a élé écrit pour un nommé Fàris, trésorier d'un grand personnage de la cour d'Al-Malik al-Zâhir, sullan mamelouk. Il manque un ou deux fenillets à la fin.

Papier. 215 fenillets. Hautenr, 27 centimètres el demi; largeur, 18 centimètres et demi. 11 lignes par page. Ms. du $x v^{\circ}$ siècle. (Ancieu fonds 1400. )

\section{9.}

Hême ouvrage.

Hs. daté de l'an $89_{2}$ de l'hégire (1487 de J. C.). A la fin se trouvent d'atutres pièces de rers.

Papier. 236 feuillets, Hauteur, 17 centimètres el demi; largeur, 13 centimètres el denii. 15 lignes par page. - (Ancien fonds, 466.)

\section{Même ouvragge.}

\section{0.}

Papier. 179 feuillets. Hanteur, 21 centimètres et demi; largeur, 15 centimètres el demi. 15 lignes par page. Ms. du $x^{2}$ siècle. (Ancien fonds 1461.)

\section{1.}

Même ouvrage.

Papier. soo feuillets. Hauteur, 26 centimètres; largeur, 18 centimètres. 15 liggnes par page. Us. du $\mathbf{x v 1}^{*}$ siècle. - (Supplément 1810. )

\section{2.}

\section{Mème ouvrage.}

Papier. 152 feuillets. Jfauteur, 18 centimètres et demi; largeur, 14 centimètres. 21 lignes par page. Ms. du xvie siècle. - (Ancien fonds $1,169$.

\section{Même onvrage.}

\section{3.}

Ms. daté de l'an 1017 de l'hégire (1608 de J. C.).

Papier. 162 feuillets. Hauteur, 18 centimètres; largeur, 13 centimètres. Au commencement 19 lignes par page, puis 17 lignes. (Supplément 3 814.)

\section{4.}

Même ouvrage.

Ms. dalé de l'an 1052 de l'hégire (164h de J. C.).

Papier. 162 feuillels. Hauteur, so centimètres et demi; largeur, 14 centimètres et demi. a I lignes par page. - (Supplément 1813.)

Même ouvrage.

\section{5.}

Papier. 134 feuillets. Hauteur, 21 centimètres; largeur, 15 centimètres et demi. 23 lignes par page. Ms. du xvie siècle. - (Supplément 1811.)

Même ouvrage.

\section{6.}

Ms. daté de l'an 1080 de l'hégire ( 1669 de J. C.).

Papier. 161 feuillets. Hauteur, 31 centimètres et demi; largeur, 15 centimètres. 19 lignes par page. - (Supplément $18,2$. ) 


\section{7.}

Nème ouvrage.

La fin manque.

Papicr. 145 feuillets. Hauteur, 21 centimètres ; largeur, 16 centimètres. 21 lignes par page. Ms. du xvin' siècle. - (Supplément 3425.$)$

\section{8.}

L'appendice (خاتمة) ou dernier chapitre du même ouvrage.

Ms. daté de l'an 1035 de l'hégire ( 1626 de J. C.).

Papier. 25 feuillets. Hautcur, 21 centimètres el demi; largeur, 1 ' centimètres el demi. a 1 liggnes par page. - (Supplément 1815.)

\section{9.}

Extrails du même ouvrage.

Papier. 18 feuillets. Hauteur, 20 centimètres el demi; largeur, 10 centimètres. Environ 20 lignes par page. Ms. dn xvı1" siècle. (Supplément 2277.)

\section{0 .}

"Suite du Soukkardann, par Ilon abî Hadjala. Dans cet ouvrage, qui se compose de cinq sections, l'auteur traite principalement du sultan AlMalik al-Nàșir et de ses propres écrits. Chaque section est suivip de cinq récits qui en forment le sommaire et qui en

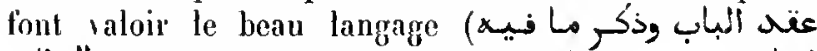

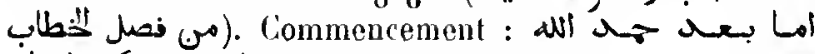

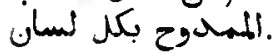

Papier. 69 feuillets. Hauteur, 18 centimètres el demi; largeur, 13 centimètres el demi. 15 liggnes par page. Ms. du vvı siècle. (Anrien fonds 1452.)

\section{1 .}

- L'Haleine du zéphyrn, anthologie composée de passages en prose et en rers et divisée en trente sections, par Hasan ibn 'Omar ibn Habìb al-Halabi, docteur schaféite, mort en 779 de lhégire ( 1377 de J. C.). La première section est consacrée au ciel et anx étoiles; la seconde. au soleil et à la lune; la troisiène, aux nuages et

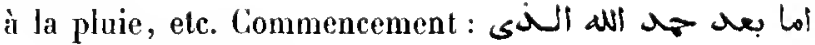

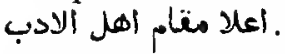

Papier. 77 feuillets. Hautour, 18 centimètres et demi; largeur, 13 centimètres. 15 lignes par page. Ifs. de la fin du xiv siècle. (Ancien fonds 1592.)

\section{2.}

1 . Nême ouvrage.

$2^{\circ}$ (Fol. $9^{2} 1^{\circ}$. ) Appréciations-laudatives de l'ouvrage précédent, par plusicurs savants docteurs.

$3^{\circ}$ (Fol. $9^{8} r^{\circ}$.) Divan composé de plusieurs pièces de poésic et de qaṣidas, dont quelques-unes écrites en l'honneur du célèbre historien et géographe Abou 'l-

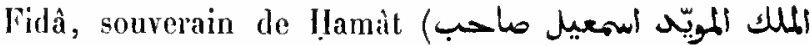
اح) . Ces pièces sont disposées dans l'ord re alphabétique des rimes. Le présent recueil répond assez bien à la description du livre inlilulé سوق الرقين - Marché d'esclaves», décrit par Hadji Khalla, dont l'auteur est Djamàl al-Din Mohammad ibn Molıanmad iłn Nobàtı, mort en 768 de l'hégire (1366-1367 de J. C.).

$4^{\circ}$ (Fol. $160 \mathrm{v}^{0}$.) Epigrammes composés par Ilasan ibn 'Omar ibn Habîb. Ces épigrammes, générałement de deux vers, sont classés en six sections, savoir : ألمعان ${ }^{\circ}$

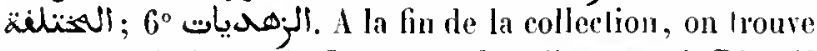
des appréciations très flatteuses, dont funne est de Djamâl al-Dìn et l'autre d'Al-Ṣafì al-lillli ("Abd al-'Azì ibn Sarâyà).

Ms. dalé de l'an 805 de lhégire (1403 de J. C.).

Papier. 206 fenillels. Hauteur, 16 centinètres et demi; largeur, 1 a centimètres et demi. 13 lignes par page. - (Ancien fonds 1/50.)

\section{3.}

Le le Hasan ibn 'Omar ibn ḷabîh alHalabì.

Ce ms., daté de l'an $9^{66}$ de l'hégire ( 1558 de J. C.), a été copié sur un exemplaire qui avait été collationné arec le ms. de lautemi".

Papier. 77 feuillets. ffauteur, 17 centimètres; largeur, 10 centimètres et demi. 15 lignes par page. - (Ancien fonds 162\%.)

\section{4.}

$1^{\circ}$ Même ouvrage. Copie du xv111 siecle. 
$2^{\circ}$ (Fol. $46 \vee^{\circ}$.) La Badíiya de Djalál al-Dìn alSoyouți. Copie datée de l'an 1 1 38 de l'hégire $(1726$ de J. C.).

Papier. 64 feullets. Hauteur, a centimètres; largeur, 14 centimètres at demi. - (Supplément 1586.)

\section{5.}

$1^{\circ}{ }^{\circ}$ intitule Parterre du regard et dilices de l'esprit". L'auteur, qui ne se nomme pas, dit avoir composé d'abord une grande anthologie, intilnlée وضغة النفاظر;, puis le présent abrégé. L'ourrage est divisé en trois jarties (قسم:), comprenant plusicurs chapitres (باب), dont chacun ren-

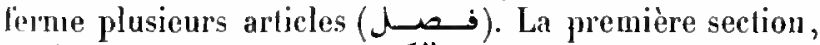

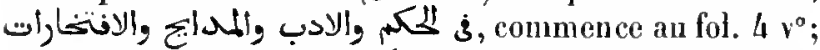
la scconde section, فيه يتعلق بالمكاتبات la troisième section, المتنغرتات, an fol. 95 v'. D'après Hadji Khalfa (t. III, p. 512 ), cette anthologie, qui est dédié à Amir llàddji Hohammad, a été composée par 'Abd al-'Azìz al-Kischì. Les pièces de vers sont alternativement arabes et persanes. Commencement : all hall

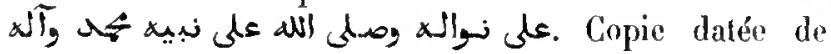
l'an $79^{3}$ de l'hégire ( $3_{9} 1$ de J. C.).

$2^{\circ}$ (Fol. $123 v^{\circ}$.) Les Cent paroles ou maximes d"dli, fils d'Aboù Tâlib. Chaque maxime est accompagnée d'un mot à mot persan et d'une glose de deux vers également en langue persane. Copie datée de l'an 764 de l'hégire ( 1362 de J. C.).

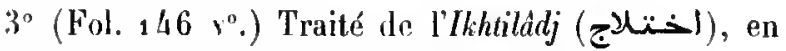
ler's persans, par Badr al-Din Ilàdjermî.

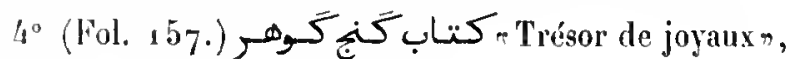
reflexions morales, en vers persans.

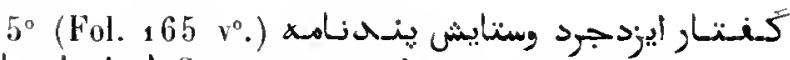
لنوشروان عادل Sentences morales en vers persans.

$6^{\circ}$ (1 1 ol. 176.) Conseils religieux, récits et historietles, en vers persans, par Badr al-Dìn țàdjermî́ qui, probablement, est aussi l'anteur des articles $4^{\circ}$ et $5^{\circ}$.

Les articles $2^{\circ}$ et $6^{\circ}$ sont écrits de la mème main.

Papier. $19^{8}$ feniltels. Hauteur, 19 centimètres; largeur, $1 / 4$ centimitres. - (Ancien fonds 1600 .)

\section{6.}

Nême ouvrage que l'article $1^{\circ} \mathrm{du} \mathrm{n}^{\circ}$ précédent.
Ms. daté de l'an 802 de l'hégire ( 1400 de J. C.). Les litres des chapitres sont écrits en or et en couleurs; les deux premières pages sont ornées de vignettes.

Papier. 110 feuillets. Hauteur, 20 centimètres; largeur, 14 centimètres. 13 lignes par page. - (Supplément 1555 .)

\section{7.}

Extraits poétiques recueillis par بـى بـ Ces extraits, généralement de deux, parfois de trois vers, sont d'Ibn Nobàta, d'Ibn al-Wardì, d'lbn al-Moctazz, d'Aboû Nowàs, de Bohlori, de Bahà al-Dìn Zohaïr, etc. Ils sont classés sous les titres suivants : 1 J茾 $3 ; 2$ (fol. 9 ) , 3 (fol. 20) ) 3; 4 (fol. 27) (fol. 30) ;

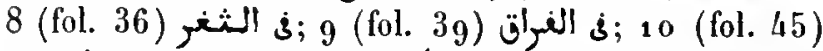
i ;

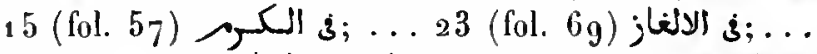

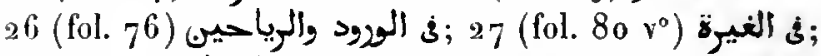

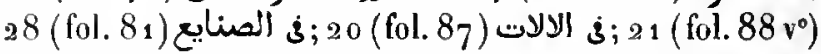

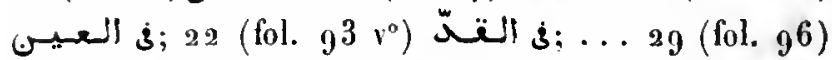
(fol. $977^{0}$ (fol. $\left.98 v^{\circ}\right)$ (fol. $98 v^{\circ}$ (fol. $99 v^{\circ}$ ) (fol. $\left.108 v^{\circ}\right)$

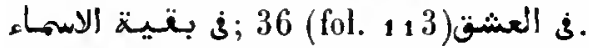

11 y a quelques lacunes et plusieurs feuillets sont intervertis.

Papier. 117 feuillets. Hauteur, 21 centimètres; largeur, $1 /$ centimètres. 17 lignes par page. Its. du $\mathbf{x v}^{\circ}$ siècle. - (Ancien fonds 1 /663.)

\section{8.}

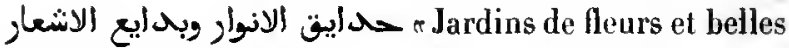
pensées en vers", par Djonaïd ibn Mạımoûd. Cette anthologie, dédiće au prince mozafféride Abon Nașr-Schâh Yaḷyì, sultan du Kermàn, a été achevée en $79^{\circ}$ de l'hégire (1388 de J. C.). Schâh Yahỹâ fut mis à mort par Timour, en $79^{5}$ de l'hégire. Les extraits, en général très courts, sont classés en huit chapitres. Commen-

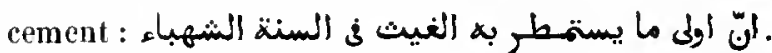

Ce ms. était desliué à la bibliotlıèque de Schâh Yahyâ. ll y a une vignette en tête et un médaillon sur le recto du premier feuillet.

Papier. 113 feuillets. Hauteur, 24 centimètres et demi; largeur, 16 centimètres et demi. 15 lignes par page. - (Supplément 1567.) 


\section{9.}

r Le Livre charmant, recueil d'anecdotes intéressantes de lout genren, par Schihâb al-Dìn Mohammad ibn Aḥmad al-Abschìhì. Cet ouvrage, dont il existe une édition, imprimée au Caire, est un recueil de sentences, de mots piquants, d'historiettes et de morceaux de poésie. Le toul est classé par ordre de matières en quatre-vingt-quatre chapitres, divisés en deux parties, chacune de quarante-deux chapitres.

Papier. 443 feuillets. Hauteur, 27 centimètres; largeur, 18 centimètres. 25 lignes par page. Ms. du $\times \mathrm{xi}^{\circ}$ siècle. - (Supplément ${ }^{1} 766$. )

Mème ouvrage.

\section{0 .}

Ms. daté de l'an 1052 de l'hégire (1642 de J. C.). A la fin se trouve une qașida d'environ soixante vers, qui commence ainsi :

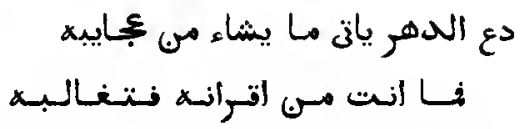

Papier. 339 feuillets. Hauteur, 29 centimètres; largeur, ao centimètres. 25 lignes par page. - (Supplément 1767.)

\section{1 .}

Mème ouvrage.

Les derniers feuillets de chacune des deux parties manquent.

Papier. 406 feuillets. Hauteur, 21 centimètres; largeur, 15 centimètres et demi. 23 lignes par pago. Uss. du xvı" siècle. - (Supplément 1768 .

\section{2.}

Première partie du mème ouvrage.

Papier. 271 feuillets. Hauteur, 21 centimètres; largeur, 15 centimètres. 21 à 23 lignes par page. Mís. du $x^{\circ} 1^{\circ}$ siècle - (Ancien fonds 411 .)

\section{3.}

Première partie du même ouvrage.

Ms. daté de l'an 1030 de l'hégire $(1621$ de J. C. $)$.
Une main plus récente a ajouté les sept premiers chapitres de la seconde partie.

Papier. 363 feuillets. Hauteur, 21 centimètres; largeur, 15 centimètres. 15 à 17 lignes par page. - (Ancien fonds 1599.)

\section{4.}

Premier volume du mème ouvrage, renfermant cinquante chapitres.

Le premier feuillet manque.

Papier. 286 feuillets. Hauteur, 20 centimètres et demi; largeur, 14 centimètres et demi. Au commencement, 21 lignes par page, puis 19 lignes. Ms. du svin' siècle. - (Supplément a 1 go.)

\section{5 .}

Volume détaché du même ourrage, renfermant les chapitres xxxill à xux.

Hs. daté de l’an 1124 de l'hégire (1712 de J. C..). Le commencement manque, ainsi que plusieurs feuillets an milieu.

Papier. 102 feuillets. Hauteur, 21 centimètres; largeur, 15 centimètres et demi. 23 lignes par page. - (Supplément 2191. )

\section{6.}

Second volume du mème ouvrage, renfermant les chapitres $\mathrm{xxx}$ à $\mathrm{LX}$.

Papier. ${ }_{267}$ feuillets. Hauteur, 20 centimètres et demi; Jargeur, 15 centimètres. 17 lignes par page. Ms. du xv11 siècle. - (Supplément 1769 .)

\section{7 .}

Second volume du mème ouvrage.

Ms. daté de l'an $99^{6}$ de l'llégire (1588 de J. C.). Vignette en tête du volume.

Papicr. 370 feuillets. Hauteur, 20 centimètres et demi; largeur, 14 centimètres et demi. 17 lignes par page. - (Ancien fonds 1598.$)$

\section{8.}

Second volume du mème ouvrage. 
Ms. daté de l'an 1025 de l'hégire (1616 de J. C.).

Papier. 293 feuillets. JJautenr, 28 centimètres et demi; largeur, 2. o centimètres. 23 lignes par page. - (Ancien fonds 157a.)

\section{9.}

Second volume du mème ouvrage, renfermant les chapilies xum à Lxxxiv.

Les demiers feuillets et quelques feuillets an milieu mancuent.

Papier. 345 feuillets. Hauteur, a 9 centimètres; largeur, 2o centimètres. 25 lignes par page. Ms. du xvi" siècle. -(Supplément 21 9.)

\section{0.}

Second volume du même ouvrage, renfermant les chapitres xum à Lxxxiv. Il y a quelques lacunes.

Papier. 322 feuillets. Hauteur, a 1 centimètres et demi; largeur, 15 centimètres et demi. 17 lignes par pagge. Ms. du xw11 sièrte. (Supplément 1770.)

\section{1 .}

Second volume du même ouvrage, renfermant les chapitres $\mathrm{L}$ à Lxxxiv.

Ms. daté de l'an 1054 de l'hégrire (1644 de J. C.).

Papier. 210 feuillets. Hauteur, 21 centimètres; largeur, 15 centimètres el demi. 23 liggnes par page. - (Supplément 530.)

\section{2.}

Les chapitres uov à Lxaxiv du mềme ourrage.

Le commencement et plusieurs feuillets an milieu manquent.

Ms. daté de l'an 1124 de l'hégire (1712 de J. C.).

Papier. 48 fenillets. Hanteur, 21 centimètres; largeur, 15 centimètres. 23 lignes par page. - (Supplément a 193 .)

\section{3.}

Olservations sur les génies, les ners, les montagnes, les fleures et les minéraux. Suivent (fol. $19 \mathrm{v}^{\circ}$ ) des nolices sur les quadrupèdes, les oiseaux et les reptiles, le tout classé par ordre alphabétique. Cette compilation, puisée dans le Mostatraf, se termine par un chapitre sur les merveilles du monde.

Papier. 76 fenillets. Hauteur, 29 centimètres; largeur, 16 centimètres. 19 lignes par page. Ns. du xvur siècle. - (Supplément 177 1.)

\section{4.}

Abrégé du Mostatraf renfermant cinquante-six chapitres, bien que, dans la préface, l'auteur n'en mentionne que les dix premiers chapitres.

Ms. daté de l'an 1075 de l'hégire (1664-1 665 de J. C.).

A la fin du volume, on a ajouté une table de divination, quatre historiettes et un traité sur l'amour, en onze

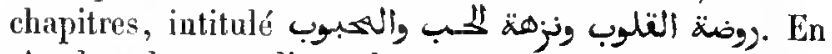
lête du rolume on lit quelques notes cabalistiques et une recette superstitieuse attribuée à Hippocrate, puis l'inrocation (ح-ب) du schaikh Abou 'l-Hasan al-Schâdsilì, et une autre invocation magique, appelée دعاء الناج والاجاب.

Papier. 209 feuillets. Ilautcur, 28 centimètres et demi; largeur, ao centimètres. 19 lignes par page. - (Supplément $177^{\circ}$ bis.)

\section{5 .}

rera Prairie fleurie et l'odeur suaver, recueil de morceaux en prose et en vers, par Moḥammad ibu abì Bakr al-Soyoûtì, descendant d'Alب̣asan, fils $d^{\star A l i ̀ ~ i b n ~ a b i ̂ ~ T ̣ a l i b . ~ L ' a u t e u r, ~ q u i ~ v i ̀ a i t ~ a u ~}$ $\mathbf{X v}^{\mathrm{e}}$ siècle, dit dans la préface que cette anthologie, divisée en cinq sections, dont chacune a cinq chapitres, n'est que le développement d'une autre qu'il avait rédigée sur le même plan et publiée sous le titre de رياض م الالباب وكاسى الآداب littérature». Hadji Khalfa (t. III, p. 516) mentionne cet ouvrage, .sans en nommer l'auteur.

Ce ms., d'après une note qu'on lit en tête du volume, est de la main de l'auteur. Il est daté de l'an 818 de l'hégire ( 1415 de J. C.).

Papier. 199 feuillets. Hauteur, a4 centimètres; largeur, 16 centimètres. 25 lignes par page. - (Ancien fonds 1569.)

Même ouvrage.

\section{6.}

Ms. daté de l'an 885 de l'hégire (1480 de J. C.).

Papier. 251 fenillets. Hauleur, 27 centimètres; largeur, 17 centimètres. 53 à 55 liggnes par page. — (Ancien fonds 1568.) 


\section{7.}

$1^{\circ}$ كناب بيوت ألعش. C'est un recueil de dix pièces de vers d'thn Nobâta et d'un égal nombre composées par l'auteur, qui, sans doute, est le célèbre Aboû Bakr jon Hiddja el-Hamawi.

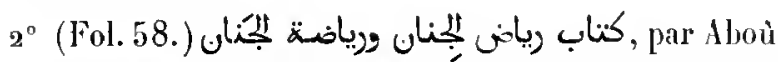
'Abdallah Molummad ibn Moluammad ibn Molammad ad-Safadi. Ce sont des maqâmât en l'honneur de Nahomet, dans chacune desquelles domine une lettre de l'alphabet. Copie datée de l'an 999 de l'hégire (1591 de J. C.).

Papier. 129 fenillets. Hauteur, 18 centimètres; largeur, 13 centimètres. Écritures différentes. - (Supplément a484.)

\section{8.}

r Miscellanées", recueil d'anecdoles, d'apophthegmes, de pièces de vers, de noles historiques, géographiques, théologiques et philologiques, par $\mathrm{Mmin}$ al-Daula Nohammad ibn Mohammad ibn Hibal Nllah

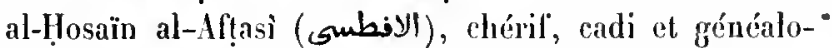
giste. La plupart des exIraits appartiennent aux auteurs du $x^{\circ}{ }^{e}$ siècle. Ce volume copié, paraît-il, sur un exemplaire écrit de la main de l'auteur, n'a pas de préface el commence par ces mots : انظل اله تسول المه عز وجل واله

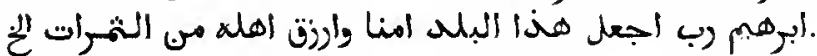
Le volume se compose de deux parties, dont la seconde commence au folio 146 .

Papier. 201 feuiltets. Hauteur, 29 centimètres; largeur, 21 centimètres. 15 lignes par page. Us. du $\mathrm{xv}^{\mathrm{e}}$ siècle. - (Ancien fonds $; /$ io.3.)

\section{9.}

1. Poèmes religieux, dont le sujet, en général, est la gloire de Dieu, puis le mérite de Malromel.

$2^{\circ}\left(F_{0}\right.$ l. $47 v^{\circ}$.) Traditions rapportées par Malik ibn Anas el accompagnées d'une Iraduclion en langue espagnole.

$3^{\circ}$ (Fol. 63.) Prières musulmanes, professions de foi et instruclions données par Mahomel à 'Mlì, fils d'Aboù Tálib, accompagnées d'une traduction espagnole.

Papier. 133 feuillets. Hauteur, 19 centimètres el demi; largenr, 13 centimètres et demi. Ms. du $v^{\mathrm{e}}$ siècle. - (Ancien fonds 1/12o, Colbert 3534.)

\section{0 .}

Recueil, divisé en vingt clrapitres, sans titre, ni nom d'auteur, qui renferme des sentences, des historjettes, des paroles spirituelles atiribuées, les unes à Mahomet, les autres à des saints personnages et à des philosophes, enfin un grand nombre de pieces de vers des principaux poètes arabes el persans, jarmi lesquelles l'auteur a inséré plusieurs morceaux de sa composition. Le prenier chapitre traite de la commaissance de Dien; le second, de l'unité de Dieu; le troisiène, de la noblesse de l'homme; le quatrième, de l'avarice; le cinquième, du couragre; le sixième, de la vérité et du mensonge, ete.

Le premier feuillet manque. It a été remplacé par un autre, avec un tilre apocryphe el la liste des dix premiers chapitres.

Papier. 186 feuillets. IIauteur, 22 centimètres; largeur, 1 a centimètres et demi. 21 lignes par page. Ms. du xv" siècle. - (Ancien fonds 413. )

\section{1 .}

Recueil de distiques (il y a anssi quelques pièces de trois vers), par différents auteurs, disposés d'après l'ordres alphabétique des rimes. Ces extraits sout de la second. époque de la poésic arabe.

Ms. dalé de l'an 876 de l'lé́gire $(147$ : de J. C.).

Papier. 99 feuillets. Hfauteur, 16 centimètres; largeur, 1 a centimètres. 15 lig̣nes par page. - (Supplément 1570.$)$

\section{2 .}

Bienvenue offerte à l'ćtranger ». Reeueil de piéces de vers de divers auteurs disposées dans l'ordir' alphabélique des rimes, par Moḷammad ibn lyasan ibn 'Mli al-Nawidji, mort en 859 de l'hégrire (1455 de J. C.). Les poètes antéislamiques el ceux des premiers siècles de lhégire n'ourt pas fourni des extraits à ce recueil. Les textes ne sont accompagnés d'aucume glose. Ce volume, renfermant la seconde moitié de l'ouvage, commence par les pièces qui riment en $\mathcal{G}$.

Ms. daté de l'an 870 de l'hégire ( 1466 de J. C.).

Papier. 168 feuillets. IIauteur, 27 centimètres; targeur, 17 rentimètres. 23 lignes par page. - (Ancien fonds 1403.)

\section{3.}

"L'Hippodrome (du cheval) alezan, on 
du (viu) rouge foncé $n$. Anthologie, divisée en vingl chapitres, des passages les plus intéressants, en prose et en vers, touchant le vin el les parties de plaisir, par Scliams al-Dìn Mọ̣ammad ibu al-ḷasan al-Nawâdjî. La préface el la liste des chapilres de cet ourrage ont élé publiées dans le Catalogue des mss. orientaux de la Bibliotlièque de Leyde, 1. I, p. 297 et suiv. Commencenient:

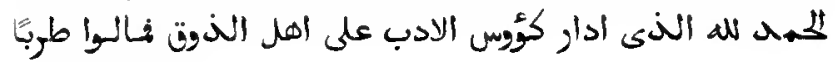
بقهوة الانشناء

Papier. 237 feuillets. IJauleur, 25 centimètres; largeur, 16 centimètres el demi. 20 à $\mathbf{a} 5$ liggnes par page. Mls. du $\mathbf{x r}^{\circ}$ siècle (quelques feuillets sont plus modernes). - (Supplément 1/81.)

\section{4.}

Mème ouvrage.

Ms. daté de l'an 883 de l'hégire ( 1478 de J. C.).

Papier. 144 feuillets. Haulenr, 26 centimètres; largeur, 18 centimètres. 25 lignes par page. - (Ancien fonds 1567. )

\section{5.}

Nème ourrage.

Papier. 174 feuillets. Hauleur, 25 centimètres; largeur, 17 centimètres. 25 lignes par page. Ms. du xvi siècle. - (Supplément 1 48..)

\section{6.}

Même ouvrage. A la fin se trouve l'éloge de cette anthologie, par Taqî al-Dìn ibn Ḥiddja.

Papier. ${ }_{1} 3$ Seuillets. Hauteur, 27 centimètres; largeur, 18 centimètres. 23 liggnes par page. Ms. du xvi ${ }^{\circ}$ siècle. - (Ancien fonds 1566.)

\section{7.}

Nème ouvrage, arec le jugement d'Ibn-Ḥiddja.

Papier. $19^{4}$ feuillets. Ilanteur, 15 centimètres; largeur, 1 a centimêtres. 17 lignes par page. Ms. du xvi sièce. - (Suppléurent 2479.)

\section{8.}

Mème ourrage, avec le jugement d'Ibn-Hiiddja.
Ms. copié sur l'exemplaire de l'auteur el daté de l'an $99^{\circ}$ de l'hégire (1 582 de J. C.).

Papier. 281 feuillets. Hauteur, 19 centimètres et demi; largeur, 12 centimètres. 21 lignes par page. - (Ancien fonds 1472.)

Mème oùrage.

\section{9 .}

Papier. 339 feuillets. Hauteur, so centimètres; largeur, 15 centimètres. 15 lignes par-page. Ms. du xvı" siècle. - (Supplément 1479.)

\section{Nême ouvrage.}

\section{0.}

Papier. 215 feuillets. Hauteur, so centimètres et demi; largeur, 15 centimètres et demi. 23 lignes par page. Ms. du xru' siècle. (Supplément 1480.)

\section{1 .}

1 . Anthologie poétique sur l'amour des éphèbes, par Schams al-Dìn Moḥammad al-Nawâdjì.

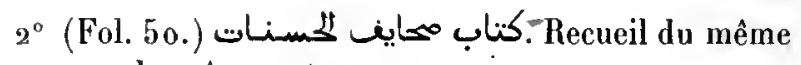
genre, par le même auteur.

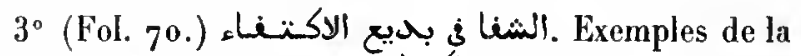
figure de rhétorique appelée أكتناء, par le même auleur.

$4^{\circ}$ (Fol. 107. ( Anthologie eli sept sections, par Aboû Manṣoûr 'Ábd al-Malik alTháấlibî.

50 (Fol. $124 v^{\circ}$.) كاسى الادب ولجتناب الكريسب. Traité de morale et des convenances sociales, en huit chapitres, par $\Lambda$ boû Yoûsof ibn Solaïmân al-Isfaràinnî, mort en 488 de l'hégire $\left(\log _{5} 5\right.$ de J. C.). (Voy. Hadji Khalfa, t. V, p. 4 1.)

$6^{\circ}$ (Fol. 205.) Lettre du schaïkh Zaïn ibn Nodjaïm au schaikh Sarì al-Din al-Ṣâïgh, touchant un fatwa an sujet d'un waqf.

Papier. 246 feuillets. Hauteur, 21 ceutimètres el demi; largeur, 16 centimètres. 19 à 21 lignes par page. Ns. du xvi siècle. - (Supplément 1915.)

\section{2.}

Prairies des 
gazelles, on description des beaux adoliscents . Extrails de divers poètes sur les jeunes gens des diverses classes de la société, par Sclıans al-Dìn Molıammad ibn alIlasan al-Nawâdji. Ces pièces sonl ordinairement de deux on trois vers. Commencement: alli $\lambda$ r lol

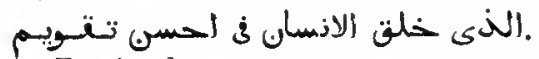

En tète du ms. se trouve une courte uotice sur l'auteur.

Papier. 179 feuillets. Ilauteur, 18 centimètres el demi; largeur, 13 centimètres et demi. 19 liguns par page. Us. du xrie siècle. (Ancien fonds 1465.)

\section{3.}

Même ouvrage.

Le commencement et la fin manquent.

Papicr. 196 feuillets. Hauteur, 18 centimẻtres; largeur, 13 centimètres. 17 lignes par page. Ms. du .svi siècle. - (Supplément 1809.)

\section{4.}

erésent pour l'homme intelligent et souhait de l'afligén, anthologie poétique, anecdotique et philologique, par Abou 'I-Fath! Molıanmad ihn Badr al-Din Molıammad, descendant d"Abd al-Raḥmân ibn 'Auf, l'un des dix Compragnons à yui Mahomet avait promis le paradis. L'anteur déclare avoir mis la dernière main à son travail en 883 de l'hégine ( $14.7^{8}$ de J. C.). Le catalogue des mss. orientaux de la Biblioflıeque de Leyde, t. I, J. 308 , renferme une anatyse très détaillée du premier et du troisième (?) volume de l'ourragre. Le présent mis. est sans doute le dernier' volume d'un exemplaire complet, puistruil se termine

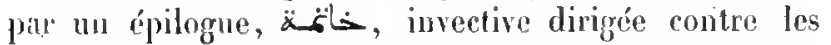
faux sarants. Le volume commence par la généalogie de l'auteur, suivie de plusieurs de ses propres gașidas rimant en $s, 3$, , etc. Au fol. $7^{4}$, on lit une note sur les cent régissants grammaticanx, suivie d'anecdotes, de poèmes disposés en forme de rayons de cercle et d'épicicles, d'un chapitre sur les amants inalheureux (مصاوع الْعتّاقة), d'autres anecdotes plus ou moins authentiques, de l'histoire des Thamoudites et du prophète Sálil! (fol. 126), de l'histoire de Loth, etc. Fn somme, c'est une compilation laite sans goct et n'offrant pas ur intéret sérieux.

Papier. 155 fenillets. Hanteur, 35 cenlimètres; largeur, 28 centimètres. 19 à 21 lignes par page. Mss. du xvº siècle. - (Ancien fonds 1401.)

Max. ohestaux. - H.

\section{5 .}

Sucrier des amants et signal pour les oreilles et les yeux», recueil d'anecdotes édifiantes, suivi d'une anthologie poétique, par l'émir Owaïs, clrambellan du gouvernement de Tri-

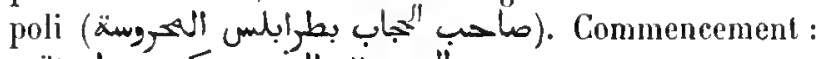
.

Papier. 9ว็ก feuillets. Hauleur, 21 centimètres; largeur, 13 centimètres el demi. a3 lignes par page. Ms. du xvuı" siècle. - (Supplément 1655.)

\section{6.}

-Conversations el entretiens». Recueil d'extraits, en prose et en ver's, d'anecdotes el d'bistorietles, par Djalàl al-Dìn 'Abd al-Raḥmàn al-Sojoûti.

Ms. dalé de l'an 1076 de l'hégire (1666 de J. C.).

On a attaché an dernier leuiltet de ce volume la moitié supérieure du premier feuillet d'un traité intitulé r Satisfaction pour l'homme dévot qui désire connaître les rites et l'èglements du pèlerinage de la Meequen, par Mohammad ibn Aḷmad محا لم نطن : docteul hanbalite. Commencement, البهوتة

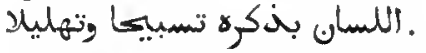

Papier. 195 fenillets. Hauleur, 20 centimètres et demi; largeur, 15 centinètres. 33 lignes par page. - (Ancien fonds 1597.)

\section{7.}

Nème ourrage.

En tète du volune, on lit un morceau, en style très

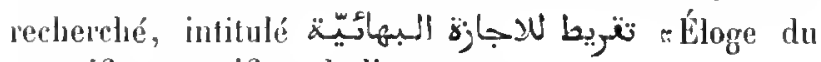
magnifique cortificat de licencen.

Papier. aso feuillets. Ilauteur, 2 a centimétres et demi; largeur, 16 centimètres el deni. a lignes par page. Mls. du xwr ${ }^{\circ}$ siècle. (Supplément 16.3.)

\section{8.}

مerles détachées du fil, à savoir des vers bien tournés. $\pi$ Anthologie, divisée en cinq chapitres, par Djalîl al-Din 'Abd alRaḷmấn al-Soyoûtị. Les extraits sont en général assez

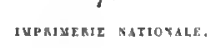




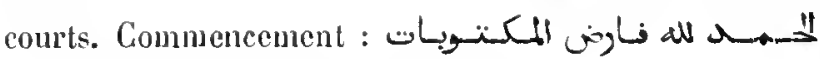

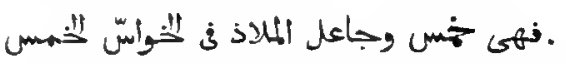

Papier. 100 fenillets. Ilauteur, so centimetres et demi; largeur, 13 centimètres et demi. 19 lignes par page. MIs. du $x^{2} I^{\circ}$ siècle. (Supplément 1565.)

\section{9.}

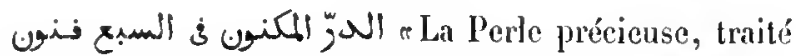
sur les sept geures (de la poésie moderne) $»$, par Mohammad ibu Alumad ibu al-Yàs al-1lanafi. Ces genres sont :

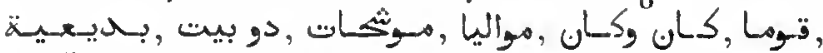
et $J_{\text {j }} \mid$. Chacun des sept fivres renferme de mombreux extraits de divers poìtes. L'auteur dit avoir acheré son travail vers la fin de l'année 1001 de l'légire (1592 de J. C.). Commencement :

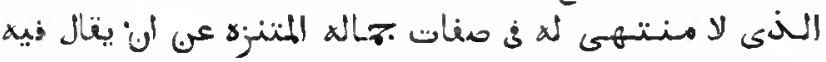

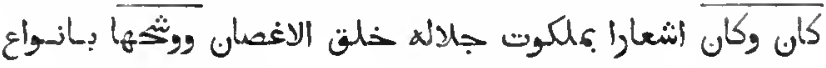

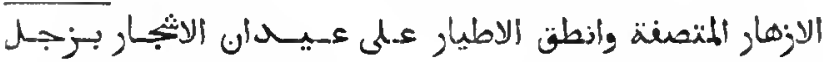

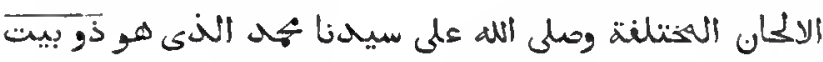

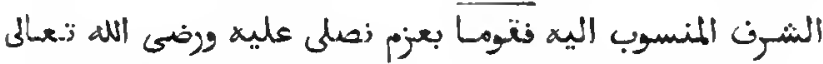

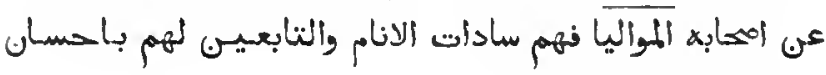
على متر الليالى والابيام

Papier. 100 fevillets. Ifauleur, 21 centimètres; largeur, 15 centimètres. 17 lignes par page. Ils. du xvi" siècle. - (Ancien fonds 1413. )

\section{0.}

Recueil d'anecdotes littéraires, de maximes, d'extraits poétiques, etc. Ces prièces, en général très courtes, offrent pour la plupart un certain intérèt. On y trouve aussi quelques extraits plus étendus, tels qu'une mimîya du céliebre Aboû Medín, de Tlemeen, et un traité, sous forme de dialogue, sur certains proverbes el maximes qui ont Icurs analogues dans le Coran. La fin manque.

Papier. $7^{5}$ feuillets. Hauteur, 18 centimetres et demi; largeur, 13 centimètres. 15 à 20 lignes par page. - (Supplément 1540.)

\section{1.}

1 م Raretés offertes aux regards (du lecteur) $\%$, anthologie en douze parties, dont Hadji Khalfa

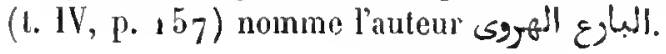

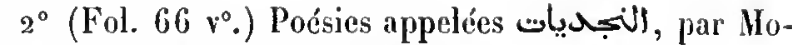
ḅammad ibn Aḷmad al-Abiwardi.

Ms. daté de l'an 980 de l'hégire ( 1582 de J. C.).

Papier. 119 fenillets. Hauteur, 21 contimètres; largeur, 11 centimètres et demi. 13 à 18 lignes par page. - (Supplément 1554.)

\section{2.}

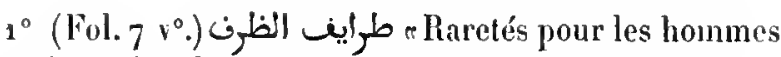
d'esprit». C'est le mème ouvrage, avec un titre légèrement différent, que l'article $1^{\circ} \mathrm{du} \mathbf{n}^{\circ}$ précédeut.

$2^{\circ}$ (Fol. 39.) Élégic du schaikh al-lslàm Ibn Taïmiya sur la mort d'ibn Khidhr al-Motaïyam (متّلم).

$3^{\circ}$ (Fol. 42.) Élégic de Djamàl al-Din al-llanbalì sul" la mort d'Ibn Taüniya.

$4^{\circ}$ (Fol. $42 v^{\circ}$.) Qasidas de Schams al-Din ibn Sa id al-Maqdisi, d'Ibn Khidr al-Motaịam et d'Ibn Taïmiya, suivies de liragments divers.

$5^{\circ}$ (Fol. $45 v^{\circ}$.) Qașida attribuée à 'Alì ibn abì Ṭilib. premier rers :

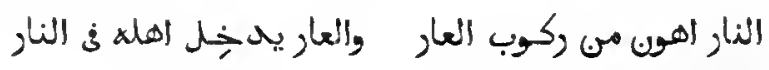

$6^{\circ}$ (Fol. $46 v^{\circ}$.) Autres poèmes attribués à 'Ali.

$7^{\circ}$ (Fol. 75.) (لفاء م Cadeau pour les lommes d'esprit, renfermant l'histoire des princes et des califes». Ordjoûza de Moḷammad ibn Aḷmad al-Bàoûnì de Damas. Ce poème mmémonique s'arrête à l'avènement de Qaït-hey, sultan mamelouk, qui monta sur le trône en 901 de l'hégire (1496 de J. C.). L'auteur termine par l'éloge, en vers, de son protecteur, Ml-Aschraf al-Zaini.

$8^{\circ}$ (Fol. $93 v^{\circ}$.) Pièces de vers de divers auteurs.

$9^{\circ}$ (Fol. $9^{5} \mathrm{v}^{\circ}$.) Histoire des sourerains ottomans. C'est un extrait d'un grand ouvrage en turc, composé par le même auteur. La chronique s'arrête à l'an 977 de l'hégire (1569-1570 de J. C.). Le copiste la désigne,

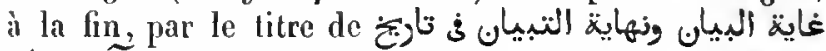
نثمن Qádhî Sådì al-Ba lbakkî. Ces renscignements ne peuvent pas ètre exacts, car Hadji Khalfa nous apprend (t. V, p. 487) qu'cAlì ibn Sacdì est mort en 717 de l'hégire ( $1317-1318$ de J. C. ).

$10^{\circ}\left(\right.$ Fol. $219 \mathrm{v}^{\circ}$.) Fragments historiques se rapportant aux années $657,1005,750$ et 758 de l'hégire.

$11^{\circ}$ (Fol. 222.) Pièces de vers tirées du الافككار

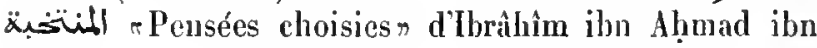


al-Mollà, suivies d'un grand nombre d'extruits en prose et en rers, dont quelques-uns sont d'Al-Soyoûtì.

Volume tout en enlier de la mềne main. Une des piéces de rers est datée de l'an 1010 de l'hégire (16011602 de J. C.). En tète dı volume se trouvent d’autres extraits poétiques.

Papier. 261 feuillets. Hauteur, 21 centimètres; largeur, 15 centimétres et demi. 15 ì 20 lignes par page. - (Ancien fonds 1471.)

\section{3.}

Recueil de qașidas el de fragments de qaṣidas composées par des poètes modernes.

Le premier et le dernier feuillet manquent.

Papier. 138 fenillels. Hautcur, 18 centimètres; largeur, 13 centimètres. 13 à 15 lignes par page. Ms. du xvi siècle. - (Supplément 1561.$)$

\section{4.}

Anthologie poétique, divisée en trente chapitres précédés d'une longue introduction. Les premier's et les derniers feuillets manquent.

Papier. 99 fenillets. Hauleur, 26 centimètres el demi largeur, 17 centimètres el demi. 13 lignes par page. Ms. du xu siècle. (Supplément 1538.)

\section{5.}

20 Les Pleines lunes dans l'ascendant, sur les Stations des réjouissancesn. Anthologie, en prose et en vers, par 'Ali ibn 'Abd Allah alGlıozoûlì. Louvrage renferme cinquante chapitres, dont chacun se rapporte à un sujet particulier. Commen-

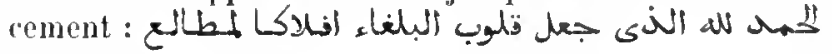
youndi.

Is. daté de l'an 1005 de l'lućgire ( $5960-1597$ de J. C.).

l’apier. 303 fenillets. Hauteur, 21 centimètres; largeur, 15 centimètres. 25 lignes par page. - (Supplément 1551.)

\section{6.}

Album composé de feuillets de différentes couleurs et renfermant des extraits, en prose et en vers, en arabe, en persan, en allemand et en latin. Ces cxtraits ont été réunis par un on deux Européens, qui se trouvaient ì Constantinople en 1582 de J. C. (Voyez fol. 24 et $381^{\circ}$.)

Papier. 151 fenillets. Hauteur, 15 centimetres; largeur, 10 centimètres. Ms. du $\mathrm{xvi}^{\circ}$ siècle. - (Ancien fonds 1488.)

\section{7.}

1 Q Quelques pièces de vers.

$2^{\circ}$ (Fol. $\left.31^{\circ}.\right)$ Lettre du schaikh Zaïn ibn Nodjaïm au schaïkh Sarì al-Dìn Mḷund ibn al-Ṣäghh. (Voyez ci-dessus, $1^{\circ} 3401,6^{\circ}$ )

3 (Fol 10.) Manzoúma, par 'Mlod al-Raḷmàn al-ḷomaïdi. Vingt-huit pièces de vers, dont chacune commence par l'une des vingt-huit lettres de l'alpliabet. Au moyen de ces vers, dit l'auteur dans l'introduclion, écrite également en vers, on peut découvrir le nom, le caractère et lhistoire d'un per'sonnage.

$4^{\circ}$ (Fol. $12 v^{\circ}$.) Pieces de vers, dont l'une est attribuée à Aboù Nowis, suivies de quelques énigmes.

$5^{\circ}$ (Fol. 13 1\%.) Traité sur les logogriphes, par 'Abr al-Io ín ibn Aḥmad lbn al-Bcki al-Balkhì. D'après Hadji Khalfa, t. V, p. 247 , le tifre de ce livre, composé en طراز الاسمكاء على كنز $99^{3}$ de l'lićgrire (1585 de J. C.), est \& Broderie de noms sur le traité intitulé Trésor

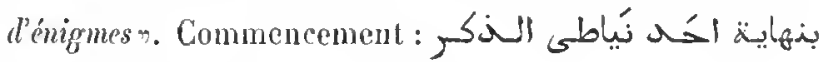

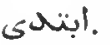

Copie datée de l'an 1036 de l'hégire $(1627-1628$ de J. C.).

$6^{\circ}$ (Fol. 22. 2. Répertoire pour l'lomme instruil", anthologie en prose et en vers. Les preniers cahiors manquent. Voici les rubriques des sections qui

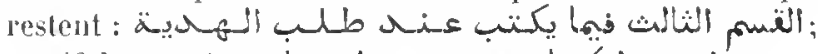
- (fol. $22 \mathrm{r}^{\circ}$ ) -

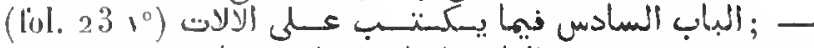

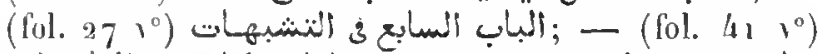

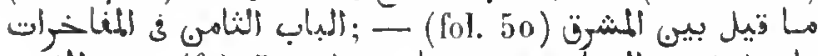

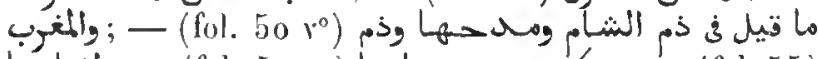

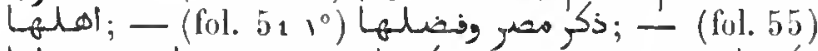

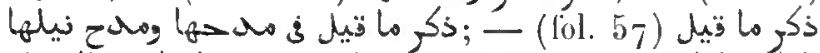

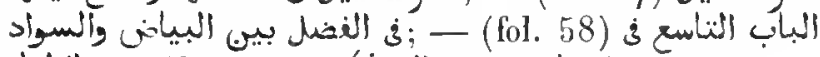

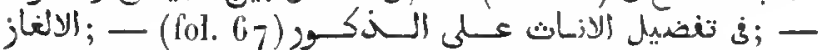

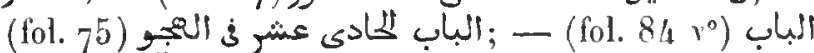

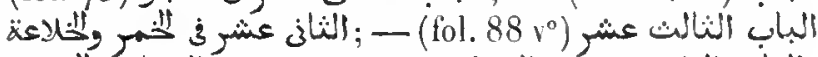

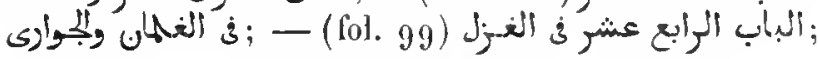

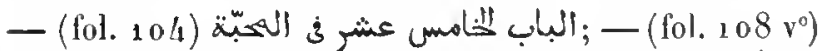

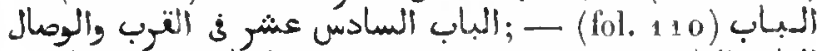

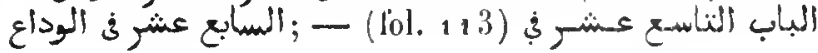
75. 


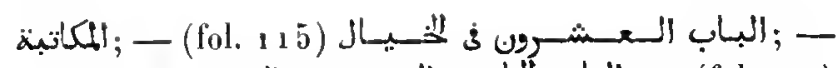

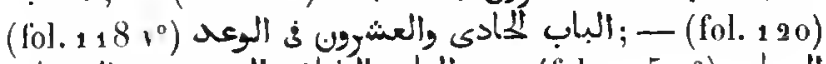

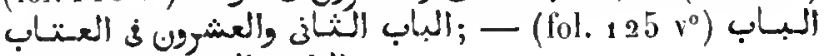

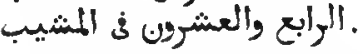

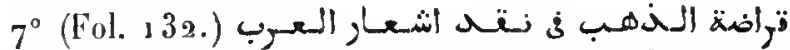
"Paillettes d'or, ou Choix de poésies des Arabesn, par Aboù 'Alì al-Ḥasan ibn Raschiry al-Qaïrawàuì, mort en 456 de l'hégrire ( 1064 de J. C.).

Papier. ${ }_{177}$ feuiltets. Hautenr, 21 centimètres; largeur, 15 cen-

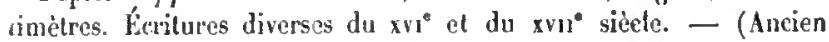
fonds 1605 .)

\section{8.}

$1^{\circ}$ Anthologic poétique, renfermant des extraits d'Aboù Tammıânı, d'A]-Boḷtorì, d'Alıon Nowìs, d'Ibn al-Roûmì, d'Ibn al-Mo'tazz, de Koschàdjim, Al-Motanabbì, d'AlMolallabi, d'Ibn Qalàis, etc.

$2^{\circ}$ (Fol. 27.) Formules de tètes de lettres, dont quelques-unes sont en rers.

$3^{\circ}$ (Fol. 34.) Sentences attribuées à 'Alì ibn abì Tàlib et disposées dans l'ordre de l'alphabet.

$4^{\circ}$ (Fol. 47.) Fragments divers, en vers el en prose.

$5^{\circ}$ (Fol. 55.) Fragment d'un divan.

60 (Fol. 65.) Un takhmis (تخميس لUكاتب).

$7^{\circ}$ Fol. $65 \mathrm{r}^{\circ}$.) Poésies du genve موآّ

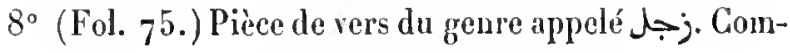
mencement :

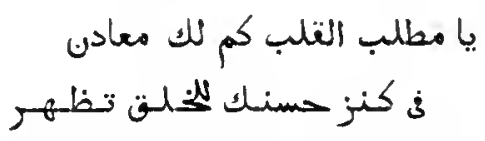

$9^{\circ}$ (Fol. $7^{6} v^{\circ}$.) Piéce de vers d’Aboù Bakr al-Arradjàni.

$10^{\circ}$ (Fol. 77.) Recueil de quatrains.

$11^{\circ}$ (Fol. 86.) Préface d'un traité anonyme, commen-

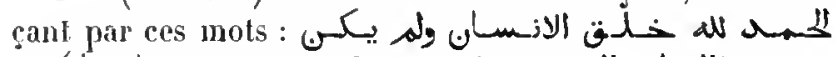

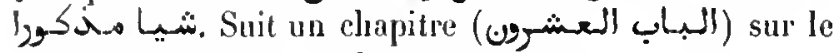
deroir de visiter les malades.

$13^{\circ}$ (Fol. $87 v^{\circ}$.) Préface d'un autre traité commen-

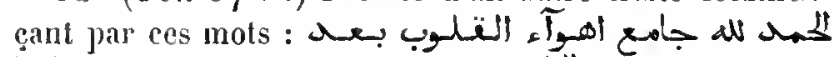

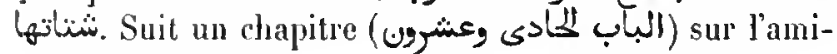
lié et la fraternité.

ऽ $3^{\circ}$ (Fol. 9o.) Quelques poésies d'Al-Hotanablyî.

$14^{\circ}$ (Fol. 96.) Anthologie poétique. C'est l'abrégé d'un onirage renfermant des extraits de soixante-sept poètes de l'Espagne et intitulé

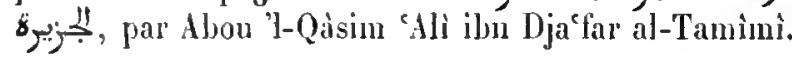

$15^{\circ}\left(F_{0 l} .110 v^{\circ}.\right)$ Mélanges en prose et en vers.

$16^{\circ}$ (Fol. $\left.146 v^{\circ}.\right)$ Vers de Lisàn al-Dìn ilon al-Khatịb.

$17^{\circ}$ (Fol. 147.) Poésic d'Al-Ṣafi al-l]illì.

$18^{\circ}$ (Fol. 148.) Suite des mélanges. On y remarque (fol. 159 ) une pièce de vers attribuée à 'Minr ilon al- Âṣ, et une lettre adressée par Timour Lenk à Al-Malik alNasil (fol. 162).

$19^{\circ}$ (Fol. $\left.214 \mathrm{v}^{\circ}.\right)$ Ordjoûza intitulée par Alımad al-cAnàyâti (ülieliا).

$20^{\circ}$ (Fol. 220 bis.) Quclques poésies du cadi Kamàl a]-Din ibn al-Nabih.

$21^{\circ}$ (Fol. $\left.224 v^{\circ}.\right)$ Autres extraits, en prose el en ver's.

Papier. 243 feuillels. Hauteur, 18 centimètres; largenr, 12 centimètres et demi. Éeritures diverses du svi" siècte. - (Aneien funds 1610 , Colbert 6064.)

\section{9.}

Beautés de la littérature pour gagner les cours $n$. Recueil d'extraits, la plupart en vers, divisé en sing chapitres, contenant chacun cinq seclions. Les poìtes cités sont en général assez modernes. Le prenier feuillet manque.

Papier. 129 feuillets. Hauteur, 30 centimètres; largenr, 15 centimètres. ${ }_{7}$ lignes par page. Ifs. du xvie siècl 3. - (Supptément 1556.)

\section{0.}

r Couronne des recueils\%, comprenant les ourrages en ver's et en prose du chérif et docteur malékite Tàdj al-Dìn al-Anșàr. Le fils de l'auteur, qui a réuni ces mólanges, y a joint d'autres pièces, telles que letlres, certificats de licence, actes de inariage, etc.

Ns. daté de l'an 1073 de l'hégire (1 663 de J. C.).

Papier. 165 feuillets. Itauteur, 21 eentimètres; largeur, 15 centimètres. 25 lignes par page. - (Supplénient 1346.)

\section{1.}

دوبيت Recueil de contes, de qasidas, de موثّئان, ete.

Papier. 64 feuillets. Hautenr, 21 centimètres; largeur, 15 centimètres. 15 lignes par page. Ms. du xrri siècle. - (Supplément 1532.) 


\section{2 .}

Reeneil renfermant des khotba, des observations sur les convenances sociales (باد), des ancedotes, des paroles de plusieurs saints personnages, des poésies sacrées et antres, des qașidas, des مورثيات, des دوبيت , des , des reuseignements utiles et d'autres pièces de divers genres. Aux folios 272 à $284 \mathrm{r}^{\circ}$ on troure la yasida inystique d'Al-Djîlî, commençant par ce vers :

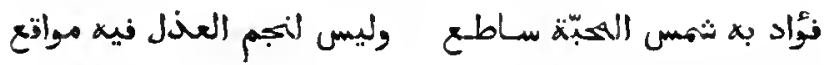

Ce recueil porte le tilre de "La Perle précicuse et l'ami intime".

Papier. a 88 feuillets. Hauteur, 21 centimètres et demi; largeur, 15 centimètres el demi. 17 lignes par page. Ms. du ruı siècle. (Supplément 15.5.)

\section{3.}

Safina, renfermant de nombrenses pièces en prose et en vers, en arabe et en persan.

Papier. 444 feuillets. Hauteur, 36 centimètres; targenr, 10 centimètres. 15 à 40 lignes par pagre. Ms. du xvır siècte. - (Supplément 1545.)

\section{4.}

Safina renfermant des poésies mystiques. On y trouve

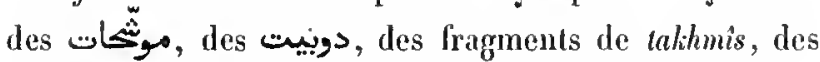
extrails des qasildas d"Omar ilon al-Fàridl, etc.

Papier. 58 fcuillets. Hauteur, 2a centimètres; larifeur, 11 centimètres. 19 à 25 lignes par page. Ms. du $\times 711^{\circ}$ siècle. - (Supplément 2180.$)$

\section{5.}

Volume dédié ì Colbert et renfermant quelques poésies et récits que Pierre Dipy, d'Alep, avait copiés dans le Specimen Arabicum de J. Fabricius. Il y a des moreeaux d'Ibn al-Fàridlı, d'Abou 'l-'Alà , d'Al-Harîri, cte., accompagués d'une traduction latiue el de notes. (Voyez Chrestomathie arabe de S. de Sacy, $2^{\circ}$ édition, t. III, p. 131.)

Is. daté de l'an 1666 de J. C.

Papier. 45 feuillets. Hauteur, as centimètres; largeur, 15 centimètres. - (Ancien fonds 1470, Colluert 4553.)

\section{6 .}

Safina renfermant des quạidas et d'antres pièces de vers de diver's genre.

Papicr, 108 feuillets. Ilauleur, 29 centimètres; largeur, 8 centimètres. 10 à s $\iota$ lignes par page. Ms. du xvil" siècle. - (Silpplément 1535.)

\section{7.}

Recueil renfermant des extraits de diver's poites, tels qu'Aboû Tammàm, Ibn Khalïidja, Al-Zamaklischari, AlSoyoûlị, Ibn Sanà al-Holk, Al-Şafi al-ḷillì, ete. Les poètes anciens ne sont pas représ nntés. 11 y a aussi quel-

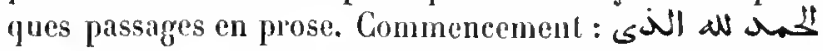

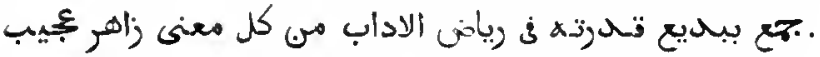

Papier. 228 feuillets. Hauteur, 31 centimètres; largeur, 15 centimètres et demi. 18 à 30 lignes par page. Ms. du xvit sièce. (Supplément 15/9.)

\section{8.}

Safina renfermant des pièces de vers, en général tris courtes et apparlenant aux genles appelés 29, a

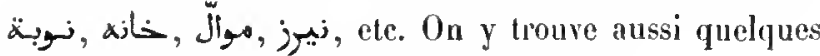
anecdotes en prose et quelques traditions.

Papier. 164 feuitlets. Ifauteur, a a centimètres; largeur, 8 centi-

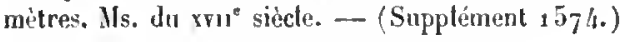

\section{9.}

Safina renfermant des pièces de ver's des genres Jig, تخميسM, ete. On y l'ouve aussi des fragrments de légendes en prose. Plusicurs fenillets sont intervertis.

Papier. go fenillets. Hauteur, 20 centimètres; largeur, 10 centimè̀tres. MIs. du xw1" siècte. - (Supplément 2 275.)

\section{0.}

Safina renfermant des morceaux en prose et en vers. On lit d'abord un trailé de soufisme intitulé ت Inspirations divinesn, et divisé en dix paragraphes, dont les Irois premicrs manquent. Cette pièce est datée de l'an 1061 de l'hégyire (1651 de J. C.). Au 


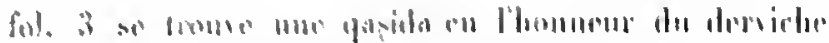

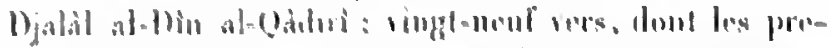

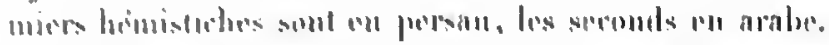

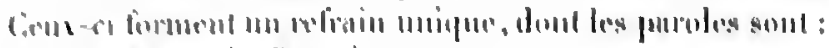

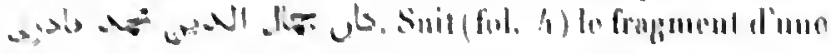

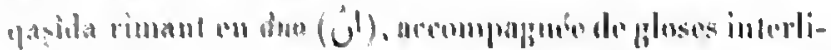

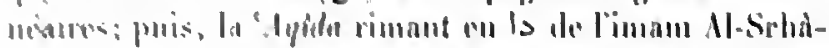

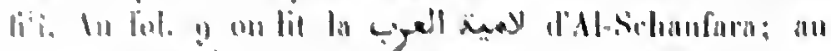

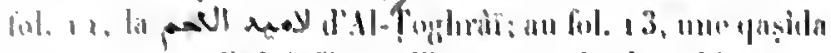

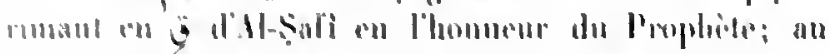

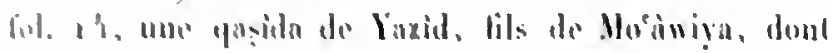
mei le promior ress:

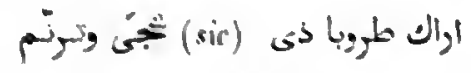

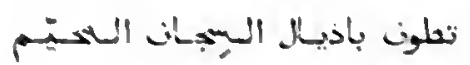

Snil (lot. 10) la moiallapa d'Imro "l-Qais; puis trois

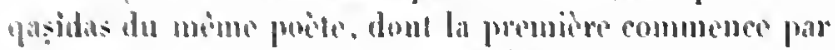

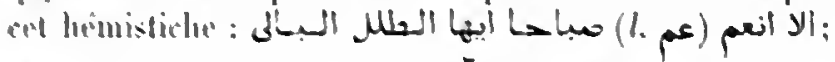

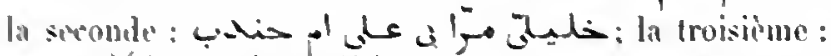

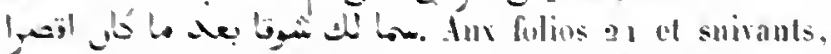

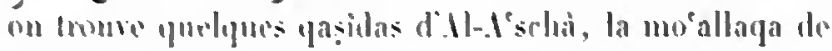

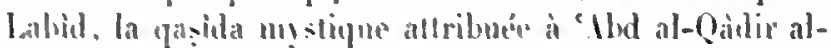

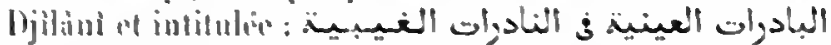

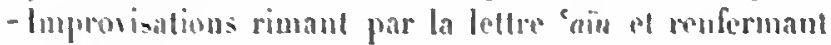
des rarelcs calluess. ot qui commence ainsi:

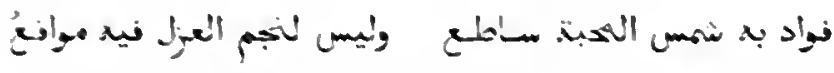

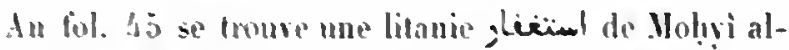
Din thumad al-Qadiri. Les folios $\$ 6$ el suivants renferment dess extraits divers en prose et en vers. puis (fol. 51)

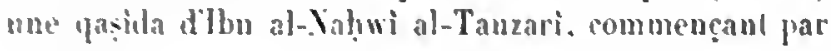
ce vers:

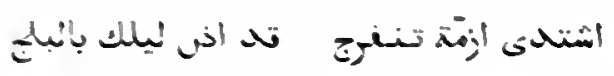

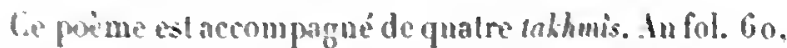
on lit d'autres pocises "ded al-Qàdir al-Djilani; au 6ol. 6\%. quelques poesirs de Molugi al-Din al-0adiri; au fol. 71. Ia Bonda dil-bousiri avec des gloses interlimeinins: des gloses sur le Binat So ad de Ka'b ibu Zohair: entu des notices sur queliques Compagnons de Yahomet.

Le conmeneement du ms. manque.

Papier. 90 lecillets. Hauteur, 25 centimètres: largeur, 11 centi-

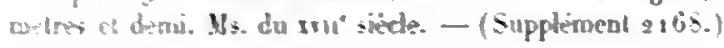

\section{1.}

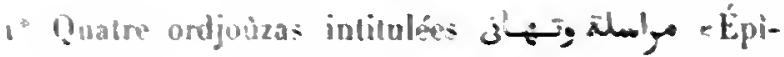

Iresent félicitntionsa. In prouniere se compose de vingt-

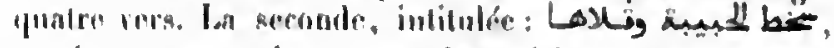
conliont quatru-vingt vers: la troisieme, de quarante

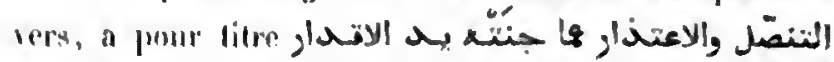

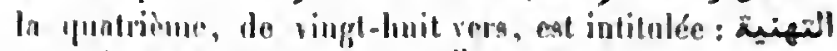

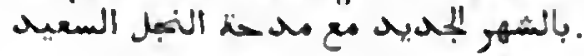

20 (lol. 7. (. Indieateur historiejue-. On y trome des noles sur l'origine, sur la dale de la naissance el de la nort de chaque calife, sur ses chambellans, ses surrítaires, son scenu el la légende de ses monmaies. Limrrage commence par Mahomel el traite ensuite des Onuayades el des Abbasides, juspu à lavienement de Mostarschid Billaih, en 51 a de l'hégire ( 11119 de J. C.); juis de la dynastie fatémide, jusquà la morl d'Ml-`idhid, en 567 de l'hégire $(1179$ de de J. C.). Ce manuel historique ist louvrage d'un houme intelligent et bien instruit. Ia copie est du $\mathrm{xm}^{\circ}$ siecle.

$3^{\circ}$ (Fol, 63.) Kho!ba ou scrmon pour la fête du sacri-

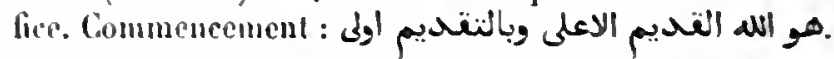

$4 \circ$ Fol. 65.) (Frésor des Nourelles. Traité sur le repentir et le pardon des péchés, par llosain al-Dimegluni. Lauteur a recueilli toutes les traditions qui se rapportint i ce sujet. Commencement : d w

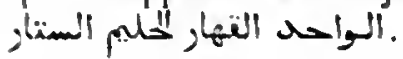

5० (Fol. 137.) Troité sur les signes précurseurs de la lin du monde el du jour de la Résurrection. Le traité est snivi llume fasida sur le mème sujel rimant en ri et intilulie : Collier composé de perles dispersées, traité où il est question de la Résurrection.?

$6^{\circ}$ (Fol. 157.$)$ Exposé de la foi musulmane. Commen-

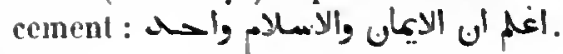

$7^{\circ}$ (Fol. 15; \%.) Traité, en huit sections, sur les obligations du rтai croyant. Commencement : اعلى بلن

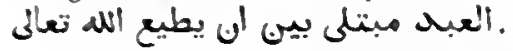

8* (Fol. $15 \mathrm{~g}$.) Liste alphabélique des noms féminins qui ont une forme masculine el des noms du genre commun.

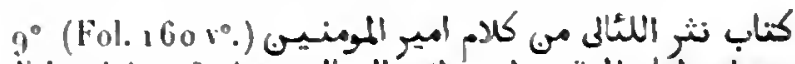

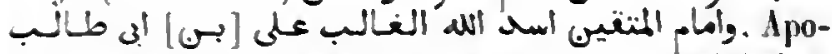
phthegmes d"Ali ibu abi Tailib, dans loordre de l'alphabet.

$10^{\circ}$ (Fol. 162.) Prenier chapitre du commentaire d'Aḷmad al-Ramadhàni sur un traité d' Institutions ou Riegles

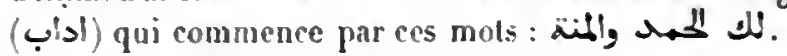

11: (Fol. 163.) Anecdoles relatives à Al-lladdjadj ibn Joúsof, à Zibriquân ibn Badr, au Prophète, ctc.,

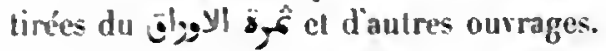


12* (Fol. 169.) Maximes de Malonmet, d'Aboù Balr, d"Ouar, ele.

13. (Fol. 170 r.) Ancedotes direnses.

14" (Fol. 173.) par Moh!l al-Din ibo al'Irabi.

Papier. 13a fenilles. Haubur, 20 centimetres of dami; Largeur.

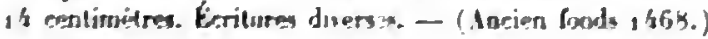

\section{2.}

1. Collertion de pieres trodres el charmantes et tolles que ni les lirres ni les cahirers pourrint fournir-. Authologie poétique compronant des extraits de dirers poetes qui vivaient entre le u" siecle de liogire ot le vu".

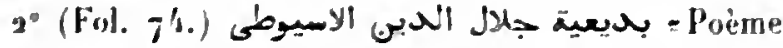
sur les figurros de rlsétoriyue, par Djalal al-Din al-Solootia, avec le commonlaire do lauteur.

3. (Fol. gf 19) Commentaire de Gásim ibn Cotlou-

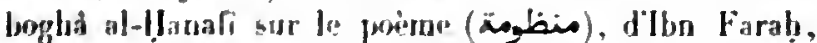
de Seille. renformant tous les arjectils qui s'mploient dans la critique des traditions sacries.

Popior. ina fenillela. Janteur, an centimitns ol demi; largenr.

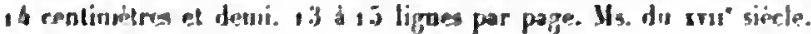
- (Ancien foods 1495.$)$

\section{3.}

Authologie prétique qui renferme auasi gueldues hittoirrs en prose.

La fin iuanque.

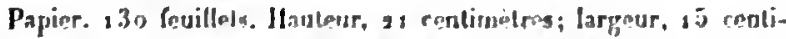

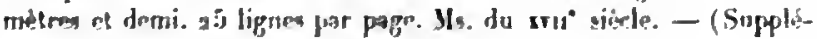
ment 15.37.$)$

\section{4.}

Iuthologie poétipur, en arabe. ture et peosan.

Papier. By feuillet. Hankeur, 21 rerlimitres; largeur, 19 contimetres el demi. is lignes par page. Ms. du sru" siocle. - (Supplement 15.9 .1

\section{5.}

Recueil de piieces de vers des genres 2 زوبيت .موال . ib, ib, ete. précédées de qualques modèles de lettres.

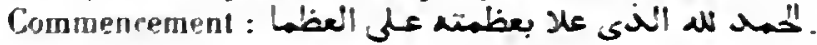

Papier. gfo feuill-ts. Hadnor, 19 cantimetres el dewi: largeur. 13 centimetres. 11 lignes par page. Us. da wri" sicide - (Sapplement 16iz.)

\section{6.}

Recueil de pieces de rers تصيیرة, دور, دوبيت, etc. On y trouve aussi quelques coutes en prose.

Le second feuillet du volume et les derniers feuillets manquent.

Papier. 345 feuillets. Haulenr, 16 centimetres; largeur, 10 renti-

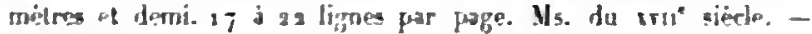
(Suppleinent 1 333 .)

\section{7.}

Anthologic proétique reufermant des extraits de $D_{j a-}$

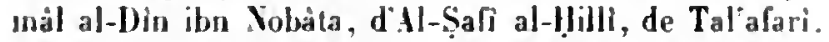
d'Al-Bahai Zohair, d't]-Qiràti, d'lbu Kharàdja. ete.

Papier. Ifig fenillets. Hauterir, 1 centinetres; largeur, aj centimotnes et demi. 1 lignes par page. Ms. du sril" siede. - (Suppliunent 1 j36.)

\section{8.}

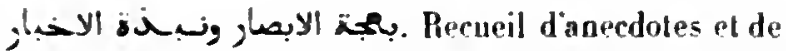
contes, en vers et eu prose, par Ilohanmad ibn 'Onar

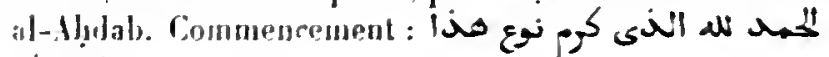
الانسان

Papier. 208 feuillets. Hauleur, 15 centiunetres el demi; largeur. 10 rentimitres. 3 lignes par page. Ms. du wri sicele. - (Supplément $1 i_{i} ; i$.)

\section{9.}

Poúsies érotiques, diviséss en quatre sections, par divers auteurs. La premiere section renferme les qasidas

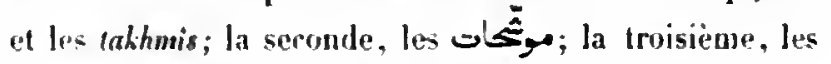
مواليّا cinguième section renferme des contes et des anecdotes, dont quelques-unes sont tri's libres. Commencement:

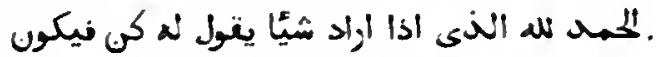

Papier. 170 fouillets. Ilauteur. 30 rentimitres; largeur, 19 centimilres el demi. 13 lignea par page. Ms. dis sru" siicle. - (Supplément ij's.) 


\section{0.}

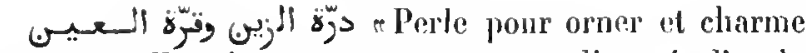
des yeux". Exiraits en prose el en vers, disposés d'après teurs sujets et précédés d'un chapilre sur l'utilité de la poésie et du bean style et d'une liste de mols et d'expressions par lesquels on peut désigner le vin. Commence-

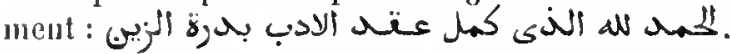

Ms. dalé de l'an 1096 de l'hégire (1685 de J. C.).

Papier. 344 fenillets. Hauteur, 31 centimètres; largenr, 15 centimètres. 17 lignes par page. - (Supplément 1557.)

\section{1 .}

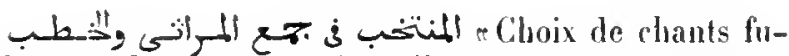
nèbres et de sermons \%. Ces pièces se rapportent toutes i Al-llosaïn et aux autres jmans de la familte d"cAlì. La collection dont le présent ms. est le premier volume, folme vingt Séances (uls dont chacune renferme trois chapitres. L'auteur, qui se cache sous le titre de Faktm al-Dìn, énumère les crimes commis par les caliles omaiyades et abbâsides envers les descendants d"Ali. Com-

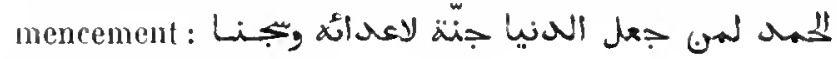

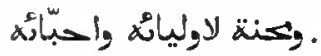

Ms. daté de l'an 1118 de l'hégire (1707 de J. C.).

Papier. 163 Seuillets. Hauteur, 25 cenlimètres; largeur, 19 centineetres. 17 lignes par page. - (Ancien fonds 1384.)

\section{2.}

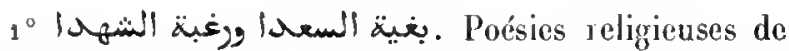
différents auteurs recueillies par Aboì Djàbir Holıammad al-Badri al-Makki.

$2^{\circ}$ (Fol. 6o.) Anecdotes au sujet des femmes.

$3^{\circ}$ (Fol, 68.) Dissertation théologique.

$4^{\circ}$ (Fol. $7^{4} \vee^{\circ}$.) Traité sur les moyens de se garantir de lis peste.

$5^{\circ}$ (liol. $81 v^{\circ}$. ) Traité sur la noblesse de la science et des savauts; extrait de l'ouvrage intitulé : أرشاد القاصده دالى أسنى de Moḷammad ibn Ibrâhîm al-Anṣârî.

$6^{\circ}$ (Fol. 8S.) Quclques pièces de vers el une klıoṭlua d'Aḷuad al-Badrî.

$\left.7^{\circ}\left(F_{0}\right] .101 r^{\circ}.\right)$ Qaşîda qui termine l'ourrage inti- lulé : نتح النجيد بكغاية المريد et qui est un commentaire sur la "Arjìda d'Al-Djazäïrî.

$8^{\circ}$ (Fol. 103.) Autres extraits en prose et en vers.

Papier. 126 fenillets. Itanteur, so centimètres; largeur, 15 centimètres. 15 à 20 lignes par page. - (Supplément 1940.)

\section{3.}

Poésies gracicuses pour charmer les yeux. nnthologie divisée en deux parties, dont la première renferme des qasijas, la seconde de petites pièces de rers et des anecdotes en prose. L'auleur, 'Abd-Allah ibn Molıammad ibn 'Âmir al-Schobràwî, dit avoir achevé son travail en 1154 de l'hégire (1 74 .

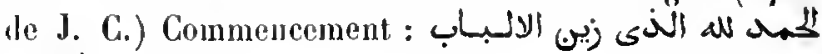
(بالادأب.

Ms. daté de l'an 1191 de l'lıégire (1 777 de J. C.).

Papier. 116 feuillets. Hauteur, as eentimètres; largeur, 14 eentinè̀tres el demi. 19 lignes par page. - (Supplément 1566).

\section{4.}

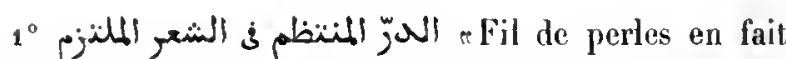
de poèmes offrant des difficultés vaincues», par ‘Abd Allah al-Adkâwî. Ce sont des paurggriques de Mahomet. Dans la prenière pièce de vers, aucun mot ne renferme la lettre alif; dans la seconde, on ne rencontre pas la lettre $b \hat{a}$, ct ainsi de suite jusqu'à la fin de l'alphabet. Le premier feuillet manque.

$2^{\circ}$ (Fol. $15 \mathrm{v}^{\circ}$.) Autre ourrage du même genre, sur le même sujet et par le même auteur, intitulé : بأيع r Exemples remarquables de difficultés vaincues, en fail de betles pièces de vers. " Con-

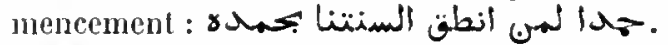

Ms. autographe daté de l'an 1180 de l'hégire (1766 de J. C.).

Papier. 45 feuillets. Hauteur, 2o centimètres el demi; largeur, 13 centimètres. 31 lignes par page. - (Supplément 15 7 .)

\section{5.}

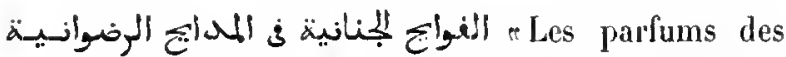
jardins, éloges de Ridhwân». Recueil de pièces de vers de divers auteurs et surtout d"Abd Allah ibn 'Abd Allah al-Adkâwî, en l'honneur d'un émir égyptien nommé 


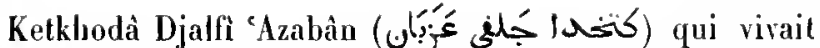
au Caire vers le milieu dı xviı siècle. Le présent ms., automraphe et, selon toute apparence, un exemplaire de présentation, est daté de l'an 1164 de l'hérgire (1751

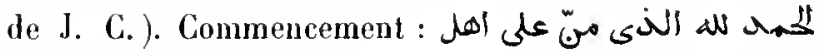
العصر برضوانه

Papier. 140 fenillets. Hauteur, a centimètres; largeur, 15 centimètres et demi. 15 ljgnes par page. - (Supplément 1498.)

\section{6.}

Marchandise de l'homme habile, se composant de poésies en style recherchér. Anthologie de poésies religieuses par 'Abd-Allah al-Adkàwì.

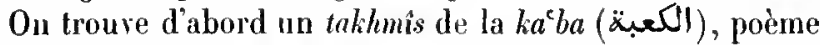
à la louange de Hahomet, puis des qașidas sur Dieu, sur les membres de la famille de Mahomet et sur certains sainls musulmans; enfin des pièces de diverse nature. L'une de ces pièces (fol. $1121^{\circ}$ ) porte la date de 1171 de l'lıégire (1 $757-1758$ de J. C.). Il y a deux préfaces qui se suivent immédiatement; la première commence

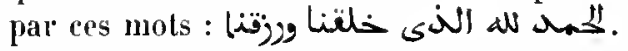

Papier. 161 feuillets. Hantenr, 21 centimètres et demi; largeur, $1 / 4$ centimètres et demi. 25 lignes par page. Ms. du xrur siècle. (Supplément 157\%.)

\section{7.}

r Narire chargé de plaisirs et prairie couverte de fleurs\%. Anthologie des divers genres de la poésie moderne. Sept chapilres précédés d'une introduction el suivis d'un appendice.

Ms. daté de l'an 1166 de l'hégire $(1752$ de J. C.).

Papier. 89 feuillets. Hauteur, 17 centimètres et demi; largeur 11 centimètres. 16 à 23 lignes par page. - (Supplément 1547.)

\section{8.}

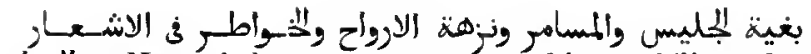
pllanuel du compagnon agréable et délices des àmes et des beaux esprits, renfermant des vers et des amecdotes curieuses. "Anıhologie divisée en vingt et un chapitres, suivis d'un appendice, par Schibàb al-Dìn Aḷmad al-Baschıchârì al-ḷlafnàwì, qui a achevé cette compilation en 1183 (1770 de J. C.). Commencement :

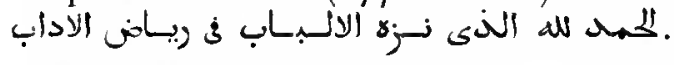

Papier. 165 feuillets. Hauteur, a centimètres; largenr, 16 centiMas. oriestaur. - It. mètres et demi. 33 lignes par page. Ms. du rvı siècle. - (Supplément 2185. )

\section{9.}

Mème ouviage.

Ms. daté de l'an 1205 de l'hégire $\left(179^{0-1791}\right.$ de J. C.) .

Papier. 329 feuillets. Hauteur, 22 centimètres; largeur, 15 centimètres et domi. ${ }_{9}$ ligues par page. - (Supplément 1560.)

\section{0.}

Même ouvrage. Exemplaire incomplet à la fin.

Papier. 101 feuillets. Hautcur, 33 centimètres el demi; largeur, 16 centimètres et demi. 23 lignes par page. Is. du xux" siècle. (Supplément 2186.)

\section{1.}

Même ourrage.

Vls. daté de l’an 1242 de l'lıégire $(1826$ de J. C.).

Papier. 18 , feuillets. Hauteur, 30 centimètres; largeur, 19 centimètres. 25 lignes par page. - (Supplément 3501.)

\section{2.}

كناب النمثّل والنحاضرة. Recueil de vers isolés, renfermant des sentences et des maximes, dans l'ordre de l'alphabet, recueilli par (goṭ al-Din ibn Schans al-Din, mufti lıanéfite de la Mecque et de Médine, au xvmı siècle.

Ms. autographe.

Papier. $15 \mathrm{~g}$ feuillets. Hauteur, so centimètres et demi; largenr, 15 centimètres. 10 à 12 lignes par page. - (Supplément 1569. )

\section{3.}

Recueil d'historiettes et de pièces de vers. On lit en tète du volume le titre de أنيس بل litre commun à plusieurs ourrages différents.

Ms. daté de l'an 1187 de l'hégire $\left(177^{3}\right.$ de J. C.).

Papier. 158 feuillets. Hauteur, 21 centimètres et demi; largeur, 16 centimè̀res et demi. 21 lignes par page. - (Supplément 1777.$)$

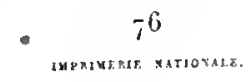




\section{4.}

Safunn comprosing par un nomme Nohammad al-Rifaci

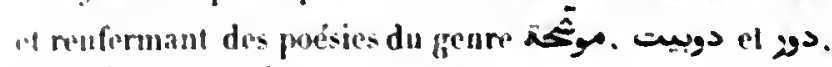
"f puelques anoedotes en prose.

V.: date do lan 1,88 de lhegire $(17-19-1775$ de J. (i.).

Papter, tie feuillets. Hauleur, 16 centimetres al demi: largeur, is nentimedns. yi lignes par page. - (Supplement i 5s6.)

\section{5.}

Fragmeut d'une aulhologic composes de pieces en urs it en prusia. dont le sujet est l'ammur conine naturr.

Papier. \& feuillets. Llauteur, al centimetres; langeur, is centi-

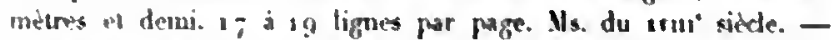
(silpplement $21 ; 8$.)

\section{6.}

Fragment diuse anthologin. Au premier feuillet, on lit te ricit de limprisounemeut d' lbou Nowàs par le prince II-Imin, fils du calife llarodu al-llaschid. dont les vers ivaient éfe mal appréciés par to poile.

Papier. A feuillets. Hauteur. 19 rentimetres of deni: largeur. 1. centimetres. 19 ligues par pape. Ns. An smo siede. - (Supplé-

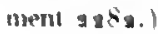

\section{7.}

" - Pleurs qui vicnnent Viltre cueillies. Iraité sur le caractèn de Mahomet -. Poéies à la lenange du Proplieli. Promier vers:

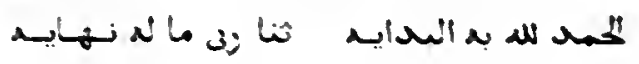

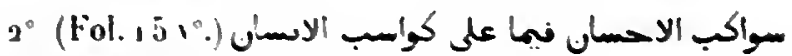
Vie de Mahomet en rers. Commencement:

$$
\begin{aligned}
& \text { حها لهى كو خلق الادمى } \\
& \text { بصوز المتعن البلدبع الاكسر }
\end{aligned}
$$

Papier. 75 feuillets. Ilauteur, as centimitns el demi: languur.

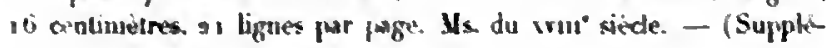
ment 1569.$)$

\section{8.}

Safima coultenant des pieces de vers du genre موآل. وبيns, itc.

l'apier. Is feuillets. Hauteur. 11 centimetres; largeur, 8 oentimetres. Environ a lignes par puge. M/s. dn armi sietde. - (Supple ment $99-6$. )

\section{9.}

Safina conlenant des qașidas el des petites picers de vers.

Papier. Is fevilleks. Hauteur, I centimetres: langeur, II centi-

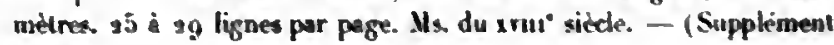
$99-8$.

\section{0.}

Llecueil de moreaux dr poésie clantés par les derviches. Ces pièces. en gúuéral très courtes. sont disposées en Stations (نوبة), dont chacune est désignét par un now technique. A la fin (fol. $1011^{\circ}$ ) se trouve un traité de

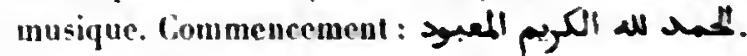

Papier. 110 feuilhts Llautear, 13 centimetres: largeur. 15 centi-

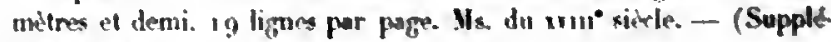
ment 1534.1

\section{1 .}

Safima renfermant des qaşidas. qui sont des prières adressées à Dieu, des qasidas en Thonneur de Nahomet, el dautres à la louange de la trauté. On y tcoure aussi des doúbait, des mandiyds, des anecalotes, etc.

Le verso de chaque feuillet esl écrit en sens inverse du rerto.

Papier. 100 fevillek Hauleur, 16 cenuaretres ef desul largeur, i 3 centimine ig lignes par page. Ms. du ur' siede. - (Supplenent, 563 .)

\section{2.}

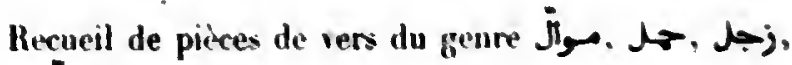
2ys. موثن. dic.

Papier. 9 feuillets. Hauteur, yi centimetres; lanjeur, 15 centimètrex 95 lignes par page. Ms du xix $^{\circ}$ sidte. - (Supplément 2993.) 
XXVII.

\section{FICTION.}

1. FABLES, APOLOGUES ET RECITS DIYERS.

\section{3.}

1 Les Fables d'Ésope.

$2^{\circ}$ (Fol. 31.) Anecdoles curieuses relatives à linde. Ms. daté de l’an 1305 de l'uégire ( 1791 de J. C.).

Papier. 36 feuillets. Hauteur, 18 centimètres et demi; langeur. 19 centimètres. 15 à 18 lignes par page. - (Supplément 1647.)

\section{4.}

Recueil de cent quarante fables, saus prélace ni introduclion. Il est dit dans lexplicit que ce ms., renfermant les fables d'Ésope, est de la main d'un interprète (مترمَ) et prêtre, nommé 'İsà Petro, de Jérusalem.

Papier. 89 feuillets. Hauteur, 22 centimètres; largeur, 16 centimètres. 17 lignes par page. Is du xis siècle. -- (Supplément 1641.)

\section{Kalila et Dimna.}

\section{5 .}

Cet exemplaire, dont le texte est pourvu de voyelles el qui renferme des figures coloriées, a servi de base à lédition publiée par S. de Sacy, en 18,6. (Yoyez Calila et Dimua, préface, p. 57.)

Papier. 146 feuillets. Hautear, 28 centimétres; largenc, \&1 centimètres et demi. 15 lignes par page. Ifs. du sm' siècle. - (tucien fonds $1483 \mathrm{~A}$.)

\section{6.}

Même ourrage. (Voỵez Calila et Dimna, préface, p. j8.) Les figures. dont la place est marquée dans le texte. nont pas élé exécutées.

Papier. 34 feuillets. Haoteur, 26 centimètres el demi ; largeur, 18 centimètres. 17 lignes par page. Ms. du $\mathbf{r v}^{*}$ siècle. - (Ancien fonds 1489, Colbert 3024.)

\section{7.}

Mème ouvrage, arec des figures coloriées.

Le commencement manque.

Papier. 119 fevillets. Hauteur, 30 centimètres; largeur, 93 centimètres. 15 liģnes par page. Ms. du w' siècle. - (Supplèment 1809.)

Mème ourrage.

\section{8.}

Ms. daté de l'an 1005 de l'hégire ( 1597 de J. C.).

Papier. 1's feuillets. Hautear, a centimètres et demi: largeur. 15 reulimètres. 19 lignes par page. - (Supplément 1794.)

Mème ourrage.

\section{9.}

Cet exemplaire porte quelques notes de la main de Gilbert Gaulmin. (Vovez Calila et Dimna. préface. p. 58 et 59 .)

- Papier. 353 feuillets. Hauteur, ao centimetres el demi; largeur, 15 centimétres. Au commencement 1 - lignes, puis 15 lignes par page. Its. du Irr' sièele. - (Ancien fonds 1509.)

\section{0.}

Mème ourrage, arec figures.

Le commencement et la fin manquent.

Papier. 199 feuillets. Hauteur, 30 centimétres; largenr, a 1 centimètres. 17 lignes par page. Ms. du $\mathbf{r r}^{\circ}{ }^{\circ}$ siède. - (Supplément 1803.)

\section{1.}

Mème ourrage. (Voyez, sur cet exemplaire, Calila et Dimna, préface, p. 59 .)

Ms. daté de lan 1053 de l'hégire (1643-1644 de J. C.).

Papier. 189 fenillets. Hauleur, 20 centimètres et derni; largeur. 15 centimètres. 17 lignes par page. - (Aucien fonds 1501.)

\section{2.}

Mème ourrage.

Il y a, dans cet exemplaire, une vignette représentant la façade dune maison et plusieurs figures coloriées. 
Vis. daté de l'an 1080 de l'bégire ( 1669 de J. C.).

Papier. 165 feuillets. Hauteur, 21 centimètres; largeur, 15 centimètres. 19 lignes par page. - (Ancien fonds $1 / 49^{2}$, Colbert 5968 .)

\section{3.}

Mème onvrage.

Ms. dalé de l'an 1110 de l'hégire (1700 de J. C.).

Papier. 104 feuillets. Hauteur, so centimètres; largeur, 14 centimètres. a lignes par page. - (Supplément 1798.)

Mème ouvragge.

\section{4.}

Ms. daté de l'an 1,56 de l'hégire (174/4 de J. C.).

Papier. 138 feuillets. Hauteur, a a centimètres et demi; largenr, 16 centimètres et demi. 17 ligues par page. - (Supplément 1800.)

\section{5 .}

Hême ouvrage, avec de nombreuses figures.

Ms. daté de l'an 1175 de l'bégire (1 762 de J. C.).

Papier. 199 feuillets. Hantenr, a a centimètres; largeur, 16 centimètres el demi. 17 lignes par page. - (Supplément 1801.)

\section{6.}

$1^{\circ}$ Même ouvrage.

Copie datée de l'an 198 de l'bégire ( 1755 de J. C.). $2^{\circ}$ (Fol. 255.) (Parure des hommes généreux et ornement des convivesn, recueil d'anecdotes, divisé en cinq chapitres et précédé d'une introduction. Le premier chapilre traite de la géuérosité; le second, de la bienfaisance; le troisième, des ancjens rois; le quatrième, des hommes el des fenmes, et le cinquième renferme des conseils. Commencement : كمل

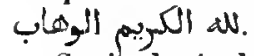

Copie datée de l’an 1169 de l'hégire ( 1756 de J. C.).

Papier. 340 feuillets. Hauteur, a a eentimètres, largeur, 15 centimètres et demi. - (Supplément 1797.)

Kalìla et Dimna.

\section{7.}

Ia fiu dı ms. manque. l'apier. 144 feuillets. Hanteur, 20 centimètres; largenr, 1 h centimètres el demi. 21 lignes par page. Ns. du xvin' siècle. - (Supplément 1793.)

\section{8.}

Même ouvrage.

Les figures, dont la place est marquée dans le lexte, n’ont pas été exéculées.

Papier. 211 feuillets. Hautenr, 21 centimètres el demi; largeur, 15 centimètres. 15 lignes par page. Ms. du xvü siècle. - (Supplément 1795.)

\section{9.}

Même ouvrage.

Is. daté de l'an 1384 de l'hégire (1 770 de J. C.).

Papier. 156 feuillets. Hauteur, 21 centimètres; largeur, 15 centimètres et demi. 18 à so lignes par page. - (Supplément 1 799.)

Même ouvrage.

\section{0.}

Ms. daté de l'an 1200 de l'hégire ( 1786 de J. C.).

Papier. 183 feuillets. Hautenr, 22 centimètres; largeur, 15 centimètres el demi. 17 lignes par page. - (Supplément 1796.)

\section{1 .}

e Les Séances», recueil de traditions, d'ancedotes el de maximes, rédigé par Aboû Bakr Aḥmad ibn Marwàu al-Dinawari al-Màliki, molt en 310 de J'hégire. Ces pièces sont en géwéral très courtes, et chacune d'elles est accompagnée d'un isnâd. L'ouvrage se compose de quarante-sept sections, dont le présent ms. renlerme les quinze dernières. A la fin de chaque section se tronvent quelques idjaza.

Ms. daté de l'an $59^{6}$ de l'hégire (1 200 de J. C.).

papier. 279 feuillets. Hanteur, 25 centimètres; largeur, 18 centimètres. 15 lignes par page. - (Supplément 16а2.)

\section{2.}

1 م نمxcitant de la conversation et histoires pour la causerien, historiettes recueillies par le cadi Aboû 'Alì ibn abi'l-Qâsim 'Alì al-Ta- 
noûkhi, mort en 384 de l'hégire (994 de J. C.). (Voyez le Diclionnaire biographique d'Ibn Klatlikàn, I. II, p. 564 de la Iraduction anglaise.)

Copie datée de l'an 730 de l'légire (1330 de J. C.).

$2^{\circ}$ (Fol. 193.) Abrégé d'un ouvrage intitulé (sic) vis (Le Collier précieux et l'agrément du convive 7 . Maximes a!tribuées à 'Ali, fils d'Aboû Ṭalib,

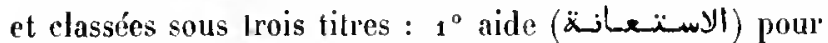
mener une bonne conduite; $2^{\circ}$ aide pour bien exprimer ses idées, et $3^{\circ}$ aide pour bien gouverner.

Copie du $\mathrm{xvl}^{\mathbf{e}}$ siècle.

Papier. 2.3 feuillets. Ilauleur, s 7 centimètres et demi; largeur, 19 centimètres et demi. 17 lignes par page dans l'article $1^{\circ}, 13$ lignes dans t'article $2^{\circ}$. - (Ancien fonds 1570 , Colbert 9487.$)$

\section{3.}

الفعرج بعد النشّة personuages historiques qui furent délivrés d'une façon inespérée des matheurs qui les accablaient, par Aboù 'Alì al-Hlasan ibn abi 'l-Qìsin al-Tanoùkhi. Quatorze chapitres. Commencement : إلـ الشحدة فيا.

Ms. daté de l'an 1126 de l'hégire ( 1715 de J. C.).

Papier. 306 feuillets. Hauteur, 24 centimètres; largeur, 17 centimètres. 2 lignes par page. - (Supplément 1786.$)$

\section{4.}

Mème ouvrage.

Ms. daté de l'an 1214 de l'hégire ( 799 de J. C.).

Papier. 242 feuillets. Hanteur, 39 centimètres; largeur, 31 centimètres. 31 lignes par page. - (Supplément 1787 .)

\section{5 .}

Abrégé du même ouvarge, intilulé all gar 'Ali ibu abì Tảlib ibn 'Alì ibn 'Alì ibn 'Alî ibn 'Nlì ibn Saeid Ibn al-Khasehschâb al-llababi.

Ms. daté de l'an 83o de l'hégire (1426-1427 de J. C.).

Papier. 150 feuillets. Hauteur, 24 centimètres; largeur, 16 centimètres. 17 à 19 lignes par page. - (Aucien fonds 1606 .)

\section{6.}

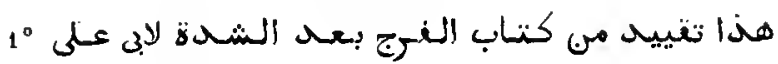

(التنسنسوخ Ceei est un extrait de l'ouvrage d'Aboù 'Alì alTumoukhì, intitulé Al-Faradj ba d al-Schidla».

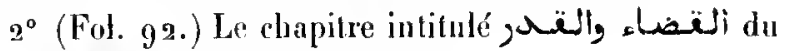
Sirâdj al-yolouk d'A1-Torṭouschi.

$3^{\circ}$ (Fol. $9^{8} v^{\circ}$.) Autre abrégé de l'ouvrage d'Alboú 'Alì a)-Tanoûkhì.

4 (Fol. 139.) Extraifs, traditions et pièces de vers.

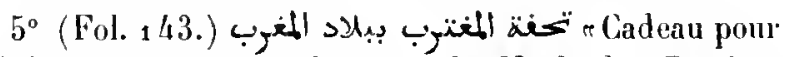
eelui qui voyage dans les pays du Maghrebr. Panégyrifue d'Ahou Marwìn, saint musulman, par Aḷmad ibn

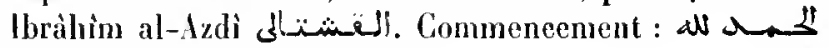

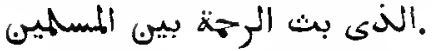

Papier. 199 feuillets. Ilautenr, 20 centimètres; largenr, 15 centimètres. 19 à 24 lignnes par page. Écritures diverses du $x v^{\circ}$ siècle. (Ancien fonds 949. )

\section{7.}

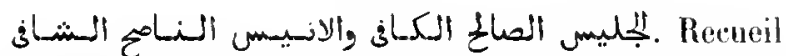
d'historietles instrucives, divisées en Séances (m-

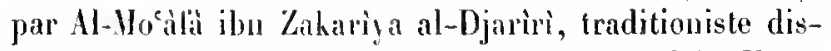
lingrué, mort en 390 de lihérrire (1 000 de J. C.). (Voyez le Dietionnaire biographique d'llon Khallikàn, tome III. p. $37^{4}$ de la traduction anglaise.)

Le présent uns. renferme les cinq premières Séances; mais le commencement de la premiere et la fin de la cinquième nanquent. P'uis vient la troisiome section de l'ouviage (fol. 27), qui commence par la douzième Séance et qui linit par la dix-septième. Au fol. 67 commence la vingt-qualrième Séance et le volume linit avec la vingtneuvieme. Le texte est sourent dépourvu de points diacritiques.

Papier. 101 fenillets. Ilautenr, 23 centimètres; largeur, 15 centimètres. 2 lignes par page. Us. dn xu1 siè̀le.--(Supplément 1 780.)

\section{8.}

Mème ouvrage. Ce ms. renlerme les Séances 63 à 97 . La fin d: la Séance 97 manque et il y a une lacune considérable entre les Séinces $7^{2}$ et $7^{5}$, et une autre entre les Séances 83 et 86 . C'est te troisième volune d'un exemplaire qui avait été écrit pour le sultan mamelouk AlIlalik al-Aschraf Schá bin, qui mourut en 1377 de J. C. A ce volume sont joints trois eahiers (ou dix-sept feuillets) d'une autre main et d'un autre format. Ce frayment renferme la fin de la Séance 97 , la $9^{8^{e}}$ et les dix prenières pages de la Séance 99.

Papier. ${ }_{262}$ feuillets. Ilauteur, 25 centimètres el demi; largeur, 
18 centimètres et demi. 17 lignes par page. Les cahiers joints au volume sont du xıv ou du $x v^{*}$ siècle. -. (Supplément 1781 bis.)

\section{9.}

Mème ouvrage. Ce ms. renferme la lin de l'ouvrage, a partir de la $51^{\circ}$ Séance.

Papier. 380 feuillets. Hauleur, 20 centimètres el demi; largeur, 15 centinètres. 19 lignes par page. Is. du xirie siècle. - (Supplétoent 1781 .)

\section{0.}

من Perles éparpillées el joyaux de prix", par "Abd AHah ibn Nașr ibn " $\Lambda$ bd al-'Azìz alZaiidi. C'est un abrégé du grand recueil d'anecdotes, de paroles de per'sonnages marquants, de renseignements littéraires, etc., en sept rolumes, intilulé également نـتَتَ y山l, du kàtib Abou "1-Honaïn (selon Hadji Khalfa, Aboû Saềd) Manşoûr al-Obaïy, mort en 421 de l'hégire ( 1030 de J. C.). D'après la préface, cet abrégé, divisé en sept sections, dont chacune renferme plusieurs chapitres, a eté composé pour un émir nommé Djamàl alDîn 'Izz al-Daula Dhiyà al-Moulk Fakhr' al-'Iràq Abou

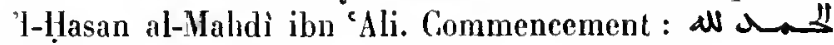
مبداع البرية وخالقها

Ms. daté de l'an 877 de l'hégire (1472 de J. C.).

Papier. 106 feuillets. Hauteur, 24 centimètres et demi; largeur, 17 centimètres. 25 lignes par page. - (Supplément 1654.)

\section{1 .}

Choix d'anecdotes curieuses m. Recueil composé par un auteur inconnu et divisé en dix ' -

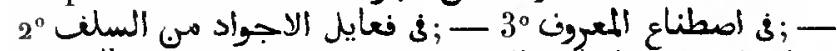

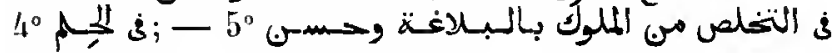
;

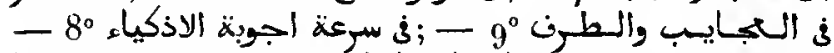
1. Un liltérateur nommé Mọ̣anmad ibn Aḷmad al-Moqrî al-Anbârì, ayant rencontré cet ouvrage, l'a complété par un onzième cliapitre, sur les saints personnages de l'islamisme, inti-

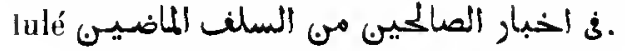

Papier. 162 feuillets. Hautcur, 26 centimètres et demi; largeur, 18 centimètres. 11 lignes par page. Ms. du xvi siècle. - (Supplément 1651.)

\section{2.}

Mème ouvrage.

Ms. daté de l'an 1043 de l'hégire (1633-1634 de J. C.).

Papier. 99 feuillets. Hauteur, 21 centimètres et demi; largeur, 15 centimètres. 19 lignes par page. - (Supplément 1652.)

\section{3.}

نزهة الاذن والباصرة وحسبر المناكهة والهاضرة C'est une autre rédaction de l'ouvrage contenu dans les deux numéros précédents. La préface commence par ces mots :

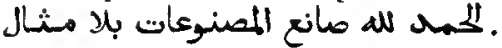

Papier. 284 feuillets. Hauteur, 21 centimètres; largeur, 15 centimètres. 17 liggnes par page. Ms. du xvı1 ${ }^{\circ}$ siècle. - (Supplément 1673 .)

\section{4.}

1. Satisfaction obtenue dans l'acquisition des réparties spirituelles». C'est encore une rédaction différente, avec la mêne division et à peu près les mêmes rubriques, de l'ouvrage contenu dans les numéros précédents. Moḥammad ibn Aḷmad al-Moqrì dẹclare avoir recueilli lui-même ces historiettes amusantes el édifianles. Commencement de la préface : a d L

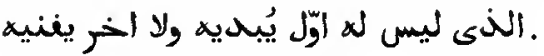

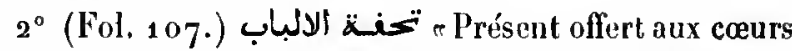
intelligents $\leadsto$, description du monde et de ses merveilles, par un anonyme qui se trouvait à Mossoul, en 557 de l'hégire ( 1162 de J. C.). L'ouvrage se compose d'une courte introduction et de quatre chapitres, dont le premier traite du monde et de ses labitants; le second, des merveilles des divers pays; le Iroisième, des mers et des animaux extraordinaires qui l'habitent; le quatrième, des souterrains et des lombeaux. Commencement:

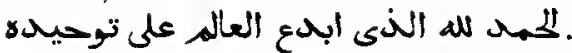

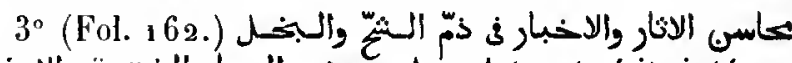
, Aneedotes et récits intéressants qui montrent combien sont laides la parcimonie et l'avarice, et combien sont louables la libéralité, la générosité et la bienfaisancen. Recueil d'histoires amusantes, par' 'Alâ al-Dìn al-Qàdirì, de Damas.

Ms. daté de l'an 1013 de l'hégire (1604-1605 de J. C.).

Papier. $19^{3}$ feuillets. Hauteur, 21 centimètres; largeur, 15 centimètres el demi. 15 à 17 lignes par page. - (Ancien fonds 16o3.) 
3495.

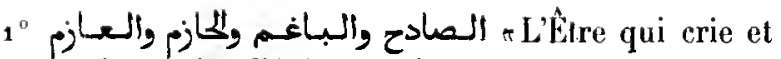
l'Étre qui mugit, l'Avisé et le Résolun. Recueil de fables versifiées, par Aboû Yaclà Moḷammad ibn al-Habbârìya. L'ouvrage est dédié à Șadaqa ibn Manșoûr alAsadì, seigneur d'A1-Hilla et chef des Arabes nomades de la Mésopotamie. Commencement :

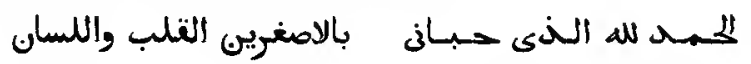

Pour la vie du poète, voyez le Dictionnaire biographique d'lbn Khallikàn, t. III, p. 150 et suiv. de la traduction, et pour la liste des chapitres, le Catalogue de la Bibliothèque bodléïenne, $t$. II, p. $3{ }_{2} 5$ et suiv. Ibn alHabbâriya mourut en 504 de l'hégire (1110-1111 de J. C.).

Ms. daté de l'an 1028 de l'hégire ( 619 de J. C.).

Papier. $9^{\circ}$ feuiltets. Hauteur, 20 centimètres et demi; largenr, 1 c centimètres. 13 lignes par page. - (Supptément 1596. )

\section{6.}

Même ouvrage.

Papier. 85 feuiltets. Hauteur, 21 centimètres; largeur, 15 centimètres. Ms. du xvı" siècle. -- (Supplément 1597.)

\section{7.}

$1^{\circ}$ Même ouvrage.

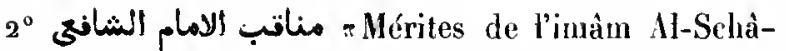
fị ’, par Fakhr al-Dìn al-Ràzì. Ce sout des fragments du septième et du neuvième chapitre de l'ouvrage. Il s'agit des vers rapportés par Al-Schafieì ou composés par lui, ainsi que de ses bons mots.

Papier. 54 feuillets. Hauteur, 21 centinètres; largeur, 15 centimètres et demi. 17 liłgnes par page. Ms. du xwi siècle. - (Ancien fonds 2436 .)

\section{8.}

I ${ }^{\circ}$ الصادح والباغم d'llbn al-Habbârìya.

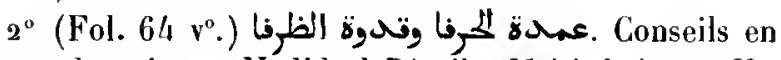
vers, adressés par Madjd al-Dìn ibn Makânis à son fils.

Ms. daté de l'an 1129 de l'hégire (1717 de J. C.).

Papier. 67 fenillets. Hauteur, 21 centimètres; largeur, 15 centimètres et demi. 26 à 27 lignes par page. — (Supplément 1598.)

\section{9.}

Ta verte prairie pour les hommes de bienn, par Abou 'l-Qàsim Mạ̣moùd al-Zamakhscharì. Recueil méthodique d'anecdotes sur dirers sujets, disposés, dans le présent exemplaire, en cent chapitres, dont la liste se trouve en tête du volume; on y remarque particulièrement les chapitres sur la météorologie, la géographie, la justice, la guerre sainte, la science, les vêtements, les chevaux, les bêtes saurages, les reptiles. etc. L'auteur expose dans la préface le but qu'il s'était proposé en formant ce recucil, mais it n'en indique pas le titre. Le copiste n'a mentionné que la moitié du titre, qui, d'après Hadji Khalfa, est ربيع الابرار ونصوص الاخيلا

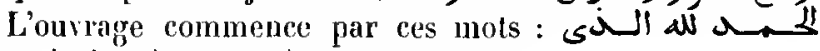
أستكمد اله عباده بموجبات النهامد :

Nombreuses uotes marginales.

Ns. daté de l'an 936 de l'hégire ( 1530 de J. C.).

Papier. 396 feuillets. Hauteur, 26 centimètres et demi; largeur, 18 centimètres. 19 lignes par page. - (Supplément 481.)

\section{0.}

Mème ourrage, divisé en quatre-vingt-dix-huit chapitres.

Ms. daté de l'an $9^{60}$ de l'hégire ( 1553 de J. C.).

Papier. 27 f feuillets. Hlauteur, 26 centimètres et demi; largeur, 18 centimètres. 31 lignes par page. - (Ancien fonds 250.)

\section{1 .}

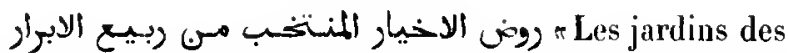
hommes rertueux, choix de passages fait dans le Rabir al-Abrìr par Noḅammad ibn Qùsim ibn Yacqoûb, mort en 940 de l'hégire $(1553$ de J. C.). Cet abrégé du Rabi al-Abrir d'Al-Zamaklischari, est une anthologie morale et littéraire, distribuée en cinquante Jardins ou chapitres, et contient aussi des passages empruntés à d'autres auteurs. Les marges du manuscrit sont couvertes de notices biographiques et philologiques.

Papier. 594 pages. Hauteur, so centimètres; largeur, 12 centimètres et demi. 17 lignes par page. - (Ancien fonds 421.)

\section{2 .}

: Même ouvrage. 
$2^{\circ}$ (Fol. $136 \mathrm{v}^{\circ}$.) Quelques traditions.

$3^{\circ}$ (Fol. 1 37.) Opinion de I!osàm al-Din 'Abd al-'Aziz al-Bokhàì sur certains cas qui se présentent lors du nomyeau mariage d'une lemme répudiée trois fois.

$4^{\circ}$ (Fol. $137{ }^{\circ}$.) Traité allribué à Djalàl al-Dìn al-

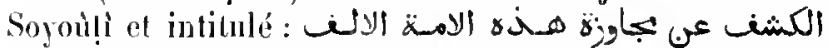
- Démonslation de la sentence qui aflime que la nation musulmane doit durer plus de mille ans.

$5^{\circ}$ (Fol. $138 \mathbf{v}^{\circ}$.) Direrses traditions, entre autres ralles qui sont relatives à la duréc de la race lumaine a jartir de l'époque où le soleil se lèvera du cóté de l'occident, phémomène qui doit précéder le jour du jugement dernier. Cette durée, selon Mahomet, sera de rent vingt ans.

$6^{\circ}$ (Fol. 139.) Note sur les degrés de parenté réelle ou contractuelle, dans lesquels le mariage est prohibé, et note sur les poids et mesures.

Papier. ${ }^{3} 3_{9}$ feuillets. Hauteur, a I eentimètres et demi; largeur, 16 centimètres. 13 lignes par page. Ms. du xvi siècle.- (Supplément 534.)

\section{3.}

Consolation du prince qui a encouru l'inimitié de ses sujets\%. Recueil d'apologues et de récits rédigé par Moḥammad ibn abî Molyammad ibn Mohammad ibn Zafar, auteur sicilien, mort en 565 de l'hégire $(1169-1170$ de I. C.). (Voyez le Dictionnaire biographique d'Ibn Khallikàn, I. III, p. 1 o de la traduction anglaise, et lintroduction de la traduclion ilalienne de cet ourrage par M. Amari.)

Ms. daté de l'an 588 de l'hégire $\left(11^{2}\right.$ 2 de J. C.). Les dix premiers feuillets sont plus modernes.

Papicr. 112 feuillets. Hauteur, 19 centimètres et demi; largeur, 14 centimètres. 16 lignes par page. -- (Supplément 536.)

$1^{\circ}$ Mème ouvrage.

\section{4.}

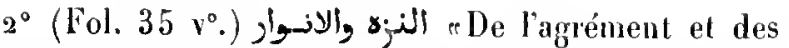
Lumières». Anthologie, en grande partie poćtique, distribuée en dix-neuf chapitres. Commencement : al $\omega_{0}$

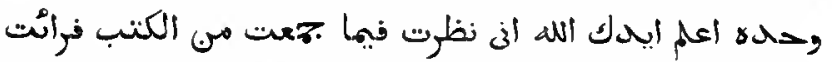
. La plupart des morceaux contenus dans cet ourrage sont empruntés aux poètes des quatre premiers siècles de l'hégire. La fin de la copie, à partir du chapitrexr, manque. $3^{\circ}$ (Fol. $84 v^{\circ}$.) Quatre pièces de vers d'un auleur dont le nom a été biffé. Le premier vers de la première pièce, qui se compose de treize vers, se termine par

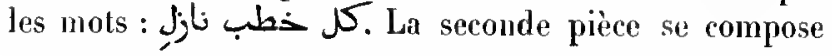
de trente-six vers dont le premier se termine par les mots : . La troisième pièce se compose de trente-cing var's, dont voici le premier :

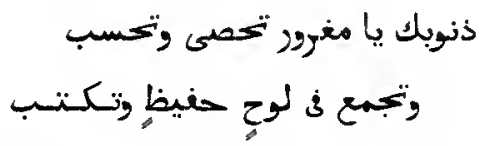

La quatrième pièce se compose de douze vers, dont le premier se termine par les mots : كايث أمس المزيل

Papier. 86 fenillets. Hauteur, a/4 centimètres et demi; largeur, 18 centimètres. Ms. du viv siècle. - (Ancien fonds $9^{53 .}$ )

\section{5 .}

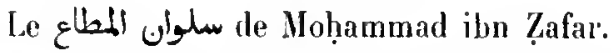

Ms. daté de l'an 867 de l'hégire (1463 de J. C.).

Papier. 162 feuillets. Hauteur, 18 centimètres; largeur, 13 centimètres el demi. 13 lignes par page. - (Ancien fonds 95.)

Mème ourrage.

\section{6.}

Papier. 65 feuillets. Hauteur, 27 centimètres; largeur, 18 centi-

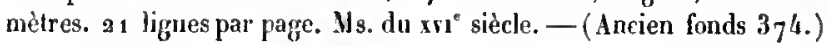

Même ouvrage.

\section{7.}

Papier. $9^{2}$ fenillets. Hauteur, ya centimètres; largeur, 15 centimétres et demi. 13 lignes par page. Vs. du xvi siècle. - (Ancien fonds 950 , Colbert 4585.)

Même owrage.

\section{8.}

Ms. daté de l'an 998 de l'hégire ( 1590 de J. C.).

Papier. ${ }^{2} 54$ feuillets. Hauteur, 19 centimètres et demi; largeur, 14 centimètres. 2 1 lignes par page. - (Supplément 537.)

Même ouvrage.

\section{9 .}


Ms. daté de l'an 1014 de l'hégire (1605 de J. C.).

Papier. 1 g feuiltels. Hauteur, 26 centimètres; largeur, 19 centimètres. 13 lignes par page. - (Supplément 535.)

Mème ouvrage.

\section{0.}

Papier. 59 feuillets. Hauteur, so centimètres et demi; largeur, 15 centimètres. 23 lignes par page. Ms. du xviı" siècle. - (Ancien fonds 9 48.)

\section{1.}

Mème ouvrage. Cet exemplaire renlerme des figures, en partie coloriées.

Papier. 72 feuillets. Hlauteur, 29 centimètres et demi; largeur, 18 centimètres et demi. 2 lignes par page. Ms. du xwı siècle. (Supplément 53g.)

Ms. daté de l'an 1185 de l'hégire ( $177_{1}$ de J. C.).

Papier. 156 feuillets. Hanteur, 16 centimètres; largeur, 10 centimètres et demi. 13 lignes par page. - (Supplément 538.)

$1^{\circ}$ Même ourrage.

\section{3.}

$2^{\circ}$ (Fol. $114 v^{\circ}$.) Sur les Compagnons du Prophète qui sont morts à l'àge de 120 ans, par ill-Soyoûțì.

3० (Fol. $117 \mathrm{v}^{\circ}$.) Traité sur le Nil, extrait du نشنق الازمار ف كُائب الاتطار Âyâs.

$4^{\circ}\left(\right.$ Fol. $\left.164 v^{\circ}.\right)$ Extrait du traité de médecine in-

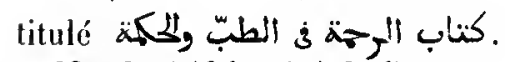

J. C.).

Ms. daté (fol. 161 ) de l'an 1119 de l'hégire ( 707 de

Papier. 173 feuillets. Hauteur, 20 centimètres; largeur, 15 centimètres. 16 lignes par page. - (Supplément ${ }_{19}^{50 .}$

\section{4.}

بـأيع البهداية. Recueil de bons mots, de réparties spirituelles, d'improvisations, etc., divisé en cinq cha- pitres. L'auteur, 'Alt ibn Zafar le Sicilien, dit avoir terminé son travail d'après les conseils du célèbre Qàdhî al-Fàdhil al-Baïsânî, et l'avoir présenté, l'an 603 de l'hégire (1206-1207 de J. C.), au sultan Al-llatik alAschraf (souverain de la haute Mésopotamie). Il exprime aussi le désir de voir son ouvrage déposé dans la bibliothèque du sultan Al-Malik al-Kàmil. Commence-

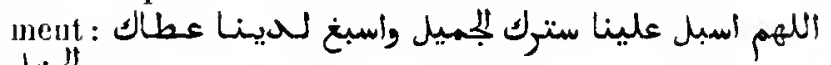
.

Is. daté de l'an 118 , de l'hégire ( 1768 de J. C.).

Papier. 185 feuillets. Hauteur, 23 centinı̀tres; largeur, 16 contimètres. 19 lignes par page. - (Supplément 1413. )

\section{5.}

كنز الملوك في كيفيـة السسـلـوك. Recueil d'aneedoles curieuses et instructives à l'usage des princes. L'auteur, Aboû Mozaffar Yoùsof Sibṭ ibn al-Djauzi, a tiré les matériaux de son ourrage intitulé :

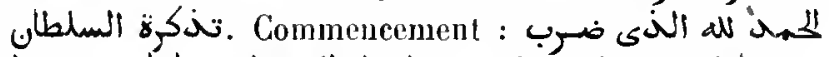

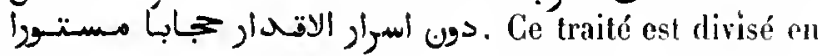
cinq chapitres : -

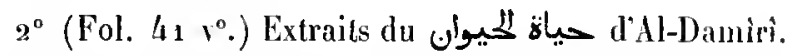

Papier. 72 feuillets. Hauteur, 21 centimètres et demi; largeur, 15 centimètres et demi. 21 tignes par page. Ms. du xviı sièrle. (Supplément 1881.)

\section{6.}

Le Goulistin de Sacdi, traduit en arabe par un auteur européen en 1048 de l'hégire. En tète de chaque paragraphe de la traduction, on lit le commencement du paragraphe correspondaut du texte persan.

Papier. 245 feuillets. Hauleur, 22 centimètres et demi; largeur, 16 centimètres et demi. - (Aucien fonds 1493. )

\section{7.}

Commentaire sur le Goulistân de Sac dì par Ya qoûlb

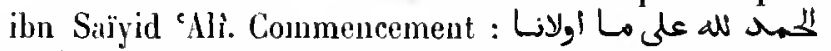
مى النع. En tète du ms. se trouve une notice sur lr commentateur, par l'auteur du تنقائت النعان.

Ms. daté de l'an $9^{34}$ de l'hégire (1528 de J. C.).

Papier. 183 feuillets. Hauteur, 16 centimètres; largeur, 11 centimètres. 17 lignes par page. - (Ancien fonds 981.)

$$
\text { MAs. oniENTAUT. - II. }
$$




\section{8.}

Mème ouvrage.

Ms. daté de l'an $9^{6} 7$ de l'héogire ( 1560 de J. C.).

Papier. 115 feuillets. Hauteur, 2 : centimètres et demi; largeur, 16 eentimètres. 17 lignes par page. - (Supplément 1788.)

\section{Mème ouvrage.}

\section{9.}

Papier. 159 feuillets. Hauteur, 20 centimètres et demi; largeur, 14 centimètres et demi. 17 lignes par page. Ms. du xvi' siècle. (Supplément 1789.)

\section{0.}

Commentaire sur le Goulistân de Sa'di, composé par Soroûrî, sous le règne du sultan Moustafì, fils de So-

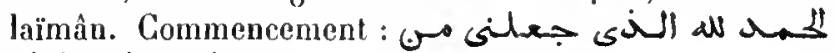
عاء البيان وألمان.

Papier. 230 feuillets. Hauteur, 21 centimètres; Jargeur, 14 centimètres et demi. a lignes par page. Ms. du xvi1 siècle. - (Supplément ${ }_{7} 89$ bis.)

\section{1 .}

10 , Allégories morales, par 'Izz al-Din 'Abd al-Salàm al-Maqdasì. Cet ouvrage a été publié et traduit par M. Garcin de Tassy. (Les Oiseaux et les fleurs. Paris, 1821 ).

$2^{\circ}$ (Fol. 27.) Maqâmât de Djalàl al-Dìn al-Soyoụṭ̂ : a. . Dialogue des fleurs.

b. (Fol. $36 \mathrm{v}^{\circ}$.) de l'ambre gris, de la civette, etc. fruits.

c. (Fol. 42.) النغاحية. Sur les diverses espèces de

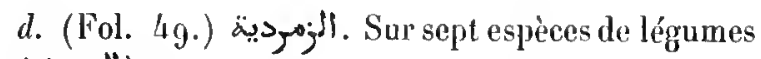
(

c. Fol. 53.) الغستتية. Sur sept espèces de dragées.

f. Fol. 56.) الياقوتية Sur sept espèces de pierres plécieuses.

3 (Fol. 61. (وسالة الازهار . Ếpître du cadi Dhiyâ alDin ibn al-Athîr. C'est un dialogue des fleurs.
$4^{\circ}\left(F_{0} .64 v^{\circ}\right.$.) Extraits et anecdotes.

Ms. daté (fol. 61) de l'an 1118 de l'hégire (1707 de J. C.).

Papier. 69 feuillets. Hauteur, 21 centimètres; largeur, i 5 centimètres. 21 lignes par page. - (Supplément 1784.)

\section{2.}

1 'Le كنثف الاسمران d'Al-Maqdasí.

$2^{\circ}$ (Fol. $30 v^{\circ}$.) Chapitres sur le Mi 'radj et le Tauhî̉. La fin se compose de morceaux de poésic.

$3^{\circ}$ (Fol. 78.) Histoire de deux amanls, Bischr et Hind.

Papier. 84 feuillets. Hauteur, 21 centimètres; largeur, 15 centimètres. Écritures diverses du xvin' siècle. - (Supplément 1783.)

\section{3 .}

\section{Le كنغ الاسراو d'Al-Maqdasi.}

Papier. $g^{\circ}$ feuillets. Ifauteur, a 1 centimétres et demi; largeur, 15 centimètres. 9 ligaes par page. Ils. du xix siècle. - (Supplément 178. .)

\section{4.}

مرزبان ناox, traduit du persan en arabe par le grand cadi Schilıàb al-Dìn. L'auteur de cet ouvrage, Merzebân, fils de Schîrouîn, était un des descendants de Kaikaous, frère d'Anoûschirwâlı le juste. L'original persan (ms. de la Bibliothèque nationale, ancien fonds 384) se compose de neuf seclions. La traduction n'en renferme que huil, à savoir : $1^{\circ}$ Sur l'origine el le titre de l'ouvrage; $2^{\circ}$ Histoire du savant et du démon; $3^{\circ}$ Les aventures des deux renards; $4^{\circ}$ Histoire du chien appelé AlZeki et de la chèvre; $5^{\circ}$ Histoire de l'hyène et du roi des éléphants; $6^{\circ}$ Histoire du chameau et du lion; $7^{\circ}$ Histoire de l'aigle et des deux perdrix; $8^{\circ}$ Devoirs réciproques des amis. On voit que l'ouvrage ressemble singulièrement par son contenu au Fakihat al-Kholafa, qui jusqu'au فe lol, a aussi la même préface. Il est probable, par conséquent, que le traducteur est Schihâb al-Dìu Ibn 'Arabschàh.

Papier. 145 feuillets. Hauteur, 17 centimètres et demi; largeur, 11 centimètres et demi. 9 lignes par page. Ms. du xvir" siecle. (Supplément 1602.) 


\section{5.}

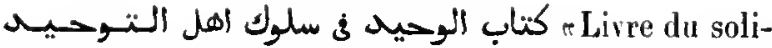
taire, traitant de la marche du monothéisle dans la voie de la dévotion" par 'Abd al-Ghaffàr ibn 'Abd al-Hamîd ibn Noûh al-Qoùsî. Cet ouvrage, commencé à Alexandrie en $7^{08}$ de l'hégire (1308-1309 de J. C.), est un recueil de légendes, d'anecdotes et d'histoires édifiantes.

Papier. $29^{3}$ feuillets. Hanteur, 28 centimètres; largeur, 18 centimètres. 25 lignes par page. Ils. du $x{ }^{\circ} v^{\circ}$ siècle. - (Ancien fonds 740 .)

\section{6 .}

r Délices des ccurs, rênfermant des anecdoles appartenant aux diverses

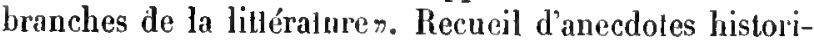
ques, biographiques et littéraires, divisé en quatre-vingt chapitres par 'Azîz al-Dìn ilon al-Kamîli (الكيلى). Un prince nommé Abou 'I-Fidà Ismâềl (très probablement l'historien el géographe), qui trouva l'ouvrage intéressant mais assez confus, en fit remettre les matériaux dans l'ordre où ils se trouvent à présent. Commencement : -

Papier. 289 feuillets. Ilanteur, 31 centimètres; largeur, so centimètres el demi. 35 lignes par page. Hs. du vrı siècle. - (Sıpplément 1804.)

\section{7.}

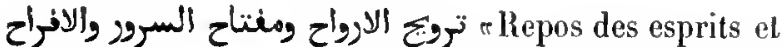
clef des plaisirs et des joiesn. Recueil d'anecdotes amusantes et instructives, par Abou '1-'Abbâs Ahmad ibn Moliammad Ibn 'Alawiya al-Schadjarî, surnommé جواب ل̈ول iValise de l'Empire». Onze chapitres. Le présent ms. renferme le premier chapitre (qui remplit plus de ceut feuillets), et la première moitié du second chapilre, qui renferme les anecdotes et bons mots d'Abou 'I- Aïnà, d'Al-Djammâz (Mohammad ibn 'Amr), d'Aboû Nowàs et de Bassehâr ibn Bord. Voici ce que dit l'auteur luimême au sujet du surnom qu'on lui avait donné :

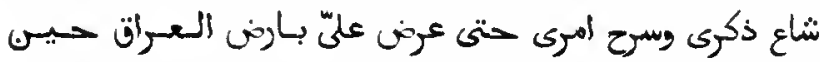
اختوتها مه بيم. ساير رلافات اسما والقاب يتناخر بها الاعتساب

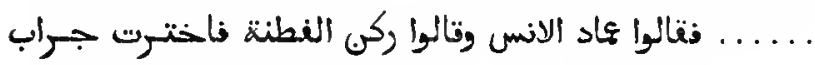

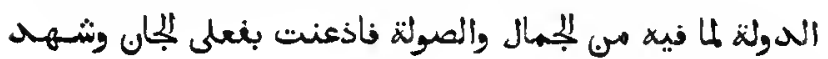

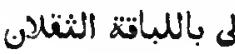

كل كلام لا يستقنتح بحمد الله فهو لغيو : Commencement

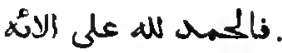

Papier. 134 feuillets. Hauteur, 25 centimètres et demi; largeur, 17 centimètres. 19 lignes par page. Ms. du $\mathrm{xrv}^{\circ}$ siècle. - (Ancien fonds 1571 .)

\section{8.}

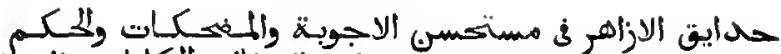
, rl Parterres fleuris, renfermant des reparties spirituclles, des anecdotes joyeuses, des apophthegmes, des proverbes, des historiettes et des jeux d'espritr, par Aboû Bakr ibn abì Yalıyâ ibn 'Âsim al-Qaïsì, vizir d'Alou 'I-lladdjàdj Yoûsof II, fils d'AlGhanì Billâlı Molıammad et petit-fils d'Abou 'l-Haddjàdj Yoûsof I. Abou 1-Ịaddjâdj II, souverain de Grenade, mourut en 799 de l'hégire $\left(139^{6-1} 397\right.$ de J. C. $)$. L'ouvrage est divisé en six sections ou parterres.

Papier. 119 feuillets. Hauteur, 28 centimètres; largeur, 19 centimètres et demi. 35 lignes par page. Ms. du $x^{e}$ sièele. -- (Ancien fonds 897 , Colbert 3101 .)

\section{9 .}

rFruits des feuilles (ou de mes lectures $r$ ). Recueil d'anecdotes littéraires et d'historiettes, avec quelques pièces de vers, par Taqî al-Din Aboû Bakr al-Hamawî, surnommé lbn Hiddja. Commencement:

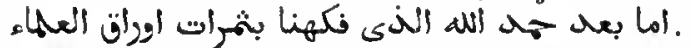

Ms. daté de l'an 878 de l'hégire (1473 de J. C.).

Papier. 257 feuillets. Hauteur, 18 centimètres; largeur, 13 centimètres et demi. 15 lignes par page. - (Ancien fonds 1596 .)

Même ouvragèe.

\section{0.}

Ms. daté de l'an 994 de l'hégire ( 1586 de J. C.).

Papier. 179 feuillets. Hauteur, 21 centimètres; largeur, 15 centimètres et demi. 23 lignes par page. - (Ancien fonds 1601.)

Mème ouvrage.

\section{1 .}

Ms. daté de l'an 1018 de l'hégire ( 1609 de J. C.).

Papier. 158 feuillets. Hauteur, 21 centimètres; largeur, 15 centimètres et demi. 19 lignes par page. - (Aneien fonds 1595.) 


\section{2.}

Nème ouvage.

Papier. 135 feuillets. Hauteur, 30 centimètres; largeur, 18 centinètres et demi. og lignes par page. MIs. du xvı" siècle. - (Supplémant 2649. )

Héme ouvrage.

\section{3.}

Us. daté de l'an 1140 de l'hégire (1727 de J. C.).

Papier. 124 feuillets. Hauteur, at centimètres et demi; largeur, 15 centimètres et demi. 25 à 37 lignes par page. - (Supplément 1618.)

Mc̀me ouvrage.

\section{4.}

Papier. 196 feuiltets. Hauteur, 20 centimètres et demi; largeur, 15 centimitres. 33 lignes par page. Mls. du xviu siècle. - (Suppléinent 1650. )

\section{5.}

. Recueil de conles el d'apologues par Aḥmad ibn Mọ̣ammad lbn 'Arabschâh.

Papier. 208 feuillets. Hauteur, 14 centimètres et demi; largenr, 9 centimètres et deni. Environ 23 lignes par page. Ms. du xvie siècle. - (Supplément 1601.)

Nème ourage.

\section{6.}

Ms. daté de l'an $97^{0}$ de l'hégire $(1562$ de J. C. ).

Papier. 208 feuillets. llauteur, 21 centimètres; largeur, 15 centimètres. 23 lignes par page. — (Supplément 1599.)

Mème ouvrage.

\section{7.}

Papier. 150 feuillets. Hauteur, a centimètres; largeur, 15 centimètres. 29 ligues par page. Mls. du xv1 siècle. - (Ancien fonds 1510.)

Mème ouvrage.

\section{8.}

Ms. daté de l'an 1041 de l'hégire $(1631$ de J. C.).

Papier. 315 feuillets. Hauteur, 31 centimètres; largeur, 15 centimetres. 1 ligrnes par page. - (Supplément 1605.)
Mème ouvrage.

\section{9 .}

A la fin se trouve un conte qui commence ainsi : تاد الاد بعض الادباء والسادة النجباء دعان بعض الاحسبـاب اله سمـاط

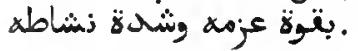

Ms. daté de l'an 1055 de l'hégire (1645 de J. C.).

Papier. ${ }_{15} 7$ feuillets. Hauteur, 20 centimètres et demi; largeur, 14 centimètres. 17 lignes par page. - (Supplément 160\%.)

Mème ouvrage.

\section{0.}

Papier. 238 feuillets. Hauteur, 22 centimètres; largeur, 16 centimètres et demi. 20 lignes par page. Ms. du xnite siècle. - (Ancien fonds 1511.)

\section{1.}

Vème ouvrage.

Ms. daté de l'an 1174 de l'hégire ( 1761 de J. C.).

Papier. 322 fenillets. llauteur, 21 centimètres; largeur, 16 centimètres. 16 à 19 ligues par page. - (Supplément 1603.)

\section{2 .}

Nème ouvrage, sans la préface.

Ms. daté de l'an 1220 de l'hégire ( 1805 de J. C.).

Papier, 220 feuillets. llauteur, 24 centimètres; largeur, 16 centimètres et demi. 19 ligues par page. - (Supplémeat 1600.)

\section{3.}

$1^{\circ}$ Extrails du même ouvrage.

$2^{\circ}$ (Fol. 104. Anecdotes des fous et des hommes distraits n par Ábou 'l-Qâsim 'Abd al-Rahmmân Ibn al-Djauzî. Commencement : al

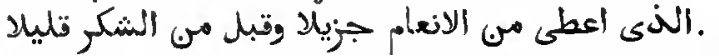

3० (Fol. 146.) Histoire de la conquête de l'Égypte par les Musulmans. C'est un extrait du Khitat d'Al-Makrîzi.

Papier. 165 feuillets. Hauteur, 18 centimètres; largeur, 10 cenlimètres et demi (les derniers feuillets, à partir du fol. 199, n'ont en général que 11 centimètres sur 8 ). Us. du xix siècle. - (Supplément 233\%.) 


\section{.3544.}

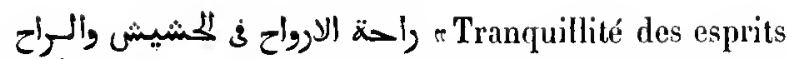
au sujet du haschich et dı vin $r$. Recueil d'anecdotes, avec quelques pièces de vers, divisé en deux parties et composé au Caire, en 869 de l'bégire (1464-1465 de J. C.)., par Taqî al-Dìn Aboû Bakr iłon 'Abd Allah alBadrî, de Damas. Commencement: :

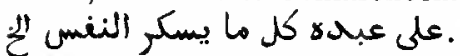

Ms. dalé de l'an 1207 de l'hégire ( $179^{2}$ de J. C.).

Papier. 112 feuillets. Hauteur, 23 centimètres; largeur, 16 centimètres et demi. 25 lignes par page. - (Supplément 1038.)

\section{5.}

r L'amusement des cours n. Recueil d'anecdotes, d'histoires édifiautes el de maximes par Aḷmad ibn 'Alì ibn Moḥammad al-Qoraschì. L'onvrage commence par des paroles du Prophète, suivies d'auecdotes louchant les Compagnons, 'Ali el d'autres saints musulmans.

Ms. dalé de l'an 873 de l'hégire ( 1469 de J. C.).

A la fin on a ajouté nuc dissertation sur l'obligation de payer la dime et une autre sur les principes de la foi. Ces prièces sont dalées, l'une de l'an 957 , et la seconde de l'an $9^{5} 9$.

Papier. 78 feuillets. Hauteur, 27 centimètres; largeur, 17 centimètres. $s 3$ lignes par page. - (Supplément 1675 .)

\section{6.}

r Sources des renseignements", par 'ìsà ibn 'Ali ibn Alınad al-Andalosì. Recueil contenant des paroles des sages, des conseils, des anecdoles, elc. Com-

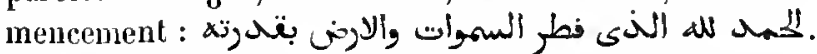
Is. daté de l'an 1119 de l'légoire ( 1708 de J. C.).

Papier. 199 feuillets. Hauteur, so centimètres el demi; largeur, 14 centimidres el demi. 23 lignes par page. - (Supplément 185.)

\section{7.}

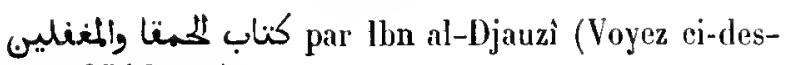
sus, $n^{\circ} 3543,2^{\circ}$ ).

Papier. 107 feuillets. Hauteur, 21 centimètres et demi; largeur, 15 centimètres et demi. 21 lignes par page. Mls. du xwi1 ${ }^{\circ}$ siècle. (Ancien fonds 1616. .)

\section{8.}

Premier volume de l'ouvrage intitulé i r. Manteaux d'étolfe fine, traitć des ruses et des artifices". Vingt chapilres. Le premier chapilre traite de l'utilité d'une grande intelligence; le second recommande l'emploi de ruses et d'artifices; le troisième monIre l'adresse cmployce par Dieu dans l'accomplissement de ses desseins; le quatrième traite des ruses des anges el des génies; le cinquième, des arlifices des prophètes; le sixième, des stratagèmes employés par les califes ef d'autres souverains; le septième, des ruses des vizirs et des fonctionnaires publics; le liuitième, des ruses des cadis; le neuvième, des ruses des jurisconsulles, et le divième, des ruses des dérôls. Les dix chapiltres de la seconde partie devaient traiter des ruses des émirs et des chels de troupe, des médecins, des poèles, des marchands, des mendiants, des voleurs et des brigands, des femmes et des enfants, et des voisins. Dans le dixneuvième chapitre il était question des ruses qui ont tourué contre leurs auleurs. Le viugtième renfermait des anecdotes diverses. Ouelques-uns de ces récits historiques sont triès intéressants. Dans la préface, l'auleur donne les titres d'un grand nombre d'ourrages qu'il arait mis ì contribution. Commencement : If

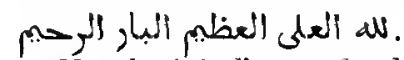

Mls. daté de l'an 1061 de l'hégire ( 165 a de J. C.).

Papier. ${ }_{1} 5_{2}$ feuillets. Hauteur, 21 centimètres; largeur, 15 centimètres. 21 lignes par page. - (Ancien fonds 1604 .)

\section{9 .}

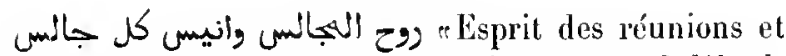
compagnon de celui qui aine y assister", par Salà alDìn ibn Moḷammad ibn 'Alì le Schaléite. Recueil d'historiettes, de récils tirés du Coran et de traditions plus ou moins labuleuses attribuées à Mahomet.

Hs. daté de l'an 1064 de l'hégire (1653-1654 de J. C.).

Papier. 70 feuillets. IIauteur, 19 centimètres; largeur, 15 centimètres et demi. 25 lignes par page. - (Supplément 479.)

Mème ouviage.

\section{0.}

Ms. daté de l'an 1204 de l'hégire ( $179^{\circ}$ de J. C.).

Papier. 144 fenillets. IIanteur, 21 centimètres et demi; largeur, 15 centimètres. 15 lignes par page. - (Supplément 180.) 


\section{1 .}

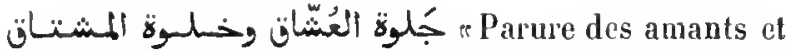
tête-ì-lĉte arec la personne aiméc n. Recueil d'listoires et d'anecdotes rédigées en style très relevé, par Balaa alDîn 'Alî ibn 'İsâ ibn abi 't-Fatḥ al-Irbilì. Commencement:

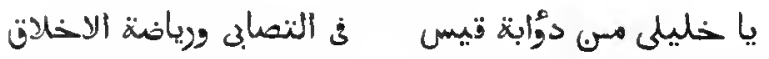

Papier. 1 a f feuillets. Jlauteur, 19 centimètres et demi; largeur, 13 centinètres. 19 lignes par page. - (Supplément 1657.)

\section{2.}

r La stupidité montrée dans les décisions de Qarâqoûschin. Recueil d'anecdoles, dont le héros étail Qarâtoûsch, officier qui gouvernail l'Égypte au nom de Saladin. Ibn Klallikân (t. II, p. 521 de la (raduction anglaise) attribue celte compilation, qu'il déclare être un recueil de mensonges, à Ascad alMammâlì, cadi du Caire, mort en 606 de l'hérire (1 209 1210 de J. G.). Dans la préface de notre exemplaire, l'auteur dit avoir composé ce petit traité en $8_{99}$ de l'hégire (1493-1494 de J. C.) el, d'après le titre qui se trouve en lête, cet écrivain serait le célèbre Djalâl alDìn al-Soyoûțì.

Papier, 10 feuillets. Hauteur, 15 centimètres; Jargenr, 10 centimètres. 11 lignes par page. Hs. du xvir siècle. - (Ancien fonds 1548. )

\section{3.}

1 Présent pour les réunions et délices du bon compagnon». Recueil d'anecdotes en quinze chapitres, dont voici les sujets : l'intelligence, la science, les prophètes, le prophète Mahomel, les califes omaïyades, les califes abbasides, les cadis, les nobles qualités, pièces de vers, les parasites, les volenr's, les femmes d'espril, les anants, les contes,

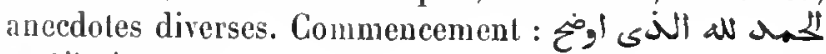
145 .

$2^{\circ}$ (Fol. $145 v^{\circ}$.) Histoire des Almohades et des Hafsides, par Ibn al-Schammấc. Le récit va jusqu’à l'an 882 de l'bégrire $\left(1477^{-14} 78\right.$ de J. C. $)$

Le premier traité de ce solume, écrit à Monastir, en Tunisie, est dalé de l'an 1235 de l'hégire (1820 de J. C.); le second de l'an 1243 de l'hégire (1827 de J. C.).

Papier. a1 4 feuillets. Hauteur, a 1 centimètres; largeur, 16 centimètres. 23 à 25 ligues par page. - (Supplément 1957.)

\section{4 et 3555 .}

نزهة المجالس ومنتخب النغايس d'historielles édifiantes, par le schaïlh 'Abd al-Raḥmân ibn 'Abd al-Salàm al-Safoûrì. Commencement : at in

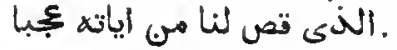

Ms. daté de l'an $119^{4}$ de l'hégire ( 1780 de J. C.).

2 vol. Papier. 389 et 289 feuillets. Hauteur, 22 centimètres; largeur, 16 centimètres. 17 lignes par page. - (Supplément 1779 I et II.)

\section{6.}

radeau pour les amis et source d'amusement pour les hommes intelligentsn. Recueil d'anecdotes, par Schams al-Din Mohammad alYamanî 3 النشخ. L'ouvrage est divisé en cinq seclions : $1^{\circ}$

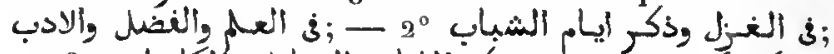

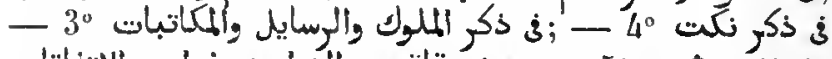

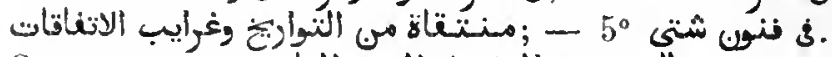

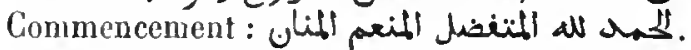

IIs. daté de l'an 1136 de l'hégire (1724 de J. C.).

Papier. 118 feuillets. Hauteur, a 1 centimètres et demi; largeur, 15 centimètres et demi. 18 \& 25 lignes par page. - (Supplément 1550$.

\section{7.}

Le langage intelligible des êtres muets $n$. Recueil de fables et de légendes loucbant les animaux, les plantes et les êtres inorganiques ayant exprimé leurs penscees, soil par des signes, soit par la parole. Six chapitres, divisés en sections. La liste des chapitres, écrite par une main plus moderne, ne s'accorde pas toujours avec les divisions du texte. L'auteur de cet ouvrage, 'Alì al-Marâghî̀ al-Qabbâní, dit l'avoir eomposé avec l'autorisation de son directeur spirituel (شيخه), Schihâb al-Dìn Aḷmad ibn Moḥammad al-Anșầì, docteur schaféite. Il l'a terminé en l'an 1001 de l'hégire ( $159^{2-1} 5_{9} 3$ de J. C.).

NIs, autographe.

Papier. 145 feuillets. Hauteur, 21 centimètres; largeur, 15 centimètres et demi. a lignes par page. - (Supplément 583.)

Même ouvrage.
3558 . 
Ms. daté de l'an 1164 de l'hégire ( 1750 de J. C.).

Papier. 122 feuillets. Hauteur, 32 centimètres; largeur, 21 centimètres. 33 lignes par page. - (Supplément 1643.)

\section{9 .}

Recueil d'auecdotes, par Schihàb al-Din Aḷmad atQalyoùbî.

Papier. 85 feuillets. Hauteur, 21 centimètres; largeur, 15 centimètres et demi. 35 lignes par page. Ms. du xvı" siècte. - (Supplément 1662.$)$

Mème ouvrage.

\section{0 .}

Ms. daté de l'an 1118 de l'hégrire (1706' de J. C.).

Papier. ${ }_{7} 6$ feuillets. Hauteur, 20 centimètres el demi; largeur, 13 centimètres et demi. 13 lignes par page. - (Supplément 1711.)

Mème ouvrage.

\section{1 .}

Ms. daté de l'an 1141 de l'hégire (1728 de J. G.).

Papier. 164 feuillets. Hauteur, 22 centimètres; largeur, 15 centimètres. s 1 lignes par pafe. - (Supplément 1663.)

\section{2.}

Même ouvrage.

Papier. $1 / 7$ fenillets. Hautenr, 21 cenlimètres; largeur, 15 centimètres. 17 lignes par page. Ms. du rrm ${ }^{\circledR}$ sièele. - (Supplément 1661.)

Mème ouvragge.

\section{3.}

Ms. daté de l'an 1166 de l'bégire (1 753 de J. C.).

Papier. 133 feuillets. Hauteur, zo centimètres el demi; largeur, 16 centimètres. 23 tignes par page. - (Supplément 1660 .)

\section{4.}

- rindicaleur, avertissement de se lenir en garde conlre les femmes». Recueit d'histoires relatives aux défauts el aux vices des femmes, notamment des femmes du Caire, par 'Alì ibn 'Omar ingit.

Ms. daté de l'an $\log _{5} 5$ de l'hégirc ( 1684 de J. C.).

Papier. $\log _{9}$ fevillets. Hauteur, a 2 centimètres; largeur, 15 centimètres et demi. 21 lignes par page. - (Supplément 1625.)

Mème ouvrage.

\section{5 .}

Ms. dalé de l'an 1133 de l'hégire (1720 de J. C.).

Papier. ${ }_{19} 3$ feuillets. Hauteur, 21 centimètres; largeur, 15 centimètres. 15 lignes par page. - (Supplément 1627.)

Mème ouvrage.

\section{6.}

Ms. daté de l’an 1169 de l'hégire (1 756 de J. C.).

Papier. 133 feuillets. Hauteur, 21 centimètres; largeur, 15 centimètres et demi. 19 ligues par page. - (Supplément 1626.)

\section{Mème ouvrage.}

\section{7.}

Papier. 299 fenillets. Hauteur, as centimètres et demi; largeur, 16 centimètres. 3 lignes par page. Ms. do xvune siècle. - (Supplément 1638.)

\section{8.}

له Auusement pour les amoureux et ptiisir pour les audileurs dotes divisé en vingt huit chapilres. Les trois deruier's chapiltes sont consacrés à la poésie. Commencenıut :

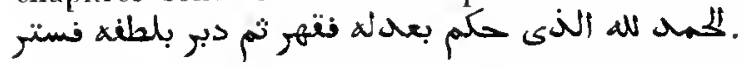

Papier. 165 feuillets. Hauteur, 2o eentimètres et demi; largeur, 1// centimètres. 21 lignes par page. Ms. du xvis siècle. - (Supplément 1671.$)$

\section{9 .}

Recueil d'histoires édifiantes. Ce ms., copié sur un volume incomplet, commence par thistoire (ta sixième d'un chapitre), de la conversion d'Aboû Dorr at-Ghaffàri à l'istamisme. Il se termine par l'histoire des Sept Dormants.

Papier. 197 feuillets. Hauteur, 20 centimètres et demi; largeur, 15 centimètres. 23 lignes par page. Ns. du xrı" siècle. - (Supplément 1 743. ) 


\section{0 .}

Légendes el récits divers, enlre autres une narration très développée du voyage noclurne de Mahomet au ciel. La seconde partie renferme des qaṣidas et d'autres poésies. A la fin se trouvent quelques prières.

Papier. 238 feuillets. Hauteur, 15 centimètres; largeur, 10 conti-

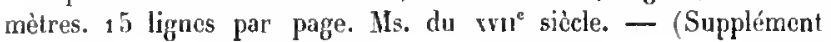
1670$.

\section{1 .}

$1^{\circ}$ Fable du filet (z) et du moineau, en strophes de quatre vers (دو).

$2^{\circ}$ (Fol. 13.) أيضاح. Trailé de l'amour conjugal.

3" (Fol. 23.) Histoire du cadi et du voleur.

$4^{\circ}$ (Fol. 33.) Histoire du paysan et de sa femme.

$5^{\circ}$ (Fol. 43.) Histoire de Hàroûn al-Raschîd.

$6^{\circ}$ (Fol. $47 v^{\circ}$.) Itistoire du lion, du loup et du renard qui ronl ensemble à la clıasse.

Papier. 50 feuillets. Ilauteur, 16 centimètres et demi; largeur, 11 centimètres. Ms. du xviı siècle. - (Supplément 1918.)

\section{2 .}

Recueil de conies et d'histoires édifiantes.

Papicr. 59 feuillets. Hauteur, 21 centimètres et demi; largeur, 15 centimètres et demi. 23 lignes par page. Mls. du xwı' siècle. (Supplément 1737.)

\section{3.}

Recueil d'aneedotes et d'histoires édifiantes. Je commencement manque.

Ms. dalé de l'an 1064 de l'héégire (1654 de J. C. ).

Papier. 111 feuillets. Hauteur, 21 centimètres; largeur, 15 centimètres. 15 lignes par page. - (Supplément 1669.)

\section{4.}

Recueil d'listoriettes.

Ms. daté de l'an 1097 de l'hégire (1686 de J. C.).
A la fin se trouve une qașida, composée à l'oceasion d'un mariage, qui commence ainsi :

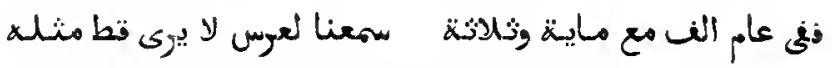

Papicr. 176 feuillets. Hauteur, 21 contimètres; largeur, 15 centimètres. a 1 lignes par page. - (Supplément 1668.)

\section{5 .}

2-Perles éparpillées pour l'instruction des grands fonctionnaires de l'État $n$. Recueil d'anecdotes puisées dans les ouvrages d'Al-Ghazzi, d'Al-Soyouttì, d'Ilon 'Arabschâh et d'autres moralisles.

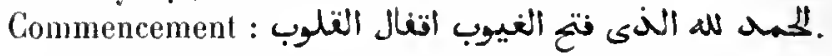

Papier. 100 feuillets. Manteur, 16 centimetres; largeur, 11 centimètres. 15 liggnes par page. Ms. du xvı ${ }^{\circ}$ siècle. - (Supplément 1658).

\section{6.}

Lill Anecdotes relatives à certains califes et autres personnages distingués par leur générosilé. A la fin, on lit, écrit de la main du copiste, le litre suivant : أما بعد : Louvage commence ainsi

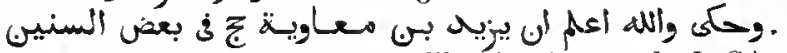

Ms. daté de l'in 1129 de l'hégire (1717 de J. C.).

Papier. 76 feuillets. Hauteur, 21 centimètres; largeur, $1^{4}$ centimètres et demi. 21 lignes par page. - (Supplément 1659.)

\section{7.}

Délices des cours el des yeux, composées d'anecdotes et d'histoires extraordinairesn, par Schams al-Dîn 'Othmân Al-Qibâbi (القباق). Dix chapilres. Commencement :

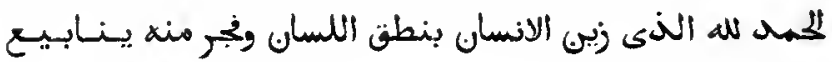

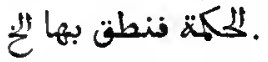

Papier. 106 feuillets. Hauteur, 19 centimètres; largeur, 14 centimètres et demi. 19 lignes par page. Ns. du xvin' siècle. - (Supplément 1672.$)$

\section{8.}

. Recueil d'anecdotes instruc- 
tives par Mohammad Amîn, fils de Ḥasan Mìrghanî (ميرغنى).

Ms. daté de l'an 1168 de l'hégire ( 1755 de J. C.).

Papier. 490 feuillets. Hauteur, a a centimètres et demi; largeur, 16 centimètres et demi. 23 lignes par page. - (Supplément 1779.)

\section{9 et 3580.}

Cadeau pour les littérateurs et amusement pour les gens d'esprit?. Recueil d'anecdotes en treize parties, par $A$ ḥmad ibn Aḷmad الستيوى. Le premier volume renferme les six premières parties; le second, les sept autres. Commencement :

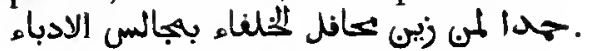

Ms. daté de l'an 1774 de l'hégire ( 1760 de J. C.).

2 vol. Papier. 165 et $9^{3}$ fenillets. Hauteur, 22 centimètres et demi ; largeur, 15 centimètres et demi. 19 lignes par page. - (Supplément 1666.)

\section{1 .}

r ll La verte prairie, souhait de celui qui écoute et de celui qui regarde".

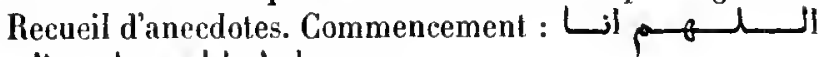
نستوهبك لسانا مصرنا من. الى

Papier. 239 feuillets. Hauteur, 23 centimètres et demi; largeur, 16 centimètres et demi. 23 lignes par page. Ms. du svui siècle. (Supplément 1656.)

\section{2.}

Recueil d'anecdotes édifiantes. En tête du volume, on lit le titre de انيس بلجيس

Ms. daté de l'an 1162 de l'hégire ( 1749 de J. C.).

Papier. 271 feuillets. Hanteur, 23 centimètres et demi; largeur, 16 centimètres et demi. 15 lignes par page. - (Supplément ${ }_{1776 .)}$

\section{3.}

Recueil de légendes et de traditions, divisées en Séances (بالm) et se rattachant à certains passages du Coran. La dernière de ces Séances est intitulée : بـإن . Dans une antre,

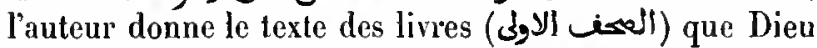
avait révélés à Adam, à Abraham, à Moïse, etc.

Man. orientaux. - If.
Le commencement manque. Le premier feuillet, ajouté après coup, est le commencement de l'histoire du mariage de Mahomet et de Khadidja.

Ms. daté de l'an $119^{1}$ de l'hégire (1777 de J. C.).

Papier. 123 feuillets. Hauteur, a a centimètres; largeur, 15 centimètres et demi. 2, lignes par page. - (Supplément $169^{3}$.)

\section{4.}

Recueil d'anecdotes de divers genres.

Ms. daté de l'an 1146 de l'hégire (1 734 de J. C.). Le commencement manque.

Papier. 433 feuillets. Hauteur, 21 centimètres et demi; largeur, 16 centimètres. 25 liggnes par page. - (Supplément 1 178.)

\section{5 .}

Recueil d'anecdotes qui, dans l'explicit, est intitulé $S a$ fina.

Ms. daté de l'an 1165 de l'hégire (1752 de J. C.).

Papier. 13 feuillets. Hauteur, 21 centimètres; largeur, 16 centimètres. 25 tignes par page. - (Supplément 2189.)

\section{6.}

$1^{\circ}$ Aventures de Mahomet, pendant sa prédication à la Mecque, avec Aboù Sofyàn, Aboû Djahl, Aboû Lahab, Habîb ibn Malik, etc.

$2^{\circ}$ (Fol. $\left.39 \mathrm{v}^{\circ}.\right)$ Histoire de Mahomet et d'Aboû Djalıl.

$3^{\circ}\left(F_{01} 52 v^{\circ}\right.$.) Entretien de Sofyân ibn 'Oyaïna avec Hàroûn al-Raschîd.

$4^{\circ}$ (Fol. 56.) Entretien de Moise avec Dieu sur le mont Sinaï.

$5^{\circ}$ (Fol. 58.) Antre entretien de Moïse avec Dieu.

$6^{\circ}$ (Fol. 6o.) Histoire racontée par un marchand d'esclaves.

$7^{\circ}$ (Fol. 62.) Histoire d'Alì cherchant à emprunter de l'argent en donnant pour gage son sabre appelé $D$ sou ' $l$-Fiqar. Suivent deux autres anecdotes pell importantes.

La fin manque.

Papier. 7o feuillets. Hautenr, go centimètres et demi; largeur, 15 centimètres. Écritures diverses du xvurt $^{\mathrm{e}}$ siècle. - (Supplément 1761$. 


\section{7.}

"Troisième partie d'une colleclion de contes amusants, propres à inilier à la connaissance de la langue usuelle». On y lrouve la fable du Renard et de la cigogne el la fable du Lion et du cheval. La copie de celte dernière n'est pas acherée.

Papier. 6 feuillets. Ilauteur, a 1 centimètres et demi; largeur, 15 centimètres et demi. ${ }_{25} 5$ lignes par page. Us. du uvin' siècle. (Supplément ${ }_{7} 39$. )

\section{8 .}

Recueil d'anecdotes et d'hisloriettes. Ce volume est désigné comme étant le second de l'ouvrage intitulé : بح "21 r mer des histoires n. Les derniers feuillets manquent.

Papier. 259 fenillets. Hauteur, \& 3 centimètres; largenr, 15 cen-

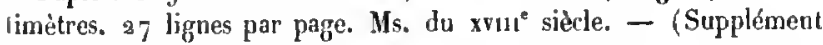
1665.)

\section{9 .}

ب.Mer des histoires». Fables et aneedotes recueillies par Asselin de Cherville, ancien consul de France, au Caire. Ce recueil est tout ì fait différent du précédent.

Papier. 72 feuillets. Hauteur, 23 centimètres et demi; largeur, 17 centimètres. 85 lignes par page. Ms. du xix" siècle. - (Suppléinent 1646.$)$

\section{0 .}

Recneil d'historiettes de la main d'Asselin.

Papier. 337 feuillets. Hauteur, 23 centimètres; largeur, 14 centimètres et demi. ${ }_{2} 3$ à ${ }_{2} 5$ lignes par page. 11 s. du xux ${ }^{e}$ siècle. (Supplément 1667 .)

\section{1 .}

Recueil d'historiettes et de fables de la main d'Asselin.

Papier. 720 feuillets. Hauteur, 17 centimètres et demi; largeur, 12 centimètres et demi. 30 lignes par page. - (Supplément 1 738. )

\section{2 .}

Recueil de fables de la main d'Asselin.

Papier. 114 pages. Hauteur, 23 centimètres; largeur, 14 centimètres et demi. 93 à a 8 lignes par page. Ns. du $x_{1 \times}{ }^{e}$ siècle. (Supplément 1645.)

\section{3.}

Recueil de fables commençant par l'histoire de l'Alouetle et l'éléphant. La dernière fable, le Serpent et le crapaud, n'est pas terminée; les deux feuillets qu'on a ajoutés après coup, contiennent un fragnenl d'un autre conte.

Papier. 135 feuillets. Hlauteur, 17 centimètres et demi; largeur, 10 centimetres et demi, (les feuillets $7^{3}$ et suivants ont 12 centimètres). 16 lignes par page. Ms. du nux siècle. - (Supplément 2197.)

\section{4 .}

Recueil de contes et de fables. Le commencement manque. Le vingt-huitième el dernier chapitre commence par ces mots :

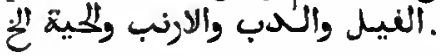

Papier. 199 feuillets. Hanteur, \&1 centimètres et demi; largeur, 16 centimètres. 11 lignes par page. Is. du $x 1 x^{\bullet}$ siècle. - (Supplément 2187. )

\section{CONTES ET ROMANS.}

\section{5 à 3597.}

Les Mille et une nuils. Le premier volmme fiuit au commencement de la $241^{\circ}$ Nuit. Le second volume renferme les Nuits 241 (reproduisant les deux dernières pages du tome 1) à 655 . Le troisième volume renferme les Nuits 656 à 1001 .

3 vol. Papier. 298,479 et 343 feuillets. Hanteur, 33 centimètres ct demi ; largeur, 18 centimètres. 27 lignes par page. Ns. du sıx" siecle. - (Supplément 1717 I-III.)

\section{8 à 3601.}

Même ouvrage. Le premier volume s'arrête au com- 
mencement de la $214^{\circ}$ Nuit. Le second renferme les Nuits 215 à 536 ; le troisième, les nuils 537 à 771 ; le quatrième, les Nuits 772 à 1001 .

4 vol. Papier. $531,334,367$ et 391 feuillets. Hauteur, a a centimètres; largeur, 16 centimètres. 21 lignes par page. Ms. du $x_{1}{ }^{e}$ siècle. - (Supplément 1718 l-IV.)

\section{2 à 3605.}

Hême ouvrage. Le premier volume s'arrête au commencement de la $214^{\circ}$ Nuit. Le second volume commence par la Nuil 218 (les Nuits 214 à 217 manquent), et s'arrête au commencement de la $536^{\mathrm{e}}$ Nuil. Le troisième commence au milieu de la $536^{\circ}$ Nuit et se termine par la $77^{\circ}$ Nuit. Le quatrième volume renferme les Nuits $77^{2}$ à 1001 .

4 vol. Papier. $481,408,414$ et a 45 fenillets. Hauteur, a 1 centimètres et demi; largeur, 16 centimètres. 21 lignes par page. Ms. du xix siècle. - (Supplément 1719 1-IV.)

\section{6 à 3608.}

Même ouvrage. Exemplaire incomplet du deuxième volume. Le premier volume s'arrête à la $219^{\circ}$ Nuit. Le troisième volume commence par les dernières lignes de la $548^{\circ}$ Nuit et s'arrête à la $77^{\circ}$ Nuit. Le quatrième volume renferme les Nuils 771 à 1001 . A la fin du premier volume se trouve un index des contes, écrit au crayon, de la main d'Asselin.

3 vol. Papier. 548, 277 et 416 feuillets. Hauteur, 23 centimètres; largeur, 16 centimètres, 21 lignes par page. - (Supplément $219^{8-}$ 2900.)

\section{9 à 3611.}

Mème ouvrage. Le premier volume s'arrête au milien de la $67^{\circ}$ Nuit; le second commence au milieu de la $67^{\mathrm{e}}$ Nuit et finit par la $166^{\mathrm{e}}$ Nuit; le lroisième commence par ta $167^{\circ}$ Nuit et finit au milieu de la $281^{\circ}$ Nuit. Deux pages, d'écriture moderne, contiennent la fin de

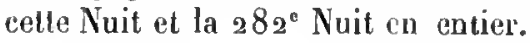

3 vol. Papier. 70,67 et 79 feuillets. Hauteur, 23 centimètres et demi; largeur 16 centimètres (le tome Il a $a 6$ centimètres sur 18 ). ${ }_{2} 5$ lignes par page. Ms. du xnv ${ }^{\circ}$ siècle. - (Ancien fonds 1508, 1507 , 1506.)

\section{2.}

Même ouvrage. Ce volume devait contenir l'ouvrage entier, mais il s'arrête au milieu de la $870^{\circ}$ Nuit. Le copisle a divisé le texte en sections, dont celles qui portaient les numéros $15,16,18,20,21,22,23,25$, 27 , manquent, ainsi que la fin de la $27^{\mathrm{e}}$ section et la section suivante, el il y a encore d'autres lacunes.

Papier. 408 feuillets. Hauteur, 30 centimètres; largeur, a centimètres. 23 lignes par page. Ms. du xvir siècle. - (Ancien fonds $\because 491$ A.)

\section{3 et 3614.}

Même ouvrage. Deux volumes l'enfermant les 231 premières Nuits. A ta fin du premier volume se trouve un feuillet d'écriture orientale qui contient quelques pièces de vers que te copiste avait omises.

a vol. Papier. 120 et 130 feuillets. Hauteur, a 3 centimètres; largeur, 17 centimètres et demi. 19 lignes par page. Ms. du xviu' siècle. - (Supplément 1715 I et I1.)

\section{5.}

Même ouvrage. Volume renfermant les 211 premières Nuits.

Papier. a 31 feuillets. Hauteur, 91 centimètres; largeur, 15 centimètres et demi, 18 à 21 lignes par page. Ms. du xvill siècle. (Supplément 1721 IV.)

\section{6.}

Même ouvrage. Volunte commençant au milieu de fa ${ }_{282^{\mathrm{e}}}$ Nuit et finissant au milieu de la $631^{\circ}$ Nuit.

Papier. 3so feuillets. Hauteur, a 7 centimètres et demi; largeur, 21 centimètres (les 50 premiers feuillets ont a 6 centimètres sur 19). 19 lignes par page. Ms. du xvm1 siècle. - (Supplément ${ }^{1} 7^{16 .)}$

\section{7.}

Même ouvrage. Volume de la main d'Asselin, conmençant par la $285^{\circ}$ Nuit et finissant par la $3{ }_{2} 6^{\mathrm{e}}$ Nuil.

Papier. $9^{4}$ fenillets. Hauteur, 15 centimètres; largeur, 11 centimètres. 18 lignes par page. - (Supplément 1720. ) 


\section{8.}

Même ouvrage. Volume commençant par la $656^{\mathrm{e}}$ Nuit et se terminant par la $1001^{\mathrm{e}}$ Nuit.

Ms. daté de l'an 1211 de l'hégire (1797 de J. C.).

Papier. ${ }_{2} 37$ feuillets. Hauteur, 23 centimètres et demi; largeur, 16 centimètres. 27 à 3o lignes par page. - (Supplément 1721 I11.)

\section{9 .}

Mème ouvrage. Volume commençant au milieu de la $823^{\mathrm{e}}$ Nuit. La $9^{\circ} 9^{\mathrm{e}}$ Nuit est immédiatement suivie de la $1001^{\mathrm{e}}$ Nuit.

Papier. $17^{6}$ feuillets. Hauteur, 21 centimètres; largeur, 15 centimètres. 19 à 21 lignes par page. Ms. du xvı' siècle. - (Supplément 1791 II.)

\section{0 .}

Une vingtaine de conles tirés des Mille et une nuits.

Le commencement manque.

Papier. 99 feuillets. Ilauteur, 18 centimèlres; largeur, 13 centimètres et demi. Environ 12 liggnes par page. Ms. du $\mathbf{x v n}^{e}$ siècle. (Supplément 1721 A.)

\section{1 .}

Histoire de Qamar al-Zamân et de Badr al-Bodoûr. Le commencement et la fin manquent.

Papier. 42 feuillets. Hauteur, 20 centimètres et demi; largeur, 14 centimètres et demi. a 1 lignes par page. Its. du xvis siècle. (Supplément 2202.)

\section{2 .}

Histoire de Qamar al-Zamân el de Badr al-Bodoûr.

Papier. 35 feuillets. Hauteur, 22 centimètres; largeur, 16 centimètres. 19 à 25 lignes par page. Ms. dı xvı" siècle. - (Ancien fonds 1497.)

\section{3.}

$1^{\circ}$ Histoire de Qamar al-Zamân et de Badr al-Bodoûr. Copie datée de l'an 1109 de l'hégire $(1697-1698$ de J. C.). $2^{\circ}$ (Fol. 13.) Ordjoûza renfermant l'histoire du célèbre cheval Al-Maïmoûn, que le Prophète avait procuré à soll gendie 'Alì Iläidar.

Papier. 31 fenillets. Hauteur, 21 centimètres et demi; largeur, 15 centimètres. Écritures diverses. - (Ancien fonds 1499.)

\section{4.}

1 . Histoire du cheval d'ébène (فرس الابنوس).

$2^{\circ}$ (Fol. $27 \mathrm{v}^{\circ}$.) Histoire de Maryam à la ceinture.

$3^{\circ}$ (Fol. 72.) Histoire de Bâsim le forgeron.

Papier. 147 feuillets. Hauteur, 20 centimètres et demi; largeur, 16 centimètres et demi. Écritures diverses du xvir siècle. - (Supplément 1733. )

\section{5 .}

$1^{\circ}$ Histoire du cheval d'ébène.

$2^{\circ}$ (Fol. 26.) Histoire de Salomon, fils de David.

$3^{\circ}$ (Fol. 43.) Histoire des Sept dormants.

$4^{\circ}$ (Fol. 54.) Histoire de la ville d'airain.

Papier. 84 feuillets. Hauteur, 16 centimètres et demi; largeur, 11 centimètres et demi. 17 lignes par page. Mts. du xvme siècle. (Supplément 1740.)

\section{6 .}

Version poétique, en dialecte vulgaire, de l'histoire d'Ons al-IVodjoûd. Commencement : امبح نبينا اللى مليج $z^{24 l}$.

Papier. 34 feuillets. Hauteur, 17 centimètres; largeur, 11 centimètres. 19 à 14 lignes par page. Ms. du xvin' siècle. - (Supplément 1725.)

\section{7.}

Même ouvrage.

Ms. daté de l'an 1218 de l'hégire (1803 de J. C.).

Papier. 33 feuillets. Hauteur, 16 centimètres et demi; largeur, 11 centimètres. $1 /$ à 16 lignes par page. - (Supplément 1734.) 


\section{8 .}

Histoire de la ville d'airain.

Papier. 32 feuillets. IIauteur, 16 centimètres et demi; largeur, 11 centimètres. 7 ligues par page. Ms. du xvu1 siècle. - (Supplément $175 \mathrm{~g}$.)

\section{9 .}

Fragment de l'histoire de Halif et du singe et fragment de l'histoire de Qoût al-Qoloûb.

Papier. 27 feuillets. Hauleur, 16 centimètres ; largeur, 10 centimètres et demi. 15 à 17 lignes par page. Ms. du xvic siècle. (Supplément 2203.)

\section{0 .}

Histoire de la belle esclave Tawaddoud.

Papier. 71 feuillets. Hauteur, 20 centimètres; largeur, 15 centimètres. 15 lignes par page. Mts. du $x v^{\circ}$ siècle. - (Ancien fonds 1505 , Colbert 4436 .)

\section{1 .}

\section{Même ouvrage.}

Papier. 49 feuillets. Hauteur, 19 centimètres; largeur, 14 centimètres. 13 lignes par page. Ms. du xvi siècle. - (Supplément 1722.)

\section{2.}

$1^{\circ}$ Mème ouvrage.

$2^{\circ}$ (Fol. $37 v^{\circ}$.) Traité sur l'enlerrement des morts, inlitulé xalob وصية Mollà Khosrau. En ture.

Papier. 40 feuillets. Hauteur, 20 centimètres et demi; largeur, 14 centimètres. 13 lignes par page. Ms. du xvi" siècte. - (Ancien fonds 1504.)

\section{3 .}

$1^{\circ}$ Histoire de la belle esclave Tawaddoud.

$2^{\circ}$ (Fol. $7_{2} v^{\circ}$.) Prière composée d'extraits du Coran.

Papier. 79 feuillets. Hauteur, 21 centimètres et demi; targeur, 14 centimètres et demi. 17 lignes par page. Ns. du xvu1 siècle. (Supplément 1714.)

\section{4.}

Histoire de Djoudar le pècheur el du sultan Al-Malik al-Zuahir Bîbars.

Papier. 117 feuillets. Hantenr, 30 centinètres et demi; largeur, 15 centimètres. 17 à 31 lignes par page. Diverses écritures du xvı1 siècle. - (Supplément 1751.)

\section{5 .}

Histoire de Gharib et 'Adjib.

Ms. daté de l'an 1097 de l'hégire (1686 de J. C.).

Papier. 104 feuillets. Hauteur, 21 centimètres; largeur, 15 centimètres. 17 lignes par page. - (Supplément 1 713. )

\section{6.}

Autre rédaction du même conte.

Ms. daté de l'an 1194 de l'hégire ( 1780 de J. C.).

Papier. 116 feuillets. Hauteur, 21 centimètres et demi; largeur, 15 centimètres et demi. 17 lignes par parge. - (Supplément 1712.)

\section{7.}

Volume renfermant les contes suivants :

L'histoire des Dix vizirs; l'bisloire du sage Haïqàr; l'histoire du roi Sâboûr; l'histoire de la fille du roi Kisrà ; l'histoire des trois Calenders; l'histoire de Gouluàr de la mer; l'histoire du jeune homme, de la femme interprète et de l'intendante; l'histoire du traiteur el du médecin persan ; l'histoire du Bìmâristân ; l'histoire d"ct tàf; l'histoire du sultan Habîb; l'histoire du calife el du pècheur; l'histoire du coq et du renard; l'hisloire du petit oiseau et du chasseur.

Ms. daté de l'an 1772 de J. C.

Papier. 7 \& pages. Hauteur, 21 centimètres et demi; largeur, 16 centimètres et demi. 15 lignes par page. - (Supplément ${ }_{1792} 3$. )

\section{8.}

Histoire des Dix vizirs.

Ms. daté de l'an 1177 de l'hégire (1 764 de J. C.). 
Papier. 12 feuillets. Hauteur, 21 centimètres et demi; largeur, 15 centimètres. 23 lignes par page. - (Supplément 1790.)

\section{9 .}

Histoire de Sindbàd ou des Sept vizirs.

Papier. 76 fenillets. IJanteur, 30 centimètres et demi; largeur, 15 centimètres et demi. 11 lignes par page. Mts. du xwi" siècle. (Supplément 1791.)

\section{0.}

Histoire de Kal'âd (sleb) roi de l'Inde, et de Schimâs (نثماس) le sage. On y a joint le commencement d'une I raduclion française.

Papier. 78 et 25 pages. Hauteur, 21 centimètres; largeur, 16 cenlimètres. 16 lignes par page. Ms. dı xvı ${ }^{\circ}$ siècle. - (Supplément 21 70.)

\section{1 .}

$1^{\circ}$ Même ourrage.

$2^{\circ}$ (Fol. 42.) Histoire du jeune homme, de la fille du roi et de la femme qui servait d'interprète.

Ms. daté de l'an $179^{2}$ de J. C.

Papier. 45 feuillets. Hauteur, 23 centimètres; largeur, 16 centimètres. 20 à 23 lignes par page. - (Supplément 1742.)

\section{2.}

Histoire de Hasan al-Bașrî.

Ms. daté de l'an 1099 de l'hégire (1687-1688 de J. C.).

Papier. 102 feuillets. Hautenr, 20 centimètres et demi; largenr, 14 centimètres. 15 lignes par page. - (Supplément 1757.)

\section{3.}

Même ouvrage.

Ms. daté de l'an 1153 de l'hégire ( 1740 de J. C.).

Papier. 98 feuillets. Hauteur, 21 centimètres; largeur, 15 centimètres. 15 lignes par page. - (Supplément 1755.)

\section{4.}

Même ouvrage.

Ms. daté de l'an 1198 de l'hégire ( 1784 de J. C.).

Papier. 137 fetillets. Hauteur, 2a à 23 centimètres; largeur, 16 centimètres. 15 lignes par page. - (Supplément 1756.)

\section{5.}

Histoire de Sindbâd le marin et de Hindbâd le porte-faix.

Papier. 42 feuillets. Hauteur, 18 centimètres; largeur, 11 centimètres el demi. 16 lignes par page. Mts. du xvir siècle. - (Ancien fonds 154.7 .)

\section{6.}

$1^{\circ}$ Mềme ouvrage.

$2^{\circ}$ (Fol. $7^{3} \vee^{\circ}$.) Histoire de Noûr al-Din et de la belle esclave.

Papier. 134 feuillets. Hauteur, 15 centimètres; largeur, 10 centimètres et demi. 13 lignes par page. Mts. du xvi' siècle. - (Supplément 1762 bis.)

\section{7.}

Histoire de Sindbâd le marin. La fin manque.

Papier. 40 fenillels. Hanteur, 24 centimètres; largeur, 16 centjmètres et demi. Euviron 19 lignes par page. Ms. du xviu' siècle. (Supplément 2201.)

\section{8.}

Même ouvrage.

Papier. 49 feuillets. Hanteur, 21 centimètres; largeur, 15 centimètres. 20 à 28 lignes par page. Ms. du xvmie siècle. - (Supplément 1762.)

\section{9.}

Commencement du même ouvrage.

Papier. 13 feuillets. Hauteur, 23 centimètres; largeur, 16 centimètres et demi. 23 lignes par page. Ms. du xviı siècle. - (Supplément 2279.) 


\section{0 .}

$1^{\circ}$ Histoire de Sitt Dounyà et de son cousin Noûr alDìn 'Alî. La fin de ce conte manque et quelques feuillets sont transposés.

$2^{\circ}$ (Fol. 45.) Recueil de poésies sans commencement ni fin. Le nom de l'auteur n'y est pas indiqué. Ces pièces de vers traitent des peines de l'amour.

$3^{\circ}$ (Fol. 66.) Fin de l'histoire d'Al-Haiffa (الهيغا), de Yousof al-Hasan, des dix jeunes filles, de Mohammad ibu Manșoùr', d'lbràhìm al-Nadim et de l'émir des croyants Ml-Ma'moûn.

$4^{\circ}$ (Fol. 68.) Prière, amulettes, ete.

$5^{\circ}$ (Fol. 7o.) dutre fragment de l'histoire d'Al-Haïà.

$6^{\circ}$ (Fol. $120 \vee^{\circ}$.) Anulette.

$7^{\circ}$ (Fol. 122.) Autre fragment de l'histoire d'AlHaïfà.

$8^{\circ}$ (Fol. 125.) Anecdotes, pièces de vers, etc.

Papier. 132 feuitlets. Hauteur, a1 centimètres et demi; largeur, 15 centimètres et demi. Ns. du xvir siècle. - (Ancien fonds 1498.$)$

\section{1.}

$1^{\circ}$ Histoire de Noûr al-Din, fils du vizir du sultan Moḷammad ibn Solaïmân al-Zaïnabî, et d'Anîs al-Djalìs.

$2^{\circ}$ (Fol. $27 \mathrm{v}^{\circ}$.) Histoire d'Al-Ward fì 'l-Akmân et d'Ons al-Wodjoùd.

$3^{\circ}$ (Fol. 4o.) Histoire de la ville d'airain.

$4^{\circ}$. (Fol. $76 \mathrm{v}^{\mathbf{0}}$.) Histoire d'une princesse qu'un fils de roi, après avoir voyagé sur mer à sa recherche et soumis les génies à son ordre, parvient à épouser.

$5^{\circ}$ (Fol. 100.) Conte très embrouillé qui se termine par ce renseignement : «Voilà ce qui nous est parvenu du discours d"Alì ibn al-Ḥarrànî $r$.

$6^{\circ}$ (Fol. 119.$)$ Histoire d"Alì ibn al-Zaïyât.

$7^{\circ}$ (Fol. 134.) Histoire d'sAli Zîbaq.

$8^{\circ}$ (Fol. 143.) Hisloire d"Alì ibn al-Moḥsinî.

$9^{\circ}$ (Fol. 146.) Histoire d"Alì al-Toûnisì. Az'ar.

$10^{\circ}$ (Fol. $148 v^{\circ}$.) Histoire du jeune homme nommé

$11^{\circ}$ (Fol. $17^{4} v^{\circ}$.) Histoire du pècheur et du génie. $12^{\circ}$ (Fol. $189 v^{\circ}$. ) Histoire d"Alischâh et de la jeune fille.

$13^{\circ}$ (Fol. 209.) Histoire d'ü saint homme nommé Fadhloûn.

$14^{\circ}$ (Fol. 215.) Histoire d'un homme paresseux et de sa feinme.

$15^{\circ}$ (Fol. 217.) Histoire de la vieille femme et de ses fils.

$16^{\circ}$ (Fol. $218 v^{\circ}$.) Histoire d'un marchand et de sal femme.

$17^{\circ}$ (Fol. 223.) Histoire du mangeur de haschich. La fill manque.

Papier. 225 feuillets. Ilauteur, 20 centimètres et demi; largeur, 15 centimèrres. 19 liggnes par page. Ms. du xviri siècle. - (Supplément 1754 .)

\section{2 .}

$1^{\circ}$ Histoire de Khodja 'Ali l'orfêvre et de Sitt Dỉnàr. $2^{\circ}$ (Fol. 20.) Histoire du roi du Khorâsân et de son fils 'Alì.

$3^{\circ}$ (Fol. $54 v^{\circ}$. ) Histoire d'Abou 'l-Hasan ibn abi Nași al-Nakhkhâl.

$4^{\circ}$ (Fol. $\left.67 v^{\circ}.\right)$ Entretien d'Al-Haddjàdj avec Abou 'l-Monemneın et Al-'Otbân (العوتبان).

$5^{\circ}\left(\right.$ Fol. $81 v^{\circ}$.) Les ruses de Dalíla.

$6^{\circ}$ (Fol. $90 v^{\circ}$.) Entretien de Jésus-Christ avec ull crâne.

$7^{\circ}$ (Fol. 94.) Histoire du capitaine de vaisseau et de la fille du roi des Francs.

$8^{\circ}$ (Fol. 98.) Histoire de Bàsim le forgeron.

$9^{\circ}$ (Fol. 140.) Histoire du fils du roi du Khorâsân dans l'île d'or.

Papier. 156 feuillets. Hauteur, so centimètres et demi; largeur, 14 à 15 centimètres. 21 lignes par page. Ms. du xvi ${ }^{\circ}$ siècle. (Supplément 1734.)

\section{3.}

$1^{\circ}$ Entretien de Babloủl (بها) avee Hâroûn al. Raschîd.

$2^{\circ}$ (Fol. 22.) Entretien d'un médecin avec un jeune homme dans l'hôpital des amants (mystiques) (بيمارستان) . 
$3^{\circ}$ (Fol. $491^{\circ}$.) Histoire de la création de Mahomet, racontée par lui à lbn 'Abbàs, suivie de l'histoire de la mère de Nahọmet, de la. magricienne Kabîla, etc.

Papier, 186 fenillets. Hauteur, 21 centimètres; largeur, 15 centimètres el demi. 9 lignes par page. Ms. du xvin siècle. - (Supplément 1736.$)$

\section{4.}

Histoire d'Ațtàf.

Ms. daté de l'an 1136 de l'hégire (1724 de J. C.).

Papier. 13 feuillets. Hauteur, as centimètres et demi; largeur, 16 centimètres et demi. 22 à 26 lignes par page. - (Supplément 1760$.

\section{5 .}

$1^{\circ}$ Histoire d'un roi de l'Inde et de son fils 'Alì Tehélébi (نُلبى).

$2^{\circ}$ (Fol. $18 \mathrm{v}^{\circ}$.) Histoire de Mohammad Tchélébi.

$3^{\circ}$ (Fol. 32.) Histoire d'un roi et d'un anneau magique qu'il retire du doigt d'une statue de bronze.

$4^{\circ}$ (Fol. 50 v $^{\circ}$.) Histoire de Tamîm al-Dârî.

$5^{\circ}$ (Fol. $5_{7} \mathrm{v}^{\circ}$.) Histoire du pêcheur et du génie.

$6^{\circ}\left(F_{0}\right.$ ol. $68 \mathrm{v}^{\circ}$.) Histoire d'Aboû Nowâs et de Hâroûn al-Raschîd.

$7^{\circ}$ (Fol. 72.) Histoire d'Al-Mohallab ibn abî Șofra.

$8^{\circ}$ (Fol. 81.) Histoire racontée par 'Abd Allah ibn Ma'mar.

$9^{\circ}$ (Fol. 84.) Sur un verset du Coran dont la récitation préserve de tout danger.

$10^{\circ}$ (Fol. $85 v^{\circ}$.) Vers récités par Toûrûn-Schåh l'Aïyonbite après sa mort.

$11^{\circ}$ (Fol. 86.) Histoire d'un vizir qui recherche un homme parfail.

$12^{\circ}$ (Fol. 96.) Histoire de Fadhlàn at-Abìd, dévôt rgui vivait sous le règne d'Omar ilon 'Abd al-'Azìz.

$13^{\circ}$ (Fol. $102 v^{\circ}$. ) Anecdotes diverses.

$14^{\circ}$ (Fol. 103 r. $^{\circ}$ ) Histoire d'Aḷmad ibn Toûloûn.

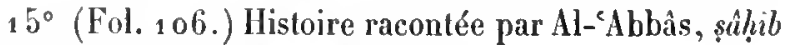
al-schorta dil calife Al-Ma'moûn.

$16^{\circ}$ (Fol. 110.$)$ Entretien de Jésus avec un crâne.

$17^{\circ}$ (Fol. 116.) Entretien d'Al-Haddjâdj avec un jeune bomme. $18^{\circ}$ (Fol. 1 24.) Histoire du chat et du rat.

$19^{\circ}$ (Fol. $126 \mathrm{v}^{\circ}$.) Histoire du chasseur et du petit oiseau.

$20^{\circ}$ (Fol. 131.) Pièces de vers et modèles de lettres.

$21^{\circ}$ (Fol. $139 v^{\circ}$.) Histoire de deux frères, adorateurs du feu.

Papier. 143 feuillets. Hauteur, 22 centimètres; largeur, 15 cenlimètres et demi. 19 lignes par page. Ms. du xvm1 siècle. - (Supplément 1792.)

\section{6.}

$1^{\circ}$ Fragment de l'histoire du mangeul de haschich et du cadi Zeqâzeq (ïj)

$2^{\circ}$ (Fol. 5.) Fragment de l'histoire d'Aboù Nowâs el de Hâroûn at-Raschîd.

$3^{\circ}$ (Fol. 19.) Fragment de l'histoire de Salomon.

$4^{\circ}$ (Fol. $32 v^{\circ}$.) Histoire du sage Ḩaïqâr.

$5^{\circ}$ (Fol. 47.) Histoire du coq et du renard.

Papier. 48 feuillets. Hauteur, 20 à 22 centimètres; largeur, 14 à 15 centimètres et demi. Écrilures diverses du xvin" siècle. - (Supplément 2a10.)

\section{7.}

Histoire du roi Schâhremân, de son vizir Azdehâr, du prince Aḥmad et de Schams al-Nahâr.

Papier. 21 feuillets. Hauteur, 2 a centimètres; largeur, 16 centimètres. 21 à 26 lignes par page. Ms. du xvm" siècle. - (Supplément 2213.)

\section{8.}

1 . Histoire d'une jeune fille morte et enterrée qui fut retirée du tombeau par son amant et rendue à la vie.

$2^{\circ}$ (Fol. 6.) Histoire d'Ibràhîm ibn al-Mahdì et d'AlFadhl ibn al-Rabíci.

$3^{\circ}$ (Fol. 17.) Histoire d'Ibn al-Mo allim el de la fille du Baïsarí.

$4^{\circ}$ (Fol. $26 \mathrm{v}^{\circ}$.) Histoire de Hâroun al-Paschìd et du marcliand de foqqde.

5० (Fol. 34.) Histoire d'Al-Aṣmái el du tailleur.

$6^{\circ}$ (Fol. 41.) Histoire de la jeune fille Qout al-Qoloub et de la dame Zobaida. 
$7^{\circ}$ (Fol. 49.) Histoire d'un pauvre.

$8^{\circ}$ (Fol. 55.) Histoire de Noûr al-Dîn de Damas.

$9^{\circ}$ (Fol. $66 v^{\circ}$.) Histoire d'Al-Iskandarì le tailleur.

$10^{\circ}\left(\right.$ Fol. $74 \mathrm{v}^{\circ}$.) Histoire du jeune homme qui vend sa belle esclave.

$11^{\circ}$ (Fol. 77.) Histoire d'Al-Ḥaddjâdj et de Hind, fille d'Al-No'mân.

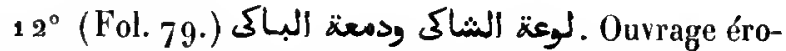
tique attribué, dans cet exemplaire, à Șalàh al-Dín alSafadì.

Papirr. 107 feuillets. Hauteur, 2o centimètres et demi; largeur, 14 centimèlres et demi. 15 à 17 lignes par page. Ms. du xvu siècle. - (Supptément 1807.)

\section{9 .}

Aventures des princesses Ghoṣoûn al-Ward, Qamar al-Asclidjâr, Badr al-Zamàn et Tìdjân avec le roi Ghoşoûn al-Bàn, seigneur de la ville de Kerdjâna (كرجانه) et du pays d'Al-Kordj (الكك)). La fin manque.

Papier. 110 feuillets. Hauteur, as centimètres; largeur, 16 centimètres. so à a 8 lignes par page. Écritures diverses du xvi" siècle. - (Supplémenl 1721 V.)

\section{0.}

$1^{\circ}$ Recueil de contes portant le titre de ites Cent et une nuits n.

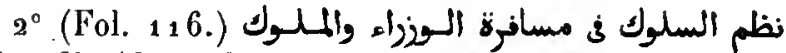
«Les fils (de perles) arrangés, à l'usage de ceux qui voyagent avec des vizirs et des rois conles.

Papier. 201 feuillets. Hauteur, 21 centimètres; largeur, 16 centimètres et demi. 15 lignes par page. Ms. du rvin' siècle. - (Supplément $17^{28 .}$ )

\section{1.}

Autre recueil de coutes portant le titre de $\pi$ Les Cent et une nuits .

Papier. 118 feuillets. Hauteur, 20 centimètres; largeur, 15 centimètres. 19 lignes par page. Ns. du xix siècle. - (Supplément a500.)

Max. ORIEstaux. - II.

\section{2 .}

$1^{\circ}$ Recueil de contes: Histoire de Ḥayât al-Nofoûs et d'Ardeschîr; histoire de Ilàroùn al-Raschîd et d'Ilun Manşoûr; histoire de Hind et de Bisehr; histoire d'Ons al-Wodjoûd; histoire de Schams al-Nahâr et du prince Aḥmad; histoire de la ville d'airain, etc.

$2^{\circ}\left(\right.$ Fol. $153 v^{\circ}$.) Autre version des $\pi$ Cent et une nuits?.

Ms. daté de l'an 1190 de l'hégire $\left(177^{6}\right.$ de J. C.).

Papier. 234 feuillets. Hauteur, 25 centimètres; largeur, 18 cenlimètres. 26 lignes par page. - (Supplément $173 \mathrm{t}$.)

\section{3.}

$1^{\circ}$ Hisloire du prêtre Nașîr d'Alexandrie et de sol fils Mare.

$2^{\circ}\left(\right.$ Fol. $68 v^{\circ}$.) Divers extraits de la main d'un Européen.

$3^{\circ}$ (Fol. 70 v $^{\circ}$.) Divan d'Ibn 'Aroûs.

$4^{\circ}$ (Fol. $\left.8, v^{\circ}.\right)$ Histoire du faux calife.

$5^{\circ}$ (Fol. 124.) Chanson lurque suivie de la Iraduction française.

$6^{\circ}$ (Fol. 125.) Insch $\hat{t}$, ou formulaire de lettres.

$7^{\circ}\left(F_{0} .134 v^{\circ}\right.$.) Noms des astres et des signes $d u$ zodiaque, en arabe et en français.

$8^{\circ}\left(\right.$ Fol. $135 v^{\circ}$.) Copie d'un traité conclu entre la Porte et la France et daté de l'an 1153 de l'hégire ( 1740 de J. C.). En ture.

$9^{\circ}$ (Fol. $146 v^{\circ}$.) Quelques exIraits de la main d'un Européen.

$10^{\circ}$ (Fol. 149.) Explication en vers des mots appelés المثلّثنات par r Gabriel, moine du mont Liban n.

$11^{\circ}$ (Fol. 156.) Notes et extraits; écriture européenue.

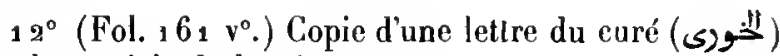
Nicolas, suivie de la réponse.

Papier. 169 feuillets. Hauteur, 23 centimètres, largeur, 17 centimètres. Écritures diverses du xvm1 $1^{\circ}$ siècle. - (Supplément 1923.)

\section{4.}

$1^{\circ}$ Histoire du fils du marchand el du petit oiseau. 
$2^{\circ}$ (Fol. 11.) Histoire de Hosaïna, du chef de la police, du cadi, du gouverneur et du vizir.

$3^{\circ}$ (Fol. 59.) Histoire d'Al-lladdjâdj et du jeune homme.

$4^{\circ}\left(\right.$ Fol. $7^{6} \mathrm{v}^{\circ}$.) Histoire d'Ml-Haddjâdj et de l'Arabe du désert.

$5^{\circ}\left(F_{0} g_{0} 6 v^{\circ}\right.$ ) Histoire du roi Schâhremân et de son fils, l'émir Ahmad.

$6^{\circ}$ (Fol. $134 \mathrm{v}^{\circ}$.) Histoire d'Al-llaïfà el de Yoùsof.

$7^{\circ}$ (fiol. 231.) Histoire du saint homme Fadhloùn.

$8^{\circ}$ (Fol. 241.) Histoire de Tamim al-Dârî.

$9^{\circ}$ (Fol. $280 v^{\circ}$.) Histoire de l'habitant de Koufa et de l'habitant de Baghdâd.

$10^{\circ}$ (Fol. 294.) Histoire d'Al-liasan al-Bașrî et de l'adorateur' du feu.

$11^{\circ}$ (Fol. $295 \mathrm{v}^{\circ}$.) Histoire du patriarche Job.

Papier. 304 feuillets. Hauteur, 31 centimètres; largeur, 16 centimètres. s a lignes par page. USs. du xux sièele. -(Supplément 174 2.)

\section{5 .}

Histoire de Tamìm al-Dàrì.

Ms. daté de l'an 994 de l'hégire (1586 de J. C.).

Papier. 15 feuillets. Hauteur, 27 centimètres et demi; largeur, go centimètres el demi. 33 lignes par page. - (Aneien fonds 1490.$)$

\section{6.}

Nême ouvroge.

Papier. 18 feuillets. Hauteur, 16 centimètres el demi; largeur, 10 eentimètres et demi. 13 lignes par page. Ms. du xur sic̀cle. (Supplément 1694 .)

\section{7 .}

1 . Histoire de Salomon, fils de David.

$2^{\circ}$ (Fol. 16.) Histoire du chasseur et du petit oiscau.

$3^{\circ}$ (Fol. 19.) Histoire du Curde et de sa valise (ج) . Au commencement il y a une petite lacume.

$4^{\circ}$ (Fol. $24 v^{\circ}$.) Histoire du marchand et du roi.

$5^{\circ}$ (Fol. $23 v^{\circ}$.) Histoire de l'intendante, de la femme interprite et du fils du roi. $6^{\circ}\left(\right.$ Fol. $3 v_{1} v^{\circ}$.) Histoire de Sindbâd le marin.

$7^{\circ}$ (Fol. 62.) Commencement de l'histoire du cheral d'ébène.

Ms. daté de l'an 1089 de l'hégire $(1678$ de J. C. $)$.

papier. 62 feuillets. Hauteur, 24 centimètres et demi; targeur, 10 centimètres. 25 lignes par page. - (Supplément 1735.)

\section{8 .}

$1^{\circ}$ Histoire de la malédiction de Cham par son père Noé et conscils de Noé adressés à son fils Sem. En tête on lit ce titre : كناب الفنتوح ف اخبار نوح.

$2^{\circ}$ (Fol. 10.) Histoire d"Abd al-Raḥmân ibn Zaịd et de son jeune esclave.

$3^{\circ}$ (Fol. $\left.12 \vee^{\circ}.\right)$ Récit fait par le saint homme Dlıou 'l-Noûn al-Mișrî.

$4^{\circ}$ (Fol. 15.) Histoire du schaikh 'Abd al-'Aziz et du lion qui accomplissait la prière comme un rrai croyant.

$5^{\circ}$ (Fol. 18.) Histoire de Hàroûn al-Raschid et de Sìdì 'Alî l'orfèrre.

$6^{\circ}$ (Fol. 52.) Quelques vers renfermant des énigmes.

$7^{\circ}$ (Fol. 53.) Récit de la conquête de la ville d'airain.

Le premier feuillet porte la liste des chapitres; to second, des notes sans imporlance et le troisième: la représentation d'un palais.

Ms. daté de l'an 1146 de l'hégire (1733 de J. C.).

Papier. 107 feuillets. Hauteur, a centimètres; largeur, 16 tentimètres et demi. 9 lignes par pagre. - (Supplément 7758. .)

\section{9 .}

$1^{\circ}$ Aventures de Zaïd ibn 'Âmill al-Kininî.

$2^{\circ}\left(\mathrm{Fol}_{\mathrm{o}} .32 \mathrm{v}^{\circ}\right.$.) Histoire des iles de l'ambre gris.

$3^{\circ}$ (Fol. $3_{7} v^{\circ}$.) Histoire de l’ile des émerandes.

$4^{\circ}$ (Fol. 43.) Les nerveilles de la mer.

5ظم المسلوك .

$6^{\circ}$ (Fol. 58.) Receltes de magie.

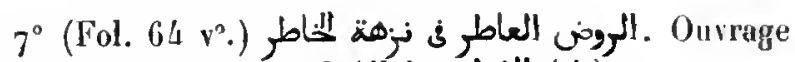

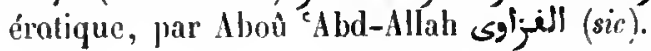


$8^{\circ}$ (Fol. $9^{4} v^{\circ}$.) Histoire du jeune homme de Cordoue et de Zahrat al-Azhâr.

Papier. ${ }_{0} 0$ fcuillets. Hauteur, ${ }_{2} 6$ centimètres; largeur, 16 centimètres. 29 lignes par page. Ms. du $x v 1^{\circ}$ siècle (l'article $8^{\circ}$ est d'une antre écriture). - (Supplément 1949.)

\section{0 .}

$1^{\circ}$ Comment le sultan Noûr al-Din entoura d'un fossé rempli de plomb l'Enclos sacré, (المجئية النثريغة), où est enterré Mahomet.

$2^{\circ}$ (Fol. 3.) Histoire de Sindbàd ou des Sept vizirs. Le commencement manque.

$3^{\circ}$ (Fol. 18.) Commencement de l'histoire de Hàroûn at-Raschìd et de la femme arabe.

Papicr. 18 feuillets. Hauteur, 21 centimètres et demi; largeur, 16 centimètres. a/ lignes par page. Ms. du xviı" siècle. - (Supplément 2919.)

\section{1 .}

ماجبريات Recueil de contes, au nombre de vingtcinq, ayant pour sujet les aventures amoureuses et les ruses des femmes. L'auteur, qui ne se nomme pas et qui écrivait après la mort du sultan mamelouk, Qalaoun (1 $29^{\circ}$ de J. C.), emploie beaucoup de tournures vulgaires dans ces récits. 11 n'est pas certain que le titre inscrit en or et en couleurs sur le recto du pre-

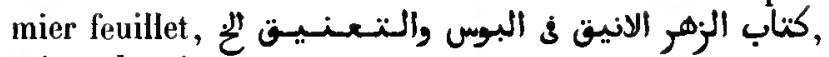
soit authentique.

Papier. 116 fenillets. Hauteur, 18 centimètres; largeur, 13 contimètres. 13 lignes par page. Ms. du $\mathbf{s v}^{*}$ siècle. - (Ancicu fonds 1464.)

\section{2.}

Histoire de Madjnoûn et Laila, comprenant le divan de Madjnoûn, par Aboû Bakr al-Wàlibî (الوالبى).

Papicr. 58 feuillets. Hauteur, 21 centimètres et demi; largeur, 14 centimètres et demi. 15 lignes par page. Ms. du xvi" siècle. (Supplément ${ }_{1595}$.)

\section{3.}

Même ouvrage.
Papier. 45 feuillets. Hauteur, 20 centimètres et demi; largeur, 14 centimètres. 19 lignes par page. Ms. du xvir siècle. - (Supplément $\left.{ }_{1} 67_{6} 6.\right)$

\section{4.}

Histoire de Madjnoûn et Laïla (avec le divan), com-

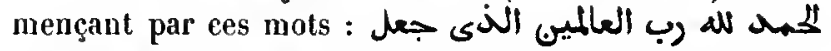

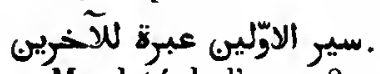

Ms. daté de l'an 1080 de l'hégire (1668 de J. C.).

Papier. 108 pages. Hauteur, 20 centimètres; largeur, 14 centimètres et demi. 15 lignes par page. - (Supplément 1677.)

\section{5.}

Histoire de Yoûsof et d'Al-Haîfâ. Le commencement manque.

Papier. 38 feuillets. Hauteur, 21 contimètres et demi; largeur, 15 cenlimètres. 13 lignes par page. NIs. du xvı" siècle. - (Supplément 1729.)

\section{6.}

Mème ouvrage.

Papier. 114 feuillets. Hatteur, so centimètres et demi; largeur, 15 centimètres. 13 lignes par page. Ms. du xix siècle. - (Supplément 1730 .)

\section{7.}

\section{Roman de Saîl al-Tìdjân.}

Papier. 137 feuillets. Hauteur, 18 centimètres et demi; largenr, 14 centimètres. Diverses écritures du svi" siècle. - (Supplément 1726.)

\section{8.}

1. Roman intitulé

$2^{\circ}$ (Fol. 6g.) Histoire de Sailf al-Tidjân, en vingtdeux clıapitres (umb).

Papier. 947 feuillets. Hauteur, 29 centimètres et demi; largeur, 17 centimètres. 15 lignes par page. Ms. du xvin" siècle. - (Supplément 1797.) 


\section{9.}

Fragment d'un roman, dont la scène est placée en Égypte. Les personnages qui y figurent sont Maümoûn, Aboû Tidj et le roi d'Osiout.

Papier. 4 feuillets. Ilauteur, 20 centimètres et demi; largeur, 15 centimètres. 17 lignes par page. Ms. du xvı" siècle. - (Supplément 2383. )

\section{0.}

Litala de Chateaubriand, traduit en arabe par le prètre 'Îsâ Petro, sous la direction d'Asselin de Cherville.

Papier. 69 feuillets. Hauteur, 22 centimètres et demi; largeur, 15 centimètres. 27 lignes par page. Ms. du xix siècle. - (Supplément 1764.)

\section{ROMLNS DE CHEVALERIE.}

\section{1 .}

Histoire d'Alexandre le Grand, traduite du grec par un chrétien melkite, qui dit avoir achevé son travail en 1660 de J. C. Lourrage commence par l'aventure d'Olympias el de l'astrologue égyptien Nectanébo, et parait ètre la traduction de l'une des rédactions du pseudoCallisthène.

Papier. 116 feuillets. Hanteur, 21 centimètres; largeur, 15 centimètres, 17 ligunes par page. Ms. du xvı" siècle. - (Supplément : 679.$)$

\section{2 .}

Histoire d'Alexandre. L'auteur' est nommé Abou 'l-Faradj al-Șonirì (الصو, au commencement, de la rédaction contenue dans les trois nuss. suivants et dans la plupart des mss. comuns. ثأن حهيث :

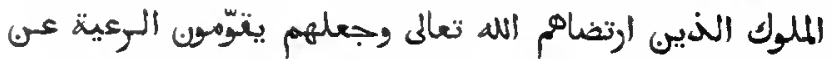

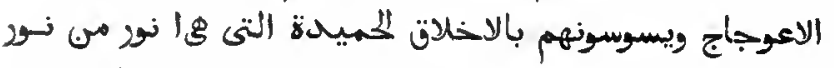

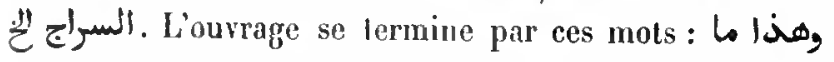

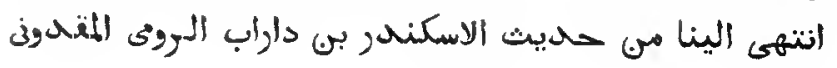

$$
\begin{aligned}
& \text { على التمام والكهال تمت هذه السيرة المـبـاركة ف وأبـع شـهـر }
\end{aligned}
$$

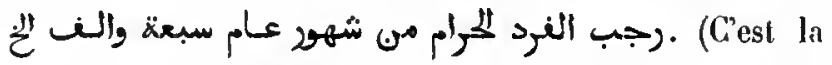
date de la copie des 50 derniers fenillets.)

Papier. 360 feuillets. Hauteur, 30 centimètres; largeur, 20 centimètres et demi. 21 lignes par page. Ms. du xvi" siècle. - (Ancien fonds 707. )

\section{3.}

Même ouvrage. L'auteur est nommé Ibrâhìm ibn Moufarradj.

Ms. daté de l'an 1053 de l'hégire (1643 de J. C.).

Papier. 359 feuillets. Hauteur, 20 centimètres; largeur, 15 centimètres et demi. 21 lignes par page. - (Supplément 1681.)

\section{4.}

Mème ouvrage. Le nom de l'auteur est donné ainsi: Aloû Jsḥåq al-Moufarradj.

Papier. 395 feuillets. Hauteur, a9 centimètres el demi; largenr, zo centimètres. 21 lignes par page. Ms. du vvı' siècle. - (Supplé. ment 1680. )

\section{5 .}

Première partie du même ouvrage. En marge un assez grand nombre d'annotations de la main de Gilbert Gaulmin.

Ms. daté de l'an 961 de l'hégire ( 1554 de J. C.).

Papier. 239 feuillets. Hatiteur, 21 centimètres et demi; largeur, 15 centimètres. 17 lignes par page. - (Ancien fonds 1494.)

\section{6.}

Autre roman d'Alexandre. Le commencement et la fin manquent.

Papier. 187 feuillets. Hauteur, 26 centimètres; largeur, 18 centimètres et demi. 21 lignes par page. Ms. du $x v^{\circ}$ siècle. - (Supplément 1682.)

\section{7.}

Histoire d'Ilexandre dsou 'l-Qarnaïn, par un anonyme. 
Ge roman renferme différentes lettres d'Alexandre et une lettre adresséc par Darius à l'empereur Tibère.

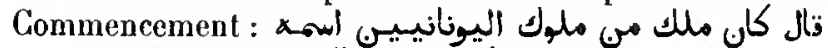

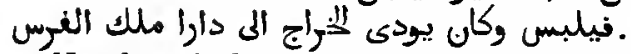

Ms. daté de l'an 1104 de l'hégire ( $169^{3}$ de J. C.).

Papier. 116 feuillets. Hauteur, a2 rentimètres ; largeur, 16 centjmètres. 17 lignes par page. - (Ancien fonds $1494 \mathrm{~A}$.)

\section{8 ì 3698 .}

Roman d"Antar. Copie exécutée à Constanlinople par les soins de Cardin de Cardonne, drogman de l'ambassade française. Le copiste, le P. Philippos, curé de la nation grecque, avait entre les mains deux exemplaires, l'un appartenant à la rédaction de Syrie, l'autre à la rédaction du Ịidjàz, et il a choisi les leçons qui lui paraissaient préférables. Seulement il a condensé la narration et supprimé quelques répétitions. Le $\mathrm{I}$. XI renferme la table des chapitres.

11 vol. Papier. 319, 3æ1, 351, 986, 350, 370, 359, 337, 987, 319 et 24 fenillets. Hauteur, 28 centimètres; largeur, 20 centimètres. ${ }_{7} 7$ lignes par page. Isss. du xvir siècle. - (Supplément 1683.)

\section{9 ฉ 3734.}

Même ouvrage. Exemplaire composé de volumes dépareillés.

36 vol. Papier. 78, 53, 91, 96, 97,81, 100, 103, 139,106 , $66,67,148,162,9^{\circ}, 79,20,79,75,44,100,76,87,19$, $84,26,100,18,71,83,97,92,123,89,99$ et 77 feuillets. IIss. de divers formats et de diverses écritures du xvı el dı vvur siècle. - (Supplément $329^{4-2329}$.)

\section{5 à 3758.}

Même ourrage. Les volumes proviennent de drux exemplaires différents qui n'étaient pas divisés de la même manière. Il y a quelques lacunes.

24 vol. Papier. 97, 58, 90, 100, 53, 92, 79,80, 94, 101, $9^{6}, 9^{6}, 62,111,9^{8}, 97,130,100,9^{2}, 91,69,80,102$ et 10 ? feuillets. Hauteur, 2a à a4 centimètres; largeur, 15 à 16 centimètres. Mss. de diverses écritıres du xvn" et du xvı" sièele - (Supplément 1684.)

\section{9 à 3782.}

Diverses parlies du même ourrage.
24 vol. Papier. $60,114,107,81,50,77,83,70,58,77,74$, $60,68,55,60,82,64,74,59,48,51,61,87$ et 67 feuillets. llauteur, a centimètres et demi; largeur, 17 centimètres. Diverses écritures du xvut" sièclo. - (Supplément 1685.)

\section{3 à 3789.}

Volumes dépareillés et incomplets du même ouvrage.

7 vol. Papier. 71, 69, 94, 71, 55, 69 et 49 feuillets. Mss. de dive:s formats et de diverses écritures du sviı el xvin' siècle. - (Supplément 1691.$)$

\section{0 et 3791.}

Les deux premiers volumes du même ouvrage. Il ne parait manquer qu'un troisième volume.

a vol. Papier. 30 o et 3 oo feuillets. Itautenr, a 1 centimètres; largeur, 15 centimètres. Mss. du xve siècle. - (Ancien fonds 1521 et 1522.$)$

\section{2.}

Première partie (l'histoire de l'origine des Arabes et I'histoire d'Abraham) du même ouvrage. Le commencement manque. Les quatre derniers fenillets appartiennent à un autre ms.

Papier. 40 feuillets. Hauteur, a centimètres; largeur, 15 centimétres. 97 lignes par page. Ms. dı vru’ sjècle. - (Supplément 2908.)

\section{3 et 3794 .}

Deux volumes dépareillés du mème ouvrage.

2 vol. Papier. 43 et 37 feuillets. Hauteur, 2 a centimètres et demi; largeur, 17 centimètres. 26 à 28 lignes par page. Mss. du svin siècte. - (Supplément a415 et 2415 bis.)

\section{5 .}

Volume dépareillé du mème ouvrage. Il est désigné comme étant le quatrième livre (كتاب).

Papier. 72 feuillets. Hauteur, ${ }_{2} 5$ centimètres; largeur, ${ }_{7} 7$ centimètres. 20 à a 4 lignes par page. - (Supplément 2415 ter.) 


\section{6.}

Volume dépareillé du mème ouvrage. La fin manque.

Papier. 69 feuillets. Ilauteur, 16 centimètres; largeur, 11 centimètres. 13 à 15 lignes par page. Ms. du xvuı" siècle. - (Supplément 2204.)

\section{7.}

Dixième volume d'un exemplaire du même ouvrage. Il y a des lacunes.

Papier. 71 feuillets. Hauteur, 2 a centimètres; largeur, 16 centimètres. 95 à 27 lignes par page. Ms. du xmo siècle. - (Supplément 2205.)

\section{8.}

Quinzième volume d'un exemplaire du même ouvrage.

Ms. daté de l'an 848 de l'hégire (1444 de J. C.).

Papier. 98 feuillets. Hauteur, 18 centimètres; largeur, 14 centimètres. 16 lignes par page. - (Supplément 1689.)

\section{9.}

Volume dépareillé du même ouvrage. Les premiers feuillets manquent.

Papier. 67 feuillets. Hauteur, 22 centimètres; largeur, 16 centimètres. Environ 27 lignes par page. Ms. do xvir siècle. - (Supplément 2206.)

\section{0 .}

Vingt-septième volume d'un exemplaire du même ouvrage. Il y a plusieurs lacunes.

Papier. 36 feuillets. Hauteur, a a centimètres et demi; largeur, 16 centimètres. 2a d̀ 97 lignes par page. Ms. du rvil siècle. (Supplément 2207.)

\section{1.}

Vingt-neuvième volume d'un exemplaire du même ouvrage.

Papier. 69 feuillets. Hauteur, 22 centimètres el demi; largeur,
16 centimètres. 27 lignes par page. Ms. du svü siècle. - (Supplément 1687.)

\section{2 .}

Volume dépareillé du même ouvrage.

Papier. 67 feuillets. Hauleur, 22 centimètres et demi; largeur, 16 centimètres. 95 à a 7 lignes par page. $M t s$. du xvur siècle. (Supplément 1687 bis.)

\section{3 .}

Fragment du même ouvrage.

Papier. 49 feuillets. Hauteur, 22 centimètres et demi; largeur, 16 centimètres. 17 d̀ 19 lignes par page. - (Supplément 1687 ter.)

\section{4.}

Fragment du même ourrage.

Papier, 76 feuillets. Hauteur, 15 centimètres; largeur, 10 centimètres. Diverses écritures du xvil' siècle. - (Supplément 1688 .)

\section{5 .}

Fragment du même ouvrage.

Papier. 50 feuillets. Hauteur, 20 à 21 centimètres; largeur, 13 à 15 centimètres. Diverses écritures du xvi' siècle. - (Supplément 3209.)

\section{6 .}

Fragnient du même ouvrage.

Papier. 58 feuillets. Hauteur, 22 centimètres; largeur, 16 centimètres. Écritures diverses. - (Supplément 1686.)

\section{7.}

Fragment du mêıne ouvrage.

Papier. 57 feuillets. Hauteur, 23 centimètres; largeur, 16 centimètres. Ecritures diverses. - (Supplément 1686 bis.) 


\section{8.}

Fragment du même ouvrage.

Papier. $7^{2}$ feuillets. Hauleur, 21 centimètres; largeur, 15 centimètres et demi. Écritures diverses. - (Supplèment $1686 \mathrm{ter}$.)

\section{9 .}

Cinq dessins à la plume et à l'encre de Chine, représentant des scènes du roman d'Antar.

Papier. 5 feuillets. Hauteur, 20 centimètres; largeur, 16 centimètres. - (Supplément 2350 .)

\section{0 et 3811 .}

Première et seconde parties du roman de Saif dsou 'lYazan, d'après la rédaction du scliaïkh Abou 'l-Ma álì. أبو الامصار وسابق: Le héros est désigné par les titres de

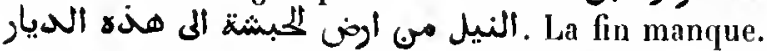

2 vol. Papier. 91 et 171 feuillets. Irauleur, 9 I centimètres; lar. geur, 15 centimètres et deni. 19 lignes par page. Ms. du vvu siècle. - (Supplément 1 709.)

\section{2 et 3813.}

Mème ouvrage.

Ms. daté de l'an 1197 de l'hégire ( 1783 de J. C.).

a vol. Papier. 366 et 366 feuillets. Hanteur, 31 centimètres et demi; largeur, 16 centinètres. 15 lignes par page - Supplément i 705.)

\section{4.}

Première partie du même ouvrage.

Papier. 145 feuillets. Hauteur, so centimètres et demi; largeur, 1 s centimètres et demi. I 3 lignes par page. Ms. du xvı' siècle. (Supplément 1707.)

\section{5 .}

Volune incomplet du même ouvrage.

Papier. 337 feuillets. Hauteur, a a centimètres; largeur, 15 centimètres et demi. Environ 17 lignes par page. Ms. du svuí siècle. (Supplément 1706.)

\section{6 et 3817 .}

Volumes dépareillés du même ouvrage.

2 vol. Papier. 127 et 154 fenillets. Hauleur, 21 centimètres; largeur, 15 centimètres. 17 lignes par page. Mss. dn $\mathbf{x w}^{\circ}$ siècle. - (Supplément 1704.)

\section{8 .}

Volume dépareillé du même ourage. Le commencement et la fin manquenI.

Papier. 184 feuillets. Hauteur, 21 centimèlres; largeur, 15 centimètres. 13 lignes par page. Ns. du xviI" siècle. - (Supplément 2211

\section{9 .}

Troisième partie du même ouvrage.

Papier. 107 feuillets. Hanteur, a 1 centimètres; largeur, 15 cenlimètres et demi. 17 lignes par page. Ms. du xvme siècle. - (Supplément 1710.$)$

\section{0.}

Dernière partie du même ouvrage.

Papier. ${ }_{173}$ feuillets. Hauteur, 23 centimètres; largeur, 16 centimètres et demi. Environ 16 lignes par page. Hs. dn ivin siècle. (Supplément 1708.)

\section{1.}

Aventures du Tobbite, lroi du Yemell n. Roman historique commençant par ces paroles

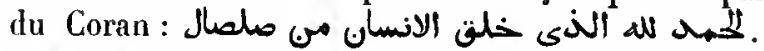

Ms. daté de l'an 1142 de l'hégire (1729 de J. C.).

Papier. 182 feuillets. Hauteur, a centimètres; largeur, 15 centimètres et demi. 23 lignes par page. - (Supplément ${ }_{16}{ }_{7} 8$.)

\section{2 .}

Histoire du chel expérimenté Sàlem al-Zìrn. Roman dont la scène est placée tantôt en Arabie, tantòt en Abyssinie, tantôt dans le Hauràn, antérieurement à l'islamisme. L'ouvrage se 
compose d'un grand nombre de qașidas rattachées les unes aux autres par des récits en prose. L'auteur commence par l'histoire de Morra et de Rabîa, chefs de la tribu de Qaïs, habilant la Syrie.

Papier. 136 feuillets. Hauteur, a 1 centimètres; largeur, 15 centimètres et demi. 23 lignes par page. Ms. du xux" siècle. - (Supplément $169^{2}$ bis.)

\section{3 .}

Histoire des guerres de Mahomet et des hauts faits de ses compagnons. Vers la fin du volume se trouve le récit de la mort de Râs al-Ghoûl, tué par 'Alî. C'est un volume détaclé d'un grand ouvrage. Le commencement manque.

Papier. 125 feuillets. Hauteur, a 1 centimètres; largeur, 15 centimètres. Environ 19 lignes par page. Ms. du xvme siècle. - (Supplément 1692 .)

\section{4 à 3829 .}

Les six premiers volumes du roman de Hamza le lıéros. L'auteur est nommé Aḥmad ibn Mohammad Abou 'l-Macâlî al-Koûfi.

Le quatrième volume est daté de l'an 1069 de l'bégire ( 1659 de J. C.)

6 vol. Papier. $90,69,71,66,67$ et 74 feuillets. Hauteur, 21 centimètres; largeur, 15 centimètres. 19 lignes par page. Mss. $\mathrm{du}$ xvu' siècle. - (Ancien fonds 1512 à 1516 et 1523, Colbert 4808-11813.)

\section{0 .}

Seplième rolume du même ouvrage.

Papier. 61 feuillets. Hauteur, 21 centimètres; largeur, 15 centimètres el demi. Écritures diverses du $x^{\prime \prime}{ }^{\circ}$ siècle. - (Ancien fonds 1524 , Colbert 48.4.)

\section{1 ¿̀ 3833.}

Huitième, neuvième et dixième volumes du même ouvrage.

3 vol. Papier. 80,88 et $7^{3}$ feuillets. Hauteur, 20 centimètres; largeur, 15 centimètres. Environ 20 lignes par page. Mss. du xvu' siècle. - (Ancien fonds $1517-1519$, Colbert 4815-4817.)

\section{4.}

Onzième volume du même ouvrage.

Papier. 103 fenillets. Hauteur, a 1 centimètres; largeur, 15 centimètres. 19 lignes par page. Ms. du xvin" siècle. - (Ancien fonds 1520, Colbert 4818.)

\section{5 et 3836 .}

Deux volumes du même ouvrage.

2 vol. Papier. 109 et 108 feuillets. Hauteur, 23 centımètres; largeur, 16 centimètres. 13 lignes par page. Miss. du xvinie siècle. - (Supplément 1695 et 1695 A.)

\section{7.}

Histoire de la conquête du Yemen par 'Alì, fils d'Aboủ Tâlib, attribuée, dans cet exemplaire, à Badr al-Dìn ibn Hischâm.

Papier. 82 feuillets. Hauteur, a a centimètres et demi; largeur, 16 cenlimètres. 17 lignes par page. Ms. du svi" siècle. - (Supplément 768.)

\section{8.}

Autre rédaction du mème ouvrage.

Ms. daté de l'an 1111 de l'hégire (1699-1 700 de J. C.).

Papier. 78 feuillets. Hauteur, 20 centimètres et demi; largeur, 15 centimètres el demi. 19 lignes par page. - (Supplément 769.)

\section{9.}

Aulre rédaction du même ouvrage, en quatre parties. L'auteur est nommé Abou 'l-Ḥasan al-Bakrì.

Ms. daté de l'an ${ }_{1}{ }_{1} 5$ de l'hégire (1 $761-1762$ de J. C.).

Papier. 126 feuillets. Hauteur, 22 centimètres; largeur, 16 cenlimètres. 33 lignes par page. - (Supplément 1696.)

\section{0 à 3851.}

Sìrat al-Modjåhidìn. Roman de clievalerie divisé, dans cet exemplaire, en soixante-sept sections. 
19 vol. Papier. $451,435,424,430,443,411,368,412$, 402, 448, 368, 371 feuillets. Hauteur, 21 centimètres; largeur, 15 centimètres. Écritures diverses du xvi", du xvü et du xix siècle. - (Supplément s400 à s411.)

\section{2 à 3855.}

Les quatre premiers volumes du même ouvrage.

4 vol. Papier. $155,137,124$ et 173 feuillets. Hauteur, 16 centimètres; largeur, 11 centimètres. Environ 17 lignes par page. Mss. du xri" siècle. - (Ancien fonds 15/4g-1552.)

\section{6.}

Secoud volume d'un exemplaire du même ouvrage. La fin manque.

Papier. 68 feuillets. Hauteur, 22 centimètres et demi; largeur, 16 centimètres. 31 lignes par page. Ms. du xvm siècle. - (Supplément 1697 .)

\section{7.}

Second volume du mème ouvrage.

Papier. 72 feuillets. Hauteur, 21 centimètres et demi; largeur, 15 centimètres. 22 lignes par page. Ms. du xviı" siècle. - (Supplément 1699.)

\section{8.}

Troisième volume du même ouvrage, Le commencement manque.

Papier. 116 feuillets. Hauteur, 20 eentimètres; largeur, 15 centimètres. 17 lignes par page. Ms. du rwı" siècle. - (Supplément 1698.)

\section{9 .}

Sixième volume du même ouvrage.

Papier. 145 feuillets. Hauteur, 17 eentimètres et demi; largeur, 13 eentimètres. 11 lignes par page. Diverses écritures du xive, du $x v^{\circ}$ et du xvi" siècle. - (Ancien fonds 1553.)

\section{0.}

Septième volume du même ouvrage. La fin manque.

Man, onibntaux. - II.
Papier. 142 feuillets. Hauteur, 22 centimètres; largeur, 15 eentimètres et demi. 27 lignes par page. Diverses écritures du $x{ }^{\circ}$ et du xvil' siècle. - (Ancien fonds 1525. )

\section{1 .}

Neuvième et dixième volumes du même ourrage.

Papier. 194 feuillets. Hauteur, ${ }_{2} 3$ centimèlres; largeur, 16 centimètres. 21 fignes par page. Ms. du xix sièele. - (Supplément 2412.)

\section{2 .}

Neuvième volume du même ouvrage. Les derniets feuillets manquent.

Papier. 166 feuillets. Hanteur, 20 centimètres et demi; largeur, 15 centimètres. Diverses écritures du xwı siècle. - (Aneien fonds 1596.).

\section{3.}

Dixième volume du même ourrage. Les premiers el les derniers feuillets manquent.

Papier. 192 fenillets. Hauteur, 18 centimètres; largeur 13 centimètres, 15 lignes par page. Ms. du xvi" siècle. - (Aneien fonds 1527.)

\section{4 .}

Douzième volume du même ouvrage. Le commencement et la fin manquent.

Papier. 99 feuillets. Hauteur, 21 centimètres et demi; largeur, 15 centimètres et demi. Diverses écritures du xvi ${ }^{\circ}$ et du xvil siècle. - (Ancien fonds 1529.)

\section{5 .}

Treizième volume du mème ouvrage. Le commencement et la fin manquent.

Papier. 102 fenillets. Hauteur, 19 centimètres et demi; largeur, 14 centimètres. Diverses éeritures du $\mathbf{x v}^{\circ}$ et du $\mathrm{xvI}^{e}$ siècle. (Ancien fonds 1503.)

\section{6.}

Treizième volume du même ouvrage. 
Papier. 128 feuillets. Hauteur, a centímètres et demi; largeur, 15 centimètres. Diverses écritures do xvi" siècle. - (Ancien fonds 1528$.

\section{7.}

Trejzième volume du même ouvrage.

Papier. $7^{8}$ feuillets. Hauteur, 17 centimètres et demi; largeur, 19 centimètres et denii. 15 lignes par page. Ms. du $x v^{\circ}$ siècle. (Ancien fonds 155\%.)

\section{8.}

Deux parties, qui paraissent être la quinzièmo et ła seizième, d'un exemplaire du mêne onvrage. Le commencement de la première partie el la fin de la seconde. partic manquent.

Papier. 161 feuillets. Hanteur, al centiniètres et demi; largeur, 15 centimètres et demi. Diverses éeritures du svi et du sur siècle. -. (Ancien fonds 1530.)

\section{9 .}

Quinzième el seizième rolumes du mème ouvrage. Le commencement el la fin de la quinzième partie et le commencement de la seizième manquent.

Ms., de deux mains différentes, daté de l'an $9^{50}$ de l'hégire (1543-1544 de J. C.).

Papier. 228 feuillets. Hauteur, 20 centimètres; largeur, 14 centimètres et demi. 15 lignes par page. - (Aneien fonds 1531.)

\section{0.}

Dix-septième volume du même ouvrage. Le commencement manque.

Papier. 58 feuillets. Hauteur, 15 centimètres et demi; largeur, 11 centimètres. 15 lignes par page. Ms. du svi siècle. - (Ancien fonds 1555.)

\section{1 .}

Dix-buitième volume du mème ouvrage. Le commencoment el la fin manquent.

Papier. 119 feuiltels. Hauteur, 18 centimètres; largeur, 13 centimitres. 15 lignes par page. Ms. du sve siècle. - (Ancien fonds $\mathbf{1 5 5 6 . )}$

\section{2 .}

Dix-neuvième volume du même ouvrage. Le commencement manque.

Ms. daté de l'an 876 de l'hégire (1471-1472 de J. C.).

Papier. 111 fenillets. Hauleur, 18 centimètres; largeur, 13 centimètres. 15 lignes par page. - (Ancien fonds 1539.)

\section{3.}

Vingtième volume du même ouvrage. La fin manque.

Papier. 174 feuillets. Hauteur, 16 centimètres; largenr, 11 centineètres. 18 lignes par page. Ms. du xv siècle. - (Ancien fonds 1557.)

\section{4.}

Vingt et unième, vingt-deuxième el vingt-troisième parties du mème ouvrage. Le commencement manque.

Papier. 68 fcuitlets. Hauteur, 21 centimètres; largeur, 15 centimètres et demi. 27 lignes par pagie. Ms. de deux mains différentes du $x^{\circ}$ siècle. - (Ancien fonds 1534.)

\section{5 .}

Vingt et unième volume du mème ouvrage. Le commencement manque.

Papicr. 174 feuillets. Hauteur, 21 centimètres; largeur, 14 centimètres et demi. Ms. de deux mains différentes du xvi" siècle. - (Ancien fonds 1533 .)

\section{6 .}

Fragment, qui paraît appartenir à la vingt-deuxième partie, du même ouvrage.

Papier. 48 feuillets. Hautenr, 16 centinètres; largeur, 11 centiunètres. 17 lignes par page. Ms. du xvi" siècle. - (Ancien fonds 1558.)

\section{7.}

Vingt-huitième volume du même ouv'age.

Papier. 1 1 3 feuillets. Hauteur. 17 eentimètres; largeur, 12 centi- 
mètres et demi. 15 lignes par page. Diverses écritures du xvi et du xv1" siècie. - (Ancien fonds 1536.)

\section{8 .}

Trenle-septième volume du même ouvrage.

Ms. daté de l'an 1106 de l'hégire (1695 de J. C.).

Papier. 94 fenillets. Hauteur, 19 centimètres; largeur, 15 centimètres. 20 à 22 lignes par page. - (Supplément 1697 bis.)

\section{9 .}

Quarante-troisième partie du même ouvrage. La lin manque. Celte partie est suivic (fol. 8o) d'une autre partie dont le commencement et la fin manquenl.

Papier. 168 feuillcts. Hauteur, 20 centimètres et demi; largeur, 14 centimètres et demi. Ns. de deux mains différentes du xvi" sjècle. - (Ancien fonds 1538.)

\section{0 .}

Quarante-septième, quarante-huitième et quaranteneuvième parties du même ouvrage. La copie de la quarante-huitième partie n'est pas achevée. Le commencement de la quarante-neuvième Hanque.

Papier. 15 o feuillets. Hauteur, a 1 centimètres; largeur, 15 centimètres. Diverses écritures du $x v^{\circ}$ siècle. - (Ancien fonds $153 \%$.)

\section{1 .}

Cinquante-et-unième partie du même ourrage.

Papier. 160 feuillets. Hauteur, 26 centimètres; largeur, 17 centimètres. 33 lignes par page. Ms. du xıv $v^{\circ}$ siècle. - (Ancieu fonds 149 l.)

\section{2.}

Deux parties du même ouvrage. La seconde (tol. $7^{6}$ ) parait être la cinquante-septième. Le commencement et la fin des deux parties manquent.

Papier. 102 feuillets. Hauteur, a 1 centinuètres; largeur, 15 centimètres. Diverses écritures du $\mathrm{xv}^{\circ}$ siècle. - (Ancien fonds 1542.$)$

\section{3.}

Soixante-donzième partie du même ouvrage. La fill manque. Cette partie est suivie (fol. 38) d'une autre partie dont le commencement manque.

Papier. 79 fenillets. Hanteur, 21 centimètres; largeur, 15 centi-

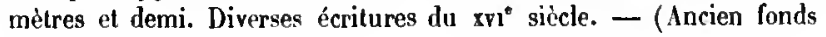
1541.)

\section{4.}

Deux parties du même ouvrage. Le commencemenl de la seconde partie manque.

Papier. ${ }_{17}^{3}$ feuillets. Hauteur, so centimètres; largeur, 14 centimètres et demi. 17 lignnes par page. Diverses écritures du xvi" siècle. - (Ancien fonds i 535.)

\section{5 .}

Volume dépareillé du même ouvrage. Le commencement et la fin manquent.

Papier. 192 feuillets. Hauteur, 15 centimètres et demi; largeur, 10 centimètres. 15 lignes par page. Mls. du $x v^{e}$ siècle. - (Ancien fonds 155g.)

\section{6 .}

Deux parties du mêmr ouvrage. Le commencement et la fin manyuenl.

Papier. 185 feuillets. Hautcur, 15 centimètres; Jargeur, 10 ceutimètres. 13 lignes par page. Ms. du xvi siècle. - (Ancien fonds 1560.)

\section{7 .}

Fragment du même ouvrage.

Papier. 59 feuillels. Hauteur, i 5 centimètres; largeur, 10 centimètres., 5 lignes par page. Ms. du $\times{ }^{\circ}{ }^{\circ}$ siècle. - (Ancien fonds 1561 .)

\section{8 .}

Volume dépareillé du même onvrage. Le commencement manque. A la fin se trouve un autre fragment du roman. 
Papier. 178 femillets. Hautcur, 20 centimètres el demi; largeur, 15 centimètres. 15 lignes par page. Ms. du $\mathbf{x v i}^{\circ}$ siècle. - (Ancien fonds 1537 .)

\section{9 .}

Deux parties incomplètes du même ouvrage.

Papier. 182 feuillets. Hauteur, 21 centimètres; largeur, 15 centimètrcs. Diverses écritures du xvi" siècle. - (Ancien fonds 1540.)

\section{0 .}

Deux parties du même ouvrage. Le commencement et la fin de la première el le commencement de la seconde partie manquent. Celle dernière esl dalée de l'an 834 de l'légire (1430-1431 de J. C.).

Papier. 198 feuillets. Haulcur, 18 centimètres; largeur, 13 centimètres. - (Ancien fonds 1543.)

\section{1.}

Fragments du même ouvrage.

Papier. 127 feuillets. Hauteur, 31 centimètres; largeur, 15 centiinètres. Diverses écritures du $\mathrm{xv}^{\circ}$ et du $\mathrm{xwi}^{\circ}$ siècle. - (Ancien fonds 1544.)

\section{2.}

Volume dépareillé du même ouvrage. Le commencement el la fin manquent.

Papier. 118 feuillets. Hauteur, 21 centimètres; largeur, 15 centimètres et deni. 15 ligues par page. Ms. du xvi siècle. - (Ancien fonds 1545.)

\section{3.}

Histoire $\mathrm{d}^{* \bullet} \mathrm{Omar}$ al-Nąmân et de ses fils.

Papier. 292 feuillets. Hauteur, 21 centimètres; largeur, 15 centimètres. 15 \ 21 lignes par page. Ms. du $\mathbf{x v}_{11}^{\circ}$ siècle. - (Aucien fonds 1496 .)

\section{4.}

Histoire du roi Badruâr, fils de Nahrwân. Seconde partie.
Papier. 48 feuillets. Hauteur, 20 centimètres et demi; largeur, 15 centimètres. Diverses écritures du xvı" siècle. - (Supplément 1701 A.)

\section{5 .}

Deuxième partie du même ouvrage. Le commencement et la fin manquent.

.Papier. 131 feuillets. Hauteur, a centimètres; largeur, 15 centimèlres et demi. 23 lignes par page. Ms. du xwi1 siècle. - (Supplément 1703 C.)

\section{6.}

Quatrième, cinquième el sixième parties du même ouvrage. La fin manque.

Papier. 182 feuillets. IIauteur, 21 centimètres; largeur, 16 centimètres. a3 lignes par page. Écritures diverses du xvi11 ${ }^{e}$ siècle. (Supplément $1703 \mathrm{~A}$.)

\section{7.}

Quatrième partie du même ouvrage.

Papicr. 67 feuillets. Hauteur, so centimètres et demi; largeur, 15 centimètres. 19 lignes par page. MIs. du xw11 ${ }^{\circ}$ siècle. - (Supplément 1701 B.)

\section{8.}

Ginquième partie du même ouvrage.

Papier. 70 feuillets. Hauteur, 21 centimètres et demi; largeur, 15 centimètres. 23 lignes par page. Ms. du xix sièele. - (Supplément 1702 A.)

\section{9 .}

Sixième partie du même ourrage.

Papier. 69 feuiliets. Hauteur, so centimètres; largeur, 14 centimètres. 21 lignes par page. Ms. du xvir1 ${ }^{\circ}$ siècle. - (Supplément 1701 G.)

\section{0.}

Huilième partie du même ouvrage. Le commencement manque. 
Ms. daté de l'an 1137 de l'hégire (1724 de J. C.).

Papier. 46 feuillets. Hauteur, 19 centimètres et demi; largeur, 14 centimètres et demi. 17 lignes par page. - (Supplément $1701 \mathrm{D}$.)

\section{1 .}

Neuvième partie du même ourrage.

Papier. 43 leuillets. Hauteur, 21 centimètres et demi; largeur, 15 centimètres. 25 lignes par page. Ms. du six' siècle. - (Supplément 1702 B.)

\section{2.}

Dixième partie du mème ouvrage.

Papier. 40 feuillets. Hauteur, 21 centimètres et demi; largenr, 15 centimètres. 23 lignes par page. Ms. du xir' siècle. - (Supplément.1 702 C.)

\section{3.}

Onzième partie du même ouvrage.

Papier. 46 feuillets. Hauteur, 21 centimètres et demi; largeur, 15 centimètres. 25 lignes par page. Ms. du xix ${ }^{\circ}$ siècle. - (Supptément 1702 D.)

\section{4.}

Douzième partie du même ouvrage.

Papier. 58 feuillets. Hauteur, 21 centimètres et demi; largeur, 15 centimètres. 25 lignes par page. Ms. du xix siècle. - (Supplément 1703 E.)

\section{5 .}

Volume dépareillé du même ouvrage.

Ms. daté de l'an 1147 de l'hégire $(1734$ de J. C.).

Papier. 147 feuillets. Hauteur, 21 centimètres; largeur, 15 centimètres et demi. Eaviron 23 lignes par page.-(Supplément 2703 li.)

\section{6.}

Premier volume du roman de Ḥâkim.
Papier. 57 feuillets. Hauteur, 21 centimètres; largeur, 15 centimètres et demi. 23 lignes par page. Ms. du xvin' siècle. - (Supplément 1765 .)

\section{7.}

Dixième et dernière partie du même roman.

Ms. daté de l'an ${ }_{1067}$ de l'hégire ( 1657 de J. C.).

Papier. 78 feuillets. Hauteur, 21 centimètres; largeur, 15 centimètres. 21 lignes par page. - (Supplément ${ }_{1}{ }_{7} 65$ bis.)

\section{8.}

Première partie du roman de Bỉbars.

Papier. 184 feuillets. Hauteur, 21 centimètres; largeur, 15 centimétres et demi. 2 lignes par page. Ns, du xwi" siècle. - (Supplément 1750 I.)

\section{9 .}

Première partie du même ourrage. La fin manque, ainsi que le second feuillet et peut-ètre quelques autres.

Papier. 66 feuillets. Hauteur, 21 centimètres; largeur, 15 centimètres et demi. 19 lignes par page. Ms. du xvil' siècle. - (Supplément 1750 IV.)

\section{0 .}

Première parlie du même ouvrage.

Papier. 242 feuillets. Hauteur, 16 centimètres et demi; largeur, 10 centimètres et demi. 16 à 18 lignes par page. Écritures diffé-

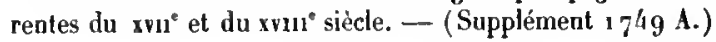

\section{1 .}

Deuxième, troisième et quatrième parties du même ouvrage. La fin de la troisième partie manque.

Papier. 187 feuillets. Hauteur, 22 centimètres; largeur, 15 à 16 centimètres, Diverses écritures du rvmı" siècle. - (Supplément ${ }_{1748 .)}$

\section{2.}

Plusieurs parties du même ouvrage. Le récit com- 


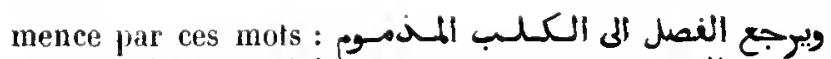

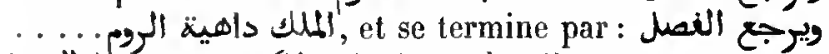

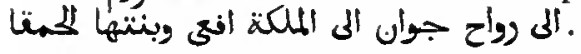

Papier. 333 feuillets. Hauteur, a centimètres et demi; largeur, 16 centimètres. 2, à 24 lignes par page. Ms. du xvm ${ }^{\circ}$ siècle. (Supplément ${ }^{1} 745$. )

\section{3.}

Volume dépareillé du même ouvrage qui porte le titre de e Ses hauts faits en Syrie n, el qui commence par l'expédilion de Bíbars dans l'Inde.

Papier. 198 feuillets. Hauteur, a a centimètres; largeur, 15 centimètres et demi. 15 lignes par page. Ms. du xwü siècle. - (Supplément 1750 11.)

\section{4.}

Autre partie du méme ouvragge. La fin manque.

Papier. 99 feuillets. Hauteur, 2 a centimètres; largeur, 15 centimètres et demi. 21 à a 3 lignes par page. 11 s. du rvmo siècle. (Supplément 1750 III.)

\section{5.}

Volume dépareitlé du mème ouvrage. La fin manque.

Papier. 50 feuillets. Hantetur, a centimètres; largeur, 17 centimètres. 25 lignes par page. Ms. du xvil siècle. - (Supplément 1 746. )

\section{6.}

Sixième parlie du mêne ouvrage.

Ms. dalé de lan 1176 de l'hégire ( $1762-1763$ de J. C.).

Papier. 103 feuillets. Hauteur, 17 centimètres; largeur, 11 centimètres. 21 tignes par page. - (Supplément 1749.)

\section{7.}

Fragment considérable du mêne ouvrage.

Papier. 220 feuillets. Hauteur, 2 a centimètres; largeur, 16 centimètres. 13 à 16 lignnes par page. Ms. du xvm" siècle. - (Supplément $1750 \mathrm{~V}$.)

\section{8.}

Volume dépareillé du mème ouvrage. Le commencement manque.

Papier. 144 feuillets. Hauteur, a centimètres et demi; largeur, 15 centimètres. 19 lignes par page. Ms. du xvi siècle. - (Supplément ${ }_{17}$ 44.)

\section{9 .}

Fragment du même ouvrage.

Papier. 154 feuillets. Hauteur, 21 à 2 a centimètres; largeur, 16 centimètres. Écritures diverses $d u \mathrm{xv}^{\mathrm{e}}$ et $\mathrm{du}$ xrü siècle. (Supplément 1747 .)

\section{0 .}

Volume dépareillé du même ourrage.

Papier. 179 feuillets. Hauteur, 20 centimètres; largeur, 16 centimètres. 17 à 21 liggnes par page. Ms. du xvil' siècle. - (Supplément 2419 .)

\section{1 .}

Roman intitulé سيرة أهد الندنسف. Les principaux personnages de cette fiction sont Ạmad al-Danaf, un sourerain appelé Al-Nalik al-Șaffâh, un guerrier, Bâriq al-Rammâh, 'Alì ibn al-Zaïyầt, 'Alì ibu al-Basṭ̂i, Dalîla, etc.

Ms. daté de l'an 1241 de l'hégire ( 1826 de J. C.).

Papier. 285 feuillets. Hauteur, 2 a d̀ 23 centimètres; largeur, 16 centimètres. 22 à a 5 lignes par page. - (Supplément 2330.)

\section{2 .}

كتاب ثاليصاريوس. Histoire de Bélisaire, traduite en arabe, sur une traduction grecque du roman français, par le prêtre 'Îsâ Petro, de Jérusalem, sous la direction d'Asselin de Cherville.

Is. daté de J'an 1812 de J. C.

Papier. 8 o feuillets. Hauteur, a 3 centimètres; largeur, 16 centimètres. 27 lignes par page. - (Supplément 1763.) 


\section{MAQÂMȦT.}

\section{3.}

Clooix de Maqàmât ou Séances d'Alımad ibn al-Ḥosaïn al-Hamadânì. (Voyez, sur l'auteur et sur cet ouvrage, le Diclionnaire biographique d'Ibn Khallikàn, I. I, p. 112 de la traduction, et la Chrestomathie arabe de S. de Sacy, $2^{\circ}$ éd., t. III, p. 259.) La préface commence par

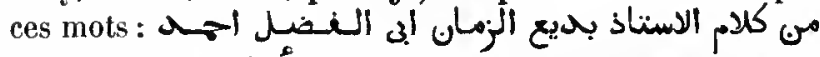

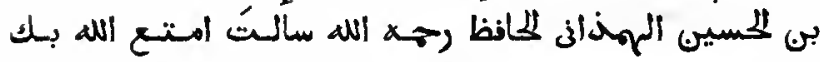

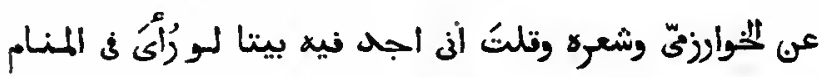

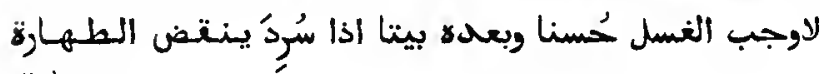
نتئil.

Papier. 109 fevillets. Hauteur, so centiuètres et demi; largeur, 13 centimètres et demi. 15 lignes par page. Ms. du xive siècle. (Ancien fonds 1591.)

\section{4.}

Les Maquàmầt d'Aboû Moḥammad al-Qàsim ibn 'Ali al-Harìrì.

Quelques noles marginales.

Ms. dalé de l'an 584 de l'hégirie ( 1118 de J. C.).

Papier. 23a feuillets. Hauteur, 28 centimètres; largeur, 29 centimètres et demi. 13 lignes par page. - (Supplément 1607.$)$

\section{5 .}

Mlème ouvrage.

Quelques notes marginales.

Papier. 149 feuillets. Hauteur, 32 centimètres; largeur, a 3 centimètres et demi. 17 lignes par page. $\mathrm{Ms}$. du $\mathrm{xu}^{\circ}$ siècle. - (Supplément 1608 .)

\section{6 .}

Mème ouvrage.

Ms. daté de l'an 611 de l'hégire (1215 de J. C.).

Papier. 143 feuillets. Hauteur, 21 centimetres et demi: largeur, 16 centimètres et demi. 17 lignes par page. - (Supplément 2183.)

\section{7.}

Méme ouvrage.

Ms. daté de l'an 611 de l'hégire (1215 de J. C.).

Papier. 131 feuillets. Hauteur, a/ centimètres; largeur, 18 centimètres. 15 lignes par page. - (Ancien fonds 1565.)

\section{8.}

Même ouvrage. A la fin se trouvent les deux épitres et سينيّة du mème auteur.

Noles marginales.

Ms. dalé de l'an 648 de l'hégire (1250 de J. C.).

Papier. sa 1 feuillets. Hauteur, so centimètres; largeur, 16 centimètres, 13 lignes par page. - (Supplément 1616. )

\section{9 .}

Même ouvrage. Cet exemplaire est orné de peintures représentant les scènes décriles dans l'ourrage. Les tètes des personnages sont entourées d'un nimbe. Plusieurs cahiers manquent; le commencement et la fin manquent également, et il y a des fenillets transposés. Cee ms. vient du couvent de Saint-Vaast à Arras.

Papier. 196 feuillets. Hauteur, a 7 centimetres et demi; largenr, 21 centimètres. 1 l lignes par page. Ms. du xu siècle. - (Supplément 1618.)

\section{0.}

llème ourrage.

Notes marginales el interlinéaires. Titre orıé.

Papier. 189 feuillets. Hauteur, 32 centimètres; largenr, 21 centimètres et demi. 15 lignes par page. Ms. du xvi $^{\circ}$ siècle. - (Aneien fonds 1564.)

\section{1 .}

Mème ouvrage.

Ms. daté de l'an 1063 de l'hégire (1653 de J. C.).

Papier. 120 feuillets. Hauteur, so centimètres et demi; largeur, 14 centinètres et demi. 19 lignes par page. - (Ancien fonds 1588. .) 


\section{2.}

Même ouvrage.

Papier. ${ }_{16}{ }_{7}$ feuillets. Hauteur, 23 centimètres et demi; largeur, 16 à 17 centimètres. 21 à 23 lignes par page. Ns. du xrut siècle. - (Supplément 1609.)

\section{3.}

Même ouvrage. Le premier feuillet manque.

Papier. $19^{3}$ fenillets. Hauteur, 31 centimètres; largeur, so centimètres. 13 à 16 lignes par page. Ms. du xvı" siècle. - (Supplément 1606.$)$

\section{4.}

Même ousrage.

Ms. daté de l'an 1187 de l'hégrire (1773 de J. C.).

Papier. 131 feuillets. Hauteur, 2a centimètres; largeur, 15 centiınètres et demi. 15 lignes par page. - (Supplément 1611.)

\section{5 .}

Mème ouvrage.

Notes marginales et interlinéaires.

Ms. daté de l'an 1214 de l'hégire (1799-180o de J. C.).

Papier. ${ }_{28} 8$ feuillets. Hauteur, 21 centimètres et demi; largenr, 15 centimètres et demi. 9 lignes par page. - (Supplément 1619.)

\section{6 .}

Premier cahier d'un exemplaire du même ouvrage, contenant la préface, la première Séance, et le commencement de la seconde.

Notes marginales et interlinéaires.

Papier. 15 feuillets. Hauteur, 2a centimètres et demi; largeur, 14 centimétres. 9 lignes par page. Ms. du svm siècle. - (Supplément 2183.$)$

\section{7.}

Commentaire de Borhân al-Dîn Nàsir ibn 'Abd alSaïyid Al-Motarrizî sur les Maqâmât d'Al-Harîrî. L'au- leur dit avoir terminé son travail en 563 de l'hégire (1 167-1 168 de J. C.). Il a placé en tête de son ouvrage un résumé de rhétorique (علمى المأن والبهيان).

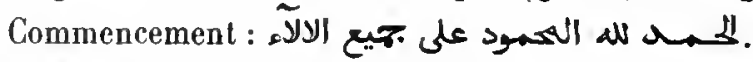

Ms. daté de l'an 1029 de l'hégire (1620 de J. C.).

Papier. 249 feuillets. Hauteur, a 1 centimètres; largeur, 15 centimètres. 15 a 21 lignes par page. - (Ancien fonds 1589 .)

\section{8.}

Même ouvrage.

Papier. 2o 3 feuillets. Hauteur, 23 centimètres et demi; largeur, 16 centimètres. 15 lignes par page. Ms. du xvi! siecle. - (Supplément 1612.$)$

\section{9 .}

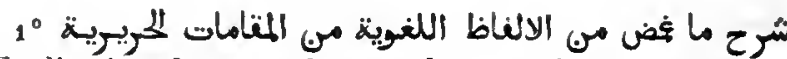
Explication des mols à sens obscur qui se rencontrent dans les Maqâmât d'Al-Harììn, par Mohibb al-Dìn abou 'J-Baqâ 'Abd Allah ibn al-Ḥosaîn al-'Okbarî (العكبs), le Baghdàd, mort en 616 de l'hégire (1 219 de J. C.). (Voyez le Dictionnaire biugraphique d'Jbn Khallikân, t. II, p. 65 de la traduction anglaise.)

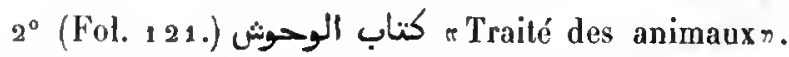
par Al-Așma'i. L'auteur indique les différents noms par lesquels on désignait l'onagre, le moufllon à manchettes (البتو), la gazelle, l'autruche, le lion, le loup, l'hyène, le renard et le lièvre. Pour chacun des synonymes il cite l'autorité d'un ancien poète.

$3^{\circ}$ (Fol. 141.) Observations orthographiques sur te o et le b.

$4^{\circ}$ (Fol. 158.) La Qașìda d'Al-Nàbigha al-Dsobyânî qui commence par les mots يا دأر ميّة . Chaque vers est suivi d'un savant commentaire qui s'appuie souvent sur l'autorité d'Al-Așma'i.

$5^{\circ}$ (Fol. 1 78.) Aventure d'Aboû Zabîd al-Ṭài avec le lion. Aboû Zabid, dont le vrai nom était Harmala ibn al-Mondsir, et qui professait la religion chrétienne, ayant récité un jour au calife 'Othmân ibn 'Affàn un poème, fut amené, par la mention du lion à raconter des anecdotes dans le langage des Arabes dı désert. Plus tard, dans une séance littéraire tenue chez Mo'àwiya ibn abî Sofyân, il énuméra les nombreuses épithètes que l'on donne au lion. Le récit se termine par l'explication des termes bédouins qui y sont employés. 
Ms. en forme d'album, daté (fol. 119 ) de l'an 802 de l'hégire ( 1400 de J. C.).

Papier. 198 fewillets. Hauleur, 14 centimètres; largeur, 18 centimètres. 13 à 15 lignes par page. - (Ancien fonds 1626 .)

\section{0.}

Commentaire d'Abou 'l-'Abbàs Ahmad ibn 'Abd alMoûmin ibn Moûsâ Al-Scharìschì surfles Maqâmàt d'AlHarìî. Commencement: . بانصح الأسنة

Ms. daté de l'an 1095 de l'hégire (1684 de J. C.).

Papier. 470 feuillets. Hauteur, 25 centimètres el demi; largeur, 16 centimètres et demi. 33 lignes par page. - (Supplément 1610.)

\section{1.}

Même ouvrage.

Ms. daté de l'an 1104 de l'hégire ( 1693 de l. C.).

Papier. 500 feuillets. Hauteur, 31 centimètres; largeur, 19 centimètres el demi. 33 lignes par page. - (Supplément 1613.)

\section{2 et 3943.}

Même ouvrage.

Ms. daté de l'an 1106 de l'hégire ( 1694 de J. C. ).

a vol. Papier. 350 et 358 feuillets. Hauteur, a 9 centimètres ; largeur, 19 centimètres. 27 lignes par page. - (Supplément 1617.$)$

\section{4 el 3945 .}

Mème ouvrage.

Is. daté de l’an 1228 de l'hégire (1813 de J. C.).

2 vol. Papier. 562 et 485 fenillets. Hauteur, 23 centimètres; largeur, 16 centimètres et demi. 33 lignes par page. - (Supplément 16.5 .)

\section{6.}

Premier volume du même ouvrage.

Man. onientadx. - Il.
Ms. daté de l'an 1134 de l'hégire (1722 de J. C.).

Papier. 248 feuillets. Hauteur, 30 centimètres; largeur, 17 centimètres. 27 lignes par page. - (Supplément 1614.)

\section{7.}

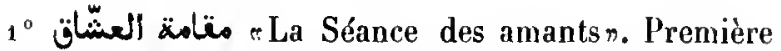
Naqàma de Moḥammad ibn al-`Afif al-Dìn al-Tilimsâni, mort en 688 de l'hégire (1 289 de J. C.). Commence-

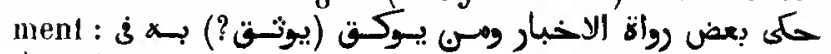
مالاخبار :

$2^{\circ}$ (Fol. 9.) Horologion de l'église grecque melkile. Le commencement et la fin manquent.

Papier. 88 fenillets. Hauteur, so centimètres; largeur, 15 centimètres. 13 lignes par page. Ms. du xvi siècle. - (Ancien fonds 1587, Colbert 3996.)

\section{8.}

$1^{\circ}$ Dix Maqàmât précédées d'une introduction, par un auteur anonyme. Commencement : . Ia première Maqàma

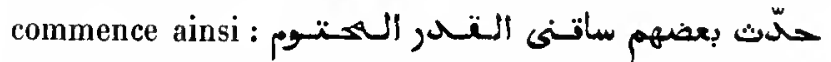

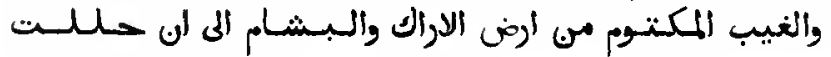
pintlens.

$2^{\circ}$ (Fol. $7^{3}$ vº $^{\circ}$ (أطوات الخذهب (Les Colliers d'or» par Djầ Allah Abou 'l-Qàsim Mahmoûd al-Zamakhscharì. Commencement : اللهم أن أحدك على مـا ألــت

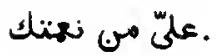

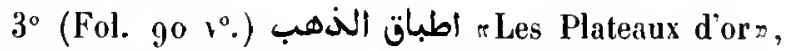
par Scharaf al-Din 'Abd al-Moûmin al-lṣfahânî. Ouvrage imité des Colliers d'or d'Al-Zamakhscharì. Commence-

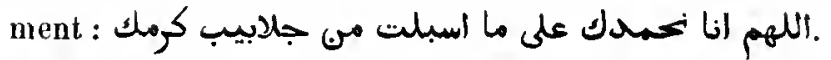

Ms. daté de l'an 1,46 de l'hégire (1 $733-1734$ de J. C.).

Papier. 135 feuillets. Hauteur, 31 centimètres; largeur, 12 centimètres. 19 lignes par page. - (Supplément 1854.)

\section{9.}

(لمين. Les Maqâmât de Djalâl al-Dìn 'Abd al-Raḥmân al-Soyoûtị, au mombre de vingt-neuf. 
(Voyez Hadji-Khalfa, 1. VI, P. 55.) Commencement de la première Maqâma : أن اول بيت وضع للناس الذَى بيكة

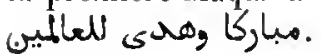

Ms. daté de l'an 1014 de l'hégire (1605 de J. C.).

Papier. 139 feuillets. Hauteur, 21 centimètres; largeur, 13 cenliuètres et demi. 27 lignes par page. — (Ancien fonds 1590. )

\section{0 .}

r مéfense d'Omar ibn al-Fâridh contre un déprécialeur $\%$. Vingt-cinquième $\mathrm{Ma}$ -

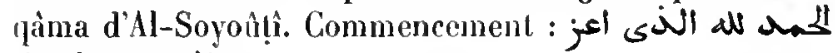

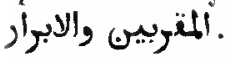

Papier. 8 feuillets. Hauteur, 21 centimètres; largeur, 15 centimètres. 19 lignes par page. Ws. du xvin siècle. - (Supplément 2184.)

\section{1.}

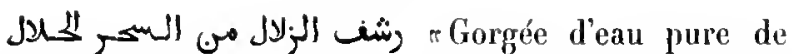
la magie liciten, c'est-à-dire de la poésie. Vingt-huilième Maqâma d'Al-Soyouți, dont le sujet est la relation laite par vingt-deux hommes instruits et de diverses professions de ce que chacun d'eux avait éprouvé la nuit de ses noces. Chaque discours renferme plusieurs des termes techniques employés dans la branche de science حكى ابو : cultivée pas le narrateur. Commencement

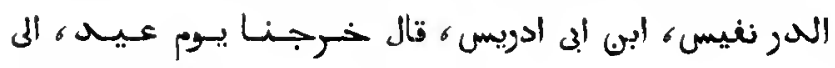

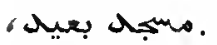

Ms. daté de l'an 1095 de l'hégire (1684 de J. C.).

Papier. 35 feuillets. Hauteur, 17 centimètres; largeur, 11 centimìlies et demi. 13 lignes par page. - (Supplément 1334.)

\section{2.}

Prairies émaillées de fleurss et zépliyrs du matin \%. Collection de dix Maqùmât composées par Schams al-Din Mohammad al-Halabì al-Qawwâs. Voici les noms des villes d'après lesquelles ces Séances ont reçu leurs tilres : la Mecque, Damiette, Safad, Damas, Tripoli, IIamáh, Antioche, Alep, le Caire el Sindjâr. L'auteur est mort arant d'avoir terminé la

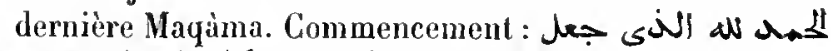

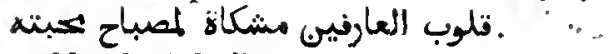

Ms. daté de l'an 1011 de l'hégire (1602 de J. C.).
Papier. 111 feuillets. Hauteur, 21 centimẹtres; largeur, 13 centimètres et demi. 19 lignes par page. — (Ancien fonds 1593.)

\section{VIII.}

\section{PROVERBES ET SENTENCES.}

\section{3.}

$1^{\circ}$ Maximes des philosophes grees : Socrate, Homère, Pyllagore, Platon, Aristote, Alexandre le Grand, etc. Le litre de cet ourrage, écril sur le frontispice, a complètement disparu, le fenillet qui le portait étant troué. Il ne reste de la première ligne de l'ouvrage que les

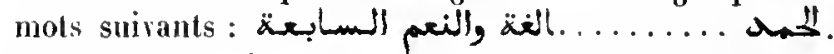
Liauteur, dont le mom ne se lit nulle part, a dédié son Iravail à Al-Malik al-Zàhir Ghîath al-Din, fils de Saladin et prince d'Alep (584 à 6.3 de l'légire). C'est à tort quion a attribué cet ouvrage à Borhàn al-Dìn alBaqấi, écrivain qui est mort en $77^{5}$ de l'hégire.

$2^{\circ}$ (Fol. 3o.) Quelques traditions attribuées à: Mahomet.

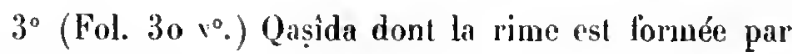
la syllabe ṕ et qui renferme l'éloge de enos seigneurs», c'est-à-dire, des derviches.

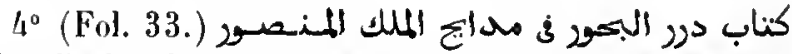
"Les Perles des mer's, recueil à l'éloge d'Al-Malik alManşoùr (Qahảoûn)», par Șafi al-Dìn. Le poète désigné sous le nom de Șafi al-Din se nommait 'Abd al'Aziz ibn Sariyà al-Hilli. Ce sont des pièces de rers, dont la première a pour rime la lettre 1 , la seconde la lettre $\varphi$, et ainsi de suite jusqu'à la fin de l'alphabet.

En tète du volume se trouvent quelques notes astrologiques.

Papier. 64 fenillels. Hauteur, 15 centimètres; largeur, 10 centimètres et demi. 15 lignes par page. Ms. du xiv' siècle (les derniers feuillets sont modernes). - (Ancien fonds 463.)

\section{4.}

$1^{\circ}$ Les Cent maximes d'Ali fils d'Abou Tàlib, avec un conmentaire en langue persane, par le kâtib Mohammad ibn Molıammad ibn 'Abd al-Djalil al-'Omari. Commen-

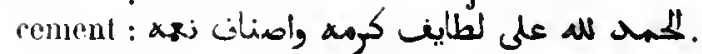


$2^{\circ}$ (Fol. 33 voplication des perles et rappel des hautes qualités $n$. Autres maximes d"Ali, fils d'Abou Tâlib disposées dans l'ordre de l'alphabet.Chaque sentence est suivie de deux vers persans qui en forment le commentaire. L'auteur se nommait Masoûd ibn Aḥmad, petit-fils (سبط) de l'émir Mohyyî

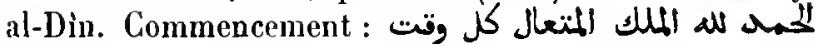
وحا-

$3^{\circ}\left(\right.$ Fol. $56 v^{\circ}$.) Prières et notes dicerses, les unes en arabe, les autres en persan.

$4^{\circ}$ (Fol. $59 v^{\circ}$. .) Trailé des chemins (qui conduisent à Dieu) $\pi$, par Nadjm al-Din. L'ourrage est précédé d'une dédicace adressée par un éditeur anonyme à un vizir dont le nom n'est pas mentionné. Com-

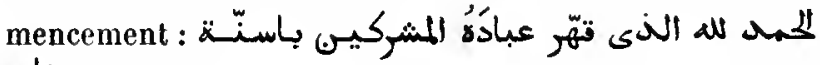
تحنير سنانx.

$5^{\circ}$ (Fol. 77.) Notes diverses cu arabe et en persan, suivies de plusieurs pièces de vers en turc.

$6^{\circ}\left(\right.$ Fol. $83 \vee^{\circ}$.) Traité en persan sur la conmaissance de Dieu et de soi-même. Commencement : شكر به يايار. .بعدد ستار8 آسمان.

$7^{\circ}$ (Fol. $9^{5} v^{n}$.) Traité sur la foi et sur ses divers

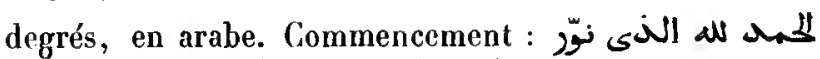
ضمابير أرباب النين بانوار الاسلام والايمان.

$8^{\circ}$ (Fol. $108 v^{\circ}$.) Extraits du Jathuawî de Djalàl alDin Roûmî et d'autres traités persins.

Papier. ${ }_{1} 3_{1}$ fenillets. Hauteur, 18 centimètres; largeur, 14 centimètres. Ms. de diverses écritures du xvi siècle. - (Ancien fonds 1422.)

\section{5 .}

1. Sentences d"Alì, fils d'Aboû Țàlib, accompagncés, en partie, d'une explication en langue turque.

$2^{\circ}$ (Fol. 9.) Traité de métrique par un auteur d'Espagne, nommé Moḥammad ibn Họsaïn Abou 'I-Djaïsch al-Anșàrî̀.

$3^{\circ}\left(\right.$ Fol. $12 \mathrm{v}^{\circ}$.) Commentaire anonỵme sur la métrique d'Abou 'l-Djaïscl.

$4^{\circ}\left(\right.$ Fol. $32 v^{\circ}$.) Commentaire anonyure sur le traité de métrique rédigé en vers par Dliyâa al-Dìn 'Abd Allah al-Khazradjî.

$\tilde{5}^{\circ}$ (Fol. $41 \vee^{\circ}$.) Troisième section du Miftâh al'Oloûm d'Al-Sakkàkî, renfermant la Rhétorique.
Il y a plusieurs notes grammaticales au commencement du volume.

Ms. daté de l'an 989 de l'hégire ( $1581-1582$ de J. C.).

Papier. 203 feuillets. Hauteur, 21 centimètres; largeur, $1 /$ centimètres. 15 lignes par page. - (Ancien fonds 1607.)

\section{6.}

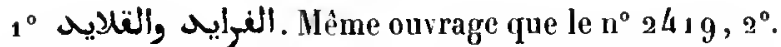
Daprès le titre du présent exemplajre, l'auteur serait. Aboû Manṣoûr 'Abd al-Karîm ibn Ismâểl al-Tha'âlibì.

$2^{\circ}$ (Fol. 27.) Album contenant un grand nombre de morccaux en prose et en vers.

Papier. 197 feuillets. Hauteur, so centinètres et demi; largenr, 15 centiuètres. Vs. de deux mains différentes du $x^{2}{ }^{\circ}{ }^{\circ}$ siècle. (Supplérnent , 8\%0.)

\section{7.}

rL'Éternelle raison », par Ahmad ibn Mol!ammad ibn Maskawaih, mort en 421 de l'hégire ( 1030 de J. C.). L'ouvrage comnence par un جاويule خ Salıl, frère du vizir d'Al-Ma'moûn. Ibn Maskawaih voulant compléter cette collection, y a ajouté un grand nombre de maximes attribués aux Perses, aux Indiens, aux Arabes et aux Grecs. Ce recueil porte aussi le titre de Préceptes de conduite des Arabes ct des Persans ᄁ. M. de Sacy a traité de ce livre dans les Mémoires de l'Académie des inscriptions et belles-lettres, t. IX, p. 1 et suivantes.

Papier. 158 feuillets. Hauteur, 31 centimètres; Jargeur, 21 centimètres. 17 lignes par page. Ns. du $\mathrm{xv}^{\circ}$ siècle. - (Ancien fonds $89^{1 .}$ )

\section{8 .}

La collection de proverbes d'Abou 'L-Fadlıl Aḷmad ibn Moḥammad al-Maidànî.

Papier. 234 feuillets. Hauteur, 31 centimètres; largeur, 20 centimètres. 26 à 32 lignes par page. Us. du $\mathbf{x v}^{*}$ siècle. - (Supplément 1629.) 


\section{9 .}

Hème ourrage.

Papier. 401 feuillets. Hauteur, a 1 centimètres et demi; largeur, 15 centimètres; 87 lignes par page. Ms. du xvı e siècle. - (Supplément 1630. )

\section{0 .}

Nème ouvrage.

Ms. dalé de f'an 11 l 2 de l'hégire ( 1730 de J. C.).

Papier. 32o feuillets. Hauteur, 2 a centimètres; largeur, 15 centimètres et demi. 25 lignes par page. - (Supplément 1631.)

\section{1 à 3963.}

Mème ouvrage.

3 vol. Papier. 318 , 300 et 299 feuillets. Hauteur, 23 centimétres; largeur, 17 centimètres. 17 lignes par page. Ms. du xıx $x^{\circ}$ siècle. - (Supplément 219 1-2196.)

\section{4.}

$1^{\circ}$ Les Colliers d'or d'Al-Zamakhschari.

$2^{\circ}$ (Fol. 18.) Les Plateaux d'or (royez ci-dessus

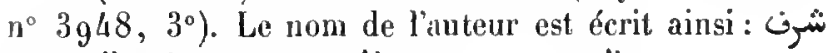

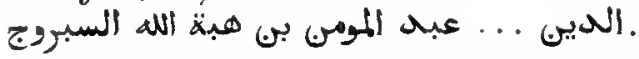

$3^{\circ}$ (Fol. 66.) Paroles et maximes de personnages de mérite. Commencement : اللهم لا تخيّب رجا مى هو منوط بك.

$4^{\circ}$ (Fol. 72.) Lettre du cadi Abou 'I-Macâti au Schaiklı al-Dìn Aboû Raschìd C'est une sorle d'amâlì.

$5^{\circ}$ (Fol. $114 v^{\circ}$.) Poésies d'lìsà ibn Mạ̣toûz. La première pièce est une سينيخة à la louange du calife abbaside Al-Nâsir li-Dìn lltàh.

Papier. 139 fenillets. Hauteur, 84 centimètres; largeur, 18 centitimètres et demi. 15 lignes par page. Ms. dn $\mathrm{xv}^{\circ}$ siècle. - (Suppl :ment 1859 .)

\section{5.}

$t^{\circ}$ Les نوأبغ de Djàr Aflah al-Zamakhscharì. $2^{\circ}$ (Fol. 18.) Chapitre du Sacrifice, extrait du traité de droit hanéfite d'AJ-Qodoûrî.

$3^{\circ}$ (Fol. 19.) Prière, suivie de quelques pièces de vel's.

$4^{\circ}$ (Fol. $25 v^{\circ}$.) Diverses poésies, les unes en turc, les autres en persan.

$5^{\circ}$ (Fol. $44 v^{\circ}$.) Pieces de vers en langue turque.

$6^{\circ}$ (Fol. $7^{\circ} \mathrm{v}^{\circ}$.) Recueil de tradilions, de maximes el de moralités, en persan, par Khodja 'Obaïd Allah.

$7^{\circ}$ (Fol. $9^{3} v^{\circ}$.) Autres pièces de vers en langue turque.

Papier. 97 feuillets. Hautenr, 20 centimètres et demi; largeur, 19 centimètres. Diverses écritures du xwr ${ }^{e}$ siècle. - (Ancien fonds 1621.)

\section{6.}

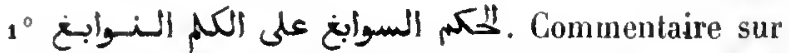
tes Nawäbigh d'Al-Zanakhscharî, par ın prince du Yemen, l'Amîr at-moûminìn Al-Nàșir li'l-Haqq al-moubìn Salàlı al-Dìn Mohammad, fils de l'Amî̀ al-moûminîn Al-Mahdì li-Din Iltàh 'Alì ibn Molıammad ibu 'Alì. Louvrage a été composé en $7^{82}$ de l'hégire ( 1380 de J. C.).

$2^{\circ}$ (Fol. 97.) Le الاححكام السلطانية d'Al-Màwardi. Copie datée de l'an 1080 de l'hégire ( $1669^{-1} 670$ de J. C.).

Papier. 367 feuillets. Hauteur, 20 centimètres; largeur, 15 centimètres. Ms. de deux mains différentes. - (Supplément 1922.)

\section{7.}

$1^{\circ}$ Choix de proverbesn, arec un commentaire en langue persane et un grand nombre de noles marginales et interlinéaires en langue turque. D'après une note, en tête du volume, le commentateur, Mostafà ibu lbrâhìm de Gallipoli (كليبولنى) a liré ces proverbes du مستتقصى de Zamakhschari.

$2^{\circ}$ (Fol. 166.) Note sur l'interprélation du Coran, et autres noles détachées.

$3^{\circ}$ (Fol. $167 \mathrm{v}^{\circ}$.) Extrails de la collection des fetwa d'Al-Bazzizi.

$4^{\circ}$ (Fol. $17^{3} \vee^{\circ}$.) Note grammaticale tirée d'une explication de la première sourate du Coran (تنسيs $\ddot{x}>$ (ل).

$5^{\circ}\left(\right.$ Fol. $174 v^{\circ}$ ) Commentaire, composé d'après les 
enseignements d'un savant de l'Inde, sur plusieurs passages du Coran, par Al-Tamînî.

$6^{\circ}$ (Fol. 190.) Fragment d'un traité sur le feu de l'enfer.

$7^{\circ}$ (Fol. 191.) Extrait d'un traité de théologie intitulé : زهرة الكرياض Fleurs des jardinsn.

$8^{\circ}\left(\right.$ Fol. $19^{8} v^{\circ}$.) Notes et extraits divers.

$9^{\circ}\left(\mathrm{F}_{0} .200 \mathbf{v}^{\circ}\right.$.) Formules de prières et invocations. $10^{\circ}\left(\right.$ Fol. $225 v^{\circ}$.) Notes et tradilions.

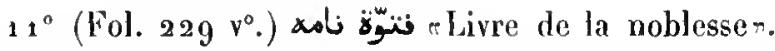
Légende ayant pour sujet l'excellence d'Alì ibn abi Tàlib.

$12^{\circ}$ (Fol. 237.) Liste d'ascètes, hommes et femmes, de derviches, de soufis, etc.

$13^{\circ}\left(F_{0} .244 v^{\circ}\right.$.) Notes et extraits divers en persan.

$14^{\circ}$ (Fol. 247.) Traité, en turc, sur l'aspect extérienr du Prophète.

Papier. 249 fenillets. Hauteur, a centimètres; largeur, $1 / t$ centimètres et demi. Diverses écrilures du xvi ${ }^{\circ}$ et du xv11 ${ }^{\circ}$ siècle. - (Ancien fonds 1609.$)$

\section{8.}

Perles uniques». Reeueil de proverbes el de maximes, avec leur explication, disposés daus l'ordre de l'alphabet. Selon Hadji Khalfa, l'auteur', dont le nom, dans le présent ms., est écrit Yoûsof ibn Țà-

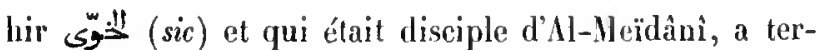
miné son ouvrage en 532 de l'hégire $\left(1137_{-11} 138\right.$ de

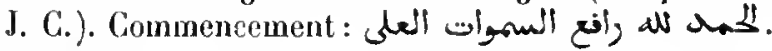

Ms. daté de l'an 1040 de l'hégire (1631 de J. C.).

Papier. $97^{\circ}$ feuillets. Hauteur, 18 centimètres; largeur, 19 centimèlres. 17 lignes par page. - (Supplément 1634.)

\section{9.}

Collection de proverbes attribuée à Aboì ,Obaïd, grammairien du $n^{e}$ siècle de l'hégire. Mais on rencontre en plusieurs passages le nom d'Aboû 'Obaïda, autre grammairien, mort dans la seconde moitié du $v^{e}$ siècle de l'hégire.

Cet exemplaire a été écrit, probablement à Tunis, en l'an 1581 de l'fncarnation, par un Européen nommé Domenico Sirlelo.
Papier. 175 fenillets. Ilautenr, 11 centimètres; largeur, 16 centimètres et demi. 5 lignes par page. - (Ancien fonds 1625.)

\section{0 .}

r Proverbes usuels». Cette collection est disposée dans l'ordre de l'alphabet.

Papier. $9^{\circ}$ feuillets. Hauteur, 14 centimètres et demi; largeur, 10 centimitres. 13 liggnes par page. Ms. du xvi siècle. - (Ancien fonds 1624 , Colbert 6600.)

\section{1 .}

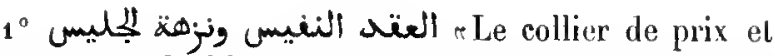
l'anusement de l'homme sociable». J'auteur anonyme traite, en huit chapitres, de la morale et cite les maximes de Platon, de Socrate et d'Aristote, ainsi que celles du Coran et de Mahomet. Il a ajouté, à titre d'appendice (fol. 36), quelques extraits d'un recueil (r) composé par Sidi Hohammad al-Ghomarì (s,il) et un traité sur le soufisme (أصمل المطريتة) rédigé par Aḷmad ibn Aḷmad ibn 'îsà al-Fâsî, surnommé Zarroûq.

$2^{\circ}$ Fol. 39.) (ل) Les apothegmes du schaikh Tidj al-Din 'Atì Allah. Il y a une lacune entre les folios actuellement cotés 47 et 48 .

$3^{\circ}$ (Fol. $49 \mathrm{v}^{\circ}$.) Premier leuillet d'un opuscule d'lbu Doraïd (Aboû Bakr Mohammad ibn al-Ịlosaïn al-Azdî), renfermant les sentences d'Mî ibn abì Tálib.

$4^{\circ}$ (Fol. 50.) Tradition de Mahomet relative aux noms des huit portes du paradis.

Papier. 5o feuillets. Hanteur, 19 centimètres et demi; largenr, 14 centimètres et demi. 21 lignes par page. Us. du xvi siècle. (Supplément 478 .)

\section{2 .}

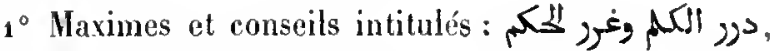
par Djalail al-Din al-Soyoùti.

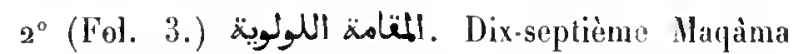
d'Al-Soyoûtì. Liauteur explique pourquoi il a cessé de donner des consultations juridiques et d'instruire des élèves. Commencement : يا مـعنئنس الاحسبـاب الصلكما وأوله . الأباب النعصاء

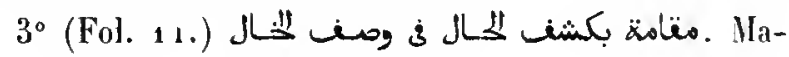
qâma d' Al-Soyoûtị sur les éphélides. 


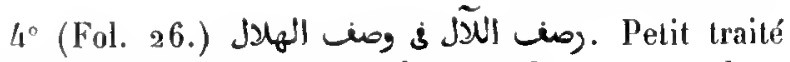
d'N-Soyouttî, qui rapporte les nombreux vers dans lesquels Kliałil ibn Aïlsak al-Ṣafadì fait mention de la nouvelle lune.

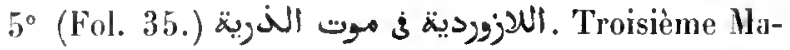
qùma d'Al-Soyoûtî.

$6^{\circ}$ (Fol. 41.) تحنة الظرناء باسماء Pièce de rers d'Al-Soyontị qui renferme les noms des califes depuis Aboû Bakr jusqu'à la fin du règne des Abbasides de la seconde branclie.

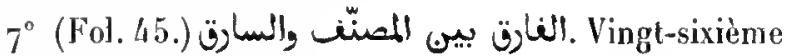
Mayåma d'Al-Soyoûtî.

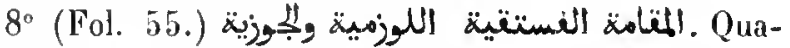
torzième Maqâma d'Al-Soyoûțî.

$9^{\circ}$ (Fol. $57 v^{\circ}$.) Défense du poète 'Omar ibn alFàriảh. Vingt-cinquième Maqâna d'Al-Soyoûțì.

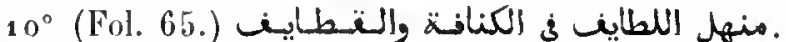
Haqàma d'A]-Soyoutti sur les deux espèces de pàtisserie appelées l'une kinâfa, l'autre qatâif.

$11^{\circ}$ (Fol. 75. (5aqua sur les trente principaux poètes arabes, par Yoûsof al-Solamî, de Saragosse.

$12^{\circ}$ (Fol. $811^{\circ}$.) Liste des divans et d'ouvrages philologiques et littéraires dont Badr al-Dìn Malımoûd al'dinì s'est servi pour composer son grand commentaire sur l'Alfiya.

$13^{\circ}$ (Fol. 83.) Deux pièces de vers.

Papier. 84 feuillets. IIauteur, 19 centimètres; largeur, 14 centimètres. 19 lignes par page. Ms. du xvi" siècle. - (Supplément 1917.)

\section{3.}

$1^{\circ}$ dessus $n^{\circ 3} 39^{48}, 3^{\circ}$ et $39^{64}, 2^{\circ}$.) Dans le titre, l'ouvrage est attribué à Aḷmad ibn 'Alî al-Khoủhî.

$2^{\circ}$ (Fol. 51.) Les Cént seutences d'Alî ibn abì Ṭâlib, arec un commentaire 'Alì.

$3^{\circ}$ (Fol. $6_{2} r^{\circ}$.) Conseils adressés par Mahonet à

$4^{\circ}$ (Fol. 70.) Traité de la conmaissance de l'islamisme.

$5^{\circ}$ (Fol. $74 \vee^{\circ}$.) Exhortations, au nombre de trente.

$6^{\circ}\left(\right.$ Fol. $87 v^{\circ}$.) Description de la Résurrection d'après une tradition rapportée à llahomet. $7^{\circ}$ (Fol. 91 vº) Le كتاب النوابغ d'Al-Zamakhscharî.

$8^{\circ}$ (Fol. 101.$)$ (ن) Les Apoplithegmes d'Alì ibn abî Tâlib.

$9^{\circ}\left(\right.$ Fol. $106 \mathrm{v}^{\circ}$.) Autre petit recueil d'apophthegmes.

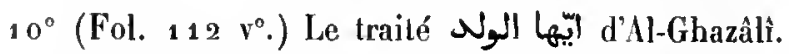

$11^{\circ}$ (Fol. 129.) Les "Colliers d'orn d'A1-Zamakhscharì.

$12^{\circ}$ (Fol. 150.) Traité du bon goût en fait de style, par Al-Soyoûtî.

13० (Fol. 1 70.) Traité des crues du Nił par Schams at-Dîn Moliammad al-Dimaschqî.

Papier. 189 feuillets. Hauteur, a centimètres; largeur, 15 centimètres. Environ 16 lignes par page. - (Supplément ${ }_{9} 39$.)

\section{4.}

Proverbes, en langue vulgaire de la Syrie, disposés dans l'ordre de l'alphabet. Commencement : الصبر مغنتاح الفوج

Papier. 40 feuillets. Hauteur, a 1 centimètres; Jargeur, 14 centimètres et demi. 15 à 17 ligues par page. Ms. du xrr" siècle. (Supplément 1639.)

\section{5 .}

Proverbes recueitlis par Asselin de Cherville pendant son séjour au Gaire.

Papier. 38 feuiltets. Hauteur, a a centimètres; largeur, 14 centimètres. Environ al lignes par page. Ms. du xix" siècle. - (Supplément 1633.$)$

\section{6.}

Recueil de proverbes et de maximes disposés dans l'ordre de l'alphabet. Commencement : لــهـم اشغنـل

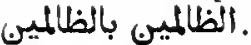

Ms. daté de l'an 1746 de J. C.

Papier. I4 feuillets. Hauteur, a centimètres; largeur, 15 centimètres. 16 lignes par page. - (Supplément 1635.)

\section{7.}

Petite collection de proverbes disposés dans l'ordre de 
l'alphabet. On a ajouté à la fin quelques passages du riturl catholique, en arabe, avec leur transeription en caractères romains.

Ms. daté de l'an $169^{2}$ de J. G.

Papier. 44 feuillets. Hauteur, 13 centimètres; largeur, 9 centimètres. 9 lignes par page. - (Supplément 1636.)

\section{8 .}

Proverbes dis i osés dans l'ordre de l'alphabet. Ms. daté de l'an $173_{1}$ de J. C.

Papier. 45 feuillets. Hauteur, 17 centimètres et demi; largeur, 12 centimètres. 9 lignoes par page. - (Supplément 1637.)

\section{9 .}

1. Recueil de proverbes commençant par ألهوم أثغل الظالfيى. différent du n ${ }^{\circ} 397^{6}$.

$2^{\circ}$ (Fol. 24.) Sentences en vers.

Papier. 35 feuillets. Hauleur, 1 a centimètres et demi; largent, 9 centimètres. 10 lignes par page. Ms. du xvir siècle. - (Supplément 1638.)

\section{0 .}

Proverlues el maximes, disposés dans l'ordre de l'alphabet.

Ms. daté de l'an ${ }_{1} 66^{8}$ de J. C.

Papier. 41 feuillets. Hauteur, 14 centimitres et demi; largenr, 10 centimètres. 10 lignes par page. - (Supplément ${ }_{1639 .}$ )

\section{1.}

Recueil de proverbes disposés dans l'ordre de l'alphabet.

Les premiers el les demiers leuillets du ms. renterment un grand nombre de derises et d'armoiries exéculées, entre les années 1611 et 1615 , par différents amis d'un nommé Elias Haüser.

Papier. 105 feuillets. Hauteur, 14 centimètres; largeur, 10 centimètres. IIs. du xvir siècle. — (Supplément 1640, Suppl. Saint-Germain 10.)

\section{2.}

- Recueil de proverbes disposés dans l'ordre de l'alplıa-

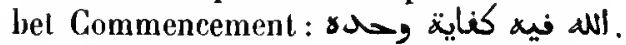

Ms. daté de l'an 1640 de J. C.

Papier. 48 feuillets. Hauteur, 17 centimètres et demi; largetır, 12 centimètres. 9 lignes par page. - (Supplément 1640 bis.)

\section{3.}

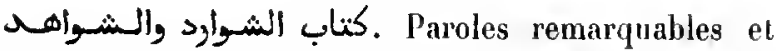
apophthegmes des prophètes, des sages, des philosoplıes arabes, persans, indiens, etc., en cinq chipuitres. A la fin du volume se trouvent quelques chames el ammlettes en arahe el en hébreu.

Papier. 66 feuillets. Hauteur, 14 centimètres et demi; largeur, 1 o centimètres. 17 lignes par page. Ms. du surn' siècle. - (Supplément 1641 , Saint-Germain 540 ter.)

\section{XXIX.}

\section{PHILOLOGIE.}

\section{EN GÉNÉRAL.}

\section{4.}

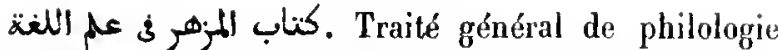
arabe, par Djalâl al-Dìn al-Soyoutṭi. L'ourrage se compose de cinquanle chapitres. (Voyez le Catalogue de la bibliothèque de Leyde, t, I, p. 45.) Commencement : .

Ms. daté de l'an 960 de l'hégire (1552-1553 de J. C.). Il a appartenu à Fresnel.

Papier. a6a feuillets. Hauteur, a 3 centimètres; largeur, 16 centimètres et demi. 25 lignes par page. - (Supplément $133_{1} 6$ ter.)

\section{5 et 3986 .}

Nème ouvrage.

Ms. exéculé au Gaire en 1251 de l'hégire (1835 de J. C.) par le célèbre philologue Al-Wafầi al-Hourînî̀. Notes marginales. 
2 vol. Papier. 182 et 184 fenillets. Hauteur, 23 centimètres et demi; largeur, 16 centimètres et demi. 97 lignes par page. - (Supplément $\$ 3 \rrbracket 6$ bis.)

\section{GRAMLIAJRE.}

\section{7.}

Le Kitab de Sibawaïh (Voyez, sur cet ourrage, l'Anthologie grammaticale de $M$. de Sacy, p. 381 et suiv.)

Papier. 596 feuillets. Hauteur, 32 centimètres; largeur, 22 centimètres. 25 lignes par pagc. Hs. du xiv siècle.-( Supplément 1155.)

\section{8.}

"Le Secret de l'art», par Abou 'L-Fath 'Othmân ibn Djinni. L'auteur traite des leltres de l'âphabet, de lenr valeur phonétique, etc. Cet exemplaire commence par une dédicace dont quelques mots sont

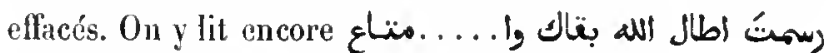

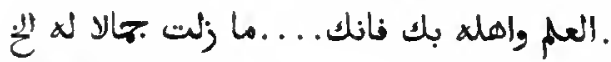

Ms. daté de l'an 552 de l'hégire (1157 de J. C.).

Papier. 229 feuillets. Hauteur, 17 centimètres; largeur, 13 centimètres. 21 lignes par page. - (Ancien fonds 1294 .)

\section{9 .}

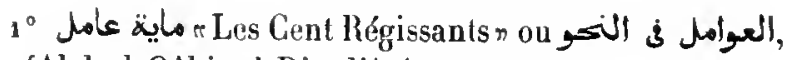
par 'Abd al-Qâhir at-Djordjânî.

$2^{\circ}$ (Fol. $10 \mathrm{v}^{\circ}$.) LiAdjorroûmîya.

$3^{\circ}$ (Fol. $42 r^{\circ}$.) Premiers feuillets d'un commentaire sur les Cent Régissants. Commencement: الن اوله ما نطقت الانا

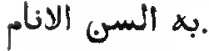

$4^{\circ}$ (Fol. $48 v^{\circ}$. ) Copie intégrale du même commentaire, écrite de la même main.

$5^{\circ}$ (Fol. $85 \mathrm{r}^{\circ}$.) Autre commentaire sur les Cent Ré-

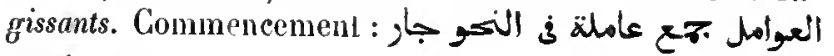
395 .

Notes marginales.

Papier. 94 feuillets. Hautcur, 22 centimètres ct demi; largeur, 16 centimètres. Écrilures diverses. - (Supplément 1224.)

\section{0.}

$1^{\circ}$ Les Cent Régissants d'Al-Djordjânî.

$2^{\circ}$ (Fol. $177^{\circ}$ ) Commentaire sur les Cent Régissants.

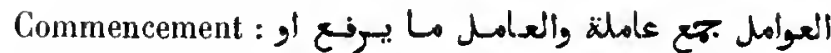

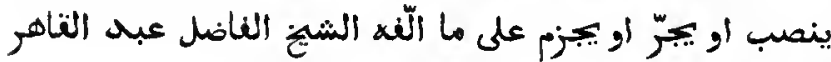

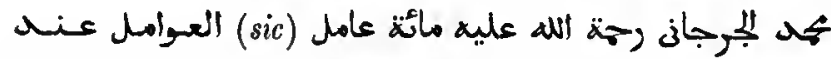

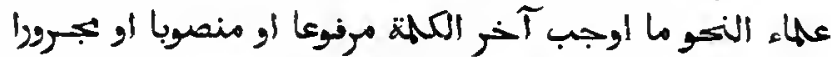

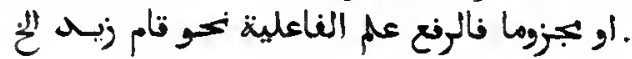

$3^{\circ}$ (Fol. $7^{\circ} \mathrm{v}^{\circ}$.) Une tradition et un exercice grammatical.

Nombreuses gloses marginales.

Aux folios 16 bis $v^{\circ}, 69 v^{0}, 7^{3}$ à 75 , se trouvent quelques notes en langue malaye.

Papier. $7^{5}$ feuitlets. Hauteur, 20 centimètres; largeur, 15 centimètres. Écritures diverses du xv11 sièclc. - (Ancien fonds 1289.$)$

\section{1.}

$1^{\circ}$ Les Cent Régissants d'Al-Djordjànî.

$2^{\circ}$ (1'ol. $19 v^{\circ}$.) Le Suffisant, traité de grammairer. C'est le texte de la Kafiya d'Ibn atHâdjib, arec quelques modificalions. Les dernjers cahiers ont élé écrits à Mâridîn, par un diacre nomné Thomas, en 959 de l'hégire ( $155_{2}$ de J. C.).

Papier. 68 feuillets. Hauteur, 15 centimetres et demi; largeur, 10 centimètres. Écritures diverses du $x_{x 1^{i}}$ et du xv11 $^{e}$ siècle. - (Supplément 1223.)

\section{2.}

1. Commentaire sur les Cent Régissants d'Al-Djordjûnî.

$2^{\circ}$ (Fol. $17 v^{\circ}$ ) حسباح. Traité de grammaire, par Al-Motarrizì.

Gloses marginales et interlinéaires.

Papier. 56 feuillets. Hauteur, 18 centimètres et demi; largeur, 14 centimètres. Diverses écritures du xvi siècle. - (Ancien fonds 1288, Colbert 6142.)

\section{3.}

$1^{\circ}$ Commentaire de Yahyâ ibn Nasoûh (نصوح) ibn 
Isrâîll sur les Cent Régissants. Commencement : توجهن .الى جنابك وقصدمنا نحو بابك.

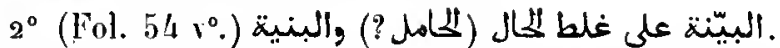
Indication des fautes d'orthographe que l'on est exposé à

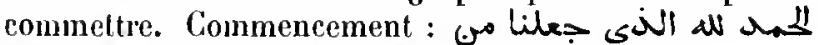

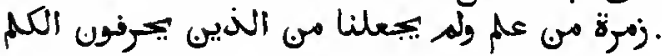

$3^{\circ}\left(F_{0} l .79 v^{\circ}\right.$.) Gloses sur un commentaire d'un Iraité de grammaire. Les premiers mots expliqués sont:

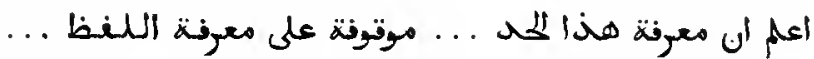
.

$4^{\circ}$ (Fol. $125 \mathrm{v}^{\circ}$.) Explication des vers cités comme exemples dans le traité de grammaire intitulé الضوء.

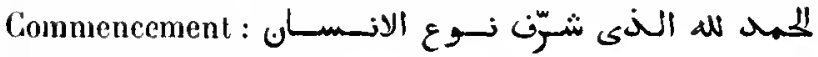

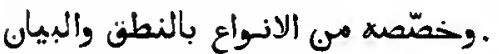

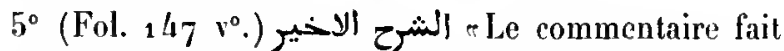
en dernier lieun. C'est le troisième traité composé par Kamâl ibn 'Alì ibn Isḥàq pour expliquer les vers cités

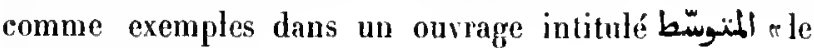
traité moyen".

$6^{\circ}$ (Fol. 184.) Traité sur les usages que l'on doit observer dans les discussions (سالة ف ألب البكث)

Ms. daté de l'an 1018 de l'hégire ( 609 de J. C.).

Papier. 184 feuillets. Hautenr, 18 centimètres et demi; largeur, 11 eentimètres. 19 lignes par page. - (Supplément 1225.)

\section{4.}

Perle du plongeur, traité des fautes (de langage) où tombent les gens distingués." Ouvrage grammatical et philologique composé par Aboû Mohammad al-Qàsim Al-Harìî. Commencement : Lol

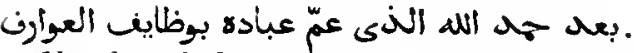

Ils. daté de l'an 1013 de l'hégire (1604 de J. C.).

Papier. 63 feuillets. Hauteur, 22 centimètres el demi; largeur, 15 cenlimètres. 23 lignes par page. - (Supplément 1197.)

\section{5 .}

Même ouvrage.

Papier. 88 feuillets. Hauteur, a I centimètres et demi; largeur, 15 eenlimètres. 19 lignes par page. Ms. du xvrü siècle. - (Supplément 2289.)

$$
\text { May. oriestac } \text { X. - Il. }
$$

\section{6.}

récréation grammaticale et chapelet de notions liltéraires". Petit traité de svutaxe désinentielle, en vers, par Aboû Mohammad alQàsim Al-Harîrî̀.

Papier. 20 feuillets. IJautenr, 18 centimètres; largeur, 13 centimètres. 11 lignes par page. Ms. du xuı siècle. - (Supplément 1 195.)

\section{7.}

Le expliqué et commenté par l'auteur lui-même.

Ms. dalé de l'an $117^{4}$ de l'hégire ( 1760 de J. C.).

Papier. 146 feuillels. Hautcur, a 1 centimètres; largeur, 15 centimètres. 17 lignes par page. - (Supplément a 391.)

\section{8.}

\section{Même ouvrage.}

Papier. it feuillets. Hauteur, 25 centimètres et deni; largeur, 19 centimètres et demi. Environ 18 lignes par page. Ms. dı xır siècle. - (Supplément 1196.$)$

\section{9 .}

Même ouvrage. Le ms. ne renferne que le premier liers du texte et du commentaire.

Papier. 26 feuillets. Hauteur, 18 centimètres; largeur, 13 centimètres. 17 lignes par page. Ms. du xvi" siècle. - (Supplément s 136.)

\section{0.}

Petit traité de grammaire arabe par Abou 'l-Fadhl Ạ̣mad ibn Mohammad al-Mä̈dânî. Commencement :

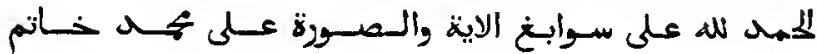
(النبيبين.

Papier. 6 feuillets. Hauteur, 19 centimètres et demi; largeur, 13 centimètres et demi. 17 lignes par page. Ms. du xvmı" siècle. (Supplément 3272.)

\section{1.}

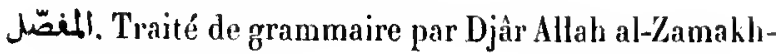




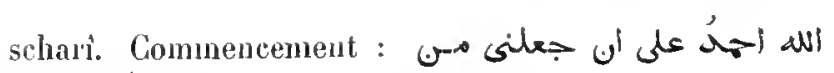
عاء العربية.

Ms. daté de l'an 738 de l'bégire (1338 de J. C.).

Notes marginales.

Papier. 224 feuillets. Hauteur, 24 centimètres; largeur, 16 centimètres. 3 lignes par page. - (Supplément 1243.)

\section{2.}

Hème ouvrage. Le commencement manque.

Ms. daté de l'an $7^{80}$ de l'hégire $(1378-1379$ de J. C. $)$. Notes marginales.

Papier. 147 feuillets. Hauteur, 25 centimètres; largeur, 17 centimètres. 13 lignes par page. - (Supplément 1244.)

\section{3.}

"La Clef\%. Commentaire très étendu sur le Mofașsal d'Al-Zamakhscharî, par Ḷ̣mad ibn Maḥmoûd Ml-Djoudi. Hadji Khalfa fait mention de cet ouvrage

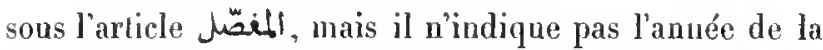
mort de l'auteur. Commencement : إياك أحد على نسم: تته

Ms. daté de l'an 754 de l’hégire (1353-1354 de J. C.).

Papier. 202 Ccuillcts. Hauteur, 26 centimètres et demi; largeur, 18 centimètres. 25 lignes par page. - (Ancien fonds 1299.)

\section{4.}

Prenière partic d'un commentaire sur le Mofașsal d'Al-Zamakhscharî. Le commencement et la fin manquent. Le ins. renferme l'explication des pages 8 à 36 du texte imprimé à Christiania. C'est peut-être le grand commentaire en quatre volumes composé par 'Alam alDỉn al-Sakhâwî̀ sous le titre de Mضّلl). (Voyez Hadji Khalfa, t. VI, p. 39.)

Papier. 235 feuillets. Hauteur, 26 centinètres et demi; largeur, 17 centimètres et demi. 15 ì 19 lignes par page. Mis. du $\mathrm{xp}^{*}$ siècle. - (Supplément 2229.)

\section{5 .}

نشّح الانموذج . Commentaire de Djamíl al-Dìn Moham- mad ibn 'Abd al-Ghanî al-Ardabîlì sur le traité de grammaire d'Al-Zamakhscharî, intitulé الآكوذج "le Spécimen». Les derniers feuillets manquent. Commence-

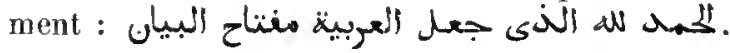

Papier. 69 feuillets. Hauteur, 18 centimètres; Iargeur, 15 centimètres et demi. Au commencement 16 , puis 15 lignes par page. Ms. du xvi" siècle. - (Supplément 1242.)

\section{6.}

$1^{\circ}$ Même ouvrage.

$2^{\circ}$ (Fol. $\left.46 v^{\circ}.\right)$ Traité de grammaire, commençant par res mots : وبعد فهذه وسالة فيما بحتاج اليه كل معرب

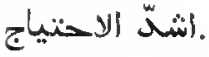

$3^{\circ}$ (Fol. $58 v^{\circ}$.) L'Adjorroumiya.

$4^{\circ}$ (Fol. $62 v^{\circ}$.) relution des difficultés du Qawấid (d'lbn-Hischàm)», par Abou 'lThand Aḷmad ibn Mohammad al-Zílì, mort en 922 de l'légire (1516 de J. C.). (Voyez Hadji Khalfa, t. I,

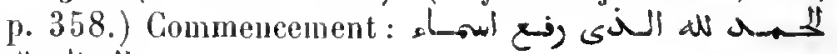
it

$5^{\circ}$ (Fol, $95 v^{\circ}$.) Commentaire de Maḥmoûd rbn Sacid ibn 'Abd Allah ibn Mikâ'ill sur le Qawểid d'lbn Hischâm.

Ms. daté de l'au 1087 de l'hégire (1676-1677 de J. C.).

Papier. 120 feuillets. Hauteur, 20 centimètres et demi; largeur, 15 centimètres, 21 à 25 lignes par page. - (Supplément 1342 bis.)

\section{7.}

Manuel du commencant et aide-mémoire du savant. Traité de grammaire, par Aboû Moḅammad 'Abd Allah ỉnn 'Alì ibn Ishàq alSaiïmarì (الصبمى), probablement l'auteur qui, d'après Hadji Khalfa (t. II, p. 1 79) est mort en 541 de l'hégire ( $1446-1147$ de J. C.). Cet ouvrage se coupose de deux parties. Le présent ms. renferme les cinq dernières pages de la première et la totalité de la seconde partie. Soyoûtî̀ mentionne l'ouvrage d'Al-Ṣaïmarî dans le Dictionnaire des grammairiens.

Ms. exécuté en Espagne et daté de l'an 502 de l'hégire ( 11109 de J. C.).

Papier. 67 feuillets. Hauteur, 23 centimètres et demi; largeur, 18 centimètres. 28 lignes par page. - (Ancien fonds 1295.) 


\section{8.}

$1^{\circ}$ حصباح. Traité de grammaire, par A1-Moṭarrizî.

$2^{\circ}$ (Fol. 41.) Les Cent Régissants d'M1-Djordjànì.

Papier. 53 feuillets. Hauteur, 15 centimètres et demi; largeur, 10 centimètres. 10 , puis 9 lignes par page. Mls. du $\mathbf{x w}^{2}$ siècle. (Ancien fonds 1358.)

\section{9.}

الضوء. Commentaire de Tàdj al-Dìn Mohammad AlIsfarâinî sur le traité de grammaire المصباح d'Al-Moṭar-

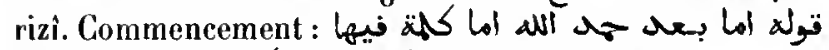

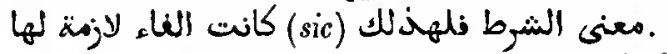

Ms. daté de l'an 779 de l'hégire ( $1377^{-1} 378$ de J. C.). Les cinf premiers feuillets sont modernes.

Nombreuses notes marginales et interlinéaires.

Papier, 206 feuillets. Hauteur, 18 centimètres; largeur, 13 centimètres. 2 lignes par page. - (Ancien fonds 127\%.)

\section{0.}

Mème ouvrage.

Ms. daté de l'an 954 de l'hégire (1547 de J. C.).

Notes marginales et interlinéaires.

Papier. 128 feuillets. Hauteur, 19 centimètres et demi; largeur, 13 centimètres et demi. 15 lignes par page. - (Ancien fonds 1274 .)

\section{1.}

Même ouvrage.

Ms. daté de l'an 1015 de l'hégire (1606-1607 de J. C.). Notes marginales et interlinéaires.

Papier. 133 feuillets. Hauteur, 18 centimètres; largeur, 13 centimètres. 13 lignes par page. - (Supplément 1236.)

\section{2.}

Mème onvrage. Cet exemplaire est précédé d'une préface rédigée avec élégance et commençant ainsi : لى النقّ

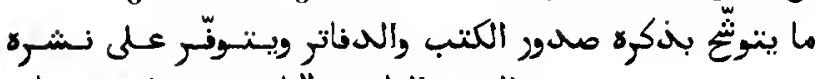

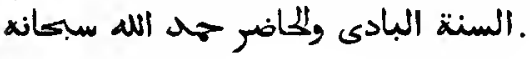

Ms. daté de l'an 1016 de l'hégire ( $1607-1608$ de J. C.).

Notes marginales et interlinéaires.

Papier. 2 20 feuillets. Hauteur, 20 centimètres; largeur, 13 centimètres. 17 lignes par page. - (Ancien fonds 1275 .)

\section{3.}

Mème ouvrage.

Ms. daté de l'an 1059 de l'hégire ( 1649 de J. C.).

Notes marginales el interlinéaires.

Papier. 122 feuillets. Hauteur, 20 centimètres; largeur, $1 /$ centimèlres. 15 lignes par page. - (Ancien fonds 1314 .)

\section{4.}

Mème ouvrage. Cet exemplaire renferme la préface de l'auteur.

Papier. 211 feuillets. Hauteur, 21 centimèlres; largeur, 15 centimètres et demi. 13 lignes par page. Ms. du xvı ${ }^{\circ}$ siècle. - (Ancien fonds 1276 .)

\section{5.}

$t^{\circ}$ Hème ouvrage.

Copie datée de l'an 1077 de l'hégire (1667 de J. C.).

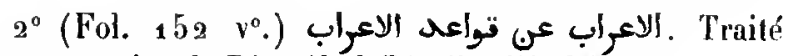
de grammaire de Djamàl al-Dìn ibn Hischâm.

$3^{\circ}$ (Fol. $17^{4} v^{\circ}$.) L'Adjorroumiya.

$4^{\circ}$ (Fol. $179 \vee^{\circ}$.) Traité de grammaire, par un auteur nommé Aboú 'Abd Allah al-Moḷammad (Masll) ibn 'Alì Sạliḥ al-'Alimî al-Moṭarriz. Commencement:

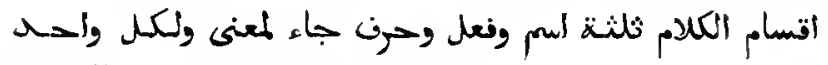

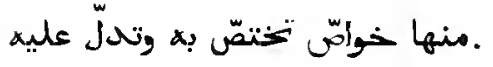

$5^{\circ}\left(F_{0}\right.$. $185 v^{\circ}$.) Commentaire sur les Cent Régrissants.

$6^{\circ}$ (Fol. $188 v^{\circ}$.) Commencement du texte des Cent Régissants.

Papier. 190 feuillets. Hauteur, 20 centimètres; largeur, 13 centimètres. Diverses écritures du xrü siècle. - (Supplémrnt 12.31, Saint-Germain 6 17.)

\section{6.}

1 Préface de l'ouvrage d'Al-Isfaràïnî. 


\section{MANUSCRITS ORIENTAUX.}

$2^{\circ}\left(\right.$ Fol. $5 v^{\circ}$.) Commentaire de Djamâl aj-Din Hoḷammad ibn 'Abd al-Ghanî al-Ardabîlì sur le traité de grammaire d'Al-Zamakhscharì intitulé

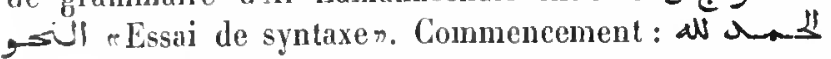

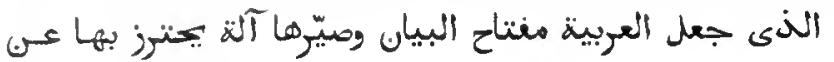
المان.

Papier. 64 feuilltets. Hauteur, 20 centimètres el demi; largeur, 14 centimètres el demi. 17 lignes par page. Ms. du xvi' siècle. (Incien fonds 1287. )

\section{. 4017.}

$1^{\circ}$ Derniers feuillets du commentaire du Mişbâh intilulé الافنتانتان.

$2^{\circ}$ (Fol. 5.) Commentaire sur les Cent Régissants.

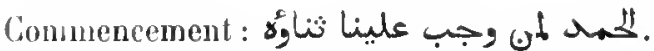

Ms. daté de l'an $99^{3}$ de l'hégire ( 1585 de J. C.).

Papier. 35 feuillets. Ilauteur, 19 centimètres; largeur, 13 centimètres et demi. 21 lignes par page. - (Supplément 19/1.)

\section{8.}

政 taire anonyme sur le Mișbahh. Commencement:

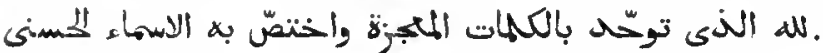

Ils. daté de lan 1064 de l'hégire (1654 de J. C.).

Papier. 226 feaillets. Ilauteur, 16 centimètres; largeur, 11 centimìtres. 11 lignes par page. - (Ancien fonds 1364.)

\section{9 .}

Commentaire sur la préface (الهيباجة) du Mişbâh .

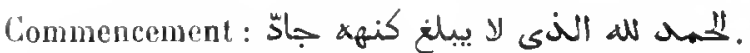

Papier. 46 feuillets. Hautenr, 20 centimètres et demi; largeur, 14 centinètres et demi. 13 ligrnes par page. Ms. du xvi1' siècle. (Supplément 1238. )

\section{0.}

$1^{\circ}$ Les cinq premiers feuillets d'un exemplaire du même ourrage.
$2^{\circ}\left(F_{01} .6 \checkmark^{\circ}\right.$.) Traité de grammaire qui commence

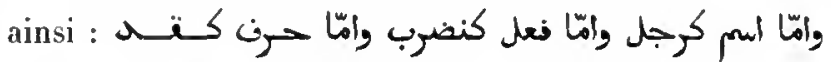

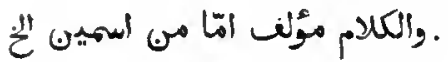

$3^{\circ}$ (Fol. $20 v^{\circ}$.) Le traité الضوء accompagné de nombreuses gloses.

Ms. daté de l'an 1064 de l'hégire ( 1654 de J. C.).

Papier. 151 feuillets. Hauteur, 21 centimètres; largeur, 15 centimètres. 17 lignes par page. - (Supplément 1239.)

\section{1 .}

$1^{\circ}$ Commentaire sur la préface du Mişbâh d'Al-Nolarrizi. Mème ourrage que les précédents, sans l'intro-

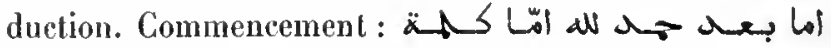

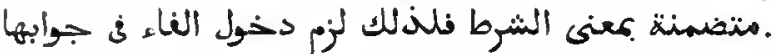

$2^{\circ}\left(\right.$ Fol. $38 v^{\circ}$.) La Káfiya d'llbn al-I!làdjib.

$3^{\circ}$ (Fol. $721^{\circ}$.) Le Miṣbâh d'Al-Moṭarrizî.

$4^{\circ}$ (Fol. $977^{\circ}$.) Les Cent Régissants d'Al-Djordjànî.

Les articles $2^{\circ}$ et $3^{\circ}$ sont datés de l'an $9_{9}^{3} 9$ de l'luégire (1532-1533 de J. C.).

Papier. 109 feuillets. Hautenr, 18 centimètres et demi; largeur, 12 centimètres el demi. - (Ancien fonds 1307 .)

\section{2.}

$1^{\circ}$ Commentaire sur la préface du Mişbahh. Même ouvrage que les précédents, sans l'introduction.

$2^{\circ}\left(\right.$ Fol. $35 v^{\circ}$.) Le Miṣbâh, accompagné de nombreuses gloses.

$3^{\circ}\left(\right.$ Fol. $7^{\circ} v^{\circ}$.) Commentaire de Djamâl al-Dìn Moḷammad jbn 'Abd al-Ghanî al-Ardabîlî̀ sur l'Anmoûdsadj d'Al-Zamakhscharî.

Les deux premières pièces sont datées de l'an $9^{83}$ de l'lıégire ( $1575-1576$ de J. C. ), la troisième, de l'an 1048 de l'hégire ( $1638-1639$ de J. C.).

Papier. 136 feuillets. Hauteur, 21 centimètres; largeur, 15 centimètres. - (Ancien fonds 1313. )

\section{3.}

$1^{\circ}$ Explication du commentaire du Mişăh contenu dans les $n^{o s}$ précédents, par Yáqoûb ibn Saiyid 'Alî. 


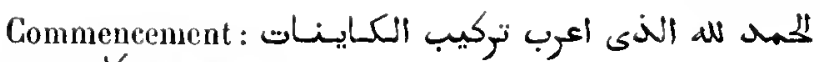

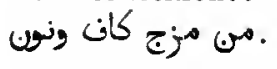

$2^{\circ}$ (Fol. $7^{5}$.) Fragment d'un commentaire sur un traité de grammaire. Dans ce commentaire on a inséré les explications données par plusieurs savants, tels que 'Alî̀ Kouschdjì, lbn Kamâl Pacha, Moṣanuifak, etc.

$3^{\circ}$ (Fol. 78 \%.) (Quintessence de la syntaxe désinentielle . Commen taire sur Ie Miṣbâh d'AlMoḷarrizi, par Hảddji Bàbà ibn al-llàddji lbrâhìn al-

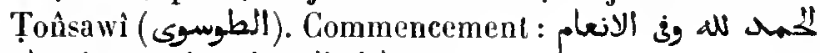
. فاطر السموأت واللإون والانعأم

$4^{\circ}$ (Fol. $145 v^{\circ}$.) Explication des vers cités comme exemples daus le Dhaou d'Al-Isfarâinì, par Ismàîl ibn 'Ali. Commencement : المهاء.

Ms. dalé des années $97^{2}$ et $97^{4}$ de l'hégire $(1565$ et 1567 de J. C.).

Papier. 156 feuillets. Hauteur, 20 centimètres et demi; largeur, 13 centimètres. 21 liggnes par pagge. - (Ancien fonds 1321.$)$

\section{4.}

Mème ouvrage que l'article $1^{\circ} \mathrm{du} \mathrm{n}^{\circ}$ précédent.

Papier. 104 feuillets. Hauteur, so centimètres; largeur, 13 centimètres. 17 lignes par page. Us. du xvü siècle. - (Supplément 1237.)

\section{5 .}

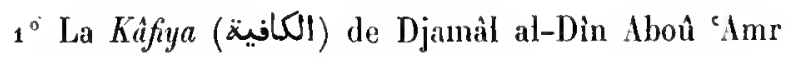
'Othmân ibn 'Omar ibn al-I!aidjils.

$2^{\circ}$ (Fol. $59 v^{\circ}$.) Le Mişbal d'Al-Notarrizi.

$3^{\circ}$ (Fol. $9^{8} v^{\circ}$.) Commentaire sur les Cent Régissants

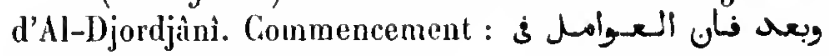

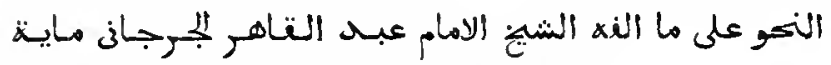

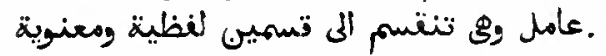

$4^{\circ}$ (Fol. $106 \mathbf{v}^{\circ}$.) Autre commentaire sur le mème traité. Coumencement : ولمه لهم وجب ثنائه (sie)

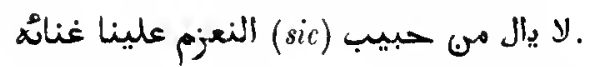

Les articles $3^{\circ}$ et $4^{\circ}$ sont datés de l'an $99^{2}$ de l'hégire (1584 de J. C.).

Papier. 140 fevillets. Hauteur, so centimètres; largeur 13 centimètres. Ns. du svl' siècle. - (Aucien fonds 1283 , Colbert 5000.)

\section{6.}

$1^{\circ}$ La Kâfya d'lbn al-Hadjib. Copie datée de l'an 979 de lhégire $\left(1571-157_{2}\right.$ de J. C.).

$2^{\circ}$ (Fol. $54 v^{\circ}$.) Le Mişbáh d'Al-Motarrizì.

Papier. 84 fenillets. Jlauteur, 19 centimètres el demi; largeur, 14 centimètres. - (Ancien fonds 1978 .)

\section{7.}

$1^{\circ}$ La Kafrya d'lbn al-I!àdjib.

Notes marginales.

Papier. 53 fenillets. Hauteur, 18 centimètres; largenr, 13 centimètres. 7 à 9 lignes par page. Ms. du xvi e siècle. - (Ancien (onds 127.')

\section{8 .}

$1^{\circ}$ Mème ourrage.

$2^{\circ}$ (Fol. 68 ro.) Le Mişbâle d'Al-Motarrizì.

$3^{\circ}$ (Fol. 111 $^{\circ}$.) Les Cont Régrissants d'Al-Djordjànì.

Hs. daté de l'an 1057 de l'hégire (1647 de J. C.).

Papier. 194 feuillets. Hanteur, 18 centimètres; largeur, 10 centimètres. 11 lignes par page. - (Supplément 1206.)

\section{9.}

$1^{\circ}$ La Káfiya d'lbn al-l!àdjib.

$3^{\circ}$ (Fol. $78 \mathrm{v}^{\circ}$.) Résumé de la grammaire arabe.

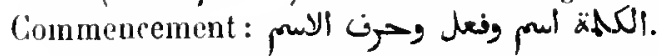

$3^{\circ}$ Notes diverses et prières, dont l'une, intitulée

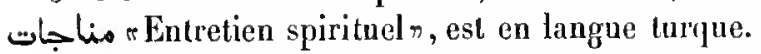

Papier. $9^{3}$ feuillets. Hauteur, 15 centimètres; largeur, 10 centimètres. 7 lignes par page. Hs. du xvı" siècle. - (Ancien fonds ı 356.)

\section{0 .}

$1^{\circ}$ La Kâfiya d'lbn al-Ḥ̂âjib.

$2^{\circ}$ (Fol. 75 v $^{\circ}$.) Le Miṣbăh d’Al-Moțarrizì.

Papier. 12 a feuillets. Hauteur, 16 centimètres; largeur, 11 centimètres. Diverses écrilures du xvi1' siècle. - (Ancien londs 1355.) 


\section{1.}

$1^{\circ}$ La Kafiya d'Ibn al-Itàdjib.

$2^{\circ}$ (Fol. $29 \vee^{\circ}$.) Le Mişbâh d'Ml-Motararizì.

$3^{\circ}$ (Fol. $50 v^{\circ}$.) Les Cent Régissants.

Ms. dalé de l'an 1180 de l'hégire (1766 de J. C.).

Papier. 60 feuillets. Hautenr, 16 centimètres, largeur, 10 centimètres et demi. 15 , puis 13 lignes par page. - (Supplément 1235.)

\section{2.}

$1^{\circ}$ La Kaffya d'Ibn al-Hàdjib. Le commencement et la fin manquent.

$2^{\circ}$ (Fol. 41.) Premier el dernier feuilltet d'une pièce de vers qui est une amplification du

Notes marginales.

Papier. 4 a fenillets. Hauteur, a a centimètres; largeur, 15 centimètres. 7 lignes par page. Its. du xvü siècle. - (Supplément 2123. )

\section{3.}

$1^{\circ}$ La Kafiya d'Ibn al-Ịâdjib.

$2^{\circ}$ (Fol. $43 \vee^{\circ}$.) Trailé de gramınaire commençant

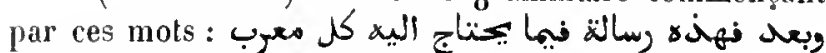
(أشهد الاحتياج (Comparez, ci-dessus, n 4006 20.)

$3^{\circ}$ (Fol. 83 v $^{\circ}$ ) Un traité des Cent Régissants qui

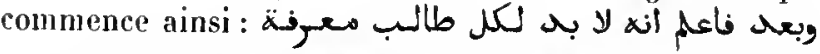

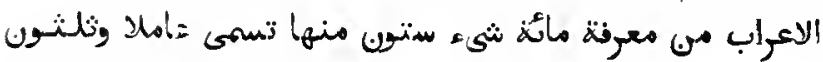

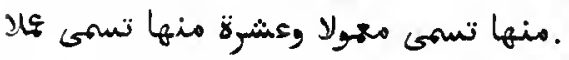

Ms. daté de l'an 1218 de l'hégire (1803-1804 de J. C.).

Papier. $9^{1}$ feuillets. Hauteur, 15 centimètres et demi; largeur, 11 centimd̀res. 11 lignes par page. - (Supplément 1222.)

\section{4.}

Têtes de chapitre de la Kafiya d'Ibn al-1̣àdjib, avec une raduction italienne. Ce texte est suivi d'une liste des noms des constellations.

Papier. 11 feuillets. Hauteur, a centimètres; largeur, 15 centimètres. Ms. du xvire siècle. - (Supplément $239^{\circ}$.)

\section{5 .}

La Káfiya d'Ibn al-ḷadjib, en vers dont la rime est la syllabe ${ }^{2}$. Cel ouvrage a été composé en l'an ذنب 752 de l'hégire, 135 1-1352 de J. C.). Commencement : كلد (75)

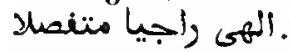

Papier. 81 fenillets. Hauleur, 24 centimètres; largeur, 16 centimètres. 5 lignes par page. Hs. da $x^{*}$ siècle. - (Supplément ${ }_{11}$ 99.)

\section{6.}

Commentaire sur la Kâfrya d'lbn al-Hiâdjib. Commen-

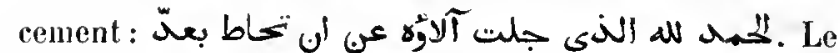
nom de l'auteur, Nadjm al-Dín al-Ridhà, ajouté après coup, en tète du volume, ne parait pas exact.

Papier. ${ }_{2} 49$ feuillets. Hauteur, 27 centimètres; largeur, 18 centimètres. 37 lignes par page. Ms. du xiv' siècle - (Ancien fonds 1227.)

\section{7.}

re Parlait, commentaire sur la Kafiya", par Rokn al-Din Ḥasan ibn Mohammad alAslarîbâdi, mort en 719 de l'bégire $(1319-1320$ de J. C.). Commencement:

Noles marginales et interlinéaires.

Ms. daté de l'an 836 de l'hégire (1432-1/33 de J. (.).

Papier. 138 feuillets. Hanteur, 27 centimètres et demi; largeur, 18 centimètres. 21 lignes par page. - (Ancien fonds 1228 .)

\section{8.}

Mème ouvrage.

Ms., de deux mains différentes, daté de l'an 1024 de l'lıégire ( 1615 de J. C.).

Papier. 218 feuillets. Hauteur, 19 centimètres et demi; largeur, 12 centimètres et demi. - (Supplément a 125. .)

\section{9.}

Même ouvrage.

Papier. 181 feuillets. Hanteur, 21 centimètres; largeur, 15 centimètres. 15 à 19 lignes. Ms. du xvir siècle. - (Supplément $119^{8}$ bis.) 


\section{0.}

rexplication des difficultés de la Wáfya, commentaire de la Kafiyar, par Mohammad ibn 'Omaïr al-Halabì. Commencement:

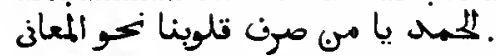

Ms. daté de l'an $9^{62}$ de l'hégire ( 1555 de J. C.).

Papier. 113 fevillets. Hauteur, 20 centimètres; largeur, 12 centimètres. 21 lignes par page. - (Supplément 1198.)

\section{1.}

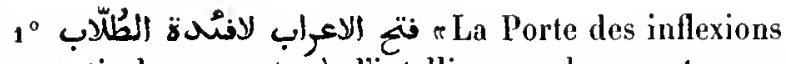
grammaticales ouverte à l'intelligence des amateursn. Commentaire sur la Kafiya d'Ibn al-llâdjib, par Yoủsof ibn Aḥmad al-Niẓàmi. L'ouvrage est dédié au sultan Moḥammad, fils de Bâyezid. Commencement : ول

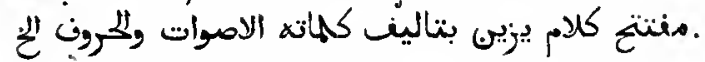

$2^{\circ}$ (Fol. $68 \mathrm{v}^{\circ}$.) Notes de diverses mains, en arabe et en turc.

$3^{\circ}$ (Fol. $6_{9} v^{\circ}$.) Les Cent Régissants d'Al-Djordjìnì, avec un commentaire perpétuel en langue turque. Com-

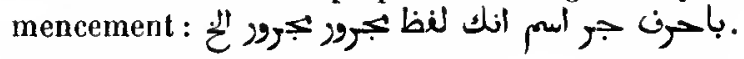

$4^{\circ}$ (Fol. 86 vo $^{\circ}$ ) Commentaire d'Al-Ardabilil sur le d'Al-Zamakhschari.

Papier. 158 feuillels. Hautcur, 17 centimètres el demi; largeur, 14 centimètres. Diverses écrilures du xvie siècle. - (Supplément 2127.)

\section{2.}

Commentaire sur la Kâfiya d'lbn al-Hàdjib. L'auteur n'est pas mentionné dans la préface; mais le mot خبيصى, écrit sur la tranche du volume, permet de supposer que cet ouvrage est d'lbn abì Bakr al-Khabị̦i (Hadji Khalfa,

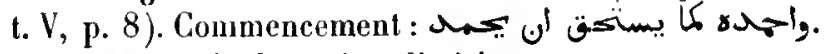
Notes marginales et interlinéaires.

Papicr. 234 fenillets. Hauteur, 21 centimètres el demi; largeur, 15 centimètres. 13 à 15 lignes par page. Us. dı wu siècle. (Supplément 1203.)

\section{3.}

Mème ouvrage.

Nombreuses notes marginales et interlinéaires. En tête du volume on lit des notes et des extraits divers.
Papier. 238 feuillcts. Hauleur, a1 centinètres; largeur, 13 centimètres el demi. 15 lignes par page. Ms. dn $\mathrm{w}^{\circ}$ ou du $\mathrm{vw}^{\circ}$ siècle. (Supplément 2126.)

\section{4.}

. Commentaire sur la Kafiya d'lbn alHảdjib, par 'Abd al-Raḥmàn ibn Aḷmad al-Djàmì.

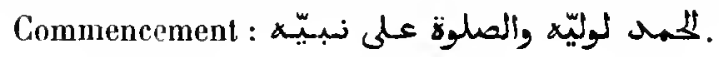

Ms. daté de l'an 948 de l'hégire (1541-1542 de J. C.).

Papier. 136 feuillets. Hauteur, 19 centimètres et demi; largeur, 12 centimètres. 25 lignes par page. - (Ancien fonds $1: 80$.)

\section{5.}

Hème omrage.

Ms. daté de l'an $9^{6} 9$ de l'hégire (1561-1562 de J. C.).

Papier. a 38 feuiltets. Hauteur, 17 centimètres; largenr, 1 a centimètres. 19 lignes par page. - (Ancien fonds 1357 .)

\section{6.}

Nème ourrage. La fin manque.

Noles marginales et interlinéaires.

Papier. 218 feuillets. Hauteur, 18 centimètres et demi; largeur, 11 centimètres. 17 lignes par page. Hs. du xvi siècle. - (Supplément 1202.)

\section{7.}

Nlème ouvrage.

Ms. daté de l'an $99^{8}$ de l'hégire $\left(1589^{-1} 59_{9}\right.$ de J. C. $)$. Notes marginales.

Papier. $3_{12}$ feuillets. Hauleur', 18 centimètres; largeur, 10 centimèıres. 17 lignes par page. - (Supplément 1901.)

\section{8.}

$1^{\circ}$ Mème ouvrage.

$2^{\circ}\left(\text { Fol. } 17^{6} \stackrel{\circ}{\circ}\right)^{\circ}$ Commentaire sur la prélace de la Wàfiya. 
$3^{\circ}$ (Fol. 1 $7^{6 .}$.) Noles diverses.

Ms. daté de l'an 1011 de J'hégire (1602 de J. C.).

papier. 178 fenillets. Hauteur, 19 centimètres; largeur, 11 centimètres. 21 lignes par page. - (Ancien fonds 1363.)

\section{9 .}

Le Fanuîid al-Dhiyấâya de Djâmî.

Ms. daté de l'an 1027 de l'hégire (1618 de J. C.).

Papier. 187 feuillets. Hauleur. 22 centinètres; largeur, 15 centimètres. 21 lignes par page. - (Ancien fonds 12 7 o.)

\section{0.}

Mème ourrage.

Papier. 387 feuillets. Hauteur, a 1 centimètres; largeur, a centimètres et demi. 13 lignes par page. Ns. du xwı siècle. - (Supplément 1200.)

\section{1 .}

$1^{\circ}$ Fragment du mểne ourrage.

$2^{\circ}\left(F_{0} l .60 v^{\circ}.\right)$ Les Cent liégissants d'Al-Djordjàni. La fin manque.

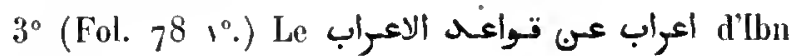
Hischâm.

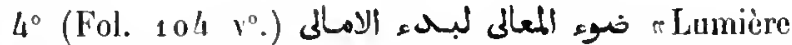
des haules (pensées) jetée sur le Bad' al-Amâlin». Comnentaire d'Alì lbun Soltân Moḷammad al-Qàrî mort en 1014 de l'héggire (1605 de J. C.) sur la qaṣîda rimanl en ali (Ji) de Sirâdj al-Din 'Alì ibn 'Othmân al-Ouschî. Ce poème est ordinairement désigné par le titre de

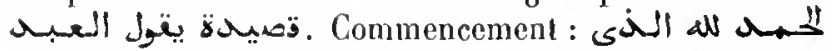

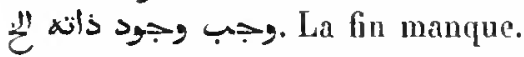

Papier. 125 fevillets. Hauteur, 16 centimètres et demi; largeur, 11 rentimèlres. Écritures diverses du svı siécle. - (Supplément 2124.)

\section{2.}

Le Fawâid al-Dhiyââya de Djâmî.

Papier. 240 fevillets. Hauteur, a 1 centimètres; largeur 15 centimètres. 17 lignes par page. Ms. du xvı" siècle. - (Ancien fonds 1285. )

\section{3.}

Nême ourrage. La fin manque.

Papier. 176 feuillets. Hauteur, 22 centimètres; largeur, 16 centimètres. 19 lignes par page. - (Supplément 1204.)

\section{4.}

Commentaire sur la Kafhya d'Ibn al-Hàdjib. C'est, d'après le titre, écrit en têle du volume, l'onvrage de Schihâb al-Dìn Aṭmad ibn 'Omar al-Hindì. Commence-

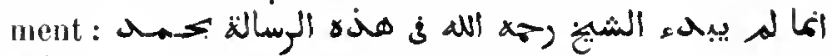
wi.

Papier. 151 feuillets. Ilauteur, go centimètres; largeur, 13 centimètres. 19 lignes par page. Ms. du xvi' siècle. — (Ancien fonds 1 2 79.)

\section{5 .}

Commentaire sur la Kafiya. Commencement:

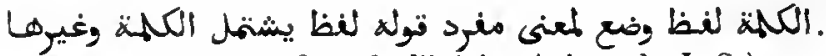
Ms. daté de l'an 895 de l'hégire ( 1490 de J. C.).

Papier. 131 feuillets. Hauteur, 22 centimètres; largeur, 15 centimètres. 16 à 18 liggnes par page. - (Ancicu fonds 1281.)

\section{6.}

elive de Rokn servant à donner de la force au langage grammalical.n Commentaire très prolixe sur la Kâfiya d'Ibn al-Hàdjib, par Rokn al-Dìn 'Alì ilon at-Fidhil al-Hadîthî. Commen-

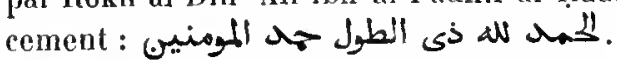

Ms. daté de l'an $109^{6}$ de l'hégire (1685 de J. C.).

Papier. 533 feuillets. Hauteur, 21 centimètres; largeur, 13 centimètres. 23 lignes par page. - (Supplément 1 259.)

\section{7.}

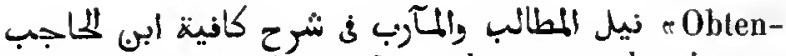
tion de ce qu'on désire et de ce dont on a besoin, en fait de commentaire sur la Kâfya d'Ibn at-Hâdjib». Le nom de l'auteur, tel qu'il est écrit sur le frontispice,

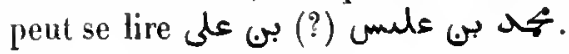

Papier. 206 feuillets. Hanteur, 21 centimètres; fargeur 15 centimètres. 19 à 24 lignes par page. Ms. du xvin' sièclc. - (Supplément 1205. ) 


\section{8.}

Traité des flexions grammaticales et de l'orthographe (خط), par Ibn al-Ḥàdjib. C'est l'ouvrage qu'on désigne ordinairement par le lilre de المنيافيـة On remarque sur te frontispice une figure circulaire formée par l'intersection de six cercles donl chacun passe par les centres des cercles voisins. Dans les intervalles se trouve une série de gloses écrites en pelits caraclères dont l'une se rapporte au mol التنصبيف. Nombreuses notes marginales.

Papier. 105 feuillets. Hauteur, 18 centimètres et demi; largeur, 11 centimètres. 9 lignes par page. Ms. du xvi siècle, - (Supplèment 1246. .)

\section{9 .}

\section{Nême ouvrage.}

Papier. 42 feuillets. Hauteur, 17 centimètres et demi; largeur, 1 a centimètres. 15 lignes par page. Ms. du xwin siècle. - (Supplément 1246 bis.)

\section{0.}

Traité dans lequel Fakhır al-Dìn Ahmad ibn al-Hasan al-Tchàrabardi (الجاربsد), mort en 740 de l'hégire (1345-1346 de J.-C.), commente le texte de la Schà-

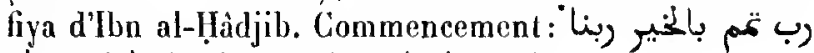

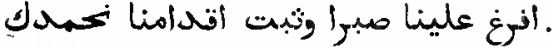

Ms. daté de l'an 785 (1383-1384 de J.-C.).

Papier. 160 feuillets. Hauteur, 29 centimètres et demi; largeur, 15 centimètres. 19 lignes par page dans la première moitié du volume, 21 dans la seconde. - (Ancien fonds 1286. )

\section{1.}

Le même commentaire d'A ḥmad ibn al-Llasan (var. alHosaïn) al-Tchârabardì sur la Schàfiya d'Tbn al-Hàdjib.

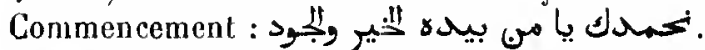

Ms. daté de l'an 1071 (1661 de J.-G.).

Papier. 196 feuillets. Hauteur, 19 centimètres et demi; largeur, 13 centimètres et demi. 17 et 18 ligues par page. - (Supplément 1 345.)

$$
\text { Max. orientaut. - } \mathrm{HI} \text {. }
$$

\section{2.}

r Voies qui suffisent pour arriver à l'intelligence de la Schâfiyan, par Aboû Yahyyâ Zakarîya al-Anșàrì. Commencement :

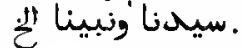

Ms. daté de l'an 1069 ( 1659 de J.-C.).

Papjer. 176 feuillets eollég sur onglets. Hauteur, 21 centimètres; largeur, 15 centimètres et demi. 23 lignes par page. - (Supplément 1230.)

\section{3.}

"Commentaire sur l'cIzzîn d'Al-Zandjâni, par Mascoùd ibn 'Omar al-Taftazìnî. Commencement :

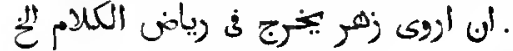

Papier. 45 feuillets. Hauteur, a1 centimètres; largeur, 15 centimètres et demi. 33 lignes par page. Ns. du svi" siècle. - (Ancien fonds 1306 .)

\section{4.}

Même ouvrage. La fin manque.

Papiier. 3o feuillets. Hauteur, 21 centimètres et demi; largeur, 13 centimètres et demi. 21 lignes par page. Ms. du xvin' siècle. (Supplément 2137.)

\section{5 .}

Commentaire anonyme sur le traité des conjugaisons inlilulé $A l-` I z z \hat{i}$. Premiers mots après les louanges de

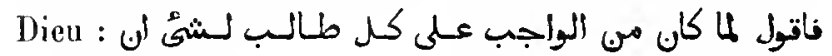

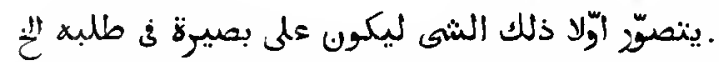

Papier. 63 feuillets. Hauteur, 17 centimètres et demi; largeur, 13 centimètres. $\mathbf{2} 5$ lignes par page. $M s$. du $x r^{\circ}$ siècle. - ( Ancien fonds 1308.)

\section{6.}

Commentaire, par قال et sur le traité des flexions inliluté $A l^{-}{ }^{\complement} I z z i$.

Ms. dalé de l'an 1049 (1639-1640 de J.-C.).

Papier. 77 feuillets. Hauteur, so centimètres et demi; largeur, 15 centimètres. 19 lignes par page. - (Ancien fonds 1309.) 


\section{7.}

1 Dernière partie d'un commentaire sur un traité de grammaire, en prose, dont l'auteur n'est désigué que par le surnom d'Aboû l'-Qásim. C'est peut-être le même personnage à qui Al-Soyoûtî a consacré un court article dans son Diclionnaire biograplique des grammairiens et qu'il appelle Aboû l'-Qâsim Aḷmad ibn

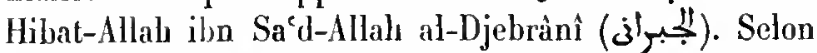
ce polygraphe (Ms. ar. de la Bibl. nat. 2119 , lol. $81 \mathrm{v}^{\circ}$ ), Aboû l'-Qàsim enseigna dans la grande mosquée d'Alep et mourut l'an 668 ( $127^{0}$ de J.-C.). Ce volume dépareillé du commentaire sur le traité d'Aboû l'-Qàsim commence

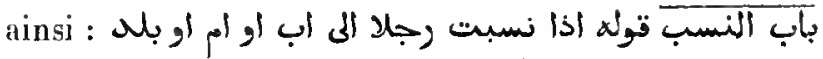

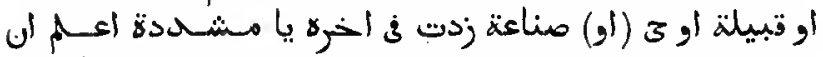
النسبب. Le second chapitre du volume (fol. $\delta v^{\circ}$ ) est intitulé : باب الن الوصل والف التطع . Le dernier a pour titre : باب م. نشواذّ الادغام : Rien n’indique le titre du commentaire ni le uom du commentateur.

$2^{\circ}$ (Fol. ${ }_{14} 4 \mathrm{v}^{\circ}$.) Définitions grammaticales par Tàdj al-Dìn Aboû 'l-Q:isim Aḷmad ibn Hibat-Allah.

$3^{\circ}$ (Fol. 149.$)$ Les

Ms. daté de l'an 685 ( 1286 de J.-C.).

Papier. 150 feuillets. Hauteur, 25 centimètres et demi; largeur, 16 centimètres el demi. 25 lignes par page. - (Ancien fonds 1232. )

\section{8.}

L'Alîya d'lbn Mâlik.

Ms. daté de l'an 861 de l'hégire (1457 de J.-C.).

Papier. 39 feuillets. Hauteur, 18 centimètres; largeur, 13 centinètres. 13 lignes par page, puis 16 lignes. - (Ancien fonds 1291.)

\section{9.}

Mème ouvrage.

Ms. daté de l'an 1078 (1668 de J.-C.).

Papier. 33 feuillets. Hauteur, 21 centimetres; largeur, 14 centimètres et demi. 17 lignes par page. La première page seulement est rocalisée. - (Supplément i159.)

\section{0.}

Mème ouvrage.

Papier. 30 feuillets. Hauteur, 15 centimètres; largeur, 10 centi- mètres et demi. so lignes par page. Mis. du xvis siècle. - (Supplémeat 1160.)

\section{1.}

Même ouvrage.

Pap̧ier. 37 feuillets. Hauteur, 21 centimètres; largeur, 14 centimètres et demi. 15 lignes par page. Ms. du xvi1 siècle. - (Supplément 1157.)

\section{2.}

Même ouvrage. Cet exemplaire a fait partie d'un volume qui renfermait quelques autres traités.

Ms. daté de l'an 1107 ( 1696 de J.-C.).

Papier. 4 a feuillets. Hauteur, a 1 centimètres el demi; largeur, 15 centimètres el demi. 13 lignes par page. - (Supplément 1156.)

\section{3.}

Nême ourrage. Daus les dernières pages, le texte n'est pas vocalisé.

Ms. daté de l'an 1115 ( 1073 de J.-C.).

Papier. 50 feuillets. Hauteur, go centimètres; largeur, 15 centimètres et demi. 11 lig̣nes par page. - (Supplément 1158.)

\section{4.}

$1^{\circ}$ Nlême ouvrage.

$2^{\circ}$ (Fol. 43 vo.) المرضيّة (sic) Commentaire de Djalâl al-Dìn al-Soyoûṭ̂t sur l'Alfîya.

Ms. daté de l'an 1154 (1741 de J.-C.).

Papier. ${ }^{15} 7$ fenillets. Hauleur, a a centimètres; largeur, 16 centimètres. 13 lignes par page dans le premier traité, 16 dans le second. - (Supplément 1168.)

\section{5 .}

Commentaire très étendı sur l'Alfîya d'lbn Mâlik

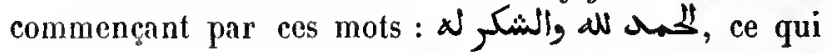
nous porte à croire que c'est l'ouvrage de Schams alDîn Ịlasan ibn al-Qâsim al-Morâdî (المأل), surnommé 
Ibn Oumm Qdsim et mort en 749 (1348-1349 de J.-G.). Voyez la Bibliographie de Hadji Khalfa, t. I, p. 408.

Papier. 241 feuillets. Hanteur, 26 centimètres et demi; largeur, 18 centimètres. Le nombre des lignes par page varie de 25 a 30 . Ils. du xiv" siècle. - (Ancien fonds 1 233.)

\section{6.}

Même ouvrage.

Ms. daté de l’an 1004 ( 1596 de J.-C.).

Papier. 191 feuillets. Hauteur, 29 centimètres; largeur, 19 centimètres. 31 lignes par page. - (Supplément 1173. )

\section{7.}

Le chemin le plus facile à l'intelligence de l'Alfya d'Hbn Mâlik», commentaire attribué par Hadji Klıalfa (t. I, p. 413) au célèbre grammairien Djamàl al-Din 'Abd Allah ibn Yousof ibn Hischâm al-Ansârì, mort en 762 de l'hégire (1360-1 361 de J.-C.). C'est l'ouvrage que l'auteur a intilulé plus tard

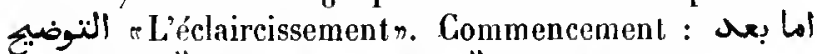

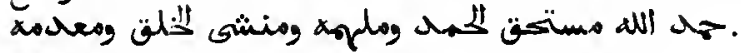

Ms. daté de l’an 1082 ( 1671 de J.-C.).

Papier. ${ }_{9} 5$ feuillets. Hauteur, 21 centimètres; largeur, 15 centimètres. 15 lignes par page. - (Supplément 1176.)

\section{8.}

Explication du contenu du Taudhîh », commentaire de Zaïn al-Dìn Klıàlid al-Azharî sur le Taudhîh de Djamâl al-Dìn Yoùsof ibn Hischàm al-Anșìi qui est le commentaire des vers dont se compose l'Alfîya d'Ibn Mlâlik. Commencement : اللهم لا سهل الا ما جell.

Papier. 357 feuillets. Hauteur, 31 centinè̀tres; largeur, 21 centimètres et demi. Ms. du xrı" siècle. - (Supplément 1179 .)

\section{9 .}

Même ouvrage.

Ms. daté de l'an 1035 ( 1625 de J.-C.).

Papier. 465 fenillets. Hauteur, 21 centimétres; largeur, 15 centimètres et demi. 25 lignes par page. - (Ancien fonds 1311 , Colbert 4992.)

\section{0 .}

Mème ouvrage. Nous lisons dans l'explicit de cel exemplaire, comme dans quelques autres, que l'auteur acheva son travail en 896 ( 1491 de J.-C.).

Ms. daté de l'an 1049 ( 1640 de J.-C.).

Papier. 370 feuillets. Hauteur, 99 centimètres et demi; largeur, 21 centimètres. 33 lignes par pałge. - (Supplément 1178 .)

\section{1.}

Nème ouvrage.

Ms. daté de l'an 1162 (1749 de J.-G.).

Papier. $7_{25} 5$ feuillets. Hauteur, a a centimètres; largeur, 16 centimètres. a3 lignes par page. - (Supplément 1180.)

\section{2 .}

Mème ouvrage. Le premier feuillet et les derniers cahiers manquent.

Papier. 431 feuillets. Hauteur, a centimètres; largeur, 16 centimètres. 21 lignes par page. Ms. du $\mathbf{x x}^{\mathrm{a}}{ }^{\mathrm{i}}$ siècle. - (Supplément 2134.)

\section{3.}

Premier volume du mème ouvrage.

Papier. 272 fenillets. Hauteur, 31 centimètres et demi; largeur, 15 centimètres. 23 lignes par page. Ms. du xvu1 ${ }^{\circ}$ siècle. - (Supplément 1177, I.)

\section{4.}

Premier fascicule d'un exemplaire du même ouvrage.

Papier. ${ }_{17} 3$ feuillets. Hauteur, 20 centimètres et deni; largenr, 15 centimètres et demi. a 1 lignes par page. Le premier calier de ce volume est du $\mathrm{xm}^{\circ}$ siècle, les cahiers suivants du xvı1'e. - (Supplément 1180 bis.)

\section{5 .}

Seconde et dernière parlie du même ouvrage.

Papier. 353 feuillets. Hauteur, 22 centimètres; largeur, 15 centi83 . 
mètres et demi. 21 lignes par page. Ns. du xvir siècle. - (Supplément $1177,11$. )

\section{6.}

"Exercice pour les étudianls qui cullivent l'art de l'analyse grammalicalen, commentaire sur l'Alfiya d'lbn Milik, par Khâlid alAzhari. Commencement : ب o أعزب بالنثهادتين.

Ms. daté de l'an 1199 ( 1785 de J.-C.).

Papier. 214 feuillets. Hauteur, 23 centimètres; largeur, 16 centimètres el demi. Le nombre des lignes par page varie de 23 à $27 .-$ (Suppéément 1181.)

\section{7.}

Volume sans commencement ni fin et renfermant une partie d'un commentaire sur l'Alfiya d'Ibn Mâlik. Le commentaire ( $ش$ c'est-ì-dire žii) sur le premier vers de la section intitulíe vill,

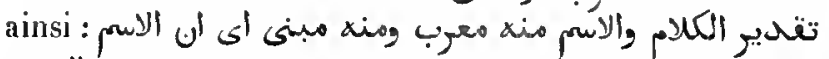

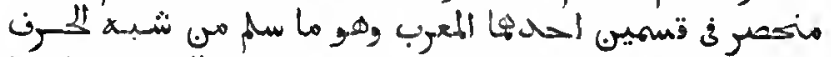

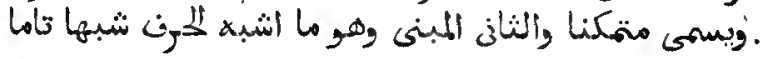

Papier. 85 feuillets. Hauteur, 24 centimètres et demi; Jargeur, 16 centimètres et demi. 21 ligues par page. Ms. du xiv $0^{\circ}$ siècle. (Supplément 2355.)

\section{8 .}

Commentaire sur l'Alfiya d'lbn Mâlik. Le premier feuillet manque. Le manuscrit débute par le quatric̀me vers de l'Alfiya et donne ensuite l'explication qui com-

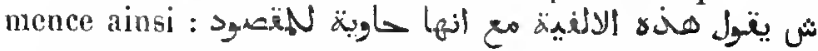

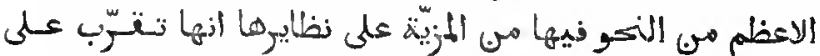

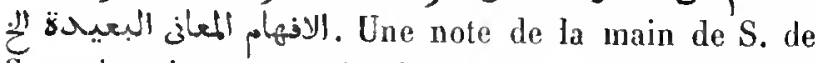
Sacy, inscrite sur un des feuillets de garde, porte que ce commentaire est excellent.

Ns. écrit à Balbec, lan 823 (1420 de J.-C.).

Papier. 239 feuillets. Hauteur, 18 centimètres; largeur, 13 centimètres et demi. 21 lignes par page. - (Supplément 1166.)

\section{9.}

Commentaire d'Ibn 'Aqîl sur l'Alfiya d'Ibn Mâlik. Le premier feuillet est d'une main moderne.
Papier. $16_{9}$ feuillets. Hauleur, 20 centimètres et demi; largeur, 15 centimètres. 25 lignes par page. Ms. du xvil sièce. - (Supplément 2130.)

\section{0.}

Même ouvragc. La fin manque.

l'apier. 197 feuillets collés sur onglets. Hauteur, 21 centimètres el demi; largeur, 15 centimètres et demi. 25 lignes par page. Ms. du xvi' siècle. - (Supplément 9131.)

\section{1.}

Mème ouvrage.

Ms. daté de l'an 1127 (1715 de J.-C.).

Papier. 18, feuillets. Hlauteur, 2 a centimètres; largeur, 15 centimètres et demi. 23 à 25 lignes par page. - (Supplément 1161.)

\section{2.}

Mème ouvrage. Notes marginales.

Ms. daté de l'an 1140 (1728 de J.-C.).

Papier. 177 feuillels. Hauteur, 21 centimètres; largeur, 15 centimètres. 21 liggnes par page. - (Suppléwent 1162.)

\section{3.}

Même ouvrage.

Papier. ${ }_{17} 5$ feuillets. Hauteur, 21 centimètres; largeur, 15 cenlimètres. 23 lignes par page. Ms. du xviu* siècle. - (Supplément 1163.)

\section{4.}

Explication importante du commentaire d'Ibn 'Agî̉ı, par le schaïkh Ahmad ibn Aḥmad al-Sadjậi (المجأG). Lauteur dit avoir composé son ouvrage en 1218 (1803 de J.-C.). Com-

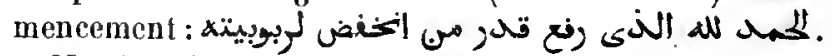

Ms. daté de l'an 1256 (1840 de J.-C.).

Papier. 307 feuillets. Hauteur, 23 centimètres; largeur, 16 centimètres et demi. 27 lignes par page. - (Supplément 1164.) 


\section{5 .}

Commenlaire sur la Kholâșa (20) aulrement appelé l'Alfíya d'Ibn Mâlik, par Schams alDîn Moḥammad ibn Aḷmad ibn Djäbir al-Hawârì

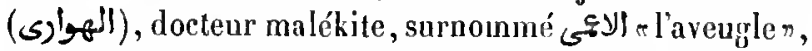
né en Espagne. Selon Hadji Khalfa, il mourut vers l'an 780 ( 1378 de J.-C.). Commencement de la préface :

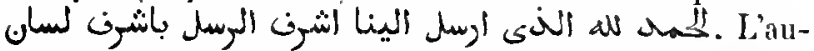
teur y a inséré une notice biographique sur Ibn Málik, qui élait son compatriole et né à Jacn (جلجياني).

Ms. daté de 855 ( 1451 de J.-C.).

Papier. 275 feuillets. Hauteur, a 7 centimelres; largenr, 18 centimètres et demi. 23 lignes par page. - (Ancien fonds 1 335 , Colbert 4237$.

\section{6.}

Commentaire sur l'Alfiya d'lbn Mâlik, par Aboû Zaïd ‘Abd al-Rahmân al-Mokoûdî (المُكودى). En tête du volume on a ajouté une qasîda liminya ayant pour sujet les propositions et leur analyse. Commencement :

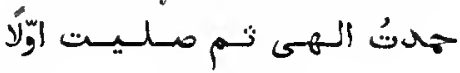

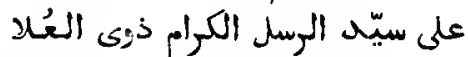

Ms. daté de l'an 1105 ( 1694 de J.-C.).

Papier. 146 feuillets. Hauteur, 24 centimètres; largeur, 17 centimètres. Écriture maghrebine. ə3 liģnes par page. - (Supplément 2133.)

\section{7.}

$1^{\circ}$ Mllème ourrage.

$2^{\circ}$ (Fol. $330 v^{\circ}$.) Notes de Sìli Aḷmad al-Modjirì (النجيرى) sur le commentaire d'Al-Mlokoùdì. Dans la préface, on Iroave une courle notice sur celui-ci. Il se nommait "Abd al-Rạımàn ibn 'Alì et mourut ì Fez l'an 801 (1398-1399 de J.-C.). Commencement : 1

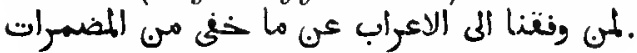

Papier. 4a/ feuillets. Hauteor, 22 centimètres; largeur, 16 centimètres. Dans le premier traité, les pages ont 21 lignes; le second traité est d'une autre main et chaque page porte 23 lignes. Ms. du xwi1 siècle. - (Supplément 117\%.)

\section{8.}

$1^{\circ}$ Commentaire sur l'Alfîya d'Ibn Màlik, par AlDjozoùlì. $2^{\circ}$ (Fol. 3 1.) Explication du Bismillih et du Al-Hamd lillàh, par Moḥammad ibn Ị̣aındoûn al-Bonânî.

$3^{\circ}$ (Fol. 72.) Commentaire sur l'Adjorroûmîya, par Al-Scharif.

$4^{\circ}$ (Fol. 129.) Note sur la conjugaison arabe.

$5^{\circ}$ (Fol. 132.) Quelques pièces de vers.

$6^{\circ}$ (Fol. 136.) Commentaire d'Al-Bodjâii sur l'Adjorroîmîya. Le nom de l'auteur n'est pas menlionné (voy. ci-après, $\left.\mathrm{n}^{\circ} 4140\right)$.

Papier, 188 feuillets. Hanteur, 22 centimètres; largeur, 15 centimètres. 21 lignes par page. Ms. du $x_{1}{ }^{\circ}$ siècle. Écritures diverses. An folio 128 , on trouve la date de 1 a 38 de l'hégire (18a3 de J.-C. ). (Supplément $2 / 73$.)

\section{9.}

.ترح تشوالهد العينى . Explicalion des exemples cilés

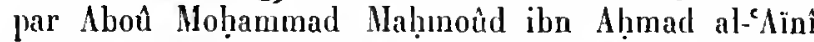
dans son commentaire sur l'Alfíya d'llbn Màlik. Ce commentaire, dont l'auteur es $\mathrm{Al}$-'Aïnî lui-même, commenco

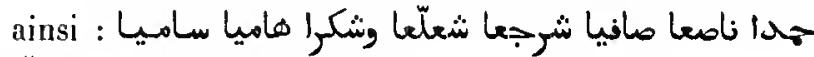
है.

Ms. daté de l'an 1052 (1642 de J.-C.).

Papier. 188 feuillets. ITauteur, 3 i centimètres; largeur, 15 centimètres. 25 lignes par page. - (Supplément 1174.)

\section{0.}

 dirige vers l'Alyina d'lbn Mălik». Commentaire sur ce célèbre trailé de grammaire, par Noûr al-Dìn Aboû l'Ilasan 'Alì ibn Moḷamnad al-Ochmoûnî, morl vers l'an 900 (1494-1495 de J.-C.). Commencement : Lol .بعد حه الله على ما منح مي اسبباب البيان.

Ms. daté de l'an 980 (1572 de J.-C.).

Papier. 196 feuillets. Hauteur, a 7 centimètres; largeur, 18 centimètres. 33 lignes par page. - (Ancien fonds 1234 .)

\section{1}

Même ouvrage. Noles marginales.

Papier. 488 feuillets collés sur onglets. Hauteur, 22 centimètres et demi; largenr, 16 centimètres. 23 lignes par page. Ms. du svit" siècle. - - (Supplẻment 1185.) 


\section{2.}

Même ouvrage.

Ms. daté de l'an 1121 (1709 de J.-C.).

Papier. 304 feuillets. Hauteur, 21 centimètres; largeur, 15 centmètres et demi. 23 lignes par page. - (Supplément 1182.)

\section{3.}

Même ouvrage. Notes marginales.

Ms. daté de l'an 1141 ( 1729 de J.-C.).

Papier. 373 feuillets collés sur onglets. Hauteur, a centimètres; largeur, 16 centimètres. 23 lignes par page. - (Supplément 1184.)

\section{4.}

\section{Même ourrage.}

Papier. 547 feuillets. Hanteur, 22 centimètres; largeur, 15 centimètres et demi. 19 lignnes par page. Ms. du xviu' siècle. - (Supplément 1183.)

\section{5.}

Première partie du mème ouvrage. Notes marginales.

Papier. 348 feuillets. Hauteur, 2 a centimètres et demi; largeur, 16 centimètres. 19 lignes par page. Ms. du xvi1 siècle. - (Supplément 1186.)

\section{6.}

Seconde partie du même ouvrage.

Papier. 411 feuillets. Hauteur, 91 centimètres et demi; largeur, 15 centimètres. 15 lignes par page. MIs. du xri1 ${ }^{\circ}$ siècle. - (Supplément 1186, II.)

\section{7.}

Seconde partic du même ouvrage.

Papier. 160 feuillets. Hauteur, 21 centimètres et demi; largeur, 16 centimèlres. a3 lignes par page. Écriture maghrebine. Ms. du xriri" siècle. - (Supplément 2132.)

\section{8 et 4109 .}

Gloses du schaïkh Moḥammad al-Ḥafnâwì (s)lieil) sur le Manhadj al-Sálik d'Al-Ochmoûní.

Ms. écril du vivant de l'auteur en 1203 de l'hégire $(1 ; 89$ de J.-G. $)$.

2 volumes. Papier. 444 et 455 feuillets. Hautenr, 23 centimètres; largeur, 16 centimètres. Environ 25 lignes par page. - (Supplément 1187$.

\section{0.}

(النجهجة (sic) chemin agréable pour arriver à l'explication de l'Alfiya», par Djalâl alDîn 'Abd al-Rạ̣màn al-Soyouttî. Commencement : إحك الكهم على نعك والايك.

Papier. 147 feuillets. Hauleur, 23 cenlimètres; largeur, 16 centimètres. 21 lignes par page. $\mathrm{Ms}$. du sviı' siècle. - (Supplément 1171.)

\section{1}

1 ' Mème ouvrage.

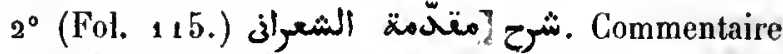
perpétuel sur la préface du traité de grammaire d"Abd al- Wahhâb al-Scha'rânì, par le schaïkh Ạmad (peutêtre Schihâb al-Dìn Aḥmad al-Ghonaïmî, voy. Hadji Khalfa, t. VI, p. 88).

Ms. daté de l'an $117^{2}$ (1758 de J.-C.).

Papier. 189 fenillets. Hauteur, 22 centimètres; largeur, 16 centimètres. 23 lignes par page dans le premier traité, 19 dans le second. - (Supplément 11 67. )

\section{2.}

Commentaire très prolixe sur la Nahdjat al-Mardìya, par Moḷammad Ṣâlị̣ ibn Ibrâhîm al-Aḥsâĩ (ألاحسساى). L'ouvrage fut achevé l'an $107^{3}$ de l'hégire (1663 de J.-C.). Commencement : نحمك يا مه رفع مه أنخـفنض

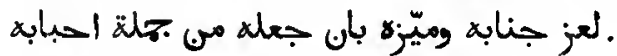

Ms. daté de l'an 1126 (1714 de J.-C.).

Papier. ${ }^{169}$ feuillets. Hautenr, 30 centimètres et demi; largenr, so centimètres. 35 liğnes par page. - (Supplément 1169.) 


\section{3.}

Même ouvrage.

Ms. daté de l'an 1201 ( 1787 de J.-C.).

Papier. 313 feuillets. Hauteur, 33 centimètres; largeur, 15 centimètres et demi. 23 lignes par page. - (Supplérnent 1170.)

\section{4.}

متح اللطين اللمالك لثرح النيّة ابر مالك l'Être gracieux qui possède tout, pour servir d'explication de l'Alfìya d'Ibn Mâlik», par 'Abd Allah ibn 'Alî

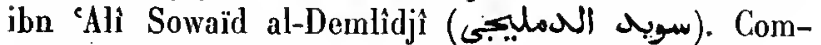
mencement : عليه .

Ms. daté de l'an 1205 ( 1791 de J.-C.).

Papier. 244 fcuillets. Hauteur. 23 centimètres et demi ; largeur, 15 centimètres et demi. 2 1 lignes par page. - (Supplément 11 75. )

\section{5.}

$1^{\circ}$ Collection de gloses sur l'Alfiya d'Ibn Mâlik. Les premiers cahiers, formant environ le tiers de l'ouvrage, manquent.

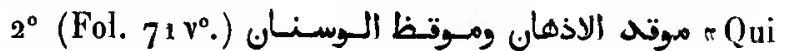
éclaire les intelligences et qui éveille l'endormin. Explication de quelques énigmes grammaticales, par Ilon Hischâm (Djamâl al-Dîn 'Abd Allah ibn Yoûsof). Com-

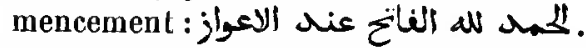

Papier. $7^{8}$ feuillets. Hautcur, 2 centimètres; largeur, 15 centimètres. 21 lignes par page dans le premier ouvrage, 19 dans le second. Ms. du xrm" siècle. - (Supplément 1189.)

\section{6.}

Traité de grammaire en vers, avec un commentaire. Ce traité paraît êlre un remaniement, avec des additions considérables, de l'Alfiya d'lbn Mâlik. Le lexte est indiqué par la lettre sad $(\infty)$ et la glose par la lettre schin (ن). Le commencement du volume manque, le premier feuillet de la partie qui nous reste finit par l'explication du vers 255 de l'Alfiya. Les vers suivants, par lesquels commence le $B a b$ al-ischtighâl, sont accompagnés

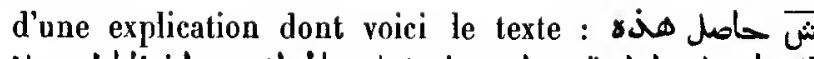

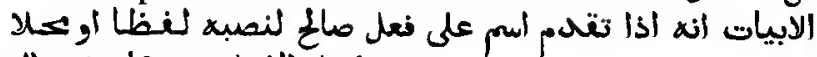

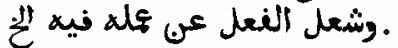

Ms. daté de l'an 742 ( 1342 de J.-C.).

Papier. 193 feuillets. Hauteur, 38 centimètres; largeur, 20 centimètres. 23 lignes par page. - (Supplément 1 165.)

\section{7.}

Le Tashîl al-Fawaiid, traité de grammaire en prose, par Ibn Mâlik, l'auteur de l'Alfiya.

Papier. 1 30 feuillets. Hauteur, 20 centimètres et demi; largeur, 15 cenlimètres. 15 lignes par page. Ms. du $81 v^{\circ}$ siède. - (Supplément 1188 .)

\section{8.}

1 Commentaire sur la Lámíyat al-Af al d'Ibn Màlik, par Mohammad ibn 'Omar al-Hadrami. L'ouvrage porte le titre de فتح الاتفال وضرب الامثنال Serrures ouvertes et

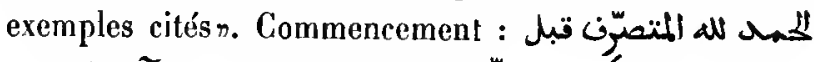

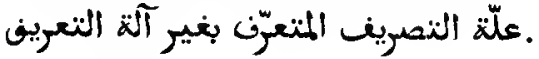

$2^{\circ}$ (Fol. 107 vº ( Commentaire sur la Qasida intilulée Al-Monfaridjan. Le poème a pour auteur lın al-Nahivi (Yoúsof ibn Maḷammad al-Tauzarî); le commentaire est d'eAlì ibn Yoúsof' atBosrawi. Celui-ci dit dans sa préface : النتهر عن.

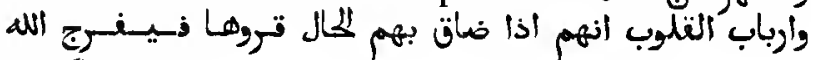

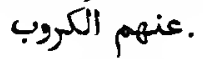

Le premier ouvrage est daté de l'an 1052 (16421643 de J.-C.); le second article parait être de la même époque.

Papier. 120 fenillets. IHauteur, 20 cenlimètres; largeur, 13 centimètres. 17 lignes par page dans le premier ourrage, 21 dans le second. - (Ancien fonds 1480.$)$

\section{9.}

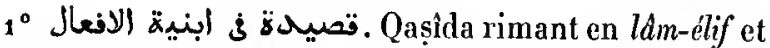
renfermant les règles de la conjugaison, par lbn Mâlik, auteur de l'Alfiya, acconpagnée d'un commentaire, par Badr al-Dìn Moḅammad, fils de l'auteur. Premier vers :

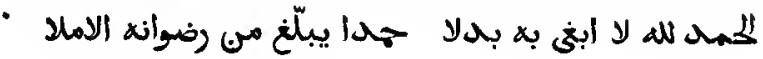


$2^{\circ}$ (Fol. $27 v^{\circ}$.) Explication, par l'Enfant Jésus, de lit vraie siguification de chaque lettre de l'alphabet arabe. Légende inusulmane.

Ms. écrit à Paris en 1712 de J.-C. par un Marocain appelé Alumad ibn Qisim, pour le nommé Aubert (?) (أبكِ médecin et interprète du roi de France. 11 porte un assez grand nombre de notes marginales en langue espagnole.

Papier. 99 feuillets. 1lanteur, 28 centimètres et demi; largenr, an centimètres. 17 el 18 lignes par page. - (Ancien fonds 1410.)

\section{0 .}

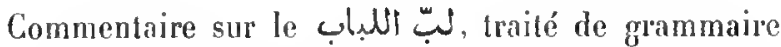
dı cadi Nâșir al-Dìn 'Mbd-Allah al-Baïdhàwì, mort en 685 ( 286 de J.-C.), par Moḷammad ibn Pîr-'Alì, sur-

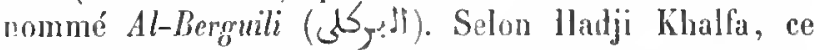
commentaire est géméralement connu sous le titre de . Épreuve pour les hommes intelligents".

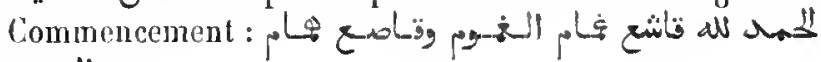

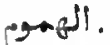

Hs. daté de l'an 865 (1460-1461 de J.-C.).

Papier. 15 e feuillets. Hauleur, a 17 centimècres. $1^{\text {ra }}$ partie, 21 lignes par page; $2^{\circ}$ partie, 23 lignes. Ws. de deux écritures, dont la première est du neskhi et ta secondo du la lîk. - (Ancien fonds $129^{3}$.)

\section{1.}

بLلباب - La moelle\%. Traité de grammaire, par Tàdj al-Dìn Hoḷammad ibn Họ̣ammad ibn A ḥmad ibu alSaîf al-Isfaràini, accompagné du commentaire de Mohamınad ibn Mascoùd al-Sìrâfì, qui a été composé à Schîriz l'an 713 de l'hégire $(1312$ de J.-C.). Commen-

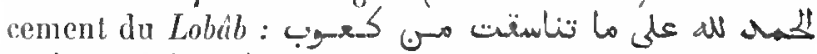

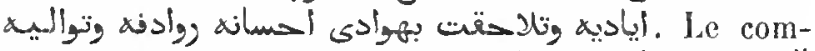

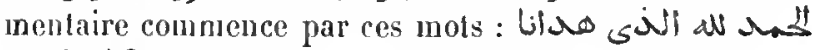

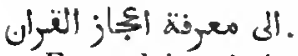

Exemplaire écrit à Basra l'an 1153 ( 1 - 40 de J.-C.) pour Otter (موشثى أوتيك النصرأن).

Papier. 426 feuillets. Hauteur, 22 centimètres; Jargeur, 16 centimètres. 16 lignes par page. - (Supplément 1261 .)

\section{2.}

$1^{\circ}$ L'Adjorroúmina. Mohammad ibn Nohammad ibn Dâoûd al-Ṣanhàdjì, l'nuteur de l'Adjorroúmiya, étaif

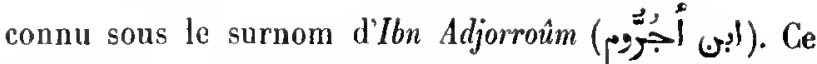
mot adjorroûm, dont l'orthographe est fixée, lettre par lettre, dans la préface de ce commentaire appartient à la langue berbère et signifie, dit-on, dévot, anachorète.

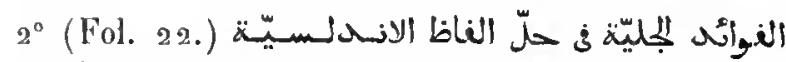
"Renseignements importants pour l'explication des termes employés dans le Iraité intitulé l'Andalousiennen. C'est un commentaire composé par Schams a1-Dìn Mohammad ibn Ahmad al-Domâti (vLovi) sur la Moqaddima ou introduction àl a connaissance de la grammaire

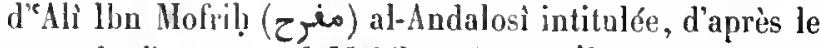
nom de l'auteur, Al-Mofrilliya (المخحية) ul-Andalosiya.

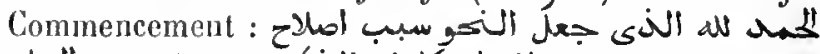

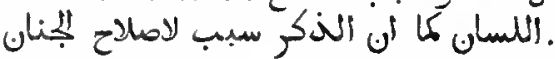

Papier, 107 feuillets. Hanteur, 17 centimètres; largeur, 12 centimètres. 11 lignes par page. La première pièce porte un frontispice en or et en coulcurs. Ms. du xvi" siècle. - (Ancien fends 1282.)

\section{3.}

$1^{\circ}$ L'Adjorroúmíya.

$2^{\circ}$ (Fol. 6.) Commentaire de Khâlid al-Azharî sur l'Adjorroûmiya.

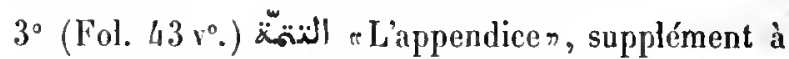

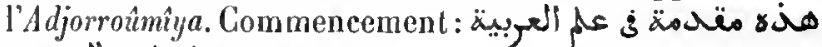

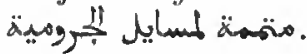

$4^{\circ}$ (Fol. $7^{5}$.) Les Cent Régissants d'A1-Djordjânî.

$5^{\circ}$ (Fol. 82.) La Káfiya d'lbn al-Ḥàdjib.

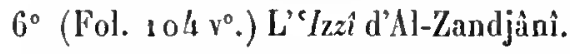

$7^{\circ}$ (Fol. $114 v^{\circ}$ ) (لنية ra salulaire $\pi$, traité des flexions grammalicales, par Ibn al-Hàdjib. Commence-

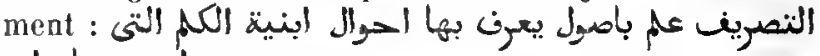

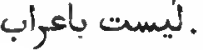

$8^{\circ}$ (Fol. $144 v^{\circ}$ ) Le Marilh al-Arwâh d’Aḷmad ibn 'Alì il)n Mascoûd.

Ms. Iout entier de la même main et daté de l'an 1152 ( 1740 de J.-C.).

Papier. 168 feuillets. Hauteur, 21 centimètres et demi; largeur, 16 centimètres. 20 lignnes par page, puis 16 lignes. - (Supplément 1207.)

\section{4.}

$1^{\circ}$ L'Adjorroúmiya.

$2^{\circ}$ (Fol. $6 v^{\circ}$.) Commentaire de Khâfid al-Azharî sur l'Adjorroûmîya. 
3० (Fol. 42 vº. Moyen prompt de faire saisir les mètres de la poésier, trailé de prosodie arabe composé par Sìdì Moḷammad Ghànim.

$4^{\circ}$ (Fol. 54 vo.) La Khazradjiya, traité de prosodie, en vers. Premier hémistiche :

$5^{\circ}$ (Fol. 64 v'.) La Lamîyat al-'Adjam d'Al-Ṭoghraii, avec un commentaire abrégé.

$6^{\circ}$ (Fol. $7^{8} \mathrm{v}^{\circ}$.) Un poème lámíya sur la prosodie. Premier vers :

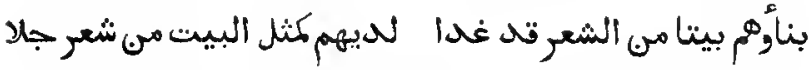

$7^{\circ}$ (Fol. 81.) La Badíiya d’cAbd al-Ralımân al-Soyoûtîi en l'honneur de Nahomet, poème dont chaque vers lournit un exemple d'une figure de rlıélorique, el qui est intitulé accompagné d'un commentaire par le même auteur.

Toutes les pièces de ce volume onl été écrites au commencement de ce siècle; la plupart sont de la main d'Elious Boctor (يوليوس بتطر).

Papier. 106 feuillets. IIauteur, 17 centimètres et demi; largeur, 12 centimètres. Toutes les pièces oni 15 lignes par page, excepté la première, qui en a 18 el 20 , el l'article $2^{\circ}$, qui en a 19 el 20 . (Supplément 2331.)

\section{5 .}

$1^{\circ}$ Fragment de l'Adjomoúmíya.

$2^{\circ}$ (Fol. 5.) Commentaire de Khâlid al-Azharì sur l'Adjorroúmíya. Le premicr feuillet manque.

Papier. 59 feuillets. Hauteur, 21 centinètres et demi; largenr, 13 centimètres. 19 lignes par pare. Mls. du xrıir siècle. - (Supplément 2128.)

\section{6.}

Premier cahier de l'Adjorroûmíya.

Papier. 7 feuillets. Hauteur, 18 centimètres; targeur, 4 centimètres et demi. 13 lignes par page. Ms. du xıx siècle. - (Supplément 1190.)

\section{7.}

مأل La perle grammalicale, commentaire sur l'Adjorroûmìya », par Moḥammad ibn

Mas. onentaut - IH.
Ahmad ibn Yacla al-Hlasanî (descendant d'Al-Hasan,

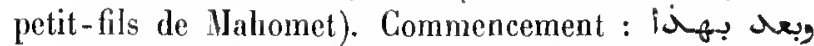

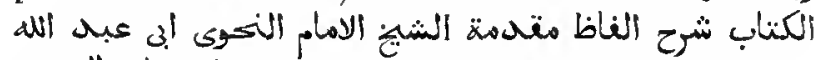

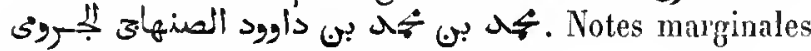
et correclions de la main d'Erpenius.

Ms. daté de l'an 1005 de l'hégire (1597 de J.-C.).

Papier. 37 feuiftets. Hauteur, a 8 centimètres et demi; largeur, 21 centimètres et demi. 28 lignes par page. Écriture maghrebine. (Ancien fonds 1230.)

\section{8.}

Commentaire d'Aboû Zaïd 'Abd al-Raḥmân ibn 'Alì al-Mokoûdî̀ sur l'Adjorroûmìya. Commencement : un

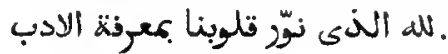

Papier. 28 feuillets. Hanteur, a 4 centimètres; łargeur, 17 centimètres. 20 el 21 lignes par page. Écriture maghrebine. 1ls. du xrı" siècle. - (Supplément 1191.)

\section{9}

$1^{\circ}$ Commentaire de Khâlicl ibn 'Abd Allah al-Azharì sur 1'Adjorronimiya. L'auleur dit (fol. 63) avoir achevé son ouvrage l'an 887 de l'hégire (1482 de J.-C.). Com-

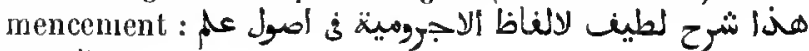
ألعبينة

$2^{\circ}$ (Fol. 63.) Prière qui remplit plus de six pages.

Papier. 66 fenillets. Hautenr, 21 centimètres; largeur, 14 centimétres. 13 lignes par page. S. de Sacy regardail ce manuscrit comme aulographe. (Voyez une note manuscrite ajoutée à son exemplaire de l'Anthologie grammaticale, p. 223.) Ms. du xvi' siècle. - (Aneien fonds 1284.)

\section{0.}

$1^{\circ}$ Commentaire d'Al-Azharî sur l'Adjorroúmîya. Les premiers feuillets manquent.

$2^{\circ}$ (Fol. $54 \mathrm{v}^{\circ}$.) Les Cent Régissants d'Al-Djordjànî.

$3^{\circ}$ (Fol. $62_{2}$ bis $\mathrm{v}^{\circ}$.) Le Mişbâh d'Al-Motarrizì. Exemplaire d'école, avec notes marginales.

Papier. 123 fcuillets. Hauteur, 2 a centimètres; largeur, 15 centimètres. 13 lignes par page dans le premicr et le second ouvrage; 7 lignes par page dans le troisième. Ms. du xvas siècle. - (Supplément 2129. .) 


\section{1.}

Commentaire de Khâtid al-Azharî sur l'Adjorroúmîya. Nombreuses notes marginales.

Ms. daté de l'an 1135 ( 1723 de J.-C.).

Papier. 69 fenillets. Hauteur, 2 1 centimètres; largeur, 15 centimétres et demi. 15 lignes par page. - (Supplément 1193.)

\section{2.}

Même ouvrage.

Ms. de diverses mains daté de l'an 1166 (1753 de J.-C.).

Papier. 52 feuillets. Hauteur, 23 centimètres; largeur, 17 centimètres. - (Supplément 1 199 9.)

\section{3.}

Commentaire très détaillé sur l'Adjorroûmîya. Le premier feuillet et les derniers manquent. Le volume se termine par tes premières lignes du باب ألاغوأه. Com-

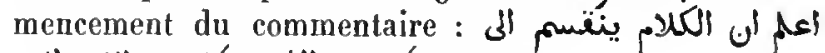

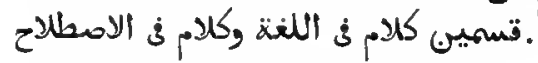

Papier. 8 a fenillets. Hauteur, 2 a centimètres; largeur, 14 centimètres. a 5 lignes par page. Écriture maghrebine. Ms. du xvi1 siècle. - (Supplément 2358.)

\section{4.}

$1^{\circ}$ Commenlaire sur l'Adjorroúmíya, sans titre ni nom d'auteur. Cet exemplaire est de diverses mains. L'auteur commence par nous informer qu'il y a dix-huit manières d'expliquer à quel antécédent se rattache le $b a \mathrm{du} B$ ismillah.

$2^{\circ}$ (Fol. 56.) Traité sur le Bismillah et le Hamdillâh, par Aboû Yahyà Zakarîya al-Anșârì.

$3^{\circ}\left(F_{0 l} .60 v^{\circ}\right.$.) Commentaire très étendu sur l'Adjorroúmiya. La fin manque.

Papier. 215 feuillets. Hauteur, a 1 centimètres et demi; largeur, 16 centimètres. 26 lignes par page, puis 21. Ms. du Xvi1 siècle. (Supplément 1910.)

\section{5.}

Commentaire sur l'Adjorroûnîya, par Zaïn al-Dìn

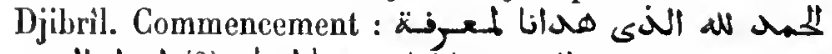

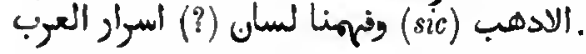

Papier. 91 feuillets. Hauteur, 21 centimètres; largeur, 15 centimètres. 21 lignes par page. Ms. du $x \mathbf{v i}^{\circ}$ siècle. - (Ancien fonds 1284 A.)

\section{6.}

$1^{\circ}$ Même ouvrage.

$2^{\circ}$ (Fol. $44 v^{\circ}$.) Court traité sur les foroûd ou devoirs imposés par Dieu à chaque musulman.

$3^{\circ}$ (Fol. ${ }_{47} \mathrm{v}^{\circ}$.) Un 'arba'in.

Ms. daté de l'an 1019 de l'hégire (1610 de J.-C.).

Papier. 48 feuillets collés sur onglets. Hauteur, 21 centimètres; largeur, 15 centimètres. 23 lignes par page. - (Supplément 1909.)

\section{7.}

م Dons accordés par le Miséricordieux à ceux qui étudient l'Adjorroûmíyan. Commentaire très détaillé, par Aboù Bakr ibn Isma'il

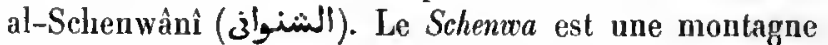
de la province d'Alger. Les derniers feuillets manquent.

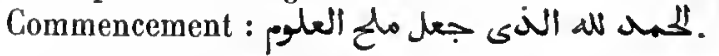

Papier. 400 feuillets. Hauteur, 20 centimètres ef demi; largeur, 14 centimètres et demi. 21 lignes par page. Ms. du xvi1" siècle. (Supplément 1194.)

\section{8.}

Commentaire sur l'Adjorroûmîya, par Hasan al-Ka-

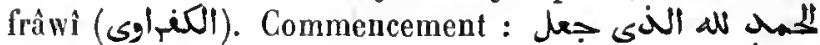
لغة العرب أحسى النغات النغات.

Ms. daté de l'an 1235 de l'hégire (1820 de J.-C.).

Papier. 113 feuillets. Hauteur, 21 centimètres; largeur, 15 centimètres. a3 lignes par page. - (Supplément 2497.)

\section{9.}

Commencement du même commentaire. Le nom de l'auteur est écrit 
Papier. \& feuillets. Hauteur, 22 centimètres; largeur, 15 centimètres et demi. Ms. du xix siècle. - (Supplément 2a 7 4.)

\section{0 .}

Commentaire sur l'Adjorroûmîya, par Al-Bodjâï (comparez Hadji Klıalfa, t. VI, p. 74). Les premiers mots de l'ouvrage cités par Hadji Khalfa ne se trouvent pas dans cet exemplaire, ni dans celui du manuscrit 4098 .

Ms. daté de l'an 1273 de l'hégire ( 1857 de J.-C.).

Papier. 94 feuillets. Hauteur, 19 centimètres; largeur, 19 centimètres. 2o lig̣nes par page. - (Supplément 2453.)

\section{1.}

Commenlaire sur l'Adjorroûmîya intitulé التيوميّة شُحح بلمّوميّة

Ms. daté de l'an 1116 de l'hégire (1705 de J.-C.).

Papier. 77 fenillets. Hauteur, so centimètres; largeur, 13 centimètres. 19 lignes par page. - (Supplément 8454 .)

\section{2.}

Appendice à l'Adjorroûmîyas, par Moḥammad ihn Mohammad ibn 'Abd al-Raḥmân

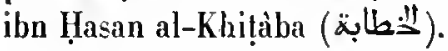

Papier. 54 feuillets (il y a une lacune entre les feuillets 51 et 52). Hauteur, 20 centimètres et demi; largenr, 15 centimètres et demi. 13 lignes par page. Écriture maghrebine. Ms. du xvile siècle. - (Supplément 1207 bis.)

\section{3.}

مغنى 3 النحو, commentaire sur le, traité de grammaire d'Al-Tchàrabardî (Fakhr al-Dìn Ahmad Ibn al-Hasan, sic), mort en 746 (1345-1346 de J.-C.). J'auteur du commentaire avait été élève de Tchârabardì et se nounmait Badr at-Dìn Mohammed ibn

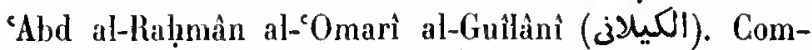
mencement : Nombreuses notes marginales.

Ms. daté de l'an 1069 (1658-1659 de J.-C.).

Papier. 171 feuillets. Hauteur, 11 centimètres; largeur, 14 centimètres et demi. 13 lignes par page. - (Supplément 1 234. )

\section{4.}

$1^{\circ}$ exposition des règles fondamentales de la syntaxe des désinencesn, par Djamâl al-Dìn al-Anṣânî ibn Hischâm, mort en 761 (1359-136o de J.-C.).

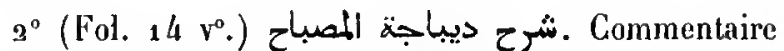
anonyme sur la préface du Mişbâh. Premiers mots :

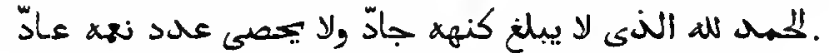
(Voyez ci-dessus, $n^{0} 4019$ et suiv.)

$3^{\circ}$ (Fol. $42 v^{\circ}$. ) Commentaire anonyme sur les Régissants grammaticaux (عول) d'cAbd al-Qâhir al-Djor-

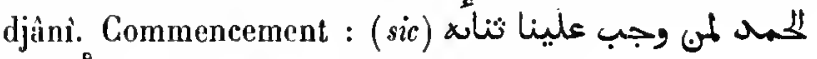

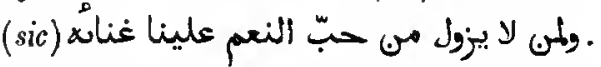

$4^{\circ}\left(\right.$ Fol. $52 \mathrm{v}^{\circ}$.) Commentaire anonyme sur la pré-

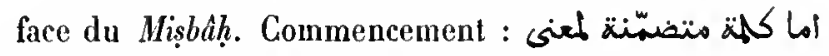

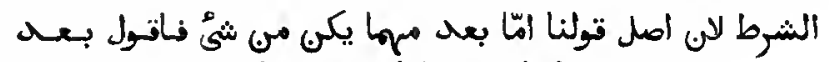

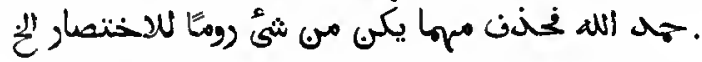

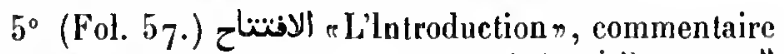

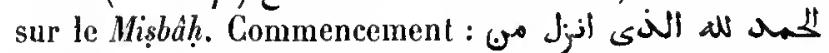
Selon Hadji Khalfa, t. V, p. 583, ce traité a pour auteur IIasan-Pacha ibn 'Alâ al-Dìn alAswad.

$6^{\circ}\left(\right.$ Fol. $145 \mathrm{v}^{\circ}$.) Commentaire sur un traité de la conjugaison des verbes. Premiers mots : يلl all

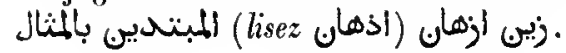

$7^{\circ}$ (Fol. 150.) Explication de quelques formes ver-

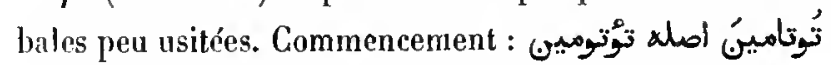

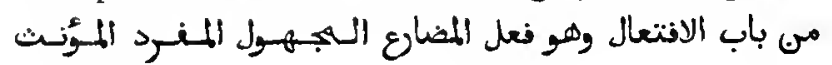
.

$8^{\circ}\left(\right.$ Fol. $_{1} 53 \mathrm{v}^{\circ}$.) Mots arabes expliqués en turc et tirés, probablement, des passages cités comme exemples dans le Miṣbăh d'Al-Motarrizî.

Ms. daté de l'an 1008 de l'hégire. Il est tout entier de la même main.

Papier. 158 feuillets. Hauteur, as centimètres; largeur, 15 rentimètres. 19 lignes par page. - (Ancien fonds 1273.)

\section{5.}

L'I rảb d'Tbn Hischâm. Nombreuses notes marginales et interlinéaires en turc.

Papier. 26 feuillets. Hauteur, 20 centimètres; largeur, 10 centi81 . 
mètres et demi. 13 liggnes par page. Ms. du xru siècle. - (Supplé' ment 12219.$)$

\section{6.}

م Guide des éludiants qui désirent comprendre (le Iraité de grammaire d'Ibn Hischâm intitulé) Qaxẩ id al-İ râb\%. Ce commentaire a pour auteur Kliâlid ibn 'Abd Allah al-Azhari. Commencement : ruas poll al ar.

Papier. 38 feuillets. Hauteur, 22 centimètres; largeur, 15 centimètres. 23 lignes par page. Ms. du xvme siècle. - (Supplément 1220.)

\section{7.}

Gloses d'Aḷmad ibn Moḷammad al-Zarqânî sur le commentaire dans lequel Khâlid al-Azharî explique le lexte du Qawấid al-I râb d'Ibn Hischâm. Commence-

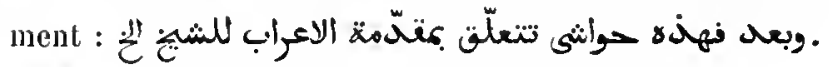

Ms. daté de l'an 1092 (1681 de J.-C.).

Papier. 89 feuillets. Hauteur, 21 centimètres et demi; largeur, 14 centimètres et demi. 25 lignes par page. - (Supplément 1330 ter.)

\section{8.}

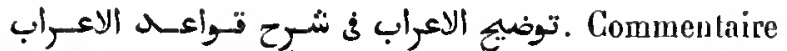

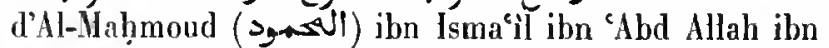

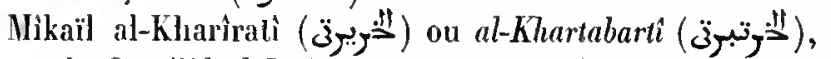
sur le Qawái $i d$ al-I râb d'lbn Hischâm. Commencement:

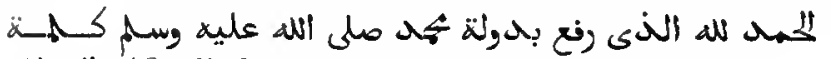
(On lit la même préface dans le ms. 4114.)

Papier. 69 feuillets. Hautenr, 20 centimètres; largeur, 14 centimètres. 21 lignes par jage. Ms. du xvi" siècle. - (Supplément 1220 bis.)

\section{9.}

$1^{\circ}$ Même ouvrage:

$2^{\circ}\left(\right.$ Fol. $\left.60 v^{\circ}.\right)$ Commenlaire sur les Cent Régissants d"Abd al-Qâhir al-Djordjànî. Commencement : fof un وجب علينا ثنائه (sic) ولمه لا يزول مر حب المنعيم عـلـيـــ (sic) غنأfi.

$3^{\circ}$ (Fol. 122.) Un arbain.

Le premier ouvrage est daté de l'an $\log ^{5}$ de l'hégire
(1684 de J.-C.), le second de 1094 de l'hégire; le troisième est de la même écriture que les précédents.

Papier. 129 feuillets. Hauteur, 20 centimètres; largeur, 18 centimètres. Environ 17 lignes par page. - (Supplément 1908.)

\section{0.}

م Délicatesses des flexions grammaticales , analyse des passages du Coran cités comme exemples dans le Qawác id al-l'crâb d'Ibn Hischâm, par Hàddji-Bâbâ ibn 'Abd al-Karîn 'Othmân al-Ṭousawî

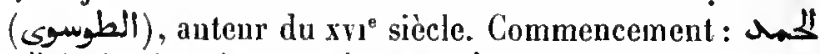

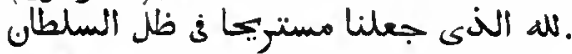

Ms. daté de l'an 939 (1532 de J.-C.).

Papier. 101 feuillets. Hauteur, 20 centimètres; largeur, 14 centimètres. 17 lignes par page. - (Ancien fonds 1271.)

\section{1.}

$1^{\circ}$ Le قط النی mâl al-Dìn Moḷammad Ibn Hischâm. Notes marginales.

$2^{\circ}$ (Fol. 24 vº) mentaire sur l'Adjorroúmíya, par le schaïkh Abou 'I-Khaïr ibn abî 'l-Sacoûd. La fin manque.

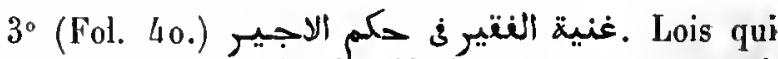
concernent celui qui fait le pèlerinage pour un autre à prix d'argent, par Abou Bakr ibn Ṭahira (طهيرة) alQoraschî. Commencement : . بيته على المستنطيع.

$4^{\circ}$ (Fol. $86 \mathrm{v}^{\circ}$.) Traité du mariage, commençant par

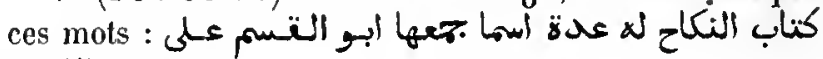

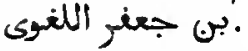

$5^{\circ}\left(\right.$ Fol. $13, \mathrm{v}^{\circ}$.) Traité qui forme la neuvième section d'un ouvrage d'Ibn Iladjar. L'auteur répond aux queslions relatives aux jeux, à la musique et autres choses défendues.

$6^{\circ}$ (Fol. $134 \mathrm{v}^{\circ}$.) L'Ordjoûza 'l-Yasimînîya. Vers techniques sur l'algèbre, par Ibn al-Yâsimîn.

$7^{\circ}$ (Fol. 137 .) Fragment qui paraît faire partie du traité d'Ibn Hadjar sur les choses défendues. Le feuillet 141, qui termine l'ouvrage, porte la date de 960 de l'hégire (1553 de J.-C.).

Papier. 142 feuillets. Hauteur, 20 centimètres et demi; largeur, 14 centimètres et demi. Écritures diverses du xvi" siècle. - (Supplément $19^{\circ} 7$.) 


\section{2.}

Réponse à la demande d'un commentaire sur le Qatar al-Nidân, par Schihâb

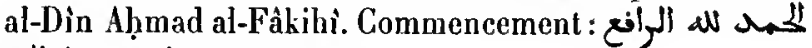

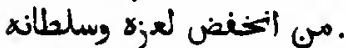

Ms. daté de l'an 1000 de l'hégire (1592 de J.-C.).

Papier. 122 feuillets. Hauteur, a1 centimètres; largeur, 15 centimètres. 19 lignes par page. - (Supplément 3135 .)

\section{3.}

Même ouvrage.

Ms. daté de l'an 1153 (1740 de J.-C.).

Papier. 132 feuillets. Hauteur, 21 centimètres et demi; largeur, 15 centimètres et demi. 16 lignes par page. - (Supplément 1229.)

\section{4.}

Gloses de Yâsin (يm) ibn Zaïn al-Dìn al-cAlìnì alHimsî sur le Modjib al-Nida d'Aḥmad ibn al-Djamâl alFàkihî. Commencement : اللههم بك استعنتت وعـلـيك توركلت.

Ms. daté de l'an 1168 (1 755 de J.-C.).

Papier. 416 feuillets. Hauteur, 22 centimètres et demi; largeur, 16 centimètres. 27 lignes par page. - (Supplément 1228.)

\section{5.}

م مغنى اللبيب عى كتب الاعاريب مe qui suffit, en fait de traités de grammaire, à l'homme intelligents, par

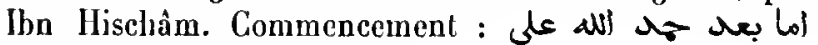
(ف). Notes marginales.

Ms. dalé de l'an 784 (1382-1383 de J.-C.).

Papier. 174 feuillets. Hauteur, a 7 centinètres; largeur, 19 centinè̀tres. 23 lignes par page. - (Ancien fonds 1231.) .

\section{6.}

Mème ouvrage. Notes marginales.

Ms. dalé de l'an 1094 ( 1683 de J.-C.).

Papier. 314 feuillets. Hanteur, 31 centimètres et demi; largeur, 15 centimètres et denii. Le nombre de lignes par page varie de 27 à 31 . - (Supplément 1233.)

\section{7.}

Mème ouvrage. Notes marginales et interlinéaires.

Ms. daté de l'an 1220 (1805 de J.-C.).

Papier. 356 feuillets. Hauteur, 22 à 25 centimètres; largeur. 17 centimètres. Le nombre de lignes par page varie de 15 à 24 . - (Supplément 1232.)

\section{8.}

تشحح شوالهد المغنى . Explication des (vers cités comme) exemples dans le Moghnî al-Labib d'Ibn Hischâm, par Djalâl al-Dîn al-Soyoûtị. L'auteur de cet ouvrage rapporte les passages où se trouve chaque vers cité, en explique la signification et donne une courte notice dı poète qui l'a composé. Il mentionne dans sa préface les sources auxquelles il avait puisé ses renseignements. Cette liste de livres se compose de tous les ouvrages les plus importants de la littérature arabe. Il semble, d'après notre manuscrit, que l'ouvrage d'Al-Soyoûți u'a jamais été achevé, car il s'arrète court après un vers cité, et le copiste a ajouté cette note : rIci finit ce qui se troure dans un exemplaire copié sur celui de lauteurn. Pre-

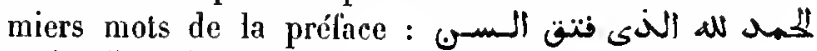

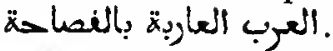

Ms. daté de l'an 973 (1565-1566 de J.-C.).

Papier. ao2 feuillets. Jlauteur, 27 centimètres; largeur, 18 centimètres. 31 lignes par page. - (Ancien fonds 1338.)

\section{9.}

Pelit recueil grammatical», par Ibn Hischâm. Commencement : و . Notes marginales.

Ms. daté de l'an 904 (1498-1499 de J.-C.).

Papier. 39 feuillets collés sur onglets. Hauteur, 26 centimètres; largeur, 15 centimètres et demi. 15 lignes par page. - (Supplément 1957.)

\section{0.}

r Flambeau pour jeler de la lumière sur le Djamic al-Saghirn. Commentaire Irès étendu d'Ismacil ibn Ibràhìm al-'Alawì al-Yamani sur le Petit recueil grammatical d'Ibn Hischìm. Ismacil al-'Alawì 
acheva la composition de son ouvrage l'an $9^{32}$ de l'hégrire (1525-1526 de J.-C.). Commencenent : w w

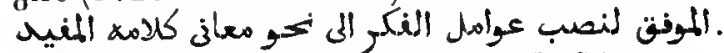

IIs. daté de l'an 1055 (1645 de J.-G.).

Papier. 34h feuillets. Hauteur, 30 centimetres et demi; largeur, 21 centimètres et demi. 33 lignes par page. - (Supplément 1258.)

\section{1.}

Commenlaire d'Ibn Hischàm sur son traité de gram-

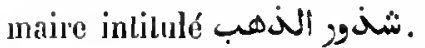

Ms. daté de l'an 1150 ( 1738 de J.-C.).

Papier. 326 feuillets. Iauteur, 21 centimètres et demi; largeur, 15 centimètres et demi. 19 lignes par page. - (Supplément 1226. )

\section{2.}

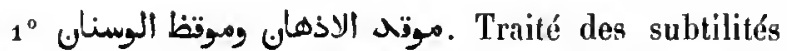
granımaticales, par Aboû Molıammad 'Abd Allah ibn Hischâm.

$2^{\circ}$ Fol. 11.) Traité d'arithmétique, par Schilhâb al-Dìn Ạ̣mad ibn al-Hàim.

3\% Fol. 27. (1) Traité desliné à prouver qu'il est permis d'entendre la musique et d'en faire, par Djamâl al-Dìn Hoḷammad al-Schâdsilì al-Toûnisî.

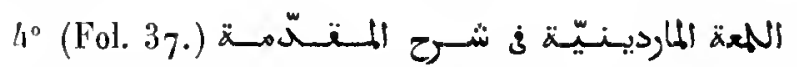

. Conmmentaire de Moḷammad ibn Mohammad Sibṭ al-Màridînî sur la Yásiminina, courte introduction en vers à la science de l'algèbre.

$5^{\circ}$ (Fol. $45 \mathrm{v}^{\circ}$.) Petit traité renfermant l'analyse grammaticale de la profession de foi musulmane.

Écritures diverses. Le second traité est daté de l'an 1105 de l'hégire ( 1694 de J.-C.), le quatriène de l'an $109^{3}$ de l'hégire (1682 de J.-C.).

Papier. 46 feuillets. Hauteur, 21 centimètres; largeur, 15 centimètres. - (Supplément 19/2.)

\section{3.}

r Gloses marginales ajoutées par notre maître Haseoud au traité composé par Al-Iṣfalıânî et inlitulé Mocarrifn. Ce petit traité reuferme un commentaire sur la définition du terme (grammatical) móarrif donnée par Al-Iṣfahânî et une discussion de la valeur de cette définition.

Papier. 11 fenillets. Hauteur, 18 centimètres el demi; largeur, 12 centimètres et demi. 19 lignes par page. Ms. du xvi siècle. (Ancien fonds 1324 .)

\section{4.}

. شكح كختصر الهروى Commentaire anonyme suc le traité abrégé des flexions grammaticales intitulé الهارونية de Nadjm al-Dìn 'Omar ibn al-Harawì. Commencement :

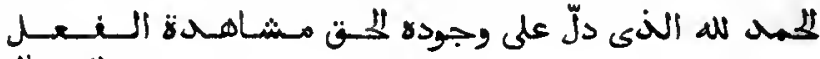
Jleive.

Ms. daté de l'an $99^{5}$ ( 1587 de J.-C.).

Papier. 56 feuillets. Hauteur, 21 centimètres; largeur. 14 centimétres. 21 lignes par page; dans les derniers cahiers, 25 lignes. (Ancien fonds 1310. .)

\section{5.}

"La dragéen, traité de grammaire en vers avec un commentairc, par Zaïn al-Dîn Schacbân; ouvrage composé dans l'Inde, en 806 (1403-1404 de J.-C.), sous le patronage d'un prince très puissant que

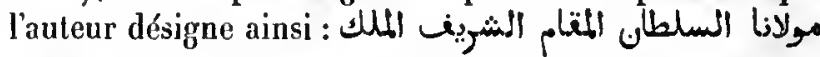

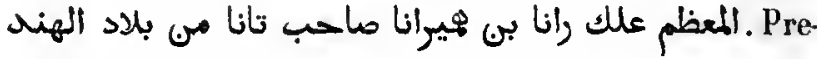
mier vers :

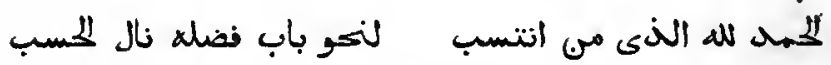

En l'an 821 , l'auleur se trouvait dans le village d'Al-Sâlihîiya, près de Damas, et là il composa sur son poème un commentaire en prose, quil intitula : זLe collier de pierreriesn et qui com-

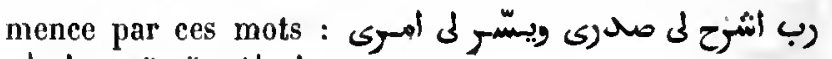

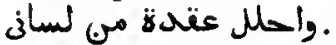

Ms. daté de l'an 844 (1440 de J.-G.).

Papier. 206 feuillets. Hauteur, 18 centimètres; largeur, 13 centimètres et demi. 15 lignes par page. - (Supplément 1262.)

\section{6.}

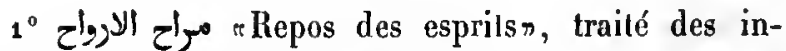
flexions grammaticales (tașrî), par Aḥmad ibn 'Alî ibn

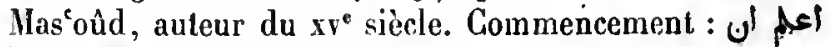
. التصوبي أم العلوم والنكو ابوها 


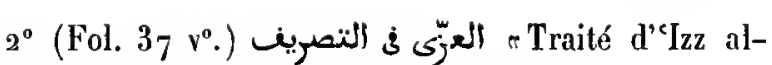
Din sur les inflexions grammaticales $\pi$.

$3^{\circ}$ (Fol. $50 v^{\circ}$.) Traité de tașrif, par un anonyme. On le désigne quelquefois par le titre de ألمعصود. Pre-

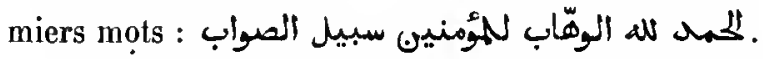

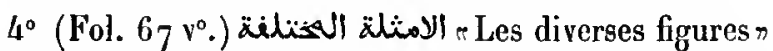
ou flexions que le verbe trilitère de la première forme peut recevoir. L'auteur a pris pour modèle le verbe نصر et en donne la conjugaison.

Des gloses très nombreuses remplissent les interlignes de ce volume et se déploient sur chacune des marges en représentant des figures de fantaisie, des arbres, des arbustes, des édifices et autres objets.

Ms. daté de l'an $9^{4} 7$ ( 1540 de J.-C.).

Papier. $7^{3}$ feuillets. Hauteur, 19 centimètres; largeur, 13 centimètres et demi. 13 lignes par page. - (Ancien fonds 1 a 96 , Colbert 61/4.)

\section{7.}

$1^{\circ}$ Le مراح الעروأح.

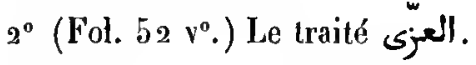

3० (Fol. 72 v $^{\circ}$.) Le Leصود.

$4^{\circ}$ (Fol. $\left.9^{6} v^{\circ}.\right)$ Conjugaison du verbe نصد.

Ms. daté de l'an 966 (1558-1559 de J.-C.).

Papier. 105 fenillets. Hanteur, 18 centimètres et demi; largeur, 11 centimètres. 11 lignes par page. - (Ancien fonds 1302.$)$

\section{8.}

$1^{\circ}$ Le Maráh al-Arwâh. Nombreuses gloses marginales.

$2^{\circ}$ (Fol. $\left.38 v^{\circ}.\right) \mathrm{L}^{\prime} \mathrm{c} I z z i$.

$3^{\circ}$ (Fol. 65 v $^{\circ}$ ) Le Taşrif ou Maqșoûd.

Papier. 81 feuillets. Hauteur, 19 centimètres; largeur, 14 centimètres. Écritures diverses du $\mathbf{x} \mathbf{r}^{\circ}$ siècle. - (Ancien fonds 1298.)

\section{9.}

$1^{\circ}$ Le Marâh al-Arwâh.

$2^{\circ}$ (Fol. $38 \mathrm{v}^{\circ}$.) L'c $I z z \hat{\imath}$.

$3^{\circ}$ (Fol. $54 v^{\circ}$.) Le Maqșoûd.
Papier. $6 g$ feuillets. Hauteur, a centimètres et demi; largeur, 1 a centimètres et demi. 13 lignes par page. Ms. du xvi siècle. (Ancien fonds 1299.)

\section{0.}

1 Le Marâh al-Arwâh.

$2^{\circ}$ (Fol. $46 \mathrm{v}^{\circ}$.) L' $\mathrm{L}^{\prime c} / z z \hat{i}$.

$3^{\circ}$ (Fol. $64 \mathrm{v}^{\circ}$.) Le Maqșoind.

$4^{\circ}$ (Fol. $82 v^{\circ}$.) Traité de la conjugaison (tașrif),

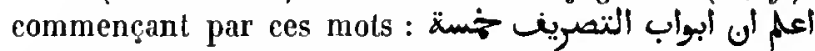

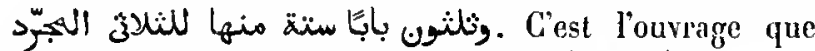
Hadji Khatfa désigne par le titre de بناء الافعال

$5^{\circ}$ (Fol. $9^{3} \mathrm{v}^{0}$.) Conjugaison du verbe نصر.

$6^{\circ}$ (Fol. 107.) Prière que l’on récite aux enterrements. En turc.

Papier. 107 feuillets. Hauteur, 19 centimètres et demi; largeur, 13 centimètres et demi. 13 lignes par page. Ms. dn xrr sièrle. (Ancien fonds 1300.)

\section{1.}

1. Le Marâh al-Arwàh.

$2^{\circ}$ (Fol. $44 \mathrm{v}^{\circ}$.) L'c $\mathrm{L}_{z z i}$.

$3^{\circ}$ (Fol. $60 v^{\circ}$.) Le Maqșoîd.

Papier. 78 feuillets. Hauteur, 18 centimètres; largeur, 12 centimètres et demi. Ms. du xvi' siècle. - (Supplément 1250.)

\section{2.}

1. Le Marâh al-Arwâh.

$2^{\circ}$ (Fol. $60 \mathrm{v}^{\circ}$.) $\mathrm{L}^{\prime c} I z z i$.

$3^{\circ}$ (Fol. $85 v^{\circ}$.) Le Maqșoúd.

Notes marginales.

Papier. 111 feuillets. Hautenr, 18 centimètres; largeur, 12 centimètres et demi. 11 lignes par page. Ms. du xvi siècle. - (Ancien fonds 1301 , Colbert 6148. )

\section{3.}

1 Le Marah al-Arwâh.

$2^{\circ}$ (Fol. 38.) L' ${ }^{\prime} / z z \hat{i}$. 
$3^{\circ}$ (Fol. 53.) Le Maqsaidd.

$4^{\circ}$ (Fol. 69.) Traité de la conjugaison, connu sous le litre de بناء الافنعال

$5^{\circ}$ (Fol. 79.) L'Amthilat al-Moliltalifa; conjugaison du verbe نصر.

Nombrenses gloses.

Ms. daté de l'an 1032-1033 (1622-1624 de J.-C.).

Papier. $9^{2}$ feuillets. Ilauteur, 21 centimètres: largeur, 19 centimètres. 15 lignes par page. - (Ancien fonds 1303.)

\section{4.}

$1^{\circ}$ Le Marâh al-Arwál.

$2^{\circ}$ (Fol. 38 v $^{\circ}$.) L'Tzzî.

$3^{\circ}$ (Fol. $52 v^{\circ}$.) Le Maqşoûd.

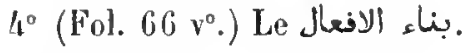

$5^{\circ}$ (Fol. $7^{4} v^{\circ}$.) L'Amthilat al-Mokhtalifa; conjugaison du verbe نصر.

Papier. 87 feuillets. Hauteur, 2 c centimètres; largeur, 13 centimètres. 13 lignes par page. Ms. du xvi' siècle. - (Ancien fonds 1305.)

\section{5.}

Le Marâh al-Arwâh, accompagné de nombreuses gloses.

Papier. 41 feuillets. Hanteur, 21 centinè̀lres; largeur, 15 centimètres. 11 lignes par page. Ms. du xvi1 siècle. - (Supplément 1214.)

\section{6.}

$1^{\circ}$ Le Marâh al-Arwâhl.

$2^{\circ}$ (Fol. $45 \mathrm{v}^{\circ}$.) L' $I z z i$.

$3^{\circ}$ (Fol. $63 r^{\circ}$.) Le Maqsou ud.

Noles marginales et interlinéaires.

Papier. 79 feuillets. Hauteur, 18 centimètres; largeur, 12 centimètres. 11 lignes par page. Hs. du xwn siècle. - (Supplément 1916.)

\section{7.}

$1^{\circ}$ Le Marâh al-Arwẩh.

$2^{\circ}\left(\right.$ Fol. $60 \mathrm{~V}^{\circ}$.) L $\mathrm{L}^{\mathrm{e}} I z \hat{\imath}$. $3^{\circ}$ (Fol. 83 v $^{\circ}$ ) Le Maqsaûd.

$4^{\circ}$ (Fol. $109 \mathrm{~V}^{\circ}$.) Le Bind al-Afeal.

$5^{\circ}\left(\right.$ Fol. $122 \mathrm{~V}^{\circ}$.) L Amthilat al-Mokhtalifa; conjugaison du verbe flexion.

Papier. 140 feuillets, Hauteur, 14 centimètres; largeur, 10 centimètres. 11 lignes par page. Ms. du xvı siècle. - (Supplément 1 218.$)$

\section{8.}

$1^{\circ}$ Le Marâh al-Arwâh.

$2^{\circ}$ (Fol. 22.) L'c Izzí.

$3^{\circ}$ (Fol. $3 \mathrm{v}^{\circ}$.) Le Maqşoûd.

$4^{\circ}$ (Fol. 4o.) Premier feuillet da Binâ al-Afâl.

Papier. 40 feuillets. Hauteur, a centimètres el demi; largeur, 16 centimètres. 21 lignes par page. Ms, du xrä siècle. - (Ancien. fonds $13.8 \mathrm{~A}$.)

\section{9.}

1 Le Marâh al Arwâh.

$2^{\circ}$ (Fol. $56 \mathrm{v}^{\circ}$.) L'Tzzí.

$3^{\circ}$ (Fol. $75 \mathrm{v}^{\circ}$.) Le Maqsoûd.

Papier. $9^{2}$ feuillets. Hauteur, 14 centimètres; largeur, 9 centimètres et demi. 11 lignes par page dans le premier traité, 13 dans le second et dans le troisième. Ms. du xvil' siècle. - (Ancien fonds 1359.)

\section{0.}

$1^{\circ}$ Le Marăh al-Arwâh.

$2^{\circ}$ (Fol. $48 v^{\circ}$.) L' $I z z \hat{\imath}$.

$3^{\circ}$ (Fol. 68 v $^{\circ}$.) Le Maqsoûd.

$4^{\circ}$ (Fol. $88 v^{\circ}$.) L'Amthilat al-Af'al (المثلة الإنعال).

Traité de la conjugaison.

50 (Fol. 100.) Conjugaison du verbe نصر.

Nombreuses notes marginales.

Papier. 109 feuillets. Hauteur, 17 centimètres; largeur, 11 centimètres et demi. 11 lignes par page. Ms. du $\mathrm{rrn}^{\circ}$ siècle. - (Ancien fonds 1360. .) 


\section{1.}

$1^{\circ}$ Le Marâh al-Arwâh.

$2^{\circ}$ (Fol. $15_{7}$.) L' Izzî.

$3^{\circ}$ (Fol. $205 r^{\circ}$.) Le Maqşoûd.

4º (Fol. 256.) Les Régissants (العوأل d'A1-Djordjànì.

$5^{\circ}$ (Fol. 266.) L'Amthilat al-Hokhtalifa, avec la conjugaison du verbe نصر.

Notes marginales.

Papier. $37^{2}$ feuillets. Hauteur, a 1 centimètres; largeur, 15 centimètres. 7 lignes par page. Ms. du xwi siècle. - (Supplément 1917.)

\section{2.}

1 Le Marâh al-Arwâl.

$2^{\circ}$ (Fol. $47 v^{\circ}$.) La Schâfiya d'Ibn al-ḷàdjib.

$3^{\circ}$ (Fol. $65 v^{\circ}$.) Le Maqșoûd.

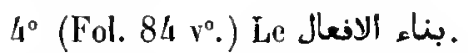

$5^{\circ}$ (Fol. $95 \mathrm{v}^{\circ}$.) L'Amthilat al-Mokhtulifa et la conjugaison du verbe نصر, avec la désignation de chaque forme en termes techniques.

Papier. 117 feuillets. Hauteur, go centimètres; largeur, i centimètres el demi. 15 lignes par page. Ms. du xrü sičcle. - (Suplément 1207 ter.)

\section{3.}

$1^{\circ}$ Le Marâh al-Arwâh.

$2^{\circ}$ (Fol. $\left.22 \mathrm{v}^{\mathrm{o}}.\right) \mathrm{L}^{\circ} \mathrm{I}_{z z \hat{i}}$.

$3^{\circ}$ (Fol. $43 v^{\circ}$.) Le Bind al-Afeal.

$4^{\circ}$ (Fol. $49 v^{\circ}$.) Le paradigme dı verbe نصر, arec la description en temres techniquès de cliaque flexion.

$5^{\circ}$ (Fol. 62.) Notes grammaticales en langue lurque.

Ms. daté de l'an 1172 ( 1758 de J.-C.).

Papier. 65 feuillets. Hauteur, a 1 centimètres; largeur, 14 centimètres et demi. 23 lignes par page, puis 21 ligues. - (Supplément 1213$.

\section{. 4184.}

$1^{\circ}$ Le Marâl al-Arwâh.

$2^{\circ}$ (Fol. 70.) Conjugaison du verbe, Dصر Dans la seMax. orientaux. - Hil. conde partie, les formes ne sont pas accompagnées de leur description technique.

Papier. 82 feuillets. Hauteur, 14 centimètres et demi; largeur, 10 centimètres. 13 lignes par page. Ms. du xrm" siècle. - (Supplé ment 2a46.)

\section{5.}

Commentaire sur le Marah al-Arwah, probablement celui que Hadji Khalfa attribue au mollah Aḷmad Dinqoûz (ديكتوز), surnom qui est écrit (Donqoûz) sur la tranche du volume. Commencement : اللهم يا مصرّن . التلوب صرّن فلوبنا نحور وضائك

Ms. daté de l'an 1009 (1600-1601 de J.-C.).

Papier. 132 feuillets. Hauteur, so centimètres; largeur, 13 centimètres et demi. 17 lignes par pare. - (Ancien fonds 1304. )

\section{6.}

Mème ouvrage.

Is. daté de l'an 1039 (163o de J.-C.).

Papier. 86 feuillets. Hauteur, 21 centimètres; largeur, 14 centimètres. 23 lignes par page. - (Supplément 1212.)

\section{7.}

$1^{\circ}$ (Fol. $2 v^{\circ}$ ) م م C Discussion de la question relative à l'emploi des mots à double sens $\pi$, par Sa d al-Dìn al-Taftàzànì.

$2^{\circ}$ (Fol. $3 \mathrm{v}^{\circ}$.) Gloses d'lbrâhî̀m ibn Mohammad alMaïmouni ajontées aux gloses du mollah `Abd al-Ghafoûr sur le commentaire de la Kafiya d'lbn al-llàdjib par Al-

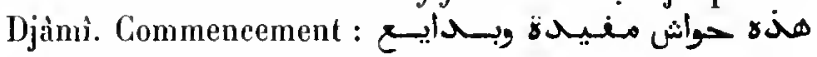

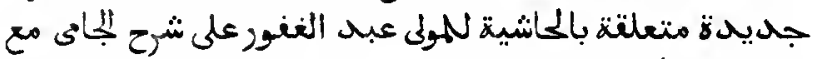

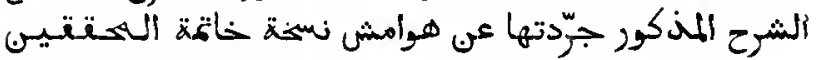

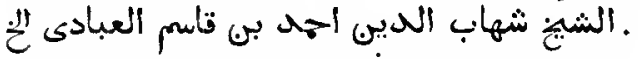

Ces gloses, qui sont autographes, ont été composées en 1012 de l'hégire ( 1603 de J.-C.).

$3^{\circ}$ (Fol. $51 v^{\circ}$.). Gloses sur un traité de théologie.

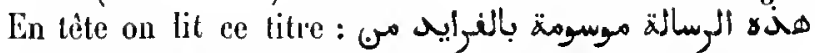
لTraité intitulé les Perles précieuses el renfermant un choix de notes inarginales éerites par Ibn al-Kamâl $\%$.

$4^{\circ}$ (Fol. $9^{\circ} \mathrm{v}^{\circ}$.) Traité sur cette parole dı Prophète : 
"Je vous parlerai de la première prière d'Abraham, de l'évangile de Jésus et de la vision de ma mère", etc.

$5^{\circ}\left(F_{0} .9^{3} \mathrm{v}^{\circ}\right.$.) Traité sur cette maxime : Le rapport de lintelligence aux objets qu'elle conçoit est comme le rapport de la vue aux objets qu'elle aperçoit

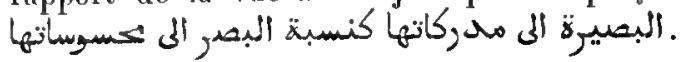

$6^{\circ}$ (Fol. 96.) Traité sur la nature et les facultés de l'àme ( 1 ), par Faklır al-Dìn al-Râzî. Commen-

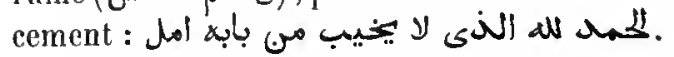

$7^{\circ}$ (Fol. 101.) Traité sur la patience, par Ibn Kamâl.

$8^{\circ}\left(F_{0} l_{.} 102 v^{\circ}\right.$.) Réfutation de l'opinion d'après laquelle Pharaon serait mort en bon musulman.

$9^{\circ}$ (Fol. $104 \mathrm{v}^{\circ}$.) Traité d'Ibn Kamâl sur le pesage des curres au jour du jugement.

$10^{\circ}$ (Fol. $105 v^{\circ}$.) Traité d'Ibn Kamâl sur les cas qui autorisent l'application de la peine fixée par la loi aux buveurs de vill.

$11^{\circ}$ (Fol. 107.) Explication des divers adjectifs que l'on emploje en traitant de l'authenticité des traditions.

$12^{\circ}$ (Fol. $109 v^{\circ}$.) Qasîta composée par le grand cadi 'Albd al-Karîm Zàdè et convertie en molihammès par Ibn al-Hanbalì (Ridhâ al-Dìn Moḷammad, fils de Borlıân al-Dìn Ibrâhîm).

$13^{\circ}$ (Fol. $116 v^{\circ}$.) La Ilamzíya, poème rimant en hamza avec dhamma et composé par Al-Bouṣirì en l'honneur du Prophète.

$14^{\circ}$ (Fol. $128 \mathbf{v}^{\circ}$.) Traité du style épistolaire, avec modèles de lettres, écrit ( 10,5 composé?) par 'Abd al-Ghani, l'an 895 (149o de J.-C.). Commencement :

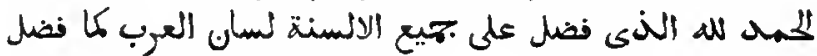

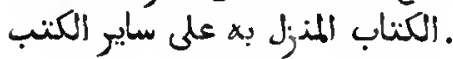

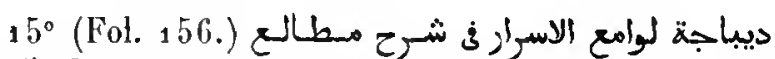
ألانول. Próface de l'ouvrage intitulé "Les lueurs des secrets n et composée pour servir de commentaire au traité de logique intitulé "r Les levers des lumières" de Maḷmoûd Ibn abî Bakr al-Ormawi, par Mohammad al-Tạ̣tânî, mort en 766 (1364-1365 de J.-C.). Commence-

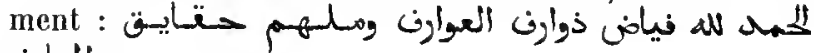
iglefl.

$16^{\circ}$ (Fol. $157 \mathrm{v}^{\circ}$.) Préface (dibadja) du commentaire de Qoṭb al-Dìn Maḥmoûd al-Râzî sur la Schamsìya, traité de logique d'Al-Kâtibî (Nadjom al-Dìn 'Omar), mort l'an $69^{3}$ ( $129^{4}$ de J.-C.).

$17^{\circ}$ (Fol. $158 v^{\circ}$. ) Préface du Molhiasar, commen- taire abrégé du Talkhiṣ al-Míftạh, par Sacd al-Dîn alTaftàzânî.

$18^{\circ}$ (Fol. 159.) Préface du Molauwal, commentaire développé du Talkhîs, par le même auteur.

$19^{\circ}$ (Fol. 161.) Préface du livre intitulé الكتاب rivre excellent sur la rédaction des contrats et des pièces notariées n. Commen-

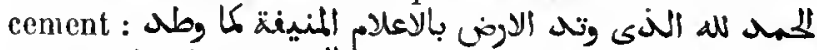

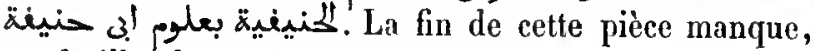
un feuillet du traité s'étant perdu.

$20^{\circ}$ (Fol. 166 .) Acte de waqf (وقفية rédigé, partie en persan, partie en turc, par 'Abd al-Ghanî Efendi; le fondateur du waqf se nommait Schams-Pacha.

$21^{\circ}$ (Fol. $180 \mathrm{v}^{\circ}$. ) Acte de waqf constitué à Damas par le sultan Sélìm-Khân.

$22^{\circ}\left(F_{0 l}{ }_{1} 9^{8} v^{\circ}\right.$.) Copie d'une lettre adressée au grand vizir Mohammad-Pacha par Ibn al-Schatkh alBakrì et renfermant l'éloge de l'efendi 'Abd al-Ghanî, qui venait d'ètre destitué d'un emploi de cadi qu'il remplissait en Égypte.

${ }_{2} 3^{\circ}$ (Fol. 199.) Lettres adressées à plusieurs grands personnages.

$24^{\circ}$ (Fol. $208 \mathrm{v}^{\circ}$.) Qașida, renfermant les louanges de Mahomet. Commencement : بكا كركب مس مسط . السعد ساطel.

$25^{\circ}$ (Fol. $\left.210 v^{\circ}.\right)$ Qasiida en persan.

$26^{\circ}$ (Fol. $213 v^{\circ}$.) Qasida en turc.

$27^{\circ}$ (Fol. $217 \vee^{\circ}$.) Qașî́da composée en l'honneur d'un Qàdhî al-'Askar (grand-juge). Premier vers :

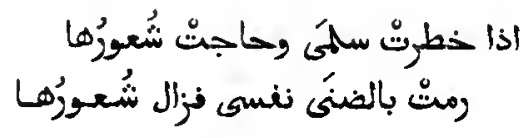

28 (Fol. 219 .) Copies de plusieurs lettres en langue turque.

$29^{\circ}$ (Fol. $227 \mathrm{v}^{\circ}$.) Gloses sur un commentaire des mots du Coran هذا المتناب لا ويب فيه

Papier. 239 feuillets. Hauteur, 20 centimètres et demi; largeur, 15 centimètres. Diverses écritures du xvir siècle. - (Ancien fonds 1322.)

\section{8.}

Grammaire arabe dont cliaque paragraphe est accompagné d'une glose très détaillée. Le texte est indiqué 
par la lettre $\infty$ (pour نصّ ) et le commentaire par la lettre ن (pour $ح$ i) . Le commencement manque.

Papier. 11 feuillets. Hauteur, g/t centimètres; largeur, 15 centimètres et demi. Le nombre de lignes par page varie de 22 à 33 . Ms. du $x \nabla^{\circ}$ siècle. - (Ancien fonds 1292.)

\section{9.}

Le Maqsoûd, accompagné d'un commentaire intitulé

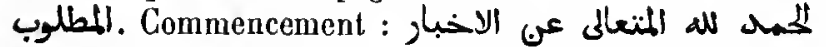

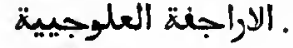

Ms. daté de l'an 1047 ( 1637 de J.-C.).

Papier. 88 feuillets. Hauteur, 21 centimètres; largeur, 15 centimètres. 25 lignes par page. - (Ancien fonds 1312.)

\section{0.}

Commentaire de Klıâlid al-Azharì sur son traité de grammaire intitulé Al-Azhariya. Commencement : L . لله على تهيع الاحوال

Papier. 49 feuillets. Hauteur, 21 centimètres et demi largeur, 15 centimètres. 23 lignes par page. Yls. du xvi1 siècle. - (Supplément 1210.)

\section{1.}

$1^{\circ}$ Mème ouvragge.

$2^{\circ}$ (Fol. 51.) Commentaire d'lbn Hischàm sur son ouvrage intitulé Schodsoûr al-Dsahab.

Le premier ouvrage est daté de l'an 1116 de l'hégire (1704 de J.-C.), le second de l'an 1211 de l'hégire (1797 de J.-C.).

Papier. 106 feuillets. Hauteur, a a centimètres; largeur, 15 centimètres. 19 lignes par page. - (Supplément 1297.)

\section{2.}

Commentaire de Khâlid al-Azharî sur son traité de grammaire intitulé Al-Azhariya.

Ms. daté de l'an 1182 (1 768 de J.-C.).

Papier. 53 feuillets. Hauteur, sa centimètres et demi; largeur, 15 centimètres et demi. 21 lignes par page. - (Supplément 1 1208.)

\section{3.}

$1^{\circ}$ Mème ouvrage.

$2^{\circ}$ (Fol. $53 \mathrm{v}^{\circ}$.) Commentaire sur l'Adjorroûmiya, par Khâlid al-Azharî.

Notes marginales.

Papier. 91 feuillets. Hauteur, g1 centimètres el demi; largeur, 16 centimètres et demi. 19 lignes par page. Ms. du xvıı' siècle. (Supplérnent 1211.)

\section{4.}

Gloses d'Aboû Bakr ibn Ismì îl al-Schıanwânî sur le commentaire de l'Azharîya par Khâlid al-Azharî. D'après un chronogramme, à la fin du volume, Al-Schanwânì mourut l'an 1019 ( 1610 de J.-G.).

Ms. daté de l'an 1038 ( 1628 de J.-C.).

Papier. 124 feuillets collés sur onglets. Hauteur, 21 centimètres et demi; largeur, 16 centimètres. 25 lignes par page. - (Supplément 1209.)

\section{5.}

r. La quintessence, commentaire sur le Mowasschall (l'orné)», traité de granmaire, en vers, de Djalâl al-Din 'Abd al-Raḥmân al-Soyouttị. L'aıteur du Monaqgah se nommait Schihâb al-Dìn Aḷmàd ibn 'Abd al-Ghaffär. Commencement : all a. Il

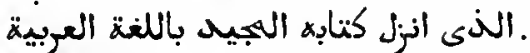

Ms. daté de l'an $9^{81}$ (1573 de J.-C.).

Papier. 11 o feuillets. Hauteur, 18 centimètres; largeur, 13 centimètres et demi. 21 lignes par page. - (Supplément 1951.)

\section{6.}

rLe plus haut degré de la beauté». Traité de grammaire en vers, commenté par l'auteur lui-même. Premier vers :

$$
\text { وبعد فان النكو علم مبيّت، لكينية التركيب ف العربية }
$$

Commencement du commentaire : بالآئx وفيا. En tête du volume se trouve une pièce de vers à la louange du Nihâyat al-Bahdja, commençant ainsi :

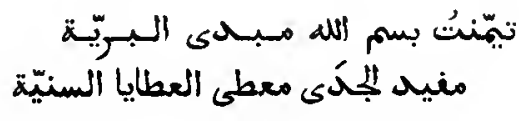


L'auteur de cette pièce dit en parlant du Nihiya :

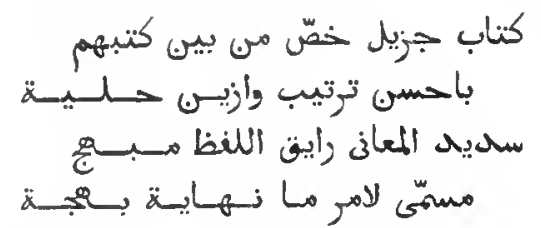

Hadji Khalfa a pris cette piece de vers pour l'ouvage commenté, qu'il attribue à Ibrâhìm al-Schabistarì.

Ms. daté de l'an 1024 (16.5 de J.-C.); mais on a changé ensuite le mot الن تmillen en ineuf cents $\%$.

Papier. 160 feuillets. Hauleur, 30 centimètres et demi; largeur, 13 centimètres. Le nombre de lignes par page varie de 17 à $20 .-$ (Supplément 1254.)

\section{7.}

$1^{\circ}$ Le Binâ al-Af âl.

$2^{\circ}$ (Fol. $63 v^{\circ}$.) L' $I z \hat{z}$.

$3^{\circ}\left(F^{\circ}\right.$ ol. $86 \mathrm{v}^{\circ}$.) Le Maqsound.

Papier. 111 feuillets. Hauteur, 15 centimètres; largeur; 7 centimètres et demi. 13 liggnes par page. Ms. du xvir' siècle. - (Supplément 1249. )

\section{8.}

Le Binâ al-Af âl et le Aznthilat al-Molhtalifa.

Papier. 94 feuillets. Hauteur, a centimètres; largeur, 13 centimètres. 11 lignes par page. Ms. du xvıI' siècle. - (Supplément 1311 bis.)

\section{9 .}

Commentaire sur le Binâ al-Afeal. Commencement:

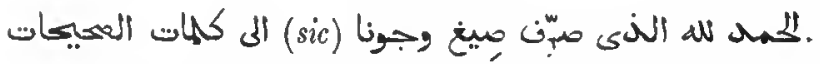

Papier. 28 feuillets. Hauteur, 21 centimètres; largeur, 14 centimètres et demi. 15 lignes par page. Ms. du xvin" siècle. - (Supplément 1247. )

\section{0.}

Même ouvrage.

Ms. daté de l'an 1048 (1638 de J.-C.).

Papier. 53 feuillets. Hauteur, 14 centimètres et demi; largeur, 9 centimètres et demi. 9 lignes par page. - (Ancien fonds 1361 .)

\section{1.}

$1^{0}$ Traité sur les particules de la grammaire arabe; sans titre ni nom d'auteur. Commencement : أعم ألى

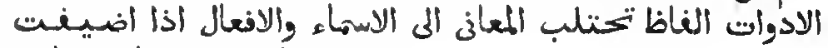

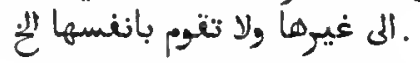

$2^{\circ}$ (Fol. $5 \mathrm{v}^{\circ}$.) Collection de bons nots, d'anecdotes, de maximes de sagesse, ete., par Aboû Manșoûr 'Abd al-Mailik ibn Mohammad ibn lsmacil al-Tha álibî, mort en 429 (1037-1038 de J.-C.). Ce recueil est divisé en douze parties renfermant les paroles des Compagnons de Mahomet; des rois et des puissants; des rois musulmans; des vizirs et des grands; des moralistes et des orateurs; des cadis et des jurisconsultes; des philosophes et des médecins; des belles femmes; des chanteurs et des musiciens; des hommes habiles en tout genre; des poètes (en prose et en vers). L'auteur dit avoil composéce traité pour la bibliothèque d'Aboû Sahl al-Ḥamdoûnî, vizir ('amîd) du sultan ghaznévide Mas'oûd.

$3^{\circ}$ (Fol. $26 v^{\circ}$.) Recueil anonyme du genre du précédent. Il renferme des anecdotes, des apophtegmes, des conseils, des pièces de vers, des expressious passées en proverbes, ete.

$4^{\circ}$ (Fol. $35 \mathrm{v}^{\circ}$.) Autre recueil du même genre. La fin manque.

$5^{\circ}$ (Fol. 53.) Traité de synonymes intitulé U⿺辶 r. Sur les signes et marques externes qui distinguent les hommes et les animaux $r$. Ce traité paraît incomplet. Suivent des morceaux divers en prose et en vers.

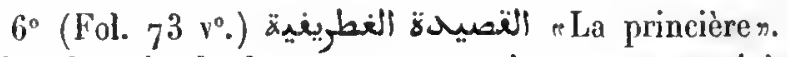
Pièce de près de deux cents vers, rimant tous en ani.

$7^{\circ}$ (Fol. $82 \mathrm{v}^{\circ}$.) Pièce de (vingt-huit) vers, se terminant tous par les mots كرى المبيت. Lauteur y exprime ses regrets d'avoir loué sa maison.

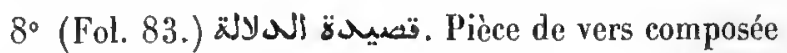
l'an 539 (1144-1 145 de J.-C.), par Samsâm al-Daula, fils d'Al-Hossîm al-Baghîdhî (البغيضى).

$9^{\circ}\left(F_{0} \mathrm{l} .85 \mathrm{v}^{\circ}\right.$.) Pièce de vers attribuée à Al-Farazdaq et composée d'environ quatre-vingt-dix vers dont voici le premier :

أرى ربع هند وأطلال عامر بدت بالاوابه وألريد عاهر

$10^{\circ}\left(\mathrm{Fol}_{\mathrm{o}} 87 \mathrm{v}^{\circ}.\right)$ Extraits de divers poètes.

$11^{\circ}$ (Fol. 96.) Maximes attribuées à divers personnages. 
$12^{\circ}$ (Fol. $118 \mathrm{v}^{\circ}$.) Explication de divers adjectifs employés en poésie et d'une pièce qui commence ainsi :

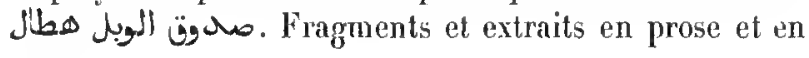
vers.

${ }_{1} 3^{\circ}\left(\right.$ Fol. $123 \mathrm{v}^{\circ}$.) Note d'Avicenne sur les facultés de l'âme.

$14^{\circ}$ (Fol. $124 \mathrm{~V}^{\circ}$.) Mélanges en prose et en vers.

${ }_{15}^{\circ}$ (Fol. 136.) Signification de certains noms terminés les uns par un alif long, les autres par un alif bref.

$16^{\circ}$ (Fol. 142.) Anecdote au sujet d'un vers qui se terminait par les mots $\lambda_{-1}$ is

$17^{\circ}$ (Fol. 144.) Une maqsoûra d'environ cent einquante vers, attribuée à Aboû 'I-Qâsim al-Ḥasan ibn Hạî̉b.

18 $8^{\circ}$ (Fol. 147.) Mélanges et anecdotes.

Papier. 153 feuillets. Hauteur, 37 centimètres; largeur, 18 centimètres. 25 lignes par page. $\mathrm{Hs}$. du $\mathrm{xv}^{\mathrm{e}}$ siècle presque tout entier de la même main. - (Ancien fonds 1239.$)$

\section{2 .}

$1^{\circ}$ Traité sur Yidhgìm.

$2^{\circ}$ (Fol. $13 v^{\circ}$.) Traité sur le fath et l'imala.

$3^{\circ}$ (Fol. $17 \mathrm{v}^{\circ}$.) Traité des panses à observer dans la récitation du Coran, par Aboû 'Amr' 'Othmân ibu Sacid ibn 'Othmân al-Hoqrî. Dans cet ouvrage, l'auteur' applique ses règles à toutes les sourates du Coran successivement.

Ms. daté de l’an 954 (1547 de J.-C.).

Papier. 178 feuillets. Hauteur, 18 centinètres; largeur, 13 centimètres. 13 lignes par page. - (Supplément 1248.)

\section{3.}

r Le succès", commentaire perpétuel sur un traité de grammaire intitulé لo lo mence par ces mots : أعلم أن العامل ف

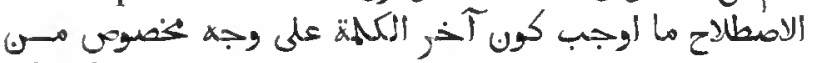
ألاعكراب. Il est à remarquer que la préface de ce conmentaire commence à peu près comme celle du Miṣbah

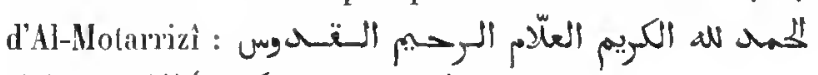

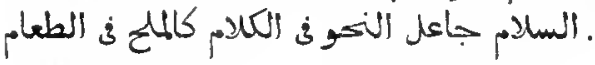

Ms. daté de l'an 997 ( 1589 de J.-C.).
Papier. 48 fenillets. Lanteur, 15 centimètres; largeur, 9 centimètres et demi. 11 lignes par page. - (Ancien fonds 1362.)

\section{4.}

Fragment d'un traité de grammaire. C'est le chapitre sur la valeur et l'influence de la lettre $f a(\dot{b})$.

Papier. 3 feuillets. Hauleur, 21 centimètres; largeur, 14 centimètres et demi. 15 lignes par page. Ms. du xvi siècle. - (Supplémenl $3: 73$.)

\section{5}

$1^{\circ}$ Traité de la conjugaison. Commencement : teyg

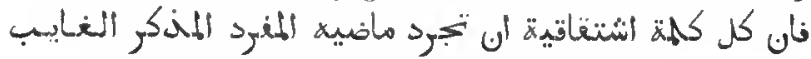

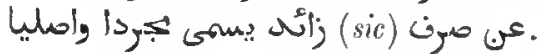

$2^{\circ}$ (Fol. $26 \mathrm{v}^{\circ}$.) Al-Amthilat al-Moklitalifa.

Ms. daté de l'an 1214 (1799-1800 de J.-C.).

Papier. 37 feuillets. Hauteur, 17 centimèlres; largeur, 11 centimètres. 15 lignes par page. - (Supplément 1259.)

\section{6.}

"Crème de l'analyse grammaticalen, par 'Abd Allah ibn Moḷammad. C'est une analyse de la grammaire composée par Mol!ammad Birguewi (بوكي) et inlitulée exposition des secrets\%. Com-

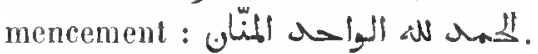

Ms. daté de l'an $117^{6}\left(17^{62-1} 7^{63}\right.$ de J.-C. $)$.

Papier. 176 feuillets. Hauteur, so centimètres; Iargeur, 15 centimètres. 13 lignes par page. - (Supplément 1256.)

\section{7.}

$1^{\circ}$ Traité de l'orthographe aube, en vers, par Mohammad ibn 'Atìq al-Todjîîî. Premier vers :

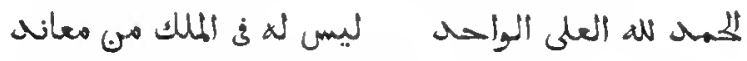

Le texte est accompagnó de beaucoup de gloses i l'encre rouge.

$2^{\circ}$ (Fol. $\left.34 \mathrm{v}^{\circ}.\right)$ Autre poème sur le même sujet, par Mohammad ibn 'Abd Allah ibn Màlik. 
$3^{\circ}\left(\right.$ Fol. $36 v^{\circ}$.) Prième et commentaire dans lesquels Molıammad ibn 'Abd Allah ibn Mâlik alDjaïyânî indique les cliangements de siguifieation que subissent certains mols selon qu'ils se prononcent avec un fatha, un dhamma ou un kesra.

$4^{\circ}$ (Fol. $52 v^{\circ}$.) Poène (daliya) composé par Alllasan ibn Mas'oûd al-Yoûsi en l'honneur de son professeur Moḷammad ibn Nâsir al-Dar'i. Premier vers :

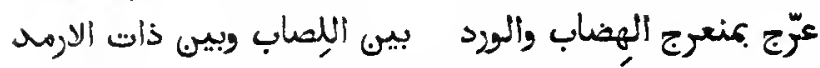

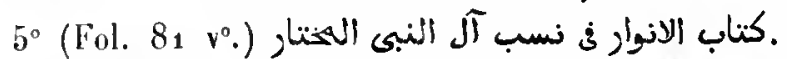
Géućalogic des descendanls du Prophète, par Molıammad ibn Moḷammad ibn Aḥmad ibn Djozay al-Kalbî

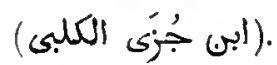

$6^{\circ}$ (Fol. $106 \mathrm{v}^{\circ}$.) Comniencement d'un traité sur l'excellence du bismillah.

$7^{\circ}$ (Fol. 111.) Deux actes de divoree.

Écritures diverses. Le premier ouvrage est daté de l'an 1132 de liégire (1720 de J.-G.); le troisième, de l'an 1162 de l'hégire (1 749 de J.-C.).

Papier. 11 a feuillets. Ilauteur, 21 centimètres ; largeur, 15 centimètres. - (Supplément 1924.)

\section{8.}

. Traité de grammaire pour servir de cadcaun, par Molıanmad ibu 'Abd Allah al-Anșârì, accompagné d'un commentaire perpétuel dont le titre a

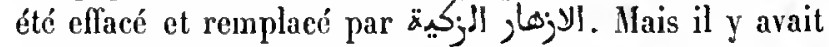
probablement deaun; le mot على est encore facile à reconnaîltre. Comتال العبد اللنتير الى أله. تعالى ثها :

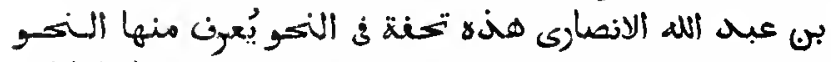
. Commencement du com-

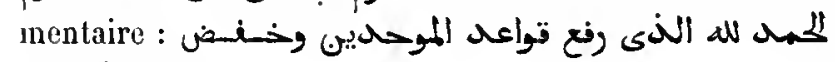

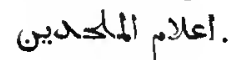

Ms. daté de l'an 1126 (1714 de J.-G.).

Papier. 80 fevillets (le cinquième feuillet ne fait pas partie de l'ouvrage). Hauteur, 21 centimètres et demi; largeur, 15 centimètres. 21 lignes par page. - (Supplément 1260.)

\section{9.}

1 - Traité de grammaire commencant par ces mots : وبعد فهذها وسالة فيما يكتاج اليه كل معرب أشدّ الاحستيـاج
(Voyez ci-dessus, $n^{\circ} 4006,2^{\circ}$.)

$2^{\circ}$ (Fol. 22.) Traité de grammaire. Commeneement :

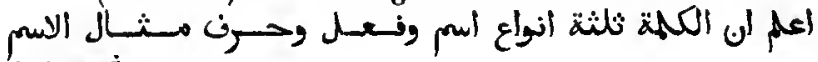

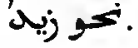

Papier. 34 feuillets collés sur onglets. Hauteur, 19 centimètres; largeur, 14 centimètres. 15 lignes par page. Ms. du xvil siècle. (Supplément 1221.)

\section{0.}

م Investigation des choses à découvrir et encouragement pour le eliercheur». Grammaire arabe composée en 1707 de J.-C. par Gabriel ibn Farhạt, archevêque d'Alep, mort en 1733 . Cet exemplaire a été copié sur celui de l'auteur.

Papier. 143 feuillets. Hauteur, 22 centimètres et demi; largeur, 14 centimètres et demi. 33 lignes par page. - (Ancien fonds 1295 A.)

\section{1.}

Traité de grammaire intitulé تنتأجُ التكصيل Résultats de l'acquisition n, accompagné d'un commentaire anonyme composé en 1138 de l'hégire (1 $725-1726$ de J.C.C.). Il n'y a pas d'introduction, mais on lit dans l'explicit que ce commentaire n'est qu'un abrégé du Nataidj. Louvrage commence par le bismillah et la taşliya; puis vient ce titre de chapitre : باب أبنية الانعال ومعانيها , suivi الابنية بخع بناء وبناء : d'une glose qui commence ainsi ل)

Ms. daté de l'an $117^{5}$ ( 1762 de J.-G.).

Papier. 279 feuillets. Hauteur, 21 centimòtres el demi;:Iargeur, 16 centimètres. 19 lignes par page. - (Supplément 1263.)

\section{2.}

Second chapitre du (sic) هدية سبيان non pour les enfants n, renfermant la conjugaison des diverses formes du verbe de la langue arabe. La plupart des titres sont en langue turque.

Papier. 11 feuillets. Hauteur, 21 centimètres et demi; largeur, 15 centimètres. 11 lignes par page. Ns. du xvin' siècle. - (Sup-plément 2226.) 


\section{3.}

L'Alphabetum arabicum, publié à Rome en 1592. Le traité est interfolié. On y a joint un cahier dans lequel un étudiant qui commençait à apprendre l'arabe a inséré une quantité de notes en latin.

Papier. 61 feuillets. Hauteur, 22 centimètres et demi; largeur, 17 cenlimètres. - (Supplément 1149.$)$

\section{4.}

Syllabaire arabe suivi de prières à l'usage des enfants musulmans.

Papier. 16 feuillets. Hauteur, 14 centimètres et demi; largeur, 10 centimètres. 7 lignes par page. Ms. du xvi" siècle. - (Ancien fonds 1354, Colbert 6410.)

\section{5.}

Syllabaire suivi de quelques modèles d'écriture.

Papier, 18 feuillets. Hauteur, a 1 centimètres et demi; largeur, 15 centimètres. Ms. du vwı siècle. -- (Supplément 1148.)

\section{6.}

\section{Syllabaire.}

Papier. 17 feuillets. Hauteur, 17 centimètres; largeur, 10 centimètres et demi. Ms. du xvı" siècle. - (Supplément 115o.)

\section{7.}

\section{Syllabaire.}

Papier. 18 leuillets. Hauteur, so centimètres et deni; largeur, 13 centimètres et demi. Ms. du xrn" siècle. - (Supplément 1151.)

\section{8.}

Syllabaire.

Papier. 16 feuillets. Hauteur, 21 centimètres el demi; largeur, 14 centimètres et demi. Ms. du xri1" siècle. - (Supplément 1152.)

\section{9.}

Syllabairc.

Papier. 18 feuillets. Hauteur, 22 centimètres; largeur, 15 centimètres et demi. Ms. du xvir" siècle. - (Supplément 1153.)

\section{0.}

Syllabaire.

Papier. 16 feuillets. Hauteur, 19 centimètres et demi; largeur,

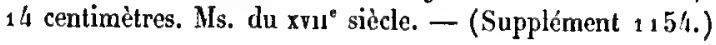

\section{1.}

"Compendium linguæ arabicæ ", par Guillaume Le Bé, graveur de caractères d'imprimerie. Voulant rendre ce titre en arabe, l'auteur a employé le mot تصور pour compendium et ليسئic (sic) pour lingua.

Ms. daté de l'an 1602.

Papier. 91 feuillets. Hauteur, 96 centimètres; largeur, 17 centimètres et demi. - (Supplément $\left.{ }_{2} 389.\right)$

\section{2.}

Essai de grammaire arabe, en latin, par Guillaume Le Bé

Ms. daté de l'an 1603.

Papier. 14 feuillets. Hauteur, 37 centimètres; largeur, 18 centimètres. - (Supplément 2374 .)

\section{3.}

Conjugaison du verbe نصر, avec une traduction latine.

Papier. 28 feuillets. Hauteur, 17 centimètres; largeur, ia centimètres. 8 lignes par page. Ms. du vwi ${ }^{\circ}$ siècle. - (Ancien fonds 1323, Colbert 5400.)

\section{4.}

Grammaire arabe, en français, avec un vocabulaire. Papier. soo feuillets. Hauteur, 27 centimètres et demi; largeur, 
19 centimètres et demi. 18 liggnes par page. Us. du xpı1 siècle. (Supplément a $139^{\circ}$, S. Germain $19^{3}$ bis.)

\section{5 .}

Grammaire arabe, en ilalien, cuvre d'un commençant, Irès mal écrite.

Papier. 44 feuillets. IJauteur, 15 centimètres; largeur, 11 centimètres. - (Supplémeut a1/10, S. Germain 614.)

\section{6.}

Grammaire et rocabulaire arabes, composés par Fourmont, professenr an College royal.

Papier. 140 feuillets collés sur ongtets. Hauteur, 24 centimètres; fargeur, 17 à 18 rentinètres. Ns. du xvin siècle. - (Supplénent 2142.)

\section{7.}

$1^{\circ}$ Gramaire arabe, en français.

$2^{\circ}$ (Fol. 152.) Autre grammaire arabe, en français.

On attribue ces deux onvrages à Le Roux Deshauterayes.

Papier. 150 leuillets. Jauteur, 21 continètres ef demi; largeur, 16 centimètres. Ms. du xvm siècle. - (Supplément ${ }_{23}{ }_{7} 5$.)

\section{8.}

"Lingux arabicæ elementa".

Ms. daté de l'an 1750 .

Papier. 27^ pages. Hauteur, 16 centimètres et demi; largeur, 10 centimètres et demi. - (Supplément ${ }_{2} 376$.)

\section{9 .}

Grammaire arabe de Th. Erpenius, traduite du latin en francais par Ch. Solvet.

Ms. daté de l'an 1831 .

Papier. 25 feuillets. Hauteur, 20 centimètres; largeur, 26 centimètres. 22 lignes par parge. - (Supplément 2503 .)

\section{3. - DICTIONNAIRES.}

\section{A. DICTIONNAIRES EXPLIQUES EX ARABE.}

\section{0 .}

$1 \circ$ Les

$2^{\circ}$ (Fol. 3.) Commentaire en vers sur le petit poème qui précède, par Schihâb al-Dìn al-Qalyoûbî.

Papier. 6 fenillets. Hauteur, 21 centimètres et demi; largeur, 15 centimètres et demi. Ms. du xri" siècte. - (Ancien fonds 1459.)

\section{1 .}

$1^{\circ}$ بLa pluie», par Aboû Zaïd al-Anṣânî (Sa'id ibn 'Aus), mort en 215 de l'hégire (roy. Hadji Klıalfa, t. V, p. 13 1). Ce sont les synonymes de la pluie, du tonnerre, des éclairs, des nuages et des eaux. L'auteur cite quelquefois comme exemples des vers de quelques anciens poètes.

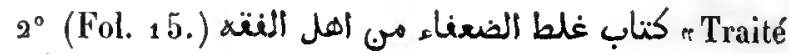
des fautes de langage commises par les juriseonsultes dont les connaissances (philologiques) sont faibles $\%$, par Ibn Barrì (بّ) al-Maqdisî (né à Jérusalem). Sur ce grammairien, dont le vrai nom était Aboû Mohammad 'Abd Allah, mort en 582 de l'hégire (1 186-1 187 de J.-G.), voyez Hadji Klıalfa, t. III, p. 205.

3० Fol. 23.) (Fautes de langage coumises par le vulgairen, par lbn al-Djawâlî́cî

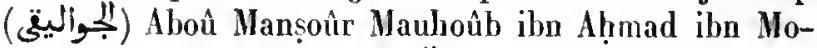
hlammad iln al-Khidr (ضil). Ce philologue mourut à Baghdàd l'an 529 (1134 de J.-C.). Voyez le dictionnaire biographique d'lon Khallikàn, t. III, p. 498 de la traduction anglaise. Une édition du traité d'lbn alDjawàliqì a été publiée $(1875)$ par M. Derenbourg fils.

$4^{\circ}$ (Fol. 6 . .) La Magșoûra d'Ibn Doraïd, avec le commentaire d'Aboû 'Abd Allah al-Hosaïn ilın Aḷmad ibn Khâlawaïh (ابر خالوبه). Ce commentateur mourut l'an 370 (980-981 de J.-C.). Sa vie se trouve dans Ilbn Khallikân, I. I, p. 456. On trouvera dans le mème ouvrage, t. III, p. 37 , une notice sur lbn Doraï, célèbre philologue, mort l'an 321 ( 933 de J.-C.).

$5^{\circ}$ (Fol. $89 v^{\circ}$.) Première section du dietionnaire

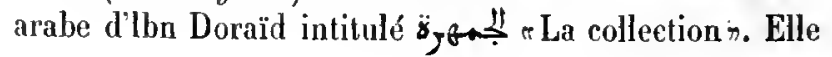


renferme les racines composées de deux lettres, dont la seconde est redoublée (ابواب النتاءى المحيح اللهغم), et les racines quadrilitères formées par la répétition de ces lettres. Sur la distribution excessivement incommode du Djamhara, voyez les observations de Hamaker (Specimen Catalogi cod. or. Biblioth. Lugd. Bat., p. 34).

Ms. daté de l'an 631 (1233-1234 de J.-C.).

Papier. 139 feuiftets. Hauteur, 21 centimètres et demi; largeur, 15 centimètres et demi. 15 lignes par page. - (Ancien fonds 13.8.)

\section{2.}

"Livre des mots", collection de synonymes disposés en cent cinquante-sept chapitres, par Aboù Yoùsof Yacqoủb ibn Isbàq ibn al-Sikkît, mort lan 244 de l'hégire (858-859 de J.-C.). Dans chaque paragraphe, ce célèbre philologue et grammairien cite avec soin ses autorités et appuie très souvent ses observations par des vers d'anciens poètes. C'est très probablement l'onvrage.dont Hadji Khalfa fait mention sous le titre de اصلاح

Ms. daté de l'an 1200 (1 785 de J.-C.).

Papier. 261 fenillets. Hauteur, 35 cenlimètres; largeur, 21 centimètres et demi. 17 lignes par page. — (Supplément 1359 bis.)

\section{3.}

Seconde partie du dictionnaire arabe intitulé Kitâb al-Djamhara, par Aboû Bakı Molyammad ibn al-llosaïn ilon Doraïd. (Voyez ci-dessus, $n^{\circ} 4231,5^{\circ}$.) Commen-

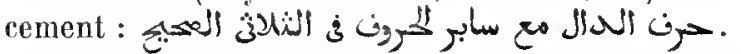

Papier. 156 feuillets. Hlanleur, 39 centimètres et demi; largeur, 21 centimètres et demi. 43 lignes par page. Ms. du xvil siècle. (Supplément 1364.)

\section{4.}

s mots arabes qui se termilent soit par un alif bref, soit par un alif long, par Aboû '1-'Abbàs A ḥmad ibn Mlohammad ibn al-Walìd ibn Wallàd ( grammairien Al-Zaddjâdj. Soyoûtị nous informe, dans son Dictionnaire des grammairiens, qu'il composa aussi une défense de Síbawaïh contre les attaques d'Al-Nobarrad, qu'il habita le Caire et qu'il mourut l'an 332 (943-944 de J.-C.). Liouvrage que nous avons ici se

\footnotetext{
Max, orientaux, - Ill.
}

compose de deux parties, dont la première, formant un dictionnaire, est consacrée aux mots dans lesquels le caractère, soit long, soit bref, de l'alif final est anor-

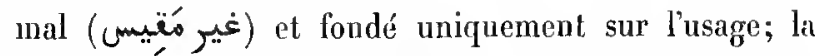
seconde partie renferme les formes dans lesquelles le mème caractère est déterminé par des règles positives (هقيس). l'auteur cite de nombreux excmples tirés des anciens poètes. Il n'y a pas de préface; les premiers

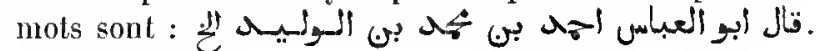
Texte ponclué.

Papier. 130 feuillets. Hauteur, 24 centimètres; largeur, 16 centimètres. 17 liģnes par pagre. Ns. du xir eiècle. - (Ancien fonds 1297.)

\section{5.}

Fragments d'un ouvrage philologique intitulé

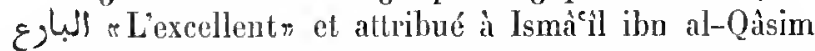
al-Baghdàdi. C'est la grande compilation qu'llon Khallikàn et Hadji Khalfa désignent par le titre de

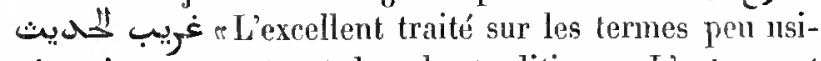
tés qui se rencontrent dans les traditions\%. L'aulcur est généralement connu sous le nom d'Aboû 'Alì al-Qàlì. Il écrivait en Lspagrne sous l'adininistration d'Al-Mansoûr ilon abî 'Amr' et il est mort à Cordoue l'an 356 de l'hégire $\left(9^{6} 7\right.$ de J.-C.). Nous ne possédons ici que les douze premiers leuillets de la $104^{e}$ partie, le commencement de la $81^{\mathrm{e}}$ partic, et, sur le recto dn dernier feuillet, la fiu de la $87^{\circ}$ partie et quelques lignes de la partie suivante. Close extraordinaire, le verso de ce leuillet est resté en blanc.

Vélin. 71 feuillets. Hanteur, 25 centimètres; largeur, 20 centimìtres et demi. 15 à 17 lignes par page. Écriture maģhrebine-espagrnole. Ns. du ${ }^{e}$ siècte. - (Ancien fonds 1252.)

\section{6.}

1 م كتناب المنوأدور ou par Ismâeil ibn al-Qàsim al-Qàlî. On lit en tête une notice sur l'auteur. (Voyez Hadji Khalfa, t. I, p. 427 et 432 .)

$2^{0}$ (Fol. 172.) Anthologie intituléc سنينة الكبوى d'AlSâlilị̂.

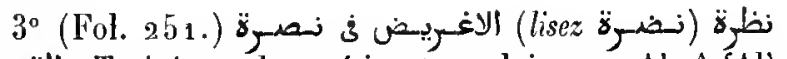

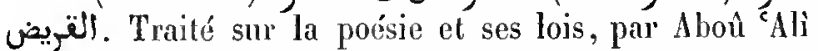
al-ÎIozaffar al-'Alawì al-ḷosaïni, suivi de quelques cxtraits et d'une notice sur le poc̀te Aboû 'l-'Alầ al-Macarrî.

Le premier ourrage est daté de l'an 1049 de l'hégire 
(1640 de J.-C.); le second, de l'an 1038 de l'hégire (1629 de J.-C.); le troisième, de la même main, de l'an 1039 de l'hégire (163o de J.-C.).

Papier. 289 feuillets. Hauteur, 27 centimètres; largeur, 18 centimètres. Environ 30 ligues par page dans le premier ouvrage; environ Ło dans les deux derniers. Écritures diverses. - (Supplément 1935.)

\section{7.}

äell par Aboû Naṣr Ismâill ibn İammâd al-Djauharî $\left(ى, \frac{11}{6}\right)$, mort en 393 de l'hégire (1002-1003 de

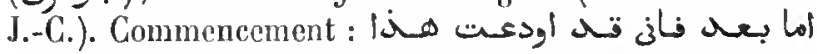

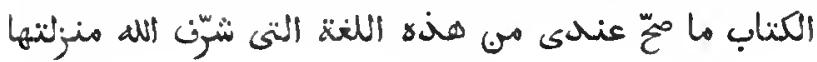
2.".

Papier. 472 feuillets, dont les trois premiers et les sept derniers datent de l'an 1013 (1604 de J.-C.). Il y a une transposition des feuillets qui se trouvent entre les fol. 39 et 44 . Hauleur, 29 centimètres; largeur, 2 a centimètres et demi. 31 lignes par page. Ms. du xil1' siècle. - (Ancien fonds 1 246. .)

\section{8.}

Mème ouvrage.

Ms. daté de l'an 690 (1291 de J.-C.).

Papier. 446 feuillets. Hauteur, 29 centimètres et demi; largeur, ao centimètres. 30 lignes par page. - (Supplément 2148.)

\section{9.}

Première partie du mêne ouvrage.

Les demiers feuillets manquent. Le texte s'arrête au milieu de la lettre b. Gloses maryinales.

Papier. 251 feuillets. ITauteur, 25 centimètres et demi; largeur, 18 centimètres. 17 lignes par page. Ms. du xuv siècle. - (Ancien fonds 1245 .)

\section{0.}

Cinquième et dernière partic du même ourrage. Le texte commence au milieu de la lettre mim (كتم).

Papier. 192 feuillets. Hauteur, 3a centimètres; largeur, 24 centimétres el demi, 19 liggnes par page. Ms. du xm1 siècle. - (Ancien fonds 1251.)

\section{1.} Ràzi.

Abrégé du Sịnạh d'Al-Djauharî, par Mohammad al-

Ms. daté de l'an $920(1514$ de J.-G. $)$.

Papier. 296 feuillets. Hauteur, 26 centimètres; largeur, 17 centimètres. 19 lignes par page. - (Supplément 1362.)

\section{2.}

Même ouvrage.

Ms. daté de l'an 958 (1551 de J.-C.).

Papier. 284 feuillets. Hauteur, 25 centimètres; largeur, 17 centimèlres. 21 lignes par page. - (Supplément 1363.)

\section{3.}

Même ouvrage.

Ms. daté de l'an 958 (1551 de J.-C.).

Papier. 298 feuillets. Hauteur, 20 centimètres et demi; largeur, 15 centimètres. 23 lignes par page, puis 19 lignes. - (Supplément 1361.)

\section{4.}

Même ouvrage. Les marges de cet exemplaire sont couvertes de notes et d'additions.

Ms. daté de l'an 973 (1566 de J.-C.).

Papier. 223 feuillets. Hauteur, 26 centimètres et demi; largeur, 17 centimètres et demi. 23 lignes par page. - (Supplément 1360.)

\section{5.}

Même ouvrage.

Sur le recto du premier feuillet on a écrit un extrait d'un traité de droit intitulé Kholdșa; cet extrait se rapporte aux lois qui règlent le divorce. Le verso du fol. 126 nous offre une note sur l'usage de la lotion funèbre. Le feuillet suivant contient une longue note extraite du wh الاسأى et traitant de la formation des pluriels réguliers. On lit sur les feuillets de garde des notes et extraits en langue turque.

Papier. 228 feuillets. Hauteur, 23 centimètres et demi; largeur, 
16 centimètres et demi. Le nombre de lignes par page varie de 19 à 21. Ms. du xw1 ${ }^{\circ}$ siècle. - (Ancien fonds 1329.)

\section{6.}

rDépouillement du Sihihh», abrégé du diclionnaire d'Al-Djauhari, par Maḷmoûd ibn Aḷmad al-Zadjânî, littérateur dont Hadji-Khalfa fait mention (t. IV, p. $9^{5}$ ), sans toutefois indiquer l'année de sa morl.

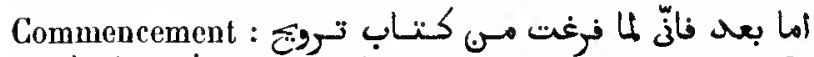
ألاؤأح في تهذيب العكاح : Le premier feuillet de garde porte quelques traditions absurdes au sujet du جبل سئيلا.

Ms. daté de l'an 1010 ( 1601 de J.-G.).

Papier. 143 feuillets. Hauteur, ${ }_{2} 6$ centimètres et demi; largeur, 18 centimètres. 19 lignes par page. - (Ancien fonds 1250 , Colbert 4359.)

\section{7 et 4248 .}

ةeغلl Collection (des mots) du langagen, dictionnaire arabe compilé et mis en ordre par A h̦mad ibn Fàris, philologue célèbre du $1 v^{\mathrm{e}}$ siècle de l'hégire. Com-

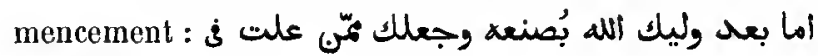
政.

Ms. daté de l'an 528 (1133-1134 de J.-C.).

2 vol. Papier. 289 et 249 feuillets. Hauteur, 22 centimètres; largeur, 16 centimètres. 21 lignes par page dans le premier volume; so lignes par page dans le second. - (Supplément 1371 et 1371 bis.)

\section{9 .}

Premier volume du mème ouvrage. Il se termine par les racines de plus de trois lettres dont la première est un șad (w). Quelques notes inarginales.

Papier. 279 feuillets y compris un onglet qui n'appartient pas à l'ouvrage. Hauteur, 25 centimèlres; largeur, 16 centimètres et demi. 16 à 18 lignes par page. Ms. du xiı' siècle. - (Supplément 1372 l.)

\section{0.}

Second volume du même ouvrage. Les premiers et les derniers feuillets manquent. Le feuillel actuellement coté 1 n'appartient pas à l'ourrage; le second feuillet commence par les dernières lignes de la section şad lâm.
Papier. 268 feuillets. Hauteur, 36 centimètres et demi; largeur, 17 centimètres et demi. 18 à 30 tignes par page. Ms. du xiv siècte. - (Supplément $137^{2}$ bis.)

\section{1.}

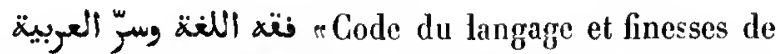
la langue arabe $\pi$, traité des synonymes arabes en trente chapitres, par Aboû Manșoûr 'Abd al-Màlik al-Thacâlibî.

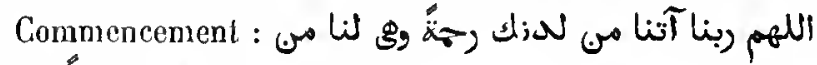

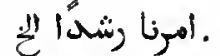

Ms. dalé de l’an 1251 (1835 de J.-G.).

Papier. 117 feuillets. Hauteur, á centimètres et demi; largeur, 17 centimètres. 23 lignes par page. - (Supplément 1357.)

\section{2.}

Fragment d'un dictionnaire arabe donuant la signification de tous les mots formés par les combinaisons de trois lettres. L'écriture n'est pas du genre maģhrebin, bien que le $q a \hat{f} f$ et le $f a \hat{~ s o i e n t ~ p o n c t u e ́ s ~ d e ~ l a ~ m a n i e ̀ r e ~}$ adoptéc en Mauritanie et en Espagne. Ces fragments paraissent dater du v viècle de l'hégire.

Vétin. 6 feuillets. Hauteur, 28 centimètres; largeur, 17 centimètres. Environ so tignes par page. - (Supplément 1364 lis.)

\section{3.}

1. Collection d'adjectifs et d'épithètes, classés sous les noms auxquels ils se rapportent ordinairement. En كفاية المتهفظ...

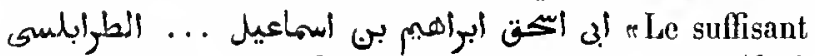
pour celui qui veut l'apprendre par cœur», par Aboû Iș̣âq Ibrâhìm ibn Ismá il al-Ṭarâbolosî.

$3^{\circ}$ (Fol. 36 $^{\circ}$. ) Gloses de Moḷammad ibn Mohammad ilın Maḅmoûd, surnommé Al-Sclıaïkh al-Bokhârî, sur le tescoles de la discussion", d"Adhod al-Dìn 'Abd al-Ralımân ibn Ahmad ibn 'Abd al-Ghaffàr

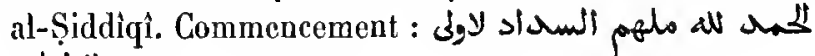
.

30 (Fol. 51 vo. ( La cosmographie telle que les saintes traditions nous la représentent "(littéralement: " La forme exaltée dans la forme sounnite n), par Djalâl al-Dìn al-Soyoûtîi. Commeneement :

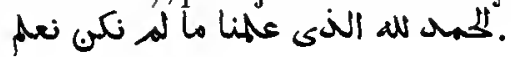


Ms. daté de l'an 1071 (1660-1661 de J.-C.).

Papier. 71 feuiliels. Hanteur, 21 centimètres; largeur, 15 ccntimètrcs. 21 lignes par page, puis 17, puis 21. - (Ancicn fonds 1327.)

\section{4.}

$1^{\circ}$ المغوب. 'Traité philologique, par Nạsir ibn 'Abd al-Saïyid al-Molarrizî, commentateur des séances d'AlHarî̀î. C'est un dictionnaire renfermant l'explicalion de certains termes peı usilés qui se présentent dans le langage des jurisconsultes et dans les traditions. Commen-

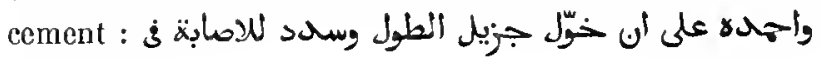
.التعل والتول :

$2^{\circ}$ (Fol. 149.) Traité de grammaire, par le mềne auteur. Cet ourrage est divisé en quatre chapitres : $1^{\circ}$ les notions préliminaires (naisons; $3^{\circ}$ les conjugaisons; $4^{\circ}$ les particules.

Ms. daté de l'an 964 (1556 de J.-C.).

Papier. 159 feuillets en y comptant huit feuillets préliminaircs. Hauteur, 27 centimètres et demi; largenr, 17 centimètres et demi. 31 lignes par page. - (Supplément 1376 .)

\section{5.}

Satisfaction au sujet de ce qui est caché sous le voilen, par Ml-Motarrizî. C'est une

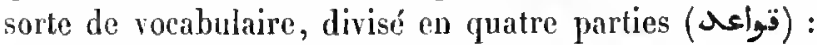
$1^{\circ}$ les noms; $2^{\circ}$ les verbes; $3^{\circ}$ les particules, et $4^{\circ}$ la syntaxe. Dans ce recueil, les mots sont classés par ordre matières. Le premier feuillet manque.

Ms. de diverses mains; les premiers cahiers sont du lemps de l'auteur'; le dernier est dalé de l'an 659 (1261 de J.-C.).

Papier. 32 a feuiltets. Hauteur, 19 centimètres; largeur, 15 centimètres. 9 lignes par page, puis 13 , puis $19 .-$ (Ancien fonds 1330.)

\section{6.}

$1^{\circ}$ Traité des noms, surnoms, patronymiques, ete., par Al-Mofaddhal ibn 'Mlì al-Maqdisì. Celte copie, qui paraît être de la main de l'auteur, s'arrête au milieu de la lettre $s$.

$2^{\circ}\left(F_{0} .3_{2} v^{\circ}\right.$.) Extrait du Moschtarili de Yàqoût alHamawi.
Le premier ouvrage est daté de l'an 643 de l'hégire (1 245 de J.-G.). Le second est de la même écriture.

Papier. 1 2 1 feuillets. Hauteur, 22 centimètres et demi; largeur, 16 centimètres. 20 d̀ 22 lignes par page. - (Supplément 1925.)

\section{7.}

$1^{\circ}$ تشرح منظومة أبر فئ. Commentaire de Yaḷyâ alQarâfî al-Isfahânî sur le poème dans lequel Schiluâb alDîn ibn Farah, de Séville, énumère les divers termes techniques qui s'emploient dans la critique des traditions.

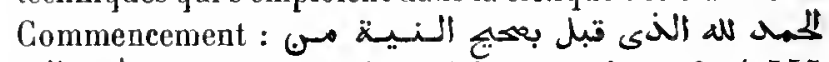

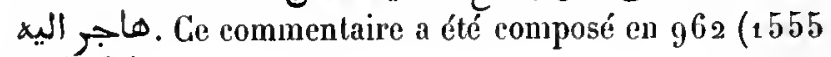
de J.-G.).

$2^{\circ}$ (Fol. 10.) Petit traité sur les termes techniques employés dans la science des traditions, intitulé rكlll Choix fait après réflexion», par Ibn Hadjar al'Asqalànî.

$3^{\circ}$ (Fol. $13 v^{\circ}$.) Le mème ouvrage avec un commentaire perpétuel, par le même Ibn Hadjar. Ce traité fut achevé vers la fin de l'an 818 (1416 de J.-C.). Selon IIadji Khalfa (t. VI, p. 316), l'auteur lui donna le titre

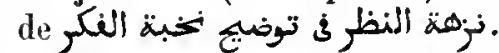

Ms. daté de l'an $9^{84}$ (1577 de J.-C.).

Papier. 47 feuillets. Hauteur, 18 centimètres; largeur, 13 centimètres et demi. 19 lignes par page, puis 21 lignes. - (Ancien fonds 1477. )

\section{8.}

Cahier d'un dictionnaire dans lequel l'auteur paraît avoir eu pour but de rassembler et d'expliquer les mots rares qui se présentent dans les traditions et autres traités théologiques. Il commence par le mot مسمهام et linit par le mot شَّ.

Papier. 8 feuillets. Hauteur, 25 centimètres et demi; largeur, 17 centimètres ct demi, 19 lignes par page. Ms. du xiv siècle. (Supplément 2149.)

\section{9 .}

rDéfinitions n, dictionnaire des termes techniques, par Al-Djordjànì.

Ms. daté de l'an 958 (1551 de J.-C.).

Papier. 72 fenillets. Hauteur, 20 centimètres et demi; largenr, 13 centimètres et demi. 19 lignes par page. - (Ancien fonds 1396.) 


\section{0 .}

Mème ouvrage. Il y a une lacune considérable entre les feuillets cotés a et 3 .

Ms. daté de l'an 964 (1557 de J.-C.).

Papier. $9^{5}$ feuillets. Hanteur, 21 centimètres et demi; largeur, 15 centimètres. 18 lignes par page. - (Supplément 3131.)

\section{1.}

1" (Fol. 3 v $^{\circ}$.) Le Ta riffat d'Al-Djordjàni.

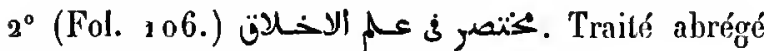
d'hygiène et d'économie domestique.

$3^{\circ}$ (Fol. $108 v^{\circ}$.) La Borda disposée en talihmis. Pre-

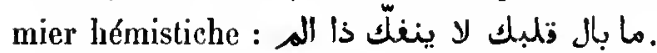

$4^{\circ}$ (Fol. $124 v^{\circ}$.) La Borda accompagnée d'une traduction en rers tures.

$5^{\circ}$ (Fol: $141 \mathrm{v}^{\circ}$.) La qasida d'Al-Farazdaq en l'honneur de Zaïn al-ç̂́bidîn, fils d'chlì ibn abì Tàilib.

$6^{\circ}\left(F_{0} .142 v^{\circ}\right.$.) Le Ta lim al-Mota allim. Notes marginales.

$7^{\circ}$ (Fol. 156.) Le Banat $S o^{\circ} a d$ de Ka $a^{e}$ ibn Zohaïr mis en takhmîs par Khalil al-Achrafî.

$8^{\circ}$ (Fol. $16_{1}$ v $^{\circ}$.) Qasîda lâmiya sur la doctrine musulnane. (Voyez ci-dessus $n^{\circ} 1251,1^{\circ}$.) Premier vers :

$$
\text { ينول العبد ف بهء الآمال لنتوحيد بنظم كالآل }
$$

$9^{\circ}$ (Fol. 163 v $^{\circ}$.) Qaṣîda commençant par ce vers :

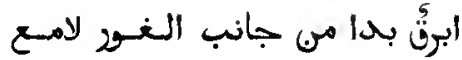

$$
\begin{aligned}
& \text { ام الرتغعت عن وجه سلمى المبراتع }
\end{aligned}
$$

$10^{\circ}$ (Fol. $165 \mathrm{v}^{\circ}$.) Qașida mîmîya d'cOmar ibn alFàridh. Cette pièce commence ainsi :

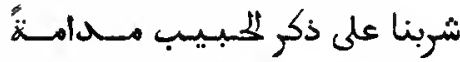

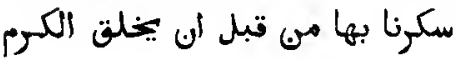

$11^{\circ}$ (Fol. $166 \mathrm{v}^{\circ}$. ) Discours sur les devoirs d'un musulman. Premiers mots : لممح المبلوة وتعديلها

$12^{\circ}$ (Fol. 176.) Notes et extraits en prose et en vers.

$13^{\circ}$ (Fol. $180^{\circ} \mathrm{v}^{\circ}$ ) Traité renfermant de courtes notices biographiques sur des savants qu'on désigne ordinairement par leurs surnoms ou leurs sobriquets, par Ibn Kemâl Pacha. $14^{\circ}$ (Fol. $184 \mathrm{r}^{\circ}$. ) Épitre de Moḥammad Tchelebi Efendi adressée à un ami et renfermant des conseils religieux. On a inscrit sur celte pièce le titre de . الوسيط بيب. الافراط والنغويط.

$15^{\circ}$ (Fol. 185 v $^{\circ}$ ) par Mohammad Tchelebi Efendi.

${ }_{16} 6^{\circ}$ (Fol. ${ }_{18} 8 v^{\circ}$.) Traité composé par Al-Soyoụṭi pour montrer que la famille de Zaïnab descend de Ma-

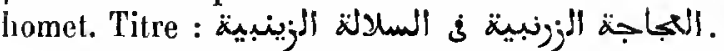

$17^{\circ}$ (Fol. 189.) Traité dans lequel Al-Soyoụtì réfute l'opinion que le corps de Mllomet ne devait pas rester dans le tombeau jusqu'au terme de mille ans.

$18^{\circ}$ (Fol. 192.) Discours sur l'inanité des biens de co monde.

$19^{\circ}$ (Fol. $\left.194 v^{\circ}.\right)$ Examen de la question : Est-il permis, en faisant la purification, de passer la main sur la chaussure externe (خَّ), sans se déchausser?

$20^{\circ}$ (Fol. $197 \vee^{\circ}$.) Petile grammaire persane en turc.

$21^{\circ}$ (Fol. 205.) Note sur la prédestination (

$22^{\circ}$ (Fol. $205 v^{\circ}$.) Album renfermant des poèmes et des extraits, des notes en prose, etc., dont les uns sont en arabe, les autres en ture. On y remarque notamment une liste alphabétique d'articles hiographiques commencant par Ibn Kathir l'historien et se Lerninant par Ilderim Khân.

Le prenier ouvrage est daté de l'an $97^{\circ}$ de l'légire.

Au commencement du volume se trouve une qasida, cn turc, par Khodja Tchelebi, et d'autres pièces de vers, en arabe et en ture.

Papier. a 49 feuillets. Hanteur, 20 cenlimètres; largeur, 1/4 centimi:-lres. Écritures diverses du xvi siècte. - (Supplément 1911.)

\section{2.}

- rotice des termes teclniques les plus importants $\pi$. Dictionnaire des termes employés dans les traités de droit et formant, pour ainsi dire, un supplément au Ta'rîfát d'Al-Djordjânì, par' 'Mbd al-Ra'ouf Mohammad al-Manàiwî. Commencement :

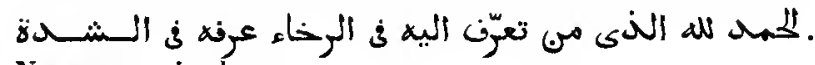
Notes marginales.

Ms. daté de l’an 1123 ( 1712 de J.-C.).

Papier. 190 feuiltets. Hanteur, 31 centimètres et demi; largeur, 15 centimètres. 19 lignes par page. - (Supplément 1316.) 


\section{3 et 4264.}

rL'océan environnant», dictionnaire de la langue arabe, par Moḥammad ibn Ya qoûb Al-Firouzâbâdî, mort en 871 (1467 de J.-C.). A la fin de l'ouvrage le titre est répété avec l'adjonction des mots الموسيط . M. Flügel a rendu ce dernier mot par exemplum.

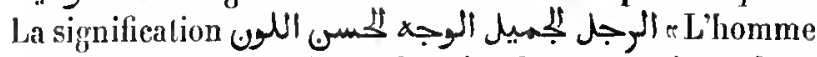
dont la figure est belle et le teint beaun, qui est donnée dans le Qâmoûs mème, ne saurait convenir dans le cas actuel.

Ms. daté de l'an $9^{8} 1\left({ }_{1} 5_{7} 3\right.$ de J.-C.).

2 vol. Papier. 344 et $31 \rho$ feuillets. Hauteur, 31 centimètres; largeur, 21 centimètres. 31 ligues par page. - (Supplément ${ }_{1367}$.)

\section{5 .}

Même ouvragge.

Ms. daté de l'an 991 (1583 de J.-C.).

Papier. 491 feuillets. Hauteur, 57 centimètres; largeur, 24 centimètres. 37 lignes par page. - (Ancien fonds $12 / 40$. )

\section{6.}

Même ouvrage.

Papier. 506 feuillets. Hauteur, 29 centimètres; largeur, 19 centimètres et demi. 31 lignes par page. En tête une vignette en or el en couleurs. Ns. du xrı" siècle. - (Supplément 1 366.)

\section{7.}

Méme ouvrage.

Papier. $7^{0} 1$ feuillets. Hauteur, 32 centimètres; largeur, 18 centimètres et demi. 35 lignes par page. Ms. du xvi'e siècle. - (Supplésnent 1365. )

\section{8.}

Même ouvrage.

Ms. daté de l'an 1073 (1663 de J.-C.).

Papier. 811 feuillets. Hauteur, 29 centimètres et demi; largeur, 19 centimètres. 29 lignes par page, ensuite 27. Au fol. $1 v^{\circ}$, vignette en or et en couleurs. - (Ancien fonds 1941.)
4269 .

Même ouvrage. Le commencement, jusqu'au mot نسim, manque.

Papier. 694 Cenillets. Hauteur, 26 centimètres et demi; largeur, 15 centimètres et demi. 35 lignes par page. Ns. du xvıı siècle. (Supplément 1370.)

\section{0 et 4271.}

Même ouvrage.

Ms. daté de l'an 1229 (1814 de J.-C.).

a vol. Papier. 36 a et $34_{2}$ feuillets. Hauteur, 29 centimètres et demi; largeur, 16 centimètres et demi. ${ }_{2} 3$ liggnes par page. - (Supplément 1396. )

\section{2.}

Première partie du même ouvrage. La copie s'arrête au commencement de la lettre $\dot{z}$.

Papier. 317 feuillets. Hauteur, 32 centimètres et demi; largeur, 23 centimètres. 23 lignes par page. Ms. du $x 7^{\circ}$ siècle. - (Ancien fonds 12/2.)

\section{3.}

Première partie du même ouvrage. Le texte se termine par le mot ع عiلt. Le premier feuillet du manuscrit a dû appartenir à un exemplaire du Coran.

Papier. 311 feuillets. Hauteur, 30 centimètres; largeur, 20 centimètres et demi. 23 lignes par page. Ms. du xvi siècle. - (Supplément $1368 \mathrm{I}$.)

\section{4.}

Seconde partie du même ouvrage, commençant par le

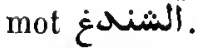

Ms. daté de l'an 1050 ( 1640 de J.-C.).

Papier. 291 feuillets. Hauteur, 30 centimètres; largeur, 20 centimètres. 29 lignes par page. - (Supplément 1368 II.)

\section{5 .}

Seconde parlie du même ouvrage, commençant par la lettre $\sim$. La lettre $s$ manque. 
Papier. 279 feuillels. Hauteur, 27 centimètres; largeur, 18 centimètres. 25 lignes par pağe. Ms. du $\mathbf{x v}^{e}$ siècle. - (Ancien fonds 1244.)

\section{6.}

Seconde partie du mème ouvrage, commençant par la lettre $\varepsilon$.

Ms. daté de l'an 963 (1556 de J.-C.).

Papier. 204 feuillets. Hauteur, 28 centimètres; largeur, 18 centimètres et demi. ag lignes par page. - (Ancien fonds 1243.)

\section{7.}

$1^{\circ}$ Commencement du mème ouvrage. Le texte s'arrête au mot $;$;

$2^{\circ}$ (Fol. $202 \mathrm{v}^{\circ}$.) Commentaire sur un traité des successions. Le texte commence par les mots w Mabil

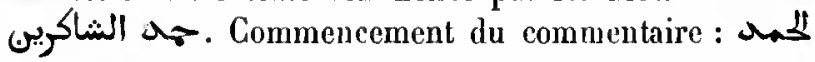

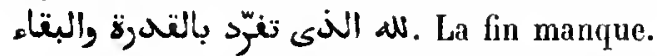

3. (Fol. $\left.209 v^{\circ}.\right)$ Traité des successions, par Nadjm al-Ṣcharîhị al-Kobrawi (نجم الثريكى الكبروى), surnommé

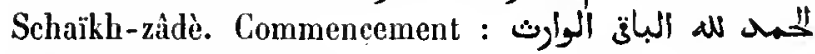
. الهيى المهيت الباعث.

Papier. 215 fenillets. Hauleur, 23 centimètres el demi; largeur, 13 centimètres. Écritures diverses dı xvı siècle. - (Supplément 1369.)

\section{8.}

Dictionnaire abrégé de la langue arabe, tiré du Sihah, du Qâmoûs, du commentaire des Séances d'Hl-Ilarìni, ele. Le commencement de la préface est devenu illisible.

Papier. ${ }_{2} 57$ feuillets. Ilauteur, 15 centimètres; largeur, 10 centimètres. 15 lignes par page. Hs. du xú siècle. - (Supplément 1378 bis.)

\section{9 .}

$1^{\circ}$ Porle de l'Explication du langage des Arabesn. Dictionuaire composé par le savant Maronite Gabriel ibn Farḷât. Commencement :

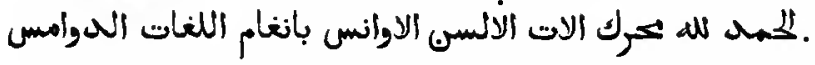
$2^{\circ}$ (Fol. 316.) Traité des Régissants grammaticaux, par le même auteur. Commencement : أعم ان اللالـن (a).

Ms. daté de l'an 1725 de J.-G.

Papier. 329 feuillets. Hauteur, 21 centimètres; largeur, 16 centimètres. 25 liggnes par page. - (Supplément 1374.)

\section{0 .}

$1^{\circ}$ Dictionnaire arabe de Gabriel ibn Farḅât.

$2^{\circ}$ (Fol. 292.) Traité des Régissants grammaticaux, par le même.

Ms. daté de l'an $17^{25}$ de J.-C.

Papier. ${ }_{2} 3$ fenillets. Hauteur, 20 centimèlres; largeur, 15 centimètres et demi. 25 lignes par page. - (Supplément 1375.)

\section{1 .}

$1^{\circ}$ بllópertoiren, dictionnaire alphabétique des mots les plus remarquables qui se trouvent dans le Coran avec leur explication, par 'Abd al-Rạ!mân ibn Moḷammad Amthâlì (مثألى). Le manuscrit ne renferme que les six premières lettres de l'alphabet. Commence-

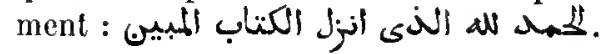

$2^{\circ}$ (Fol. $55 \mathrm{v}^{\circ}$.) Vocabulaire arabe-malais.

Papier. $7^{3}$ feuillets. Hauteur, 21 centimètres et demi; largeur, 16 centimètres. 19 lignes par page. Ms. du xvin siècle. - (Supplément ${ }_{1} 377$.)

\section{2.}

Petit vocabulaire commençant par la lettre alif. Chaque mot est accompagné d'une ou de deux phrases pour servir d'exemples. On y remarque beaucoup d'incorrections. L'auteur a mis en tête de ce travail un titre ainsi concu : كناب دزّ المنظوم لاهل العلوم.

Papier. 15 feuillets. Hauteur, 17 centimètres; largeur, 11 centimètres et demi. 18 à 20 lignes par page. Ms. du $x^{\circ} x^{\circ}$ siècle exécult́ par un Européen. - (Supplément 1389.)

\section{B. DICTIOXNAIRES .ARABES-PERSANS.}

\section{3.}

$1^{\circ}$ Dictionnaire arabe-persan des noms d'action, dis- 
posé d'après l'or dre des consonnes finales. Sous quelquesuns des mots persans se trouve une traduction interlinéaire en lurc. Le copiste a donné à l'ouvrage le titre de (t) Vocabulaire extrait du dictionnaire d'AlDjaulrarin.

$2^{\circ}$ (Fol. $94{ }^{\circ}$.) La Noqaddimat al-Adab d'Al-Zamakhscharì. Cet exemplaire s'arrête après la première section, celle qui est consacrée au nom.

$3^{\circ}$ (Fol. 134.) Dictionnaire arabe-persan, arec explications interlinéraires cu langue turque. Le commencement inanque.

Les deux premiers ouvrages sont datés de l'an 866 de l'hégrine (1462 de J.-C.); le troisième, de l'an 842 de thégire (1438 de J.-C.).

Papier. 191 feuillets. IVantenr, s1 centimitres el demi; largeur, 1/4 centimètres el demi. 12 lignes par page dans les deur premiers ouvrages, 9 ligues dans le troisième. - (Ancien fonds 1336 B.)

\section{4.}

"L'élevé, trailé des nomsn, vocabulaire de noms arabes el de leurs synonymes, expliqués en persan. La ${ }^{\mathrm{rc}}$ section, renfermant cinq clrapitres, contient les termes relatifs à la loi musulmane; la $2^{\mathrm{e}}$, consacrée aux noms d'animaux, renferme vingt-sept clapilres; la $3^{\mathrm{e}}$ donne les noms des objets célestes el renferme cing chapitres; la $4^{\circ}$ et dernière, consacrée aux oljets lerrestres, contient six chapitres. Commencement : : Co manuscrit est la copie d'un exemplaire qui portait la dale de 497 ( $1103-1104$ de J.-C.). Hadji Khalla, sans avoir vu l'ouvrage, l'attribue à Aḷmad ibn Moḷammad al-Maïdànì. L'auteur dit dans sa préface qu'il dédia son ouvrage ì un personnagre très haut placé dans l'administration

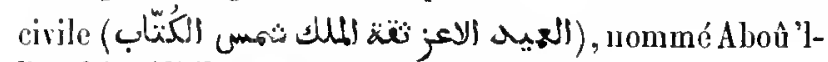
Barakât 'Mlì ibn Ma'soûd ibn Ismacil.

Le premier feuillet et le dernier ont été ajoutés après coup.

Papier. 132 feuillets. Hautenr, 22 centimètres et demi; largeur, 15 centimètres et demi. 17 lignes par page. Ms. du xus siècle. (Ancien fonds 133\%.)

\section{5 .}

Dictionnaire arabe-persan. En tète du volume on lit ce titre, ajouté après coup : كتاب الماتى ف الاسبائ L'élevé, traité des noms $6 \ddot{\text { sll. }}$

Ms. daté de l'an $875(1470-1471$ de J.-C.).

Papier. 354 feuillets. Ilauteur, 27 centimètres et demi; largeur, 18 centimetres. 15 lignes par page. - (Ancien fonds 1258.)

\section{6.}

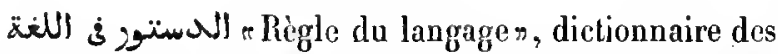
mots authentiques de la langue arabe, avec leur explication, soit en persan, soit en arabe vulgaire (العربية (المسايرة). L'ouvrage se termine par quelques observations sur la conjugaison des verbes et sur l'influence grammalıcale de certaines particules. Selon Hadji Khalfa, l'auteur, qui se nommait Al-Natanzî (النطنتى), İlosain ibn Ibrâhim, mourut l'an 499 (1105-1106 de J.-C.). Commen-

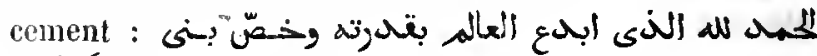

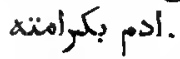

Papier. 149 feuillets. Hauteur, 24 centimètres et demi; largeur, 19 centimètres et demi, 16 à 20 lignes par page. Ils. du $\mathbf{s v}^{\circ}$ siècle (il est daté de l'an 536 de l'hégire (114 1 de J.-C.), mais cette souscription est d'une main très moderne). - (Ancien fonds 1253.)

\section{7.}

و Aboû 'Abdallah al-Ḥosaīn ibn Aḅmad al-Zauzanî, mort, selon Hadji Khalfa, en 486 de l'hégire ( $109^{3}$ de J.-C.). La préface est en arabe, le reste de l'ouvrage, en persan.

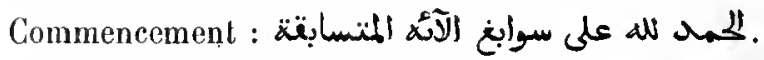

Papier. 116 feuillels. Hauteur, 22 centimètres et demi; largeur, 14 centinı̀tres et demi. 19 lignes par page. Mls. du xrı' siècle. (Ancien fonds 1333.)

\section{8.}

\section{Même ouvrage.}

Papier. 156 feuillets. Ilauteur, 18 centimètres ct demi; largeur, 14 centimètres. 11 lignes par page. Ms. du xviı siècle. - (Supplément 1388.)

\section{9 .}

Introduction à la philologien, par 'l-Qàsim Malımoûd ibn 'Omar Al-Zamakhscharî. Aboû 
Ce lexique arabe-persan a été publié par M. Wetzstein (in-4ㄴ, Leipzig, 1850). La prélace, accompagnée d'une traduction persane interlinéaire, commence ainsi : د.J

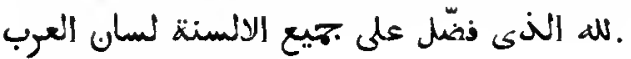

La fin manque.

Papier. 130 feuillets. Hauteur, 16 centimètres et demi; largeur, 12 centimètres. 6 lignes par page. $\mathrm{Ms}$. du $\mathrm{xv}^{\mathrm{e}}$ siècle. - (Ancien fonds 1315 , Colberl fo 48 .)

\section{0 .}

$1^{\circ}$ Mème ouvrage.

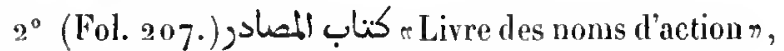
expliqués en persan, par le cadi Al-Zauzani.

Au commencement el à la fur du volume se trouvent un grand nombre de noles philologiques, grammaticales, biographiques, elc., et quelques pièces de vers, en arabe et en persan. Ces notes sont de diverses époques.

Papier. 353 feuillets. Hauteur, 26 centimè̀res; largeur, 18 centimètres. Les pages du premier ouvrage portent 10 ou 11 lignes, celles du sccond en porlent $\mathbf{~} 9$. Ms. du xu ${ }^{\circ}$ siècle. - (Ancien fonds 1356 , Colbert 4163.)

\section{1 .}

Introduction à la philologien, par N1Zamakhsehari.

Papier. 51 fenillets. Hauteur, 18 centimètres et demi; largeur, 13 centimètres. 9 lignes par page. Ms. du xvi siècle. - (Ancien fonds 1290.)

\section{2 .}

Première parlie du mème ouvrage. Dans cet exemplaire, les explications sont ordinairement en persan et en ture.

Papier. 49 feuillets. Hauteur, 18 centimètres; largeur, 13 centimètres. 7 lignes par page. Ms. du xvi siècle. - (Ancien fonds 1317.$)$

\section{3.}

Dictionnaire des noms d'action arabes expliqués en persan. L'ouvrage ne renferme que les racines trilitères. Dans chaque section, les racines sont classées par ordre alphabétique d'après leurs consonnes finales. Les premiers feuillets manquent.

Ms. daté de l'an 606 ( 1209 de J.-C.).

Papier. 117 feuillets. Hautcur, 19 centimètres; largeur, 15 centimètres. 10 lignes par page. - (Ancien fonds 1335.)

\section{4.}

Jerive des verbesn. C'est un vocabulaire composé des diverses classes des verbes de la première forme. La signification de chaque mol est indiquée en persan, dans les entrelignes.

IIs. daté de l'an 736 (1335 de J.-C.).

Papier. 187 feuillets. Ilauteur, 25 centimètres; largeur, 17 centimètres. 9 lignes par page. - (Ancien fonds 1354. )

\section{5.}

Liste de verbes avee leur significalion, tantôt en persan, tantôt en ture. Au verso du demier fuullet se trome une nole sur les passages du Coran dans lesquels certaines prépositions $($ ) حروف $)$ sont remplacées par d'autres.

Papier. 258 pages. llauteur, 18 centimètres; largeur, 13 centi-

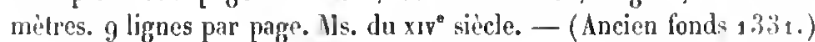

\section{6.}

: Les Dizains enchanteurs ou Vers qui font rélléchir», traité en vers persans, renfermant des mots arabes arec leurs équivalents persans. Ce trailé se compose de plusieurs morceaux, chacun de dix vers d'un mètre différent. La préface est

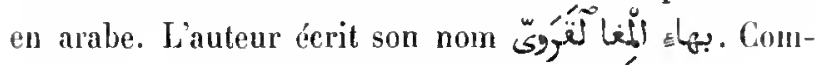

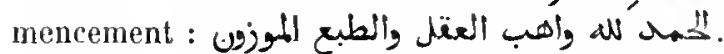

Ms. écrit à Brousse et dalé de 812 (1410 de J.-C.).

Papier. 56 feuillets. Hauteur, 21 centimètres; largeur, 15 centimètres. 7 lignes par page. - (Ancien fonds 1336 A.)

\section{7.}

s r.interprète des noms $\%$, roeabulaire arabe expliqué en persan et dédié à Bajazet (ابليزيه), 
fils de Mohammad Khân. Commencement : بر مه لطغ

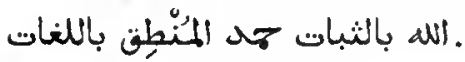

IIs. daté de l'an 859 (1455 de J.-C.).

Papier. ${ }_{2} 8$ feuillets. Hauteur, ${ }_{2} 6$ centimètres; largeur, 16 centimètres et demi. - (Ancien fonds 1255.)

\section{8.}

كنز Sietionnaire arabe expliqué en persan, par Mollammad ibn 'Abd al-Klıâlik ibn Ma'roûf. D'autres exemplaires de cet ouvrage se trouvent au supplément persan, $\mathrm{n}^{\text {os }} 438$ et suiv.

Papier. 299 feuillets. Ilauteur, 32 centimètres et derni; largeur, 31 centimètres. 39 lignes par page. Ms. du xvie siècle. - (Ancien fonds 1248. )

\section{9 et 4300.}

Même onvrage.

Ms. daté de 1024 et 1025 de l'hégire $(1615$ et 1616 de J.-C.).

9 vol. Papier. 296 et 295 feuillets. Hauteur, 26 centimètres; largeur, 15 centimètres et demi. 16 lignes par page. - (Ancien fouds 12 ig et 1257 .)

\section{1.}

rLe livre philologique intituló Louange et éloge\%. L'ourrage, qui commence par ces mots, fait connaitre la signification de plusieurs termes et expressions d'un usage général en arabe.

Ms. daté de l'an $9^{36}$ (1530 de J.-G.).

Papier. 40 feuillets. Hauteur, 17 centimètres et demi; largeur, 12 centimètres et demi. 7 lignes par page. - (Ancien fonds 1332. )

\section{2 .}

1 م الاورלات Les feuillets", opuscule en vers persans, formant un vocabulaire arabe-persan, avec traduction interlinéaire en langue turque. Il est divisé en sections (تطعة). Commencement :

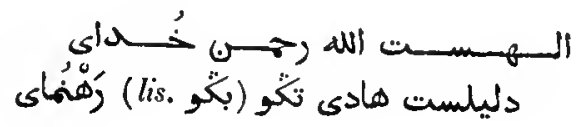

$2^{\circ}\left(\right.$ Fol. $14 \mathrm{r}^{\circ}$.) Dictionnaire des mots les plus usités en arabe, disposés d'après leurs initiales, avec une traduction turque interlinéaire.

$3^{\circ}$ (Fol. 19.) Autre dictionnaire du même genre; seulement la traduction turque est donnée dans le texte

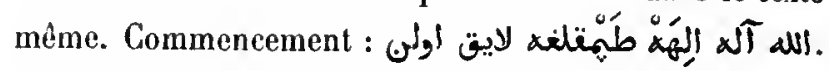

$4^{\circ}\left(\right.$ Fol. $41 v^{\circ}$.) Dialogues en persan, avec une version lurque interlinéaire. Premiers mots :

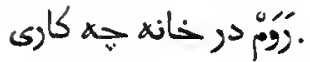

$5^{\circ}\left(\right.$ Fol. $45 v^{\circ}$.) Note en langue turque sur les endroits du Coran où le lecteur, s'il faisait une pause (وتف كغر), commettrait un acte d'infidélité.

$6^{\circ}$ (Fol. 46 et suiv.) Prì̀res, les unes en turc, les autres en arabe.

Papier. 5o feuillets. Hauteur, 21 cenlimètres; largeur, 15 centimètres. 9 lignes par page; à partil du fol. 21, 13 lignes. Ms. du $\mathrm{xv1}^{\circ}$ siecle. - (Ancien fonds 1336.$)$

\section{3.}

Vocabulaire arabe-persan, suivi de quelques dialogues en arabe, en persan et en turc, par Maula Șàliḥ alRoûmi.

Papier. 37 feuillets. Hauteur, a a centimètres et demi; largeur, 19 centimètres et demi. 29 et 23 lignes par page. Ifs. du xruir siècle. - (Supplément 1379.)

\section{IC. DICTIONNAIRES ARABES-TURCS.}

\section{4.}

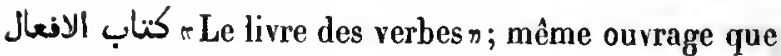
le $n^{\circ} 4294$, mais les mots sont expliqués en turc. La fin manque.

Papier. 294 feuillets. Hauteur, 17 centimètres et demi; largeur, 13 centimètres et demi. 7 lignes par page. Ms. du xive siècle. - (Ancien fonds 1318.)

\section{5.}

Vocabulaire arabe-turc, en vers, composé par Ferichté Oghlou 'Abd al-Latîf (فرشتنه اوغلى عبد اللسطيف). Les 
mots les plus usités de la langue arabe s'y trouvent arec le turc à côté. Dans cet exemplaire, il y a beaucoup de notes et d'additions sur les marges et entre les lignes. La préface est en tur'c et commence par ces mots : ur

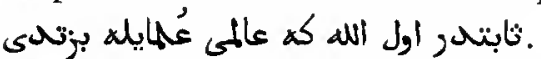

Ms. daté de l'an 935 (1528-1529 de J.-C.).

Papier. 30 feuillets. Hauteur, 21 centimètres; largeur, 15 centimètres. 10 lignes par page. - (Ancien fonds 1347.)

\section{6.}

Même ouvrage.

Papier. 20 feuillets. Hauteur, 20 centimètres; largeur, 11 centimètres, 16 lignes par page. Ms. du xvi siècle. - (Ancien fonds 1367$.

\section{7.}

Même ouvrage.

Ms. daté de l'an $97^{2}$ (1564 de J.-C.).

Papicr. 53 feuillets. Hauteur, 14 centimètres et demi; largeur, 9 centimètres et demi. 9 lignes par page. - (Ancien fonds 1368.)

\section{8.}

Même ouvrage; copie exécutée par un Européen.

Papier. 38 feuillets. Hauteur, so centimètres; largeur, 13 centimètres et demi. 9 lignes par page. Ms. du xvi! siècle. - (Ancien fonds 1352, Colbert 6124.)

\section{9.}

Fragment d'un dictionnaire arabe-turc. Les mots arabes sont classés d'après leurs iniliales. Ce rocabulaire s'arrête au mot تغتنشش, et la traduction interlinéaire turque au mot بسّ

Papier. $7^{5}$ feuillets. Hauteur, 23 centimètres et demi; largeur, 18 centimètres. 5 lignes par page et 5 mots dans chaque ligne. Ms. du xvi siècle. - (Ancien fonds $1336 \mathrm{C}$, Colbert 366o.)

\section{0 .}

Vocabulaire arabe rangé par ordre alphabétique, avec une traduction interlinéaire en langue turque.
Première ligne de l'arabe : اذأن آل آل ميحد آل أبرهيn ن

Ms. daté de l'an $9^{33}$ (1526-1527 de J.-C.).

Papier. 150 feuillets. Hauteur, 31 centimètres et demi; largeur, 15 centimètres et demi. 6 lignes par page. - (Supplément 1381.)

\section{1.}

Mème ourrage.

Ms. daté de l'an $9^{56}$ ( 1549 de J.-C.).

Papier. 207 feuillets. Hauteur, a 1 centimètres; largeur, $1 / 4$ centimètres et demi. 7 lignes par page. - (Ancien fonds 1341.)

\section{2.}

Même ourrage. Le commencement manque.

Ms. daté de l'an 962 (1555 de J.-C.).

Papier. 138 fevillets. Hauteur, 30 centimètres; largeur, 14 centimètres. 9 lignes par page. - (Ancien fonds 134 a.)

\section{3.}

Même ouvrage.

Ms. daté de l'an 977 (1569-1570 de J.-C.).

Papier. 147 feuillets. Hauteur, a centimètres; largeur, 15 centimètres. 9 lignes par page. - (Ancien fonds 1340.)

\section{4.}

Mème ouvrage. La traduction turque ne commence qu'au fol. 91. Le copiste s'est arrêté aux mols ناقِ $x \rightarrow$ $\rightarrow$ r

Papier. 174 feuillets. Hauteur, 21 centimètres; largeur, 15 centimètres. 7 lignes par page. Ms. du xvi siècle. - (Ancien fonds 1344.)

\section{5 .}

Mème ouvrage. Un libraire turc a inscrit sur la première page de ce volume le titre de لغت المنتخب a Vocabulaire choisi 
Hs. daté de lan 988 ( 1580 de J.-C.).

Papier. 283 feuillets. Hauleur, 21 centimètres; largeur, 15 centimètres. 7 lignes par page. -- (Ancien fonds 1339.)

\section{6.}

Même ourrage. La préface manque.

Hs. daté de l'an 999 (1590-15 gi de J.-C.).

Papier. 197 feuillets. Hautenr, 21 centimètros; largeur, 15 centimètres et demi. 7 lignes par page. - (Supplément 1382.)

\section{7.}

Vocabulaire arabe disposé dans l'ordre de l'alplabel, arec une fraduclion interlinéaire en langue turque. Pre-

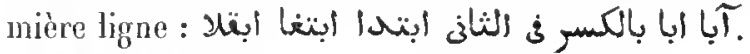

Is. daté de l'an 947 (1540-1541 de J.-C.).

Papier. 247 feuillets. Hauteur, 2 a centimètres; largeur, 15 centimètres. 9 lignes par page. - (Supplément $\mathbf{1 3 8 0 .}$ )

\section{8.}

Hême ouvrage. Au commencement se trouvent des notes et des vers en langue turque. Une note en langue arménienne se lit sur le recto du premier feuillet; en regard, sur l'intérieur du plat, est une note en mauvais français, qui parait être la traduction de l'arménien.

Papier. a 5 feuillets. Hauteur, 21 centimètres; largeur, 15 centimètres. 9 liggnes par page. Hs. du $\mathrm{Xr}^{\circ}$ siècte. - (Ancien fonds 1343.)

\section{9.}

"L'échelle de la languer. Vocabulaire dont les mots, extraits dı Qâmoûs et du Sihah, sont expliqués eu ture. Commencement de la préface :

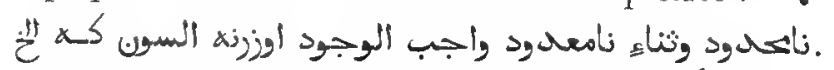

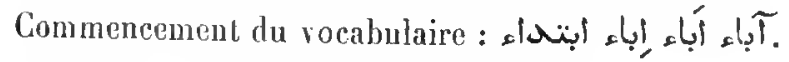

Ms. daté de l'an 953 ( 1546 de J.-C.).

Papier. 285 feuillets. Hauteur, 36 centimètres et demi; largeur, 18 centimètres et demi. 11 lignes et cinq colounes par page. (Ancien fonds 1947. .)

\section{0.}

Même ouvrage.

Ms. daté de l'an 962 ( 1555 de J.-C.).

Papier. 248 feuillets. Hauteur, ${ }_{2} 3$ centinètres el demi; targeur, 17 centimètres. 7 lignes par page. - (Ancien fonds 1337. )

\section{1.}

Nême ouvrage. Sans la préface.

Ms. daté de l'an $976(1569$ de J.-C.).

Papier. 177 feuillets. Hauteur, a o centimètres et demi; largeur, 14 centimètres et demi. 7 lignes par page. - (Ancien fonds 1345.)

\section{2.}

Mème ouvrage.

Ms. daté de l'an 978 ( $1570-1571$ de J.-C. $)$.

Papier. 197 feuillets. Hanteur, 25 centinètres; largeur, 16 centimètres et demi. 10 lignes et 6 ou 7 colonnes par page. - (Ancien fonds 1264. )

\section{3.}

Hême ouvrage.

Papier. 2 29 feuillets. Hauleur, 21 centimètres et demi; largeur, 15 centimètres. 9 lignes par page. Ms, du xvı siècle. - (Ancien fonds 3338 .)

\section{4.}

الاختنىى. Dictionnaire arabe-ture très célèbre et désigné par le surnom de l'auteur, Moṣtafâ iłon Schams alDin al-Kara-Hissârî̀ al-Akbtarî, mort en 968 (15601561 de J.-C.). Commencement de la préface : al

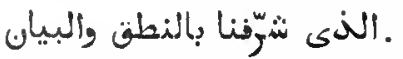

Quelques notes marginales.

Ms. daté de l'an 974 ( 1566 de J.-C.).

Papier. 368 feuillets. Hauteur, 27 centimètres et demi; largeur, 17 centimètres et demi. 27 lignes par page. - (Ancien fonds 1263.) 


\section{5.}

Mème ouvrage.

Papier. 331 feuillets. Hanteur, 31 centimètres; largeur, 21 centimètres. 29 lignes par page. Ms. du xvı' siècle. - (Ancien fonds 1260.)

\section{6.}

Nème ouvrage.

Ils. daté de l'an 1038 (1629 de J.-C.).

Papier. 288 fenillets. Hauteur, 29 centimètres; largenr, so centimètres et demi. 25 lignes par page. $-($ Aucien fonds 1261.)

\section{7.}

Nème ouvrage.

Papier. 296 feuillets. Hauteur, 31 centimètres; largeur, so centimètres. 23 à 25 lignes par page. Is. du xvı" siècle. - (Ancien fonds 1362, Colbert 3100.)

\section{8.}

raillettes d'or, traité pour apprendre la langue turquer. C'est un vocabulaire de mots arabes cxpliqués en ture et des mots lures expliqués en arabe. La préface est en arabe et

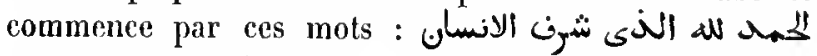
. Les derniers clapitres sont en lurc.

Ms. daté de l'an 1924 (1809 de J.-C.).

Papier. 114 feuillets. Hauteur, 17 centimètres; largeur, 10 centinuétres. 11 lignes par page. - (Supplément 126\%.)

\section{9.}

r.Les parcelles d'or el les morceaux (destinés?) à Aṭmad r. Vocabulaire arabe et turc, à l'usage des Aıabes qui désiraient apprendre celte dernière langue, devenue maintenant, dit l'auteur, la langue officielle. Il a été composé sur la demande d'un personnage haut placé daus l'administration civile du nom d'Ahmad. Commencement : . الانسان وزئنه بالنطنت واللسهان.
Ms. daté de l'an 1073 (1662-1663 de J.-C.).

Papier. 37 fenillets. Hauteur, 21 centimètres et demi; targeur, 15 centimètres et demi. 15 lignes par page. Dans les vocabulaires, huit lignes d'aralse et autant de ture. - (Ancien fonds 1316 .)

\section{0 .}

Vocabulaire arabe-ture, par Maula Mohammad Șảliṭ. C'est le mème ouvrage que le précédent. Les verbes arabes y sont classés selon leurs flexions grammaticales, et les autres mots par ordre de matières.

Papier. 34 feuilleis. Hauteur, an centimètres; largeur, 13 centimètres et demi. Environ 15 lignes par page. Ms. du xvi" siècle. (Supplément 1383.)

\section{1.}

Mème ouvrage. Le copiste n'a pas reproduit la préface.

Papier. 3a feuillets. Hauteur, 23 centimètres; largeur, 16 centimètres. 19 lignes par page: Ils. du xvi' siècle. - (Supplément 1386.)

\section{2.}

Mème ourrage, sans la préface.

Papier. 3s feuillets. Hauteur, 16 centimètres el demi; targeur, 1 centimètres. 12 lignes par page. Ms. du xrä siècle. - (Supplément 1387.$)$

\section{3.}

Mème ouvrage.

Papier. 33 feuillets. Hautenr, 33 centimètres; largeur, 16 centimètres. a7 ligoes par page dans la préface, environ 26 dans le reste du volume. Ms. du xrule siècle. - (Supplément 1385.)

\section{4.}

Nème ourrage.

Ms. (en caractères maghrebins) daté de l'an 1252 (1836 de J.-C.).

Papier. 48 feuillets. Hauteur, 29 centimètres; largeur, 31 centimètres. 13 lignes par page dans la préface, 14 dans le reste du volume. - (Supplément 1384.) 


\section{5.}

Dictionnaire arabe-turc. Commencement de la pré-

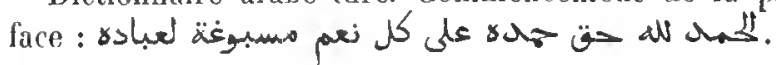

Papier, 119 feuillets. Hauteur, 31 centimètres; largeur, 21 centimètres. 13 lignes par page, sans compter les interlignes. Ms. du xvII ${ }^{e}$ siècle. - (Ancien fonds 1259 .)

\section{6.}

$1^{\circ}$ Vocabnlaire de mots arabes, classés selon leurs formes grammaticales et accompagnés de leurs équivalents en langue turque.

$g^{\circ}$ (Fol. 19.) Les quatre premières pages d'un petit traité en arabe sur la langue tarque, par Jbn Moḥmmad Șàlih.

$3^{\circ}$ (Fol. 21.) Vocabulaire el fables de la main d'Asselin.

$4^{\circ}$ (Fol. 43.) Liste alphabétique d'un certain nombre de mots arabes commençant par la lettre bâ (ب), avec leur explication. en arabe. Gette pièce est aussi de la main d'Asselin.

Papier. 66 feuillets. Hauteur, 17 centimètres et demi; largeur, 11 centimètres el demi. Les deux premières pièces sont du xvir ${ }^{\circ}$ siècłe, les autres du xix . - (Supplément 2151.)

\section{DICTIONNaIRES RÉdigés PAR DES EURopéENS.}

\section{7.}

Dictionnaire arabe-latin, classé par ordre des racines. L'auteur, Guillaume Bedwell, ecclésiastique anglican, a achevé ce dictionnaire en 1599 de J.-C. Il a tiré ses matériaux de la traduction arabe des Psaumes et du Nouveau Teslament.

Papicr. 31 feuillets à deux colonnes. Ifauteur, 19 centimètres; largeur, 14 centimètres et demi. - (Ancien fonds 1350 , Colberi 473a.)

\section{8.}

Dictionnaire arabe-latin, suivi d'un index en latin; ouvrage composé à Rome par les Maronites Victorius
Accorensis el Gabriel Sionita; puis remanié el mis au nel par Jean-Baptiste du Val, iuterprète du roi. Ce travail est daté de Paris, 1612 et 1613 . En tête de l'index se Ironve une préface dans laquelle l'auleur parle de ses études, de ses travaux et de la littérature arabe.

Papier. 1004 pages (les pages 693 à 761 sont restées en blanc). Ilauteur, 29 centimc̀ires; largeur, 20 'centimètres el demi. - (Ancien fonds 1265 , Colthert 1035.)

\section{9.}

Diclionnaire arabe-latin copié par un Européen sur le Lexicon arabicum de Rapheleng (Leyde, 1613 ).

Papier. 579 feuillets. Hanteur, a a centimc̀tres et demi ; largeur, 16 centimètres et demi. Ms. du xviI siècle. - (Ancien fonds 1349 .)

\section{0.}

Dictionnaire arabe-latin, par Thomas Pererius.

Papier. sgo feuillets. Hautcur, 33 centimètres; largeur, s1 centimètres. Ms. du xvil siècle. - (Ancien fonds 1266, Colbert 1084.)

\section{1.}

Dictionnaire arabe-latin, composé par un Européen au $\mathrm{XvI}^{\circ}$ siècle. L'auteur s'est borné à expliquer les noms. Chaque second feuillet est resté en blanc.

Papier. 168 fenillets. Hanteur, 31 centimètres; largeur, a centimètres et demi. - (Ancien fonds 1267.)

\section{2.}

Dictionnaire arabe-latin.

Papier. 103 fcuillels. Hanteur, 24 cenlimètres; largeur, 17 centimètres et demi. Ms. du xri" siècle.-. (Supplément 2222.)

\section{3.}

Dictionnaire arabe-latin, par Petis de Lacroix.

Ms. daté de l'an 1696 .

Papier. 570 feuillets. Hauteur, 16 centimètres; largeur, 11 centimètres. Environ douze articles par page. - (Supplément 2288.) 


\section{4.}

Dictionnaire arabe-latin. Plus de la moitié des termes arabes sonl restés sans explicalion.

Papier. 5 3 fenillets. Hauteur, 33 centimètres et demi; largeur, 21 centimètres. Ms. du xrü siècle. - (Ancien fonds 1268.)

\section{5 .}

Dictionnaire arabe-latin, composépar Abraham Ecchellensis et dédié au chancelier Séguier. Exemplaire de présentation.

Papier.. $33_{7}$ feuillets. Hauteur, ${ }_{2} 5$ centimètres; largeur, 18 centimètres. 11 a 16 lignes par page. - (Supplément 2150, S. Germain 474.)

\section{6.}

Projet d'un dictionnaire arabe-latin, fondé sur celui de Golius.

Papier. 1 pages. Hauteur, 20 centimètres et demi ; targeur, 15 centimètres et demi. - (Supplément ${ }_{2} 349$.)

\section{7.}

Vocabulaire arabe-latin, commençant par les noms de Dieu qui se rencontrent dans le Coran. Le reste de l'ouvrage est disposé par ordre alphabélique.

Papier. $9^{52}$ pages. Hauteur, 20 centimètres; largeur, 13 centimètres et demi. 9 lignes par page. - (Aneien fonds $\$ 353$, Colbert $399^{8}$.)

\section{8.}

Dictionnaire arabe-latin. On y a interealé quelques cahiers de vocabulaires.

Papier. 189 feuillets. Hauteur, a 5 centimètres; largeur, 19 centimètres. Mts. dı xvı" siècle. - (Supplément a 383.)

\section{9.}

Essai d'un dictionnaire arabe, par un Européen. On y trouve un très petit nombre de mots avec leur significalion en latin. Ourrage inachevé.

Papier. 146 fenillets. Hauteur, 33 centimètres et demi; largenr, 21 centimètres. Ms. du xviı siècle. - (Supplément 1373 .)

\section{0.}

Vocabulaire latin-arabe, par ordre des matières et par ordre alphabétique. Un index alphabétique de 62 feuillets termine le volume.

Papier. 502 feuillets. Hauteur, 18 centimètres et demi; largeur, 12 centimètres. Ms. du xvir siècle. - (Supplément a 379 .)

\section{1.}

Dictiounaire français-arabe, avec la transcription des mots arabes, par Jean-Baptiste Fenix, ancien gouverneur de la Calle.

Papier. 904 pages. Hauteur, 25 centimètres et demi; largeur, 17 centinètres et demi. Nis. du xvit sièzle. - (Supplément 238\%.)

\section{2.}

Vocabulaire arabe-italien, disposé dans l'ordre alplaabélique des racines.

Papier. 137 feuillets. Hauteur, 20 centimètres; largeur, $1 / 1$ centimètres et demi. 23 lignes par page. Ms. du xvi" siècle. - (Ancien fonls , $353 \mathrm{~A}$.)

\section{3.}

Diclionnaire français-italien-arabe. On trouve aussi un certain nombre d'équivalents turcs transcrils en earactères européens. Les mots arabes sont d'une main orientale, mais ils ne paraissent plus à partir du second tiers du volume.

Papier. 248 feuillets. Hauteur, 19 centimètres et demi; largeur, 14 centimètres et demi. Ms. du xvi e siéele. - (Supplément 2 233.)

\section{4.}

Dictionnaire français avec les équivalents arabes en dialecte vulgaire de la Syrie. 
Volume écrit par Michul A. A. Le Roux (Deshautesrayes) en 1738 .

Papier. 736 pages, dont chacune est divisée en trois colonnes, l'une pour le français, l'autre pour l'arabe et la troisième pour la transcription. Hauteur, 17 centimètres el demi; largeur, 11 centimètres et demi. - (Supplément $\mathbf{3} 380$.)

\section{5.}

$1^{\circ}$ Copie du volume précédeut portant ces deux titres .

$2^{\circ}$ (Page 724 .) Litanie de la Vierge, en latin et en arabe, avec la transcription, suivie des vocabulaires et d'une colleclion de phrases et de dialogues en dialecte arabe de la Syrie.

Hs. daté de lan 1739 .

Papier. La première partie remplit 739 pages, la seconde 135 ; it $y$ a de plus 7 feuillets préliminaires. Hauteur, 17 centimètres et demi; largeur, 11 centimètres el demi. - (Supplément 2381.)

\section{6.}

Vocabulaire francais-arahe, par Mareel. Cet ouvrage a été iniprimé au Caire en 1800.

Papier. 199 pages. llauteur, 24 centimètres et demi; largeur, 17 centimètres. Ils. du xix siècle. - (Supplément ${ }_{1392}$ bis.)

\section{7.}

$1^{\circ}$ Dictionnaire francais et arabe vulgaire d'Afrique, composé probablement par Asselin.

$2^{\circ}$ (Fol. 105.$)$ Dialogues français-arabes. L'arabe est écrit en caractères européens.

Papier. 126 feuillets. Hauteur, 31 centimètres; largeur, a centimètres. Le premier ouvrage est du $\mathbf{x i x}^{\mathrm{e}}$ siècle, le second du $\mathbf{x v i n}$. - (Supplément 2372.$)$

\section{8 à 4360.}

* Diclionnaire français-arabe, par MI. Solvet, président de cliambre à la cour impériale d'Alger. 1855-1865. A la suite du titre on lit cette note : " Ce manuserit est inentionné dans un article du Journal des Savants (avril 1876, p. 248 ) .
3 vol. Papier. 304,485 et 522 fenillets. Hauleur, 30 centimètres; largeur, 20 centimètres. 20 à 30 lignes par page. - (Supplément 2422 aे 2424.)

\section{1.}

Chrestomathie arabe, composée principalement de dialogues, de proverbes et d'historiettes, par Petis de Lacroix. L'auteur l'a intitulée : "Seconde partie de la méthode d'apprendre l'arabe facilenent en faisant la praliquen.

Hs. daté de l'an ${ }_{1} 67^{3}$ de J.-C.

Papier. 108 feuillets. Hauteur, 20 eentimètres; largeur, 15 centimètres. Le texte arabe, écrit par un oriental, occupe a ligges sur le verso de la plupart des feuillets; la traduction française écrile au recio est de la main de Petis de Lacroix. - (Supplément ${ }_{2} 378$. )

\section{2 et 4363.}

Recueil de plirases et d'expressions en arabe vulgaire, avec le francais en regard. Titre du premier volume : "Suite de l'lntroduction à la langue Arabesque, contenant la Pratique des aduerbes et particules du nombre, de ciuilité et les particules négatiues el affirmatiues $\%$ Titre du second volume : "Suite de l'Introduction à la langue Arabesque, contenant la Pratique des particules affirmatives et négatives, les aduerbes el particules modules, respectiues et causales et autres dictions semblables aux particules \%. Ces deux volumes font suite à un premier volume que la Bibliothèque ne possède pas.

2 vol. Papier, 167 et 148 pages (colées $17^{5}$ à 491 ). Hauteur 16 centimètres; largeur, 10 centimètres. N]s. du xvı" siècle. - (Supplément 2377 el 2384.)

\section{4.}

Phrases et dialogues en arabe vulgaire de la Syrie, accompagnées d'une transcription et d'uue traduction francaise. Le texte arabe est de la main d'un natif de la Syrie; le texte français est de Petis de Lacroix. La fin manque.

Papier. 169 feuillets. Hauteur, a 1 centimètres; largeur, 15 centimètres $€$ t demi. 11 lignes par page d'arabe et 22 lignes par page de français. Ils. du xvıı siècle. - - (Supplément 1 392. .)

\section{5 .}

Cahier renfermant des dialogues en arabe et en grec moderne, des phrases arabes et iurques écrites en ca- 
ractères hébraiques, des fragments de lettres, des vocabulaires et des notes dont une partie est de la main de Picques. La partie grecque est d'un nommé Dimitri Amirali, qui l'a exécutée en 1680 de J.-C.

Papier. 73 feuillets de formats divers. Hauteur du volume, 22 centimètres et demi; largeur, 17 centimètres. - (Supplément a388.)

\section{6.}

Vocabulaire, dialogues et contes en langue vulgaire de la Syrie.

Papier. $9^{6}$ feuillets (dont quelques-uns sont restés en blanc). Hauteur, 16 centimétres et demi; largeur, 10 centimètres. 17 lignes par page. ${ }^{2}$ Ms. du xvir" siècle. - (Supplément 1390. )

\section{7.}

Dialogues et contes en arabe vulgaire de la Syrie.

Papier. 36 feuillets. Hauteur, 14 centimètres; largeur, 10 centimètres et demi. 18 lignes par page. Ms. du xvm ${ }^{\circ}$ siècle. - (Supplément 1391.)

\section{8.}

1 Dialogues et contes en arabe vulgaire de la Syrie.

$2^{\circ}$ (Fol. $32 v^{\circ}$.) L'histoire des dix vizirs. Commence-

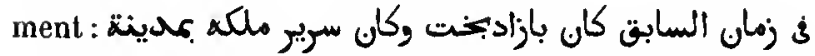

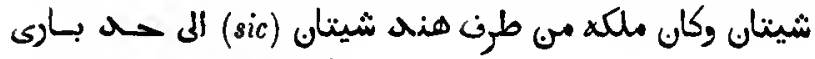

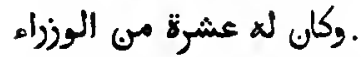

Papier. 62 feuillets. Hauteur, 21 centimètres et demi; largeur, 15 centimètres et demi. 33 lignes par page. Ms. du xw111" siècle; écriture européenne. - (Supplément 1393.)

\section{9.}

Locutions et dialogues en arabe vulgaire de la Syrie, de la main d'Asselin.

Papier. 32 feuillets. Hauteur, 17 centimètres; largeur, 1 a centimètres. Environ 20 lignes par page. - (Supplément 2 138. )

Max. ozientade. - Il.

\section{XXX.}

\section{RHÉTORIQUE.}

\section{0.}

Traité des deux arts, la composition en prose et en vers $n$, ourrage composé en 394 de l'hégire (1003-1004 de J.-C.) par Aboû Hilâl al-Hasan ibn 'Abd-Allah al-'Askarî. Commencement :

Ms. daté de l'an 907 (1501 de J.-C.).

Papier. 364 feuillets. Hauteur, 26 centimètres et demi ; largeur, 18 centimètres. 17 lignes par page. - (Supplément 1358.)

\section{1.}

r.Clef des sciences n. Encyclopédic des sciences philologiques, par Sirâdj al-Dîn Aboû Yacqoûb Yoûsof ibn abî Bakr al-Sakkâkî. La fin manque.

Papier. 106 feuillets (il y a une lacune entre les feuillets 105 et 106). Hauteur, 30 centimètres; largeur, 21 centimètres. 33 lignes par page. Ms. du xvı" siècle. - (Supplément 1274.)

\section{2.}

Troisième partie du même ouvrage.

Ms. daté de l'an 971 (1563 de J.-C.).

Papier. 123 feuillets. Hauteur, 21 centimitres; largeur, 14 centimètres et demi. 19 lignes par page. - (Ancien fonds 935.)

\section{3.}

Fragment du commentaire de Sacd al-Din al-Taftâzânì sur le Miftâh al-'Oloûm d'Al-Sakkâkî. Les premiers feuillets sont consacrés à la grammaire; le dernier renferme la fin de la section intitulée jlefl ع.

Papier. 5/4 feuillets. Hauteur, 38 centimètres; largeur, 18 centimètres et demi. 33 lignes par page, puis 29. Ms. du xvi siècle. (Ancien fonds 1236.) 


\section{4.}

10 تغيير ألمنتاح Le texte du Miftàh remanién, avee un commentaire, par le molla Ibn Kamâl-Pacha-Zàdè (Schams al-Dìn Aḷmad ibn Solaïmân), mort en 940 (1533-1534 de J.-C.).

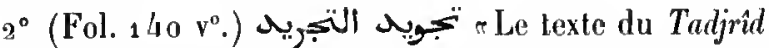
améliorér, avec un commentaire, par Ibn Kamâl-PachaZàdè. Le Tadjrid al-Kalam r Simplification de la théologie scolastiquer a pour auteur Nașir al-Dìn Abou Djacfar Mohammad al-Toûsî.

Ws. daté de l'an 994 ( 1586 de J.-C.).

Beaucoup de noles marginales.

Papier. 159 feuillets. Hauteur, 18 centimètres; largeur, 19 centimètres. 15 lignes par page. - (Ancien fonds 401.)

\section{5.}

( La lampe n, traité de rhétorique (نان كتاب (لمصباح), par Badr al-Dìn Moḷammad, fils de Djamâl al-Dìn Moḥammad ibn 'Abd Allah ibn Mâlik al-Taïyî al-Djaïyânî, auteur de l'Alfiya. Hadji-Khalfa donne à entendre (t. V, p. 580) que ce traité n'est qu'uu abrégé du Miftâh al-'Oloûm d'Al-Sakkâkì. Commencement : Lol

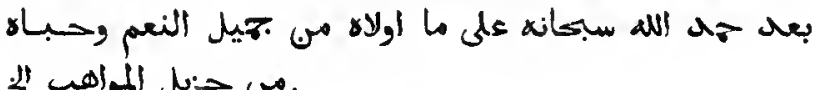

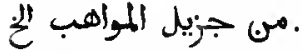

Ms. daté de l'an 687 ( 1288 de J. C.).

Papier. 8a feuillets. Lauteur, 21 centimètres; largeur, 15 centimètres. 17 lignes par page. - (Ancien fonds $\mathbf{1 3} 19$.

\section{6.}

Commentaire sur la troisième partie du Miftâh al-` $O$ -

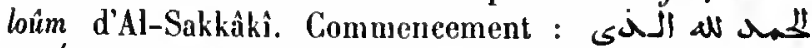
تنتابعت عوأرن كرمه L'Lauteur ne saurait être Sacd Solţàn-Schâh, qui a composé un commentaire commençant par ces mêmes mots. Solțân-Sehâh était contemporain de Hadji-Khalfa, qui l'appelle Maulânâ, tandis que le présent ouvrage est antérieur à la seconde moitié du xive siècle. Une note ajoutée après coup au folio $16_{7}$ désigne l'auteur de ce commentaire par le surnom d'AlMowaddsinî (ij).

Ms. daté de l’an 749 ( 1348 de J.-C.).

Papier. 25o feuillets. Hauteur, 18 centimètres; largeur, 14 centimètres et demi. as lignes par page. - (Ancien fonds 937.)

\section{7.}

Seconde partie du commentaire d'Al-Schirâzi sur la troisième partie du Miftâh al-'Oloûm d'Al-Sakkâkî. Com-

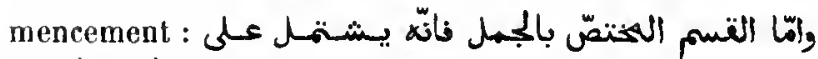

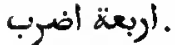

Ms. daté de l'an 724 ( 1324 de J.-C.).

Papier. 177 feuillets. Hauteur, 26 centimètres; largeur, 18 centimètres el demi. 23 lignes par page. - (Ancien fonds 12 37.)

\section{8.}

$1^{\circ}$ r Sommairc du Miftâhı», par Djalâl al-Dìn Mohammad al-Qazwìn. Il s’agit de la troisième partie du Miftăl, celle qui est consacrée à la rhétorique, avec les observations d'Al-Qazwinnì. Commencement :

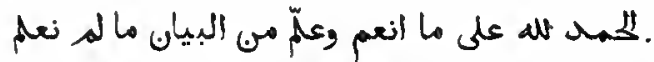

$2^{\circ}$ (Fol. 59.) (لبs lis cussion n, par Sehams al-Dín Moḷammad ibn Aschraf alSamarqandi.

Nombreuses notes marginales et interlinéaires.

Ms. daté de l'an 763 (1361-1362 de J.-C.).

Papier. 64 feuillets. Hauteur, 18 centimètres; largeur, 13 centimètres et demi. 15 lignes par page. - (Supplément 1279.)

\section{9.}

Le Talkhis al-Mifläh. On a ajouté, après coup, au commencement dn volume, un certain nombre de synonymes et, à la fin, nne liste de plusieurs genres de métaphores, etc.

Nombreuses notes marginales.

Papier. 132 feuitlets. Hauteur, a o centimètres; targeur, 12 centimètres et demi. 9 lignes par page. Ms. du xru' siècle. - (Supplément 1913.)

\section{0 .}

Même ouvrage. Nombreuses notes marginales.

Papier. 102 feuillets (il $y$ a une lacune entre les feuillets 101 et 102). Hauteur, 15 centimètres; largeur, 10 centimètres et demi. 9 lignes par page. Ms. du xvu" siècle. - (Supplément 1277.) 


\section{1 .}

Mème ouvrage. Nombreuses notes marginales.

Papier. 83 feuillets. Hauteur, 19 centimètres; largeur, 12 centimètres. 11 lignes par page. Ms. du xvı sièele. - (Supplément 1276.)

\section{2.}

Même ouvrage.

Papier. 33 feuillets. Hauteur, 18 centimètres; largeur, 1 a centimètres. 19 lignes par page. Ms. du $\mathbf{x r n}^{\circ}$ siècle. - (Supplément $197^{8 .)}$

\section{3.}

Même ouvrage. Notes marginales.

Ms. daté de l'an $118_{2}\left({ }_{1} 7^{68-1} 7^{6} 9\right.$ de J.-C.. $)$.

Papier. 64 feuillets. Hauteur, 16 centimètres et demi; largeur, 11 centimètres. 15 lignes par page. - (Supplément 1275.)

\section{4.}

ill'Exposé, pour servir de commentajre du Talkhîs al-Miftâh $\leadsto$. Les denx ouvragos sont du même auteur, Djalâl al-Dîn Mohammad ibn 'Abd al-Raḥmân al-Qazwînî. Commencement : lue lol

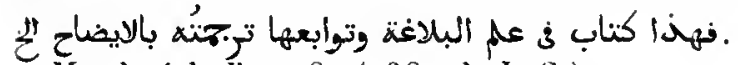

Ms. daté de l'an 782 (1380 de J.-C.).

Papier. a 6 feuillets. Hauteur, a 4 centimètres; largenr, 13 centimètres et demi. 19 lignes par page. - (Supplément 1303.)

\section{5.}

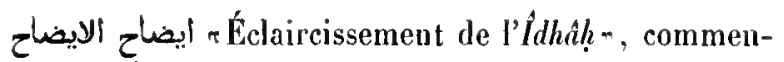
taire sur l'l̂lhâh d'Al-Qazwìì. Le nom de l'auteur n'est pas indiqué, mais Hadji-Khalfa nous apprend (t. I, p. 509 ) qu'il s'appelait Al-Âqsarâii (Djamâl al-Dìn Mohammad ibn Mohammad). Le texle de l'l̂hdhâl est reproduit en entier à l'encre rouge. Commencement : فم

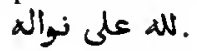

Ms. daté de l'an 1097 (1686 de J.-C.).

Papier. 186 feuillets. Hauteur, 24 centimètres; largeur, 14 centimètres et demi. 31 lignes par page. - (Supplément 1304.)

\section{6.}

$1^{\circ}$ "Traité développén, par Sąd al-Dîn Mascoûd ibn 'Omar al-Taflâzânî. C'est un commentaire

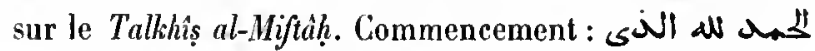

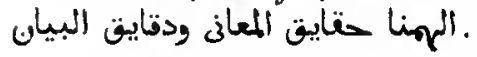

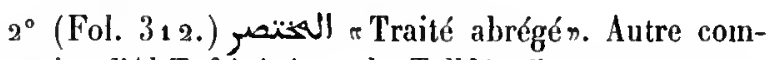
mentaire d'Al-Taftâzànî sur le Talkhiṣ. Commencement :

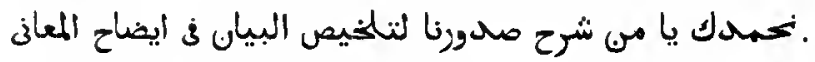

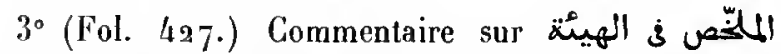
« Abrégé d'astronomie đ'Al-Djaghmînî, par Qâdhî-Zàdè al-Roưmî (Noûsû ibu Naḥmoûd). L'auteur, chargé par Olough-Beg d'expliquer les difficultés du Molakkhas, acheva son travail l'an $815(1412-1413$ de J.-C.).

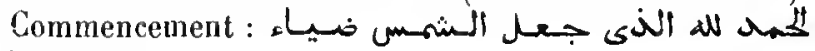

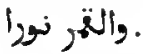

Ms. daté de l'an 1000 ( 1591 de J.-C.).

Papier. 505 feuillets. Hauteur, 21 centimètres et demi; largeur, 15 centimètres. Le nombre des lignes par page varie de 19 à 26 . (Ancien fonds 934.)

\section{7.}

المطوّل Même ouvrage que l'article $1^{\circ}$ du numéro précédent. Notes marginales.

Ms. daté de l'an 1021 ( 1612 de J.-C.).

Papier. 24a feujllets. Hauteur, as centimètres; largeur, 14 centimètres. a ligues par page. - (Ancien fonds 1618.)

\section{8.}

Hême ouvrage. Nombreuses notes marginales.

Ms. daté de l'an 1085 ( $167_{4}^{4}$ de J.-C.).

Papier. ${ }_{2} 57$ feuillets. Hauteur, a 6 centinètres; largeur, 15 centimètres. 21 lignes par page. - (Supplément 1 a84.)

\section{9.}

Même onvrage. Copie inachevée. Notes marginales.

Papier. a 86 feuillets. Hauteur, a 3 centimètres; largeur, 16 centimètres et demi. 17 lignes par page. Ms. du xru⿰氵 sièele. - (Supplément 1981.) 


\section{0.}

Même ouvrage. Notes marginales.

Ms. daté de l'an 1166 (1753 de J.-G. ).

Papier. 615 feuillets. Hauteur, 2 a centimètres; largeur, 16 centimètres et demi. 17 lignes par page. - (Supplément 1982.)

\section{1.}

Même ouvrage.

Ms. daté de l'an 1185 (1771 de J.-C.).

Papier. 44 a feuillets. Hauteur, 29 centimètres et demi ; largeur, 16 centimètres. 21 lignes par page. - (Supplément 1283.)

\section{2.}

1 Gloses sur le Motanxal, par "Alì ibn Mohammad alDjordjânî. Copie datée de l'an 870 (1465-1466 de J.-C.).

$2^{\circ}$ (Fol. $118 v^{\circ}$.) Poème religieux dont voici le pre-

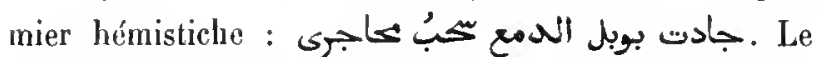
feuillet suivant porte un autre poème du même genre, commençant ainsi : جاد الخبيب بوصل مُن هوأه هu recto du folio 120 se trouve mu extrait du recueil de gloses de Såd al-Dìn al-Taftàzânî sur le Kasschaf, commentaire du Coran d'Al-Zamaklıschari.

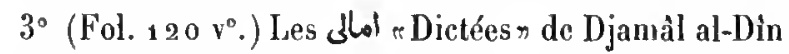
Aboû 'Amr 'Othmàn ibı al-llàdjib. Ce sont des observations grammaticales sur quelques textes du Coran et quelques passages du Mofașşal d'Al-Zanakhscharî. L'auteur les avait dictées, les unes à Damas, les antres au Caire, entre les années 610 et 624 de l'hégire.

$4^{\circ}$ (Fol. $167 v^{\circ}$. ) r Dietées sur les vers du Macanin. Gloses d'Ibn al-Hàdjib sur les vers cités dans l'ouvrage intitulé Máâni 'l-Qor'ân. (Voyez l'Anthologie grammaticale de S. de Sacy, p. 454.)

$5^{\circ}$ (Fol. $186 \mathrm{v}^{\circ}$.) Recueil d'observations grammalicales dictées par Ibn al-Hâdjib et intitulé "Dictées sur des questions générales".

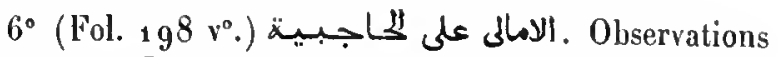
dictées par Ibn al-Ḥadjil lui-même sur soll traité de grammaire intitulé Al-Moqaddima $\int^{\prime \prime} l-N a h w$.

$7^{\circ}$ (Fol. $228 v^{\circ}$.) Les trois premières pages d'un ouvrage de morale dont la préface commence par ees

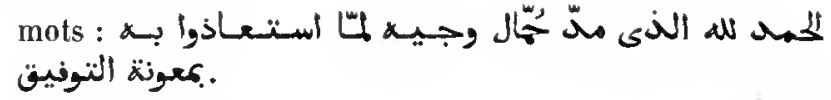

Fn tête du volume se trouvent deux pièces de vers dont la première a été composée par Ibn Labbâna sur le fils de Fakhr al-Daula; puis, au folio 3 , le dessin et la deseription d'un siphon qui, selon l'inventeur, devait faire monter l'eau d'un puits.

Papier. 229 feuillets. Hauteur, 20 centimètres; largeur, 14 centimètres et demi. Feritures diverses du $x v^{\circ}$ siècle. - (Ancien fonds 568.)

\section{3.}

Gloses d'Al-Djordjânî sur le Moṭauwal d'Al-Taftâzâni. La fin manque.

Papier. 150 feuillets. Hauteur, 19 centimètres; largeur, 12 centimètres. 19 lignes par page. Ns. du $x v^{\circ}$ siècle. - (Supplément 1286.)

\section{4.}

Même ouvrage.

Exemplaire écrit dans la ville de تبّة الاسلكم Coupole de l'islamismen, e'est-à-dire Samareande, en 1004 ( 1596 de J.-C.).

Papier. 146 feuillets. Hauteur, 19 centimètres; largeur, 13 centimètres. 21 lignes par page. - (Supplément 1 185.)

\section{5.}

هloses sur le Motanwals, par Yahỵà ibn Saïf al-Sìrâmî (السيوانى). Il est dit dans notre manuscrit que l'auteur des Gloses a terminé son travail en 830 de l'hégire (1426-1427 de J.-C.).

Ms. daté de l'an 974 (1566-1567 de J.-C.).

Papier. 324 feuillets. Hauteur, 20 centimètres et demi; largeur, 14 centimètres et demi. 97 lignes par page. - (Ancien fonds 567.)

\section{6.}

$1^{\circ}$ Gloses sur un eommentaire de la troisième partie du Miftăh al-'Oloúm. D'après une note qu'on lit en tête 
du volume, ces gloses auraient pour auteur "Alà al-Dìn 'Alì ibn Mohammad Mosannifek; le commentaire est de Sacd al-Dìn al-Taftàzànî. L'ouvrage commence ainsi :

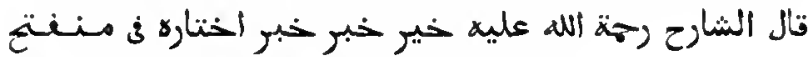

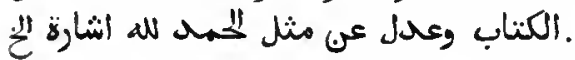

$2^{\circ}$ (Fol. $9^{8} \mathrm{v}^{\circ}$.) Gloses sur un commentaire du Miṣbâh al-'Oloúm. L'anteur n'est désigné que par le titre d'Al-Fadhil al-Scharîf. Commencement : قال المغاضd

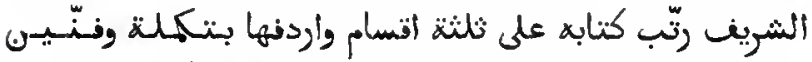

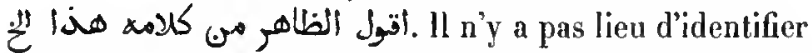
l'auteur avec Al-Djordjânî dont le titre honorifique était Al-Saïid al-Scharif. Une note inscrite sur le recto du feuillet $9^{8}$ dit que cet ouvrage est le commentaire de

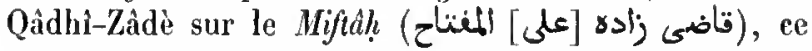
qui ne saurait être exact, puisque c'est un commentaire sur un commentaire.

Ms. daté de l'an 991-992 (1583-1585 de J.-C.).

Papier. s33 feuillets. Hauteur, 30 centimètres et demi; largeur, 13 centimètres. 23 lignes par page. - (Ancien fonds $9^{36 .}$ )

\section{7.}

Autre commentaire sur le Talkhis al-Miftal. Commen-

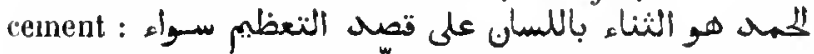

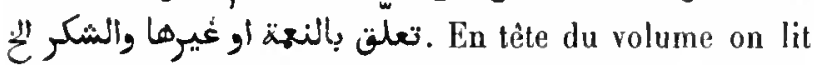

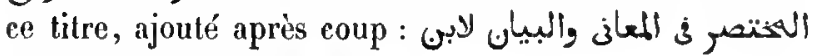

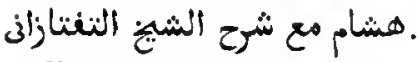

Une autre main a éerit sur les derniers feuillets un petit traité de rhétorique en vers : أرجوزة 3 عم الببيان ilelly.

Ms. daté de l'an 784 (1383 de J.-C.).

Papier. 194 fenillets. Hauteur, 17 centimètres; largeur, 12 centimètres et demi. 17 lignes par page. - (Supplément 1 180.)

\section{8.}

Commentaire moyen d'Al-Taftâzânî sur le Talkhiṣ al-Miftah. (Voyez ci-dessus, $\mathrm{n}^{\circ}$ 4386, ${ }^{\circ}$.) Nombreuses notes marginales.

Papier. 92 feuillets. Havteur, 24 centimètres; largeur, 16 centimètres. 21 lignes par page (les deruières pages portent 23 lignes). Ms. dont la première moitié est du $x v^{\circ}$ siècle, la seconde moitié du xri: - (Supplément 1 a go.)

\section{9.}

Nème ouvrage.

Papier. 204 feuillets. Hauteur, 30 centimètres et demi; largeur, 15 centimètres et demi. 19 lignes par page. $.1 s$ s. du xvi siècle. (Supplément 1291 bis.)

\section{0.}

Commencement du même ouvrage, accompagné de nombreuses notes marginales, tirées de divers commentaires, notamment des gloses du petit-fils de Taftảzânî.

Papier. 24 feuillets. Hauteur, 24 centimètres; largeur, 15 centimètres et demi. 21 lignes par page. Ms. du xwn' siècle. - (Supplément 2117. )

\section{1}

Même ourrage.

Papier. 181 feuillets. Hauteur, 21 centimètres et demi; largeur, 15 centimètres et demi. 23 lignes par page et quelquefois 22 . Ms. du xrit" siècle. - (Supplément 1291.)

\section{2.}

Mêne ouvrage.

Ms. daté de l'an 1153 ( 174 1 de J.-C.).

Papier. 195 feuillets. Hauteur, 22 centimètres; largeur, 15 centimètres et demi. ${ }_{7} 7$ lignes par page. - (Supplément 1289.)

\section{3.}

Mème ouvrage.

Ms. daté de l'an 1167 (1754 de J.-C.).

Papier. 347 fevillets. Hauteur, 21 centimètres et demi; largeur, 16 centimètres. 17 lignes par page. - (Supplément 1 288.)

\section{4.}

Même ouvrage.

Papier. 380 feuillets. Hauteur, 21 centimètres el demi; largenr, 16 centimètres. 15 lignes par page. Ms. du xviu' siècle. - (Supplément 1287 .) 


\section{5.}

Même ouvrage avec de nombreuses gloses.

Ms. daté de l'an 1194 ( 1780 de J.-C.).

Papier. 150 fenillets. Hauteur, 22 à 24 centimètres; largeur, 15 a 17 centimètres. 21 lignes par page. - (Supplément 1300.)

\section{6.}

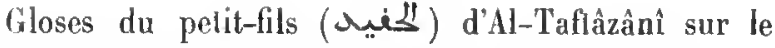
Mokhtașar. Commencement, immédiatement après le

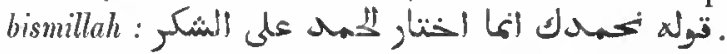

papier. 86 feuillets. Hauteur, so centimètres et demi; largeur, 1 is centimètres et demi. 23 lignes par page. Ms. du xvi siècle. (Supplément 1295.)

\section{7.}

Mềme ouvrage. Le présent exemplaire ne commence que par la glose قولَّ هو الثننا أى الخذكر بإلمير.

Ms. daté de l'an 1005 (1597 de J.-C.).

Papier. $9^{8}$ feuillets. Hautenr, 19 centimètres; largeur, 15 centimètres. 21 lignes par page. - (Supplément 2483. )

\section{8.}

حانثية . Gloses de Maula-Zâdè Mâlik-Schâh Qâsim Qâdirî Al-Klıatâî sur le Mokhtașar. Commence-

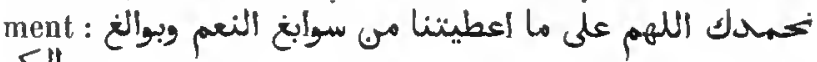
त)

Ms. daté de l'an 1118 (1706 de J.-C.).

Papier. 76 feuillets. Hauteur, 19 centimètres; largeur, 10 centimètres et demi. 16 lignes par page. - (Supplément 21 20.)

\section{9.}

Gloses sur le Mokhtasar, par Schihåb al-Dìn Ahmad ibn Qâsim al-'Ibâdi. (Voy. Hadji-Khalfa, t. II, p. $40 \mathrm{~g}$.)

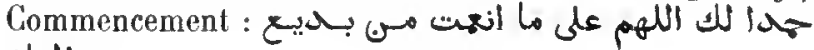
ilefl.

Ms. daté de l'an 1134 (1722 de J.-C.).

Papier. 397 feuillets. Hauteur, 21 centimètres et demi; largeur, 15 centimètres. 23 lignes par page. - (Supplément 1 297.)

\section{0.}

Même ouvrage.

Papier. 295 feuillets. Hauteur, 21 centimètres et derai ; largeur, 16 centimètres. 95 lignes par page, el 27 lignes dans les derniers cahiers. Ms. du xix siècle. - (Supplément 1296 .)

\section{1}

Même ouvrage. Le commencement manque.

Papier. 232 feuillets. Hauteur, 21 centimètres; largeur, 14 centimètres. 21 à 23 lignes par page. Écritures diverses du sm' siècle. - (Supplément a 488.)

\section{2 .}

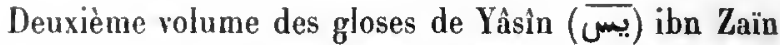
al-Dîn al-'Alìmî al-Himșî sur le Mokhtașar d'Al-Taftâzânî.

Ms. dalé de l'an 1123 ( 1711 de J.-G.).

Papier. 277 feuillets. Hauteur, a 1 centimètres; largeur, 15 centimètres. 21 lignes par page. - (Supplément 1 298.)

\section{3.}

Commentaire de Yoûsof al-Hafnâwî sur le Mokhtasar d'Al-Taftâzânî. L'auteur dit avoir composé son ouvrage en 1180 de l'hégire ( 1766 de J.-C.). Commencement :

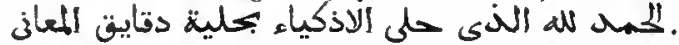

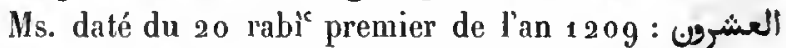
(1794 de J.-C.).

Papier. 408 feuillets. Hauteur, 23 centimètres; largeur, 16 centimètres. 23 lignes par page. - (Supplément 1994.)

\section{4.}

Commentaire de Sîdì Aḥmad ibn Moḥammad ibn Yacqoûb sur la préface du Mokhtașar d'Al-Taftâzânî. Com-

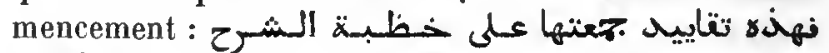

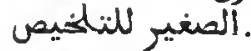

Ms. daté de l'an 1133 (1 721 de J.-C.).

Papier. 10 feuillets. Hauteur, 21 centimètres; largeur, 15 centimètres et derai. 93 lignes par page. - (Supplément 1292.) 


\section{5.}

$1^{\circ}$ Le même commentaire sur la préface dn Mokhtașar d'Al-Taftâzânî.

\section{$2^{\circ}$ (Fol. $22 \mathbf{v}^{\circ}$.) Le Molhtaṣar d'Al-Taftâzâni.}

Papier. 388 feuillets. Hauteur, 31 centimètres et demi; largeur, 16 centimètres. 19 lignes par page dans le commentaire de la préface, et 15 dans le Mokhtaṣar. Ms. du xvı1' siècle. - (Supplément 1393.)

\section{6.}

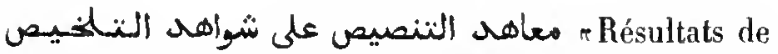
l'insistance, à l'égard des vers cités comme exemples dans le Talkhiṣn. Cet ouvrage est très détaillé. L'auteur, 'Abd al-Rahịim ibn Aḥnad al-'Abbâsì (mort en 963 de l'hégire), explique tons les passages des poètes dont les

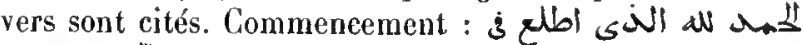
لسماء البيان أهلّة الثعانة

Ms. daté de l'an 1027 (1618 de J.-C.).

Papier. 497 feuillets. Hauteur, 36 centimètres; targeur, 15 centimètres. 25 lignes par page. - (Supplément 1301.)

\section{7.}

Explication des rers cités comme exemples dans le Talkhiss d'Al-Qazwìi et dans le Miftâh d'Al-Sakkâkî. Ouvrage sans nom d'auteur. Commencement : at holl ألثوئ بحسى توفيغه

Ms. daté de l'an $9^{8} 1$ ( 1573 de J.-C.).

Papier. 114 feuillets. Hauteur, 97 centimètres; Jargeur, 18 centimètres. 27 lignes par page. - (Supplément 1305. )

\section{8.}

Commentair'e perpètuel sur le traité de rlétorique intitulé

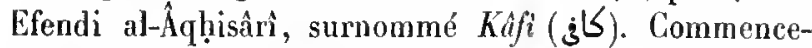
ment : لإلبيان.

Ms. daté de l'an 1050 (1640-1641 de J.-G.).

Papier. 86 feuilfets. Hauteur, 20 centimètres et demi; largeur, 13 centimètres et demi. 13 lignes par page. - (Ancien fonds 1617 .)

\section{9}

吕 "La Lampen, commentaire du chéril 'Alì ibn Moḷammad al--Djordjâni sur la troisième partie du Miftah al-'Oloum. Commencement : نك-

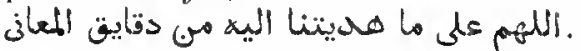

Nombreuses notes marginales et interlinéaires.

Ms. daté de l'an $\delta_{92}$ (1487 de J.-C.).

Papier. 209 feuillets. Hauteur, a 7 centimètres; largeur, 18 centimètres. 25 à 27 lignes par page. - (Supplément 1 274 bis.)

\section{0.}

1 " Fraicheur de la fleur du dattier on défense de la Poésien, ouvrage composé en 642 de l'hégire (1244-1245 de J.-C.) par Aboù 'Alì al-Mozaffar ibn al-Sầid abî 'l-Qâsim at-Fadhl al'Alawî al-Hosaïni. L'auteur traite son sujet à fond dans cinq chapitres ( $\mathrm{fasl}$ ), dont on peut trouver les titres dans le Dictionnaire bibliographique de Hadji-Khalfa, t. VI,

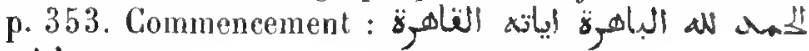
xistr.w.

Copie datée de l'an 1100 ( 1689 de J.-C.).

2 Belle action, ou commentaire sur l'ouvrage intitulé Fleur du printempsn, par 'Abd al-Lațif al-'Aschmàwì. Le poène, composé en 1059 de l'hégire par 'Abd Allalı al-Ziftâwí, est une badk, qui présente presque dans chaque vers l'exemple d'une figure de rhétorique. Commencement :

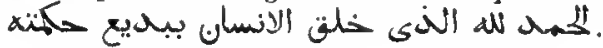

Copie datée de l'an $108_{7}$ ( 1676 de J.-C.).

Papier. 277 fenillets. Hanteur, 20 centimètres; largeur, 14 centimètres. 21 lignes par page dans le premier ouvrage, 17 lignes dans le second. - (Supplément 1914.)

\section{1.}

it Le modèle qu'on doit passer de main en main, renfermant des instructions pour les prosaleurs et les poètes \%. C'est un traité de rhétorique très étendı, dans lequel l'autenr, Dhyyì al-Dìn ibn al-Athir, prodigue des enseignements à ceux qui veulent employer le style recherché. Commence-

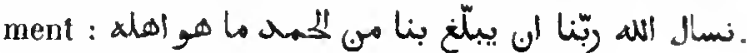

Ms. daté de l'an 1118 (1706 de J.-C.). 
Papier. Exemplaire en deux volumes réunis dans un étui. 221 et 2.14 feuillets. Hauteur, 24 centimèlres el demi; largeur, 17 centimètres. 17 lignes par page. - (Supplément $1355 \mathrm{~A}$.)

\section{2.}

eÉclaircissement sur la manière de bien énoncer ses idées n, Irailé de rhétorique divisé en Lrois sections : jleلll rLes penséesn, البيان rL'Lexposi-

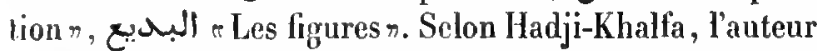
de cel ouvrage se nommait Scharaf al-Din Hosaïn ibn Mohammad al-Ṭaiyibî, mort en 743 de l'hégire (13421343 de J.-C.). Commencement : الثرة

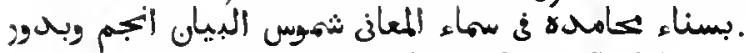

Ms. daté de l'an 784 (1382-1383 de J.-C.).

Papier. ${ }_{16}$ feuillets. Hauteur, 21 centimètres et demi; largeur, 13 centimètres et demi. 15 lignes par page. - (Ancien fonds 1583.)

\section{3.}

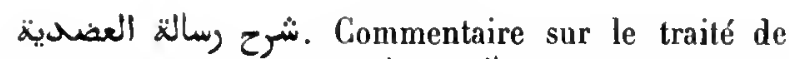
l'imposition des mots (وسالة is الوخع) d'Adhod al-Dîn 'Abd al-Raḥmàn ibn Ạmmad al-Îdjî, auteur du المواتقا.

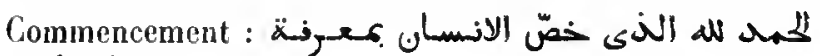
- أوضاع ألكاع.

Noles marginales.

Ms. dalé de l'an 1117 (1705-1706 de J.-G.).

Papier. 21 feuillets. Hauteur, 20 centimètres et demi; largeur, 15 centimètres. 19 lignes par page. - (Supptément 1309.)

\section{4.}

$1^{\circ}$ Gloses sur le commentaire composé par 'Isâm alDîn sur le Iraité de l'imposition d"Adhod al-Dîn. Com-

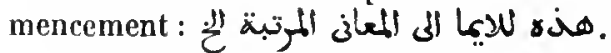

$2^{\circ}$ (Fol. $52 v^{\circ}$.) Commentaire sur le traité de l'imposition d"Adhod al-Dìn. Commencement : عـلى [هjo] تقدير تقدم الليباجة على الرسالغ

$3^{\circ}$ (Fol. 88.) Texte du traité de l'imposition arec le commentaire d'cAbd Allah al-Schobrâwî. Commence-

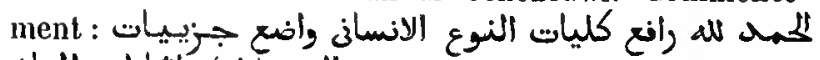

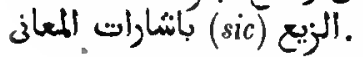

$4^{\circ}$ (Fol. $9^{8}$ bis.) Commentaire d'Aboû 'l-Qisim ibn abî Bakr al-Laïthì al-Samarqandì sur le 1raité de l'imposition d'Adhod al-Dîn. $5^{\circ}$ (Fol. $118 v^{\circ}$.) Commentaire d'lbrâhìm ibn Mohammad ibn 'Arabschâh sur les nances de la discussion" d'Adhod al-Dín al-Îdjî. Commencement: نحمدك يا من لا ناتص لما لاعطيت.

$6^{\circ}$ (Fol. ${ }^{3} 37 v^{\circ}$.) Le traité d'Adhod al-Din sur l'imposilion, mis en vers et commenté par Mohammad ibn Aḷmad al-Behoûtí (البهون). Commencement du com-

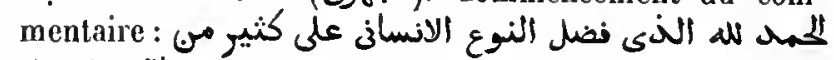

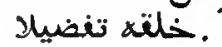

$7^{\circ}$ (Fol. $152 v^{\circ}$.) Commentaire d'Thn 'Arabchâh sur l'Âdâb al-Monąara d'Adhod al-Dîn al-Îdjî. C'est le mème ouvrage que l'article $5^{\circ}$ de ce ms.

Papier. 162 feuillets. Hauteur, 29 centimètres; largeur, 16 centimètres. Le premier traité a 21 lignes par page; le second et le trojsième, 23 lignes; le quatrième, 21 lignes; le cinquième, 17 lignes; le sixième, 25 lignes; et le septième, 21 lignes. Écritures diverses du xvi1" siècle. - (Supplément 1312.)

\section{5.}

$1^{\circ}$ Gloses sur le commentaire du traité de la métaphore d'Aboû '1-Qâsim al-Laïthì al-Samarqandi, par 'Iṣâm al-Dîn Ibrâhîm ibn Moḥammad. Commencement :

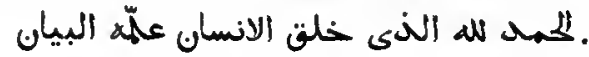

$2^{\circ}$ (Fol. 51 vo.) Commentaire d'Iṣâm al-Dîn lbrâhîm ibn Mohammad sur le traité de la métaphore d'Aboû 'l-Qâsim al-Laïthî al-Samarqandì.

$3^{\circ}$ (Fol. 70.) Le lexte du traité de la métaphore. Commencement : لهمبد لوالهب العبية.

$4^{\circ}$ (Fol. $7^{3}$.) Gloses sur le commentaire du traité de la métaphore, par 'Iṣâm al-Dìn.

$5^{\circ}$ (Fol. $102 v^{\circ}$.) Commentaire du Hạfid Al-'Iṣâm sur le traité de la métaphore. Commencement : آل . مستتشند لانوار هل إيتك

$6^{\circ}$ (Fol. 132.) Commentaire sur le traité de l'imposition, par Aboû 'l-Qâșim al-Laïthì al-Samarqandî. (Voy. ci-dessus 4423 et $4424,4^{\circ}$ )

$7^{\circ}$ (Fol. $163 \mathrm{v}^{\circ}$.) Commentaire d'Aboû 'H-Qâșim ibn abî Bakr al-Laïthî al-Samarqandî sur le traité de l'imposition. Commencement : سبكان مى نطق بذكره اللسار تسببيكا وتهليكا. Al-Laithî dit avoir achevé ce commentaire en 888 de l'hégire.

$8^{\circ}$ (Fol. $192 v^{\circ}$.) Gloses d'c Ișâm al-Dîn sur le traité de l'imposition d'Adhod al-Din al-Îdjì. (Voyez ci-dessus $\left.4424,1^{\circ}.\right)$

$9^{\circ}$ (Fol. $240 v^{\circ}$.) Gloses d'Aboû 'l-Baqâ sur le com. 
mentaire du traité de l'imposition d'Adlıod al-Dìn, par Al-Samarqandi. Commencement : باسم سبs مالصلوة على وسونه.

Nombreuses notes marginales et interlinéaires.

La plupart de ces pièces sont datées de l'au 1 1 08 de l'hégire (1696-1697 de J.-C.).

Papier. 251 feuillets. Hauteur, 21 centimètres; largeur, 15 centimètres. 19 lignes par page dans la première pièce, 17 dans la seconde, 23 dans la quatrième et la cinquième, 13 dans la sixième, 23 dans la septième, 17 dans la huitième et 18 dans la neuvième. Écritures diverses. - (Supplément 1311 .)

\section{6.}

. شرح وسالة السمرقنحى. Commentaire sur le traité des expressions métaphoriques d'Al-Samarqandì, par Ahmad ibn 'Abd al-Fattâh al Malawî. Le texte du traité d'Al-Samarqandì est reproduit en entier. Comınence-

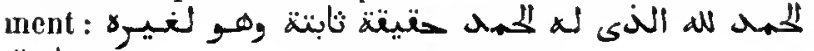
¿"

Ms. daté de l'an 1160 de l'hégire ( 1747 de J.-C.).

Papier. 16 fenillets. Hauteur, 21 centimètres; largeur, 16 centimètres. a 3 lignes par page. - (Supplément 1308.)

\section{7.}

$1^{\circ}$ Revision des corrections qui fixent le sens de l'Ifșahn. Traité de rhétorique par Ridhâ al-Dìn Moḷammad al-Ghazzì al-'̂̂mirì, mort en 935 (1528-1529 de J.-C.). Le texte est accompagné d'un commentaire rédigé par le mème auteur et comInençant par ces mots : .بتنوير ألافصاح.

$2^{\circ}$ (Fol. $173 v^{\circ}$.) Commencement d'un traité sur cerlaines questions qui se rattachent au chapitre du droit musulman relatif à l'ablution.

$3^{\circ}$ (Fol. 181 v $^{\circ}$.) Poème de Ridhâ al-Dìn al-càmirì, où sont employés tous les mots qui renferment la lettre b. Chaque vers est suivi d'un commentaire composé par le fils de l'auteur. L'ouvrage se termine par des observations sur les lettres $b$ et $\dot{\sim}$. Cette pièce est datée de l'an 922 de l'hégire ( 1516 de J.-C.)

Papier. 206 feuillets. Hauteur, 18 centimètres; largeur, 13 centimètres el demi. 15 lignes par page dans la première pièce, 21 dans la seconde, 24 à 26 dans la troisième. Écrilures diverses du $x \mathbf{x i}^{\circ} \mathrm{s}$. $-($ Aneien fonds 16.9.$)$

\section{8.}

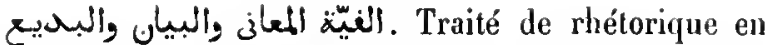
vers, par Ahmad al-Malawi, avec un commentaire par le nême auteur qui déclare avoir pris pour base de son travail le Talkhiş al-Miftâh. Commencement : ك/

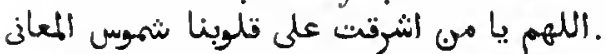

Is. daté de l'an 1169 de l'hégire ( 1756 de J.-C.).

Papier. 423 feuillets. Hauteur, 22 centimètres; targeur, 15 centimètres el demi. 33 lignes par page. - (Supplément 1302.)

\section{9.}

1 ' الرسالة العصامية. Traité d'lṣâm al-Dì sur la métaphore, traduit du persan en arabe par Alımad al-Ma-

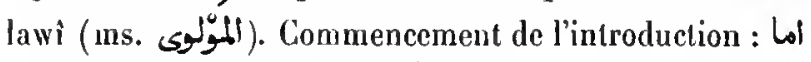
بعد ذهذه وسالة

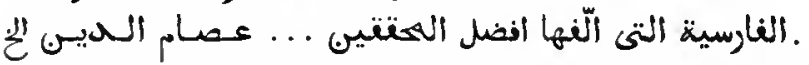
Commencement du traité : أعر أن الله تعاله جعل الانسان • مدنيّا بالطبع أى عحتاجا الى التمدلّن بالطبع والاجتماع

$2^{\circ}$ (Fol. $88 \mathbf{v}^{\circ}$.) Commentaire d'Iṣâm al-Dìn Moḥaumad sur le traité de la métaphore d'Aboû 'l-Qâșim al-Laïliì al-Samaryandì. Conmencement du commen-

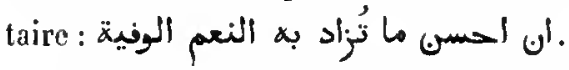

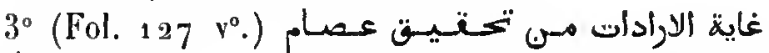
"But des souhaits au sujet des recherches d'Isâm sur les mélaphoresn. Commentaire de Moḷam-

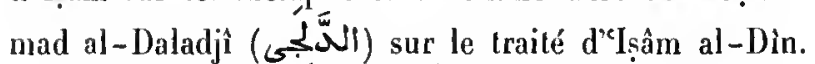

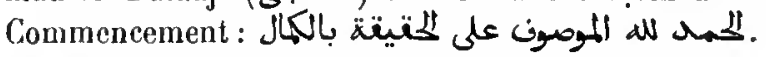

Ms. daté de l'an 1207 de l'hégire (1792 de J.-C.).

Papier. a 18 feuillets. Hauteur, a centimètres; largeur, 15 centimètres. 14 lignes par page dans les deux premiers trailés, a 1 dans le troisième. - (Supplément 1310. )

\section{0.}

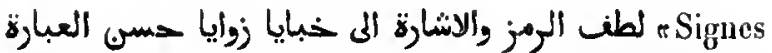
adroits pour indiquer les (notions) cachées dans les recoins du (livre intitulé) Hosn al-'Ibara ». Les deux traités sont du même auteur, Moḥammad 'Alì ibn 'Allân al-Siddiqî. Le Hosn al- Ibara est en vers et traite de la

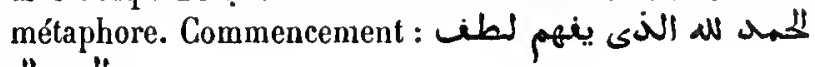
(1) الرمز 
Ms. daté de l'an 1130 de l'hégire (1718 de J.-C.).

Papier. 41 feuillets. Hauteur, a 1 centimètres; largeur, 15 centimètres et demi. 21 lignes par page. - (Supplément 1307.)

\section{1.}

$1^{\circ}{ }^{\circ}$ i Beauté de l'art du style orné et amusement pour l'homme accompli ᄁ. Traité de rhétorique en vers, accompagné d'un commentaire. L'au-

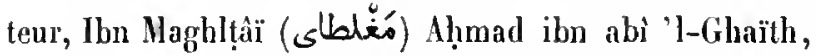
a composé cet ouvrage, texte et commentaire, dans l'Inde, en 1116 de l'uégire (1704-1 705 de J.-C.), en le dédiant au sultan 'Âdham-Selıàlı, fils d'Aurang-Zèb 'Ảlam-Guìr. La dédicace aussi est en vers. Commence-

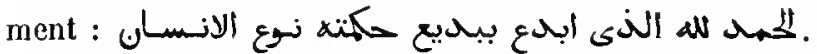
Ciet exemplaire parait être celui qui a été présenté au prince.

$2^{\circ}$ Fol. 126. Cadeau pour celui qui avait demandé des réponses à ses questions", par Aḷmad ibn Moḥammad al-'Abbàsì. C'est un recueil de trois cents questions au sujet de Hahomet, des patriarches et de divers passages du Coran. Chaque question est accompagnée de sa réponse. Commence-

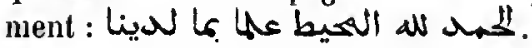

Papier. 171 feuitlets. Hauteur, 25 centimètres et demi; largeur, 15 centimètres. 11 lignes par page dans le premier ouvrage, 21 dans le second. Ms. du xwir" siècle. Écritures différentes. - (Supplément 1313.)

\section{XXX1.}

INSCH ì.

\section{2.}

.أدب الكانتب Manuel des connaissances littéraires, historiques et grammaticales qui sont indispensables à l'écrivain rédacteur, par 'Abd Allah ibn Moslim ibn Qotaiba, inort au commencement du $x^{8}$ siècle de J.-C. Commencement : بعد هد الله بجميع كاميده.

Papier. 166 fenillets. Hauteur, 20 centimètres et demi; largeur, 15 centimètres. 15 lignes par page. Ms. du xvm! siècle. - (Supplément 1348.)

\section{3.}

Inschâ. Ce volume se compose d'extraits de pièces officielles et de lettres, ainsi que d'un récit historique touchant certains événements qui se passèrent chez les Ghaznévides, au $\mathbf{x i}^{\mathrm{e}}$ siècle. Les extraits consistent en la partie des documents qui se distinguent par la recherche du langage et par les beautés du style. La plupart de ces pièces émanent, probablement, de la chancellerie ghaznévide, depuis le commencement du $\mathbf{x i}^{e}$ siècle de notre ère jusqu'aux premières années du $\mathrm{XI}^{\circ}$. On trouve d'abord l'éloge d'un vizir appelé Aboû Naṣr Aț̣mad ibn Qauwàm al-Dìn; puis des lettres officielles adressées à des personnages dont la plupart nous sont inconnus, tels que l'Isfahsalàr Naşr al-Daulat Qàsim al-

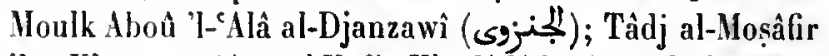
ibn Khosrau; 'Aïn al-Kofàt Klıodàdàd; Aboú Ṭâhir Mloḷammad ilon 'Alì; 'Abd al-Karîm Ismấil; le vizir Bahâ al-Din Moḷammad ibn al-Hosain. Au fol. $9^{1} \mathrm{v}^{0}$ se trouve une letlre datée de l'an 502 de l'hégire ( 1108 1109 de J.-C.) et adressée du divan du calife de Baghdâd (مدينتة السلكم) à un personnage qui porte le titre Ml-Mowaffaq al-Moqaddas al-Nabawî al-Imâmî al-Mostadhiri. Au feuillet 183 il est fait mention de l'émir Altoun-Tasch qui était gouverneur du Kharizm en 407 de l'hégire (1016-1017 de J.-C.). Le présent volume se compose de deux parties dont la première se termine au folio 91. Une note, ajoutée par un lecteur, qu'on lit au nième feuillet, porte la date de 643 ( 1245 de J.-C.).

Papier. ${ }_{2} 69$ feuillets. Hauteur, 18 centinètres et demi; largeur, 14 centimètres. 11 lignes par page. Ms. du xiı" siècle. - (Ancien fonds 161 g.)

\section{4.}

$1^{\circ}$ Pièces officielles provenant de la chancellerie des sultans de Kharizm snus les règnes d'Atsiz, de son fils Il Arslân et de Mạ̣moûd, fils d'll Arslàn. C'est pour la bibliothèque du sultan Mahımoûd que Râschid al-Dìn Aboù Bakr Mọ̣ammad ib́n Moḷammad ibn 'Abd alDjalil al-Ma'marî, rédacteur de ces pièces, a réuni le présent recueil, probablement entre 568 et 588 de l'hégire ( $117^{2}$ et $119^{2}$ de J.-C.). Le volume ne porte pas de titre; celui qui est inscrit sur le recto du premier

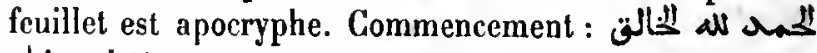
. بالستشناد

$2^{\circ}\left(\right.$ Fol. $109 \mathrm{v}^{\circ}$.) Qașî́da du même auteur à lá louange du sultan Mahmoûd Kharizm-Schâh, suivi de quelques autres poèmes du même. 
$3^{\circ}$ (Fol. 126.) Lettres d'un sultan à un autre. La première, en persan, est de Schâh-Rokh à MoûrâdKhân. Une autre est de Moưrâd-Khân au sultan d'Égrypte; les deux suivantes sont de Mohammad-Khân au sultan d'Égypte. Suivent une lhotba de mariage et une lettre, en persan, adressée au sultan Orkhân et annonçant la prise d'Iznîq (لزيقن, Nicée en Bithynie). On trouve elicore deux lettres, en persan, de Timoûr à Hderim-Khân, et plusieurs autres adressées par des souverains ottomans aux sultans d'Égypte.

$4^{\circ}$ (Fol. $172 \mathrm{v}^{\circ}$.) Recueil de quarante-lıuit lettres écrites en beau style persan sur des sujets divers. Une dernière leltre, accompagnée de sa réponse, est écrite dans le langage technique des derviches Qalenders بـى (مصطأح قلنح

$5^{\circ}$ (Fol. 223.) Quatrains, lettres de compliments et pièces de vers; le tout en langue turque et d'une autre écriture que le reste du ms.

Ms. daté de l'an 877 de l'hégire (1473 de J.-G.). (Voyez fol. $170 \mathrm{v}^{\circ}$.)

Papier. 226 feuillets. Hauteur, 17 centimètres; largeur, 12 centimètres. 13 lignes par page et ensuite 15 . - (Ancien fonds 1615. )

\section{5.}

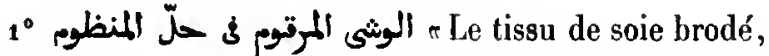
traité qui enseigne la manière de paraphraser les passages ẹ style cadencén, par Dhiyâ al-Dìn Naṣr-Allah ibn al-Athîr, frère du célèbre historien 'All ibn alAthîr. Ciet ouvrage, destiné aux écrivains rédacteurs, se compose de trois sections $(f a s ̣ l)$, dont la première expose la manière de paraphraser les vers des grands poètes. La seconde indique comment on peut paraphraser les versets du Coran, et la troisième donne des exemples de la même opération appliquée aux sentences et maximes de Mahomet. Les premières lignes de la préface sont restées en blanc. L'ouvrage se termine, sans explicit, au fol. $25 \mathrm{v}^{\circ}$.

$2^{\circ}$ (Fol. $25 \mathrm{v}^{\circ}$.) Les sept derniers chapitres $(b a b)$ de la troisième partie d'un traité des ornements du style, in-

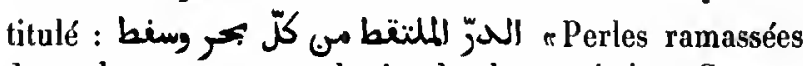
dans chaque mer et enlevées de chaque écrin ᄁ. Cet ourrage, composé de quatre parties et renfermant trente chapitres, a pour auteur Schams al-Din Mohammad ibn 'Alî ibn Mạ̣moutd, écrivain rédacteur en prose et en vers. Le dix-septième chapitre, celui par lequel cet النزّ النغيس ف اجناس : extrait commence, a pour titre التجنيس. $3^{\circ}$ (Fol. 1 14.) La quatrième et dernière partie (les

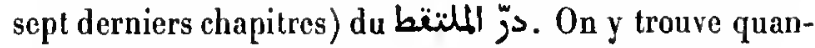
tité d'extraits en prose et en vers, dont plusieurs offrent un certain iutérèt.

Le copiste de ce manuserit, n'ayant pas eu à sa disposition les seize premiers chapitres de l'ouvrage, a cru devoir les remplacer par le traité d'Lbn al-Athîr.

Ms. daté de l'an 98 a de l'hégire ( 1575 de J.-C.).

Papier. 205 feuillets. Hauteur, 27 centimètres et demi; largeur, 18 centimètres. 29 lignes par page. - (Supplément 1351.)

\section{6.}

r La bonne voie pour atteindre à la pratique de l'art épistolaire». Traité de rhétorique illustré par de nombreux exemples, d'anecdotes intéressantes et de formules de pièces officielles et autres. L’auteur, Schilıâb al-Dîn Nahmoûd ibn Salmân ibı Fahd al-Halabî, employé dans la chancelleric égyptienne sous le règue du sultan Baïbars, est mort, d'après Hadji-Khalfa (t. IlI, p. 67), en $7_{25} 5$ de l'hégire (1325

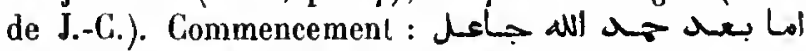

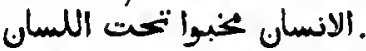

Ms. exécuté, sous les yeux de l'auteur, en 716 de l'hégire ( 1316 de J.-C.).

Papier. 113 fevillets. Hauteur, 25 centimètres; largeur, 16 centimètres et demi. 19 lignes par page. - (Ancien fonds 1574 ; Colbert 5ag4.)

\section{7.}

r Réponse à celui qui demande à connaître l'art épistolaire \%. C'est un manuel du secrétaire renfermant les formules qui s'emploient dans les dépêches et les lettres adressées par le gouverncment égyptien au sultan, aux souverains étrangers, aux émirs, aux princes chrétiens, etc. L'auteur y a joint des modèles de lettres aux fonctionnaires publics de toutes les classes et des formules de traités, d'actes, de leltres patentes (مناش-ر) et de lettres de provision (تناليد), etc. Il était attaché à la chancellerie égyptienne en qualité d'écrivain rédacteur et on voit (fol. $\left.9 \mathrm{v}^{\circ}\right)$ qu'il s'y trouvait encore en $77^{6}$ de l'hégire $\left({ }_{13} 7_{5}\right.$ de J.-C.). Le premier feuillet manque, et il manque un feuillet entre les folios 1 et 2 .

Papier. 135 feuillets. Hauteur, 20 centimètres et demi; largeur, 14 centimètres et demi. 13 à 18 lignes par page. Ms. du xvl' siècle. - (Supplément 1349.) 


\section{8.}

Premier volume du du style officieln, par Taqì al-Dìn Aboû Bakı ibn Hoddja al-Ịanawi, ćcrivain rédacteur à la chancellerie égyptienne dans les premières années $\mathrm{du} x \mathrm{xv}^{\mathrm{e}}$ siècle. C"est un recueil de pieces et d'extraits, modeles du beau style. On y remarque plusieurs diplônes et lettres d'investiture. Quelques-unes de ces pièces sont datées de l'an 817 de l'hégire (1414-1415 de J.-C.) Commencennent : u. ل⿺辶

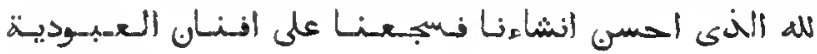
sursin.

Hs. daté de l'an 845 de l'hégire (1441-1442 de J.-C.).

Papier. 97 fenillels. Hauteur, 17 centimètres; largeur, 12 centimètres. 13 lignes par page. - (Ancien fonds 1613.$)$

\section{9.}

كتناب ديولن الانشنl. Traité sur le fonctionnement de la chancellerie égyptienne et sur les connaissances qu'un écrivain rédacteur doit posséder. Cet ouvrage, sans [réface ni titre, commence par ces mots :

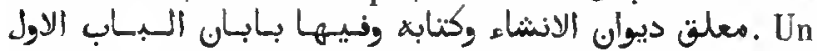
Turc, peu versé dans la connaissance de l'arabe, a écrit sur le recto da fevillet 2 , en guise de litre:

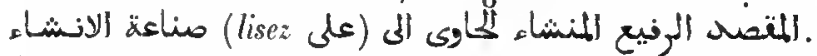
Ce même titre est reproduit par d'autres mains, encore deux fois, sur le même feuillet, $11^{\circ}$ et $11^{\circ}$. L'importance des matières renfermées dans cet ouvrage est bien connue. On y trouve, distribuées en treize sections (قسمم), toutes les connaissances dont pouvaient avoir besoin les commis de la clancellerie, sous le règne de Barasbåï, sultan mamlouck circassien, qui mourut l'an 84 ! de l'hégire (1/438 de J.-C.). La date de la composition de cette encyclopédie est parfaitement indiquée par deux passages : fol. $57 r^{\circ}$ et fol. $266 r^{\circ}$, ligne 13. Outre les renseignements liistoriques, les listes des souverains musulmans et les notions géograpliques, on trouve, dans la dernière section, les protocoles des traités de paix que le sultan avait contractés avec les autres puissances, tant musulmanes que chrétiennes, et les formules des dépêches et des lettres qu'il leur envoyait.

Papier. 330 feuillets. Hauteur, 28 centimètres; largeur, 18 centimètres et demi. 33 lignes par page. Ms. du $x^{e}$ siècle. - (Ancien fonds 1573 ; Colbert 2486 .)

\section{0.}

Choix de lettres pour servị de modèles aux amateurs qui cultirent le style épistolaire. Ces lettres émanent, pour la plupart, de la chancellerie des sultans mamloucks circassiens et sont adressées aux princes musulmans de divers pays. On y trouve aussi quelques lettres écrites par des particuliers. Parmi ces pièces on remarque des épitres composées par le cadi Aboú 'l-Thanâ Mạmoûd, par Al-Salâ! al-Safadì, par Tàdj al-Dîn ibn al-Athîr et par Djanâl al-Dìn ibn Nobàta. Ajoutons une lettre adressée par $\Lambda$ boû 'l-Walid ibn Zaïdoûn à Aboû 'l-Hazm, gouverneur de Cordoue; une autre du Qàdhî al-Fâdhil; une dépèche adressée au souverain de Dehli, dans l'Inde; une autre du sultan Djakmak au seigneur de Tunis; une autre adressée au souverain nașeride qui régnait en Espague; une autre envoyée au sultan Inàl par les musulmans domiciliés à Lisbonne, et d'autres adressées au souverain du Yemen, à Qarâ Yoûsof, seigneur des deux 'Iràđ, aux souverains de Ḥiṣn-Kaïfa, de Mâridîn et de Tokroûr. La pièce la plus récente est datée de l'an 872 de l'hégire (1468 de J.-C.); elle fut adressée par le souverain de Tunis (voyez fol. 61) à Al-Màlik al-Aschraf Qâïbâii. Aucun ordre n'a présidé à l'arrangement de ces documents. Le nom du compilateur n'est pas indiqué.

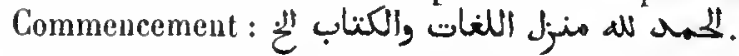

Papier. 210 feuillets. Hauteur, 27 centimètres; largeur, 18 centimètres et demi. 23 lignes par page. Ns. du xv' siecle. - (Ancien fonds 1575 .)

\section{1.}

Guide du Kâlib. Volume composé de plusieurs traités et formant un manuel des connaissances dont tont employé de l'administration a besoin. On y trouve les éléments de l'arithmétique, de la géométrie, de l'arpentage, de l'assiette des impôts en Égypte, des procédés agricoles, etc. La liste de ces traités et chapitres, rédigće par M. de Sacy, se trouve en tête dn ms.

Ms. daté de l'an 979 de l'hégire $\left(157_{1-1} 57^{2}\right.$ de J.-C.).

Papier. 180 feuillets. Hauteur, 21 centimètres; Jargeur, 15 centimètres. 23 lignes par page. - (Supplément 1912.)

\section{2.}

Apparitions heureuses des beautés du sérail, en fait des correspon- 
dances littéraires entre contemporains", par Darwìsch Efendi al-Ṭàlawî (الطالوى). C'est un recueil de diverses épitres en vers que l'auteur avait adressées ì des personnages marquants et plusieurs pièces quili avait reçues de ses correspondants. Il dit avoir achevé son travail l'nn $9^{81}$ de l'hégire $(1573-1574$ de J.-C.). Com

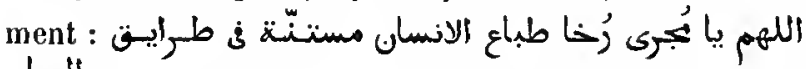
.

Is. daté de l'an 1064 de l'hégire ( 1654 de J.-C.).

Papier. 173 feuillets. Hauteur, 36 centimètres; targeur, 16 centimètres. 25 lignes par page. - (Supplément 135.)

\section{3.}

Formulaire de lettres oflicielles, par le Scliaikh Moḷammad al-Bakrì al-Ṣiddìqi, qui a rédigé tontes ces pièces en Egypte, sous le gouvernement ottoman.

Papier. ${ }_{2} 34$ fenillets. Hauteur, 21 centimètres; largeur, 15 centimètres el demi. 13 lignes par page. Hs. du xw1 siècle. - (Supplément 1350.)

\section{4.}

rivre de cluarmes, ou science des écrits . Traité d'épistolograpbie, intitulé anssi, sur le frontispice, is la perle précicuse, pour l'instruction de cliacun r. L'anteur, 'Abd al-Raḥmàn Efendi, s'est borné, en général, à recueillir des passages remarquables dans les letlres de divers écrivains. Ces pièces ne renferment que des compliments; quelques-unes sont en vers. Commencement : as على نعة الاسلام.

Papier. 50 feuillels. Hauteur, 21 centimètres; largenr, 15 centimètres. 15 lignes par page. Is. du xvi' siècle. -( Ancien fonds 1614.$)$

\section{5.}

Formulaire renfermant des modèles de lettres, par Mar'i ibn Yoûsof al-

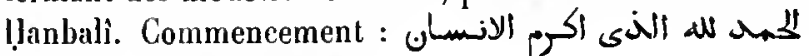
. وحلاه بحلية ألنطن والبيان.

Papier. 55 feuillets. Hauteur, 21 centimètres; largeur, 15 centimètres et demi. 18 ligues par page. Ms. du xwı* siècle. - (Supplément 1353.)

\section{XXXII.}

\section{PROSODIE ET MÉTRIQUE.}

\section{6.}

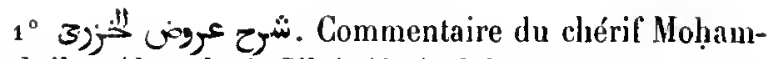
mad ibn Aḥmad al-Sibtî Al-Andalosì, sur le célèbre Iraité de prosodie arabe, en vers, de Dhiyâ al-Dìn Mohammad al-Khazradjì. Commencement : sjl w d J بكمبه نستنتح وهو الغتاح العليم.

$2^{\circ}$ (Fol. $68 v^{\circ}$.) Traité d'énigmes en seize paragraphes, par Niẓam al-Dìn, fils du schaỉklı Maḅmoùd. L'ouvrage est en persan et commence par ces mols :

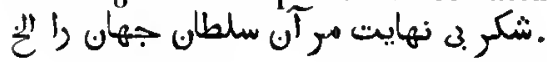

$3^{\circ}\left(F_{0} l .80 v^{\circ}.\right)$ Autre traité d'énigmes, en persan.

Papier. 83 feuillets. Hauteur, 21 cenlimètres; largeur, 1/4 centimètres et demi. 19 lignes par page, puis 21, puis 19. Diverses écritures du $\mathbf{x r}^{\circ}$ siècle. - (Ancien fonds 1483.)

\section{7.}

Pierreries éclatantes posées sur la Ramiza du Khazradjiten. Commentaile d'Aboù 'l-Baqà Moḷammad ibn 'Alì ibn Khalaf

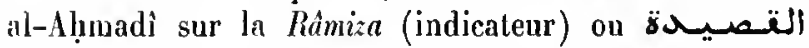
גّيّ Din Moḷammad al-Khazradjî. Ce commentaire a été composé en go2 de l'hégire (1497 de J.-C.). Commen-

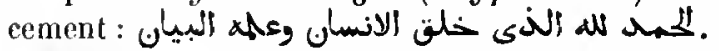

Hs. daté de l'an 1087 de l'hégire ( 1676 de J.-C.).

Papier. 135 feuillets. Hauteur, 20 centimètres; largeur, 13 centimètres. 3 lignes par page. - (Supplément 1.70.)

\section{8.}

Commentaire sur la Khazradjîya de Dhiyâ al-Dîn alKhazradji, par Schihàb al-Din al-Balawî (البلوى). L'auteur dit avoir achevé son ouvrage en 908 de l'hégire

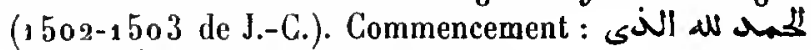

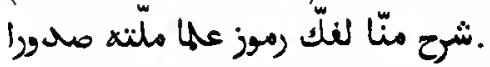

Papier. 280 feuillets. Hauteur, 21 centimetres; largeur, 15 centimètres. a 3 lignes par page. Ms. du xrm! siècle. - (Supplérnent 1 271.) 


\section{9.}

Inspiration du Seigneur des choses créées, pour servir de commentaire à la Khazradjiyan, par Zakarîya ibn Moḥammad al-Ansârì. Le commentaire commence par le qualrième vers

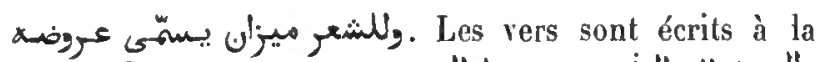

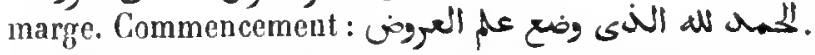

Papier. 54 feuillets. Hauteur, 22 centimètres; largeur, 16 centimètres. 2 liggnes par page. Ms. du xvis siècle. - (Supplément 1273.)

\section{0.}

"Les perles de Khôdj”. Commentaire sur la Khazradjìya, par Badr al-Dîn ibn ‘Omar Khôdj ibn 'Atân Allâh al-Fetnî (de فتر, village de l'Inde). Com-

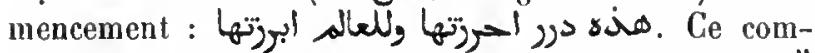
mentaire est accompagné de gloses intitulées "Les pierres fines", dont l'auteur est nommé AlSaïyid 'Abd al-Raḥmân ibn Moṣtafâ, et qui commencent

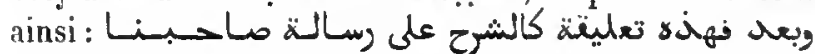

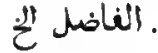

Papier. 113 feuillets. Hauteur, a centimètres; largeur, 15 centimètres et demi. 19 et 20 lignes par page. Ms. du xvu1 siècle. (Supplément 1273.)

\section{1.}

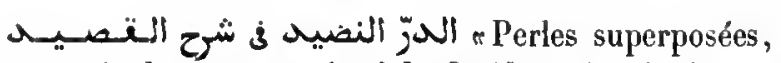
pour servir de commentaire à la Qasilda n, c'est-à-dire au traité en vers sur la métrique arabe du célèbre grammairien Aboû 'Amr ibn al-Ḥâdjib, par Moḷammad ibn Sâlim ibn Naṣr Allah ibn Sâlim ibn Wâșil, auteur de l'Histoire des Aïyoubides. Commencement : لله الغضل والاحسان ولمبود والاهتنان. En tête du volume on a ajouté, après coup, un takhmis et un éloge composé par Moḥammad al-Ḥalabì, généralement connu sous le nom d'Al-Raschîd.

Ms. daté de l'an 732 de l'hégire ( 1332 de J.-C.).

Papier. 86 feuillets. Hauteur, 26 centimètres; targeur, 17 centimètres. 21 lignes par page. - (Ancien fonds 1379.)

\section{2.}

$1^{\circ}$ Qașîda de Moḥammad ibn Aḥmad ibn 'Alì, généralement connu sous le nom d'lbn Djâbir al-Hawârî, sur la prosodie arabe. Les vers de ce poème riment tous en ע. Premier vers :

بحمد اله العرث ابـها اولا ليجصل ما لرجوه منه وبكيكا

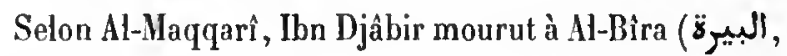
très probablement Birédjec sur l'Euphrate) en 780 de l'hégire ( $137^{8}$ de J.-C.).

$2^{\circ}$ (Fol. 34.) Qașî̀da du même auteur, sur la prosodie et la rime. Dans cette pièce, les rimes varient, mais les hémistiches de chaque vers riment ensemble. Commencement :

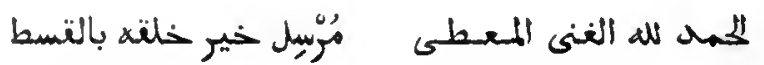

$3^{\circ}\left(\right.$ Fol. $39 v^{\circ}$.) Qașìda plus abrégée sur les mêmes sujets, par le même anteur. Premier vers :

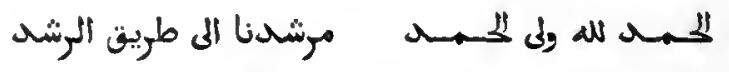

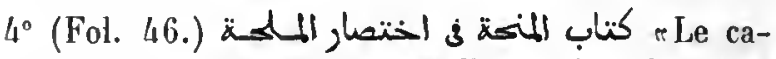
deau, renfermant un abrégé du Molhan. Poème du même auteur, donnant un abrégé du Mollhat al-I'râb, poème sur la grammaire, par A1-Ḥarìrì.

$5^{\circ}$ (Fol. 53.) Traité de gramnaaire, en vers, par le même auteur. Premier vers :

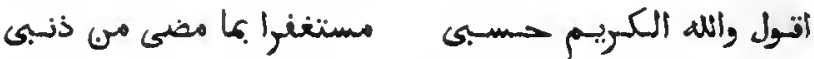

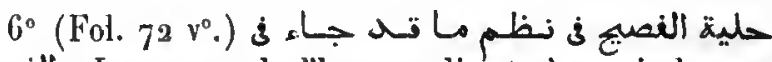
ئill rLa parure de lhomme disert, à savoir le contenu du Fasîn, mis en vers", par le même auteur. Le Faşîh, traité de philologie très connu, a pour auteur le célèbre grammairien Aboû 'I-'Abbâs Tha\%lab (ثعلب), mort en 291 de l'hégire (903-904 de J.-G.). Premier vers :

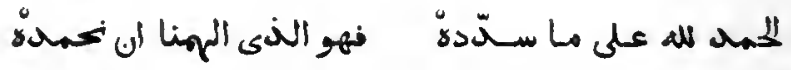

$7^{\circ}$ (Fol. $119 \mathrm{r}^{\circ}$.) Maqsoûra, poème dont tous les vers se terminent par un alif bref, par le même auteur. C'est un éloge de Mahomet. Le poème est divisé en morceaux de dix vers rimant ensemble; dans le premier morceau, la lettre pénultième est un alif; dans le second, un ba et ainsi de suite jusqu'à la fin de l'alphabet. Premier vers :

$$
\text { بادر قلبى للمهـوى ومـا آرنتهائى }
$$

$8^{\circ}\left(F_{01 .} 129 v^{\circ}\right.$.) Traité en vers sur la manière de distinguer entre l'alif bref et l'alif long, par le même auteur.

$9^{\circ}$ (Fol. $135 \mathrm{r}^{\circ}$.) Traité en vers, rimant en mìm, sur 
la inanière de distinguer entre le $b$ el le $\dot{0}$, par le mème auleur.

$10^{\circ}$ (Fol. $139 v^{\circ}$.) Traité en vers où sont énumérés, dans l'ordre de l'alphabel, les noms dont la lettre iniliale peut se prononcer avec l'une ou l'autre des trois voyelles (نشم), par le même auteur. Premier vers :

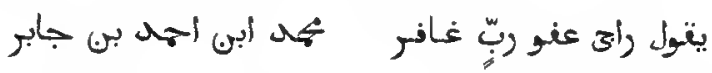

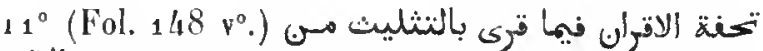
Cadeau pour mes contemporains, indiquant les mots du Coran dont une des lettres se lit avec deux royelles différentesn, par Schihâb at-Din Mhmad ibn Yoûsof ibn llálik al-Roªïnî, docteur malékite de

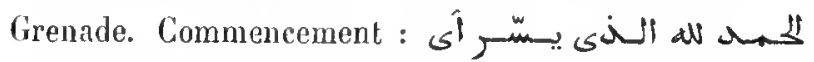

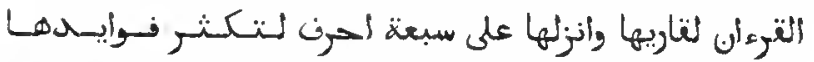
انيهانيه . Cet ouvrage a élé composé à Al-Bìra (Birédjec) sur l'Euplirale en 745 de l'hégire ( 344 de J.-C.).

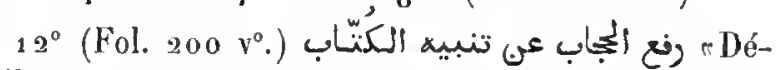
voilement d'un avertissement aux copistes», par le mème Al-Rocainî. L'auteur commente assez longuemenl, el vers par vers, le poème d'llbn Djảbir (voyez ci-dessus, $n^{\circ}$ 9) sur l'orthographe du b et du $\dot{\sigma}^{\circ}$. Commence-

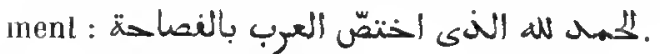

Ms. exécuté à Médine, en $77^{\circ}$ de l'hégire $(1369$ de J.-C.), par le neveu de l'auteur des deux dernières pièces.

Papier. 963 feuillets. Hauleur, a 7 centimètres el demi; largeur, 18 centimètres. 19 lignes par page. - (Ancien fonds 1369.)

\section{3.}

Introduction à l'art des vers; par Schams al-Din atNawàịi. L'auteur dit (fol. 6.) qu'il avail été étève de Kamâl al-Din al-Damîrî, l'auteur du Hayât al-Haîwân.

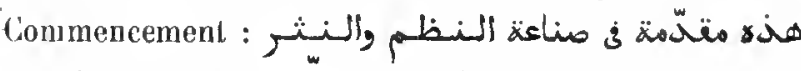

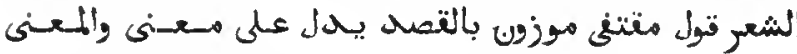
ل"

Papier. 10 feuillets. Hauteur, 21 centimètres et demi; largeur, 16 centinètres. 23 lignes par page. Ms. du xwrie siècle. - (Supplément 1356. )

\section{4.}

$1^{\circ}$ unensonge éloignés, en ce qui regarde l'art de composer dans les deux genres", par Tâdj al-Dîn 'Abd al-Wahháb
a]-Benoûni. L'auteur expose les règles qui doivent pré-

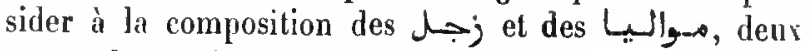
genres de poésies cultivés en Espagne.

$2^{\circ}$ (Fol. 32.) Pièces de vers, par le mème auteur.

Ms. dalé de l'an 1084 de l'hégire $(1673$ de J.-C.).

Papier. 40 feuillets. Hanteur, 20 centimètres et demi; largenr, 15 centimètres. a l lignes par page. - (Supplément 1 hig.)

\section{5.}

Commentaire sur la préface du traité de prosodie de

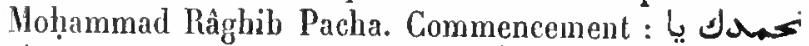

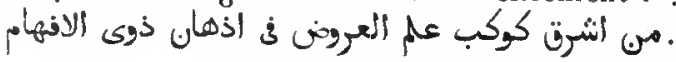

Papier. 1 is feuillets. Hauleur, 21 centimètres; largeur, 15 centimòtres el demi. ${ }_{7}$ lignes par page. Ms. du xviı siècle. - (Supplément 1969.$)$

\section{6.}

Opuscule éerit dans un slyle très recherché el qui commence par un éloge d'un traité de prosodie composé par un nommé Aboû 'l-Hasau. Puis vient l'éloge d'un vizir appelé Moṭammad Pacha, ef un commentaire très prolixe sur les premiers mots d'un traité, probablement le même. Plus loin un docteur schaféite nommé Solaïmân ibn Yạyyâ al-Zobaïdi parle de lui-même et de ses professeurs. Des notices biographiques de quelques-uns de ces professeurs terminent l'ouvrage. Au fol. $3 \mathrm{r}^{\circ}$, on lit que ce traité a été écrit (كتبد) l'an 1171 de l'hégire (1 757 de J.-C.), par un nommé 'Alî ibn abî 'Abd Allah al-Adkârî, au Caire. Commencement : لأ

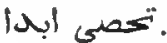

Papier. 1 s fenillets. Hauteur, s3 centimètres; largeur, 17 centimètres el demi. 19 lignes par page. Ms. du xvır siècle. - (Supplément 1268 .)

\section{III.}

\section{BIBLIOGRA PHIE.}

\section{7.}

Première partie du Cن Catalogue des livres», par Aboû '1-Faradj Moḥammad ibn Is!̣âq alWarrâq, connu sous le nom d'Ibn abî Yacqoûb al-Na- 
dìm. Le texle entier de l'ouvrage a été publié par Flügel.

Manuscrit collationné en 627 de l'hégire (1229-123o de J.-C.)

Papier. 237 fenillets. Hauteur, 20 centimètres; largeur, 13 centimètres et demi. 16 lignes par page. - (Ancien fonds 87 h.)

\section{8.}

Seconde partie du كتناب الغهرست d'lbn al-Nadim. Le lexte commence par le cinquième chapilre (ف) du cinquième discours (متالة).

Ms. copié en 1846 sur l'exemplaire de la Bibliothèque Kieuprulu, à Constantinople, par les soius de M. de Slane.

Papier. 246 feuillets. Hauteur, 24 centimètres; largeur, 16 centimètres. 17 lignes par page. - (Supplément 1400 bis.)

\section{9.}

(2) Qui dissipe les erreurs en ce qui concerne les titres des livres et la nature des diverses branches de la seiencen. Grand dictionnaire bibliographique, par Moștafâ ibn 'Abd Allah, surnommé Kiâtib Tchélébi, connu sous le nom de Hâddji Khalîfa ou Hadji Khalfa, mort en 1658 de J.-C.

Ms. daté de l'an 1091 de l'hégire ( 1680 de J.-C.).

Papier. 448 feuillets. Hauteur, 29 centimètres; largeur, 16 centimètres. 41 lignes par page. - (Ancien fonds 733. )

\section{0.}

Même ouvrage.

Ms. daté de l'an 1091 de l'hégire ( 1680 de J.-C.).

Papier. 618 feuillets. Hauteur, 23 centimètres et demi; largeur, 15 centimètres. 35 lignes par page. - (Ancien fonds 875 .)

\section{1.}

Même ouvrage. C'est le texte revu par Ibrâhîm ibn 'Alî Arabadjibachi (chef des troupes du train), mort vers l'an 1773 de J.-C.

Ms. daté de l'an 1200 de l'hégire (1805 de J.-C.).

Papier. $4{ }_{7} 5$ feuillets. Hauteur, 34 centimètres; largeur, 20 centimètres. $3 g$ lignes par page. - (Supplément 1395 .)

\section{2 à 4464.}

Même ouvrage, accompagné d'une traduction française, par Petis de la Croix. Le premier volume se termine par la lettre $\dot{\sim}$. Le second volume contient le reste du dictionnaire, et le troisième, la table des matières dressée par le traducteur. Le tout de la main de Petis de la Croix.

Ms. daté des années 1702-1703 de J.-C.

3 vol. Papier. 1213 et 1051 pages et 465 feuillets. Hauteur, 37 centimètres; largeur, 24 centimètres. - (Supplément 2385 à 2387.)

\section{5.}

Extraits du même ouvrage. Copie faite à mi-marge, probablement à Paris, vers la fin du $x{ }^{e}{ }^{e}$ siècle. En regard d'un petit nombre d'articles se trouve une traduction latine de la main de Renaudot.

Papier. 399 feuillets. Hauteur, 39 centimètres; largeur, 26 centimètres. 25 lignes par page. - (Supplément 1394.)

\section{6.}

Abrégé du dictionnaire bibliographique de Hadji Khalfa. M. de Sacy a inséré une notice de ce manuscrit dans le tome VIII, p. 200 et suiv., des Notices et extraits.

Papier. 404 feuillets. Hauteur, 34 centimètres; Jargeur, 10 centimèlres et demi. 35 lignes par page. Ms. du svü siècle. - (Supplément 1397 bis.)

\section{7.}

Autre abrégé du dictionnaire bibliographique de $\mathrm{Ha}$ -

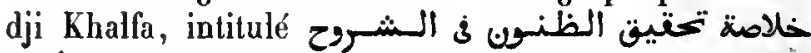
(1) .

Papier. 295 feuiltets. Hauteur, 23 centimètres; largeur, 15 centimètres. 17 lignes par page. Ms. du xv111 $1^{\circ}$ siècle. - (Supplément 1398.)

\section{8.}

Même ouvrage.

Papier. 279 feuillets. Hauteur, 22 centimètres; largeur, 16 centimètres et demi. 23 lignes par page. Ms. du xıx siècle. - (Supplément 1397 .) 


\section{9.}

Liste de livres dont la plupart traitent de matières de théologie musulmane. La seconde moilié du volume contient un grand nombre de légendes se rapportant aux patriarches et aux prophètes, jusqu'à Jésus-Christ, dont il est fait mention dans le Coran.

Papier. 45 feuillets. Hauteur, 48 centimètres; largeur, 17 centimètres et demi. Environ 57 lignes par page. Ms. du xvil' siècle. (Supplément 1399.)

\section{0.}

 seurs à la troupe de nos prédécesseurs n, par Moḥammad ibn Solaïmân الكاد, mort à Damas l'an 1094 de l'hégire (1683 de J.-C.). L'auteur indique les fitières par lesquelles les textes des ourrages sur les traditions et sur la loi musulmane sont arrivés aux savants de son temps. C'est un calalogue alphabétique de livres avec l'indication des noms des savants qui se sont transmis successivement le texte de chaque ouvrage. Dans le titre, l'auteur joue sur les termes grammaticaux sila et mansoûl. L'ouvrage n'a pas de préface. Quatre feuillets, placés en tête du volume, contiennent des certificats d'étude.

Ms. daté de l'an 1142 de l'hégire ( 1729 de J.-C.).

Papier. ${ }^{2} 5_{1}$ feuillets. Hauteur, a centimètres et demi; largenr, 16 centimètres et demi. 25 et ensuite 23 lignes par page. - (Supplément 1404.)

\section{1.}

$1^{\circ}$ Liste des ourrages d'Al-Râfi'i (الjانع), docteur schaféite, et de l'imâm Al-Nawawî.

$2^{\circ}\left(\right.$ Fol. $^{1} \mathrm{v}^{\circ}$.) Liste chronologique des principaux ouvrages sur le droit schaféite et des docteurs schaféites les plus distingués.

Papier. 10 feuillets. Hauteur, 23 centimètres; largeur, 17 centimètres. 26 et 27 lignes par page. Ms. du xviı" siècle. - (Supplément 2160 .)

\section{2.}

Catalogue raisonné des ourrages de Djalâl al-Dìn 'Abd al-Rahmoàn al-Soyoûtị̂. Cette liste est de l'auteur luimème.

$$
\text { Mas. orientalu. - II. }
$$

Ms. daté de l'an 1129 de l'hégire ( $17^{1} 7$ de J.-C.).

Papier. 10 feuillets. Hauteur, 23 centimètres; largeur 16 centimètres ct demi. 23 lignes par page. - (Supplément 1401.)

\section{3.}

Liste des ouvrages dont le schaïkh Ahmad ibn Mosțafầ al-Màlikî al-Azlıarì al-Ṣabbâgh avait fait une étude spéciale; noms des maîtres sous lesquels il avait étudié ces ourrages.

Ms. dalé de l'an 1178 de l'hégire (i 764 de J.-C.).

Papier. 9 feuillets. Ilauteur, 29 centimètres et demi; largeur, 16 conlimètres. a 7 lignes par page. - (Supplément 1403.)

\section{4.}

Catalogue des manuscrits conservés dans les bibliothèques de Constantinople, à savoir les bibliothèques d"Âttif (عاطن), de Râghib-Pacha (اغب ياشا), de Kieupréli, de Nouri-Osmaniyé, d'Ibràhîm Pacha, d'Aïya

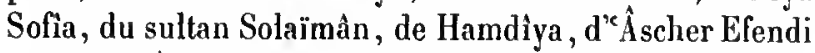
(عانثر افندىى), de Yéni-Djâmé, du sultan Bayézid, de La'lélî (لdale), du sultan Moṣtafâ. Ces catalogues ont été copiés sur les catalogues originaux de ces bibliothèques, en 1846, par les soins et sous la direction de II. de Slane. Il existe à Constantinople encore d'autres bibliothèques, dont celle d'Aḥmad III, placée au VieuxSérail, à Top-Capou, est la plus remarquable.

Papier. 380 feuillets. Hauteur, 26 centimètres; largeur, 18 centimètres. 19 lignes par page. - (Supplément 1405 bis.)

\section{5 .}

Liste d'ouvrages historiques qui se trouvent dans quelques-unes des bibliothèques de Constantinople.

Papier. a feuillets. Hauteur, 40 centimètres; largeur, 16 centimètres. - (Supplément 1405.)

\section{.4476.}

Catalogue de plusieurs collections de livres qui se trouvaient dans P'endroit (du Caire?) appelé Portique d'AlSâdat al-Schauxam (روات السادات الشوام)). Cetle liste contient plus de deux mille titres non classés. 
Papier. 9o feuiltets. Ilauteur, 32 centimètres et demi; largenr, 16 centimètres. 13 lignes par page. Ms. du xvme siècle. - (Supplément 1400.)

\section{7.}

Catalogue des livres qui se trourent dans deux cham-

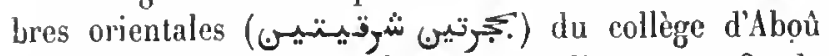
'Omar (au Caire?). Cette liste a été rédigée en 1032 de l'bégire ( 1622 de J.-C.), par les soins du bibliothécaire de l'établissement.

Papier. 23 feuillets. Hautcur, 23 centimètres; largeur, 15 centimètres. ${ }_{7} 7$ tignes par page. - (Supplément 1402.)

\section{8.}

Catalogue des manuscrits dont se compose la bibliothèque de la grande mosquée Al-Zaïtoûna (لأزيتون à Tunis, précédé d'une liste des manuscrits appartenant à er Sid Hassouna Bel Hadj, à Tunis». A ces documents est jointe une notice rédigée par $A$. Rousseau et $H_{\text {. Co- }}$ telle, interprètes du consulat général de France à Tunis.

Ce ms. a été probablement écrit en 1848 ou 1849 .

Papier. 47 fenillets. Hautcur, 3 s centimètres; Jargeur, a 1 centimètres. - (Supplément 1399 bis.)

\section{9.}

Même ouvrage. Copie faite à Alger, en 1874 , sur l'exemplaire de M. Rousseau, pas $M^{\text {Hle }}$ Lucie de Fauconnet de Fontanier.

Papier. 3 a feuilhets. Hauteur, 29 centimètres et demi; largeur, 18 centimètres el demi. 30 à 32 lignes par page. - (Supplément ${ }_{3} 39^{2}$.)

\section{0.}

Catalogue de la bibliothèque Al-Ṣâdiqiya de la mosquée Zaïtoûna, à Tunis. Exemplaire imprimé (en 1292 de l'légire) avec des additions manuscrites.

Papier. 63 feuiltets. Hauteur, 45 centimètres; largeur, 15 centimètres. - (Supplément 2504.)

\section{1 .}

Inventaire des manuscrits de la bibliothèque d'Asselin de Cherville, en arabe et en français.

Papier. 111 fcuillets. Hanteur, 30 centimètres et demi; largeur, 21 centimètres. It y a cn général 7 articles par page. Ms. du xir siècle. - (Supplément 2161.)

\section{2.}

Liste de fragments de manuscrits qui se trouvaient dans le fonds Asselin, par M. de Slane.

Papier. 6 feuittets. Hauteur, 15 centimètres; largeur, 18 centimètres et demi. Ms. du xix* siècle, - (Supplément 2281.)

\section{3.}

:Cathalogus librorun qui arabice manuscripti in Bibliotheca Hlustrissimi Domini D. Petri Seguier supremi Regis Regnique Gallix cancellarii asservantur.s Ce catalogue a été rédigé en 1657 par le moine capucin Elzéar de Sanxay. A la fin, à titre d'appendice, se trouve une liste des manuscrits turcs, persans et coptes.

Papier. 109 feuitlets. Hauteur, 31 centimètres; largeur, 21 cenlimètres. - (Fonds des catalogues $66 \mathrm{~A}$.)

\section{4.}

Catalogue des manuscrits arabes de la Bibliothèque du Roi, rédigé en 1677 , par Pierre Dipy (Diyâb) d'Alep. Les manuscrits sont cotés 368 à 1228 .

Papier. 301 feuillets. Hauteur, 37 centimètres; largeur, 25 centimèlres. - (Fonds des catalogues 26 , fonds des traductions 121.)

\section{5.}

* Catalogus manuscriptorum arabicorum. $\$$ Les notices de ce catalogue des manuscrits arabes de la Bibliothèque du Roi commencent par le $\mathrm{n}^{\circ} 368$. Ia copie, inconplète à la fin, paraît avoir été exécutée sur un original dont plusieur's fenillets étaient transposés. Elle est suivie d'un abrégé dı même calalogue rédigé en français, dont 
le dernier numéro est 1228 , et d'une liste des manuscrits persans de la Bibliothèque du Roi cotés 1479 à 1609 .

Ms. daté de l'an 1718. Il a été sans doute exécuté pour l'abbé Renaudot.

Papier. 14 a feuillets, colés 1 à 56 et 1 à 86 . Hauteur, 38 centimètres; Jargeur, 25 centimèlres. - (Fonds des calalogues 26 bis, fonds des traductions 122.)

\section{6 à 4491.}

Catalogue des manuscrits 1 à 1952 du supplément arabe de la Bibliothèque nationale. Les notices des manuscrits qui provenaient de la collection d'Asselin de Cherville ont toutes été rédigées par M. de Slane, les autres par M. Reinaud qui a revu l'ensemble du travail. Un certain nombre de bulletins manquent.

6 vol. Papier. Les feuillets sont cotés de 1 à 1952 . Hauteur, 25 centimètres; largeur, 18 centinnètres. - (Fonds des calalogues $337-343$.

\section{2 et 4493.}

Copie du catalogue contenu sous les $\mathrm{n}^{\circ \mathrm{s}} 4486$ à 4491 , de la main de M. Ch. Defrémery. Eu tête, on lit ce titre de la main de M. Reinaud : «Supplément du Catalogue des manuscrits arabes de la Bibliothèque royale, par M. Reinaud. Paris, 1846.

2 vol. Papier. 739 pages. Hauteur, 38 centimètres; largeur, ${ }_{24} 4$ centimètres. - (Fonds des calalogues 62.)

\section{4 à 4501.}

Calalogue des manuscrits arabes de la Bibliothèque nationale, par M. Amari. Ce catalogue comprend les $n^{\circ 5} 1$ à 881 de l'ancien fonds et les $n^{\text {os }} 1$ à 534,885 à $9^{5} 4$ et quelques manuscrits isolés du supplément.

8 vol. Papier. ${ }_{2} 56,208,190,335,122,132,{ }_{2} 54$ et 327 feuillets. Hauteur, 24 centimètres; largeur, 19 centimètres. - (Supplément 2361 à 3368 .)

\section{2 à 4504.}

Catalogue des manuserits arabes 883 à $\mathbf{1 6 2 6}$ de l'ancien fonds et, à partir du $n^{\circ} 535$, d'une partie des manuscrits du supplément, par M. H. Derenbourg.
3 vol. Papier. 356,374 et 383 fenillets. Hauteur, 24 centimètres; largeur, 19 centimètres. - (Fonds des catalogues 477.)

\section{5 .}

Catalogue des manuscrits $19^{5} 9$ bis à $22^{2} 8$ du supplément arabe de la Bibliothèque nationale, par M. H. Derenbourg.

Papier. 86 feuillets. Hauteur, 24 centimètres; largeur, 19 centimètres. - (Fonds des catalogues $34_{2}$ bis.)

\section{6 à 4518.}

Catalogue des manuserits arabes de la Bibliothèque nationale, par M. de Slane. Ce sont les bulletins du présent catalogue.

13 vol. Papier. $332,466,528,474,303,358,266,295$, ${ }_{2} 60,{ }_{2} 54,273,400$ et 178 feuillets. Hauleur, 25 centimètres; largeur, 20 centimètres. - (Fonds des calalogues 478.)

\section{XXXIV.}

\section{OUVRAGES DIVERS ET SUPPLÉMENT.}

\section{9.}

Cahier renfermant une nouvelle rédaction des huit premiers psaumes de David. Ce travail, fait par un faussaire musulman, consiste en quelques versets de chaque psaume avec des interpolations en style coranique. Partout Dieu est censé s'adresser à David, dont le nom parait très souvent. Chacun de ces prétendus psaumes est intitulé rsouraten $\left(\ddot{B}_{2}\right)$ et porte en tête le bismillah.

Papier. 7 feuillets. Hauteur, 21 centimètres; largeur, 14 centimètres. 13 lignes par page. Ms. du xvu" siècle. - (Supplément 1966 bis.)

\section{0.}

Les psaumes. Le ms. est incomplet. II ne reste que les psaumes 1 à 47 .

Papier. 34 feuillets. Hauteur, 20 centimètres; largeur, 14 centimètres. 14 lignes par page. Ifs. du xix siècle. - (Supplément 2427.) 


\section{1.}

Exposition des croyances des Samaritains et défense de leurs doctrines. Le premier chapitre traite du prophétisme et le second des animaux dont il est permis de se servir. Les textes de la Bible sont écrits en caractères samaritains. Commencement : المتنغ (ر) L'auteur se nommait Aboû 'l-Hasan al-Ṣoûrî (الحمود).

Ms. daté de l'an 1103 de l'hégire (1692 de J.-C.).

Papier. 1 oh feuillets. Hauteur, 33 centimètres; largeur, 32 centimètres. 19 \& 21 lignes par page. - (Supplément 1966.)

\section{2.}

Les chapitres 1 à xı de l'Évangile de saint Mathieu. La copie n’a pas été achevée.

Ms. daté de l'an 1794 .

Papier 16 feuillets. Hauteur, 21 centimètres; largeur, 16 centimètres. 18 tignes par page. - (Supplément 3445.)

\section{3.}

$1^{\circ}{ }_{0}^{\circ}$ soucis \%. Traité de morale composé par Nar Élie, métropolitain nestorien de Nisibe. L'ouvrage se compose de douze chapitres : $1^{\circ}$ Sur la piété; $2^{\circ}$ Sur la reconnaissance; $3^{\circ}$ Sur la continence; $4^{\circ}$ Sur l'humilité; $5^{\circ}$ Sur la miséricorde; $6^{\circ}$ Sur le repentir; $7^{\circ}$ Sur la conduite qui est conforme à la raison; $8^{\circ}$ Sur l'utilité de prendre l'avis d'autrui; $9^{\circ}$ Sur la bonté du caractère; $10^{\circ}$ Sur la libéralité; $11^{\circ}$ Sur l'équité; $12^{\circ}$ Sur la clémence. L'auteur, en parlant de chaque vertu, traite du vice qui en est l'opposé.

$2^{\circ}$ (Fol. $153 \mathrm{v}^{\circ}$.) Traité attribué à Platon et dans lequel ce philosophe recommande la mortification des sens comme le moyen de chasser les soucis.

Ms. daté de l'an 1357 de l'ère des martyrs (16411642 de J.-C.).

Papier. 159 feuiltets. Hauteur, 20 centimètres et demi; largeur, 15 centimètres. 11 lignes par page. - (Ancien fonds 951.)

\section{4.}

Première partie de la chronique d'Al-Makin. Copie très fautive.
Ms. daté de l'an 1083 de l'hégire $\left(167^{2}\right.$ de J.-C. $)$.

Papier. 238 feuillets. Hauteur, 30 centimètres; largeur, 20 centimètres. 21 lignes par page. - (Ancien fonds 618. )

\section{5 .}

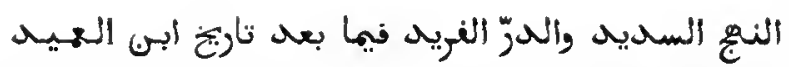

"Le sentier droit et la Perle unique, faisant suite à l'histoire d'lbn al-Amid $\pi$. Ouvrage composé par Nofaddhal ibn abî '1-Fadhâîl, chrétien d'Égypte, et renfermant l'histoire très détaillée des sultans mamlouks, depuis l'arènement d'Al-Malik al-Ẓâhir Baïbars, l'an 658 de l'hégire ( 1260 de J.-C.), jusqu'à la mort d'Al-Malik alNàsir, fils de Qalâwoûn, l'an 741 de l'héggire (1341 de J.-C.). On y trouve de plus la mention de quelques événements qui eurent lieı depuis cette dernière époque jusqu'à l'an 749 de l'hégire. L'auteur, dans son récit, ne se borne pas à l'histoire politique de l'Égypte et de la Syrie; il parle des califes abbasides de ta seconde race, el mentionne des faits relatifs aux patriarches jacobites de l'Égypte, aux musulmans de l'Inde et du Yemen et aux Tartares. Il y a inséré aussi quelques pièces diplomatiques. Cet exemplaire, qui est très bien écrit et de la main mềne de l'auteur (d'après une note du premier feuillet), formail primitivement deux volumes; plus tard, après la disparition d'un assez grand nombre de feuillets, dont quelques-ıns se trouvaient en tête du second volume, on les a reliés ensemble.

Papier. 270 feuillets. Hauteur, 25 centimètres et demi; largeur, 17 centimètres et demi. 18 lignes par page. - (Ancien fonds 619 , Colbert 4475.$)$

\section{6.}

Fragment d'une mauvaise copie de l'Histoire des dynasties d'Aboû '1-Faradj.

Papier. 39 feuillets. Hautenr, 25 centimètres; largeur, 18 centimètres et demi. 20 lignes par page. Ms. du xvic siècle. - (Supplément 2060 .)

\section{7.}

Les sourates 22 à 25 du Coran. On lit, à la fin, cette note: "Livre de prières habituel d'Achmet-bey de Constantine, détrôné en 1837. Trouvé sur sa lable. Extraits du Goran. $"$ Puis en dessous : «Donné à Raffet 
en 1840 par M. G. de Bussy en remerciement d'un dessin du combat d'Oued-Alleg. A. Raffet."

Papier. 40 fenillets. Hauteur, 28 centimètres; largeur, 20 centimètres. 9 liggnes par page. Ms. du xvü siècle. - (Supplément a 467.)

\section{8.}

$1^{\circ}$ Les sourates 36 à 91 du Coran.

$2^{\circ}$ (Fol. go.) Poène sur les perfections de Dieu, par Hoḥammad al-Sâlih.

$3^{\circ}$ (Fol. $9^{6 .}$ ) L'Adjorroûmìna.

Ms. dalé de l'an 1092 de l'hégire (168^ de J.-C.).

Papier. 101 feuillets. Hauteur, 21 centinètres; largeur, 15 centimètres. 15 à 17 lignes par page. - (Supplément 1933.)

\section{9 .}

Copie des textes du Coran inscrits sur les parois du mausolée appelé Tadj Mahall et érigé à Agra par SchâhDjahàn sur le tombeau de sa femme. Le texte est écrit sur le recto de chaque feuillel. Un essai de traduction anglaise se trouve au verso des premiers feuillets. Ces textes sont suivis de la liste des noms de Dieu et de cinq pièces en persan relatives au monument et à Schàh Djahân.

Ms. daté de l'an 1220 de l'hégire (1805-1806 de J.-C.).

Papier. 72 fenillets. Hauteur, ${ }_{2} 5$ centimètres et demi; largeur, 19 centimètres. 6 lignes par page. - (Supplément 2181.)

\section{0.}

"Trésor des pensées, commentaire sur l'Amulette à souhaits». Commentaire anonyme sur le Hirz al-Amani, poème d'Ibn Ferro alSchâlibi sur les leçons coraniques. (Voyez Notices et extraits, t. VIII, p. 334.) Commencement :

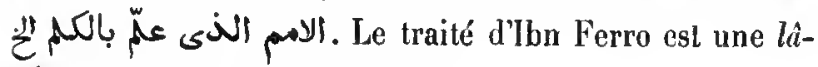
miga el commence par ce vers:

$$
\text { بدات ببسم الله في النظم أولا }
$$

En tête du volume se trouve une qasida intitulée من من qui délivre des soucis n, pièce d'une verlu merveilleuse composée par Yoûsof ibn Hohammad alTauzarì (التنوزى), surnommé Ibn al-Nalıwi :le fils du grammairien". Suit un autre poème du même genre el atıribué à Hoddjat al-Islâm Mohammad ibn Mohannmad ibn Mohammad al-Ghazâlì. Une lroisième pièce, sans nom d'auteur, est une wasîla.

Papier. 100 feuillets. Hauteur, 28 centimètres; largeur, 18 centimètres. á lignes par page, à l'exception dn second cahier qui en porte 29. Ms. du xvie siècle. - (Ancien fonds 1407.)

\section{1.}

Les perles magnifiques, commentaire sur le Djazaríya». L’auteur, Moḥammad al-Nàdsifi al-Halabi, généralement connu sous le nom d'Jbn al-Hanbalî (voyez Hadji-Khalfa, t. VJ, p. 79), acheva son travail l'an 941 de l'hégire (1534-1535 de J.-C.).

Ms. daté de l'an 973 de l'hégire (1565-1566 de J.-C.).

Papier. 100 feuillets. Hauteur, 21 centimètres; largenr, 15 centimẹ̀tres. 19 lignes par page. - (Ancien fonds 1419.$)$

\section{2.}

Divers traités sur la lecture du Coran :

1, par Mohaumad ibn Ahmad ibn abî 'l-Qâsim al-Djozoûli.

$2^{\circ}$ (Fol. $7 \mathrm{v}^{\circ}$.) Autre trailé sur le mème sujet, par le schaïkh Aboû 'Amr 'Othmân ibn Sacîd (al-Dànî) alMaqqarî.

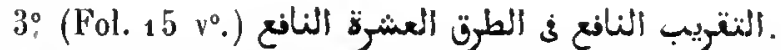
Qaṣida lâmîya, par Mloḥammad ibn Aḥmad ibn Djamà a

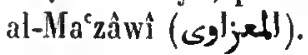

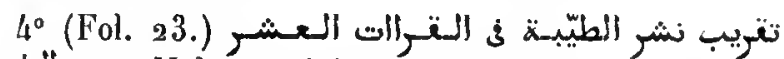

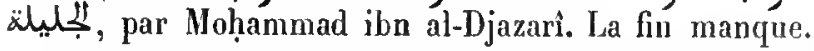

50 (Fol. 43 vº) La Schațibiya (الامان) d'Ibn Ferro.

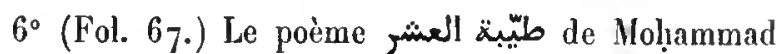
ibn al-Djazarî sur la lecture du Coran.

Ms. daté de l'an 1149 de l'hégire ( ${ }_{7} 37$ de J.-C.).

Papier. 85 feuillets. Hauteur, $\mathbf{2} 3$ centimètres; largeur, 17 centimètres. 20 à 30 lignes par page. - (Supplément 2489.) 


\section{3.}

1 C Cruide de ceux qui étudient les règles concernant la leltre noûn et le tanwînn. Traité sur la prononciation du texte du Coran, par Nạșir al-Dìn Moḥammad al-Ṭablàwî. Cet ouvrage est accompagné d'un commentaire perpétuel dont l'auteur s'appelait Schams al-Dîn Mohammad

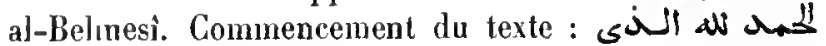
جr. Commencement du commen-

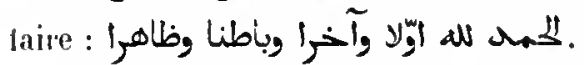

$2^{\circ}$ ( Fol. 62.) Autre traité sur le même sujet. Com-

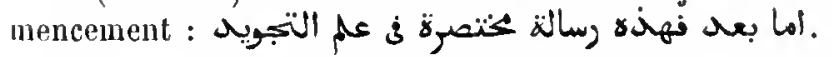

Papier. 68 feuillets (dont quelques-uns sont restés en bianc). Hạtour, 21 centimètres; largeur, 15 centimètres et demi. Dans le premier ouvrage, 21 lignes par page; dans le second, 14 à 19 lignes. Écritures différentes du xvi1 et du xvm1 ${ }^{\circ}$ siècle. - (Supplément 1255.)

\section{4.}

$1^{\circ}$ Poème sur les règles à observer dans la prononciation de certaines lettres du texte du Coran. Le commencemeut manque. La pièce se termine par ce vers :

$$
\text { مستنثغعا بسيد الانام عليه هنى أذضل السلام }
$$

$2^{\circ}$ (Fol. $3 v^{\circ}$.) Autre poème sur le même sujet, par Aboû '1-'Abbàs Ahmad al-Tâzerî. Premier vers :

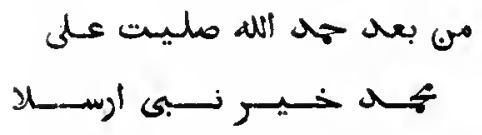

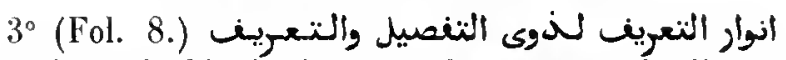
"Lumières de l'indication pour les hommes de discernement et d'enseignement ". Traité en prose, sur le même sujet, par Nohammad ibn Aḥmad ibn Ghâzî al-Djozoûlì.

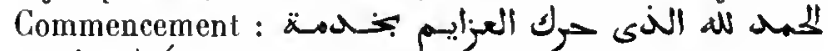
كe derrier feuillet manque.

Papier. 10 feuillets. Hauteur, 21 cenlimètres et demi; largeur, s/4 centimètres. 25 lignes par page. Ms. du xvir siècle. - (Supplément 2118.)

\section{5 .}

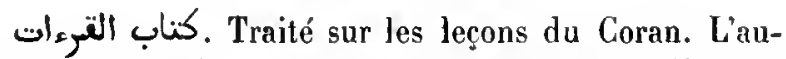
teur donne d'abord les leçons (حروف) particulières à chaque lecteur, puis celles an sujet desquelles deux ou plusieurs lecteurs sont d'accord. Commencement du premier article, celui d'Ihn Kathir : باب الواحه ابسى خثير وحله باربعة وتسعيى حرفا عليهم بكسر الهاء والثـبساع ضـم

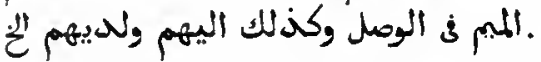

Ms. daté de l'an $77^{3}$ de l'hégire (1371-1372 de J.-C.).

Papier. Hauteur, 14 centimètres; largeur, 9 centimètres et demi. 15 lignes par page. - (Ancien fonds 1365 .)

\section{6.}

Traité de la prononciation du Coran (تجبوبد). Résumé des notions les plus imporlantes.

Papier. 5 fenillets. Hauteur, 21 centimètres et demi; largeur, 15 centimètres. 7 lignes par page. Mts. du xvı! siècle. - (Supplément 1253.)

\section{7.}

Recueil de dissertations sur certains passages du Colan, sur certaines traditions et sur quelques points de morale. Chacune de ces pièces commence par une préface qui remplit ordinairement deux ou trois pages. Fn

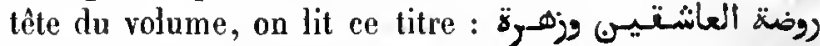
ألطالبيب., ouvrage attribué au schaïkh Aḷmad al-Hanafi

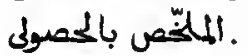

Papier. 150 feuillets. Hauteur, 21 centimètres; largeur, 15 centimètres. 17 lignes par page. Ms. du xvin' siècle. - (Supplément 1354. )

\section{8.}

La Mowatta. (Voyez ci-dessus $\mathrm{n}^{\circ s} 6_{7} 5$ et suiv.)

Ms. daté de l'an 596 de l'hégire (1200 de J.-C.).

Vélin. 110 feuillets. Hauteur, 23 centimètres; largeur, 18 centimètres. 23 lignes par page. - (Supplément a 485.)

\section{9.}

Fragment d'un Arbain.

Papier. 4 feuillets. Hauteur, 20 centimètres et demi; largeur, 15 centimètres et demi. 23 lignes par page. Ms. du xrm1 siècle. (Supplément i 963 bis.) 


\section{0.}

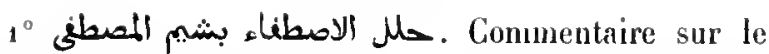
شئم المصنى (Voyez ci-dessus $n^{\circ} 7^{16 .}$.)

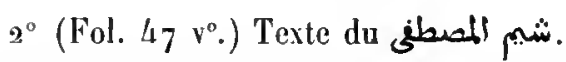

Papier. 62 feuillets. Hauteur, 21 centimètres; largeur, 16 centimètres. ${ }_{7}$ lignes par page. Ms. du xvir siècle. - (Supplément 2012.)

\section{1.}

"Les Principes 》. Traité de théologie et de droit canonique, par 'Alì ibn Moḥammad al-Pazdawì.

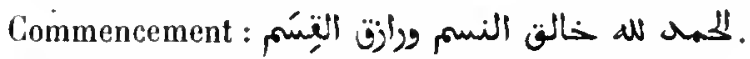

Nombreuses notes marginales et interlinéaires.

Ms. daté de l'an 788 de l'hégire ( $137_{7} 6$ de J.-C..).

papier. 216 feuillets. Hauteur, 26 centimètres et demi; largeur, 18 centimètres. 13 à 17 lignes par page. - (Supplément 2166.)

\section{2.}

$1^{\circ}$ r Plaisir pour l'écolier' *. Texte versifié du الانورأ traité élémentaire de jurisprudence d'Abou '1-Barakât 'Abd Allah Hàfiz al-Dìn al-Nasafí. Premier, quatrième et lıuitième vers:

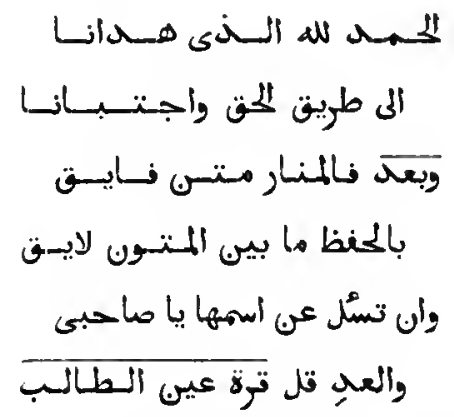

$2^{\circ}$ (Fol. $32 \mathrm{v}^{\circ}$.) Poème dans lequel tous les adjectifs sont tirés de la terminologie de la science des traditions. L'auteur les a employés en dissimulant leur véritable sens (على سبيل المتوربة).

$3^{\circ}$ (Fol. $33 v^{\circ}$.) Poème qui renferme la solution des questions singulières (مسابيل غوأيب) qui se présentent daus les traités de jurisprudence hanéfite. L'auteur suit l'ordre de clapitres généralement reçu dans ces traités.
$4^{\circ}\left(F_{0} 1.65 v^{\circ}.\right)$ Poème sur le partage des successions.

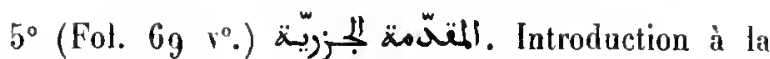
la lecture du Coran, par Moḥammad ibn Moḥammad al-Djazarî.

$6^{\circ}\left(\right.$ Fol. $73 \mathrm{v}^{\circ}$.) Éléments de jurisprudence hanéfite. en vers. Conmencement :

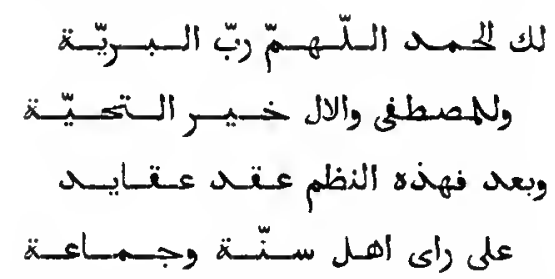

$7^{\circ}$ (Fol. $7^{6} v^{\circ}$.) Traité de prosodic, eu vers. Commencement :

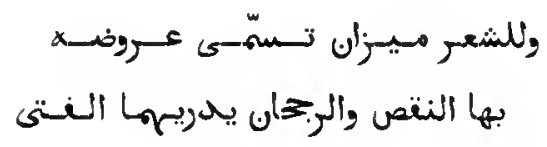

$8^{\circ}\left(\right.$ Fol. $80 v^{\circ}$.) Traité de logique, en vers. Commencement :

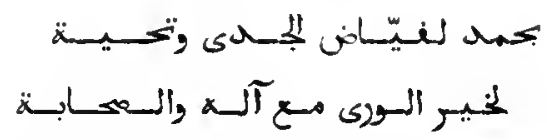

$9^{\circ}$ (Fol. $85 \mathrm{v}^{\circ}$.) Traité de rhétorique, en vers. Commencement :

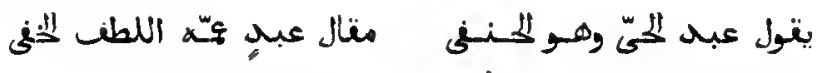

$10^{\circ}$ (Fol. $103 \mathrm{v}^{\circ}$.) Traité de grammaire, en vers. Commencement :

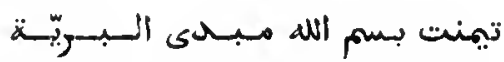

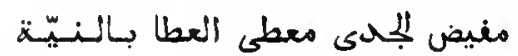

Cet ouvrage a été composé en l'an 900 de l'hégire (1494-1495 de J. -C.).

$11^{\circ}$ (Fol. $133 \mathrm{v}^{\circ}$.) Traité des flexions grammaticales (s) (s) en vers. Commencement :

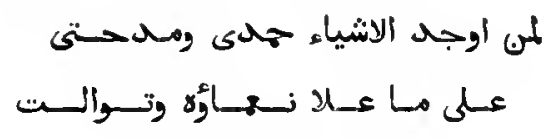

İ la fin se trouvent quelques prières.

Ms. daté de l'an 1078 de l'hégire ( 1667 -1 668 de J.-C.).

Papier. 148 feuillets. Hauteur, so centimètres el demi; largeur, 11 centimètres, 17 lignes par page. - (Ancien fonds $1 / 135, \mathrm{C}_{0} \mathrm{l}-$ bert 5221 .) 


\section{3.}

Rédaction en vers du commentaire d'Aboû Mohammad Mahmoûd ibn Aḷmad al-'Aïnî sur le Madjmac alBahrain, traité de droit hanéfite d'Ibn al-Sacâtî. Commencement :

$$
\begin{aligned}
& \text { بحات ببسم أله نظمى تنفوّدلا }
\end{aligned}
$$

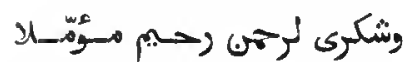

Le titre الإبكار في الملذأهب الهبعة rLes océans, traité sur les quatre écoles de jurisprudencer, inscrit dans un médaillon qui occupe le centre de la première page, est apocryphe.

Ms. daté de l'an 864 de l'hégire (1459-146o de J.-C.).

Papier. ${ }_{175}$ feuillels. Hanteur, 27 centimètres et demi; largeur, 16 centimètres et demi. 13 lignes par page. - (Ancien fonds 1390 .)

\section{4.}

$1^{\circ}$ Même ouvrage.

$2^{\circ}$ (Fol. 19.) Traité de jurisprudence, en vers. ILe conmencement et la fin manquent. Ce sont des fetwas du schä̈kh Aboû Ḥanîfa et de son disciple Moḥammad ibn al-Hịasan al-Schaïbânî. Le tilre de cliaque cas commence par le mot كتاب النكاح ,كتـاب اللبيـيوع) كتاب, كتاب الذبـايح, etc.).

Nombreuses notes marginales.

$3^{\circ}$ (Fol. 61.) Fragment d'un traité de jurisprudence. Les sous-titres commencent en général par les mots is فصل.

$4^{\circ}$ (Fol. 69.) Fragment d'un traité de jurisprudence, chapitre des purifications.

$5^{\circ}$ (Fol. 70.) Quelques traditions de Mahomet.

$6^{\circ}$ (Fol. 75.) Quelques traditions en turc.

$7^{\circ}$ (Fol. 80.) Fragment d'un chapitre sur les successions.

$8^{\circ}$ (Fol. 81.) Fragment d'un chapitre sur le droit de préemption.

$9^{\circ}$ (Fol. 84.) Fragment d'un traité de droit, chapitre du payement fait d'avance et de l'interdiction, etc.

$10^{\circ}$ (Fol. 92.) Fragment d'un traité de droit, chapitres des dommages commis par des esclaves ou par des animaux.

$11^{\circ}$ (Fol. 94.) Fragment d'un traité de droit, chapitres de l'affranchissement, du tation, etc. $12^{\circ}$ (Fol. 199.) Fragıneuts de divers traités de droit.

Papier. 977 feuillets. Hauteur, a a centimètres; targeur, 15 centimètres el demi. Diverses écrilures du $\mathrm{xv}^{\circ}$ siècłe. - (Ancien fonds 1437.)

\section{5.}

$1^{\circ}$ Album renfermant une grande quantité de notes et d'extraits, dont le plus considérable (fol. $18 v^{\circ}$ ) est un chapitre pris dans un traité de jurisprudence et consacré à l'état d'impureté légale dans lequel les femmes se trouvent à la suite de leurs infirmités périodiques et des accouchements.

$2^{\circ}$ (Fol. 40.) Le Minhâdj al-Ṭalibìn, traité de droit schaféite, par Mohyyî al-Dîn ibn Scharîf al-Nawawî.

$3^{\circ}$ (Fol. $279 v^{\circ}$.) Liste des animaux purs et impurs, selon la doctrine schaféite.

$4^{\circ}\left(\right.$ Fol. $281 v^{\circ}$.) Explication des termes particuliers au droit schaféite qui se rencontrent dans le Minhadj.

Notes marginales et interlinéaires.

Ms. daté de l'an 1070 de l'hégire (1659-1660 de J.-C.).

Papier. 296 feuillets. Hauteur, 30 centimètres; largeur, 13 contimètres. 13 à 15 lignes par page. Écritures diverses. - (Supplèment 3108.$)$

\section{6.}

Commentaire du schaïkh Djałâl at-Dìn al-Mahallî sur le Minhâdj al-Ṭấlibin d'Al-Nawawî.

Notes marginales et interlinéaires.

Ms. daté de l'an $9^{42}$ de l'hégire (1533 de J.-C.).

Papier. ${ }_{29} 5$ feuillets. Hauteur, ${ }_{2} 6$ centimèires; largeur, 19 centimètres. 31 lignes par page. - (Supplément 3469.)

\section{7.}

Commentaire du chérif al-Hasanî al-Nassâb sur un traité de droit, en vers, de Schibâb a1-Dîn Ahmad ibn Yoûsof al-Aqfahsî intitulé الاقتتصاد ف كناية العُبّاد. (Comparez, ci-dessus, $n^{\circ} 1029$.) La première partie de ce traité a pour sujet le mariage. Commencement :

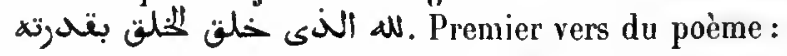

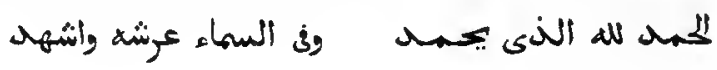


Ms. daté de l'an $99^{5}$ de l'hégire ( 1587 de J.-C.).

Papier. $a 66$ fenillels. Hauteur, go centimitres el demi; Jargeur, 15 centimètres. 21 lignes par page. - (Supplément 1575.)

\section{8.}

تنوير المقالة في حلّ الناظ المرسالة. Commentaire sur le traité de droit malékite d'Aboù-Moḷanmad 'Abdallah ibn abì Zaïd al-Qaïrawâni, par Aboù 'Abdallah Moḥmmad ibn Ibràbìm ibn Khalì al-Tatài.

Ms. daté de l'an 1091 de l'hégire ( 1680 de J.-C.).

Papier. 357 feuillets. Hauteur, 21 conlimètres; largeur, 15 eentimètres. 33 lignes par page. - (Supplément 2477.$)$

\section{9.}

Seconde partie du توضيح, commentaire sur l'abrégé de droil d'Ibn al-Hàdjib. (Voyez Hadji-Khalfa, I. II, p. 465 , et $\mathrm{t} . \mathrm{V}, \mathrm{p} .441$.

Ms. daté de l'an $99^{8}$ de l'luégire ( 1590 de J.-C.).

Papier. 177 feuillets. Hauteur, 28 centimètres; largeur, 21 centimètres. 33 lignes par page. - (Supplément 2493.)

\section{0 .}

L'abrégé de droit malékite de Sìdi-Klıatil. Les feuillets 155 à 163 sont trausposés.

Ms. daté de l’an 1182 de l'luégire (1 768 de J.-C.).

Papier. 163 feuillets. Hauteur, 17 centimètres; lar mètres. 17 lignes par page. - (Supplément 2474 .)

\section{1.}

Nème ouvrage. Il y a quelques lacunes.

Papier. 318 feuillets. Hauteur, 10 centimètres; largeur, 11 centimètres. 10 lignes par page. Is. du xvis ${ }^{e}$ siècle. - (Supplément 2475 .)

\section{2.}

Première partie du grand commentaire de Tàdj alDìn Bahrâm ibn 'Aludallalı al-Damirî sur l'abrégé de Sìdì Khalil.

Man. orientaux. - HI.
Ms. daté de l'an $97^{2}$ de l'hégire ( $1565^{\circ}$ de J.-C.).

Papier. 946 feuillets. Hauteur, 97 centimitres; Jargeur, 18 centimètres. 3.3 lignes par page. - (Supplément 24 7o.)

\section{3.}

Seconde partie du petit commentaire de Babràn alDamìì sur l'abrégé de Sìdi-Khalil. Copie exécutée pour le sultan du Darfour, lbråhìm ibı Bảkoû, mort en 1050 de l'hégire.

Papicr. ${ }_{7} 6$ feuillets. Hauteur, 29 centimètres; Jargeur, so centimètres. 35 lignes par page. - (Supplément 2476 .)

\section{4.}

Première partie du commentaire de Nàsir al-Dìn alLoqînî sur l'abrégé de Sìdi-Khalìl. La fin manque.

Papier, ${ }_{2} 57$ feuillets. Hauteur, 29 centimètres; Jargeur, a 1 centimètres. 3. lignes par page. Ms. du xix siècle. - (Supplément $\left.{ }_{2} 496.\right)$

\section{5.}

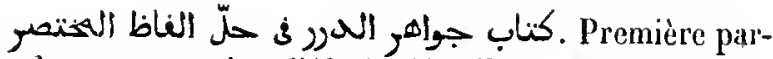
lie du commentaire d'Abou 'Abdallah Molımmad ibn lbrâlıìm ibn Khalì al-Talâi sur l'abrégé de Sidî-Khalì. Notes marginales.

Papier. 135 feuillets. Hauteur, 29 centimètres; largeur, a centimètres. 31 lignes par page. Ms. du xvi siècle, - (Supplément 2505. )

\section{6 .}

Prenjère partite du comnentaire d'Al-Kharaschì sur l'abrégré de Sidi-Khalil. Le commencement manque.

Notes marginales.

Papier. 164 Ceuillets. Hautour, 31 centimètres; largeur, \& a centimètres. Environ 40 lignes par page. Ns. du xvı" siècle. - (Supplément 2486 .)

\section{7.}

Seconde partie du même ouvrage. Noles marginales. 
Ms. daté de l'an 1123 de l'hégrire (1711 de J.-C.).

Papier. 264 feuillets. Hauteur, 30 centimètres; largenr, 21 centimètres. 34 lignes par page. - (Supplément 2492.)

\section{8.}

Premiel volume de la seconde partie du même ouvrage.

Notes nuarginales.

Vs. dató de l'an 1103 de l'hégire (1692 de J.-C.). A lin fin se trouve, d'une aulte écriture, le chapitre الفوائ d'un aul.re commenlaire.

Papier. 236 feuillets. llautrur, 27 centimètres; largeur, 19 centimètres. 37 lignes par page. - (Supplément 8506.$)$

\section{9.}

Second volume de la seconde partie du même ourage.

Ms. dalé de l'an 1146 de l'hégire (1 733 de J.-C.).

Papier. ${ }_{15}$ feuillets. Hauteur, a 5 centimètres; largeur, 18 centimètres. 34 lignes par page. - (Supplément 2/187.)

\section{0.}

Seconde partie du commentaire d'lbràhîm al-Schobrakhîtì sur l'abrégé de Sidi-Khalìl. La fin, à partir du chapilre

Papier. 167 feuillets. Hauteur, 33 centimètres; largeur, 33 centimètres. 44 lignes par page. Ms. du xwı" siècle. - (Supplément 3468$.

\section{1.}

Première pattie d'un commentaire sur l'abrégé de Sîdi-Khalil. Le commencement manque. A la fin on lil :

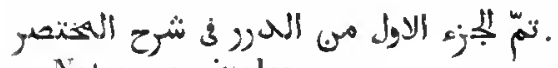

Foles inarginales.

Ms. daté de l'an 1069 de l'hégire ( 1656 de J.-C.).

Papier. 197 feuillets. Hauteur, 29 centimètres; largeur, 21 centimètres. 3 a à 36 lignes par page. - (Supplément 2507 .)

\section{2.}

Seconde partie d'un commentaire sur l'alyrégé de Sidì-Khatìl.

Papier. 187 feuillets. Hanteur, 98 cenlimètres; largeur, 22 centimètres. 33 lignes par page. Ns. du xviı" siècle. - (Supplément 2491.)

\section{3.}

Second rolume d'un commentaire sur un traité de droit, commençant au milieu du chapilre (باب) de la priere. Viennent ensuile les chapitres de la dime, dı jeune et de la pratique des doclrines qu'on a apprises (dell بلإl).

Papier. 186 feuillets. Ilauteur, 28 centimètres et demi; largeur, 20 centimètres. 22 lignes par page. Ms. dn $x 1^{\circ}$ siècle. - (Ancien fonds 278.)

\section{4.}

Première partie d'un traité de droit, divisé en sections (باب) el en paragraphes (نصل), qui commence par la section de la purificalion et finit par celle de la prière. Chaque paragraplıe renferme une question à résoudre et la solution donnéc par l'un on l'aulre des quatre grands imàms, chefs d'école. Les premiers l'euillets manquenl; il en manque d'autres dans le corps de l'ouvrage et plusieur's feuillels sont transposés.

Papier. 130 feuillets. Hanteur, 26 centimètres; largeur, 17 centimètres et demi. 21 lignes par page. Ms. du rvi siècle. - (Ancien fonds 580 bis, Colbert 4274.)

\section{5.}

$1^{\circ}$ Poème didactique sur le partage des snccessions, par Aboù Isḷầq Ibrâhì̀n ibn abì Bakr al-Anṣâri al-Tilinsåní, accompagné d'un commentaire, par Aḷmad ibn Saîl al-Bodjầ al-Zawàwì al-Schât. Le poème a élé composé en 635 de l'hégire (1237-1238 de J.-C.).

$2^{0}$ (Fol. $109 \mathrm{v}^{\circ}$.) Autre commenlaire sur le mème poème, par 'Mlì ibn Molıammad al-Qoraschì al-Qalașâdi, composé au Caire en 808 de l'hégire (1406 de J.-C.).

Ms. daté de l'an 1070 de l'hégire (1659-166o de J.-C.).

Papier. 152 feuillets. Hauteur, 21 centimètres ef demi; largeur, 15 centimètres. 20 lignes par page. - (Supplément 159 h bis.) 


\section{6.}

منظومة النسنى. Traité en vers sur les différences de doetrine (خلافيات) qui existent entre les quatre écoles orlhodoxes de jurisprudence, par Aboù Hafș 'Omar ibn Moḷammad al-Nasafi, morl en 537 de l'bégire ( $1142-$ 1143 de J.-C.). Commencement :

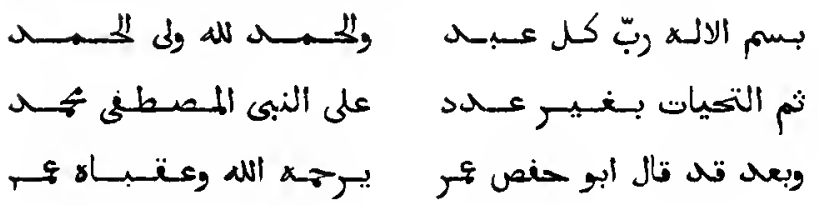

Notes marginales el interlinéaires.

Exemplaire restauré, d'après une indication qu'on lit sur le reclo du premier feuillet; il date de l'an 762 de l'bégire (1360-1361 de J.-C.); le premier cahier est du xvi ${ }^{\circ}$ siècle.

Papier. 170 feuillets. Hauteur, 18 centinètres; largeur, 13 centimètres. 9 lignes par page. - (Ancien fonds 1436.).

\section{7.}

Même ouvrage.

Notes marginales el interlinéaires.

Ms. daté de l'an 766 de l'hégire ( 1364 de J.-C.).

Papier. 141 fenillets. Hauteur, 19 centimètres; largeur, 13 centimètres et demi. 13 lignes par page. - (Ancien fonds 1434 .)

\section{8.}

Même ourrage.

Notes marginales el inlerlinéaires.

Les derniers feuillets, à parlir du folio 119 , sont de l'an 936 de l'hégire (1529-1530 de J.-C.).

Papier. 140 feuillets. Hautcur, 26 centimètres cl demi; largeur, 18 centimètres 11 lignes par page. Ms. du xve siècle. - (Ancien fonds 1385 .)

\section{9 .}

Second volume du commentaire de Borhân al-Dìn lbrâbîm ibn Ahmmad, de Mossoul, sur la Manzoûma d'AlNasafi. La fin manque. Selon Hadji-Khalfa (t. Vll, p. 196$)$, ce commentateur mourut l'an 652 de l'hégire (1254-1255 de J.-C.).
Papier. 181 feuillets. Hanteur, so centimètres et demi; largeur 17 centimètres. 25 lignes par page. - (Ancien fouds $1388, \mathrm{Col}-$ bert 1338 .)

\section{0 .}

"Les vérités de la Manzoûman. Commenlaire de Mạ̣moùd ibn Dàwoûd al-Loulouî al-Bokhàrì al-Afschandji (الافنشنجى), mort en 671 de l'hégire (1272-1273 de J.-C.), sur la Manzoûma d'Al-Nasafi.

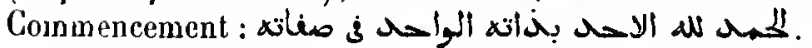

Notes marginales.

Papier. 283 feuillets. Hanteur, 29 centimètres; largeur, 18 centimètres et demi. go à 24 lignes par page. Ms. du xu1 siècle. (Aucien fonds 1387. )

\section{1.}

ن d'Al-Nasafi, par Aboù (sic) 'Abdallah ibn Aṭmad ibu Maḥmoud al-Nasafi. (Voyez fol. 214.) L'auleur dit en

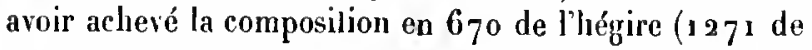

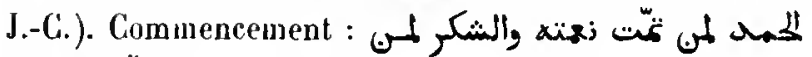

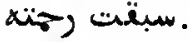

Hs. dalé de l'an 855 (ضن) de l'hégire (1451 de J.-C.).

Papier. 214 feuillets. Hauteur, 28 centimètres; largeur, 18 cenlimètres et demi. 27 lignes par page. - (Ancien fonds 1386.)

\section{2.}

هنظومة ابه وهبان. Traité en vers sur le système de jurisprudence enseigné par Aboû Ḥanifa, par 'Abd alWahhàb ibn Aḷmad, surnommé Ibn Wahbàn, de Damas, morl en 768 de l'hégire ( $1366-1367$ de J.-C..). Commencement:

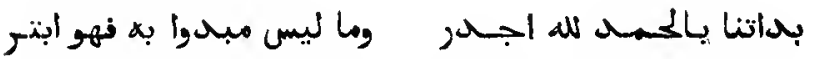

Hs. dalé de l'an 1005 de l'hégire (1597 de J.-C.).

Papier. 31 feuillets. Hauteur, 36 centinètres et demi; largeur, 16 centimètres. 17 vers par page. - (Ancien fonds 1389 .)

\section{3.}

Commentaire sur un formulaire d'actes notariés. Le commencement manque, ainsi que les derniers feuillets. 
Papier. 151 feuillets. Hauteur, 21 centimètres; largeur, 14 centimètres. 25 à 29 lignes par page. $\mathrm{Hs.} \mathrm{du} \mathrm{xve} \mathrm{siècle.} \mathrm{-} \mathrm{(Supplément}$ 2143.)

\section{4.}

$1^{\circ}$ عiو. Choix de formules préliminaires pour les actes de mariage, do vente et de constitution de waqf. l.es rubriques sont en langue turque.

$2^{\circ}$ (Fol. $\left.9 v^{\circ}.\right)$ Formulaire d'actes notariés, à l'usage des cadis, divisé en neuf sections, pal' Aboû '1-Sacoûd ibı Moḥammad al-Isklibì (الاسكليبى).

خط مئايون) (Fol. 33.) Copie de quelques firmans (نشتريغ (1).

Les deux premiers traités sont de la méme main; le sccond est daté de l'an 990 de l'hégire (1582 de J.-C.).

- Papier. 35 feuillets. Hauteur, 24 centimitres et demi; largeur, 1 a centimèlres et demi. 25 lignes par page. - (Supplément 2119.)

\section{5.}

Acte original d'une fondation pie constituée au Caire, l'an 1163 de l'hégire (1750 de J.-C.), par un officiel' des janissaires, nommé Aḷmad jbn 'Abdallalı. La pièce porte les signatures des eadis el de plusieurs témoins.

Rouleau, long de 3 mètres et largèe de 37 centimètres. En tête, une grosse vignette d'une exécution peu élégante. - (Supplément 2019.)

\section{6.}

Rouleau composé de six actes origrinaux de fondations pies et renfermant un fatwa relatif à une condition énoncée dans un de ces actes. Une de ces pièces est datée de l'an 1202 de l'bégire $\left(17^{87-1} 7^{88}\right.$ de J.-G.).

Rouleau, long de plus de 13 mètres et large de 26 centimètres et demi. En tête, une vignette. - (Supplément 2043.)

\section{7.}

$1^{\circ}$ Prière en vers, attribuée à l'imâm Al-Schâfici. Extrail de l'ouvrage inlitulé ألعوأروا.

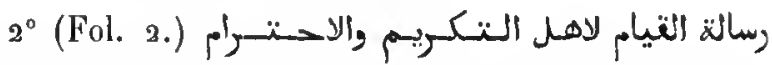
«Traité sur l'obligation de se lever devant les liommes dignes de considération et de respectn, par Mohyî alDìn Yalyaà ibu Scharaf al-Nawawî. Dans cet ouvrage, qui a été composé en 665 de l'bégire ( $1266-1267$ de J.-C.), l'auteur cite, avec un grand appareil d'autorités, les traditions qui commandent cet acte (fol. 4), et celles (fol. ${ }_{14} \mathrm{v}^{0}$ ) qui le condamnent. Commencement :

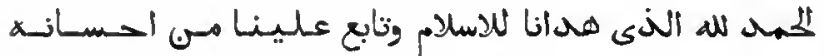

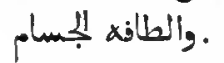

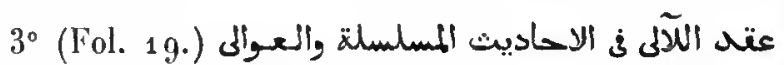
"Collier de perles, traité sur les traditions remontant sans interruption à Mahomet ou à de très hautes autorités n, par Moḷammad ibn Moḷammad al-Djazarì. Cette collection a été formée à Schiråz en 808 de l'hégire

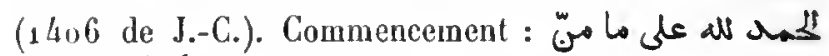

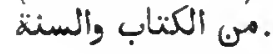

$4^{\circ}\left(F_{0} .3_{1} v^{\circ}.\right)$ Autre recucil de traditions du neême genre, par le mème auteur.

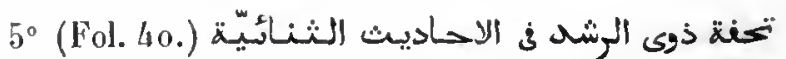
(lin Cadeạu pour les lommes à l'esprit droit, renfermant les traditions à double isnâd\%. Petit traité composé, en 755 de l'liégire (1354 de J.-C.), par 'Abd alRalı̣nàn ibn al-Mocanmar al- Wìsitì. Commencement :

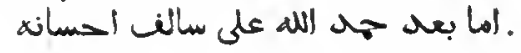

$6^{\circ}$ (Fol. $42 v^{\circ}$.) résumé des connaissances qui se rapportent aux traditions $n$, par Aboù 'l-Fidả Ismấîl ibn 'Omar, surnommé 'Imâd alDin. L'auteur traite des sources d'où proviennent les traditions de Mahomet et des soixante-cinq catégories dans lesquelles on les a classées. Commencement : وبعل

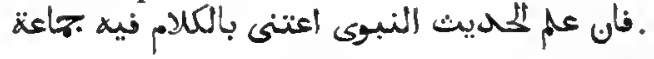

$7^{\circ}$ (Fol. 77.) Fragment d'un commentaire sur un ouvrage traitant des classes des traditionnistes.

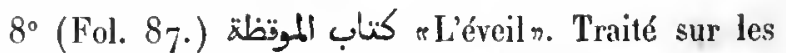
diverses classes de traditions, par Moḷammad ibn A!!mad al-Dsababî. Cie sont les premières pages seulement.

$9^{\circ}$ (Fol. 9o.) Extraits dı commentaire d'Imâd al-IDin ibn Kathìr sur le Coran.

$10^{\circ}$ (Fol. 93.) Commentaire de Hâroûn ibn Moûsâ ibn al-Djonaild sur un recueil de quarante traditions formées par son grand-père. Commencement : w und

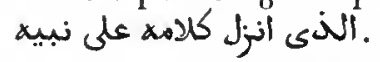

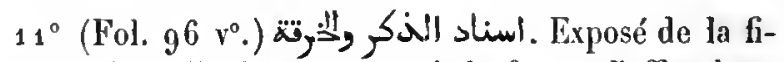
lière par laquelle furent transmis le froc et l'oflice à un derviche nommé Al-Djonaïd ibn Mahmoûd ibn 'Omar al-'Oinarí.

$12^{\circ}$ (Fol. $97 v^{\circ}$.) Prière ou office dont il est fait mention dans l'article précédent. 
$13^{\circ}\left(\right.$ Fol. $9^{8} v^{0}$ ) متر عiايه عضد.. Texte de la profession de foi d'Adhod al-Din "Abd al-Rahmain ibn Aḷmad al-îdji.

$14^{\circ}$ (Fol. 99.) Commentaire de Fahhr al-Din Mohammad ibn 'Omar al-Ràzi sur la sourate iutituléc Al-Ihihlas.s.

$15^{\circ}$ (Fol. $1011^{\circ}$.) Commentaire (du mème auteur?) sur une autre sourate du Coran.

$16^{\circ}$ (Fol. 106.) Dernière partie de la première moi-

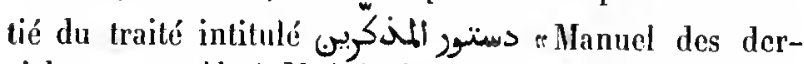
viches", par Aboû Moùsâ ał-Madinì. Cette section commence par les mots ذكر يوم النَيَّروز (Sa fin manque.

$17^{\circ}$ (Fol. 112.) Note sur le jour de l'an (nawroûz), en persan. Lc commencement manque.

$18^{\circ}$ (Fol. $113 \gamma^{\circ}$.) Commentaire sur la sourate AlIkhlâs, par un derviche nommé Haìroûn ibn Moûsâ. La fin manque.

$19^{\circ}$ (Fol. 117.$)$ Commentaire de la Borda. Le premier feuillet, contenant l'introduction et le premier vers avec l'explication, manque.

$20^{\circ}$ (Fol. 146.) Dernier feuillet d'une dissertation métaphysique.

$21^{\circ}$ (Fol. $146 v^{\circ}$.) Traité du nom (لنظ), sa définition et ses diverses espèces.

$22^{\circ}$ (Fol. $147 v^{\circ}$.) Traité dans lequel on pose pour principe que le rapport qui existe entre la faculté perceptive et les perceptions est comme le rapport qui existe entre la vue et les objets aperçns. Commencement : أن نسمة البصيرة اله ملركاتها كنسبة البصر الى عسوساتهها

$23^{\circ}$ (Fol. 149.) Autre traité philosoplique qui com-

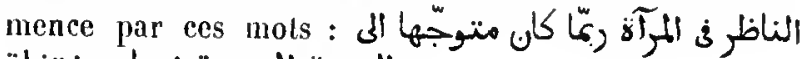
الصورة المرتسمة فيها ومنتنغلة.

$24^{\circ}$ (Fol. 150.) Premières lignes du traité mystique intitulé Temple de lumièren.

La plupart des pièces sont de la même main.

Papier. 150 feuillets. Hauteur, 24 et ${ }_{25}$ centimètres; largeur, 15 centimètres. 19 à 30 lignes par page. Mr. du xvi ${ }^{*}$ siècle. - (Ancien fonds 1562.)

\section{8.}

$1^{\circ}$ Le Dalâil al-Khairdt d'Al-Djozoûll.

$2^{\circ}\left(\right.$ Fol. $81 v^{\circ}$.) Prière que l'on récite après aroir fini la lecture du Dalaiil al-Khairat. $3^{\circ}$ (Fol. 83.) Poème à la louange de Dieu intitulé المزمزوقية.

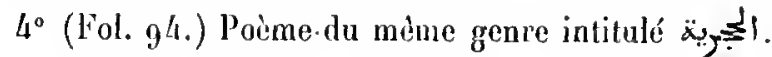

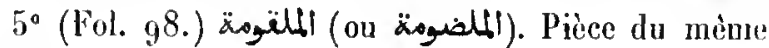
genre.

Papier. 111 feuillets. Irauteur, 11 centimètres; largeur, 8 centimètres et demi. 12 liģnes par page. Ms. du rwü siècle. - (Supplément 2141.)

\section{9.}

Abrégé du الحياء sاموم المين de Ghazâlit. En tête du voكتاب مختصر احيا علوم الديبر لمؤنغه : lume, on lit ce titre

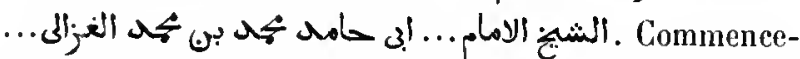

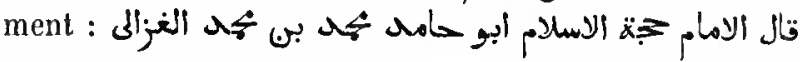

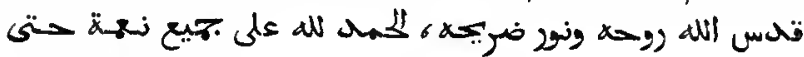

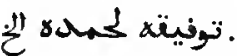

Papier. 123 feuillets. Ifauleur, a centimètres; largeur; 14 centimètres. 19 lignes par page. MIs. du xw' siècle. - (Supplément 2437. )

\section{0 .}

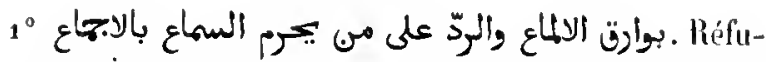
tation de l'opinion qui proscrit la musique dans les réunions religicuses, par Aḷmad ibn Moḷammad al-Ghazalli.

$2^{\circ}$ (Fol. 14.) Collection de préfaces et de titres de lettres.

30 Fol. 54. (كفاية القنوع بالعل بالربع المغطوع . Traité de Sibt al-Màridini sur l'emploi du quart de cercle tronqué.

$4^{\circ}$ (Fol. 62 $v^{\circ}$.) Traité de Moḷammad ibn 'Omar ibn Siddìq al-Bakrî sur l'emploi de l'astrolabe. Titre : بغية ألطلّب في العل بالاسطرلاب.

$5^{\circ}$ (Fol. $7^{3} v^{\circ}$.) Traité des quatre saisons de l'année, des divisions des temps, des lueures de la prière, de la direction de la qibla, par 'Abd al-Raḥmân al-Tìdjoûrì at-Maghribi.

كتاب هرمس المهرامسة المنتول مى كتناب (Fol. 86. (دويس Traité d'astrologie et de divination.

$7^{\circ}$ (Fol. 102.) Traité de l'horoscope.

$8^{\circ}$ (Fol. 131.) Notes, figures et tableaux se rapportant à l'astrologie et à la divination. 
Papier. 138 fenillets. Hauteur, 20 centimètres et demi; largeur, 15 centimètres. Environ 25 lignes par page. Écritures diverses du xrue siècle. - (Supplément 1921.)

\section{1.}

$1^{\circ}$ Traité de lhéologie et de morale, divisé en chapilres (باب). La préface et une parlie de la table des cliapilrcs manquent. Cet ouvrage renferme un graud nombre de vers, de lraditions et d'histoires pieuses.

$2^{\circ}$ (Fol. $77 v^{\circ}$.) Dissertation sur les principes de la foi musulmane.

$3^{\circ}$ (Fol. 79.) Biograp̧hie d’Abd al-Qâdir al-Djîlì (ou al-Djìlàuî). La fin manque.

$4^{\circ}$ (Fol. 96.) Fragment d'un traité de morale.

$5^{\circ}$ (Fol. $9^{8} v^{\circ}$.) Exhortation par Aboû 'l-'Abbâs Aḥmad ibn 'Ațà Allah.

Papier. 110 feuillets. Hauteur, 27 centimètres; largeur, 19 centimètres. 31 lignes par page. Ms. du xv" siècle. - (Supplément a'49o.)

\section{2.}

Commentaire d'Alí ibn Solṭân ibn Moḷanmad alQàrî sur la qașida بل به (voy. ci-dessus n $n^{\circ} 1251,1^{\circ}$ ). Ms. daté de l'an 1153 de l'bégire ( 1740 de J.-C.).

Papier. 45 feuillets. Hanteur, 21 centimètres; largeur, 15 centimètres. ${ }_{9}$ lignes par page. — (Supplément 1936.)

\section{3.}

$1^{\circ}$ Commentaire de Mohatamuad ibn Yoûsof al-Sa-

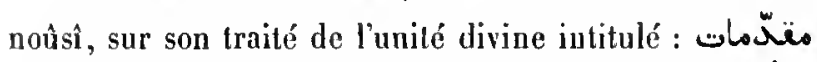
"Comaissances préliminaires". Commencenent : هذ

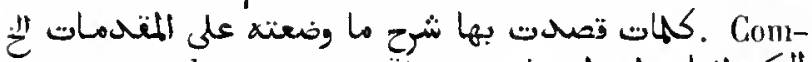

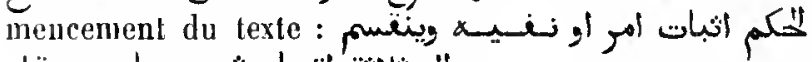

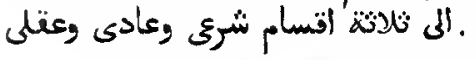

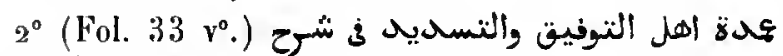
(ه) Appui de ceux qui sont favorisés et dirigés par la grâce de Dicu, traité servant de commenlaire à l'ourrage intitulé Profession de foi des uuilaires». Le texte el le commentaire sont de Moḷammad ilon Yoûsof al-Sanoûsî. Commencement : شلى

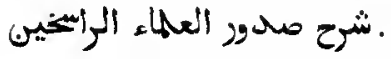

Ms. daté de l'an 1105 de l'bégire (1694 de J.-C.).
Papier. 166 feuillets. Hanteur, so centimètres et demi; largeur, 15 centimètres. 25 lignes par page. - (Supplément 1345.)

\section{4.}

Commentaire de Moḥammad ibn Yoûsof al-Sanoûsì sur son ouvrage intitulé r Source des preuves \#, exposé des preuves des articles de la foi musulmane.

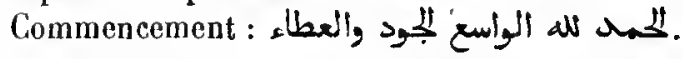

papier. 49 feuillets. Hauteur, as centimètres; largeur, 16 centimètres et demi. 21 à 33 liggnes par page. Ms. du xvir" siècle. (Supplément 1341.)

\section{5.}

$1^{\circ}$ عنيحة 'Aqîda sur l'unité de Dieu et les dogmes de la religion, par Aboû 'l-'Abbâs Ahmad ibn "Abdallah al-Djazâirîi, suivi de l'aqîda de Sclıäbânî.

$2^{\circ}$ (Fol. 16.) Commentaire sur l'saqîda d'Abou Madyan.

$3^{\circ}$ (Fol. $31 v^{\circ}$.) Commentaire sur un taşrîf ou traité des déclinaisons.

$4^{\circ}$ (Fol. 41.) Commentaire d"Iṣàm al-Din Mohammad sur le traité des métaphores d'Aboû 'l-Qâsim alLaiilhî al-Samarqandì.

5० (Fol. 6o.) كتاب Petit Iraité d'arithmétique, par Schihâb al-Dîn Aḷmad ibn al-Hâîm.

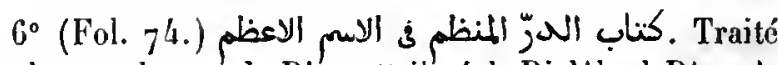
sur le grand nom de Dieu attribué à Djalâl al-Dìn alSoyoûtî.

$7^{\circ}$ (Fol. $7^{8} \vee^{\circ}$. ) Traité de prosodie, en ture.

$8^{\circ}\left(\right.$ Fol. $\left.136 \mathrm{v}^{\circ}.\right)$ Pend-Namè, poème persan de Farîd al-Dìn 'Attâr. Le comnencement du texte est accompagné d'une traduclion turque interlinéaire. La fin manque.

Le premier ouvrage est daté de l'an 1069 de l'hégire; le second, de l'an 1075 ; le troisième, de l'an 1082 ; le quatrième, de l'an 1149 .

Papier. 165 fenillets. Hauteur, 21 centimètres; largeur, 15 centimètres. Écritures diverses du xir' et du xrı⿰氵 ${ }^{\bullet}$ sècle. - (Supplément 1929.)

\section{6.}

$1^{\circ}$ Explication des noms de Dieu. En tête du volume 


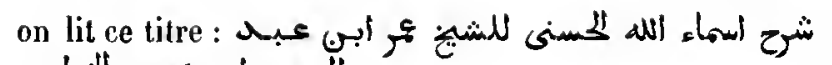

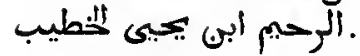

$2^{\circ}$ (Fol. 65 vo.) الزئ日). Recueil d'historiettes.

$3^{\circ}$ (Fol. 81 1 ${ }^{\circ}$.) Chapitre sur les animaux, extrait de l'listoire naturelle d'Al-Damîri.

$4^{\circ}$ (Fol. $132 v^{\circ}$.) Histoire du peuple de Lolh, histoires d'Alexandre Dsoû 'l-Qarnaïn, de Joseph, de Job, de Schocaïb et d'autres patriarches. La fin manque.

Papier. ${ }_{157}$ feuillets. Hauleur, 16 centimètres; largeur 12 centimètres. Environ 30 lignes par page. Mts. du xvi' siècle. - (Supplément 1998.)

\section{7.}

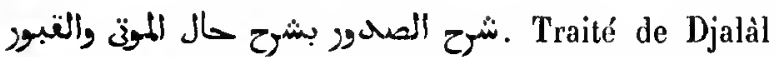
al-Din al-Soyoùti sur l'élat des âmes entre la mort et la résurrection. (Voyez Hadji-Khalfa, t. IV, p. 39.)

Papier. $9^{6}$ feuillets. Hanteur, 29 centimètres; largeur, 21 centimètres. 27 lignes par page. Ms. du xvie siècle. - (Supplément a 435 .)

\section{8.}

Opuscules théologiques de Djalâl al-Din 'Abd alRaḷmân al-Soyoùtị, suivis de quelques maqâmát du ınême ạuteur:

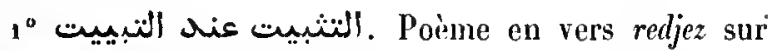
linterrogatoire du tombeau.

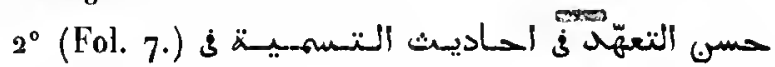

المثشقهد. Traditions relatives à la formule dinvocation appelée تشنهّه.

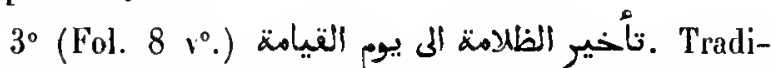
tions relatives au retard de la rétribution des œuvres jusqu'au jour du Jugement.

$4^{\circ}$ (Fol. 12.) Traditions sur le pèlerinage des femmes et sur le vin.

$5 \circ$ (Fol. $12 v^{\circ}$. Foudies lancés contre les braillards 7 . Traditions et exemples pour prouver que la faculté de l'idjtihâd (prononcer en maître sur des questions de droil) existe encore.

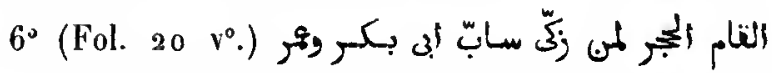
"Baillon pour celui qui justifie le calomniateur d'Aboû Bakr et d'Omar». Traité qui parait dirigé contre les Schiïtes.

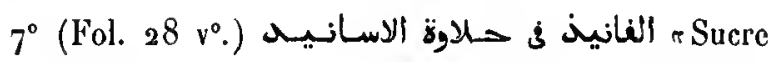

candi ou doucenr des isnadm. L'auteur discute la question de savoir si l'imàm Aboù Ḥanîfa a enseigné une tradition sur l'autorité de limâm Màlik ibn Anas.

80 (Fol. 32.) iLa flamme du feu». Traité où l'on examine si le Propliète, en recevant l'autorité de condamner un criminel sur des prenves bien établies, a aussi reçu l'autorité de s'appuyer sur la confession d'un criminel pour le condamner.

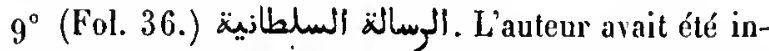
vité par le sullan Qàitbàï à venir souvent le voir. Il s'en excuse en citant les traditions qui défendent aux uléma de fréquenter les souverains.

$10^{\circ}$ (Fol. 38.) Epitre adressée aux rois de Tokrour (les rois niggres) pour leur recommander la crainte de Dieu.

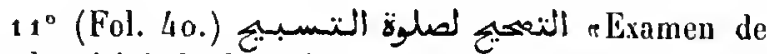
l'authenticité de la prière nommée Tasbil̆». L'auteur cite plusieurs tıaditions se rapportant à ce sujet.

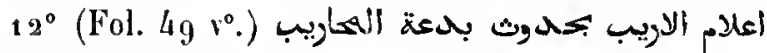
Enseignements pour les hommes intelligents, montrant que l'établissement des miḩrâb dans les mosquées est une innovation $n$.

$13^{\circ}$ (Fol. 51 vo.) ( I La flèche qui atteint le but, traité sur les formules de prières que Dieu est disposé à exaucer.

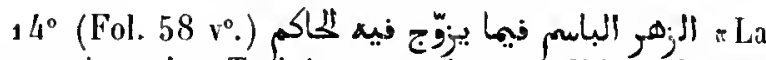
fleur qui sourit ᄁ. Traité sur certaines conditions de mariage, rédigé en forme de qaṣida par Siràdj al-Dìn alBolqaïnî et réduit à cinq vers par Al-Soyoûțì.

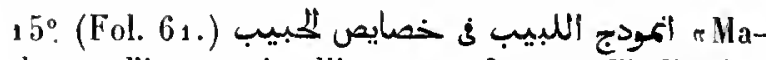
nuel pour l'homme intelligent, renfermant l'indication des qualités distinctives du Bien-Aimé (c'est-à-dire de Hallomet) $r$.

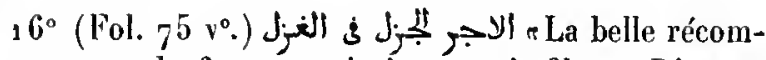
pense pour la femme qui s'occupe à filer'n. Diverses traditions à ce sujet.

$17^{\circ}$ Fol. 77. Portes du bonheur ou causes qui donnent droit au titre de martyr $n$.

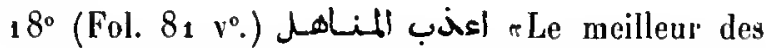
abreuvoirs\%. Examen de la tradition dans laquelle on parle de celui qui se disait savant et qui n'était qu'un ignorant.

$19^{\circ}$ (Fol. 83 v.) à une personne en évitant sa société . Traditions à ce sujet.

$20^{\circ}$ Fol. 88. Décision 
équitable au sujet de (l'emploi des fonds et des provisions assignés à certaines) fondations religieuses $\pi$.

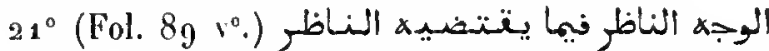
r.Examen de ce que l'inspecteur (d'une fondation religieuse) peut réclamern.

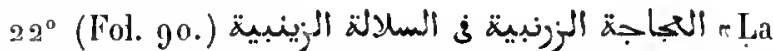
poussière parfumée (?) au sujet de la postérité de Zeïnab (fille d'ctì) $)$.

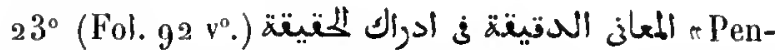
sées subtiles qui aident à atteindre la vérité». Discussion des passages du Coran où il est dit que les ouvres de l'homme prendront un corps matériel pour se présenter ì luj au jour du Jugement, et qu'il en serait de même de la mort.

$24^{\circ}$ (Fol. 98.) J Jangée de perles (collection de pièces de vers) dans lesquelles on parle de la nouvelle lune r. Cies morreanx se composent ordinairement de deux vers.

$25^{\circ}$ Fol. 103. ( L'obtention de ce qu'on cherche dans le but de se procurer ta nourriture . Traité renfermant les passages du Coran quion peut employer comme amulettes pour cet objet.

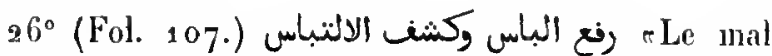
entevé et le doute éclairci \%. Justification de l'emploi de passages du Coran dans les discours et les écrits.

$27^{\circ}$ (Fol. $114 v^{\circ}$.) slefl نsur. Questions et réponses touchant l'état des morts dans leurs tombeaux. Entendeut-ils les paroles des vivanls? Comment répondent-its ¿l linterrogatoire du tombeau? etc.

$28^{\circ}$ (Fol. 118. (الاعلام بككم عيسى عليه الاسلقم. Examen de la question de savoir si, au jour de la résurrection, Jésus jugera les lıommes d'après sa propre loi ou d'après la loi de Mahomet.

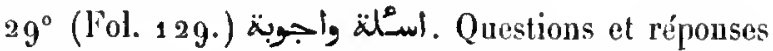
au sujet de divers passages dı Coran et des traditions. La première question se rapporte à une tradition selon laquelle Mahomet aurait dit : $\mathrm{Si}$ quelque chose eût existé avant la prédestination, cela aurait été l'oeil \%.

$30^{\circ}$ (Fol. 135.) (15) Occupation de la réflexion pour qu'elle reconnaisse le grand mérite des exercices et des chants des derviches daus les masquées $n$.

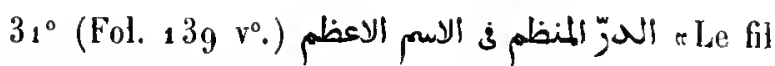
de perles, traité sur le grand nom de Dieun.

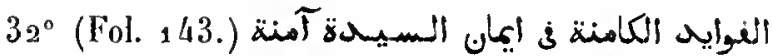
"Renseignements secrets au sujet de lislamisme de la dame Amina (mère de Mahomet)n. $33^{\circ}$ (Fol. $154 \mathrm{v}^{\circ}$.) Opinion orthodoxe touchant le salut de ceux qui sont morts avant la prédication de Nahomet.

$34^{\circ}$ (Fol. 160.) Énumération des aïeux de Mahomet qu'on s'accorde à regarder comme vrais musulmans.

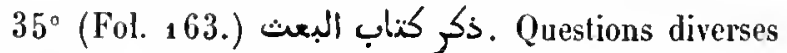
relatives au Coran, aux traditions, au paradis, etc., avec leurs réponses.

$36^{\circ}$ Fol. 1 73. (ذك الغتاوى التقرانية. Solution de certaines difficultés que présente le texte du Corall.

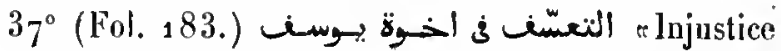
commise à l'égard des frères de Joseph \%. L'auteur examine la question de savoir s̈ils possédaient la qualité de prophète.

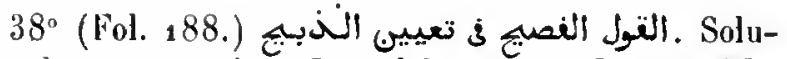
tion de cette question : Lequel des deux, d'Isaac ou d'Ismaél, fut celui qu’dbraham voulait sacrifier?

$39^{\circ}$ Fol. 193.) م Collection (de traditions) au sujet de cette tradition : le mot takbir ne doil pas recevoir de voyelle finale\%.

$40^{\circ}$ (Fol. 198.) Question relative à la manière (كيغيّة) de la révélation.

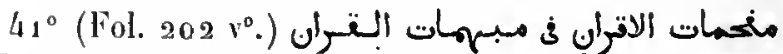
r Textes, c'est-à-dire ertains cversets obscurs du Cioran, qui confondent nos contemporains $\%$.

$42^{\circ}$ (Fol. 233.) Les maqamât intitulées النثّاثش على

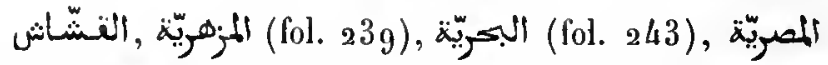
(fol. الاسيوطيّة (fol. 248), 250), (fol. 240),

Hs. daté de l'an 1040 de l'lıégire (1630-1631 de J.-C.).

Papier. 23 o feuiltets. Hauteur, 33 centimètres et demi; largeur, 13 centimètres ef demi. 27 tignes par parge. - (Ancien fonds 1608. )

\section{9.}

$1^{\circ}$ Traité anonyme sur les mérites qu'on acquiert en faisant la guerre aux infidèles. Liourrage pourrait s'intituler كناب فضايل بل Coran et de traditions ayant rapport à ce sujet, le tout accompagné des réflexions de l'auteur, dont, du reste, on n'est pas parvenu à découvrir le nom. L'ouvrage com-

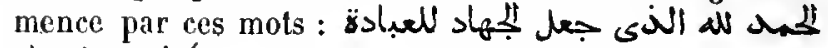
كذروة السنام

$2^{\circ}$ (Fol. 64.) Prière que l'on récite après avoir lu le texte entier du Coran.

$3^{\circ}$ (Fol. $\left.64 r^{\circ}.\right)$ Extrait d'un ouvrage intitulé govi 
- Les perles . Ce fragment renferme des anecdotes dont la première concerne la pratique de se couper les ongles le rendredi.

10 (Fol. $66 v^{\circ}$.) Le LSUl $_{5} \leq$, traité de théologie, par Mờn al-Dîn Maümoûn ibn Moḷammad al-Nasafí.

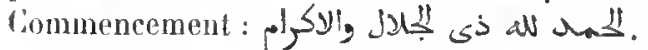

$5^{\circ}$ (Fol. 1 3.) Anecdotes, traditions et noles diverses.

$6^{\circ}$ (Fol. $143 \%$ \%) Ouvrage sans titre ni nom d'auteur. C"est un commentaire sur le texte diun autre commentaire, peut-ètre celni de Sa'd al-Dín al-Taftàzànî sur I"Aqâid d'Al-Nasafí. Au fol. 139 , commence un long chapitre sur les mérites de 1'Imâm Aboủ Ḥanîla. Un chapitre

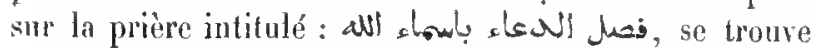

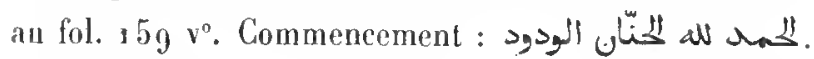

$7^{\circ}$ (Fol. 199.) Fragments arabes et tures sur des sujets religieux.

Papier. soo feuitlets. Hauteur, 20 centimètres; largeur, 15 centimètres. 15 lignes par page (à l'exception du sixième ouvrage qui n'en a) que 13). Ecritures diverses da xw1" siècle. - (Ancien fonds 446.)

\section{0.}

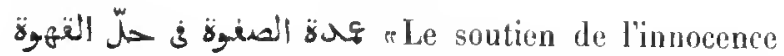
tonehant la légitimité du cafés, par 'Abd al-Qàdir ibn Moḷammad al-Anșài al-Djazari. On conuaít cet ourrage par l'extrait que S. de Sacy en a domné dans sa Chrestomathie arabe.

Papier. 68 feuillets. Hauteur, 20 centimètres et demi: largenr, 15 centimètres. 21 lignes par page. Ms. du $\mathrm{xv}^{\circ}$ siècle. - (Ancien fonds 971.)

\section{1.}

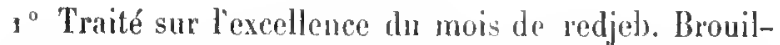

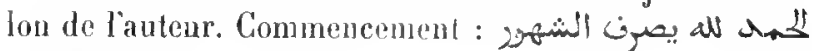

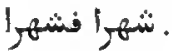

$a^{\circ}$ (Fol. $7 v^{\circ}$.) Traité sur la mission dirine de Mahomet. Bronillon de la nème main que la piéce pré-

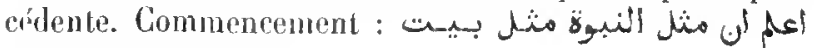

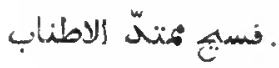

$3^{\circ}$ (Fol. $15 v^{0}$.) Traité dans lequel Hohammad itn Yoúsof al-Ilalabi expose l'état de corruption dans lequel était tombé le soufisme à l'ápoque où il écrivait, c'est-àdire en 1 1 6 de l'hégire (1704-1705 de J.-C.). Com-

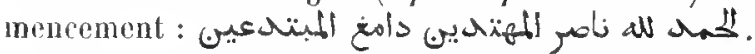

$1^{\circ}$ (Fol. $33 \mathrm{v}^{\circ}$.) Vole sur une parole de Mahomet.

Mas. oriestalx. - - $\mid$ I. $5^{\circ}$ (Fol. $37 v^{\circ}$.) Traité de Taqî al-Din a1-Saiyid alḤiṣıi (mort, selon Hadji-Khalfa, en 829 de l'hérrire, 1429 de J.-C.) sur l'emploi seandaleux de la nuusique ( ع'ill par certains sonfis.

6) Fol. 45. (Fogres de celui qui s'est engagé dans la meillenre des voies». Traité de Taqì al-Din al-Hisuì sur la voie conduisant

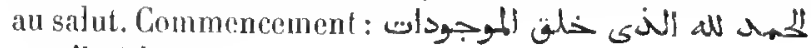
مull

$7^{\circ}$ (Fol. $7^{3 .}$ ) Les deux premiers feuillets d'un traité de théologie.

$8^{\circ}$ (Fol. $75 \mathrm{v}^{\circ}$.) Dissertation sur l'usage légitime du chapelet.

$9^{\circ}$ (Fol. $77 v^{\circ}$.) Traité en rers sur les causes de l'oubli (quion montre pour ses devoirs).

$10^{\circ}$ (Fol. $80 v^{\circ}$.) Sur certains mariages qui ne penvent être autorisés que par lo magistrat.

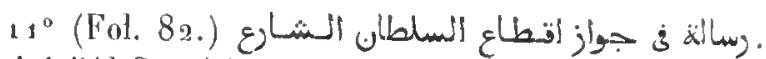
Traité d'Al-Soyoûtị, sur la question de savoir si le sultan a le droit d'aliéner par une concession la voie publique.

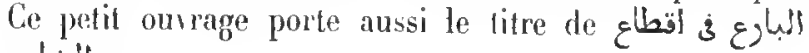
Estill.

$12^{\circ}$ (Fol. 86.) Liste des omvages d'Al--Soyoûṭi.

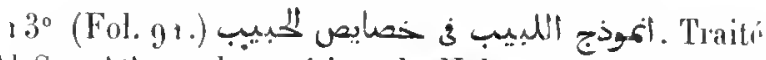
d'Al-Soyoùtì sur les mérites de Malıomet. Commencement: :

$14^{\circ}$ (Fol. 110.) Examen de la question de saroir si le personnage montionné par quelques commentateurs du Coran sous te nom d'c Audj ibn 'Anat a réellenent existé.

$15^{\circ}$ (Fol. $112 \mathrm{r}^{\circ}$.) Dissertation de Taqi al-Din alSolsì sur cette parole d'Al-Schafie : "Quand une tradition est authentique, elle fait partie de ma doctrinen.

Papier. 194 fonillets. Hauteur, a centimètres; largeur, 15 centimètres el demi. Diverses écritures du xv" et du xru siecte, - (Sup) ptément 1855.)

\section{2 .}

10 Traité anonyme dans lequel se trouvent plusieurs chapitres consacrés à la dẹffuition de l'intelligrence, de l'amour, de la noblesse, de la douleur, de la pureté, de la contribution aunôniè̀’e, dı jeùne, ete.

$2^{\circ}$ (Fol. 18.) Khatba ou sermon, attribué au calile 'Ali. 
$3^{\circ}$ (Fol. 20.) Versets du Coran el prières pour éloigner la peste.

$4^{\circ}$ (Fol. 22.) Litanic de Mahomet.

$5^{\circ}$ (Fol. 24.) Conseils adressés par Malromet à Aboû Horaïra.

$6^{\circ}$ (Fol. 41.) Chapitre dans lequel sont condamnés plusieurs usages comne contraires à la religion. Titre:

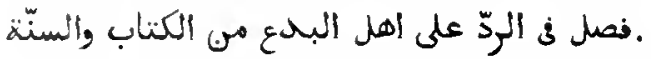

$7^{\circ}$ (Fol. 51.) Histoire de la ville de l'Humanité (النlu qui est gourernée par la Foi et attaquée par les Passions.

$8^{\circ}$ (Fol. 56.) Exhortations dévotes el anecdotes tirées de l'ouvrage d'Al-Sohrawardì intitulé معلم الطرفين.

$9^{\circ}\left(\right.$ Fol. $\left.61 v^{\circ}.\right)$ Conversation de Hàroûn al-Raschìd avec un Arabe du désert.

$10^{\circ}$ (Fol. $65 \mathrm{v}^{\circ}$.) Histoire de Moïse lorsqu'il se dirigea vers te feu (le buisson ardent).

$11^{\circ}$ (Fol. 70.) Anecdotes dont la première a pour sujet la défense de manger du haschîch, défense faite par le Prophète lui-même.

$12^{\circ}$ (Fol. 73.) Notes sur divers sujels.

$13^{\circ}$ (Fol. 83.) Anecdotes et questions de droil.

$14^{\circ}$ (Fol. 94.) Commencement d'un traité de droit, par Hibat Allâh Mạ̣ınoûd ibn Ismâcil al-Ḥalabì.

$15^{\circ}$ (Fol. 99.) Traité élémentaire, en persan, sur les croyances et les devoirs d'un musulman.

Papier. 109 feuillels. Hauteur, 17 centimètres et demi; largeur, 13 centimètres. Écritures diverses du xvº siècle. - - (Ancien fonds 439.$)$

\section{3.}

. T'raditions de Mahomet sur' divers sujets de morale et de conduite, par Aboù Yahyà Zakarìya al-Anșiri al-Schâfii. Cet ouvrage, d'après la préface, est un abrégé du كتاب الاداب d'Alymad ibn alHosaï al-Baïlaqi. A la fin on lit qu’il a élé achevé le 9 du mois dson̂ 'l-luiddja de l'an 900 de l'hégire.

Papier. 70 feuillels. Hauteur, 18 centimètres; largeur, 13 centimètres. 21 lignes par pagc. Ms. du xví siècle. - (Supplément a444.)

\section{4.}

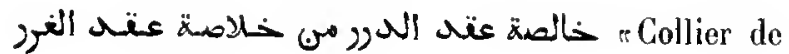

perles choisies dans la quintessence du Collier des brillants n. Ouvrage d'éthique, par 'Alì ibn Molıammad alGhazàli, qui parait avoir récu dans les premières années du $x y^{e}$ siècle. L'auteur s'apporle en seize chapitres, dont chacun est divisé en trois sections, des réllexions el des anecdotes au sujet des vertus et des vices. II dit

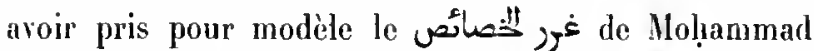
ibn Ibraihim al-Qotbì et avoir écrit son ouvrage pour faire homneur à un grand personnage (äll) de la conr des sultans d'Égyple, nommé Qànsoń. Il s'agit probableincnt de celui qui, en 922 de l'hégire, devint souverain de l'Égypte et régna sous te nom de Qìnṣoù 'l-Ghauri. Liouvrage a deux préfaces dont la première commence

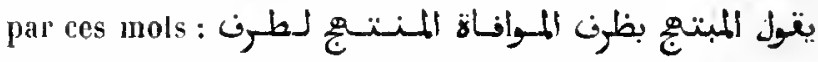

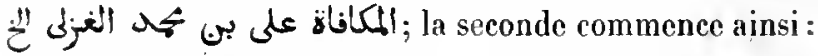

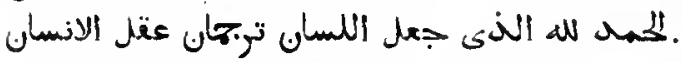

Papier. 103 feuillets. Hanteur, 27 centimètres; largeur, 18 centimètres et demi. ${ }_{7} 7$ lignes par page. Ms. du $x \mathbf{x v}^{\circ}$ siècle. Plusieurs cahiers sont transposés. - (Ancien fonds 1406 , Colberl 3701.)

\section{5.}

فض. Traitẹ́ servant d'appendice à l'ouvrage intitulé Règles de conduite pour les instituteurs et pour leurs élèves », par Aboû 'I-Ḥasan 'Ali ibn Moḷammad al-Qàbisi (الغأبm). Cet ouvrage est divisé en trois sections. L'auteur commence par expliquer la signification des termes foi, islam, etc.; il traite ensuite de l'enseignement, du salaire des instituteurs et des punitions qu'il est permis d'infliger aux élèves. Vers la fin de la dernière partic, il parle des sept lectures du Coran.

Ms. daté de l'an 706 de l'hégire (1306-1307 de J.-C.).

Papier. 97 feuillets. Hauteur, 17 centimètres el demi; largeur, 1 a cenlinètres. 13 lignes par page. - (Ancien fonds 443.)

\section{6.}

rInstructions pour se conduire à tablen, par Djamâl al-Din Aboû 'l-Ḥosaïn Yạ̣yâ ibn 'Abd al'Adhî̀n al-Djazzâr.

Papier. 37 feuillets. Hauteur, 15 centimètres; largeur, 10 centimètres et demi. 11 lignes par page. Ms. du xvul siècle. - (Ancien fonds 1623. .) 


\section{7.}

rLive des septénaires pour l'iustruction morale des hommes", par Aboú Nașr Moḷammad ibn 'Abd al-laḥmàn al-Hamadàni. L'auteur' Iraite, en sept Séances, des choses que Dieu a créées et disposées par sep1. Commencement : العزيز الغنيز

Papier. 97 feuillels. Hauteur, 20 centinètres et demi; Jargeur, 15 rentimètres et demi. 16 liggnes par page. Mls. du xvit siècle. (Supplément 1104.)

\section{8.}

$1^{\circ}$ Khotba altribuée à 'Alì et dans laquelle la lettre alif n'est pas employée.

3o (Fol. 7. (·) Les Septénaires 》 d'Al-Hamadàn1ิ.

Hs. daté de l'au 889 de l'hégire (1484 de J.-C.).

Papier. $1_{2}$ feuillets. Hauleur, 18 eentimètres; Jargeur, 13 eentimètres et demi. Environ 13 lignes par page. - (Supplément 1919.)

\section{9.}

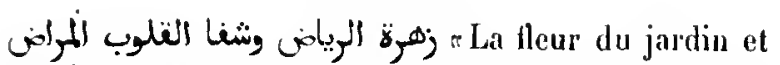
la guérison des couls maladesn. Soixante sermons (litt. "séances" (ب) sur certains versets du Coran, par Solaïmân ibn Dâwoûd al-Sawàrì (السوازي).

Ms. daté de l'an 1015 de l'luégire (1607 de J.-C.).

Papier. 201 feuillets. Itautenr, 25 centimètres; largeur, 16 çentimètres. 27 lignes par page. -- (Supplément $162 \%$.)

\section{0.}

Ouvrage scolaire, sans titre ni nom d'auteur. Après une courte préface, tout à fait insignifiante, commence un chapitre intitulé باب الاب م le desnier chapitre est consacré aux particules et aux expressions adverbiales. Ce paraît être un de ces traités qui avaient pour sujet les fondamentaux de la jurisprudence (أمول النقx), principes que les légistes étaient tenus à observer en faisant leurs déductions. Commencement de la préface :

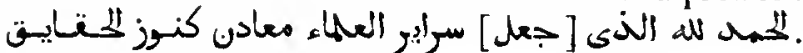
Nombreuses notes marginales.
Papier. 18 2 feuillets. Hauteur, a 1 centimètres; largeur, 15 eentimètres. 1 lignes par page. Ms. du xrn' siècle. - (Supplément 1342 , Saint-Germain s99.)

\section{$4601 \div 4603$.}

. Commentaire de Mohlammad ibn Solaïmàn al-Sàïm ibn 'Mbd al-Riḷmàn alTilimısânì al-Djozoûlì sur la qașida mystique de Moùsâ ibn 'Alî al-Tilimsânì. Commencement :

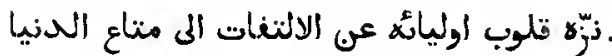

Copie datée de l'an $127^{5}$ de l'hégire (1858 de J.-C.).

3 vol. Papier. 305, 227 et 273 feuitlcls. Hauteur, a a centimètres; largeur, 18 eentimètres. 25 lignes par page. - (Supplément 9460 à 2463 .)

\section{4.}

ب. Source de ta cerlitude, traité sur les principes des principes de la religion” ou r Lumières el mystères", par Moḥammad ibn Mortadhâ Moḥsin. Liauteur expose les connaissances que Dieu lui avait révélées au sujet de li religion, de l'homme et du monde. Conmencement :

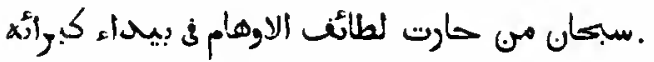

Papier. 319 pages. Hauteur, 19 centimètres el demi; largeur, 13 centimètres. 18 lignes par page. Its. du xvı sièele. - (Supplément 18148.$)$

\section{5.}

o Livre de la Majesté divine, transmis à la postérité par le prophète Daniel \%. C'est un traité de cosmogonie. On lit dans la préface que cette révélation, écrite sur une toile de soie blanche, avait été envoyée par Dieu à Adanı, Un nommé 'Aludallah ibn Salàm, ayant déterré ce trésor, en comnuniqua le contenu au calife 'Othmàn.

Ms. daté de l'an 1053 (1642-1643 de J.-C.).

Papier. 35 feuillels. Hauteur, a 1 centimètres; largeur, 15 centimètres. 93 lignes par page. - (Ancien fonds 384.)

\section{6.}

$1^{\circ}$ Le traité de cabale de Kamâl al-Din Aboû-Sàlim $9 \%$ 
Mohammad ibn Ṭalha. (Voyez ci-dessus, $n^{\text {os }}{ }_{2} 663$ et suiv.)

$2^{\circ}$ (Fol. $85 v^{\circ}$.) Controverse théologique entre un juif el un Turc. En turc.

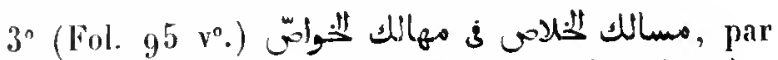
Tisch-Kuprizadè. (Voyez Hadji-Khalla, t. V, p. 507.)

$4^{\circ}\left(\right.$ Eol. $\left.107 \mathrm{v}^{\circ}.\right)$ Gloses de Yoûsof ibn Djamâl sur quelques passag̣es du Miftâț.

$5^{\circ}$ (Fol. $\left.{ }_{12} 6.\right)$ Gloses de Maulà Hanbali-zâdè sur le commenlaire de l'Isagoge par Al-Fanàrî.

$6^{\circ}$ (Fol. $155 v^{\circ}$.) Préface de Bàbâ ał-Scherwânî.

$7^{\circ}$ (Fol. $158 v^{\circ}$.)

$8^{\circ}\left(F_{0} l_{1} \mathbf{1}_{2} v^{\circ}\right.$.) Observations sur le chapitre de la Hidàya relatif au jeûne.

$9^{\circ}$ (Fol. $173 v^{\circ}$.) Observations d'Al-Scherwânî sur le commentaire des 'Aqäìd d'Al-Nasafì par Al-Taftàzânî.

$10^{\circ}$ (Fol. 177.) Pend-nàmè. En turc. Titre :

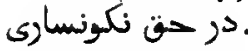

$11^{\circ}$ (Fol. 188.) Fragments et extrails divers.

$12^{\circ}$ (Fol. $\left.251 v^{\circ}.\right)$ Commentaire d'Aboû Haiyân alAndalosî sur l'Adjorroûmîya.

Papier. 274 feuillets. Hauteur, 21 centimètres; largeur, 15 centimètres. Écritures diverses du xvi et du xvir siècle. - (Supplément 193h.)

\section{7.}

Liste des chapitres contenus dans sept volumes dépareillés du Kámil d'Ibn al-Athîr, par Michel Sabbâgh.

Papier. 69 feuillets. Hauteur, 27 centimètres et demi; largeur, 19 centimètres. - (Supplément 2360 .)

\section{8.}

$1^{\circ}$ Le كناب Al-Schatịibî. (Voyez ci-dessus, ${ }^{\circ s} 1545$ et suiv.)

$2^{\circ}$ (Fol. $135 v^{\circ}$.) Quelques recettes magiques.

$3^{\circ}$ (Fol. $136 \mathrm{v}^{\circ}$.) Notes sur les saints de Tlemcen, depuis le $\mathbf{v}^{\mathrm{e}}$ siècle de l'hégire, el sur la généalogie d'Idrìs et des Idrîsites.

$4^{\circ}$ (Fol. ${ }_{13} 3_{9} r^{\circ}$.) Entretien de Moïse avec Dieu. Suivent quelques recettes superstitieuses.

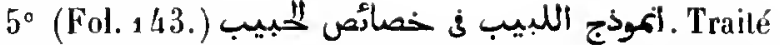
sur les qualités du Prophète, par Djalâl al-Dìn 'Abd al-Rahmân al-Soyoûtî. C'est un abrégé de l'ouvrage du mème auteur inlitulé

$6^{\circ}$ (Fol, 151.) Tradition et prédiction du Prophète concernant le Daddjàl.

$7^{\circ}$ (Fol. 153.) Prières, litanies et invocatious, par 'Abd al-Qàdir al-Djilàni. Le commencement manque.

Les six premiers traités sont de la même main et datés de l’an 1239 de l'hégire, sauf le troisième, qui porte la date de 1243 . Le septième est d'une écriture plus ancienne.

Papier. 190 feuillets. Jlauteur, 29 centimètres; largeur, 15 centimètres. 35 à 38 lignes par page; 23 lignes dans le dernier ouvrage. - (Supplément 2478 .)

\section{9 .}

$1^{\circ}$ Histoire des sultans Rasoulides (بنو رسول), souverains du Yémen, précédée d'une chronologie universelle, depuis la chute d'Adam, père du genre humain, jusqu'à l'an 845 (1441-1442 de J.-C.), qui s'étend surtout sur le règne du sullan Al-Màlik al-Zâhbir, fils de Yaḷyâ, fils d'Al-Màlik al-Aschraf.

$2^{\circ}$ (Fol. $7^{5} \vee^{\circ}$.) Tableaux des prídiclions qu'on peut. lirer des mouvenıents involontaires du corps (ikhtiladj) et des mourements de la lune et des étoiles.

$3^{\circ}$ (Fol. 98.) Almanach et prédictions pour l'an 841 de l'hégire (1437-1438 de J.-C.). Suivent des tableaux indiquant les divers phénomènes astronomiques de cliaque mois de l'année.

Ms. daté de l'an 845 (1441 de J.-C.).

Le texte est disposé en forne de tableaux.

Papier. 192 feuillets. Hauteur, 27 centimètres; targeur, 18 centimètres. - (Ancien fonds $1119 \mathrm{~g}$ A.)

\section{0.}

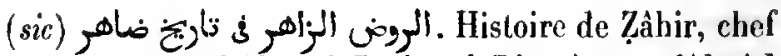
syrien du temps d'Aḥmad-Pacha al-Djazzâr, par 'Aboud Sabbaigh.

La copie n'est pas terminée.

Papicr. 40 feuillets. Hauteur, 16 centimètres; largeur, 10 centimètres. 17 lignes par page. Ms. du xvmı siècle. - (Supplément 2472.) 


\section{1.}

Fragment d'un exemplaire du Hosn al-Mohadira d'AlSoyoûtị. On y Irouve l'autobiograplie, précédée de deux pièces de vers donl l'une est d'Al-Sialàh al-Safadi.

Papier. 10 feuillets. Hauteur, 20 centimètres et demi; largeur, 14 centimètres et demi. 19 lignes par page. Ms. du xvin' siècle. (Supplément 2984.)

\section{2.}

Histoire de la conquête de l'Égyple sur les Mamloucks circassiens par te sullan Sélìm, par Nohammad alZanbalì al-Rammâl. C'est le même ouvrage que le $\mathrm{n}^{\circ}{ }_{1832}$ dans une rédaction différente.

Ms. daté de l'an 1264 de l'hégire (1848 de J.-C.).

Papier. 117 feuillels. Hauteur, 21 centimètres; largeur, 15 centi: mètres. э3 lignes par page. - (Supplément 9471.)

\section{3.}

. Dissertation sur l'origine des Circassiens, dont l'anteur fait remonter la généalogie à l'ancêtre de la tribu de Qoraïsch. Cet ouvrage a été composé après la conquète de l'Égyple par le sultan Sélîm.

Ms. daté de l'an 1043 (1633 de J.-C.).

Papier. 32 feuillets. Hauteur, a 1 centimètres et demi; largeur, 15 centimètres. 15 lignes par page. - (Supplément 1837.)

\section{4.}

$1^{\circ}$ Histoire de la dynastie des 'Obaidites, par Abou 'Abdallah Moḥammad ibn 'Alì ibn Ulammàd. (Voyez cidessus, $\mathrm{n}^{\circ}{ }_{1888 .}$ )

$2^{\circ}\left(\right.$ Fol. $101 v^{\circ}$.) Extrails du reccueil biographique de Badr al-Dîn Moḷammad ibn Yaḷyâ ibn 'Omar al-Qarâfi, intitule توشيج الديباج وحلية الابنهاج

$3^{\circ}$ (Fol. $127 v^{\circ}$.) Extrail de l'bistoire de l'Algérie sous la domination des Turcs, par Aboû-Râs Moṭammad ilon Aḷmad ibn 'Abd al-Qûdir.

Papier. 138 feuillets. Hauteur, 20 centimètres; largeur, 13 centimètres. 9 lignes par page dans le premier ouvrage, 15 à 17 lignes dans les deux autres, qui sont d'une autre main. Ms. du xis siècle. - (Supplément 2457. )

\section{5 .}

Hisloire de la dynastie des 'Obaïdites, par flbn Ịammâd. Copie exéculée à Alger en 1882 .

Papier. 55 feuillets. Hauteur, 16 eentimètres; largeır, 10 centimètres. 14 lignes par page. - (Supplément 2480. )

\section{6.}

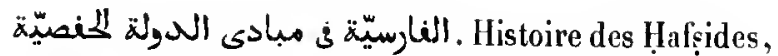
par Aboù 'l-'Abbàs Aḥmad al-Khațîb. (Voyez Journal asiatique, octobre 1848 ; mai 1849 ; janvier 1851 ; aoûtseptembre 1852.)

Ms. dalé de l'an 1882.

Papier. 83 feuillets. Hauteur, 16 centimètres; largeur, 11 centimètres. $1 / 4$ lignes par page. - (Supplément 2494 .)

\section{7.}

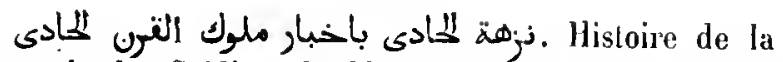
dynastie des $\mathrm{Sa}^{\mathrm{c}}$ dites du Maroc, au $\mathrm{xl}^{\mathrm{e}}$ siècle de l'hégire, par Mohammad ibn al-Ịâddj Moḷanınad alOfrânî. Ce texte a été publié par M. O. lloudas (Paris. 1888).

Ms. daté de l'an 1284 de l'hégire ( 1867 de J.-C.).

Papier. 126 feuillets. Hauteur, 38 centimètres; largeur, 26 centimètres. 19 lignes par page. - (Supplément 2465.)

\section{8.}

. ويائب الاسنار ولطائف الاخبـار . Qaṣìda sur l'histoire d'Oran et d'Alger avec commentaire, par Mohammad Aboû Ràs ibn Ahmad ibn 'Abd al-Qâdir al-Nașrî. Cet ouvrage a été composé en 1206 de l'hégire.

Ms. daté de l'an 1283 de l'hégire (1866 de J.-C.).

Papier. 154 feuillets. Hauteur, 24 centimètres: largeur, 19 centi= mètres. a lignes par page. - (Supplément 248 .)

\section{9.}

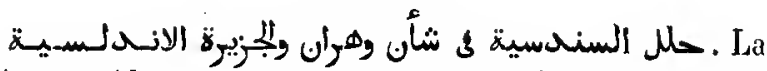
même qașida, avec un autre commentaire composé par l'auteur. Le poème présente des variantes nombreuses. 
Papier. $9^{8}$ feuillels. Hauteur, 94 centimètres; largeur, 17 centimétres. 23 lignes par page. Ms. du $\mathrm{nx}^{\mathrm{e}}$ siècle. - (Supplément 2464.)

\section{0.}

Histoire de la conquête de la Mauritanie sous le règne d'Othmàn (voyez ci-dessus, $n^{0 s} 1879$ et suiv.).

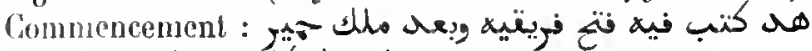

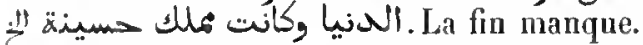

Hs. daté de l'an 1057 (1647-1648 de J.-C.); très manvaise écriture naghrébine.

Papier. 142 feuillets. Hauleur, 20 centimètres et demi; largeur, 15 centimètres. 18 à 25 lignes par page. - (Ancien fonds 1500 .)

\section{1 .}

Seconde partie de l'histoire de la conquète de l'Afrique (فنتوح المغب) par les musulmans.

Ms. daté de l'an 1245 de l'hégire (1830 de J.-G.).

Papier. 189 feuillets. Hauteur, 21 centimètres; largeur, 15 centimòtres. 19 lignes par page. - (Supplément \$466.)

\section{2.}

Discours à la louange de Louis $X \mathrm{IV}$, composé par Paul Pellisson et traduit en arabe par Stephano Petro, patriarche d'Antioche. En tète se trouve une dédicace à l'adresse de ce sourerain signée Bonnecorse. Suit un dialogue en vers français, entre l'Asic el je Soleil. Le texte arabe du discours est accompagné d'une traduction italienne. A ce volume est jointe une lettre arabe adressée par Pierre Ignace, patriarche de Syrie, à Louis XIV, pour implorer sa proteclion auprès de la Porte Ottomane. Celte lettre est écrite en caractères syriaques.

IIs. daté de l'an 1671 .

Papier. 20 feuillets. Hauteur, 20 centimètres el demi; largeur, 14 centimètres el demi. - (Ancien fonds 1620.)

\section{3.}

1 Histoire du patriarche Joseph, composée principalement des récits atlribués à Kacb al-Ahbàr. Le commencemenl et la fiu manquent. $3^{\circ}$ (Fol. 7o.) Collection de légendes musulmanes, dont les premières se rapportent aux miracles de JésusChrist. Dans les dernières, il s'agit de Mahomet. Le commencement et la fin manquent.

Papier. 84 fenillets. Hauteur, 19 centimètres; largeur, 14 centimètres et demi. 17 lignes par page dans la première pièce et 13 dans la seconde. Ms. du $\mathrm{xrl}^{\mathrm{e}}$ siécle. Deux écritures différentes. - (Ancien fonds 1546.)

\section{4.}

- Histoire du patriarche Joseph, en vers. Commencement :

$$
\text { سلام مى الله المكوبم على أثترن العربان }
$$

$2^{\circ}$ (Fol. 87.) Histoire d'Al-Fașị̣, en vers. Dans ce poème el dans le précédent, la rime change toujours aú troisième et au cinquième vers. On y remarque des locutions et des tournures vulgaires.

$3^{\circ}$ (Fol. $123 v^{\circ}$.) Sermon pour la solennifé du sacrifice à la Meeque.

Ms. daté de l'an 1099 ( 1688 de J.-C.).

Papier. 130 feuillets. Hauteur, 15 centimètres; largeur, 10 centimètres. 14 lignes par page. - (Supplément 1916.)

\section{5.}

- Histoire du prophète Khâlid ibn-Sinân.

$3^{\circ}$ (Fol. $12 v^{\circ}$.) Chronique des 'Obaïdites, par Aboû 'Ahdallah Mohammad ibn Alì ibn Hammâd.

$3^{\circ}$ (Fol. $42 v^{\circ}$.) Histoire de la dynastic des BeniHafs, par Aboû 'Abdallal Mohammad ibn Aḷmad ibn Schammâ‘ (Voyez Journal asialique, 1855 , t. I, p. 399.)

Ms. daté de l'an 1264 de l'hégire (1848 de J.-C.).

Papier.' 91 feuillets. Hauteur, 23 centimètres; largeur, 18 centimètres. 15 lignes par page. - (Supplément 2458.)

\section{6.}

r Traité qui fait disparaître l'obscurité des termes employés dans le Schifàn, par Aḷmad ibn Molıammad al-Schomonnî. La souseription nous apprend que l'ourrage a été achevé en 780 de l'hégire $(1378-1379)$; il faut donc regarder comme inexacte la date de 872 donnée par Hadji-Khalfa. (Voyez 
ci-dessus, $n^{\circ} 19^{5} 7,2^{n}$.) Commencement :

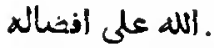

Papier. 74 feuillets. Hauteur, a centimètres; largeur, 15 centimètres. 14 lignes par page, puis 19 , puis 3o, à partir dı feuillet 49 . .Is. de deux écritures du xri siècle. - (Ancien fonds 1348.)

\section{7.}

توشيح الديباج وحلية الابتهاج Supplément au dictionnaire biographique des docleurs malékites intitulé ديباج المذهب ذي معرفة أعبان علهاء المذهب de Borhàn alDin Ibrâhîm ibn Farḥoûn, par Badr al-Din Moḥammad ibn Yaḷyâ al-Qarâfî. (Voyez Journal asiatique, 1859 , ı. I, p. 94.$)$

Papier. 96 feuillets. Hauteur, 21 centimètres; largeur, 12 centimìtres. 21 lignes par page. Ms. du xvi $^{\mathrm{e}}$ siècle. - (Supplément 2455.)

\section{8.}

ك. Supplément au dictionnaire biographique des docteurs malékites d'Ibn Farḥoûn, par Aḥmad Bâbà ibn Aḥmad al-Timbouktì (voyez Journal asiatique, 1853 , t. I, p. $9^{3}$ et suiv.). L'auteur dit dans la préface que le présent ouvrage est un abrégé d'un recueil plus étendu el inlitulé : نيل الابتهاج بتنطيز المبياج

Ms. exéculé pour M. Cherbonneau en 1279 de l'hégire ( 1863 de J.-C.).

Papier. ${ }_{2} 87$ feuillets. Hauteur, 20 centimètres; largeur, 15 centimètres. 17 lignes par page. - (Supplément 3463.)

\section{9 .}

Dictionnaire chronologique des compagnons du Prophète, des traditionnistes et des savants, par Aboû 'l'Abbàs Alymad ibn al-Hasan ibn 'Alî ibn al-Khatib ibu al-Qonfouds, de Constantine. (Voyez Journal asiatique, 1852 , t. 11, p. 208 et suiv.)

Ms. daté de l'au ${ }_{12} 69$ de l'hégire (1853 de J.-C.).

Papies. 81 feuillets. Hauteur, 16 centimètres; largenr, 11 centimètres. 9 lignes par page. - (Supplément a 481 .)

\section{0.}

Biographies des saints et des savants de Tlemeen, par Molyammad ibn Moḥammad ibn Ạ̣mad ibn Maryam al-Tilimsânî.

Copie moderne. La date à la fiı a été changée (1269?).

Papier. $9^{5}$ fenillets. Hauterr, 28 centimètres: largeur, 19 cenlimètres. 26 lignes par page. - (Supplément 2459 .)

\section{1.}

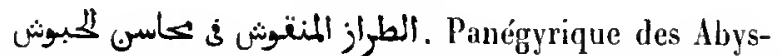
sins; trailé composé à Médine, l'an 991 de l'hégire (1583 de J.-C.), par 'Alà al-Dìn Mohammad ibn 'Abd-

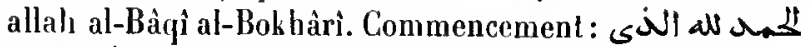

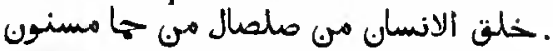

Ms. dalé de l'an 1065 de l'hégire (1655 de J.-C.).

Papier. 74 feuillets. Hauteur, 20 centimètres et demi; largenr, 15 centimètres. 21 lignes par page. - (Supplément 1838.)

\section{2.}

. C'est une autre rédaclion de l'ouvrage précédent. Il est dit dans la prélace que ce

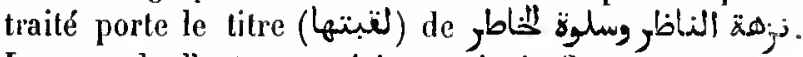
Le nom de l'auteur a été supprimé. Commencement :

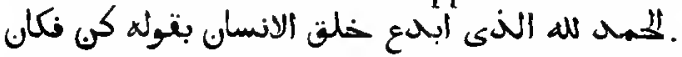

Papier. 104 feuillets. Hauteur, so centimètres; largeur, 14 centimètres. 13 lignes par page. Ms. du xrü siècle. - (Supplément 1839 .)

\section{3 et 4634.}

Deux passeports arabes sur papyrus datés de l'an 133 de l'hégire. M. de Sacy en a donné une notice dans le tome IX des Mémoires de l'Institut, Académie des inscriptions et belles-lettres.

(Supplément 1956 et $1956 \AA$.)

\section{5.}

Fragment de papyrus contenant des traces de quelques mots arabes.

(Supplément 1956 bis.) 


\section{6.}

Deux lettres en arabe, datées de 1657 et 1658 et adressées à Henri de Guise, et trois firmans, en ture, accordés à Bernard de Montano, Barthelemy Daux et Richard Le Poignant. Ces firmans, dout l'un est accompagné de la traduction française, sont datés de l'an 985 de l'luégire ( 1577 de J.-C.).

Papier. 6 feuillets. Hauteur, 40 centimètres; largeur, 27 centimètres. - (Supplément 1352 bis.)

\section{7.}

Traité sur les vices des femmes, etc., qui se compose principalement de maximes et forme la douzième section d'un ouvrage dont le titre n'est pas indiqué.

Papier. 8 feuillets. Ilanteur, 16 centimètres; largenr, 11 centimètres et demi. $1 / 4$ et 15 lignes par page. Ms. du xix siècte. (Supplémeni 2264.)

\section{8.}

Livre de l'étiquette et du cérémonial r. Ce traité, écrit en un jargon moitié arabe, moitié turc, renferme des instruetions et des règles de conduite pour les officiers attaehés à la maison militaire du paclua établi en Égypte, maison qui se composait d'un eorps de janissaires. Le copiste, qui était commis principal de l'administration (Bach-Khalifat al-Mostahfisin), désigne cet ouvrage par le titre de r Panearte (تيمة) de l'étiquette et de la voie qui mène vers Hiàddj Baktàch (patron des janissaires) n.

Ms. daté de l'an 1187 de l'lıégire $\left(177^{3-1} 77^{4}\right.$ de J.-C.).

Papier. 59 feuilleis. Hauteur, 23 centirrètres; largeur, 16 centimèlres. 13 lignes par page. - (Supplément 55\%.)

\section{9.}

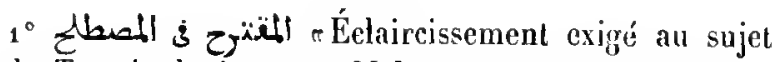
de la Terminologien, par Moḥammad ibn Ismấill, surnommé lbn Wadấa (äsis وأبر), et aussi Ibn al-Bakkàl. L'auteur explique les usages, les règyles très compliquées et les termes techniques qu'il faut connaître si l'on veut prendre part à un eertain jeı prineier dans lequel on luttait d'adresse pour abattre les gros oiseaux avec l'are et l'arbalète. L'ourrage, composé de dix ehapitres, est dédié au calife Al-Nâș̣ir li-Dìn IHlâh, qui régna de 575 à 622 de l'hégire. Cominencement de la préface

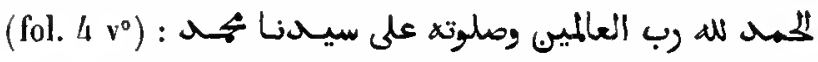

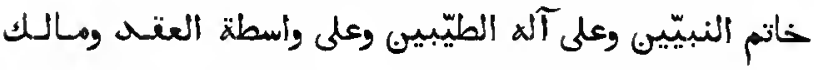

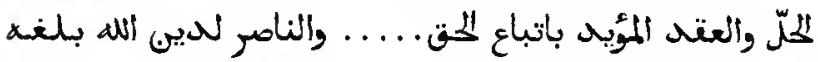

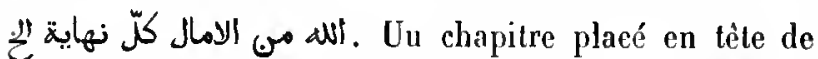
Fouvrage et composé par un nommé cAbd al-Madjid fournit des renscignements eurieux sur les diverses espèces d'oiseaux qui se voyaient dans les réserves du sultan Al-Mâlik al-Nâsir Aḷmad (probablement lè calife abbaside Al-Nâșir li-Dìn lllâh Aḷmad). On y lit que ce prinee se distingua particulièrement dans une partie de tir qui eut lieu en 576 . Plus loin, l'auteur donne des renseignements analogues sur le prince Aiyoubide AlMâlik al-Asehraf Moùsâ, fils d'Al-Màlik al- 'Âdil Saîf al-Din.

$2^{\circ}$ (Fol. 38. Déeisions juridiques au sujet des eas obseurs qui se présentent dans le jeu du tir à l'arbalèten. C'est uu nommé Șalât (صاوات) Ibn Ghâzì qui paraît avoir résolu ees questions.

$3^{\circ}$ (Fol. 6 1.) Poème en strophes de einq hémistiches dans lequel Al-Safí al-tililli donne des instructions pour le jeu du tir à l'arbalète.

$4^{\circ}$ (Fol. 68.) Autres poèmes sur te même sujet.

$5^{\circ}$ (Fol. 81 v $^{\circ}$.) Qaṣida d'Al-Ḥâddj Mahkî al-Qauwâs (l'archer), suivi d'autres poèmes du même genre.

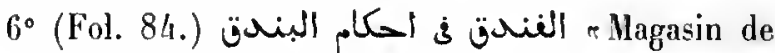
décisions au sujet des cas qui se présentent dans le jeu du tir à larbalèten, par Șalât Ibn Ghàzì. Commence-

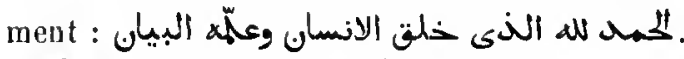

Mls. daté de l'an 1038 (1629 de J.-C.).

Papier. 112 feuillets. Hauteur, 20 centimètres et demi; targeur, 14 centimètres. 21 lignes par page. - (Ancien fonds 1579.$)$

\section{0.}

Recueil choisi, servant à dévoiler les secretsn, par "Abd al-Raḥmân ibn ab̂̂ Bakr al-Djaubarì (ب) de Damas. L'auteur expose, dans une série de chapitres formant trente sections, les fraudes, impostures et fourberies auxquelles se livrent les charlatans et les gens des divers métiers. Il indique, dans la préface, les livres qu'il avait compulsés et dont 
la liste a un certain intérèt bibliographique. Comnence-

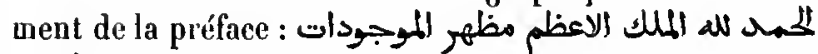
.

Papier. 142 feuillets. Hauteur, 17 centimètres et demi; largeur, 1 a centimètres. 18 lignes par page, puis 11 . Ms. du xiv siècle. (Ancien fonds 939.)

\section{1.}

Paillettes d'or, dictionnaire de termes médicaux», par Mohammad ibn 'Omar al-Toúnesi, ancien élève de l'École de médecine du Caire. L'auteur a réuni, sous forme de dictionnaire, et expliqué les termes anciens et modernes des sciences médicales, naturelles ct vétérinaires. Cet ourrage a été fait sous la direction du docteur Clot-Bey.

Ms. autographe daté de l'an 1265 (1849 de J.-C.).

Papier. 599 feuillets. Hanteur, 98 centimètres et demi; largeur, 20 centimètres et demi. 27 liøgnes par page. - (Supplément ${ }_{13}{ }_{7} 8$.)

\section{2.}

م Tristesse de (l'amant) qui se plainl et larmes de celui qui pleure» (voyez ci-dessus, $\left.\mathrm{n}^{\circ} 3074\right)$. L'auleur, d'après Hadji Khalfa, est Zaïn alDìn Manşoûr ibn 'Abd al-liạmàn.

Papier. 64 feuillets. Hauteur, 20 centimètres et demi; largeur, 15 centimètres. 17 lignes par page. Ms. dı xvu' siècle. - (Supplétnent 1806.)

\section{3.}

Recueil de traités, principalement sur des sujets érotiques, dont la plupart ont élé composés et transcrits par Aboû Dsâkir Mohammad ḷasan, surnommé Kitlàbat al-Moḷammadiya ou le secrétaire de la Moḷammadiya, vers $117^{0}$ de l'hégire. On trouve dans le volume le récit d'un royage que Mobammad fit dans la ville de Girgé, d'un aulre qu'il fit en s'embarquant au port de Cosseïr pour le llidjàz, ete.

Papier. 250 feuillets. Hauteur, 22 centimètres; largeur, 16 eentimètres. 20 à 24 lignes par page. Ils. de diverses écrilures du xvı" siècle. - (Supplément 1 836.)

\section{4.}

Dévoilement Max. orientadx. - ll. des mystères au moyen de la parole donnée aux oiseaux et aux fleurs n, ouvrage allégorique rédigé avec beaucoup d'élégance par 'Tzz al-Din ibn Ghânim al-Maqdisî. Com-

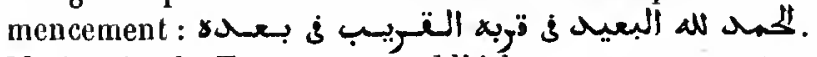
M. Garein de Tassy en a publié le texte avec une traduction française, en 1821 .

Papier. 35 feuillets. Hauteur, 18 centimètres; largeur, 13 centimètres et demi. 17 lignes par page. Ms. du xvi siècle. - (Ancien fonds 966 , Colbert 5300.)

\section{5 .}

Cahiers d'étude d'un Français qui séjournait à Constantinople en ${ }^{106} 7$ de l'hégire (1656-1657 de J.-C.) et qui se faisait appeler 'Alì ibn 'Abdallah al-Ifrandjî. On trouve dans ce recueil une partie assez considérable des Moqaddimát al-Adab d'Al-Zamakhschari, et un grand nombre de passages en ture, avec transeription en caractères européens et des notes en arabe, en persan et en latin. Ce volume porte la signature de Galland, qui étail à Constantinople en $16_{70}$.

Papier. 578 feuillets. Hauteur, 15 à 16 centimètres; largeur, 10 eentimètres et demi. - (Aneien fonds 1366.)

\section{6.}

Quatre feuillets de carton, portant des beaux modeles d'écriture neskhi orientale. L'une de ces pièces est datée de l'an $9^{80}$ de l'hégire $\left(1572-157^{3}\right.$ de J.-G.).

Papier. 4 feuillets. Hantenr, 25 centimètres; largeur 18 centimètres. - (Supplément 307 bis.)

\section{7.}

Modèles d'écriture arabe qui paraissent être de la main d'un prètre syrien.

Papier. 31 feuillets. Hauteur, 16 centimètres; largeur, 22 centimètres et demi. Ifs. du xrie siècle. - (Supplément 1146.)

\section{8.}

Grand feuillet plié en forme de paravent et couvert de modèles d'écriture. Les proportions des lettres sont indiquées par des points. C'est l'ourrage d'un' fameux calli- 
graphe, Moḥammad al-Hàschimi, qui l’a exécuté pour les enfants du célèbre Moștafâ-Pacha Kiuperli.

Pièce datée de l'an 1100 (1688-1689 de J.-C.).

Papier. Hauteur, 21 centimètres; largeur, 13 centimètres. (Supplément 1147.)

\section{9.}

Quelques spécimens de bonne écriture arabe.

Papier. 5 fenillets. Hauteur, 56 eentimètres; Jargeur, 27 centimètres. - (Supplément a336.)

\section{0 .}

Quatre tablelles de bois, de forme oblongue et aux extrémités arrondies. Ces planches, appelées لوح, servent aux enfants dans les écoles pour apprendre à lire et à écrire. On y a inscrit des passages du Coran et d'autres morceaux, le tout en mauvais caractère maghrébin.

(Supplément s335.)

\section{1.}

Calques de plusieurs tableaux représentant les alphabets samaritain, hébreu, gree, et quełques alphabels cabalistiques et hermétiques, avec transcriptions, rubriques et explicatious en arabe.

Papier. 8 feuillets. Hauteur, 38 centimètres; largeur, 19 centimètres. - (Supplément פ129.)

\section{2 .}

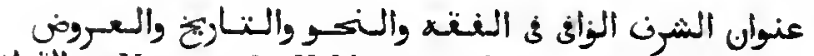
والثتوأف "Marque de Noblesse parfaite, ouvrage renfermant la jurisprudence, la grammaire, l'histoire (des Rasoulides du Yemen), la prosodie et les règles auxquelles. sont soumises les rimesn. Chaque page de ce livre siugulier, esl divisée en colonnes, donl quałre se composent de mots et de letlres écrits à l'encre rouge. Ces mots et ces lettres font partie du traité de jurisprudence, mais en les lisant de haut en bas, ils fournissent un sens suivi et forment quatre traités séparés (voy. le Catalogue de la Bibl. de Vienne, ᄂ. I, p. 1.4). L'auteur de ce tour de force se nommait Scharaf al-Dìn Ismâîl Ibn al-Moqrì
al-Yamani, mort, selon Hadji-Khalfa, en 837 de l'hégire (1433-1434 de J.-C.). Commencement : لمحمد له تعاله

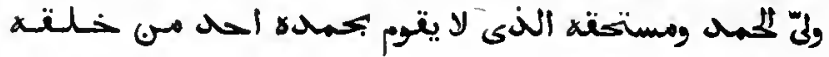

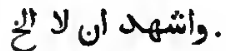

Ms. daté de l'an 84i1 de l'hégire (1440-1441 de J.-C.).

Papier. 8s feuillets. Hauteur, 30 centimètres; largeur, a a centimètres. - (Supplément 1864.)

\section{3.}

Même ouvrage.

Ms. daté de l'an 1055 de l'hégire (1645 de J.-C.).

Papier. $7^{8}$ feuillets. Hauteur, 23 centimètres; largeur, 16 centimètres. - (Supplément 1863.)

\section{4.}

Même ouvrage.

Papier. 57 feuillets. Hautcur, 35 centimètres; largeur, 16 centimètres. Ms. du xñt siècle. - (Ancien fonds 1391.)

\section{5.}

Même ourrage.

Papier. 73 feuillets. Hauteur, 85 centimètres; largeur, 20 centimètres. Ms. du xv11 ${ }^{\circ}$ siècle. - (Supplément 2061.)

\section{6.}

Même ouvrage.

Ms. daté de l'an 1214 (1 799-1800 de J.-C.). Il parait être de la main de Michel Sabbâgh.

Papier. $9^{6}$ feuillets. Hautenr, 48 centimètres; largeur, 31 centimètres et demi. - (Supplément 186a.)

\section{7.}

Opuscules de Maqrîzì, savoir :

$1^{\circ}$ Traité des famines de l'Égypte. La fin manque.

$\mathbf{2}^{\circ}$ (Fol. 20.) Traité des monnaies chez les musul- 
mans. Cet opuscule a été publié en arabe et en latin par G. Tychsen. S. de Sacy en a inséré une traduetion francaise dans le Magasin encyclopédique. Le comnıncement manque.

$3^{\circ}\left(\mathrm{Fol}_{0}{ }_{4} \mathrm{v}^{\circ}\right.$.) Traités sur les abeilles.

$4^{\circ}$ (Fol. $7^{6} v^{\circ}$.) Traité historique sur la vallée de Hadhramant.

$5^{\circ}$ (Fol. $82 v^{\circ}$.) Traité relatif à Tamìm-Dârî et inti-

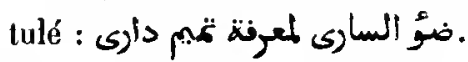

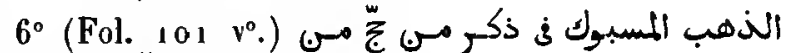
Sur les califes et les rois qui ont fait le pèlerinage de la Mecque.

$7^{\circ}$ (Fol. $132 \mathrm{v}^{\circ}$.) Réfutation des prétentions des descendants d'Omaïya au titre de Calife.

$8^{\circ}$ (Fol. $168 v^{\circ}$.) Traité des droits et des prérogatives de la famille du Prophète.

$9^{\circ}\left(\right.$ Fol. $19^{\circ} \mathrm{v}^{\circ}$.) Traité des substances minérales.

$10^{\circ}\left(\right.$ Fol. $200 \mathrm{v}^{\circ}$.) Traité des tribus arabes établies en Egypte.

$11^{\circ}$ (Fol. $220 \mathrm{v}^{\circ}$.) Traité des princes musulmans qui ont régné en Abyssinie. Cet opuscule a été publié en arabe et en latin par Rinek.

$12^{\circ}$ (Fol. 231 vo.) كتاب تجريد اللتوحيـد اللغنيسل. Traité de l'unité de Dieu.

$13^{\circ}$ (Fol. $251 \mathrm{v}^{\circ}$.) Motifs qui invitent les hommes à mettre tout en œuvre pour acquérir une réputation durable.

$14^{\circ}$ (Fol. $254 v^{\circ}$.) Que l'homme doit demander à mourir pieusement (خاتمة خليم)

${ }_{15}^{\circ}\left(F_{0}\right.$. $260 \mathrm{v}^{\circ}$.) Explication d'une énigme dont l'eau était le sujet.

(Voyez la préface de l'histoire des sultans mamloucks, de Maqrîzî, traduite par Quatremère, p. xıv et suiv., et la Chrestomathie de S. de Sacy, $2^{\circ}$ éd., t. I, p. 117 et suiv. Voyez aussi les Notices de M. Reinhardt Dozy, p. 17 et suiv.).

Papier. 265 feuillets. Hauteur, 22 centimètres; largeur, 15 centimètres. 25 lignes par page. Ms. du xvm1 siècle. - (Supptément 1938.)

\section{8.}

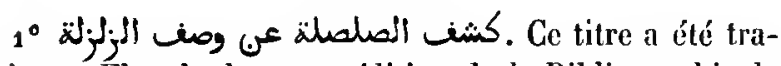
duit par Flügel, dans son édition de la Bibliographie de Hadji-Khalfa, par : Detectio fragoris de descriptione terre motus . Le traité commence par ces mots all $\alpha \_$H

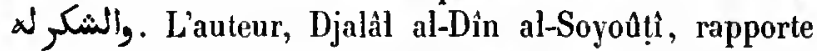
d'abord toutes les traditions de Mahomet au sujet des tremblements de terre; puis il donne une liste de ces phénomènes, depuis le tremblement de terre qui eut lieu lors de la naissance de Mahomet jusqu'à celui qui désola l'Égypte et la Syrie l'an 702 (1303 de J.-C.). A la suite de cette notice, vient une liste complémentaire

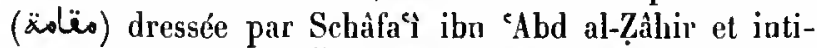
tulée : r Indications manifestes des grands événements et des tremblements de terre r qui s'arrête à l'an 996 (1588 de J.-C.).

$2^{\circ}$ (Fol. 36. (J'obtention de la faveur (divine) alin de se procurer les moyens d'existence », par Djạâl al-Dîn al-Soyoûṭi. L'auteur énumère les traditions se rapportant à ce sujet.

Au commencement et à la fin se trouvent de nombreuses notes, recettes, traditions, etc.

Ms. daté de l'an 1 15 Ł (1741-174a de J.-C.).

Papier. 42 feuillets. Hauteur, 21 centimètres; largeur, 25 centimètres. 17 lignes par page. - (Supplément 869.)

\section{9 .}

Divers traités d'Al-Soyoûṭ̂̀ :

$1^{\circ}$ Paroles d'Al-Soyoûti sur ce qui fait la ruine des divers pays.

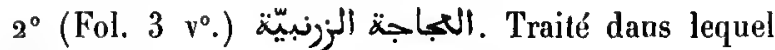
l'auteur démontre que les chérifs zaïnabides descendent de Mahomet.

$3^{\circ}$ Fol. 11.) (كن) Notice chronologique des tremblements de terre.

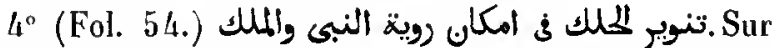
la question de savoir si l'apparition du Prophète ou d'un ange à un soufi pendant qu'il est dans un état d'exaltation doit être considérée comme réelle ou non.

$5^{\circ}$ (Fol. $35 \%^{\circ}$.) Sur la prière de l'avant-midi ( $\mathrm{Al}$ Dhola $\hat{a})$.

$6^{\circ}\left(\mathrm{Fol}_{.} 97 \mathrm{v}^{\circ}.\right)$ Un étudiant de droit doit-il porter l'habit de légiste on conserver son habillement ordinaire?

$7^{\circ}$ (Fol. 101.) äeNl. Réponses à sept questions touchant les âmes des morts.

$8^{\circ}\left(F_{01} .110 v^{\circ}\right.$.) Réfutation de la doctrine de l'incarnation. 
$9^{\circ}$ (Fol. 123.) Quelques questions résolues par AlSoyoûtî.

$10^{\circ}\left(\right.$ Fol. $126 \mathrm{v}^{\circ}$.) Réprobation manifestée par l'abstention ". Sur l'obligation d'éviter la société des faux docteurs.

Papier. 130 feuillets. Hauteur, a 1 centimètres; largeur, 14 centimètres. 15 lignes par page. Ms. du xviri siècle. - (Supplément 1917 bis.)

\section{0.}

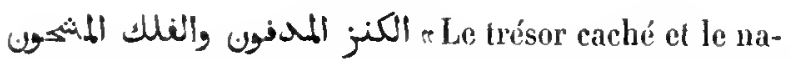
vire chargén. Recueil d'extraits, de recelles, de renseignements utiles et d'anecdotes curieuses, par un homme de lettres nommé (par Hadji Khalla) Yoûnos le Malékite. Le commencement manque.

Papier. 33o feuillets. Hauteur, so centimètres et demi; largeur, 14 centimètres et demi. 21 lignes par page. Ns. du xvur' siècle. (Supplément 1841.)

\section{1.}

Album renfermant des notes, des prières, de la cabale et quelques pièces en langue turque. Au fol. $16 \mathrm{v}^{\circ}$ se trouve un commentaire sur le traité mystique intitulé

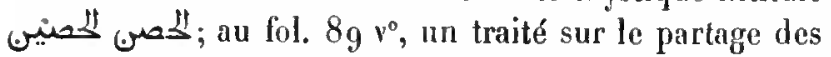
successions; au fol. $130 \mathrm{v}^{\circ}$, un traité sur la terminologie de la science des traditions; et au fol. $140 \mathrm{v}^{\circ}$, un traité

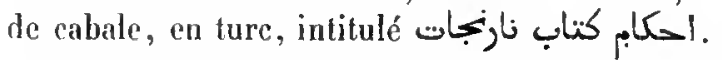

Papier. 169 feuillets. Hauteur, 16 centimètres et demi; largeur, 11 centimètres. Ms. du xvic siècle. - (Supptément 1858.)

\section{2.}

$1^{\circ}$ Notes ef exfraits en prose et en vers.

$2^{\circ}$ (Fol. 8.) Passages du Coran avec gloses se rapportant aux croyances des musulmans.

$3^{\circ}\left(\mathrm{Fol} .14 \mathrm{v}^{\circ}\right.$.) Ouvrage, divisé en vingt et un chapitres, relatif aux croyances et aux pratiques religieuses des musulnans. Il se compose principalement d'anecdotes édifinutes.

$4^{\circ}$ (Fol. 249.) Notes et extraits de diverses mains.

$5^{\circ}\left(\right.$ Fol. $264 \mathrm{v}^{\circ}$.) Explication el analyse grammaticale de quelques passages du Coran. $6^{\circ}$ (Fol. $278 \vee^{\circ}$.) Un Arba in de Moḥammad ibn abî Bakr. Incomplet.

$7^{\circ}$ (Fol. 297.) Fragments divers.

$8^{\circ}\left(\right.$ Fol. $301 v^{\circ}$.) Fragment qui parait appartenir au même ouvrage que l'article $1^{\circ}$. Autres fragments et feuillets détachés; notes et extraits divers.

$9^{\circ}$ (Fol. $3_{2} 8 v^{\circ}$.) Truité des convenances sociales, à l'usage des derviches.

$10^{\circ}$ (Fol. 341.) Traité sur la prière.

$11^{\circ}$ (Fol. $358 v^{\circ}$.) Traité sur les devoirs d'un musulman.

$12^{\circ}\left(\right.$ Fol. $37^{6} v^{\circ}$.) La Borda d'Al-Bousirit. Les premiers vers sont accompagnés d'une traduction interlinéaire en langue turque.

$13^{\circ}$ (Fol. $386 \mathbf{v}^{\circ}$. ) Autre traité sur les devoirs d'un musulman.

$14^{\circ}$ (Fol. $392 v^{\circ}$.) Petit traité d'arithmétique élémentaire.

$15^{\circ}$ (Fol. $4001^{\circ}$.) Traité en vers sur la prononcialion du texte du Coran, par Hoḷammad Ibn al-Djazarí.

${ }_{16}^{\circ}$ (Fol. 404.) Qașida rimant en ani (ayant pour sujet les dogmes de lislamisme, intifulée äll, "composé à la laâten, par Klidu-Beg ibn Djalàl alDìn.

Papier. 109 pages. Hauteur, 21 centimètres; largeur, 15 centimètres et demi. Mls. de diverses écritures du xvirı siècte. - (Supplément ${ }_{1955}$.)

\section{3.}

Recueil de pièces de diverses natures et de diver's formats : brouillons, noles, extraits, copies de lettres, fragments, etc., les uns en arabe, les autres en ture et en français, dont la plupart ont été écrits au commencement de ce siècle et auxquels on a joint un exemplaire de la grammaire française-italienne de Scoppa, portant, en quelques endroits, des anmotations en langue turque. On distingue plus particulièrement:

$1^{\circ}$ Extraits du Divan d'Al-Notanabbi.

$2^{\circ}$ (Fol. 9.) Dissertation (2ّالة) de l'émir Fakhr alDin sur la religrion des Druzes.

$3^{\circ}$ (Fol. 2o.) Copie d'un des écrits sacrés des Diuzes.

$4^{\circ}$ (Fol. 25.) Dialogues en langue turque.

$5^{\circ}$ (Fol. 29.) Notes sur le musicien Zeryâb, extrait 


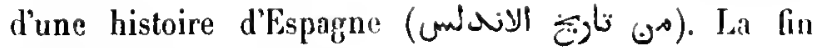
manque.

$6^{\circ}$ (Fol. 3o.) Le deruier chapitre du Fâkihat al-Kholafa d'Ibn 'Arabschàh.

$7^{\circ}$ (Fol. 50.) Dialogues arabes-turcs.

8० (Fol. 69.) Traité de philosophie commmençant

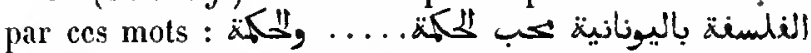

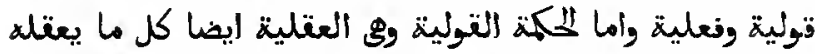

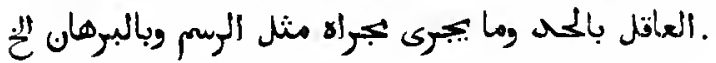

$9^{\circ}$ (Fol. $7^{5}$.) Fragments divers en franģais et copies de quelques pièces officielles.

$10^{\circ}\left(\right.$ Fol. $9^{4} v^{\circ}$.) Copic de la préface du diclionnaire bibliographique de Hadji-Khalfa.

$11^{\circ}$ (Fol. $119 v^{\circ}$.) Vie d'Aboù 'l-Fidà, cxlrail du Manhal al-Saffi.

$12^{\circ}$ (Fol. 113.) Notice biographique d'Jbn' 'Arabschâh.

${ }_{13}^{\circ}$ (Fol. 118.) Extraits divers.

$14^{\circ}$ (Fol. 130.) Chapitre de l'lkhwân al-Ṣafí qui traite de la musique.

$15^{\circ}$ (Fol. 145.) Nolices, lirées du dictionnaire bibliographique de Hadji Khalla sur Jes diverses sciences.

A la fin du volume se trouve une copie de la préface du tome I des Notices et extraits.

Papier. 216 feuillets. -- (Supplément ${ }_{2} 33 \%$.)

\section{4 .}

Garton renfermant des pièces diverses :

$1^{\circ}$ Papiers provenanl de feu N. Jomard (quelques copies, ébauche d'un dictionnaire arabe, des alphabets, etc.).

$2^{\circ}$ Fragments d'un commentaire sur un lraité de grammaire.

Papier. 38 feuillets. Hauteur, 30 centimìres et demi; largenr, 2a centimètres. 37 lignes par page. Écriture unaghréline du xru' siècle.

$3^{\circ}$ Fragment d'un commenlaire sur un traité de droil rédigé en vers. Premiers mots du texte commenté :

$$
\begin{aligned}
& \text { باب الضهان وما يتعلّق به }
\end{aligned}
$$

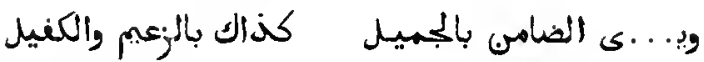

Papier. 4 faillets. Hautenr, 30 centimètres; lazgenr, 21 eantinèties. 29 lignes par page. Eeriture maghrébine du xvie siècle.

$4^{\circ}$ Fragments d'un commenlaire sur un trailé de droit. On y Irouve la section du divorce et le commencement de la section أستبراء.

Papier, 13 feuillets. Hauteur, 28 centimètres el demi; largeur. 32 centimètres. 36 lignes par page, Écrilure maghrébine dı xvı siècle.

$5^{\circ}$ Deux cahiers d'une histoire des califes. Ils renferment les années 243 à 286 de l'bégire.

Papier. 18 feuillets. Hauteur, 29 centimètres; largeur, 15 centimètres. 19 lignes par page. Ms. du xvi11 siècle.

$6^{\circ}$ Dialogue en arabe vulgaire du Maroc et en anglais.

$7^{\circ}$ Volume renfermanl une liste alphabétique des mols francais auxqueis on se proposail d'ajouter les équivalents arabes. Un petit nombre de mots orientaux transcrils en caractères romains, y ont élé inscrits.

Papier. 165 pages. IJautenr, 19 centimètres; largeur, 19 centimètres. Ms. du sviı siècle.

(Supplément 2286.)

\section{5 .}

Carton dans lequel se trourent les pièces suivantes:

$1^{\circ}$ Deux feuillets d'un ourrage sur les traditions.

Papier. Hauteur, ag centimètres el demi; largeur, so centimètres. 29 et 30 lignes par page. Belle écriture maghrébine espagnole du xiv siècle.

$2^{\circ}$ Onze feuillets d'un trailé de théologie scolastique. Beaucoup de noles marginales el inlerlinéaires.

Papier. Hanteur, ig centimètres et demi; largeur, 13 centimètres. 17 lignnes par pagre. Écriture cursive lurque du xvi' sièele.

$3^{\circ} \mathrm{U}_{n}$ feuillel el la moitié d'un feuillet d'un recueil de traditions. On y trouve une parlie du chapitre sur les mets (ä) ألإ).

Parchemin. Hanteur, go centimètres; largeur, 16 centimètres et demi. so lignes par page. Relle écriture maghrébine du $x^{*}$ siècle (?).

$4^{\circ}$ Quatre feuillets d'un recueil d'ancedotes édifianles; dans le premier il est queslion du calife $A 1$-Wàthiq, el dans le dernier de Jésus-Clırist.

Papier. IJanteur, 21 centimètres; largeur, 15 centimètres et demi. 23 lignes par page. Écriture du xrü siècle.

$5^{\circ}$ Dernier feuillet d'un exemplaire du Qämoùs.

Papier. Hlauteur, 25 centimètres; largeur, 15 centimètres. 22 lignes par page. Éerilure du svü siècle. 
$6^{\circ}$ Deux feuillets d'un exemplaire du Kalila et Dimna.

Papier. Hauteur, 20 centimètres; largeur, 15 centimètres. 15 ligunes par page. Écriture du xvm siècle.

$7^{\circ}$ Un feuillet d'une histoire de la dynastie ottomane; nous y lisons que le sultan Sélim, fils du sultan Solaïmân, monla sur le trône l'an 974 de l'légire.

Papier. Hauteur, 21 centimètres; largeur, 15 centimètres. 19 lignes par page. Bonne écriture du xvm" sic̀cle.

So Deux feuillets d'un recueil de traditions.

Papier. Hauteur, 26 centimètres; largenr, so centimètres. 22 lignes par page. Bonne écriture maghrébine du xIv siècle.

$9^{\circ}$ Fragmenls dont se composaient les plats de la reliure d'un volume arabe.

$10^{\circ}$ Dernier feuillet d'un traité nustique intitulé el composé par lloł̣ammad ibn 'Omar

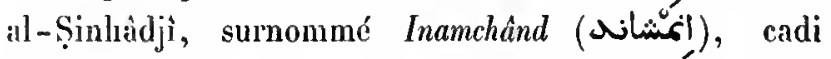
d'Azemmor, dans le Maroc. Il est daté de l'an 1056 (1646 de J.-C.).

Papier. Hauteur, 21 centimètres; largeur, 15 centimètres. 21 lignes par page. Bonue écriture orientale.

$11^{\circ}$ Cahier dun ouvrage de théologie. C'est le cha-

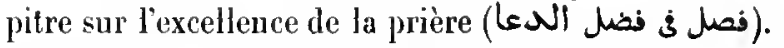

Papier. Hauteur, 17 centimètres; largenr, 12 centimètres et demi. 19 liggnes par page. Écriture maghrébine du xvire siècle.

$12^{\circ}$ Huit petits rouleaux de parchemin contenant une sorte de grammaire arabe, le Lamiyat als'Adjam d'AlToghrâï, des passages du Coran, la première Séance d'Al-Harîrî et d'autres morceaux écrils pour l'usage du $D^{r}$ Picques.

$13^{\circ}$ Un tallhmis de la Borda. Premier hémistiche : L بال قلبك لا ينغك من. ألم
Papier. 24 pages. Hanteur, 40 centimètres et demi; largeur, 14 centimètres et demi. Ms. da xvin' siècle.

$14^{\circ}$ Traité sur des questions qui se rattachent au droit de préemption des propriétés adjacentes (شُعَة).

Papier. 4 feuillets. Hauteur, 21 centimètres et demi; largeur,

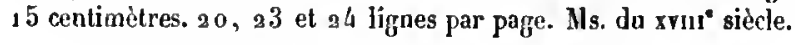

$15^{\circ}$ Fragment d'un traité de thérapeutique.

Papier. 6 feuillets. Hauteur, 22 centimètres; largeur, 16 centimètres. 12 lignes par page. Ms. du xrun siècle.

$16^{\circ}$ Commencement d'un commentaire sur un traité de logique, comprenant une introduction, trois discours (maquilit) et un appendice.

Beaucoup de gloses marginales et interlinéaires.

Papier. 3 feuillets. Hauteur, 17 centimètres et demi; largeur, 12 centimètres. 15 lignes par page. Écriture cursive du svir siècle.

$17^{\circ}$ Fragment d'un dictionnaire biographique d'homonymes el autres fragments; le tout en très mauvais état.

16 feuillets.

$18^{\circ}$ Fragments d'un commentaire sur un traité de grammaire.

Papier. 15 feuillets. Hauteur, 25 centimètres et demi; largeur, 16 centimètres. 30 à 40 lignes par page. Sur quelques pages, les lignes sont écrites obliquement. Écriture très cursive du xv11" siècle.

$19^{\circ}$ Fragments d'un ouvrage de médecine et de quelques traités de droit, provenant des plats de la reliure du ms. $99^{1}$.

$20^{\circ}$ Fragments de deux traités de droit.

Il y a dans le même carton quantité de feuillets détachés, de morceaux de feuillets, de notes, etc., dont nous n'avons pas pris note, vu leur peu d'importance.

(Supplément 2287.) 


\title{
TABLE
}

DES

\section{DIVISIONS DU GATALOGUE DU FONDS ARABE}

\author{
ET DES MATIÈRES SE RATTACHANT À CHACUNE D'Elles.
}

\section{A. OUVRAGES CHRÉtieNS.}

I. Bible. $N^{\circ} 1$ à $67 .-69,7^{\circ} .80,3^{\circ}$. $108,3^{\circ} .143,8^{\circ} .144,3^{\circ} .153,88^{\circ}$ a $33^{\circ}$, $35^{\circ} .214,5^{\circ} .4519$ à 4522 .

II. Livres apocryplies et pseudépigraphes. $\mathrm{N}^{\circ *} 68$ à $81 .-49,8^{\circ} .50,7^{\circ} .51 .107,3^{\circ}$. $132,1^{\circ}, 11^{\circ}, 13^{\circ} .141,1^{\circ} \dot{a} 3^{\circ} .147,10^{\circ}$, $14^{\circ} .150,2^{\circ}, 10^{\circ} .159,7^{\circ}, 153,4^{\circ} .154$, $9^{\circ}, 10^{\circ} .155,1^{\circ}, 6^{\circ}, 19^{\circ}, 13^{\circ}, 177,3^{\circ}, 4^{\circ}$. $17^{\circ}, 3^{\circ} .212,12^{\circ} .213,13^{\circ} .214,6^{\circ} .258$, $22^{\circ} \dot{a} 25^{\circ} .269,7^{\circ}, 16^{\circ}, 29^{\circ} .263,15^{\circ}$. ${ }_{264} 67^{\circ}, 8^{\circ} .265,3^{\circ}, 6^{\circ}, 7^{\circ} .275,2^{\circ}, 5^{\circ}$ à $9^{\circ}, 15^{\circ}, 981,5^{\circ}, 6^{\circ}, 8^{\circ}, 10^{\circ}, 93^{\circ}, 24^{\circ}$.

III. Commentaires de la Bible. $\mathrm{N}^{\text {tos }} 8 \mathrm{~g}$ à 96. - 4.6.17 à 21.23.40.41.43.50 à 52. 54 à 59.61 .63 à 65.67 .68 .106$. 153. 204.205 .

\section{Liturgies et rituels. $N^{\text {es }} 97$ à 101 .}

V. Offices et prières. $N^{\text {or }} 102$ à 130 . ${ }_{2} 8,3^{\circ}, 4^{\circ}, 6^{\circ}$ aे $9^{\circ}, 12^{\circ} .31 .36 .39,3^{\circ}$. 40, $7^{\circ}$. 43. $69,7^{\circ}$ à $9^{\circ} \cdot 7^{5}, 7^{\circ}$ à $10^{\circ} .103,1^{\circ}$, $2^{\circ}$. 104. 110.114, $2^{\circ}$. 145, $7^{\circ} .150,4^{\circ}$. $152,6^{\circ} .157,7^{\circ} .177,5^{\circ} .205,8^{\circ} .206$, $11^{\circ} .211,2^{\circ} .262,34^{\circ}$. $305,11^{\circ} .311,3^{\circ}$ a $6^{\circ}$. 313. 3041, $9^{\circ}, 5^{\circ}, 8^{\circ}, 10^{\circ}, 11^{\circ} .39^{4} 7,3^{\circ}$.

VI. Homélies. $N^{\circ s} 131$ à 156 . - 40, $5^{\circ}$. 43. $68,3^{\circ}, 4^{\circ}, 6^{\circ}$ à $12^{\circ}, 15^{\circ}$ à $30^{\circ} .69,2^{\circ}$, $10^{\circ}, 11^{\circ} .7^{2}, 3^{\circ}, 5^{\circ} .7^{4}, 4^{\circ}$ à $16^{\circ} .82,10^{\circ}$. $84.88,2^{\circ}$ à $4^{\circ}$. $9^{2} \cdot 9^{5} \cdot 9^{6} \cdot 157,5^{\circ}, 9^{\circ}, 1^{\circ}$. $206,3^{\circ}, 12^{\circ} .212,2^{\circ}$ à $6^{\circ} .221,2^{\circ} .253,3^{\circ}$, $6^{\circ} .257,8^{\circ}$ à $11^{\circ}, 14^{\circ}, 15^{\circ} .258,37^{\circ} .260$, $4^{\circ}$ à $6^{\circ}, 8^{\circ}$. $962,5^{\circ}, 8^{\circ}, 9^{\circ}, 13^{\circ}, 15^{\circ}, 17^{\circ}$, $20^{\circ}, 21^{\circ} .263,4^{\circ}$ à $7^{\circ}, 11^{\circ}$ à $13^{\circ} .264,3^{\circ}$ à $6^{\circ} .265,2^{\circ}, 4^{\circ}, 5^{\circ}, 9^{\circ}$ à $12^{\circ}, 14^{\circ}, 15^{\circ} .267$, $5^{\circ} .275,4^{\circ}, 18^{\circ}, 19^{\circ}, 280,6^{\circ} .281,2^{\circ}, 3^{\circ}$, $9^{\circ}, 16^{\circ}, 20^{\circ}$ à $22^{\circ}, 28^{\circ}$ à $30^{\circ}, 32^{\circ} .281,31^{\circ}$, $33^{\circ} .286 .305,2^{\circ}, 10^{\circ}$.
VII. Traités de théologie. $N^{\circ n} 157$ à 233 . $-28,10^{\circ} .40,9^{\circ} .43 .51 .70,4^{\circ} .71,2^{\circ}$. $72,3^{\circ}, 4^{\circ} .82,3^{\circ}$ à $5^{\circ}, 7^{\circ}, 238.250,3^{\circ}$. $253,4^{\circ}, 7^{\circ} \cdot 258,4^{\circ}$ à $10^{\circ}, 14^{\circ}, 15^{\circ}, 26^{\circ}$. $264,9^{\circ} .275,20^{\circ}$ à $22^{\circ} .280,4^{\circ} .309,16^{\circ}$, $17^{\circ}$. 315. 3041, $6^{\circ}, 7^{\circ}$.

VIII. Conciles et Canons. $N^{\text {o* }} 234$ à 252 . $-150,15^{\circ}, 16^{\circ} .213,7^{\circ}, 16^{\circ} .309,15^{\circ}$.

IX. Vies des saints. $\mathrm{N}^{\circ \mathrm{s}}{ }_{2} 53$ à 286 . $49,8^{\circ}, 68,5^{\circ} .69,6^{\circ}, 7^{\circ}, 2^{\circ}, 3^{\circ} .7^{2}, 6^{\circ}$. $7^{3} .81,20^{\circ} .115,7^{\circ} \cdot 131,1^{\circ}, 2^{\circ}, 4^{\circ} .132$, $8^{\circ}, 19^{\circ}, 14^{\circ} .135$ à $139.143, a^{\circ} .145, a^{\circ}$, $11^{\circ}, 147,11^{\circ}$ à $13^{\circ}, 15^{\circ} .148,1^{\circ}$ à $4^{\circ}, 6^{\circ}$ à $10^{\circ} .150,3^{\circ}$ à $7^{\circ}, 13^{\circ}, 14^{\circ} .151,24^{\circ} .153$, $1^{\circ}, 2^{\circ}, 5^{\circ}, 153,2^{\circ}, 7^{\circ}, 8^{\circ}, 10^{\circ}$ à $27^{\circ}, 37^{\circ}$, $38^{\circ} .154,1^{\circ}$ à $7^{\circ} .157,4^{\circ}, 8^{\circ}, 178,9^{\circ}$. $205,11^{\circ}, 12^{\circ}, 14^{\circ} .206,7^{\circ} .212,9^{\circ}$ à $11^{\circ}$, $13^{\circ}, 14^{\circ} .213,13^{\circ}, 20^{\circ} .214,9^{\circ}, 11^{\circ} .215$, $5^{\circ} .305,3^{\circ}$ à $9^{\circ}$. $3041,9^{\circ}$.

X. Histoire. $\mathrm{N}^{\circ \mathrm{s}}{ }_{2} 87$ à 308. - 4. 40 , $4^{\circ} .132,4^{\circ} .153,3^{\circ}, 158,3^{\circ} .177,2^{\circ} .200$. 969, $14^{\circ} .280,7^{\circ} .31 \mathrm{~s}, 9^{\circ} .809,8^{\circ} .4594$ à 4536 .

XI. Ouvrages divers. Nos 309 à 393 . $28,13^{\circ} .49,7^{\circ}, 9^{\circ}, 11^{\circ} .68,2^{\circ} .82,10^{\circ}$, $11^{\circ} .108,2^{\circ} .139,6^{\circ} .147,3^{\circ} .149,2^{\circ} .3^{\circ}$. $150,17^{\circ} .163,3^{\circ} .165,2^{\circ} .173,16^{\circ}, 19^{\circ}$. 181. $19^{8}, 9^{\circ}$. 202. $206,8^{\circ}$. 209. $212,15^{\circ}$. $213,10^{\circ}, 15^{\circ} .214,12^{\circ} .250,4^{\circ} .253,5^{\circ}$. $253,2^{\circ} .257,16^{\circ} .264,10^{\circ} .875,1^{\circ}, 14^{\circ}$. $37^{6}, 1^{\circ}, 7^{\circ}, 14^{\circ}, 15^{\circ}, 34^{\circ} .285 .286 .307$. 313.4523 .

\section{B. OUVRages MUSUlians.}

I. Coran. $\mathrm{N}^{\circ *} 324$ à $589 .-4527.4528$, $1^{\circ} .4529$.

II. Commentaires du Coran. $\mathrm{N}^{\circ} 590$ à
$674 .-387.402 .448 .459 .499 .573$. $606,2^{\circ} .650 .9^{45}, 3^{3} \cdot 1057,18^{\circ} .1060$, $2^{\circ}, 7^{\circ} \cdot 1061,5^{\circ}, 6^{\circ}, 8^{\circ} .1077,4^{\circ}, 5^{\circ} .1123$ $4^{\circ}, 5^{\circ}, 1160,15^{\circ} .1310 .1768, a^{\circ} .1951$, $3^{\circ}, 6^{\circ} .1973,5^{\circ} .2254,13^{\circ} .3314,3^{\circ}$. ${ }_{2} 571,6^{\circ}, 7^{\circ} \cdot{ }_{26} 67,8^{\circ} .2731,2^{\circ} .3264,6^{\circ}$, $7^{\circ} .3967,9^{\circ}, 5^{\circ} .4187,29^{\circ} .4202,3^{\circ}$. $43 \mathrm{~g}_{2}, 9^{\circ} .4530$ aे $4537.4542,5^{\circ} .4577$, $9^{\circ}, 14^{\circ}, 15^{\circ}, 18^{\circ} .4588,36^{\circ}, 41^{\circ} .466$. $2^{\circ}, 5^{\circ}, 15^{\circ}$.

III. Traditions. $N^{\text {os }} 675$ à $783,-40$ h. $606,4^{\circ} .666,13^{\circ} .77^{4}, 1^{\circ}, 9^{\circ}, 809,7^{\circ}$. $9^{21}, 2^{\circ}, 1060,10^{\circ} .1129,3^{\circ} .1128,2^{\circ}, 6^{\circ}$. $117^{6}, 99^{\circ} .1230,14^{\circ} 1391,1^{\circ}$ aे $4^{\circ}, 13^{\circ}$, $15^{\circ} .1395,5^{\circ} .1744,4^{\circ}$. $2254,4^{\circ} .2322$, $2^{\circ}$ à $5^{\circ}, 10^{\circ}, 11^{\circ} .2365,5^{\circ}$. s420, $2^{\circ}$. 2446, $4^{\circ} .2568,9^{\circ} .{ }_{2} 661,6^{\circ}, 7^{\circ} .{ }_{2} 677,7^{\circ}, 9^{\circ}$, $10^{\circ}, 19^{\circ} \cdot 2727,4^{\circ} .2758,10^{\circ} .2800,3^{\circ}, 5^{\circ}$, $8^{\circ}, 14^{\circ}, 17^{\circ} .3389,2^{\circ} .3481 .3502,2^{\circ}, 5^{\circ}$. $3953,2^{\circ} .3965,6^{\circ} .3967,10^{\circ} .3971,4^{\circ}$. $3973,6^{\circ} .399^{\circ}, 3^{\circ}$. $4136,3^{\circ} .4149,3^{\circ}$. $4187,4^{\circ}, 11^{\circ} .4538$ a $4540.4544,5^{\circ}, 6^{\circ}$. $4577,9^{\circ}$ à $8^{\circ}, 10^{\circ} .4588,4^{\circ}, 5^{\circ}, 9^{\circ}, 11^{\circ}$, ${ }_{16^{\circ}}, 18^{\circ}, 19^{\circ}, 39^{\circ} .4589,5^{\circ} .459^{3}$. 4662 , $6^{\circ} .4665,1^{\circ}, 3^{\circ}, 8^{\circ}$.

IV. Droit.

A. Principes du droit. $\mathrm{N}^{\text {os }} 7^{84}$ à 819 . $-672,5^{\circ} .673,9^{\circ} \cdot 7^{2} 7,2^{\circ} \cdot 7^{36.760,}$ 3. $1266,2^{\circ}$. $1396,8^{\circ}$. 4541. 4542 . 4600 .

B. Droit spécial.

1. Droit hanéfite. Nos 820 à 98 ฯ. $1160,3^{\circ}, 4^{\circ}, 8^{\circ}, 19^{\circ} .1230,7^{\circ}, 1966$, $4^{\circ}$ à $7^{\circ} .1338,3,4^{\circ} .3944,6^{\circ} .3965$, $3^{\circ} .3967,33^{\circ} .454$ a ते 4544.4572 . $4606,8^{\circ}$.

2. Droit schaféite. $\mathrm{N}^{\circ 3} 983$ à 1049 . - 1966, $9^{\circ} .1396,8^{\circ}$. 2800, $11^{\circ}$, $15^{\circ} .4545$ à $45^{\prime} 17.4591,11^{\circ}$. 
3. Droit malékite. $\mathrm{N}^{\text {os }} 1050$ ì 1103. $-1179,2^{\circ} .2580,4^{\circ} .3244,7^{\circ}$. 4548 à 4565 .

4. Droit hanbalite. $N^{08} 1104$ à 1107.

5. Droit schiite. $\mathrm{N}^{\circ} 1108$.

6. F́coles non déterminées. $N^{\circ 1} 1109$ a $1130 .-410.592,6^{\circ} .694,3^{\circ}$. $666^{\circ}, 2^{\circ}, 11^{\circ} .669,3^{\circ} .673,3^{\circ} .7^{44}$, $9^{\circ} \cdot 760,10^{\circ} \cdot 78 \%, 3^{\circ}, 1057,15^{\circ}, 16^{\circ}$. $1060,9^{\circ}, 10^{\circ} .317^{6}, 28^{\circ}, 1284,2^{\circ}$. $137^{8}, 6^{\circ} .1286,5^{\circ} .139^{1}, 9^{\circ}, 12^{\circ}$. $1396,10^{\circ} .1641,4^{\circ} .2009,6^{\circ} .3254$, $5^{\circ} .231 /, 2^{\circ} .2322,5^{\circ}, 6^{\circ}, 8^{\circ} .2365$, $4^{\circ} .2416,5^{\circ} .2571,4^{\circ} .8800,11^{\circ}$, ${ }_{15}^{\circ}$. 3244, $8^{\circ} .3509,3^{\circ}, 6^{\circ} .3545$. $3967,3^{\circ} .4151,3^{\circ}$ à $5^{\circ}, 7^{\circ} .4187,10^{\circ}$, $19^{\circ}$ à $31^{\circ} .4207,7^{\circ} .4245 .4261,19^{\circ}$. $4: 77,2^{\circ}, 3^{\circ} .4427,3^{\circ}, 4547,4566$ a $4576.4591,10^{\circ}, 11^{\circ} .459^{3}, 14^{\circ}$. $1661.4664,3^{\circ}, 4^{\circ} .4665,14^{\circ}, 20^{\circ}$.

\section{Théologie.}

1. Trailés sur la prière. $N^{\circ s} 1121$ à $1163 .-830,2^{\circ} .833,2^{\circ} .1114 .1768$, $3^{\circ} .2318,2^{\circ} .2690,2^{\circ} .4659,5^{\circ} .4662$, $10^{\circ} .4665,11^{\circ}$.

2. Prières et invocalions. $\mathrm{N}^{\circ 8} 1163$ à 1228. - 429.441. 475.477.480.577. $663,7^{\circ}, 10^{\circ} .665,5^{\circ} \cdot 7^{21} \cdot 7^{65} \cdot 77^{4}$, $2^{\circ}, 5^{\circ}$ a $7^{\circ}, 10^{\circ}, 15^{\circ} .77^{5}, 6^{\circ} .8: 8.884$, $2^{\circ} .1057,10^{\circ} .1060,14^{\circ} .1128,8^{\circ}$. 1163. $1316,2^{\circ} .1326,1367,1667,3^{\circ}$. $1668,4^{\circ}, 5^{\circ}, 1973,2^{\circ}$ à $4^{\circ}, 1974,3^{\circ}$. $2254,2^{\circ} .2350,3^{\circ} .2357,14^{\circ} .2360$. $2365,9^{\circ}$. $2502,12^{\circ}, 13^{\circ} .9563,23^{\circ}$. $2569,1^{\circ} .2637,3^{\circ}, 5^{n}, 7^{\circ}, 12^{\circ}, 13^{\circ}$. $2718,4^{\circ}$ à $6^{\circ}, 13^{\circ}, 2738,4^{\circ} .2758,7^{\circ}$. $29^{42}, 6^{\circ} .3389,3^{\circ} .3430,3633,3^{\circ}$. $3650,4^{n} .3954,3^{n} .3965,3^{\circ} .3967,9^{\circ}$. $4099,3^{\circ} .4129,2^{\circ} .4170,60^{\circ} .4214$. $4302,66^{\circ}$. $1539.4542 .4577,1^{\circ}, 12^{\circ}$. $45-8,1^{\circ}, 2^{\circ} .4589,2^{\circ} .459^{3}, 3^{\circ}, 4^{\circ}$. $4606,7^{\circ} \cdot 4608,7^{\circ} \cdot 4661$.

3. Théologie dogmatique et scolastique. $J^{\text {os }} 1229$ à $1288 .-668,3^{\circ} .978,4^{\circ}$. 1042, $33^{\circ}$ à $35^{\circ}, 32^{\circ}$. $1046,5^{\circ}, 6^{\circ}$. $1057,15^{\circ}$ à $17^{\circ}, 1060,3^{\circ}$ à $6^{\circ}, 11^{\circ}$. $1061,3^{\circ}, 10^{\circ}, 11^{\circ}, 119^{3}, 3^{\circ}, 1197,3^{\circ}$. $1206,4^{\circ}, 5^{\circ}, 7^{\circ}, 2307,5^{\circ}, 2316,4^{\circ}$. $2317,2^{\circ}, 3318,3^{\circ}, 2332,12^{\circ} .2365$, $2^{\circ} .2500,2^{\circ}, 3^{\circ}, 2637,6^{\circ}, 3677,17^{\circ}$. $2758,7^{\circ} .3019,3^{\circ} .3136,1^{\circ} .3137,1^{\circ}$. $3138,1^{\circ} .317_{1}, 8^{\circ}, 3264,3^{\circ}, 4^{\circ} .3389$, $3^{\circ}$. $3431,6^{\circ} .3442,3^{\circ}, 7^{\circ} .3522,2^{\circ}$. $3954,6^{\circ}, 7^{\circ} .4187,3^{\circ} .4261,8^{\circ} .4528$, $3^{\circ} .4577,13^{\circ} .4579 .4581,2^{\circ}$. 458 a. $4583,1^{\circ}, 2^{\circ} .4584 .4585,1^{\circ}, 2^{\circ} .4589$, $4^{\circ}, 6^{\circ} .4591,2^{\circ}, 7^{\circ} .4606,9^{\circ} .4657,19^{\circ}$. $4662,16^{\circ} .4665,2^{\circ}$.

4. Théologie morale. $X^{\circ 8} 1289$ à 1329 . $-665,2^{\circ}, 3^{\circ}, 6^{\circ} .666,12^{\circ} .743,2^{\circ}$.
$7^{48,}, 3^{\circ}, 3^{\circ} \cdot 7_{60}, 2^{\circ}, 3^{\circ}, 9^{\circ} \cdot 7^{63}, 7^{64}$. $77^{4}, 5^{\circ}, 7^{\circ} \cdot 7^{80}, 3^{\circ} \cdot 812,2^{\circ} \cdot 9^{31} \cdot 97^{8}$, $6^{\circ} .1046,4^{\circ} .1057,24^{\circ}, 25^{\circ} .117^{6}, 25^{\circ}$ à $27^{\circ}, 34^{\circ}, 35^{\circ} .1230,3^{\circ} .1287,5^{\circ}$. $1363,4^{\circ}, 1546,6^{\circ}, 1667,5^{\circ}, 1913,8^{\circ}$ à $12^{\circ} \cdot 1931,1974,4^{\circ} .2026,9^{\circ}$ à $5^{\circ}$. 2033. $2034.2035,3^{\circ} .2254,4^{\circ}, 10^{\circ}$. $2316,2^{\circ}, 3^{\circ} .2405,8^{\circ} .2637,10^{\circ} .2661$, $1^{\circ} .2677,5^{\circ} .2738,8^{\circ}$ à $19^{\circ} .2761,4^{\circ}$. 2 $800,9^{\circ} .2811,3^{\circ} .3136,2^{\circ} .3137,9^{\circ}$. $3200,2^{\circ} .3251,3^{\circ}, 4^{\circ} .3365,4^{\circ}, 5^{\circ}$. $3389,3^{\circ} .3401,5^{\circ} .3431,3^{\circ}$. 3442, $6^{\circ}$. 3525. 3545. 3546. 3569. 3579. 3573 . 3582. $39^{54}, 4^{\circ}$. $4136,2^{\circ}$. $4253,2^{\circ}$. $4361,2^{\circ}, 11^{\circ}, 14^{\circ}, 15^{\circ}, 17^{\circ}, 18^{\circ}, 21^{\circ}$. $4378,9^{\circ} .4392,7^{\circ} .4424,5^{\circ}, 7^{\circ} .4577$, $3^{\circ}$. $4581,1^{\circ}, 3^{\circ}, 4^{\circ} .4591,9^{\circ}$. 4592, $2^{\circ}$, $8^{\circ}$ à $11^{\circ} .4593$ à $4598.4624,3^{\circ} .4657$, $13^{\circ}, 14^{\circ} .4662,3^{\circ}, 9^{\circ}, 11^{\circ}, 13^{\circ} .4665$, $4^{\circ}$.

5. Théologie mystique. $N^{\text {os }} 1330$ à 1380. - $7^{60}, 6^{\circ}$ à $8^{\circ} \cdot 7^{62}, 3^{\circ} \cdot 77^{4}$, $12^{\circ}, 13^{\circ} .9^{\prime} 5,2^{\circ}$. $1141,5^{\circ} .1178,3^{\circ}$. $1187,3^{\circ} .119^{3}, 5^{\circ}, 7^{\circ} .1287,2^{\circ} .1316$, $3^{\circ}$. $1546,7^{\circ}$. $1605,3^{\circ} .1641,3^{\circ}, 3^{\circ}$. $1903,2^{\circ} .1966 .2016,2^{\circ}, 4^{\circ}, 2037,2^{\circ}$ a $7^{\circ}$. 2338, 2348, 20.2405, $6^{\circ}, 7^{\circ}$. 9450, $3^{\circ} .2502,3^{\circ}, 8^{\circ} .2577,24^{\circ} .2677$, $13^{\circ}, 14^{\circ} .2800,6^{\circ}, 7^{\circ} .3035,2^{\circ} .3146$, $9^{\circ} .3154,4^{\circ}, 3156,4^{\circ} .3167$ a 3173 . 3208. 3222. 3243 . 3295 à 3227. 3329 à 3234. 3237 . 3941. 3ง59. 3953. 3256 . $3261,2^{\circ} .3$ a 63.3422 .3434 .3430 .3431 , $14^{\circ} .3971,1^{\circ} .4577,11^{\circ}, 12^{\circ}, 16^{\circ}, 24^{\circ}$. 4601 à $4603.4659,4^{\circ} .4661 .4665$, $10^{\circ}$.

6. Matières diverses de théologie. Nos 1381 à $, 405 .-666,3^{\circ}$ à $5^{\circ}$. $1,68,3^{\circ}$, $4^{\circ} \cdot 7^{44}, 8^{\circ} \cdot 781.834,2^{\circ} .1057,11^{\circ}$. $1176,24^{\circ}, 30^{\circ}, 1306,3^{\circ}, 9^{\circ}, 1913,15^{\circ}$. $2679,3^{\circ} .277^{\circ}, 5^{\circ} .2800,18^{\circ} .2962$, $9^{\circ} .3244,4^{\circ} .3248,1^{\circ} .3264,5^{\circ} .3431$, $4^{\circ}, 5^{\circ}, 7^{\circ} .3967,6^{\circ}, 7^{\circ} .4136,2^{\circ} .4187$, $7^{\circ}$ à $9^{\circ}, 4207,6^{\circ} .4580,1^{\circ} .4585,6^{\circ}$. $4586,1^{\circ} .4587 .4588 .4589,1^{\circ}$. 459o. $459^{1}, 1^{\circ}, 8^{\circ} .4659,7^{\circ}$.

7. Croyances hétérodoxes. $\hat{N}^{-o s} 1406$ à $1451 .-4663,2^{\circ}, 3^{\circ}$.

8. Controverse. $\mathrm{N}^{\text {os }} 145 \mathrm{a} 2$ à 1464 . $1699,2^{\circ} .19^{13}, 13^{\circ} .2405,5^{\circ}$. 3204, $2^{\circ} .4606,2^{\circ} .4659,8^{\circ}$.

\section{Histoire.}

1. Histoire nniverselle. $N^{\circ 1} 1465$ à 1565. - 1621.1951, $7^{\circ}$. 4607. 4608, $1^{\circ} .4609,1^{\circ}$.

2. Histoire des califes. $\mathrm{N}^{\mathrm{os}} 1566$ à 1687 - $1203,8^{\circ}$ à $10^{\circ} .1832,3^{\circ}$. 1997. $3254,9^{\circ}$. $3309,2^{\circ}$. 3950, $2^{\circ}$. $3412,7^{\circ}, 9^{\circ}, 10^{\circ} .3431,2^{\circ} .4664,5^{\circ}$, $7^{\circ}$.
3. Histoire des villes saintes. $\mathrm{N}^{\circ 16}{ }_{162} 8$ à 1642 .

4. Histoire du Yémen. Nos 1643 à 1651 . - $4609,1^{\circ} .4652$ a 4656 .

5. Histoire de la Syrie. $\mathrm{N}^{\circ} 1652$ à 1685. - 2234, 2". 4610 .

6. Histoire d'Égypte. $\mathrm{N}^{\mathrm{os}} 1686$ à 1866 . $-1931,29^{\circ} .2446,2^{\circ} .4611$ à 4613 . $4657,1^{\circ}, 10^{\circ}$.

7. Histoire de l'Afrique et de l'Espagne. Nos 1867 à 1893 . - 1997. 3553, $2^{\circ}$. 4614 à 4621 .

8. Histoire des contrées orientales. Nos 1894 वे 1905 .

9. Divers. $\mathrm{N}^{\circ \mathrm{s}} 1906$ à 1908 .

VII. Biographie.

1. Vies des patriarches et prophètes. Nos $^{\circ} 1909$ à $1947 .-77^{4}, 11^{\circ} .1363$, $7^{\circ} .4469 .4586,4^{\circ} .4592,10^{\circ} .4623$ à 4625 .

2. Vie de Mahomet. Nor 1948 à 2010. - $77^{4}, 3^{\circ} .1046,5^{\circ}$. $1050,2^{\circ}, 3^{\circ}$. $1363,3^{\circ}, 8^{\circ}, 15^{\circ}, 1546,5^{\circ}, 1667,6^{\circ}$. $1819,3^{\circ} .1916,3^{\circ} .19^{3} 1,3^{\circ}, 5^{\circ}, 8^{\circ}, 16^{\circ}$, $18^{\circ}, 23^{\circ} .2677,6^{\circ} .2758,3^{\circ}$ à $5^{\circ} .2568$, $9^{\circ} .3016,4^{\circ} .3136,3^{\circ} .3457,2^{\circ} .3967$, $14^{\circ}, 4626$.

3. Vies des Compagnons. $\mathrm{N}^{\circ} 2011$ à 2017 . $-1971,2^{\circ} .2568,13^{\circ}$. 3430. $3513,2^{\circ} .3967,11^{\circ}$.

4. Vies des descendants d"Ali. $\mathrm{N}^{\text {tos }} 2018$ à $2026 .-1871,9^{\circ}$ à $4^{\circ}, 187^{2}, 189^{2}$, $7^{\circ}$.

5. Vies des saints et des soufis. $\mathrm{N}_{202}$ à $3046 .-1363,2^{\circ}, 10^{\circ}, 1546,2^{\circ}$. $2918,8^{\circ}$. $3070,2^{\circ}$. 3486, 50.3491. $3497,2^{\circ} .3967,12^{\circ} .4581,3^{\circ} .4608,3^{\circ}$. $4657,5^{\circ}$.

6. Biographies générales. $N^{0 s} 2047$ à $2083 .-1587.4665,17^{\circ}$.

7. Biographies spéciales. $N^{\circ 0} 2084$ à $2132 .-669,2^{\circ} .1108,2^{\circ} .1338,4^{\circ}$. 1672. $2410,2^{\circ} .2800,19^{\circ}, 20^{\circ}, 23^{\circ}$. $3111.3200,7^{\circ} .3951,11^{\circ} .3955 .3347$, $1^{\circ}$. $4261,13^{\circ}, 22^{\circ} .4614,2^{\circ} .4627$ à $4630.4663,5^{\circ}, 11^{\circ}, 12^{\circ}$.

8. Biographies locales. $\mathrm{N}^{\circ 0} 2123$ à 2166 .

\section{Cosmographie el géographie.}

1. Cosmographie. $N^{\circ} 2167$ à 2212. $2776,5^{\circ}$. $4253,3^{\circ}$.

2. Géographie générale. $\mathrm{N}^{\text {os }} 2213$ ม̀ $2249 .-4256,2^{\circ}$.

3. Géographie spéciale. $N^{\circ 8} 2250$ à 
$2280,-1203,2^{\circ}, 2446,4^{\circ}, 2761,2^{\circ}$. $3513,3^{\circ} .397^{3}, 13^{\circ}$.

4. Voyages. $\mathrm{N}^{\text {on }} 2281$ à 2299 .

IX. Encyclopédies. $N^{\text {os }}$ 2300 à 2345 . $97^{8}, 5^{\circ}$.

X. Philosophie. $\mathrm{N}_{2}^{\circ}{ }_{2} 346$ à 2415 . 202. $809,6^{\circ} .1013,6^{\circ}$ à $10^{\circ}, 1042,26^{\circ}$ मे $34^{\circ}, 1267,2^{\circ} .1278,4^{\circ}, 5^{\circ}, 1286,9^{\circ}$. $139^{6}, 9^{\circ}, 4^{\circ}$ à $7^{\circ}, 11^{\circ}$ à $13^{\circ}, 2281,4^{\circ}$. 2307, $7^{\circ}$ à $9^{\circ}$. $16^{\circ} .4201,13^{\circ} .4542,8^{\circ} .4577,20^{\circ}, 22^{\circ}$, ${ }_{2}^{\circ} .459^{2}, 1^{\circ} .4606,5^{\circ} .4663,8^{\circ}$. 4665 , $16^{\circ}$.

XI. Norale el politique. Nos $N^{\circ 16}$ à 3451 . $-176,3^{\circ}$.

XIl. Administration. $N^{\circ}{ }_{2} 45_{2}$ à 2456 . $666,8^{\circ}$ à $10^{\circ} .29^{69}, 3^{\circ}$.

XIII. Mathématiques. Nos 2457 à 2475 . $-1396,9^{\circ} .1769,3^{\circ}$. $2204,2^{\circ}$. 2330, $8^{\circ}$ à $14^{\circ} .2500,4^{\circ} .2732,8^{\circ} .2865,12^{\circ}$. $3136,3^{\circ} .3250,3^{\circ} .4151,6^{\circ} .4162,2^{\circ}$, $4^{\circ} .4661,14^{\circ} .4585,5^{\circ}$.

XIV. Mécanique. $N^{02}{ }_{947} 6$ à 2478 . $1230,19^{\circ} .1360,3^{\circ}$.

XV. Musique. Nos 2479 à 2481 . - 9466 , $2^{\circ} .2865,2^{\circ}, 13^{\circ} .3250,4^{\circ}$.

XVI. Astronomie. $\mathrm{N}_{2}^{\circ \mathrm{a}}{ }_{2} / 8 \mathrm{a}$ से 2555 . $117^{6}, 10^{\circ} .2330,3^{\circ}, 7^{\circ}, 8^{\circ} .2365,7^{\circ}$. $2457,12^{\circ}$ aे $14^{\circ}, 17^{\circ}, 21^{\circ}$ aे $23^{\circ}, 2558,3^{\circ}$ à $13^{\circ}$. $2559,2^{\circ}$ à $9^{\circ} .2560,4^{\circ}$ à $18^{\circ} .2561$. $2566,2^{\circ}, 2579,2^{\circ} .2865,3^{\circ}, 4^{\circ}, 9^{\circ}, 1^{\circ}$. $3264,8^{\circ} .4386,3^{\circ}$. $4580,3^{\circ}$ à $5^{\circ}$.

XVII. Calendrier. $\mathrm{N}^{\circ}{ }_{2} 556$ \̀ ${ }_{2} 576$. 314. $315.651,1^{\circ} .870,4^{\circ}, 1061,4^{\circ}$. $1176,15^{\circ} .2250,2^{\circ} .2521,7^{\circ} .2547,20^{\circ}$. $2549,3^{\circ} .2637,2^{\circ}, 5^{\circ}, 2677,21^{\circ} .29^{46}$, $10^{\circ} .4609,3^{\circ}$.

XVIII. Astrologie. $\mathrm{N}^{\mathrm{as}}{ }_{2} 577$ à $260 \%$. $117^{6}, 8^{\circ}, 20^{\circ}, 31^{\circ}, 1206,13^{\circ}, 1331,5^{\circ}$. $1360,2^{\circ} .1769,2^{\circ} .2330,3^{\circ}, 6^{\circ}$. 2357 , $7^{\circ}, 8^{\circ} .2487,2^{\circ}$ à $4^{\circ} .2521,3^{\circ}$ d̀ $5^{\circ} .{ }_{2} 52 /$, $11^{\circ} .2562,2^{\circ}, l^{\circ} .{ }_{2} 568,5^{\circ}$. 2570. $257^{2}$ मे $257^{\prime}$ '. $2684,5^{\circ}, 7^{\circ}$. $2700,3^{\circ}, 2738,3^{\circ}$. $2865,5^{\circ}, 8^{\circ} .2946,10^{\circ} .4580,6^{\circ}$ à $8^{\circ}$.

XIX. Sciences occultes.

1. Alchimie. $\mathrm{N}_{2}{ }_{20} 65$ à ${ }_{2} 629 .-420$. ${ }_{2} 568,{ }_{1} 4^{\circ}$ à $16^{\circ}$.

2. Nagie. $\mathrm{N}^{\circ{ }_{2}}{ }_{2630}$ à $2741,-158$, $4^{\circ} .309,14^{\circ}$. 410. 419. 429. 4/46. 448. 484. $7^{43}, 3^{\circ}$ aे $13^{\circ}, 17^{\circ} .7^{65} .809,4^{\circ}$, $5^{\circ} .1031 .1050,5^{\circ} .1128,5^{\circ}, 7^{\circ} .1140$, $3^{\circ}, 1163$ à $1228,1286,13^{\circ}, 1381,4^{\circ}$, $5^{\circ}$. $2250,3^{\circ} .2307,2^{\circ} .2357,3^{\circ}, 4^{\circ}, 9^{\circ}$ aे $13^{\circ}, 15^{\circ}$ à $18^{\circ}, 2 / 19,6^{\circ}, 250 \mathrm{a}, 4^{\circ}, 5^{\circ}$. $2521,6^{\circ} .2524,11^{\circ} .2541,2^{\circ} .2562,5^{\circ}$ à $9^{\circ}, 22^{\circ}, 23^{\circ}, 2568,10^{\circ}, 12^{\circ}, 2577,2^{\circ}$. $2595,1^{\circ}, 3^{\circ}, 4^{\circ}, 6^{\circ}$ a $8^{\circ}, 2600,2^{\circ}$ à $4^{\circ}$. ${ }_{2} 602,1^{\circ}, 3^{\circ}, 6^{\circ}$ à $9^{\circ} .{ }_{2} 58,8^{\circ}$ à $13^{\circ}$. $2763,2^{\circ} .2767,2^{\circ}$ à $4^{\circ} .277^{2}, 2^{\circ} .2865$, $7^{\circ} .9954,3^{\circ} .2993,2^{\circ} .3083 .312 /, 2^{\circ}$. $3178.3250,5^{\circ} .3384 .3650,4^{\circ}, 1^{\circ} .3669$, $6^{\circ} .4588,25^{\circ} .4606,1^{\circ}, 7^{\circ} .4608,2^{\circ}$, $4^{\circ} .4609,3^{\circ} .4661$.

3. Onirocritie. $\mathrm{N}_{24}{ }_{24} 4 \mathrm{a} 2{ }_{27} 57$. $809,3^{\circ} .2580,5^{\circ} .2758,2^{\circ}$.

4. Physionomique. $\mathrm{N}^{\text {or }}{ }_{27} 58$ à 2762 . $-1381,6^{\circ} .2562,21^{\circ} .3365,3^{\circ} .4609$ $2^{\circ}$.

5. Recherclies des trésors. $N^{* *} 2763$ à $2767 .-2357,2^{\circ}$. $2602,10^{\circ}$.

XX. Histoire naturelle.

1. Trailés généraux. $\mathrm{N}_{27}{ }_{278}$ à 2771 .

2. Minéralogie. $\mathrm{N}^{\mathrm{os}} 277^{2}$ à 2780 . -

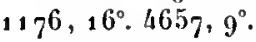

3. Botanique. $N_{27}^{\circ} 21-29_{2}, 4^{\circ}$.

4. Zoologie. $\mathrm{N}^{\text {os }} 2782$ à 2801 . $4657,3^{\circ}$.

XXl. Agriculture. $\mathrm{N}^{\text {os }}{ }_{2} 802$ à 2809 . $29^{4} 9,4^{\circ}$.

XXII. Hippologie et lippiatrique. $\mathrm{N}^{\mathrm{s}}$ 2810 à $2822 .-3019,4^{\circ}$.

XXIll. Équitation, clıasse et art militaire. $\mathrm{N}^{n *} 28.3$ aे $2834 .-2839$.

XXIV. Médecine. $\mathrm{N}^{\mathrm{os}}{ }_{2} 835$ à 3050 . $178,4^{\circ}, 117^{6}, 6^{\circ}, 7^{\circ}, 11^{\circ}, 12^{\circ}, 22^{\circ}, 23^{\circ}$. $1299,2^{\circ} .1814 .1817 .218 \mathrm{a}, 3^{\circ}, 3^{\circ}, 2454$, $8^{\circ}, 3281,5^{\circ} .3 / 19,5^{\circ} .2457,22^{\circ} .2500$, $6^{\circ}, 8^{\circ}, 9^{\circ}, 256$ ฯ $, 3^{\circ}, 9^{\circ}$ à $20^{\circ}, 2568,6^{\circ}$ à $8^{\circ} .2677,17^{\circ}$. $27^{00}, 3^{\circ} .377^{0}, 4^{\circ} .377^{6}$, $8^{\circ}, 9^{\circ} \cdot 2800,16^{\circ} .3513,4^{\circ} .4641 .4665$, $15^{\circ}, 19^{\circ}$.

XXV. Onvrages érotiques. $\mathrm{N}^{\mathrm{au}} 3051$ à $307^{4}$. $-3039,3^{\circ}$ à $5^{\circ}, 11^{\circ}$ à $17^{\circ}, 20^{\circ}$. $338 \%, 3401,1^{\circ}, 2^{\circ}$. 3455. 3658, $12^{\circ}$. $3669,7^{\circ} .3571,2^{\circ}$. 4641. 4642 .

\section{Poésie.}

1. Divans et qasidas. $\mathrm{N}^{\circ 3} 3075$ à 327\%. - 624, $4^{\circ} \cdot 7^{43}, 15^{\circ} \cdot 7^{60}, 4^{\circ} \cdot 77^{5}$, $4^{\circ}, 7^{\circ}, 9^{332 .} 1057,21^{\circ}, 22^{\circ}, 1128$, $4^{\circ}, 1143,2^{\circ}, 1160,10^{\circ}, 1167,10^{\circ}$. $117^{6}, 5^{\circ}, 1178,3^{\circ}, 4^{\circ} .119^{8}, 2^{\circ}$. $1203,5^{\circ}, 6^{\circ} .1206,9^{\circ}$ à $13^{\circ}$. $1210,1^{\circ}$. $1213,3^{\circ} .1230,10^{\circ} .1251 .1268 .1287$, $8^{\circ} .1293,2^{\circ}, 1303,3^{\circ} .1317,2^{\circ}, 1339$, $5^{\circ}$. $1343,3^{\circ}$ à $5^{\circ}$. $135 \%$. $1363,12^{\circ}$, 136\%. $1385.1449,2^{\circ}, 1450, y^{\circ}$ à $11^{\circ}$. $1607.1608 .1615,2^{\circ}, 3^{\circ}, 1617 \cdot 1620$, $2^{\circ}$ à $13^{\circ}, 1635,1668,3^{\circ}, 1672,167^{8}$.
1696. $1699,5^{\circ}, 6^{\circ}, 1716,2^{\circ} .179^{4}$ $1876.1889,2^{\circ}, 3^{\circ}$. 193a, $4^{\circ}$ à $6^{\circ} .1997$. 1998. 2024. 2060. 2098. 2099. 2120 , $4^{\circ} .2134 .2135$. $2147,3^{\circ} .2149 .2165$. 2199. $2198.2234,4^{\circ}, 5^{\circ}, 2246.2254$, $6^{\circ} .2399,2^{\circ}$ à $6^{\circ}$. $2322,9^{\circ}, 12^{\circ}$. 2348 , $3^{\circ}$. 2365, $2^{\circ}$. 2405, $3^{\circ}, 4^{\circ}, 2419,7^{\circ}$. $2480,2^{\circ} .2492 .2502,4^{\circ}, 5^{\circ}, 1^{\circ} .2530$. ${ }_{2} 541,3^{\circ} .2559,5^{\circ}$ à $8^{\circ} .{ }_{2} 562,9^{\circ}, 11^{\circ}$ à $13^{\circ}, 15^{\circ}, 21^{\circ}, 2566,2^{\circ} .2568,4^{\circ}, 11^{\circ}$ à $13^{\circ},{ }_{2} 571,6^{\circ} .2580,5^{\circ} .2593,2^{\circ} .2602$, $9^{\circ} .2608,1^{\circ} .2610,1^{\circ}, 2^{\circ} .2611,1^{\circ}$ ${ }_{26} 65,6^{\circ}, 10^{\circ} .2637,6^{\circ}, 7^{\circ}, 9^{\circ}, 14^{\circ}$. $2661,4^{\circ}, 8^{\circ} .2669,11^{\circ}, 13^{\circ} .{ }_{2} 675,2^{\circ}$. ${ }_{2} 677,2^{\circ}, 4^{\circ}, 20^{\circ} .2684,12^{\circ}, 16^{\circ} .2697$, $6^{\circ} .2708,3^{\circ} .27^{16}, 11^{\circ} .2718,8^{\circ}$. 2722. $27^{3} \cdot 2,9^{\circ}, 10^{\circ} .277^{6}, 6^{\circ} .2800,4^{\circ} .2833$ $29^{4}$, $1^{\circ}$ aे $3^{\circ} .2943,1^{\circ}$ à $4^{\circ} .29^{4} 4$. $299^{\circ}, 3^{\circ}$. $2997.299^{8}, 1^{\circ}$. 3016, $3^{\circ}$. $3019,2^{\circ}, 5^{\circ}, 7^{\circ}, 3038,3^{\circ} .3039,9^{\circ}$ à à $11^{\circ}, 19^{\circ}, 21^{\circ} .3570 .3571,1^{\circ} .357^{4}$. $36{ }_{2} 3$, $2^{\circ}$. 3626. 3627. $3650,2^{\circ}, 8^{\circ}$. $3663,3^{\circ}, 5^{\circ} .3953,3^{\circ}, 4^{\circ} .3954,5^{\circ}$, $8^{\circ} .3956,2^{\circ} .3964,5^{\circ} .3965,3^{\circ}$ à $5^{\circ}$, $7^{\circ} .397^{2}, 4^{\circ}, 6^{\circ}, 13^{\circ} .4051,4^{\circ} .4098$, $5^{\circ} .4118,3^{\circ} .4134,5^{\circ}$ à $7^{\circ}$. $1451,6^{\circ}$. $4187,12^{\circ}, 13^{\circ}, 25^{\circ}$ à $27^{\circ} .4301,3^{\circ}, 6^{\circ}$ à $10^{\circ}, 14^{\circ}, 17^{\circ}, 4207,1^{\circ}$ à $4^{\circ}, 4261,3^{\circ}$ à $10^{\circ}, 12^{\circ}, 28^{\circ} .4296 .439 .3,2^{\circ}$. 44.27, $3^{\circ}$. 4434, $2^{\circ}, 5^{\circ}$. 4451, $4452,1^{\circ}$ à $10^{\circ}$, $12^{\circ}$. 4454, $2^{\circ} .45 .8,2^{\circ}$. 4530. 453., $3^{\circ}, 5^{\circ}, 6^{\circ} .4534,1^{\circ}, 2^{\circ} .454 .2,1^{\circ}$ à $11^{\circ}$. 4543. $4544,1^{\circ}, 2^{\circ} .4565$ à 4568.4572 . $4577,19^{\circ} .4585,8^{\circ} .4588,14^{\circ}, 24^{\circ}$. $4591,9^{\circ} .4611 .4618 .4619 .4624,1^{\circ}$, $2^{\circ} .4639,3^{\circ}$ à $5^{\circ} .4662,1^{\circ}, 12^{\circ}, 15^{\circ}$, $16^{\circ}, 4665,12^{\circ}, 13^{\circ}$.

2. Collections et antlıologies. $\mathrm{N}^{\circ 3} 3_{27} 3$ à $3462 .-2865,6^{\circ}$. $1601,3^{\circ}$ a $4^{\circ}$. $4 \times 36,2^{\circ}$.

\section{XXVIl. Fiction.}

1. Fables, apologues el récils divers. $N^{\circ 2} 3463$ à 359 h. $-17^{5} .809,11^{n}$. 31 g $4,3^{\circ}$ à $6^{\circ}$. 3131, $2^{\circ}$. 3200, $3^{\circ}$. 3365, $6^{\circ} .3384 .4201,2^{\circ}$ à $4^{\circ} .4336,3^{\circ} .4586$, $2^{\circ} .4665,6^{\circ}$.

2. Contes et romans. Noa 3595 à 3680 . $-1363,6^{\circ}, 13^{\circ} .2661,9^{\circ} .2738,7^{\circ}$, $13^{\circ} .30_{11}, 4^{\circ} .3070,3^{\circ}$ à $5^{\circ} .3118,3^{\circ}$ à $18^{\circ} .3522,3^{\circ} .3336 .3539 .3571,3^{\circ}$ à $5^{\circ} .35 \%$ ข. 3573.4366 à 4368 .

3. Romans de chevalerie. $\mathrm{N}^{\circ} 368_{1}$ à 393 . $-1363,11^{\circ}$.

4. Naqåmảt. $\mathrm{N}^{\circ} 3923$ à 3959.3972 , $3^{\circ}, 5^{\circ}, 7^{\circ}$ à $11^{\circ}$.

XXVIII. Proverbes et sentences. $\mathrm{N}^{\circ 8} 3953$ à $3983 .-644,3^{\circ} .778,2^{\circ} .780,2^{\circ} .1377$. $1396,7^{\circ}$. $1667,5^{\circ} .1716,2^{\circ}$. 1892, $4^{\circ}$. $1903,3^{\circ}, 1952.2044 .2419,2^{\circ}, 9450$, $4^{\circ} .2489,2^{\circ} .2502,10^{\circ}, 14^{\circ} .277^{0}, 2^{\circ}$. 


\section{6}

$3250,1^{\circ}, 3376,3^{\circ} .3365,2^{\circ}, 4^{\circ}$ à $6^{\circ}$ $339^{\circ}, 3418,33^{\circ}, 3431,9^{\circ}, 13^{\circ}$. 3481 . $348 \mathrm{a}, 3^{\circ} .3545 .3954,1^{\circ} .3973,4^{\circ} .1201$ $2^{\circ} \dot{\dot{1}} 4^{\circ}, 11^{\circ} .4637^{\circ}$.

\section{Philologic.}

1. Fn géuéral. $\backslash * 3984$ à 3986 .

2. Crammaire. $N^{\circ *} 3987$ à 4299 . $663,13^{\circ} .670 .674,1^{\circ}, 3^{\circ} .797,3^{\circ}$. $792, y^{n}$ à $4^{\circ} .812,7^{\circ}, 1013,5^{\circ} .1057$. $7^{\circ}, 8^{n}, 33^{\circ}, 2 n^{\circ}, 26^{\circ}, 97^{\circ}, 1060,8^{\circ}$ $3077,2^{\circ}, 3^{\circ}, 8^{\circ}, 1136,3,4^{n}, 1206$. $13^{\circ} .1230,133^{\circ}, 16^{\circ}, 1366,3^{\circ} .1086$, $7^{\circ}, 10^{\circ}$ ม่ $19^{\circ}, 1287,6^{\circ}, 7^{\circ}, 1997 \cdot 3307$, $3^{\circ}, 4^{\circ}, 23,6,6^{\circ}$ à $8^{\circ}, 2365,3^{\circ}, 3369$, $7^{\circ}$ à $9^{\circ} \cdot 3571,2^{\circ}, 3^{\circ}, 5^{\circ}, 7^{\circ}$ à $9^{\circ} \cdot 9677$, $11^{\circ}, 13^{\circ}, 3088,3^{n}, 4^{\circ}, 3 \circ 90,3191, ?^{\circ}$.

\section{MANUSGRITS ARABES.}

$3204,4^{\circ}, 5^{\circ} .3257,3^{\circ} .3431,8^{\circ} .3939$, $3^{\circ} .3967,4^{\circ} .4313$ a 4320.4245 .4354 , $\because 4361,200^{\circ} .4279,93^{\circ} .1980,2^{\circ} .4336$ $2^{\circ}$. 4392, $3^{\circ}, 5^{\circ}, 6^{\circ}, 4152,4^{\circ}$ à $6^{\circ}, 8^{\circ}$ à 19". 45.8, 3. $4542,10^{\circ}, 11^{\circ} .4577$,

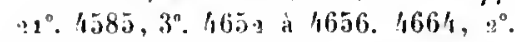
$166.5,19,18^{\circ}$.

3. Dictionuaires. Nos 4.30 a 4369 . $895,4^{\circ} .936,6^{\circ}, 1057,28^{\circ}, 1306,6^{\circ}$. $1348,55^{\circ} .9435,3^{\circ} .2721,3^{\circ}, 3663$, $10^{\circ}, 3939,3^{\circ} .4201,5^{\circ}, 12^{\circ}, 15^{\circ} .4549$, $\because 4661.4663,4^{\circ}, 7^{\circ} .4664,6^{\circ} .4665,5^{n}$.

AXX. Hhetorique. $\mathrm{N}^{\circ 3} 4370$ à 4331 . $117^{6}, 33^{\circ}, 33^{\circ} .1286,33^{\circ} .2954,13^{\circ}$. $3307,6^{\circ} .3346 .2373,2.3502,9^{\circ} .3401$, :3. $3955,5.397^{3}, 13^{\circ} .4187,17^{\circ}, 18^{\circ}$. $451,2,9.4585,4^{\circ}, 4606,4^{\circ}$.

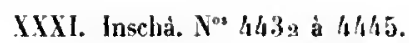

XXXII. Prosodie et métrique. $N^{\text {os }} 4446$ a $4456 .-1077,6^{\circ}, 7^{\circ} .1286,4^{\circ} .1303$, $3^{\circ}, 2346.2357,5^{\circ}, 3088,6^{\circ}, 3955,3^{\circ}$ a $4^{\circ}, 4134,3^{\circ}, 1^{\circ}, 6^{\circ}, 4336,3^{\circ}, 4542,7^{\circ}$. $1585,7^{\circ} .4652$ à 4656 .

XXX11. Bibliograplice. $N^{\circ 8} 4457$ à 4518 . $-{ }^{2} 800,21^{\circ} .397^{3}, 12^{\circ} .4591,13^{\circ} .4663$, $10^{\circ}$.

XXXIY. Ourrages divers et supplément. रे 4529 à $4665 .-82,66^{\circ} .206,10^{\circ}$. 442. 458.651, $7^{\circ} .669,4^{\circ} .809,9^{\circ} \cdot 996$, $4^{\circ}, 5^{\circ}, 7^{\circ}, 8^{\circ} \cdot 29^{5} 1,5^{\circ}, 219^{8} \cdot 2295.2967$, 3. 4215.4622 . 


\section{TABLE ALPHABÉTIQUE DES TITRES.}

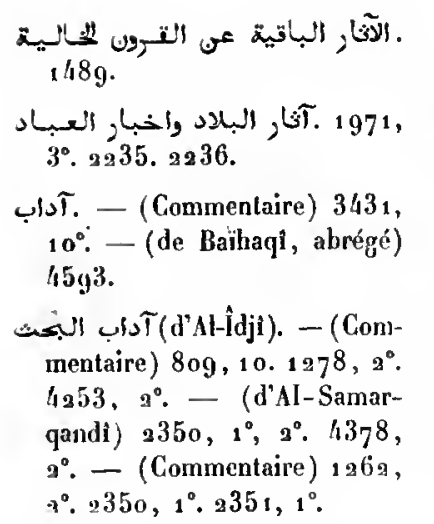

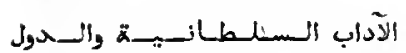
g/s/11. - (Abrégé) 9h4.

3338, 20.

كناب Voyez

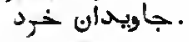

21546,606. . 1337,6 .

(Commentaire) $4 / 24,5^{\circ}, 7^{\circ}$.

آكام العقيلن 3 أحكام بلمصيسان. $2800,11^{\circ}$.

التوفئ. $367_{7} 8,1^{\circ}$.

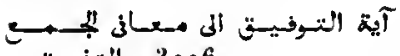
3236.

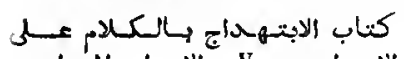

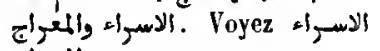

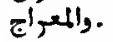

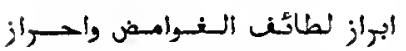
1031.

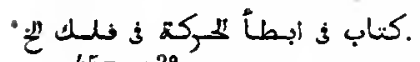
$9457,13^{\circ}$.

ابكا, المعان المخحرة واسكرا, المبان 3239.

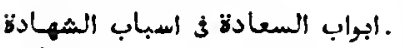
$4588,17^{\circ}$.

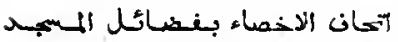
2255-2257.

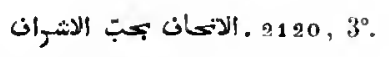

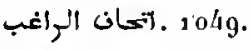

9800, 7\% .

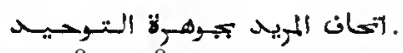
1281.1283.

4456. 24.

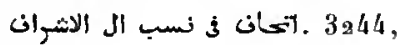
$6^{\circ}$.

656-658 ـالاتعان 3 ملوم الـتبكاب.

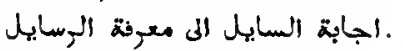
4437 .

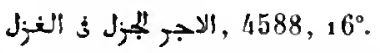

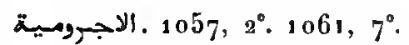
$1206,12^{\circ} .1230,16^{\circ} .2307$, $4^{\circ} .2571,5^{\circ} .3989,2^{\circ} .4006$, $3^{\circ}$. $4015,3^{\circ}$. 4122-4126. $45.8,33^{\circ}$. - (Comment.) $4098,3^{\circ}, 6^{\circ} .4123,2^{\circ} .4124$, $2^{\circ}$. 4125, $2^{\circ}$. 4127-4141. $4151,2^{\circ}$. $4193,2^{\circ}$. $4606,12^{\circ}$.

الاجرية لإلية عي الاسئلة الينـيـة 1279.

الاجرية الفاخـرة رةًا عـى المـاتـة 8افㄴ. $1456,1^{\circ}$.

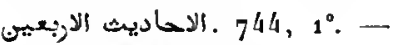
(Commentaire) 745-749.

1566.

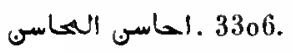

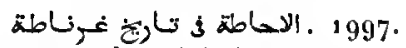
- (Alurégé) 3347.

كتباب Voyez - كتـاب الاجهبار

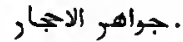

2772, $1 \%$

أحسى المسالك لاخـبـا, الـبـرامكك. 2107.

- - (Commenlaire) 1073.

كتاب الاحكام i أصـول الاحسكسام. $79^{1 .}$

2588.
1458.

. 3966, 20.

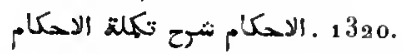

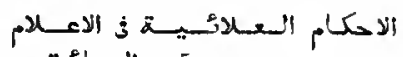

السكائية.

4661 ـ احكام كتاب نازئبات .

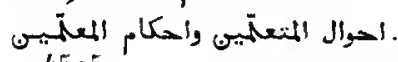
4595.

- . (Abrégé) 4579.

276 ـ اخبار 3 اجتناب الحينـونة ) $5^{\circ}$.

1381, $3^{\circ}$. اخبار أهل لبنة

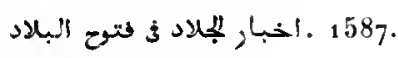

. $310,1^{\circ}$.

-556 . اخبلا, الهحول وآثا, الاول 1559 .

1/701475 .

2281, كتاب أخبا, الصيى والهند $1^{\circ} .228$ a $1^{\circ}$.

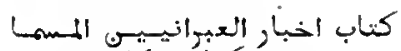

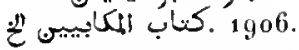

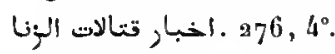

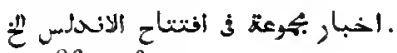
$1867,2^{\circ}$.

4324-4327.

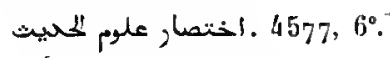

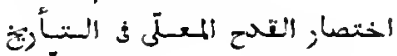
3340.

كتاب الاختلاج مى كتوب النلافسة $2758,1^{\circ}$.

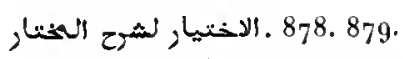

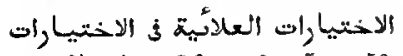
.

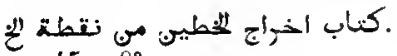
$2457,8^{\circ}$.

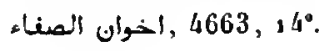

4593 .كناب الادب ذ3 تبليغ الارب .

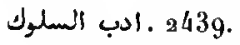

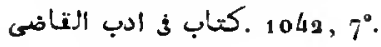

996.

4432. ادب الكاتب ادب الكيل.

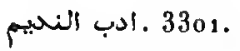

الادعوبية المنتخبة ف الادوية المبربة. 2691 .

. 2583 . 2581 .كتاب الادوإ والانون .

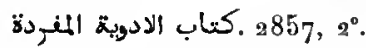

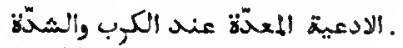
$7^{44}, 2^{\circ}$.

, 1130. - (Commentaire) 1131 .

اذكار الاذكا, المستخـتبّة بـالــيـل . $1178,1^{\circ}$.

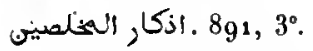

أ. $23 / 48,1$.

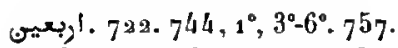
$763,1^{\circ} \cdot 77^{8}, 1^{\circ} \cdot 779 \cdot 7^{82}$, $1^{\circ} .1042,2^{\circ} .1177,2^{\circ} .1185$, $2^{\circ} .1230,9^{\circ} \cdot 2009,4^{\circ} .2254$, $7^{\circ} .3154,5^{\circ}$. $4136,3^{\circ}$. 4149, $3^{\circ}$. 4539.466 s, $6^{\circ}$. - (Conmentaire) $4577,10^{\circ}$. - (Voy. aussi الاحاديث الاربعين.)

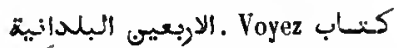

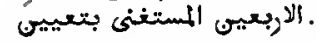

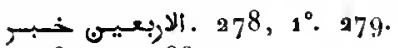
$280,1^{\circ} .283$.

722, 50.

775, 20.

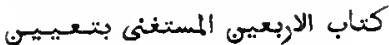

722, $1^{\circ}$.

729, $3^{\circ}$.اربعيى النكتمبيه.

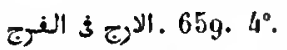

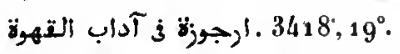

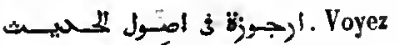

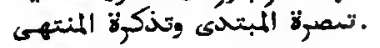

94. 
ه559, 5 ـ الارجيوزة السبعية

ارجسوزة ث السطبـ (d'Avicenne). $117^{6}, 12^{\circ} .29^{4} 9,1^{\circ} .2943$ $3^{\circ}$. - (Commenlaire) 9918 , 6. $2943,1^{\circ}$.

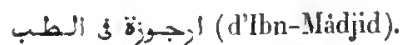

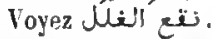

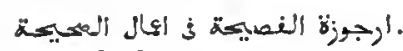
$277^{6}, 6^{\circ}$.

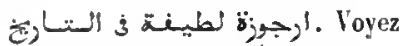

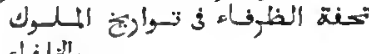
و والنفاء

\%

ارجوزة الياسمينية (Commenlaire) $4162,4^{\circ}$.

أرناد. $2544,19^{\circ}$.

1987, $11^{\circ}$.

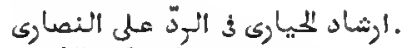
$1457.3204,2^{\circ}$.

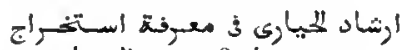
314.

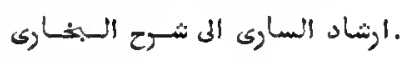
701. 702 .

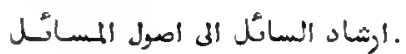
2533.

كتاب الإنشاد اله سبيل السرنثـاد 1105.

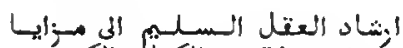

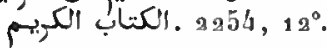

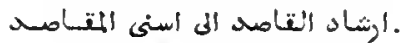
2331-s333. - (Extrail) 3442, $5^{\circ}$

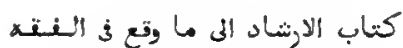

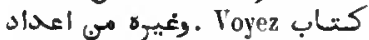

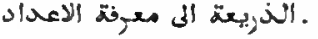

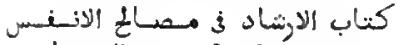
. 1276 , 6. 6 . 1293.

ازالة العبـوس عـى قسميـحة البــن . 325 . عبروس

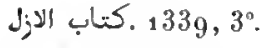

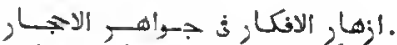

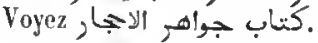

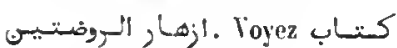
المروضتين.

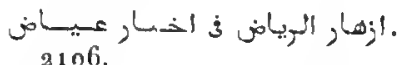

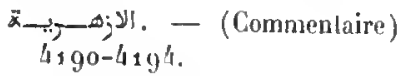

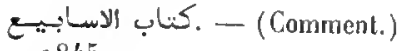
2845.

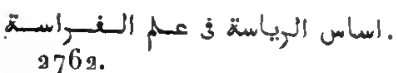

2974 - $297^{4}$ ـ الاسباب والعلامـات 3009 .

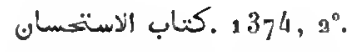

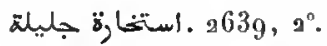

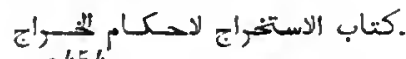

2454

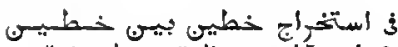

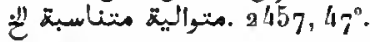

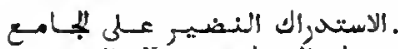

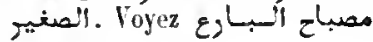
النضير.

. 2192.

1587 . استيعاب الماب 158

. 1985.

1366.

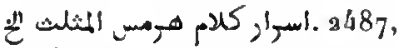
$3^{\circ}$

كتاب (جالبينوس) في الاسطتصيات

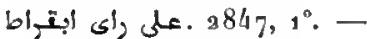
(Commentaire) $2848,1^{\circ}$.

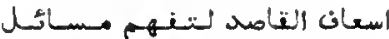

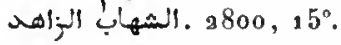

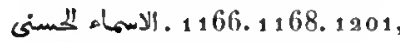
$2^{\circ}$. 1209. 1217. 1227. (Commentaire) 1383. 1405.

2086.

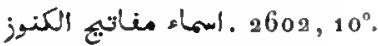
.1141, 40.

. 1160.

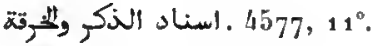

أسنى المطائب 3 نثرح روض الطالب 993- $99^{5}$.

اسنى المتاصد واعذب المواون . Voy.

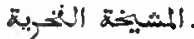

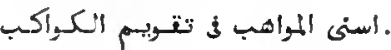
2537-2538.

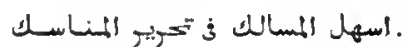
$1126,2^{\circ}$.

3065 ـ أسواق الانشواق

. 1449 . كتاب الاسوس 1 .

اسولتة التران البجيه واجبريتتهـا 633. 624, 1․ 625.

. 4588. 290.

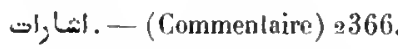
. 2752 . الانثارات 3

2744.

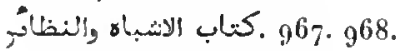
2800, 24 . 28 .
. 2014 ـانثراق التوإنخ

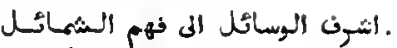
714

(الشعار الستة 3273. - (Commenlaire) 3274 .

896. 3 ـ أشعار الهذلييي.

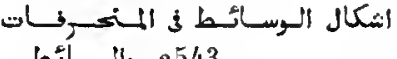
s543. 254

2487, 1‥

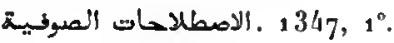
$1374,1^{\circ}$.

ح 917-920. (Commenlaire) $921,1^{\circ}$

. 2467, 28.

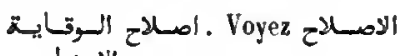

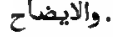

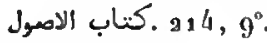

ال 454 ـ الاصول الاصول.

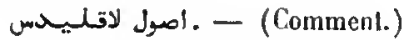
$2457,6^{\circ}, 7^{\circ}, 9^{\circ}, 39^{\circ}, 41^{\circ}$. 2465. $2466,1^{\circ} .2467,16^{\circ}-$ 18. - (Abrégé) 3458, 4\%. $2484,2^{\circ}$.

620, 20 .كتاب الاصول بحايع المرصول . $6^{\circ}$.

836 . اصول البزدوى . 186.

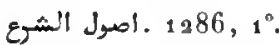

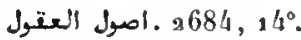

.

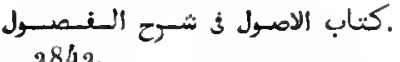

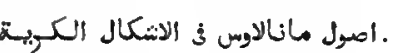
a $467,1^{\circ}$.

7 1367 ـأصول مقدمات الوصول.

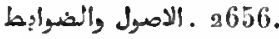

1450, 10.

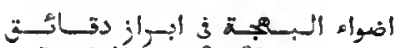
. $2708,3^{\circ}$.

3680. كتاب اطنالا

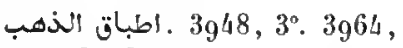
$2^{\circ} .397^{3}, x^{\circ}$.

, 3948, 2․ 3964, $1^{\circ} .397^{3}, 11^{\circ}$.

('اظها, الاسـر' - (Commentaire) 4806.

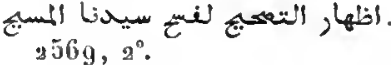

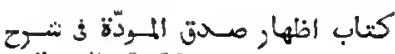

مئرة 3188.

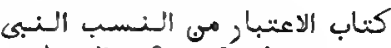
. $1871,3^{\circ}, 4^{\circ}$.
كتاب الاعتران والعل الذيى يخلص

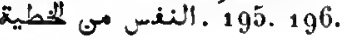
. 1247,3 .

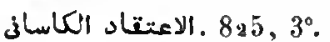

. $1261,1^{\circ}$. الاعتماد 3 الاعتتاد الاد

3305. 20.

lهill $4588,18^{\circ}$.

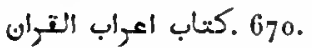

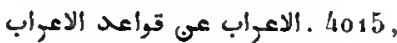
$2^{\circ}$. 4051, 30.4144, $1^{\circ}$. 4145. - (Commentaire) 4146-4150.

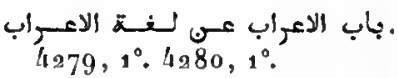

1451, 1\%. 1450.

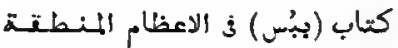

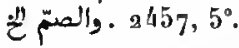

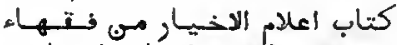

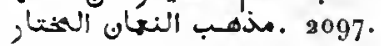

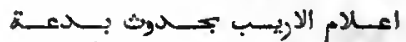
. $2800,10^{\circ}$. 4588, $12^{\circ}$.

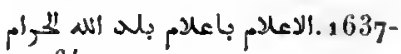
$164 \mathrm{~g}$.

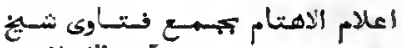
950.

. 2488 ـ. الاعلام 3 تفسير الاحلام .

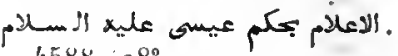
$4588,28^{\circ}$.

553 .كتاب الاعلام بتواطع الاسلام

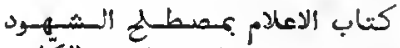
. 925. 926, . $^{\circ}$.

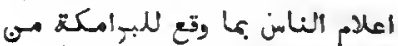

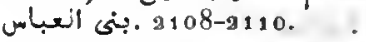

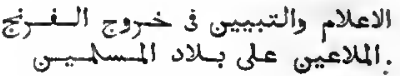
$2234,2^{\circ}$.

4588, .اءال النكر ف فضل النذك, . $30^{\circ}$.

3292-3298. كتاب الانغانز.

3030, 40.

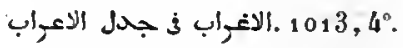

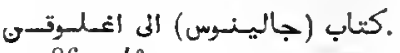
$2860,4^{\circ}$.

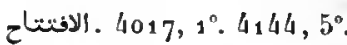

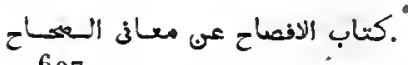
607 .

. 4994 . 4304.

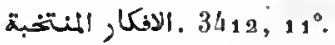

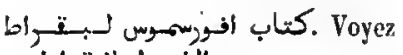

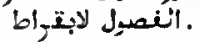

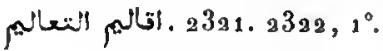




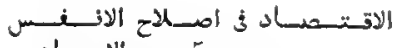

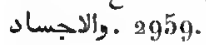

1029 ـالاقتصاد في كفاية السعتّاد 4547.

8023. 302.

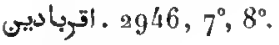

4003. 4003.

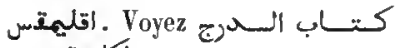
. اكلبمغس

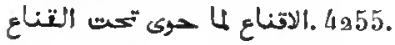
253, 2 ـاقوال الاباء التحديسين.

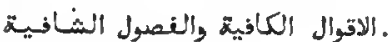
2820.2821.

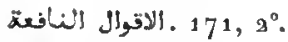

388. كتاب الاكتناه في مغازى المسطسطنى

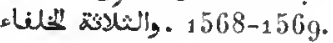

3042. كتاب الاكحال والانتيافات.

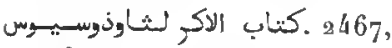
$19^{\circ}$.

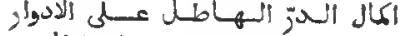
3944, 3 .

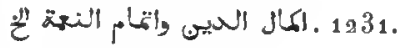

亗

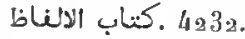

812, 51 .

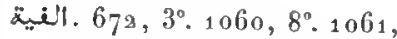
$9^{\circ} \cdot 1077,3^{\circ} .4068-4074,1^{\circ}$. - (Commentaire) $407^{4}, 2^{\circ}$. $4075-4116$.

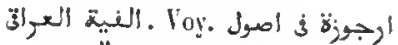

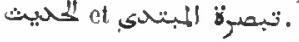

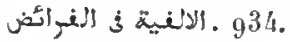

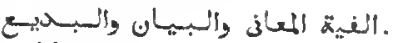
4428.

64, 30. - (Commentaire) $1276,2^{\circ} .4584$.

الامان (d'Al-Qáli). 4236, 1․ (d'Ibn al-Iladjib) $4392,3^{\text {n }}$.

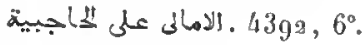

4120.

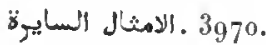

. $4166,4^{\circ} .4167$ $4^{\circ} .417^{3}, 5^{\circ} .417^{4}, 5^{\circ} .4177$ $5^{\circ} .4180,4^{\circ} .4181,5^{\circ} .4188$. 5. $4198.4205,3^{\circ}$.

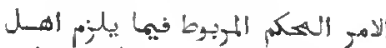

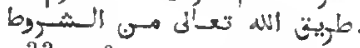
$1337,1^{\circ}$.

. 4الاملاء على ابيات المعان $4392,4^{\circ}$.

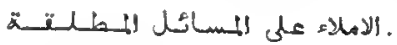
$4392,5^{\circ}$.

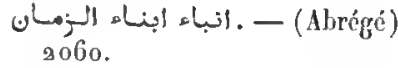

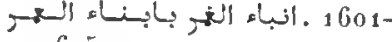
1605.

. 212122.21 . 212

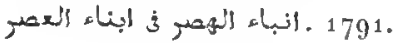

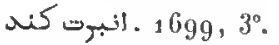

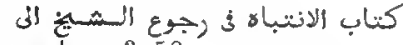
مباه 3058.

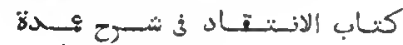
الاعتباد 1245.

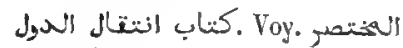

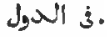

. $2316,6^{\circ}$. 4203.

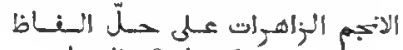

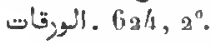

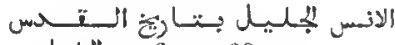
.

2832, 10.

吕 735 .

3304. انس الموحيد .

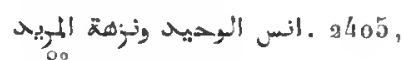

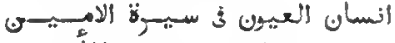
0. 1999-2006.

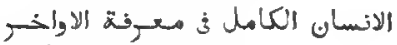

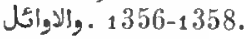

2480, كتعاب الانعام بمعرفة الانغام ولائر $1^{\circ}$.

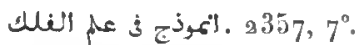

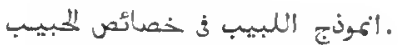
4588, 150.4591, $13^{\circ}$. 4608, $5 "$.

انموذّح لطيف نتل مبر إّل كتاب

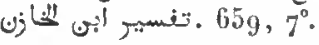

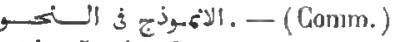
4005. $4006,1^{\circ} .4016,2^{\circ}$ $4022,3^{\circ} .4041,4^{\circ}$.

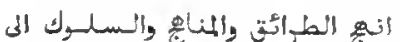

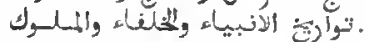
$1815,3^{\circ} \sim 5^{\circ}$.

الأولوار البهوية ف الفرائض الانثنهية 1037.

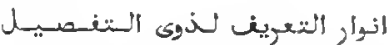

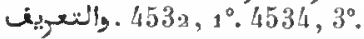

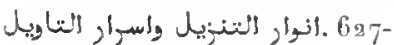
635. - (Comment.) 636.

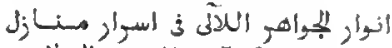
otell ureil. $2596,1^{\circ}$.

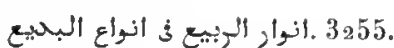

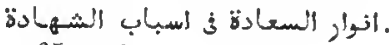
$659,2^{\circ}$.

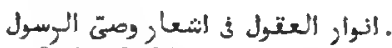
308. 3083.

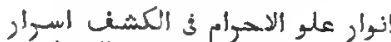

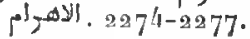

1027.

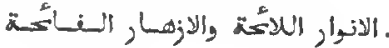
2017.

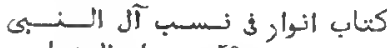
, 4207, 50

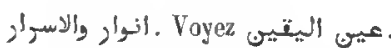
كناب اللاتوار وكيف خلتق الله النبى الني وكينا 1984.

3453.

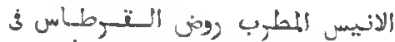

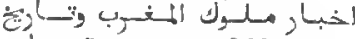
1868-1870. $1871,5^{\circ}$.

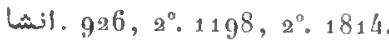
$1815,2^{\circ}$. $1892,3^{\circ} .2286^{\circ}$. $2309,3^{\circ} . \operatorname{s}^{\prime} 19,8^{\circ} .3206,2^{\circ}$. $3418,2^{\circ}$. $3435.3663,6^{\circ}, 8^{\circ}$ $12^{\circ} .4187,14^{\circ}, 22^{\circ}, 23^{\circ}, 28^{\circ}$. $4432-4445.4580,2^{\circ}$.

S3, 1199

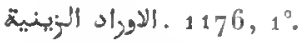

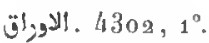

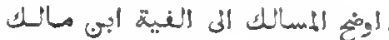
4077 . - (Comment.) 4078 4085 .

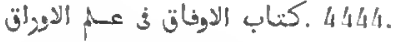
. 592,3 . 392.

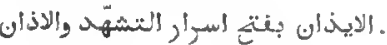
2139.

329. - 2307, $7^{\circ}$. - (de Porpliyre) э346. - (Comm.) $1243,2^{\circ}$. - (d'Al- Ablari) $2307,8^{\circ} .2353,2^{\circ} .2354,2^{\circ}$. 2356, $3^{\circ}$. 335้ $7,6^{\circ}$. $23359,3^{\circ}$. $2500,10^{\circ}$. - (Comment.) $1013,10^{\circ}, 1267,2^{\circ} .1396$, $7^{\circ} .2307,9^{\circ} .2353,1^{\circ}, 3^{\circ}$. $2354,1^{\circ}, 3^{\circ} .2355 .2356,1^{\circ}$, $2^{\circ} .2357,1^{\circ} .2358,1^{\circ} .2359$, $1^{\circ}, 2^{\circ} .2406,2^{\circ} .4606,5^{\circ}$.

ح . 3571, 2.

ح . الإيضاح

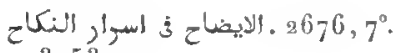
3053 .

4385.

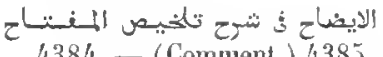

3060, 30.

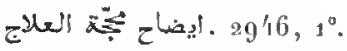

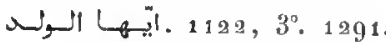

$2351,4^{\circ}$. $2405,9^{\circ} .3973$, $10^{\circ}$

1339, $4^{\circ}$

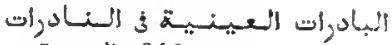
3430. الغيبية الغية

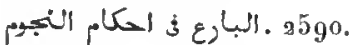

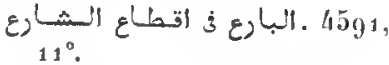

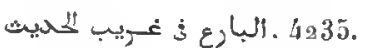

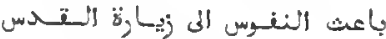

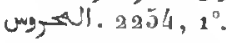

1620, 50, $12^{\circ}$. بـانست سعباد, $307^{8}, 1^{\circ}$. 3079. 3088, $5^{\circ}$. $3198,5^{\circ} .3248,7^{\circ}$.-- (Moutsallats et Taklumis) $1620,5^{\circ}$. $3080,1^{\circ} .3248,4^{\circ}, 5^{\circ} .4261$, $7^{\circ}$. - (Comment.) $1620,12^{\circ}$. $3078,1^{\circ}, 2^{\circ}$. 3079. 3081. $3248,6^{\circ} .3430$.

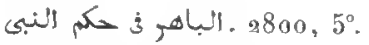

. $1187,1^{\circ}$.

4910. 4210.

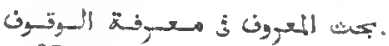

$650,1^{\circ}$.

3588. 3589.

1297.

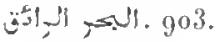

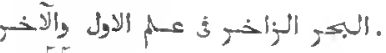
15) 1$.

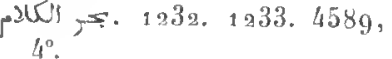
811. 811.

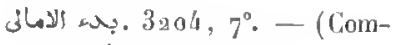
mentaire) $1251,1^{\circ} .1285,3^{\circ}$. $4051,4^{\circ} .1158 \%$

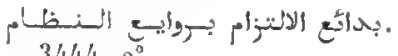

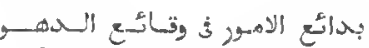
18.4. 1895. - (Voyez anssi

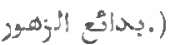

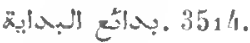

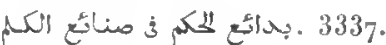
$3338,1^{\circ}$.

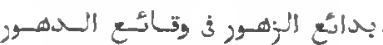
1403. 1552. 1833 el 1823 . (Voycz aussi بحانُع الامور.)

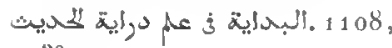
3 . 
(927. - (Comm.) 842-844. - (Voyez همائة) •بحائة المبتحيى ف نظم ام الببرأهيى $3264,3^{\circ}$.

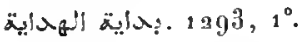

الحئ. 1516.

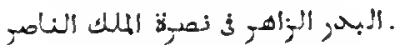
$179^{3}$.

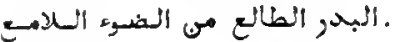
2078.

. $1216,7^{\circ}$.

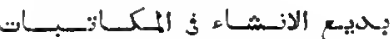
. 4445.

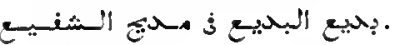
$3248,9^{\circ}$.

(Commentaire) 1960.

بحيعية (d'Al-Soyoûtí) $1160,6^{\circ}$. $3207,3^{\circ} .3364,2^{\circ}$. 3432, $2^{\circ}$. $4124,7^{\circ}$ - - (d'lbn-Saràyâ) $9307,6^{\circ}$. - (d'lbn-Hiddja, avec le comment.) $3906,4^{\circ}$. 3207, 2. 3213-3×18. (d'Ni-Ṣafi al-Hilli) $3206,1^{\circ}$. $3207,1^{\circ} .3248,10^{\circ}$. - (d'Ismâ'il al-Hosain) $33_{20} 6,5^{\circ}$. (d'Ismàil ibn al-Mocri) 39o6, $6^{\circ}$. - (de Schábàn ibn Johyammad) $3 \mathrm{a} 48,9^{\circ}$. - (d'AlHomaidi) $3{ }^{4} 48,11^{\circ}$. Comm., 3s38. - (de Sadr al-Din Ali) 3255 (avec le commentaire). $3259,3^{\circ}$.

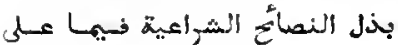
ت

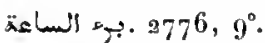

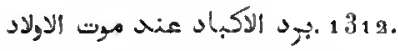

8., $441.1128,4^{\circ} .1167,4^{\circ}$. $1170,2^{\circ} .1206,10^{\circ} .1224$, $8^{\circ} .1395,9^{\circ} .1660,3^{\circ}, 4^{\circ}$. $1903,4^{\circ} .2637,9^{\circ}$. 2793. $3154,3^{\circ}$. 3177-3181. 3430 . $4261,4^{\circ} .4662,12^{\circ}$. - (Takhmis, tasbit, etc.) $1251,3^{\circ}, 4^{\circ}$. $3080,2^{\circ} .3182-3185,3248$, $3^{\circ}, 3^{\circ} .4961,3^{\circ} .4665,13^{n}$. - (Comm.) 744, $7^{\circ} \cdot 1251$, $9^{\circ}$. 1620, 3०. 3187-3194. $3198,4^{\circ} .4577,19^{\circ}$.

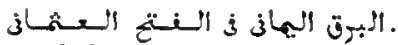
1644-1650.

. 2449.

كتاب المبرهاب ذي اسمرار علم الميزأن. 1355.

بزوغ الهـل Jنظ. $9800,18^{\circ}$
Yoyez

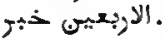

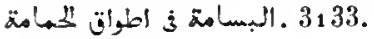

كئ. 1663 ـ البستان.

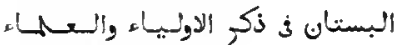
4630. بنتمساء. والنها.

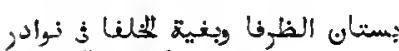

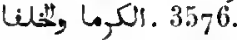

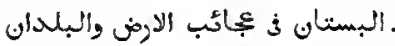
2212, $1^{\circ}$.

بستان المواعظيى وزتزة الناظلريى. 1311.

933 .البسيط 3 المثروط

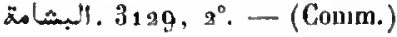
$3127-3134 .-$ (Supplément) $3134,2^{\circ}$.

كتاب بمَرى الكثيب بلقاء للمبيبـ. $139^{0}, 1^{\circ}$.

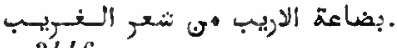
3446 .

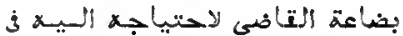

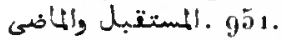

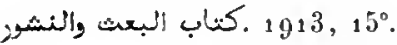

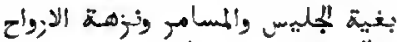

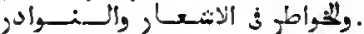
3448-3451.

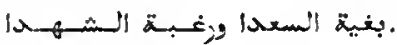
$3442,3^{\circ}$.

2138.

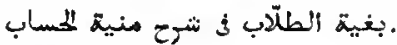
$9204,2^{\circ}$.

بغية الطتّب ن العل بالاسطـلاب $4580,4^{\circ}$

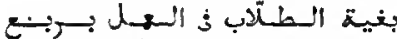
14, $10^{\circ}$.

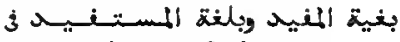

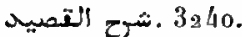

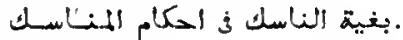
3406.

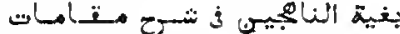
. 1345.

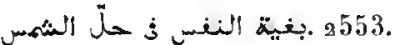
$2561,6^{\circ}$.

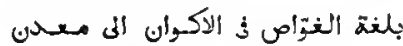

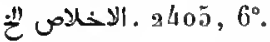

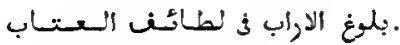
$349^{4}, 1^{\circ}$.

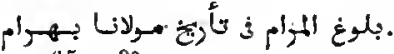
$1651,3^{\circ}$.

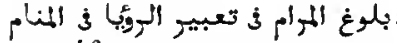
2746.

. 4170, 40. 4i73; 40.
$417^{4}, 4^{\circ} .4177,4^{\circ} \cdot 417^{8}, 4^{\circ}$ $4183,4^{\circ} .4183,3^{\circ} .4197,3^{\circ}$. 4198. - (Commentaire) 4199 4200 .

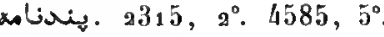
$4607,10^{\circ}$.

3438 .بمجية الابصار ونبذة الاخبك,

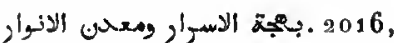
$4^{\circ}$. s038. s030.

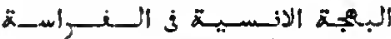
2760.

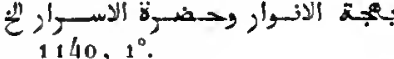

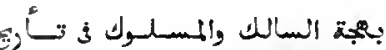

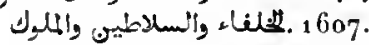
3545.

بمجة العكادث ف الحكام بهلة مسته ن2597.

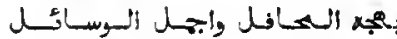

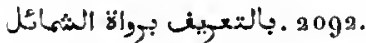

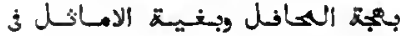

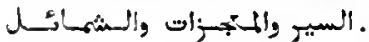
1976 .

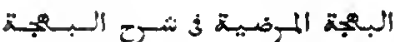
999.

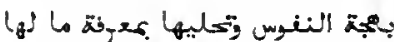
أ. 695 . 5 .

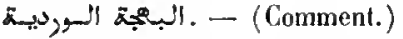
999. 1000.

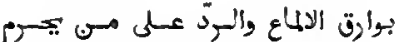
. 4580, 1. . السماع بالاجهاع

30.

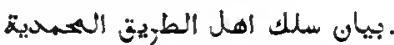
1354.

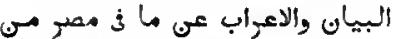

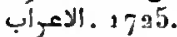

. 2818 . $2810,1^{\circ}$.كتاب البيطر .

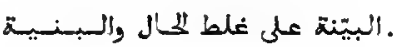
$399^{3}, a^{\circ}$.

3387, $1^{\circ}$.كتاب :يبوت العثيثرة

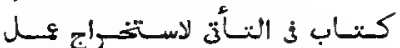

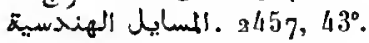

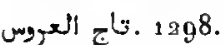

2947, $4^{\circ}$.

3420.

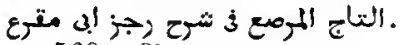
${ }_{2} 568,13^{\circ}$.

1608.

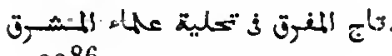

كأخيَ الظلامة اله بيوم التقيـامتح $659,3^{\circ}$. $4588,3^{\circ}$.

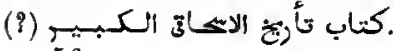
1562 .

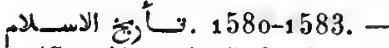
(Supplément) 1598-1600.

1867, 18.

- (Abrégé) 1555.

د 21.28-2131. (Albrégé) 213\%. - (Supplément) 2 133 .

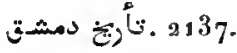

1643.

1466-1468.

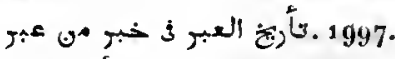
. 1894 . 1895.

. 295 . 295. 4524.

.

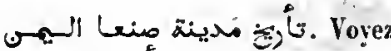
تأربخ الوازئ.

1688.

خضائل . Voy. تأريخ مصر وفضائلها

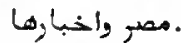

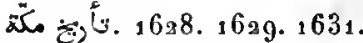

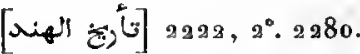

3025 et 3026.

تأسيس التواعح والاصول وتكسيـل 1380 :الغوايد لذوى الوصول

. 2061 .تاله كتاب ونيات الاعيان.

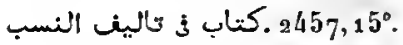

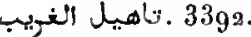

3171; 3164: $5^{\circ}$. - (Comm.) 3163. 3164.

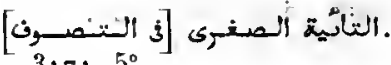
$3171,5^{\circ}$.

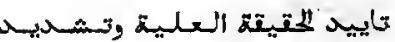

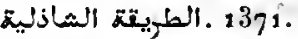

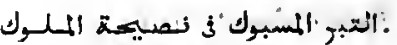
Voyez نصيحة المبرك.

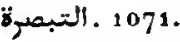

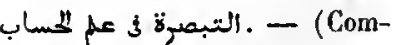
mentaire) $2463,3^{\circ}$.

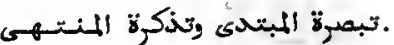
(d'Al-Iráql) 754. 755. (Commentaire) $7^{56 .}$ - (d'AlSaïmart) 4007 . 


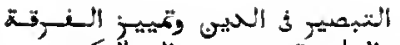

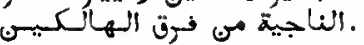
\$45.

1328, $1^{\circ}$. كتاب التبكليان.

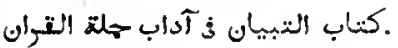
$59^{2}, 5^{\circ}$.

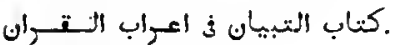
620.621.

4422.

. تبيييض المهيفة بمناقب إن حنيفة 2094.

802.

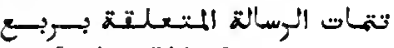
. $2544,8^{\circ}$.

.تنمة $1344,1^{\circ}$.

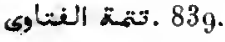

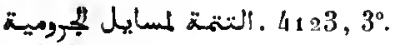
4112 .

4588, 1 . التثبيت عند التبييت - (Commentaire) 3224.

2013.

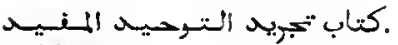
$4657,12^{\circ}$.

- (Comnient.) 2368. $2369,1^{\circ}$.

- - (Commentaire) $4374,2^{\circ}$.

3156, 4.

330, 12 . 230 $14^{\circ}$.

4374, $a^{\circ}$.

612, 3 . 61 .كتاب التعبير .

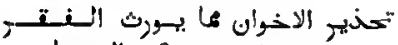
3200, 20.

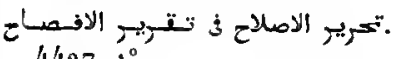
$4497,1^{\circ}$.

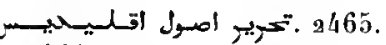
$2466,1^{\circ}$.

(تمير تنتيج اللباب (Comm.) 1038-1040.

1244.

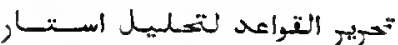

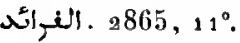

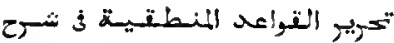
. 2373. 2376.2377 . — (Comment.) $2373,2^{\circ} \cdot 2377,1^{\circ}$. 2378 .

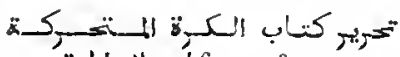

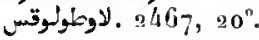

. 2467, 4. 4 .

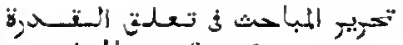

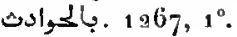

2/85.

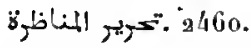

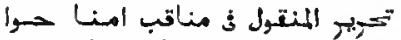
1927, 10.

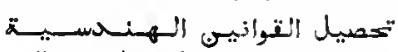
"4 $458,2^{\circ}$.

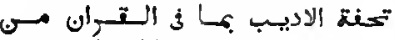
644, 1\% .الغريب ميب

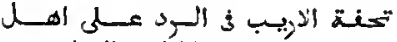

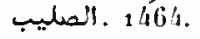

تحنة الامعاب ذذ معانثرة الاحسبـاب. $3039,17^{\circ}$.

تحفة الامعاب وزيزهة ذوى الالمباب. 3556.

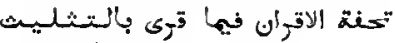

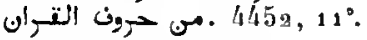

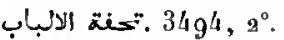

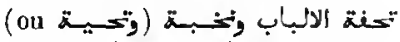

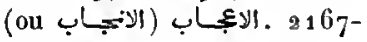
2171.

تمغة الهل الصايتية بـاسبانسيـح

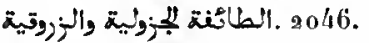

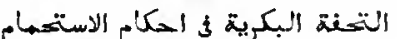
3034, 10.

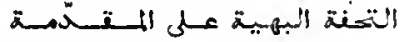
. $247^{5}, 1^{\circ}$.

4208 .التحفة على التحفة التهبه

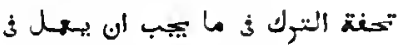
. $2445.2446,1^{\circ}$.

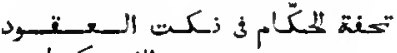
1100. 1101. (Comment.) 1102.

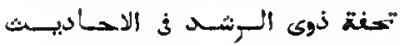
.

.

تكفة السايل ف اجوية المـسـايهل $41431,3^{\circ}$.

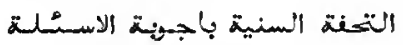
. 1394.

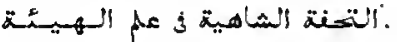
2516.

التحفة المئريغة والطبرفة المنـيـة 2010.

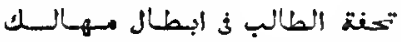
. 27 . $203,1^{\circ}$.

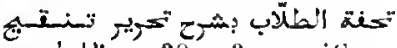
- ClConment.) 1040.

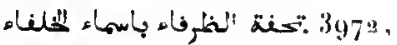
$6^{\circ}$.

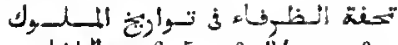
. $1615,1^{\circ}$. 3412, $7^{\circ}$.

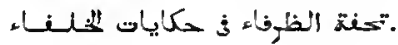
1618.

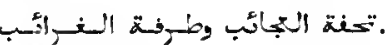
2172.

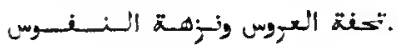
$3061-3064$.

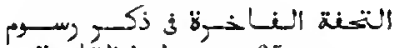
. 2265.

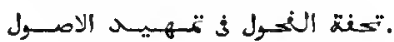
$255_{9}, 2^{\circ}$. - (Comm.) จ 559 , $9^{\circ}$.

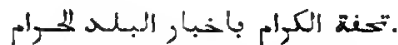
1633. $1668,3^{\circ}$.

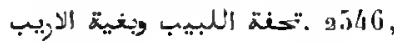
$a^{\circ}$

3404. تحفة اللبيب وبغية الكثئيب.

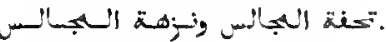
$3553,1^{\circ}$.

1143, 200.

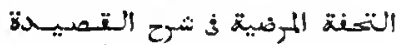

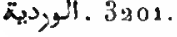

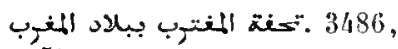
$\tilde{5}^{\circ}$.

. - (Comment.) 874 .

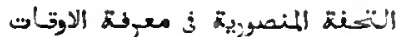

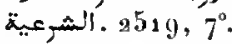

4807, 30.

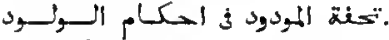
129 .

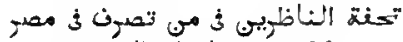
1860.

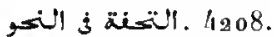

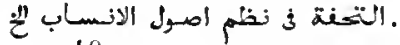
2048.

تحقيق الظنون باخبار الطاعهون. $\operatorname{sos} 6,2^{\circ}$.

تحكيم العتول بأفول البحدر للدنـول. 3125.

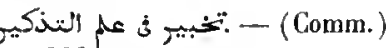
1383 .

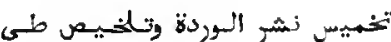

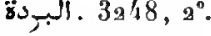

كناب (جالينوسر) ف تدبير الـعهمة 9858 .

التخكار فيمي ملك ط-روبـلمس ومها . 1889, 1 . 8. - (de Nașir al-1)in alToûsî) $2330,8^{\circ}$. - (d'Aboú 'i-Alà Zohir) $29^{60}, 2^{\circ}$. -
(d'Al-Sowaidi. Mbrégé) 3003. $3016,5^{\circ}$.

تنذكرة الازيسب وت-بسمسرة اللاديسب

$3129,3^{\circ}$.

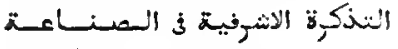
. 2955.

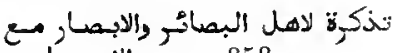
1858.

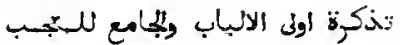
3031-3033.

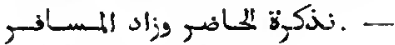
(Abrégé) 3028, 2\%.

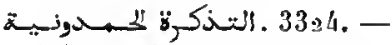
(Alirégé) 33ะ5.

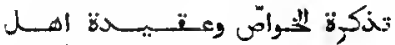

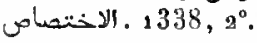

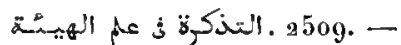
(Comment.) 2510.

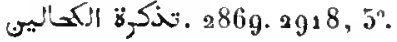
الم 3001 .كناب التذكرة المنفيـة 3002. - (Abrégé) 3003.

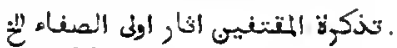
эo36.

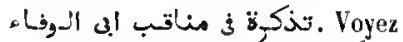

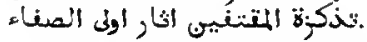

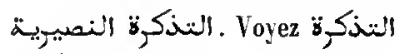

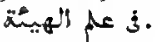

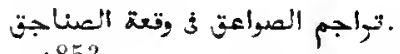
1853.

1339, 50. 3167$3170.3172,2^{\circ}$.

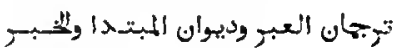
1517-1535.

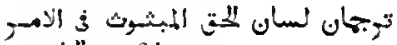
2642. و ولإلق

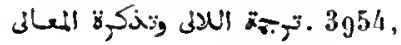
3 .

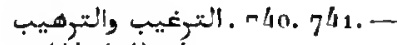
(Abrégé) 742.

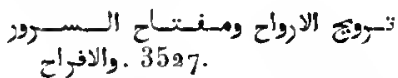

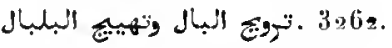

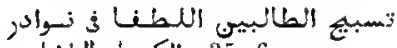

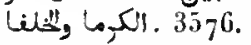

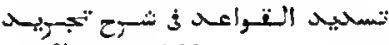
2368. ـانعتايُح

206, 20 .تسملية الاحزئ.

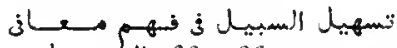
. 661. 662.

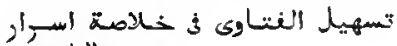
(5) (1). 1001. 


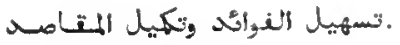
$1077,2^{\circ} .4117$.

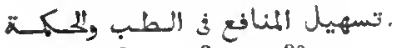
3020. 3091. 3020, 30.

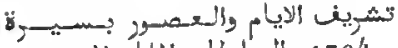

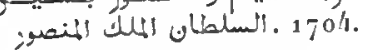

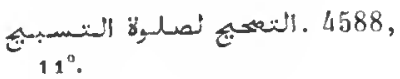

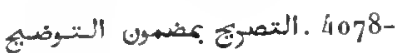
ho85.

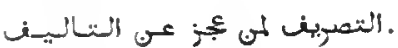
ag53.

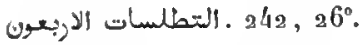

9742. 2743.

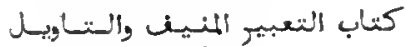
2753.

. 425,20 . 4259$4961,1^{\circ}$.

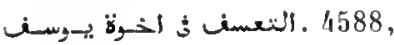
$37^{\circ}$.

كمث التناع Voyez. تعليق .

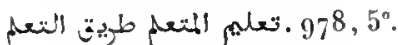
$1391,10^{\prime \prime}$. $2312-9319.4261$, $6^{\circ}$. - (Comment.) 2320.

181 . تعلم ووصانة لمكهينة

$79^{8}$.

4374, 1\%.

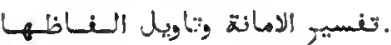
$171,1^{\circ}$.

652-655.

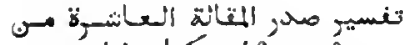

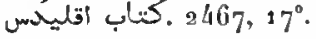

(Alrégé) 6.4-619.

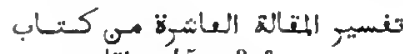

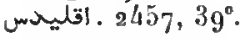

. 59 ـ التغصيل

已"

2835, 20. (Comment.) $2835,3^{n}$. 2844 , $3^{\circ}$.

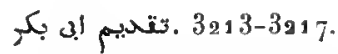

617 و .التقريب ف اسكار النتركيبب $2618,1^{\circ}$.

كتريب الاقصا مى مسايل بى المبتا . $2464,2^{\circ}$.

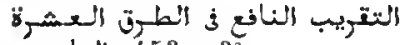

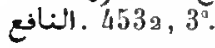

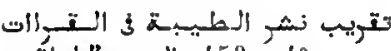
4532, 4\%. 40.

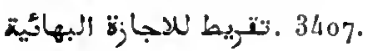

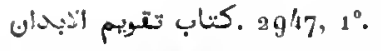

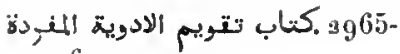
2969 .

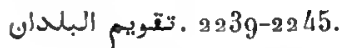

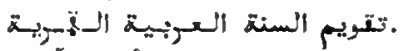
$2571,1^{\circ}$.

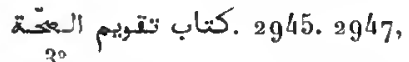
$3^{\circ}$.

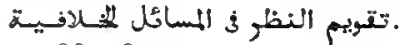
788. 789 .

\section{8, $1^{\circ}$.}

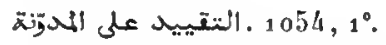

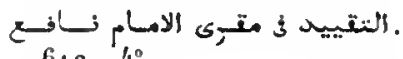
$619,4^{\circ}$

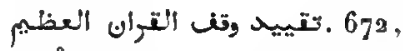
$1^{\circ}$.

1237 .نكليل الناج بجواهـ المعرأج,

(Comment.) 854.

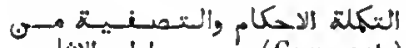
(Comment.) 1320.

1469 ـ تكملة تأريخ الطبرىى

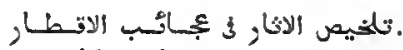
2246.2247 .

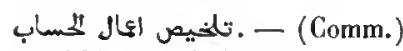
$2463,1^{\circ} .2464,1^{\circ}, 2^{\circ}$.

2120, 2 . 21 .

تكلفيص العويص لنيل التخصيس. $1360,1^{\circ}$.

ح 1286, 30. $3^{\circ} 37^{2}$, 2. 4378-4383. - (Comm.) $4187,17^{\circ}, 18^{\circ} .4384-4418$.

و33 . تلقيي العتول.

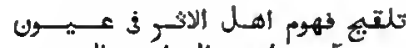
. 724. 725 . التواريخ والسيخ

1060, 100 .كناب التلتيى والنير

1965 . 195 .كناب النميذ والمعلم

2941.

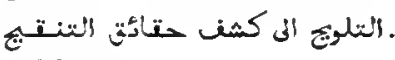
797 .

3452 .كتاب التمثل والمهاضرة.

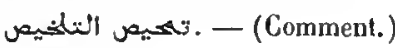
4418 .

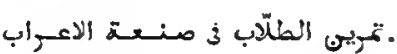
4086.

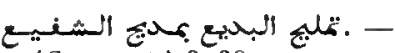
(Comment.) 3238.

1152 .تمنية المتملى 11 .

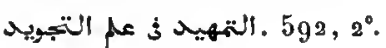

كائ (Comment.) 1023.

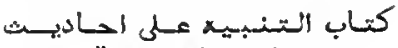

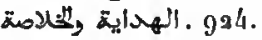

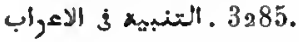

606, 3․ 774, $4^{\circ} .931$.

1487 .كتاب التنبيx والانثران .

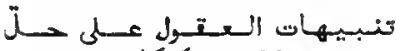
2841.

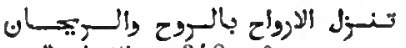

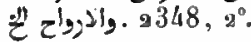

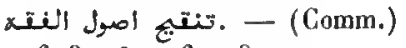
$673,2^{\circ} \cdot 79^{6-79^{8}}$

كتاب التنقيج ف تحيم فير المسيج $2569,3^{\circ}$.

4246. تنتقيج المعاح .

- 1038 - (Comm. - تنتيج النباب العباح 1040.

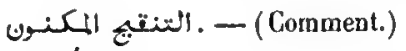
2941.

. 1348 ـ التنوير 3 أستاط التندبير .

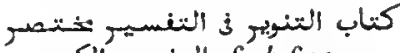
614-619.

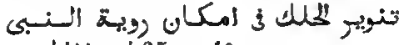
U1, $4659,4^{\circ}$.

2388.

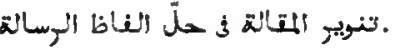
4548.

. النهافت (Comm.) $2399,1^{\circ}$.

التهخيب (d'Ilbn Hadjar al-AsqaJànî) 1587 . - (d'Al-Taftàzànî, comment.) $1396,5^{\circ} .2351$, $3 \circ .2396$.

1109.

744, $10^{\circ}$. 753.

35 . 35 1, 3 . كتاب التهذيب لذهى السلـبـيسب $9^{45,1^{\circ}}$.

973.

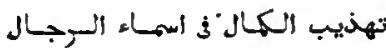
2089-2091.

•تهخيب مسائل المحرونة والمنتلطة 1051-1053. 1054, 20. (Comment.) $1054,1^{\circ}$.

.تهذيب متالات ثادوسيوس في الاكر. $2468,1^{\circ}$.

1013, 101 ـ التهذيب المنطتق وايكلام . ${ }_{13} 9^{6}, 4^{\circ}$. - (Commentaire) $1396,5^{\circ}$.

التهذيب Voyez .تهذيب المواتعات

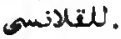

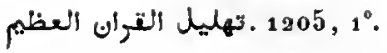
(384. 1385.

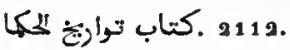

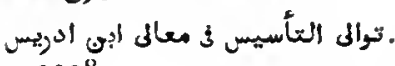
2098.

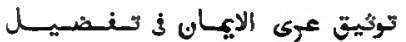
1970. 1970.

توجيه أعراب أبيات ملغزة الاعراب البيا. 3303.

398 , 13 .كتاب التونثية والتوفية

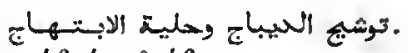
$4614, a^{0} .4627$.

(d'lbn al-Haddjib) 4549 . - (d'Ibn Aidoghmisch) $1124-$

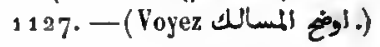

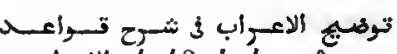
. $4148.4949,1^{\circ}$.

. 2510.

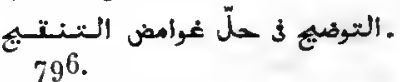

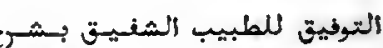

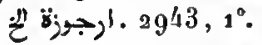

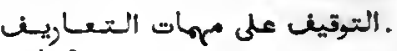
4262 .

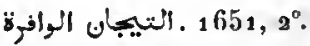

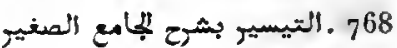
et 769 .

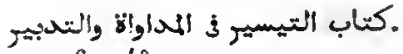
$2960,4^{\circ}$.

2707 .تيسير المطالب

742.

تيسير الموصول الن جامسع الاصــرل. 730 .

3529-3534.

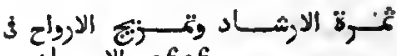
.الاجساد 2626 .

كواب العبادات وفضـائـل الاوتـات. $1249,2^{\circ}$.

ثوأب تضاء حوالثُج الاخران واغنانه 1699, 4\%

كتاب جامع الاحاديث السنسبـويـة $1374,4^{\circ}$.

ئ 2976-2989.

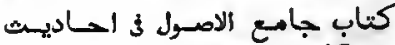
. 728. 729. - (Comment.) 730 .

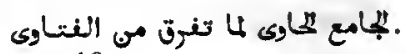
1043.

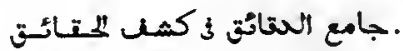
2370 .

(d'Al-Schaibainl) 
8ət-8ะ3. - (de Mohyì alDin al-Maghribi) 2594 .

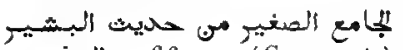
766. - (Comment.) 767-772.

(Comment.) 4160.

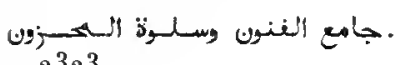

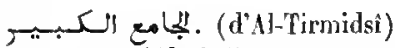
709. - (Abrégé) 710 et 711 - (d'Al-Schaibânî, rédaction en vers el comment.) 890 .

el 2508.

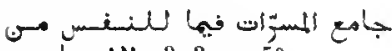
. $3039,15^{\circ}$.

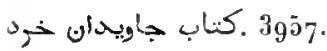

•2 219

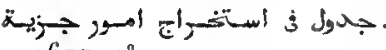
$2677,1^{\circ}$.

كتاب جمول فضل السحاثٔم وأيهال 尖, 2558.

年 - (Comment.) 4531.

2220.

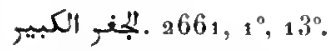

政 $1339,2^{\circ}$.

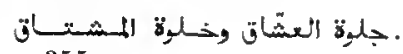
3551 .

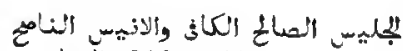
3487.3489.

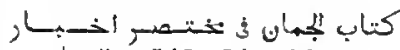
ن. 1545-1549.4608, ${ }^{\circ}$.

(1) 803 803 et 804 . (Comment.) 803-810.

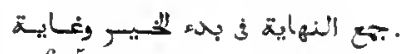
695 .

J. $1396,12^{\circ}$. - (Comm.) $1396,6^{\circ}$.

83 $4231,5^{\circ} .4233$.

. 20177. .

3253. البهات 3 علم النوجيهات .

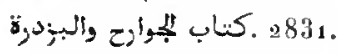

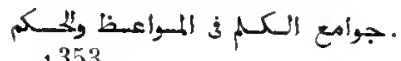
1353.

.939-93a.

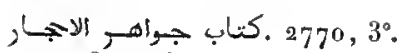
2773-2778.

1026 . جوأهر البحر النحيط.

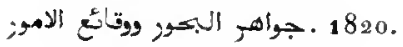

Mav. onestaux. - III.

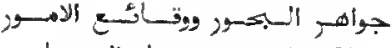

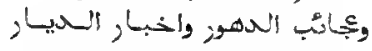
艺 1819,1 .

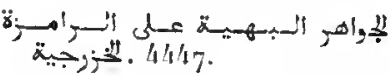

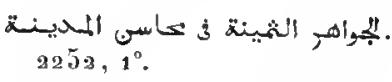

.

. $1197,1^{\circ}$.

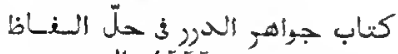
455. 45.

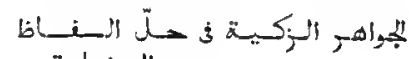
. 1129.

450. 450.

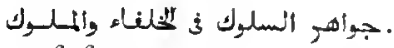
1616.

لمبوأهـر السنية ذي النسبة والكرامات

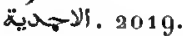

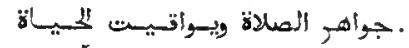
1157 .

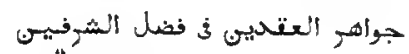
ث̈. $197 \%$.

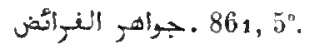

3342. 3343.

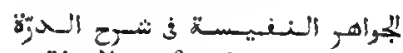
. $976,1^{\circ}$.

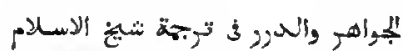
· 105.

نํ. $1215.1216,1^{\circ}$.

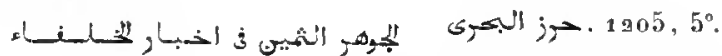

1617 . 1617.

1391, $12^{n}$

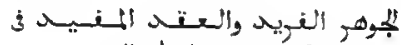

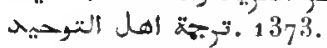

. $1216,4^{0}$. $1153,9^{\circ}$.

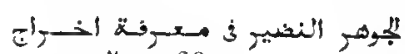

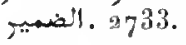

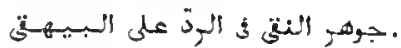
753.

.- (Comment.) 1281. 1282.

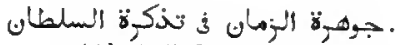
- (Abrégé) 3515.

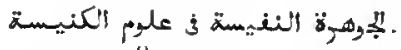
207.208.

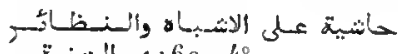
. $1160,4^{\circ}$.

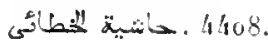

1241. - (Comment.) 1242-1243.

. $1241,2^{\circ}$.

↔) (4). $2918,4^{\circ} .29^{4} 7,2^{\circ}$.

الكوى للاعثال السـلطانسية ورستورم 2462.

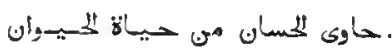
2799 .

(Comm.) 998-1001.

. 181.182.257, $16^{\circ}$.

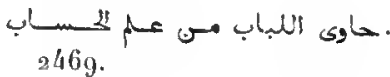

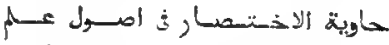
, $2292,2^{\circ} .2559,8^{\circ}$.

1389. 139.

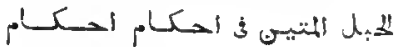
. $77^{6}$

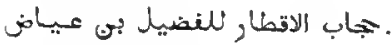
$2741,3^{\circ}$.

. حباب عظيم $1172,2^{\circ}$.

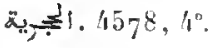

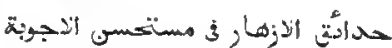
टौ

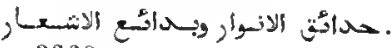
3368 .

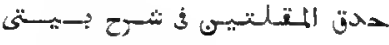
. 3242.

783.

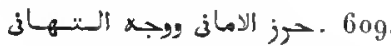

$672,3^{\circ} .1060,7^{\circ} \cdot 1077,4^{\circ}$.

453a, 5०. - (Comm.) 611

$612,1^{\circ} .4530$.

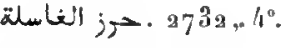

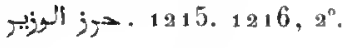

•

年. $7^{43}, 4^{\circ}, 5^{\circ} .1201,1^{\circ}$. $1903,3^{\circ} .1973,4^{\circ}$. 3384.

. حكب البك $119^{3}, 2^{\circ}$. $1974,3^{\circ}$. ${ }_{2} 637,3^{\circ} .2729 .2758,6^{\circ}$. $4606,7^{\circ}$.

1200, 1200.

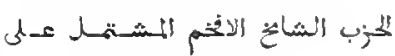
743, 30.

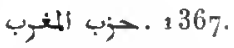

743, 7 .

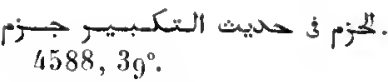

2472, 20.

. $2738,2^{\circ}$. حساب المريض

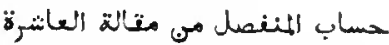

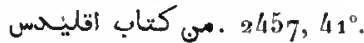

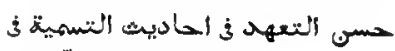

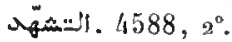

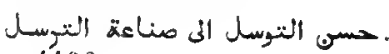
4436.

حسى الصنيع بشرح نور المرب-بيسع. $4120,2^{\circ}$.

4430. حسمى النعبارة .

كتاب حسى المهاضـرة في أخـبـار. 1794-1811. 4611.

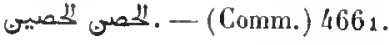

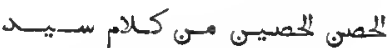
. $1169-117$.

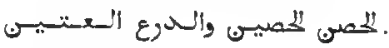
$117^{2}, 1^{\circ}$.

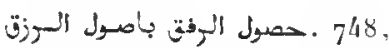
$3^{\circ}$. 4588, $25^{\circ} .4658,2^{\circ}$.

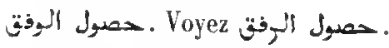

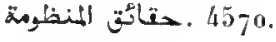

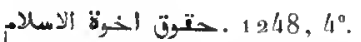

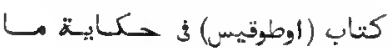

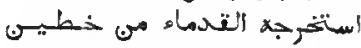

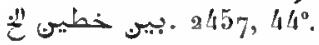

(Comm. ) a45o, 4\%

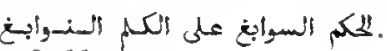
$3966,1^{\circ}$.

2349. 3971, 20

- (Comment.) 1349-135 .

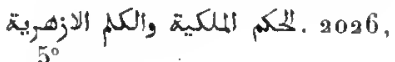

ل

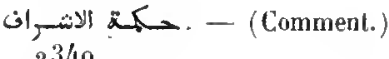

(Comm.) 2381. 2385.

.

2307 ـالّ المموز في مفاتيم الكنوز $x^{\circ} .2701$.

. حلَ التمموز وفت الاقلام والطلسمات. 2703.

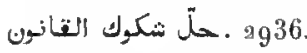

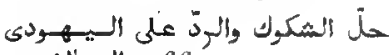

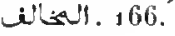




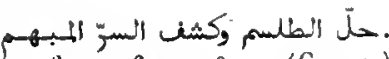
a61 9. $2620,1^{\circ}$. - (Comm.) $2621,1^{\circ}$

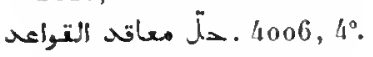

. $1201,5^{\circ}$.

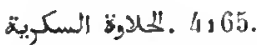

3393-3400.

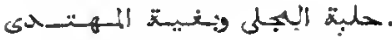
1147 et 1148 .

67 .7 .حل الاصطناء بيُشيم المصطنى $45 / 40,1^{\circ}$.

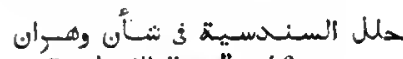

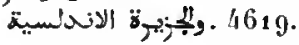

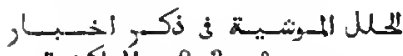

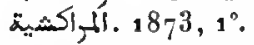

حلية اللابحال وما بئهر عنهها مـ

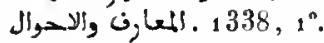

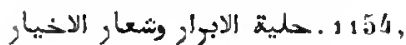
$3^{\circ}$. $1177,1^{\circ}$. $1178,1^{\circ}$.

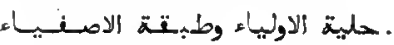
э028-зо32.

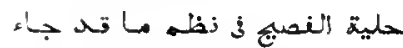
. $3452,6^{\circ}$.

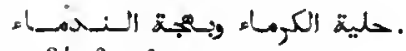
$3 / 476,2^{\circ}$.

年. 328 romment.) 3283-3285.

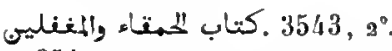
3547.

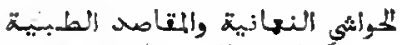

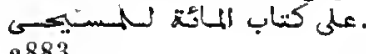
2883.

. $77^{3}, 2^{\circ}$. حون "حيباة.

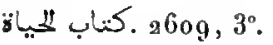

. 2562,1403 2798. $4586,3^{\circ}$. 一 (Abrégé) 3799-2801.

991 .خادم المافتى والروهة

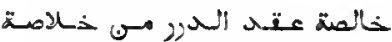
, 4 āgú.

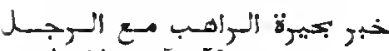
)

2452.2453.

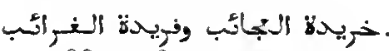
2188-2206.

خريحة القصر وجريدمة السعصد, 1303, 3․ 33.6-3332.

826.

年 $1077,6^{\circ} .4194,4^{\circ}$. $4446,3^{\circ}$.

1667 . خصائصن افضل النخلوقيه , $6^{\circ}$.
كـتـاب Voyez. لمعائص الكـبـىى

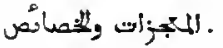

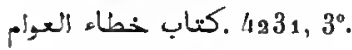

1289, 180

(Comment.) 1290 .

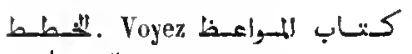
.

8. $223.3041,7^{\circ}$.

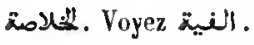

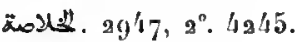

840.

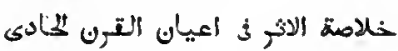
.عشى 2083.

4023, 3ㅇ.

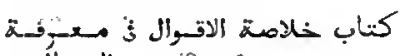

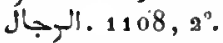

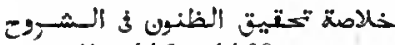
(1/46767 . 4/468.

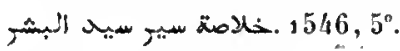

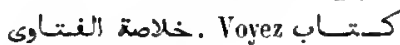
iصellell.

.

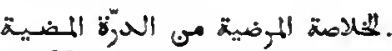
$1337,5^{\circ}$.

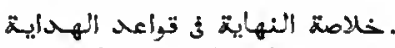
- (Comment.) 924 .

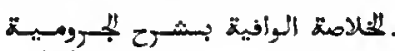
$4151,2^{\circ}$.

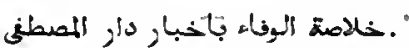
1634-1636.2252, 2.

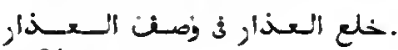
$3401,1^{\circ}$.

. 2717 .كتاب العلتطرات.

645, 20. $1343,4^{\circ} .1932$, $5^{\circ}$. - (Comment.) 645, $2^{\circ}$. $3343,4^{\circ}$.

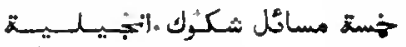
ئرو، 166.

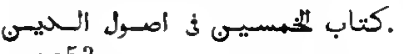
1253.

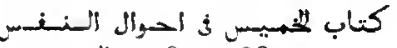
. 1983 . 1983.

ى 2636.

.

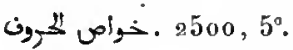

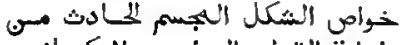

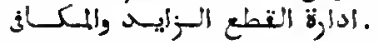
$2457,98^{\circ}$.

, 3457 . $29^{\circ}$.

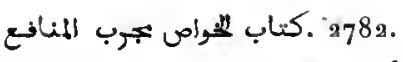

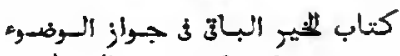

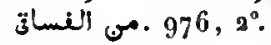

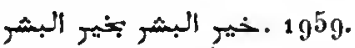

3578 . خبر جليس وانغع النيس.

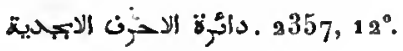

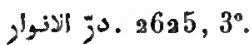

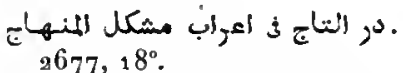

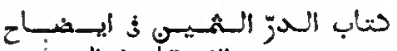

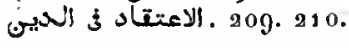

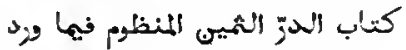
" $2 / 446,2^{\circ}$.

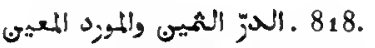

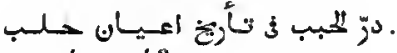
$2140-2143$.

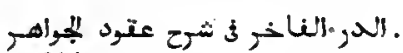
$644,2^{\circ}$.

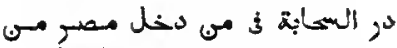
. $2016,1^{\circ}$.

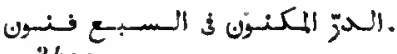
3409 .

المر الملتعط مى كئ بك وسـنـ $4435,2^{\circ}, 3^{\circ}$.

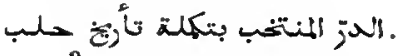
$2+39$.

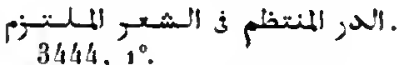

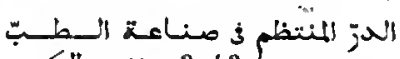
3043.

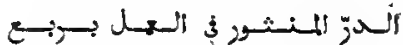
(الحستور $2519^{1}, 9^{\circ}$. - (Comm.) 2533.

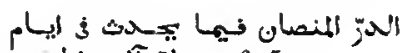

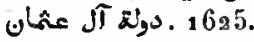

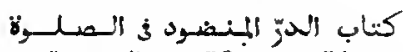
¿" 4588, الدزّ المنظم 3 الاسم الاعظم .

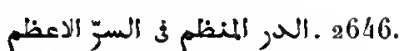
2663-2669.4606, $1^{\circ}$.

كتاب دزّ المنظـوم لاهـل الـعـلـوم . 4282

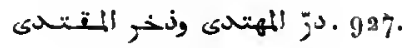

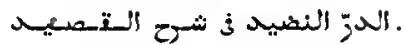
4451 .

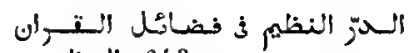
و 643.

المزّ النفيس 3 تعليم كل جليس

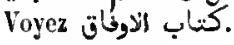

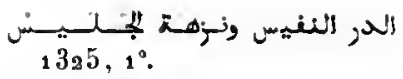

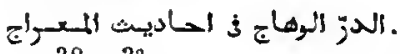
1381,3 .

-1719 .درة اللاسلكك في دولت الاتراك 1721.

الدزّة الثمبينة فخ الخبار المهيسنسة 1630.

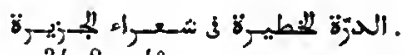
$3418,14^{\circ}$.

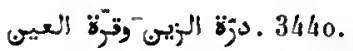

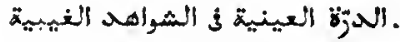

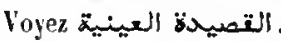

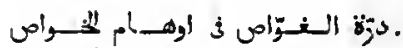
399 4. 3995 .

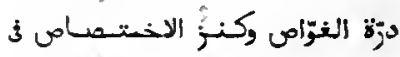

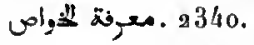

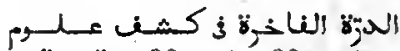
1 $1381,1^{\circ} .1382,1^{\circ}$.

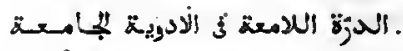
$369^{\circ}, 1^{\circ}$.

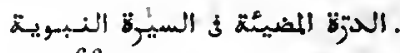
1966.

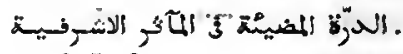
$1615,3^{\circ}$.

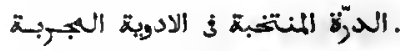
$2685,3^{\circ} .299^{2}, 1^{\circ}$.

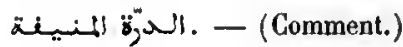
$97^{6}, 1^{\circ}$.

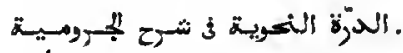
4127.

1344, 1 . 1 .

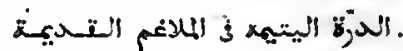
9568, $16^{\circ}$.

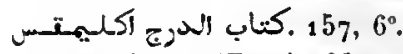
161. 162. - (Extr.) 283.

2007. $4589,3^{\circ}$.

, 928.

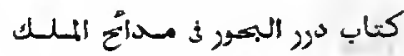
$3953,4^{\circ}$.

در لمسان ذذ حوادث أبناء التزمان. 2111.

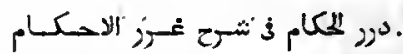
936-942: - (Comm.) $9^{43}$.

4450. 4450.

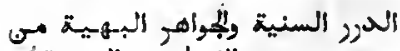
721. 721.

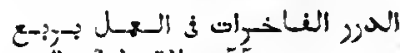
.

1965. 


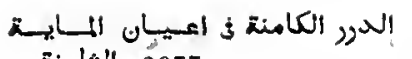

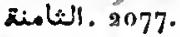

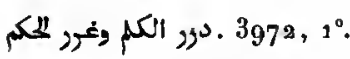

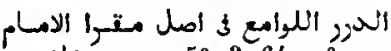
. $1077,5^{\circ} .3264,7^{\circ}$.

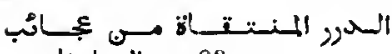

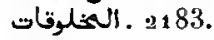

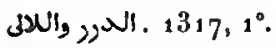

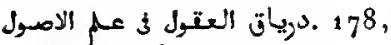
1.0 179.180.

2540, $3^{\circ}$.الحستور النجيب

4. 4286.

.

2758, $7^{\circ}$. دماء التتوحيح .

1913, $18^{\circ}$. دعاء البرونته.

. 2637, $7^{\circ}$. دعاء العهيفة .

. 789, 480.

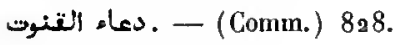

884, 80.

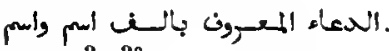
$1973,3^{\circ}$.

3381.

. 743, $7^{\circ}$.

النعوة الكبحي . Voyez. .

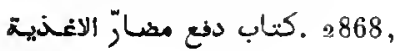
$1^{\circ}$.

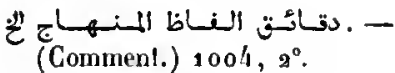
36. 736 . دلائل الاحكام.

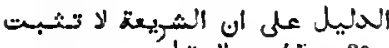
1451, 30.

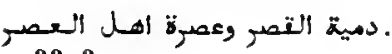
33.3.

3024 ـورا النغس مى النفكس.

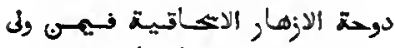

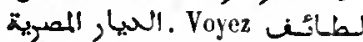
أخبار الاول

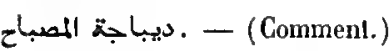
$4144,8^{\circ}, 4^{\circ}$.

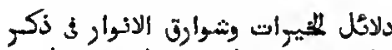

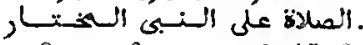
1180-1196.1970, 9. 4578, $i^{\circ}$.

3251, 50 $5^{\circ}$.

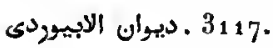

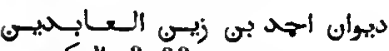

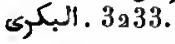

.4439. كتاب ديوان الانشماء
3086.

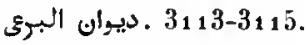

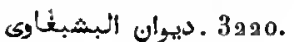

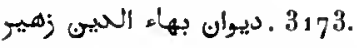

. 3142.

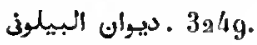

3140. 3140.

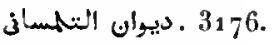

3085. ـديوان إقد تمّام.

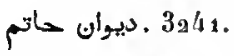

.3219 .ديوان أبر جهر العسقلان.

3084.

.

2800, $1^{\circ}$.

3135 . ديوان ابق خغاجة . 3800 .

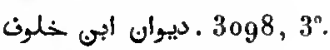

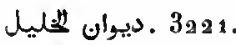

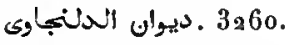

ديوان الحواويت وزيكان الرياحيى. 3 „5 56.

. 2420, . ديوان الرنتيخى .

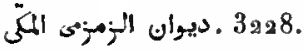

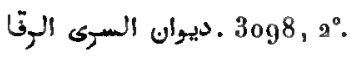

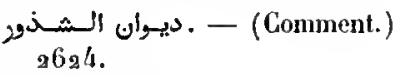

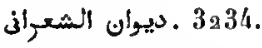

•3348-3359 ـ ديوان الصبابة ، ديوان المبران.

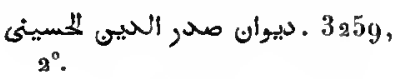

50523 ـ ديوان منى الحيب لمتلى

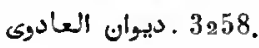

3171, 3473 ـ ديوان عبد الوحان افندى : 1 .

63 23 . ديوان ابي عبد الشكور.

3663, 3030.

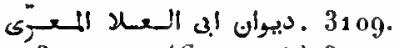

$3110 .-$ (Comment.) 3111 . 3112

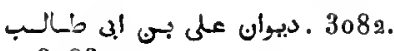
3083.

3962 . ديوان العيدروس.

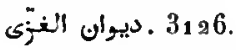

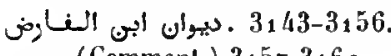
- (Comment.) 3157-3168.

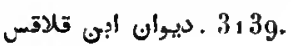

3209 . ديوأن التيراطى مانى

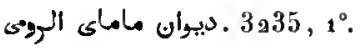

3091-3100. 3137, $3^{\circ}$. 4663, $1^{\circ}$. - (Commenl.) 3097. 3101-3107.

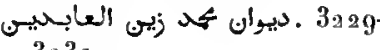
3a3a.

مو308. ديوأن يهم ونا

تنزل Voyez . ديوان المعارن الإهية الاروأح الأهن.

3087 ـ ديوان ابه المعتتز

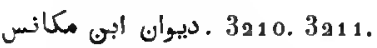

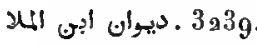

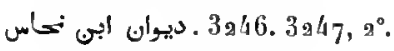

3272.

. 3251, $10^{\circ}$.

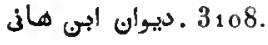

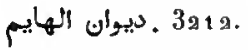

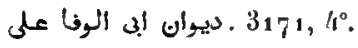

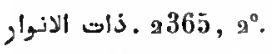

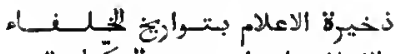

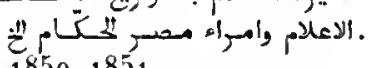
1850.1851.

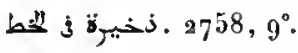

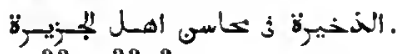
33 2 1-33 a 3 .

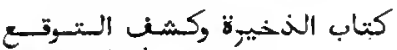
الخدان. 755.

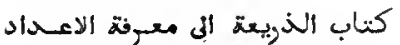

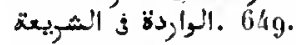

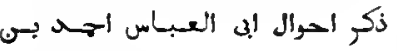
ماندية 2104.

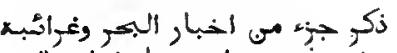

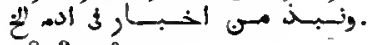
$1873,2^{\circ}$.

ذكر خراب البلدان ف اختر المزمان. $2669,12^{\circ}$.

345 ـ ـ ذكر العاتل وتتبيه الغافلل. 4 4588, 36 . ذكر الغتاوى الترانية. 1663, 160.

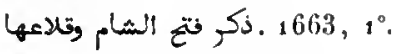
1663, 3.

4588, 35\%.

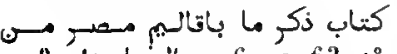

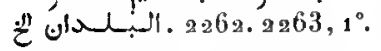

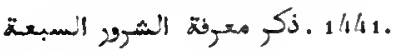

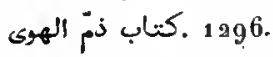

الخهب المسبوك ذخ ذكر هـ 4657, 6 . 6 .

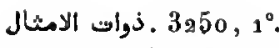

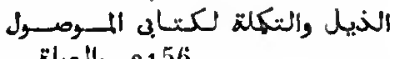

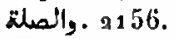

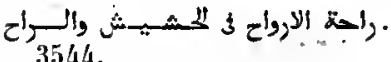

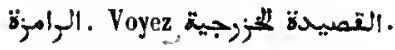

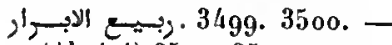

(Abrégé) 3501. 3502, $1^{\circ}$.

. $2612,1^{\circ}$. 2613.

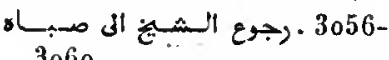
3060 .

. $2287-2991$. رحلة ابي بطوطة

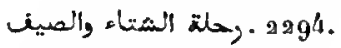

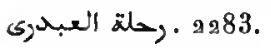

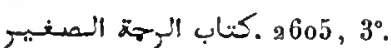
- (Commient.) a607.

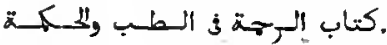
2700, 20.3016-3018. 3513, $44^{\circ}$.

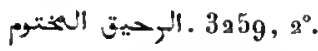

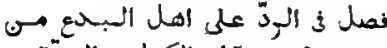

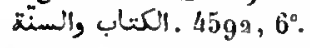

3993, 60.

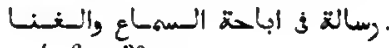
4162,3 .

1057 .وسالة أبى إبه زيه التيووان 1. 1058. 105g. 1060, $1^{\circ}$. $1061,1^{\circ}$. - (Comm.) 10621070.4548 .

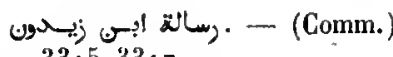
3315-3317.

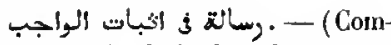
menl.) $2398,3^{\circ}$. $2399,3^{\circ}$.

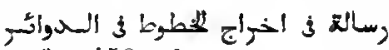
光. $2458,1^{\circ}$.

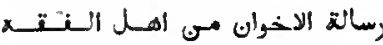
1372.

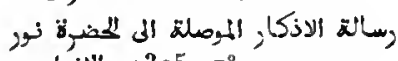

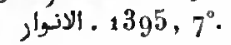

3521, 3 . .رسالة الازهمار.

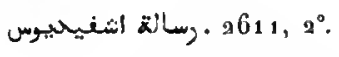

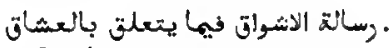
3074 .

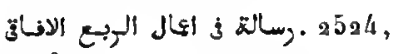
$1^{\circ}$.

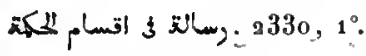

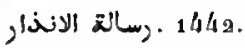

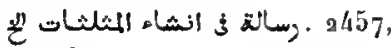
$20^{\circ}$.

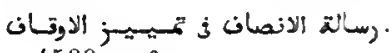
$4588,20^{\circ}$. 
رسالة الانوار فـبهـا يمنح مـاحسب

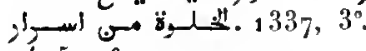
$2405,7^{\circ}$.

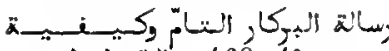
بيط $2468,4^{\circ}$.

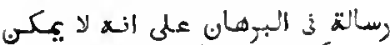

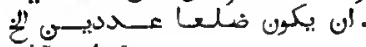
a $457,49^{\circ}$.

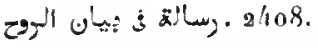

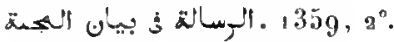

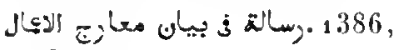
$a^{\circ}$.

. 3027 ـرسالة 3 تعتيق الوباء.

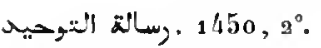

. 1977 .رسالة في التوحيد التوحيد

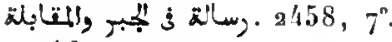
2461 .

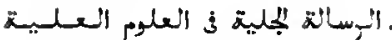
$3035,2^{\circ}$.

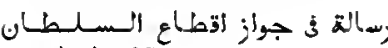

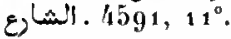

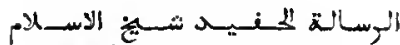
. 3257, . 35 .

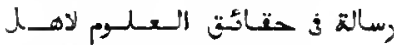

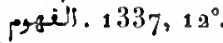

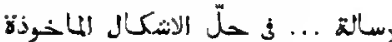

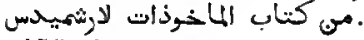
2458,3 .

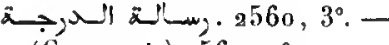
(Comment.) $2560,1^{\circ}$.

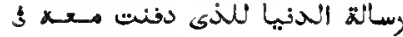
$8,3.2611,3^{\circ}$.

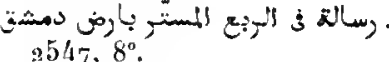

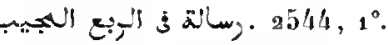

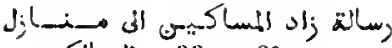

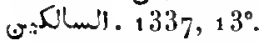

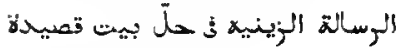
.

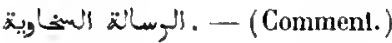
$2463,3^{\circ}$.

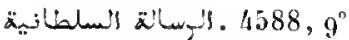

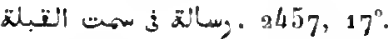

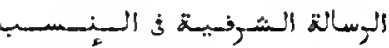
2479.

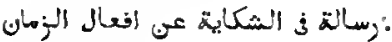
$926,3^{\circ}$.

J2610, $1^{\circ} .2611,1^{\circ}$.

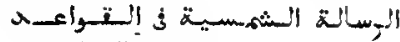
2470.

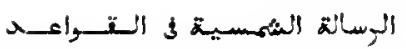
. 1264, 20. 2359, $4^{\circ}$. ${ }_{2} 371,1^{\circ} .2372,1^{\circ}$. $-(\mathrm{Com}-$ menl.) $2359,5^{\circ}$. $2371,2^{\circ}$. $2372-2383$.

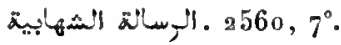

3951, 4º .

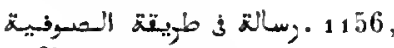
$6^{\circ}$.

. $760,6^{\circ}$. رسالة العاثتق وللمعشــوت

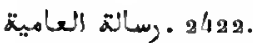

1386, 20.

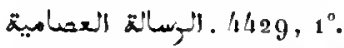

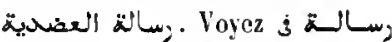

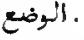

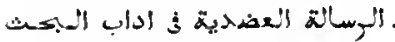
- (Comment.) $1264 ; 1^{\circ}$.

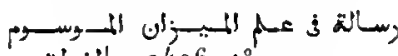
2/406, . . 1 .

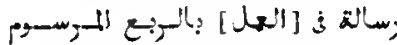
. $2547,3^{\circ}$.

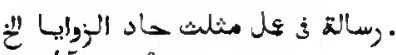
$2457,27^{\circ}$.

3962, 10.

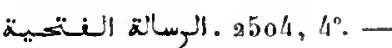
(Comment.) $2504,5^{\circ}$.

1622 .أوسالة الفتحية الرادوسية 1330.

ك2506, 200.

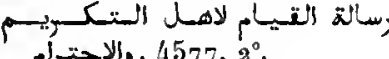
. $4577,8^{\circ}$

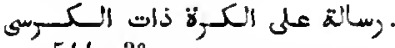
$2544,3^{\circ}$.

رسالة ختصرية ذي العل بوبع الحداثٔرة है. $23 / 47,9^{\circ}$.

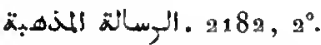

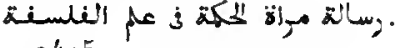
2415.

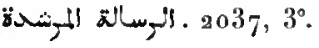

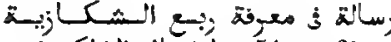
. $2547,16^{\circ}$.

2037, $6^{\circ}$

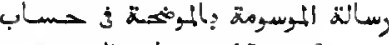
.

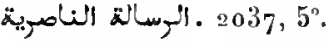

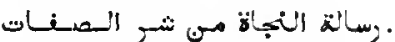
$1337,7^{\circ}$.

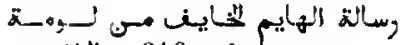
1343, 13 . الللايم .

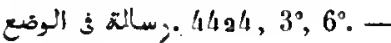

(Comm.) 4423. 4424, $1^{\circ}-4^{\circ}$, $6^{\circ}$.

.2303-2309 . رساقل اخرأن. الصغا $2596,2^{\circ}$.

2044. رثحات عيى لالهيا8

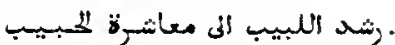
3051. 3059. - (Abrégé) $3060,2^{\circ}$.

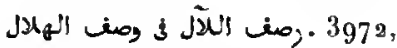
$4^{\circ} .4588,21^{\circ}$.

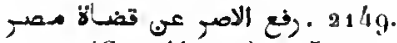
- (Complément) 2150. (Abrégé du Complém.) 2151.

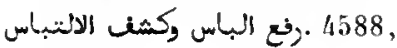
$96^{\circ}$.

•رفع الجيجاب عى تـنبـيه المكتّاب $4452,12^{\circ}$.

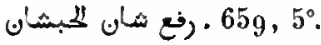

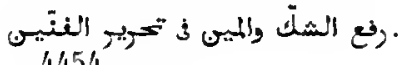
1454 .

4586, . الرتائق .

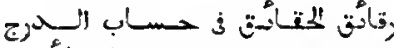

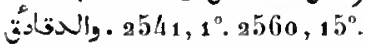

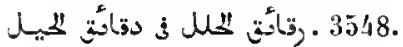

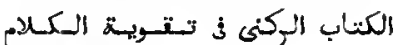
النحوي 4056.

•رمز للتائق ذي ثرح كنز الـدقائتق 899 et $9^{00 .}$

29. 62 . 60 .

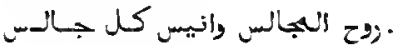
3549. 3550.

758 , 758 $2^{\circ}$.

روض الاخيا, المنـتخهب مس ربـيسع '3501. 3502, $1^{\circ}$.

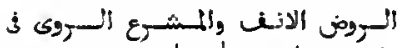

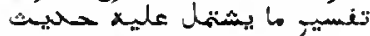
1960-1963.

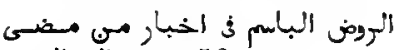
1562. من من التعولهي

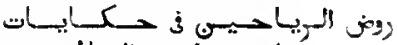
2040. 2041.

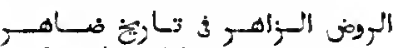
(1. (ظ) 4610 .

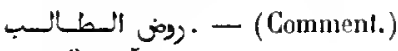
993-995.

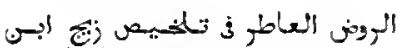

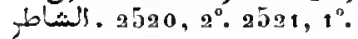

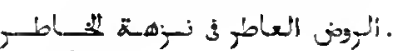
$3669,7^{\circ}$.

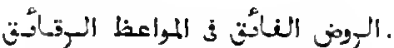
$7^{43}, 2^{\circ} .78 \mathrm{a}, 2^{\circ}$. $1305-1309$.

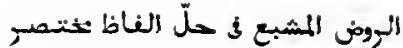

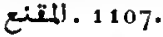

مون المناظبر 3 عم الاوائل وألاولخر. 1537-1541.2212, $2^{\circ}$.

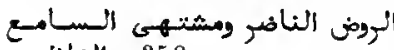
ارئر.

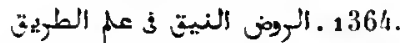

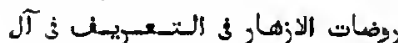
.

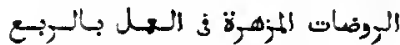
. $2547,14^{\circ}$. المتنطيل

. 990. - (Comm.) 991-995.

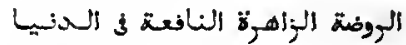
. $1126,3^{\circ}$.

. $3028,3^{\circ}$ ـالروضة الطبتية

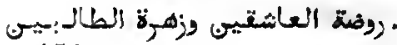
4537.

193 • روخة الفويه وسلوة الموحيح 194.

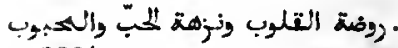
3384 .

369 ـ موضة المريحيى .

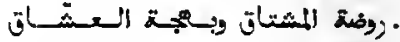
$3_{2} 35,1^{\circ}$.

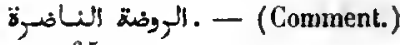
1965.

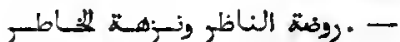
(Abrégé) 3365, $1^{\circ} .3366$.

كتاب الورضتيى ف الخبا, الدولتيه. 1700.1701.

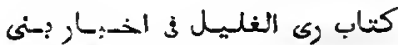
893.

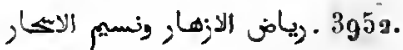

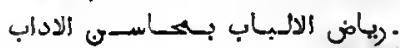
3419.

كتاب ريام المنان ورياضة للهنـان. $3387,2^{\circ}$.

743, $1^{\circ}$. ريان الصالحيى .

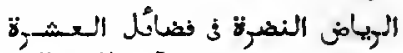

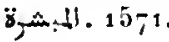

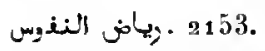

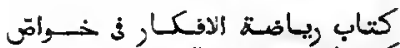

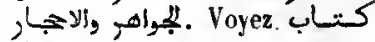
. جبراهـ الاحيب)

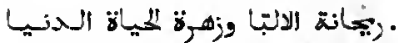
$2134-2136$.

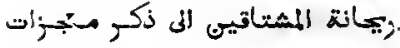
2008.

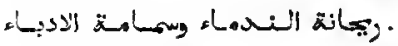
Voyez الالبّاء 


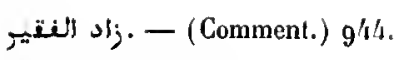
2884.

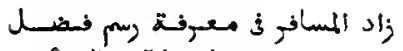
ل 2541,40 .

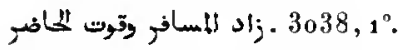
زبد الادباء وثمارح مدور الالهبّاء 3579 et 3580 .

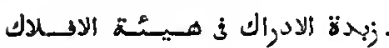
$2511,1^{\circ}$.

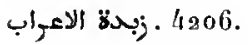

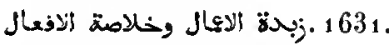
. 3967,1 .

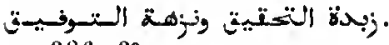
$1386,3^{\circ}$.

1666. . $1251,2^{\circ}$. زبحة الصلوات ويدة الستسلبهات $1211,1^{\circ}$.

زبحة الفابيهة ف للبراب عن الابيـات

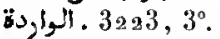

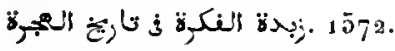

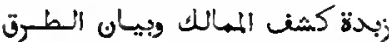
بحمن $1724,1^{\circ}$. 2258.

2146.

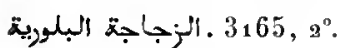

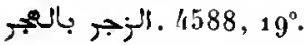

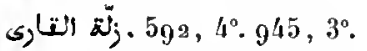

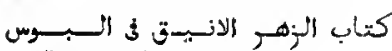

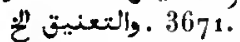

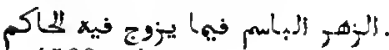
4588, $11^{\circ}$.

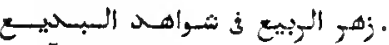
$2503,9^{\circ}$.

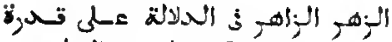

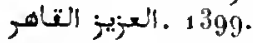

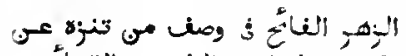

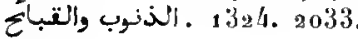
2034.

. 1933-1938.

. 4261, $15^{\circ}$.

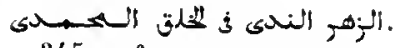
$3457,1^{\circ}$.

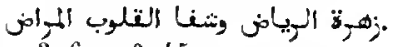
$3967,7^{\circ} .4599$.

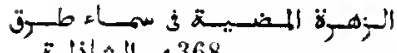
1368.

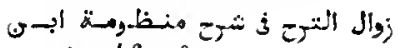

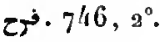

. 610,3 . الزوايد .
2730 - زيادة الغطل في عم الترمل .

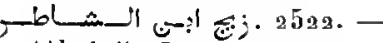

(Abrégé) $2520,2^{\circ} .2521,1^{\circ}$.

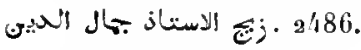

2538. 2534.

ل (Cormment.) 2530.

.

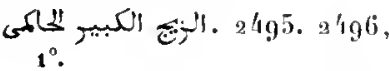

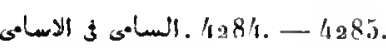

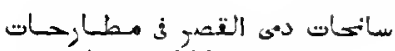

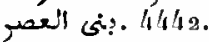

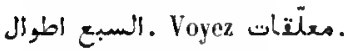

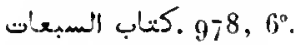

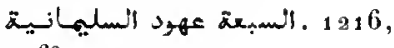
$6^{\circ}$.

كتاب السبعيات 3 هواعظ البويات. 13114. 1315. $4597.4598,2^{\circ}$.

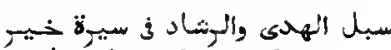

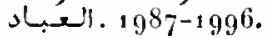

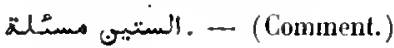
$2800,15^{\circ}$.

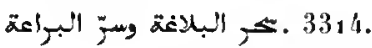

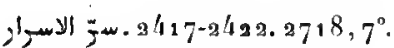

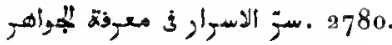

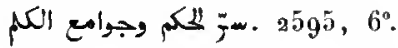

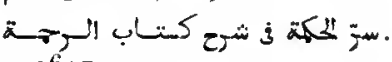
2607

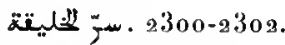

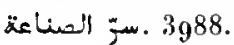

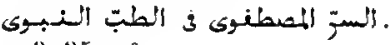
$3035,1^{\circ}$.

النسّ المصرون المستنبط من المنتران. ن $1206,15^{\circ} .2741,2^{\circ}$. 2645 ـ السبّ المكتوم . 206.

2692 ـالستّ المكتوم والكنز المختوم. السبراج العالئ . $2568,10^{\circ}$.

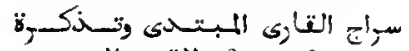
. 612,1 .

1230, 50.

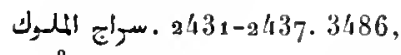
$2^{\circ}$.

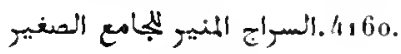

(C50m-863. - (Comment.) $861,2^{\circ}, 3^{\circ} .864-872$. $1398,3^{\circ}$.

3/1/7 .سفينل الهسرو, وروضة النزهمو2
4.336, 20.

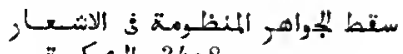
3408.

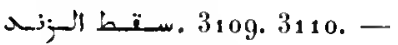

(Comment.) 3111.3112.

"5316, 230.

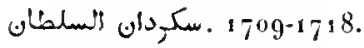

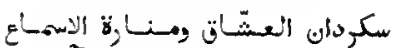

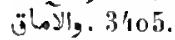

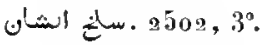

. 2981, 1.

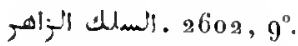

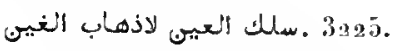

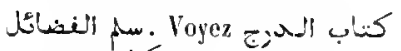
اكاكليمتحس.

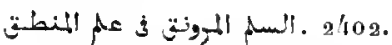
- (Comment.) 2 103. 240\%.

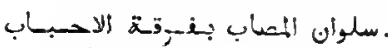
$2026,3^{\circ}$.

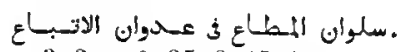
3131, 3․ 3503-3513.

.السلوك ف طبتات العلهاء والملـوك. 3127 .

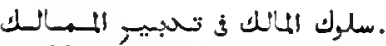
3/47, $2^{\circ} .2448$.

كتباب المسلوك لمعرفة دول الملـوك. 1796-1 728.

كتاب السمات ف اسمـاء السنـبـات 3004.

2602, 4".

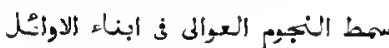
1563. 153.

708. 707.

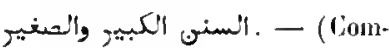
ment.) 753.

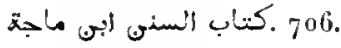

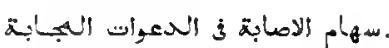
$1588,13^{\circ}$

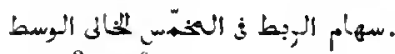
$8732,1^{\circ}$.

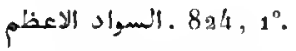

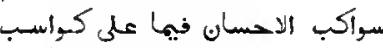
ن. 34. 3457, 20.

3362 . سروق الرقيتق

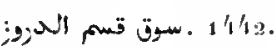

(Comment.) $2511,2^{\circ} .2512$.

. 83, $11^{\circ} .176,8^{\circ}$.كتاب السيلسة

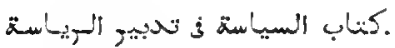

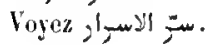

السباسة المشرعية د اصلاح السرائ

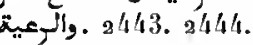

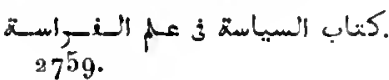

• 3987 .كتاب سيبوبي .

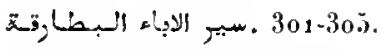

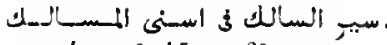
$20 / 2,2^{\circ} .4591,6^{\circ}$.

2012.

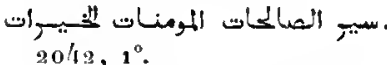

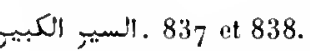

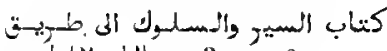
. $1379,1^{\circ}$.

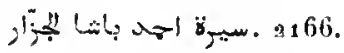

3921. 3921 .

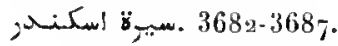

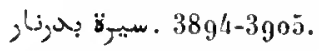

3908-3930.

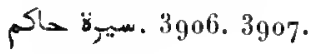

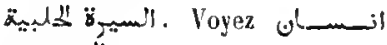
البعيون.

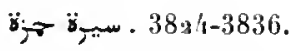

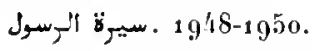

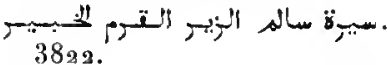

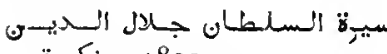

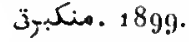

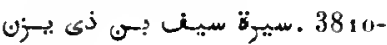
3820.

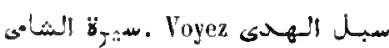

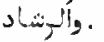

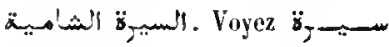

ن بيبرس

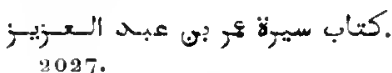

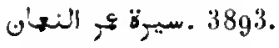

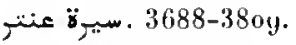

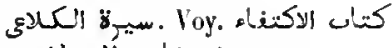
.

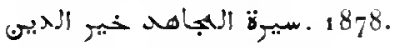

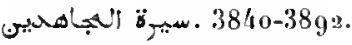

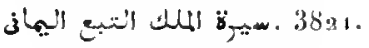

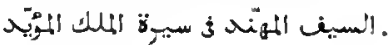

1733.

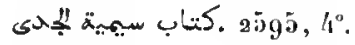

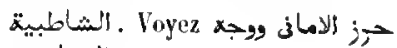
. التهائي

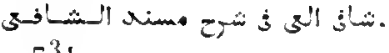
731. 


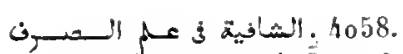
4059. 4123, 7. 4182, $2^{\circ}$. - (Comm.) 4060-1062.

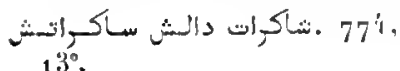

ل.

- (Abrégé) 2502, $3^{\circ}$.

天

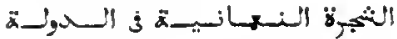

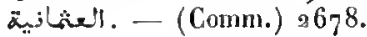
2679, $1^{\circ} .2680,1^{\circ}$.

. 26233.

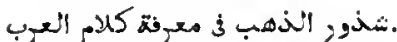
$3677,11^{\circ}$. - (Comment.) $2677,12^{\circ} .4161$. 4191, $2^{\circ}$.

.المخور الذهبية ذي الالغلظ الطبّية 46/1.

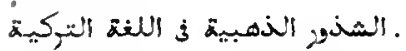
4328.

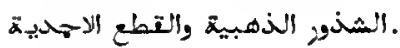
$4329-4334$.

•3299 .كتب المثراب

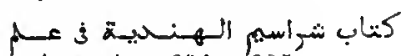
. 2634. 2635.

3993, 50.

ثثرح حال الاولياء ومناقب الاتنتياء $1641,2^{\circ}$. $2035,1^{\circ}$.

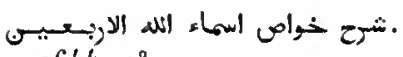
$264 h, 1^{\circ}$.

$1205,3^{\circ}$.

. $1964,2^{\circ}$.

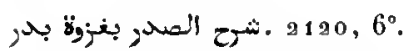

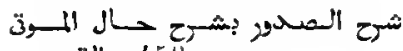
. 4587.

1986.

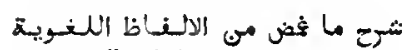

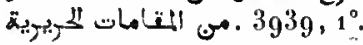

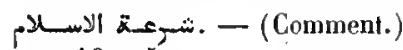
12/8-1250.

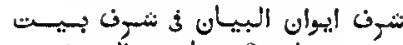
31713.

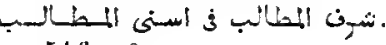
$15 / 16,2^{\circ}$.

نثرن الموضوع بيبان هعنى الموضوع $3377,3^{n}$.

slual bون $828,2^{\circ} .833$, $2^{\circ} .1134,2^{\circ} .1136,2^{\circ} .1141$ $1145.2318,2^{\circ}$. - (Comm.) $11 / 6$.

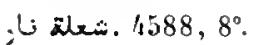

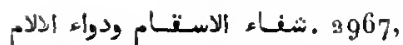
2. 3012-3014.

3401, 30.

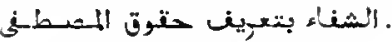
$1953-1956.2758,5^{\circ}$. (Comment.) $1957 \cdot 1958$.

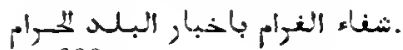
1633.

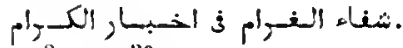
$3300,3^{\circ}$.

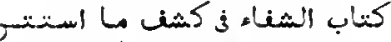
197.

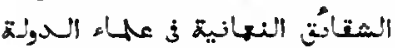
ة 936. 2157-9162. - (Supplément) $2164,1^{\circ}$.

(Comment.) $714.715 .-$ (Abrégé) 716.

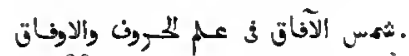
${ }_{2} 68 \mathrm{~g}$.

• 2709 . شهـس الانوأ, وكنسوز الاســار 2710.

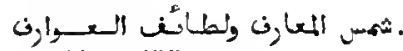
2647-3655.

(النشهسية (d'Al-Kitibi) $1396,2^{\circ}$. - (Comment.) $4187,16^{\circ}$. - (Poème astrologique, Comment.) $2684,5^{\circ}$.

1952 . نثهاب الاخبار

1620, $9^{\circ}$.

(C) - (Comment.) 4099.

(Comment.)

4158 .

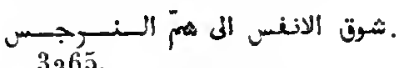
716. 4540, 9. (Comment.) 716. $4540,1^{\circ}$.

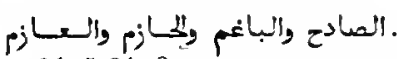
$349^{5-3498}$.

J $2037,7^{\circ}$.

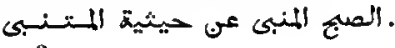
3107.

zة (.tbrégé) 4a'11-1246.

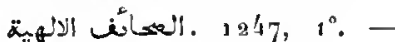
(Coniment.) $12 / 17,2^{\circ}$.

3401, $2^{\circ}$

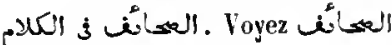

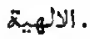

النجئ (de Bokhárí) 676. 679694 . - (Comm.) 695-703. $2677,7^{\circ}, 9^{\circ}, 10^{\circ}, 19^{\circ}$. (de Moslim) 70\%. - (Abrégé) 705.

.

908-913. - (Comment.) $914-922$.

" 1449, .كتاب الصراط

- 2030. 2031 . صغورة الـصـــورة (Abrégé) 2032.

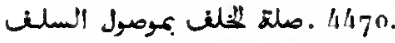

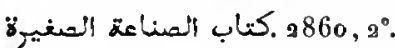

المصناعة المبيرة وهو حيلة المبروء 2855.

كتاب الصناعتيه الكنابة والمثعت 4370 .

4588, 50. المعرأعت على النوأعتى

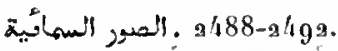

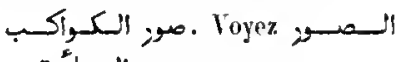

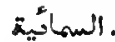

J - (Comment.) ${ }_{2} 609,1^{\circ}, 2^{\circ}$.

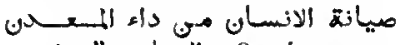
3024.

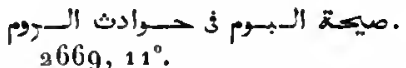
. $4009-4016,2^{\circ}$. 4020, $3^{\circ}$. - (Comment.) $3993, t^{\circ}$. $4023,4^{\circ}$.

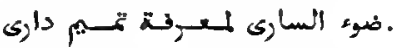
$1657,5^{\circ}$.

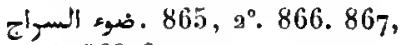
$1^{\circ}$. 868-871.

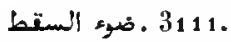

ـالضوء اللامع لاهل التون التاسنغ 2078.

$1251,1^{\circ}$. $4051,4^{\circ}$.

1997 ـ الضياء المبلني.

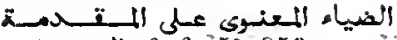
. $606,50.853$.

3360 ـ الطاري على السكردان.

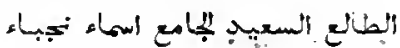
2148.

2580, -باب 3 طالع سنى المعالم $s^{n}$.

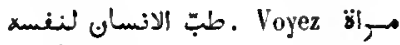
illit.

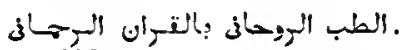
2643 .

(de Mohammad alMaqdisî) $2562,18^{\circ}$. (de Djalâl al-Din al-Mạ̣alli) 2800 ,
16. - (d'Ibn Qaìim al-

Djauziya) 3045 .

4521. 450.

435.

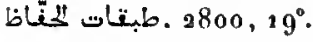

2100-2102 . طبتات البـافعيـة

1361-1363, 1 . طبتات النثرنيد

309 309 . طبقات الغتهاء.

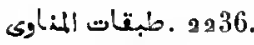

. 2119.

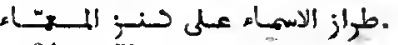
$3417,5^{\circ}$.

.الطواز المنتقوش ق انسراع ليـبـوثن. 1632.

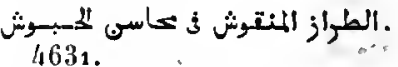

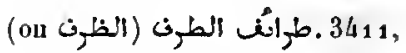
$1^{\circ} .3412,1^{\circ}$.

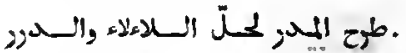
$1716,2^{\circ}$.

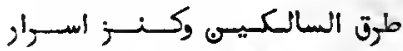
2684, 3 .

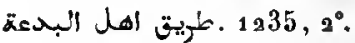

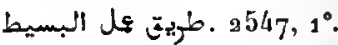

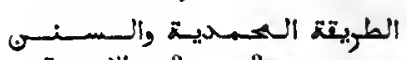
1321. 1323. . الاحية والحية

4638 .كتاب الطريتَّ والادب .

. $114,1^{\circ}$.

2595, 20.

. $610,5^{\circ}$. طها, التحلو .

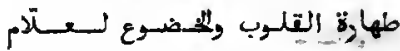
و 1313.

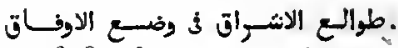
${ }_{2} 69^{8}, 1^{\circ}$.

طرالع الانوار مى مطالع الانسظبا, 1255. 1256. - (Comment.) 1255. $1257.1258 .2369,3^{\circ}$. 2389. 239 o.

طبالع البمدو; . 2557 . 250.

طوالع البهدور لمهر, ديوان المشخوز ${ }_{2} 624$.

3189.

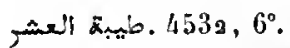

1584 .كتاب العبر 3 خبر مى عبر et 1585 .

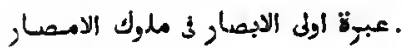
$3134,1^{\circ}$. 
. 1055.

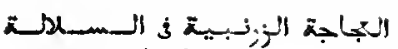

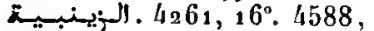
$9 a^{\circ} .4659,2^{\circ}$

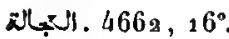

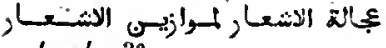
$4124,3^{\circ}$.

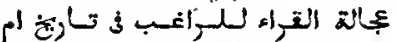

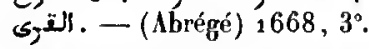

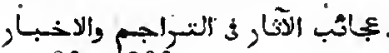
1861-1866.

عبائب ألاسفار وإطائف الاخهبـار 4618.

. 1567 .عبائب البحاثٔع

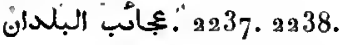

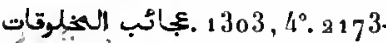
2183. $2776,5^{\circ} .2918,11^{\circ}$.

2181، 181 . $2182,1^{\circ} .2419,3^{\circ}$

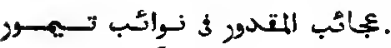
1900-1905.

3489, 3 .

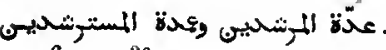
$2677,13^{\circ}$.

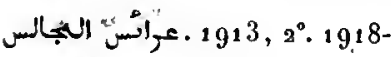
1923.

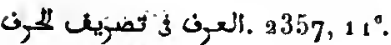
$9602,3^{\circ}$.

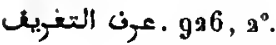

كناب عرن المفا ث مدايج السيد

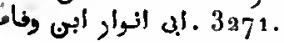

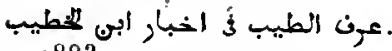
1883

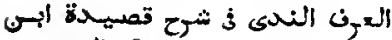

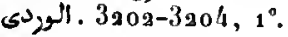

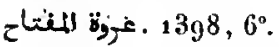

العروس البجلية على نور السشمسعة

20 $1160,2^{\circ}$

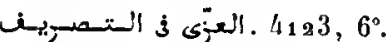
$4166,2^{\circ} .4167,2^{\circ} .4168$ $3^{\circ} .4169,3^{\circ} .4170,2^{\circ} .4171$, $2^{\circ} .4173,2^{\circ} .4174,2^{\circ} .4176$ $2^{\circ} .4177,2^{\circ} .4178,9^{\circ} .4179$, $2^{\circ} .4180,2^{\circ} .4181,2^{\circ} .4183$, $2^{\circ} .4197,2^{\circ}$. - (Comment.) 4063-4066.

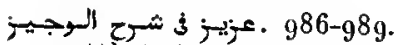
- (Abrégé) 990. - (Comment.) $991-995$.

. $1932,4^{\circ}$.

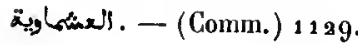

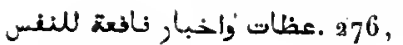
$16^{\circ}$.

عظة الدلباب ونخيزة الاككتسمباب. $1344,1^{\circ}$.

كتباب العظهة المنتورل عى دانـيـار

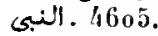

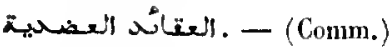
1263.

$1261,2^{\circ}$. 1286, $2^{\circ}$. - (Comm.) 1234-1245. $1269,3^{\circ} .4589,6^{\circ} .4606,9^{\circ}$.

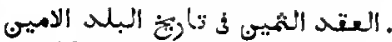
1668, $3^{\circ}$. 21 23-2 1 26.

العتحد الثميبي بما يتعلق بالمولزيهى. 2476 .

عتد لإمان 3 تارئ أهل الهزمـان. 154a-1544.

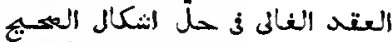

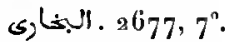

3287-3291 . العتح الغويح

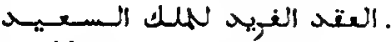
3440.

عتح الملّز في الاحاديث المسملسملة ل $4577,3^{\circ}$.

1871, 1\%.

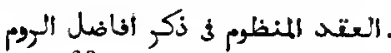
- 2163.

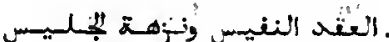
$3971,1^{\circ}$. - (Abrégé) 3/18\%, $3^{\circ}$.

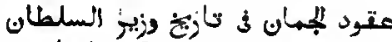
. $33_{35} 5,1^{\circ}$.

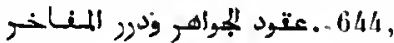
$2^{\circ}$.

(عترد المبوهريات - (Comment.) $1379,2^{\circ}$.

العتود اللدوية ذي الامـراء المصديـة 1608.

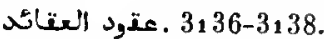

ة (d'Ali ibn abi Tálib) $667,2^{\circ} .3264,4^{\circ} .-\left(d^{\prime} \mathrm{A}\right)$ Djazâirí) $4585,1^{\circ}$ - (de

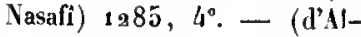
Sanoùsî) $1057,17^{\circ}$. 1060 , $3^{\circ}, 4^{\circ} .1061,10^{\circ} .1141,3^{\circ}$ $1206,7^{\circ} \cdot 1270,1^{\circ}, 1285,5^{\circ}$. - (Comm.) $1206,5^{\circ} .1271$ $1276.4583,2^{\circ}$. - (d'A1-Schâfii) 3430. - (d'Ai-Scbaïbàí) $3019,3^{\circ}$. - (Comm.) 3.4 $6^{\circ}$. - (anonyme) $1451,9^{\circ}$.

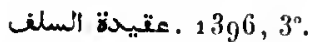

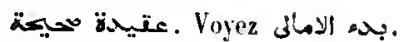

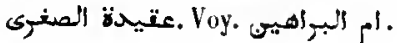

(Comm.) 610, - (عقيلت

3030, 30.

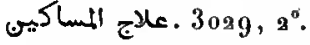

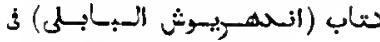

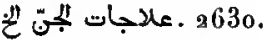

لع 300-2302.

2605, 40.

2830.

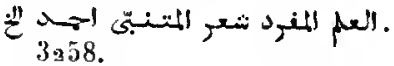

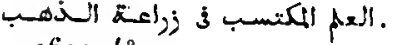
$2611,4^{\circ}$.

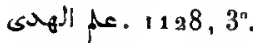

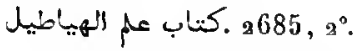

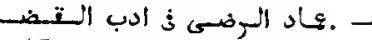
(Comment.) 1045.

80ل - (Comment.) 1099.

. 796. 797, 1 ${ }^{\circ}$. - (Comment.) (Abrégé) 2088.

. عدنة الادبا \$ دفع أطلاعوب والـوبـا $3019,1^{\circ}$.

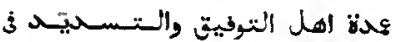

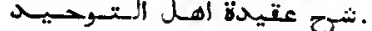
1271. 1272. 4583, 9. (Comment.) 1273.1274. (Abrégé) 1275 .

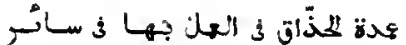
ت560, 50 .

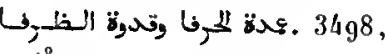

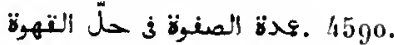

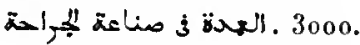

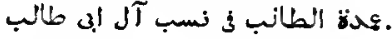
2021.

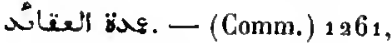
$1^{\circ}$.

784 $3^{\circ}$.

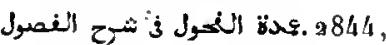
$1^{\circ}$.

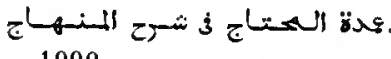

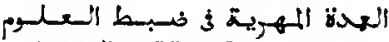
$x_{x \rightarrow 1}=2559,3^{\circ}$.

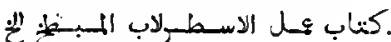
21157, $30^{\circ}$.

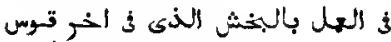

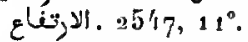

كتاب (جالينوس) في عل النتسمريج 2851.985.

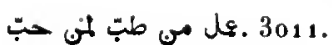

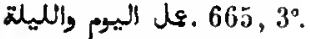

846-847.

2358, 20.

. 1339,1 . عنتاء مغرب

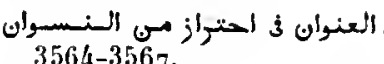

. عنوأث البيبكن وبسـتـان. الازهـان. $2120,2^{\circ}$.

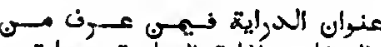

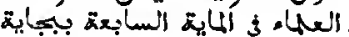
2155 .

منوان المثرن الوالف

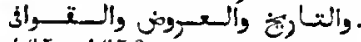
4652-4656.

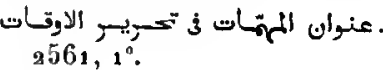

4574, 1 .

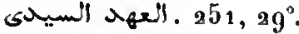

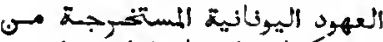

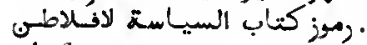
2h16.

1338 . عوارن

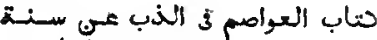
ألتاسم 1460.

. 257 1, 8. (de Gabriel ibn Farṭât) 4979 ,

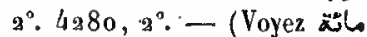
dole).

عيى اليتيو 3 اصول اصول انحيب. 4604.

(d'Avicenne). - (Comment.) $39 / 4 .-(d ' \Lambda l-D j i l i)$ 3มง. - (Takhmis) 3ะ23, $1^{\circ}$. - (Comment.) $3283,2^{\circ}$.

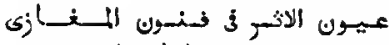
- - $196{ }^{6}$. (Comment.) 1968-196ig.

3546 ـ عيدون أندخبا,

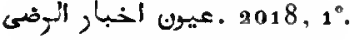

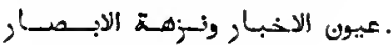
1560. 1561 . 1693.

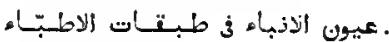
व1 13-2118.

1586-1588 1 . عيبون النوأزئ.

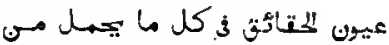
.

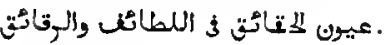
$2685,1^{\circ}$.

عيون لاتنائق وإيضاح انسطرائق 9673. 967 4. 


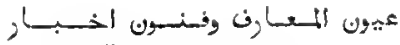
ن넨. 1490.1491.

666, 70.2718, $12^{\circ} .9761,3^{\circ}$.

ثاية الاحكام ثي الغحاديث والاحكا. $79^{3}$.

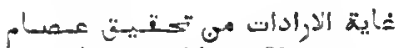

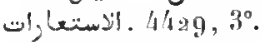

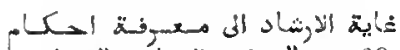

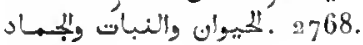
2769 .

2563 . غاية القعد ثي عم الغصد . $13^{\circ}$.

(الناية النتصـوى - (Comment.) $102 /$.

كتاب غائة المارب ف المنائح ولثبايا . 2764 .

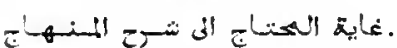
1017-1020. - (Comment.) 1021 et 1022 .

غاية المطلب في العل باتربـع الافات 50.

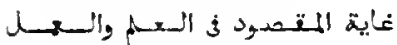
. $2827,3^{\circ}$.

غاية الوصول الى عـلم السنــمــول. 1035.

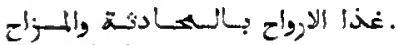
$2026,4^{\circ}$.

غربال السزمبـن فئ وفـانه الاعسيـان. $159^{3}$.

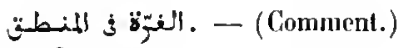
2397 .

. 956-942.

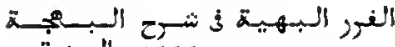

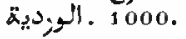

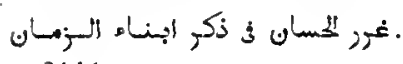
2111.

2503, $14^{\circ}$.

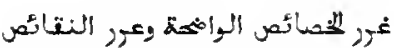

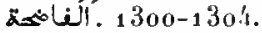

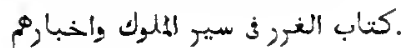
1488.

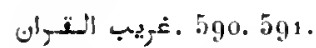

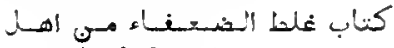
. 4231, $2^{\circ}$.

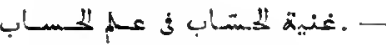
(Comment.) $24 \%$.

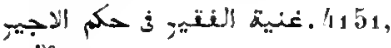
$3^{\circ}$.

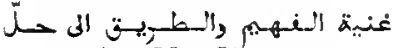
2531, 30.

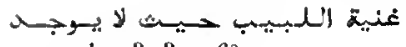

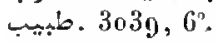

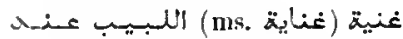

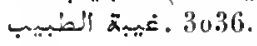

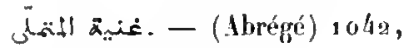
6. 1149-1151.

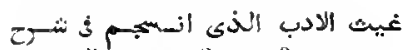

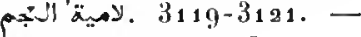
(Mrégé) 3132. 3123.

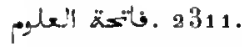

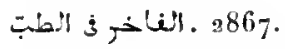

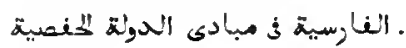
4616.

3552 ـ الفانشوشن 3 احككم قراقوث

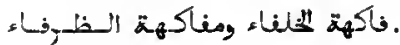
3535-3542.3543, $\AA^{\circ}$. 4663, $6^{\circ}$.

. $401.418 .2721,1^{\circ}$.

2800 ـ النفانيد ف حلاوة الاسانيد . $3^{\circ} .1588,7^{\circ}$.

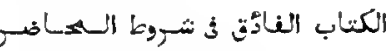
. 4187, 19. 19 .

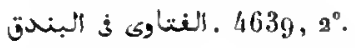

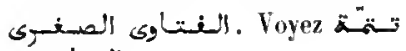
sأill.

. 1156,3 . النتاوى الصوفية

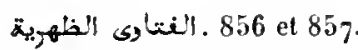

983 . فتاوى التانهى حسيى.

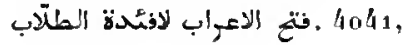
$1^{\circ}$.

فتوح افريتية مoyez فتح أفيتية.

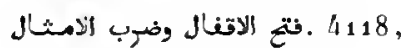
$1^{\circ}$.

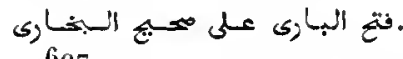
697 .

نتح لبليل على نثخح ابه عتنـيـل 4094.

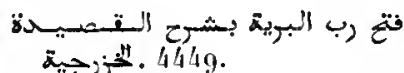

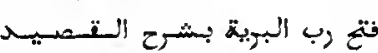

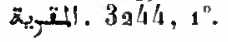

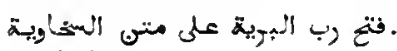
प4ti3, 2 .

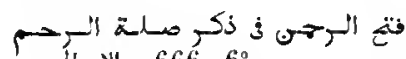
666, 6. 6 .

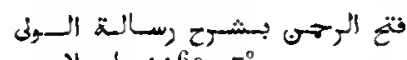
نlu, $1160,7^{\circ}$.

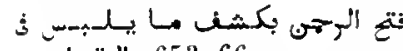
653.660. 650 .

فتح الغنور بشرح منظومة النــبسون. 3224.

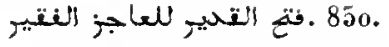

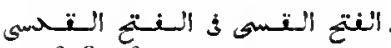
1693-1699.

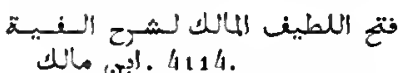
.النتع المبيى ثهواب بعض السائليى. $2037,4^{\circ}$.

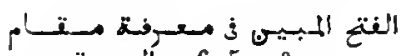

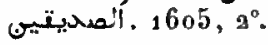

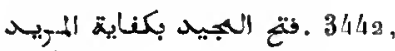
$7^{\circ}$.

فتع مى لا يـى ثل حلَ رموز الحائرة ' $1627,2^{\circ}$.

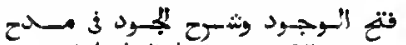

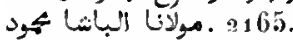

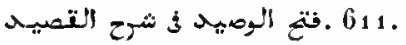

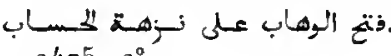
$2475,2^{\circ}$.

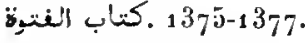

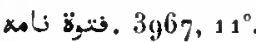

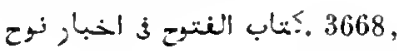
$1^{\circ}$.

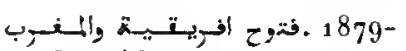
1881. 4620 .

.690-1692 .كتاب فتوح البهنسا. 1652-1662. (Voyez

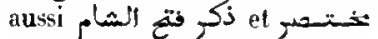

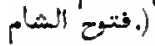

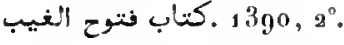

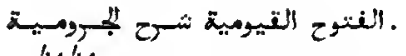
4141.

1689.

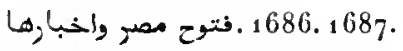

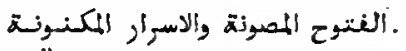
3227.

4621. فتبوح المغرب .

1816, 3.

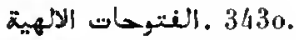

النتوحات الربانية ذي مزج الانثارات 1903, 20.

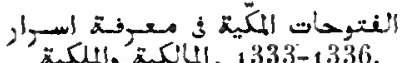

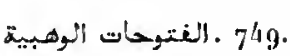

الانفهرى . Yoyez الاداب السلطانية.

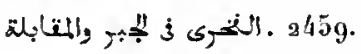

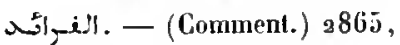
$11^{\circ}$.

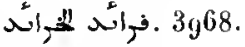

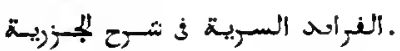
4531 .

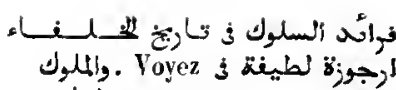
النتاريخ.

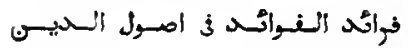
206, 20 . والعتائي

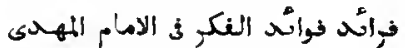
年. $2026,1^{\circ}$.

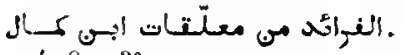
$4187,3^{\circ}$.

2419, 20. $3956,1^{\circ}$.

. $780,1^{\circ}$.

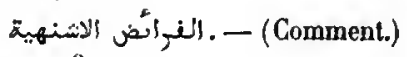
1037.

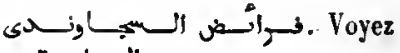
المبراجية.

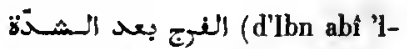
Dounyà). - (Abrégé) 659. $4^{\circ}$. - (d'Al-Tanoúkhi) 3483 . 3484. - (Abrégé) 3485 . $3486,1^{\circ}, 3^{\circ}$.

83. 83.

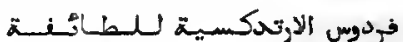
. 250, 1 . 252, 250 ,

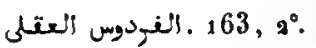

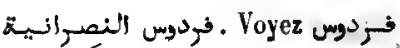
. الارتحكسية المية

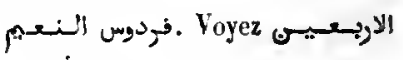

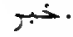

كتاب (جالينوس) ف فـرق السطبّ $2860,1^{\circ}$.

•2825, 2829 . كتاب الغروسية . . 812 . كتاب النبروق

113.

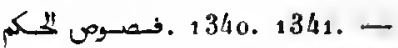
(Conment.) 1342.

• نصوه الغصـول وعــود الـعـتهـول 3333.

b) $2835,1^{\circ}$. 2836. - (Comment.) $2837-9844$.

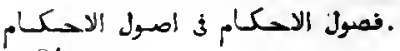
841.

2605, $1^{\circ}$. فصول اسطانس تلككيم .

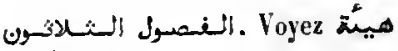

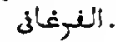

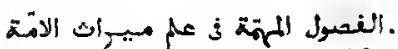
- (Comment.) 1035. 1036.

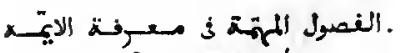
1927, 20. 2022-2024.

النعيج (Comment.) 4459, - (C) $6^{\circ}$. 
2099 . حكائل اللامام المافعى

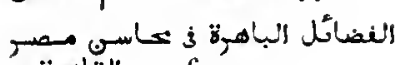

1767.

4589, 1 . كتاب فضائل لإبهاد .

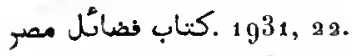

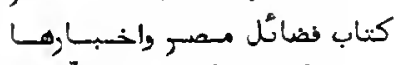

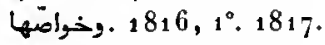

. 2569 , كناب ا'نضل .

2800, فضل البلح عند ختح اللولد . $9^{\circ}$.

2816. كتاب فضل كليل .

138a, a․

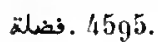

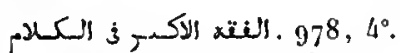
$1123,6^{\circ}$. 1239. $1230,1^{\circ}$. - (Comment.) 1229 .

$1230,4^{\circ}$.

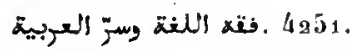

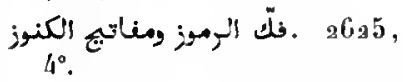

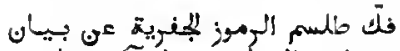
حوادث الزمان في دولة آل عثمان. 16 a $7,1^{\circ}$.

2804. 2807 et 2808 .

2803. (Abrégé) 2942, $4^{\circ}$.

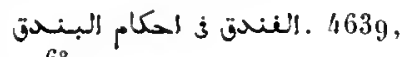
6

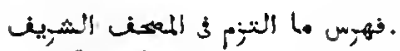
$1169 ; 2^{\circ}$.

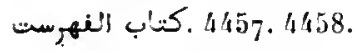

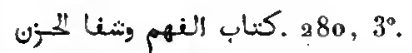

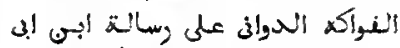
1063-1069.

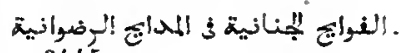
3445.

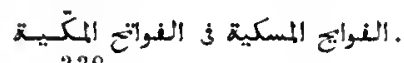
3338.

كتاب النوائد 3 أصول عم السجحس

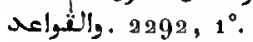

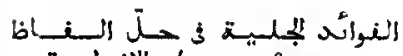
.الانحلسية الحسة

40/4-4053. النوائح الضيائية.

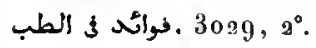

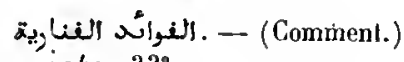
io4a, $33^{\circ}$.

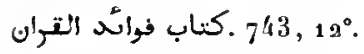

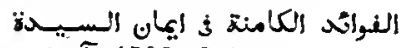

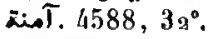

النوائد المستجبادات خ حلَ العتـود . $1379,2^{\circ}$.

4596. كوائد الموائد .

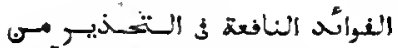
2661, 50.

كتاب النوائد والسملاكة والمعبوائح

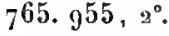

. 3922 .كناب ثاليصاريوس.

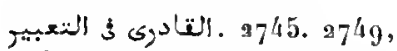
$3^{\circ}$.

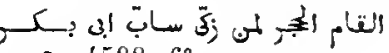
4588, $6^{\circ}$.

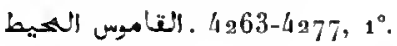
$4665,5^{\circ}$.

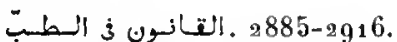
$2918,3^{\circ}$. - (Commentaires el abrégés) 2917-29'11.

2681 .قبس الانوار وجامع الاسكر' 2683.

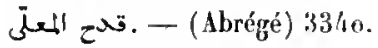

4535. كتاب الترءات .

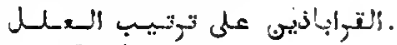
$2967,4^{\circ}$.

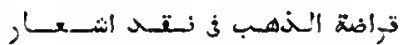

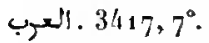

(ن) 324-589. 1004, 3ㅇ. 4527-4529. - (eu espagnol) $425.447 \cdot 77^{4}, 8^{\circ}$.

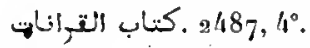

: 2580 . كتاب قرانات الكواكسب الت

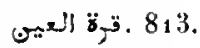

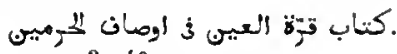
$1203,4^{\circ}$.

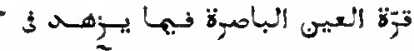

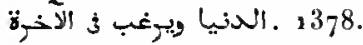

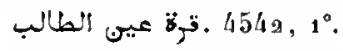

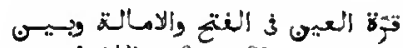
. $2677,8^{\circ}$.

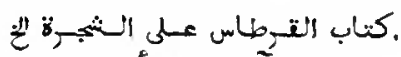

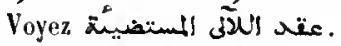

2637, $6^{\circ}$. النترطبية 26.

و 2715.

. $2638,1^{\circ} .2639,1^{\circ}, 6^{\circ} .2716$, $10^{\circ} .2758,11^{\circ}$.

2706.

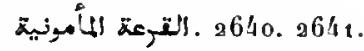

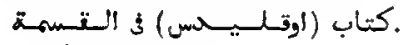
$2457,11^{\circ}$.

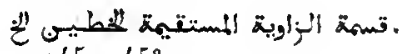
$2457,45^{\circ}$.
. التصائد السبع . Voyez مeلغات.

. 1946.

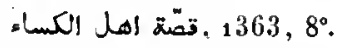

206, 40 . تعد النفس روبيل

-1909-1917-1933 . تصد الانبيا 1995.

1635.

. $4119,1^{\circ}$. - (Comment.) $4119,1^{\circ}$.

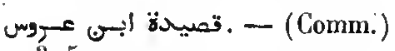
3252.

(Takhmis) $3075,9^{\circ}$.

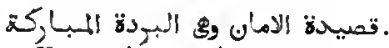

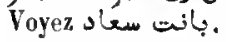

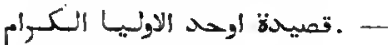
(Comment.) $320 \%, 3^{\circ}$.

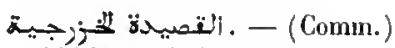
4446, $1^{\circ}$. 4447-4450.

- (Comment.) $3165,1^{\circ}, 2^{\circ} .3166$.

4201, 80.

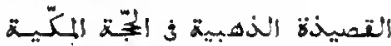
ㄹ. $1668,3^{\circ}$.

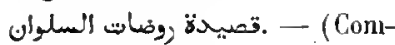
ment.) 3 s 36 .

. $3198,6^{\circ}$.تصيدة سين النتصر

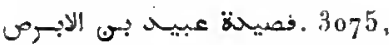
$11^{\circ} .3076$.

. 3171, مالتصيدة العينية

4التصيدة الغطرينية $4201,6^{\circ}$.

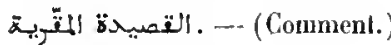
$33^{\prime} 1$, 1․ 3245.

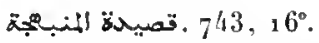

743, $14^{\circ} .4530$. - (Comm.) 2708, $3^{\circ} .4118$ $2^{\circ}$.

3198, 3 . 3 . 3/110. .قعيدة الميمية

1620, $10^{\circ}$ $2322,9^{\circ} .25 / 1,3^{\circ} .3171$, $13^{\circ}$

. 2559, ـ التعيده الهادية

3154, 20.

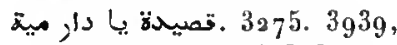
$4^{\circ}$. - (Comment.) 3280. (Takhmis) $3075,10^{\circ} .3076$.

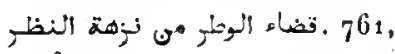
$2^{\circ}$.

تطب السروز ف وصف الإبذة وبلتهور 3302.

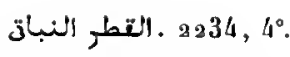

(Commení) $4152-4154$.

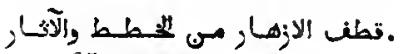
1765.

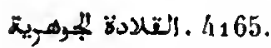

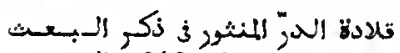
3431, 5 .

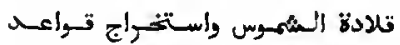
ئ.

تلائحد العتيان. 3ُ فضائل آل عتمان. 1624 .

تلائح العتيان 3 عاسى الاعيـان. 3318-3320.

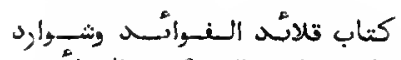

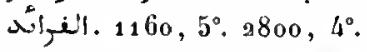

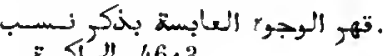
. 4613.

4438. . تهوة الانشاء

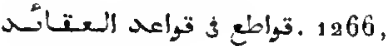
$1^{\circ}$.

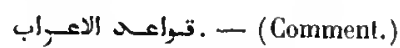
$128.7,7^{\circ} .4006,4^{\circ}, 5^{\circ}$. (Abrégé) $1287,6^{\circ}$.

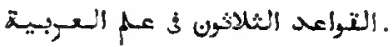

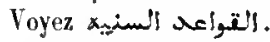

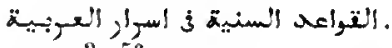
$1013,5^{\circ}$.

(Conment.) $1013,2^{\circ}$.

مال $1165,3^{\circ}$.

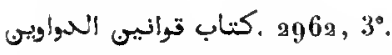

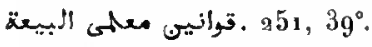

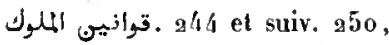
$1^{\circ} .251,9^{\circ}, 25^{\circ}-28^{\circ}$.

قوت القلوب 3 معاهلة السكسبـوب. $2016,2^{\circ}$.

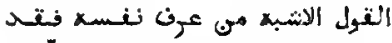

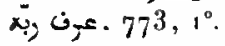

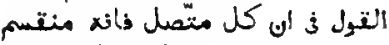
है. $2457,42^{\circ}$.

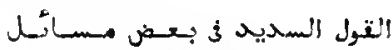
816.

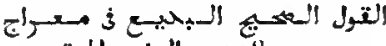

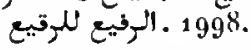

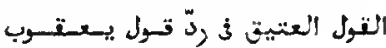
2405, 5 . البطريتي

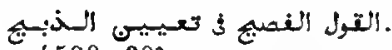
$4588,38^{\circ}$.

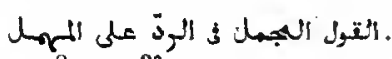
$2800,13^{\circ}$. 


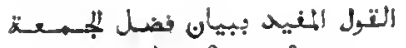

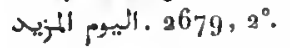

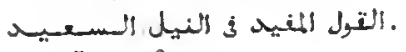
2259. 2260 .

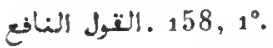

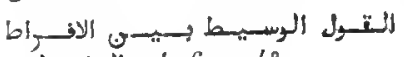

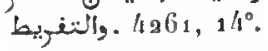

. $2857,1^{\circ}$.كتاب قوى الاغنية .

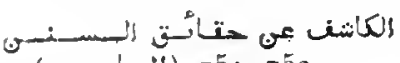

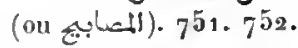

3LC1. - (de Nasafi) 89o. (d'Ihı al-Madjdi) 1031. (d'Íbn-Qodàma) 1104.

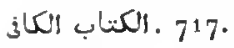

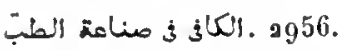

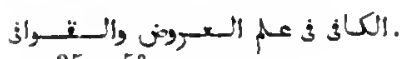
${ }_{235} 3,5^{\circ}$.

2999 ـ الكان ثي الكمل .

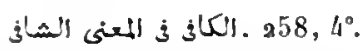

. $1136,3^{\circ}$. 1286, $11^{\circ}$. $399^{1}, 2^{\circ}$. 4021, $2^{\circ}$. 4025$4035.4123,5^{\circ}$. - (Commentaire) $2369,9^{\circ}, 4036-4057$. $4187,2^{\circ}$.

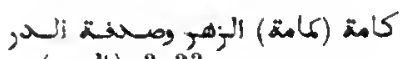
(z), 31333 . 313

h.res. 2591.

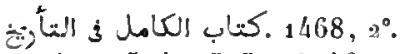
$149^{9-1504 . ~} 1595,2^{\circ}$. 4607.

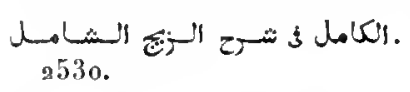

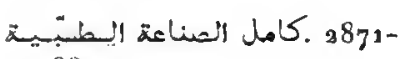
2880 .

كـمـن Vayez .كامل الصناعتيـي الوبيل

. الكمل النفيس لجلاء أعيى الوئيس. $294 \%$.

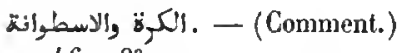
$2467,8^{\circ}$.

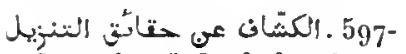
599. 600-603. 606, 20.(Comment.) 6o4-606. 439\%, $2^{\circ}$.

كئن الاستار عه حرون السغبـار. $2732,8^{\circ}$.

كشف اسرور لمارون ووصف مسعان 2686. 26 .الظرون

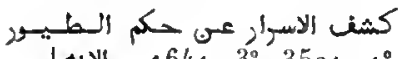
, 16/11,30. 3521, $1^{\circ}$. $3522,1^{\circ}$. 3523.4644.

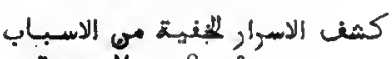
178, 1 .

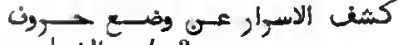

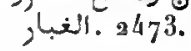

كمغ البلباب عـى عـم لمستساب. 2463, 3․ - (Abrégé) ${ }_{24} 43$.

كمف عى جواز (جباوز8

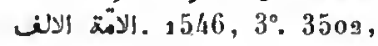
$4^{\circ}$.

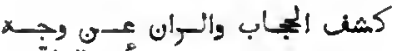
2348, 3․ 2405, $1^{\circ}$.

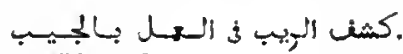
${ }_{2} 5^{\prime} 17,13^{\circ}$.

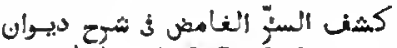

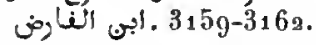

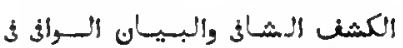

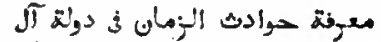
النمان 1626 .

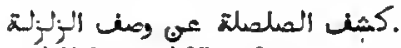
$4658,1^{\circ}$. 4659, $3^{\circ}$.

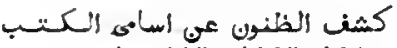

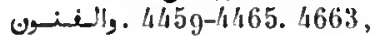
$10^{\circ}, 15^{\circ}$. - (Abrégé) 446641468 .

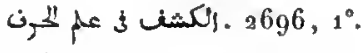

كثغ الغوامدن ف عـم الـنـرائض $870,2^{\circ}$.

الكمثن الغيوبن للقطب المثرنسو.

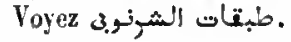

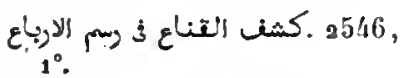

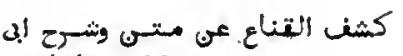
ع 1048.

كمف التناع عـى وجه السـنــان

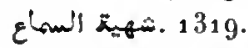

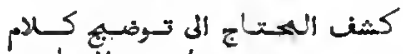
द्री 1014.

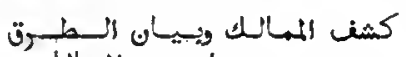
Uالمان. 1724.

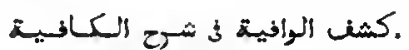
4040.

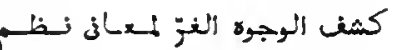
2ل) 3163.

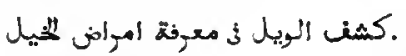
2813. 2814 .

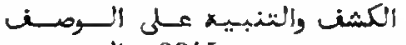

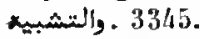

كعبة الطائفيى وتمجة العاكنيس. 4601-4603.

لكناية - (Comment.) 1034.

كناية الطالب الربان لدسالمة ابسى 1062.

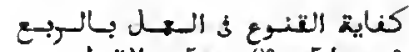

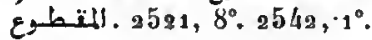
$4580,3^{\circ}$.

. $1953,1^{\circ}$. كناية المتحفنظ

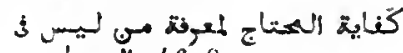
4628.

2544, 8ㅇ.

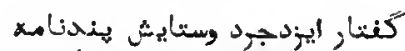

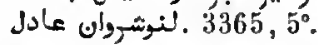

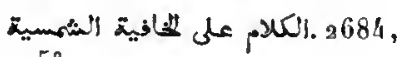
$5^{\circ}$.

1451, 28.

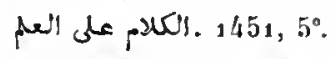

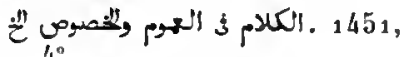
$4^{\circ}$.

(Comment.) $3517-3520$.

1060, $10^{\circ}$.كتاب الكنلكل

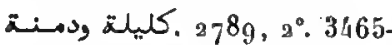
$3480.4665,6^{\circ}$.

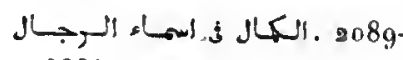
3091 .

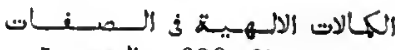

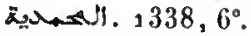

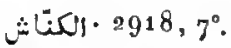

3365, $4^{\circ}$.كتاب كنج كوهر .

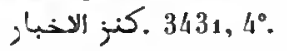

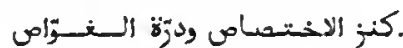

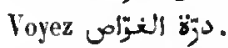

كنز الاسر', الامهية ولطائ انوار 2687, $1^{\circ}$.

1400. $1401.4665,10^{\circ}$.

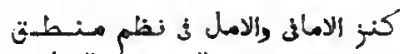
.

9799 .كتز التبجا, 3 معرنة الاجيا,

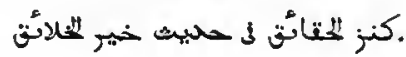
772.

(Com- - (C91-896. ment.) 896-904.

كنز الطتلب 3 العل بالاسـطـرلاب $2524,3^{\circ}$.

كنت العباد في فضائل الغزو ولإمهاد. $955,1^{\circ}$.

4898-4300.

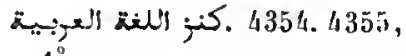
$1 \%$

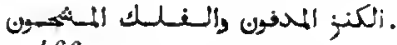
466 o.

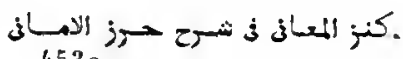
4530.

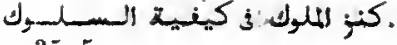
3515.

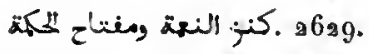

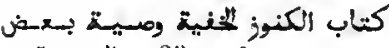
1337, . أثموفية

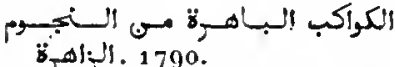
الصور Voyez كتاب كواكب النقابتة .

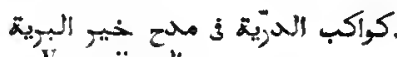

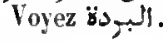

النكواكب الزأهرة ف اجتماع الاؤسيـاء

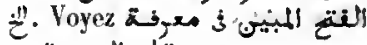

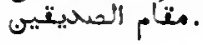

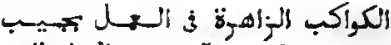

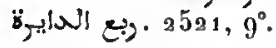

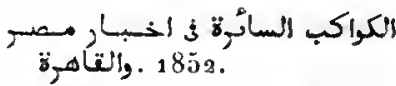

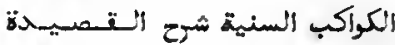

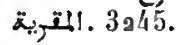

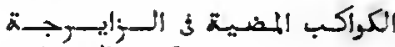
. $2732,10^{\circ}$.

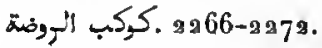

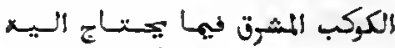
. 1047.

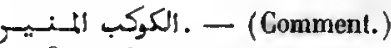

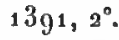

كيفية للاكم على تهويل سنى العاله. $259^{3}, 1^{\circ}$.

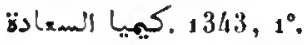

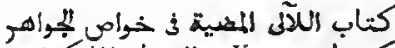

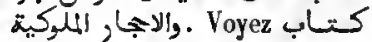
. جوأهر الاجميار.

.

Jلافل $672,4^{\circ}$. $1057,6^{\circ}$. - (Comment.) 4118, $1^{\circ}$.

1620, $7^{\circ}, 2060$. $2503,11^{\circ} .3430 .4134,5^{\circ}$. $4665,12^{\circ} . \quad-$ (Taschtîr) $3200,5^{\circ}, 6^{\circ}$. - (Comment.) ${ }_{2} 502,11^{\circ} .3119-3125$.

. $3019,2^{\circ} .3075,1^{\circ}$. لامية العرب 30. 3076. 3077. 3430. - (Comment.) 3077 .

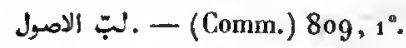

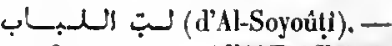
$2800,20^{\circ}$. - (d'A1-Baïdhatwi, comment.) 4120.

(d'lbn al-Athir). - (Abrégé) $2800,20^{\circ}$. - (d'AIIsfaraìiı, avec commentaire) 4121.

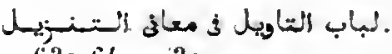
639-6/12. 1310. 
- - (Conm.) 1038 - لباب النتئ 1040. $1046,1^{\circ}$.

. $2800,6^{\circ}$.

. s o63. (Voyez Additions et Corrections.)

935.

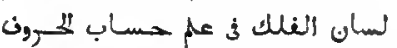
है. $2695,1^{\circ}$.

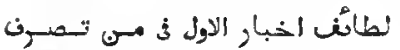
है مصن 3. 1839-1849.

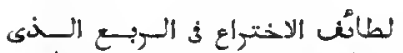

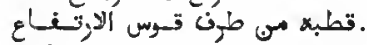
$2547,18^{\circ}$.

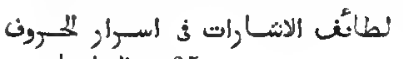
2657. 26 .

4150.

- 1926.

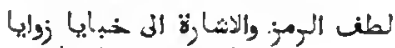
4430.

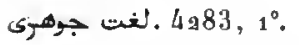

4301.

4315.

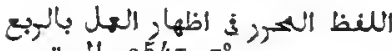
. $2547,7^{\circ}$.

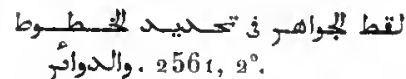

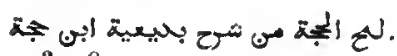
3218.

åul. - (Comment.) 3025 et $30_{2} 6$.

. $1398,2^{\circ}$.

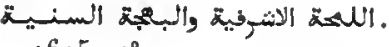
$1615,2^{\circ}$.

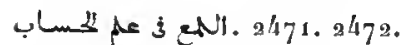
$4 \times 62,2^{\circ} .4585,5^{\circ}$ - (Comment.) 2471.2472.

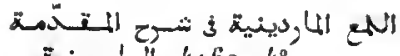
4162, 40.

and]. 4659, 7".

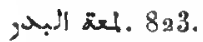

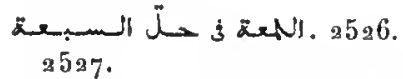

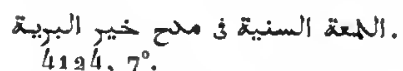

. 1295.126.

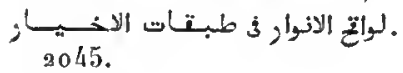

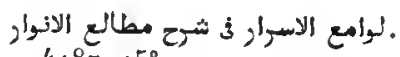
$1187,15^{\circ}$.

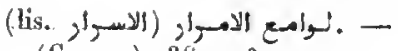
(Comm.) 2381 , 2.

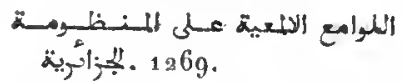

.

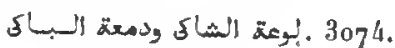
3658 , 12". 464a.

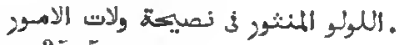
3575.

كتاب ما لا يسع الطبيبي جهـهل 3005.3006.

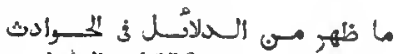
J'll, 4658,1 .

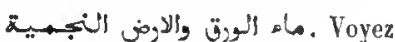

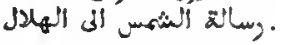

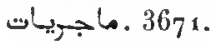

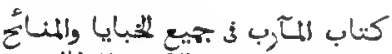
. $0357,2^{\circ}$.

2881.2882. - (Comment.) 2883.

. 3088, $3^{\circ} .3989,1^{\circ}$. $399^{\circ}, 1^{\circ} .3999,1^{\circ}$. $4008,2^{\circ}$. $4015,6^{\circ} .4021,4^{\circ} .4027,3^{\circ}$. $4031,3^{\circ} .4041,3^{\circ} .4123,4^{\circ}$. $4130,2^{\circ}$ - (Comm.) 3989 , $3^{\circ}-5^{\circ}$. 3990, $2^{\circ}$. 3992, $1^{\circ}$. $3993.1^{\circ} .4015,50.4017,2^{\circ}$. $4025,3^{\circ}, 4^{\circ} .4033,3^{\circ} .4041$, $3^{\circ} .4051,2^{\circ} .4144,3^{\circ} .4149$, $2^{\circ} .4181,4^{\circ}$.

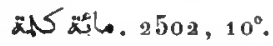

3660, 1․ 3661, $3662,2^{\circ}$.

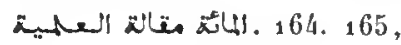
$1^{\circ}$.

اللمباحث اللغوية والمشلات المثلثة $3204,4^{\circ}$.

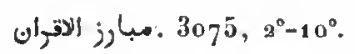

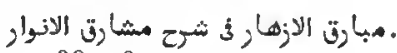
$7^{38} \cdot 7^{3} 9$.

a776, $4^{\circ}$.

slell $4588,97^{\circ}$.

술. $1176,35^{\circ}$.

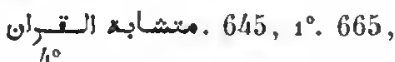

4577, $13^{\circ}$. متتى عثانُم عضدىى

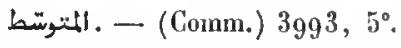

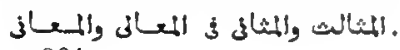
3341.

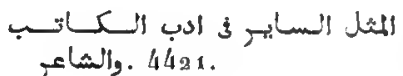

825, 4 . $1206,6^{\circ}$. $4032,2^{\circ} .4067,3^{\circ} .4230,1^{\circ}$. - (Comment.) $1057,28^{\circ}$. $4930,2^{\circ}$.

3954, $8^{\circ}$.

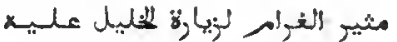
مالمال 1667,2 . $1668,2^{\circ}$.

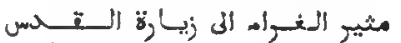

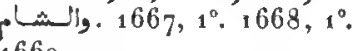
$166 \mathrm{~g}$.

مثئر الغرأم وخلاصة الكلام في فضل

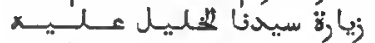
م2llin. 1929.1930.

1323.

1964, : 3481.

J 190-192. 199, $3^{\circ}-5^{\circ}$.

. $2661,4^{\circ}$.

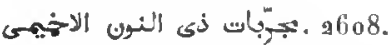

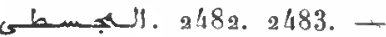
(Abrégé) 2484, 1\%. - (Remanié) 3/185. - (Comment.) $2458,6^{\circ}, 2544,9^{\circ}$.

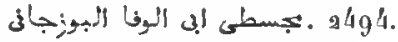

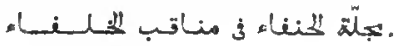
1571 .

. بميع الاحباب وتنكرة اوف الالباب 2032.

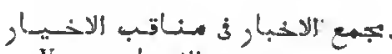
Voyez sجي الاحباب

3. 3958-3963.

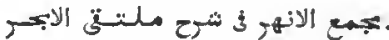
$9^{63}$ et $9^{63 .} 9^{65}$ el 966 .

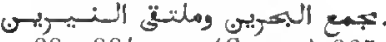
881-881. - (Comm.) 885$889.97^{\circ}, 2^{\circ} .4543 .4544$.

كتاب تجهع من جليلة وهو نجربات 3029, 1 . 30 .

. 250,10

天ili ل4. 4247-4250.

1327.

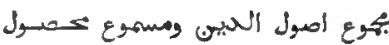
200. 201.

2765.

. 1025, 10. 1025 .

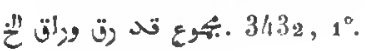

3421.

3388.

. 324 . 23 .

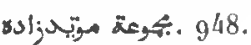

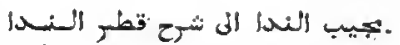

415. 4153. - (Comment.) 4154.

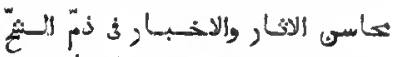
है 3494 . 34 . 3 .

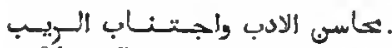
$3401,5^{\circ}$.

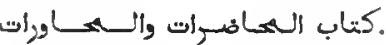
3406.3407 .

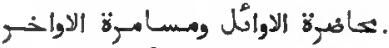
2079. 2080.

تIrLUt. 2367. - (Comment.) $2399,2^{\circ}$.

ث人⒈ 1451, $7^{\circ}$.

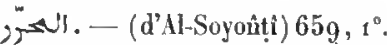
- (d'Al-Rảfì comm.) 1002.

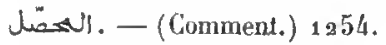

790 - النهصول في أصول الغتن.

(Comment.) 1012.

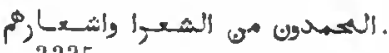
3335.

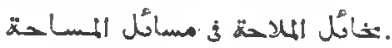
2474.

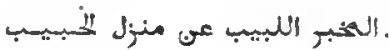
2951.

1383 . بختا, الاتخييو (التخبييو) .

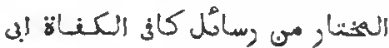
. $3314,3^{0}$.

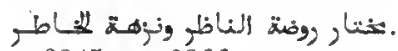
$3365,1^{\circ} .3366$.

8. 875-877. 891, $2^{\circ}$. - (Comment.) 878. 879 . 4640.

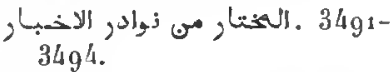

851.

(d'Al-Akhsíkati , comm.) 880 . - (d'A\}-Taftâzånî) 4386, $2^{\circ}$. 4398-4405. $4415,2^{\circ}$. (Comm.) 4400 . $4406-1415$.

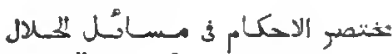
ए), 1106.

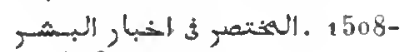
1513.

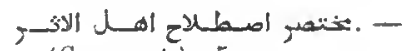
(Comment.) 759 .

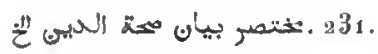

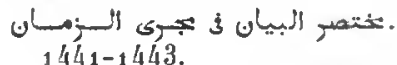

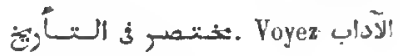
.'لملطانية. 
296-299.809, $8^{\circ}$.

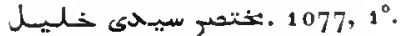
$1078.4550 .4551 .-(\mathrm{Com}-$

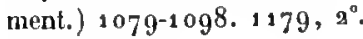
$4552-4562$.

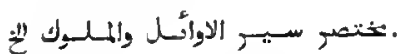
1507.

اخـبـا, Voyez كتنص, الهبكائب الزمان.

2955.

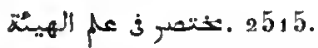

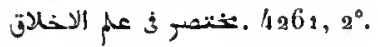

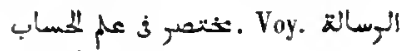

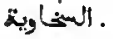

- " (Comment.) $2316,6^{\circ} .4203$.

. 1664 . 1665. 2802.2805.

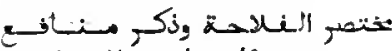
. $29^{\text {ha }}, 4^{\circ}$.

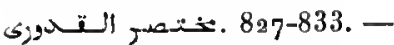
(Commentaire) 834. 835. (Supplém.) 854.

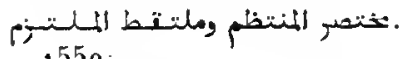
1550 .

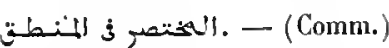
21400. 2401.

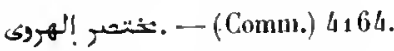

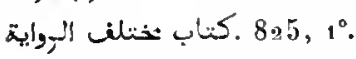

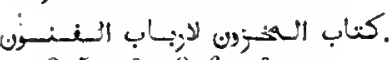
$2825,2^{\circ} .2836,2^{\circ}$.

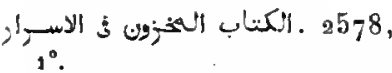

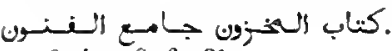
2824. $2826,3^{\circ}$.

3251, 13 .

jخدمl. - (Abrégé) $2696,2^{\circ}$. . $2330,2^{\circ}$. كتاب المخلر

. $2865,1^{\circ}$.

.

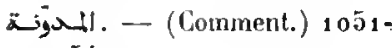
1054.

J6. 1365.

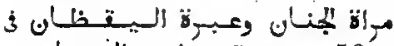

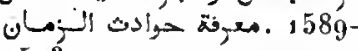
1593.

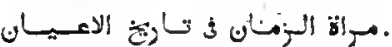
:1505-1506.

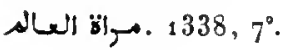

•مراك المعان لادراك العاله الانسبان $1699,3^{\circ}$.

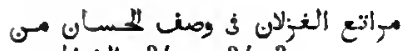
نان 3402.3403 .

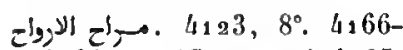
4184 . - (Comment.) 4185 . 4186 .

3431 .مراسلة وتهان.

موامد اللاطلاع على اسمـاء الامككنة . 2232.

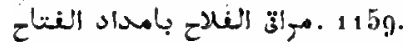

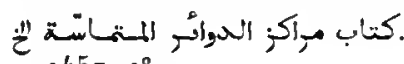
$2457,3^{\circ}$.

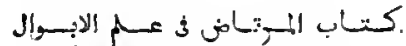
. 3039,18 . والانبان 18 .

1554.

3385. 3386 .

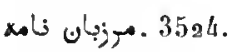

. $4578,3^{\circ}$.

حن̈_ll. - (Abrégé) 667, 1\%.

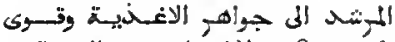

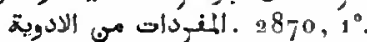

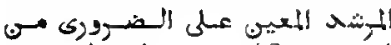
(C)mment.) 818.

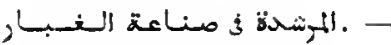

(Comment.) $2475,2^{2}$.

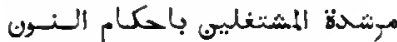
4533, 1 . والتنفوينيو

4319-4323.

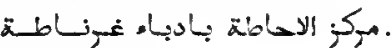
$3347,1^{\circ}$.

1198, 1 . موموزات 1 .

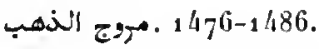

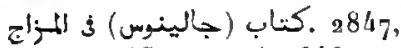
$2^{\circ}$. - (Comment.) $2848,2^{\circ}$.

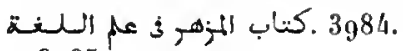
3985 .

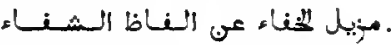
$1957,2^{\circ} .4626$.

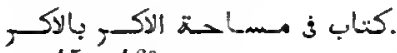
$2457,46^{\circ}$.

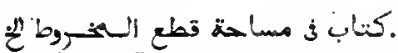
$2457,25^{\circ}$.

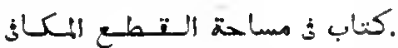
$2457,26^{\circ}$.

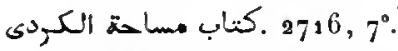

كتاب ذٔ مساحة المجسمات المكافيتة $2457,21^{\circ}$.
. مسابك الابصار 3 2199. 2325-2329.

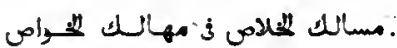
$4606,3^{\circ}$.

(l'lbn Khordàdhbeh) 2213. - (d'llon Hauqal) 221522217. - (d'Aldallah ibn 'Abd al-'Aziz) 2218.

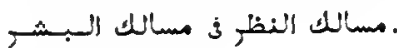
1454.9455.

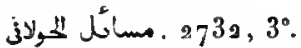

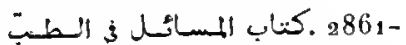
2863. - (Comment.) 2811 . 2861-2863.

1973, $1^{\circ} .197^{4}, 1^{\circ}$.

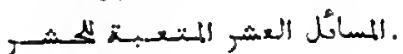
$1266,3^{\circ}$.

. مسأل عددية لطيـنة حسبــة $2457,35^{\circ}$.

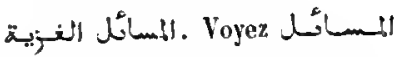
.

.لمسائل اللغتية ث احكام المثرعية. $812,1^{\circ}$.

كتاب مستحسمى الطرائق ف3 نـظم . .

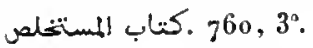

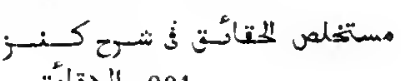
كائقان.

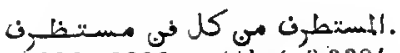
3369-3383.- - (Abrégé) 3384.

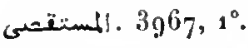

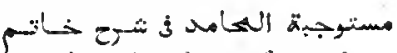

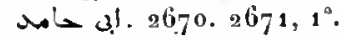

2800, 8 . المسلفسلكات الكبوى

(Conment.) $7^{31 .}$

المهي . Voyez.

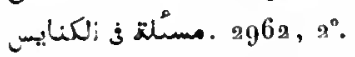

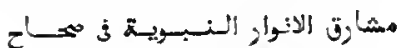

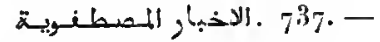
(Comment.) 738.739 .

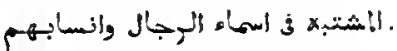
2075 .

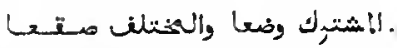
2233. $4256,2^{\circ}$.

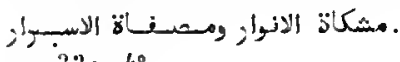
$1331,4^{\circ}$.

20. 720.

ح 1018.

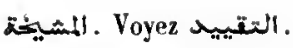

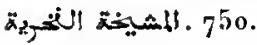

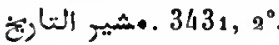

. $211,3^{\circ}, 4^{\circ}$.

(d'Al-Taïyibì). - (Comment.) 751 .

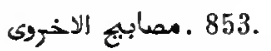

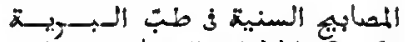

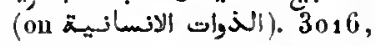
$2^{\circ} .3034,3^{\circ}$. 3044, $1^{\circ}$.

720. 79.

. 218.219 . مصاحبات روحانية.

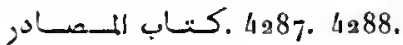

$429^{\circ}, 3^{\circ}$.

ت $2467,5^{\circ}$ a $7^{\circ}$.

599.

z-11. 1136, 40.3992, 2". $4008,1^{\circ} .4021,3^{\circ}$. 4022, $3^{\circ}$. $4025,3^{\circ} .4026,2^{\circ} .4028,2^{\circ}$. $4030,2^{\circ} .4031,2^{\circ} .4130,3^{\circ}$. 4375 . - (Comment.) 2369 , 7. 4009-4024. $1144,5^{\circ}$.

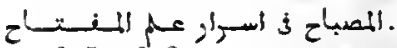
2615. 2616 .

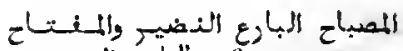
. 767 .

ح 4419.

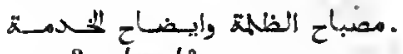
203. $342,4^{\circ}$.

. 212, 80.

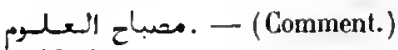
$4396,2^{\circ}$.

الممباح اللضى في كتئاب السنسيى الامى

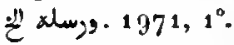

ل ز

:

4297 . مصرحة الاسماء.

.المصنى 4571.

1331, المخنوب بx عن غير الهلـ . $3^{\circ}$.

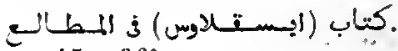
$2457,36^{\circ}$.

, 1257 . 1258 . 125 . 369 , 3. 2389. - (Comment.). 2390.

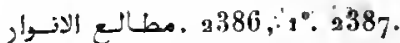
-- (Conm.) $2369,22^{\circ}$. 238 , 2. $2388.2398,4^{\circ} .4187$, $15 \%$.

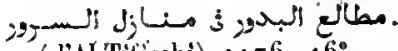
(dAf-Titaschi) 1176,16 . (d'Al-Glozoùli) 3/415. 
.

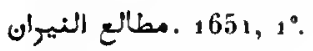

. 14331, 19.

. $4281,1^{\circ}$.

3417,6 6.

.المطلب 3 العل بالربع الـهـيـبـ. $2519,3^{\circ}$.

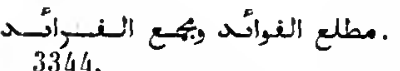

2568 . المطلع ملى مسائل المتنع

4 4189 .

. 4386-4391. - (Comm.) $673,5^{\circ} .4392-4395$.

1331, 6² . معارج السالكيي. 1465.

1465.

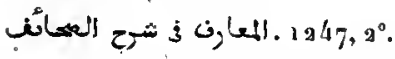

1331, 1. 1 .

. 3223, 20.

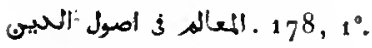

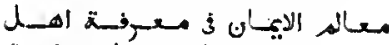
. 2154 ـ التيروان.

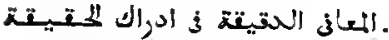
4588, $33^{\circ}$.

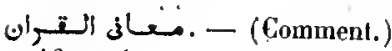
$4392,4^{\circ}$.

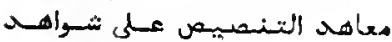

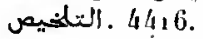

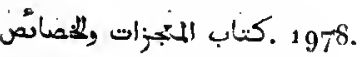

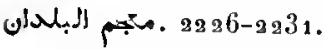

(d'Al-Ṭabarâni) 2011 - (d'Al-Dsahabi) 2076.

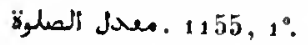

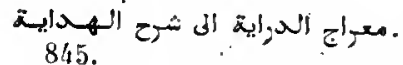

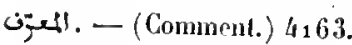

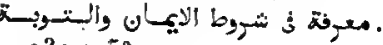
$2307,5^{\circ}$.

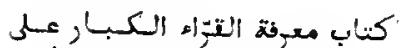
. 2084.

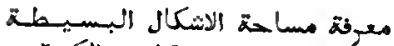
. 2467, 30 3.

أ $3171,1^{\circ} .3179,1^{\circ}$. $3431,14^{\circ}$.

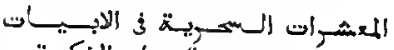
. 4 ag6.

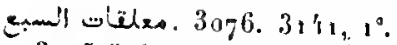
3.7.5-3 $90.3430 .-$ (Takh. mis) $3075,2^{\circ}-8^{\circ}$. - (Comment.) $3275-3$ a 80 .

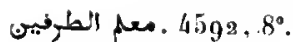

. 1/55 , 1 , 6 .

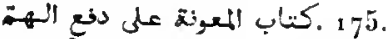
$176,1^{\circ} .45_{2} 3,1^{\circ}$.

,

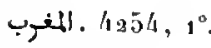

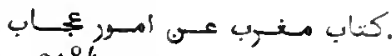
2184

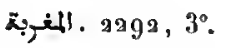

3990. 2991.

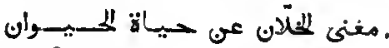
2801 .

399/1-2939.

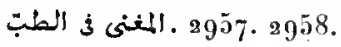

(Abrégé)

. 3991, 20.

مغنى اللبيب عه كتـب الاعـاريـب 4155-1157. - (Comment.) 4158.

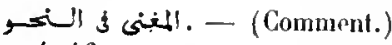
4143.

مغيث الثلق 3 اخستسيسار الاحستق $9^{84 .}$

مناتيج اسرار لمرون ومصابيج انسوار . 2660.2688.

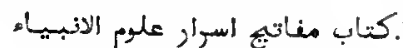
$2675,1^{\circ} .2676 .2726,2^{\circ}$.

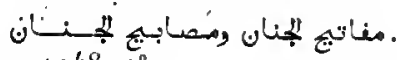
$1248,1^{\circ}$.

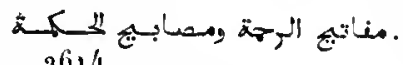
2614 .

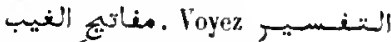
النبيي.

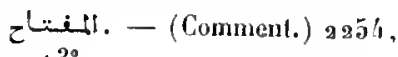
$13^{\circ}$.

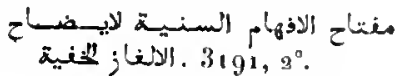

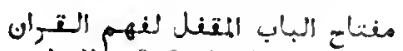
ل $1398,4^{\circ}, 6^{\circ}$.

. 437 . - (Comment.) 4373 . $4374,1^{\circ} .4376 .4377 .4396$, $1^{\circ}$. 4417. 4/19. 4606, 4". - (Abrégéé) voyez

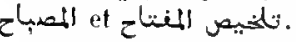

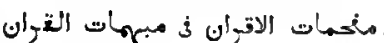
$4588,41^{\circ}$.

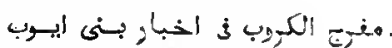
1702. 1703 .

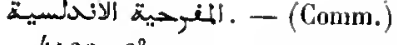
$4122,3^{\circ}$.

4 . كتاب المغروضات . $2467,4^{\circ}$.

لingill. 4001. 4002. - (Comment.) $4003.4004 .4392,3^{\circ}$. 1254.

أll. 4004.

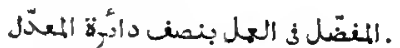
$2547,15^{\circ}$.

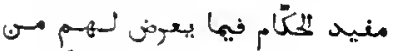
( 107 . 107.

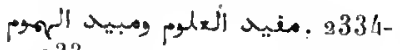
2337 .

3)زال - (Commeni.) 1265 .

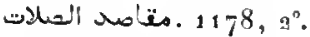

202 . متاصم الغلاسنة

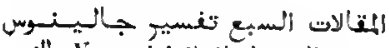

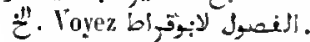

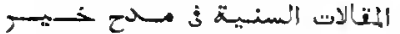

المبريت 1997. - (Abrégé) $179^{8 .}$

مقالة ق استخراج الاعباد المتحابية है. $2457,38^{\circ}$.

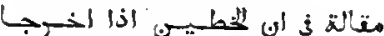

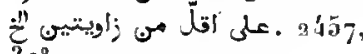
$32^{\circ}$.

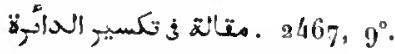

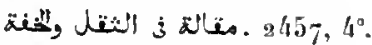

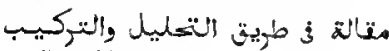
है. $2457,1^{\circ}$.

. 9953.

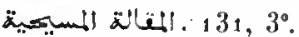

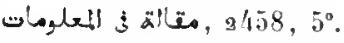

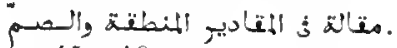
$2457,48^{\circ}$.

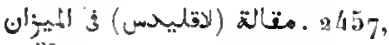
3 .

مـنـ. de Naqoùlà alTourki) 3972. - (d'Al-Soyoniti) $3521,3^{\circ} .3949-395 \mathrm{~L}$. $397^{*}, 9^{\circ}, 3^{\circ}, 5^{\circ}, 7^{\circ}-10^{\circ} .4588$, $42^{\circ}$. - (d'Al-Hamadài) 3923 . - (d'Il-Hariri) 3994-3936. $4665,12^{\circ}$. - (Comm.) $3937-$ 3946 . - (de Nolummad atTilimsaini) 3947. - (anon.) $3 y 48,1^{\circ} .-\left(d^{*}\right.$ ll-llababi alQanw is) 3953. - (de Yorksof al-Solami) $3_{972,} 11^{\circ}$.

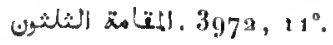

.

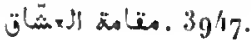

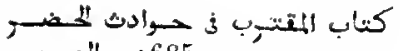
1685.

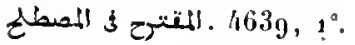

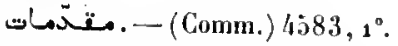

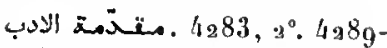
1293.4645.

1 1 $286,7^{\circ} .257$. $6^{\circ}$. 4542, $5^{\circ}$.

1042, 1‥ (Comment.) $947^{5}, 1^{\circ}, 3^{\circ}$

1293, $123^{\circ}$.

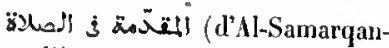
di) 1121-1123. 11/41, $2^{\circ}$ $11 / 2,2^{\circ}$. - (Comm.) 11241198. - (d'Al-Aschmàwi, comment.) 11 29. - (d'Al-Fanàri, comment.) $1134,4^{\circ}$.

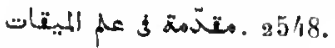

859. - (Comment.) $606,5^{\circ}: 853$.

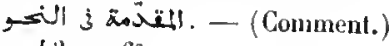
$4393,6^{\circ}$.

.

المتعد الابنى فيها يتعلق بـاسياء . 1/405, 1.

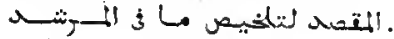
$667, \mathrm{t}^{\circ}$.

د. 8307,3 . 3571.90 . $4166,3^{\circ} .4167,3^{\circ} .4168,3^{\circ}$. $4169,3^{\circ} .417^{\circ}, 3^{\circ}$. 4171, $3^{\circ} .417^{2}, 3^{\circ} .4173,3^{\circ} .417^{1}$, $3^{\circ} .4176,3^{\circ} .4177,3^{\circ} .4178$, $3^{\circ} .4179,3^{\circ} .4180,3^{\circ} .4181$, $3^{\circ} .4182,3^{\circ} .4189 .4197,3^{\circ}$.

.4234. 42.

8_ll (d'lbn-Doraid) 3088, $1^{\circ} .327^{6}, 9^{n} .4231,4^{\circ}$. (Comment.) 792, $2^{\circ}$. 3089. $3090.327^{6}, 3^{\circ} .4231,4^{\circ}$. (d'Aboù 'l-'Abbis Thafab) $4452,7^{\circ}$.

. 2144

Eتل (d'lbu-Qolàma, comment. de l'abrégé) 1107 . (d'AlSoùsi, comment.) $2568, r^{\circ}$. - (d'Ahoù lloqra', comment.) $2568,3^{\circ}, 4^{\circ}, 13^{\circ}$.

. $9^{\circ}$.

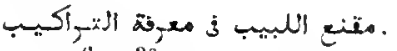
$117^{6}, 23^{\circ}$.

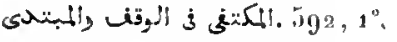

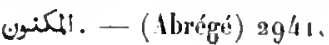




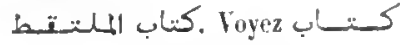

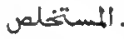

(Comment.) $9^{62}$ et $9^{63 .} 9^{65}$ et $9^{66}$.

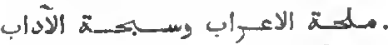
3571, 9. 3996. 3997-3999. - (Comment.) 3997-3999. - (Abrégé) 4452, 4n.

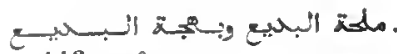
$4431,1^{\circ}$.

2. ـ . $2593,3^{n} .2675,3^{n}$. 2736 .

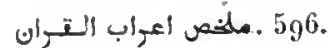

.

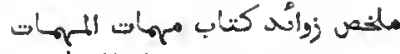
992.

ح 2330, $7^{\circ}$. 2500-2505. - (Comment.) $2501,3^{\circ}$. $2505.4386,3^{\circ}$.

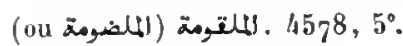
U ب ك.ب $2605,2^{\circ}$.

1406.1407.

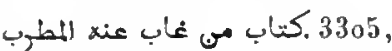
$1^{\circ}$. 3/401, $4^{\circ}$.

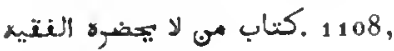
$1^{\circ}$.

8ن $4029,3^{\circ}$.

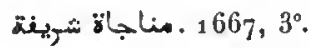

. $213,13^{\circ} .275$. $3^{\circ}, 5^{\circ} \cdot 77^{\circ}, 14^{\circ}, 1363,14^{\circ}$ $3586,4^{\circ}, 5^{\circ} .4608,4^{\circ}$.

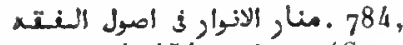
$2^{\circ}$. 794. 4542, $1^{\circ}$. - (Comment.) $79^{4} \cdot 79^{5}$.

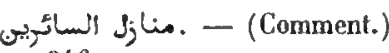
1346.

2693, $202^{\circ}-4^{\circ}$. مناسيب التيسيرية

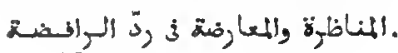
$1461,1^{\circ}$.

. $2775,3^{\circ}$. منافع الائار , .

. 1973, 6.

كتناب (جالينوس) ف3 منافع الاعضاء 2853. - (Comment.) a 854 .

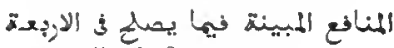
3039, 30 . الا:منة

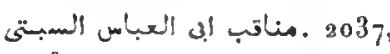
$1 "$.

3497, 20.

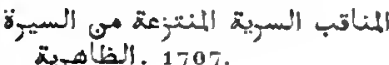

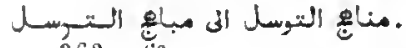
$1363,16^{\circ}$.

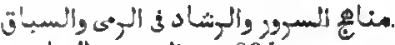
2834.

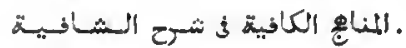
4062.

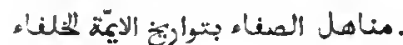
1609-16:11614.—(Abrégé) +612. 1613.

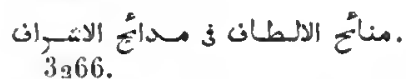

منتّة لبليل في تبول تول السوكيـل . $1160,3^{\circ}$.

(d'Al-Akbsikati). (Comment.) 802. - (anon.) 9602, $7^{\circ}$. - (d'Al-Khalili alDåri) $2749,1^{\circ}$.

1721.

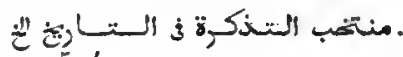
1514 .

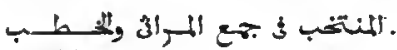
3441 .

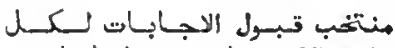

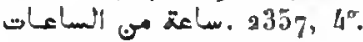

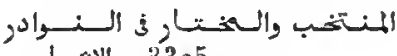

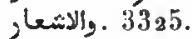

مختصر المنتظم Voyez. المنتظم.

.لمنتى 3022.

1032.

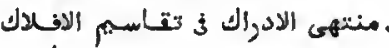
3499.

1076.

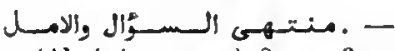
(Abrégé, comm.) 801. ^391. 4549.

3164.

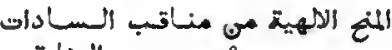

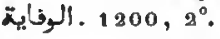

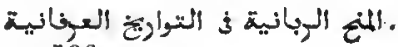
1536.

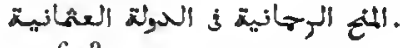
1623.

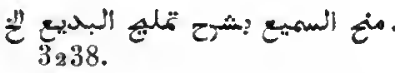

ت 3197.

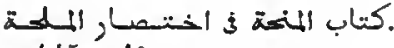
$445 \mathrm{a}, 4^{\circ}$.

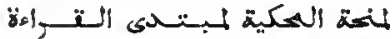
مئمئم $1057,18^{\circ}$.

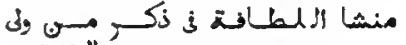
2013. 1770.

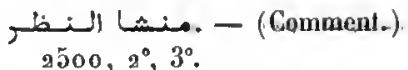

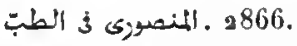

2727. 27. 27. $3^{\circ}$.

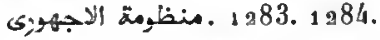

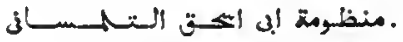
- (Comment.) 1076.

3248, $1^{\circ}$. منظومة الاسماء "لمسنى

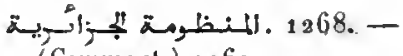
(Comment.) $186 \mathrm{~g}$.

2833 ـ المنظظومة في الرمى مع تشرحها.

29!2, 30. 3 . $3038,3^{\circ}$.

(منظومة ابه فرح - (Commenl.) $746,2^{\circ} .3432,3^{\circ} .4257,1^{\circ}$. 4566-4568. (Comment.) 4569-45̃7r.

.4579 . منظومة أبى وهببان.

810.

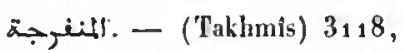
$1^{\circ}$.

. 4195.

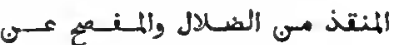

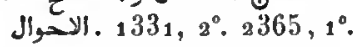

. 1146.

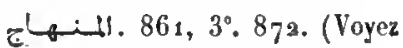

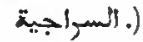

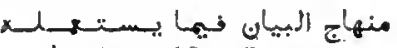
2948-2952.

منهاج الحكان. ودستستور الاعـيـان. 2965, a'. 2993-2996.

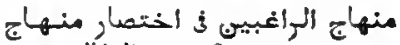
1006.

1008-1004, 10. 4545, 2. - (Comm.) 1004 , $2^{\circ}$. - 1022. $2677,18^{\circ} .4545$, $4^{\circ} .4546$.

1248, 30. 1292.

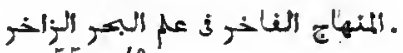
$2559,4^{\circ}$.

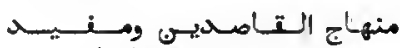
. 1995.

ئه 1227.

727, 20. -- (Comment.) 799. 800.

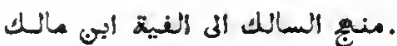
4100-4107. - (Comment.) 1108.4109.

- (Comm.) 1049.

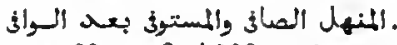
2068-2 ن 73. 4663, $11^{\circ}$.
. لمنهل .أعذب الرائق السلسبال

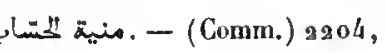
$2^{\circ}$.

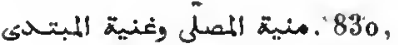
20.1139-1138. - (Comm.). 1147 et 1148.1152 .

858.

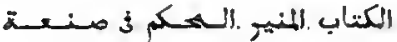
2747.

2954, 8.

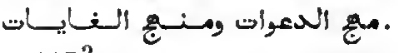
1173.

2568,6\% .

.

. $1299,1^{\circ}$.

. $2016,3^{\circ}$. كتاب الموأعيظ .

المواعظ للهذكرة لموت وأمور الاخرة 1318.

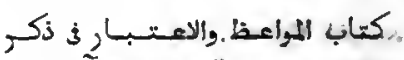
, 1 7.99-1766. $3543,3^{\circ}$.

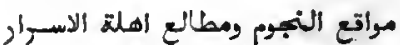
1338, $3^{\circ}$.

2392. - (Comment.) $67^{3}, 4^{\circ} .1262,1^{\circ}$. 23393-23y 5 .

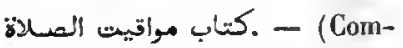
ment.) 1161 .

2587-2718, 2583 .كناب المواليد . $2^{\circ}, 3^{\circ}$.

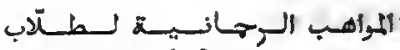

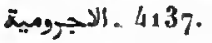

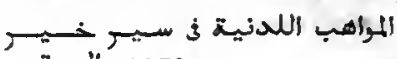
1979. 1979.

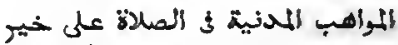
كا 1212.

2919-2923. (Comment.) s924-2932.

. 2844,3 . 3 . 3 . 634, 60.

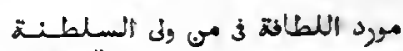
. 1606.

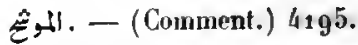

موصل الطلاب اله تـواعده الاعـاب. 4146. - (Comment.) 4147 .

غوأ 3101-3104.

Üإ) 675-678. 4538.

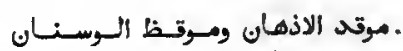
$4115,2^{\circ} .4162,1^{\circ}$.

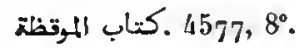




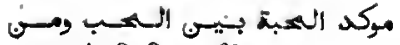
$x_{a}=1.3039,16^{\circ}$.

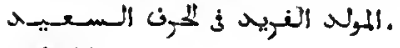
2711.

937 , $14^{\circ}$. مولوديات .

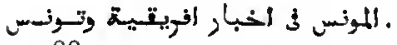
1887 .

814. 815. 815. $1641, h^{\circ}$.

. $139 \mathfrak{6}, 11^{\circ}$. ميزان المنطق

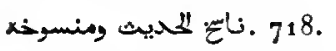

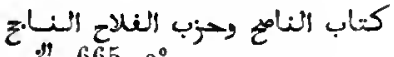
尙. $665,2^{\circ}$.

كنشغ السريـل ث

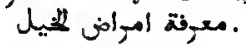

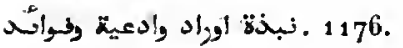

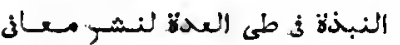

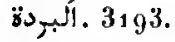

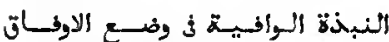

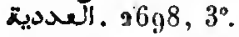

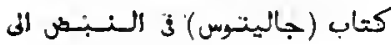
. $2860,3^{\circ}$.

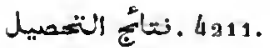

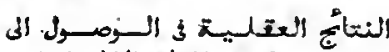
2961.

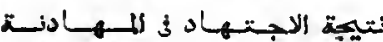
خ

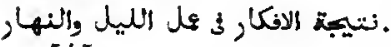
9545.

نتيجة النكر ف علاج امرام البمر 3007.

نمخ - (Albrégé) 3490.

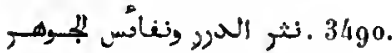
. 3431, 34 . 3973, 3 .

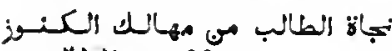
2766.

جلمبأ. 3485.

.النجايات $3411,2^{\circ}$.

. 1294,5 .

638.

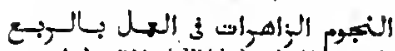
أli (d"Abd al-Azíz alWafiii) ${ }_{2} 531,1^{\circ} .3544,15^{\circ}$. - (d'Al-Nâridìni) $5547,17^{\circ}$.

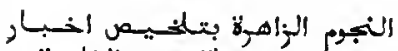

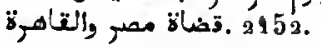

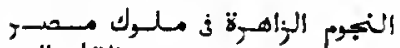
177-1790.

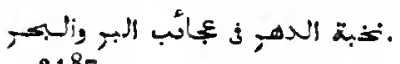
2187 .

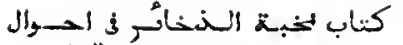
.

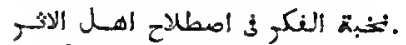
$760,1^{\circ} .4957,2^{\circ}, 3^{\circ}$. (Comment.) $761,1^{\circ} .4257$, $3^{\circ}$.

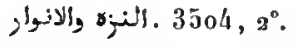

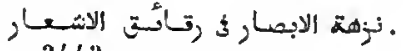
3443.

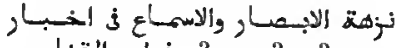
. 3071-3073.

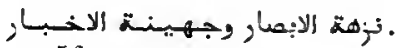
1561.

نزهة الإجاب اله معاثرة الاحساب $3039,20^{\circ}$.

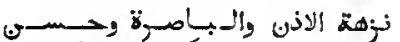

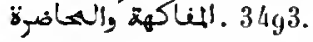

تزهة الاميكاب في معانترة الاحمباب 3054 .

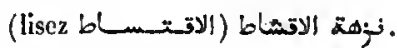
$27^{3}, 7^{\circ}$.

3346.

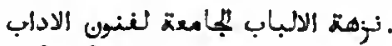
3526 .

تزهة الالباب فيها لا يوجد خ كتاب. 3055.

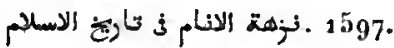

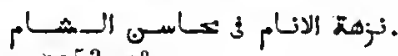
2553, $3^{\circ}$.

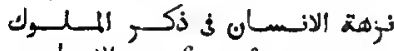
. $1769,1^{\circ}$.

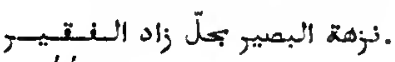
944.

نزهة للادى بإخبار ملفوك الستـرن ى 4617.

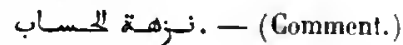
$2475,2^{\circ}$.

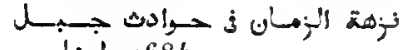
1684.

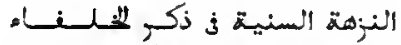

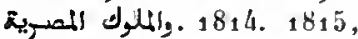
$1^{\circ}$.

•زهة الطالبيه وتكنة المراغـبـيسى . 3190.

نزهة الماشقيى ورنذة السامعيسى 3 อ6 68.

نزهة العيوب النواظر وتحنة القلوب . 2040.2041.

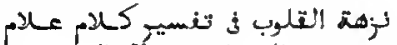

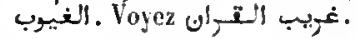

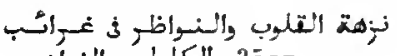
• 3577 . لمكابيات والننرأدر.

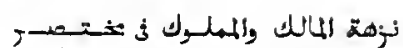

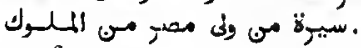
1706.

نزهة البجالس ومنتخب النـنـافَس. 3554 et 3555 .

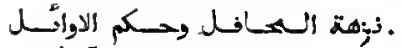
$2405,3^{\circ}$.

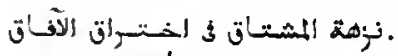
2221-2234.

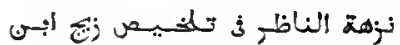

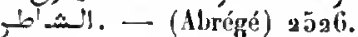
2527 .

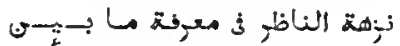
.

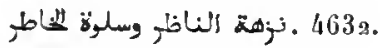

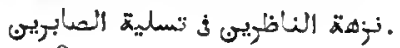
1310.

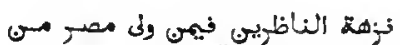
. 183 . 1831.

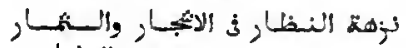
, $777^{\circ}, 1^{\circ}$.

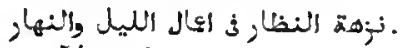
$3549,3^{\circ}$.

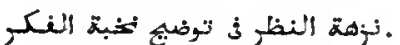
$761,1^{\circ}$. $4257,3^{\circ}$. - (Comment.) $; 61,2^{\circ}$.

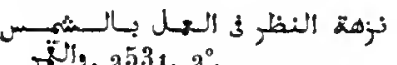

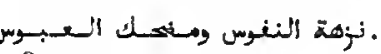
3220.

1791 .نزئة النـــوس والابهان.

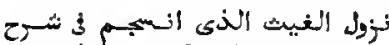

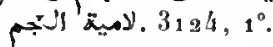

. 3206, 3032. 3244, $2^{\circ}$. 3361-3364.

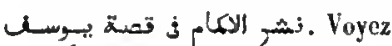

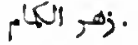

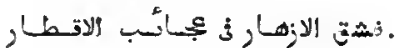
$2207-2211.3513,3^{\circ}$.

نمشوان المعاضرة واخبار المخذاكـرة $3482,1^{\circ}$

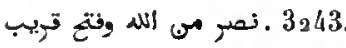

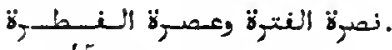
2145 .

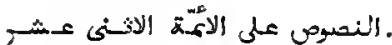
य018, $2^{\circ}$.

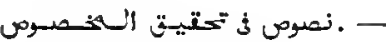
(Comment.) 1386, 30.

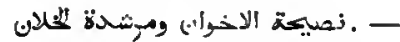
(Takhmis) 3199. 3200, $1^{\circ}$. - (Comm.) 3201-3204, $1^{\circ}$. (d'Al-Ghazáli)
2035, $3^{\circ}$. 2494-3430. (d'Ml-Máwardi) $9447,3^{\circ}$.

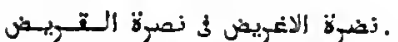
$1303,2^{\circ}$. 4236, $3^{\circ}$. 4420 , $1^{\circ}$.

النطق المنهوم مى أهـل الستصدمبت

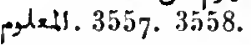

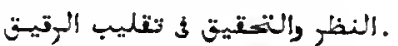
$2234,3^{\circ}$.

كتاب نظم البحييع 3 ملح النشغيع. $1160,6^{\circ}$.

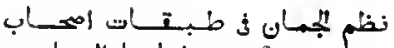
.

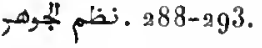

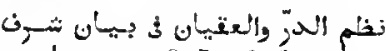
.بن 1875. 1876.

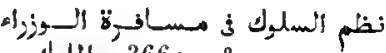
. 3660, 2 .

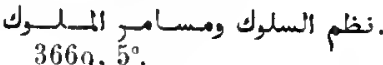

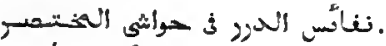
$2400,2^{\circ}$.

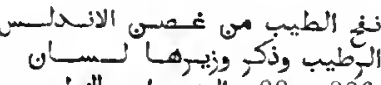

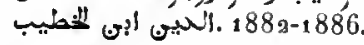

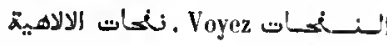
الزبانية الالية

نفكات الانس مى حضرات التحس. 1370.

1354.

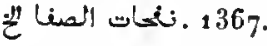

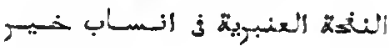
. 1979.

2533.

2997 ـ نتع الغلل وزنسع الـعلـ $399^{8}, 1^{\circ}$.

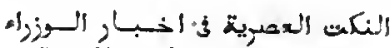
. $2147,1^{\circ}$.

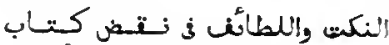
1461, 20.

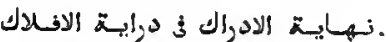
2517. 9518.

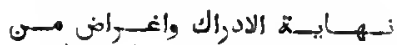

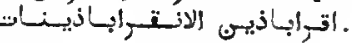
9970.

- 1573 ـنهاية الارب ف فنسون الادب 1579. 1587 . 1588.

• نهابة الارب 3 معرفة انساب العرب 2049.

.

66 419 ـنهاية البهمجة 


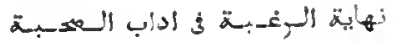
1176,25 .

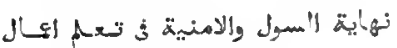

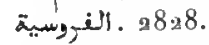

1, 929".

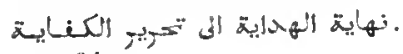
1034 .

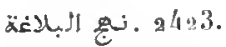

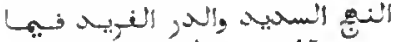

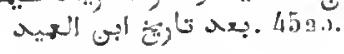

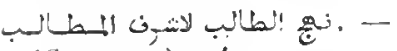
(Comment.) 1049 .

النسج المسلوك ف سياسـة الملـوك $2 / 138$.

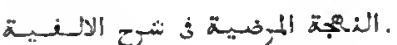
$407^{\circ}, 0^{\circ}$. $4110.4111,1^{\circ}$. (Comment.) 4113.4113 .

W' نوإبغ $1620,8^{\circ} .3965,1^{\circ}$. $397^{3}, 7^{\circ}$. - (Comm.) 3966 . .

3068 .نوأضر الايك في نوادر النيك .

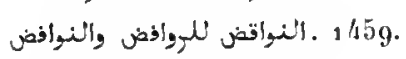
.

(Abrégé) 2560, 5 .

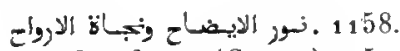
$1230,6^{\circ}$. - (Comm.) $115 \mathrm{~g}$.

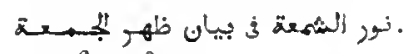
$1160,1^{\circ}$.

3008 .نور العيون وجأهع الغنسورن ,

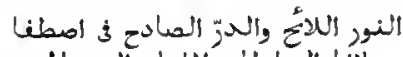

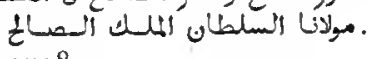
1708.

نور النبراس على سيرة ابمق سبيـد . 1968 et 1969 . النفاس

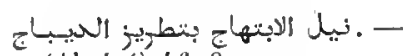
(Abrégé) 4628

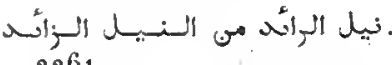
2261

نبل المطالب والمّرب ف ثنرح كافية 4057. أبي.

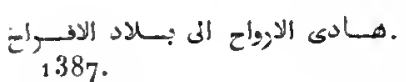

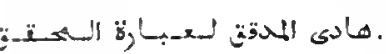
$101 \%$.

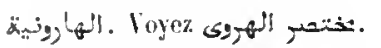

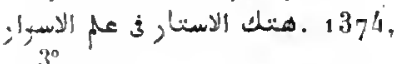

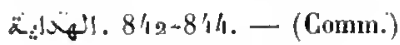
8!5-850. 905-(1)22. 4606, 8n.

- (Abrégé) 851 .

.

2330, 5 . - - (Comment.) $2500,7^{\circ} \cdot 2360-2365$, 1 .

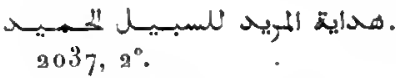

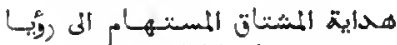
"." $1546,4^{\circ}$.

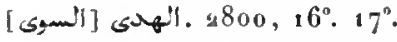

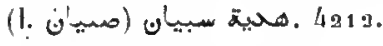

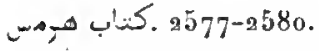

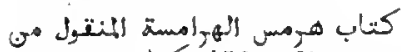

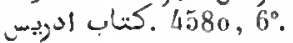

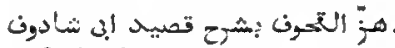
$3267-3270$.

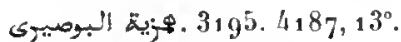
- (Takhmis) 3196 . - (Comment.) $3197.319^{8}, 1^{\circ}$.

. $310,1^{\circ}$.

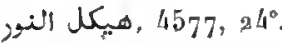

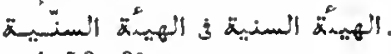
$4253,3^{\circ}$

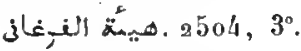

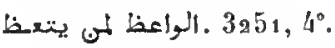

أئمأ (d'Al-Nasafi). — (Comm.) 890 .

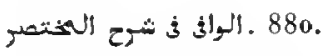

3064-2066.

. $4037-4039$. - (Comment.) $4040.4048,2^{\circ}$.

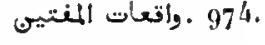

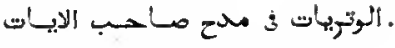

$1057,21^{\circ}$.

• 1057 . الوثائق الفأسية

الوجه الناظر فيها يتنخيه ,لناظلر. $4588,21^{\circ}$.

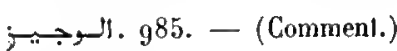
986-995. 103 .

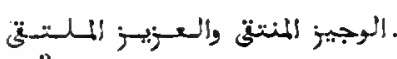
3010.

. 3939 . كنتب الوخحونز

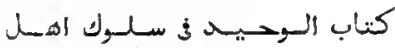
.ا'يتوحيح 3595.

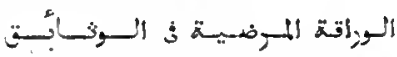
1041 ـوالتعلقات النئرعية

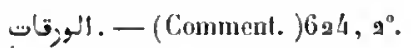
$813.1966,9^{\circ} .139^{6}, 8^{\circ}$.

659 ـ الموسائل أن معرفـة الاوائل $6^{\circ}$.

. -. (Commen1.) (الوسيط 602.

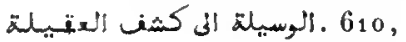
1 .

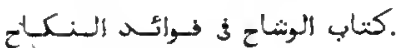
3066.3067 .

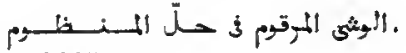
$4435,1^{\circ}$.

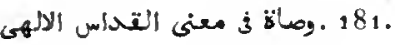

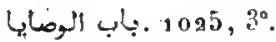

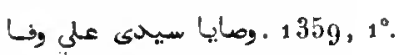

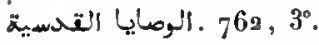

201.

.وصف المواء في كمن أفات الوبـاء. $2687,3^{\circ}$.

كتياب الوصرل الن مسـثـل الامسول. 786 .

281, 3 . ومية Tكم

49, 50 . 309, $10^{\circ} .310,5^{\circ}$.

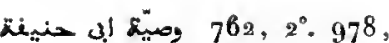
$3^{\circ}$. 1122, $7^{\circ}+1230,2^{\circ}$. 1391 , $11^{\circ} .2316,2^{\circ}, 3^{\circ}$.

. 131 (Comm. 131 . - وصية الادب

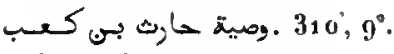
$312,13^{\circ}$.

49, 6 . وصية ستراطيس

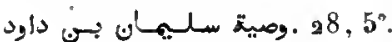
$49,4^{\circ} .310,5^{\circ}$.

• 1607 ـ الموصية الصبوعرية.

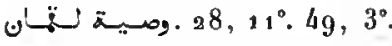
$309,10^{\circ} .310, h^{\circ} .312,12^{\circ}$. $1913,17^{\circ}$.

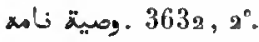

978, 2. $1278,3^{\circ}$. وصيّة السنسبى 97 . $1363,9^{\circ}$. 1913, $16^{\circ}$. 1931, $5^{\circ} .397^{2}, 3^{\circ} .459^{2}, 5^{\circ}$

3668, $1^{\circ}$. وصية نوح

.

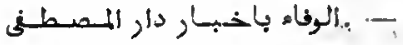
(Abrégé) 1634.

نثون المطانب Voyez .الوفيات.

. وويات رلاعيان وأنباء أبناء الزمان. 2050-2061.

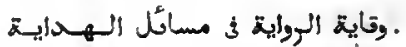
905-907. - (Comm.) 908922.

651, 1ㅇ․

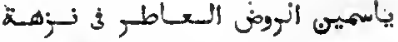
طاطر $3069.3070,2^{\circ}$.

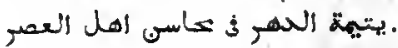
3111. 3308-3312.

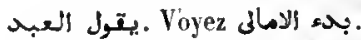

اليهانيات المسلولغ عـلى الــروافسض 1462. 14 . المخذولة الهرافة

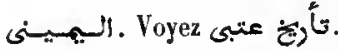

608.

. $17^{6}$. 11 . يواتيت المواتيتيت 


\section{TABLE DES AUTEURS.}

ABbis ibn Ahmad ibn 'Abd alKarím al-Ḥ̆addåd al-Marhoûmi. 2008 .

Aboù '-l-Akвîs (lis. Aboù Bakr Moḷammad) al-Ṣoûli.

Aboù 'I-Agbás TaÁLAB. 445a, $6^{\circ}$.

Al-Abrâsî. Voyez 'Abo al-Ranì ibn Aḥmad.

'ABD AL - Aẓîy al - Mondsirì (Zaki al-Din). 705. $7^{40}$ et suiv.

Abo at - 'Azìz ibe 'Abd al-Salàm at-Solami. $1178,3^{\circ}$.

Abo aL-Aziz [ibn Ahmad] al-Bokhàri (Hosám al-Din). $350 \mathrm{0}, 3^{\circ}$.

ABd AL-Aziz jbn 'Ali bl-0schnohí (Abou๋ 'l-Fadhl). 1037 .

'ABD AL-Azìz al-Kâschî. 3365, $1^{\circ}$. 3366.

Agם aL-Aziz Moḷammad ibn Allmad ibn Sa'id al-Damirî aj-Dîrìní ał-Schâfíî ('Izz al-Dîn). 1313.1457 .

ABD aL-Azíz ibn Molyammad ibn Djamấa ('Izz al-Dìn). 3346.

A вd at-Azíz Moḷammad al-Wafaì (Aboư 'I-Fadhâil). 2365 , $7^{\circ} .{ }_{2} 521,10^{\circ} .9531,1^{\circ}, 2^{\circ}$. $2532,1^{\circ} .2544,7^{\circ}, 8^{\circ}, 15^{\circ}$.

'Aвo Al-'Azíz ibn Sarâyà al-Ḥillî (Șafi al-Din). $2307,6^{\circ}$. $307^{4}$. 3205.3206 et suiv. 3348 , $10^{\circ} .3341 .3418,17^{\circ}$. 3430 . $3953,4^{\circ} .4639,3^{\circ}$.

'Aво AL-Aziz al-Zamzamí al-Yakkî ('Izz al-Dín). 3228 .

Abd $\triangle \mathrm{L}$-Bìcî ihn Yoûsof al-Zarqânî. $1082-1091$.

'Abo AL-Bîaí al 'Aschmâwì. 11 ag. IBx Abd al-Baha (?). 1587 .

ABo al-Dâix. $1057,7^{\circ}$.

Abd al-Duabia ibu 'abd alDjabbår iba Moḷammad al-

Man. ofizmtaex. - 111.
Thàbiti al-Kbiraqi [ lis. al-Kharaqi] (A boû Nohạmmad). 2499 .

Abo al-Guafris ibn 'abd alHamid ibn Noûl! al-Qoûsí. 3525 .

'A Bo AL-GaAfFà h al-Qazwìni (Nadjm al-Dia). 997 .

'Abo al-Ganfoưa al-Lárì. 3257 , $2^{\circ} .4187,2^{\circ}$.

'A bo Al-Ghani. $4187,1 \mathrm{~h}^{\circ}$.

'Amo al-Ganil ibn 'Abd al-Wahid ibn 'Alì ibn abi Soroùr alMaqdisí (Aboû Mollammad). $7^{2} 6.7^{2} 7,1^{\circ} .1966 .2088$.

Abo al-Guani Efendi. $4187,20^{\circ}$.

'A a al-Ganà ibn Ismâ'il alNâbolosì (Zain al-Dîn). ${ }_{16} 6$. $1627.315_{9}$ à $316 \mathrm{~s}$. 3 3. 3 , $x^{\circ}$ à $4^{\circ} .3256$.

Ibn 'Abo al-Hakay. Voyez 'Abo al-Rụ̣mín ibn 'Abdallah.

'Aвo aL-Ḥkì ibn Schams alDín. $1046,6^{\circ} .1242$.

'Aво aL-Haqo ibn Ibrâhim ibn Sabin. $2684,11^{\circ}$.

'A вoìscroồ. 58. 204, 20, $3^{\circ}$.

'Amoìschoû́. $82,5^{\circ}$.

'Abo at-Kaaly ibn Hawàzin alQoschaïrî (Aboû 'I-QÁsim). 1330. 1383

'Aeo al Kaaju ibn Ibrâhîm ibu 'Abd al-Karim tba Khaliffa alDjiti. $1338,6^{\circ}$. 1356 . ${ }_{2} 595$, $1^{\circ}$ et suiv. $3171,2^{\circ}$. 3222 et suiv. 3422 .

'A bo at-Kanì ibe Ismấîl al-'Pluaâlibi (A boù Mansouir). 3956 , $1^{\circ}$.

'Abo aL-Kakin ibn Molammad a]Qazwini al-Ráfíi (Aboú 'l-Qâsim ). 986 et suiv. 1002.1032 .
Áro aL-Kariu [ibn Molummad] al-Sam'aní (A boủ Sád). 2133 .

'Abo al-Karim Zâdè. $4187,12^{\circ}$.

'A Bo AL-Koillen ibn abì 'I-Qàsim al-Miṣni al-Khazradji. $1360,1^{\circ}$.

'Abonleau ibn 'Abhâs. 1141, $4^{\circ}$.

Aracena ibn Abdallah lbn Khordâdhbeh. 2213.

'Agonleau ibn 'Abd al-'Aziz Aboú 'Obaid al-Bakrí. 2218.

'Aballau ibn 'Abd al-Azíz ibn Moúsd al-Sîwâsí. $2844,1^{\circ}, a^{\circ}$.

Aboalla ibn 'Abd al-Raḥmân ibn Djozaĩy. 2086.

'Aeonluar ibn 'Abd al-Tahir (Aboú ')-Fadhli). 1707.

'Abdallail al-Adkawì. 3444, $1^{\circ}$, $2^{\circ} .3445 .3446$.

'Abosecan ibn Alumad (Aboú '।Qasim). $17^{4}, 5^{\circ}$.

'Abonlea ibn almad Ibn alBaitạar. ${ }^{2} 976$ et suiv. $399^{\circ}$ et suiv.

Aroaclaa ibn Alymad al-Maqdisî al-Hanbalì. $2546,2^{\circ}$.

'Abonllan ibn Allmad ibn Mạmoùd al-Nasafi (Hâfiz al-Dî̀ A boú 'l-Barakât). $784,2^{\circ}, 3^{\circ}$. $79^{4}$ et suiv. 890 el suiv. 1176 , $30^{\circ} .1261,1^{\circ}$. 4542, $1^{\circ}$. 4571 .

'Abonlasa ibn Alumad al-Maqdisî tbn Qodáma (Nowaffiq al-Dín). 1104.1107 .1384 et suiv.

'A boarcan ibn Ahtan. 763 .

'Abdalea ibn 'Alî ibn Ishâaq alṢaimari (A boú Moḷammad). 4007 .

'Aboaleas ibn 'Alí ibn Aiyoûb (Djamâl al-Dìn). 3024.

'Aboulla ibn 'Ali ibn 'Ali Sowaid ad-Demlidji. 4114.
'Arosllaa 'Alj ibn Aḷmad al-Hiràli (FakJır al-Dín). 1398.

'Abonllah ibn as'ad al-Yâfít alYamaul (Afif al-Din). 1589 et sniv. a 040 .

'Abdalla al-Bakrî. ${ }^{8} 871,3^{\circ}$.

'Abonilah lbn Barri al-Magdisî (Aboû lloḥammad). 4231, $2^{\circ}$.

'Abonelar al-Bașî̀. 1403.

Aboalla ibn Djibrì ibn Baklitisschoùc. $978 \mathrm{~s}$.

Abdalla lbn aj-Fadh' (Aboû 'lFatl!). $83,6^{\circ}$.

'A вomlar Ibn al-Fadhl. 96 .

Abdalcar ibn Fadhl al-Khabisî. ${ }_{13} 3_{9} 6,5^{\circ}$. 2396 .

'Aboslua ibn Fakhr al Dîn alMausilit. $3078,1^{\circ}$.

'Abdalla ibn Fârisal-Tázi. 1461, $1^{\circ}$.

'Aeoulzau lbn Hischàm aj-Anșârì (Djamâl al-Dín Aboù Moḥammad). 3081 .

'Abonlla Ibn Hidjàzì al-Scliar(qà)î al-Klralwatî. 1860 .

'Abonlea ibn al-Hosain al-'Okbarî al-Faradhî (Moḥibb al-Dìn Aboû'l-Baqa). 630.621.3939,

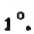

'A bdallä [ibn Khalil] ai-Màridinf (Djamal al-Din). 2525, $1^{\circ}$. ${ }_{2} 531,1^{\circ}$. $2544,15^{\circ} .2547$, $17^{\circ}$.

'A boarla al-Khazradji (Dhiyà al Din). $3955,4^{\circ}$.

'Abeslla ibn Mahmoúd ibn Naudoûd al-Baldadji al-Mausili (DjamâI al-Dìn). 875 et suiv.

'Abdatua ibn Mâlik al-Djaīyânî. $4207,3^{\circ}$.

'Aвodlata al-Ma'moûa. 2640. 
'Abdaleak al-Mảridiní (Aboì 'Abd al-Rạımàn ). 2533 .

Abpallan ibn Moḷammad ihn 'Abbåd. $1201,2^{\circ}$.

'Abon lean ibn Moḥammad [ibn Ahmad]. 4206.

Agpalzan ibn Noluammad ihn Âmir al-Schobrîwì. $2120,1^{\circ}$ à $6^{\circ} .3266 .3443$. 44.4, 3․

Aodilzall ibn Mohammad alBodrì. 2353, $2^{\circ}$.

A Farghanini. 103\%.

'Aboalla ihn Mohammad atlfarawi. 1346 .

Abancara ibn Mohammad ibn al-Khanwåm. 2470.

'Aboaluan ibn Molımmad al-Mlàliki (Aboû Bakr). 2153.

'Ardalean ibn Ilohammad Schâhâwer al-Asadi. $7^{60}, 6^{\circ}$.

Andalsth ibn Molıammad alSchanschoûri. 759 .

Abmalar ibn Moluammad (lisez: Aboù 'Abdallah Moḷammad) al-Tidjảni. 3061 et suiv.

'Abnaleau Jbn al-Maqaffa'. 1344 , $1^{\circ}$.

Abdaluan ibn Maslim Ibn (0)taiba. 1 \}65. 1566 . 4432 .

'A bDallak lbn al-Mo'tazz (Aboû'l'Abbâs). 3087.3 399.

'AdDalua ibn Moûsâ al-Saràqi $1060,9^{\circ}$.

A edsucau Nasr ibn 'Abd al-Axiz al-Zaïdi. 3490 .

'Abdalea ibn 'Omar al-Baïlhàwi (Nàsir al-Dìu). 697 et suiv. $727,2^{\circ}$. 799. 800. 1024. 1255 et suiv. $2369,3^{\circ} .4120$.

'Abdalcan ibn Sa'id ibn abî Djamra al-Azdì (Ahoû Mloļammad). 695 .

Agballair ibn Salàm. $197^{3}, 1^{\circ}$. $197^{4}, 1^{\circ} .{ }_{29} 54,3^{\circ}$.

'A bdaldal Jbn al-Taiyih (AboúlFaradj). 41. 85. 86. $173,17^{\circ}$. $177,1^{\circ} .250,1^{\circ} .252,4^{\circ}$ 2848 .

Aballan Tardjomàn. 1464.

'Aroulcala al-Tidjäni (Aboú Moḥammad). 2285 .

Abosluata ibn Yâsìn. 1202.
'A edallah ibn Yoùsof ibn Hischâm al-Ansårì (Djamal alDin). $1387,6^{\circ} .1620,12^{\circ}$. ${ }_{2}^{6} 677,1^{\circ}$. $4006,4^{\circ}, 5^{\circ}$. $4015,2^{\circ} .4051,3^{\circ} .4077$ et suiv. $4115,2^{\circ} .4144$ et suiv. 4151 et suiv. 4155 et suiv. 4159 et suiv. 4161.4162 . $4191,2^{\circ}$.

'Abdallar iho abî Zaîd al-Qairawảni (Aboú Mohamammad). 1057 et suiv. 4548 .

'A bDalezin al-Ziftâwíl. $4420,2^{\circ}$.

'Abosleak ibn al-Zohair. 1363 , $10^{\circ}$.

Ahoủ 'A gdalda ibu Hamdoún. $1343,6^{\circ}$.

Aboû 'A boalan iłn Hâroûn alSạighl. $1450,3^{\circ}$.

Aboù 'A bdallas al-Nafáánì. 3669, $7^{\circ}$.

Ahoù 'Amonlesa al-Zarq̨aschí. 1874.

'Ano al-Latir ibn 'Abd al-'Aziz ibn $A m i n$ al-Dìn. 886 à 889 . $970,2^{\circ}$.

Agn al-Latir ibn 'Abd al-Aziz Forischta tho al-Malik. 738 . 739.794. $79^{5}$. 4305 et suiv.

Aвo al-Latir al-Asclomâwi. $4420,2^{\circ}$.

'Abd al-Latir ilon Yoùsof alBảghdàdí (Ahoú Mohammad). $387^{\circ}, 2^{\circ}$.

'Aba alm-Nabid. $4639,1^{\circ}$.

['A вD al-UIadid] lbn 'Abdoun. 3127 et suiv.

'Abo sL-Msuix ibn 'Abdallah ihn Bạdroủn. 3127 et suiv.

ABd aL-MaLiK [ibn 'Abdallah] al-Djowaïni (Imâm al-Haranaain A boú'

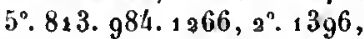
$8^{\circ}$.

'And AL-HaLIx ibn Hischâm (Aboû NInḥatnmed). 1948 el suiv.

'And aL-II Alix ヨl-lsàmi. 1563.

And at-Mhank ihn al-Marwâu. $189^{2}, 4^{\circ}$.

'ABd aL-MaLiK ibn Mlohamuad ibn Ismà'il al-Tháálibî (Aboû Mlansoûr). $1176,35^{\circ}$. 3111. $3401,4^{\circ}$. 3304. 3305, $1^{\circ}, 2^{\circ}$. 3306 el suiv. $3314,1^{\circ} .4201$, $3^{\circ} .4851$.
Ago az-Malix ibn Zohr ibn 'Abd al-Malik (Ahoủ Nlarwán). $2950.2960,1^{\circ}, 4^{\circ}$.

'ABd a L-Masing. 1564.

'Abd at-Masin ihn 'Abdallah ibn Nàima. 2347.

Abs al-Monsws Ahmad ibn alMabdi. $2716,5^{\circ}$.

'Abo al-Mo'iv ibn Almmad Ibu alHakkả al-Balkbìi. 3 / 17, $5^{\circ}$.

'Ado al-Movin (Aboúll-Nááli). $723,5^{\circ}$.

'Abo al-Movias ibn 'Omar ibn Hassân al-Gliassanuti. 3140.

'Asd AL-Monim al-Tindjaní (on alṬandjâni?). $3344,8^{\circ}$.

'ABn AL-Moúy in ihn 'Abd al-Haqq (Taqi al-Din). $\mathbf{2 3} 3 \mathbf{2}$.

'ABd a L-MoĹyix ibn 'Alì (Aboù Nohammad). 1451.

'Ada AL-Dloú un al-Dimyâti (Scharaf al-Din ). 9816.

'A во AL-Motimis al-Jşfahâní (Scbaraf al-Din). $3948,3^{\circ} .3964$, $2^{\circ}$

'A bo al-Qímo ilm Alumad al-'Adjmáwí (Schihâb al-Dìn). ${ }_{9} 578$, $2^{\circ}$.

'Ano AL-QÁnir ibn Ahmad jlın 'Alì al-Fâguihì (Zaïı al-Dîn). 283 ,

'Abd al-QÁda [ỉhn 'Ali] al-Sakhâwî. $2463,2^{\circ}$.

And AL-Qjdors ihn Djâr Allah alA min. 1555.

'A bd AL-Qầmin Efendi Yaländjaq. 2164 .

ABD AL-QÁñn al-GưlânI (ou alDjillàni). $665,6^{\circ} .3171,15^{\circ}$. $3430.4608,7^{\circ}$.

'Aro at-Qida ibn Hosain ibn Moghaizit. $₫ 605,9^{\circ}$.

'Abo al-Qídir ibn Molammad âl-Ansảrì al-l)jazarí. 45 go.

'Abo al-Qidar (ibo Mohyji al-Dín). 2345 .

'Ano al-QẦna ibn 'Omar ibn IIaJjih al-Safadì. 3225 .

'ABd AL-QÁdir ibo abì Sâtilı alHanbeli (Moḥ yî al.Din Aboû Molıammad). $1390,2^{\circ}$.

ABD AL-QÁdit al Sohrawardì (Dhiyà al-Dìn Aboúll-Nadjib). $1337,6^{\circ}$.
'Abd Li-Qádar iba Yeúsol. 974.

'AdD iL-QÂma ibn 'Ald al-Rahmân al-Djordjânl. $2571,8^{\circ}$. $3088,3^{\circ} .3989,1^{\circ}$. 3990 et suiv. $4008,2^{\circ}$. $4021,4^{\circ}$ $4027,3^{\circ}$. 4041, $3^{\circ}$. 4051 , $2^{\circ} .4123,4^{\circ} .4130,2^{\circ}$. 4144, $3^{\circ} .4149,2^{\circ} .4181,4^{\circ}$.

llu 'Abn Rabarit. Voyez Af̣man ilı Mohammad.

'And aL-Ranis ilon Ahmad al'Abhâsî. 4416.

'ABo al-Raṇis al-Baisânt (AlQAdhi al-Fadhil). 3333.

'A go al-Ragị at-Borí (Zaïn alDin). 3113 et suiv. $3156,2^{\circ}$.

'Add at-Ravim ibn al-Hosain alAthîrì al-'Irâqî. $754-756$.

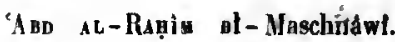
944

Ard ac Ranir al-Mizzt. 2519, $1^{\circ}$.

Abn al-Raṇim ibn Mohammad ihn Ismáill Ibn Nobata al-Fáraqí (Aboù Yahyâ): 1289, , $1^{\circ}$.

Abo al-Ragmin. 1057, 16.1206 , $9^{\circ}$.

Ago AL-Rạnî. $33_{3} 51,9^{\circ}$

'And at-Ranyâr ibn 'Abdallah ibn 'A hd al-Ḥakam ilun A'yán. 1686 el suiv.

'Ano al-Hanmis ibn 'Abdallah at Sobailì (Aboú'l-QAsim) 1960 et suiv.

'Abd at-hanañ ibn 'Abdal-Malik lbn al Sảlih al-Hâschiml. 214 , $3^{\circ}, 215,3^{\circ}$.

'Adu al-Rạ̣mà ibn 'Abd al-Salam al-Safoưrí. 3554 el 3555.

Abd al-Raguí ibn Alumad ibn 'Abd al-Ghaffär al-Siddiqi ("Adhod Bl-Din). 4253, 2.

Ada al-Ragmás ibn Ahmad alDjàmî (Noùr al-Din).' 1370 . 3152 . 4044 et suiv. $4187,2^{\circ}$.

"Aín al-Rạnañ [ibn Ahmod] alHomaïdî. $33_{3} 38,3$ 3 $48,11^{\circ}$. $3417,3^{\circ}$.

'Abp al-Ranuir ibn' ahmad alÎdji ('Adhod al-Din). 801. $809,10^{\circ} .1262,1^{\circ}$. 1263. $1264,1^{\circ} .127^{8}, 1^{\circ}$. 2391 . 2392 et suiv. 4493 et suiv. $4577,13^{\circ}$. 
TABLE DES AUTEURS.

'A BD A-Ranañ ibn Alimad atIsfahànî. $2369,1^{\circ}$ 。

ABd al-Ruguis ibn Alumad ibn Radjab (Aboù'J-Faradj). 2454 .

Аво xL-Rạuś ibn Ahmad alRàzî. $3338,2^{*}$.

'A во ar-Ranian ibn 'Alí (Mohaddsib al-Dîn). $2835,3^{\circ}$.

'Abd al-Raumân ibn Alî ibn alDjauzî ('Djamâl al-Din Aboû'lFaradj Aboûl-Qâsion). 724. 725.1295 et suiv. 1550.1567 . $19^{51}, 7^{\circ} \cdot 2030$ et suiv. 2033 et suiv. $3543,2^{\circ} .3547$.

'Aв a R-Ramiñ ilon 'Alî al-Makoûdi (Aboú Zaïd). 4096 et suiv. 4128 .

"Abo al-Mhạir ibn 'Ali ibu abí Sảdiq (Aboú'I-Qásim ). a 838 et suiv. $285 \%$. 2861 et suiv.

'Abd at-Bannấ ibn 'Ali al-Schaibânî al-Dibar (Walı̂̀d al-Dîn). 730 .

'Abo al-Rạnin ihn abî Bakr alDjaubarî. 4640.

Agd al-Raduin ilm abî Bakr al-Soyoùlì̀ (Djalâl ol-Dîn). 65 a ct suiv. $665,3^{\circ} .7^{4} 8,3^{\circ}$. 766 et suiv, $1160,5^{\circ}, 6^{\circ}$. $1178,1^{\circ} \cdot 1371$. $1389 \cdot 1390$, $1^{\circ}$. $1546,3^{\circ}$. 1552. 1608 . 1609 et suiv. 1794 et suiv. $1832,3^{\circ} .1871,1^{\circ} .1978$. $1997.2016,1^{\circ} .2043 .2079$. 2094. 2119. 2266 et suiv. $2677,18^{\circ} .2800,1^{\circ}$ it $14^{\circ}, 18^{\circ}$ à $22^{\circ} .3060,3^{\circ} .3066$ et suiv. 3068 . 3154, 50. 3207, $3^{\circ}$. 3а24. 3364, $0^{\circ}$. 3406.3407. 3408 . $3432,2^{\circ}$. 3502, $4^{\circ}$. $3513,2^{\circ} .3521,2^{\circ}$. 3552. 3949 et suiv. $397^{2}, 1^{\circ}$ à $10^{\circ}$. $397^{3}, 12^{\circ}$. 3984 et suiv. $407^{4}, 2^{\circ} .4110$ et suiv. 4124 , $7^{\circ}$. 4158. $4195.4253,3^{\circ}$. $4261,16^{\circ}, 17^{\circ}$. 4472. 4585 , $6^{\circ} \cdot 4587 \cdot 4588 \cdot 4591,11^{\circ}$ à 13․ $4608,5^{\circ} .4611 .4658$, $1^{\circ}, 2^{\circ} .4659$.

Abo al-Raçmin ibn Renefschà (Aboû Horaira). $\$ 521,9^{\circ}$.

'Aво á-Ranquá Efendi, $3 ₫ 47,1^{\circ}$. $-11444$.

Abd al-Ranuas ibn Hasan alDjabarti. 1861 et suiv.

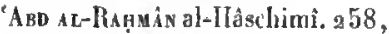
$96^{\circ}$. Firkảh. 1 a $66,2^{\circ}$.

'Abo al-Raṇmix [ilon 'Isâ] alMorschidi al-Omari (Hanif alDin ). $2679,2^{\circ}$.

'Aвo at-Ranuír ibn Ismầil alMaqdisí (Schilaâb al-Dîn Aboù Schâma). $1620,3^{\circ} .1700$ et suiv. $3141,1^{\circ}$.

'ABD AL-Riнмí al-Mahallî. 1048.

'A gd aL-Ranuấn Ibn Makánis (Faklir al-Din). 3210 et suiv.

'And a c-liangân ibn al-Mlóammar al-Wàsiti. $4577,5^{\circ}$.

'Ab at-Rapmí ibn Mohammad ibn "Ahdallah al-Anșấî al-Dabhậ̣̂̂l. 2154 .

'Aab at-Rạnuis [ilon Molıammad] al-Akhdharit. 2402 et suiv.

'Abd al-Rahaí ibn Mohammad Amtluâli. $4281,1^{\circ}$.

'Agn al-Rangin ibn Mohammal al-Anbấrì (Kamâl al-Din Aboû'] Barakât). $1013,4^{\circ}$.

Abo aL-Runuîn ibn Mohnammad ilın 'Ali al-Ristàmi. $1363,16^{\circ}$. 2338. 2686 et suiv.

Aed al-Raṇmây ibn Mohammad al-Fảsi (Ahoủ Zaỉ). $1203,3^{\circ}$.

Agd at-lhagnân jon Moliammad Ithn Kbaldoûn (Aboù Zaid). 1515 et suiv. $2684,2^{\circ} .{ }_{2} 693$, $1 \%$

'Aad at-linumin ibn Mohanmad al-'Omarî al-Alînî (Morjîr al-Din Aboû'l-Yann). $1671 \mathrm{et}$ suiv.

Aqu al-Raumâs ibn Mohammad ibn Salaimàn Schaïh Zàdè. 965 et 966 .

'ÁD at-llapunas ibn Molyammad ibn Makhloûf al-Tha ălibi. 646 . $648.1187,2^{\circ} .1546,7^{\circ}$.

And al-Rạnâx [ibn Moluammad] al-Tâdjoúri al-Maghbribi. 2560 $1^{\circ}, 4^{\circ}, 5^{\circ}, 10^{\circ} .4580,5^{\circ}$.

'Abu at-Rianâr Moliammad alTourkoumánî. 1696 .

"Aad al-Rạmin ibu Maștafä. 4450 .

"Abd at-Rап̣mĩn ibn Moṣtafa al'Aïlaroús. 3262.

Abo al-Ra!nây ibn al-Mo'ayyad al-Amâsî. 948 .

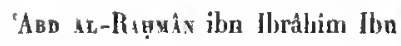

"Abd a linamix ihn Naşr ibn 'Abdallah al-Sclıîrâzî. 2438. 3053 .

Ano a-Ranuás ibn omar alSoûfi (Aboùl-Hosaïn). ะ33o, 2. 2488 et suiv. 2493.2498 , 20

'Abd al-Mhanan Pacha. 1394.

Abd at-Ragmán ibn al-Qàsim. $1050,1^{\circ}$.

'Abd al-Rianâx al-Raqii. 1061, $3^{\circ}$.

Aro al-Ragimin al-Salihịí. 2496 , $a^{\circ}$.

"Aro al-Rạ̣mis al-Ṭanâní. 2553.

Aan as-Raguîn al-Tilimsâní (Abuâ Zaïd). $1061,3^{\circ}$.

'Abo al-Raụin al-Zíraf(?) (Aboú Zaïd). 2568, $3^{\circ}$.

'Ano al-Rícr Mohammad alManåwî. 768 et 769.777 . 1045. $1046,1^{\circ} .1957,1^{\circ}$. 2236. 2768 et suiv. 4262 .

'Abd al-Rascnì Sâlih ibn Noûrî al-Bấkawî. 3246 et suiv.

Ado at-Razzầ jon Rize Allâb ibn abill-Ilaidjà al-Raśanî ('lez al-J)în). 62a.

'Add ae-Razz Âa al-Kàschî (Kanâl al-Dîn Aboủ'l-Ghanảim). 1346. ${ }^{3} 34,1^{\circ}$.

'A bo al-Salàm ibn 'Abd al-Rahmân al-Lakhmî llı̀n Barridjăn. 2642 .

'Abd al-Satím ibn Ahmad ibn Ghânim al-Maqdisî("Izz al-Dín). $1641,2^{\circ}, 3^{\circ}$. $2307,2^{\circ}$. 3521 el suiv.

'ABD aL-SaLÀ ibn Ibrâhìm alLoqâaî. 128 , et suiv.

'Abo al-Șamid (Zaïn al-Dín). 2019 .

'ABd aL-Wangí ibn Ahmad alSchairânî (ou al-Scha'rấii). 814. $815.1248,4^{\circ} .1641$, $4^{\circ} .2045 .2348,3^{\circ} .2405,1^{\circ}$. $3016,2^{\circ} .3234 .4111,2^{\circ}$.

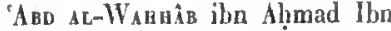
Wahbån. 4572 .

Abo a - Wanhâb 'Ali ibn 'Ali. 707 .

'Aad at-Wanaá íbn 'Alî ibn 'Abd al-Kảfi al-Sobkî (Tadj al-Dîn Aboú Nașr). 803.804 .810 .
2100 et suiv. $2447,10.3244$, $2^{\circ}$.

'Áo aL-Waнhấb al-Bennúnì (lis. al - Benwånî) (Tâdj al - Dîn). $4454,1^{\circ}, 2^{\circ}$.

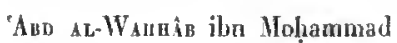
al-Khatî̉b Ibn al-Ghanurî. 3 302 et suiv.

ABd at-Wạndo ibn 'Abd al-Raz zåq. 2947,4 .

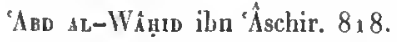

'Abe al-Wâhud ibn Mohammad. $2511,2^{\circ}$.

'A ab al-Wần [ihn Mohammad] al-Amidì al-Tamîmì. ^502, $14^{\circ}$.

AI-Aвdaî. Vojez Mopamad ibr Vohammad.

Ibn 'Arooún. Voyez "Abd al- $\mathrm{M}$ จง วิ๊

Al-Abuari. Voyez Mofabohat ibn 'Omar.

"ABìd ibn al-Abras. 3075, 11 ". 3070 .

Al-Auriri. Voyez Mohamand ibn Alimad.

AI-Abiwardí. Voyez Anmad alAbîwardí et Монамия ibn Ahmad.

Aruoto Șabagh 4610.

Aunanar le protospathaire. 135 et suiv.

Anbâ Aвraha de Tibériade. $214,2^{\circ} .215,2^{\circ}$.

Al-A вschîní. Voyez Monamad iわ Alımad.

Al-Ansi. Voyez Marșoúr al-'Absí.

Accorensis (Victorius). 4338 .

Al-Adawí. Voyez Moganand ibn 'Tallua.

Al-Amamî. Voyez Ag̣mo Elendi.

lbn al-Abìm. Voyez "O Djaráda.

Ibn Aosixâ. Voyez Monamad ibn abî Bakr.

Al-Aosuoứnî. Voyez 'Alî̀ al-Adjlloûrì.

Al-Adjlaûnì. 1672 .

Al-Adraíwí. Voyez 'Abo al-Qídr ibn Alimad.

Al-Ẩosonî. Voyez Moвамuad ibn 'Ali.

Ibn-Apjoraóve. Voyez Hohamma 
ibn Dâ'oủd et Mopasmad ibn Mohammad.

Al-Adjroúd. Voyez Al-Hasan alAdjrouid.

Al-Ankíwi. Yoyez 'Abonllah alAdkâwî.

"Aorir ibn Naşr al-Aïn-Zarbì (Aboû Nașr). 2956.

Al-Advivi. Voyez Moganuad ibn abî Bakr.

AdYAM SAGAD, roi d'Abyssinie. 3.1.

Afoual al-Kâschi. 2530.

A-Arschandil, Yoyez Mạmoúd ibn Dảoûd.

Al-Arfasî. Voyez Moyaman ibn Ilohanmad ibn Hibat-Allåh.

Agapies, moine du mont Athos. 323.

Al-Agubarí. Yoyez Dâ'oủd ibn Nâsir.

Al-Audaz. Voyez Al-Hosaiv ilun 'Abd al-Rạ̣mân.

A ỵM AD. 2192.

Auman (Schaikh). $119^{3}, 7^{\circ}$.

Aỵmad ibn 'Abbåd ibn Scho'aỉb alQanâi (Qonnầi?). 2357, $5^{\circ}$.

Aнุ

Ạ̣mad ibn 'Abd ał-Dâim al-Ansấrì. $1889,1^{\circ}$.

A ̣̣man ibn 'Abd al-Fattáh al-Maławî. 1131. \$377, ${ }^{\circ}$. 4426 .

A ̣̣mad ilon 'Alod al-Ghaffár (Schihàlh al-Dín). 4195.

A guman ibn 'Alodallah (Aboũ Djaefar). $2457,30^{\circ}$.

Ag̣mad ibn 'Abdallah al-Bakrì (Aboû'l-Abbas). $1871,4^{\circ}$.

A ̣̣má ibn 'Abdallah al-Bornoụṣi. $1892,6^{\circ}$.

Aụa ibn 'Alodallah al-Djazâirì (Aboù']-'Abbås). 1268. 3442, $7^{\circ} .4585$.

Ạ̣ad ibn "Abdallah al-Iṣfahàni (Aboú Nơaïm). gog8 et suiv.

Aต̣xad ihn 'Abdallah al-llâridinî. $2547,4^{\circ}$.

A ụm ad ibn 'Abdallah ibn Holıammad al-Râzi (Ảboû'l-'Abbâs). 1643.

Aụman ibn 'Abdallah ibn Mohammad al-Tabari (Nohibb al-
Din Aboủ Djáfar). 793.1546 , $5^{\circ} .1571$.

Aт̣м мп [ibn 'Abdallah] Ibn Zaidoùn (Aboî'l-Walid). 3315 et suiv.

Aq̣MaD [ibo Abd al-Halím] ibn Taimiya (Taqî al-Din). 914 , $3^{\circ}$. 215, $8^{\circ}$. 2/443 et suiv. g962, $2^{\circ} .3412,2^{\circ}, 4^{\circ}$.

Aṇmad ibn 'Abd al-Latif al-Bischbischi. 1394 .

Aỵan ibn 'Abd al-Mon'im alSchabrìsî al-Wâsitì (Schibâb al-Dîn). 2036 .

Angan ibn 'Abd al-lloúmin ibn Mloûsá al-Sclıaríschì (Aboûl'Abbås). 3940 et suiv.

A ̣̣mad ibn 'Abd al-Qâdir Roủmî Efendi. 1393.

Aṇma ibn 'Abd al-Raḷîm al-'Iråtî (Aboû Zor'a). 999 .

Ạ̣má ihn 'Abd al-Razzåq a]-Ṭantarànî. $1160,9^{\circ}$. $9405,4^{\circ}$. $3088,2^{\circ} .3116$

A ̣̣mad al-Abiwardi. 2378 .

Aพ̣mad ibn Alimad ibn 'Abd alLatif al-Schardji al-Zobaidi (Schihâb al-Dìn). 765 .

Ạ̣мaD ibn Ahmad al-Bornisî. 1380 .

Ạ̣man ibn Aḥmad ibn 'Îsà alFasî Zarroúq. $3971,1^{\circ}$.

Aạmad ibn Aḷmad al-Kordi. $2677,7^{\circ} \cdot 2716,7^{\circ}$.

Aậa ibn Aḷmmad ibn Noḥammad al-Adawi. 3258.

Aụmad ibn Ahmad al-Sadjâ'í. 4094 .

Aнุмa Risí ibn Aḷmad al-Timboukt\}. 4628 .

A ุ̣ ติ [ibn 'Alì] al-Boùní (Schihàb al-Dín Aboû́l-'Abbås). $743,6^{\circ} .1225$ et suiv. 2595 , 6. 3646.2647 et suiv. 2656 . a657 et suiv. 8659. 2763 , $2^{\circ}$.

Aỵa ibn "Alì lbn Hadjr al-Asqualànî (Schihâb al-Dìn Aboû'lFadhl): 697. 744, 8. 760 , $1^{\circ} .761,1^{\circ} .1176,24^{\circ} .1587$. 1601 et suiv. 3077.9098 . 3149. 3319. 4151, 5, $7^{\circ}$. $4257,2^{\circ}, 3^{\circ}$.

Ạ̣mad ibn 'Ali al-Hamdåni Ibn a)-Fașih. 904 .
Ạ̣mad ibn 'Ali Ibn al-Hariri. $2234,2^{\circ}$.

Ạ̣mad ibn 'Alî al-Khoûlıi. 3973 , $1 \%$.

Aṇad ibn 'Alì al-Maqrizi (Taqi al-Din). 1795. 1796 et suiv. 1799 et suiv. $2144.3543,3^{\circ}$. 4657 .

A $4123,8^{\circ} .4166$ et suiv.

A ب̣mad ibn 'Alî ibn Molıammad al-Qoraschî. 3545.

Aq̣and ibn 'Alî ibn 'Othmân. 636.

Anuıd ibn (Schaikh) 'Alì al-Qãdhî 'Ảrikân (Nizâm al-Dìn). 1344.

Atyusd ibn 'Alì Ibn al-Săâti (Mozaffar al-Dín et Borhân alDin). 881 et suiv. $97^{\circ}, 2^{\circ}$. 1260.4543 et suiv.

A pqu sp ibn 'Ali al-Sandoûb' (Schihảb al-Din). $3244,1^{\circ}$.

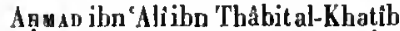
al-Baghdádí (Abon Bakr). 2128 et suiv.

Ạ̣mad ibn 'Alwân. 3227.

Aạman al-'Anáyàtî. $3418,19^{\circ}$.

Ạ̣uad ibn 'Ața Allah (Aboûll'Abbás). 4581, 50.

Ạ̣mad al-Badrî. 3442, $6^{\circ}$.

Ạ̣mad al-Bahloûl. 1 ๖3o, $7^{\circ}$.

Aru an ibn abì Bakr ibn Khalîl al-Tabaránî (Aboîl-'Abbâs). 1516 .

Aq̣uco ibn abl Bakr ibn Mohammad Nakbdjowåni. 2936.

Aṇad ihn abî Bakr ihn Mohammad al-Raddåd. 3677 , $13^{\circ}$.

A н̣мıD al-Baschschâri al-Hafnâwi (Schibåb al-Dîn). 3448 et suiv.

Ạ̣u a al-Bodjâ'î (Schihàb al-1)ị̣) . 306 .

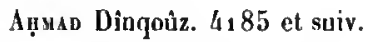

A ̣̣má al-Ijauhari. 783 .

Ap̣man al-Dolandjảwi. $3185,2^{\circ}$. 3260 .

A ỵua Efendi al-Adbami. 3245.

A ̣̣m an al-Fâkihì (Schibâb al-Dîn). $45_{2}$ et suiv.

Alimad ibn Fàris. 4247 et suiv.
Aụmav ibn abì '1-Gbaith Ibn Naghltâi. 4431, $1^{\circ}$.

Ạ̣ma al-Ghamri (ou al-Ghomrì) (Aboû̉'-Abbås). 2619 et suiv.

Aaman al-Ghobríni (Aboûl'Abbås). 2155.

A ̣̣mad ibn Gholån Allâh al-Koúm a]-Rîschl (Schihåb al-Din). ${ }_{2} 5.6$ el suiv.

A بุмa ibn Gbonaìm ibn Sàlim (Schihâb al-Din). 1063 et suiv.

Ạ̣min al-Ghonaïmí. $4111,2^{\circ}$.

Aṇmá ibn Hadjar al-Haïthami al-Makkî (Schilıâl, al-Dín). $71 /$ et suiv. $748,1^{\circ} .953$. $1553,1^{\circ}, 2^{\circ} .1,54,1^{\circ} .3197$.

A ̣̣mad ibn Hamdân al-Adsra'i (Schihâb al-Din). 1005.

Ạ̣uá ibn Hamdân ibn Schabíb al-Harrâni (Nadjom al-Dîn). a 323 .

Ag̣ A a al-Hanaff. 4537 .

Aụman ibn Hasan al-Khatib. $29^{49,} 3^{\circ}$.

A ụmá ibn al-Hasan ibn 'Alt ibn al-Khatîb ibn al-Qonfouds (Abou'l-'Abbås). 4629.

Ap̣sıo ibn al-ḷasan al-Tschárabardi (Fakhr al-Din). 4060 et suiv. 4,43 .

Aṇan ibn Hibat-Allâh ibn Sa'd Allâh a]-Djabrâní (Tàdj alDîn Aboúl-Qảsim). 4067 , $1^{\circ}, 3^{\circ}$.

Ạ̣man al-Hidjâzf (Scluihâb alDin). 2961 .

Ạ̣s ibn al-Hosaîn al-Hamadànî (Badì al-Zamân AboûlFadhl). 2147, 2". 3923.

A Hyan ibn al-Hosain al-Khnsroûdj̉irdî al-Baihaqî (Aboù Bakr). 753.4593 .

Aṇya ihn al-Hosaïn al-Hotanabbî. 3091 et suiv. $3137,3^{\circ}$. $3300.3418,13^{\circ} .4663,1^{\circ}$.

Аทุ หมะ ibn al-Hosaīn al-Schaqqâq (A boù 'Abdallah). a462.

Agma dibn Hosain al-Ramli (Schihâb al-Dîn). 800 .

A ̣̣Ma o ibn lbrảhìm (Mohyî ał-Din Aboû'l-'Abbâs). 975 .

Aหุษ ibo Ibrâhim al-Azdí alQoschtàli. 3486, $5^{\circ}$ 


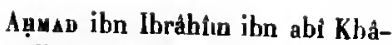
lid Ibn al-Djazzâr (Abou Dja'(ar). 2884 .

Aพ̣mav ibn Ibrâhîm ibn Khalil al-Ḥalabi. $2524,10^{\circ}$.

A ạmad ibn Idris al-Ṣinhàdji alQarâfi (Schihảb al-Dìn). $1013,5^{\circ}$.

Aṇyad Ibn al-'Tmàd (Schibàb alDỉn Aboû'l-'Abbảs). $\quad 2039$. 3960 .

A ̣̣̣ Ad ilon 'Îsâ. ${ }_{2563}, 23^{\circ}$.

Aṇuad itn Khalaf al-Kalài alỊaufi (Abon̂̀]-QÁsim). 1075.

Aṭ̣ad ibn Khalì al-Fảkhoûrî. $2594,1^{\circ}$.

Aṇma ibn Khalìl al-Khowaïyi (Schihab al-Din). 6:3. (Schams al-Din). 233 \& et suiv.

A ̣̣mad ibn Khalil al-Sobkî. 3 924. Ạ̣mad al-Khâmì. $743,15^{\circ}$.

Ạ̣mad al-Khațib (Aboù'l-'Abbảs). 4616 .

Ạ̣mad al-Khodjandî (Djalàl alDîn Aboû Tâhhir). 3289 .

A พ̣qad al-Lakhmî (Aboú'l-Abbâs). 747.

Ạ̣man ibn Madjid ibn Mohammad... ibn Ma'laq al-Sa'di ibn abîl-Rakâib al-Nadjdi (Schihâb al-Dìn). $229^{3}, 1^{\circ}$, $6^{\circ} .2559,5^{\circ}$ \& $8^{\circ}$.

Aạman Ibn al-Madjdi (Schibâb al-Dín Aboúl'-Abbás). 2531 , $3^{\circ} .2547,3^{\circ}$

Aạyad al-Maghribi. 2 to6.

Aṇmad ibn al-Mahdì al-Ghazzàl al-Fàsî. 2397 .

Aạmad ibn Mahmoùd al-Djondi. 4003.

Ạ̣mao ibo Mabmoûd al-Harawi (Maulàná Zádè). 2360 et suiv.

A ạmad al-Nalawí (Schihàb alDin). 1288. 2403 et suiv. 4428. $4439,1^{\circ}$.

A ̣̣yad Ibn al-Yanfah! Ibn 'Olwàn (Nadjm al-Din) 2842 .

Ạ̣mad al-Marrákoschì (Schiháb al-Din). $2693,3^{\circ}-4^{\circ}$.

Anuad ibn Marwân al-Daünawari at Mâliki (Abon̂ Bakr). 3481.

Aṇuá ibo Masoúd. 2120, $4^{\circ}$. A ̣̣vad al-Mlodjirì. $4097,2^{\circ}$.
Ạ̣ma ibn Moḷammad al-A Abbåsi. $4431,3^{\circ}$.

Ag̣mad ibn Nolammad ibn "Abd al-Djalit al-Sidjzi. $2457,10^{\circ}$, $27^{\circ}, 28^{\circ}, 32^{\circ}, 46^{\circ} .9458,1^{\circ} \mathrm{a}$ $3^{\circ}$.

A pumad ibn Molyammad ibn 'Alud al-Karìm Ibn 'Atá Allàh alIskandarànì al-Schâdsili ('Tàdj al-Dín). $\$ 348.1349$ et suiv.

Ạ̣ma ibn Molyammad Ibn 'Ahd Rabbihi. $3{ }_{2} 87$ et suiv.

A ỵmad ibn Moḷammad ibn 'Abd ał-Ralımân. $1303,5^{\circ}$.

Ap̣vad ibn Molnammad ibn 'abd al-Salàm al-Manoùfi. 2078.

Aṇmad ibn Moḷammad Ibn 'Alawiya al-Schadjari (Djirảb alDaula Aboù'l-Abbàs). 35 27.

A ưa ibn Mohammad ibn Ali - ibn Zighlàn al-Maghribî. 3243.

A ̣̣mad ibn Mohammad ibn Aḷmad al-Azbari al-Khàniqìi. $2547,7^{\circ}$.

Ansad ibn Nohammad ibn 'Ali ibn Imâd Ibn at-Hämm (Schihåb al-Din). $2475,4^{\circ}, 5^{\circ}$.

A ana ibn Noliammad lbn 'Arabschah. tgoo et suiv. 3524. 3535 et suiv. $4663,6^{\circ}$.

AḤyad ibn Mohammad Ibn alAscheath. $284^{\circ}, 1^{\circ}, 2^{\circ}$.

[Aḷmad ibn Nohammad] al-Arradjàni (Aboù Bakr). 3418, $9^{\circ}$.

A ̣̣mas ilon Mollammad ibn abi Bakr. $3: 90$.

Ạ̣mad ibn Mohammad al-Bornoùșî. $1193,5^{\circ}$.

Aạmad ibn Mohammad ibn Djafar al-Baghdàdi al-Aqta'. 834 .

Aụman ibn Mollammad al-Ghazâli (Djamâl al-Islàm). 1318 , $2^{\circ} .4580,3^{\circ}$.

Ap̣mau ibn Iolammad al-Ghaznawif. $606,5^{\circ} .853 .853$.

Aн̣ма ibn Moḷammad al-Iläim al-Salami al-Mansoùri (Schibâb al-Dìn). 3 ×2. $4585,5^{\circ}$.

Aạmad ibn Molanmad Ibn alHäim (Schihẩb al-Din Aboù'l'Abbâs). 1034 . 1035.1036. ${ }_{2} 47^{1}$ et suiv. $4162,2^{\circ}$.

A ạas ibn Mohammad al-Kalàbâdsì (Aboủ Naṣr). 2086.

A ̣̣mad ibn Nolamamad ibn Kathìr al- Farghhâni (Aboû'l-Abbàs). $2504,3^{\circ} .2546,5^{\circ}$.

Aṇmad ibn Moḷammad al-Khafâdji (Schibâb al-Día). a đิs et suiv. $3{ }_{2} 50,1^{\circ} .33_{2} 5,2^{\circ}$.

A หุuso ibn Mohammad ibn Khallikån (Schams al-Din). 2050 et suiv.

Aq̣uad ibn Mcluammad al-Loboûdi (Nadjm al-Din). 2918 , $i^{\circ}$

Anuav ilon Mohammad Aboû']Ma'àli al-Koûfi. 3834 et suiv.

Ạ̣man ibn Jloḷammad al-Hlaghn:sầì (Aboù']-IIounlahi). 2229 .

Aṇmad ibn Molıammad at-Ilatıimili. 1038

Apurad ibn Molammad al-Vaidâni (A boù'l-Fadhl). 3958 et suiv. 4000 . 4284 .

Ạ̣mad ibn Mloḷammad ibn Makkî al-Qamoûlì (Nadjm al-Din). 1036 .

Ag̣uad ibn Nolammad al-ylaqdisi (Djamál al-Dỉn Aboù Maḥmoúd). 1667 et suiv.

Ạ̣mad ibn Moḷammad al.Yaqqari. 2882 et suiv. $3944,2^{\circ}$. 3245 .

Alımad ibn Nohammad al-Maqrizi (Taqi al-Din). $3244,5^{\circ}$.

Ag̣map ibn Molıammad Ibn Maskawaïh. 3957 .

Aumas ilm Nolammad al-Matboúli. $7^{6} 7$

A pavad ibn Noluammad al-Qastalâni (Sclibảb al-Din). 70 . 702. 979 .

Aỵy an ibn Mohammad lbn Qolaita (lbn-Folaita?). 305 z et suiv.

A unma ibn Molammad lbn abi'lRabi'. 2448.

An!mad ibn Molıamuad al-Schomonnì. $1957,3^{\circ} .4626$.

Ạ̣man ibn Nolıammad al-Sidjistảnì. 3085 .

Iụma ibn Ioluammad al-Sikandarì (Tàdj al-Din). $2450,4^{\circ}$.

Aṇmà [ibn Noliammad] at-Silafi (Áboú Țảhìr). $722,2^{\circ}$.

A ỵmá ibn Noluammad al-Thálabù ( $A$ boủ Islỵàq). 1913, $2^{\circ}$. 2918 et suiv. 1923.
Aụmad ibn Molrammad ibn alWalid ibn Wallâd (Aboùl'Abbâs). 4834.

Ạ̣mad ihn Moḷammad ibn Yalıyà al-Bokhảrí. $760,2^{\circ}$.

Ạ̣Map ithn Moḷammad ibn $\mathrm{Ya}^{\circ}$ qoùb. $44_{1} 4$ et suiv.

Aหุмaо ibn Molrammad al-Zăhid (Schihåb al-Din Aboư'l-Abbâs). $665,2^{\circ}$.

A ỵmad ibn Moluammad al-Zálini (Djamàl al-Dìn). 750 .

Aq̣and ibn Molrammad al-Zarqâni. $1079 \cdot 4147$.

Ạ̣na ibn Nolnammad Zarroùq al-Bornosí. $3_{17}, 3^{\circ}$.

Aụvad ibn Nobammad at-Zili (Aboù'l-Thaná). 4006, $4^{\circ}$.

Aṇsad ibn Montaṣer. 2563, $9^{\circ}$, $3^{\circ}$.

Aṇmad al-Moqrì al-Fàsi (Schihàb al-Din). 1547 .

Ạ̣mad ibn Joṣtafa La'li. 23:4,

A ḥmad ibn Mostafâ al-Nuálikí alAzhari al-Șabbâgb. 4473 .

A ̣̣mad ibn Moṣtafâ Tâschkeuprizâdè. $1134,4^{\circ} .1278,5^{\circ} .2157$ et suiv. $4606,3^{\circ}$.

A ̣̣mad ibn Moùsá. $2467,3^{\circ}$.

Aṇmad ibn Noúsà ibn abd alGhaffàr al-Màliki. $347^{2}, 1^{\circ}$.

Angad ibn abi'l-No'ayyad alHamoùdi al-Nasafi (Abou Nasr). 8 a 0 .

Ap̣as ibn 'Obaïdallah al-Mabboủbi (Sadr al-Scharía). 933.

Ạ̣mad ibn 'Omar al-Hindi (Schibàb al-Din). 4054.

Aụa ad ibn 'Omar al-Khaiyoùqi (Nadjm al-Din at-Kotrà). $1343,2^{\circ}$.

A ̣̣mad ibn 'Othmân al-Qaîsi (Fatl al-Din). 3007 .

Aṇmad ibn 'Othmảu al-Scharnoùbi. 1361 et suiv.

Aq̣as Pacba. 1119 .

A p̣yad al-Qdidiri (Mohyì al-Dìn). 3430 .

Ạ̣mad Ibn al-Qâsim at-Andalosi Ibn Khaloúf. $3 \log 8,3^{\circ}$.

Ap̣mà Ibn Qàsim al-'lbàdi (Schibàb at-Din). 4log et suiv. 
A ỵas ibn al-Qàsim ilın Khalifa... Ibn abi Osaibia ( Nouwallin al-Din). 2113 et sniv.

Aỵa Ibu Qunfods. $1546,2^{\circ}$.

A luvan ihn [Radjab] Ibn al-Madjdi (Schihảl, al-1)in Aboû ']-'Abbås). $1031.2541,7^{\circ}$

A!nu ibn Radjab al T'anboghıa (Schihâb al-I)ỉn). 2533.

Ạ̣man al-Ramaadhànt. $3431.10^{\circ}$.

Ạm.d ibn Rascbid al-țanhali. 2299.

Auma iln Sa 'd al-Din al-Ghomri in]-Oothunâni. $1850 \mathrm{el} \mathrm{suiv.}$

Anvad iln Sarid al-Bodjini alZawàwì al-Schàt. $4565,1^{\circ}$.

A numad [ibn Salàma] al-Qalyoúbi (Sclibib al-Din). ${ }_{27} 54.3016$, $2^{\circ}$. 3034, $3^{\circ}$. 3044, $1^{\circ}$. 3559 et suiv.

A ̣̣mad al-Scharqî̀ al-Ṣafàysì. 3551 .

A ห̣sa ibn Schilına (Aboù ']-Walid). 935 .

Aṇหun al-Sibti (A boú 'J-Ablàs). $9684,1^{\circ}$.

Anyad al-Solırawardi (Scbilıàb alDin $) .9644,1^{\circ}, 2^{\circ}$.

A ̣man ibn Solaïmán lba Kamàl Pacha (Scliams al-Din). 798. $861,5^{\circ} .9^{17}$ et suiv. $9^{32}$. 2399. $4187,: 3^{\circ}, 7^{\circ}, 9^{\circ}, 10^{\circ}$. $4261,13^{\circ} .437^{\prime}, 1^{\circ}, 9^{\circ}$.

A A mín al-Soủdàni. 4141.

A ụmo al-Ṭabaschàwì. 2705, $1^{\circ}$. L!̣mad al-T'̉zeri (Aboủ J-Abbàs). $4534,2^{\circ}$.

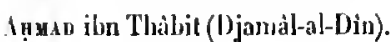
2474 .

Ạ̣uro ibn Torki ibn Alumad. 1129 .

Aụmad ibn Yadyâ ihu Fadh Mllàh al-'Oniarì (Schilıàb al-Dìn). ${ }_{3} 325$ et suiv.

A بxas ibn Yalyyá ibn abi liadjala (Ahoû 'Abdallah). 1709 el suiv. 3348 et suiv. 3360 .

Aнsнo ibn Yalyyà al - Mabdi (Schams al-1)in). 1320 .

Aụmad ibn Yoùsof ilun Alumad alDimaschqi (Aloũ ']-'Abbås). 1556 et suiv.

Aห̣mad ibn Youisof al-Aqfalisi (Schihab al-Din). 45/47.

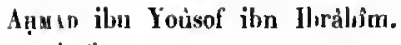
2/16.

AHuan iln Yoúsof ibn Mâlik alTớäni (Schilaâb al-Din). 4452 , $11^{\circ}, 12^{\circ}$.

A yuso ibn Yoùsof ibn Molaammad Fìroùz. $1651,1^{\circ}$.

Aụxad ilun Yoúsof al-Ṣafadì (Schihàไ a J-Din). 3010.

Ạ̣men ihn Yoủsof al-Tîfàschì (Schilhăb al-bin Aloû́ 'l-'Ahlhàs et Aloủ 'Abdallah). $1176,16^{\circ}$. 9770, $3^{\circ}, 277^{3}$ et suiv. 3055 .

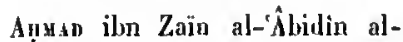
Bakri al-Șiddliqi. 3233 .

A yaun ilon Zanbal al-llammàal. Yoyez Mounsmas al-Zanbalí.

Ạ̣mà ilm Zerdouk (?) (Schihàb at-Din). 3016 et suiv.

Al-Aụsìi. Voyez Monamao ibn Ilıràhìn.

At-Anwizì. $2467,18^{\circ}$.

Al-Auwazic. Foyez Mog̣amad ilon al-Hosain.

Aĩosgra ilon 'Alì al-Djildaki ('lzz al-Dìn). ${ }^{1355 .}{ }_{2615}$ et suiv. 2617 ef suiv. $2621,2^{\circ}$.

Al-Aìdhoứs. Vuyez 'Aad aL-JianMîn ibn al-Uostafâ.

All- Mĩxí. Voyez Mạmoúo ibn Aṇyao et Monammo ilon Alimad.

Ilen Airas. Voyez Moụaman ihn Alimad.

Al-Akfixi. Voyez Nohaymad ibn lbrâhim.

Al-A kuoaní. Voyez Abd al-Rạ̣uí iln Nohammad.

Axinoư Díoúd al-Balàt. Voyez Alooû 'l-'Alà ibn Nơallà.

Al-Akutani. Yoyez Moṣtari ibn Scbams al-])ìn.

Al-Akisikati. Voyez Mopamad ibn Moḷammad.

A!-'AкḰ́nì. 1274 .

Al-Akrami. Vojez Scrans aL-Div alAkrani.

Al-duA ibu Sabl, $2457,29^{\circ}$.

Aloú 'l- 'Alì al-Máarri., 3109 et suiv.

Alooù 'J-Axû̉ ibn Mo'allà al-Ṣäigh. $17^{9}, 3^{\circ}-8^{\circ}$.

'AlA at-Dis ibn Nohammad Ibn a]-Ridhå al-Hosainì al-Mloủsawì
al-Toûsi ('Alà al-Dìn). 3075 , $2^{\circ}$ à $10^{\circ}$.

'A LA AL-Dis al-Qdidiri. $3494,3^{\circ}$.

ALì AL-Din al-Qoủschdjì. 250 h, $4^{\circ}$.

'ALÁ AL-Dix iln Ṣadaqqa. $1343,5^{\circ}$.

'Alí aL-IJix ibn al-Schàtir. 2590 , $2^{\circ} .2521,1^{\circ} .2522 .2526$ et suiv. $2541,5^{\circ}$

A]- 'A LÁi. Voyez Ianâaim ibn abì Snid.

Al-'Alavi. Voyez 'Aui al-Alawi et IsMÀ í ibn Ibrảhlm.

Al-'Aului. Voyez 'Abo at-Rapimix al-'Alimi et Monamsun ilın 'All.

ALEXaNDRos. 1564 .

'Alì ("Alà al-Dìn). $11 ; 6,7^{\circ}$.

Ati ibn 'Abbâs al-Madjoùsî. 2871 el suiv.

'A cì [ilon 'Abuallah] ibn Aḷmad ilun al-Hosain al-Sanhoùdi (Noủr al-D)in aboú 'l-Ịasan). 1634 et suiv, $1977 \cdot 2252,2^{\circ}$.

'A Lì iłn 'Alubllab al-Bahài ("Alà al-Din). $1176,16^{\circ}$.

'A Li ilın 'Abdallah al-Ghozoùli. 3415.

'Alí ibn 'Abdallah al-lfrandji. 4645.

'Ari ibn 'Abd al-lialuim ibn Alymatl. $1703,2^{\circ}$.

'A Lì al-Adjłıứrî ( L boù 'J-Irschâd). 1080 et 1081 .

'Aıi al-Adjhourri (Noûr al-I)ìn). 1283 el suiv. $3944,7^{\circ}$.

'Ali ibn Aḷmad al-Bakri (Alıù 'l-Hasan). $1816,9^{\circ}$.

'ALì ibn Ahmad al-1jjamâli ("Alầ al-I)in). 851 .

'All ibn Ahmad Fakhr al-1)in lba al-Bokbârì (Aboư 'l-Ḥasan). $7^{50}$.

'Aut ihn Alımad lbn Hobảl (Ahoư 'J-Hasan). $2348,1^{\circ}$.

'ALi ibn Alınad al-Hosaint (Sadr al-Din ). $3259, a^{3}$.

'ALì ibn Aḷmad ibn Makkí al-llàzi (Hosâm al-Din). 854.

'Aní ibn Ahmad ibn Mohammad al-Schargí al-Ṣafàgosí. $227^{8}$.

' $\lambda_{\text {Lì }}$ ibn Aḷmad ibn Noḥanmad ibn Mạ́oúm (Ṣadr al-Din). $3{ }_{2} 55$.
'Aul ibn Abmad al-Tarsoủsî (Aboú Isłây). $9_{2} 5$.

'Ali al-'Alawí al-Yamani (Aboú 'I-Ḥasan). 765. 955, 2*.

'A al-Din). 791 .

'Iui ibn Arfa' Rás al-Nlaghribi. 3 253.

'Alí [ibn Moluammad] Ibn alAthîr ('lzz aj-Din). 1898 .

'Alì il n 'Atiya al-Hamawí 'N 'wån. 3225.3226 .

'A Li al-Azhari (Aboù-lbrahlm). 1368.

'Atì ibn alit Bakr ibn "Abd alDjalil al-Nlarghinânl (Borhån a]-Din Aboú 'I-Hasan). $842 \mathrm{et}$ suiv. 927 .

'Ál ibn ahì Bakr ilın al-Djamál a] $-A$ nșâri. $3 / 75,2^{\circ}$.

'Alî̉ ibu Bàlt̀ 'Tehemuaq. a 163.

'Aul ibn Bassám (Aboú 'L-Hasan). 3321 et suiv.

'Axi jlon Dáoúd al-Khatíb alDjauharî (Noưr al-Dín). 1791. 1812 et sniv, 2h46, $2^{\circ}$.

'Auì Dedeh al-Sektewảrl al-Roûini. 2080 .

'ALi ilın Djâbir al-Fàrâsí. $77^{4}$, $12^{\circ}$.

'Alì ilon Dja'far al-Loghawí (Aboủ 'J-Qàsin). $4151,4^{\circ}$.

'Ali ilm Djáfar ibn Molyammad al-Tàwuus (Aboû 'J-Q̨Asim). $117^{3}$.

'Alì ibn Djáfar al-Tamim! (Aboú '-Qàsion). $3418,14^{\circ}$.

'Atồ llbn al-Djazzàr (Noúr al-D)in Aboú 'I-Hasan). $3 \circ 35,1^{\circ}$.

'Alî Ibn aJ-Fàdbil al-Hadiths (Hokn al-j)in ). 4056.

'Arí ilon Ilamza a]-Kisâ'l (Aboû 'lḤasan). 665, $4^{\circ}$.

'Auì iłon Hasan ibn Mohammad alZaïtoủnì al-Aufi. $29^{43}, 4^{\circ}$.

'Ali ibn al-Hasan ibn abt Taiyib al-Bàkharzi. 3313.

ALl ibn abí 'l-Hazun al-Qoraschí Ihn al-Nafis ("Alâ al-Dìn Aboû 'l-Ḥasan). $2843.2844,2^{\circ} \cdot 3919$ et suiv. $29^{3} \mathrm{~g}$.

'Aul ibn al-Hosain ibn 'Abdallah al-Hodsalî al - Mas'oúdí (Aboù '1-Ḥasan). ${ }^{4} 40$ et sniv. 
Auí ilon Hossảm al-Dìn al-Mottarti. $1 \dot{3} \overline{3} 3$.

'Atî ibn Ibràhî̀m al-Ghamrî. 1 a 6 , $2^{\circ}$ :

'Auî [ibn lbråhîm] al-Ḥajabî (Noưr a-1)ín). 1015 et sniv. 1999 et suiv.

"ALì ibn Ibrálím ibn Idris al-Antâki. 3,87 .

'Áti ibn 'îsâ. 2918, $5^{\circ}$.

"Ali ibn 'tsà al-Djasrì. $1450,2^{\circ}$, $19^{\circ}$.

'Áî ibn 'Îsà ilın ahì 't-Fath (Bahâ al-1)in) al-Śrbilit (ou al-Arbili). 3551 .

'Alt' ilbu 'îsá al-Romànt. 3303 .

'ALí al-Kaizzawâni ( ( Atrố 'l-Ḥasan). $1337,13^{\circ}$.

"Alí Ketkbodá. 11 a 0.

'Alí al-Khatịib. $1379,2^{\circ}$.

'Alì ibn Khidhr. 861, 4\%.

'Alti ibn abî 'ł-Lotf. a 151.

'A Łì ibn Maïmoǹn. 137 9.

'ALì al-Mákhoưsì. 3951, $1^{\circ}$.

'A út ilon Manșoǹr. 1450, $9^{\circ}$.

'A ci al-Haqdisi ar-Hanafî. $1160,4^{\circ}$.

'A cl al-Marałghì al-Qabbânî. 3557 et suiv.

'Ani ibı al-Mobàrak ibn Mauhıỏb (Aboú 'I-Ḥasan). 24 ag.

'Azí ibn Mofrih al-Andalosí. h1 as, $a^{n}$.

'Axí ibn Mohammad ilon Aqubars (Alì al-Dìn). 31 95.

'Arì ihn Moḷammad ibn 'Asákir. 2137.

'Alt' ibn Moḥammatl al-Baghdâdí al-Sclîhtî́ al-Khàzin. $63 \mathrm{~g}$ et suiv. $659,7^{\circ} \cdot 1310$.

"I Lî ibn Mohammad al-Djihrini Kbațib al-Nàsirirya. 2139

'Atî ibn Molạammad at-J)jorljảni (al-Saiyid ol-Scharif). $9360,1^{\circ}$.

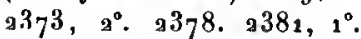
a 390.9393 et suiv, $9425,9^{\circ}$. 2505. 4959 et suiv. 4392 et suiv. 4429 .

'Ati ibn Moḷammad al-Ghazáli. 4594.

A Lì ibn Nohammad ilon Ḥabil al-Maawardi (Aboù 'l-Ḥasan). $24 h, 3^{\circ} .3966,2^{\circ}$.
Ací ibn Molammad al-Mlisrí. 1279. $1319.3804,4^{\circ}$.

'Auí iba (Madjd al-Din) Molrammad al-Schâthroûdì al-Bisțàmí Moșannifak ('Alà al-Din) 1550 . $4396,1^{\circ}$.

'ALì ibu Mohamnad al-Naqqȧsch. $2560,9^{\circ}$.

'Aul ibn Moluammad at-Oschmoún (Noủr al-Dín Aboù '1-Hasan). 4100 et suiv.

'A Lî ibn Mohammad al-Pazdawî. 836. 4541 .

'Áî ibn Mohammad al-Qảhisi (Ahoû 'l-I!̣asan). $45 \mathrm{~g} 5$.

'Axî ibn Molıammad at-Qalasâdi (Aloû '1-Hasan). 2463, $3^{2}$. 2464, $1^{\circ} .2473 .4565,2^{\circ}$.

'Axí ibn Muhammad ibn abí '1Qàsim. 1460.

'Aut ibn Moltammad ibn Barrl alRibátị. $1077,5^{\circ}$.

'Alì ibe Mohammad flbn al-Salblàgb al-Nàlikî (Noùr al-pîn). $1927,1^{\circ}, 9^{\circ} .2022$ et suiv.

'Alì ibn Mohammad ilon 'Abd alSamad al-Sakhàwì ("Alam alDîn Ahoú 'L-Hasan). $610,1^{\circ}$. $611.651,4^{\circ} .3141,1^{\circ}$. 4004.

'Auí ilon Molammad Ibn abt Zar' ( $($ bout '1-Ḥasan). 1868 et suiv. $1871,5^{\circ}$.

'Á เ̇̀ ol-Mortadhâ. 2423.

'Alì ihn Moùsà al-Andalosî. 9633.

'Aui ibn Moúsà al-Ridhà (Aboǹ 'lḤasan). a $18 \mathrm{a}, \mathrm{a}^{\circ}$.

'Atì ibn Moủsà ibn Saiul (Aboù 'l-Ḥasan). 3340.

'Alî ibn Moủsâ al-Schodsoùri (Abuì 'l-Hasan). 2643 .

'A ìi ibn Nâșir (Aboú 'l-Ḥasan). 1631 et sniv.

'Alt' ibn 'Omar al-Banoủnì (lis. Batnoûnì). 3564 et suiv.

'Alì ilon "Onar al-Kâtibî al-(yazwiní (Aboû 'l-Ḥasan). 1954. 2370 .

'Alì ibn 'Uthmàn al-Oúsclî̀ (Siraddj al-Din). 858, 1251, $1^{\circ}$. $1985,2^{\circ} .3204,7^{\circ} .4051,4^{\circ}$.

'ALì ibn 'Othmàn lhn-al-Qkișih al'Odsci (Abon'l-Bayâ). 612, $1^{\circ}$. ${ }_{9677} 68^{\circ}$.
'A ứ ibn 'Othmản al-Tourkomàni ("Alà al-Dìn). 753. 994.

'Aut ibn abil 'l-Ridjâl al Schaïbưnî. aรgo.

'Alí ihn Saîd al-Khaulanî alQașạar. 2746.

'Axì ihn Saîd al-Naghhribí. э 34, $1^{\circ}$

'A cî ibe Șàrim. 1449, 20.

'Áî al-Schobrâmelsî (Schabrâmalissi) (Aboù l'-Dhiyá Noúr al-J)iu). 1021 et suiv. 1048.

'A cî il un Solaìmáu al-Silikfoui (on Silikfanî?). 1 9ง1, $1^{\circ}$.

'Azî ilnn Soitàn Mlohammad alCirì. $1251,1^{\circ}, 2^{\circ}$. $105 \overline{8} 8$. 2079 (?). $4051,4^{\circ} .4583$.

'Alî ilın Suúlloùn al-Baschlıaģhàwî. 3 a 0 .

'Alî ilın abì Ṭâlilı. 448. 667 , a'. $117^{9}, 2^{\circ} .117^{4}, 1916,5^{\circ}$. $1690,3^{\circ} .1667,5^{\circ} .2293,6^{\circ}$ 9493. 9502, $10^{\circ}, 14^{\circ} .96 f_{1}$ 1. 3082 et suiv. $3264,4^{\circ}$ $3365,9^{\circ} .341 \mathrm{~g}, 5^{\circ}, 6^{\circ} .3418$, $3^{\circ} .3431,9^{\circ} .3482,3^{\circ} .3954$, $7^{\circ}, 9^{\circ} .3955,1^{\circ} .397$, $3^{\circ}$. $397^{3}, 2^{\circ}, 8^{\circ} .459^{8}, 1^{\circ}$.

'Alì ilon âbí Tàlib ibn 'Alî... Ibn al-Khascbschath al-Halatio 3485 .

'Anî Tchelebi. $1287,9^{\circ}$. - 2624. $2625,3^{\circ}$.

'A Li al-Ṭoùsì ('Ala al-J)ìn). 1 a6a, $1^{\circ}$.

'A Lî ilon alî 'ł-Wafâ. $135 \mathrm{~g}, 1^{\circ}$. $2480,2^{\circ} .3171,4^{\circ}$.

'A ti ihn Yalyyâ al-Zendoủbestì (?) (Aloû 'l-Hasan). 824, $2^{\circ}$.

'A cì ibn Yaqqoủb jbn 'Alí ilon al-

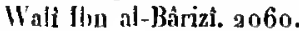

'Alî ihn Yoùsof al-Boṣrawi. 4118 , $3^{\circ}$.

'Ani ilm Yousof ilon Djarir (ou Ilarìz) ibn Ni dhàd ilon Fathl. an38 et suiv. (Comparez 'Alì iłon Yoúsof al-Lakhmî. )

'Ali ibn Joúsof al-Lakhmi (Noîr at-Din). go16, $4^{\circ}$. (Comparez 'Ali ilon Yousol ibn ijarìr.)

'A Lì ilon Yoúsof Ibn al-Qjifti. 3335.

'A cî ihu Zafar. 3514.

Aci Zaiu al-'́lbidìn. $663,10^{\circ}$.
Aboû 'Act́ ibn abí 'l-Hosain alSoúfi. $\$ 56 \imath, 4^{\circ}$.

Aboû 'A Lí al-Zaddjàdjî. 1109

'Alqaua. 3273 et sniv.

al-'Aloquí. Vojez Monamano al'Aly̧amí.

Aman1 (M.). 4494 et suiv.

Al-Amäsí. Vojez 'Abo al-Ragui. ibn al Mo'ayyad.

Ibn al-Amîn al-Makìn. Voyez A!Maxiv.

Al-ìvroî. Voyez 'Alî íbn abi 'Ali el Moyamso lon al-Âmidi.

Axîn Kîtı ibn Amir 'Omar alIṭânt. 802

Amîa Pádscilín. Voyez Mọ̣amano Aniv.

'Àma ibn Àmir al-Bașrî. a 365 , $a^{\circ}$.

Amanal (Dimitri). 4365

Ml'Ámuí. Voyez Mogamma ibn Moḷommad et Yại ibo abi Bakr.

'Awa ilon Kolthoûm. 3075,8 . 3076.3275 et suiv.

'Ayn ibn Mataï al-Ṭairṭấuí (Ṭ̂̀!̣̣ânî). 190.191.

Abon' 'A xn ibn al Hiadjib. 4/5้.

Aboù 'Ama ibn Manzoứr. 1077. $1{ }^{\circ}$.

Aboì 'Aмn al-Qortobi. $610,3^{\circ}$, $4^{\circ}$.

'A maîs, $205,3^{\circ}$.

A boû 'A maîn al-Zanàlî. $2758,9^{\circ}$.

A w nou ']-Qsis. $3075,2^{\circ} .3076$. 3373 et suiv. 3975 et suiv. 3430 .

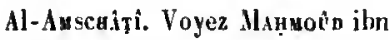
Ahmat.

llin Amis al Tamimî. Voyez Shoнаммад ibn Amyal.

Ax.s ibn Malik. 1916, $4^{\circ}$

Anastase, évèque de Samothrare. $145,10^{\circ}$.

Axastase, allié du couvent de Sinaï. $267,5^{\circ} .281,16^{\circ}$

Al-'Anîyîtí. Voy. Aụmad al-'Aniyåti.

Al-Axdâri. Voyez 'Ago at-Raumàs ihn Nohammad; - Уонями А ibn Alumad al-Noqri et Moमамма Ibn at-Qisiun. 
ANDEÉ. $214,8^{\circ}$.

Anoné, de Jérusalem. $150,12^{\circ}$.

Al-Axtấî. Yoy. 'Alî ibn lbrâhû́n: —Díoús ibn Khalil; - - Dáoùn ibn 'Omar et Yanyî ibn Sa'îd.

'Arsns ibn Mo'aswiya ibn Schaddàd. $3075,6^{\circ} .3076 .327^{3}$ et suiv. 3975 el suiv.

Artorve, nojine. 976 .

Amolonits, de Tyane. ag5o, $3^{\circ}$. 300 et suiv.

À-Bognî al Kibàsekì. 2265 .

Al-Ảoụusânî. $1: 60,14^{\circ}$.- Voyez Hasan Efendi.

lon 'Noir. 4089 et suiv.

Âsarii. Voyez Mogammad ibo Djamâl al-Dîn ef Moнaysa ibn Mohammad.

Ibu al- Arabí. Voy. Mohagmad ibn 'dî̀.

Ibo 'Aanbschá. Voyez Anuan ibu Moḷammad et loràuí ibn Moḷammad.

Aachrcaüs, évèque d'Îrna, 145 , $12^{\circ} \cdot 148,3^{\circ}$.

A Rch MÈde. $2457,4^{\circ}, 44^{\circ} .2458$ $3^{\circ}, 2467,8^{\circ}, 9^{\circ}, 2468,2^{\circ}$.

Al-Ardabìlî. Voyez Aui ibn Îsâ;Bado ibn lshấq;-Ahoû'l-Fatu ; - Moụam ma ibn 'Abd al-Ghrnì et Yoủsor ibn lbråhîn.

Anistote. $82,11^{\circ} .132,17^{\circ}$. $176,9^{\circ} .309, a^{\circ}, 3^{\circ} .666$, $7^{\circ} .1892,4^{\circ} .228 \mathrm{t}, 4^{\circ} .2346$. 2347.2417 et suiv. $2578,1^{\circ}$. ง $277^{2}, 1^{\circ}$.

Aamain. 2082.

lha 'A aoûs al-Mlaglırabî. $32_{2}$. $3663,3^{\circ}$.

Aramouixí. Voyez Ammo ibn Molyanmad.

Aasève al-Fảkłoúri. 323.

Arsuax. $3223,4^{\circ}$.

As'sD al-Xlammâtì. 3552 .

Ibn 'Asíxia. Voyez 'Alí ibn Molyamnaad.

Ibo Asbät. Voyez Hamza ilon Al?mad.

Al-A'schâ Mlä́moûn ibn Qaís ibn Djandal. $3075,9^{\circ}$. 3076 . 3275.3430 .
Al-Ascu'aní. Voyez Aboû 'l-Hasak al-Asclíarí.

Ibn al-Ascíctr. Voyez Aụus ilon Moliammad.

Al-Ascuuabì. Vojez lohâuîm ibn 'Ollımån.

'iscirio Tchelebi. 2164.

Al-'Aschmîwî. Voyez 'ABd al-Bâaí al-'Aschmâwi et 'Ano al-Latip al-'Aschmâwî.

Al-Aschafí. Voyez Kualíl alAsclirafi.

Ascuépits. $2611,2^{\circ}$.

A boû '̉-Aṣ̣ân al-Kermânî. a 758 , $2^{\circ}$.

Askar al-Halabî. 3 250, $5^{\circ}, 6^{n}$.

Al-Askanì. Voyez Al-Hasar ibn 'Abdallah.

Al-Așì. sho5, $3^{\circ} .33_{9}, 2^{\circ}$.

A/-Asxawí. Vojez Duahíl al-Dis al-Asnawi.

lbn al-'Assî́ (Aboủ Isluáq ilbn alFadhı ou al-Fadhâil). $19^{8}$, $1^{\circ}$. 199, $1^{\circ}$. 200, 214, $9^{\circ}$ $241,3.245$ et suiv.

Asseun de Clierville. 3589.3680 . $3_{932} 3_{97} 5.4357$, ${ }^{\circ}$.

Al-Astaníbídî. Voyez Hasax ibn Nohammad.

Ibn abî 'l-Aswad. $2329,12^{\circ}$.

'A tî Alıâh (Tàdj al-Din). 3971, $2^{\circ}$.

Ibn 'Atî Aluíh al-lskandarí. 1298. $1299,1^{\circ}$.

Al-Ataxí. Voyez Zohaíz ibn Mohammad.

Atuasase, patriarche d'Alexendrie. $89 \cdot 9^{3}, 114,1^{\circ}, 132$, $1^{\circ} .143,5^{\circ}, 153,39^{\circ}, 40^{\circ}$. $213,15^{\circ} .214,10^{\circ} .238,19^{\circ}$. $251,40^{\circ}, 257,1^{\circ}, 267,4^{\circ}$. $276,14^{\circ} .305,2^{\circ} .310,2^{\circ}$. $311,1^{\circ}, 6^{\circ}$.

Iruasase, évêque de Cos. $2: 3$ $\mathrm{t}^{\circ}$

llu al-Aтuîn. Voyez 'Alî iba MoJ̣ammad; - Daryì sL-Dís lon al-Atlî́r; - Issấic ilon A hmad - Movbáasr ibn Nohammad et Nasa Aldàj lbn al-Athír.

Ibn al-Aruí ['lzz al-Din "Alì ibn Moḥammad al-Djazarî]. 1468 , $2^{\circ}$. 1492 el suiv. $1595,9^{\circ}$. $9800,20^{\circ} .4607$. lba al-Aтuîa al-Djazarî [ Bl-Moubârak ibn abi '1-Karam Hobammad]. 2172.

A]-Atriali. Voyez 'Abd al-Ragìn al-Athirî.

lbn Atrya. Voyez Moỵamad ibo 'Alî.

A]-Atrîd. Voyez Mopaumad Diyàb.

llon Ataed. 8a, $9^{\circ}$.

AṬtar [Faríd al-Dìn Mohammad ibn lbrâhím ]. $2315, a^{\circ}$.

Ibn al-Amtáa. Voyez Kualíl iho Solaímán; - Moнamasd ibn Alimad et Monamua ibn Molyanmad.

Al-Aurî. Voyez 'Alî ilon Hasan et Monamad ibn Alumad.

Aca (Anba), évêque de Faiyonim. $148,4^{\circ}$.

Antolycus. $2467,20^{\circ}$.

Ibn al-Aowán. Voyez Yaụâ ibn Moliammad.

Avennoss. Voyez Moyammad ibn Alinad.

Aricexve, Voyez Al-Hosaix ibn Abdallah.

Al-Aza rwâlî. Yoyez Monamaad ibn 'Abd al Ralımán.

Al-Azíwt. Voyez Monasuano ibn al-Fadhl.

Al-Azoî. Voyez HıscuÂu ibn 'Abdallab.

Al-Aztaní. Vuyez 'Azí al-Azhari et KHấud ibn 'Abdallab.

'Azîz AL-Dîs Ibn al-Kamili. 3596.

Al-Azraqí. Voyez Ibrínim ibn 'Abd al-Rahmán et Mog̣a Mas ibn "Abdallah.

BẢBÁ al-Scharwànt. $4606,6^{\circ}, 9^{\circ}$.

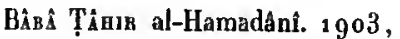
$2^{\circ}, 3^{\circ}$.

Al-Bäbarti. Voyez Mogamman jbo Mahmoúd.

lbn Bàbawaīe. Voyez Mog̣amad ibn 'Ali.

A]-B⿳亠口冋iL1. 2480, a․ Voyez Mo!1 м Mad al-Bâbilî.

Al-Badamásl. Voyez Shams al-Dív al-Badamásí

Ibn at-BADí. 1555 .

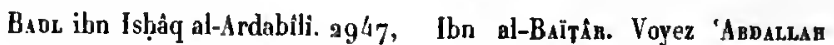
$2^{\circ}$.
Badn al-Dír ibn Bekr (ou AbouBakr ibn Badr?). 2813 et suiv.

Bagr al-Dín Hádjermí. $3365,3^{\circ}$ à $6^{\circ}$.

Badn aL-Díx ibn Hischám. 3837 .

BADR AL-Dłs al-Noûhâní. 2562 , $8^{\circ}$

Badr a L-Dîn ibn 'Omar Khơdj ibn 'Atá Alláh al-Fetní. 4450 .

Bıon at-Dîs ibn Sálim ibn Moḷammad Tábi al-Ṣiddìq. 3071 et suiv.

Al-Badaĩ. Voyez Ausan al-Badri; - Aboû 'l-Baxà ibn al-Djaì 'ân et $A$ boù Baxk ibn 'Abdallah.

Ibll Badroún. Voyez 'ABd aL-Maux ibn 'Abdallab.

A1-Baguawi. Voyez Hosaix ibn Mas 'oùd.

Al-Baguidí. Voyez Saysam atDaula ibn al-Hossám.

Band al-Dis [Mohammad] at'Ámilî. 776 .

Ba À al-Dł ibn Babádour. 760 , $4^{\circ}$.

Babì aL-Mhghì al-Qaranî (?). 4296 .

Al-BanAì. Voyez 'Arì ibn 'Ahdallab.

Al-Banlotizí. Voyez Moнамaаd ilon Solaïmân.

Al-Banoûtì. Voyez Maxsoutz ilon Yoúnos el Moganuad ibn Ab. mad.

BАня⿱亠䒑 (Tádj al-Dín). 4552 et suiv.

Baниĭm Scyân ibn Farroukl Schâh. 3142.

Baïsars al-Manşoùri(Roknal-Dîn). 1579.

Al-BaĩdaÂwî. Voyez Abdalah ibn 'Omar.

Al-Baìnal. Voyez Aṇan ibn alHosaïn.

BaİLax Qabdjâqî. a779.

Al-Bsicoûxí. Voyez Fatḥ Altía ibn Mahmoud.

Al-Baĩstuml. Voyez 'Abo al-liag̣im al-Baīsán?

ibn Alımad. 
Al-Baspazzi. Voyez 'Álí ibn alḤesan.

Ibn Babutíscnou'. Vayez 'Abdalla ibn Djibrîl el 'Obaidalzau ibn Djibrîl.

Al-Bàk awì. Voyez 'Abd AL-RascuÎd Șìtụ̣.

Ibn Bakkât. Voyez Moḷamad ibn Ismấîl.

Aboû Bakn ibn 'Abdallalı al-Badri (Taq̣i al-Dîn). 3544.

Aboû Bakr ibn Aḷmad ibn 'Alí Ibn Wahscluiya. 2803.

Ahoù Bakr ibn Aḷmad ibn Mohammad Ibn Qaddhî Schohbo (Taqii al-Dín). ${ }_{159} 8$ et suiv. 1721. 2102.

Aboû BAKn ibn 'Alí al-Haddàdí. 835.

Aboû Bakr ibn 'Alî ibn Hiddja alHamawî (Taqî al-Dîn). 3 ๖o6, $4^{\circ} .3207,2^{\circ} .3213$ et suiv. $3948,3^{\circ} .3387,1^{\circ} .3396$ et suiv. 3529 et suiv. 4438 .

Aboû-Bakr jbn 'All̂ ibn Moûsă al-Hâmilì (Sirâdj al-Dìn). 927.

Aboù Barn 'Atio jbn 'All (Dhiyà al-Din). $722,4^{\circ}$.

Aboû Bakn ibn Bahrâm al-Anṣấrî al-Zaïni. 1032 .

Aboù Baxn ibn Baschir al-Ḥaulàni. $27^{39}, 3^{\circ}$.

Aboủ BAkr âl-Fårisî. 2999, $1^{\circ}$.

Aboú Baxr gl-Ḥiṣnî al-Ḥosaünt (Taqi al-Dín). $2042,1^{\circ}$ et $2^{\circ}$. $459^{1}, 5^{\circ}$ et $6^{\circ}$.

Aboũ Baxn ibn Ismấíl al-Schanwăni. 4137.4194 .

Aboû Baxn ibn Isınătîl al-Senkeloûn' (Madjd al-Din). 1023.

Aboư Baxh al-Maqrìź (Tàqi alDìn). 1514 .

Aboù Bakn ibn Masoûd ibn A! mad al-Krisannî. 8 25, $3^{\circ}$.

Aboû Baxn Moḥammad ibn abî 'l-Hasan Zain al-Ábidîn alBakrì al-Ṣiddíqî. 3 sag et suiv.

Aboú B เкห Mợamad al-Klaawâfi (Zaïn al-Dìn). $7^{62}, 3^{\circ}$.

Aboû Bakr [Moñyyad] al-Răzí. $1395,3^{\circ}$.

Anoû Bakr Momamuad al-Seháschí. 1099 .

Nas, oniestaux. - III
Aboù Basn ibn Molammad ibn Ibràhı̀m al-Halabì. $666,6^{\circ}$.

Aboú Bakn Monasumad ihn Mohammad ibn 'Abd al-Djalîl alMámari (Rảschid al-Dín). $4434,1^{\circ}$ et $2^{\circ}$.

Aboû Baxn ibn 'Omar al-Kâtibí à-Qazwînî (Nadjm al-Dín). 2384 et suiv.

Abdû Bakr ibn Thahira (lbn $\mathrm{Zo-}$ haîra?) al-Qorascbî. $4151,3^{\circ}$.

Aboú Baxn al Wàlibí. $367^{2}$ et suiv.

Aboú Bakn [Monammad ibn abí Yahỵă ibn 'Ầim al-Qäisí. 3528 .

Aboû Bakn ibn abì 'l-Waqt Dáoûd (Aboú 'l.Ṣafả). 1973, $4^{\circ}$.

Aboû Bakr ibn Yalyyá al-Kảtib al-Klìràt. $3776,6^{\circ}$.

Al-Bakní. 1998.

Al-BaLÀsí. Voyez Al-Scharap alBalâsì.

AI-Babawi. Voyez Kaîudo ibn 'Îsâ et Scumà B AL-Dix al-Balawí.

Al-Baldadji. Vovez 'Abdallau ibn Mạ̣moúd.

Balisós. Voyez Apolloxits de Tyane.

Al-BÁusil. Voyez Mohammad ibn 'Aqîl.

Ibn BẦÂ. Voyez Yoứros ibn 'Abdallah.

Ibn al-Baswâ [Aḅmad ibn Mlohammad]. $2463,1^{\circ}$. 2464, $1^{\circ}$.

Al Bíoutsi. Voyez Mlopaymad ibn Yoúsof.

Aboú 'l-BıQA. 4425, 9०.

Aboû 'l-BaQA ibn al-Djaĩân alBadrì. 2557.

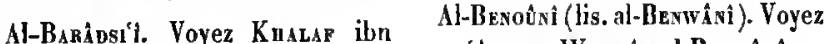
abî 'I-Qàsim.

Aboû 'l-Baraxìt ibn Sa'id al-Bosri. 5.

A boủ 'I-BARAEÁt (Ilibat-Allâhl). 18.

Ahoú 'l-Barasît Ibn Kabar. 203. $242,4^{\circ}$.

Aboú 'I-Banaxît al-Khalwati (Karìm al-Din). $7^{433}, 3^{\circ}$.

Ibo Banakât. Voyez Mognamy.d ibn 'Ali.

Al-Babamoûxì. Voyez Mlọaymad ibn Hasan.
Al-Baníwi. Voyez 'îsầ ibn Moḷammad.

Al-BARDA i. $2359,1^{\circ}$.

Al-Bînt' al-Harawî. 3411 et suiv.

Al-Bàrizì. Voyez 'Aul ibn Yáqoûb.

lbn al-Bimzi. Voyez Ilibat Aluín ibn 'Abd al-Ralımân.

Ibo Banq(?). 3367 .

lbn B.ıni. $1061,6^{\circ} .1266,3^{\circ}$.

Ibn Barnidjan. Voyez 'Ard al-SaLÀy ibn 'Ahd al-Rahmân.

Bagtuélemy. 3o49.

M-Bazzandi. Voyez Dusan ibu Hasan et MoHaymao ibn Rar. son̂l.

Al-Bascibignâtuí. Voyez 'Aû́ ibn Soùdoùa.

Aboù-Bischar. 7 a , $4^{\circ}$.

Basile, S., évêque de Césarée. $17.89 .133 .134,1^{\circ} .150,9^{\circ}$. $154,8^{\circ} .155,5^{\circ} .181 .205$, $10^{\circ} .213,2^{\circ} .234,29^{\circ} \cdot 235$, $29^{\circ} .238,18^{\circ} .245 .251,24^{\circ}$. ${ }_{2} 58,11^{\circ} .262,15^{\circ}, 20^{\circ} .263$, $6^{\circ} .275,4^{\circ} .281,91^{\circ}, 22^{\circ}$.

Basuse, évèque de Nanbadj. 147 , $12^{\circ}$.

BasILI PAKUR. 2554 et 2555 .

al-Baski. Voyez Mopammad ibn 'Abdallah.

Ibn Bassìy. Voyez 'Alî ibn Bassâm.

al-Batuîsî. Voyez Kahĩ aL Dîs al-Batlisí.

Al-Batroûvî. Voyez 'Alî ibn 'Omar.

Ibn Bıтоúța. 2987 et suiv.

Al-Bızzîzí. $3967,3^{\circ}$.

Bedwell (Guillaume). 4337 . 'ABd al Wanina al-Benounní.

BeũIt, prieur de Saint-Val. 228 .

Ml-Biniscitti. Voyez Moụanuav als Bilischti.

Al-BıQิÂî. Voyez Ionínì ibn ' 0 mar.

Al-Binguril ol al-Binguewi. Voyez Monamad ibn 'Ali.

Al-Bisțìmì. Voyez 'Abo at-Rı̣yAx ibn Moḷanmad et 'ALî̀ ihn Mloliammad.

Al-Bodjai[ [Ṃ̣mad ibn 'Ali]. 4098 , $6^{\circ} .4140$. - Voyez aussi AụץaD al-Bodjấî et Ap̣mad ibn Sacîd.

Bonaira. $215,5^{\circ}$.

Al-Boṛtoni. Voyez Walid ibn 'Obaid.

Al-BokuÀrî [Moḥammad ibn Ismâ'il]. 676.679 et suiv. $2677,7^{\circ}$, $9^{\circ}, 10^{\circ}, 19^{\circ}$. - Voyez aussi ${ }^{A} A B D$ AL-'Azîz ibn Ahmad; - A HuAD jbn Molaammad; - 'All ibn Ahmad; - Moras мs ibn'Abdallalı; - Mog̣mmad ibn abî Bakr; - Monammad ibn dhmad; - Monamad ilon Mohammad; - Nopammad ibn Moubârak-Sclaah ; - OMAR ibn 'Abd al-Aziz; - S S Adid ALDis al-Bokhârì ; T Tíuln ibn Alimad.

Al-BoLDînî. Voyez Moưsî̀ al-Boldâni.

Al-Bocoîni (lis. a\}-Bolqaüní). 99 a. $1013,3^{\circ}$. - Vojez aussi Moỵammad al - Bolquinî et Strî́oJ AL-Dì al-Bolqaïní.

Al-Boxínî. Voyez Mopammad ibn Hamdoûn.

Al-Bondìaì. Voyez Al-Fatu ilon 'Ali.

BONYBCORSE. 4692.

Boniñ al-Dix al Nasalì. 250 $2^{\circ}, 3^{\circ}$.

Bonhầ aL-div al-Zarnoûdjî. 2312 et suiv.

Al-Bonîi. Voyez 'Ade at-Rạ̣is al-Borit.

Al-Boazosi. Voyez Knıbn ibn 'Abd al-Qâdir.

Az-Bonsâwî. Voyez lloṣtapầ ibn Yoûsof.

Al-Bosnîtwí. Voyez 'Alì ibn Yoûsof.

Al-Bostî̀ì. Voyez Yápoùz ibn Moủsâ.

Al-Bossi. Voyez Aboû 'I-Fatụ alBosti.

Ibn Botrîtw. Voyez Al-Mosmtîn ilon a)-Hasan.

A1-Boûni. Voyez Aụmad ibn 'Alí.

Al-Boúaîxí. Voyez Al-Hasax alBoùrîní.

Al-Boúșiai. 441. 744, $7^{\circ} \cdot 1128$, $4^{\circ} .1167,4^{\circ} .1170,2^{\circ} .1206$, $10^{\circ} .1224,8^{\circ} .1251,2^{\circ} .139^{5}$, $2^{\circ}, 1620,3^{\circ}, 4^{\circ}, 1903,4^{\circ}$. 
$2637,9^{\circ}, 2722.3080,2^{\circ}$. $3,54,2^{\circ}, 3^{\circ} .3156,3^{\circ} .3177$ et suiv. $319^{5}$ et suiv. $319^{8}$, $4^{\circ} .3248,2^{\circ}, 3^{\circ} .3430 .4187$, $13^{\circ} .4669,19^{\circ}$.

Al-Botzzosîni. Voyez Moṇamuo ibn Mohammad.

Beirlus. 315.

Calnastuèxe. 3681 .

Capadanios ( $(2) \cdot 2832,2^{\circ}$.

Cassiaxus. $257,17^{\circ}$.

Célestin, pape. $150,14^{\circ}$.

Cinatganbiano. 3680 .

Christodule, patriarche d'Alexandrie. $251,42^{\circ}$.

Chaistoorle, métropolitain do Damiette. $238,26^{\circ} .251,52^{\circ}$.

Chément (S.). 76 et suiv. 150 , $16^{\circ},{ }_{2} 34,3^{\circ}, 4^{\circ}, 37^{\circ} \cdot{ }_{2} 35,19^{\circ}$. $236,6^{\circ}, 7^{\circ} .242,5^{\circ}, 6^{\circ}, 8^{\circ}$. $243,4^{\circ}, 8^{\circ} .245 .251,5^{\circ}, 6^{\circ}$, $8^{\circ}, 30^{\circ}$.

Cosstaxt. $234,22^{\circ}$.

Constantin. 103.

Constanuin, prêtre. $9^{5}$.

Cotglie (1I.). 4478.

Cyprien, S. $309,14^{\circ}$.

Crnnour, évèque de Bebneså. $132,13^{\circ}$. $150,8^{\circ} .152,1^{\circ}$. $153,1^{\circ} .155,9^{\circ}, 10^{\circ} .219$, $11^{\circ}$.

Crancs, S., patriurclie d'Alexandrie. 55. 89. 93. 13a, $10^{\circ}$. $141,3^{\circ} .151,6^{\circ} .155,4^{\circ}, 7^{\circ}$. $212,3^{\circ} .237,1^{\circ} .238,21^{\circ}$ à $25^{\circ} .263,4^{\circ}, 5^{\circ}$.

Cranlte, $\left(67^{\circ}\right)$ patriarche d'Alexandrie. $238,26^{\circ} .251$, $43^{\circ}, 47^{\circ}$ à $59^{\circ}$.

Crrmete ibn laqlaq, patriarche d'Alexandrie. 195.

Craille, S., patriarche de Jérusalem. $68,15^{\circ}$ à $20^{\circ} .141,1^{\circ}$. $145,7^{\circ} .150,11^{\circ} .154,9^{\circ}$. $155,3^{\circ}, 6^{\circ}$.

Cralue, de Saint-Saba. $857,7^{\circ}$.

Al-Da bsiriwi. Voyez Monammadibn Mlohammad.

Ibn al-Dakain. Voyez Mog̣amuo ibn 'Ali.

Al-Daísawant. Voyez Aụma ibn Marwân et Nıṣn ibn Yaqqoûb.
Al-Daladji (ou al-Doladji). Voyez Moğamsa al-Daladji.

Al-Dimagnixî. Voyez Hosais alDàmaghâní.

Ibn al-Damimîxi. Yoyez Monamano ibn abî Bakr.

Al-Dasiaì. Voyez 'Abo aL-'Azìz Монаммaо; -Benna ibn'Abd-

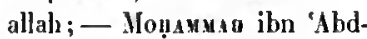
al-Qüdir; - Monasмan ibn Moủsà.

lbn abì al-Daws. Voyez Iвniuin ibn 'Abdallah.

Al-Dinì. Voyez '0tunix ilon Sa'id.

Daxıe (Abbâ). $276,6^{\circ}, 8^{\circ}$ ì $10^{\circ}$

Il)n Dinyíl. 1608.

Díovis, le médecin. $2357,7^{\circ}$.

Díờo ibn Khalìl al-Antâki. a $625,8^{\circ}$.

Díov̂s ibn Mahmoùd al-Q日ị̄ari. $645,2^{\circ} .3 \times 65,1^{\circ}$.

Dìoủa ibn Nàșir al-Aghharì. 2970.

Díoù ibn 'Omar al-Antákí. $2562,16^{\circ} .2944 .3031$ et suiv. $3034,1^{\circ}, 2^{\circ}$.

Al-Diri. Voyez Al-Hosaīs ibn alHiasan.

Al-Dagî. Voyez Monamad ibn Nâșir.

Dayia (Anbâ). 139, $19^{\circ}$.

Danwiscu Efendi al-Tảlawi. 4442.

Al-D.uwììi. Voyez Danlî́t at-Dix ul-Dauwâní et Aboû Jazio alDauwåni.

Draer Efendi. 92.

Dḱx́x́mus, patriarche d'Alexandrie. $213,12^{\circ}$.

Déxétrics, patriarche d'Antioche. $131,1^{\circ} .150,5^{\circ}$.

Al-Desiojoj. Voyez Aboulla ibn 'Ali.

Démocnite. 2802.

Dexrs, S., l'Aréopagite. 212, $9^{\circ}$. $242,3^{\circ} .257,16^{\circ}$.

Dexrs Bar-Ṣalibi. 4. 17 .

Demenbourg (H.). 4502 et suiv. 4505 .

Al-Duannil. Voyez Monamand ibn Aḥmad.
Durî̀ al-Dix Ibn al-Athîr. 3521, $3^{\circ}$. 4421.

A]-Drbsì. Voyez Yśgovia ibn Náma.

Al-Diaxl. Voyez Moștafi ibn 'Abd ul-Qàdir.

Ibon Diạya. Voyez 'Omar ibn alḤasan.

Al-Disvirt. Voyez Aad aL-Mot́miv al-Dimyáti; - Nop̣nma ibn Yoùsof; - Noủn AL - Div alDimyâtî.

Ibn abî Dixik. Voyez Monammad jbn abì 'l-Qâsim.

D10scoside. 2849 et suiv.

Al-Dinixì. 3204, 2 ${ }^{\circ}$ - Voyez aussi 'Aвa AL-'Azìz ibn Aḷmad.

Al-Dirisbakal. Voyez Hosiiv jbn Mohammad.

Al-Djabaatì. Voyez Abd al-Rậmís ibn Hasan et Hasavibn Ibrâhim.

Dsỉbia ibn Hajyàn (A boủ Moûsả). $2605,2^{\circ}, 3^{\circ} .2606$ et suiv. $2625,6^{\circ}$.

Al-Dja gílí. Voyez Hitim al-Djndíli.

Duśran ibn Hasan al-Barzandjì. $1216,7^{\circ}$.

Duśrar al-Sảdiq. 1224, $1^{\circ}, 4^{\circ}$. $1449,3^{\circ}$. 1913, $18^{\circ}$. $250 \%$, $10^{\circ}, 2637$ et suiv. $2716,10^{\circ}$. $2758,11^{\circ}$.

Duśrar ibn Thatab al-Odfawl (ou al-Odfowi) (Kamal al-Din Aboú 'l-Fadhi). 2148.

Ahoù Duíraa nl-Khâzin. 2467 , $17^{\circ}$.

Abou Duśra ibn Nohammad ibn al-Hosain. $2457,47^{\circ}, 49^{\circ}$.

Al-Djáfari. Voyez Mohammo alDjafari; - Mog̣amma ibn Mohammad.

AL-DJagayixi. Voyez Mạnotid ibn Nohammad et Монимsia ilin Nohammad

Aboú 'l-Dusisca. Voyez Mog̣ann.8 ibn al-H losaīn.

Al-Duairixt. Voyez 'Abontcin ibn Màlik; - Mogamua ibn 'Al ibn Yàsir; - Yopıмmı ibn Mobammad ibn "Abdhallah.

DJalí al-Dik: [Molyammad ibn Aśad] al - Dauwâní. $2398,3^{n}$, $4^{\circ},{ }_{2}^{3}{ }_{99}, 3^{\circ}$.
DJalíl AL-Dix a]-Mahalli. 1011. ${ }_{1396} 3^{\circ}$. $225 \overline{9}$ et suiv. $3_{1} 9_{1}$, 1 . 4546 .

DuLlâl al-Dix al-Roûmì. 3954 , $8^{\circ}$.

Ibn Dusis. 1061, $2^{\circ}$. - Voyez aussi 'ABD al-'Aziz ibn Mohammad et Mognsusa ibn Abmad.

Dugil al-Div al-Asnawi. 992.

DJiMil AL-Dír ibn al-Djazzâr. 1608 .

DJsmil aL-Div al-Hanbali. 3419 , $3^{\circ}$.

Duavir sL-Dis ibn a]-Hosain ibn 'Oqua al-Ḥalabí. 2021.

Dunile al-Dis al Q日ramani. $1156,4^{\circ}$.

Al-Dumílì. Voyez 'Al'̂̉ ibn Ahmad.

Al-Djimi. Voyez 'Abd ar-Rạmix ibn Alimad.

Al-Duasadí. Voyez Yoúsor ibn Ya:qoủb.

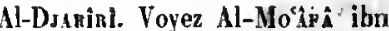
Zakariyá.

Al-Dussbì. Voyez 'Atl ibn 'Isã.

Al-Djacbins. Voyez 'Abd al-RagwÂx ibn abì Bakr.

Al-Djacdurit. Voyez Magamaad ibn 'Abd al-Monim.

Al-Dunuari. Foyez Anmad alDjeubnri; - 'Áli ibn Dâ'oùd; - IsMÂ"il ibn Ghonaim; Is MAil ibn Hammâd; - Noụ4M世ad nl-Djaubarí.

lbn al-D Jaczl. Voyez 'A ad AL-RaHmiv ibn 'Alí.

Al-Djawiliọi. Voyez Machotb ibn Alımad.

Dusxixi Efendi. 1619 .

Al-Duszï̄iò. Voyez Angad ibn 'Abdallalı.

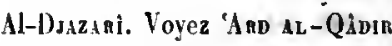
ibn Nolammad; - Ibnal-Atain al-Djazari; - Isudíl al-Djazarí; - Monsmanad ibn Mohammad.

Ibn Duaze. Yoyez Yaqyi ibn 'Isà.

Ibn al-Dsızz in. Voyez Aaman ibu Jbrảbìm; - Ali lbn al-Djazzàr ; -DuMíc AL-Div Ilon al: Djazzàr. 
Ibn al-Djazzî. $3+18,20^{\circ}$.

Djsanic (Zaïn al-Din). 4135 et suiv.

Al-Durarinî. Voyez 'Ali ibn Moḷammad.

Al-Djimaxì. Voyez Aīoamin ibn Ali.

Al-Djili. Voyez 'Aad a -Kanim ibn lbrâhîm et Koủscaxîn ibn Labbân.

Ibn Dunxî. Voyez 'Otumîs ibu Djinni.

Al-Duzoii. Voyez 'Omas ibn Abd al-Rahımån.

Dsonaīo ibn Malımoủd. 3368.

Ibn al-Djoxaĩd. Voyez Hàroûx ibu Moìsã.

Al-Djondininî. Voyez Abo AL-Q.jnIx ibn 'Abd al-Rahımån; 'Alî ibn Mohammad; - Ismiit. ibn al-Hasan; - Mọtammad ibn Scharif.

Al-Droawivi. Voyez Moụamad ibn 'Abdallab.

Al-Djowivi. Voyez Mọ̣amad ibn al-Ḥasan.

Al-Djowaini. Voyez 'And at-Miur ibn 'Abdallah et Yoûsor ibn Ismầil.

Ibn Duozaix. Voyez 'Aaduchu ibn 'Abd al-Rahmàn et Mog̣amap ibn Molyammad.

Al-DjozoúLì. $\log _{9} 8,1^{\circ}$. - Voyez aussi Moỵamad ibn 'Abd al'Aziz; - Mohammad ibn AlImad ibn abì 'l-Qàsim; - Mo-

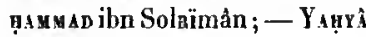
ibı Moùsâ.

Ibn al-Doваiтtil. Voyez Mog̣ама ibn Said.

Aboü Docar. 2284.

A]-Dorandîxî. Voyez Ạ̣mad alDolandjâwî.

Al-Domaĩzí. loyez Kamil al-Dîn al-Domairì

Al-Domít. Voyez Mog̣aman ibn Alimad.

Ibu Doquá. Voyez Iaraniu ibn Molıammad.

Ibn Doraĩd. Voyez Moн̣amá ibn al-Hosaïn.

llon abî 'l-Douryî. 659 , $4^{\circ}$.

Al-Dsanagi. Voyez Mogavmao ibn Ahmad ibn 'Othmán.
Dsoù 'L-Noûx al-Mișrit. 2608 . $2609,4^{\circ}$.

Doval (Jean-Baptiste). 4338.

Ecchelansis (Abraham). 4345 .

Éur, évèque d'Abṣaii. $154, t^{\circ}$.

Élie, évèquc de Jórusalem. 206 , 1 .

Élar, métropolitain de Nisibe. 31. $82,10^{\circ} .166 .175 .176$, $1^{\circ} .206,9^{\circ}, 10^{\circ} .4523,1^{\circ}$.

Épвавм le Syrien. 17. $69,8^{\circ}$. $7^{2}, 5^{\circ} .7^{4}, 13^{\circ} .114,1^{\circ}$. $13 s, 2^{\circ}, 5^{\circ}, 7^{\circ} \cdot 135$ et suiv. $139,1^{\circ}$. 140.143, 6 .151 $10^{\circ}, 11^{\circ}, 13^{\circ}, 11^{\circ}, 21^{\circ} .155$, $2^{\circ} .214,11^{\circ} .257,9^{\circ}$ à $11^{\circ}$ $260,4^{\circ} .262,5^{\circ}, 8^{\circ} .265$ $2^{\circ}, 11^{\circ}, 12^{\circ} .27^{5}, 9^{\circ}$.

Épiphane, patriarche de Constantinople. $234,23^{\circ} .235,21^{\circ}$, $34^{\circ} .236,29^{\circ} .251,33^{\circ}$.

Épipars, éveque de Chypre. 40, $4^{\circ} .55 .7^{h,}, 8^{\circ} .143,3^{\circ} .147$, $1^{\circ} .151, h^{\circ}$.

ERPENiUs. 4299.

Ésope. 3463 et suiv.

Étiexis, protomartyr. $213,14^{\circ}$.

ÉTueNRe. 2849 et suiv.

Étienne Piekne, patriarcbe d'Antioche. 308 .

Etiknne de Saint-Saba. $139,2^{\circ}$ s53, $7^{\circ}$.

Euchde. $2457,3^{\circ}, 6^{\circ}, 11^{\circ}, 18^{\circ}$, $34^{\circ}, 39^{\circ}, 41^{\circ}, 2458,4^{\circ}$. 2465. $2466,1^{\circ} .2467,2^{\circ}$, $5^{\circ}$ à $7^{\circ}, 16^{\circ}$ à $18^{\circ} .2484,2^{\circ}$.

Eusìar Pamphile. $147,15^{\circ}$.

Eurocius. $2457,44^{\circ}$.

Eutreures. Voyez Sa ỉ Ibn Batriq.

Evagries. 157 .

Ahoù'-Fadvitu al-Safi. 283 .

Al-Fidar al-Scharif. $43 y 6,2^{\circ}$.

Al-Fant ibn Hâtim al-Nairîzí. $2457,17^{\circ} \cdot 2467,7^{\circ}$.

Fadiz Aluár ibn abi'l-Fakhr alȘaqài. $206 r$.

Faghe Alcaín ibn Mohammad ibn Aiyoûb. $1156,3^{\circ}$

Fadnt-Aleâu ibn Tádros. 1 .

Al-Figuibl. Yoyez 'Aad al-Qida ibo Ahmad.
DD-FAaD. 721

Ml-Fikaoúrí. Voyez Aasène.

Abon̂l-Faxhr al-Masîlịi. 172 , $3^{\circ}$ à $8^{\circ}$.

Faner al-Dix. 3441 .

Fakar al-Dîn, émir. 4663, 20.

Faxar at-Dîn al-Harawí, 3257 , $2^{\circ}$

Farar al-Dín al-Khodjandí. 2941.

Fakan al-Dîn al-Râzî. $3497,9^{\circ}$.

At-Fàkunì. Voyez Aụmad al-Fâkihi.

A1-Faxínî. Voyez Mouammad ibn Alí et Monanaso ibn Hamza.

Ml-Fabioni. Voyez Aboaluh ibu al-Hosain.

Al-Firadaî. Voyez Ibrîuim ibn al-Hosaïn.

Aboù'l-Faradj al-Ișfahâní. 3292 et suiv.

Aboùl-Fanad al-Kindí. 2697 , $4^{\circ}$.

Aboù'l-FaraDJ al-Soûrî. 3682.

Aboûl-Faranj Hon al-Taiyib. Voy. 'Aapalra Ibn al-Taïyib.

Faradj-Aleîa al-Ikhmìmì. 25o, $1 \%$

Ibn Fabạ (Sehihâb al-Dín). $746,2^{\circ} .343$ ฯ, $3^{\circ}$. 4257, $1^{\circ}$.

Al-Faniuí. Voyez Уạmoúd ibn abî Bakr.

Al-Finâsì. Voyez 'Áî ibn Djâbir.

Al-Fanazda. $1203,6^{\circ} .4201$, $9^{\circ} .4961,5^{\circ}$.

Al-Faggấí. Voyez 'Amdalcap ibn Molıammad et Armad ibn Mohammad.

Ibo Fanuit. Voyez Gabre ibn Fariat et Geamasos ibn Farhat.

Fáio at-Dir 'Attín. 4585, $8^{\circ}$.

lan al-Firidu. Voyez 'Oras ibn 'Alí.

Farios Ro'aîs. $282,6^{\circ}$.

lon Firis. Voyez Auyso ibn Fàris et Aluốl-Latiïr.

lon-Farisghts. $743,12^{\circ}$.

Al-Finisì. Vovez Aboú Baxa alFàrisî.
Ibn Farroot xn. Voyez Monamuad ibn 'Abd al-'Aẓìm.

Al-Fâsl. Voyez Mogamand ibn Alemad; - Monammad ol-Fâsî ; - Mogarmad al-Mahdì.

Ibn al-Fasla. Voyez Anma ibn 'Alî.

Al-Fata ibn "Alt ibn Mohammad al-Bondári. $\quad 1896$ et suiv. 2 46 .

Al-Fatu ibn Mohammad al-Qaïsî Ibn Khăquản (Aboû Naṣr). 3318 et suiv.

Aboñ'l-Fata al-Ardabílí. 1264 , $1 \%$

Aboúl-Faṭ̣ al-Bostî. $1293,2^{\circ}$. Aboùl-Fata ibn Makhdoûm alHasanî. 3257, $2^{\circ}$.

lbn abî’l-Fatạ al-Ṣoûfí. 2602 3 .

Fatụ Aleîn. $3257,2^{\circ}$.

Faty Aluâu ibn Malumoúd alBaîloûnî. 3249 .

Fath Achía al-Halabi Ilon alNahbâs. $3246.3247,2$.

Fatụ Acrầ Ibn al-Ṣaigh. 1685. 2298 et suiv.

Al-Fawixisi. Voyez Mognamad ibn 'Omar.

Al-Fazíni. Voyez I arìiłix al-Qazấwî.

Al-Fazíwí. Voyez Aboñ 'Aadalar al-Nafzâwi.

Féntenté Oghrou. Voyez 'Aad alLatír.

Al-Frtuì. Voygez Baon aL-Dìn ibn Omar.

Ahoû'l-Fidà. Voyez 'Ismälz ibu 'Alì.

Al-Fidjidjî. Voyez Aboùl-Q.istu ibn Mohammad.

lbn Fierao. Voyez Aboú'l-Qìsiм ibn Fierro.

Al-Firdoùsî. Voỵez Aboùl-Qísın.

Al-Fínoùzíaidì. Voyez Igrìity ilon Alî el Mọ̣amad ibn Yacqoùb.

lbı al-Forit. Voyez Mohaman ibn 'Abd al-Rahịm.

Fenir (Jean-Baptiste). 4351.

Fíexifos (?). $7^{3}$.

Nasn ibn Makhloutf lbo Qalàqis (Abon̂ll-Fotoûh). 3139 . 
Foumost. 4226

Fanncols or Sales, S. 197, 20.

Fresnel (F.). 2299 .

Gsanel, (lbn Tarik). (70 ) patriarche d'Alexandrie. $251,44^{\circ}$ à $46^{\circ}$.

Gaarec, $\left(88^{\circ}\right)$ patriorche d' $A$ lexandrie. 98 .

GAarizl, $\left(95^{\circ}\right)$ patrioruluc d'Alexandrie. 3,6 et suiv.

Garrier ilnn Farhâat. 322. 4210. 4279 et suiv.

Gagera Sionita. 4338.

Garor (Mare-Antoine). 222.

Galiex, $309,11^{\circ}, 12^{\circ} .310,7^{\circ}$. ฯ837. 2845. 2846. 2847 et suiv. 2851 et suiv. 2853 et suiv. 2855 à $3860.2868,3^{n}$ $3039,2^{\circ}$.

Gacluis (Gilbert). 3685.

Geonges, patriarche d'Alexandrie. $266,1^{\circ}, 267,1^{\circ}$.

Georges, moine de Saint-Siméon. 186 et suiv.

Gźanasiar. $258,4^{\circ}$.

Genmaxos ilon Farhât. 323.

Ibn al-Guaïr. Tojez AboúlКнаїа.

Al-Guaïți. Voyez Mog̣amad ibn Ahurad.

Al-Guamí (et al-Guomri). Voyez 'Aen aL-W mad; - A Hạna al-Ghamrí; -. Anyad ibn Sa'd al-Din; 'A í ibn Ibrâbím; - Mọ̣a Mna al-Ghamri.

Al-Gruximì. Voyez Aboủl-IkuıÂs al-Ghanîmi.

Al-Guabi. Voyez Hamza ibn A!mad.

Al-Guaraítí. Voyez Mọ̣aumad ibn Aḷmad.

Gurrs at-Dix ibn Schibàb alDin Aḷmad al-Naqîb al-.lladjdi. $2544,1^{\circ} .2547,5^{\circ}$.

Al-Guassivì. Voyez lbn Rasoûl al-Ghassânî.

Al-Guavri (Sultan). 1814 .

Al-Grazàli. Voyez Azqua ibn Mohammad; - 'Alí ibn Mlohammad; - Monaysa ibn Moḷammad.
Ibn Guizi. Voyez Monamma ibn Ahimad.

Al-Ghazlawí. Voyez Mopammad ibn 'Omar.

Al-Ghazsawi. Voyez Ap̣mo ilm Mohammad.

A]-Gnazzî (ou al-Grozzî). Voyez Iвnâuin ibn 'Othmàn et Serams at-Dìn ibn Qàsim.

Al-Guoarinì. Voyez Aụad alGhobrini.

Al-Guonaini. Voyez Aỵman alGhonaïmî.

Al-Guozoûlî. Voyez'A Lî ibn 'Abdallol et Scuaus aL-Dis alGhozoủli.

Golivs. 4346.

Grégoire Bar-Hebracus (AboülFaradj). 296 et suiv. $809,8^{\circ}$. 45,6 .

Gnégorne, évêque. $275,19^{\circ}$.

Grégorre le Grand. 276, $1^{\circ}$.

Gaḱgojar, maitre de SaintÉphrem(?). $214,11^{\circ}$.

Grécoune de Nazianze. $40,5^{\circ}$. $42,1^{\circ}$. 43. 55. 88, $3^{\circ} .9^{3}$. $108,2^{\circ} .147,3^{\circ}$ à $9^{\circ} .151,2^{\circ}$. $206,8^{\circ} .213,2^{\circ} .258,27^{\circ}$. $310,7^{\circ}$.

Gá́goine de Nysse. $7^{4}, 16^{\circ}$. $147,2^{\circ} .134,1^{\circ}, 2^{\circ} .135$. 136. $137.138 .251,36^{\circ}$.

Al-Goluânî. Voyez 'Abo al-Qinar al-Guilài et Monanva ibn 'Aan al-Rauguás.

Al-II cascuí. Voyez Monamua ibn abi Zaid.

M-Haati. Voyez Mogamman ibn abi Djomía.

lbn al-Habвíkíra. Voyez MopaatMaD Ibn al-Habbârìya.

Ilabì ibn Aus al-Tà'ii (Aboú Tammåm). 3085. 3281 et suiv.

llaai ibn Khadina (Aboí Räita). $8 a, 5^{\circ} .169,13^{\circ}$ à $17^{\circ}$.

Ilabir al-Schiraizî (Mlírzadjàn). $2385,2^{\circ}$. 2391 .

lbn Hàib al-Halabi. Voyez AlHasin ibn "Omar.

Al-Hàdawi. Vojez Mogammad ibn Ibràhîm.

Al-Haddidì. Voyez Aboú Barr ibn 'Alí.
Al-Hádoj Makkî al-Qauwàs. $4639,5^{\circ}$.

Al-Hânds al-Scuátia. Voyez MoHaymad ibn 'Alì

Ibn al-Hínds al-Tilimsâni. 2709 et suiv.

Hạdoul Bâbî ibn Ibrảhìm 'Abd al-Karìm 'Othımăn al-Toúsawî. $4023,3^{\circ}$. 4150.

Hàdoji Pacha. Voyez Kurdua ibn 'Ali.

Al-Híburí. Voyez 'Izz a L-DiN al-Hàdbiri.

Al-Hapnrumi. Voyez Moyammad ibn 'Omar et 'Oman al-Hadlırami.

Al-Hanîtal. Voyez 'Ali ibn alFàdbil.

Ibn abl Hadjala. Voyez Ag̣mad ibn Yaḷyâ.

Ian lladir al-Asqalânî. Voyez Agman ibn 'Alí.

Ilın Hanjan al-Makkî. Voyez Aṇmad ibn Hadjr.

Al-Hầugaki. Voyez Bada al-Díx al-Hàdjermí

Hadjl Kualfa. Vovez Mostafí ibn 'Abdallah.

Ibn al-Hinsta. Voyez 'Otunîx ibn 'Omar.

Al-Hîfí. Voyez Mohamad ibn Soliammad.

Al-Hafnài. Voyez Aṇas alBaschschári; - Mонамñ⿰ alḤafnâwî; - Yoúsor al-Hånảwi.

Aboù Hafs al-Kabir. $834,1^{\circ}$.

Aboù Hạs llon Scluảhin. 718 .

Haídan (Monlâ). $2385,4^{\circ}$

Aboú Haìîn al-Andalosi. 4606 , $12^{\circ}$.

Ibn al-Hẫu. Voyez Aụna ibu Nohammad.

Ihn al-Haïtam. Voyez Al-Hasax ibn Hasan.

Al-Ḥı ‘̇aî. $3 \approx 57,1^{\circ}$.

Al-Hamadixi. Voyez Amuna ibn al-Hosain et Bisi Tinre alHamadâni.

Haudix [ibn 'Othımân]. 2456.

Hıмdis ibn Hamdoùya (AboúlTaiyib) $99^{\circ}, 6^{\circ}$.

al-Hamdixì. loyez Moṇmad ibn 'Abd al-Malik et Monamy a ibn 'Abd al-Rahmân.

HAMín al-Sa'di ibn 'Abd al-Karim al- W adjbâni. $1276,2^{\circ}$.

Aboů Hinio al-Maqdisf. $1811,1^{\circ}$.

Al-Himal. Voyez Aboù Bakr ibn "Alî.

Ihn Hamyan. Voyez Mopamman ibn 'Alí.

Ibn al-Ham iay. Voyez Mohaumad ibn 'Abd al-Wạid.

Aboú Hsmmov̂. 1876 .

Hıмza ibn Alımad Iton Asbàt alGharbi. 1821.

IIsmza ibn Ibráhim ibn Wali alDin al-Roùmí (Moslih al-Dín). 853.

Ḥans Qarảliesârí. 952, $1^{\circ}$.

II axbaci Zadè. $4606,5^{\circ}$.

Ibn al-II a mali. Voyez Mogammad al-Nảdsifi.

Ibn IJâxi. Voyez Moụamad ihn Ilân!.

Aboú Haxira. $762,2^{\circ} .97^{8}, 4^{\circ}:$ $1122,6^{\circ}, 7^{\circ}$. 1229 et suiv. $139^{1}, 11^{\circ} .2316,2^{\circ}$ à $4^{\circ}$. $454^{\prime}, 2^{\circ}$.

Ilaxis. 1443.

Al-Haxxití. Voyez Al-Hosaix ibn Mohammad.

al-Hanawi. Voyez 'Aramear ibn Mohammad.

Ibn al-Harawi. Voyez 'Ovar lbn al-Harawî.

Al-lianizi. Voyez Anuad ibn All et Al-Qisın ibn 'Ali.

Al-Higrtu (ou al-Ilirth) ibn Hilliza. $307^{5}, 7^{\circ} .3076 .327^{5}$ et suiv.

Al-Ilikaru al-Hlohâsibî (A boũ 'Abdallah). $1943,15^{\circ}$.

Hantru ibn Sinån ibn Sambât. 13. 14.50.

Hâxoûx ibn Moủsả. $4577,18^{\circ}$.

Higoûs ibn Noủsâ ibn al-Djonoỉd. $4577,10^{\circ}$.

Hasan (Schaïkli) $1330,7^{\circ}$.

Al:Hasax ibn 'Abdallah al-Askari (A hoù Hilal). 4370.

Al-Hasix al-Adjroud. $1450,11^{\circ}$. Al-Has iv ibn 'Alì ibn 'Omar alMarrikoschì. 2507 et 2508 . 
A)-Hasar ibn 'Ali al-Qommí (Áboú Naṣr). 2589 .

Ḥas.ax ibn 'All al-Qoùmnâtí. 2530 .

Ḥasav ibn 'Alì al-Sanbànî. 3 gho.

Al-Ḥsax al-Baṣrì. $780,1^{\circ} .2250$, $1^{\circ}$.

Al-Ḥssav al-Boûrini. 3157 et suiv.

Ḥısas Efendi al-Âqhisảiri Kàfí. 4418.

Al-Hasan iłn Habìb (Aboû'lQàsim). $4201,17^{\circ}$.

Hasar ibn Habib al-Halabi. $3206,3^{\circ}$.

Hạasar ibn Hànì (Aboù Nowàs). $3{ }_{2} 51,7^{\circ}, 10^{\circ} .3417,4^{\circ}$.

Al-Hasax ibn Hasan lbn al-Haitham. $2458,5^{\circ} .2460$.

Hasav ibn Hosain ibn Ahmad alToùloủní. 1814 et suiv.

Ḥasıs ibn Hosain al-Aqqàd. 3036 .

Al-Husıx ibn al Hosaîn al-Sokkari (Aboù Sáid). $33_{86}$.

Hasıs ibn Ibráhim al-Djabarli. 2476 .

Hassav al-Kafrảwì. 4138 el suiv.

Husà al-Kânì (al-Kàti) (Ḥosảm al-Din). $1243,2^{\circ} .1267,2^{\circ}$. ${ }_{2} 307,9^{\circ}$. s353, $3^{\circ}$. s354, $3^{\circ}$. 2653 et suiv. $2406,3^{\circ}$.

Hasix ibn Khalil ibn 'Ali ibn Mazcoû' al-Ṭobni (Badr al-Din). 2543.

Hısıs al-Madảbiglıi al-Azbarì. 1040. 1986.

Hasar ibn Masoúd al-Yoús?. $1060,12^{\circ} .1273 .2400, a^{\circ}$. $4207,4^{\circ}$.

II Asas ilon Noḷammad al-Astarâbảdi (Rokn al-Din). $2369,9^{\circ}$. 4037 et suiv.

Al-Hasas ibn Mohammad al-Naisàboúrì. 2510 .

IIısax ibn Molıammad al-Ṣaghıàni (Radhi al-Din). $7^{3} 7$.

Al-Ḥssus ibn abl Moḷammad 'Abdallah al-'Abbàsî al-Hàsclimi al-Safadi. 1706.1931 , $22^{\circ}$.

Al-II Asıx ibn abi' 1-No'màni. $667,1^{\circ}$.
Al-Husas ibn 'Omar Ibn Hahíl, al-Halabî. 1719 et suiv. $3_{2} 44$, $2^{\circ}$. 3361 et suiv.

Ḥısıx al-Schoronbilâlì. 98 s.

Hassa ibn 'Omâra ibn 'Alì alWafäi al-Schoronbilâli (Aboñ'llkhlàs). 1158 el suiv. 1160 , $3^{\circ}, 8^{\circ}, 12^{\circ}$. $1230,6^{\circ}$.

Hasas ibn al-Qâsim al-Uorảdi lbn Oumm Qâsim (Schams alDin). 4075 et suiv.

Al-Husar ibn ahı̂' l-Qàsim 'Alì alTanoukhhì (Aboù 'Ali). 3482 , $1^{\circ} .3483$ el suiv.

Al-Ḥ̂sss ibn Rahluâal (Aboù 'Alî). - 1102.

Hasiv al-Rammàh al-Aludab (Nadjm al-Din). $3825,1^{\circ}$, 2. $2826,2^{\circ} .28 \times 7,1^{\circ}$.

Al-Il isan ibn Raschiqg al-Qairawàní (Aboù 'Ali). $3417,7^{\circ}$.

Ml-Hisan ibn Sahl. 3957 .

Hasta ihn Sawar. 2346.

Al-Hilasax ibn Schacaf a]-Tibrizi. $9^{28}$.

Al-Ḥısıs al-Siràfí (Aboù Zaïd). $2281,1^{\circ}$

Hasss Tchelebî Qanâli-Zàdè. $666,11^{\circ}$.

Al-Hasan ibn Yoúsof ibn al-Hoțahhâr (Djamâl al-Dìn). 1108 , $2^{\circ}$.

$\Lambda$ boù 'l-Hasay al-Ansảri. 2624.

Aboû 'l-Ị̂sas al-Asclíarì. 1077 , $8^{\circ}$.

Aboû 'l-HAsan al-Bakrí. 1363 , $3^{\circ} .18 \dot{80}, 1931,6^{\circ} .383 \mathrm{~g}$.

Aboú 'I-Hısıs al-Bakri. 661. 662.

Aboû 'I-Ḥsss al-Bakrí al-Ṣiddiqi. $101 \mathrm{~s}$.

Aboǹ 'I-J̣ Asts al-Kliaraquàni. 760 , $6^{\circ}$.

Aboî 'l-ỊAsan al-Lakhmì. 1071.

Aboù 'I-Ḥasan al-Màlikì. 1062.

Aboù 'l-Ḥasıv al-Schådsilì. 7 \3, $9^{\circ} .119^{3}, 2^{\circ} .1197,2^{\circ} .1203$, $3^{\circ} .1974,3^{\circ} .2637,3^{\circ} .2758$, $6^{\circ} .3384 .4606,7^{\circ}$.

Aboú 'I-IIısax al-Sounrî. 4521.

Al-Ḥ. ssıxî̀ al-Nassàb. 4547.

Hiscum ibn 'Îsa' ibn 'Omar alSarkhadf. 1950. lbn al-Hașyafí. Voyez Nịṣa atDin ibn 'Îsà.

Al-Hiscurmí. Voyez Mọ̣amad ilın 'Abd al-'Azìz

Hassî̀ ibn Thâbit. $2677,4^{\circ}$. 3084 .

Ilírı (Al-Saiyid). 3241.

If iт1 a al-Djadili. $3251,12^{\circ}$.

Al-lịuguixí. Voyez aboú Bara ibn Baschir.

lbn II avque. 2215 el suiv.

M-Hiwirí. Voyez Monamad ibn Aḷmad ibn 'Alí.

IIizım ilm Vloḷanmad ilı JIasan ibn Hizion al-Ancârî (Iboù Ilasan). 3175 .

Aboủ Ỵizzy al-Madanì. 9行, $2^{\circ}$.

Jiant Allia ibu 'Abd al-Ralımàn thu al-Bàrizi. 1970.

Hadat Aluin ibn Djafar Ibn Sanà al-.llolk. 2099 .

Ilı.ıт ALıîn ibu Djami" al-Isràilì ( $A$ boù'l-Ylakảrim). 2963 .

Illaxt Aléiu ibn Salâma. 760 , $5^{\circ}$.

Ibn Hı̀os.. Voyez Aboû Bakn ibn 'Ali.

Al-Hıdiâzí. Voyez Moụısmad ilon Schóaïb.

НАЕпотни́. $234,30^{\circ}, 235,{ }_{2} 3^{\circ}$. $243,2^{\circ}$.

Hubanos, disciple de S. Basile. $153,11^{\circ} .258,1^{\circ}$.

IItprocrate. 2556. 2835 el suir. 2845. 3846.2847 et suiv. $29^{46}, 4^{\circ}, 3039,7^{\circ}$.

IIIPPOLYTE, S. $17 \cdot 238,17^{\circ} \cdot 245$. $251,23^{\circ}$.

Al-Hhîíl. Voyez 'Abdalau Alî ibn Alumad.

Huscuir ibn 'Abdallah al-Azdi (A bou'l-Walid). 1074 .

Ilsscuis ibn Moḷammad al-Kalbi. 2047 .

Ibn Hischix. Voyez 'Aaduluan ibn Yoúsof et 'Alad AL- MALIK ibn Jlischâm.

Jlon Hlıscuis al-Laklımi. $792,2^{\circ}$. Iln Iloatins. Voyez Yañi ibu Holịmmad.

llon Hoaiz. Voyez 'A Lî ibn Aḥmad.

Al-Ilomaidi. Voyez. 'Aad ac-linumis ibr Alumad.
Hov tïn (Schaikh). ${ }_{2} 560,3^{\circ}$.

Hoxsix ibn Islạqq (Aboú Yazid). $2775,2^{\circ} .2810,1^{\circ} .2835$ et suiv. 2845.2846 .2847 et suiv. 2849 et suiv. 2851 et suiv. 2853 et suiv. 2855 . $285_{9}$ et suiv.

Hุosot̂s ibn 'Ounar ibn Yoḥanna ibn al-Salt. $173,16^{\circ}$.

M1-Ḥontïiscu. $743,2^{\circ} \cdot 782,2^{\circ}$. -- Voyez aussi Scuóaĩa alDanoúscheri.

Ilosair ibn 'Abdallalı al-Schirwảni. 1458.

Al-Ilosxis ibn 'Abdallah Ibn Sina (.Houi 'tlî). $1176,12^{\circ} .1338$, $8^{\circ}$. $1620,10^{\circ} .2322,9^{\circ}$. 2366. $2484,1^{\circ}, 2502,8^{\circ}$. $2541,3^{\circ}, 2562,11^{\circ}, 18^{\circ}$, $15^{\circ} .2661,4^{\circ} .2885$ el suiv. $29^{4} 2,1^{\circ} . \quad 29^{43}, 1^{\circ}, 2^{n}$. 2944. $299^{3}, 3^{\circ} .3038,3^{\circ}$ $3039,9^{\circ} .317_{1}, 13^{\circ} .4201$, $13^{\circ}$.

Al-Ilosair ilon 'Abd al-Rahımán al-Aludal. 15,3 .

Hossiiv ibn 'Abd al-Schokouir. 3263.

Hossīx iln Alumad ibn khâlawailı ( $\mathrm{d}$ boù 'Abdallah). 4231 , $4^{\circ}$.

Al-Jlos.ïx ibn Alımad al-Zauzani (Alroû 'Abdallab). $\quad 3_{27} 6$ et suiv. 4287 et suiv. $4290,2^{\circ}$.

Hoșïn ibn cAlì ibn Ḥaddjâdj alSaghınàqi. 880 .

Al-Ilosaix ibn 'Alî al-Maghloribi (Aboû'l-Qàsim). 206, $9^{\circ}$.

J̣osıix ibn 'Alì al-Ṭoghrå'î. 1620 , $7^{\circ}$. $2060.2502,11^{\circ} .2607$. 2614.2620, $9^{\circ} .3119$ et suiv. $3200,5^{\circ}, 6^{\circ}$. 3430. 4124, $5^{\circ}$.

Hostĩn ibn 'Alì Wẩz al-Kâschifí. so44.

Ḥosıin al-Dàmaghànì. $3431, t^{\circ}$. Ḩossix al-Fatlui al-Schirizî. j63.

Al-Hossix ibn Hamdàn al-Klrasibi. $1450,3^{\circ}$.

Al-J̣̣osıĩx ilon Hâroùn al-Şâight. $1450,12^{\circ}$.

Ml-Hosaĩ ibn Hasan ilon lbrâluim al-Khalilì al-Dârí. $2749,1^{\circ}$. Ilosain ilon Ibrálim al-Natanzí. 4286. 
Ḥosaix ibn Kamảl. 1625.

Hossix ibn Maśoùd al-Farrâ alBaglıani. $7^{19} 9$ et suiv.

Ilosıíx ibn Noḷammad ibn 'Alxlallahı at-Táyilû́ (Scharaf alDiv). 751.4 4.2.

Al-Hosair ibn Molammad al. İiamåtí. \& $2016,3^{\circ}$.

Hosaix ibn Nlollammad ibn alHasan al- l)iyảrbakrì. ${ }^{1} 9^{80}$ et suiv.

Ilosain iton Moḷammad al-Nalalli. $2463,2^{\circ}$.

A-Hosainı ilm Kolnmmad al-

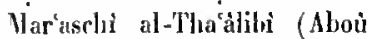
Manşoùr). 1488.

Al-Hosain ibn Molıammad atNarwaroúdi (Aboù 'Ali). 983.

Hosaĩ ibn Móin al-Din al-Mlailodsi. 2363.

M-Ilosain ibn Moûsá. $2467,3^{n}$.

Abonk'l-Ilosins. 835.

Ịosì a L-Dîn. 839 •

Ilosin AL-Din. $1156,1^{\circ}$.

Iosim AL-Din al-Roltaiwi. 644, 2 .

lloủn (Abbá). 1418, $1^{\circ}$.

Hypsicuès. $2457,36^{\circ}$.

Al-Trâdi. Vogez Aụvan ibn Qâsin.

Irnisiy (Schaikh). $3251,13^{\circ}$.

leainin ibn 'Abdallah Ibn abì al-Damm (Scharaf al-1)in). $99^{6}$.

Jneigì ibn 'Aldallah al-Qiràtí (Borlain al-Din). 2405,3 . 3209 .

I quinîn ibn 'Abd al-Raḥmân alAzraqi. $3029,3^{\circ}$.

I griaim ilon 'Abd al-Ralımèn lbn al-Karakî. $1931,1^{\circ}$.

Jgrinin ihn 'Abd al-Rahmmàn ibn 'Abdallab al-Qaïsarinì al-Khitlidi. 1708 .

luniuin ibn Aḷmad al-Mlausili (Borbân al-Din). 4569 .

Ioníuîn ibn Alımad ibn Mlolammad Ibn al-IIodlá. 3239.3412 , $11^{\circ}$.

Ianîuîn ibn Aḷmad (ou Moḥmmad) itun T'arkhàn al-Sowaïdi. 3001 et stiv. 3c04. $3016,5^{\circ}$.
Inaînîn ibn 'Alì Arabadjibachi. 4161 .

leniuîn ibn 'Alì ibn alî Bakr alAzraq. 3020 et suiv.

Inninîu ihn 'Alî al-Fîroûzâbàdì. $139^{5}, 4^{\circ}$.

Ininim ibn 'Alì al-Tarsoûsí alḷanafì (Borhàn al-Dín). $9^{2} 6$. $2445.2446,1^{\circ}$.

Ieniuím ilon 'Alì ilon Yoùsof alSchirázi (A boú 1sṭåq). 786 . $1023,1396,3^{n}$.

laninîm ibn 'Moun. 166.

loniuîy ibn abi Bakr al-Ansạs! al-Tilimsànî (Aboû lsı̣ăqu). 1076.4565 .

Inniuin ibn abi Bakr al-Silili. 18.33.

Innivir Efendi, $1167,7^{\circ}$.

lanirin ibn abi'l-Fall! Khafidja (Aloư Islata). 3135 .

luriuin al-Halabì. $2677,7^{\circ}$.

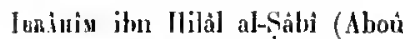
lslìq q). $3314,3^{\circ}$.

Jasihis ibn Ilosain al-Fàradhi. 1227.

Iroinìn ibn Ismàiłl al-Ṭarâbolosi (Aboù Iș̣ầq) $4253,1^{\circ}$.

lanizîn ion Khali] a]-Halabi Sibt llon al-A'djami (Berhân al-Din). 1968 et suiv.

Innîuîu al-Logànî (Aboủ'l-Amdâd ou Imdád). $7^{61}$, $2^{0} .209^{2}$.

Jasinim ibn Maḷnoûd al-Dimaschqi (Borhân al-Dỉi). $3200,2^{\circ}$.

Ianiain ibn Mahmoùd al-Schâdsili. 1367 .

Iвnílim ibn Marí ibn Atiya alScholıảkhiti. 7 १9. 4560 .

lввinix ilon Molıanmad. gon.

IsRiuim ibn Nolammad ibn Aïdamir al-Alàyi lbu Doqmâq. 1597.2096 .

Iniuin ilm Mlohammad al-Anșàrì. $3200,5^{\circ}$.

Inninis ibn Nolammad lbu 'Arabschåh al-lsfircäini ('Ișàm al-Din). 3257, $2^{\circ}$. 4424, $1^{\circ}$, $5^{\circ}, 7^{\circ}$. 4425, $1^{\circ}, 2^{\circ}, 4^{\circ}, 8^{\circ}$. $4429,1^{\circ}$ à $3^{\circ} .4585,4^{\circ}$.

Ianiuis ibn Molammad al-Hakìm al-Samarqandi (Aboû'l-Qàsim). $824,1^{\circ}$. loniuis ibn Nolıammad al-Halabl. $9^{56}$ et suiv, $1042,6^{\circ}$. 1149 et suiv.

laninis ibn Noḷammad ibn Khalil (Aboù'l-Waqt). ${ }_{2677}$, $10^{\circ}$.

Itrinin ibn Nohammad al-Naïmoúni. $4187,2^{\circ}$.

Iarinim ibn Moufarradj. 3683 et suiv.

Imsiniy ibn al-Noqri (Scharaf - al-Din). $99^{3}$.

Jnnânim ibn Nàfi al-Sătihịi. 2699 .

Igniryis ibn 'Omar al-Biqă'i (Borhân al-Dìn). $1139 \cdot 1587$. 3065 .

Ínìî̀ ibn 'Olhmân ibn Mohammad al-Kalbi al-Aschhabì al-Ghazzí ( $A$ boù lș̣åq). 3126 .

Iвniнiห ibn al-Qâsim Ibn alRaqiq Qaïrawảni. 3302.

Janinim ibn abì Saìd al-'Alà'i. $2965,1^{\circ}$ et suiv.

laniuin al-Sandoủbł (AboủlFauz). 3271.

lanisis al-Schabistari. $419^{6}$.

Iari iui ù ibn Sinàn. $245_{7}, 1^{\circ}, 26^{\circ}$.

[laniuim] al-Qaziwi (ou Al-Fazârî) (Borllàn al-Dìn). 9254 , $1^{\circ}$.

I Bniaì al-Soúhábi (al-Sauhà'i?). $3191,2^{\circ}$.

Iqaíaim al-Tanimi. $11 / 1,5^{\circ}$.

Iariaim, de Tibériade. $258,6^{\circ}$.

laniuix ibn Yahỵa ibn Ghannåm. 2750 et suiv.

Ac-îmí. Voyez 'Abr at-Mag̣mín ibn Alımad.

Al-Ionisi [Molammad ibn Nollammad]. 2221 et suiv. Voyez aussi Mogasumad ibn 'Abd a]-'Azîz.

Irlâtoûn-Zisè. Voyez Nogay.s. ibn Ibrăhim.

dl-Iranojì. Voyez 'Au ibn 'Abdallah.

Igrige (P.), d'Orléans. 228.

Abeủ 'I-IKHLẬ al-Ghaniml. 3201.

Al-îligî. Voyez Schanar al-Dì al-îlàqí.

Îlyà (Aboù Nakhlad). $206,11^{\circ}$.

Ibn al-'Tyad. Voyez Mopasy uad ibn Alimad.
Al-'Twìnt. Voyez Aboủ Sáoûd ibn Nolianmad.

Inim atharamain. Voyez 'Abo aLMíuk ibn 'Abdallah.

Імім-Zím. Voyez Mopamuıd ibn abí Bakr.

Ixamscuino. Voyez Nopaymad ibn Omar.

Al-Inarlì. Voyez 'Alî ibn 'Îsâ et Nonaymad ibn Ahmmad ibn abî Schảkir.

'Îsâ, métropolitain. $3_{12}, 3^{\circ}$.

'Tsà ibn 'Alî. a $869.299^{8}, 2^{\circ}$.

'Îsà ibn 'Alî ilon Aḷmad al-Andalosi. 3546 .

'Îsi, fils de Constantin. $257,6^{\circ}$. 'Îsì ibn 'Îsà ibn Ishàq lhn Zor'a (Aboù 'Ali). ${ }_{7}^{3} 3,2^{\circ}, 4^{\circ}, 6^{\circ}, 7^{\circ}$, $9^{\circ}, 11^{\circ}, 19^{\circ}, 17^{4}$.

'Îsâ ibn Jṣıàq ibn Zor'a. 132, $15^{\circ}, 16^{\circ}$.

'ÎsA ibn Naḷfoủz. 3964,5 .

'̣̂si ibn Noliammad al-Raráwí. 806 .

'Îsî ibn Moḥammad al Ṣafaivi (Qoṭb al-Dîn). 2397.

'îsì Presno. 1564. 3464.3680. 3922.

'Îsî ibn Yalyấ al-Masíḥ' (Aboù Sahl). 2881 et suiv.

lbn '̂̀si. 1940.

Aboủ 'îs. al-Warráq. Voyez Momasmad ibn Hâroủn.

Istac (Nar). ${ }_{157}, 9^{\circ}$.

Isuac (Mar). $253,2^{\circ}$.

IsaAc, évèque d'Antinoë. $153,8^{\circ}$.

Isasc, de Ninive. $149,4^{\circ}, 5^{\circ}, 25 \%$, $8^{\circ}, 265,9^{\mathrm{n}}$.

Issac le Syrien. $69,9^{\circ}, 17^{3}$, $14^{\circ}, 16^{\circ}$.

Istíz (Anbì). $257,15^{\circ}$.

Al-'Isi vi. Yovez Aan al-Miluk al'Tşàmi.

Al-Iscunici. Voyez Mobanmad ibn Abdallah.

A1-Ispauini. 4163. - Yoyez aussi Abou' 'l-Farados al-lśfabâui; Isvi'ic ibn llolummad; Nạ̧หอบิอ ibn 'Abd al-Raḥmân; - Moвамяар ibn Mohammad ibn $A$ ḥmad.

Al-Isfariíni. Voyez Jarîhlm ibn 
Mohammad ; - Mog̣amsab ibn Alemad; - Nonanua iln Mohammad; - Sio AL-DiN al-Isfaräïuí; - TÁtan ibn Molıanmad; - Ysígoû́ ibn Solaïmàn.

Al-Isfeacedit. Voyez Al-Mlozaffa al-Isferledî.

Isnịo ibn al-Ḥasan lbn al-Zaiyât. 2186.

Isậa ibn Honain ibn Isḥâq. $2457,36^{\circ} .2482$ et suiv.

Isụinq ibon Ibràhîm ibn Aḷmad ibn Mohamnad ibn Kàmil al-Tadmori (Tàdj al-Din ). $19^{2} 9$ el suiv.

Isụiạ ibn lbrâluím al-Khalilì (Aboú 'l-Fidà). $\quad 1667,2^{\circ}$. $1668, a^{\circ}$.

Isụiq ibn Solaïmàn. $29^{42}, 5^{\circ}$.

Aboủ Iṣịq. 1112.

Al-lsuioị. 1562. - Voyez aussi Möammad ibn 'Abd al-Nlo'ti.

Isivone, S. $77^{4}, 13^{\circ}$.

Al-IskLììi. Voyez Aboû SÁoûd ibn Mohammad.

Isvâ'ì ibn 'Abbàd al-Sảhủb (Aboù '1-QAsim). $3314,2^{\circ}$.

IsuAili ibn Nlimàd Tadj al-Din al-Haqq al-Katib ibn Scharaf al-Din Saî̀d lbn al-Athî ('Imàd al-Din Abaú 'I-Zạahir). 3088. $3134,1^{\circ}, 2^{\circ}$.

Isuíit ibn 'Ali. 4093, 4".

Is $\hat{A}^{\prime}$ ìi [ibn 'Alí] (Al-Malik alMo'aiyad Imád al-Dín Aboû 'l-Fidd). 1508 et suiv, 2239 et suiv.

Issi'ilu ibn abî Bakr Ibn alNoqri al-Yamani (Seltaraf alDin). $3306,6^{\circ} .4652$ el suiv.

Ismâ'î̀ al-Djazarì (Abaù 'I-'Izz). 2477 .

IssÂ'iz iton Ghonaim al-Djauhari. 716. $4540,1^{\circ}$

lsuÀ la ibn Hammâd al-Djauhari (Aboû Nașr). ${ }_{2} 3_{7}$ et suiv.

Isyìiz ibn al-Ḥasan al-Djordjânî. ag55.

Ismî ỉ ibn al-Ḥasain. 3206, $5^{\circ}$.

Isvîic ibn Ibrâhìm al-'Alawt alYamanî. 4160 .

IsuÄ'ì Khasschâb. 1858.

Isu'i'ic al-Mausilì (Aboû '1-Fadhl). 2747 .
IsMÁic ibn Moluammad ibn alFadlıl al-T'aïmi (ou al-T'ayami) al-Hàfiz al-I:̣ahàni (A boù '1-Qàsim). 2012.

Ismíin ibn 'Omar lin Kathi" ('Imàd al-Din Aboù 'I-Fida). 1515 et suiv. $4577,6^{\circ}, 9^{\circ}$.

Ismícic lbn al-Qàsim al-Qàlì (Abou 'Ali). $4235.4236,1^{\circ}$.

[suấtL Santa al-Molk (Aboî \% Tàhir). 2963.

lbn IsuÁî. 23 20.

Ibn IsMi'il ilon 'Alì ibn Ibrăhim. $3{ }_{2} 5_{1}, 5^{\circ}, 6^{\circ}$.

Al-Istakhrî. 2214 .

Al-Jiquàni. Voyez Amin Kítib.

'Iyìni ibn Maùsả al-Yalı́sohi (Ahou 'l-Fadhl). 1953 et suiv. $2758,5^{\circ}$.

lbn al-'izz. Yoyez [вRinim ibn 'Ali al-Ṭarsoùsì

'Izz AL-Dis ibn Ghânim al-Hlaq. disí. 4644 .

'izz aL-Dis al-Hadhirí. $2677,9^{\circ}$.

Tzz AL-Dis al-Zaxosasl. 4063 et suiv. $4123,6^{\circ} .4166,3^{\circ}$. 4167 et suiv.

JicQues (Saint-), l'apôtre. 147 , $14^{\circ} .262,7^{\circ}$.

JacQres, évèque d'Édesse. 17.

JACQues de Saroug. 17. $7^{4}, 6^{\circ}$, $15^{\circ} .88,3^{\circ} .132,6^{\circ} .15 ., 4^{\circ}$. $153,41^{\circ} .212,4^{\circ}, 260,5^{\circ}$. $264,3^{\circ} .265,5^{\circ} .305,10^{\circ}$.

Jsix V1. $334,22^{\circ}$.

Jeas d'Antioche. Voyez Yạyí Ibn Said.

JeaY Carpathius. $157,7^{\circ}$.

JeAs Chrysastame (Saint). 17. $28,7^{\circ} .40,2^{\circ} .53 .55 .59$. $68,3^{\circ} .69,3^{\circ} .7^{4}, 9^{\circ}$ aे $39^{\circ}$. 84. 87.89 .92 à 96.106 . $139,3^{\circ}, 143$ à 146. $151,3^{\circ}$, $5^{\circ}, 7^{\circ}, 8^{\circ}, 12^{\circ}, 15^{\circ}$ d d $20^{\circ}, 22^{\circ}$, ${ }_{2} 3^{\circ}$. ${ }_{152}, 3^{\circ}$. $155,8^{\circ} .158$, $2^{\circ} .173,3^{\circ} .205,4^{\circ}$. $238,27^{\circ}$. $251,34^{\circ} .253,6^{\circ}, 260,6^{\circ}$. $262,9^{\circ}, 13^{\circ}, 17^{\circ}, 21^{\circ} .264$, $4^{\circ}$ à $6^{\circ} .265,4^{\circ}, 14^{\circ}, 15^{\circ} .260$ $13^{\circ} .280,6^{\circ} .281,2^{\circ}, 3^{\circ}, 9^{\circ}$, $15^{\circ}, 29^{\circ}, 30^{\circ}$.

JeAx Climaque. $157,6^{\circ}, 161$ et suiv.

J $\varepsilon_{A}$, prètre de Constantinaple. $68,5^{\circ}$.
Je.1n Damascène. $28,8^{\circ}, 151$, $1^{\circ}, 164.165,1^{\circ}, 3^{\circ}$.

JEAY, moine dn mont Naqgloun. $154,11^{\circ}$.

Jesw Thaumaturge. $281,20^{n}$.

Jeax, fils de Zébédée. $275,15^{\circ}$.

JÉsus. $309,10^{\circ}$.

Јомнар. 4664, $1^{\circ}$.

JaseriI, capucin. 230 .

Josepu ben Garian. 287. 1906.

Josaphitr, moine. 1 ag.

Joundir. 1596 .

Juzes d'Aqfahsả. 81,20 .

Ks's ibn Zoluair. $1620,50.3078$ el suiv. $3088,5^{\circ} .3198,5^{\circ}$ $32 / 48,4^{\circ}$ ì $7^{\circ} .3430 .4261,7^{n}$

al-Kafawi. Voyez Monunum ibn Homaïd el Haquniso iton Solaimàn.

Kirl. Voyez ILssav Efendi.

Kirtyadi. Voyez Ionaumad ibn Solaïmàn.

Al-Kafaiwi. Voyez Hasay al-Kafriwi.

Al-Kıizzıwisi. Voyez 'Alì al-Kaïzawàní.

Al-Kikl. Voyez Monnuma ibn Molıammad.

Al-Kalíbiasi. Voyez Ainma ibn Nohammad.

Al-Kata't. Voyez Monumua ilo Scharaf el Soctiviviv ibn Mousis

Al-Katizi. Vayez Moнnuna al- Kalàzi.

Al-KaLbi, Voyez Hrscrian ibn Nolıammad.

Ksmí ibn 'Alì ibn Isḥàq. $3_{99} 3$. 5 .

Ibn Kamiz Pacha (ou Pachazâdé). Voyez Aṭuna ibn Soliamàn.

Kimic at-Din al-Domairi. 3192.

KaniL aL-Dix Hamdàn. 894, $3^{\circ}$.

Kamì at-Dix f'Alî ibn llolammad] lbn al-Nabill. $3418,20^{\circ}$

Ibn al-Kamiti. Voyez 'Aziz ALDiv lba al-Kamili.

Al-Kixi (Al-Kàli). Voyez Has.ı al-Kùní.

Al-Kinyauì (Kafiyddi). Vayez Jloṇмy «D ibn Soläman.
Iba Al-Kanakì. Voyez Ianiaìn ibu 'dbd al-Ralımån.

Kanì ibn Ibràhìm. 2415.

Al-Kankui. Voyez Noụ.smano iln al-Ịasan.

Al-Kisisì. Voyez Abaù Bıkn ibn Masound.

Al-Kâschenani. Voyez Sadía ALDix al-Kàschghlarì.

Al-Kiscini. Voyez 'Aan at-Aziz alKischi; - 'Aro aL-Rizzì alKàschî et Araq 4r al-Kàschì.

Al-Kiscmiri. Vayez Hosaïn ibu 'Alì.

II-Kizanoisi. Vayez Sadio ALDix al-Kàzaroùní

Al-Kuabìs?. Voyez 'Aboalzan ibn Fadhl el Mohamao ibn abi Bakr.

Al-Kunimusi. Voyez Aboù SA'id alḰhàdimi.

[Ibn] Kntríma. Voyez ImRihiu ihn ahì 'l-Fatll.

Al-Kmininj. Voyez Airma ibn Molıammad.

A boì 'I-Kınin. 2716, a".

Aboû 'l-Katin lbn al-Ghaïb. 178 , $1^{\circ}$.

A baư 'I-Krain ibn abi' 'I-Sa'oùd. $25+9,6^{\circ} .4151,2^{\circ}$.

Kusĩn at-Din al-Batlisî. 1013 $10^{\circ}$.

Al-Knairimi. $2458,7^{\circ} \cdot 2461$

Al-Ḱntîyoùọi. Voyez Aṇııo jbn'Omar.

Konc.aF ibn 'Albbà al-Zabràni (Abaù 'l-Qàsim). 2953.

Kualaf ibn abì '-Qâsim al-Băràdsiì (Aboù Said). 1051 el suiv.

lbn Kuilawain. Vayez llosaîn ibn Ahmad.

lbn Kunizaoùv. Vayez Ago 11. Ranyis ibn Hahammad.

Kutìto ibn 'Abdallah al- Izlawi (Zain at-Din). $7^{44}, 7^{\circ} .1330$, $16^{\circ}, 2316,7^{\circ} .319^{3}, 407^{8}$ of suiv. 4086, 4123, $3^{\circ}$. 1194. $2^{\circ} .4130,1^{\circ} .4131$ et suiv. 4146 et suiv. 419 a et suiv.

Kuicuo ibn 'Isà al-Balawi (Aboi 'I-Baqà). 2286.

A-Kuhudi. loyez Inniuis iln 
'Abd al-Rahmân et Mlous Mad al-Djauhari.

Kunzipa ibn abò 'l-Maḥåsin. 2999.

Kusuí ibn Aibak al-Safadi (Salal! al-Dia). 2062 et suiv. $2678 \mathrm{ct}$ suiv. 3119 et suiv. 3316 et suiv. $3345.3658,12^{\circ} .397^{2}$, $4^{\circ} .4611$.

KnaLiu al-Asclirafi. 4261, 7".

KnaLí ibn ls!̣aq ibn Yaqqoùb. $1077,1^{\circ}$ et suiv, $1179,2^{\circ}$. 4550 et suiv.

Kaslì al-Mailiki (Aboù 'l-Morschid). $2377,3^{\circ}$.

KuALì Sabbàłğı al-Selıâmî. 313.

KutLí ibn Schåhin al-Zâhirł. 1724.2258 .2752 .

KunLì ibn Solaïmản Ibn al-'Attâr al-Ḥanlsalì. 1345 .

Kunaic Aluía ibn Noùr Allàh ibo Mo'in al-Din Yazdî. $1359,2^{\circ}$.

ḰnaLìtLì. 3221.

Ibn Kualukâk. Voyez Auman ibn Molyammad.

Al-Kunwwati. $3{ }_{25} 5$. - Voyez anssi Aboủ 'l-Banakít al-Khalwalí et Moștafầ ilon Kamál al-Din.

Al-Kuìví. Voyez Aụma al-Khàmî.

Ibn KaÃoìn. Voyez Al-Faț̣ ibu Mohammad.

Al-KnandeÀi. Voyez Aboủl I! ssux al-K'haraqaani et Hounuman ibn Aḷmad al-`ahrawànî.

Al-Kunasscui. Voyez Moụumad ilon 'Ahdalloh.

II-Kuaninati. Voyez Mansot́ ibn Ismấil.

Al-Kinatanantî. Vojez Ma!̣mot́n ibn Ismă il.

Al-KuAseki. Voyez Ậ-Bogni.

Al-Kậși. Voyez Nadm aL-DjvalKhâșì.

Ml-Kunṣibì. Voyez Ml-Ḥosaîx jlun Hamdàn.

Ibn al-Kussscrios [Molyammad itn Allmad]. 643. - Voyez aussi 'A uî ibn abì Tálib.

Al-Kunțî́. Voyez MathấZZidè.

Ibn al-Kнат̣ín. Voyez Аймad ibn Hasan et Mopaymao ibn 'Abdallah.
Kuaţí al-Nàsısira. Voyez 'Alî jbn Mllaammad.

lbu al-Kuatrí. Voyez Kuonn ilụ 'Ali et Molifoùz Ilon alKliattàb.

Al-Kanlixi. Voyez 'Alì ibn Said.

Ilon al-Kinuwas. Voyez 'AmDaLLaIn ibn Moḷammad.

Al-Khawiri. Voyez Aboú Raka Moḷammad al-Klıawâfi.

Al-KHawwi. Yoyez Yoúsop ibn Țihisir.

Al-Kuizrs. Voyez Stì ibn Mlohammad.

Al-Kuazaajî. Voyez 'Aboallail ibn Molıammad et Mouamsa al-Khazradji.

Kumon ibn 'Abd al-Qàdir alBorlosi al-Qabbâní. 314.

Kauor ibn 'Mlì lbn al-Khattàb Hàddjì Paclıa. 2388. $2967,2^{\circ}$ 3012 et suiv.

Kunda-Beg ibn Djalàl al-Dìn. $4662,16^{\circ}$

Ibn Kuiba al-Motaïyam. 3412 , $4^{\circ}$.

Al-Kuraqi (lisez Al-Kmaraqî). Voyez 'A ad al-Duadeấa ilon Moliammad.

Al-Kinxìl. $1236,3^{\circ}, 4^{\circ}, 1241$ et suiv.

Al-Khodjandí. Voyez Ap̣ab alKhodjandi et FaKнa at-Din alkhodjandi.

Ibn-Khonbânaben. Voyez 'AbealLAu ibn 'Abdallah.

Ḱnosnoú al-Roûmî (Mollà). $936^{\circ}$ et suiv. $3632,2^{\circ}$.

Al-Kúsnoîujirdì. Voyez Ạ̣ma ibn al-Ḥosain.

Al-Kuoùmabjì. Voyez Monamman ibn Nâmwar.

Al-Knoùyí. Voyez Mọanmad jbn Qotb al-Dín.

Al-Kuowiaszม่̀. $2357,15^{\circ}$.

Knwàdo-Zàdè. Vuyez Moștafì ibn Yoùsof.

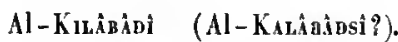
Voyez llạ̣soìn ibn abì Bakr.

Al-Kindi. Voyez Yáooû́ ibn Isḷàq.

Al-Kinuìní. Voyez Nafís ibn 'Iwadll.
Al-Kıshìi. Voyez 'Alî ibn Hamza et Monsyas ibn 'Abdallall.

Ibn Kızogntl. Voyez Yoúsor ibn Kizoghli.

Al-Kosnawî. Voyez Nabux ol-Scharilịî.

Kónês at-'Atrin. Voyez Aboû '1Moxí.

Al-Kọ̣naí. Voyez Aụmso ibn $A ! ̣-$ mad.

Kòschkeniai. Voyez Qotr a a -Dis Kóschkenảrí

Al-Koţì. Voyez Mop̣amad ibn Ithràhìm.

Al-Koìmî. Voyez Moụamad ibn Moḷammad.

Al-Koûràxì. Voyez Zaĩn aL- $\hat{A}_{\text {Bl- }}$ dix ibn Yoùsol et Yoúsor ibn Molyammad.

KoúscaYìa ibn Labbân ibn Bâschahri al-Djili (Aboû' 'l-Ḥasan). $2487,1^{\circ} .2521$.

Ibll al-Lamuâs [Moḷammad ibn Alunad ]. $641,1^{\circ}$.

Hon-LaBbîsa. 4392.

Labì iba Rabî'a. $3075,5^{\circ}$. 3076 . 3275 et suiv. 3430 .

Al-Limsapî. Voyez Moganyan ibn Mohamimad.

Al-Lakumí. Voyez Aboû 'I-Hasay al-Laklımi et Ibn Hıscuin alLakbmí.

LALANDB. 2554 et 2555 .

Al-Láni. Voyez Mog̣ammad Moṣlị! al-Din.

aboû 'l-LaTîì lbn Färis. 1200 , $2^{\circ}$.

LE Bé (Guillaume). 42a1. 42a2.

LegaANd. 2973.

LÉor le Sage. 103.

Léoner, évêque de Néapolis. 151 , $24^{\circ} .153,26^{\circ} .259,4^{\circ}$.

l.e Roex Desaatieanies. 42. 7 .

Al-Loboùbì. Voyez Anmad ibn Molammad.

Al-Lograwi. Voyez 'Atí ibn Dja'far.

Al-Loqixi. Voyez 'Abd al-Saliy ibn lbrâbìm; - lnaintis al-Loqânî et Nị̦ı ar--Dìr al-Loqânì.

Lopmin. $28,11^{\circ}$. 49, $3^{\circ} .309$, $7^{\circ}, 10^{\circ}, 310,4^{\circ}, 312,12^{\circ}$ $1913,17^{\circ}$.

Lotf Aluik ibn Ahmad al-Hosainini. 1277.

Lot̂̀î ibn Sérapion. $277^{2}, 1^{\circ}$.

Luerus. $157,1^{\circ}$.

Al-MA Áraj. Voyez Moụamad ibn Ibrảhìm.

Aboú 'l-MA'âtî. 3810 et suiv. - Voyez aussi 'ABo AL-MiLK ilon 'Abdallah et Aumad ibn Mohammad.

Aboû 'l-M M'ili (al-Qâdhi). 3964 , $4^{\circ}$.

Al-Ma'anni. Voyez Aboû 'l-'ALA.

Macaire (Saint). $253,3^{\circ}, 4^{\circ}, 5^{\circ}$. $257,14^{\circ} .276,15^{\circ} .305,4^{\circ}$.

Maenae (Saint) d'Alexandrie, $178,3^{\circ}$.

Macarius, patriarche d'Antioche. $224,1^{\circ}$.

Al-Madígugî. Voyez Hasan alMadàbighî.

Aboú 'I-MAdjo ibn Loùs. 205, $5^{\circ}$.

Manuo At-Dìv Ibn Makânis. 3498 , $2^{\circ}$.

Ibn al-Mlladoì. Voyez Anuad ibn Radjab et Gusss aL-Dis alMadjdf.

Ibn Nidso. $32_{264}, 8^{\circ}$

Al-Mhadoutsi. Voyez 'Alí ibn 'Abbâs.

Al-Manarịi. Voyez Mascama ibn Aḷmad.

Al-MadjRoúd. 3204, 5 .

Abou Madran. Voyez Serocait Aboú Madyan.

Al-Magnxísíwi. Voyez Aguad ibn Moḷammad.

MAGHoìscu al-Maghribi. $2620,5^{\circ}$. Mahà dakhîscy (?). $310,6^{\circ}$.

Al-Manalí. Voyez Dualấ at-Día al-Malialli; - Hossir ibn Molyammad; - Nog̣ı m mo ibn Abmad; - Mogamma iln 'Omar; - Aboú 'l-Qisir al-Maḅalli.

Al-Vaụimul. Voyez Aṇmad ibn Mohammad.

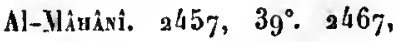
$16^{\circ}$.

Aboû '1-Maụ̂s ibn Bint alA'azz. $945,1^{\circ}$. 
Ml-Mạpoùbi. Yoyez Aụmad ibn 'Obaidallah ibn Masoùd.

A1-MIAHDi , calife. $215,6^{\circ}$.

Maudì ibn 'Alì al-Ṣobonrî. a 70o, $2^{\circ} .3016$ el suiv.

Ma!̣roữ Ibn al-Kattàb al-Ṭoúbảdi (?). 9o5.

Manmoûd ibn 'Abd al-Rahmàn al-Iṣfahàni (Scliams a)-Din Aboû́ 'l-T'hanå). 799. $1257 \mathrm{et}$ sniv. $2369,33^{\circ}$. 2389 .

M⿻ب̣moûd ibn Aḷmad al-Aïni (Badr al-Dìn Aboú Mlọammad). 698 et suiv, 1542 et suiv. $1723.3979,19^{\circ} .4099$. 4543 et suiv.

Maṭmov̂̀ ibọ Aḷmad al-Amscluâtì (Nozaffar al-Din). 2930.3025 et 3026 .

Mạ̣หoûd ibn Aḷmad al-Q̨oâni. 924.

Mạ̣ot̂d ibn Aḷmad al-Zandjânì. 4946.

NA!umoìD ibn abì Bakr al-Farâhî (Badr al-Din Aboù Nasr). 8ะ3. $3088,6^{\circ}$.

Mạ̣moìd ibn abì Bakr al-Kilàbâdì. $865,2^{\circ}$.

Mạmoúd ibn abi Bakr al-Ormawl (Siràdj al-Din). 2369 , 2. $2381,2^{\circ}$. 2386 et suiv. a $398,4^{\circ}$ (dans ces notices, lisez partout Mahmoúd an lien de Mobammad). $4187,15^{\circ}$.

Mạ̣yoû̉ ibn Dàoùd al-Lonlouî à-Boklıâtri al-Afschandji. 4570 .

Mạnoừn ibn Ismà'îl ibn 'Abdallah ibn Mikà'il al-Kharìrati (on al-Khartabartî). 4148 et suiv.

Hạ̣moùd jbn Ismấî̀ al-Halabì (Hibat Allàb). 4592, $14^{\circ}$.

Mạnmoùd ibn Nasoñd al-Schiràzì (Qotb al-Din). 2349.2516 et suiv. 2940.4377 .

Mạ̣moûd ibn Ilohammad ibn 'Omar al-Jjaghmini al-Khowàrazmí (Scharaf al-Din). 2330 , 7. 2500 el suiv. $9589 \cdot 2865$, $11^{\circ} .4386,3^{\circ}$

Mạ̣movid [ibn Moḷammad] alRâzì (Qoṭb al-Dìn). $4187,16^{\circ}$.

Hạ̣หoûn ibu 'Omar al-Zamakhscbarì (Djàr Allah Aboû 'l-Qàsim). 597 et suiv. $1620,8^{\circ}$. 2919. 3077. 3499 et suiv. $3948,9^{\circ} .3964$ et suiv. 3973 , $7^{\circ}, 11^{\circ} .4001$ et suiv. 4016 $2^{\circ}$. 4092, $3^{\circ}$. 4041, 4․ 4283, $3^{\circ} .4289$ et suiv. $4392,3^{\circ}, 3^{\circ}$. 4645 .

Mạ̣moûn ibn Sa'id ibn 'Abdallah ibn Nikâ'îl. 4006, $5^{\circ}$.

Mạmoûd ibn Salmàn ibn Falıd al-Halabi (Schibầb al-Dìn). 4436 .

Mạmoùd ibn Sadr al Scharìa (Borhân al-Scharína). 905 et suiv.

MA!̣MOث̀̃ lbn al-Sindi al-Kâtib Kischådjim (Abon̂ '1-Fatli ). 3301 .

Al-Mä̃dodsi. Voyez Hosaîn ibn Moìn al-Dì.

Al-Maidixi. Voyez Aguad ibn Moḷammad.

Muimoìs. 2673 et sniv. Voyez aussi Mloćsầ ibn 'Obaïdallab.

Maĩmoíx ibn Moltammad al-Nasafi (Mơin al-Dîn Aboù '1Mo'in). 1232 et suiv. 4589 , $4^{\circ}$.

MAïmoû́ ibn Qaìs. Voyez A1- $A$ 'scui.

Ibn-Maìmoùn. Voyez Mờ̉sâ ibn 'Obaïdallah.

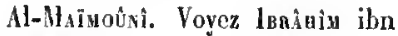
Mohammad.

Jba Makints. Toyez Abo at-RayMîs Ibn Makànis et MADJD alDix Ibn Makânis.

Aboủ Maknuad. Voyez îlyà.

Al-Mixuoûsì. Voyez 'ALî al-Mlàkhoûsí.

A-MAkis. $29^{4}$. 295.4524.

A1-Hakiv. Voyez Samên ibn Kalil.

Al-Mkoủdí. Voyez 'AbD aL-Ra!MÂx ibn 'Ali.

NìuK ibn Anas. $67 \tilde{a}$ et suiv. $1310.3389,2^{\circ}$.

A1-Mìtı al-Kåmil. $870,3^{\circ}$.

Ibn Matuk. Voyez Mogaman ibn 'Abdallab.

Màn̂̀i. Voyez Mog̣auma ibn Aḷmad al-Roủmí.

Al-Mámanî. Vayez Aboú Bakr Hohlammad.

Ml-Mavintì̀. Voyez As'ad al-Mlammâti.

Al-M,Mgû́n. $19^{8}, 3^{\circ} .215,4^{\circ}, 9^{\circ}$.
Al-Maxínî. Voyez 'Aвo AL-Ra'ô̂F JOHAMMAD.

Maxșoûn ibn 'Abd al-Raḥmàn (Zain al-Dîn). 4642 .

Max̣oủn ibn Hibat Allàh (Qoụb al-Din Aboử'-Barakât). $79 \dot{3}$.

Maș̣oưn ibn 'îsâ (Aboù Sa îd). $3028,3^{\circ}$.

Havsoín al-'Absì. $258,{ }_{2} 6^{\circ}$.

Masṣoûte al-Obaïy (Aboủ Sa'd on A boû́ 'l-Ḥonainn ). 3490 .

Maxṣoûn ibn Yoùnos al-Balroútî. 1107.

Al-M INToúrí. $1077,5^{\circ}$

MAQAAR. 251.

A - M IqQani. 670. - Voyez aussi Anyad ibn Molnammad.

AL-Maqrìzì. Yoyez Aboù Bika alMarrizí; - A M MaD ibn 'Alì et Aп̣mad ibn Moliammad.

Al-Mareascuì. Voyez Al-Hosaĩ ibn Mohammad et MoniammaD ibn Wàiz.

Al-Mlarî́ail. Voyez 'AL' al-Maràghtii.

Marc lbn Zor'a. 301 el suiv.

Nancel. 4356.

al-Handiví. Voyez Hoyanuad alMardjânt.

Al-Magmininì. Voyez 'Alì ibn abl Bakr.

Al-Marg̣oûmi. Voyez 'Anbàs ibn Alimad.

Mìsì ib: Solaïmân. 190.

Mari it Younsof al-Maqdisì alHanbali. ${ }_{1624}{ }^{2} 1896$ et suiv. 2026.4445 .

Al-Mani. Voyez Moṭmasa ibn Said.

Al-Miandisi. Yoyez Adoallait ibn Khalil et Anuan ibn' 'Abdaltah.

al-Marmani. Voyez Monamma alMarmari.

Al-Manbikoscuî. Voyez Hasax ibn 'Ali et Monanum ibn IIohammad.

Mantiv, pape. $234,22^{\circ}$.

Al-Manwarotidr. Yoyez Al-Hostin ibn Nolıammad.

Marzenir ibn Schirouin. 3594.

Ibn Harzovie. Voyez Homamad ibn Alimad.
Aboù Máschar [Djafar] ibn Mohạmmad al-Balkhî. $2580,3^{\circ}$ ${ }_{2} 581$ et suiv, $2696, a^{\circ}$. ${ }_{2} 18$, 9 .

Al - Maschnîimi. Voyez AD ALRuṇim al-Maschnấwi.

Al-Mascotodit. Voyez Monamad ibn 'Alt.

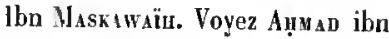
Nohlammad.

Mastami jbn Ahmad al-Madjríti. 2306 et suiv. $2612,1^{\circ} .2613$.

Al-Mlașmoûdì. Voyez Mopamad ibn Alimad.

MaśồD. 4163.

Maśoûd ibn Aḥmad. $3954,2^{\circ}$.

MAs'oûd ibn 'Omar al-Taftâzâní (Sadd al-Din). 797. 926, $3^{\circ}$. $1013,6^{\circ} .1234$ et suiv, 1262 , $3^{\circ} .1265 .1396,4^{\circ}, 5^{\circ} .2351$, $3^{\circ} .2379$ et suiv. 2396.3244 , $4^{\circ} .4063$ et suiv. $4187,1^{\circ}, 17^{\circ}$, $18^{\circ} .4373 .4386$ et suiv. 4400 . 4406 et suiv. $4589,60.4606$, $9^{n}$

HAsoûd al-Schìrwàni (Kamàl alDir) $.1262,2^{\circ}, 2351,1^{\circ}, 2^{\circ}$.

Aboù MAs'oíd, $2316,5^{\circ}$.

Al-Nas'ociot. Voyez 'Atì ibn alHosain.

Ibn Mśṣoùm. Voyez 'Átî ibn Alımad itho Molnammad.

Matriieu (Anbâ). i 53, əa 3 .

MATTHEU,$\left(3^{\circ}\right)$ patriarche d'Mlexandrie. 3 i9.

Hatrieg, patriarche d'Alexandrie. 225 et suiv.

Mathoûd ibn Ahmad ibn Mohammad ibn al-Khidhr Jlon al-Djawàlìqi (Aboû Mansoùr). 3279. $4231,3^{\circ}$.

HavioutB ibn Nansoûr. $3 e_{1}$ et suiv.

Hadi-Zìò̀ Màilk Schàh Qàsim Qàdirì al-Khatài. 4/08.

M-Mausirì. Voyez Zïan aL-Âbidin al-'Omarî.

Al-Mavsili. Voyez lobinin ibn Alumad et Ismấic al-Mausili.

Al-Hawardi. Voyez Alì ibn Mohansmad.

Mахіне, S. $163,1^{\circ} .{ }_{25} 5,16^{\circ}$.

Al-Mazánî̉. Vovez Momammad iba Ahmad ibn Djanàa. 
MÉLÉTIOS, métropolitain d'Alep. $37^{6}, 34^{\circ}$.

Menelaís. $2457,37^{\circ} \cdot 2467,1^{\circ}$, $10^{\circ}$.

Mıcıé ibn Bodaïr (Ahoú Djaib). 303.

Mıcire, mérropolitain de Daniette. $338,20^{\circ}$. $251,43^{\circ}$.

Micial évèque de Malig. $213,3^{\circ}$.

Hıcuec Sabbàgh. 4607 .

Micast, évèque de Tanis. 251, $40^{\circ}$.

Al-Mikxissí. Voyez Monamyad ibn Aḷmad.

Ibn Mílio. 3338, 20.

Ml-Milawì. Voyez Yoûsor ibn Mloliammad.

al-Misnàdi, Voyez Moỵamad ibn Alumad.

Vlinam Tcuelemb. $250 /, 5^{\circ}$.

Al-Mirgani. Voyez Mopamuad A mín.

Mizzi Makadoưn. 145g.

Mírziduin. Voyez Hazîz al-Schirâzî.

Al-Mizzí. Toyez Abo at-Rag̣im alMizzi ; - Mounsmuad ibn Al!mad ibn 'Ahd at-Rahîn et Yoúsor ilon 'Abd al-Ralımann.

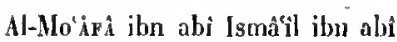
'I-Sinån. 732 .

Al-Mơîi ihn Zakarîyâ al-Djâriri. 3487 et suiv.

Ibu al-Móatur. Voyez Mog̣anya ilon Molıammad.

Al-Modjini. Voyez Aumad al-Modjiri.

A-Mofudnets ibn "Alì al-Maqdisi. $4256,1^{\circ}$.

Mofaddiat ibn abî '1-Fadhatil. 4525 .

Moraddaac ibn Màdjid Ibn alBischr. 2997 et suiv.

Ml-Mopadpual ibn 'Omar. 1449 , $3^{\circ} .1450,7^{\circ}$.

Al-Mopadd iL ibn 'Omar al-Ablraci (Athir al-Din). 1013, $10^{\circ}$. $1267,2^{\circ}, 1286,9^{\circ}, 1396,7^{\circ}$. $2307,8^{\circ}, 9^{\circ}, 2330,3^{\circ}, 5^{\circ}$. 2353 et suiv. 2360 et suiv. $2365,1^{\circ}$. 2 $406,2^{\circ} .2500$, 10․ $2515.2544,5^{\circ}$.
Ibn Mopring. Voyez 'Alì ibn IIofril!.

Monamad ihn al-Abbás ibn Ahmad al-Moqri. 1941.

Mopaumad ibn 'Abd al "Aẓim ibn Farroukh. 816 .

Mogamma ibn 'Abd al'Aziz ibn abi Rakr at-Djozoùli al-Ya'qoùbî al-Resmoúki. $2568,1^{\circ}$,

Mopaymad ibn 'Abd al-'Aziz alIlàschionì. $245 \overline{7}, 16^{\circ}$.

Moụamanad ibn 'Abd al-Azíz alIdrisî (Djamâl al-Din aboû Dja far). $227^{4}$ et suiv.

Moganuad ibn "Abd al Djabbàr al-'Othî (A boù 'l-Naṣr). $189^{4}$ et suiv.

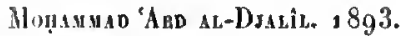

Mogamua ibn "abd al-Ghanl alArdabili (Djamál al-Dìn). 4005 et suiv. $4016,2^{\circ}$. 4022 , $3^{\circ} .4041,4^{\circ}$.

Mopunued ibn 'Abd al-Karim alScliahrastảni (Aboú 'l-Fath). 1246.1406 et suiv.

Nogavas ibn cAbd al-Khàliq ibn Mároûf. 4398 et suiv.

Jouna m id ibn Abdallah ibn [Abd al-] Djalil (Aboù 'Abdallalı). 3340 .

Monaman ibn "Abdallah Ilon 'Abd al-Djalil al-Tanasí. 1875 et suiv.

Monayma ibn 'Abdallab al-Ansârì. 4308.

Mounamm ibn 'Abd-Allâhi al-Azdi al-Rașri (Aboù Ismốil). 166h et suiv.

Мoganmad ibn 'Abd-Alláhi alBàqì al-Bokhâru ('Alâ al-Din). 4631 et suiv.

Mopanmad ibn 'Abdallah al-Djorwàni. 1047 .

Momamas ilon 'Abdallah al-Ischbili. 1388 .

Joụsunan ibn "Abdallah al-Kbatib (Wali al-Din Ahoú 'Abdaliali). 720 .

Mognamad ibn 'Abdallah Ibn alKhatịb (Lisân al-Din). 1997 . $3011.3347,1^{\circ}$ à $3^{\circ} .3418$, $16^{\circ}$.

Monayмad ibn 'Abdallah al-Hosainí Kibril (on Kirit). 2252, $1^{\circ} .2294$.
Nogaviad [ibn 'Abdallah] alKharaschi. $\log ^{3}$ et suir. 4556 et suiv.

Monamand ibn 'Abdallah al-Kisà'i (Aboù 'I-Hasan). 1909 et suiv. 1933.

Mopaumad ibn 'Abdallah al-Tát al-Djairyâni Ibn Mâlik. $67^{2}, 3^{\circ}$, $4^{\circ} .1057,6^{\circ} .1060,8^{\circ} \cdot 1061$, $9^{\circ} .4068$ et suiv. 4117.4118 , $1^{\circ}, 4119,1^{\circ} .4207,2^{\circ}, 3^{\circ}$.

Monayyad ibn 'Abdallah... ibn al-IValid ibn 'Okba Ibn al-Azraq... al-Azraqî al-Ghassânî (Ahoù 'l-Walid). 1628 et suiv. 1631 .

Мочаммар ibn 'Abd al-Latiff. 874.

Nounamad ibn abd al-Mabk alLamdàni (Aboú 'I-Ịlasan). 1469 .

Monamuad ibn 'Abd al-Mon"im al Djaudjari. $319^{8}, 1^{\circ}$.

Mounanad ibn 'Abd al-Mo'tí alIsțâqii. 1839 et suiv.

Mogaymad ibn 'Abd al Qådir ibn Molımmad al-Damiri. 1605 , $1^{\circ} .2799$.

Mogamad ibn "Abd al-Rahim "Alì ibon al-Hasan Ibn al-Forât. ${ }_{1595}$ et suiv.

Mogaman ibn 'Abd al-Ralum Ibn Nobâta (Aboû Țálhir). 1389 , $2^{\circ}$.

Monamad ibn 'Abd al-Rahim alQaisi. 2167 et suiv.

Monamyso ibn 'Abd al-Ralimàn al-Azarwåli. $612,4^{\circ}$.

Mopaumad ibn "Abd al-Rahmàn alHamdàni (Aboù'l-Nașr). 1314 et suiv. $4597 \cdot 4598,2^{\circ}$.

Nogsmmo ibn 'Abd al-Ralunản ihn Hasan ibn Sowaid al-Nldliki. .533.

Jloṇasuad ibn 'Abd al-Rahmàn al-Omari al-Guilâni (Badr alDin ). 4143.

Monaunas ibn 'Abd aJ-Rahnà่n al-Qazwìni (Djalâl al-Dìn). 4378 et suiv. 4384 el suiv.

Moyaumad ibn Abd al-Ralımân al-Saklaàwì (Schams al-Din Alsoư 'l-Khair). $1317,1^{\circ}$ (?). $1615,3^{\circ} .2078 .2150$.

Monamuad ibn 'Abd al-Wallid Ibn al-Hamınàm (Kamål aj-Din). 850.944.
Nogasmad ibn 'Abd al-Wábid alHaqdisî, $2563,18^{\circ}$.

Nouasmad ibn 'Adjloûn (Nadjm al-Din). $3_{2} 04,6^{\circ}$.

Mọayus ibn Ahınad. 2684, $7^{\circ}$.

Mouanuad ibn Altmad (Schams al-Din ). $2761, a^{\circ}$.

Moganuad ibn Aḷmad ibn 'Abd al-'Aziz al-'0tbí. 1055.

Monamma ibn Ahmad ibn "Abdallah al-Qalqascbandit. 2049 .

Momanato ibn alumad ibn 'Abd al-Qàdir al-Nașrì (Aboù Ràs). $4614,3^{\mathrm{a}} .4618$ et suiv.

Monaumad ibn Ahmad ibn "abd al-Ralilm al-Mizzi (Schams alDin). $2531,1^{\circ} .2544,15^{\circ}$. $8547,6^{\circ}, 13^{\circ}, 14^{\circ},{ }_{2}^{\circ}$.

Monsм м a ibn Aḷmad al-Abschîhí. 3369 et suiv.

Mo!̣a ma ibn Alymad al-1biwardi (Aboú 'l-Mozạaffar). 3117.3411 ; $2^{\circ}$.

Mов̆.м⿻а ibn Ahınad al-Ainni. 899 .

Mounquad ihn Alımad ibn 'Âīscha (?) al-Zaïtounini al-Auf. $2942,5^{\circ}$.

Monasmad ibn Alumad Ibn Aìyâs. 1822 et 1823.1894 et suiv. 3307 et suiv. $3513,3^{\text {s }}$.

Mounamad ibn Alumad al-Albiri (Aboú Abdallah). 2961.

Monaumad ibn Alumad ibn 'Alî atFàsi al-Hasanì (Taql al-Dín Alıoùl Ṭaiyili). 1633. 1668, 3.. 2123 et suiv.

Mopamana ibn Alymad ibn 'All Ibn Djäbir al-Hawàrì. $4095.445_{2}$, $1^{\circ}$ à $10^{\circ}$.

Jlous ma ibn Alunad [ibn?] 'Ali al-Nasani (Schihăb al-Din). 1899 .

Mop̣amad ibn Ahmad Ibn al-Ạs. $3038,3^{\circ}$.

Monaurad ibn Aḷmad Ibn al-'Attàr. 293 .

Llogavea ihn A hmad al-Bahoutti. 3406 . 4424, $6^{\circ}$

Monamas ibn Ahmad al-Bíronini (Aboú 'l-Raïlıản). 1489. 2222, $3^{\circ} .2380 .3497 .249^{8}, 3^{\circ}$.

Moụs y yad ibn Alumad al-Bokhàrì (Zabir al-Din Aboù Bakr) 856 et 857 . 
Mop̣amad ibo Aḷmad al-Dhakhrí. จ568, $5^{\circ}$.

Mọ̣ muad ibn Aḅmad lbn Djamâ'a a]-Ma'zấuĺ ("izz al-Din). 746, $2^{\circ} .1285,3^{\circ} .3090 .4532,3^{\circ}$.

Mognuma ibn Aḅmad at-Damâti (Schams al-Din). $4123,3^{\circ}$.

Monamma ibn AḷmarJ al-Ghaiti (Nadjm al-Din). 1044.1985 et suiv.

Monamma ibn Aḷmad al-Gbarnâtî (Aboù Abdallab). 3175 .

Monayuad ibn Ahmad ibn Hamza a]-Ramli al-Ansárí (Zain alDin). $1017 \cdot 1020$.

Mog̣angad al-Hadri (Aboú 'l-Ḥasan). $1449,3^{\circ}$.

Mognamad ibn Ahmad al-Hanafi. $746,1^{\circ}$.

Nop̣ıman ibn Aḷmad İbn Ilyàs al-Ḥanaft. 3409.

Noнamuno ibn Ahmad ibn al'Imàd (Schams al-Din). 649. 1029.

Monaymad ibn Alimad ibn Jyás al-Mișri. 1554 .

Nohimman ibn Almad al- $\mathrm{Ia}$ ḷallî (Djalâl al-Dìn). 652 et suiv. 803 et suiv. $2800,16^{\circ}$, $17^{\circ}$.

Mợumuad ibn (abî 'l-'Abbâs) Aḷmad - Maiyăra (Aboú 'Alddallah). 818. 1102 .

Megayuad ibn Alymad ibn Marzoùq al-Tilimsàn (Aboù 'Aldallah). $1330,10^{\circ}, 1396,6^{\circ}$. 3188 .

Mopaymad ibn Alumad al-Nlasmoùdi. $1057,18^{\circ}$.

Mopaymad ibn Alımad al-Miknăsì lbn Ghıâzî al.'0thmâní $1057,13^{\circ}$. 22a4, $2^{\circ}$.

Nouamuad ibu alimad al-llinhâdjî al-Osyoûtî. 2255 et suiv.

Hohannmad ibn Alumad ilon Hohammad al-Qoùnawî. 1354 .

Mop̣anua ibn Aịmad al-llogri al.Anbârî. 3 hyy 1 et suiv.

Mopammad ibn Alumad al-Nalurawânî al-Makhì al-Hanafì alQádirí al-Kharaqânî (Qałb alDîn). 1637 et suiv. 1644 et suiv.

Mohammad ibn Alumad ibn 'Otínmân ibn Qäïmåz lbn al-Dsa- labi (Schams al-Dín Aboi 'Abdallah). 1580 et suiv. 1584 et $1585.1997 .2013 .207^{5}$ et suiv. $2084.4577,8^{\circ}$.

Mopanmad ibn Alhmad ibn abillQásim İbn Ghảzì al-Djozoùlì. $453 \mathrm{2}, 1^{\circ} .4534 ; 3^{\circ}$.

Mopauma ibn Aḷmad al-Q azwint (Djamảl al-Dîn Aboǹ 'Ahdal(ah). 2334 et suiv.

Nopamyad ibn Aḷmad Ibn alQoraschi. 853

Mogammad ibn Aḷmad Ibn Roschd (Abou'l-Walid).1057, $i^{\circ} .1072$ $2458,6^{\circ} .2918,6^{\circ}$.

Nounuma ibn Aḷmad al-Roùnt Hảmầi. 3 s $35,1^{\circ}$

Moṇama ibn Aḷmad al-Sakhâwì. $3248,2^{\circ}$

Johaman ibo Alumad ibn Saíd al-Tamimi. $2870,1^{\circ}$.

Moнamá ibn Alimad al-Samnoùdi. 3218 .

Monasya [ibn Ahmad] al-Schàdsili al-Toùnisi (Djamál al-I)in Aboû'ł-llawảhih). $277^{\circ}, 5^{\circ}$. $4162,3^{\circ}$.

Iоймми ibn Alumad ibn aht Schákir al-Irbilì (Hadjd alDîn). $3_{129}, 3^{\circ}$.

Monamad ibn allmad lbn Schammâ' (Abaù 'Abdallalı). $46,5,3^{\circ}$.

Mohnsma ibn Aiımad al-Sibt al-Andalosi. $4446,1^{\circ}$.

Mọ̣ y mad ibo Aḷmad al-Tafráwi. $1871,2^{\circ}$.

Moụaysa ibn Ainmad ibu Yála (ai-Scharif) al-Hasant. 4098 3․ 4127.

Мon asmad ibn Aïoúb al-Tàdsiff (Badr al-Dìn). 1965.

Монамma ibn 'Alà al-Dín íbu al-Ridhà. 1375 et suiv.

Monaman ibn 'Alî. g405, $5^{\circ}$.

Monamuad ilon 'All ibn 'Abd al'Aziz ibn 'Alí ibn Barakât. 1507 .

Nog̣anmad ibn 'All al-Âdjorrî (Alroú 'Obaïd). 2085.

Noganmad ibn 'All ibn Ahmad (Aboú 'Abdallah). 2475, $1^{\circ}$.

Nounama ibn 'Alí ibn Ahmad Ibn Hadida al-Ansårì al.Klıazradji. $1971,1^{\circ}$.
Mogamuan 'Ali ibn 'Aliân alSiddiqî. 4430 .

Mopamyad ibn 'Alî al-Ansárí (Kamàl al-Dîn). 3711.

Mopauman ibn 'Alì al-Ansâri (Abou'1-lla âli). 2322, 6, $7^{\circ}$.

Nogaymad ibn 'Alî lbn al-'Arabî (Mohyi al-Din). $743,7^{\circ} .1199$. 1333 et suiv. $1337,1^{\circ}, 3^{\circ}$, $4^{\circ} .1338,1^{\circ}$ à $5^{\circ} .1339 .1340$ et suiv. $1343,1^{\circ} .1344 .1347$, $9^{\circ} .1386,1^{\circ}, 3^{\circ}, 1699,3^{\circ}, 4^{\circ}$. 1794. $2348,2^{\circ} .2358,1^{\circ}$. $2405,6^{\sigma}, 7^{\circ} .2502,3^{\circ} .2661$, $3^{\circ} .2669,11^{\circ}$ à $14^{\circ} .2675$, $3^{\circ}$. 2678 et suiv. $2684,14^{\circ}$. 3167 et suiv. 3171 et suiv. $3204,3^{\circ}, 3344,8^{\circ} .3431,14^{\circ}$.

Moụama ihn 'Alì ibn 'Atiya alMakkî (Aboú Tàlib). 2016 , $3^{\circ}$

Nonaman ibn (Pir) Alì al-Birguelî (ou Birguewi'). 1331 et suiv. 4120.4206

Mognamad ibn 'Alì al-Fanårî. $9^{2} 6,3^{\circ}$.

Mopayma ibn 'Alî al-Ilâddj alSchátib. $2758,2^{\circ}$.

Moụayyad ibn 'Ali ihn Iläidar al-Hosaint. $3259,1^{\circ}$.

Mohamado ibn "All ibn Hammâd (Aboû 'Abdatlah). 1888.4614, $1^{\circ} .4615 .4625,3^{\circ}$.

Momammad iln 'Ali ibn al-Hosain ibn Moùsâ al-Qommi Ibn Bàbawaïh (Aboủ Djafar). 1108 , $1^{\circ} .1231 .2018,1^{\circ}, 2^{\circ}$.

Moụamad ibn 'Alì ibn Ibrähim íbu Zariq al-Khairi. $2520,2^{\circ}$. ${ }_{2} 521,1^{\circ}$.

Momumad ibn 'Alí ibu Klaajaf al-Aịmadì (Aboù'l-Baqà). 4447 .

Monanya ibn 'All ibn Mahmoñd (Schams al-Din). 4435, $2^{\circ}$, $3^{\circ}$.

Noụamua ibn 'Alì al-Maschtoûll. 2017.

Mopanmad ibn Ali ibn Nohammad al-Khatỉbî al-Zauzanî. g112.

Mopanmad ibn 'Alì ibn Mohammad al-Schatibì al-Andalosì (Aboû 'Abd 'Alíah). 1545 et suiv. $4608,1^{\circ}$.

Moụıma ibn 'Ali aj-Sakhămì Moụumad al-Bäbilli. 1699, g":
(Schams al-Dln Aboú'l-Khaïr). 3105.

Mogaunad ibn 'Ali Sảlih al 'Alimi al-Motarriz (Abon' 'Abdallah). $4015,4^{\circ}$.

Nopammad ibn 'Alî ibn 'Omar alSamarqandi (Nadjib ak-Din). $29^{46}, 7^{\circ}, 8^{\circ} .2967,4^{\circ} .297^{1}$ et suiv.

Mogamad ibn 'Alt ibn Scho'ail Ibn al-Dahuân (Aboù Schodjấ) 788.

Уogamma ibn 'All al-Schobrấmolst. ง597. $269^{8} 8,1^{\circ}$ à $3^{\circ}$.

Moнамма ibn 'Ail ibn T'abătabà ibn al-Ṭiqtaqà (Ṣafi aí-Dín). ghas et suiv.

Mounamad ibn 'All lbn Wadeân (Aboù Nașr). 722, $7^{\circ}$.

Moйıммa ibn 'Alí ibn Yàsir alDjaiyanìi (Abaủ Bakr). 722, $3^{\circ}$.

Moнамия ibn علس ibn 'Alí. 4057 .

Mounuyad al-Alqami (Schams al Din) $77^{0-77^{2}}$.

Moụaymad Ibn al-Âmidi (Schams al-Din). $117^{6}, 31^{\circ}$.

Monsumad Amin (on Amíra) alBokbàri Amír Pàdischâh. ${ }_{2} 679,3^{\circ} .3257,2^{\circ}$.

Monaman Amin ibu flasan Mirgìani. 3578 .

Nohimad Amis (al-Amin alSchấmi al-Moụibbl) ibo liibb al-1)in ibn abi't-FadhJ al'0\}พwàní. 9083 .

Mom imana ibn 'Ammâr al-Maliki. 743.

Maнamado ibn Amyal al.Tominı (Aboú 'Abdalialı). $2609,1^{\circ}$, $2^{\circ} .9610,9611,1^{\circ} .2620, a^{\circ}$

Mogamya ibn 'Aqil al-Bàlis (Nadjm al-Din). 710 et 711 .

lioụamad ibn abr̂"l-Ậ. 3027.

Moğamma ibn Aschraf al-Samarqandi (Schams al-Din). 1963, $2^{\circ} .2350,1^{\circ}, 2^{\circ} .4378,9^{\circ}$.

Mopamad ibn 'Atiq al-Todjetbî. $4307,1^{\circ}$.

Mogammad ibn 'Az1z al-SidjistánI (Aboù Bakr). 590 . 
Lionaman al-Badrí al-Makbi (Aboù Djábir). 344a, $\mathrm{t}^{\circ}$.

Mog̣amad ibn Bahthdour ibn - Abdallah al-Zarkaschí (Badr al-Din). $69^{6 .} 811.99^{1}$. 1007 et suiv. $1013,2^{\circ}$.

Ionammad al-Bahnasì (Schams al-Din). $4533,1^{\circ}$.

Monnsyan ilon Balırân lhu alQalânisi (Badr al-Din). $29^{46}$, $3^{\circ}$.

Noụuna ilsn abi Bakr. $78 \approx, 1^{\circ}$. $2254,7^{\circ} .4662,6^{\circ}$.

Mounuma ibn abî Bakr ibn 'Abd al-Qâdir al-Râzì. 623 et suiv.

Monaимa ilon abi Bakr ibn Airoùb al-Zarai ( ou al-Zori) lbu Qayim al-Djauziya.1 a94.3045.

Moụıund ibn alì bakr fbn alb)amàminì. $3124,1^{\circ} .3125$.

[ Họ̣ammad ilun abî Bakr] ImầnZảdè (Rokn al-Islàm). 1 a18 et suiv.

[Nollammad] ibn abî Bakr alKhabiși. 4042 et suiv.

Мonamad ilm abî Bakr lbu alM̀louftî al-Bokhầìi. $760,4^{\circ}$.

Monamad ibn abì Bakr ibn Raschîd al-Baglıdàdì. $1668,3^{\circ}$.

Monamad [ibn abl Bakr] alRàzì. 4241 et suiv.

Monasmad ibn abì Bakr ał-Ràz (Zain al-Din). $812,6^{\circ} .87^{3}$ et suiv.

Mọ̣a va a i inn abî Bakr Ibn Schoroùn. 2308 .

Monany.d ibn abi Bakr al-Soyoûtị. 3385 et suiv.

Mogayand ibn abì Bakr al-Tizài. $2547,16^{\circ}$.

Noñamad ibn abî Bakr iln Yoủsof al-'Adnånî lbo Adjànà. 1075 .

Jloụanud ibn abî Bakr al-Zohrì. 2220.

Nonanmad al - Bakrí. $2037,2^{\circ}$. $2246.3156,5^{\circ}$.

Mounamad al-Bakrí. 2580, $4^{\circ}$.

Mopammad al-Bakrì al-Ṣiddiquí. 4443.

MoHamad al-Bihischtî. $1160,9^{\circ}$.

Mog̣ımá al - Bolquinî (lisez al Bolqainini). 1361 et suiv.
Monamad al-Daladjî (ou al-Doladji ). $4429,3^{\circ}$.

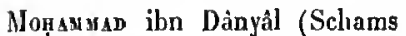
al-Dîn). 2149 .

Mọayya ibn al-Dluiyâ (Aboû'lBaqà). $606,5^{\circ}$.

Mog̣asuad ibn Dikrà. 1351.

Мовамma al-Dimaschqî (Schams al-Din). 1312.

Monaman Diria al-Allidi. a 108 et suiv.

Mohamad al-Djáfarí (Naşr alDì). 1041

Mọ̣usuad ibn Djamâl al-Din Aqusarầi. $775,2^{\circ}$.

Monuma ibn Djarir al-Tabarì (Aboủ Dja far). 1466 et suiv. 1944.

Moйansan al-Djuulıarî al-Khâlidì 1049. $196 \mathrm{~g}$.

Mopamana ibn abi Djomia al-Habati (ou al-Habti). $67^{2}, 1^{\circ}$.

Monamad Efendi. $1699,5^{\circ}, 6^{\circ}$.

Mọnamad Efendi. 2296 .

Mopammad lbn al-Fadhl al-Azâwì (aI-Forâwi?) (Aboú 'Abdallah). $722,4^{\circ}$.

Moḥamad al-Fâsî. 2732, $1^{\circ}$.

Nonamad ibn abí'l-Fotoûla jbn abi'l-Yomn Solaïmân (Aboư'lFadhâil). 1972.

Mognayad al-Ghamri. $2621,1^{\circ}$.

Mog̣myad Grixim. 4124, $3^{\circ}$.

Monimaso al-Ghomarî (lisez alGhamrî). $3971,1^{\circ}$.

MoHay ma I Iba al-Habbâriva (Aboù Ya'lâ). $219^{8} .3495$ et suiv.

Mohammad al-Hafnâwl. 817 4108 et 4109 .

Nopa was il-Hakim. s405, $3^{\circ}$

Moungyá al-Halabi al-Qzuwâs (Schams al-Din). 395a.

Moụayy.d al-Halabi al-Raschid. 4451.

Noñymad ibn Hamdoún al-Ronâni (ou al-Banàni). $4098,2^{\circ}$.

Nopaumad ibn Hamza. 1156, $6^{\circ}$.

Monauma ibn Hamza al-Fanári (Schams al-Dìn). 864. 1134, $4^{\circ}, 1396,7^{\circ} \cdot 2353,1^{\circ} .2354$, $1^{\circ} .2355,4606,5^{\circ}$.

Mohasyad al-Hanafi. $743,4^{\circ}$.
Momamyad al-Ḥanafí (Aboû 'Abdallah). $3171,3^{\circ}$.

Molımmad al-Hanafî al-Tibrizí. $809,10^{\circ}$.

Moụısus lbn al-Ḥanafí. 1364.

Moụnmad ibn Hâní (Aboư'lQàsim). 3108.

Joṇayad ibn Hâroủn al-Warràq ( $A$ boừ Îsầ). 167. 168.

Mop̣amad Hasan (Aboú Dsâkir Kittâbat al-Moḥamtadiya). 4643.

Noнaмmad ibn Hasan ibn 'Abdallah al-Hosaini. 2o32.

Momamad ibn al-Hasan ibn 'Mli ilun al-Hosaĩn al-Djowảní (Aboủ'-Qásim). 2010.

Mopamad ibn Hasan ibn 'Alí alNawâdji (Schams al-Din). 2098 . 3392. $339^{3}$ et suiv. $3401,1^{\circ}$ a $3^{\circ}$. 3402 et suiv. 4453.

Nopammad ilon Hasan al-Baramoủni. 3193 .

Momuyrad ibn al-Hasan. . . ibn Hamdoủn Kafîl-Kofât (AboûlMåâlî̀). 3324 .

Mogammad ibn al-Hasan al-Karkhì (Aboủ Bakr). 8459 .

Moпnм⿻а ibn al-Hasan al-Schaïbâní. $784,1^{\circ} .785 .820$ et suiv. 837 et 838 . 3019, $3^{\circ}$. $3204,6^{\circ}$. 4544, $3^{\circ}$. 4585, $1^{\circ}$.

Nop̣smad ibn Ḥtomaïd al-Ǩflawî. $3078,2^{\circ}$.

Moнamad ibn al-Hosain. 2468, $4^{\circ}$

Monaumad ibn al-Hosaïn (Aboû Djafar). $2457,20^{\circ}$.

Moṇayyad ibn al-Hosaïn al-Ahwâzî. $2419,2^{\circ}$.

Monaymad ibn Hosaïn AboùlDjaïsch al-Anșàril al-Khazradjì al-Andalosi (Dhiyâ al-Din Aboù 'Abdullah ). $1077,6^{\circ}, 1286,4^{\circ}$. $3955,2^{\circ}, 3^{\circ} .4446,1^{\circ}$ el suiv.

Monasmad ihn al-Hosăn lbn Donaid al-Azdi (Aboú Bakr). $792,3^{\circ} .3088$ et suiv. $397^{1}$, $3^{\prime \prime} .4231,4^{\circ}, 5^{\circ} .4233$.

Mogavisıo ibn abì'I-Hosain alSiddiqi. $2037,4^{\circ}$ à $7^{\circ}$.

Monamma ibn al-Hosain al-Solamî. 2043 .
Nop̣ammad ibn à-Ḥosain Yazdân Yầ (Aboủ Djafar). 1369.

Noụas an al - Hosaini BouzourgZâdè. $2954,19^{\circ}$.

Moṇamad (Sâlilụ) ibn Ibráhim al-Alısà'î. 411 a et suiv.

Noạıмad ibn Ibráhîm ał-Anșârì. 2769 .

Moganuma ibn Ibráhím al-Bakri al-Roùdì (lis. al-Rondi). 2450 , $4^{\circ}$

Mopaymad ibn Ibrâhîm lbn alḤanbali (Ridhâ al-Din). $2474.4187,12^{\circ}$.

Noyamuad ilon Ibràbîm al-Hasant à-Qâsimi al-Hâdawí (Aboụ (Abdallah). 1460.

Mohamuad ibn lbrihim ibn Khalì al-Tatâ'i (Aboù 'Abdailah). 4548.4555 .

Mogaмหà ibn Ibrâbîm al-Kotbí (al-Kotobi) (Djamâl al-DIn), 1300 et suiv.

Moнaymad ibn Ibrâhím Ibn alMarri al-Maéfiri. $758,3^{\circ}$.

Moṇamsad ibn Ibrâllìm ibn Moḷammad ibn Hischàm. $27^{61}$, $1^{\circ}$

Mopayman ilon lbrâbìm al-Nafzí al-Sardanì lbn 'Abbâd. 1350.

Nọ̣ay yad ibn Ibráhìm al-Omawi al-Scliarischí. $1061,5^{\circ}$.

Mog̣ıyum ibn lbrảhìm al-Raba'i al-Tadafi lbn al-Hanbalf. 2140 et suiv.

Mouammad ibn lbrälitim ibn Sáfid Ibn al-Akfànî al-Sakłıáwi alAnsârl. 2234, $3^{\circ}$. 2331 el suiw. $277^{6}, 1^{\circ} .3442,5^{\circ}$.

Momamyad ibn Idris. 2548.

Iọ̣amaso ibn lfaatoun al-Roûmi (Iflàtoûn Zâdè). $952,3^{\circ}$.

Moụamad ibn 'Îsả al-Andalosî. 2692 .

Nlọ̣uy nad ibn 'Îsâ al-Tirmidst́ (Aboû 'ìsâ). 709 et suiv.

Moganumad ibn Islạâ al-Mottalihf (Aboù Bakr). 1960 et suiv.

Nopaunad ibn Ishâaq al-Qoúnawì (Ṣadr al-Dîn). 1354. $1386,3^{\circ}$.

Mọ̣amsad ibn Islıạq al-Warràq Ibn abî Yáqoûb al-Nadîm (Alsoùl.Faradj). 4457 et suiv. 
Moṇimgap ibn Ismáîl ibn Moliammad. $2943,1^{\circ}$.

Mogaryad ibn Ismâtil Ibn Wadắa Ibn al-Bakkàl. $4639,1^{\circ}$.

Jounamad al-Kałăzi. $1450,10^{\circ}$.

Монам мa ibn Khalil Ghaiboùn. $1889,1^{\circ}$.

Monamuad ibn Kbatîn al-Din ibn Báyazid ihn Khodja Farîd al'Attâr. $1197,1^{\circ}$.

Mọ̣ayxad ibn Ladjin ad-Ḥossámî at-T arảbolosf. $2827,2^{\circ}$.

Monaumad al-Mabdì ibn Ạmmad al-Fâsî. 2046 .

Mogamyá ibn al-Maludì li-Dín Allàb 'Alì ibn Mohammad ilon 'All (Al-Nàsir li'l-Haqq al-Moubin Salah al-Din). $3966,1^{\circ}$.

Mogamuad al-Nahdjoúb (Aboủ 'Abdallah). $1203,4^{\circ}$.

Mopamyad ibn Maḥmoúd al-Bàbartí (Akmal-al-Dìn). 846 et 847 .

Monayuad ibn Mahmoúd ibn alNaddjår ał-Baghidaddi (Molụbb al-Din). 1630. 2089 el suiv.

Monam uad ibn Maḥmoûd ibn abì'l. Sacadàt... ibn abl'\}-Djoûd alSalmoûnî. 1608 .

Moñaxuad al-Ma'moùn ibn Mohammad al-Hafsis. $137^{6}, 1^{\circ}$.

Mogammad ilon Malik (Djamat alDin). $1077,2^{\circ}, 3^{\circ}$.

Momayyad ibn Mansoûr. 2571, $\therefore$.

Mogunuad al-Mardjảní. 2739, $3^{\circ}$.

Monamand al-Marmall (Schams al-Din). $2684,16^{\circ}$.

Mounuma ibn Mároûf (Taqi alDìn). 3478

Moyammad ibn Masooùd al-Sirnaff. 41 a1.

Monamad ibn Menkell. a83a, $1^{\circ}$.

Monaymad ibn Moubàrak al-Tonoûkhì. $1344,3^{\circ}$.

Mog̣a ma vibn Moubårakschâh ałBokhàrî (Schams al-Dìn). a384 et suiv.

Alohaman [ibn Mohammad] (Badr al-Dîn). $4119,1^{\circ}$.

Momanusd ibn Mohammad (Aboû'l-Fatḷ). 340'.
Mogamad ibn Mohammad ibn 'Abdallah ibn Malik al-Taiyi â-Djaïyàní (Djamäl al-Din). 4375 .

Mopuyyad ibn Moḷammad ibn 'Abd al-Djalîl al $\odot^{\circ}$ Omari. 3954 , $1{ }^{\circ}$

Nonamyad [ibn Nolammad ibm 'Abd al-Riạmân] (Kamâl alDin). $624,2^{\circ}$.

Moнuмmad ihn Molammad ibn 'Abd al-Raḷmân ibn Hasan al-Khitàba. 4142

Nog̣aymad ibn llọammad ibn 'Abd al-Ralırnân al - Khattâl. 813.

Mogıмма ibn Ilohammad ibn 'Abd al-Malik al-Ausi al-Ansảrì al-Marràkoschì. 2156 .

Monamyad ibu Mohammad ibn 'Abd al-Rascbîd al-Sadjâwandi (Sirådj al-Dìn Abon TTàhir). $85 \mathrm{~g}$ et suiv. ${ }_{1} 3_{2} 8,3^{\circ} .{ }_{3} 330$, $12^{\circ}, 14^{\circ}$.

Mionamua ibn Mohammad al'Abdarì. $1889,2^{\circ} .2283$.

Mopasmad ibn Mohammad ibn Alımad. 1129.

Moụamıd ibn Molạmmad ibn Alumad ibn Djozaily al-Kalbi. $4207,5^{\circ}$.

Моймма ibn Mohammad ibn Aḷmad al-Isfarâinì (Tàdj alDin). 4009 et suiv. $4020,3^{\circ}$. $4023,4^{\circ} .4121$.

Mouasuad ibn Mohammad ibn Alymad ibn Naryarn al-Tilimsânî. 4630 .

Mogaymad ibn Mollammad ibn Alymad ibn Nohammad Sibt al-Màridîn. 2/41, 4162, $\mathfrak{l}^{\circ}$.

Mop̣unad ibn Mohammad ibn Alunad Sibt al-Màridini (Badr aj-Din Abon']-Djoủd). 8\%0, $3^{\circ}$. $1049,1^{\circ}$.

Mloinamad ibn Nolammad alAklhsìkatì (Hosâm a] - Din). 80 a. 880 .

Nomamyad ibn Mohammad alAqqsarâi (Djamâl al-Dln). 885. 4385.

Monamad ibu Mohammad ibn Âsim al-Qaisì. 1100 et suiv.

Mohasmad ibn Nohammad... ibn al-Attàr al-Bakrì (Aboù 'Abdallah). $2546,1^{\circ}$.
Moṇamad ibn Molammad ibn abì Bakr al-Halabi. 2547, $21^{\circ}, 22^{\circ}$.

Monanyad ibn Nolyammad ibn abî Bakr al-Tizinî. 2521, $2^{\circ}$. ${ }_{2} 5 / 7,9^{\circ} .2558,3^{\circ}$.

Mopasyad ibn Molammad alBokhârt al-Kàkî (Qiwàm alDin). 845 .

Monam xad ibn Moḷammad alBonzzljànl (Aboû̀'l-Wafầ). $2 / 94$.

Nonammad ibn Molammad alDabsiyâwî. 1399

Noncumad ibn Nolonmmad ibn Däoûd ad-Sinlıàdjî llon Adjarroúm. $1057,2^{2} .1906,12^{2}$. $2307,4^{\circ}$. $3571,5^{\circ} .4122$ et suiv.

Mopanyas ibn Mohanmad alGhazzì al-Âmiri (Nadjm alDìn et al-Ridhà al-Dîn). 3226 . $4927,1^{\circ}, 3^{\circ}$.

Monsmma ibn Molammad alHầfi (Zain al-Dîn). $1176,1^{\circ}$.

Monames ibn Mohammad at Ḥaabì (lbn Amir Ḥàddj Schams al-Din). 1147 et 1148 .

Mop̣t unad ibn Ylọnammad ibn Hàmid... lbn Oloh al-fsfahànì ('Imâd al-Dìn Aboû́ 'Abdallah ). $1303,3^{\circ} .1693$ et suiv. 2145.3326 .

Mouguyso ibn Molanmad ibn Hibat Allảh al-Hosaïn al-Aftasì (Amin al-Daula). 3388

Mogryua ibn Mohammad ibn abì" Khaïr al-Hasanî. 2569 , $3^{\circ}$

Nopaymad ibn Mohammad ibn Khalifa (Sadl al-Din Aboû Said). 65) $1,1^{\circ}$.

Ilopunuas ibn Mobammad alLâdsacji (ou al-Làdsiqî). a5j3.

Mounymad ibn Nolarmmad ibn Malımond al-Schaikh al-Boklıầî̀. $4253,2^{\circ}$.

Nollawmad ihn Molanmmad lbn at-Moallim. 638.

Moytmus ibn Molyammad ibn Nolnammad ibn Almad alYaimari al-Rabi Iton Siayid atNàs (Fallı al-Din Aboùl-Fall ). $19^{6} 7 \mathrm{el}$ suiv.

Mohnмap ibn Nohammad ibn Molammad al-Djáfari. 1607 $1815,3^{\circ}$ à 5 .
Mogamas ihn Mollammad ibn Mohammad al-Djazarl (Schams al-Din Aboû'l-Khaïr). 59a, $2^{\circ}$. $7^{62}, 1^{\circ} .1169$ et suiv. 2571, $6^{\circ} .453 \mathrm{a}, 4^{\circ}, 6^{\circ} .454 \mathrm{a}$, $5^{\circ} .4577,3^{\circ} .4662,15^{\circ}$.

Momanua ibn Molnammad ihn Moḷammad al-Khalili (Srliams al-Din). 2558.

Mopumud ibn Mohammad ibn Nohammad al-Safadi (Mhou 'A bd Allah). $3387,2^{\text {" }}$.

Moncumad ibn Nolnammad ibn Mohammad al-Tounsi al-Ghazàlí (Hoddjat al-lsłàm Aboú Hàmid). 203. 448. $748,3^{\circ}$. 985. 1026. 1032. 1122, 3․ $1154,2^{\circ} .1176,26^{\circ} .1206$, $15^{\circ} .1248,33^{\circ} .1291$ et suiv. $1331,1327,12^{\circ}, 1381,1^{\circ}$ et suiv. $1405,2^{\circ}$. 2035, $3^{\circ}$. 2310. 2311. $2351,4^{\circ} .2365$, $1^{\circ}$. $2405,9^{\circ}$. 243/l et suiv. $2701.2741,2^{\circ} .2763,1^{\circ}$. $3198,3^{\circ} .397^{3}, 10^{\circ}$. 4530 . 4579 .

Monasuco ibn Nolammad Hon Nobàta - (Djamàl a]-Din). $2234,4^{\circ}, 5^{\circ}$. 3315. 3344. $336 \circ, 2^{\circ}$.

Mopısмa ibn Molyammad atOfràni. 4617

Noụtumad ibn Nohammad al'Omari al-Qasiri. $3165,2^{\circ}$.

Montume ibn Molhammad alRâż al-Talıtàn (Qolb al-Lin). $2369,2^{\circ} .2371,2^{\circ} .2373$ et suiv. $1187,15^{\circ}$

Monanad ibn Mohammad ibm Scharaf al-Zaraî (ou al-Zori i). 33 ia el suiv.

Monsusso [ibn Moluammad] Ibn al-Schilma (Nohilb al-Din Abou'l-Walid). 934. 1940. ${ }_{1537}$ et suiv. 1683.3912 , $2^{\circ}$.

Nomusya ibn Mohammad Sibt al-Vharidini (Badr al-Din). $9521,8^{\circ} .25 / 1,6^{\circ} .35 / 3,1^{\circ}$. $4580,3^{\circ}$.

[Nonısman ibn Mohammad] Sibt al-Màridinì (Djamall al-Din). $2519,2^{2}$.

Moụumud ibn Nolnammad ibn abi'l-Soroûr al-Siddìtì al-Bakrì (Schams al-Dìn). 781. 1560 el suiv. 1623.185 . 
Monnmuar iln Mulammad alSchálut. 1037 .

Monamad [ibn Molyammad] alToủsí (Nazî al-Din Aboù Djaffar). $2330,6^{\circ}, 8^{\circ}$. 2366 . \$368 el suiv. 9465. 9466. $2467,1^{\circ}, 5^{\circ}, 8^{\circ}, 10^{\circ}$ à $19^{\circ}$. 9/185. 2509 et suiv. 2716,5 . $437^{1}, 2^{\circ}$.

Momamaso ibn Melammad ibn Yáqoûl, al-Koûmî al-Toûnisí. 2707.

Monama ibn abi Molammad ibn Molanmmad ibn Zalfar (Herdjat al-Dín). 6e8. 1959 . 219 1 et suiv. $3131,2^{\circ} .3503$ et sıiv.

Moụaman ibn al-Mólâ (Qoṭt alDiil). 2753 .

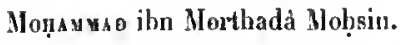
$160 \%$.

Monamma Mosliḷ al-I)ín al-Làrì (Scluams al-Din). 2364 .

Moụamad ibn Mostafâ Schäklı Zâdè (Moḷyî al-Dín). $319^{8}$, $1 \%$

Mọ̣us ya ibn Moủsá. $9467,3^{\circ}$.

Pír Moṇamá ibn Mloúeâ alBroúsî. 95 J.

Hounanas ibn Hoùsâ ibn 'Ísà alDamiri (Kamîl al-Dín). 2783 et suiv. $4586,3^{\circ}$.

Monнмия ibn Moûsí al-Naddjâr. $1620,9^{\circ}$.

Moиямх в iln Hoyassar. 1688.

Noụnsav al-Nâdsifí al-Ḥalabî Ibn al-Hanbalî. 4531.

Jañmmo al- Yafzáwî. 3070 .

Manınหa ibn Nâmwar al-Klıoûnaadjî ( ( hoû́ 'l-Fadháil). 1396 , $6^{\circ}, 12^{\circ} \cdot 29^{3} 7$ et suiv.

Mọ̣ayma ibn Nâșir al-Darí. $3198,6^{\circ}$.

Mohanua ibu 'Omaïr al-Ḥalabí. 4040.

Nonamad ibn 'Omar al-1ludah. 31338 .

Mlopamana ibn 'Omar al-Balıírí al-Malıaliti. 2706 .

Moỵanad ibn "Omar al-Glazlawí. 3069 .

Mounanay ibn 'Omar al-Hadhramí (Djarnâl al-Dỉn). $2502,11^{\circ}$.

Nongmase ibn "Omar lbn alQoůtîya. $1867,2^{\circ}$.
Moṇanuas ibn 'Omar' al-Bàzí (Faklıral-Dìn Aboù Abdallah ). $178,1^{\circ} .613 .790 .1253 .1254$. $1360,3^{\circ}$. 2521, 50. 2592. $2599,2^{\circ} .2645 .29^{36.2937}$ et suiv. $4187,6^{\circ} .4577,14^{\circ}, 15^{\circ}$.

Monkus aso ibn "Omar ibn Șàdiq ilmn 'Omar al-Bakrì al-Fanânîsi ou al-Qqaxinisî. 2545. 2561 .

Mounaman ibn 'Omar ibn Siddiq al-Bakri. $4580, \mathrm{t}^{\circ}$.

Nohaymad ibu 'Onar al-Șinlıadji It:amschánd. 4665, $10^{\circ}$.

Moụnya ibn 'Omar al-Toûnîsî. 4641 .

Mọ̣a ymav ibn 'Othmàu al-Anșârì. 3670 .

Monamua ibn Qaïyun al-Djauziya (Schams al-I)in). 1387.

Monayuso ibn al-Qàsim al-Anbàrì (Alıอถ Bakr). 651, $2^{\circ}$.

Mounamao ibn Qaisim ihn Yá qoûb. 3501 et suiv.

Noṇansua ibn abî 'l-Qâsim ibn 'Abd al-Salàn al-Rìghhí (Schanı al-Din Aboù Abdallalı). 614.

Мoganaa ibn abî ']-Qâsion alRơaüni lbn abî Dínâr alQaïrawånî (Abuñ 'Abdallah). 1887 .

Moйıммsо ibn Qorqamás (Nạsir al-Din). $2502,9^{\circ}$.

Moвama (Pír) ibn Qotb al-Din al-Khoûyi. $1386,3^{\circ}$.

Monamao Ríghiz Pacha. 4455.

Mounuma ibn Rasoúl al-Barzandji. $145 \mathrm{~g}$.

Moganasan al-Razzio (Djalâl alDin). $6{ }_{2} 6$.

Mogamma al-Rifắî. 3454.

Nogamma ibn Roschd al-Baghdâdî. $1057,21^{\circ}$.

Мон̆мma ibn abí Sahl al-Saraklısì (Abøủ Bakr). 785.837 . 838

Mop̣uman ibn Said ibn al-Dobaïthi al-Wàsitî. 2133.

Mognama ibn Saíd al-Marí. ${ }_{2} 568,4^{\circ}$.

Moñmma ibn Sa'id al-Ṣinhâdji (Abou 'Abdallah). 1400 et suiv.

Mочамма jbn Saîd al-Soñsí. $2568,11^{\circ}$.
Mọ̣ uma ibn Saláma ilın Khadhır (ibn Hakmoûn) al-Qodhă'i (Ahøû 'Abdallah) ). 1490 el suiv. 1952 .

Mounamun Síntạ. 4329 et suiv. $4336,2^{\circ}$.

Nohismá at-Șíla. $4528,2^{\circ}$.

Moṇuna ilun Sâlim ol-Kballả (Schams al-Dîn). $2661,1^{\circ}, 13^{\circ}$.

Moyamea ibn Sálim ibn Naṣr Allàh ilun Sâlim Ibn Wâșil alỊamawi (Djamàl al-Dîn). 1702 et suiv. 4451.

Moụaymad al-Samarqandî (Rokn al-Din). $77^{3}, 2^{\circ} .1699,3 \circ$.

Mopaymad Sandjakdår al-Scbarî. 2536 .

Mogamaso al-Sarsari (Aboú 'Abdallalı) 1607 .

Mopanyas Ibn Sehaba al-II larrânt. $1450,1^{\circ}$.

Monayma ibn Sclaákir al-Kotobi (Fakhr al-Din). 1586 et suiv.

Mounanua ibn Scharaf al-Kalà'i. $1025,1^{\circ}$.

Monamaa ilm Scharif al-Hosaini al-Djordjânî (Noùr al-Dlu). $1013,7^{\circ}, 8^{\circ} .2397$.

Moụumaa ibu abî Scharîf (Kamâl al-Iìin ). 2 a55.

Mọ̣ıммa al-Scbamoñbi (Schams al-Dìn). $199^{3}, 3^{\circ}$.

Mogumman al-Schirâzú (Mír Sạdr al-Din) $239^{8}, 3^{\circ}$.

Mognmas ibn Schóaïb al-Hidjàzì. 1373 .

Nog̣ıмm v Sibt al-Mârìdint. 2560 , $7^{\circ},{ }^{\circ}$.

Mopammad Sibt al-Máridini (Schams al-Din). 1056.2541 , $1^{\circ}$.

Mog̣ımмa ibn Sibt al-Máridínî. ${ }_{2} 547,8^{\circ}$.

Mopasma al-Siddî̃. $1337,2^{n}$.

Monıмма al-Simnânì (Sadid alDin). $2917,2^{\circ}$.

Nogamma ibn Sírfn. 274a el suiv. 2744.

Mounaxyo ibn Solaimán alBalıleùlî. $782,4^{\circ}$.

Moụa us ao ibn Solaïmần al-Djozuv̂lì (A boû 'Abdallalı). 1180 et suiv.
Mop̣umao ibn Solaimân al-Kafawi. 2097 .

Mонамма ibn Solaïmân al-Redâní. 4470 .

Mog̣ums iln Selaïmân al-Roùmi al Kànyådjî [ Kâffiyadjî] (Moḥyi al-Din). $1126,3^{\circ}$.

Moụıหx ilı 'Abd ał-Ralımân al-Tilimsảnî al-Djozoưli. 4601 el suiv.

Mөнамиа ә ibn ('Afiffal-Dín) Solaimân al-Tilimsànî (Schams alDin). $3176.3947,1^{\circ}$.

Moи̣aн ya al-Ṭablåmî (Náṣir alDin). $4533,1^{\circ}$.

Monaмmid ibn Talha al-Qoraschî al-'Adawì (Kamál al-Dîn Aboû Sálim). 9440. 2663 et suiv. $4606,1^{\circ}$.

Moyamma ibn abt Tàlib al-Ansàri al-Dimaschlqi (Schams alDin Abou 'Abdallah). 2187 . $2562,20^{\circ} \cdot 37^{5} 9.3973,13^{\circ}$.

Mopamana Tchelebi Efendi. 4261 , $14^{\circ}, 15^{\circ}$.

Moṇaman al-Tifâsclî́ (Aboû 'IBarakât Scliams al-Din). 3057 .

Mog̣amà al-Touâtí. $1230,10^{\circ}$. Monamuab ibn Toumert. 1451.

Mog̣ay y (Aboú 'l-Wafà). 1200 , $1^{\circ}$.

Monnaman ibn al-Wafá. 3186 . 3208 .

Mọ̣ıммะ ibn Wăiz ibn Walídjân al-Mlar aschî. $2358,2^{\circ}$.

Monamsid ibn al-Walid al-Tartoùschî al - Qoraschî (Aboú Bakr). 2431 et suiv. $3486,2^{\circ}$.

Moganma ibu Yabyá al-Motaiyib. $1651,3^{\circ}$.

Monanya ibn Yalıyâ ibn 'Omar al-Qarâfi (Badr al-Din). 4614; $8^{\circ} .4627$.

Noụı w M so ibn Yalụyá al-Schîrwâní. $67^{3}, 1^{\circ}$.

Moṇa M⿻ av al-Yamani al-Schardji (Schams al-Dîn). 3556.

Nợamas ibn Ya'qoûb ibn akbí Khozâm (Aboû Abdallab). 28 33. 2834 .

Mọ̣auad ibn Yáqoúb al-Fíroùzâbâdi. 4 a 63 el suiv.

Moṇamyad ibn Yoủsof al-Addjân. 1364. 
Mogamuso ibn Yoisof ibn Ahmad al-Báouinl (Schams alDill). $1615,1^{\circ}, 2^{\circ} .3412,7^{\circ}$.

Mopamas ibn Yousof ibn 'All alSchàmi. 1987 et suiv.

Moụaman ibn Yoúsof al Dimyàțí. $2569,2^{\circ}$.

Mọ̣aม « ibn Yoùsof ibn Haìàn al-Andalosl (Atbir al-Dîn Aboù Haïyân). 644, $1^{\circ}$.

Monamad ibn Yoúsof al-Halabí. $4591,3^{\circ}$.

Mop̣amad ibn Yoủsof al-Qon̉nawi (Scliams al-Dín). 1006.

Nogam иad ibn Yoúsof al-Sanoísí (Aboû 'Abdallah). $1057,17^{\circ}$. $1060,3^{\circ} \mathrm{a} 5^{\circ} .1061,10^{\circ} \mathrm{a}$ $12^{\circ} .1141,3^{\circ}$. 1206, $5^{\circ}, 7^{\circ}$. 1268 . $127^{\circ}$ et suiv. $127^{6}, 2^{\circ}$. $1285,5^{\circ} .2400$ et suiv. 2502 , 1 $3^{\circ} .3264,3^{\circ}, 4583,1^{\circ}, 2^{\circ}$. 4584 .

Mogamad ibn abi Zaïd 'Abd alRaḥmán al-Habascht (Djamál al-Dín). a4tig.

Mọ̣ıмма ibn Zakariyá al-Rázi (Fakhr al-Din Aboủ Bakr). $1176,22^{\circ} .1383 .277^{6}, 9^{\circ}$. 2865, : $^{\circ} 2866$ à ฉ 868 . 29 18 , $4^{\circ} \cdot 29^{4} 7,9^{\circ}$.

Monsmad al-Zanbalí (ou lbn Zanbal) al-Rammâl al-Mahalì (on al-Mahlawi). 183 a et suiv. 4612.

Al-Mọ̣ísıl. Voyez Al-Hititu alMohạsibí.

Moḥıa al-Din ibn Taqî al-Dín ibn Dâ'oûd. 2293 .

Mloṇsı al-Qaișarí. $867,4^{\circ}, 5^{\circ}$. $1266,7^{\circ}$.

Mowrí AL-DIx al-'Adjami al-Iṣfahâní. 202.

Moụu at-Dls ał-Tálidji (on al Tátischî). $1243,9^{\circ} .2356,1^{\circ}$

Al-Moxarian ibn al-Hasan Ibn 'Abdoûn lbn al-Botiàn (Aboú'1-Hasan). $166 . \operatorname{2g} 8,2^{\circ}$. 2945. $29^{4} 7,3^{\circ}$.

Ibu al-Molaqeix. Voyez 'Oxan ibn Ali.

Ilun al-Mowi. Voyez Ianîuín ibn Aḷmad.

Abou 'l-Howi ibn abi Nasr ibri Haffáz Kohên al-Attâr. 2965 , $2^{\circ}$. 2993 et suiv.
At-Mondsial. Voyez 'Aad az-Aẓi M al-Mondsiri.

Ibn al-Mogafra'. Voyez 'A adulaa Ibn al-Moqaffa' et Sévèn lbn al-Moqaifar.

Aboù Moqá. $1206,13^{\circ}$.

Al-Monní. Vovez laniris lbn alMoqri; - Iswîtì ibn abi Bakr; - Moramad ibn al-Abbás; Mogasmad ibn Ahmnad.

Al-Monint. Voyez Hasay ibn alQâsim.

Mosanxirax. Voyez Aul ibn Mohammad.

Joṣtiṇ at-Dis al-Qastalàni. $1241,3^{\circ}$.

Mosım ibn Haddjadj. $7^{04}$ et suiv.

Aboù Mosulu. $77^{4}, 5^{\circ}$.

Mostąi. $2544,14^{\circ}$.

Mlostarà jon 'Abdallalı Kiâtib T'chélébi (Hadji Khalfa). 4459 et suiv. $4663,10^{\circ}, 15^{\circ}$.

Mostapì ibu 'Abd nl-Qádir alDibni. 1212.

Mostapî al-Bakrî. $743,16^{\circ}$.

Moștapi ibn Ibrahìm. $3967,1^{\circ}$.

Mostafa ibn Kamál al-Dín alKhalwatî. 1377 .

Moștapì al-Khaïyât. $2561,5^{\circ}$.

Mostarí Khòdja ibn Qásim alMișrî. $1891.1892,1^{\circ}$

Mostrati ilon Qdsim ibn 'Abd alKarim. $3_{2} 43$.

Mostapi ibn Schams al-Din alKara-Hissârí al-Akhtari. 4324 et suiv.

Mostarì Sibt Â al-Hasanaïn. $3261,2^{\circ}$.

Mostari ilon Yoúsof al-Borsawî Klıwàdja Zádè. $23 \mathrm{~g} 8,1^{\circ}$.

Mo misch al-Qaramani. 1124 et suiv.

Al-Motracibì. Voyez Moụansb ibn Ishạqq.

Al-Motayazî̀. Vovez Anqad ibn al-Hosaïn.

Al-Motraql. Voyez ALi ibn Hessám al-Dỉn.

Al-Motanaz. Yoyez Moun msed ibn 'All.
Al-Motraaizì. Voyez Nișı ibn Abd al-Saïyid.

Ibn al-Mótazz. Voyez 'Aadulan lbn al-Mo'tazz.

Moobinsk ibn Moḥammod al-Djazari lbn at-Athir (Madjd alDîn Ahoû 'l Sa'àdát). $7^{28}$ et suiv. 731 .

Mocrti al-Khadim. Voyez Aboù Sślo al-Khádinni.

lbn al-Moufti. Voyez Mog̣amao ibın alı̂ Bakr.

Moúsì ibn Ahmad al-Maqdisi (Scliaraf al-Dìn Aboú 'l-Nadjii). 1107.

Moúsi ibn 'Alì al-Tilimsini. h'jo1 et suiv.

Mot̀si al-Boldànî (lis. al-Yaldĩní) (Scharaf al-Din). $117^{\circ}, \mathrm{a} 3^{n}$.

Moúsỉ ibn Malımoud Qàdhì-Zadè al-Roûmì. $2504,2^{\circ}$. 4386, $3^{\circ}$.

Mloủsi ibn Mlolıammad al-Klıalilı (lisez Mohammad au lieu de Ahmal). 9547, 8, $12^{\circ}$.

Mocisi ibn 'Obaïd Allàh Ibn Maïmoûn ( $\Lambda$ boû 'mrân). $178,1^{\circ}$. $205,9^{\circ} \cdot 3^{6} 6,1^{\circ}$.

Moûsì al-Rabt. 1450, $9^{\circ}$.

Ibn abì Moèsì al-Hâschimí. 1105.

Aboû Moúsi al-Madînt. $4577,16^{\circ}$.

Aboû Moûsî ibn Qàsim al-Mlaghrabi. $247^{5}, 1^{\circ}$.

Al-Mlowadusisl. 4376 .

M-Mlozaffar al-Isterledi. s $458,4^{\circ}$.

Noznfraa ibn Joliammad alSchìraizi (Şadr al-Dìn Aboí 'lMáilii). $1198,1^{\circ}$.

Al-Mozaran ibn al-Săid abì 'lQàsim al-Fadhl al-Alawí alHosainî́ ( $4336,3^{\circ}$. 4420, $1^{\circ}$.

Al-MożfFı [ibn 'Abd al-Salàm ibn 'A bd al-Rahmain] (Badr al-Din). $2835,3^{n}$.

Ml-Niatglla al-1)sobyàní. 3, 075 , $10^{\circ} .30_{7} 6.39_{7} 3$ et suiv. 3280 . $39^{3} 9,4^{\circ}$.

lbn al-Nabin. Vayez Kavil stDix lbn al-Nạbili.

Ibn al-Yaddir. Voyez Moparmad ibn Malımoúd.

Ibn Nissi. $215 \%$
NADu al-Scharîhî al-Kobrawi Schaikh Zàdè. $4277,3^{\circ}$.

Nadja al-Dls. $3954,4^{\circ}$.

NADjm aL-Dîx al-Khàsî. 858 .

Al-Nıdsaotini. Yoyez Youtsof ilu 'Ali.

Nafis ibn 'Iwadh al-Kirmani. 2932 .

Ibn al-Yaris. Voyez 'Alí ibn abì 1-Hazm.

Al-Nafziwi. Voyez Aboú 'Aadalcall a)-Nafzâwî et Moụıмı al-Nafzałพ1ิ.

al Nafzí. Vojez Mouanus ibn Ibràlìm.

Jhon al-Naunis. Voyez Fatu Arqin al-Halabi.

Al-Nanaswixi. Voyez Mounamad ibn Alımad.

thn Ni'ins. Voyez Abo at-Vasiy ilon 'Abdallah.

Ml-N.uinizi. Voyez Ml-Fadnc ibn Hiru.

Ml-Naisinotni. Voyez M-Hasay ibn Molammad.

NsQoủ LÀ al-Tourkì. $1857 \cdot 337^{2}$.

Al-Jasafí. Voyez 'Aadallan ibn Alumad; - Bobuì aL-Dín alNasafi et 'OMan ibn Molammad.

Al-Nasawi. Vovez Monsmmad ibn Aḷmad ibn 'Ali.

Nisa ibn 'Abd al-Srivid al-1lotarrizì (Borhân al-Dîn) 1136 , $4^{\circ} .39 .37$ et suiv. $3902,2^{\circ}$. 1008 et suiv. $1021,3^{\circ}$. 4025 $2^{\circ} .4026,2^{\circ} .4028,2^{\circ} .4030$ $2^{\circ} .4031,9^{\circ} .4130,3^{\circ} .4144$ $2^{\circ}, 4^{\circ}, 8^{\circ}, 4254,1^{\circ}, 2^{\circ} .4355$

Niṣı a L-Dix ibn 'Îsa lbn al-Ḥas kafi. $2540,3^{\circ}$.

Niṣı al-Dix al-Loqaini. $80 \%$. 4.5.) 4 .

Vista at-Dix ibn Samoùn. aja $3^{\circ}$.

Yism at-.Dis (al-Ostad) ibn alTarảbolosi. $98,6, \mathrm{a}^{\circ}$.

Nasr ibn Mlakhloûf ibn Qalàgis (Alıûll-Fotoúlı). 3139 .

Nasa ilon Molnammad ibn lbrìhìn al-Samarqandì (Alıoi 'llailh). $606,3^{\circ} .77^{4}, h^{\circ} .825$, $1^{\circ}$. $826.11,1 / 1121$ et suiv. $11 ! 1,4^{\circ} .1143,3^{\circ}, 1317,2^{\circ}$. 
Naṣn ibn Yíquoúb al-Dainawarî (Ahoủ Said). 2745.

Aboú Naș. $1057,14^{\circ}$.

Aboǹ Naş Qáitbåi. 118.

Niṣn Alcia lba al-Athir (Dliyá al-Din). $4435,1^{\circ}$.

Al-Naşaî. Voyez Moụamud ibn Alimad ibn Alod al-(Qádir.

Al-Xisscribî. Voyez Yoćsor lbn al-Adjoúz.

A-Națaxzi. Voyez Ilosain ibu lbràlim.

A]- Kawidui. Veyez Morannid ilon Hasan ibn 'Alì.

Al-Nawawí. Joyez Yạya ibn Scliaraf.

Micolas (curé). 3663 , 12 ".

Nicos (métropolitain de Manbedj ). $265,12^{\circ}$.

NioÁ ibn '̂́s jon al-Hàddj Nidâ ibn 'Jurian. 3933 .

Niz̨im.te-Dixiln Maḷmoủd. 4446 , $2^{n}$.

A]-Xizini. Voyez Iotsor ibn Al!mad.

Aboû Nóaĩy. loyez Aụma ibn 'Abdallah.

lbn Nosita ["Mbd al-Aziz iln Omar $] .3387,1^{\circ}$. - Voyez aussi 'Aво al-Rayis ibo Mloliammad; - Mona y us jon Abdal-Ralim et Moṇusa ihn Moliammad.

Nósix ilon abì 'l-Fidbá al-lsräilî. 2883.

Al-Yo:ụi al-Nâsilui. 1157.

Norans (Chrysanthus). 2249 .

Al-Navarini. Yeyez Bjor at-Din.

Novia at-Dín al-Dimyâtî̀. $11 \mathrm{~g}^{3}$, $5^{\circ} .1317,2^{\circ} .2562,22^{\circ}$.

Al-Nowaĩni. $157^{3}$ et suiv. 1587 . 1588 .

Aboù Nowâs. Veyez llasax ibn Ilầnî.

Aไoû 'Oваі̄a. 3969 .

Aloû 'Os

'Osaĩo Allîu (Khodja). $3965,6^{\circ}$.

Obaío Aluîa ilon Djiluril ibn 'Abdallal ibn Bakhtischoù. 3028, $2^{\circ}$.

'Obaĩa Allâli jbn Maśoûd (Tâdj al-Scharia ). 908 et suiv.
Oanio Aluía ibn Masoúd ibn Tâdj al-Scharì'a al-Malıboủbî (Sadr al-Scharìa). $79^{6} \cdot 797$.

A -Oprawi. Toyez Dusara ibn Tha'lab.

Á-Oasnì. Voyez 'Alî ibn 'Othmàn.

al-Ofoixî. Voyez Meyammad ibn Noliamnad.

Al-'Okbabì. Vojez 'Aboalla ibn a]-Mostĩx.

Olocgn Beg. 9496, 2. 2534 et suiv.

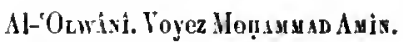

'Oman ibn al-'Aziz al-Boklıảrì (Hosâm al-Din). 821 et suiv.

'Oman ibn ' $A$ bd al-Ralím ibn Yaḷ̣â. 4586, 1\%.

'Osan ibo 'Abd al-Rahmân alDjizqầi. $2568,12^{\circ}$.

Osis Agha. 3944, $6^{\circ}$.

'Ома [ibn 'Alî] lon al-Fâridh. (Scharaf al-Dín Aboù Hafș). $645,2^{\circ} .1343,3^{\circ}, 4^{\circ} .19^{32}$, $5^{\circ}$. 3143 el suiv. $3171,55^{\circ}$. $4261,10^{\circ}$.

'Omıa ibn 'Alî al-Kâtibl el-Qazwînî (Nadjn al-Dìn). 1396 , 2. $2359,4 \% 237$ ' et suir. $4187,16^{\circ}$

'Oman jbn 'Ali Ibn al-Molaqqin (Sirâdj al-Dinn). 1009.1667 , $6^{\circ}$.

'Oras ibn abł Djarâda Ibn al'Adím (Kamål al-Dín Aboí Hafş) 1666.9138.

'Oma ECendi. 1 s3o, $3^{\circ}$.

'Omaaibn Ferdjân al-Tịrân. 2600 , $1^{\circ}$.

Oraa al-Hadlurami. $1418,1^{\circ}$.

'Orsa Ibn al-Ilarawî (NudjmalJin). 4164.

'Osıa ibn al-liasan ibn Dilya (Aboúl-Khattàb). 3141, $2^{\circ}$.

[OMiñ ilm] lbrâlî́m al Ausî alAnșàrî (Aboú lshâa). 1933 et suiv.

'OMa ilon Klualil ibn 'Alî al Salqâuî. 2748 .

Oman ibn Mataī. Teyez Aus ibn Mataï.

'Oyss ibn Moliammad al-Nasafî (Nadjin al-Dín Abon Hafṣ). $59^{2}, 4^{\circ} .1234$ et suiv. i261, $2^{\circ} .1969,3^{\circ} .1285,4^{\circ} .1286$, $2^{\circ} .3136$ et suiv, 4566 et suiv. $4606,9^{\circ}$.

['Oman ihn Moliammad] al-Sebrawardì (Schilıâb al-[in Aboû Hafs). $124 \% 3^{\circ}$. 1332 .

'Oran ibn Mlohammad Ibn alViardi (Aboù Hafș). 2188 et suiv.

Omas ibn al-Mlozaffar al-Wardi (Zaïu al-Din). 999. 2580, $5^{\circ}$. 3 ig9 el suiv.

'Oraa ibn 'Omar al Zohrì. 976, $1^{n}$.

'Oraa al 'Ordhí (Aboûl-Wafa). $3118,7^{\circ}, 22^{\circ}$.

lon-Omia. $2605,1^{\circ}$.

'Omnin Ibn al-Jlotawakkil ibn Hàroún al-Thagafi. 1374 .

'Ominat al-Yamanî (Nadjm alDin). $2147,1^{\circ}$.

Al-Onuni. Voyez Mogamma ibn Abd al-Ralımán; - Moнam yad ihn Molıammad; - Scaraìa AL-Dix al-Omarl; - Zain atDis a]-'Omarì.

al-Omawî. Voyez Mọamad ibn lbrâhî̀m.

Oxn llixì. $1206,11^{\circ}$.

Al-'Ononi. Veyez 'Oman al-Ordhî.

Al-Onyawi. Voyez Mạmoúd ibn abî Bakr.

Al-Oamiyoûvî. Voyez Yoûsor ibn 'Abdallab.

lbo abî Oșaĩata. Voyez Aụma ibn al-Qàsim.

At-Oscamoúní. Veyez Ati ibn Moliaromad.

Al-Oscanohî. Toyez 'A Bd al-'Aziz ibn 'Ali.

Ostanés. $2605,1^{\circ}, 4^{\circ}$.

Al-Osyoưtî. Voyez Mọ̣amad ibn Ạ̣mad al-Mlinhádjí.

'Oriasd ibn Mohammad. a $77^{5}, 33^{\prime}$.

Al-'Orbí. Voyez Mlogammao ibn ' $\Lambda$ bul al-Djabbâr et Moнамma ibn Almad ibn 'Abd al-'Azîz.

'Oтнмís ibo 'Alì al-Zäla'i. 897 et $898.902,2^{\circ}$.

'Oramix Bey ibn 'Alì-Bey. 1997. 'Oramis ibn Djunnl (Aboûll-Fath). $3_{2} 85.3988$.

'Orumàn ibn 'Omar lbn al-Hàdjib (Djamâl al-Dín Aboú 'Amr h $801.1136,3^{\circ} .2369,9^{\circ}$. 2391. 399 1, 2. $4021,2^{\circ}$. 4025 et suiv. 4058 et Buiv. $4123,5^{\circ}, 7^{\circ} .4182,2^{\circ} .4187$, $3^{\circ} .439^{2}, 3^{\circ}$ à $6^{\circ} .4549$.

'Otavì al-Qibåbî(Schamsal-Dìn). 3577 .

'Otruix ibn Said al-Dânî (Aboû Amr). 592, $1^{\circ}, 3^{\circ} .593 .4202$, $3^{\circ} .4532,2^{\circ}$.

Abeû 'Otumin. 2457,6 '.

Al-OO ramîxi al-Ṣafadi (Schams alDin). 2093.

Ouessint. 573.577 .

A)-Oúscuì. Voyez 'Alí ibn 'OthMÂN.

Owaîs. 3405.

Pappes (?). $2457,5^{\circ}$.

Pava d'Antioclie (évêque de Sidon). $165,4^{\circ}, 5^{\circ}, 258,5^{\circ}$ a $10^{\circ}$.

Paul Boúschì. $69,10^{\circ} .7^{4}, 4^{\circ}$, $5^{\circ}, 7^{\circ} \cdot 141,4^{\circ}$ a $6^{\circ} .195 .212$ $2^{\circ}, 5^{\circ}, 6^{\circ}$.

Paul (évêque de Monembasie) $276,22^{\circ}$.

Al-Pazd awi. Voyez Aul ibn Moham. mad.

Pellisson (Paul). 4622.

Penenics (Thomas). 4340 .

Petis oe la Caolx. 216g. 4343. 4361.4364 .4462 et suiv.

Petros ibn Petros. $127,1^{\circ}$.

Philippe. 205, $13^{\circ}$.

Piccini (P. Onufre). 129.

Picques $\left(D^{r}\right) .218$.

Prerre (évêque de Behnesa). 75 , $9^{\circ}$.

Pierae Dipy (ou Diyâb). 3425 . 4484 .

Pieane lgnace (patriarche de Syrie). 4622 .

Pisenti. $150,1^{\circ}$.

Platox. $2577,2^{\circ}$.

Ptoléméb. 2489 et suiv. 2544 , $9^{\circ}$.

Ponphyse. $1243,2^{\circ} .2346 .2347$.

Ibn al-QABÂQABí. 318a.

Al-QaввÀ vi. Voyez 'Auî al-Marághí el Kaidur ibn 'Abd al-Qádir. 
A-Qírisi. 3a44, $3^{\circ}$. - Voyez aussi 'Atì ibn Mohammad.

Al-Qidni al-Aschraf. 3333 .

Al-Qidni AL-Fidpht. Voyez 'AgD AL-Risuîn al-Bāisâni.

Ibn Qidnt Scgoras. 2076.

Ml-Qhidrai. Voyez Aụmad al-Qådiri et 'Aci ax-Dîn al-Qâdirí.

Al-Raīrawànì. Voyez Al-Hasavibn Raschîq et İRìuì ibn al-Q̨àsim.

Qaisar ibn 'Abd al-Qâsim al-Hanafi ('Alam al-Din). $246 \dot{7}^{\circ}, 6^{\circ}$.

M-Qsísanisi. Voyez Isrinim ibn Abd al Ralımàn.

Al-Quișanl . Voyez Dảoûd ibn Maj!moúd et Moụsin al-Qãșarí.

Al-Quisi. Voyez Aboủ Baxa Molyamniad.

A1-Qaisoìni. 3039, $1^{\circ}$.

Q Qiitzài. Voyez Aboú Nașn.

Ibn Quiyim al-Djanziya. Voyez MoHanmid ibn abi Bakr.

Qıxinisí. 973. - Voyez aussi Mohaymad ibn Bahrâm.

Ibn Qariques. Voyez Naṣa ibn Maklıloủf.

Al-Qalașidìi. Voyez 'Alì ibn Mo. lıammad.

QALiwotr. $1815,2^{\circ}$.

Al-Qíti. Voyez Isriìi ibn al-Qàsim.

A1-Qazqaschandi. Vovez Mohamuab ilon Abmad ibn "Ablallah.

Al-Qseroínì. Voyez Aṇad al-Qalyoùli.

Al-Qavoúlí. Voyez Ap̣an ibn Nohammad al-Makkî.

Qama Kamil. $2.43,1^{\circ}$.

Al-Qiniri. Vuyez Molnamad iln Yahyá et YạYi al-Qaràfi.

Qaraụisìì. Voycz Hayza Qaráhisàrì.

Al-Qinamisi. Voyez Damil alDiv al-Qaramàni ; - Moștari ibn Zakariyà et YÁqoùB ibn Atà Nllah.

Al-Qíri. Voyez Alí ibn Soltàn Molyammad.

Al-QÁscnixi. 3, 63.

Ibn al-QẠșụ. Voyez 'Ani ibn 'Othmàn.

Mas. onientaux. - III.
Al-QÀGIY ibn 'Alì al-Harirí (Aboù Nolammad ) $2571,9^{\circ} .3924$ et suiv. 3994 et suiv. 3996 et suiv. $4452,4^{\circ} .4665,12^{\circ}$.

Al-Qisı ibn al-Fadhl al-Thaqufi (Aboú 'Abdallals). $722,6^{\circ}$.

Qisım ibn Qotloủboghá. $343_{2}, 3^{\circ}$.

Aboù'l-Qisiy al-Anșàri. $2697, a^{n}$.

Abou'l-QAsıs ibn abl Bakr al-iaithi al-Samarqandil. $760,3^{\circ}$ : $4424,4^{\circ} .4425$ et suiv. 4585 , $4^{\circ}$

Aboù'l-Qisim ibn Fierro al-Schàtibi (Aboi Nolıammad). $60 \mathrm{~g}$. $650,2^{\circ} .67 \%, 2^{\circ} .1060,7^{\circ}$. $1077,4^{\circ} .4530 .453 \mathrm{a}, 5^{\circ}$.

Aboú'l-Qissm ibn Nạıfoùz (Djamâl al Din ). 2486 .

Aboî̉'-Qisim al-Malialli (Nadjm al-Din). 1106.

Aboưl-Qisim Marsoùr at-Hasak al-Ṭoûs al-Firdoúsi. 1 896 et suiv.

Aboú'l-QAisı ibn Noḷammad ibu 'Abd al-Djabbår ilun Alımad alFidjidji. $3 \_36$.

Al-Qasínì. Voyez Muhaumad ibn Wohammad al-OOmari

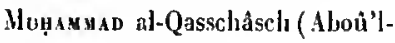
Ghaith). $146 \%$.

Al-Qastalînl. Voyez aḥmad ibn Nohammad et Yosuty at-1)is al Qustalàni.

Al-Qłwàntsì. Yoyez Moụ unus dibn 'Omar.

Ibn-al-Qiyiti. I'oyez Schays atDìs Ibur al-Qàyàti.

Al-Qnziwi. loyez daninim al-Qazâw.

Al-Qazwivi. Voyez 'tgo al-Gilappì al-Qnzwini; - 'Aro AL-Kanix ibn Mohammad; - 'Aci ibn 'Omar; - Aboù Bakr ibn 'Omar; - Hohamma ibu 'Abd al-Ralmaan; - Nonıмmad ibn Abniad; - 'OMAR ibn 'Ali: Zikakira ibn Molammad.

Al-Qrвàвi. Voyez 'Otumiv al-Qibåbi.

Al-Qìrațí. Voyez larinin ibu ‘udallah.

Ibn Qodima. Vuyez 'Aboallah ibn Alımad.

Al-Qodhi'l. Voyez Mohammad ibn Salâme.
M1-Qodoúnì. 897 et suiv. 3965 , $2^{\circ}$.

Ibn al-Qppr. Voyez YÁQoús ibn Isháq.

Al-Qomini. 2220.

Al-Qonml. Voyez Al-Hasar ibn 'Ali et Mopamanad ibn 'Ali ibn il-Ḥosain.

Ibn Qonfods. Voyez Aụmad ibn alHasen et Aụmad ibn Qonfods.

Aboû Qorá (évếque de Harrân). $7^{0}, 4^{\circ}, 71,9^{\circ} .82,5^{\circ}, 19^{8}$, $3^{\circ} .215,4^{\circ}, 9^{\circ}$.

Al-Qoschaĩrì. Voyez 'Abd aL-KLRì ibn Hawâzin.

Ibn Qotaíba. Voyez Admalesilun Voslim.

Qoт̄в AL-Dis Kòschkenárí. $119^{8}$, $3^{\circ}$.

Qọ̣в at-Dix ibn Schans al-Dín. 345 s.

Qote aL-Dì al-Schirâzî. 6o/.

lhn Qotroùzogni. Voyez Qisim ibn Qotloủboghâ.

Qотпов. 835, $4^{\circ} .1057,28^{\circ}$. $1206,6^{\circ} .403 a, 3^{\circ} .4067,3^{\circ}$. $4230,1^{\circ}$.

Al-Qdudulisinì. Voyez $\mathrm{Y}_{\mathrm{AHY}}$ alQoudjḥisåri.

M-Qoùmaìi. loyez Hasur ibn "Ali.

M-Qoúnawi. Voyez Nohanna ibn Ahmad ibn Molammad; - Mo-

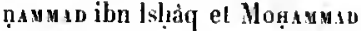
ibn Yoúsof.

Al-Qoúsi. Vovez Maghoùd ilon $\|_{1}$ mad.

Al-Qooschdi. $3257,2^{\circ}$. - Yoyez aussi 'ALi At-Div al-Qousschdjî.

M-Qoìsí. Voyez 'Abd aL.Ginsfain ibn 'Abd al-Hamid.

Ibn al-Qoùtira. Voyez Nonangad ibn 'Omar.

Aboú Ràita. Voyez Hạaí ibu Khadma.

RaMaOHAX. 1632

Ramaduixibn Àmir ibn 'Ali. 2165.

Ramadi in ibn Mostafà ibm al- $\mid W_{a l i}$ ibn al-Ḥàddj Yoùsof. 955, $1^{\circ}$.

Al-Ramadnimi. Toyez Aingad alRambdhâni.

a1-Raml. Voyez Mogamyad ibon llımad ibn Hamza.
Rapnelexg. 4339.

Al-Raqi. Voyez 'Asd al-Rahaín alRaqi.

Ibn al-Raqio. Voyez Igrâuim ibn al-Qâsim.

Resculo at-Din. 2324 .

Raschìd al-Díx ibn Molannmad al.'Omari al-Watwat. a $77^{\circ}, x^{\circ}$.

lbn Raschíg. Voyez Al-Hasay ibn Raschì.

Raslivibn Yáqoùb lbn al-Dja'tarí. $3146,3^{\circ}, 3^{\circ}$.

Ibn Rissoíc al-Ghassàni. $277^{6}$,

Al-Rizi. Voyez Abo al-Rahuaxibu llumad; - Aunus ibn "Abdallah; - Alí ibn Ahmad; Mhoil Bakb Mohammad; Fakiln al-Din al-Ràzi ; - Mahnoúd ibn Hohammad; - Moняммио ibn abi Bakr; - HoHausud ibn Volugmmad; Hopammad ibn Omar; - No"uAMAD ibn Zakbríyá.

Pelsaco. 4486 et suir

REsAUDOT. 2984. 4465

Al-Resmoúkí. Voyez Mogay mad ibu 'Ald al-'Aziz.

Al-Ruzipî. Voyez Auî ibn Moḷammad.

Al-Riríi. Voyez Mopamuad at-Rifă i; - Yaurà ibu "Ali et Yoủnos al-Rifä́i.

Al-Righi. Foyez Monamad ibu abi 'l-Qâsim.

A1-Róaĩvi. Voyez Aạmad ibn Yoùsof.

Rodywir Efendi. 2537 et suiv.

Al-Rohàwi. Voyez Ḥosîn al-Dix.

RoLLIs, 1564.

Al-Rominî. Voyez 'Alì ibn 'îâa

Al-Rondi. Voyez Mounamad ibu Ibrâhìm.

Ibn Ruschd. Voyez Monamana ibn Alimad.

Bousseac (A.). 4478.

Ibn Rozsie al-Baghdádi. 2024.

SAADIAS Ggon. 1. 3.

Ibn al-Säiri. Voyez Aụmad ibu 'Ali.

SABA, S. $157,10^{\circ} .159 . \quad 160$. $173,15^{\circ}$. 


\section{MANUSGRITS ARABES.}

Ibn SaAÁ. Voyez Yạyà ibn abi Zakarìyâ.

Sabeign. Voyez Micnec Sạbbàgh.

Ibn al-Stabaigr. Voyez 'Alí ibn Moḷammad.

Al-Ṣimi. Voyez Igrâuîn ibn Hilăl.

S'd ALLïn ibn Ḥosain Salmàsí. $650,1^{\circ}$.

SÁD AL-Dî al-Isfarảinit. 1631 et suiv.

SÁdi. 3516 el suiv.

Al-SÁdi. Voyez Hịidid al-Sa'di.

SÁpi ibul Tâdjî. 3082 el suiv.

Sadin AL-Dir al-Bokhârí. 3,36 et suiv.

Sadin AL-Dín al-Kàsclighıari. 830 , $a^{\circ} .1132$.

Sadid AL-Dix al-Kâzaroûnî. 2924 et suiv.

Al-Sadjawaxol. Voyez Hoyamad ibn Mohnmmad.

Şadn at-Dix Nog̣amad. 1366.

ŞADn AL Din al-Schîrwânî, 671 .

Sidaratesgatió. Voyez Amad ihn 'Obaìd Allâh.

Al-Ṣafadì. Voyez Aṇmad ibn Yoûsof; - Al-Hasax ibn abi Mohammad; - Kralíl ibn Aibak ; - Mopamao ibn Mohammad et Ml-Ótasínì al-Șafadí.

Al-Ṣ̣ầoosí. Voyez Auî ibn Ạ̣mad.

Ml-Ṣatwî. Voyez Îs mad.

Al-Ṣafoúrì. Voyez "ABd at-RaGMân ibn "Ald al-Sălàm.

Al-Şaguixi. Voyez Hasax ibn Molyammad.

A-Saguniqi. Voyez Hornïr ibn 'Ali.

Sirub aL SÁDA. $177,1^{\circ}$.

thoû Sıgr al-Qoủhî. Voyez Winuîx ibn Wastam.

Sa'id. Voyez Stadiss Gron.

Saíio ibn Aus al-Anșârî (Aboû Zaid). $4231,1^{\circ}$.

Sa id Ibn Batríq. 288 et suiv.

Stid ibn Dáwoùd Ischoú (Dâdyêschoû'a? (Aboù 'Ali). 169 , $11^{\circ}$.

Sxiv ibn Hibat-Allåh ilm al-Ha- san (Aboû "l-Hosain). 3957 et suiv.

SAlib ibn Khafif al-Samarqandi (A boủ 'I-Falli). $2506,1^{\circ}$.

S. î̀ ibn Noùsâ al-Ḥiabî. 1128, $3^{\circ}$.

Abon SA'id ibn abt'l-Hosain ibn abt Said. 5 et suiv.

Aboû SA'îd al-Khâdimî. $1337,10^{\circ}$, $11^{\circ}$.

Al-Suidiwi. Voyez Scuans aL-Dix al-Ṣaìdàwî.

Ibn al-Siîgy. Voyez Fata Actiu ibn al-Siliggh.

A1-Saimani. Voyez "Madalcan ibn 'Ali.

Ibn Stimd aLNis. Voyez Mop̣ayMad ibn Mohammad.

Al-Siñyo at-Scharip. Voyez 'Ati ibn Moḷannrad.

Stînd Somanip al-Hosajnî. 1013 , $8^{\circ}$.

Ml-Saknâwt. Voyez ABd AL- Q Qim ibn 'Alì; - 'Alî ibn Mohammad; - Molnamad ibn 'Abd al-Ralı̣mân; - Moụam Mad ibn Alumad; - Mousuma ibn 'Alí; - Mogammá ibn Ibrâhim.

Al-SAkxikí. Voyez Yoùsoz ibn abí Bakr.

Aboù ȘAL.1̣ ul-Armani. 307.

Salî! AL-Dir al-Halabi. 1932, $4 \circ$.

Salà AL-Div ibn Mohammad ibn 'Alí. 3549 et suiv.

ŞaLîy AL-Div ibn Yoûsof al-Kahhẩi. 3008 .

Al-SALA MII. $2544,8^{\circ}$.

SaLı̂muscu ibn Kondogdi al-Sálị̣̂î. $2212,1^{\circ}$.

Ṣ̣ALÀT Ibn Ghåzì. $4639,2^{\circ}, 6^{\circ}$.

Șiciỵ ibn 'Abd al-Halìm (Aboù Moḥmmad). 1868.

Şítiụ ibn 'Abd al-Qadoùs. 206 , $6^{\circ}$.

Șícụ̣ al-Roûmî. 4303.

Şíuụ ibn Yalı̣â. 1670 .

Al-Ṣaluại. Voyez 'Abd aL-Raumír gl-Sălihịi ; - Ianinin ibn abí Bakr et Ianâni im ibn Nâfí.

Sisum al-Wafài (Aboû 'l-Taufíq). $1937,2^{\circ}$.
Salmîsì. Voyez Síb Aluín ibn Hosaïn.

AI-Sacmoíxí. Voyez Mohammad ibn Mahmoûd.

Al-Salqivi. Voyez 'Onas ibn Khalil.

Saxiis ibn Kalìl lbn Maqaâra (M!Makin). 40, 1․ 41. 43. 193. 194.

Al-Saminisi. Voyez 'Aad al-Kapin ibn Mohammad.

Al-Samaqaydi. Voyez lerîtim ibn Mohammad; - Nonamusd ibn Alí iba 'Omar; - Mounma ibn Aschraf; - Mongmado alSamarqandi; - Nass ibn Mohammad; - Aboú 'l-Q isim ibn abì Bakr; - Ssio ibn Khafif

11-SaพnoL̂̉. Voyez 'Alt' ibn Abdallah.

Al-Saraknsî. Voyez Moụamad ibn abi Sahl.

AI-S.smoutot (al-Stmanoûdî́). Voyez Mop̣amad ibn Alumad.

Samșin AL-Diula ibn a1-Hosåm sl-Baghithli. Lao1, $8^{\circ}$.

SimurL, abbé de Calamoûn. 131 , $2^{\circ} .205,11^{\circ}$.

Samere ibn Yạyæ̀ al-Naghribì. $1456,1^{\circ}$ à $3^{\circ}$.

Al-S.sxaixì. Yoyez Hasay ibn Ali.

Ibn Sanbât. Voyez Hibutu ibn Sinân.

11-Sandoúbí. Voyez Ibriuim alSandoûbi.

ŞAxís d L-MoLk. Voyez Ismitiu Ṣanía al-lIolk.

Al-Sanoúsí. Voyez Hoụammad ibn Yoûsof.

Sanxay (Elzéar de). 4483.

Aboû 'I-SÁcoùn ibn Mohammad all*klibt. $4574,2^{\circ}$.

lboû Sáoún ilon Moḷmmmad al'Imàdi. $2254,12^{\circ}$.

MI-Saqii. Voyez Fadol Allàn ibn abi 'i-Fakbr.

A-Saniqi. Voyez Aadalla ibm lloùstั.

Ibn Sanira. Voyez 'Aвo al-'Aziz ibn Sarầyâ.

Al-Sinì al-Raffâ. $3098,2^{\circ}$.

Ml-Sarkandi. Voyez Hiscum ibn "1ิ่ง̀̀.
Al-Sạaşani. Voyez Momanuad al: Sarșarî.

Sayary. 15/9.

Al-Sawint. Voyez Soutivis jbn Dảoùd.

Scháais (Zaïn al-Din). 4165.

Scráaix ibn Nobammad al-Q0raschî. 3248, $9^{\circ}$.

al-Scrá bí. Voyez Monammad ibu Molıammad.

Al-Scraalstant. Voyez Iarìim alSchabistart.

Ibn Scunddîn. Voyez Yoúsor ilon Râfí:

AI-SchàdsiLî. Voyez Aboú 'I-Hasas a!-Schădsilí; 一 IвnÂuîn ibn Małımoûd et Yoưsor ibn Yahyâ.

ScaÂr1 ibn 'Ali ibn 'Abbás. 1707.

Al-SCHÂPII (lmăm). 743, $5^{\circ}$. $1363,5^{\circ}, 12^{\circ} .3016,4^{\circ}, 3430$. $4577,1^{\circ}$.

Scuäríi jbn 'Abd al Zâhìr. 4658 , $1^{\circ}$.

Schìd Ismíito 1814

Scusụind al Yamaní. $2571,7^{\circ}$.

Ibn Scnànix. Voyez Aboû Hars Ibı Schẩhỉn.

AI-Scuantiastaví. Voyez Mopismat ibn 'Abd al-Karìm.

Al-Schâhrodidi. Voyez 'Alî ibn Mlọammad.

Al-Scanibâx. Yoyez 'A Ái ibn aljí 'I-Ridjål et Mog̣anadibn Hasan.

Ibn al-Schaíku at-Bakrì. 4187, $22^{\circ}$.

Al-Schaíka al-Bokuàní. Voyez Moganama ibn Moḷammad.

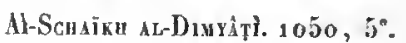

Aboù Scnâkın ibn abî 'l-Karm Petros. 197 .

Ibn abì Scuínin. Voyez Monamuan ibn Aḷmad et Mounuman Ibn Schåkir.

Al-Sgraloviair. 3243.

Aboủ Scuäsa. Voyez Aed at-Rin. м.iv ibn lsmâ'it.

Ibn al-Scusmaí. $3553,2^{\circ}$. Voyez aussi Iloн̣мmad ibn Ahmad Ibn Schammấ.

Al-Schanov'al ibn Yạ̣â ibn 'All al-3Iaghuibî. 305'. 
Scuans aL-Din al-Akrami. $9^{33}$.

Scurays al-Dín al Badamâșf. 3o80, $2^{\circ}$.

Scnays aL-Dir al-Ghazoûli (ou alGhozoúli). $2519,11^{\circ}$.

Schums AL-Dìn al-Nawâhî̀ (alNawấdjì ?). 4453 .

Sconys al-Dix ibn Qâsim alGhozzl (ou al-Ghazzi). 1048.

Scrays al-Din ibn al-Qâyâtî. $1013,1^{\circ}$.

Scanmb al-Dir al-Saidîîi. 2480 , $1^{\circ}$.

Ál-Schasschoúnal. Voyez 'Abdalcat ibn Mohammad.

Al-Scramawisi. Voyez Alioû Baxr ibn Ismà'îl.

Al-Schaxfarì. $3019,2^{\circ} 307^{5}$, $1^{\circ} .3076$ et suiv. 3430 .

Al-Schamtumani. Voyez Yoúsor ibn Soblaìmàn.

Al-Scharap al-Balâsí. $139^{5}, 7^{\circ}$.

Schabaf ac-Dìs al-Îlàqí. agi 7 .

Al-Schánìì (ou al-Schápấwi). Voyez "ABD AL-W mad.

Al-Schankisl. Voyez Yoûsor ibrt Mohammad.

Al<Schandi. Voyez Mohaumad a!Yamanl.

Al-Schahí aL-Hasasu. Voyez Monaмmad ibn Ahmad ibn Ya 'la.

Al-Schaniscui. Yoyez Mogamua ibn Ibrảhim.

al-Schannoû́bl. Voyez Ap̣mad ibn -Othmán el Mopammad al-Scharnoûbí.

Al-Schanwiví. Voyez Bâbí alSclaarwåni.

Al-Scrìischí. Voyez Aboú BaKB Mugammad al-Schảschì.

Al-Schipini. Voyez Aboú 'l-QAaiM ibn Fierro.

Al-Scuuţìt. Voyez Mopam mad ibn All ibn Mohemmad.

lbn al-Schițir. Voyez 'ALî aLDix lbn al-Schátír.

Scвемонт1. $144,2^{\circ}$.

Schraibiv. 2634 et suiv.

Scaugán ac-Din ibn Alimad alSchoscbtari. $3019,1^{\circ}$.
Scurnì at-Dlk ibn Ibrâhîm ibn

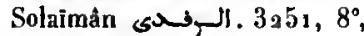
$9^{\circ}$.

Schickant, G. 2941 et 2942.

Scunầ AL-Dis al-Balawi. 4448 .

Schinà B AL-Din al-Ómarî. 9199 .

Ibn al-Schinga. Voyez Ag̣mad ibn Schihna et Moнammad ibn Not!ammad;

Al-Scuírizi. Voyez Ha bís al-Schlrảzí; - Mạ̣но0์ ibn Masoud et Монаммаd al-Schírâzí.

Al-Schînwànì. Voyez Hasaĩ ibn 'Abdallah; - Mis'oús al-Schirwânì ; - Monavyad ibn Yahvà et $S_{A D n}$ AL-Div nl-Schírwâní.

ScróAïr al-Danoúscherî al-Horaïfisch (Zaïn at-Din). 1305 et Buiv.

Scuró $\operatorname{ci}$ (Aboù Madyan). 1930, $10^{\circ} .1337,5^{\circ} .2405,8^{\circ} .3410$ $4585,2^{\circ}$.

Al-Schoвнiкнiтt. Voyez Iвnàim ibn Marî.

Al-Schoв hia woLet (al-Schabråmalissi). Voyez 'Átî al-Schobrâmetsi' et Mopayuad ibn 'All.

A]-Scnobaîit. Voyez 'Andallah ibn Moḷammad.

Aboñ Scyonjล̂́. 1048.

Al-Scuodsoûai. Voyez 'Au' ihn Moûsủ.

Ibn Scuoura. Voyez Aboù Barh ihn Aḷmad.

Ibn abî Scнокn. Voyez Ya!̣ù̃ ibn Nolıammad.

Al-Scuososxi. Voyez Aymad ibn Holtammad.

Al-Schoronnililit. Voyez Hagax alSchoronbilalit el Hasar ibn 'Omára.

Ibn Schoroús. Voyez Mohamyad ibn abi Bakr.

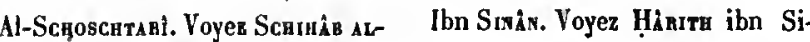
Div ibn Ahmad.

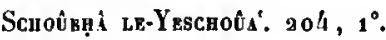

Al-Senreloûnl. Voyez Aboủ Bakr ibn Ismånl.

Sérapıor, disciple de S. Antoine. ${ }_{2} 57,3^{\circ} .258,18.259,1^{\circ}$.

Sarajes. $258,2^{\circ}$.

Stvekr, patriarche d'Antioche. 55.
93. $148,1^{\circ} .150,13^{\circ} .153$, $22^{\circ} .250,3^{\circ}$

Sévìne 1 bn al-Lloqaffa', évéque d'Aschmouniïn. 49, $10^{\circ} .81$, $18^{\circ}, 170$ et suiv. $212,7^{\circ}, 8^{\circ}$. $213,19^{\circ} .301$ et suiv.

Sevíninus de Gabała. $68,4^{\circ}$.

Sibawair. 3987 .

Sibt lan al-Adasami. Voyez lahämim ibn Klali!.

Sibt lan aL-Dsauzl. Voyez Yoûsor ibn Kizoghli.

Sibt al-Mindini. 250\%, $7^{\circ}$ $560.6^{\circ}$. - Voyez aussi MoHaysad ibn Mohemmad et Mop̣anuad Sibt al-Måridint.

Al-Sinti. Voyez Aguad al-Sibti et Mogyamad ibn Alumad.

Stovio ibn Măroưf (Ridhá alDin). $1140,1^{\circ}, 2^{\circ}$.

Al-Sidjistíxi. Voyez Augad ibn Molammad; - Nohav vad ibn 'Azíz et Yoúnor ibn ahî Sa'd.

Sizure (Paul-Astoin). 1558 et -1559 .

Al-Sigaxdatí. Voyez Augnad ibn Molammad.

Ibn al-Sıxкir. Voyez YAqoû́ ibn Iṣ̣áq.

Al-Sicupl. Voyez Aṇxad ibn Mobammad.

Al-Siligroui. Voyez 'Alí Solaïmàn.

SimÉon Stylite. $149,1^{\circ}$ à $3^{\circ}$. 953 , $3^{\circ}$.

Sivéon le Zélateur. $234,5^{\circ}$. 936

Al-Sigrís?. Voyez llohamyad alSimnảnì.

Ibn-Stxi. Voyez Al-Hosair ibn 'Abdallah.

Sinix Efendi. 606, $2^{\circ}$. nân.

Al-ṢınBibst. Voyez AṇMad ibn Idris; - Mohamad ibn Mohammàd ibn Dà 'oủd; - Mogamas ibn 0 mar et Monam. inAD ibn Salid.

Al-Sinìds al-Hindi. 1260.

SthâdS AL-Dîn al-Bolqaīnt. 4588 , $14^{\circ}$, $8^{\circ} .24 ., 7^{\circ} \cdot 243,7^{\circ}$.
Ad-Sinhipi. Voyez Al-Hisas al-Sirdfi et Mozamma ibn llasoùd.

Al-Sinimi. Voyez Yanvi ihn Saif.

Siruìis al-Samradjl (Aboù 'IFatlu). 2923, $1^{\circ}$.

Ibn Sinikr. Voyez Moṇamad ibn Sirin.

Al-Siwisist. Voyez 'Abdalua ibn 'Ahd al-'Aziz

Slank (de). 4474. 4482.4486 et suiv. 4506 et suiv.

Al-Sozrí. Voyez 'Agd aL-W Wabîs ibn 'All; - Aụma ibn Khalì et Troqi aL-Div al-Sobk?.

Al-Ṣoвorri. Yoyez Mand ibn 'Ali.

Socrate. $213,20^{\circ}$.

Al-Somaít. Voyez 'Abd at-Rag̣vax ibn 'Abdallah.

Sop̣noùv. $1050,1^{\circ}$.

Al-Sodrawand [ "'sả ibn Mohammad ]. $459^{2}, 8^{\circ}$.

Al-Sograwandì [Yahyá iḅn Hăbasch ]. a 3hg. - Vovez aussi 'A ad al-Qìdr al-Sohrawardi ; - Aạuad al-Sohrawardi el 'Ouan ibn Mlobammad.

A!-Soxanki. Voyez Al-Hasas ibn al-Hosain.

Al-Solam. $1176,25^{\circ} .-$ Voyez aussi Motnamad ibn al-Hosain.

Solämîx. $2981,1^{\circ}$.

Sochimmín ibn Aḷmad ibn Aïgoúh a!-Ṭabarânî (Aboû 'l-Qâsim). 2011.

SoLAìivi ibn Aḷmad ibn Solaīmân al-Nlahrî ul-Molıanmadì. a 559, $a^{\circ}$ à $t^{\circ}, 9^{\circ}$.

Sozaimâr ibn al-Aschiath al-Sidjiståni (Ahoủ Dâ'oưd). 707 et suiv. 2085 .

Solaìmàr ibn Dảoủd al-Sawârî (Siwârî ou Sonwàrî). 4599.

Solaímín ibn Moûsá al-Kalăì (Abou 'l-Rahi'). 1568 et suiv.

Solnīmâx ibn Thâbit. 3253.

Sounimà ibn Yahyâ al-Zobaidí. 4456.

Solaimân ibn Yoúsof. $35_{1}, 14^{\circ}$.

Solvbt, Ch. 2244.42 ag. 4358 a 4360 .

Aboú 'I-Sonoưr ibn Molıammad ibn abl 'I-Soroûr al-Ṣiddiqî. 1765 et suiv. 
Ibn bbi Sonodr. Voyez "ABD ALGraxi ibn "thd al-Wahlid.

Ibn ahí Souoû a al-Såwi al-Isräili. 3025 et 3026 .

Al-Sовоúri. 35 gо.

11-Soúníxi. Yoyez A!rmad al-Sonđåni.

A]-Sờnài. Voyez Iвnizin alSon̉hâbi (Soû̉ıải?).

11-Soùl. Voyez Abou' 'I-'Arais a)-Soibli.

Al-Şoủni. Voyez Aboú 'l-I!lsas alSoùri.

H-Soúsi. 2568, , - Yoyez aussi Mounman ibn Sriid.

|l-Sownioi. Yoyez Ianâin ihn Alumad (lloluanmad).

Al-Soyoútí. Voyez 'ÁD A.-Ra!nwiv ibn abj Bakr et Momanad ibn alsì Bakr.

Strphaso l'etвo, patriarclie d'Intioche. 4623.

Al-Tamarisi. Voyez Solainin ibn Abmad.

Al-Taвari. Voyez Aḷmadibn Abd. allah et Monaymad ibn Djarir

Al-Tabliwi. Voyez Moḷaym alTablàwi.

Al-Tàoni. Voyez Monamus ibu Ibråhìn.

Tins AL-Div [ibn Alımad al-Màliki] al-Ansârî. 3ígo.

Tỉd .lL-Dix ibn 'Atấ Allâh. 3237.

Tids aL-Dis ibn Zakariya ibn Soltàn al-'Otlımån (lisez 'Othmâni). 1370.2044 .

Az-Tídoứci. Voyez 'A вo at-Ra!Mix ihn Mohammad.

Al-Tinsifi. Voyez Moнamma ibn Niyoúb.

Al-Támoni. Voyez Isnào ibn Ibràhim.

Al-Tafnâwì. Voyez Moganyad ibn Abmad.

Al-Tartázaxi. Voyez Maśoúo ibn Omar.

Tía1s (Aboù Solaimàn). $173,10^{\circ}$.

Táms ibn Alumad ibn 'Abd alRaschid al-Bokhåri. 840 .

Ṭina ibn Ibråhîm ibn Moḥammad. $2946,1^{\circ}$.

Táhir ibn Islăm ibn Qåsim al-
Anșìri al-Khowârazmì. 939 et suiv.

Гіная ibn Nobammad al-lsfaràini (Aboù 'I-Hozaffar). 1453.

Tлиовна al-Aschrafi al-Baklsmis a]-Yoùnànt. 2833

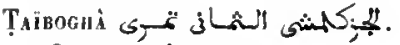
2807 et suiv.

M-'Taimi. Vovez Isväí ibn Molummad.

Ibn-Taivira. loyez Anma ibn 'Mlot al-Halim.

M-Täronix. Yoyez 'Iva ibn Vataii.

Ihn al-Taiver. Toyez Aadulua Iba al-Taïib.

M-Tärai. Coyez Hosaix ibn Moliammad.

ll-Tilawi. Yoyez Darwisu Efendi.

M-Tiumsi (ou al-Tísscui). Voyez Mọ̣ri at-Dis al-Tâlıdji.

Al-Tauivi. $3967,5^{\circ}$ - Voyez aussi 'Ali ilon Dja'far; - Ianiniv al-Tamimi; -- Moyıv.un ibn Alymad ibn Said et $H_{0-}$ uamas ilon Amyal.

Tavis ibn 'Abd al-Salàm. 1906 . 6 . .

Aboñ-Tamin. Toyez Habì ibu Aus.

Tุнтін. 2505,3 .

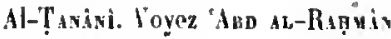
al-Tanài.

Al-Tavasi. Yoyez Mohamad ibu 'Abdallah.

Al-Tanoùknì. Voyez Al-Hasax ibn phìl-Qàsim.

Al-Taxtanixi. Voyez Augao ibn 'Abd al-Razziq.

T'api at-Div al Djaraiidi (?). 6 เ $2^{\circ}$.

Taqi a L-Dix al-Hanbalì. $346 y$.

Taqi ac-Dis al-Sobki. $4591,15 \%$

Al-Taribolosi. Voyez Iariaim ibn Ismáil el Molavma jbr Ládjìn.

lbu a]-Tanibolosi. Voyez Nișta a LDir lbn-al-Tarâbolosí.

Taliafa lbn al-Abd. 3075,3 . 30,6 . $3: 73$ et suiv.

ibn Takkan. Vovez I rriaim ibn Ahmad.
Al-Ṭasoơst. Voyez Aui ibn Aḥmad et Iвriuis ibn 'Ali.

M-Țantoćschi. Vojez Mongamad ibn al-Walid.

Thisukecpnziak. Voyez Aụ a d ibn Moștafá.

Al-Tatáì. Voyez Monavena iba Ibrihim.

Al-Tuzani. Voyez Yoùsor ibn Molammad.

Al-Tizeai. Voyez Aṇman al-Tázeri.

Al-Teuibarando. Voyez Aụmo ibu al-Hasan.

Al-Tazi. Vovez Ampilutu ibn Fàris.

Tuisir jbn Qorra al-Harráni (Aboûll-Hasan). 2457, $13^{\circ}$, $15^{\circ}, 24^{\circ}, 25^{\circ}, 32^{\circ}, 36^{\circ}$ a $38^{\circ}$, $43^{\circ}$ a $45^{\circ}$. 2467, $4^{\circ}, 13^{\circ}, 20^{\circ}$. a 482 et suiv. $2810, a^{n}$.

A]-Tháilibi. Voyez 'I niм ilon lsmấil; - 'A BD AlMím ibn Moḷammad; - ABD A.-Rнязд ibn Molıammad; Anua ibn Molrammad; - Alllosaĩ ibn Mohammad.

Al-Tulititi. Voyez Abd al-Duabnin ibn Molaamnad.

Aboúl-Tuavi. Voyez Muman ibn Molrammad et Mansoúd ibn 'Abd al-liạımân.

M-Tuaqufi. Voyez Oyain ibn alMotawakkil et Ml-Qissu ibn alFadbl.

Théoone, patriarche d'Antioche. 148, $8^{\circ} .363,3^{\circ}$

'Тнв́onoas, évèque. $275^{\circ}, 38^{n}$.

T'uÉodose. $2467,19^{\circ} .2168,1^{\circ}$.

Tuconoss, patriarche d'Alexandric. $145,9^{\circ}$,

Tuéonose, éve̊que de Gangres. $448,6^{\circ}$.

TuÉ0oเiLe, 365, $10^{\circ}$.

Théopine, patriarche d'Alexandrie. $68,12^{\circ} .143,4^{\circ} .155$, $11 \%$

11-Tin nizi. Voyez Ml-Hasan ibn Scharaf; - Yanyi ibn 'Ali et Monamuad al-Hanafí.

Al-Tidisi. Yoyez 'Aboaldail alTidjâni et 'Aвnatzan ibn Mohammad.

Al-Tìriscui. Voyez Aṇad ibn
Yousof et Monanyá al Tifáscbì.

Al-Thumsivi. Voyez "A bo al,-Ranmâs al-Tilimsâní; - lbn alHínds al-Tilimsåni; - Isniuim ibn sbi Bakr; - Monaмya ibn Alımad; - Monнмихр ibı Mohammad; - Nonsм мa ibn Solaimân ; - Moúsi ibu 'Ali.

Thuotiée. $82,4^{\prime}$.

Al-TINDBAisi. Voyez ÁD AL-Moris al-Tiıdjâni.

Ibn al-Tiotaqi. Voyez Moнam ua ibn 'Ali.

a-'Tinmosi. Voyez Moham an ibu Isá.

Tirus. 55.

Ál-Tizâi. Voyez Mog̣aman ibn abi Bakr.

Al-Tizlsi. Voyez Monanuad ibn Molıamnod ibn abi Bakr.

Al-Tobri. Voyez Hasan ibn Kbalil.

Al-'Tonjibì. Pojez Moụayman jhn Aliq.

Al-Ṭonal'i. Voyez Hosaì ibn 'Ali.

Al-T'oxoóxни. Yoyez Mounaman ihn Moubårak.

Al-Tớbiof. Yoyez M MHFoĹz ibn a)-Khaț̣áb.

Al-Toúzotni. Yoyez Hasaxibn Hosaïn.

Ibn Toóment. 1451.

Al-Tocisisi. Voyez Monavmap ibn Aḷmád el Mognumad ibn Moluammad.

Al-Ṭotsi. Voyez 'Atì al-Ṭoủsì et Moganua ibn Mohrmmad.

Al-Tovaкомivi. Voyez Azíibn 'Othmàn.

Tounsoun Ziok̀ Efendi. $861,6^{\circ}$. Al-Toúsawi. Voyez Hinnj Bíi."

Ғiстов, évèque d'Antinoè. 15/, $7^{\circ}$.

V'icton, sbbé d'Al-Håbetoûn. 305 , $7^{\circ}$.

Ventuae de Pahadis. 1826.1854.

lbn Wadia. Voyez Mouamin ibn Ismâil.

Ibn Wadix. Voyez Moyamaadibu 'Alì.

Al-Wariî. Voyez Abo al-Aziz Mognamad. 
Al-Wiṇıoi. 3097

Ibn Wạscujya. Voyez Aboù Bak ibn A Ihmad.

lbn al-Wîż. Voyez Hosaix ilın Ali.

M-Wadnixi. Vogez Hanio alSaidi.

Al-Wilì Anstîn. 1 160, $7^{\circ}$.

Wali at-Dín al-Baṣir lii Ain Qalbihi. $744,6^{\circ}$.

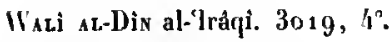

Al-Wiusi. Yoyez Aboú Bakr alWòlibî.

Whin ibn Obaid al-Bolitor' (Aboù 'Obáda). 3086. 3300.

Ibn-Wallíd. Voyez Mṇuad ibn Uohanmad.

Al-WÁqdi. 1652 el suiv. 1689

Al-Waapl. Vovez Oyan ibn $M_{0-}$ hammad et 'Oxsi lbn al-Mozaffar.

Ibn al-Warix. 1072.

Ibn WașıL. Voyez Mop̣ınuso ibn SAlim.

Al-1Visıţi. Voyez 'Abd al-R.tụuîs ibn Mo'ammar.

Al-Waţwat. Voyez Rascuid atDix ibn Moliammad.

Al-Wazia at-Wía al-Antáki. $1156,4^{\circ}$.

Winsar ibn llastam al-Qoúlui (Aboú Sabl). $2457,2^{\circ}, 8^{n}$

A-Yifíi. Voyez 'Aboaluan ilm As'ad.

Al-Yạ̣sori. Voyez "Iring ibn Moùsả.

Yalyi ibn 'Abd al-Azim alDjazzàr (Djamàl al-Dìn Aboù 1-Hosàm). $45 g 6$.

Y s!̣̂: ibn Adi. 167.168 .169 , ${ }^{\circ}$ d $12^{\circ} \cdot 17^{3}, 13^{n}$

Yı̣yi ibn Aḷmad ibn Molammad al-Nafzí al-Himyari alSarrâdj. $758,1^{\circ}$.

Ya axi ibn 'Ali al-Khatib al-Tibrỉzi (Aboû Zakarìya). 596 . $310 \mathrm{~J}$ et suiv. 3112.3280 . 3283 et suiv.

Yạyi ibn 'Alì al-Zanẩi ou alMafái (al-Rifáli). 2354 et suiv.

Yaụrî ibn alı̂ Bakr al-'̇uniri. $197^{6 .}$
Ya!̣ri ibn abi Bakr al-Hanafi. $1966,5^{\circ}, 1287,1^{\circ}, 1391$, $1 h^{\circ}$.

Yaụi Ibn al-Batriq. Yoyez Yoب̣arxi lbn al-Batriq.

Yị̣ri Efendi Hlinqàmådè. 669 ,

Yạri ibn Inamid ilon Zakariyá. $17^{4}, 6^{\circ}$.

Yạ̣rí ibn 'sà lbu Djazla (Mbor Ali) $2947,2^{\circ} .2948$ et suiv.

Yạyi ibn Mlolanımad. $669,1^{\circ}$.

Y.uyi ibn Molammad ibn Nlımad i)n al-Auwấm (Aloú Zakariya). 2804 .

Yaụri [ibn Moḷammad] Jbn Jlobaira ("Aun al-Din dboû 'l-./lozallar). 607 .

Ya!̣i ibn Holuammad lbn abi Sclıokr al-Mlaglıribì ( Molıyì alDin). $2468,1^{\circ} .2593,1^{\circ}$. 2594 .

Ya!yi jbn Moúsá al-Djozoúli. $1060,3^{\circ}$.

Yạ̣vi ilon Nasoúl! ilın Isiâ'il. $3_{9 y} 3,1^{\circ}$

YạYi al-Qarâfi al-lṣfahài. $4257,1^{\circ}$.

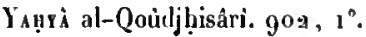

Yạ̣i ibn Saif al-Sìràmi. 4395 .

Yạyî ibn Sa̛id al-Antáki. a 88 . 291 .

Yauyi ibn Selnaraf al-Nawawi (Molyyí al-Din Alsoû Zakariya). $59^{3}, 5^{\circ} \cdot 7^{43}, 1^{\circ} \cdot 7^{44}, 1^{\circ}, 2^{\circ}$, $10^{\circ} .715$ el suiv. 753 . 990 . 1009 el suiv. 1130.1154 , $3^{\circ} .1177,1^{\circ} .1178,3^{\circ} .2009$, 4. $4515, a^{\circ}$. 4546. 45 77 ,

Yṣ̣xí ibn Yalyà. 675.

Yụ̂r ibn Jaklıschi. 1250.

Yanrá ibn alji Zakariya lbu Sulä. 307 et suir.

Al-Yámuat. Voyez Monumud iln Moluammad.

Yáooú в, Maphrien. 100.

Yàoûa ibn 'Atâ Allàlı al-Roùmi al-Qaramâni. 9014

Yìooù ibn lbrâhîm (Aboù Yoùsof). 2452 et suiv.

Y Áoov́s ibn Ishâq al-Kindi (Abon Yoûsof). $169,12^{\circ}$. 2347 . $2467,2^{\circ} .2541,9^{\circ}$.
YáQoús ibn Isḥàq lbn al-Qol (Amin al-Daula Aboú 'l-Faradj). 2842.3000 .

YÁQoûB iłn Jshå Jbn al-Sikkit (Aboù Yousof). 4233.

YáqoủB ibn Noûsà ibn 'Abd alBalı̣màn al-Bostâni. 1076 .

I Ávoù Ibn-Náma al-Dibsì ( $A^{\prime}$ 'où '(-Nawảlib). 58.

Yiqoús Paclia. 91/1 et sniv.

Yáots ibn Saîyid Ali. 1348, $1^{\circ}$. $12 / 9,1^{\circ}$. 3517 et suiv. Los $3,1^{\circ}$ el suiv.

[Yiqoú ] ibn Solaimàn al-Isfaräini (Aboù Yoủsof). $3401,5^{\circ}$.

Yinotit al-Hamawi. 2226 et suiv $1256,2^{\circ}$.

Tisix ibn Zain al-Din al-'Nimi al-Himșí. 4154. 4'1 2 .

Ibn al-Yisivis. 4151, 67.

Ibn Yazdày-Yata. Voyez MonnmMAD ibn al-Hosain.

Al-Yazdí. Voyez Kualíl AlLàa ibn Noùr Allâh.

Yszio ibu Mo'àwiya. 3/43o.

Lboì Yazid al-Dauwàní. 998.

Yoğaxi. $262,8^{\circ}$.

Younaxi Ibn al-Batriq. 2417 el suiv. $3946,4^{\circ}$.

Yoụxyi ibn Sérapion. $2918,7^{\circ}$

Yônaxxâ ibn Yousof ilon al-Jlàrill, $2157,10^{\circ}, 48^{\circ}$.

Youvos ibn Aidoghmisel ibn Hilsan. $1328,1^{\circ}$.

Yoûxos, patriarche d'Alexandrie. 215, $7^{\circ} .251,48^{\circ}$

Yoûxos, évèque d'Isyoùt. 780 , $3^{\circ}$.

Yoùxos, évèque d'Esnà. $153,37^{\circ}$.

Yoûsos ibn 'Abdallab lbn Bànà (Alyoû Salâlı). „252, $3^{\circ}$.

Yoûxos al-Vlàlikí. 4660 .

Yot́vos al-Rifäì. $3146,5^{\circ}$.

Ibn Youtyos. 2467, $15^{\circ}$. 2/195 et suiv. $2531,4^{\circ}$.

Yoûsâb, moine de Scété. 280 , $2^{n}$

Al-Yoùsì. Yoyez Hasax ibn Masond.

Yotsor ibn 'Abdallal al-Hosain (al-Hasani ) al-Ormiyoûni. 74 4, $3^{\prime \prime}+5^{\circ}$.
Yoúsor ilun 'Abd al-Latif al-Hamawì (Salậị al-Dín). 1042, $1^{\circ}$.

Yoúsor ibn (al-Zaki on ibn alMozakkà) 'Abd al-Raḥmàn ibn Yoủsof al Mizzi ( Djamâl al-J)in Aboư 'I-Ḥaddjådj). 7 כ̄o. 2089 et suiv.

Youtsor ibn al.'Adjoìz al-Ḥalabi alNasscliabi. 1450, $6^{\circ}$.

Yoủsor ibn Alumad al-Vizàmi. $4041,1^{\circ}$.

Yoisor ibn "Ali ibn Alımad ibı Molıammad al-Nadsrounni alMaghribi. 2681 et suiv.

Yoûsor ibn 'Iríb. 1/49, $a^{\circ}$.

Yot'sor al-Badiii. 3107.

Yoưsor ibn afn̂ Bakr al-Sakkàki (Si:âdj al-Din Aboú Yáqoủb). $33_{95} 55^{\circ} .4371$ et suiv.

Yot̀sor ibn Ijaunảl. $4606,4^{\circ}$

Yoisor al-JIafnaivi. 4/13.

Yotsor lbn al-Hakim (ou lbn abi'l-1Jakim, ou Aboù'l-Hakim ) al-Bol!airi. $132,15^{\circ} .17^{3}, 6^{\circ}$, $7^{\circ}, 17^{4}, 8^{\circ}, 9^{\circ}$

Yotsof ibn lbrâlıin al-Ardahili 1037 .

Youbor ilm Ibrâlim al-Maghribi (Djumál al-Din d looú Yáqoùb). $644,2^{\circ}$.

Yotsor ibn lsmàil lbn al-Kotobi il-Djowaini (Djamál al-Din). 3005 et suiv.

Yoćsor Ibn Kizoghli Sibt lbı alDjauzi ( Aloù'l-Wozaffar). 1505 et suiv. 3515 .

Yolsor al-Maghribi. $3200,1^{\circ}$.

Yoćsor ibn Moliammad jbu 'Abd al-Djauwàd ilin Khidr al-Scharbini. $1716,2^{\circ}$. 3244, $3^{\circ}$. $3{ }_{2} 68$ et suiv.

Youtsor ibn Holıammad al-Koúrâni (Zän al-'Abidin) . 1469 .

Yoisop ilon Mohammad al-Milawi. 2107

Yoúsor ilm Molıammad al-. \alıni al-Tauzari (Aboúl.Fadhl). $3118,1^{\circ}$. 3430. 4118, $2^{\circ}$. 4530 .

Yoúsor jln Rafi ilu Taunim Ibn Scladdàd (Bahà al-Dín AboùlMalıàsiu). $7^{36 .} 1997$.

Yoûsor al-Roùmî (Sinàn al-Dìı). $3351,1^{\circ}$. 
Yotsor ibn abł Sa'd ibn Alımad al-Sidjistâni. 858 .

Youtsor ibn Scluâluîn (Djalàl alDin). 2152 .

Yov̂sof al-Şinlıadj. 1216,3 .

Youtsơ ibn Solaínån. $3251,3^{n}$.

Youtsof [ibn Solaümân] al-Sclıantamarî. $327^{\text {h. }}$

Yoúsor al-Solamî. $397^{2}, 11^{\circ}$.

Yoúsoy ibn Taghri Bardi (Djamál al-Dìn Aboû̉'-Mạıásin). 1551 . 1606. $177^{\circ}$. $177^{1}$ et suiv. 1790.2062 et suiv.

Yoúsor ibn 'Tahlir al-Khawwi. 3968 .

Yoúsor ibn Yaluya ibn 'îså alSchâdsili. $2037,1^{\circ}$.

Yoưsor ibn Yaqqoûl, al-Djanadi (Bahâ al-bìn Aboú 'Abdallah). 2127.

Aboù Yot̂sor. $2506,2^{\circ}$.

At-Zadpjâdul. Voyez Aboủ 'A Lî.

llon Zifar. Voyez 'Auî ibn Zafar et Moнамма ibn abt Noḷammad.

Al Zỉnà. Voyez Aụmad ibn Mohammad et Kna Lî́c ibn Schăhî́n.

lbn abi Zaĩo. Voyez Ardalua ibn abî Zäd.
Al-Zaíd. Voyez 'Aboalua ibn Vasr.

Il) Zinooús. Poyez Ạ̣mad ibn 'Abdallals.

Al-Zailai. Voyez 'Othuâs ibn 'Ali.

Zaix ibn Nadjim. Yoyez Zaix al-Âridir ibn llurábím.

Zaix a $-\hat{A}$ bloix ibn Ibrahim alMiši (Zaîn ibn Nadjim). go3. $9^{67} \cdot 9^{68} .976,2^{\circ} .3401,6^{\circ}$. $3417,2^{\circ}$.

Zair atMausafí (al-Marșafi?). 1546 , $4^{\circ}$.

Zaìs al-Ấnoin ibn Yoüsol alKoûrànì. $2351,3^{\circ}$.

Zaí al-Ayima. $1949,2^{\circ}$.

Zaí al-Díx ibn 'Alì ibn al-Hâdja. $1108,3^{\circ}$.

Zaĩx aL-Dì al-'Irâqì. $99^{2}$.

Zaín al-Din al-'Omari. 2760.

Zain at-Din al-Ramli. $215,10^{\circ}$.

Zaî́ al-Mlila al-Khawafi. 760 , $7^{\circ}$.

Al-Zaïroûsi. Voyez Aul ibn Hasan

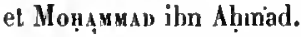

lbn al-Zsirît. Yoyez Ispạe ibn al-Hasan.

Zaxarìs ibn Molıammad ibn Ahmad al-Sonaiki al-Ansârì
(Zain al-Dìn ou Badr al-Dîn Aboû Yahyai). 653. 66o. 667, 1․ 756 . 950. $99^{3}$ et suiv. 1000.1015 et Buiv. 1034 et suiv. 1038.1045 .1049 .1160 $7^{\circ} .139^{6}, 1^{\circ}$. $4062.4134,2^{\circ}$. 4449.4593 .

Zakarît ibn Mohammad ibn Mahmoủd al-Qazwini. 1303 . $4^{\circ}$. $197,1,3^{\circ} .217^{3}$ et suiv. 2235 el suiv. $2419,3^{\circ} .2918$, $11^{\circ}$

Zaxariya al-Marrákoschj (Ahoû Yalıyâ). $2625,10^{\circ}$.

Al-Zamâ'i. Voyez Yạ̣ü ibn 'Ali.

Al-Zamakhbcharì. Yoyez Mahmoute ibn 'Omar.

Al-Zaxát. Voyez Aboû 'Annán.

A]-ZaNduini. Voyez 'laz aL-DiN al-Zandjání et Mạnnoứ ihn Ahmad.

Ml-Zana'i (ou al-Zos'í). Voyez Monamad ibn abi Bakr et MoHamua ibn Mobammad.

Ibn Zanie al-Khairit. Voyez $\mathrm{Mo}$ намма jbn "Ali ibn Jbrâhim.

Al-Zarvoủduì. Voyez Bomuín atDìn al-Zarnoủdji.

Al-Zarqáxí. Voyez 'Abd al-Bäql ibn Yousof el Arrad ibn Mohammad.

Al-Zarqaschi. Voyez Aboú 'Abo- ausa al-Zarqaschi et MoHavmo ibn Bahadour.

A-Zaczani. Voyez Al-Hossix ibn Ahmad el Mlọ̣ammad ibn Ali ibu Moḷammad.

A] Zexdotersti. Voyez 'Ali ibn Yạya.

Al-Ziftiwi. Voyez Aroaliar alZiftâwe.

Al-Zobaĩol. 3oza. - Voyez aussì Solaimin ibn Yahyâ.

Zouain ibn Mohammad al-Yohallabî al- Âtakì (Bahâ al-Dln) 3173 .

Zousĭk ibn abì Solmá. $3075,4^{\circ}$. $3076.327^{3}$ et suiv.

Zoun ibn abì Marwån 'Abd alMalik ibn Zohr (Abon̂'l-Alâ). $2954,1^{\circ} .2960,2^{\circ}$.

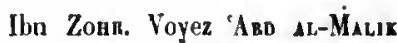
jbn Zohr et Zohr ibı abì Marwàn.

A]-Zonrawl. Voyez Kaalat ibn 'Abbâs.

Al-Zonri. Voyez MoHammo ibn abí Bakr et 'Oman jbn 'Omar.

Aboủ Zon'A al'-Iráqii. 1038.

Ibn Zor'a. Voyez Manc jbn Żoŕa.

Zosine. $276,16^{\circ} .281,19^{\circ}$.

Ibll Zot́LìQ. $1816,1^{\circ} .1817$. 1818 . 
FONDS ARABE.

CONCORDANGE DES NUMÉROS DE LANCIEN FONDS ET DU SUPPLÉMENT ARABE

AVEG

LES NOUVEAUX NUMÉROS DU PRÉSENT CATALOGUE.

ANCIEN FONDS.

\begin{tabular}{|c|c|c|c|c|c|c|c|c|c|}
\hline $\begin{array}{c}\text { ANC1EX } \\
\text { GATALOGUE. }\end{array}$ & $\begin{array}{l}\text { NOUVEAU } \\
\text { CITALOGUE. }\end{array}$ & $\begin{array}{c}\text { ANCIEN } \\
\text { CATALOGUE. }\end{array}$ & $\begin{array}{c}\text { souvead } \\
\text { Cetalogete. }\end{array}$ & $\begin{array}{c}\text { ANCLEN } \\
\text { CATILOGEE. }\end{array}$ & $\begin{array}{l}\text { NOUYEAU } \\
\text { CATALBgUk. }\end{array}$ & $\begin{array}{c}\text { ANCIEN } \\
\text { CATALOGEE. }\end{array}$ & $\begin{array}{c}\text { MOUVEAU } \\
\text { GATALOGUE. } \\
.\end{array}$ & $\begin{array}{c}\text { ANGIEN } \\
\text { CatalOGUE. }\end{array}$ & $\begin{array}{c}\text { NOLYEad } \\
\text { CATALOGUE. }\end{array}$ \\
\hline 1 & 1 & 21 & 63 & 46 & 102 & $7^{2}$ & 213 & 100 & 167 \\
\hline 2 & 5 & 29 & 64 & 47 & 114 & $7^{3}$ & 147 & 101 & 189 \\
\hline 3 & 4 & 23 & 67 & 48 & 108 & $7^{\prime \prime}$ & 144 & 102 & 178 \\
\hline 4 & 6 & 24 & 62 & 49 & 109 & 75 & 183 & 102 bis & 210 \\
\hline 5 & 14 & 244 & 57 & 50 & 107 & $7^{6}$ & 151 & 103 & 199 \\
\hline $5 \mathrm{~A}$ & 10 & $24 B$ & 58 & 51 & 104 & 77 & 311 & $103 \Lambda$ & 180 \\
\hline 6 & 17 & 25 & 88 & 52 & 88 & 78 & 182 & 104 & 177 \\
\hline 7 & 18 & 26 & 108 & 53 & 77 & 79 & 184 & 105 & 204 \\
\hline 8 & 20 & 27 & 54 & $53 \mathrm{~A}$ & 73 & 80 & 200 & 106 & 188 \\
\hline 9 & 45 & $27 \mathrm{~A}$ & 61 & 54 & 78 & 81 & 201 & 107 & 150 \\
\hline \multirow{2}{*}{$9 \Lambda$} & Arabe (Cat, ms.) & 28 & 59 & 55 & 137 & 83 & 190 & 108 & 148 \\
\hline & $\{\quad 5134$ & 29 & 92 & 56 & 139 & 83 & 170 & & ( Ture (Supp). \\
\hline \multirow{2}{*}{${ }_{9} B$} & (Arabe (Cat. ms.) & $3 o$ & 93 & 57 & 135 & 84 & 203 & 109 & 763 \\
\hline & 5135 & 31 & 19 & 58 & 133 & 85 & 185 & 110 & 315 \\
\hline 10 & 13 & 38 & 89 & $5_{9}$ & 134 & 86 & 159 & 111 & 222 \\
\hline 11 & 15 & 33 & 90 & 60 & 84 & 87 & 193 & 112 & 82 \\
\hline 12 & 8 & $3 / 4$ & 91 & 61 & 87 & 88 & 214 & 113 & 207 \\
\hline 13 & 41 & 35 & 83 & 62 & 96 & 89 & 156 & 114 & 208 \\
\hline 14 & 40 & 36 & 105 & 63 & 143 & $9^{\circ}$ & 173 & 115 & 198 \\
\hline 15 & 28 & 37 & 100 & 64 & 157 & 91 & 314 & 116 & 198 \\
\hline 16 & 33 & 38 & 319 & 65 & 160 & $9^{2}$ & 225 & 117 & 220 \\
\hline $36 \mathrm{~A}$ & 38 & 39 & 317 & 66 & 276 & 93 & 228 & 118 & 236 \\
\hline 17 & 30 & 60 & 110 & 67 & 161 & $9^{4}$ & 316 & 119 & 239 \\
\hline 18 & 39 & 41 & 113 & 68 & 181 & $9^{5}$ & 205 & 120 & 250 \\
\hline 19 & 29 & 42 & 98 & 69 & 146 & $9^{6}$ & 164 & 121 & 247 \\
\hline $19 A$ & 44 & 43 & 111 & $69 \mathrm{~A}$ & 275 & 97 & 179 & 123 & 248 \\
\hline 20 & 37 & 44 & 103 & 70 & 79 & $9^{8}$ & 174 & 123 & 245 \\
\hline $20 \mathrm{~A}$ & 47 & 45 & 112 & 71 & 132 & 99 & 208 & 194 & 237 \\
\hline
\end{tabular}




\begin{tabular}{|c|c|c|c|c|c|c|c|c|c|}
\hline $\begin{array}{c}\text { AXCIEY } \\
\text { CATALOGEF. }\end{array}$ & $\begin{array}{l}\text { VOTVEAU } \\
\text { CATALOSEL. }\end{array}$ & $\begin{array}{c}\text { ANCIEY } \\
\text { CATILOGCE. }\end{array}$ & $\begin{array}{c}\text { SOUVAU } \\
\text { Catalogue. }\end{array}$ & $\begin{array}{c}\text { avcies } \\
\text { Caralogte. }\end{array}$ & $\begin{array}{l}\text { YOUVEAU } \\
\text { CATALOGUE. }\end{array}$ & $\begin{array}{c}\text { ANGIEN } \\
\text { CATALOGCF. }\end{array}$ & $\begin{array}{l}\text { Novieat } \\
\text { CATALOGU. }\end{array}$ & $\begin{array}{c}\text { ANCIEV } \\
\text { CATALOGUE. }\end{array}$ & $\begin{array}{l}\text { NoEveat } \\
\text { CATALOGEE. }\end{array}$ \\
\hline 125 & 242 & $17^{3}$ & 408 & 223 & 444 & ${ }_{2} 68$ & 662 & 315 & 1170 \\
\hline 126 & 243 & $17^{/ 1}$ & 414 & 224 & 445 & 269 & 660 & & ( Ture (Suppl.) \\
\hline 127 & 234 & 175 & 418 & 285 & 477 & 970 & 624 & 316 & 773 \\
\hline 128 & 235 & 176 & 401 & 296 & Turc (Suppl.) & 271 & 1115 & 317 & ( Turc (Suppl.) \\
\hline 129 & 1947 & 177 & 397 & 220 & 765 & $27^{3}$ & 623 & 017 & 774 \\
\hline 130 & 1906 & 178 & En déficil & 227 & Ture (Suppl.) & $27^{3}$ & 1255 & 3,8 & Turc (Suppl.) \\
\hline 131 & 288 & 179 & 467 & 827 & 766 & $27^{4}$ & 668 & 010 & 775 \\
\hline $131 \mathrm{~A}$ & 291 & 180 & 419 & 328 & $\left\{\begin{array}{c}\text { Turc }(\text { Suppl. }) \\
767\end{array}\right.$ & $274 \mathrm{~A}$ & 671 & 319 & $\begin{array}{c}\text { Ture (Suppl.) } \\
776\end{array}$ \\
\hline 13. & 292 & 81 & Turc ( Suppl.) & & Persan (Suppl.) & 275 & 1124 & & 776 \\
\hline 133 & 290 & 101 & 784 & 229 & 1173 & 276 & 1152 & 320 & $\begin{array}{c}\text { Ture (Suppl.) } \\
\mathbf{7 7 7}\end{array}$ \\
\hline 134 & 289 & 182 & 410 & 230 & 432 & 277 & 778 & & Ture (Suppl.) \\
\hline 135 & 293 & 18.3 & 468 & 231 & 433 & 278 & 4563 & 321 & 778 \\
\hline 136 & 298 & 184 & 460 & & Ture (Suppl.) & 279 & 2720 & & Ture (Supp].) \\
\hline $136 \mathrm{~A}$ & 299 & $18 \%$ & 451 & $\mathbf{2} 32$ & 768 & & (Arabe (Cat. ms.) & $321 \mathrm{~A}$ & 779 \\
\hline 137 & 296 & 186 & 450 & & Ture (Suppl.) & 280 & 4932 & 322 & Ture (Suppl.) \\
\hline 138 & 307 & 87 & 500 & 233 & 769 & 281 & 1173 & & 780 \\
\hline $\mathbf{1} 39$ & 301 & 188 & 420 & 834 & 448 & 282 & 2543 & $3 s 3$ & $\left\{\begin{array}{c}\text { Turc }(\text { Suppl.) } \\
781\end{array}\right.$ \\
\hline 140 & 302 & 189 & 448 & & Turc (Suppl.) & 283 & 1135 & & 181 \\
\hline 141 & 255 & $19^{\circ}$ & 421 & 235 & 770 & 284 & 1146 & 324 & $\begin{array}{c}\text { Tare (Suppl.) } \\
782\end{array}$ \\
\hline 142 & 80 & 191 & 422 & 236 & 478 & 285 & 775 & & Turc (Suppl.) \\
\hline 143 & 155 & 192 & 400 & 237 & 479 & 286 & 1113 & 325 & 783 \\
\hline 144 & 253 & $19^{3}$ & 469 & 238 & 480 & 387 & 1136 & & (Turc (Suppl.) \\
\hline 145 & 257 & $19^{4}$ & 408 & 239 & 593 & 288 & 1184 & .930 & 784 \\
\hline 146 & 270 & 195 & 405 & 240 & 1176 & 289 & (Turc (Suppl.) & 327 & Ture (Suppl.) \\
\hline 147 & 297 & $19^{6}$ & 470 & 241 & 661 & 209 & 771 & 227 & 785 \\
\hline 148 & 304 & 197 & 441 & $2 / 12$ & 688 & $29^{\circ}$ & 1155 & 328 & Turc (Suppl.) \\
\hline 149 & 153 & ${ }^{1} 9^{8}$ & 1187 & 2,33 & 690 & 291 & 1125 & & \\
\hline 150 & 254 & 199 & 442 & $2 / 4$ & 691 & 292 & 1132 & 329 & $\begin{array}{c}\text { Turc (Suppl.) } \\
\mathbf{7 8 7}\end{array}$ \\
\hline 151 & 74 & 200 & 452 & 245 & 694 & $39^{3}$ & 1134 & & Turc (Suppl.) \\
\hline 152 & 75 & 201 & 447 & 246 & 696 & $29^{\prime}$ & 1133 & 330 & 788 \\
\hline 153 & 263 & 208 & 423 & 247 & 607 & 295 & 2365 & 331 & Ture (Suppl.) \\
\hline 154 & 262 & 203 & 471 & 248 & 608 & $29^{6}$ & 1187 & गנ 1 & 789 \\
\hline 155 & 280 & 204 & 2407 & 249 & 604 & 297 & 1186 & $33_{2}$ & Turc (Suppl.) \\
\hline 156 & 258 & 205 & 472 & 250 & 3500 & 298 & 1200 & & 790 \\
\hline 157 & 282 & 206 & 424 & 251 & 621 & 299 & 1201 & 333 & $\begin{array}{c}\text { Turc (Suppl.) } \\
791\end{array}$ \\
\hline 158 & 281 & 207 & 473 & 252 & 628 & 300 & 1181 & & Turc (Suppl.) \\
\hline 159 & 284 & 208 & 425 & 253 & 834 & 301 & 1188 & 334 & 792 \\
\hline 160 & 152 & 209 & 384 & 254 & 848 & 309 & 1270 & 335 & Turc (Suppl.) \\
\hline $160 A$ & 272 & 210 & 394 & 255 & 1260 & 303 & 1225 & $35 \mathrm{~J}$ & 793 \\
\hline 161 & 303 & 211 & 426 & 256 & 1918 & 304 . & 1178 & 336 & 1278 \\
\hline 163 & 171 & 212 & 427 & 257 & 606 & 305 & 1197 & 337 & 1220 \\
\hline 163 & 279 & 213 & 474 & $\$ 58$ & 590 & 306 & 1137 & 338 & 1219 \\
\hline 164 & 266 & 214 & 464 & 259 & 651 & 307 & 1141 & 339 & 1221 \\
\hline 165 & 261 & 215 & 428 & 260 & 663 & 308 & 1127 & 340 & 1224 \\
\hline 166 & 265 & 816 & 429 & 261 & 2321 & $3 \circ 9$ & 1121 & & Turc (Suppl.) \\
\hline 167 & 259 & 217 & 430 . & 262 & 850 & 310 & 1143 & 341 & 794 \\
\hline 168 & 260 & 218 & 431 & ${ }_{2} 63$ & 630 & 311 & 1139 & 340 & Turc (Suppl.) \\
\hline 169 & 269 & 219 & 395 & 264 & 636 & 312 & 1185 & & 795 \\
\hline $17^{\circ}$ & 70 & 230 & 443 & 265 & 629 & 313 & 1189 & 343 & 1171 \\
\hline 171 & 71 & 221 & 475 & ${ }_{2} 66$ & 605 & 314 & Turc (Suppl.) & 344 & Turc (Suppl.) \\
\hline 172 & 407 & 222 & 476 & 267 & 644 & & 772 & & 796 \\
\hline
\end{tabular}


TABLES DE CONCORDANCE.

\begin{tabular}{|c|c|c|c|c|c|c|c|c|c|}
\hline $\begin{array}{c}\text { ANCIEN } \\
\text { CATALOGER. }\end{array}$ & $\begin{array}{c}\text { NOUVEAU } \\
\text { CATALOGUE. }\end{array}$ & $\begin{array}{c}\text { ANCIEN } \\
\text { CATALOGDE. }\end{array}$ & $\begin{array}{c}\text { NOUVEAU } \\
\text { CATALOGUE. }\end{array}$ & $\begin{array}{c}\text { ANCIEN } \\
\text { CATALOGUE. }\end{array}$ & $\begin{array}{l}\text { NOUVEAU } \\
\text { CATALOGUE. }\end{array}$ & $\begin{array}{c}\text { ANGIEN } \\
\text { CATILOGUE. }\end{array}$ & $\begin{array}{l}\text { MOUVEAO } \\
\text { CATALOGEE. }\end{array}$ & $\begin{array}{c}\text { ANCIEN } \\
\text { CATALOGUE. }\end{array}$ & $\begin{array}{c}\text { NOLVEAO } \\
\text { GATALOGCE. }\end{array}$ \\
\hline 345 & 1223 & 395 & 1326 & 444 & 1156 & 494 & 846 & 545 & 1047 \\
\hline 346 & 1215 & $39^{6}$ & 1243 & 445 & 1384 & 495 & 843 & 546 & 1323 \\
\hline & (Ture (Suppl.) & 397 & 1957 & 446 & 4589 & 496 & 1109 & 547 & 951 \\
\hline 347 & 797 & $39^{8}$ & 1247 & 447 & 1305 & 497 & 983 & $5 \dot{4} 8$ & 1116 \\
\hline 348 & 1168 & 399 & 1463 & 448 & 1353 & 498 & 1043 & 549 & 1037 \\
\hline 349 & 730 & 400 & 1231 & 449 & 1952 & 499 & 975 & 550 & 860 \\
\hline 350 & 757 & 401 & 4374 & 450 & 1290 & 500 & 854 & 551 & 864 \\
\hline 351 & 697 & has & (Persan (Suppl.) & 451 & 1289 & 501 & 908 & $55_{2}$ & 867 \\
\hline 352 & 1014 & 402 & 1174 & $45_{2}$ & 1253 & 502 & 835 & 553 & 869 \\
\hline 353 & 720 & 403 & 1256 & 453 & 1375 & 503 & 820 & 554 & 865 \\
\hline $35 \prime$ & 708 & 404 & 1254 & 454 & 1236 & 504 & 939 & 555 & 1042 \\
\hline 355 & 687 & 405 & 1266 & 455 & 1142 & 505 & 1007 & 556 & 1031 \\
\hline 356 & 2324 & 406 & 1108 & 456 & 721 & 506 & 848 & 557 & 1036 \\
\hline 357 & 1244 & 407 & 1236 & 457 & 1340 & 507 & 794 & 558 & 946 \\
\hline 358 & 1974 & 408 & 790 & 458 & 1369 & 508 & 879 & & Turc (Suppl.) \\
\hline 359 & 786 & 409 & 1386 & 459 & 1228 & $5 \circ 9$ & 785 & 559 & . 799 \\
\hline 360 & 1257 & 410 & 1258 & 460 & 1226 & 510 & 913 & 560 & 945 \\
\hline 361 & 1245 & 411 & 3372 & 461 & 1343 & 511 & 1024 & 561 & 880 \\
\hline 362 & 1336 & 412 & 1261 & 462 & 773 & 512 & 970 & 562 & 986 \\
\hline 363 & 2647 & 413 & 3390 & 463 & 3953 & 513 & 1110 & 563 & 1250 \\
\hline 364 & 2657 & 414 & 1341 & 464 & 1312 & 514 & 1006 & 564 & 1013 \\
\hline 365 & 1280 & 415 & 1342 & 465 & 1264 & 515 & 2314 & 565 & 1045 \\
\hline 366 & 1265 & 46 & (Arabe (cat. ms.) & 466 & 1249 & 516 & 2313 & 566 & 944 \\
\hline 367 & 2323 & 410 & 5133 & 467 & 1112 & 517 & 844 & 567 & 4395 \\
\hline 368 & 1454 & 417 & 929 & 468 & 1964 & 5,8 & 707 & 568 & 4392 \\
\hline 369 & 814 & 418 & 1262 & 469 & 1054 & 519 & 2334 & 569 & 872 \\
\hline 370 & 1460 & 419 & 1352 & $47^{\circ}$ & 905 & 520 & 977 & 570 & 2319 \\
\hline 371 & 1402 & 420 & 2663 & 472 & 710 & 521 & 821 & 571 & 971 \\
\hline $37^{2}$ & 1346 & 421 & 3501 & 472 & 711 & 522 & 972 & 572 & 958 \\
\hline $37^{3}$ & 1349 & 422 & 2310 & 473 & 891 & 523 & 990 & 573 & 956 \\
\hline $37^{4}$ & 3508 & 423 & 714 & 474 & 892 & 524 & 881 & 574 & 812 \\
\hline 375 & 1332 & 4.4 & 1359 & 475 & 1105 & $5_{2} 5$ & 1055 & 575 & 863 \\
\hline 376 & 750 & 425 & 1347 & 476 & Turc (Suppl.) & 526 & 1057 & $5_{7} 6$ & 859 \\
\hline 377 & 918 & 426 & 1354 & 470 & 798 & 597 & 836 & 577 & 2188 \\
\hline 378 & 2650 & 427 & 1360 & 477 & 753 & 5.8 & 799 & 578 & 2239 \\
\hline 379 & 2013 & 428 & 1033 & 478 & 705 & $5_{29}$ & 967 & 579 & 2240 \\
\hline 380 & 760 & 429 & 1453 & 479 & 937 & 530 & 828 & 580 & 2218 \\
\hline 381 & 2028 & 430 & 1059 & 480 & 1073 & 531 & 1002 & 580 bis & 4584 \\
\hline 382 & 758 & 431 & 1365 & 481 & 1053 & 532 & 954 & 581 & 2187 \\
\hline 383 & 718 & 432 & 740 & 482 & 881 & 533 & 1104 & 582 & 2214 \\
\hline 384 & 4805 & 433 & 1321 & 483 & 884 & 534 & 1114 & 583 & 2325 \\
\hline 385 & 744 & 434 & 1303 & 484 & 889 & 535 & 992 & 584 & 2497 \\
\hline 386 & 762 & 435 & 1398 & 485 & 793 & 536 & 894 & 585 & 2246 \\
\hline 387 & 737 & 436 & 1372 & 486 & 784 & 537 & 916 & 586 & 2167 \\
\hline 388 . & 1316 & 437 & 1358 & 487 & 855 & 538 & 920 & 587 & 2241 \\
\hline 389 & 722 & 438 & 2638 & 488 & 909 & 539 & 1077 & $587 \mathrm{~A}$ & 2242 \\
\hline 390 & 780 & 439 & 4592 & 489 & 704 & 540 & 935 & 588 & 2193 \\
\hline 391 & 723 & 440 & 1396 & 490 & 792 & 541 & 858 & 589 & 2199 \\
\hline $39^{2}$ & 693 & 441 & 659 & 491 & 791 & 542 & 950 & $59^{\circ}$ & 2198 \\
\hline $3_{9} 3$ & 746 & 442 & 781 & 492 & 839 & 543 & 875 & $59^{1}$ & 2194 \\
\hline 394 & 924 & 443 & 4595 & $4 \varphi^{3} 3$ & 841 & 544 & 876 & $59^{2}$ & 2197 \\
\hline
\end{tabular}

Min. onientacx. - III. 


\begin{tabular}{|c|c|c|c|c|c|c|c|c|c|}
\hline $\begin{array}{c}\text { ANCIEN } \\
\text { CATALOGUE. }\end{array}$ & NOEVEAU & $\begin{array}{c}\text { A\$CIEY } \\
\text { CATALOGUE. }\end{array}$ & $\begin{array}{l}\text { NOUVEAU } \\
\text { CATALOGUB. }\end{array}$ & $\begin{array}{c}\text { ANCIEN } \\
\text { CATALOGEE. }\end{array}$ & NOUVEAU & $\begin{array}{c}\text { ANCIEN } \\
\text { CATALOGER. }\end{array}$ & $\begin{array}{l}\text { NOUYEAU } \\
\text { CATALOGLE. }\end{array}$ & $\begin{array}{l}\text { AXCIEY } \\
\text { CATALOGUE. }\end{array}$ & $\begin{array}{l}\text { KOEVEAU } \\
\text { CATALOOUE. }\end{array}$ \\
\hline $59^{3}$ & 2191 & 637 & 1589 & 680 & 1780 & 729 & 2143 & $77^{6}$ & 1810 \\
\hline 594 & 2192 & 638 & 1587 & 681 & 1762 & 730 & 2050 & 777 & 1806 \\
\hline 595 & 2209 & $638 \mathrm{~A}$ & 1588 & 689 & 1736 & 731 & 2057 & 778 & 1607 \\
\hline $595 \mathrm{~A}$ & 1822 & 639 & 1611 & 683 & 1579 & $73 x$ & 2081 & 779 & 1618 \\
\hline $59^{5} \mathrm{~B}$ & 1823 & 640 & 1505 & 684 & 1544 & 733 & 4459 & 780 & 1814 \\
\hline${ }^{5} 9^{6}$ & 2220 & 641 & 1508 & 685 & 1723 & $7^{34}$ & 3318 & 781 & 1819 \\
\hline 597 & 2281 & 642 & 2328 & 686 & 1824 & 735 & 2087 & 782 & 1843 \\
\hline $5_{9} 8$ & 1485 & 643 & 1598 & 687 & 1599 & 736 & 2088 & $783 \mathrm{~A}$ & 1844 \\
\hline 599 & 1484 & 644 & 1590 & 688 & 1719 & $7^{3} 7$ & 2100 & 783 & 1815 \\
\hline 599 A & 1478 & 645 & 1574 & $68 g$ & 1825 & 738 & 2030 & 784 & 1852 \\
\hline $599 \mathrm{~B}$ & 1488 & 646 & 1581 & 690 & 2150 & 7.3 .9 & 2031 & 785 & 1888 \\
\hline 600 & 2503 & $6 ! 7$ & 1576 & $69_{1}$ & 2152 & . 740 & 3525 & 786 & 1827 \\
\hline 601 & 2196 & 648 & 1804 & $69^{2}$ & 1712 & 741 & 2098 & $7^{87}$ & 1845 \\
\hline 602 & 2293 & 649 & 1800 & 693 & 2282 & 742 & 2084 & 788 & 1847 \\
\hline 603 & 2545 & 650 & 2018 & $69^{4}$ & 1713 & 743 & 1883 & $7^{8} 9$ & 1790 \\
\hline $60 h$ & 2558 & 651 & 2268 & 695 & 1724 & 744 & 2039 & 790 & 1794 \\
\hline 605 & 2486 & 659 & 1799 & 696 & 1854 & $7^{145}$ & 2133 & 791 & 1801 \\
\hline 606 & 2528 & 653 & 1569 & 697 & 1653 & 746 & 3340 & $79^{2}$ & 1802 \\
\hline 607 & 2522 & 654 & 1771 & 698 & 1652 & $7^{4} 7$ & 2088 & $79^{3}$ & 1795 \\
\hline 608 & 2530 & 655 & 1687 & 699 & 1855 & $7^{48}$ & 2089 & $79^{4}$ & 1807 \\
\hline $60_{9}$ & 2559 & 656 & 1601 & 700 & 1573 & 749 & 2070 & $79^{5}$ & 1770 \\
\hline 610 & 2571 & 657 & 1602 & 701 & 1643 & 750 & 2071 & $79^{5} \mathrm{~A} \mathrm{I}$ & 1737 \\
\hline 611 & 2557 & 658 & 1603 & $7^{02}$ & 1575 & 751 & 2072 & $79^{5} \mathrm{~A}$ II & 1738 \\
\hline 612 & 2524 & 659 & 1772 & $702 \mathrm{~A}$ & 1577 & $751 \mathrm{~A}$ & 2052 & $79^{5}$ A III & 1739 \\
\hline 613 & 2547 & $659 \Lambda$ & 1551 & 703 & 1875 & 751 A bis & 2053 & $795 \mathrm{~A}$ IV & 1740 \\
\hline 614 & 2582 & 660 & 1775 & 704 & 1882 & 759 & 2153 & $79^{6}$ & 1514 \\
\hline 615 & 1553 & 661 & 1780 & 705 & 1885 & $7^{53}$ & 1582 & 797 & 1731 \\
\hline $615 \mathrm{~A}$ & 1511 & $661 \mathrm{~A}$ & 1782 & 706 & 1867 & 754 & 1800 & $79^{8}$ & 1732 \\
\hline $615 \mathrm{~B}$ & 1512 & 662 & 1784 & 707 & 3682 & 755 & 2093 & 799 & 1751 \\
\hline 616 & 1548 & 663 & 1783 & $707 \mathrm{~A}$ & 1700 & 756 & 2117 & 800 & 1757 \\
\hline 617 & 1537 & 664 & 1785 & 708 & 1903 & $7^{5} 7$ & 2115 & $8 n 1$ & 1758 \\
\hline $617 \mathrm{~A}$ & 1554 & 665 & 1788 & 709 & 1902 & 758 & 1884 & $801 \mathrm{~A}$ & 1888 \\
\hline 618 & 4524 & 666 & 1787 & 710 & 1678 & $7^{5} 9$ & 1886 & 802 & 1788 \\
\hline 619 & 4525 & $66_{7}$ & 1788 & 711 & 1674 & 760 & 2165 & 803 & 1707 \\
\hline 620 & 1913 & 668 & 1572 & 712 & 1681 & $7^{61}$ & 1491 & 804 & 1605 \\
\hline 621 & 1918 & 669 & 1774 & 713 & 1671 & 762 & 1547 & 805 & 1793 \\
\hline 622 & 1911 & 670 & 1781 & 714 & 1694 & $7^{63}$ & 1560 & 806 & 1709 \\
\hline 623 & 1921 & 671 & 1777 & 715 & 1695 & 764 & 1914 & 807 & 1717 \\
\hline 634 & 1896 & 672 & 1728 & 716 & 1668 & 765 & 1935 & 808 & 1711 \\
\hline 695 & 1897 & 673 & 1727 & 717 & 1693 & $7^{66}$ & 1934 & 809 & 1835 \\
\hline 696 & 1580 & $673 \mathrm{~A}$ & 1729 & 718 & 1831 & -67 & 1923 & 810 & 2147 \\
\hline 627 & 1487 & $6_{7} 3 \mathrm{~B}$ & 1730 & $7^{19}$ & 2123 & $767 A$ & 2146 & 811 & 2151 \\
\hline 628 & En déficit & $673 \mathrm{C}$ & 1741 & 720 & 2124 & $7^{68}$ & 1555 & 812 & 1813 \\
\hline 629 & 1948 & $673 \mathrm{C}$ bis & 1742 & 721 & 2125 & $7^{6} 9$ & 1545 & 813 & 2260 \\
\hline 630 & 1970 & 673 C ter & 1743 & 722 & 1633 & $77^{\circ}$ & 2667 & 814 & 1691 \\
\hline 631 & 724 & 674 & 1728 & $7^{23}$ & 1629 & 771 & 1967 & 815 & 1690 \\
\hline $63_{2}$ & 1819 & 675 & 2144 & 724 & 1830 & $77^{2}$ & 1550 & 816 & 2784 \\
\hline 633 & 1568 & 676 & 1744 & $7^{25}$ & 2141 & $77^{3}$ & 1490 & 817 & 2785 \\
\hline 634 & 2132 & $6_{77}$ & 1752 & $7 \cdot 6$ & 2138 & $77^{4}$ & 1538 & 818 & 1898 \\
\hline 635 & 1980 & 678 & 1753 & 727 & 2140 & $774 \mathrm{~A}$ & 1618 & 819 & 1684 \\
\hline 636 & 2021 & 679 & 1764 & 728 & 1668 & $77^{5}$ & 1571 & 820 & 1680 \\
\hline
\end{tabular}


TABLES DE CONGORDANGE.

\begin{tabular}{|c|c|c|c|c|c|c|c|c|c|}
\hline $\begin{array}{c}\text { Ascies } \\
\text { Catalogue. }\end{array}$ & $\begin{array}{l}\text { NOUVEAD } \\
\text { CATALOGEE. }\end{array}$ & $\begin{array}{c}\text { ANGIEN } \\
\text { CATALOGEE. }\end{array}$ & $\begin{array}{c}\text { NOUVEAU } \\
\text { CATALOGUE. }\end{array}$ & $\begin{array}{c}\text { ANCIEX } \\
\text { GATALOGUE. }\end{array}$ & $\begin{array}{c}\text { NoUteat } \\
\text { cataloger. }\end{array}$ & $\begin{array}{c}\text { ANCFEN } \\
\text { CATALOGEE. }\end{array}$ & $\begin{array}{c}\text { NOUVEAU } \\
\text { Catalogue. }\end{array}$ & $\begin{array}{c}\text { ANCIEN } \\
\text { CATALOGUE. }\end{array}$ & $\begin{array}{c}\text { Nouvea } \\
\text { Catalogue. }\end{array}$ \\
\hline 821 & 1870 & 871 & 2160 & $9^{21}$ & 2408 & $97^{2}$ & 2605 & 1092 & 2946 \\
\hline 892 & 1865 & $87^{2}$ & 2078 & $9^{22}$ & 2330 & $97^{3}$ & 2612 & 1023 & 2976 \\
\hline 893 & 2253 & 873 & 2118 & $9^{23}$ & 2398 & $97^{4}$ & 2814 & 1024 & 3001 \\
\hline 824 & 1881 & $87^{4}$ & 4457 & $9^{2 / 4}$ & 2399 & $97^{5}$ & 2811 & 1085 & 2979 \\
\hline 895 & 1873 & 875 & 4480 & 925 & 2389 & $97^{6}$ & 2320 & 1026 & 2987 \\
\hline 826 & 1649 & 876 & 3257 & $9^{26} 6$ & 2359 & 977 & 2354 & 1027 & 2965 \\
\hline $896 \mathrm{~A}$ & 1844 & 877 & 2338 & $9^{27}$ & 2353 & $97^{8}$ & 2374 & 1028 & 2960 \\
\hline 827 & 1650 & 878 & 1787 & $9^{28}$ & 2382 & 979 & 2439 & 1029 & 3015 \\
\hline 898 & 1847 & 879 & 2281 & $9^{29}$ & 2357 & $9^{80}$ & 2443 & 1030 & 3005 \\
\hline 829 & 1651 & 880 & 1834 & 930 & 2383 & 981 & 3517 & 1031 & 2861 \\
\hline 830 & 1822 & 881 & 1927 & $9^{31}$ & 2350 & 98 & 2442 & 1032 & 2986 \\
\hline 831 & 1879 & $88_{2}$ & 202 & $9^{32}$ & 2370 & $9^{83}$ & 2180 & 1033 & 2995 \\
\hline 832 & 1677 & $88, A$ & 2348 & $9^{33}$ & 2368 & $9^{84}$ & 2818 & 1034 & 3002 \\
\hline 833 & 1882 & 883 & 2392 & 934 & 4386 & 985 & 2837 & 1035 & 2949 \\
\hline 834 & 1880 & 884 & 1331 & $9^{35}$ & 4372 & $9^{86}$ & 2858 & 1036 & 2970 \\
\hline 835 & 1876 & 885 & 2418 & $9^{36}$ & 4396 & $9^{8} 7$ & 2847 & 1037 & 2771 \\
\hline 836. & 2255 & 886 & 1300 & $9^{37}$ & 4376 & $9^{88}$ & 2853 & 1038 & 2810 \\
\hline 837 & 2254 & 887 & 2431 & 938 & 2381 & $9^{8} 9$ & 2894 & 1039 & 2645 \\
\hline 838 & 2257 & 888 & 2437 & 939 & 2390 & $99^{\circ}$ & 2898 & 1040 & 2835 \\
\hline $83 q$ & 1699 & 889 & 2436 & 940 & 2373 & $99^{\circ} \mathrm{A}$ & 2183 & 1041 & 2839 \\
\hline 840 & 1698 & 890 & 2440 & $9^{41}$ & 2383 & $99^{1}$ & 2910 & 1012 & 2843 \\
\hline 841 & 1667 & $89^{1}$ & 3957 & $9^{42}$ & 2379 & $99^{2}$ & 2898 & 1043 & 2880 \\
\hline 843 & 1889 & $89^{2}$ & 2433 & $9^{43}$ & 310 & $99^{3}$ & 2905 & 1044 & 2854 \\
\hline 843 & 1828 & 893 & 2447 & 944 & 2418 & $99^{4}$ & 2899 & 1045 & 2928 \\
\hline 844 & 1632 & 894 & 2425 & $9^{45}$ & 2419 & $99^{5}$ & 2893 & 1046 & 3038 \\
\hline 845 & 1638 & 895 & 2441 & $9^{\prime / 6}$ & 2444 & $99^{6}$ & 2902 & 1047 & 2900 \\
\hline 846. & 2778 & 896 & 2448 & $9^{4} 7$ & 2445 & 997 & 2904 & 1048 & 2897 \\
\hline 847 & 2278 & 897 & 3528 & 948 & 3510 & $99^{8}$ & 2911 & 1049 & 2941 \\
\hline 848 & 1635 & $89^{8}$ & 2173 & $9^{4} 9$ & 3488 & 999 & 2916 & 1050 & 2919 \\
\hline 849 & 1899 & 899 & 2235 & 950 & 3507 & 1000 & 2909 & 1051 & 2920 \\
\hline 850 & 1900 & $9^{\circ 0}$ & 2177 & 951 & 4523 & 1001 & 2934 & 1052 & 2933 \\
\hline 851 & 1808 & 901 & 1470 & $9^{52}$ & 3505 & 1002 & 2939 & 1053 & 2936 \\
\hline $85_{2}$ & 2022 & $9^{02}$ & 2380 & 953 & 3504 & 1003 & 2940 & 1054 & 2865 \\
\hline 853 & 1972 & $9 \circ 3$ & 2172 & $9^{54}$ & 2168 & 1004 & 2927 & 1055 & 3010 \\
\hline 854 & 2040 & 904 & 2329 & $9^{55}$ & 1472 & 1005 & 2924 & 1056 & 2918 \\
\hline 855 & 2042 & 905 & 2815 & $9^{56}$ & 2184 & 1006 & 2925 & 1057 & 2922 \\
\hline 856 & 2099 & 906 & 2790 & $9^{5} 7$ & 2238 & 1007 & 2958 & 1058 & 3031 \\
\hline 857 & 285 & 907 & 2788 & $9^{58}$ & 2174 & 1008 & 2990 & 1059 & 2878 \\
\hline 858 & 2104 & $9^{\circ 8}$ & 2783 & 959 & 2302 & 1009 & 2882 & 1060 & 2874 \\
\hline 859 & 1721 & $9 \circ 9$ & 2791 & 960 & 2381 & 1010 & 2881 & 1061 & 2877 \\
\hline 860 & 2101 & 910 & 2784 & 961 & 2780 & 1011 & 2872 & 1062 & 2878 \\
\hline 861 & 2102 & $9^{11}$ & 2787 & $9^{62}$ & 2782 & 1013 & 2871 & 1063 & 2972 \\
\hline 862 & 2075 & $9^{12}$ & 2804 & $9^{63}$ & 2759 & 1013 & 2873 & 1064 & 2974 \\
\hline 863 & 2128 & 913 & 2803 & $9^{64}$ & 2781 & 1014 & 2880 & 1065 & 2975 \\
\hline 864 & 2054 & 914 & 2802 & $9^{65}$ & 2789 & 1015 & 2879 & 1066 & 3028 \\
\hline 865 & 2081 & $9^{15}$ & 2805 & $9^{66}$ & 4644 & 1016 & 2875 & 1067 & 2956 \\
\hline 866 & 2085 & $9^{16}$ & 2781 & $9^{6} z$ & 2801 & 1017 & 3012 & 1068 & 2981 \\
\hline 867 & 3347 & $9^{17}$ & 2397 & $9^{68}$ & 2850 & 1018 & 2971 & 1069 & 3044 \\
\hline 868 & 2157 & 918 & 2311 & $9^{6} 9$ & 2770 & 1019 & 2955 & $107^{\circ}$ & 3011 \\
\hline 869 & 2158 & $9^{19}$ & 4640 & $97^{\circ}$ & 2779 & 1020 & 2947 & 1071 & 2978 \\
\hline $87^{\circ}$ & 2159 & 920 & 2332 & 971 & 4590 & 1021 & 2950 & $107^{2}$ & 3006 \\
\hline
\end{tabular}


MANUSGRITS ARABES.

\begin{tabular}{|c|c|c|c|c|c|c|c|c|c|}
\hline $\begin{array}{c}\text { Axcien } \\
\text { CATALaGu. }\end{array}$ & $\begin{array}{l}\text { Nouveau } \\
\text { Catalogue. }\end{array}$ & $\begin{array}{c}\text { ANCIEN } \\
\text { CATALOGUE. }\end{array}$ & $\begin{array}{l}\text { NOUVEAU } \\
\text { CATALOGU. }\end{array}$ & $\begin{array}{c}\text { A NCIEN } \\
\text { CATALOGUE. }\end{array}$ & $\begin{array}{c}\text { Notvead } \\
\text { Catalogev. }\end{array}$ & $\begin{array}{c}\text { ANCIEN } \\
\text { CATALOGUE. }\end{array}$ & $\begin{array}{l}\text { NOUYEAU } \\
\text { CATALOGUE. }\end{array}$ & $\begin{array}{c}\text { ANCSEY } \\
\text { CATALOGEE. }\end{array}$ & $\begin{array}{c}\text { NOEVEAU } \\
\text { CATALOGUE. }\end{array}$ \\
\hline $107^{3}$ & 2857 & 1123 & 2051 & $117^{4}$ & 2861 & 1224 & 2703 & 1974 & 4010 \\
\hline $107^{4}$ & 2981 & 1124 & 2075 & $117^{5}$ & 2700 & 1225 & 2715 & $127^{5}$ & 4012 \\
\hline 1075 & 2957 & 1125 & 2897 & $1177^{\circ}$ & 2662 & 1226 & 2630 & 1276 & 4014 \\
\hline 1076 & 2954 & 1126 & 2755 & 1177 & 2689 & 1227 & 4036 & 1277 & 4027 \\
\hline 1077 & 2782 & 1127 & 2825 & 1178 & 2810 & 1298 & 4037 & $127^{8}$ & 4026 \\
\hline 1078 & 2951 & 1128 & 2826 & 1179 & 2732 & 1229 & 4003 & 1279 & 4054 \\
\hline 1079 & 2952 & 1129 & 2466 & 1180 & 2676 & 1230 & 4127 & 1280 & 4044 \\
\hline 1080. & 3038 & 1130 & 2460 & $118 t$ & 2881 & 1231 & $\mathbf{4 1 5 5}$ & 1281 & 4055 \\
\hline 1081 & 2864 & 1131 & 2474 & 1182 & 2726 & 123. & 4067 & 1282 & 4122 \\
\hline 1082 & 3029 & 1132 & En déficit & 1183 & 2727 & 1233 & 4075 & 1283 & 4025 \\
\hline 1083 & 2608 & 1133 & 2470 & 1184 & 2682 & 1234 & 4100 & 1284 & 4129 \\
\hline 1084 & 3024 & 1134 & 2473 & 1185 & 2658 & 1235 & 4095 & $1284 \mathrm{~A}$ & 4135 \\
\hline 1085 & 2992 & 1135 & 2472 & 1186 & 2698 & 1236 & 4373 & 1285 & 4052 \\
\hline 1086 & 2993 & 1136 & 2461 & 1187 & 2672 & 1237 & 4377 & 1986 & 4060 \\
\hline 1087 & 2690 & ${ }_{11} 37$ & 2580 & 1188 & 2684 & 1238 & 4153 & 1287 & 4016 \\
\hline 1088 & 2870 & 1138 & 2494 & 1189 & 2707 & 1239 & 4201 & 1288 & 3992 \\
\hline 1089 & 2932 & $1 \times 39$ & 2483 & $119^{\circ}$ & 2713 & 1240 & 4265 & 1289 & 3990 \\
\hline $109^{\circ}$ & 2862 & 1140 & 2512 & 1191 & 2679 & 1241 & 4268 & 1290 & 4291 \\
\hline 1091 & 3053 & 1142 & 2529 & 1192 & 2868 & 1218 & 4.272 & 1291 & 4008 \\
\hline $109^{2}$ & 3054 & 11/49 & 2594 & $119^{3}$ & 2728 & 1243 & 4276 & 1292 & 4188 \\
\hline 1093 & 2942 & 1143 & 2523 & $119^{4}$ & 2644 & 1214 & 4275 & 1293 & 4120 \\
\hline 1094 & 2962 & 1144 & 2520 & $119^{5}$ & 2634 & 1245 & 4239 & 1294 & 3988 \\
\hline $\log 5$ & 2814 & 1145 & En défirit & 1196 & 2699 & 1246 & 4237 & $129^{5}$ & 4007 \\
\hline $\log 6$ & 2840 & 1146 & 2549 & 1197 & 2706 & 1247 & 4319 & $1295 \mathrm{~A}$ & 4210 \\
\hline 1097 & 2848 & 1147 & 2507 & 1198 & 2704 & 1348 & 4298 & 1296 & 4166 \\
\hline $\log 8$ & 2973 & 1148 & 2508 & 1199 & 2768 & 1249 & 4299 & 1297 & 4234 \\
\hline 1099 & 2741 & 1149 & 2502 & 1200 & 2701 & $125 a$ & 4246 & 1298 & 4168 \\
\hline 1100 & 2869 & 1150 & 2517 & 1201 & 2673 & 1251 & 4240 & 1299 & 4169 \\
\hline 1101 & 3023 & 1151 & 2511 & 1202 & 2763 & 1252 & 4235 & 1300 & 4170 \\
\hline 1102 & 3042 & 1152 & 2505 & 1203 & 2705 & ${ }_{12} 53$ & 4280 & 1301 & 4172 \\
\hline 1103 & 2533 & 1153 & 2501 & 1204 & 2637 & 1254 & 4294 & 1302 & $\mathbf{4 1 6 7}$ \\
\hline 1104 & 2458 & 1154 & 2595 & 1205 & 2639 & 1255 & 4297 & 1303 & 4173 \\
\hline 1105 & 2304 & 1155 & 2525 & 1206 & 2877 & ${ }_{12} 56$ & 4290 & 1304 & 4185 \\
\hline 1106 & 2462 & 1156 & 2553 & & Ture (Suppl.) & ${ }_{12} 5_{7}$ & 4300 & 1305 & 4174 \\
\hline 1107 & 2482 & 1157 & 2544 & 1207 & 800 & 1258 & 4285 & 1306 & 4063 \\
\hline 1108 & 2485 & 1158 & 2519 & 1208 & 2717 & 1259 & 4335 & 1307 & 4021 \\
\hline 1109 & 2540 & 1159 & 2498 & 1209 & 2716 & 1260 & 4325 & 1308 & 4065 \\
\hline 1110 & 2490 & 1160 & 2870 & 1210 & 2742 & 1261 & $432 \theta$ & 1309 & 4086 \\
\hline 1111 & 2488 & 1161 & 2593 & 1211 & 2758 & 1262 & 4327 & 1310 & 4164 \\
\hline 1112 & 2496 & 1162 & 2601 & 1213 & 2744 & 1263 & 4324 & 1311 & 4079 \\
\hline 1113 & 2489 & 1163 & 2698 & 1213 & 2748 & 1264 & 4322 & 1312 & 4189 \\
\hline 1114 & 2500 & 1164 & 2695 & 1214 & 2490 & 1265 & 4333 & 1313 & 4022 \\
\hline 1115 & 2499 & 1165 & 2584 & 1215 & 2308 & 1266 & 4340 & 1314 & 4013 \\
\hline 1116 & 2534 & 1166 & 2693 & 1216 & 2465 & 1267 & 4341 & 1315 & 4289 \\
\hline 1117 & 2552 & 1167 & 2577 & 1217 & En déficit & 1268 & 4344 & 1316 & 4329 \\
\hline 1118 & 2521 & 1168 & 2718 & 1218 & 2550 & & (Persan (Suppl.) & 1317 & 4292 \\
\hline 1119 & 2572 & 1169 & 2678 & 1219 & 2532 & 1269 & 1176 & 1318 & 4304 \\
\hline $1119 A$ & 4609 & $117^{\circ}$ & 2592 & 1220 & 2506 & $127^{\circ}$ & 4049 & 1319 & 4375 \\
\hline 1120 & 2573 & $117^{1}$ & 2578 & 1221 & 2656 & 1271 & 4150 & 1320 & 2888 \\
\hline 1121 & 2478 & $117^{2}$ & 2643 & 1222 & 2714 & $127^{2}$ & 4009 & 1321 & 4023 \\
\hline 1122 & 2649 & $117^{3}$ & 2689 & 1223 & 2702 & 1273 & 4144 & 1322 & 4187 \\
\hline
\end{tabular}




\begin{tabular}{|c|c|c|c|c|c|c|c|c|c|}
\hline $\begin{array}{c}\text { AXCIEN } \\
\text { CATALOGUE. }\end{array}$ & $\begin{array}{c}\text { NOUYEAU } \\
\text { CATALOGUE. }\end{array}$ & $\begin{array}{c}\text { ANCIEN } \\
\text { CATALOGUE. }\end{array}$ & $\begin{array}{l}\text { NOCPEAU } \\
\text { CATALOGCE. }\end{array}$ & $\begin{array}{c}\text { ArCiEN } \\
\text { CATALOGUE. }\end{array}$ & $\begin{array}{c}\text { NOUVEIU } \\
\text { CATALOGUE. }\end{array}$ & $\begin{array}{c}\text { ANCIEN } \\
\text { Cath Logue. }\end{array}$ & $\begin{array}{c}\text { NOUVEAU } \\
\text { CATALOGUE. }\end{array}$ & $\begin{array}{c}\text { ANCIEN } \\
\text { Gatilogue. }\end{array}$ & $\begin{array}{c}\text { NouveaU } \\
\text { Gatalogue. }\end{array}$ \\
\hline 1323 & 4223 & 1367 & 4306 & 1417 & 3278 & 1467 & 3153 & 1514 & 3826 \\
\hline 1324 & 4163 & 1368 & 4307 & 1418 & 3136 & 1468 & 3431 & 1515 & 3827 \\
\hline 13,5 & 2339 & ${ }^{1} 369$ & 4452 & $1 / 119$ & 4531 & 1469 & 3232 & 1516 & 3828 \\
\hline $13 a 6$ & 4259 & ${ }_{1} 37^{\circ}$ & 3309 & 1420 & 3389 & $147^{\circ}$ & 3425 & $15: 7$ & 3831 \\
\hline 1337 & 4253 & 1371 & 2326 & & Turr (Suppl.) & 1471 & 3412 & 1518 & 3832 \\
\hline 13.8 & 4231 & $137^{2}$ & 2327 & 1421 & 802 & $147 a$ & 3398 & 1519 & 3833 \\
\hline $1328 \mathrm{~A}$ & 4178 & 1373 & 3327 & 1422 & 3954 & 1473 & 3299 & 1520 & 3834 \\
\hline 1329 & 4245 & $137^{4}$ & 3328 & $1 / 123$ & 3083 & 1474 & 3307 & 1521 & 3790 \\
\hline 1330 & 4255 & 1375 & 3330 & 1424 & 3149 & 1475 & 3218 & 1522 & 3791 \\
\hline 1331 & 4295 & 1376 & 3331 & 1425 & 3145 & 1476 & 3141 & $15_{2} 3$ & 3829 \\
\hline 1339 & 4301 & 1377 & 2106 & 1426 & 3497 & 1477 & 4257 & 1524 & 3830 \\
\hline 1333 & 4287 & 1378 & 3346 & 1427 & 3093 & 1478 & 3129 & 1525 & 3860 \\
\hline 1334 & 4284 & 1379 & 4451 & 1498 & 3091 & 1479 & 3157 & 1526 & 3862 \\
\hline 1335 & 4293 & 1380 & 3182 & 1429 & 3097 & $1 / 480$ & 4118 & 1597 & 3883 \\
\hline 1336 & 4302 & 1381 & 3218 & $1 / 130$ & 3092 & 1481 & 3120 & 1528 & 3866 \\
\hline $1336 \mathrm{~A}$ & 4290 & 1383 & 3214 & 1431 & 3101 & 1482 & 4448 & 1529 & 3864 \\
\hline $1336 \mathrm{~B}$ & 4283 & 1383 & 3098 & $143_{2}$ & 3102 & $1482 A$ & 322 & 1530 & 3868 \\
\hline $1336 \mathrm{C}$ & 4309 & $1383 \mathrm{~A}$ & 3100 & 1433 & 3103 & 1483 & 3082 & 1531 & 3889 \\
\hline${ }_{1} 337$ & 4320 & 1384 & 3441 & 1434 & 4567 & $1483 A$ & 3465 & 1533 & 3330 \\
\hline 1338 & 4323 & 1385 & 4568 & 1435 & 4542 & 1484 & 3177 & 1533 & 3875 \\
\hline 1339 & 4315 & 1386 & 4571 & 1436 & 4568 & 1485 & 3186 & 1534 & 3874 \\
\hline 1340 & 4313 & 1387 & 4570 & 1437 & 4544 & 1486 & 3243 & 1535 & 3884 \\
\hline 1341 & 4311 & 1388 & 4569 & 1438 & 3251 & 1487 & 3128 & 1536 & 3877 \\
\hline 1343 & 4312 & 1389 & 4572 & 1439 & 3087 & 1488 & 3416 & 1537 & 3888 \\
\hline 1343 & 4318 & $139^{\circ}$ & 4543 & 1440 & 3212 & $1 / 489$ & 3466 & 1538 & 3879 \\
\hline 1344 & 4314 & 1391 & 4854 & 1441 & 3219 & $149^{\circ}$ & 3665 & 1539 & 3872 \\
\hline 1345 & 4321 & 1392 & 3086 & 1442 & 3210 & 1491 & 3881 & 1540 & 3889 \\
\hline & (Turc (Suppl.) & 1393 & 3119 & 1443 & 3211 & $1491 \mathrm{~A}$ & 3612 & 154 & 3383 \\
\hline 1346 & 801 & $139^{4}$ & 3140 & 1444 & 3171 & 1492 & 3472 & 1542 & 8882 \\
\hline 1347 & 4305 & 1395 & 3144 & 1445 & 3432 & 1493 & 3516 & 1543 & 3890 \\
\hline 1348 & 4628 & 1396 & 3148 & 1146 & 3139 & 1494 & 3685 & 154 ' & 3891 \\
\hline 1349 & 4339 & 1397 & 3146 & 1447 & 3326 & $1494 \mathrm{~A}$ & 3837 & 1545 & 3892 \\
\hline 1350 & 4337 & 1398 & 3117 & 14,8 & 3173 & 1495 & 3118 & 1546 & 4623 \\
\hline 35 & (Ture (Suppl.) & 1399 & 3098 & 1449 & 3205 & 1496 & 3893 & 1547 & 3645 \\
\hline 1321 & 803 & $1 / 100$ & 3348 & 1450 & 3382 & 1497 & 3622 & 1548 & 3552 \\
\hline 1353 & 4308 & 1401 & 3404 & 1451 & 3178 & $149^{8}$ & 3650 & $15 / 49$ & 3852 \\
\hline 1353 & 4347 & 1402 & 3392 & 1452 & 3360 & 1499 & 3623 & $155 ว ั 0$ & 3853 \\
\hline $1353 \mathrm{~A}$ & 4352 & 1403 & 3338 & 1453 & 3172 & 1500 & 4820 & 1551 & 3854 \\
\hline 1354 & 4214 & 1404 & 3305 & 1451 & 3088 & 1501 & 3471 & 1552 & 3855 \\
\hline 1355 & 4030 & 1405 & 3314 & 1455 & 3075 & 1502 & 3469 & 1553 & 3859 \\
\hline 1356 & 4029 & 1406 & 4594 & 1456 & 3223 & 1503 & 3865 & 1554 & 3867 \\
\hline 1357 & 4045 & $1 / 407$ & 4530 & $1 / 57$ & 3225 & 1504 & 3632 & 1555 & 3370 \\
\hline 1358 & 4008 & 1408 & 3215 & 1458 & 3221 & 1505 & 3630 & 1556 & 3871 \\
\hline 1359 & 4179 & 1409 & 3111 & 1159 & 4230 & 1506 & 3611 & 1557 & 3873 \\
\hline 1360 & 4180 & 1110 & 4119 & 1160 & 3143 & 1507 & 3810 & 1558 & 3876 \\
\hline 1361 & 4200 & 1411 & 3131 & 1461 & 3350 & 1508 & 3609 & 1559 & 3885 \\
\hline 1362 & 4203 & 1413 & 3217 & 1462 & 3352 & 1509 & En déficit & 1560 & 3886 \\
\hline 1363 & 4048 & 1413 & 3409 & 1163 & 3387 & 1510 & 3537 & 1561 & 3887 \\
\hline 1364 & 4018 & 1414 & 3329 & 1164 & 3671 & 1511 & 3540 & 1562 & 4577 \\
\hline 1365 & 4535 & 1415 & 3319 & 1465 & 3402 & 1512 & 3824 & 1563 & 2423 \\
\hline 1366 & 4645 & 1416 & 3277 & 1466 & $33 \div 9$ & $15: 3$ & 3825 & 1564 & 3930 \\
\hline
\end{tabular}




\begin{tabular}{|c|c|c|c|c|c|c|c|c|c|}
\hline $\begin{array}{c}\text { ANCIEN } \\
\text { CATALOGLE. }\end{array}$ & $\begin{array}{c}\text { NOLVEAU } \\
\text { CATALOGLE. }\end{array}$ & $\begin{array}{c}\text { ANCLEN } \\
\text { CATALOGUE. }\end{array}$ & $\begin{array}{c}\text { NOUVEad } \\
\text { Catatogle. }\end{array}$ & $\begin{array}{c}\text { ANGIEY } \\
\text { CATALOGLE. }\end{array}$ & $\begin{array}{c}\text { NOLVEAU } \\
\text { CATALOGEE. }\end{array}$ & $\begin{array}{c}\text { ANCIEN } \\
\text { CATALOGLE. }\end{array}$ & $\begin{array}{l}\text { NOUVEAU } \\
\text { GATALOGEE. }\end{array}$ & $\begin{array}{c}\text { ANCIEN } \\
\text { CATALOONE. }\end{array}$ & $\begin{array}{c}\text { Nodveav } \\
\text { CatAlogie. }\end{array}$ \\
\hline 1565 & 3927 & 1578 & 2819 & 1591 & 3923 & 1603 & 3494 & 1615 & 4434 \\
\hline 1566 & 3396 & 1579 & 4839 & $159^{2}$ & 3361 & 1604 & 3548 & 1616 & 3547 \\
\hline 1567 & 3394 & 1580 & 1408 & 1593 & 3952 & 1605 & 3417 & 1617 & 4418 \\
\hline 1568 & 3386 & 1581 & 1415 & $159^{4}$ & 3304 & $16 \circ 6$ & 3485 & 1618 & 4387 \\
\hline 1569 & 3385 & 1583 & 1427 & 1595 & 3531 & 1607 & 3955 & 1619 & 4427 \\
\hline 1570 & 3482 & 1583 & 1429 & 1596 & 3529 & 1608 & 4588 & 1620 & 4622 \\
\hline 1571 & 3527 & 1584 & 3345 & 1597 & 3406 & $16 \circ 9^{\prime \prime}$ & 3987 & 1691 & 3965 \\
\hline 1572 & 3378 & 1585 & 4422 & 1598 & 3377 & 1610 & 3418 & 1622 & 3363 \\
\hline${ }_{157} 3$ & 4439 & 1586 & 3333 & 1599 & 3373 & 1611 & 3343 & $16 \unlhd 3$ & 4598 \\
\hline 1574 & 4436 & 1587 & 3947 & 1600 & 3385 & 1612 & 4433 & 1634 & 3970 \\
\hline 1575 & 4440 & 1588 & 3931 & 1601 & 3530 & $16 i 3$ & 4438 & ${ }_{1} 625$ & 3969 \\
\hline 1576 & 3342 & 1589 & 3937 & 1609 & 3324 & 1614 & 4444 & ${ }_{16} 66$ & 3939 \\
\hline 1577 & 2477 & 1590 & 3949 & & & & & & - \\
\hline
\end{tabular}

SUPPLÉMENT.

\begin{tabular}{|c|c|c|c|c|c|c|c|c|c|}
\hline $\begin{array}{c}\text { ANGIEX } \\
\text { CATALOGLE. }\end{array}$ & $\begin{array}{l}\text { NOLVEAE } \\
\text { CATALOGLE. }\end{array}$ & $\begin{array}{c}\text { ANCiEN } \\
\text { CATALOGEE. }\end{array}$ & $\begin{array}{c}\text { Nolvead } \\
\text { Catalogue. }\end{array}$ & $\begin{array}{c}\text { ANGiEN } \\
\text { Catalogue. }\end{array}$ & $\begin{array}{c}\text { NOEVE.SE } \\
\text { CATALOGUE. }\end{array}$ & $\begin{array}{c}\text { AXG1EN } \\
\text { GATALOGEE. }\end{array}$ & $\begin{array}{c}\text { NOUVEAE } \\
\text { CATALOGUE. }\end{array}$ & $\begin{array}{c}\text { AXG1EN " } \\
\text { CATALOGEE. }\end{array}$ & $\begin{array}{c}\text { NOUVEAC } \\
\text { CiTALOGEE. }\end{array}$ \\
\hline & & & & & & & & & $y_{4}$ \\
\hline 1 & 2 & 95 & 51 & 50 & 229 & $7^{2}$ & 158 & 96 & 267 \\
\hline 2 & 7 & ${ }_{96} 6$ & 60 & 51 & 183 & 73 & 141 & 97 & 278 \\
\hline 3 & 9 & 27 & 56 & 52 & 197 & $7^{4}$ & 149 & $9^{8}$ & 283 \\
\hline $3 \mathrm{bis}$ & 12 & 28 & 88 & 53 & 191 & $7^{5}$ & 88 & 99 & 221 \\
\hline 4 & 11 & $98 \mathrm{bis}$ & 85 & 53 bis & 192 & $7^{6}$ & 154 & 100 & 188 \\
\hline $4 \mathrm{bis}$ & 3 & 39 & 55 & 54 & 209 & 77 & 165 & 101 & 189 \\
\hline 5 & 10 & 30 & En délicit & 55 & 212 & $7^{8}$ & 252 & 103 & En defleit \\
\hline 6 & 21 & 31 & 65 & 56 & 194 & 79 & 172 & 103 & 187 \\
\hline 7 & 23 & $3 \approx$ & 94 & 57 & 211 & $80^{\circ}$ & 240 & $10 /$ & 218 \\
\hline 8 & 22 & 33 & 128 & 58 & 175 & 81 & 241 & & Transmis \\
\hline 9 & 24 & 34 & 118 & 59 & 223 & 89 & 244 & & aủ départęment \\
\hline 10 & 38 & 35 & 117 & 60 & 232 & 83 & 251 & 105 & oú it porte la cote \\
\hline 11 & 43 & 36 & 115 & Go bis & 233 & 84 & 249 & & $\mathrm{Og}^{2} 383$ \\
\hline 12 & 27 & 37 & 123 & 61 & 128 & 85 & 246 & $105 \mathrm{bis}$ & 219 \\
\hline 13 & 32 & 38 & 121 & 62 & 162 & 86 & 238 & 106 & 188 \\
\hline 14 & 42 & 39 & 118 & 63 & 176 & 87 & 131 & $106 \mathrm{bis}$ & 217 \\
\hline 15 & 34 & 40 & 97 & 64 & 228 & 88 & 81 & 107 & 215 \\
\hline 16 & 35 & 41 & 129 & $64 \mathrm{bis}$ & 230 & 89 & 227 & 108 & 188 \\
\hline 17 & 31 & 49 & 130 & 65 & 145 & $8 g$ bis & 277 & 109 & 231 \\
\hline 18 & 48 & 43 & 119 & 66 & Syriaque & $9^{\circ}$ & 258 & 110 & 273 \\
\hline 19 & $\mathrm{~N}^{\circ}$ non euployé & 44 & 120 & & 192 & $9 \circ b$ is & 320 & 111 & 288 \\
\hline 20 & 50 & 45 & 122 & 67 & 138 & $9^{1}$ & 72 & 119 & 271 \\
\hline 21 & 288 & 46 & 125 & 68 & 140 & $9^{2}$ & 284 & 113 & 274 \\
\hline 22 & 25 & 47 & 216 & 69 & 136 & 93 & 49 & 114 & 399 \\
\hline 93 & 52 & 48 & 195 & $7^{0}$ & 142 & $9^{4}$ & 69 & 115 & 481 \\
\hline 34 & 53 & 49 & 124 & 71 & 95 & $9^{5}$ & 309 & 116 & 463 \\
\hline
\end{tabular}




\begin{tabular}{|c|c|c|c|c|c|c|c|c|c|}
\hline $\begin{array}{c}\text { ANCIEN } \\
\text { CATALOGUE. }\end{array}$ & $\begin{array}{c}\text { sotvead } \\
\text { catalogee. }\end{array}$ & $\begin{array}{c}\text { ANGIEN } \\
\text { GATALOGEB. }\end{array}$ & $\begin{array}{c}\text { NOUVEAU } \\
\text { GaTaLOGEE. }\end{array}$ & $\begin{array}{c}\text { ANCIEN } \\
\text { GATALOGEE. }\end{array}$ & $\begin{array}{l}\text { SOLVEAU } \\
\text { CATALOGEE. }\end{array}$ & $\begin{array}{c}\text { AXC1EN } \\
\text { CATALOGUE. }\end{array}$ & $\begin{array}{c}\text { aOUVEJ } \\
\text { Gatalogue. }\end{array}$ & $\begin{array}{c}\text { ANGIEN } \\
\text { CATALOGCE. }\end{array}$ & $\begin{array}{c}\text { SOCVEAC } \\
\text { CATALOGOE. }\end{array}$ \\
\hline 117 & 482 & $150 \mathrm{E}$ & 326 & $150 \mathrm{FFF}$ & 374 & 164 II & 543 & 177 & 613 \\
\hline 118 & 416 & $150 \mathrm{~F}$ & 333 & $150 \mathrm{GGG}$ & 383 & 164 III & 544 & $178 \mathrm{~A}$ & 614 \\
\hline 119 & 483 & $150 \mathrm{G}$ & 334 & 150 IIHII & 375 & $164 \mathrm{IV}$ & 545 & $178 \mathrm{~B}$ & 615 \\
\hline 120 & 413 & 1 పे० II & 336 & 150 III & 324 & $164 \mathrm{~V}$ & 546 & $178 \mathrm{G}$ & 616 \\
\hline $121 A$ & 454 & 150 I & 337 & 151 & 492 & $164 \mathrm{VI}$ & 547 & $178 \mathrm{D}$ & 617 \\
\hline $121 \mathrm{~B}$ & 465 & $150 \mathrm{~K}$ & 327 & $159 \mathrm{~A}$ & 389 & 164 VII & 548 & $178 \mathrm{E}$ & 618 \\
\hline 19 & 417 & $150 \mathrm{~L}$ & 335 & $152 \mathrm{~B}$ & 390 & 164 IX & 549 & $178 \mathrm{~F}$ & 619 \\
\hline 123 & 449 & $150 \mathrm{M}$ & 329 & $152 \mathrm{C}$ & 391 & 164 . IX bis & 550 & 179 & 620 \\
\hline 124 & 402 & $150 \mathrm{~N}$ & 338 & $152 \mathrm{D}$ & 392 & $164 \mathrm{X}$ & 551 & 180 & 595 \\
\hline$i_{2} 5$ & 589 & 1500 & 370 & ${ }_{152}$ bis & 437 & $164 \mathrm{XI}$ & 552 & 181 & 594 \\
\hline 136 & 484 & $150 \mathrm{P}$ & - 340 & 153 & 461 & 164 XII & 553 & 183 & 652 \\
\hline 137 & 415 & $150 Q$ & 339 & 154 & 466 & 164 XIII & 554 & 183 & 653 \\
\hline 128 & 455 & $150 \mathrm{R}$ & 343 & 155 & 493 & 164 XIV & 555 & 184 & 654 \\
\hline 129 & 458 & $150 \mathrm{~S}$ & 344 & 155 bis & 494 & ${ }_{164}$ XIV bis & 556 & 185 & 622 \\
\hline 130 & 453 & $150 \mathrm{~T}$ & 345 & 156 & 495 & $164 X V$ & 557 & $186 \mathrm{I}$ & 639 \\
\hline 131 & 577 & $150 \mathrm{U}$ & 369 & 157 & 388 & 164 XVI & 558 & $186 \mathrm{lis}$ & 596 \\
\hline 139 & 485 & $150 V$ & 342 & 158 & 378 & 164 XVI bis & 559 & 186 III & 641 \\
\hline 133 & 573 & $150 \mathrm{~W}$ & 379 & 159 & 774 & 164 XVII & 560 & 186 IV & 642 \\
\hline 134 & 574 & $150 X$ & 346 & $159 \mathrm{bis}$ & 513 & 164 XVIII & 561 & 187 & 640 \\
\hline 135 & 386 & $150 Y$ & 347 & 160 & 588 & $164 X X$ & 562 & 188 & 637 \\
\hline 136 & 499 & $150 Z$ & 348 & 161 & 509 & $164 \mathrm{XXI}$ & 563 & 189 & 625 \\
\hline 1.37 & 403 & $150 \mathrm{AA}$ & 371 & 162 & 510 & 164 XXIV & 564 & 190 & 670 \\
\hline 138 & 434 & $150 \mathrm{BB}$ & 349 & $163 \mathrm{I}$ & 514 & ${ }_{1}$ i 4 XXIV bis & 565 & 191 & 643 \\
\hline 139 & 387 & $150 \mathrm{CC}$ & 325 & $163 \mathrm{I} \mathrm{bis}$ & 515 & $164 \times X V$ & 566 & 192 & 656 \\
\hline 140 & 501 & $150 \mathrm{DD}$ & 341 & $163 \mathrm{II}$ & 516 & $164 X X V I$ & 567 & $19^{3}$ & 610 \\
\hline 141 & 486 & $150 \mathrm{EE}$ & 350 & $163 \mathrm{II} \mathrm{bis}$ & 517 & 164 XXVII & 568 & $19^{4}$ & 592 \\
\hline $141 \mathrm{bis}$ & 398 & $150 \mathrm{FF}$ & 351 & $163 \mathrm{III}$ & $\mathbf{5 1 8}$ & 164 XXVIII & 569 & 195 & 667 \\
\hline 149 & 587 & $15 \cap G G$ & 352 & $163 \mathrm{IV}$ & 519 & 164 XXIX & 570 & $195 \mathrm{bis}$ & 672 \\
\hline 143 & 385 & $150 \mathrm{HH}$ & 376 & $163 \mathrm{~V}$ & 520 & 165 & 412 & 196 & 609 \\
\hline 144 & 411 & $150 \mathrm{II}$ & 353 & $163 \mathrm{VI}$ & 521 & 166 & 496 & 197 & 611 \\
\hline 1.45 & 462 & 1 อั๐ KK & 354 & $163 \mathrm{VII}$ & 522 & 167 & 511 & 198 & 612 \\
\hline 146 & 487 & $150 \mathrm{LL}$ & 355 & 163 VIII & 523 & 168 & 497 & 199 & 664 \\
\hline 147 & $\cdot 488$ & 1 อัo MU & 372 & $163 \mathrm{IX}$ & 524 & 168 lis & 498 & -200 & 638 \\
\hline $148 I$ & 459 & $150 \mathrm{NN}$ & 356 & $163 \mathrm{X}$ & 525 & 169 & 457 & 2201 & 649 \\
\hline 148 bis & 512 & 15000 & 357 & ${ }_{1} 63 \mathrm{XII}$ & 526 & $170 \mathrm{I}$ & 438 & 202 & 1227 \\
\hline $148 \mathrm{ter}$ & 502 & $150 \mathrm{PP}$ & 380 & ${ }_{1} 63$ XII bis & $\mathbf{5 2 7}$ & 17011 & 439 & 203 & 1172 \\
\hline 148 IV & 572 & $150 Q Q$ & 358 & $163 \mathrm{XIII}$ & 528 & 170 III & 440 & 204 & 1217 \\
\hline $148 \mathrm{~V}$ & 456 & $150 \mathrm{RR}$ & 359 & $163 \mathrm{XIV}$ & 529 & $171 \mathrm{~A} \mathrm{bis}$ & 657 & 205 & 1211 \\
\hline $148 \mathrm{VI}$ & 404 & $150 \mathrm{SS}$ & 360 & $163 \times V$ & $\mathbf{5 3 0}$ & $171 \mathrm{~B} \mathrm{bis}$ & 658 & 206 & 1212 \\
\hline 148 VII & 489 & $150 \mathrm{TT}$ & 361 & 163 XV bis & 531 & $171 A$ & 597 & 206 bis & 1196 \\
\hline 148 VIII & $\mathbf{5 7 1}$ & $150 \mathrm{UU}$ & 362 & 163 XVI & 532 & $171 \mathrm{~B}$ & 598 & 207 & 1216 \\
\hline $148 \mathrm{IX}$ & 585 & $150 V V$ & 363 & $163 \mathrm{XXII}$ & 533 & $171 \mathrm{G}$ & 599 & $207 \mathrm{bis}$ & 4646 \\
\hline 149 & 490 & $150 \mathrm{IVIV}$ & 364 & $163 \mathrm{XXIII}$ & 534 & $172 \mathrm{~A}$ & 600 & 208 & 1222 \\
\hline $149 \mathrm{bis}$ & 491 & $150 X X$ & 365 & $163 X X I Y$ & 535 & $172 \mathrm{~B}$ & 601 & 209 & 1168 \\
\hline 149 ter & 435 & $150 \mathrm{YY}$ & 366 & $163 \mathrm{XXV}$ & 536 & $17 \cdot \mathrm{C}$ & 602 & 210 & 1218 \\
\hline${ }_{149} \mathrm{IV}$ & 586 & $150 Z Z$ & 367 & $163 \mathrm{XXV}$ bis & 537 & $172 \mathrm{D}$ & 603 & 211 & 1165 \\
\hline 150 & 436 & $150 \mathrm{AAA}$ & 381 & 163 XXVII & 538 & $17^{3}$ & 627 & 212 & 1164 \\
\hline $150 A$ & 328 & $150^{\circ} \mathrm{BBB}$ & 368 & $163 \mathrm{XXVIII}$ & 539 & 174 & 635 & 213 & 1161 \\
\hline $150 \mathrm{~B}$ & 330 & $150 \mathrm{CCC}$ & 373 & 163 XXIX & 540 & 175 & 631 & 213 bis & 1204 \\
\hline $150 \mathrm{C}$ & 331 & $150 \mathrm{DDD}$ & 382 & $163 \mathrm{XXX}$ & 541 & $17^{6 \mathrm{~A}}$ & 632 & 214 & 1174 \\
\hline $150 D$ & 332 & 15 o EEE & 377 & $164 \mathrm{I}$ & 542 & ${ }^{1} 7^{6 B} \mathrm{~B}$ & 633 & $914 \mathrm{bis}$ & 1214 \\
\hline
\end{tabular}




\begin{tabular}{|c|c|c|c|c|c|c|c|c|c|}
\hline $\begin{array}{c}\text { ANGIEY } \\
\text { CATALOGUB. }\end{array}$ & $\begin{array}{l}\text { NOTVEAO } \\
\text { CATALOGUE. }\end{array}$ & $\begin{array}{c}\text { ANCiEX } \\
\text { Catalogle. }\end{array}$ & $\begin{array}{c}\text { MOUTEAU } \\
\text { CATALOGUE. }\end{array}$ & $\begin{array}{c}\text { ANGIEN } \\
\text { CATALOGUE. }\end{array}$ & $\begin{array}{l}\text { NouveaU } \\
\text { Catalogue. }\end{array}$ & $\begin{array}{c}\text { ANGIEN } \\
\text { GATALOGUE. }\end{array}$ & $\begin{array}{l}\text { NOUVEAU } \\
\text { CATALOGLE. }\end{array}$ & $\begin{array}{c}\text { ANCIEN } \\
\text { CATALOGUE. }\end{array}$ & $\begin{array}{l}\text { NOUVBAU } \\
\text { CATALOGUE. }\end{array}$ \\
\hline 215 & 1199 & 259 & 1252 & 297 & 698 & 333 & 832 & 379 & 823 \\
\hline 916 & 1205 & 260 & 1382 & a97 bis & 699 & 334 & 833 & 380 & 837 \\
\hline $216 \mathrm{bis}$ & 1203 & 261 & 1381 & $297 \mathrm{ter}^{*}$ & 700 & 335 & En déficit & 380 bis & 838 \\
\hline 217 & 1177 & 962 & 1368 & 298 & 692 & 336 & 827 & 381 & 826 \\
\hline $217 \mathrm{bis}$ & 1175 & 263 & 1183 & 299 & 679 & 337 & 829 & 389 & 824 \\
\hline 218 & 1153 & 264 & 1277 & $300 \mathrm{I}$ & 680 & 338 & 831 & 383 & 873 \\
\hline 219 & 1154 & 365 & 816 & 300 II & 681 & $33_{9}$ & 834 & 383 bis & 851 \\
\hline 220 & 1126 & ${ }_{2} 66$ & 1232 & 300 III & 682 & 340 & 825 & 384 & 874 \\
\hline 221 & 1123 & ${ }_{2} 67$ & 1233 & 300 IV & 683 & 341 & 910 & 385 & 849 \\
\hline 222 & 1140 & 268 & 1445 & 301 & 686 & 3491 & 911 & 386 & 973 \\
\hline 223 & 743 & 268 bis & 1440 & 301 bis & 701 & $342 I I=$ & 912 & 387 & 678 \\
\hline 224 & 1158 & 269 & 1444 & 302 & 709 & 343 & 908 & 388 & 675 \\
\hline 285 & 1159 & 269 bis & 1443 & 303 & 719 & $3 / 4$ & 914 & 389 & 677 \\
\hline 926 & 1157 & 970 & 1420 & $303 \mathrm{bis}$ & 777 & 345 & 917 & 390 & 1050 \\
\hline 227 & 1151 & $370 \mathrm{bis}$ & 1421 & 304 & 751 & 346 & 919 & 391 & 1058. \\
\hline 228 & 1138 & 271 & 1416 & 305 & 752 & 347 & 798 & $3_{92}$ I & 1063 \\
\hline 2291 & 1147 & $27^{1}$ bis & 1414 & 306 & 708 & 348 & 796 & $3 g^{2}$ II & 1064 \\
\hline 229 II & 1148 & 279 & 1432 & $306 \mathrm{bis}$ & 739 & 349 & 797 & $3 g_{2}$ III & 1065 \\
\hline $330 \mathrm{I}$ & 1149 & $272 \mathrm{bis}$ & 1435 & 307 & 741 & 350 & 915 & $3_{92}$ IV & 1066 \\
\hline 230 II & 1150 & $27 . \operatorname{ter}$ & 1441 & 308 & 742 & $350 \mathrm{bis}$ & 922 & $39_{2} \mathrm{~V}$ & 1067 \\
\hline 231 I & No non employé & $27^{3}$ & 1417 & $=309$ & 764 & 351 & 923 & 39 a VI & 1068 \\
\hline 231 II & $X$ non enployé & $27^{h}$ & 1430 & 310 & 763 & 352 & 890 & $3_{9}:$ VII & 1069 \\
\hline 232 & 1144 & $27 / \mathrm{bis}$ & 1424 & 311 & 765 & 353 & 928 & $3_{9 a}$ bis & 1058 \\
\hline 233 & 1327 & $274 \operatorname{ler}$ & 1412 & 312 & 736 & 354 & 856 & $3 g^{3}$ & 1100 \\
\hline 2.34 & 1283 & 275 & 1425 & 313 & 729 & 354 bis & 857 & $39^{4}$ & 1102 \\
\hline 235 & 1284 & $275 \mathrm{bis}$ & 1442 & 314 & 783 & 355 & 897 & 395 & 1051 \\
\hline 236 & 1397 & $275 \mathrm{ter}$ & 1419 & $315 \mathrm{~A}$ & 770 & 356 & 898 & 396 & 1052 \\
\hline 937 A & 1333 & $275 \mathrm{D}$ & 1449 & $315 \mathrm{~B}$ & 771 & 3.57 & 904 & 3971 & 1080 \\
\hline $237 \mathrm{~B}$ & 1334 & $275 \mathrm{E}$ & 1450 & $315 \mathrm{C}$ & 772 & 358 & 896 & 397 II & 1081 \\
\hline $237 \mathrm{C}$ & 1335 & 976 & 717 & $315 \mathrm{bis}$ & 767 & 359 & 901 & 398 & 1072 \\
\hline 238 & 1451 & 377 & 1406 & 315 ter $A$ & 768 & 360 & 900 & 399 & 1071 \\
\hline 939 & 1248 & 278 & 1407 & $315 \operatorname{ter} B$ & 789 & 361 & 893 & 400 & 1028 \\
\hline 240 & 1268 & 379 & 1452 & 316 & 930 & 362 & 895 & $400 \mathrm{bis}$ & 1074. \\
\hline 241 & 1269 & 280 & 1453 & 316 bis & 756 & 363 & 902 & 400 ter & 1078 \\
\hline 342 & 1259 & 381 & 1462 & 317 & 931 & 364 & 903 & $401 \mathrm{I}$ & 1088 \\
\hline 243 & 2642 & 282 & 1481 & 318 & 936 & 365 & 957 & 40111 & 1089 \\
\hline 244 & 1281 & 283 & 1459 & 3191 & 941 & 366 & 961 & $401 \mathrm{III}$ & 1090 \\
\hline $2 / 45$ & 1282 & 284 & 1456 & 319 II & 942 & 367 & 959 & 402 & 1079 \\
\hline 246 & 1272 & 285 & 1464 & 320 & 943 & 368 & 965 & 402 bis & 1091 \\
\hline 247 & 1271 & 286 & 1455 & $3_{21}$ & 938 & $368 \mathrm{bis}$ & 968 & 403 & 1093 \\
\hline 248 & 1273 & 287 & 759 & 322 & 940 & $369^{l}$ & 982 & 404 & 1098 \\
\hline 249 & 1276 & 288 & 755 & $3_{2} 3$ & 974 & 369 II & 963 & 405 & 1094 \\
\hline 350 & 1239 & 989 & 727 & $3_{24}$ & 802 & 370 & 980 & 406 & 801 \\
\hline 351 & 1235 & $9^{\circ}$ & 726 & 325 & 852 & 371 & 949 & 407 & 1070 \\
\hline 252 & 1240 & $89^{1}$ & 782 & 326 & 853 & 372 & 877 & 4081 & 987 \\
\hline 253 & 1241 & $29^{2}$ & 749 & $3_{27}$ & 1099 & 373 & 948 & $408 \mathrm{II}$ & 988 \\
\hline 251 & 1242 & $29^{3}$ & 748 & 328 & 883 & 374 & 840 & $408 \mathrm{III}$ & 989 \\
\hline 255 & En déticit & 294 & 747 & 329 & 882 & 375 & 795 & $408 \mathrm{bis}$ & 1026 \\
\hline 256 & 1311 & $295 \mathrm{I}$ & 684 & 330 & 885 & 376 & 978 & 469 & 985 \\
\hline 257 & 1229 & $295 \mathrm{II}$ & 685 & 331 & 888 & 377 & 878 & 410 & 1032 \\
\hline 258 & 1350 & 296 & 689 & $33 \cdot 2$ & 886 & 378 & 822 & $410 \mathrm{bis}$ & 984 \\
\hline
\end{tabular}


TABLES DE GONGORDANGE.

\begin{tabular}{|c|c|c|c|c|c|c|c|c|c|}
\hline $\begin{array}{c}\text { ANCIEN } \\
\text { CATALOGUE. }\end{array}$ & $\begin{array}{c}\text { NOUVEAU } \\
\text { CATALOGUE. }\end{array}$ & $\begin{array}{c}\text { ANCIEX } \\
\text { CATALOGOE. }\end{array}$ & $\begin{array}{c}\text { NOUTEAU } \\
\text { CATALOGUE. }\end{array}$ & $\begin{array}{c}\text { AYCIEN } \\
\text { CITALOGUE. }\end{array}$ & $\begin{array}{c}\text { YOUVEAV } \\
\text { CATALOGUE. }\end{array}$ & $\begin{array}{c}\text { ANCLEN } \\
\text { CATALOGUR. }\end{array}$ & $\begin{array}{c}\text { roUpBIE } \\
\text { CaTALOGLE. }\end{array}$ & $\begin{array}{c}\text { ANGIEN } \\
\text { CATALOGLE. }\end{array}$ & $\begin{array}{c}\text { NOUVRAU } \\
\text { CATILOGUE. }\end{array}$ \\
\hline 411 & 1023 & 451 & 815 & 501 & 734 & 549 & 2424 & $596 \mathrm{I}$ & 1999 \\
\hline 413 & 1027 & 452 & 787 & 503 & 733 & 550 & 2428 & 596 II & 2000 \\
\hline 413 & 1039 & 453 & 925 & 503 & 732 & 551 & 2429 & $5_{97}$ & 2001 \\
\hline 414 & 1038 & 454 & 1041 & 5̄o4 & 1951 & 552 & 2427 & 598 & 2008 \\
\hline 414 bis & 1040 & 455 & 933 & 505 & 1978 & $55_{2}$ bis & 2453 & 599 & 2003 \\
\hline 415 & 1000 & 456 & 952 & 506 & 713 & 55 ater & 2454 & 600 & 1987 \\
\hline $415 \mathrm{bis}$ & 999 & $45_{7}$ & 998 & 507 & 712 & $55_{2}$ IV & $N^{\circ}$ non employé & 600 bis $\mathrm{A}$ & 1990 \\
\hline 416 & 997 & 458 & 1117 & 508 & 716 & 553 & 2438 & 600 bis B & 1993 \\
\hline 417 & 998 & 459 & 953 & 509 & 1385 & 554 & 4838 & 600 bis $\mathrm{C}$ & 1998 \\
\hline 418 & 1004 & 460 & 1029 & 510 & 1310 & 555 & 1371 & 601 I & 1994 \\
\hline 419 & 1012 & 461 & 870 & 511 & 1297 & 556 & 1394 & $601 \mathrm{II}$ & 1995 \\
\hline 430 & 1008 & 463 & 934 & 512 & 1295 & 557 & 1315 & 602 & 1988 \\
\hline 4211 & 1017 & 463 & 1035 & 513 & 1298 & 558 & 1380 & $603 \mathrm{II}$ & 1989 \\
\hline $421 \mathrm{Il}$ & 1018 & 464 & 1025 & 514 & 1294 & 559 & 1337 & Go3 III & 1992 \\
\hline $431 \mathrm{III}$ & 1019 & 465 & 1075 & 515 & 1298 & 560 & 1364 & $603 \mathrm{bis}$ & 1991 \\
\hline $421 \mathrm{IV}$ & 1020 & 466 & 1076 & 516 & 1301 & 561 & 1330 & 603 ter I & 1988 \\
\hline 422 & 1021 & $46_{7}$ & 868 & 517 & 1302 & 562 & 1383 & 603 ter II & 1989 \\
\hline 423 & 1048 & 468 & 868 & 518 & 1304 & 563 & 1373 & 604 & 1980 \\
\hline $4_{22} 3$ bis & 1022 & 469 & $\varepsilon 62$ & 519 & 1363 & 564 & 1374 & $605 \mathrm{I}$ & 1981 \\
\hline 424 & 1009 & $47^{\circ}$ & 1120 & 520 & 1348 & 565 & 1344 & 605 II & 1983 \\
\hline 195 & 1015 & 471 & 1118 & 521 & 1291 & 566 & 1367 & 606 & 1982 \\
\hline $425 \mathrm{lis}$ & 1016 & 473 & 1044 & 523 & 1378 & $56_{7}$ & 1351 & $60_{7}$ & 1881 \\
\hline 426 & 1030 & 473 & 1119 & $5_{2} 3$ & 1318 & 568 & 1377 & 607 bis & 1982 \\
\hline 427 & 1011 & $47^{4}$ & 982 & $52 / 4$ & 1320 & 569 & 1378 & 608 & 1983 \\
\hline 438 & 1003 & $47^{5}$ & 969 & 5.5 & 1319 & 570 & 1368 & 609 & 1997 \\
\hline 429 & 1005 & $47^{6}$ & 955 & 526 & 1325 & 571 & 932 & $f_{10}$ & 1985 \\
\hline 430 & 731 & 477 & 2834 & 527 & 1287 & $57^{2}$ & 1399 & 611 & 1966 \\
\hline 431 & 811 & 478 & 3971 & 528 & 1314 & 573 & 1403 & 612 & 1984 \\
\hline 432 & 891 & 479 & 3549 & 529 & 1292 & 574 & 1356 & 613 & 1949 \\
\hline 433 & 1034 & 480 & 3550 & 530 & 3381 & 575 & 1357 & 6.4 & 1950 \\
\hline 4341 & 993 & 481 & 3499 & 531 & 2316 & 576 & 1400 & 615 & 1945 \\
\hline $434 \mathrm{Il}$ & 994 & 482 & 1973 & 532 & 2317 & 577 & 1401 & 6.6 & 1930 \\
\hline $434 \mathrm{III}$ & 995 & 483 & En défirit & 533 & 2312 & 578 & 1387 & 617 & 1929 \\
\hline 435 & 804 & 484 & 1169 & 534 & 3502 & $5_{79}$ & 1915 & 618 & 1931 \\
\hline 436 & 803 & 485 & 1953 & 534 bis & 1322 & 580 & Ea deficit & $f_{10}$ & Syriaque \\
\hline $436 \mathrm{lis}$ & 805 & 486 & 1955 & 535 & 3509 & 581 & 1383 & 019 & 275 \\
\hline 437 & 810 & 487 & 1954 & 536 & 3503 & 583 & 1355 & 690 & 1938 \\
\hline 438 & 807 & 488 & 1958 & 537 & 3508 & 583 & 3557 & 621 & 1933 \\
\hline 438 bis & 806 & 489 & 1958 & 538 & 3512 & 584 & 1976 & 622 & 1938 \\
\hline 439 & 808 & 490 & 2008 & 539 & 3511 & 585 & 2009 & 623 & 1942 \\
\hline 440 & 842 & 491 & 1977 & 540 & 2417 & 586 & 1950 & 624 & 1943 \\
\hline 442 & 850 & 492 & 1979 & 541 & 2422 & 587 & 1998 & 6.5 & 1941 \\
\hline 442 & 847 & 493 & 1130 & 542 & 2420 & 588 & 1985 & 626 & $N^{\circ}$ non employé \\
\hline 443 & 845 & 494 & 1192 & 543 & 2421 & 589 & 1988 & 627 & 1946 \\
\hline 444 & 927 & 495 & 1190 & 543 bis & 1566 & 590 & 728 & 628 & 1919 \\
\hline 445 & 1107 & 496 & 1191 & 544 & 2451 & 591 & 1975 & 629 & 1920 \\
\hline 446 & 1108 & 497 & 1182 & $544 b i s$ & 2458 & $59^{2}$ & 2015 & 630 & 1922 \\
\hline 447 & 1010 & 498 & 1183 & 545 & 2432 & $5 g^{3}$ & 2010 & $630 \mathrm{bis}$ & 1925 \\
\hline 448 & 1279 & 499 & 1195 & 546 & 2435 & 594 & 2004 & 631 & 1910 \\
\hline 449 & 788 & 499 bis & 1193 & 547 & 2434 & 595 & 2002 & $63_{2}$ & 1909 \\
\hline 450 & 789 & 500 & 735 & 548 & 2428 & ${ }_{9} 5 \mathrm{bis}$ & 2005 & 633 & 1912 \\
\hline
\end{tabular}




\begin{tabular}{|c|c|c|c|c|c|c|c|c|c|}
\hline $\begin{array}{c}\text { ANCIEN } \\
\text { CATALOGUR. }\end{array}$ & $\begin{array}{l}\text { NOUVEAU } \\
\text { CATALOGE. }\end{array}$ & $\begin{array}{c}\text { ANGIEN } \\
\text { CATALOGUE. }\end{array}$ & $\begin{array}{c}\text { NOUVEAO } \\
\text { C.ITALOGE. }\end{array}$ & $\begin{array}{c}\text { ANCIEN } \\
\text { CATALOGUE. }\end{array}$ & $\begin{array}{c}\text { NOUVEAC } \\
\text { CATALOGE. }\end{array}$ & $\begin{array}{c}\text { AXCIEN } \\
\text { CATALOGUR. }\end{array}$ & $\begin{array}{l}\text { Novveau } \\
\text { Catalogue. }\end{array}$ & $\begin{array}{c}\text { ANCIEN } \\
\text { CATALOGUE. }\end{array}$ & $\begin{array}{l}\text { NOUPEAU } \\
\text { CATALOGEE. }\end{array}$ \\
\hline 634 & 1926 & 681 & 3335 & 793 & 1591 & $7^{\text {19 } \mathrm{T}}$ & 1531 & $7^{85}$ & 1673 \\
\hline 635 & 1924 & 682 & 2156 & $7^{24}$ & 1593 & $7^{4.2} \mathrm{U}$ & 1524 & 786 & 1896 \\
\hline 636 & 2014 & 683 & 2119 & 725 & 1702 & $7^{43}$ & 1595 & $7^{87}$ & 1697 \\
\hline 637 & 1309 & 684 & 2128 & 726 & 1570 & 744 & 1468 & 788 & 1701 \\
\hline 638 & $20 \div 1$ & $684 \mathrm{bis}$ & 2129 & 727 & 1608 & 744 bis & 1469 & $7^{8} 9$ & 1683 \\
\hline $63_{9}$ & 1382 & 685 & 2130 & $7^{38}$ & 1552 & $7^{45}$ & 1536 & $79^{\circ}$ & 1816 \\
\hline 640 & 2043 & 686 & 2131 & $7^{29}$ & 1609 & $7^{461}$ & 1584 & 791 & 1689 \\
\hline 641 & 2037 & 687 & 2137 & 730 & 1612 & 746 II & 1585 & 792 & 1692 \\
\hline 642 & 2036 & 688 & 2139 & 731 & 1613 & 747 & 1587 & $79^{3}$ & 1725 \\
\hline $6.19 \mathrm{bis}$ & 2046 & 689 & 2142 & 732 & 1814 & $7^{48}$ & 1510 & $79^{4}$ & 1832 \\
\hline 643 & 2019 & $69^{\circ}$ & 2105 & 733 & 1594 & 749 & 1513 & $79^{5}$ & 1837 \\
\hline 644 & 2033 & 691 & 2149 & 734 & 1563 & 750 & 1508 & $79^{6}$ & 1833 \\
\hline 645 & 2031 & $69^{2}$ & 1592 & 735 & 1562 & $7^{51}$ & 294 & 797 & 1836 \\
\hline 646 & $20 \pm 5$ & 693 & 2012 & $7^{36}$ & 1515 & 751 bis & 295 & $79^{8}$ & 1838 \\
\hline 647 & 2029 & $69^{\prime}$ & 2074 & $7^{3} 7$ & 1542 & $7^{52}$ & 300 & 799 & 2148 \\
\hline 648 & 1361 & $69_{9} 5$ & 2162 & 738 & En délicit & 753 & 1557 & 800 & 1804 \\
\hline $6{ }^{\prime} 9$ & 2024 & $69^{6}$ & $218 t$ & 739 & 1578 & 754 & 1556 & 801 & 1796 \\
\hline 650 & 2023 & 697 & 2007 & $740 \mathrm{I}$ & 1496 & 755 & 1548 & 802 & 1793 \\
\hline 651 & 2018 & 698 & 2067 & 74011 & 1497 & 756 & 1561 & 803 & 1797 \\
\hline $65:$ & 2026 & 699 & 2097 & $740 \mathrm{III}$ & 1500 & 756 bis & 1565 & 804 & 1811 \\
\hline 653 & 2079 & 700 & 2055 & 740 IV & 1501 & $7^{5} 7$ & 1543 & 805 & 1803 \\
\hline 654 & 2080 & 701 & 2056 & $740 \mathrm{~V}$ & 1503 & 758 & 1617 & $8 \circ 6$ & 1806 \\
\hline 655 & 2049 & 702 & 2053 & $740 \mathrm{VI}$ & 1504 & $7^{59}$ & 1612 & 807 & 1805 \\
\hline 655 bis & 2047 & $7^{03}$ & 2060 & 740 bis 1 & 1492 & 760 & 1637 & 808 & 1810 \\
\hline $655 \mathrm{ter}$ & 2048 & 704 & 2051 & 7 ho bis II & 1493 & 761 & $18 \notin 0$ & 809 & 1789 \\
\hline 656 & 305 & 705 & 2059 & $740 \mathrm{bis}$ III & 1494 & 763 & 1639 & 810 & 1704 \\
\hline 657 & 2017 & $7^{06}$ & 2065 & 740 bis IV & 1495 & 763 & 1636 & 811 & 1815 \\
\hline 658 & 1971 & $706 \mathrm{lis}$ & 2064 & 740 bis V & 1499 & 763 bis & 1634 & 812 & 1812 \\
\hline 659 & 2032 & $706 \mathrm{ter}$ & 2155 & $7^{41}$ & 1502 & 764 & 1646 & 813 & 1708 \\
\hline 660 & 2098 & 707 & 2109 & 741 bis & 1493 & $7^{65}$ & 1648 & 814 & 1516 \\
\hline 661 & 2088 & 708 & 2108 & 749 & 1703 & $7^{66}$ & 1645 & 815 & 1773 \\
\hline $66 a$ & 2092 & $7^{\circ 9}$ & 2110 & $742 \mathrm{~A}$ & 1488 & $7^{67}$ & 2127 & $815 \mathrm{bis}$ & 1778 \\
\hline 663 & 2011 & 710 & 2107 & $742 B$ & 1517 & $7^{68}$ & 3837 & 816 & 1778 \\
\hline 664 & 2044 & 711 & 2111 & $742 \mathrm{C}$ & 1518 & $7^{69}$ & 3838 & $816 \mathrm{bis}$ & 1779 \\
\hline 665 & 2089 & 712 & 2186 & $742 \mathrm{D}$ & 1519 & $77^{\circ}$ & 1894 & 817 & 1715 \\
\hline 666 & 2091 & 713 & 1584 & $742 \mathrm{E}$ & 1520 & $77^{1}$ & 1895 & 817 bis & 1716 \\
\hline 667 & 2090 & $713 \mathrm{bis}$ & 1489 & $742 \mathrm{~F}$ & 1521 & $77^{2}$ & 2145 & 818 & 1710 \\
\hline 668 & 725 & 7141 & 1478 & $742 \mathrm{G}$ & 1522 & $77^{3}$ & 1905 & 819 & 1714 \\
\hline 669 & 2103 & $714 \mathrm{II}$ & 1477 & $7^{4}$ a II & 1523 & $77^{4}$ & 1904 & 820 & 1817 \\
\hline $67^{\circ}$ & 2134 & 715 & 1479 & $-4,1$ & (A rabe (cat.ms.) & $77^{5}$ & 1901 & $8=1$ & 1818 \\
\hline $67^{1}$ & 2135 & $716 \mathrm{I}$ & 1480 & 7421 & 5076 & $77^{6}$ & 1791 & 82. & 1860 \\
\hline $67^{2}$ & 2112 & $716 \mathrm{II}$ & 1481 & $7^{4}$ a J & 1526 & 777 & 1661 & 823 & 1706 \\
\hline $6_{7} 3$ & 2113 & $716 \mathrm{III}$ & 1482 & $7^{43 \mathrm{~K}}$ & 1525 & 778 & 1662 & 894 & 1849 \\
\hline $673 \mathrm{bis}$ & 2114 & $716 \mathrm{IV}$ & 1483 & 7/12L & 1534 & 779 III & 1658 & 8,5 & 1840 \\
\hline $67^{4}$ & 2116 & 717 & 1473 & $\gamma^{4}$ a M & 1529 & $779 \mathrm{~V}$ & 1657 & 8,6 & 1842 \\
\hline 675 & 2077 & 717 bis & 1475 & $74.2 \mathrm{~N}$ & 1530 & $779 \mathrm{II}$ & 1658 & 827 & 1848 \\
\hline${ }^{6} 7^{6}$ & 2083 & 718 & 1474 & 7420 & 1533 & 780 & 1659 & 828 & 1848 \\
\hline 677 & 3320 & 719 & 1471 & $749 \mathrm{P}$ & 1535 & $7^{81}$ & 1863 & 829 & 1839 \\
\hline $67^{8}$ & 2122 & 720 & 1821 & 7420 & 1527 & $7^{82}$ & 308 & 830 & 1841 \\
\hline 679 & 2121 & 721 & 1597 & $742 \mathrm{~K}$ & 1528 & 783 & 1675 & 831 & 1851 \\
\hline 680 & 2163 & 722 & 1507 & $7^{42 S}$ & 1532 & 784 & 672 & 839 & 1850 \\
\hline
\end{tabular}


TABLES DE GONGORDANCE.

\begin{tabular}{|c|c|c|c|c|c|c|c|c|c|}
\hline $\begin{array}{c}\text { ANGIEN } \\
\text { CATALOGUE. }\end{array}$ & $\begin{array}{c}\text { NOUVEAT } \\
\text { C.ITALOGEE. }\end{array}$ & $\begin{array}{c}\text { ANGiex } \\
\text { CATALOGUE. }\end{array}$ & $\begin{array}{l}\text { Nolvead } \\
\text { Catiloger. }\end{array}$ & $\begin{array}{c}\text { ANCIEN } \\
\text { CATILOGUE. }\end{array}$ & $\begin{array}{l}\text { NOUVEAU } \\
\text { CATALOGUE. }\end{array}$ & $\begin{array}{c}\text { AXC1EN } \\
\text { CATALOGUE. }\end{array}$ & $\begin{array}{c}\text { NOUVEAU } \\
\text { CATALOGLE. }\end{array}$ & $\begin{array}{c}\text { ANCIEN } \\
\text { CATALOGLE. }\end{array}$ & $\begin{array}{c}\text { NOUVEAU } \\
\text { CATALOOUE. }\end{array}$ \\
\hline 833 & 1828 & 872 & 2785 & 910 & 2289 & $9^{51}$ & 2469 & $9^{8} 9$ & 2833 \\
\hline 834 & 1829 & $873 \mathrm{I}$ & 2795 & 911 & 2288 & $9^{51}$ bis & 2484 & $99^{\circ}$ & 2674 \\
\hline 835 & 1830 & 873 bis & 2796 & $911 \mathrm{his}$ & 2285 & $9^{5}+$ ter & 2463 & $99^{1}$ & 2827 \\
\hline 836 & 1831 & $873 \mathrm{ter}$ & 2786 & 911 ter & 2283 & $9^{52}$ & 2459 & $99^{2}$ & 2816 \\
\hline 837 & 1828 & $87^{4}$ & 2799 & 912 & 2294 & $95_{3}$ bis & 2457 & $99^{3}$ & 2817 \\
\hline 838 & 1789 & 875 & 2798 & $912 \mathrm{bis}$ & 2286 & 953 & 2554 & $99^{4}$ & 2813 \\
\hline 839 & 1705 & 876 & 2772 & $9^{13}$ & 2249 & $953 \mathrm{bis}$ & 2555 & $99^{5}$ & 2815 \\
\hline $840 \mathrm{I}$ & 1861 & 877 & 3004 & $9^{14}$ & 2248 & $9^{54}$ & 2548 & $99^{6}$ & 2820 \\
\hline 840 II & 1862 & 878 & 2775 & $9^{15}$ & En déficit & 954 bis & 2504 & 997 & 2818 \\
\hline 840 III & 1863 & 879 & 2780 & 916 & 2237 & 955 & 2468 & 997 bis & 2812 \\
\hline $841 \mathrm{I}$ & 1864 & 880 & 2773 & 917 & 2238 & 955 bis & 2467 & $99^{8}$ & 2556 \\
\hline 841 II & 1865 & 881 & 2777 & 918 & 2252 & $9^{56}$ & 2186 & $99^{8}$ bis & 2836 \\
\hline 841 III & 1866 & 889 & 2808 & 919 & 2258 & 957 & 2515 & 999 & 2838 \\
\hline 842 & 1857 & 883 & 2807 & 930 & 2285 & 958 & 2514 & 1000 & 2841 \\
\hline 843 & 1853 & 883 bis & 2808 & 931 & 2258 & $9^{5} 9$ & 2527 & 1001 & 2844 \\
\hline 844 & 1854 & 884 & 2809 & 922 & 1781 & $9^{60}$ & 2526 & 1002 & 2859 \\
\hline 845 & 1722 & 885 & 2215 & 923 & 1747 & $9^{61}$ & 2551 & $1002 \mathrm{bis}$ & 2851 \\
\hline 846 & No non employé & 885 bis & 2216 & 933 bis & 1759 & $961 \mathrm{bis}$ & 2589 & 1002 ter & 2846 \\
\hline 847 & 1820 & 885 ter & 2217 & $9^{24}$ & 1748 & $9^{62}$ & 2509 & 1003 & 2863 \\
\hline 848 & 1858 & $886 \mathrm{I}$ & 2226 & 924 II & $\mathrm{N}^{\circ}$ non employé & $9^{63}$ & 2510 & 1004 & 2867 \\
\hline 849 & 1720 & 886 II & 2227 & 925 & 1748 & $9^{64}$ & 2491 & 1005 & 2866 \\
\hline 850 & 1858 & $886 \mathrm{III}$ & 2228 & $925 \mathrm{bis}$ & 1763 & 964 bis & 2492 & 1006 & 2915 \\
\hline $850 \mathrm{bis}$ & 1890 & $886 \mathrm{IV}$ & 2229 & $9^{26}$ & 1734 & $9^{65}$ & 2495 & $1006 \mathrm{~A}$ & 2885 \\
\hline 850 ter & 1893 & $886 \mathrm{~V}$ & 2230 & 926 bis & 1735 & $9^{66}$ & 2513 & $1006 \mathrm{~B}$ & 2886 \\
\hline 851 & 1887 & 886 VI & 2231 & $9^{27}$ & 1750 & $9^{67}$ & 2531 & $1006 \mathrm{C}$ & 2857 \\
\hline 852 & 1874 & 887 & 2247 & 927 bis & 1755 & $9^{68}$ & 2535 & $1006 \mathrm{D}$ & 2888 \\
\hline 852 bis & 1878 & 888 & 2189 & $9^{28}$ & En déficit & 968 bis & 2538 & $1006 \mathrm{E}$ & 2889 \\
\hline $85 a t e r$ & 1876 & 889 & 2219 & 929 & 1754 & $9^{6} 9$ & 2518 & $1006 \mathrm{~F}$ & 2890 \\
\hline 853 & 1868 & 890 & 2233 & 930 & 1749 & $97^{\circ}$ & 2539 & $1006 \mathrm{G}$ & 2891 \\
\hline 853 bis & 1870 & 891 & 2232 & $9^{31}$ & 1765 & $97^{\circ}$ bis I & 2537 & $1006 \mathrm{H}$ & 2914 \\
\hline 853 ter & 1869 & 891 bis & 2292 & $9^{32}$ & 2284 & $97^{\circ}$ bis II & 2538 & 1007 & 2892 \\
\hline 854 & 1871 & 892 & 2221 & $9^{33}$ & 2259 & $97^{1}$ & 2542 & 1008 & 2884 \\
\hline 855 & 1826 & $8 g^{3}$ & 2222 & $9^{34}$ & 2280 & $971 \mathrm{bis}$ & 2546 & 1009 & 2895 \\
\hline 856 & 1627 & $8 g^{4}$ & 2223 & y35 & 2270 & $97^{2}$ & 2565 & 1010 & 2906 \\
\hline 857 & 1824 & 895 & 2224 & $9^{36}$ & 2272 & $97^{3}$ & 2597 & 1011 & 2901 \\
\hline 857 bis & 1621 & 895 bis & 2213 & $9^{3} 7$ & 2288 & $97^{4}$ & 2584 & 1012 & 2903 \\
\hline 858 & 1623 & 896 & 2201 & $9^{38}$ & 2267 & $97^{5}$ & 2603 & 1013 & 2907 \\
\hline 859 & 2768 & 897 & 2195 & $9^{3} 9$ & 2269 & $97^{6}$ & 2804 & 1014 & 2912 \\
\hline 860 & 2769 & $89^{8}$ & 2202 & 940 & 2275 & 977 & 2569 & 1015 & 2935 \\
\hline 861 & 2169 & 899 & 2203 & 941 & 2276 & $97^{8}$ & 2570 & $1015 \mathrm{bis}$ & 2937 \\
\hline 862 & 2171 & 900 & 2190 & 941 bis & 2274 & 979 & 2561 & 1016 & 2913 \\
\hline 863 & 2170 & 901 & 1487 & $9^{42}$ & 2277 & $9^{80}$ & 2586 & 1017 & 2938 \\
\hline 864 & 2175 & 902 & 2279 & $9^{43}$ & 2297 & $9^{81}$ & 2563 & 1018 & 2908 \\
\hline 865 & 2182 & $9^{\circ 3}$ & 2212 & $9^{44}$ & 2298 & $9^{82}$ & 2576 & 1019 & 2917 \\
\hline 866 & 2178 & $9^{\circ 4}$ & 2208 & $9^{45}$ & 2298 & $9^{83}$ & 2579 & 1020 & 2930 \\
\hline 867 & 2176 & $9^{05}$ & 2207 & $9^{46}$ & 2299 & $9^{84}$ & 2479 & & Français, \\
\hline 868 & 2181 & 906 & 2210 & $9^{4} 7$ & 1685 & $9^{85}$ & 2476 & 1030 bis & nouv. acq. \\
\hline 869 & 4658 & $9^{\circ 6}$ bis & 2225 & 948 & 313 & 986 & 2832 & & 4355 \\
\hline $87^{\circ}$ & 2793 & 907 & 2291 & $9^{4} 9$ & 312 & $9^{8} 7$ & 2831 & 1021 & 2997 \\
\hline 870 bis & 2797 & 908 & 2290 & 950 & 2471 & $9^{88}$ & 2829 & 1022 & 2943 \\
\hline 871 & 2794 & $9 \circ 9$ & 2287 & $9^{50}$ bis & 2475 & 988 bis & 2824 & 1023 & 3000 \\
\hline
\end{tabular}




\begin{tabular}{|c|c|c|c|c|c|c|c|c|c|}
\hline $\begin{array}{c}\text { AYCIEX } \\
\text { CATALOGUE. }\end{array}$ & $\begin{array}{l}\text { NOEVEAO } \\
\text { CITALOEE. }\end{array}$ & $\begin{array}{c}\text { Aycien } \\
\text { CATALOGUE. }\end{array}$ & $\begin{array}{c}\text { NOUVRAC } \\
\text { CATALOGE. }\end{array}$ & $\begin{array}{c}\text { AXCIEN } \\
\text { CATALOGLE. }\end{array}$ & $\begin{array}{c}\text { NOUVEAU } \\
\text { CATALOGUE. }\end{array}$ & $\begin{array}{c}\text { ANCIEN } \\
\text { CATALOGUE. }\end{array}$ & $\begin{array}{c}\text { NOUVEAU } \\
\text { CITALOGUF. }\end{array}$ & $\begin{array}{l}\text { AXCiEN } \\
\text { CATALOGUE. }\end{array}$ & $\begin{array}{c}\text { NOUVEad } \\
\text { CATILOGUE. }\end{array}$ \\
\hline 100,1 & 2883 & 1066 & 2994 & 1113 & 2632 & 1161 & .091 & 1207 & 4123 \\
\hline 1025 & 2977 & 1067 & 2849 & 1114 & 2734 & $1: 62$ & 4092 & $1207 b \mathrm{is}$ & 4142 \\
\hline $1095 \mathrm{bis}$ & 2984 & 1068 & 3302 & 1115 & 2731 & 1163 & 4093 & 1207 ter & 4182 \\
\hline 1026 & 2980 & 1069 & 2619 & 1116 & 2711 & 1164 & 4094 & 1208 & 4192 \\
\hline 1026 lis & 2982 & $100 \hat{9}$ bis & 2626 & 1117 & 2694 & 1165 & 4116 & 1209 & 4194 \\
\hline $1026 \mathrm{ter}$ & 2985 & $107^{\circ}$ & 2623 & 1118 & 2733 & 1166 & 4088 & 1210 & 4190 \\
\hline $1026 \mathrm{IV}$ & 2983 & 1071 & 2624 & 1119 & 2310 & 1167 & 4111 & 1211 & 4193 \\
\hline 1027 & 2936 & 1072 & 2625 & 1120 & 2664 & 1168 & 4074 & $1211 \mathrm{bis}$ & 4198 \\
\hline 1028 & 2983 & $107^{3}$ & 2607 & 1121 & 2692 & 1169 & 4112 & 1212 & 4186 \\
\hline 1039 & 2991 & 1074 & 2827 & 1122 & 2641 & $117^{\circ}$ & 4113 & 1313 & 4183 \\
\hline 1039 bis & 3032 & $107^{\prime} \mathrm{bis}$ & 2609 & 1133 & 2736 & 1171 & 4110 & 1214 & 4175 \\
\hline 1030 & 2967 & 1075 & En déficit & 1124 & 2723 & 1172 & 4097 & 1215 & Én déficit \\
\hline 1031 & 2993 & 1076 & 2628 & 1125 & 2708 & 1173 & 4076 & 1216 & 4176 \\
\hline 1032 & 2931 & 1077 & 2855 & 1196 & 2593 & $117^{4}$ & 4099 & 1217 & 4181 \\
\hline 1033 & 2921 & $107^{8}$ & 2813 & $1196 \mathrm{bis}$ & 2593 & 1175 & 4114 & 1218 & 4177 \\
\hline 1034 & 2929 & 1079 & 2618 & 1137 & 2590 & $117^{6}$ & 4077 & 1219 & 4145 \\
\hline 1035 & 2926 & 1080 & 2606 & 1128 & 2598 & 11771 & $40 \equiv 3$ & 1220 & 4148 \\
\hline 1036 & 3009 & 1081 & 2629 & 1129 & 2591 & $1177 \mathrm{II}$ & 4035 & 1920 bis & 4148 \\
\hline 1037 & S' non employé & 1082 & 2621 & 1130 & $25=5$ & 1178 & $40 \Xi 0$ & $1220 \mathrm{ter}$ & 4147 \\
\hline 1038 & 3544 & 1083 & 2737 & 1131 & 2581 & 1179 & 4078 & 1221 & 4209 \\
\hline 1039 & 3037 & 1084 & 2671 & $113_{2}$ & 2586 & 1180 & 4031 & 1222 & 4033 \\
\hline 1040 & .3034 & 1085 & 2710 & 1133 & 2583 & $118 n b i s$ & 4034 & 1233 & 3991 \\
\hline 1041 & 2968 & $1085 \mathrm{bis}$ & 2709 & 1134 & En d'ficil & 1181 & 4036 & 1224 & 3989 \\
\hline $1041 \mathrm{bis}$ & 2969 & 1086 & 2683 & 1135 & 2587 & 1182 & 4102 & 1225 & 3993 \\
\hline $10 / 4$ & 3008 & 1087 & 2646 & $1135 \mathrm{bis}$ & 2582 & 1183 & $410 \prime$ & 1296 & 4161 \\
\hline 1043 & 2999 & $1088 I$ & 2652 & 1136 & 2756 & 1184 & 4103 & 1227 & 4191 \\
\hline 1044 & 3007 & $1088 \mathrm{II}$ & 2653 & 1137 & 2757 & 1185 & 4101 & 1238 & 4154 \\
\hline 1045 & 3016 & 1089 & 2654 & 1137 bis & 2754 & 1186 & 4105 & 1229 & 4153 \\
\hline 1046 & 2948 & 1090 & 2655 & 1138 & 2753 & 1186 II & 4106 & 1230 & 4062 \\
\hline 1047 & 3048 & 1091 & 2648 & 139 & 2750 & 1187 & 4103 & 1231 & 4015 \\
\hline 1048 & 3020 & $\log 2$ & En déficit & 1140 & 2749 & 1187 II & 4109 & 1232 & 4157 \\
\hline 1049 & 3021 & $\log 3$ & 2640 & 1111 & 2751 & 1188 & 4117 & 1233 & 4156 \\
\hline 1050 & 3022 & $\log 4$ & 2309 & 1149 & 2747 & 1189 & 4115 & 1234 & 4143 \\
\hline 1051 & 3046 & $109^{5}$ & 2635 & 1143 & 2746 & $119^{\circ}$ & 4126 & 1235 & 4031 \\
\hline 1052 & 2691 & $\log 6$ & 2301 & 1144 & 2745 & 1191 & 4126 & 1236 & 4011 \\
\hline 1053 & 3027 & 1097 & 2300 & 1145 & 2752 & 1192 & 4132 & 1237 & 4024 \\
\hline 1054 & 3003 & $\log 8$ & 2686 & 1146 & 4647 & 1193 & 4131 & 1238 & 4019 \\
\hline 1055 & 3043 & 1099 & 2665 & 1147 & 4648 & $119^{4}$ & 4137 & 1239 & 4020 \\
\hline 1056 & 3030 & 1100 & 2735 & 1148 & 4215 & $119^{5}$ & 3996 & & Na 1 du fonds \\
\hline 1057 & 2959 & 1101 & 2680 & 1149 & 4213 & 1196 & 3998 & $12 / 40$ & $\begin{array}{l}\text { des livres } \\
\text { imprimés }\end{array}$ \\
\hline 1058 & 2856 & 1102 & Nonon employé & 1150 & 4216 & 1197 & 3994 & & en Orient. \\
\hline 1059 & 2953 & 1103 & 2668 & 1151 & 4217 & $119^{8}$ & 4040 & 1241 & 4017 \\
\hline 1060 & 3013 & 1104 & 4597 & 1152 & 4218 & $119^{8}$ bis & 4039 & 1243 & 4005 \\
\hline 1060 bis & 3014 & 1105 & 2660 & 1153 & 4219 & 1199 & 4035 & $1242 \mathrm{bis}$ & 4008 \\
\hline 1061 & 2945 & 1106 & 2724 & 1154 & 4220 & 1300 & 4050 & 1243 & 4001 \\
\hline $1061 \mathrm{bis}$ & 3045 & 1107 & $N^{\circ}$ nos employé & 1155 & 3987 & 1201 & 4047 & 1246 & 4002 \\
\hline 1062 & 2963 & 1108 & 2725 & 1156 & 4072 & 1202 & 4046 & 1345 & 4081 \\
\hline 1063 & 3049 & 1109 & 2633 & 1157 & 4071 & 1203 & 4042 & 1246 & 4058 \\
\hline 1064 & 3039 & 1110 & 2767 & 1158 & 4073 & 1204 & 4053 & $1246 \mathrm{bis}$ & $405 \theta$ \\
\hline $1064 \mathrm{bis}$ & 3050 & 1111 & 2831 & 1159 & 4069 & 1205 & 4057 & 1247 & 4199 \\
\hline 1065 & 2868 & 1112 & 2730 & 1160 & 4070 & 1206 & 4028 & 1248 & 4202 \\
\hline
\end{tabular}


TABLES DE GONGORDANGE.

\begin{tabular}{|c|c|c|c|c|c|c|c|c|c|}
\hline $\begin{array}{c}\text { axcien } \\
\text { Catalogue. }\end{array}$ & $\begin{array}{c}\text { NOUVEAU } \\
\text { CATALOGUE. }\end{array}$ & $\begin{array}{c}\text { ANCiex } \\
\text { Catalogue. }\end{array}$ & $\begin{array}{c}\text { NOUVEAU } \\
\text { C.ITALOGUE. }\end{array}$ & $\begin{array}{c}\text { ANCIEY } \\
\text { GATALOGUE. }\end{array}$ & $\begin{array}{c}\text { Novveau } \\
\text { CaTalogue. }\end{array}$ & $\begin{array}{c}\text { ANCIEN } \\
\text { CATALOGUE. }\end{array}$ & $\begin{array}{c}\text { NOLVEAU } \\
\text { CATALOGUE. }\end{array}$ & $\begin{array}{c}\text { ANCEN } \\
\text { CATALOGUE. }\end{array}$ & $\begin{array}{c}\text { NOUYaAU } \\
\text { CATALOGUE. }\end{array}$ \\
\hline 1249 & 4197 & $1: 95$ & 4408 & 1340 & 2333 & 1382 & 4316 & 1421 & 3278 \\
\hline 1950 & 4171 & 1296 & 4410 & 1341 & 4584 & 1383 & 4330 & 1422 & 3275 \\
\hline 1951 & 4195 & 1297 & 4409 & $134: 3$ & 4600 & 1384 & 4334 & 1423 & 3280 \\
\hline 1252 & 4205 & $129^{8}$ & 4412 & 1343 & 2347 & 1385 & 4333 & 1424 & 3274 \\
\hline 1253 & 4536 & 1299 & En défirit & 1314 & 2400 & 1386 & 4331 & 1425 & 3273 \\
\hline 1254 & 4198 & 1300 & 4405 & 1345 & 4583 & 1387 & 4332 & $1 / 426$ & 3078 \\
\hline 1255 & 4533 & 1301 & 4416 & 1346 & 3420 & 1388 & 4288 & 1426 bis & 3077 \\
\hline 1956 & 4208 & 1302 & 4428 & 1347 & 3301 & 1389 & 4282 & 1427 & 3286 \\
\hline 1257 & 4159 & 1303 & 4.384 & 1348 & 4432 & $13 g^{\circ}$ & 4366 & 1428 & 3078 \\
\hline 1958 & 4180 & 1304 & 4385 & 1349 & 4437 & 1391 & 4387 & 1429 & 3079 \\
\hline 1259 & 4058 & 1305 & 4417 & 1350 & 4443 & 1392 & 4384 & 1430 & 3081 \\
\hline 1260 & 4208 & 1306 & No non employé & 1351 & 4435 & 139 a bis & 4356 & 1431 & 3080 \\
\hline 1261 & 4121 & 1307 & 4430 & 1359 & 4442 & 1393 & 4363 & 1432 & 3084 \\
\hline 1262 & 4165 & 1308 & 4426 & $1352 \mathrm{bis}$ & 4636 & $139^{4}$ & 4465 & 1433 & 3090 \\
\hline 1963 & 4211 & 1309 & 4423 & 1353 & 4445 & 1395 & 4481 & 1434 & 3281 \\
\hline 1264 & 4328 & 1310 & 4429 & 1354 & 4537 & $1396 \mathrm{I}$ & 4270 & $1 / 435$ & 3285 \\
\hline & Syriaque & 1311 & 4425 & 1355 & & 1396 II & 4271 & 1436 & 3284 \\
\hline 1200 & 282 & 1312 & 4.24 & $1355 \mathrm{~A}$ & 4421 & 1397 & 4468 & ${ }_{1} 437$ & 3283 \\
\hline & (Persan (Suppl.) & 1313 & 4431 & 1356 & 4453 & 1397 bis & 4466 & 1438 & 3282 \\
\hline 1200 & 1175 & 1314 & En déficit & 1357 & 4251 & 1398 & 4467 & 1439 & 3109 \\
\hline & Syriague & 1315 & 2450 & 1358 & 4370 & 1399 & 4469 & 1440 & 3110 \\
\hline 1267 & 287 & 1316 & 4282 & 1359 & 3337 & 1399 bis & .4473 & 1441 & 3112 \\
\hline 1968 & 4456 & $13{ }_{1} 6$ bis I & 3985 & 1359 bis & 4232 & 1400 & 4476 & 1442 & 3151 \\
\hline 1269 & 4455 & 1316 bis II & 3986 & 1360 & 4244 & $1400 \mathrm{bis}$ & 4458 & 1443 & 3158 \\
\hline $127^{\circ}$ & 4447 & $1316 \mathrm{ter}$ & 3984 & $136 t$ & 4243 & $1 / 401$ & 4472 & 1444 & 3155 \\
\hline 1271 & $44: 8$ & 1317 & 2402 & 1363 & 4241 & 1403 & 4477 & $14 / 45$ & 3150 \\
\hline 1972 & 4449 & 1318 & 24.03 & 1363 & 4242 & 1403 & 4473 & $1 / 146$ & 3152 \\
\hline $127^{3}$ & 4450 & 1319 & 2404 & 1364 & 4233 & $140 \%$ & 4470 & 1447 & 3158 \\
\hline $127^{4}$ & 4371 & 1320 & 2394 & 1364 bis & 4252 & $1 / 405$ & 4475 & $1447 \mathrm{bis}$ & 3147 \\
\hline 1274 bis & 4419 & 1320 bis & 2393 & 1365 & 4267 & 1405 bis & 4474 & 1448 & 315t \\
\hline $127^{5}$ & 4383 & 1321 & 2395 & 1366 & 4266 & $1 / 406$ & 3308 & 1449 I & 3159 \\
\hline $127^{6}$ & 4381 & 1322 & 2398 & $1367 \mathrm{I}$ & 4283 & 1407 & 3311 & 1449 II & 3160 \\
\hline 1977 & 4380 & 13.3 & 2371 & ${ }_{1367}$ II & 4264 & 1408 & 3312 & 1449 III & $\mathbf{3 1 8 1}$ \\
\hline $127^{8}$ & 4382 & 1324 & 2375 & 13681 & 4273 & 1409 & 3310 & $1449 \mathrm{IV}$ & 3162 \\
\hline 1279 & 4378 & $1324 \mathrm{bis}$ & 2372 & $\mathbf{1 3 6 8}$ II & 4271 & 1410 & 3313 & $1 / 450$ & 3168 \\
\hline 1280 & 4397 & 1325 & 2376 & 1369 & 4277 & 1411 & 3332 & 1451 & 3165 \\
\hline 1981 & 4390 & 1326 & 2377 & $137^{\circ}$ & 4289 & 1419 & 2136 & $1451 \mathrm{bis}$ & 3164 \\
\hline 1982 & 4390 & 1397 & 2378 & 1371 & 4247 & 1413 & 3514 & 1452 & 3163 \\
\hline 1 \& 83 & 4391 & $1327 \mathrm{bis}$ & 2385 & 1371 bis & 4248 & $1414 \mathrm{I}$ & 3292 & 1453 & N' non enployé \\
\hline 1284 & 4388 & 1328 & 2380 & 1372[ & 4249 & 1414 II & 3293 & $1 / 54$ & 3184 \\
\hline 1285 & 4394 & 1329 & 2358 & 137 a bis & 4250 & 1414 III & $329 \pm$ & 1455 & 3189 \\
\hline 1286 & 4393 & 1330 & 2355 & ${ }_{13} 7^{3}$ & 4349 & $1414 \mathrm{IV}$ & 3293 & 1456 & 3180 \\
\hline 1287 & 4401 & 1331 & 2358 & $137^{\prime \prime}$ & 4279 & 1415 & 3297 & 1456 bis & 3181 \\
\hline 1288 & 4403 & 1332 & 2336 & 1375 & 4280 & 1416 & 3293 & 1457 & 3179 \\
\hline 1289 & 4402 & 1333 & 2388 & $137^{6}$ & 4254 & 1417 & 3296 & $1457 \mathrm{bis}$ & 3178 \\
\hline 1290 & 4398 & 1334 & 3951 & 1377 & 4281 & $1 / 118$ & 3290 & 1458 & 3190 \\
\hline $129^{1}$ & 4401 & 1335 & 2409 & ${ }_{1} 3_{7}^{8}$ & 4641 & 1418 bis I & 3287 & 1459 & 3185 \\
\hline $1 \mathrm{ag}^{1}$ bis & 4399 & 1336 & 2391 & 1378 bis & 4278 & 1418 bis II & 3288 & 1460 & 3183 \\
\hline $129^{2}$ & 4414 & 1337 & 2349 & 1379 & 4303 & $1 / 118$ bis III & 3289 & $146 t$ & 3194 \\
\hline 1293 & 4415 & 1338 & 2387 & 1.380 & 4317 & 1419 & 4454 & 1462 & 3193 \\
\hline $129^{\prime}$ & 4413 & 1339 & 2411 & 1381 & 4310 & 1420 & 3279 & 1463 & 3187 \\
\hline
\end{tabular}




\begin{tabular}{|c|c|c|c|c|c|c|c|c|c|}
\hline $\begin{array}{c}\text { AXCIEN } \\
\text { CATILOGUE. }\end{array}$ & $\begin{array}{c}\text { NOUVEAU } \\
\text { CITLLOTUE. }\end{array}$ & $\begin{array}{c}\text { ANCAEY } \\
\text { GATALOGEE. }\end{array}$ & $\begin{array}{l}\text { NOEVEAU } \\
\text { CATALOGLE. }\end{array}$ & $\begin{array}{c}\text { ANCIEN } \\
\text { GATALOGLE. }\end{array}$ & $\begin{array}{l}\text { NOEVEAU } \\
\text { CATALOGUE. }\end{array}$ & $\begin{array}{c}\text { ANCIEN } \\
\text { G.ITALOGUE. }\end{array}$ & $\begin{array}{l}\text { NOCVEAU } \\
\text { CATALOGUE. }\end{array}$ & $\begin{array}{c}\text { ANCIEN } \\
\text { CITALOGUE. }\end{array}$ & $\begin{array}{l}\text { NOUVRAU } \\
\text { CATALOGUR. }\end{array}$ \\
\hline 1464 & 3192 & $151 /$ & 3229 & 1565 & 3408 & 1614 & 3946 & 1661 & 3562 \\
\hline $1 / 165$ & 3248 & 1515 & 3231 & 1566 & 3443 & 16151 & 3944 & $166_{2}$ & 3559 \\
\hline $1 / 666$ & 1620 & 1516 & 3230 & 1567 & 3368 & $1615 \mathrm{Il}$ & 3945 & 1663 & 3561 \\
\hline${ }_{1} 1,67$ & 3197 & 1517 & 3209 & 1568 & 3286 & 1616 & 3928 & 1664 & $N^{\circ}$ mon employé \\
\hline 1468 & 3195 & 1518 & 3135 & 1569 & 3452 & 1617 I & 3942 & 1665 & 3588 \\
\hline 1469 & 3196 & 1519 & 3246 & 1570 & 3391 & ${ }_{1617}$ II & 3943 & $1666 I$ & 3579 \\
\hline 1470 & 3198 & 1520 & 3260 & 1571 & 3271 & 1618 & 3929 & 1666 II & 3580 \\
\hline 1471 & 1251 & 1521 & 3241 & $157^{2}$ & 3446 & 1619 & 3935 & 1667 & 3580 \\
\hline $147^{2}$ & 3118 & 1522 & 3208 & 1573 & $3 \$ 44$ & 16801 & 3267 & 1668 & 3574 \\
\hline${ }_{14}^{4} 3$ & 3123 & 1523 & 3254 & $157 /$ & 3428 & $1620 \mathrm{II}$ & 3268 & 1669 & 3573 \\
\hline 1474 & 3125 & 1534 & 3258 & 1575 & 4547 & 1621 & 3289 & $167^{\circ}$ & 3570 \\
\hline 1475 & 3122 & 1525 & 3235 & 1576 & 3242 & 1622 & 3481 & 1671 & 3588 \\
\hline $1 / 7^{6} 6$ & 3121 & 1526 & 3247 & 1577 & 3228 & 1623 & 3407 & $167^{3}$ & 3577 \\
\hline $1 / 77$ & 3124 & 1527 & 2822 & 1578 & 3253 & 1624 & 4599 & 1673 & 3493 \\
\hline $1 / 78$ & 3200 & 1528 & 3272 & 1579 & 3170 & 1685 & 3584 & $167^{4}$ & 3438 \\
\hline 1479 & 3399 & 1529 & 3263 & 1580 & 3169 & 1626 & 3566 & 1675 & 3545 \\
\hline 1480 & 3400 & 1530 & $323:$ & $1580 \mathrm{bis}$ & 3187 & 1627 & 3565 & 1676 & 3673 \\
\hline 1481 & 3393 & 1531 & 3174. & 1581 & 3213 & 1628 & 3567 & 1677 & 3874 \\
\hline $148 \%$ & 3395 & 1532 & $3 \pm 21$ & $158 \mathrm{a}$ & 3238 & 1629 & 3958 & 1678 & 3821 \\
\hline 1483 & 3300 & 1533 & 3438 & 1583 & 3338 & 9630 & 3959 & 1679 & 3681 \\
\hline 1484 & 309 & 1534 & 3245 & 1584 & 3206 & 1031 & 3960 & 1680 & 3884 \\
\hline 1485 & 3105 & 1535 & 3426 & 1585 & 3224 & 1632 & 3974 & 1681 & 3683 \\
\hline 1486 & 3108 & 1536 & 3437 & 1586 & 3364 & 1633 & 3975 & 1682 & 3686 \\
\hline 1487 & 3095 & 1537 & 3433 & 1587 & 3202 & 1634 & 3968 & 1683 I & 3888 \\
\hline 1488 & 3099 & 1538 & 3414 & 1588 & 3201 & 1635 & 3976 & 1683 II & 3689 \\
\hline $1: 89$ & 3137 & 1539 & 3434 & 1589 & 3199 & 1636 & 3977 & 1683 III & 3690 \\
\hline 1490 & 3104 & 1540 & $3 \div 10$ & $159^{\circ}$ & 3203 & 1637 & 3978 & $1683 \mathrm{IV}$ & 3691 \\
\hline $1 / 491$ & 3107 & 1541 & ...? Turc (Sup.) & 1591 & 3303 & 1638 & 3979 & $1683 \mathrm{~V}$ & 3692 \\
\hline 1499 & 3222 & 1542 & 3227 & 1592 & 3265 & 1639 & 3980 & $1683 \mathrm{VI}$ & 3693 \\
\hline 1193 & 3223 & 1543 & No mon employé & 1593 & 3252 & 1640 & 3981 & ${ }_{1} 683 \mathrm{VII}$ & 3894 \\
\hline 1494 & 3207 & 1544 & 3460 & $15 g^{\prime}$ & 3240 & $1640 \mathrm{bis}$ & 3982 & 1683 VIII & 3695 \\
\hline 1495 & 3262 & 1545 & 3423 & $159^{\prime}$ bis & 4565 & 1641 & 3983 & 1683 IX & 3696 \\
\hline $1 / 196$ & 3258 & 1546 & 3454 & 1595 & 3672 & 1642 & 3435 & $1683 \mathrm{X}$ & 3897 \\
\hline 1497 & 3142 & 1547 & $34 \pm 7$ & 1596 & 3495 & 1643 & 3558 & $1583 \mathrm{XI}$ & 3698 \\
\hline 1498 & 3445 & 1548 & 3439 & 1597 & $3 \div 96$ & 1644 & 3464 & $1684 I$ & 3735 \\
\hline 1499 & 3133 & 1549 & 3427 & 1 598 & 3498 & 1645 & 3592 & 1684 II & 3736 \\
\hline 1500 & 3130 & 1550 & 3558 & 1599 & 3536 & 1646 & 3589 & 1684 IV & 3737 \\
\hline 1501 & 3132 & 1551 & 3415 & 1600 & 3542 & 1647 & 3463 & $1684 \mathrm{VI}$ & 3738 \\
\hline 1502 & 3127 & 1552 & 3255 & 1601 & 3535 & $16 / 18$ & 3533 & 1684 VI bis & 3739 \\
\hline 1503 & 3317 & 1553 & $33 / 1$ & 1602 & 3524 & $16 / 49$ & 3532 & 1684 VII & 3740 \\
\hline 1504 & 3316 & 1554 & 3411 & 1603 & 3541 & 1650 & 3534 & 1684 VIII & 3741 \\
\hline $1504 \mathrm{bis}$ & 3315 & 1555 & 3386 & 1604 & 3539 & 1651 & 3491 & 1684 XIII & 3742 \\
\hline 1505 & 3134 & 1556 & 3419 & 1605 & 3538 & 1652 & 3492 & $1684 \times V$ & 3743 \\
\hline 1506 & 3108 & 1557 & 3440 & 1606 & 3933 & 1653 & 3306 & 1684 X VIII & 3744 \\
\hline 1507 & 3249 & 1558 & 3344 & 1607 & 3924 & 1654 & 3490 & ${ }_{1684}$ XIX & 3745 \\
\hline 1508 & 3114 & 1559 & 3422 & 1608 & 3925 & 1655 & 3405 & 1684 XXIX & 3746 \\
\hline 1509 & 3115 & 1560 & 3449 & 1609 & 3932 & 1656 & 3581 & ${ }_{1684}$ XXXIII & 3747 \\
\hline 1510 & 3113 & 1561 & 3413 & 1610 & 3940 & 1657 & 3551 & ${ }_{1684}$ XXXIIl bis & 3748 \\
\hline 1511 & 3220 & 1562 & 3457 & 1611 & 3934 & 1658 & 3575 & $1684 \times X X V$ & 3749 \\
\hline 1513 & 3259 & 1563 & $3 \pm 61$ & 1612 & 3938 & 1659 & 3576 & 1684 XXXVII & 3750 \\
\hline 1513 & 3239 & 1564 & 3339 & 1613 & 3941 & 1660 & 3563 & 1684 XXXIX & 3751 \\
\hline
\end{tabular}




\begin{tabular}{|c|c|c|c|c|c|c|c|c|c|}
\hline $\begin{array}{c}\text { ANCieN } \\
\text { CATALOGUE. }\end{array}$ & $\begin{array}{c}\text { NOUVEAU } \\
\text { CATALOGUE. }\end{array}$ & $\begin{array}{c}\text { Axciev } \\
\text { CaTALOGU. }\end{array}$ & $\begin{array}{l}\text { Notvelu } \\
\text { Cataloge. }\end{array}$ & $\begin{array}{c}\text { ANCIEN } \\
\text { CATALOGUE. }\end{array}$ & $\begin{array}{l}\text { NOUVEAU } \\
\text { CATALOGEE. }\end{array}$ & $\begin{array}{c}\text { ANGIEN } \\
\text { CATALOGUE. }\end{array}$ & $\begin{array}{c}\text { NoOVRaU } \\
\text { Catalogub. }\end{array}$ & $\begin{array}{c}\text { ANCIEN } \\
\text { CATALOGOE. }\end{array}$ & $\begin{array}{c}\text { NOUVEAU } \\
\text { C.ITALOGEE. }\end{array}$ \\
\hline & 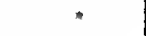 & & & & & & & & \\
\hline 1684 XLI & 3752 & 1695 & 3835 & 1721 III & 3613 & 1764 & 3680 & 1810 & 3351 \\
\hline 1684 XLIII & 3753 & ${ }_{1} 695 \mathrm{~A}$ & 3836 & $1721 \mathrm{IV}$ & 3615 & 1765 & 3906 & 1811 & 3355 \\
\hline${ }_{1684} \mathrm{XI.V}$ & 3754 & ${ }_{1} 69^{6}$ & 3839 & $1721 \mathrm{~V}$ & 3659 & ${ }_{17} 65$ bis & 3907 & 1812 & 3356 \\
\hline 1684 Xl.VII & 3755 & 1697 & 3856 & 1723 & 3631 & 1766 & 3369 & 1813 & 3354 \\
\hline 1684 XLIX & 3756 & 1697 bis & 3878 & 1723 & 3637 & 1767 & 3370 & 1814 & 3353 \\
\hline $1684 \mathrm{LI}$ & 3757 & 1698 & 3858 & 1724 & 3627 & 1768 & 3371 & 1815 & 3358 \\
\hline $1684 \mathrm{LV}$ & 3758 & 1699 & 3857 & 1725 & 3626 & 1769 & 3376 & 1816 & 3069 \\
\hline $1685 \mathrm{II}$ & 3759 & 1700 & No nos employé & 1726 & 3677 & $177^{\circ}$ & 3380 & 1817 & 3070 \\
\hline${ }_{1} 685 \mathrm{~V}$ & 3760 & $1701 \mathrm{~A}$ & 3894 & 1727 & 3678 & $177^{\circ} \mathrm{bis}$ & 3384 & 1818 & 3065 \\
\hline $1685 \mathrm{VI}$ & 3761 & $1701 \mathrm{~B}$ & 3897 & $17^{98}$ & 3660 & 1771 & 3383 & 1819 & 3063 \\
\hline $1685 \mathrm{XI}$ & 3762 & 17016 & 3899 & 1729 & 3675 & 17721 & 3551 & 1820 & 3061 \\
\hline 1685 XII & 3763 & $1701 \mathrm{D}$ & 3900 & 1730 & 3676 & 1773 II & 3555 & 1821 & 3062 \\
\hline 1685 XIII & 3764 & $1702 \mathrm{~A}$ & 3898 & $173 t$ & 3662 & 1773 & 1303 & 1822 & Eo déficit \\
\hline $1685 \mathrm{XV}$ & 3765 & $1709 \mathrm{~B}$ & 3901 & $173_{3}$ & 3291 & $177^{4}$ & 1306 & 1823 & 3056 \\
\hline${ }_{1} 685 \mathrm{XVI}$ & 3766 & $1702 \mathrm{G}$ & 3902 & 1733 & 3624 & $177^{5}$ & 1307 & $18 \cdot 4$ & 3057 \\
\hline 1685 X VII & 3767 & $1702 \mathrm{D}$ & 3903 & 1734 & 3652 & 1776 & 3582 & 18.5 & 3058 \\
\hline 1685 XIX & 3768 & $1702 \mathrm{E}$ & 3904 & 1735 & 3667 & 1777 & 3453 & 1826 & 3060 \\
\hline $1685 X X I$ & 3769 & $703 \mathrm{~A}$ & 3896 & 1736 & 3653 & $177^{8}$ & $358 t$ & 18.7 & 3059 \\
\hline 1685 XXII & 3770 & $1703 \mathrm{~B}$ & 3905 & $17^{3} 7$ & 3572 & 1779 & 3578 & 18.8 & 3051 \\
\hline 1685 XXIII & 3771 & $1703 \mathrm{C}$ & 3895 & 1738 & 3591 & 1780 & 3487 & 1829 & 3052 \\
\hline 1685 XXIV & 3772 & 17041 & 3816 & 1739 & 3587 & 1781 & 3489 & 1830 & 3071 \\
\hline $1685 \mathrm{XXV}$ & 3773 & $170 / 1$ II & 3817 & $17 / 10$ & 3625 & $1781 \mathrm{bis}$ & 3488 & 1831 & 3072 \\
\hline${ }_{1685}$ XX VI & 3774 & $1705 I$ & 3812 & 1711 & $366 !$ & 1782 & 3523 & 1832 & 3073 \\
\hline ^ 685 XXVIII & 3775 & 170511 & 3813 & 1742 & $36 \pm 1$ & 1783 & 3522 & 1833 & 3066 \\
\hline ^685 XXVIII & 3776 & 1706 & 3815 & 1743 & 3569 & 1784 & 3521 & 1834 & 3067 \\
\hline $1685 X X X$ & 3777 & 1707 & 3814 & 1744 & 3918 & 1785 & $N^{\circ}$ non employé & 1835 & 3068 \\
\hline $1685 \mathrm{XXXI}$ & 3778 & 1708 & 3820 & 1745 & 3912 & 1786 & 3483 & 1836 & 4643 \\
\hline 1685 XXXII & 3779 & $1709 \mathrm{I}$ & 3810 & 1746 & 3915 & 1787 & $348 t$ & 1837 & 4613 \\
\hline 1685 XXXIII & 3780 & 1709 II & 3811 & 1747 & 3919 & 1788 & 3518 & 1838 & 4631 \\
\hline${ }_{1685} \mathrm{XXXIV}$ & 3781 & 1710 & 3819 & 1748 & 3911 & 1789 & 3519 & 1839 & 4632 \\
\hline $1685 \mathrm{XXXV}$ & 3782 & 1711 & 3560 & 1749 & 3916 & 1789 bis & 3520 & 1840 & 3956 \\
\hline 1686 & 3806 & 1719 & 3636 & $1749 A$ & 3910 & $179^{\circ}$ & 3638 & 1841 & 4660 \\
\hline 1686 bis & 3807 & 1713 & 3635 & 17501 & 3908 & $\pm 79^{1}$ & 3639 & 1842 & 3325 \\
\hline 1686 ter & 3808 & 1714 & 3633 & $1750 \mathrm{II}$ & 3913 & $179^{2}$ & 3655 & 1843 & 3250 \\
\hline 1687 & 3801 & 1715 I & 3613 & 175 o III & 3914 & 1793 & 3477 & 1844 & 2305 \\
\hline 1687 bis & 3802 & $1715 \mathrm{II}$ & 3614 & $17^{50} \mathrm{IV}$ & 3909 & $179^{4}$ & $3 \pm 63$ & 1845 & 2303 \\
\hline${ }_{1687} \mathrm{tev}^{\circ}$ & 3803 & 1716 & 3616 & $1750 \mathrm{~V}$ & 3917 & $179^{5}$ & 3478 & 1846 & 2306 \\
\hline 1688 & 3804 & 1717 I & 3595 & 1751 & 3634 & $179^{6}$ & 3480 & 1847 & 3207 \\
\hline 1689 & 3798 & 1717 II & 3596 & 1752 & N'non employé & 1797 & 3476 & 1848 & 4604 \\
\hline 1690 & En léficit & 1717 III & 3597 & 1753 & V'non employé & $179^{8}$ & 3473 & 1849 & 2341 \\
\hline $16 g_{1} I$ & 3783 & 17.81 & 3598 & 1754 & 3651 & 1799 & 3479 & $1850 \mathrm{I}$ & 2342 \\
\hline $169_{1}$ III & 3784 & $17^{18} \mathrm{II}$ & 3599 & 1755 & $36 \pm 3$ & 1800 & 3474 & 18500 II & 2343 \\
\hline $16_{9_{1}}$ VIII & 3785 & $1718 \mathrm{III}$ & 3600 & $17^{56}$ & 3614 & 1801 & 3475 & $1850 \mathrm{III}$ & 2344 \\
\hline $169, \mathrm{IX}$ & 3786 & $1718 \mathrm{IV}$ & 3601 & $17^{57}$ & 3642 & 1802 & 3467 & 1851 & 2335 \\
\hline 1691 XII & 3787 & $1719 I$ & 3602 & 1758 & 3668 & 1803 & 3470 & $1851 \mathrm{~A}$ & 2336 \\
\hline $169_{1} \mathrm{XIV}$ & 3788 & $1719 \mathrm{II}$ & 3603 & $17^{5} 9$ & 3628 & 1804 & 3526 & 1852 & 3546 \\
\hline $16 g_{1} \mathrm{XXI}$ & 3789 & 1719 III & 3604 & 1760 & 3654 & 1805 & 3055 & 1853 & 2322 \\
\hline $16 g_{2}$ & 3823 & $1719 \mathrm{IV}$ & 3605 & $17^{61}$ & 3536 & 1806 & 4642 & 1854 & $39 \pm 8$ \\
\hline $169^{2}$ bis & 3822 & 1720 & 3617 & 1762 & $36 \pm 8$ & 1807 & 3658 & 1855 & 4591 \\
\hline 1693 & 3583 & $1721 \mathrm{~A}$ & 3620 & $1762 \mathrm{bis}$ & 3616 & 1808 & 3074 & 1856 & 1391 \\
\hline $169^{\prime}$ & 3666 & 1731 II & 3619 & 1763 & 3922 & 1809 & 3103 & 1857 & 3244 \\
\hline
\end{tabular}




\begin{tabular}{|c|c|c|c|c|c|c|c|c|c|}
\hline $\begin{array}{c}\text { ArGiEN } \\
\text { CATALOGE. }\end{array}$ & $\begin{array}{l}\text { NOUVEAU } \\
\text { CATALOGE }\end{array}$ & $\begin{array}{c}\text { ANCIEN } \\
\text { CATALOGEE. }\end{array}$ & $\begin{array}{l}\text { NOUPEAU } \\
\text { CATALOGUE. }\end{array}$ & $\begin{array}{c}\text { ANCIEN } \\
\text { CATALOGEE. }\end{array}$ & $\begin{array}{l}\text { NOUVEAU } \\
\text { CATALOGCE. }\end{array}$ & $\begin{array}{c}\text { ANCIEN } \\
\text { CATALOGUE. }\end{array}$ & $\begin{array}{l}\text { NOUYEAU } \\
\text { CATALOGUE. }\end{array}$ & $\begin{array}{c}\text { AXCIEN } \\
\text { CATALOGUR. }\end{array}$ & $\begin{array}{l}\text { NOUVEAU } \\
\text { CATALOGLE. }\end{array}$ \\
\hline 1858 & 4661 & 1909 & 4138 & 1957 & 3553 & 3000 & 1411 & 2051 & 2430 \\
\hline 1859 & 3964 & 1910 & 4134 & 1958 & 3033 & 2001 & 1436 & 2052 & 964 \\
\hline 1860 & 1395 & 1911 & 4281 & 1959 & 2038 & 2002 & 1437 & 2053 & 1404 \\
\hline 1861 & 669 & 1914 & 4441 & 1959 lis & 101 & 2003 & 1438 & 2054 & 1937 \\
\hline 186.2 & 4656 & 1913 & 4379 & 1960 & 3025 & 2004 & 1439 & 2055 & 2035 \\
\hline 1863 & 4653 & $191 / 6$ & 4420 & $19^{60}$ lis & 306 & $200 \overline{5}$ & 1446 & 2056 & 1940 \\
\hline 1864 & 4652 & 1915 & 3401 & 1961 & 3026 & 2006 & 1448 & 2057 & 1944 \\
\hline 1865 & 673 & 1916 & $\$ 824$ & $19^{6} \mathrm{lis}$ & 99 & 2007 & 702 & 20.58 & 1917 \\
\hline $1866^{\circ}$ & 1128 & 1917 & 3972 & 1962 & 2923 & 3008 & 703 & 2059 & 1465 \\
\hline 1867 & 1122 & $1917 \mathrm{bis}$ & 4859 & ${ }_{19} 6_{2}$ bis & 224 & 2009 & 695 & 2060 & 4526 \\
\hline 1868 & 1285 & 1918 & 3571 & $19^{63}$ & 2944 & 2010 & 738 & 2061 & 4855 \\
\hline 869 & 1248 & 1919 & 4598 & 1963 bis & 4539 & 2011 & 766 & 2063 & N' noo employé \\
\hline $187^{0}$ & 1206 & 1920 & 2800 & 1964 & 2493 & 2012 & 4540 & 2063 & No non employé \\
\hline 1871 & 1287 & 1921 & 4530 & 1964 bis & 73 & 2013 & 778 & 2064 & $N^{\circ}$ non enployé \\
\hline 1872 & 1237 & 1923 & 3968 & 1965 & 127 & 2014 & 745 & 2065 & $N^{\circ}$ non employé \\
\hline 1873 & 830 & 1923 & 3683 & 1965 bis & 28 & 2015 & 819 & 2066 & No non employé \\
\hline${ }_{1} 87^{4}$ & 1230 & 1924 & 4207 & 1966 & 4521 & 2016 & 1393 & 2067 & 287 \\
\hline 1875 & 1061 & 1925 & 4256 & 1966 bis & 4519 & 2017 & 1313 & 2068 & 1509 \\
\hline 1876 & 1060 & 1926 & 3204 & 1967 & 575 & 2018 & 754 & 2069 & 1583 \\
\hline${ }_{1} 877$ & 926 & 1927 & 2448 & 1968 & 578 & 2019 & 761 & 2070 & 1809 \\
\hline 1878 & En déficit & 1928 & 4586 & $19^{6} 9$ & 503 & 2090 & 715 & 2071 & 1808 \\
\hline 1879 & 1379 & 1929 & 4585 & $197^{\circ}$ & 504 & 2021 & 1062 & 2072 & 1733 \\
\hline 1880 & 2315 & $19^{30}$ & 2382 & 1971 & 505 & 9022 & 818 & 2073 & 1745 \\
\hline 1881 & 3515 & $19^{31}$ & 3138 & 1972 & 579 & 2023 & 1288 & 2074 & 1758 \\
\hline 1882 & 1293 & 1939 & 2449 & 1973 & 578 & 2021 & 1097 & 2075 & 1588 \\
\hline 1883 & 1299 & 1933 & 4528 & 1974 & 393 & 2035 & 1111 & $207^{6}$ & 1718 \\
\hline 1884 & 978 & 1934 & 4608 & 1975 & 506 & 2036 & 809 & 2077 & 1855 \\
\hline 1885 & 1317 & 1935 & 4236 & $197^{6}$ & 507 & 2027 & 1018 & 2078 & 1625 \\
\hline 1886 & En déticit & $1936^{\circ}$ & 4582 & 1977 & 508 & 2028 & 899 & 2079 & 2263 \\
\hline $188_{7}$ & 1641 & $19^{3} 7$ & 1328 & 1978 & 647 & 2029 & 979 & 2080 & 2078 \\
\hline 1888 & En déficit & 1938 & 4857 & 1979 & 648 & 2030 & 887 & 2081 & 1884 \\
\hline 889 & 1768 & 1939 & 3973 & 1980 & 655 & 2031 & 1095 & 2082 & 2295 \\
\hline 1890 & 2120 & $19 \dot{0} 0$ & 3442 & $19^{81}$ & 1939 & 2033 & 1049 & 2483 & 1891 \\
\hline $18 y^{1}$ & 2600 & $19^{41}$ & 3191 & 198 & 591 & 2033 & 871 & 2084 & 1859 \\
\hline 1892 & 2602 & 1942 & 4182 & 1983 & 1207 & $203 /$ & 921 & 2085 & 2094 \\
\hline 1893 & 2687 & 1943 & 3019 & $19^{84}$ & 1208 & 2035 & 1315 & 2086 & 2792 \\
\hline $189^{4}$ & 2738 & 1944 & 2250 & 1985 & 1180 & ฉo36 & 1324 & 2087 & 2179 \\
\hline 1895 & 2620 & 1945 & 688 & $19^{86}$ & 1202 & 2037 & 1129 & 2088 & 2822 \\
\hline $18_{9} 6$ & En défieit & $19 / 46$ & 685 & $19^{8} 7$ & 1131 & 2038 & 907 & 2089 & 2599 \\
\hline 1897 & 3035 & $19^{4} 7$ & 1160 & $19^{88}$ & 1209 & 2039 & 1283 & $209^{\circ}$ & 2712 \\
\hline 1898 & 2685 & 1948 & 1286 & 1989 & 1210 & 2040 & 1234 & $\operatorname{sog} 1$ & 2567 \\
\hline 1899 & 3041 & 1949 & 3669 & $199^{\circ}$ & 1433 & 2041 & 1162 & $209^{2}$ & 2580 \\
\hline 1900 & 2811 & 1950 & 3513 & 1991 & 1434 & 2042 & 4575 & $\operatorname{sog} 3$ & 2574 \\
\hline 1901 & 2487 & 1951 & 2778 & $199^{2}$ & 1431 & 2043 & 4576 & 2094 & 2284 \\
\hline 1902 & 2568 & 1952 & 1198 & $199^{3}$ & 1409 & 2044 & 1370 & 2095 & 2282 \\
\hline 1903 & $\aleph^{\circ}$ non employé & $19^{53}$ & 2345 & $199^{4}$ & 1428 & 2045 & 1338 & 2096 & 2273 \\
\hline 1904 & 2541 & $195 / 4$ & 1892 & 1995 & 1423 & 2046 & 1339 & 9097 & 2484 \\
\hline 1905 & 2234 & 1955 & 4862 & $199^{6}$ & 1428 & $20 / 17$ & 3168 & $\operatorname{3og} 8$ & $2243^{\circ}$ \\
\hline 1906 & 2200 & 1956 & 4633 & 1997 & 1418 & 2048 & 3233 & 3099 & $2245^{\circ}$ \\
\hline 1907 & 4151 & $1956 \mathrm{~A}$ & 4834 & 1998 & 1422 & 2049 & 3334 & 2100 & 2205 \\
\hline 1908 & 4149 & $1956 \mathrm{bis}$ & 4635 & 1999 & 1413 & 2050 & 2719 & 2101 & 2208 \\
\hline
\end{tabular}




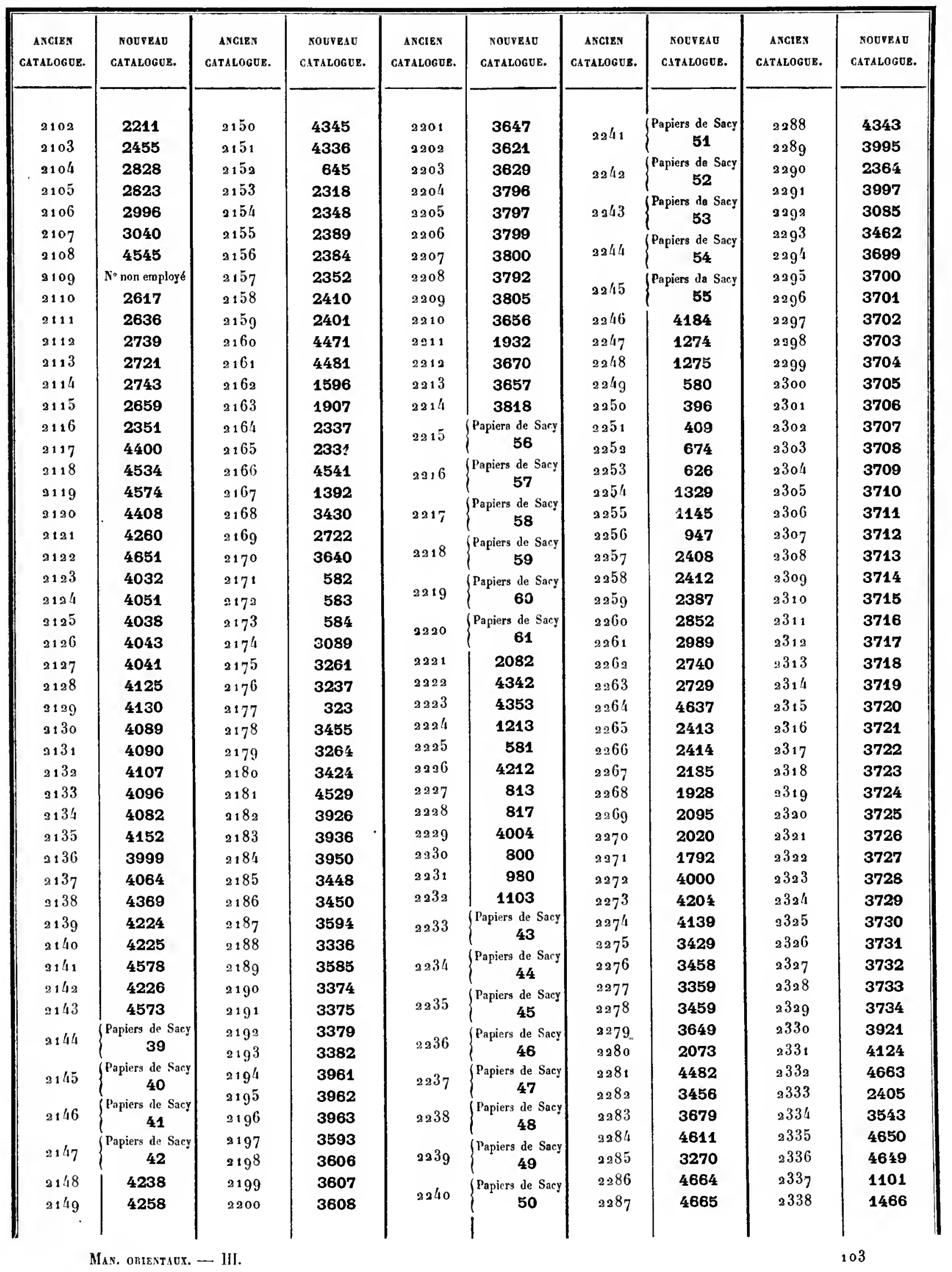


MANUSCRITS ARABES.

\begin{tabular}{|c|c|c|c|c|c|c|c|c|c|}
\hline $\begin{array}{c}\text { ANCIEN } \\
\text { CATALOGUR. }\end{array}$ & $\begin{array}{c}\text { NOUREAE } \\
\text { CATALOGUE. }\end{array}$ & $\begin{array}{c}\text { ANCIEN } \\
\text { Gatalogue. }\end{array}$ & $\begin{array}{l}\text { NOUVEAT } \\
\text { CATALOGUE. }\end{array}$ & $\begin{array}{c}\text { ANGiBN } \\
\text { CATALOGUE. }\end{array}$ & $\begin{array}{l}\text { rOUVEAC } \\
\text { CATALOGER. }\end{array}$ & $\begin{array}{c}\text { AxGiex } \\
\text { CAtALOGUE. }\end{array}$ & $\begin{array}{l}\text { NOUREAU } \\
\text { CATALOGUE. }\end{array}$ & $\begin{array}{c}\text { ANGIBY } \\
\text { GATALOGUE. }\end{array}$ & $\begin{array}{c}\text { NOUYBAU } \\
\text { GATALOGCE. }\end{array}$ \\
\hline 2339 & 2452 & 3378 & 4361 & 2416 & 3064 & 2456 & 1888 & 2496 & 4554 \\
\hline & (Persan (Suppl.) & 2379 & 4350 & 9417 & 1001 & 2457 & 4614 & 2497 & 4138 \\
\hline 2340 & 1033 & 2380 & 4354 & 2418 & 2251 & 2458 & 4625 & 2498 & 2821 \\
\hline 9341 & 2204 & 2381 & 4355 & 2419 & 3920 & 2459 & 4630 & 2499 & 2830 \\
\hline 2342 & 1880 & э38 & 4351 & 2420 & 3047 & 2460 & 4601 & 2500 & 3661 \\
\hline 2343 & 1889 & ะ 383 & 4348 & 2421 & 1410 & 2461 & 4602 & 2501 & 3451 \\
\hline э344 & 318 & ๑384 & 4363 & 2422 & 4358 & 2462 & 4603 & 2502 & 2244 \\
\hline 2345 & 1872 & 2385 & 4462 & 2423 & 4359 & 2463 & 4628 & 2503 & 4229 \\
\hline 2346 & 1447 & 2386 & 4463 & 2424 & 4360 & 2464 & 4619 & $250 !$ & 4480 \\
\hline 2347 & 3175 & 3387 & 4464 & $2 / 425$ & 3357 & 2465 & 4617 & 2505 & 4555 \\
\hline 2348 & 2842 & 2388 & 4365 & 2426 & 2154 & $2 / 166$ & 4621 & 2506 & 4558 \\
\hline פ349 & 4346 & 2389 & 4221 & 2427 & 4520 & 2467 & 4527 & 2507 & 4561 \\
\hline 350 & 3809 & ${ }_{2} 390$ & 4034 & 2428 & 4618 & 2468 & 4560 & ${ }_{2508}$ & -4666 \\
\hline 2351 & 1092 & ${ }_{2} 39^{1}$ & 2845 & 9429 & 1879 & 2469 & 4546 & 2509 & 电 4667 \\
\hline „352 & 3017 & 2392 & 4479 & 2430 & 2062 & 2470 & 4552 & 2510 & 总 4668 \\
\hline ะ353 & 779 & 8393 & 3321 & 2431 & 2063 & 2471 & 4612 & 2511 & 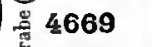 \\
\hline 2354 & 676 & 2394 & 1082 & 2432 & 2066 & 2473 & 4610 & 2512 & 4670 \\
\hline ๑355 & 4087 & 2395 & 1083 & 2433 & 2964 & ${ }_{247} 3$ & 4098 & ${ }_{2513}$ & 2366 \\
\hline 2356 & 1098 & 2396 & 1084 & 2434 & 2271 & 2474 & 4550 & 2514 & 2415 \\
\hline 3357 & 3018 & 2397 & 1085 & .2435 & 4567 & 2475 & 4551 & 2515 & 4671 \\
\hline 3358 & 4133 & 398 & 1086 & 2436 & 968 & 2476 & 4553 & 2516 & 4672 \\
\hline ะ359 & 2516 & 2399 & 1087 & 2437 & 4579 & 2477 & 4548 & 2517 & 4673 \\
\hline 2360 & 4607 & 9400 & 3640 & 2438 & 1405 & 2478 & 4608 & 2518 & 4674 \\
\hline 2361 & 4494 & 2401 & 3641 & 2439 & 2027 & 2479 & 3397 & 2519 & 4675 \\
\hline 2362 & 4495 & 2402 & 3842 & 2440 & 2025 & 2480 & 4615 & 2520 & 4676 \\
\hline s363 & 4496 & 2403 & 3843 & 2441 & 1457 & 2481 & 4629 & 2521 & 4677 \\
\hline 2364 & 4497 & 3404 & 3844 & 2442 & 1390 & 2482 & 3126 & 2529 & -4678 \\
\hline${ }_{2} 365$ & 4498 & 8405 & 3845 & 2443 & 1389 & 2483 & 4407 & 2523 & $\stackrel{\text { a }}{a} 4679$ \\
\hline ə366 & 4499 & 2406 & 3846 & 2444 & 4593 & 2484 & 3387 & 2524 & 可 4680 \\
\hline ๖ 367 & 4500 & 2407 & 3647 & 2445 & 4522 & 2485 & 4538 & $25{ }_{2} 5$ & 4681 \\
\hline 3368 & 4501 & 2408 & 3648 & 21946 & 1194 & 2486 & 4556 & 2526 & 4682 \\
\hline 3369 & 1549 & 2409 & 3849 & 3447 & 1179 & 2487 & 4559 & 2527 & 4683 \\
\hline 2370 & 46 & 2410 & 3850 & 2448 & 1877 & 2488 & 4411 & 2528 & 4684 \\
\hline $237:$ & 2481 & 8411 & 3851 & 2449 & $N^{\circ}$ non employs & 2489 & 4532 & 2529 & 4685 \\
\hline $937^{2}$ & 4357 & 2412 & 3861 & 2450 & 3322 & 2490 & 4581 & ${ }_{2} 530$ & 4686 \\
\hline 8373 & 2575 & 2413 & 321 & 9451 & 3323 & 2491 & 4562 & ${ }_{2531}$ & 4687 \\
\hline 9374 & 4222 & 2414 & 981 & 2459 & 3236 & 2492 & 4557 & 2532 & 4688 \\
\hline 2375 & 4227 & 2415 & 3793 & 2453 & 4140 & 2493 & 4549 & 2533 & 4689 \\
\hline${ }_{2} 37_{7} 6$ & 4228 & 2415 bis & 3794 & 2454 & 4141 & 2494 & 4616 & 2534 & 2774 \\
\hline $\mathbf{2} 377$ & 4362 & $2415 \mathrm{ter}$ & 3795 & 2455 & 4627 & 2495 & 3188 & & \\
\hline
\end{tabular}




\section{GONGORDANGE DES NUMÉROS DU FONDS DES CATALOGUES}

INSÉRÉS DANS LE FONDS ARABE.

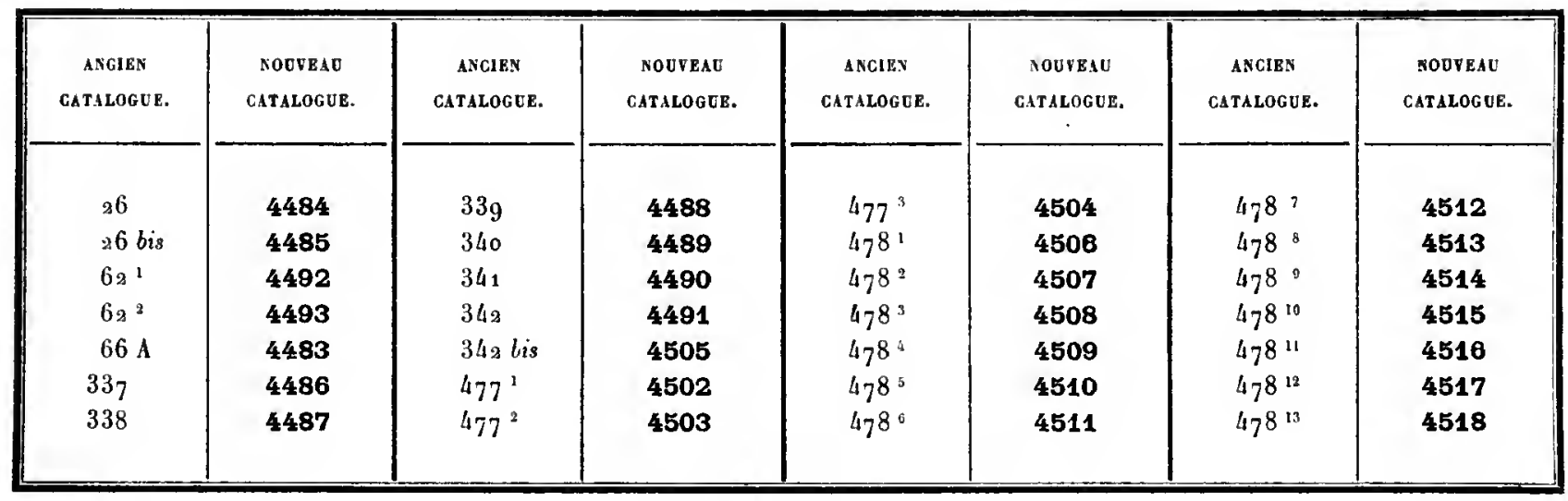

\section{GONCORDANCE DES NUMÉROS DU FONDS DES TRADUCTIONS}

INSÉRÉS DANS LE FONDS ARABE.

\begin{tabular}{|c|c|c|c|c|c|c|c|}
\hline $\begin{array}{c}\text { ANCIEN } \\
\text { CATALOGOE. }\end{array}$ & $\begin{array}{l}\text { soutrau } \\
\text { catalogue. }\end{array}$ & $\begin{array}{c}\text { ANCIEN } \\
\text { CATALOGOR. }\end{array}$ & $\begin{array}{l}\text { NOUVEAO } \\
\text { CATALOGUE. }\end{array}$ & $\begin{array}{c}\text { AKCIEN } \\
\text { CATALOGUE. }\end{array}$ & $\begin{array}{l}\text { NOUVEAO } \\
\text { CATALOGUE. }\end{array}$ & $\begin{array}{c}\text { ANCIEN } \\
\text { CATALOGEE. }\end{array}$ & $\begin{array}{l}\text { NOUVBAU } \\
\text { CATALOGUR. }\end{array}$ \\
\hline $\begin{array}{l}3 \\
3\end{array}$ & $\begin{array}{l}1558 \\
1559\end{array}$ & $\begin{array}{l}51 \\
83\end{array}$ & $\begin{array}{l}2181 \\
1539\end{array}$ & $\begin{array}{l}84 \\
85\end{array}$ & $\begin{array}{l}1540 \\
1541\end{array}$ & $\begin{array}{l}191 \\
192\end{array}$ & $\begin{array}{l}4484 \\
4485\end{array}$ \\
\hline
\end{tabular}




\section{ADDITIONS ET CORRECTIONS.}

Pagge $10, \mathrm{n}^{\circ}$ 48, au lieu de: Supplément 19 , lisez: Supplément 18.

$28, \mathrm{n}^{\circ}{ }_{131}$, au lieu de : Supplément ${ }_{2} 7$, lisez : Supplément 87 .

$47, \mathrm{n}^{\circ} 188$, au lieu de: Supplément 101, lisez: Supplément 100.

$18, \mathrm{n}^{\circ} 19^{4}$, au lieu de: Prière du solitaire, lisez : Prairie du Solitaire.

$118, \mathrm{n}^{\circ} 385$, au lieu de: Ancien fonds 143 , lisez: Supplément 143.

$124, \mathrm{n}^{\circ} 425$, au lieu de: Ancien fonds 108, lisez: Ancien fonds 208 .

$128, \mathrm{n}^{\circ} 454$, au lieu de: Supplément 121, lisez: Supplément $121 \mathrm{~A}$.

$129, \mathrm{n}^{\circ} 459$, au lieu de: Supplément 148, lisez: Supplément $148 \mathrm{I}$.

${ }_{13} 39, n^{\circ *} 597$ à 599 , an lieu de : Aboû 'l-QÁsim Moḥammad, lisez : Aboû 'l-QÁsim Maḥmoûd.

$145, \mathrm{n}^{\circ} 639$, au lieu de : Supplément 1861, lisez : Supplément $186 \mathrm{I}$.

148, $\mathrm{n}^{\circ} 657$, au lieu de : Supplément $171 \mathrm{~A}$, lisez : Supplément $171 \mathrm{~A}$ bis.

148, $\mathrm{n}^{\circ} 658$, au lieu de: Supplément ${ }_{11} 1$ B, lisez: Supplément $17_{1}^{1}$ B bis.

204, $\mathrm{n}^{\circ}{ }_{1027}$, au lieu de: Ardobilli, lisez: Ardabill.

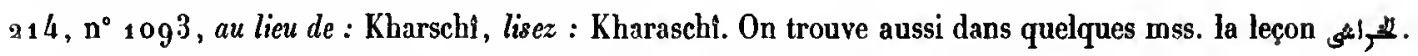

220, n' 1129, au lieu de : العسماوية et Al-Asmâwí, lisez : Al'Aschmâwi.

${ }_{2} 39, \mathrm{n}^{\circ} 1250$, au licu de: Yạ̣yâ ibn Yaïsch, lisez : Yạ̣yà ibn Yakhschs.

${ }_{2} 66, \mathrm{n}^{\circ} 1395$, au lieu de : Supplément 1840 , lisez : Supplément 1860 .

${ }_{2} 86, \mathrm{n}^{\circ}{ }_{1} 504$, au lieu de : Supplément 740 IV, lisez : Supplément $7^{40} \mathrm{Vl}$.

$312, \mathrm{n}^{\circ} 1668,3^{\circ}$, au lieu de: Voyez ci-après, lisez: Voyez ci-dessus.

$364, \mathrm{n}^{\circ} 2044$, au lien de : 'All, fils de Ḥosain, lisez : Ḥosaïn, fils d'All.

$367, \mathrm{n}^{\circ} 2062$. Cette introduction n'est pas celle du Dictionnaire biographique, mais peut-être la $2^{\circ}$ introduction du traité

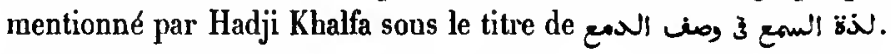

$415, \mathrm{n}_{2}^{\circ} 365,1^{\circ}$, au lieu de: المنفخ : lisez : المنتخ :

$421, n^{\circ} 2405,5^{\circ}$, au lieu de : العتيق, lisez: الانيف : المنيق :

$449, \mathrm{n}_{2}^{\circ} 5_{21}, 5^{\circ}$, an lieu de : 'Omar al-Râzî, lisez: Moḥammad ibn 'Omar al-Ràzî.

$45_{2}, n^{\circ} 2531,1^{\circ}$, au lieu de : بلع

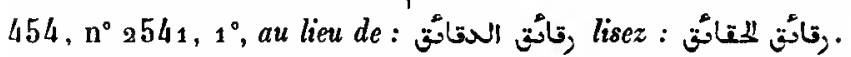

$468, \mathrm{n}^{\circ}{ }_{2} 589$, au lieu de : Scharîf al-Dîn Moḥammad ... al-Djaghmini, lisez : Scharaf al-Dîn Maḥmoûd ... al-Djaghmînł. $493, \mathrm{n}^{\circ} 27_{32}, 7^{\circ}$, au lieu de : الألاتنساط: lisez.

$583, \mathrm{n}^{\circ} 3333$, au lieu de : Al-Baïkânł lisez : Al-Baïsâní.

$618, \mathrm{n}^{\circ} 35 \mathrm{~g}$. Ce ms. renferme la première partie du recueil de contes du ms. $358 \mathrm{~g}$.

$704, \mathrm{n}^{\circ} 4422$, au lieu de: Ancien fonds 1583 , lisez: Ancien fonds 1585 .

$7^{2} 6, \mathrm{n}^{\circ} 4585,4^{\circ}$, au lieu de : 'Ișâm al-Dîn Moḥammad, lisez : 'Ișâm al-Din lhrâhîm ibn Moḥammad. 




, . 
Z

6621

P22A6

Páris. Bibliothèque nationale. Departenent des manuscrits arabes

Catalogue des manuscrits

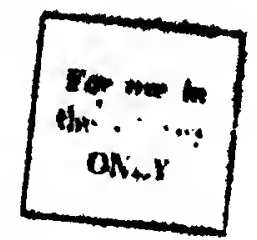

PLEASE DO NOT REMOVE SLIPS FROM THIS POCKET
For use in the Library ONLY

\section{UNIVERSITY OF TORONTO}

LIBRARY 


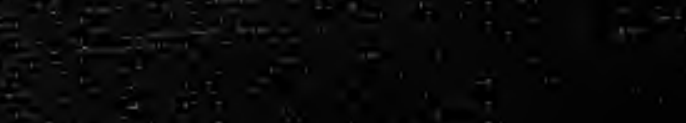

